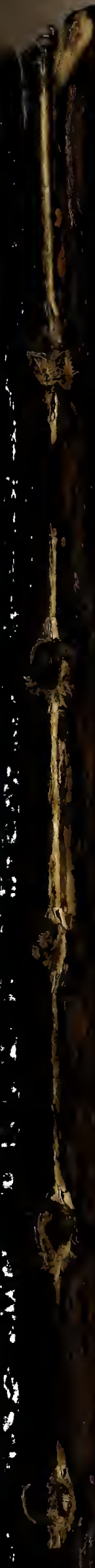

$+4 x^{2}+2$ 


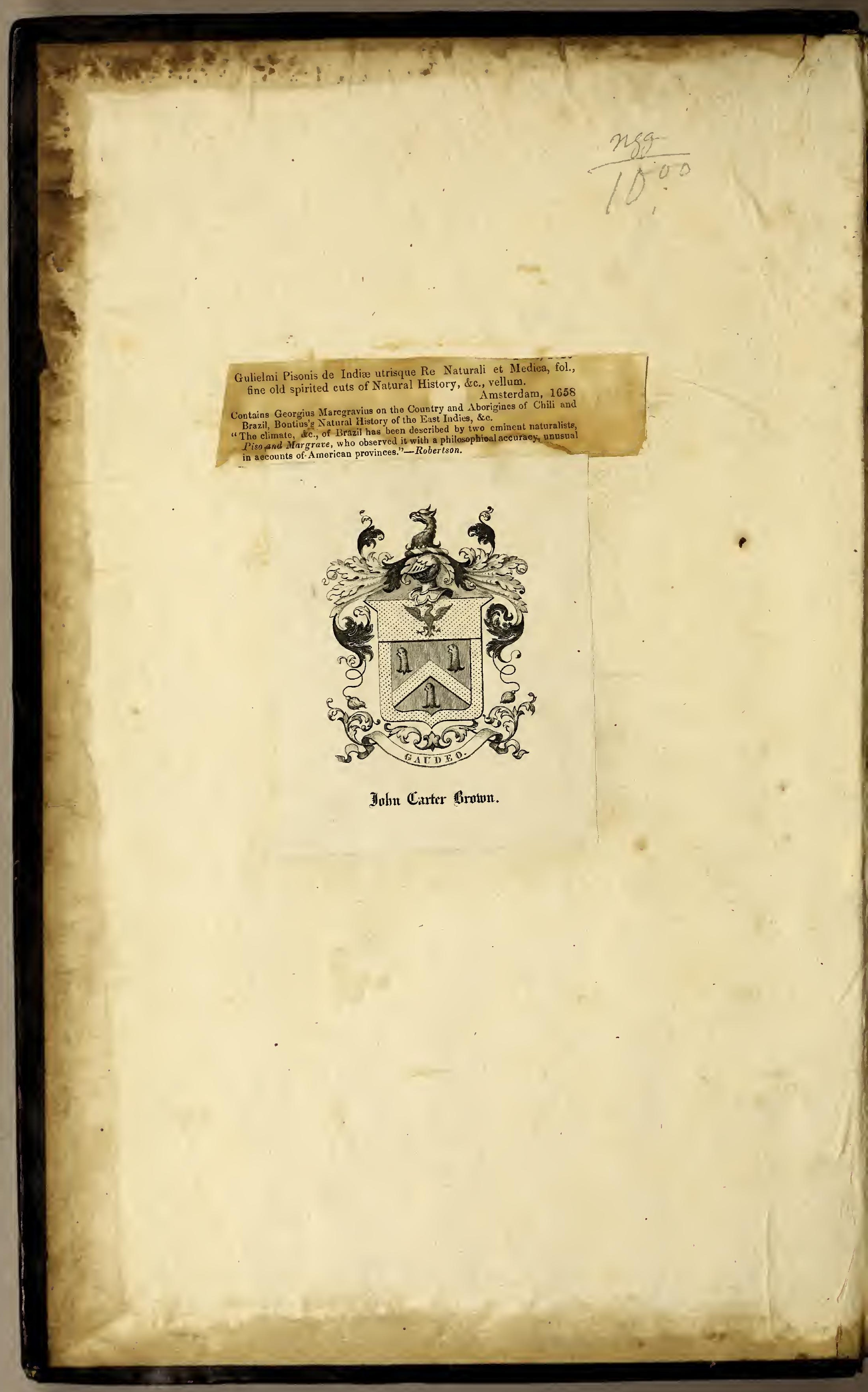



C

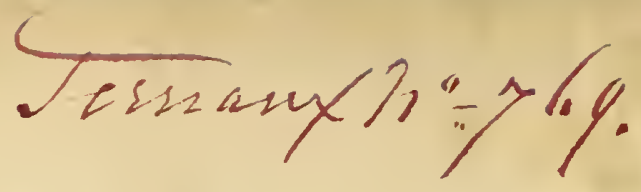




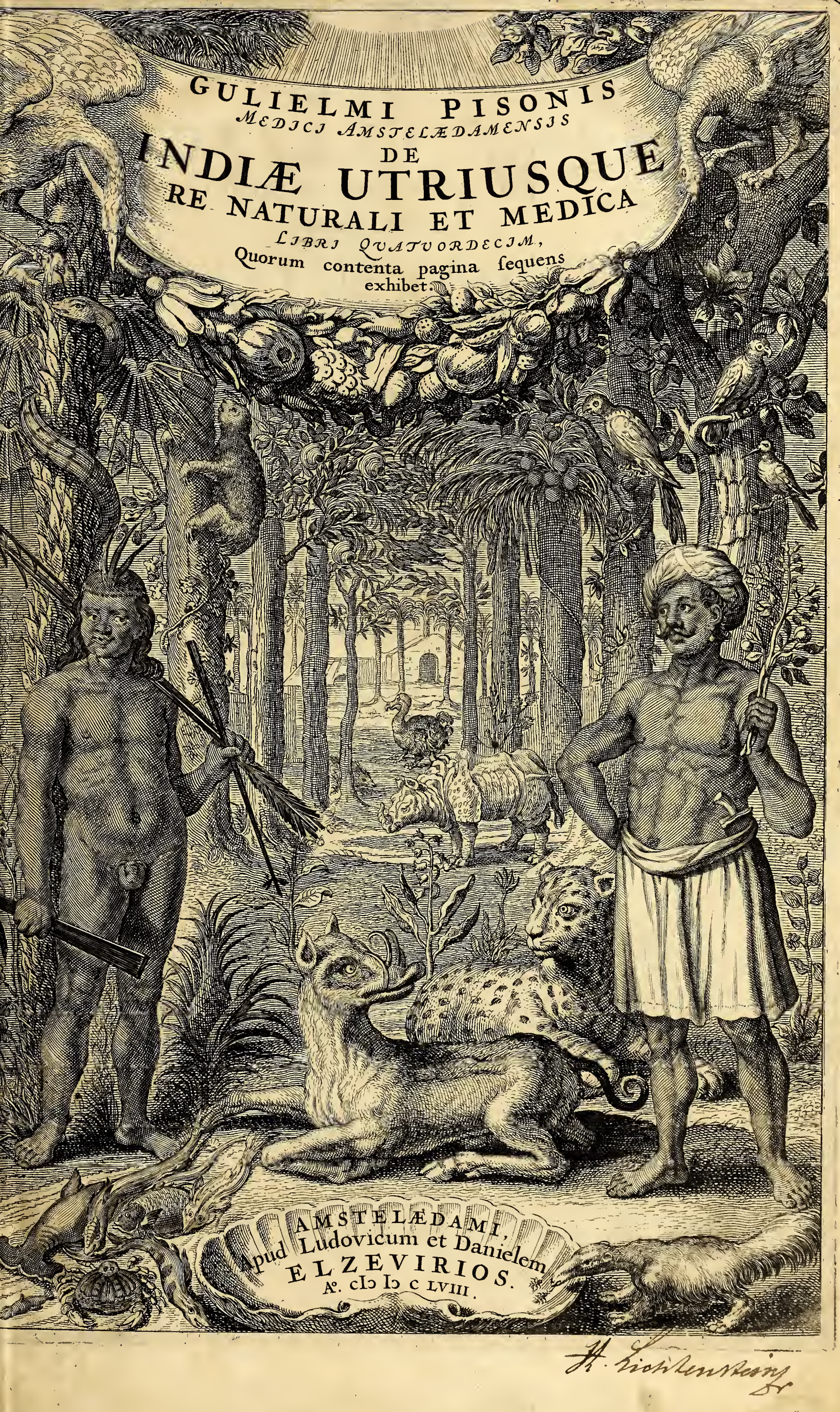





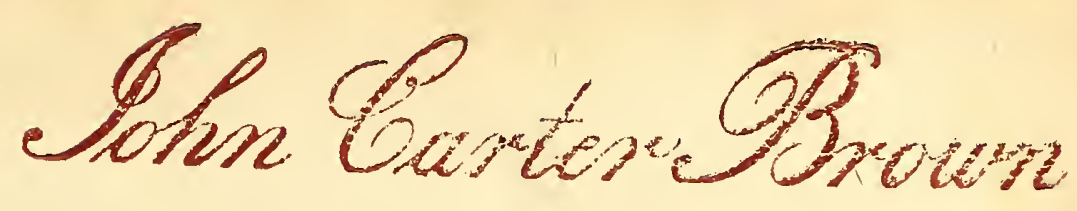

AVTORES ET TIT V L I

Librorum, qui hoc Volumine exhibentur.

\section{G V L I E L M P I S O I S, Medici Amftelædamenfis,}

1. De Aëribus, Aquis, \& Locis.

II. De Natura \& cura Morborum, Occidentali Indix, imprimis Brafilix, familiarium.

III. DeAnimalibus, aquatilibus, volatilibus, \& terreftribus, edulibus .

IV.De Arboribus, fructibus, \& herbis medicis, atque alimentariis; nafcentibus in Brafilia \& regionibus vicinis.

V. De Noxiis \& venenatis, eorumque Antidotis. Quibus inferte funt Animalium quorundam vivæ fectiones; Tum \& aliquot $\mathrm{Me}=$ tamorphofes Infectorim.

VI. Mantiffa aromatica \&c. Pofita poft Bontii tractatus.

\section{GE OR G I MAR G RA V I I Pe $\mathfrak{S i c p / t a b t}$}

t. Tractatus Topographicus \& Metcorologicus Brafilix, cum Obfervatione Eclipfis Solaris.

II. Commentarius de Brafilienfum \& Chilenfium indole ac lingua \& $\&$.

\section{A C O B I $\mathrm{B}$ O $\mathrm{N} \cdot \mathrm{T}$ I I,} Bataviæ in majore Java novæ Medici ordinarii,

I. De Confervanda valetudine.

II. Methodus medendi.

III. Obfervationes in cadaveribus.

IV. Notx in Garciam ab Orta.

V. Hiftoria Animalium. [Quibus fparfim inferuit G. P I s o AnnotatioVI. Hiftoria Plantarum. nes \& Additiones quà icones atque res ne.

$S_{E N} \mathrm{E} C \mathrm{~A}$ : Veniet tempus, quo iffa, qua sunc latent, in lacem dies extrabet, s. longioris avidiligentia. 


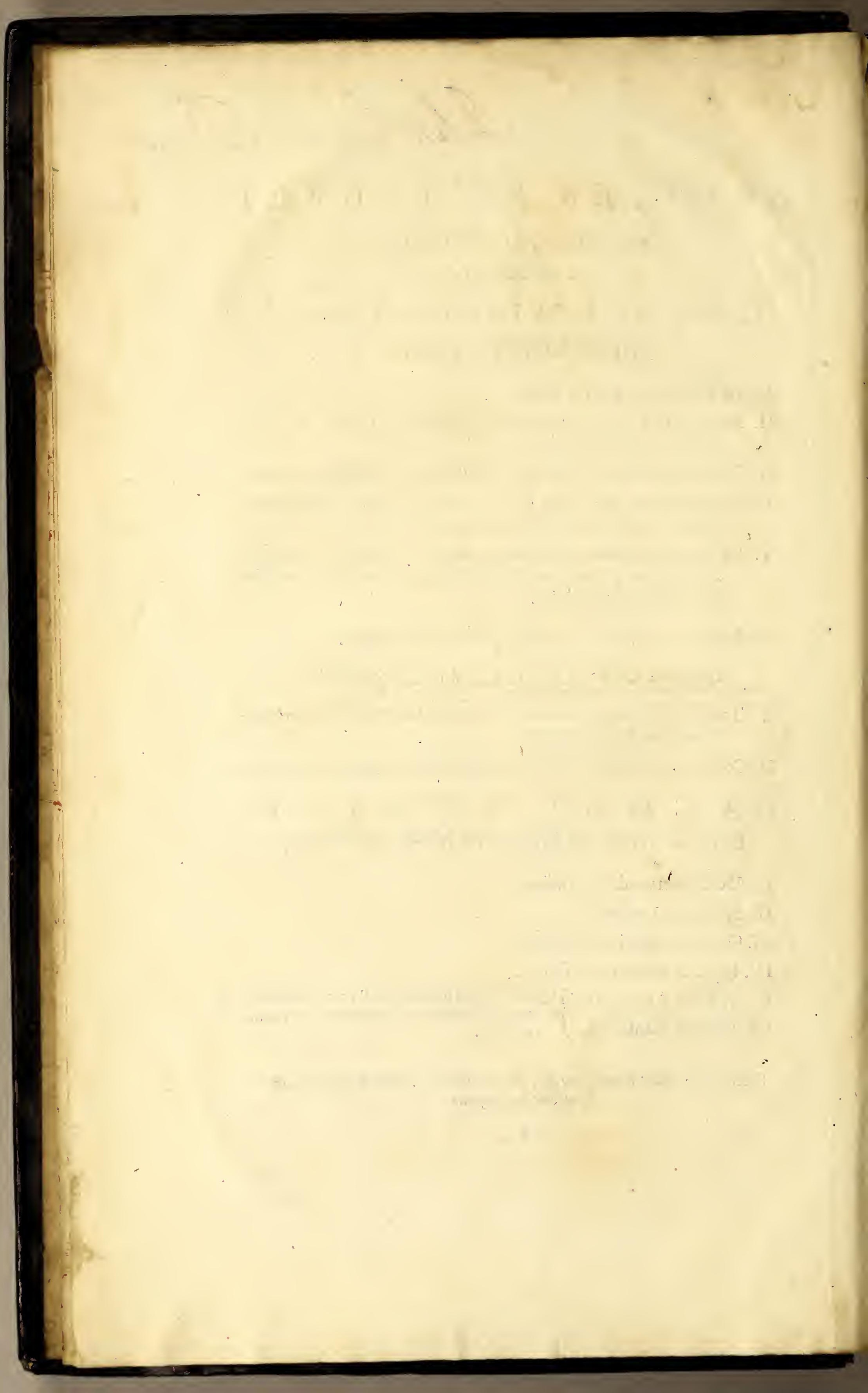




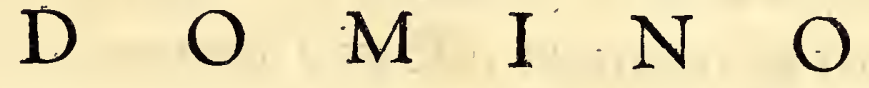 \\ F R I D E R I C O \\ G U L I E L M O:}

DEI GRATIA MARCHIONI BRANDEBVRGICO: S: ROM: IMP: ARCHICAMERARIO ET ELECTORI: MAGDEBVRGI: BOR VSSI A: CLIVI $A$ : I VLI E: MONTIVM: STETIN: POMERANOR: CASSVBIOR: VANDALORVM: ET IN SILESIA CROSNA AC IAGERSDORFFII DVCI: BVRGRAVIO NORIBERGENSI: PRINCIPI HALBERSTADIENSI AC MINDENSI: COMITI MARCÆ ET RAVENSBERGI: DYNAST I IN RAVENSTEIN: \&C.

SERENISSIME PRINCEPS, ELECTOR AVGVSTE:

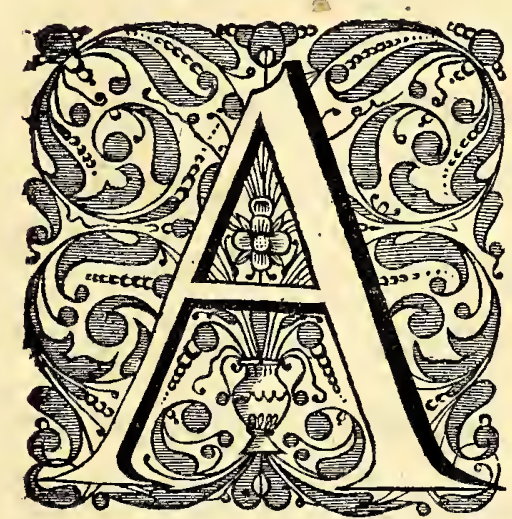

Vgufta res eft Hiftoria Naturalis, utpote eifdem, quibus hoc Vniverfum, terminis comprehenfa. Quo ipfo conftare arbitror, quantx molis opus fuis fibi humeris imponant, qui eam pofteritati tradendam fumunt. Fecit olim, \& tam felici fucceffu, quam ftupendo aufu, Plinius major. Etiamne perfecit? Certe non potuit: non fatifcente animi qua facile vel alterum valuiffet Orbem complecti, magnitudine; fed deficiente rerum materia. Defectus illius caufa fuit, non una; potiores tamen dux. Altera, quod Indix, jam tum notx, non fatis tamen effent cognitx, nedum perfpectx. Vtpote adiri folitx, non mari, non pace, fed terra atque bello. Quorum nihileffe aut ifto difficilius atque mille difcriminum plenius, docuere integri per fo* 3 litudi- 


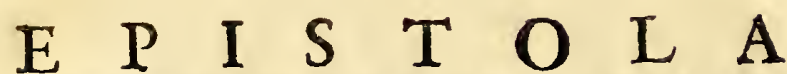

litudinum vaftitates $\&$ omnium rerum egeftatem deleti exercitus: aut illo inimicius fcientiarum propagationi, omnium temporum hiftorix loquuntur; ut ne dicam, experientia quotidiana. Altera, quod major terrx pars, univerfa America fcilicet, fpiffisignorantix tenebris involuta, velut in Chao deliteret. Qux temporibus avorum reperta, patrum detecta, noftro luftrata, præbuic uberrimum prifcis adjiciendum copix rerum cornu. Quarum quia ipfe non contemnendam partem fui \& infpector \& notator, fub aufpiciis Illuftriffimi Io. Mauritii, Naffavii Principis, \& Brafilix, terra marique, Prafecti, Turque nunc Celfitudinis ad Imperii Comitia Legati, certe non debui hoc talentum, quod mihi Deus ad enarrandam gloriam fuam concre. didit , abfcondere, \& fervum me facere inutilem. Quod à me amoliri crimen fatagens, coepi ex obfervationibus illo tempore collectis concinnare Hiftoriam, cum Naturalem, tum Medicam, eorum, qux Occidentalis India fuo in finu fovet falubria humanx faluti. Qux nunc, cum Orientalis Indix defideratis Naturx thefauris fimul in lucem prodire geftiens, Sereniffimain Tuam Celfitudinem adeundam fibi putavit, quo fub tanti nominis non folum aufpiciis decus, fi quod habet, tue$\mathrm{ri}$; fed \& patrocinio ac favore tuta, facilius featque efficacius probare aliis poffit. Id vero audendum fibi tanto fidentius exiftimat, quo minus, prefentis feculi calamitate, \& perftrepentibus undique bellorum procellis, fecuri ac tranquilli feceffus conceduntur Mufis his, qux fanitati imprimis prodeffe, \& , fi fas eft dicere, fatalia ac dccretoria vivendi tempora, quafi novis rationibus propagare velle; oftendunt. Qua etiam de caufa, \& quod non interpretem fe corum, quxad fenfuum blandimenta ac voluptatum illecebras. funt excogitata, vel ad pompam \& often- 


\section{E D I C A T O R A.}

\& oftentationem vanam comparata, fed fimplici ftylo circa fummi Creatoris opera verfari profiteatur, indigna non debet videri, qux Tuum Nomen geftet in frontifpicio, \& fub tam auguftx infcriptionis tutela vivere ac vigere in oculis hominum defideret. Fuit illa prifeis feculis Regix dignitatis pars non infima, Cælique Terreque tractus \& Marium fpatia atque proprietates percontari, eorumque interpretibus bene velle; $\&$ combinatis pacis bellique ftudiis firmiorem ac beatiorem imperii poffeffionem fibi afferere : idque non adeo multa literarum peritia, quam ex vero earum ufu. Eruditiau. diebant Tiberius, Nero, Domitianus, aliique; maximo interim humanigeneris exitio nati. Trajanus contra \& Alexander, eorumque fimiles, etfi minus eruditi, lucem tamen vel imprimis mundo intulerunt. Eadem ratione recentiores inter multi Chriftiani Principes longe potentioribus prævaluerunt, \& $\dot{x}$ fupra Mortalitatem fe tantum non extulerunt, potentix femper animi cultum adjungendo, \& ad fuam fuorumque falutem, in omnibus ceu Cynofuram intendendo. Qux procul dubio cau. fa eft, quare omnium largitor Deus homines docuerit tot fcientias \& artes, ingenio item \& fapientia atque prudentia inftuxerit. Tu certe, PrInCEPS CELS I S S I M E, qui copiis, \& imperio tam late patenti, non vi \& fanguine quxfitis, fed ab avis \& atavis longa ferie, veluti per manus, traditis, ac vigore animi corporifque carus fimul \& fufpiciendus factus, magnum \& illuftre ejus exemplum præbes, dum premendo majorum veftigia,tantarum felicitatum cumulo, tanquam colophonem fuperaddere illam fapientix partem contendis, qux in contemplatione operum Deinaturalium confiftit. Quod inCelfitudine Tua ftudium procul dubio non parum promovit, recens ejufdem commatis documentum Illuftrif- 


\section{EPISTOLA DEDICATORIA.}

fimi Io. Mauritii, qui publicx omnino falutis intereffe exiftimavit, fi impofterum Europxis non lateret, quam longe lateque per univerfum terrarum Orbem diffufa fit immenfa rerum Natura. Quod ut effectum daret erectioris animi Princeps, inveftigationum difflcultates fumptibus fuis $\&$ auctoritate non folum fublevavit olim in India Ocçidentali; fed \& omnes illos, qui agricultura, venatu, aucupio, pifcatu vitam tolerarent, mihi parere juffit. Quid mirum, fi tanti Heroïs ftudium atque favor me inflammarint, ut \& volumen hoc ad umbilicum perducerem, \& confectum atque meliori cura excultum, additis quamplurimis, hactenus aut incognitis, aut neglectis, neque tumido aut precipiti conamine in umbra excogitatis, fed propria ut plurimum experientia atque ufu comprobatis, ad Tuos pedes deponerem. Quod fi fufcipere dignaberis, perque otium infpicere, \& vel umbra favoris Tui profequi, certe nihil vel auctori optabilius vel operi honorabilius evenire poterit.Quod fupereft, DEv $\mathrm{O}_{\mathrm{p} \text { T. }} \mathrm{M}_{\mathrm{Ax}}$. veneror, ut Celfitudinem Tuam impleat omni benedictione, profperitate, felicitate.

\section{SERENISSIMÆ \& AVGVSTE}

\section{CELSITVDINI TVE}

Devotiffimus cliens

GVLIELMVS PISO. 
GVLIELMVS PISO

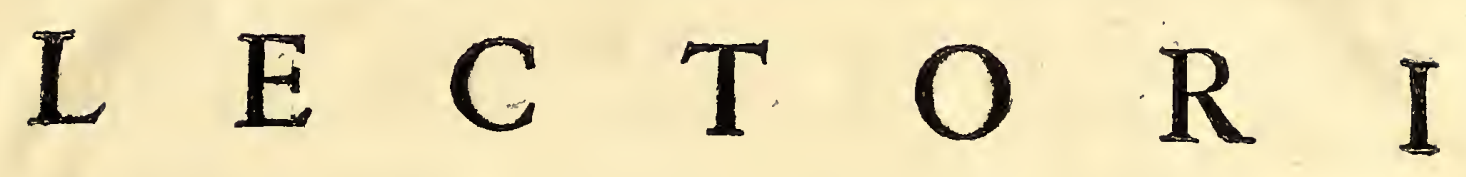

S A L

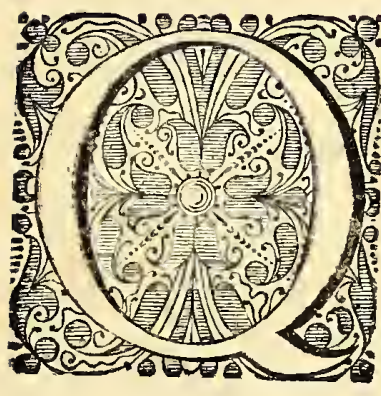

Vanto cum molimine, ac vite difcrimine olim majores noftri extremos mundi cardines per immenfa marium Jpatia adierint ac lufrarint; quantaque etiam nun regnandi rabies, \& auri facra fames pectora mortalium accendat ad fubigendas Orientis \& Occidentis Indias, neminem latere opinor. Verum quanto contra neglectui permulta fupenda Dei \& $\mathcal{J}$ Cature opera, in terque ea infolite marium foderumque imprimis reciprocationes $\sigma$, quese inde flunt, birtutes inferiorum moderatrices, fubjaceant, illi potiffimwm experiuntur, qui lucubrationes fuas Thy fcas pofteritati reponere, \& tante novitatis arcana morbis medendis applicare geftiunt. Cum porro cujufcunque ingenui Hiftoringrapbi fuproma lex \& cura fit, veritatis fe antifitem prebere, \& illa omnino evitare, qua genuinam reigefte, \& pari ratione in ea, quam nos jam tractamus, materia, nature faciem obfufcare poffont : nibilominus id genus friptorum ob tantam rerum caliginem in fcopulos facile impingunt; unde quidem errores preter opinionem propagant, imo etiam fublefte fidei fujpicionem incurrunt, imprimis fa aliqua, vel citraveterum auctoritatem, vel fupra confuetam nature bim \& ordinem facta exponantur. Que omniatantum abeft, ut me ob rei difficultatem \& argumenti novitatem à propofito abfterrere potuerint, ut materice illa ip fa novitas ac difficultas, propter utilitatem \& dignitatem, animum addiderint. Prefertim cum non alience fidei vel fame (que tam ficti so provi tenax eft, quam recti con(cia) Jed Jenfurm fabilitus fuffragio, quecumque ex ampliffimo illo $\mathcal{N}$ ature Theatro vel ipfe obfervabi, vel d̀ veteranis indigenis accepi, examini of praxi fubjecerim. Indignum quippe non tantum. fed o deteftabile effe autumo, in re feria, \& in qua tot bominum Salus verfatur, ea docere, que experimentis baut congrumnt, vitamque egro- 


\section{P R E F A T I O}

iorum ob inanis gloriole aucupium exponere periculo pofjunt. Ideoque, ut telam banc felicius pertexerem, partem oneris deribaram in domeficos meos, pre ceteris in doctiffimum \& diligentiffmum D. Georg. Markgravium, Mathefros \& Medicina candidatum, quem in Indias mecum adduxeram, ut, preter exercitia Aftronomica of Geograpbica, penfecu. late obfervaret externas potiffimum fguras illarum rèmm naturalium, quarum ego virtutes internas pra fidiaque medica firmandae vel refituendevaletudini nata, follicite experirer. Animalium denique, \&o avium ac pifcium exta crebris Sectionibus luftravi, tandemque aviis terrarum peragratis nulliufque antè pede tritis, imagines ad vioum à pictore, mecum

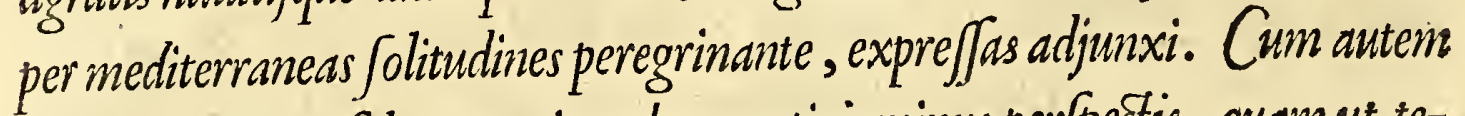
nibilfrequentius foleat evenire rebus exoticis minus perjpectis, quam ut temere, vel ad uperfitionem u que extollantur, vel infra meritum depriman. tur, \& abjiciantur: omnino intere fJe putavi, quo ne confusa Mu Jarum fupellex apud cibilioris note populos profituatur, ut, id quod ante decennium in editione Hiftorice $\mathcal{N}$ (aturalis Braflice (nimis precipitanter, per meam a prelo abfentiam in hicem protrufe) promiferam, nunc tandem praftem; fcilicet utilia ab inutilibus, vera a dubiis of Juperftitiofos, falutaria a noxiis feparem: tum, ut ea fimul promam, qua difficilioris argumenti, of altioris indaginis, in fchedis bactenus meis, ob enarrata impedimenta, delituerant. Quod an pari facultate perfecerim, qua alacritate Jufeperim, aliorum erit judicium. Quidquid fat, ego amoto ornni fcrupulo, tandem laborem bunc, licet dias fatis occupatus, fubivi, folidifque rationibus commotus, fatius fore duxi, paucis quibufdam difplicere, quam magnorum eruditorumque virorum defideriis non fatisfacere. Etenim im. muni a cacoëthe fcripturientis avi animo bec, ad ulteriorem rerum cognitionem acquirendam, veternumque ingeniis excutiendum, exbibentur. Pre. fertim autem, cum tot iuotidie Europai Indias peragrantes, atque per commercia perpetua peregrini cum indigenis infinita in ufum bumanum cominutantes, fruftra tomen beatitudinem ex earum divitiis quaritent, nifibona ac vitce utilia feligere, atque nocitura vel imprimis fugere do declinare didicerint. Tantum vero abeft, ut vel ab Indis petita Aromata, vel ab externis accepta populis remedia; putem nofree domi natis pre. ferenda, 


\section{A D L E C T O R E M.}

ferenda, ut potius exiftimem, ubique gentium majorem babere cum bumana natura confenfum, \& plus in eam poffe, quxe propter folum calumque commune illi funt familiariora; 6 eapropter effe turpius in bis, quam in illis crecutire. Certe nulli, ut egregie Comelius vere Celfus obfervavit, adeo fe $\mathcal{N a t u r a p r a b u i t n o v e r c a m , ~ c u i ~ n o n ~ u f f i c i e n t i a ~ e ́ s ~ m e d i c a m e n t a ~ o f ~ a l i - ~}$ menta Juppeditaverit. Quo ć alluditillud Regum Sapientiffimi: Credbit, uteffent omnia ubique, \& Sanabiles fecit nationes terrarum. Verum perpetuus ille diverfarum undique gentium concur fus \& mutur focietas effecerunt, ut vix aliqua reperiatur terra fuis contenta bonis, of que non, Jub neceffitatis pretextu, omni prene luxu \& intemperantia, byberno velut fla$t u$, fat occupata. Vide tandem pertinax confuetudo obtinuit, ut exotica fimulac patria pari zelo, tanquam vite \&o valetudini twendee unice nece $\iint_{a}$ ria, promifcue expetantur.

Quod cum ita fat, ego, quo multis fmul prodeffem, conterranei mei $T_{a-}$ cobiBontii, olim in Batabia Nova Medici primarii, Schediafmata baEtenus Sepulta ablattis tineifque vindicabi, atque fomul curas ejus priores $\&$ pofteriores Operi buic affociavi. Primo, ut defuncti tum cineribus jua redderentir, tum memoric debita perfolverentur promia. Deinde, ut ipfius Iave \& Braflice (qua utraque fub ejuldem quafi latitudinis gradu pofita eft) dona Salutifera juxta fe pofita clarius eluce fcerent, atque inde cuique innotefceret, in quibus vel difcrepet vel conveniat Oriens ab Occidente. $\mathcal{X}$ (am, fecut multre Indiarum partes circa naturalia inter fe congrumnt, licet ratione fitus toto colo differint: ita \& vicini earundem loci Juprafidem aliquando difcrepant, \& peculiare quid pra fe ferunt, quamvis videantur primafronte maxime inter fe concordare. Quod/scui infituta-comparatione videbitur Bontium pre nobis felicius aliqua, tum animalia, tum vegetabilia cum Europais contuliffe; eum cogitare velim, illi, non mibi glaciem fuiffe fractam: illi Afaticam antiquitatem obftetricatam, mibi nil nif 2 Coni Orbis ip frffmam barbariem novercatam fuiffe. Vnde \& neglectum fyli nitorem ipfa facile argumenti afperitas excu fabit, cum $\mathcal{N}$ Cature indagationis quam elaborate Orationis potior mibi cura fuerit. Quamobrem mercibus bis bederam appendere nibil neceffe eft, multo mimus in editione po/thumi Bontii foetus jejune fuperbire, quum folummodo 


\section{PR EFATIO AD LECTOREM.}

parentis lufrici vices fubivi, ne quid illi temere accederet aut decederet. Quippe etiam 6 ob immaturam Auctoris mortem non omnibus partibus perfecte conformatus prodeat, tamen ex eo facile patebit, quam

$$
\text { tenui rerum fub imagine multum }
$$

Nacura fatique fubelt, \& grandis origo. Annotationes antem \&o Appendices per me inferte \& Latinitate donate, if fidiffemis Indice Orientalis Prafectis Juppeditate funt, quas illi ab exer citatiffimis indigenarum Medicaftris obfervarunt.

Siper qualecunque boc opus, combinatis viribus peractum, remotiffimas Afice do Americe celi folique regiones à crafjes illis ignorantice nebulis paulatim vindicatas, of fic aditum ad meliora factum cen fueris, Satis fuperque boc labori noftro pramii arbitrabor. Etenim quamvis admirana dam univerfe $\mathcal{N}$ (ature ceconomiam, ejufque occultos confenfus, pro majefate Divini Artificispenetrare bumana conditio non ferat : attamen, ex quo erudita indufria in rimandis Macrocofmi \& Microcofmi vi]Ceribus occupari copit, baut poenitendos exinde fructus ad bumanum genus quotidie redundaturos, inficiari nolent, nif quibus efficacia erroris \& ignorantixe impofuit, vel male feriata mens veritatis \& f fientiarum imperat contemptum. 


\title{
CONSTANTINVS HVGENIVS
}

Eques, Dominus Zuylichemii \& $\mathrm{c}$.

$$
\text { I N }
$$

G VILIELMI PISONIS, D. $M$.

\section{Indiarum Hiforiam Naturalem. LECTORT.}

\begin{abstract}
610. 6 (3) Mpiger extremos fuge, vel fpectator, ad Indos
Currere; res facta eft futilis ifte labor.

Prson I placuit quidquid fub cardine nafci

Sciverat Eoo, viderat Occiduo,
\end{abstract}

Sic Belgis praftare fuis, quafi pareat uni

Naturæ prope nos \& procul imperium.

Ecce breves Tabulas majeftas extera rerum,

Vno fic Batavo precipiente, fubit;

Vtraque ad Amftelias accerfitur India ripas;

Vtraque quas juffa eft promere promit opes;

Promit opes, quas fida bonas, infida nocentes.

Terra dat, has fugias, filicet, has ut ames,

Hic ftupeas, ubi nacta novas animalia formas

Gaudeat inventis Nafo favere fuis.

Nec tamen hoc Tabulx, Lector, ne fallere, dirunt,

Sola nec has vires muta papyrus habet:

Quod fpectas nihili eft; has quà facundia tanti

De tota meruit pofteritate Viri,

Has Tabulas reverenter habe: praftantior omni eft

Icone qui docto manat $\mathrm{ab}$ ore lepor:

Hoc duce deductus per tot miracula grandi

Materiâ, dices, grandior ifta manus.

CONSTANTER. 


\section{THEODORI GR ASWINKELII,}

E Q V I T I s \&c.

Ad Belgas Juper editionem Hiftorice $\mathcal{N}$ (aturalis

\& Medice adlocutio.

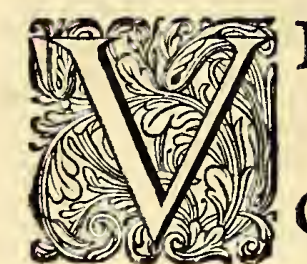

Eftigatricis fublimia munera curæ,

Depofitum cxli nobile, B E L G A tenes:

Quique vides diteis quas fufficit utraque gazas

India, fe cumulis addere rite tuis;

Omnem in Naturam penetrantis acumina mentis Ingeniique fimul judiciique ftupes.

Optima fumma foves : nihil hic nifi præmia defunt:

Hæc Themis, hæc Mufx, Numina cafta, velint.

Tollat prima Deus, fuccedat in altera, rerum

Dia parens: primus proxima $\mathrm{P}$ i so ferat. 


\section{A L EX A N D R MORVS}

Ecclefiaftes é Jacrarum litterarum Profeffor.

I $\mathrm{N}$

D. GVILIEIMI PISONIS,

De Vtriufque Indix Re Naturali \& Medica,

L I B R O S.

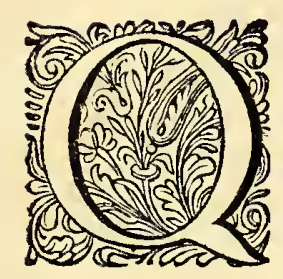

Vis nopus bic Myftes Nature arcana parentis

Elatebris dias in luminis eruit oras?

Que certat cum Sole manus? quod pagina nomen

Prefcribet, $f$ promit opes, quas condit Eoo,

Condit of Hesperio flagrans Jub cardine tellus?

Quod nifi Pis on Is, vel A P O I I I Is ? auctor Apollo

Paonii, Aoniique Chori, Medicaque repertor

Artis, amoenarumque Pater. quem $\mathrm{P}$ is o Sacerdos

Non fimplex bis rite colit, Mufffque Salutem

Confociat felice jugo: mea gaudia P I s o;

Delitie Phobi: non or Pblegetbontis avari,

Quem Ditem nimis effe petat, vacuumque relinquit

Quà datur; or magis atque magis deludit biantem:

Evocat ille animas mediis ex faucibus Orci

Pallentes: fatisque moram, quis credere pofit?

Injiciens, reddit Superis, of luce redonat.

Non babet ille parem docte dulcedine linguse

Multiplicique fono. Seu prisce nobile gentis

Eloquium, noftrumpe petis: Jeu nomina prifco

Et pariter noftro placeant incognita feclo.

Doctor adeft, aperitque libens quod maximus olim

$\mathrm{Ne}$ fciit Hippocrates; non ipje Epidaurius beros,

Pbabigenaque duo: charos docuiffet alumnos

Talia, fed P I S O E prior nefcivit Apollo:

Si qua fides, ipfas fugiunt tot barbara MuJas, Surdaque, nec vulgo tantum ignorata profano Mille fed utilium peregrina vocabula rerum, Pane timenda fono, guttur lefura loquentis: Res tamen ipfa magis guttur lafura bibentis; 2uam bene! fivitam fugientem in pectore fiftat.

Non ego, qui teneras cantu demulceat aures, Mellitos globulos, of parfa papavere multo $V$ erba, fed agroto minus auxiliantia fundens, $V i$ cera cum febris torret fitibunda, requiro: Hunc volo, qui pollens facunde munere lingus, Intempeftious non utitur: wtitur berbis, 
Et morbos paribus tetros medicatibus arcet. Dulce fonat, fo que potuit conferre falutem Vox mibi: Cannibalum quamvis fit nata Jub oris, Magajataf pe inter duros, es pinguia labra Tuppinaquîm, facili verfu quos dicere non eft, Pattagonafque truces, or nudos membra Tapuyas.

Hos ubi per populos Victoria leta vebebat

M A V R I I I v M Heroëm, bene tu comes additus ibas, Corporis Augufi fervator, or axe fub illo $V$ tilis baud raro monitor, cufto fque Salutis. Ille fed indomito dum pulfat robore Solem Occiduwm, or fufco nigrantes reepere frontes, Brafiliaque domos, ơ forti vulnera dextrâ Hofibus imponit Patric, tu vulnera queris Quo pacto Janare queas, vire que fub illo Plantarum, fuccofque niotas, ¿o femina calo: Sic redivino aderas Chiron redivivus Acbilli.

Pugnat M A V R I I v s, dat leges, oppida condit, Barbaricis fulgens spoliis, lawrof que recentes Invenit Orbe Novo: tu bellum indicere morbis Ausus, in bis ipfis collecto milite campis Gramineo, or tanquam telis radicibus ufus, Fébriculo a fugas procul agmina: Sava malorum Peftiferûm dat terga cobors: prenuntia lethi Victa jacet legio, debellatique dolores:

Ip $\int e$ Ducem victor Sequeris, pariterque triumphas, Nec minus aterna pracinctustempora lauro.

Nam, quod pace tua liceat mibi dicere, Sanguis N A S A V IV S, qui nunc ad Moeni fuminis oram Imperio quaris Caput, to de Cafare certas: Magna tui fuperant illis veftigia terris Et manfura diu: tamen avum proferat ultra Cognatum PIS ON IS opus. fundataque moles Regifico luxu, $\sigma^{\circ}$ nigris fivdata lacertis Hoc durante cadet : que tu fafigia calo Eduxti, or vario pofuifi fplendida ligno, $V$ ndique marmoreis centum fuffulta columnis, Multum Tamarica, multum admirante Paryba, Tandem aquata folo tempus feret: atraque faxis Mors reniet: non buic veniet, me judice, charte.

Donec erunt morbi: dum Solem promet ab ortus Memnonis almaparens, Thety fque fub aquore condet, Pis ONIs mea Mufa mei celebrabit bonores, Vivet inocciduo Pr $\mathrm{s}$ ON Is gloria Pbocbo. Nec folum extremis, qua Sol oriturque caditque, Gentibus à toto divifis Orbe, fed Orbis 2 Qù patet, inluftrans mortalis conmoda vite, 
Non Batavis tantum, patrieque falutifer ore, $V i v e$ Liber, mundumque levans of fecula morbis.

Tuque adeo, quem non lucri malefana cupido Compulit, aut fulva pretiofum littus arena Ire per Aurore thalamos, Solifque cubile: Qui nec pallentis penetralia caca metalli Effodis, ¿r quicquid prudens Natura recondit Sub pedibus, meliusque latet, producis in auras, Tot fcelerum caufsam: fed quod Nova Terrabenigno Extulit efficditque inu fub Sole propinquo Accerfis, noftrofque bonus diffundis in ufus: Non piper, aut cafus lacrymans opobalfama cortex, Non Americcana qui manat arundine fuccus, Hyblaum fuperans nectar: tot pabula iuxus, Et recte gladioplures occidere dicte

Scitamenta gule, merces tibi Jumma laboris: Humani fed amor generis, fudiumque juvandi Egit in ignotas alio fub fidere Terras, Trans Indos, extraque vias or Solis or anni; Ac mirum in varias fingens animalia formas Nature ludentis opus: populifque falubres Arborei foetus: invifaque littore noftro Squamigeri gens uda gregis: nec dulcibus berbe Indolis infolita purgantes vifcera fuccis. Magne opifer; $\sqrt{2 c}$ leta fuant tibi tempora vita, Fortunate operum! certe digniffimus unus 2ui fuit in Batavis Phobi exornare Lycaum, Seu quà Rbene fluis, feu qua Padus amne Juperbo Labitur Euganeis, feu quà mons Pelion ardet: Si non Amftelie probiberent otia terre Aurea, totque falus populorum, or gratia florens, Nec Procerum Spernendus amor, fanctique penates.

Hasego P I S ON Is laudes, laudefque medentum Ex animo cecini: noli dubitare legendo:

2uifquis enim dubitat, verbo mibi victus abibit: Audiat boc unum, quefo: dictavimus agri.

Ex grabato meo Proprid.

Kal. Jun. ARE VvLG.

A. M DCLVIII. 


\section{FRA NCISCVS DE VICQ,}

M. D.

Ad Collegam fuum

\section{G. $\mathrm{P} I \mathrm{I} S \mathrm{O} \quad \mathrm{N}$ E $\mathrm{M}$.}

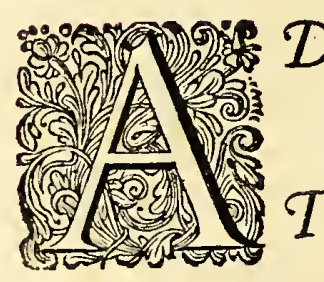

Dmiranda, ftum, mores, populo'fque locofque Braflice tractîs nofcere quifquis aset: Te legito. Dicet: Oterque quaterque beatos!

Quiviffent Batavi fa Juanoffe Bona. $\mathcal{N}$ unc quid no/fe jurvat? Lufi dominantur in oris, Quas chartis P I so tollis ad aftratuis. Attamen bec olim for fan fcripfff]e juvabit;

Vt fimulent Batasi Vindicis arma, manus. 


\section{I $N$}

Hiftoriam Naturalem es Medicam

A

\section{G VIL I E L M O P I S O N E}

\section{Confcriptam}

\section{E L E G I A.}

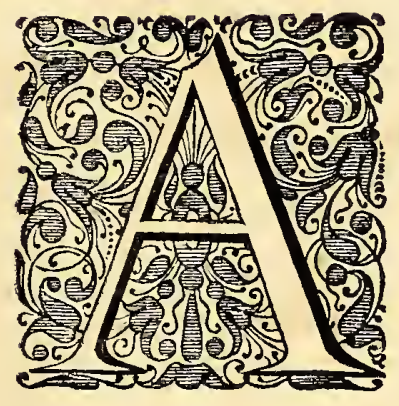

Via mutandis dum mercibus aquora ferpent, Que lucri cupidâ puppe Batanus arat;

P I s o meus (non ille fequi mortalia natus)

A fragili tutas tempore captat opes.

Hoc vehit Occiduo polium predator ab Indo:

Has illi exuvias victa paravit bumus.

Quamlibet immenfum non fruftratura laborem

Premia mercedis fert dator ipfe fux.

Incitat bortatrix, validumque, capacia laudis

Pectora quo fimulet, Gloria calcar habet.

otia Letbaầnil diftant forte, quie que

Turpibus affimilat nos taciturna feris.

Carpere fecla labor Superis parcentia folis

Nominis aterni conciliator amat.

Vixque favet votis Sudore carentibus attier,

Ardua plus bumili quem prece capta movent.

Ignea mens natale folum fibi vindicat orbem,

Et patrio Jpatium pro lare Solis babet.

Sic adite magno fe jactant Hercule Gades,

Et frabula Heperii Geryonêa boves.

$\mathcal{X}$ (ec Bacchum fua cepit bumus. vos cinnama teftes,

Thuraque, longinquo munus ab orbe datum.

2uod fuit Atride medicis Podalirius berbis,

Sevaque conflilio bella regente, potens;

Luctantem exagitant dum longa decennia Troiam:

Id tibi, Naffavi maxime, P I so fuit.

Pis o Jagax, Natura twos fugitiva recefJus,

Et tacitâ cecos pandere nocte finus; 
Belligeri comes arma Ducis non victa Secutus,

Pracipites Pbabi quâ rota mergit equos.

Dumque per optate difcrimina lucis emendas

Et rapit, or raptas quifque recondit opes;

Duxque triumphator dum diruta Marte Batavo.

Menia dat flammis, Nerea claffe premit;

P is o Machaonia meditatur pralia lucte:

Fauftaque cum Lacbefi, cum Styge bella gerit.

PISONEM fama fitis intempefta fatigat:

Cura viro foinnos effecit illa breves.

Hec trabit, hac fudio victoria quaritur omni,

Palniaque, Jed nullo facta cruore nocens.

Iamque fub examen, quodcunque dat Indica Tetbys,

Mittitur, or tellus barbara quicquid alit.

Vt neque fit regio pretiofis orba metallis;

Gramine nec campi, fruge nec arva vacent:

Arceat ut nimism denfa nemus arbore Solem:

Equet arundineus cerea mella liquor:

Prapete quam variâ tranetur Americus ä̈r:

Obfeffam coluber Jente quis adflet bumum:

Quadrupedum faltus ut inundet turba ferarum:

Bellua pifcofas que populetur aquas:

Plaga quibus fuccis, vel ab aspide fixa vel arcu,

C'edat, or in certam febris itura necem.

Denique conspicui fi quid novus educat orbis,

Pectora non pigeat quo fudiofa capi.

Morborum domitor, Natura Myfta latentis

Intime, que titulis Mufa fit apta tuis?

Laudis avaritie qui mentem raptus bonefte,

Nulla quod evertant $\int a c u l a$, condis opus.

Vifcera qui rerum rimaris inbofpita: per quem

India jam noftra non peregrina domi eft.

Sic te dos celebret non unica; fine potentis

Eloquii, medice fine fit ufus opus:

Te lector volvatque frequens, placitumque revolvat;

Rara nec annumeret bibliotbeca fibi.

Piso, pater Venerum, cor amabile, Piso, Leporumi

Seria five libet promere fove jocos:

Pectora fordentis non fracta cupidine lucri

Altius bumaná fer Juper aftra ciá. 
Quod facis, afjuetam jam plaufibus erige mentem,

Mnemofyne quo te laudis amica vocat.

Ipje tibi prefta, fenium lature, medenti,

Plurimus acceptam quam tulit ager opem.

Longum iter extremos cum fis molitus ad Indos,

Pagina conficiet plus tibi docta vie.

Huic nil per terras, per terris latius aquor,

$V$ aftus, inacceffum, qua patet orbis, erit.

Indue barbariem domitura nepotibus arma:

Naviget exemplo poftera turba tuo:

Cedat amans latebras infcitia: cedat, iniqus

Pallada qui Livor rodere dente folet.

$E$ debellato conspectius bofte tropaum

Nemo tulit. Dusx boc non neget ipfe tuns.

NICOLAVS ...HEINSIVS, DAN. F. 


\section{Ad \\ GVILIELMVM PISONEM,}

M. D.

Cum fore Opus hoc juris brevi publici,
ex itinere forte inaudiviffem.

E L E G I A.

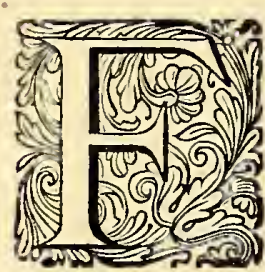

Ando aliquid, Vir fumme, meas pervenit ad aures, (Perplacuitque meis auribusille Sonus)

Te fuperaturis in fecula tradere chartis, Occidui, Eoi cardinis Hiftoriam.

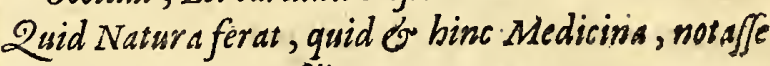

Dicere, Natura filius atque parens.

Filius; illa dedit genium tibinempe : parenfque; Scilicet, in lucem quod venit illa, tuum eft.

Viveret , o, Pbryx ille, fuis animalia linguis, si qua fides, faciens cum ratione loqui!

Quadrupedes, bipedum mifti, mi PIs o, catervis, Proferrent laudes voce repente tuas.

2uando creature, Medicorum Maxime, mute Deficiunt, bomines \& vocat ifte labor,

Primusinexhauftam celebraret Barbarus arteme, Si Latii poffet Barbarus ore loqui.

primus anbelaret mundo narrare, medelas Quot fibi, quam dextre fecerit ifta manus.

Primus anbelabam twa dicere, meque volentens Impulit in modulos fuet a Thaleia novos.

(Cunctorum licet illa foret bene confcia; cuncte Nam meminiffe queunt, of mernorare Dea)

Iam male tentabam deductum dicere carmen, Tardior o folito pes erat atque manus.

Miranti, quo forte forem vel fulmine tacius, Carmine vel Magico mens mibi tact a foret,

Adfitit, \& torvum ridens mibi Cyntbius aurers Vellit, \& admonuit, increpuitque Lyra.

Tune velis, inquit, tot oloribus anfer adeffe, Tune interftrepere hos, fridere tune velis?

Debeat Hugeniuste deterrere: nec unus; Inftar cunctorum fit licet ille tibi.

Ille, alii plures, quorum veftigin adoras, Hanc merito laudem praripuere tibi:

Qui tot nominibus, toties fuperatur ab iftis, An decet hunc inter nomina tanta legi?

Sic pater Aonidums : tonitru fic tactus amara Vocis, Io, dixi, parce, o Apollo, precor.

si veriam, veriam fi nefciviffe meretur, Nefciit, \& Bruno defiit effe nocens.

Cum magnis nequiit am dicere magna; fatendum eft.

Sit faitis, in magnis quod voluiffe fat eft.

Sitames affectu primo poftrema probentur,

Non deceat me poft nomina tanta lggi?

Annuit, \& placido ridens jam Cynthius ore:

LVMINA TV POSSIS HAC, SED VT VMBRA, SEQVI.

HENRICVS BR V NO. 


\section{GVILIELMI PISONIS}

\section{I B R O S,}

\section{De utriugue Indice Re $\mathcal{N}$ (aturali \& Medicî.}

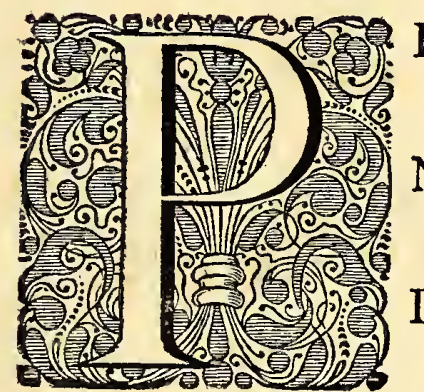

I s o peragrati promit miracula mundi, Clarior \& fero Vefpere Phœbus adeft. Non fat Naffovium fervaffe Heroa putavit. Profuit, excuflis omnibus, una falus.

Doctior indigenis, tenues, queis vefcimur, auras, Et necis \& vitæ fercula noffe dedit.

Dic: quando Indarum hæc congefta volumina Rerum

Evolviffe manu, lumine, mente juvat,

Et luftras gentes, geminus quas educat Orbis;

Brutaque, qux terras, aëra, aquafque colunt;

Et qux Vefta finu parit, \& penetralibus abdit;

Quxque notanda ferunt lucida regna Poli;

An te Natura diffufa potentia Matris

Plus capit? an nunc tot grandia corde capi ?

Cuncta prior perfpexit Adam, puri Arbiter xvi;

Dein Salomon, cui non æmulus alter erit.

Non erit: ut facræ produnt oracula chartx.

Primus, qui pandit plurima, P I s o redit. 


\section{E I' $\Sigma$ \\ $\mathrm{BI} \Lambda \mathrm{E} \Lambda \mathrm{MON} \Pi \mathrm{EI} \Sigma \Omega \mathrm{NA}$,}

\section{I' A T P O' N O Y' T YX O'N T A.}

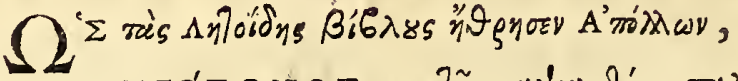

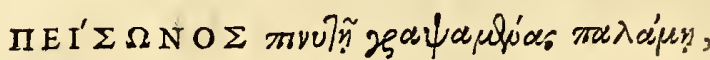

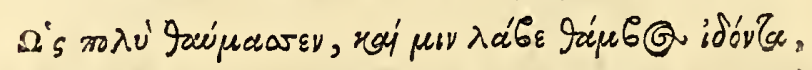

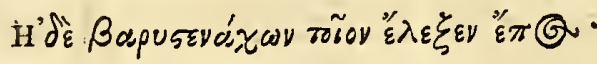

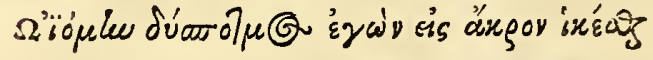

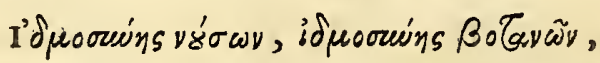

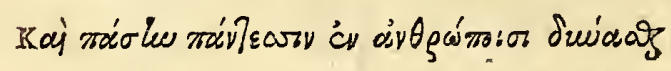

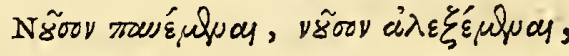

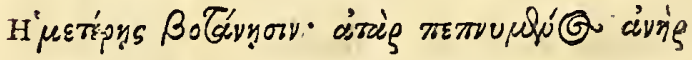

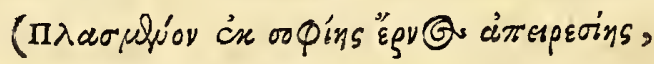

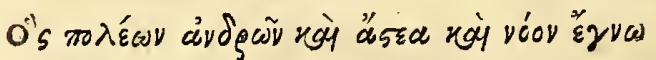

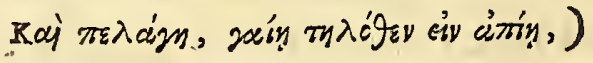

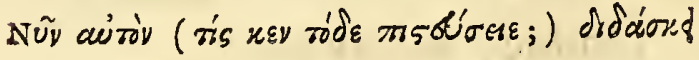

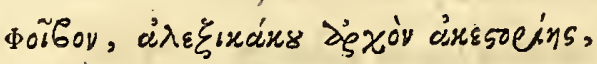

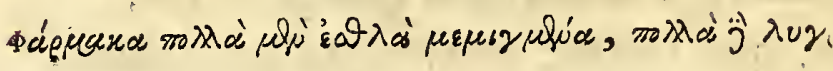

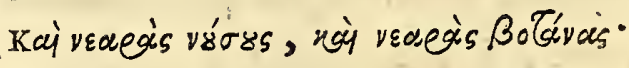

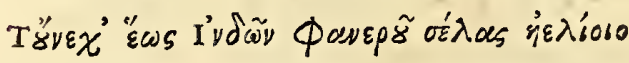

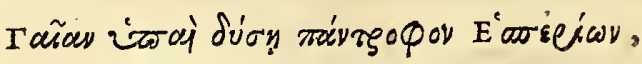

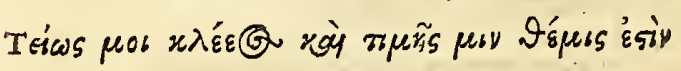

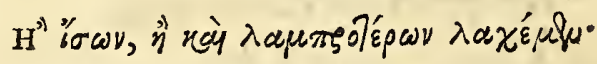

$E^{\prime \prime}$ :

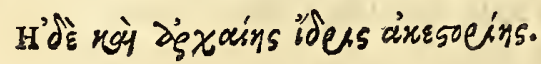

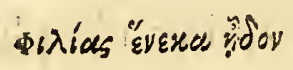

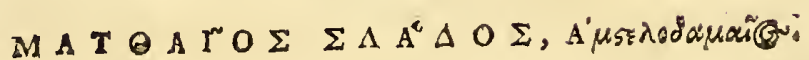




\section{GVIIELMIPISONIS,}

- Medici Amftelodamenfis,

H I S T O R I $Æ$ Naturalis \& Medicæ

\section{INDIA OCCIDENTALIS}

LIBRI 2VIN QVE. 


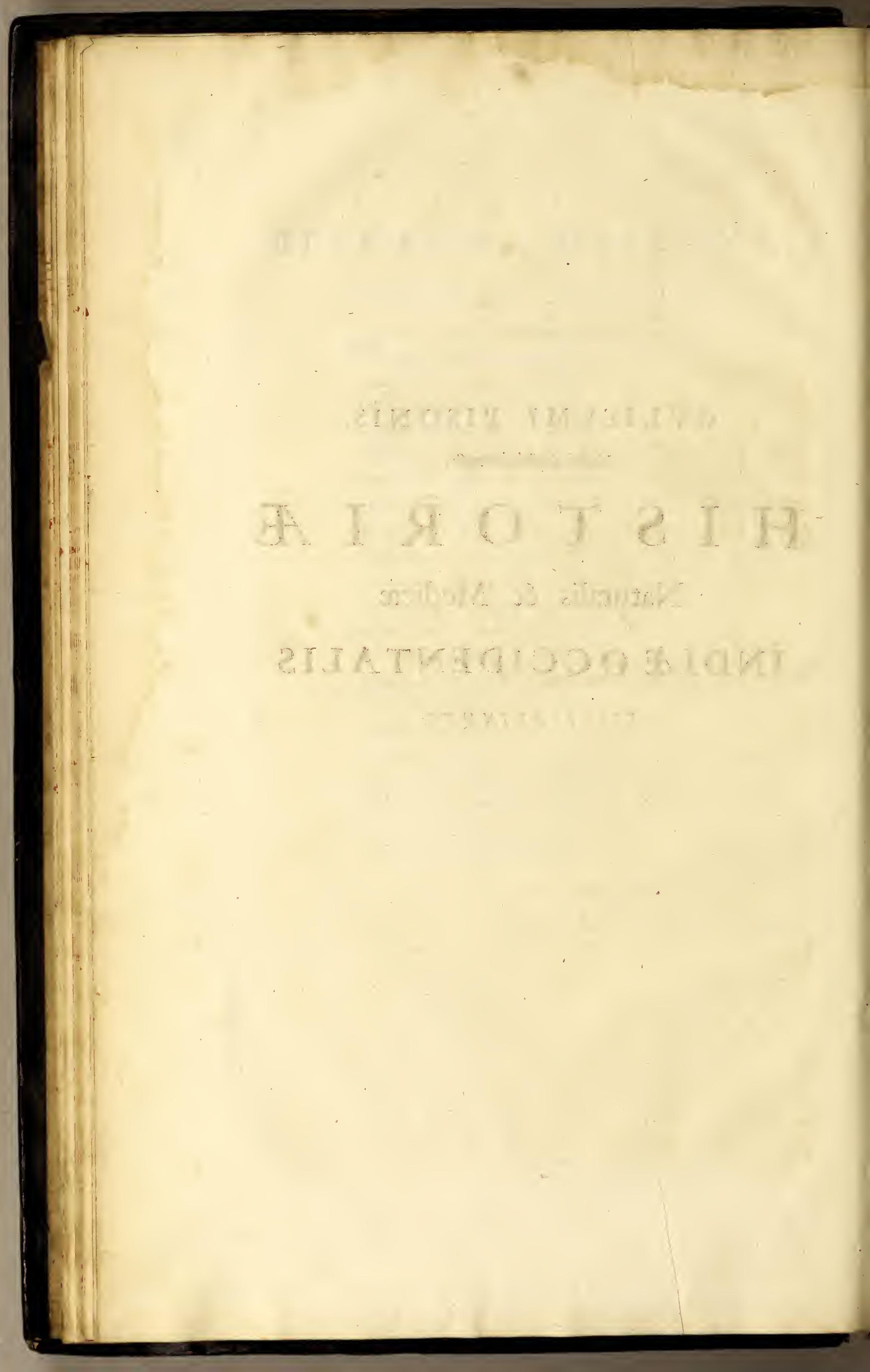


G V L I E L M I P I S O I S

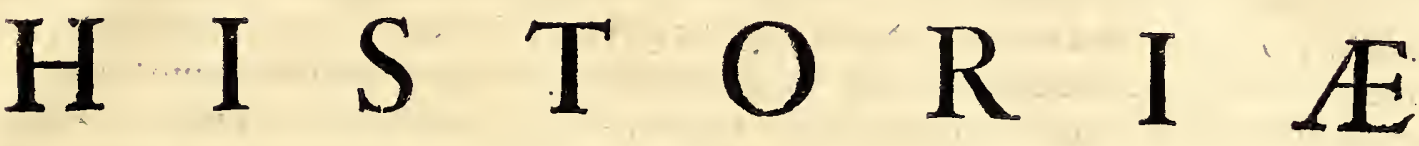

\section{NATVRALIS \& MEDIC曆}

\author{
$L I B E R \quad P R I M V S$.
}

De Aëribus, cÁquis, \& Locis.

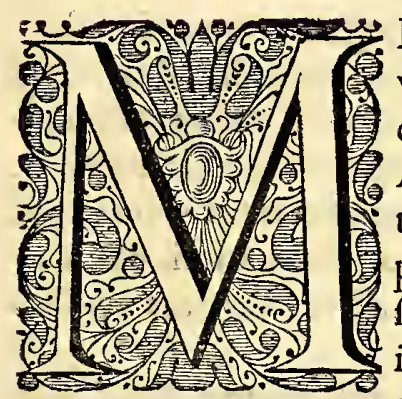

Edicinam ignotos inter homines feliciter five conftiturendi five faciendi aptior fabricari norma non poteft eâ, quam Hippocrates, omnis in arte boni auctor optimus, tradidit initio l. de Aëre, Aquis \& Locis. Quicunque artem Medicam, inquit, in- "s tegrè confequi volet, hæc faciat oportet. Primo quidem temporum anni rationem habeat, quid unumquodque illorum pof- « fit. Nulla enim in re fimilia funt; fed multum differunt, , tum $c$ ipfa ad invicem, tum in propriis permutationibus. Deinde ، etiam Ventos calidos \& frigidos, maxime quidem omnibus ho- " minibus communes, mox autem eos, qui unicuique Regioni funt peculiares. Aqua- « rum item facultates examinare convenit; Quemadmodum enim guftu differunt, \& $\&$ pondere : fic quoque virtute, alix aliis longe preftant. Quare fi quis ad urbem fibi ، incognitam perveniat, circumfpicere oportet ejus fitum, quomodo fcilicet ad velI- « tos, \& Solis exortus jaceat. non enim idem poteft, fi ad Boream jaceat, \& fi ad Au-cc ftrum; neque fi ad folis exortum, neque fi ad occafum. Et hrec quidem diligenter c oportet perfcrutari ; tum quomodo in aquis fe habeat : utrum paluftribus utatur $\&$ ، mollibus, an duris: five ex fublimi, five ex faxofo loco fcaturientibus : falfis item crudif- « ve. Terra etiam ipfa confideranda, nudane fit $\&$ aquis carens, an dẹfa \& aquofa : item c an concava $\& x$ ftuofa, an alta $\&$ frigida. Hominum infuper viotus ratio perquirenda, “ an bibaces fint an lurcones $\&$ otio dediti, an vero exercitiis corporis $\&$ laboribus aliis “ ftudeant, \& edaces, \& vini temperantes. Et ab his quidem fingula conjectare oporter. “، Nam qui hæc omnia probe cognoverit, aut certe horum plurima', in quamcunque “ urbem licet ignotam, ingreffus fueri, neque morbos ci regioni peculiares $\&$ pro- $،$ prios, neque communium naturam, quixcunque tandem ea fuerit, ignorabit : \& pro- “ pterea neque in eorundem curatione vel dubitabit vel errabit. Quorum utrunque illis ، evenire folet, qui non hec ipfa fedulo edoctus fuerit.

Quum ergo conftet, curari morbos non poffe, fine prævia cognitione, cognofic vero nequeant fine notitia rerum, quibuscum vivere homines confuerunt : omnino neceffe habeo, Medicinam Indiis \& imprimis Brafiliz congruam ex propria experientia traditurus, ad exemplum Maximi Medicorum, de Natura Cæli Solique ea præmittere; qux lectorem meum veluti manuducant in notitiam eorum, qux curationem morborum iftis in oris occutrientium propius concernunt. Quod vel ideo neceflarium duxi', quia fideribus mire faventibus \& regionibus fertilifimis omnino ac faluberrimis perperam folet attribui; quod erat vel incolarum vel advenarum intemperantix aut imprudentix : eorumque imprimis infcitix imputandum, qui in extremas \& incognitas mundi plagas abeunt, \& profeffione artis, falutis human $x$ facile præfidis, operam prattent mortalibus; Hippocratis interim præcepti immemores non raro deficiunt in fanitate curanda, five ea confervanda fit, five erigenda.

Brafilix Continens, ut maxima \& præftantiffima totius novi Orbis pars magno fuo merito cenfetur: ita, fi penitius introfipiciatur, non minus jucunda atque falubris deprehenditur. Adeo etiam, ut Aëris, Aquarumque \&Locorum cum temperie tum falubritate poflit cum quibuslibet Europ $x$ vel Afix regionibus certare. Situm quippe fi fpectes, figuramque, à fecundo circiter $a b$ Æquatore àd quartum fupra trigefinum laritudinis gradum excurrens longioris Trigoni fpeciem refert. Bafin habet ad Orientem: angulis Aquatorem \& Septentrionem fpectantibus. Ab illa Bafi in Occidentem 
recta porrigitur: ita ut Angulus extrenus ignotis ad Meridiem regionibus abforbeatur. Quod in Orientem fpectat latus, Hefperiis objacet $Æ$ thiopibus; interpofito vaftiffimo mari. Vnde eft, quod non minore valetudinis ac vitx commodo, quam animi oblectamento habitetur. Erenim tota cjus frons blandum \& benignum Subfolanum, ab auris matutinis natum, continenter recipit. Is mirum in modum homines cæteraque animantia demulcens, atque ab intolciabili Solis, vertici perpetuo imminentis, æftu vin: dicans magnum quid fanitati thend $x$ confert. Flatus ille, fiquidem accedat mare, fummo mane: fin recedat, adultiori demum aurora exoritur, totofque dies pervadit. $\mathrm{Ne}$ que enim, ut multis Indorum in locis, circa vefperam languefcit : quin intenditur adeo, virefque fumir eundo \& comitante Sole, ut ultra medias noctis horas non raro vigeat, \& aëris nocturna condenfatio nequeat dilatationem ipfius $\&$ motum naturalem facile hebetare ac fuperare.

Alterum latus (quod à Peruano Regno celfiffima montium juga \& immenfa difterminant (patia) Zephyrus perflat, ventufque Mediterraneus fera nocte infeftar. Qui licet ob admixtos infinitis è paludibus furgentes vapores, habeatur infaluber; adeo tamen à montibus mari vicinis coërcetur, \& propulfatur à fuccedente marina aura, ut vix queat ad littora ufque penetrare. Quodfi ob pluviofas quandoque malacias per diem integrum (quod rarum eft valde) fpiraffe contigerit, remotior es à mari, \& Occidenti objectos, vehementius; maris vero accolas, atque imprimis nautas, una vix lel.ca à littore remotos, clementius exercet.

Quemadmodum vero annuis temporibus integri femeftris mutationes haud magnæ: ita diurnis \& nocturnis evidentior es contingunt; eo quod dies \& noctes non magis pares fint fpatiis, quam differentes calore $\&<$ frigore. Nam Sol altius afcendens, poftquan terrarum $\&$ hominum poros aperuit, profundius \& pari intervallo fe occulit; unde condenfatus aër extremam noctis partem magis rorifluam efficit Hinc rigidum \& penetrans frigus corpora ferit inde à tertia nocturna, maxime vero circa gallicinium, ufque ad exortum Solis. Ideoque incautioribus advenis hanc terram recens ingreffis perquam moleftum atque noxium effe folet, \&x tantum non omnem fpem pracidere vitam in hifce vel aliis Indiarum oris beatam tranfigendi. Hujus rei non ignari indigenx, focum perennem juxta lectos penfiles alunt, ejus ut beneficio infecta non folum vencnata, fed etiam nocturnum frigus, fimul $\&$ terr $\mathfrak{X}$ fuligines arcere à fe queant.

Porro rectus afcenfus \& defcenfus Solis breviffima facit crepufcula, noctefque adeo diebus pares, ut ne quidem unius horæ difcrimen agnofcant. Noctibus æltivis, frigus intenfius : hybernis, quod mirere, mitius fxpe perfentifcitur : aëre fcilicet tranquillo, $\&$ nubibus undiquaque preffo pluviafque minante. Ruricolx poft noctes folito frigidiores, dies ferenos \& fementi proficuos: Medici vero firmam, validamque corporis conftitutionem pollicere confuerunt : contra, fi tepidæ noctes præcefferint.

Pluvialis temporis initium fit menfe Martio vel Aprili; finis eft Augufto. Quo Sol redux ex Cancro materiam pluviæ ex parte diffolvir in ventos, unde procellæ \& turbines fubinde nafcuntur. Has mox vernum tempus excipit, blandiffimeque componit. Diverfitatem quidem umbrarum, nunc in Auftrum, nunc in Septentrionem projectarum, experiuntur Brafilix cæterique Tropicorum Incolæ, (Amphifcii propterea dicti) nullam tamen, ut Doctif. Scaliger, aliique non infimx fortis Philofophi, fuere arbinullam tame circa anni tempeftates mutationem; bis nempe accedentis, $\& \dot{\angle}$ bis recedentis Solis; fed tunc folummodo cum abit ab : Aquatore ad Tropicum vel Cancri vel Capricorni, ufque dum co redierit \& Equinoctium abfolverit. Profper Alpinus duplicem xttatem quod uno anno dari teftetur in Egypto, id non tam à Solis quam admirando Nili acceffu \& receffu provenire exiftimandum eft.

Tempora anni non nifi duo funt, calidum \& ficcum xeftas dicitur : alterum quod calidum \& humidum, ac Veri Europro fimile, brumæ vicem fupplet. Idque veriffimum omnibus in Indiis intra utrumque Tropicum deprehenditur. Hiemis enim \& aftatis initium atque finis licet ob particularia incidentia loci, tum $\&$ Equatoris majorem vel minorem vicinitatem, non in idem tcmpus incidant: plerumque tamen annus $f$ ex fere menfibus ad humidum $\&$ totidem ad ficcum vergentibus abfolvitur. Adeo ut vel hinc etiam veritas Strabonis dicti confirmetur, nullum fcilicet annum in Indiis inveniri utroque tempore fine pluviis. Et quidem ea ratione, ut hic non, ficut in multis Africa \&Afix, ejufdem nobifcum Latitudinis, oris, 
maxima exinde intenfio \& remiffio xftus, fed nulla vel faltem exigua percipiatur, (Sole licet Brafilienfum zenith menfe Octobri \& Februario tranfeunte, radiifque fecundum angulos acutiffimos reflexis feriente terram.) Qux diverficas iftarum regionum Incolis, ob crebras malacias noxiofque tepores, interitum: harum contra ob dominatricem auram falutem promittit perpetuam. Vnde facile eft colligere anni tempeftates effe non tam immediate ex Sole \& aftris eorumque motu æftimandas; quam ventorum fpecie \& diverfitate, Regionifque qualitate ac fitu peculiari. Eadem caufa folempibus illis Torridx Subfolanis vel Favoniis reddi poteft. Quin in locis hifce Mediterraneis paulo verfus occidentem noctes non folum, fed $\&$ dies aliquando funt frigidior es, quam in orientalibus littoralibus, ufque adeo ut pruina aliquibus quandoque capillos riguiffe confet. Etenim in Indiis cum multa fint admiranda, illud tamenvel imprimis videtur omnium phyficorum ingenia fuperare, quodin eadem Coeli plaga, Solis acceffu \& receffu pari, iifdemque anni menfibus ab orientali parte quidem circa Oceanum aftas \& ficcitas fit; ab occidentali vero trans juga montium \& paludes Brafilix, hiems, nebulx \& pluvix. Vt in tanta locorum vicinitate, quod ad rationem tempeftatum attinet, iidem pæne populi fibi mutuo antipodes videantur effe. Quam miram diffonamque naturævarietatem, atque alia ejufcemodi, fi quis diligentius apud fereputer, profecto intelliget, Antiquos multa de Equinoctiali circulo \& Torrida zona falfo opinatos effe. Cum, contra quam Ariftoteles \& Plinius aliique funt arbitrati, non folum habitabile hoc Clima, fed \& temperatum ac fertile utique reddant tum rores perpetui, tum pluvix \& jucundi à pelago flatus, dum vapores mane furgentes \& nebulas tempeftive difcutiunt, xfumque meridionalem temperant, ac Soles puriffimos \& nitidifimos reddunt. Hinc vero humorum, qui in nobis funt, à putredine confervatio. Neque tamen præcipua falubritatis vel longxvitatis ratio, ut quidam voluerunt, $\mathbb{E}$ quatoris eft vicinitas, ob aqualitatem quam imaginantur tempeftatum. Nam multis fub linea Equinoctiali locis habitatis nec Solum nec CœIum ad falubritatem favet: ficut Infula D. Thomx, Guinea aliæque provincix teftantur, ubi corpora à torrente calore arefcunt \& refolvuntur, minimeque longxva fiunt. Etenim attracti à Sole verticali \& præfentiffimo vapores ob perpetuas malacias non difperguntur, neque aquæ agitantur, fed ftagnant. Tum fi qui perfiant venti, languidi funt, $\&$ veluti longo itinere feffi, ventis fubitis aut mediterraners facile fefubmittunt. Vnde tepores vaporofi, nebulx $\&$ putredines enafcuntur. Quod fub Equatore navigantes non fine miferia experiuntur in penu \& aqua imprimis, qux putredine fotoreque concepto bis terve folet corrumpi in vafis recens infuia, priufquam incorrupta $\&$ durabilis haberi queat. Brafilix vero vaftifimus Oceanus tum pluviis', tum ventis perpetuam ad exhilarandum littus materiam fuppeditat, non tepidam, ficut extra Tropicos folet, fed egelidam \& ficcam, eamque à Sole illuftratam ab oriente in occidentem ad milliaria aliquot fpirat. Accedit, quod paluftribus $\&$ male olentibus pluviis ex continenti ortis, nunquam infeftetur. Denique, ut multx Orientalis Indix \& Africx partes, non cingitur vicinis Infulis, neu ventis agitatur turbidis \& procellofis.

Calum fxpe quidem nubibus, ex oriente in occidentem latis, obductum videas, fed rariffimis \& tenuiffimis, inque fublimia aëris elevatis, præterquam diebus pluviis. Sol oriens $\&$ occidens inconniventibus oculis adfpici poteft: tumque fere ordinario apparet ut colore, ita \& magnitudine ; adeo ut perquam commode Diameter ejus menfurari queat. Mira undiqueferenitas eft, præfertim circa vefperam. quæ nullos unquam fuccedenti Lunæ tradit vapores vel nebulas : fed noctes reddit adco claras ut uno eodemque die Luna vetus $\&$ nova confpici, litteræeque ad Lunam quadratam fatis recte legi poffint. Eadem Aftronomo $\&$ ad cæleftia intento promittit multa circa Eclipfes \&Nubeculas Magellanicas, Veneremque poft emerfionem à Sole falcatam, Mercurium fcintillantem \& corniculatum, acceflus denique Lunæ ad ftellas cum fixas tum Planetas, cæteraque Phainomena, partim antea Europxis non vifa: ficut multoties fuit à nobis obfervatum ex fpecula eminentiori Aftronomicis ufibus per llluftriflimum D. I. Mauritium Naffavix Principem, exftructa, \& à domeftico meo accurate defcripta, ad quem curiofum lectorem remitto.

Ether pro diverfitate afpectuum Planetarum, accedentibus caufis inferioribus, fuas recipit intemperies. Crebris fulguribus Colum fub vefperam corufcat, tempefta- 
te vel maximeferena, fed ficca. Tonitna fi qux circa Equinoctia fuboriantur, rariffime in Pernambuco \& fine fragore audiuntur, utut imbres effundat: in Maranhan ceu propiore Æquatori, vehementius \& crebrius intonant. MultæIrides, Halones, Dracones ignei volantes apparent. Grandines vix unquam confpiciuntur. Nec eft, qui obfervaverit altiflima montium cacumina nive tecta; aut brumalem oftentafle caniticm.

Pluviarum guttæadmodum funt magnæ, gravique decidunt impetu, quas moleftus aliquando tepor pracedere vel fequi folet. Ros Europxo, cum pinguior, atque adeo fxcundior, fic ob nitri quo impregnatur copiam penetrantior multo ac tenuior, præcipue æftate, exiftit. Manifeftum hoc in ferro imprimis, multo magis in materiis minus folidis. Qux fub dio pofita facile corroduntur $\&$ exeduntur. Intenfior enim Solis radiorum fervor, poros corporum fublunarium aperit ufque adeo de die ut nocturno rori fubtiliflimo facilem ufque in profunda aditum faciat. Vnde per quotidianam viciffitudinem humiditatis $\&$ caloris illata putredine, vermium diverforum generum fit generatio. Quantum vero omnibus his noxius eft ros, tantum gramini \& pafcuis proficuus, imo neceflarius, nexfate inopia pluviarum torreantur. Hoc folo enim arentia loca \& humorem fitientia refocillantur. Nihil item rore magis alimentofum, quo folo tot beftiol $\&$ infinita infecta vivunt : quod $\&$ divinus Poëta dixit; 2 uantum ros nocte reponit. Eftque adeo eximix efficaciæ ros matutinus, ut $\&$ pecora $\&$ homines $x$ fuantes, acfpirituum profufione fractos mirifice roboret. Concentrando enim calorem nativum ingeminat, atque appetitum acuit, adhæc urinam provocat.

Etefuis ceu anniverfariis ventis fereniffimis hæo or $x$ diverfis temporibus gaudent. Semeftri enim hibernofive pluviofo, ex nubilofa auftrina plaga intenduntur \& 2 Vulturni velut naturam induunt. Hinc vehementius quam Aquilo, menfibus æeftivis, dominantur, aërifque imperium obtinent. Adeo etiam ut ductus aquarum inde à menfe Martio ad Octobrem illis obfequia præftent. Reliquo anni tempore ex Septentrione in Auftrum maria coguntur. Circa Africæ latus occidentale, Brafilize oppofitum, plane diverfo modoferes habet. Quippe ab Aprili ad Iulium menfem, verfus. Septentrionem rapidus eft fluxus; inde ad Octobrem tranquillum mare. Hinc ad Ianuarium verfus Meridionalem plagam Oceanus truditur : mox circa medium Aprilis denuo nullum Currens maris (ut fluxum illum generalem Verulamius appellat) experiuntur nau$\mathfrak{x}$. Atque hæ diverfitates potiflimum quidem intra Tropicos libero æquore navigantibus percipiuntur. Adeo ut hi venti generales, Tropæi dicti, minime fegnes, partim regendo Currens maris, partim proprio flatu (non fpontaneo aliquo raptu ab ortu in Occafum, ut Scaliger \& ante eum veteres quidam imaginati funt) id efficiant, ut hinc navigantes verfus Africx, vel Europæo oras, eadem redire, qua venerant via, nequeant.

Æquor Brafilienfe ut plurimum tranquillum eft. Cui temeritas Barbarorum fe fidens, gemino ligno fuberofo, Iangáda diato, infidentes, fecure pifcaturam exercent aliquot leucis à littore remoti. Cærulea \& fubnigra ejus facies exterius eft, interius viridis. Agitatum noctu ignefcit, magnoque lumine refulget. Salfius quoque deprehenditur quam verfus Polos', adeoque pellucidum, ut pifces ultra vigintiorgyarum profunditatem aureo colore micantes, ex altis puppibus commode confpiciantur, meridiano tempore, Soleque fplendente. Ac tum fimul intueri licet, quam diverfus \& contrarius fubinde fit motus in profundo mari, ab eo qui in fuperficie à tumultuariis fit ventis. Quodjactas bolides, aliafque artis nauticx conjecturasnon parum eludit.

Si mare circa Aquinoctium nimis languidum deprehendatur, admodum infidiofa habetur illa tranquillitas. præertim, ubiatr $\&$ fordid $x$ nubes conglobat $x$, ut fit, accedant, quxque univerfo repente impetufefe effundant, unde momento immenfix rates evertuntur.

Licet autem juxta littora æftu fatis vehementi falum intumefcat, non tamen agros invadit, aut vicinas terras depreflas inundat, fed ingenti fremitu rupem quandam five maris teniam, Reçiffo Lufitanis dictam, pulfat maximoque impetu verberat. Illam fummo natura miraculo \& beneficio ibi pofitam fateri, quotquot videre, coguntur. Crepido enim cautium longo tractu cxcurrens, inftar muri fe violentix barbari \& indignantis elementi objicit, fidafque ac tutas navibus ftationes \& portus praftat. Largiffimam praterea $x$ dibus materiam, qua Olind $x \&$ Parayb $x$ templa ac monafteria fuperbiunt, fuppeditat. Maximam Brafilix partem eadem nunc interrupto $\&$ flexuofo, nunc concinuato 
HIS T. NATVRA L. \& MEDIC. LI B. I.

tinuato rectoque ductu tuetur. Ejus lacitudo (qux planiffima eft, \& quafi arte fuperficie tenus polita) ad paffus viginti, fubinde triginta $\&$ cultra fe extendit. Tantæ vero altitudinis eft, ut vix maximo aftu inundetur.

Nova plenaque Luna mare ad duodecim pedumaltitudinem (quod in Paranambucenfi littore fit circa quintam ) attollitur, pariterque deprimitur. Verum non rite obfervata fexhorarum viciffitudine, fed pro ratione decurfus fluviorum \& $\&$ pelagi intemperic, vel citius vel tardius xftum vaftiflimus Oceanus abfolvit. Ita tamen, ut menfibus aftivis acceflus : hibernis vero receflus fint $\&$ longiores $\&$ vehementiores. Quid, quod fluxus lunares, paucis tantum à littore miliaribus; Currens vero maris per univerfum $x$ quor perfentilcant navigantes.

Cxterum ad extricandas perpetuas nautarum controverfias circa longitudinem hujus Continentis, fcirê intereft, magis ad Occidentem à natura collocaram effe quam. peritiflimi quique Geographi \& Hydrographi hactenus funt opinati. Operæ pretium jtaque duxi illud addere, quod ex fedula obfervatione Eclipfium Lunarium nobis conftat. Initium fiquidem deliquii, quod in vigefimum Decembris anni millefimi fexcentefimi trigefimi octavi incidit, inter Olindam Paranambuci, \& Vranoburgum Danix, tribus horis \& quatuor minutis differre deprehendimus. Vndereducto cal culo, facile erit colligere, qux caufa fit erroris ; cum plerique naucleri ultra quinquaginta minuta à nobis difcrepent.

Vniverfa Brafilia (cujus Incolæ Antœci funt Hifpanis \& Athiopibus; Perioci Iavenfibus: Antipodes Aurex Cherfonefi populis) Coloniis \& Prafecturis quatuordecim, totidemque circiter fluviis diftinguitur. Horum beneficio territoria fertilitate $\&$ commoditate differunt. Præter quamplurimos amnes, fontibus inclytis \& utcunque herbofis habitata Orientalis pars fcatet; iifque pafium, mira divina bonitate irrigatur, potumque hominibus juxta ac pecoribus abunde fubminiftrat. Armenta filveftria fiti xefuantia eo confugiunt, leque ad luxum inebriantia aquis, præda fiunt venatoribus. Rapidi funt plerique fiuvii menfibus pluviis, \& tunc de fubito in altum excrefcunt acripas egrediuntur. Econtra vero is, qui Paranambucenfis Præfecturæ terminator \& D. Francifco facer, totius Brafilix facile maximus eft : menfibus quidèm æeftivis rapidiffimus fimul \& altiffimus exiftit, ruptifque obicibus valentius ruit in campos \& mare. Menfibus autem pluviis, quod mirandum fane, aquas decrefcere, modiceque tantum in pelagus fefe exon'erare videas. Cujus inauditæ diverfitatis caufam, alii aliam perhibent. Sed fub accuratinimis Regionum luftratoribus \&.ipfis Philofophis etiam nunc lis hretet. Quamvis autem tanti fluminis fons aut origo nondum à quoquam fuerit luftrata, tamen evidens ratio videtur evincere ex intima parte hujus Continentis defcendere, \& quidem è Lacui illo mediterraneo à multis celebrato, qui omnes fluvios, ut $\&$ hunc noftrum, ab altifimis Peruviæ montibus verfus ortum demiffos, recipit $\&$ in Oceanum emittit. Noftrates hoc flumen celocibus aliifque ratibus Canóas dictis ad quadraginta milliaria afcendentes adhuc fatis latum $\&$ profundum, infulifque amœnum \& ficopulis horridum invenerunt. Indigenarum quoque $\&$ Lufitanorum fide conftat circa quinquaginta milliaribus à mari, ipfum de altiffimis rupibus feu cataractis, Cacoéras vocant, præceps ruere nec altius $a b$ is qui è mari veniunt afcendi poffe. Supra cataractas fiuminis alveum porro pergere verfus Corum ad aliquot milliaria, ufque ad ingentem illum Lacum, in quo multx fint infulx perquam fertiles \& habitatæ. Inque hunc Lacum aureas arenas à rupibus auriferis verfus Pertuviam jacentibus detritas per infinitos torrentes deduci.

Cxteri plerique Ruvii vel potius rivi, qui ad hanc Brafilix oram in Oceanum effluunt, ad minimarum etiam navium onera è mediterraneis defer enda funt incpti, quod aquis deftituantur. Illi enim paucis exceptis, licet tribus aut quatuor milliaribus non abfint à fontibus fuis, nihilominus in oftiis magnorum fuminum fpeciem prefe ferunt. Quod fit propter maris acceflus, fauces illorum illudentes. Exemplo fit Rio formofo, item Rio grande, \& alii, omnes magnarum navium qua oltia capaces : qui tamen, ut verfus mediterranea vix duabus leucis à littore abfunt, ita pedibus genu tenus tranfeuntur. Cum nulli tamen alii in hac America parte reperiantur, qui tantos imbres alveo fuo excipiant. fed conftat ratio. Vaftifima montium juga procul à littore demittunt vimillam pluviarum à tergo, \& exonerantfe verfus Occidentem. Mox

$$
A_{4} \text { ver- }
$$


verfus Orientem ad rapidiffima, ne dicam $\&$ totius mundi maxima: uno quidem brachio verfus Septentrionem in Amazonum \& Maranhan flumina: altero ad divi Francifci, atque illa qux de la Plata \& de Ianeiro dicuntur, verfus Auftrum erumpunt. 'Hæc receptis in fe quibufdam amnibus invalefcunt $\& x$ aliquando ad milliaria triginta in Oceanum labuntur, tanto impetu, ut in ipfo mari dulces à nautis hauriantur latices; ac fi è fonte aliquo falirent. Porro Lacus juxta littus reperiuntur, qui mari licet vicini \& quafi contigui, aquis tamen funt dulciffimis. Præterea putei, paucis ante annis, circa ipfum littus, $\&$ quo xftus maris pertingit, effoffi, potabiles aquas $\&$ dulces ignoto vel dubio venarum commercio, impertiunt. Vnde percolatas omnifquefalfedinis expertes prorfis haurire datum:qux licet fontanis inferiores fint, domefticis tamen officiis fufficiunt. In remotiffimis vero defertis rivuli quidam è lacubus oriundi, hieme dulces, fubfalfi æeftate exiftunt; quod ftagnantes Solis affiduitare adurantur.

Tellus hæc ex diverfo naturæ lufu conftat. Qua enim in planitiem longe lateque fternitur, glebofo ponderofoque \& prepingui ac irriguo eft folo Vergea Lufitanis dicta: multorum fructuum ferax: cannas facchareas imprimis, tum $\& z$ credita quxque femina multiplici reddit foenore. Aprici campi minus xftate, fed menfibus potifimum pluviis (licet terra tunc habitantibus triftior videatur) latiffme virefcunt, prataque meffem negantia pabulis vigent. Frumentum \& fecale nimis celeriter in germen evocantur àjugi perpetuoque folis fervore $\&$ indulgentia agri. Qui proinde multa verfatione (nec autem interquiete unquam indiget) fatigari debet, additaque potius arena quam ftercore, ferendis frugibus aptior reddi. Secus enim germinatio nimis feftinara aduritur vel exhauritur. Quiab exoticis feminibus $\&$ his qux diutius in terra foveri debent, proventum expectant, maturationem retardent oportet. Ne foliis luxurient plantæ , ac granis poftea $\&$ feminibus caffereperiantur, atque ita fpem votaque agricolarum deftituant. Committere terræ plantas \& femina oportet menfibus Februario \& Martio, quum nempe finem æettatis excipit tempeftas humida. Fieri vero utrumque debet prima vefpera, non de die, nec adulta nocte. Quxcunque profundius \& quo radii folares non pertingunt, inhumant, in vitæ difcrimen ea incurrunt, quodfub cute fua intenfe frigida terra, præcipua ærtate, taleas \& $\&$ femina facile enecet. Cujus rei adven $x \&$ novitii experimentum non fine magna jactura fecerunt. Semina ficut \& fructus colligunt diverfo plane tempore in locis acclivis \& fitientibus quan declivioribus $\&$ uliginofis. Quid quod horum plurima toto anno $\&$ omni tempore plantentur \& germinent: felicius licet vel infelicius, pro locorum \& 2 plantarum diverfitate. Quod evidentiffime apparet, præfertim circa proceras illas arbores, quas Co$\cos \&$ Palmitas nuncupant. Etenim hx citra ullam anni temporis, fenique arborum obfervationem tranfplantatx virefcunt jucunde, $\&$ fructibus eximiis abundant, in littore fterili gaudentes foveri; modo radices, quas infinitas $\&$ brevifimas habent, leviter tantum terra cooperiantur. Harum enim cæeterarumque Indicarum arborum radices adeo à frigore fubterraneo abhorrere deprehenduntur, ut nonnunquam Solis defiderio foras prorumpentes, terra fe condi vix patiantur. Nonnullæa arbores \& quidem nobiliores, ficut Acaiú, Vbapisánga, Cajá , Andá, Iaçapucáia, Mureçy', Ietaibá, Araticú, Ibabirába, Ficus \& Myrtus fylveftres Iamacarí \& Cambuy' dictx: Planta quoque Ananás \& alia femel dumtaxat in anno florent, tempore verno, quod circa Octobrem eft : mox fructus proferunt, Sole ingrediente Capricornum, \& durant ultra tres menfes, pofteaque quiefcunt. Solus, quantum conftat, fructus Guitycoroó femel biennio; fructus autem arboris Ibiraée quod eft Guajaci Brafilienfis, vix quadriennio producitur. Pauciores arbores nativx hactenus ad fativas relatx: fylveftres tamen cum fint, fruCus elegantes, \& gratiffimi faporis proferunt, maxima quidem ex parte frigidos, cum aftringendi facultate. Quafi natura benigna hæc mortalibus immodice xeftuantibus folatio dederit, proruentibufque humoribus frenum impofuerit. Plurimx arbores $\&$ frutices toto fere anni tempore flores $\&$ fructus feliciter protrudunt, fimulque $V \mathrm{cr}$, Æftas \& Autumnus in iis confipiciuntur. Horum facile principes, Murucujáa, M1angába, Pacóba, Banána, Ianipápa, Araçá, Pindóva, Cocos, Mamáon Pinboins, Piementa. Quibus annumerantur, Vitis, Citrus, Malus Medica, Ficus, Cucumeres, Melopepones, Citrulli Malogranata bifera \& trifera, aliaque plutima ex Lufitania \& Angola olim, $\&$ nupcr è Belgio adducta legumina, radices \& olera paffim in hortis exculta, atque 
HIST. NATVRA L. \& MEDIC. L I E. I.

In culinis domeftica facta. Imo \& Piper orientale, \& alia infinita exotica, tam fata Europæa,quam Aromata Afiatica benigne fert tellus. Sed regio quondam diplomate ne vilefcerent propter abbundantiam, prohibita \& prorfus eradicata. Qui racemos per totum annum defiderant, vineas diverfas, diverfis putant menfibus, maturafque poftea uvas colligunt. Vnde non ignobile vinum, creticum æmulans, exprimitur. Q uin \& omnis gener is fructus atque frumenta etiam noftratia fingulari fertilitate explerent colonorum fpem, fi quod univerfale remedium contra Formicarum illam. Strumam inveniri poffet. Nam locis anguftis \& quoque uliginofis vel ignis vel aquæ beneficio per impigrum agricolam facile arcentur. Sed cum nulla regio ab omni parte beata, vix credo potentifimum hunc hoftem fuperatum iri poffe. Quod non tam à Soli quam Solis vi procedat, qui ubicunque fub zona torrida, etiam in Indiis Orientalibus, atque in vicina Peruvia, infinitas Formicarum turmas generat. Partes autem Indix, ut quoque Brafilix, extra Tropicum fitz, Formicas vix norunt; unde \& fruges ibi uberrima. Vtinam natura plures feras formicavoras collocaffet, quæ fimul tot myriades abligurirent, ficut mira illa afpectu animalia quadrupedia Tamendoá dicta, qux Canis magnitudine, longis inftructa unguibus, alte fodiendo formicarum latebras detegunt, iifque illico exertam trium fere dodrantium linguam immittunt exilem, opertamque Formicis repente contrahunt, deglutiuntque deceptas. Formicx autem ha (Rey do Brafil Lufitanis non immerito diatre, quod perpetuam tyrannidem exerceant) aliqux Europæarum plane fimiles, aliqux triplo majores \& alatx, omnivor $x$ funt. Aggeres quoque $\&$ tumulos ingentes, in modum metarum foeni, è terra ab illis exftructos, videas. Huc inopi metuentes fenectre, non tecto vel calle anguftis, ut Virgilius eleganter de fuis Formicis cecinit, fed anguftis convectant atque reponunt quidquid populant nigra hæc Formicaium agmina ; ita ut in campis, in fylvis, aliquot leucarum fpatio, perpetux femitx, opere earum ferveant. Quam vero noctu Luna plena operentur, interlunioque ceffent, quam celebres undique earum conventus, quam diligens cum obviis collocutio atque perconctatio, quam denique futurorum quidam fenfus, cum, imminentibus menfibus pluviis, tumulos fuos cavernofos altiores ftruant, $\&$, quod omnem fere intelligentiam fuperare videtur, granorum in penu reconditorum umbilicum, quo germen enitti folet, follicite excidant, hic confpicere datur. Ita ut vel ftupidiffimus fipectator Salomonis proverbium in memoriam revocet, ubi ignavos ex earum oconomia incitamentum laboris capere jubet. Plura de mirando regimine dicenda forent, nifi jam dudum propofiti limites tranfiiffem.

Qua lacuftris eft hæc Regio, ob perpetuam uliginem funditus æxque ac in fuperficie viret. Tum diverfo plane herbarum fruticumque paluftrium genere, adeoque mira naturæ folertia luxuriat, ut herbofam terram, non aquam diceres, amphibiorum xque \& pifcium latibulis deftinatam. Non omnia loca paludofa \& lacuftria infalubria effe, monumenta veterum quoque confirmant in Italia, ubi infignia quædam \& fertiliffima habitacula paludibus proxima, incredibili tamen falubritate fruebantur, propterea quod commercium haberent cum mari, \& motione perpetua non paterentur ftagnantes putrefcere. Circa oftia vero fluviorum, ubi paludem aqua marina fingulis aftibus inundat, ab immenfa Oftreorurn \& Cancrorum multitudine perreptatur, atque tortuofo illo arborum genere, Mangle dicto, ita obfidetur, ut viatoribus \& pifcatoribus prorfus lit inacceffa.

Qua montofa, raro fterilis vel otiofa appareti, fed in acclives $\&$ amœnos colles (exceptis vaftiffimis montium jugis in defertis mediterraneis) exfurgit. Contingit quidem arbores \& gramina menfibus pluviis lxte virentia, æftivis ob ardores folarcs emori, eaque incenfa ingenti fpatio fubinde incendium producere; fed ipfi Incol $x$ iis incommodis profpicere norunt, dum loca illa excifarum \& recenter combuftarum cineribus foccundant, ut frugibus Cerealibus Americanis aptiora fiant.

$Q$ ua arbuftis fylvifque denfiffimis veftitur, multo olim labore Lufitanos ad pyxiden nauticam iter fuum inftituere coëgit. Quod noftratibus etiam nunc \& mihi ufui fuit, in muniendis viis per dcferta, patentque nemora in longitudinem aliquando ul tra du-

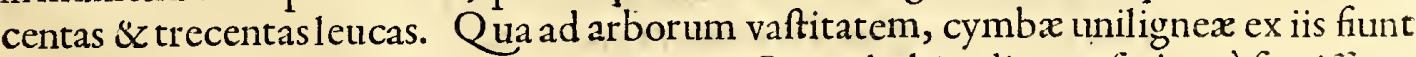
centum \& quinquaginta hominum capaces. Qua ad altitudinem, ragitta à fortillimo emiffa quarindam fummitatem haud facile fuperat. Arbores denique varix magni- 
tudinis indifcriminatim hinc inde per campos \& fylvas videre eft, earumque ramos variis carduis, imo $\&$ integris diverf $x$ fpeciei arbufculis frugiferis onuftos $\&$ ornatos. Haud dubie, quia tot volucrum cohortes, cum excrementis fimul alvi nucleos feminaque fructuum ibi deponunt: qux in fervido earum ventriculo præmacerata, facilius germinant. Ex hifce nemoribus fragrantiflimæ quoque arbores balfamis \& gummi gravidæ, non tantum medicinæ gratia, ut Copaiba, Cabureíba, Icicaríba, fed lucri caufa ob colores \& tincturas varias, aliofque ufus eximios ad Europæos apportantur. ut

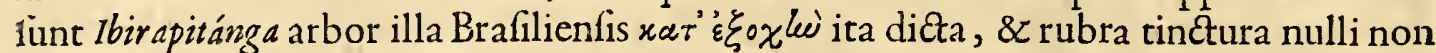
nota. Tatniba five lignum flavum. Arariba cortice rubro. Vrúcu. Iacarandá. Antimuba five Cedrus alba, \& aliæ mult $x$ qux $æ$ dificiis navibufque ftruendis aptifim $x$, quod aquis minus perviæ fint $\&$ ferant $x$ tatem. Ex quarundam corticibus nunc funes igniarii, in militantium ufum, nunc in navium neceffitates torquentur, \& rudentibus materiam fubminiftrant. Denique è collifis lignis Caraguatá, Tataiba, Ambaiba, aliifque ferulaceis plantis ibidem nafcentibus, ignis luculentius, quam, ex concuffo filice, à Barbaris elicitur.

Si qux loca fint aridiora, mirabiles illas Climaces, feu funes potius á $\varphi^{\prime} \gamma_{\lambda}$ ४s,generali nomine Timbó \& çipó appellatos proferunt, quæ fua flexilitate \& tenacitate apud fabros $\&$ vietores ligaminum, contufa apud pifcatores, coriarios, \& naupegas, rhoïs $\&$ ftupx vicem fupplent. Inter has Climaces, non minus notatu digna illa qux Guembé nomen à Brafilianis accepit. Texitur enim Cannabis $\&$ Sparti modo, cum alios in ufus, tum præcipue in anchoralia : neque materia ulla ad nauticos funes $\&$ maris impetus aptior ; namque ut falfuginem amat ea planta, funis quoque ex illa confecta marinis aquis immerfa, identidem revirefcit. Et anchoris alligata, fluitantes in falo naves egregie continet, non tam ab innata duritie, vel operis firmitate, quam viriditate ipfa, \&t lentitia quadam ad inftar corii: ut fefe vel in altum elato navigio, modo in tenuitatem extendat, vel refidente rutfus in craffitudinem contrahat: quod fecus in noftris evenir rudentibus, quæ nimirum ipfa vi ac pertinacia fxpe rumpuntur.

Nemorum plerreque arbores, cum ab Autumni $\&$ Veris viciffitudine nihil fere $p a=$ tiantur, frondibus tamen $\alpha$ foliis non eodem fimul tempore veftiuntur $\&$ fpoliantur. Præterea non unaquæque arbor foliis fimul omnibus orbatur, fed parte una deciderte altera tam diu manet, donec prior repullulet. Mirari quoque fubit, primum naturæ hoc focundiffimum theatrum contemplantem, herbas \& $x$ plantas in Europa à natura molles, hic caulibus lignefcentibus luxuriare: Earum quoque non paucas ratione loci inter fe plurimum difcrepare; nam qux vix fruticis magnitudinem æauarent in pratis, in denfis nemoribus fummæ videri proceritatis. Accedit, quod varii generis Heder $\mathfrak{x}$ fabifer $\mathfrak{x}$, Phafeolique pulcherrimi, fuprema arborum cacumina fcandentes, topiarii inftar operis perpetuam umbram prabeant. Inter hæc virgultorum opa$c a$, ipfis Faunis confecrata homines pariter ac feræ fe abdunt vivuntque fecure. Multi enim in illis funt fecreti tramites; qui fui gnaros haud parva in venando voluptate perfundunt. Quxfylvarum fontiumque prærogativa multis Indiarum regionibus denegata eft, maximeque occidentalis Africx parti habitatx, ac propterca Torridarum regionum nomen merito obtincnt: ab immodico enim \&zingenti xftu dehifcunt illæ, ut ad fluvios umbrofofque faltus diffitiflimos pecorum greges amandari neceffum lit. In agro enim arenofo longe majores ab incolis perferuntur calores, quam fi terreus effet eodem Solo, Cxlo \& Sole. Ita \& montofa differunt à planis \& nemorofa à nudis, ac perinde ut humilioribus aut altioribus montibus affurgunt, magifque aut minus fylvis veftita funt, frigus aut calorem aëri majorem aut minorem conciliant.

Porro ficut Peruvia crebro ex æftuantibus cavernarum latebris: ita nunquam Continentis hujus tractus orientalis terr $x$ motum fuit expertus. Metallis enim \&rigne fubterraneo, fpirituum \& vaporum genitore paflim deftituitur. Excipe montes in $\operatorname{Pr} x$ fectura şeára adeo argentiferos, ut thefauros hactenus pollicitos, nunc cum foenore Batavis praftare coperint, atque etiam nunc praftarent, modo Plautinum illud minus in nos quadraret.

$$
\begin{aligned}
& \text { Tum denique bomines moftra intelligimus borsa, } \\
& \text { Cum que in poteftase babuimus, es amifimus. }
\end{aligned}
$$

Atque hace de diverfitate terra nobis cognitx.

Illa autem deferta \& folitudines frequentibus jugis arduas, inque Occidentem por- 
HIST. NATVRAL. \& MEDIC. LIв. I.

rectas Anthropophagi tenent. Europxi qui inveftigando loca incognita vaftiffmos iftos $\&$ fragofos faltus penetrarunt, teftantur, fe non minus fertiles ibi, herbofofque montes $\&$ convalles vario animalium genere occupatos vidiffe, quam in littoralibus \& 2 habitatioribus locis. Quod ipfum poltea verum comperi : hoc tamen difcrimine, quod quo ad mediterranea loca penetres altius, eo plura quidem mineralia eaque ignobiliora fe offerunt, fed fontium inopia atque ob auras devigefcentes æeftus diurnus major", \& noctium frigus intenfius : frequentiores denique lacus pifcofos hybernæ pluvix, in xftivam penuriam, fuppeditant. Mediterranea enim opem plurimam à cxlo imbrido habent, non circa vegetabilia folum, fed $\&$ ferarum atque pif cium miram obxlitatem, ut condimento proinde minori indigeant. Mel quoque fylveftre, fructus Iaçabucájo, Ietaibse, Palmx \& fylveftres Ficus, defectum fructuum Acají in delertis locis fupplent. Que tefquis \& rubis, caterifque fpinofis fruticibus paffim adeo horrent, ut vi via faciendafit. Inter catera, Caragúatá, aliique cardui, rorem $\& \dot{z}$ aquam pluvialem copiofe concavis foliis, calicis inftar perpetuo continent, quæ deficientibus rivis \& pluviis ingenti folatio hominibus æque ac animalibus exiftunt.

Dux tantum indomitx feræ (ferpentibus exceptis) in tam valta Regione extimefcendæ reperiuntur, Tigres \& Apri. Quarum illæ. infidiof $x$, velocitate valent: hi tardiore funt curfu.V træque autem famelicx exiftunt. Exdem paft $x$, quod mirere, adeo fiunt ignavæ \& meticulof $x$, ut ab ipfis Tapuyeris, \& gregariis etiam canibus, in fugam confeftim agantur $\&$ capiantur. Vfque adeo fatietas non homines tantum fed $\&$ feras enervat. Inter belluas marinas vero, plures invenias feroces $\&$ prodigiofas fatis.licet enim fummè admirabilis Dei potentia atque folertia in rebus cœleftibus, iifque qux in aëre $\&$ terra fiunt, unicuique patefcat; maxime tamen ea in mari prælucere videtur, in quo tam varix $\&$ ftupend $x$ rerum form $x$ confpiciuntur, earumque vires $\&$ proprietates deteguntur, ut quarendi \& contemplandi nullus unquam futurus fit finis, meritifimoque jure ea quæ dignofcitur pars, illius qux ignoratur minima dici poffit: Sunt autem Thynni, Delphini incredibili velocitate cxteros fuperantes. Serræ porro, \& Lamix five Tuberones inter rapaces primum locum obtinent. Hi formidabili rictu pifces non tantum, fed $\&$ urinatores devorant, nimiæque voracitatis pœnas aliquando dant; quod pifces echinati, cornuti, tum quoque venenati, deglutiti eos interimant. Sicut eleganter Oppianus olim cecinit :

occife occidunt boftem, perimuntque necantem.

Serrà vero perpetuum cum Cetis bellum gerentes, corumque prxcordia gladio radiis acutiffimis horrido fodicantes, mare tingunt cruore.

\section{- His eft audacia tanta. \\ Hi forten Ponti Regem formidine nulla \\ A grege fejunctum afpiciunt, folumque vagantem:}

Atque catervatim veniunt ad martia bella.

Cetorum vero menfibus præfertim pluviis magna apparet copia, quod fotus ibi edant. Quos cum maris receffu contingit harere in vadis, multum olei inde redundat. His quoque monftris annumerantur Vaccæ marinæ \& Nereides, Brafilianis Iupipiápre, Lufitanis Peixemulber dictx. de quibus Virgilius,

Frons hominem prafert, in pifcem definit alvus.

Nọtatu dignum, quod eximix tot arbores, frutices $\&$ herb $x$, figura, foliis $\&$ fruatibus à veteris orbis vegetabilibus, paucis exceptis, diffimiles appareant. Idem in avibus, animancibus $\&$ pifcibus deprehenditur: ut $\&$ infectis alatis atque non alatis. Quafi ex diverfitate Climatum, non tantum hominum, fed etiam fenfitivorum $\&$ vegetabilium prodir ent differentix, idque non adeo ex aftrorum fynergia, quam vi Solis $\&$ Soli genio peculiari. Qux omnia ut ineffabili colorum pulchritudine, fic $\&$ infinita multitudine hifce in oris generantur, partim nota nobis, partim incognita. Quorum aliqua, fapore \& dignitate Europæa fuperant; aliqua longe inferiora exifunt. Ex quibus utique apparet, quam mirus $\&$ varius lufus fit in orbe terrarum. Meritoque beati Incolæhaberentur fromnium horum Creatorem cognofcerent. Quumè contrà tam faufto fub cœlo, tam agreftia \& diftorta illis fint ingenia.

Hæc breviter de Aëre, Aquis \& Locis dicta fufficiant. Quorum utique temperies optima parum eft exfe culpabilis. Neque enim Solis calore torretur hac terra, neque 
fqualore vel aquarum penuria reficcatur, neque frigore extinguitur, fed rore perpetuo imbribufque multis ac fontibus irrigatur. Vnde \& feraciffimum effe, \& multa iilic tempeftive nafci oportet. Praterquam enim quod Balfamis nativis, oleis, mellibus non unius generis abundet, herbarumque ac radicum medicarum $\&$ ad tutandam valetudinem potentium ferax fit : quxefuofiffimam infuper culturam facit, quantum exaliquot retro annorum meffibus colligi potuit. Animalium denique omne genus ac boum imprimis armenta in maximum numerum augeri \& crebrius parere, certum eft. Quæ loci falubritatis fama non paucos olim fenes aliofque minus profpera utentes valetudine , ex Hifpania, \& Indiis aliifque diffitis locis excivit ad aërem \& a aquas has Colo datas, tamquam ad duo validiffima vitæ $\&$ valitudinis præfidia. Perquam mature enim pubefcunt Incol $x$ : lenefcunt tarde, idque fine canitie aut calvitio. Quo fit, quod longe ultra centefimum ætatis annum, viridi fenecta, non Americani tantum, fed $\&$ ipfi Europæi fruantur, totumque adeo territorium Macrobium dici mereatur. Nonaliter ac fi fervor juvenilis frigore fenectutis repreffus, temperatiorem illam in calidioribus hifce plagis efficeret. Advenarum enim proles crebris licer morbis infeftentur, multique fuccumbant, imprimis noltrates infantes, non tamen id tam debet Coeli intemperiei, quam prapoftero nutriendi modo imputari. Exemplo funt vel maxime Brafilianorum liberi vivacifimi. Qui cum ventre duro fint \& 2 prominulo, folidifque toris, quamvis fubucula tantum leviori induantur, nihilominus injurias Colifecure contemnunt. Rident matres ineptam noftratium $\&$ veftiendis $\&$ educandis parvulis induftriam, qua.perfirationem impediri \& catarrhos multos generari aiunt. Nulli inter illos, ftrabones, lufciof $f_{1}$ claudi, gibbove deformati inveniuntur: cum tamen infantes nỵnquam aut linteis involvantur, aut involuti fafciis Europæorum moreligentur. Frigida frequenter lavantur. Idem provectioribus ufitatiffimum eft: cum ob innatam genti munditiem, tum ad firmandam $\&$ tuendam corporis fanitatem. Porro alacres funt $\&$ fucculenti omnes, vafifque amplis, brachiis cruribufque lacertofis $\&$ firmiter compactis, minus tamen pinguedine farctis. Qui nobifcum militant maris accolx, non admodum funt aut moribus agreftes, aut corpore proceri, funtque mares invicem maribus, mulieres mulieribus fimiles : eo quod paucioribus anni tempeftatibus obnoxii, etiam rariora vitia in femine feminifque efformatione concipiant. Plerumque enim ut hominum inftituta $\&$ mores, ita quoque naturam pro varia Regionis conftitutione mutari videmus. Præter longævitatis beneficium $\&$ alterum eft quod rariffime adverfa valetudine afficiantur. Primo quod fortibus nafcantur, \& incomparabili aëris ventorumque ferenitati atque æqualitati exponantur : tum quod tantum non ignorent, quid cur $x$ fint, quid animi affectus, quid corporea voluptates. Sub eodem tecto, eoque levi $\&$ ad inverf $x$ modum carin $x$ palmis inftrato, mult $x$ fimul familix degunt. Has cafas peregrinaturi deferunt ad tempus, fupellectilem quam curtam habent $\&$ liberos humeris impigre portantibus fominis. Eodem femper victu $\&$ amiatu, eoque fimplici gaudent. Quippefolum goffypium ad veftitum iilis fufficit, juxta illud Lucanifcilicet:

Terra fuis contenta bonis, soon indigä mercis ơ.

Nullus denique 1 llis habendi amor, paupertatique fe addicunt voluntarix, ea quidem xquitate, ut cui plus eft, lubens impertiat minus habentibus, pari dandi \& $\propto$ pofcendi invicem facilitate. Radices omnes alimentofas, quod dignitate Mandioce cedant, imo ipfum panem ex oryza aut milio, Afiaticis tantopere expetitum,contemnunt. Omnibus fructibus poma filveftria, Acajú dicta, præferunt, quod egregiefuccofa fint, \& ad victum $x$ que ac potum fufficiant. Nam ficeram ipfis fuppeditat, in multos menfes, $\mathrm{f} x$ cibus depofitis, duraturam; \& prxftantiffimas caftaneas, penu recondi aptas. Alii ctian fructus, prafertim Pacóba, Ananás, Mangába, Ianipába, Caraguatá expreffi fimile vinum vel ficeram fuppeditant, nec minus inebriando idonea. Fiunt \& alia ex radicibus Mandioca, Patáta, Milio Turcico, Oryza, quæ mafticata multa cum faliva exfpuuntur. Sputumhoc vafis tandiu conditur, donec ferveat, fiecefque ejiciat. Vina vero hxccitius aut tardius ad fermentandum infurgunt, prout dulciores, acidiores vel acerbiores funt fucci exhifce plantis frttctibufque expreffi. An non à fimili materix conditione dependeat quoque anticipationis \& poftpofitionis ratio in febrium paroxyfmis, viderint Medicorum fcholx.

Servitutis jugum nequaquam tolerant. Tripudiis inconditis \& potationibus impendio 
HIST. NATVRAL. \& MEDIC. LI в. T.

pendiò funt dediti. Cibum capiendiftata tempora ignorant. Recte aut perperam faAtis, nihil poft mortem præmii aut fupplicii fuper effe exiftimant. Vane interim fabulati, eorum, quos fua mors extinxit, animas immortales fore. Otium amant, magnofque labores declinant, fecure $\&$ in diem viventes. Cujus rationem cum Hippocrate eam effe arbitror, quod rerum ac temporum uno modo fe habentium facies eadem ingeneret focordiam, varietas autem animum $8 z$ corpus ad labores excitct. Q uin etiam otio \& quiete crefcit ignavia ; exercitatione vero, mentis \& animi robur alitur. 迁tatem ac vitæ decurfum æftimant ex Heliaco Pleiadum exortu, qui fit menfe Maio. Numerum autem annorum xtatis fux ut retinere poffint, fingulis annis reponunt unam caftaneam de Acajú femel duntaxat in anno circa lanuarium provenientem. Fominx pudicx non deformes ab octennio ultra fexagefimum annum fupra fidem foecund $\mathfrak{x}$; ino feptuagenarix orbos infantes lactantes vifx funt. Facili negotio \& nemine obftetricante pariunt, rariffime abortientes. Pleræque puerperx ftatim poft partum furgunt, ad proximum flumen properant ablutum corpus, $\&$ impigre, cum ad cxtera domeftica officia redeunt, victum hinc inde conquirendum. Liberos defunctos ultra biduum aut triduum non deplorant, matribus miferando ejulatu totam domum implentibus. Lachrymis, quas in poteftate habent, profufis, cognatos reducefque excipiunt amicos, eorumque labores peregre exantlatos, multis fufpiriis atque gemitibus deflent, circumdatis collo brachiis $\&$ capite ad pectus adpreflo. Olim antequam Lufitanos agnofcerent numerofi \& prene infiniti erant, ac pagi undiquaque adeo frequentes, ut Indiarum luftratores fagacifimi dubitarint an ulla orbis pars Brafilia populofior fuerit unquam. Nunc autem ad paucitatem redacti, nam Lufitanorum frevitia, alii pæne ad internecionem deleti, alii in miferam fervitutem abrepti, alii fuga fibi confulere $\&$ intra Continentem latere funt coacti. Qui inter Lufitanos \& Belgas degunt Neophyti, Chrifto quidem dant nom en ; ejufque facra fequuntur ; fed frigidius. Quin adulti circa ea adeo funt remiffi, ut merito putes, ore duntaxat, non corde Chriftum colere. Vix etiam placita noftra, nifi tenellæ ætati, nondum præoccupatis aninis, remotifque parentibus, inftillari poffunt. Lingua inter fe haud differunt. Et quamvis quondam ex feroci profapiâ fuerint orti , mutıo tamen cum Europxis commercio \& confuetudine ufque adeo funt cicurati excultique, ut exuta barbarie, humanitate nonnulli cum noAtratibus contendant. ut \& hicillud Taciti ufurpare liceat, Mitius circa Oceanum vi- 6 。 vitur. Qui etiam nunc litterarum $\& z$ characterum ignari, nihilominus antiquitatis memoriam, tam pace quam bello gefta accurate confervant. diligentifime namquejunioribus tradunt quxà majoribus acceperunt, imo fenes dies noctesque integras in illis tradendis confumunt, juniores vero tradita facile accipiunt, $\&$ retenta fideliter alis quoque inculcant.

Mediterranei contra, immanes, truculenti, finélege, fine religione, feríno prorfus ritu in hunc ufque diem, nulla ftabili aut fixa fede morantur, quin vagantur huc illuc, prout victus ubertas aut penuria tenuerit aut abegerit illos. Soli vivere amant. Tnguria neclatibula ferunt, fed fub dio perpetuo victitant. Ita ut pauca qux de ipfis dici aut fcribi mereantur occurrant. Pifcibus \& feris mira tam odoris quam curfus fagacitate infidiantur. Iacula validiffimis lacertis atque ttupenda arte, fine arcu torquere norunt. Mari non nifi nantes utuntur, qua in exercitątione tantum valent, ut truculentum illud maris monftrum Tuberonem five Lamiam affequantur \& capiant,finiftra ad natandum utentes, dextra acuminatum palum geftantes, quem obvio hofti contra ipfos expanfo rictu horrendoque hiatu infurgenti infidiofe in os immittunt; bellua interim marina manum apprehendere fatagens tali artificio decepta, fefe profunde defigit, \& capere cupiens, vel ab inertibus barbaris capitur, qui dorfo furentis infilientes (pugna fane admirabilis, \& ancipitis eventus) jumenti inftar illam circumagendo per undas, minores pifces in efcam venantur. Præterea adeo ftrenui funt urinatores, ut fi pifcis vel aliud quid in fundo quxrendum fit, patentibus oculis vrinentur totius horæ fpatio. Quod Lectori nonincredibile erit cum dé Egyptiis proditum fit, per totam diem in aquis poffe delitefcere, $\&$ ubi ad fummitatem aqux enataverint, capite non prolatorefirare. Viri pariter a $€$ foemin $x$ fufis capillis, diverfa licet tonfura, cxteris corporis partibus depilatis, vix ullo circa pudenda velamento, incedunt, aviumque difcolorum plumis fe exornant. Colore quodam fufco ex Ianipápa pomo expreflo, corpus turpiter pingunt, ut terribiliores in bello videantur. Et ne facies ornamento de- 
Rtituatur, lapillos viliffimos \& longiffimos, perforatis à prima infantia auriculis, labiifque inferiobus \& maxillis infigunt. Quod licet vifu foedum, illis tamen regium videtur. Ominibus \& auguriis dediti, ariolis, fagis \& impoftoribus quæftui funt. Alii Tonitru; alii Vrfam minorem, aliaque fidera pro numine habent. 'Tanta eft inter illos confufio $\&$ diverfitas linguarum, ut exinde folum atrocifima bella \& crebra nafcantur, inimicitiasque inter fe exerceant perpetuas, fupraque fas humanitatis \& odii fievas:imo vel ipfos ludos aliquando in ferias clades convertant.' Ad bella ituri, miro quidem filentio \& ordine fumplici procedunt. Ad manus ubi ventum eft, horrendo fremitu \& ululatu aërem feriunt, imbrefque fagittarum utrimque emittunt, tam lethali veneno infe¿tas, ut vel leviffime vulneratos crudeliffime interimant. Fœminælactantes \& prægnantes deinceps à virorum confor tio abftinent. Vbi autem pepererint, fecedunt in filvam, $\&$ infanti umbilicum concha precidunt, \& una cum fecundinis coctum devorant. $\mathrm{Ma}$ ritus rempore puerperii uxoris loco decumbit primis à partu diebus, \& puerper $x$ inftar bellariis \& epulis fruitur, fubindicans neceffitatem lapfas vires reftaurandi. Cum in morbum eorum quis inciderit, amici accedunt, quifque ingenium advocat, remedia quorum notitiam experientia fibi comparavit, profert. Mox fpinis arborum Carnaiba, pifciumque dentibus, quibus fagittas afperant, in torofis brachiorum $\& \mathrm{fe}$ morum partibus alte cutem fcarificant $\&$ incidunt, membraque à laffitudine potiffmum vindicant. Idem fere præftant per validam fuctionem, ore pando parti dolenti applicato. Vomitum vi concitant contortis filveftribus foliis, gulæ immiffis. His \& $\mathrm{fl}_{1}$ milibus remediis fruftra adhibitis, nihil ultra tentant, nec tamen $x$ grum relinquunt, fed unanimi confenfi, tamquam de ejus falute defperantes, clavis ligneis illum ferociter interimunt: gratificantes tamen illi, \& ille fibi, quod mafcule interire ipfi contingat, omnibufque miferiis eripiatur. Hoc enim lætabundi in ipfo mortis articulo, quafi de Euthanafia, gloriantur. Non minori cum applaufu in parentis quam victi hoftis cadaver freviunt, illud præx turpi amore, hoc præimmani vindicta crudeliffimarum ferarum ritu dilaniantes \& intra fe fepelientes. Vtriufque carnes (modo non à veneno extincti) offa tenus dentibus abraf $x$ dir $x$ ipfis epulx exiftunt. Optimatum vero cadavera ab aliis optimatibus toita comeduntur, præter offa; qux à proximis confanguineis fervantur ad nuptralia convivia, \& tunc in minutiffimas particulas contufa, bellariorum loco devorantur. Quibus nondum confumtis, capillos fibi, in fignumluctus, evellunt. Vix poffum, quin his addam, quibus præftigiis verbipotentes Sagæ (quas quoque Medicorum loco in pretio habent) \& alii Sortilegi miris artibus populo imponant, miferifque perfuadent, fe ex eorum corporibus, animantia, lapides aliaque exfugere, qux ipfis videntibus evomunt. Imo Reguli ipfi quoque fibi medendi facultatemarrogant, ad quos matres fuos infantes ægros adducunt, quiab illis fricati \& Tabaco confputati , fi interea moriantur, à matre \& confanguineis comeduntur.

Nemo itaque mirabitur fi majorem herbarum cognitionem habuerint Afiatici; quam Americani : cum hi animantibus non contenti, in rationalia quoque ruant. Illorum autem multi ex inftituto Pythagoræ vel abjectiffimo parcentes infecto vegetabilibus vitam fuftineant.

Non abs re forcexiftimavi, fi facta à propofito paulifperdigreffione, aberraverim, barbariemque illam miferam, tum qux huic genti paterna \& innata funt, paucis expofuerim: præterea ut conftet, nullis creaturis adeo voluiffe novercari naturam, quin abunde alimenta \& medicamenta fuppeditaverit, eaque exacte à venenis diftinguere docuerit. Quod cum in animantibus \& plantis quam plurimis folertiffume, tum in radice Mandibóca, Americx primo alimento; imprimis videre eft. Denique ut demonftrem, longe hancà nobis diverfam vivendi rationem \& temperamenta diverios aliquando morbos \& medendi modos fuppeditare.

Reftat ut confideremus, qux valetudini potiffimum vel profint vel averfentur, \& unde originem ducant morbi. Inquit enim Hippocrates, Corrivatio una, confpiratio una, confentientia omnia. Quorum $f_{i}$ vel unum deficiat, tota hominis ftructura facile corruit. Enimvero cum fub Zona torrida, omnia aftra verticalia vehementius agant, \&\&, quoad motum annuum, exceflu fubinde ficcitatis \& humiditatis : quoad motum vero diurnum, perpetua viciffitudine caloris $\&$ frigoris: non poteft non eofdem effectus microcofmus experiri. Vt enim planta novella, Soligeniun, tamquam naturacjus minus conveniens, licet in melius trarifplantata, fxpe non fert : ita multi Euro. 
HIS T. NATVRAL. \& MEDIC. L I в. I.

pxi,aut imbecillitate naturali, aut rite vivendi imperitia vel intemperantia, aëri \& aquis hifce faluberrimis, primariifque vitæ fulcris, minus afluefcere poflunt. Vnde non raro illis de laffitudine fpontanea primæ querela, qux ex fententia Hippocratis, v'́ன\&s $\phi e^{\prime}$ ¿\&\%. Boreales, licet æque ac Meridionales corporibus fint compactis, mollitiem carnium tamen exintemperie incurrunt, nifi tempeftive ea cacochymia exturbetur, miffiș compofitis, folis fimplicioribus tenuiorumque partium alimentis fe tradant, ne cruditas $\&$ craffities humorum fomitem obftructioni, obftructio perfpirationi \& circulationi fanguinis impedimentum adferat. Adeoque fi Hippocratis effatum, $\Xi \dot{u} \mu \pi \pi v i \sigma_{\circ}$ mid, locum habeat, hic fane ejus, tam neceffitas, quam perpetua veritas elucefcit. Quippeimmodico exiftente calore, fiperfiratio undique eft libera, nulla exinde perfentifcitur moleftia; finminus, ponderofius fit corpus, ac brevi materia morbi futura colligitur. Circulatione enim naturx perpetua impedita, \& humoribus fpiritibufque, five ab interna five externa caufa, cohibitis, ingeminatur fervor, pejusque inde quemlibet fe habere oportet. Quod ficut in omni vitx officio veriffimum, ita in fomno manifefto deprehenditur. Idem cogita filaffo vel febricitanti intempeftive medicamentum vel cibus exhibeatur. Ab his itaque fequentibus vitæ inftitutum fiat:

Quisque excelfiorem locum \& contra occidentem opertum, atque in Orientem apertum eligat ad habitandum:talem inquam ubi Continentis craffum ventum ab $æ$ dibus arcere, tenuem vero $\&$ folifequan marinam auram perpetuo admittere commode poffit. Adeo denique mediterraneis locis maritima à veteribus quoque præalata fuiffe conftat, ut Vitruvius narret, tranflatum oppidi \& quatuor tantum milliarium propius mari admotum, falubritate morbofum ftatum mutaffe. Pectoris ac ftomachi regionem probe tectam quifque domi ac foris habeat: quod nilhil hifce corporis partibus magis inimicum, quam poft æftum diurnum, frigus nocturnum. Quo fit, ut claufis cutis meatibus, fudores retro pulfi, varios morbos progenerent. Quibus enim tempeftive fudores fluunt, rarius valetudinem adverfam incurrunt, aut fi quando in morbum incidant, minorenegotio reftituuntur. E contra fit iis qui difficulter fudant. Partes vefte, umbra aut quavis alia re tectx exudant: ex vero quas Sol ferit, infenfibiliter perfirant. Per vim enim à Sole fudor elicitur, fervatur à tegumento.

Aqux thermales vel balnex hactenus incognitæ funt. Artificiales humid $x \&$ ficcx, contra externa mala magno falutis commodo in ufu exiftunt. Qux nunc ex pura puta aqua, nunc compofitxex odoriferis herbis (quas Brafilia producit eximias) conficiuntur. Cavendum tamen, præfertim noviciis $\&$ advenis, ab immoderato vel frigida-
rum vel calidarum ufu. Q uarum illæ torpores $\&$ obftructiones, materiam intus cogen-
do :hæ membrorum langurores, carnium do : hæmembrorum languores, carniumque effæminationes faciunt ob fpirituum exolutionem. Quamobrem ne humor alimentarius facile foras evocetur, temereque refolvatur, Incolx cavent oleis balfamifque nativis. Quafi barbaries commune quid habeat cum erudita antiquitate, cui familiaris olim fuit, licet nunc exoleverit, un-
ationis ufus.

Porro exercitia vehementiora fedulo vitanda funt. Aura hæclicet blandiffimeterram exhilaret, Solisque ardores clementer mitiget, tamen motu defatigatis obeft. A vento enim adiapneuftia : ab immoderatiori vero exercitio, fumma humorum fpirituumque accenfio \& acrimonia proficifcitur. Tempus arnbulationis opportunum eft matutinum, modo maris acceffus auram intendat $\&$ maturet; exhalationesque nocturnæ prius cifpellantur: tunc enim blande ftringitur \& concentratur calor naturalis: Maxime autem ambulare circa Solis occafum prima vefpera conducit: quod vires corpori, robur \& appetitum ftomacho reftituat, ob temperiem optimam aëris \& auram intenfiorem : Cum tamen aliis Europæ \& Africx regionibus calidioribus vefpertinus flatus; Seren Lufitanis dictus, merito extimerifoleat. Labores \& motus vehementiores tum animi tum corporis, maxime obeffe: lucubrationibus quoque mentem citius turbari, memoriamque labefactari afferunt. Hoc certum eft, difficilius vigilias \& labores ob citam virium exhauftionem tolerari fub $Z$ onis torridis, quam temperatis; torporemque advenas $\&$ defidiam primo quidem invifam, at poftea placitam contrahere. Somnus diurnus brevis, quem in lectis penfilibus promifcua multitudo capit, commendatur. Infuetis tamen aliquando obeft, ac propterea multum concedendum hacin re confuetudini. Corporis vigilantis decubitus merito præferendus fomno, præfertim eo lociad quem aura marina, non radii Solares poffunt pertingere. Somnus nocturnus in

$$
\mathrm{B}_{2} \quad \text { lecto }
$$


lecto mollióri, \& plumis avium referto, admodum improbatur, quod vifcera accendar, Qui Sanitati confultum vult, pedibus coxifve nudis ne jaceat, præfertim poft mediam noctem. Denfato enim corporis habitu à nocturno vento venæ arteriæque per fe meanti fanguini tranfitum, tum \& perfirationi infenfibili atque fudori exitum præcludunt: ac tum quidem, ob tranfpirationem cohibitam, poftridie pejus \& gravius habent. E diverfo illi qui mediocriter cooperti fomnum eapiunt, jucunde ac optime valent, levior efque fe fentiunt, emiffo pr $x$ fertim fudor levi $\&$ roris inftar tenui. Adeo ut facile fit in hifce Regionibus, concedere Sanctorio, Per tranfpirationem infenfibilem plus evacuari, quam per omnes fenfibiles junctas.

Qui Veneris æltui frenum injicere nefciunt, hujus cæli temperiem ferendo non funt, ardorem juvenilem extinguunt, fenectutem ante tempus maturant, perfpirationemque remorantur. Vnde cruditates ad ambitum effunduntur, catarrhos in cerebro, in corde palpitationes moventes.

Inediam Incolæimpatientius ferunt. Ante omnes biliofis vehementer obeft. Qui fi Itomacho forte vacuo fomnum capiunt, facile tum capiti, tum cordi mala accerfunt. Proinde ægris juxta $\&$ fanis conducit modice $\&$ frpiufcule cibum $\&$ potum capere.qui quo minus compofiti vel calidi, eo conducibiliores ad fanitatem. Quisquis enimféram $\&$ beatam Senectam attingere defiderat, five advena, five indigena, caveat fibi à vini $\&$ carnium ufu quotidiano. Qux enim ex nutrientium $\&$ calefacientium funt ge. nere , fiquidem vincantur, corpora quidem fanguine $\&$ calore replent : Sed fin minus, frigidi $\&$ aquofi folent nafci humores. Calida omnia $\&$ amara atque acria mane imprimis vitanda. Poma vero Aurea, Limonia, Citria, Mangába Murucujá, melopepones, Citrulli, reliquaque refrigerantia, five cruda five condita utiliter comeduntur à jejunis, quibus inter delicias facra habentur, quod cordi conferant, tum $\& z$ menfibus præcipue $x$ tivis adjucundiffimam maturitatem perveniant. Vnde abiit in proverbium, Non intrat $æ$ des medicus, in quarum veltibulo crebri Arantiorum cortices mane confpiciuntur. Sedulo cavendum ne fructus ulli colligantur, antequam radiifolares ab exhalationibus nocturnis eos repurgaverint. Præftat illos, aftringentibus exceptis, ante potius quam poft paftum, \& faccharo conditos quam crudos apponere. Fugaces enim cum eorum multi fint, facile corrumpuntur, imprimis iis, quibus imbecillis $\&$ intemperatus eft ventriculus. Ego quidem Galenum imitatus, pepetuo fuafor fui amicis, ut rarius horariis fructibus fefe oblectarent : unde ipfis diu multumque bene fuit. In quotidiano ufu potiffimum funt (nam reliquiad Hiftoriam Naturalem pertinent) Ananas, Mangába Acajú, Araçá major \& minor, Guajába, diverfǽ fpecies CMurucujá, Ibapitánga, Majarandiba, Acajá, Araticú Guiticarói, Biringéla, pinoguaçu, Cocos, Banána, Pacóba, ficus quoque filveftres. Hi omnes inter patrios habentur, eorumque maxima pars fponte provenit : nonnulli à Batavis \& Lufitanis in hor tis excoluntur tam feliciter, ut ipfi fructus vilefcant. Inter fubterranea funt Radices Patáta \& I mbú, tum glandes Americani Munduy optimi faporis \& nutrimenti, atque fecund $x$ menfe delici $x$. Non procul à littore in locis arenofis \& falfa xquor is unda imbutis, adeo fponte luxuriat Portulac $\&$ Braffic $x$ marin $x$ five Soldanellæx quoddam genus, ut pro acetariis quotidiznis fufficiant.

Inter feras plurimæ exifunt, quæ victui fervire queunt. Apri majores $\&$ minores, umbilico in dorfo præditi, carnibus optimis \& faluberrimis cenfentur. Amphibii porci, capiverres Lufitanis dicti, licet dignitate cæteris inferiores, integris militum $\&$ Barbarorum cohortibus alimento probo funt. Idem de Erinaceis diatum volo. Antxetiam lucifugx, mira vifu animalia, carnes bubulas referunt. Caprex, tum Lepores \& Cuniculi, Europax haud cedunt. Tatufix denique diverf $x$ fpeciei loricat $x, \&$ infignes ill $x$ lacertæ, corrupte Leguána dictæ, in delicatiores epulas expolitæ. Neque hæc tantum, fed \& alia identidem filveftria \& domeftica, catervatim in faltibus oberrantia, nuper ab Europais invecta funt pecorum armenta, imprimis boves, porci $\&$ arietes. qux bifera \& trifera utcumque exiftunt. Inter hæc nefrendes teneritate carnis excellunt ufque adeo, ut ægror um diætam ingrediantur, \& ovillæ longe præferantur. Experientia enim conftat, multa quadrupedia, pifces ac aves in conofis $\& \mathrm{c}$ paludofis locis viventia, non idcirco adeo poftponenda effe montanis \& fluviatilibus, ficut plerumque fit in feptentrionali Europa, quod in hifce regionibus calidioribus eximia aëris temperies \& ferenitas correctorii vicem quafífubire videatur circa naturam ejufmodi animalium. Avibus 
HIST. NATVRAL. \& MEDIC. LIB. I.

Avibus filveltribus, partim in nemoribus, partim in aquis viventibus, optimi guftus, haudquaquam deftituuntur. Licet non fit hujus inftituti eas prolixe enarrare, tamen præterire nolo, qux palato \& fanitati ferviunt. Vt funt quæ in montanis habitant, Phafiani, Perdices, Accipitres diverfe fpeciei, ac carne optima \& tenerrima. His fuccedunt Pfittaci, Coturnices, Turtures, Palumbi, Turdi, Fringillæ, Columbæ filveftres, quæ omnes toftæ menfis inferri folent. Ex amphibiis celebrantur Anferes \& Anates diverfæ fpeciei, quarum quædam Europæas dignitate \& magnitudine fuperant, quædam vero iis cedunt.

Caterum inter tot volatilium genera riparia \& littoria (eorum licet aliqua fint carne minus tenera ) Ardex ftellares \& non ftellares, Rufticulæatque Gallinæ paluftres, \& fimilia, minus funt prxtereunda. Adde \& Struthiones primarios Ambræ grifex præ dones. Nobile illud Bituminis genus Ambra dictum, Spiritibus imprimis vitalibus reRaurandis per omnes Indias celebre, ex ignotis Oceani faucibus copiofe in Brafilix littora eructans, non nifi procellofo mari alluit. Vnde fit, ut vix ceffante tempeftate aves \& quadrupedes nonnull $x$ in ipfo littore certatim eam devorent, priufquam ipfi maris accolæiftuc perveniant. Quod equidem mirum, cum omnis ante infolationem mol1e tantum gluten fit Ambra, ingratoque adeo odore nares feriens ut ab inexpertis plane refpuatur : animalia tamen dulcem ejus odorem, licet hominibus adhuc latentem, prius perfentifcant, ejufque fapore ftrenue fe oblectent:

Enarrato carnium ufu quotidiano, de pifcibus nunc dicendum. Dubito nobilitate $\&$ frequentia pifcium an ulla Regio beatior hac cenferi poffit ; Mari, fluviis \& lactibus pifcoffflimis, fquamatos, afperos, læves, molles, cartilagineos, turbinatos, omne genus abunde fuppeditantibus. Vnde advenæx æue ac primi Incolæ rgri ac fani perpetui funt Ichtyophagi: quippe non folum exhaufto omni penu, pro primario fuftentaculo, fed præ: cateris deliciis, ficut olim Romani, eos amplectuntur. Inter quos Cyprini, Alburni, 'Tincæ, Carpiones, Trutæ, Auratx, Lupi, imo ipfi Afelli, Europæorum figura \& fapore æmuli, primum facile locum tenent. Tum Orbes, Solex, Scombri, Acus, Raja, diverfæ fpeciei. Cancris quoque, Tefudinibus, Gammaris, Squillis, Conchis, Oftreis, omnibufque teftaceis $\&$ cruftatis, præfertim paludes receflu maris exficcatæ , magnopere fcatent. Congri denique, Scari, Anguilla, \& hujus generis alii , quibus fuperfedeo.

Qui in fuperficie maris degunt pifces, menfibus potiflimum pluviis, quod imbribus zaudeant, capiuntur: iis vero qui in receflu fluviorum \& alto mari funt, omni fere anni rempore, fed ut plurimum xftate pifcatores infidiantur; atque, tum melioris pabuli gratia, tum ardoris extimefcendi caufa, proxima fcopulis domicilia inque iis falubriorapafcua deligunt, ac proinde faxatiles \& fundi pifces dicti. Præcipuorum nomina, icones, differentias $\&$ proprietates videre eft in fequenti libro.

In finubus vero $\&$ lacubus nec pifcium copia nec varietate à maritimis fuperantur, quod, licet promifcue alii aliis celerius pariant, \& crefcant, in lacubus tamen his æque ac in fluviis citius, quam in ipfo mari id fieri contingit. Iiquelicet marinis $\& \dot{\&}$ fluvialibus dicantur inferiores, dignitate haud multum tamen cedunt, quod non ftagnantes vere fint aqux, fed perfpirent, indeque fluenta \& rivi aliquando egrediantur.

Pifces denique vel Sole exficcantur, vel fale (qui copiofe in falinis hic colligitur) condiuntur, inque penu confervantur. Quodfi crudioris cibi imprimis pifcium concodioni aqux potun minus fufficere experiantur, pulverem ex fale $\&$ modico piperis Brafilienfis praparatum, Iuquitajá dictum, intermifcent, condimentumque inde conficiunt ventriculo faluberrimum, atque in omni peregrinatione merito circumferendum. Ita ut verifimum tandem in hife calidioribus terris compererim illud Galeni teftimonium de Graciæ pifcibus. Alimentum fcilicet ex plerifque pelagiorum \& Huvialium proveniens, fanguinem confiftentia tenuiorem gignere, quam quod ex pedeftribus animalibus producitur, adeo ut non copiofe nutriat, \& celerius difcutiatur. Hæc de cibis fufficiant.

Potus porro ufitatus \& longefaluberrimus (fupra illum quem cx tot fructibus exprimi diximus) aqua eft limpidiffima, divinitus hifce regionibus concefla. Quxjucundo'refrigerio, Solis imprimis ardore fractos, refocillare ac fummopere recreare folet. largius \& crebrius pota, nullos in ventre vel hypochondriis flatus aut tormina excitat, neque ventriculum debilitat, fed melius quifque inde fe habet: modo 'voróñ⿻ \& 5 (a), \& Regionis temperamento conformis fuerit: Atque hinc quidem ilico fudores \& uri- 
nas provocat, adeoque appetitum ftomacho acuit, ut voraces Incolas reddat. ob miram enim fuam tenuitatem alimentum in partes liquidiores penetrans intimius dividit, impediens, ne vel pinguior alimenti fuccus aduratur, vel ejus cruditates ad renes aut membra externa protrudantur. Vndefit, ut à calculi imprimis \& articulorum morbis præfervet, rarifim $x$ que de duobus illis malis fint querelæ. Conftat, plurimos beata admodum fenecta à to xrumnis libera centefimum attigiffe annum, nec alium potum pixter aquam toto vitæ curriculo guftaffe. Vnde facile eft affentiri Veteribus,

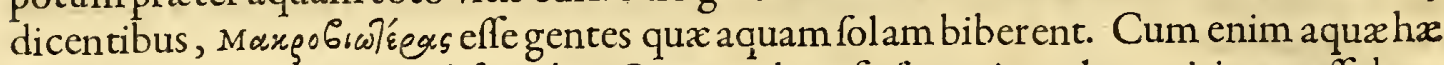
nive $\&:$ metallis deftitutæ è fontibus Orienti obverfis fcaturiant, longo itinere affiduoque Solis ardore excoquuntur, gratifimæ $\&$ tenuiffim $x$ evadunt, nihilque deponunt. Hibernis menfibus minus quandoque limpid $æ$ ob crebras pluvias, nec æque frigid $\approx$ : Eftivis, ob auram intenfiorem, frigidifimæ funt, nec tamen dur $x$, ficut in frigidioribus regionibus; fed molles, leves atque concoctu faciles. Aquæ eximbribus collectx leves quidem fed calid $x$ funt, $\&$ facile putrefcunt, quod ex plurimis $\&$ diverfis partibus conftent; ravimque fubinde inducunt nifi excoquantur. Sicut enim contingit hominibus nudis fub Sole fedentibus tenuiflimum educi per poros, relictis veluti fæcibus : ita Sol vertical is facile quod leviffimum furfum rapit ex lacubus ipfoque mari,relicto quod falfum eft propter craffitiem \& gravitatem. Qux ex tumulis \& montibus profluunt, iis conducunt, qui ventre funt duriore. fi qux vero aquæ faxa $\&$ ferrum recipiant, iis conducunt, qui humidiori \& molligori funt ventre, quod reficcent. Ab aquis fubfallis \& $\mathrm{pa}$ luftribus in totum abftinendum, quod indomitx $\&$ duræ ventres adfringant. Ac proinde ob imperitiam illi qui ventrem folvere exiftimant, falluntur, quia raro perfluunt, $\&$ cum ftabiles funt, à Sole exuruntur, novoque accedente imbre, crafl $\&$ olid $x$ evadunt, unde fit, ut bibentibus lienes magni \& compacti fiant, ventrefque duri \& calidi. Veterani non minus folertes funt in aquarum differentiis guftan dis, quam Europæi in diverfis vinorum qualitatibus difcernendis, quos imprudentix infumulant, fi nullo habito difcrimine aquas bibant. Illi enim optimas nihilque fubfidentes hauriunt, quas fublimioribus locis (fubterraneis ob teporem neglectis) in urceis fictilibus noctefque diefque fub dio refervant, ubi invitis radiis verticalibus intenfiffime ipfo momento refrigeren, , tur, ad Aphorif.Hippocr. Aqua qux cito calefit \& cito frigefit, leviffima eft. $\mathbb{E}$ Afuantibus tamen eam licet gratiffimam, nifi offa conditurx ante deguftata, bibere non convenit. Cum è contrario pubes nautica $\&$ milites, peffima omnino confuetudine, frigida largiffime haufta Spiritum vini metu cruditatum fuperbibunt. Quafi cjufmodi vehiculo opus effet, eque duobus hifce contrariis, cordis aliorumque vifcerum tenus nihil pateretur. Prxterea Afrorum \& Europæorum promifcua turba, olenteillo \& nimium familiari potu, qui Gsrápa vulgo appellatur, fe implent, quem caupones, lucro inhiantes, ex nigro faccharo \& aqua conficiunt, \& vix defrecatum vili pretio divendunt, additis fubinde foliis arboris Acajuéra, quorum calore vapores excitantur, citiufque inebriare facit. Concedi tamen poteft, fi fumatur modice, fi rite factum \& vetus fit. Dilutum quoque aliud exaqua fontana faccharo $\&$ limonibus confectum fani pariter ac xgri in deliciis habent. Sicut \&illum liquorem quem Lucanus apud Indix populos in ufu fuiffe teftatus eft.

2uique bibunt tenera dulces ab harundine fuccos.

Cerevifiam vero Europæam, Vinum abfinthites, vini quoque Spiritum quidam ceufalubriora his oris maximopere commendant, fed immerito. Vinum Creticum per omnes Indias quod per fe fine arte fubfiftat, cxteris vinis Europæis eft præferendum. Cujus ufus modicus fit vefperi, mane nullus. Necleviter peccant, qui Torridis plagis paulo plus jufto illud bibunt. Quippe nunquam expertum eft, potus frigidior is exceffum, tantum nocuiffe, quantum calidioris, quidquid nafutiores refragentur, quibus ob malam confuetudinem \& intemperiem jam vini ufu acquifitam fecus videtur. Ventriculus enim eorum extenuatus ob inopiam caloris nativi, atque etiam ad ipfum aliunde influentis, cogit eos vino uti, atque in ejus ufu perfeverare. Quod quoque Galenus lib. v. de fanitate tuenda cap. X I r. confirmat. Spiritum enim exvino vel fructuum ficera deftillatum calere non tantum, fed $\&$ ficcare conftat, tum potiffimum quando pituita cruda ac freculenta colluvies pabulum haud fufficiens objiciunt, in quo acerri$\mathrm{ma}$ atque cxurens vis fefe hebetet. Et tunc vifcera accendit, appetentiam profternit, \& pedetentim nimia confuctudine exequias ante mortem maturat, ut millies, proh dolor, 
HIST. NATVRAL. \& MEDIC. LIB. I.

dolor, obfervatum eft in Indiis. Quin vinum ipfum, ejufque extractum, tamquam Mcdicina infirmis tum animi tum corporis, data funt : hoc ad nimiam Spirituum diffufionem verfus centrum in momento revocandum; illud, vel ad hilaritatem excitandam, vel ad laffitudinem tollendam, vel denique ad ftomachum in fenibus roborandum: fed quia pauci non infirmi, facta funt tandem omnibus potus. Ex his itaque fatis liquere puto, veras longxvitatis fimul \& incolumitatis caufas ; cum aër, olera, fructus, animalium carnes aquarum naturam fequutx, per continuam generationem eo deveniant ut hominum temperies fere fit qualis aquarum.

Hactenus de ufu $\&$ abufu rerum, ut inde conftet, hunc orbeim habitanti, quibus $\&$ quo pacto tueri ac firmare valetudinem poffit $\&$ debeat. Antequam autem de lapfà reftituenda agamus, paucis attingendum duxi, quinam morbi quxvis anni tempora ac conftellationes, præcipue Lunæ, xftufque aquarum refpiciant : quique inter diverfas gentes, vel difcrepantes vel communes fint. Primum quidem, cum ob conftantiam \&xqualitatem tempeftatum, hæc plaga faluberrimam temperiem ex calido \& humido fit nacta, mutationes nec tam magne, nec tam crebrx, ut fupra dictum eft, fiunt: unde certa falutis \& longevitatis indicia proficifcuntur. Quia, ut ait Hippocrates, Mutationes temporum potiffmum pariunt morbos; \& in ipfis temporibus magna mul- c tationes aut frigoris aut caloris, \& alia pro ratione eodem modo. Semeftre fiquidem c pluviofum, licet humiditas prædominetur, tamen à jugi Solis fiplendore moderamen accipit. Q uod fi ex debito \& tempeftive fiat, annum proximum faluberrimum, \&zà multis morbis immunem prænunciat. Semeftre eftivum, rore copiofiore imbrium raritatem compenfat. Hifce temporibus aftivis, ficut morbi citius definunt, ita acuti ut plurimum \& boni judicii funt. Secundum illum Aphor. X v. lib. I I I. Ex conftitutionibus c anni in univerfum ficcitates affiduis imbribus funt falubriores $\&$ minus mortifer $x$. c Hinclaterales morbi, febres ardentes, raro lethales. Per ficcitates autem febres acutæ fiunt, \& fi quidem annus maxima ex parte talis extiterit, qualem effecerit confitutionem, tales ut plurimum quoque morbos expectare oportet. Licet enim Lepra \& Scabies hic incognitx; impetigines tamen contumaces, pruritus, dyfenterix, haimorrhoides, inflammationes ani $\&$ oculorum, ex fervido Sanguine generari contingit. Quibus malis medendis aqux frigid $x$ vel tepid $x$ tam externus quam internus ufus cxteris prafidiis facile palmam eripit. Ephemeras, ob accenfionem fpirituum, vel ex Sole verticali, experimur, quas multa frigid $x$ irroratione per totum corpus facta, Empirici in Athletis, inftinctu naturali potius quam Hippocratis vel Galeni preceptis
ducti, reftituunt.

Hibernis menfibus fi Aufter perpetuus corpora exfolvat, humectet languidaque reddat, qui generantur morbi, prxcipue funt febres putridx, multa capitis ac ventris pituita, (juxta A phorifm. X v I. lib. I I I : Affiduis imbribus morbi fere funt febres longe, , c fluxiones alvi, putredines.) prolapfus cartilaginis enfiformis, albus alvi fluxus caeliaco cs affectui fimillimus, hydrops, hernia. Omnium autem maxime, oppilatio hepatis \& ventriculi imbecillitates: quæVifcera fimul cum anni tempeftatibus mutationes accipere folent. Spafmus, torpor, ftupor, cxterique nervorum affectus in Indiis apud advenas frequentes funt, atque præcæteris pifcatores, fabri, piftores, tum milites humi cubantes, illis infeftantur. Porro ficut capitis vulnera $\&$ ulcera, vel fpontevel folo gummi Elemni indigena facillime curantur;ita pedum ulcera tantæ funt malignitatis, ut vix curationem nifi æettate recipiant.' Omnibus pariter fervidioribus plagis commune videtur, plurima mala tum externa tum interna, qux infra hepatis regionem funt, difficilioris effe curationis: contra vero, qux fupra; quod à perpetuo defcenfu humorum acrium fint libera. Morbi alii ad alia tempora bene vel male fe habent, \& fine Medicamentis aliquando, auctore quoque Hippocrate, curantur. Plerifque tamen his morbis æettas non vacat,juxta A phorifm. X I X. lib. I I I. Atque hi omnes enarrati affectus huic Regioni tamquam patrii funt. Febres quotidianz rariffime hic inveniuntur. Imo cum Galeno affercre audeo, me quoque nunquam Iuvenem ullum, aut Virum natura calidum quoquomodo aut biliofum, iis febribus correptum vidife: fed pueros tantum voraciores $\&$ hyeme prafertim exiftente valde humida.

Quantumad xtatem, infantia \& juventus, ut dictum fupra, morbis frequentioribus infeftantur : Senes vero rarioribus. ad Aph. I I r. lib. I I I. Morbi alii ad alia bene " vel malefe habent: \& quxdam ætates ad anni tempora \& loca, \& victus genera. Et "

$\mathrm{B}_{4}$ Apho- 
, Aphorifm. x x X v I I I. lib. I I. Magnam partem fenes juvenibus minus æogrotant. Catarrhi qui frigidis Regionibus fenes, hic potiflimum Ituvenes \& Infantes infeftant'; unde nervofum genus quoque inficitur.

Morbi diverfis in nationibus variant. Noftratibus, imprimis noviciis \& mulieribus, funt compofiti plerumque \& chronici. Atque eorum longc plures morbis capiuntur frigidis quam calidis, quod à nocturno frigore minus fibi caveant, \& à diurno æeftu calorem innatum cvocari patiantır; tum quoque ex nimia nutricntis cibi \& potus ingurgitatione, calor naturalis inftar flammx imbecillis, cui multum olei confertim infunditur, fuffocctur : unde corporanon folum non calefiunt, fed \& frigida vitia gignuntur. Quippe in tam pertinaces incurrunt vel vifcerum obftructiones, vel alvi fluxus, ut paffim languentes decoloresque ac viva cadavera incedere videas. Lufitanis minus compofiti, fed acutiores folent obvenire morbi : Brafilianis rari, iique acuti $\&$ fimplices, ac proinde eor um curationes \& prædictiones minus fallaces.

Quodfi æftas admodum ficca fuerit, biliofis \& melancholicis ob nimiam aduftionem male fit. Humidum fiquidem, quod in ipforum corpore adhuc reliquum eft, calor depopulatur $\&$ deficcar, partibus vifcofis $\&$ craffioribus manentibus. Vnde Tertian $x$ exquifitx \& Quartanæ non minus quam in Europa graves. Sed majori cum acumine citiufque terminum attingentes. Pituitofis hæc omnia è contrario eveniunt. Hieme autcm minus pluviofa, teporibufque ob defectum auræ marinæ fufcitatis, corpora non conftringuntur, fed cerebrum nervique humiditate aculigine opplentur, quææftatis mutatione fubito accedente, circa $\overparen{A}$ quinoctrum Autumnale valde noxia. Nam quia venter à redundante humore liberari nequit, aquam intercutem, profluvium album $\&$ difficultares inteftinorum inde naf ci oportet. fic mulieres, licet foecund $x$, non concipiunt tamen, crebroque abortiunt, aut fi quando parturiant, difficulter fotum enituntur, eumque debilem brevique interiturum, aut certe valctudinarium. Quod quidem potifimum de advenis mulieribus dictum fit. Quantumvis tempus $x$ ftivum hiberno fit magis falubre, quoniam in Brafilia ficcitas humiditati prævalet, naturarum ramen aliæ ad $x$ ftatem alix ad hiemem bene vel male fe habent. Proinde mulieres \& infantes, cum corpore fint magis pituitofo; xftate melius quam hieme valent. Contra gracilia \& biliofa corpora, mclius hieme, pejus æftate. Et hæc quidem de intemperatis, qux moderato contrariorum ufu confervantur, corrumpuntur à fimilibus. Contrarium vero in temperatis fieri confuevit.

Cxterum à morbis, qui è vaporibus ex terrá aut lacubus ortis nafcuntur, non eft libera Brafilia. Cœlo enim exiftente turbido, \& vento marino à terreftri victo, fubito fiunt febres, catarrhi $\&$ raucedines. Incolæ teftantur, occulta quadam vicifftudine fingulis feptenis annis humidos admodum $\&$ morbofos menfes hibernos dari ; \& his fex alios falubriores ac ficciores fucccedcre. Verumque comperi, non contemnenda effe ipforum monita. Ab iis tamen qui Epidemici vere dicuntur, \& à tetra qualitate hinc inde eructante, vel à maligno Syderum influxu, certis temporibus feviunt, immunis femper fuir habita. Anno millefimo fexcentefimo quadragefimo tertio, xitate admodum ficca, Anthraces non lethales apparucrunt. Variolæ peftiferæ, quas teftatur Profper Alpinusin Ægypto bis in anno graffari inter pueros, hic incognitx. Triginta annorum decurfum femel duntaxat Africana mancipia huc Variolis laborantes devecta, reliquos, nullo modo contaminatos, ingenti Barbarorum ftrage, inquinarunt. Pari fere modo contagiofa Lues inter pecora domeftica, hieme pluviofa, aliquos greges depopulata eft. Eo tamen malignitatis contagium afcendiffe, ut peltis, (ficutin Peruvia non folum, fed \& in multis Afix \& Africx partibus contingit) aut morbus pefti affinis, inde cxor tus fuerit, à nemine unquam compcrtum eft. Magnos autem \& frequentes illos dyfentericos affectus nunquam in Epidemios tranfiifle, admiratione dignum puto. Quafi affiduitas Euri, ex Oceanofpirantis, aërem ferenet $\&$ verrat adeo, ut feminaria contagii impediantur haud aliter à calido $\&$ ficco, quam fub Zonis tempcratis à frigido \& ficco extingui videntur. Vel quia deleteria miafmata, eximia Aëris puritate abforpta atque cvicta, finon in totum percant, faltem vigore deftituta, vernaculis quidem, fed non graflantibus illis morbis pariendis fufficiunt. Vnde apparet quanto Epidemici cxteris vulgaribus funt vehementiores, tanto in aëre ad mutandum corporis habitum, \& ad peius aut melius difponendum, incfic vim majorem quam in dixta $\&$ cateris non naturalibus.

Plenilu. 
HIST. NATVRAL. \& MEDIC. LIB. I.

Plenilunio ac novilunio, imo $\&$ quadrantibus fingulis, alterationes manifeftas corpora recipiunt. Quo fit, ut Medici non nifin neceffitate urgente, medicamenta propinent. tunc enim dolor exafperatur, \& pejus habet æger. Idem cogita de Solis motu diurno, cum fupra fidem circa meridiem, biliofi morbi, noctu vero pituitofi, ingravefcant. Motus Lunx diurnus non minus quam mentruus, mutationes evidentes fufcitans, obfervatu digniflima operatur. Singulis enim fex horis, accedente mari, morbum ingravefcere ac dolorem exacerbari : viciffim fex aliis, quibus mare recedit, cruciatus paulatim minui \& mitigari, ipfi ægri teftantur. Quod in acutioribus juxta ac minus acutis morbis, præcipue in iis qui è fluxionibus \& plenitudine oriuntur, apparet. Adeo accrefcentibus aquis, eftuque maris in plenilunium incidente configuntur cum infirmitate nonnulli; ut etiam vitam cum morte commutare videantur : quum tamen vix quemquam tuncinteriiffe obfervatum fit. Plerofque autem pelago decrefcente extingui xgrotos, quia preter aliorum teftimonia ipfe toties experientia comprobatum habeo, confidentius confirmare aufim. Idem in partu fieri ab obftetricibus obfervatur. Ita ut validifim $x$ h $x$ influenti $x$ occult $x$ Coeli mariumque qualitates, eofdem effectus nafcenti \& denafcenti impertiri videantur, \& hunc à vit $x$ anguftiis, illum à carcere \& vinculis uteri materni abfolvant. Hxc eadem de animantibus brutis affirmant, quod àme tamen nondum expertum fateor. Ariftoteles nullum animal maris xftu exfpirare inquit. Nec eft cur Plinio aliifque veterum hac in re pareamus, quafiab Aftris, vel Lunx potiffimum defectibus \& auctibus id dependerer. Cum frdus illud molle; fomineum, nocturnum, fi in conchylia, frondes, fimiliaquie fublunaria agat tanquam caufa remota; minus verifimile tamen, in hominem eo ufque vires fuas exerere, ied eum potius ex propiore caufa pati. Cum enim abundat vaftifimus hic vicinus Oceanus, omnia non folum quæ proxima funt, fed etiam longius diffita, multo vegetiora \& quodammodo repletiora fiunt, atque alterantur emacianturque illo recedente, præcipue qux aliquo humore madent, ut cerebella, medullx, fanguis, \& fimilia. Sicut in corporibus noftris commercia funt firitualia, ita quoque in profundis vafti Oceani nares quafi mundi conftitutx per quas remifffanhelitus vel reducti modo efflent maria, modo revocent, unde ejus accolx imprimis non parum afficiuntur. A plurimis haud vanæ fidei expertiffimis viris accepi, fenes Empiricos in praxi exercitatifimos, ad hor $x$ f patium mortem fibi prædixiffe, \& tunc demum pronuntiaffe, poftquam jam aquxreceffiffent; cumque illum defluxum evafiffent, fpem certam concefiffe ad fequentem receflum fe fore fuperftites. Quod ipfum ita contigit, temporeque dicto occubuerunt. Hxc, ut admiratione digna, ita Medico perquam neceffaria, ut de alterius falute, fuoque honoreminus periclitetur. Hanc naturx latentem vim anxie difputare, non eft hujus propofiti : fufficiat per effectus fciviffe, quod perturbatio hæc criticum, aliquando fymptomaticum quid prxfe ferat, pro difpofitione naturæaut materix morbificx. Sicut enim nox, ad Aphorifm. x I I r. lib. I I. crifin pr $x$ cedens, $x$ gris molerta effe folet, qux vero fubfequitur, levis : ita oppreffio hac aquis decrefcentibus definens, quo gravior fuerit, eo melius $\&$ levius diffofitum relinquit corpus, fi modo requifita ad crifin adfint : fin minus, mors eo certius fubfequitur. Obfervandum autem quod hre perturbationes noctu fortiores, quam interdiu exiftant. Quafi hi motus, Lunæ plerumque motum fequerentur, quæ noctumagis quam interdiu vires fuas exerit.

Crifum obfervationes frequentiflime occurrunt, modo morbi natura rite cognofcatur, principium cxteraque morbi tempora non negligantur. Et totum hoc quidem in fubjectis ad Coeli Solique hujus temperiem conftitutis, omniumque maxime in Indigenis, comperies. Crifes frepe perfect $x$ fiunt, \& quidem tempore xttivo potifimum, quia magis conftantia \& $x$ qualia tunc funt tempora. Quapropter Hippocratis Aphorifinum lib. I I r. veriffimum quotidic experiri datur. Conftantibus temporibus, fi c tcmpeftiva tempeftive fiant, morbi ftabiles \& boni judicii accidunt: incontantibus c。 autem inftabiles \& mali judicii. fxpe quidem per hæmorrhagias, fapiffime vero per c fudores; quos calidos \& magna copia è corporibus fuentes, maxime falutares comperi, idque diebus imparibus, juxta Aphor. Xx X v r. lib. I v. fin minus, ut ex defeatu virium fit, \& citius quam die feptimo, malum. Nec minus crebro per fluxus ventris crífes manifefte apparent. In quantum Symptomatici fluxus alvi, mortales in his terris excruciant, in tantum natura critice aliquando per eandem fe exone- 
rare amat. Tum, ficut longo alvi profluvio detento vomitus arte concitarus, prodeft? ita fponte fuperveniens frepifime folvit morbum.

Porro, quemadmodum hodicrnæ novi orbis navigationes confirmant, quodfecundum diverfa illa mundi Climata mores gentium \& victus diverfi funt; ita \& morbi mortefque difcrepant: Vtque veteres morbos extingui contingit, ita \& novos ex infolita hac fiderum reciprocatione \& inclinatione, atque Terr $x$ Autralis temperie generari: quorum aliqui tranfeunt ad alias mundi regiones, aliqui permanent; aliqui vero graffari defierunt (ficut de Egypto quoque teftantur authores) ob mutatam viđus rationcm. Imo, præter hæc quod Cælum, Anni tempora, Aquarum \& Ciborum diverfitas , Ratioque vivendi prorfus alia, facile temperamenta immutent, accedit variarum quoque nationum mixtura. Sic Europxi coëuntes cum Americanis foeminis. Mamelucos, cum Æthiopiffis Mulatos: denique Americani cum Africanis Nigritis Cabocles vocatos progenerant. Ex Athiopifis cum Lufitanis aliquando gemelios alterum alba cute alterum nigra, crifpis capillis, oculis crfiis nafci vidimus. Quafi non folum vegetabilia $\&$ fenfitiva tranflata degenerarent; fed $\&$ gentes alio traductx $\&$ gentibus externis commixtæ nativum genium amitterent, haudfecus ac fluvii falum ingreffi propriam perdunt aquarum dulcedinem. Quod cum ita fit, quis dubitet, ex ejufmodi variis infitionibus \& femente, non diverfas fructuum crafes exfurgere, atque inde nunc implicatos, nunc novos generari morbos; qui exercitatiflimos quandôque viros ita defatigarunt in praxi, ut circa morbi diagnofin \& prognofin, quam maxime vacillaverint? Atque in tanta rei incertitudine non minus hi circa morbos Endemios, quam illi fuam. olim in Luce Venerea, Sudore Anglico, Scorbuto, Plica Polonica, Mentagra ÆEgyptiorum, aliifque id genus morbis dignofcendis $\&$ curandis, infcitiam ingenue fine confeffi. Donec tandem remediis exquifitioribus inventis, morborumque temporibus accuratius obfervatis, quofdam expulerint. Nonnulli morbi ex parte novi videntur, quia periodum, tempus, eademque accidentia, non rite obfervant, curandi tamen rationenon femper differunt. Qux omnia ut recte dignofcantur, folerti $\&$ fagaci judicio, multaque experientia opus eft. Ego, quantum temporis publicis curis fubcidere potui, Obfervationibus hifce colligendis impendere volui. Spe certa fretus, poftventuros Iatrofophos fuo ingenio atque induftria, ea qux adhuc defiderántur, aliquando fuppleturos, aut fi qux minus recte dicta, candide reftituturos.

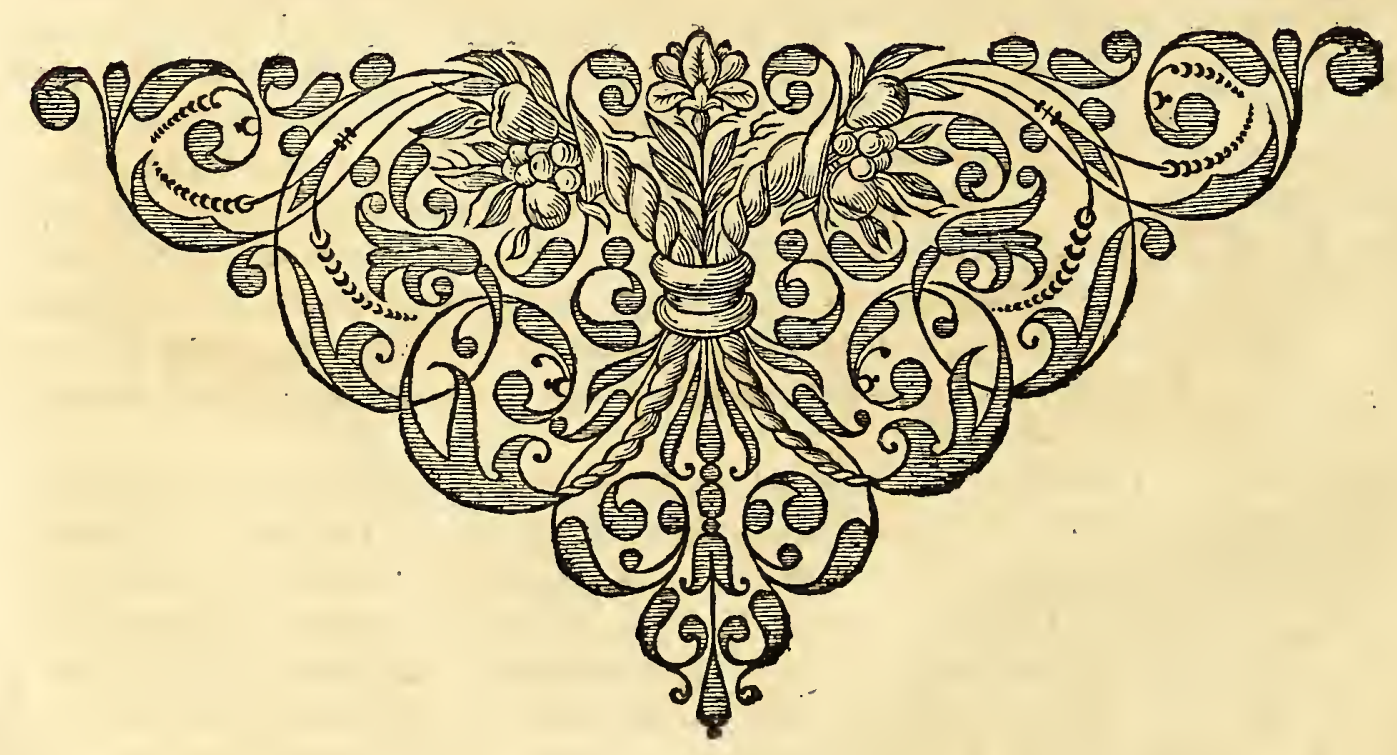

GVIIEL- 
GIVIIELMI PISONIS

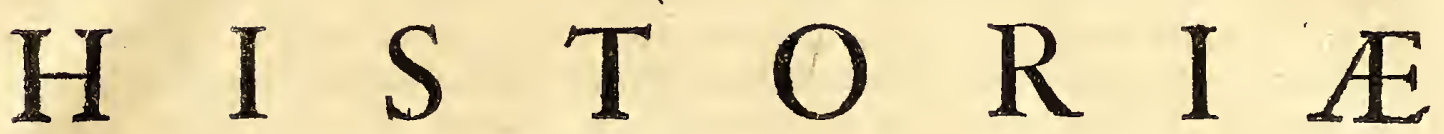

\section{NATVRALIS \& MEDIC㤅}

\author{
$L I B E R S E C V N D V S$.
}

\section{De Natura \&. Cura Morborum in India Occidentali;, Imprimis vero in Braflia Familiarium.}

\section{N T R O D V C T I O.}

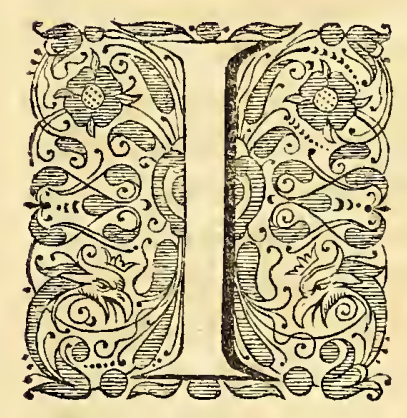

Ndia Occidentalis atque Orientalis cum fit Medicamentis omnium generum $\&$ ad omnem curandi neceffitatem inftructior,quam Medicis Rationalibus: mirum effe nulli debet quod hactenus tam multa infignium virtutum recondita in finu gerat, merita inlucem protrahi. Quamvis enim plurima in hac Barbarie occurrant cruda corruptaque \& Hippocratica arte indigna : funt tamen non pauca infuper utiliffima atque antiqui- • tatis æmula, quxque vel eruditiffimos Medicos exercere queant. Multarum fane artium rudimenta ipfis ab animantibus ( $Q u x$ benigna mater natura noluit carere arte infita imprimis curandi morbos fuos) ad nos redundare fatendum eft. Quis dubitet ab his etiam mortalibus, licèt remotiffimis à Dogmatica medendiarte, non plurima faluberrima \& fecreta remedia atque antidota medendique modos veteribus incognitos ad nos poffe derivari ; quibus paulatim per manus traditis, \& tandem quafi in fuccum \& fanguinem à Rationalibus converfis, Dectorum Scholx \& Libri fuperbiant, modo acceptis è vulgo remediis ratio \& rectus ufus adhibeatur, in quo Summa artis pofita eft? Experientia authorumque teftimoniis conftat, omnes paflim Indiarum Incolas Medicinam facere, \& Morborum notitiam exfymptomatibus venari, ac caufis neglectis, communi quadam animi notione eruere indicationes ex Morbis, iifoue fatisfacere contrarium remedium opponendo. Calidius enim $\&$ tenuius quod evafit, refrigerando $\&$ incraffando : quod factum eft frigidius \& craffius, calefaciendo, attenuandoque: quod abundat aut turget; evacuando conantur reftituere in integrum. In quibus medendi conatibus, quantum vel fibi conftent, vel deficiant, folertiores facile viderint, ex hac qualicunque Medicina Brafilienfi, à me per feptennium obfervata, \& ut potui fuccincte tradita.

Quantum vero feptentrionalium Terrarum Incolæ Indiarum Aromatibus, aliifve medicamentis atque alimentis calefacientibus, ultra quam decet funt dediti: tamè contrario Indi $\mathbb{E}$ gyptiique nimis funt proclives in vehementiora refrigerantia, imme. mores ait ignorantes, fi par fuerit utrobique error in exceffit, hunc majorem vitæ noxam minari. Nec dubium eft, de Brafilia aliifque Indiarum locis recte dici, quod de

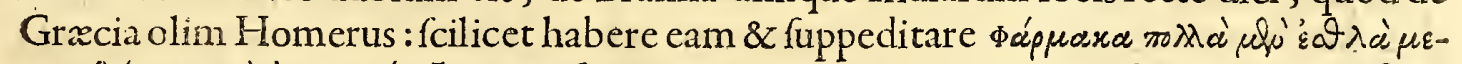

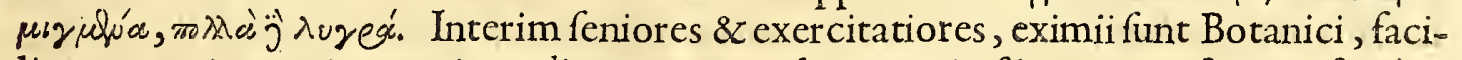
lique negotio omnis generis medicamina ex undiquaque in filvis conquifitis conficiunt. Qux tanta fagacitate interne \& externe illos a dhibere videas, præcipue in morbis à veneno natis; ut quis illorum manibus tutius \& fecurius fe tradat, quam Medicaftris noftris fciolis, qui fecreta quedam in umbra nata atque educata crepant perpetuo, \& ob hæxc Rationales dici volunt. Quos quia Andabatarum more cum morbis congredi conftat, quis dubitet experimenta per mortes agere, \& fe Themifones ftrenue pr $x$ Itare? dé quo Iuvenalis;

(2) uot agros Themifon Autummo occiderat uno.

Vtvel hinc, videre fit, quam confone gentes, Idiotxlicet, ac nullis litteris excultx, cun 
nobis Medicinam exerceant. Per manus vero tradita fibi præcepta medendi adeo mordicus retinent, ut vel mortem potius fubituri fint, quam in ea re opiniones fuas abjiciant. Memini in caftris membra militum globulis fcolopetarumicta, \& jamjamab Europxis chirurgis tam Lufitanis quam Batavis amputanda, Barbaros recentibus gummi, fiuccis \& balfamis à ferro \& igneliberaffe, \& feliciter reftituiffe. Oculatus itidem teft is fum, in nofocomiis relicta ulcera $\&$ gangrænas, ab illis vel folo fucco $T_{a}-$ baci curata. Imo moribundos ex venenatorum fungorum aliorumque toxicorum eftr folo potu infufi recentis radicis Jabor andi in initanti à letho vindicatos, me aliifque $\mathrm{Ga}$ Icninepotibus, haud parum pudore fuffufis, poft tot Alexipharmacorum \& Theriacalium Antidotalium irritos conatus. Ita ut poftea ejufmodi collegas Barbaros fubinde mihi adjungi paffus fim, non adeo quidem Noftratium valetudinem ad tactum arteriarum moderari, quam dictis modis confilii copiam prxbere folitos.

Febres \& morbi plerique in hoc Americ $x$ tractu familiares, prognofi \& curatione ab Europxorum fapius; $a b$ Indorum Orientalium rarius differunt ; iifque partim ex veterum inftitutis partim ex more Regionis mederi contingit. Reluctante autem morbi pertinacia, Brafilianorum pater vel mater familias adit vicinos, ut, fi quis tali morbo vel dolore infeftatus fucrit, remedium ilico promat, debitæque charitatis officia viciffim pr reftet. Sicut olim in Grxcia moris fuiffe legimus.

Quotquot hanc artem profitentur, five Indigenx, five advenx, five mixtigeneris Molste \& Mamoluce, religiofi funt admodum in præfcribenda xgrotantium diæta. Sxpius \& ftatis horis, ob citam virium proftrationem, cibant. Defectum enim quam exceffum $x$ gris plus femper in Indiis quam alibi nocuife, multis experimentis ratum habent. In quo tamen medium cordatiores tenent. Errores in tenui viau, pravalente - indicatione virtutis, deteriores in defectu ; prævalente morbo, deteriores in exceffu : in pari indicatione pares errores. Cum autem in febribus hifce multifque aliis morbis acutioribus (raro à falfa pituita, crebro à bile ortis) liberior exhalatio fiar, \& (piritus nimium attenuati, facile ad delirium exacuantur; victus paulo plenior \& humidior non abfque ratione conceditur, quod acrimoniam bilis retundat, exficcationi hecticx occurrat, \& Spiritui elabenti fuccefforem faciat copiofiorem. Huc accedir falutar is ille ante enarratus, lotionum, irrorationum, balnearum frigidarum \& tepidarum ufus. Adeo denique eos tranfipirationis liberæx cura follicitat, ut nihil æque caveant, quam nequis convalefcentium vel folis radiis, vel vento terreftri nocturno fe exponat. Ita, ut ex noftris Belgis quofdam paulo rigidioris vitæ impatientes ab ipfis prorfis derelictos viderim. Quamobrem morbo licet profligato, exquifitifimam vivendi rationem diutius inftituunt, ne languidis vifceribus bilis repullulet, \& febrilis miafmatis incrementum fiat.

Cordialia refrigerantia \& putredini refiftentia, nunc in fyrupi, nunc in conditi for-" mạm redacta, hæc maxime probantur qux fiunt ex pomis cuurucujá five Grảnadillis, (ex celebri illo flore paffionis natis) Limoniis, Arantiis eorumque floribus Mangábas, Vbapitánga, Ficubus filveftribus fragrantibus Iamacarú dictis, pulpa Citrulli, Cucurbitx majoris \& pomorum Ianipápa : tum è piris \& prunis punicis quæ Araçá \& Guajaba vulgo dicuntur. Radices porro fucculentæ arboris' Vmbú (qux dignitate $\&$ fapore Citrullis haud cedunt) recentes mirifice ardorem \& fitim extinguunt : accedentelargiori frigidx potu, \& decantata illa ptifana ex radice Mandiboca facta, qux vires imprimis reficit.

Si purgandifit neceffitas, abftinent à medicamento fortiori, imo ultra Tamarindos Mechoacannaque recentis condituram, vel fimilia laxativa, vix afcendunt in morbis acutioribus. Qua in re folertiores difpenfant, quafi memores Aphorifm. x x I I I. lib. I. pro quo magnum cft quod fuppeditat Barbarorum praxis. Cxterum conftitutio \& temperamentum Regionis, victufque ratio fimplicior \& alia plura facile dirimunt litem, utrum majus debeat haberi remedium, Venæefectio an Purgatio: adde quod tum criticx Hxmorrlagix, tum praxis quotidiana, circa morborum rationem \& curationem, Phlebotomix prærogativam fatis demonftent: Catharfis vero, tarde potius, benigne $\&$ raro fiat, tantumque in Meridionalibus terris poftponenda, quantum in ficptentrionalibus preponi folet, five confervandx valetudi, ni, feu morbo tollendo id fiat. Ad illud Platonis fcilicet diftum: Morbos̀non magna „, pericula denumtiantes, minime cfficirritandos medicamentis purgantibus. Quod ta- 
men ftrictius inter primos Incolas, quam Advenas feptentrionales, victu craffiori utentes, chronicifque morbis à cruditatibus ortis obnoxios obfervandum eft.

Adhxe, licet anni tempeftates inter fe differant parum, fimilefque fibi multum fint, ut alibi notatum eft, fub folftitio tamen hiberno, Sole Cancrum ingrediente, tum quoque fub Cane $\&$ ante Canem, ob ventorum Meridionalium tepores $\&$ humiditates præxdominantes, non xque feliciter inftituuntur purgationes. Idem cogita de folftitio xftivo, quod in Capricorno fit, ob nimias ficcitates. Estate per fuperiora, quod ob dominium bilis in ventriculo contentx, plurimi fint faciles ad vomitum: hieme vero per inferiora corpus purgare convenit, ob redundantiam pituitx, præfertim fi materia peccans infra feptum tranfverfum hæreat, juxta Aphorifm. I v. lib. I v. Cujus neceffitas

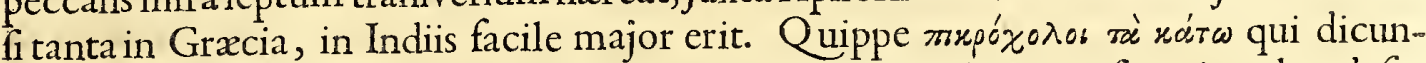
tur, lævitatibus inteftinorum infeftari folent, purgationeqque per fuperiora haud facile ferunt. ad Aphorifin. x I I. lib. I v.

Dubium hæret plerifque artem medendi profitentibus, quare fub zonis torridis, medicamenta purgantia, majore licet dofi exhibeantur, minus tamen operentur: Cum à preceptoribus edoctifint, tutius fortiora medicamenta, majorique quantitate in Terris feptentrionalibus quam meridionalibus fubminiftrari, ubi lapfus virium, \& humorum accenfio minus extimefcenda. Quam diverfitatis rationem, partim ex difpofitione individui nafci crediderim, quod fub hoc coelo calor vitalis ab extraneo ambiente attractus, minufque concentratus, debilius agat in id, quod à circumferentia trahere debet: partim ex effatis medicamentis exoticis, quorum plurima quia minus durabilia,nobiliores partes deponunt, ac terreftres retinent.

In modo etiam praparandi medicamenta differunt Americani ab Europxis. Pr $x-$ terquam enim quod virentes \& recentes herbarum fuccos perpetuo ad manus habentes, Apothecis facile careant: Remedia quoque ex variis compofita admodum averfantur; Sed fimpliciora in quovis medendigenere amplectuntur, à quibus nempe corpora non ufque adeo irritantur. Quam erroneam quorundam Medicamentorum farraginem Fernelius lib. v I I I. eleganti fimilitudine confirmat. Adde, quod nuda \& genuina efficacia fimplicium clarius elucelcat. Hujus autem indagationi ftrenue incubuiffe in hoc novo rerum incognitarum mundo, non infimx utilitatis effe exiftimo. Præterea Lufitani æque ac Brafiliani, nativi Medicamenti infufum raro igni, fed aëri \& rorinodurno verfus Orientem exponunt. Vnde frigidiufcula aura fubtiliffimufque ros vicem correctorii attenuatione fua præbet, dum medicamenti acrioris \& calidioris vires moderatur. Certe cum confidero gentem hanc fimplicibus \& cuivis obviis ac vilioribus herbis feliciter mederi affectibus contra naturam, tam externis quam internis : non dubito prifcam Medicinam omnino talem fuife, ac maximam partem compofitorum iftorum Medicamentorum à recentioribus inventam effe, fuo potius quam zgrotantium commodo. Vt vix me contineam quin cum Plinio exclamem; Quo “" Deorum iftam perfidiam monftrante, hxc conftituta funt, ut fepe contrariis qua- c litatibus conftantia medicamenta fimul mifceantur, nifiut carnificinam (addo \& aul- ، rificinam) in humanum genus exerceamus. Quod \&alio in loco mecum confirmat, qui vilia Medicamenta primo afpectu non contemnit. E contrario attonitus, ut ipfe is ait, quorundam perfuafiones, qui prodeffe nil nifi pretiofa putant, \& ficut victum ex “ Artocreis tantum, ita ex fuperftitiofis compofitionibus medelam fruftra quarere fatagunt. Sed defino, ne à non emunctx naris hominibus hreteticus vel paradoxus in Medicina audiam.

Medendi fupinitas infebrium fynochorum \& ardentium principiis, ut ubivis terrarum, ita in Indiis imprimis nocet, ad Aphor. X x I x. lib. I I. Incipientibus morbis fi- " quid movendum videtur, move; vigentibus autem quiefcere oporter. Nec atténden- ، “ dum ad Avicennx confilium, qui non nifi poft concoctiones, venas fecandas precipit, principio \& vigore morbijam elapfis. Febres enim acutxa deo invalefcunt $f i$ in ipfo ftatim initio magna remedia non adhibeantur, ut non raro lethum fecum trahant. Quin frep poft fecundum diem nihil movendum, quod motum pridie non fuit. Imo in acutiffimis turgente materia, frepe poft primum, ob exolutas vires, quiefcendum eft . Cujus rei veritas ut fuit per experientiam deprehenfa à Gracis: fic indies magis magifque in Indiis elucet. Et fanguinis quidem miffiones in Noftratibus ac plerif́que advenis noviciis religiofus cautiufque oportet inftituere, co quod Lufitanorum \& prafer- 
tim Indorum folida \& compacta corpora amplis vafis a crara pinguedine farcta, ferendis fatigationibus \& vacuationibus fanguinis aptiora fint. A prima namque infantia ad ipfam ufque fenectam (qux utraque firma in Indigenis effe folct) cito, tuto \& jucunde, amiciamicis omni dieinoctifve hora venas incidunt. In illo Rhafin, in hoc Aviccnnam imitantes, invitis tot Galenialiorumque veterum interdictis. Celfique illud dictum lib. I I. c. X. refpiciendum, Non qux xtas fit, neque quid in corpore intus geratur, fed qux vires fint. Ea tamen cautione, ut quanto Europros ac Boreales fuperent fecandi frequentia: tanto cedant illis in quantitate mittendi una vice : ut enim in ea funt libcrales latis, ita hi è contrario parci. Nec unquam Hippocratis exemplum affecutos memini, atque ad animi deliquium ufque fanguinem detraxiffe; quod requifita ad id uno in fubjecto raro concurrant. In juvenili, vegeto ac plethorico corpore vix feptem uncias excedunt: quater tamen imo quinquies uno die feliciter incifionem repetunt. In quo nec Agyptios plane imitantur, qui à fumpto cibo; nec Europxos noftros, qui jejunis utcunque Sanguinem educere amant. Sed ad concentrandas vires \& lipothymias evitandas offam conditur $x$ cum modico frigid $x$ potu exhibent.

Raro hirudinibus, qux funt Europæis minores, utuntur: fearificationibus autem frequentifime; tum \& cucurbitalis corneis rite applicatis, phlebotomix defectum fupplent. Solus cornearum cucurbitularum apud Americanos ufus exiftit, exque funt Taurorum parvx perpolitx quibus altera extremitas lata, altera anguftiflima parvo meatu conftat, quas non igne vel aqua calent, , fed oris fuctione cuti validiffime affigunt, reiterantque pro lubitu. Suctum illum ad Medicinam fpectare novit Homerus, qui de Machaone Menelaum vulneratum curante, Sanguinem, inquit, exfugens, lenia medicamenta adfparfit. Quam vero tutum $\&$ validum fcarificatio fit remedium contra plurima mala externa \& interna, præter Galenum \& Celfum, Oribafius ex Herodoto refert. lib. V I I I. c. X V I I. Et de fe ipfe teftatur Oribafius, pefte laboranti, duas circiter fanguinis libras, fibi cum fucceflu per fcarificationem fuifle eductas. Hocidem. Indigen $x$ faciunt volentes cute fcarificata fanguinem demere : hincque copiofior; quam cucurbitulis, educi folet. Verum quod ad magnas fcarificationes, ac citra cucurbitulas abfolvendas, in his non convenit Brafilianis \& Europxis, neque in modo neque in quantitate. Raro enim cultello, \& fuperficiarie, fed fpinis arborum; vel dentibus pifcis Lamix (fine quibus vix quemquam eorum peregrinari videas) fiunt, altifque plagis, non adeo in malleolis veterum more, caterifque externis membris, ficut $Æ$ gyptii aliique folent: fed femoribus, furis, brachiis, omnibufque carnofis corporis partibus. Hac rationelibras fanguinis educunt, non fecus ac alii per venæfectionem. Plurimumque adeo differunt à cucurbitulis fcarificatis. Vt vero doloribus f́carificationis fuccurrant, antequam opus aggrediantur, non folum frictionibus, fed $\&$ manuum verberationibus crebris, ftuporem quafi membris inferunt. Peracto opere, vulnera aqua calida irrorant, eaque Balfamis \& fuccis linunt anodinis: Atque his folum remediis plurimos affectus reftituunt, internafque partes nobilior es à noxis liberant.

Videamus tandem qua circa Vomitoria, Sudorifera, \& Opiata animadverfione digna funt.

Qui Incolarum \& Regionis tempcramentum calidum $\&$ humidum effe perfpexerit, haud difficile dijudicabit, quando \& quibus per fuperiora ventres exonerare fit neceffe. Eftate enim ficca bilem qualemcunque, à crebro fructuum fugacium \& horariorum efu in ventriculo collectam, haud tutum exiftimant per inferiora ducere, præfertim iis, qui mré́x re hic abfolvi meris vegetabilibus, (quarum copia facile inopiam mineralium compenfat) vomitoria plurima in ufufunt. Sed cater is facile palmam preripiunt celebres $11 l x$ radices Ipecacuanhe, in tractatu fimplicium delineat $x$. Ad has primum refugium capiunt omnes pariter Incolx, utpote tutiffimas ad exturbandum five aflumtum venenum, five cacochymicam faburram circa præcordia hærentem. Pr cæterisautem rcvulfionis gratia exhibentur contra huxus ventris, nimium in Indiis familiares. Pluribus encomiis hanc eximiam Panaceam extollerem; fed vereor ne Satyricus quifpiam id de mea Ipecacuanba, quod tempore Catonis de Braflica nimium laudata dixit: Braffica Día Catonis. Cateri fructus vel herbx ufuales per fuperiora potifimum operantes, funt nuces Catharticx, Ands, tum Ricinus Americanus major \& minor. Quarum dotes \& noxit in tractatu fimplicium expofitx funt. Caaponónga, Iitó, Manacá, alixque 
HIST: NATVRAL。 \& MEDIC. IXB。 It: alixque ejufdem quidem farinæ, fed indomita exturbandi qualitate præditæ. De qư̆ rum ulteriori ufu \& abufu fedula pofteritas cogitet.

Licet autem de fudorifer is exhibendis minus follicita eft Medicantium turba ; atta men cum oporteat miniftros naturä eam recte agentem imitari $\&$ eo ducere quo vergit; non difficile erit in Regionibus ad Meridiem \& $x$ xtuofum coli afpectum tendentibus fudores promovere cum Euphoria. Medici multis abhine annis in praxi exer citati ipfi adeo Theriacx fimilifque compofitionis fudoriferis temperatius \& minus compofitum unum atque alterum longe præferendum arbitrantur, eoque tanquam ad facrum febrifugum cuivis obvium confugiunt. Quod fit ex aqua fontana, \& facchari momentö, cum multo recenti limonum acerrimorum fucco ad mellis fere confítentiam cocto, eamque fatis calidam bis terve de die, prǽfertim initio exacerbationum, reiterant. Atque hoc modo fudores copiofe educunt, ac turgentes fervidos humores aciditate fimul frenant fedantque. Quod ego multoties, paucis generalibus præmiffis, feliciflime imitatus fum, ftupendofque effectus à tam Euporifto remedio, addito fubinde fale prunellæx vel oleo tartari, contigit videre. Etiamfi enim culpanda fir futilis illa credendi cacoëthes; qux in Indiis mire afficer folet mortales, de febrifugis fuperftitiofis, fympathicis amuletis $\&$ fimilibus; tamen vel inviti cogimur fateri quarundam rerum effe eam vim, ut paroxyfmum febrilem fine noxa infringant \& putredini fimul refiftant. Quomodo creta vitium acëfcèntis ccrevifiæ̀ emendet : quomódo fuccus limonum vehementiffum $x$ ebullitionï facchari in capacifimo cacabo refiftat: Spiritus item vitrioli cum fale tartari miftus aciditatem perdat, $8 \mathrm{cmult}$ ta alia, quibus brevitatis caufa fuperfedeo , haud facile erit pronunciare. Interim argutulos illos acerrimos abftrufarum rerum, $f(D i s$ placet, inveftigatores, qui occultas proprietates pro ignorantix afylo perpetuo reputant, omnemque caufam ad manifeftas qualitates àcceptam referunt, invito, ut me hæc \& quædam fupra enarrata naturæarcana edoceant.

Cum vero perpetux vigilia $\&$ doloris vehementia, magnis illis remediis evacuantibus contraindicent, fomnum nunc per interna foporifera $\&$ anodyna, nunc per externa qüx cogendis fint ruentibus humoribus, conciliảnt. Quod totius corporis, præcipue capitis, frigid $x$ irroratione, $\&$ unctione vifcid $x$ cujufdam $\&$ frigid $x$ materiæe, è planta Vrucatú, tum è ramis Cardui littoralis contưfe, inftituunt Barbari, quibus ufus opii nondum innotuit.

Quia autem narcotica non immerito tantopere extolluntur per omnes Indias, ubi morbi acutiffimi cum fpirituum $\&$ humorum orgafmo, præfertim ventris illi fuxus fanguinei malemorati, Catarrhi \& Hæmorrhagia contumaces graffantur, operæ pretium erit circa eorum abufum breviter quædanin monuiffe 3 nè temere ad auram popularem captandam, ut fxpe fit, adulatoris potius quam veri Medici officium prætent; $\&$ in graviffimos fcopulos impingant. Non fine noxa datur iis, qui ex craflis humoribus $\&$ frigidis morbis laborant ; tum quoque quibus vires five à morbi vehementia, five $a b$ immoderata forte Venere nimis exhauftx funt. Neque tuto exhibetur, quibus in morbis à fluxione natis non àliqux generales evàcuationes præmifæx funt, quod pectus opprimant, hoftem includant, cum evidenti ægrotantis periculo. Verum fi dolor atrox $\&$ vigilize ex fpirituum $\&$ humorim tenuitate, $x$ ftu $\&$ mordacitate ferociente, natæ fint; eos non tantum fedant, fed $\&$ naturam armant contra inimicum, eumque obortis fudoribus, quod in Regionibuis calidioribus haud raro fit, propellunt ad extima, fpiritufque victor foras diffunditur, unde morbi fimul \& fymptomata tolluncur. Cérte enim quam amica eft fipiritibus ac humoribus coagulatis diffolutio, tam grata acceptaque diffolutis coagulatio, qux fubtiles halitus denfat, efferos ichores figit, mordaces fuccos mitigat.

Atque hæc de modó curandorum mörborum acitior un, $\&$ Febriüm potifimum, in genere diata velim. Deftillationes \& Oppilationes illas chronicas, ex quibus febres, fluxus ventris, aliique morbi graviores non raro pullulant, adven $x$ intemperanter viventes haud facile evadunt. Eo quod Cruditates, qux vera femina funt morborum, ob fupra enarratas caufas, non rite præcavent. Ex iis enim educti vapor es faciunt Inflationes : iidem in capite condenfati Deltillationes : in aliis membris \& vifceribus $\mathrm{Ob}$ Atructiones: unde fequitur aut Putredo aut Inflammatio: Atque ab aliqua harum caufarum, intemperies humorum, exindeque nafentes morbos, provenire dixerim:

$$
\text { C } 2
$$

C. A- 


\section{A $A \quad P \quad T$ \\ De Catarbis.}

II.

$Q^{v}$

Vum inftituti noftri ratio poftulet, profequi Cruditates, Obftructiones, cateraque mala inde pullulantia ; videndum quid notatu dignum circa Catarrhos.

Rariffimis deftillationibus veterani incolæ, creberrimis adven $x$ juvenes \& pueri moleftantur: Exque vel à frigore nocturno, aftricto, \& compr effo capite: velà caloribus diurnis rarefactis carnibus exoriuntur. Qux plurimas fxpe noxas vel per fe vel ratione parris in quam fluunt, fecum trahunt. Eftivo xque tempore, ac pluviofo oriuntur, humoribus capitis in fauces, quandoque in afperam arteriam partefque diffitas decidentibus. Quemadmodum enim omnia oppleti capitis fymptomata in primigenia febre (tefte ippecrate) ftatim enafcuntur; itanon minus aliquando vis Solis ciere catarrhos animaćvertitur, è cujus affiduitate maxima interdum mala oriri folent. Vt enim aquæ ftillatitix, fubtracto aut extincto igne, profluere ceffant ; ita catarrhus ab intenfiffimo folis calor e fufcitatus, non prius aliquando fubfiftit quam xetus deferbuerit. Hyeme pluviofa, perpetui redundantes humores vifcer a laxiora pervadunt, unde tuffes, tabes prxcordiorum, maxime vero ventriculi oppletiones, alvique albi fluxus, (qui cerebrales vulgo practicis dicti) cum phlegmate ex capite defcendente, proficifcuntur : ad A phor. XXX.lib. V I I. Quibusper diarrbeas Jpumofa funt alvi excrementa, iis à capite fit defluxio. Quid quod ipfa nervorum paria, fpinalemque medullam invadunt, quod humores oppito mobiles, partiumque facultates retentrices minus valid $x$ in his terris deprehendantur. Maxime vero homines recens fanitati reftitutos, recidive quafi, iteratoque corviviunt Catarrhi, tanto impetu, ut omnes pene nervos occupent, unde cxcitates in opticis, ftupores \& tarditates in fenforiis \& motoriis excitantur. Atque hæc omnia graviora oriri exiftima, fi ventus è continenti oriundus ante diluculum, apertis fudariis caput \& pectus frigido malignoque vapore fubito feriat, tranfpirationemque cohibeat.

Porro fi quando contingat virilem vel fenilem ætatem ftillicidiis è capite, vagifque artuum doloribus (Curimentos vocant Lufitani) tentari, diuturni \& curatu difficiles effe folent:qui tempore plenilunii, tum accedente æeftu maris,præfertim poft Solis occafum, exafperantur ufque adeo, ut miffa caufa, folis fxpe fymptomatibus occurrendum fit: inticulos non folum alternatis vicibus, fed $\&$ vifcera interna doloribus profundis afficiuntur. Ita ut Rheumatifmum vere experiantur de quo Hip. l. de locis in hom. \& Gal. de diff: feb. c. 7 . agunt. Qui ob analogiam quam habet partim cum catarrho, partim cum arthritide, vulgo medicorum non raro imponit. Non quod plane negandum fit à cerebro fubinde humores iftos immediate defcendere, cum pareat fape dolor es in cervice incipere, $\&$ poftmodum ad humores defcendere, fed primam feroforum \& a crium humorum generationem fieri in hepate fervidiori; unde debilius redditum, non fatis conveniens nutritioni alimentum generat. qux duo tam nobilis vifceris incommoda, quam fint nimis frequentia in calidis regionibus, alias fatis fuperque demonfratum eft. Affectus porro hic utcunque comitem habet febrem lentam fympromaticam, \& propter diuturnitatem potius quam vitæ difcrimen extimefcendam.

In principio curationis abftinendum à quocunque validiori medicamento. Evacuationes enim five per alvum, five per fudores, nunquam nifr in morbi declinatione profuile, expertum eft. Quapropter poft reiteratas venæfectiones, pro re nata, materia morbifica eft præparanda, mitiganda ; intemperies corrigenda, omnefque partes tam mandantes quam recipientes roborandx. Interim ad obtundendam humorum acrimoniam, \& fedandam ágitationem, julepi celebrantur ex Aqua cannx faccarex, Granatorum, lanipape \& Ptifanx ex radice Mandiboca præparatx cum tamarindis. Quibus fuccedant decocta ex Iupicánga $\&$ Salfaparilla ad fudores proliciendos.

Hxe breviter inferenda judicavi, ne ca qux de catarrho dicta funt cum hoc affectu confundantur. In curatione enim catarrhi proprie dicti, fi utroque remedio, fcilicet purgationis \& venxfectionis utendum fit, pracedat Venæfectio, ut moti humores divertantur, Huxufque è cerebro excidentes fiftantur.

Catharticum unum atque alterum pituitam ducens ex nuce Andá, vel excatapotiis qux Mechoacanam, Colocynthidem, Aloën \& Guttam camboidem recipiunt, infti- 
HIST. NATVRAL. \& MEDIC. I, B. II.

tuiffe fufficiet. His fuccedat Syrupus Tabaciad magis incidendos vifcidos humores, atque ad arcendos afthmaticos affectus. Quod ut tuto fiat, cautione opus eft circa tam validum medicamentum. Scilicet ut gradatim dofis fyrupi augeatur, atque, prxparatio cjus rite inftituatur. Sicut in hujus libri calce docebitur. Quibus fi forte ruens acris humor refragetur \& gravius periculum minetur à fupefacientibus, quod eximii fint in fimili neceffitate profectus, non ulterius abftinendum; quia tabificam pruinamqua pulmones madens cerebrum fubinde perpluit, intercipiunt. Qux tamen cautius exhibenda, quandiu figna repletionis in capite \& pectore apparent: nam tunc eorum loco fudorifera, frictiones \& unctiones præferend $x$ : maxime vero, ubi deftillationes vifcera \& membrajam diu obfederint. Recipe fummitates Tupeiçava, radices Aninge, Betis, Iaborandi, Aguaxima , cortices arboris çebipira, folia Iaparandiba, Caaróba , Camará, Pimente filveftre longo. Ex quibus, accedentibus foliis Myrti, \& 2 radicibus d'Araça, balnea \& fomenta concinnentur, partefque dolentes aliquotics laventur. Mox fpiritus vini, infufo Pipere Brafilienfi, ftupa afpergantur. Frictones denique ex oleo Tabaci, Rici$\mathrm{ni}$, Chamomeli \& Myrti Americani, in quo thus aliquandiu maceratum fit, inftituantur. Præx cateris probatur linimentum, quod ex pinguedine vermium toftorum larumai, \& venenofa rana Cotorá, conficitur. Portea emplaftrum ex praftantifimo Elemni gummi lciçaiba, Anime, Pipere Brafilienfi \& adipe capræx, partibus afflictis apponendum. Quod ab empiricis, \& rationalibus, profpero eventu inftituitur.

Fonticulorum denique neceffitas, fi ullibi, his terris magna eft, modo temporius, ob majorem humorum mobilitatem, inferioribus æque ac fuperioribus membris applicentur, quod feroros humores à nobilioribus partibus derivant, $\&$ æque exiftenti quam fienti morbo opem ferunt. Adde mafticatoria, quorum principem locum facile obtinet Iaborandi decantata illa radix, quæ mane modice manducata, grato acore pituitam attenuat \& educit.Sternutatoria quoque ex pulvere Tabaci felici cum fucceflu ufurpantur.

Cibus fit temperatus ad caliditatem $\&$ ficcitatem inclinans, totalifque abftinentia à Venere \& Baccho. Ad hæc ab illa perpetua viciflitudine noctis atque diei fibi caveant, ne modo calor, modo frigus, quid moveant; quod incautis advenis familiare eft. Poftremo potus fit defacatus ex aqua fontana, quemque Vbirareé frve Guajaci cortices, farfaparilla, faffafras, liquiritia nativa ingrediantur.

Caterum cum cerebrum pituitæe effe fontem Medicorum princeps affirmet; eam partim gignit, partim calefactum, itt fxpenumero hic fieri folet, è toto corpore trahit, ac rurfus in pulmonem demittit, eumque exulcerat aliquando, unde Tabes enafcitur. Cujus peculiarem curandi modum operx pretium duxi paucis addidiffe. Cum enim non minus beato cxlo foloque hic Americx tractus gaudeat, quam Italia vel Græcia, Galenum imitari lubuit. Qui ut tabidos ad Infulam Tabiam, ita ego ad faluberrimum montem mari vicinum, pulmone laborantes ablegare fum folitus, æxdibus verfus ortum. apertis, Euroque expofitis, occidentem vero fpectantibus, obtectis. Quod quidem. non menfibus pluviis fed $x$ tivis fieri convenit, cum eximia illa aëris tenuitas $\&$ ficcitas, pulmonis ulceribus amiciffima, collapfis vifceribus vitalibus robur reftituat. Aërem enim pro refpiratione attractum, non minus ventriculum $\&$ inteftina ingredi, quam pulmones, eleganter probat Hofmannus in Inftitut.

Inter fquillas, cancros pifcefque cartilagineos, ii qui facilioris concoctionis funt eliguntur; ut $\&$ aves montan $x$, phafiani, columbx \& palumbx, atque aliæ, exceptis carnivoris $\&$ altius ad $\mathfrak{x t h e r a}$ volitantibus, utpote calidiflimis. Lac caprinum, præc cæteris vero pulmenta, emulfiones, boleti, placentæè Tipióca exficcantes \& confolidantes, reliquis alimentis medicamentofis facile palmam præripiunt. His addantur aquze florum Aurantix \& Ibabirába. Loco confervæ Rofar. illa quæ ex fragrantibus prunis $\$$ piris Granatenfibus fit præftantiffima, fubftitui folet. Navigatio quoque modica circa littus, cxlo ac mari clementiori, animo \& corpori proficua habetur.

Licet autem fyrupi Tabaci fupra enarrati præparatio diverfis modis inftituatur, diverfafque aliquando recipiat compofitiones pro varietate affectuum vel temperamentorum: Ego relictis cxteris fequentem praferre folebam quem ex ficco Tabaci maris rec. expreffi tbj. Aquæ Cannæ faccariferærec. 3 iij. Mell. filveft. (grato fuo acore oxymel fuperantis) $\zeta$ j. Præpararijuffi fecundum regulas artis. addita tamen ea perpetua cautione ut fucci Tabacini exquifitifluna fiat primum digeftio, quå vomitiva \& purgativa atque alia qualifcunque violenta qualitas infringatur, ficut in aliis mul tis validis medicamen tis fierifolet.

C 3 C A 


\section{A P $\quad \mathrm{V}$ T I I I. \\ De Oculorum malis.}

$\mathrm{M}$

Erito quidem Hippocrates lib. de Aëre, aquis \& locis, oculorum mala, turm imprimis lippitudines duras ac vehementes meridionalem plagam habitantibus familiares effe, tum quoque iis quibus carnes calid $x \&$ ficc $x$ funt, teftatum reliquit. Inter primas noviciorum in Indiis querelas haud poftremum locum fibi vindicant oculorum vitia cum videndi facultate depravata vel fublata. Ex his quidam Sole occidente, quod minus lucis prabeatur, quam opus eft, maxime rempore plenilunii : nonnulli crepufculo matutino videre definunt. Prior affectus vvr $\tau_{a} \lambda \omega \pi^{\prime} \alpha^{2}$, po-

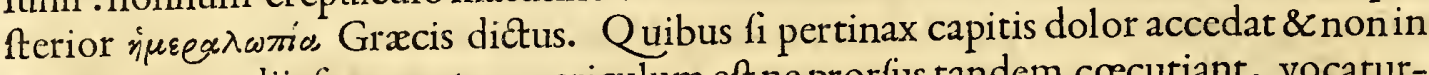
tempore remediis fuccurratur, periculum eft ne prorfus tandem cocutiant, vocaturque Gutta Serena five ópaúpwors. Omni quidem anni tempore fed xftate potifimum ficca qux aquarum exors fit, hic oculorum affectus advenas, vix indigenas, infeftat, rariufquenunc quam olim dominatur. Quod noftrates quondam adventitii, Solis \& Soli Indici ignari, multorum morborum origines nondum habuere perfpectas, quas

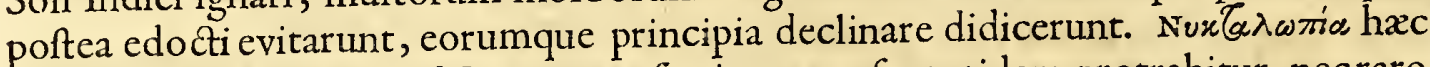
fponte fua curatur, aliis ad feptimanas fex imo menfes totidem protrahitur, necraro recidiva eft. Duplex eft hocmalum. Externum, quando nubeculx tranfparentes vel non tranfparentes fuperveniunt. Internum, cum nihil omnino exterius in oculo apparet. Pofterius hoc priori frequentius infeftat, \& difficilius curatur. Vtrumque externam \& internam caufam fomitem habet. Pauperes \& milites gregarii, corruptis falitisfrepe alimentis, aquis præterea ftagnantibus, vinoqueardenti rancido ac focculento vefcuntur. Addo quod intolerabilis ille Solis verticalis percuffus, ad torridum littus (quiod non raro plantas pedum viatoribus comburit) oculorum aciem vehementer obfufcet \& debilitet, catarrhofque ad nervos ufque opticos folvat. Sicut frepiffime in caftris Illuftr. Principis Naffav. à me eft obfervatum. Moxdelaffatis, porifque apertis, \& totas fxpe noctes fub dio, luna plena, ftante mediterraneo vento, recubantibus, fluxiones figuntur.

Hxcincommoda oculorum atque caligines, incolarum ritu, hoc modo tolli vel emendari folent.Primo interdictis illis alimentis, qux diu in penuariis recondita, mucorem atque fitum contraxerunt, in eorum locum recentia, ficca, temperata fubftituuntur, quod labefactato ventriculo firititus viforii craffis $\&$ vaporofis halitibus facile inficiantur. Præterea tam aftum diurnum, omneque objectum jufto for tius; quam frigus nocturnum, quod caput replet, arcent. Ad hxc, cephalica purgantia aliquoties repetunt. mox venas temporum $\&$ poft aures aperiunt. Dein rafis capillis, afpergines, cucuphas adhibent. Sternutatoria ex pulvere Arboris Ibabirábe \& Tabaci momento, cæeterifque fimilibus exficcantibus apprime preparant. Mafticatoriis item ex radice Iaborandi non leve folamen adferunt. Cucurbitularum cornearum \& hirudinum quoque ufus, imprimis in cervice, commendabilis eft. Setones in nucha, veficatoria, fonticulos denique eodem modo quo in Europa applicant. Tum in hoc externo \& interno ; tum in aliis oculorum affectibus, aquam, qux ex fragrante illo flore arboris Ibabirábe \& è canna Saccharifera recenti deftillat, exinia virtute pollere, quotidie experimur. Ros' fimplex, vel dilutus ceruffa cum lacte mulieris; denique liquor ille praftantiffimus ex fpinis arboris Samouna expreflus, oculifque infufus vel circumcirca illitus, vifum acuunt \& corroborant. Externo autem oculorum vitio cum nubecula ovum recens adhibent ad duritiem coctum, additis tribus Sacchari Candi \& pulveris Ibabirábe partibus, \& una vitrioli albi. Ex quo liquor exprimitur, qui cubitum ituri oculis adhibetur. Idem quoque praftat aqua Manipuéra ex radice Mandiboca, qux licet pota venenofa habeatur, oculis tamen prodeft, vifumque emendat. Quodfi malum ulterius renitatur, fumus contriti carbonis è cortice lbabirába \& Tabaci in oculos xgroti infufflatur; mox mafticato alliojejuno ore, linguæque impofitis Ibabirába cincribus, cilia ejus identidem lambuntur. Præter remedia modo dicta, Lufitani æque ac Barbari fyncrafia quadam vifum reftitui teftantur jecore pifcis Lamix recenti,vel fale paulum condito, manducato. Quodipfum I. Bontius de Indis Orientalibus memo- 
rat. Quo videtur quoque fpectare illud Hippocrat. dictum lib. de Vifu. Inum aut duo frufta prout maxima devorare poteft de hepate bubulo cruda, in melle tincta exbibeto. Mihi utriufque enarrati remedii felicem fubinde effectum videre contigit. Hif́ce potiffimum fubfidiis accedente tenui dixta curatio abfolvitur ; modo æger à fupra dictis caufis externis $\&$ internis fedulo, diuque etiam reftitutus fibi caveat, præfertim cum intus dominatur affectus, nervufque opticus dudum receperit fluxiones. Atque hæc quidem mala plenilunio imprimis ingravefcunt. Vnde humores moti non parum augentur, quo tempore caputpurgia evitare præftat.

\section{A P V T I V.}

\section{De Spafmo.}

C Vm nihil fere moderatum fub hoc colo ea corpora fublunaria recipiant qux xftus diurni \& frigoris nocturni viciffituidinibus expofita funt, fit, ut, ficut acutiffimi \& calidiflimi, ita frigidi imprimis \& Chronici morbi in Indiis magis fint familiares. Inter acutos quidem facile primus fatale hoc Spafmi genus, Græcis res $\sigma \mu^{\circ}$, , Belgis De Iflem/nuncupatum : quod frequens admodum eft, dictoque citius hominem ftantem fedentemve invadit, \& rigidum tanquam ftatuam, nunc Tetani, nunc Opifthotoni inftar, tenet. (Vide Hofman. Inftitut. lib. 3. cap. 86.) Ita ut per intervalla miferando fpectaculo retrahatur $\&$ concidat. Vnde tandem fit, ut fpafmo cynico interveniente, ablataque refpirationis ac deglutiendi facultate, (ob convulfum credo diaphragma \& $\propto$ fophagum) terrifica nonnum quam fymptomata concurrant, \& murmur quod. dam horridum, Epilepticorum ritu, exaudiatur. Nonnulli vero tardius, citraque tor dicta accidentia, corripiuntur, dentibus primum ftridentibus, ore mox diftorto,adeoque occlufo, ut vi acf pecillo ferreo effringi debeant. Tunc quidem non raro fuffocationis periculum incurrunt, excrementaque retinere nequeunt. Infeftantur potiffimúm hoc affectu vel leviffime vulnerati, Pifcatores, Fabri, Piftores : tum quod interdiu madidi ac fudore $x$ ftuantes, ab ingruente nocturno frigore fibi non cavent; tum quod craffiori \& $\&$ veteri alimento affueti obftructiones lienis graviores incurrant, indeque quibufdam noviciis calamitofum Scorbuti fymptoma fejungat. (Vide Sennert.de oris convulf. \& Scorbuto. ) Tempeftive itaque remedium adhibeas oportet: fin minus, ante quartam \& vicefimam à convulfione horam æger fuccumbit.

Primum, finullum grave contraindicans obftet, confeftim vena fecanda eft, mox acribus clyfteribus, aliquoties reiteratis infiftendum. Pofthxcfudorifera ex AlexipharQuodfi protrahatur morbus, decocto Salfaparillx, corticum Guajaci, Iupicánga, Saffafras, Iaborandi, Betis, Nhambi, aliifque nativis ejus generis herbis, fuccurrendum eft. Hæc fubfequantur balnea humida $\&$ ficca, fuffumigia è ftercore caballino, cum gummi Anime, \& fimilibus aromaticis. Poftea fudoribus alte abfterfis, frictiones validæ inftituend $\mathfrak{x}$ funt. Mox inunctio colli, fpinæ dorfi, partiumque vicinarum fuccedat exoleis \& balfamis appropriatis, nativis $\&$ exoticis, imprimis vero oleo corticum Arantiorum cum fucco Tabaci recentis. Ager probe cooperiatur, corpore perpetuo fudore diffluente. Sxpe $\&$ modice cibetur, ob lapfum virium, bibatque calidum. Nequeraro, fi prædicta obferventur, eluctatur: præcipue vero fi febris, vel alvi quoque profluvium fuperveniat, quod evacuet materiam convulfivam tranflatam è nervis ad venas. (Hippocrat. lib. IV. Aphorifm. 57. Spafmo aut Tetano vexato, febrisfi accefferit, morbum folvit. Et Coac. 358 . Convulfiones autem derepente ortas febris folvit, ac alvifluxus.) Sin minus; medicufque ac ipfe æger vel aftantes officii immemores; vel leviffimo errore, antequam materia peccans victa fuerit, commiffo, certo certius de vita erit actum. Quod aliquando accidiffe memini ore arcte claufo, ac motu convulfivo immaniter per paroxyfmos, maximis cum doloribus $\&$ ejulatibus, in-
furgente. 


\section{$\begin{array}{llllll}\text { C } & A & P & V & T & \text { V. }\end{array}$ \\ De Stupore Membrorum.}

Tter Chronicos morbos in America familiares eft ille qui nervos tentat, altumque membrorum torporem inducit. Cujus naturam nemo, quod fciam, tradidit. Eum

Lufitani appellant Air, quod ab aëris inclementia \& ex incompleta obftructione, intemperieque frigida nervofarum partium oriatur. Pituita enim lenta \& glutinofa, loco f́pirituum, nunc ex capite promanans, nunc è fpinali medulla in artus deftillans, facile nervos occupat, ac tendines brachiorum vel pedum, vel utror umque fimul infeftat : accedente refrigeratione non tantum nervorum, fed $\&$ venarum, arteriarum, carnis, membranarum, cutis. Id ex diffectione Æthiopis, ex hocftupore dum viveret laborantis, animadverti, cujus nervi frigido \& tenaci phlegmate obducti erant. Senfus non in totum tollitur, pulfu exiftente exiguo $\&$ debili, cum profundo $\&$ obtufo dolore, ponder eque membiorum fummo; ac cum titillatione fubinde fenfus oberrat. Stupentis fenfus ac tıtillationis vera ratio ex Rod. à Veiga Comm. in Galen. delocis affectis petenda. A paralyfi differt quod fenfus hic perpetuo adfit, licet frepe moleftus. A Spafmo quod convulfivis motibus utcunque deftituatur, quia artus prolongantur, non contrahuntur, humore frigido \& humido in juncturas fe infinuante, ita ut ligamenta \& nervi inde laxentur. A Beribery diftinguitur, quod hoc malo divexatis membra minus contremilcant. Aliquando præter medullofam nervorum fubftantiam, membranofam quoque cum paroxyfmis ac vehementibus doloribus tentari comperi, præcipue circa vefperam ac æftus maris viciffitudinem. Vfque adeo invalefcit aliquando hoc malum, ut ob maximos atque continuos cruciatus, facultates omnes de tono dejiciat. Affectus potius ærumnofus ob diuturnitatem, quam lethal is per fe; nifi forte recidivus ex alio morbo, ut fape fit, fpirituumque defectus fubfequatur: cum mentis $\&$ vocis interceptione, ad fententiam Hippocratis lib. I. de prædiction. Vocis interruptiones cum exfolutione, Atupore detinente, funt periculo $\int e$, tum \& illa qua fubito in utramique partem tranfabuntur. Multis enim ex obftructione morbis fupernafcitur, iifque præcxteris fuccedit, qui mali judicii funt $\&$ tranflatione fymptomatica formidabiles fiunt. Quibus fi accedant gravitates \& acuti capitis dolores, convulfiones fieri folent, quod ab Hippocrate in Coac. confirmatum eft. Citius evadunt xgri, fi febris accefferit, quxnon talis fit, ut fruftra ciendo tenaces humores oppreffionem faciat, fed acuta, qux nervos \& mufculos iis liberare, intemperiemque frigidam exficcando corrigere val eat. Illis vero qui calori diurno aut frigori nocturno caput $\&$ lumbos derepente exponunt, folutione vel compreffione pituita in nervos partefque vicinas labitur, ibique radices agic. Adeo ut paucos ante trium vel quatuor menfium decurfum, quofdam ne anni quidem intervallo, reftitutos viderim. Vixfubito unquam, fed plerumque fenfim \& per gradus invadit magnus hic morbus, ac magnis generofifque remediis propulfari poftulat, quibus defectus virium non raro contradicit.

Primo, aër non nifi à folis radiis repurgatus admittatur. Noctu aër fuffumigiis tepefiat. Potus fit vinum dilutum actu calidum, vel decoctum ligni Saffafras nativi. Cibus optimi, ficci tamen efto nutrimenti. Aves montanx, perdices, phafiani, palumbi , caterique id genus alites, tofti agro exhibeantur. Si elixatis plus delectetur, aromatibus condiantur. Allium quoque $\&$ cepas piperque Brafilienfe, fi febris non impediat, atque evactuationes jam inftitute fuerint, adjiciantur, qux ex jufculis $\&$ lacte caprino pota, robur addidiffe ac multum profuiffe memini. Semel atque iterum purgationes inftituantur ex Mcchoacana, quæ recens $\&$ fucculenta fit, additis correctoriis è Spica Nardi \& Zinzzibere, tum \& Atimulis ex Hermodactylis \& Coloquintide, fi extractum Mechoacanæin pilulas redigatur.

Ad hre balncis \& fuffumigiis ficcis potius quam humidis, imprimis ex accenfa herba Ambiaembó, vel ftercore caballino, cum gummi Anime caterifque fimilibus accenfis ad decem plus minufve dies utatur. Mox poft haufum decoctum Sarfaparillæ \& $\mathrm{Saf}-$ fafras, altis frictionibus fudores abltergantur, collum, fcapulx, toraque dorfi fpina ad focum fideliter inungantur : accedente adipe colubrorum, \& infufo Piperis Brafilienfis ex fpiritu vini. Confultum quoque validiflimo per cucurbitas corneas fuctu 
fpiritus attrahere, tum imprimis per altas illas fcarificationes partem affectam liberare. Tandem, fi neceffitas urgeat, ferro candenti cutem pertundente, membra languida roboranda, lentaque nervorum pituita digerenda eft. Convalefcente ægro, noctes diefque partes affectxita obtectx fint ut nullum aër em admittant, fitque exercitium $\&$ membrorum perpetua agitatio. Mira equidem tum tuendx fanitatis ergo, tum in plerifque morbis fanandis, frictione \& unctione frequenti incola præftant; illam in frigidioribus \& chronicis, hancin acutioribus adhibentes. Que remedia lubenter advenæ imitantur, \& ut par eft ex legibusartis, hæc \& plura medendi Empiricorum genera moderantur. Qux paffim docet Galen. lib. 2. De fanitate tucnda, \& Celfus cap. I4.

\section{A $\quad$ P $\quad$ V}

De Obfructionibus vifcermun nuturalium.

$\mathrm{V}$ Bique Terrarum confervatio humani corporis, inter alia in Sanguinis \& 2 fpirituum motu perpetuo confiftic, qui fi impeditus vel inordinatus fuerit, pertinaciores plerumque $\&$ graviores vel obftructiones vel fluxiones concitare folet. Hinc oppilationes illæ hypochondriacx ac perniciofi ventris fluxus, non immerito Indiarum peftes habentur, cum inter populares morbos, nulli tanta vehementia dominentur, aut plures Mortales è medio tollant. Qui quoniam ex variis cauffis, potiffimum vero ex impedita tranfpiratione primam originem trahunt: de frequentioribus obftructionibus ex cruditatibus natis \& vifceribus naturalibus fupervenientibus, antequam ad fluxus defcendo, quxdam neceffario præmittenda exiftimavi. Hepar, Lien, Inteftina, præc cxteris Pancreas \& Mefenterium, à Ventriculo multa patiuntur mala: qui, licet per fe tot morborum caufa non fit, tamen ab intemperantia vivendi toties tentatus, vegeto fuo calore tandem deftituitur, craffifque ac crudis humoribus obfitus, officio rite funginon poteft. Neque ventres hieme in his terris calidiores ficut in aliis, teftante Hippocrate: fed frigidiores potius funt, multoque humore abundantes ob crebras pluvias aëremque calidum \& humidum, ac proinde pauciori alimento indigent. Iuvenes \& advenæ maximopere hoc malo affliguntur : (veteranos enim \& fenes obftructionibus rarius infeftari videas) tam ob faburram fcorbuticam in itinere conceptam: quam ob cacochymiam ex immoderato cibi potufque freculenti \& compofiti ufiu contractam. Enimvero promifcua multitudo, nunc ad vitam neceffariis deftituta, modo eifdem nimiumabundans, facillime cruditates atque obftructiones incurrit. Potu præxterea viliffimo (quem Garápa vocant) ex facchari fæecibus $\&$ aqua confecto, tum $\&$ Spiritu urenti ex eodem potu concinnato, multi avidiffime fe implent, unde ebrii acreftiantes, totique fudore diffluentes, humi procumbunt, ac malignis vaporibus ex terra afcendentibus corpus denudatum per integras noctes exponunt. Quo fit, ut venis arteriifque corporis occlufis, circulatio \& tranfpiratio illico impediantur, moxque tonus ventriculi \& robur hepatis enerventur. Vnde debilitas cum tanto labore \& laffitudine fpontanea atque naufea oritur, ut ferendis cibis \& medicamentis impares f $x$ pe exiftant. accedit quod clam glifcat malum, \& paulatim fine ullo fere fenfu doloris primum invadat. Hincneglecto facile morbi principio, multa mala fubfequi videas, manente tamen priori calamitate. Chylus fiquidem craflus, \& crudus, venas lacteas tranfire non potens, eas obftruit: Iecori, Inteftinis, Pancreati, cxteroque corpori, non quam debet fed quam poteft miniftrat. Vnde functiones naturales non folum impediuntur, fed \& ob diaphragmatis fympathiam ex pondere hepatis \& lienis enatam, magna comitatur refpirandi difficultas, \& ex infaretu Pancreatis perpetuæ querelx. Accedunt Sudores frigidi in partibus fuperioribus, fummus virium languor, canina appetentia, durities atque murmur utriufque hypochondrii: denique longo ventilationis defectu, febris, fitis \& inflammatio. Quid quod fuffufio flavx bilis ex fcirrhofo hepate prognata, \& hydrops fípe fejungat. Idem de India Orientali (cum qua Indía Occidentalis plurimos morbos habet communes), teftatur $\mathrm{D}^{r}$. Bontius. Si quem à tot fimul ærumnis vindicatum iri conftet, hoc non adeo manu Medici, quam fingulari Naturx beneficio, idque fxpifime per liberale biliofum alvi profluvium, critice fit. Hinc obftructiones fuxu tolluntur. Scilicet in gravioribus \& longis 
anorbis cxhauita Medici fcientia \& fatigata arte, fxpe fic folet Natüra velut è màchina adefle æris, \& fanare defertos poft longam \& infanam curationem. Quorum exempla paffim obvia, etiamfi non memoria fint tradita. Forte quod nihil prxfelaudis habent.

Si quis autem Medicamentis locus fuperef, antequam ad eorum adminiculum confugimus, optima \& itricta prius diata per multum temporis inftituenda eft, qux potiffmum fit ex cibo \& potu recentibus partiumque tenuium ac digeftu facillimis, accedente mane \& vefperi motu corporis liberali, quem ob difficilem refpirationem declinare folent. Venæfectionem, fi non præens febris, faltem futura fxpe poftulat. Etenim materia morbi quamvis ex fe fit frigida, non raro vel calidis humoribus augetur, vel ipia fervorem concipit poftmodum, ut hepatis quoque inflammatio merito exeimefcenda fit. Blandioribus primo medicamentis incidentibus \& aperientibus, ne vires dejiciantur, tormina cruditatéqque ex alto provocentur, infiftendum, ut funt radices herbarum $A c a-$ riçoba, Iuripeba, Pagimirióba, Tapyrapecí, Aguapé, \& Aguaxima, ut \& Cortices Rad. Arborum limonum, liquiritix, Araćá, Ibiraée, \& fimilium, unde Apozemata reiterantur cum fucceflu. Et quia in his implicatis morbis fxpe fcorbutici quid intercurrit, herbæ⿱亠乂 \& fruatus minus fugaces ied acidiores aflumendi, ut funt Braffica marina \& Portulaca aceto conditx. Inter hxe primas tenent nuces quas Cocos appellant, quarum liquor recens medullaque, praterquam quod gulæ lenocinentur, faluti profunt: ut \& mala Aurantià, Citria, Citrulli, Caraguatá, Guajába, Ainanas, Murucujá. Deinde conducit ut Pharmacia cathartica Diætam excipiat ex more Regionis, \& materia præparata exturbetur per fuperiora vel inferiora. Id autem nullo remedio tutius vel convenientius fit, quam infu1o duarum drachmarum radicis Pecacuánba, vel nucleo nucis Andá. Exinde ipfius mali quafi antidotum per triginta dies \& ultra,fi morbi pertinacia expofcat; exhibeatur, quod fit ex pulvere corticis Ibiraée, fcorix ferri, ana $z_{i j}$, Milij Indici $\zeta_{j}$. Fabarum minorum, cucurbitx amaræ, fem. \& pulp. fol. fen. ana $z \mathrm{j}$. Q Quæ trita in pulverem exhibeantuir à $\zeta^{\text {ij }}$ ad $弓 ß$ mane $\&$ vefperi cum liquore convenienti. Huic mox exercitium corporis fuccedat, curfus fcilicet aliquot paffum, qui indies, accrefcente liberaliori motu diaphramatis major inftituitur. A quo redeuntes cibis facilis digeftionis refocillentur, præfertim pulte è farina Tipioce cum faccharo. Nemo miretur remedio tam populari, tam gravem morbum exftirpari. Medicamenti enim hujus bafis eft Chalybs \& Cortex Ibiraée, (quod eft Guajacum Brafilienfe:) quorum hic cum primo gradu calidus, tenuium partium, dulcis \& aromatici faporis fit, valide aperit: ille lentos in vifcerum oppilatione humores incidens, merito cxteris præfertur.Inter Topica (quæ magni hic ufus effe folent) Emplaftrum ex gummi Elemni, Içicariba \& balfamo Capaiba vel Cobureiba cum melle filveftriapplicatur ventriculi \& hepatis regıoni. His omnibus accurate obfervatis, plurimi convaluerunt, nifi forte aliquid pejus in hepate delitefcat, quod accedentibus reli-quiis \& debilitate vifcerum, recidivam faciat. Quapropter confultum eft, fublato mali fomite, morboque fecundum præf criptum artis expugnato; decoctum Salfeparillæ Brafilienfis aliquandiu exhibere. Tametfi autem hac medicamenta eorumque utendi methodus, nequeratione, neque experientia, deftituta fint, \& minime improbanda, necefle tamen ad rationis amufim ea exigere, \& nonnihil inventis addere vel demere.

Cum vero hx obftructiones exiifdem caufis enarratis pronat $x$, mulieres quoque Europæas gravidas æque ac non gravidas exerceant, quid mirum fi generationi deftinatusutcrus per intemperiem magno illinaturx operi ineptus cloaca fiat multorum excrementorum \& cruditatum, unde varix calamitates maxime vero uteri profluvia alba fuccedunt: Quod dum pudore vel negligentia $x$ grx occultare fudent, funt pallid $x \&$ triftes atque ingrat $x$ viris. Temporis decurfu conduplicatur $\&$ eo ufque augetur malum, ut non minus de corroborantibus vifcerumque tonum reftituentibus, quam de cvacuantibus remediis cogitandum fit. Quod quiden, partim balneis artificialibus factis ex fragrantibus herbis indigenis calefacientibus $\&$ aftringentibus, partim fupradictis medicamentis deoppilantibus, accedente fyrupo Tabaci \& melle filveltri, vel fimplici vel cum aromatibus mixto, ablolvitur. Non neglectis interim quibufdam pituitofam cacochymiam evacuantibus, tum cum profluvia hac modum, tempus $\&$ colorem variant, fecundum Aphor. $\mathrm{x}$ x x v I lib. v.

Infintes autem noftates prater hxreditaria genitricum mala, facile ex prepoftera cducationefuperius cnarrata nova accumulant. Vnde aquofo humore inflantur, durif- 
que hypochondriis paulatim contabefcunt antequam ad pueritiam attingunt. Si qux medendi prefidia ex fupradictis adhiberi contingat, raro profunt, exceptis quibufdam ventris externis frictionibus $\&$ unctionibus deobftuentibus; $\&$ pr $\mathfrak{x}$ cæteris, fi, remota matre, Brafilienfes \& AEthiopiffx nutrices lacte fuo vegeto eos ad biennium circa educant.

$$
\begin{aligned}
& \text { C A P V T VII. } \\
& \text { De Hydrope. }
\end{aligned}
$$

I Nter morbos qui ex obftructionibus pronalci folent, \& in hac cum alterius mundi parte communes funt, eft ille qui Latinis A qua Intercus dicitur, advenas pueros at que juvenes præcipue infeftans. Illis enim potiffinum ex imperita educatione \& tranfpiratione impedita; his ex fupradicta vivendi intemperantia, vifcera fanguificatio nis affliguntur, omnifque generis Hydrops vel primario inducitur, vel fecundario aliis morbis, ut Cachexix, Ictero, Dyienteriis, Quartanis, febribufque acutioribus male expurgatis, ut Hipp. paffim comprobat l. de affect. , fuccedit. Quemadmodum omnes hepatis affectus in Indiis facilius \& crebrius quam in frigidioribus plagis generantur; ita non adeo infeliciter curationem recipiunt ii qui non ex alio morbo nati fuerint. Facilius tamen quam cæteri morbi recidivam patiuntur. Hinc cautio in prognofi $\&$ curatione exfurgit, fecundumillud Hipp. effatum. Hydrops qui Medicine revenit ac concedit, depperatues eft: precipue fi ex alio morbo, quod fape fit, profectus fuerit. Quippe fi atonia hepatis vel firrhus, extinctio item caloris naturalis, omnes denique alienatx vel impeditæ virtutis fanguificæ caufre inferantur, multum quidem folatii ea remedia æorotanti tunc conciliant, quibus abdomen \& pedes detumefcunt : fed ceflante Medicina (à qua neceflitas fractæque vires frepe medicum recedere cogunt) morbus à perennitate caufæ morbificx renafcitur. In cadaverum diffectione, corum imprimis, qui ex Anafarca aut Afcite interierant, quandoque hepar colore albicante rimifque fatifcens reperi, ne veftigio quidem fanguinis in jecinore apparente. Vnde facile liquet qua fpes à vifceribus captanda fit. Contrarium vero non raro contingit, fi malum hoc cadat in fubjectum viferibus bene moratis, quando Afcites de fubito nafcitur is quibus ex aqua inordinate ingurgitata fanguificus calor læditur. 'Tunc enim $\&$ per cognitas $\&$ latentes vias infperatxexcretiones, medicamentorum virtute, tum per alvum utramque egeruntur. Quas vias fi fponte fua natura inveniat, non exiguum folatium xgrotanti præftat; quod verba Hipp. in Coac. de Hydrope c. X I X. fentent. V I I I. comprobant. lam vero ineunte Hydrope, $f$ aquofa incidat diarrbea cruditatis expers, morbum exolvit: fecus enim eger, non morbus, tollitur. Si vero medicamentorum adminiculo opus, confultius hoc per Perirrhœam quam Diarthœam inftituitur, quoniam difficile eft excretionem illam hydropici humoris fufceptam, ex lege critica per inteftina perficere. Tum alvus, arte liberaliter mora merito in Indiis fufpicionis plena habetur, quod in diuturnum imo lethiferum profuvium non raro degeneret. Perirrhœa tutius aquæ educuntur; tum ob majorem in vifceribus pororum apertionem; tum ob eximiorum medicamentorum indigenarum affluentiam; quxaperiendo, ficcando, aftringendo mirabiliter fane curationem ab. folvunt. Quippenon raro contigit, ut fola radice diuretica Caapéba (in tractatu fimplicium dicta) ex vino vel aqua, fubinde agro propinata, latex intercus fucrit edu. Etus. Idem prætant Mirabilis Pervanx, Caapomonga, Iaborandi, Saffafr. Sarçaparilla, Liquiritia, cortic. Limoniorum \& prunorum Granatenfium, radices Iuripéba, Aguaxima, Guabipocaiba, Irupecanga. Quibus nativis, utpote recentibus \& validifimis plus confidentix, quam exoticis effretis $\&$ ad naufeam fape refervatis, ponendum eft. Alvus purgatur commode fequentibus remediis. Pilulis, quæ recipiunt Guttam Cam boid in aceto maceratam, cum Zalapx \& Mechoacana recentis vel facula, vel extra Eto. Quorum ulteriorem præparandi modum videre eft in capite de fuxu albo. Sy rupus itidem Tabaci, five fimplex, five compofitus, tenaces $\&$ vifcidos humores tuto \&potenter educit, fi reiteratis vicibus cochleatim exhibeatur. His fuccedant aromatica $\&$ diaphoretica, qux tranfiratione recuperata diffolvendi vim habeant tenuiorcs humores ferofos, eofque per laxiores abdominis \& vifcerum poros expellant cum Euphoria. Balnea conducunt qux parantur ex foliis piperis longi, Mali aurex, Bctel, Arte-

mifix, 
mifix, falvix lilveftris, Camará, Tupeiçavá, althex, Albabáca, Laborandiba, aliifque quam plurimis. His adftringentia addi folent, ut funt çebipira, radices fraçá fructus $\&$ folia Mytri Silveftris. Inunctiones ex prædictarum herbarum oleis. Accedit Spicitus ex corticibus Auriac. \& Citri deftillatus, valide corroborans five extus five intus exhibitus. Sed ut dicam quod res eft, ad miraculum fere Paracenthefis, qux maxime Afciti convenit, folet inftitui,idque exlege Magni Præceptoris, ubifexto Epidemion Aquofos cito fecari debere precipit. Quod per epicrafin ter quaterve uno die, mediantibus perpetuis corroborantibus, in ipfo umbelico toties cum inopinato fucceflu factum vidi. Sin minus ob virium jacturam licuerit, pedibus ex leucophlegmatia tumentibus, cutis fupra \& infra talos, in carnofis quoque membris, ex more Regionis inciditur. Plurimi ex ulcere in crure, modo fponte orto, modo igne comparato, curantur. Quidquid enim Paracenthefis (adeo apud Authores \& hodiernos paffim practicos decantata) vane utcunque promittit, in feptentrionalibus pracipue Europæ regionibus, ubi hydropes calamitof $2 x$ diutina plerumque vivendi intemperantia \& fervidiori potu clam glifcunt : id illa in Indiis ob enarratam caufarum diverfitatem feliciffime fape præftat, ut ego cum multis aliis rei medicæ peritis teftari poffum; modo requifita, tam in fubjecto xgri quam in moderamine medentis, concurrant, antequam ea tentetur, ne falutare remedium hoc, ut aliquando fit, proftituatur.

Cxterum Hernix in ventrem inferiorem, pracipue vero in fcrotum defcendentes, non raro hydropum comites funt. In expeditionibus per afpera \& confragofa loca milites armati iter facientes hanc calamitatem incurrunt: mox fracti, toto corpore xetuantes, frigidiffimam reftinguendo calori affluentius hauriunt ; fomnumque fub aperto love capiunt. Hinc cruditates \& flatus generantur, \& peritonæum nonunquam rumpitur. Ratio vero curandi eadem qux in Europa, fomentis fcilicet, inunctionibus, ligaturis \& fimilibus.

\section{$\begin{array}{lllllllll}C & A & P & V & T & \text { V I I I. }\end{array}$ \\ De Prolapju Cartilaginis Mucronatede}

$\mathrm{M}$ Orbus ille cujus Codronchius, Sennertus \& alii videntur meminiffe, Spinela Lufitanis appellatus, interque Endemios habitus, non infrequens in his terrarum oris graffatur. Fernelius quoque v r. Patholog. cap. 3. fingultus orti ex compreffione ventriculi à coft $x$ extremo meminit. Hanc cartilaginem prolabi non pofie, incurvari poffe, putar Hofman.

Corporis totius languorem inducit, cum dolore Stomachi, aliquando vomitu, tumma refpirationis difficultate, qux ex refrigeratione pectoris mufculorum, tum imprimis mucronatæ cartilaginis compreffione oritur. Hinc mox ex dejectione appetitus magna virium imbecillitas fubfequitur, \& atrophiam minatur. Chronicus eft morbus $\&$ frigidus, non tamen per fe lethalis, paulatim invadens, \& cognitu in principio difficilis.

Empirici primarium, ut putant, ejus fignum ex infpectione \& contactu colligunt brachii xgroti, in quo fivalvularum inftar nodos comperiant, morbum hunc adeffe pronuntiant. Differt ab oppilatione cachectica, quod pectoris hoc vitio moleftati, vultu tamet fi dejecto $\&$ trifti , non tamen decoloro \& livido funt, nec pondus aut duritiem utriufque hypochondrii fentiant : tum comedendi quoque concupifcentia primxque concoctionis infrumentum langueat. Frequentius forte graflatur quod pauci fententiam Celfilib. cap. 2. tam fricte obfervari debere exiftimant, quando ait; Siquis interdiu fe implevit, poft cibum neque frigori neque aftui neque laborife debet committerc. Curatio au tcrnis ablolvi poftulat. Interna funt Pilulæ ftomachicx, Mel filveftre, Syrupus Tabaci: Vinum generofum \& guttxaliquot Balfami de Copaiba diffoluti: decocta Sallaparillæx, Saffatias, cum femine Anifi \& Cinnamomo, pugilloque pulveris Ibiraée \& Nhambi. Iufcula, quibus utitur xger, croco terreftri Irucis, pipere Brafilienfi fativo \&e filveftri, $\mathbb{E}$, , i nil hil impediar, ceppis atque allio condiantur.

Extcrna funt cucurbituleficcar reitcrat $x$, mammarumque regioniappofit $x$. Mox ftomachi 
HIST. NATVRAL. \& MEDIC. Lí. II.

ftomachi \& pectoris inunctiones ex oleo cortic. Tabaci, Aurant. Artemifix \& Menta ftri. Scutum dein ftomachale, ex herbis corroborantibus. Atque confortans tandem
emplaftrum ex prædiatis gummi $\&$ balfamis toties enarratis fuccedat.

Non indigna eft obfervatu topicorum \& externorum omnium remediorum neceffitas, quod eorum efficacia cutis \& carnis poros patentes altius penetret, quam in frigi-
dioribus regionibus; Cucurbitulas quoque corneas, qux folo fuctu ex alto trahthant, omnes pariter incolx felicifimo fucceffu applicant. Ego tot profperis effectibus motus, ufüm harum imprimis Chirurgis noftris commendavi, iifque in colicis cruciatibus $\&$ ventris fluxibus fanguineis fiftendis, atque principio atrophix membrorum occurrendo, infigni profectu fum ufus.

\section{$\begin{array}{lllllll}C & A & P & V & T & I X\end{array}$ \\ De Ventris Fluxibus.}

$\mathrm{V}$ Ifcera naturalia oppilata, ac toties ab humoribus qualitate \& quantitate peccantibus laceffita, tandcm exonerationem moliuntur. Et tunc quidem fluxus varii, pro diverfitate partis affect $\&$ naturæ humoris vel bene vel male morati, fequuntur. Vnde vel critici, vel fymptomatici judicantur. Sicut enim ex cruditate ventriculi, \& chylificationis fruftratione, fymptoma Lienterix fe prodit, \& Huxum hepaticum læxfa hepatis fubftantia \& venarum mefaraicarum regurgitatio profert:Præterea ficut inteftinorum eorum que venarum erofio, ulcus dyfentericum; ita ani exefio inflammationem \& putredinem caufatur, qux Bicha Lufitahis dicitur. Adhæc orgafmus acerrimi liumoris ex aëre \& fructibus calidis \& humidis prognatus, choleram, multafque colicas paffiones producit. Horum omnium proxim $\&$ immediat $x$ cauf $x$ impeditæ tranfpirationes vel obftructiones non funt; fed illorum potiffimum qui diarrhœx $\&$ fluxus alvi vocantur.Sin vero ab aliqua acrimonia \& malignitate materiæ morbificx, vel atonia partium, incidant tales, qui Dyfenterix, Fluxus hepatici vel Cholerre appellantur, fymptomatici \& fxpe lethales habentur. Diarrhoea fimplex, vel ex arte, vel per fe facile \& cito curationem recipit; fin minus, in pejores fluxus degenerat, qui vel ex calida aut frigida materia oriuntur. Qui ex frigida, album alvi profluvium fine febre vocatur, (excipitur autem ille quem Galenus ab adipe, à calore igneo liquefacto, proficifci teftatur) quando nimirum crudus ac pituitofus humor perpetuo delabicur, xgrumque magno dolore paulatim languefcere facit. Atque hic quidem fluxus omnem promifcue xtatem, hyberno potius quam xftivo tempore infeftans, ad multos free menfes, nonnunquam ad annos durat;. Tametfi fine febre minufquc lethalis fit quam cxteri, non inter eos cenferi debet tamen, quem Hipp. in prediç. 1. 2. f. 2. mitem \& parum durabilem effe tradit; quod hic diuturnus \& difficilis admodlım deprehendatur; cum hujus mali caufa fit cruditas pituitofa redundans ex frigore, qux tranfpirationem; $\&$ circulationem impediat, collecta, \& à prrecipuis corporis partibus ad inteftina abeat. Curatio primo à clyfteribus abftergentibus qui mel filveftre imprimis recipiant, incipit. Interim corpus fyrupis aliquandiu fimilibus prxparatur:Dehinc ad radicem Ipecacuánba, tanquam adfacram anchoram, confugiendum, qua nullum præftantius aut tutius, curn in hoc, tum in plerifque aliis, cum, vel finc fanguine, fluxibus compefcendis, natura excogitavit remedium. Quippe praterquam quod tuto \& efficaciter tenacifimos quorque humores per ipfam alvum, frepifime autem per vomitum ejiciat, \& à parte affecta deriver, vim quoque aftrictivam poft fe relinquit: Non enim vomitus folum fponte fuperveniens, ut ait Hipp.A ph. I 5.1. G. fed \& arte concitatus, fub eodem A phorifmo comprehendi poteft. Illud vero hoc modo perficitur. Drachmæ dux radicis Ipecacuánha in

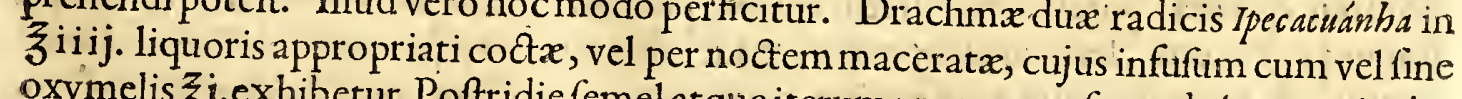
oxymelis $\xi j$.exhibetur. Poftridie femel atque iterum pro re nata,fectunda imo tertia ejus decodtio repetenda; tam quod ægri debiliores eam facilius ferant; quam quod aftrictoria ejus vis tunc magis efficax appareat. Cæ̉terum nuces Murday-guaçúlive vomicx (quibus vulgus imperitum non tam utitur quam abutitur, cum vehementer per vomitum \&feceffum exturbent) fi ex præfcripto exhibeantur, haud exiguum commodum proftant. Rec. nuclcos fex vel feptem : ablata taminteriori quam exteriori tunica, contcrantur amygdalarum inftar pro emulfione, addito momento facchari \& fol. fen. $3 \mathrm{j}$. vẹl 
Zj B. feminis anifi 3 B. in pulverem trita mifceantur, fiatque paftillus in furno ficcandus. Sic nuces Andá, quarum nuclei, etiam citra ullam praparationem, dignitate illis non cedunt. Syrupus itidem Tabaci oppido conducit, iis imprimis quibus humores tenaces abfque multo calore peccant. Dein ol. de Copaiba guttæaliquot faccharo diffolutx, ori ex ovo forbili, five ano per clyfterem immittuntur. Quod fi remedia hxo enarrata, forte non in promptu fint, eorum locum Mechoacanna, vel pugillus feminis Ricini Americani in fpiritu vini macerati, fupplere folent; hoc fiquidem humorem vitiofum ac redundantem fortius, illud vero benignius educit. Non parum quoque hoc morbo exhauftos reficir decoctum ligni Iacarandá, \& Saffafras indigena, quod evacuata materia morbifica tonum reftituat vifceribus languentibus; comitante dixta facilis digeftionis \& paulo aftringentis. Emplaftrum fuper ventriculo imponatur ex Gummi Icicaríiba, balfamo de Cabureiba \& Copaiba, vel expafta de Tipioca, vino de Acaju, pulpa item prunorum Araça, flore Nhamba, atque ovorum vitellis. Adhæctofta potius quam liquida aut frixa alimenta eligantur, idque frepe $\&$ parum. Vino indantur guttulæ aliquot olei cort. arant. præcipue tum, cum ventris cruciatus inftar colici adfit, quem vefparum quoque Brafilienfium nidus exvino potus, vel ventri impofitus, clementer mitigat. Idem feliciter præftant herbæ caftxin aceto frixx. Quando neceffitas ad magis corroborantia \& aftringentia compellit, his \& fimilibus remediis nativis, utendum. Summitates fructuum Bacóba aut Banárza femitofta aut arefacta ex vino de Acaju $\&$ immaturo pomo Ianipába. Teftæ teftudinis fluviatilis toftær rafuram, in hoc fluxus genere, Barbari propinant, quod valide aftringant. Sicut $\&$ jecur caprex tóftum, \&\& caftanea arboris Cedri Brafilienfis.

$$
\begin{aligned}
& \text { C A P V T X } \\
& \text { De Teneemo. }
\end{aligned}
$$

$\checkmark$ Vm omnia quxad ventris fluxiones fpectant, in examen revocaffe neceffum fit; operxpretium duxi, ea qux circa Tenefmum notatu digna cortidie obfervavi, paucis exhibere. Morbus nimium familiaris \& 2 merito formidabilis prægnantibus, quod foctum fimul cum foeta, mifere extinguat. Irritus enim hic conatus ex quovis acri \& ulcerifero humore ano adhærefcente natus, nullam aliquando nifi fpu$m \mathfrak{x}$ vel fanguinis aut puris excretionem comitem habet. Interdum vero ex pituita acida $\&$ bile mordaci dyfenteriam præcedit. Quibus, froculi nictantes, inquietudines, cruciatus, long $x$ vigiliæ atque excubix nocturn $x$ accedant, tunc $x g r e$ finiri folet. Exaliis fubinde dyfentericis fluxionibus nafcitur hic morbus, quibus medetur ac finem imponit, curatuque tunc eft facilior, quando tantum funt reliquix \& fanies ulceris inteftini recti; qux fomentis \& enematibus facile fuperantur. Quando ex fuperioribus ventris partibus, videlicet ventriculo, mefenterio $\&$ inteftinis; materia cruda delabitur; præter inceffiones \& reliqua quæ anum refpiciunt; caufa fovens revulfione per vomitum tollenda, idque ufitatiffimo illo remedio, Radice Ipepacuárba. Eadem porro curandi ratio fere circa externa, qux eft in fanguinis profluvio, eaque anodynis fuffimentis \& fomentis aftringentibus tepefactis ex foliis arboris. Aroeí$r a$, Araçá, Acajá \& fimilibus, fi protuberet aut hiet anus; fi ulcus adfit, facculis ex lacte, malvx, \& Bafoure fummitatibus inftituitur. His enim, tum intus tum foris continue admotis, multum promovetur; quippe quod fymptoma ipfumque adeo morbum tollunt. Allium quoque affatum, fi caufa plane frigida, cum ficceffu admovetur. Somnus qua fieri poteft, concilietur; primo pultibus ex Carimá \& hordeo. Quibus fi minus provocetur, lenocinia foporifera addenda funt, interponendo clyfteres abiftergentes. A motu quoque \& exercitio corporis abftinendum. quo fpectat illud Celfi confilium haud quaquam negligendum: Cum in omni fluore ventris, tum in boc pracipuse Tenefmo, neceffe eft, non quoties libet defidere, fed quoties oportet, ut hac ipfa noor a in confuetudinem ferendi oneris intefina deducat. Si tandem aftringentibus remediis internis: Huxibilitatem humorum colibere conducat, prater fuccum ftillatitium poni tanipaba imnnaturi , rafura infuper ligni notiffimi Iacarandá, ut \& nuclei fructus Guetisorói triti \&rjejunc ex convenienti liquore haufti, eximie profunt. 


\section{$\begin{array}{lllllll}\text { C } & \text { A } & \mathrm{P} & \mathrm{V} & \mathrm{T} & \mathrm{X} & \mathrm{I}\end{array}$}

\section{De Cholera.}

$\mathrm{P}$

Erniciofus nec infrequens his quoque regionibus eft fluxus ille qui Cholera dicitur. Morbus femper fymptomaticus \& vere acutus, ab aëre calido \& humido, corpus perpetuo ambiente, immodicoque fructuum fugacium \& horariorum efu proficifcens. Omnem ætatem omni anni tempore infeftat. Attate tamen ab æruginofa porracea atque xftuante bile, potu calido intempeftive accedente, juventutem vehementius exercet, cum fubita quadam firituum effufione aclipothymia ex tetris \& fuliginofis vaporibus orta; adeo ut, fi ante viginti quatuor horas non evadant, fuccumbant. Quod ex manifefta diagnofi conftabit, fi nimirum pulfus debilior, aut impedita refpiratio, exteriorum membrorum, tum fudorum frigiditas, fummum interiorum circa cor incendium, convulfionefque interveniant. Hunchumorem efferum \& quafi orgafmo ad fuperiora $\&$ inferiora delatum compefcere, res profecto haud exigux difficultatis eft. Primumad ea remedia qux cor, ventriculum ac inteftina modice refrigerando \& aftringendo corroborant $\&$ furorem a cerrim $x$ bilis retundunt, confugiendum. Corpus enim evacuare (etiam invita Plethora \& Cacochymia) quamvis benigne, periculo non caret ; tum quod vires collapfe atque exhauftx, ulteriori irritatione reformidand $x$ fint. Vltra Tamarindos, quos hxc terra producit, quxeque biliofos \& accenfos humores refrenant, nihil tentandum; fed fyrupis potius \& conditis de $\mathbf{A 1 u r u c u -}$ já, Ianipápa $a$ Limoniis, Arantiis, Araçá, Guajába; ut \& Ficubus Indicis, Vbapitanga, Mureçy', imprimis $T$ ipioca utendum, cxterifque medicamentis roborantibus, \&refrigerantibus. Externis quoque fequentibus infiftes. Fomenta $\&$ inunctiones fint ex aftringentibus $\&$ rrefrigerantibus. Tum cataplafmata ex Portulaca, Myrto, Araçá, oculis arboris Imbaíba confecta, qux cum aceto præparata rite ægroto impofita, prxcordia fovent, ventremque ac anum afflicum demulcent. Clyfteres ejufdem generis (modo tantillum temporis fuperfit) requiruntur, creteraque remedia in capite de Dyfenteria \& inflammatione ani prolixe enarrata. Verum, quemadmodum hac frpe auxilio funt, non raro confulto ob temporis anguftiam \& morbi frvitiem omittuntur, confeftimque ad foporifera devenitur. Linimenta denique opiata, çapiti \& pectori admovere convenit. Adeo nihil tutum nifi fomnum omni induftria concilies. Cholera ficca eifdem remediis fere curatur, maxime fir regioni hepatis cornex cucurbitulx applicentur. De quibus merito hoc teftor quod Galenus de fuis cucurbitulis quas in Colico affectu incantamenti inftar operari tradidit.

$$
\text { C A } \quad P \quad V \quad T \quad X I I .
$$

\section{De Dy enteria.}

$S$ Equuntur Fluxus cum febre $\&$ fanguine, ut funt Dyfenteria, Fluxus hepaticus $\&$ Inflammatio ani. Affectus Dyfentericus nimium his terris eft familiaris. Oritur potiffimum exfudoribus vi frigoris nocturni ac venti mediterranei fubito admiffi retroactis; tum fructuum fugacium \& frculenti potus immoderato ufu, accedente aëre calido \& humido. Hxc excretio fanguinolenta licet pari vehementia per omnes Indias frviat, numquam tamen in Brafilia morbi Epidemici inftar graflatam, alioque per contagium migraffe, conftat. Ita ut perpetuo nobis fporadica \& popularis, nunquam vero epidemia exiftat: cum alias pertinacifima aliquando malignitas; fi in alio quopiam, in hoc morbo imprimis apparet. Quibus excretio biliofa, adufta \& fpumofa, ut in juvenibus frpe videre eft, merito ab Hippocrate habetur calamitofa atque funefta ; quippe qux nullis remediis cedat, licet hxc tellus, contra malum tam familiare nobilifima minimeque vulgaria auxilia medica producat, \& prxftantiora induftria acfolertra hominum indies fufcitentur. Verum miffis iis, qux fatis fuperque jam ante ab aliis de natura \& curatione Dyfenterix diata funt, ea tantum profequar, quibus potifimum differant $a b$ Europa. Affectui huic (prafertim fi multa cacochymia adfit) tot fimul folent fupervenire fymptomata, tamque horridi cruciatus, ut frpiffime anguftia rei $\&$

$$
\mathrm{D}_{2} \text { temporis }
$$


temporis legitimam methodum remorentur. Hac itaque neceffitate exigente, venam tundere, haud confultum habent; (nifi ipfo quidem principio, aut febre atque hepate affecto id maxime poftulantibus) quoniam, etiamfi revellendi indicationi for te fatisfactum eatur;male moratx tamen materiæ morbificx \& virium inopix male fit, quia raro occafio deperditum refarciendi adfit. Porro vel folo Rhco, vel laxativo quovis benigniffimo mordacem humorem provocaffe, partifque affect $x$ cruciatus ingeminaffe, fufpicione plenum habetur. Si quando tamen evacuationilocus, radicem vomitivam Ipepacuanba, exquifitiflimum naturæ munus, cæeteris remediis praferre conducit : quamvis ingenue fatear, plurimos medicaftros incolas ad fudorifera \& cordialia, quamad evacuantia per alvum, benigniora licet, inclinare; etiam tunc cum major cacochymix quam ulcerationis figna appareant. Morbo durante preter confolidantes, abftergentes $\&$ refrigerantes clyfteres, nutrimentis $\&$ anodynis ex jufculo gallinarum hordeaceo att furfuraceo, lacte caprino chalybeato $\&$ fimilibus infiftendum. Pr $\mathfrak{X}$ cxteris pulmento ex Tipioca $\&$ emulfionibus inde factis, quod multis indicationibus fatisfaciant, utendum per inferiora $x$ que ac fuperiora: quippe mirifice confolidante $\&$ refrigerante qualitate partes afflictas demulcent, Huxiones quoque ruentes compefcunt atque coagulant, \& orificia venarum claudunt. Quodfi neceffitas ulterius infurgat, viribus corroborandis \& fiftendis fluxibus invigilandum, fcilicet opiatis :tum medicamentis quoque $\&$ alimentis aftringentibus confolidantibus, imprimis quæ lumborum, ventris \& jecinoris refrigerio $\&$ robori funt. Præterea fingulis vicibus quibus alvus dejicitur, fomenta ex iifdem parata immittantur, unde putredines $\&$ calores, vel præfentes, vel futuri avertantur. De quibus latius dicetur in capite de Inflammatione ani. Potus quo xger utatur, ptifana fit, ex decocto de Carimá. Ovum quoque forbile cum tribus quatuorve guttulis olei Copaiba conducit, quod leniendo fimul partes læfas confolidet, ac proinde totidem guttulæ cum albumine ovi ex bombace ano inditæ vel per Clyfterem injecta folamen adferunt. Affata elixatis præferantur. Pacóba \& Bariána femitoftx, fxpe pro alimento medicamentofo accipiantur. Iidem quoque fructus diffecantur $\&$ in Sole ficcantur, atque in maffam, addendo aceti momento, coquuntur loco panis. His accedunt plurima alia remedia nativa, aftringendi fimul $\&$ refrigerandi qualitate pollentia, qux primi incolæ partim ut arcana celant, fecumque interire cupiunt, partim innotuere $\&$ in tractatu de Simplicibus tradita funt. Horum quidem primum locum obtinent, Confervæ \& Rob fructuum Myrti Granatorum, utriufque Araça, Gujiába, Mureçi, Murucujá, Ianıápa, Acajú.

\section{A P $\quad$ V $\quad$ T, X I I I.}

\section{De Fluxu alvi Hepatico.}

A Nno I 638 , urbe Salvador in Babia menfibus admodum pluviis obfeffa, nulla clades æque exercitum noftrum attrivit, quam fluxus fanguineus, fignis \& curatione nonnihil à Dyfenteria diverfus.qui, licet non minus quam illa perniciofus, fymptomata tamen longe minora eum comitari folent. Sxpe enim ad finem ufque, abfque ullis torminibus, cruciatibus, exulcerationibus, cumque facili excernendi modo, exiftit. Dejectio autem hæc eft, vel puri fanguinis, vel cum grumis, \& lotur $x$ carnis fimilis; idque dupliciter fit : vel ab atonia hepatis, qux licet curata, ad priftinam cruditatem redit: vel à quantitate ex venis mefaraicis atque inteftinis regutgitante, quxplus timoris quam detrimenti inferat, \& juventutem maxime infeftet. Quippe tales excretiones'aliquando febrium acutarum critic $x$ habentur, exque eutonia jecinoris, non inteftinorum exulccratione caufatxfunt. Fit demum hic fluxus ex qualitatefimul, orificia venarum corrodente $\&$ referante. Atque tunc quidem Dyfenteriam propter ulcus \& dolores inteftinorum mentitur. Ea qux ex hepate profluxio fit, iis remediis oppugnanda, qux confirmando jecinorifuam operam tam intrinfecus quam extrinfecus dicarunt. Raro in principio folamen ullum à clyfteribus confolidantibus aut anodynis accederevideas. Venxfectio, tametfi in reliquis fanguinis profluviis vix admitratur, in hoc tamen laudabilis habetur : noftratibus vero utique mollioribus, intenfiorique calori non affuetis, cautius ac parcius inftituenda eft. Immo in cucurbitulis revellentibus, lumbis ac natibus impofitis, aliquando fubfintendum. Reliqua qux 
tractu temporis exfurgunt circa curationem, quum Dyfentericis affectibus magis communia funt, iifdem remediis, in capite de Dyfenteria monftratis, propulfantur. Ad eum autem fluxum qui ex atonia hepatis nafcitur, compefcendum, irriti, ut plurimum, curandi funt conatus, ita ut præ virium lapfin ne quidem Rhabarb. Myrobal. aliaque fimilia adhibere confultum fit, ac proinde fi acrimonia comitetur, ad blandientia \& ftupefacientia quoque confugiendum eft. Non neglectis feminibus quatuor frigidis recentibus, neque iis quæ urinam benigne provocant, ut íunt, decoctum Iuripéba maris, radicis Araçá, fructus Alkekengi, rad. liquirit. Solatrum, Acariçóba \& pagimirioba, atque fimilium quæ hepatis $\&$.venarum mefaraicarum ardores mitigant. Horum præc ceteris palmam obtinent emulfiones \& pultes quæ Carimá diąæ ex Tipioca de Maszdioca. Inter fructus in pretio habentur, illi omnes qui in curatione Dyfenteriz enarrati funt. Aqua quoque ftillatitia ex canna faccharea \& flore Ibabirába cum albumine ovi pota, addito momento fucci aurantiorum. Denique cataplafimata ex Portulaca $\&$ Solatro cuIh aceto temperata, dorfo \& ventri applicata, intemperiem hepatis folantut, fluxumque inordinatum compefcunt.

$\begin{array}{lllllllll}C & A & P & V & T & X & I & V\end{array}$

\section{De Vlcere \& Inflammatione Ani.}

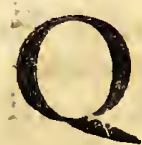

$V x a ̀$ Barbaris meaque longa experientia circa rationem \& curationem tam funefti \& lamentabilis mali confecutus fum, in medium proferam. HuncaffeEtum Indigenx Teicoaraiba, Lufitani Doenç do Richo five Bicho del Cúlo abufive vocant, vel quod dolor pruriens principio fentiatur, vel quod Vermiculigangrænam inferant. Lis hæret inter Medicorum filios, novus ne an vetus fit morbus hic Endemius. Ego quidem eum potius crediderim in aliis Orbis plagis tanquam hoftem occultum infidiole frvire ; adeoque longe abeffe novum appellandum fore, ut probabilius, antiquiffimum effe, atque deillo intelligendum r. Reg. c. 5. v. 6. Aggravata eft autem manus domini fuper Azotios, $\&$ demolitus eft eos, \& percuffit in fecretiori parte natium Azotum \& fines ejus. Hujus quoque David videtur meminiffe Pfalmo 77. v. 66. dicens, \&z percuflit inimicos fuos in pofteriora. Non eft Endemium malum huic regioni, fed frequens indigenas æque ac adventitios infeftans. Conftat, in Angola $\&$ aliis fervidis Indiarum partibus diutius cognitum; atque olim Brafilix incolas plane ab eo immunes fuiffe. Nil autem aliud eft, quam incendium $\&$ corruptio ani cum ulcere depafcente, fine vel cum fanguinis fiuxu dolorifico, tempore imprimis æettivo graffante. Hunc morbum, aut præcedunt fuxiones Dyfentericx cum inteftinorum caloribus; aut per $\mathrm{fe}, \&$ citra ullum morbum prævium ingruit. Cum Dyfenteriam prxcedentem habet, \& ob medicinam adhibitam Symptomata excretionefque ceflant, minus fidendum eft. Detenta fiquidem materia acerrima, à calore nimio accenfa, maximeque à fquallente $\&$ fordida corporis celluvic intus alta, magnum putredinis gradum, cum tam atroci dolore $\&$ inflammatione acquirit, ut mufculum fphincterem atque ora venarum hæmorrhoidalium ftatim exedat. Vnde fluxus cruentus exoritur, altiufque ad inteitinorum tunicas afcendit, tam deformi afpectu, ut anus late diductus cloacx inftar livido \& 2 plumbeo colore appareat. Nonnunquam vitium hoc per fe manifeftatur, nimirum ex dolore, cum retentione excrementorum, qux calore ar efacta atque indurata, non fine maxima difficultate $\&$ cruciatu egeruntur. Aliquando vero, ingenti licet conatu, nihil prorfus ejicitur (ut ipfe in me quoque expertus fum) ano multum prominente. Hincatroces fape dolores ex retentis fæcibus fúfitantur, quos febres poftea, laffitudines, vigilix, concitatio ftomachi, ac capitis imprimis dolores $\&$ ardores fequuntur. Quamobrem, antequam malum ferpat (ferpit autem citiffime) internis laxantibus \& refrigerantibus remediis refiftatur. Clyftercs ejufdem generis femel atque iterum admoveantur. Suppofitoriis, inunctionibus, lavacris, balneis, fuffumigiis, perpetuo infiftendum. Venæe etiones præcipue non negligantur. Quibus omnibus fi morbus non brevi cedat, proculdubio in lethiferum degenerabit. Multoties praterea fieri confuevit, ut nullo morbo inteftinali, vel quovis alio figno pracedenti, parti minus fenfibili feminarium clam infinuetur, ipfumque agrum \& medicum 
in principio lateat. Quod, quoniam gangrænam non raro inferat, incurabile haber cur. Si autem prodat fe malum, pravia utcunque hac diagnofi fierifolet; ut, fpontanea lallitudine, capitis \& membrorum doloribus, appetentix cibi languore, calida totius corporis intemperie, infomniis, pulfu arteriarum inæquali \& celeri, abfque manifefta podicis afflictione, nifi forte aliquo pruritu aut inani exonerandi alvum defiderio. Quamobrem in omni inteftinali præcipue affectu, de ani difpofitione Medici percontarifolent. Quo incolx Empirici non contenti, vifu \& tactu explorant podicem, num aliquid praternaturale appareat; mox pulpx limonum affrictu partesillas tentant $\&$ dolores excitant. Differt autem ab hæmorrhoidibus hic affectus, fequentibus potiffmum fignis. Gravis capitis dolor adeft, ac hiantis late ani oftium fatif́cit. Dein, ratione prognofeos, quod morbus hic nonnunquam mortem \& quidem confeftim adferat; hxmorrhoides autem non item, qux eifdem, quibus in Europa medicamentis, imo folis hirudinibus Brafilienfibus curantur, \& liquore pulpæ nucis Cocos putrefact $x$ pius admoto, mitigantur. Cxterum, qui contra hanclabem fe tueri fudet, aqua marina frigida vel tepida \& limonior um fucco recentium, anum, quoties ventrem exonerat, probe abluat. Iabor andi-miri cum falis \& piperis Brafilienfis momento cæteris remediis facile eft præfer endum. Quando vero fenfibiles ani partes excoriatæ tam acria remedia haud ferunt, temperantur cum vitello ovi \& aqua cann $x$ facchare $x, \&$ imprimis cum fummitatibus herbæx infigniter mundificantis Lacuacanga dict $x$. Si lapfus virium contra indicet venæe ectioni, cucurbitulæ infra dorfum affigantur. Exinde clyfteres refrigerantes, confolidantes \& adftringentes, qui anodyna imo ftupefacientia opiata recipiant, progrediendum. Poftea veterum incolarum ritu, a qua faccharea, gummi Taréroqui, amyl. ex Tipioca de Mandihoca, foluta, digitis infertis pofteriora proluantur. Poft hæc, dilutum ex ceruffa, a qua rofarum $\&$ flor. $16 a b i r a ́ b a$, faccharo rubro, ovi albumine 8 lacte cum momento opii concinnandum, in quo tæda madefacta, ano profunde immittatur, idque frequenter. Idem fere praftant herb $x$ quxdam nativ $\boldsymbol{x}$ pr $\boldsymbol{x}$ cæteris contra hunc morbum receptæ ufuque longo comprobatæ; ut funt, folia \& Hores utriufque Pagimirióba \& Tapiá arboris longe præetantifimæx, addita Aguaraguya, toties inferta quoties defidendo tædæ vel fuppofitoria intromiffa. removentur. Quodfi pars afflicta manuum attactum reformidet, fuffimenta ex emollientibus \& ficcantibus fubftituenda funt. Porro quantum ad victus rationem, alimentis frigidis $\&$ roborantibus maxime uti convenit: irritantia autem cane pejus $\&$ angue declinanda. Si vermiculi fimul à putredine orti in feftent partem affectam, ii oppugnandi unguento quod pulverem anarum fructus Angelyn cun cinere Tabaci receperit.

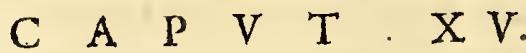

\section{De Lumbricis.}

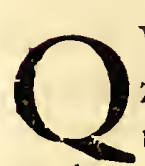

Vam nihil in hifce orbis partibus à putredine fit liberum, omnes quicunque fub zona torrida vivunt experiuntur. Vnde Infectorum, maxime vero Vermium tantus proventus, ut nihil propemodum intactum $a b$ iis relinquatur. Eodem modo cum Microcofmofe res habet, quem non minus quam totum hoc univerfum, varii generis vermes identidem exagitant; tamque vifcera intus puerorum juxta ac adultorum; quam foriniecus vulnera atque ulcera, à calido $\&$ humido ambiente, miris modis infeftant. Hi Chirurgorum opera, quxque vulnera \& ulcera mundificant, profligantur; illorum vero curationem perficere, totque latentes hoftes exturbare, leve non eft propter ingentem conceptæ putredinis propagationem. Hinc febres graves, ne di.cam \& malign $x$ generantur, aliaque fymptomata fubfequuntur. Quippe non folum ano \& inteftinis familiares, fed frepifime quoque ventriculo, folliculo fellis, utero, quin \& ipfi Cordi vermiculos innafci, Anatome milhi notum fecit. Qui car dialgias, deliquia animi, palpitationes cordis, fridores dentium, \& horrores nocturnos inferunt. Vnde fit , ut cachectici, multoque halitus fætore, viva veluti cadavera, vix mortem effugiant, nifi forte ipfo initio remedia adhibeantur. Theriaca \& Mithridatium celebratalicet remedia, ob febrium incendia, aliafque rationes toties repetitas, haud admittendas cenfent. Ego quidem ut fatear quod res eft, miflis longe petitis compolitis, in pueris atque adultis 
adultis cum Tabaci-Syrupo felicius voti compos factus fum, atque ob infignem mun dificandi \& abftergendi qualitatem tum in hoc morbo tum in aliis frigidis affectibus, atque à veneno natis, merito eum prætuli. Barbarorum æque ac noftrorum ufitatiora remedia funt fructus acidiffimi Caraguata dicti, eorumque liquor deftillatus, idque exigua quantitate cochleari exhibitus, addito tantillo Tamarindorum \& mellis filveftris. Semina, olea $\&$ fyrupi Citrorum \& Arantiorum propinati, vermibus contrariantur. Licet autem à quibufdam animantibus inftinctu naturali, ut $\&$ ab Indigen is robuftioribus, contra hæc \& alia mala expetantur nuces arboris Angelin; tamen ob indomitam vim, jufta dofis ac preparatio requiritur. Nimium fiquidem eft, quod dimidium fcrupuli excedit, ficut poftea fuo loco latius demonftrabitur. fumme enim amara eft, atque umbilico tutius imponitur rafura, qux etiam ano indita contra afcarides eximize eft utilitatis, quas fumma fua amaritudine brevi interficit.

\section{A P V T $\quad X V I$.}

\section{De Lue Indica.}

L Ves quædam ex coitu non tantum per contagium, vel parentum hreditario malo in liberos, fed ex leviori attactu atque per fe contrahitur, or ta potiffimum ex alimento fotido \& falfo, potu rancido \& corrupto. Inter Afros non folum at que Americanos, fed Lufitanos \& Belgas quoque favit, tumoribufque fcirrhofis \& virulentis ulceribus, totum corpus infeftat. Q uæ quidem lues huic regioni eft Endemia, \& Bubas ab Hifpanis, atque Miá à Brafilianis appellatur. Et ficuti citius fanatur à folis remediis indigenis ; ita citius contaminat, quam illa qux lues gallica vulgo vocatur $\&$ ad Incolas huc defertur. De qua dicere non eft propofiti mei, fed de præfenti. quæ licet in quibufdam conveniat cum illa ; accidentibus \& curatione tamen maxima ex parte differt. Empirici initio data opera eam negligunt, humorifque tenacitatem, in quo mali fomes maxime inhæret, aliquot feptimanarum intervallum requirere ad præpara tionem, credunt. Vitam interim intemperatam vivere interdicunt, aquæ calid $x$ lavacra inftituunt, frigus nocturnum, ne perfpiratio cohibeatur, maximopere arcent, car nes recentes, imprimis ferinas, toftas, præcipiunt. Vinum permittunt, quod fudores $\&$ fuligines, non fine ægrotantis levamine, per poros expellcre comperiantur. Qui ab hoc medendi modo recedunt, fymptomatum quidem pro tempore levamen allaturos, fed poltea recidivam artuumque dolores fucceffuros, ratum habent. Tandem praparato hoc modo corpore, evacuationes infituunt : mox eos, qui præfertim tenuioris fortis funt, ad molendinas facchareas ignefque luculentiflimos ablegant ; \& folo decocto, cujus bafis Caaróba \& Sarçaparilla, curationem felicifime abfolvunt. Vlcera

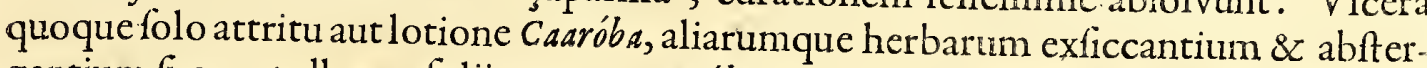
gentium fucco, tollunt. foliis autem Caaróba nunc coctis pro balneo, nunc ore jejuno mafticatis, ulcera, quæ per fe non evanefcunt, exficcant, \& malignitatem extrahunt Quod ipfum aliquoties per Chirurgos in Nofocomio imitari juffi, \& \& voti nos compo-
tes reddidit.

Nequis autem fallatur, hrc lues five ex Hifpanica mixta, ut fape fit ; five fimplex Endemia, Europxis præfertim, non adeo parvi facienda five in principio five in progrelfu. Neque enim ut quidam exiftimarunt, intra Tropicos levior ob halituum à fole perpetuam extractionem; gravior tantum in feptentrionalibus regionibus datur: Acfinocturnum frigus modo leviter admiffum, apertos diurno calore poros non cum fummo detrimento ægri altius occluderet, difcuffionem tetrorum vaporum impediret, verfufque perioftium, in quo dolor, repelleret. Sicut quotidie fit, vel xgrorum vel medico rum incuria, qui differentias diei \& noctis contemnunt. Et tunc quidem male morata ulcera, quibus hoc malo infeftati turpiter fcatere folent, prater alia fymptomata, cariem in offibus caufari videas. Sicut in reiteratis diffectionibus corporum autoplia nos
docuit.

Atque tunc fimul aratomix, in Ethiopibus exercitii gratia inftitutx, certos nos fecere, nigredinem illam cutaneam ultra epidermidem non penetrare, eaque ablata mox ipfam cutem albam Euxopxorum plane more fe offerre. Si vero contigerit aliquos epi- 
dermide alba nafci (ficut in puella \& juvene pilis crifpis \& oculis cxfiis ex Nigritis natis videre licuit) inter natur $x$ monftra recenfentur, adeoque ob albedinem conterraneis fivis contemtuiexiftunt, quam fi nigra cute aliqui Europæi nafcerentur.

Sed miffa hac digreffione ad inftitutum redeo, pauca additurus qux de Gonorrhœa notatu digna exiftimavi. Gonorrhœa fimplex, ficut haud difficilis habetur curationis, 1ta facile acquiritur, modo à diuturna equitatione fub xftu meridiano. A purgantibus initio fibi cavent in omni Gonorrhœa, five virulenta five non virulenta. Tam falutaria contra hunc affectum domi nancifcuntur remedia Incolx, ut rato in exotica, qux in officinis proftant, inquirere illis neceffum fit. Prxferunt, Guabipocaiba, Lufitanis Pao Podre, quam ego arborem fliquofam, in tractatu de Simplicibus, appellavi. Ejus radix in taleolas diffecta $\&$ in aqua ex canna faccharea deftillata, macerata, aërique expofita, eam abfterforia \& diur etica qualitate imbuit, qux mane \& vefperi pota, paraftatas \& renes infigniter mundificar. Cavendum tamen ne immodice hoc medicamento valido utare, quod fanguinem ducat. His accedit Iuripéba, Canna filveftris Iacuacíng a dicta, radix item Iaborandi, qux noctu fub dio macerata in aqua fontana diluitur, cjufque diluti quatuor plus minus uncix per quindecim circiter dies bibuntur, unde renes \& vefica repurgantur. Poft hxc pro potu quotidiano, ejufdem cann $x$ filveftris decocto utuntur. Atque alternatim ob calores fufcitatos, mane ptifanam feu liquor em ex Tipióca exhibent. Dilutum radicis de Aguaxíma, Iacuacanga, Pagimirióba , Caaponónga, Emulfiones ex Tipióca, nuce Coco recenti, \& feminibus frigidis, cannæque faccharex aqua preparatx, familiaria illis funt remedia. Contra inflammationes lotii, poft frigidam dorfi \& perinæi inunctionem, genitalia emollientibus fomentant, nempe decocto fummitatum Imbaiba , \& Tupeiçáva, floribufque malvæ American $\&$ Fabarum vulgarium, atque id genus aliis. Calorifica vero, tam à medicamento quam cibis procul efle jubent, he virulentia $\&$ incendium invalefcant. Ego tamen nimium refrigerantium ufum aliquando noxam intuliffe expertus fum, quod tonus genitalium inde debiliretur. Scmper enim condonandum eft Empiricis, utpote diligentioribus in exhibendis medicamentis quam in diftinguendis morborum caufis. Quippe ficut ex his medendi formulis apparet, Profluvia genitura cum Gonorrhocis videntur confundere. Quod qui evitare velit, adeat Plater. Obf. pag. 729 . Lang. Epift. 2.1. 5. Solenand. pag. 199. v. 45. Hofm. pag. 540. Qưocirca in Gonorrhoea virulenta malignitate exturbata fubfiftunt peritiores, quando indicatio aftringendi, confolidandi, \& ficcandi eft. Luod quidem optime fit balfamo Copaiba, faccharo vel oleo olivarum diffoluto atqueper os \& peneminjecto.

\section{A P V T XVII. \\ De Vumeribus es Vlceribus.}

$\mathrm{T}$ Ametfi pleraque vulnera \& ulcera ejufdem fere natur $\&$ cur $x$ in novi hujus ac veteris Mundi partibus videantur; ea tamen in quibus differunt, filentio præterirc nolui. Sicut enim in multis malis internis confider andum qux infra hepar fint aut qux fupra; ita maxime in extérnis. Qux fuperne funt, precipue in capite, multo benigniora \& curatu faciliora exiftunt. Tum quod ab humorum affluxul libera, tum quod favente aëre ambiente calidiori fola mundicatione reftituantur freje. Ea alltem quæ in inferioribus partibus corporis, maxime in pedibus exiftunt, difficilli$m x$ curationis funt; ob perpetuum defcenfum $\&$ mobilitatem calidi humoris inacrimoniam degenerantis; Atque hrec quidem veriffima deprehenduntur, fi tempus anni refpondear, nimirum conftitutio calida \& humida: æxtate enim ficca fponte vel felicius faltem curantur. Quid mirum, fi hac regione qux toto coelo ab Europa diftat, vulnera \&ulccra aëri expofitá, diverfum quid \& peculiare habcant? cum authores paffim teftentur, nonnunquam ob diverfum urbis aut regionis fitum, aut pejora, aut meliora tum capitis, tum pedum mala fieri. Ab ipfo principio ufque ad curationis finem, five lociaffecti corrupeclx, five vicinæ carnis mollitiei invigilantes, nativas fuas aftringentcs, mundificantes \& ficcantes herbas, refinas \& pulveres non facile deferunt. A vino \& fructu inprimis illo celebri Anana/s fibi cavent. Quia curationem vulnerum \& ulcerum remor ari, recidivam que faccre confat, quod calore infenfo humores permeet \& accendar. 
HIST. NATVRAL. \& MEDIC. Li B. II.'

accendat. Quibus recens inflicta funt vulnera, xftum diurnum devitant, ne fanguis -attenuetur, venarumque orificia aperiantur, quöd ingenti virium jactura ob diffipationem fpirituum \& febrilis caloris accenfionem in caftris aliquoties contigiffe memini. Cui malo eximie opitulatur ufus Ambra grife ex jufculis vel ovo forbili exhibitx. Deinde ne noctu fub dio cubent, unde maximam calamitatem, fpafmos, convulfiones mortemque ipfam poftea incurrant. Cum vero in curatione vulnerum $8 z$ ulcerum Lufitani plerique \& Brafiliani peritiores longo ufu facti, \& filvas remediorum quavis regionis parte, omnique anni tempore fibi in promptu habcant, ea proferam qux oppido approbata \& à noftris recepta, longaque experientia confirmata funt. Optato fucceffu balfamis illis fragrantibus Cabureiba \& Copaiba vulnera reftitume, haimorrhagiamque non tantum fiftunt, fed $\&$ interne ac externe exhibita nervis opitulantur. Gummi illud admodum familiare, Içicariba (quod Elemni vere dixeris) capitis affectibus præ cæteris remediis medetur. Tipióca autem; ficut pota fiuxus fanguinis hepaticos \& dyfentericos internos coërcet, \& incraflat; ita haimorrhagias à vulnere concitatas, five haufta, five plagis emplaftri aut cataplafmatis forma applicata, mundificat, temperat \& fanat. Idem arboris Ambaiba fummitates pollicentur \& 2 præftant, fi carum. fuccus vulneribus inftilletur.

Popularia denique remedia funt decocta vel fucci herbarum Iuripéba, Pagimirióba, Nymphæa Cuipoúna, Tapiá, Mamangá, Caapéba, Ricini Americani Bacoveira \& Queraíba, aliaque infinita incolis ufitata, de quibus in hiftoria Simplicium. Adduntur, fi fimul pedum tumores adfint, balnéa vel fomenta ex radicibus Ar açá \& citriorum: atque ex corticibus Myrti filveftris, arboris çebipíra, fummitatibusque Ánínge, Tupeiçáva, 1babirába, Camará, \& fimilibus, denique foliis recentis Tabaci contufis, defperata reftituunt mala, \& majores facile ipfis redeunt fructus in curatione multorum malorum, ex ufu foliorum viridium corumque fuccis $\&$ oleis ; quam cæteris or bis incolis ex fumo exficcatorum. Furunculos \& Apoftemata maturare folent foliis Araticú vulgaris, Cararú, Pagimirióba, Potinçoba, Inquirí. Radicibus mirabilis Peruanx rubræ, \& bulbis sieerú; Anthracibus vero imponunt folia Tabaci.

Equidem fi debitis encomiis polychreftum Tabacum profequerer, inftituti limites tranfirem. Præterquam enim quod ejus decocta plurimis morbis frigidis five intus affumpta, five extus per fornenta \& frictiones adhibita medeantur; gangranas quoque, ulcera cancrofa, vulnera antiqua $\&$ fordida vermibus ab ambiente calido \& humido fcatentia, recens fuccus $\&$ cineres ejus feliciter curant. Imo vulneribus à fagittis Indorum lethali toxico imbutis, morfibus quoque virulentorum quorundam animalitim, præfenti remedio exiftunt folia trita eorumque fuccus, fi tempeftive indantur. Incolx proinde merito ejus pulverem \& fuccum loco balfami circumferunt peregrinantes, quippe utilitatem \& neceffitatem ejus contra ipforum brutorum \& jumentorum externa mala vermibus perpetuis obnoxia experiuntur quotidie. Ego ulcera cancrofa in nofocomiis à Chirurgis Europxis rationalibus relicta, ab exercitatis Empiricis reftitui vidi remediis quorum bafis erat fuccus Tabaci addita Caphura \& Spiritu vini. Ita utjure merito vegetabilis hæc panacea Herba Sancta ab Hifpanis, vulneraria Indica à Came-

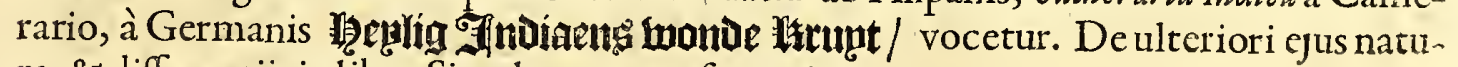
ra, \& differentiis in libro Simpl. ex propofito egi.

$$
\begin{aligned}
& \text { C A P V T X V I I I. } \\
& \text { De Papulis d Impetigine. }
\end{aligned}
$$

I

Nter vitia Cutanea nondum ulli Medicorum ex quo detecta fuit hæc Americx pars Scabiem, Lepram, Elephantiafin obfervaffe contigit, ficut in IEgypto aliifoue fervidioribus regionibus graffari teftatum eft ab Autoribus. Sed papulæ feu fudamina, quibus cutis exafperatur \& rubet, advenas fere omnes recens Indias ingreflos, genioque imprimis largius indulgentes, fummo cum pruritu invadunt. Hx pufula totum corpus fepenumero arrodunt, fixaque ac ftabiles totam ventris regionem occupant, ut zona dici poffint. Quod malum abolere plerique fudent minus caute, feu frigid $x$ lotione, balneoque nimis aftringenti, five per fortiora purgantia, acrem humorem ì circumferentia revocantia. Si vero fudamina hec nimis excrefcant, longiufque ferpant, leves 
admodium \& faciles purgationes ex temperatis componantur, quxhepatis calorem, fentinæque corporis, mefenterii fcilicet, obftructiones tollant, ut funt decocta radicum Iuripéba Limoniorum \& fimilium. Venæfectio femel atque iterum inftituenda eft. Externis ita utatur; ut fudore crebro abfterfo, fubuculam frequenter mutet. Mox fomentis ex aqua fulphuris \& nitri, albumine ovi, feminibus frigidis majoribus, cum aceto \& Limoniorum fucco coctis, immiffo linteamine, corpus defricetur. Qux, licet primo attactu acres fxpe dolores excitent, cutemque vellicent, ftatim tamen ceflare folent. quos fi quis impatientior ferre non potuerit; eorum loco, balneo tepido ex refrigerantibus $\&$ emollientibus herbis utatur. Plerique quamdiu hoc malo tentantur ac pruriunt, à multis morbis funt immunes, ac profpere valent. Quamobrem qui hæc incommoda fanitatis gratia aliquatenus obdurare malint, rectius fecerint. Ante omnia moderatam vivendirationem inftituant, ciboque ac potu temperato $\&$ tenui utantur, ut humor attenuatus, felicius per fudores evocetur, ne ex intempeftiva illa materix biliofix repreffionead interna, fluxus ventris Dyfenterici enafcantur; quod aliquoties factum memini.

Quum vero eruptiones hx biliof $x$ per poros exitum fibi quarentes, intra cutem detent $x$, vique frigor is nocturni reprefl $x$ atque obftruct $x$ in acres $\&$ igneos halitus de. generent, cum multa materia falfa $\&$ adufta in orbem quafi fe cogunt \& conglomerantur, pertinaciterque ad annos fxpe cuti adherefcunt. Et tunc quidem perverfam \& plane alienam naturam induunt. Aliquando autem mobiles puftulæfejugatæ, non fine cruciatu, maximoque fcalpendi ardore ac pruritu, præcipue ærtate, juvenes ut

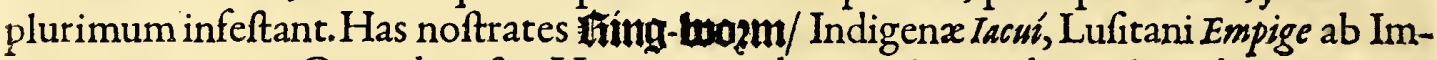
petigine vocant. Quando inftar Herpetis exedentis, aliquandiu malum duraverit, externis fupradictis facile refragatur. lethale autem effe hoc malum fi corpus cinxerit, ego fane, quidquid authores fcribant, hic nunquam comperi. Inter topica remedia qux requiruntur, exactiffima illa graminis juncei fpecies, Iupicai dicta, \& Siliquæ herbæ GuajanaTimbó, primarium obtinent. Horum attritu morbus non leviter emendatur, imo in totum nonnunquam tollitur. Interdum locus affectus mutatur, \& 2 que vehementer poftea, fi ab interna caufa foveatur, divexat. Quamobrem medicamentum compofitum ex fuccis fupradictis ad lavamenti vel unguenti formam, partibus affectis applicuiffe, eximix eft utilitatis. Rec. fucci Graminis, Tabaci, \& Siliquarum prædictarum partem unam, Sulphuris vivi $\&$ Nitri partem dimidiatam. Exercitatiores incolæ ut nullum fere remedium in extergendis malignis quibufvis ulceribus preferunt cortici çebipira; ita hanc quoque Impetiginem ejus affrictu \& lotione feliciter reftituunt.

Subinde eo pertinaciæ devenit hic affectus, ut fupradictis remediis internis \& externis minus cedat. Atque tunc quidem à vegetabilitum ad Mercurii ufum internum confugiunt Europxi medicaftri.

$$
\text { FINIS LIBRISECVNDI. }
$$

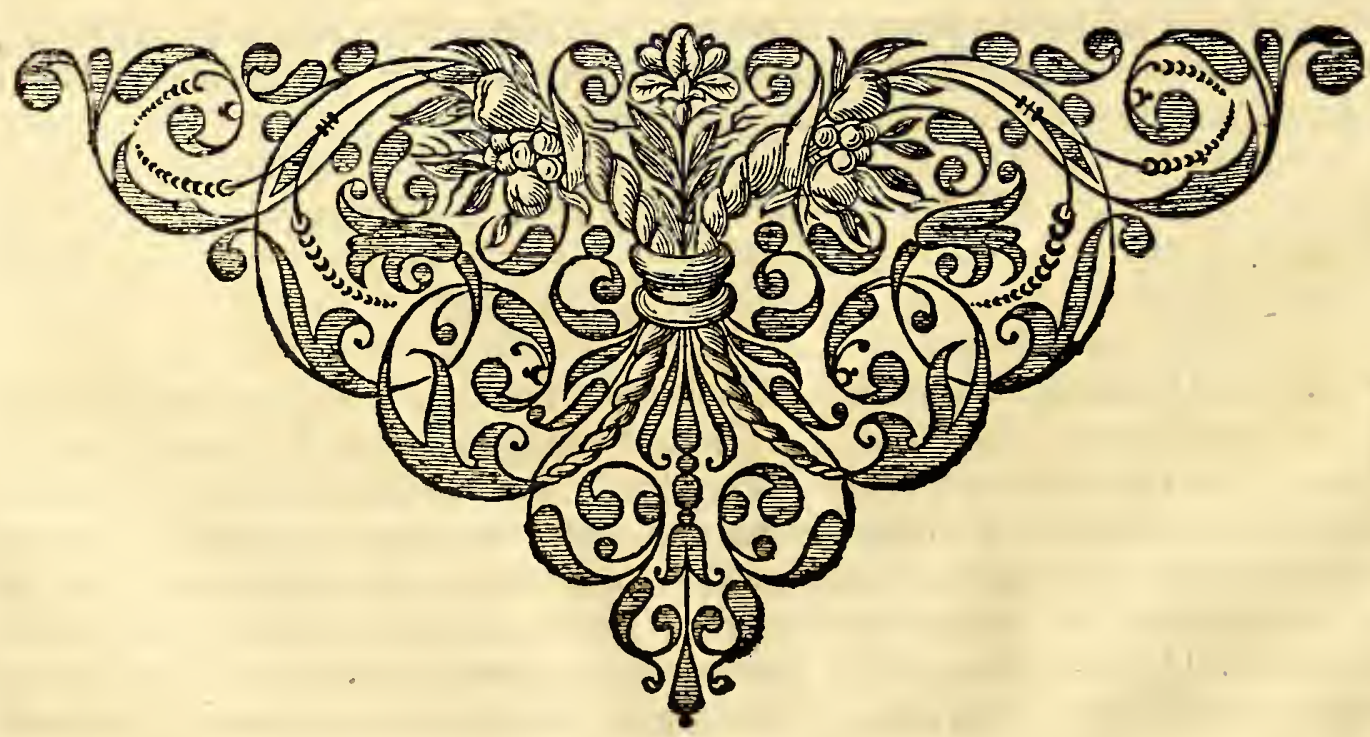

G V I I E L- 


\section{GVLIELMI PISONIS}

\section{H}

\section{NATVRALIS \& MEDIC}

$L I B E R$ TERTIVS.

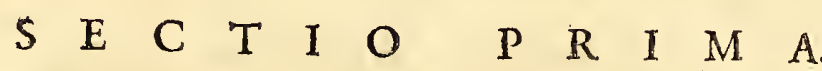

De Animalibus eAmericanis Aquatilibus, Aèreis ef
Terrefribus edulibus.

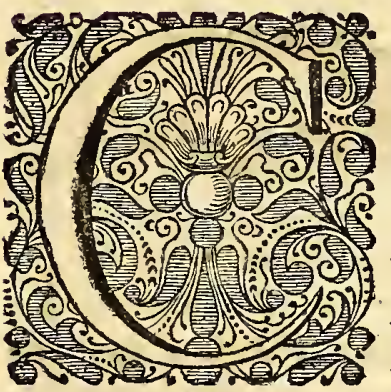

$V m$ in precedentibus libris ínfituti ratio poftularet, vefcorum animalium nifi tranfitorie meminifle ; ex re fore exiftimavi hoo libro fingulatim profequi, qui pifces, aves $\&$ animalia in Aquis, Aëribus \& Locis enarratis ad humanos ufus producantur, eorumque brevem acfuccinctam defcriptionem cum iconibus ad vivum depictis addidiffe ; idque non adeo oblectamento vel admirationilectoris; fed commodo imprimis xgrotantium atque medentium. Imitatus f cilicet illos antiquos $\&$ modernos, qui tum novi tum veteris Orbis collatis polydxdalx natur $x$ beneficiis, faluberrimifque repertis medicamentis \& alimentis, neceffitati $\&$ fragilitat mortalium confultum irent.

Poftquam autem in immenfa hac rerum multitudine plurimorum qualitates \& proprietates lateant, æquum putavi, non paginas replere iis quæ vel dubia vel minus perfpectafunt; fed pauciora eaque ufu quotidiano comprobata contrahere. Quod vero pifcium copia, quadrupedum \& volatilium numerum longe excedat, id non adeo terræfterilitati imputandum velim, quam quod aucupia \& venationes rarius exerceantur à noftratibus; fxpius autem à mediterraneis indigenis, qui magnam partem prædx acquifitæ fibi refervant. Cum è contra fluvii inclyti atque mare pifcofiffimum invitent littorales populos; tum quod facilem \& quxftuofam pifcationem fuppeditent ; cum quod ipfi pifces nutrimentum tenuius \& $\&$ anguinem temperatiorem quam quadrupedes \& volatilia furrogent.

Illos qui à pifcatoribus quotidie ad nos deferuntur ac celebrantur, hic potifimum recenfeo, eorumque nomina Brafilico idiomate vel Lufitanico, quatenus vilgo notiora, exprimo. Quod antequam aggrediar, operæe pretium exiftimo, in tanta pifcium, formarum, temperamentorum, fuccorum difparitate indicafe, quales pro pabuli non folum, fed temporis \& aquarum quibus innatant varictate, cateris vel praferendi "vel poltponendi fint.' Cum enim pif́ces five gulæ dediti, five efcarum probitatem fectantes, ancipitem agant vitam, pauciffimi quidem fuis fedibus contenti, fua læti carpunt pabula; fed aliqui priftini domicilii plane immemores; aliqui anadro$\mathrm{mi}$, ut abitus, fic reditus certa habent tcmpora. Hujus rei fidem facit, five in fluviis five in mari ftatis anni temporibus, ejufdem generis pifces femper, alios nufquam capi. Quod fluviatilis aqua menfibus pluviis, tum \& pleniluniis in mare prolabatur, hinc fit ut immenfa pifcium agmina hifce illecebris illecta, mare deferant. AEftate vero appetente ardorem pertimefcentes dulci humore faginati, folum \& falum repetunt. Vndeinter mollitiem fuviatilium $\&$ duritiem marinorum utriufque natur $x$ participant, gratifimoque alimento exiftunt, imo ufque adeo falubres judicantur maxima pars, ut ne quidem febricitantibus noceant, ficut ipfe multoties aliique mecum experti funt: modo recentiffimi fint antequam Solis $x$ ftus perfentifcant.

Vnicuin, quod prafatum volui, reftat circa nominum rebus impofitorum diffenfronem \& perplexitatem, qua de re ipfa erudita antiquitas merito conquefta cft. Cum enim quotufquifque agricola vel maricola nomina pro arbitrio rebus indat, ac proinde 
affidua illa difcrepantia Scriptori xque ac Lectori moleftiam creet; pronuntio me uíta. to illi $\mathrm{C} æ$ faris dicto inhææfurum, quod monet, Cum multis effe loquendum, cum paucis fentiendum: hoc eft, me tritis receptifque ut vegetabilium, ita \& fenfitivorum vocibus ufurum, donec confentientibus eruditorum \& barbarorum calculis, certius quid definitum fuerit. Interim non eft quod lector front $\mathrm{em}$ corruget propter infueta auribus vocabula, fi à noftra dialecto plerumque abhorreant. cogitandum enim, nos extra Latium \& Grxeciam verfari; neque folis veteris orbis populis conceffum effe voces condere; cum etiam penes Americanos fir jus \& norma ad placitum fua effer endi.

Pira generice qualemcunque pifcem; Pir acatú vero pifcem edulem exprimit Brafilien: fium lingua: Quorum primus fe offert

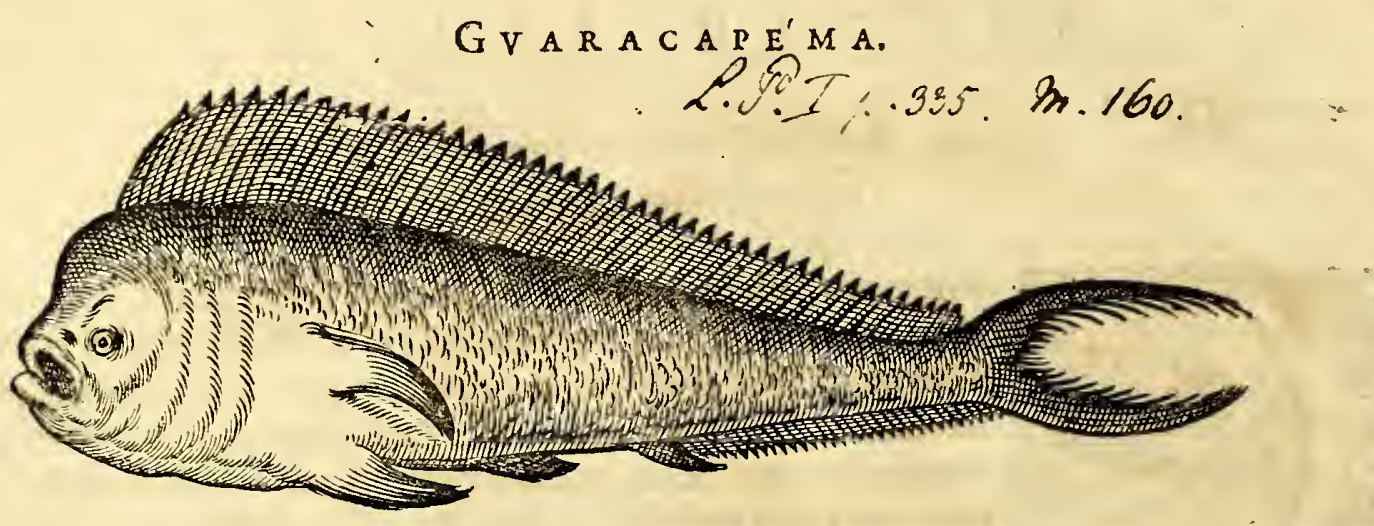

Guaracapéma mas eft Dorade pifcis. Nottrates Dolfinn appellant; Quibus nominin bus fi Oratæ vel Auratæ five Delfini exprimantur, parum concinne mihividentur appropriata, eo quod Rondeletius, Salvianus aliique Ichtyographorum Confultiflimi, Icones non folum ab hac no:tra difcrepantes, fed \& illorum indolem \& virtutes quoque admodum diverfas exhibeant : nifif forte, ratione rapiditatis qua cum Delfinis, vel ratione fplendentis coloris quo cum Auratis nonnihil convenit, nomina fint indita. Porro quam inufitat $x$ figurx hic pifcis fit, quamque acumine capitis continuato pinnarum ductu, cauda bifurcata, totius denique corporis conformatione ad velociter natandum æquorumque fluctus fulcandos natus videatur, facile eft difcernere, qui iconem hujus bellux recte confideraverit. Adeo denique principatum celeritatis tenet inter tor Neptuni pecora, ut licet fimili faliendi modo cum Thynnis five Porcis marinis; diffmili tamen celeritate progrediatur. Vt aliquoties in vafto Oceano vidi, cum certatim natare viderentur Thynnus \& hic Guaracapéma.

Squamulis adeo eft exiguis, ut toto corpore ad tactum lavis, non fquamofins videatur. Non aureo fed ex argenteo viridi eleganter fulget, maculis hinc inde cæruleis variegatus. Carne licet fit ficciori, non tamen vel ingrati faporis vel difficilis digeftionis, ut deDelfinis teftatum eft. Multis modis præparatur: nuncrecens, nuncfalitus, in optimum multorum pabulum ufurpatur.

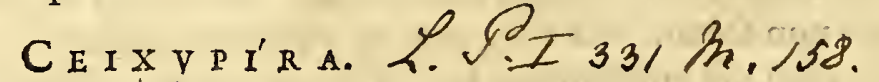

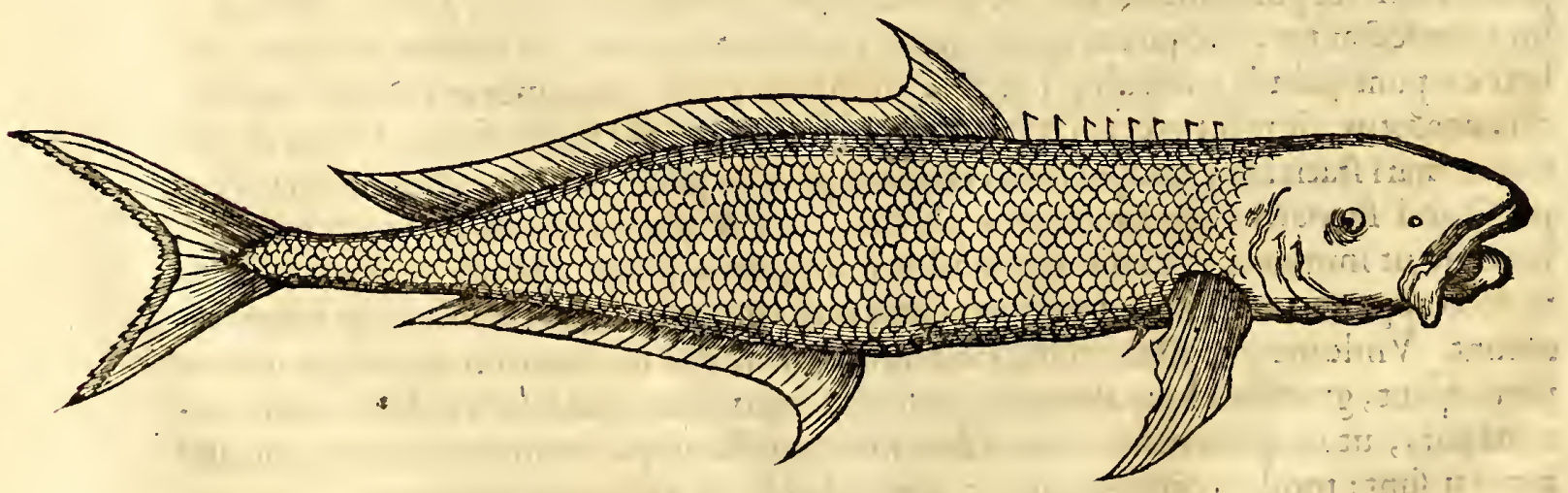

Ceixupira ut dignitate ita \& longitudine atque craflitie celebris, quippe hominis craffitiem æquat, \&longitudinem multo fuperat. Corporis, fed potifimum capitis figura oflea \& glabra à Tuberone non multum abludens. Ante quemliber oculum 
HIST. NATVRA L. \& MEDIC. L I B. II.I

funt foraminula, quorum ufum neque à pifcatoribus refcifcere, neque per fectionem capitis explorare potui. Squamulx, quibus veftitur elegantibus, adeo exigux funt, ut to. tus pifcis glaber videatur. Maxima pars pinnarum \& corporis eft colorenigro, excepto ventre, qui eo ufque albicat ut ne quidem lacti cedat. Peculiare autem huic pifci, quod octo offei triangulares aculei illi conceffi inter occiput \& dorfalem pinnam, quos in carne recondit, velirritatus erigit atque pro armis ufurpat. Marinus eft pifcis multa tenerrima carne \& pinguedine gravis, nec immerito faporis vel nutrimenti præetantia $c x-$ teris Brafilix pifcibus palmam eripit, prafertim fi juvenis fit. 'Eum quem hic exhibeo vix trium pedum erat longitudinis : atque à pifcatore domi mex delatum, mox cum domefticis meis diffecui , delineavi, \& coctum comedi.

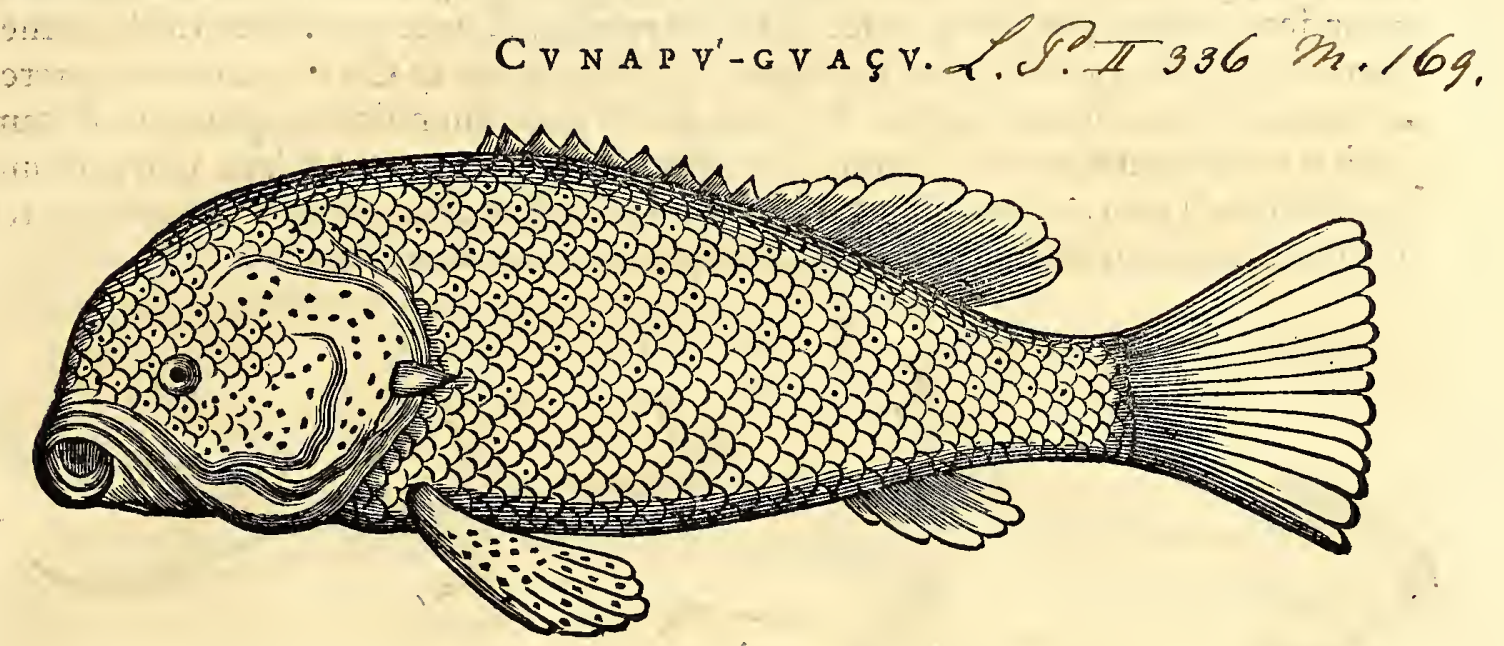

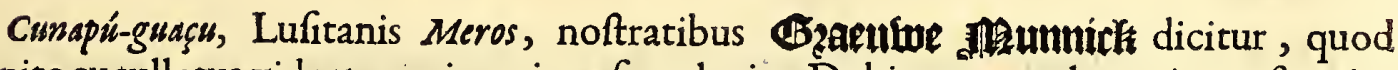
capite cucullatus videatur, cinereique fit coloris. Dubito num vel carnis preftantia, vel magnitudine corporis, ullus celebrior. Preterquam quod fit craflus, pinguis, fex pedum longitudinem evadit; tantrque contigit fuifle molis, ut hamo vel unco affixus aufugerit, ipfumque pifcatorem præd $x$ inhiantem fecum traxerit in mare cum magno vitæ difcrimine. Capite eft magno. ore edentulo \& rotundo, branchiis quoque in ambitu rotundis. Cauda magna \& fere quadrata. Squamis mediocribus cinerei coloris, interjectis punctulis nigris, excepto ventre, qui albicat, ficut $\&$ caro totius pifcis. Carne eff folida, non dura tamen, optimi faporis \& nutrimenti. Multis modis pro ritu incolarum preparatur, plurimifque fimul hoininibus fufficienti eft alimento.

Alius praterea eft pifcis qui Meros Lufitanis dictus huic non adeo diffimilis, fed rubicante colore difcrepans potiffimum.

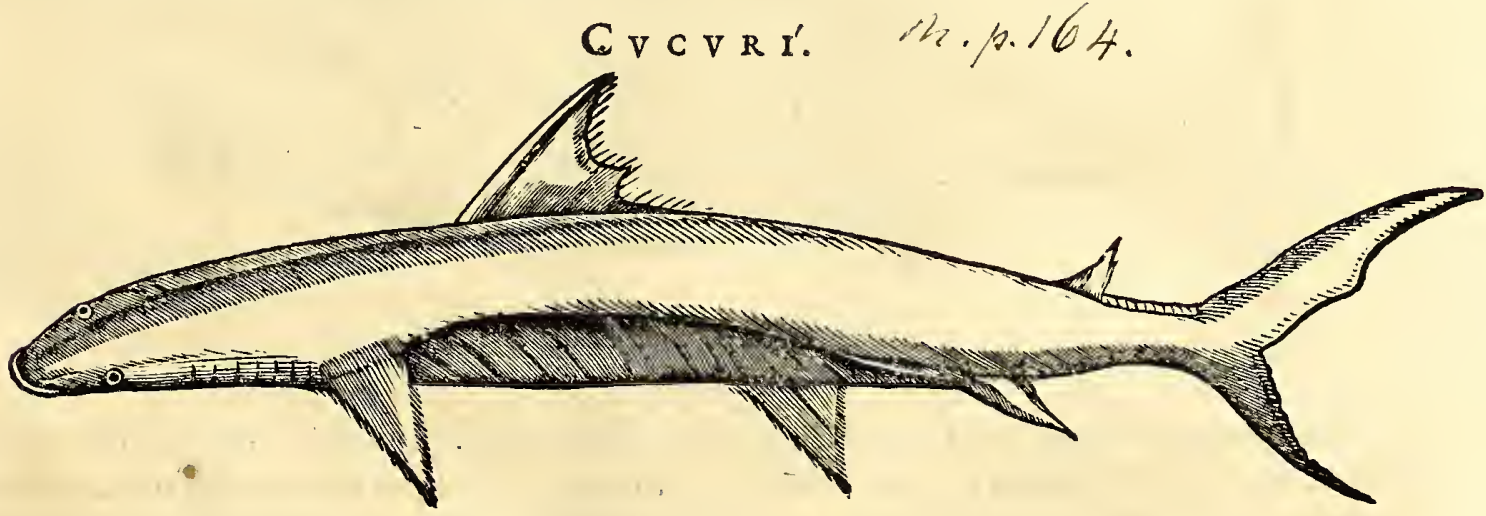

Cucurt. Lufitanis Cafjaon. Inter Cartilagineos ex genere Lamiarum five Tubero. num eft; fed folus quantum conftat, inter cæeteros innoxius, unicoque tantum ordine denticulorum minimorum præditus; quum è contra majoribus Lamiis horrendus fit rictus in utraque mandibula, duplici dentium ordine conftans. ac proinde plerique Tuberones per totum orbem, non carnis dignitate, fed rapina tantum celebres, excepto hoc Cucuri, qui Caniculx vel Galei potius eft fpecies, ut ex Rondeletio aliifque Authoribus liquet. quibus ficut figura $\&$ indole eft fimilis; ita alimenti praltantia fuperior atque diffimilis exfiftit. 
Porro Pinnx, Cauda, Cutis ejufdem figur $x \&$ coloris cum Tuberonibus, ex cinereo fcilicet albicante. In hoc pifce (quem cum Markgravio meo domi mex diffecui) tres catuli perfecti fe obtulerunt. Patuitque, eum inter ea cartilaginea effe, qux Ariftoteles, in Hiftor. Animalium, teftatur, Animal parere, idque ex ovis, qux in media vulva geftata, in uteri finus defcendunt, unde mox per venam umbilicalem fotus excluditur; ita ut ovis abfumptis partus non aliter quam in quadrupedibus contineri videatur. Notatu dignum fane, quod tanta fit Tuberonibus \& Caniculis his charitas in teneros Catulos (quod itidem de Phocis, Balænis \& Delfinis teftatum eft ab aliis) ut eos ex aliqua caufa pavidos intra fe recipiant, idque non per manticam talem in utero pendentem, ficut quadrupedia illa de quibus fuo loco egi, fed per os $\&$ in ventrem aliquandiu recondere, donec pro libitu rurfus in lucem prodeant, ficut multoties viderunt me"cum infiniti teftes, quafiventer quórundam Cetaceorum \& Cartilagineorum pateretur aliquantulum alienas animas. Vnicum eft illi inteftinum fatis amplum; unde tam inufitata contingit voracitas. Stomachus vaftus, hepar candens, ut \&lien. Cor parvum, fubalbidum, laxum, ventriculifque diftinctum, \& ufque adeo vivax ut in varias partes diffectuń imo veru affixum palpitet, vitamque adeo mordicus retineat.

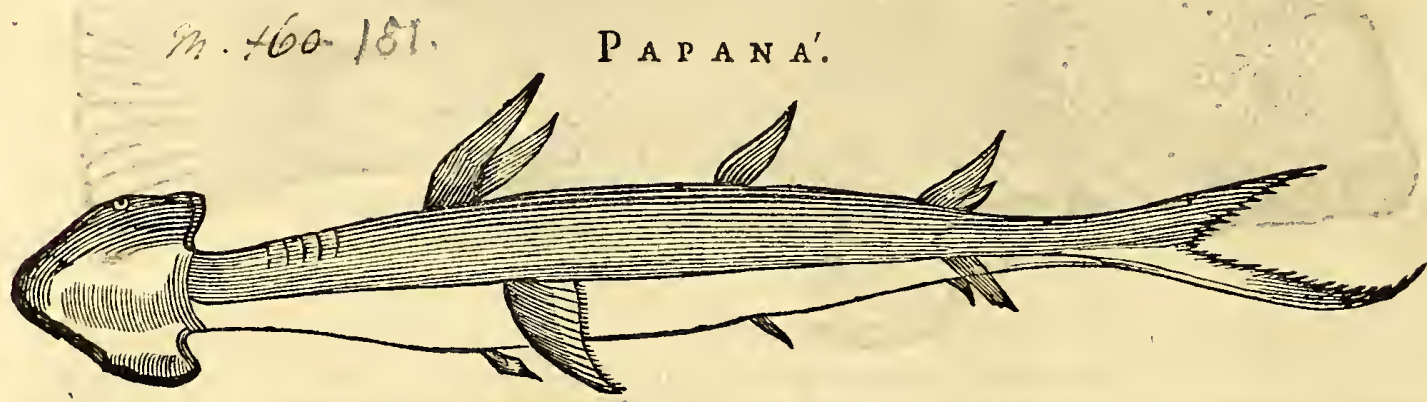

Alia Lamix minoris fpecies elt $P$ apaná, Noftratibus beronibus potiffumum differens Capite, quod Cordis fere figura eft: oculis parvis, ore itidem parvo longe infra pofito : cum triplici dentium minorum ordine, quibus vehementer mordet \& lacerat. Quia à pube non folum nautica caro ejus, ficut majorum Lamiarum, fedà delicatioribus expetita ob bonum $\&$ ficcum quod præbet nutrimentum, hanc quoque inufitatæ figuræ Lamiam minime prætereundam putavi.

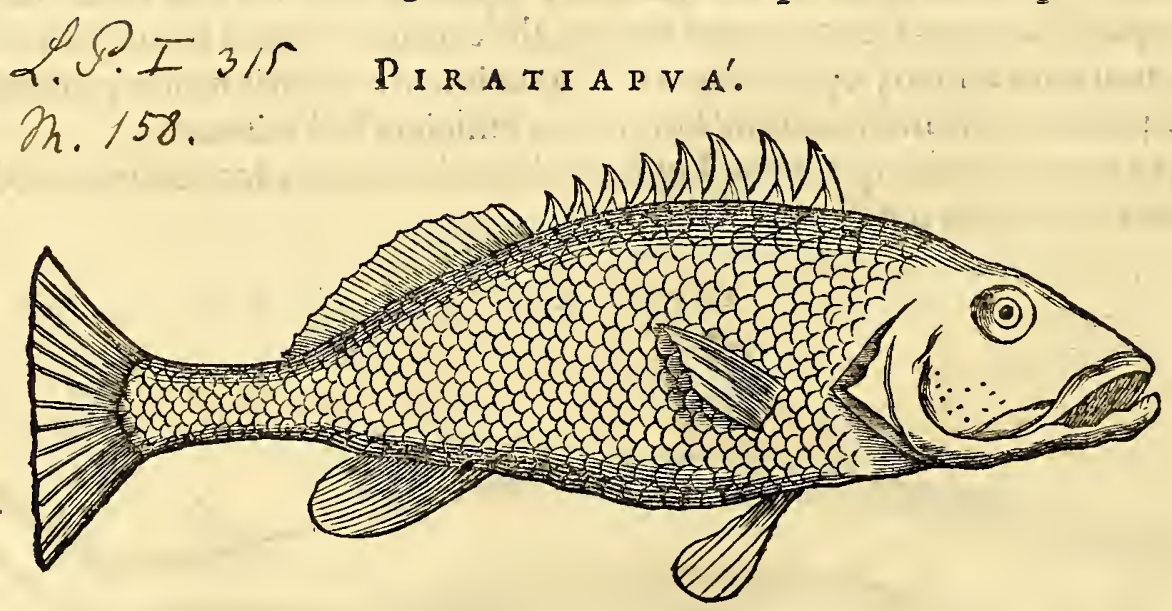

Piratiapuá in fluviis \& mari vivit. Corpore eft obefo, craffo:menfibus hibernis dulcibus fuviorumaquis faginatus repetit maris fcopulos, ponderifque fubinde fit ultra quinquaginta librarum. Ore eft magno, dentato, lingua rubicante. Branchiis eft amplis. Pinnis exiguis, excepta dorfali, qux ex parte in Spinas dilatatur. Ornatis mediocribus fquamis variegati undique eft coloris, fed potiffimum fufci $\&$ cinnabrii. Frequens eft pifcis, atque ob præftantiflimam carnem ab omnibus pafim Incolis merito expetitus, prefertim fi coctus exaceto vel alio convenienti condimento apponatur.

Acarapitánga, Barbo Europæo, craffitie \& longitudine corporis, elegantibus vero fquamis ex purpureo cæruleis Carpioni fimilis. Ab utroquelater e in medio fecundum longitudinem excurrunt linex aurex, cum infinitis punctis aureis : ejufdem fplendor is quoque funt Pinne \& Cauda, exque non folum de die micant, fed noctu quoquelucent adeo ut, 
HIST: NATVRAL. \& MEDIC. LIB. II, SI

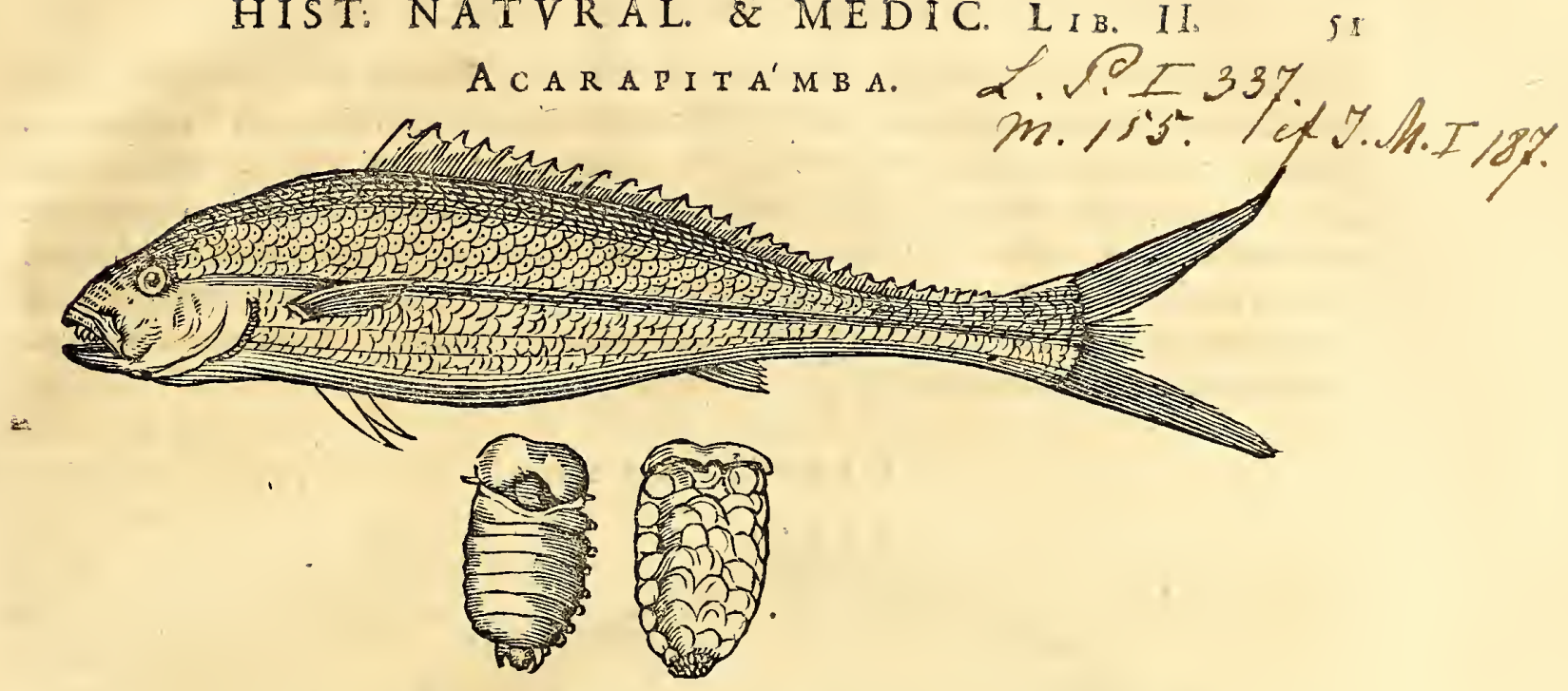

adeo ut, fi multi fimul copulati fint, litteræ iftius luminis beneficio legantur. Marinus hic pifcis magno in pretio habetur, imprimis affatus.

Icones, quas hic fubtus depictas vides, funt cruftaceorum infectorum, quæ invito pifce ori illius fe ingerunt, \& unguiculis fuis arcte faucibus inhærent. Neque facile hoftem hunc infertum evadit.

Alius preterea hujus magnitudinis datur pifcis nobilis in cono maris vivens, qui I $Z$ - $^{-}$ rumenbéca dicitur, Lufitanis Boca molle, totus argenteus, cujus icon defideratur.

Acará Piníma. Si cum aùthoribus Cyprinorum multa genera ftatuenda funt, eis non inepte pifcem hunc fubijciemus. Squamis enim, corporis fpecie, vita Cyprino fimilis eft,fed latiore corpore $\&$ compreffo; ac proinde inter Cyprinos latos barbare Prafemos dictos numerandi funt. Cum certum fit, in quibufdam tractibus mundi Percas, Cyprinos,

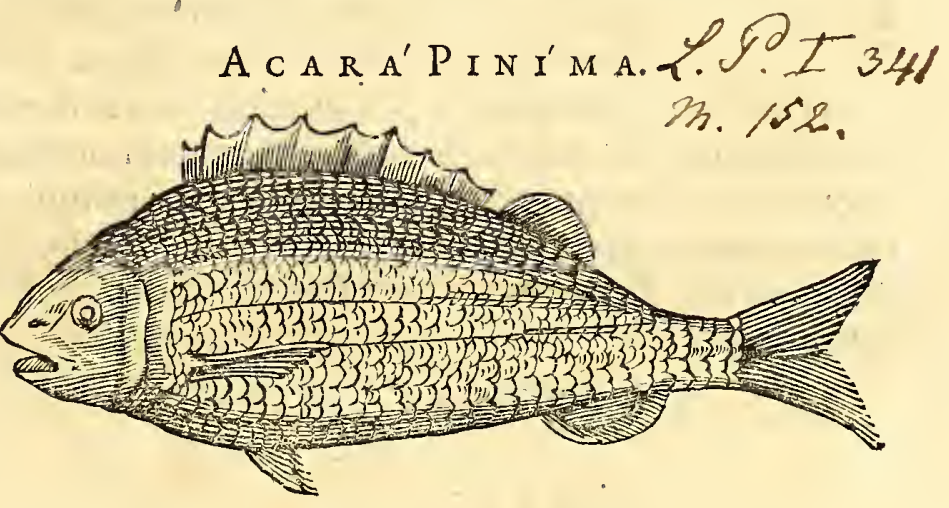

Carpiones, non folum fluviis fed \& mari dicatos effe. Hichofter quoque inter fcopulos marinos victitat, ibique parit \& pinguefcit; ipfi Carpioni \& Cyprino dignitate faporis non folum fed \& nutrimenti minime cedens. Elegantibus Squamul is auroargenties micat, Atriifque aliquor flavefcentibus fecundum corporis longitudinem excurrentibus.

Datur \& alia Prafemi fpecies nobiliffima, qux Acarpeba, aliis Acaratíng a dicta; fi figuram, colorem, magnitudinem \& nativitatem confideres, inter Cyprinos quoque latos habita ; quia parum adeo abludit à præcedenti Acará Pinima Iconem addidiffe fupervacaneum duxi ; adeo eft carne alba, friabili \& probx digeftionis, ut noftrates Praemos facilefuperet. $\quad \mathrm{CVRVATA^{ \prime }} P \mathrm{INI} \mathrm{I}_{\mathrm{MA}}$.

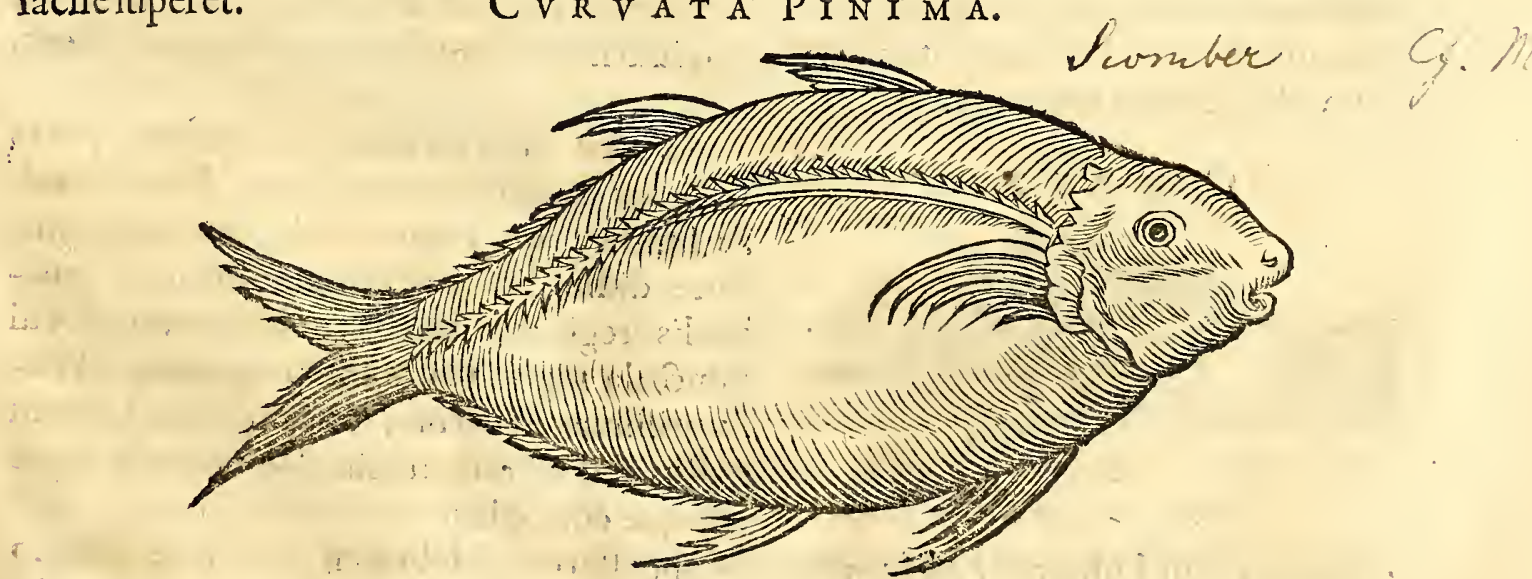

Duo mihi innotucre pifces Caruatá, vulgo Bonitos diat ; quorum alteri cognomen ab Indigeniis Curaatá Piníma additum. Vterque celebris eft pifcis \& magnus, atque 
excepta craflitie \&longitudine, fimillimi fibinatura, colore \& figura: ille enim co:pore eft craffiore \& compreffiore : hic vero longe proceriore. Vterque eft coloris ar: gentei fubvirefcentis, non fquamatus fed cute tantum coopertus, excepto utroque latere, ubi per longitudinem linea aculeata aurei color is fquamata excurrit. Pinnæ fune feptem exigux. Cauda utrique furcata. In oftiis fluviorum $x$ ftate, in mari al to hyeme capitur, multaque carne $\&$ pinguedine abundat, eaque fatis proba, ac proinde magno vitx eft fuftentaculo maris a ccolis quocunque modo praparatus, imprimis autem fifale \& pipere parum condiatur.

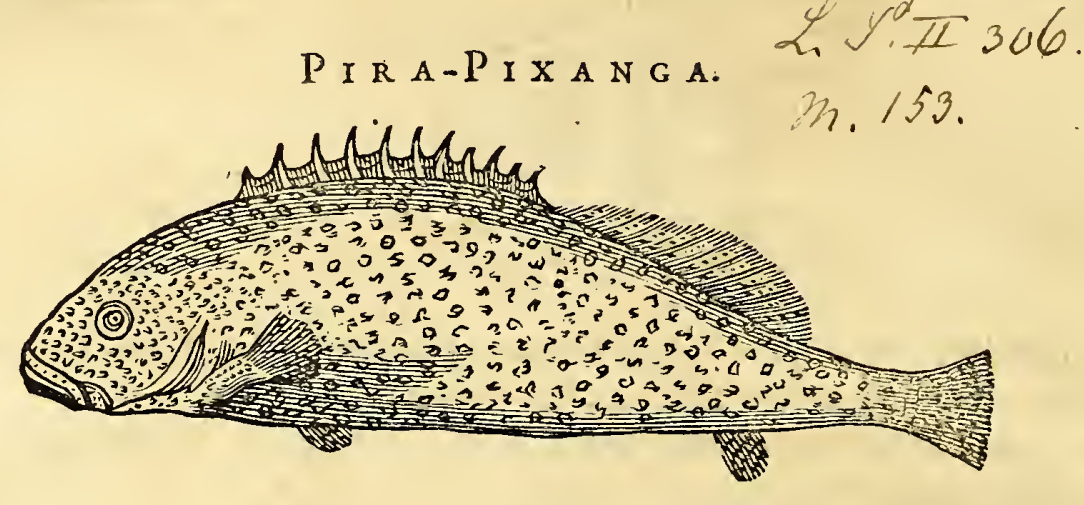

Pira-Pixanga, Lufit. Pefche gatto noftratibus pifcatoribus Bat-bita appellatus; for te quia in antris fcopulorum fe abfcondit. adeo exiguis fquamulis cooperitur, ut lævis videatur. Toto corpore flavefcit, intercurrentibus egregiis maculis fanguinei coloris. Cauda \& pinnæ numero feptem funt exigux. Domiinde delatus ultra trihorium vixit : bihorium poftquam mortuus effet, à me $\&$ domeftico meo diffectus, vidimus cor exemptum adhuc moveri : quod fitum erat immediate poft fauces, cui inferebatur afpera arteria, eratque vix digitum remotum à reliquis vifceribus per mediaftinum, minimum utique $\&$ vix granum tritici æquans, licet fpiritu inflatum. Ceterum pifcis optimi palati, frequens ex mari toto fere anno adducitur. Coctus xque ac affatus probi eft nutrimenti.

G V A T V C V Р A J V' в A. L. N. I. 181 Guatucupajüba. Si ad Euro:

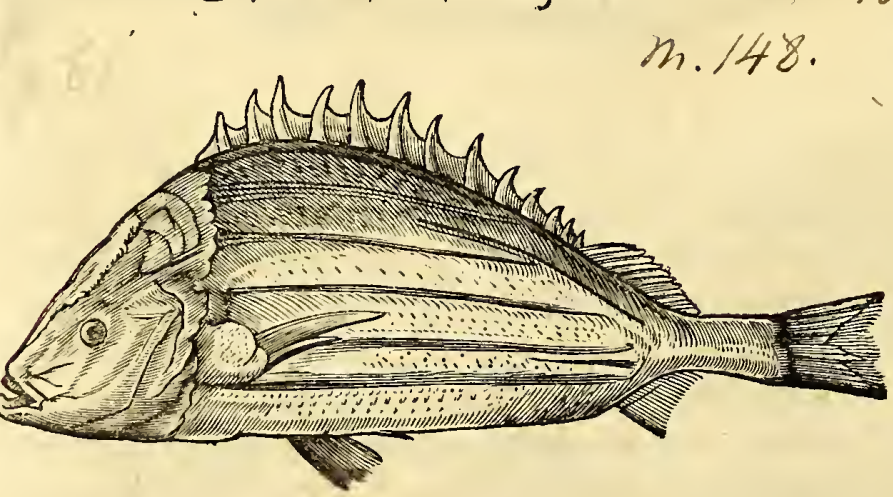
pxorum pifcium fpecies referatur, Cyprinis latis, quos barbare Prafemum vocant, afcribendus ob carnis \& faporis convenientiam. Cxterum color eis diffimillimus, quod pifcis hic à capite ad caudam perpetuis fquamis argenteis fulgeat, lineis \& friis flavefcentibus fecundum corporis longitudinem excurrentibus. Toto fere anno frequens, atque ex maris fcopulis $\&$ fluviorum oftiis ad nos defertur magno incolarum oblectamento ; vix ulli pifcium faxatilium faporis præftantia cedens, imprimis fiaffetur in craticula.

$$
\begin{aligned}
& 25 ? .1 \cdot 333 \text { C A R A V'N A. } \\
& 2 \% .14 \%
\end{aligned}
$$

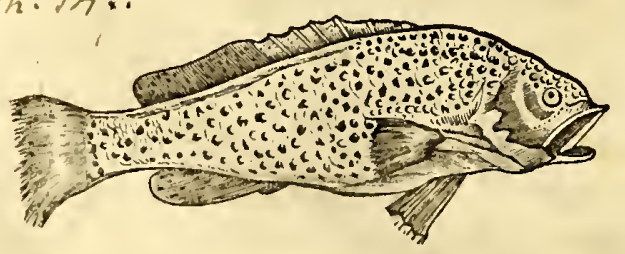

Caraúna inter celebres quoque pifces faxatiles marinos numeratur. Figura Itaiára fimilis, fed capite, colore $\&$ magnitu= dine diffimilis. Corpus undiquaque fquamulis tegitur, lunatis, coloris miniati, cui punctula nigra paflim infparguntur. Pr $x$ ftantiffimx eft carnis, optimi non tantum guftus fed $\&$ nutrimenti, ac proinde agris quoque conceffus.

Aipimixica, qui Lufitanis Pudiáno vermelho appellatur, celebris eft pifcis ficut Carpio apud Europxos, cui magnitudine $\&$, forma qua ad mollitiem tactus, fquamafque fubtilcs \& arcte complicatas, finilis; fed admodum diverfus fi totius corporis colorem ex 
HIST. NATVRAL。 \&EDIC。IIE. ITL

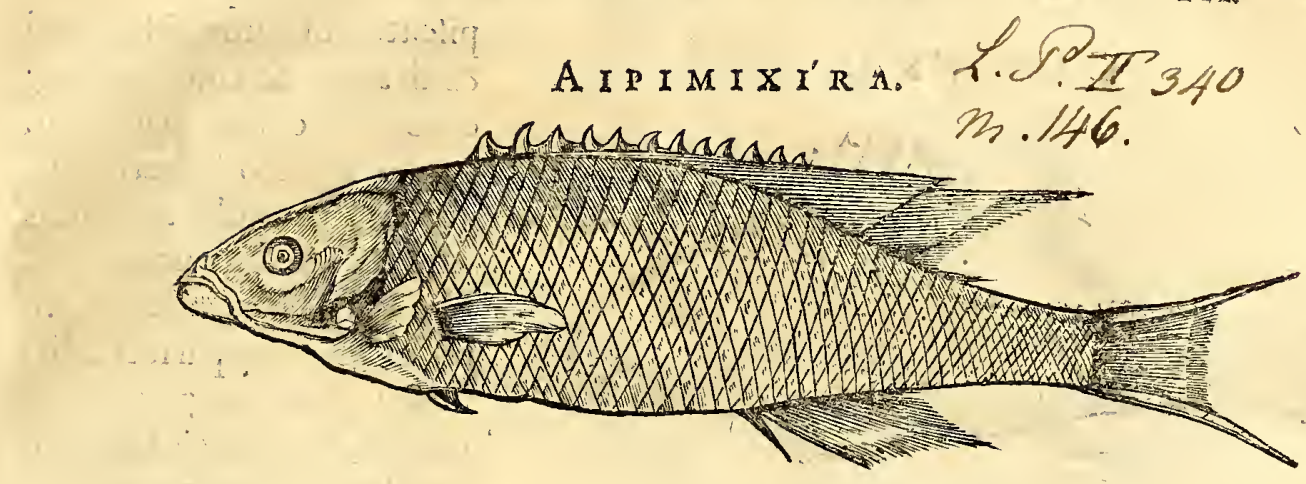

flavo cum aureo micantem confideres. omnibus pariter Incolis in deliciis habitus fi probe elixetur. Huic dignitate \& figura fimilis eft Puranéma, totus argenteus, cui lacca intermixta eft.
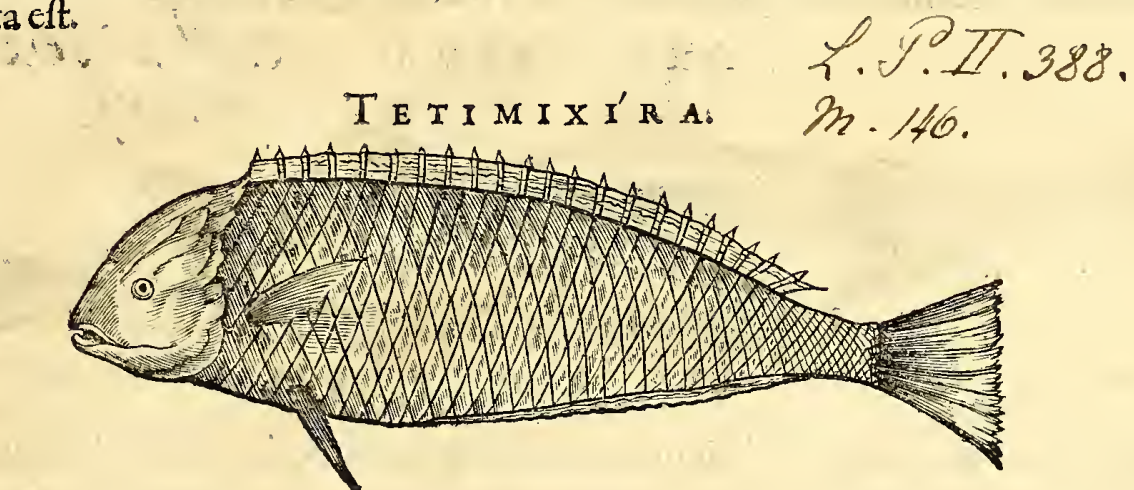

Tetimixíra autem eft altera fpecies, qux Pudianó Verde à Lufitanis nomen accepit, quod præter aureum colorem quo elegantiffime micat, 'viridibus imprimis thalaflinis atque aureis cubis \& ftriis undulatis fit infignis. Rite preparatus antecedenti Pudianó teneritate carnis non cedit. Vterque in mari \& oftiis fluviorum capitur. Huic affinis videtur pifcis fluvialis Acarapucú dictus, totus argenteus, carne friabili commendabilis. Fluviis fe committit. Alburnum noftrum refert。

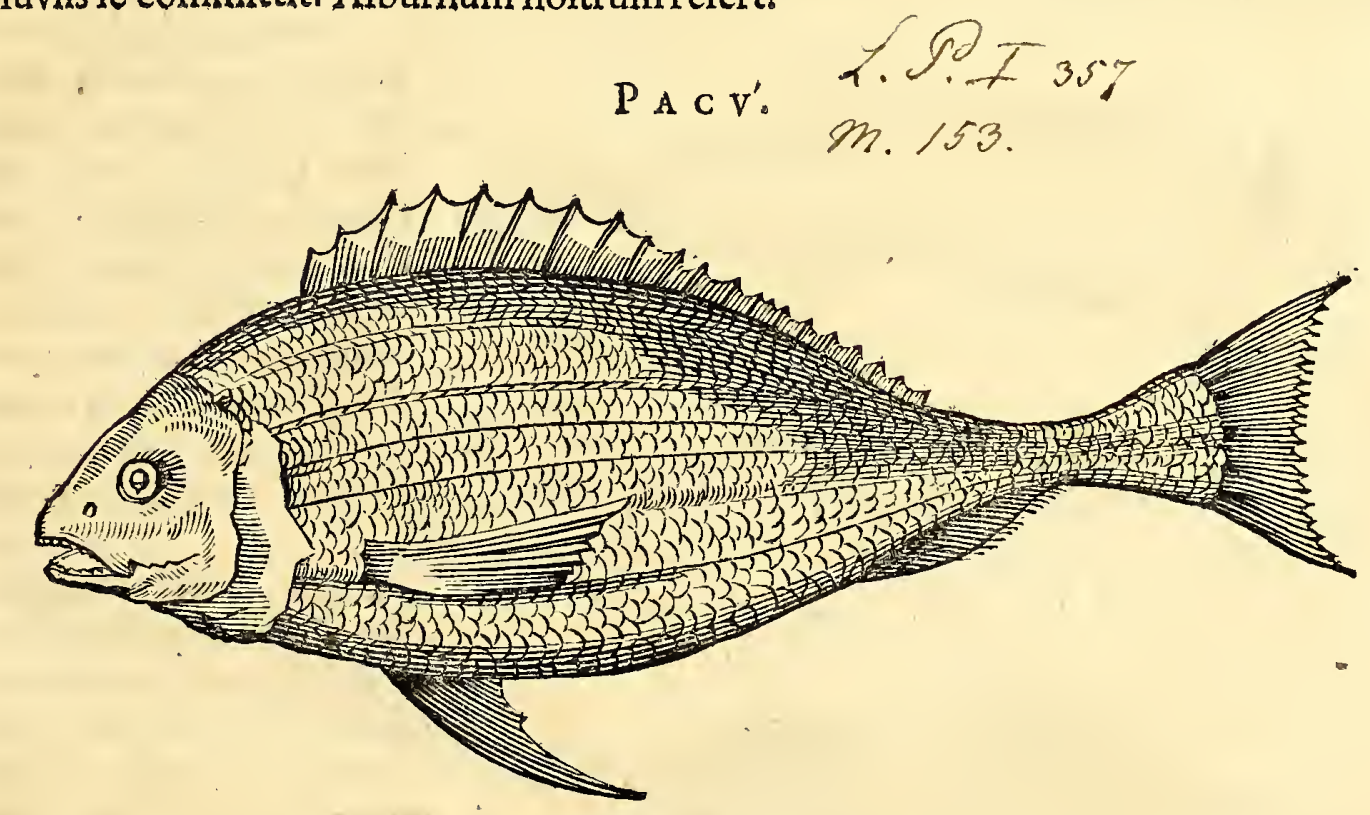

Pacú familiaris omnibus maris accolis. Noftrates Steen-hizaterui vocant. Lufitanico idíomate Salema, Græcis \& Latinis Salpa diatus. Ore autem, Capite, Dentibus \& Pinnis Sargo fimillimus eft ; colore tantum \& ftriis illis à capite ad Caudam confpicuis ex argenteo \& flavo ab eo differens. Pro iemporis anni diverfitate mare vel fluvios petit ut pinguefcat. Ventriculo eft magno, inteftinis latis, hepate rubro, folliculo fellis magno, corde angulato. Melioris faporis \& nutrimenti habetur quam Sargus Europaus.

Capeúna ex ordine quoque optimorum pifcium faxatilium marinorum numeratur à pifcato- 


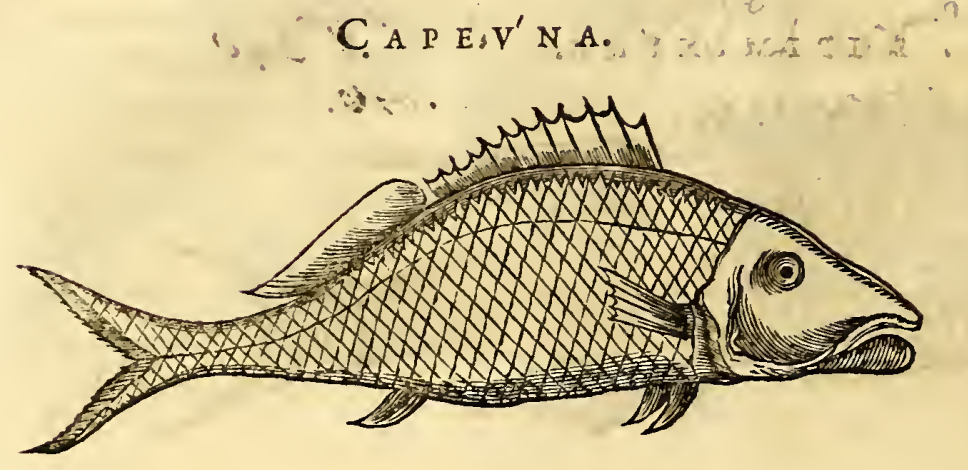

pifcatoribus non folum fed $\&$ ab ægris \& $c$ fanis, quibus caro ejus cocta magno in pretio merito habetur. Egregiis fquamulis argenteis cxteris pifcibus prafulget. Hic, ut \& Itaiára atque alii pifces recentes parieti affixi noctu toto corpore adeo lucent, ut litteris legendis fatis luminis prabeant.

Elegans \& celebris datur pifcis, huic præcedenti non adeo diffimilis, five argenteum $\&$ igneum fplendorem five carnis bonitatem confideres, quiab Indigenis pira Acangatá dicitur.

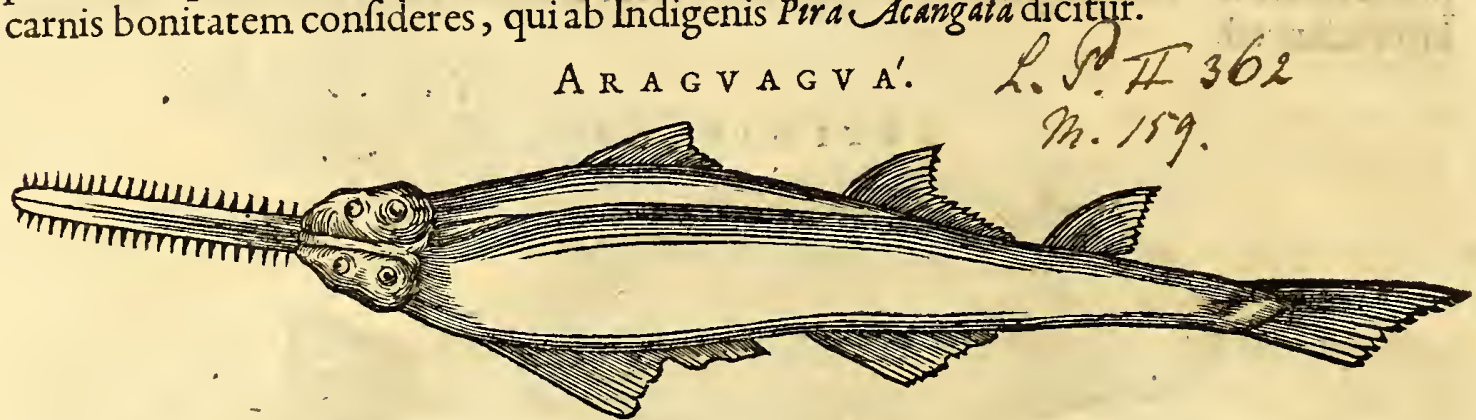

Areguaguámarinus pifcis, celebris magis in Europa, Afia \& America, ob dentatum gladium qua fuos hoftes integrafque Balænas profternit; quam ob bonitatem carnis, qua tamen rite præparata $f_{1} j u v e n i s$ fit, cartilagineis pifcibus non cedit. Cute eft non fquamofa, fed ad tactum afpera $\&$ dura. Dentes non ori quidem, fed prominenti ejus gladio conceffi. Capite eft compreffo, in quo poft oculos, fpiracula duo confpiciuntur,per qux aquam efflat bellua. In inferiori vero corporis parte verfus enfem fubftantia branchialis apparet, cujus beneficio nobis admodum probabile videbatur enfem dirigi, quia ejus origo ibilatitabat.

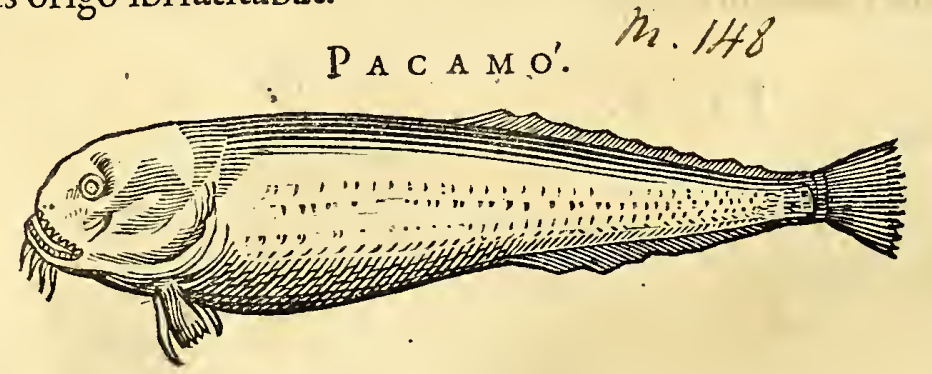

Pacamó, quem Lufitani improprie Enxaróco five Ranam marinam vocant, inter Muftellas noftratitibus Butut-aal potius referri poffet. quibus, excepta capitis craflitie, multum fimilis eft. Cute eft glabra ac molli, ficut $\&$ Branchiis, Pinnis, atque Cauda.Dignitatenutrimenti \& faporis Europæam muftellam facile fuperat, quodinter faxa \& fcopulos victitet, friabili mollique carne ægris æque acfanis oblectamento eft.

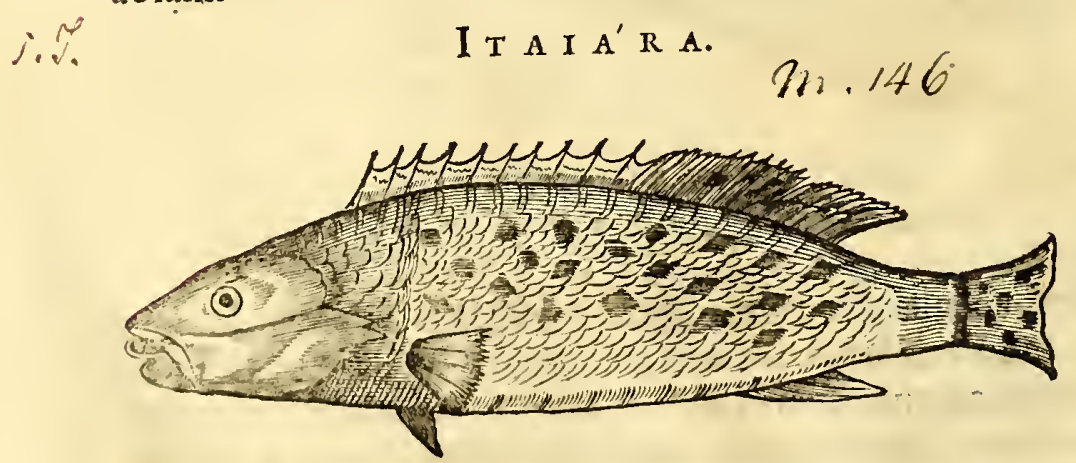

Itaíra, ficut rubri \& variegati coloris elegantia, ita \& guftu cum creteris pifcibus marinis certat. Iuxta fcopulos \& Reçiffo pifcatores iis infidiari folent, quia falubrioris pabuli gratia latitant in fundo. Licet inter fquammatos numeretur, tamen ad tactum glaber ef $f e$ videtur. Affatus $x q u e ~ a c$ clixus optimi cft palati \& nutrimenti, imprimis menfibus pluviis, cum multa \& grata pinguedine abundet. Prxter Caudam, Pinnas habet fex parvas, excepta dof
\& nagna; qux onnes fumul ut totum corpus, rubent cum maculis nigris.

Inter 
HIST. NATVARL. \& MEDIC. LIB. III Inter Pifces edulesnu- : 2. Pि 308 . P A R V'. meratur ille qui Parí difus; lunulafque flavas in nigricante corpore geftare videtur. Pinnx fuperiori \& inferiori in fine prominentix dux inftar funiculi verfus caudam extenduntur. Pifcis eftlatus \& fubrotundus, non tamen craffus ita, ut participare videatur nature \& figur 2 Pafferis fquamo-

fi lari : differt autem ab eo, quod utrumque latus ejufdem fit coloris, \& utrimque oculatum, nec Pafferum more tanquam altero oculo orbatus natet. Cauda eft circinata $\&$ inftar ventilabri extenfa.

Qui Acarauna nomen accepit, precedenti Parì fimilis faporc, natura\& figura, paucis exceptis circa Caput, Pinnas \& Caudam. Hic enim in utroque latere prope caudam acutiffimum habet aculeum, quos in latere recondere \& evaginare poteft alios ledendi caufa. Cauda eft extenfa \& bi-

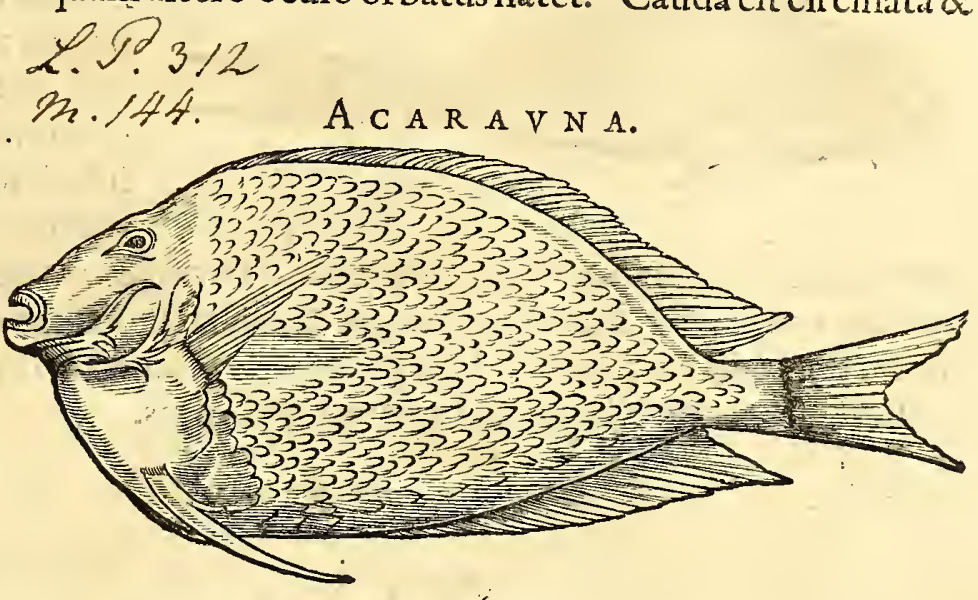

fida. Color fquamarum niger. Affatus \& elixus in pretio habitus, quod facilis fit digeftionis. In mari circa fluviorum oftia capitur.

Abacatuajá;quem Lufitanis placuit Peixe gallo appellare. Cujus etymon fi referant ad Gal. lum five Fabrum marinum, de quo Rondeletius, Aldrovandus, Gefinerus \& alii tractarunt, toto cxlo errant. Planis potius quam fubrotundis pifcibus afcribendus: licet pinnis, furcata cauda, imprimis nigris filamentis longiffimis extenfis, natando à vulgari Rhomborum \& Pafferum fa-

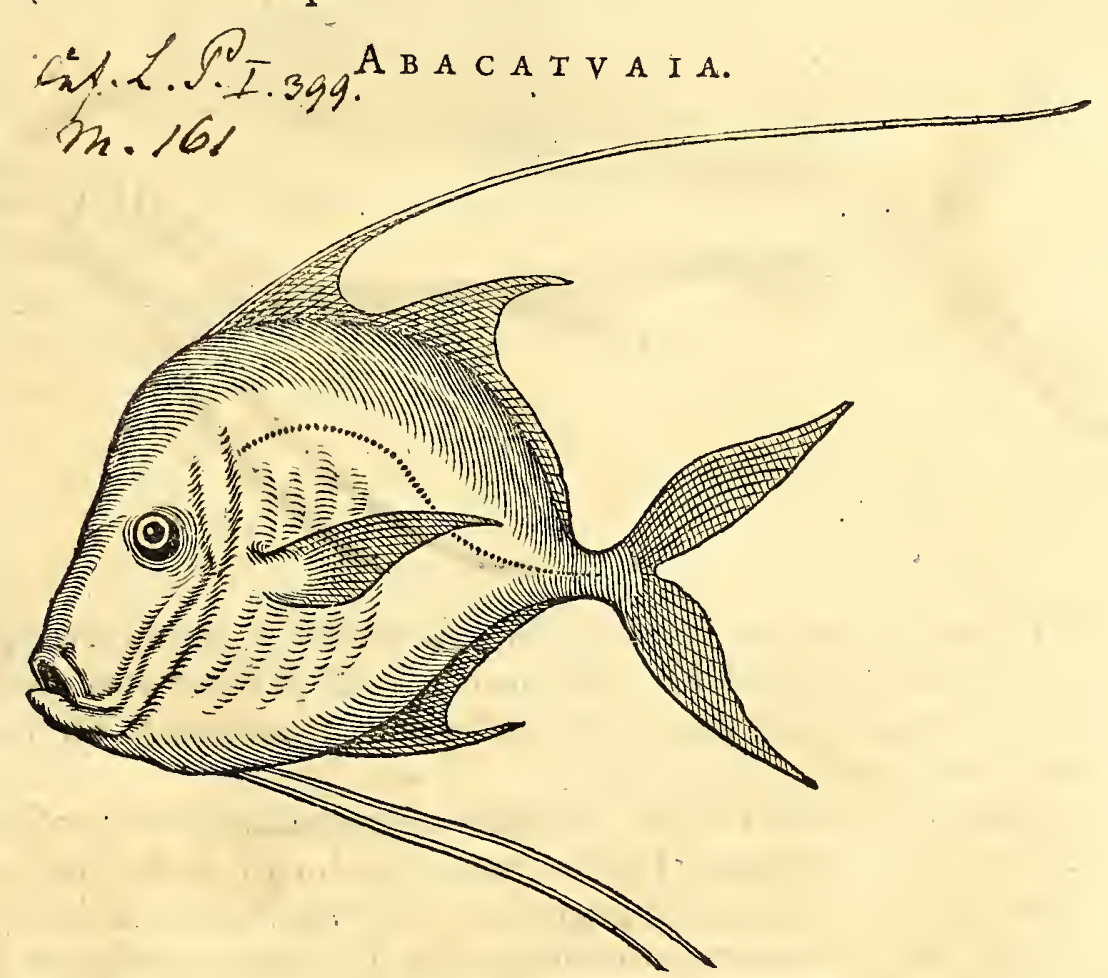
milia difcrepet. Cute eft læviffima, non fquamofa: adeoque fplendentis argentei coloris: Pinnis \& Cauda plane virefcentibus. Vbi primo capitur, grunnit intar porci. Marinus eft: præftantia $\&$ duritie carnis fuviatili præfertur : proinde ab omnibus pariter incolis vel coquitur vel frigitur in fartagine, atque pro bono gratoque cibo ha. betur. In quiburdam femen five lac, in aliis vero ova reperiuntur. proinde hoc genus

$$
\text { E } 4 \text { non }
$$


non ponendum inter eos de quibus Ariftoteles lib. 4. hif. Animal. cap. II. teftatuf, In ftirpibus \& teftaceis non folum, fed \& pifcibus, f cilicet Paffere, Rubellione \&zc. effe quod pariat \& generet, deeffe autem quod maris officio fungatur.

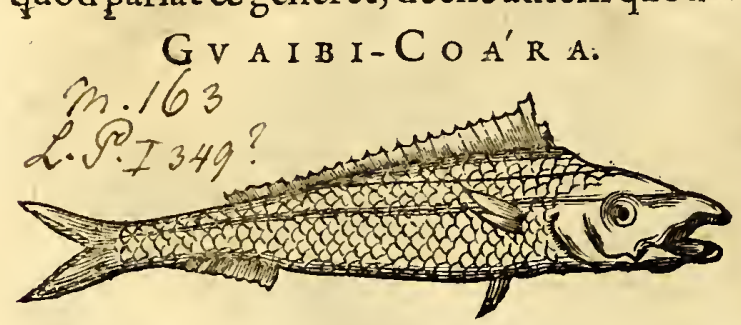

Guaibi-Coára, Lufitanis Buracöde Vel. $\mathrm{ba}$, fquamofus eft pifcis;argenteo \& melino colore fplendens. ejufdem fplendoris $\&$ coloris eft linea quæ per utrumque latus fecundum longitudinem tendit. Magna copia ex fopulis marinis littori vicinis ad nos defertur à pifcatoribus, ob carnem friabilem in pretio habitus à multis. Cauda eft bicornis, quæ feptimam conftituit pinnam. I A G V A R A C A'. L. I 353 Percx ut magnitudine ita \& figura

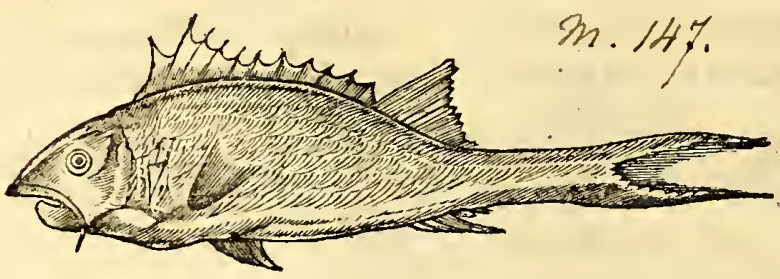
atque guftu non multum diffimilis . Aflatus $\&$ elixus benefapit: menfibus pluviis maxime pingueficit, victitatque circa fcopulos, unde unco eos eliciunt barbari fagaciflimi pifcium infidiatores, qui ex mari reduces multos argenteo $\&$ incarnato colore micantes copulatim venum exponunt. Totus pifcis el egantibus fuamulis in ambitu ferratis cooperitur: branchiis quoque $\&$ aculeis pinnifque acutiflimis armatur, quas pro libitu erigit, iifque potenter ferit pifcatores. Caudx pars reliquo corpori fubtenfa longiflima eft, definens in pinnas furcatas fatis longas.

$$
\text { 2.5. I.403 GVEBVçv'. }
$$

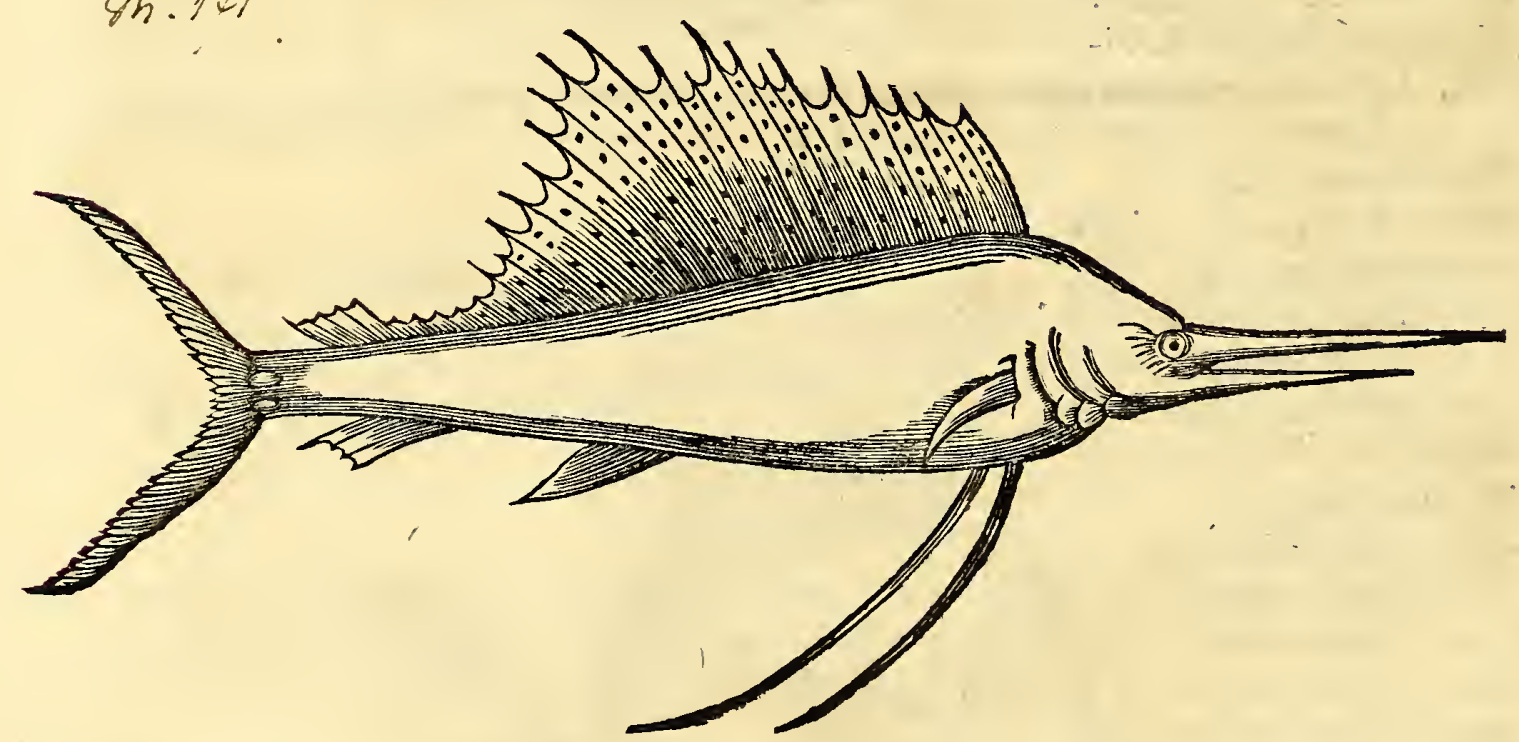

Etiamfihic pifcis cetaceus, quibufdam notis, imprimis vero pinnæ dorfalis elegantia , \& duobus proceffibus offeis in ventre à Xiphiis veterum nonnihil abludat, illis tamen plane adcenfendus, præfertim fi præcipua externa $\&$ interna ad examen revocentur. Itaque nofter

Guebuçú, Lufitanis Bicuida. Inufitatæ figurx pifcis (quam penficulatius D. domeftico meo graphice depingere juffi) corpore eft oblongo, tereti, roftro acuto offeo, utrimque mobili, ore edentulo, lingua tereti oblonga. Cauda in duo cornua diducta, ad cujus exor tum duxauriculæ membranacex. Præter pinnas ventris, juxta caput duo offea bacilliformia corpora extenduntur in multam longitudinem : maxima illa pinna dorfalis conftans membrana pergameni xmula, coftis, maculifque variegatis intertexta eft, quam pro lubitu in fulcum recondit fatis profundum. Squamis caret, fed cute craf fa fpinulis afpera ex cinerco argentei coloris veftitur. Carne eft copiofa, pingui, non fpinofa nec glutinofa, fed fatis bona, imprimis fijuvenis fit, alias bajulis \& nautis dicata.

Confor- 
HIST. NATVRAL。 \& MEDIC. LIB. III.

Conformatio totius pifcis velocitatem non folum, fed \& pugnacitatem arguit. Cum enim unumquodque vim fuam fentiat qua poffet abuti, hic ab ipfa adolefcentia contra homines non folum fed \& belluas marinas bellum gerit roftrofuo validiffimo, victof. que aliquando hoftes devorat. In diffectione ventriculum interiorem multis pifcibus, oneratum vidimus. Tant 2 denique agilitatis \& roboris eft hoc roftrum,ur ipfumlignum illicedat, fi ab ceftro pungente irritatus navem eo petat. Diverfa enim cornua inventa funt, profunde navium carinis immerfa inftar clavi. Cæteræ partes internæ ejufdem conformationis \& conftitutionis funt cum Xiphiis $\&$ Thunnis.

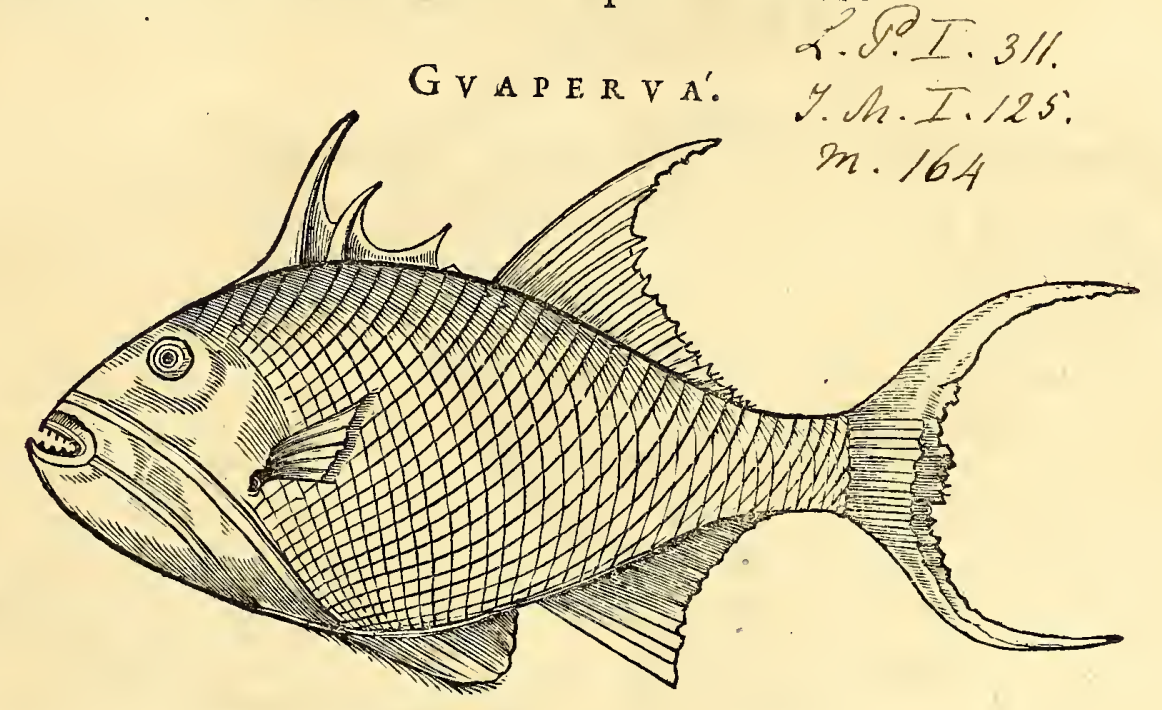

Guaperuá, Lufitanis Peixe Porco. Qui fi non idem quem Caprifcum vel Carpum Rondeletius \& Salvianus nominant, faltem ejufdem fpeciei effe facile probari poteft. Cum enim operofum adeo fit animalia five vegetabilia novi orbis Americani adfpecies Europzas referre, condonandum nobis fi fimilitudines aliquando claudicent ob infinitos naturx lufus.

Capite eft porcino, dentibus caninis, fquamis \& lineis elegantiffime fplendentibus ex cæruleo variegati coloris. In dorfo intra pinnas \& caput duo habet cornua, alterum alteri per tcnacem membranam annexum, qux nunc in rimam recondit, nunc denuo erigit, prefertim fi irritetur ad pugnam. Cauda in duo cornua fatis longa dilatatur, ideoque potiffimum difcrepat à Caprifcis, quibus brevis \& quadrata exiftit.

Si omnes partes noftri Guapervác conferantur \& confiderentur, non eft dubium quin fit pugnax \& velox.

Quantum ad dignitates alimentofas, edulis quidem affatus, non coctus, verum utique inter inferioris notæ habitos.

$$
3.122
$$

G VARA-TER E B $A^{\prime}$.

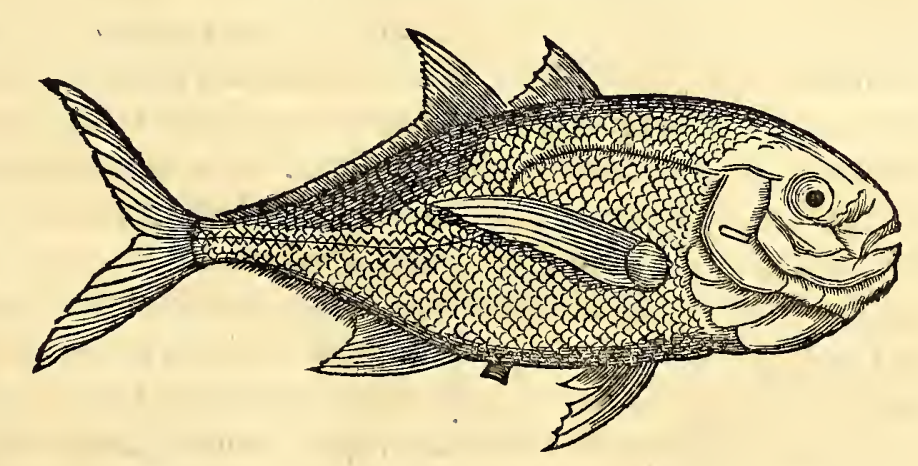

Guara-Terebá, Pifcis craffus, obefus capite obtufo, dorfo incurvato, unde Corcovádo minor à Lufitanis \& noftratibus nomen obtinuit. Triangularibus operitur fquamulis minimis, ita ut lavis potius ad tactum quam fquamofus videatur. Solis radiis expofitus, infignitur exaureo, \&hyalino cærulefcens fplendet. Edulisquidem, fed àvulgo potifimum expetitus. 


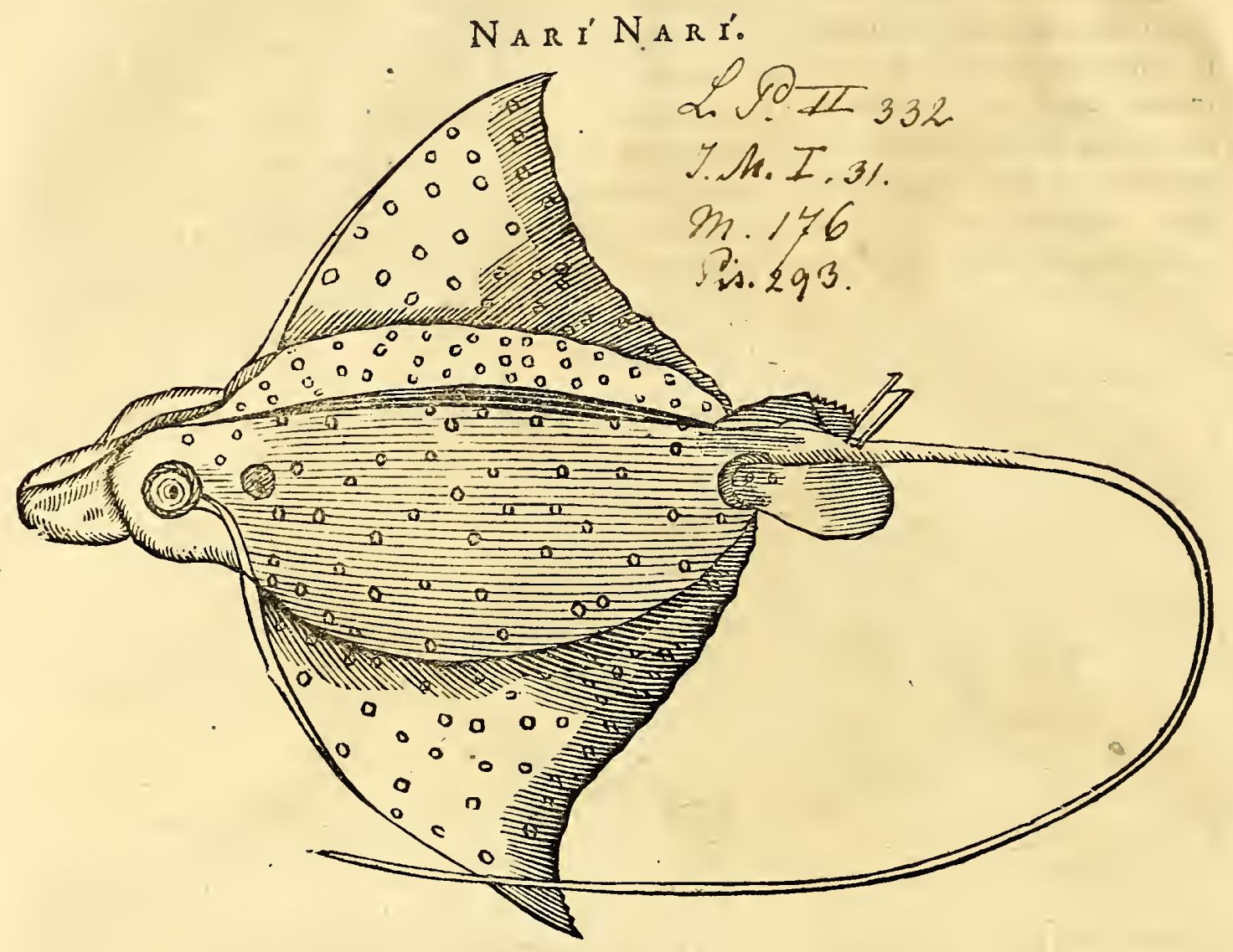

Vt terra Spinis, Rhamnis ; ita Oceanus Rajis, Paftinacis \& fimilibus luxuriat. Licet enim unum duntaxat aut fummum duo ova teftacea fimul edant; eadèm tamen illis focunditatis caufa eft, quam in Gallinis quotidie experimur, qux unum ovum unico partu ponunt, cum plurima alia in utero geftent, quorum fingula poltea ut prius abfoluta fuerint, ita prius eduntur: Ex diffectione Rajarum idem comperi quod Rondeletiusteftatus eft, perfecta ova in inferiori vulvæ parte, \& fere infinita in fuperiori ejus parte contineri. Coëunt tergo fæminarum fupinis earum pártibus fuperpofitis. Vterus iis eft oblongus. Ventriculus parvus anguftufque in ecphyfin definit, à qua breve inteftinum dependet. Latitudine corporis natant, quod pinnis careant. Tota $\mathrm{Pa}$ ftinacarum \& Rajarum familia aculeis $\&$ radiis munita, quorum venenatam qualitatem corumque antidota multi prodiderunt authores, probaruntque finul noxiam vim iis folis ineffe falva carne pifcium, qua vefca eft, ficut ego multoties quoque expertus fum. Præ cæteris eminent illæ quarum icones hic apponuntur. Prior Naríla$r i$, ob frequentiam $\&$ ufum quotidianum notiffimus. varia illorum funt fpecies, quarum illa quam exhibeo à quibufdam Brafilianis NaríNarípinima nomen accepit, à Lufitanis Raja, à noftratibus Pylftaert. Eft Paftinaca marina Americana, corpore magno, lato, ferme triangulari; conftante ad utraque latera pinna latiffima xqualis longitudinis. Capite porci fere magnitudinis $\&$ craffitiei. Ore fubrotundo edentulo, in promufcidem definente cartilagineam, habentem quafi foffam in medio. Cranii cavromus fatis capax eft cum multa cerebrifubltantia. Poft oculos in quolibet latere fpiraculum amplum, pomi vulgaris capax; intra hac, branchiarum folia recondita jacent, ad latera inferius à fine capitis in quolibet quinque, ob longas incifuras. Color totius fuperius ferreus, maculis albis per totum infperfis. Cutis tota glabra lxvifque. Caud $x$ longitudo quatuor pedum \& trium digitorum; qux fenfim gracilefcit. Paulo poft exortum caudx fuperius parvam pinnam cur tam haber, \& mox poft eam duos hamulos fibi invicem fupererectos, pifcatorils hamulis fimiles \& incurvatos. Caro boni faporis eft, fufficiens quadraginta hominibus faturandis. Ita ut quantum puncturis aculcorum humano generiobfit (ut in libro de venenis demonftravi) tantum probitate carnis profit. 
HIST. NATVRAI. \& MEDIC. LI B. III.

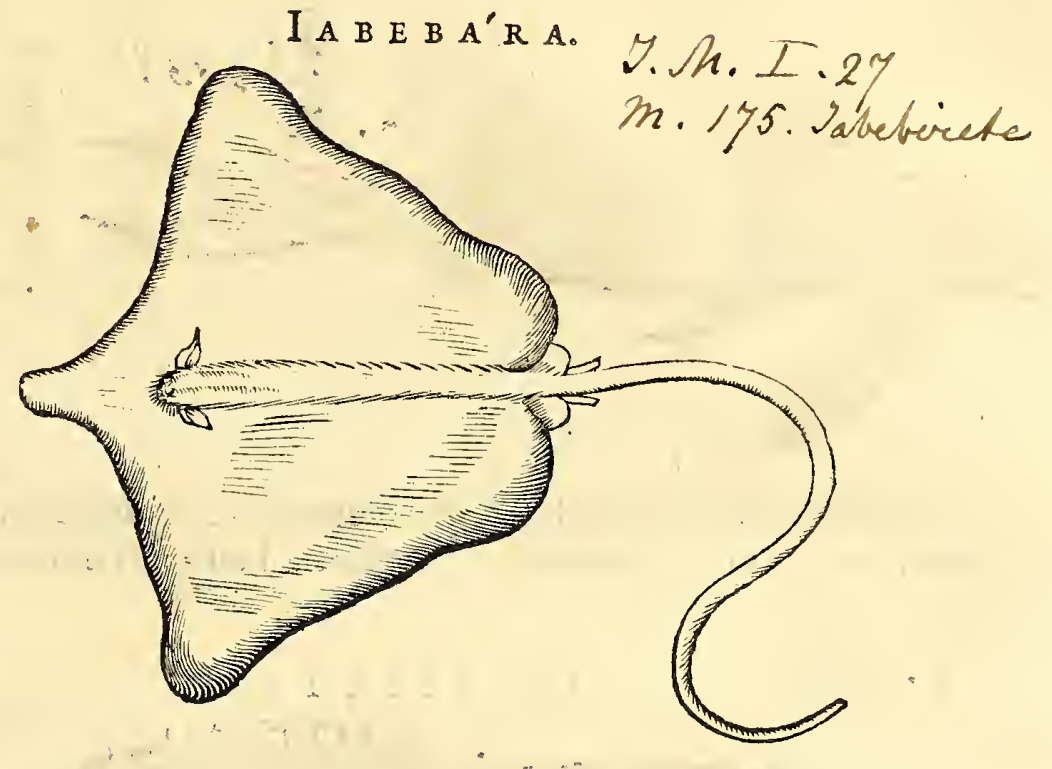

Altera Rajx fpecies Iabebára, aliis Iabebiretéappellata,ejufdem magnitudinis cum Aiereba, figura autem obtufi vomeris ad latera extuberantis. Cauda longa, cutis glabra, coloris fufci. Carne quoque ut præcedens Nari Nari probata \& boni faporis. Idem pifcatores mihi teftati funt de aliis Rajis; qux huc adferrem, fi hiftoriam prolixam, non brevem edulium pifcium exhiberem narrationem.

Corocorósa Pifcis marinus fquamulis majufculis argenteis operitur. Carne eft probata, fed dura, ideoque à delicatioribus non adeo expetita. Pedalis eft longitudinis. Frequens toto fere anno.Pinnas habet fex, quarum dorfalis acutis fpinis fuftentatur quam in rima recondit. Murmur edit corocoro quando capitur, unde nomen accepit.
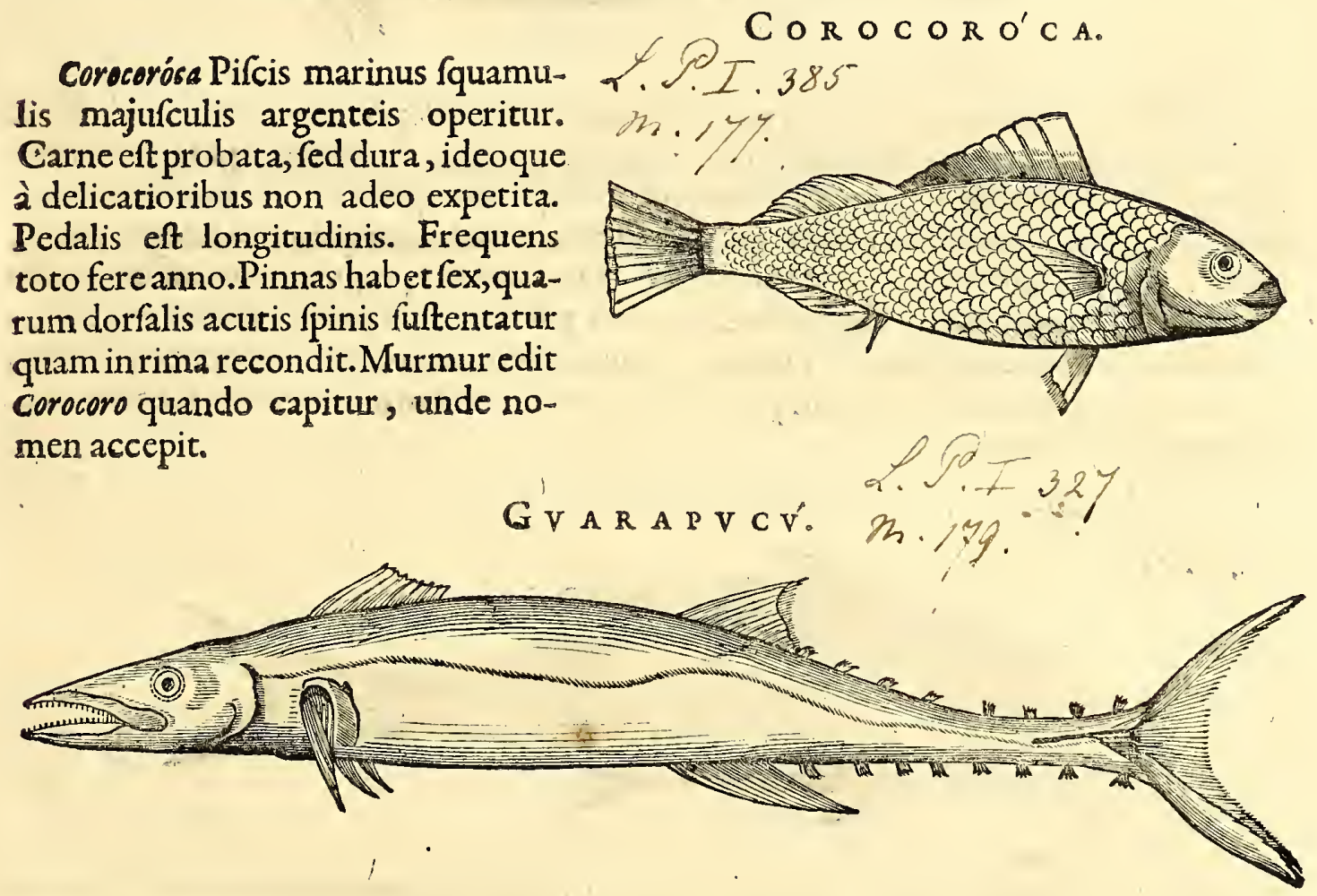

Guarapucí, Lufitanis Caválo, Belgis lyomiugg-big. Corpore eft, ubi adoleverit, feptem pedes longo, non fquamis, fed cute lævi argentei $\&$ cxrulei coloris operta, intercurrente linea à capite ad caudam ex tenuifimis fquamulis contorta. Pifcis potiflimum, marinus quod ibi pariat, licet in oftiis fluviorum dulcibus aquis fubinde videatur delectari. Si ad fpecies Europxas referatur, minus cum figura \& natura Scombri quam Pelamydis $\&$ Thunni Ariftotelis convenit, quamvis corporis proceritate \& elegantia , atque carnis quoque dignitate utrofque fuperet. Nofter hic Guar apucú, ut Thunnus, eft quoque gregalis, pifcivorus, velox; menfibus pluviis coiens \& pinguefcens. Proinde tunc omnibus paflim incolis tam recens quam falitus $\&$ in penu reconditus, magno eft oblectamento. Carne enim quarnvis fit ficciori, falubri tamen $\&$ grata, fi juvenis fit. 


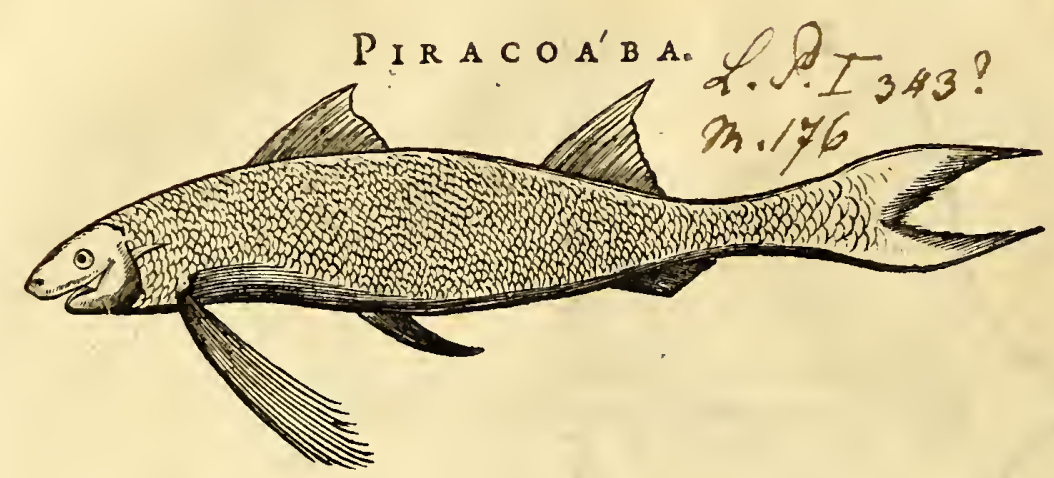

Piracoába, fi figuram, magnitudinem, pinnas, caput caudam denique furcatam confideres, nulli melius comparandus quam Chalcidi Rondeletii. Squamulis argenteis egregie fplendet. Barba eft alba. Pifcatores mihi teftati funt, folum menfibus hybernis, arenofis locis maris $\&$ circa fluviorum oftia capi. Teneritate carnis \& nutrimenti præftantia haud inferioris notæhabetur quam Chalcidis.

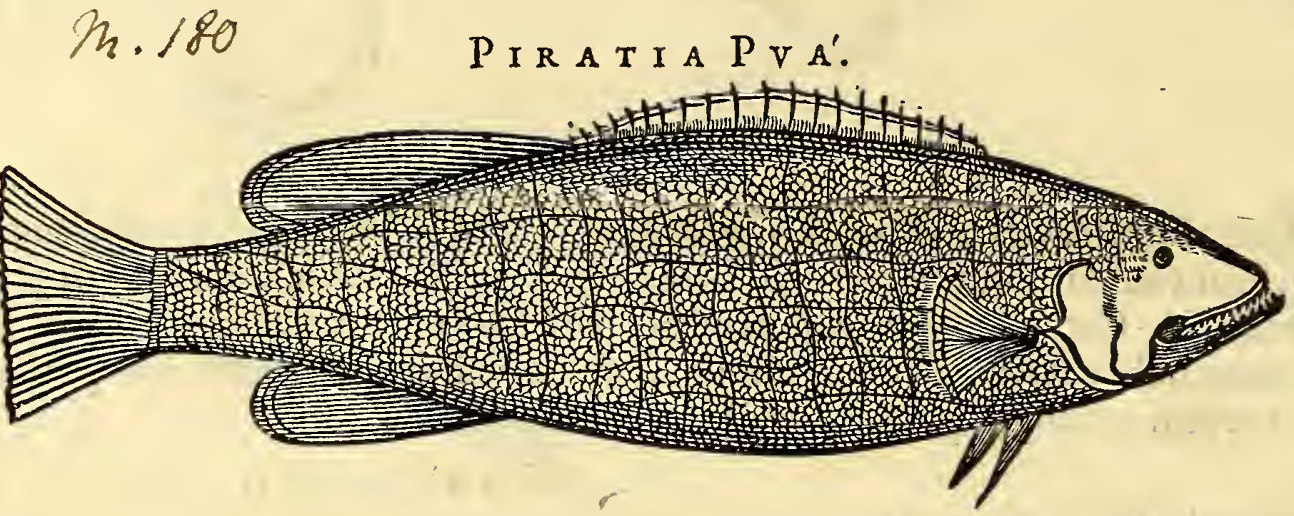

Piratia Puá, Marinus eft pifcis, necunquam in fluviis repertum memini. Maximx fit molis ubi adoleverit, fæe ultra ducentorum pondo, ob carnis \& pinguedinis copiam: fed tunc ob elegantiam $\&$ aur eum colorem potius, quam ob ufus humanos expetitus, quod adeo tenacis fit carnis : quando autem gracilis, atque infra decem pondo exiftit, ab optimatibus in deliciis habetur. Ob multam pinguedinem affatus cocto vel frixo præferrifolet. Squamulis veftitur adeo parvis, ut ad tactum glaber videatur, etiamfi antrorfum mulceatur. Totum corpus $\&$ pinnæ omnes coloris funt ex obfcuro aureo hepatici : huic autem colori per totum retis in modum cinerei coloris litur $x$ cancellatæobtenduntur.

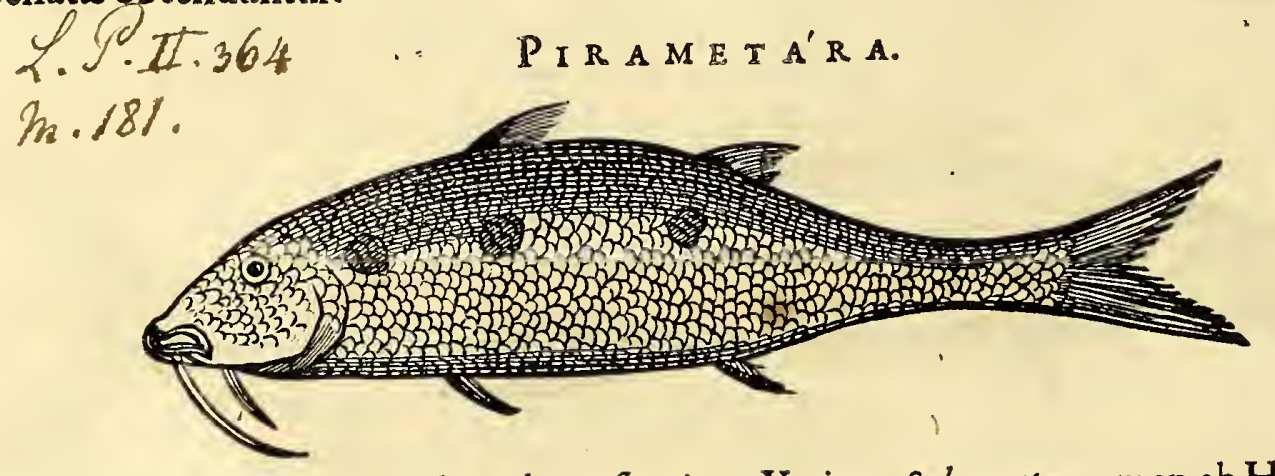

Pirametára Mulli vel Barbi videtur fpecies. Vtrique Salmonete nomen ab Hifpanis in ditum. Qux de Mulli figura,indole \& dignitate Salvianus Gefnerus, \& Matthiolus prodiderunt, huic noftro applicari poffunt, paucis tantum exceptis, prafertim quod in $P i$ rametára maculæ grandes rotund $x$ nigræ in latere utroque appareant; Cauda etiam in fine auream habeat fimbriam : convenit autem cum mullo $\&$ Barbo, quod in inferioris mandibula extremitate barbam habeat conftantem duobus quafi funiculis craffufculis ; color quoque pifcis à capite ad caudam dum vivit fanguineus fit, ifque poft mortem in aureum $\&$ flavum mutetur. Quam colorum mutationem, Plinius non folum fed \& Rondeletius aliique recentiores Mullis quoque attribuerunt, iifque imprimis quibarbati funt $\&$ in alto mari degunt, ficut nofter hic Pirametáre, qui ut coloris elegantia, ita \& nutrimenti pr æftantia in conofis ftagnis viventes longe fuperat. Carne eit friabili, cum aliquo lentore \& pinguedine, ac proinde minus durabili, nifi condia- 
HIST. NATVRAL. \& MEDIC. L в. III.

condiatur. Hepate eft ex albo rubefcente, fine felle: quamobrem ex hepate condimentum paratur.

G VI R Y B A C O'。 F. I. I. 389 Acarapitanga
m. 17 thibaco

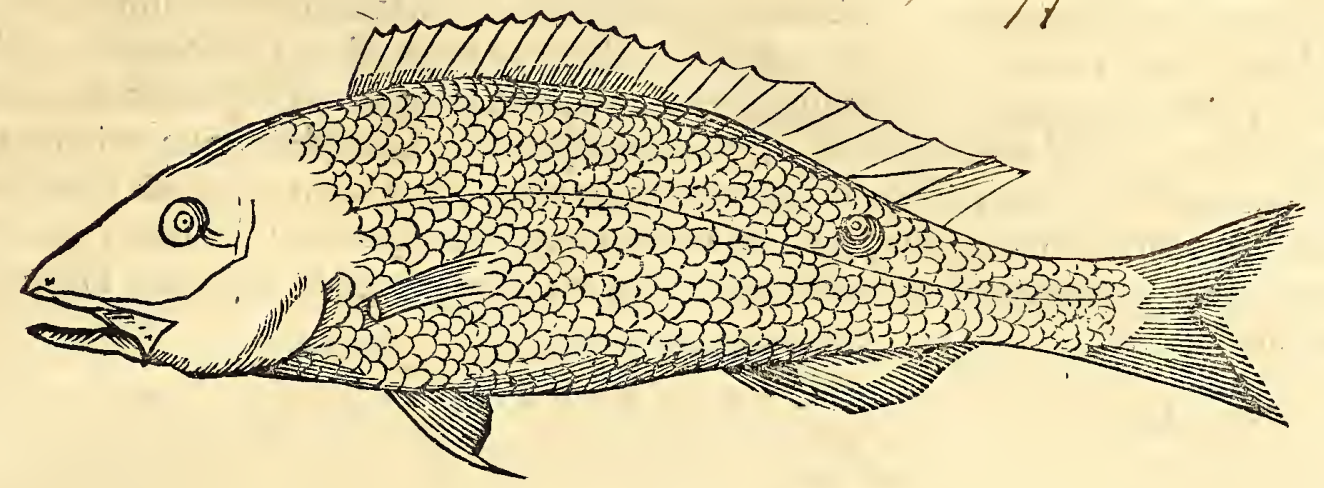

Inter Edules Marinos pifces Guirybacó numeratur, corpore groffo, pingui, multa probataque carne præditus. Veftitur magnis fuamis partim cinnabrio partim argenteo colore fplendentibus, intercurrente linea rubra à capite ad caudam. Coctus aflato præferri folet. Vifcera omnia ejufdem coloris \& conformationis ut Afellorum noftratium,

Pirabebé. Pifcis volans, five Hirundo pifcis, non Brafilix proprius, fed, ut ex variis authoribus liquet, omnibus innotuit inter Tropicos navigantibus, qui figur $\&$ alarum magnitudine, carnis dignitate, colorifque varietate inter fe difcrepant. Plurimi autem Haleci fimiles exiftunt. Quibuldamad utramque alam in initio ejufdem parva quafi ala exit. Conftant eorum alæ tenui membrana fubfufci coloris, ha-

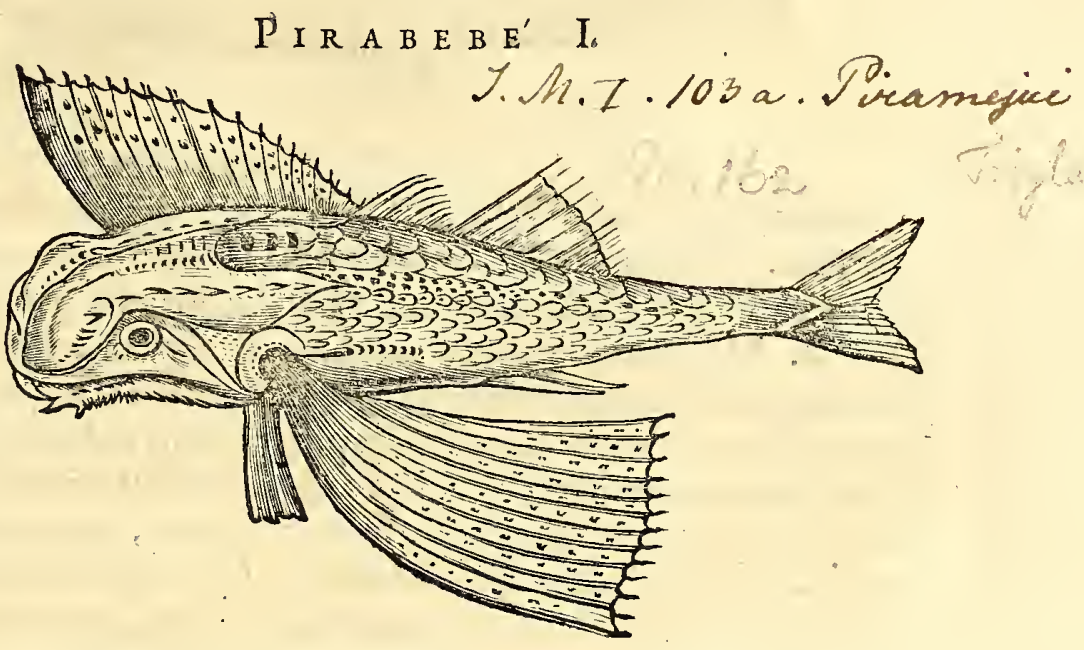

bentque plicas, \& fuftentantur Spinis tenuibus per longitudinem extenfis. Sicut ex hac priori icone videre licet, qux capite $\&$ corpore craffiori depingitur.

PIR A B E B E' II.

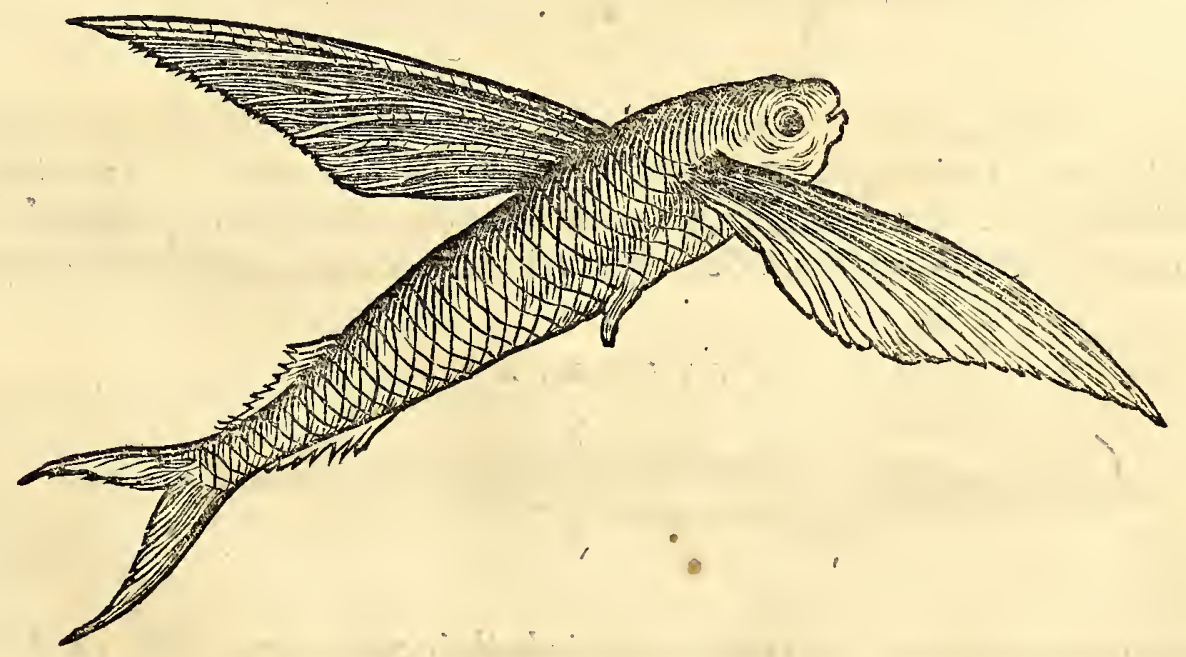

Altera autem colore, figura corporis, \& alarum imprimis, multum difcrepat. Alæ enim ejus duplo funt longiores $\&$ multo angutiores fine plicis. Tanta denique inter 
Pifces volantes difcrepantia à capite ad caudam, ut nihil fere inter fe commune has: beant quam quod alati $\&$ edules fint. Pifcatores promifcue vivos hamis affigunt, profundoque mari immittunt, atque ingenti fonore illos redimunt, dum corum perfecutores ipfi decipiuntur $\&$ capiluntur. Merito Hirundinis nomen illis attributum ob volatum, quia demiffe earum more volitant, atque inftar illarum aviumqux è flumine aquam haufturx, vel è terra feftucas collecturæ. Millenos videre eft ex Oceano fubito félevantes, quxx, dum fuga fibi confulunt, ut rapaces pifces, imprimis Delphinos, evadant, fubinde à circumvolantibus avibus in ipfo aëre capiuntur, Charybdimque evitantes in Scyllam incidunt. mox iterumad humectandas alas, (qux brevi temporis fpatio exficcantur) leviter aqux fuperficiei fe immittunt : unde fit aliquando ut in naves precipitentur, grataque præda fiant pubi nauticx, qux coctos pro grato alimento Halecum loco apponunt.

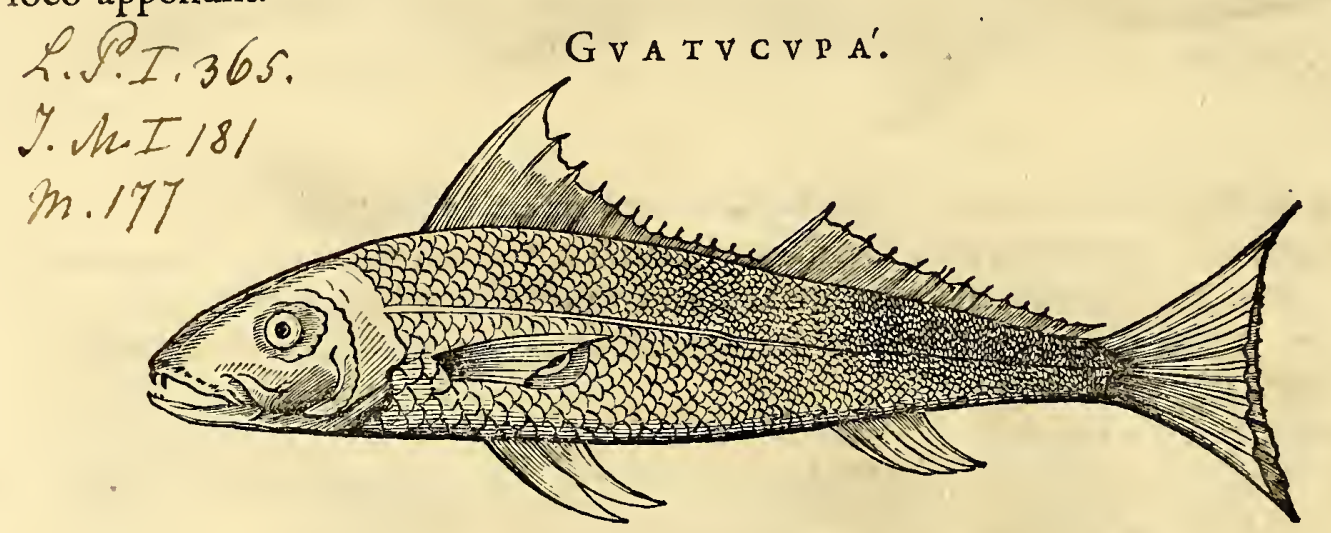

Guatucupá, Corvina Lufitanis, noftratibus pifcatoribus 5rfjelbig. Quod Afellum exprimit. fane fapore $\&$ dignitate fi Afellos Europxos non fuperet, faltem iis par eft. præterea figura \& magnitudine (paucis conceffis pro naturælufu) ab iis non multum recedit. Minoribus fquamulis rotundis ex auroargenteis fplendet. Pinnis \& ventre eft albicantibus. Linea quoque argentea fecundum longitudinem per medium latus tendente. Pifcatores teftantur, nufquam in fluviis fed in mari capi. Carnis bonitate cum faxatilibus contendunt, tamen pro diverfa victus fui ratione deteriores vel meliores efficiuntur. Omni anni tempore fere capiuntur, magno incolarum folatio \& oblectamento. Afelli hi pifciculis vefcuntur, quos integros devorant, quia dentes tantum ha bent priores, non adeo ad incidendum, quam ad retinendam predam.

T I M V c v'.

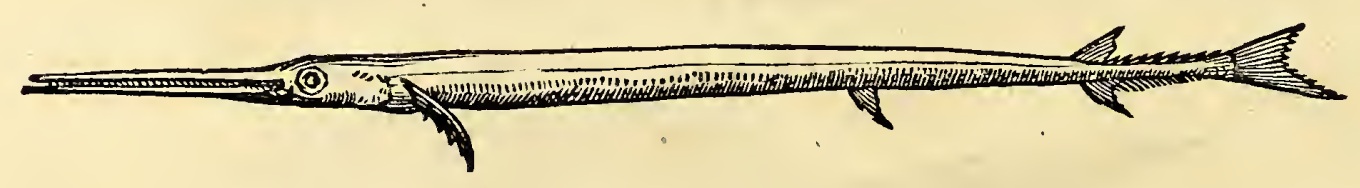

Timucí, Lufitanis Peixe agulha, inter Acus numerandus. Roftro eft offeo. Non fquamis fed cute tegitur, partim olivacei; partim argentei coloris. In mari \& fluviorum oftiis frequens. Carne eft ficca, non fpinofa, atquc boni faporis, præfertim in fartagine cum oleo vel butyro frixus. Sed ob paucitatem carnis à menfis divitum rejicitur.

(a) PETIM B V A BA.

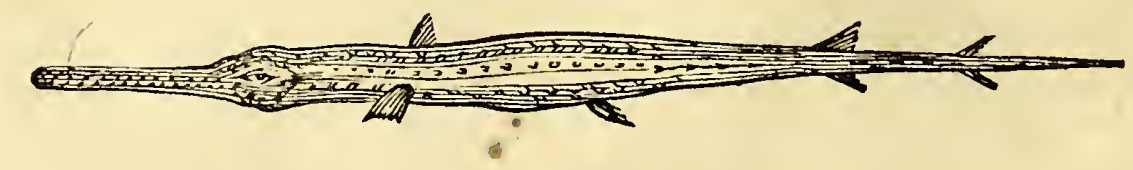

Dubito an inter Acus pifces mifores Petimbuába locum teneat. Cute eft glabra, inftar Anguill $x$, coloris primum hepatici, mox maculis cœruleis $\&$ virefcentibus infignis. capite $\&$ roftro admodum producto. Caro ejus vefca, licet pauca \& ficca. Corpore cft non exacte tereti, fed compreffo \& latiufculo.

Vubara 


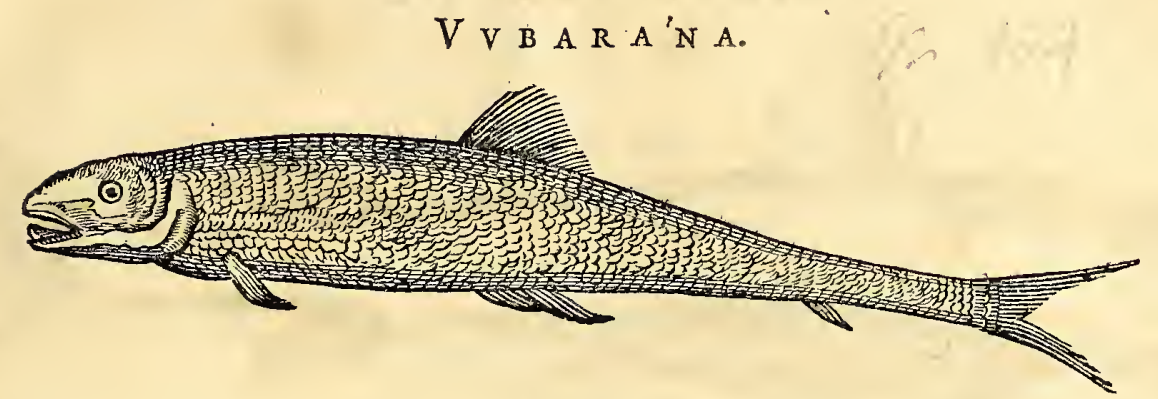

Vubarána, in oftiis fluviorum degens, fi ulli pifci Europæo, certe 'Truttis maxime comparandus, five figuram externam fquamarumque feriem, five carnem cjus confideres. Colore tamen differt, quod hic exargenteo mire fplendeat. Ore eft edentulo, unde lapis illi loco lingux eminet. Pifcis ab omnibus paffim expetitus, five coctus, frve in craticula aflatus, nifi quod infinitis fit pertextus fpinulis.

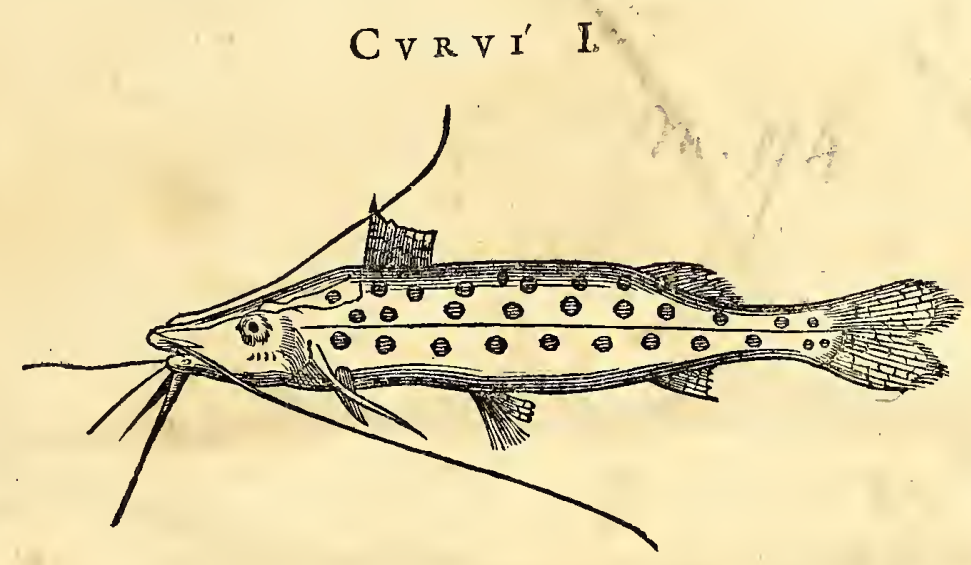

NH A N D I A' II.

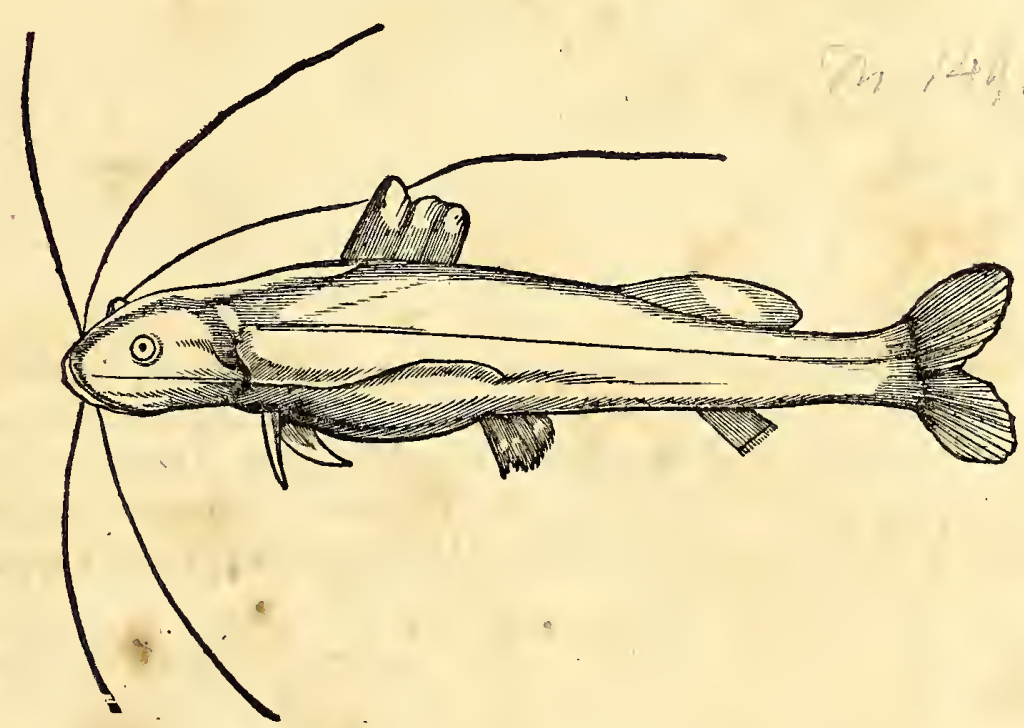

Varii ejufdem generis, fed diverfefpeciei pifces. Læves, non fquamofi, barbati, dulcium aquarum perpetuialumnireperiuntur. Quorum fex potifimum mihi innotuerunt, quilncolis familiares funt, \& vili pretio diftrahuntur, partim ob frequentiam, partim quod Iudxi à non fquamatis abftineant.

Lufitani \& Belgx hos omnes Bagres appellant; fed Indigenæx cuique nomen fuum indiderunt. Primo Curuí. Secundo Nhandià. Qui ambo omnium facile optimi cenfentur, tam ratione palati, quam nutrimenti: atque licet raptu fluminis (imprimis divi Francifci, ubi potiflimum abundant) in mare prolabantur, dulces tamen aquas non deferunt. Vterque eft barbatus fed cirris barbx difcrepantibus. Vterque cute cinerea, non fquam ofa, tectus; fed primus folum maculis perpetuis variegatur. 


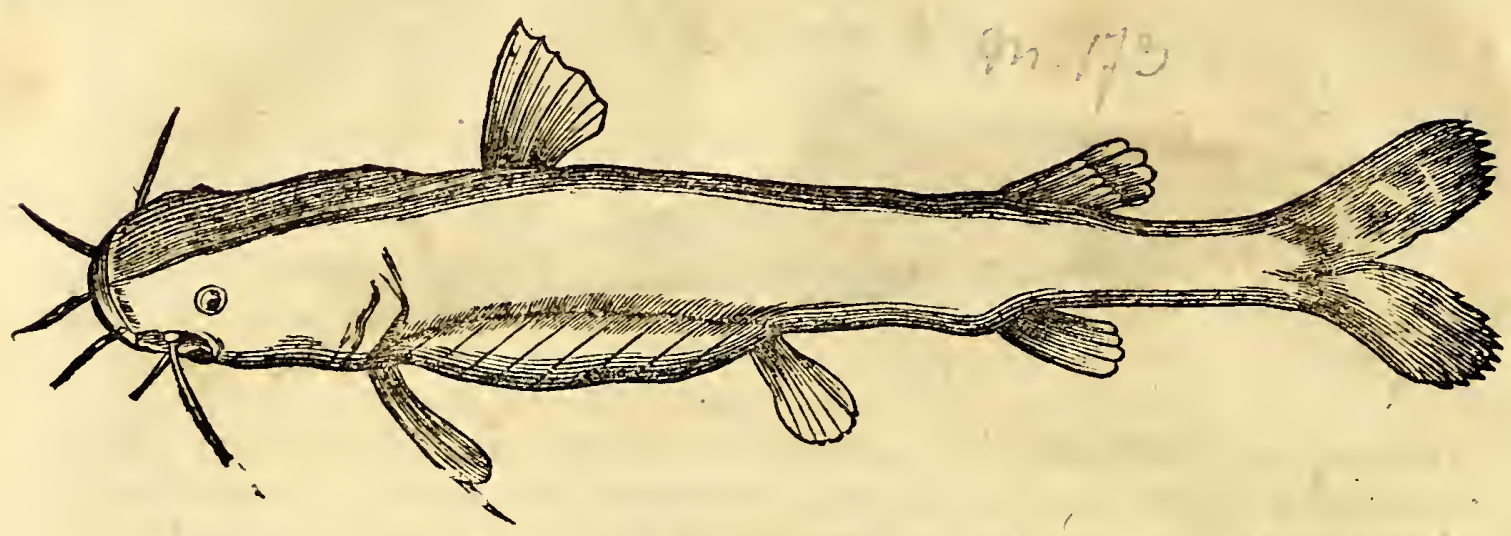

GVIRAGVAç $V^{\prime} I V$.

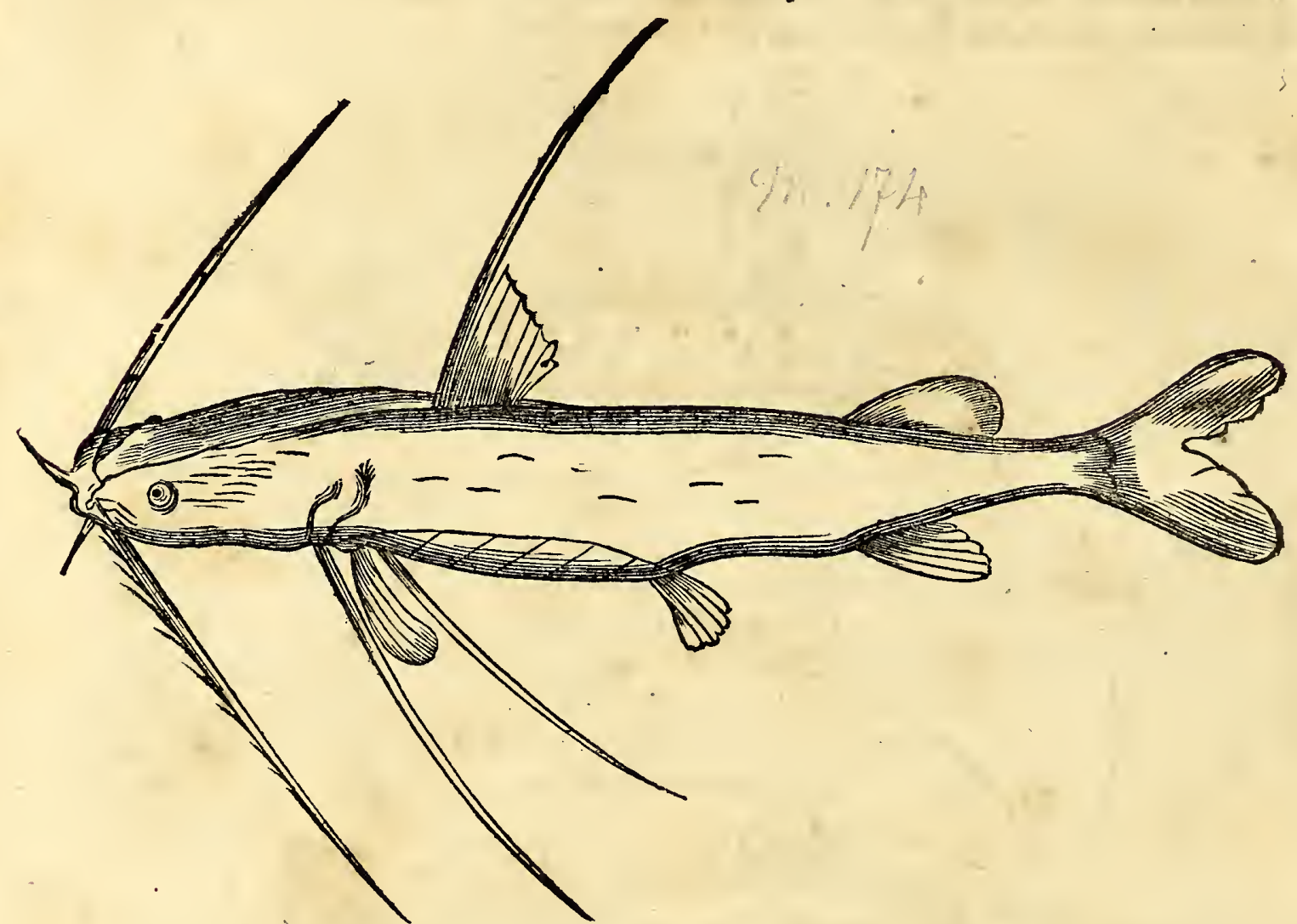

His fupra enarratis dignitate efculenta fuccedunt duo majores, Guiritinga \& Guiráguą̧ú dicti, quorum icones admodum fibi inter fe fimiles exceptis cirris, qui numero, fitu \& magnitudine differunt, ut ex appofitis Iconibus liquet. Ambo lavi cute,candidi, cum diluto flavo $\&$ aureo mixti coloris funt. Capitibus obtufis $\&$ dura tefta munitis. Septem pinnis, Cauda furcata gryfei coloris. Quovis modo preparati apponuntur.

I V N D I A $\quad$ V.

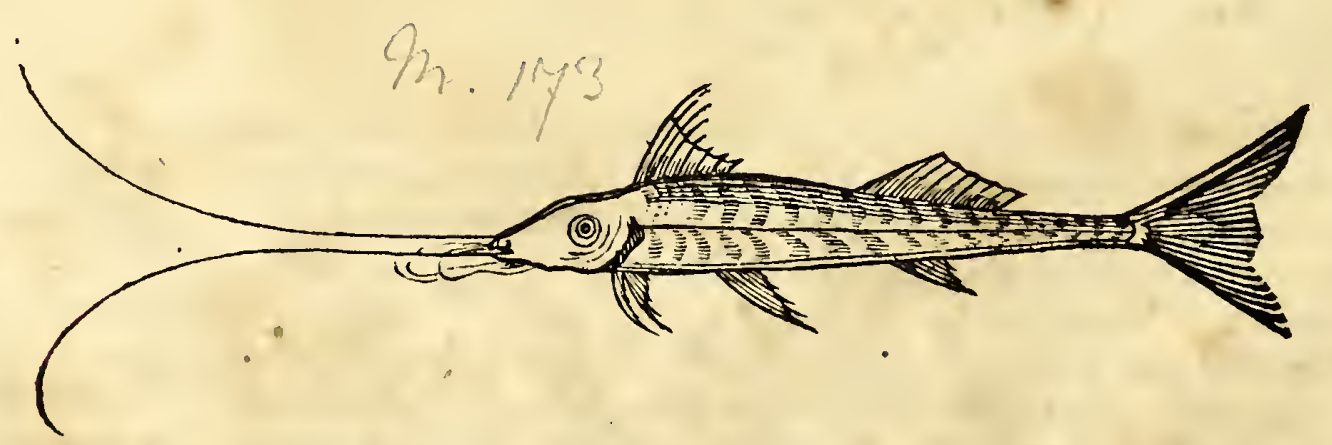

Quintus vero Iundiá capite eft conico, dura tefta tecto. Quatuor cirris brevibus \&tenuibus, duobus vero fupernis longiffimis \& lunatim extenfis. Totus pifcis argentei eft coloris, 
HIST. NATVRAL. \& MEDIC. L $\%$. III。

coloris, ficut \& linea illa latera corporis ad caudam ufque cum perpetuis argenteis protuberantiis fecans. Pinnis omnibus prexpofiti funt fortes aculei dentati, qquibus dolorifica infligit vulnera.

Sextus Vrutú, noftratibus 拄负-25agre; cui barba quoque ex fex cirris data, non fquamatus fed cute tegitur glabia, umbræ coloris fufcis variegatus maculis. per utrumque latus fecundum longitudinem mirus ordo den-

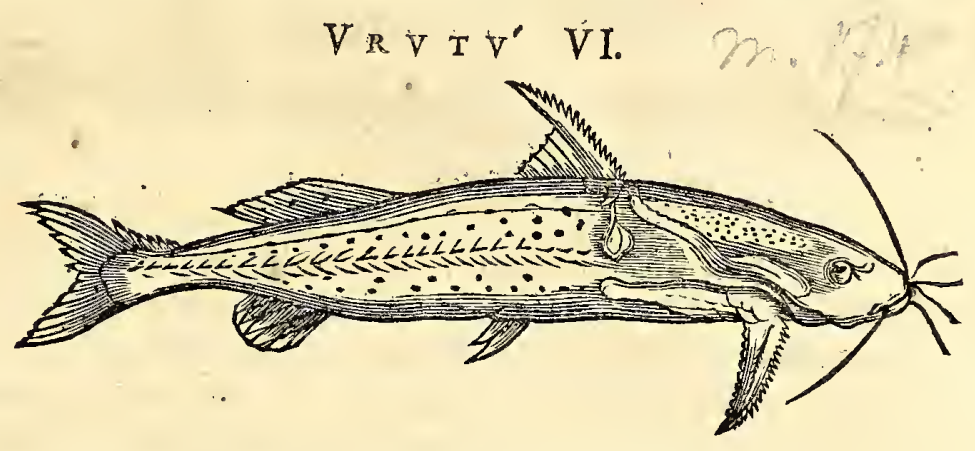
ticulorum acutorum tendit ad finem ùfque. anteriori pinnæ dorfali fpina craffa offea dupliciter ferrata incumbit, qua incaute tangentem mifere lædit.

Proinde edules licet duo hi pofteriores Iundiá \& Vrutu, à retibus fuis tamen eos ar: cent pifcatores,ob puncturas quas tanta cum inflammatione, \& tumore excitant, ut fpatio viginti quatuor horarum vix ulli cedant remedio, imo in mentis vel animi defectum aliquando fauciati dejiciantur. unicum hactenus innotuit remedium, quod quantocius paratur exhepate ipfius pifcis cum oleo frixi, vulnerique applicato. Ita ut hinc quioque liqueat id quod fxpius antea probavi, pleraque venenata fecum ferre fua antidota ; modo nos rite illa expifcemur, eaque in aliquo vifccrum prxcipuorum, imprimis in hepate, non raro latere, edifcamus.

\section{A M A R I P V G Y A ç $\mathrm{V}^{\prime}$}

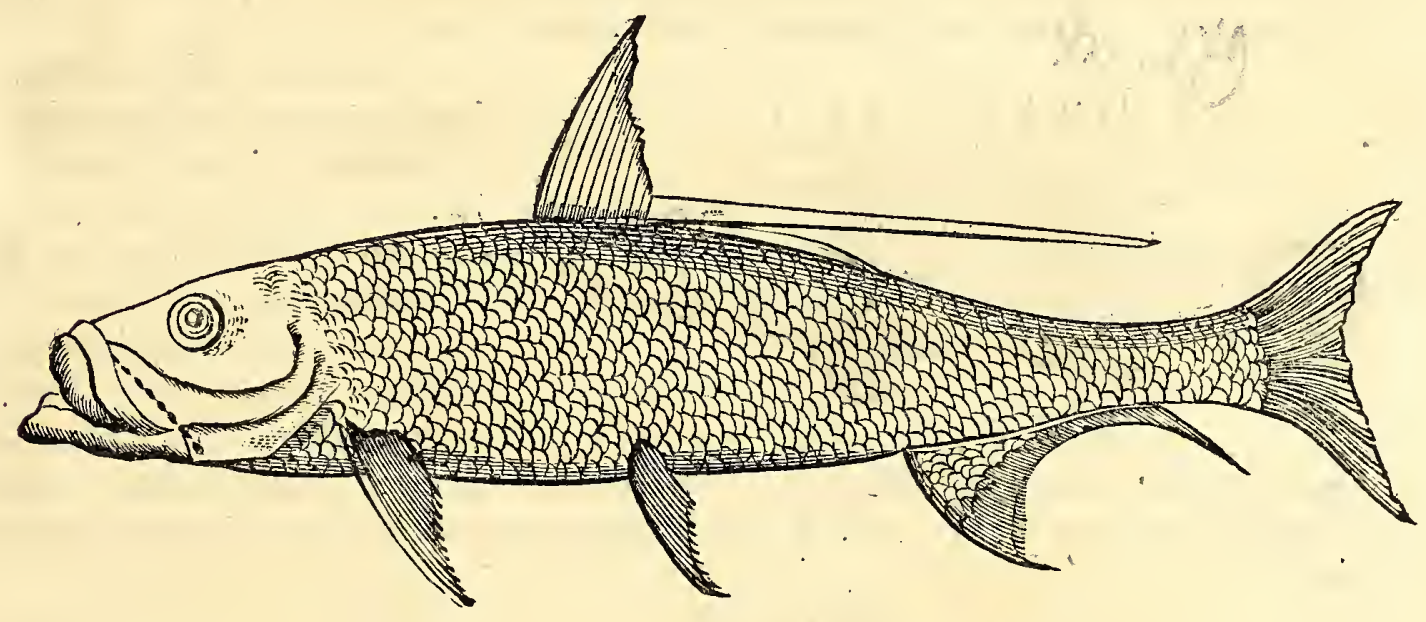

Inter vulgares pifces marinos Camaripuguaçú cenfetur, qui viri craflitiem \& longitu= dinem cum multa pinguedine acquirit ubi adoleverit. Ore eft edentulo valde amplo; mandibula inferiori immobili, \& fuperiori breviori. Oculis magnis argenteis. Cauda lata, paulo bifurcata. Pinnæ dorfali elatxappendix data eft longa inftar furis craffioris recta ad caudam vergens. Squamis totùs, pifcis tegitur magnis arcte fibi impofitis, adeoque eleganter ex cæruleo argenteis undatus, ut quafi mero argento obductus videatur. Vt palato gratior fit, juvenis eligatur, diutiufque coquatur; ob multam $\&$ folidam carnem craffis f́inis obfitam: ubi enim adolefcentiam excefferit, lenta fit ejus caro, \& bajulis tantum dicata:

Duas potiffimum fpecies Punarú obfervare licuit, qùz: ut externa figura, ita $\& x$ internis qualitatibus fibi frmiles: Vtraque pecies intra fcopulos circa littora vivit, \& teftaceorum dornicilia intrat. Pifciculi funt parvi,

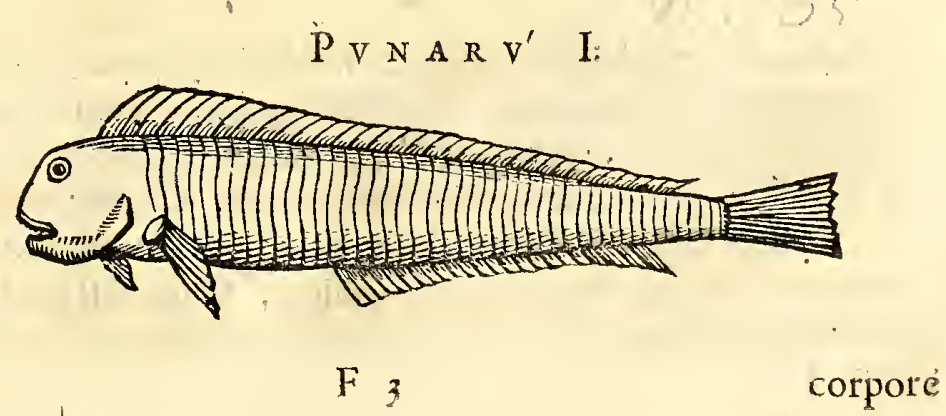


corpore tereti 8 oblongo , capite craffo \& obtufo, oculis fuperius in fronte pofitis, branchiis amplis. Pinna $\mathrm{ab}$ occipitis fummitate ad caudre exortum extenfa, mollibufque fpinis non prominulis texta, fumili pinna à medio ventris ferme åd podicem ufque pertingente. Cauda utrifque longitufcula \& parallelogramma. Cute teguntur fufca \& glabra. Ita ut uterque Punarú fimiles fibi fint paucis exceptis: prior variegatus eft in lateribus lineis curvis obfcure purpureis, pofterior mandibulas habet roftratas quafi è minimis denticulis compofitas. Vterque palato gratiffimus, ob carnis teneritatem, atque ob alimenti præftantiam ab ægris æque ac fanis expetitus.

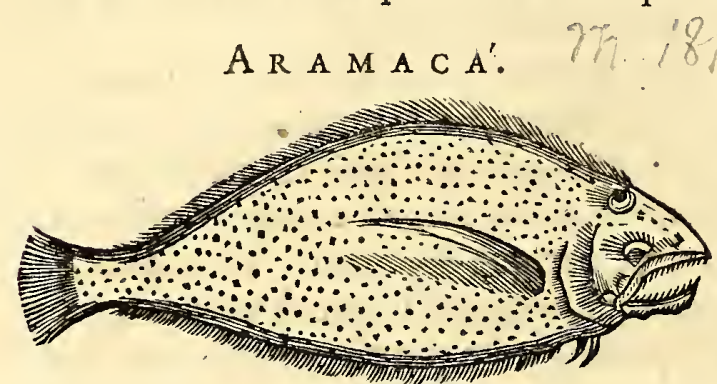

Aramacá, Lufitanis Lingoáda, vulgo etiam Cubricurba, Lingulx, five Solex potius quam Pafferis eft fpecies. Noftrates reang appellant. Eft Pifcis planus tenuiori \& contractiori corpore quam $\mathrm{Paf}-$ fer. Eftate ex maris domicilio fluvios petit, ubi carne fit molliori \& fuaviori, omnique Paffere preftantiori. Ore eft magno, dentato, elingui. Veftitur fquamulis adeo parvis ut vix defquamari poffit. In dextro latere albi coloris, in finiftro lapidei cum ftigmatis variegati : oculos quoque duos habet in hoc latere, in altero nullum. Ita ut Solex altero oculo orbati eodem modo natent.

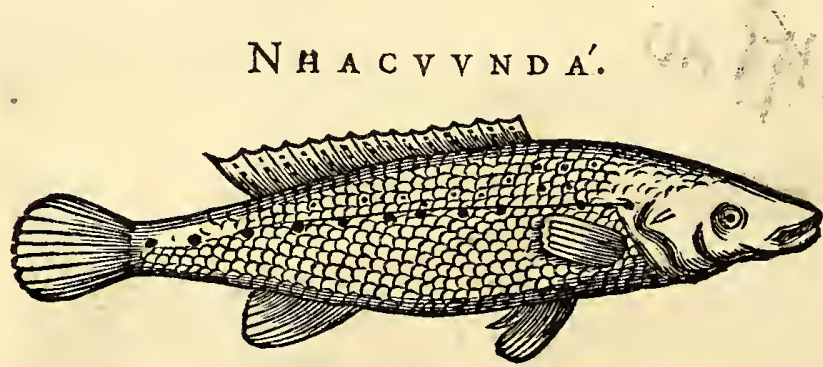

Nhacuundá Mas foeminxe bonitate carnis $\&$ figura fimilis, exceptis crruleis punetulis. Ore Lucium xmulatur. Dentium loco habet limas $\&$ linguam_tenuem. Cauda, nigra tefta dura tegitur. Squam $x$ obfcure gryfei funt coloris cum argenteo tranfplendente. In medio corporis maculæ nigrx per longitudinem excurrunt, concomitante linea fplendente. Frequens eft in receflu fluviorum, gratique faporis \& probi nutrimenti habetur.

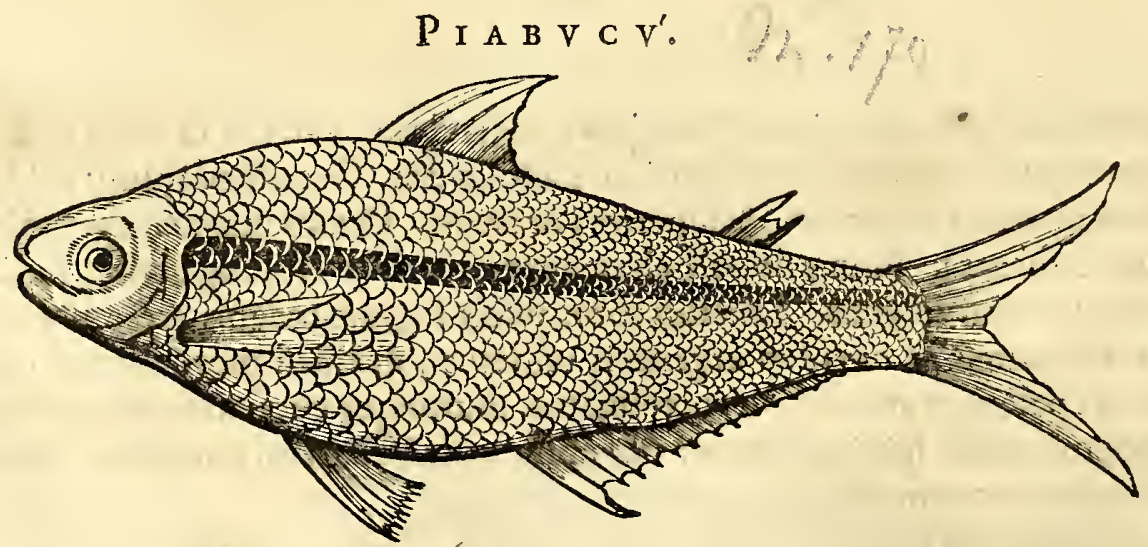

Piabucú inter fluviatiles pifces non inferioris not $x$ exiftit. Oculis \& fquamulis argenteis cgregie fplendentibus. Per medium latus fecundum longitudinem linea lata non fplendens excurrit, qux in hac Icone nimis nigra depicta ; quod pictori concedendum cft. Dorfum olivacei \& hyacinthini coloris. Capiuntur facile vivis pilciculis hamis affixis. Adeo appetens eft fanguinis humani, ut natantibus vulnus vel qualccunque ulcufculum fugendo \& mordendo infligat. Carne eft probata \& boni palati quocunque modo praparetur. 
HIST NATRAL。 \&EDIC. LIB. III.

Piába pirciculus femipedis longitudinis, non figura tantum fed natura Phoxinis veterum eft fimilis, quorum præter Ari. Itotelem Gefnerus \& $\&$ Rondeletius meminerunt. Caput \& fquąmx eleganter argenteo viridi colore fplendent. Circa Pinnas \& Caudam macul $x$ funt magnx Indici coloris, quibus Phoxini deftituun-

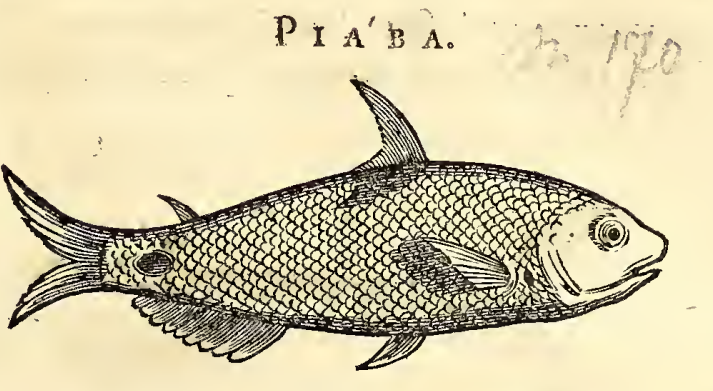
tur. Nufquam in ftagnis dulcibus fed fluviis tantum rapidis capiuntur, amantque contra aquarum raptum niti. Saporis quidem: non contemnendi funt, verum apud Indigenas in majori pr etio habentur, qui eos cineribus conditos foliifque arborum involutos craticulix imponunt, affatofque pro epulis ápponunt, quod milhi per deferta cum illis peregrinanti præftiterunt barbari.

Acaraayá, qui vulgo corrupte Garanba dicitur, inlacubus potiffimum reperitur. Atque inter eos pifces numeratur qui æque fole \& fale ficcatur \& conditur, quamrecens comeditur. Figura Carpioni fimilis, fed non magnitudine. Prater communes pinnas rubicantes unam alperam longam expanfam.

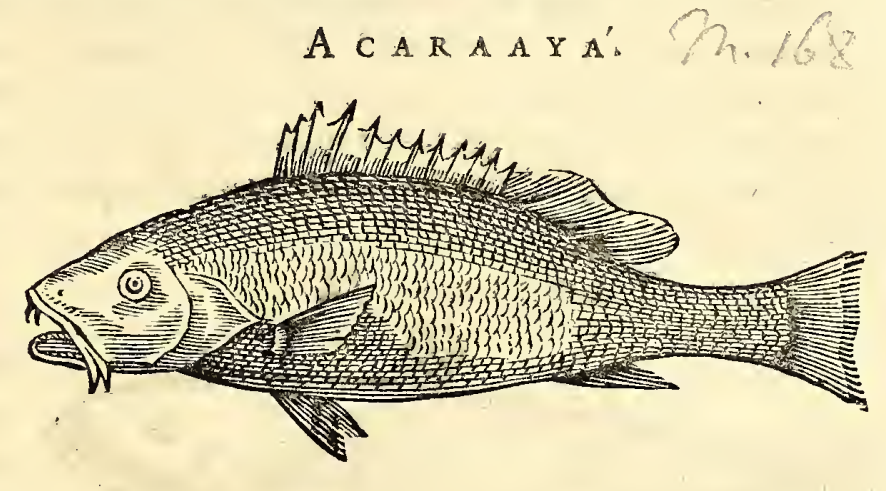
habet, cujus 'mediam partem nunc erigit, nunc in rimam recondit. Squamis argenteis fanguineo colore umbratis decoratur.

Acará, inter eos qui alte fluvios fubeunt. Pifcis hic vix palmum longus, craffo capite \& corpore. Dentium loco limam tenet ore. Squamis eft argenteis ex umbra mixtis. In quolibet latere duas habet maculus nigras majores \& rotundas. Cauda pro mole pifcis fatis longa lataque. Caro ejus haud ingrata nec infalubris, Percarumque loco apponitur.

Maturaqué, Capite craflo, dura tefta tecto. Ornate fquamofus ex nigro. fplendens. Eodem viotu \& natali folo gandet quo Tamoatá, fcilicet crnofo \& lacubus ftagnantibus. Figura autem fiinilis Tareira do Rio, verum mole corporis fuperior. A. AR A: 72.168

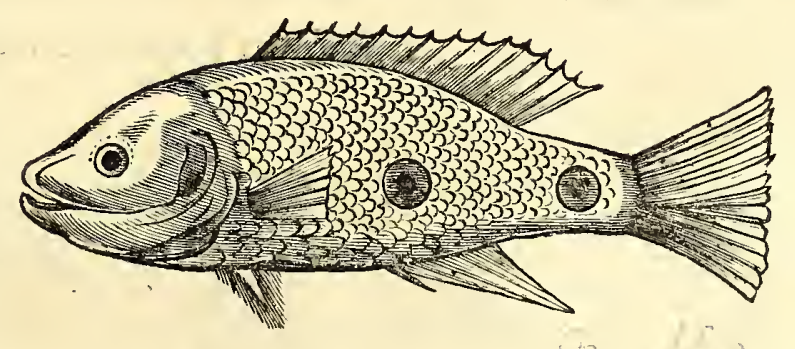
Caro ejus boni eft faporis, fed nou fatís ficca, pröinde condimentis eget. Eifdem lacu bus innatat egregius pifcis $M u n c u$ dictus.

Piquitínga, pif́ciculus fluviatilis ob carnis frimilitudinem \& lineam rectam per corporis longitudinem currentem pifci Pisbuçúcomparatur, licet colore \& mole corpus multum difcrepet. Tegitur fquamulis albis, ex qui-

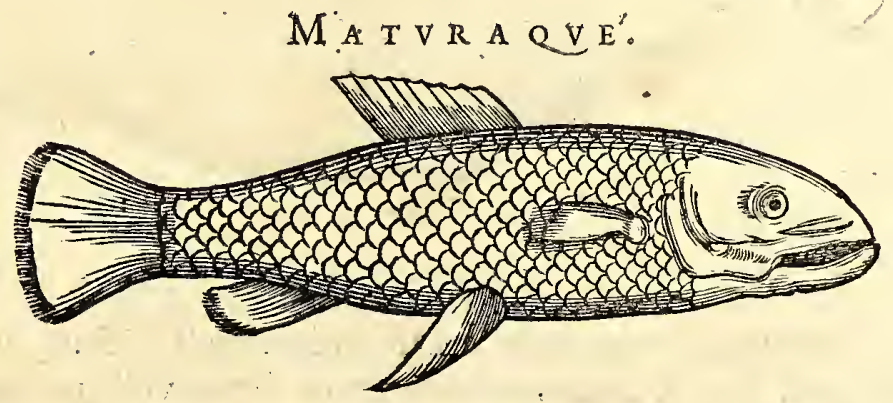
bus hinc inde olivaceus color tranfluet. Pinnis eftalbis, \& cauda bifurcata. Linea lata, qax- 
ta, quxper utriufque lateris medium ad Caudam definit, argenteo colore emicat. Carne eft friabili \& bona, imprimis fi frigatur $\&$ clixetur.

$$
\text { TAREIR A I. }
$$

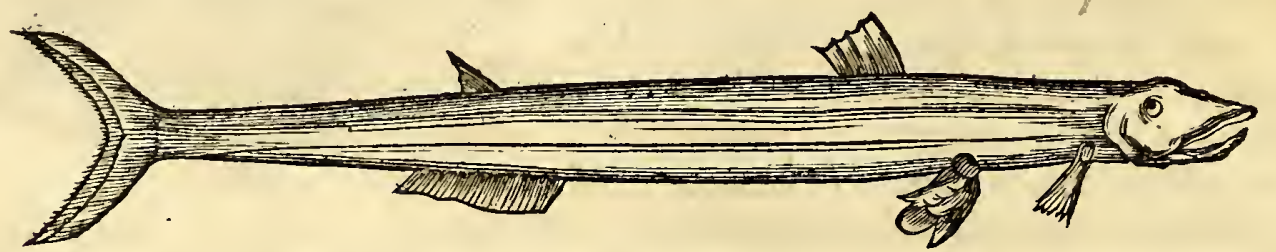

Quia placuit Incolis Brafilix nomen Tareira indidiffe utrifque his pifcibus, licet figura \& natali folo difcrepantibus; malui cos conjunctim quam feparatim exhibere, \& una quafi fidelia dealbare. Prior Corpore eft oblongo tereti; fquamulis brunnis adeo exiguis \& affabre compofitis ut pifcis ad tactum glaber videatur;lineis rectis à càpite ad caudam alternatim flavis $\&$ viridibus confpicuis. Pinnas habet octo admodum tenues, quarum maxima eft cauda late diducta \& furcata. Capite colubrino. Ore patulo admodum, dentato, quafi ad rapinam facto. Huic Tareire Lufitani ad diftinctionem compofitum nomen indiderunt, Tareira d'Alto appellantes, quia in alto mari potiffimum capitur.

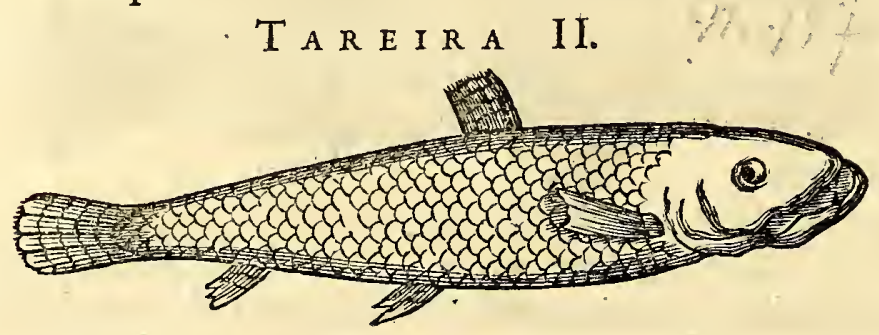

Pofterior Tareirado Rio,id eft fluviatilis, infigniter fquamatus ex argenteo fufcus. Vterque edulis, imprimis affatus, uterque dignitate $\&$ fapore bi fim ilis, nifi quod Caro Marini fit minus fpinofa carne fluviatilis. Riatu eft patulo, inferiori mandibula longa $\&$ admodum dentata, qua hoftibus vim infert. Pinnas habet fex; quarum maxima eft cauda in extremitate circinata, ex nigro undulata.

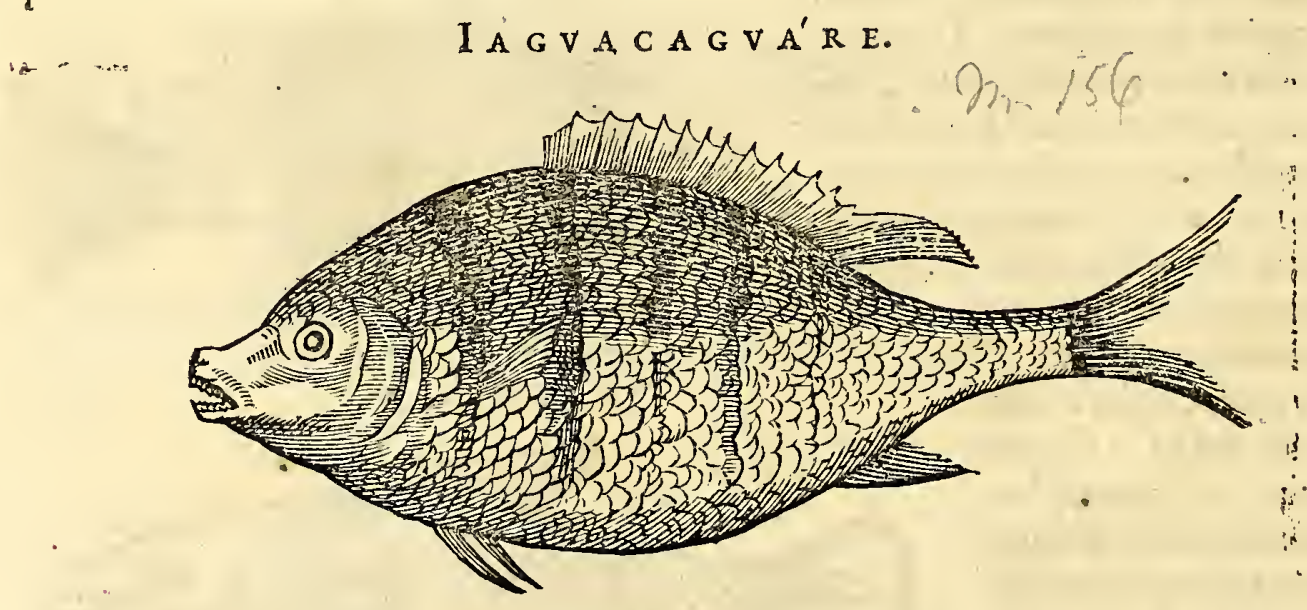

Inguàiguáre improprie à Lufitanis Iaqueta dictus. Inftar Perex noftratis obrotundus, fed-latior. Squamis quoque ut Perca veftitur majufculis è cæruleo cinerefcentibus. Si plures pullæà dorfo ad ventrem defcenderent, haud male conveniret cum Mormyro Hyppoliti, Salviani \& Gefneri. Cæterum pifcis edulis, fed à plebe potiffmum expetitus.

T A I A S I C A'。

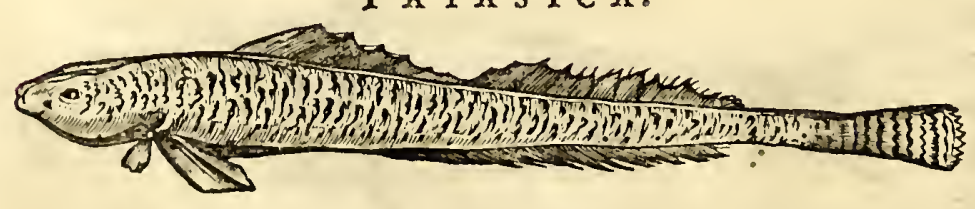

Tainficá, Pifcis parvus fed nobilis. Ægris pariter ac fanis in deliciis habitus, ficut Porcellus Belgis, \& Gobius Germanis.pr $\boldsymbol{x}$ terquam enim quod figura illi non diffimilis, ita \& natura quoquc convenit cum littoralibus \& Eaxatilibus Gobiis. Pratefantifimus 
HIST. NATVRAL. \& MEDIC. LrB. III.

equidem eft nofter hic Taiaficá ad voluptatem fimul ac diftributionem, \& fucci bonitatem. In arenofis littoribus degit, ita ut pedibus calcando arenam à quovis facile capiatur. Coloris eft hyalini pallidi, exiguis maculis fufcis variegatus. Ejufdem magnitudinis pifciculus frequens Araberi dictus : Belgis $\mathbf{S p g}$ pat.

A C A R P E B A.

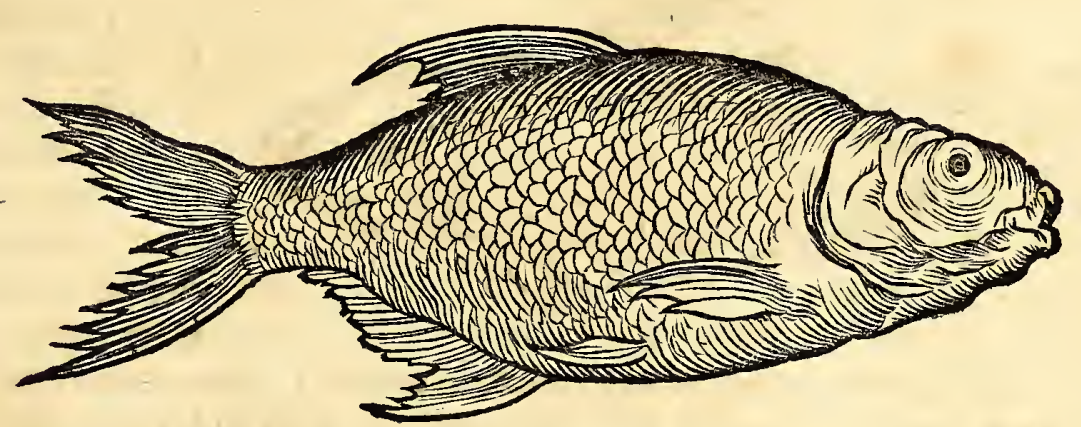

Acarpeba ficut in Europa, ita in America videntur variæ Cyprinorum fpecies. Supra in defcriptione pifcisfeptimi Acarapinimu mentionem fecimus hujus, tanquam illi congeneris ejufdemque indolis \& faporis. Cujus Iconem propterea præterire conftitueram, fed quia externa figura nimium difcrepant, mutavi mentem, eumque appingi operx pretium putavi; imprimis cum hic Acarcéba, noftratium $25 \mathbf{a k f} \mathbf{f m} /$ veterum Cyprino fimillimus fit, five internas qualitates five externam figuram confideres : adeo enimfuavis fimul \& faluber habetur, ut nulli pifcium dignitate cedat, ingentique incolarum fit fuftentaculo. Sefquipedalis frepe eft longitudinis. Corpore lato, fquamis majoribus tenuibus argenteo colore fplendentibus. Ore edentulo parvo, quod extendere \& contrahere poteft. Dentium loco offa duo incifa habet. Linguxe vicem fupplet palatum carnofum, avulfumqủe linguam adeo refert, ut non mirum fit multis imponere: quod ad imitationem folertiffmi Rondeletii edoctus in diffectione viva comperi, carnofam fcilicet illam fubftantiam fuperius fixam, non folutan more lingux, inveni. Pupilla oculorum eft nigricans cryftallina. Pinnis natat latis, quæ omnes, imprimis dorfalis, firmis fatis fpinis fuftentantur. albicantes funt \& tranfplendentes. Caudx pinna furcata \& lata. Capitur inter fcopulos in mari \& oftiis fluviorum. Ventriculus, lien \& hepar cum nigricante annexa felle ordinarix funt conftitutionis pro mole $\&$ more hujus pifcis. Fœcundus eft, feptiefque \& fxpius anno parit. Multa portat ova, qux fxpe per eunt, quia foeminæ adeo inftabiles funt, ut mares, qui eas perpetuo profequuntur, femen ovis afpergere non poffint.

An vero hic Nofter Acarpeba Cyprinorum more fine maris $\&$ foeminx commiftione quoque nafcatur, utab Authoribus de Cyprinis teftatum eft, ego experiri nondum

potui : licet id fape obfervare conatus fum in vivariis Illuftriffimi principis Mauritii.
Piranha, quorum tres quatuorve fpecies vidiffe contigit, omnes fluviis dicati, magnitudine quidem, non autem figura, natura, colore vel dignitate multum inter fe difcrepantes. Major omnium quem hic exhibeo, voracitate imprimis celebris. Capite eft obtufo ut Doráde, fed rictu majori, in quo

PIR A $A^{\prime}$ H A.

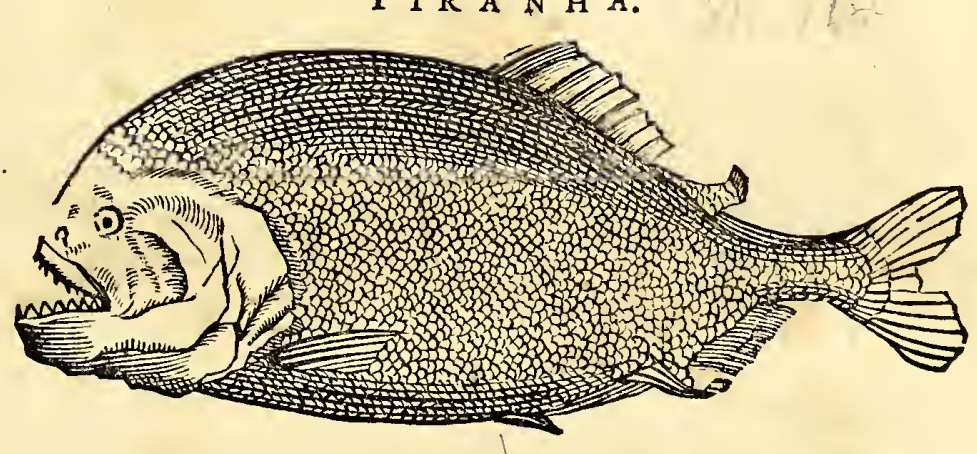
videre eft ordinem dentium triangulatorum acutiffimorum, quibus abripit quicquid mordet:adeo denique fanguinis humani fitiens, ut incauti urinatores cum membri alicujus jactura id experiantur.Pulcre variegatus eft coloribus: fquamæ cinerei cum cxruleo mixti, fimbrix ignei cum caruleo, inventre flavi funt coloris. Edulis non folum caro ejus albifima, fed quod friabilis \& ficca, optimi faporis $\&$ nutrimenti fit, per to- 
tam regionem in pretio habetur. Si mortuus paulo diutius affervetur, tenerior redditur, ficut evenit omnibus fere qux duracarne funt. Quaficalor naturalis qui partes continet cvanefccret, \& calor externus carnem colliquans humidiorem eam cfficeret.
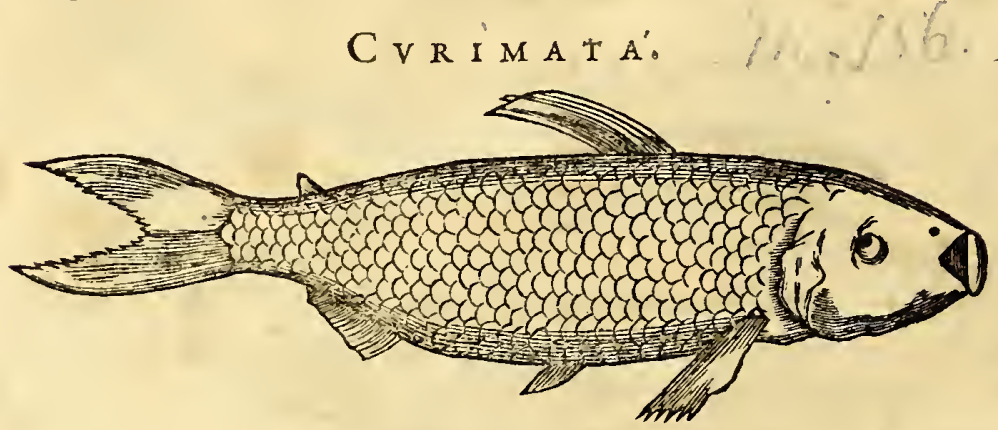

Cúrimatá. Inter Brafilienfes pifces nullus qui Carpioni fapore, colore argenteo, fquamis, figura (paucis exceptis) adeo eft fimilis. Quare, quum carne fir non glutinofa fed ficca \& friabili , merito inter délicias habetur, cum, vel fine condimentis, exfolo aceto, elixus. imo ipfi Carpioni à multis prxfertur, cjufdemque eft indolis $\&$ natalis foli ; in vivariis enim \& dulcibus lacubus tantum capitur.

$$
\text { PIR A V M B v'. The } 167
$$

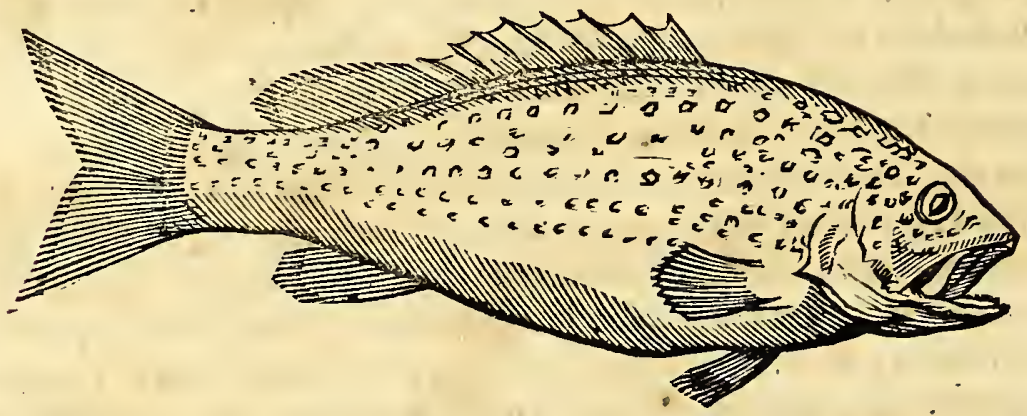

Piraumbéob ron chos quos edit ita appellatus, Lufitanis Chayquaróna, inter fluviatiles celebris pifcis, magnitudine \& figura non folum, fed ore, $\&$ fquamis ex auroargenteis Carpioni non adeo diffinilis.

Imo teneritate carnis illi non cedens, ita ut tuto ab $x$ gtis $\&$ fanis hic expetatur, firite praparetur. In orefuperius $\&$ inferius duos habet lapides latos $\&$ validos, denticulis vix fenfibilibus præditos. his buccinas aliaque duriora quibus vivit, comminuere folet. Huic affinis habetur fluvialis ille pifcis Cururúsa dicus, fed major, argenteifque fquamis fplendens. Pinnas habet octo: quarum maxima Caudam conftituit furcatam. Gluten optimum ex hoc pifce conficitur, quod omnibus in familiari eft uftu.

GVARVGVARV'. 168 Guaruguarú pifciculus nobilis', red exi-

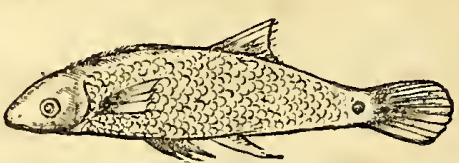
guus, in ftagnis $\&$ lacubus frequens, fapote ut $\&$ fquamarum aurearum elegantia pifcem Piabá æmulatur. In quotidiano apud plebem eft ufu.

Curemá \& Paratí $\mathrm{Mu}-$

CVR E M A'.

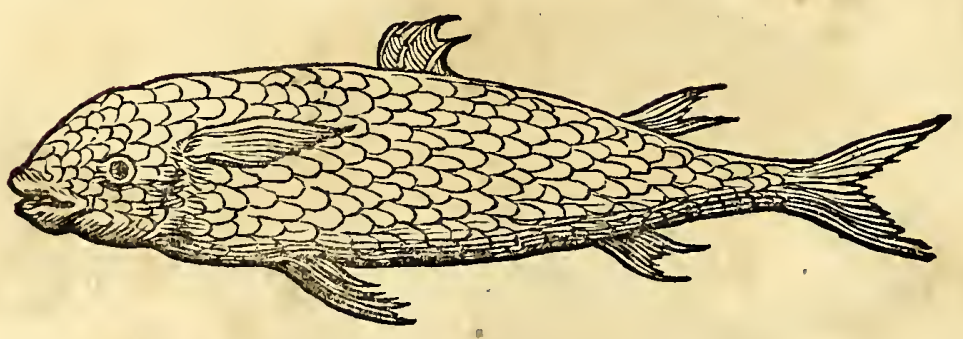

giles Brafilienfes, Lufitanis Tainba, noftratibus Harderg dicti. Qui ut toto fere orbe notiffimi, ita in hoc Ameri$c \mathfrak{x}$ tractu familiares, atque recentes non folum in quotidiano ufu, fed $\&$ faliti in penu refervantur. Ex hoc Mugilum gencre, illa fpecies qux Curemá dicitur maxime eft celebris. Q ux rurfus magnitudine diftinguitur ; majores enim duorum, minores unius pedis funt longitudinis, \& à maris accolis nominc Paratí exprimuntur. Cxterum craflo \& pingui corpore fibi fimiles, oblongiad inftar Truttax fluviatilis. Capite funt compreffo, lato, craffo, duris fquamis tecto \& in conum obtufum definente. Supra os, quod eft magnum \& edentulum, duo foramina funt, oculi nigri, magni, anterius pofiti. Btanchix exigux. Pinnx octo, quarum 
quarum una parvalin fummo dorfo, tribus fpinis durioribus fuffulta eR. Cauda bifurcata , fuam $x$ magn $x$ clypeatx plane, coloris obfcure cinerei, cui hyalinus $\&$ argenteus infelius tranfplendet. Nulli noftratium pifcium figura $\&$ indole adeo fimilis quam Mugilimarino, qui Cephali nomen apud Ichthyographos accepit. Mugiles enim xque àc hi Paratíatque Curerná, aliqui marini, aliqui lacubus conofis $\&$ ftagnis gaudent, ùnde exiftente malacia magno numero lafcivientes exfiliunt. Quin \& faltu retia aliquando tranfiliiffe vidimus : hàc enim ratione evadunt ut vitæ fuæ confulant, quod de iis Oppianus eleganter teftatus eft. Prxpinguis eft cocta vel affata corum caro, atque fine oleo vel butyro comeditur, quod multum flavæ pinguedinis de fe fundat. Salitus cum muria, ficcatus in fole refervatur. Optima ejus pars venter eft, fed diutitus in fale refervata fit rancida. Ova quoque eorum falita \& ficcata fervantur in gratiam bibacium, quia fitim excitant, ficut ex Mugilibus Europxis fit quod vulgus Botarga appellat. Vifcera funt difpofita ut in aliis ejus generis pifcibus, nifi quod hepar, vefica fellis, ventriculus \& inteftina pro mole corporis fint exigua. Quod frequens eft in iis qui non exrapina vivunt, nam etiamfi gulofi \& falaces, carnivori tamen non funt. Corde funt angulato. Sub pinna eft locus aëre plenus. Omnes Marini Lacuftribus præftantiores, quod minus limum fapiant.

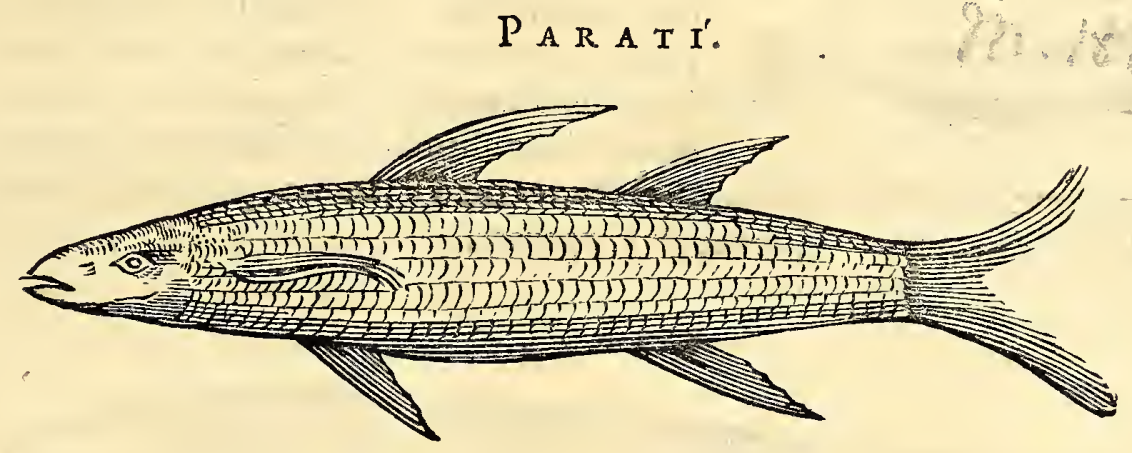

Alia quoque fpecies datur $P$ aratı dicta, qux in his oris frequens Truttæ magnitudine $\&$ figura, fed Mugilis indolis æmula, fi natale folum \& Carnis faporem confideres, $a b$ utraque tamen capitis figura abludens, imprimis autem quod hic branchiis deftituatur. Caterum oculis eft ellipticis, fquamis argenteis lineari ordine difpofitis, lineis gryfeis à capite ad caudam mugilum more intertextis. Pinnas habet feptem albicantes longas, caudam in duo ampla cornua divifam. Magna copia in lacubus falfis fimul capiuntur. Recentes rque ac faliti in pretio habiti. Carne funt ficca \& probata. Pluviis menfibus adeo pinguedine abundant, ut nullo fere obfonio indigeant.

Tamoatá, parvus' fed mirus afpectu eft pifcis . praterquam enim quod caput ejus fatis amplum fuperius tegatur tefta dura inftar clypei,univerfum quoque corpus loricatum $\&$ fquamofis armatum annulis, ac proinde Soldido nomen à Lufitanis inditum. Ore eft edentulo, fed barbato, geminis filis oblongis. Coloris eft tocus pifcis fulvi \& fubnigri. Adeo fugit aquam falfam, ut tempore reftivo \& ic-

TA M O A T A'.

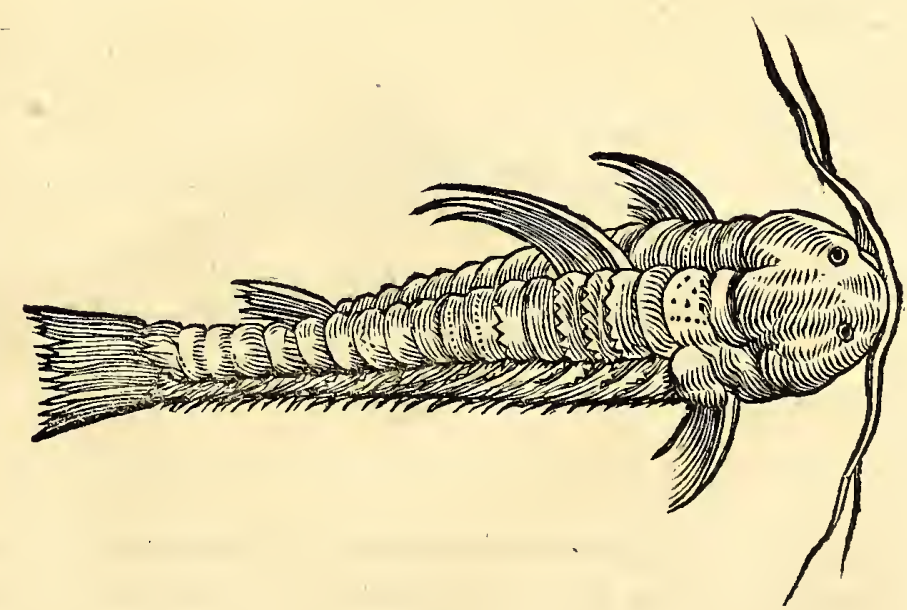
co per terramabeat dul-

cem aquam quxritans. Caro ejus laudabilis eft fapor is \& nutrimenti, interque fecund $x$ menfx delicias apponitur, imprimis fifale $\&$ pipere arrofa, in veru vel craticula affetur. Eifdem ftagnis innatant Nbandia, Gueba, Noia dicti, qui bonitate carnis pracedentem æmulantur. 


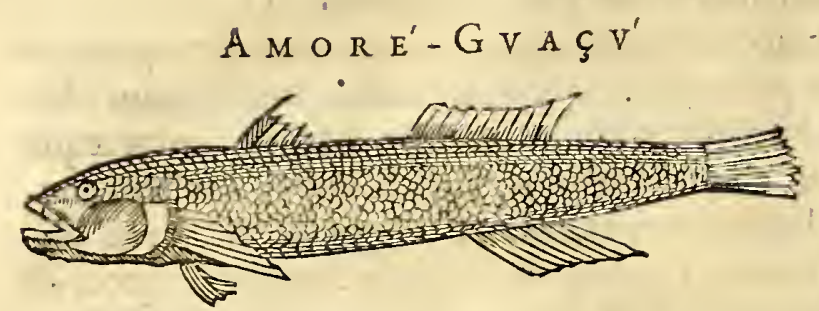

Inter lacuftres pifces primatum quoque obtinent illi qui generale nomen vernaculum Amoré audiunt, vulgo Amoréa corrupte dicti; quorum diverf $x$ fpecies, addito agnomine diftinguuntur, ut Amoré-guaçú, Amoré-Pixuma \& Amoré-Tinga, omnes natali folo, colore ferreo, \& qualitate alimentofa fibi fimiles, fed figura \& magnitudine difcrepantes, uti in Amoré-guaçuapparet, qui primo fe offert, adeoque expetitus ut Indigenx illum fub ripæ vel fundi arena utcumque fepultum exinde cum mole ftia eruere non graventur. Qui enim Amoré-Tinga dicitur, corpore eft exiguo; habetque fquamas in totum albicantis coloris, intermixtis maculis fúcis ut Tainfica. Carne cft tenerrima \& friabili, ac ab omnibus in pretio habita, non fanis tantum, fed \& agris, quibus admodum conducit.

$$
\text { , in } 8 \text {. } 76 \text {. }
$$

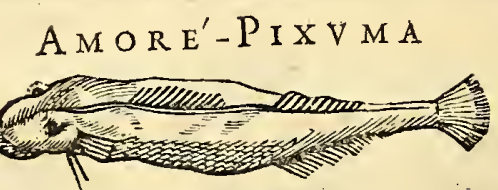

-lle qui Amoré-Pixuma nomen accepit, capite eft lato, ore amplo \& edentulo, corpore oblongo, ventre extuberante albo, cxterum coloris ferrei ut pifcis Tamoatá, quem nonnihil æmulatur figura \& qualitate alimentofa; Cum enim dulcium aquarum ftagnantium incola fit xque ac Tamoatá, carne eft, ut illa, probata, $\&$ ficca, atque inter epulas appofita, codemque modo præparata.

\section{$C A R A P O^{\prime}$}

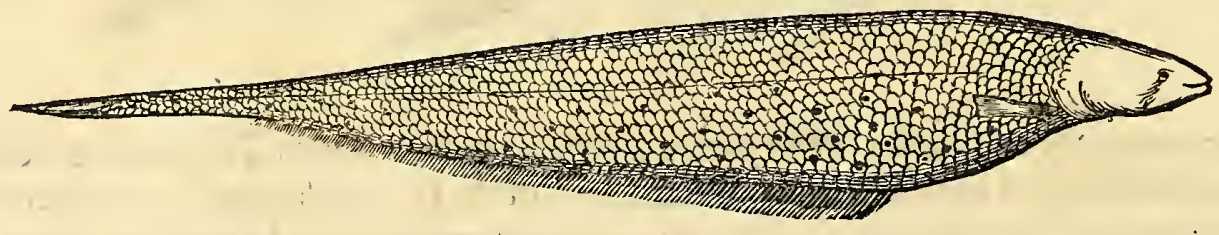

Diver $x$ fpeciei Carapó in lacubus \& fluviis reperiuntur, partim fibi fimiles, partim diffimiles. Prima (cujus hic tantum iconem exhibeo) cultri figuram nonnihil æmulatur, imprimis fi obtufum $\&$ rectum dorfum, atque ventrem acutum $\&$ prominentiorem, inftar Barbot $x$ Rondeletii confideres. Capite \& cauda eft admodum tenuibus $\&$ acuminatis. Squamis ex fufco $\&$ nigro rubefcentibus. Grati licèt faporis fit ejus caro $\&$ ab omnibus in pretio habita, tamen fluviatilibus $\&$ marinis Carapó nutrimenti dignitate cedit.

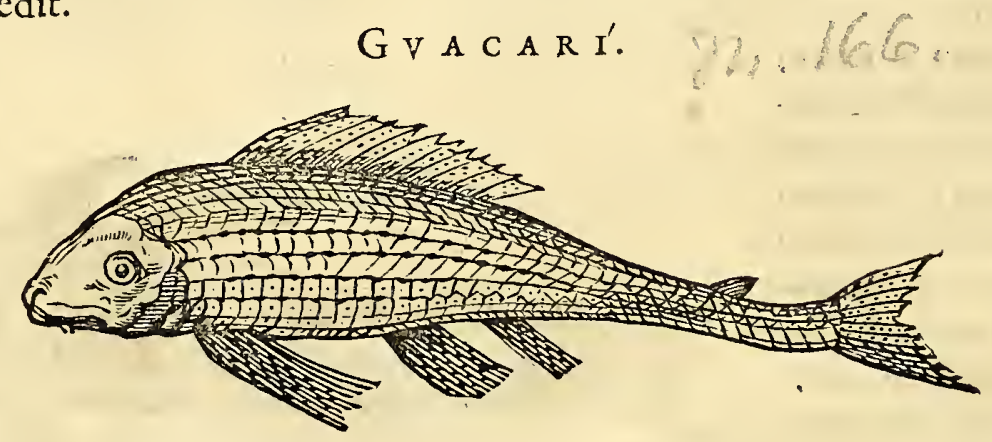

Dux fpecies Guacari in mari \& oftiis fluviorum capiuntur, figura pyramidali \& magnitudine circa pedali fibi fimiles, fed alimenti dignitate $\&$ colore difcrepantes. Omnes afperfi maculis obrotundis fufcis, feminis finapi magnitudine; fed illi quorum fquamx dilute croceo colore fplendent, paucioris funt carnis; qui vero umbra funt coloris, carnis præftantia cateris praferuntur. Omnium caput tefta veftitur dura \& hifpida, oculis \& ore parvis. loco dentium in utroque latere proceflus apparent quafi fetis equinis $\mathrm{f}_{\mathrm{a}}$ a pendent. 
HIST: NATVRAL \& MEDIC. I IB. III.

pendent. Pinnæ imprimis fuperiores fpinis offeis fuftentantur, quibüs alios pifces $\&$ pifcatores lædunt. Cauda conftant bicorni itidem fpinis firmis fuffulta. Ita ut totum corpushorum pifcium loricatum dici poffit, adeo ipłx fquamæ funt afper 2 , cum quadrangulari extuberantia in medio fui.

Detracta hac lorica hifpida, fublatifque inteftinis, (qux longifima, $\& x$ inftar fil $x$ qualis craffitiei funt) pifces coquuntur $\&$ affantur ex more incolarum. Frequentius in ufu funt divi Francifci rapidiffimi fluminis accolis, ficut quoque precedens pificis Carapó.

$$
\text { A I B A CORETT A. }
$$

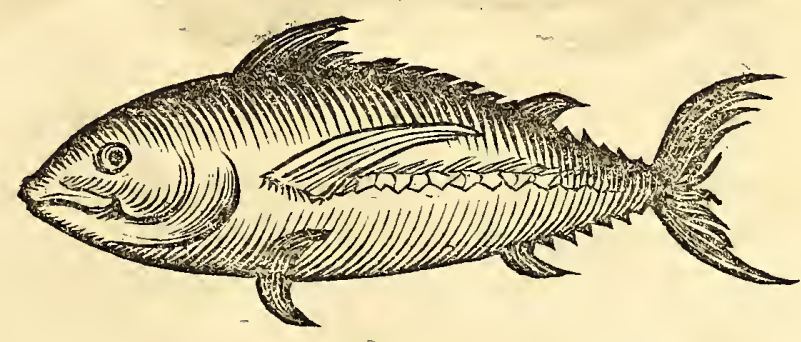

Inter Cetaceos gregales pifces altum mare incolentes non magnitudine folum, fed $\&$ carnis bonitate cclebres funť illi quorum aliqui à pube nautica \& pifcatoribus Coor$\sum \hat{z}$, aliqui Coretti dicti, qui omnes ejufdem quidem generis funt, fed diverf $x$ fpeciei ob magnitudinis \& molis differentiam: hi enim Afelli noftratium circa funt magnitudinis, optimi infuper palati \& boni nutrimenti. Cæruleis fquamis in dorfo, argenteis vero in ventre, ac proinde Albi Coretti vulgo vides.

\section{CoOrz A.}

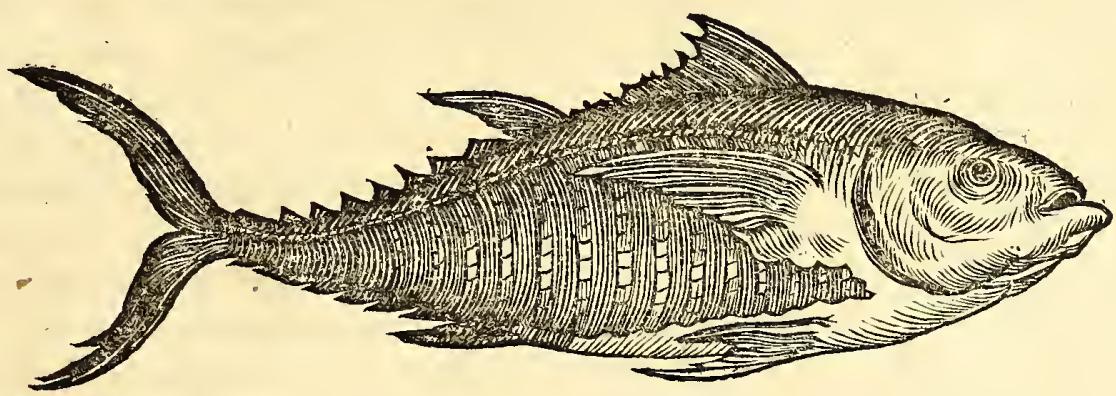

Atveroalterafpecies præcedenti fimillima eft fi figuram \& naturam examines; verum magnitudine multum ab ea differens; quippe fexdecim vel octodecim palmarum eft longitudinis. Pelamydim Amiarumque familix afcribenda, fi Ichthyographos confulas, adeoque cum iis participat, ut quantum ab aliquo eorum una corporis parte recedat, tantum alteri fua fimilitudine appropinquet, quafi perpetuus appareret naturæ lufus inter novi \& veteris Orbis animalia. Corporis enim capitifque ac caudx figura ad parvos Thunnos; fi ftrias nigricantes autem cxteraque externa confideres, ad Amias Pelamydefque potius referridebent: Squamis teguntur ex nigricante caruleis magnis (qux in coctione dehifcunt) fed ita ad amuffim compactis ut læves effe videantur. Sunt roftro acuto, ventre craffo, cauda tenui in figuram Lunx in cornua curvatx̉ definente; dorfo crruleo fplendente, ventre argenteo. Pinnas häbent duas branchiales, \& duas dorfales, totidemque in ventre, atque unam verfus podicem. Ventriculus, ficut in plerifque voracibus \& rapacibus folet, magnus cum infinitis appendicibus. Inteftina tenuiora. Lien nigricans. Hepar ex albo rubefcens. Vefica fellis hepati non folum fed toto inteftino annexa. Pifcatores teftantur, hos quoque Thunnorum morecertis temporibus œetto infeftari adeo dolorofo ut è mari exiliant aliquando in naves. Caro eorum eft multa, non f́pinofa, fuavis, ad flavedinẹm ver- 
gens, ficcioris $\&$ durioris fed multi nutrimenti, ac proinde à pube nautica admodum ex. petita. Si condiatur \& obfoniis aromaticis inftar carpionis apponatur antequam adoleverit, à delicatioribus minime̊ contemnitur.

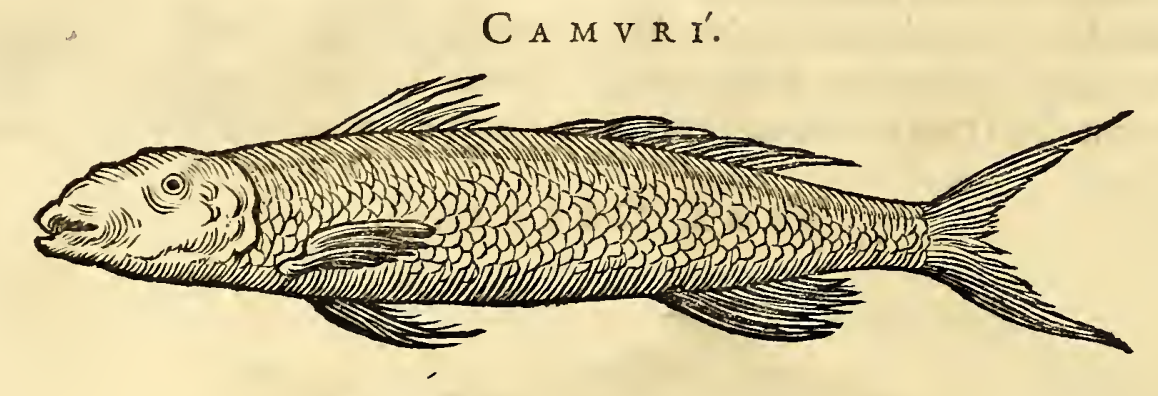

Diverfápecies Camurí, Lufitanis Robálo, noftratibus Snaeclit. Quorum illi qui dulcium \& ftagnantium tantum aquarum incolæ funt, Lucii Latinis, Brafilianis Picudo, vel qui inter eos maximi Camúripi dicti, adeoque Europxis fimiles externa figura, fapore \& qualitatibus alimentofis, ut nihil differ entix inter eos notare potuerim.quamobrem eorum defcriptionem \& iconem exhibere fupervacaneum duxi, lectorem ad Ichthyographos r emittens.

Illivero qui in mari nafcuntur \& oftia fluviorum fubeunt, Lupi Latinis, fed Indigenis Camuriapéba, \& qui majores, Camuri-guaçu dicti.quorum aliqui inter fe adeo magnitudine \& colore difcrepant, ut diverfæe fpeciei videantur. Frequentioris \& preftantioris iconem exhibeo qui à figura noftratium Luporum non multum abludit, ut neque fapore, nifi quod tota familia Luciorum \& Luporum Brafilienfium Europæos di. gnitate facile fuperat, xgrifque pariter ac fanis conveniat. Eft hic Lupus, magnus, fipiflus, fquamis veftitus ut Carpio argenteis, fed ventre albicante: dorfo, lateribus \& pinnis aurei coloris. In quolibet latere fuperius à fine branchiarum ufque ad caudam producitur linea nigra craffa. Capite eft oblongo, branchiis quaternis, oculis magnis, patulo oris hiatu ad rapinam compófito : loco dentium, offibus afperioribus palato conceffis. Pinnas habet octo. quarum prior in dorfo firmisfpinis, tenui membrana connexis, fuftentatur, \& in rima reconditur. Cauda eft longa \& lata atque furcata. Vifcera pro mole pifcis magna \& capacia; imo ab ipfo ventriculo, \& inteftinis longis, rapacitatis figna defumi poffunt, cum contrarium appareat in diffectione corum quilimo \& alga tanium vivunt. Bis anno parit focundiffime, imprimis ubi fluvii in mare influunt. Pifcium carne nutritur, eaque pinguefcit, ex cujus victus locorumque ratione in quibus degit fucci \& nutrimenti probitas facile colligitur. Hic cum inter Neptuni pecora vere Lupum fe præbeat, fubinde nimix voracitatis pœnas dat, quodfquillx devoratæa aculeo quem fronte gerunt, vifcera ejus faucient, \& 2 pari vindiata necantem hoftem interimant. Luporum optimi albifimaque carne funt pelagii , mox fluviatiles, deinde in ftagnis viventes, ad illud Galeni dictum, alimentum quod ex pelagiis Lupis provenit, fanguinem confiftentia tenuiorem gignere. Lapides qui in Luporum, ficut \& Tuberonum aliortumque multorum pifcium Capitibus inveniuntur, atque adverfus nephriticos conferre perhibentur, id cum doctiflimo Rondeletio fentirem à gravitate potius fua (quam omni fimili lapidex fubftantix ineffe comperi) calculum deprimente, quam ab occulta quadam antinephritica qualitate prodire.

Lupi diverfo condimentorum apparatu magnatum menfis imponuntur, nunc elixi, nunc affati, imprimis illi qui duorum pedum longitudinem vix $x$ quant.

Ova eorum condita quoque in pretio habentur : tunc enim non folum pro penu fed $\&$ deliciis refervantur, arque pro falfamento, loco Botárge ufurpantur. 
HIST. NATVRAL。\& MEDIC. LIB. III.

\section{R V S T A C E I P I S C E S.}

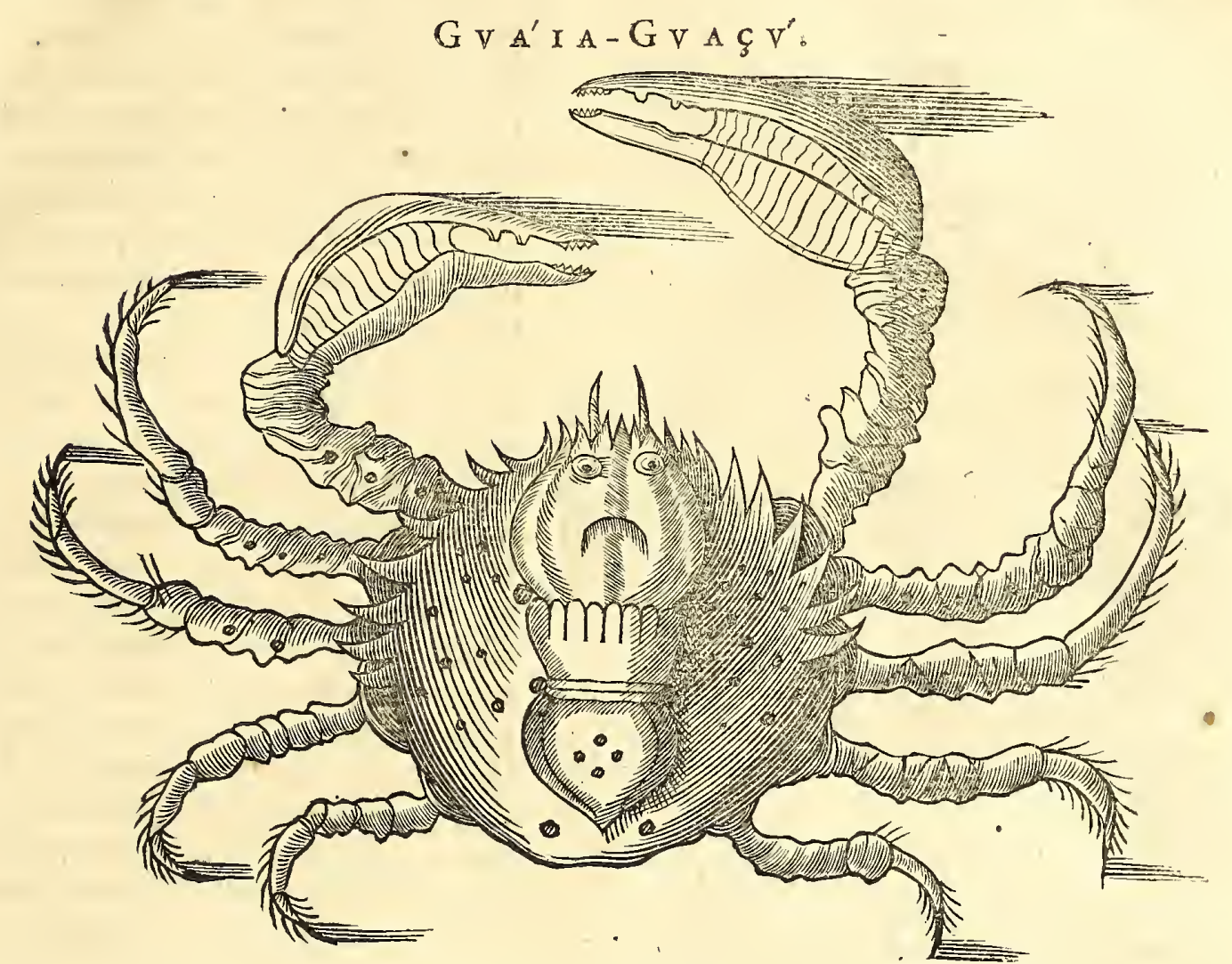

Tota provincia infinitis Cruftaceis pifcibus, imprimis Cancris aquaticis \& terreftribus fcatet: quorum aliqui medicamentofi, ut fuo loco probavi; aliqui alimentofi ; aliquorum qualitates latent. Ego ex multis paucos perftringam, qui in ufu quotidiano omnibus maris accolis funt. Compertum eft, hic quoque totum genus cruftaceum deponere tempore plenilunii antiquas cruftas more ferpentum, infimaque ventris parte erumperc, ut nova cl egantiori veftiatur.

Plures funt fpecies Guáia, quibus cognomina varia addita. Illorum qui fimpliciter. nomen Guáia audiunt, alii albicantes non edules, quos pretereo: alii edules, quorum. primam iconem hic exhibeo, utpote qui afpectu, magnitudine \& dignitate cæeteris facile fuperior, ac proinde Guáia-guaçú dictus, eoque magis acceptus, quod non adeo frequenter capiatur. Tegitur tefta elliptica, in ambitu multis exiguis corniculis, fuperius autem convallibus pradita. Odto eft pedibus cum quatuor juncturis cruris pilofis, unguiculis nigris, brachiis inæqualis longitudinis, forcipibus validis roftratis \& dentatis. Color totius cancri five vivi five cocti eft fature rubens. Multa \& grata eft came, qux optimx noftratium minime cedit, atque ingenti peregrinantium folatio exiftit: xgrotantibus quoque ex pectoris morbis multum profunt.

Sequitur Guáia-Apará, inter majores \& elegantiores variegatos habitus; tanta vi natans utper os aquam exfuflet, quafi ex fonte exiliret. Tefta lunata in utroque latere pófterius exfecta, \& in acumina definens. Colore eft obfcure brunno, \& macullis ex albo flavefcentibus, Atriifque brunnis eleganter variegata \& ornata. Pcdibus - eft octo, cim

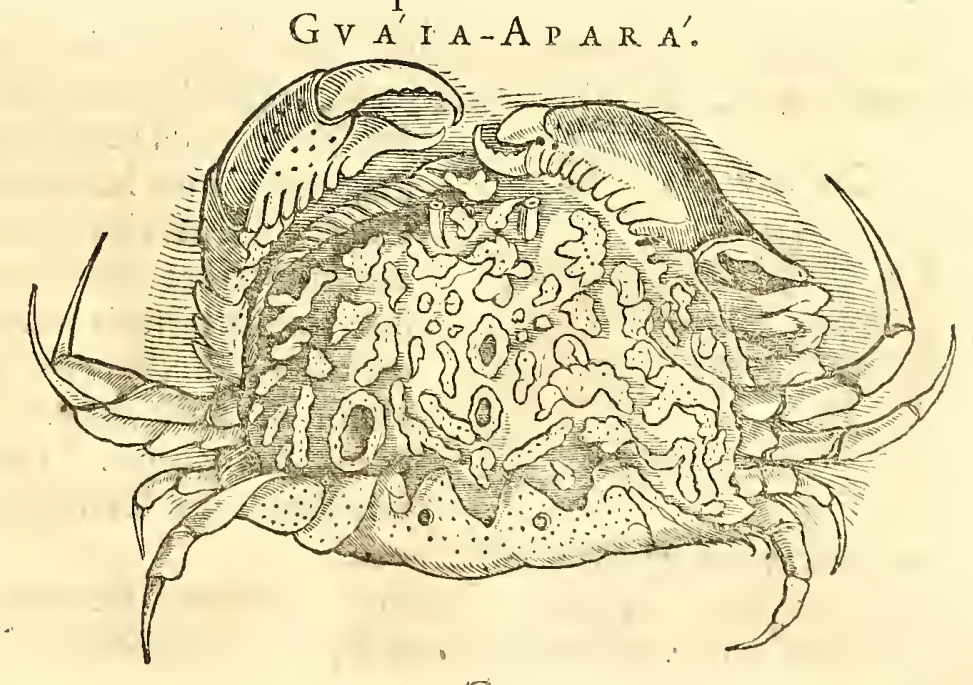

G 2

quatlor 
quatuor folidis internodiis; brachiis \& tenacul is Galli roftrum cum fua crifta reprafentantibus, ita ut Gefnerus merito tales Gallos marinos appellaffe mihi vifus fit:

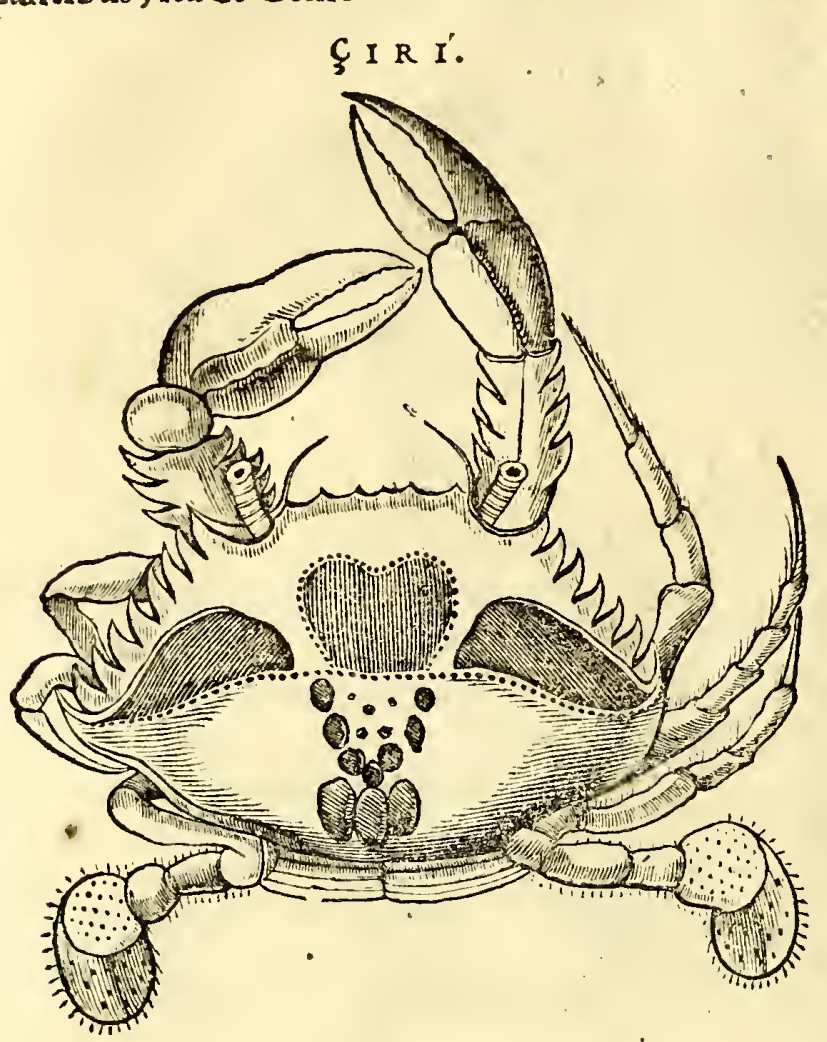

Inter Cancros marinos aliqui çirı generice nomen obtinent, \& addito cognomine diftinguuntur, ut çiri-o'bi \& şiri-sipoá, \& alii. Omnes hælpecies fundos aqux falfx obambulant, rarius ad littora prodeunt, nifi amore Ambræ grifex, quod è mari alluit, ideoque magno tan tum refluxu capiuntur.

(iri-Apoŕ, cujus iconem tantum exhibeo, eft Cancri mediocris magnitudinis. In teft $x$ meditullio nigricans cordis figura, aliaque ornate depicta funt. in ambitu ipfa tefta brachiaque dentata fufci coloris, forcipibus ex cæruleo albefcentibus. Crura fex ex albo \& viridi mixta: loco feptimi \& octavi cruris pofterius duo remiges partim cærulei,plani, hirfuti, quibus natando curfum potiffimum dirigit. Oculis eft parvis prominentibus \& longe à fe invicem diftantibus. Corpus interius cærulefcit. Caro eft optimi faporis, nec facile nocet ventriculo, etiamfimulta quantitate ex aceto comedatur.

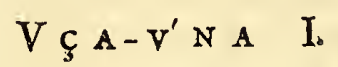

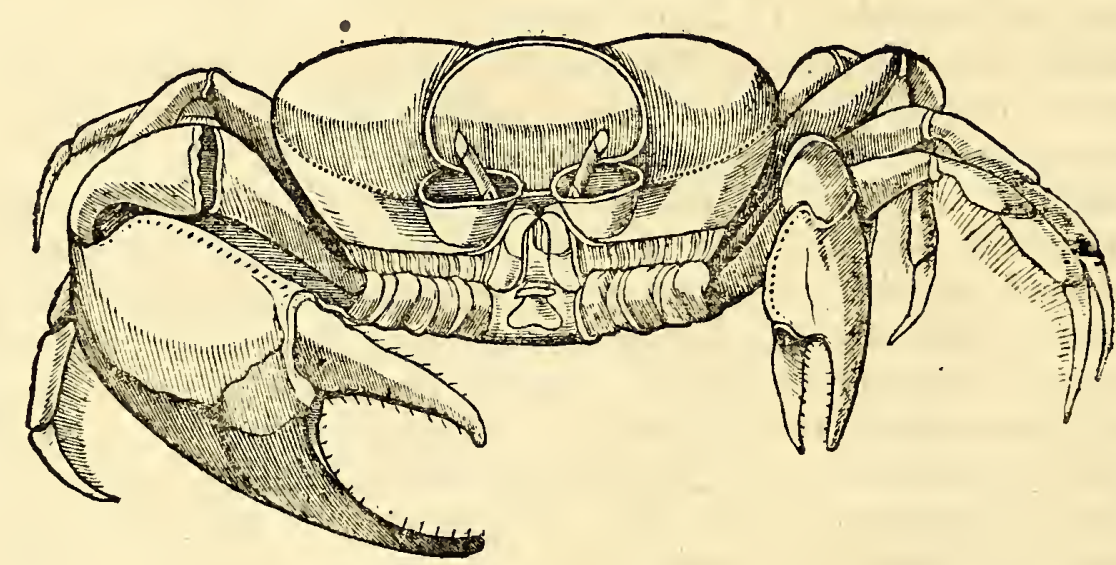

Varii paluftres variæ magnitudinis Cancri dantur, interque eos maxime ufuales $V_{c ̧}$ nomen audiunt. Ego illos tantum exhibeo qui $V c ̧ a-u ́ m a, \&$ cujus fæmella Cunurúdici-

$C \vee N \vee R V^{\prime} I I$.

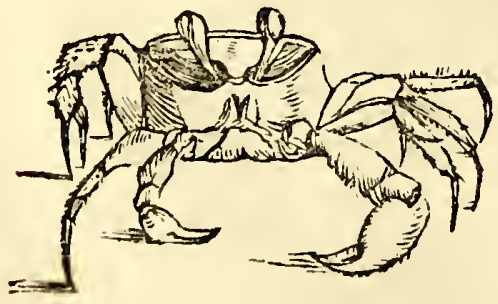
tur. V terque eft bona carne, fed mas fomina multo major \& minus hirfutus, ficut ex Iconibus apparet. Corpus illi eft ellipticum, fuperius convexum : $a b$ utroque latere cruribus quaternis, totidemque eft internodiis hirfutis caltanei coloris : oculis flavefcentibus cylindraceis, quos erigit \& recondit. Brachium dextrum cum fuo forcipe, grandius finiftro, $\&$ interius acutius. Tefta eft coloris olivacei, inferius flavefcens. Carne funt fatis probabili, nec potui animadvertere niar inis dignitate cedere.

Inter minores Marinos Cancros Maracoani cenfetur, qui corpore eft quadrato, fulvi coloris, cruribus octo, rarifque pilis fufcis veftitis. Brachiis eft duobus, fed 
HIST. NATVRAL. \& MEDIC. LIB. III.

adeo magnitudine difcrepantibus, ut finiftrum minus fit uno è pedibus : cum è contra dextrum adeo fit magnum, ut totum corpus poft illud abfcondere poffit. Forcipe itidem eft admodum lato, extuberantiis prædito. Oculis fibi invicem oppofitis longis \& eminentibus, inftar aciculx tenuibus, quos momento erigit, $\&$ in rima rurfus recondit. Edulis eft, atque boni nutrimenti, fed pracedentibus dignitate inferioris.

Tandem ex terreftribus unum promam, eumque facile præftantiorem, Guanbumi ab Indigenis vocatum.Is corpore eft rotundo. Cruribus octonis pilofis fibi æqualibus, quatuor internodiis diftinctis. Brachiis eft duobus, fed dextro multo major finiftro. Oculos altiffime erigit, atque momento in longa cavitate abfcondit. Turmatim antra fub vefpcram deferunt pabuli gratia, \& filvas paludofas cum magno ftrepitu oberrant, infequentefque non raro evadunt, quod celerrime currant, \& quidem tranfverfim:

MARACOAN $x_{0}$

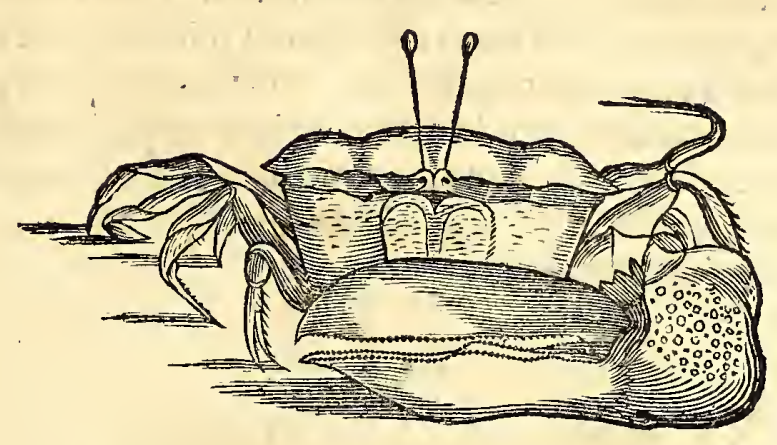

G V A N H V $\mathrm{V}^{\prime} \mathrm{I}_{\mathrm{b}}$

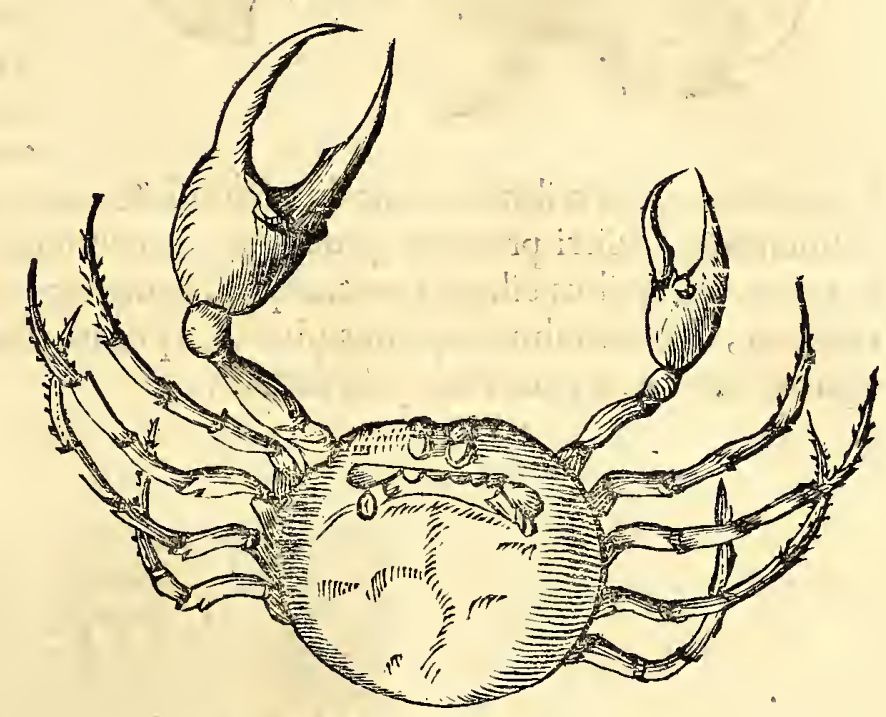

tuncque oculos ad latus convertunt, brachio longiori utcunque elevato. His vefperibarbari non folum, fed \& milites infidiari amant. quodque adeo bona fint carne, integris cohortibus fufficienti funt fuftentaculo.

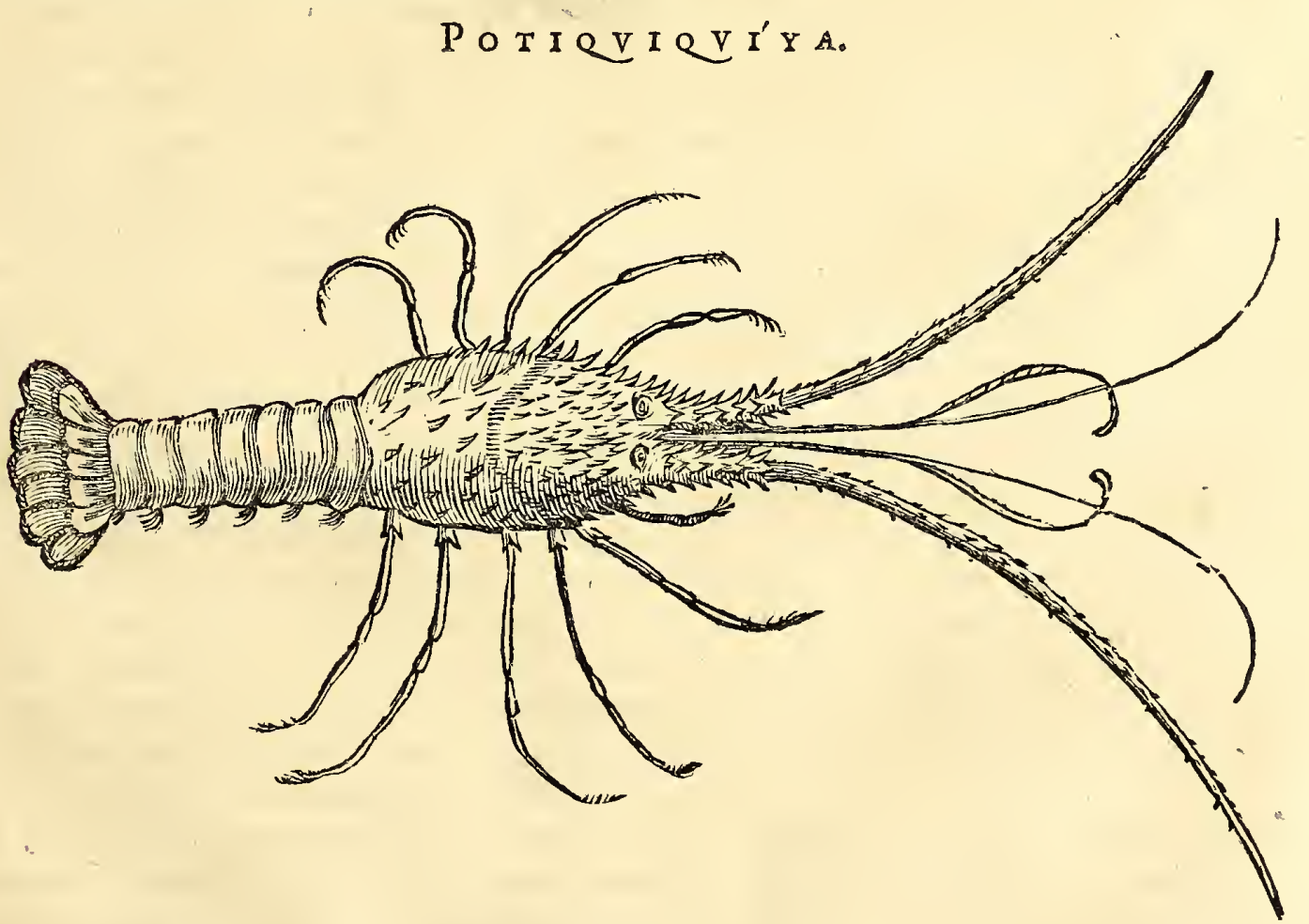

Locufta Potiquiquía crebro ad nos è mari \& oftiis flitviorum defertur. Tefta ejus frequentibus eminentiis inftar corniculorum acutorum anterius fcatet. In quolibet 
latere quinque habet crura, totidem internodiis diftincta. Quodlibet crus unguem habet incurvum, acutum \& pilofum. Oculi prominentes cylindracei: ante eos, fupra os, quatuor cirri exortum fumunt fpinofi, inter quos duo minores teretes non fpinofi, ac ultra medietatem bifccti. Pofterior pars corporis feptem juncturis fibi invicem appofitis conftat, cauda definente in quinque pinnas. Tefta tota cocta fanguinei fit coloris, ejufque caro xque in pretio habita apud magnates ut noftratium; à quibus cum neque fapore neque alimentofa qualitate difcrepare animadverterem, ulteriori defcriptioninon inhæreo.

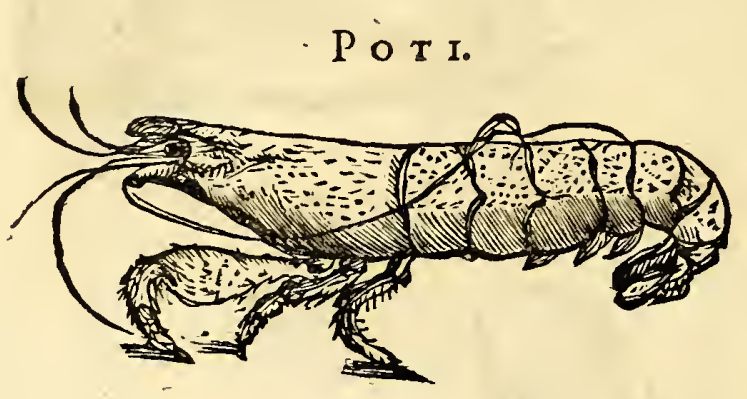

Varias Gammarorum fpecies fuppeditat Brafilia, quorum aliqui in teftis habitant, fed minus expetiti ; aliqui fine conchis degunt, $\&$ generali nomine Poti exprimuntur. Ille autem qui Guaricurú nomen audit, elegantia $\&$ dignitate cæteris facile fuperior, cujus iconem tantum exhibeo. Vulgo Camaraon dicitur, qui fufci eft coloris,

fex cruribus cum tribus internodiis fpinofis \& aculeatis, unguiculis in extremitatem definentibus. Cirri prope os prodeunt, quorum duo longiffimi, quatuor breviores $\&$ tenuiores, quibus cibum tenet, atque frequenter ex fluvis \& maris littore, omni fere tempore, fed menfibusimprimis pluviis, à pifcatoribus ad incolas deferuntur. Cocti optima funt carne, nec Europxis cedunt.

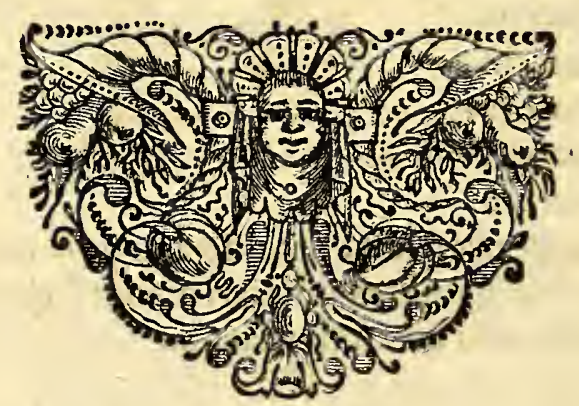




\section{S E C T I O S E C V N D A.}

\section{Que agit de Arvibus.}

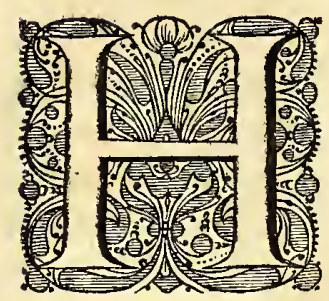

Actenus de Pifcibis,nuinćde Avibus àgendium. Quod antequam aggrediar, operx pretium erit, de carum indole \& conformatione pauca in genere præfarier; Miffis Gallinis \& Columbis aliisque Palmipedibuis huc ex Europaillatis, quæ haud magnam fubeunt in melius vel in pejus mutationem : nifi quod in calidioribus hifce regionibus prolific 2 magis fint, atque incubatus minori temporis fpatio foleat abfolvi quam apud noftrates.

De indigenis itaque Brafilix Volatilibus potiffimum dicturus, quantum inter fevarient, \& quantum cum veteris Orbis Avibus aut difcrepent aut conveniant. Si diverfitatem plumarum, $\&$ colorum elegantiam, fpectes, nullis totius mundi Avibus cedunt: verum cantul longe ab Europæis fuperantur. Vt quxdam cicuratœ ædes quidem garrulitate, ita filveftres clangoribus inconcinnis nemora refonarefaciunt, fed vix alterutras grato aliquo modulamine aures demulcere compertum eft. Menfibus pluviis maxima earum pars pinguefcit, ob fructuum \& vermium ubertatem. Menfibus xftivis ad ripas fluviorum convolant, cibi, aëris \& aqux captandæ caufa, ac plurimæx tunc ripariæ evadunt, ibique dum fecure apricantur caffes aliafque aucupum technas haud facile evadunt. Pauciores quæ roftro vel unguibus funt armatx, hoftes fuos minus extimefcunt, atque in cavitatibus arborum, vel humi, fe fidunt; verum pluri$m æ$ in fummitatibus altarum arborum, ramorumque extremiratibus ad ferpentum infidias eludendas mirum in modum nidificant. Pro penuria aut abundantia alimenti, ut abitus fic reditus tempora obfervant ad loca vicina. tantum vero abeft ut mare tranfvolent, aliafque diffitas terras vifitent, ut ne quidem hujus Continentis mediterranea verfus Peruviam unquam penetraffe compertum fit'; quod adeo immenfa fint interpofita fpatia, ut ipfos avium volatus fatigare dicantur, omneque cum Peruvix tam animantibus quam hominibus commercium fecludant. Palmipedes amphibix agreftes \&. domefticx, lacuum \& fluviorum alumn $x$, ob perpetuas virefcentes herbas paluftes, montanis dignitate non cedunt.

Omnianni tempore ob infignem aëris temperiem calidam \&humidam pariune. In minoribus vero (quarum pleræque quotannis tantummodo femel ova ponunt) vix ovarium reperire eft: in majoribus ovaria, pariendique tempora, ex confuetis naturæ legibus fe habent. Avibus fere, omnibus, ut in diffecando videre contigit, duplex quafi ventriculus à natura conceffus eft. Quorum alter ingluvies in infima colli parte hæret, ut facilius cibum maceratun pullis regurgitet. Alter, ventriculus proprie diCus, intra abdominis capacitatem, infra cor, pulmonem \& jecur fitus', ex duobus vel tribus præter morem adeo validis \& ligamentofis mufculis compactus, ut mirum non fit, multa duriora \& afpera facile atteri, imo ipfos calculos in eo levigari. Inteftina à ventriculo fuperius orta fecundum longitudinem furfum $\&$ deorfum utcunque replicata funt. Felle, licet minori, 'omnes majores aves praditz, quamvis fitus \& color fubinde varient; In minoribus vero, quantum vifu confequi licuit, fi non ipfum fel, faltem porus cholidochus apparuit. Vreteres \& renes, quod cum pace veterum philofophorum libere pronuntiaverim, plerifque conceffi. Vefica autem carent, ni fallor, omnes, quod dum pitiffando bibant, parvaque in is redundet urinx copia, lotium in communem alvum cum ficco excremento deponant. adco fcilicet placuit naturx, ut ne quid neceffarii deeffet vel redundaret fuperflui. volatilibus enim in aëre pendul is oneri fine dubio fuiffet vefica urina diftenta.

Primo fe offerunt diverfa: Phafianorum fpecies, prate cxteris avibus vefcis, primatum facilc obtinentes. Licet enim circa ciborum electus \& victus rationes tres conviværaro confentire videantur : attamen cujufcunque terrx incol $x$ vel mediocriter tantum palatum docti, in teneritate \& nóbilitate eorum carnis, facile convenire crediderim.

$$
\text { G } 4
$$




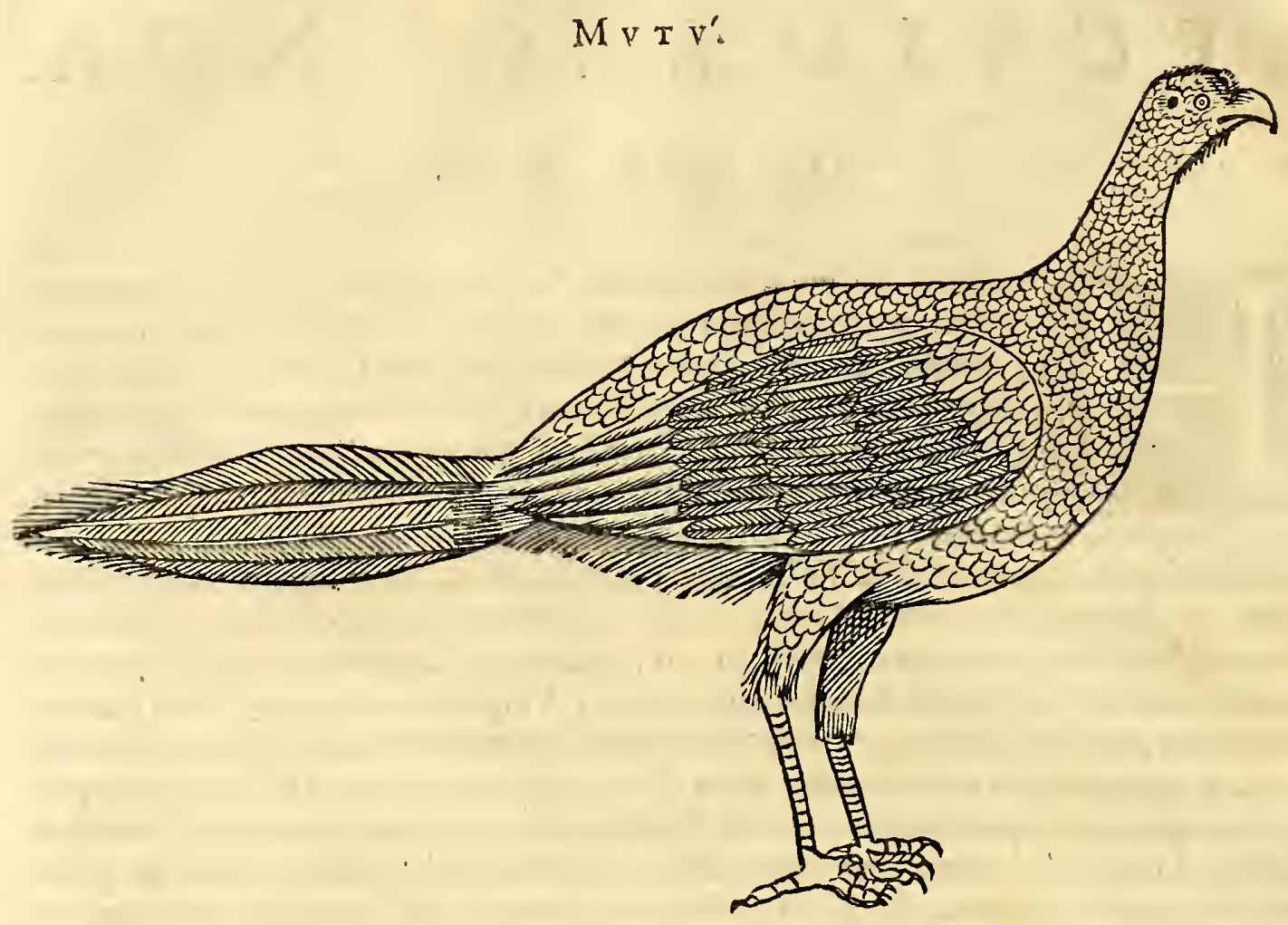

Si in celebri hac ave Mutí carnis teneritatem \& excellentiam confideres, ex phafianorum eft genere: quibus etiam figura \& colore haud multum diffimilis; quamvis non pauca in eo concurrant circa indolem \& conformationem corporis, unde Pavoni comparari poffit. Tota avis fplendet prenigredine, cui hinc inde aliquid viridis tranfplendet, cum albis pennis in cauda. In fummo capite ex nigris pennis quafi mirellam gerit.Roftro eft egregie incarnato. Oculis magnis nigris. Cruribus gallinaceis. Cauda longa inftar Gallo-Pavi, quam erigit \& extendit. Lubenter quoque Pavonum more in tectis vel arboribus confidet, alteque clamat Racuá Racuá. Carnis probitate quoquo modo preparata, imprimis affata, nulli avium Americanarum nec Europæarum cedit , ac proinde apud optimates ob dignitatem atque elegantiam cicuratur \& alitur.

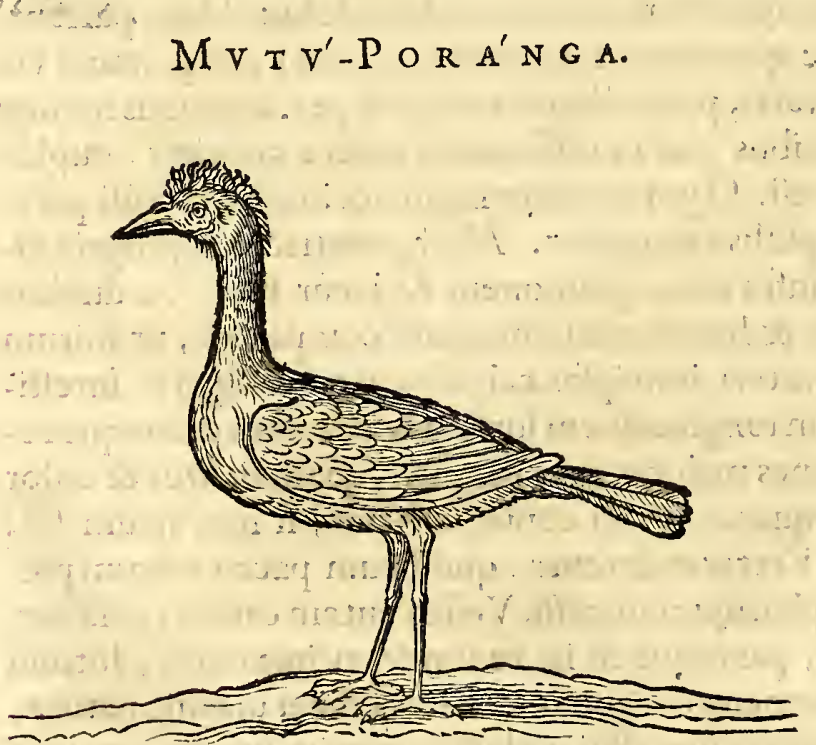

Reperitur \& alia ejufdem fpecies, cujus Iconem hic appono, quam Mutí-Poránga vocant. Qux licet magnitudine precedenti Mutú cedit, dignitate tamen carnis illi par eft, \& indole plane fimilis, roftro potiffimum \& pennis capitis differens, quiod hæc roftro fit recto; \& nigro. in extremitate, in exortu vero crocei coloris: A fummitate capitis ad colli initium nigerrimis pennis, inftar holoferici, cochleatim tortis, decoratur, precedentis Mutu multo majoribus \& elegantioribus, quas in criftam crifpam erigit. Hxc ut \& cxteræ Phafianorum \& Perdicum fpecies, pectoris carnem, prx cxteris partibus corporis, habent magis albicantem, ficut Europxi ; eodemque modo cicurantur \& faginantur cavea inclufi. Preterea ficut Europxi ; eodemque modo ciltis aliis negatum eft) ingluvies ventriculo pr $x$ nobilon qux femefum $\&$ crudum cibum prius recipit, quafi aliquid fimilitudinis cum suminantium animalium genere haberent. Ova illis funt grandia, dura \& alba.

Tertia 
HIST. NATVRA.L. \& MEDIC. LIB. III

Tertia Phafiani fpecies, medix eft magnitudinis intra duas præcedentes, Iacu-Pema dicta. Quodnomen fortaffe accepit à fuo clamore, quia adeo alte clamat Iacu Iacu, ut meminerim per deferta cumperegrinarer, ipfa nemora refonuifle à multarum clamoribus gregatim volitantibus. Gallina domefticx nigrx fimilis eft, ejufque plus minus magnitudinis, multafque cum ea partes corporís communes habet; nifi quod cauda fit longiori, pedibus $\&$ cruribus magis rubicundis, $\&$ longis, ftaturaque erectiori incedat, tum quoque verticis plumas in crifte modum erigat. Caro ejus $I \cdot A C Y-P E \cdot M A$

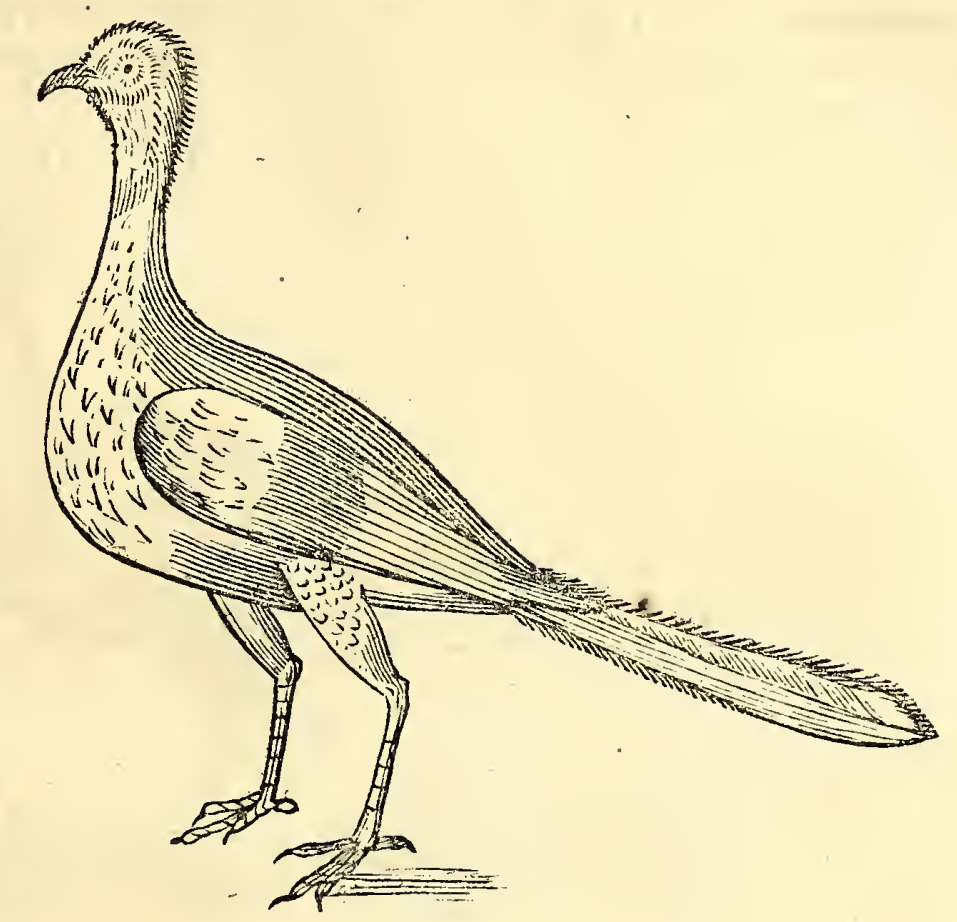
præcedentium carniguftu \& nutrimenti præftantia non cedit: quamobrem fupervacancum puto; dicta repetere.

Poftquam de diverfis Phafianorum fpeciebus egimus, merito füccedunt Perdices Iambí dictx: Q uarum dure in filvis littoralibus dantur fpecies, majores, $\&$ minores. Hx magnitudine noftratibus cedunt:ill $x$ figura carnis mole \& 2 prxftantia, Europxis Perdicibus pares funt. Vtriufque penne funt per totum corpus obfcure flavefcentes, verum fufco mixtæatque maculatæ̈.

Cætera qux ad Perdicum noftratium indolem, carnifque teneritatem, atque vifcerum conformationem pertinent, adeo hifce Brafilienfibus quadrant, ut vix quicquam folidi à me huc adferri poffit, quod non antea ab Authoribus Ornithographis fatis fuperque enarratumfit.

Egregia hxc avis filveftris Cariamá ex aquaticarum quoque eft genere, udofifque locis ob prædam delectatur more Ardearum, quas mole corporis non folum, fed \& carnis dignitate longe fuperat : quafi peculiare effet hifee calidioribus regionibus, ut aves aquaticx pleræque montanis non fint dignitate inferiores : fed è contra teneritate catnis ipfis rifticolis Europxis aquaticis facile pares inveniantursinter quas cenfetur hæc Caramá. in exortu roftri adunci flavefcentis criftam plumatan nigricantem ercctamgerens, oculos habens aureos: Totum corpus pennis veftitum grifeis fufco undatis more Falconum. Cla-

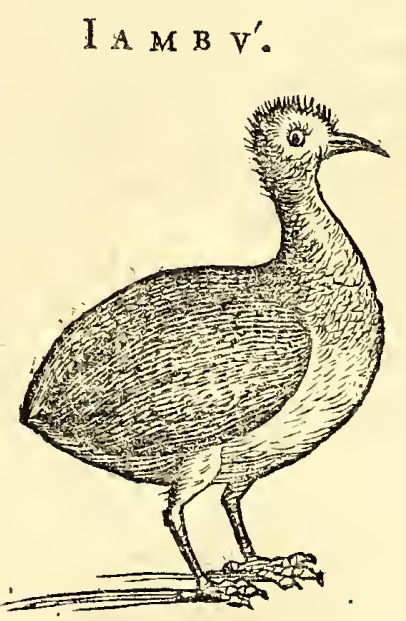

CARI A M Á

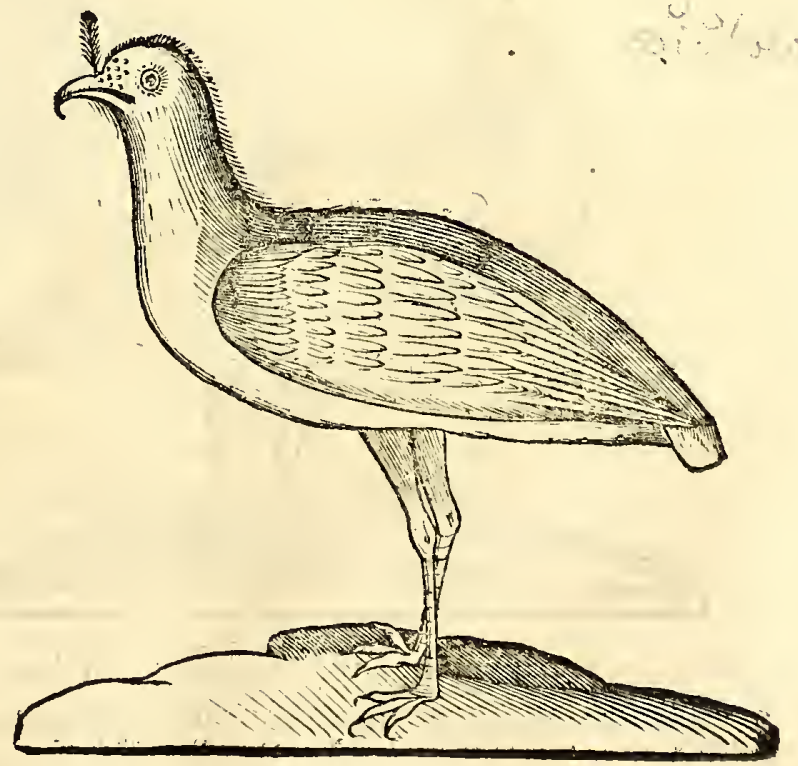


mor eft inftar Gallo-Pavi fæminæ, \&longe infilvis auditur fuo equidem malo; quod. aucupes convocet. Toto fere anno probatiflima eft carne, $\&$ ab optimatibus inter primas delicias expetita. Manfuefacta æeque ac filveftris affatur $\&$ coquitur.

\section{$C A R A C A R A^{\prime}$.}

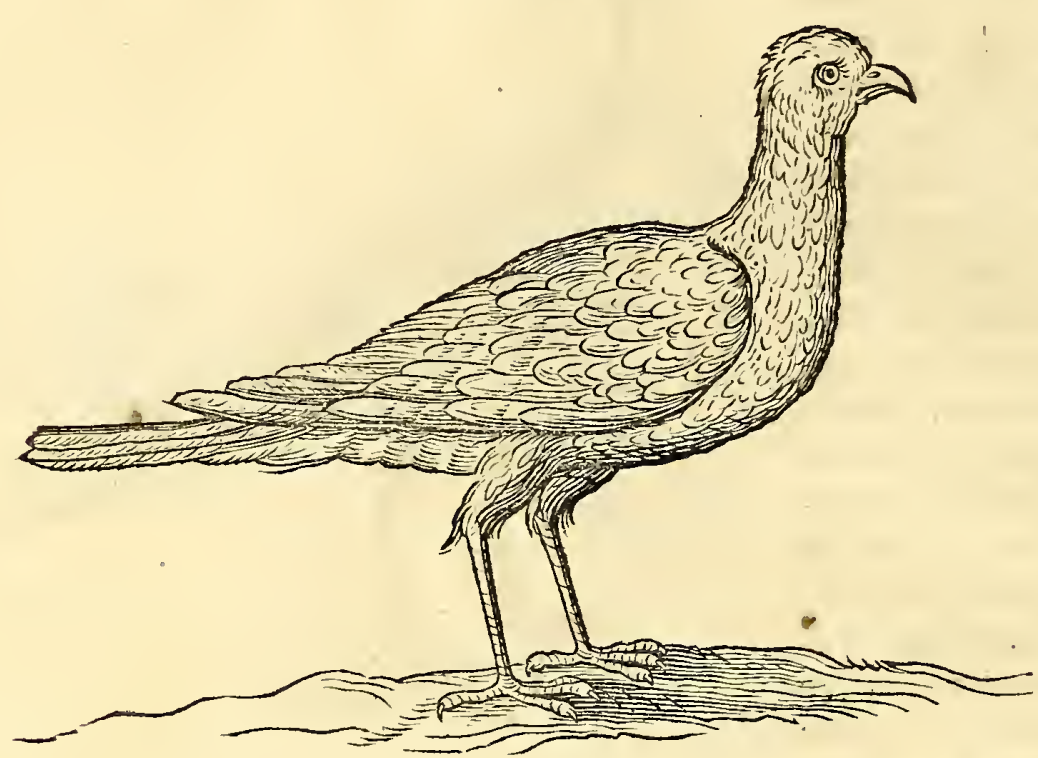

Licet Caracará Accipitris fringillaris frve Nifi habeatur fpecies, quæ Lufitanis Gaviaon dicta: tamen non inter vere rapaces cenfetur. Palumbis, Turdis, Columbis \& Gal linis infefta, quibus perpetuo infidiatur, \& facile potitur, quod vifu, volatu, unguibus $\&$ roftro firmis, acutifque valeat. Carne eft fatis laudabili, imprimis fi juvenis fit. Egregia eft avis, cauda exalbo \& fufco variegata. Pennis ravi coloris cum albis \& flavis punctulis.

Aliæ præterea ejufdem fpeciei exiftunt, præltantia carnis præcedenti pares, figura quoque externa illi haud multum abfimiles, qua ab Indigenis Teguato \& Inaio diatx. In hifce, cxterifque plurimis exdem appendices five inteftinorum diverticula inferne confpiciuntur, qux paffim in noftratium avibus deprehenduntur.

IPECA TI APOA'。

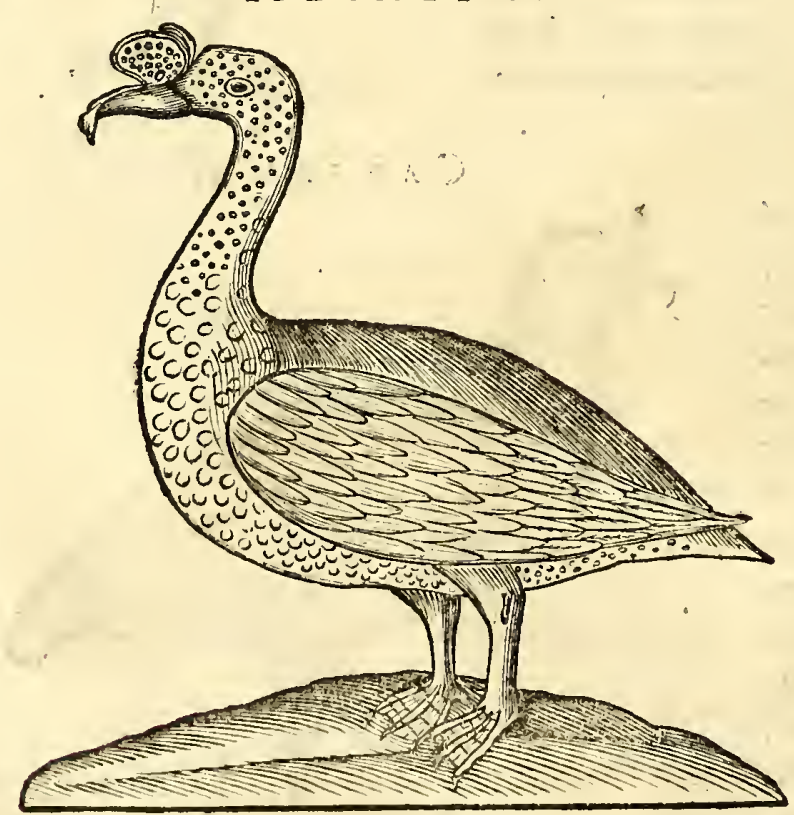

Inter tot diverfas Anatum \& Anferum Brafilienfum fpecies hæc Ipecati Apóa principatum facile tenet, quas Lufitani uno nomine Patos nominant; ad Anates filveftres Indicas referend $x$, etiamfi ad Anferum pane magnitudinem accedant. Omnes egregie variegatis funt pennis ficut noftrates Anates domefticx, à quibus, ut corporis mole, ita \& pedum colore fufco, roftroque adunco \& nigro, differunt; imprimis autem crifta carnea, canis albifque maculis infignita. Foramen juxta criftam roftrum

perforans quod narium vice fungitur, in hac imagine à pictore non expreflum eft. Cariac funt multa \& pingui, noftratiumque teneriori. Inter aves amphibias palfripedes primatum tencint. Facili negotio figuntur in altis arboribus confidentes, 
HIST. NATVRAL. \& MEDIC. LIB. III.

quas poftlotionem in aqua frigida fubeunt captandi aëris caufa. Idem de indole $\&$ carnis prætantia cæterarum Anatum filveftrium minorum dictum volo, quarum alix criftam plumaceam gerunt, alix fine criftis funt, qux omnes nomen Barecá audiunt. Hanc aliafque aves hifce affines fine ingluvie, fed cum gula capaci inve.. ni. Penem prater modum longum rigidum circumfert, donec fœminam five in terrafive in aqua reperiat, quam oppreffam adeo fine motu tenet, acfi ambo clavo in coitu affixi effent; folummodo mas capitis gefticulatione, \& crebra anhelatione voluptatis fenfum exprimens. Ita ut inter fumme falaces aves hre Anatis fpecies recenfeatur.

Sequitur domeftica palmipes zpeca-Guaçú dicta, ob carnis bonitatem celebris. Mole \& figura corporis medix magnitudinis inter Anates \& Anferes noftratium. Cæterum pennarum \& colorum elegantia utrumque fuperans. Roftri extremitate ad medietatem eft flavefcente; mox rubra macula mediam partem capitis egregie tingente. toto corporeà vertice ad caudam albo colore Cygniinftar nitefcit. pedibus eft anatinis

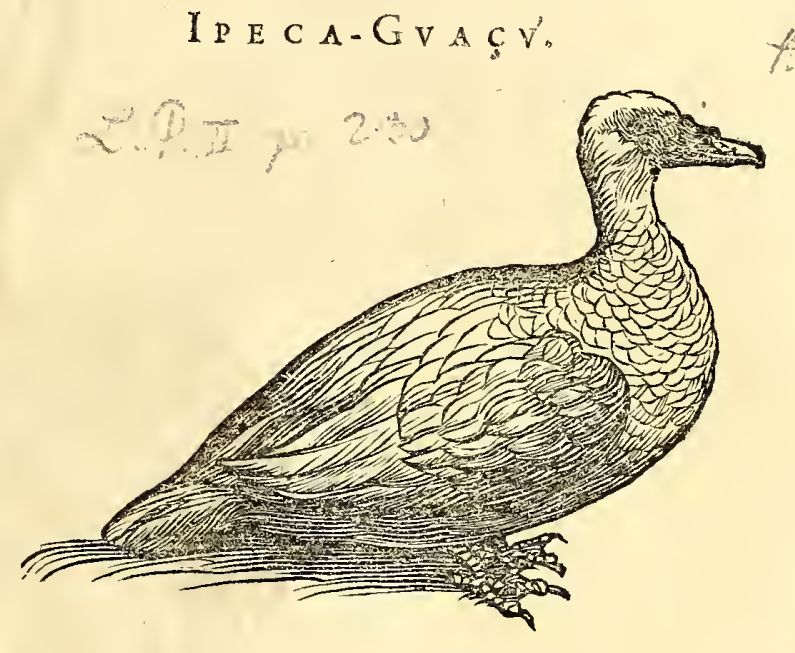
ex flavo rubefcentibus. Pinguefcit xque in terra ac in ftagnis. Dignitate carnis, Anatibus noftratibus fimilis, \& apud magnates in pretio habita. Cxterum fertilis eft avis: magna 8 multa ponit ova, omni fere anni tempore incubatum brevi abfolvens. Salax quoque hæc fpecies. Mentula cxterifque partibus internis generationi dicatis præter morem validis \& magnis. Cretera vifcerafolitæ conftitutionis ficut in noftratium Anatibus.

M A I A G V E'.

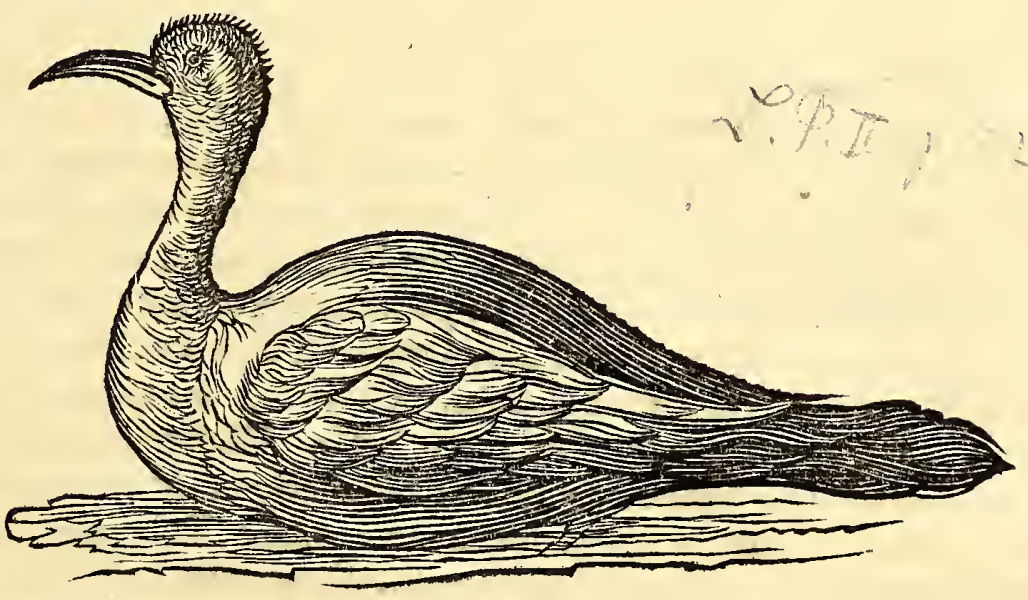

Maingue in familiam quoque edulium palmipedum fed marinorum ferorum recepta. Anferis eft magnitudine \& figura. Cxterum magnis illis Mergis nigris noftratibus non diffimilis, adeoque adunca parte roftri extrema ad rapinam pifcium compofta , ut Corvum aquaticum Gefneri æmulari videatur. Capite eft craffiufculo \& rotundo. Oculis paulo fulgentibus, collo oblongo \& ornate Cygni more incurvato. Tota avis fufci \& fubnigricantis eft coloris, colli tantum parte anteriori flavis plumis deVelox eft natatrix \& Velox eft natatrix \& vrinatrix, atque aucupum infidias eludens. Carne eft eduli \& 
bona, imprimis fi juvenis fit, fed quod perpetuo pifcivora, à quibufdam contemnitur.

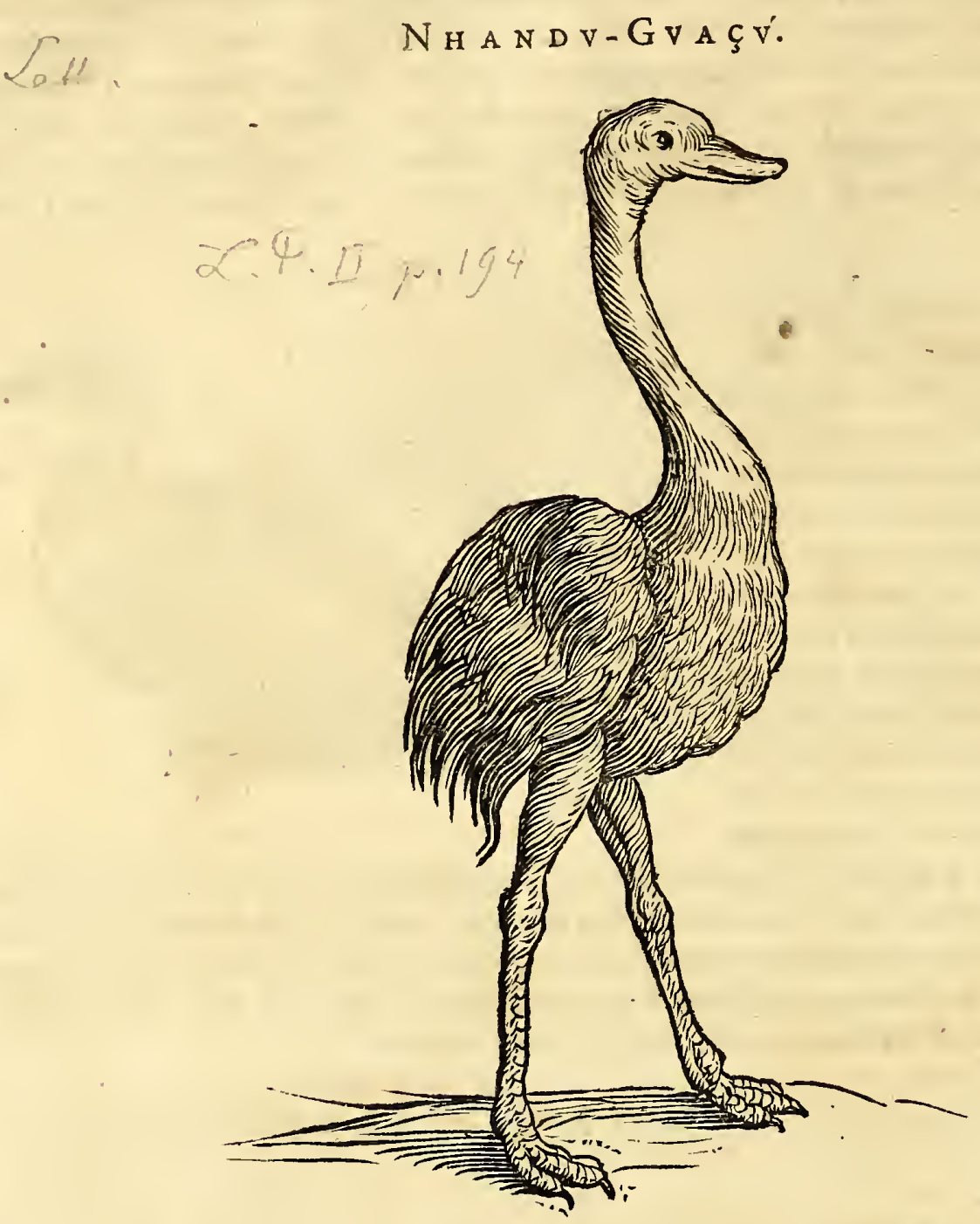

Diverfx magnitudinis Struthiones hic reperiuntur, ita tamen ut maximæx Africanis minores aliquanto exiftant, Nhandu-Guaçú Brafilianis, Ema Lufitanis dißzx. Rarius in diftrictu hoc Paranambu cenfi, fed frequentius paulo verfus Septentrionalem tractum fluminum ripas obambulant. Cxterum ejufdem cum Africanis funt figur $x \&$ indolis. Ferrum quoque $\&$ lapides deglutire amant, eaque inconcocta $\&$ integra per anum reddunt. Tres habent in pedibus digitos anterius verfos, unguibus nigris, craffis, haud acutis ; pofterius unum digitum fubrotundum, groffum, unde difficulter inarealæviaut tabulato incedunt. Collo funt incurvato olorino, capite anferino, oculis elegantibus nigris, roftro compreffo. Alis funt parvis, ad volandum quidem ineptis, quarum ope tamen alteram inftar,veli erigunt \& expandunt, adeoque curfum promovent non folum ut gregarios canes evadant, fed, quod mirum vifu in vafris his avibus, alterutram alarum diftendendo, dextrorfum \& finiftrorfum ita curfum dirigunt, utbarbarorum tela eludere norint. Cæterum plumis per totum corpus grifeis inftar gruis, in dorfo longioribus \& elegantioribus cooperiuntur. Caudx vero non funt cjufmodi criftis præditæ, ut Africanæ vulgo pinguntur. Plumis per dorfum expanfis ad anum ufque, fed ignobilioribus $\&$ minus elegantibus. Ponunt ova, ut cxterx Struthiones, fed minora, eaque in arena fovent, maribus is feduincubantibus. Salaces funt admodum, mentulamque aliquantum aduncam vibrant $f x p e$, donec reperta foemella eam rigidiffime ineant, fuppreffanque diu immobilem teneant. Carne \& fructibus opti mis, tum quo que pifciculis ad ripam alluentibus vefci amant, ipfique Ambræ grifex non parcunt, fi ea ad littora potiri queant. Cane funt fatis probata $\&$ folida, noftratium olorum \& anferum $æ$ mula, quamobrem inter alimenta $a b$ incolis expetita.

Pfittaci 
HIST. NATVRAL. \& MEDIC. LIB. III.

Pfittaci Afiatici, Africani \& A mericani, toti orbi ob garrulitatem ac colorum elegantiam, non vero ob guftus $\&$ nutrimenti præftantiam, celebres. Qui licet dictarum regionum fervidiorum alumni, nullibi tamen putem tantam copiam $\&$ varietatem dari quam in Brafilix mediterraneis : quos communi nomine Aiurú \& Aráca; minores vero Tuy', vulgo Perroquet vocant. V traque fpecies edulis catervatim femper volitant, nimirum bini ac bini, al toque $\&$ ingrato clangore filvas refonare faciunt. Vt enim plerafque Brafilix aves incredibili colorum pulchritudine vifum quidem ; ita nullam fere cantu. auditum demulcere, alio loco proba$\mathrm{vi}$; Pfittacis autem folis prærogativa conceffa videtur ut feliciffime garrire,imo tanquam ratione praditi, cum hominibus colloqui difcant. Mirandumfane, invafta hac folitudine \& barbarie, ubi tam craffa brutalitas ipfos homines occupat ; Pfittacos tamen \& Simias adeo cxteris animalibus non folum prælucere docilitate, fed \& humanos geftus \& collocutiones ad amuffim imitari ac xmulari. Omnis generis $P$ fittacis lingua eft lata $\&$ craffa , cum folidiffimis præter morem ligamentis \& nervis, quafi perpetuo motui \& garrulitati faventibus;ita ut merito Pfittaci à Græcis etiam áv-

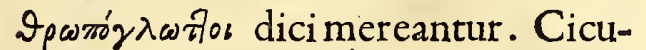
ratus unus atque alter (quem domeftico meo cuftodiendum dederam) fapius de nocte fe ipfum expergefaciens, vel à nobis appellatus, femifomnus fublocutus eft, unde conftitit, non falfum effe quod $S$ caliger in Ariftot. de Aquilis venaticis aliifque avibus teftatus eft, fcilicet ea animalia qux ova pariunt non folum dormire fed \& fomniare.

In diffitis nemoribus altiflimas occupat arbores tota pfittacorum familia , unde temporius exipfis nidis eximuntur ut garritum humanum addificant. Nam ubi adoleverint, manibus fe tractari haud permittunt. Mediterranei Barbari, tot elegantiffimis Pfittacorum coloribus non contenti , eos deplumant, cutemque variis tincturis inficiunt, quibus portea ad pompam fefe exornent. In cavis arboribus nidificant, ubi foramen ex-
$A I V R v^{\prime} \& A R$ A $A$.

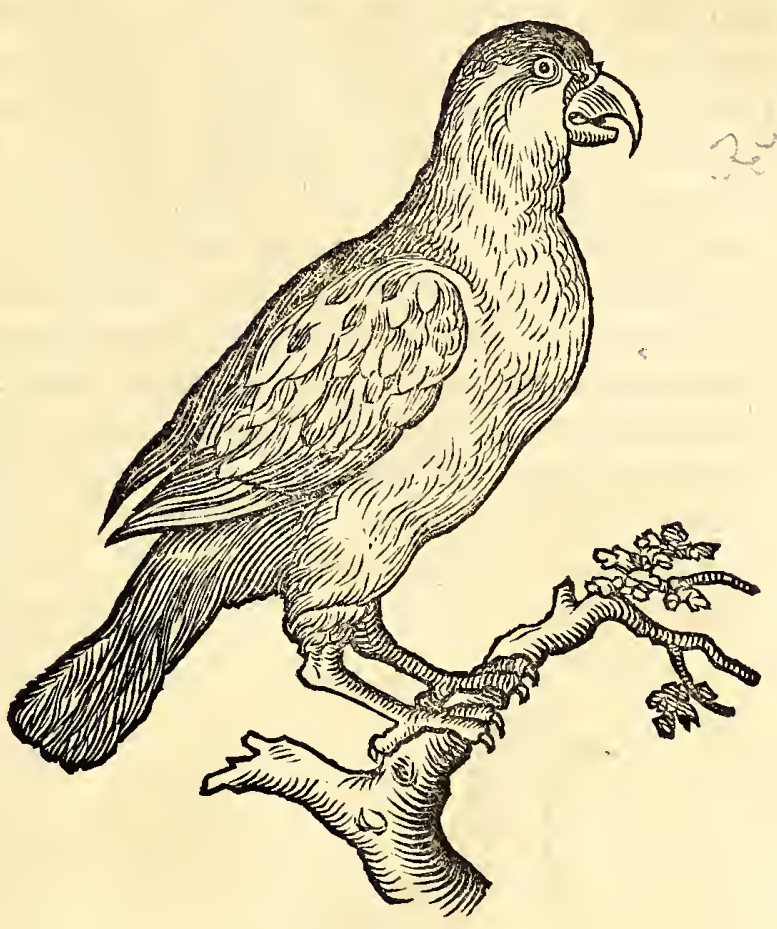

'T $\vee r^{\prime}$.

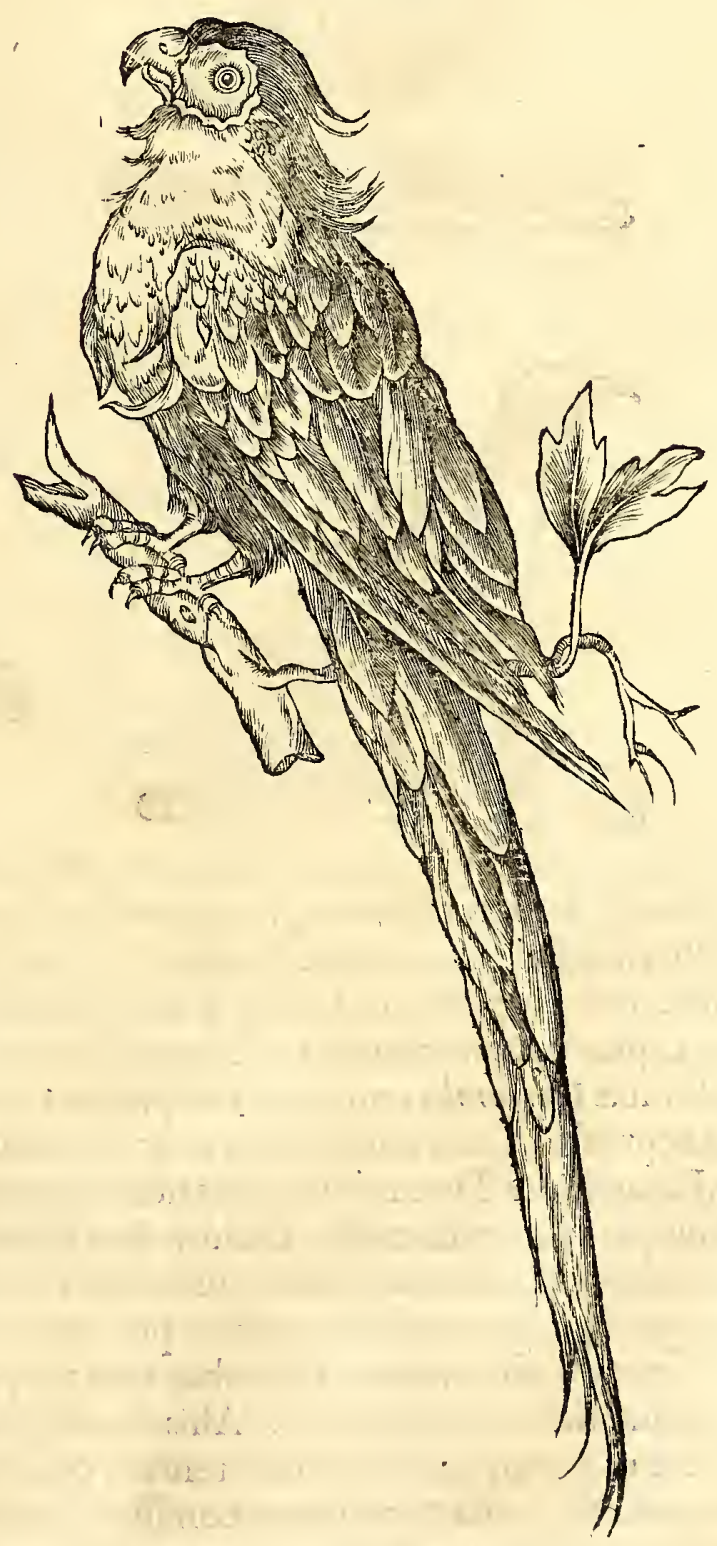

H 
tra rotundum faciunt, ac ova duo aut tria columbinis fimilia imponunt, fine nido aliquo ficto. Ova fitangas, non idcirco à parentibus deferuntur, fed xque feliciter excluduntur, quod fit fub finem menfis Iunii: plumati pulli circa Augufum auferrifolent, tuncque vermiculus craffus, in quolibet narium foramine unus, \& quoque in fummitate capitis tuberculum quoddam in quo itidem fimilis vermis latet, omnes brevi fponte excidunt, nullo manente veftigio. Fructibus arborum delectantur. Pulli eorum non minus in pretio habiti quam in Europa Columbæ; quos affati, frixi, elixi adeo fapore æmulantur, ut meminerim convivas inter epulandum deceptos, quiloco Columbarum Pfittacos comederant. Quamobrem, quod adeo ejufdem cum Columbis fint qualitatis \& dignitatis fupervacaneum duco earum narrationi diutius inhærere. Longxvi funt admodum five agreftes five cicurati. Sclopetis à militibus figuntur in filvis, vel ad crocitantem Pfittacum exarbore, in cujus ramis auceps latet, facile capi fe patiuntur. Nil enim vifo aucupe terrentur, fed ut laqueo trahantur ad collum conjecto expectant, nec aufugiunt uno captato, \& in mantica qua pracinctus eft auceps, ipfis afpicientibus repofito.

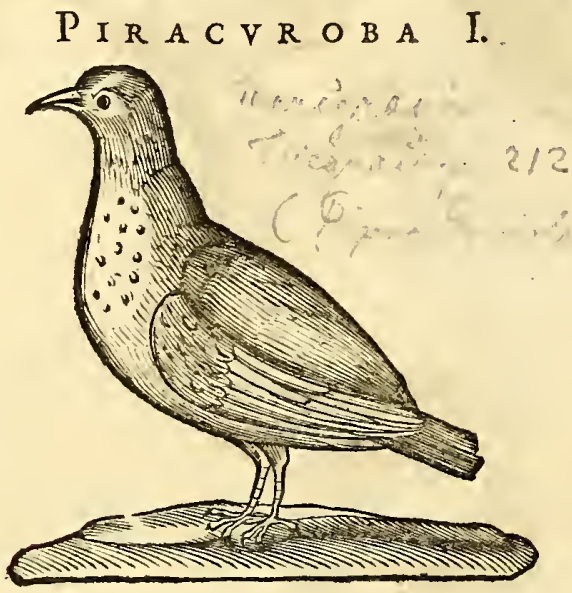

III.

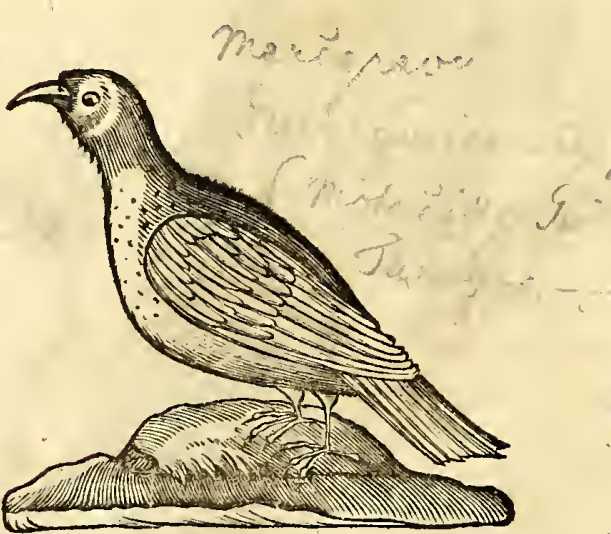

PICVIPINIMA II.

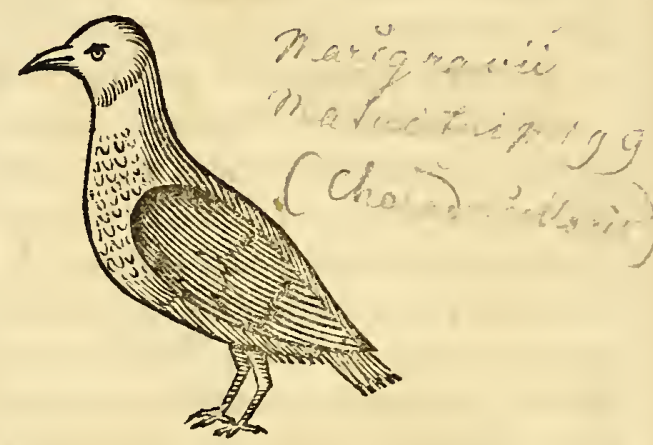

IV.

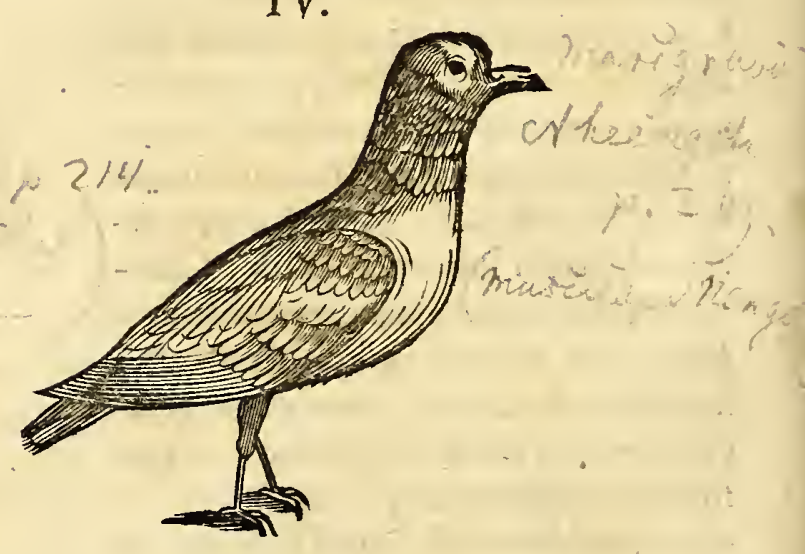

Præter Columbas domefticas Europæas olim huc allatas, quarum fummum in columbariis eft incrementum, variæ quoque dantur fpecies indigenarum filveftrium Columbarum,Palumborum \& Turturum, quæ noftratibus, colore, magnitudine, figura ,' indole \& fapore partim fimles, partim diffimiles, eafque utpote ejufdem fanilix fub uno capite comprehendere, \& uniufcujufque iconem exhibere conftitui. Majores Columbx Piracuroba, minores Picuipinira ab indigenis appellantur, qua pinguiores utique \& præftantior es cæteris habentur. Pleræque fiad fpeciem fuam referantur, Columbis, Palumbis \& Turturibus noftratibus magnitudine cedunt, fed roftro fubinde majori, minufque adunco $\&$ craffo. Color is funt diverfi \& eleganter variegati;nunc ex cxruleo cum albo \& dilute flavo mixti; nunc cinerei vel fanguinei. Quxedam ex Africana quondam profapia natæ pennis teguntur per totum viridibus inftar Pfittaci, \& remiges alarum exviridi fufcefcunt. Omnibus crura \& pedes eleganter rolei, vel crocei coloris, \& unguiculi fulci atque acuti. Aliis cauda plane nigricat, aliis medictas exterior alba; ita ut pracipua avium differentia, cum noftratibus ejufdem fpeciei in perpetua colorum el egantia \& varietate confiftat. Omnes hre raro feparatim volitant, iifdemque locis nidulantur, \& amicitias inter fe exercent, nifi quod fübinde certis temporibus 
HIST. NATVRAL. \& MEDIC. Liв. III

fefefejungant, ob fructuum filveftrium defectum, quos certatim depopulantur. Pinguefactx ad Silvas remotiores recedentes fclopetis facile figuntur, \&r maxima copia à militibus \& mancipiis venum exponuntur. Aliqux earum, imprimis Turtures, cicurari fepatiuntur. Pane, radicis Mandioca farina, vefcuntur. Defectu dicti alimenti, fructus avellanæ magnitudinis, ex arbore illa littorali, Mangle dicta, deglutiunt, à quorum ufu caro earum adeo amarefcit, ut minus efculenta evadat. Quamobrem iis fructibus vi. gentibus, minus expetitx funt. Menfibus pluviis potifimum capiuntur, \& grato alimento five filveftres five faginatx exiftunt, noftratefque bonitate æmulantur, nifi quod carne fint magis ficca \& calida, atque fervidum fanguinem generent, ac proinde cjufinodi alımenta, ut alias monui, in hifce calidioribus regionibus poftponenda ab iis qui ficco funt temperamento. Pulli ante quam adoleverint eligendi, \& $\mathrm{fi}$ macri fint, jufculis elixantur eodem modo quo noftrates aliquando Anates \& Columbæ præparantur.

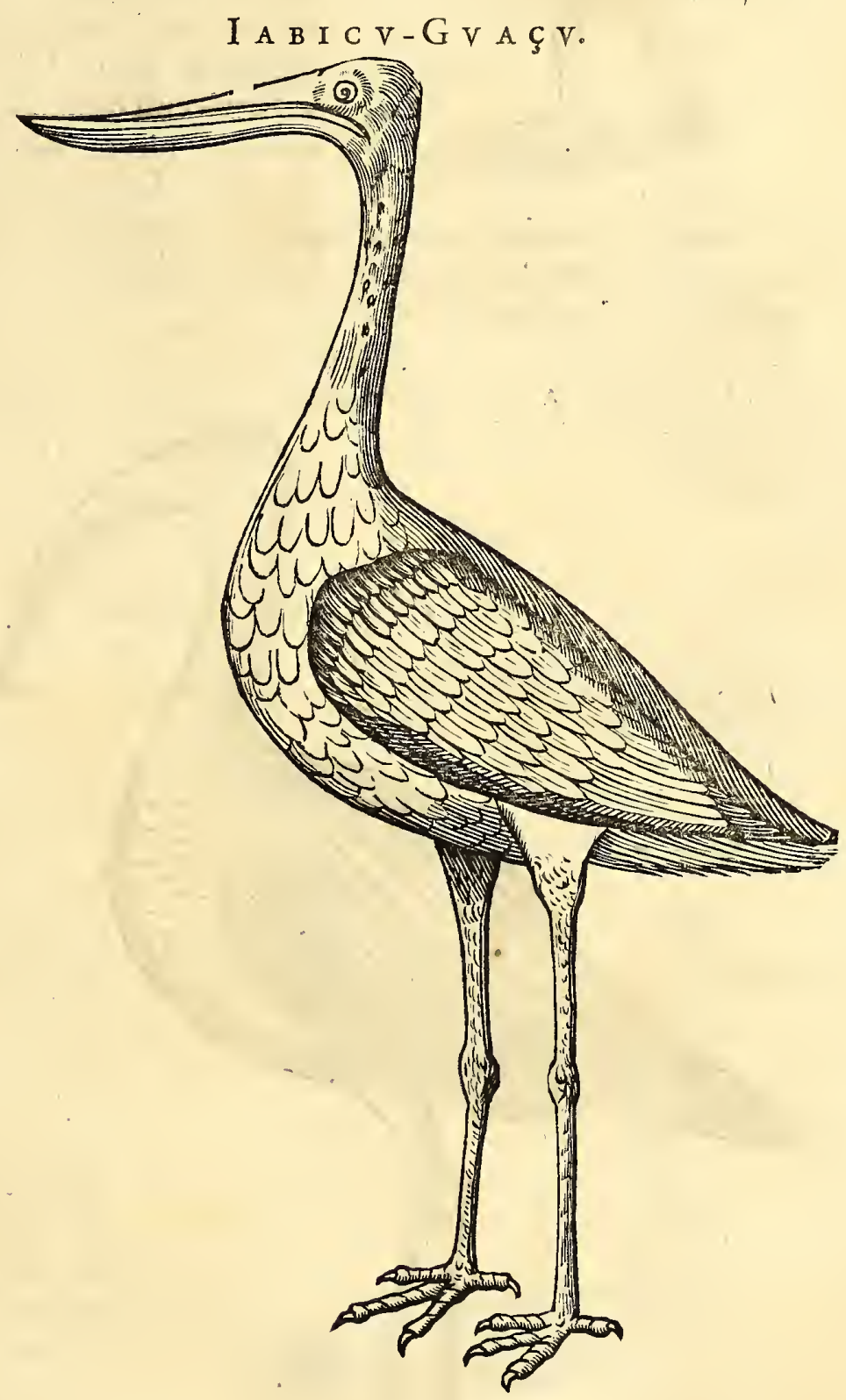

In diffitis locis juxta fluvios \& lacus frequens eft infignis hxc avis, qux Brafilienfibus quibufdam Iabrcu-Guacu, aliis mediterraneis Nhanduapoá, noftratibus Gerur-hogel dicta. Roftro eft magno, craffo, inferius cano, elingui. Mitra oflea coloris albi in vertice decoratur. Corporis mole Ciconiam facile fuperat. Cauda brevior cum alis definit, maxima ex parte albicantibus, exceptis alis remigibus, qux rubini colore tranfplendent. Pelle ejus fatis dura detracta, caro quovis modo praparatur, rarius tamen affata apponitur. Carne quidem eft proba fed ficciori. Tempore hyberno five pluviofo pingtiefcit; gratoque fit incolis alimento. Facile à barbaris \& militibus vel fagittis vel fclopetis petitur.

$\mathrm{H}_{2} \quad$ Gallinæ 


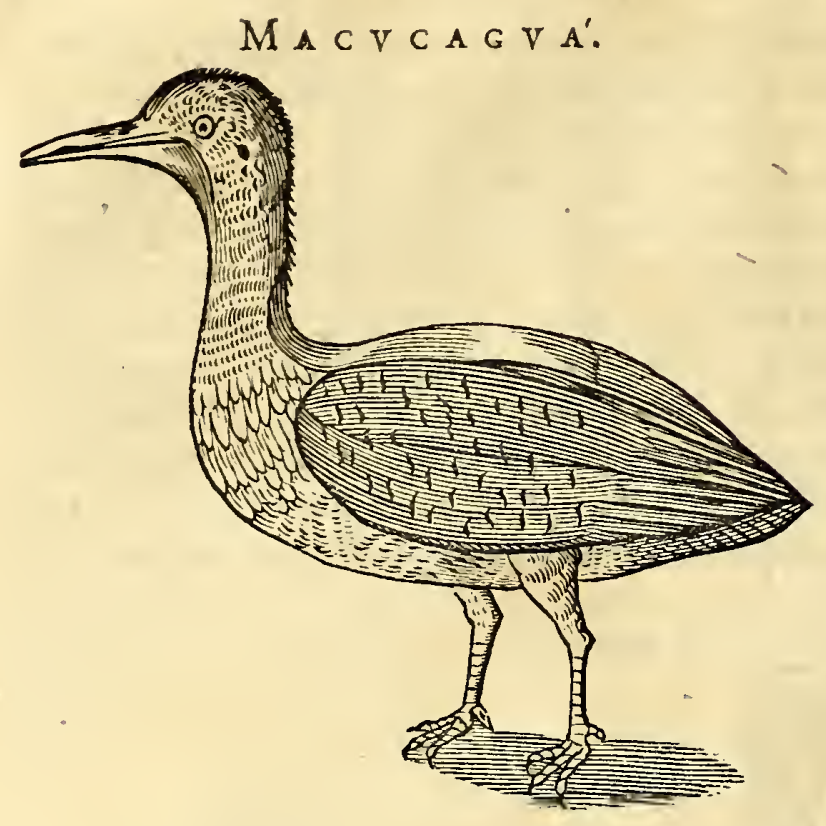

Gallinæ filveftris eft fpecies $\mathrm{Ma-}$ cucaguá, fed domeftica noftrati craffior \& major; adeoque carnofa ut duarum Europæarum Gallinarum fuperet, iifque dignitate \& fapore quoque non cedit: imprimis fi ejus cuticula triplex rite dematur, atque elixa vel aflata apponatur. Manfuefacta xque acfilveftris leguminibus \& optimis arborum fructibus vefci amat. In diffectione vifcera \& ovarium Gailinarum more difpofita inveni, fed ova Anferis magnitudinis, ex cæruleo viridis coloris. Qux quotannis bis ponit, idque quindecim vel fexdecim fimul.Roftro eft recto, oblongo, nigro. Alis nigricantibus fine cauda. Capite \& collo punctulato ex obfcure flavo \& nigro. Cruribus cærulefcentibus. Multæ funt diverfx fpecies, qux omnes facili negotio figuntur \& capiuntur. Humi gradiuntur, fed ad hominum confpectum in arboribus fe abfcondunt.

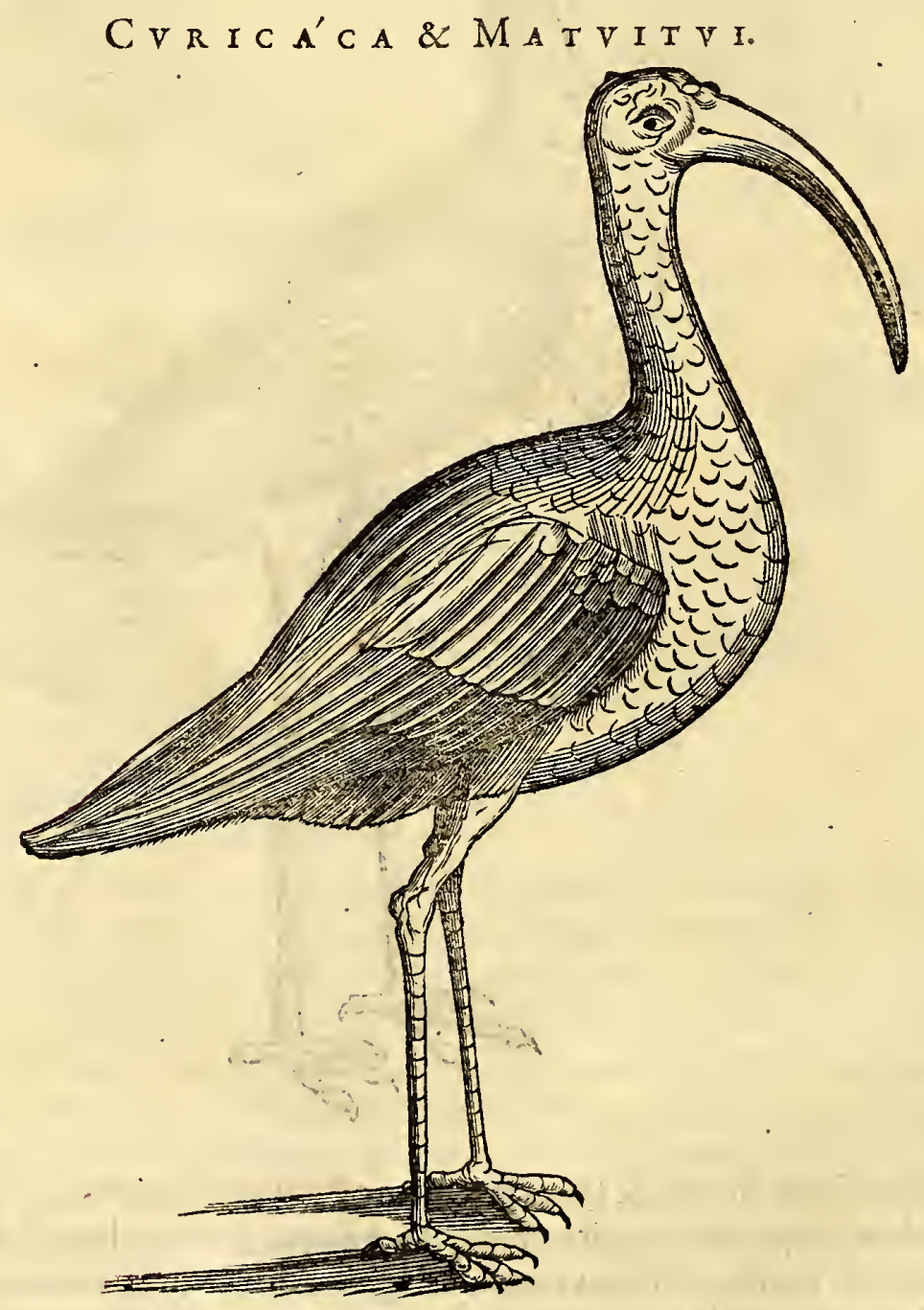

Ad fluviorum \& lacuum ftagnantium oras frequenter obambulant aves Curicác \& Matuitui, quarum pofterior ejufdem quidem fpeciei fed tantum magnitudine gallinx, cum prior hxc Oloris magnitudinem fubinde aquat. Non immerito illam Numenio Indico Clufii comparaveris, quod ejufdem pane fit figur $x$, natur $\&$ \&atalis foli, pau- 
HIST. NATVRAL. \& MEDIC. LIB。IIt。

cis exceptis circa magnitudinem \& colorem. Lufitanis Mafarino dicta, $\&$ Iconi Ibidum veterum cognata videtur. Roftro eft admodum longo, acuto falcifque meflorize inftar incurvo, coloris ex igneo fulci. Collo quoque oblongo, plumis albicantibus ex flavo mixtis. Cruribus itidem præter morem oblongis rubri coloris: parte femoris fupra genu, tibiifque fuperioribus, ad medietatem ufque pennis deftitutis; quod cum aliis avibus in paludofis locis verfari folitis commune haber. Brevi eft cauda alas non fuperante, coloris albi cano mixti, ut in Ciconiis. In humidis pratis Lumbricos venatur, quos roftro ex terra eruit. Pifciculis quoque circa ripas fluviorum infidiatur. Carne eft faporofa, fatis bona, ut inter epulas apponatur, imprimis firite preparetur coctione vel frixione antequam adoleverit.

Ardearum varix fpecies una quafi fidelia dealband $x$ fluviorum $\&$ locorum lacuftrium incolx $\&$ acco1x. çocoí indigenis. Quarum aliqux Stellares, Belgis Bittoo dictx,exque ut colore ita \& carne creteris facile præfer endx. Barbari \& Europxi poft carecta latentes illis perpetuo infidiantur, eafque tum fagittis tum fclopetis facile figunt: qux fi nondum adoleverint, multum expetuntur.Hxc, qux primo fe offert, roftro eft longiffimo, recto \& acuto; lingua brevi \& acuta; collo haud adeo longo; capite parvo. Plumis eft undique variegati coloris, thore Ardearum ftellarium, fed alarum pennis virefcentibus. Carne eft fatis proba, \& à noftratibus xque $a c a b$ indigenis expetita.

Ad Ardearum quoque fpecies refe'renda videtur hæc avis çocoí, licet pulchritudine eas longe fuperet. Roftro cft acuto, in exortu ex flavo virefcente. Crifta eleganti in vertice crecta, cum egregiis plumis deorfum dependentibus, ex nigro cinerei coloris. Collo \& gutture ex variegatis fubtilibus egregiis plumis ornato. Pinguefcit circa lacus paludofos \& rivos, imprimis menfibus pluviis. Paucre eft carnis, fed bonx \& ab omnibus expetitx ço co I $\quad$ I.

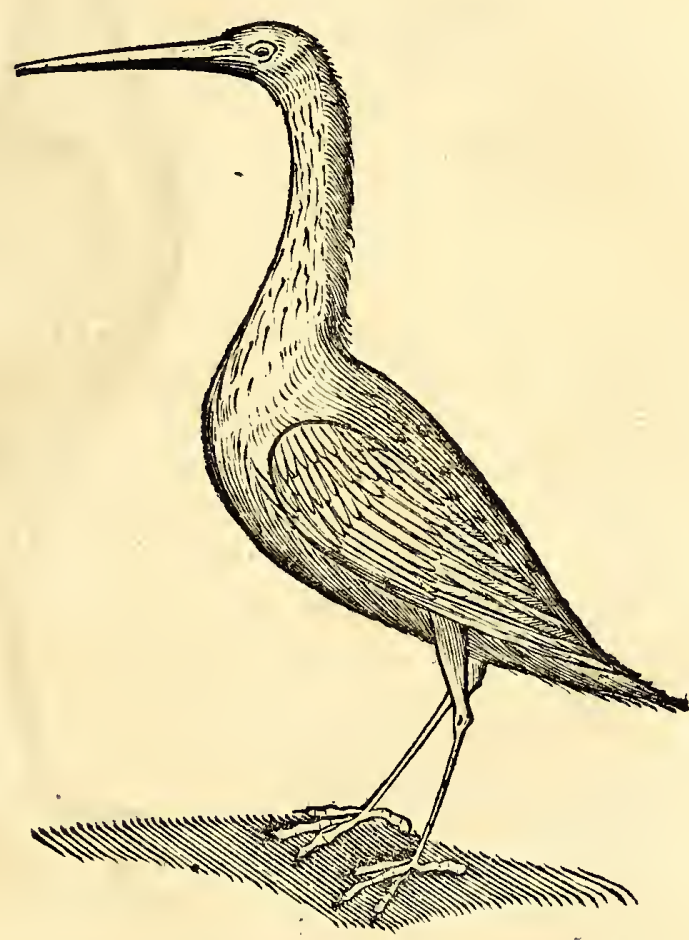

Ç O C O I' II. fijuvenis fit.

Multæalix dantur adhuc Ardearum fpecies edules, fed ut magnitndine ita \& bonitate carnis inter fe difcrepantes. 


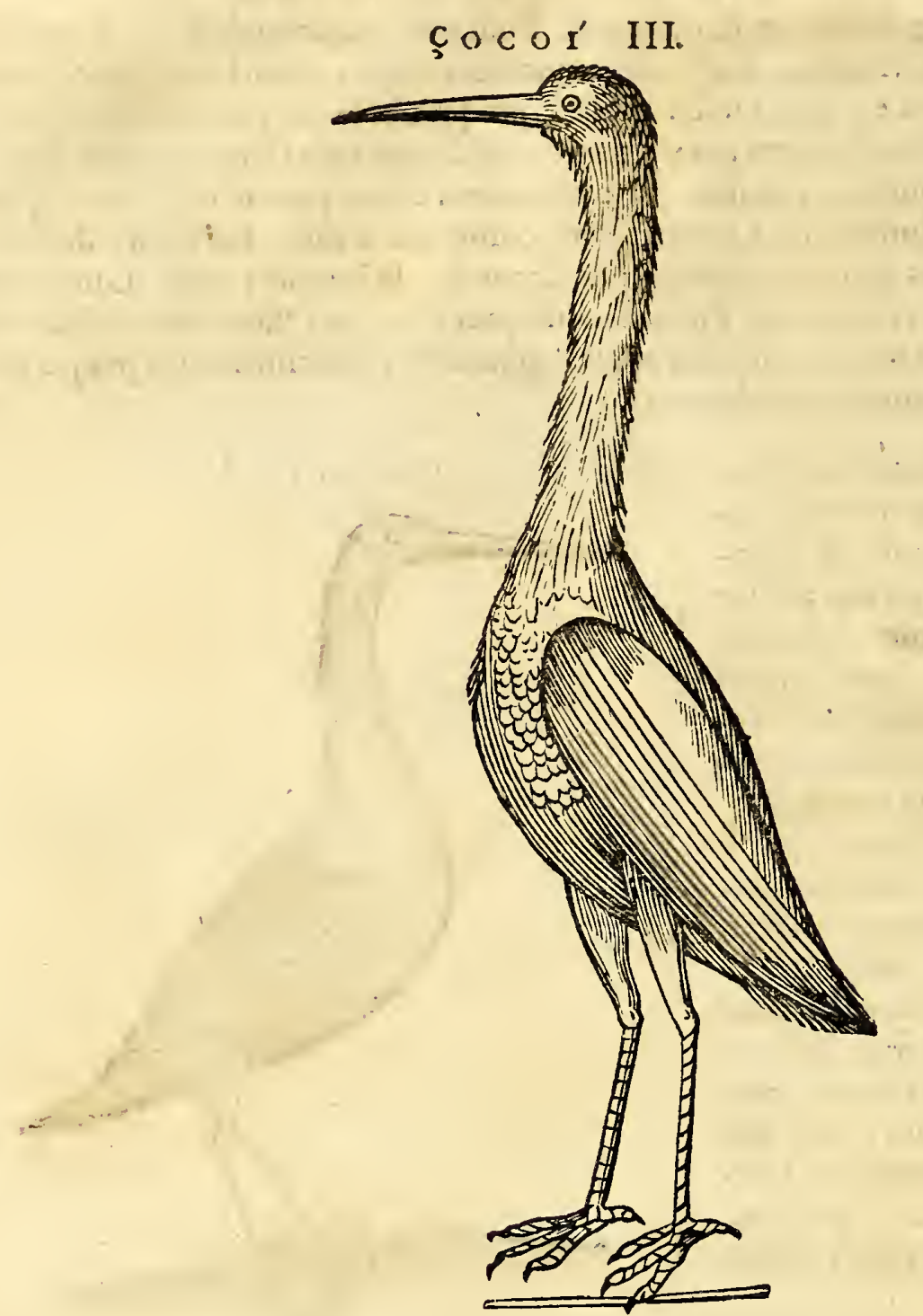

Tertia hæc çoco, pifcivora, quæ erecta incedit, \& decenter, roftro eft longo, acuto, nigro. Collo \& pedibus promole corporis fatis longis. Pennis \& plumis minus elegantibus veftitur, qux, ut noftrates, albo, nigro $\&$ brunno variegantuir. Indole atque alimentofis qualitatibus prioribus fimilis eft.

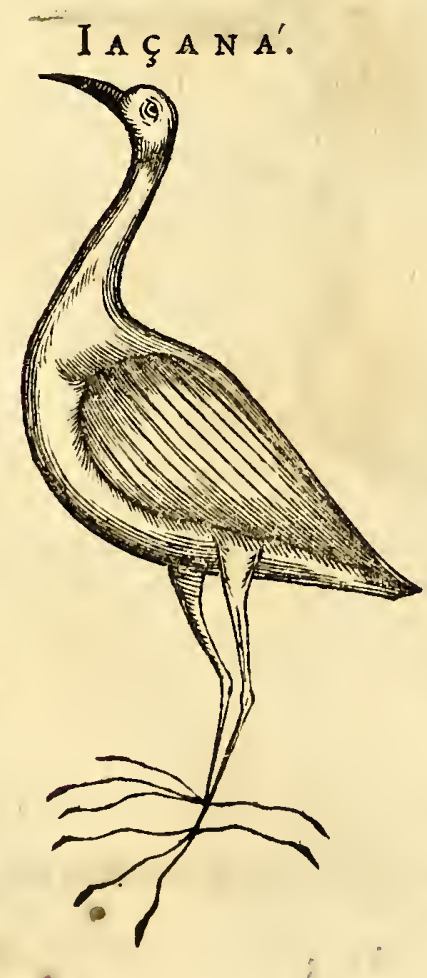

Iaçaná. Gallina paluftris. Noftratibus $\mathbf{D} \mathfrak{\mathbb { a }}=$ ter-boen. Quarum quinque ad minimum f́pecies vidi, natura \& figura fibi fimiles, fed magnitudine $\&$ colore potiffimum differentes. Omnes vero colorum elegantia europxas Gallinas palu* Itres longe fuperant. Frequentifimæ funt in lacubus ftagnantibus. Hanc unicam ex familia I Iaģaná utpote pulcherrimam $\&$ facile maximam exhibeo. Corporis mole, cauda, capite Gallinam filveftrem æmulatur.Sed roftro, collo, cruribus, $\&$ coloris varietate, ab iis diffimillima: crura enim, eorumque digiti, nuda, ut in ripariis folet, longiffima, flavi \& viridis funt coloris. Caput, collum, al $x$, \& pectus elegantiflime fplendent, $\mathrm{fi}-$ cut Pavones. Omnes in anteriori parte alx corniculum habent acutiffimum, quibus fe defendunt. Menfibus pluviis potiffimum pinguefcunt vermibus \&z pifciculis, ficut Rufticulæ paluftres. vefcuntur. AEftivis menfibus macr $x$ funt, ac proinde tunc minus expetitx. Crterum boni fapor is cft caro, fed ficca, proinde condimento opus eft. 
Quod fupra in genere de Brafilix avibus ripariis monui, id ntinc in fpecie huic Guaraune five Rufticulæ aquatic e tribuendum, fcilicet probitate carnis cum pluribus montanis avibus certare. Vt enim figura \& natura Rufticulam aquaticam paucis exceptis xmulatur; ita $\&$ dignitate guftus illi non cedit quocunque modo paretur. Tota avis fufci eft coloris atque hinc inde albo punctulata. Roftro admodum longo \& tereti; in extremitate incurvo \& fufco. Cruribus \& digitis pedum longis. Caudx veftigium nullum. Catera communi more avium difpolita.

Inter immenfas avium cohortes fola fere hæc infignis \& pulchra cornigera Anbyma non culinæ folum fed \& medicis ufibus infervit. Frequenter quidem pecora cornuta in terra \& $\mathrm{ma}$ ri ; raro autem in aëre avem cornu gerentem. videre contingit. Accedit, quod ficut Rinocerotis, Cervi,aliorumque terreftrium, ut \& maritimorum, imprimis monftri ifti us Monocerotis, cornua medicinalem imo antidotalem qualitatem pretendant: ita quoque hoc cornu ex vertice Anbyme pro- minens, creteris facile palmam præripit. Avis itaque hæc forma, fiGVARAVN先。
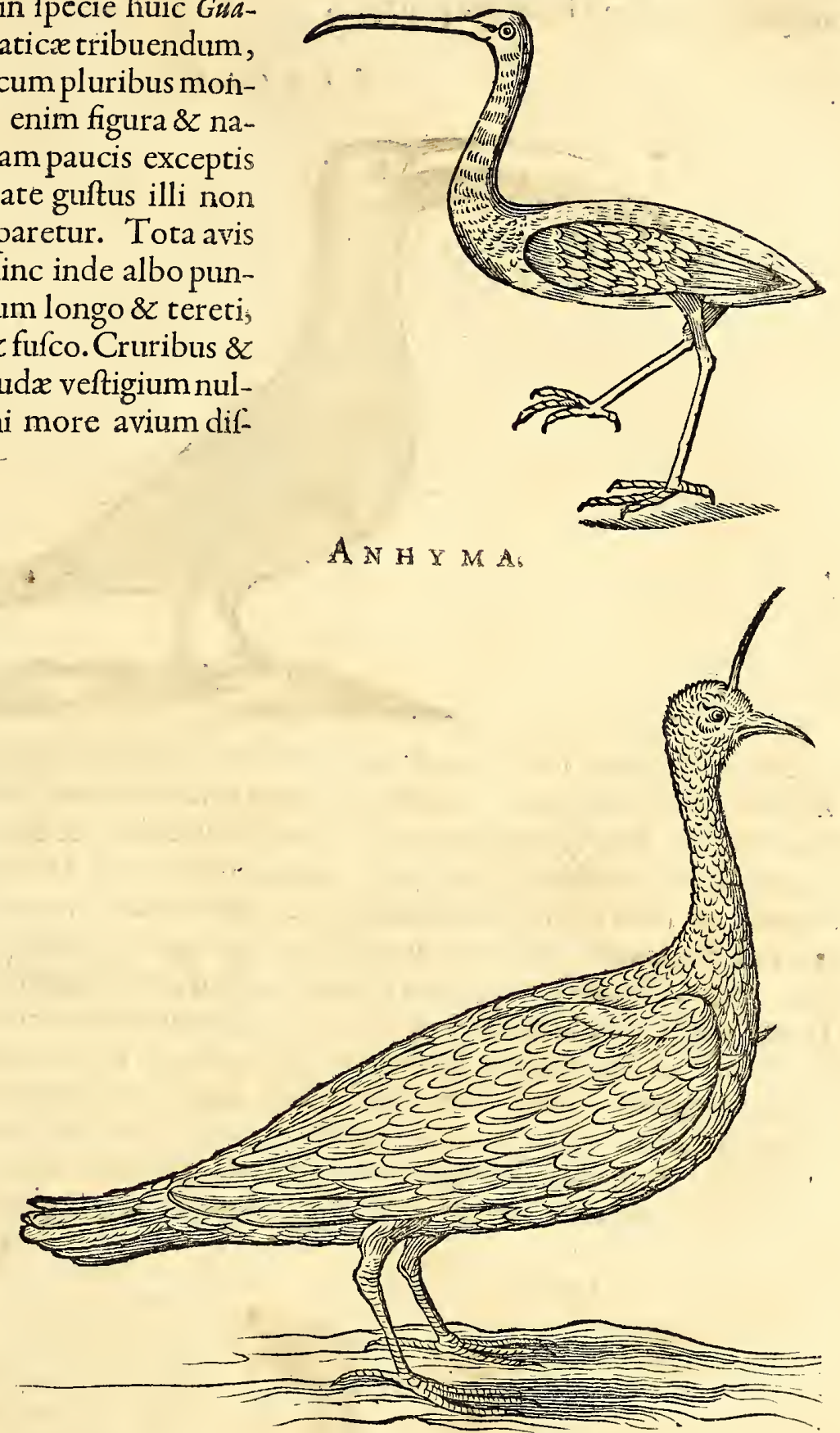
gura, \& ufu quidem,

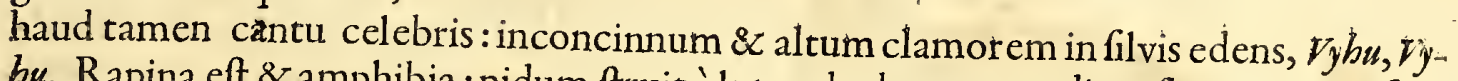
bu. Rapina eft \& amphibia : nidum ftruit è luto ad arborum caudices fuper terram, furni figura. Pavone imo Cygno major eft fomina cujus Iconem hic exhibeo; mas enim quem nancifci non potui in nemoribus, dupla eft magnitudinis. Carne eft probata, Pavonis æmula. Prominente pectore incedit, fed raro fola, verum junctim mas $\&$ foemina. Teftantur omnes pariter incolx, una mortua alteram inftar turturum lugere, \&c vixà fepulchro difcedere.

Porro hrec Anbyma roftro eft nigro paulum incurvato, collo oblongo, oculis aureis, pupillis nigris. Capite eft Galli Indici fimili, plumulis variegato, cui in vertice cornu erigitur, extremitate fua antrorfum verfus incurvatum, duos digitos longum, calami fcriptorii fere craflitiei, oflei coloris. Alæ, dorfum, cauda nigricant; venter cinereis \&z nigris pennis variegatur. Crura potifimum pénnis nuda, fed cute fufca tecta. Quilibet pes quatuor digitos obtinet longos, unguibus corniculatis. In cujufque alæ antica parte ex ipfo alx offe cornua brevia triangulata enafcuntur. Quibus itidem vis antidotalis à barbaris attribuitur. Mihi autem de virtute verticalis cornu conftat, quod in convenienti liquore maceratum ad $\vartheta_{\text {ij }}$ plus minus, contra febres malignas \& venena potiffimumaffumtum cum fucceffu fepiffime exhibetur, movendo fudores, \& nia-

$$
\mathrm{H}_{4} \text { lignam }
$$


lignam veneni qualitatem ad circumferentiam corporis. Nec minus quoque feliciter ufirpatur cum vino in multis gynaciis.

A R A C A R I'.

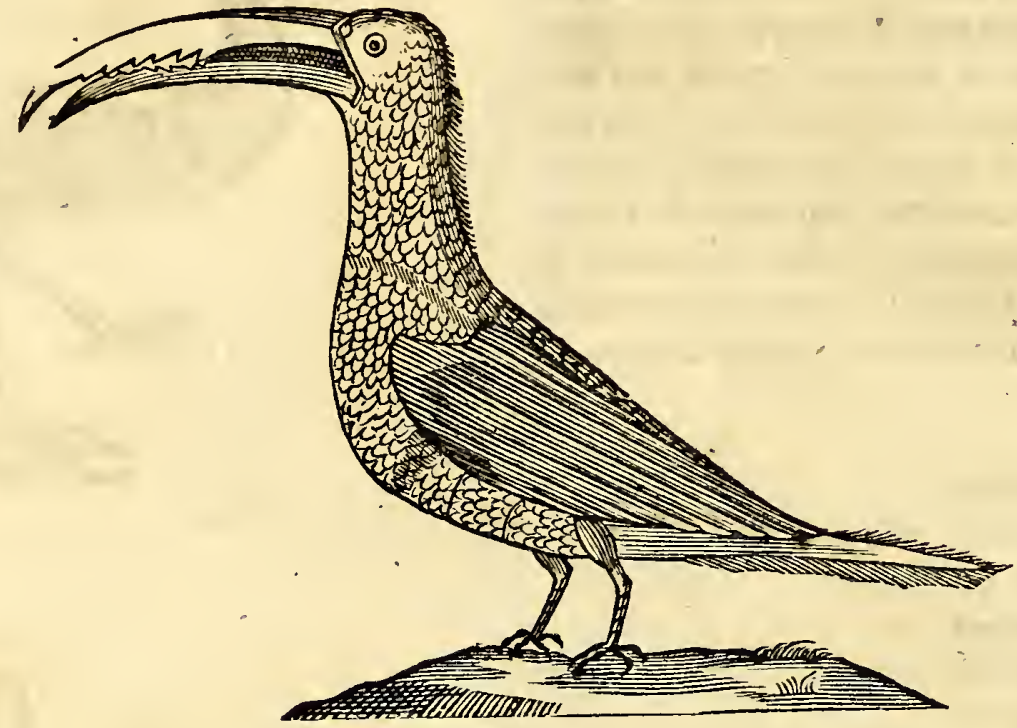

Aracarímajoris Rufticulæe eft magnitudine. A proprio clangore, ut multæaliæa aves Brafilix, nomen accepit, atque ex patulo roftro acutum fonum edens Aracarí perpetuo clamat. Prxter inufitatam roftri magnitudinem, \& dentatam conformationem, admiratione potiflimum dignum, quod leviffimum $\&$ tenuiflimum fit inftar membranx, ac loco lingux pluma five penna nigra mobilis in eo contineatur. Capite eft parvo, compr effo, collo oblongo \& nigris plumis in extremitate circulariter finientibus obfito. Pectoris \& ventris plumis eodem modo conformatis, fed colore flavefente cum pavonio mixto, linea eleganti fanguinei coloris tranfverfim intercurrente. Dorfo \& alis ex nigro viridicante fulgentibus. Cauda inftar Picxlongiufcula fanguinei exparte coloris. Rara hæc avis in denfis nemoribus habitat, fructibus potiffimum victitans. Cicuratur non folum ob elegantiam fed quoque ob ufum rei familiaris. Caro enim ejus eft edulis \& boni fapor is, fed littoralibus populis minus frequens. Interna ejus vifcera more aliarum id genus avium conformata inveni.

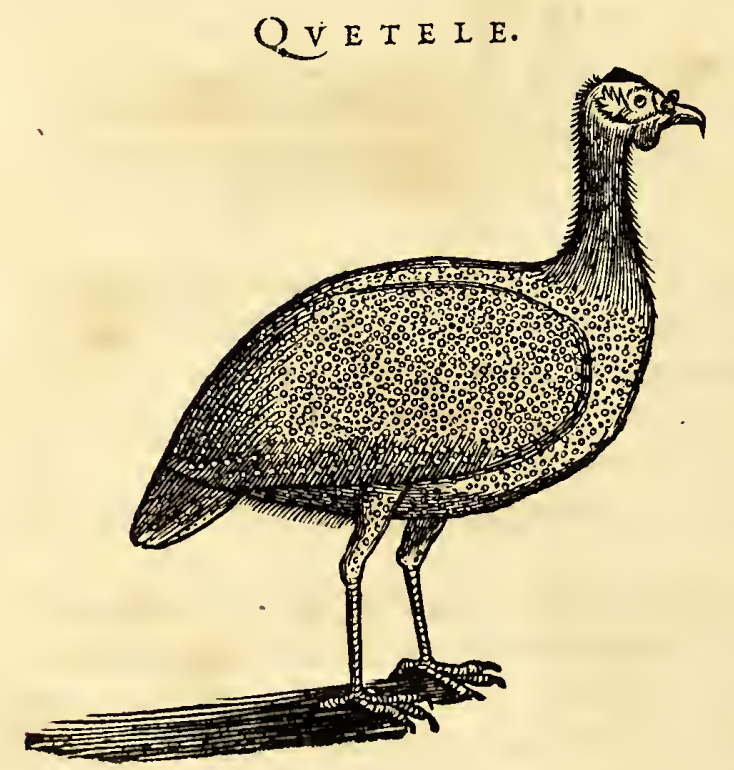

2uetele. Vegetabilia, \& Senfitiva quædam, licet aliunde advecta, tractu temporis inter nativa recenfentur : eo proinde minime prætereunda,imprimis qua ufibus humanis inferviunt, ficut hæc Meleagris five Gallina Numidica filveftris, Congenfibus 2 uetele didta.Aliquæ ex continenti Africx circa Sierra Lyona; aliqux ex infulis Africæ vicinis adferuntur, parumab hac icone abludentes: utraque ob fertilem proventum in Brafilia adeo multiplicatz, ut $\mathrm{ab}$ omnibus opulentioribus eas cicurari \& faginari videas. Si corporis magnitudinem \& crurum pedumque conformationem confideres, noftratium gallinas xmulatur ; fi figuram avis $\&$ caudam dimiflam, Perdici fimillima. Capitc eft parvo, cui mitella cutacea fufca impofita ad utrumque latus capitis alba, $\&$ crifta rubra ad tempora protenfa: roftro flavo, curvo. collo tenui oblongo, quafi coronato. Pennis nigris elegantiffimis, maculis albis variegatis, totum corpus ornate cooperitur. Caro inter delicias expetita Gallinæ noftratium non cedens ; imo probo alimento faginata more Perdicum, ad earum dignitatem accedit.

Abfoluris 
Abfolutis præcipuis \& nobilioribus avibus edulibus; defcribendæ nunc quidem reftarent tot minorum myriades, quarum pleræque nomine vernaculo Guira exprimuncrum, Pafferum, Turdorum, Fringillarum, \& fimilium, recenfentur : fed, quod ratione qualitatum adeo inter fe congeneres fint;tum quoque vifcerum conformatione $\&$ conftitutione cum noftratium ut plurimum conveniant, particulari earum defcriptioni fuperfedeo, ne lectorem xque ac memet remorer, quamobrem inftituto meo fatisfactum iri puto, fi pauciores ufuales, uno quafi penicillo graphice depingam, atque earum icones fimul fub eodem capite conjungam. Aliqux opacorumnemorum alumnæ funt, fructum que filveftrium, imprimis Mangábas, Pacóbas, Papáios, Guaiábas, Araçá, perpetui prædones: aliqux vero fluviorum ripas obambulant, vermiculifque $\&$ pifficulis vefci amant. Sxpe frixx, raro autem toftx apponuntur, quod paucx \& ficcioris fint carnis, fanguinemque in nobis fervidiorem generantis. Noftratibus aviculis fapore $\&$ alimenti bonitate, paucis exceptis, plerum-
que cedunt.

\section{GVIRAPVNGA. MAs.}

GYIRAPVNGA FOEMINA.
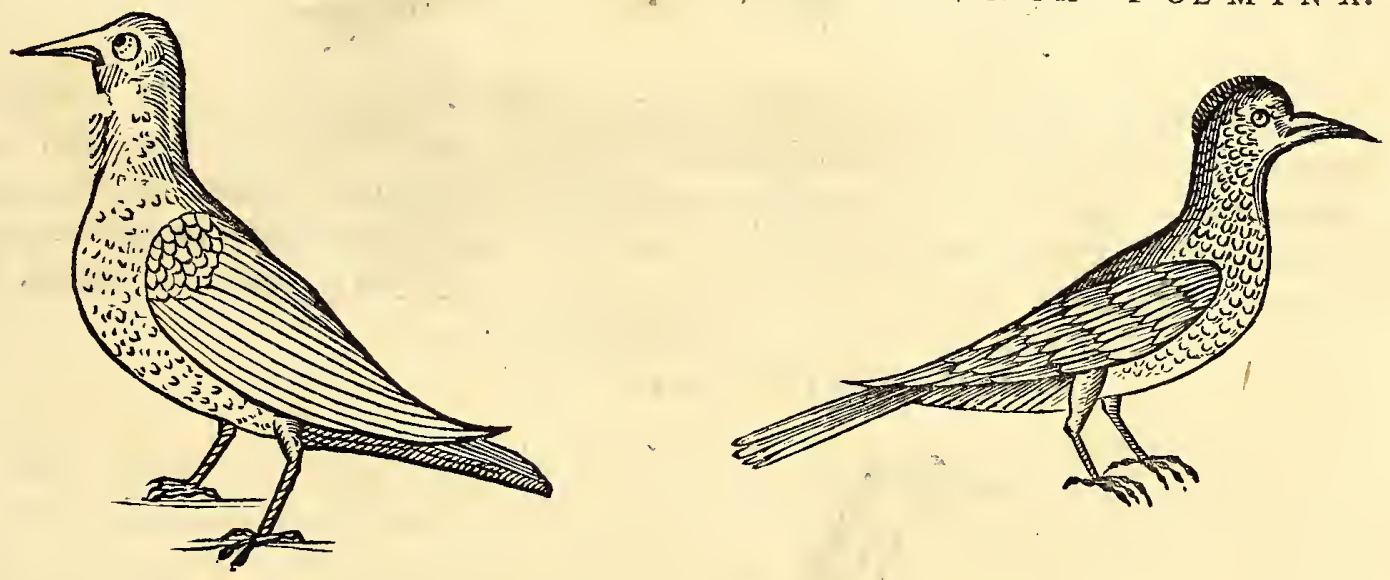

Vtraque Guirapunga, mas \& fomina, celebris, tam ob multam carnem pinguem, quam ob clamorem $\&$ duplicem fonum quem edit, idque non toto anno, fed menfibus æftivis, vigentibus fructibus Acaju. Pectus habent bifidum feu convallem, per medium fecundum longitudinem; tracheam amplam; unde eft, quod alte clamare pof fint, fuo potius quam aucupis malo. Vtraque Turdelam majorem fuperat. Pennis veftiuntur fufcis \& nigris, quibus virentes funt intermixtæ, roftro longo, acuto, oreque admodum magno \& patulo. Crura,pedes cæteraque nihil differunt à communi avium norma. Mas \& foemina vix inter fe difcrepant, nifi quod illi fub gutture propendeant particulæ carnex nigræ; huic vertex plumis decoretur mollibus. Inter præftantiores aves, ficut Turdelænoftratibus, habentur.

Guira-Guainumbi, Palumbi eft magnitudine, plumis undique elegantiffimis veftita. Vertex quafi mitra ex pennis fapphirinis decoratur, in cujus medio macula nigra, magna. Guttur, pectus \& venter funt lutei. fuperior colli pars, dorfum, alæ \& cauda, graminei coloris, admixto thalaffino, more Anatum vel Pavonum. roftro eft oblongo, $\mathrm{ni}$ gro, incurvo ab utroque latere, fuperne $\&$ inferne ferrato dentium loco. Cruribus

GVIRA-GVAIN $\vee M B I$.

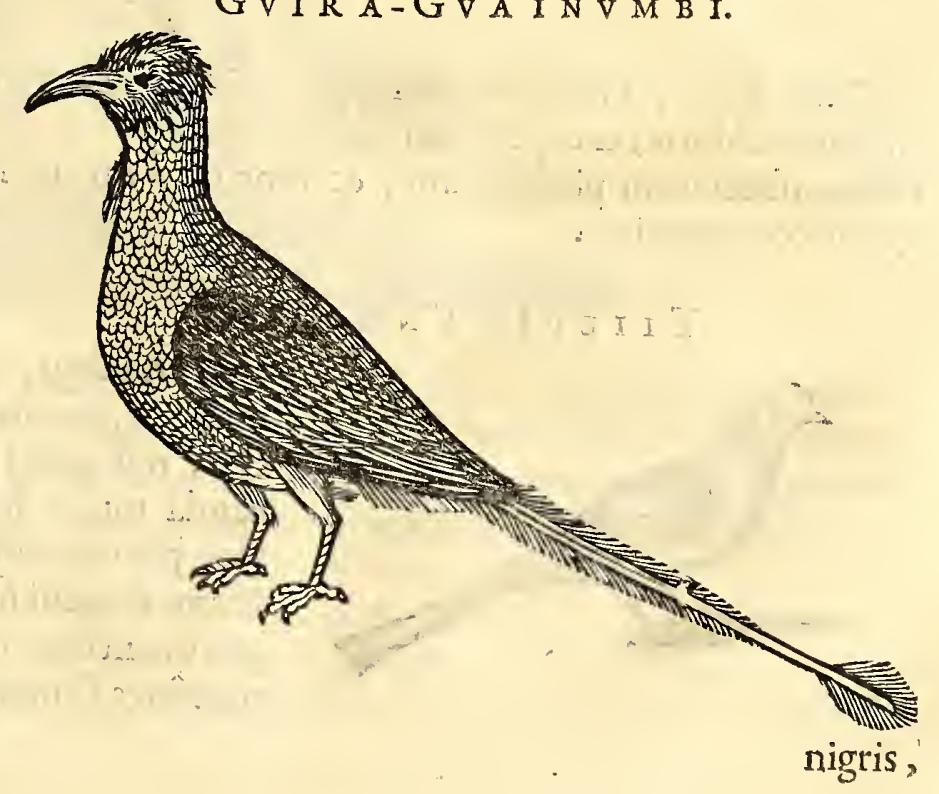


nigris, pedum digitis \& unguibus vulgari modo difpofitis. Cauda longiffima ex duabus pennis reetis facta, \& multis plumis tranfverfis veftita. Fructibus gaudet. In altis arboribus nidificat, unde fclopetis facile figitur. Cicuratur ob elegantiam $\&$ carnis bonitatem, licet enim columbis dignitate cedat, minufque carnofa fit, tamen rite præparata pro cibis apponitur.

GVIRA QVEREA.

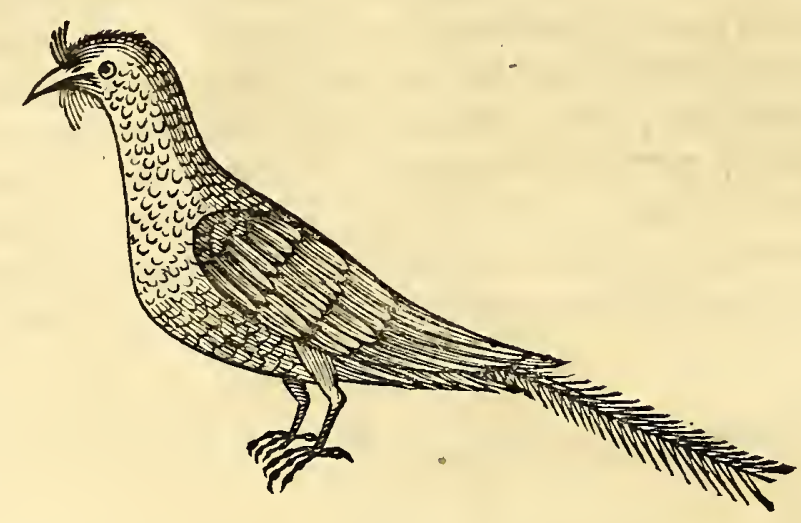

Guiraquerea, Sturnum magnitudine xquat, etiamfi ob alarum $\&$ caudx longitudinem major videatur. Eft ex fufco cinerei coloris cum maculis flavis $\&$ albo mixtis. in vertice circulus apparet aur eus. roftello parvo, triangulari, parum adunco, à cujus initio in utroque latere multæ fet $x$ craffx fuillæx exfurgunt. Cæterum nihil peculiare pr $x$ ter caudx elegantiam. Vefca eft ejus caro, fed ficca. Fructibus potiflumum victitat.

\section{GVIRA-I E N O I A.}

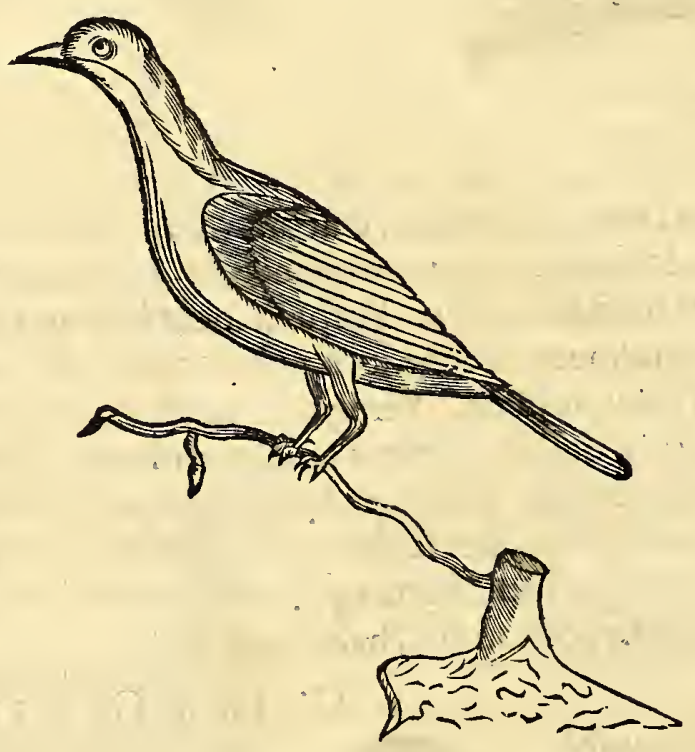

Guira-ienoia, Fringillæ funt magnitudinis, fed corpore magis procero. Cxrulci potifimum coloris, exceptis extrcmitatibus caud $\&$ alarum. Menfibus pluviis ob fructuum ubertatem pingucfcunt, \& tunc caro earum magis faporofa, Fringillarumque loco comeditur.

TIIEIIRA'NGA.

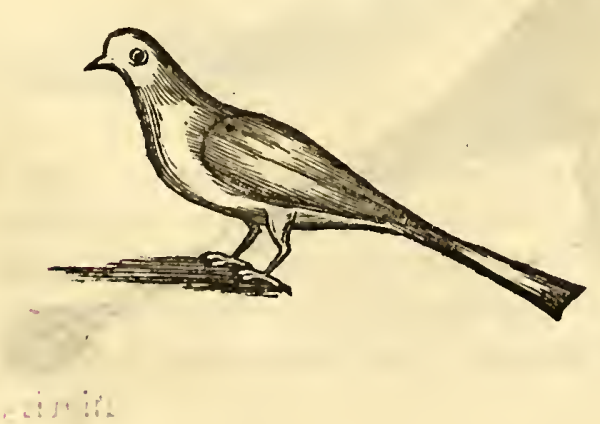

Tiiepiránga, Avicula hæc cantu, conformatione, pennis Fringillam noftratium æmulatur, nifi quod corpore fic magis carnofo \& cauda multo longiori, plufque fanguinei coloris per omnes pennas appareat. Gregatim volitant, \& facili negotio retibus \& decipulis magna quantitate capiuntur. Eodemque modo, ut noftrates Fringillx, prxparatx apponuntur.

Guira- 
GVIRAPEREA'.

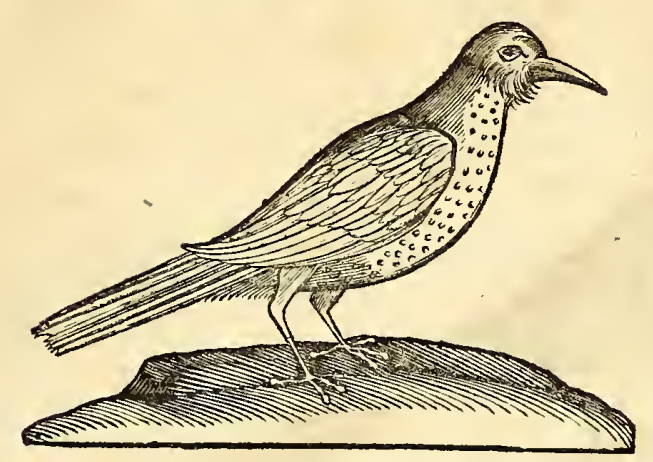

Guirapereá, Alaudx eft magnitudine, aurei coloris, excepta cauda \& alis, qux dilute virides funt. Sub gutture maculam habet nigram, toto pectore $\&$ ventre maculis inftar Sturni confpicuis. Roftello recto, acuto, Havo. Cætera vulgari modo difpofita : Inter aviculas apponitur, $\&$ mediocris eft faporis, imprimis cum fructus illi maturuerint, qui Araça \& Guaiaba dicuntur.

GVIRA-ACANGATARA'.

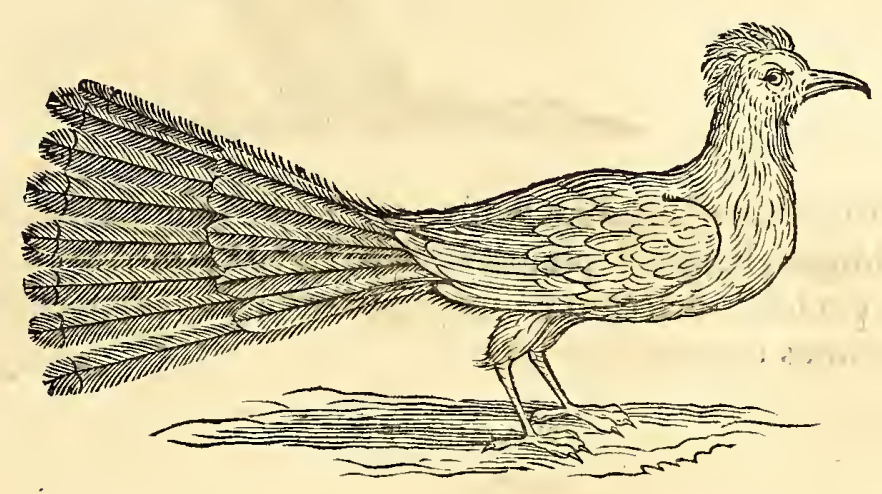

Guira-acangatará, elegans eft avis, Picæe magnitudinis, ob elegantiam \& ingentem clamorem potius, quam carnis excellentiam celebris : paucæenim eft carnis; licet ob infignes pennas \& plumas major videatur. Roftro adunco, acuto, \& flavefcente. Vertex longioribus plumis, criftæ in modum decoratur, qux ficut totum corpus fere, fufci eft coloris. Cauda longiffima, conftans octo pennis ornate expanfis, in extremitate albicantibus. Cum cxteris avibus loco Fringillarum menfis imponitur, faporifque eft non contemnendi.

\section{$M$ A T $V I T \vee I^{\prime}$.}

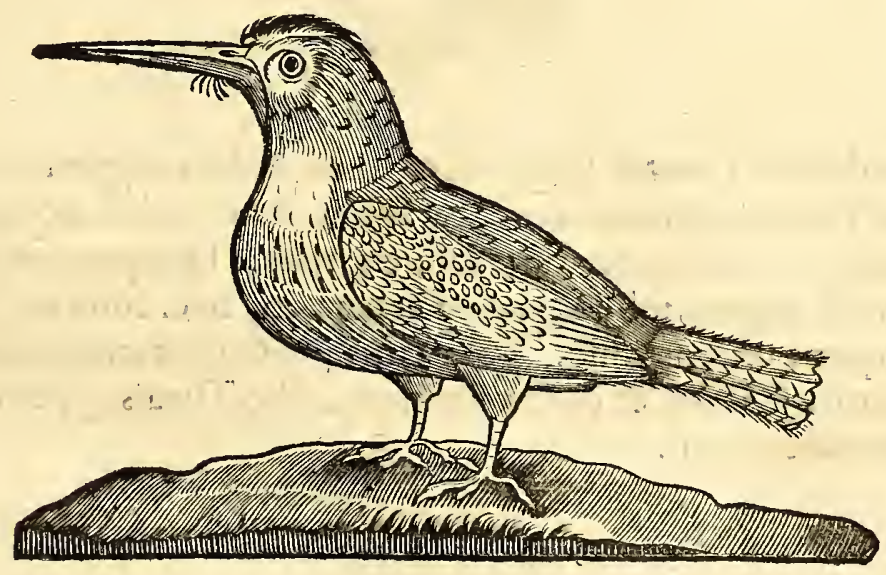

Matuituí, Sturni eft magnitudinis. Roftro longiffimo, rceto \& forti. Pennis undique veftitur fufcis, pallide flavo maculatis, ut in Nifo. Catera vulgari norma avium difpofita, nifi quod pectore fit admodum carnofo. Pifciculis infidiatur circa ripas fluviorum, iifque pinguefcit . Magna copia toto anno apparent. Carnefunt multa $\&$ pingui. 
I A C A M A C I R I'.

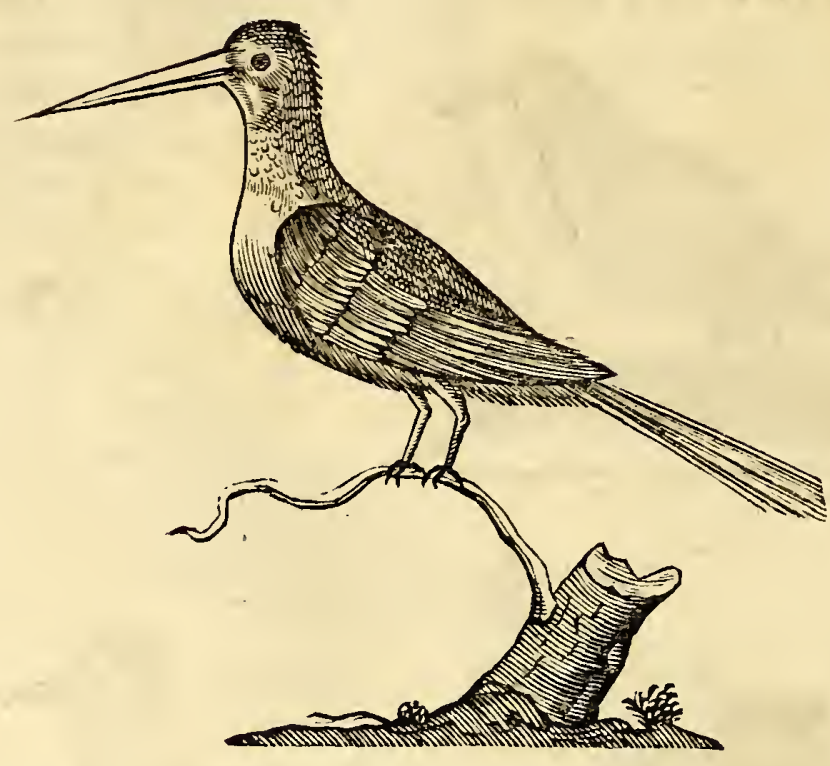

Iacamacirí, Sturni eft magnitudine. Roftro admodum longo, \& in extremitate acuto. Cauda tenui \& longá. Pennis \& plumis ex flavo ac viridi mixtis. Circa ripas fluviorum victitat, \& pifciculis delectatur. Inter cæeteras aviculas apponitur, fed non adeo expetita, quod minus teneræ fit carnis.

T A M A T I A'.

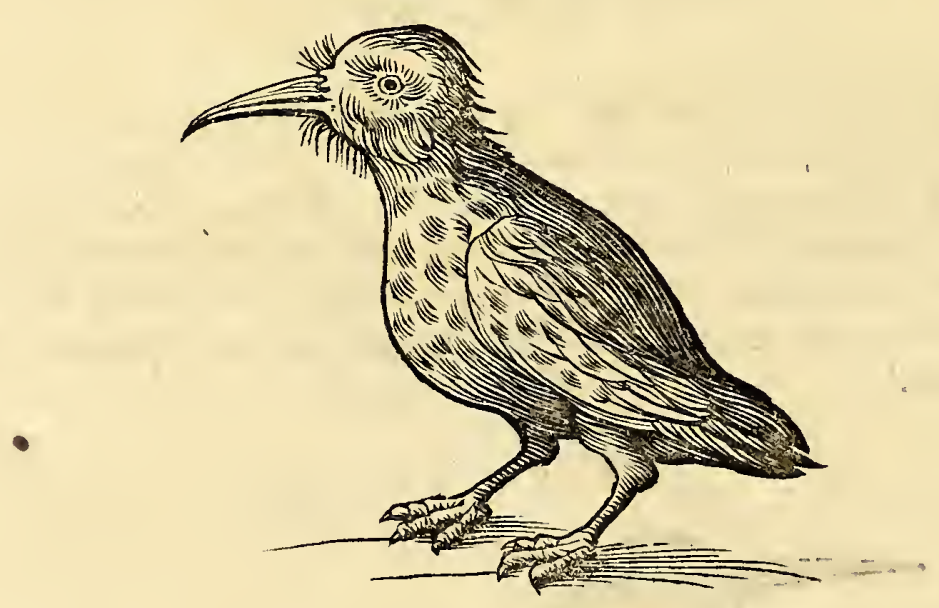

Diverf fpecies dantur Tamatiá. Quarum maxima,addito cognomine, Tamatia-guaçú exprimitur, adeo Turdis noftratium externa figura, ut $\&$ indole ac fapore fimilis, ut nulli avium (paucis pro confueto naturæ lufu exceptis) Europæarum melius comparanda fit. Roftro eft magno, folido, parum incurvato, fufci coloris. Capite quoque grandiori pro corporis proportione. Tota cutis punctulis confpicuis \& magnis maculis fufcis variegatur. Collum $\&$ guttur flavefcunt. Pro Turdis apponuntur utcunque affat $x$, ejufdemque funt faporis. 


\section{S E C T I O T E R T I A, Que agit de Animalibus Quadrupedibus.}

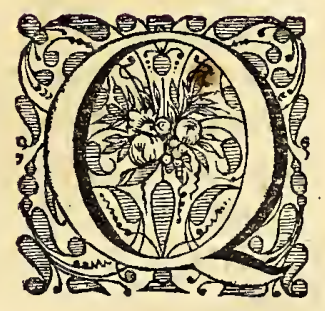

Vemadmodum Eruditiff. Scaliger non immerito diffentit à Philofopho dicente, vel omnibus terræ locis omnia, vel nulla ufquam nafci: fic è contra, quadam in quibufdam locis, quadam autem non provenire, apprime fane confenfiffe mihi vifus eft; imprimis cum eo naturx moderamine, ut ficut illanumero, ita \& vitx tum habitudine, tum longniquitace inferiora vel fuperiora evadant. Cujus reiveritatem confirmant paffim omnes acerrimi Indiarum imprimis Luftratores, quodque etiam Naturæ œconomix maxime, confentaneum fit, ne alicubi vel abundantia nimium luxuriaret, vel neceflatiorum pentria Mundus fatifceret.

Inter alia animadverfione digna circa $Q$ uadrupeda, non pretereundum puto, quod aliqua pecora Europæa in Indias invecta, prafertim Oves, Boves, Arietes, etiamfi ob aëris temperiem calidiorem fatis prolifici;tamen macriores utique reperiantur,carneque minus fuccida \& tenera quam in natali quondam folo ; vel quia ex infueto frigore noCurno, vel fervore diurno peculiaris terra genius refultans, ficut tenerioribus Europa vegetabilibus; ita quibufdam animalibus exoticis minus faveat. Excipiuntur tamen quxdam, præfertim Porci, qui in melius mutati, foccunditatis non folum, fed \& ntttrimenti dignitatis ufque adeo prærogativam obtinent, ut ægris æque ac fanis tutæ $\&$ jucund $x$ fint délicix, carneque ovilla preferantur: Ac proinde minus applicandum videtur hifce regionibus Novi Orbis illud Philofophi, ubi ait, Omnium Q uadrupedum carnes deteriores exiftere, qux locis paluftribus, quam qux editioribus pafcuntur.

Indigen $x$ Quadrupedes viviparx rei familiari dicatx, pauciores quidem in tanta multitudine detectr. Q uas, ut \& tot alia fenfiriva, conduceret quidem ad cognitas Veteris Orbis redegiffe fpecies, fed ob adeo varium \& perpetuum Naturx lufum, facilius eas ( pauciffimis quidem exceptis) guftus, quam externæ figuræ fimilitudine, cum Afiaticis vel Europæis contuleris. Accedit quod diatx Beftix in Novi hujus Orbis remotioribus faltibus minus familiares fint maris accolis : noctambulx quoque multx \& latebras quarentes exftant, etiam ex, qux contra Philofophi fententiam multum caloris $\& \&$ ficcitatis habeant; adeoque tantum prodire ament ingeuentibus menfibus pluviis, ut pinguefcant \& copulentur. Vt mirum non fit, earum differentias, mores, naturas, aliaque ad Hiftorix Naturalis \& Anatomix cognitionem facientia, difficilitus dignofci \& perfcrutaripoffe.

Quamobrem licet inter omnia Animalia, nullum tantam affinitatem cum temperamento humano habeat; nullius quoque Anatomia tantum lucis adferat, quam Quadrupedis viviparæ: veniam tamen facile mer ebor, $\mathrm{f}_{1}$ vel qualitates vel diffectiones earum rudiori Minerva fortaffis explicavero, quam curiofus quifque Iatrofophos defideraverit.

DRxter Dorcades Europæas Brafilienfibus non multum diffimiles Caprex Indigenx Cuguacu-eténon cornutx, \& Cuguaçu-apará cornutx præcedentibus minores exiltunt. Pilis funt (plendentibus, glabris, hinc inde fufco \& albo variegatis, imprimis fi juvenes fint, nam maculix albx accrefcente xtate pereunt. Pes quilibet duas habet ungulas nigras, \& fupra has duas minor es fupra fe invicem pofitas. Cauda funt brevi, ut folet in Capreis. Oculis magnis nigris, naribus patentibus. Cornibus mediocribus ex tribus ramufculis fabricatis, villofis, cineritii coloris, qux quotannis amittunt. Caftitate \& foccunditate cum Europxis certant, ftatoque tantum tempore, initio fcilicet menfum pluviorum, quod veris vices fupplet, mares admittunt; poftea defervefcunt, \& $\mathrm{me}$ ticulofe fiunt. In uteri cornibus concipiunt, fexque menfibus, \& minus aliquando, in utero gerunt: quod tempus in frigidioribus Europær regionibus tardius abfolvitur.Non 
C V G V A Ç V-ETE'.

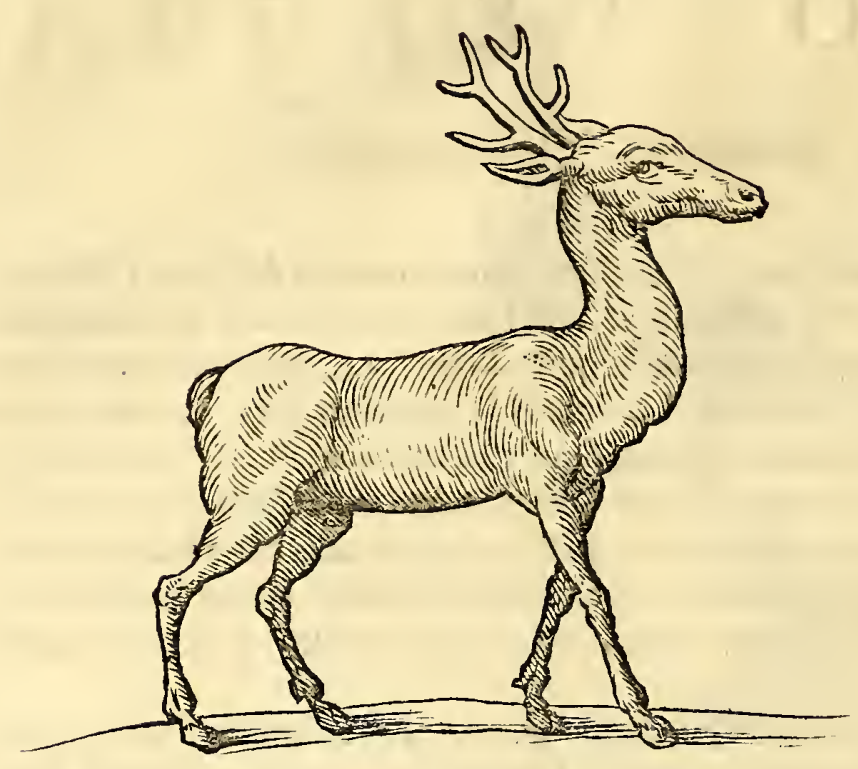

adeo filveftres funt, quin facile cicurentur. Fructus $\&$ frondes quas depopulantur, omnem denique cibum, ruminant:vifcera quoque naturalia more aliorum ruminantium difpofita funt, ficut in cornutis, alteraque tantum maxilla dentatis, folet fieri. Quum porroà veteribus Philofophis teftatum fit, quafdam non folum aves, fed \& animalia terreftria nonnulla, inter qux Cerva \& Caprex, felle carere; ego attentius circa duo potiffimum loca illis à Natura conceffa, hepar $\&$ inteftina inquirens, $\mathrm{fel}$ nullum quidem fubinde comperi; quia forte vifum effugerat, atque alia aliqua parte diffufum latitaverat, quod fellis vices illis fuppleret. tanta interim fellis neceffitas in corporibus animalium mihi videtur, ut eo non apparente locis folitis, Natura maluerit collocaffe in capite quorundam pifciculorum, quam in totum denegaffe vifcus tam nobile. Imo, funt aves qux tefte Ariftotele vefica $\&$ urina deftituuntur ; tamen fel ipfis perpetuo conceffum effe fatetur. Caprearum Brafilienfium caro eft optimi palati \& nutrimenti, quæ vel affatur, vel aromatibus conditur pro epulis, ejufdemque planc faporis eft \& dignitatis cum noftratibus. Verum, ficut hæc Caprex fpecies, qux villofis eft cornibus, carne fua alimentum, ita lapide in ventriculo contento, nedicamentum præbet haud contemnendum, fcilicet lapidem Bezoardicum Occidentalem, nunc Orientali minus celebrem quidem, attamen apud incolas contra mala quoque venenata in pretio habitum. Quo lapide venatores difficilius aliquando potiuntur, quam ipro animali in quo generatur. vulneratum enim telo, aufugitfummo ftudio, eructatque è ventriculi fundo per os ipfum lapidem, quem finon fagaciter obfervet venator, fpe omni excidit eo potiundi, ut mihi aliifque contigit fubinde.

T A I A ç $v^{\prime}$.

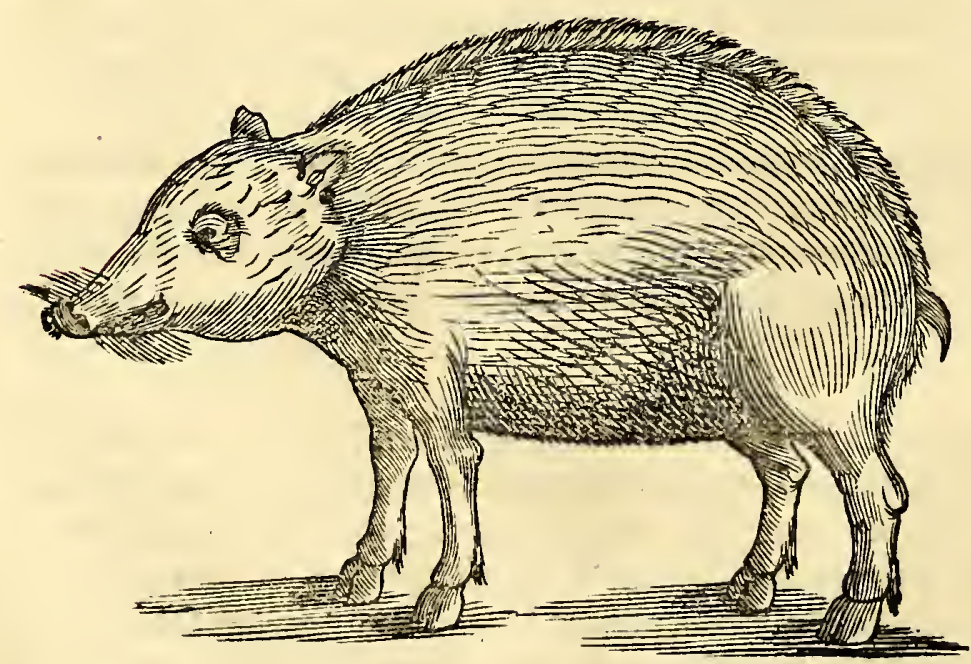

Taiaçí, Pö́cus eft filveAtris, fed Apris magnitudine \& ferocitate çedens;vix enim noftratium Porcorum domefticorum molem acquirit. Auribus, pilis $\&$ fetis in dorfo eft folito brevioribus \& mollioribus nigri coloris, punctulis minimis albis variegatus. Cauda eft nulla. Admodum probatx eft carnis, ut facile noftratium domefticorum fuperet. lardo eft tenuiori atque bono. In dorfo inter fetas promi-
concurfu vaforum lacteonentia apparet partim carnea partim membranofa, quafi ex concurfu vaforum lacteorum contorta, qux vulgo Vmbilici nomen audit. Quem tamen ego in diffectione verum umbilicum effe neutiquam potui animadvertere,ficuti neque Clariff. Anatomicus Leydenfis D. Falcoburgius, qui tranfmiflum ex Brafilia Porcum fimilem diligenter incidit. Mammarum quoque vicem præbere, quia vafa mammaria videbantur, qux la- 
HIST. NATVRAI。 \& MEDI C. I I B. III.

cteum humorem perpetuo deftillant, haud verifimile, quod fugendum prabeat papillis, quas more aliorum Porcorum fub ventre gerit. Per hunc ductum fpiritum. emittere, ficut Sues marini per nares, Lerius \& Thevetus putarunt ; fed attentior cenfura Fr. Hernandi magis mihi placet, qui in diffectione eorum, tam narium, quam umbilici, ufum illis mecum derogat. In multis Americæ regionibus, præfertim in nova Hifpania , ejufmodi A pri ejufdemque conformationis \& natur $æ$ inveniuntur, quorum çaro æque probata, qụæque mactata ut durabilior fit, ftatim liberari debet à du. tuillo lacteo dorfali, alioquin facile corrumpitur. Iracundi funt $\&$ vindictx admodum memores. Vulnerati enim infinitos folent fui generis convocare, ut holtes fuos, five Venatores five Tigrides, cum quibus perpetuam exercent inimicitiam, gregatim adoriantur. Ita ut non raro afcenfu in arborem falvare fe coacti fuerint vel fagaciffimi venatores, ubi tunc dux gregis, cum militibus fremens, truncum arboris loco hoftis amiffi mordet \& lacerat. illi interim tot feris circumdati, eas fuperne, vel venabulo, vel fclopetis tuti cxdunt, cum tamen illæ haud facile patiantur focietatem diffolvi, nifi forte mor $æ$ vel famis tædio.

Capybára, inter Porcos aquaticos five fluviatiles recipitur, quia figura \& natura bimulum Porcum xmulatur. brevibus eft cruribus $\&$ ungulis, fed porcinis, cæte. rum Porcis diffimilis, fi craffitiem \& figuram capitis, \& oris pilos aurefque parvas confideres. $\mathrm{Ca}$ ret cauda. Peculiare quid praterea huic Natura dedit, quod ( præter duos infignes dentes incurva. tos extra alveum prominentes) in qualibet maxilla dentes viginti quatuor habeat. Herbis \& fru-

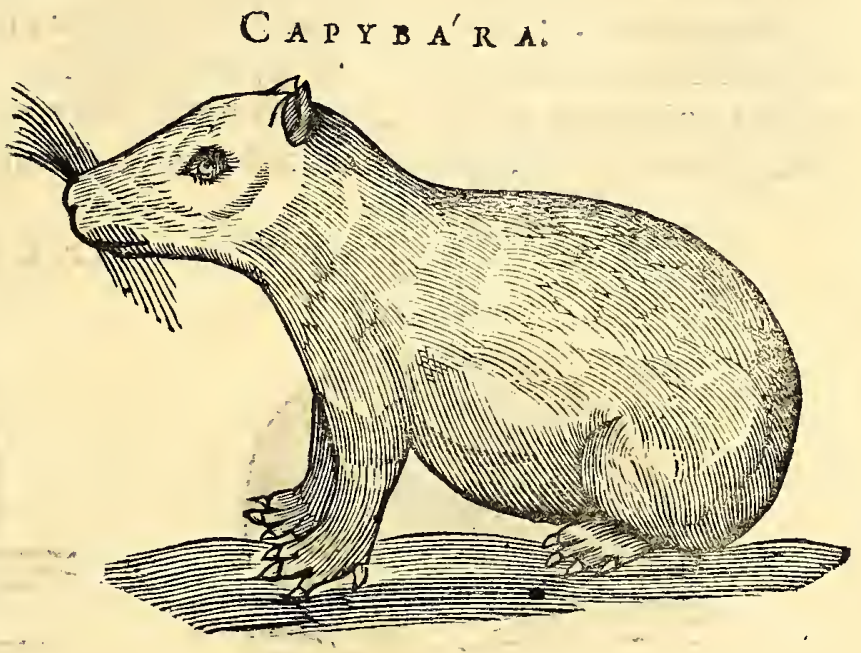
ctibus vefcitur. Noctambulum eft animal, pabulique gratia fluvios \& torrentes tranfnatat, clamoremque adeo horribilem edit de noate, ut nobis infuetis primum terrorem incufferit. Gregatim infinito numero circa ripas fluviorum oberrant ; cumque tardigrada fint, non curfu, fed velociffima natatione fe falvant à venatoribus, quia urinari vel maxime norunt. Cxterum haud difficile magna copia fclopetis vel fagittis figuntur, integrifque militum cohortibus probo fatis alimento fuerunt, imprimis fi affetur caro; fed quia dignitate Aprorum \& domefticorum carnicedit, caput hujus Capybára tantum pro deliciis apponitur.

\section{$C \vee A N D V^{\prime}$.}

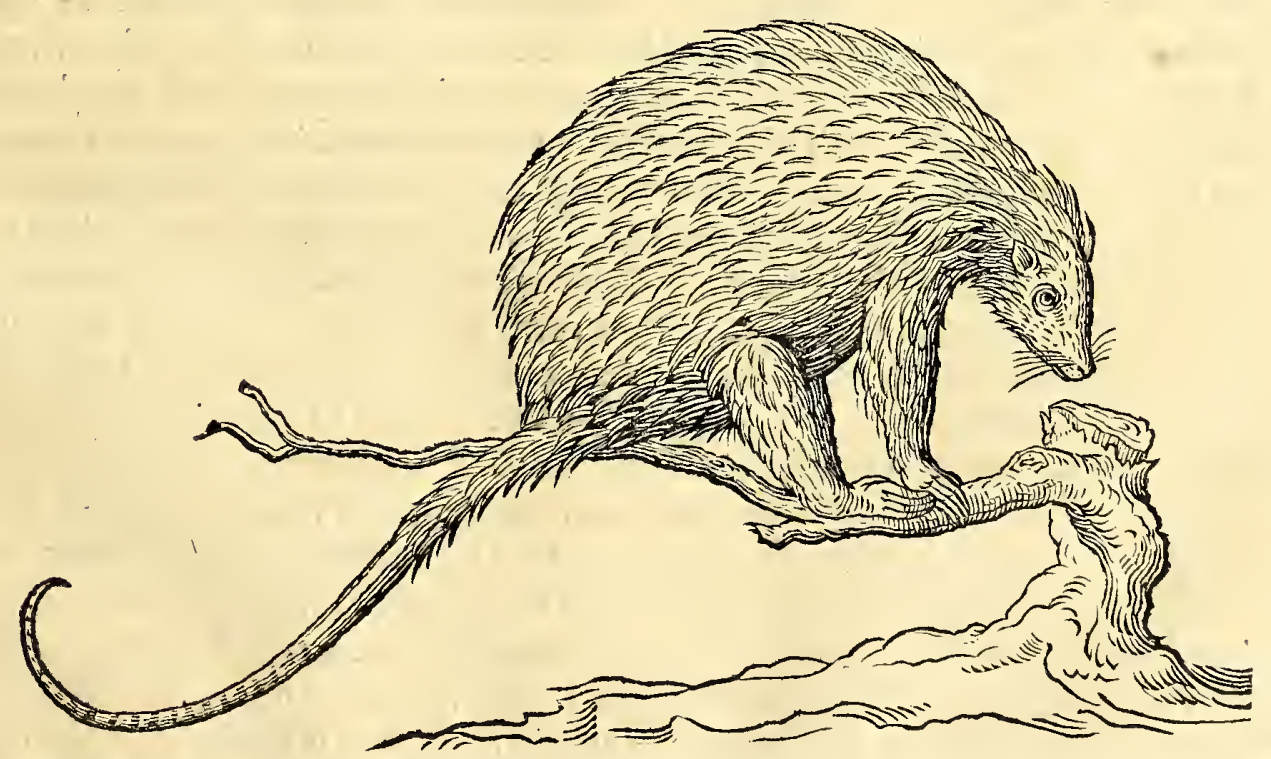

Cuandi, Major \& Minor, Africanis Erinaceis ex parte fimilis. Noftratibus 甚fot-

Dredfen, 


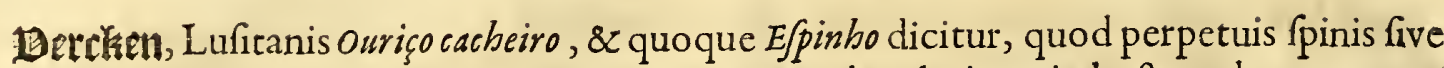
aciculis armatum fit animal. de quarum tamen ejaculatione in hoftem deque earum venenofa vel medica qualitate nihil nobis hic terrarum compertum eft, ficut de alia Erinaceorum fpecie in Africa atque in nova Hifpania teftantur Autores. Hxc enim Hiftrix ob infignes alimentofas qualitates potifimum celebris Simix majoris eft magnitudinis. Totum corpus pilis caret, fed fpiculis armatur undiquaque oblongis flavefcentibus. Ab infitione in cutem ad dimidiam fere longitudinem reliquam, pars dimidia nigricat, cufpis albicat. Capite eft quoque aculeato, excepta regioneaurium \& oris. Circum nares pilos habet multos, qui barbam Felinam illi faciunt. Oculi prominentes \& fulgidi. Cauda oblonga ab exortu fuo ad medietatem aculeata. exterior medietas nuda eft, \& raras habet fetas Porcorum inftar. Interdiu dormit, noctu circumvagatur, fpiratque naribus quafi anhelaret: vocem edit ut Sus i i iu. Scandit arbores, fed tardo greffu, quia pollice caret; idcirco defcendens, caudam circumvolvit, ne labatur. Fruetibus non folum, fed Gallinarum Columbarumque pullis multum damni infert, iifque perpetuo infidiari amat. Exinde pinguefactus facile præda fit venatoribus. Carne eft admodum candida, pingui, eaque gratıffima, ac proinde inter delicias apponitur five affata, five elixa, five ar tocrex modo condita. Inter Erinaceos enim qux vocem Caninam edunt, inferioris funt notæ; qux ore vero voceque Suilla, ut hic nofter, carne funt, tefte quoque Scaligero, longe delicatiori.

T A T $V^{\prime}$ five ARMADIL H
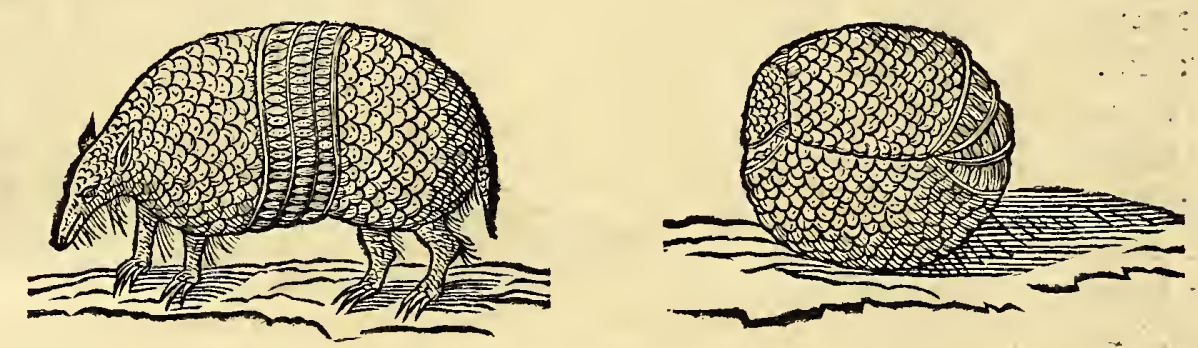

Cum in Occidentalis non folum, fed $\&$ Orientalis Indix partibus frequens adeo fit hoc inufitatæ conformationis animal, non mirum $f_{1}$ vel nomine, vel magnitudine, figura quoque fubinde variet. Hifpani Armadilho fatis appropriate, hoc eft, Cataphractum, Belgx Schift-Dercken nominarunt. Brafilix indigenæ nomine $\mathcal{T}$ atú generice totum hoc animalium genus loricatum exprimunt, variafque illarum fpecies peculiari addito cognomine diftinguunt. Prima \& maxima Tatu-péba:cujus defcriptioni fuperfedeo, utpote quæ non edulis. Secunda \& præftantiffima Tatu-eté, fed priori minor. Tertia Tatu-apará, præcedenti magnitudine par, cujus folum iconem exhibeo, fed alteram incedentis, alteram dormientis beftiz. Omnibus his commune eft, quod lorica offea ex fquamis elegantibus compofita operiantur, quod Porcellorum quafi fint roftro, figura, oculis, pilis \& pedibus, licet magnitudine $\&$ dignitate inter fe difcrepent. Item quod noctambula \& falacia, roftro fodientes Talparum more, nunc fub terra in cavernis latitent, nunc in aquis inftar amphibiorum, imprimis vero fupra terram more alioruim quadrapedum degant. Horum denique caro, excepta illius Tatu-péba, nơ folum vefea, fed ob teneritatem \& albedinem apud magnates pro deliciis appofita, affata, elixa \& in artocrex modum condita, Cuniculorum \& Porcellorum carni præferatur. Tantum abeft ut cum Talpis in terra potiffimum nutriantur ad mentem Monardi, ut fructibus Batatis, Bacobis \& Melonibus cxterifque plantariis, imo Gallinis vefcantur. Q uamobrem ruftici ea exofi habent, iifque perpetuo vel decipulis vel canicul is infidiantur. Hæc autem fpecies peculiare haber, quod dormituriens, aut venatorem eludere volens, prioribus ac pofterioribus pedibus collećtis, more infantium in utero jacentium, ac auriculis intro tractis, cum, cauda capite $\&$ ad caput relatis, inftar pilæ fe componat, atque per commiffuras incurvato dorfo ac clypeo, ita lateralibus extremitatibus, ac antica $\&$ poftica parte confertis, ut nilhil apparcat nif lorica capitis $\&$ caud $x$; adeoque inftar conch $x$ firmiter $f e$ claudit, ut ne à validifima quidem manu aperiri $\&$ dilatari fe patiatur. Quamobrem miræ iftius fortitudinis rationem defiderans, aliquoties illud diflecui domi mex, loricamque 
camque convexam, qua tégitur, inveni cum quatuor commiffuris tranfverfalibus, lenta admodum cute conftantibus, quibus loricam extendere $\&$ contrahere poteft. Qu $x$ lorica figuris quinquangularibus eleganti ordinę difpofitis conftat ; inter commiffuras vero parallelogrammis, \& quælibet figura fquamulis lenticularibus, coloris exalbo flavefcentis. In quolibet latere mufculum reperi infignem longum \& figuram $\mathrm{X}$ habentem, plurimis fibris ita decuffatim difcurrentibus fecundum longitudinem, quorum ope validiffimam illam contractionem $\&$ corporis conglobationem exercet. Cxterum coëunt \& generant more aliorum animalium. Præter alia falacitatis figna, accedit quod genitalia in omni. Tatú præter modum longa \& craffa atque rigida promineant. De carnis præftantia alimentofa fupra monui. De vi medicamentofa Lamiarum Fr. Ximenes vir haud vanæ fidei, ut \& Monardus, multa annotarunt; verum à me haEtenus incomperta.

Tapiiereté, Lufitanis Anta, mirum afpectu animal, magnitudine Iuvencifemeftris; dorfo incurvato, figura corporis quodammodo ad Porcum accedens, imprimis oculis, capite $\&$ pedibus. Promufide eft fuper os præeminente; quam validiffimo nervo contrahere \& extendere poteft: Ore dentato in utraque maxilla. Loco caudx exiguum proceflum habet depilem. Cute eft folida inftar Alcis, brevibus pilis, umbrx \& fufci coloris. Salax eft T A P I I E R E T E'.

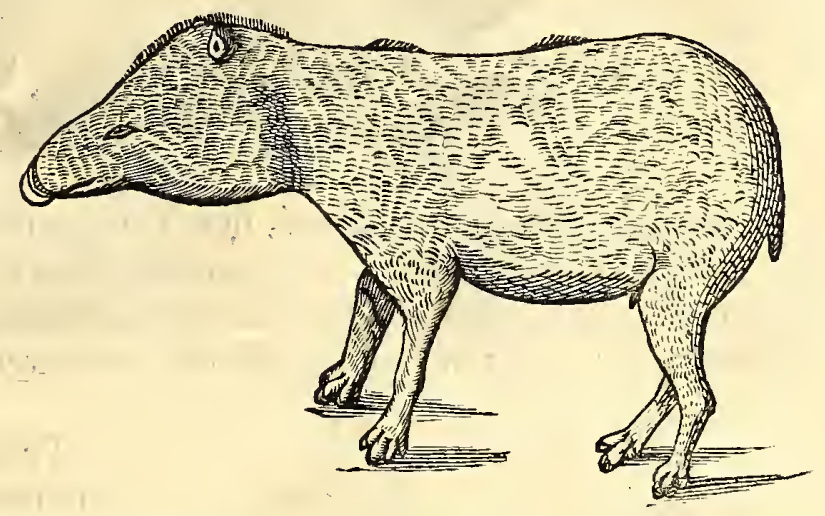
beftia $\&$ noctambula, qux arborum fructus, arundines facchareas, depopulatur. Inter amphibia non recenfetur : fluvios tamen tranfnatat rapidiffimos. Cxterum iners $\&$ focors apparet, adeoque lucifuga, ut in denfis mediterraneis filvis interdiu dormire amet: Ita ut, fi detur animal aliquod quod noctu tantum, nunquam vero de die vene-

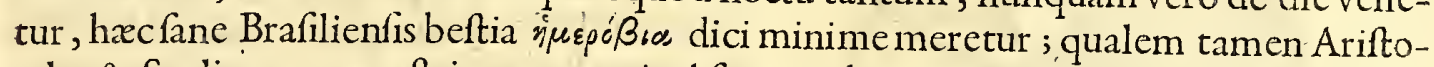
teles \& Scaliger ex terreftrium genere in Afia non dari autumant. Caro ejus vefca, $\mathrm{f}$ juvenis, \&rite prxparetur, bubulamque æmulatur, eaque mediterraneis ac maris accolis in frequenti ufu exiftit.

Inter $Q$ uadrupeda vefca in hifce filvis $\&$ campis littoralibus frequentia, fex feptemve Cuniculorum \& Leporum fpecies exfant, communi nomine corrupte Lufitanis Ratos domato dicta. Quxut magnitudine, colore, \& figura nonnihil inter fe difcrepant; ita natura, indole, natali folo, atque fapore multum inter fe conveniunt, \& ob carnis bonitatem, omnibus pariter in deliciis habita ; quamobrem multi incolx , nunc decipulis,nunc Canis venatici vel odori ope iis infidiari amant, reper toque antro id ab utraque parte fodiunt, \& cuniculum actum ab utroque latere obturant, \& demum in locum quo confidere autumant, longum cultrum infigunt, ut ita transfigant prædam fub terra latitantem. Q ui vivi capiuntur, cicurari fe patiuntur \& pinguefcunt. Vniverfa hæc Leporum \& Cuniculorum familia admodum eft foecunda: feptenos \& ultra uno partu catulos ter uno anno profert, non cxcos tamen more noftratium.

Prima, qux maxima \& nobiliffima facile inter eos exiftit, eft Páca, magnitudine pinguis \& craffi Porcelli, cujus inftar grunnit. Cibum oblatum. non pedibus more Cuniculorum detinet, fed in terra depofitum devorat. Capite èf craffo, auribus prater morem parvis, abfque cauda, ut plerique hi Cuniculi. Crura priora paulo pofterioribus breviora; ita ut non adeo velocitate, quam vehementi quidem morfu, fe $a b$ holte vindicet. Pilis eft

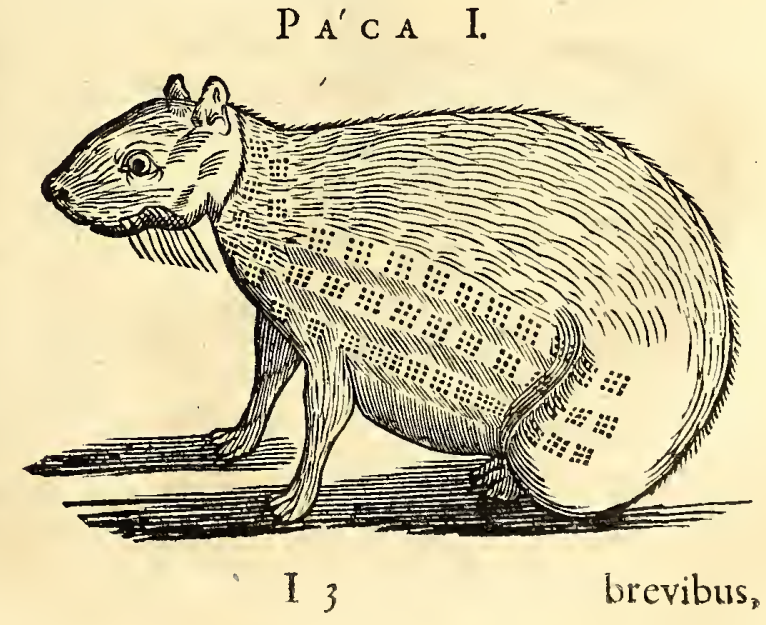


brevibus, ad tactum duris, umbræ coloris, in lateribus maculis cinereis prædita. Carne eft tenera, pingtu, lardo non indigens, fi affetur, fed inter cpulas magnatum, ficut Lepores \& Caprexin Europa, habetur.

TAPETIII.

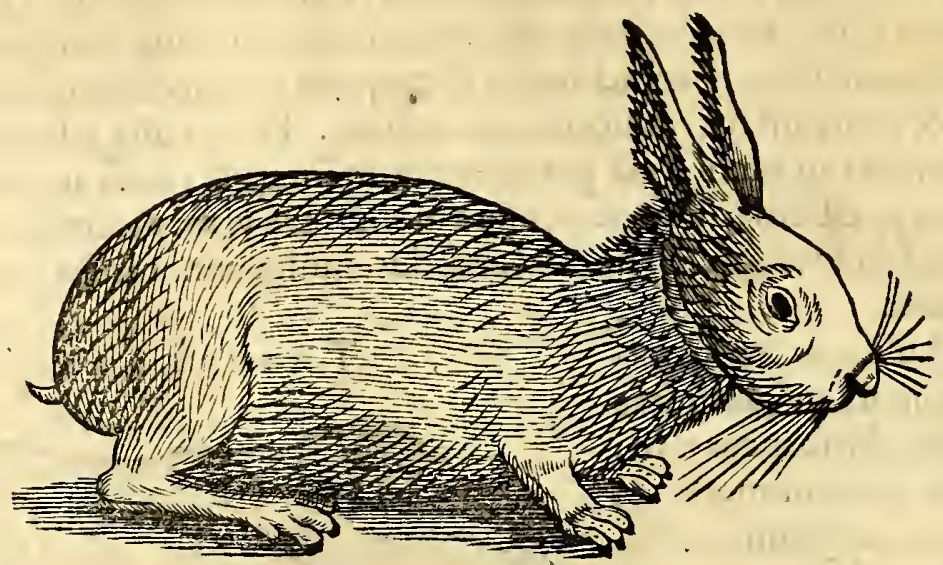

Secunda fpecies dicitur Tapetí, figura, magnitudine, pilis, auribus, barba, Leporibus noftratibus inter omnes has fpecies maxime fimilis : victu quoque, fertilitate, carnis bonitate ab Europxis minus difcrepans. Eorumque more in filvis, non intra terram, nidificat. Quamobrem non neceffe eft ejus narrationi inhærere.

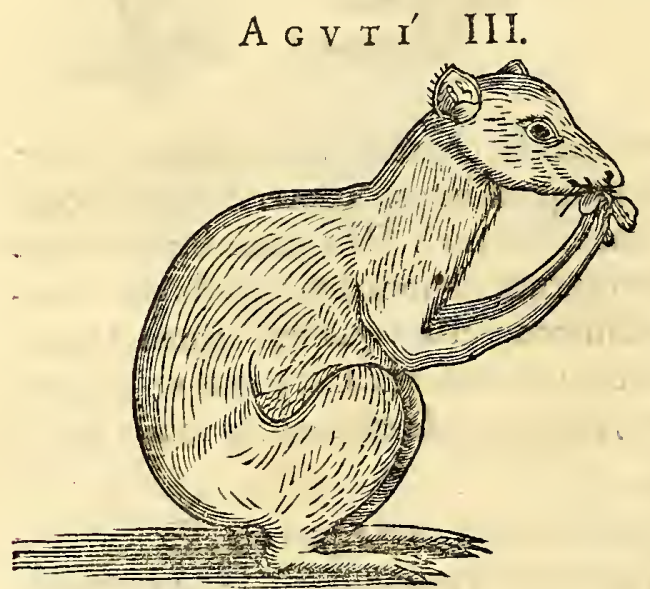

Tertia Cuniculifpecies eft Agutí, vulgo. corrupte Cotiá. Quæ magnitudine \& figura eft noftratium : fed inter cos quibus aliquid porcini intercurrit. Præterquam quod pilis fit fplendentibus, rufis \& duris, ut in Porcellis junioribus; grunnit quoque eodem modo; inferiorque mandibula, ut in Suibus, brevior eft fuperiori. Si corporis proceritatem, velocitatem, voracitatem, dentes, caudam, mores denique refpicias, cum Leporibus quadrat; auribus tamen, qux rotundx funt, difcrepat. Pofteriora crura glabra, longiora, digitis fex; anteriora breviora quatuor tantum funt præedita;iifque directe anterius extenfis, incedit, $\&$ arripit cibum oblatum, devoratque quam ociffime. Adeo denique à natura munitus, ut fi non unguibus $\&$ dentibus fe tueri valeat, velocitate pedum fe falvare poffit: ubi vero irritatus, vindictx minus potens fiat, grunniendo quatit humum pofterioribus cruribus multo fortius quam $\mathrm{Cu}$ niculinoftrates, dorfique pilos erigit. Caterum cicuratur, ut pinguefcat, atque philanthropos fit. Sed teneritate carnis proftat, fi filveftris mactetur.

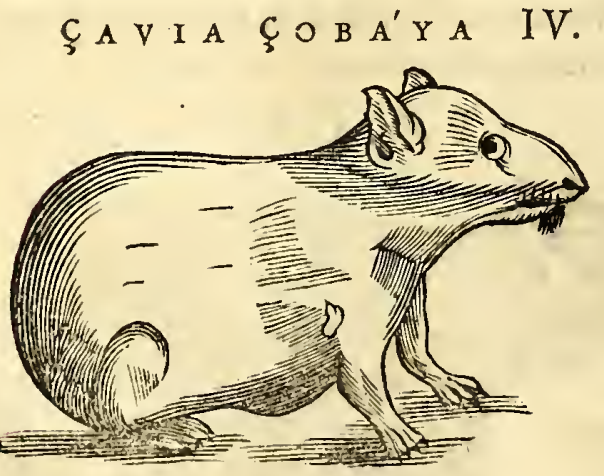

Quarta fpecies f̧avia cobáya. Qux ut Europxis Cuniculis magnitudine cedit ; ita diverfitate \& elegantia colorum cos fuperat. Pilis eft molliufculis, maculis albis, nigris, rufis; Cruribus brcvioribus; anterius digitis fenis, pofterus quinis. Capite \& dentibus Gliris fimili bus.caudæ veftigium nullum fere. Nulla Cuniculorum fpecies tam familiariter in $x$ dibus cicuratur, quam hæc, imo in alias Europær regiones feliciter vehitur, ubi $x$ que prolificus eft, \& pinguefcit. Grunniendo cibum quafi à domefticis mendicat inftar Canicula domenticx. Dignitate carnis cxteris haud cedit, imprimis filveftris adhuc. affata, \& elixa, apponitur, minufque alba \& ficca quam noftratium ; adcoque humore abundans, ut male fiat illi, finimium aqux potet. 
HIST. NATVRA L. \& MEDIC. LIB. III.

Quinta, Apereá dicta, Noftratibus Bellt-rat Cuniculi eft fpecies minima, abfque cauda, pilis Leporinis, ut \& capite, barba $\&$ inceffu. Vivit $\mathrm{Cu}$ niculorum more, ejufque natura participat ; nifi quod petrofis potius cavernis, quam arenofis gaudeat, unde à venatoribus $\&$ viatoribus ope caniculæ elicitur $\&$ capitur. Elixus, affatus, conditus apponitur. Adeo enim carne eft tenera $\&$ bona ut Cuniculos Europæos facile fuperet.

$A P E R E A^{\prime} V$.

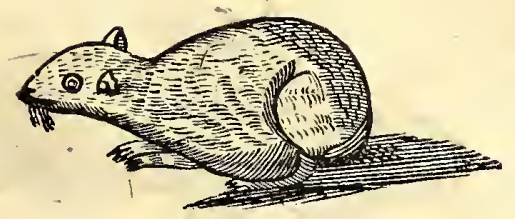

$I A G V A^{\prime} R^{*} A$.

Variæ Tygridum fpecies in filvis reperiuntur, quarum aliqux majores $\&$ ob crudelitatem nimium celebres, quas, utpote non edules, prætereo. Hæ minores vefcæ Lufitanis Onça generaliter dictx, Brafilianis peculiari nomine diftin. ctx: Quarum prima mactilata Iaguára, fecunda Iaguareté, tertia Cuguacuara, cujus icon defideratur. Seniores brevibus,juniores longioribus funt pilis \& paulum crifpis inftar lanæ ovillæ; nunc Capræ inftar ex flavo rufefcentis coloris, nunc maculis nigricantibus eleganter difpofitis. lupi ferefunt magnitudinis \& molis, rapaces quoque, $\&$ hominibus xque ac beftiis infeft $x$, cum famelicx funt; alias enim à gregariis canibus, imo vel folo accenfo rogo de nocte in fugam facile aguntur ; ignis enim vel luminis be-

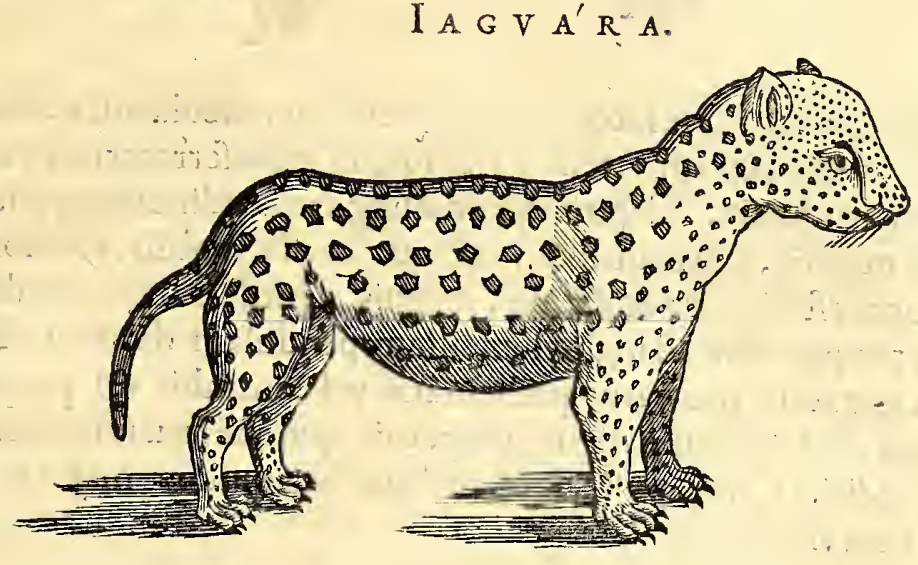

I A G V A R E T E'.

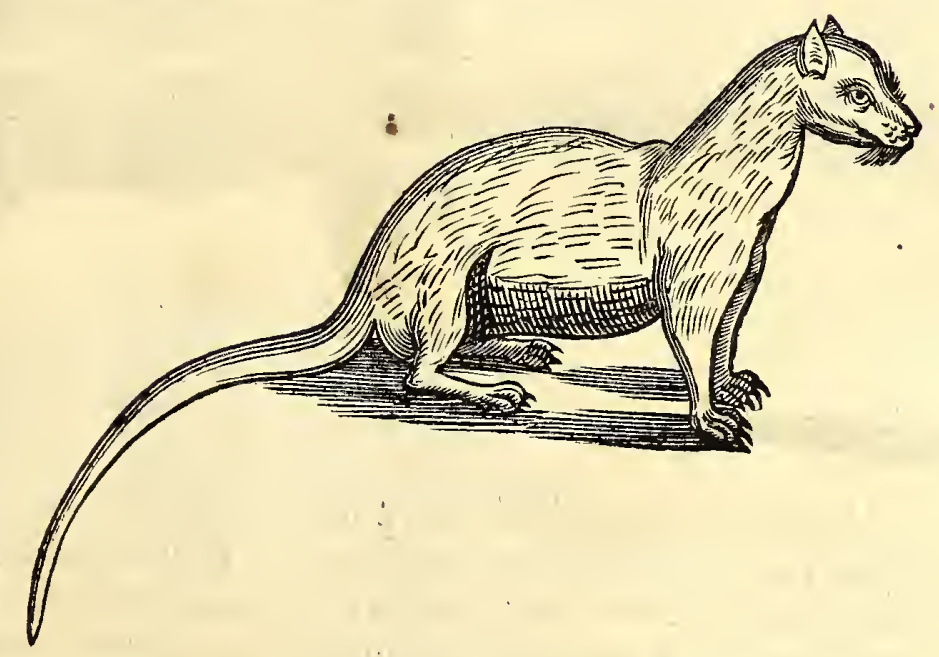

neficio me fociofque itineris mei ab his aliifque noxiis animantibus tutari folebam Terriblem noctu clamorem $u$ inftar Canis famelicx excitare folent. Prxda potitæ eam dilacerant, caputque in ipfum cadaver immittunt, fanguinemque imprimis fugunt. Licet carnis bonitate, mole capitis, corporis, cauda $\&$ maculis cutis inter fe differant, oculis tamen igneis, barba \&ungulis felinis, dentibus acutiffimis, atque indole conveniunt. Nec eft, quod aliquis putet à Barbaris' Tapuyeris tantum expeti carnem harum rapacium animalium; ill $x$ enim qux rufefcentibus $\&$ flavefcentibus maculis funt, $a b$ omnibus paffim Europxis incolis, inftar Vitulinx aftimatur. Atque ipfe non fine admiratione edoctus fum, non plus ferinam fapuiffe tam rapacium animalium carnem. Attamen monitos volui femper amicos, imprimis valetudinarios, ut ab ea fe abftine rent, vel rarius faltem vefcerentur, ob fervidum quem generat fanguinem \& fuccum omnis beftia $\&$ avis rapina.

Inter tot Lacertorum exercitus præ cxteris magnitudine \& pulchritudine excellunt quos hic damus. Prior Iguánà (corrupte Leguáme, ) aliis Śenembi; polterior Tejuguaçu diatus. Qui, ut exterius nonnihil difcrepant forma, ita interius plane inter fe conveniunt, ejufdemque funt naturæ. Prioris corpus duos eft pedes longum, ficut \& cauda. Tota beftia exterius late viret inftar Pfittaci, nifi quod maculis nigricantibus \& albis in modum panni undulati hine inde variegetur. Cute eft undique fquamofa. pone

$$
\text { I } 4 \text { caput }
$$




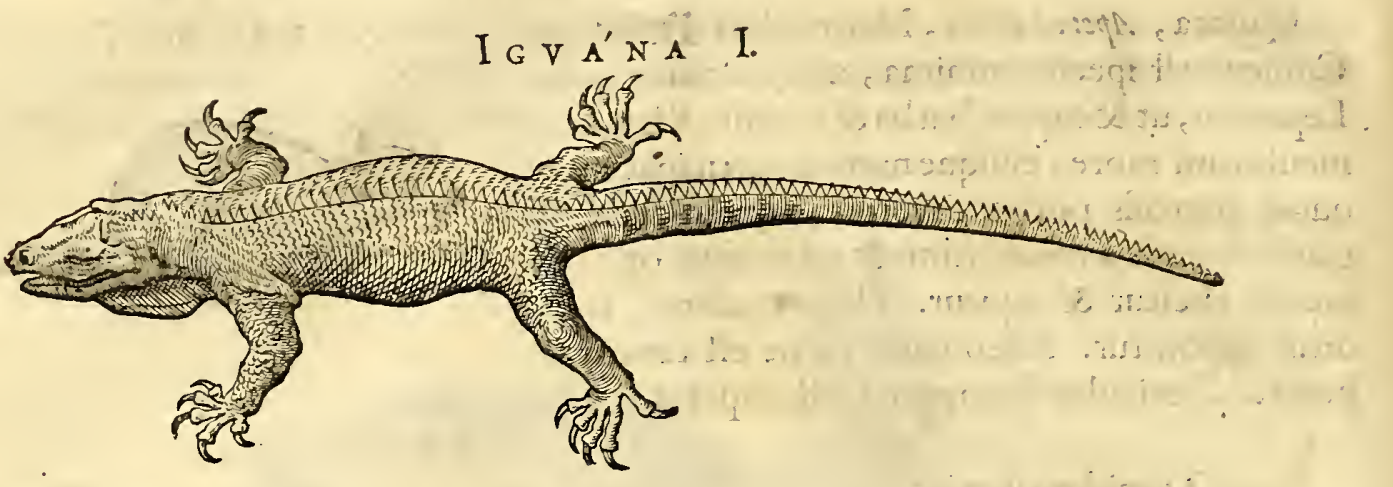

caput in utroquelatere albicans emicat macula inftar Branchiarum pifcis. A cervice ad caudx extremitatem feries fuamarum ferratarum excurrit viridis fecundum dorfi longitudinem. Capitis fquamx fingulari ordine funt pofitx. Naribus eft patulis. Oculis magnis, nigricantibus. Lingua craffa mobili, fed non bifida ut fequentis figuræx. Rictu eft diducto \& patulo, exiguis dentibus nigricantibus oblito, cibumque is rite præparatum ad ingluviem illam pendulam dimittit. hanc ingluviem nigricantem \& ferratam pro variis pathematis vel contrahit vel propendere finit. Crura non folum, fed \& eorum digiti , perpetuis quoque fquamis veftiti, \& variis articulationibus præditi. Crura pofteriora anterioribus quidem majora, fed omnia paribus unguiculis curvis armati.

$I G \mathrm{VA}^{\prime} \mathrm{N}$ A $I I$.

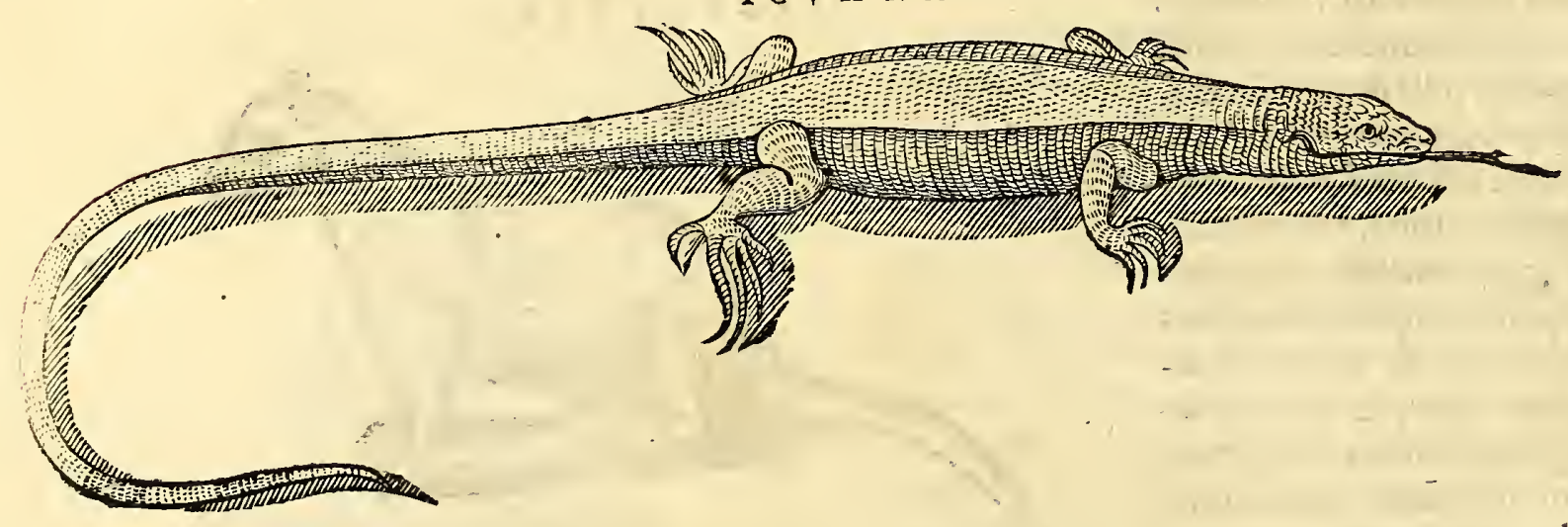

Altera hæc à præcedenti in eo potiflimum differt, quod colore fit nigro cum maculis albis. Digitis pedum multo longioribus. Cauda quoque longiori \& craffiori, non ferrata. Lingua bifida, lavi, rubra, quam multo velocius \& longius, quam præcedens senembe exerit, \& more ferpentum retrahit. Vtrumque animal domi mex ligatum detinui, expertufque fum fupidum effe $\&$ inedıx patientiffinum, quxdam ad fex,quxdam ultra octo menfium fpatium, ut ne mufcam vel culicem comederent, fed tantîn ore fubinde patulo immota jacentia aliquandiu apertis feneftris matutino rơre auraque vefci vifa fint, attamen, licet Lacerti, Serpentes aliaque reptilia frigidioris utcumque fint temperamenti, hi elapfo circiter femeftri, fi non efca exhibeatur, inedia contabefcunt $\&$ moriuntur. Fructibus $\&$ ovis crudis vefci amant, unde multa pinguedo \& caro albiffima illis nafcitur. qux elixavel frixa, inter delicias expetita, nec Gallinaceis pullis cedit, ejufdemque dignitatis, \& faporis, cujus eft caro Armadilla, nifi quod ficcioris fit nutrimenti. Aphona funt plane, velociffime currunt, facile tamen exarboribus fe illaqueari patiuntur. V.fque adeo tenacis funt vit $\mathfrak{x}$, ut, fi aliquoties feriantur in capite, non moriantur, nifi cervix cultro infixo vulneretur. Vnde difficile Ariftoteli aflentiendum puto, Lacertos vix ultra fex menfium fpatium vivere. Mactata vero \& plane excoriats diu adhuc moventur, cordaque excepta, admodum fubfiliunt. Ovipara funt, idque fingulis fex menfibus, ac in utroque latere duodecim aliquando ova cerafi minoris magnitudine apparuere. Etiamfi inter amphibia poffit cenferi Iguána, quia fluvios quoque intrat; tamen more cxterorum amphibiorum in terra generat. Ova qux ponit, rotunda funt, \& tenuiori tefta quam Gallinacea, prxdita: cæxterum vitellum \& albumen Gallinarum fimilia fapore, quxaddita aqua, non oleo aut butyro, friguntur. Porro pinguedo Senembíapud Chirurgos Americanos in pretio habetur ad cutis vulnera lananda. 
HIST. NATVRAL. \& MEDIC. LI\$. III. Ios

In diffectione vifcera omnia vitalia $\&$ naturalia, ficut in aliis animantibus reperi, fed duplici ventriculo prædita. Anterior, cibi licet pauci receptaculum, inde inteftinum admodum tenue, cui alter ventriculus concoctioni ciborum dicatus annectitur. In hoc ventriculo ut \& inteftinis teretes lumbrici latebant. Lapis quoque ex eodem ventriculo exemptus ovi fere gallinacei figura \& magnitudine exterius; interius vero, lapidis bezoardici coloris \& fubftantix erat; quippe contufus, à tunicis quibus componebatur, facile feparabatur. Idem lapis ab incolis celebratur. Verum an aliqua vi medicinali polleat, à me nondum compertum. Francifc. Ximenes in nova Hifpania fimilem lapidem in cerebro ejufdem Iguane reperiri, doloribufque nephriticis \& calculis frangendis, fi drachmæ pondere è liquore convenienti hauriatur, mederi teftatur.

Varix Teftudinum Brafilienfum fpecies, ut nomine ac natali folo ; ita figura, colore, magnitudine, atque dignitate inter fe differunt. Antequam agmen edulium animalium claudam, eas tantum recenfebo Teftudines, quarum qualitates mihi compertx funt. D̈ux occurrunt marinx, vel amphibix potius, quia ova fua ad littus maris ponunt in fovea, quam arena tumulant, donec excludantur. ultra ducenta fubinde fimul reperiuntur, magnitudine gallinarum ovis paria, rotunda, alba, non tefta, fed valida tantum membrana tecta.

Prior Tartaruga Lufitanis,Iurucuá Indigenis, adeo magna, ut à tribus bajulis vix dimcveatur, plurimifque hominibus faturandis caro earum fufficiat. Loco pedum habet quafialas : anteriores quidem longas : pofteriores breves: (quarum figuras paffim videre eft apud authores) caudam acutam, conicam: oculos nigros, magnos: os edentulum \& inftar roftri volucrum.

Altera minor cateris Teftudinibus Iururá dieta, Lufitanis Cagádo; atque ad differentiam Cagádo d'Agoa nominatur. Hxc intra teftam fe recondit pro lubitu, \& collum rurfus ad trium digitorum longitudinem foras extendit. Capite eft oblongo; nafo elevato $\&$ acuminato; ore amplo; oculis $\&$ unguibus pedum nigricantibus. Cauda brevi, acuminata : cute rugofa quafi fquamis conftante.

\section{A B O I I I.}

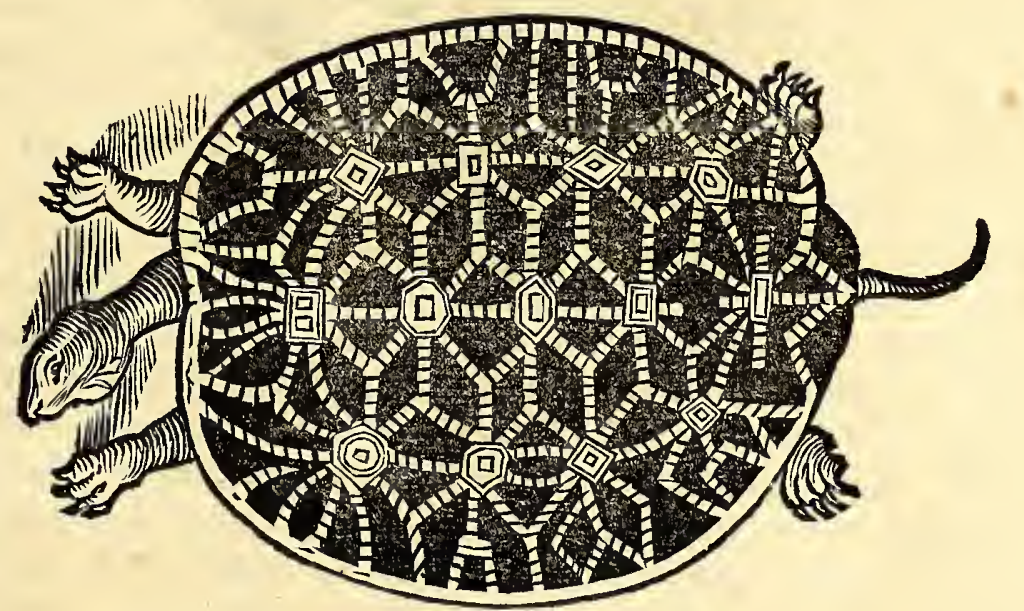

II.

$\bullet$

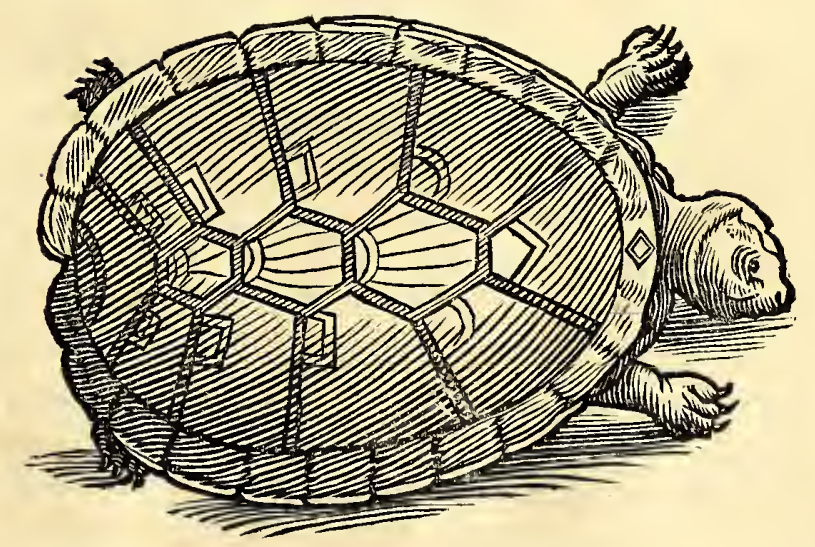

Tertia \& quarta fpecies, terreftres funt plus minus manus magnitudine, figura in- 
ter fefibi, paucis exceptis, multum fimiles. qux Cagádo da terra Lufitanis, IabotíIndigenis appellantur. His caput $\&$ crura funt fufca, verum maculis ex umbra variegata. Caro $\&$ ova funt vefca:jecur vero palati eft optimi, atque antecellit omnium animalium ecora fuo fapore.

Pleræque terreftres tefta operiuntur nigricante, cui varix nigricantes \& flavefcentes figuræ geometrice quafi infculpta vifuntur. Sicut ex appofitis hifce figuris liquet. Vix fonum nifi brevem, cxiguum, eumque breviflimum, kik kik edunt. Inedix patientiffimæ funt ad biennium fere, tantillum aqux folum domi mex forbentes. Cxterunı radicibus \& fructibus filveftribus vefciamant.

Cum ex Philofopho conftet, quod pleraque ovipara, ut quoque aves $\&$ pifces, vefica $\&$ renibus deftituta fint, tefudini tamen marinæ conceffos efle exautopfia confirmatum habeo.

Multa præterea Græci Philofophi de Teftudinum indole \& generatione narrarunt, qux fi conferantur cum hujus Novi Orbis Teftudinibus, aliqua dubiæ fidei videri poflent.

FI $N I S \quad L I B R I$ T E R T II.

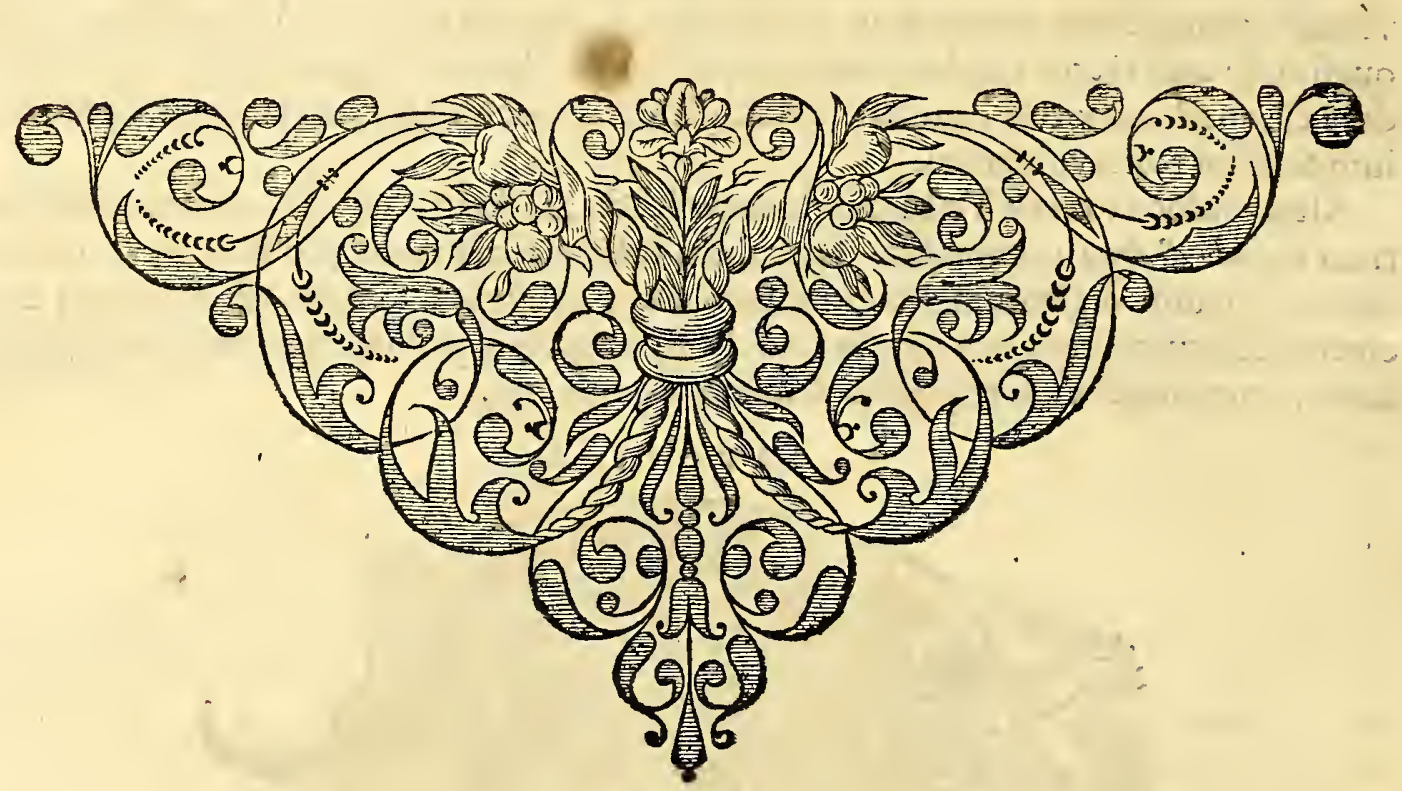

G V L I E L 
GVLIELMI PISONIS

\section{$\begin{array}{llllllll}H & I & S & T & O & R & I & \mathbb{E}\end{array}$ NATVRALIS \& MEDIC}

\section{$L I B E R$ QV ARIVS.}

\section{De Arboribus, Fruticibus, \& Herbis Medicinalibus, ac Alimento/ss, in Braflia os circumjacentibus Indix Occidentalis Regionibus nafcentibus.}

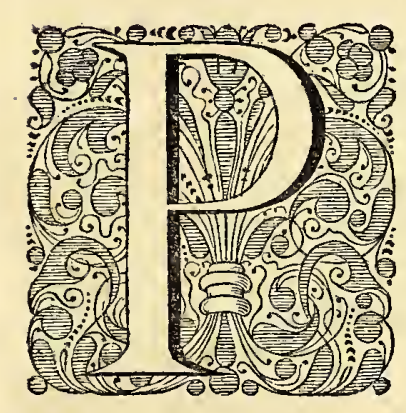

Eracto 'Tractatu de Animalibus edulibus, ordo poftulare videtur; ut Vegetabilia Alimentofa \& Medicamentola iis fuccedant antequam ad Venena \& Antidota tranfeam. Miffis itaque omnibus illis, quorum vel ufus Medicus adhuc latet; vel qux huc aliunde illata, \& abaliis fatis fuperque ante me expofita, ut Malus Medica, Citrus, Punica, Milium Turcicum, Lapis Bezoar Occidentalis, Ambra grifea, \& fimilia; vel quxfolummodo quxetui comparata funt, ut infinita ligna in ædificiis celebrata; Ea tantum perftringenda duxi, qua in Medicinam funt recepta, atque ab aliis $\&$ me ad Artis noftr $x$ incrementum, profpero ufurpata fucceffi. Adeo enim ex re fore putavi, ne quam multa (ut folet fubinde farrago exoticorum hauftu facili \& fupino congeri) fed quam proficua exftarent materiz Medicæ monumenta. ad imitationem fcilicet Diofcoridis potius, quam Plinii \& Theoprafti, quorum hi ranquam Naturæ admirabilia, ille ut Medico ufui adoptentur, propofuit. Verum cum tantx molis femper fuerit, novis auctoritatem, obfcuris lucem, dubiis fidem dediffe, non elt, quod mihi arrogem in re tam difficili voto lector is fatisfactum iri, fed principii gravitatem, incultumque Solum, ingenuis his conatibus patrocinaturum confido; atque pofteros, quibus plus otii \& eruditionis fupererit, non folum quæ in enartatione Vegetabilium \& Senfitivorum defiderantur, fuppleturos; fed \& mulca convenientia cum aliis Mundi partibus obfervaturos. Nam quemadmodum unaquaque terra quxdam peculiaria producit, aliis regionibus negata: (ficut liquet inter cxtera in hujus Continentis Occidentali parte Peruvia Argentifera, fed minus falutifera, atque è contra in Brafilia mineralium inopi, fed Aëre, Aquis, \& Locis, eorumque Vegetabilibus, admodum beata,) ita certifimum eft hanc quoque à r eliquis novi Orbis Infulis in multis naturalibus non difcrepare.

Ex quibus facile patefcet perpetuus ille immenf $x$ Naturæ lufus in falutem mortalium longe laterque diffufus. Quin Prifcorum plerique, ac Recentiorum non pauci, qui de
Medica materia verba fecerunt, una tamen omnes nondum ad medium, ne dicam ad calcem faftigiumque, rem perduxere. Quippe adeo fieciebus ac viribus abundans $8 \approx$ amplus eft ille campus, ut meritiffimo jure ea qux dignofcitur pars, illius quæ igno-
ratur, minima dici poflit.

Porro non me anxic adeo Botanicorum confueto ordini obftrinxi, ut herbæ, frutices $\&$ arbor es fingul $x$, ad clafies fuas venirent. Sed à nobilifimis \& maxime ufualibus Vegetabilibus ad cxteras defcendi, prout variis locis $\&$ temporibusfefe offerrent. Quafdam icones $\&$ annotationes ab optimo $\&$ diligentifimo meo domeftico D. Markgravio, in noftris peregrinationibus obfervatas mutuatus fum. Quod idcirco præmonere volui, ne malevolus quifpiam furtivis coloribus me fcripta ornaffe fibilet. Erenim quando horas fubcifivas publica munia mihi denegabant, id fedula opera ejus adimplerijuff, ut quarum ego naturas \& proprietates penficulatius inveftigarem \& experirer ; earumdem ille figuras externas per otium graphice depinger et. parum filicet inter effe arbitratus, fi inventa noftra illi vel mihi impertirentur, aut fub cujus noftrum nomine lucem afpicerent, modo illa, dubia nonnulla diffolverent, errorefque deteger ent atque tum Novi, tum Vereris Orbis xgrotantium \& medentium commodo futura fint.

C A. 


\section{$\begin{array}{lllllll}C & A & P & V & T & \text { I. }\end{array}$ \\ Tacomareé five Arundo Saccbarifera.}

P.

Oftquam vaftifimi hujus Continentis in Indiis Occidentalibus pars, qux nune vulgo Brafilia dicitur, inter duos fluvios Maranhor \& de la Plata, fita, paulo poft

Capralis acceffum à Vefputio Emmanuëlis Regis Portugalliza ạufpiciis, paulo accuratius anno circiter $\mathrm{C} I J$ Io effer explorata, Lufitani, intra promontorium olinde amocnifimum \& Infulam Itamar aca, primum littora antea incognita legerunt. Vbijuxta rupen fiftam Brafilianorum tuguriis confpectis, ad terram appulerunt, \& de nomine loci folliciti, quantuin potucrunt inquirentes, Paranambuco, hoc eft, mare perforatum vocari, à Barbaris refponfum tulerunt. Vnde hodie quoque, omnium Prafecturarum feliciflima, idem nomen obtinet. Cujus receffus cum altius explorarent, indignum exiftimarunt, ligno rubro, licet maximi proventus ad tingendos pannos, acquiefcere:prafertim cum preter confragofos montes \& faltus inacceffos, miro Deibencficio, longe lateque partim in planitics folutas, partim in colles clementer affurgentes terras confípicerent; tum \& prxftantifimis animalibus, fructibus \& frugibus Europxis invectis, mirabili proventu ea producere $\&$ foetificare cxperirentur. Tandem focundum hoc folum Cannis Sacchariferis aptiffimum judicarunt: eafque à campeftribus quondam hominibus detectas in Infulis Fortunatis, huc detulerunt, qux ob firavem fuccum quafi ad manus traditx, ufum quem pollicebantur, olim filveftres, nunc excultx \& domefticx, toto fere generi humano præftant. Ita ut cœlefte hoc donum, Attico melli multis partibus praterendum, excelfis inclufum arundinibus, hifce regionibus imprimis conceffum fit, è quibus tum aquaria mola tum boum indefeffo labore agitata, dulciffimus liquor expreffus, in ahenis excoqueretur, quemadmodum hac imagine expreffum videtur.

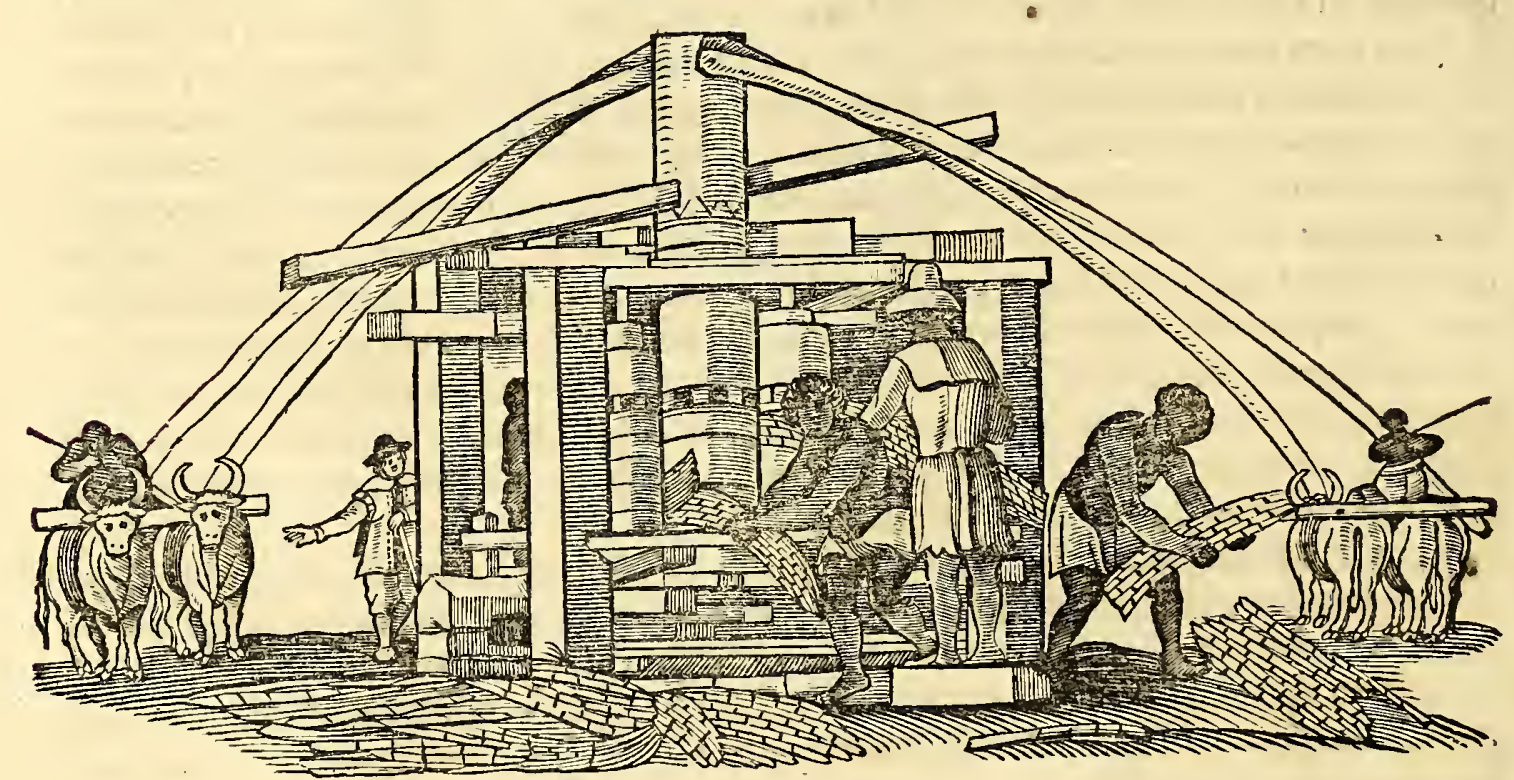

Mult $x$ hodie hujus generis machinx confpiciuntur. Nec ulla hujus terræx merx eft, ex qua plus lucri \& emolumenti ad negotiatores redundet. Nam Saccharorum ex omni Brafilia olim colligebantur Aroba decies centics mille, idque quotannis, atque in Europam devecta certifimo compendio divendebantur.

In Ægypto Sacar Arabicum (unde Saccharum noftrum dictum volunt) ex humili \& exigua planta, inftar cryftalli vi Solis coagulatur. In India vero Orientali, ex Mambú arbore arundinea (vide Garc. ab Orta cap. x I I. ) \& nodofa, popilo infigni non abfimili, Sacar Mambrí, quem Tabaxir appellant, vifcofum albicantemque liquorem promanarc conftat, ut Avicenna, Rhafis, \& Scrapio teftantur. In Provincia Riode la plata, Cannas Sacchari fponte enafci, adolefereque in arbor is proceritatem, atque cryftalla Saccharea xftu Solis exfudare, conftat. Tamen al terutrum vel infita qualitate, vel conficiendi dexteritate adxquari huic arundinacco poffe, nemo credat. Planta fiquidem 
- HIST. NATVRAL. \& MEDIC. I I B. IV.

hæc noftra fruticis inftar firmitate prædita, fucco dulci turget. Silveftri Arundini externa facie eft fimillima; nifi quod hæc crebrioribus articulis aliquando diftinguatur, imprimis fi anni, terræque intemperies minus refpondeat. Quo enim majora internodia, co feliciorem meflem, quo breviora, eo infeliciorem agricolæ prænuntiant.

Hre Arundo, $V^{\prime}$ iba \& Tacomaree, Lufitanis Canna d'Acuquare dicta, minus in montibus \& collibus, licet irriguis, quam pratis glebofis $\&$ pinguibus, luxuriat, ficuti videre eft in Parnambucenfis præfectur $x$ maxima fertilitate \& planitie agris, optimeque cannifer is : qui inclytis undiquaque amnibus dividuntur, \& à pluviis \& inundationibus ripas egredientibus rigantur; quarum beneficio a formicis cæterifque infectis noxiis liberantur, ficut per nivem in Europxis regionibus folent. Sed miffa digreffione ad propofitum redeo.

Primo agri vomere invertuntur, cratibufque aut ferro ancipiti farriuntur, inque rectos $\& 2$ æqualiter diftantes fulcos profcinduntur. Quibus Cannarum taleæ ita inhumantur, ut fummitates utriufque fe contingant : atque ea ratione lacun $x$ vomer fact $x$, manent reple-tx, quxipla eadem terra poftea adimplentur. Plus terræx $x$ tate, qua operiantur, requirunt, ne intenfior Solis xtus penetret, Cannafque exficcet: Hyeme vero minus, ut facilius uligine imbuantur, \& terræ pondus germinationem retardet. Quo major humiditas, eo citius exfurgit arundo, hincque quilibet articulus novas producit Cannas, ab omni parte eas ac radices ex lacuna, cui impofita eft, extendens. Nodo Canne circumcirca pullulat turio, à quo, terræ incumbens, truditur, frutexque emergit: ita ut decem aut ad fummum duodecim menfium fpacio, Canna maturefcat, inque juftam longitudinem excrefcat. Expertiores agricolæ menfes Augufum \& Ianuarium plantationi confecrarunt. Augufto tamen, qui menfium hibernorum poftremus, felicius hac inftituunt, quod tellus noviffimis pluviis imbuta, plantas fuo gremio mollius foveat.

Arundo maturata tempore præfato exfcinditur; nonnunquam $\&$ ad annum ufque

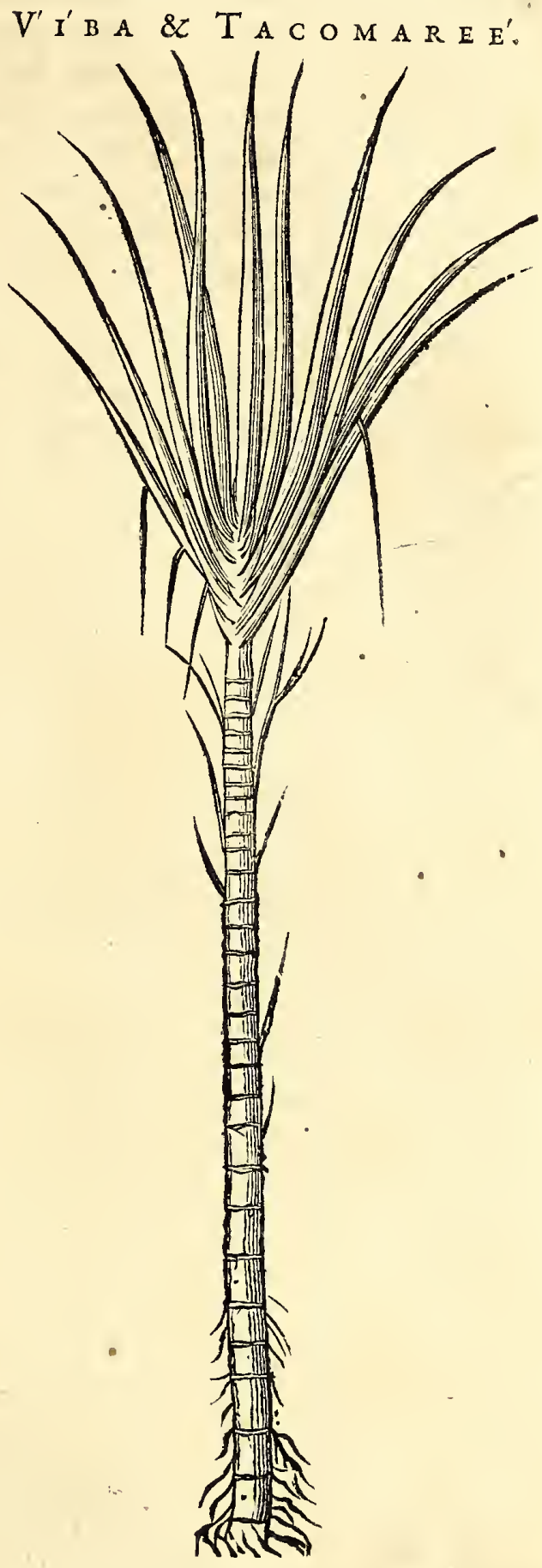
fequentem in agro relinquitur, \& tunc Canna vetus nominatur, quafifeges reftibilis. Intra hoc tempus nova denuo progerminat, qux poftea fimul cum veteri refecatur. Si intra biennium non findatur, nullius exinde pretii habetur : paulatim enim in agro marcefcit, ac deficiente humore extinguitur ; nifi forte peculiari terræ beneficio prorogetur ultra ordinarium durtaionis tempus. Plantæ tenellæ \& juvenes, bene inhuma$\mathfrak{x}$, denuo propagari numquam fere indigent, quod diuturnitate temporis non emoriantur, ne ad quadraginta vel quinquaginta annos quidem; ita ut fuapte natura vel nemoris durationem adæquare valeant, nimirum folo bene pingui ; nam qux in fitienti $\&$ arido crefcunt, vix ultra quinquennium vivunt. Interitum autem ex accidenti Cannis inferunt, fideratio, caries, potiflimum vero fi immiffo ab zftate incendio, nec fuperveniente pluvia, ad radicem ufque pranimia ficcitate comburantur, magno hercle poffefforis damno. Proinde qui Cannas inutiles $\&$ frugiperdas exftirpare, fuoque 
bono comburere cogitat, ut novæ renafcantur, hyberno tempore, non aftivo, hoc inftituat. Immodica quoque inundatione, cum nulla cacumina emergunt, Cannx fuffocantur : ita ut utriufque exceffu, nimio aftu exarefcant, nimiaque fluviorum illuvie, eaque ftagnante, refrigerentur, unde ftirpitus cvelli, alixque de novo plantari poftulane. Genus denique quoddam Vermiculi nigri alati, Guirapeacoca Brafilienfes, Pao de Galinba vulgus Lufitanorum appellat, in locis potifimum uliginofis, radices corrodit, Cannafque interimit. Poftremo ab herbis voluntariis male illis fit, qux mirum in modum frepe luxuriantes, hifce fativis admodum obeffe folent. Proinde fingulis annis ter quaterve, imo \& fxpius aliquando, fi terra poftulet, ager à noxiis herbis liberetur, idque tantifper, donec ad tantam maturitatem pervenerint talex, ut fuo robore zizaniis obniti poffint. Terra fiquidem earum herbarum quas fponte profert mater c:, cxterarum vero quas quafi vi coacta fufcipit, fxpeque invita fovet, noverca judicatur.

Porro Cannæ maturx factx, circa fundum acin ipfo geniculo abfcinduntur, quod in eo aqueus quidam humor contineatur. Mox amputarx, frondibufque, quibus maximam partem veftiuntur, refectis, in fafciculos coguntur, \& currui imponuntur.

Molendina tribus graviffimis axibus ex folidiflimo ligno confectis, circulifque ferreis obductis, nituntur. Inter quos Arundo continenter inferta, \& axium fe contingentium anguftia compreffa, liquorem fundit dulcifimum. Mola aquaria nullis indiget jumentis, aqux fiquidem impetu circumagitur, qux longiffimo canale deducta, laplu impetuofa ex alto in fupernos eximix magnitudinis rotælintres decidit. Quod quidem licet celerius fiat, plufque Sacchari inde redundet, quam à fex vel octo robuftifimis bobus : eorum tamen contentione exactius \& fidelius Canna exprimitur.

Cxterum liquor hic, qui in Saccharum ipfum poftea abit, ad viginti quatuor duntaxat horas durat, moxque acefcit, $\&$ ad conficiendum Saccharum prorfus fitinidoneum : fed fi diutius fervetur, bonum inde nafcitur acetum.

Axes aflerefque,per quos fuccus expreffus fluit, tum \& alveus, per quem decidit, bis fpacio viginti quatuor horarum, vel una Tareffa ('Tareffa eft fpacium terræx, cujus quadra viginti circiter eft paffuum, \& tot Cannas profert, quot per diem Naturalcm moli poflunt) lavari debent.

Canna primo à tergo axium excepta, vicino denuo immittitur, ut fi quid fucci in ca fit reliquum, penitus exprimatur, tunc Bagaffo vocatum, quod tanquam inutile excrementum flammis abfumitur. Adeo corufcantes $\&$ formidabiles nocte dieque conftruuntur ignes, qui ahenis fubjiciuntur, ut à quindecim lignorum vehibus ad quadraginta ufque, fpacio diei naturalis, prout cruditas liquoris requirit, abfumantur, integræque filvæ exfcindantur.

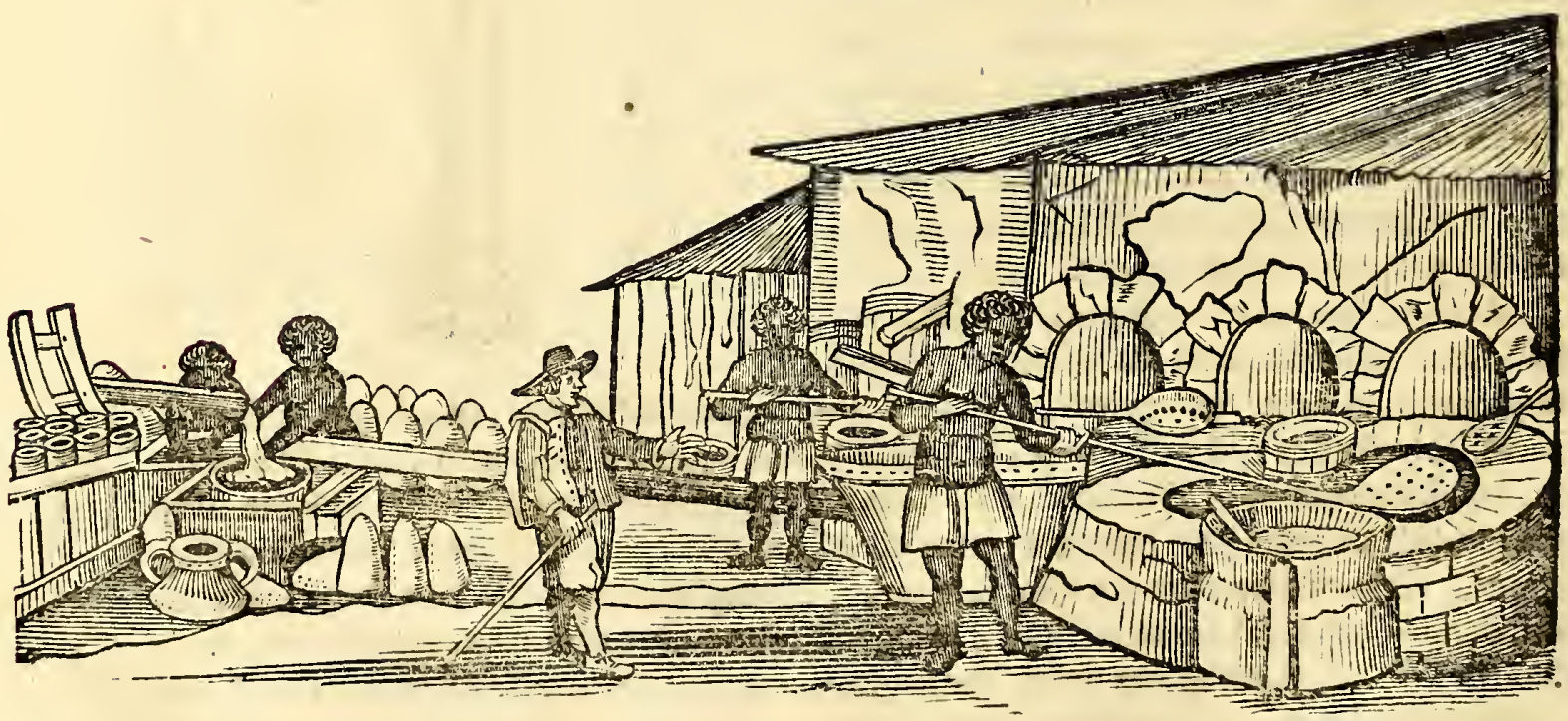

Succus, quem Cardo vocant Hifpani, per canales \& ductus ligneos, in amplifimos arcos cacabos derivatur: in quibus continenter, nunc vehementius nunc lenius, toto quo molx agitantur temporc, fervefcit, frigidxque afperfione intenfior ebullitio coërcetur, ut fubftantia minus confumatur. Ab hoc fucco in primo aheno confiftente, modicoque 
HIST. NATVRAL. \& MEDIC. LiB. IV.

modicoque fubftructo igne, paulo fxculentior $\& c$ copiofior fpuma aufertur, vocatur que Cagaffa, qux folis pecoribus efcam potumque fuppeditat.

Sublata Cagaffa, liquor feu Caldo in proximum ahenum, Calderade mellar Lufitanis, effunditur: in quo coquitur, \& prxgrandi cochleari, crebris foraminibus pertufo, à fordibus liberatur. $V t$ exquifitius immundities fecernatur, forte quoddam lixivium affunditur. Hinc per linteum percolatur, ac tandem fuccus eo pacto novifimum excrementum, fi quod habet, deponit. Hxx fxces mancipiis viecum fufficiunt, qui is contenti tam improbos atque indefeffos labor es exhauriunt: quippe toto femeftri antivo noctes atque dies perpetuo molendina agitantur. Vinum quoque exinde, vulgo Garapa dictum, conficiunt, intermifcendo aquam: quod avidifime expetunt incolx, eoque, fi vetus fit redditum, fe inebriant. Vinum itaque Sacchareum, Vinum aduftum, Acetum, Mel coctum,ipfumque Saccharum, ex primo hocliquore concinnari poffunt.

Porro minores qui fubfequuntur Cacabi, Tachas appellant, aliifunt ad concutiendum, alii ad coquendun parati. In quibus ficcus jan dictus tantifper condenfatur, donec Serapii \& mox Sacchari confiftentiam acquirat. Ad hxc vehementi \& arduolabore, primum in majoribus, tum in minoribus ahenis, inter coquendum, capaciffimis cochlearibus agitatur, quatiturque, $\& z$ ad altitudinem viginti plus minus pedum attollitur, unde rurfus in vafa prolabatur.

In Cacabis minoribus ob ignem intenfiffimum vehementioris ebullitionis habenda eft ratio, ftatutifque temporibus olei modicum guttatim inftillatur, ne ignis vehementia Saccharum aliquid detrimenti capiat. Obfervatu dignum, fi oleum majoribus inderetur ahenis, in quibus liquor, primo Caldo dictus, purificatur, Saccharo conficiendo plane foret ineptus. Vicifin, fi minoribus lixivium, ficut majoribus, infundatur, xque impoffibile, Saccharum conficere. Si denique momentum fucci Limonii, vel acidiquid injiciatur, Sacchari confiftentiam numquam acquiret, fed in totum perditur.

Form $x$ porro fictiles innumer $x$, quando fuccum fluidum acceperunt, ordine afferibus perforatis, in ampliffimis ædibus (Cafadopurgar vulgo) imponuntur; mox fuperimpofito luto humefacto, dicta vafa, à melle, quod fubfufco antea colore Saccharum tingebar, repurgantur. E formis excuffum, candidum à nigricante, Mafcovádo dicto, feparatur, \& in frufta redactum Soli fereno exponitur, probeque exficcatur, donec ciftis recondatur. Hæc omnia incredibilis funt laboris \& ingentium fumtuum; præterquam quod operariorum multitudo, jumentorum infuper $\& \subset$ mancipiorum affluentia, multum ex emolumentis deroget.

Medica Sacchari auxilia, quoniam maximam partem Europxis cognita, paucis tantum funt perftringenda. Cann $x$ viridis fuccus frigidus eft, multoque, fi deftilletur per alembicum, durabilior \& efficacior. Multis oculorum malis, tum hepatis, renumque ardoribus medetur. Sed cummedulla hæc Cannarum tot mutationes fubeat antequam repurgata in grana reducatur, primam naturam ex parte deponit, imo alienam induit,fubinde palato magis gratam, quam valetudini proficuam, finimia calcis \& fortis lixivii efficacia exacuetur ad delicias noftras. Quamobrem illud quod fanitatis gratia Pharmacixinfertur, præftat ut modice tantum repurgetur: quippe quod ingenttas refervet vires, intenfiufque ferapia, electuaria $\&$ fimilia dulcificet. Imo rubrum Saccharum, alias inferius habitum, (ficut \& illud quod ex Infula S. Thomx affertur, omnis lixivii expers) minime contemnendum, præxipue in clyfteribus. Saccharum itaque primo gradu licet calidum $\&$ humidum, tamen quo antiquius $\&$ defæcatius, eo calidius eft, faciliufque in bilem convertitur, atque intenfius digerit $\&$ folvit. Recens vero non folum pectori\& ftomacho, fed $\&$ veficæ renibufque prodeft. In omni denique agrorum condimento, veteri Saccharo longe debet antefcrri.

$$
\begin{aligned}
& \begin{array}{llllll}
C & A & P & V & T & \text { I I. }
\end{array} \\
& \text { Iira, foue Mel filuefte. }
\end{aligned}
$$

I

Nter prima quidem, etiam antequam Canna Saccharifera hic coleretur, mel Silveftre, quod ipfi Iira vocant, Brafilianorum folertia ex vaftiffimis filvis $\&$ faltibus fibi comparavit, quod in ufu atque deliciis, Europæis æque ac gentilibus, tam fa- 
nis quam $x$ gris habetur. Cujus dignitates ingenti mortalium bono quotidie magis magifque illuftrantur.

Apes, Eirúba illis dictx, diverforum generum hic reperiuntur, qux in arboribus, miris \& variis modis nidificantes, noftris quidem non plane funt diffimiles, fed utcumque paulo minor es, quarum examina hinc inde per egrinari, immenfaque nemora iis fervere videas, ubi erumpentibus floribus cereas domos exftruunt, \& optimo melle implent. Agreftes illæ funt, nec cujufquam cura aut paftum aut tecta accipiunt. Ita ut idem primatus quem Philofophus fuis Apibus olim tribuit (invita formicarum induftria, \& araneorum aftutia) hifce quoque jur e merito debeatur; utpote qux ex quatuor illis celcbribus operibus, fcilicet venari,facere, colligere, \& reponere, tria pofteriora fol $x$ exerceant. Quafi Natura nufquam magis quam in minimis perfectior femper apparere voluerit. Regem quoque eligunt, cxteris mole corporis tenuiorem \& maxime flavefcentem. Reliqua quæ de illarum regimine produntur, ob difficiles ad eas in nemora aditus, nondum experiri datum eft. Ignavum pecus, Fucos, Crabrones, Oeftra, Vefpas melliferas \& non melliferas, pluraque alia Infecta fimilia, de quibus in Infectorum Hiftoria dicetur, quænimis quam multa Brafilia nutrit, viatoribus $\&$ armentis infeftifima, nunc prætereo.

Induftria atque ufus præftantia, cæteris omnibus Infectis alatis, præcellunt facile Apes mellificantes, quarum tredecim ad minimum genera obfervantur, ut funt Amanacay-mirí, Amanacayné, Aibú, Mambucá, Pixuná, Vrutuétra , Tuburá, Tuiubá, Eiruçú, Eixu, Cubiára , Curupiréira, Copii, quarum ultima Curupiréira à Brafilienfibus contemnitur. Qux autem inter illas omnes merito obfervand $x$, funt potiffimum hæe fequentes.

Primo Eiriçu, grandiores, non pungentes, quæ bonum faciunt mel, licet non quotidiani ufus. In concavitatibus arborum nidificant, ut Virgilius de fuis Aprbus,

- Nec non of Apes examina condunt,

Corticibufque cavis, vitiofaque Ilicis Alno.

Equibus veluti alveariis Brafiliani arte $\&$ dolo mel eliciunt per ductus aliquos, ut foras ernanet.

Deinde Eixu \& Copii Apes minores, nigricantes, extetius in cortice nidum affabre conftructum componunt inftar alvearii, favis exarte $\&$ concinne difpofitis, ac propoli, $\& x$ cera candida veftitis, è quibus optimum mel colligitur, fed minore quantitate, $\& \subset$ quia infigniter aculeo appropinquantes infeftant, minus expetitum.

Denique Apes Munbucá flavæ \& exigux in arboribus nidificant, optimum hoc $\mathrm{Mel}$, de quo potiflimum ago, \& faluberrimum producentes, quod ab Indigenis arbores proceras confcendentibus, ad Europæos incolas, magna quantitate, exiguoque pretio affertur. Maxima autem copia hujus reperitur in Infula Maranhon, cum multa cera nigra, ubi copiofus colligitur, vafifque integris completis, xetate, cum flores filvefres maxime virefcere folent, fervatur. Inter hofee flores reperitur unicus in arbore Tapuráiba flos, quem poftquam apes guftarunt, Mel amarum conficiunt, ficut de Apibus in Syria Abfinthio infidentibus teftantur Authores. Qualitate \& dignitate nihil hercle hoc Europxo melli concedit, in fecundo gradu calidum, confiftentia admodum fluida, clara \& tenui : odore fuavi quidem, fed filveftri, nec nimia aut ingrata dulcedine, naufeam parit, fed gratiflimo acore, oxymelis inftar, palatum afficit. Abfterforia qualitate, partiumque tenuitate, tantum ftomachum, vifcofis humoribus obfitum, abftergit, quantum calida languidum confortat. Inteftina imprimis $\&$ renes, five fuperius, five inferius exhibitum, à cruditatibus vindicat, atque urinas promover. Tum \& infantibus ad abftergenda $\&$ demulcenda vifcera, à reliquiis Variolarum \& Morbillorum obfita, fummopere prodeft. Simplex vel compolitum (ut in capite de Mulierum morbis diaum eft) uteri intemperiei frigidæ fummum adfert folatium.

Long $x$ durationis $\&$ magn $x$ dignitatis Vinum quoddam inde confici folet, fortiffmum quidem \& admodum abftergens. Sin temperatius placeat, hydromel vel mulfum ex aqua fontana, fine coctione, ror i nocturno exponitur.

Pharmaca denique non folum, fed \& cibos potufque quotidianos ingreditur decantatum hoc trium Apum mel, ficut in Tractatu de aëre, aquis, \& locis dictum eft: meritoque de illo idem predicare licet, quod Plinius lib. XX I I. cap. 24. teftatur. Mellis nacuranı 
naturam talem efle, qux corpora putrefcere non finat: tum, multos exftitiffe qui fenectam longam mulfi tantim nutritu toleraverunt: Hac folum adhibita cautione, ne biliofis, hepatis, renum \& ftomachi ardore laborantibus, nif fumme dilutum, exhibeatur.

Cera ejus, retiéillis dieta, qux nigricans eft, Europæx poftponenda quidẹm, fed ad emplaftra emollientia \& diger entia, contra mala è frigore nata, utilifima habetur.

Qui cum Tapuys Mediterraneis in defertis vixerunt, multas alias f́pecies Apum commemorant : qux ut nomine \& figura, ita \& 2 natura ab is qux enarratæ fúnt, dif́crepant. Quxdam enim earum in arboribus pumilis, quxdam vero intra terram miris modis nidificant \& mellificant, earumque $\mathrm{Mel}$ utcumque igne $\&$ fumo excitato colligitur. Sed quia preter inftituti rationem eft ea enarrare, qux dubio aliorum relati nixa funt, iis fuperfedeo.

Porro,præter tot documenta fertilitatis circa V'égetabilia \& Senfitiva marina, telluris æmula, accedit \& illud, quod paucis à Paranambucenfi littore milliaribus, pifcatoris uncum citra intentionem contingat infigi vadis petrofis, \& loco pifcis fpongias, coralla aliafque arbufculas marinas capi. Inter hæc inufitat $x$ formæ prodit fpongiofa arbufcula, fefquipedis longitudinis, brevioribus radicibus, lapideis nitens vadis, \& rupibus infixa, erigiturque in corpus fpongiofum molle oblongum rotuindum turbinaเum: intus miris cancellis \& alveis fabricatum; extus autem tenaci glutine, inftà
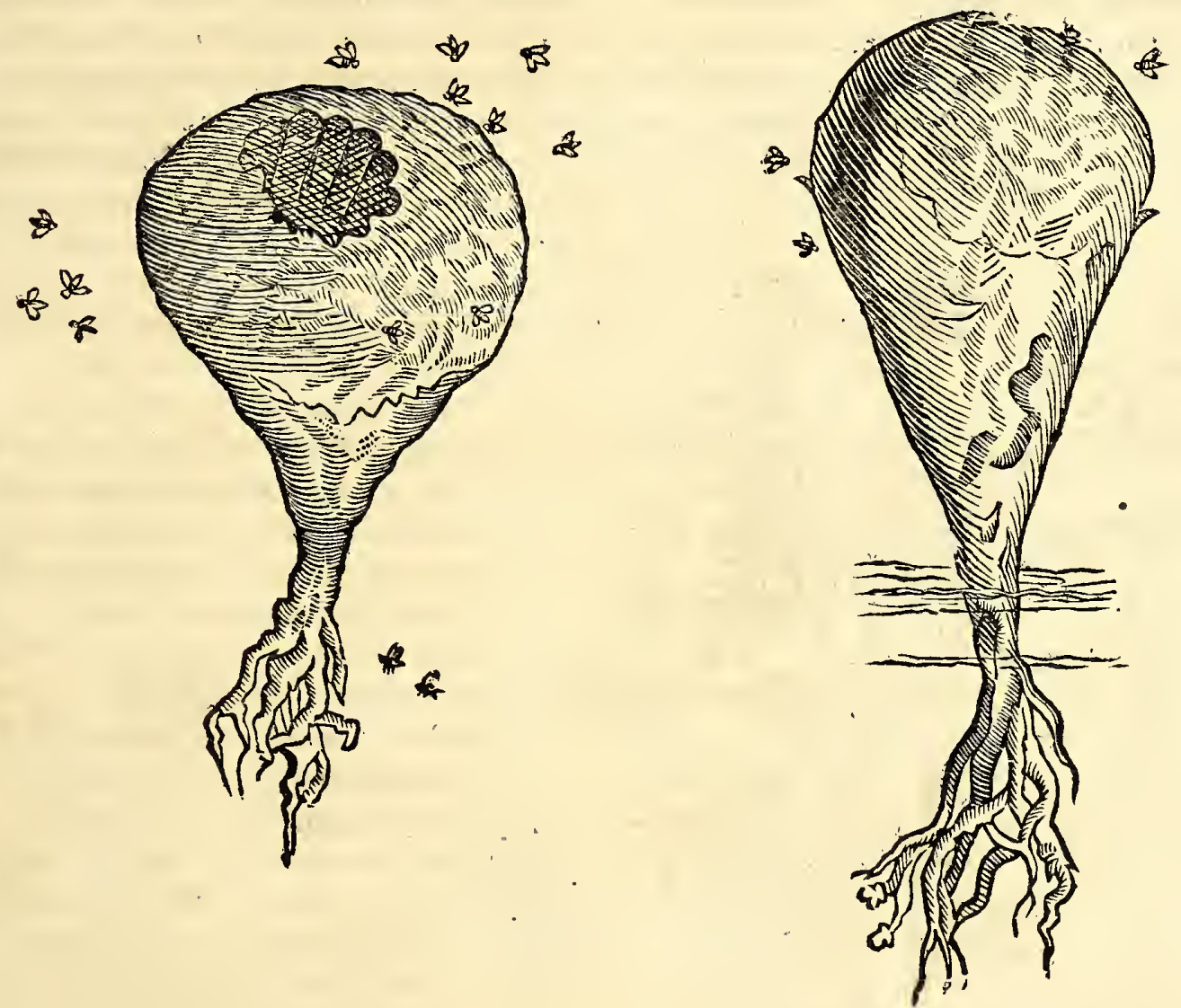

Apum propolis, undique veftitum. oftio fatis patulo \& profundo in fummitate relicto, ficut ex altera Iconum, probe depicta, videre licet. Ita ut Apiarium marinum veré dixeris. Primo enim intuitu è mari ad terram delatum vermiculis fcatebat cæruleis, parvis; qui moxà calore Solis in Mufcas, vel Apes potius, eofque exiguos \& nigros transformabantur, circumvolantefque evanefcebant: ita ut de eorum mellificatione nihil. certiconfici datum fuerit, cum tamen cerofa mareria propolis, Apumque cell xánifefte apparerent. A tque ipfa Mellis qualifcumque fubftantia procul dubio urinatoribus patebit , ubi curiofius inquifiverint hæc Apiaria, eaque in natali folo \& falo diverfis temporibus penitius luftrarint: 


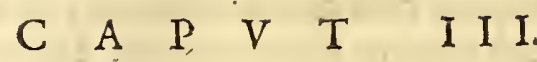 Radix Mondiboca.}

$\mathrm{F}$

Rumento complures Indiarum regiones ad hæc ufque tempora caruerunt: ea

4 'tamen, quibus hominum \& animalium fuftentatur' vita, frumentique vicem

fupplent, defiderari, benigna mater Natura noluit. Radix enim fativa feu altilis, qux Mandiboca Barbaris appellatur, in farinam redacta \& in panem coacta, Gum optimo pane finilagineo certat. Qua planta licet Angolx \& Hifpaniolxatque aliarum Infularum incolæx gaudeant, (ubi radicem hanc $r_{u c a}$, aliis Mexicanis 2uaubcamotli, prxparatam $\&$ in farinam redactam Caffavi vocari Monardes teftatur) Brafilix tamen naruralem, fummoque ftudio ibi excultam conftar.

Plures hujus futicicis, quem Maniiba \& Manduba Brafiliani vocant, dantur fpecies: qualicer prima fronte intcr fe haudddifferre videantur, tamen ab experientibus agricolis dignitate, caule, \& colore diftinguntur, ac diverfa fortiuntur nomina.

Qux antequam explicem, monitum volo lectorem, ne in tanta nominum varictate (qux in hoc \& fequentibus quibufdam capitibus occurret) confundatur. Inter Barbaros enim Americanos non tantum, fed \& ubique terrarum quotufquifque in eo variat ac difcrepat. Nam interdum unaquæque res multis nominibus à quibufdam defignatur, quxapud alios nomina funt diverforum pifcium $\&$ herbarum. Interdum idem nomen à diverfis authoribus, diverfis rebus naturalibus pofirum eft. Aliter enim Plinius, aliter Gaza, aliter alii Latini explicarunt monumenta veterum Grxcorum. Ex quibus inutilibus amphibologiis haud levis exfurgit moleftia, \& in ex-

$M A N D I H O C A$.

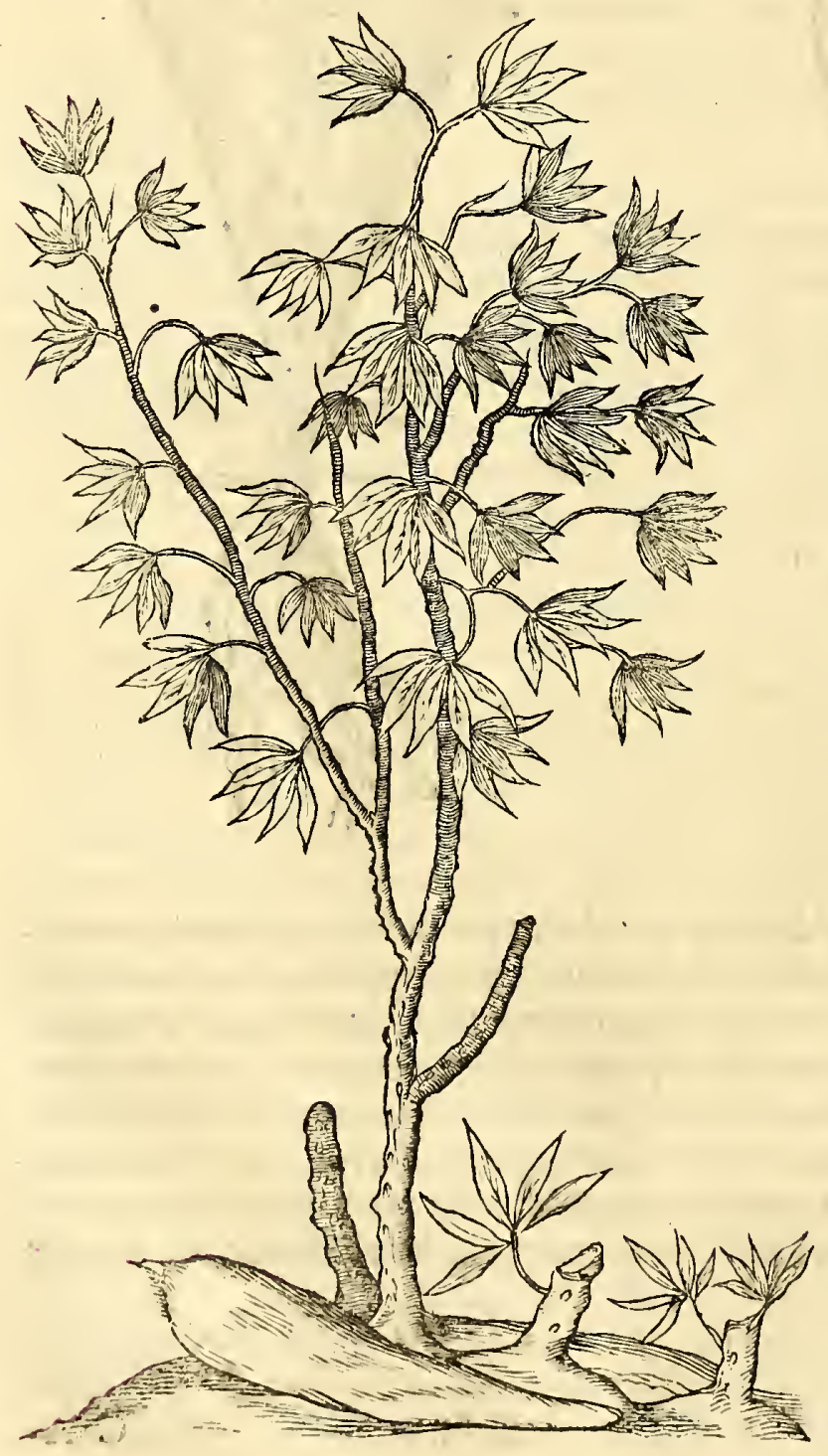
quifita rerum cognitione obfuritatem creat. Quaproptcr ego non fine ratione cum Galeno optavi aliquando, respoffe tradi fine nominibus, ut fophiftis eriperetur decertandi \& calumniandi occafio.

Decantatæitaque hujus fruticis prima fpecies à maris accolis Brafilianis vocatur Mandiibabuára, Marsdiibparat a, \& alix albicantibus radicibus \& truncis, Mandiipéba, Mardiipuçu, Mandibimána, Aipi, (qux iterum fuas habet fpecies) Tapeçima, Aipipóca, Mandijupéba, Aipimacaxera. Hax novem pofteriores rubentibus funt \& lactefcentibus radicibus \& caulibus. Omnium harum firpium radicibus folum Mandiboca nomen inditum, \& alimentofis, medicamentofis, venenofifque qualitatibus, licet impari inter 1 egradu, pollent. Quas proprietates, utpote admiracione digniffimas, penitius introfpexiffe operxpretium erit. $\mathrm{H} \mathfrak{x}$ frutices omnes cleganti ac ftellatim fefe explicante funt folio. Caule recto, nodofo, hominis ftaturam raro excedente. Ejus craffities pro foecunditate foli, colique temperic, varia. Florem fert cxiguum, femen autem, Ricini Americanifemini fimile, fed inutile. Reliqua exipfa planta ad vivum depicta cognofcere licet. 
HIS T. NATVRAL. \& MEDIC. L i в. IV. II

Fructum vero fubterraneum, ipfam fcilicet radicem efculentam Mandihocam, Paftinacxehaud diffimilem producit, qux lacteum trahens fuccum, ab oculis prorumpentibus, è trunci internodiis natis, hoc̀liquore egregie intumefcit.

Terra minime glebofa ant irrigua, ut Canna faccharifera, gaudet, fed ficca potius, fitiente \& montołá, atque in tuberćulos, quafi à talpis, egefta. Adeo humiditatis omnis inimica eft, ut xftivis dumtaxat menfibus terræ committi velit, idque locis apricis ac minime umbrofis. Quod, ficuti in hac, ita in quavis plantatione obfervandum, quia guttatim ex arboribus deftillans aqua perquam noxia habeatur. Cum adeo acclive $\&$ arenofum folum requiratur, malunt incolæ denfiffima demoliri nemora, demolita exurere, eaque arvis \& fegetibus (Chocas Lufitanis) deftinare. Extra terram duobus vel tribus furculis germinant, qui, ubi octavo, decimo $\&$ duodecimo menfe liquefcere coeperunt, pro femine funt. Hoc frugum noftratium difcrimine, quod Mandiboca nihil de fructu decedat ad fui propagationem, noftris decedat, quibus ipfi fructus fementem faciant. Per radicem nulla poteft fieri tranfiplantatio : nam ea extracta è terra \& tacta ftatim moritur.

Tres hujus plant $x$ trunci, frondibus f́poliati, figura propemodum pyramidalig haud profunde fimul tesræ grumis, trium circiter pedum inter fe diftantia, inferuntur, prominentefque ad palmx altitudinem, fuperius fe invicem amplectuntur. Qui foliis licet denudati, novis tamen ilico veftiuntur, nec quicquam radix inde detrimenti patitur, modo caulis integer \& illxfus maneat.

Dignitate $\&$ mole excellit Mandiboca, fi anni terræque temperies ficca fuerit: tunc enim qualibet radix fefquipedem, vel duos, interdum etiam tres pedes longa evadit, craffitiem habens brachii, vel etiam cruris humani, quando fatis adoleverit.

Ratio habenda ut ager à zizaniis, quæ valde fuppullulant, ter quaterve repurgetur, donec plantx adoleverint, ad octo nimirum vel decem menfiumfpatium. Maturitatem aflecutæradices, quod annuo circiter à plantatione fpatio fieri folet, ad rertium vix fub terra durant; altero tamen plerumque anno pars illarum putrefcit \& corrumpitur; ideo ad fummum linquuntur annuo f pacio, \& de novo per taleas plantantur. Ingruente nimix humiditatis neceffitate, exfcindiftatim poftulat, fex menfibus ante juftx maturitatis tempus.

Mandiba, quæ vocatur Mandiibumana, omnium citiflime crefcit \& maturefcit, atque optima inde conficitur farina. Hxc planta maxime gaudet folo ar enofo $8 \mathrm{z}$ magis ambufto quạm reliqux. Primaria omnium, inque quotidiano ufu \& lucro, producietur quidem promifcue in quavis terra, vocaturque Mandiibparati .

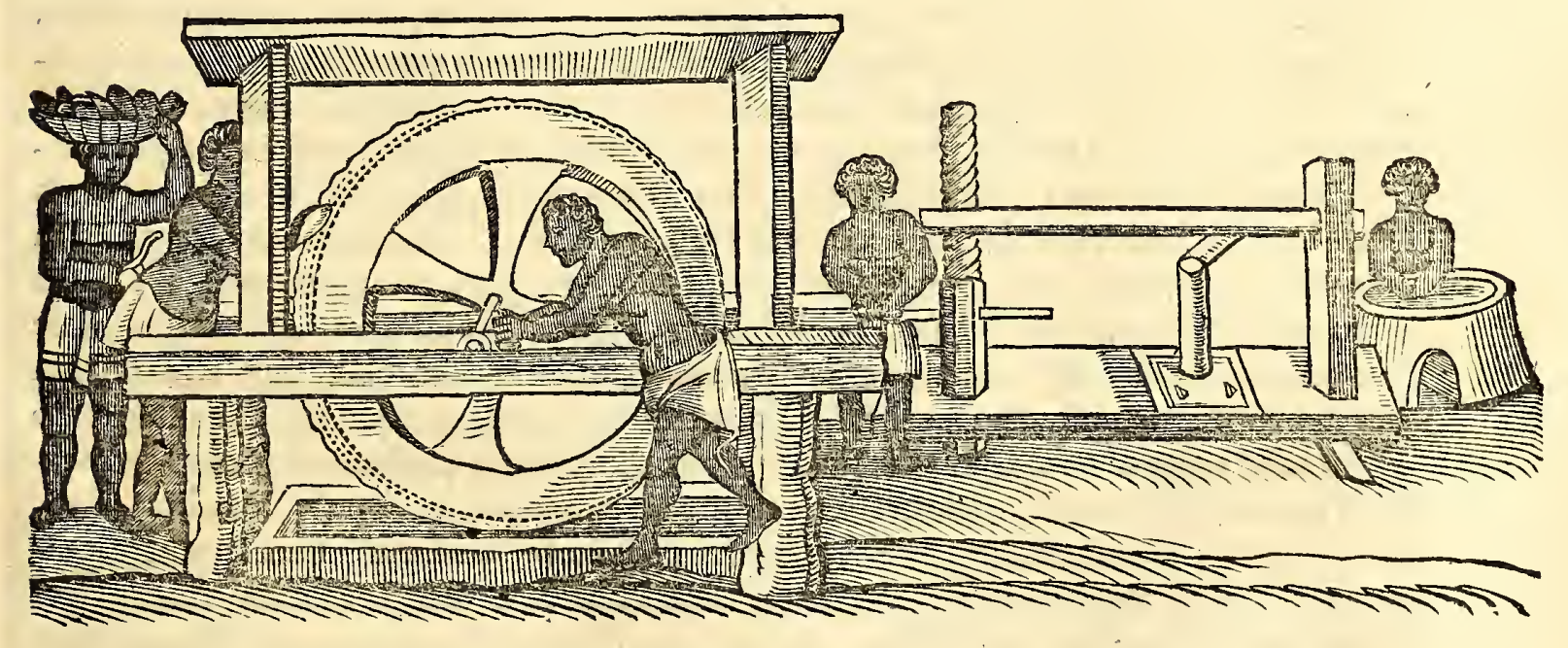

E terra evulfa radices, vix per triduum durant, etiamfi fideliter horreis recondantur. Mundatx, \& à cortice, quem tenuifimum habent, liberatx, molx trufatili, cujus Iconem hic exprimimus, à duobus hominibis circumact $x$, admoventur, ferrique cufpide conteruntur; \& contufarum radicum farinam excipit alveus. Alii radendi modi pedetentim exoleverunt, ob majores labores \& fumtus. Pauperibus tamen ufus Scobinx mantalis fupereft, qux ab Indigenis Tapiti nuncupatur. Rafura deinceps torculari vel pralo fubjicitur, quo magna vi humor ille fuperfluus \&ُ noxius exprimitur, 
ut fícca atquie abfque ulla humiditate mancat. Mox cribro, Vrupeba dicto, percolatur. Exinde planefacto fictili aut æneo injicitur, in quo fubftructo igne circumagitatur tantiffer donec coquatur. Semicocta vero, \& adhuc mollis, efculenta eft, \& vocatur $\mathrm{Fa}$ rians reladia; quod eft Farina cocta non cxficcata. Reliquum quod fupcreft, \& refervare volunt, fupra majorem vel minorem ignem pro arbitrio mifcent, a tque cxacte ficcant. Farina enim hac quo plus exficcata \& excoeta, eo durabilior eft. Optime tamen ficcata $\&$ fideliter ab aëre defenfa, ultra annum vix fervari poteft: nam fi vel levifima uligo eam infecerit, corrumpitur, unde non parvam militum ftragem in caftris exortam vidi. Quapropter noftri, Barbaros imitati, cam in bolos, quos vocant Bejus, paltillos \& liba cogunt, fuperque craticulas modico igne induratam in penu aliquandiu recondunt.

Ex hoc frutice expreffo manat liquor, Manipuera Barbaris dictus, qui vafi infufus poft duas horas fundo adhærefcit: ex quo alia fit Farina, melior priori, ac majori afflucntia flor is; quam cremorcm de Tipióca vocant. Ex aqua Farinæ, in fundo fubfidente, bolos quoque conficiunt, Tiprocéto dictos, optimi faporis. Tum Gummi quoddam feu potitis amylum exea fir, atque cidem ufui infervit. Hic liquor Manipuera, quod dulcis fit faporis, ab animalibus avidiffime hauftus, vi quadam vencnata, ea ftatim exftinguit: exradice tamen non expreffus (quod mirum) cxtera animantia, excepto, homine, nutrit.

Præter ea è radice, à Sole exficcata, alia fit Farina \& pollen albicans, imo \& panis filigincus $\&$ bifcoctus, qualis è tritico (cui \& fimillimus eft) pinfitır. Hoc alimentum integrum $\&$ non comminutum pro jumentis \& pecoribus, quibus in pabulum cedit, refervatur.

A vermibus, \& integris formicarum cohortibus, hæc planta mifere folet infeitari, magno agricolarum incommodo: non folum folia atque caulem, fed ipfam quoque radicem depopulantur ferarum greges $\&$ animalia domeftica. Ipfi Brafiliani, Æthiopes, \& noftratium non pauci, hujus plant $x$ folia amant adeo, ut contufa, cocta $\&$ probe condita pro cibis \& lactucis apponant; quæ in maffam efformata, Maniçóba nuncupant Brafiliani.

Porro radix hæc quatuor aut quinque dierum (pacio in aqua macerata \& emollita, Mandiopiba dicitur, quæ affata maxime ab agreftiori Indorum $\&$ Barbarorum multitudine cxpetitur \& manducatur. E fedimento hujus confiftentix, Farina mollis, not $x$ que mclioris, conficitur : quam Brafiliani Vipéba ; Lufitani Farinba frefca cognominant.

Ex Mardiboca contufa, butyro \& faccharo, infignes fiunt boli vel paft $x$, ad edendum optimx.

Pultis denique genus prxparant ex Mandiopeba, quod nomen accepit Mingau-petinga.

Mandihoca illa mollis, illis Puba, igni impofita exficcatur; exficcata appellatur Carimá. Ex hac Afri panem optimæ notæ conficiunt, quem Mufam vel Angu, interdum Enfonde appcllant. Omnium autem præftantiffimum pultis genus condiunt, quod vocant Mingau de Carimá, cui aromatum loco momentum piperis Brafilienfis, \&z floris Nhambi, admifcent: quod optimi cum fit faporis, fanitatíque conducat, frequens in prandiis effe folet; nec fuaviter fe vivere exiftimant nifi hoc alimento utantur. Sanis rque atque rgris ejufmodi pultes, cmulfiones, atque adeo ptifanas faluberrimas inde confectas, exhibent. Tipióca fiquidem, \& Carimá, pota, vel fyrupi fpecie cum aqua florum Auriacorum \& pauxillo Sacchari exhibita,antidoti loco plcrumquc eft. Quantæ porro dignitatis Tipióca \& Carimá fint, in defcriptione morborum Endemiorum fátis explicavi. Tipióca enim, fi multa lotione defæcata atque exficcata, probe ab omni humiditaterefervetur, Tabidis \& Dyfentcricis, exarte propinata, medetur. Febricitantes, animodeficientes; veneno infectos reftituit Præter hæc, violento excrcitio fractis vires recupcrat, fudorefque immodicos compefcit, Ptifana illius fimplex. Quafcunque Hæmorrhagias, imprimis ex vulnere infliatas, tum intus affumta, tum emplaftri forma applicata, cohibet.

Ex Macaxera optimum fit Vinum, ferum lactis fapore referens. Mandibocaraha, vulneribus \& ulceribus antiquis impofita, ea mundificat, atque attemperat.

Manipuera cocta craffefcit pultis in modum, alimentoque convenienti exiftit. Quod fi Oryzam \& Saccharum, cum aqua deftillata ex floribus aurantiorum fuperinfundas, Confervx gratiflim $x$ formam induct, mutatoque nomine Marmelada de Masdiboca appel- 
HIST. NATVRAL. \& MEDIC. LIR. IV. II7 appellatur. Poftremo illa fpecies Macaxéra, præterquam quod vicem Farinæ prædictx fuppleat, igne etiam affata, abfque ulla alia praparatione, comeditur, ac Macapére
appellatur.

A cxteris radicibus abftinendum eft, quod præfens fint venenum. Dantur enim quxdam , quas citius combufferis, quam ut virus fuum deponant, \& ad edendum idonex reddantur. Quin ipli Indigen $x$, olim minus exercitati, in feparatione alimentofi \& venenoli, multoties mortem oppetierunt: nunc eruditiores facti, non folum illis pracipuo exiftic vitx fuftentaculo, fed omnibus Europæis in America degentibus. Idque pani triticeo praferre non verentur, licet minoris habeatur nutrimenti.

Ethiopes \& Brafiliani inter edendum pugnos Farinæ plenos in os injiciunt, ut manu quoque longius ab ore remota, vix tamen mica pereat. Raro aut parum inter prandendum potu utuntur, quod farina aquam nimis imbibat, \& tomachum inflet.

Cum aratrum ejufque ufus hic ignoretur, \& improbi ac mul tijugi laboris tædia declinent, facilem hanc $\&$ minus xrumnofam agriculturam, tam vitæ ac rei familiari tuend $x$, quam $x$ ri corradendo, egregie adhuc amplectuntur. Quippe unius dumtaxat mancipii induftria $\&$ labore, centum tuberculos, aliquando unius diei decurfu abfolvunt. Hujus autem Farinx una, qux viginti cantharos noftrates continet, aut fefqui Alkeira, hoc eft, modius unus aut fefqui, homini robufto \& laboriofo, in menfem integrum plerumque fufficit. Quem modium fex aut feptem aut ad fummum octo foli-
dis comparaveris.

Hæc funt qua ufu \& fedula in hanc radicem inquifitione, à rufticis \& mea experientia refcifcere potui; qux fufus \& explicatius perfequi volui, quod hxc planta ubique frequens fit \& domeftica , tamque excellentis ufus, ut vaftiffimi orbis Americani incolis abunde victum fuppeditet. I

Tapuyeri, vita \& moribus agreftiores, nec Mandibocam hanc, nec quicquam fimile plantant, fed arborum fructibus, variis herbis \& melle agrefti fe fuftentant. Inter radices quas comedere amant, eft Mandiboca quxdam filveftris, fponte proveniens, frutexque arborefcens: cxterum fativæ fimillima, fi caulem \& folia confideres, vcrum dignitate longe inferior. Mediterraneis Cuguacucuremia, maris accolis Cua. çú-mandiiba dica. $\mathrm{Cu}$ jus Iconem expreffam hic videre eft.

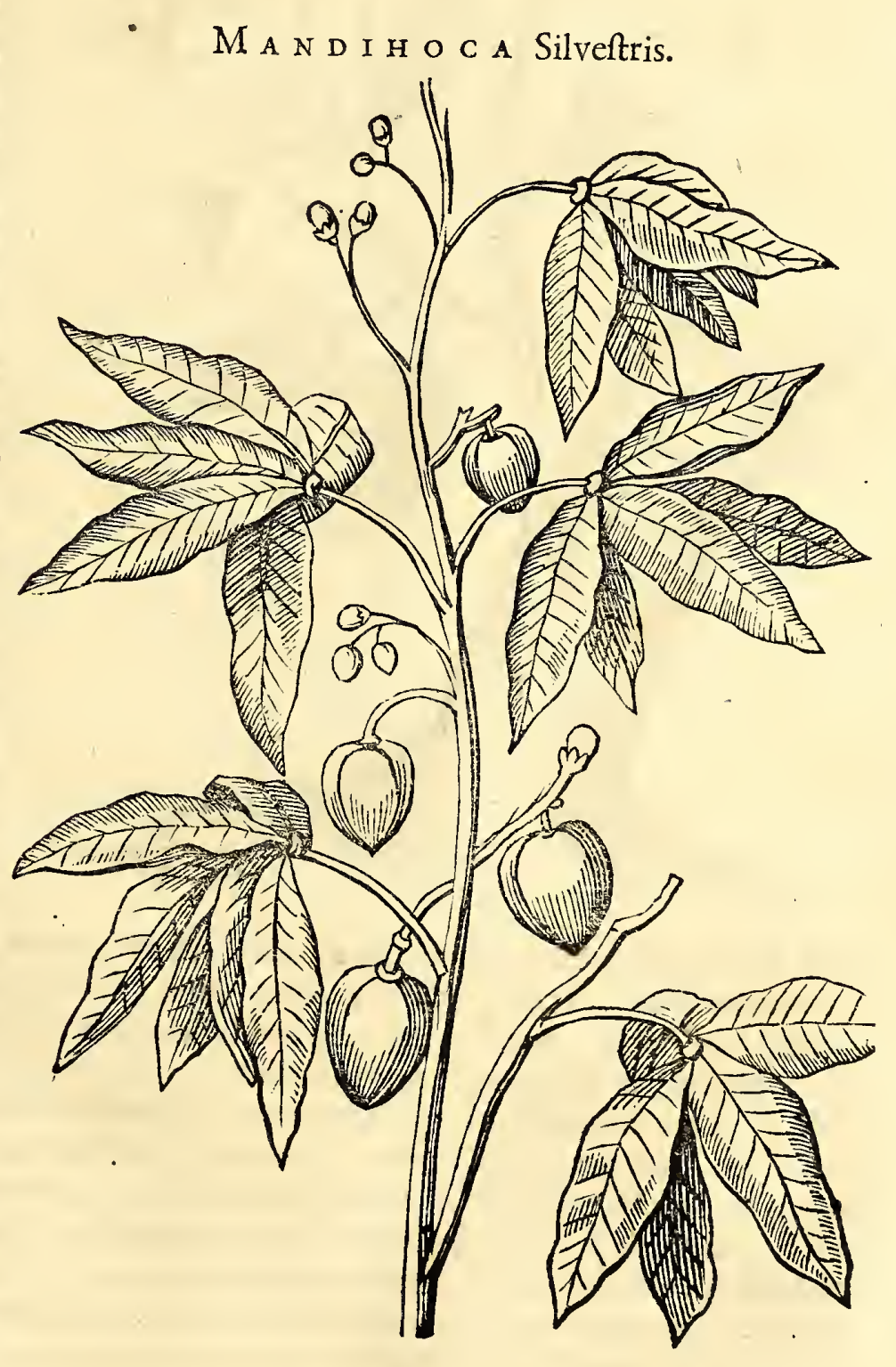

C A. 


$$
\begin{gathered}
\text { C A P V T IV. } \\
\text { Copaíba. }
\end{gathered}
$$

$\mathrm{P}$

Lerique Americani communi nomine omnes Refinas odoratas \& Gummi vocant Copal, variafque illarum fpecies peculiaribus diftinguunt nominibus. Ita \& $\mathrm{Bra}-$ narunt. In denfis nemoribus mediterraneis hre fatis procera reperitur : cui lignum

C OP A I'B A.

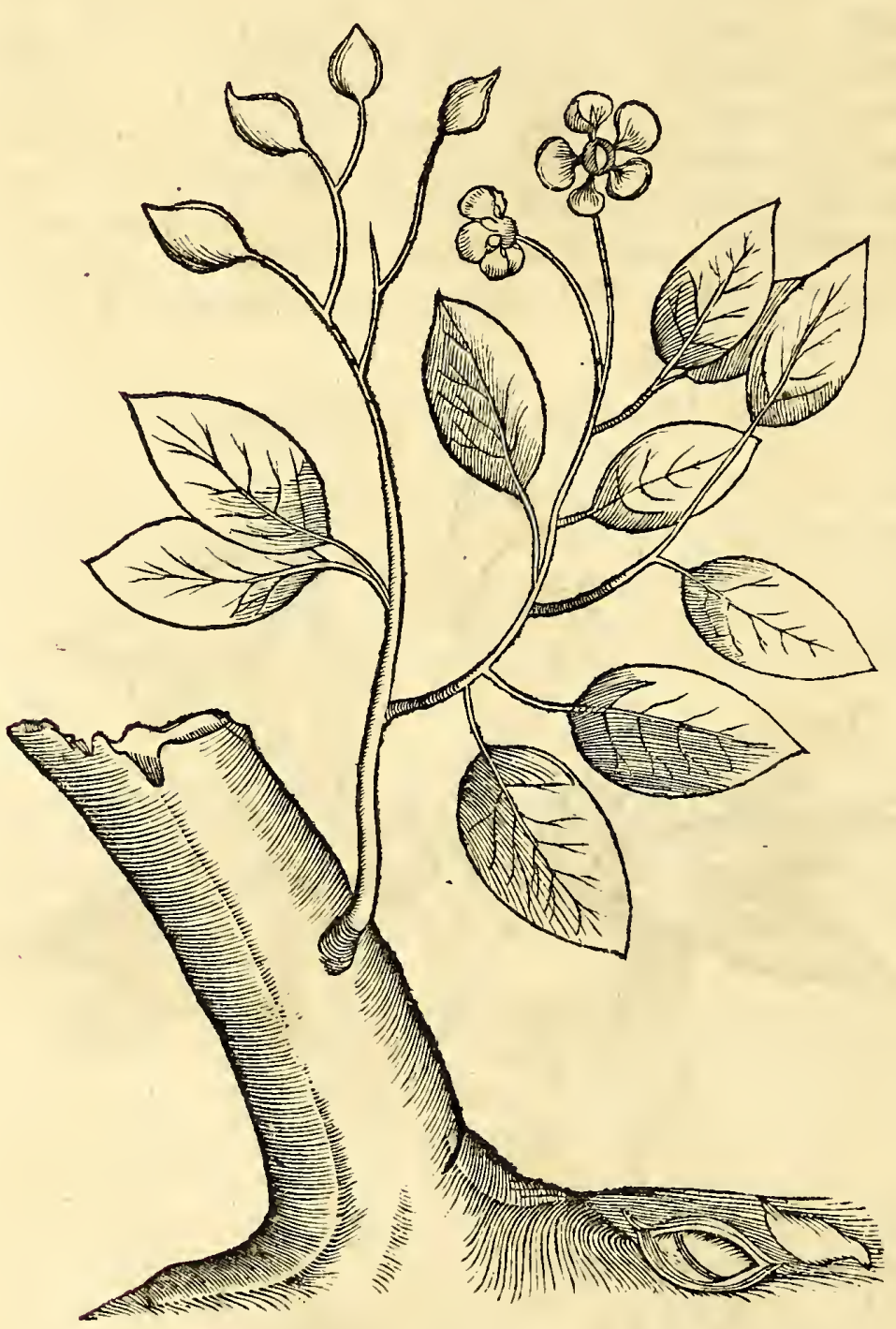

rubrum quafi minio tinCtum, adeoque durum ur ex eo afferes latiflimi fiant. Foliis eft ovalibus, cum pediculis \& nervis craflis poftica parte maxime eminentibus. Flore eft pentaphyllo rotundo. Fructus inftar filiqux \& coloris nigricantis ubi maturuerit, qui facile aperitur, continens nucleum nucis magnitudine \& figura, coopertum cuticula nigra, quæ pauca pulpa lutea, lenta, molli, eduli quidem fed non faporofa, itaut inter fatuos fructus numeretur, ut folet in Arboribus balfamiferis. Simix has filiquas depopulari amant. Ego eas menfe Maio \& Iunio collegi, \& mox femigerminatas mandavi terræ atque late provenerunt. Pinguis \& odoriferus autem ille liquor adeo celebratus, ab incifo cortice ad medullam ufque, Luna plena, tanta quantitate deftillat, ut fpatio trium horarum, ad duodecim libras olei effundat. Sin nihil forte profluat, ftatim vulnus cera aut argilla obturandum eft, ne quid effluere poffic, \& duabus pofthebdomadis cum foenore moram compenfaffe videbis. Non adeo frequens in Prafectura Parnambucenfi hac Arbor, quam quidem in Infula Maranhon, ubi valde luxuriat, unde quoque copiofe illius Balfamum ad nos affertur.

Non autem folum mirifica pollet vi mun difican di $\&$ confolidandi , $\&$ ad quavis vulnera (imprimis nervorum) prima intentione reftituenda, morfufque ferpentum curandos \& cicatrices tollendas: fed \& ab omnibus pariter incolis, \& à me, interne exhibitum, infignem prabere utilitatem, obfervatum fuit. Tam fuavis tamen odoris, ficut Maffxus vult, non eft. Calidum in fecundo gradu, craflum, valdeque pingue $\&$ refinofum. Ejus falutares vir es nunc denuo in circumcifione Iudæi experiuntur : qui fanguinem ex vulnere illo crudeli profuentem feliciter admodum co coërcent, cum antea vulnus effet curatu difficile, \& non paucis exitium intuliffet.

Pectori, ad ftomachum languidum, ventri ad colicos frigidos cruciatus, illitum conducit. Guttulx aliquot convenienter exhibita per os robur addunt vifceribus, illifque 
H. IS T. NATVRA L. \& MEDIC. LI B. IV.

lifque tonum reddunt: fluxiones mulicbres, curfus ventris \& gonorrhøeas quoque $\mathfrak{f i}_{\text {- }}$ ftunt. In anum per clyfteres, in penem per fyringam cum Saccharo ex aqua plantaginis, vel oleo rofarum diffolutum, adverfus eadem mala profpero fucceflu injicitur.

\section{$\begin{array}{lllllll}\text { C } & A & P & V & T & \text { V. }\end{array}$ \\ Cabureiba five Balfamum Peruvianum.}

Nter arbores infructiferas primaria elt Cabureiba. Quarum duas fpecies, non in habitata Brafilia,fed in remotiffimis defertis trans immenfa illa montium juga,vidi. Vtraque eft excelfiflima, vaftiflima, \& odorifera, fed cortice \& ligno differentes. Altera rubefcentis eft coloris, odor eque Cedro Brafilienf, quæ Incolis Acaiacatínga dicitur, non diffimilis. Altera, de qua nos in præenti agimus, folio eft exiguo, inftar Myrti, cortice cinereo, digitum craffo, tenui membrana miniati coloris, exterius cooperto, fub qua flavus liquor, quo totus cortex turgere folet, latitat, qui vetus gratiorem fpirat odorem quam fi recens fit, fitque confiftentiz craffioris \& coloris punicei . Cortex contufus $\&$ in maflam redactus, fuaviffmos efficit globulos, \& alia multa. Lignum illius fingularem ufum prabet in $x$ dificiis.

Revirefcente arbore circa Februarium \& Martium, Luna plena, ex lafo cortice, pendulis vafculis, excipitur hoc Balfamum fragrantifimum $\mathrm{Cabu}$ reiçica dictum.

Ædes non folum, fed Lucos integros gratifimo odore, Peruviano perquam fimili, inficit. Subftantia eft compacta $\&$ tenaci, fed calefactum fequaci \& ductili. Circa fluvium potiflimum Ieneiro \& 2 in diftriCibus Divi Vincentii \& Spiritus Sancti, quam in Parnambucenfi, crebrius reperitur, licet non adeo magna quantita-

CA B VREI' E A.

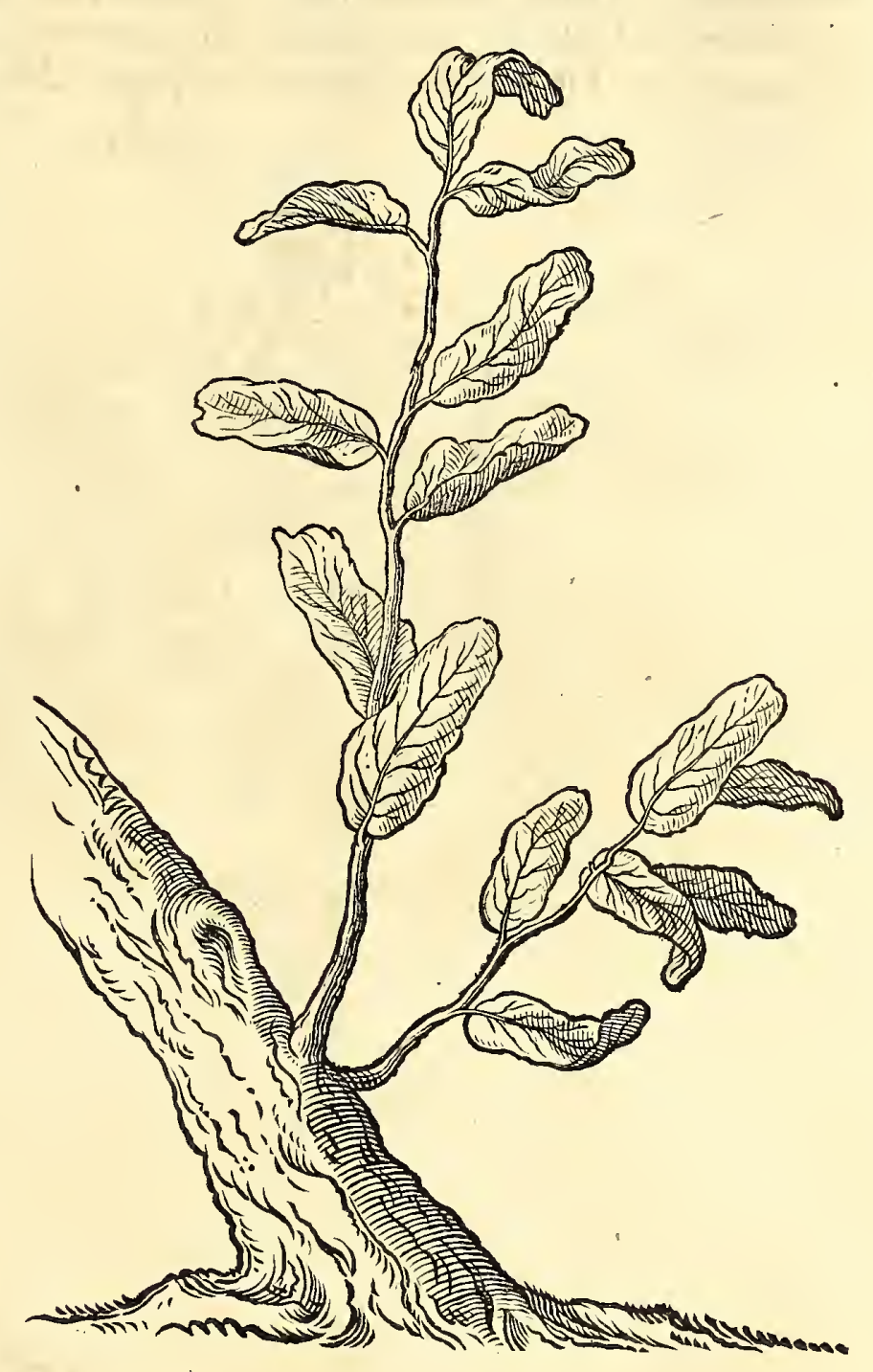
te inde ad nos deferatur.

Ad internos \& externos affèctus non inferiori gaudet qualitate quam Copaiba. Calidum \& ficcum eft in fecundo gradu, diffolvens, digerens $\&$ confortans. Aliquot illius guttulx per os jejunis exhibitx, Afthmati profunt: intemperiem quoque ventriculi, vifcerum languores inveteratos corrigit: tepidum pectori \& hypochondriis illitum, corum oppilationes \& frigiditates tollit. Irrigatione $\&$ frictione capitis $\&$ cervicis ex panno rubro,corroborat cerebrum, \& præe fervat à Paralyfi \& Spafmo; imo debilitatum omne nervorum genus in priftinum vigorem reftituife, fapiffime hic fumus experti. In nervorum puncturis acrimoniam faniei, unde tot dolores $\&$ convulfiones oriri folent, retundit.

Cæterum Lufitani æque ac Brafiliani adverfus vulnera $\&$ morfus venenatorum animalium inefle illi virtutem quandam fingularem teftantur, ad quam animalia, inftinctu 
folo naturali confugientia, corticemque deterentia, parti $1 \mathfrak{x} \mathfrak{x}$ prefentiflimum inveniant remedium. Qux omnia in Caftris \& Nofocomio noftro, tum imprimis militibus ictis à feris atque Barbaris, mecum per deferta peregrinantibus, comprobavi. Quippe folo hoc eximio Balfamo recenter exipfis corticibus collecto, vulneratos \& luxatos reftitui.

$$
\begin{gathered}
\text { С } \mathrm{A} \quad \mathrm{P} \quad \mathrm{V} \text { T } \mathrm{V} \text { I. } \\
\text { Acaiába, \& fructus cjus Acajú. }
\end{gathered}
$$

Q

Vantum lenta folent inter Viburna Cupreffi, tantum inter cæteras Brafiliæ Arbores eminet Acaiarba, divino beneficio harum regionum incolis concefla. Quxutafpectu pulcherrima, ita multifaria virtute cel ebratifima. Ac quamvis umbrola $\&$ patula, ramifque multis fpeciofa, non tamen adeo in altum exfurgit; fed cum revera Malus fit, variis \& finuofis flexibus fefe incurvat, ramis humum verfus dependentibus. Eft duriffimo ligno, à naupegis valde expetito, ac Gummi optimo A C A I I I B A.

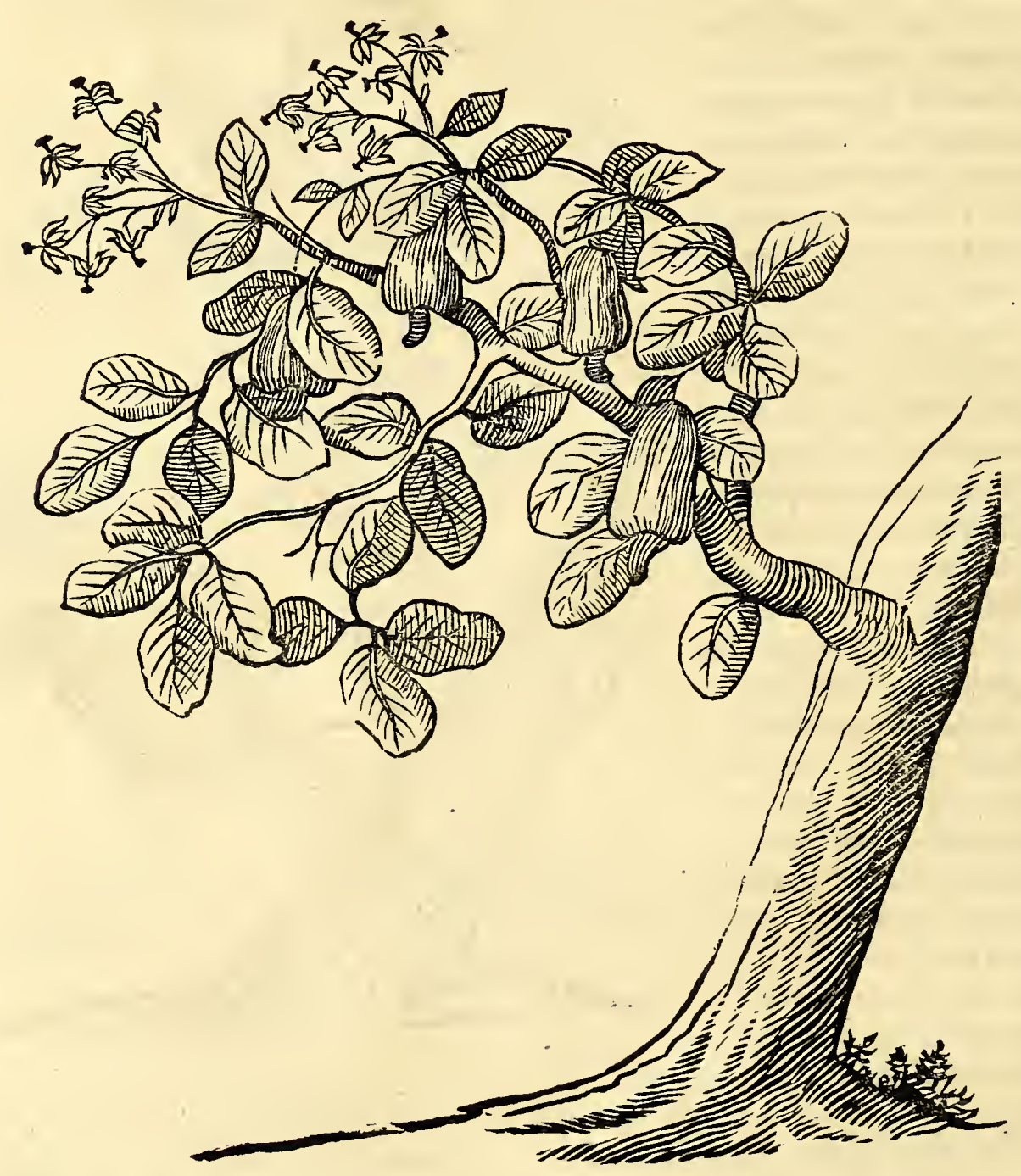

turgente, quod fua fponte $x$ ftivis menfibus erumpit, ob facultatem, pellucidum colorem, fragrantemque odorem, Arabico vix cedens. Foliis eft, finervos, fi figuram fpeates, Iuglandi fimilibus, fed fragrantioribus, nec aromaticum odorem deponentibus nifi diftillatione forti. Multo autem magis odorifera illa folia, quæ verno tempore Brafilicnfi pullulant, \& hinc quidem pulchre $\&$ fature rubicantia paffim in filvis videas, annuaque folia, tamquam inutilia, detrudunt circa hibernum tempus. Flofculos fert pentaphyllos nultos jux ta fe pofitos, \& in una umbella ad centum ufque conjunctos: in cujufque 
cujufque medio ftaminulum cum exiguo capitello habentes. Cum primo erumpunt, quod fic potiffimum initio Seprembris, funt candidi mox incarnati coloris. Odore fragrantiffimo Liliorum convallium æmulo integras filvas replent. Flori fuccedit caftanea ex qua excrefcit pomum oblongum conftans ex carnefpongiofa ac lenta acinis \& feminum cellulis diftincta, fucco dulci acido aftringente turgens. Qui fuccus adeo maculat linteamina ferrugineo colore, ut nulla arte elüi poffit antequam arbores denuo floreant. Liquor hic recens albicat inftar lactis faporis aftringentis, cujus color \& fapor paulatim pereunt fermentando, manetque fortis $\&$ inebrians. Exterior pomi pellicula tenuifima partim flavefcens, partim rufefcens, ita ut pro vario natur $x$ lufu celeberrimus hic fructus, figura, colore $\&$ fapore inter fe-difcrepet. Caftanea ut $\&$ nucleus renis ovilli figura funt, hic tenui pellicula, illa craffo \& fpongiofo cortice cinereo veftitur, in quo oleum acre $\&$ admodum mordicans later, ut fi quis illud incaute ore attigerit, labia \& linguam ignis modo urat. Vt oleum in cortice abfumatur fub cineribus caftanea torretur; hinc malleo contufá, nucleus eximitur, qui vel ad annos incorrupte confer-
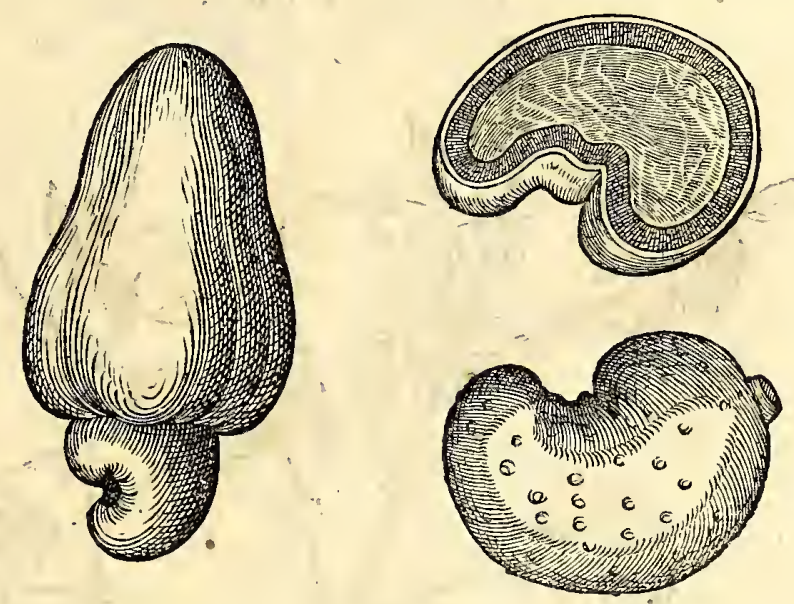

vatur, vel recens comeditur, adeoque fapit toftus ut caftaneas longe anrecellat.

Brafilianis vero non minus quam Arcadibus olim Quercus, pomum hoc, tum glans ei adhærefcens $\&$ fuperinnafcens, à totjam feculis, vitæ folatio fuerunt. Bella, qux frequentia inter illos excitari folent, ex parte hujus fructus amore geruntur. Victores enim caftris pofitis loci expugnati poffeffores tamdiu manent, donec omnem arboris fructum depafti fuerint. $Æ$ tatem exinde fuo more dimetiuntur, nam femel in anno dumtaxat provenit, idque menfibus Decembri, Ianuario \& Februario, tunc enim deficit fub latitudine Parnambucenfis Præfecturx; quia meflis tempora pro fitu regionis mutari folent. Soleredeunte à Tropico Capricorni, terra iis irrigatur aquis quas pluvias de Acairí appellant, quibus fi non prorfus deftituatur, nec nimium obruatur glandifera \& pomifera hæc arbor optime cum Barbarorum meffe $\&$ vindemia agitur.

Caftanex autem feu glandes pingues $\&$ fecundo gradu calid $x$. Crud $x$ ac recentes; fi cum vino \& momento falis manducentur, juglandes guftu referunt ; fin affatas aut faccharo conditas malueris, multo fuaviores, $\&$ durabiliores comperies ; quapropter quoque pro deliciis inter bellaria apponuntur: Oleum quod fub ejus putaminelatere dictum eft, herpeti medetur. Calidum eft à tertio ad quartum gradum, cancrofis $\&$ malignis ulceribus vitiofa carne laborantibus, adhibetur. Lichenes quoque, \& pedum vermictilos Bicho dictos, expugnat. Maturefcenteautem caftanea ipfa cum oleo intus contento fenfim mitefcit, ac vim fuam maxima ex parte deponit.

Incolx arboris Gummi redactum in pulverem, ex liquore convenienti propinant mulieribus obftructione menftruorum laborantibus.

\section{A P. VII. Iabuticába.}

F St arbor recta procera atque elegans, vaftiffimis ornata ramis : fructum fert cineE rei coloris parem magnitudine Limonii, fucco dulci, tenui pellicula inftar uvæ bene matur : qualitatis temperatæ atque falubris, febricitantibusjucundiffimum. Non fert flores, fed fructus in tubere, qui ab ima radice ufque ad fummitatem ramorum ita per totam arborem conjunctim cateryatimque extuberant, ut continuus potius racemus, quam arbor videatur.

Species quxdam hujus arboris invenitur in filvis Pagi T abucurána, fed fructus fert minime cum aliis comparandos. Ex quibus Incolx exprimunt vinum delicatum \& dulce, quod nifi ftatim ebibatur deterius fit, \& in acetum convertitur. V traque hæc arbor nifi in vaftis filvis Mediterraneis, \& frequens eft in Præfectura $S$. Vincentii, tefte Emanuele de Morais : Eam enim fateor me nondum vidiffe, licet non perfunctorie tars elegantem arborem in.filvis mediterraneis quxfiverim.

I $C A$. 


\section{A P $\quad$ V $T$ T V I I I. \\ Içicariba, \& illius Gummi Içicá, five Elemni.}

$\mathrm{I}$

$\mathrm{N}$ arenofis $\&$ efforis nemoribus excelfa réperitur arbor gunımifera, qux à Barbaris Içicariba appellatur à lacryma quam fundit, qux ipfis Içicá, Lufitanis Almaçiga dicitur. Arbor hæc Fagi in modum crefcit, caudice non ita craffo, cortice glabro \&

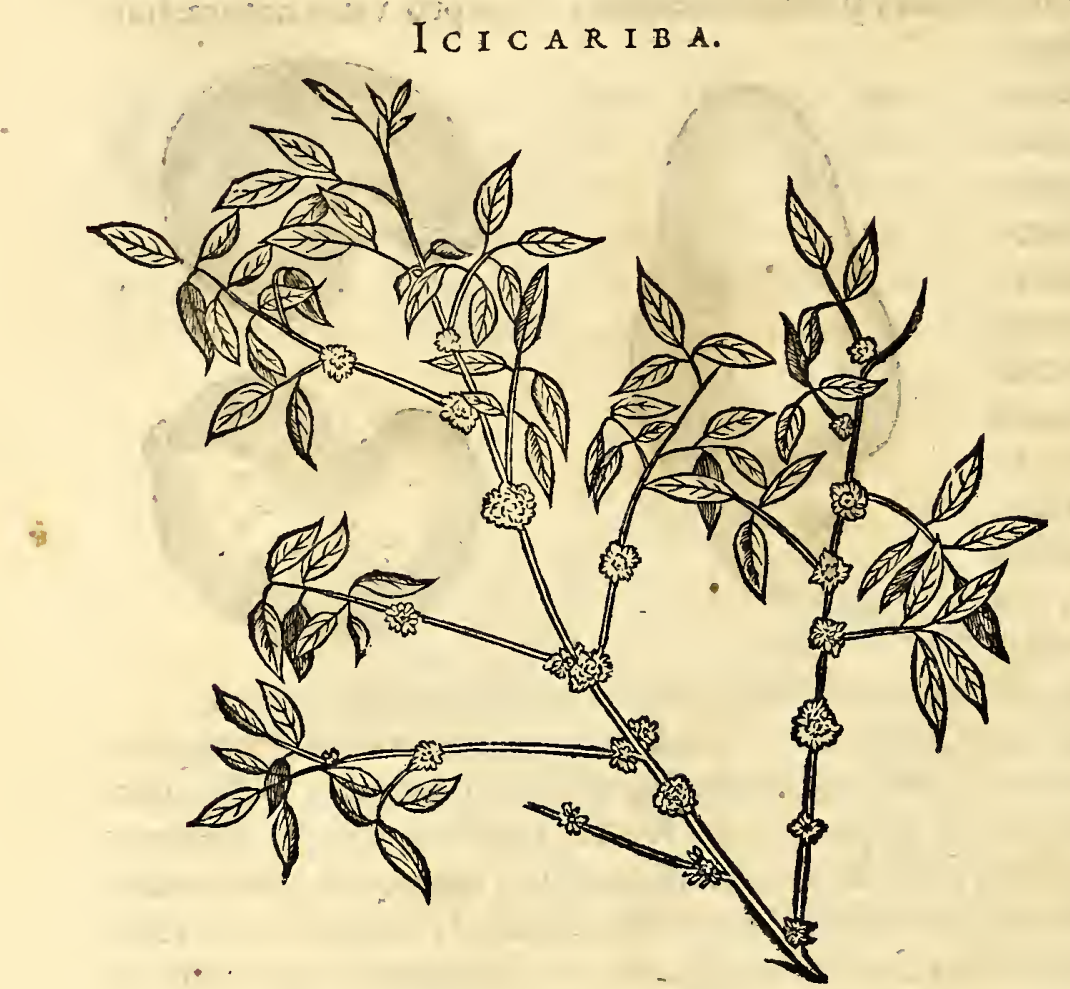
grifeo. Folia fert in ramulis, duo femper fibi invicem oppofita \& tertium folitarium in fine. Sunt autem pyri foliis fimilia, oblonga, anterius acuminata, craffa inftar pergameni,. late viridia $\&$ fiplendentia, nervo fecundum longitudinem, $\&$ venis oblique difcuirrentibus. In ramulis ad foliorum exortum copiofi pronafcuntur flofculi, racematim feu verticilla: tim pofiti five congefti, parvuli, quatuor foliolis viridibus conftantes, ftellulx pene figura: Foliola autem illa in ambitu lineola alba funt circumdata, \& in medio exftant

Itamin ula aliquot flavefcentia. Poft florem fequitur fructus, figura \& magnitudine Oliv $x$, colorc autem Mali granati, intus habens pulpam odoriferam, uti \& lacryma eft arboris. Cortex exterior fi manu vel paulum mulceatur, infignem, mox odorem de fe fundit.

Interior cortex alte vulneratus, plenilunio imprimis, ftatim, nonnumquam poltridie, aut tertio poft die Gummi feu Refinam fundit odoratiffimam (odoris inftar Anethi recentis contufi) præftantiflimamque, colore albicante $\&$ virefcente. Eft Gummi Elemni plane fimile, quod tamen noftro officinarum, utpote recentius, odore, \& qualitate efficacius. Calidum eft ad tertium gradum, primum molle, mox indurefcens, pracipue frigefactum. In omni topico, five fimplex, five compofitum, ad vulnera aperta $\&$ ad interiora mala, ex frigore potiflimum nata, adeo expetitum, ut profanum habeatur illud aut ignoraffe aut nori applicuiffe. Hoc, cum partim rufticorum indulgentia ad me allatum, in quotidiano ufu effet, vix ulli umquam emplaftro ftomachali; vel ceroto corroboranti adeo fum fifus, quam huic.' Vifcera enim roborare, flatus diffipare $\&$ doloribus feliciter mederi aliquoties fum expertus; ita ut in frequentiori praxi hoc præx cxteris commendare, reliquifque omnibus præferre voluerim. Poftremo, ad omnia qux Gummi Elemni ufurpatur capitis vulnera, licet gravifima, eaque fanat, ac prima intentione reftituit.

Ejufdem arboris \& Gummi meminit quoque Fr. Ximenes in nova Hifpania.

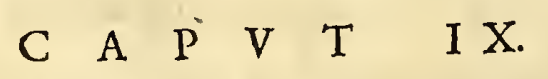

\section{Arbor Ietaibá, \& illins-acryma, Anime.}

Ariora quidem aromata \& balfama, pro fua fertilitate, hic Brafilix tractus profert, quoad refcifcere potui, qux tamen gummi \& lacrymarum copia compenfar. Inter hxc perpetuo virore confpicua nemora, prafertim in Paraybx diftrictu, 
HIST. NATVRAL. \& MEDIC. LIB. IV.

diftrictu, fpiffam \& fpe. ciofam producunt Arborem Ietaibá, ligno duro; albo, $x$ dificiis \& machinis aptiffimo, cortice lento, punctulis exalbo flavefcentibus variegato, $\&$ hinc inde clypeiformibus maculis, ex albo fubflavefcentibus. In ramis continet folia duo vel tria fibi oppofita figura parva, fed oblonga, viridia, ad tactum lavia, nervo fecundum longitudinem \& venulis tranfverfis, eleganter inferius confpicuis, prædita. Fructum fert in filiquis oblongis compreffis duriufculis, coloris hepatici \& quafi lævigati. E filiqua fracta. promanat fubftantia molliffima filamentofa fubincarnati coloris, faporis farinacei \& fubdulcis, qux cruda edulis eft. Huic farinacex fubftantix tres utcunque lapides compreffi glabri nigri involvuntur, figuræ \& magnitudinis dactylorum.

Refina odorifera arboris ab Indigenis Ietica-cica nominatur;Lufitanis vero Anime, ob fimilitudinem quam habet cum Anime Novæ Hifpanix.

Hoc Gummi per meatus corticis interiores decidere certiffimum eft; illud enim, tellure effor$f a$, fub arboris trunco \& radice occul tatum extraherefolent. Quod potiffimum fit fub finem xftatis menfe Februario. Monardes ex vulnerataarbore; in Nova Hifpania, colligi teftatur, haud aliter quam Maftiche aut Thus. Eo non folum Medici, fed $\&$ vulgus familiariter $\mathfrak{u}$ tuntur, pracipue in capitis doloribus à frigorenatis. Solus autem illius fuffitus ad roborandum non
IETAIBA ARBOR \& FRVTVS。
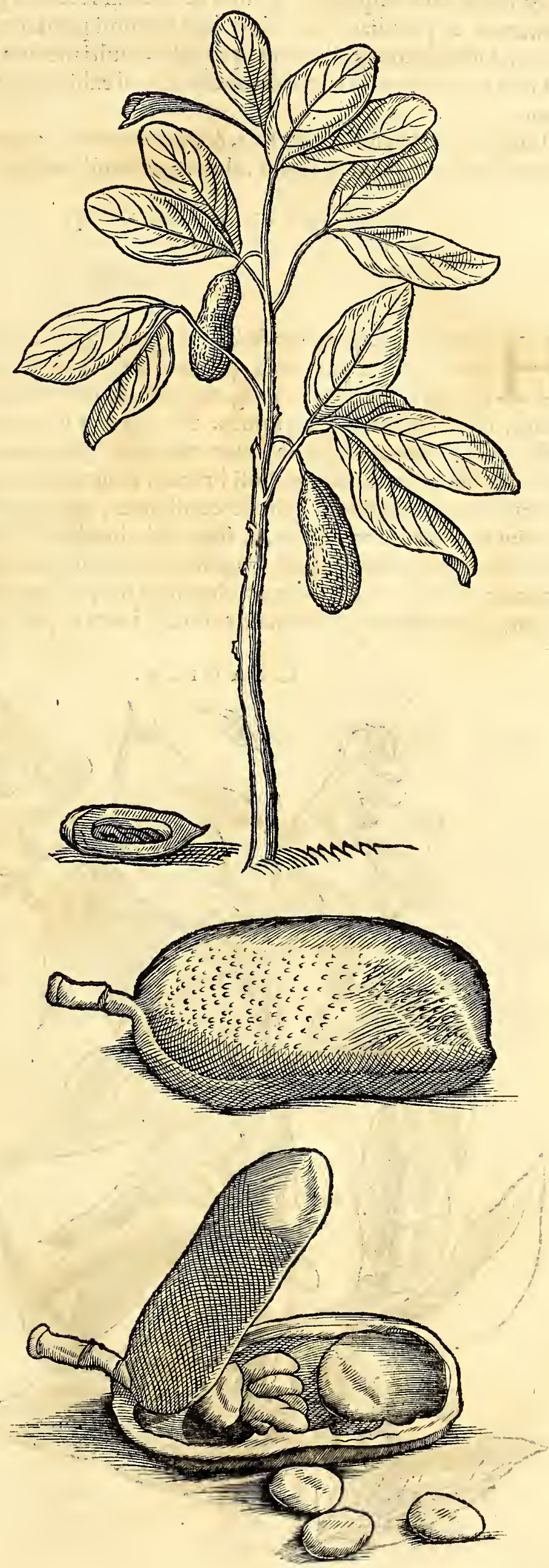

L 2

folum 
folum caput, fed \& r cliquas corporis partes frigore affectas, valet. Suavifimi eft odoris, \& facilis confumptionis. Calida $\&$ ficca in fecundo gradu. Cærerum vi quadam. aromatica \& peculiari fuo calore hoc Gummi præltare, ac partibus nervofis illitum, vel emplaftri forma applicatum, prodeffe, multi mecum experti funt.

Folia arboris contufa lumbricos enecare, fi exhibeantur, conftanter Indigen $x$ affirmant.

Interior corticis fubftantia rafa, \&zaquximpofita, contra ventriculi ventofitates, ad potiunculæ formam prxparatur, alvumque fimul movet.

\section{A P V V \\ Caaopicí.}

$\mathrm{H}$ V́milis ac tenera hæc Arbufcula güttifera, à Lufitanis Pao de Lacra appellatur, quod gummi feu gutta quædam vifcofa ex cortice ejus defluat. Päflim $\&$ c̀ quovis terræ genere progerminat. Ligno eft lento, cortice è cinereo rufefcente: difpefcitur in multos ramos. Folia habet folida, inferiori parte ex viridi quafi rufefcentia \& afpera , fuperna dilute viridia \& f flendentia. Florum in umbellas congeftorum rudimenta funt globuli brunni, magnitudinelentis, qui fucceffu temporis protrudunt flores quinque foliolis conftantes, exterius ex viridi flavefcentis coloris, interius tomento albo veftitis, \& ftaminulis luteis fubtilibus repletos. Poft flores proveniunt baccx, primo virides, magnitudine cerafi, rotund $x$; quæ diffectrex molli, quó teguntur, cortice, fucci multum eleganter flavi exfudant ; intra corticem autem continetur pulpa alba conitans meris cylindris juxta fe pofitis, qui fibi invicem cohærent.

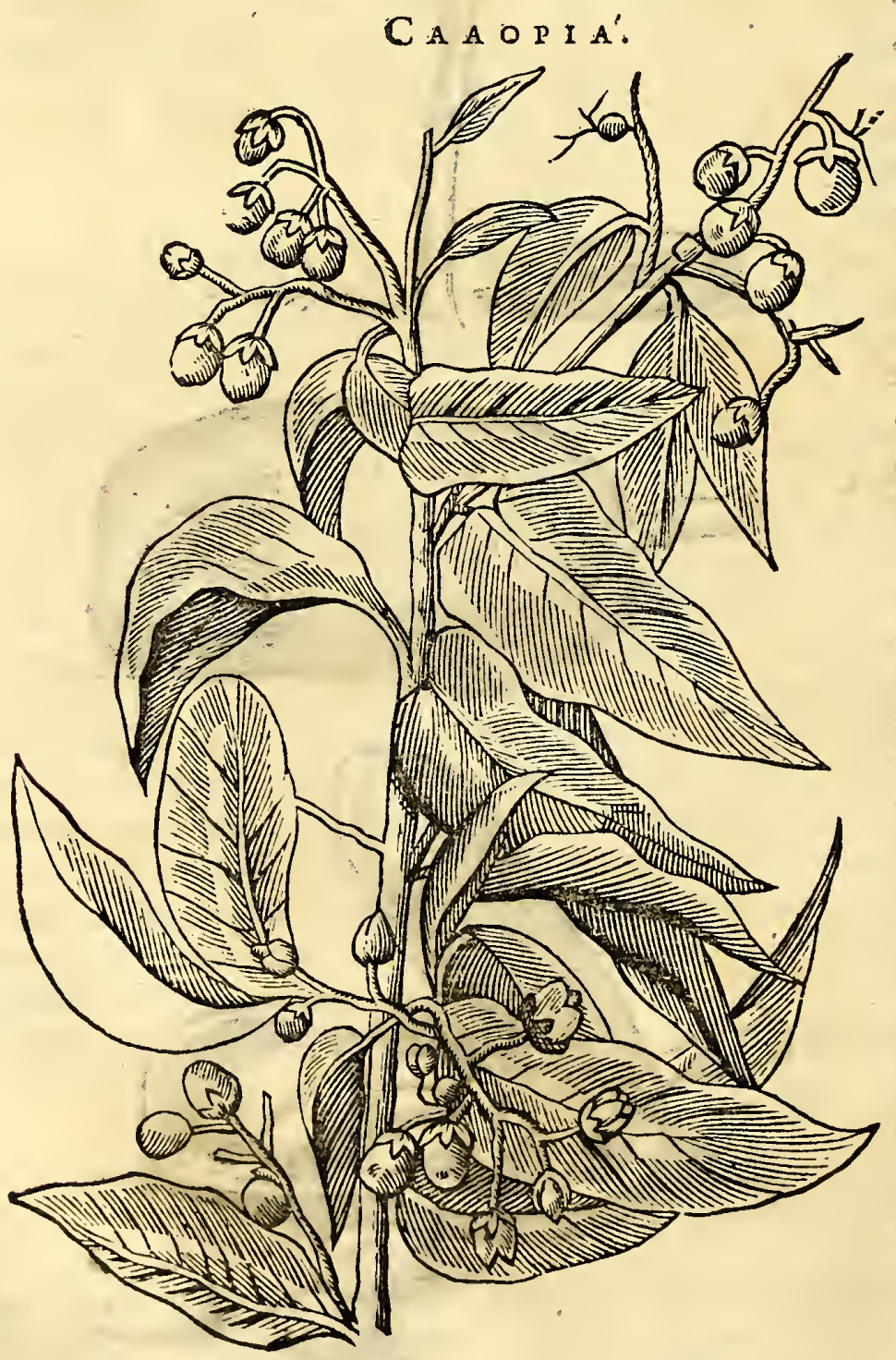

In extremitatibus ramorum, qui rudimenta aut flores fuftinent, femper duo foliola acuminata brunni coloris compacta funt invicem, quaft femiglutinata effent, $\& 2$ haftam five venabulum referunt: hæc decerpta ex pediculo croceum humorem emittunt.

Florent hæ Arbores potiffimum menfe Novembri \& Decem bri : Ianuario \& $\mathrm{Fc}$. bruario baccx funt maturx.

Si cortex medius hujus arboris incidatur, prefertim quando Horere incipit, \& linquatur per unum atque alterum diem; exfidar lacryma cro. ceo-rubra, egregia, coagulaturque ; qua initio mollis, poftea induref́cit. Convenit colore \& confiftentia cum Ghitaremi five Gutta gamba, \& codem 
HIST. NATVRAL. \& MEDIC. LIE. IV.

fere modo purgat. Eft è Havo paulo ruficris coloris, quam illud, nimirum ficcatum; nam molle, croceum tingit colore lutco five aureo paullo faturatius. Diffolvi poteft eodem modo in fpiritu vini, \& tincturam facit croceam. Nonnumquam ignes luculenti ftruuntur juxta arborem, quorum poteftate cortex dehifcit, majoremque fundit lacrymæ copiam, quxin maflam coacta in ufum Medicinalem fervatur. Quodà me primum tentatum, optime fucceffit.

Olim affrictu hujus Refinx, in aqua diffolutx, impetiginem tollebant. Licet autem tantx efficaciæ non fit, quam Gutta Camboides, vulgo Gutta gamba (quod an infitæ tarditati, an prxparandi modo fit imputandum, dubito) tamen à drachna dimidiata, ad drachmam unam, per integram noctem in aceto fquillitico, aut fípiritu vini macerata, \& ex vino propinata, ventrem folvit, fortiterque per inferiora exonerat. Meo tamen judicio rectius faciunt, qui dilutum ex aceto prædicto, in pilulas accedenteftimulo conglobant, quam qui potiones ex illa conficiunt; quod ob tenacitatem difficillime folvatur.

$$
\begin{aligned}
& \text { C A P V T XI. } \\
& \text { Palme Brafilienfes. }
\end{aligned}
$$

$\mathrm{P}$ Lurima Palmarum genera producit Brafilia. Quarum aliqux fponte crefcunt in filvis, ut Inaiá, Carnaiba, Tucín, Vrucurí, Giçáara, Aqué, Iráiba, Airí, Miriti, Maraiáiba, Gioçará, \& alix: Quxdam vero aliunde huc olim tranflatx \& quafinativx factx, ut Cocoeíro \& Palma dactylifera.

Inter Silveftres indigenas frequentiffima eft, qux Inaiá Brafilianis, vulgo Lufit. Pindóva nucifera dicitur. Eximia \& procera eft arbor, denfifima nemora conficiens : lignum albicans \& $\mathrm{fca}-$ brofum corticis loco habet; ligni autem loco fungofam \& intus filofam medullam facile combuftibilem, è qua fana $\&$ fortiffima lixivia norunt conficere. Nullum prxterea aut certe exiguum praftat ufum : ad ornatum duntaxat ob infignem altitudinem $\&$ ramos pulchre porrectos expetitur; iis fiquidem eleganter comatis, \& foliis radiatis utrimque veftitis, Lufitani atria \& templorum parietes exornant, Indigenæ vero loco tegularum tuguria fua ad pluvias arcendas fternunt. Fifcellas quoque $\&$ vafa viminea ex illis conficiunt. Folia autem hujus arboris non ita dependent in orbem, ut Cocoeiro, fed maximam partem ftant furrecta. Haud commode cxditur arbor, ob mollitiem qua ferri aciem obtundit.

Prope foliorum exortum, etiam rami proveniunt penduli, proferentes racemos, quatuor vel quinque pedes longos, plenos flofculis, poft quos etiam racematim proveniunt fructus vel centum in uno racemo, ovi gallinacei figura $\&$ mole, aut etiam majore, faftigium habentes acuminatum : altera extremitate infident calici vel cupu$l x$, ut Nux pinea, foliis triangularibus conftanti.

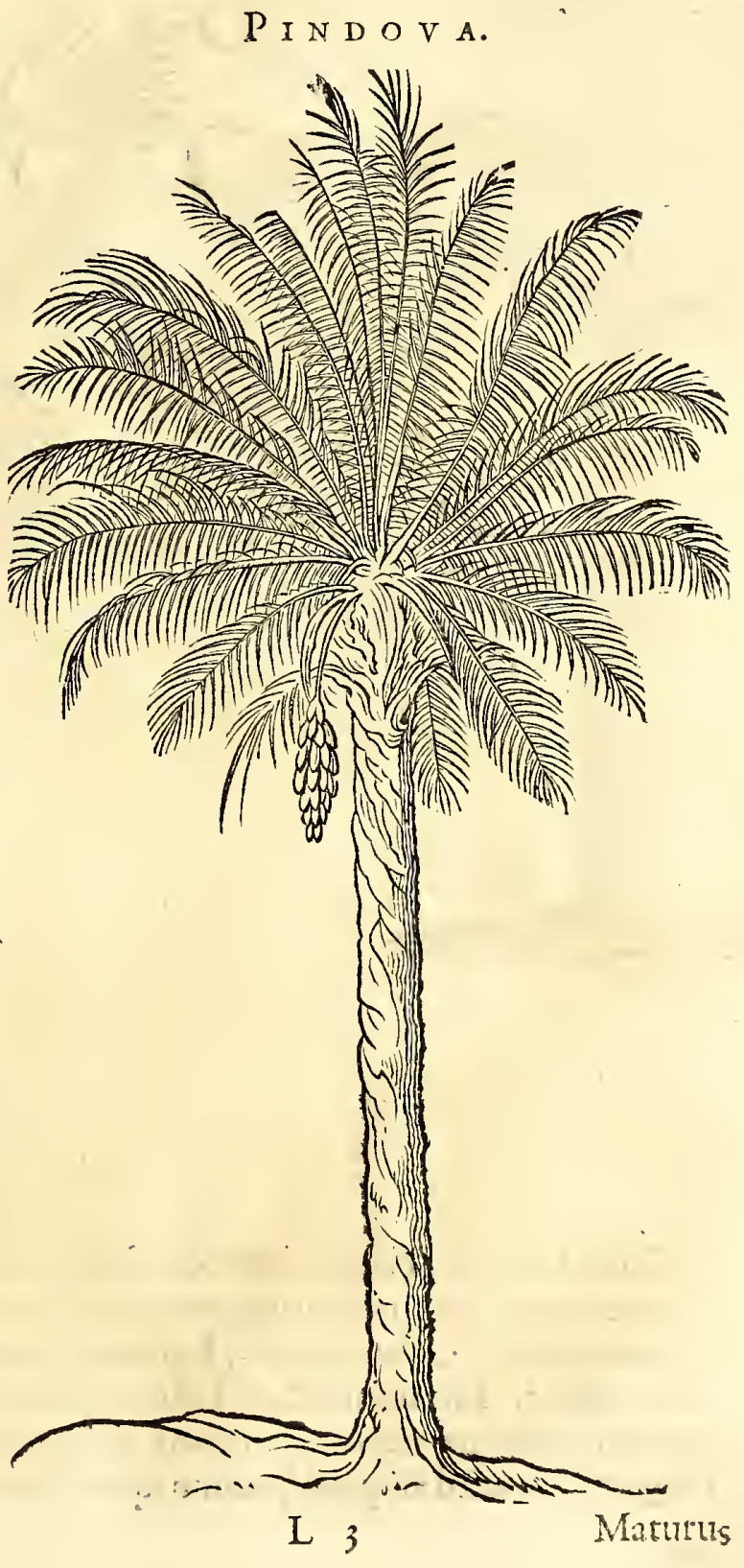


Maturus fructus exterius ex viridi flavefcit, vel etiam brunefcit. Cortex cxterior filamentofus eft, ut in Coco, verum haud craflus, fed duplam tantum habens ovi Gallinæ teft $x$ craffitiem. Hic morfus detrahi poteft: illo detracto apparet pauca caro crocei coloris, vix ullo manifefto fapore prexdita, quxà Nigritis cum farina comeditur. Caro autem hrc ambit nucem duriffimam, inftar Coco ovalem, ejufdem fere craffitiei, fed fi. ne foraminibus. Hacfracta, apparet in cavo, per interftitium more Iuglandium diftincto, nucleus magnitudine Iuglandis, albus, duriufculus, paulo ficcior, neque tam fuavis ut Coco. Colliguntur per totum annum, \& nuclei tam ab indigenis quam advenis comeduntur, Inaia-miri, id eft, Cocos parvæ Indigenis dictx.

Oleum infuper optimum inde exprimitur, album $\&$ jucundi odoris, quod, quia refrigerat, defectum rofati fepe fupplet : $\&$ cum recens eft, in cibis; cum vero vetus, ad lucernas ufurpatur. E fructus quoque cortice aliud non ignobile \& magis flavum elicitur, fed minus refrigerans, quod tamen ad multa mala emollienda adhibetur.

Efaftigio Arboris Gummi pellucidum, odoratum \& pulcherrimum fluit, quod in locum Arabicinonnumquam venit. Poftremo medulla coloris albicantis, $\&$ recentem Iuglandem refipiens, in vertice ligni continetur, optimum alimentum fi cum pane \& fale comedatur.

CAR N A I B A I.
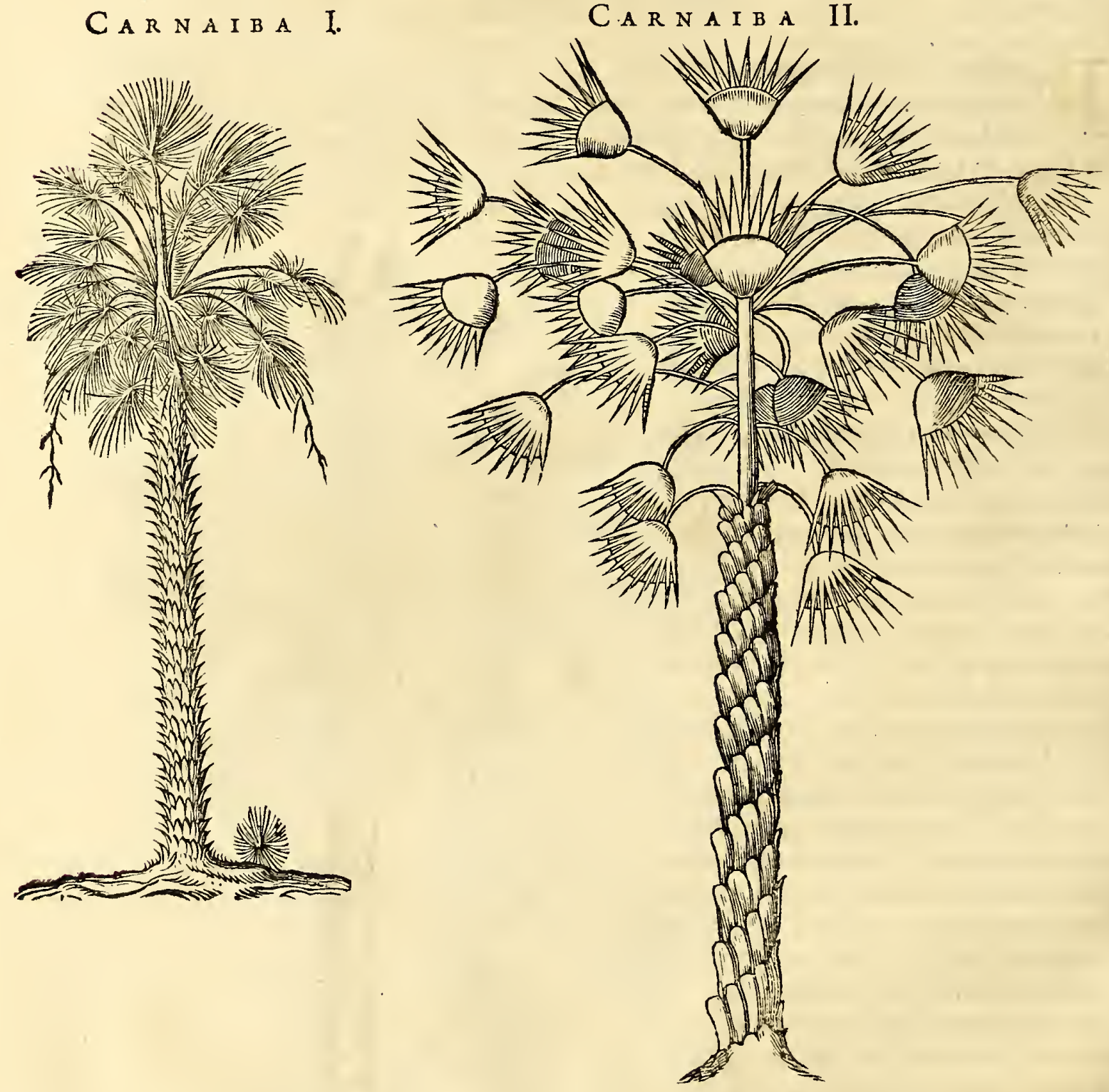

C.A R N A I B A II.

Circa Diøcefin Parayba è remotiffimis nemoribus ad hor tos ob elegantiam traductr Palmæ confpiciuntur, quarum brachia five rami caudam Pavoniam æmulantur. Barbari Caranaibam \& Anachecariri, Lufitani Tamar appellant, forte, quod fructus Dactylis fimiles ferat. Eftautem arbor Palmæ dactyliferæ altitudine, habens lignum rufum, durum, craflis nervis intus conftans, nullius tamen ufus : cortex exterior grifeus \& cartilaginc à terraad al iquod fpacium fquamatus, fquamis ordine cochleatim pofitis; qux 
HIST. NATVRAL. \& MEDIC. LIB. IV.

primo longiores, fenfim fiunt breviores, imo tandem decidunt fuperne : nam Arbores adultiores caudicis fuperioris medietatem habent glabram, inferiorem folum fquamatam.Squamæe enim nihil aliud funt, quam ramorum qui exciderunt reliquix, arbore in altum furgente, \& enafcentibus aliis ramis. Arbor in fummitate ramos fuos orbiculatim expandit, directe fuirfum, deorfum, \& ad latera, ut Palma dactylifera, fed longe elegantiori afpectu. Ramus quilibet duos vel amplius pedes longus, fatis craffus, compreffis in utroque latere, fpinis duris nigris armatus, figura dentifcalpium referentibus.

Vnicum in cujullibet rami extremitate folium rotund $x$ figurx, eft ita plicis donatum, ut manuarium fominarum umbraculum, coloris viridis, ab extremitate ad medietatem fere introrfum fectum in multa alia carinata folia, foliis Palme dactylifer $x$ ftructura fimilia : quodlibet ex his fectis foliis duos circiter pedes longum. Duas has Carnabbe fpecies obfervavi fibi invicem multum fimiles, nifi quod mira foliorum $\&$ corticis conformatione difcrepent, ut ex appofitis Iconibus liquet. Vtriufque Arboris fcapus interior egregie flammam concipit, \& inftar facis diu fovet; ita ut mihi per deferta perégrinanti folatio fuerit non folum ad illuminandum, fed ad abigenda quxvis infecta \& ferpentes noctu vagantes.

Inter ramos folia ferentes alii prodeunt longiores, nimirum quatuor aut plures pedes longi, in multos ramos, \& in ramulos lanugine albefcente obductos, expanfi alternatim, five quafi ex vaginula prodeuntes. In ramulis hifce alternata ferie exiftunt flofculi pallide Havi, line pediculis, finguli tribus foliolis conftantes.

Poft flofculos illos proveniunt fructus, figura \& magnitudine Olivæ; primum virides amari, non edules; mox maturi nigrefcentes, evadunt dulces menfe Februario : \& licet noftratibus nullius ufus, gentilibus tamen tam crudi quam prxparati in deliciis habiti , Tirade nuncupantur. Tarde crefcit hæc Arbor.

Folid apprime ferviunt ad tegendas ædes \& corbes.

Ex nomine furpicari quis poffet, hanc effe Arborem qux fundit Refinam illam, qux hodie magna copia Europæe infertur ex America nomine Caranna. Verum tefte Ximene, Ionge abeft : fiquidem Refina qux $a b$ Hifpanis Caranna dicitur, exlonge alia Arbore fluit.

Ex vero qux inter Palmas filveftres Tucun \& $\$$ Vrucury ${ }^{\prime}$ indigenis vocantur, in tantam proceritatem non excrefcunt, multoque cxteris funt humiliores, \& minus cognitx; quxdam fpinis afperrimis horrent, \& ligno funt ferreo; quædam vero funt filis non finofis, Vrucuri-Iba appellatx. Flore ut Gioçará.Fructus (qui \& Vrucurívocatur) ferunt racematim ut $P$ indóva. Quilibet eft Pruni magnitudinis, \& cupulx fquamof $x$ infidens: cuticula grifea, pulpa lutea filamentofa, pauca, dulci, conftans. Intus continet lapidem durum, in quo nucleus candidus, edulis. Lignum arboris ob perpetua filamenta contunditur, indeque $\mathrm{Fa}$ rina elicitur Vrucurivi dicta, Lufitani Farirba do PaO vocant: rufefcentis eft coloris, \& defectu edulis Farinæ de Mandiboca pro pano ufurpatur. Rami Arborislentiffimi funt, ac ad multos ufus

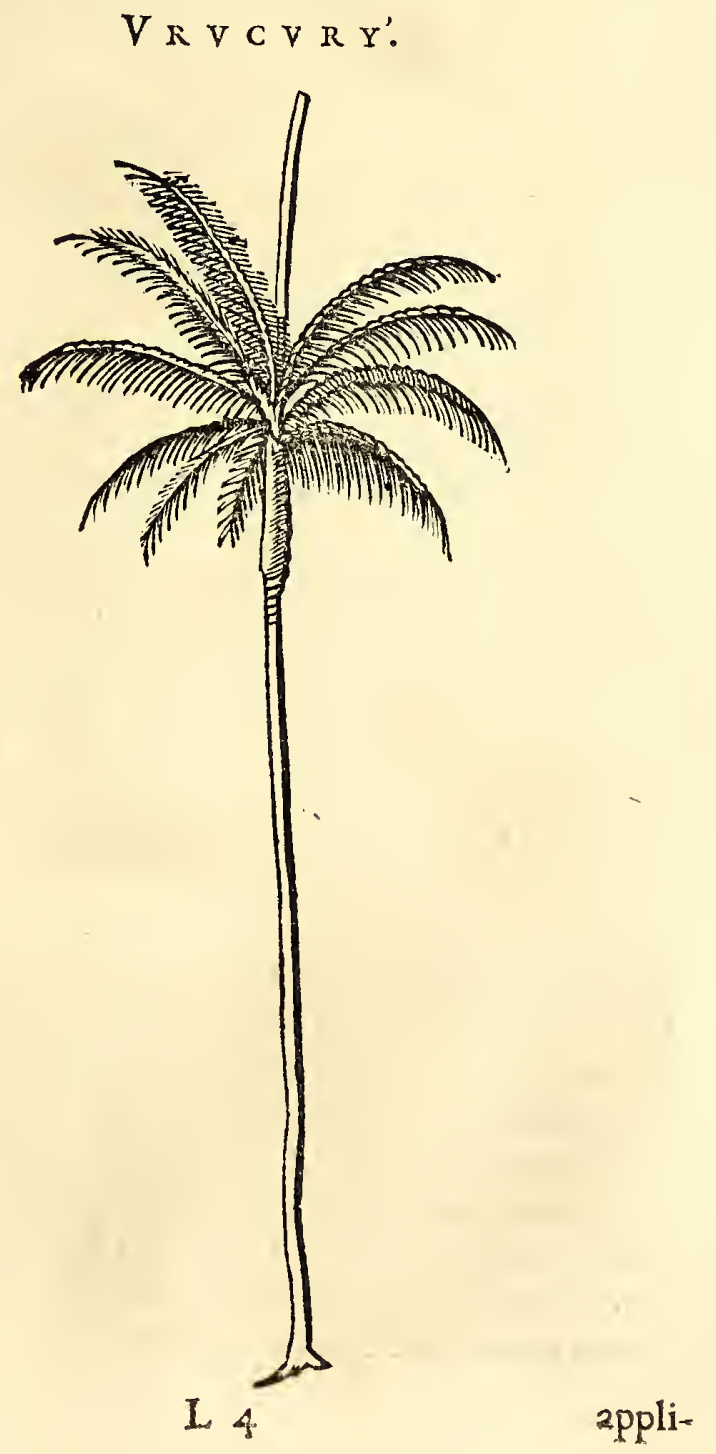


pplicantur. Ex fructu fit Oleum uti ex fructu Pindova, fed hoc de quo nuncfermo, valde eft medicinale, imprimis adverfus Raiarum puncturas venenatas. Nec puto, præftantius remedium dari contra illud malum. In ipfa Arbore nafcitur Polypodium \& Caraguatá, qux aquam fuppeditat per egrinantibus ad bibendum.

Quarta Palm indigen $æ$ fpecies Giogará: caudice tenui, recto, grifeo, exfurgit more arboris coqueiro, fed vix dimidia altitudinis. Flores flavefentes cum ftaminulis flavis è filiqua flavef́cente proveniunt. Hifcefuccedunt parvuli fructus racemofi more Palmarum; qui cum icone à pictore non expreffi funt. Adeo lentus eft floris ramus, ut pro fcopis \& flagellis ufurpetur. In fummitate Arbor is folium convolvitur,erectum inftar fiftulæ. Fructus maturus nigricat, \& tunc, defectu melioris nutrimenti, comeditur.

$$
T \vee C \quad v^{\prime} M
$$

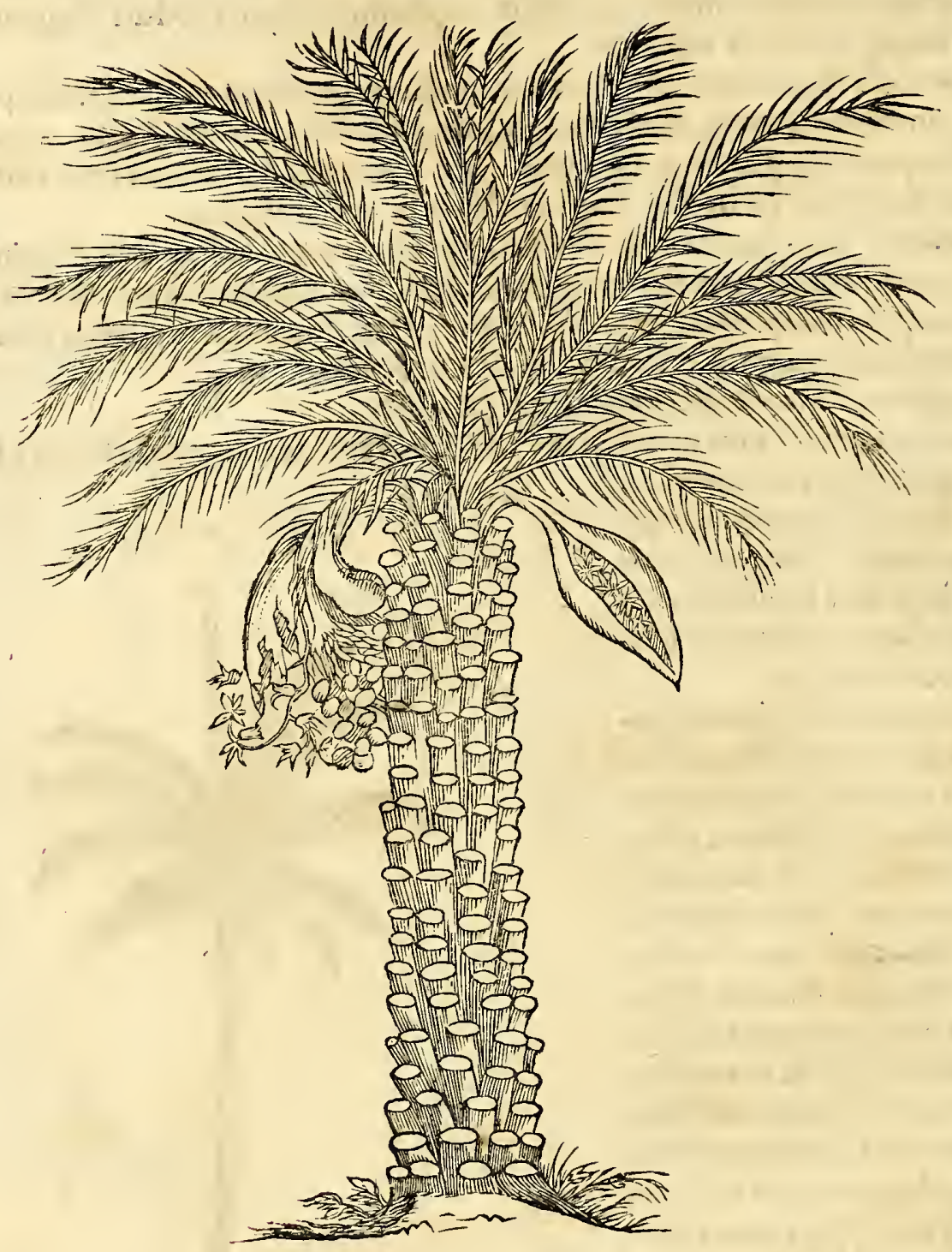

Quinta Tucum, Palma eft mediocris altitudinis: fi frondes fpectes, pindovam; fi catera, Palmam dactyliferam reprafentat: truncum, ramos atque folia habet aculcata: lignum vero nigrum $\& \mathcal{C}$ duriffimum, quo Indigen $x$ fagittas exafperant. Fructus producit rotundos racematim, Pruni Damafceni magnitudine \& figura, ducentos, trecentos, \& plures aliquando, uno eodemque racemo. Sues \& fimix iis faginantur. Oleum exinde limpidiflimum exprimitur, iifdem ufibus quibus nuces Pirdove, dicatum, magnique fit apud omnes paffim incolas. Fructus hi maturi exterius nigricant : nuclco funt albo non infuavi, præfertim recenti. Ex foliis Brafiliani filum deducunt tenuifimum \& fortiffmum, rubicundo Serico perfínile. 


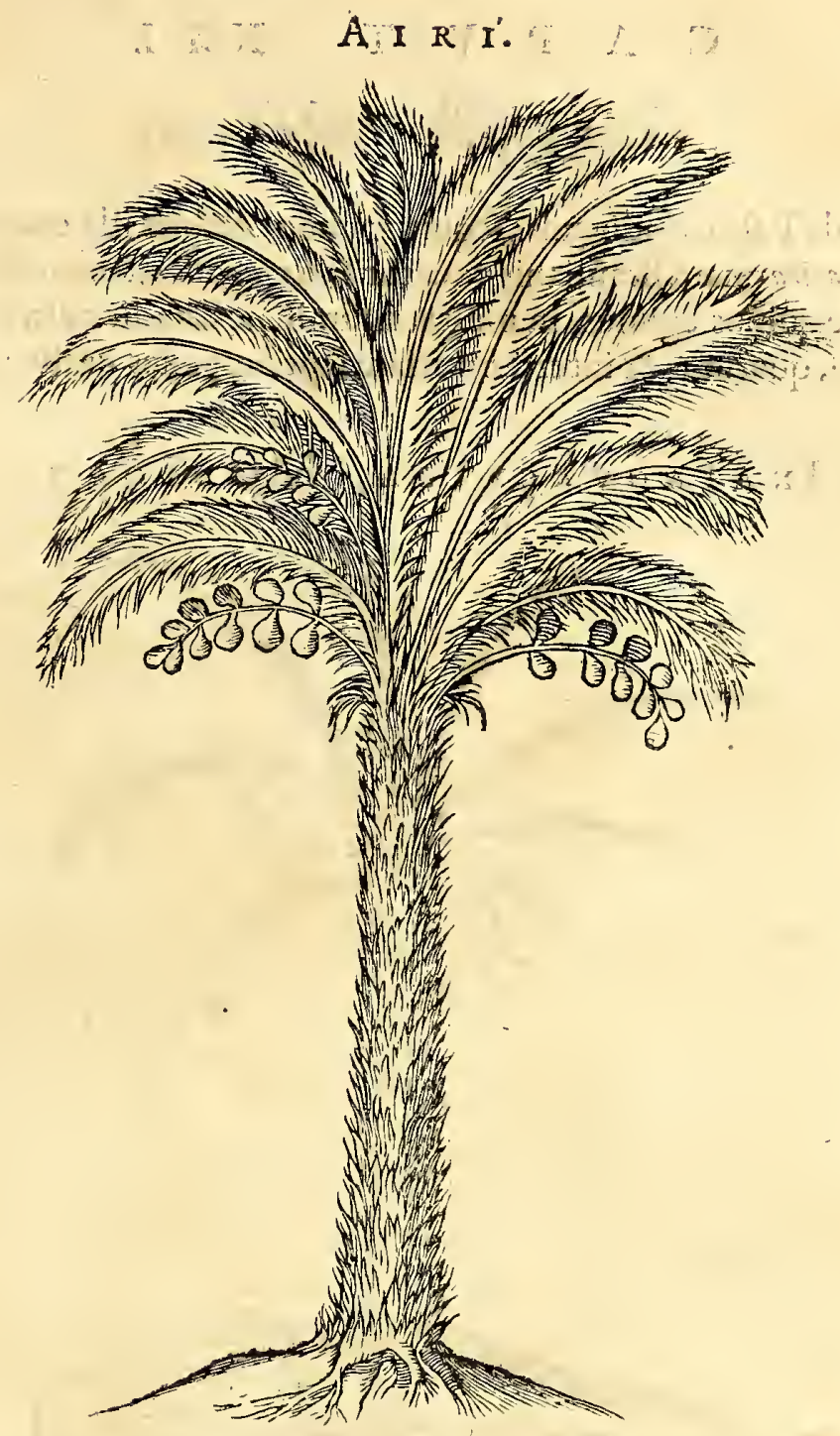

Sexta Airíngens eft Palmà, foliis longioribus; trunco (́pinis acutiffimis ündiqua: que armato, fructu rotundo ut cater $x$ Palm $x$, fed non adeo racemofo:medulla intus albicante pingui, fed non eduli. Ligno eft nigro gravi $\&$ duro, fundum petente, fi aquis injiciatur : Ebeni fpeciem quidam credunt. Brafiliani \& Tapuy $x$ exinde clavas fuas conะ ficiunt, fagittafque afperant: qux ubi carnem penetraverint, tenaciffime hætent. E caudice vulnerato vinum elicitur.

Septima AquéPalma mediocris, foliis cinereis, fructus fert racematim pruni magnitudinc, flavos ubi maturuerint, dulcifimi faporis, nuclco albo ac pergrato, ex quo incol $x$ vinum conficiunt. Nigritæillam appellant proprio idiomate Catolé. Familiaris :o hæc arbor Brafilix Septentrionali, non Auftrali.

Octava Iraibá precedentibus major, familiaris in piratininga filvis. Ad fummitatem illius circa ramos medulla continetur candidifima, qux cruda vel etiam cocta cum earne vel oleo inter bonos cibos numeratur. Subftantia vero durior, candida, quxe contufa cogitur in maffam farinæx fimilem, ünde placentulæ non ingratæ fiunt, ex freco vero illius pulmentumadmodum dulce \& fuave. Fructus quoque producit fapidos \& dulces. Remedium contra famem iis qui per illas filvas \& vaftas folitudines peregrinantur.

Nona Miriti familiaris Prefecturis geara \& Maranban. Fructum fert unicum edulem atquic dulcem; ovali etiam magnitudine. Cortice eft rubicundo, nigris maculis; intus vero rubro. Folia illius magni fiunt $a b$ Indigenis, ut illis tegularum vice utantur.

Decima Maraiáiba Palma familiaris Præfecturæ S. Vincentii, cortice fpinis armato: matcria duriffima; ex qua fiunt arcus nigri coloris. Fruetus fert ovi columbini magnitudine; cdules, \& fatis gratos: 


$$
\begin{aligned}
& \text { C A P V T X I I. } \\
& \text { Inaiaguaçuiba, vulgo Cocos. }
\end{aligned}
$$

$\mathrm{H}$

Adtenus de Palmis indigenis, fequitur nunc celebris illa exotica per omnes Indias Coquoeiro qux à Brafilianis vocatur Inaiaguaçuiba, \& fructus illius Inaiaguaçu, Palmis de quibus egimus, in multis diffimilis. Caudice eft, raro reato, fed plerumque inclinato, quatuor, \& interdum etiam feptem pedes craffo : \& fxpe ad quin-

$$
\text { INAIAGVAÇVIBA, vulgo Cocos. }
$$

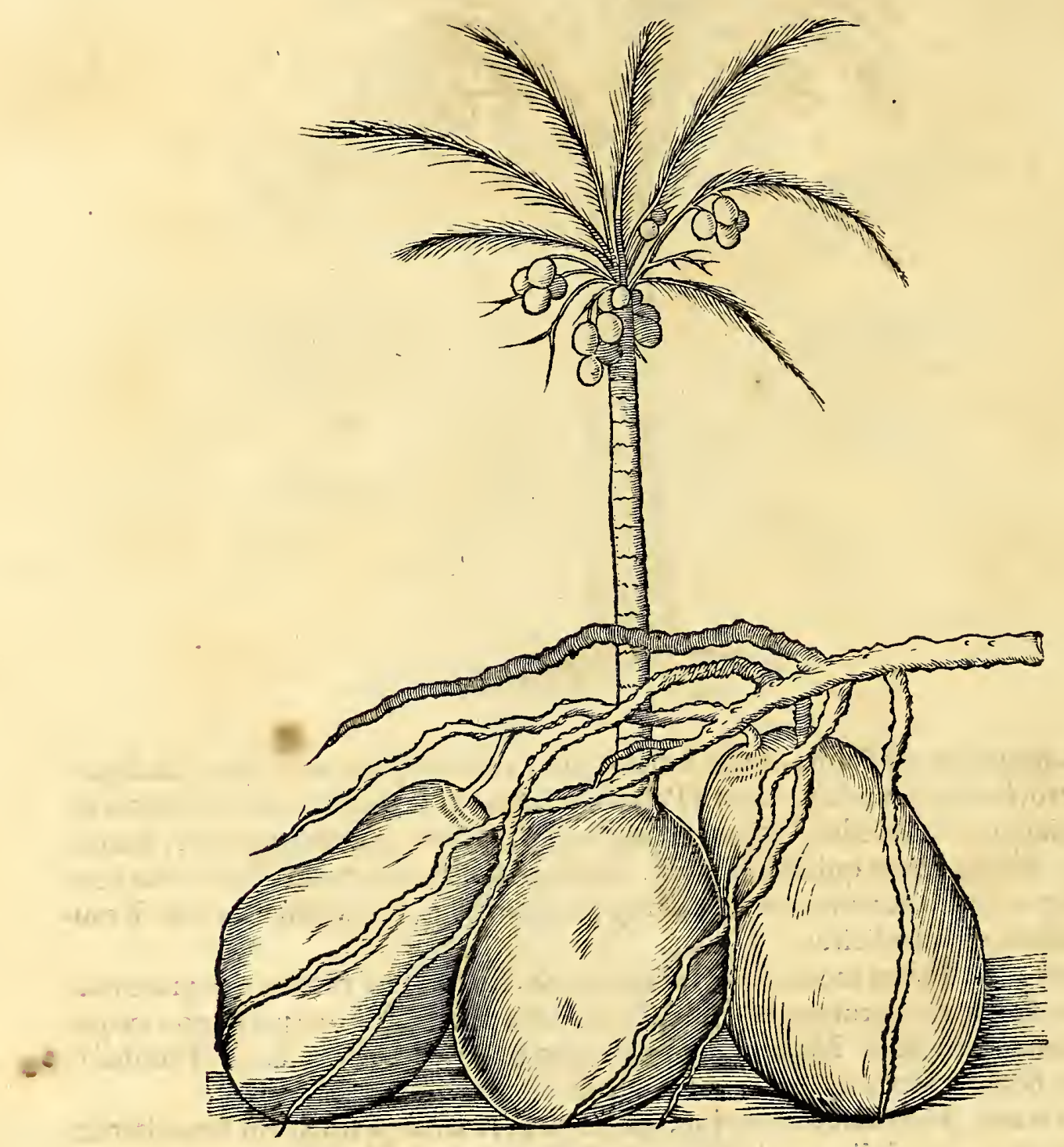

quaginta pedes alto. Quapropter mirum eft, earum truncos poffe fic brevibus, tenuibùs $\&$ vix terra coopertis radicibus in aëre fubfiftere, neque fuo multo pondere $\&$ fructuum mole, ventifque etiam vehementibus frpe eas quatientibus, humi concidere. Accedit quod pars caudicis humi proxima, non craffior aut fortior quam in fummirate exiftar. Cxterum eft cortice cinereo, \& quafi vibicibus hinc inde tranfverfim notato per ambitum. Lignum non multi eft ufus; conftat enim ex meris filamentis: eft dulce \& $<$ quafi lacteo fucco turgens, unde arbore cæafa à formicis appetitur. Caret ramis, fed in fummitate quindecim, viginti aut plura habet folia magna, alata, in orbem difperfa, partim furrecta, partim dependentia, grato afpectu. In exordio fuo hac folia alata quadam textura veftita funt, obfcurc grifei coloris, qux folvitur fubfequente alia. Quodlibet folium longum eft circiter fedecim pedes, ac in exortu unum circiter pedem craflum, diffectum in folia five alas, ordine juxta fe pofitas aut oppofi- 
HIST. NATVRAL。 MEDIC. LIE. IV.

tas; longitudinem nervum offeum flavefenten, ac tranfverfim fubtilifinäs lincas fet frias virides. Inter folia alata in fummitate arboris oritur filiqua five vagina duios pe-
des aut amplius longa in extremitatibus faftigiata, viridis, ftriata, que deinde rufefcit \& fponte fe aperit. Antequam autem fe pandat, caulis intus reperirür eleganter compofitus pedem longus, tres aut quatuor digitos craftus, in plures ramos pe-gnam fjicam reprafentant. gnam ficam reprafentant. Rami autem hi onufti funt triangularibus corpuffulis, magnitudine amygdalx excorticatæ , albis, quæ, rudimenta funt florum $\$$ deinde nucum. Nam rupta vagina rami hi fe explicant $\&$ oftendunt forculos luteos, Hinc fuccrefcit fructus, quilibet infiftens brevi pediculo, pennam anferinam craffo, \& $\&$ cupulæx, fquamis conftanti ex rufo flavefcentibus. Pondere $\&$ duritie fumma nuces caput humanum excedentes profert. Toto anni tempore maturis pariter atque immaturis fructibus decoratur, qui ar\&te $\&$ racematim caudicis fummitati adhærefcunt, $\&$ putaminibus craflis, filamentofis \& tenacibus veftiuntur: quibus fublatis ligneus calix apparet : quem fi immaturum perforaveris, aliquando fupra heminam dulciffimi \& gratiffimi liquoris emiteet, qui actu frigidiffimus licet, potentia tamen calidus eft, \& tenuiorum partium, urinamque cunctantem provocat. Nucibuis autem maturatis, lacteus ille humor condenfatur \& coaguli inftar calami fcriptorii craffitie concavo adhærefcit, qui exemtus ac manducatus vix ulli nucleo, quamvis fapidiflimo, dignitate cedit: nutrit enim $\&$ fuavitèr reficit : proinde à viatoribus marino itinere delaffatis \& fcorbuto infectis valde expetitur. Calidus $\&$ humidus exiftit in primo gradu. Oleum inde premendo extractum, in plurimos culinx \& pharmacopœx ufus refervatur, nec amygdalorum oleo præftantia cedit:

Per os aflumtum pectoris malis medetur Oleum, alvum quoque laxat fil $_{3}$ largius exhibeatur: ex alto læfis mirumin modùn prodeft, urinafque ciet.

Præterea liquor quidam ftillatitius, albicans \& eximix virtutis exinde elicitur, tenum $\& \approx$ genitalium vifcofitatibus exftinguendis titiliffimus, tum à mulierculis inter cofmetica adhibitus. Obfervandum autem aquam illam copiofiffimam \& gratifimam inveniri in medix xtatis nucibus: in plane matúris tantum modicam, neque ita gratam. Nucleum autem tum optime fapere, quum ad fummam maturitatem pervenit.

E trunci porro vertice medulla quxdam älbiffima quafi bulbofa qux Palma dicitur; arbufculx inftar novx; exfurgit, qux ex loculo, quo continebatur, prorumpens, ejufdem fere qualitatis, cujus concretus ille nucis humor, de quo jam diximus, exiftit; qux non cruda folum, fed \& cocta inter epulas apponitur, \& cum Brafica Cyprina certat. Nondum matura magis refrigerat; quocirca vicem acetariorum \& lactucarum preftat. Sed ea ablata arbor moritur, unde proverbium Palmam referre. Quod non æque contingit inferiori radicum parte læé vel concifa. Hinc fit ut plures indigenæefibí perfuadeant idem, quod Profper Alpinus de Ægypti populis circa dactyliferas narrat Palmas ; eas fcilicet non terra radicibus attracta, fed aëre ex fublimiori arboris parte aliac vivere. Plura egregia tradidit Ximenes de hac Palma Mexicanis Coyolli dicta qua
in Hiftoria noftra Naturali Brafilixfuffus exhibentur.

Atque hxc de Palmis earumque Medicis præefidiis diata fint; quarum aliquæx, imprimis Cocoqueiro præter ufus dictos, multa fuppeditant ad victum \& amictum humanigeneris: quippe filofa fubftantia caudiciadnata veftium materiam; folia, tecta redium: fructus immaturi potim; maturi alimentum gratiffimum ad hæc oleum acetum \& $\&$ fpi-
ritus abunde exinde elicitur.

De Palma autem illa dactylifera fcribere fuperfedeo: tum quod in plurimis Europx Regionibus fit notiflima : tum quod nihil novi mihi contigerit experiri ex illa arbo-
re quin ab aliis ante me dictum fit. 


\section{- C A P V T XIII. Arocira five Lentifous.}

A

Rbor arenofis, littore imprimis \& promontorio Olindæx frequens, Aroeiranuncupatur. Myrto filveftri noftrati qualitate non valde abfimilis, ad Lentifcos taenreferri debet. Forma quoq Garcilaffus \& alii. Præter eximias facultates, ma de qua arbore Clufius, Monardes, Garcilantus $\&$ cum Araca, \& Myrto, reliquifque

AROEIRA.

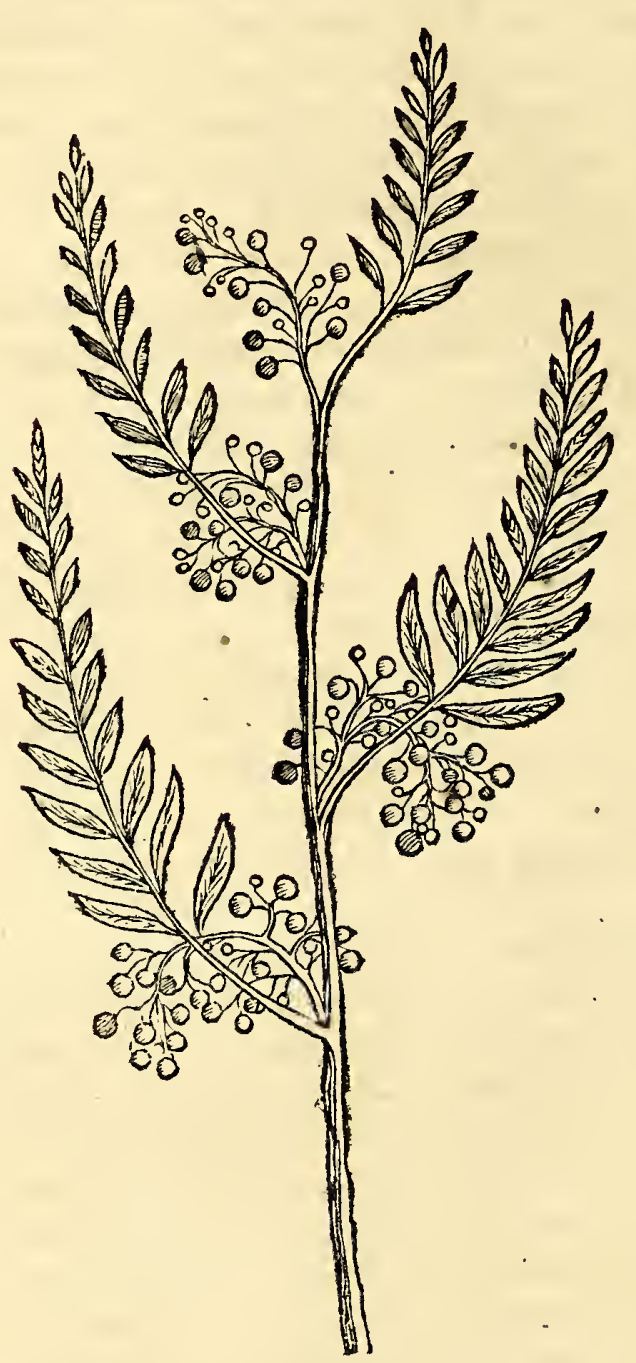
aftringentibus $\&$ odoriferis arboribus habet communes, hifce peculiaribus pollet, quod refinam fundat fragrantiffmam inftar Lentifci, ex qua emplaftrum adverfus frigidos affectus componitur.

Sunt autem folia in ramulis bina fibi invicem oppofita, \& quinque aut feptem in extremitate. Ad cujuflibet ramuli exortum, ramulus eft brevior, plenus flofculis minimis, qui conftant quinque foliolis ex albo fubluteis.

Flores hos fequitur fructus nimirum quafi uva, baccis plena, magnitudine piperis initio quidem viridibus, per maturitatem autem rubris, fed rubedo illa in folo cortice tenui, quilponte fe abfolvit, $\&$ decidit grano decidente: granum autem quod pellicula continetur, rotundum \& compreflum ac oleagin $\varnothing$ fum; ; odoris jucundi inftar foeniculirecentis triti, \& in fenucleum parvum lenta cuticula teatum continens. Maturefcunt baccæx menfe Iulio, quod eft, tempore hyberno. Earum acrimonia \& ficcitate carnes recentes à putredine confervantur.

Oleum quoque ex fucculentis illius baccis exprimitur, eidem ufui cum refina inferviens.

Folia infignem $\&$ nobiliffimum odorem emittunt, fi conterantur, qux fubamara, cum quadam vi adftringendi, aromaticas calidafque partes habent conjunctas, quemadmodum è balneis $\&$ lavacris, qux ex illis fiunt, videre eft.

Has vero virtutes tam profunde exerit, ut per deftillationem foliorum, imprimis recentium, odorifera $\&$ adftringens aqua inde eliciatur, qux tum ad pellendos corporis affectus, tum ad delicias fervatur.

Tempore paroxyfmi febricitanti, Empiricorum more, exhibent cum fucceffu oculos feu gemmas arboris ex aqua nocturno rori expofitos.

Caterum fciendum eft, in ramis Aroeira luxuriare fxpe polypodium, illo quod è terra profilit longe probatius. 
HIS T. NATVRAL. \& MEDIC. LIB. IV.

\section{A P V T $\quad$ X I V. \\ Vrucú \& Iaçabucáio.}

Ocum inter arborefcentes Plantas obtinet Vrucú, filveftris quidem, fed ab In colis inter hortenfes \& fativas jam olim tranflata; multaque etiam nunc indu-

ftria eam excolunt ; partim ut granulorum folliculis involutorum minio fefo exornent ac pingant; partim vero ut Lufitanis divendant, quxftumque ex tinctura illa

V R V C V'.
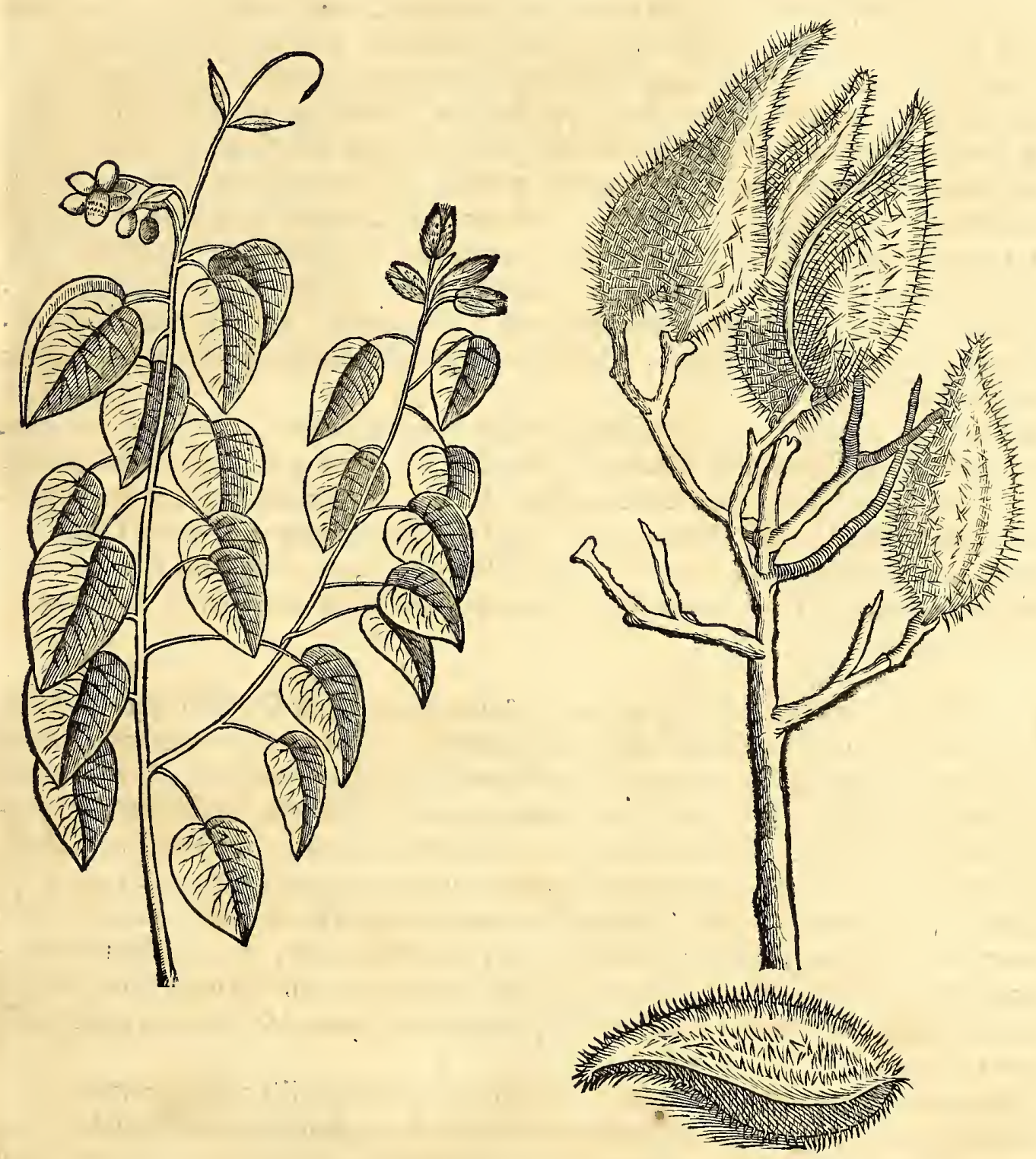

Orellana vulgo dicta faciant. Lingua ipforum hanc plantam Vrucú dictam, Clufius Bixam Americanam Oviedi effe exiftimat. Fr. Ximenes eandem accurate defcribit, fub nomine Acbiote. Et fructuum grana rubra delicatre potioni Chocolata qux ex fructu Cacáo fit in nova Hifpania, tam faporis quam coloris gratia mifceri, teftatur. Ego noftr $x$ Vrucú arboris \& fructus Icones feparatim exhibeo, ur filiquarum figuræe magis dilucide apparerent curiofo lectori.

Foliis eft grandioribus $\&$ mucronatis, figura cordis, ut pingi folet, alternatim pofitis, in pediculis, duos, tres, interdum \& quinque digitos longis, nervum fecundum longitudinem \& venas obliquas inferius prominentes habentibus, læte viribus : cauli- 
bus calamo fcriptorio tenuioribus, ligno albo \& cortice fufco, inftar. Coryli. Circa extremitatem ramorum in brevibus pediculis multi proveniunt flores, in uvæ figuram difpofiti : quilibet flos eft rofx magnitudine, quinque foliis conftans albis incarnatis dilutis. In medio cujufvis floris ingens numerus eft ftaminulorum luteorum apicibus purpureis : vix fenfibilem aliquem habet odorem. Poft florem fructus fequitur in filiqua myrobalani oblongi figura, feu pyramidali rotunda fefquidigitum aut duos digitos longa: (uc ex appofitis fructibus liquet) qux depofita viriditate immaturitatis mox ubi maturuerit matura rufefcit, eftque tota hifpida ob fila prominentia fed non aculeata. In qualibet autem filiqua ultra triginta, imo quadraginta grana, quodque fuo pediculo innitens, continentur, figuræ conicæ acutre, \& in duobus lateribus quafi digito compreflum. Color granorum infigniter miniatus $\&$ fplendefcens, fuccoque tali madens, ita ut ad tactum inficiat manus egregio miniato colore. Grana recentia funt mollia, cum punctulis argenteis. Siliqua matura fponte fe aperit: grana ficcata evadunt rubra, obfcure nihilominus tamen, ut antea, tincturam in fe continent; \& recentia five ficcata ufurpari poffunt : Trita fimpliciter in aqua fimplici feu tillatitia, egregiam dant tincturam miniatam. Collecta grana in maffam coguntur, fphærulæque $\&$ tabellæ in multos annos durabiles inde conficiuntur, qux in Europam tranfmiffa longe lateque diftrahuntur. Cum urina mixta, tam pertinaci colore tingit lineos pannos, ut in pofterum elui non poffit. Magifterium etiam inde, more coralli, præparatur $\&$ in ufus refervatur. Grana recentia matura \& exficcata, inque paftillos conformata, quantitate indefinita, cum pulte ex Tipióca, qux Carimá dicitur, alioque conveniente decumbentibus exhibent, five veneno, five aliunde infirmitatem contraxerint. Corroborat Ventriculum, ventrifque fluxibus prodeft. Cum aqua ejufdem temperaturæ haufta mitigat xtuis febriles.

Radices ipfe, nec grana, multi funt faporis, proinde ad medendum faciliores, cum aliqua ficcandi $\&$ aftringendi qualitate. Radix cum carne gallinacea couta, præter croceum color em, bonum faporem conciliat. Incolarum nonnulli radices granis præferunt, quod harum recens, illorum vero ufus longe fit antiquior, \& vicem Croci terreftris (ficut de Curucuma I. Bontius retulit) fupplet. Tum extractum ejus ex vino adufto confectum fibi refervant. Quod etiam nunc hodie colonorum non paucos imitari videmus.

Atiffima arbor eft, cortico grifeo, duro \& inæquali, inftar Quercus veteris. Folia A juniora rufa funt, vetuftoria autem viridia, fimilia foliis Mori, in ambitu ferrata, \& quodammodo contorta $\&$ incurvata. Poft florem (quem nondum videre licuit) fequitur fructus menfe Martio magnitudine capitis infantis, qui fuo pediculo craffo dependet. Cortice eft ligneo ochræ coloris . Capaciffimi hi $\&$ fummæ duritiei calyces funt, ore in terram obverfo, \& operculo, admirabili naturæ lufu, inftar pyxidis, operti. In iis continentur nuces jucundi faporis, qux ubi maturitatem fuerint confecutæ, excuffo illico tegumento, fine cujufquam auxilio è calycibus decidunt, \& gratiffimum incolis æque \& animalibus fuppeditant alimentum. Semel in anno maturefcunt, media videlicethyeme. Sapore $\&$ excellentia Piftaceis adæquantur, $\&$ venerem fopitam dicuntur excitare.

Potiones \& pultes, tam ad Medicinam quam ad epulas ex illis comparantur.

Olcum quoque pinguiffimum ex illis exprimitur, Amygdalino calidius; nuclei enim; è quibus elicitur, in fecundo gradu calidi $\&$ in primo ficci perhibentur. Præftat affatis quam crudis vefci, quod caput infeftent. Plufquam triginta ordine ipfi calyci, mediante vifcofa materia, agglutinati hærent, figuraque fere triangulari exiftunt, Myrobalano Chebulo non adeo diffimiles. Tantæ duritiei hæ pyxides funt, ut Tepuyeris non folum vafa potoria, fed \& difcos, \& ollas fufficiant. Cæterum arbor in faltibus \& locis mediterraneis adeo luxuriat, ut jufto exercitui, fufficientifuftentaculo fructus ejus aliquando fuerint.

Dux reperiuntur fpecies fibi fimiles, externa figura, fed qualitatibus internis difcrepantes. Vtriufque lignum, putredini mire refiftit, unde ob fummam fimul duritien, molendinorum faccharcorum axes exillo fabricantur, caterafque arbores multum antecellit.

Corti- 
I A ÇA P VAI'OARBOR \& FR V C T VS.

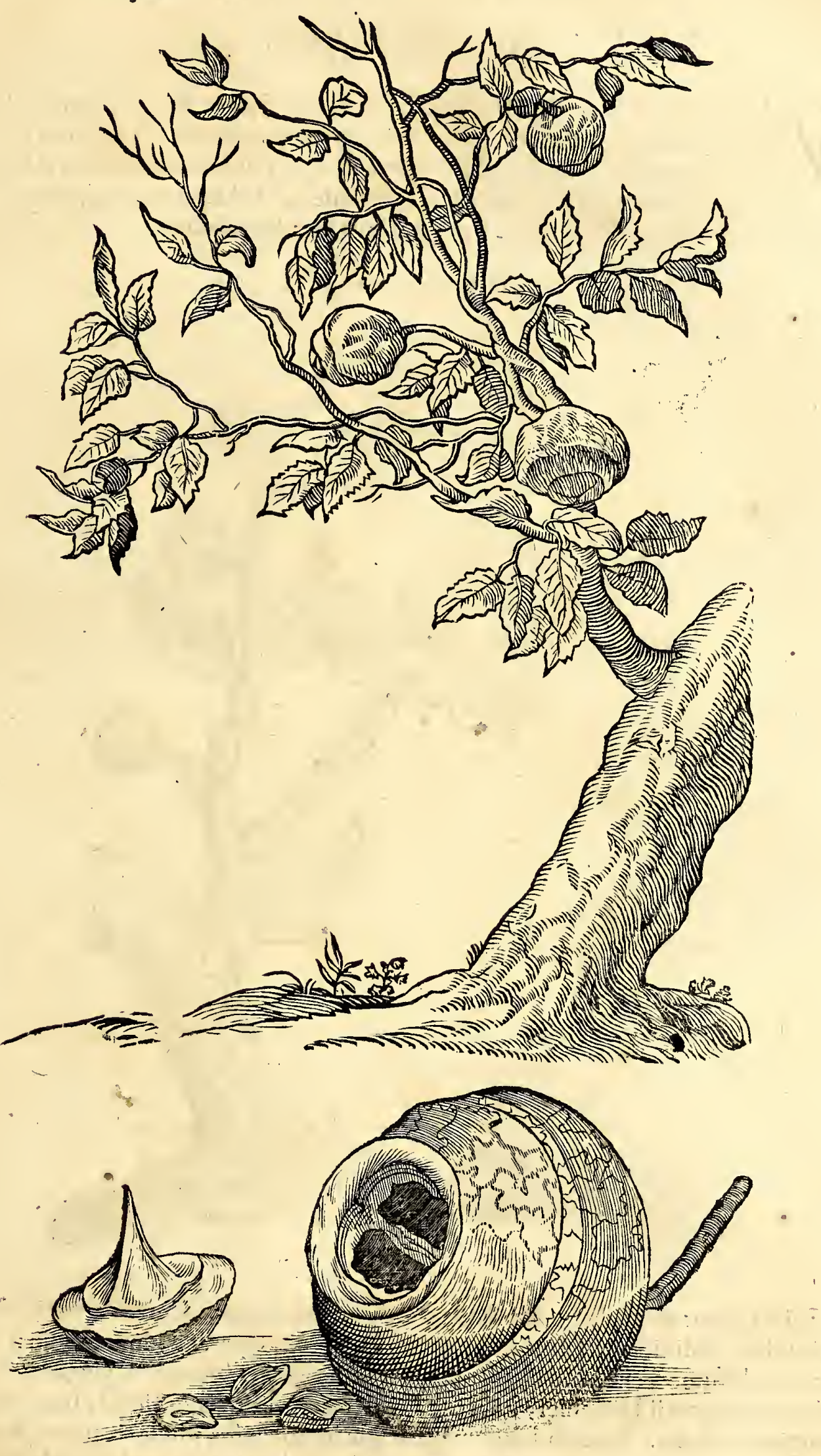

Cortices preterea contufi \& rite preparati naupegis loco ftupx inferviunt.

Alia adhuc datur iifdem locis Iaçapucaío arbor, priori fimillima, nifi quod calices magis deformes producat, earumque nuces dignitate inferiores habeantur: quippe ex immoderato illarum ufu, quibufdam capillos defluxifle Incol $x$ teftantur.

$$
\therefore \mathrm{M}_{2} \text { C A- }
$$




\section{A P V T X V. \\ Guitys diverfe fpecies.} $\checkmark \begin{aligned} & \text { Arix arbores excelfx Guitys, ejufdem generis fructus flavefcentes producunt, } \\ & \text { pauca carne, magnoquelapide ovalis figurx intus refertos; quorum fructuum }\end{aligned}$ ad minimum mihi tres vidiffe fpecies contigit, Guiti-coroya, Guiti-toroba, \& Guitimirí, dictos; qui omnes, vel medicinales, vel efculenti, fed à paucioribus 'expetiti, ex. cepto primo, eoque pragrandi, \& à magnatibus in deliciis habito.

GVITI-IBA I.

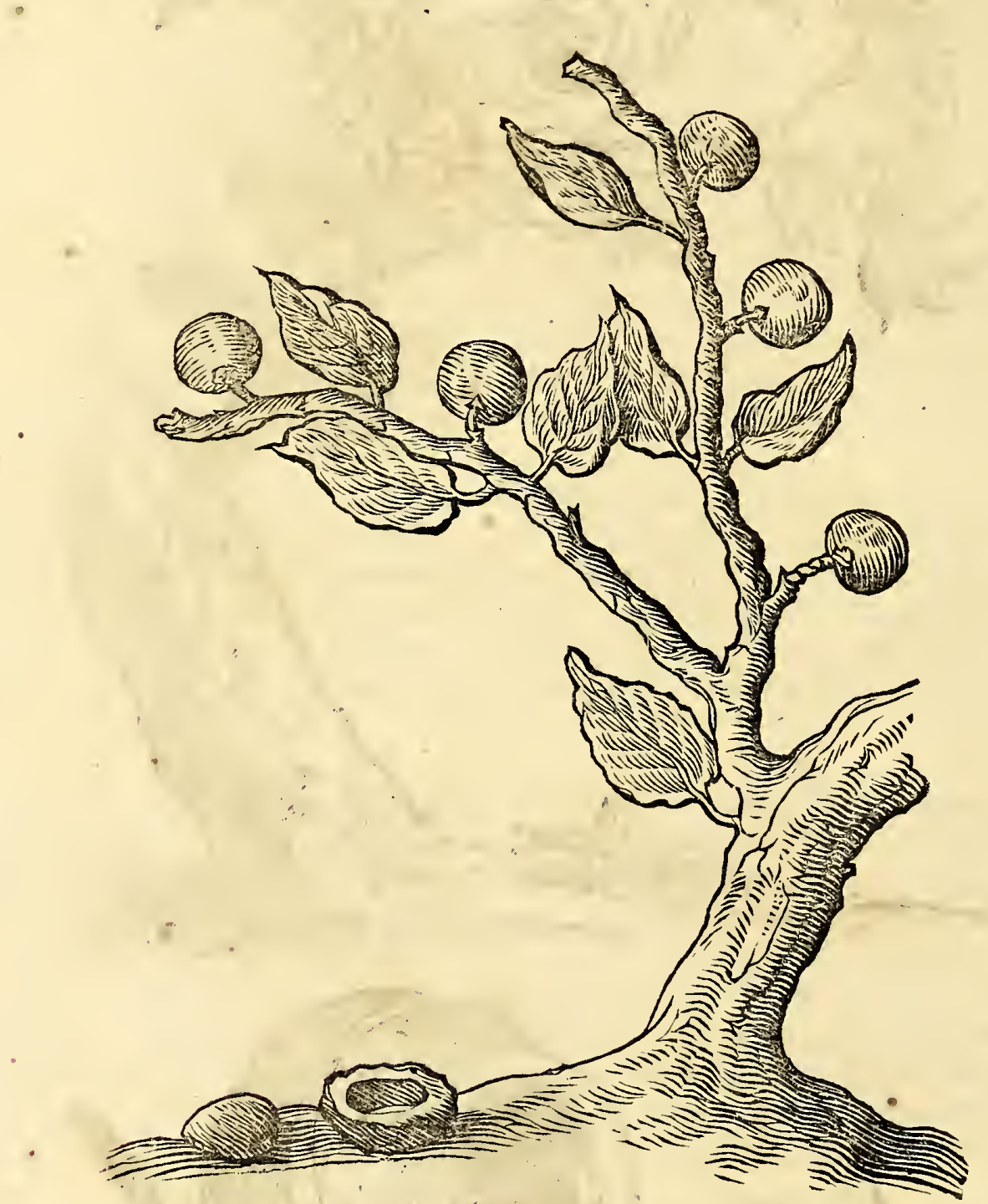

Prima arbor Guiti-iba, cujus fructus Guiti-coroya dicitur. Cortex arboris eft grifeus, altitudine, foliditate \& duratione ipfam Quercum fuperans, lignumque à fabris in pretio habitum. Rami folia habent alternatim pofita, oblonga, linguxfere figura, ad ractum inftar corii Hifpanici, nervo recto \& conis obliquis diftincta, hinc inde molli lanugine obducta. flores in longum quafi fpicam longefti, inodori, parvi, flavi, quos pictor non cxpreffit. diu flor et \& 2 tarde fructificat.fubinde al terum larus arboris uno anno, al terum fecundo, fructus profert maturos, tertio quiefcit, quarto demum tota fruCiffra. Fructus pomum vulgare magnitudine excedit, informis rotunditatis \& $x$ tuberofus. Color cutis eft inftar panis atri ; pulpa mollis, flava, grati ac dulcis faporis 3 odoris, panem recentem xmulans. Lapis (quem hic ex fructu exertun vides) magnitudine $\&$ figura eft ovi anferini, cortice lignofo, hirfuto, continens nucleum albicantem, non edul $\mathrm{cm}$, fed medicinalem, confiftentia nucis Cocós aftringentis. drachma ejus 
HIST. NATVRA L. \& MEDIC. LIB. TV.

plus minus rafa optimo cum fucceffu ex liquore datur convenienti contra dyfenteriam. Idem præftat nuclei infufum dûplici quantitate exhibitum ad fiftendos quofvis fanguinis fluxus.

Secunda quantumì præcedenti altitudine cedit, tantum Elegantia eam fuperat Guyti-toroba dicta. Folia enim fert in frondes congefta, faturate viridia, fplendentia $\&$ craffa inftar pergameni,ad tactum lævia,cxrerum figura nucis Iuglandis foliis non diffimilia. Inter copiofa folia ad frondium extremitates in ipfis ramulis egregie copiofi flores proveniunt flavi, odore \& magnitudine florum Tilix. Diu floret tardeque fructificat idque menfibus æeltivis : Caudex difleatus lac acre exfudat inutile. Fructus Aurantix quidem eft magnitudine, fed non figura, quia inæqualis eft fuperficiei \& formæfuperius turbinat $x$, dulcis faporis fed odoris fortis \& naufeabundi. Maturefactus è purpureo flavefcit;fponteque decidens edulis fit, alias enim noxius ob lacteum fuccum acrem. Lapis contentus Iuglandis eft magnitudine, fed figura compreffiori, altera parte grifei , altera umbrxe coloris fplendentis ; huic nucleus inclufus eft iifdem ufibus dicatus ut fupra.

Tertia Guyti-iba, cujus fuiCus Guyti-miri dicitur. Prxcedentibus Guytys minor \& tenuior. Foliis eft oblongis fplendentibus, inferius alba lanugine obductis. cuilibet fere foliorum pediculo uvulæ, parvis globulis veftitx adnafcuntur, unde flofculi albi prodeunt cum multis ftaminulis erectis ficut ex hac icone feparatim pofita liquet. Menfibus Martio \& Aprili fru. ctus magnitudinis \& figuræ ovi gallinacei, flavefcentis coloris, profert. Caro fructus pauca, mollis, dulcis faporis, quafi mufcus admixtus. Lapis ovalis villofus, magnum quoque ut $\mathrm{cx}$ teri Guytys nucleum ficcum amaricantem aftringentem continet, quifupra enarratis minus ufualis eft.

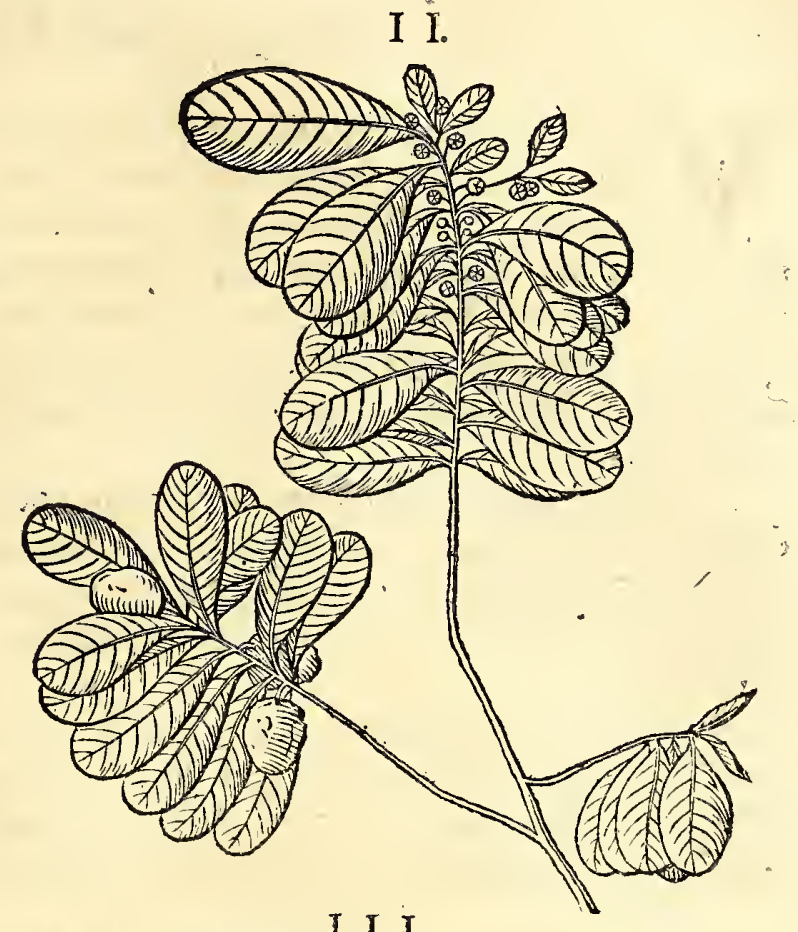

I II.

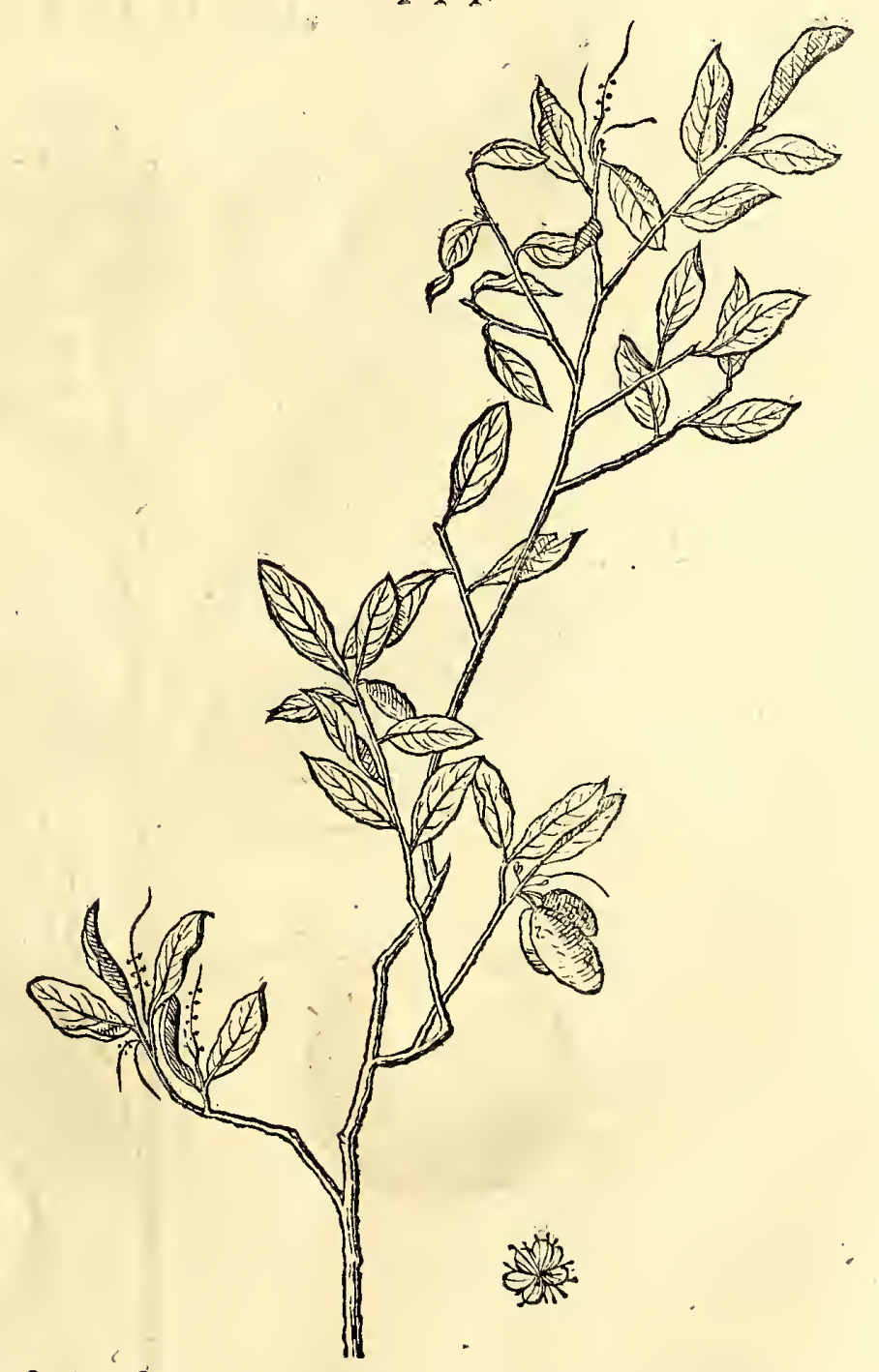




$$
\begin{gathered}
\text { C A P V T X V I. } \\
\text { Ianipába, Açaiá, Tapiá đo Pekia. }
\end{gathered}
$$

V

$\mathrm{Na}$ ex procerioribus Brafilix arboribus eft Ianipába : quæ figura convenit cum Fago. corticem habet gryfeum feu canum; lignum fragile \& medullofum. Rami foliis veftiti oblongis, lingux bubulx figura, fed in utraque parte faftigiatis feptem, octo vel novem juxta fe difpofitis, unum aut fefquipedem longis, fuperius fplendentibus ac dilute virentibus, inferius faturate viridibus, quxfingulis annis, menfe imprimis decembri Decidunt, non omnia quidem fimul, fed pars illorum, diverfo tempore. Mox nova prioribus multo lætiora \& majora acquirit, idque fingulis menfibus.

Florem gignit exiguum, menfe Martio \& Aprili, cxterum Narciffo haud multum diffimilem, qui odorem Caryophylli Carthufianorum æmulatur; coloris albi, cum unguibus interius flavis: in medio floris ftamen craffiufculum flavum habens, acinfuper inter duo folia floris corniculum pallidum è medio floris prodiens, deorfum incurvatum.

Fructus illius, magnitudinem habet mali Auraici, vel major em, rotundus, cortice tenui, lento, cinereo, fub quo primum continet carnem folidam, lentam, fucculentam, flavefcentem, faporis acidi, \& refrigerantis, odoris grati. In medio alttem fructus cft cavitas repleta feminibus molliori pulpa circumdatis, ejufdem cum re-

I A N I P A B A.

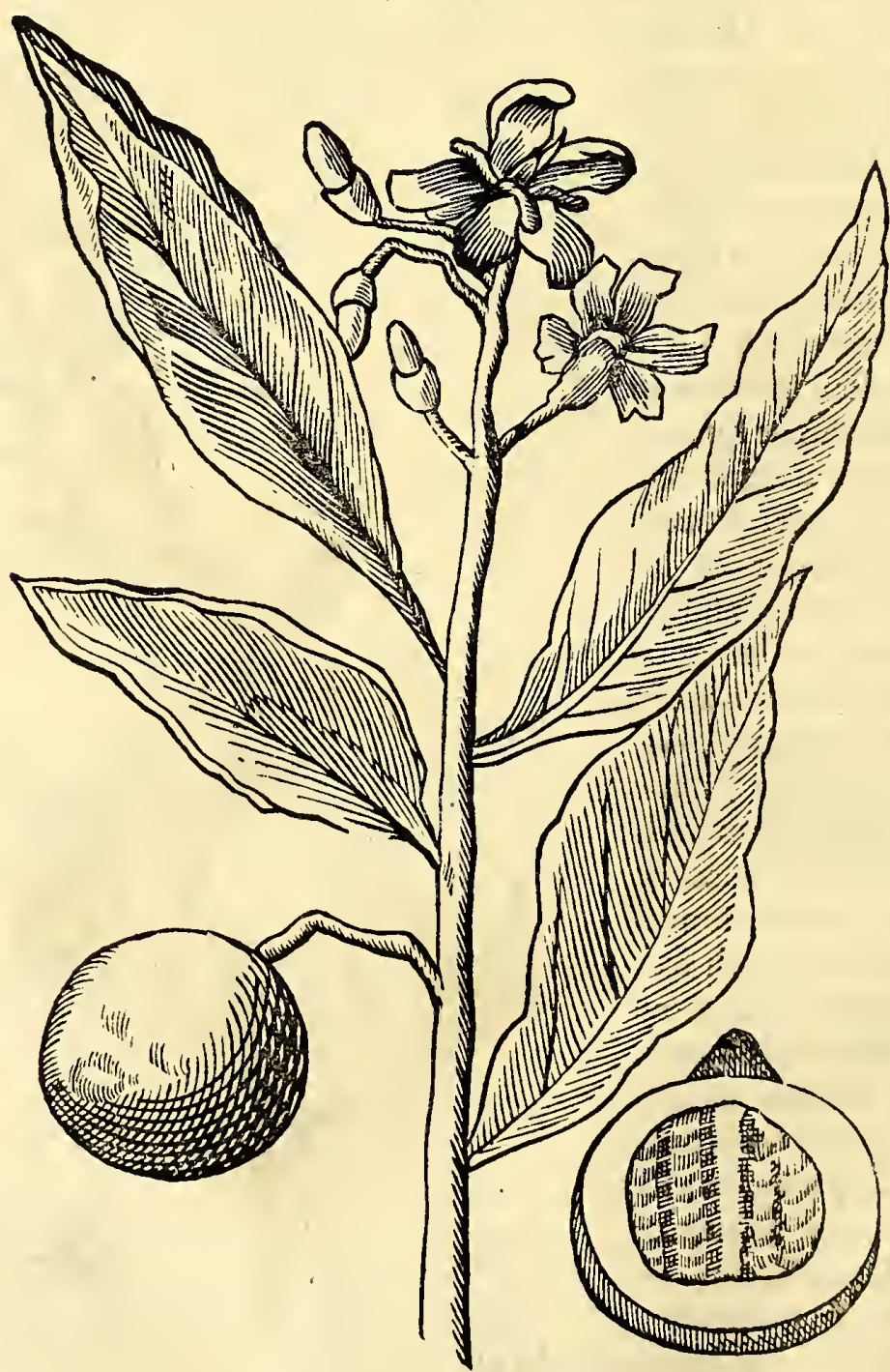

liqua carne faporis. Seminis grana funt compreffa, \& fuborbicularia, fere ut Mangá$b a$, qux una comeduntur. Immatura'poma viridia fint, mox matura, mefpilorum inftar, 
HIST. NATVRAL。 \& MEDIC. LI inftar, putrefcunt atque efui apta fiunt, unde à plebe noftrate appellantur thot-as pels / \& toto anno proveniunt. Cruda, non cocta appetuntur. Saccharata \& condita lautiora funt. Contra fluxum ventris feliciter exhibentur. Ardores palati \& Itomachi compefcunt, fanifque \& 2 gris folatio funt, nifi quod for tioris fint odoris caput infcientis. Immatura poma trita $\&$ in cataplafmatis formam redacta, ulceribus mali. gnis \& clavis luis venerex imponuntur.

Vinum, quod ex illis exprimitur, in eofdem ufus refervatur, fed vetus redditum calidius exfiftit, minufque adftringens.

Ex pomo nondum maturo vi ignis liquorem extrahunt Indigenæ, quo adverfus eadem mala utuntur.

Ex pomi cortice immaturo pigmenti quoddam genus eliciunt, quod recens aquetim eft, moxnigrefcit, quo corpus pingunt, ut veftitum nigrum eminus, foedo equidem fpectaculo, mentiantur, \& ut ad bellum ituri terribiliores hoftibus evadant. Nullum alium ufum hic fuccus habet, ad nequitias dumtaxat excogitatus. Tinctura enim illius corpori vel chartx illita, circa nonum diem evanefcit; nulla alia ratione ablui poteft. Lignum feu ramus decerptus eodem modo tingit. Fr. Ximenes eandem arborem in nova Hifpania crefcere, eifdemque ufibus dicatam teftatur, quam Xabual vocant.

Etuftiorem \& frondofiorem arborem in Brafilia me vidiffe vix memini. Cortice eft craffo, rugofo \& è cinereo albicante, inftar Sambuci. Altitudine proceram \& patulam Tiliam fuperat.

Folia illius funt lævia, directe fibi invicem oppofita, ad quatuor interdum digitos longa, fplendentia, nervo lato fecundum longitudinem $\&$ venis tranfverfis, \& juglandis foliis haud abfimilia, verum acutiora; qux media æftate deponit, novifque antehyemem decoratur, ut redintegrato quali robore fruAtum melius proferat. Flofculos habet copiofos, in magnos racemos congeftos, ex albo fubflavefcentes : poft flores proveniunt pruna flava, noftratium magnitudine \& figura; paucæ quidem, fed fucculentæ carnis : lapidem continentia magnum ex filamentis lignofis, nec durum, fed dentibus ce$A$ ç A I A $A^{\prime}$ dentem; qui nucleum continet in fe, ex albo flavefcentem. Fructus hic grati eft acoris, ac proinde inter tragemata locum fibi vendicat, \& tunica tenaci veftitur. Fo cundiffima eft arbor, toto fere annofructificat. Fructus maturi ftatim decidunt, terramque omnem tegunt, \& fuaviffimumodorem fpirant.

Inter refrigerantes $\&$ aftringentes habiti ufque adeo, ut immaturi dentibus inferant ftuporem, qui ex manducatione durioris alicujus ligni tollitur, Naufeabundis $\& x$ ftuantibus profunt, \& contra fanguinis alvi fluxus in pretio habiti. Vinum ex iis conficitur, quod vetus inebriat. Gemm \& fummitates hujus arboris fanis \& $x$ gris in acetariis exhibentur. exquibus contufis emanat fpuma fortis $\&$ tenuium partium, qux oculis indita inflammationes arcet, vifum clarificat, nxvos \& nubeculas oculorum tollit. dolor quem primo infert, facile evanefcit.

Folia, fucci, oculi \& cortex externis juxta $\&$-internis affectibus medentur, qux omnia in gargarifmum, contra gutturis inflammationem $\&$ fimilia mala preparantur; vel in lavacro, contra multos externos pedum $\&$ corporis calidos affectus adhibentur.

Folia, imo \& lignum, faporis funt egregie acidi \& aftringentis, ac ad appetitum proM 4

ftratum 
ftratum revocandum \& fitim levandam utiliter ufurpantur. Fiunt $\&$ intinctus ad carnes affas exjunioribus foliis tritis gratiffimi faporis. Lignum rufum \& leve ut fuber, cujus loco ufurpari potent.

Peculiare habet hæc Acaiá arbor, quod volucres picæ magnitudinis, nigris \& aureis plumis eleganter veftitx, in extremitatibus ramorum affabre \& concinne pendulos fuos nidos conftruant, ut infidias ferpentum aliorumque noxiorum infectorum declinent.

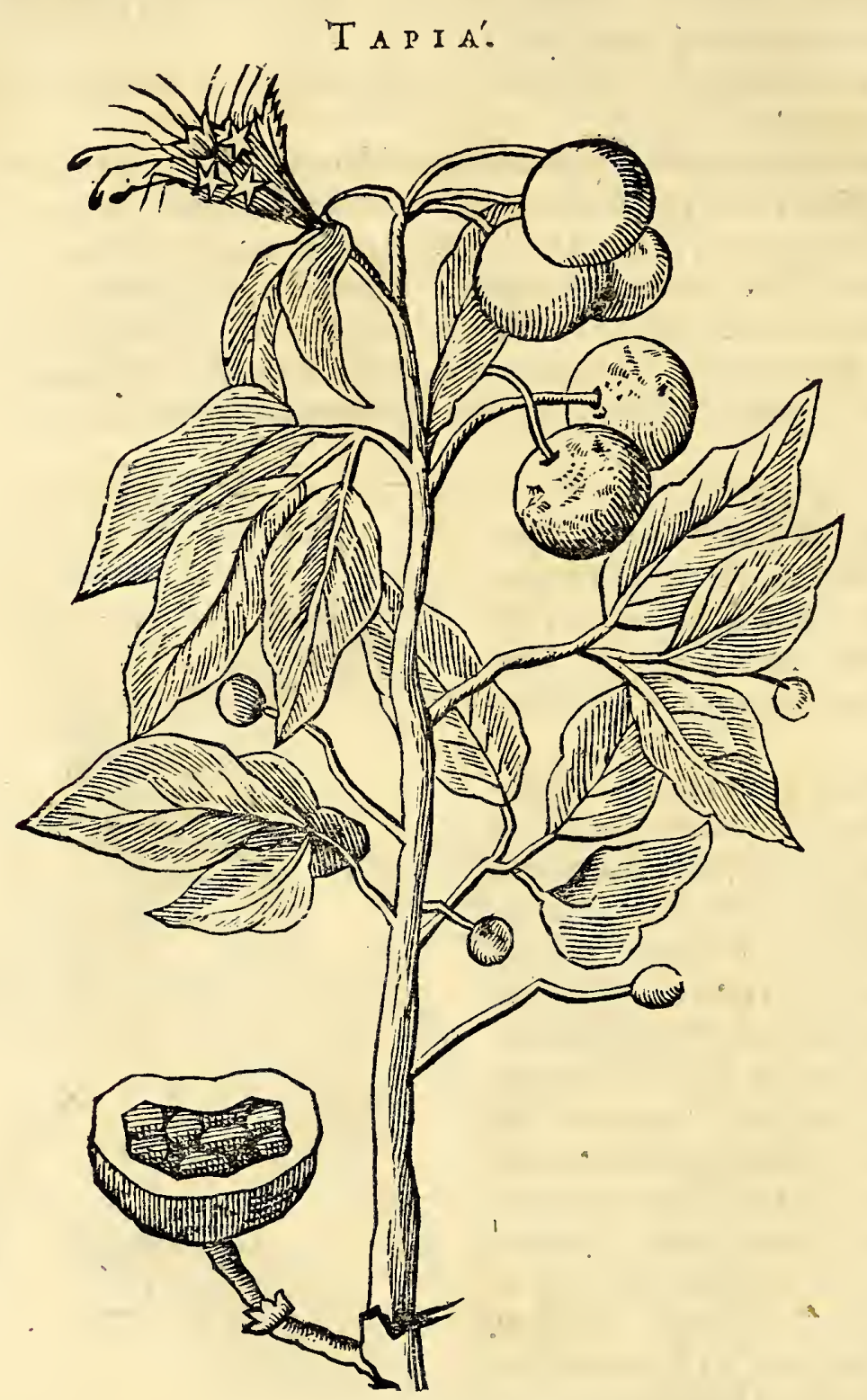

In Vrbe Olinda, totaque fere præfectura Parnambucenfi Tapiá arbor nafcitur. in Fagi altitudinem affurgit, ligno fragili, medulla fambucina, cortice lævi, cinereo. multos habet ramos; \& folia in fingulis pediculis triafibi invicem appofita, lavia, fplendentia, fupcrne faturatiore, inferne dilutiore virore confpicua.

In extremitatibus ramulorum plures pediculi, cerafini quafi, collecti, in quorum quolibet flos nafcitur, quatuor foliis conftans albis \& digitum longis. Quodlibet habet fuum petiolum, figura ferri venabuli, \&nervum fecundum longitudinem, ac venulas obliquas virefcentes, $\&$ cum his alternatim pofita quatuor foliola brevia virefcentia; inter omnia hæc enafcuntur ftaminula multa fubrufa. Fructus fert nunc copulatos, nunc folitarios, figura, magnitudine, cortice, \& colore Aurantiis fimiles, edules quidem \& dulces, fed naufeabundi odoris, lapillis duris oblongis flavis, nucleumque continentibus referti.

Folia contufa excellentiffimo funt rem edio contra malum hic perfamiliare Ani inflammationcm, fi exterius applicentur, tædarumque inftar anoi ndantur: omnes denique fervores refrigerio fuo reftinguunt, dolorefque mitigant. Præeter hæc auribus inditareftituunt dolores capitis ex calore natos. 


\section{HIST. NATVRAL. \&E MEDIC. LIB. IV.}

Dux hujus vaftx arboris reperiuntur fpecies. Priorislignum judicatur duriflimum, omniumque in hislocis nafcentium graviffimum, quam Lufitani Setim appellant, fedà menondum vifam. arbor infructifera habetur. lignum putredinis quafi expers omni corruptioni refiftitac proinde navibus ftruendis dicatum. Altera; qux mihi innotuit, folio eft glabro, magno, uno nervo recto, \& rarioribus veris obliquis prædito. Fructum fert Aurantio Malo majorem, cortice craflo, duro, fulvo, cinereifque maculis variegato, quo melleus .quidam liquor continetur,dulcedine fua certans cum Saccharo, cui nuclei multi funt permixti, qui, exficcato liquore pomi, ftrepitum edunt ut capita papaverum . $\mathrm{Ab}$ omnibus paffim Barbaris peregrinantiPE Q V E A five PEK I $A^{\prime}$.

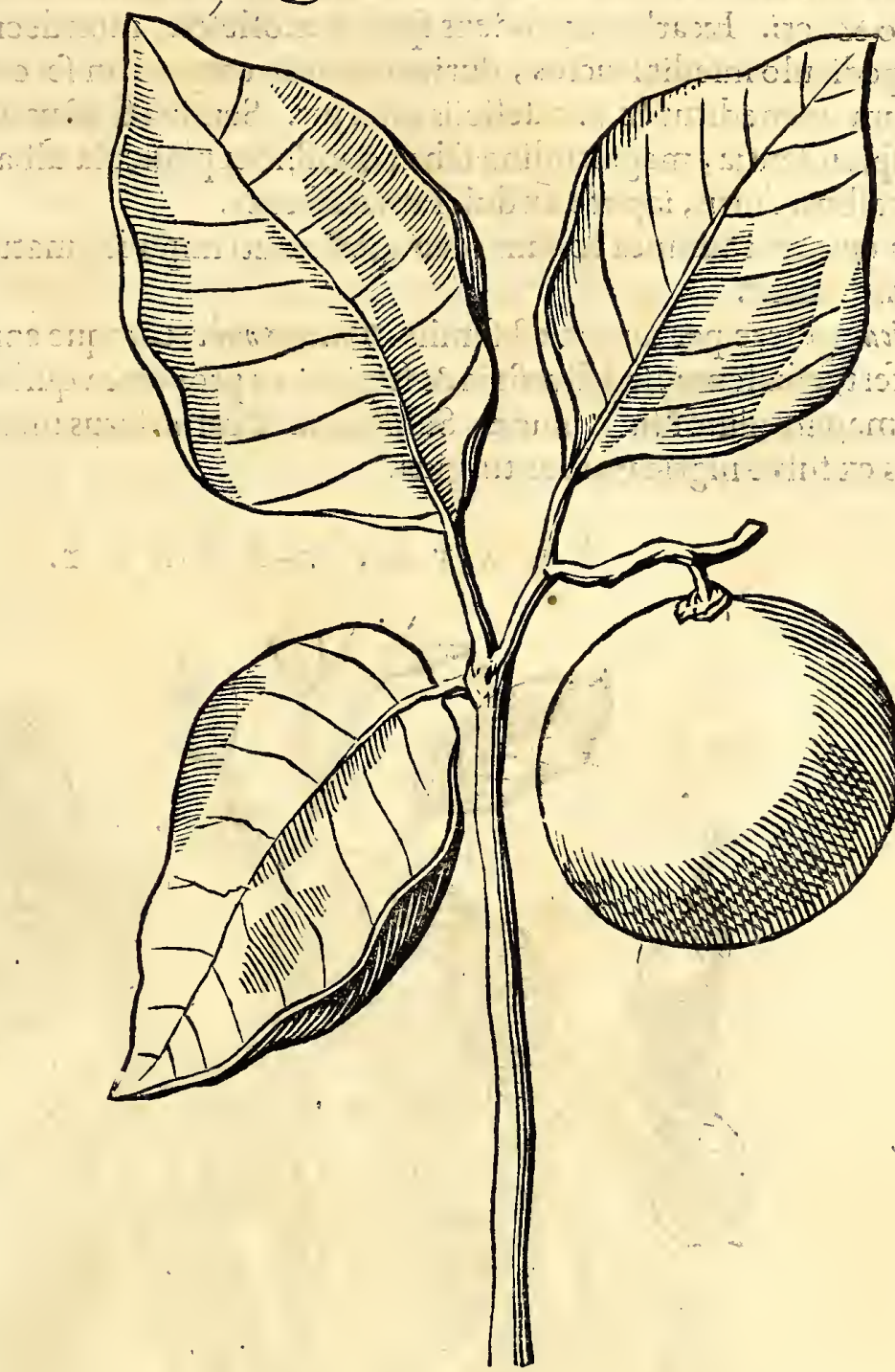
bus fructus ob dulcedinem gratam expetitus eft: Europxis tantum pro pectoris morbis in ufu habitus.

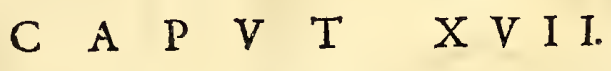 Araticu diverfe.pecies.}

A Raticú arbores Indigen $x$ variæ hic confpiciuntur: quarum duæ, quæ Araticú-ponbe \& Araticu-apé à Brafilienfibus dicuntur, parum differunt.

Araticu-porbe enim eft arbor caudice, ramorum figura, corticis colore, Aurantix Malo fimilis, fed folia, flores, \& fructus differunt. Folia craffa $\&$ foli$\mathrm{da}$, oblonga, alternatim fibi' invicem oppofita, fuperius faturate virentia, Splendentia, inferius dilute viridia, craffa, \& ad tactum folida, in extremitate acuminata. Hinc inde flos provenit magnus, primo fuavis, mox naufeabundi odoris: totus flavus, compofitus exterius ex tribus foliis cordiformibus, inftar corticis Mali Aurantii, craffis, erecte ftantibus. Hæc in fe continent alia tria folia minora, ita inter fe compofita, ut integrum globum, interius cavum, magnitudine Nucis juglandis repræfentent, $\&$ in eo ftamen rotundum luteum cum apice fuo orbiculari. Floret menfibus Septembri, Octobri, \& Novembri. Flores multi fingulis diebus fe aperiunt, $\&$ mox fponte decidentes, ob gravitatem, ftrepitum inter cadendum edunt, quafi aliquis baculo feriret arborem. Florem fequitur fructus; qui maturatur prafertim Decembri \& Ianuario, eftque figurx turbinatx; cutis cjus quafi fquamis ex albo viridibus videtur compofita, cum tuberculis exiguis fufcis, ita. ut 
Nucem pineam diceres. Pulpa eft flava quafi ex filamentis pyramidalibus compofita, \& nucleis variis intermixta. Odore maffam panis fermentatam refert, fapore ex dulci fubacido $\&$ acri. Exarbore pendens fponte mollefeit, mox decidit \& 2 fit edulis. Eo loco, ubi pediculo infedit fructus, durioris carnis corpus, in fe continet, quod feorfim extractum comeditur $\&$ pro deliciis offertur. Semina frucus funtovalis figur $x$, compreffa, fplendentia, magnitudine fabx, quodlibet pellicula alba obductum; intus eft nucleus albus; durys, fapor e ex dulci amarefcente.

Folia ejus igni admota $\&$ cum oleo apoltemati impofita, maturare faciunt, aperiunt, \& optime fanant.

Araticu-apé fere per omnia eft fimilis Araticu-ponbe: utraque enim poma ex acido dulcia profert, efculenta, fed filveftria \& frigida, ac propterea quibuddam non expetita,figura \& magnitudine Nucis pinex. Subftantia \& carne intus molliori \& flavefcente, feminibus ex fulvo nigricantibus turgida.

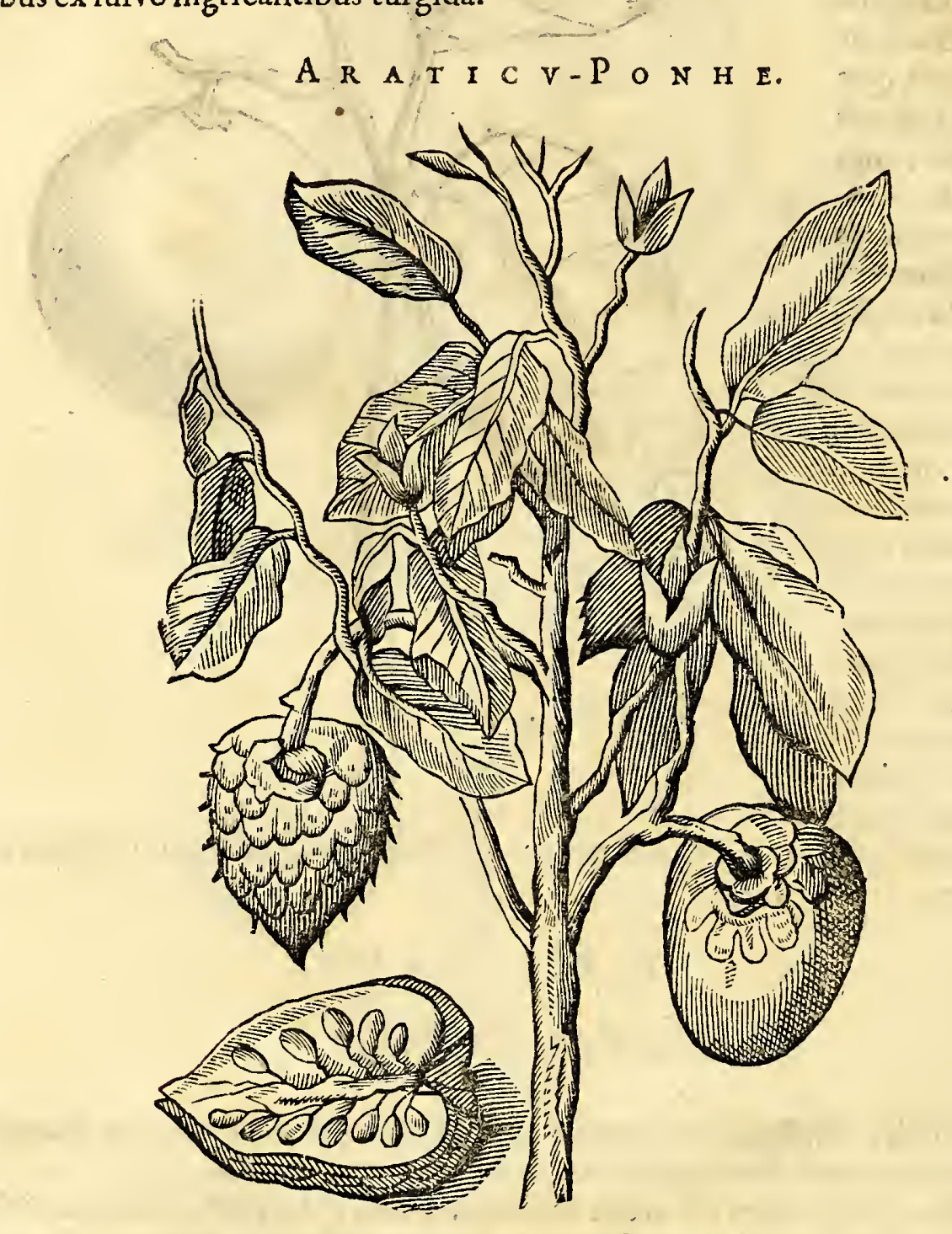

Araticu paná, in arborem excrefcit haud grandem, ramis Araticú-ponbe fimilibus, fed foliis minoribus, figura ut folia noftratis Pyri. Flos ejufdem figuræ \& totidem foliis conftans, quot Araticú-ponhe; fed minor eft, \& intus lutei, extus vero fanguinei color is. Fructus figura \& confiftentia fimilis priori, fed minor : cortex \& pulpa aurei funt coloris, odoris ut cafeus putridus, \& multos nucleos habentes ex flavo albicantes. Radices agit hrc arbor amplas, craffiffimas, longas, ligno levi inftar Suberis, ex quibus clypci formantur, leves enim funt, nec fagittx aut gladiorum ictus pcnetrare poffunt. lcon ejus exhibetur in libro de venenis.

Notatu autem dignum, ejus radicem in paludibus crefcentem, profunde in terram defcendere; ( quod tamen in aliis Brafilix arboribus haud facile confpicias) unde cre- 
HIST. NATVRAL。 \& MEDIQ. LIB. IV. I430 'dibile, noxiam ejus frigidamque. qualitatem, 'qua fructum nocere conftat, ex infefto terr $x$ frigore acquirere.

Araticúdo mato excrefcit ut Araticú Paná. Fert fructus congeftos, oblongos, Сæрæ junioris oblongx figura, virides, qui interius finguli duo habent fplendentia femina, Amygdalx figura \& magnitudine.

$$
\begin{array}{llllllllll}
C & A & P & V & T & X & \text { V I I I. }
\end{array}
$$

\section{Caaróba, Pindaiba, Anbuiba five Saffafras, \& Ibiraée five Guaiacum.}

Aaróba filveftris arbor, terris potiffimum glebofis in Præfectura Parnambucenfidelectatur. Si minus felici folo crefcat, parvæ arbufculæ vix æquatur. Florem fert è caruleo purpurafcentem, idque menfe Iunio : Semen autem nigri-

CA A R Ó B A.

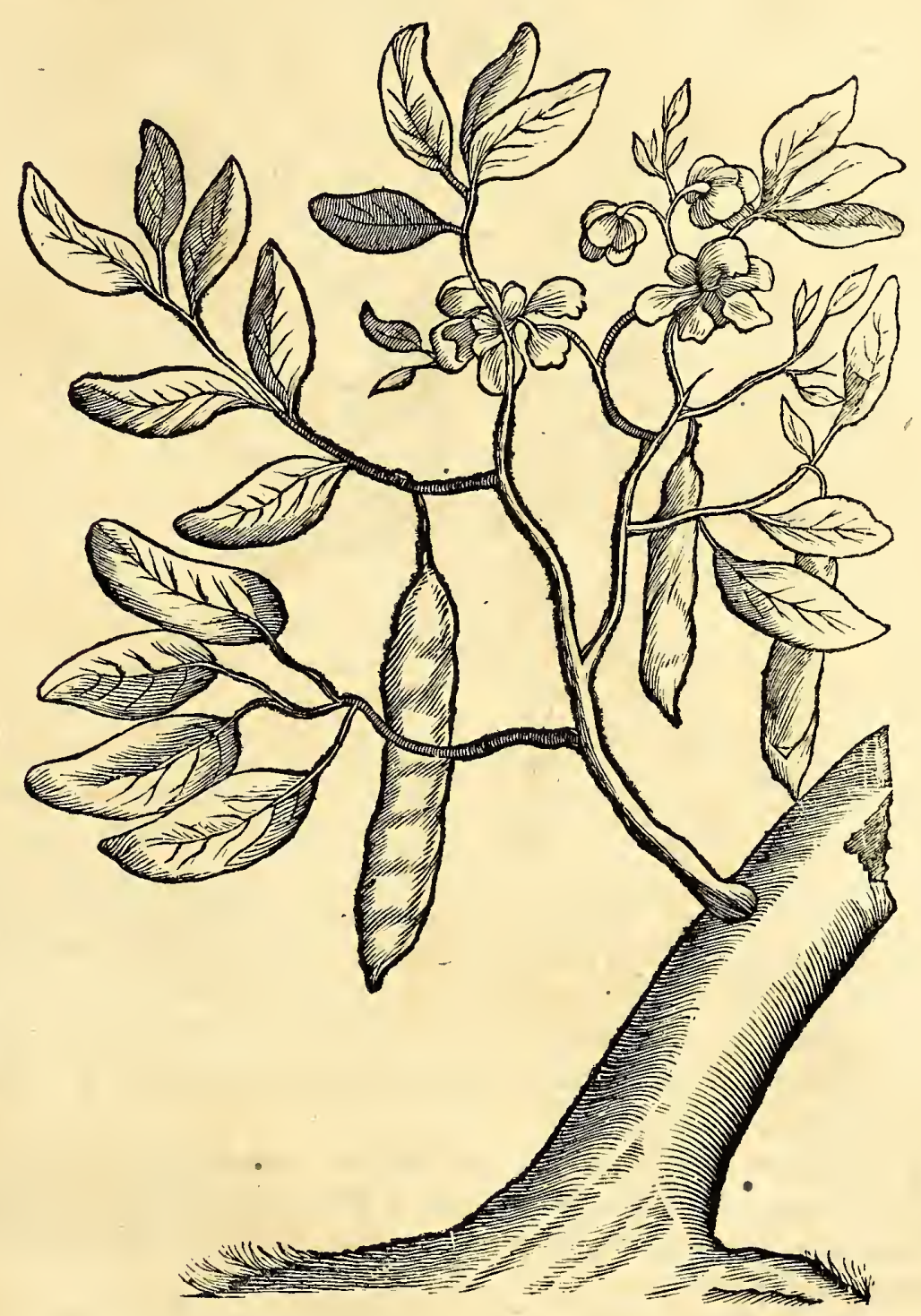

cans, quod maturefcit menfe Septembri : Fructum rarum, fed inutilem, phafeolo maximo fimilem, qui maturus factus aperitur, manetque vacuus.

Ejus folia oblonga funt, lingux figura, dilute viridia, nervo fecundum longitudinem $\&$ coftis obliquis eminentibus predita. Guftu funt amara ; ficcata \& contufa fomentis ac balneis peridonea. Q ux ex illis conficiuntur remedia, etiam interne affumta, exficcandi,mundificandi \& fanandi vi pollent: quod feliciter in plurimis chronicis \& articularibus morbis, imprimis autem in Lue Venerea curanda, fum expertus. Eadem trita atque in emplaftrum præparata, ulceribufque applicata, mirifice profunt, morbumque radicitusfexpe expugnant. Prefertim, firepurgato primum corpore, eorum deco- 
Atum per aliquot dies bibatur, \& fudores provocentur. Efloribus quoque componunt confervam ad eundem ufum.

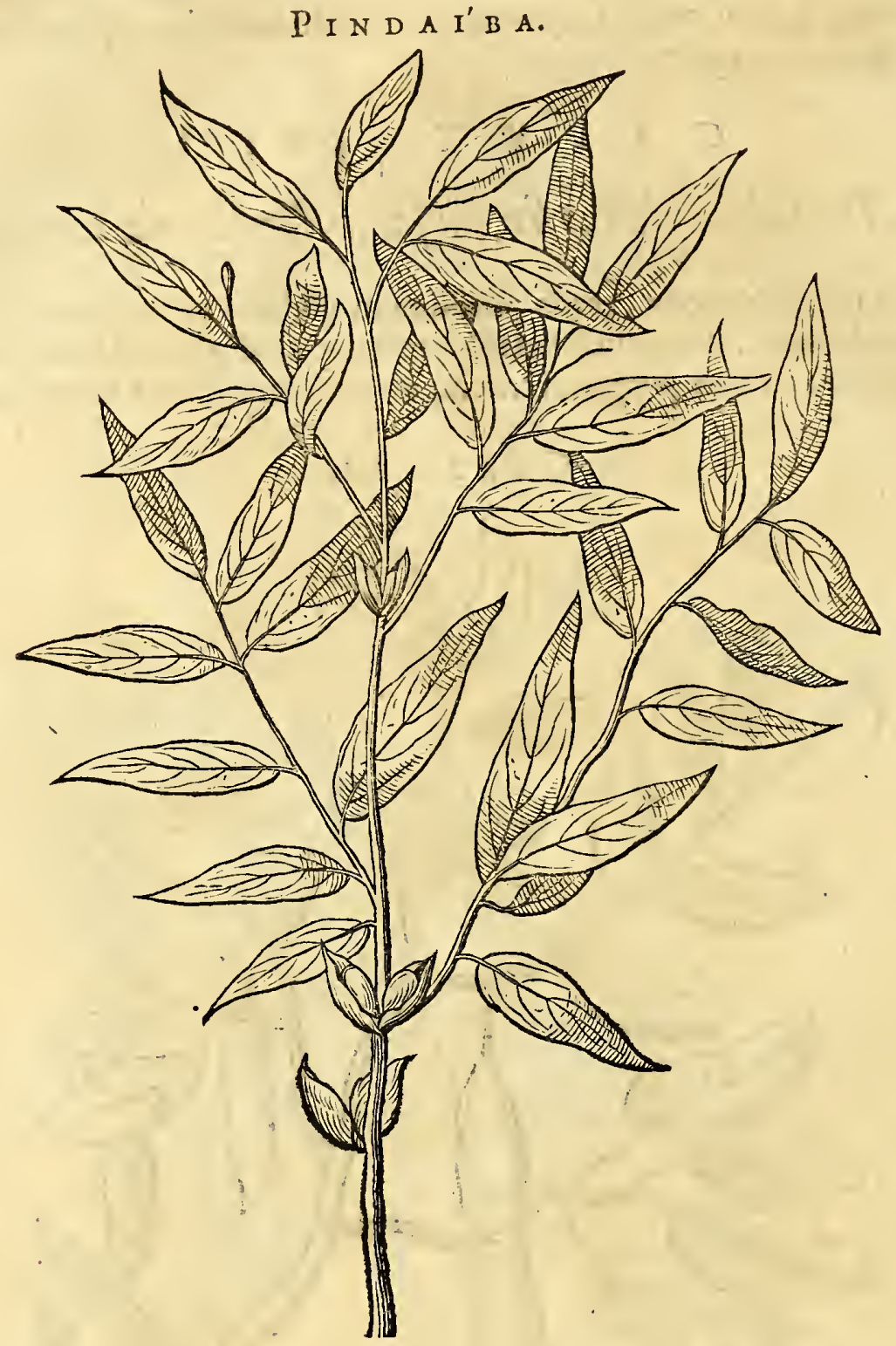

Equitur filveftris hæc arbor Pindaiba, à nonnullis indigenis Ibíra quoque dicta, ob $S$ convenientiam quam habet cum fequentis ver 1 Ibir $r$ qualitatibus fructuum $\&$ corticis ligni. Iuxta Olindæ promontorium fpeciofe ut plurimum nafcitur , \& ob acrimoniam fructus, cæterafque qualitates, Piperis Brafilienfis æmula. Folia fert exigua \& acuminata, \& Olivæ foliis fimillima: lignum ejus tenue. Procera eft admodum arbor, $\&$ in fummam altitudinem recta affurgit.

Menfibus pluviis acini illius virent, fed maturefcentes menfibus Decembri \& Ianuario rubent, atque decidunt: qui fi fuerint deficcati, nigrefcunt, uruntque linguam, \& aromaticum quid fapiunt, ablato femine nigro oblongo, quod in illis continetur, quod Iuniperum redolet.

A jejunis manducati ftomachum debilem corroborant, \& difcutiunt flatus. Tum contufi \& applicati morfibus ferpentum medentur. Ex eifdem fructibus in pulverem redactis \& exficcatis gargarifmata conficiunt contra frigidos gutturis affectus. ftant.

Excoquuntur ut referventur in officinis. Culinis quoque vicem Piperis pra-

Ex Arboris denique corticibus, funes igniarii, quo milites ignem fovent; conficiuntur.

Altera hxe, fpecies vera lbíre eft. Arbor, Betulx figura crefcens, cortice tenuifufco \& punctulis albis notito. In ramis ramulos alternatim pofitos habet, $\&$ folia angufta, acu-minata, figura foliorum Salicis, fupernefaturate viridia, glabra, fplendentia, inferne 


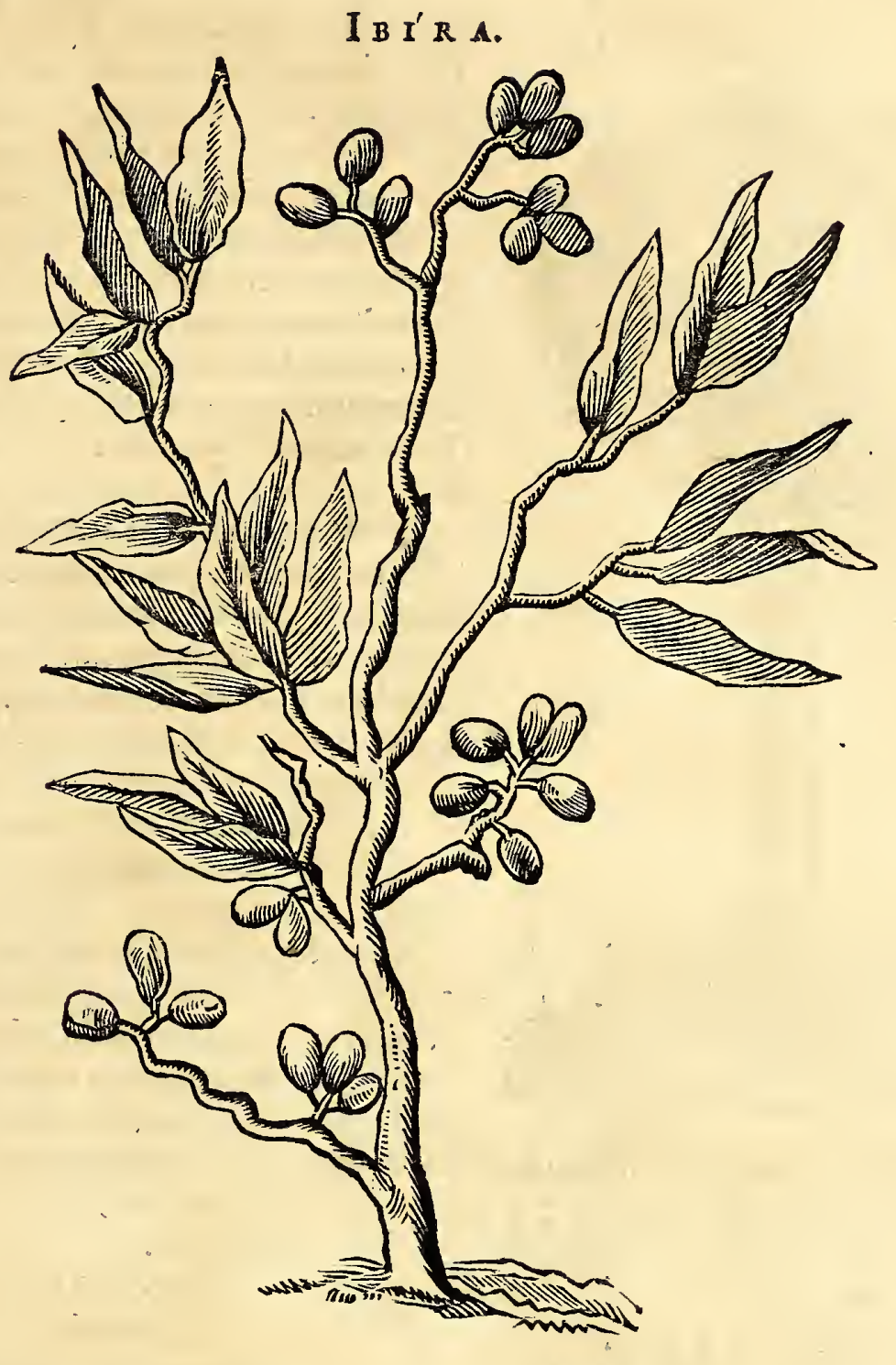

cinerea \& quafi lanugine tecta : qux deorfum fe inclinant. Flores fert menfe Februario albos odoratos, ad fingula paria foliorum binos. Fructus eft oval is, \& magnitudine avellanx:faporis aromatici ac acris, qui loco Piperis in cibis ufurpatur ficcatus $\&$ in pulverem redactus. Habet enim infignem vim aromaticam, necita acris eft ut Capficum.

Cortex arboris primo albus eft, quo detracto ftatim rufefcit. Loco funium ufurpatur, eft enim lentifimus. Ex eodem etiam fiunt funiculi igniarii pro fclopetis.

$\mathrm{N}$ vaftiffimis $\&$ diffitis faltibus dux vel tres infignium \& fragrantium arborum fpe1 cies reperiuntur, qux Anbuiba ab Indigenis dicuntur. Quarum quxdam albicante \& Havefcente funt ligno, ac proinde Lufitanis f̧edro-branco vel Canéla ob odorem dittx: Brafilienfes Anhuypitangavocant. Foliis funt parvis, anguft is \& tenuibus. Quxdam Anbuyba-peáyba dictxe, quarum lignum merito ab Hifpanis $P$ ao funcbo nominatur, quod infigni foeniculi fragrantia totam domum repleat, tam ipfum lignum quam cortex \& radix. Proinde Monardis defcriptioni circa lignum Safafras non acquiefcendum, licet accurate ufum $\&$ abufum ejus defcripferit : nam cum de del ectu $\&$ præftantia partium arboris agit, Saffafras Florid $x$ decorticatum lignum vix dignitatis ullius effe affirmat, cum hoc Brafilienfe eximiæ virtutis \& dignitatis habeatur, atque à cortice liberatum in aliquot annos immune fervetur.

Ad hrc for tioris odoris eft $\& x$ efficacix, atque ad fecundum caloris \& ficcitatis gradum accedit.

Illa autem qux inter majores:fpecies Anbuiba five Saffafras recenfentur, Pini funt magnitudinis \& form $x$. Nam praterquam quod funt trunco unico, valido \& recto; ramos in cacumine habent coronæ inftar ornate expanfos, \& inftar Pinus repurgatæ, quemadmodum ex appofita Icone liquet. Cortice funt tenui, glabro, ex gilvo nigricante, ve- 
Avhvíba five Sassafras.

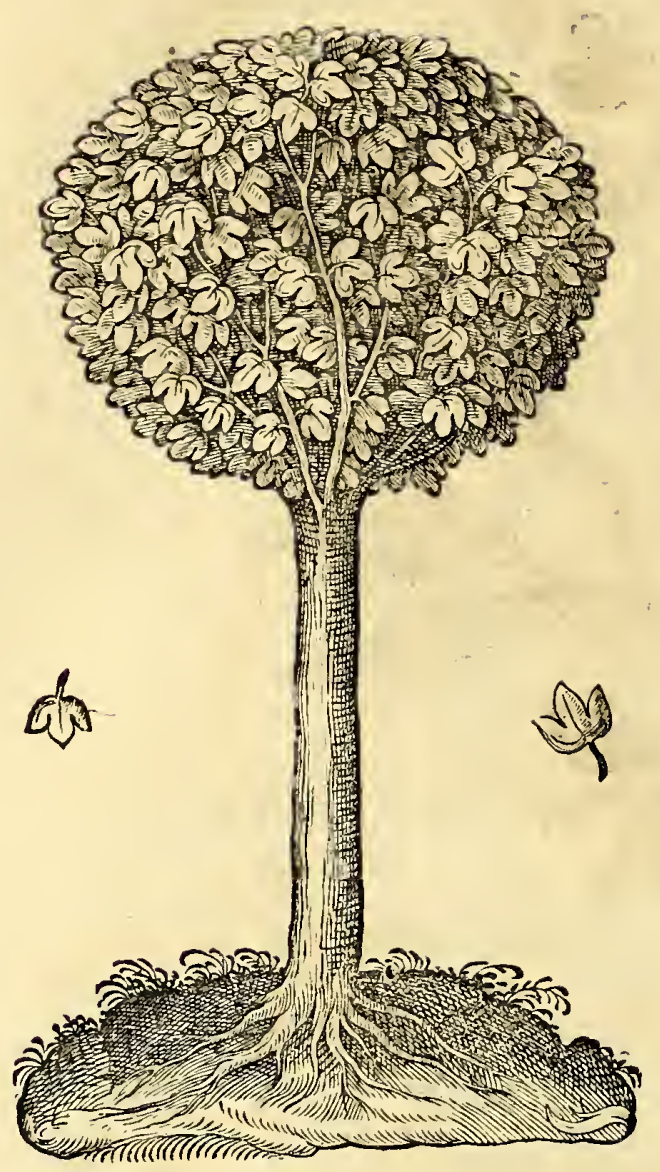

luti odore, ita $\&$ fapore admodum aromatico,ad foniculaceum accedente. Folia quoque funt odorata, ficulnea, tenuia, obfcure viridia, laciniata $\&$ foliis vitis albæ fimilia: floribus fructibufque adhuc incognitis. Radicibus denique funt nunc craffis, nunc tenuibus, ad terræ fuperficiem expanfis. quarum cortices, arborum corticibus ut odoratiores; ita $\&$ in Medicina praftantiores, ultraque fecundum gradum calidi $\&$ ficci habentur. Licet autem Corticis \& Ligni ufus tantum in Medicina celebretur; Indigenæ tamen recentibus foliis vulnera reftituunt.

Tertia autem fpecies Aubuiba-miri, quantum duabus prioribus magnitudine inferior, tantum vir tutibus fuperior, omnibus pariter incolis in quotidianos ufus repofita. Folio eft Lauri, feu minori, fructu odorifero \& nigro, ubi maturuerit;eoque fimul cum foliis, ligno, cortice $\&$ radice intenfe calidis. Hujus Iconem nondum licuit nancifci, quia in hoc diftrictu vix occurrit.

Decocta ex his non tantum contra luem veneream, fed $\&$ alios plurimos morbos à frigore natos adhibentur. Sudores $\&$ urinas movent, tum vifcerum obftructiones atque uteri imprimis intemperiem frigidam tollunt. languidos denique à morbis chronicis refufcitatos, hydropicos quoque ab aquis

I I I A E' E five $G$ V A I A C V M.

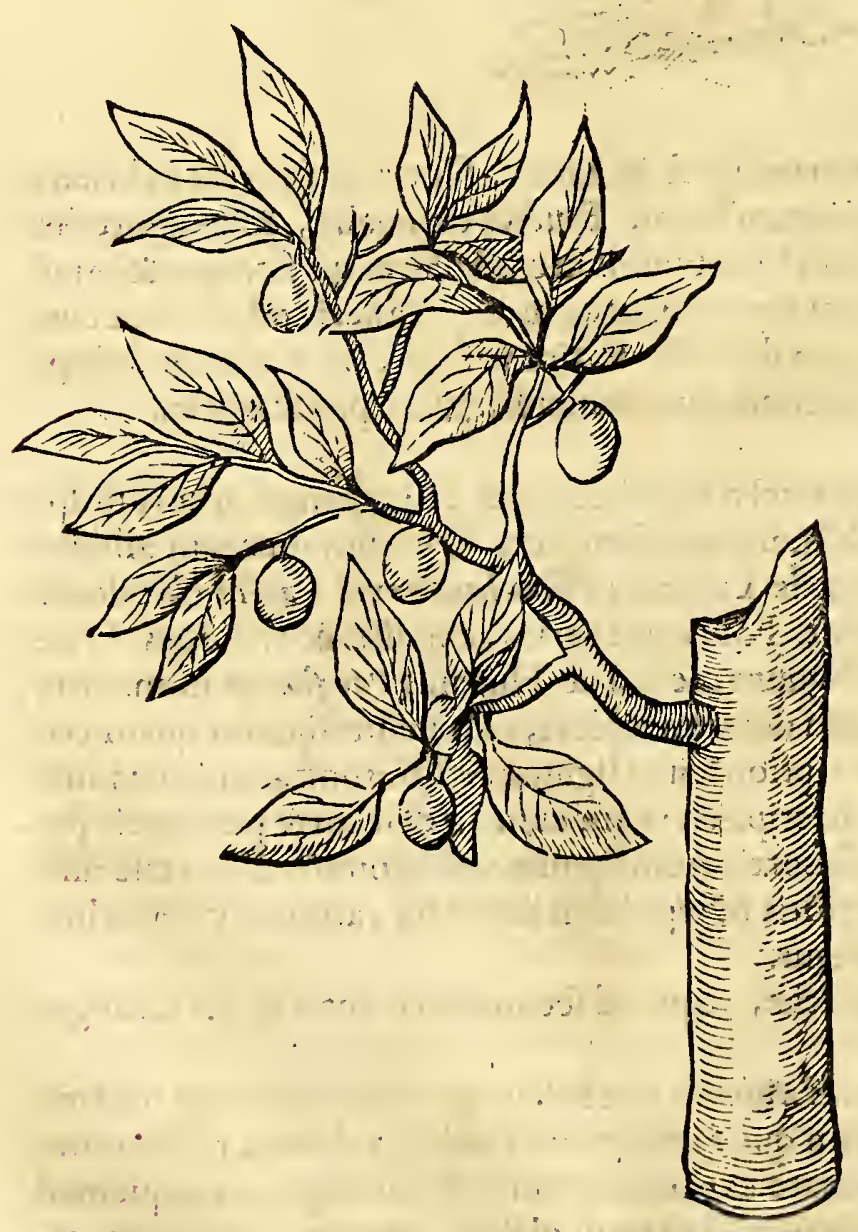

liberatos, à recidivæ metu liberant.

Cæterum multum difcrepant in decoctione $\&$ prxparatione \&cutendi modo;fed cum otii mihi non fit eas lites componere, id totum judicio Medici relinquio.

A Ntiqua nemora hanc vaA ftam \& proceram arborem producunt. IndigenæIbiraée, id eft, Lignum dulce, non autem Hourace, ( nifi forte nomina varientur diverfis locis) ut Lerius $\&$ Thevetus, appellant. Folia habet inordinate pofita, late viridia,fimilia foliis Cerafinoftratis acid $x$, fed non ferrata. Truncus cortice glabro, intus albicante, exterius rubefcente fpectatur.

Fructus fert flavefcentes, Prunis fimiles, gratiffimique faporis, verum non quotannis, immo vix fingulis quadrienniis. His continctur nucleus exiguus, fuavis atque $x g r i s$ gratus.

Ligno eft praftantifimo \& praduro, \& purredini refiltente, quod à Naupegis expetitur.

Arbo- 
HIST. NATVRAL. \&EDIC. LEB. IÝ。

Arboris hujus virtutes auxiliatrices foli cortici inefle creduntur : qui exterña parte argenteus; interna, fubruber eft: \& recens avulfus, liquorem albicantem fibi agglutinatum habet, cujus color mox perditur, paulatimque decrefcit, $\&$ cortice fimul exficcato, in naturam \& dulcem illius fubftantiam abit. Düriffimus exiftit, femidigitali craffitie : fapore aromatico Cinnamomum, dulcedine Glycyrrhizam æquans. Sunt qui Guiaci feu Lignï fancti fpeciem effe contendunt, à quibuis non diffentio.

Moderate calidus eft \& tenuium partium, quapropter pectoris \&jecinoris affectibus optime convenit. Præcipuum enim incolarum refugitum eft in veteribus vifcerum obftructionibus, it jam diximus: tum quoque adverfus Luem Veneream eximium remedium fubminiftrat decoctum illitss ex aqua fontana, palato quidemnon ingratum, per aliquot dies reiteratum.

Pugillus denique, ventriculo adhucjejuno, ex ovo forbili, jufculo aut aliquo conveniente liquore affumtus, bronchia pul monis aperit, \& ceffantem quoque urinam edicit. Quapropteromnibus artis Medicx indagatoribus fuafor fuerim, ut corticem hunc in ulteriores ufus reponant. Succus autem lacteus exrecenti cortice expreffus, CCabiei, $_{\text {, }}$ $\& x$ tinex capitis, prax cætẹris medetur.

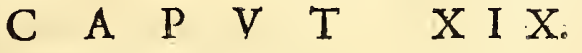 -Ambaiba, ¿r eAndä.}

A Rbor hæc in filvis raro reperitur, fed arvis quondam excultis delectatur, in quibus fponte nafcitur, annuoque fpatio elegantem nancifcitur altitudinem, \& fere $e$ rectam ut plurimum, $\&$ fine ramis ; quxdam $\&$ ramos habent, fed in fummitate tantum. Cortex exterior fimilis Ficui, (nonnulli eam inter ficus filveftres recenfent) conftans primo córtice tenui, cinereo, $\&$, fub eo,craffo, lento ac viridi : lignum ejus album inftar Betulæ, verum molle \& quod facile poteft findi. Totus caudex eft cavus, per interftitia femidigiti ubique diftinctus tranfverfali membrana, in cujus inedio foramen rotundum, per qux formicx rubr $x$ oberrant perpetuo. Ex ligno hujus arboris exficcato ignem line pyrite $\&$ chalybe eliciunt incolx , foraminique ab illis excavato immittunt bacillum faftigiatum ex duro aliquo liǵnio, quod quafi ter ebrando circumaguit, donec appofita folia arborum exficcata, vel goffypium, accendantur. Verfus arboris fummitatem folia circumpofita ut in Mamoeira, quodlibet innitens fuo pediculo fatis craffo, exterius rufo, interius fpongiofo: ipfum folium latum, rotundum, in novem aut decem lacinias fectum, quarum centro infixus pediculus, à quo per fingulas lacihias nervus rufus tendit per longitudinem, \& ven $x$ eminentes per obliquum : fuperius funt $\mathrm{fa}-$ turate viridia, \& inferiùs cincrea, hifpida ut folia Ficus:in extremitate laciniarum, linea cinerea funt fim-

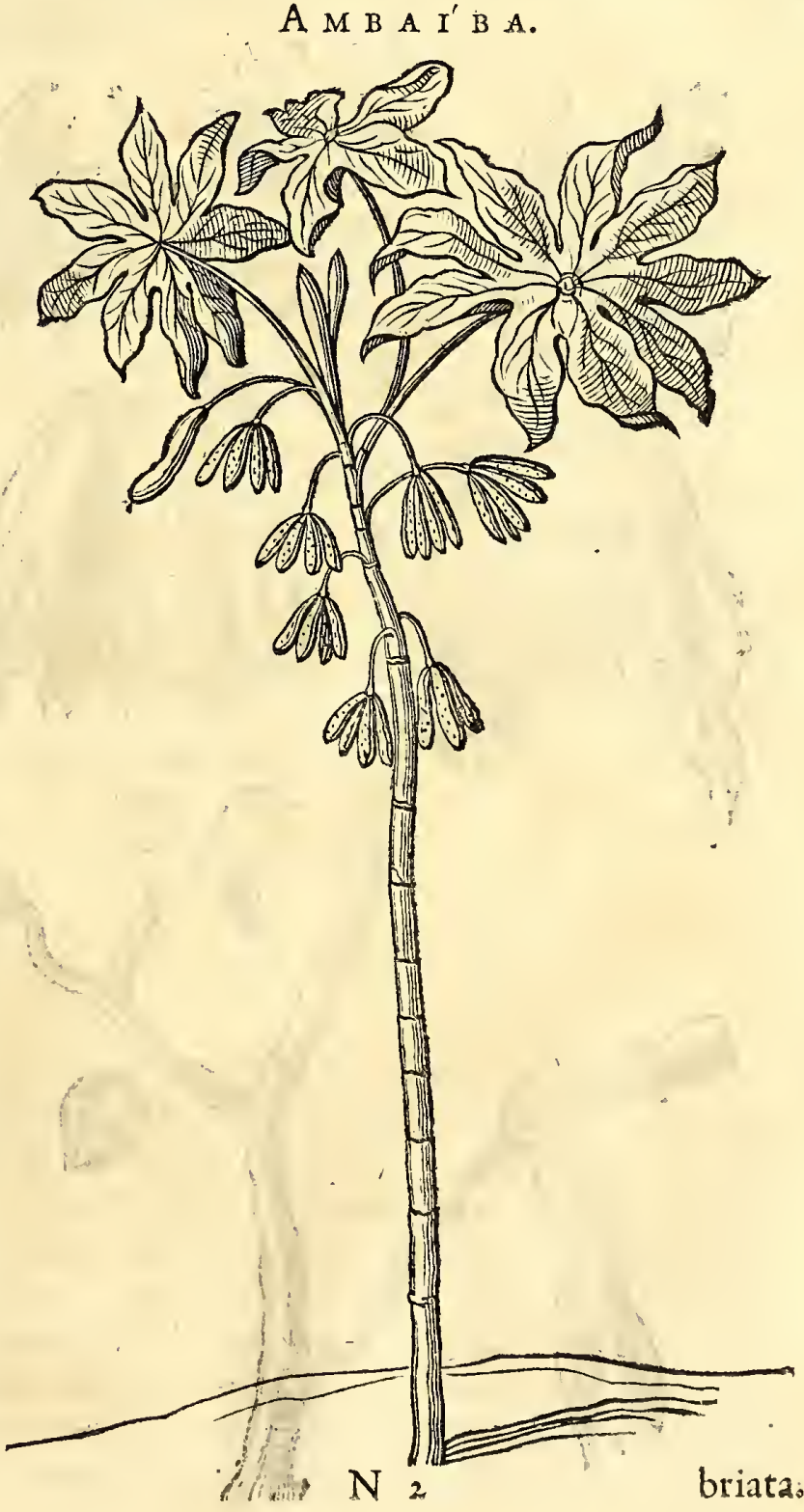


briata. In fummitate arborís exiftit theca oblonga foliacea, incana, qua fe aperiente arqor folio augetur \& fenfim fit altior. Flores in brevi pediculo quatuor vel quinque enafcuntur, ut cylindriaca corpora farciminum inftar copulata, intus quafi goflypio referta, exterius autem acinis bruni coloris ut floris filiginis nọtratis, quibus decidentitus acini illi fiunt edules.

Pinguis ex eorum fummitatibus expreffus fuccus, recentibus non folum, fed $\&$ inveteratis ulceribus feliciter medetur. Folium quoque tenerum \&recens, aut levior arboris hujus cortex, $f_{1}$ apponantur, temperant \& mundificant partem affectam. Succus è gemmis expreflus, qui facultate re frigerandi atque aftringendi pollet, pulti de Tipioca inditus, calidam ventris proluviem fiftit. Menfes denique nimium flucntes, tum \& virulentum genitalium profluvium, compefcit.

Tradunt Indigenarum \& Lufitanor um peritiffimi, hocremedium puerperis, immodico menftruorum profluvio laborantibus, infigniter prodeffe, fi in modum cataplafimatis umbilico apponatur, cujus rei veriffim reftem me præbeo.

Nihil mirum itaque, fi hæc arbor primis Brafili $x$ incolis, ut $\&$ advenis, tantopere fit prædicata. Digna medius fidius, cujus virtutes, etiam nunc latentes, pofteri fcrutentur \& inlucem protrahant.

Altera ejufdem generis, mediterraneis, Ambaitinga appellatur, \& ramo eft rubicundo, \& ligno minus cavo, foliis vero fuperius faturate, inferius dilute viridibus, adeoque afperis, ut loco limæ quædam cum is poffint lævigari. Liquorem continet oleofum ejufdem cum fucco Ambaiba ufus \& efficacix. Fructus fert magnos, tenues, palmælongitudinis : maturefcentes dulc efcunt $\&$ edulesfiunt.

Crteras ejus facultates, \& auxilia Medica, quia nondum fatis explorata habeo,filentio prætereo. An vero fit $A b i e g n a ́$, de qua Clufius in Notis ad Monardem, ego valde dubito.

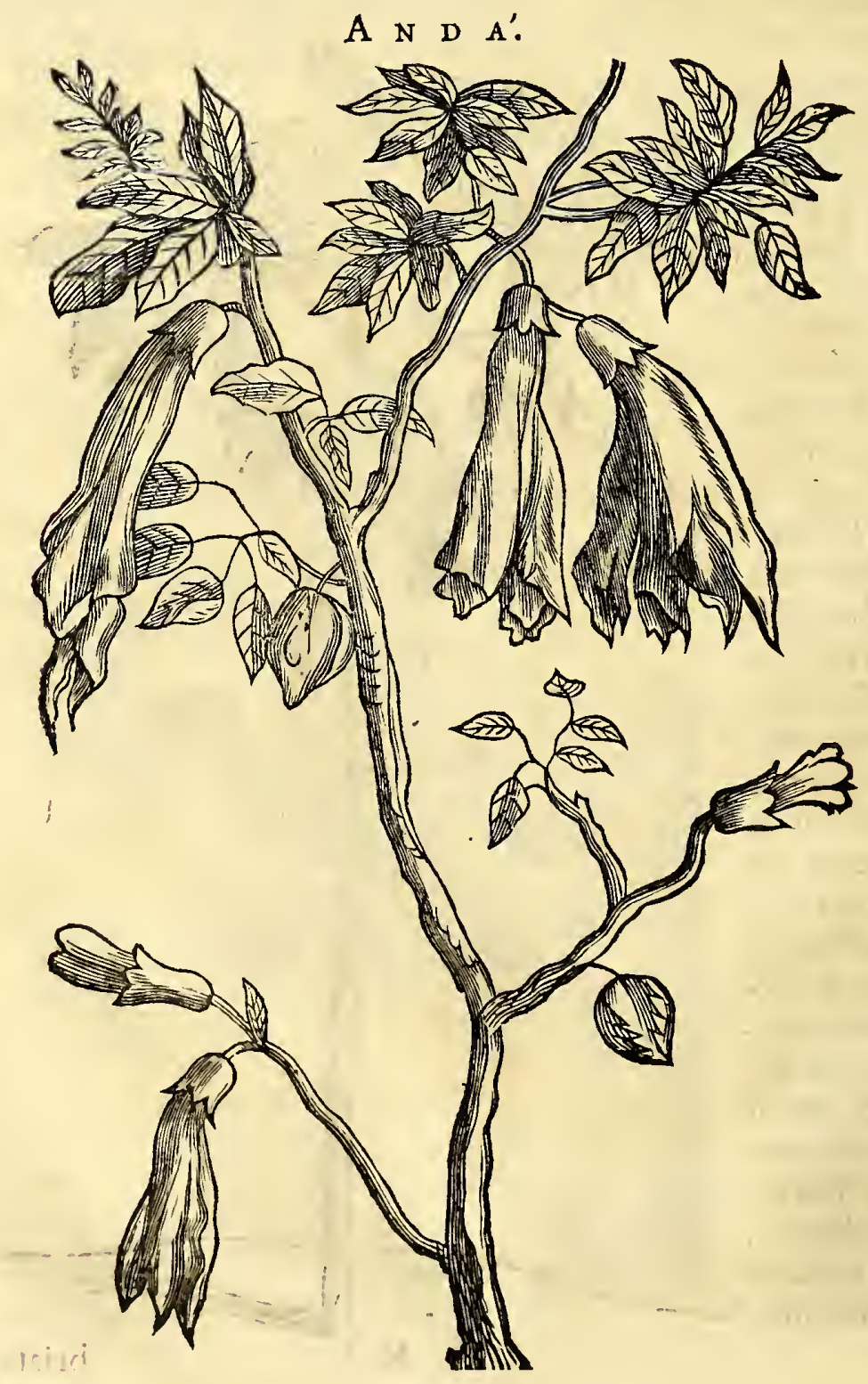

Ton procul à littoIreinfilvis, nuncmediocri, nunc fumma altitudine, proterrx temperie, exfurgit arbor $A n$ dá: qux ligno eft lavi, raro \& fpongiofo, multique ufus. Florem fert magnum \& concavum, aurei coloris. Folia nunc copulata, nuncinordinate $\&$ folitarie pofita, in extremitate acuminata, nervo recto \& venis obliquis confpicua. Fructum feu nucem gignit cortice duplici, exteriore cineritio, ligneo pr $x$ duro \& perforato putamine veftitam, quo dux glandes continentur, jecinorileporino non valde diffimiles, \& nuces caftaneas fapore quodammodo referentes, licet virtute \& qualitate differentes. Vna fiquidem atque altera cruda manducata, alvum ducit: quibufdam fimul \& vomitum excitat. Olim magnates, tum \& $\mathrm{fa}$ crorum 
HIST. NATVRAL. \& MEDIC. LIt. IV. I 49

FR. CT.VS AND. $A^{\prime}$.

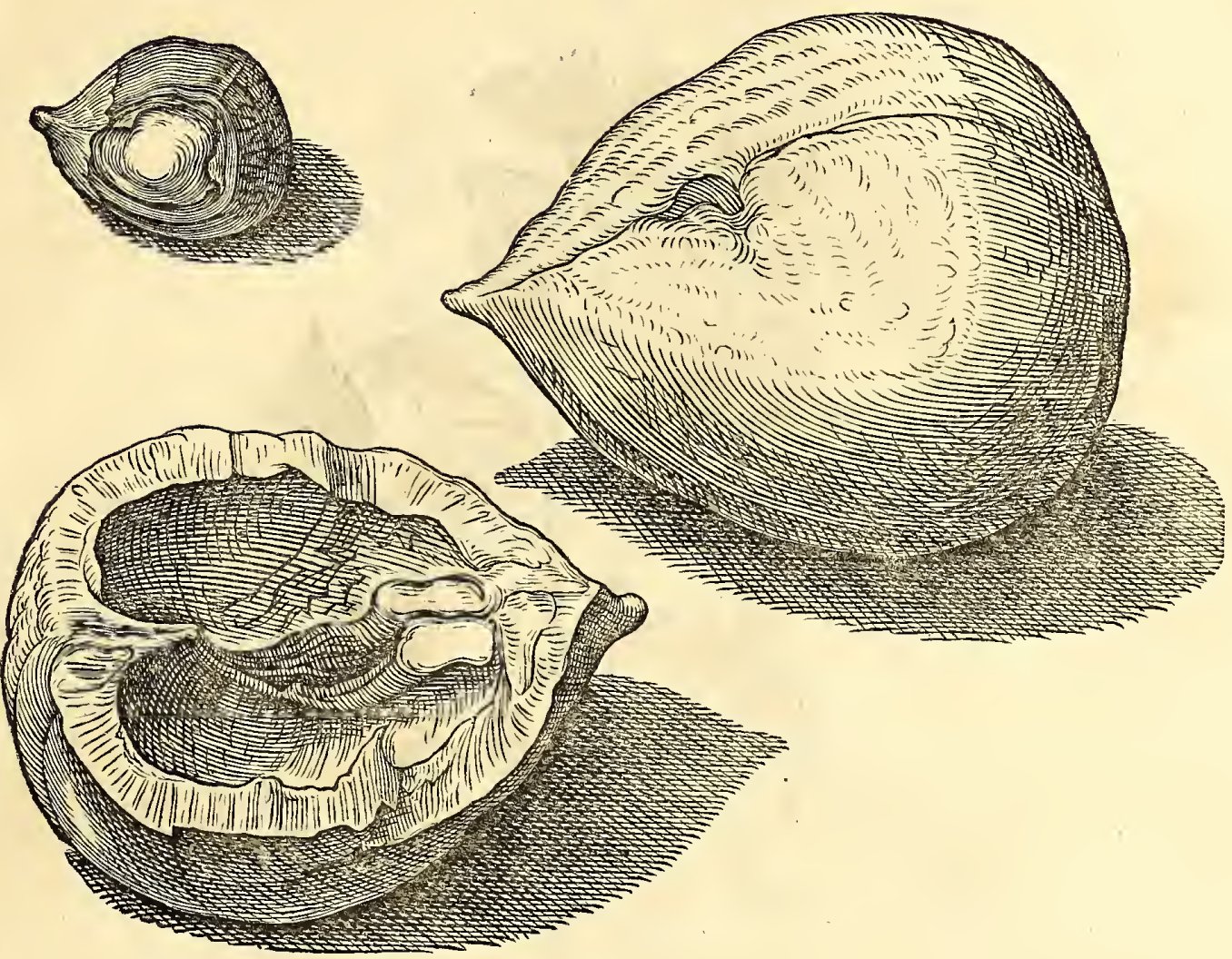
crorum in Brafilia antiftites, purgans hoc $\&$ falutare remedium, cxteris omnibus prax
ferebant. Validx eft operationis; quamobrem $x$ gris morbo fractis haud tuto exhibetur, nifi opportune à manu Medici correctorium accipiat, inque Electuarii aut tabularum formasredigatur. Accipe duas vel tres caltaneas contufas \& cum faccharo defpumato excoctas, addito anifi \& cinnamomi momento, gratiffimum non folum erit medicamentum, fed \& tutiffimum, infantibus, iifque omnibus qui à purgantibus folent abhorrere.

Lufitani \& Indigenæex eadem nuce oleum exprimunt, quod lychnis affundunt, atque co corpus inungunt. E cortice autemillius uftulato, incolæoptimum \& familiare remedium contra ventris fluxum, iifque, quibus poft affumtam nucem, alvus immoderatius ruit, fibminiftrant. Contufus cortex fumina inficit, atque enecat pifces. Iconem nucis integræ \& diffectx, eleganter ad vivum expreffam, ea mole qua erat, addidi. minoris eft magnitudinis nucleus, quam Prunum vulgare, licet pictor refpectu aliarum iconum eum pinxerit aliquanto majorem.

\section{A P V T}

\section{Ibabirába, Araçá duse, \&o Guaiába.}

$I^{2}$

N confragofis nemoribus Brafilix, reperitur vafta arbor, qux gentilitio vocabulo Ibabirába, corrupte à Lufitanis \& Noftris Guabirába appellatur; ligno obliquo, multifque flexibus tortuofo, al tiffimo infuper atque duriffimo; \& contra putredinem optimo. In collibus vero \& campis eadem 1 lbabirába ad longe minorem molem affurgit, vix Prunum adæquans: foliaque multo minora, fructufque fert minus agreftes. Adeo denique, ob diverfitatem foli; difcrepantes inter fe, ùt ha à Medicis, illx à fabris potius expetantur. Ibabirába itaque omnis eft caudice contor to, cortice cinereo, foliis dilute virentibus, rugofis, multis craffiufculis coftis praditis, directe fibi invicem oppofitis : digitis trita fpirant odorem Majoranæ æmulum. Inter hæc fparfim provenit pediculus, fuperius tripliciter velut in crucem divifus, ferens tres fores pentaphyllos, 
I B A B I R A B A.

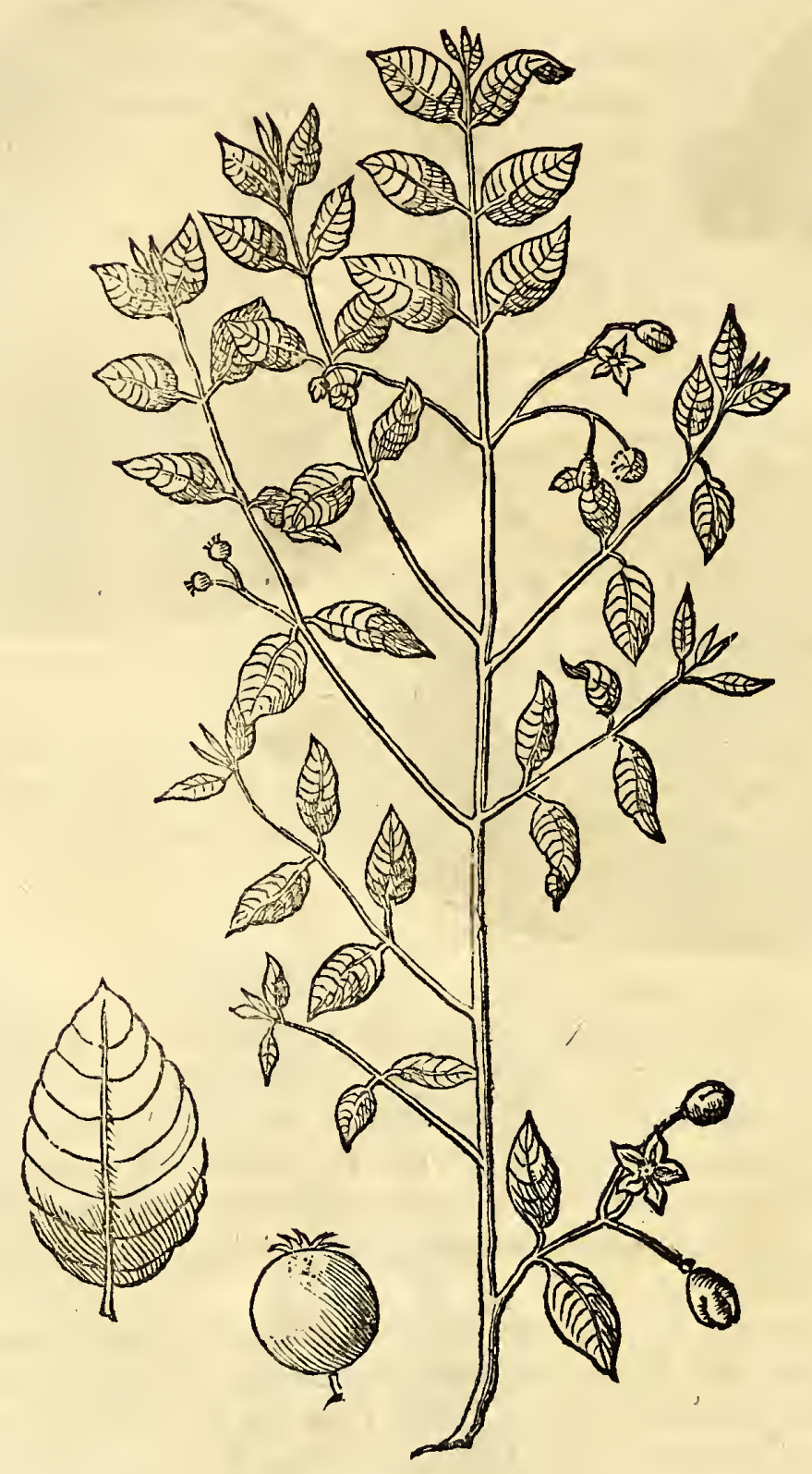

albos, odore, figura \& mole fere filveftris Rof $x$; menfe imprimis Ianuario integros campos fragrantia replens. Menfe autcm Maio fuccedit fructus rotundus, cerafi magnitudine pediculo infidens, exterius coloris brunni, cum umbilico quinquefolio rufefcente: continet pulpam mollen, pallidam, cui aliquot nuclei coloris incarnati, obrotundi, compreffi, molliufculi immixti, qui una comeduntur : fapor autem illius dulcis, aliquid refinofiadmixtum habens. Et poft frequentem ufum imprimit tandem gutturiardorem Piperi mulum. Folia aut flores cum Camará utiliflime adhibentur ad lotionem pedum, in dolore capiris. Mane antequam fol rorem exhauferit, flores colliguntur, \& alembico induntur unde eximix virtutis liquor deftillatur, quir efrigerans præfertim, \& mundificans, oculorum inflammationes optime temperat. Ex foliis quoque fimilis aqua fragrans deftillatur, eifdemque fere ufibus refervatur. Quantum pulvis hujus ligni, in carbonem redacti, oculis inflatus conferat, in morbis oculorum dictum eft.

I Vjus arboris fructus à Brafilianis appellatur Araca-miri; Prunum Granatenfe me 1 rito vocant noftrates. Externa facie, fructu, frequentia, tempore, \& loco natali, convenit cum Minori Ibabirába; de qua Capite pracedenti egimus.

Frutex 


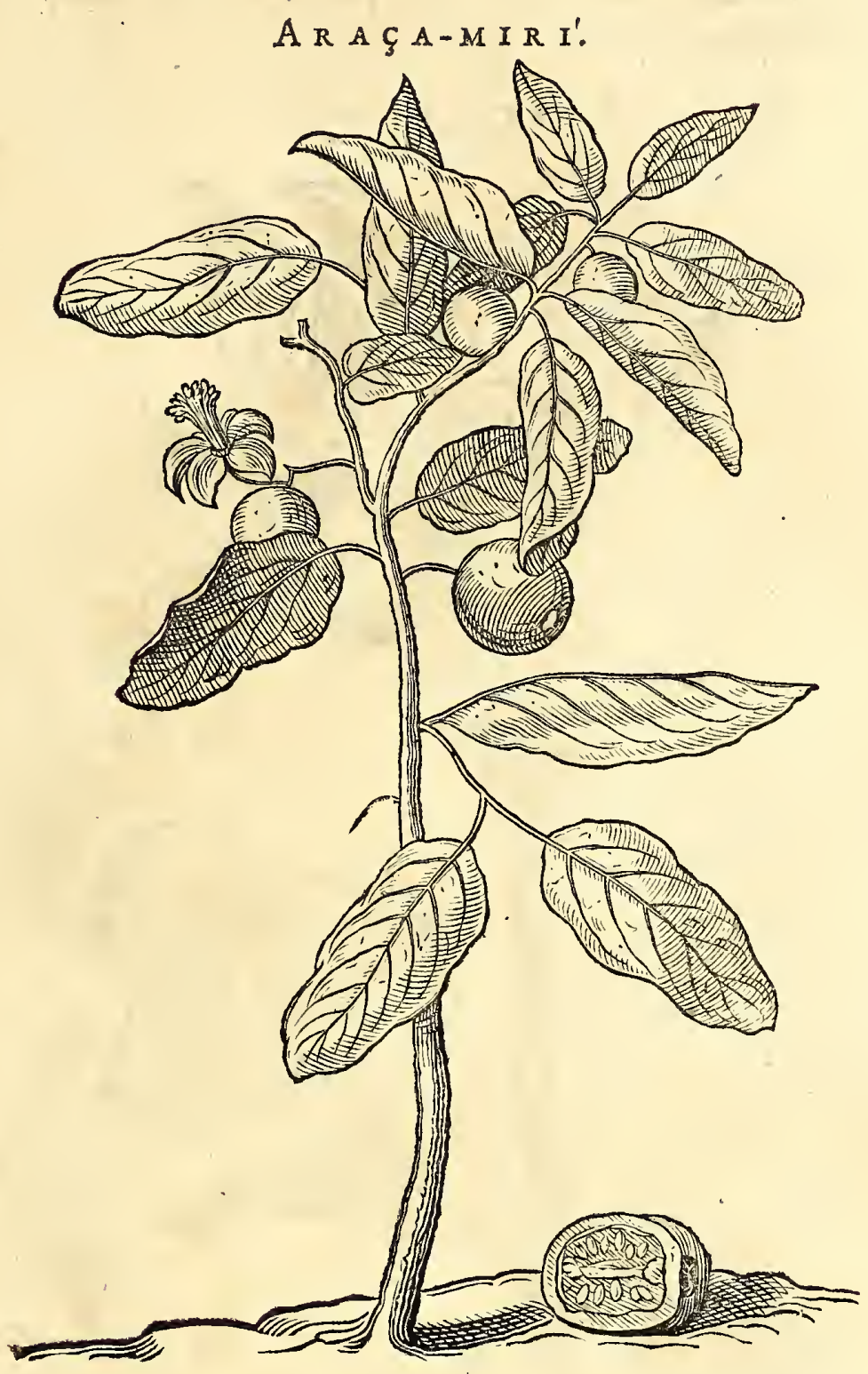

Frutex eft, ligno, foliis \& floribus ut Gnajába, magnitudine vero differınt $\&$ fructu. Sed varius naturx lufus, omnes dignitates, eafque eximias, fructui $\&$ radici infevit, cum Ibabiraba inferiores five in radice five in fructu, fed potiores in floribus $\&$ foliis infitas virtutes dederit.

Locis gaudet apricis, raroque in filvis aut umbrofis nemoribus confpicitur. Flores habet albicantes pentaphyllos, cum mul tis ftaminulis longis.

Floret bis quotannis, bis quoque fert fructum, menfe nimirum Martio \& rurfus Septembri. Pruna coronis (quxà pictore hic neglectx) mefpilorum inftar, eleganter ornata, innumerifque acinis turgentia, profert, qux, ubi maturuerint, flavent, mufteamque habent in fe dulcedinem, atque fraga quodammodo referunt fapore. Cruda potius quam cocta appetuntur, fuaviffimique odoris exiftunt \& faporis. Oportet autem ut tempeftive decerpantur; nam propter intenfiffimum Solis ardorem, non minor injuria fit, fi paulo tardius, quam fi citius avellatur.

Conditus qui ex hoc fructu fiunt, jucunde refrigerant, adftringunt \& corroborant, locoque carnis cidoneorum, confervæ rofarum, aliorumque fimilium, exhibentur.

Cæterun ipfe frutex virtute medicinali non deftituitur. Ex foliis fiquidem $\&$ oculis, utpote adftringentibus, optima balnea componuntur, tam contra internos quam externos corporis affectus, ut fupra in capite de Vlceribus diximus. Prx cxteris autem hujus fruticis partibus, radix dictis qualitatibus excellit, \& dyfentevix medetur. Atque hoc peculiare habet, quodfit diuretica, partiumque fubtilium 
152

cum adftringendi facultate polleat. Proinde præter eximias quas præftat virtutes, lienis \& renum affectibus conducit.

A R A çA-G V A ç $V^{\prime}$.

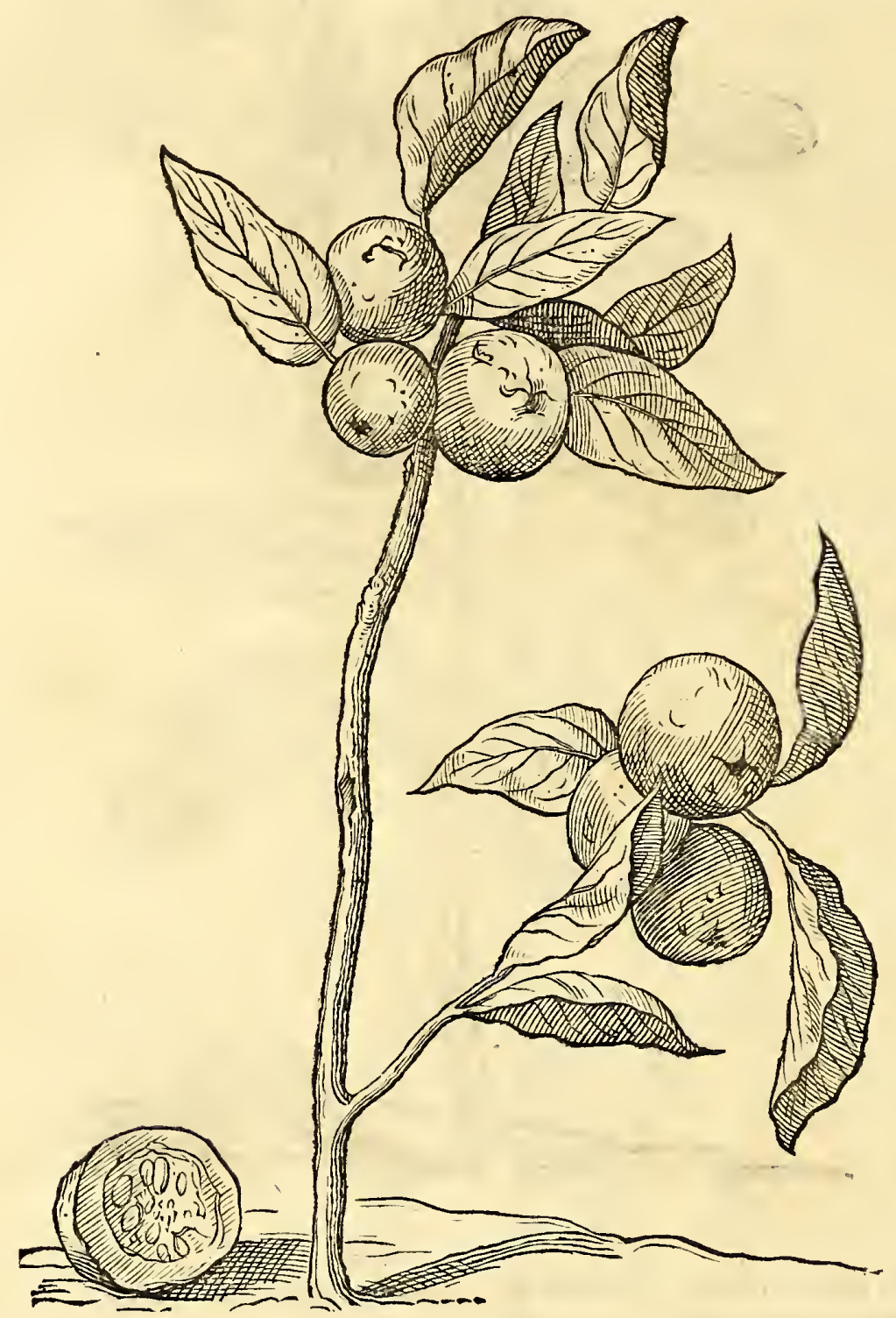

Alia ejufdem generis Araçá reperitur, fed non ita frequens, quæ tamen fructum facile praftantiorem procreat, \& multo majorem. Quapropter ab Indigenis Araçaguaçu, id eft, Araça major, appellatur, quod in juftam arborem excrefcat: folioque eft glabro, læte viridi : figura \& fragrante odore Laurum æmulatur. Fructum fert mali mediocris magnitudine, rotundum, fuperne umbilicum continentem: carnem habet albam, carni Araça-mirí, odore, fapore \& fubftantia fimilem, in medio multos lapides, pifis minoribus xquales, continentem, obrotundos, paulum compreffos, ex albo fubflavos $\&$ duros, ut nuclei ceraforum, intus continentes nucleum album. Adhærent hilapides carni per multa tenuiflima filamenta. Eifdem dignitatibus medicis hæc gaudet, quibus Araca-miri. Gargarifmata quoque cum fimilibus abftergendi $\&$ aftringendi qualitate praditis herbis, contra gutturis \& faucium inflammationes aliaque mala, quotidic inftituuntur.

Agna affinitate inter fe conjuncta funt Guaiába \& Araça-guaçu; ejufdem quippe

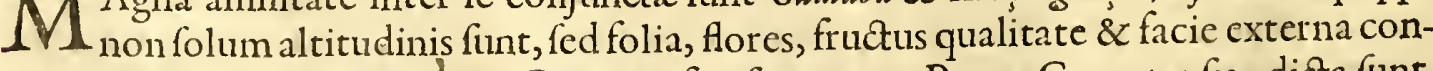
veniunt. Meritoquehac Pyra Granatenfia, ficut Araç Pruna Granatenfia, dicta funt. Arbor in Mali figuram excrefcit $\&$ in plurimos fe diffundit ramos. Cortex illius $l a-$ vis eft, pallidus inftar corticis Aceris. Fert folia bina, fibi oppofita, ad tactum dura,fplendentia 
dentia; inferius autem venis obliquis \& confpicuis protuberantia. Florem fert ex quinque foliis \& multis ftaminulis conftantem inftar crifte pavonis. his fubfequitur fructus, magnitudine \& figura pomi noftratis, non quidem adeo diffimilis, nifi quod oblongior \& cortice magis rugofo fit. pulpa pallide fanguinei eft coloris, lapidibus edulibus mefpilorum inftar referta. Fructus ipfe pro diverfitate temporis, triplicis faporis participat. Maturefcens enim antequam mollefcat ac flavefcat aufterus $\&$ aftringens eft, tuncque coctus ftomacho prodeft. Mox paulo maturior mediæ naturæ atque optimus evadit ; melius tamen fanitati confulit, qui eum five coctum five faccharo conditum, quam qui crudum menfis infert: accedit quod odoris $\&$ faporis fit gratioris palatoque magis abblandientis. Vbi vero flavedine $\&$ mollitie integram maturitatem acquifiverit, odoris $\&$ faporis eft inftar fructus Rubi Idæi, alvum movens, nec ita falubris paulo largius affumtus, quia facile corrumpitur \& vermes producit.

Radix arboris longiffima eft, extus rufi, intus albicantis coloris; fubfantix fucculentx ac fubdulcis. Hæc cum cortice aftringente in aqua cocta \& pota, mirifice medetur dyfenterix, quando indicatio eft aftringendi \& roborandi. Folia funt acida \& aftringentia, odorata, balneifque dicata. Digna profecto ar bor, quæ Europæ importata, Magnatum \& Principum hortos illuftret. Montibus aut filvis denfioribus non innafcitur, fed planitiem \& camposamat. Agreftis effe defiit, villicorum quippe induAtria viridariis illata, numcrofas plantas concipit $\&$ procreat, ut nihil frequentius occurrat: fructuum enim grana ab avibus \& pecoribus deglutita, \& mox per alvum cum excrementis depofita, locis licet arenofis \& triftioribus, altifime germinant maximeque luxuriant. Aliis Indiarum regionibus communis hæc arbor, ac proinde hic patriam Brafiliani negant, fed tractu temporis inter illas habita eft. Numerofo proventu, totis menfibus pluviis, maximo omnium Incolarum oblectamento exiftit. Meminere quoque hujus arboris Ximenes, Gomara, Oviedus , \& Monar-
des ; \&alii. 


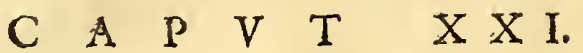

\section{Pacoeira \& Bananiera.}

Rutices lippis \& tonforibus noti, tamque familiares, ut nulli prorfus in Brafiliajam -1 reperiantur horti, in quibus illi paffim non fpectentur. Indigenx tamen hic non - funt, fed aliunde huc deportatæ plantæ. Lufitani fructus Pacóba, Brafiliani Pacobeténominant : Afris vero atque Afiaticis olim fuiffe notos, Serapion \& Avicenna

PACOEI'RA \& BANANIERA.
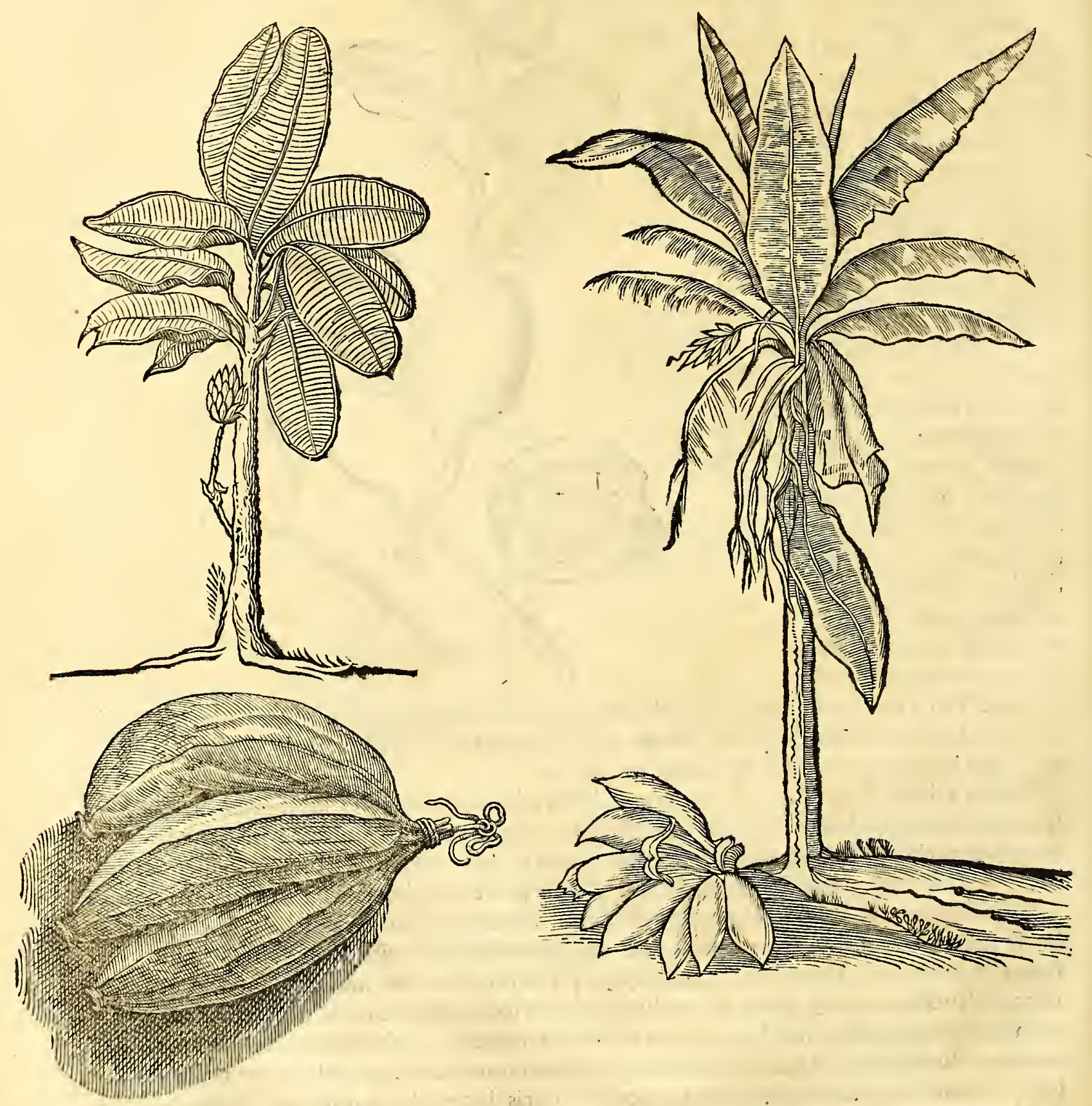

teftantur, qui Mufas appellarunt. Earum itaque defcriptionem, quam Matthiolus, Clufius, \& Dodonæus habent, libenter amplector, paucis tamen, in quibus hallu. cinati funt, mutatis.

Duo autem funt ejus genera, qux ob maximam affinitatem quam habent, una (quod aiunt) fidelia dealbabimus. Pulcherrimæ fane plant $x$, five fructum five folium, five cultur $x$, nafcendique peculiarem modum fpectes. In quovis folo, licet trifti $\&$ fiticnte, proveniunt. Quovis anni tempore incolæ earum fructu gaudent. $P_{\text {acoeira vero }}$ 
HIST. NA T VRAL. \& MEID C. LIB. IV.

ex radice propagatur. Vnde primo erumpunt tria quatuorve folia in fiftulam convo. luta, qux plantæ caudicem f pongiofum, craffum, efficiunt, in quo fuperius expanduntur decem vel plura folia eleganter viridia, ad tactum lævia, inftarque chartæ membranaceæ crepitant, à vento agitata dilacerantur tranfverfim fecundum ductum ftriarum, \& ftrepitum excitant commota. Nervùs digitum craflus fecundum foliorum longitudinem excurrit, qui in fu periori fuperficie tanquam canalis excavatur, \& tranfverfim linex fubtiles à nervo ad latera extenduntur. Ex fummitate caudicis hujus fpongiofi ramus prodit primo tener, continens in extremitate fua corpus turbinatx figuræ, magnitudine ftrobili majoris, conftans è foliis latis, brunni coloris, obfcuris, quibus quafi pulvis afperfus cinereus.

Subter foliis his expanfis apparent feptem aut octo flores, ordine juxta fe pofiti, ex albo flavefcentes, fuavis odoris. Ex fcapo florum prominent quinque foliola angufta, figuram habentia illius inftumenti quo nautæ utuntur in humectandis velis: In fcapha hacfub tegmine manna feu lentus humor continetur frigidus, faporis mellei, confiftentia \& colore fimilis albumini ovi recentis; quo nectare formic $x$ admodum delectantur: in hoc humore ortum fumunt quinque illa foliola cum famine. Flores hos fequuntur fructus ordine \& arcte juxta fe pofiti. Continentur plerumque in uno ramo, quatuordecim aut fedecim numero, utita una planta proferat feptuaginta aut octuaginta, qui fubinde virides avulf, nunc in 2 dibus, nunc in navibus fufpenduntur, donec juftam maturitatem \& flavedinem confequantur. Fructus autem maturefactus magnitudinis eft cucumeris noftratis, oblongus \& trilaterus quafi, corio craffiori tectus, quod facillime in tres partes digitis fe dividi \& detrahi finit. Pulpa, mollis inftar butyri, medullam quafi cucumeris per medium fecundum longitudinem habet: boni eft faporis \& frequentiffime comeditur vel folus vel cum farina Mandioc, , vel coctus \& frixus in oleo aut butyro. Ramus autem ille fructibus onuftus interea dum illi maturefcunt, augetur, florefque femper protrudit ex corpore illo foliaceo, fed qui decidunt fine fpe fructus. Maturis porro fructibus ramus cum illis abfcinditur, ut $\&$ tota planta: nam una planta unum tantum vivit annum, \& femel tantum fructificat. Antequam fenefcit, filius unus aut alter ex radice natus eft $\&$ adftat parenti, morientique fuccedit, \& fic in infinitum propagatio hujus plantæ fuccedit. Banána, planta qux Brafilienfibus Pacobuçú dicta, tota eft ut Pacoeira ; at turbinatum illud, floriferum \& odoriferum corpus paulo minus eft, \& flores parum differunt : eftque floris fcapus, non inftar faphæ, fed rectus, attamen cavus, fructus etiam haud multum differunt à Pacoeira, fed minus craffi, verum longiores \& incurvati. Subftantia quoque ficciores \& meliores ad coquendum. Vtraque tam Pacóba, quam Banána, inter horarios fructus, \&, ut nonnullis placet, inter Ficus recenfentur. V Vraque flatus excitat; modice refrigerat \& Venerem fopitam adjuvat. Pauci funt alimenti, pectorifque potius quam ftomachi oblectamento. Toftr biliofis profunt, pituitofis non item. Nondum matura fi affentur, adverfus alvi profluvia auxiliantur. Ad folem ignemque exficcatæ diu fervantur, \& Europæ importatx, diftrahuntur. Exdem in taleolas diffectx, cum ovis \& faccharo frix vel in placentas ad artocrex modum coactx, gratiffimi funt faporis, optimiquealimenti.

Aqua, qux ex earum truncis, perpetuo humore turgentibus, elicitur , cum frigidiffima fit, in magno ab Incollis.pretio habetur contra calidos, internos \& externos corpo-
ris affectus.

In Maranhan, ubi maximopere luxuriant, vinum inde exprimitur, non diu durabile, quod tamen inebriandi facultate pollet.

\section{A P V:T X X I I.}

\section{Mangaíba, Inbay frve Tamarindi, \& Tapiracoanana.}

7 Ximium hujus arboris pomum, quod Mangaiba vocatur, necignorandum, nec 1 pratereundum arbitror, tametli ad menfarum potius delicias, quam ad Medicum noftrum inftitutum facere videatur. Tanta enim fuavitate gulx lenocinatur, tanta faporis eft praftantia, ut haud fciam, an venuftiorem aut gratior em fructum America producat.

Arbor 


\section{$M \wedge N G \wedge I^{\prime}$ B A.}

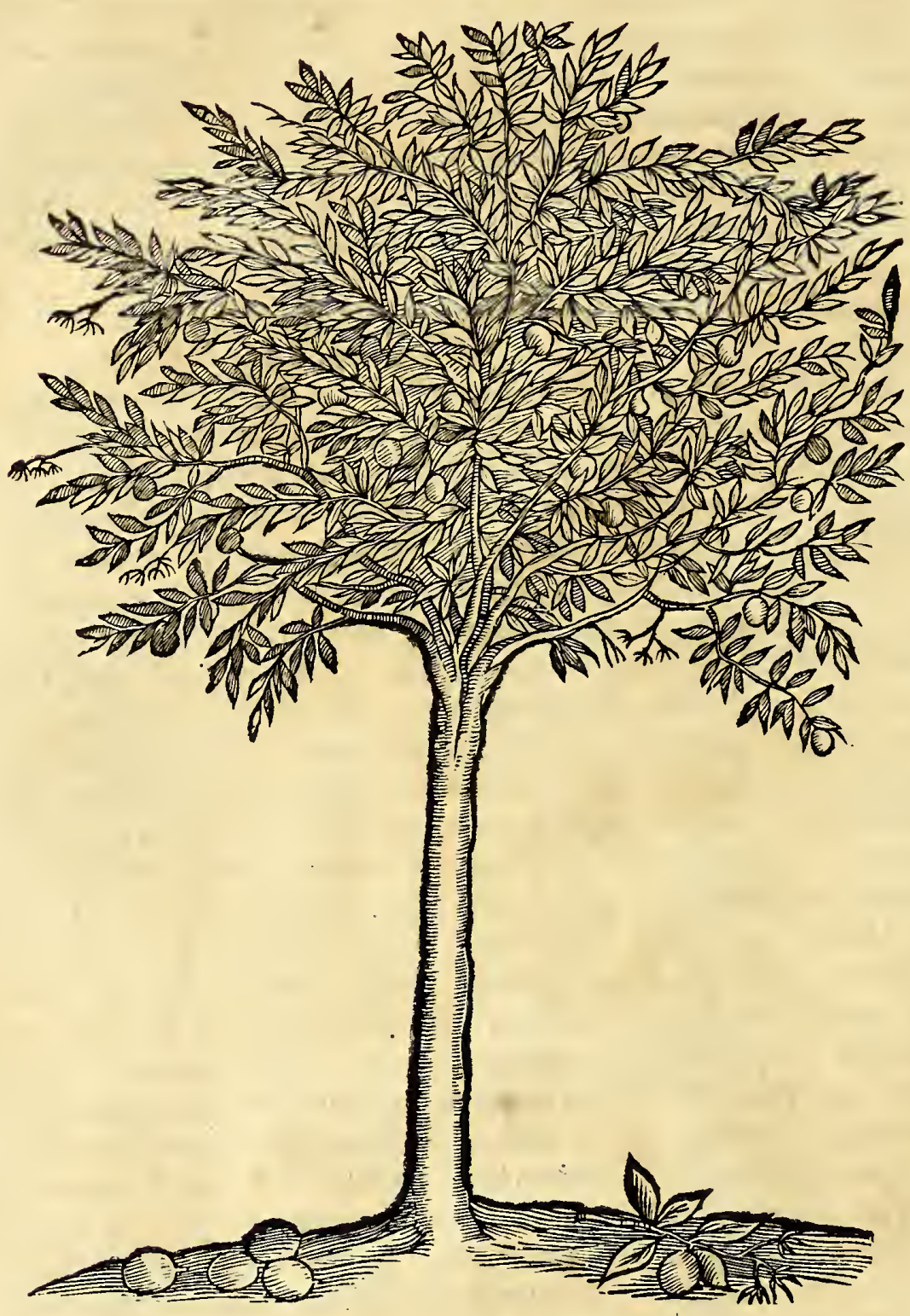

Arbor pulchra, crifpa \& focundiffima, fupra altitudinem Pruni Europæx non attollitur, quam fructu, præcipue vero ligno $\&$ foliis æmulatur. In quibufdam Bahiæ $\& 2$ Paranambuci locis in integra nemora hafce luxuriare videas. Seri, non plantari amat in terra ficca, ubi nulla copialuxuriantium herbarum. Folia fert parva, folida, egregie virentia, bina femper fibi invicem oppofita, qux in medio, fecundum longitudinem nervi, non tam venulas quam lineas habent fubtiliffimas parallele difpofitas. Exfpirante hyeme, menfe nimirum Auguto, florere incipit, ultraque novem menfes pomis feu prunis oneratur $\&$ ornatur. Flor em producit exiguum, album $\&$ fumme odorum, ftellula figura Iafmini modo difpofitum. Fructum rotundulum, efculentum; qua Soli exponitur aureum, rubrifque maculis diftinctum, Abricocum diceres. Tenuiflima cuticula tegitur, intufque lapillos quinque vel fex continet ; turget lacte, unde velleviter preffus niveum palatoque gratifimum fundit liquorem; \& licet fequax ac ductilis illius pulpa videatur, tamen manducando nihil tale deprehenditur, orique inferta, ftatim liquefcit. In arbore numquam maturefcit, fed decidens in terram ilico maturitatem confequitur. Cujus rei ignari adventitii, \& externa pomi pulchritudine illecti, ubi primis labris deguftarunt, ftatim ut aufterum \& $\&$ amariffimum abjiciunt ; quid, quod ne pecora quidem immaturum curant. Probe maturum facilis eft digeftionis, ardores vifcerum domat $\&$ febricitantibus auxiliatur, ut in meipfo aliifque multis fum expertus. Porro haud facile hac poma noxam, etiam abundejejuno ftomacho mandu- 
HIS T: NATVRAL. \& MEDIC. L. в. IV.

manducata, inferunt: nifi quod frigida $\&$ humida fugaciaque alvum dejiciant, flatufque excitent, quod folertia muliercularum noftratium; aromatibus corrigi folet. Lufitani integros fructus conditos apponunt, nullifque tunc epulis cedunt.

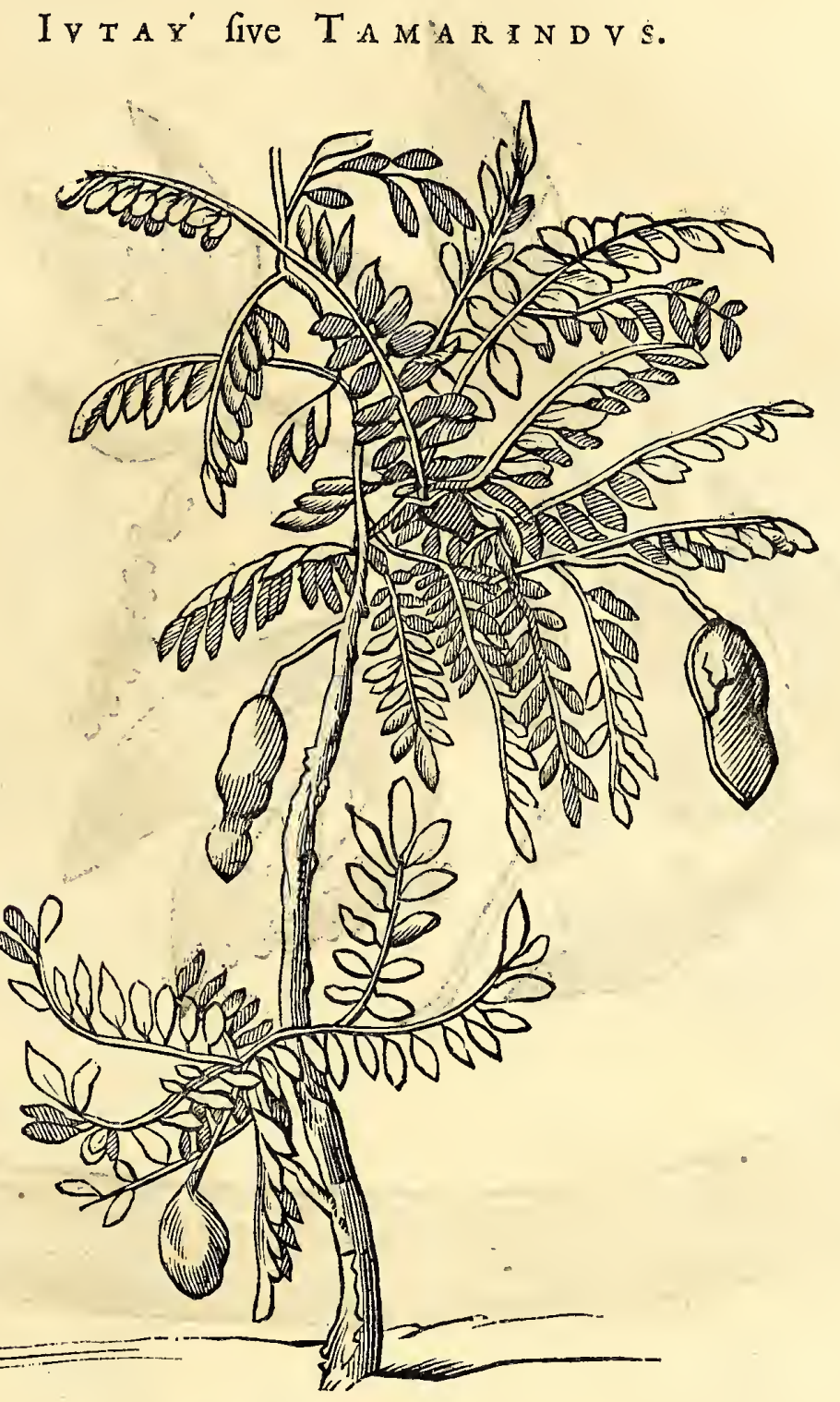

Nter eas arbores quæ aliunde huc olim tranflatx, ac proinde rarius confpiciuntur; eft hæc quæ Lufitanis Tamara azécla, Barbaris Iutaý, vulgo Tamarindus dicitur, inter Palmulas dactyliferas habita veteribus.

In Quercus proceritatem excrefcit, caudice exterius grifeo, ligno albo, lento: Rami foliolis parvis, anguftis binis ubique fibi arcte oppofitis inferne dilutë, fuperne faturate viridibus veftiuntur. Quæ manducata $x$ tuantibus gratam fuppeditant aciditatem. Flores albi Aurantii mali flori fimiles. Fructus in quolibet pediculo folitarie proveniunt, figura variantes, fed utcunque compreffi inftar filiqux fabæ majoris. Cortice cooperiuntur fragili coloris mefpilorum, tenui: intus pulpa nigricante, filamentofa, gratifimæaciditatis referti in qua tres quatuorve lapides fplendentes, compreffi fabævulgaris magnitudinis immerfi funt. Nucleus terra commiffus annuo fpatio alte excrefcit. Vtinam æque frequens hic effet ficut in Afia \& Africa. Quodrefrigerando $\&$ æeftringendo humoribus biliofis frenum imponat, à Græcis merito Oxyphonica dictá.

Quantum hæc Americana differat vel conveniat cum Afratica ex hac Icone cum Bontii collata, facile apparebit.

Affia arbor cujus fructus Canna ffftola Lufitanis $\&$ aliis. Arbor alta $\&$ magna, atque $\checkmark$ in plurimos ramos late expanfa colore exterius ex cinereo albicante. Folia fert ordine fibi oppofita, paulatimque furrectim ftantia, figura cylindracea, breviffimo 
TAPYRACOAYNA'NA \& FR V CTV $S_{2}$ Cassia Fistula Dictrs.
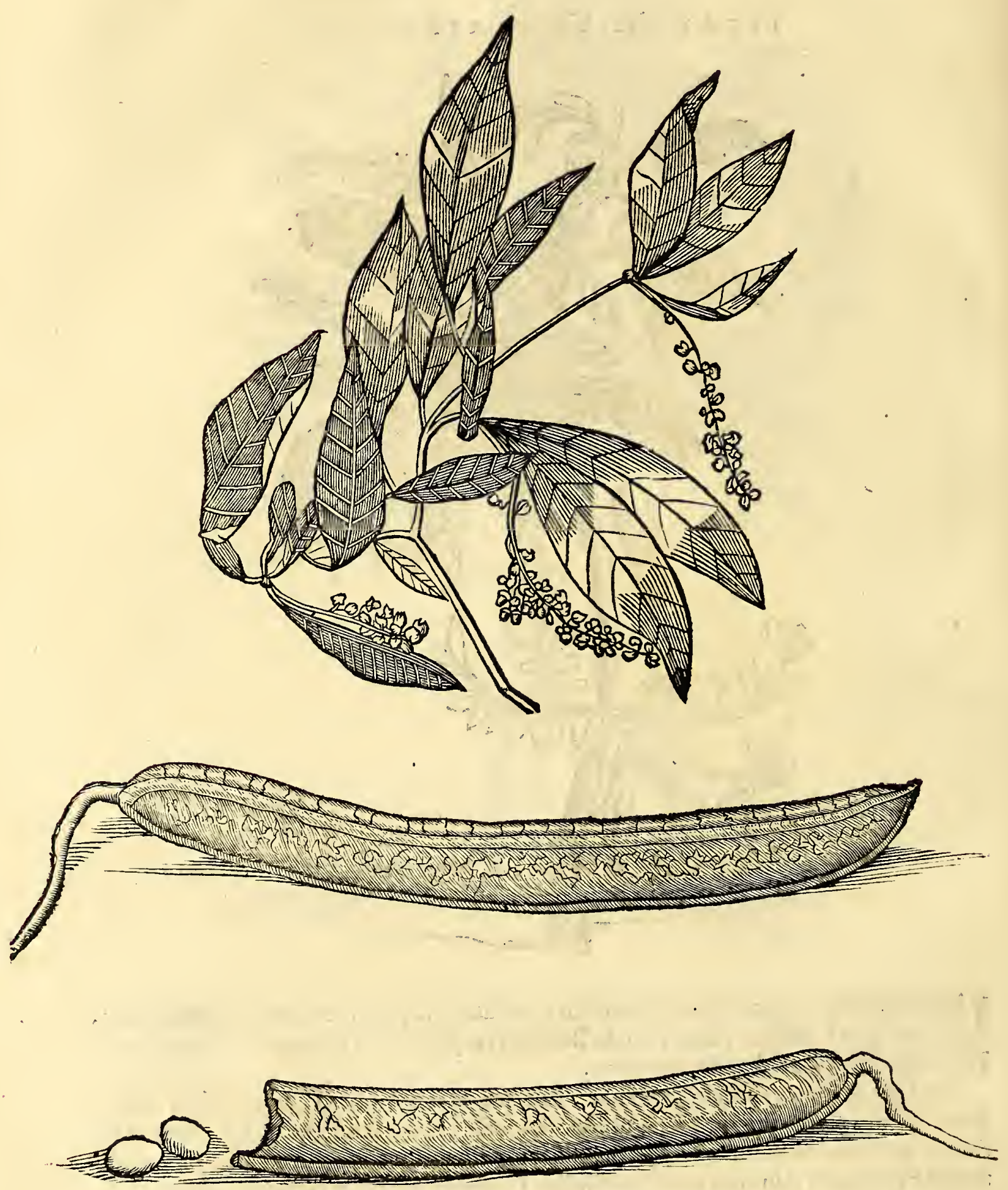

pediculo innitentia inftar Foliorum Senx, dilute viridia ; fubtiliter hirfuta, ad tactum mollia, rubefcente nervo fecundum longitudinem, \& venulis fecundum latitudinem ordine pofitis prædita. Flores fert fpicatim congeftos fine ramulis, qui color is incarnati elegantiffimi, longe adventanti confpiciuntur. hifce floribus fuccedunt filiquæ viteorfum propenden tes paulo incurvatx ubi maturuerint. Corrides, mox nigricantes dicus ha fitice funt durilfimo lignofo, qui ut frangantur, mal figura \& colore, fed fplendentiliqux tranfverfim cellulas habent, nucleis amy $x$ glutinof $x$ nigricanti inftar Caflixfobus lavibus $\&$ duris, qui immerfi funt pulp $x$ glatino $x$ nimo ante maturitatem cum aftrictione lutivx, fed ingrati \& amari faporis, qux primo ante maturifaterit, laxat alvum. conjuncta cft. V bi vero gradum ulteriorem maturitatis acquiliverit, laxat
Summitates foliorum vulneribus \& puftulis male moratis applicata medentur.

C A- 
HIST. NATVRAI. \& MEDIC. LIB. IV.

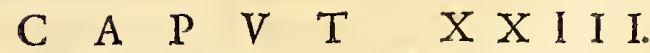

\section{Pinoguaçú mas es foemina, \& Iaracatiá.}

$\mathrm{V}$ Traque pinoguaçu, Mamoeira Lufitanis dicitur, vulgo Papay', cujus Fructum Mamaon vocant à figura, quia Mammx inftar pendet in arbore: Mas ubique in filvis obvia , raro autem foemina, quæ in Hortis exculta luxuriat. Mas in vulgaris arboris fructiferx altitudinem exfurgit, cortice cinereo \& lævi. Foliis ubique

PINOGYÁ
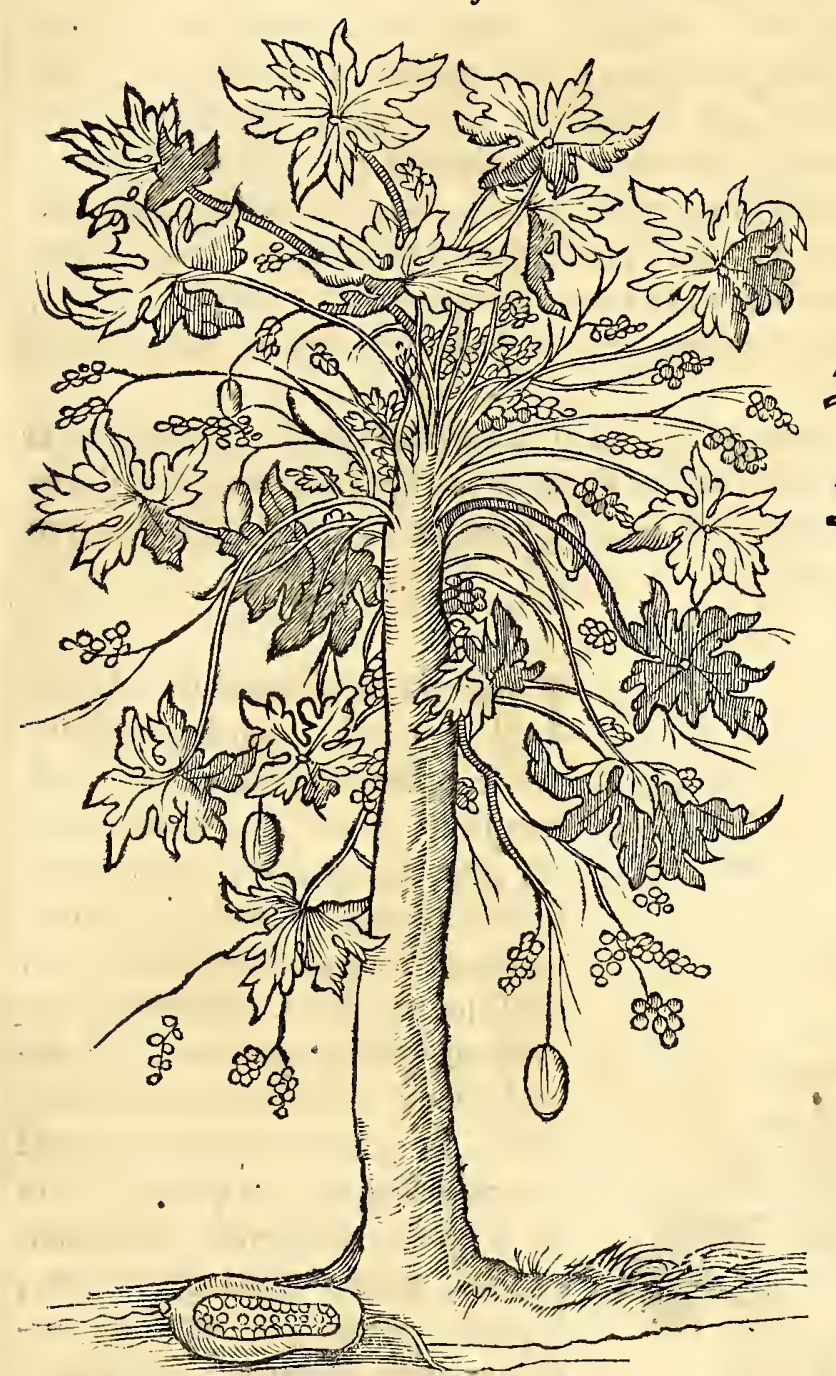

erumpentibus circa caudicem qux à terra ad medietatem altitudinis ftatim abfcinduntur in junioribus, reliqua medietas ufque ad fummum foliis veftita relinquitur.Quodlibet folium in fex feptemve lacinias diffectum cum totidem incifuris infidet fuo pediculo rotundo, cavo rufefcenti. In ramulis ex pediculis majoribus oriundi multi fiores longi inodori pallide flavi, quinque foliis incurvatis conftantes, nafcuntur. Quibus fructus rar o fuccedunt, nifi arbore tranfplantata qux trium ad minimum fit annorum. Falfum por-
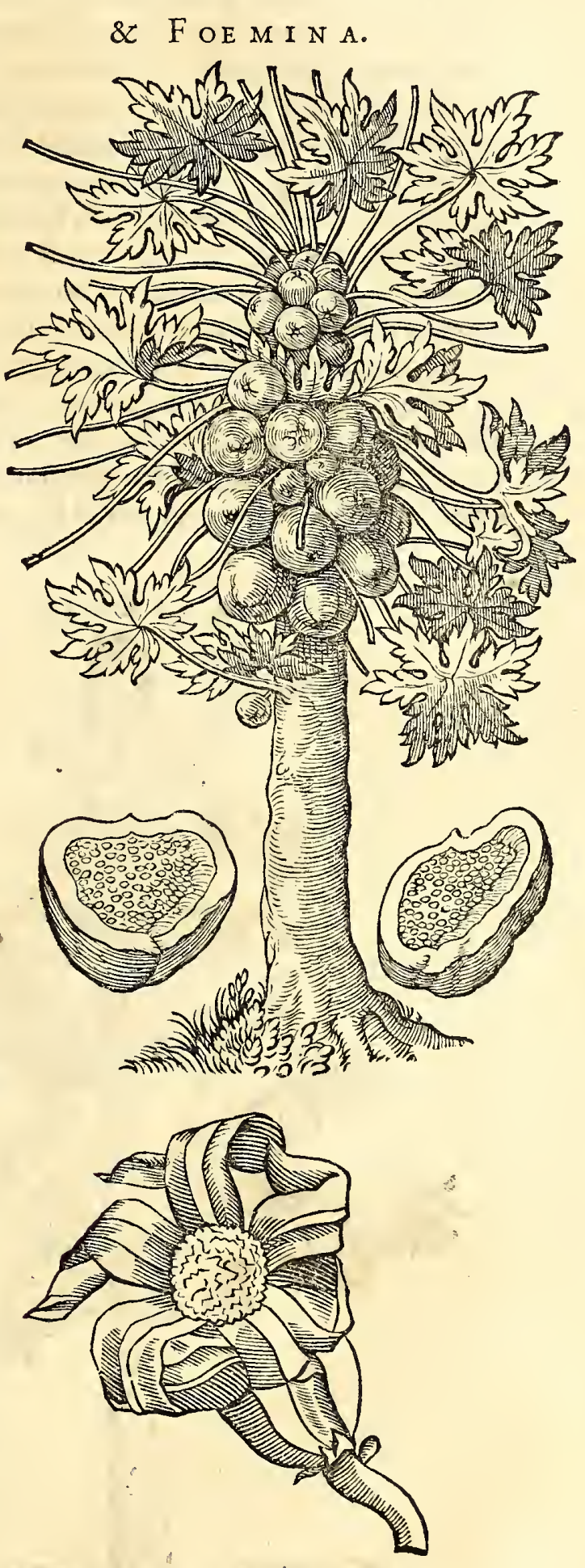

ro mares nonferre fructum, uti \& foeminam non ferre fructum nifi mas adftet; contrarium enim multiplex experientia docuit : fructus vero maris quando nafcitur pediculo illo longo pendulus eft deorfum verfus, figura fimilis fruatui foeminæ, fed oblongior \& minor \& exterius ftriatus quafi Pepo, nimirum quinque ftriis fecundum longitudinem, \& quinque minus profundis alternatim pofitis. Interius carnem \& femina

$$
\mathrm{O}_{2} \text { liabet }
$$


habet ut fuemina, fed non ita flavam aut bonam. Immaturi fructus copiofe lacteum fuccum fundunt. Lignum arboris fragile $\&$ molle, quod in lufus \& ufus varios excavatur turgetque eodem lacteo fucco, ingrati \& acerbi faporis, quo contra cutanea vitia ex fervore nata utuntur barbari.

Pinoguacú focmina fimilis mari caudice $\&$ foliis, fed ut plurimum majoribus; neque pediculi foliorum funt rufi, fed virides. maxima pars caret ramis, atque ita fpeciofior apparet. Toto anno Fructus \& Flores fert non in pediculis longis, fed ad ipfum caudicem, ubi pediculi foliorum inferuntur. Flos eft magnitudine floris Gladioli, conftans quinque foliis flavis, odoris Lilii convallium è cujus medio nafcuntur fructus, qui caudici adnati funt minoris Melonis figurx \& magnitudinis, adeoque luxuriant ut ob abundantiam vilefcant. Immaturus eft viridis \& incifus exfudat lac: in arena fub dio abfconditus maturefcic ftatim \& maturus ex viridi flavefcit, carne lutea inftar Melonum, fed fapore ignobiliori. In medio pulpæ copiofiffima habet grana, ovalis figurx, magnitudine Coriandri, in fuperficie rugofa, fufca, nucleo intus albo : faporis funt hæc grana ejufdem cum Nafturtio aquatico noftrate, includunturque pelliculæ tenui, fiplendenti ; qux detrahenda eft, fi quis femina velit fervare. Fructus crudi edules quidem, fed longe præeftant vel cum carnibus cocti, vel placentæex iis factx. Ex quolibet femine annuo fpatio habetur arbor fructifera, fed non duratura ultra quadriennium. Signum prognofticon mortis eft, quod cacumen cjus fponte corrumpatur; illam enim corruptionem fequitur totalis interitus.

Fructus licet rite preparatus boni quidem faporis, fed non fat is probi nutrimenti, fi plufculum comedatur laxat alvum leniter : fuccus vero ex eo expreffus mitigat dolores ventris ex calore natos. Idem præftat conferva exinde preparata. Fr. Ximenes quoque celebrat hanc arborem in nova Hifpania.

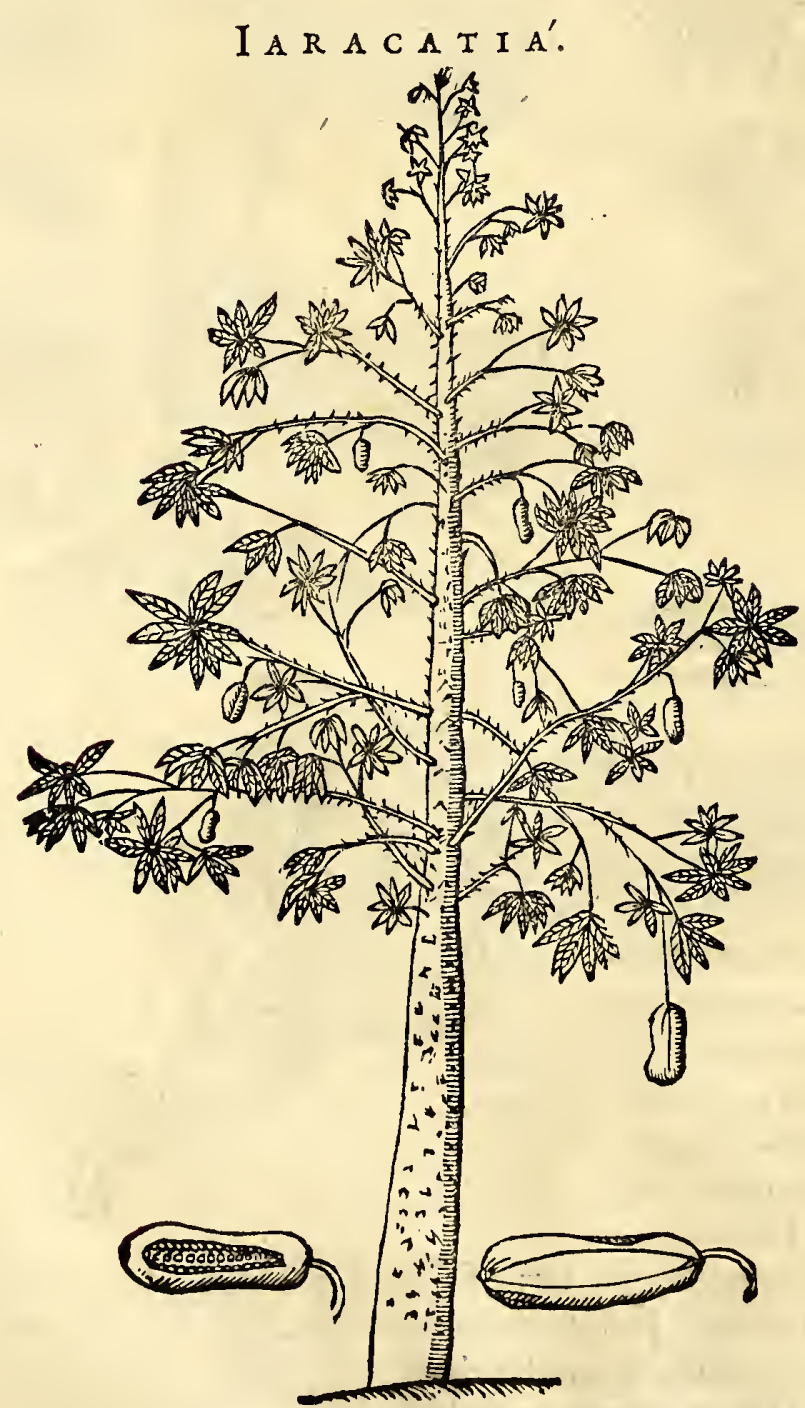

TAracatiá Brafilienfibus, Arbor 1 eft alta recta, caudice inferius craffo, qui verfus faftigium magis magifque gracilefcit $\&$ attenuatur, cortice grifeo, ligno molli $\&$ lactefcente. Caudex autem \& rami armantur fpinis brevibus, craffiufculis duris. Et ramos quidem in orbem projicit, fed inordinate, fuperiorefque inferioribus breviores; neque ramuli magis ordinati, in quibus folia in frondes congefta chandiibe modo, figura \& $\&$ magnitudine, fuperius fplendide viridia, inferius incanefcentia, quinque, feptem vel novem in ftellx modum fibi appofita; nervo fecundum long itudinem \& venis obliquis. Florem fert \& fructum ut Pinoguaçú mas petiolo longo dependentem Atriis haud profundis fecundum longitudinem, vel quafi lineis folum notatum, coloris. exterius \& interius crocèi ut $\mathrm{Ma}$ mao, \& carne cjufmodi fubftantix $\&$ fimili modo granis refertum, magnitudine \& figura grani hordei,faporis haud manifafti. Immaturus adhuc lactefcic, ac vellicat linguam, maturus autem fponte. decidit $\&$ comeditur crudus affatus atque coctus. Facilis eft digeftionis, nec nocet licet 
HIST. NATVRAL. \& MEDIC. LIB. IV.

licet magna quantitate comedatur, proinde etiamfi maris accolis minus familiaris; non tamen inter inferioris not $x$ fructus habendus. Folia amittit fingulis annis $\&$ men fe Martio nova protrudit, hinc floret \& fructum fert, qui fine Aprilis \& Maio maturatur.

Duplex eft Arbor, mas \& foemina : qux fibi fimiles funt excepta magnitudine, nam foemina per omnia minor eft mare. Frequentes funt in Prxfectura Itamaracá \& Rì grande.

\section{A P V T $\quad$ T X X I V. \\ Ibirúba, Ibixuma, do Quity'.}

Birüba per taleolas tranfplantatur, ob excellentiam, fructum exfilvis in hortos tranflata. Arbor cortice, ligno \& nafcendi modo Guaiaba fimilis, ramos autem

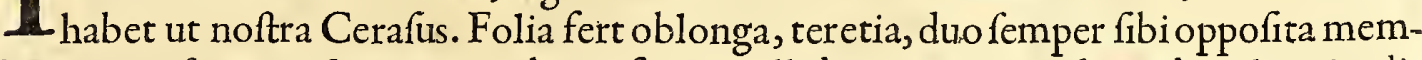
branacea, fuperius faturate viridia, inferius pallida, uno nervo fecundum longitudi-

I B I R $\mathrm{V}^{\prime}$ B A。

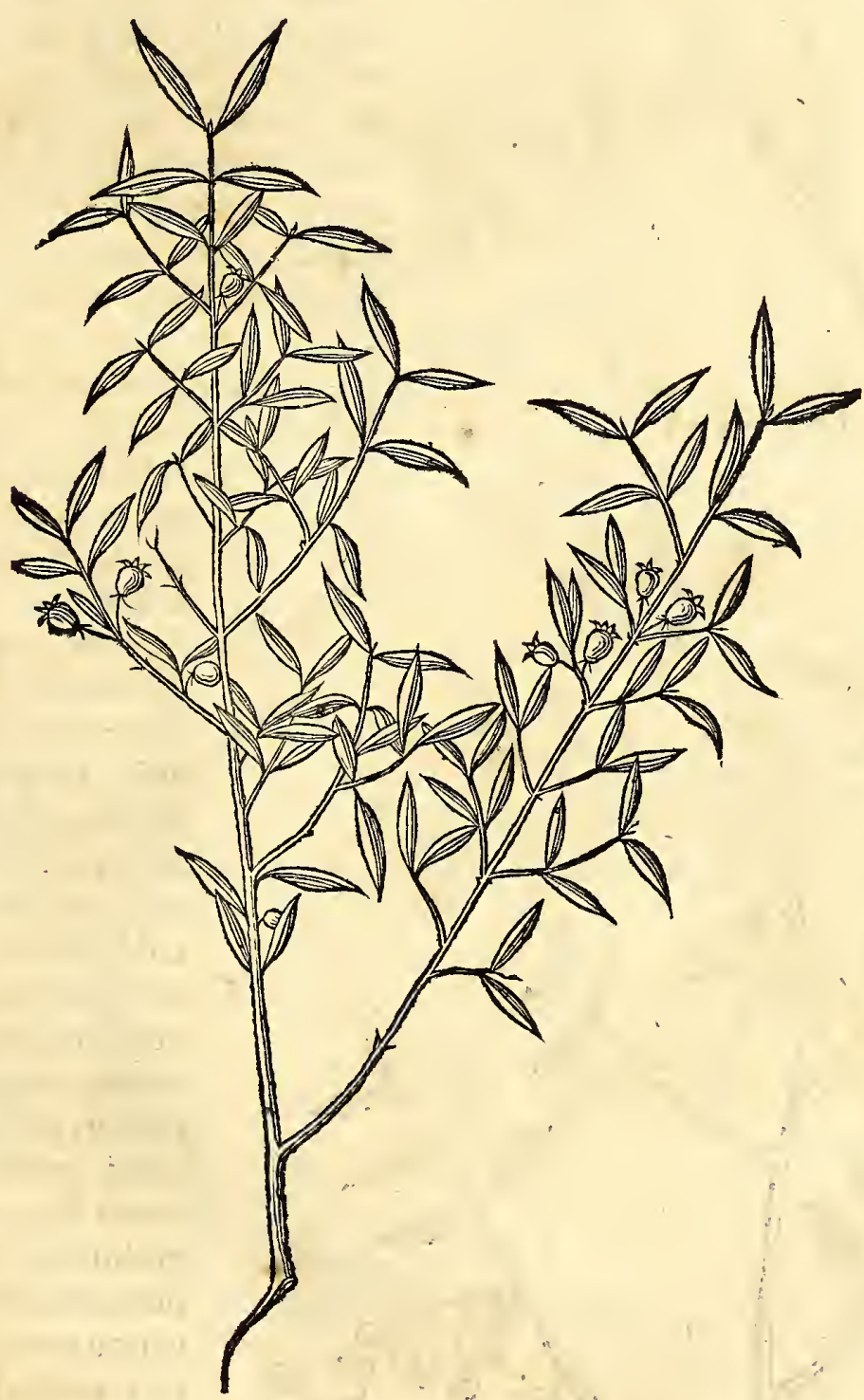

nem, nullis venis tranfverfis. Inter quxhinc inde caudici flores cum pediculo adnafcuntur albi ut in Graiáaba fere, quibus umbilicatus fructus fuccedit egregie flavus turbinatus rotundus magnitudine Pruni, cuticula tenui veltitus \& carne fucculenta fulva, faporis acidiufculiac paulatim amaricantis, haud ingrati : odoris fubdulcis \& vinofi. Magna copia fine noxa comeditur, \& $\& b$ incolis venum exponitur. Con-

$$
031 \text { tinet }
$$


Ibixv'ma ARbor Saponaria.
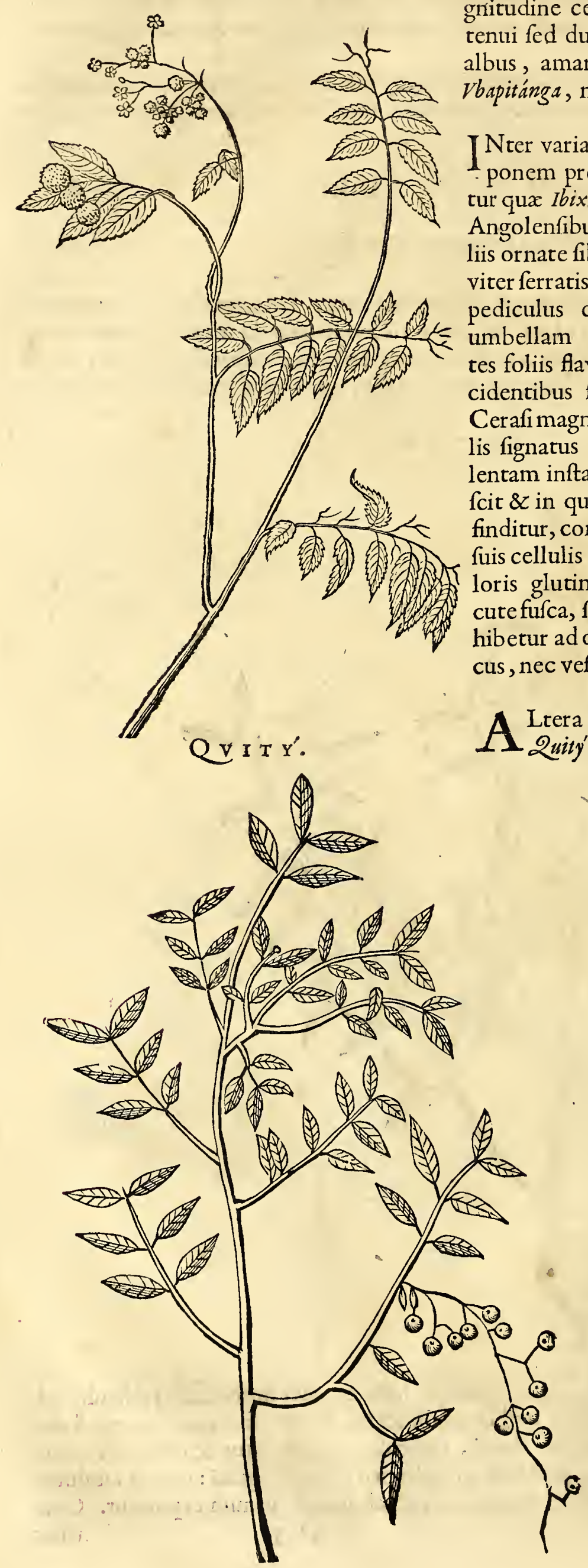

P I O N IS

tinet lapidem unum atque alterum $\mathrm{ma}$ gritudine cerafini, rotundum, cortice tenti fed duro veftitum;in 'quo nucleus albus, amaricans, qui fimilis eft lapidi Vbapitánga, nec facile dignofcuntur.

INter varias plantas \& arbores quæ Sa1 ponem producunt, illa facile præfertur qux Ibixúma nomen habet, Motamba Angolenfibus. Arbor inftar Cerafi, foliis ornate fibi oppofitis,per ambitum leviter ferratis : juxta qux brevis enafcitur pediculus continens flofculos quafi in umbellam congeftos, quinque conftantes foliis flavis deorfum flexis. His decidentibus fructus fuccedit orbicularis Cerafi magnitudine immaturus tuberculis fignatus concifus continet materiam lentam inftar vifci; maturus autem nigrefcit $\&$ in quinque partes $x$ quales fponte finditur, continens femina fufca oblonga, fuis cellulis inclufa. Cortex cineritii coloris glutinofus eft, \& derafa exteriori cute fufca, feu recens feu ficcus tuto adhibetur ad omnia ad quæ Sapo Hifpanicus, nec veftibus nocet.

A Ltera Saponaria eft arbor pumila; Quity'Indigenis, Lufitanis Pao de Sebaon dicta. Cortice eft cinereo, ligno molli \& fragili ramis contortis inftar Rufci. Foliis læte viridibus, ejufdem ut pracedentis figur $x$ $\&$ conftructionis, exceptis denticulis. Floribus eft exiguis. In fingularibus ramulis dependent multi fructus menfe Octobre maturefcentes, quilibet proprio pediculo infidentes magnitudine fphxrulæ luforix, cum duplici rotunda flava eminentia adeo tranfplendentes, ut globulus contentus cerni poffit, \& fructu commoto ftrepitum edat. Hic globulus eft niger, adeoque durus ut nifi malleo confringinon poffit. Ex his perforatis corollx fiunt precarix ebeno praftantiores \& leviores. Pulpa hrec fupernafcens Saponis vicem expletadeoque amari \& acris faporis, ut creber ejus ufus veftibus noceat, ac proinde prioris arbo- 
HIS T. NATVRAI. \& MEDIC. LI в. IV.

arboris fructus magis ufualis. Hic enim contufus $\&$ rivis inditus aquam inficit $\&$ pifces enecat ficut Timbó $\&$ alix cortices arborum.

Eadem arbor in multis Americx regionibus frequens eft, tefte Oviedo, Clufio \& aliis.

\section{$\begin{array}{llllllllll}C & A & P & V & T & X & X & \text { V. }\end{array}$}

\section{Tatai-iba, Ibirapitánga, Iacarandá, \&o Queraíba.}

$\mathrm{A}$

Rbor filveftris Tatai-iba dida, quibufdam Morus alba ob affinitatem figurx \& naturx Mori albx appellatur. undiquaque in filvis littoralibus frequens. Ex ligno veteri parant tincturam egregie flavam coquendo. Cortex arboris $\mathrm{cft}$

T A T A $I^{\prime}-I$ B A.

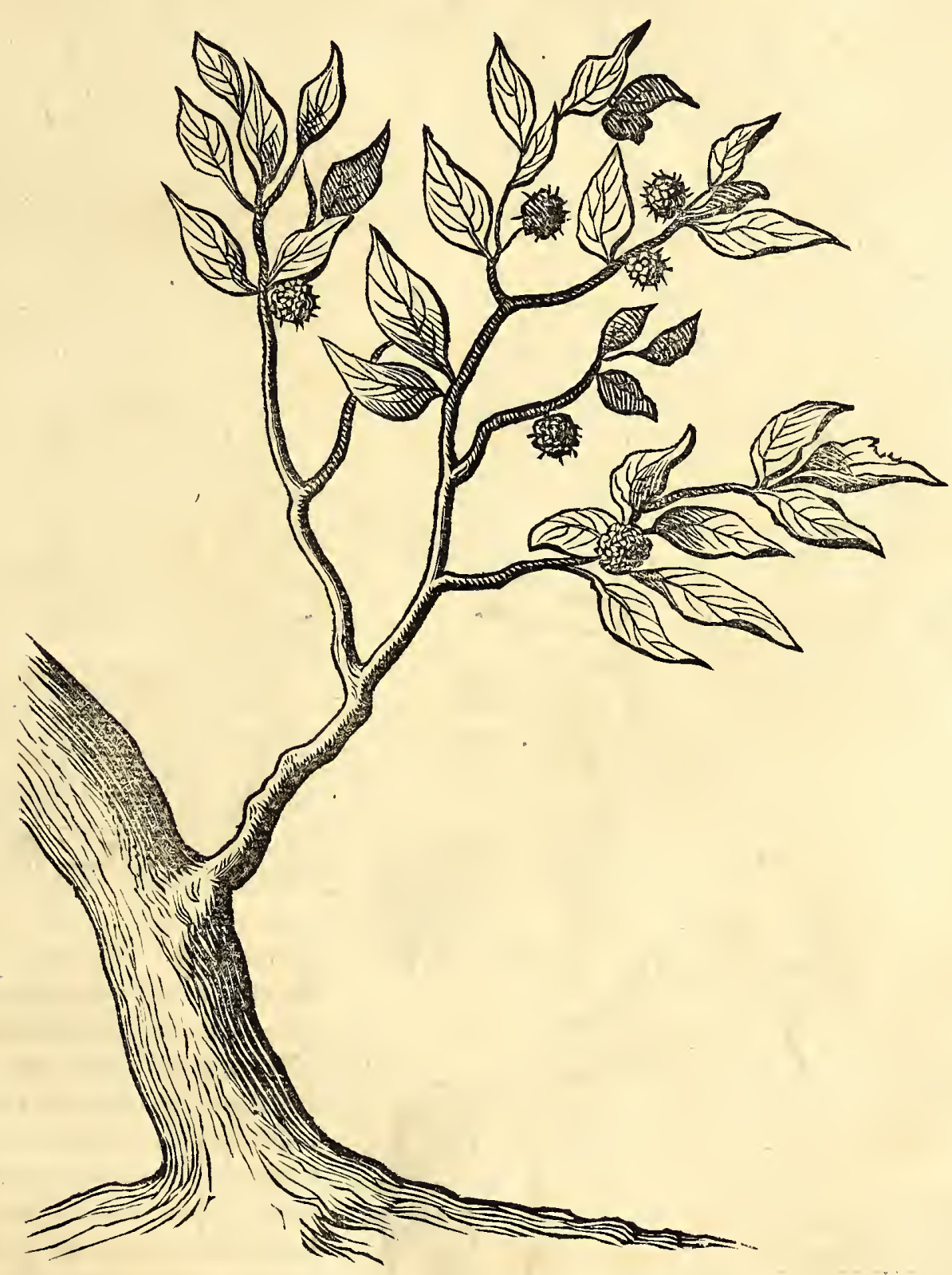

cinereus, fed lignum intus flavum $\&$ duriffimum. Folia acuminata $\&$ fubtiliter ferrata, in ramis inordinate pofita. Fructus maturefcit fine xeftatis circa Martium, mediocris Mori eft magnitudine, rotundus, è tuberculis compofitus, pallidi coloris, exterius exigua habens filamenta fufca. Succulentus eft $\&$ faporofus, atque comeditur ut Morum fed quia magis filveftris \& minus dulcis, additur vinum \& faccharum. In Pulpa multa granula albicantia funt difperfa. 

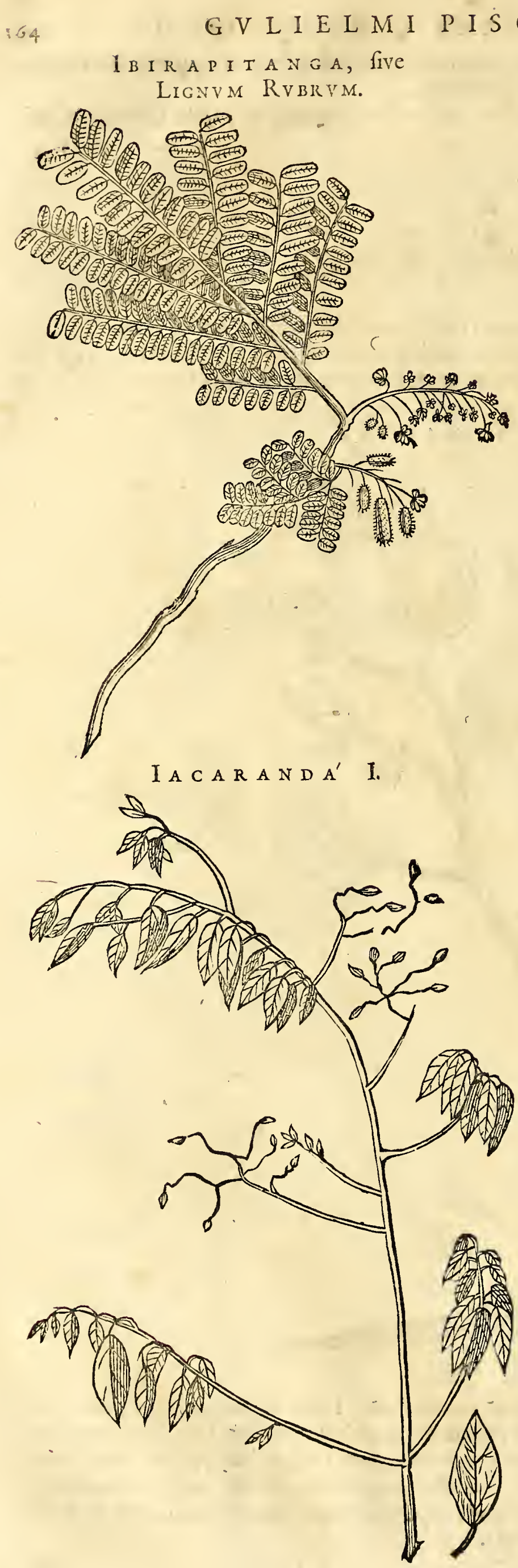

Birapitánga, qux arbor, mè= 1 rito à Lufitanis Pao do Brafil per excellentiam dicta, alta eft \& vafta, cortice fufco brevibus fpinis armato:ramis $\&$ foliis alternatim pofitis figura Buxi foliis fimilibus fplendentibus \& faturate viridibus. In ramis hinc inde etiam ramuli proveniunt multis exiguis floribus copulatis ornati ipfo $\mathrm{Li}$ lio convallium fragrantioribus pulchre variegati coloris $\mathrm{fla}$ vefcentis. His pereuntibus fuccedunt filiqux, oblongx, planx, compreffx, exterius aculeatæ, obfcure fufcx, rubras, fpiendentes exiguas fabas aliquot in fe continentes. In locis mari vicinis non apparet, fed tantum in mediterraneis filvis, unde magno labore ad littoralia vehitur.

Tinctura hujus ligni rubra toto orbe eft notiffima. Sed minima moles tam vaft $x$ arboris tingit, dempta enin magna parte ligni fuperioris, fola matrix tibiam circa craffa rubri eft coloris. cujus poftea rafura quanti fit laboris novit optime Ergaftulum Amftelodamenfe.

Lignum eft frigidum \& ficcum, mitigat febres, reftringit \& corroborat inftar Sandali. Maceratum in frigida inter collyria contra ophthal. mias ufurpatur cum fucceffu.

TAcarandá. Ob ligni variegati coloris elegantiam $x$ que ac ob ufum medicum, celeberrimam hanc arborem dedi: quarum dux funt fpecies facie \& efficacia fatis difcrepantes. Prioris lignum eft album ; altcrius, nigrum, ut Palo vel Pao Santo, ac bene olens, atque durum, frequens eft in Bahia omnium Sanctorum.

Iacarandá alba, inodora \& Pruno Europxx fimilis, in apricis locis mediterrancis reperitur. Foliis parvis acuminatis 
HIST. NATVRAL. \& MEDIC. LIE. IV.

natis directe fibi oppofitis, fuperne fplendentibus, inferne albicantibus. In quolibet ramo verfus exteriora multi proveniunt ramuli,qui quafi racematim per multos dies habent globulos nuclei cerafini magnitudine, coloris olivacei qui fe aperientes in quinque finduntur folia, deorfum inclinata qua interius tactu \& vifu referunt holofericum olivaceum fplendens : his infidet flos dulcis odoris unico folio luteo fubrotundo ad latus explicato conftans: in medio autem foris eriguntur, multa ftamina alba apicibus luteis fatis magnis, in fcoparumfeta cearum modum. Floribus fuccedit fructus palmæ manus magnitudinis \& craffitiei afpectu rarus ob in ufitatos naturæ lufus, quod gibbofus \& finuofus admodum $\&$ contortus appareat, atque ob gravitatem fernper pendulus, quem viridem \& albicante fmegmate (quod Barbari Saponis loco ufurpant) turgentem avulferunt fo cii mei in remotiffimis defertis, ex viridi mutatur in Havefcentem, exficcatus in cinericium colorem, moxque fe aperit. Fructus haud edulis nifi co.. ctus. Incolx exinde coquint pulmentum quoddam ftomacho imprimis amicum \& falubre quod Manipoy vocant.

$\mathrm{Q}$

Veraiba nafcitur locis apricis graminofis. Arbor corticerugofo $\&$ grifeo, in ramis habens tria, quatuor, aut quinque folia in frondem. congefta, pediculis fuis tres innitentia, pallide viridia, figura Salvia, folida \& ad tactum dura, neivo fecundum longitudinem \& venis obliquis predita. Flores fert flavos, inodo-: ros, menfe potiffimum Ianuario, figura campanx, fuperius in quinquie partes fectos. Ita ut arbor florens tota flava appareat, inftar arboris quam Lufitani vocant $P_{a o d} d$ arco: nam race-
I A C A R A N D A' II.
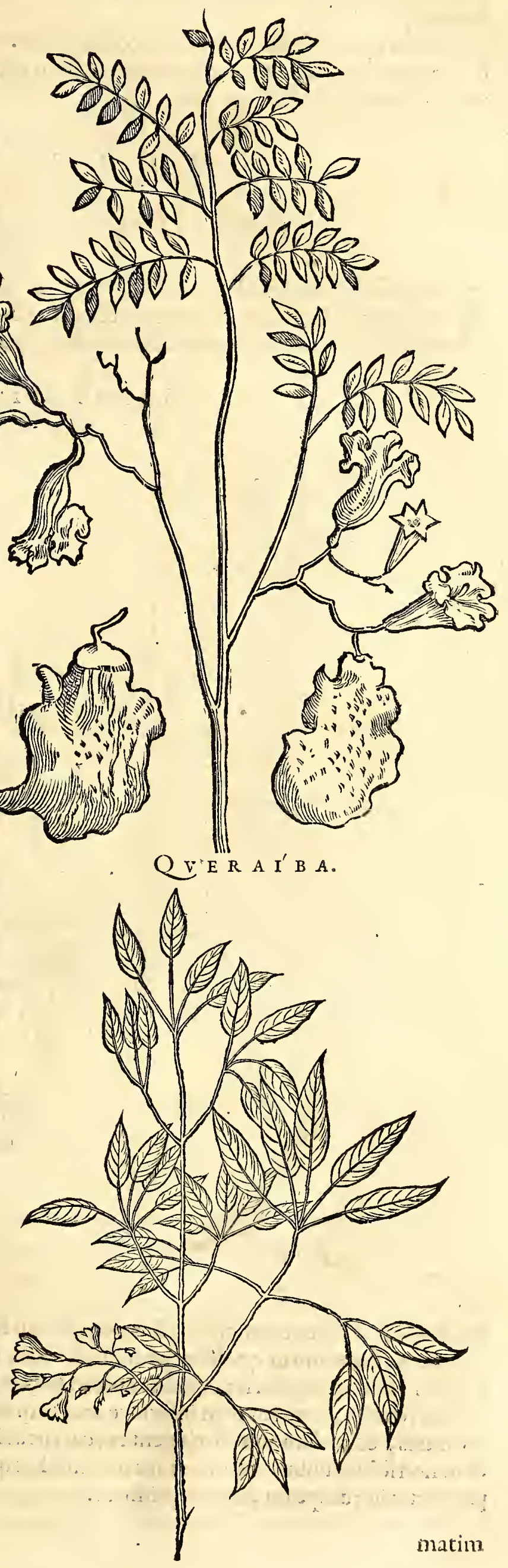
matim congefti funt flores, quibus filiqux long $\&$ compreffx fuccedunt, fed nullius ufus.

Cortex hujus arboris contufus \& coctus oleum fuppeditat ad vulnera fananda , \& ulcera vetera in tibiis aut aliis partibus curanda efficaciffimum. Ac proinde in nofocomiis frequens mili ejus fuit ufus.

$$
\text { C A P V T } \mathrm{XXV} \text {. }
$$

Iabotipita: Vimbú, \& Avaramo-temó.

$\mathrm{I}$

Abetapitá littoralibus Brafilix locis luxuriat. Arbor eft mediocris altitudinis; cortice grifeo, inæquali, ligno molli \& lento: Folia fert, alternatim oppofita, dilute

viridia; $\&$ in certis ramulis copiofos flofculos racematim congeftos, pentaphyl-

I A. B O T A P I T A

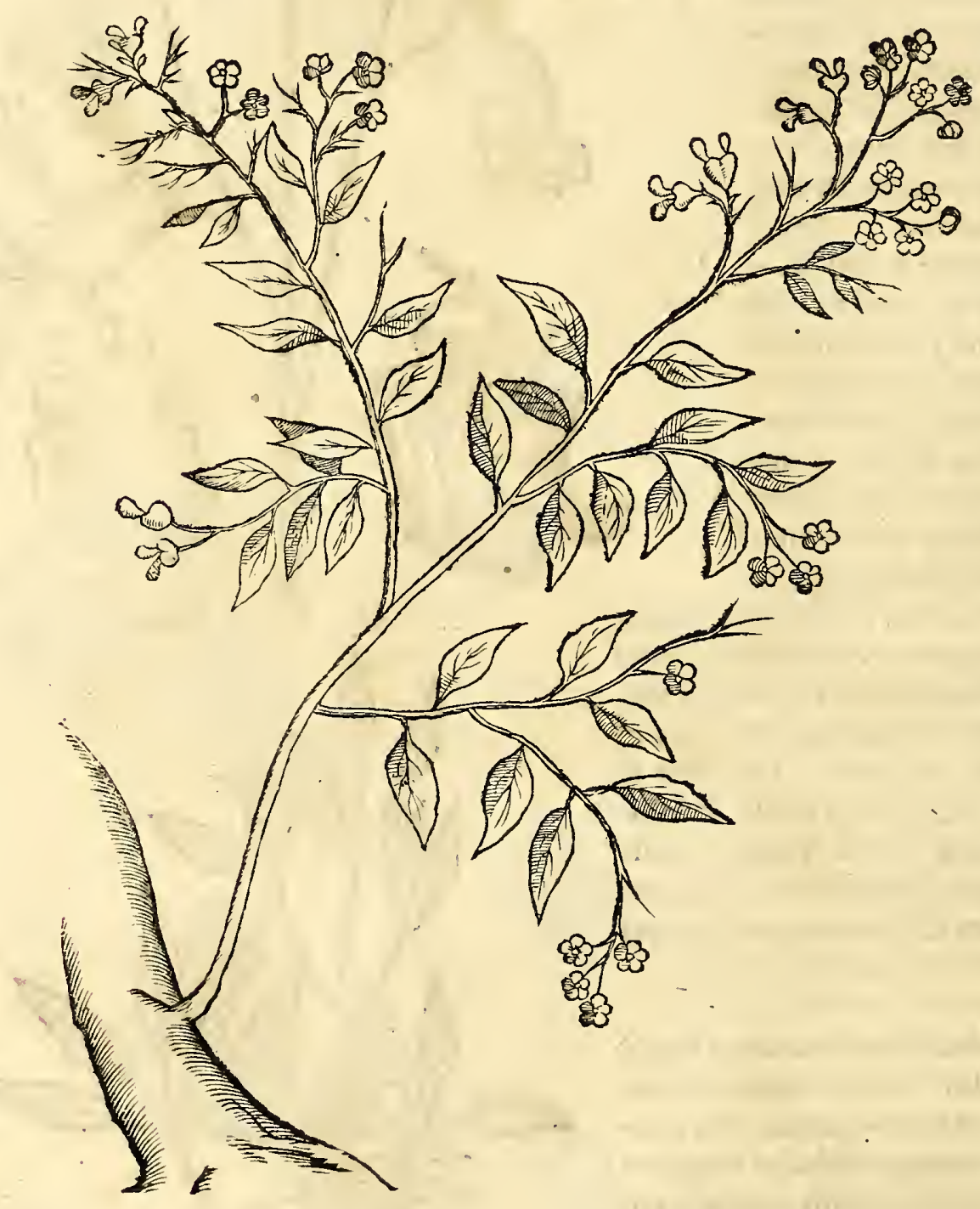

Ios flavos fuavifimi odoris. Fructus quoque qui maturefcit Martio menfe provenit racematim : nimiruin in quolibet pediculo bacca, magnitudine nuclei cerafini, conica ferc vel quafi triangularis; cuilibet autem baccx, alix tres quatuorve infident fine pediculis, ovales, ejufdem cum inferiore magnitudinis, omnes coloris nigri, ut myrtilli noftrates, \& codem modo tingentes, carent acinis, \& funt faporis adftringentis; eifdem non folum ufibus dicati quibus myrtilli Europxi; fed \& oleum in quotidianos ufus pro acetariis receptúm ex is exprimitur. 


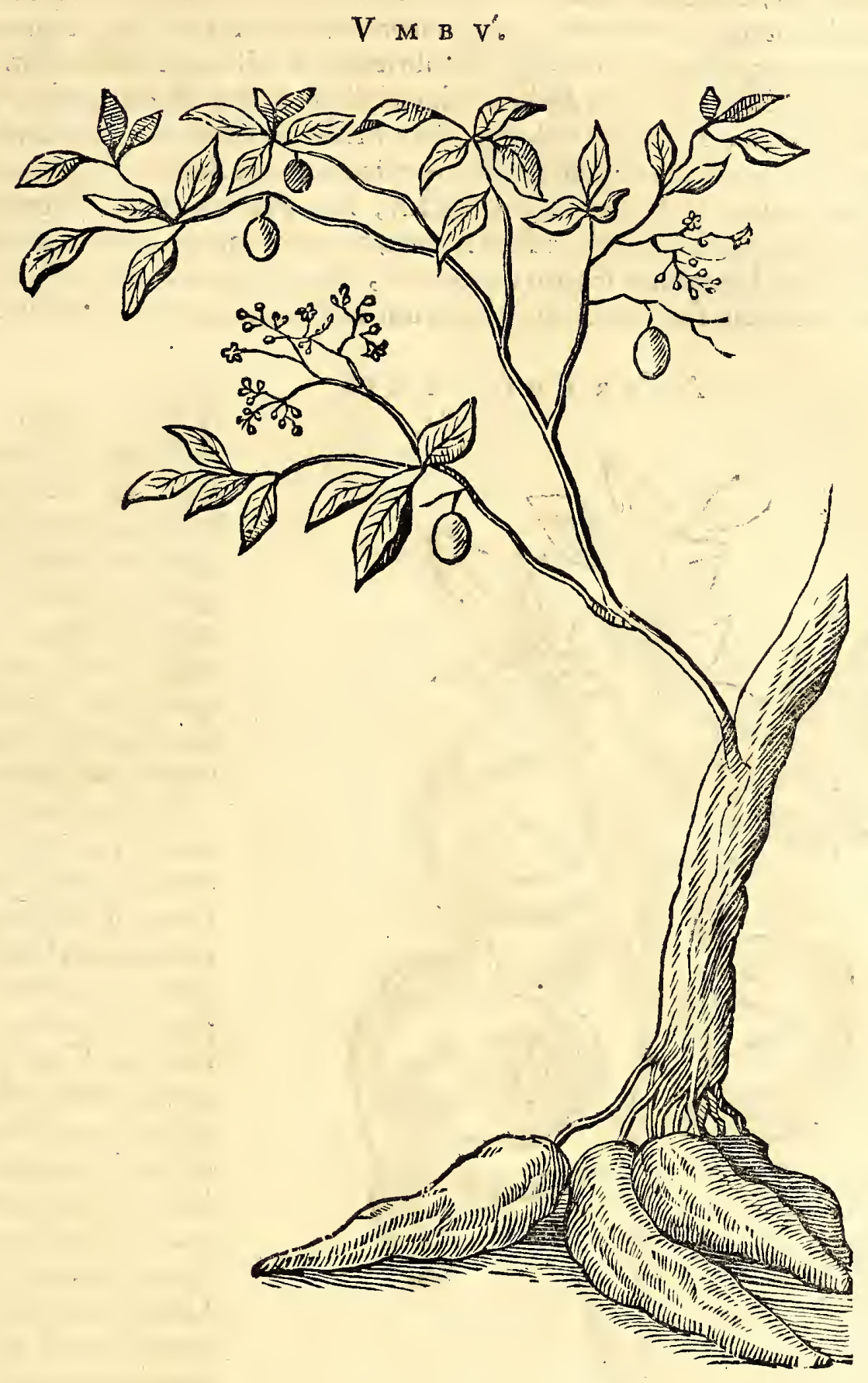

TNicam tantum ex hoc Arborum genere in habitata Brafilix parte, hactenus con f́piccre licuit in pago Iguaraçú excultam : diffitæ autem fylvæinter Guojanam $\& 2 p_{a-}$ raybam fluvios iis luxuriant. E longinquo profpicienti, magnitudine, ftructura \& fructu, parva Citrus vel Limonia videtur.

Trunco eft breviori nec craffo, fed ramis multis tortuofis, inbelle quidem fabricatis -dividitur. Folia fert haud magna, lævia, læteque virentia, guftu autem acida \& adftringentia: Florem albicantem: Fructum exalbo flavefcentem, Pruno majori fimilen fed carne duriori, licet pauca, quod intus magnum contineat lapidem, ficut fructus Acaia, qui ubi maturuerit menfibus pluviis, faporis fit gratiflimi ex acido dulcis: fin minus adeo eftaufterus, ut fuporem dentibus inferat; proindeque tunc eidem ufui cui folia, fcilicet ad refrigerandum \& adftringendum refervantur. Radix autem, cui peculiare quid præ cxteris arborum radicibus conceflum, imprimis eft notanda: quod -longe lateque, in diverfa $\&$ crafla,ponderof $x$ molis tubera fub terra luxuriet; fi pondus, figuram atque colorem, exterius cinereum, confideres, majores radices Batate aut Inbyame diceres; à quibus tamen ablata levi pellicula, differunt : quippeinterius confpiciun tur nivei coloris, molli turgidaque medulla, Cucurbitx plane fimili, qua mandu- 
cata, in aquofum, frigidum fuccum, eumque dulcifimum atque palato gratiffimum, folvitur. Febricitantes, xftuantes peregrinatores mirifice reficit: ut ipfe quam pluries fum expertus; neque aqux dulcedine \& falubritate Citrullo quicquam cedit.

Datur \& alia fpecies qux Iva.umbá Brafilienf. dicta, Arbor eft cortice fufco, ac hinc inde in ramis fpinofa. Folia fert oblonga, late virìidia, craffiufcula, ad tactum mollia, nunc alternatim, nunc fibi oppofita; eifdem pediculis multi flofculi exigui pentaphylli junctim promanant, quibus fuccedunt fructus, flavi Pruni noftratis magnitudine \& figura \& carnc qux grati ac fubbacidi eft faporis, cui amari quid intermixtium eft. Menfibus æftivis circa Ianuarium fructus maturefcit, tuncque fponte decidit \& colligitur. Lapis in eo contentus fragilis continet nucleum avellanæin omnibus frmilem.

A V ARAMO-TEMO'.

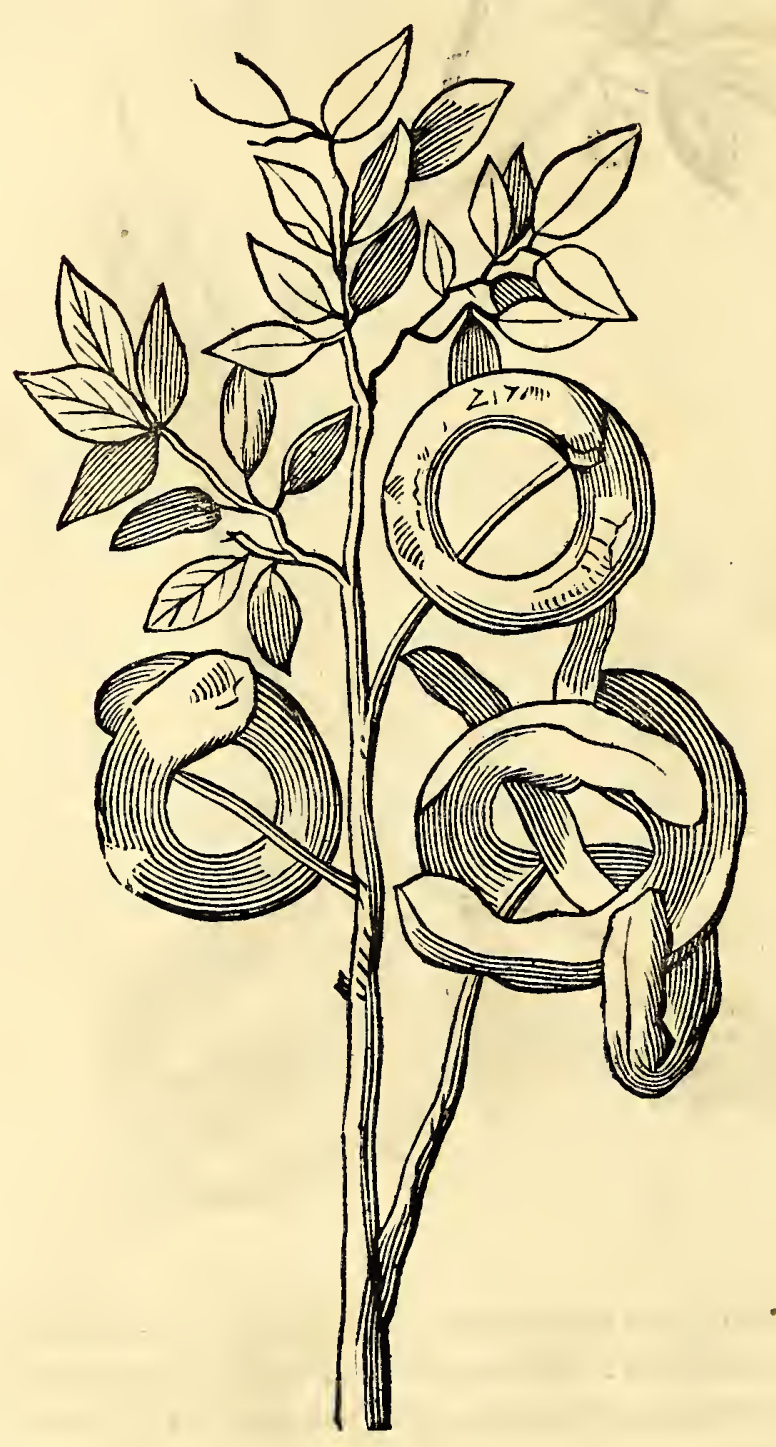

TI Ác arbor mediocris eft altitudinis, montofis locis crefcens, foliis trifte viridibus, exiguis, buccini fimilibus, filiquis eft inutilibus ex minio nigrefcentibus, miris variifque modis incurvatis, qux aftivis menfibus confpiciuntur $\&$ acinis rubris exiguis repletx funt.

Cortice exterius eft cineritio, interius fature rubente, quem folum expertiores in Médicinæ ufum receperunt, licet foliis exdem qualitates adftringentes à nonnullis attribuantur. Cortex enim qui guifu amarus eft, five in pulveremredactus, five excoctus, \& fomentiloco adhibitus, ulceribus inveteratis \& male moratis feliciter medetur, ipfumque Cancrum fubinde, infigni mundificandi \& ficcandi qualitate curaffe fuit compertum.

Præter hrec quia efficaciflime adftringit, balnea ad firmandas efforminatas carnes ex illis conficiuntur. Potiffimum vero meretricesiis utuntur, ut laxis pudendi partibus tonum reftituant, xtatemque tuto mentiantur; imo qua poffibile, virginitatem hoc dolo pratendant.

\section{A P V $\quad \mathrm{T} \quad \mathrm{X} \times \mathrm{X}$ I I.}

$$
\text { Cebipira, Iitó, Guabipocacabiba, do Mureçi. }
$$

Raffitie \& altitudine infignis Arbor in rariffimis nemoribus reperitur, çebipiraguaçú Brafilienfibus dicta, ad differentiam ejus notandam ab ea qux çebipiramiri, id eft, çebipira minor, ab illis appellatur. Vtraque funt foliis exilibus oblongis, fplendentibus, Olex fimilibus, fed craffioribus, minufque acuminatis, ordine digeftis, 
HIST. NATVRAL。 \& MEDIC. LIB. IV.

digeftis, \&z pediculis utrimquefe contingentibus.

Flores ferunt copiofifimos inodoros fuo quollibet pediculoinfiftentes, quinque foliolis corruga tis $\&$ dilute cæruleis confantes. Ex horum calyce nafcitur filiquula ex viridi flavefcens, in qua femen continetur.

Vtriufque arboris lignum commendatur, \& non minus celebre apud fabros ad axes machinarum Saccharearum conficiendos, quam cortex apud Brafilianos ad ufum medicum exiftit. Qui craffus eft \& compactus, grifeus cum fufco mixtus, faporis amari atque adftringentis, calidus infuper $\&$ ficcus in fecundo gradu. Balnea \& decocta ex illo folo fiunt præetantiffima adverfus morbos à frigore natos, pedum \& ventris tumores, dolorefque membrorum, Curimentos Lufitanis dictos ; ipfam denique Luem veneream, non inveteratam, forinfecus \& intrinfecus adhibita, reftituunt, fudor efque provo cant.

Cum vero abftergendi facultate fimul \& acrimonia quadam agant, fcabiei, tinexque $\&$ aliis ejufdem generis cutaneis affectibus medentur.

T. Ec Arbor eft Pyri Europxæ magnitudine, undiquaque obvia: Foliis tenuibus, oblongis, acuminatis, nervo eminentifecundum longitudinem excurrente, parvo pediculo cauli ordinate appofitis. Fructus racematim copulatos profert. Arbor ut ob fructuum rarum afpectum multis nota; ita paucioribus ejus radicis qualitates probeconftant. Si ulli figura, colore, totaque prorfus facic, racemos uvarum

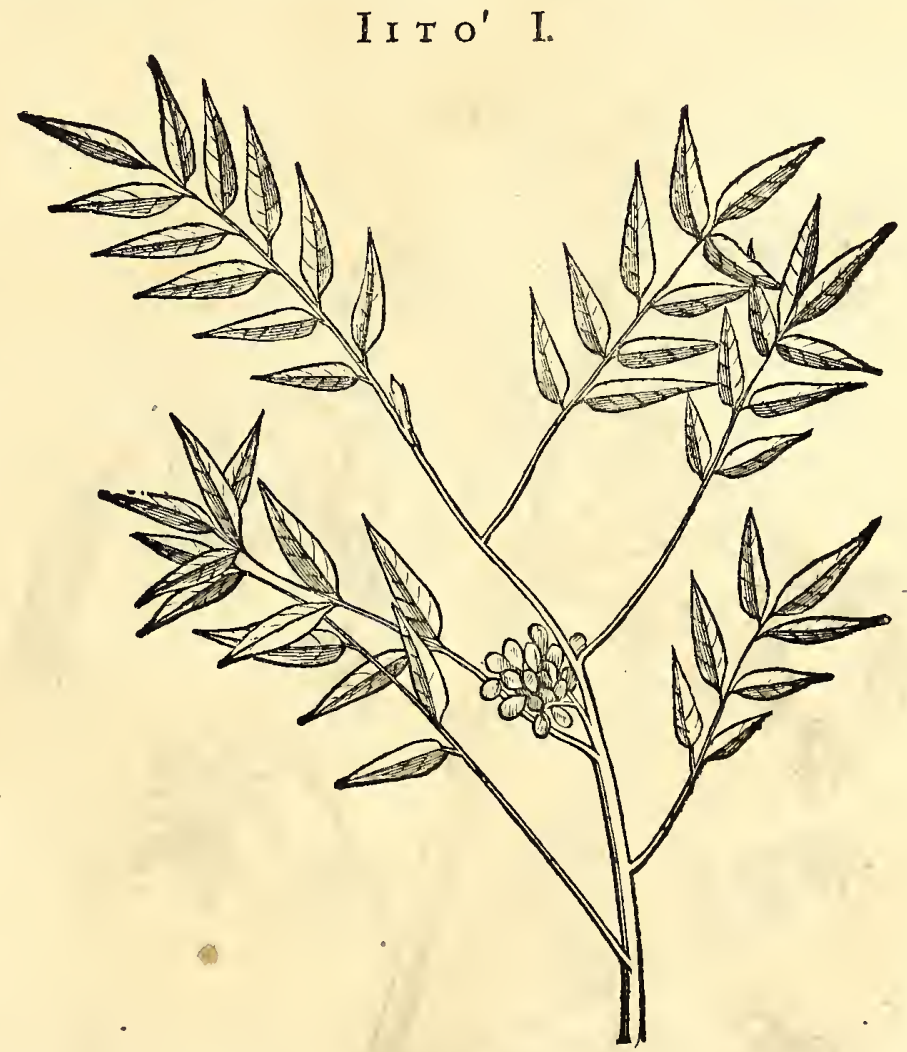

c̀ longinquo adfpicienti videantur, hujus fane arb oris fructus funt, quorum uvæ tamen inutiles habitx, lignexque intus exiftunt. Toto anno apparent, verno tempore lxte Havefcentes, moxtriftis miniati coloris funt, nihilque promittunt, ut neque folia, neque lignum ipfum arboris : fed totum in cortice radicis quod ad rem noftram faciat, confi- 
170

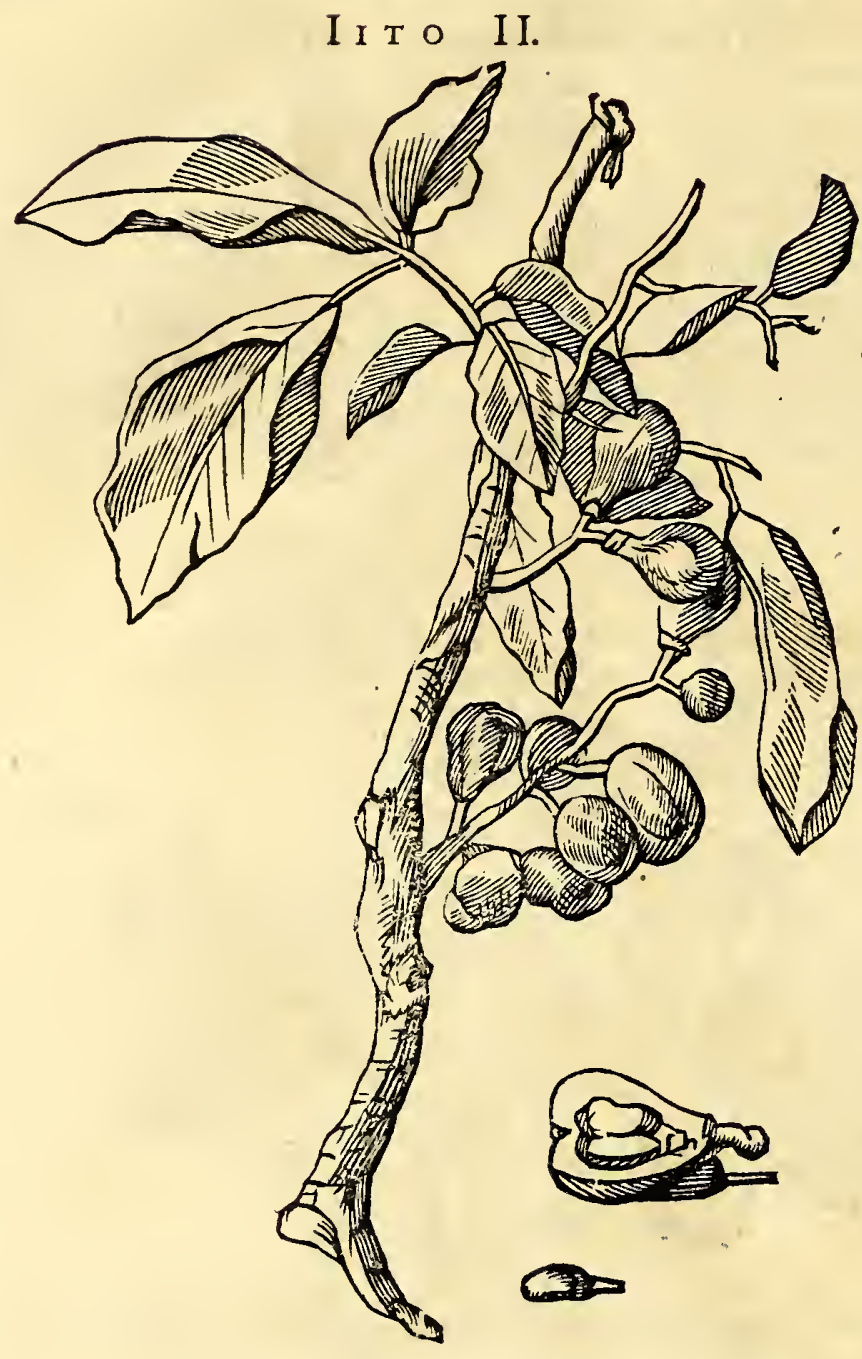

GV A в I P O C A C $А$ в I'B $A$.

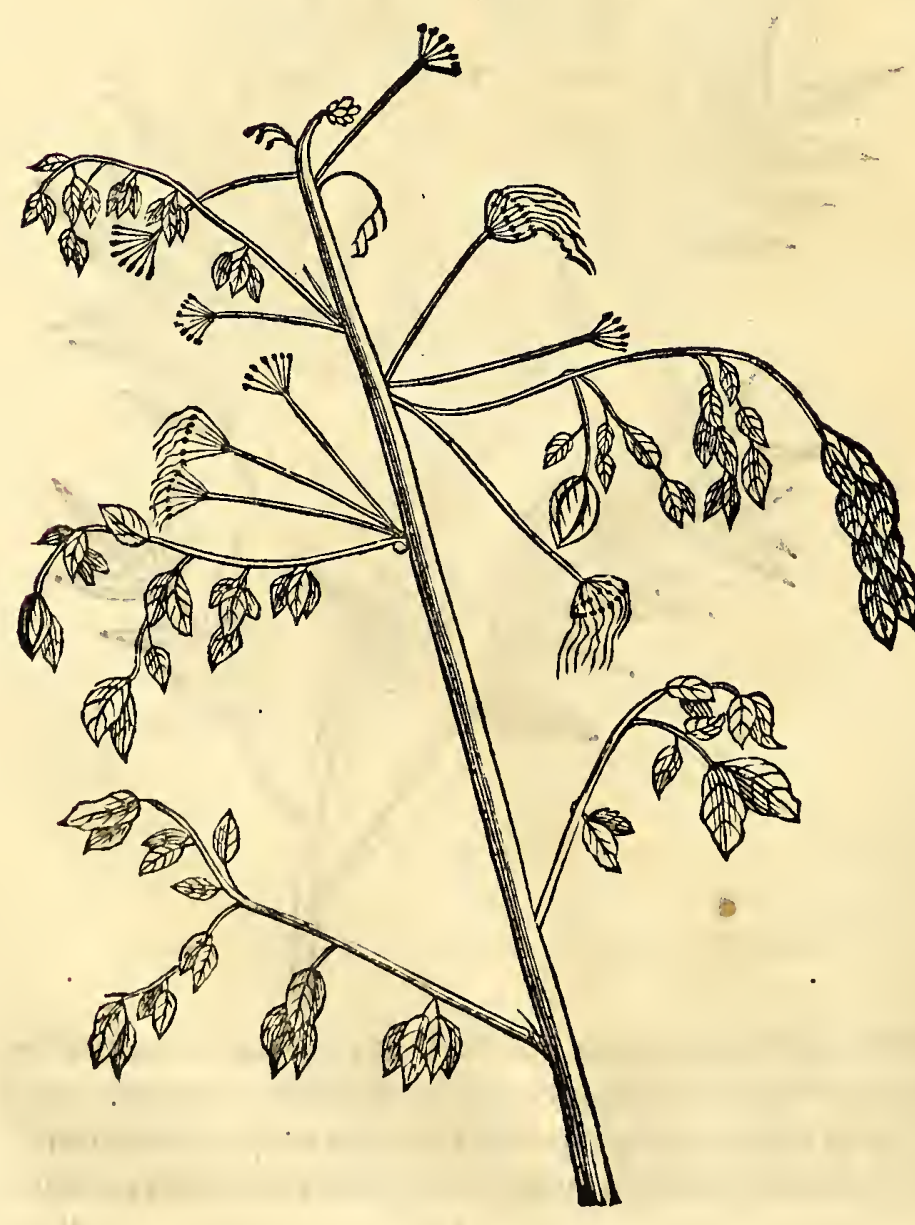

tit. Cujus efficacia indomita ad turbandum \& purgandum corpus, tam alteà natura pofita, ut non impune ab imperito vulgo tractetur. Quippe dubito an plures calamitates ex illius abufu an optatos fucceffus ex oportuno ufu, promanaffe viderim. Nec mirum, cum unufquifque idiota ad Medicinx Sacraria afpirare audens, nec remedii agentis, nec fubjecti patientis rationem habeat, loco medicamenti, venenum porrigat.

Cortex enim hujus radicis, qui faporis eft acris \& calidi in pulverem redactus $a b$ indigenis $\&$ robuftioribus agricolis Lufitanis contra inveteratas obftructiones capitur indifcreta quantitate, femipugillus circiter. Mihi rarior fuit illius ufus, idque nifi deficiente forte benigniore medicamento, mediantibus tamen correctoriis, \& qux vim purgatricem infringunt, ficut oportet fieri ex judicio Medici, præcipue circa validiora $\&$ incognita fimplicia.

Datur \& alia fpecies Iitó (cujus quidem qualitates à me nondum exploratx) cortice,fufco, qui multa punctula hinc inde fparfa lutea habet. Folia bina fibi opponuntur, nervo confpicuo \& prominente fecundum longitudinem, venis in quibufdam fibi invicem oppofitis, in quibufdam autem alternatim pofitis.

Poft florem fequitur fruCus, parvx Ficus figura, obfcure lutei coloris, qui in fe tria ovalia femina continet, magnitudine feminis Pomi vulgaris, cuticula obfcure flava tedta, nucleo albicante.

FI Anc ego Siliquofam arFl borem nominavi, quod vix fibi conftent incolx de genuino nomine. Quidam Portugalli $P a o$ velbo \& Pao molle dixerunt; quod cortex illius adeo mollis \& rugofus exiftat. Parum admodum differt ab ea arbore, qux filiqua dulcis Dodonxo, Offi-

cinis 
HIST. NATVRAL. \& MEIDC. LIB. IV.

cinis panis Sancti Ioannis dicitur ; floribus enim decidentibus, quod fit menfe Martio, fliquæ fuccedunt, dulces, tortuof $\&$ deformes, primum quidem virides, mo\& maturitatem confecutæ, fiunt nigræ \& putrefcunt.

Arbor hæc, non umbrofis filvis, fed apricis campis gaudet, mirificeque peregrinan. tes delectat florum elegantia \& odore. Ligno, cortice,medulla \& fragilitate Sambuci xmula. In extremitatibus ramorum longa germina protrudit. Folia ad tactum dura, inftar membranacex chartx fuperius dilute viridia. Circa foliorum ramulos prodeunt pediculi in quorum extremitate flofculimulti umbellatim congefti nafcuntur coloris Havi, odoris fuaviffimi. In medio autem ftaminum loco propendent multa filamenta crifpa ipfi croco figura \& colore fimilia.

Radicis medulla exalbo flavefcens, à leviori cortice liberata in taleolas diffecatur, exque aqua fontana macerata per noctem fub dio, \&aliquoties pota, non uni malo medetur. "Vrinam enim cunctantem cit, renum \& vefic $x$ obftructionibus opitulatur, ejufque decoctum vel folum Gonorrhœas reftituiffe vidi. Succus corticis recens oculis inditus eorum inflammationes tollit. Dilutum ejus fubamari nec tamen ingrati eft faporis, partiumque eft valde tenuium, \& aftrictionem aliquam poft fe relinquit.

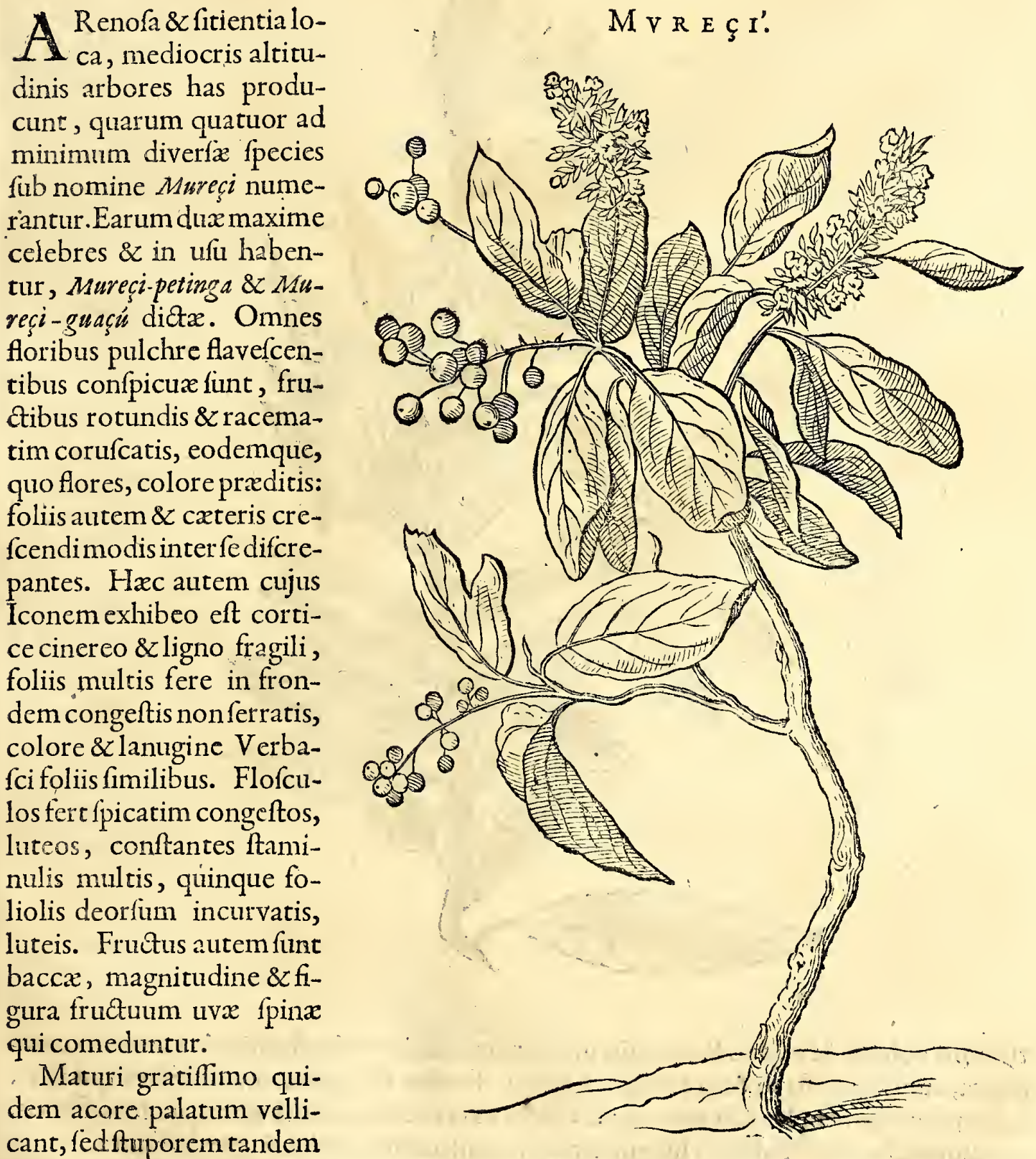
dentibus inferunt, fimulque aftringendo intenfe refrigerant. Quapropter probe condiri folent \& loco Berberis, quibus fapore \& efficacia fimiles funt, ægris ad exftinguendam fitim \& Itomachum recreandum exhibentur.

Prima harum, utpote fructu minus filveftri, à me maxime fuit expetita, $\&$ in officina repofita. Ejus quoque corticibus retia $\&$ coria tinguntur \& contra putrefactio-

$\mathrm{P}_{2}$ nes 
nes muniuntur. Barbari exiifdem potiones conficiunt, ad purgandum alvum, quodà menondum comprobatum eft.

$$
\begin{aligned}
& \begin{array}{lllllll}
C & A & P & V & T & X & X
\end{array} \\
& \text { Iaparandiba, Cuieté, \& Iaróba. }
\end{aligned}
$$

Abor eft cortice cinereo inftar Alni, ligno duro, medullofo. Cui folia inordinaA e \& copiofe circumpofita cum pediculis, foliis Ianipapa fimilia, oblonga, acuRe \& copio $\&$ coftis eminentibus obliquis perducta. Flores fert infignes ex octo craffioribus foliis factos; $\&$ junctim in trifido pediculo copulatos, figur $x$, magni-

I A I A R A N D I'BA.

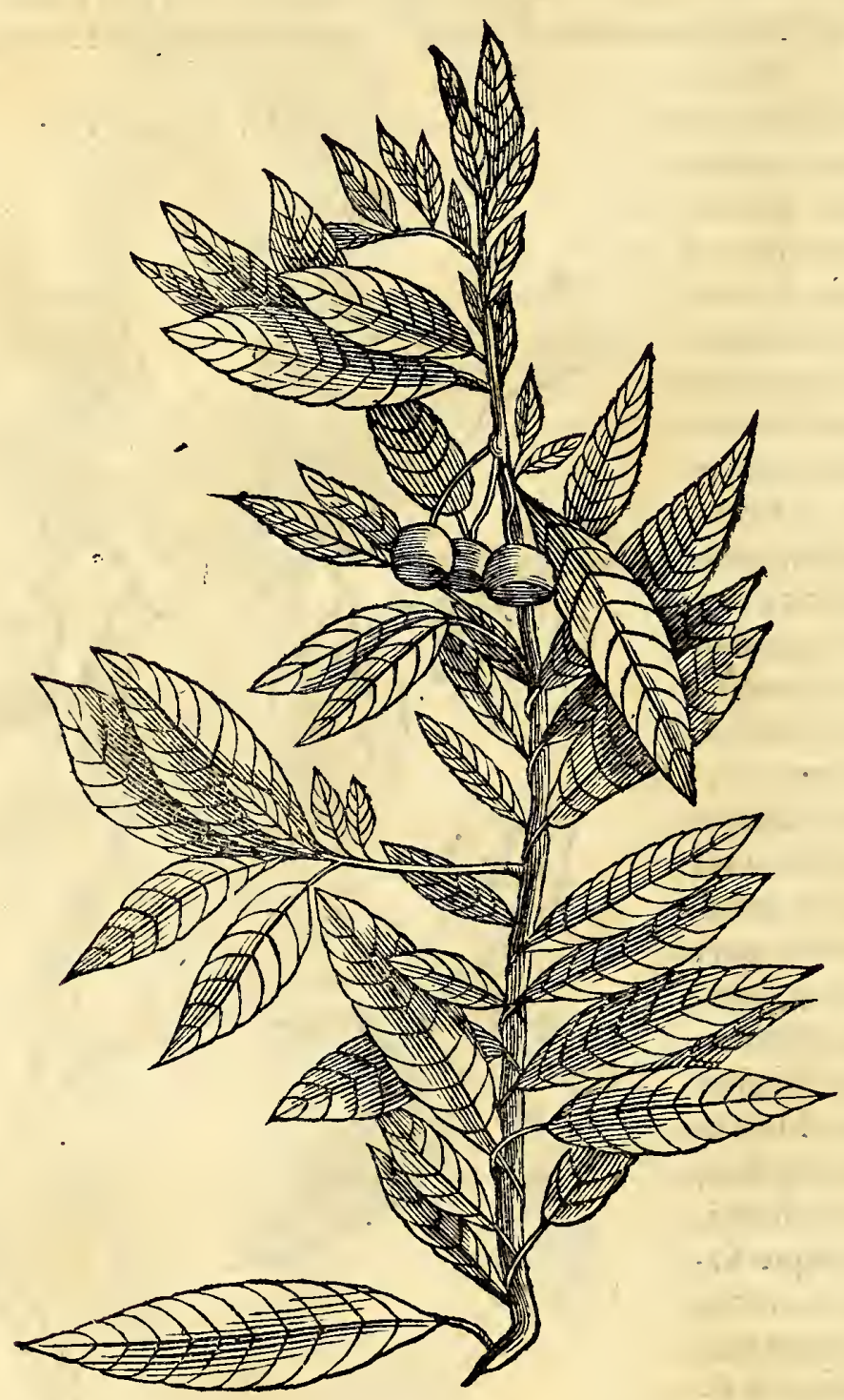

tudinis, coloris \& odoris Rofarum, in quorum medio multa ftaminula in orbem compofita, cum apice flavo \& tremulo. Quibus fruetus fuccedint maliformes quidem, fed fuperna parte plani, extus grifei, intus flavi coloris, contincntes nucleos fatuos, angulofos, hepatici coloris, fplendentes, magnitudine Avellan $x$, cordis figura.

De vulgari hac arbore pauca addenda habco. Ramorum paucitatem foliorum frequentia compenfat, quibus folis vis medicatrix, quantum hactenus conftitit, infita eft. Nam flore licer pulcherrimo fuavifimique odoris ; tum fructibus egregic copulatis, ornetur, nihil tamen Culinæ vel Pharmacopœix ufui funt. Folia autem vel integra vel contufa hepatifquercgioni applicata, durities hypochondriorum reftituunt, cifdcm- 
HIST. NAT VRAL. \& MEDIC. LIB. IY.

que malis, fir rite ex arte prxparentur, atque in Apozemate exhibeantur, conducunt ac proinde numero aperientium afcribenda funt.

Quotufquifque enim advena vel indigena, optime fanitati fux fe confuluiffe putat, fi contra Hepatis \& Mefenteriioppilationes medicamina conficiat, quorum bafis eft Iuripeba, Tapirapeck \& foliorum hujus Iaparandiba decoctum, aliquoties reiteratum pro ratione $\&$ conftitutione xgrotantis.

Vieté in triviis littoralibus toto fere anno obvia

familiaris \& el egans hæc arbor, qux vulgo corrupte Cochine. Cortice grifeo, ut Sambucus, contorte nafcitur, longos habens rames, \& in iis folia frondatim $\&$ alternatim pofita certis temporibus, fimul omnia folia amittit, biduo autem poft iterum foliis onufta cernitur. Per ramos decifos $\&$ terr $x$ infixos facile propagatur. Folia inufitat $x$ funt figur $x$, verfus extremitatem enim fenfim ampliantur, fuperius faturate viridia \& fplendentia inferius dilutiora, nervo recto \& venis tranfverfis confpicua.

Non folum in ramis fed \& paffim in caudice proveniunt tres quatuorve flores juxta fe pofiti, oblongi, figura pene Campanulix feu Convolvuli minoris, coloris ex albo \& viridi mixti, odoris naufeabundi. In medio autem quinque ftamina ejufdem coloris. His, fructus varix magnitudinis $\&$ figur $x$, primo virides mox nigri fuccedunt. Semina Cucurbitx modo ac nucleo flavefcente continentes. Immaturus fructus pulpam albam fucculentam dulcem continet, odore Nafturtium æmulans : qux Saccharo condita ab xgris \& fanis expetita ficut $\mathrm{Cu}-$ curbita $\&$ Citrullus, ejufdemque fere faporis $\&$ refrigerii. Vbi maturuerint fructus in aqua fervida coquuntur \& excavantur patinarum, poculorum \& lagenarum vices fupplentes. Pulpa enim matura non edulis, fed ad placandos capitis dolores pr $x$ fertim ex fervore Solis natos infigne remedium, fi convenienter temporibus \& fronti, forma cataplafmatis applicetur.

Familiaris eftarbor multis Americæ regionibus. Oviedus quoque ejus meminit fub nomine Higuero, de qua Clufius.

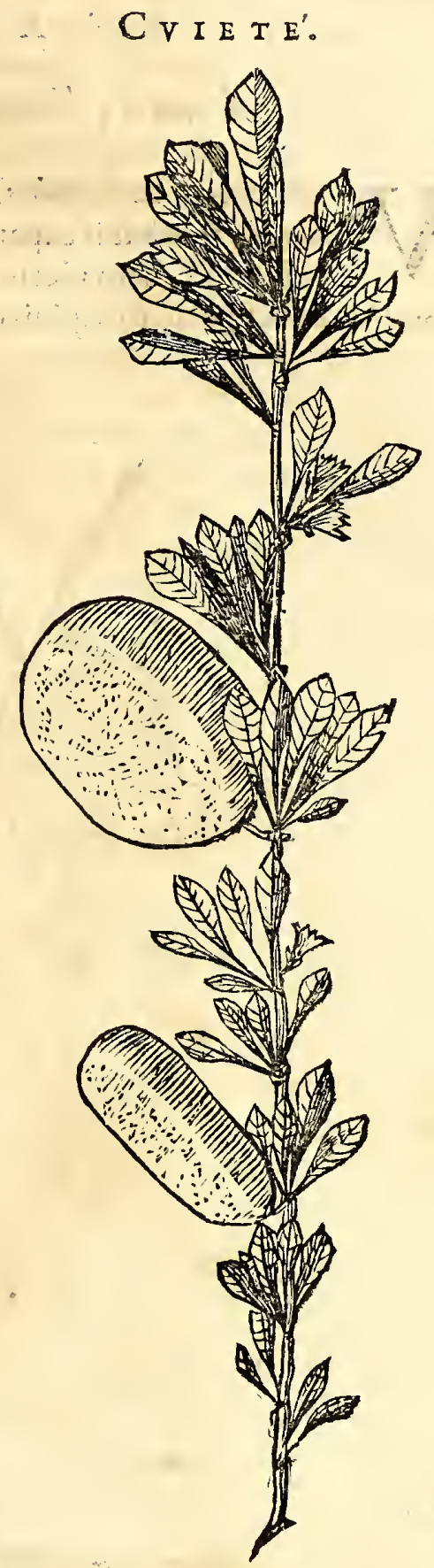

$S$ Armentofa hxc plan$S_{\text {ta Laróba , Lufitanis Că- }}$ fca amargofa ob amaritudinem diota. Enarratx arbori Cuicté diflimilis quidem fi externam figuram confideres; fed ratione fructuum, rei familiari dicatorum, admodum congener, ut merito fub eodem capite defcribi mereatur. Altiflima tecta \& arbores

IA K O B A.

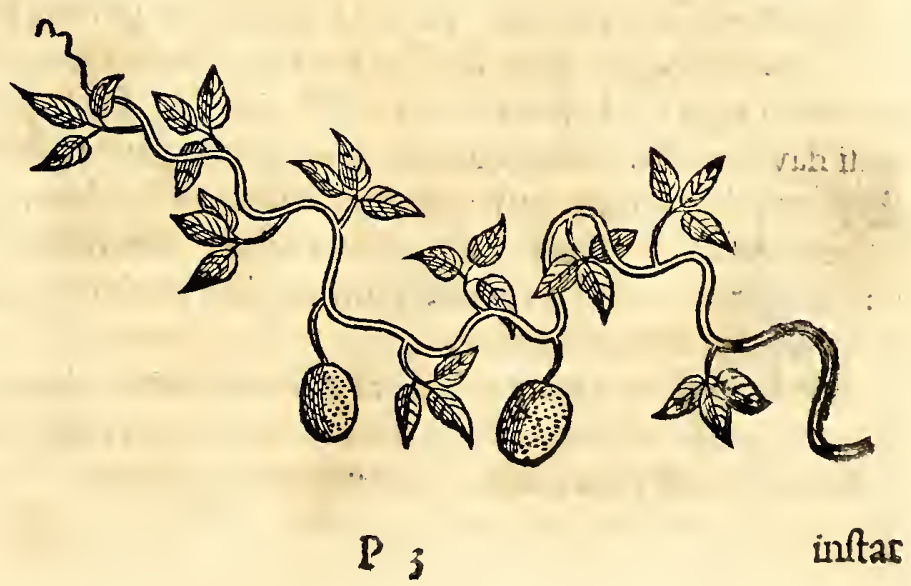


inftar hederæ confcendit caule lento tereti, cui hinc inde tria folia modo phafeoli, adnafcuntur.

\section{A P V T X.X I X. \\ Vmari, Saamóuna, Andira, \& Tremaé.}

$\mathrm{V}$

Mari, vulgo Camarinhas. Arbor vix medioctis altitudinis in campis graminofis ample ramis fuis expanditur, ligno albo Betalinum fere referente. caudice haud craffo, nam plerumque tres vel plures juxta fe nafcuntur : in ramis autem ramulos habet perpetuis f́pinis obfitos. Folia cylindracea parva vel directe vel alter-

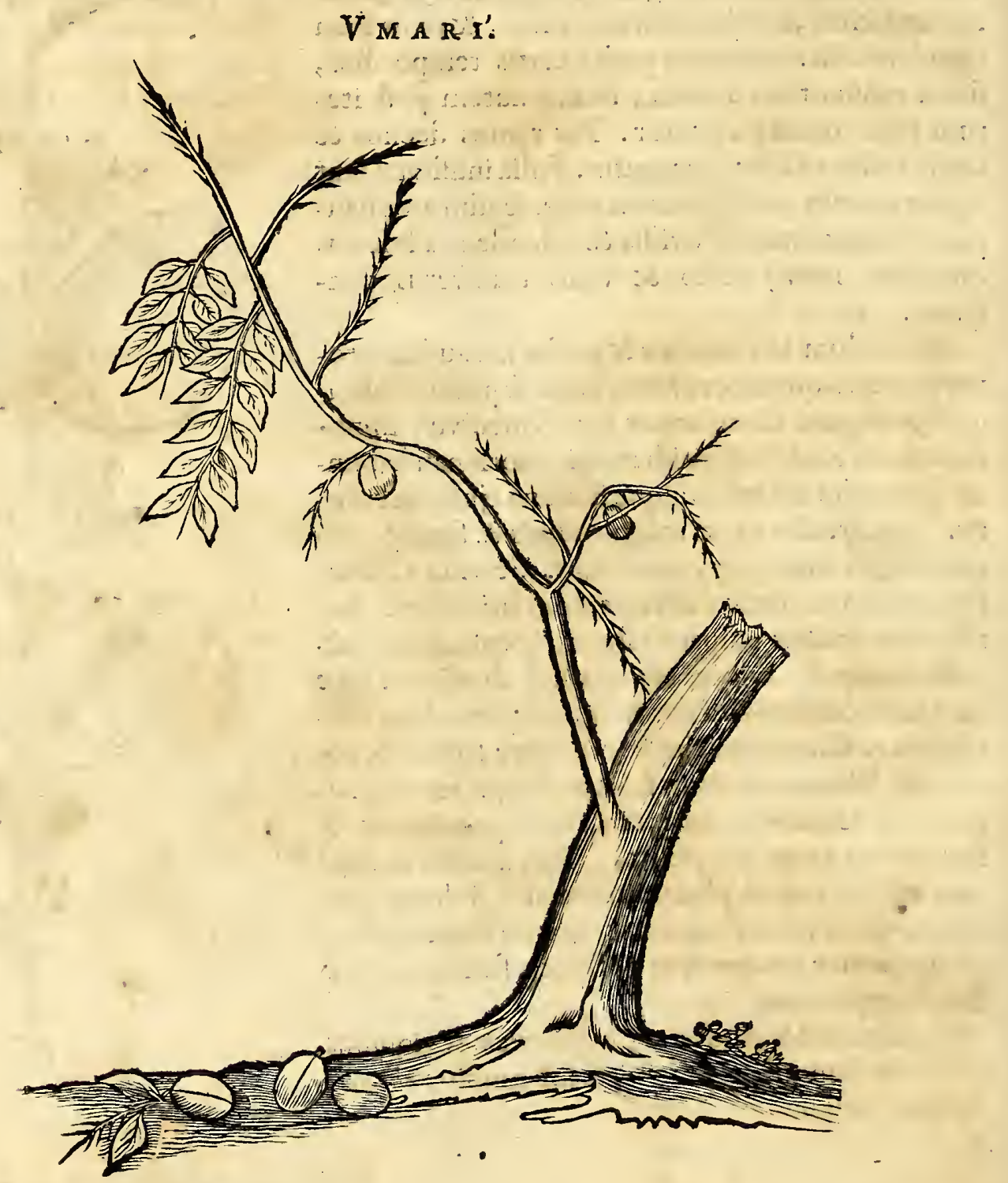

natim oppofita, faturate viridia, nervo fecundum longitudinem \& venis obliquis, vix digitum longa. Poft florem parvum flavum fuccedit fructus forma ovalis, magnitudine Pruni, ad vifum \& ad tactum referens Perficum noftras, coloris autem ex viridi flavefcentis: carne quoque flavefcente, pauca, dulci, qux ambit lapidem magnum ovalemalbicantem, qui continet nucleum edulem. Maturus fructus menfe Martio ponte decidit. Crudus comeftus turbat ventriculum \& facile excitat vomitum: ideo integer folet coqui, \& $z$ una cum nucleo contundi, atque cum carne vel pifcibusloco panis feu farin $x$ comedi.

Altera fpecies Vmari minus alta fructu, præcedentinon diffimili; fed nigricante coiore\& fapore acidiori. Qui ftomachi xftum temperat \& à febricitantibus expetitur. ufitani hos \& illos fructus Camarinhas appellant. 
HIS T. NATVRAL。 \& MEDIC. LI B. IV. IT5

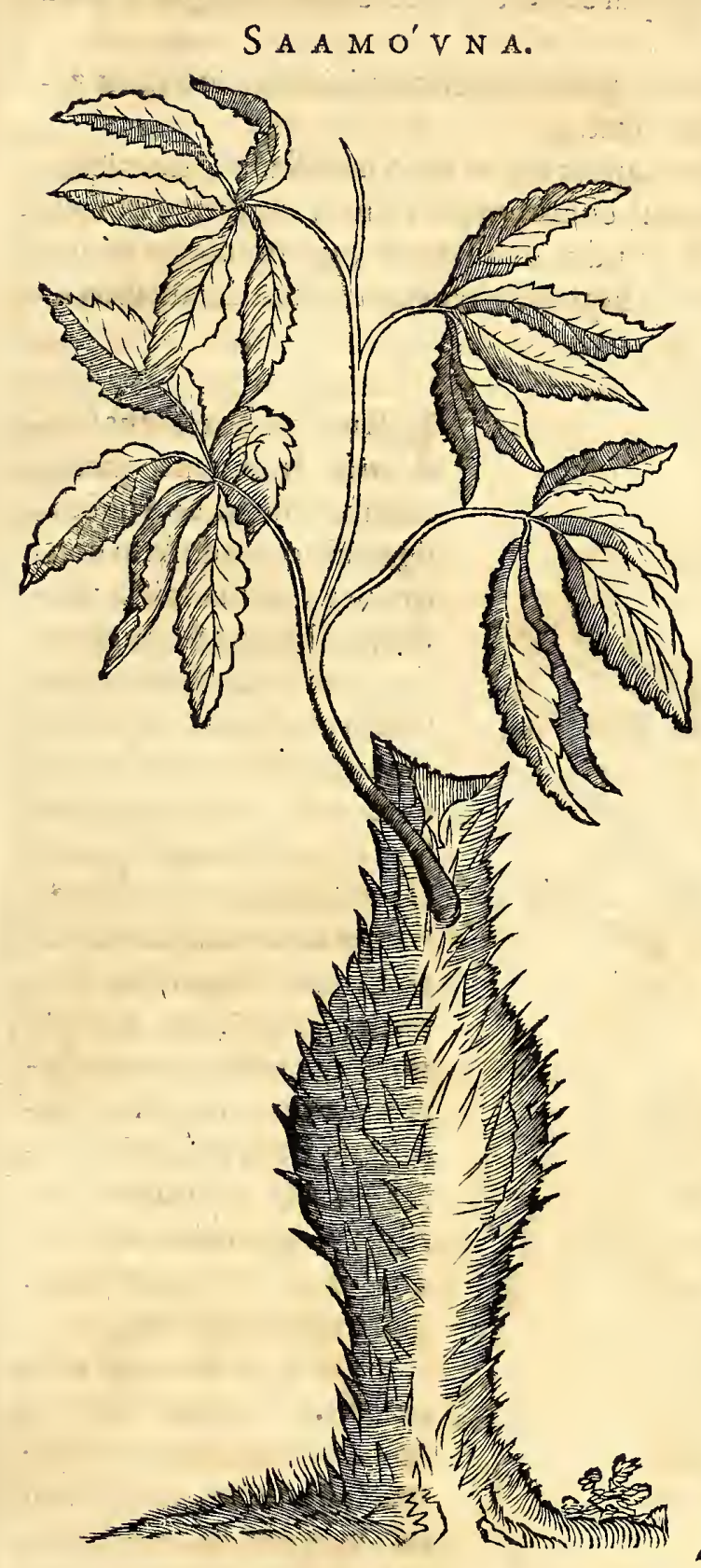

S Iquæx adfpectu mirabilis, excelfa $8:$ $\checkmark$ patula, fane eft hæc arbor Saanóuna, iifdem filvis mediterraneis, quibus $\mathrm{Ca}$ biréiba confpicienda. Quxfuperiori \& inferiori trunci parte, ordinaria eft craffitiei, fed in medio duplo plus obefa, inftar amphorx, adeoque tumida apparet ut peregrinantem attonitum remoretur. Ex ramis pediculi emergunt longi, pentaphyllum quisque protrudens ornate divifum \& ferratum, multis obliquis venis veftitum. Siliquas fert oblongas, pifa rubra continentes. Totus truncus fubftantia eft intus alba, medullofa $\&$ plane fuberofa exterius cinerei coloris, validis $\&$ horridis fpinis à pede ad verticem ufque obfeffa.

Ex turgidis fpinis rafis \& contufis, fuc. cus elicitur eximius, cujus vel exigua quantitas, inflammatis $\&$ involuntaric lacrymantibus oculis affrictus, medetur; tum manifefte quoque vifum acuit, atque robur illi addit.

A N D $\mathrm{r}^{\prime} \mathrm{R} A$, vulgo

$A$ N GELYN.

$\mathrm{D}$

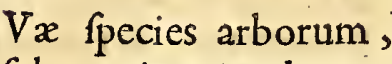
fub nomine Angelyn nominatæ, hinc inde in nemoribus confpiciuntur. Vtraque externa facie inter fe fibi fimiles; fed interna qualitate multum difcrepantes, qux facile utique dignofcuntur quod alterius cortex, lignum \& fructus amariffimi inftar Aloës;altera major nullius manifefti fit faporis, ex cujus fructibus Feræ pinguefcunt. Vtraque ligno eft duro \&zad æedés fabricandas apto, utraque cortice cinereo, foliis Lauri fimilibus, fed minoribus, oculis feu gemmis nigricantibus, è

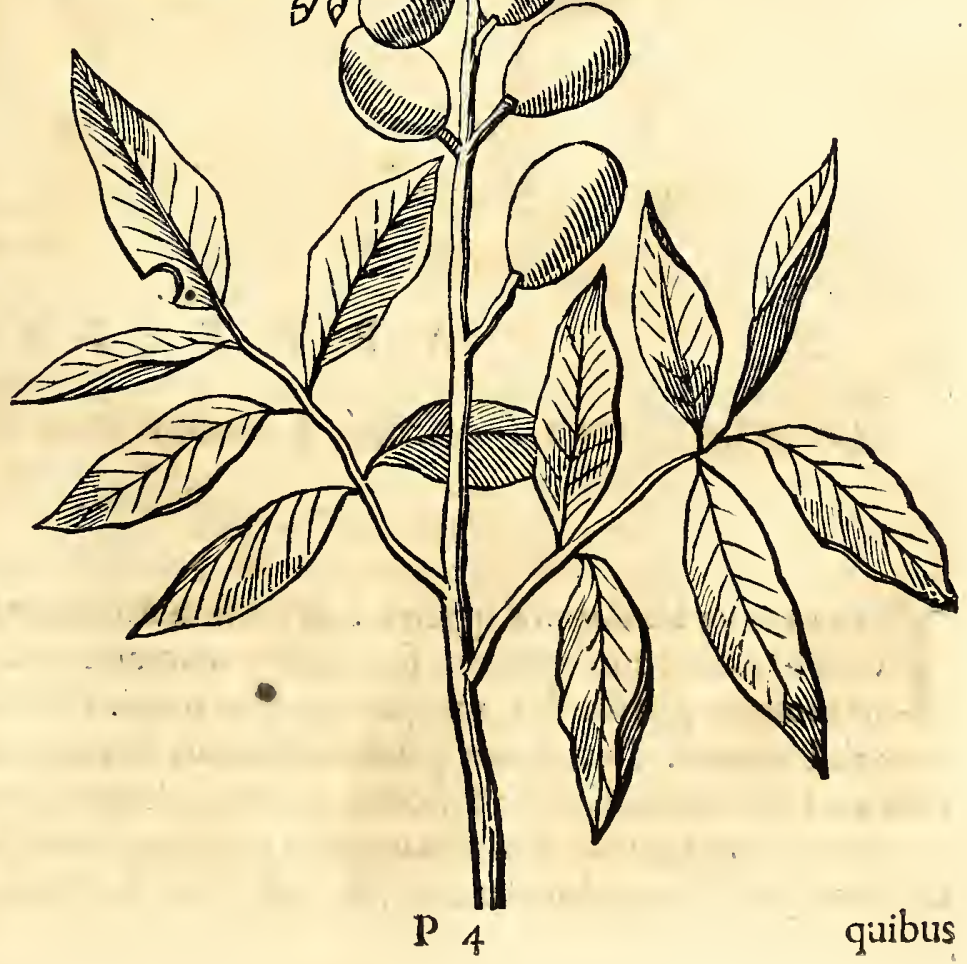


176

quibus plurimi flores fragrantes, copulati, purpureo \& cæruleo colore infignes, prorumpunt.

Fructum profert ovi figura \& magnitudine, primo faturate viridem, fed mox nigrefcentem, qui unolatere quafiluturam monftrat.

Fracto duro putamine, granum feu nucleus apparet, ex albo flavefcens, amaricantis $\&$ ingrati faporis, cum adftrictione quadam, cujus pulvis ventris lumbricos expugnat; ea tamen cautione, ut infra fcrupuli pondus exhibeatur, ne medicamentum in venenum abeat, quod quibufdam imperitis aliquando contigit, cum infantibus illud incaute exhibuiflent.

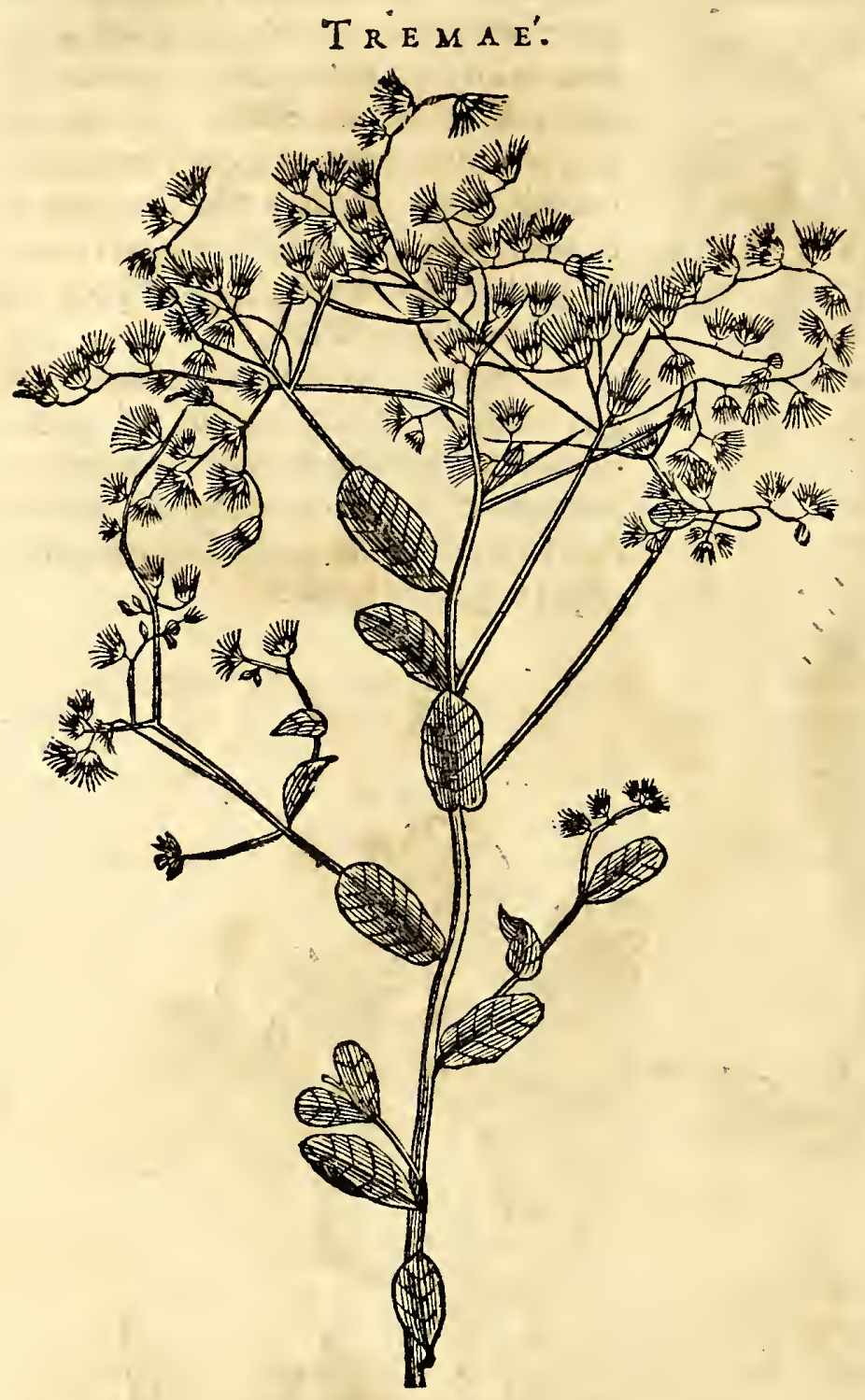

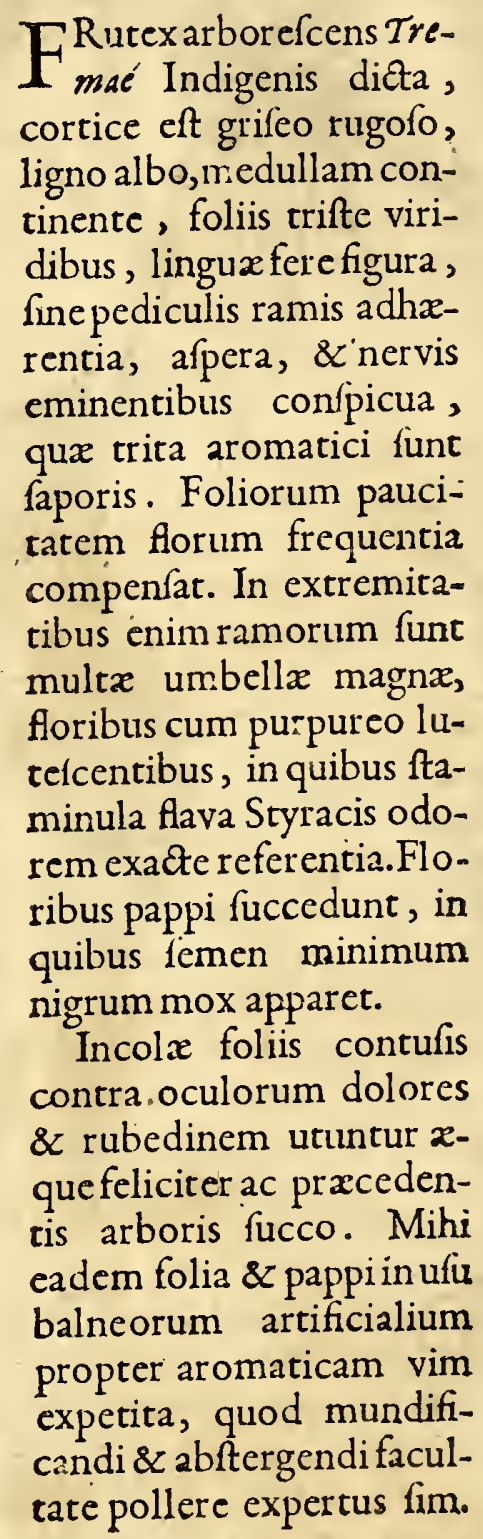

\section{A P V T $\mathrm{X} X \mathrm{X}$. \\ Diverfe Species Camare', Cambuy five Myrti Americane,
\& Cuipouna.}

I

Nter tot varias Camara $e^{\prime}$ pecies, tres tantum medicinales mihi innotuerunt, ’̀ quovis folo paffim emergentes. ficut infitis aromaticis qualitatibus; ita $\&$ facie externa multum fibi fimiles, nifi quod aliqux magis vel minus fruticefcant, floribufque nonnihil varient. Dux enim gaudent floribus exaureo rubris, qua Camará-tinga, \& Camara-Vmba dictx. Calid $\&$ ficcx habentur ad fecundum gradum.

Camará-Tinga in eximiam altitudinem exfurgit, ut caulibus, ita $\&$ foliis hirfutis $\&$ ad tactum afperis, in ambitu ferratis, foliis Vrticx fimilibus in $x$ qualis magnitudinis. In uvula, 
extrcmitate ramorum, ut $\&$ ad exortum foliorum ad caulem proveniunt oblongi pediculi aliquot juxta fe pofiti, multos flofculos habentes rubros. Poft flores fequitur uvula, baccis plena viridibus, magnitudine baccarum Sambuci. Flos infignis odoris : \& ipfa herba fuperat odore Mentham, dignaque fane qux inter $\mathrm{f}$ tivas plantas excolatur, tam ob pulchritudinein quam ob ufum. Hujus fpeciei tantum Iconem, hic exhibeo. Cxteræenim excepta colorum diverfitate huic fimillimx funt etiam internis qualitatibus.

Camará-Vaba, caule quoque eft hirfuto inque multos expanditur ramos: folia habet ferrata, Mentha crifp $x$ fimilia, fed magis fplendentia, leni hirfutic prædita, \& ad tactummollia, bina fibi invicem oppolita, quodlibet brevi pediculo. infidens. In extremitatibus ramorum enafcuntur flores, floribus præcedentis Camara haud diffimiles, egregie lutei, novem foliis conftantes, \& $\mathrm{z}$ in medio umbilico luteo, cui admixta ftaminula nigra.

Camará flore albo, caule eft lignofo, duro, quadrato, hifpido; in duorum aut trium pcdum affurgit altitudinem cum multis expanfis ramis, partim in terram procumbentibus. Folia rugola, hirta \& ad tactum dura, in ambitu ferrata, fplendentia, faturate viridia, bina fibi oppofita, excepto ramorum exortu: ibique umbellatim proveniunt flofculi parvi ; coloris candidi feu lactei, fuavis odor is, ut \& tota planta, imprimis fi fricetur.

Balnea ex hifce nobilioribus Camare fpeciebus optima conficiuntur tam ad roborandum interne, loco Meliffe \& Menthaftri : quam mundificandum externe; multos namque cutis affectus, ipfamque Scabiem abolent. Decoetum fiffatum curat ulcerd, vetera, \&lenit dolor es capitis ex frigore ortos, fi illo abluantur.

Quar ta denique Camara-miri dicta cæeteris annumeratur, cubitum longa, catule tenui \& lignofo, flore unico, exiguo, lutei coloris, qui (quod mirandum) quovis aiñni tempore fe aperit de die hora undecima, manetque expanfus ad fecundam pomeridianam, atque omnes fimul tunc eadem hora clauduntur, ufque in poiterum diem : quod ficut veriffimum, ita $\&$ raro oblectamento exiftit. Mihique per deferta peregrinanti horologii defectum ex parte fupplebat. Nec tamen pracedentim $\epsilon_{\text {atmar }}$ qualitattiti expers etiamfinferiori gradu habita. 
C A M B V Y, five MÝRTS Americana Silvestris.

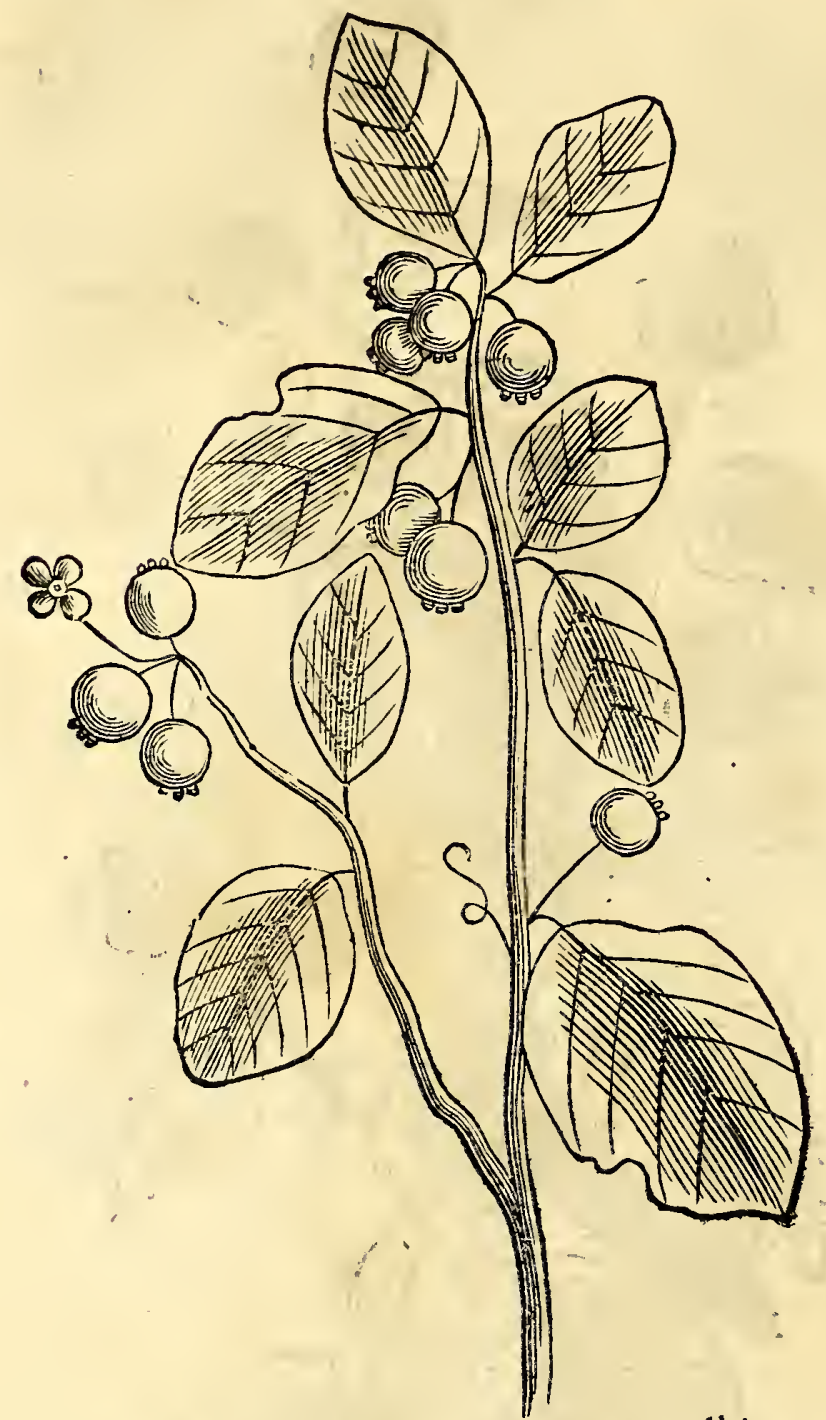

IN glebofis terris dux fpecies ar$I_{\text {buficularum, Cambuy dictroluxu- }}$ riant, ligno utraque lento $\&$ cortice cinereo. Qux ob fragrantiam, adfrictionem foliorum, florum $\&$ fructuum, CMyrti filveftris nomen merito obtinent. Prior arborefcens, (cujus hic Iconem addidi) latifolia Cerafumnigram per omnia externa xmulatur, firamos, folia, flores \& fructus confideres : caterum interna qualitate eam fuperat, quod folia \& flores optimi non folum odoris, fed fructus nigriadmodum fint faporofi, grata accedente adffriatione, omnibus pariter Incolis expetiti, \& in foro publico venales.

Pofterior autem Myrtus eft ru. bra, quantumque magnitudine pradictx cedit, tantum dignitate illam fuperat, ac proinde fruetus. inter delicias Pharmacopœix habentur.

Frutex hicelt foliis folidis, lxte viridibus, oblongis, magis acuminatis quam Pictor in hac icone expreffit, utcumque alternatim fibi appofitis, fed raro oppofitis.

Semel per annum floret, Sole ad Scorpionem accedente, tam grato odore olfactum quam niveo colore vifum reficiens. Flos enim totus albicat, ex quatuor foliolis conftans.

Fructus crocei baccarum funt magnitudine, raro folitarii, fed Ceraforum more copulatim pofiti \& pediculis fuis innitentes rotundo umbilico papillari præditi qui fi tempeftive avellantur, fucco turgent optimo, fed tandem fauces, fi multum illis vefcaris, conftringunt. Continent intus nucleum tenui cortici inclufum. Cæxterum ftomachum reficiunt, corroborant, æftumque fedant. Nullus eft incolarum hujus diftrictus, qui non ad fructus \& folia hæc utiliffima confugiat. \& medicamentum fibi exipfis conficiat, five interno five externo malo conveniens. Succi \& fomenta illorum, tibiarum imprimis ulceribus, atque aliis malis, adftringendo \& mundificando medentur. Balnea integra, tam fluxibus alvi, quam utcri dicata, cum feliciflimo fucceffu adhibentur. Omnia præterea bona pollicetur hæc Myrtus Americana agreftis, qux de Europæa Auctores paffim teftantur.

qux de Europza Athores pafies hic reperitur, qux Myrtus alba appellatur, fed infrequentior eft, neque à me hactenus in ufus Medicinx applicata.

$$
\text { C V I I P }
$$
$M_{\text {jus Icon injuria temporis mihi periit. Ego pauca, fed vera, \& qux ipfe fum exper- }}^{\text {Vlti multis \& cximiis dotibus excellere agreftem hanc arborem teftantur. Cu- }}$ tus, de ea, qux floribus flavis decoratur, exhibeo.Succus è cortice rafo expreffus \& cum aqua limpida mixtus, ulcera inveterata mundificat \& purulenta, eaque carne replet.

Pretcrea ex codem fucco atramentum conveniens elicitur, quo etiam ad tingendos pannos utuntur. Gluten quoque cfficax exinde concinnatur in ufus familiares receptum.

C At 


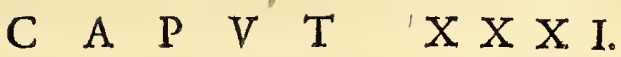

\section{Munduy guaçú, frve $\mathcal{X}$ (ux Cathartica Americana, \& N Dambu Guaçu, five Ricinus Americana.}

A Rborum pumilarum vix ulla lætius provenit, quam qux Nuces catharticas profcrt, quas Lufitani Pinhones, Pharmacopœi Cataputian majorem appellant. Ejus ramuli amputati omni anni tempore novas emittunt plantas, fructufque per totum fere annum ferunt. Excrefcit in Ficus altitudinem \& figuram,ligno molli \& fragili,lacteo humore acri turgido. Foliis eft læte virentibus glabris fucco plenis, anterius acuminatis \& quafi in tres angulos definentibus. Flofculis parvis racemofis fubdulcis odoris, fuccedit fructus turbinat $x$ figur $x$ feu inftar Iuglandis, primo viridis mox flavus, ubi maturuerit niger. finditur in tres partes, quamvis fex concamerationibus diftinctus, in quolibet fructu funt tres nuclei magnitudine \& figura Pineis fimiles. Radice eft craffa lignofa recta \& profunde in terram defcendente. Quod quidem raro admodum fit in hifce regionibus. Pinex (quas ad vivum ea qua erant mole cum corticibus depictas appofui) interius albefcunt $\&$ funt pingues; cali$\mathrm{d} \boldsymbol{x}$ ad tertium, ficcx ad fecundum gradum. Et quemadmodum palato lenocinantur, ita ventriculo funt infenfiffim $x$, nam tres vel quatuor nuclei manducati, crudos humores ilico provocatos per fuperiora $\&$ inferiora exturbant, tanta vehementia, ut in vitæ difcrimen, prixcipue imbecilliores nonnumquam conjiciant, atque alexipharmacis \& opiatis ruentes humores fedare neceffe fuerit. Sed ut legitimus earum ufus conftet, in diuturnis obftructionibus vifcerum naturalium imprimis conveniunt: quatuor alt quinque nuclei maturi,fi à pelliculis interioribus ac exterioribus liberentur, \& mox leviter torreantur \& macerati è vino, additis correctoriis exhibeantur. Vtut fit,

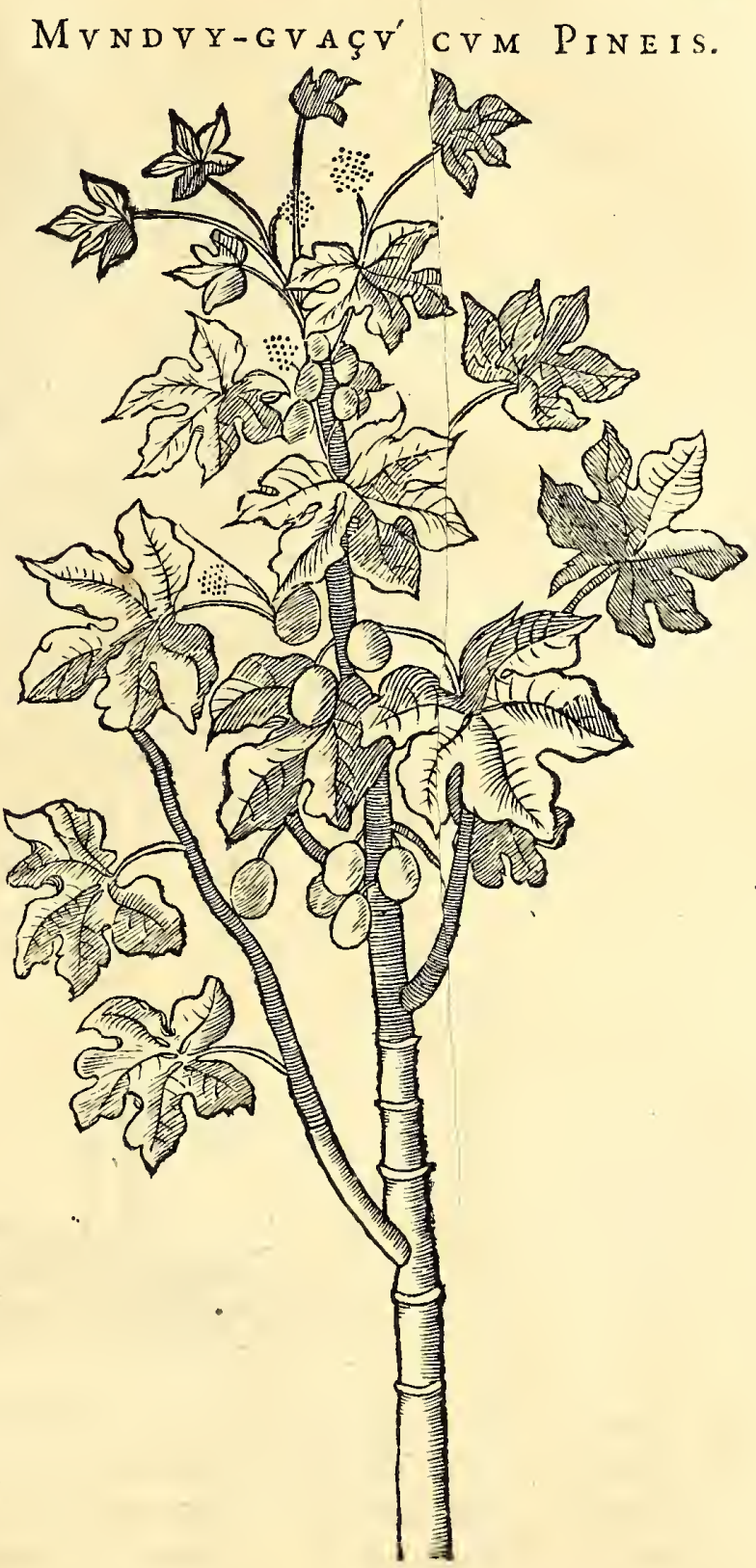
fuafor fum cum cau-
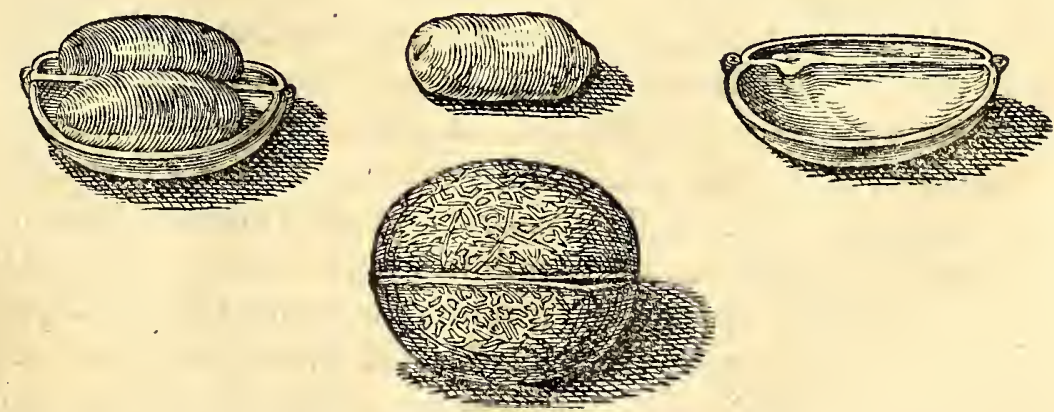
I 0

G V L I E L M I PISON I S

tionefemper exhiberdum effe hocmedicamentum, habendamque rationem ætatis \& virium illorum quibus exhibetur.

Porro ad rem famiiarem, ufumque domefticum hre arbufcula à multis expetitur: ex nucleis enim oleur quod exprimitur, ellychniis affunditur, quod inventum Brafilia Lufitanis debet. Teftrur Monardes cap. Iv. de olco Ricini, in Nova Hifpania pro infigni cathartico referveri, ejufque qualitates quas illi attribuit, hujus oleo Nucis quoque proprix funt. Quamcbrem nomine potius Monardes \& Clufius à nobis difcrepant, qui Curcas hunc fructun vocari teftantur, idque fub Ricini fpecie.

a $\mathrm{NHAMBVGVAç}^{\prime}$, five RICINVSAMERICANA.

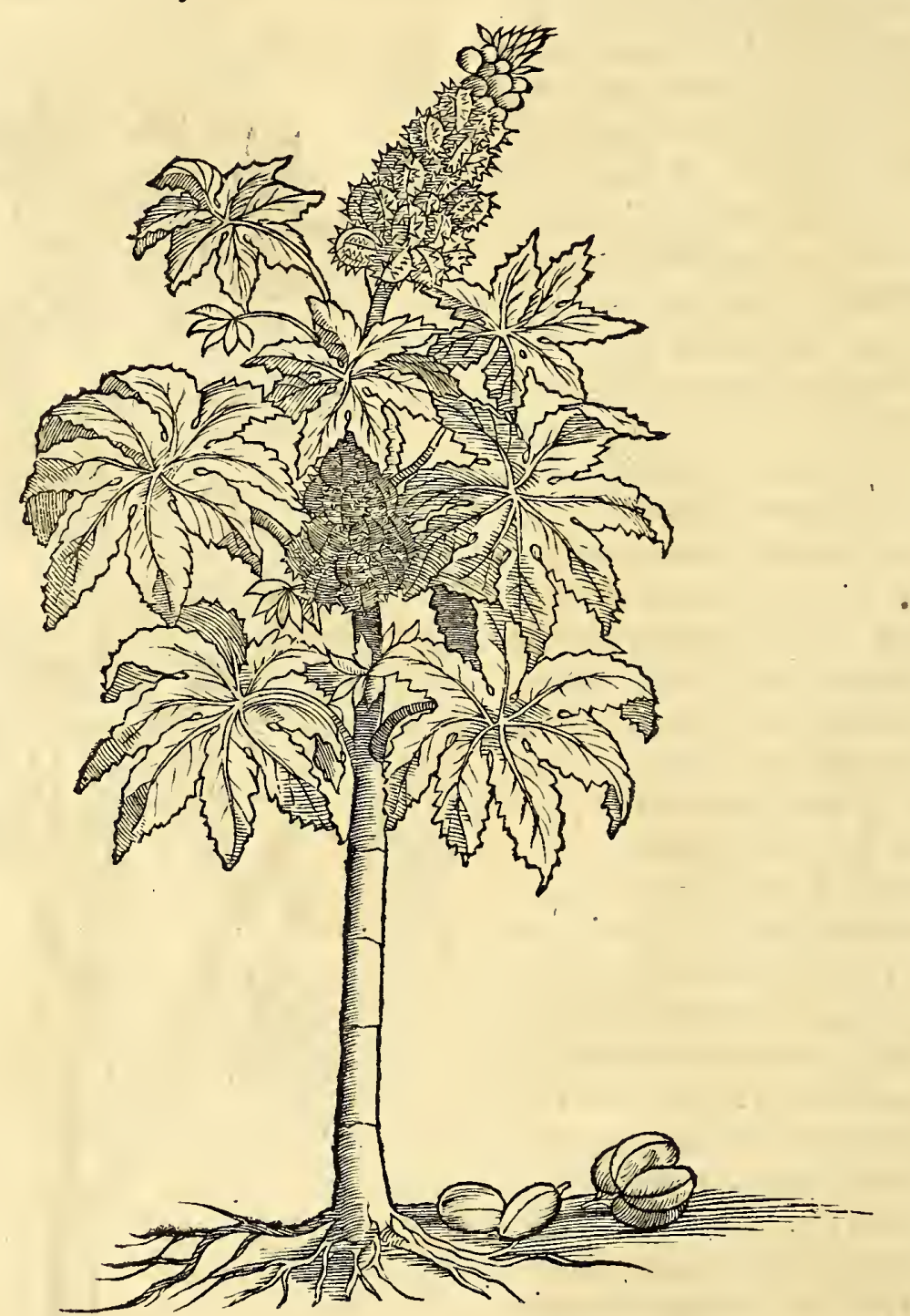

D Icinum duorum generum producit Brafilia, majorem quidem unam, minorem $R_{\text {autem alteram. Vtraque eft arborefcens, fpeciofa facie, non filveftris folum, fed }}$ $\&$ hortenfis \& 2 altilis in multos ramos expanfa; Hxc à Lufitanis Figuero d'Inferno vocatur. Folia fert in longis pediculis, in medio folii infixis, in octo aut novem lacinias acuminatas \& profundas fcifla, per ambitum dentatas nervo tendente è centro folii per omnes lacinias. Inferius funt læte, fuperius faturate viridia, ad tactum mollia, tenera. In ramorum extremitatibus autem proveniunt fingulares pediculi, in quibus alternata ferie \& ficx forma in propriis petiolis, proveniunt virides lavefque globuli quinque aut fex juxta fe pofiti, inftar uva, qui fe aperientes exhibent flofculos fubtiles, figura \& odore ut in Sambuco, fedmulto minores, ex albo fubflavefcentes. His fuccedunt corpora rotunda, viridia, cinnabriis umbilicis notata, magnitudine Avellanx, in totum hifpi$\mathrm{da}$, quinquaginta aut fexaginta in unum racemum congefta, qui fructus, à Lufitanis Carapatos ob fimilitudinem iftus infecti dicti. Maturi nigricant acfponte difliliunt in tres capfulas, quarum quælibet etiam fe aperit \& continet Nucem lavem, cinerei coloris \& nigro elcganter maculati, figura \& magnitudine Piftaceorum. Nux à cuticula libe- 
HIST. NATVRAI. \& MEDIC. LIB. IV.

rata albiffimum in fe continet nucleum oleaginofum, exquo oleum exprimitur, variis ufibus dicatum : quippe Lychnis non folum affunditur; fed omnibus pafim Incolis in ufu eft quotidiano, contra affectus frigidos, tam intcrnos quam externos.

Calidum habetur ad tertium gradum. Nec potui animadvertere, hujus Americani Ricini qualitates \& vires difcrepare ab iis quas Galenus \& Diofcorides olim illi attribuerunt. Refolvit apoftemata, \& matricis ventrifque tormina ac flatus illitum difcutit; prodeft tinnitibus aurium; reftituit tenfos convulfofque nervos. Tres vel quatuor guttulx, ex conveniente liquore fubinde per os vel anum exhibitæ, fanant frigidos articulorum affectus \& fimul alvum laxant. Cutem quoque à pfora, reliquifque externis corporis affectibus vindicat. Vmbilico inunctum lumbricos puerorum expugnat.

Semen illius catharticum eft, \& multo validius quam oleum : humores enim crudos per fuperiora \& inferiora exturbat, ac proinde præparatione indiget. Convenit in firitu vini optimo, loco correctorii, macerare femina multa, \& inde unciam circiter è cochleari exhiberi, ut venter benignius à craffis humoribus evacuetur.

Si jpfa feminis grana in fubftantia accipere malis, minus tutum exiftimant incolæx, feptenarium numerum excedere, licet Dodonæus id fuadeat.

Folia aqua vel aceto macerata Herpeti, aut hujus generis affectibus mederi, præter Diofcoridem, teftem habeo quotidianam experientiam.

\section{A P V T $\quad$ X X X I I.}

\section{Iuripéba mas \& formina, Ivabeba \& Tapirapecu.}

T Omine Iuripéba, duo ejufdem generis, fed non ejufdem fexus, frutices nafcun. tur in arenofis Brafilix locis. Vterque pulchris $\&$ umbrofis frondibus ado-

lefcit, uterque gramineos fertacinos, more racemorum copulatos $\&$ è brevi pediculo pendulos.

$$
\text { I V R I P E'B A. }
$$

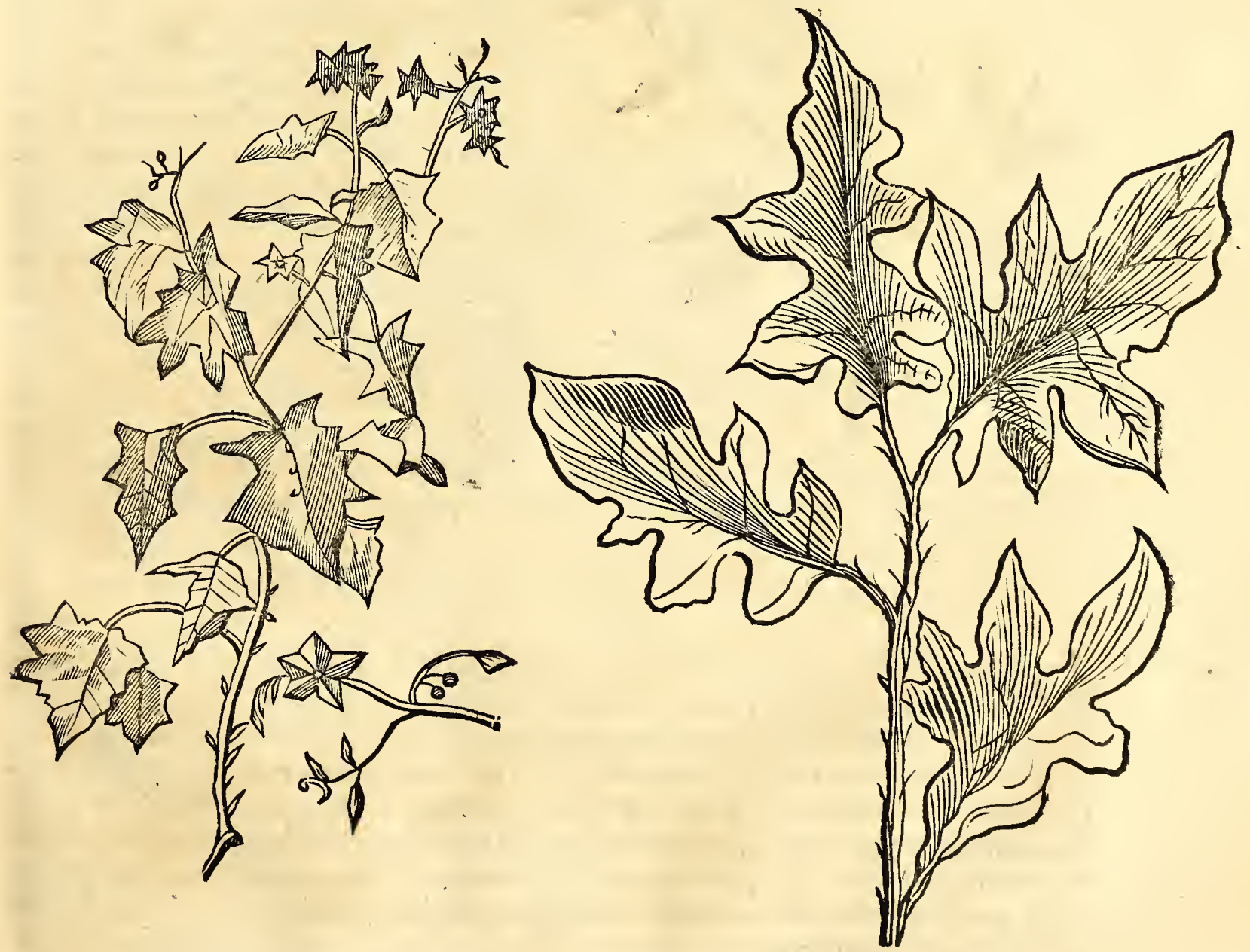

Prior, \& quidem mas, paulo fomina eft minor, ad hominis altitudinem vix afcen-

Q dit, 
dit, foliaque habet minora, nec multum finuofa, fed laciniata caulemque rarioribus fpinis obfitum.

In fummitate ramorum fert flofculos umbellatim quafi congeftos lactei coloris cum creruleo mixti, qui exacte quinquangularem ftellam reprefentant conftantque unico folio in tot triangula effigiato \& quafi divifo, in medio autem quafi quinque ftaminula ftant erecta, flor em boraginis è longinquo diceres.

Pofterior altior, fpinofior, folia hąbet grandiora, inferius lanuginofa \& fpinofa ornate, laciniata \& fature virentia; florem eundem cum mare, fed nitidior em. Vterque ob Medicinx ufum quotidianum officinis notiffimus.

Folia enim \& fuccus temperandis \& mundificandis vulneribus \& ulceribus adhibentur, eifque egregie auxiliantur. Licet autem amarum quid fapiant folia $\&$ radices, ficut Cichor eum \& Fumaria, tamen inter calida vixrecenfentur.

Omnium autem maxime radix virtute \& efficacia excellit, multoque amarior exiftit , præcipue vero Maris, quæ partium adeo eft tenuium. Quippe folum illius decoctum, urinam cunctantem educit. Ad hepatis $\&$ paraftatarum obftructiones tollendas loco radicum aperientium, cum fucceffu frpe a dhibetur. Vfque adeo invaluit ejus utilitas \& preftantia, ut à doctis pariter $\&$ indocta plebe expetatur $\&$ inter facra reponatur.

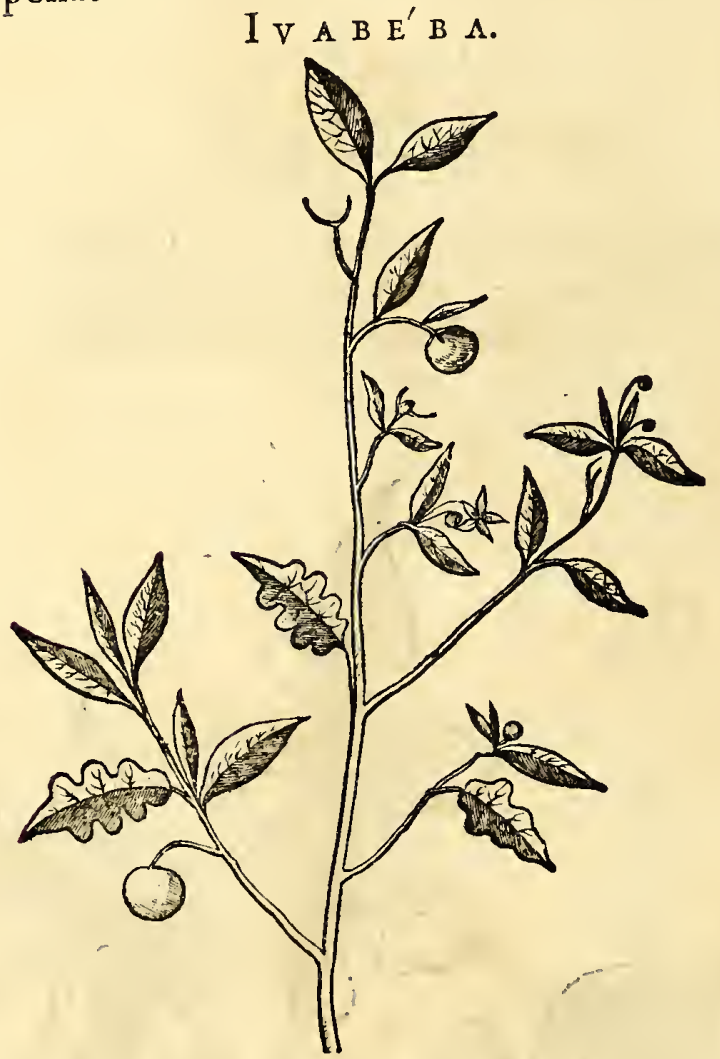

Equitur lvabeba præcedenti fimilis, fi $S_{\text {medicos ufus refipicias, eft frutex eo- }}$ dem modo crefcens quo Iuripéba, fimilique ligno, fed folet altius affurgere. Caudexfpinofus ac leni hirfutie præditus quod pictor non probe fatis expreffit in hac Icone. Folia diverfe figur $x$, pallide viridia, oblonga, lanuginofa non ita laciniata ut Iuripéba.

Flores itidem fert ut Iuripéba, lacteos, quinque foliis conftantes, inftar ftell $x$ expanfos, in medio cum ftaminibus luteis. Hinc fructus promanat rotundus inftar Pomi fplendens, primo faturate viridis ac brunna lanugine tectus, qui maturefactus citrini fit coloris. Cortex fructus eft frangibilis inftar teftx ovi,cumfeminibus Lentibus fimilibus, pulpa flava fucculenta dulcis \& grata formicis, cxterum non edulis. Radix plantx eft amara \& tenuium partium, atque inter remedia deobftruentia in pretio habita, potiflimum vero in renum vifcofitatibus abftergendis. Quia radix quibufdam nimis amara videtur ; decocta exinde parata faporis gratia temperantur cum liquiritia Americana.

$$
\text { Tapirapecí, SONCHI I }
$$

$\mathrm{O}$ Mnes paffim incol $x$ adven $x$ \& indigen $x$ inter fe conveniunt de qualitatibus tam nobilis herb $x$ : verum de nomine difcrepant, quod vel ex fimilitudine vel ex ufu, hic aut ille rufticus Lufitanus pro arbitrio imponit, quibufdam, fatis licet improprie Lingua di vacca hoc eft Bugloffa ; aliis vero Erva do figado magis appropriate dicta, quia inter Iecorarias \& Cichoraceas, me judice, merito cenfend:a eft hxc Brafilienfuum Tapirapecí; tum, quod eximie hepatis imprimis lienis oppilationibus medeatur, tum quod facie \& figura externa iis potiffimum comparanda fit, licet pro foli hujus genio nonnihil ab Europxis abludat ficut ex defcriptione patebit, quia Icon ob itineris injurias mihi periit.

Inglebofa, potifimum terra fponte nafcitur facie $\&$ ufu nulli incognita planta qux caule 
HIST. NATVRAI. \& MEDIC. II в. IV.

caule plerumque nititur único, fupra tibix altitudinem affurgente. Folia fert dentata oblonga, angufta, intus dilute viridia lanuginofa, more Cichorei circa caulcm complicata, donec verfus fummitatem caulis foliis tenuifimis \& fofculis albis ornate finiatur. Qui poftea brevi fenefcentes, in pappos evadunt, \& leviflimo flatu difcutiuntur.

Herba cum radicibus integra quovis modo præparata eximii eft ufus, apo'zemata enim $\&$ decocta familiaria exinde concinnantur: adeoque celebris evafit, ut æxue Chiturgis ac Medicis decantata fit, contra externa $\&$ interna mala.

\section{A $P$ P $T$ T X X X III. C.Manaingá, Manacá, es due Paiomirióba.}

$\mathrm{M}$ Amangá Brafilienfibus dicta, frutex eft trivialis arborefcens, ubique obvius, quem Lavapratas Lufitanorum vulgus appellat.

Flores fert multos pendulos \& luteos; \& polt hos plurimas filiquas oblongas copulatas, primum quidem virides, fed mox nigras $\&$ putridas, $\&$ frequens femen in illis contentum.

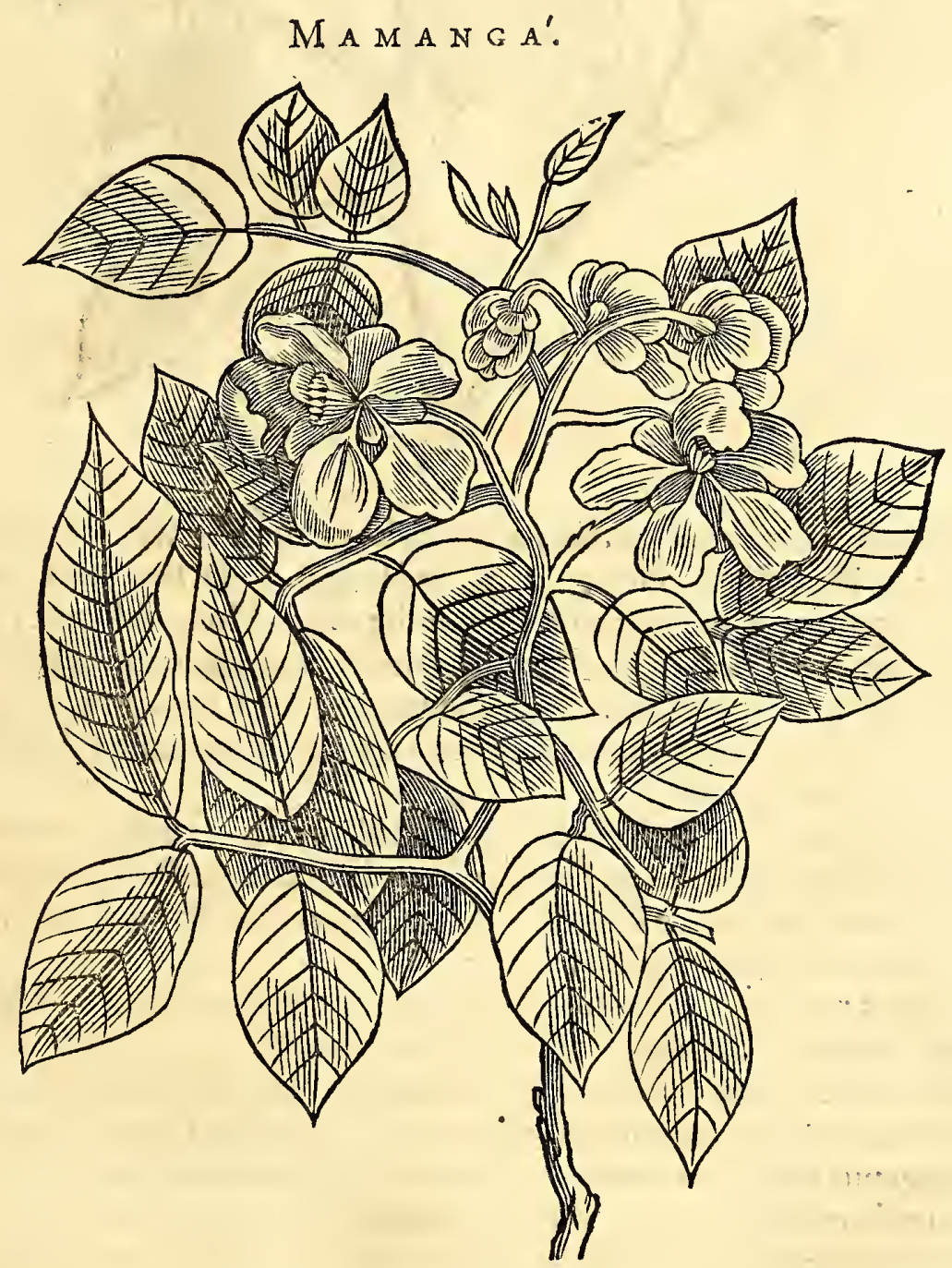

Folia habet citriis haud diffimilia, paulo tamen lougiora \& molliora, \& qualitate refrigerandi \& abftergendi prædita.

Prxter alias dotes, quibus excellunt, vulneribus atque ulceribus opitulantur, partefquevitiatas reparant. Cujus rei Chirurgi noftri non ignari, ea in quotidianum ufum colligunt.

Raro videas viatores iter fufcipere, nifi probe hoc remedio inftructos.

Succus oleofus denique è filiquis expreffus, ad maturanda apoftemata refervatur, \& applicatur cum profpero fucceffu.

$$
Q_{2}
$$




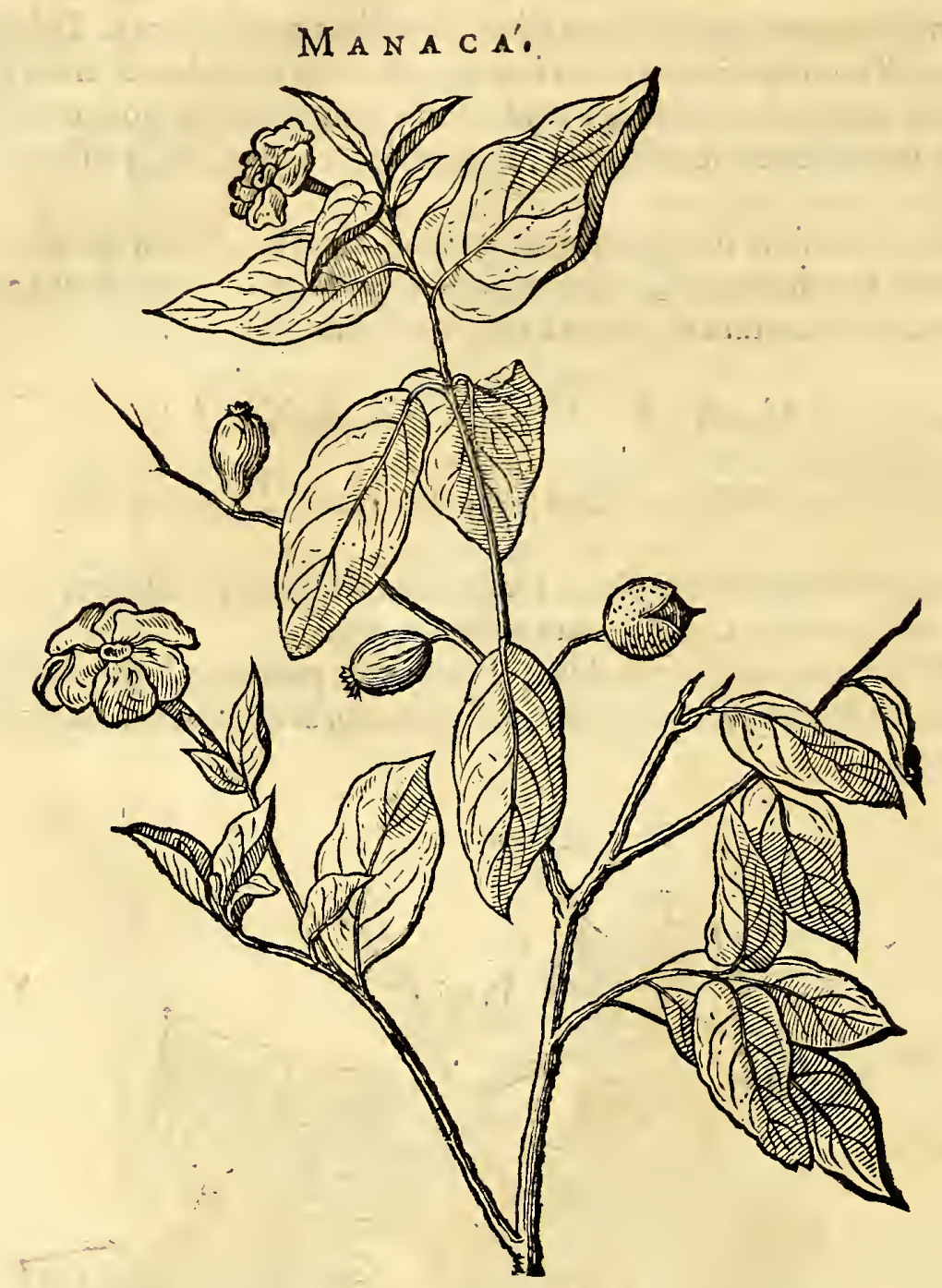

T Ocis umbrofis, maxime circa Aldeam Tapiçirica luxuriat Frutex arborefcens Mana$\mathcal{L}_{c a}$, cortice grifeo, ligno duro quidem, fed fragili, folia piri foliis fimilia, nunc inordinate fibi oppofita, nunc in frondes quafi difpofita. Flores folitarie pofiti ex longo calyce prodeunt in quinque folia diffecti. In uno codemque frutice cærul eo purpurei \& lactefcentes reperiuntur menfe imprimis Ianuario, quod ut rarum vifu ratione coloris; ita non minus odore jucundum, cum integras filvas infigni fragrantia inftar Violarum Martiarum repleant.

Flori fuccedit fructus baccx Iuniperifimilis, fed inutilis , viridis, rotundus, cortice grifeo tectus, qui fuperius quinque fiffuras habet ut fructus per fiffuras ftellam quinquangularem reprefenter. Continet in fe tria gramina, feminis magnitudinelentis, vel etiam majores, figurx ellipticx.

Radicem habet magnam, folidam \& albicantem, cujus medullofa fubftantia in pulvercm redacta, magna in Medicina pollicetur \& præftat.

Incolx pcne omnes, tam Lufitani quam Brafiliani, licet magni xftiment, tamen ob indomitas operationes hactenus in ufum admittere vix aufi fuerunt. Quippe periculo non vacat hoc genus medicamminis, quod nimis violenter corpus fuperne $\&$ inferne moveat. Quamobrem tantum hominibus robuftiffimis exhiberifolet idque additis correctoriis, tum \& jufta obfervata dofi, qux Scammonei vel Efulx potius inferior quam fuperior effe debet: ad illud enim validum medicamentnm proxime accedit hæc radix: verum non ita infipida eft, amarore enim $\&$ acore non plane deftituitur. Eadem quoque Manacá in aquis maccrata lavacra fuppeditat quibus vagis articulotum doloribus ex frigore potiffimum natis, medentur. Inter vulneraria quoque apudindigenas ufurpatur.

Dum generum Paiomirioba in Brafilia reperitur. Vtramque Lufitani Herva do Bicho à quotidiano ufu nominant : quippe lippis \& tonforibus ob frequentiam nota eft, quod 
HIST. NATVRAL. \& MEDIC. LIE, IV.

quod nimirum folia earum contufa, \& fuccus recenter expreffus, anoque inflammato infertus, prxfentiflimum quafi antidotum fit, contra calamitofum illud $\&$ familiare malum Bicho del culo abufive Lufitanis dictum. Vtraque planta fruticefens, in qualibet terra, prảcipue tamen arenofa littorali fponte nafcitur, Orobique fpecies judicatutr. Prior hæc à fecunda vix differt nifi foliis multo acuminatioribus, \& Orobi Pannonici Clufii, fimillima. Ex unica radice multi prodeunt caules, circiter tres pedes longi, lignofi virides, nodofi, in multos ramos divaricati, qui è no dis prodeunt: in quolibet ramulo octo vel novem folia, fibi oppofita. In extremitate ramorum enafcuntur flofculi, quitique foliis confantes, plane fimiles illius $\mathrm{O}$ robi Pannonici, fed omnino lutei. Flores fequuntur filiqux quatuot aut fex digitos longx, teretes, paulum compreffx, maturefact $x$ fufcefcunt, \& f ponte rumpuntur, atque effundunt femen rotundum fufcum paulo majus lentibus. Toto anno floret $\&$ fert femen. Radix longa, recta multa fuperius habens filamenta, flavi coloris. Eadem contra venena : femen autem cum aceto contra impetiginem valet. Planta qualitate pollet refrigerandi, abftergendi, \& mundificandi. Aqua enim ex floribus $\&$ foliis deAtillata urinas \& calculos veficx fortius mover quam Orobus, ardorefque renum \& ftrangurias temperat.

Altera fpecies Paiomirióba, Tareroqui Brafilienfibus, Matapafto Lufitanis dicta; eft eadem figura \& radice ac flore: differt tamen foliorum figura: nam hujus funt, ovalis, ad exortum fuum anguftiora, Poft Solis occafum folia fua componit \& quafi marcefcit, mane iterum explicat. Semen rotundum, nigrum, minutum \& multum, diverfum à femine Paiomiriob.e.

Folia non folum ani inflammationi, fed \& ulceribus anthracibufque applicata medentur. Ex eifdem denique foliis aqux impofitis \& putrefactis, crafla quxdam \& pinguis fubftantia emanat, qua un-
PAIOMIRIO'BA I。

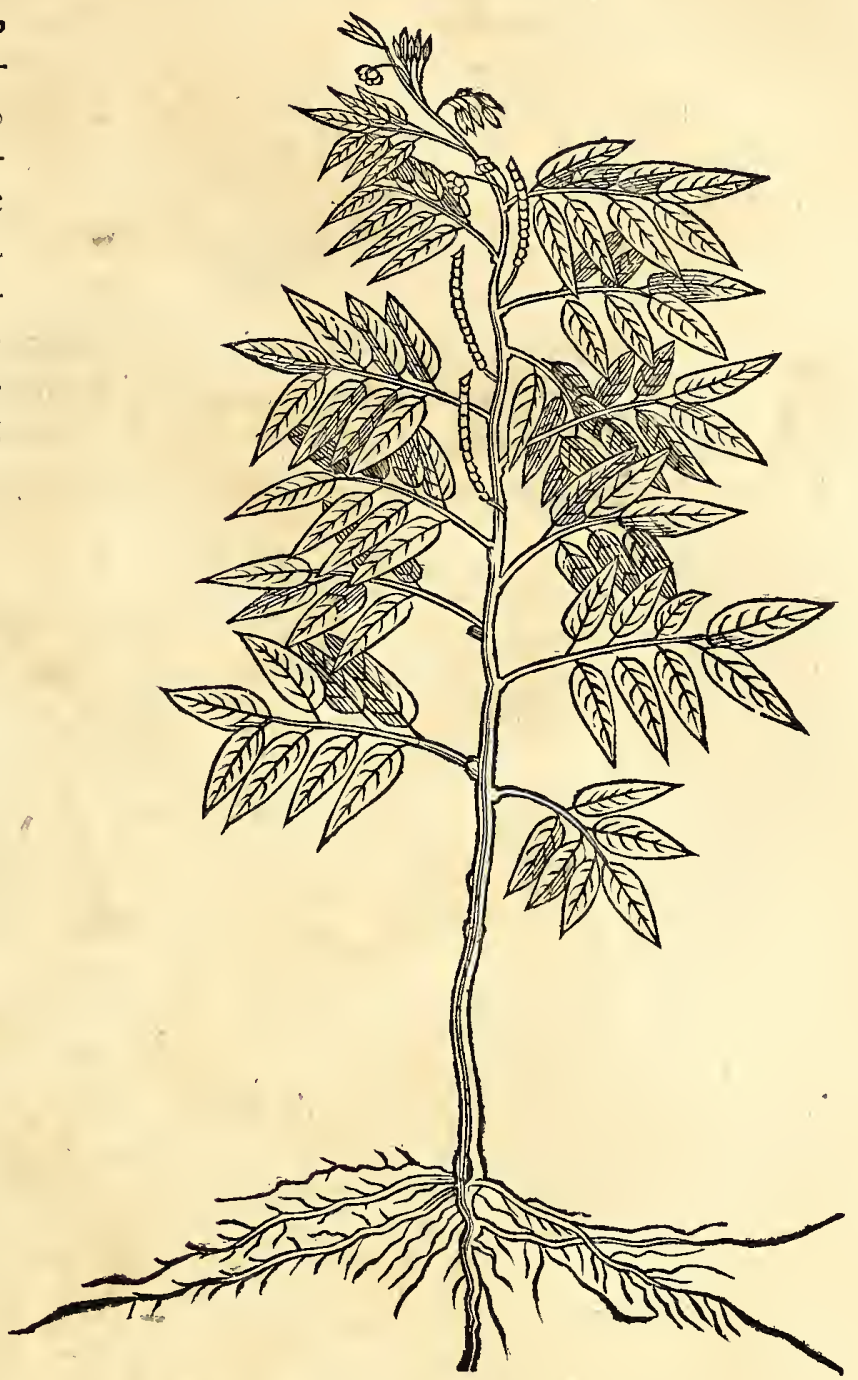

P I I O M $\mathrm{R} I \mathrm{O}^{\prime} \mathrm{B} \Lambda$ II.

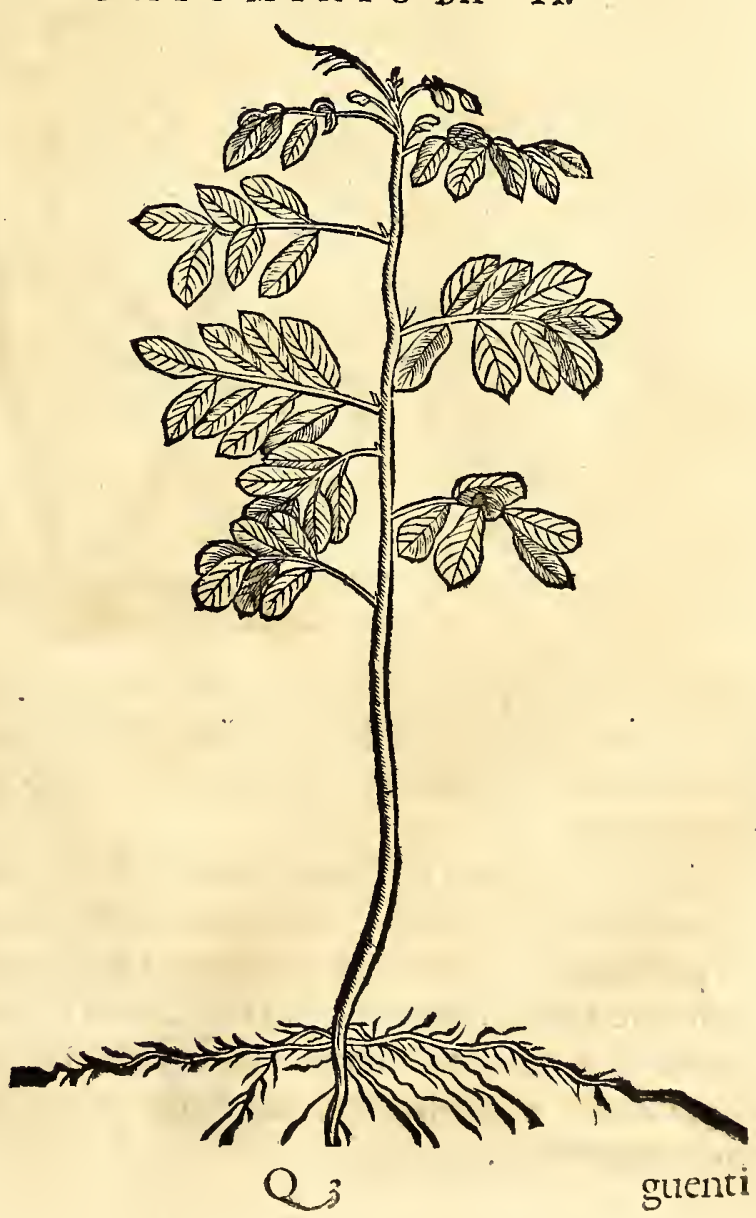


inundificantis loco utuntur. Qui veterinariam artem exercent teftati funt miLiv, fe nullum prxfentius amplecti remedium in curatione vulnerum equorum.

$$
\text { C A P V T } \quad X X X I V \text {. }
$$

Aminiiu, fove Goljpinim, Ibitúnga, \& Maçarandiba.

A Miniiú eft Fructex eleganter arborefcens ligno molli, foliis teneris dilute viridibus, in tres lacinias fectis, qui magnis floribus pentaphyllis læte flavefcentibus, ttamine \& tuberculis ejufdem coloris, in medio unguibus purpureis decoratur. His fuccedit corpus ovale, viride, nigrifque punctulis variegatum \& quod ubi matu-

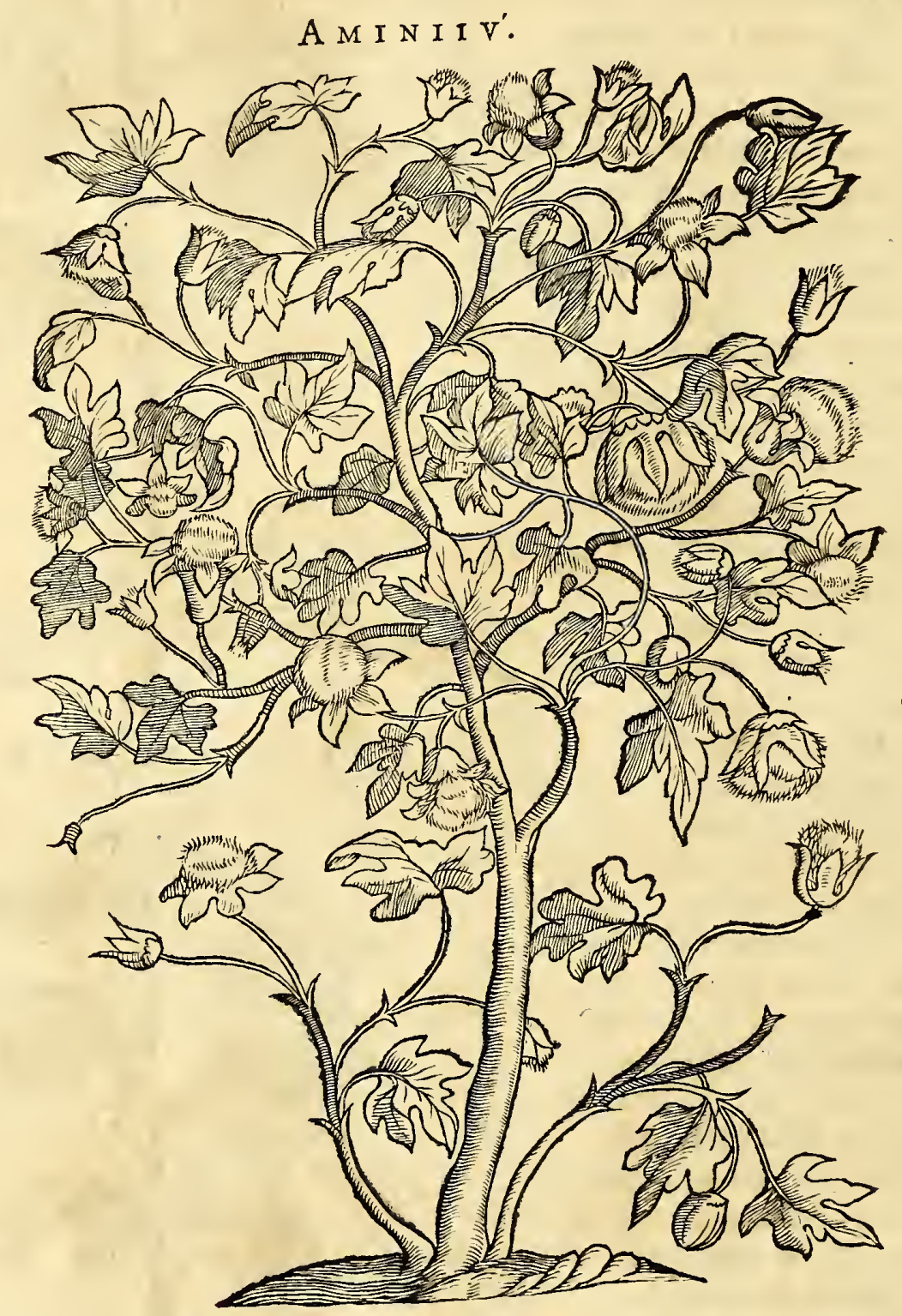

ruerit in tres capfulas diffilit, unde albiffimum Goffypium erumpit, in cujus flocco immerfi funt feptem nigri fructus piftaceorum fere magnitudinis $\&$ figuræ , quibus continetur nucleus albefcens, pinguis, dulcis faporis inftar amygdali, ex quo femine planta propagatur.

Semina \& oculi foliorum contra fluxus ventris fanguineos vel fola vel aliis remediis mixta exhibentur. Eorum mucilagne incol $x$ paffim utuntur contra febres ardentes pectorifque morbos atque venena erofionem ventriculo $\&$ inteftinis inferentia. Semen hoc terr $x$ commiffum in Hollandia felicifime pullulavit \& ultra pedalem altitudinem excrevit, fed inclementiam hyemis ferre non potuit Fr. Ximenes teftatur ftolones contufos non folum eifden malis, fed \& morfibus puncturifque venenatorum animalium mederi.

Olim 
HIST. NATVRA L. \& MEDIC. L I B. IV. I 87

Ibipitánga five Cerasts brasiliana. Lim filveftris tan\& elegantiam in hortis Lufitanorum exculta arbor, figura Cerafi noftratis acid $x$, nifi quod truncus contortior hinc inde cum ramis difpergatur. Foliis eft faturate virididibus, lævibus, duobus femper fibi oppofitis,juxta quorum exortum floresalbi, cum multis fta. minulis cerafinis prodeunt, quibus fuccedit fructus rotundus inftar bacce Mori, primo miniatus, mox latius paullo rubefcens, \& octies profunde ftriatus, umbilico præditus. menfibus potiffimum pluviis maturefcit, cuticula non folum fed \& pulpa quoque miniata, fucculenta, faporis calidi \& fubamari, cumque grato acore aftringentis. Lapis qui continetur unicus albicat, nucleum calidum \& amarum habens, lapidi Cerafi Maģarandibafimillimus.

Fructus autem hi, fecund $x$ menfx deliciis non folum fed æxris prodeffe folent. Ventriculum enim languidum mire reficiunt, Hatus difcutiunt, naufeam ftomachi reprimunt.
A Rbor hæc Cerafum 1 altitudine non fo- lum, fed \& ligno, foliis fructibufque æmulatur, eique, fi c̀ longinquo con- fpiciatur, fimillima ap- paret. Olim filveftris \& in montofis potiffimum locis nafcens, nunc in hortis Lufitanorum quo- que excolitur. Floret menfibus hybernis, mox- que fert fructus infinitos, Cerafi quidem Europari
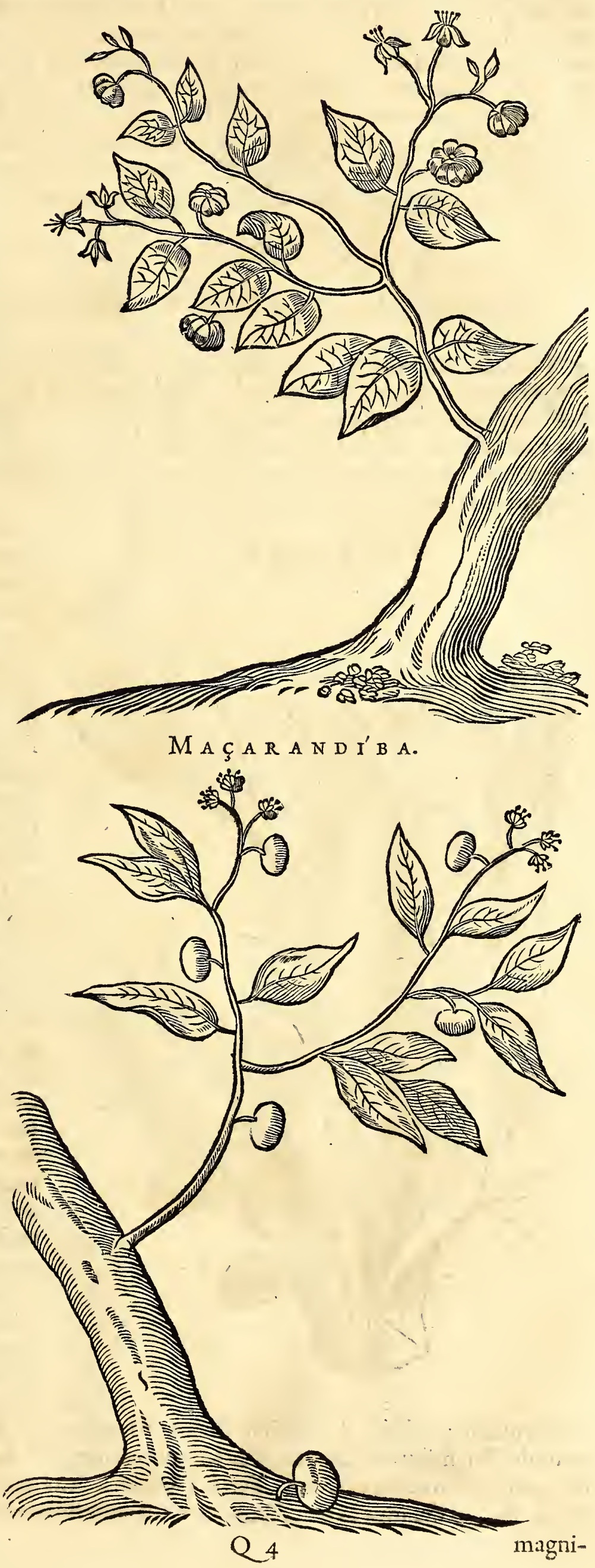
magnitudine, fed figura nonnihil diffimiles, quod hi non exactefphrrulæ inftar rotundi fint, fed paulo compreffiores, \& pediculis brevioribus craffioribufque ipfis ramis adnafcantur.accedit quod pellicula veftiantur tenaci, crafla, prius rubefcente, fed ubi maturuerint, miniati \& triftis coloris. Prxter duriorem quem continent lapidem, lacteo turgent liquore dulciffimo, eoque non ingrato, ac proinde ab omnibus pariter incolis inter epulas expetito. Quia temperate calidus eft hic fuccus, \& nutriendi facultate pollet, expreflus emulfionis inftar exhibetur; tum imprimis contra frigidiores pectoris affectus, vel folus, vel aliis remediis pectoralibus admixtus: guttur denique $\&$ afperam arteriam male affectan, maximopere mulcere compertum eft.

$$
\text { C A P } \quad \mathrm{V} \quad \mathrm{T} \quad \mathrm{X} \times \mathrm{XV} \text {. }
$$

\section{Sex species Tunarum, fove Ficuum Indicarum Iomacarú.}

Iin ullis Americx plantis mirus Naturæ lufus, certe in his Carduis five Ficubus filveftribus apparet. Quippe adeo inter fe variant, pro natalis foli diverfitate, ut vix omnes ad eafdem fpecies quis referat, nifi flore $\&$ fructu, tum interna qualitate convenire deprehenderentur. In diffitis enim $\&$ denfis nemoribus, ad qux vix aditus patebat, aliquas communis arboris magnitudinem fuperare, in littore vero fitienti aliquas vix fruticis altitudinem adæquare vidi.

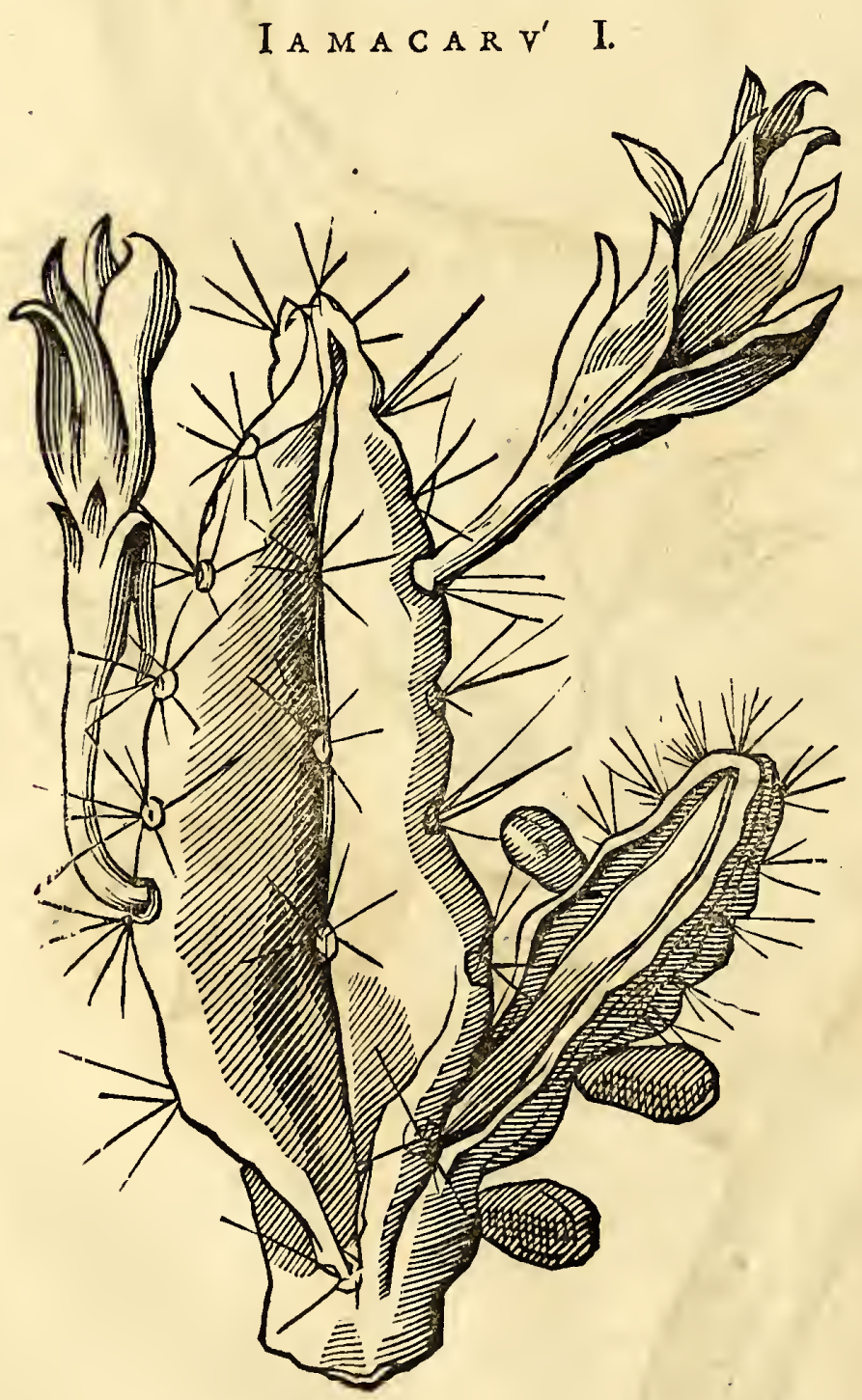

Prima fpinofa qux fe offert Iamacarú, Lufitanis Cardon, fruticibus aut arboribus adnafcitur tenues radices habens quibus fe illis inferit. Folia ejus crafla , folida, inftar Aloës triangularia, vario modo fibi invicem oppofita, ut in Ficu Indica: Folia viridia, turgentia fucco vifcido, fed infipido. in extremitatibus angularibus foliorum, rudimenta fructuum funt, \& fpinulx acutæ juxta fe pofitx quatuor cinerex. Provenit in ejus fummitate flos fuavis odoris, crterum Nymphæx majori fimilis, exterius conftans multis foliis viridibus, anguftis, oblongis, $\&$ in medio horum columna Hava, rotunda, fuperius in multas partes diducta. Fructus eft ovalis figur $x$ \& plus minus magnitudinis, triangularibus eminentiis confpicuus, cute tectus inftar corticis Mali arantii, interne $\&$ externe colore elegantiffimo feu laccx \& cinnabrii mixto. $\mathrm{Ca}$ ro interior alba, fucculenta, faporofa, feminibus nigris fplendentibus referta, qux fimul cum pulpa comeduntur.

Prxterquam quod ob delectabilem fructum fragrantiam $\&$ ob fuccum ex acido dulcem, ab xttuantibus expctuntur: febricitantibus imprimis \& biliofis conveniunt recentes, quod grato acore palatum afficiant, \& fitim fedent, cor ac ventriculum mire reficiant. Succus denique exhac planta extractus, febribus ex bile natis medetur.

Secunda 


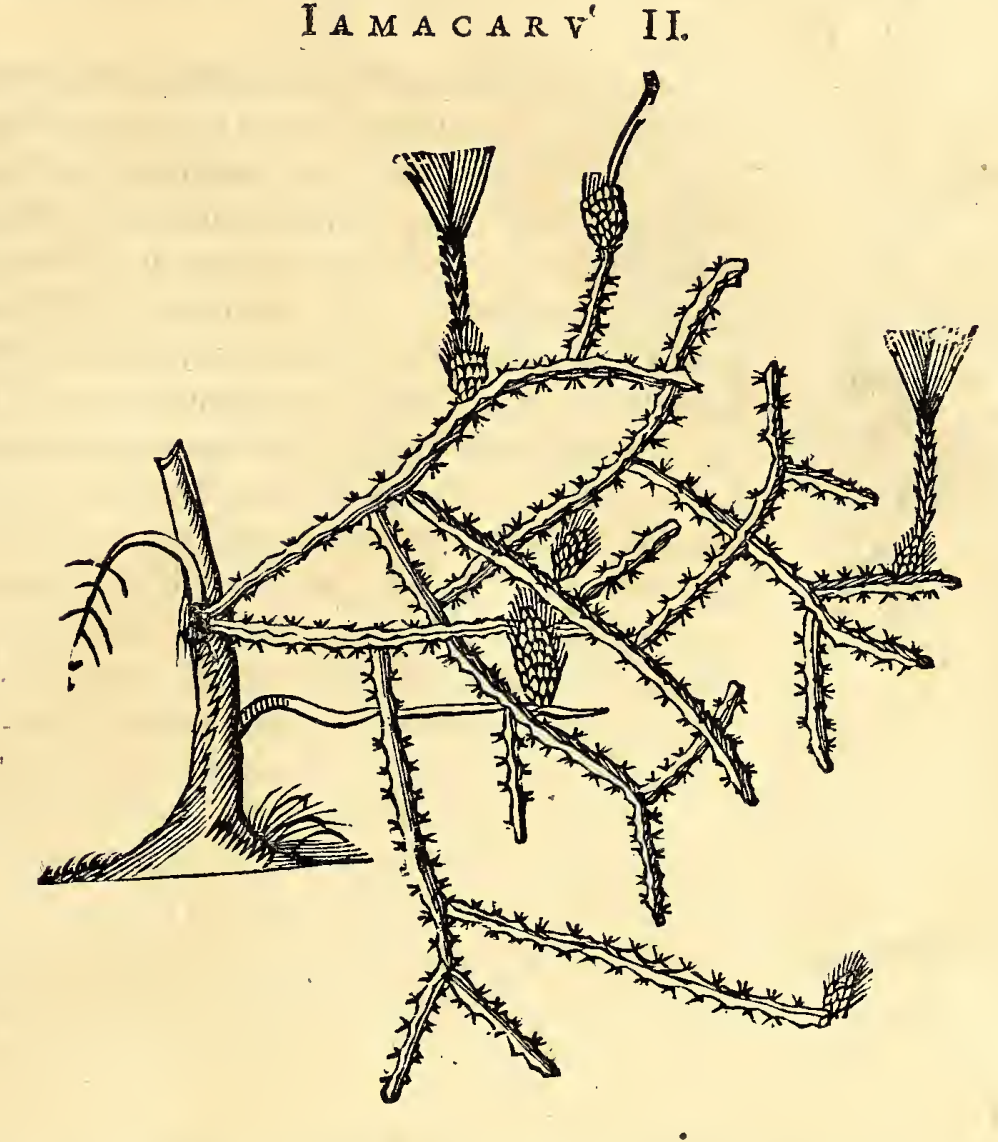

Secunda Iamacarú eft mediocris magnitudinis frutex arborefcens, caudice tereti, grifeo, \& ftellatis aculeis obfito: fuperiores autem rami deorfum propendent, quorum exordia funt longi proceffus teretes ftellatim aculeati ut caudex; his ramis verfus exteriora, infident folia Tuna modo, ovalia, compreffa, in ambitu aculeis fingulatim pofitis. Fert florem albicantem qui ex illis tuberculis foliorum enafcitur $\&$ in multa ftaminula definit. Fructus haud multum à præcedente differt, fed minor, cæterum guftu \& dignitate illi par.

Tertia Iamacarú aliis Caxabu arbor magna $\&$ procera admodum, fponte erumpit ex unico folio craffo, octangulo, fpinulis in Atellulæ modum pofitis armato. Huic uni folio alia plura in altum erecta brachium craffa Tunarum more adnafcuntur: fucceflu autem temporis folium inferius corticem grifeum acquirit, ac in caudicem lignofum $\&$ craffum abit, fpongiofum tamen $\&$ facile cxduum; folia vero qux caudici proxima ramorum vicem fupplent, cætera. foliorum. Caudex vetus, ac ramofa illa folia fpinas denique amittunt, folia autem fpinofa femper remanent. Flos huic caudici folitarius provenir albus, magnus. fequitur fructus, ovo anferino duplo major, ovalis figurx exterius ruber oblcure, qui quod refrigerantis eft qualitatis \& grati faporis ab xtuantibus, ficut mihi in longis peregrinationibus contigit, comeditur.

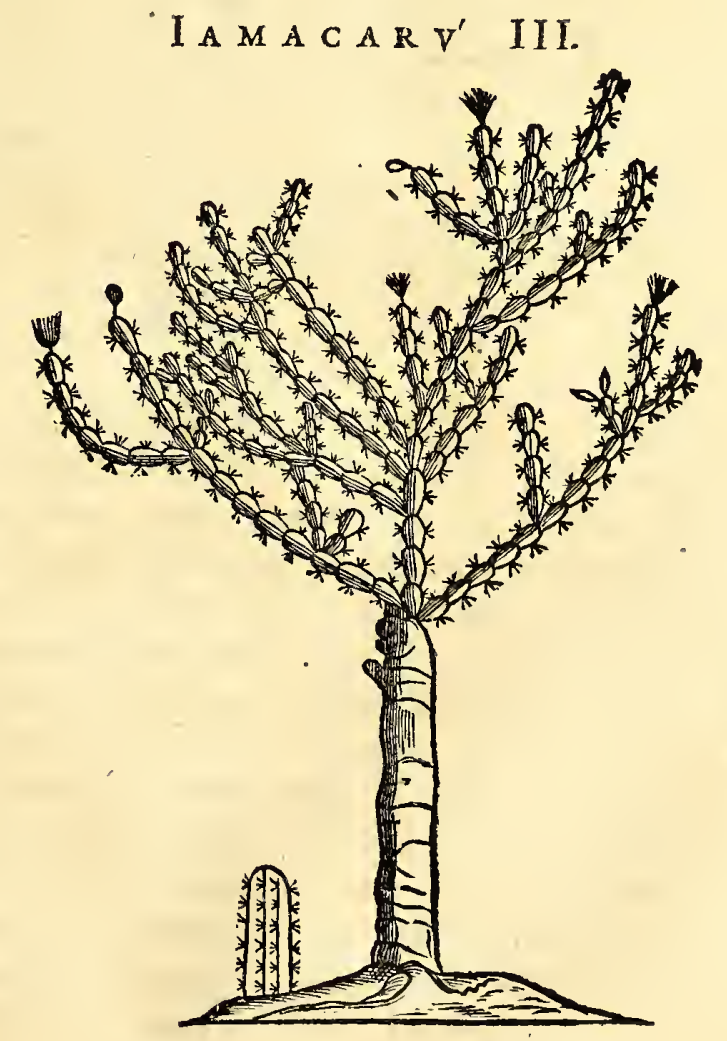

Quarta 
I A M A C A R $V^{\prime} I V$.

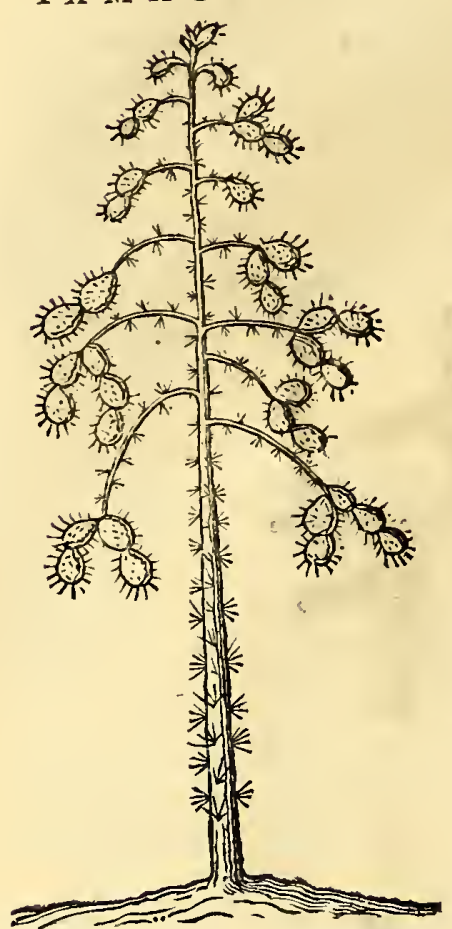

Quarta fpecies teretibus eft ramis \& nodofis, ad quos nodos funt fpinx ut in creteris, cum quibus in reliquis convenit. Trunco eft admodum finofo, eoque rectiffimo ficut Iaracatia arbor (cujus nomen abufive huic quoque $\mathcal{T}_{u-}$ ne attribuitur) vere Pinum diceres, fi rectitudinem $\&$ altirudinem confideres, verum in cæreris differt, quod foliis potius feinvicem protrudentibus, quam ramis in arboris fummitate, decoratur, quæ rotunditate $\&$ craflitie palmam, longiflimis finis digitos manus æmulantur. Diffitre hujus arboris nuper à nobis detectæ fructus, mihi \& fenioribus Brafilianis mecum peregrinantibus, hactenus minus innotuerunt. Caudicis medulla eft Sambucina facile mollior, qux fecta arbore, continuo exficcatur, abitque in leviffimum pulverem, qui decidit, moxque ablato fpinofo cortice, relinquitur fcapus concavus, arundine levior, miris cancellis, quafi ex arte fabricatus : qui fi ab igne accendatur, flammam luculenter fovet, facifque loco nobis iter facientibus de nocte inferviebat. Quamobrem fumma induftria inde huc, tibiæ craffitiei, viginti circiter pedum longitudinis fcaptim transferri juffi, \& nunc in Horto Academico Lugduni Batavorum, apud Clariff. Profeflorem D. Vorftium refervandum dedi.

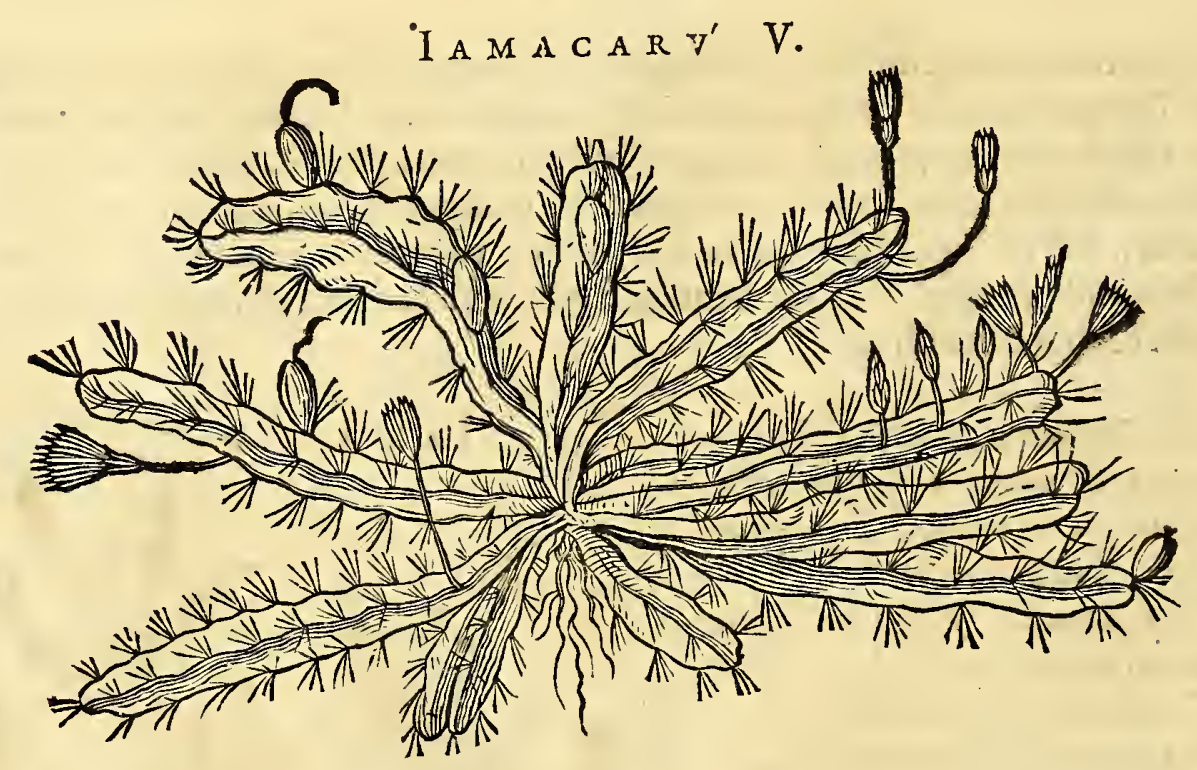

Quinta Ficus fpinofa, Cumbéba appellata. Ex radicibus tenuibus nafcuntur triangularia aut etiam quadrata folia, viridia, quibus alia hinc inde annafcuntur ut in Ficu Indica: funtque duplo craffiora quam Iamacarú qux fruticibus \& arboribus annafcitur; fed hujus longiora funt: in angulofis extremitatibus, aculeis munita, flavefcentis feu lignei coloris; inæqualis magnitudinis juxta fe pofita. Florem fert ut præcedentes fed minorem. Fructus, figurx oblongx, conftans cute craffa, egregie rubra. Pulpa friabilis alba,fucculenta, \& quafi in multos globulos conglobata ut nix gelu indurata: Eadem cum feminibus fuis nigris comeditur, boni faporis, Ficum vulgarem fuperans. Succus c̀ cortice rubro expreflus acidi adftringentis faporis ut fuccus Ribium immaturorum. Fuccum dant braficx fimilem: qui fi aimarus effet, planta hæc Euphorbium effet, nam per omnia convenit cum illius defcriptione.

Hæc Species Tunæ in Nova Hifpania profert Cochinillam, qux tamen hic locorum licet fedulo indagantibus nunquam apparuit.

Omnes hx plantæ Iamacarí nunc tenuibus, nunc craffis fpinis horridx, adeo, profunde carnem humanam pen etrant, ut vix ullo remedio evelli poflint prxcipue autem haequinta figura, Cumbeba dicta.

Sexta 
Sexta, \& ultima Iamacarú, quantum quidem mihi \& diligentiflimo meo domeftico haEtenus conftitit, peculiare nomen, ficut \& alix nonnull $x, a b$ Indigenis accepit, fcilicet Vrurumbeba, ex familia quoque Tunarum five Ficuum Indicarum. Qux in defertis mediterraneis tantum reperitur, atque licet in ufus Medicinx nondum recepta, pofteritati tamen indaganda, ac proinde hic non negligenda. Caudice eft recto, folido, fpinis validis inordinate pofitis armato, cui in fummitate multa folia, crafla, fpinis horrida, Palmx figura, ramorum vicem fubeuntia, adnafcuntur.

Fr. Ximenes varias quoque (Nochtli in nova Hifpania appellatas) harum Plantarum diffeI A M A A R V' VंI。

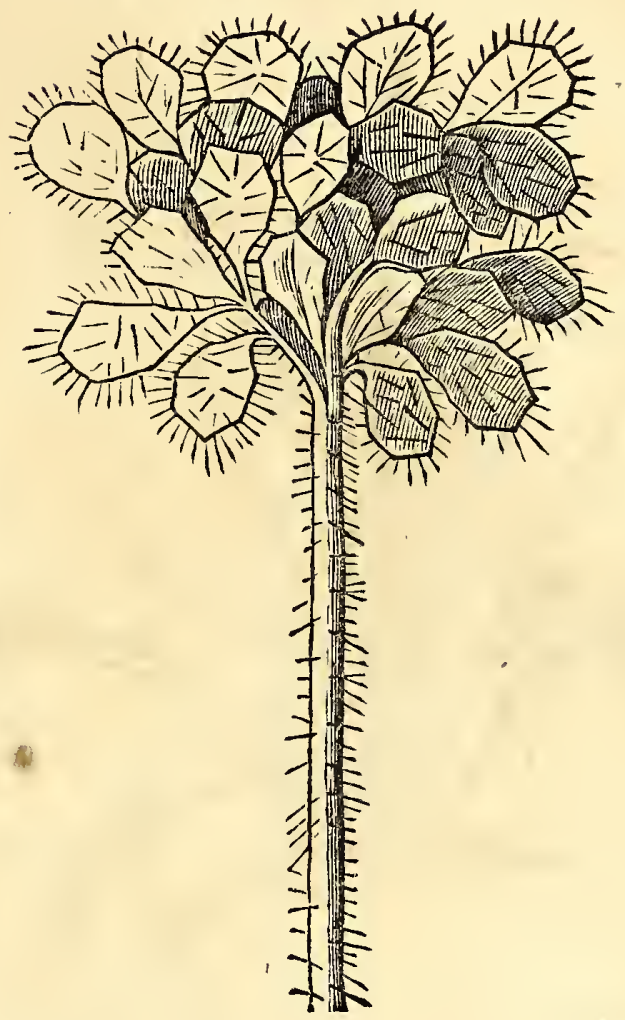
rentias dedit, quas potifimum fumfit à fructuum varietate.

Omnes Iamacarú frigidas \& humidas, licet gradu differentes, comperi , exceptis granis quæ funt ficca \& aftringentia. Quamobrem gummi quod ex illis deftillat, fruaus, folia, radices, febribus, aliifque malis exintemperie calida natis, five affumta five extus admota medentur. Fructus imprimis, tam fanis voluptati, quam ægris folatio exiftunt.

Licet ego paffim (ut $\&$ alii Autores ante me) in explicatione harum Ficuum Indicarum frondes quafi ex meris foliis conftare dixerim : fateor tamen, fi penitius ad examen reducantur, rami potius quam folii naturæ participare. Primo, quia nullum Botanicorum crediderim vidife folium ex folio ficut hic, fed quidem ramum ex ramo pronafci, ficut perpetuo in hifce Ficubus contingit. Secundo, quia folia decidua funt, quod nunquam in hifce Ficubus obfervatum eft. Tertio, quia folia contigua tantum funt arbori; è contra omne quod rami vicem fubit, continuum fit ficut quoque ex anatomia quarundam Ficuum apparuit, ubi radices immediate continuatas vidi ifti frondi, qux folii nomen audit.

\section{$\begin{array}{lllllllllll}C & A & P & V & T & X & X & X & V & I\end{array}$ \\ Caraguata Jpecies varice.}

$\mathrm{I}$ Mmenfi effet laboris omnes \& fingulas elegantium harum ftirpium differentias notare. Primam itaque \& præcipuam Caraguatá-acanga, ex univerfa illarum familia, defcribendam fufcepi, qux fructu efculento $\&$ medica facultate commendatur.

E terris potifimum glebofis provenit, olim filveftris tantum, nunc ob ufum $\&$ elegantiam exculta.

Nafcitur foliis læte viridibus, cavis, in fpeciem gladii mucronatis, prælongis, utrimque ferratis, denticulifque adeo acutis, ut nulla arte tractari, fructufque, quem intimo gremio occultat, vix impine erui poffit. Eo loci proxime ad terram multi flotes juxta fe in orbem pofiti proveniunt ex cæruleo purpurei \& in medio alba ftamina habentes. quilibet flos digitum longus, conftat tribus foliis. Fructum exinde promanantem (quem vides hic ad vivum alterum integrum, alterum diffecatum) Barbari proclamant divenduntque. Figura eft digitali, cujus longitudinem \& craffitiem ad xquat; colore tam intus quam extus albo, \& ad flavum inclinante; femine rotundo \& nigricante : Carne eft fri- 

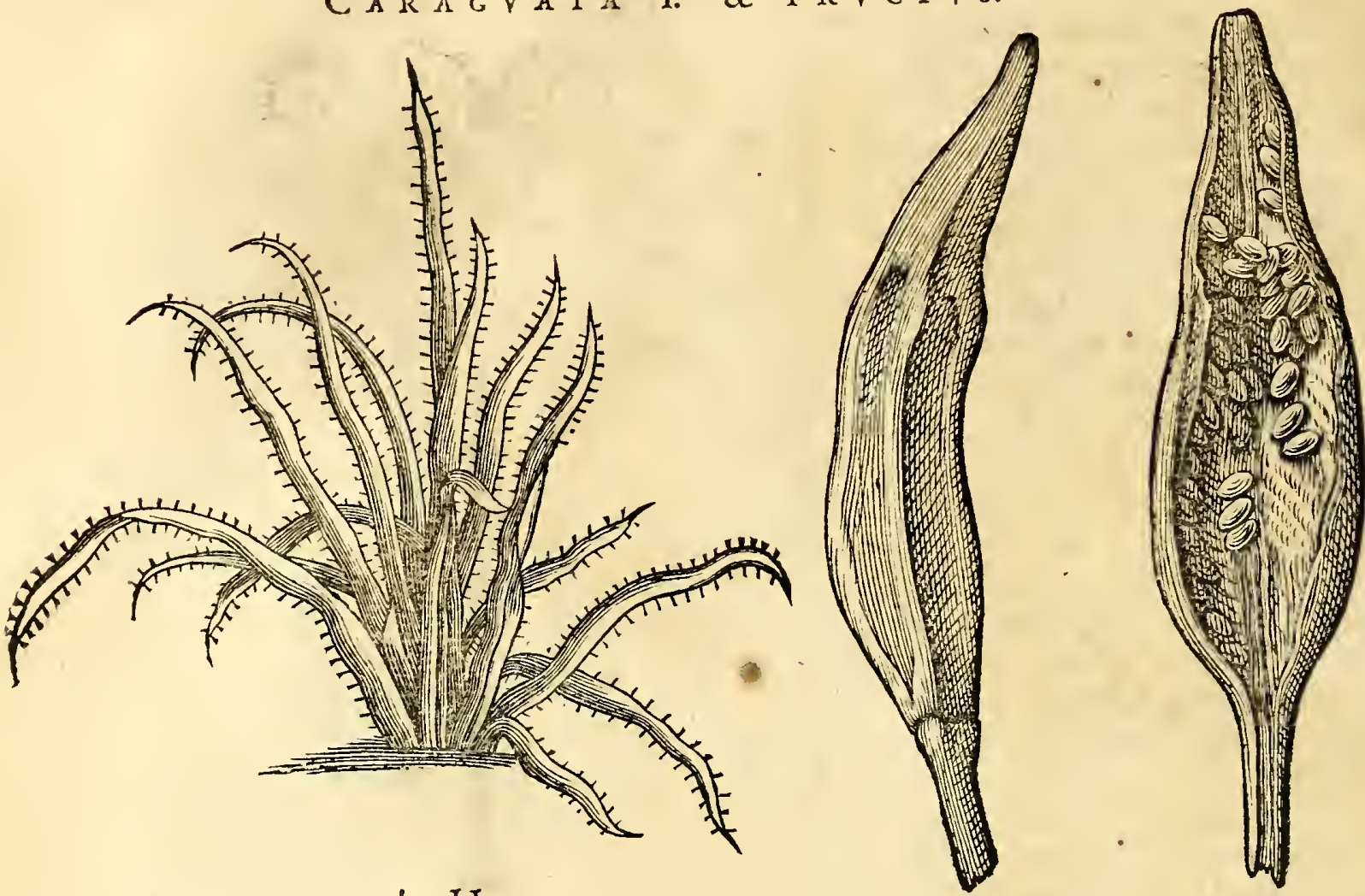

CARAG A T A

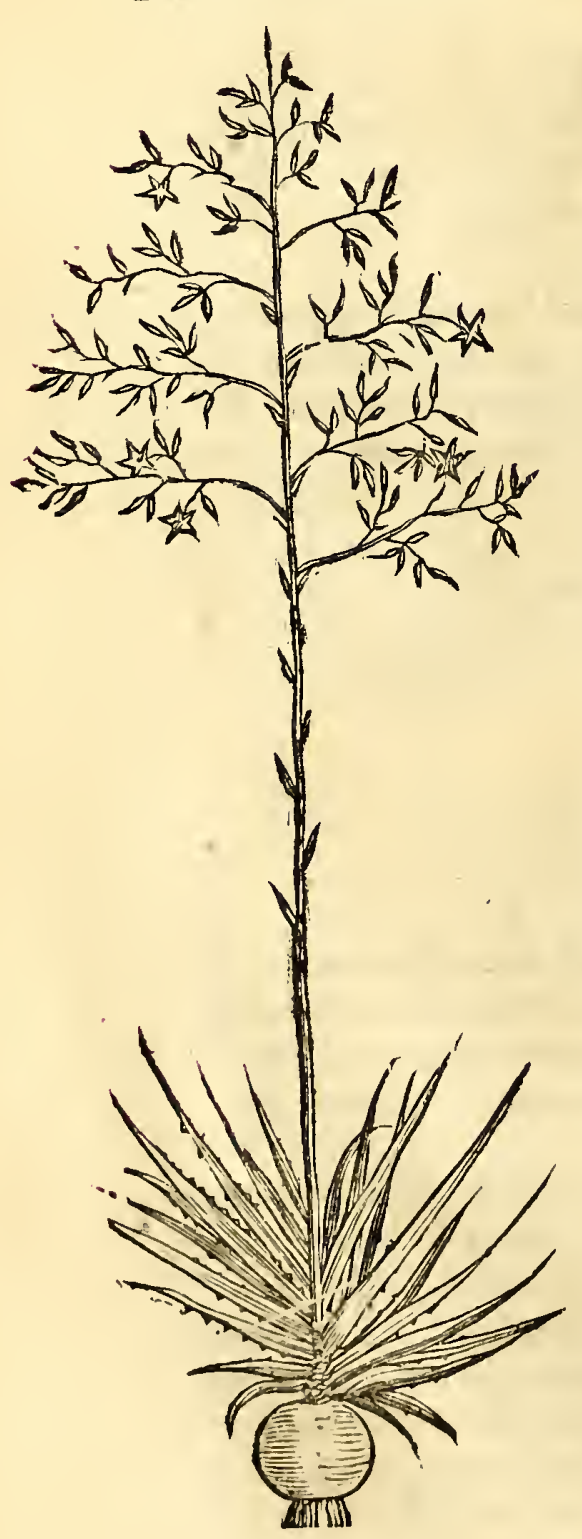

II.

gida, lubrica \& fpongiofa, multoque fucco turgida, qux palato acidulo fapore apprime applaudit. Cavendum tamen ne affluentius utaris, quod dentium ftuporem non folum inducat , fed \& linguam atque fauces fauciet, palatumque excoriet, ut non immerito Sinptonge à nautica pube nominetur. Succus cochlearis menfura, addito pauxillo Sacchari infantibus exhibitus eos vermibus \& oris Scorbuto liberat. Adhæc febricitantibus ex cacochymia fall $x$ pituitæ prodeft. Menftrua $\&$ urinas ftrenue, imo plus jufto, fi non decenti dofi propinetur provocat. à prægnantibus manducatus fotum ejicit : cujus rei non ignaræ meretrices, ut viris tuto fe proftituant fceleratum. aliquando infanticidium exercent.

Optimum vinum ex eodem plantæ fructu exprimitur $\&$ ufui refervatur. Sed quia forte eft, inebriat \& fanguinem accendit. Secunda, Caraguatá-guacú five major fpecies,nafcitur ex fabulofa radice qux magnitudine, figura \& colore plane Cepam xmulatur, atque inferius multa habet filamenta : primo affurgunt quatuor aut quinque folia craffa, fucculenta, viridia , cava, dein proveniunt plura, figuram habentia trianguli acutifimi, ftantque erecta, in orbem adnata, acutis denticulis rufecentibus munita. Poft biennium è medio foliorum exfurgit fcapus femoris humani craffitiei; rectus, fpongiofus hinc inde triangularibus foliis minoribus veftitus, altitudine fubinde viginti quinque pedum ; in fummitate autem explicat tenerum \& faftigiatum truncum inftar arboris cum fuis ramis; unde itcrum enafcuntur multa conica corpufcula, qux fefe aperientia fiorem exhibent ftellarem ex quinque foliolis conftantem.

Ex foliis hujus plantx optimus pannus conficitur, qui fi rie preparetur, panno lineo vix cedit. Ex fubttantia conicorum corpuficulorum, antequam in flores abeant, alba filamenta goflypii xmula cxtrahi poffunt. Folia fupam quoque $\& \mathrm{fi}-$ lofam materiam fuppeditant, è qua fila \&retia fua contexunt pifcatores.

Eadem 
HIST. NATVRAL。 \& MEDIC. LIB. IV.

Eadem vel leviter vulnerata fuccum tenacem $\&$ pinguem exfudant, fmegmatifque defectum fupplent. Radix aut etiam folia hujus plantæ recentia trita ac aqux injectas pifces ita exanimant ut ftatim manu prehendi poffint.

Planta junior in mufeo noftro diu fufpenfa, nova produxit folia ad parietem. $\mathrm{Li}$ gnum Caraguatá-guaçú ficcatum inftar funiculifulfurati ardet; ex eo ignis elici poteft durioreligno applicato. Pulcherrima fane \& rariffima vifu planta, cujus elegantiffimus fcapus exficcatus lectis penfilibus portandis eft aptiffimus. Ego unum ex Brafilia mecum detuli , quem Clariffimo Viro D. Vorftio in Horto Publico Lugd. Batav. fervandum dedi.

Tertia Caraguatá, Lufitanis Erva-babofa, Latinis Aloë dicta. Ex radice craffa fucculenta brevi affurgunt folia multa, craffa, fucculenta, acuminata, utroque latere dentata, pallide viridia, atque hincinde grifeo colore maculata. Inter folia prodit caulis, in duos ramos divifus, quorum quilibet fert fpicam forum flavorum ; eft autem quilibet flos cavus, ad oram fextupliciter fciffus, apercus, deorfum propendens, inodorus.

Hæc Planta aut eadem eft, aut ejufdem fpeciei, cum Manguey aut CMetli Mexicanorum,cujus plures reperiuntur fpecies in nova Hifpania de quibus Ximenes accurate egit, non folum tanquam Theoricus Botanicus, fed ut Practicus. Quippe infignes eorumufus Medicos, noftris $\mathrm{Ca}$ raguate dignitatibus multum fimiles annotavit : Qux qui curiofius videre volet, adeat Annotata in Hiftor. noftram Brafilix.

Porro plerique Scriptores qui de rebus Americanis commenta-

ti funt meminerunt hujus plantx, Gomara, Acofta, Clufius qui omnes fere confentientia tradunt iis, quæ Franc. Ximenes hic tradit ex Doct. Franc. Hernandez : Longe autem aliam plantam effe oportet quam D. Ioachimus Camerarius defcribit \& cujus Iconem dat in Epitome de plantis, fub nomine Aloës Amerícanæ; quia fcribit folia abundare fucco amaro, \& alia qux minime conveniunt cum fuperiori defcriptione. Quare differentia harum plantarum bene eft obfervanda, cum alioquin foliis \& quibufdam aliis notis inter fe conveniant. Ego enim hujus de qua nunc fermo nobis, nunquam purgantes; fed Chirurgi deterforias \& mundificantes qualitates in ulceribus foetidis quotidie experti funt.

Quarta Caraguatáplanta eft crefcens in arboribus \& putridis earum caudicibus. Ex radiće filamentofa, proveniunt fex feptem a!ıt plur a folia, ab uno ad quinque pedes longa, \& craffa ut folia Ananás: tres aut quatuor digitos lata \& cava inftar canalis, atque in ambitu dentata aculeis brunnis, acuris, furfum erectis. Caulis in medio exfurgit craffus, lignofus, altus, hinc inde foliis obfitus, in fummitate vero corona variegati coloris decoratur.

Alia denique Caraguate fpecies faxis horridis \& montibus adhærere confpicitur. Fructu fatuo quidem fed purpurei coloris infigni, Ananas filveftrem diceres: femine 
CARAGVATA IV.

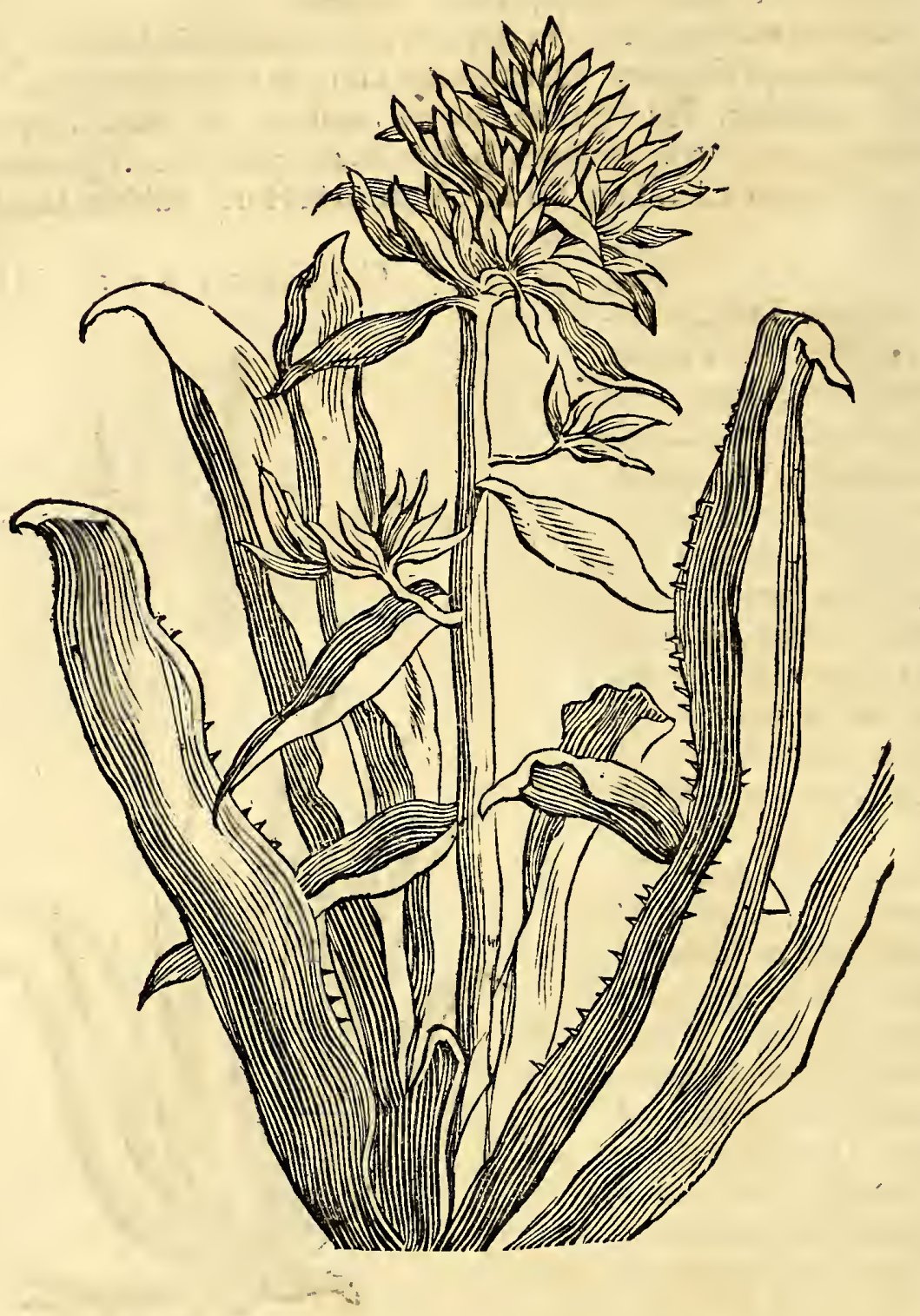

numerofo turgens ; Foliis vero craffis denticulatis, amplis \& inftar Dipfaci incurvatis, qux aliquando medium fextarium, plus minufve, aquælimpidifimæ, continent, maximo eorum folatio, qui per loca deferta, nullifque fontibus irrigua iter facientes, ad hafce plantas confugiunt \& fitim extinguunt. Sicut mihi non femel contigit, cum Indigenis Mediterranea loca perluftranti.

Polypodium praftantifimum his plantis (ficut in Europa Robori) fupernafci folet; omni Polypodio ad ufus medicos præferendum.

$$
\begin{gathered}
\text { C A P V T } \mathrm{X} \times \mathrm{X} \text { V I I. } \\
\text { Cana, Brafilianis; Ananas, Luftanis. }
\end{gathered}
$$

Ctum agere nonnullis videbor, quod fructum toties defcriptum \& ad vivum exhibitum hic denuo producam. Verum cum ea profequi fit inftituti noftri, qux praxin æque ac Hiftoriam Botanicam illuftrent ; proferam qua de Ananas qualitatibus, tum ab aliis, tum propria experientia didici. Eoque magis quod à fide dignis fenibus Incolis teftatum fit, primum hunc fructum exhifce provinciis ad Peruviam, inde ad Indias Orientales delatum effe. Recte quidem in comparanda rerum novarum notitia, follicite infitas vires inveltigamus : fed non minus intereffe exiftimo, etiam indies cognitarum herbarum \& fructuum ulteriores dignitates latentes fcrutari, ficut in hoc \& multis fumilibus veriflime milhi contigit, \& proculdubio fxpilfime mihi \& 2 aliis polthac continget.

Altilis 


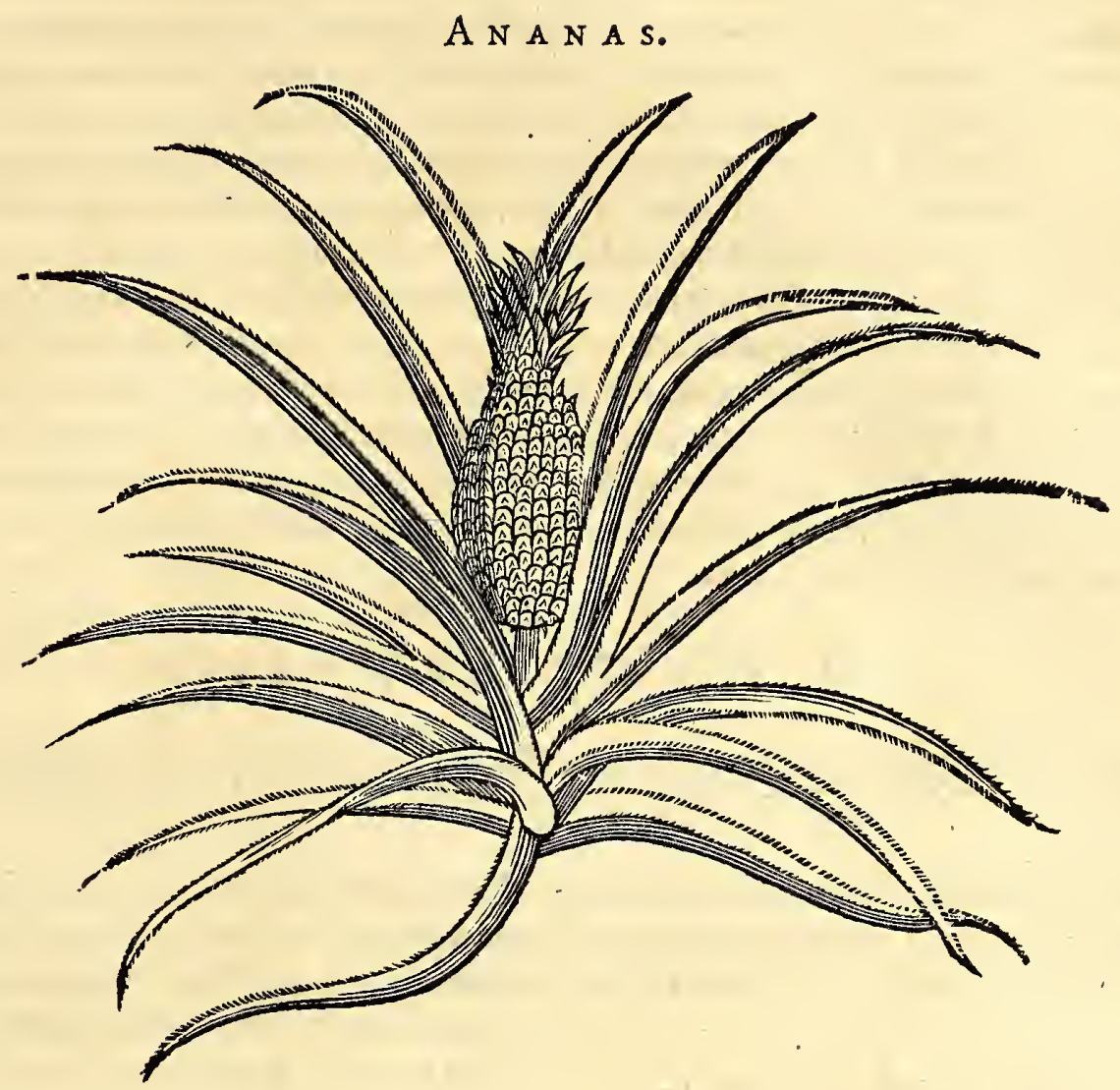

Altilis hujus Cardui fpecies, Oviedo Iaiáma, Monardo Strobylus aut nux Pinea dîatus, nemini credo ignotus, facileque optimus Indiarum fructus atque fecund $x$ menfxo oblectamentum, \& ornamentum, five crudus five Saccharo conditus. Cinaræ in modum fpicis compactilibus inftar criftarum, in fummitatibus emergentibus nafcitur, \& dum augetur, inter foliola ejus prodeunt flofculi multi variegati, fed potiffimum cxrulei coloris, tribus foliolis conftantes, qui maturefcente fructu decidunt. Folia autern ex quibus emergit Ananas funt circa viginti, oblonga, in ambitu dentata $\&$ in fpeciem gladii mucronata foliis Aloës æmula. Menfibus xftivis, Sole exiftente in Capricorno, maxime viget. Exigua femina feu grana fubrufa in fuperficie pulpx latitant. Fructus apprime fucculentus, eft infignis cinnabrii coloris, Melonis fere magnitudinis, figur $x$ ovalis, per oras autem incarnati, odoris fimul ac faporis fuaviffimi. Extuberantibus bullis ex flavo albicantibus exterius paffim diftinguitur, \& quafi vermiculis aut tefferulis variatur.

Fructus maturus fuperius plantam juniorem habct, qux decerpitur, \& ita fine radice (nullam enim habet) terr $x$ imponitur, qux fequenti anno fructum fert. Vnaquxque planta femel \& unicum fructum profert annuo fpatio, \& fructus novam fimul plantam, quæ cum plantatur, vetus eradicatur \& abjicitur, ut pote inutilis. Ananas vi Solis maturefactus minoris fit apud Incolas quam ille qui in conclavi fufpenfus aliquamdiu fuit.

Hic fructus, quia fucco corrofivo immodice fumto linguam vellicat, ac gutturis ardores infert, defciffo cortice in taleolas fecatur, inque vino Hifpanico maceratur tantifper, donec qualitatem noxiam deponat, qui gratum faporem $\&$ odorem vino quidem communicat, lingux tamen morfus $\&$ gutturis inflammationem, fi potetur vinum, inducit. Ipfe autem fuccus, quo turget fructus, mirifice animum languidum recreat, \& f piritus fopitos fufcitat, \& imprimis ftomachum naufeabundum reftituit. Addo , quod recens ejus liquor, tum vinum inde expreffum, urin $x$ fuppreffioni $\&$ doloribus nephriticis fuccurrat; tum quoque venenis, imprimis fucco chandihoce, adverfatur. Idem illius radix, fructu deficiente, praftat.

Omnia hrec efficacius operatur liquor ftillatitius è fructu vi ignis extractus, fi modica quantitate exhibeatur: verum fi largius concedatur, vafa urinaria infeftat, adeoque corrodendi qualitate pollet, ut non tantum linguam $\&$ palatum fauciet, fed $\&$ in cultro, quo fecatur, mordacitatis veftigia relinquat, idque intenfius, fi nón probe maturus

$$
R_{2} \text { fuerit. }
$$


fuerit. Maculas denique è veftibus eleganter abfterget. Atque tunc prxgnantibus non minus obeft quam fructus Caraguata. Febricitantibus, tum vulneribus vel ulceribus in feftatis, prorfus abftinendum ab hoc fructu; adeo enim humores accendit, ut non folum impediat reftitutionem xgrorum, fed $\&$ in pejus eos difponat.

Quapropter miror optimum Monardem, fructum Ananas frigidum \& humidum dixifle. Minus fallitur Chriftophorus à Cofta, qui calidum \& humidum effe affirmat.

Silveftres quoque dantur Ananas, ex Carduorum familia, qui nunc humi, nuncaltis arboribus fupernafcuntur, cujus fructus ut plurimum exiftit oval is Citrulli magnitudine, compofitus è quadrangularibus cylindris in extremitate quadrate pyramidalibus, per maturitatem flavefcentibus. Cavi hi funt, continentes granula ovalia innumera pallide flavefcentia, papaveris majoris femine majora, fuavia, $\&$ dulciflimo rore imbuta inftar mellis. Qui exprimitur digitis in os, \& pro fummis deliciis abforbetur. Fructus etiam tranfverfim difcinditur in taleas. Plura qui volet de hoc Silveftri five 2 anabrava, adeat Bellonii C. 40 .

$$
\text { C A P V T X X X V I I I. }
$$

\section{Betys velBetre, N Dandíf en Piper caudatum, \& Aguaxima.}

$\mathrm{F}$

Requens tum in filvis, tum in ruderibus Vrbis Olindæe effe folet Betys, frutex elegans, vel potius arbufcula quatuor aut quinque pedes alta; caudice recto, nodofo, digitum craffo, pallide viridi \& per totum punctulis albis notato. Superius ad aliquot nodos, ramulos adipifcitur identi-

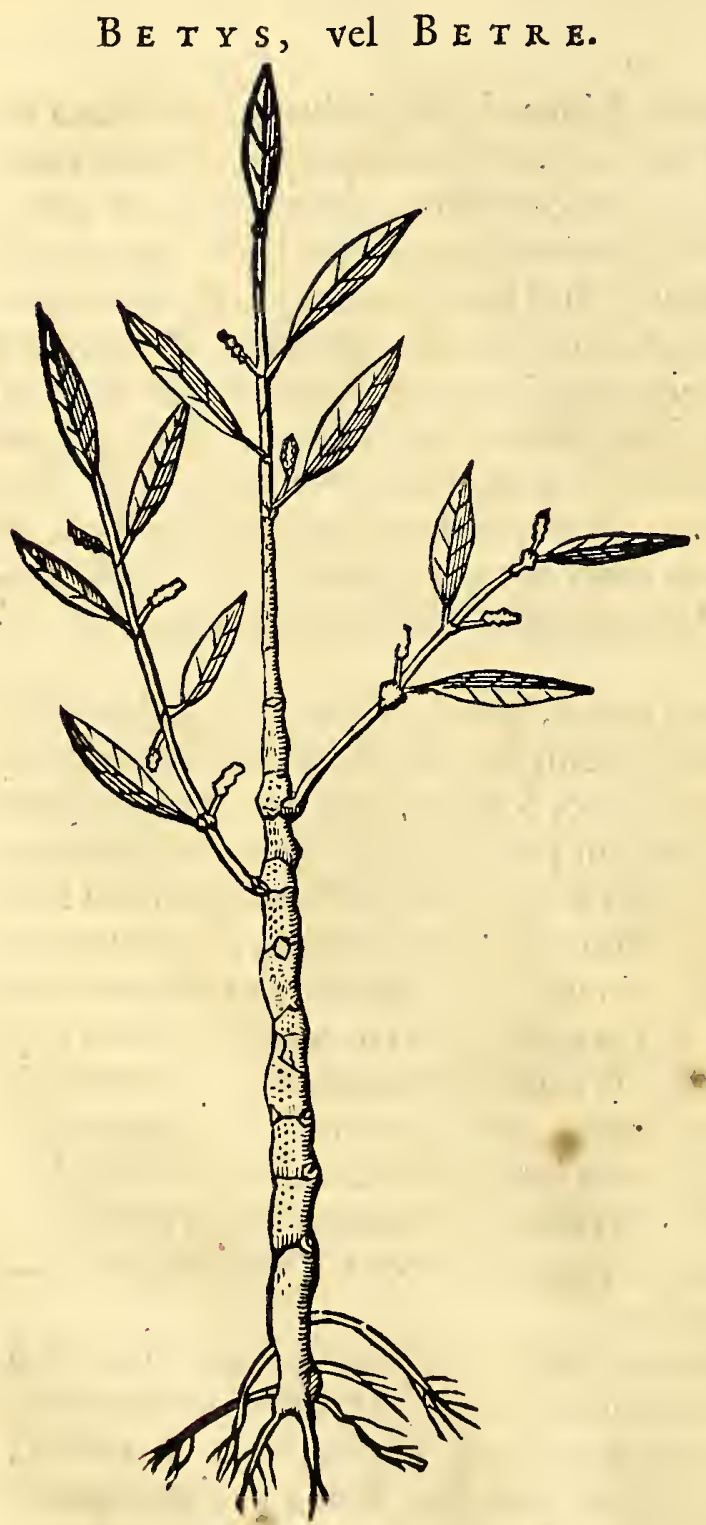
dem nodofos \& ejuldem cum caudice coloris. In ramis habet folia, ad quemlibet nodum unum, \& fimul unum julum. Folium, lingux figura, pallide viridis feu fubflavefcentis coloris, fuperius fplendens, craffitie Lauri foliis pene fimile. Denique Piperis ftirpi farmentis, caule \& $\mathrm{fa-}$ cie externa fimillima. In hoc tamen differt, quod folio \& fructu paulo quam $\mathrm{Pi}$ per eft grandiori. Arbufcula plane nobilis \& 2 quantivis pretii.

Iuli qui ex ramulis dependent, formam Piperis longi mentiuntur, fed infipidi funt \&nullius ufus. Verum licet fructus $f_{-}$ tuus fit, radix tamen fapidiffima eft $\&$ celeberrima; nam $\&$ aromaticum quid fpirat , \& Zinziberis præftantiam fapore, colore, atque odore æmulatur, præcipue fi recens fit ; tunc enim, dignitate illi vix cedit, calida $\&$ ficca habetur in gradu intenfiori.

Folio rum \& radicum decoctum colicum dolorem fedat, dolores membrorum mitigat, ventrem flatibus turgidum componit, pedumque tumores ex frigore natos amolitur.

Idem prxftant balnea $\&$ fomenta inde confecta.

Præter hanc Betyn, alixadhuc, inter quas eft Betys fomina, in ̣̂l tibus reperiuntur, julis gracilibus \& exiguis botrorum modo congeftis \& pendulis. 
$\mathrm{N}$ arborefcentis fruticis pene altitudinem caule te$I_{\text {nui,nodofo affurgit filveftris planta, qux Pimienta dos }}$ Indios à Lufitanis vulgo, à quibufdam Betre appellatur. cui egregie mucronata folia fingulatim pofita cum fuis pediculis adnafcuntur juxta nodos, ad quos itidem proveniunt multi juli, longi, incurvati, figura fere ut muris cauda, virides, qui prima xetate decerpuntur, ac in Sole ficcati nigrefcunt : continentque granula ro. tunda, nigra, feminis papaveris magnitudine, arcte juxta fe in uvam compofita, acrisfaporis, inftar Piperis optimi quod ex India Orientali affertur. Radix in alias plures tenues dividitur, fufcas, infignis odoris, inftar Thymi, \& faporis acris qui linguam vellicat. Decoctum radicis \& ftolonum difcutit atque incidit craffos $\&$ vifcofos corporis humores, fanat Hydropem pedum.

Folia hujus plantæ medentur ulceribus tibiarum. Radix mirabiliter valet adverfus apoftemata. Vtraque, cum fumme fint fortia, etiam exficcata $\&$ dit repofita, ad balnea calida contra mąla frigida ufurpantur. Pharmacopœa æque ac culina jam dudum frequentiorem agnoviffet ufum, tam utilis herbx; nifi tot Capfici Brafilienfis fpecies in hortis alerentur $\&$ omnium Piperum vices fupplerent.

Fr. Ximenes inter plantas novæ Hifpaniæ hanc eamdem videtur defcripfiffe; non minus figura quam quaJitatibus noftrx fimilem.

Quam vero Clufius defcribit julis potiffimum $a b$ hac differt.

Reperitur in Brafilia \& alia ejus jpecies ubique obvia $\&$ frequentiflima in filvis mediterraneis : per omnia fimilis priori, excepto quod folia anguftiflima funt $\&$ oblonga, fructus quoque feụ cauda piperina longior \& melior.

IN filvis littoralibus, maxi1 me vero in fertilifimo $\mathrm{O}$ lind $x$ Promontorio copiofe nafcitur hæc planta, Lufitanis Malva d'Ifso : Plurimxque ejufdem generis reperiuntur, fed quarum qualitates hactenus mihi funt incognitx.

Frutex eft elegans, inftar arbufculx excrefcens, ad trium, atque etiam fex pedum altitudinem. Caulis nodofus, teres, viridis, lignofus, fere ut caulis Solani ad afpectum.

Folia fert Titix fimilia,
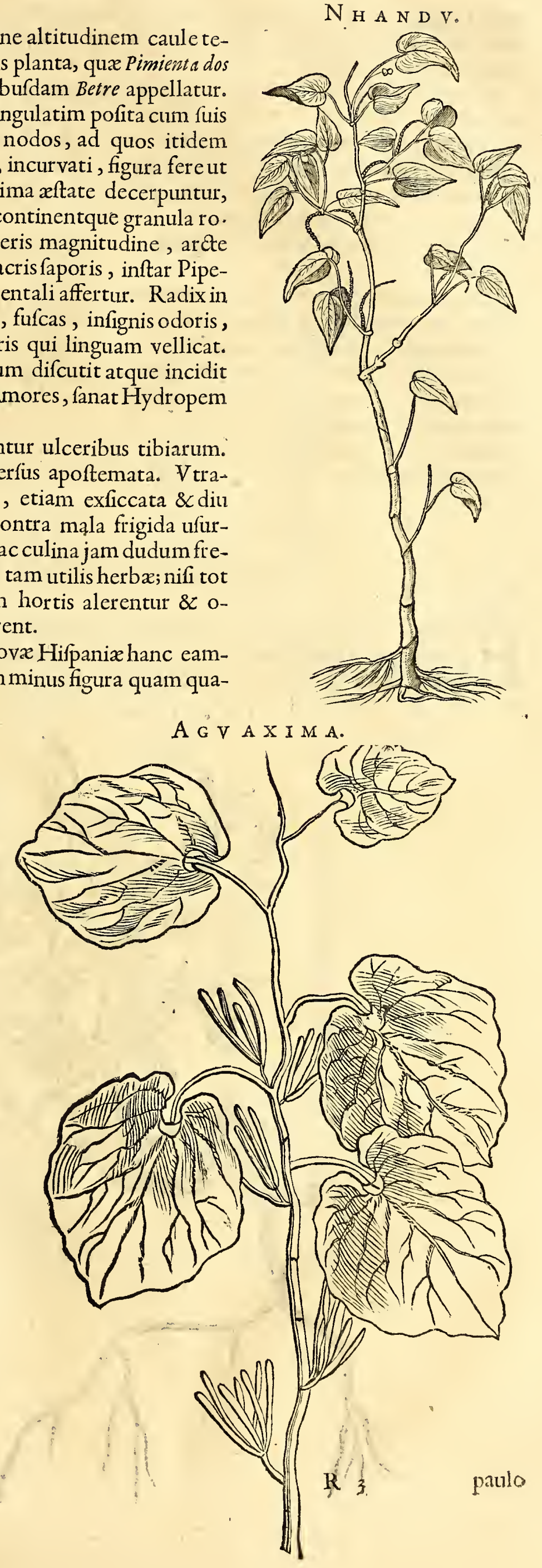
paulo tamen grandiora, qux fingulatim pofita, quodlibet fuo pediculo ad nodos innititur : funt autem folia lata, figura cordis, multis venis fecundum longitudinem arcuatim eleganter notata.

Ad nodos, ubi folia proveniunt, etiam Iuli multi, quatuor aut fex digitoslongi enafcuntur, incurvati, figurx ut cauda muris, unde Lufitani Pimenta rabuda, hoc eft, Piper caudatum appellant. Sunt autem virides, \& menfe Octobri \& Novembri decerpuntur, ac in Sole ficcati, evadunt nigri. Continent granula rotunda, nigra,inftar feminum Papaveris magnitudine, arcte juxta fe in unum compolita, faporis acris, inftar Piperis, quod ex India adfertur.

Si ex aqua bulliat \& Soli dein exponatur, fortius evadit \& magis durabile in omnes ufus.

Radicem fundit exterius nigricantem, optimam, atque utiliffimam; qux odore $\mathrm{Ca}$ ryophyllum, fubtili \& mordaci acore radicem Iaborandi, xmulatur.

Calida eft \& acris faporis atque inter antidotales habita, cumque partium fit tenuium, valide aperit, ac deobftruit. Nemini non ob preclaras virtutes, quibus abundat , cognita. Contufa, inque malagmatis aut emplaftri modum partibus afflictis impofita, optime maturat \& mundificat.

Succus vero foliorum frigidus, membris ambuftis efficaciter illinitur. Ipfa folia, propter virtutes quas cum Malvis habent communes, Clyfteribus induntur.

$$
\begin{aligned}
& \text { C A P V T . X X X } 1 \text { X. } \\
& \text { Caacbire dure, unde fit Anil. }
\end{aligned}
$$

Tiamfi ad humanos ufus \& tincturas minus exculta in hifce terris celebris illa planta quam Lufitani Erva d'arir, Indigenæ Caachira appellant : tamen undiquaque luxuriat, \& ex radice gracili, longa lenta plures affurgunt caules teretes,

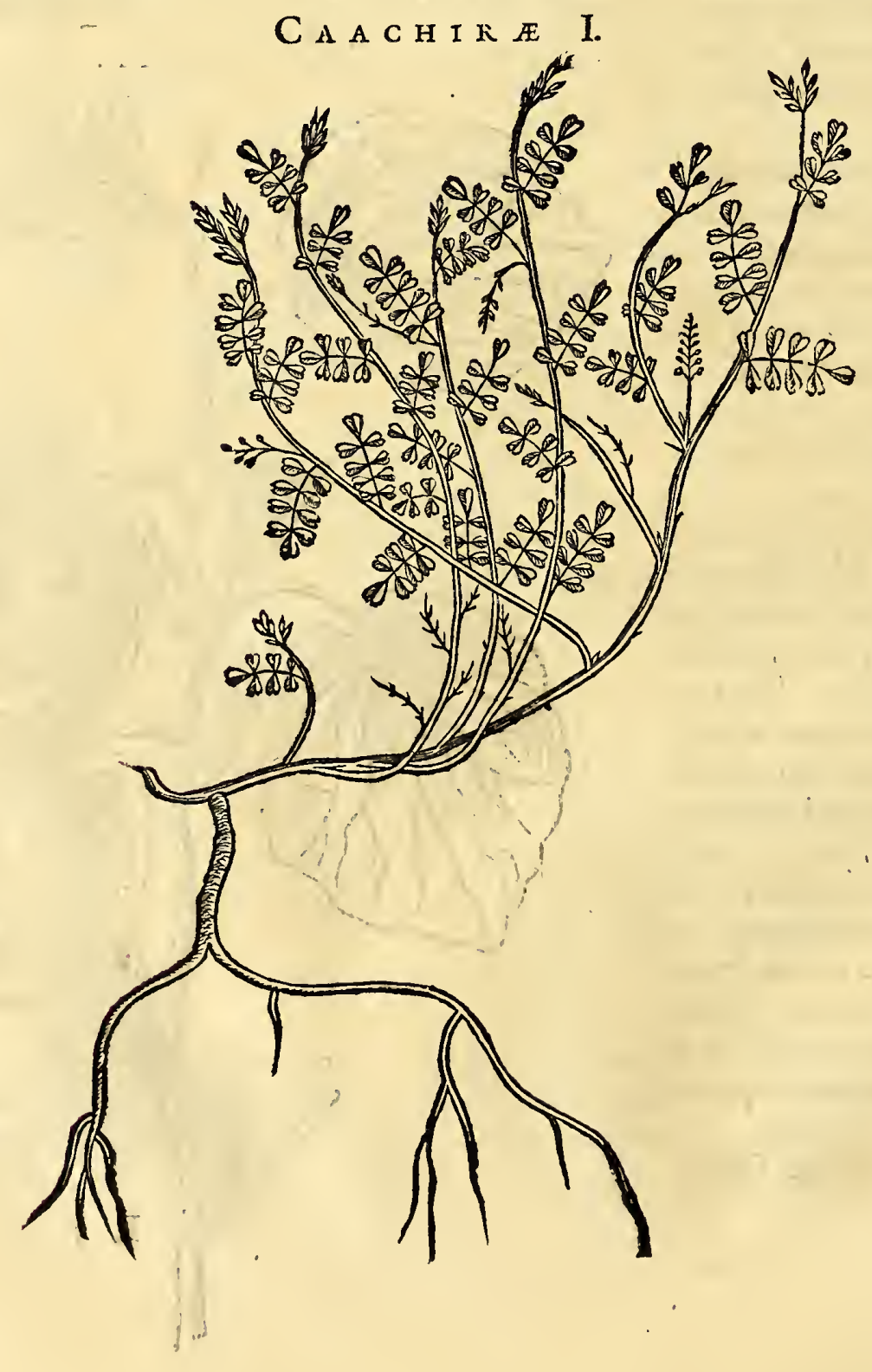


HIST. NATVRA L. \& MEDI C. L I в. IV. 199 hinc inde filamentis in terram dimiffis radicantes, \& verfus extremitatem fe furrigentes. Qui omnes ornantur ramulis, alternata ferie difpofitis; \& quilibet habet feptem vel novem cinerefcentia foliola, bina fibi oppofita excepto extremo. Iuxta ramulos enafcuntur breves pediculi \& in iis flofculi fragrantiffimi, fex aut plures, purpurei cum albo diluti, figura caffidis apertx.

Nafcitur paffim in Brafilia, imprimis circa littoralia, fed ab Incolis hactenus neglecta qua ad lucrum \& culturam, cæterum inter vulnerarias habita.

Datur \& alia fpecies in Brafilia ex qua Anir fit. Sed quia illius qualitates medicx potiffimun mihi compertæ funt, citra propofitum effet ulteriori defcriptioni inhærere . utraque enim vulneraria apud omnes pene America populos habetur, diverfifque modis prxparata, contra inveterata pedum \& capitis ulcera applicatur.

Qualitatibus medicis cæterifque ufibus familiaribus licet inter fe conveniant duæ hæ plantæ ; tamen figura multum difcrepant, quod pofterior hæc altius exfurgat caule unico rotundo geniculato fpongiofo, \& hinc inde pilis rufefcentibus veftito, adeoque fucculento, ut fi frangatur ftatim liquor cæruleus effluat. Pauci rami caudiciadnati, folia habent fine pediculis duo femper oppofita angufta, inftar foliorum Lyfimachix viridia, paulum hifpida. In ramorum geniculis fuperioribus circumftant folia copulata ex quibus flos albus circularis emergit magnitudine Bellidis. Radix tenuis lenta cxruleo quoque fucco turgida.

Fr. Ximenes teftatur folia contufa dolorem capitis mitigare, maxime in infantibus : etiam in aqua macerata \& cerebro appofita. Planta nonnihil amaricat, eftque acuta, calida \& ficca in fecundo gradu; Pulvis medetur plagis veteribus, fi ante urina $a b$ luantur.

Ióf. Scaliger. Nil vel potius Nir Arabibus eft color cæruleus; qui vulgo Hifpanis tam Anir quam Anil dicitur. Arabes quoque Ifatidem HerCAAC'HIR II.

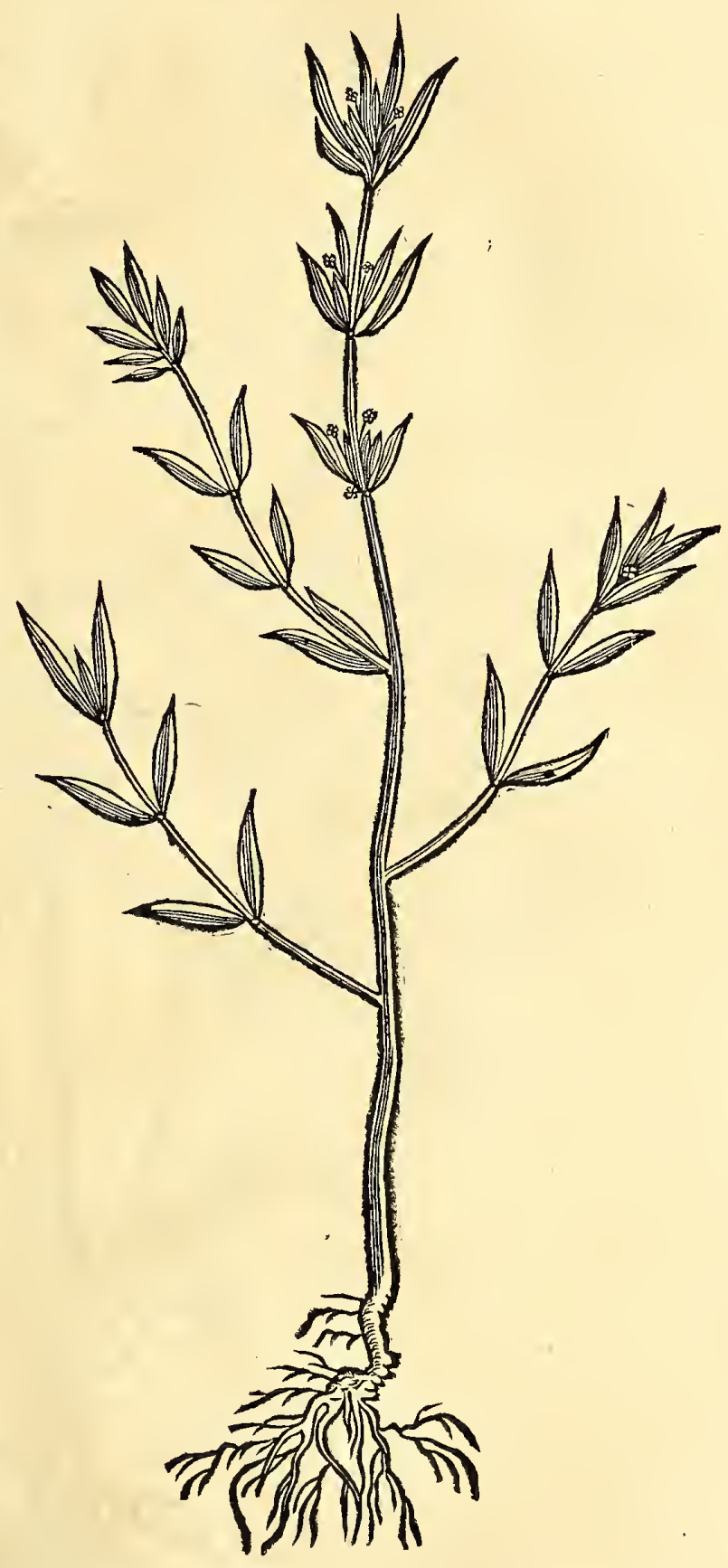

bam vocant 2 il. Garfias ab Horto lib. I r. cap. xxvi. Anil Arabibus, Turcis, omnibufque is nationibus dictum, vocatur in Guzarate, ubi fit, Gali, nunc vero plerif que Nil.

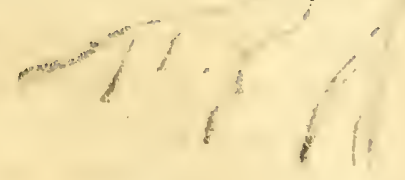

C A. 


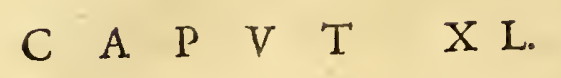

Caapomónga varice Jpecies.

Aapomínga aliis Caciandiroap eft herba filveftris fruticefcens, in locis confragofis \& aridis luxurians, Lufitanis Erva do vina dicta. Radicem habet longam, lentam, tenuem, rectam, aliis radiculis interdum præditam, exterius fubcroceam, interius candidiffimam, fubdulcis faporis : è qua prodeınt caules tres vel qua-

C A A P O M O' N G A I.

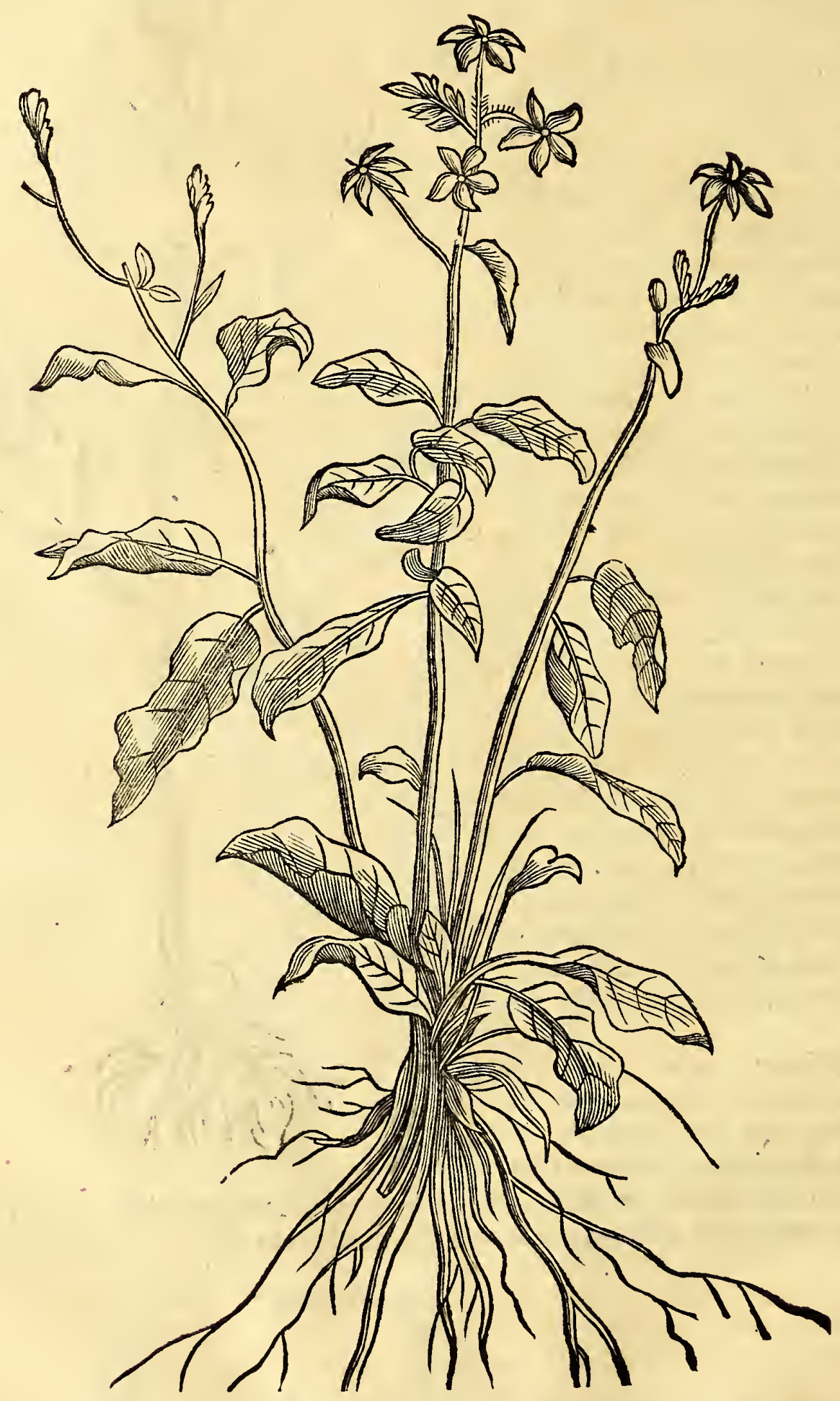

tuor, rotundi, nodofi, virides, ex parterufi ; quibus adnafcuntur folia longa, mollia, fuperius faturate viridia, inferius incana: In fummitate caulium rami funt continentes 
nentes flofculos parvos umbellatim pofitos, dilute rubro purpureos. propter exilis tatem eorum conformatio confpici non poteft, fed adhibito Megafcopio, funt delineati. Erumpunt è conico cylindraceo corpufculo viridi, quod antequam fe aperiat, hifpidum eft $\&$ pingue, ita ut facile adherefcat veftimentis. unde Lufitani vocant Carapicos, \& Hervad'amor.

Herba Clyfteri indita alvum cunctantem provócat, \& vifcofitates inteftinorum exturbat. Radicem inter antidota femper habuere Incol $x, f_{1}$ in convenienti liquore preparata hauriatur, quod partim vomitu, partim mictu quodcunque venenum tuto ejiciat.

Datur \& alia Caapomónga fpecies, eifdem locis crefcens, priori, fi formam \& figuram fpectes, diffimillima, fed medica facultate non multum difcrepans. Radix enim tenuium partium eft, \& ab indigenis ex aqua fontana ; à noftris ex aqua Paiomirióba cocta \& iteratis vicibus potatá, urinam provocat, renibufque prodeft.

Tertia Caapomónga dignitate cæteris minime cedens à quibufdam Trévo, $a \dot{b}$ aliis Erva d' Amor dicta , 'quod vifcofitate quadam digitis \& veftibus adh $x$ reat. Si folia eorumque conformationem confideres, Trifolium Americanum fpicatum æmulatur. Ex radicelonga, lenta, gracili exfurgit caulis rotundus, pilofus \& quafi geniculatus. Vnde in brevi pediculo nafcuntur juxta fe tria folia viridia, inferius pilofa \& canefcentia. In fummitate caulis proveniunt flofculi purpurei coloris in ficam congefti, quibus fuccedunt filiquulx compreffx, hirtx \& quafi lunatx. His femen continetur magnitudine Sinapi exalbo flavefcens, fapore \& figura Phafeoli : Radix illius calida in fecundo gradu, cbullitione ex aqua fontana vel alio convenienti liquore præparata $\&$ ægris propinata, facile inter prima habetur remedia, qux fluxibus ventris ex frigore natis profunt. Folia quoque apud primos Incolas in pretio habita, quod eorum fuffumigia operto capite recepta, dolores ex frigore \& catarrho natos feliciter reftituant.

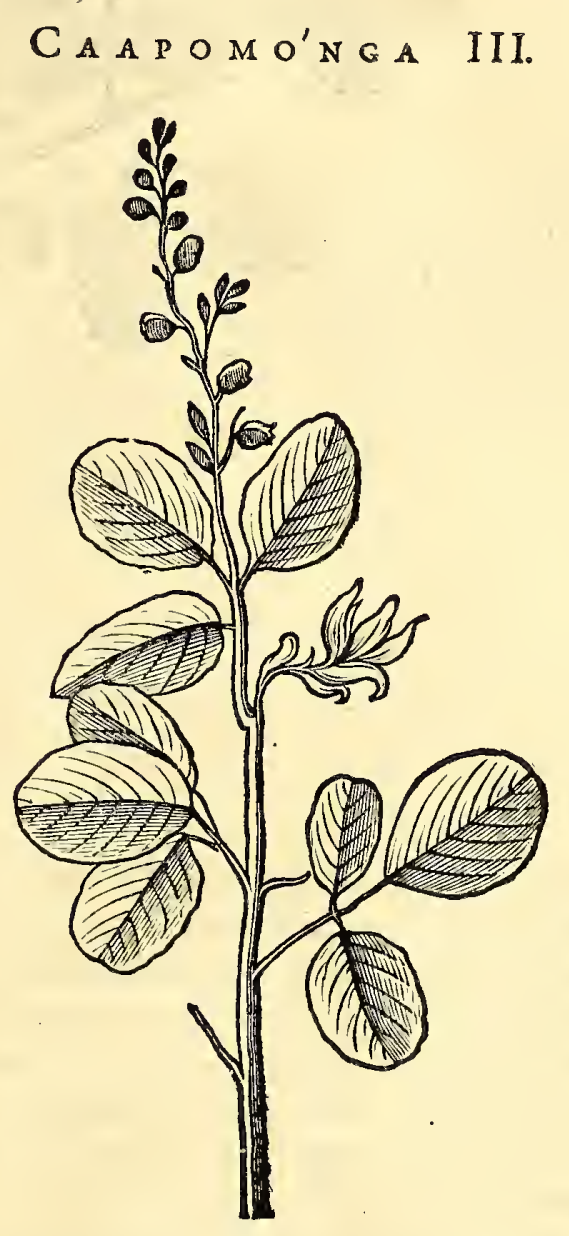

$$
\text { C A P V T } \mathrm{X} \mathrm{L} \mathrm{I.}
$$

$$
\text { Caacó fove berbe Cafes due fpecies. }
$$

Aaeóaliis Iuquerii, Lufitanis Erva Mimofa, Latinis herba Cafta vel Viva dicitur. Varix hæ plantarum fpecies varia fortiuntur nomina, quas Markgravius meus in Hiftoria naturali Brafilix accurate exhibuit, quo lectorem curiofum remitto. Ego vero, ut antea monui, facultatibus \& ufibus rerum potiflimum intentus, duas tantum earum fpecies in medium profero. Quarum prima, quantum cxteris proceritate inferior, tantum efficacia $\& z$ elegantia fuperior exiftit. Celebris hac herba, caule eft ftriato, viridi, lignofo, aculeato, fragili tamen $\&$ medullofo, qui partim terr $x$ incumbit, partim aflurgit \& aliis fe implicat : in varios panditur ramos aculeatos; quilibet autem ramulus aliquot coftas habet fibi femper oppofitas, qux continent foliola lxte viridia, ordine pofita $\&$ fibi oppofita, angufta, oblonga, ut lentium, fine pediculis, ad tactum tenera, in medio fecundum longitudinem fubtili nervulo, non confí- 


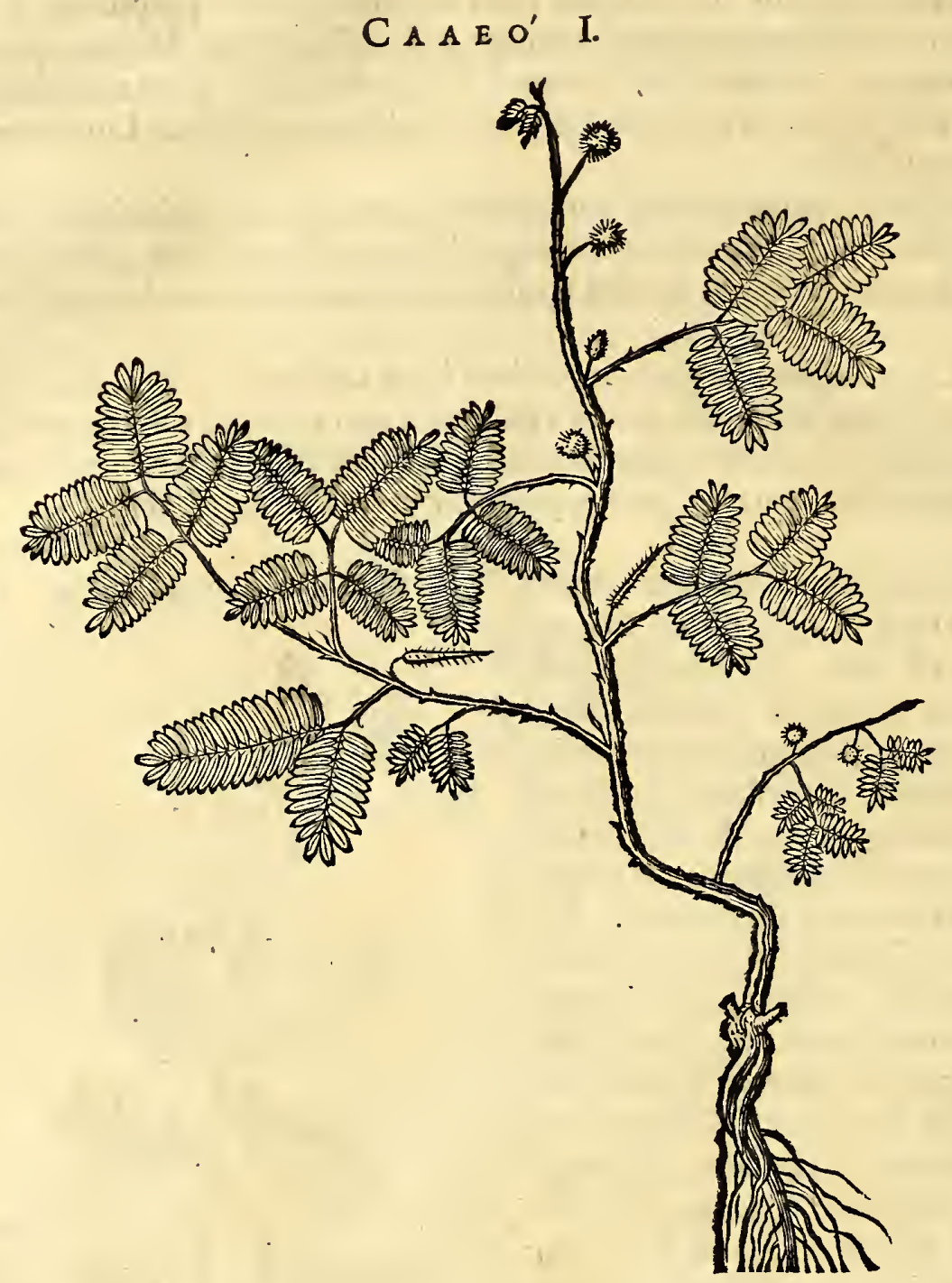

cuo niff folium obvertatur. Ad caulem circa ramulos brevis provenit pediculus capitulum producens hirfutum, nunc cæruleo purpureis, nunc incarnati coloris conftans flofculis egregiis. His fuccedunt filiqux tenues ftriatx, mollibus aculeis munitx, in quibus femen fplendens, nigrum, oblongum latet. Herba eft dulcis faporis $\&$ inodora, fed radix fortis $\&$ ingrati odoris, medullofa, lenta, interius alba, exterius umbr $x$ coloris. Mirabilis fane planta, quod vel leviffime manu, baculo, vel afflatu ta$c t a f e$ contrahat $\&$ mox fe componat. Ipfe vidi filentibus ventis integros campos his plantis obfitos foliis expanfis; mox, vel oris vel auræ marinx leviffimo afflatu folia omnium concidiffe, $\&$ in momento fe explicuiffe.

Sequitur Secunda fpecies Caaé, Lufitanis Sylva do Praya vulgo dicta, qux affurgit in altitudinem Pruni filveftris : folia illius fimilia foliis prioris fpeciei, fed anguftiora, in ramulis difpofita. Flos convenit cum flore primæ fpeciei, paulo tamen major. Lignum fubrufum, lentum, multis fpinis munitum. Fert femen in filiquis magnis, latis, plane hifpidis, brunni coloris, tres digitos longis ; quo maturefacto filiqux fponte in tot partes diffiliunt, quot feminis grana continent, qux farris funt magnitudinis, coloris olivacci,capfulæ inclufa. Cum hæè à præcedentibus vix differat nifi magnitudine filiquarum, operæ pretium duxi, illarum unam, ob elegantiam, ea mole qua erat, adjungere.

$\mathrm{Hxc}, \&$ alix ejus fpecies arenofo \& effoeto folo nafcuntur. Sole quoque cadente fenefcere, oriente vero denuo revirefcere, veriffimum eft. Sunt qui motum fpontaneum \& fenfum illi male tribuunt. Sed quia inftitutinoftri non eft aliorum opinionibus refellendis temporis jacturam facere, proferemus ea qux circa celebris hujus plantx ufum \& abufum experientia comprobata funt, \& à nemine antea prodita.

Brafiliani, fi cui forte necem moliantur, momentum exficcatx herbx in pulverem trita, epulis indunt, vitamque eripiunt. Hoc admiratione dignum, quod nullum huic malo 
HIST. NATVRAL。 \& MEDIC. I в. IV.

malo remedium aut antidotum à Medicis huc ufque repertum, ipfi radici hujus plantx praferendum. Hac fiquidem liberalius porreeta; vim veneni retundit. ficut latius probavimus in tractatu venenorum. Folia illius venenata, in emplaftri formam reda ata, Atrumas refolvunt \& curant.

Francifcus Lopez de Gomara in Hiftoria fua generali cap. 194 fcribit in Peruvia nafei arbufculas quarum folia marcefcant, fimanu tangantur, \&, cap: 205 , fimiles reperiri in Nicaragua. Cxterum Garfias ab Horto lib، I I. cap. 27. Nafcitur, inquit, in Malavar, tlasta mir nature. nam fiquis manum admovieat, ilico contrabitur. Folia. Polypodii, flores vero babet tuteos. Chriftophorus à Colta cap. Lvi. Herbam hanc vocat vivam. Caterum \& Antiquis nota finit, fiquidem accurate ádmodum defcribitur à Theophr. lib. Iv. Hift. plantar. cap. II I. fub fi-

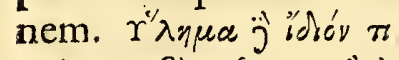

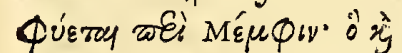

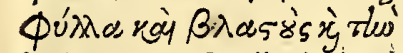

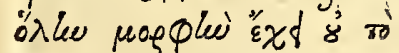

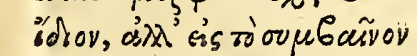

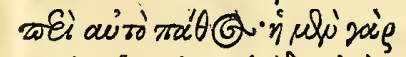

$C A \cap E O^{\prime} I I$

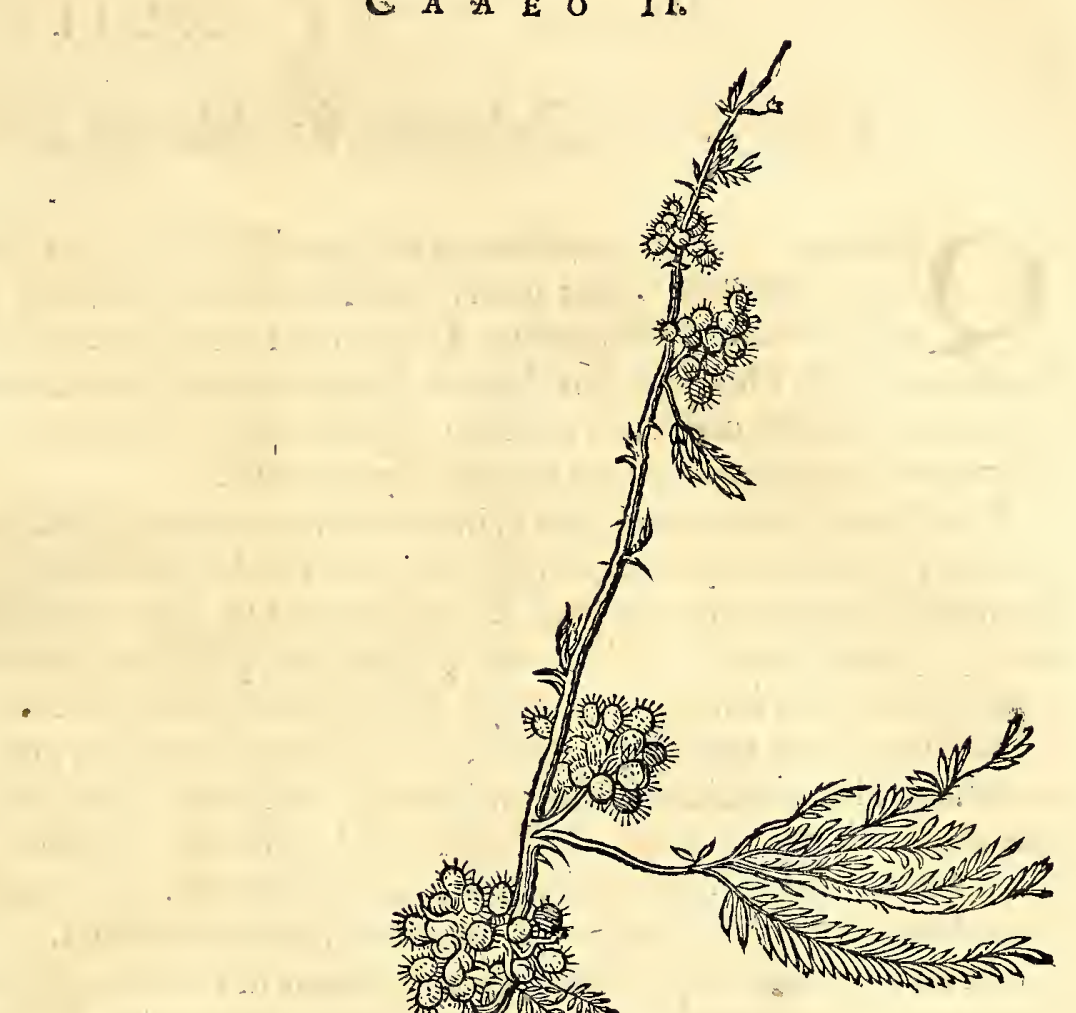

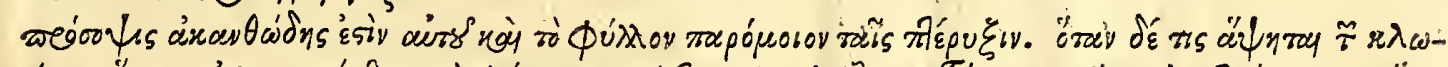

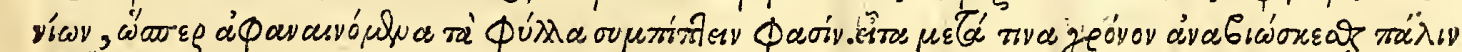
rag Grìnesv. Id eft: Nafcitur peculiare quoddam virgultum circa Memphim, quod quidem neque folia, neque ramulos, neque totam förmam peculiarem habet, fed accidentem tantum illi paffionem. Quippe facies ipfi fpinofa \& folium perquam fimile filicibus; ubi autem quis attigerit ramulos, folia quafi hebetata concidere aiunt; atque hinc poft aliquot tempus revivifcere denuo atque folia fua explicare. Etiam Plinio non incognita fuit lib. xxIv, cap. I7. Adjecit his, inquit, Apollodorus affectator ejus, herbam alchynomenen, quoniam appropinquante manu folia contraheret. Memorat autem inter herbas à Magis celebratas, cum nihil certius fit, quam hancherbam hæc pati. Ximenes de Plantis Novæ Hifpanix agens, eafdem videtur novific. Vt \& Nofter Bontius in Indiis Orientalibus fimilem nafici teftatur. 


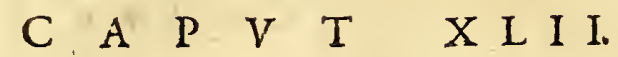 \\ Varice fpecies 7 Mangues five Mangles ér Inimboy.}

Q Vantum à rerum exoticarum fcriptoribus didici, per omnes Indias, paludofa loca, falfcdine vicini maris imbuta, ab hoc arborum genere, quod Mangue vulgo vocant, obfidentur. Cujus non folum Oviedus, Clufius aliique Neoterici, verum $\&$ Theophraftus, Strabo, Plinius meminiffe videntur. Sed cum potius ob rarum \& eximium crefcendi modum, quam ufum, hactenus tradita fuerint, oper $x$ pretium erit penitius naturam illarum introf exiffe.

1 res dantur fpecies Mangues: Prima Cereiba, qux Mangue eft alba. Arbor inftar Salicis pumilæ, tali ligno, ejus denique figuræ, foliis itidem fimilibus, fed paulo craffioribus $\&$ directe fibi invicem oppofitis. In extremitatibus autem ramulorum inter tria, quatuor, \& interdum duo folia, duo proveniunt pediculi, quilibet tres, quatuor aut quinque flofculos habentes, congeftos, ex albo dilute flavefcentes, quatuor foliolis conftantes, $\&$ in medio totidem ftaminulis nigris furrectis, mellei odoris. Folia hujus arboris, lucente Sole falem albifimum continent in fua fuperficie; quando vero coelum nubilum aut tempus nocturnum, fal diffolvitur \& inftar roris adhæret: interdiu autem ficcus \& albiffimus, digitis detergi poteft. Ac tantum ex duobus vel tribus foliis colligitur, quantum jufculo probe faliendo fufficiat.

Secunda çereibuina, qux non radices ex ramis in terram agit, nec tam tortuofo flexu luxuriat. Folio eft craffo, glabro, rotundo, dilute viridi, flore albicante, exiguo fructu \& valdeamaro, nucis avellanæ magnitudine, quo cum Palumbi \& cæteræ volu-

$G \vee A P A R A I^{\prime} B A$.

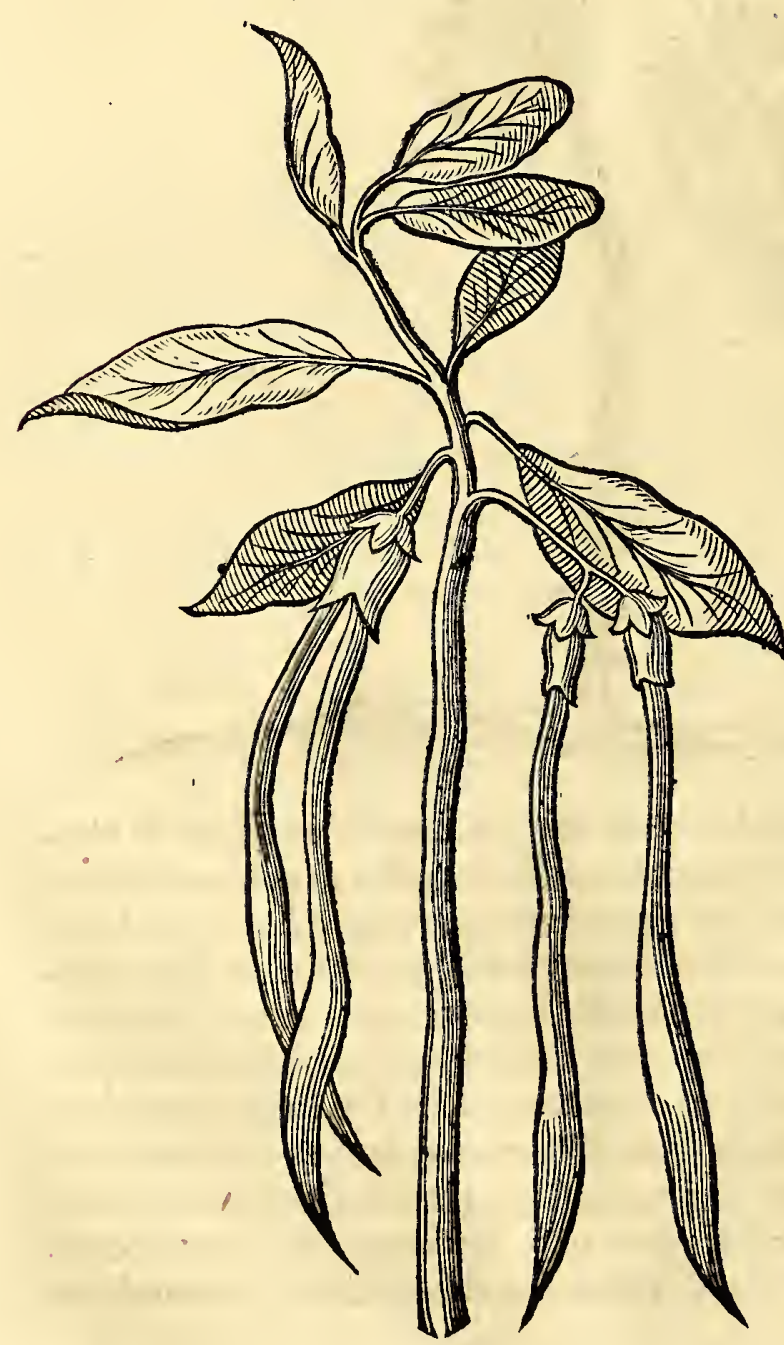
cres, defectu melioris alimenti, fefe ingurgitarunt, adeo eorum caro amarefcit, ut vix efculenta fit. Cortice exiftit rubro, ex quo Rhois coriaria, Europæa haud inferior, conficitur, pifcatoribus quoque ad retia tingenda, in quotidianoufu.

Tertia \& poftrema vera eft Gisapariiba dicta Lufitanis Mangue Verdadeiro c $x$ teris magnitudine \& preftantia longe fuperior. Æftivis menfibus fert filiquas inutiles fufci coloris pulpa amara refertas, oblongas duas fimul copulatas; ejufque admirandus eft crefcendi modus. Sicut enim ramos in altum vergentes \& Pyri inftar frondefcentes habet, ita multi ejus rami á $\phi u \gg \lambda$ or in radices converti videntur, quod deorfum tendant \& fub terram fe figant, aliifque ramis apprehenfis, iis copulentur, $f_{1}$ mulque fe protrudant, nec minus firmiter cohæreant, quam primarii arboris trunci; ita ut ex multis caudicibus fimul connexis arbor conflata videatur, egregio fane fpectaculo \& fingulari arboris hujus natura, vepreti inftar oram obfepiente, difficilemque aditum præbente. Lignum arboris eft grave, folidum $\&$ corticem habet brunnum : ramos $\&$ folia fibi oppofita; atque hæc quidem crafla nervo fecundum longitudinem, \& multis venis fecundum latitudinem, 
HIST. NATVRAL. \& MEDIC. LIB. I Vi.

late viridia. Flofculos fert multos in calicibus oblongis ex viridi fubluteos. Fructus decidens, Cancrorum terre éftrium pötius quam hominum eft pabulum.

Radix autem ipfa qux mollis eft $\&$ humida, fifla $\&$ tofta, calida puncturæ venenat 2 utriufque pifcis Niqui applicata, ejus dolores fedat $\&$ membrum læfum reftituir, licet prima fronte dolores exafperet. Magnum fane remedium eft, \& à pifcatoribus prime inventum nobifque traditum.

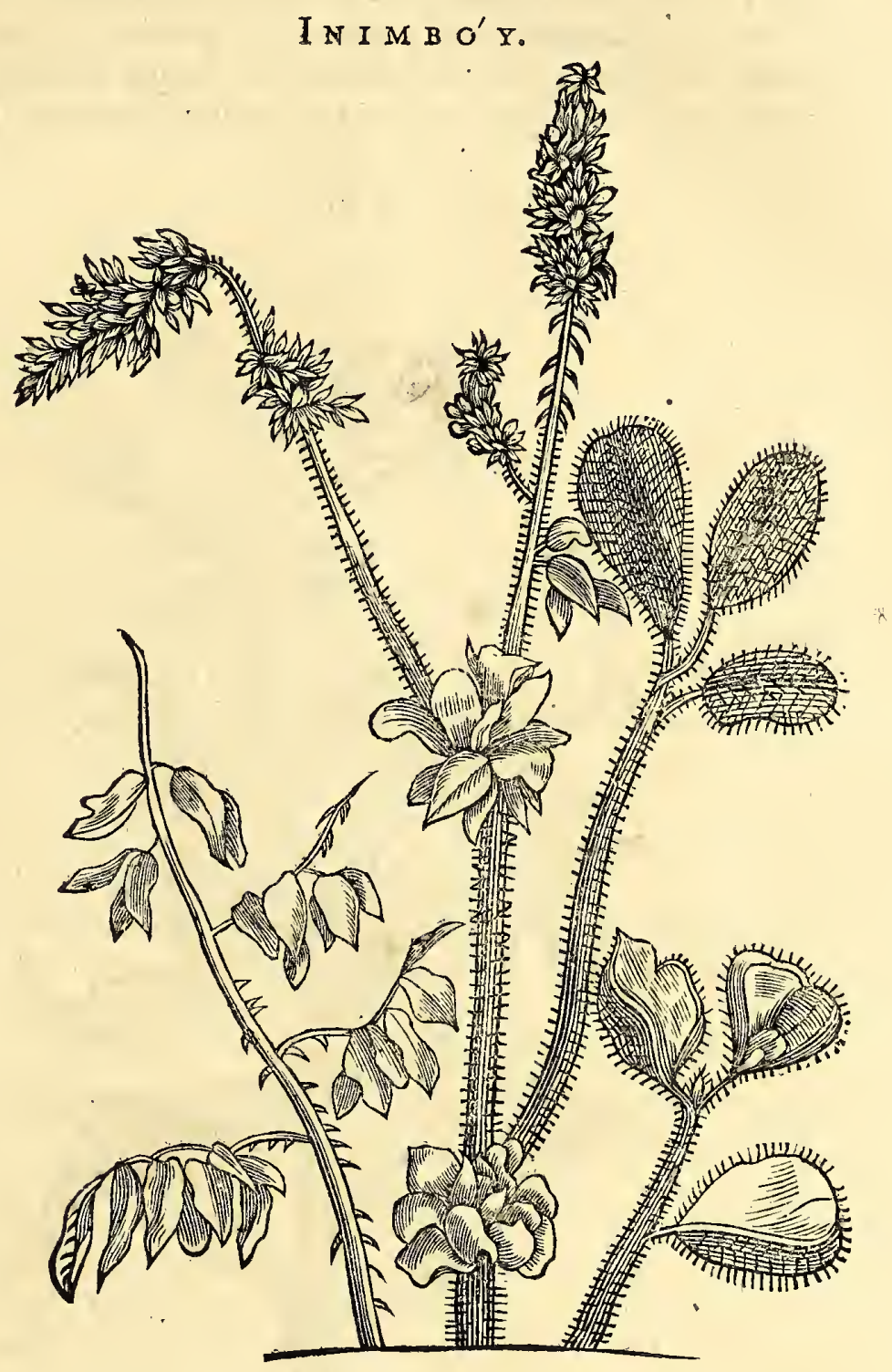

Nimbóy. Afperè echinatus ille \& vix tractabilis Brafiliæ frutex in filvis arenofis \& lit1 toribus fitientibus abunde pullulat ac jucunde virefcit, quem vulgus Lufitanorum silva do Praya nominarunt. Lobos, echinoides quos C. Clufus vocat, profert duabus vel tribus fphærulis lapideis refertos : in Cynosbati magnitudinem excrefcit. caudex, \& ramuli pleni fpinulis hepatici coloris, lignum intus medullofum infar Sambuci. Sunt autem folia late viridia, fplendentia. Flores fert in fpicam congeftos luteolos. Hosfequiuntur lobi finofi, hirfuti, coloris, cum maturuerunt, hepatici, in quibus fingulis continentur duo globuli duriffimi ; matur efacti ex lobis erumpunt, cinerei coloris, glabri \& plendentes, qui quaffato lobo ftrepitum edunt : nucleus interior ex albo Havus, amari faporis, inftar Lupinorum.

Radice eft gracili $\&$ dura, interius albicante, ad tcrtium gradum calida $\&$ faporis amari. Hujus refina, ad pugillum, plus minufve, affumta, excitat vomitum. Contraque illa venena potiffithum operari teftantur Empirici, qux lente vires fuas deleterias exferunt, \& 2 tarde vitam depafcuntur. de quibus in tractatuVenenorum latius egi. 


\section{A P V T XIIII。 \\ Petúme fove Tabacum.}

Elebris herba Tabacum, five Petum, quæ Brafilienfibus Petúme dicta, per omnes fere Indias Occidentales, antiquitus ipfis Incolis in pretio habita ad vulnera imprimis curanda. Mox Europxi ejus confcii facti, atque ulteriores vires indagantes, primo recentia folia eorumque fuccum in varios ufus humanos; mox exficcata

$$
\text { PET.V'ME. }
$$

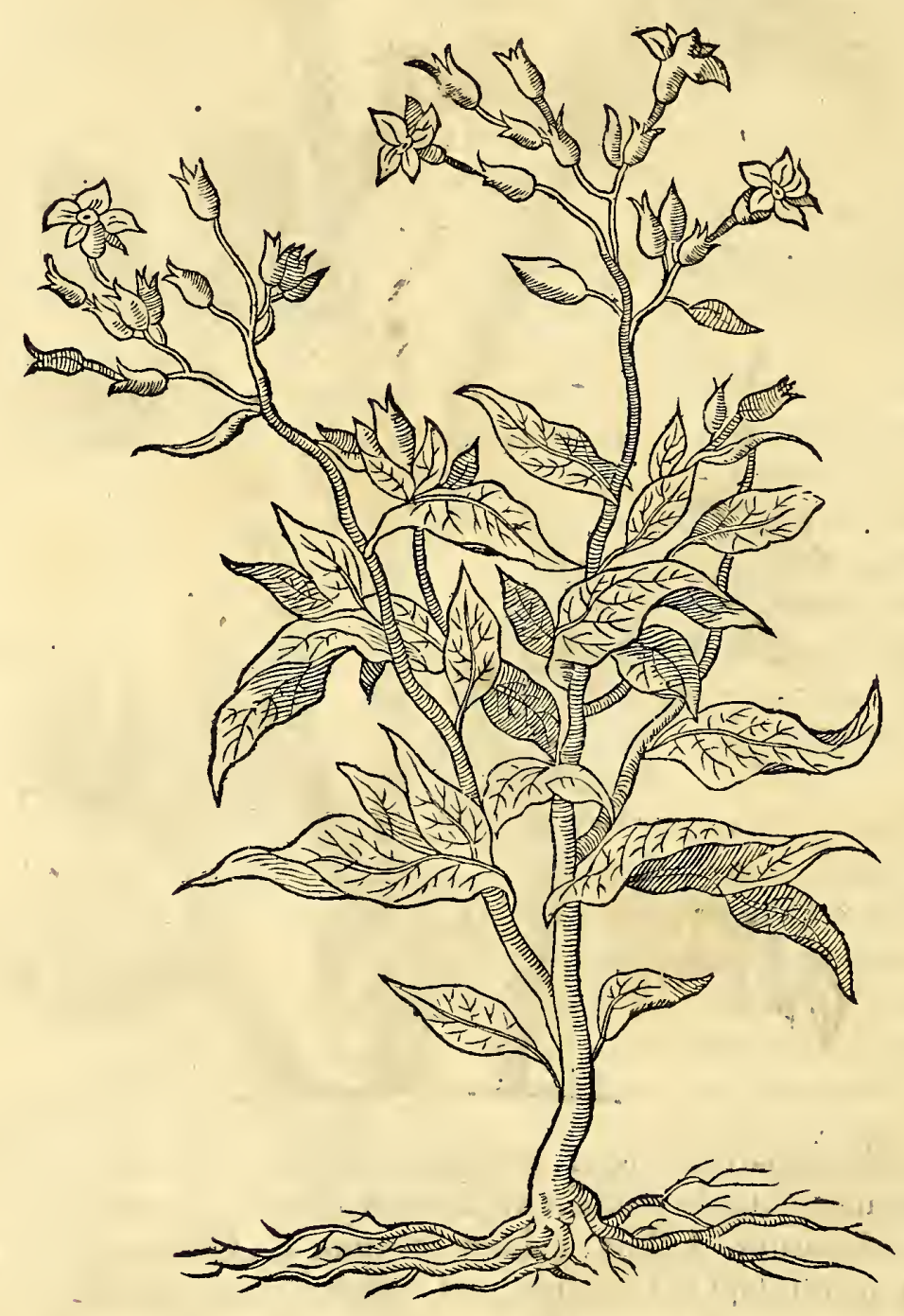

in abufus quoque $\&$ delicias applicarunt. Ita ut nunc, tanquam hibernus flatus, fumus Tabaci univerfum Orbem infecerit. cujus qualitates nimium forte etiamipfis Lippis \& Tonforibus notas, enarrarefuperfedeo, folummodo eas traditurus dignitates, quas virefens herba in natali hocfolo ad folatium xyrorum fuppeditare folet. Equidem nihil putem vel leviffime rei Botanicæ initiato notius effe quam calefaciendi \& exficcandi cjus manifeftas qualitates; fed quantum abfterforia, mundificativa, erofiva, refolutiva, aftrictoria, imo vi quoque antidotali polleat, non omnibus forte conftare putem. Ita ut non immerito Nicotiana hæc, Herva fanta à Lufitanis appelletur. Equiden fi quis univerfam vegctabilium naturam penitius infpiciat, vix credo, veterem orbem aliquas plantas, tribus noftris nobiliffimis Americanis polychreftis dignitate pares producere. Quarum prima eftradix CMandiora, qux alimentum, venenum \& antidotum valtiflimis 
HIST. NATVRAL。 \& MEDIC. LI B. IV. 207 valtiffimis totius mundi partibus fuppeditat, ut filo loco probavi. Secunda, Palma illa nuces cocos producens, unde non folum varia medicamenta concinnantur, fed potus, ne dicam victus \& amictus, aliaque ex variis arboris partibus neceffariafuppeditantur. Tertia eft hre Petúme, quæ quantum alimentofa qualitate duabus præcedentibus cedit, tantum medicamentofis viribus eas facile fuperat, cujus varias \& difcrepantes operationes haud adeo facile eft recenfere, quapropter compendium earum quxà me ufu crebro confirmatx funt in medium proferam.

Petume five Tabaci alii duas, alii plures dederunt fpecies, ego maris id eft ma. joris tantum Iconem \& defcriptionem exhibeo; qux aliquando-ultra fruticis altitudinem exfurgit, fi excul to \& glebofo folo commit tatur. Ex radicibus multis, filamentofis, amaris, caulis unicus, craffus exfurgit; unde rami ornate expanfi ena. fcuntur in foliis magnis amplis denfis, qux Solani atque Oxylapathi foliis non diffimilia funt, \& fine ullo pediculo dictum caulem \& ramulos amplectıntur : omni anni tempore plantatur, \& à frigore imprimis arceri deber, atque tunc folum quoque Europxum non afpernatur, licet in ufus medicos minus efficax fit. Semel tantum flores fert in fummitaribus ramorum candidos, purpurafcentes, campanulæ figura, quibus decidentibus fuccedunt veluti capitula papaveris femen nigrum parvum continentia. Nunc videamus quem ufum quxque pars plantx fup-
peditat.

Recentia folia eorumque fuccus \& balfamum ulceribus cancrofis non folum frenum imponit; fed venenatis quoque morfibus medetur. Aqua vel alius conveniens liquor in quo maceratum eft Tabacum pediculos enecat, $\&$ multa capitis cutanea mala mundificat. Cineres foliorum exficcatorum, vermes enecant; Malticata laffitudinem $\&$ famemfedant in defertis peregrinantibus, ut mili $\&$ itineris fociis meis contigit. Ventrictulum \& cor aromatica vi roborant. An vero fumus per tubum attractus vel pulvis mafticatus loco fternutatorii cerebrum expurget ? an quibufdam quoque fomnum; aliis vero ebrietatem conciliet? illi facile norunt qui utrumque perpetuo circumferunt. Syrupus denique Tabaci (cujus in morbis Endemiis prxparatio tradita eft) Afthmati \& Hydropi multum prodeft, imprimis fi caufa frigida \& vifcida in iis prædominentur, quod validifime incidat \& ab. ftergat.

Sed quia animadverti Indis eorumque imitatoribus idem frepe evenire, quod circulatoribus Europxis ut vel füperftitiofa credulitas vel ipfa auri fames intercurrat, cautiones abhibend $x$ funt, ne quis herbam hanc, tanquam Panaceam celebret, eamque in omni cafu proftituat. Cum enim folium ejufque fuccus, five infufum, five fyrupus affumptus vehementer turbent corpus, vomitum vel alvum provocantes, iis non propinari debere fuafor fui, qui vel biliofo vel delicatiori fuerunt temperamento. quamobrem crebræ indicationes in corporibus fub coelo fervidiori habitantibus exfurgunt, ut potius Peti ufui circa externa quam circa interna mala diu infiftamus.

\section{A P V T X X I V.}

\section{Mirabilis Peruana, \& çuambú, pecies Carvopbyllate.}

$\mathrm{N}$

Obilis hæc planta, nominibus non folum pro Regionum diverfiéate, fed colore \& odore quoque variat. Nativa eft huic Americx Continenti, \& in glebofis faxofifque terris fponte luxurians: In Peruvia tamen qua ad nomen \& culturam magis celebris, unde in Europxorum hortos tranflata, ob florum nobilitatem ab ipfis rei botanicx ignaris excolitur: à me autem ob radicis qualitates medicas hic exhibita. Peruviani eam Hachal-Indi, Latini Mirabilem Peruanam dixerunt. Caule firmo, fucculento, fubflavo, geniculato in fruticis altitudinem exfurgit, ex quo ramuli nodofi proveniunt, circa quos nodos folia bina adverfis pediculis nafcuntur, foliis Siliquaftri vel Solani fimilia. Flores è fummitatibus ramulorun quinquangulares, longi, concavi, convolvuli floribus fimiles exfurgunt; tanta colorum elegantia \& diverfitate certantes, utvel purpurei vel nivei, vel flavi, imo binis colo-

$$
\mathrm{S}_{2} \text { ribus }
$$


Mirabílis PER VANa.

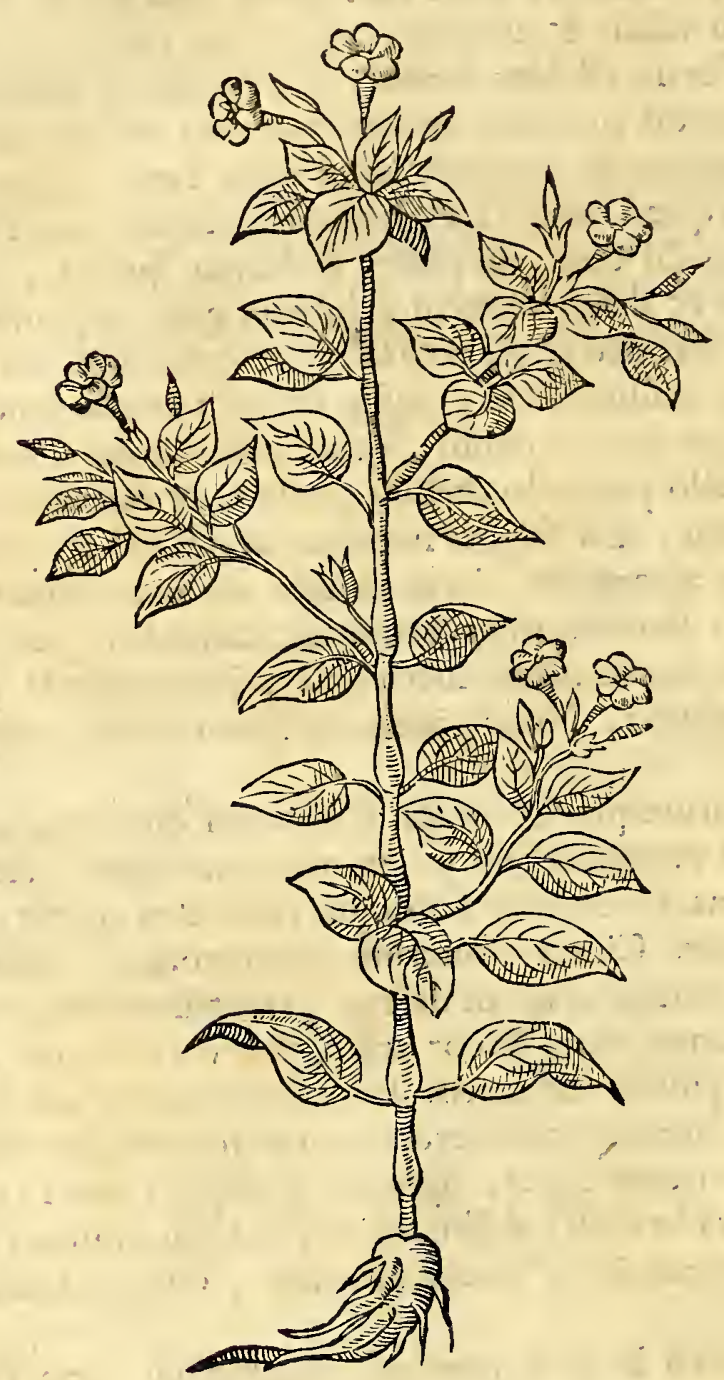

ribus inter fe mixtis elucefcant, atque odore fuavi Narciflum nonnihil æmulentur. Quapropter non mirum, fi feplafiarii, ignorantes vim medicam radicis, ex ipfis floribus colorem extrahere malint, \& mixturas inde confectas, mulierculis pro cofmeticis care divendant. Parum funt durabiles flores fed numerofa fobole, \& afidua fucceffione jacturam illam compenfant. Accedit, quod notatu dignum, illos media nocte ad lumen aperiri \& patentiffimos fieri; nec more aliorum Sole delectari, quia cjus calor em ferre nequeunt, quod minimo fervore humor florum tenuis $\&$ paucus difipetur. Contra fit iis quibus humor lentus, copiofus \& nifi ad Solis calorem hiar. Eadem videtur diurni aut nocturni in plantis odoris efle ratio.

Porro membranacei florum calices unum femen quafi pentagonum, obtufium, fufcum, tuberofum continent, quod vel minimo motu dejicitur $\&$ apertum alba pulpa micat. Radice quoque eft intus albicante, extus nigricante, filamentofa, acris, fed non ingrati faporis.

Animadverti, Clufio aliifque exoticorum fcriptoribus, ex relatu tantum, ufum ejus medicum efie commendatum, quem ego tamen tractu tempor is comperi veriffimum, fcilicet in ter hydragoga ufurpari radicem, cujus effectus fatis felices in Hydropicis memini me vidiffe.

Cxtcrum an tabefcente hac planta, circa caulium nodos candida quxdam lacryma appareat, qux à Sole concreta falis guftum referat, ficut de ea Clarifi. Camerarius tcftatum reliquit, mihi in Brafilia experiri datum non fuit, licet non perfunctorie id obfervare conatus fim.

$\checkmark$ Bique in littoralibus campis fponte luxuriat \& ul tra Europæx Caryophyllata altitudincm afurgit, cxterum internis qualitatibus, \& facie externa, exceptis foliis illi fimilis, unde idem quoque nomen Caryophyllatx indidimus. Caulis unicus rectus ul- 
Crambi', five Caryophyilata.

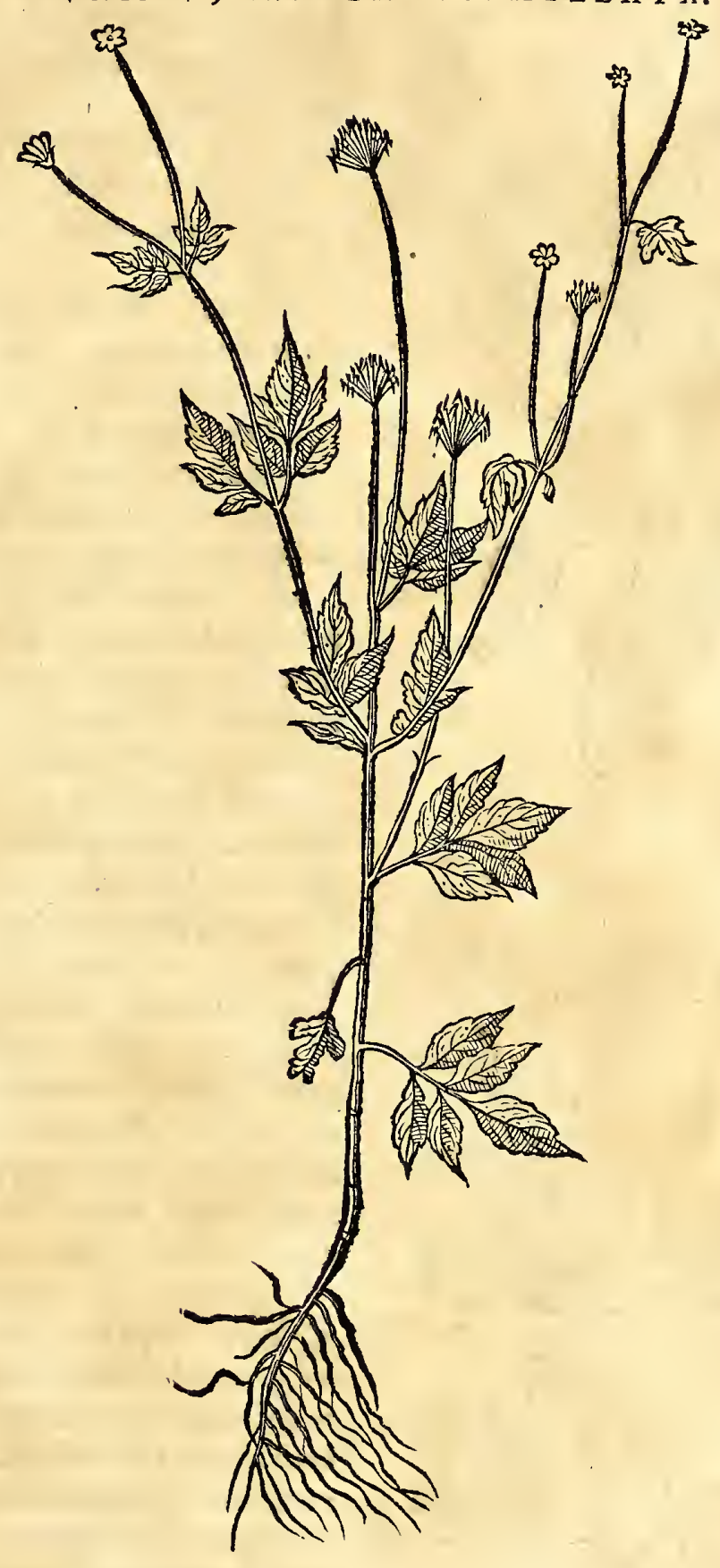

tra quatuor pedum eft altitudinis, cui ad fingula genicula bini rami \& læte viridia, Europæx foliis acutiora $\&$ anguftiora. ad ramufculorum extremitates fingulas provenit flos flavus, Tormentillæx æmulus, conftans quinque foliis anguftis. Cuificcedit Capitulum rotundum, hifpidum, repletum femine oblongo. Radice eft multa, tenui, filamentofa, qua odore Caryophyllos refert. Calida \& ficca eft in intenfo gradu, attenuandi non folum \& abftergendi, fed aftringendi quoque vi pollens, ac proinde tam ad corroboranda vifcera, quam ad incidendos vifcidos humores ufurpatur cum fuc-
ceffu.

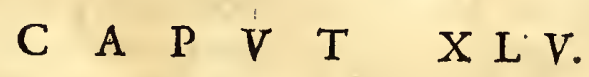

Belingéla, Quigómbo vel Alcea Mufcata, \& Gangila five Se famum.

Icut Europai plantas \& fata qux felicis proventus arbitrati funt, in Americam aliquando tranftulerunt, ita \& Africani inter herbas ufuales huc adductas ftudiofe etiam nunc alunt eam, qux Belingéla Lufitanis, Tongu vel Macombo An- 
B E I I

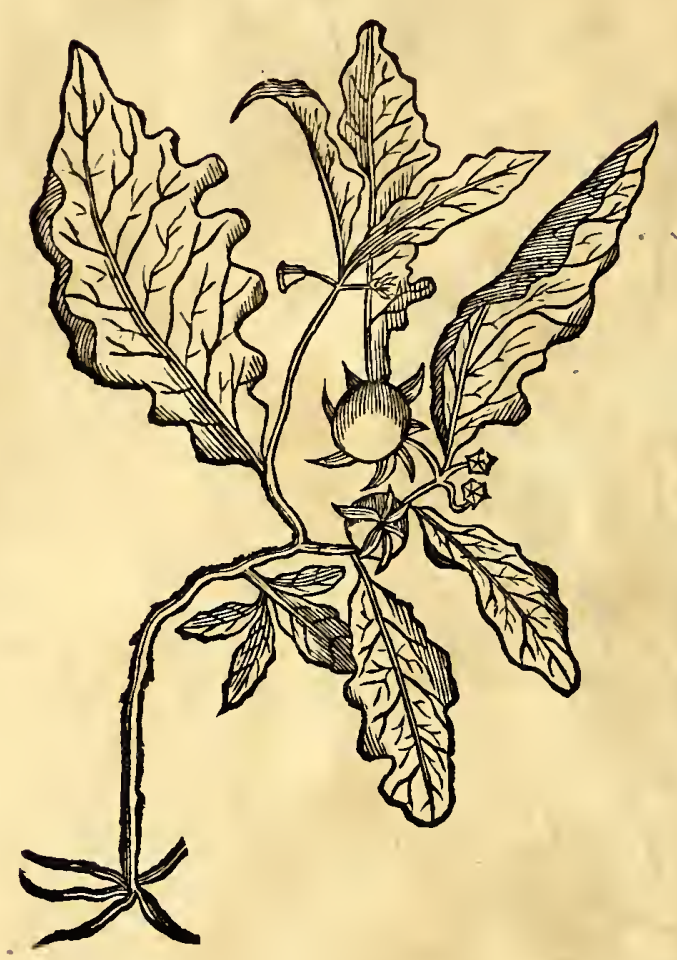

QVIG O'M B prior, five ALCEA M v S C A T A.

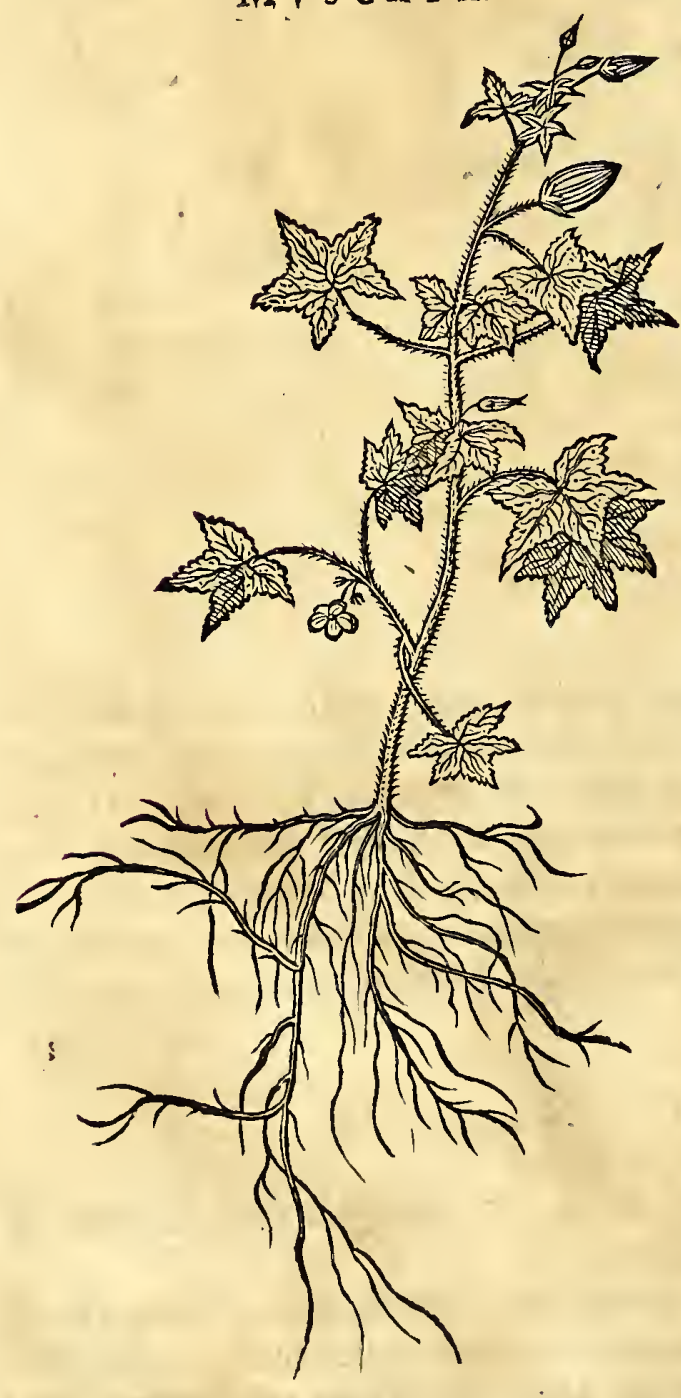

golenfibus Africanis dicta, ut $\&$ duas has Quigómbo \& Sefamum. Si ad Europæas plantas primam hanc Belingela compares, fructus ejus Mandragorx fructui ; fi folia Melongelæ potius limilis; fi qualitates, utriufque præcedentis herbæ participat. Adeo Africana Belingela hic exculta, medium videtur tenere inter illas herbas fibi cognatas.

Ex radicibus craffis brevibus exfurgit caulis unus atque alter varie flexus, cuihinc inde folia elegantia, magna, laciniata,obfcure virentia, nervis \& venis purpurafcentibus, colore $\&$ odore Brafficx noftr $\mathfrak{x}$ mulis adnafcuntur. Flores juxta fe pofiti duo vel tres, lacteis $\&$ dilute purpureis venis intertexti, unico folio conftantes, quod inftar ftellæ fexangularis expanfum \& divifum fructum à tergo veftit. Qui fructus Pomi eft magnitudine, rotundus, lævis exalbo fplendens, cum ftriis, primo ex viridi purpurei, mox flavi coloris, interius carne alba, femina multa inftar Sefami continente. Pomahxc in pretio habita apud incolas, quorum ufum $\&$ præzparationem Africani Incolis Americanis fuppeditarunt. Coeta pro epulis apponunt addito oleo $\&$ pipere, faporis funt grate acidi, Citri æmula; tantum enim abeft, ea cruda falutaria effe, ut ob infignem refrigerandi vim, qua pollent,etiam cum aromatibus \& calefacientibus obfoniis nimius ufus aliquando obfit.

S Equitur prima nobilior fpecies 2ui$S$ gómbo Africana, cui à Lufitanis cognomen additum fatis appropriatum 2uigómbode chero, hoc eft odoratum, ob femen mufcatum. Si ufum totius herbx, inter Alceas \& Malvas recentes, fi feminis odorem confideres Bamix Profperi Alpini non male refpondet; caterum externa figura ab utraque multum recedens.

Advena quondam hxc planta non perennat, fed fingulis annis in hortis feritur, radicem multam albam; tenuem, filamentofam, longiffimam próferens, unde caulis unicus, rotundus, hirfutus, ex parte rufus, ex parte viridis exoritur, hinc inde pediculos proferéns ejufdem coloris, quorum cuilibet adnafcitur unicum folium quinquangulare in ambitu ferratum, rugofum, multis venis $\&$ nervis intertextum. Flores pentaphylli, flavi, inodori hinc inde prodeunt, propriis pediculis adhrentes. Qui circa trihorium ante meridiem fe aperiunt (quod Alcxa quoque Europxa com- 
HIST. NATVRAL. \& MEDIC. LIB. IV.

commune habet cum hac noftra) $\&$ mox poft meridiem corrugantur. His fuccedit corpus turbinatum, pentagonum, hirfutum, intus in quinque cellulas diftinctum, quibus infinita femina adhærent grifea, quafi leviter ftriata figura renis ovilli, interius alba, qux non folum mafticata, fed manus attactu leviter modo incal efacta fragrantiffimum odorem mofchireferunt, adeo fortem, ut quibufdam capitis doloręm inferat. His cofmetici utuntur \& abutuntur ad adulterandum verum mofchum. Alium præterea ufum in medicina an præftent femina, nondum comperi. Herba loco Malvæ adhibetur in fomentis \& clyfteribus, ejufdemque fere habetur qualitatis.

Secunda 2 uigómbo ex Africa traducta \& tandem Brafilix ob felicem proventum quafi nativa facta, eftilla, qux vulgo ab omnibus $G$ A N G I I A five paffim Incolis 2uigómbo, Angolenfibus autem Quillobo no- Sefamum Africanum. minatur. Caule unico, craffo, nodofo, \& rufo ad fruticis fere altitudinem affurgit. Pediculis, ramunculorum loco alternatim pofitis decoratur; quorum quilibet fuftinet folium in quinque lacinias fectum, ac toto ambitu ferratum, Vinex folio non multum diffimile, fuperius obfcure, inferius dilute virens, acibidem nervum rufum $\&$ venas virides habens. Ex fummitate caulis emergunt flores pentaphyllicum famine \& apicibus fulfurei coloris. Fructus ejus pericarpium eft, pyramidale, novangulare, ex viridi fufcefcens : conftans alba \& parum glutinofa carne, cortice craffo inftar Mali aurantii ; intus in octo loculamenta longa divifum in quovis duplex ordo feminum rotundorum petiolis fuis adhærentium. Pericarpium hoc viride totum coquitur in aqua, \& coctum comeditur cum oleo, aceto $\&$ pipere: quo immaturius eo melius eft ad coquendum, \&melioris faporis, alias enim nimis dulcefcit.

Radix lenta albicans in multa tenuiflima filamenta divifa, infipida, ac ab indigenis \& advenis hactenus tantum neglecta, quantum fructus expetitus.

Varta herba exilla parte Africx quæ Congo dicitur per Athiopes huc tranflata, à Lufitanis Girgilin dicta, apud Indigenas innominata, nobis Sefami habetur fpecies. Ex radice tenera, exfurgit caulis rectus, quadratus, viridis; cum foliis oblongis, haudlatis, teneris, colore Atriplicis albx, quafi farina inferius afperfa, plerumque binis velut fibi oppofitis. Flores fert albos, deciduos, figura Campanulx: quas fequuntur filiquæ erecte ftantes ad caulem quadrangul $x$, qux maturefact $x$ fufcefcunt $\&$ fponte diffiliunt, contentumque femen excidit, quod parvum $\&$ album eft, figura cordis.

Fr. Ioannes de Santos Hiftor. Æthiopix Orientalis lib. 1. cap. 4. In omnibus, inquit, his Provinciis plurimum Gergilim reperitur, candidiflimum \& optimum, ex quo fit ol eum, quod vulgo ufurpatur \& comeditur, ut in Portugallia oliva-

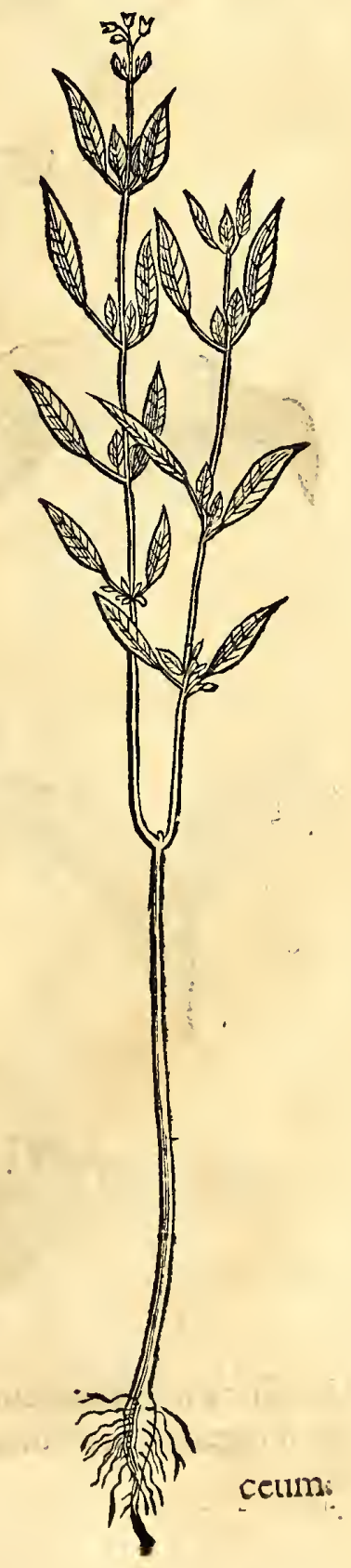


ceum. Contunduntur femina in vafeligneo, grandi, facto ad modum mortarii. Poftquam bene contufum fuerit, \& coactum in maffam, exprimitur riteiifdem lignis quibus contufum fuit; effluitque oleum valde clarum : \&amurca, quæ reliqua fit, comeditur à Nigritis, cum milio cocto, loco butyri.

\section{A P $\quad$ V $\quad$ T $\quad$ X L V I. \\ Cammarum Indicarum diverja jpecies, CMeeru', Albará, Paco- çeróca, \& Paco-caatinga.}

Tter eas Plantas quæ in Europæ regionibus calidioribus ex Indiis tranflatæ vigent, hæc ornatiffima quoque datur, quam Cannam Americanam non immerito appellarunt, quod ejus ftolones Arundinum modo firmi, nodofi extus, \& fpongiofi intus, recta in octo vel novem pedum altitudinem exfurgant. Prima autem occurrit

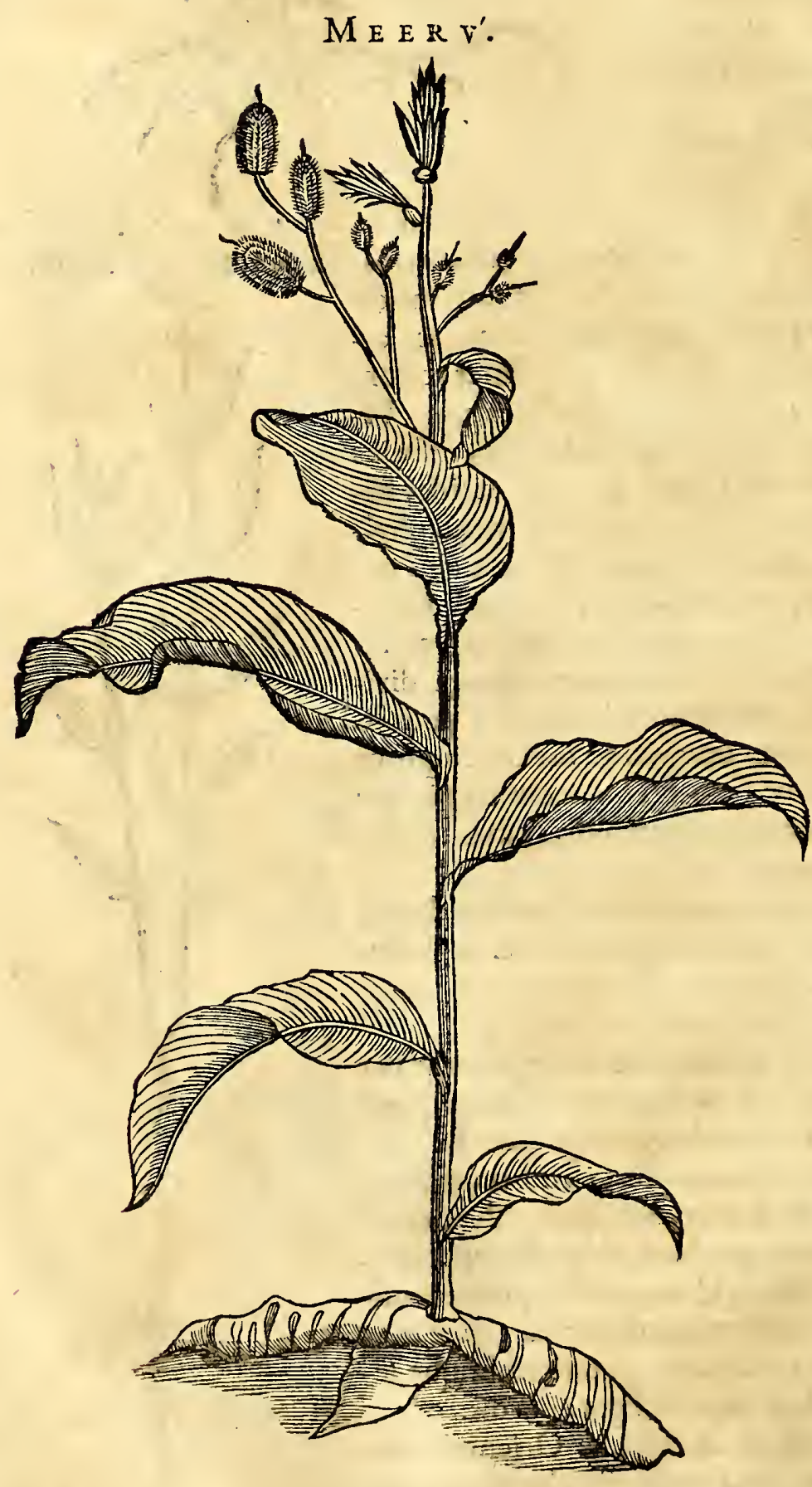
illa, quxc Meerú Brafilianis dicta : cujus caulem viridem folia folitarie pofita ambiunt, duos fere pedes longa. Caulisfuperius in alios ramulos dividirur, aurei coloris flores inodoros producentes, quibus capfula five fructus echinatus, primum viridis, mox nigrefcens, ubi maturuerit, fuccedit, in quo per cellulas divifa funt multa feminis grana , nigra, lævia , magnitudine $\&$ duritie Pifis fimillima, albaque fubftantia quadam repleta. Ex iis vulgo corollx precarix fiunt.

Radix mirum in modum eft craffa, tuberofa, longa, fucculenta, fplendens, \& inftar Cepx fquammis rufis prædita. Hujus plantx vel Cannex Indicx Clufius quoque meminit. Ego ejus foliorum dignitates experientia comprobatas exhiberefatago, qux ad fecundum gradum refrigerantia , tum \& abftergentia, contra multa mala cutanea calida, externa atque interna applicantur. Hypochondrio denique utrique contra Lienis \& Hepatis calores cum oleo Aning $x$ \& Nymph $x x$ Brafilicx impofita, curationem abfolvunt feliciter. Idem praftat lacryma quadam alba Tragacanthi $x$ mula $\&$ fubdulcis, qux ex vetuftis folonibus deftillat. 
Secunda, Albará,aliis Paçivira dicta. Iifdem locis filveftribus atque triviis umbrofis luxuriat hæc fpecies Meeru, afpectu pulchra, ftolonis \&radicis firmitate atque pondere Cannam quoque Indicam, fed fummitate fua Liliuin Americanum filveftre amulans : foliis quoque licet prælongis, anguftioribus tamen eft \& ex imo caulis erumpentibus. Flore denique magno, flavo, inodoro \& cochleari formi, nunc incurvato, nunc in poftica parte inftar cufpidis extenfo. Semine eft nigro, \& radice bulbofa, ficut Mecru, prædita.

Folia vulneribus $\&$ ulceribus utiliter adhibentur, unde Erva dosferidos vulgus Lufitanicum nominat. 'Tuberofa \& fucculenta ejus radix à Nigritis comeditur, \& ab omnibus pariter Incolis intenf $x$ habetur caliditaris, ac proinde Hifpanis æque ac noftris Chirurgis Batavis in quotidiano eft ufu; maxime in apoftematis \& ulceribus maturandis.

Tertia eft Paco-ceróca Brafil. dicta, in fex fe. ptemve pedum alcitudinem affurgit; caule recto, fpongiofo \& viridi, inftar Meeru: habetque folia planeilli fumilia codem modo, fed in fummitate folium convolutum ut in $P$ aco. Inferius ad caulis exortum ramuli funt, multis cavis incarnate rubentibus fioribus onufti. Quibus fubfequitur fructus in uvam congeftus Pruni magnitudine, coloris fufci,triangularis figur $x$, fuperius eminenti papula præditus. Intus eft parva pulpa filamentofa, cinabrii coloris, magnitudine nucis avellanx, in tres partes divifibilis, odoris grati \& vinofi, in qua continentur infinita grana triangularia, fufca; albo nucleo prædita. Cortex exterior fucculentus, qui cutem tingit colore brunno, ut Cerafa noftratia nigra ; atque adeo ufurpatur loco atramenti.

Foliarecentia ut \& caulis \& fructus imma- 
turus, fi fricentur, odorem de fe fundunt Zinziberis, \& fuavem admodum. Ac proinde defcetum aromatum fupplent. Balnea quoque calida exiis conficiuntur.

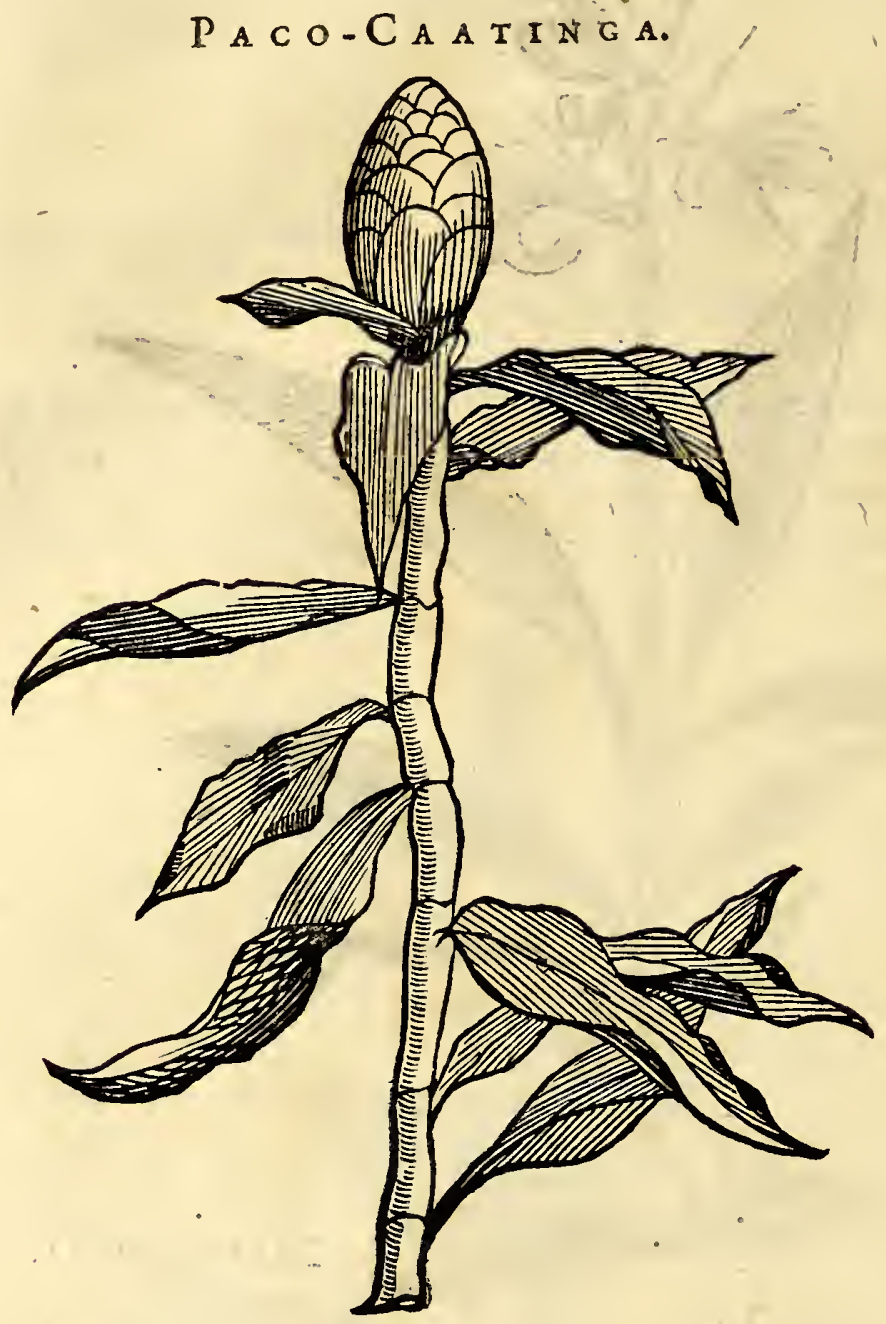

Quarta eft Paco-cantinga, aliis Periná. Quæ inter innumera Brafiliz Arundinum filveftrium genera reperitur. Præter eximiam illam fativam Sacchari Cannam, reliquarum omnium facile reginam in nemoribus exfurguntiadmodum excelfxplumifqueveftitx, utarborum altitudinem, tibiæ vero human $x$ craffitiem adæquent. Quxdam duriores, fagittifque funt dicatæ. E quarum radicibus decoctis lixivium contra capillorum defluvium concinnatur. Plurimæ quoque dantur alix, quas filentio prxtereo, ob ornatum vel ufum ab opificibus dumtaxat aut agrorum colonis expetitx.

$\mathrm{H} x \mathrm{c}$ vero qux ufum in Medicina præftar, bulbofa $\&$ femper virefcens, vulgo Canna do mato à Lufitanis nominata.

Caulem haber Arundinaceum digitalis craffitudinis, rotundum, $\&$ intus continentem fucculentam medullam fubdulcis faporis, confiftentix fere ut Canna faccharifera: Hunc porro ambiunt fine pediculis hinc inde folia folida, longa, in medio, nervo fecundum longitudinem, nullis fecundum latitudinem venis: fed fubtiliffimis lineis oblique difcurrentibus, ut in foliis Meerú: funtque fuperius glabra $\&$ dilute viridia, inferius molli hirfutie prædita \& fubalbicantia. In fummitate caulis, provenit conus (ut in pinu) in faftigio paulo acutior, fquamis preditus, qux in prominentibus extremitatibus aurei, $\boldsymbol{c x}^{2}$ rerum miniati funt coloris. Sub his tandem dilatatis, flofculus canus inftar alvearii apiarii, fub quo cuticula eft albefcens, inftar loculi, continens ultra viginti grana nigra,magnitudinis feminis Ceparum, albifque filamentis adhærentia. Caulis hujus plantæ mafticatus detrahit humores è capite, calefacit ejus fuccus, $\&$ diuretica vi pollet. Atque eft infigneremedium contra gonorrhœam $\&$ dolor es nephriticos.

Ego fuccum ejus acidum exprimi, certaque dofi, addito convenienti fyrupo, xgr is bis de die exhiberi confultius duxi, \& multum profuiffe fum expertus. Ea tamen cautione, ut ufus illius frequens vitetur, quod fuo acore ventriculum infeltet, genitalibus quoque obfit, quemadmodum in multis videre contigit, qui temere illo utebantur.

Reperiuntur \&aliæ fpecies præcedenti in multis fimiles, fed quia ejus qualitates medicæ nec Incolis nec mihi compert $x$, iis fuperfedeo.

Quinta eft Arundo filveftris, multis incognita, quam olim aliunde huc delatam Qun Saccharex altitudinem excedens, cxterum illi quam fimillima. Radice eft admodum magna, nodofa, dilute flava, atque Radicis Chinæinftar ponderofa.

Ejus fubftantia in pulverem redacta, \& ex vino pauxilla quantitate exhibita, tam valide urinas $\&$ menftua movere, imo foetum mortuum expellere dicitur ; ụt inter ruta medicamenta vix haberi poffit. 


\section{A $\quad \mathbf{P} \quad \mathrm{V} \quad \mathrm{T} \quad \mathrm{X} \mathbf{L}$ V I I.}

\section{Diverfe Jpecies Iaborand'́.}

Ta primis Incolis, quatuor hifce plantis, placuit indidiffe idem nomen taborandi:

Nec immerito, quod quantum facie difcrepent; tantum efficacia eaque nobilifi

ma mul tum fibi fimiles exiftant, quippe omnium radices (quarum vires Brafiliani Lufitanis \& Noftratibus Belgis revelarunt) adeo commendabiles, ut inter Panaceas hodie habeantur: ufumquc in medicina præftent eximium.
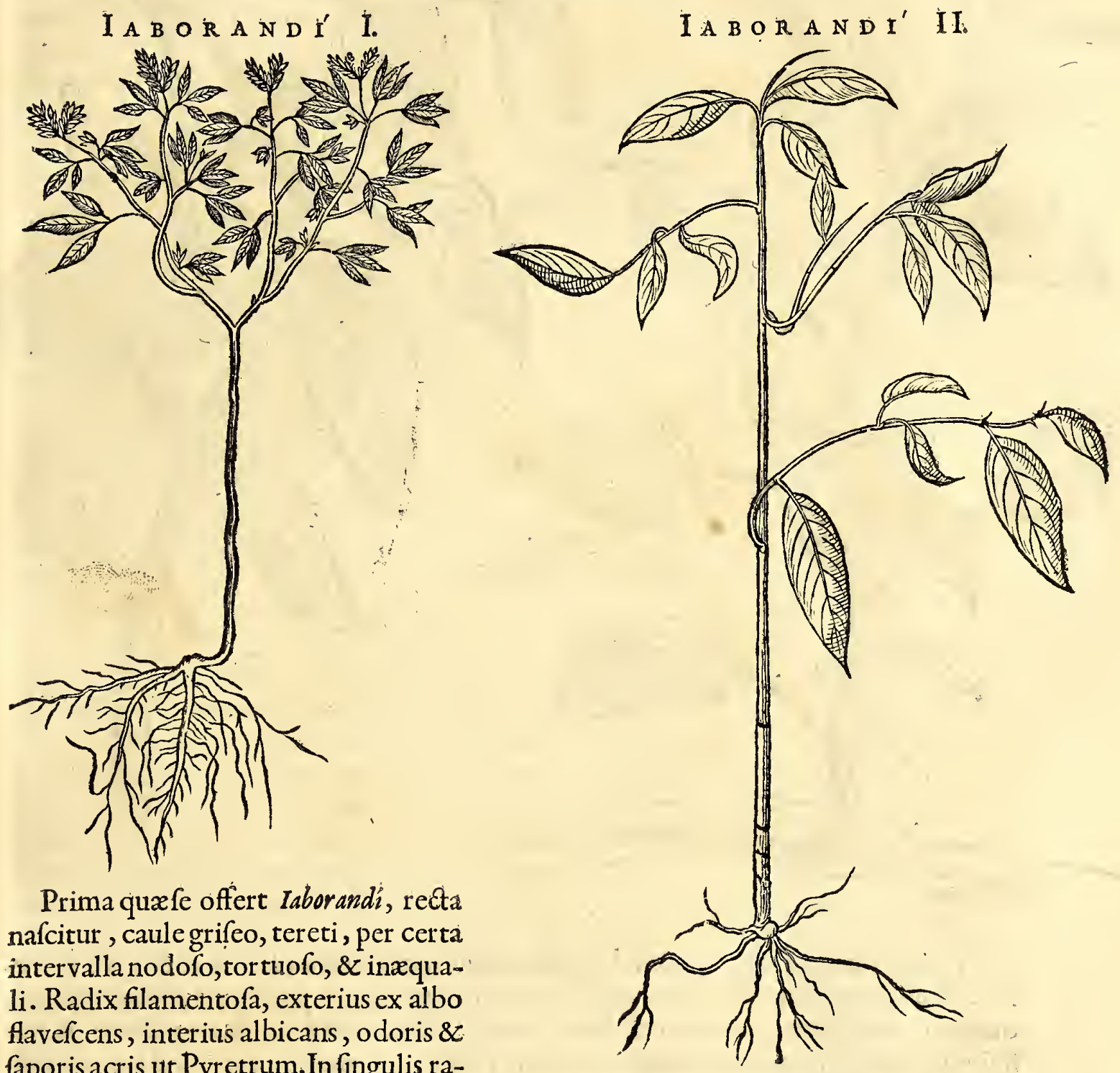

Prima quæfe offert Iaborandi, recta nafcitur, caule grifeo, tereti, per certa intervalla nodofo, tortuofo, \& inæquali. Radix filamentofa, exterius ex albo flavefcens, interitus albicans, odoris $\&$ faporis acris ut Pyretrum. In fingulis ramulis ab internodiis tria habet folia fibi appofita, ad tactum mollia, partum pilofa, nervo confpicuo $\&$ venis oblíquis, pallide virentia, inferne paulum candicantia. In extre: mitate ramulorum multa foliola parva, venabuli figura, fibi invicem confertim funt appofita,in duos ramulos diducta, in quibus flofculi albi,quatuor foliolis conftantes; quos fequitur femen, duplici palea tectum, ut in Cannabi, fufcum, compreffum, parvulum, cordis figura, cui $a b$ unolatere pars abfciffa videtur. Radix valet contra venena imprimis frigida: Pugillus fiquidem recentis radicis contufus atque è convenienti liquore propinatus, vim cujufcumque fere veneni per fudores $\&$ urinas exturbat. Cujus portentofum fpecimen Barbaros edidiffe vidi, præfente Illuftriff. Naffavix Principe, in Capitaneo, qui Fungos venenofos comederat.

Secunda fpecies fruticefcens : cauilibuis affuirgit, per longa intervalla nodofis \& teretibus. Foliis eft faturate viridibus, fplendentibus, $\&$ ad tactum inftar membranace $x$ chartæ in extremitate incurvatis, nervis \& venis eraffioribus confpicuis. Radice eft tenui, 
tenui, filamentofa, qux primo infipida, fed altius mafticata, acrius urit pal atum quam jpfum Pyretrum, cujus ločo ad libèrandurn caput $\&$ dentes à pituita, adhibetur. Alii Empirici adverfus urinæx fuppreffiones \& venena à frigore nata, ea utuntur cum fucceflu fatis felici.

IA BORANDI' III.

I $A$ B $O R \wedge N D I^{\prime} I V$.

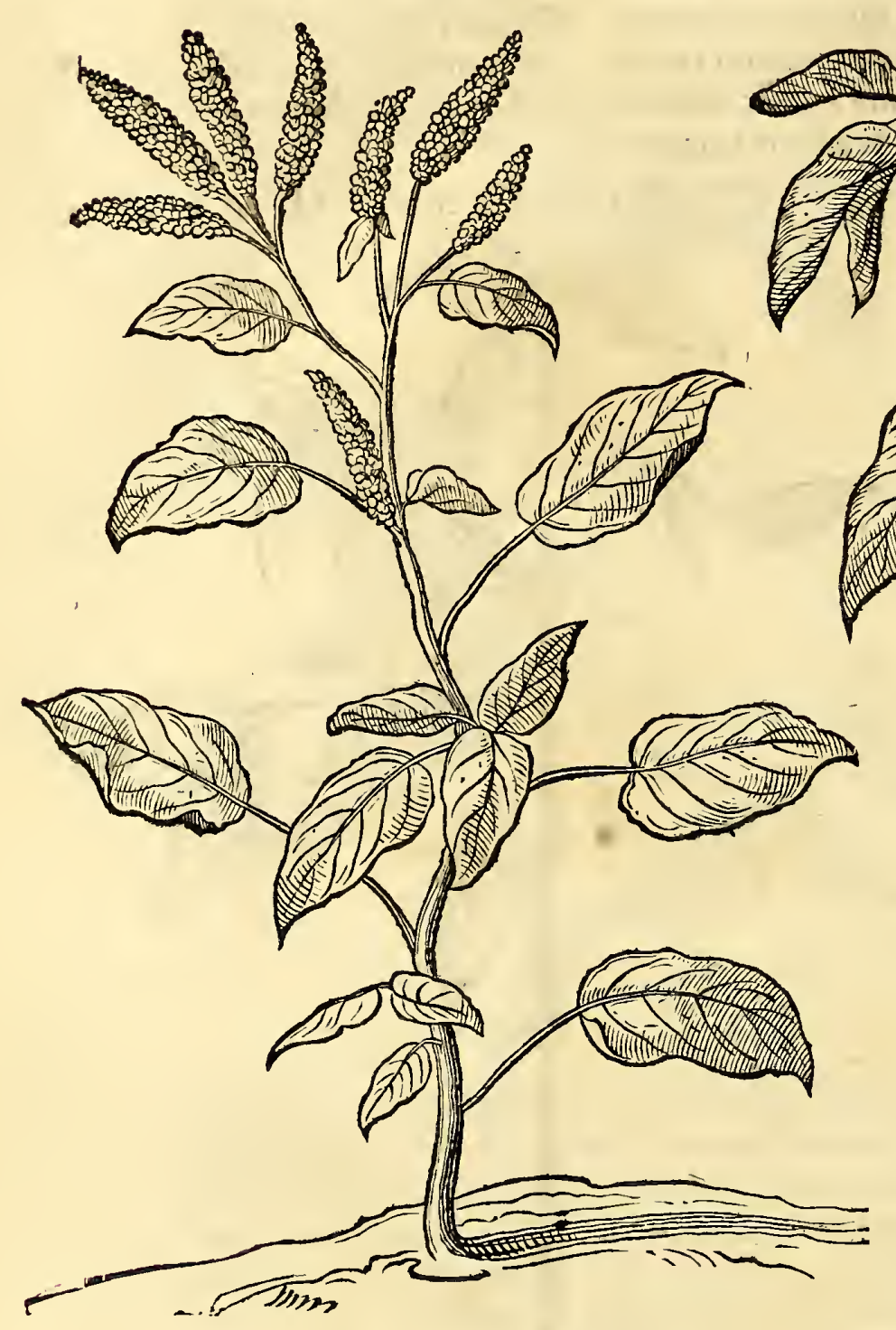

Tertia, Fruticis altitudinem adæquat, inque terris tantum folidis \& pinguibus crefcit. Foliis latioribus $\&$ minus acuminatis. In fummitate pappis vel julis decoratur, quibus femen inhæret intenfe calidum $\&$ urens. Radice eft tenui \&luxuriante, in qua hujus plant $x$ dignitas potiffimum confiftit. Ad tertium gradum calida eft $\&$ ficca, fubtilium partium, Pyretrique vicem non raro fupplet in praxi. Peculiari denique vi venenis à frigore natis adverfatur.

Quarta: eft frutex arborefcens, caudice duro \& nodofo, fature viridi, Lauri majore, cxterum non diffimili. Fructus five Iuli potius, Piperis; longiffimi non qualitates, fed tantum formam æmullantur, \& caudici adnafcuntur, foliis magnis, linguæ figur $x$, acuminatis, nuncalternatis, nunc fibi \& Iulis oppofitis. Radice eft precedentium Iaborandíefficacia; fimili : folia pro balneis \& fomentis contra affectus frigidos in ufu exiftunt. 


\section{A P $\quad \mathrm{V} \quad \mathrm{T} \quad \mathrm{X}$ L V I I I.}

\section{Caagbiyzyo, Marrubium, Camara-Lápo fone Mentaftrum, éceAninga-Peri.}

$\mathrm{C}$ Aaghiyujo non imbellis planta, luxuriat pluribus in locis Brafilix, ad Fruticis altitudinem, caule lignofo, unico, exfurgens. Foliis eft acuminatis, hirfutis, ad tactum mollibus, leviter ferratis, binis fibi oppofitis, quæ tribus eminentibus nervis fecundum longitudinem, multis autem venulis fecundum latitudinem intertexta funt, $2 \mathrm{c}$ fuperius tuberculis pilofis, inferius fcrobiculis fcatent albicantibus. Flofculis albis fuccedunt bacca nigræx, magnitudine baccarum Iuniperi, dulcis faporis, qux com. eduntur à Barbaris, '\& fuccum dant inftar Myrtilli fere. Vnde fmegma ad lavanda linteamina extrahunt.

Foliorum pulvis non folum, red \&- fuccus, ulceribus male moratis \& ex calore potiffimum ortis inditus, feliciter illa reftituit. Ac proinde à Chirurgis multum expetitus.

$$
\text { C A A G H I Y Y Y O. }
$$

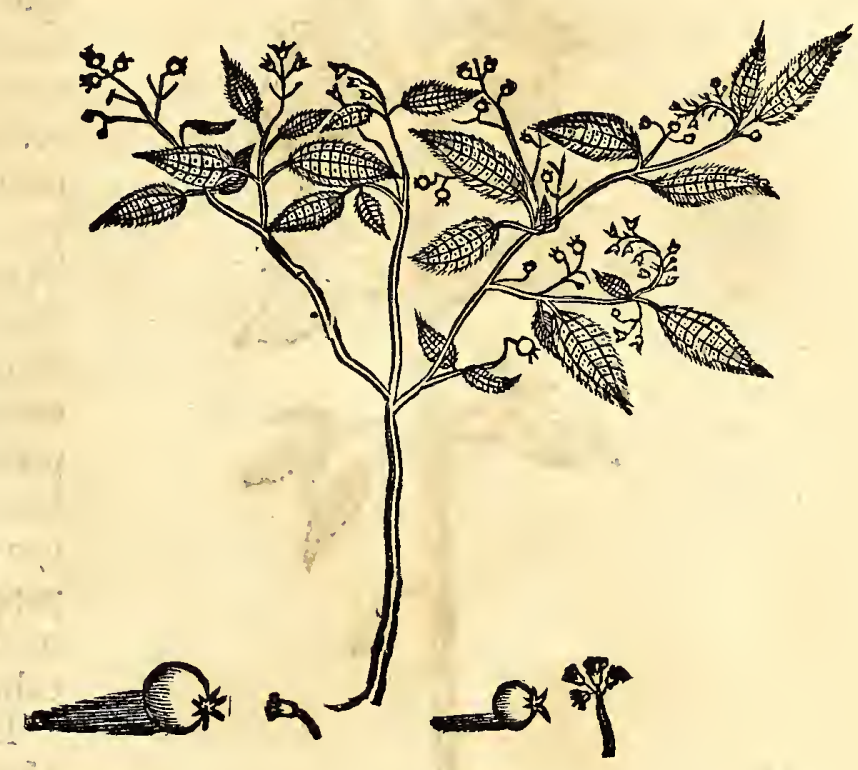

S Icut quxdam Novi Orbis plantæ, ob externam fo= $S_{\text {lummodo figuram, itaquxdam ob internas potiffi- }}$ mum qualitates, cum Veteris Orbis herbis conferri folent. Ita tota equidem hxc cum vulgari noftra tium Marrubio, eundem fpirat odorem \& quidem fuaviffimum, efficacixque eft facile majoris. A quocumque Marrubio in hoc potiffimum difcrepans, quod hic flores non in ambitu ipfius caulis ad certa interftitia, fed in extremitatibus ramtlorum verticillatim pofitifint, \& quidem cartulei, tribus foliis conftantes: Cxterum proxime accedit ad Marrubium Pannonicum Clufii, quod illa quoque folia ficut hæc noftra habeat magis tenuia, oblongiora, acuminatiora, lanuginofiora \& fubtiliffime ferrata.

Ad trium circiter pedum altitudinem affurgit, caule Atriato, nodofo, leniter hirfuto. Circa fingulos nodos in caule, ad certa intervalla, ramuli tres aut quatuor proveniunt, directe fibi oppofiti, foliis quoque aliquot copulatim ibidem dependentibus. Ramuli autem foliis cum parvis pediculis ad fex feptemve paria fibi directe oppofitis ornantur, \& $\&$ floribus verticillis finiuntur. Tota planta ad tactum eft glutinofa, aromatici odoris, \& amarefcentis faporis. Calida acficca habetur, ac inter deobftruentia, contra pectoris imprimis vitia frigida ufurpatur. Syrupi quoque $\&$ condita inde concinnantur flątulento ventriculo dicata.

$M$ A R R V B I V N Americanum.

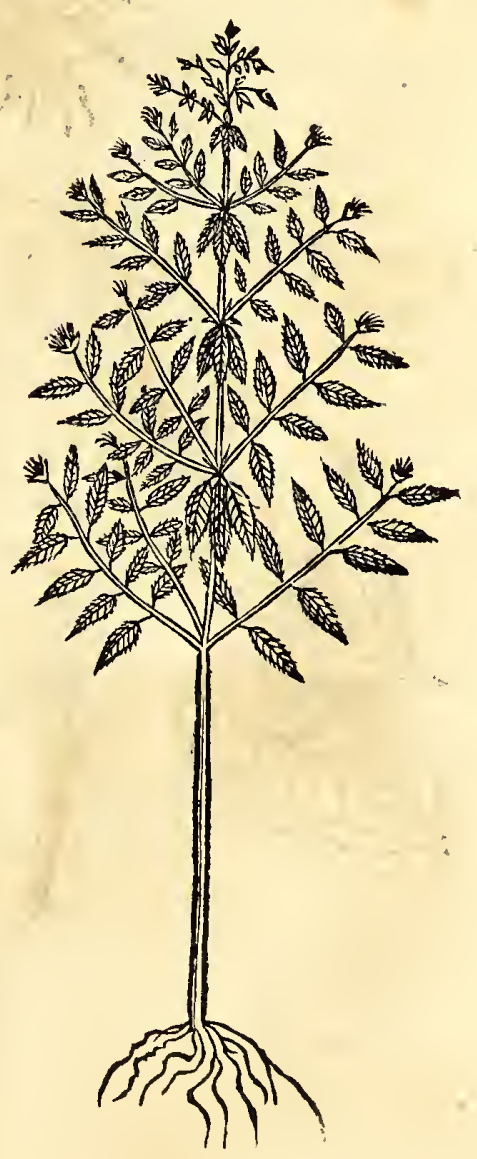


CAMAR $A-I_{A}$ Po five MENT A S T R V M Americanum.

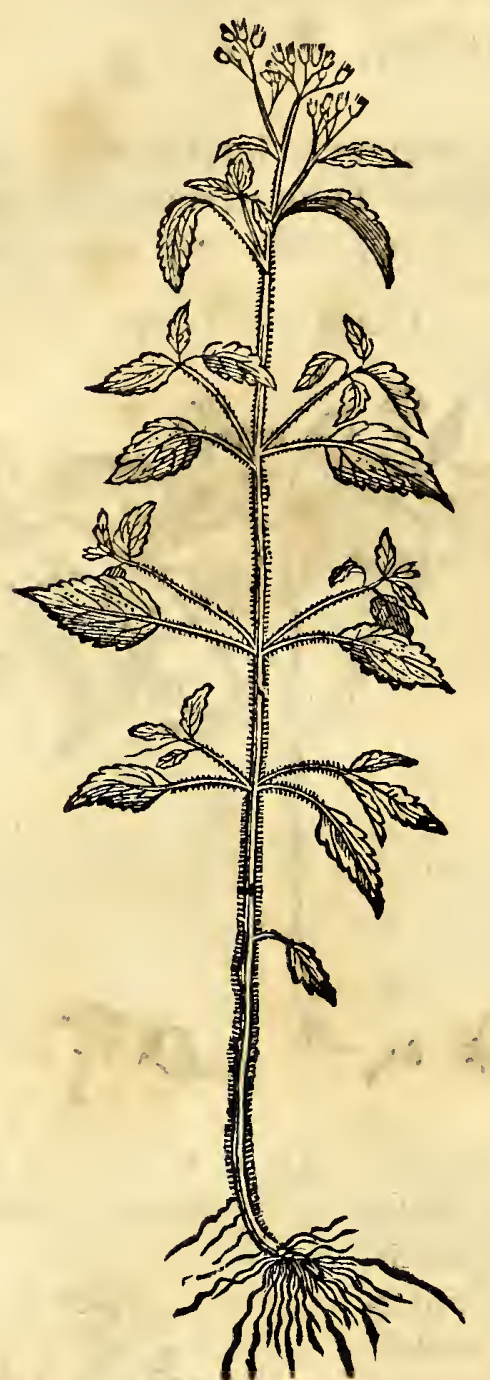

A NINGA PERI.

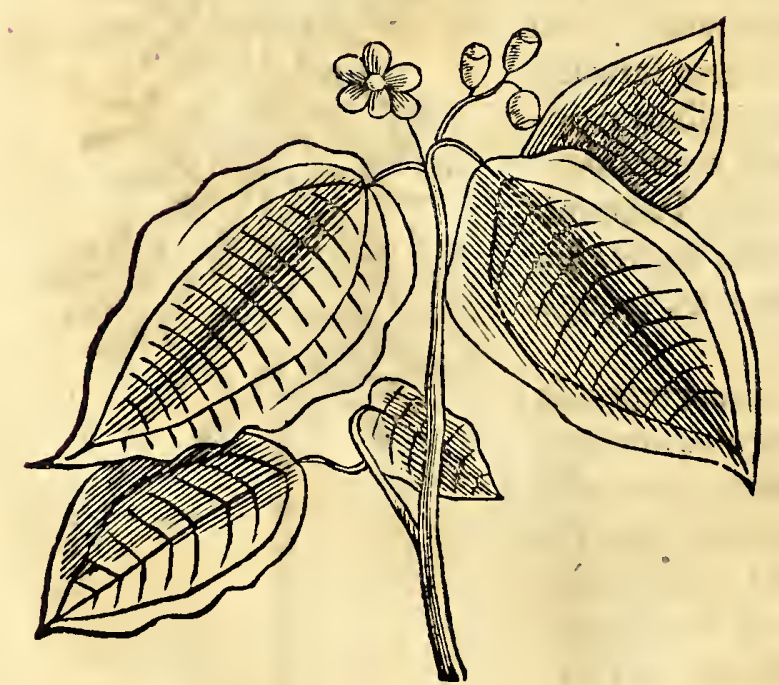

S ulla in campis toto anno fponte Sluxuriat herba Medicinalis; hæc quidem Camara-lápo, five Menthx fpecies, facile primatum tenet. Etiamfi enim foliis noftratium fit acutioribus, aliifque partibus externis hinc inde $a b$ ea abludat: tamen, fi odorem, faporem, $\&$ qualitates examines, ufque adeo congener Menthæe eft Europæx, ut vix quicquam ab ea recedat. Lufitani eam quoque Mentaftro appellant. Affurgit caule unico, procero, tereti, hirfuto $\&$ rufo, in bipedalem altitudinem, foliis leviter ferratis, hirfutis, inferius quafi incanis, binis fibi oppofitis, cum parvulis adjunctis. In fuperioribus ramulis caulis, multi flores umbellatim pofiti, toto anno Tanaceti fere modo proveniunt, cum ftaminulis dilute cærulci coloris. Quorum odor, ut \& totius plantæ, eft Mentaftri æmula, faporis amaricantis $\&$ aromatici. Semine nigro, exili, oblongo, quod maturum pappis evolat. Radice eft tenella, filamentis multis prædita. Tota planta calida \& fieca habetur gradu intenfo.

Eifdem porro ufibus dicata, quibus Mentha , magnique fit apud Incolas ; tenuium enim $\&<$ aromaticarum cum partium fit, Syrupi \& Electuaria inde cordialia flatus difcutientia, pectus $\&$ ventriculum roborantia praparantur.

A Linga PeriBrafilienfibus dicta eft A planta fruticefcens, qux pafim in filvis denfis nafcitur, flore exiguo albicante, cui paucæ uvulæ è cæruleo nigricantes, Sambucibaccis fimiles, fuccedunt. Foliis decoratur lanuginofis, ovalis figur $x$, trifte viridibus quidem, fed afpectu pulcherrimis; ad tactum inftar Vrticx mortuæ, mollibus \& veluti lanuginofis, quæque nervis multis \& craffis diftinguuntur.

Folia recenter contufa vel in pulveremredacta, recentibus $\&$ inveteratis ulceribus medentur prima intentione, fi profunde illorum fucctis aut pulvis iisimmittatur. 


\section{A P V:T X L I X.}

\section{Aguapéfrue Nymphaca, Aninga durepalufires, of Potinçóba fove Hydropiper.}

Trer illas herbas qü̈ mundo Occidentali cum Europa funt communès, Nymphea eft, Brafilianis Aguapé, Lufitanis Golvaon dicta, qua lacubus \& 2 ftagnis paffim innatare confpicitur. Folia noftratiNymphæx habet fimilia, inferius multis venis implexis prædita : florem etiam talem, fed qui conftat duodecim foliis oblongis, acutis, anguftis, albis, \& quatuor viridibus foliis fubtus, fuavis odoris. Ejus folia \& flores ficut externa facie, ita qualitatibus admodum conveniunt cum noftratium, iifdemque funt ufibus dicata, apud omnes paffim incolas. Quippe folia fola, vel radices tibiarum ulceribus, inflammationibus \& eryfipelati applicata, medentur.

Oleum radicis 2 ymphas quoque præftantifimum exiftitit, atque contra internos \& externos affectus calidiores in quotiano ufu receptũ.

Radices Aguapéhujus longx \& fucculentr funt, coct $x$ five leviter affatz inter medicamenta alimentofa numerantur, \& apponuntur inter acetaria.

Prxterquam énith quod bilem retundant radices, fluxibus ventris dyfentericis folamen afferunt \& feenum imponunt. Ita ut ipfi quoque Empirici comprobent quo$\dot{A}$ G V A P E' fivé N Y M H A A:

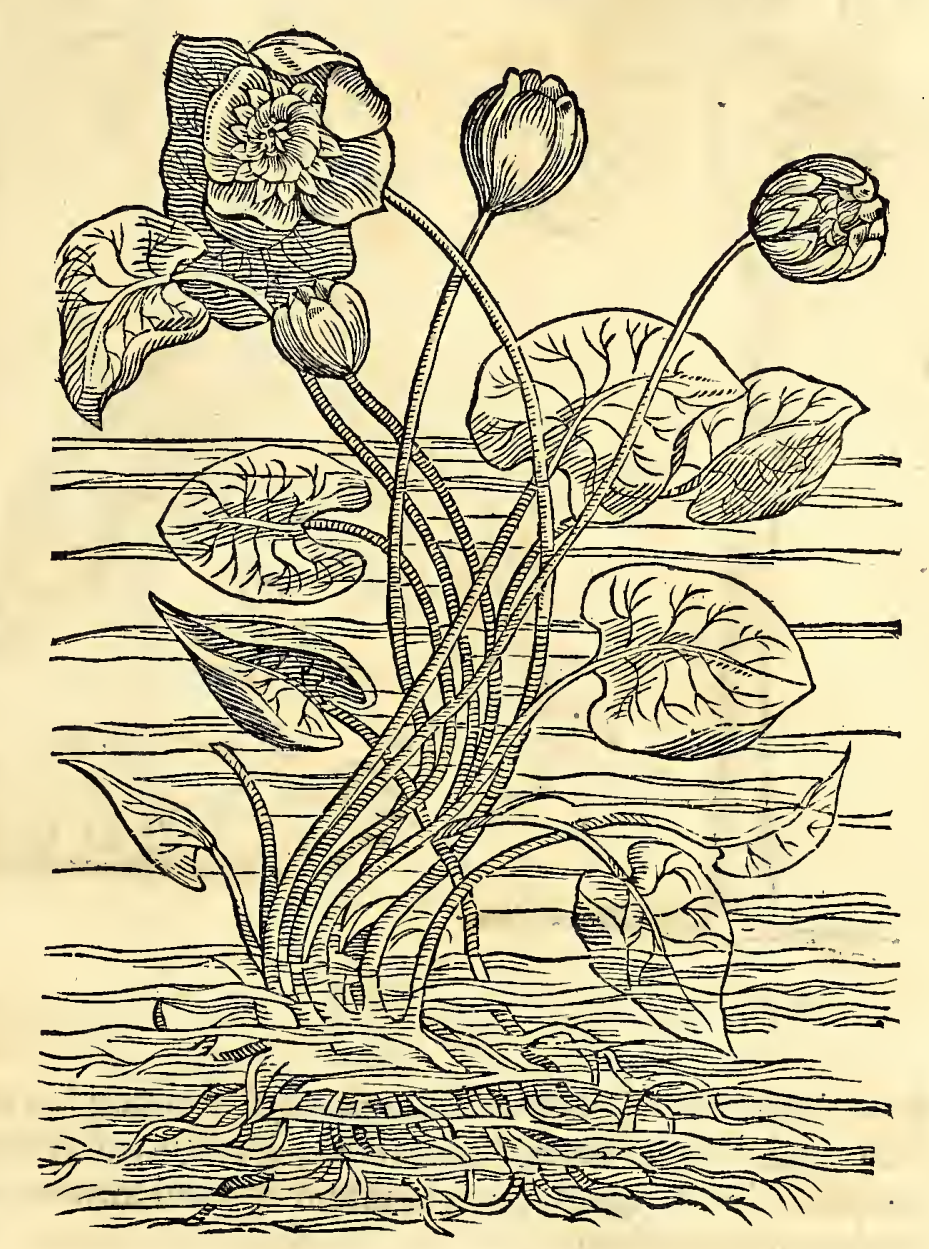
tidiana experientia id quod veteres Arabes \& Græci de qualitatibus Nymphæx olim teftati funt; fcilicet fiores ejus quidem refrigerare \& humectare, fed in radicibus $\&$ femine ficcandi \& refrigerandi qualitates prælucere. Accedit quod in non paucis id vegetabilibus pateat, ut una eademque planta pro diverfa uniuf́cujufque partis natura fuum variet temperamentum.

Nier tot immenfas paluftres herbas, adhuc tres ufuales hoc capite defcribendas fufce: pi. Quarum primo fe offerunt duo frutices, fub nomine Aningx, qux ficut ob rarain \& pulchram faciem cxteris facile pracellunt, ita qualitate Medica haud inferi ores exiftunt. Qux autem Aninga-iba dicta, frutex eft qui quinque aut fex pedes ex aqua erigitur unico tantum caudice fragili quafi interno diis divifo, cinereo inftar Iuglandis, in cujus fummitate aliquot folia magna, læte viridia, craffa, lævia, figura pene Nym phxx vel Sagittalis, nervo recto $\&$ venis tranfverfis confpicua. Qux fingula pediculo innituntur ultra pedem longo, fucculento. In eadem caulis fummitate inter folia exfurgit flos unicus, magnus, concavus, folio unico incarnato conftans, coloris pallide flavi,cum ftamine craffo, flavo, in medio floris concavo. Huic fuccedit julus, qui fructus evadit, perpetuis quadratis conftans, ovi Struthionis plus minus, magnitudinis $\&$ figu- 
A N I N G A I.

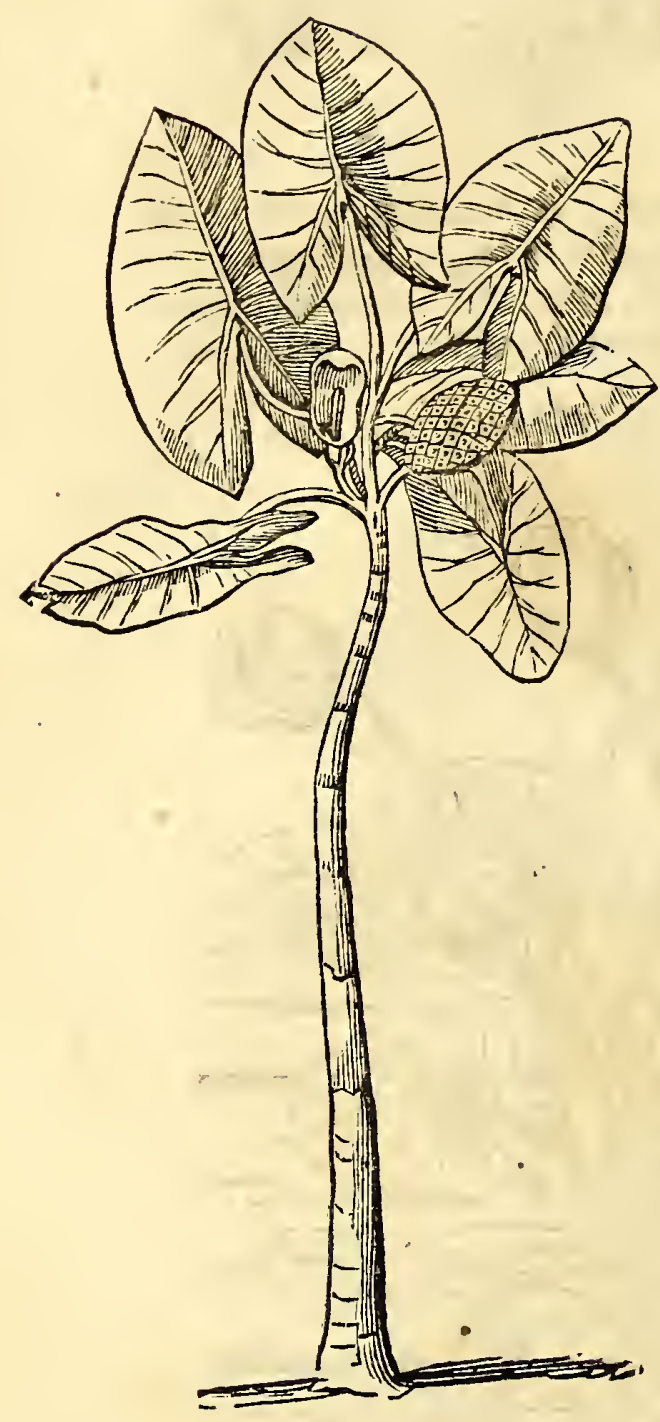

$A N$ I N G A

II.

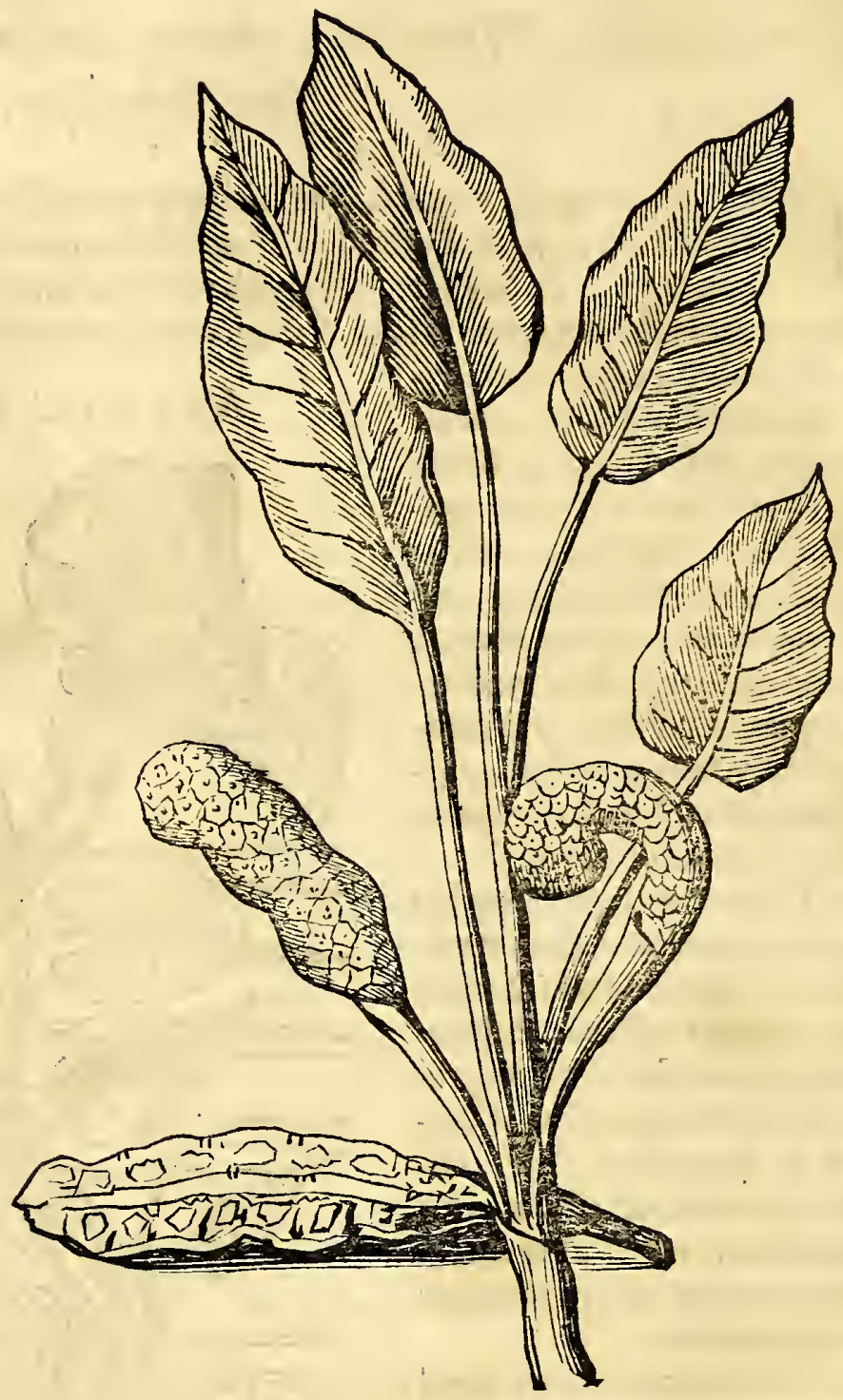

$\mathrm{r} \mathfrak{X}$, coloris viridis, intus refertus pulpa alba, humida, qux matur efacta $\&$ exficcata, farinacei fit faporis \& tempore famis comeditur. Cujus tamen exceflus cum evidenti vitx periculo fit, quod ob frigiditatem \& flatulentiam, more Fungorum terreftrium fuffocationem minetur.

Lignum corum qui ad arboream altitudinem excreverunt, ad varia mechanica ufurpatur, cum enim levis fit, tenax, fuberofus totus caudex, Indigen $¥ 2$ Nigritæ exinde Iangadas potiffimum conficiunt, id eft, rates fuas ex trilignio copulato, ad fluvios raptim trajiciendos.. Medica autem qualitas in bulbofa fua radice confiftit, de qua mox in fecunda Aninija agam, quia utr $x$ que earundem funt virium.

Alter autem Aninga eifdem locis ftagnantibus, ejufdemque altitudinis confpicitur. Caudice itidem unico; fed qui difpefcitur mox in varios caules crafliufculos, molles $\&$ junceos, Mufx five Bacob\& inftar; unde ex unoquoque caule folium prægrande, oblongum, raris venis confpicuum faftigiatur. Flore eft unico atque magno \& candido, ex quo progerminat fructus haud vulgaris , primo viridis, mox ex cinereo flavefcens, oblongus, craflus, compactus, ac veluti granis $\&$ punctulis diftinctus. Nobis inutilis habetur fere, Barbaris autem edulis ex defectu melioris alimenti.

Vterque Aninga radice eft crafla, bulbofa, que fola foliis \& fructui harum plantarum in Medicina præferenda eft. Quippe cum præter primas qualitates frigidas, tenuium quoque fit partium \& deobftuens, in varios ufus adhibetur à Lufitanis \& Barbaris.?

Contra 
Contra hypochondriorum $\&$ renum inflammationes ac obftructiones, fomenta exinde conficiuntur. Oleum denique expreflum, præftantiffimum habetur contra prædicta mala, atque olei Nymphææ \& Capparum vices fupplet.

Si ex radicibus denique in urina humana coatis balnea fiant, eaque aliquoties calida reiterentur, fummo exiftunt folatio contra morbos articulares, tam inveteratos, quam recentes.

$$
\text { P O T IN } O^{\prime} \cdot \text { B A }
$$

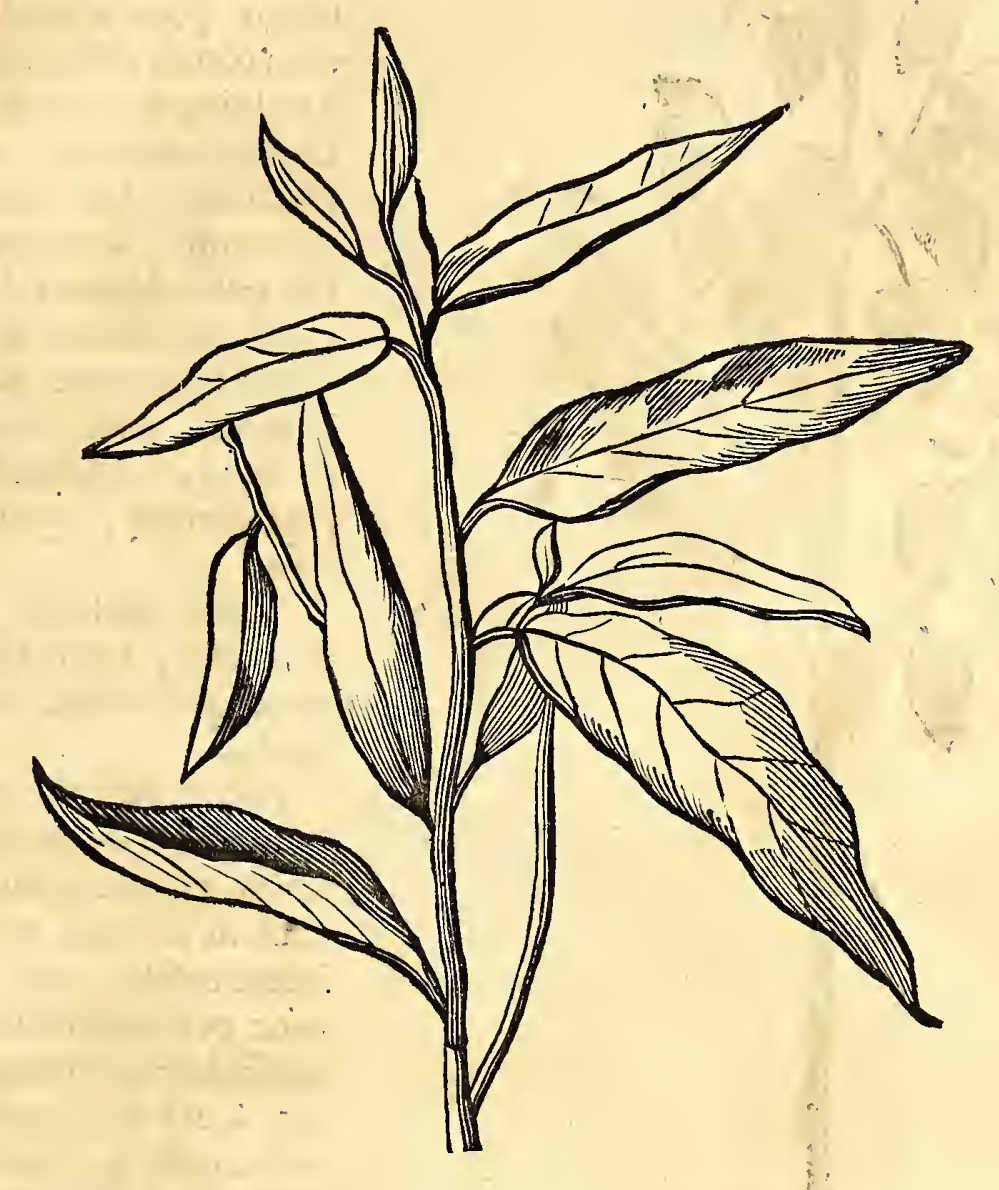

Dotinçóba, omnibus paffim nota, Herba ultra tibix altitudinem vix affurgens, Pulgera Lufitanis dicta, folio oblongo, nunc maculato, nunc immaculato, hinc inde per paludofa \& aquofa loca ftagnantia confpicitur, Perficarize per omnia fimilis unde eam Perficariam Americanam appellare placuit. Caulem habet nodofum, teretem, viridem, \& ad nodos rufefcentem: folia fimilia foliis Salignis. In Summitate ramu* lorum proveniunt fícx florum tenues \& longx, plenx flofculis albis. Fert femen triargulare, fplendens, fufcum, parvum. Radix eft inftar capillorum longorum, quibus fub aqua fe fuftentat: nam caules oblique fub aqua natantes, ad nodos habent fibras capillatas fatis copiofas. Radix illius commanfa intenfiore, fervore \& acrimonia linguam inficit, Europrumque Hydropiper tantum non fuperat.

Fomenta è foliis veteres membrorum dolores diffolvunt, frigiditarefque abolent Pubi fxpius applicata urinas è frigore cunctantes ciunt. Cærterum recens herba inter cauftica primas tenet, cujus rei non ignari Chirurgi, ea quotidie utuntur contra ulcera putrida, \& vermibus fcatentia. Tumores induratos digerit, cataplafmatis in modo impofita.

\section{C. $A \cap P V T$. L .}

\section{Altbea, Camaru, Agnara-quiy'i, or Acutiguépoobi.}

Nter diverfas Malvarum \& Althæarum fpecies Americanas; Europæarum æmulas, hæ quidem dux familiariffim $x \&$ ab omnibus expetita funt. Q Quarum nomina vernacula mihi exciderunt. Lufitani eas communi nomine Malvilifco vocant

$$
T_{3} \text { Prior }
$$


A I T H EA.

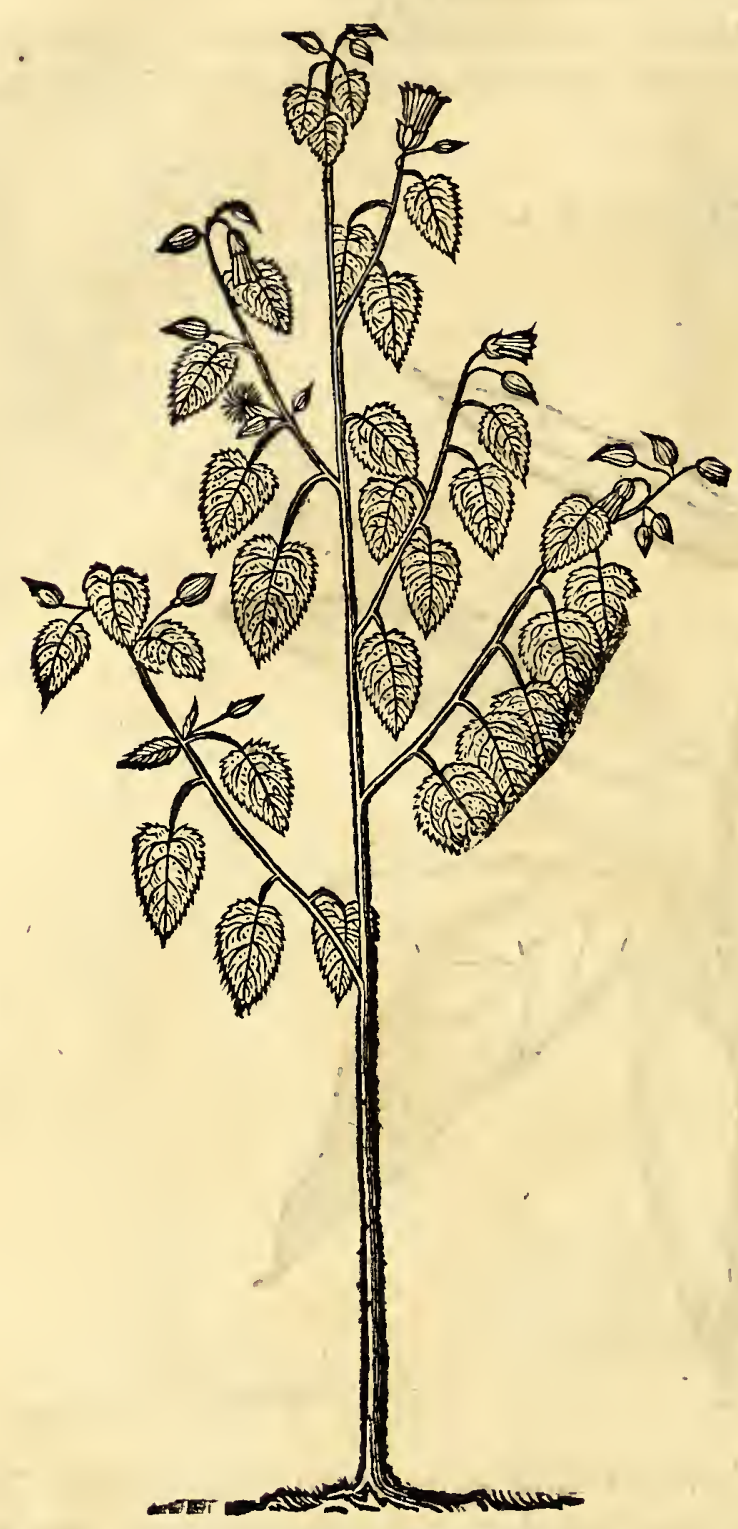

Prior (cujus iconem hic exhibco) Malva eft eleganter arborefcens, caudice recto, inferius ramis orbo, fuperius in multos diftributo, in quibus fo: lia magna, Malvæ hortenfis Eu ropæx, vel Abutili Avicennæmodo, folitarie pofitacum longis pediculis adnafcuntur. ea in totum funt hirfuta; inferne albicantia, in ambitu fubtiliffime dentata, ad tactum glutinofa. In extremitatibus ramorum, \& capitellis hirfutis, inftar Alcæx vel Bamix $Æ$ gyptiacx enafcuntur flores infigniter incarnati, pentaphylli, glutinofi, cum ftaminulis multis flavis. Semen eft fplendens, nigerrimum, quafi triangulare.

Folia \& flores quotidiani funt ufus, loco Malvæ, ficut mox probabitur in fequenti herba.

Altera Althrea magnitudine quidem, fed non dignitate inferior, ex radicc multa tenui in caulem rectum, teretem, uno latere rufefcentem, vix ad quatuor pedum altitudinem, ramufculis ornate expanfis, affurgit. Cui folia fingulatim pofita, in longiffimis pediculis Malvarum more adnafcuntur, inque tres vel quatuor lacinias fecta,

craffe in ambitu ferrata, quibus notis potiffimum à præcedenti planta difcrepat. Superne faturate viridia, inferne incana, hirfuta, \& ad tactum mollia, nervis \& venis rufefcentibus. Prope exortum foliorum ad caulem $\&$ in fummitate caulis ac extremitatibus ramorum provenit flos egregie incarnatus, pentaphyllo, ftamineque in medio incurvato : tot triangulares, hifpid $\boldsymbol{x}$, adhærentes capfulæ grifei coloris, juxta fe in orbem pofitx funt, quot folia flos habuit; in quibus femen triangulare, fubrotundum, \& figura Lunæ gibb $x$, coloris grifei, magnitudine Farris. Ego utriufque herbæ decoctum pro clyfteribus $\&$ fomentis quotidie prafcripfi : quod inter-modice refrigerantia \& emollientia principatum teneat. Necaliam peculiarem qualitatem, ab Alchæa veterum difcrepantem, in hac potui animadvertere.

Amarú, five Solanum veficarium. etiamfi enim hixc Solani fpecies Americani filveftris foliis fuis dentatis, caule pilofo, nonnihil abludat à veterum Solano Halicacabo ; tamen fi cætera externa \& interna rite confiderentur, nulli alteri plantx comparari poteft. adde quod hujus filveftris folia in ambitu ferrata plane conveniant cum foliis Solani hortenfis Fuchfii.

Ex radice parva, alba, filamentofa, enafcitur caulis fatis craffus, quadrangularis, nodofus, pilis albis veftitus. Ramis itidem pilofis folia adnafcuntur dilute viridia, ad cactum mollia, longis pediculis innitentia ; figura cordis, craffa, modo in ambitu dentata , fimilia foliis noftratis Solani Halicacabi. Ex thecula rotunda prodeunt flofcull parvi, pallide flavi, in quinque angulos expanfi; intra florem funt quinque macula $\& \subset$ totidem 
C A M A R V'.

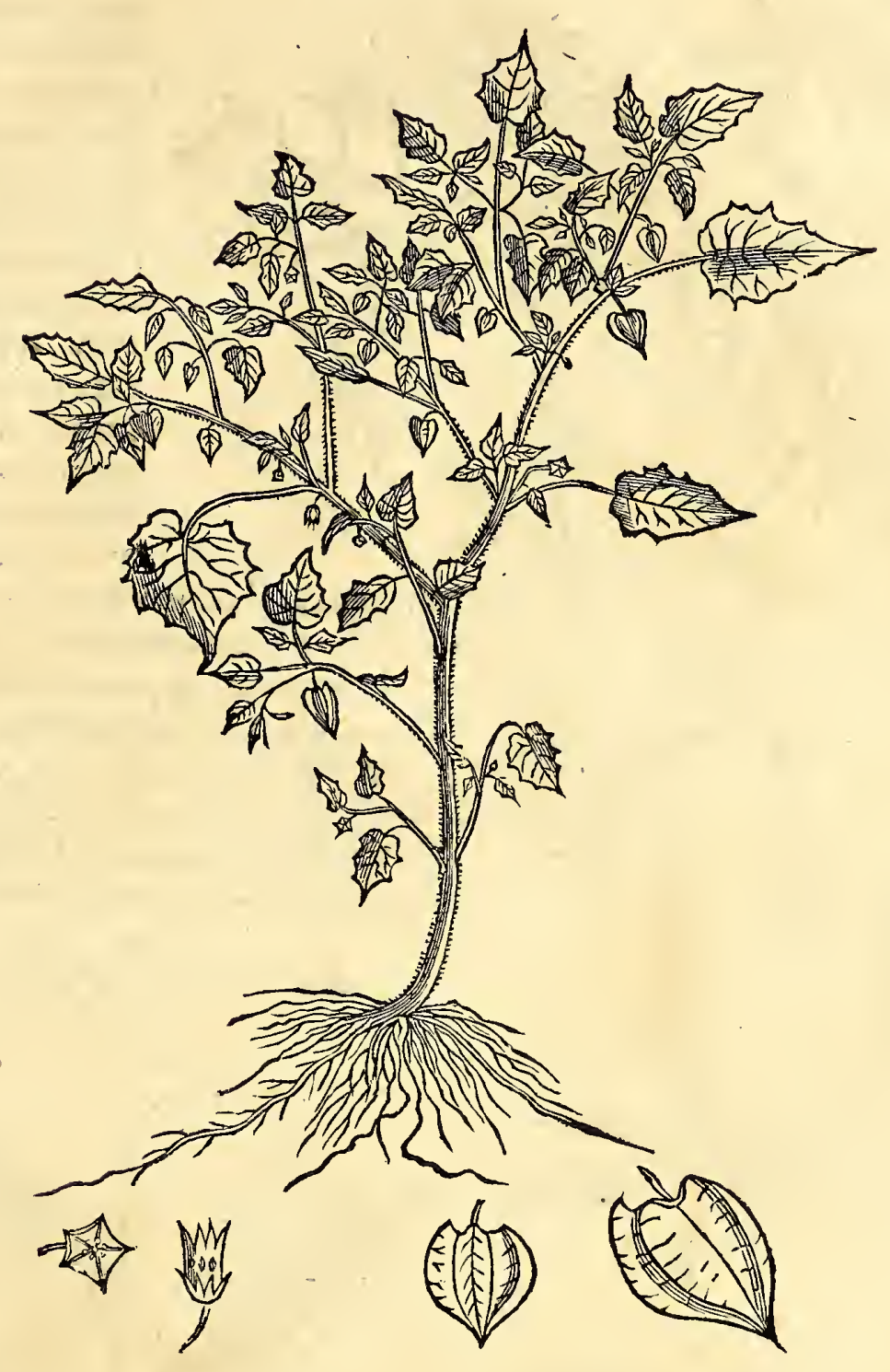

totidem ftaminula purpurea : ita ut flos claufus quinquangularem ftellam referat. Poft quos fequitur fructus pallide flavefcens, Cerafi magnitudine, folliculo inclufus modo noftratis Halicacabi fructus, nimirum pentagono, turbinato, cujus anguli lineis purpureis intexti. Fructus comeditur $\& x$ eft fapore fere ut noftras Halicacabus. Herba cocta fervit lavandis cruribus, ac proinde frequenter balnea ex is conficiuntur.

Fructus tenuium partium cum fit, hepatis \& renum abftructionibus dicatus eft, eodemque modo ut in Europa exhibetur. In eo folum differens, quod diuretica qualitas in remiffiori gradu huic videatur conceffa.

A Guara-quiy'a, five Solanum bacciferum Americanum. Sponte in agris \& deviis arenofis luxuriat notiffima hæc planta . vulgus. Lufitanorum diverfa indidit nomina: alii enim Erva Moura vel Pimente do Gallinha ; alii Erva do Bicho merito appellarunt, quod frequens ejus fit vfus in Endemia illa ani inflammatione Bicho del culo dicta. Frutex hic ex radice filamentofa, alba, caule unico, viridi, medullofo ornate exfurgit. Folia habet Capfico Brafilienfi fimilia, duo, tria, vel quatuor juxta fe pofita, inæqual is magnitudinis. In quolibet pediculorum hinc inde nafcentium emergit flofculus albus ex quinque foliolis retrorfum inclinatis, quinque ftaminulis erectis, luteis, in medio pofitis. His flofculis verno tempore potiffimum fuccedunt bacc $x$ rotund $x$, qu mature fact $x$, præ nigredine fplendent, copulatim pendulx, fucculent $x$, multos acinos purpurafcentes continentes, qux ab avibus devorantur.

Folia 


$$
\text { 224 GVIIELMI PISONIS }
$$

,

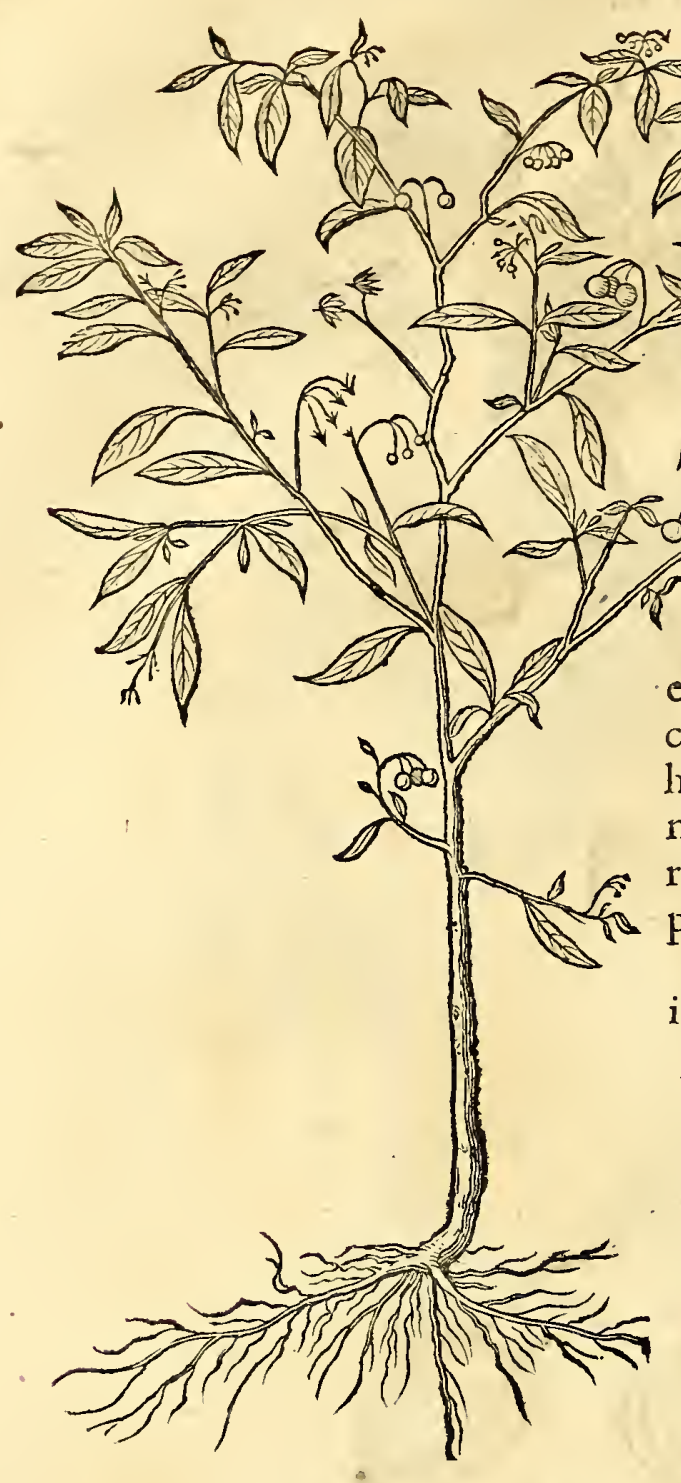

A Cutiguépo-obi. Non imbellis planta A fruticefcens in filvis hinc inde confpici datur, quæ ex radice fuperius rotunda inftar Bulbi, fucculenta, inferius filamentofa, exfurgit unico caule longo, recto, arundinaceo, ex quo hinc indepromanant in pediculis folia longa, acuminata, eleganter viridia, fplendentia, ad tactum inftar membranacex chartxe, nervo fecundum longitudinem \&\& fubtiliffimis lineis obliquis decorata, $\&$ in ambitu linea rubra, fimbriata. In fummitate caulis, provenit flos inftar Lilii egregic incurvati \& ignei coloris, tribus vel quatuor foliis conftans : apud quodlibet folium tria, quatuor, aut quinque ftamina extant, ejufdem coloris, figur $x$ ut dens apri. Radix affata vel cocta tempore famis comeditur. Et inprimis a Medicinx peritis expctitur, quia fola abfque alio remedio ulcera malc morata fanat, fi contufa iis applicctur.

Folia imprimis, magni funt in Medicina, à Chirurgis æque ac à Medicis expetita. Cum aftringendi \& refrigerandi infigni qualitate vim quoque anodynam habent conjunetam, non tamen foporiferam. Vulneribus tibiarum, rimis papillarum mulierum, folia cum optimo fucceffu apponuntur. omni denique excedenti calori atque inflammationi profunt, ardorefque nimios ani extinguunt, fi corum fuccus recens expreffus cum tædis ano immittatur. Cautio tamenadhibenda perpetua, ne promifcue in omni inflammatione pro topico apponantur, ob infignem repellendi \& refrigerandi vim, qux in tota hac planta videcur prælucere.

Cortex ejus contufus $\&$ aquis impofitus pifces inebriat, ut in retia præcipitentur.

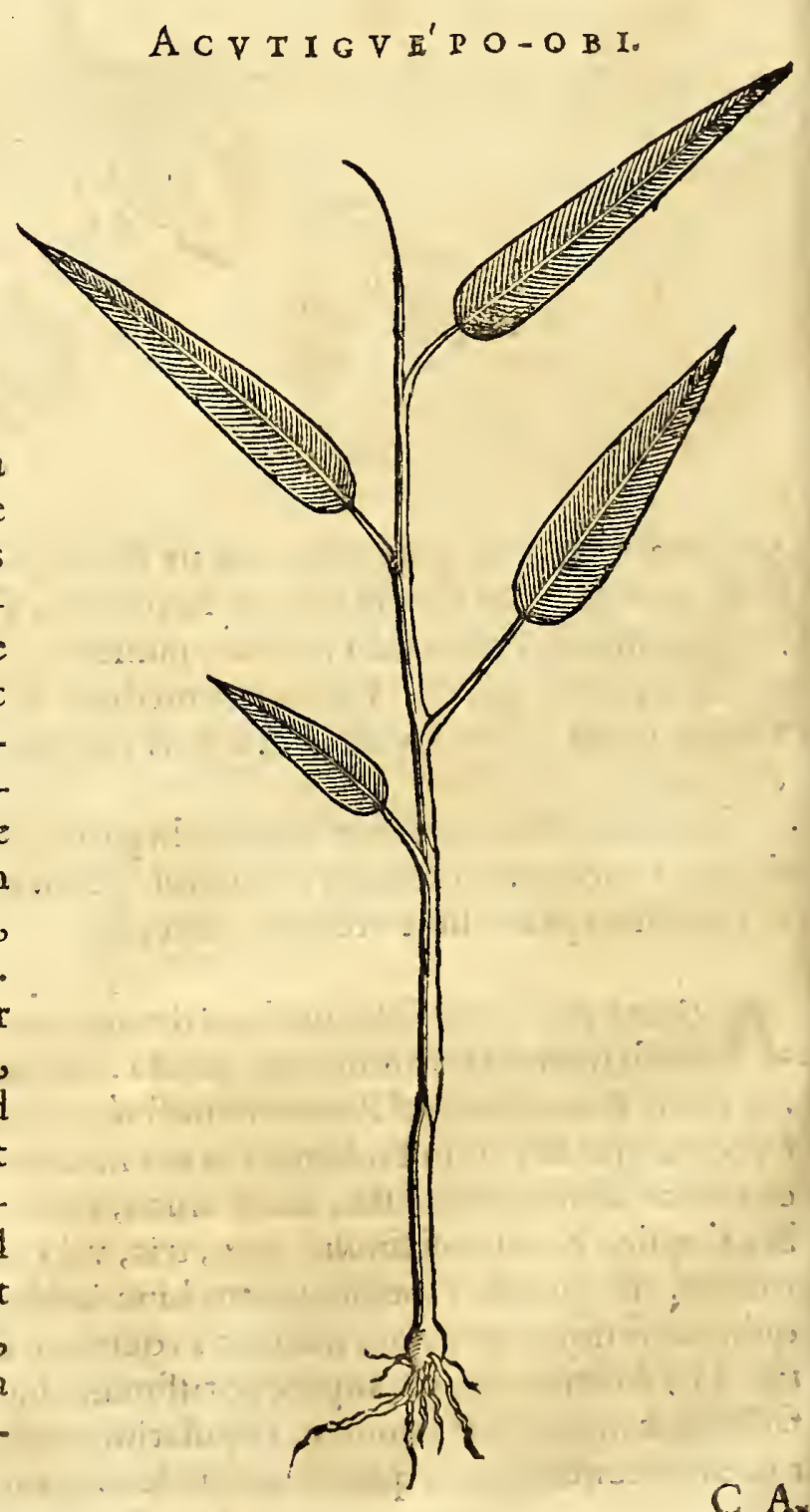

C A 


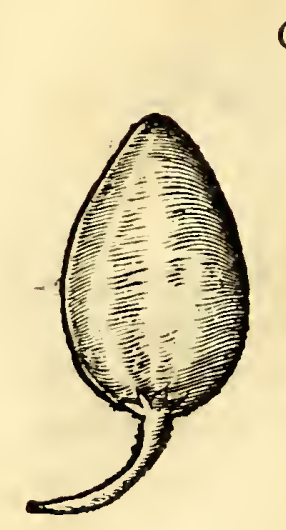

Q V I Y A.
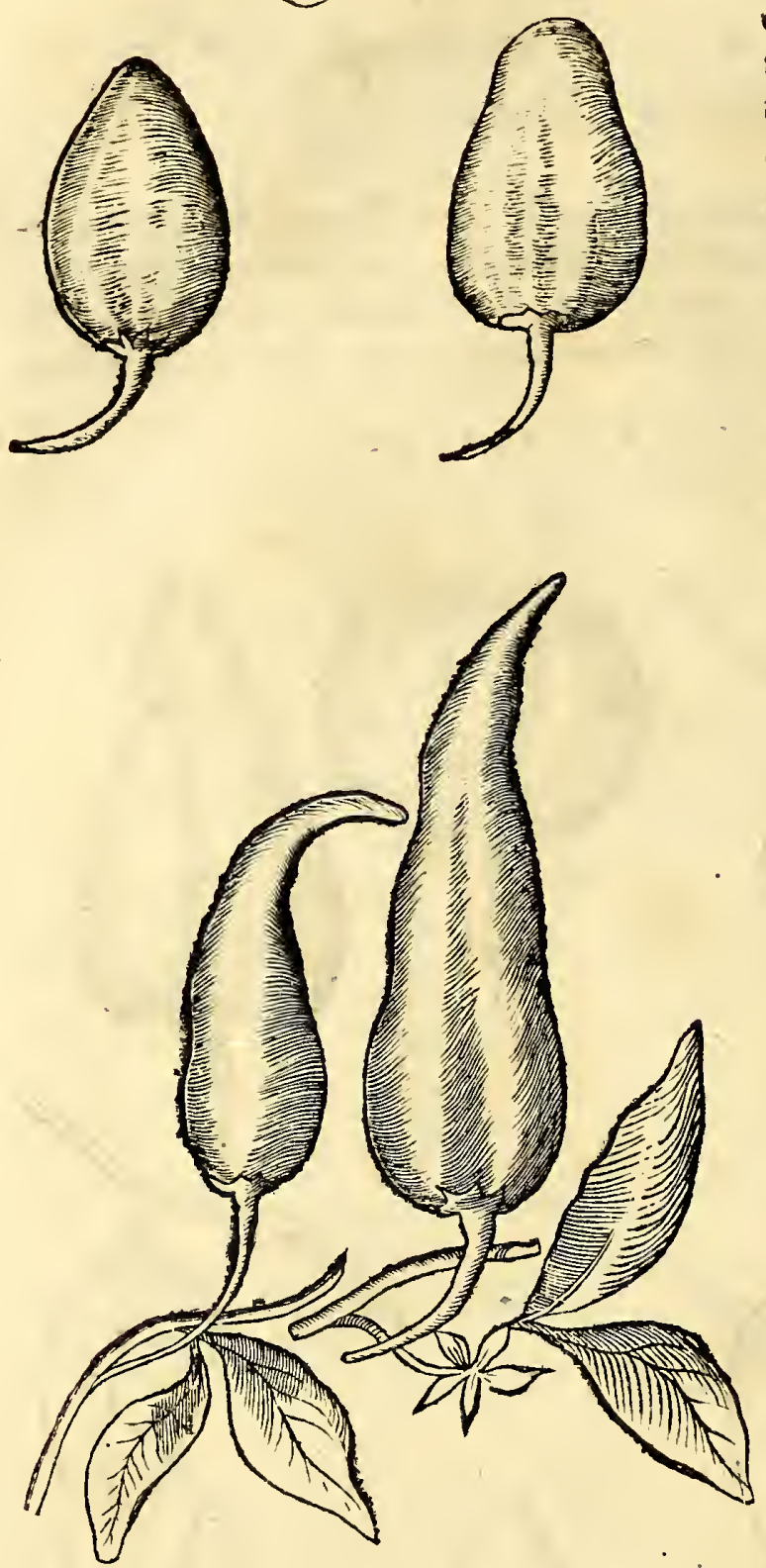

2uiya-carapo. Excipitur tantum unica qux Pimentá dolce appellatur, \& Tive cruda five condita menf $x$ deliciis infertur fine ullo calore molefto. Flores omnium funt candidi, fructus fanguinei coloris, femine funt ex flavo albicante \& ferventis caloris, foliis Sohani frmilibus, late virentibus.

Tefte Ximene Mexicani hanc plan: tam Chilli vocant, qux fert filiquas illas, Hifpaniolx Incolx $A x i, \&$ Antiqui Siliquaftrum, Hifpani piper Americanum, \& Aduarius Capficum. De quarum viribus \& ufu Ximenes prolixe egit.

Olim ob infignem acrimoniam, neque in medicinam, neque in cibum admittebatur, fed poftquam humanum genus excogitavit correctoria \& utendi modum, utriufque nunc participat.

Indigen ; Lufitani, \& noftrates, hæc Piperís genera omnia, Orientali Piperi longe præferrefolent, eaque, tum recentia, tum exficcata, concifa, cibo, imprimis pifcibus, optimum faporem conciliant, \& fanitati conducunt. In multiplicem ufum præterea à Medicis juxta ac vulgo arefacta refervantur, nec facile vires deponunt, fed potius fumunt ad ficcitatis \& caliditatis fupremos gradus. Integrum Piper recens (quod minoris eft fortis) deglutitum; fummopere valet ad difcutiendos ftomachi flatus, languidamque concoctionem, corroborat denique vif́cera à frigore obfita. Vrinam cit in fpiritu vini maceratæ filiquæ infufum; membra torpida \& paralytica refticuit. fi eo reiteraris vicibus laventur. Pulvis ejus apoftemata frigida refolvit gallinæ axungiæ mixtus. Tutius autem \& jucundius hæc præftat, fi rite præparatum cibor quoquefi in pulvediatur, quod fit ace to, cui integrum Piper immerfum fuerit : tum quoquefi in pulverem redigatur cum modico Salis Brafilienfis.

Eximiæ hæ plantæ jam dudum in hortis Hifpaniæ \& alibi, non modo propter ornatum, verum \& ufum medicum ac condimentorum fuere exculta: In hortis aurem totius fere habitatæ America plures illius fpecies obfervantur, \& filiquæ illarum in tam frequenti funt ufu, ut vix edulia reperias quibus non admifceantur. Quamobrem cautio habenda, ne quis iis crebrius \& immoderatius utatur. Renes enim, oculi \& hepar exinde inflammantur in regionibus his fervidioribus, præcipue juvenibus \& viris quià vino non abftinent, dolores hypochondriorum, abfceffus internos excitant. Semen hujus plantæ adeo eft acre, ut cavendum fit, ne quis digitos ad oculos ferat, cum illud confricuit. Qui plura volet, adeat Clufii Curas pofteriores, ubi exhibetur 7 ractatus egregius Patris Gregorii de Siliquaftris. Recens enim tufim validam proritat, corpus turbat, atque pectus maxime infeftat, fi carbonibus impofzam, ejus fumus excipiatur or vel naribus. Omnium horum fruticum folia \& radices prima balneorum calidorum funt ingredientia.

Rte colitur, non fponte crefcit, Mangaratiá, quæ apud totius orbis Incolas in deliciis ufurpatur. Ac proinde cum neque cultura vel externa facie, neque interna qualitate 
HIST. NATVRAL. Q MEDIC. LIB. VI.

qualitate $a b$ alio Zinzibere multum difcrepet, defcriptioni hujus noftr $x$ non inhxrebo. Recens \& viridis, faporis eft fortioris quam quæxtate ficcatá ex India affertur, magnaque quantitate hic Saccharo conditur. Quod anrequam fir, Soli exponitur, ut fuperflua humiditas. confumatur : fed cave tibi à nimio ufu, præcipue qui fanguine es fervidiori : adeo enim ofcula venarum acrimonia fua aperit, ut fanguinem fubinde per urinas cliciat. Quando cum caule \& folio tranfplantatur, folia decidunt, $\&$ poft trimeltre demum fpacium novagenerantur; ideo fine caule fola radix plantanda.

Etiamfi putem non effe Brafilix nativam, fed ex Indiis orientalibus ficut oryza huc traductam; tamen in omnibus Americx provinciis luxuriat ; feritur enim \& propagatur tam per femen quam per radicem, idque felicius men-

fibus æfivis. Interdum integra radix, parieti appenfa, ibi progerminat. Vide quæ $\mathrm{Clu}^{-}$ fius \& Garzias ab Horto fuper hac Planta notarunt.

Fr. Ximenes. Quod Mexicani vocant Chilti, Orientis Arabes, Turcæ, \& Perfedicunt Ginzibit, officina Ginziber. Dux autem illius reperiuntur fpecies : quarum una dicitur mas, altera, fomina. Mas habet folia magis afpera quam Gingiber, \& craffiora, verum ejufdem figur $x$ : radicem quoque majorem $\&$ craffiorem, faporis acris $\&$ aliquantum amari; ufurpatur adverfus affectus ventriculi $\&$ inteftinorum è caufa frigida.

\section{A P V T $\mathrm{T}$ L I I.}

\section{Xhambi, Iacua - Acánga, aliis Aguaraquinba, \&o Herba Lanuginofa.}

$\mathrm{O}$

Lim neglecta planta, in filvis \& nemorofis dumtaxat locis reperiebatur; tandem, cognitis illitis virtutibus, hortis eft illata. Pro vario natur $x \&$ cultur $x$ lufï, variis modis excrefcit, \& faciem fubinde mutat. Herba eft caule fatis craffo, lignófo, tereti, geniculato, qui Portulacx modo partim humi ferpit , partim erigitur atque radices agit multas, filamentofas, teneras, albas. Caulis \& $\mathrm{c}$ ramuli perpetua hirfutie quafi veltiuntur, atque hinc indefe ornate difpergunt, duo fibi oppofiti, quifque folium producens magnum, dilute viride ; quod ut variæ magnitudinis, ita $\&$ figuræ eft; aliquando enim leviter eft ferratum, aliquando profundel laciniatum.

In extremitate ramulorum flores proveniunt folitarii, magnitudine Cerafimino- 


\section{NHA B I.}

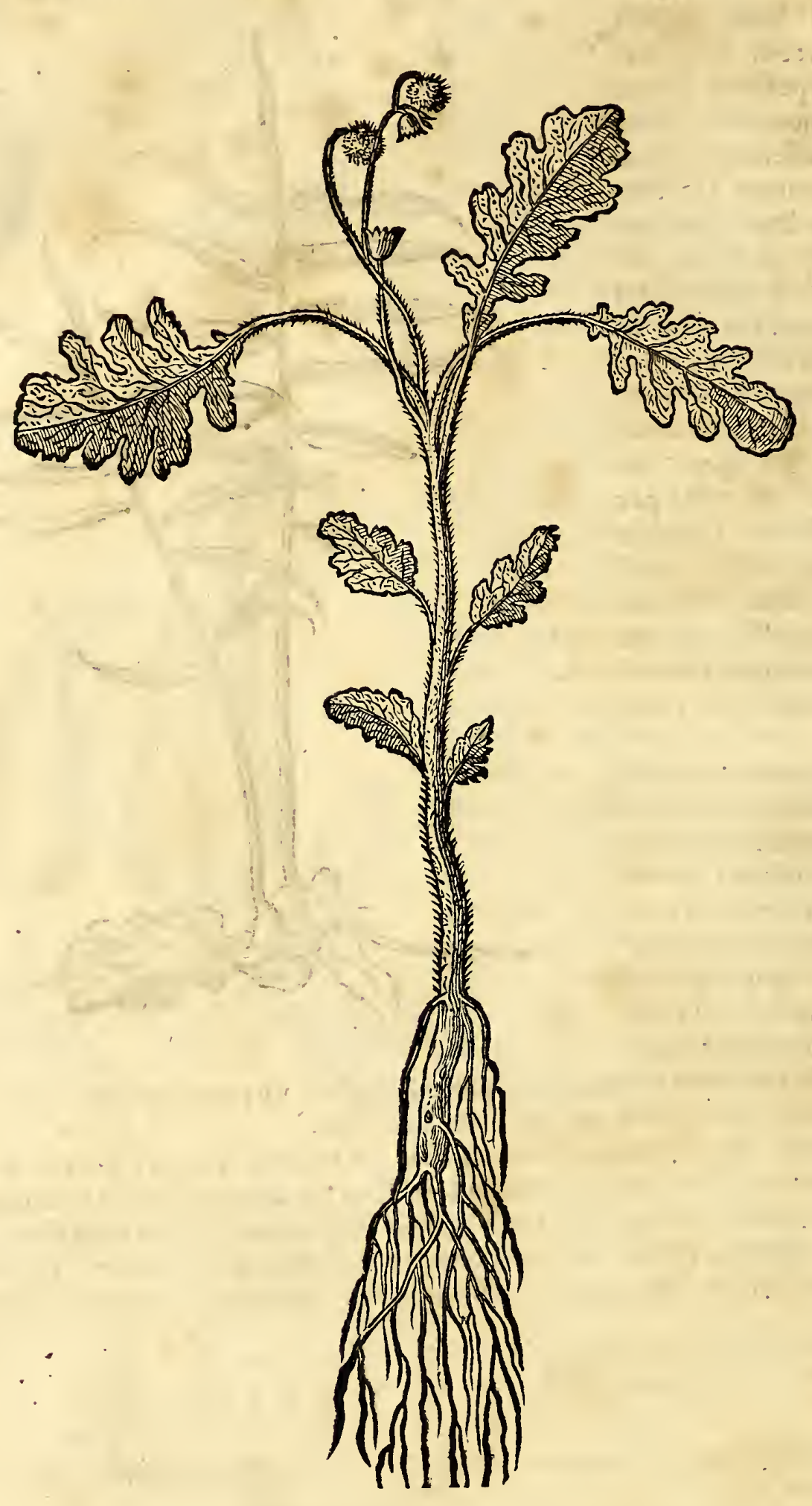

ris , conftantes folo umbilico rotundo fine foliis : Caterum Chamomælo non multum diffimiles. Semen in umbilico, ovali figura, plane compreffum, ex fufco grifei coloris fplendentis.

Calida \& ficca eft in tertio gradu, linguamque praguftata vellicat. Lactucas cæeterafque himectantes $\&$ refrigerantes herbas, quæ pro acetariis folent apponi, temperat, \& fapore aromatico imbuit. Præererquam quod tenuitate partium \& caliditate intenfa calculum frangat, vis peculiaris contra colicos affectus illi ineft. Tum quoque fi flofculi \& pappi comedantur, renum vifcofitates \& uteri immundities expellunt. Syrupus eirdem malis dicatus prxparatur. Flatus \& obftructiones ex frigore ortas diffipat, fi intus aflumatur, aut balneis, fovendo corpori concinnatis, injiciatur. 
HIST. NATVRAL。 \& MEDIC. LrB. IV.

Potentia antidotali præftare $\&$ toxico fumme adverfari, experimento compertum habeo. Itaque quod vidi, hic referam. Brafilianus quidam Bufonem nactus pregrandem $\&$ veneno tumidum, fucco floris $\&$ foliorum tergo leviter inftillato, eum confefim enecavit. Nec tantum animantia venenata exftinguit, fed \& prxcordia hominum adverfus venena munit, fi mane \& ventriculo adhucjejuno manducetur.

Aquas hydropicorum feliciter educit, \& robur addit vifceribus. Indigenæ ad firmandam valetudinem, pultibus è Mandiboca factis, lianc herbam indunt, non fine profpero fucceflu, quod frigiditatem ejus egregie retundat.

I A C V A $A \subset A^{\prime} N G A$.

${ }_{-1}$ Rutcefcens \& ornaItiflima planta, in arenofis potiffimum locis luxurians, à noftris ac Barbaris in ufum quotidianum recepta: Vulgus LufitanorumFedagofo nomen indiderunt. Affurgit ultra duorum pedum altitudinem caule hirfuto.

Foliis eft craffis Nepet fimilibus, palmæ magnicudinis, rugofis, \& ad ractum plufquam Vrticx afperis, \& ut Scarlea corrugatis. Ex quibus exfurgit caulis, five fpica potius, decem cirça digitos longa, granulis perpetuis, eifque viridibus cooper tus more Plantaginis, nifi quod fummitas illius caud $x$, Scorpionis inftar incurvetur, qux finitur flofculis parvis, è cæruleo \&lureo mixtis, figuræ inftar parvi calicis. Radix pedem longa eft, fere recta, pauca aut nulla filamenta habens, intus alba, lignofa \& lenta , fere infipida, cortice fufco.

Inter abftergentes \&

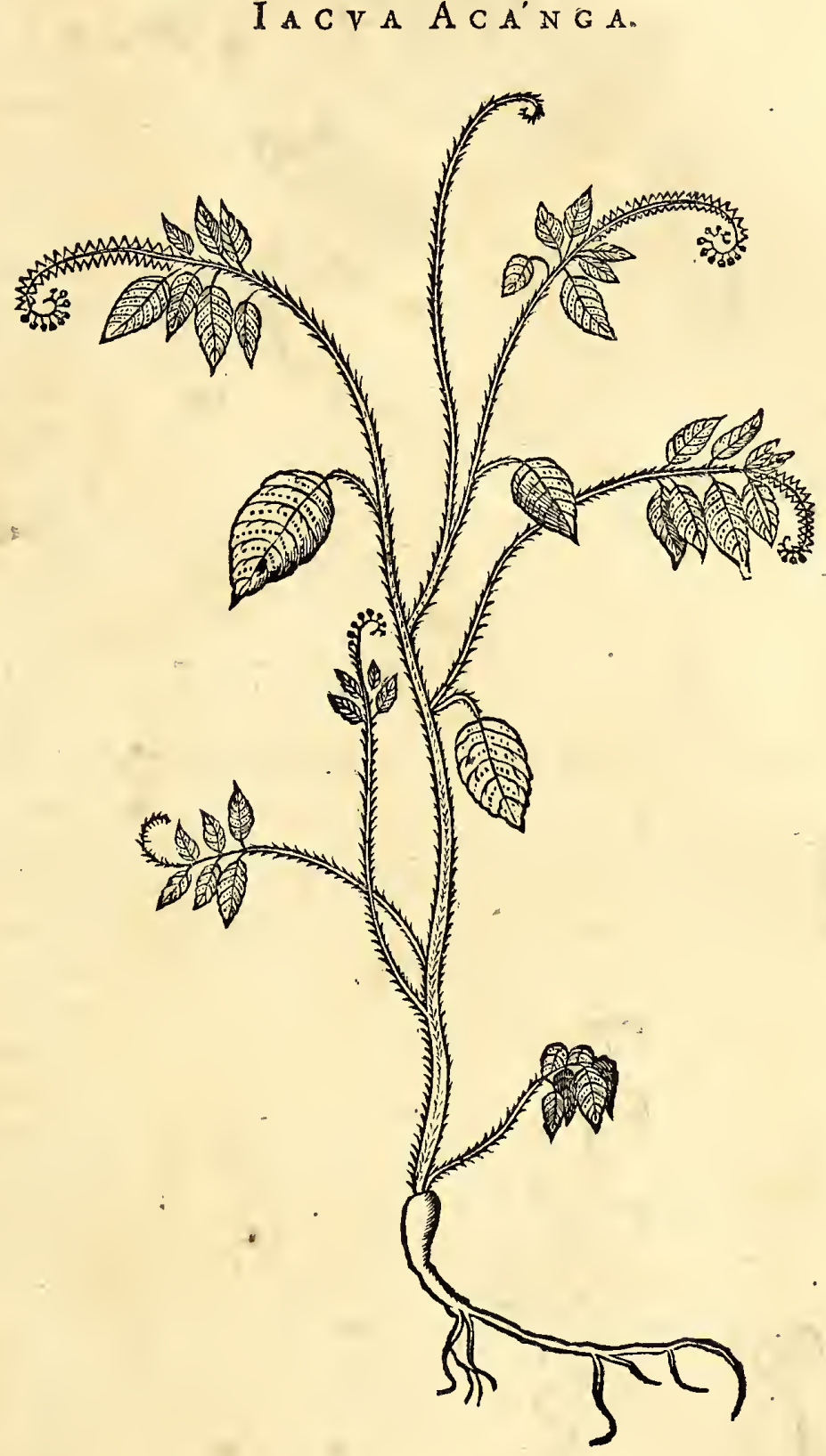
mundificantes numera-

tur hæc planta, contra vulnera \& ulcera, quod fimul confolidandi qualitate polleat: tum \& contra cutaneos affectus, ex aduftione natos, feliciter adhibetur, five fimplex, five compofita.

Reperitur \& alia fpecies priori plane fimilis, nifi quod paulo major fit quoad caules. Radix eadem eft, folia autem paulo molliora, fpica quoque incurvata, flofculis albis, quinque foliolis conftantibus. Semen denique rotundum, non triangulare, ut in priori. Hæc nomen audit Aguaraquinha. Vulgaris quoque \& trivialis planta, cujus folia contufa, apoftemata $\&$ tumores refolvunt, fi reiteratis vicibus eorum fucco fricentur. Multis porro ufibus dicarunt, \& contra interna mala exhibent Incolx. 
Herba Lanvginosa.

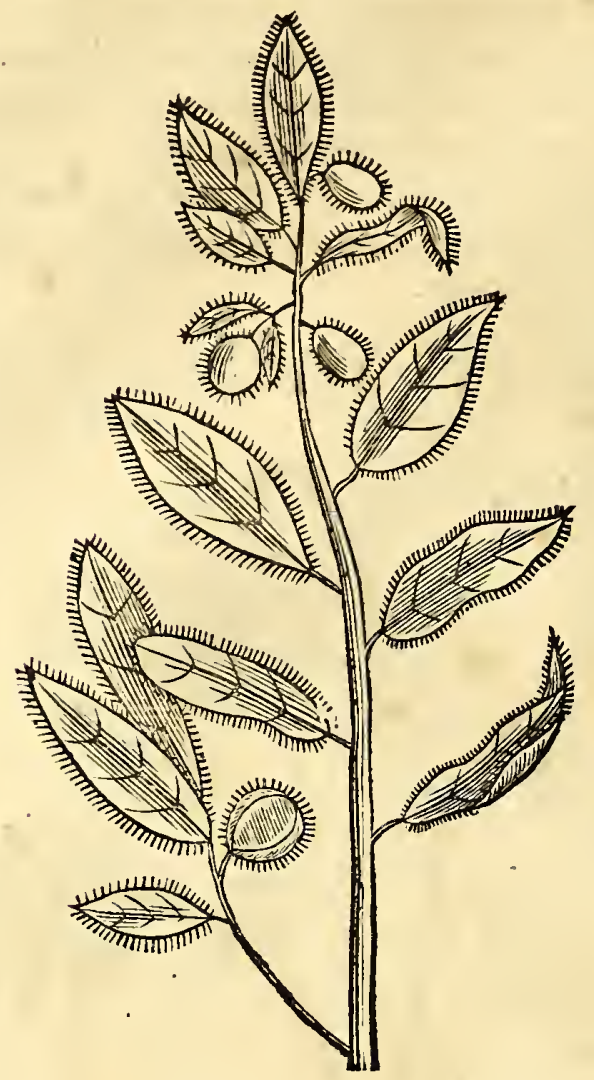

PAucioribus cognita, \&ín nu1 perrima peregrinatione mihi tradita hæc herba, afpectu egre. gia. Quam hactenus vero nomine deftitutam, primo intuitu Lanuginofam appellare placuit, quod caulem $\&$ folia, eaque exigua, pulchra, longa \& molli lanugine obducta inveniffem.

Fructum fert rotundum $\&$ viridem, lanuginofum, fatuum : Radicem habet parvam \& tenuem, non ingrati fed fubamarifaporis, cum quadam adifrictione, in qua fola parte plantre qualitatem medicam latere compertum eft.

Contra fluxus ventris à frigore natos, apud mediterraneos $\&$ remotiores incolas, familiare eft remedium, mihique admodum commendatum, fed nondum in ufus adhibitum, quod in habitata parte Braftliz vix occurrat.

L I I I.

\section{Caa-atija, Ipecacuánba, \& Caa-apiá.}

N pratis uliginofis \& apricis campis elegans planta Caa-atája reperitur: Lufitanis Erva de purga de Ioan Pays dicta. Vnico tenuiffimo quadrangulari caule, vix palm altitudine affurgit, femper læete virefcens, partim terræ incumbens, ad genicula ite-

C A A - A T A $A^{\prime} I$.

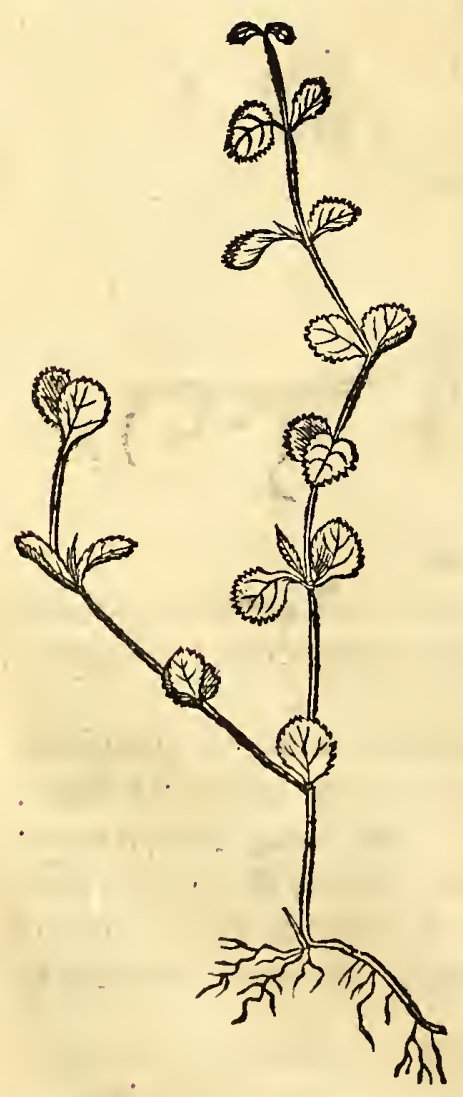

rum in terram radices agens parvulas, partim erecta ftans. Ad quodlibet geniculum, duo foliola fibi opponuntur, Nummulariæ figura \& magnitudine feu rectius Veronicx aut Chamxdryos, in ambitu ferrata, \& pallide viridia. Ad quodlibet par foliorum flofculus minimus provenit, quafi galeatus, albus. Pofthunc fequitur filiquula grani aven $x$ magnitudine $\&$ figura, qux fponte fe ape. riens, femen effundit minimum, rotundum, obfcurc flavum, minus femine papaver is minimi. Nullius odoris eft planta,fed faporis amari.

Radice eft fibrofa, tenui, parva, fubamari faporis.

Inter nobilifimas \& vere medicinales purgantes \& aperientes hxc herba merito cenfetur à peritioribus Incolis : à vulgo profano vix cognita, \& nondum in ufus applicata: urpote cujus manibus vix tuto permictitur tam efficax medicamentum. 
HIST. NA T VRA.L. \& MEDIC. I I B. IV.

dicamentum. Quippeillius decoctum vel fuccus, tum quoque pulvis, fi exficcetut. pauca quantitate exhibitus, tam valide menfes mover, ut non impune ab cmnibus. capiatur. Ego fuccum recenter expreffum ad $\mathbf{j}$. circiter, ex convenienti liquore propinatum, menftua $\&$ urinas, tum quoque excrementa per alvum fatis vehementer aliquando exturbafle obfervavi.

IPECACV A'NHA。

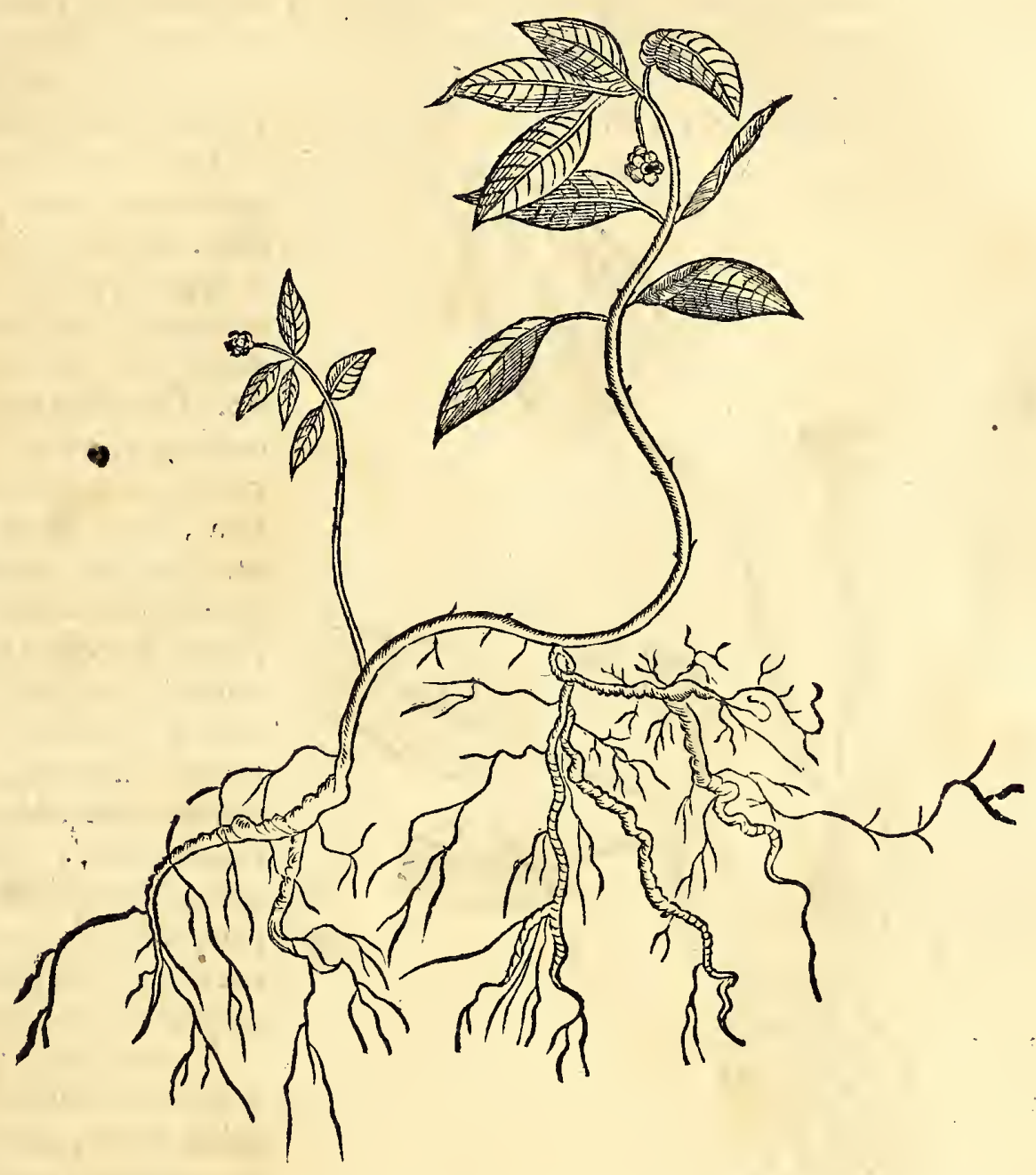

Andem ad decantatas has falutiferas radices ordo nos deducit, qux preter facultatem purgatricem per fuperiora $\&$ inferiora, omni veneno eximie adverfantur. Nec credo, praftantius remedium adverfus plurimios morbos ex longa obftructione ortos, imprimis in ventris fluxibus medendis, in hifce terris reperiri facile.

Dux exiftunt fpecies, ncutra à nemine, quod fciam, defcripta, earumve qualitates eximix in lucem protractx. Vtraque eidem ufui dicata, fed gradibus facultatum, tum $\&$ facie, \& natali folo, differunt. Vna enim earum humi depreffa, exiguior in pratis crefcit, Pugelio non admodum diffimilis. nam caulis foliis lanuginofis exfurgit multis, albifque flofculis cingitur: radixillius eft craffa, filofa, albicans, à Lufitanis ad differentiam, Ipecacuárba Blanca diata, qux, quod minus turbet corpus, \& venenis validiffime refiftat, xque pueris ac gravidis exhibetur.

Altera, cujus Iconem hic damus, eft longitudinis femicubitalis, trinis vel quinis tantum foliis ornata. Gaudet locis opacis, \& tantum in denfioribus reperitur nemoribus. In fummitate caulis baccas producit nigras, fed paucas. Radice eft tenui, tortuofa, nodofa, fufci coloris, faporis ingrati, amari, calidi \& acris. Exficcata in multos annos refervatur, nec facile vires deponit antidotales, fudoriferas, fed quidem vomitivas. Ejus in pulverem redactx dofis eft drachma; in infufo, drachmx, plus, minus, dux. Facultatem habet abftergendi, meatus referandi, ac infarctus exfolvendi.

Vtriufque quotidianus eft ufus, malunt tamen dilutum, quod vel unius noctis fub $\mathrm{V}_{2}$ 
dio maceratione aut coctione in aqua, medicam fuam virtutem abunde liquoribus communicet. Poftea caput mortuum refervatum, denuoque eodem modo præparatum, in eumdem ufum exhibetur; minus quidem efficax ad purgandum vel vomendum, fed magis adftringens. Ita ut radix hæc non folum materiam morbificam, licet tenaciflimam, à parte affecta revellat, eamque per fuperiora expellat, fed \& 2 aftringendo vifcerum tonum reftituat. Præterquam enim quod fluxibus ventris, aliifque morbis medeatur, venenis adverfatur, virufque, tum occulta qualitate, tum manifefta, per vomitum ftatim expellit. Quamobrem religiofe à Brafilienfibus refervatur, qui illius virtutes primi nobis revelarunt.

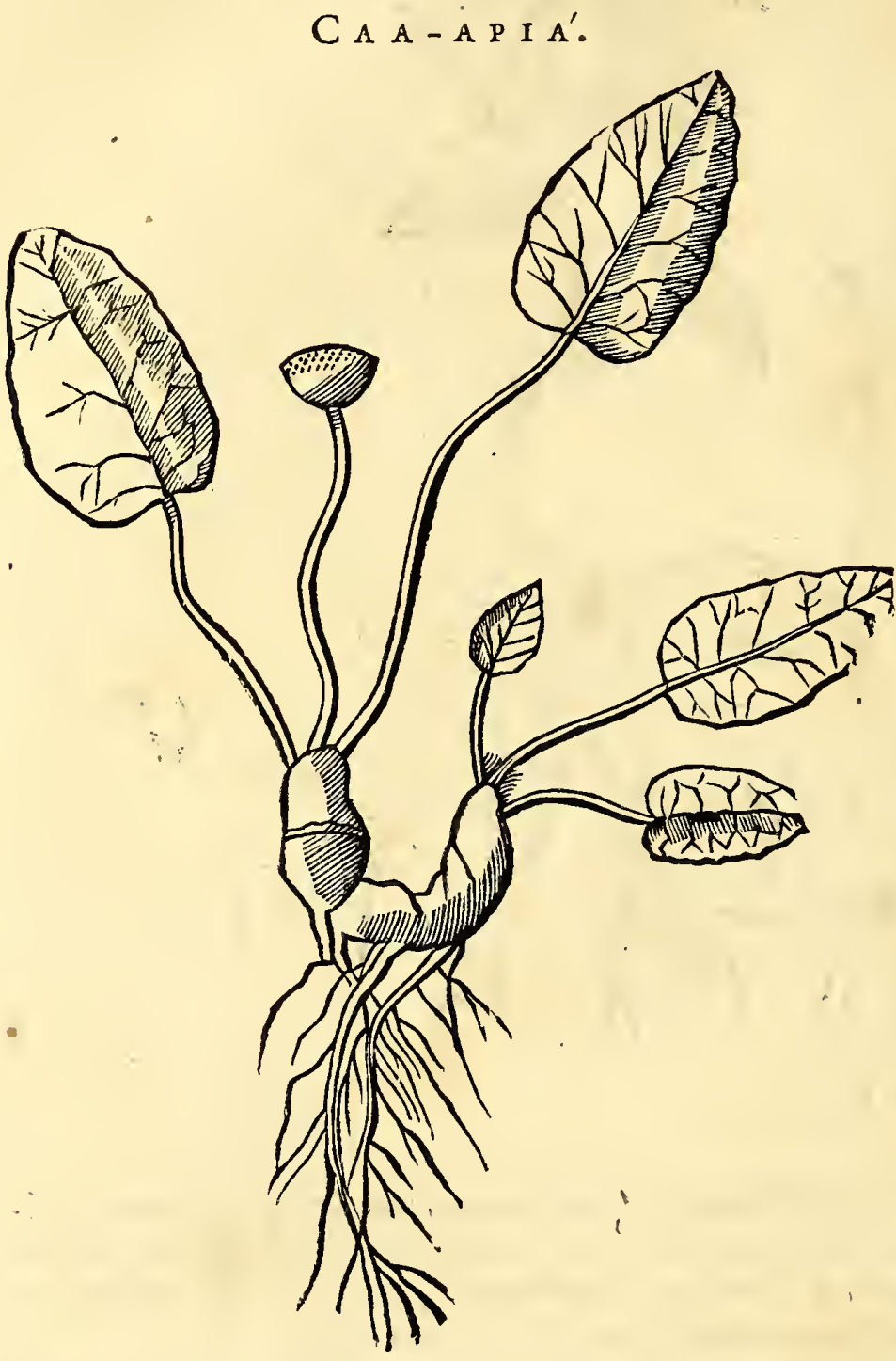

Scretum hujus herbx $\checkmark$ Lufitanis debemus, qui nobis eam fuppeditarunt. Pufilla eft planta \& deprefla, fed qux humilitatem præclaris dotibus abunde compenfet. Ex radice enim pennam oloringm craffa, verrucofa, filamentis ad latera, \& inferius tenuibus prædita, exterius c̀ grifeo flavefcente, interius alba, tres vel quatuor pullulant pediculi, teretes, qui quilibet unicum folium fuftinent, obrotundum vel oblongum, tenerrimum, fuperius fplendide viride, inferius paulum albicans, habens nervum, \& inferius venas tranfverfim confpicuas.

Florem fert in proprio pediculo rotundum, umbilici figura, fioris Bellidis æmulum, multis ftaminulis conftantem, ex quo femen provenit minus Sinapi. Radix ejufdem fere cum Ipecacuánba praftantix \& efficacix, unde \& Ipecacuánha abufive à quibufdam appellatur. Cujus vicem in vomitu ciendo, $\&$ alvi profluvio compefcen do egregic fupplet. Eo tamen difcrimine obfervato, quod primam fuam dignitatem à virtute antidotali fortiatur, quam an aliunde mereatur, nifi quod vifcera tetris fuliginibus liberet, mihi nondum experiri licuit. Radix primum haud manifefto fapore eft prædita, fed manfa, quodammodo acris eft, \& relinquit in lingua vellicantem humorem.

Differt porro ab Ipecacuánba, quod ad vomitum proritandum minus fit valida, nec pari efficacia humores peccantes per fuperiora exturbet : quo fit, ut radix, qux odore $\&$ fapore alteri cedit, majori quantitate exhibeatur.

Indigen $æ$ integram plantam contundunt, \& fucco prælibato virus à ventre excludunt : à colubris læf $\mathrm{f}$, aut fagittis venenatis percuff, eundem, antidotiloco, vulneri inftillanenon fine fucceflu.

Datur hic \& alia Caa-apíe fpecies, priori per omnia fimilis, exceptis foliis ; qux quidem ejufdem funt figur $x$, fed in ambitu ferrata $\&$ hirfuta: pediculi horum raris veftiuntur pilis. Florem fert in proprio pediculo roturdum cum umbilico in medio, inftar floris Chamomeli.

C A- 


\section{A P V T I I V.}

\section{- Conambatiafue Filix, Coaticaí fue Polypodium, Ononidis Jpecies, Conambai-mirí fone Adianti jpecies dire, \& Pinó fove Vrtica.}

I $\mathrm{N}$ denfis nemoribus mediterraneis variæ Filicis fpecies luxuriant, quarum præcipuam, minufque ab Europæa abludentem in medium hic profero. Qux in trium aut quatuor pedum altitudinem affurgit, caule quadrato, ex rufo nigricante fplen. dente lanugine rufa obducto. Folia ejus alata fibi invicem al= ternatim opponuntur. Foliola autem al $x$, funt tenera, viridia, itidem alternatim oppofita, in ambitu fubtiliter ferrata; in uno autem latere cujufque folioli, pulvis fecundum oram folioli in longum adpendet rufus. Qui inftar farinx ulceribus tetris infpergitur cum fucceflu. Nec florem, nec fruEtum, nec femen fert. Radice eftlonga faporis amari, nec tamen mordicantis; ulceribus exficcandis non folum exterius, fed lumbricis enecandis intus exhibita medetur. Iifdem porro uftbus dicata quibus veterum Filix. Acproinde ob infignem abftergendi \& deobftruendi efficaciam $a b$ advenis xque ac indigenis in medicinam recepta. An vero peculiari vi vulneribus fagitta arundinea factis auxilio fit ut Diofcorides de ea teftatul, à me nondum compertum eft, licet vulnera à fagittis ejufmodi inflicta, hic nimis frequentia exiftant.

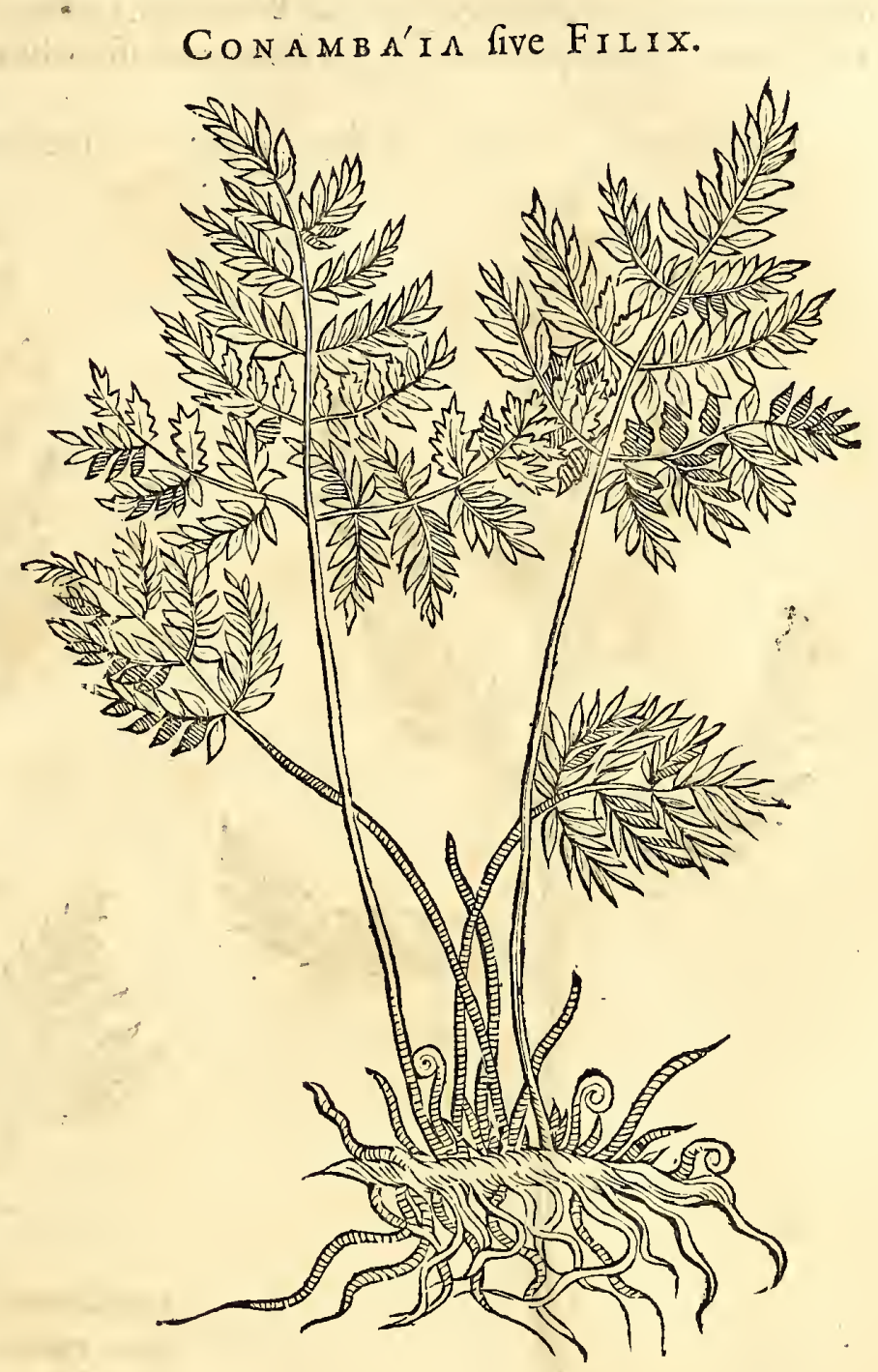

\section{CATICAA' five POLYPODIVM.}

Verum Polypodium, undiquaque in iplis arboribus, præfertim vero in Palma Trma curi \& Carduo Caraguatá cref́cit. Cxterum vulgari Polypodio externa faciefimilis. Radice eft longa pilofa nodofa fubrufo mufco obducta, interius exalbo flavefcente, fucculenta, dulci, cum aufteritate mixta. Vnde caules cubitum alti, contor ti , ftriati, nigri aut rub ri recta exfurgunt. Qui in fummitate multa habent folia, trina fibi directe vel alternatim oppofita, late viridia, mollia, nervo obfcure rufo fecundum longitudinem : juxta quem in utroque latere inferiori quadruplex feries punctorum pulveris lutefcentis è rufo confpicitur; $\&$ inter punctula à nervo per latera tranfverfim mult $x$ tenues venul $x$ virides. 'Quantum ad vires hujus Polypodii Americani, facile Europrum dignitate fuperat, atque validum remedium deobftruens $\&$ incidens, bilemque ạbftergendo purgans per alvum. 


\section{$O \quad N \quad O \quad N$ I $D$ I $S$ fpecies.}

TRivialis herba, cujus nomen Brafilienfe incognitum, vera Ononis non fpinofa no-

1 bis vifa eft. Cui multicaules teretes, lenti, pilofi, ex una radice enafcuntur longi, partim furrecti, ad tactum quafi pinguiufculi feu glutinofi i ̀̀ quibus hinc inde alternatim \& quafi mutuo amplexu in exortu prodeunt ramuli, quos eodem modo, petioli breves complectuntur, atque quilibet tria foliola, quidam etiam tantum unicum continentes : funtque foliola oblonga, angufta, nervo fecundum longitudinem \& venulis obliquis inferne prædita, \& leviter pilofa. Flofculos ex finu prodeuntes fert luteolos Ononidis noftratis modo, cui etiam circa facultates medicas non abfimilis eft: quamobrem fupervacaneum duxi, earum herbarum cognitas qualitates, fufius enarrare, qux ab Auctoribus Botanicis traditx funt. Radix enim eft ex ordine calefacientium atque tenuium partium, vifcofitatibus vefic $x$ dicata.

Conambai - Miri five dux Adianti f́pecies.
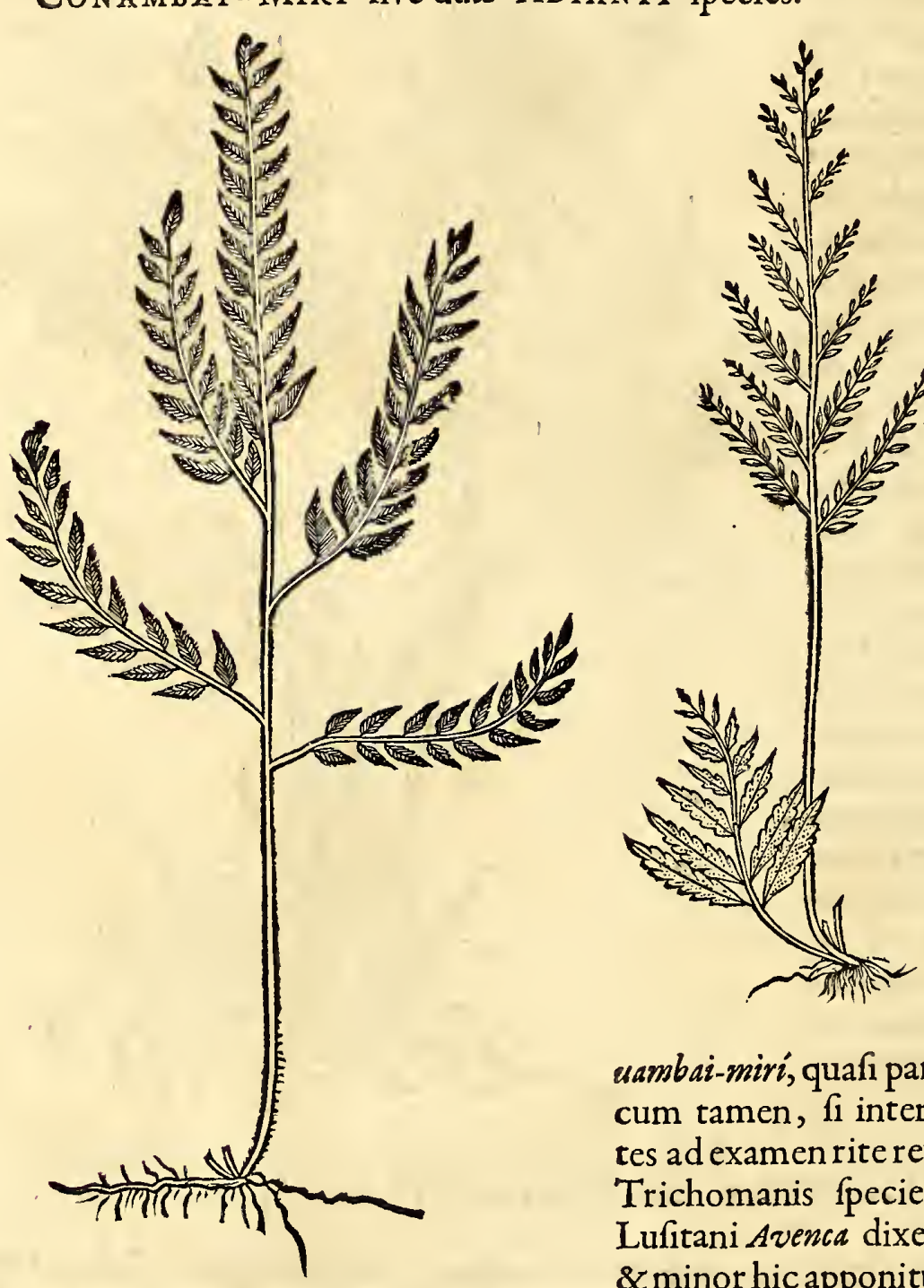

VEniam facile merebitur qui Novi Orbis vegetabilia non fatis exacte femper ad veterum fpecies redegerit. Cum enim figura magna ex parte accordent,omnes tamé ejufdem plantx qualitates atque partes externx rariflime conveniunt. Quem Naturx lufum etiam eft obfervare in nobili hac, partim agrefti, partim domeftica facta planta. Indigen $x$ ob fimilitudinem quam cum $\mathrm{Fi}$ lice habet, imprimis minor hæc, idem fere nomen quod Filici etiam huic indiderunt. Scilicet Couambai-miri, quafi parvam Filicem dicerent, cum tamen, fi internx præfertim qualitates ad examen rite revocentur, Adianti vel Trichomanis fpecies fit habenda, quam Lufitani Avenca dixerunt. Quarum major \& minor hic apponitur. Vtraque celebris, \& in quotidianos ufus apud ægros recepta. Affurgit major ultra duorum pedum altitudinem ex radice intus flava, extus nigricante, filamentofa fub terra ferpente. Caulis hujus tenuis, ftriatus, ex brunno nigricantis \& fplendentis coloris, ac lanugine quadam hepatici color is veftitus. Superius ramulos aliquot habet inordinate politos, qui, ut $\&$ caulis, folia habent alternatim pofita, dilute viridia, in ambitu dentata, atque fingular is figuræ. Nec florem necfemen ejus unquam vidi, licet diverfis anni temporibus accurate eam obfervaverim, quod quidem cum vero Adianto Europxo commune habet. Ejufdem quoque eft qualitatis, ejufdemque ufus ad expectorandas vifciditates.

II. Adianti minoris caules ejufdem cum priore figur $\&$ coloris, fed non veftiti lanugine, verum veluti farina quadam afperfi. Folia alata diverfa magnitudinis alternatim polita, fuperne faturate viridis coloris, inferius farina pulvere nigerrimo mix- 
HIST. NATVRAI. \& MEDIC. LIB. IV.

to aiperfa. Nec florem fert necfemen hæc quoque. Non putem convenientius remedium excogitatum in pectoris affectibus, quam Syrupi \& decoata utriufque hujus cosambai, quod eximie bronchias pulmonum aperic.

\begin{abstract}
A Deo notx herbx qux prius A tacu de nocte peregrinanti, quam de die vifu percipitur, non eft quod pluribus inhæream. Exfurgit ex radice parva filamentofa, in terris arenofis fponte luxuriat, caule ftriato, aliquantulum pilofo, \& craffo. Folia autem Vrticx noftrati fimilia, magna, in ambitu ornate triangularibus dentibus, \& $\&$ raris pilis prædita. Fert fuperius racematim plures flofculos plane parvulos, candidi coloris,longo pediculo infidentes.

Vrtica hac eifdem ufibus dicata quibus Europxa. Nec fpecificas in ea qualitates hactenus comperi. Semen enim \& radix inter digerentia, \& urinas moventia ufurpantur.
\end{abstract}

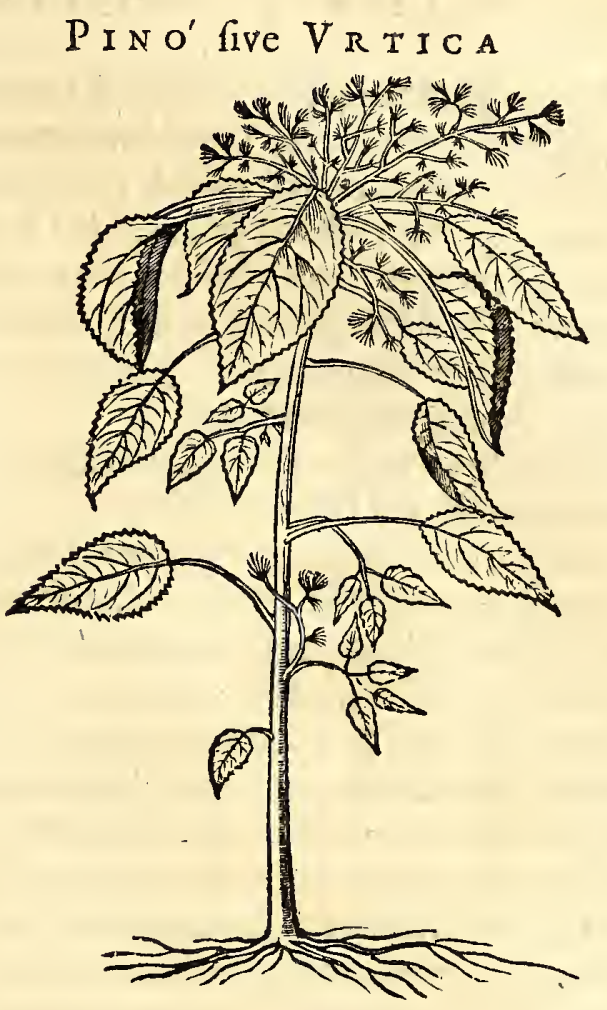

\title{
$\begin{array}{lllllll}C & A & P & V & T & \text { LV. }\end{array}$
}

\section{Tupaipi \& Irucatú, Alliarice tres Jpecies, Ciporéma, Tipi, Ibirarémo, of quatuor Taiaóba five Brafica jpecies.}

$P$ Lanta eft nobilis, qux nunc humi, nunc fuper arbore (ficut aliæ multx plantæ) fineradice luxuriat, interque bulbofas, quod Bulbum habeat prægrandem \& uti$\mathrm{lem}$, facile primum locum meretur. Cujus fi formam externam, fi vires fpectes, Squillam Europxam diceres, quod illam per omnia referat; ac proinde aliqui Indigenæ à potiori videntur nomen Tupaípi, quod Bulbum fignificat, Lufitani. Gebóla five Cepam, impofuiffe. Fo. lia habet numero quinque vel fex, tribus nervis fecundum longitudinem more Plantaginis predita, nec florem, nec fructum ferentia ; funt autem cubitum longa, gladiata, inferius definentia in Bulbum illum pragrandem, qui medullam virefcentem, pinguem, \& inodoram, ad tactum frigidam inftar unguenti factitii, fed fatis efficacem fuppeditat. Dolores enim fedare ex calore natos, perhibent Barbari,foporem quoque inducere experientia comprobatum eft. Lufitani vero mecum ipfum bulbum in ufum quotidianum ficut ficut Squillam Europæam feliciter ap-

$$
\text { TVIPA I P I \& VRVCATV'. }
$$

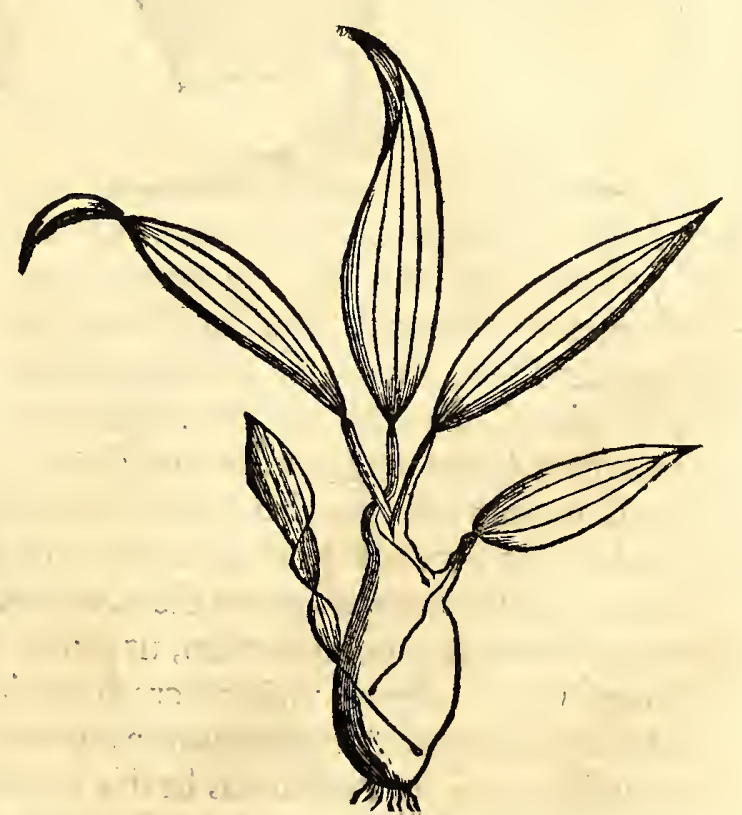
plicabant. Illa autem qux humi crefcit, facie \& efficacia præcedenti eft fimilis, Lufitanis gebola albara. Bulba eft rotunda, alba, pugni magnitudinis, cuticula nigricante: 
folia fert quatuor vel quinque fefquipedalis longitudinis, lineis fecundum longitudinem viridibus texta, infra multis radiculis filamentofis fe fuftentat.

TRESAIIIAIÆ fpecies, çIPORE'MA, TIPI', IBIRAREMO.

A Liquot plantæ in valtis Brafilix nemoribus reperiuntur, qux ufque adeo Allii A qualitates æmulantur, ut vel levifime attactæ gravifimo odor efilvas \& $x$ des integotuerunt, quare finul capiti \& narbus obfint. Tré diver 2 potifimum mihi innomine sipó comple prior ciporema, fed Lufrum tifimarum arborum ca cumina adæquantes, eas flexuofo \& tenaci ductu amplectuntur. Ac proinde cum omni fronde exceptis foliis deftitutx fint, non habeo quo earum deferiptionen ulterius protraham.

Secunda Tipí fruticis altitudinem xquat, flores albicantes, fructus nigros rotundos prunorum inftar, fed fatuos profert.

Tertia procera eft arbor Ibiraremo, in filvis, tum quoque Olind $x$ promontorio reperitur, ligno adeo duro ut cift $x$ faccharifer $x$ inde conficiantur. Foliis eft $\&$ fructibus rotundis. Ejus facultates cum præcedentibus conveniunt \& iifdem ufibus infer viunt. Barbari ad duo potiffimum mala applicant. Cortices admixta aqua contundunt, indeque vifcidum mucum, five fmegma vi eliciunt, quo puerorum corpora qux febribus lentis \& obftructionibus illis diuturnis è frigore natis, obnoxia funt; adultor um quoque membra vagis articulorum doloribus infeftata inungunt $\&$ fricant cum felici fuccefiu. Ego $\mathrm{ob}$ ingentem harum plantarum calor em $\&$ efficaciam, pofteriorem hanc potius curationem, quam illam prior em in puer is exercere malui. Multi enim adulti a frigidis illis mufculorum, nervorum \& tendinum affectibus internis \& externis (Curímentos generali nomine appellant Lufitani) crebra $\&$ forti hujus mucilaginis inunctione reftitui folent.

T A I A O' B A $I$.

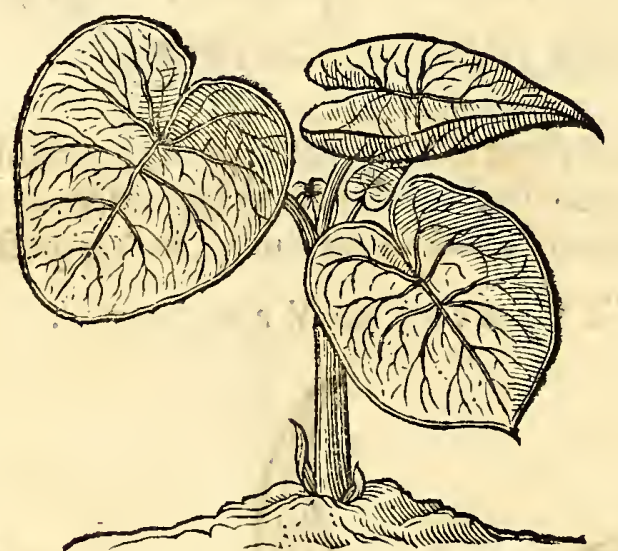

Iverf $x$ Brafficx quas Novus hic Orbis 1) producit, Taisóba, Radices autem Taia $a b$ Indigenis vocantur. Harum Prima lactefcens \& alba exiftit radice or biculari non tamen bulbofa, exterius incarnati coloris, interius flavi, Cepæ magnitudine aut Porri, multa filamenta inferius obtinente, caule autem brunno feu fufco, folia habente pœne orbicularia \& nervos foliorum rufefcentes. Radix \& folium funt edulia, laxant alvum.

Secunda qux changará peuna dicta, foliis eft faturate viridibus \& lactefcentibus. Radicem habet itidem orbicularem, ut prior. Ex qua radice porro prodeunt caules multi fpongiof, fucculenti, virides, crafli, cuilibet autem cauli infidet folium unicum fagittalis herbx figura \& magnitudine, quando junior adhuc eft planta ; alias triplo aut quadruplo majus, \& Petafitidis herbx foliorum magnitudine, nervos habens confpicuos iviride $\&$ ad taceum molle ut Braffica, ac in ambiru cingitur duabus venis.

Radix cocta vulgo comeditur ut Batata, eftque dulcis, \& fingularis quafi mofchati faporis aut floris violacei, qux etiam febricitantes oblectat, \& conducit multum. 
HIST. NATVRAL. \& MEDIC. LIB. IV. • 237

Vtriufque fpeciei folia cum caulibus craffiffimis etiam inciduntur $\& x$ pro olere in aqua coquuntur ; mollefcunt ftatim \& optime fapiunt.

Tertia Taiaóba vel Mangara-mirí Foliis eft minoribus, durioribus, inedulibus, nec lactefcentibus, nifi fola radice qua cæertis Taiaóbe radicibus eft fimilis. Caules, ut primx, fufci; folia acuminata ut fecund $\boldsymbol{x}$, fed anguftiora, fuperius faturate viridia, inferius albicantia, nervo $\&$ venis ex viridi flavefcentibus, $\&$ in centro folii purpurafentibus. In caule autem longo flos inodorus unicus longus, albus, unico folio conftans, inferior medietas hians, viridis coloris, magnitudine juglandis \& ejufdem figuræ, aperturam habens; Ita autem compofita funt clypeiformia corpufcula ut columna feu ftamen læve \& ter es appareat. Hxc corpufcula funt femen.

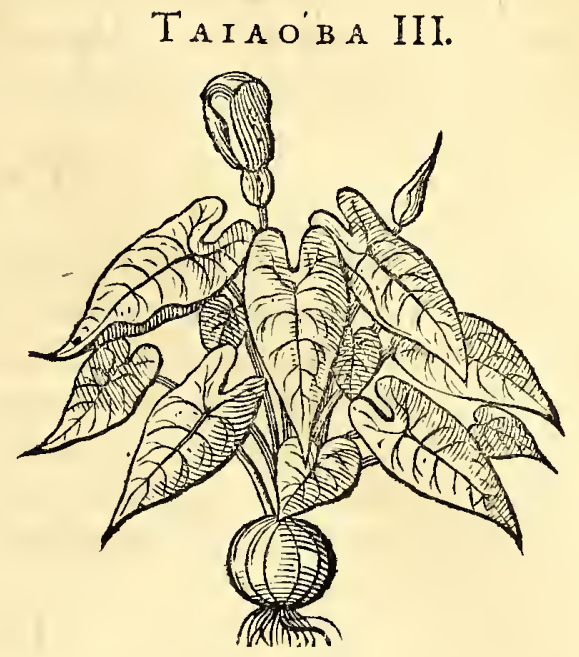

Quarta, eft Taiaóba filveftris aliis Taiobaraon dicta \&Lufitanis Mangara-brava. Ex qua fuperftitiofum vulgus philtra aliaque fimilia ridicula confici poffe exiftimat. Radicem autem.vere caulticum effe, ejufque loco profpere ufur pari experientiam teftem habeo. Quippe preter balnea qux ex iis folis contra morbos cutaneos, tum imprimis frigidos articulares, apprime conficiuntur, membra quoque affecta, prævia fcarificatione, contufis recenter radicibus fricantur cum optimo fucceflu. Mox cataplafmata ex iifdem, parti dolenti undiquaque imponuntur : qux fi per vices aliquot reiterentur, inveterata quxque mala, citra recidivæ metum exterminare folent.

Quxalia præterea Brafficarum genera hæc tellus producat, ad Medicinam ulterius fpectantia, fedula pofteritas inveftiget.

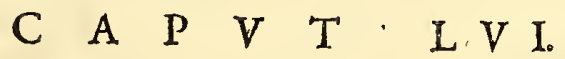

\section{Quinque Graminum Jpecies Iaçapé, Taraturá, Capunpéba, Iupicai, \& Amongeaba.}

Ramina ut alibi, ita \& in Brafilia varia reperiuntur, quæ ultra duodecim diverfa à me \& Markgravio meo obfervata funt. Quorum quinque tantum vel fex in Medicina celebrantur.

Primum eft gramen junceum ad fefqui tibix altitudinem aliquando exfurgens, Indigenis Iaçapé aliis corrupte çapé dicta. Ex radicula geniculata juncea, alba, exfurgit caulis primum fimplex, inftar culmi filiginis, teres qui poftea in aliquot folia finditur graminea, angufta, in medio album nervum fecundum longitudinem habentia. Nullius eft odoris, nec florem gerit nec femen, folo ut plurimum effœeto nafcitur, radices fub terra longe lateque agit, novarqueherbas tenaces ductiles protrudit, quibus Indigen $x$ plerique \& Europxi quoque utuntur ad membrorum vulnera liganda, morfufque ferpentum,

$I$ A ç A P É。

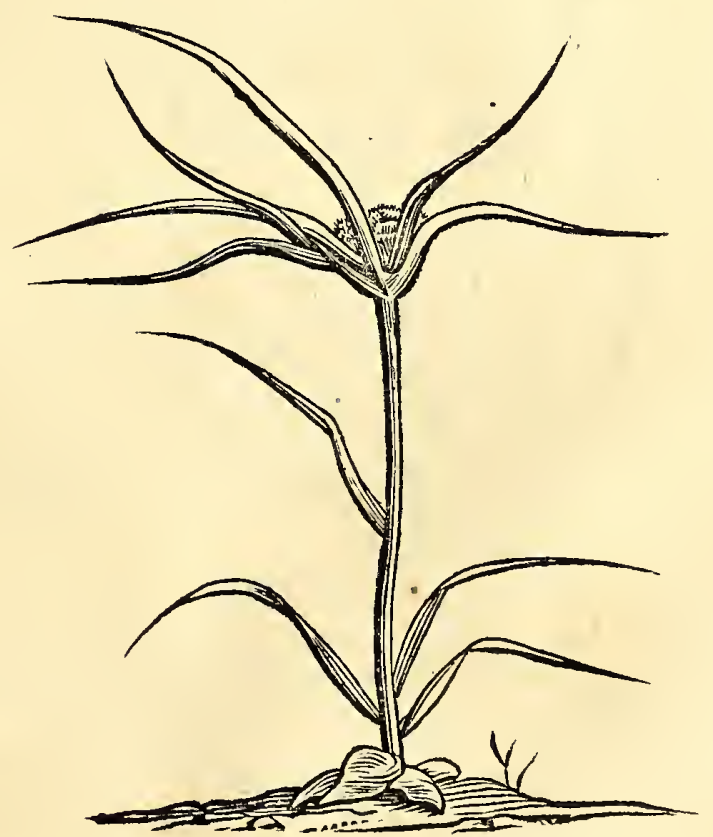


quo minus virus ad cor afcendat, conftringendos, donec vulnus fanatum fuerit.

Sed miffo hoc curandi modo, cui videtur aliquid fuperftitiofi intercurrere, ego vires $\&$ facultates quas expertus fum commendo, quæ illius radicibus junceis fuccoque grato turgentibus infunt. Multis enim profuifle experientia comprobavi decocta. illarum poft affumptum venenum.

PAR A TVR A'.

Herbam hanc licet à vero gramine nonnihil abludentem tamen inter gramina ponere lubet. Sicut enim Carex, Belgis alm in locis Hollandix arenofis circa mare; ita fere in firientibus Brafilix littoribus hæc Paraturá confpicitur. Raro ad cruris humani altitudinem afcendit. Caulc eft duro, ligneo, rufi coloris, foliis multis tenuibus, fature viridibus, ad tactum afperrimis, ornate comatim affurgentibus. Radice eft tenui, aromatici odoris, qux fuffumigiis, balneis in ani $\&$ inteftinorum affectibus indita, emolliendi non folum, fed \& roborandi facultate pollet.

$$
\text { C A P V V P E'B A. }
$$

Tametfi pauca habeam qux de tertio hoc Gramine teftari poffim ; minime tamen prætereundum duxi. Lufitanis optima comparatione Pe de Gallinba appellatum, quod fummitates ejus in tres veluti unguiculos definant. Gramen eft plumeum, ad duorum pedum altitudinem affurgens, caule tereti, geniculato, foliis ad genicula longiffimis. Caules egregie rufelcunt, \& in varios tenuiores cauliculos dividuntur, quorum quilibet verfus fummitatem argentea veftitur panicula, quæ in medio femen continet. Omni terra feliciter fponte nafcitur.

Radix contufa \& cum aliquo convenienti liquore propinata quodvis venenum fere feliciter exturbat, ut teftantur omnes exercitatior es Indigenx, fed à me nondum com- $_{\text {- }}$ probata.

IV P I C A I.

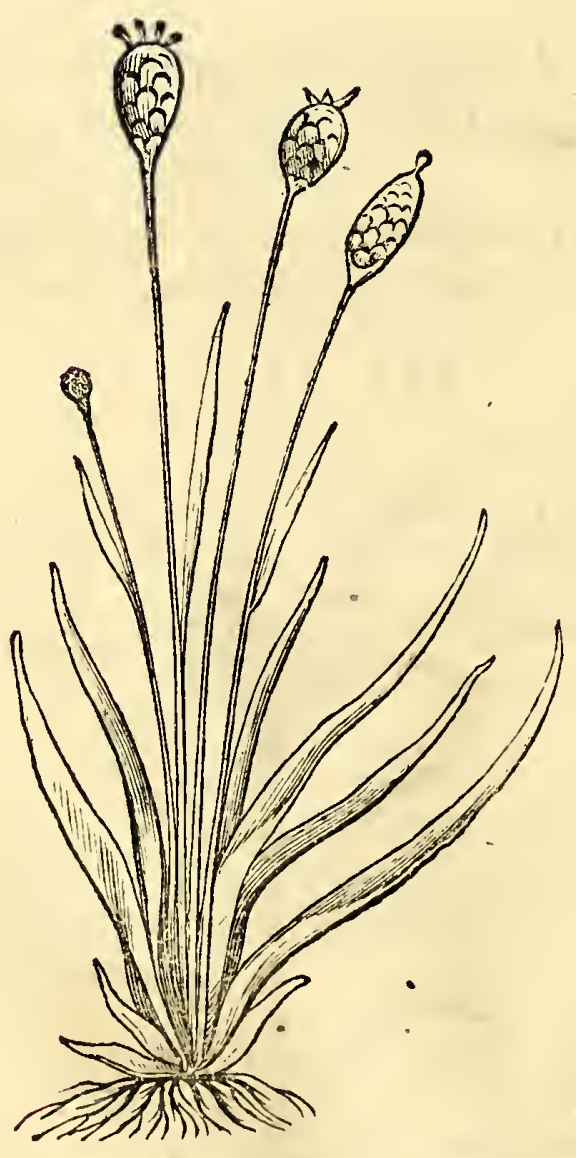

In pafcuis irriguis Gramen flo: rens menfibus potiffimum pluviis eleganti facieluxuriat. E pilofis radiculis caules protruduntur multi tenues juncei,plufquam pedem longi, qui inferiori parte gramineis fo liis veftiuntur. Quilibet caulis gaudet capitulo ovali fquamofo, fplendenti, coloris fublute feentis \& ex pallido variegati: his fuperius flofculus infidet, unicus, tribus quatuorve foliolis luteis conftans. Indigenx Iupicai, Lufitani Erva d'Empige quia Impetigini medetur, appellant.

Ob præclaras virtutes, præcipue ad curandam moleftiffimam Impetiginem atque fimiles cutaneos ex calore $\&$ humorum acrimonia natos affectus, vix ulli Incolarum eft incognita. Quippe, cum tota planta concava fit quafi juncea, \& fucco refrigerante referta multum liquoris recens contufa fuppeditat, quo pars affecta fortiter fricata, fummum accipit folatium \& pruritus intolerabilis mitigatur. 


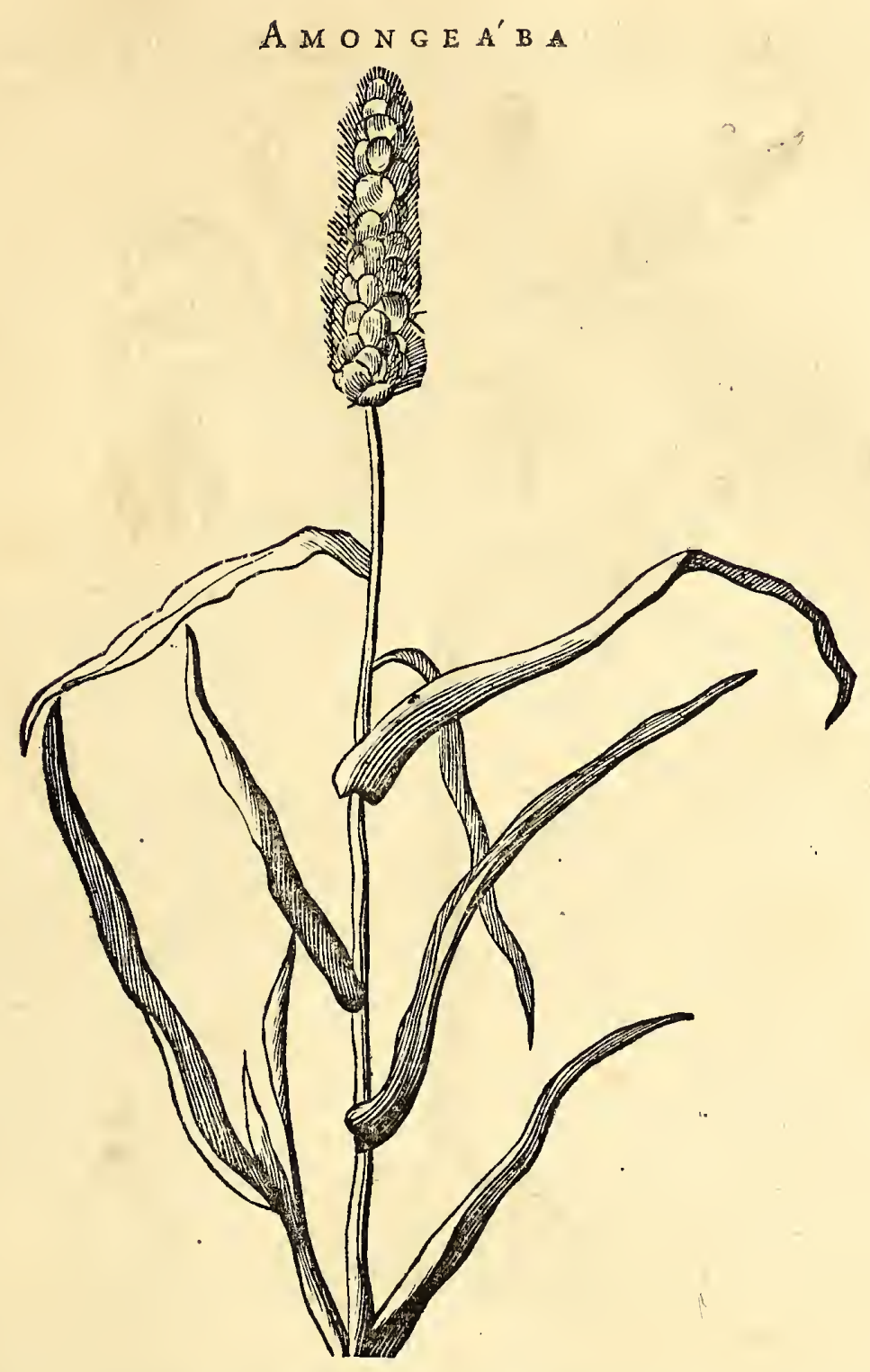

Quinta Graminis fpecies eleganter plicata atque miliacea, ad trium vel quatuor pedum altitudinem, ex radiculis filamentofis Arundinis modo in pafcuis affurgit. Folia viridia longa hinc inde caulis geniculis annata $\&$ folitaric pofita. In fummitate caulis fpica longa, Milii fpicx vel ariftie Panici filveftris figura $8 x$ magnitudine fimilis.

Facies hujus plantx Graminex mihi diutius nota quam ejus qualitates;quippe ab illis Incolis tantum mihi traditæ, quibus Malvæ \& Tupeiçava copia deeft, quod emollientium herbarum vices fuppleat, \& codem modo externe adhibita, eofdem quoque ufus fuppeditet. Imprimis autem fomenta $\&$ lavacra ex ex confecta Anum ex Tenefmo af flictum demulcent.

\section{A P $\quad$ V $\quad$ T $\quad$ L V I I.}

Erva de $S^{\text {ta }}$ Maria five Dracunculus major, Capicatinga alins $I_{a}$. çarecatinga e Acori pecies, Cararú fone Blitum eAmericanum, V.ue Crifper, of Meliffer pecies agreftes.

Nter plantas huc olim ex aliis regionibus illatas, atque tractu temporis domefticas factas; eft illa qux Serpentarix majoris polyphylli nomen habet. Quamobrem tanquam exotica à primis incolis neglecta, ac proinde vernaculo nomine deftituta, eam Lufitanorum vulgus Erva de Sta Maria nominarunt. Hortis irriguis, terris glebofis gauldet, idque menfibus pluviofis, ficut magna pars herbarum exoticarum; aridiora enim loca maritima, menfefque aftivos vix ferunt fata aliunde huc illata, ficut fito loco probavi. 
ERVA de Siz MARIA five DRACVNCVIVS major.

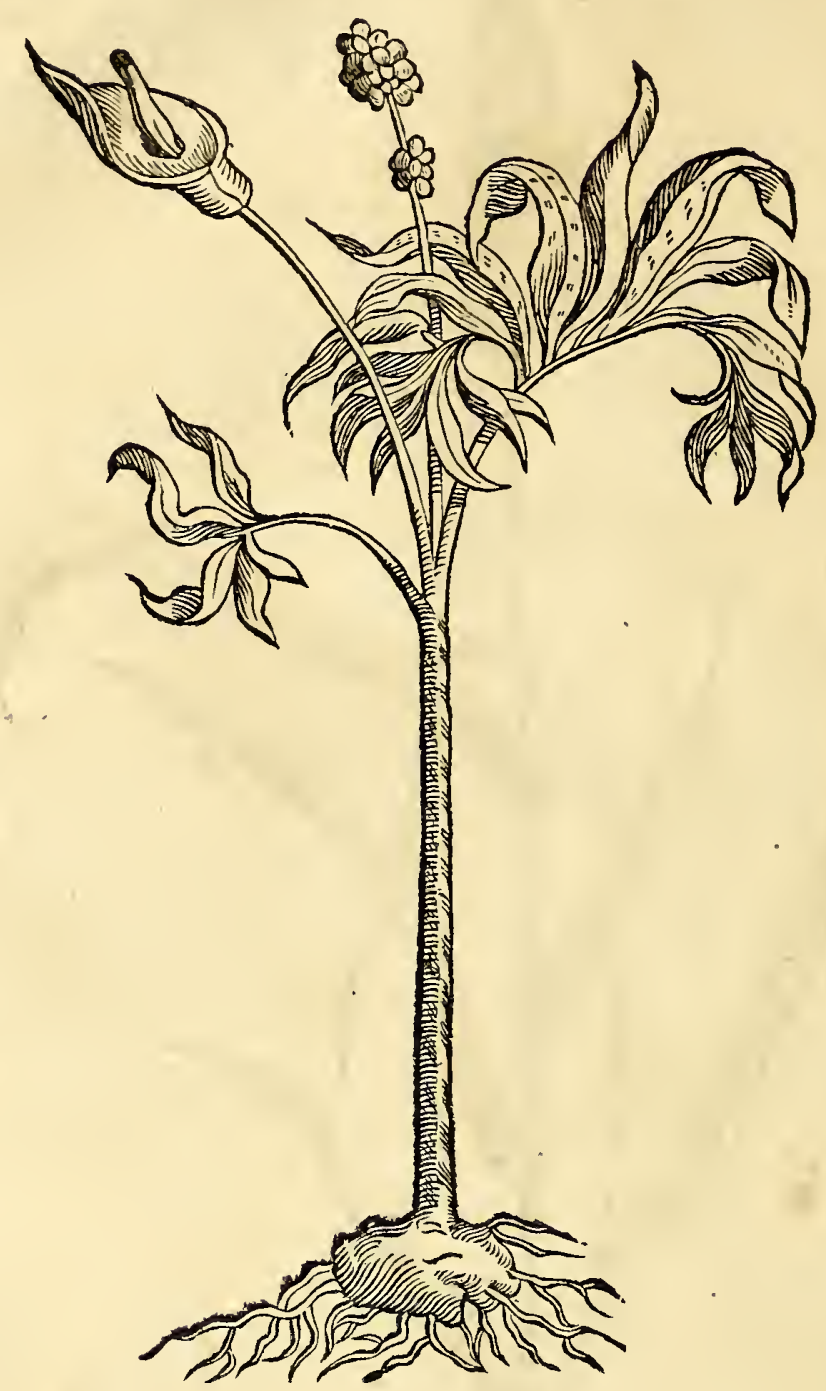

Ex caule nafcitur erecto, rotundo, craffo, viridi, flavo $\&$ albo, more Serpentum variegato. Hinc novi caules ramorum inftar emergunt, quilibet definens in folium quater vel quinquies laciniatum more noftratis Dracunculi, viride \& glabrum : continetque quælibet lacinia nervum craffum varie $\&$ profunde exfectum. Præter enarratum caulem alius priori fimilis exfurgit, è cujus fummitate vagina prodit in acumen definens, pedem longa, ad cujus pediculum f́picx in modum inftar Milii Indici componuntur grana fucculenta, ftriata, flava $\&$ punctulis rubris variegata, in quibus femen continetur. Radice eft tuberofa, craffa, rotunda, filamentofa, pellicula ex albo parum rufefcente.

Quantum ad qualitates medicas, eafdem quidem cum noftrati communes habet, fed in gradu intenfiori. Vt enim aliqua fata, quamvis ad terram \& Solem clementiorem tranflata, remiffioribus aliquando exiftant viribus; ita quadam, ob peculiarem foligenium, majoris fiunt efficacix, quod in Serpentaria hac quoque locum habuit. Folia $\&$ radices acris $\&$ amari funt faporis, $\&$ fimile quid habent cum Aro ac Dracunculo vererum. Lentos enim \& craffos humores extenuat, obftructiones aperit. Prxter hæclevem aftrictoriam vim cum enarratis qualitatibus habet conjunctam . Vnde fit quod inter efficacia medicamenta, \& ab omnibus paffim incolis, contra contumacia vulnera ufurpatur.

Iffis difputationum falebris de vero Acoro vel Calamo Aromatico Veterum ac Neotericorum? ego nobilem hanc plantam Capicatinga dictam, veri Acorifpeciem pronuntiarim. Europxo noftro externa figura five radicem five folia fpectes excepta magnitudine, multum fimilis. Sed quantum mole inferior tantum efficacia fuperior exiftitimprimis radix, qua calida $\&$ ficca eft, grato amarore $\&$ aromatico fapore 
HIST. NATVRAL. \& MEDIC. LIE. IV.

CARICATINGA, aliis IACARECATINGA ACORI fPecies.

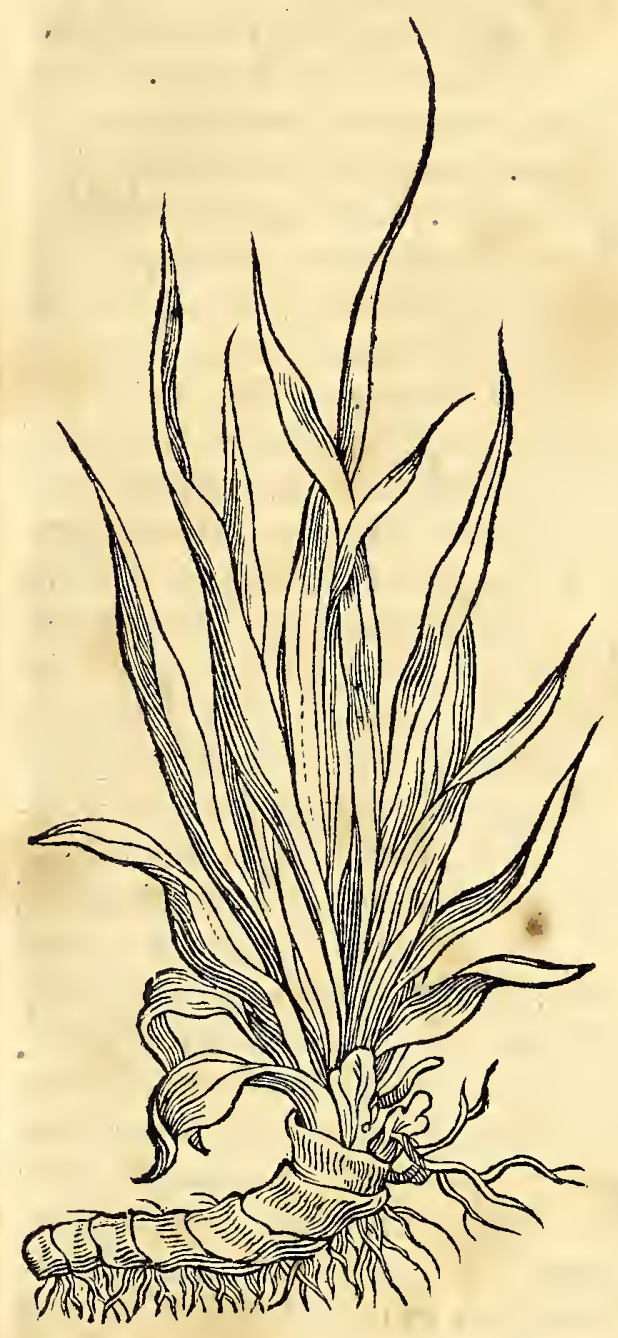

CARARV' '́pecies BIITI Americáni.

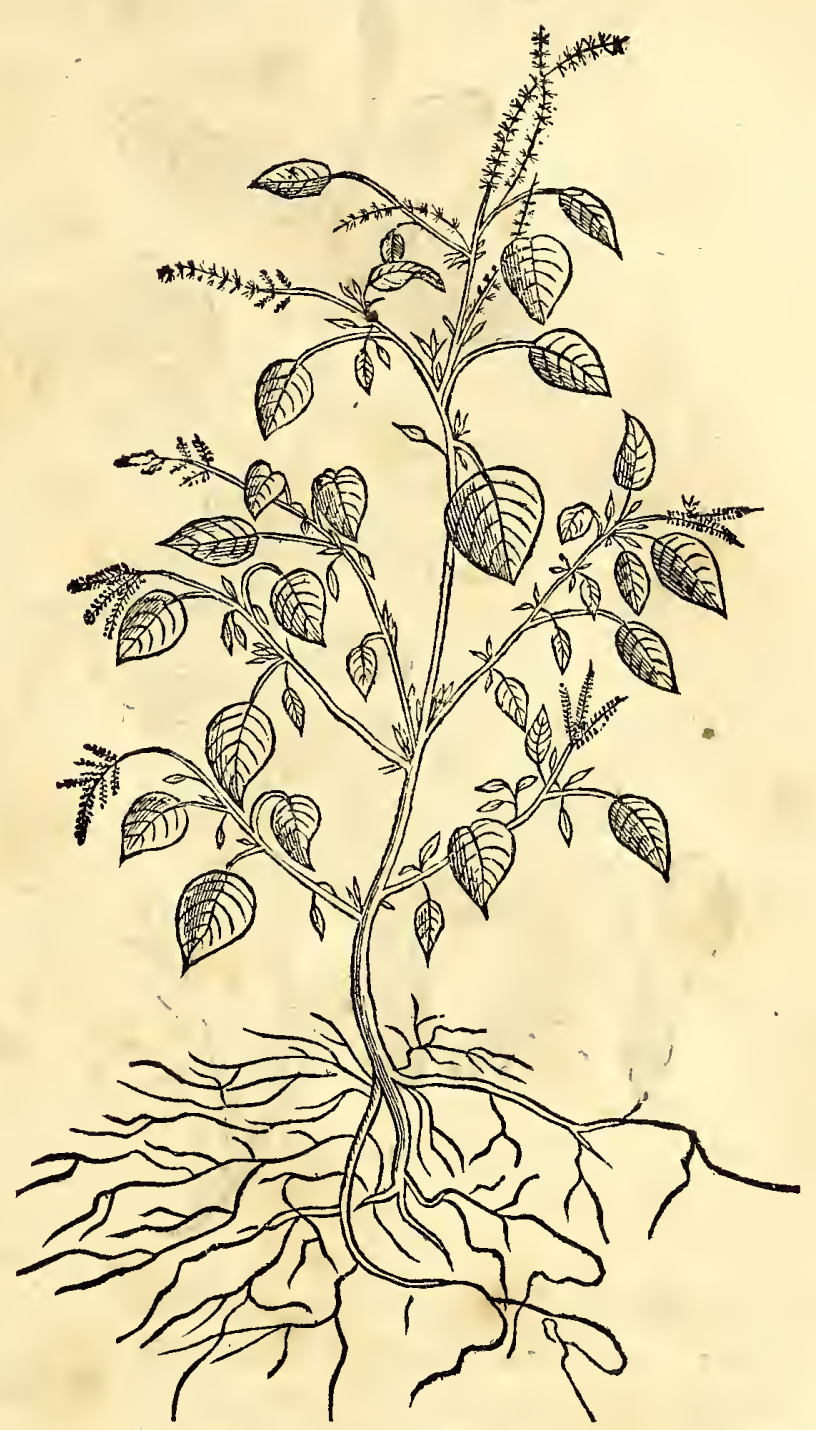

linguam vellicans. Ea fola vel aliis mixta non tantum ad incidendos frigidos humores peccantes feliciter adhibetur, fed \& contra venena affumta imprimis ufurpatur, ab advenis æque ac indigenis. Vnde facile eft colligere intenfo fatis gradu qualitatis eam effe calidx, \& confiftentix admodum tenuis. Non femper uliginofis locis, ficut Iris crefcit; fed etiam promifcue aliis terris gaudet depreffis glebofis, unde magna quantitate à Barbaris ad nos defertur.

VVlgaris herba Cararú in campis \& hortis nafcens Bliti albi potius quam rubri vide$\checkmark$ tur fpecies qux Bredos vulgo Lufitanorum dicta. Ex radice alba, craffa, filamentofa, caulis unus atque alter provenit cui hinc inde ramufculi adnafcuntur, cum foliis Bliti fimilibus, qux farina quafi videntur afperfa. In extremitatibus ramulorum proveniunt flofculi virides, fpicatim congefti moreBliti, nifi quod multo fint tenuiores. Semen producunt nigerrimum fplendens, rotundum, parvum inftar Papaveris.

Blitum hocoleris modo eftur \& loco Spinachix coquitur, ejufdemque eft faporis $\&$ efficaciæ, addito fucco Limonum pro condimento. Nec minoris fit in Medicina quam officinarum Blitum, benigne enim alvum laxat, facillimreft digeftionis, humidæque ac frigidæ temperaturæ. Proinde ego malo circa ejus qualitates Galeno quam Plinio vel Diofcoridi fubfcribere; quod hi Blitum iners plane, nulliufque in Medicina ulus pronuntiaverint.

Fr. Ximenes multas Atriplicis fpecies teftatur dari in Nova Hifpania Mexicanis Hautiquilite, Hifpanis corrupte $\mathscr{Q}$ uilites nominatas.

Ejufdem hæc videtur Species, cujus Clufus meminit fub nomine Quimia five Bliti Americani. 
V v a C R is pa Americana.

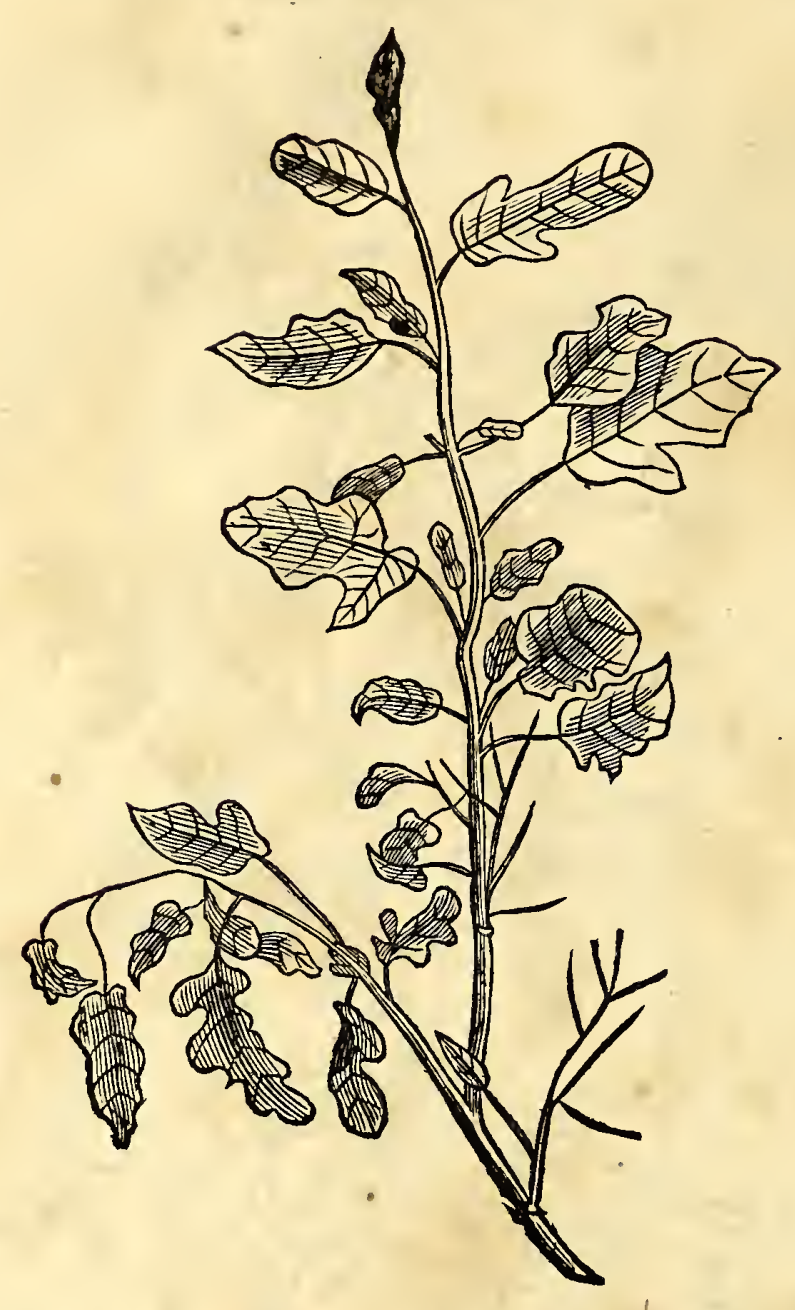

Menfibus potiffimum plu$1 I_{\text {viis (quibus magna } \text { pars }}$ fructuum hic vigere folet) fructifera eft hxc planta. Qux ex radice alba, longa filamentofa, caulibus, è viridi albicantibus ad ordinarize fruticis altitudinem exfurgit, fpinis undiquaque armata. Cui hinc inde alternata ferie cum longiffimis pediculis adnafcuntur folia diverfa fi. guræ \& magnitudinis, Iuripeb e foliis fimilia, dilute viridia ad tactum mollia, tenera, acà̀ tergo fecundum longitudinem aculeata. In extremitate \& medio caulis $\&$ ramorum, veniunt tres vel quatuor flofculi, ex viridi adluteum inclinantes pentaphylli cum multis ftaminulis erectis. His fuccedunt fructus ( qui fimul cum floribus à piEtore prxtermifli ob itineris injurias) Mefpili magnitudine, rotundi, læves, coloris è viridi albicantis, ftriis viridibus faturatis fecundum longitudinem, mox dilute flavefcentes, folliculo \& pulpa conftantes, ut uvx crifpx noftrates, faporis acidi grati. Semina orbicularia, compreffa, flavefcentia, figuræ ferme ut Lentes pulpæinfperfa; qux fimul cum fructibus deglutiuntur. fructus antequam plane maturuerit, fanis æque $\&$ gris ad ob gratum acorem ad fitim fedandam in ufu eft frequenti. Alia præfidia medica promittitradix hujus fruticis, fed quia à me nondum experta, ejus de fcriptioni fuperfedeo \& curiof $x$ pofteritati relinquo.

\section{MEIISSA Áfecies A G R T T S.}

Elebris planta (cujus nomen vernaculum fimul cum ejus icone exciderunt), à Lufitanis Erva Cidreira ob Citri odorem dicta, à me ob odoris $\&$ facultatum convenientiam inter Meliffæ filveftris fpecies relata, licet externa facie ab ea abludat.

Ex tenui radice caulis ftriatus, geniculatus ultra noftratis Meliffe altitudinem affurgit, unicuique geniculo duo folia oppofita, tam in caule quam in ramulis apparent. Folia acuminata in ambitu ferrata, brevi pediculo nituntur. In fummitatibus ramorum oblongx fpicx nafcuntur, cum flofculis minimis, ex albo cæruleis.

Omnes partes plantæ fragrantiflimæ funt, imprimis folia, qux non folum recentia,fed ad annos exficcata, tenaciflime refervant odor em, facile gratior $\mathrm{em} \&$ fortiorem quam Meliffa fativa: proinde mihi aliifque rei medicæ peritis incolis in quotidiano funt ufu, non tantum ad externa fomenta fed ad potiones cardiacas, loco aqu $x$ Meliffæ deftillat exhibendas, in frigidis potiffimum affectibus ad flatus $\&$ colicos dolores difcutiendos maxime celebratas. 


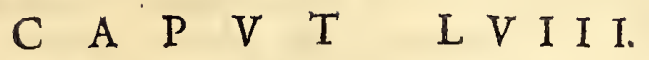

\section{Canponge five Critbmi marini diverfe Jpecies, que vulgo Soldanelle, é Portulacenomina äudiunt.}

Res hafce plantas facie $\&$ nomine non folum fed $\&$ qualitate fibi congeneres, una quafi fidelia dealbare conftitui, quia omnes hæ quotidiani ufus funt, tamque in Pharmacopoea quam in Culina receptx pro acetariis. In locis maritimis ubi falfo humore terra imbuitur, luxuriat familiaris planta, Lufitani Perexil do mar vocant. Ex uno atque altero caule fucculento, rufefcente, molli, nodofo, partim hu. mi incumbente, partim fe erigente, nafcitur. Foliis itidem fucculentis, oblongis craffis hinc inde ad fingulos nodos provenientibus. In fummitate autem cujufcunque fere caulis, capitulum oblongum album ut in Trifolio, fere, loco floris exiftit, habens in fe aliquot ftaminula parva crocei coloris. Folia $\&$ breves ramuli decerptiac parum cocti fuperfufo aceto condiuntur, $\&$ eduntur, cum carnibus aut pifcibus pro acetariis ; excitant enim appetitum, movent urinam \& aperiunt vifcerum oppilationes, ita ut fi referatur ad plantas Europæas, licet Crithmo marino facie nonnihil diffimilis, ratione tamen qualitatum illa fimillima fit.

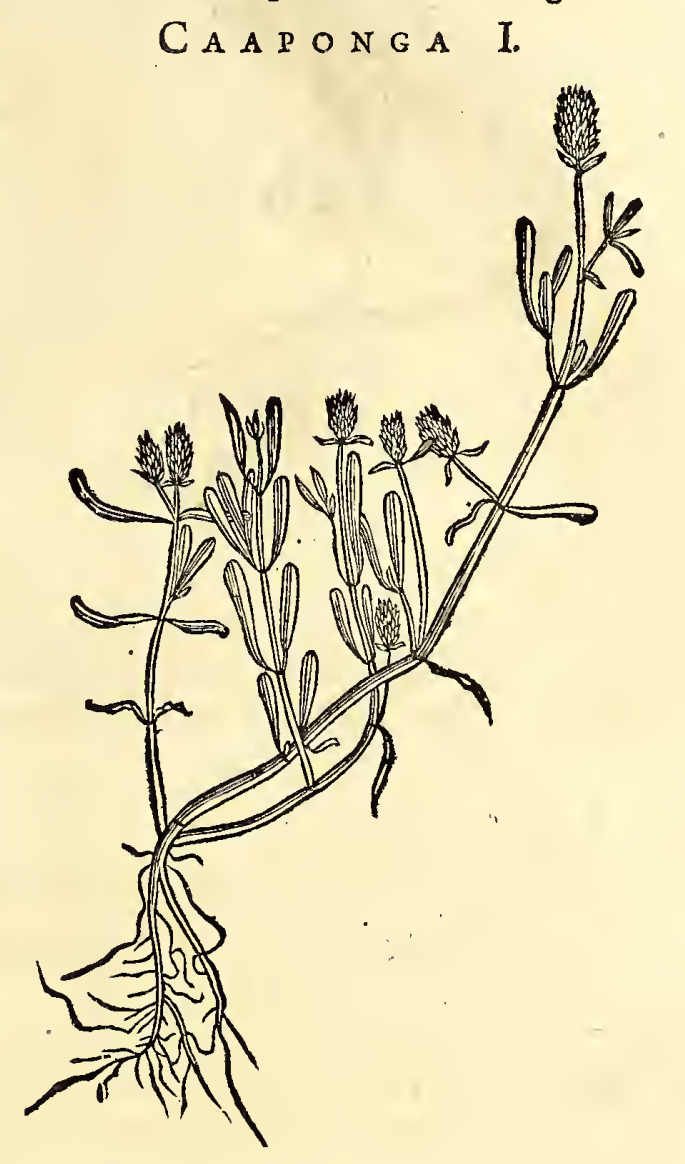

\section{CAAPONGA II.}

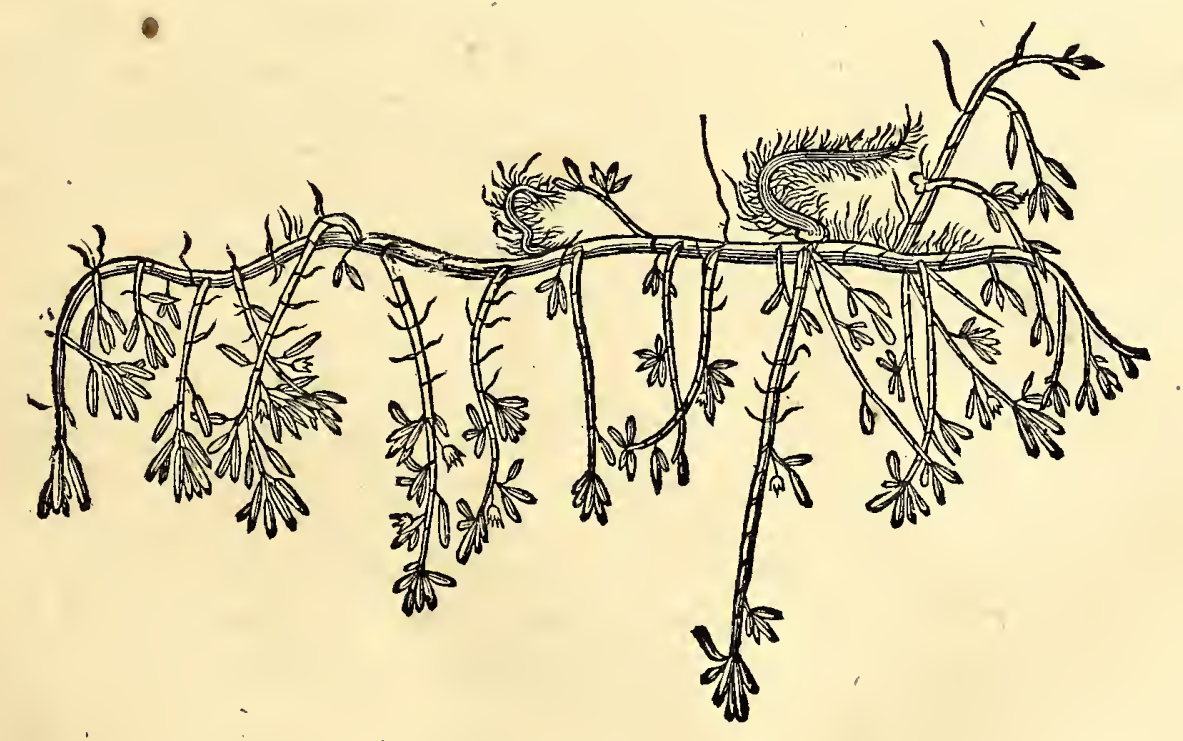

Secunda, caule eft Portulacx, tereti, geniculato, rufo humi ferpit, atque circa maritima luxuriat in infinitum. ad quodlibet autem geniculum quinque aut fex folia appofita, figura foliorum Lavendulx, veruntamen craffa \& fucculenta ut Portulacx. Inter folia in fingulari pediculo fert flofculum dilute purpureum, quinque foliolis conftantem deorfum incurvatis \& multis ejuldem coloris ftaminulis in orbem difpofitis, qux in medio adluuc ftamen viride ovale continent. Radices hinc inde unicas 
agit, innumerabilibus fubtiliffimis filamentis circumdatas, \& fibræ ex illo variis locis prodeuntes, fe terræ infigunt. Folia muria \& aceto condiuntur, \& pro acetariis ufurpantur, ficut Crithmum marinum, Soldanella \& fimilia.

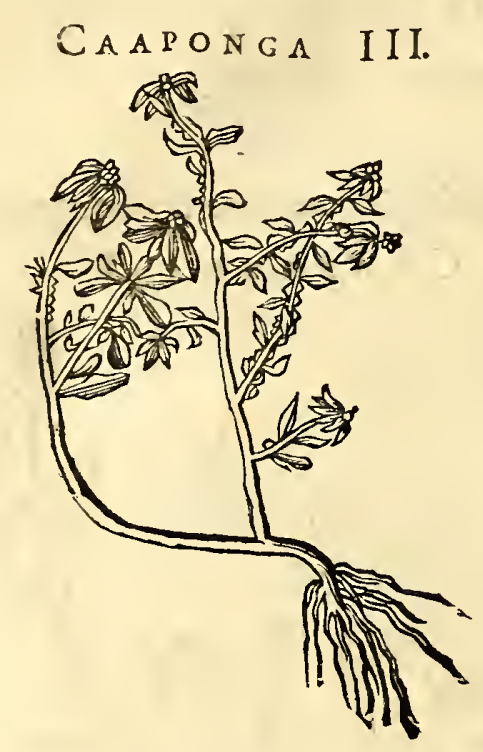

Tertia Caaponga, Portulacx eft quoquefpecies qua Beldroga Lufitanis dicitur; 'ex radice autem brevi $\&$ in multa filamenta alba definente, producit caulem rotundum, fucculentum foliis quoque inftar Portulacx fucculentis. Rami quafi lana alba circumdati $\& c$ in extremitate cujuflibet rami, octo folia in ftellæ modum difpofita funt, ex quorum medio flos enafcitur luteus, inftar floris Portulacx noftratis. Cui fupermanet corpufculum quoddam, pappo albo circumdatum, in quo femen continetur nigricans rotundum, papaveris femine paulo minus. Cocta loco acetariorum tota herba comeditur ad excitandam or exin.

Quia Acetofa Brafilienfis, cum hifce Portulace fpeciebus in quotidianis quoque acetariis recepta, hic fubjungendam putavi. Caule eft tereti viridi \& fucculento: foliis itidem fucculentis obTongis \& lavibus. Floribus dilute purpureis in ramulis triangularibus prodeuntibus. Tota planta gratifim $x$ eft aciditatis, nec Europæx acetofx cedens.

\section{A $P$ P $T$ T L I X.}

\section{Herba lanuginofa Dictamni comula, Ibiracém fove Liquiritia flbefris} Iupeicava fise Scoparia, É Caiatiáaliis Caaçicá.

$\mathrm{N}$ HER B A LANGINOSA.

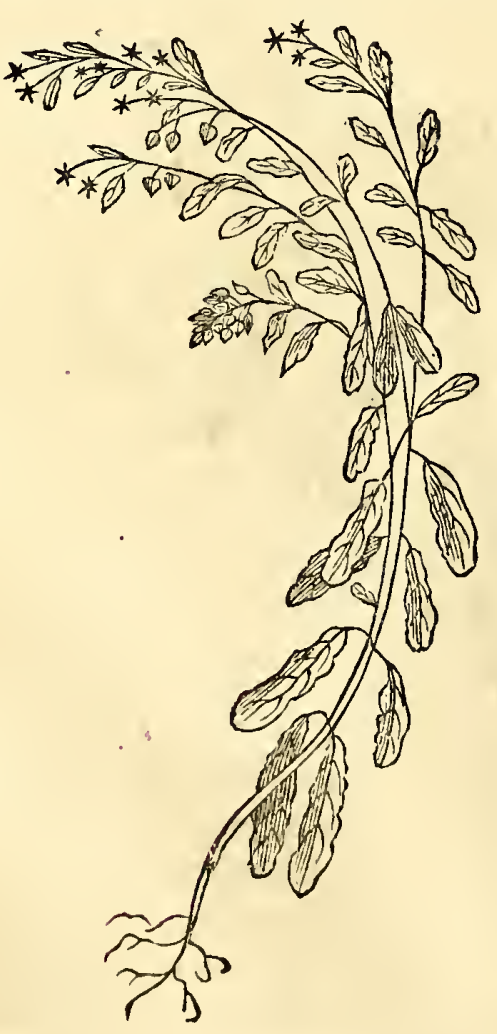

Obilis hæc odorifera planta, qux ferius mihi innotuit, quod in diffitis locis tantum reperiatur, ac proinde rarius in folamen xgrorum exhibita; tamen, quia ob infignem aromaticum faporem \& odorem multa promittit in re medica, eam fedulæ pofteritati revelandam putavi, ut ulterius de ejus cogitet qualitątibus.

In filveftribus terris ficcioribus luxuriat tenella herba ex radice exili, filamentofa. Ad pedis circa altitudinem affurgit caule uno atque altea ro tereti, ex viridi albicante adeo lanuginolo, ut totus goffypio afperfus videatur. Pro vario Naturæ lufu ramuli longi hinc inde à terra furfum expanduntur, foliis, nunc fibi oppofitis, nune folitarie pofitis, inæqualis longitudinis in ambitu leviter crifpatis, qux omnia cumramufculis more Didamni Cretici lanuginofa inftar mollis ferici ad tactum apparent. In extremitatibus caulis \& ramulorum flores fpicatim congefti proveniunt, parvuli fplendentes ex argenteo fubflavi, quibus decidentibus ftellulx argentex remanent.

Folia odoris funt fingularis proxime ad DiAtamnum Creticum accedentis fi modo leviffime confricentur. Succus eorum recenter expreffus \&leniter afperfus culicum \& mufcarum non folum puncturis, fed $\mathbb{Z}$ aliorum infectorum ictibus malignis medetur virus extrahendo. Multa 
HIST. NATVRAI. \& MEDIC. II B. IV. 245 præterea incolæ de dignitate hujus plantæ prædicarunt, quæ experiri non mihi datum fuit.

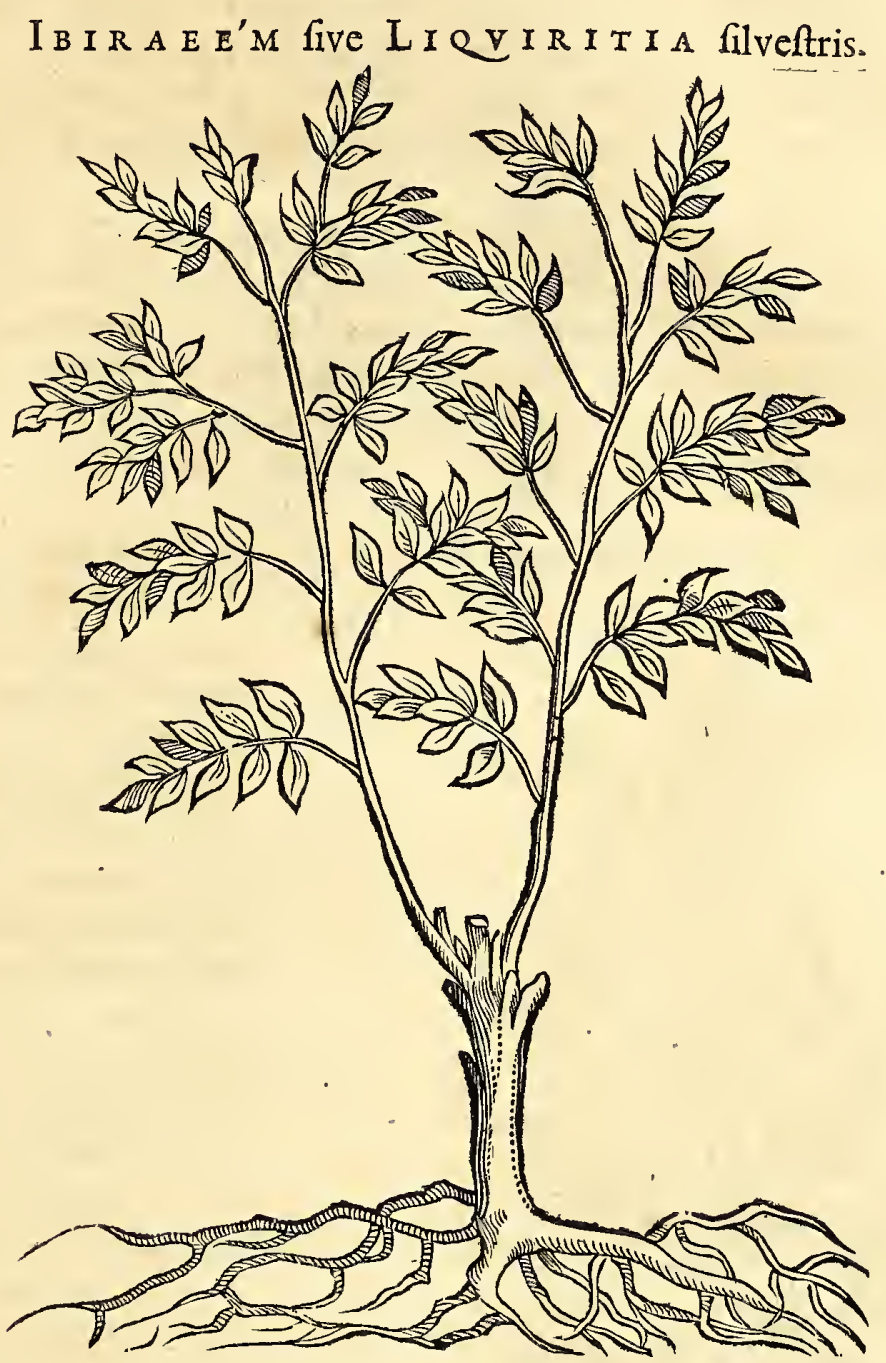

FAmiliariflima illa radix quæ Brafilianis Ibiréeém (quod dulcedinem exprimit), LuFfitanis Alcaçú, dicitur, eadem plane habetur quæ Liquiritiæ nomen à Latinis accepit. Majoris fruticis eft altitudine, caule lignofo, foliis Pyri fimilibus : locis aridioribus crefcit in filvis Paranambuci. Glycyrrhizæ virium eft xmula, non xque tamen dulcis fi mafticetur radix, caterum grata $\&$ iifdem ufibus quibus $\mathrm{Li}$ quiritia noftratium, dicata. Pectori enim amiciffima, \& difficultatibus urinæ fuccurrens.

D Ræetantifima hæc Herba, merito à Lufi1 tanis Erva dos Cobres eft appellata, quod Colubrorum morfibus feliciffime medeatur, nec ulli Antidotalium herbarum dignitate cedat. Lippis \& tonforibus, tam ob infignem ufum, quam frequentiam notiflima, quod in triviis ubique crefcat, omnique folo gaudeat. Exigua hæc Panacea lacticefcens eft inftar Efulæ, foliis Menthæ non diffimilibus, fed /longioribus paulo $\&$ anguftioribus exiftit, iifque criftatis, fed admodum triftis \& fature viridis coloris, cauliculis ad rubedinem vergentibus, radicibus filamentofis \& miniatis, terræ hinc inde infertis. Inter folia ad nodos multi prodeunt flofculi viridis coloris cum aliquantillo rubore mixti, in umbellam compofiti. Humi

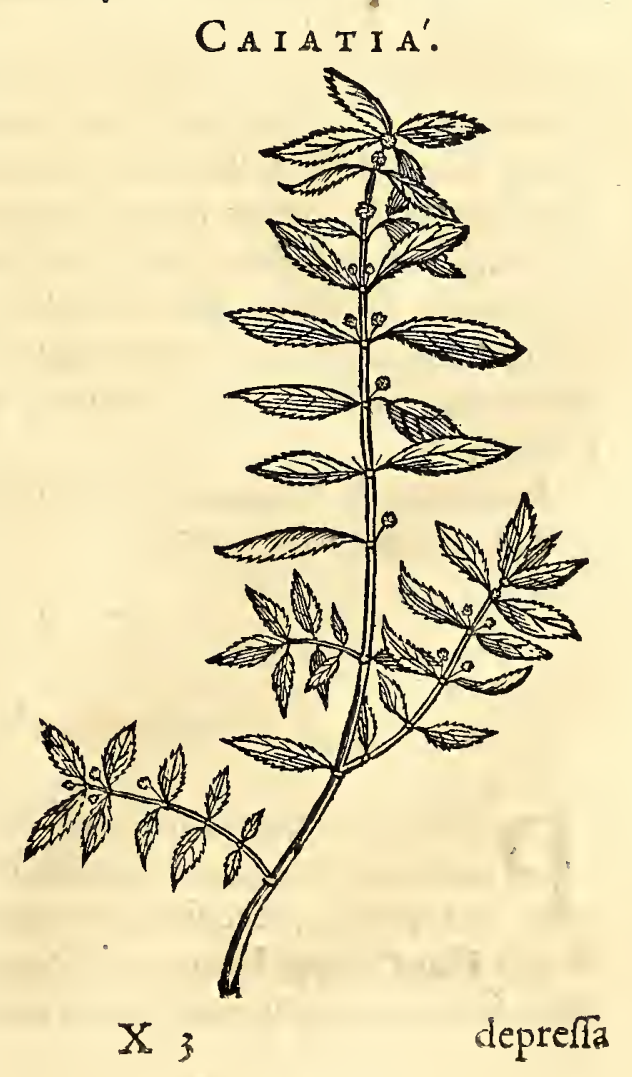


depreffa tota repit planta. Ita ut licet afpectus imbellis ac ignobilis fit, qualitate tamen interna compenfetur. Quippe recens mafticatavel contufa, \& morfui Serpentum applicata, dolorem non folum fedat, fed ipfum venenum validiffime extrahit, $\&$ vulnera reftituit in integrum. Sicca vero, \& in pulverem redacta, fi è convenienti liquore, ad pugillum exhibeatur, munit cor, virefque à veneno lapfas reftituit.

Datur \& alia fpecies Caaçica à domeftico meo primum detecta. Quxe ejufdem licet figuræ fere \& nominis, non ejufdem tamen qualitatis hactenus eft deprehenfa. Lac enim quo tota planta turget, contra rubedines $\&$ dolores oculorum commendatur, fed à me nondum comprobatum. An polleat vi antidotali ut præcedens Caaçica, nondum mihi conftat. Quod humi repar, \&ladtefcens fit herba, Peplo majori Clufi non male refpondet, cæterum externa figura illi multum diffimilis.

TVPEIÇA VA five SCOPARIA.

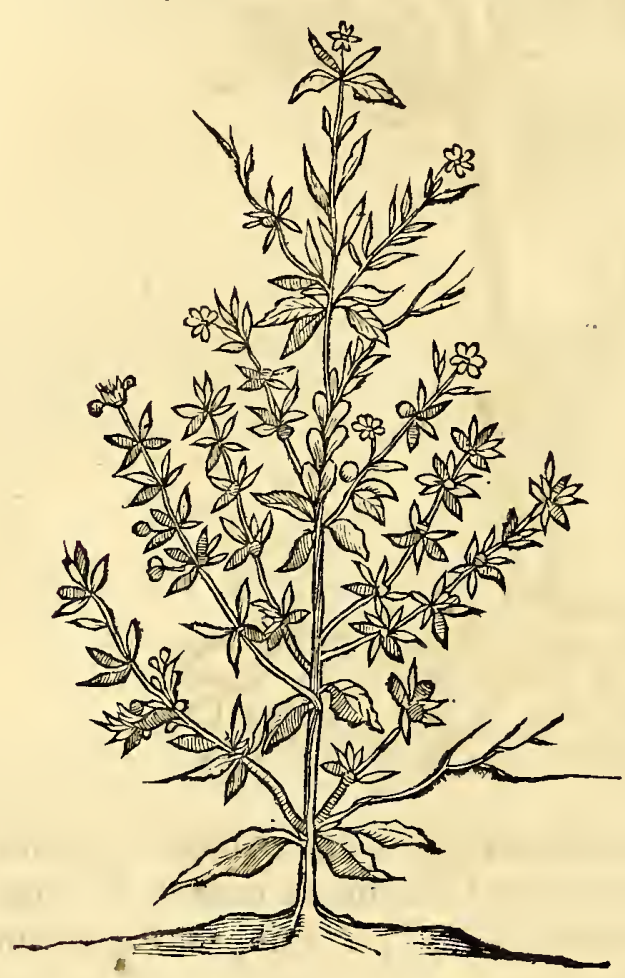

Thil vulgarius in triviis undiquaque crefcit quam $B a-$ foura, qua Æthiopes dominorum fuorum $x$ des verrere folent. Alia huic affinis, fed minor, Lufitanis Bafourinba dicta, in longe nobiliores ufus à Medicinæ peritis applicata, Brafilienfibus Tupeiçava nominatur, qux Verbenx fere eft facie.

Herba non filvis, fed apricis campis gaudet. Vix cubitum alta, tenaci lignofo unico plerumque caule affurgit, cui à fundo ad verticem ufque perpetui ramufculi adnafcuntur ornate expanfi fuperne, pyramidis in$\mathrm{ftar}$. Qui undiquaque plurimis anguftis \& exiguis acuminatis foliis, ftellatim compactis hinc inde fibi invicem oppofitis veftiuntur. His inferti apparent infiniti oculi virides, acicul $x$ capitis magnitudine, è quibus flofculi dilute albicantes \& cærulei erumpunt. Et poft illos rotunda corpufcula inftar Baccularum quibus continetur femen minimum fufcum. Radice eft recta, brevi, candida, filamentofa, qux ficut \& tota planta manifefto fapore \& odore caret. Integræ herbæ, præfertim juvenis, decocta, balnea, fuffumigia, admodum funt anodyna, emollientia \& attemperantia, ut tot infignibus Malvis in Brafilia.luxuriantibus præferri debeant. Nec memini me in Tenefmo, Hxmorrhoidibus, ani inflammationibus vel doloribus, prafentius adhibuiffe remedium tam familiare, five externe, ut fupra dictum, admotum, five per clyfteres injectum.

Huic emolliendi qualitate $x$ mulæ funt herbæ Paratura \& Amongeaba, cæterum dignitate multum inferiores.

\section{C $\quad A \quad P \quad V \quad T \quad L X$. \\ Varice Jpecies Murucuiá, Granadillee dicta.}

$\mathrm{P}$ Oft fedulam inquifitionem decem fpecies Murucuiá repperi. Quarum dux majorcs non in campeftribus fed tantum in hortis inveniuntur. Prima \& nobilifima qux fe offert fimplexnomen vernaculum Murucuiá, ab Hifpanis Granadilla à Belgis Itanclk-apuelg accepit. Secunda Pyriformis Murucuia-guaç five magna vocatur. Cxter $x$ octo fpecies minores funt, nec ad fativas traduct $x$, inque faltibus remotioribus 
248

G V L I E L M I P ISONIS

la feminis nigri, variis tuberculis infigniti \& folliculo inclufi. Mirandum vero, aliquos fcribere (inter quos docuus Monardus) Pomum hoc effe infipidum. Nifi forte de Peruviana Granadilla fint locuri, cujus meminit Petrus de Cieca in Hiftoria Peruviana, quam colore $\&$ fapore ab hac noftra differre facile crediderim. Ad Medicam illius hiftoriam tranfeo.

Pulpa qux fummo febricitantium folatio \& oblectamento eft, mihi in quotidiano ufu effe confuevit, vicemque fyrupi cordialis, ut $\&$ Rob Ribium vel Berberis egregie fupplet. Qualitate refrigerandi cæteras Granadillas omnes antecellit, nullamque noxam, etiamfi abunde comedatur, adfert: nifi quod immoderato cjus ufu dentes ftupore obtorpefcant. Eftu laborantes mirifice refocillat fitimque exftinguit. Ad hæc appetitum excitat, ftomachi ardores reprimit, fpiritufque vitales, cumrecens pomum, tum fuccus ejus in fyrupi confiftentiam coactus, \& ex pofca propinatus, reftaurat. Idem præeftant flores $\& z$ pomi cortices conditi, qui vix ulli fructui dignitate concedunt. Folia loco hederx cauteriis applicata, multum profunt.

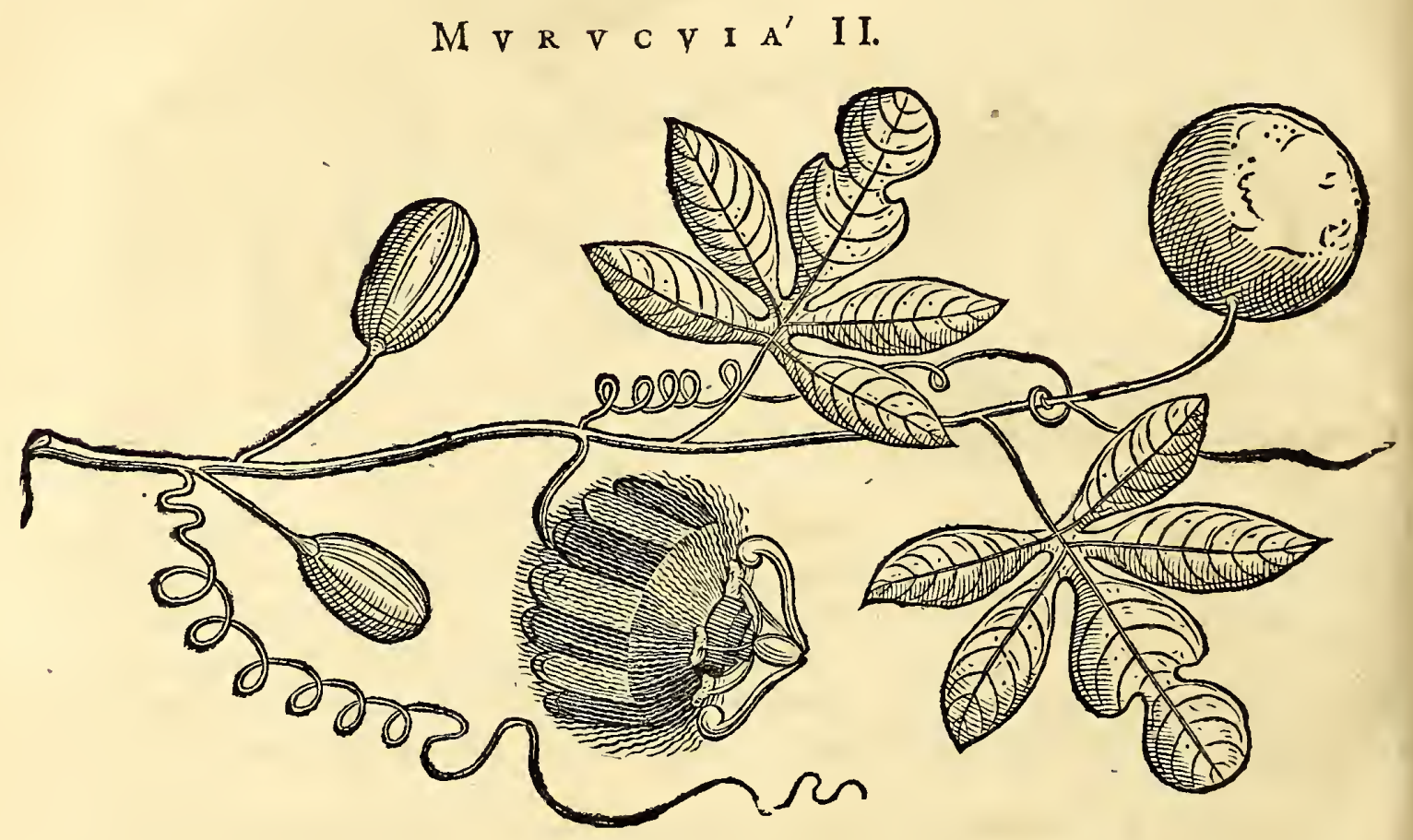

Secunda fpecies maliformis Murucuiá inter filveftres habita,caule itidem eft, ut Bryonia farmentofo fed fubrufo, in quo cum fuo petiolo folia hinc inde folitarie pofita $\&$ in quinque alia fecta, nafcuntur, quorum medium utrimque rara incifura laciniatum, fingula late virentia nervo recto $\&$ venis tranfverfis obfita. flos fuavis eft odoris, ejufdem figuræ \& colorum clegantix ut præcedentis, fed minor circumferentia filamentorum, antequam fe aperit ita fe habet, ut fupra in Icone. Fructus xquat Pomum noftrum vulgare rotundus, cortice craffo, flavefcentis coloris, cone ftans pulpa fucculenta, vinofe acida, tam odore quam fapore commendabili, linguam quoque croceo colore tingente. Fructus pulpa xgris ac fanis ad vifcerum ardores temperandos \& fitim extinguendam licet præcedenti inferior, tamen in pretio quoque habita.

Tertia maliformis Murucuiá five Granadilla eodem modo quidem ut aliqua præcedentium in caule folia difpofita habet, fed peculiari natur $x$ lufu in tres lacinias fecta, in ambitu ferrata, læte virentia, nervis rectis $\&$ venis obliquis multis prædita. Flore cft fuavis odoris, magnitudine $\&$ figura convenit cum plerifque antecedentibus, idem de cjus filamentis $\&$ columella, imo $\&$ de fructu ipfo dictum volo, qui immaturus fplendet atque ex viridi fubflavefcit, ex albo inftar Colocynthidis varicgatus, maturefactus citrini fit coloris \& digito attactus cum Itrepitu diffolvitur. 
decerptus, \& vermiculi in illo generantur ut incafeo. Fruatus pyriformis eft, initio viridis, maturus flavefcentis è viridi coloris. Intus multi proceflus, quibus femen cum pulpa fructus per tenues cuticulas annectitur. Pulpa, alba, fucculenta, glabra, inftar rudimenti avis in ovo, cui inhærent infinita grana feminis fuo folliculo inclufa, nigra, fplendida, compreffa. Odor $\&$ fapor fructus dulcis $\&$ fuavis, nihilque aciditatis fapir ficut pleræque alix. Cortex craffior eft quam Mali aurantii. Quando comeditur, fcinditur tranfverfim (non fecundum longitudinem) \& pulpa paulum feparatur à corti$c e$, adhrerens illis proceffibus, ac dein una cum feminibus forbendo inftar ovi tremuli exhauritur. Febricitantibus, tabidifque multum prodeft. Temperat renum calores, \& mucilagine fua fanat ulcera inteftinorum ex dyfenteria orta inflammationes pulmonum mitigat.

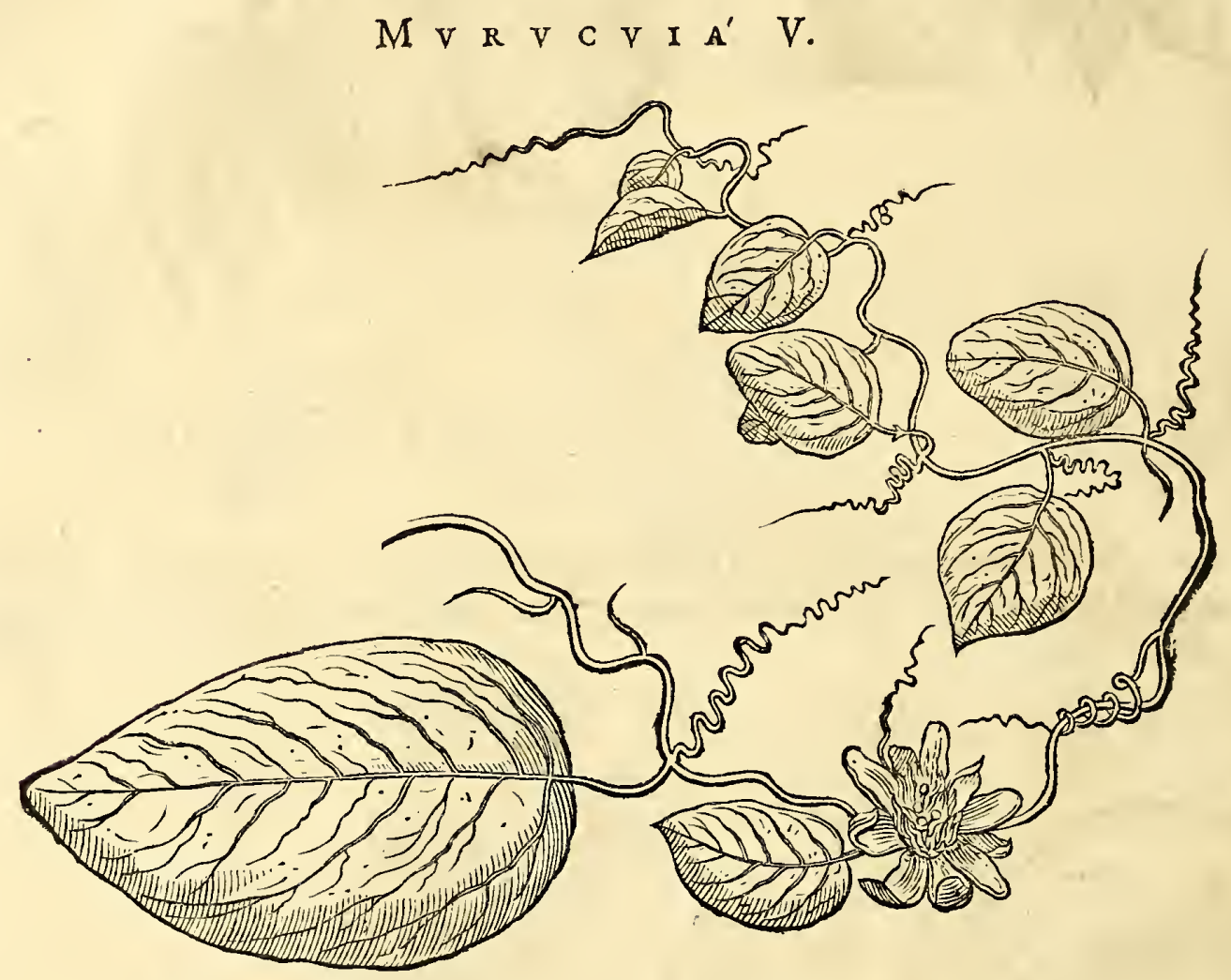

Quinta Murucuiá-miri five parva pyriformis altera, folia habet folitaric pofita, cordis bubuli figura, læete virentia, lævia, non laciniata neque ferrata, ficut in maliformi Murucuiá. Ad quemlibet quoque pediculum folii etiam capreolum habet caulis, quo fe annectit more Vitis. Flos, qui fuavis eft odoris, in eodem caule ex decem foliolis fuperne $\&$ inferne, nunc viridis, nunc rubri coloris, alternatim ita pofitis, emergit, cujus facies, color \&z ornamenta, paucis exceptis cum precedentibus conveniunt. Quamobrem ad internas ejus qualitates, quas noviffe plus intereft, me nunc confero.

Quantum enim hæc nobilis Granadilla præcedentibus magnitudine cedit : tantum dignitate virium medicinalium creteras fuperat. Quippe ufque adeo infignis habetur efficaciæ hæc planta (licet paucioribus Incolis nota) ut non folum officinarum çarçaparillam xmuletur, fed eam facile fuperet, deobftrudendo, fudores atque uri nas movendo. Integra enim herba qux pauci eft faporis, modo leviter attrita, \& ex vino, vel aqua exhibita, tuto, cito \& jucunde fecundinas \& cxteras uteri immundities expellit, mox robur vifceribus reftituit. Quod cum ab exercitatiffimis rei Botanicx Brafilianis ad Fluvium Divi Francifci habitantibus, accepiffem, qui nullum remedi' rm, huic Murucuiá-miri in obftructionibus \& frigiditatibus præferrent: illud tan-, dem a Lufitanis \& Batavis noftris colonis imitandum volui, qui profpero fucceflu ctiam nunc id in ufus quotidianos applicant.

Folia denique contufa, ferventique aqux, donec tepefcat, indita, atque podici aliquoties applicata, prxfentiffimum præbent remedium contra hæmorrhoides.

C A- 


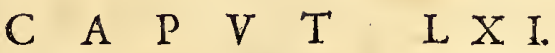

\section{Varie Timbó, Cururú-apé, \&o Tety-pote-ibafere Vitis Arbufini.}

$\mathrm{P}$

Ræter eas quas generali nomine çipó nuncupatas effe diximus: variæ $\&$ mirabiles dantur Herbx ö $\varphi$ usior Timbó vulgo dict $x, \&$ variis ufibus $\&$ abufibus dicatx ; qux omnes jucundum dant fpectaculum. Quædam enim inftar funium, in aëre tenf $x$, vix pollicis craflitiei, ad altiffimarum arborum faftigia enituntur', indeque rurfum de. mifix humi fe præcipitant; unde denuo continuato \& tenaciffimo ductu infurgunt in infinitas chordas, ita ut filvas vix penetrabiles conficiant. Quadam vero funt humani crur is craffitie triangularis, quadrangularis , \& rotund figuræ , arborumque cacumina adæquant, eafquenunc hederæ in modum amplectuntur, nunc eas rurfus deferunt atque in nodofos gyros \& concinnos hinc inde luxuriant, adeo flexibiles $\&$ valid $x$, ut quoquomodo conftringas, numquam rumpantur. His Timbó-guaçú à magnitudine; illis Timbó de Cono à Brafilianis, Barbafco à Lufitanis nomen inditum, vietoribus ad vafa liganda, contufa coriariis rhois, naupegis vero ftupx vices præbet. Pifcatoribus ad retia non folum tingenda, \& præervanda : fed $\&$ ad pifces capiendos interior $\&$ exterior fubftantia infervit. Quibus ad Fluviorum ripas (ut ipfe multoties vidi) contufis, aquas atro colore \& virulentia quadam inficiunt, unde Pifces non tam moriuntur ftatim, quam vertiginofi $\&$ quafi ebrii in retia fe præcipitant. Male quoque fit pecoribus fi ex hac aqua nimium bibant. Multi tamen teftantur fe lymphas multoties abfque damno licet ejus fucco infectas, haufiffe.

Sequitur tandem Guaiána-Timbó, nomine $\&$ noxia hac qualitate præcedentibus fimilis, caterum diffimillima apparens, qux fola in Medicos ufus recepta eft, nec frondibus deftituta, ficut pleræque Timbó, fed floribus, foliis magnis, glabris, acuminatis hincinde vagatur, atque in caulis extremitate tenuibus filiquis, lævibus, cubitum longis, copulatifque ornatur. Qux merito à Lufitanis Faifaons d'impige five Fabx Impetiginis appellantur, quod earum cortex, fuccum, pifcibus quidem infeftum ficut \& præcedentes Timbó, fed impetigini \& puerorum fcabiei,cxterifque hujus generis affectibus cutaneis, proficuum continet. Menfibus enim pluviis immaturæ filiqux $\&$ virides, fucco turgent prætantiffimo, eoque frigido $\&$ acri, quo fi fricetur qui impetigine laborat curabitur ; modo aliquoties reiteretur remedium.

Quando maturuerunt filiqux tempore xftivo, mox exficcantur,tuncque non folum tunicam externam, fed \& fuccum atque femina, quibus fcatent, paulatim nigrefcere $\&$ aromaticum odorem fpirare comperies ; verum tunc prædictis malis minus apta judicantur.

Inter has çipó, illa quoque cenfetur qux Guembé nomen habet mirabilis fane herba ad Ancoralia imprimis utiliffima, ut in tractatu de Aëre. Aquis \& Locis latius egi. Sicut \& illa quxe Guembe-guaçu hoc eft Guembé magna, dicta qux radices habet ultra triginta cubitos longas. Cortices autem contufi \& prunis ardentibus impofiti, fuffumigio fuo fiftunt fanguinis fluxum, præfertim in fominis. 
- cviviv-apé.

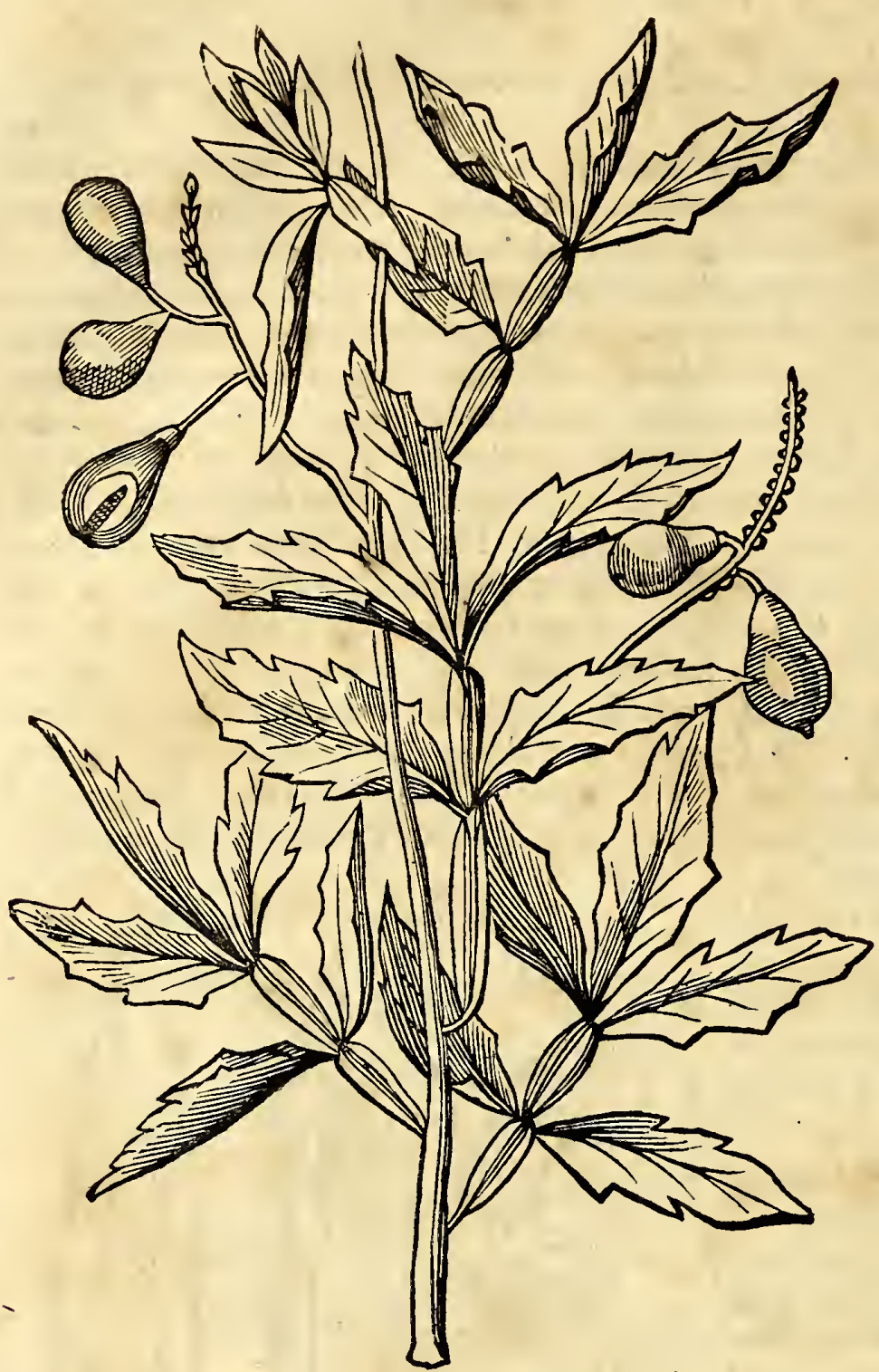

T tanta vegetabilium 1 multitudine, non mirum eft, quafdam hominibus tantum, quafdam folum cxteris animalibus, vel prodefle, vel obeffe. Inter has exiftunt imprimis Cururu-apé \& GuaianaTimbó, de qua modo egi. Vtraque in Medicinam recepra; utraque pifcibus noxia. Quas proinde potius inter falutiferas quam venenatas recenfendas exiftimo.

Hxc itaque Cururu-apé nec facie, nec efficacia vulgaris exiftit: In vaftis nemoribus aliis arboribus innititur. Ligno eft tenaci farmentofo \& flexibili, foliis decoratur oblongis, fuperius viride fplendentibus, dentatis, exfe invicem, ad ficus fere Indicx modum, pronafcentibus.Ita ut non raro,pro naturx lufu, quinquefolium conficiant, inferius duobus expanfis foliis, fuperius tribus eminentibus.

In extremitatibus ramulorum proveniunt longx fpicx, onutx flofculis ex albo \& viridi lutefcentibus; poft quos fequuntur capful $x$, triangulat $x, \&$ ubi maturiores ovalis figuræ, quæf fponte in tres partes dehifcunt; cortex autem exterior rubicundus, interius eximie eft ruber, continetque quilibet fructus duas fabas, quarum quxlibet involuta materix molli, albx, nuci confiftentia fimili, ad tactum frigi$\mathrm{d} x$ : ex illo albo involucro faba fecundum longitudinem eminet, nigerrima macula fplendens, reliqua pars fabxeft fufci coloris. Continet denique fabainterius carnem fabaceam flavam. 'Hi fructus ad abufus potius quam ufus, recepti funt : quippe contufi, aquas venenata qualitate inficiunt, ita ut pifces inebrientur \& moriantur. Folia autem viridia contufa applicata, eorumque recens fuccus vulneratis tantum prodeft, quantum fructus affumtus aliis animantibus folet obeffe. Adeo enim qualiacunque vulnera, etiam prima intentione, mundificat $\&$ reftituit, ut merito inter præcipuas vulnerarias hxc herba numerari mereatur.

$$
\text { TETY-POTE-IBA five VITIS ARBVSTINA. }
$$

FXftercore avium, qux Tetyns dicuntur, ad arbores Aurantiorum depofito, herba E nafcitur voluntaria, Indigenis Tety-pote-iba appeilata qux Vitis Arbuftinx inftar, fed folio Myrti majoris fimili, ipfi arbori maritatur: quam prx nimia lixuria tandem cooperiens, exitium totale illi infert. Sed quantum hac Zizania Affyrix malo noxia, tantum homini atque ipfis avibus Tetyns dictis proficua exiftit. Quippe exdem avicula herbam hanc è ftercore fúo natam, five amore alimenti, five medicamenti depopulari amant. Denique à radicibus \& ramulis contufis \& ex oleo communi frixis, emanat infigne medica. 
medicamentum calidum, cujus crebris inunctionibus, ad vices aliquot reiteratis, ventris $\&$ pedum inflationes, tam adultorum quam puerorum, ex frigido enat $x$, felicifime reftituuntur. Adeo difcutere $\&$ confortare creditur hoc oleum, præfertim vetus, ut nulli remedio cedat, meritoque à rufticis tanquam domefticum refervetur. Rafura caulium in aqua macerata oculorum obfcuritates abltergit, præcipue in affectibus iatericis.

$$
\begin{gathered}
\text { C A P V T L X I I. } \\
\text { Varia Pbajeolomm fpecies Cumandí dicte. }
\end{gathered}
$$

Q Vum antea lectori indicarim, inftituti mei effe, eas tantum perftringere plantas $\&$ animalia, quorum qualitates alimento $\dddot{x}$, ; medicx , vel venenatæ mihi innotuerint : Idem imprimis circa Phafeolos, Ciceres \& Pifa nunc profequor quoniam immenfi effer laboris, imo charta mihi prius quam materia deficeret, antequam tot luxuriantium Fabarum \& Siliquarum fil vam graphice depingerem.

Hocitaque capite eas tantum recenfeo, quæ omnibus pariter incolis familiares, \& inter alimentofas potiffimum habitx. Vt funt primo Cumanda-guacu, id eft Fabæ magnx dictx. Quxpollicis funt craffitie, \& ficut preftant Europæis magnitudine, ita etiam fapore \& falubritate. Inftar funis ad arborum cacumina enituntur, eafque Heder $x$ modo amplectuntur. Fabx torrefactx \& contufix cumque ovo exhibit $x$ contra fluxus ventris in ufu funt. Coctx vero ad cataplafmatis modum ventri impofitz colicis doloribus medentur; ad refolvenda quoque apoftemata parti affectx appplicantur.

Cumandá-guirá eft frutex elegans toto anno florens \& fructifera. Cortice viridi, ligno fragili,ramis furrectis fibi oppofitis exfurgit, foliis oblongis Salvix acutx limilibus, inferne albicantibus, fuperne viridioribus, lanuginofis, floribus luteis magnitudinis noftratium Piforum, quibus filiqux compreffx \& quafi contortx fuccedunt noftris paulo minores. Horum ufus omnibus paffim incolis frequens fi coquantur, præterquam enim quod palato blandiantur, lubricam reddunt alvum.

Illæ autem qux fimpliciter nomen Cumandá induunt, Fabis Turcicis tum fapore tum magnitudine fimillimx, fed fubinde colore tantum, non forma differunt, aliæ enim prorfus funt albæe, aliæe dilute è candido flavefcentes, alix obfcure purpurexrenis formam referentes: omnium cutis admodum nitet, \& eleganter maculis diftincta.

Cumandá-mirí, id eft, Fabx parve, funt Pifa, Europæis magnitudine paria , fed oblonga $\&$ non rotunda, albi quoque \& leucopœi coloris.

Sequuntur tandem \& illæ qux Cumandatiá appellatx, Lablab Profp. Alpini. de quibus vide Carol. Clufum Rar. plant. pag. ccxxvir. Planta hxc ex Africa in Brafiliam creditur tranflata, undique nota tam ob elegantiam quam ob ufum; perpetuis floribus \& farmentis luxuriat toto anno. Semina nigra, filiquis latioribus haud longis continentur, qux edulia non folum fed guftu gratiffima exiftunt, fi cibis inmifceantur \& coquantur. Pectoris morbis medentur. Profp. Alpinus teftatur,urinam \& menftrua movere.

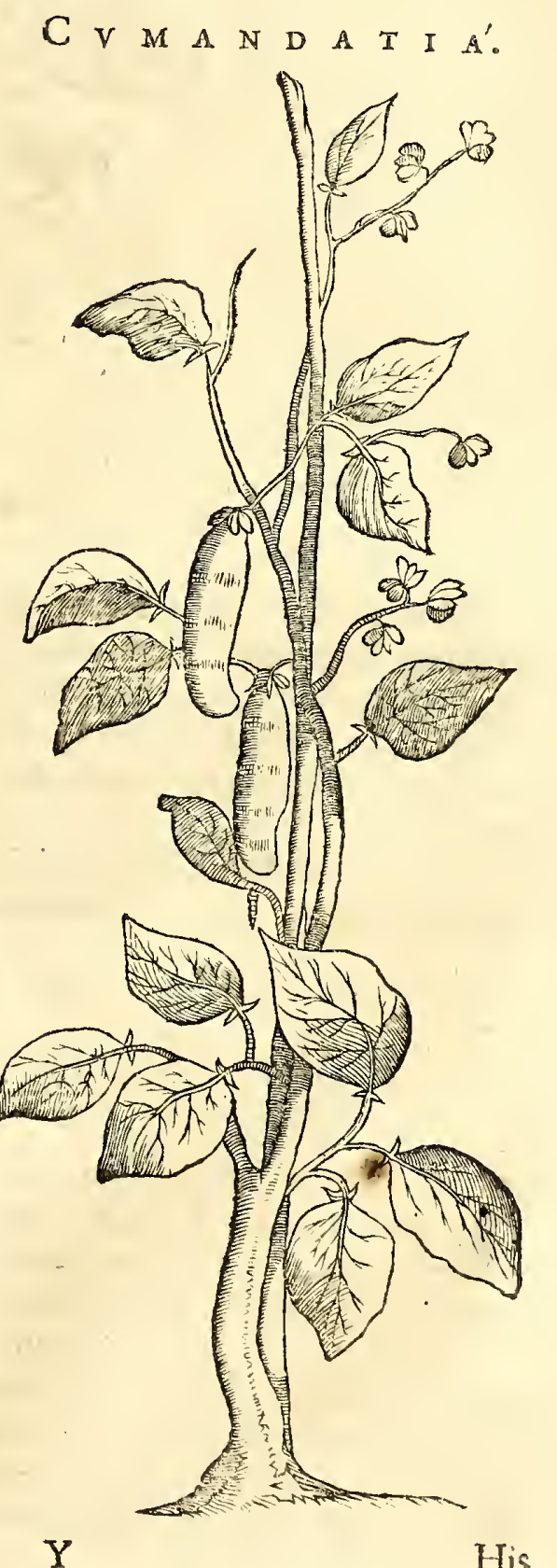




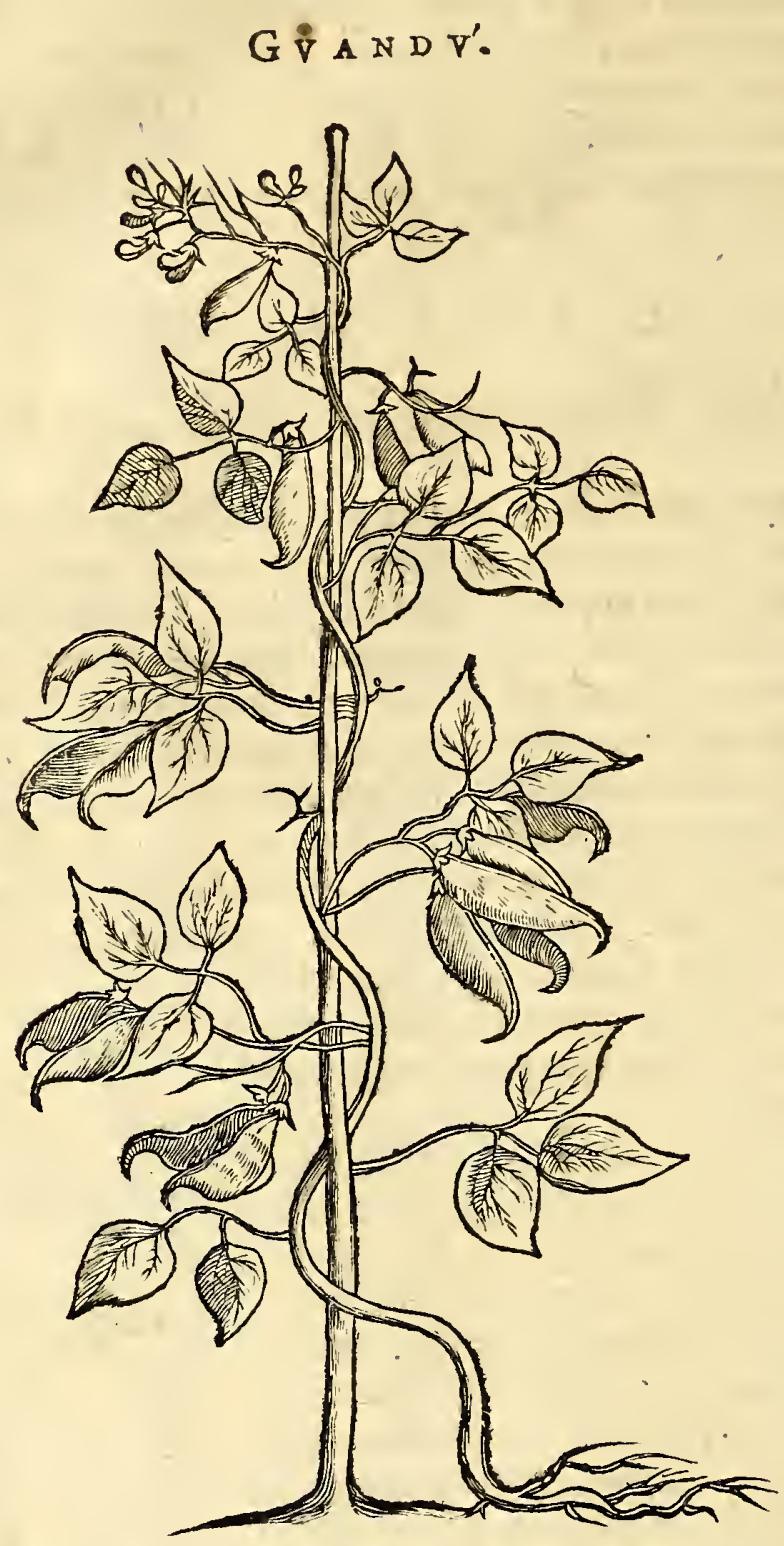

His annumerantur Ciceres quibus Guandú Brafiliani, Belgx, à filiquarum forma Bitte frrombeltie nomen dederunt, adeo expetiti præ cæteris, ut non minus ægris, quam fanis conducant. Elegans hic Phafeolus Turcicorum modo fcandit, iifdemque eft foliis $\&$ floribus, fed multo minoribus. Iucunde femper viret, perpetuifque copulatis filiquis parvis decoratur : ita ut ob ornatum xque ac ufum fativa facta fit planta.

Qux Guarumbeédictx, Turcicis Phafeolis aliquanto funt majores, coloris nigerrimi \& optimi faporis, fed minus frequentes præcedentibus.

\section{A $P$ V $\quad \mathrm{T} \quad$ L X I I I.}

\section{Ietucu five Mechoacan, \& Xalappí.}

$\mathrm{D}$

E ea nunc agendum radice medicinali, qua in Novo \& Veteri orbe nomen audit à fua Regione Americx natali qux Mechoacan appellatur. Adeo per omnes filvas fponte luxuriat; ut non minus terram frequentia radicum, quam nemora elegantibus farmentis \& floribus impleat.

Docte fane $\&$ curiofe harum plantarum quatuor fpecies gradu $\&$ dignitate impares Ximenes tractavit, ut videre eft in Annotatione fub capite Mechoacannx in Pafilix naturali. quarum natura ut $\&$ femina, licet ab hac noftra Hitoria noltra Brafe videantur: tamen farmentis, foliis, floribufque convenire apnonnihil difcrepare videantur : tamen farfife fpecies, facie fibi fimillimas; led ut paret. Mihi, hic non licuit ultra duas vidifle tpecies, facie fibi fimilliacia 
HIST. NATVRAL. \& MEDIC. LIB. IV. 253 efficacia differentes, ita \& radice, quæ in pofteriori hac Mechoacannæ fpecie non folum longior, circulofior \& nigricantior, fed \& purgandi qualitate fuperior exiftit. Ac, ut verbo abfolvam, eadem eft quæ nomen Xalappæ in nova Hifpania accepit. Qux, cum nuper ibidem adhuc latitaverit, quis mirabitur, fi etiam nunc in vafta hac Barbarie minus innotuerit, \& fub communi Mechoacannæ nomine in ufu fuerit.

Omnis itaque Ietucí five $\mathrm{Me}$ choacannx fpecies Lufitanis Patáta da purga dicitur : qux adeo toto fere anno in agris luxuriat, ut exofa fit rufticis, atque ob nimiam ubertatem vilefeat. Terræ impofita radix, fpatio octidui adoleficit cum foliis : imo parieti appenfa progerminat feliciter. Planta caule lactefcente farmentofo, rufo, multangulari, lento repit vel fcandit. Foliis folitariis hinc inde veftitur teneris, fature viridibus, inodoris, cordis figuram, cum vel fine auriculis repræfentantibus. Flore decoratur quadrifolio (quam hic feparatim ad vivum ea qua erat forma \& magnitudine appofui) dilute incarnato, intus purpureo ; in cujus medio capfula, loco umbilici rotunda prominet, ex qua femina aliquot nigricantia Pifi magnitudine fed non figura, quia compreffä \& quafi triangularia apparent. Radice eft magna bifida utcunque extus fufca, intus tota laEtefcente, in quo refinofo liquore medica qualitas refidet; ac proinde verno tempore Brafilienfi collecta, atque in taleolas circulares diffecta, atque filo tranfutim excepta, follicite refervatur, quod ab externa injuria facile afficiatur.

Pulvis radicis à femiuncia ad integram ex convenienti liquore tuto exhibetur ad deturbandum pituitofum imprimis \& aqueum humorem. Vel radix recens, mundato cortice, exprimitur per pannum ad horas aliquot; quod fubfedit ficcatur in umbra (ob fimilitudinem Tipioca dictum) drachma in pueris, dux vel tres drachmx in adultis, exhibentur. Delicatioribus autem

$$
\begin{gathered}
\text { IETVCV' five MECHOACANNA, } \\
\text { cum FIORE. }
\end{gathered}
$$
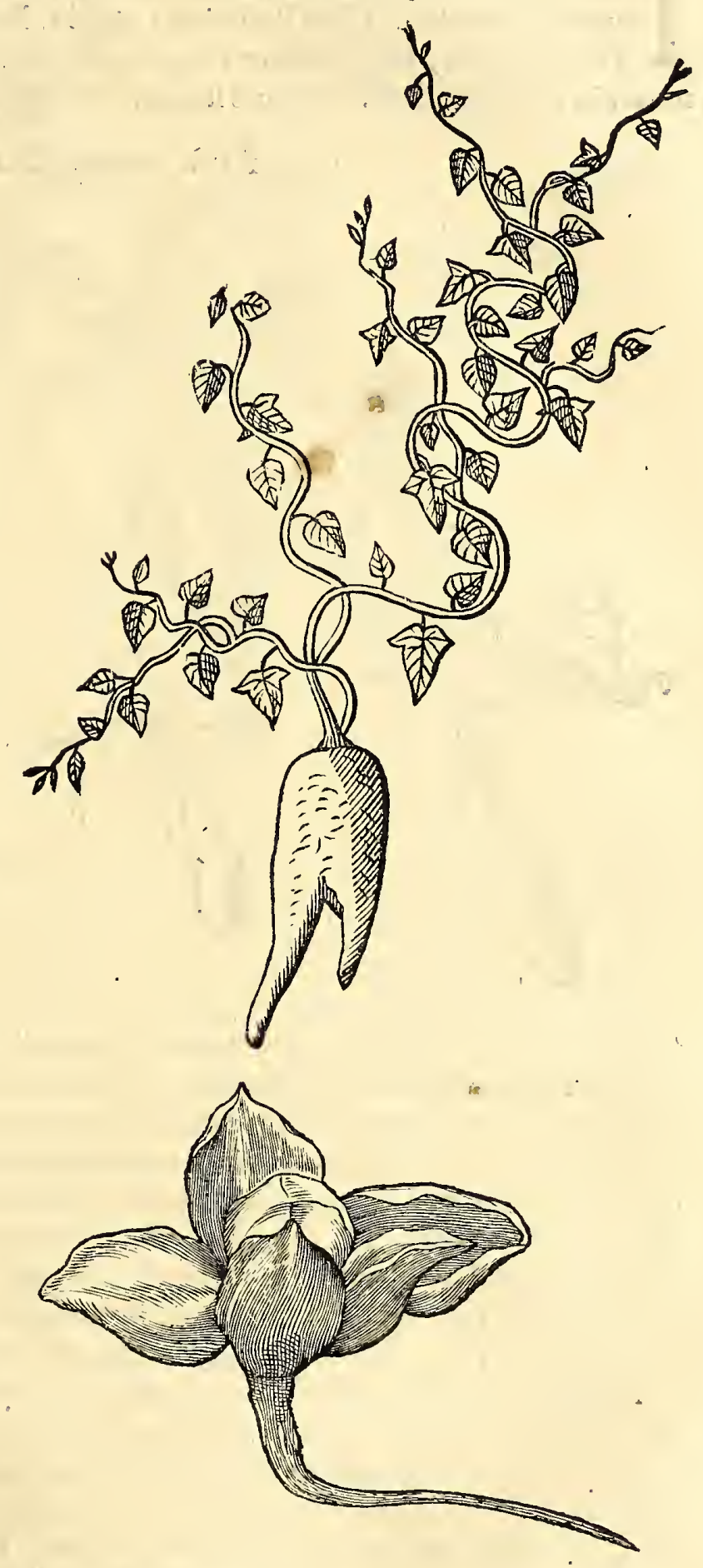

quiabomni medicamento abhorrent, conferva" exinde cum faccharo fit, cujus dofis caftanex circiter eft magnitudinis. Hxc conditura, quod blandum $\&$ gratum fimul fit medicamentum, magnopere expetitur, \& inyarias Europx regiones di-
Atrahitur. 


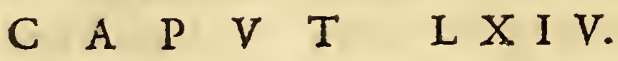 \\ Ictica vulgo Batáta, Cará, Tamoatarána, Mundubi, es cMandobi.}

$\mathrm{I}$

Nter fructus fubterraneos alimentofos primum locum merentur, quos Batátas, nuncupant vulgo. Qux Peruvianis Apichu, Brafilianis Ietica dietx, exque quidem diverfi coloris, fed qualitate congeneres, nutrientes, magnoque incolarum commodo in viatum cedunt. Pingues funt $\mathscr{\&}$ dulces atque flatulentæ : $\&$ in hortis mul-

$$
\text { I E T I' C A vulgo BA T A } A^{\prime} \text { T A. }
$$

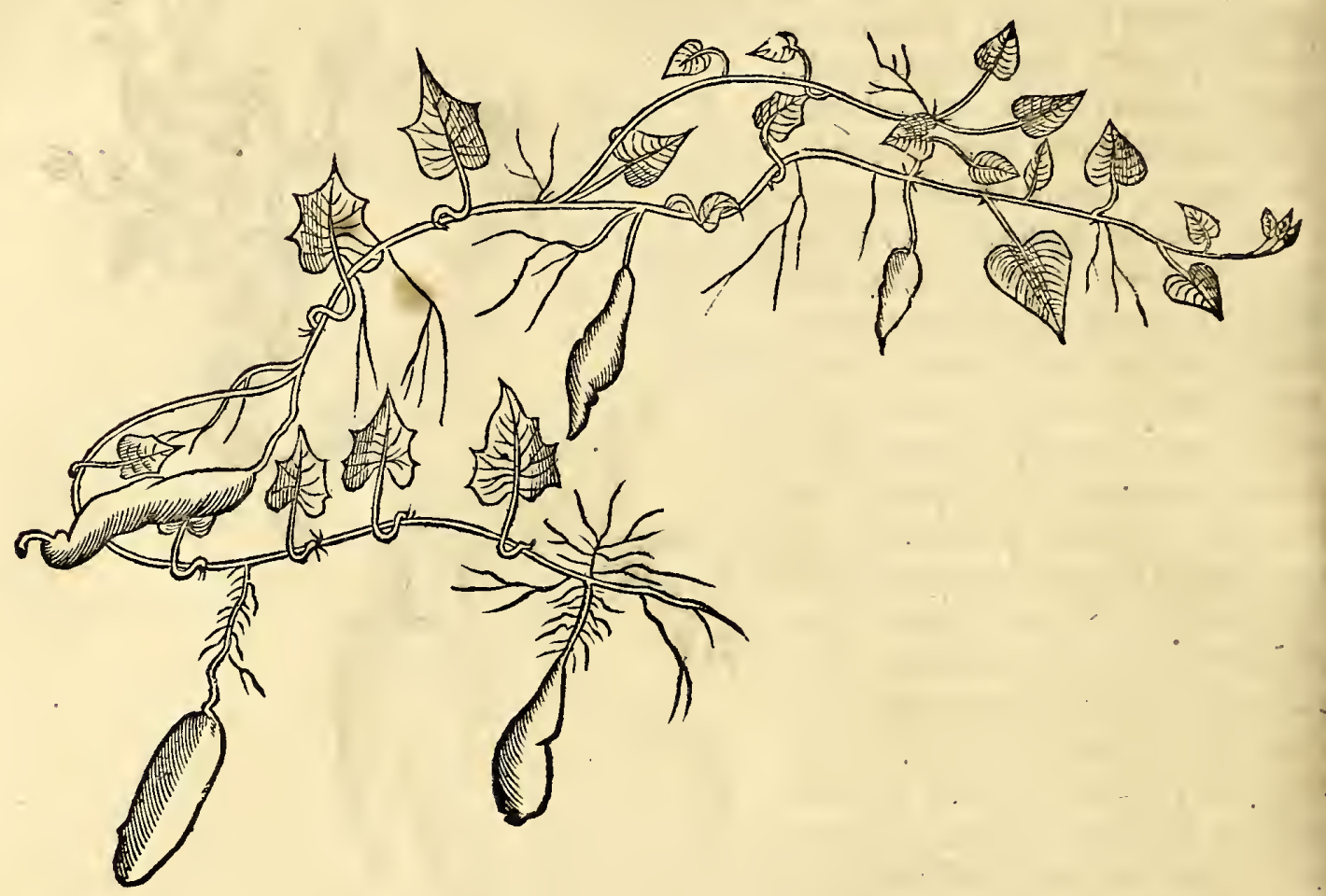

tum excoluntur. Caule farmentofo, lento, viridi, tenuifuper terram repunt, femper nova filamenta terræ ingerentes, ex quibus novæ radices generantur vari $x$ figur $\boldsymbol{x}$, coloris extus flavefcentis, intus lacteo ficco turgentes. Quibus pediculus ad caulem in exortu incurvatus, folium fuftinet dilute virefcens, inferne canefcens, figura cordis, ut vulgo pingitur, vel etian ad latera auriculas habens ut Mechoacanna. Flores ferunt exterius dilute virides, interius candidos figura Campanulx, quibus deficientibus femen quoddam videtur formari, fed nullius ufus, quia optime tranfplantantur findendo radices in taleolas \& imponendo terrx. Coquuntur aut fub cineribus affantur, funtque optimi faporis \& præferend $x$ noftris Rapis.

Batáta recens contufa \& affufa paucula aqua atque macerata, fermentando fit potus, quo Indigenæ utuntur, imo, fubinde abutuntur ad inebriandum.

Alix quoque dantur Batáte f́pecies, quarum prima vocatur Omenapó yeima, humi ferpens caule farmentofo, viridi : folia quoque habens cordis figura, vel etiam aurita, folitarie pofita, nervis \& venis viridibus obfita. Radix ut plurimum eft rotunda, cruda, alba, fed cocta fit per totam fubftantiam, inftar Betx rubra, manufque tingit cxrulco. Cuticula eft obfcure rubra; cultro incifa nigrefcit inftar atramenti futorii.

Sccunda $P$ araro dicta eft caule $\&$ foliis ficut pracedens, nifi quod caulis hujus fit purpuretis, \& hervi atque venæ foliorum itidem purpurex, ut \& radix.

Qux Ietiopé vocatur alba eft quoque radice optimi faporis, paulo macerata comeditur, fed imprimis à febricitantibus.

Vxautem Inbame de S. Thome vulgo, \& Brafilienfibus Carádictx, quantum omnibus enarratis batátis mole fuperiores: tantum dignitare inferiores exiftunt, \&zà 
Nullius ufus, quantum conftat, folia \& caulis; excipiuntur Bulbi, qui more Batatx pro bono alimento apponuntur.

MVNDVBI \& FRVCTVS.
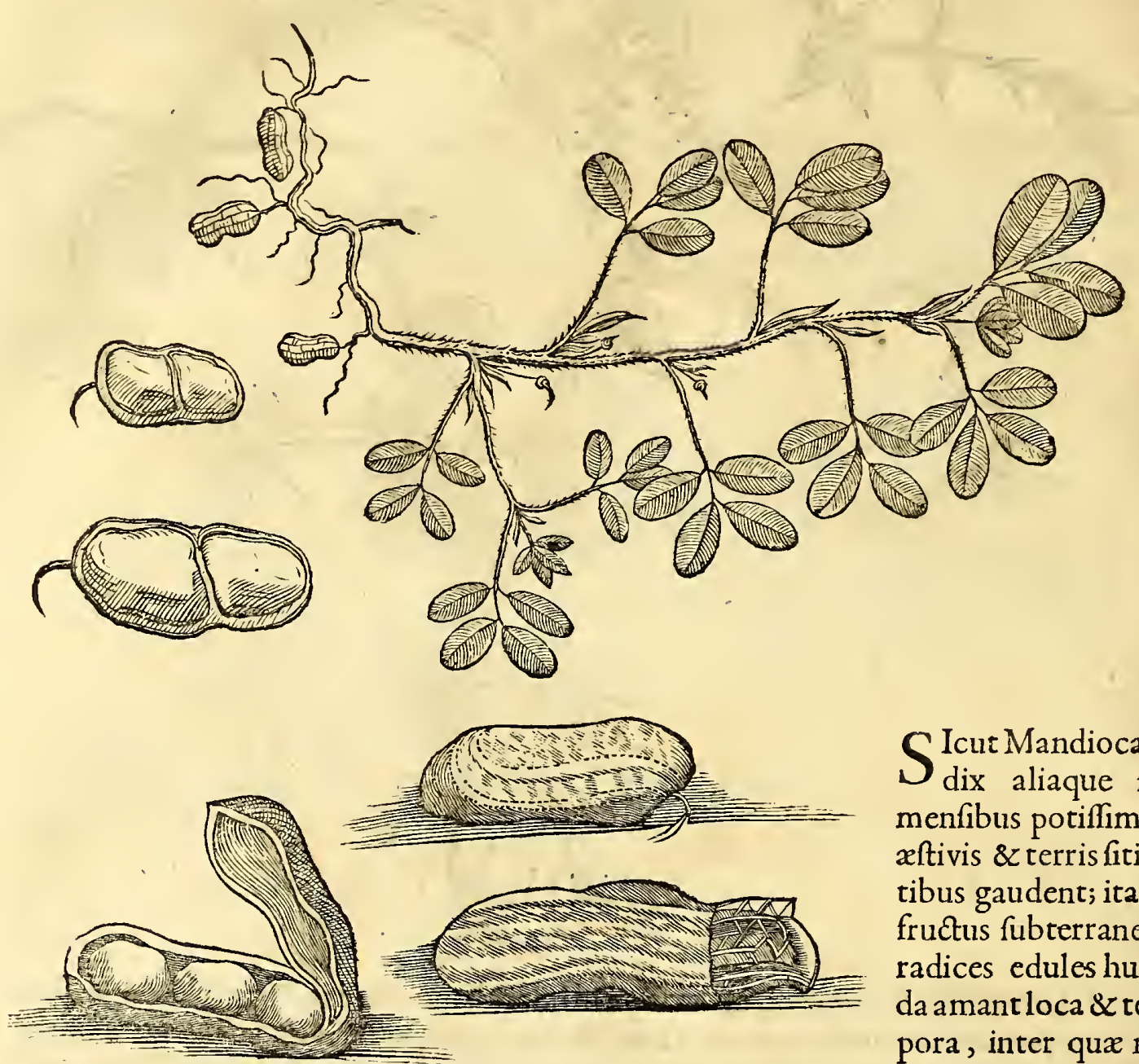

S Icut Mandiocara. $S_{\text {dix }}$ aliaque fata menfibus potiffimum xttivis \& terris fitientibus gaudent; ita alii fructus fubterranei 2 radices edules humida amant loca \& tempora, inter qux non folum Batatas mox defcripta, fed \& Mundubi \& Mandobíprimatum tenent. Horum prior Lufitanis corrupto Amenduinas, Lerio Manobí. Peruvianis, tefte Monardo Anchic, Hifpanis Ibimani vocatur. Familiaris hæc planta domeftica facta,nunc humi decumbens, nunc ultra pedalem erigitur altitudinem. Caule eft quadrato aut ftriato, ex viridi rufefcente, \& pilofo. Hincinde enafcuntur ramuli primo quafi caulem amplectentes $\&$ foliolis anguftis acuminatis circa nodos ftipati;continetque quilibet ramulus quatuor folia, ovalis figur: in extremitate obtufa, leviter pilofa, unico nervo recto \& fubtilibus venis conficicua, inferne canefcentia, fupernelæte viridia. Flofculos habet flavos, per ora rubentes. Radice eft brevi, tenui, contorta,filamentofa, cui adnafcuntur folliculi ex albicante grifei, figura minimi Cucumeris, fragiles, fed ftrepitum edentes: quilibet autem continet in fe tres nucleos, pellicula faturate purpurea veftitos, carne intus alba, oleaginofa, fapore Piftaceorum, qui comeduntur cocti \& inter bellaria apponuntur. Flatulenti funt atque ad Venerem incitantes. Multum tamen comefti capitis dolores caufant. Forma cataplafmatis contufi,\& morfui ferpentum applicati, dolori medentur. Ex illis quoque oleum clariffimum exprimitur, non ingrati faporis, iifdemque ufibus dicatum, quibus oleum Amygdali.

\section{A N D O B I'.}

P Ofterior fructus fubterraneus, ex oris Africx olim tranflatus, tandem Americx na1 tivus quafi factus Mandobi vocatur: qui non erigitur, fed more Cucumerum tenuibus farmentis fupra terram luxuriat, unde hinc inde pediculi ftriati exfurgunt, quibus flofculi flavi, \& folia, more Phafeolorum fibi tria conjuncta adnafcuntur. Fibris fubterrancis horum caulium reticulati folliculi, nucis avellanx magnitudinis adhærent. Quilibet autem folliculus fecundum longitudinem circum circa quafi futuram monftrat \& preflus circa illam finditur, continens in fe duo utcumque grana pifformia \& ejufdem 
HIST. NATVRAL. \& MEDIC. LrB. IV.

ejufdem magnitudinis flavo pallida, ejufdem cum pifis recentibus confiftentix, \& faporis , cruda \& cocta comeduntur, quod boni fint faporis, fed flatulenta, omnibus paffim incolis in quotidiano ufu exiftentia, cxterum prioribus CMurdubi congenera qui$\mathrm{dem}$, fed nutriendi qualitate iis cedunt.

$$
\begin{array}{lllllllll}
C & A & P & V & T & L & X & \text { V. }
\end{array}
$$

Iupicánga vulgo Radix (bins, Ivapecánga vulgo çarçap.urilla, of Convolvulus marinus.

Imilem quam Chinæ radicem folent nominare hæc quoque producit terra. Pfeudo Chinam, de qua Dodonæus \& alii fcribunt, verius dixeris, camque admodum nodofam, \& lignofam, in Territorio imprimis Paraybienfi, ubi copiofe nafcitur. Formatur in aliquor tubera ficut ex appofita Icone liquet, intus \& extus fubrutilo co-

IV P I A A G A vulgo RADIX CHIN E.

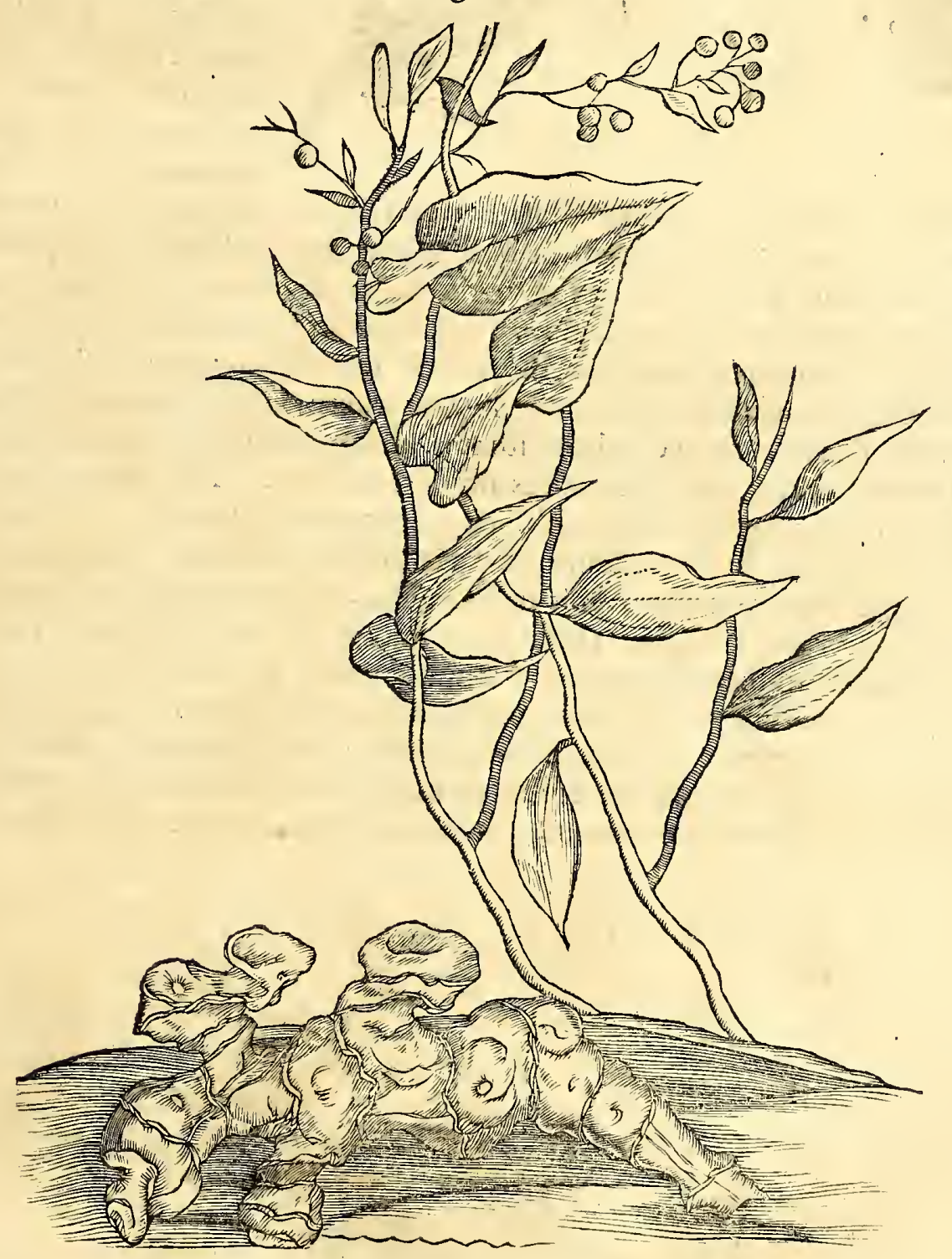

lore. Tres omnino reperiuntur fpecies, licet paucioribus cognitx, qux ommes fub codem nomine comprehenduntur, ob fummam quam inter fe habent, fimilitudinem; quas tamen fi in ufus applices, diftinguere neceffe eft: quapropter eligenda eft qux magis craffa, glabra \& rubefcens eft, qux facile ex magnitudine pedis plantx, tum \&, ex in frequentibus caulium fpinis, internofci poteft. Ejus brachia fpinis acutiffimis hinc inde obfita, Clematis inftar, vicinas arbores, earumque fummitates, finuofis flexibus amplectuntur. Folia fert Plantagini haud diffimilia, \& baccas croceas ad aurcum colorem vergentes.

In hac planta cum nihil fit fere, quin ab aliis Scriptoribus tractatum, follicite aut

$$
\mathrm{Y}_{4} \quad \text { prolixe }
$$


prolixe differere operæpretium non erit. Ea uti folent ad eadem mala expugnanda, qux in Europa expellifolent : tametfi Chinenfi (ut, quod fentió, dicam) dignitate $\&$ preftantia nonnihil concedat.

I VA PECANGA vulgo ÇAR çAPARILIA.

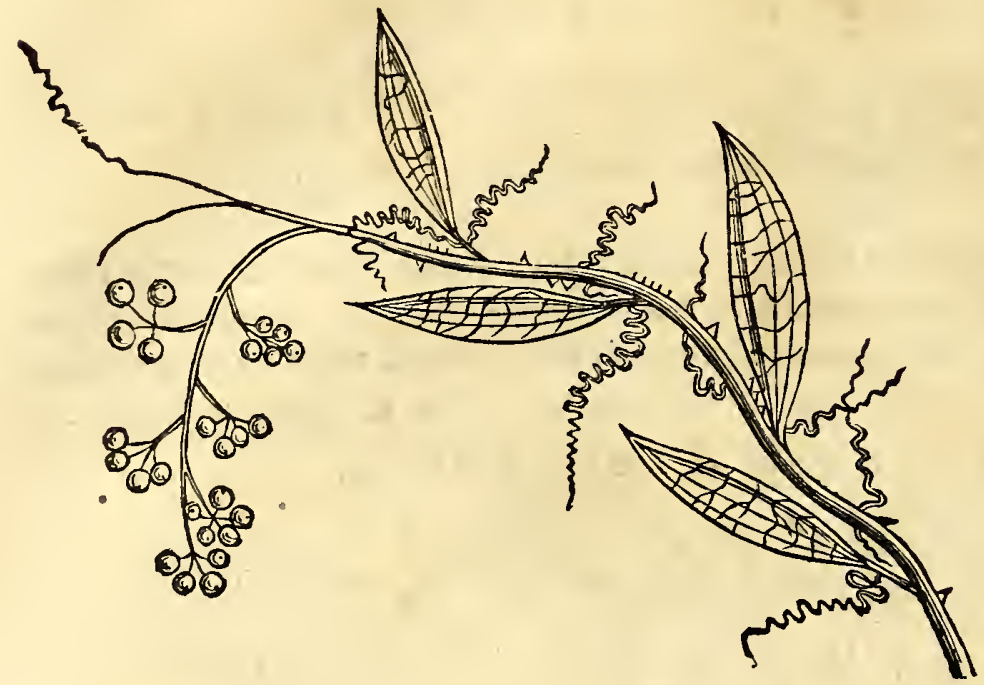

Icet à plurimis Incolis, 1 tam advenis quam Indigenis, neglecta fere fuerit hæc, quod vulgaris illa $\&$ notiffima farçaparilla ex aliis Americx regionibus huc adferatur ; tamen à peritioribus Empiricis, mox propria experientia edoctus, hac Ivapecanga à me aliifque Lufitanis in ufus Medicos eft recepta.

Dux reperiuntur fpecies fibi fimiles, in filvis littoralibus repentes, caule farmentofo, lento, viridi, aculeos feufpinas hinc inde habente acutas. Folia acuminata diver $\{x$ longitudinis \& latitudinis, exterius dilute, interius fature virentia. folitarie alternatim cauliadnafcuntur, in quibus tres nervi infigniter confpicui fecundum longitudinem, tranfverfim autem multæ minutæ venulæ vario flexu tendunt. Ad quemlibet cujuflibet folii pediculum dux claviculæ prodeunt lentæx, longx, quibus aliis plantis fe firmiter annectit. Flores fert racematim : fequuntur dein baccx, primo virides, mox cinnabrix, ubi autem maturuere, nigr $x$, rotund $\mathfrak{x}$, rugof $\mathfrak{x}$, moprimo virides ficcatorum pediculisinfiftentes. Intus continent unum aut duos lapides albo flavos', duros, in quibus durus albicans nucleus. Vide Monard. cap. Xx I I.

Fr. Ximenes quoque diverfas \& nobiliores Sarçaparillæ fpecies, variofque parandi modos in Mexico \& Nova Hifpania dari teftatur, Mecapatli illis diEtas. Optima autem creditur efle ea, qux provenit in Hondura, quxque potiflimum infertur Europæ. Sunt qui omnes has plantas referendas putent ad fpecies Chinæ, verum quia radices plurimum differunt, non eft dubium quin fui generis fint plantx, licet figura foliorum, caulium volubilitate $\&$ capreolis conveniant. Quibus autem ufbus benigna mater natura condiderit hanc nobiliffimam herbam, toto fere mundo innotuit, fed quanto validius \& felicius in Indiis ubi indigena eft, morbis chronicis medeatur, illi optime norunt qui Indias Orientales \& Occidentales habitarunt.

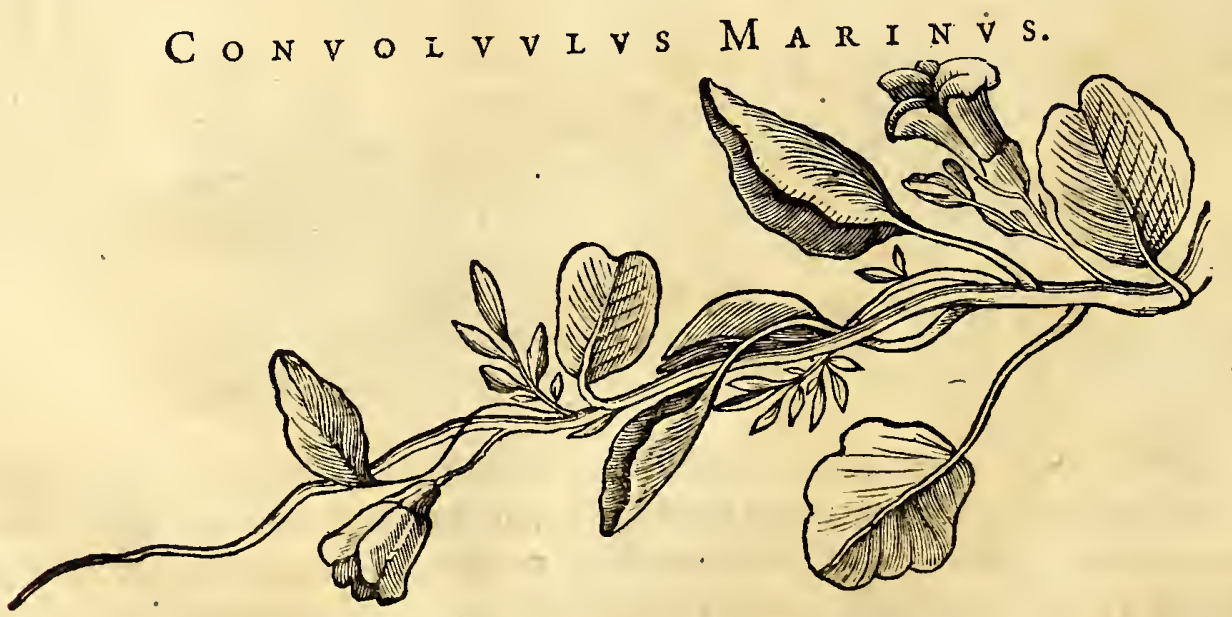

PRter çarçaparillam officinarum, altera hæc non imbellis, licet ignobilior, reperitur. Lufitanis Sal/s do Praya, five Carça littoralis nuncupata, quam tamen Convolvlum maximum rectius dixeris. Ex radicelenta, longa, non craffa, fed gracili, paucis fibris pradita, nigricantis exterius coloris, intus alba \& lactis glutinofi plena, na- 
fcuntur aliquot caules, longiffime repentes fupra terrám atque hinc inde iterum radices agentes. His adnafcuntur folia alternatim pofita, læte viridia, crafla, obrotunda. Ex pediculis flores prodeunt fuperius quinquangulares, Campanulæ figura, coloris dilute purpurei, qui poft meridiem clauduntur, mane excluduntur.

Sarmenta \& folia recentia, temperate calida habentur, \& emolliendi quoque vi pollent, ac proinde in balneis factitandis ufum habent haud exiguum, tum ad corroborandum corpus in affectibus pracipue frigidis, fumme profunt.

Decoctá denique è farmentis $\&$ radicibus exficcatis per os exhibita, eidem ufui inferviunt. Folia recenter avulfa fonticulis appofita folatium adferunt.

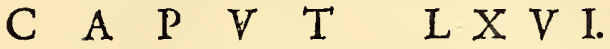

\section{Ploandiróba, Acariçóba, Ambuyaembó, és Caapéba.}

Ederæ fcandentis fpecies, möre Bryonix, farmentis paulo tenerioribus faftigia arborum enititur. Folia habet difpofita more Hederæ, fubrotunda \& quafi in tres angulos definentia, viridia, glabra; fplendentia. Flofculos parvos ex pallido lutefcentes fructus fequitur rotundus, viridis, fplëndens, Pomi majoris

$N H_{A} A \quad N \quad D \quad I \quad R \quad O^{\prime} \quad B \quad A$.

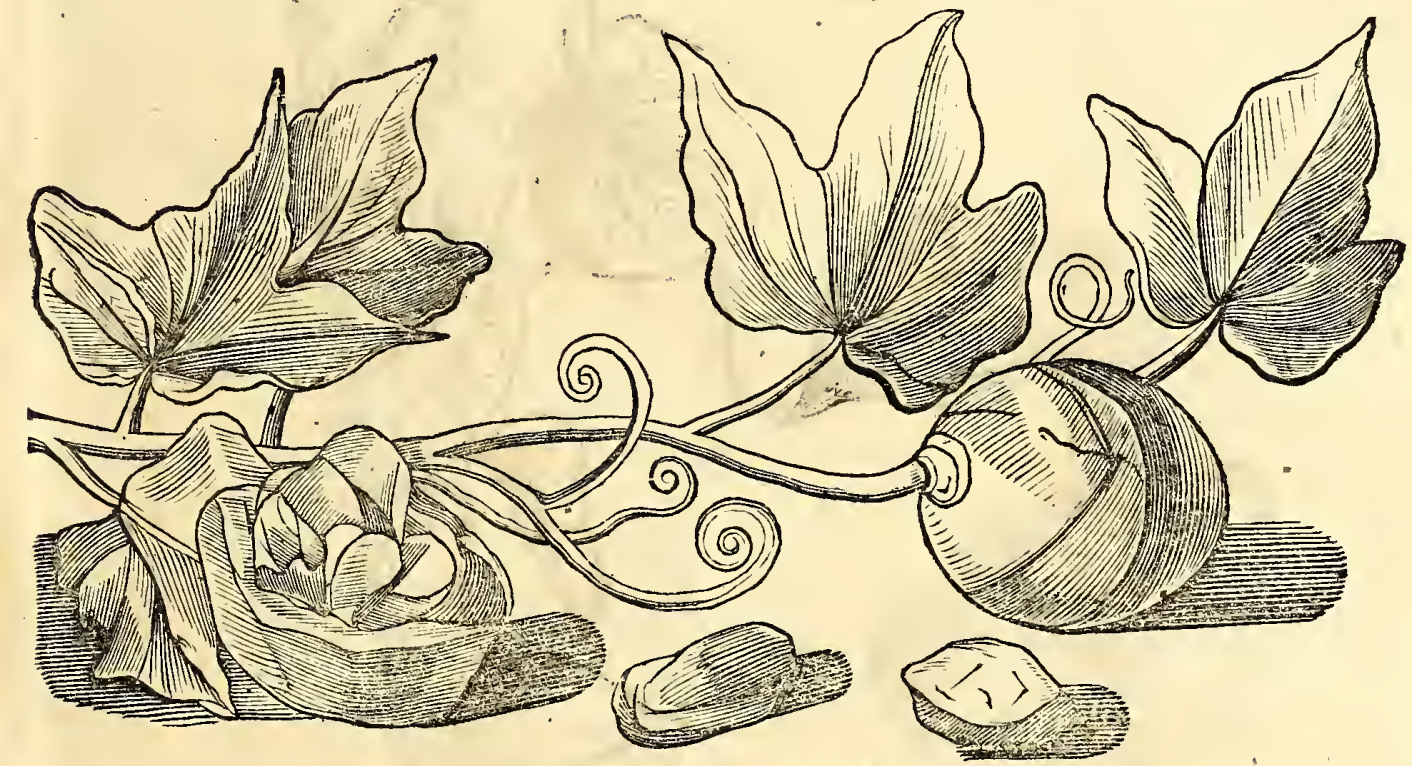

magnitudine, fuperius circulum infculptum quafi continens \& $\alpha$ in centro ejus tres lineas, una extremitate ad angulos obtulos fe contingentes. Fructus in medio per interfticia morejuglandis, in tres difpefcitur cavitates, continetque multa or dine" difpolita corpora fubrotunda, fatis crafla, qux tracto cortice intus alba apparent, continentque oleaginofum nucleum ex albo flavefcentem, pelliculx inclufum. Ex hoc nucleo oleum parant, quo in lucernis utuntur, clarifimum \&optimum, tarde enim confumitur : in cibo non poteft ufurpari, quia amarum eft, quemadmodum \& totus fructus. Præterea oleo hoc, utpote calido, contra dolores ex frigore natos utuntur. Integras familias Brafilianorum ex nocturno frigore dolentes, folo hujus olei affrictu, meminir eftitutas.

PLanta reperitur præftantifima, locis irriguis, maxime vero circa rivos \& aquas $f a-$ 1 lientes, quæab Indigenis Acariçóba, à Lufitanis Erva do Capitaon appellatur. Radix teres, geniculata, alba, fub terra ferpit, ad genicula multa tenuia filamenta agens, ibidemque ex albo purpureum, fucculentum, fiftulofum, teretem, in altum protrudens caulem, in cujus fummitatc unicum follum rotundum, læte viride inftar Nymphæx, \& leviter in ambitu more Vmbilici Veneris crenatum, protrudit. Eninus eam intuenti Scabiofe Alpini fimilis apparet. Ex centro infer tionis caulis in folium, tenues venæ ad circumferentiam fparguntur. Flores hincinde ex diverfis caulibus ex luteo albefcentes fert. Radix quix longa \& farmentofa quafi eft, contrita odoris eft radicis Petrofelini, 


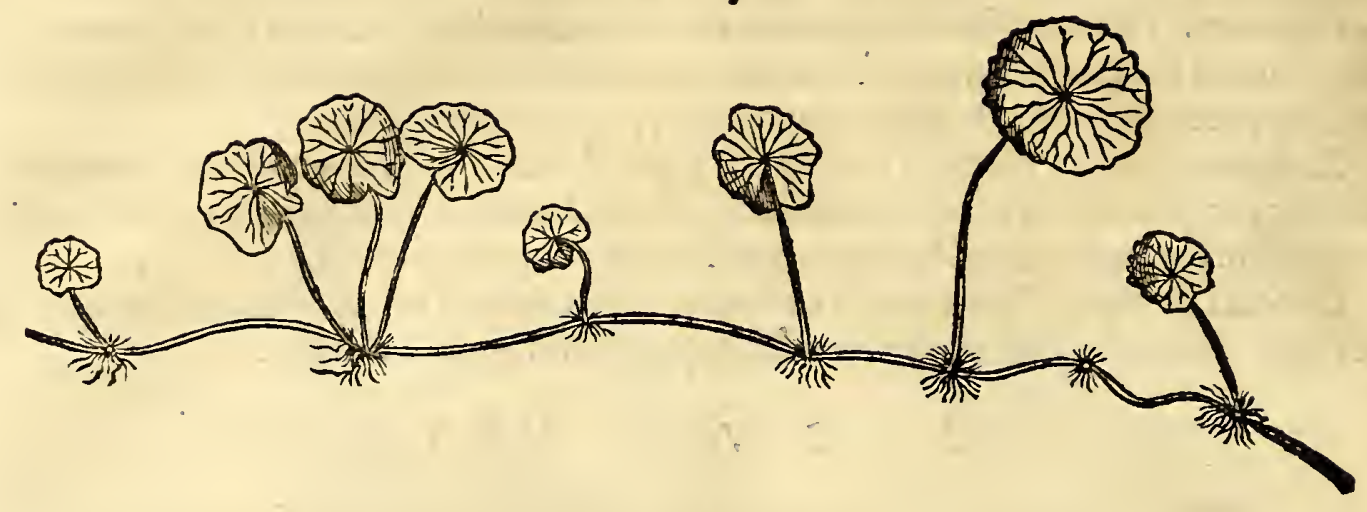

trofelini, guftatu perquam jucunda \& aromatica, tenuium \& calidarum eft partium, ac inter radices aperientes haud poftremum locum meretur. Hepatis \& renum obftuctiones \& intemperies àdeo feliciter emendat, ut nullum remedium illi prætulerim. Incolæ quoque recentem foliorum fuccum inter decantata habent antidota, vomitumque ficut noftrates foliis Afari, eo fufcitant.

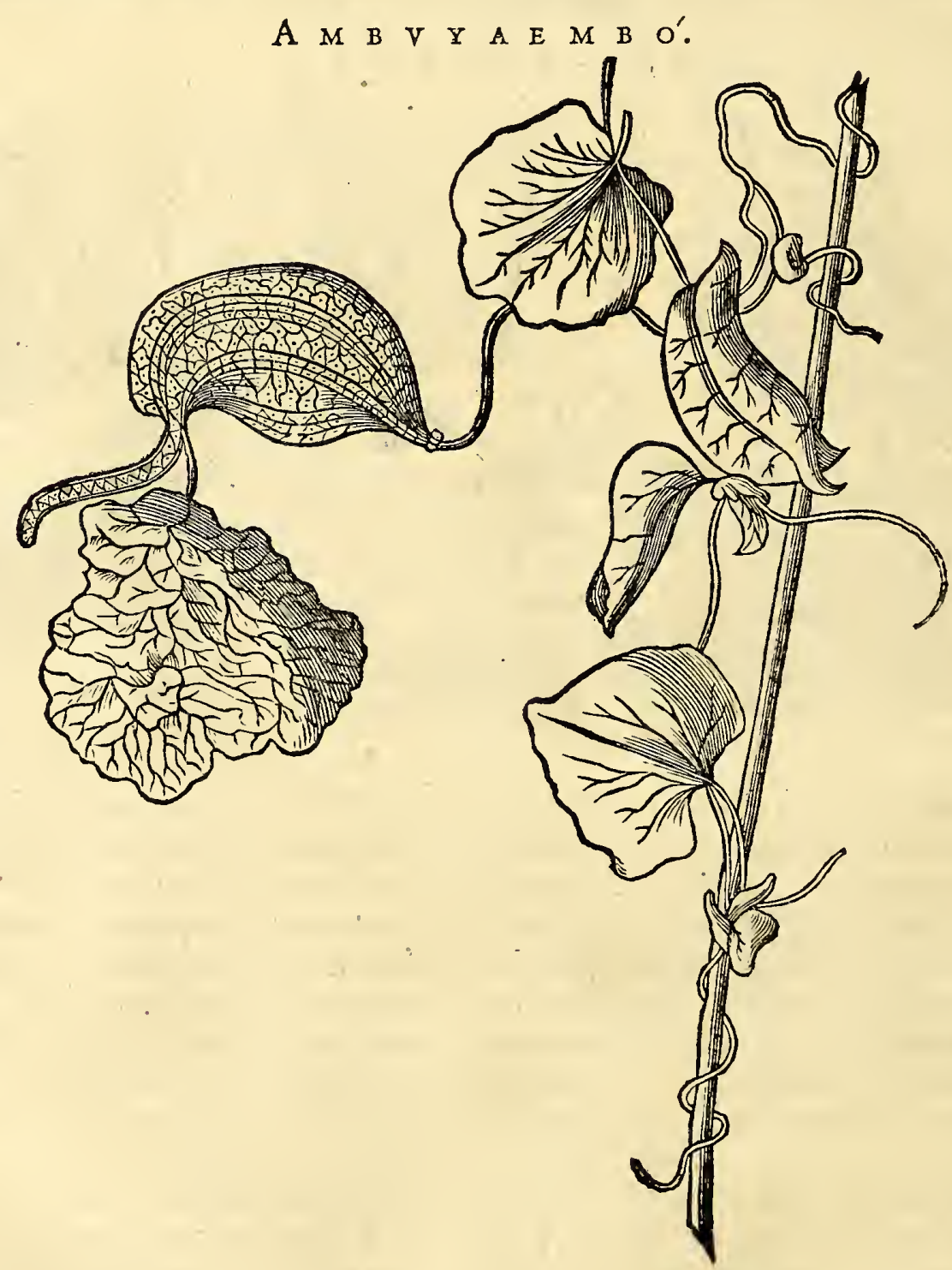

S I ulla farmentofa planta egregie topiarium opus in filvis reprefentet, haxc fanc ob $\checkmark$ inufitatam faciem oblectat. Ex tenui enim \& lento caulefolitaria \& lata folia pallide virentia prodeunt, ncrvo craffo \& venis tenuibus obliquis dotata, ex quibus proma. nant hinc inde flores inodori, ex albo flavefcentes, \& venis punctulifque purpureis intertexti, quorum figura \& ftructura humani ventriculi cum utroque proceflu amula. Cui defuper adnectitur tenuis membrana obrotunda, ipfo flore mul to major, innume- 
tis venulis rubris varie intertexta, haud male referens hepar humanum ventriculo in cumbens.

Integra herba in varios ufus medicos ufurpatur. Amari eft faporis, balnea exinde confortantia $\&$ difcutientia conficiuntur. Suffumigia ex iis parantur ficca, qux nudo corpore vel leviter cooperto Europæi æque ac Barbari excipiunt, membraque externa $\&$ vifcera interna à frigidis humoribus torpentia ad priftinum vigorem reftituunt. Imprimis autem decoctum ejus folum, vel cum radice Iuripéba mixtum, obftructiones hypochondriorum ex frigore natas tollit, fi aliquandiu affumantur.

C A A P E' B A.

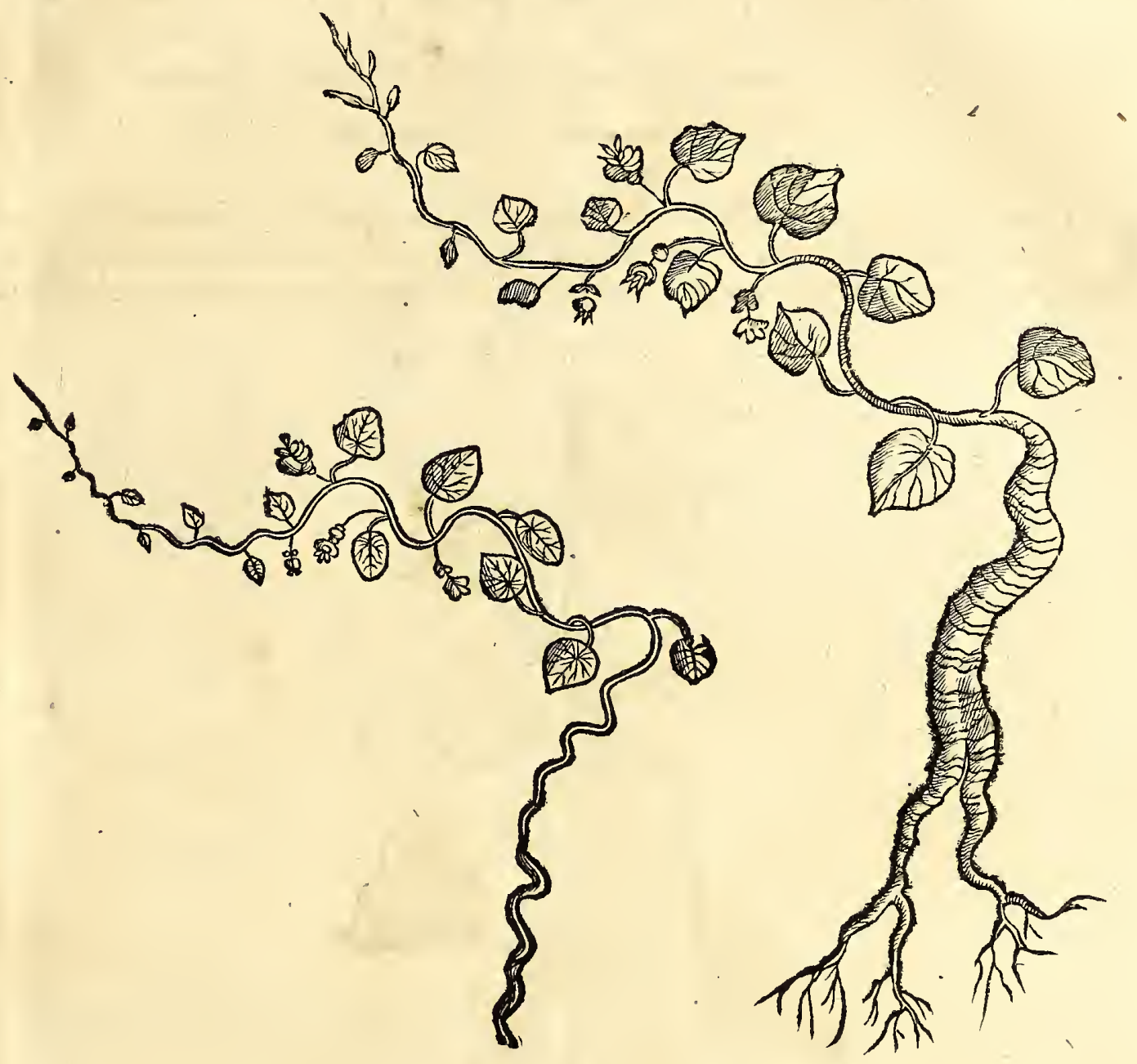

Lematiti non abfimilis, tenaciac prælongo farmento, nunc vicinas arbor es ornate confendit, nunchumi inftar Colubri repit hæc herba; ob fimilitudinem cipó de Cobras, ob eximias virtutes \& præftantiam Ervade noffa Senbora à plebe Lufitanica cognominatur. Tenuiffimo eft folio, rotundo, lateque femper virente, feorfim pofito in caule, nunc orbiculari, nunc cordis latioris figura, fuperius dilute virefcente, inferius albefcente. Ad horum foliorum pediculos rufefcentes, flores pallidi flavefcentes proveniunt. In fummitate pediculi granum provenit magnitudine parvi pifi, figurxe ovalis, interius viride, hinc rubrum. Radice tortuofa, è cineritio nigricante, \& digitalis circiter craffitiei, fi juvenis fit, fin vetuftior, brachium fere adxquat, nigraque exiftit. Vt ex duabus hic appofitis liquet. Obque hanc differentiam, aliqui duas ejus fpecies effe putarunt.

Subftantia intus eft folida, compacta \& $\&$ pingui, non multi, fed tamen fubamari, fa poris, partium calidarum $\&$ tenuium, qux manducando fe produnt.

Floret planta menfe Iulio, \& femen fert magnum coloris rofacei è capfulis (lupulo fimilibus) prominens.

Ego duplicem radicis fimul \& foliorum ufum fum expertus.

Radix in taleolas fecta, perque aliquot dies fub dio in liquido convenienti macerata, vim fuam illi communicat, necingrato adeo fapore aut cerevifiam, aut vinum, quo

diluitur, 
diluitur, imbuit ; quin potus ordinarii loco ægri illo utuntur, quod renum, ureterum \& veficx obftructionibus medeatur. Vfque adeo Calculi expellit materiam - (licet rariushic detur hoc malum) ut Magnates Lufitani aliud nullum medicamentum huic prætulerint. Cæterum hæc tantopere prædicata herba, non tantum propter virtures jam dictas, fed \& eximiam, qua contra venena valer, facultatem, ab omnibus expetitur. Quippe fuccus ex recentibus foliis expreflus, ferpentum fanat morfas : proinde Erva do Cobres Lufitanis dicta: radix autem cum foliis contufa, \& è vino haufta, veneni intus affumti vim retundit, penitufque expellit, fi imprimis ab exceflu frigiditatis nata fuerit.

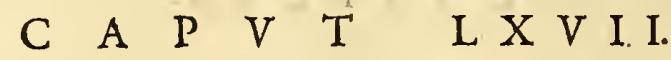

Curuá bel Curuba, Iacé aliis Iba-guaçufrie Anguria, Iurumú Ieruá, Taquera, \& Guareruc-obe ize (ucumer A foninus.

Vruável ut aliis placet, Curubá, herba farmentofa, fpecies eft Cucurbitæ, arbores \& tecta afcendens. Primo protrudit duo folia Cucumeris modo, fibi oppofita, è quorum medio poftea prodit caulis ftriatus, farmentofus, primo hirfu-

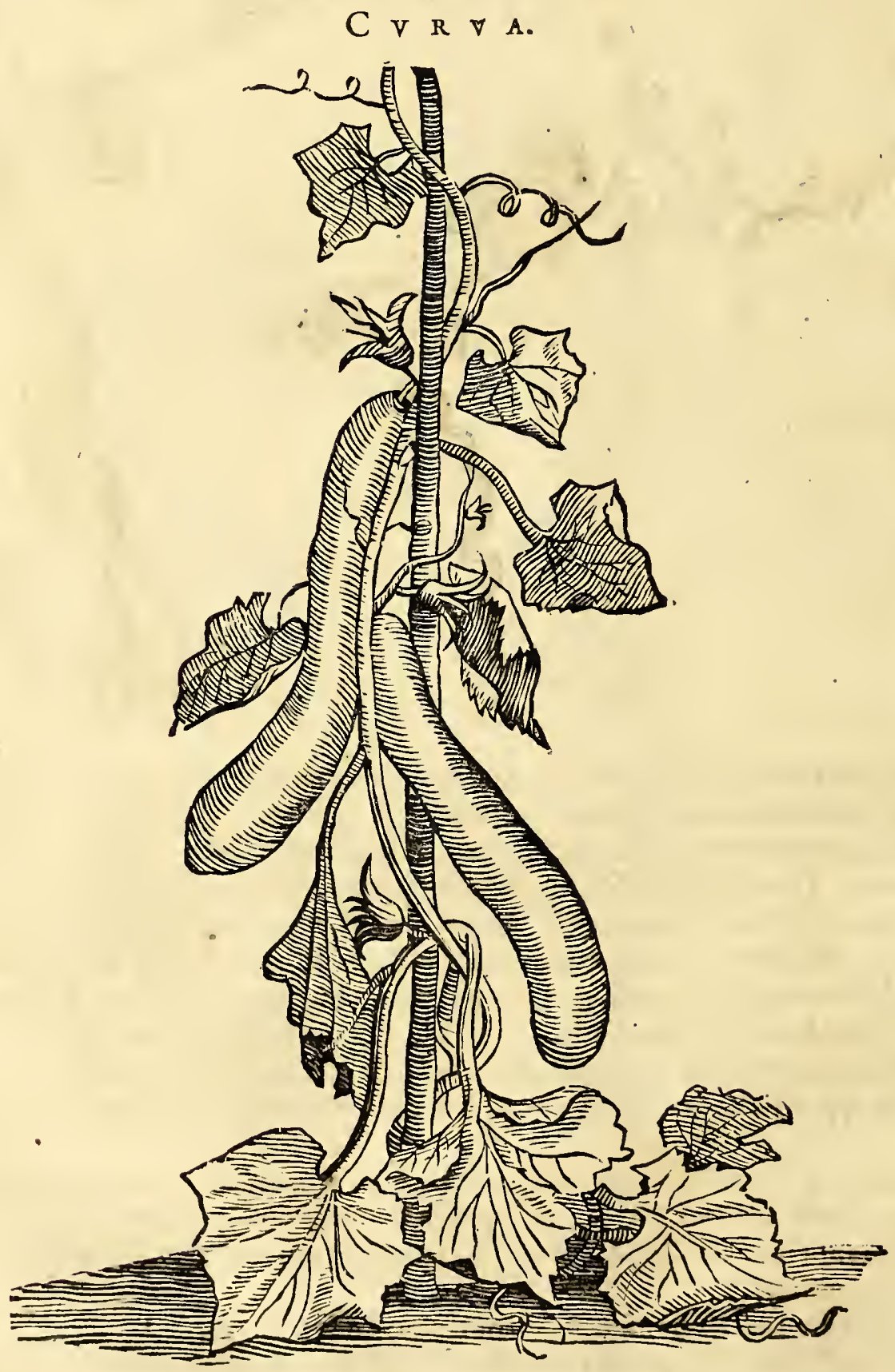
tus mox glaber, humi repes autfcanndens Cucurbitarum modo, ac capreolis fuisfe
annectens. 
HIST. NATVRAL. \& MEDIC. Lre. IV.

annectens. Folia hinc inde Cucumerum modo appofita habet, fingula fitis pediculis longis infiftentia, in lacinias divifa, inferius hirfuta, albicantia, fuperius viridia \& glabra:Prope pediculum cujuflibet folii clavicula prodit longa, contorta, arcte fe implicans vicinis arboribus aut pedamentis appofitis. Inter folia hinc inde in propriis pediculis nafcuntur florum rudimenta conicæ figuræx, unde prodeunt flores magni, crafil, dilute flavi, exterius ftriis virefcentibus diftincti. Fructus longus eft aliquando viginti digitös, cortice glabro ut Pepo, ex rübro purpureus. Caro feu pulpa ad flavedinem accedit, odoris dulci-acidi, inftar pyrorum agreftium, faporis ingrati , ideo vix comeditur nifi affata: femen continet copiofum, figura \& magnitudine Cucurbitæ feminis, fed quod exterius in fuperficie fua fufco eft punctulatum. Fructus ob fragrantem odorem imprimis expetiti, imprimis fi per menfes aliquot (ut ipfe frepe tentavi) ciftxinclufre $\&$ veftibus appofitz fint. Pulpa eft refrigerans $\&$ humectans, ac proinde Barbari febri: citantes ea utuntur.

\section{IAE E' five A'NGVRIA.}

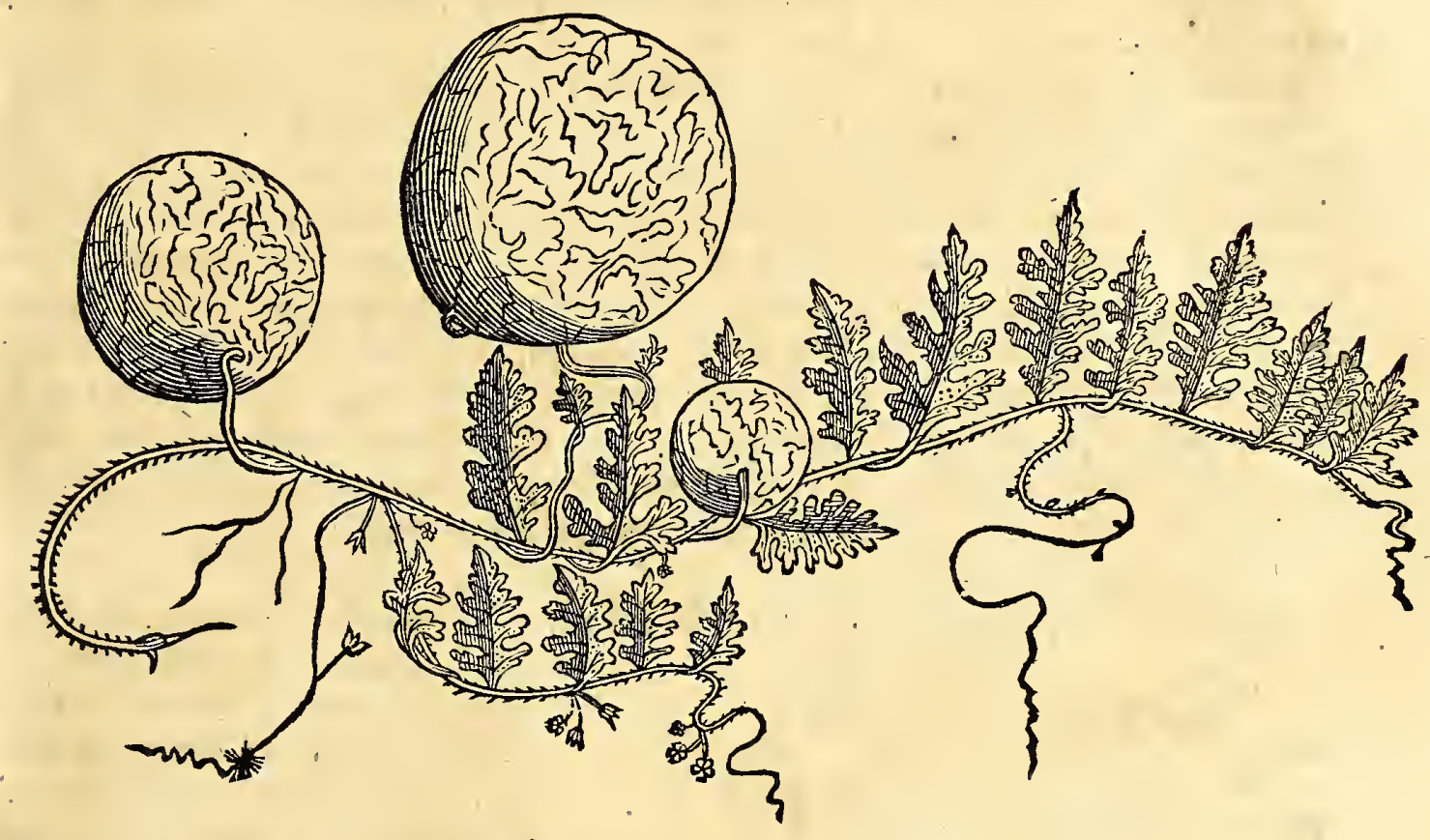

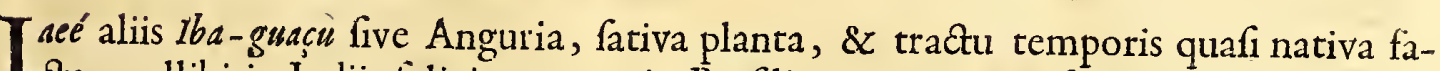
1 eta; nullibi in Indiis felicius quam in Brafilia provenit, Lufitanis Balançia, Belgis 1Bater-meloen five Melo aquaticus, non improprie dicta. Per omnes Europæ Americaque regiones calidiores notiflima. Repit caule farmentofo, hirfuto, multis capreolis feterræ affigente: foliis profundis laciniatis \& incifis, longis, erectis, friatis. Ex flore pentaphyllo, parvo, flavo, ingens fructus rotundus cum cortice viridi tenaci nafcitur. Carnem habet fucculentiffimam in mediojuxta femina rofacei, ceterum albi coloris, tanta aqux dulcis \& frigidæx copia refertam, ut inter edendum tanquam è poculo hauriri poflit. Adeoque æftum vifcerum compefcit, ut haud facile febricitantibus convenientius refrigerium fuaferim. Idem præfant faccharo condit $x$. Ingentis molis feliciffime toto anno, imprimis menfibus æeftivis próveniunt, terralicet fterili \& arenofa. Seminibus fcatent multis, Cucurbitarum magnitudine \& figura, diverfi coloris, quæ primum locum obtinent inter femina frigida majora. Vnde emulfiones, aliaque medicamina refrigerantia quotidic parantur; accedentibus cxteris feminibus frigidis, imprimis Melopeponum \& Cucumerum.

Adeo enim horti Incolarum Melopeponibus imprimis luxuriant, ob facilem culturam \& felicem proventuni, ut nimia abindantia vilcfcant; excipiuntur tamen qui carne funt viridi, folida, guftu \& olfacu fuavifirna, \& cæereris flavis Melonibus falubriori ; fed quia figura \& natura cum Europxis conveniunt, eorum defcriptioni non immoror, Iconemque fatis fuperque ab autoribis exhibitam, fupervacaneum duxi denuo hic addidifle. 
I $V$ R $V$ M $\mathrm{V}^{\prime}$.

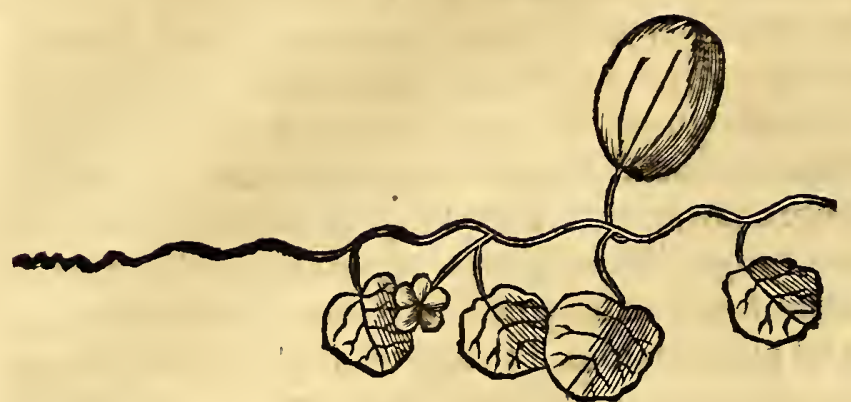

Equuntur aliquot plantx hu$S$ mi repentes, ex parte Peponibus, exparte autem Cucurbitis five Hifpanorum Calabaçis afcribend $x$; figura potius externa quam qualitatibusinternis, ab iis abludentes. Prima \& optima eft Vrumis, Lufitanis Bobora, Folia fert fere fimilia noftratibus Peponibus filveftribus rotundiformibus; \& florem quoque flavum pentaphyllum, magnum. Fructus eft magnus, orbicularis, ftriatus, compreffus, cortice tenuifimo, coloris cinnabrii cum plurimo albo mixti, interius autem croceus, femine multo, albo, noftratium fimillimo.

Boni faporis eft coctus feu etiam affatus fub cineribus. Incolæeo, tam ad fanitatem quam ad palatum, cum melle vefcuntur.

Secunda vocatur, Ieruá figura \& qualitatibus priori haud multum diffimilis.

Tertia , Taquéra dicta,, inter Cucurbitas lageniformes potifimum numerata. Foliis cæterarum Cucurbitarum fpeciebus fimilibus. Flore quoque albo, magno, pentaphyllo, obrotundo, in medio habente ftamina brevia lutefcentia. Semine pallido, compreffo, utraque extremitate quafi bicorni. Fructus eft cortice duriori, faporis dulcis, qui inter alimenta medicamentofa primis Incolis $\&$ ipfis Europxis refervatur, refrigerandi fimul \& nutriendi facultate pollens. Saccharo conditus inter bellaria apponitur; alias enim, licet diverfos apparandi modos admittat, minus gratus eft ftomacho. Cruda enim non folum minus fuavis, fed fi pravos offenderit humores in ventriculo, ibique moretur, corruptio concoction em anteverterefolet. Quod idem Gal. Diofcorid. \& alii veteres de Cucurbitarum natura teftati funt.

Givarerya-oba five Cvcrmer Afininus.

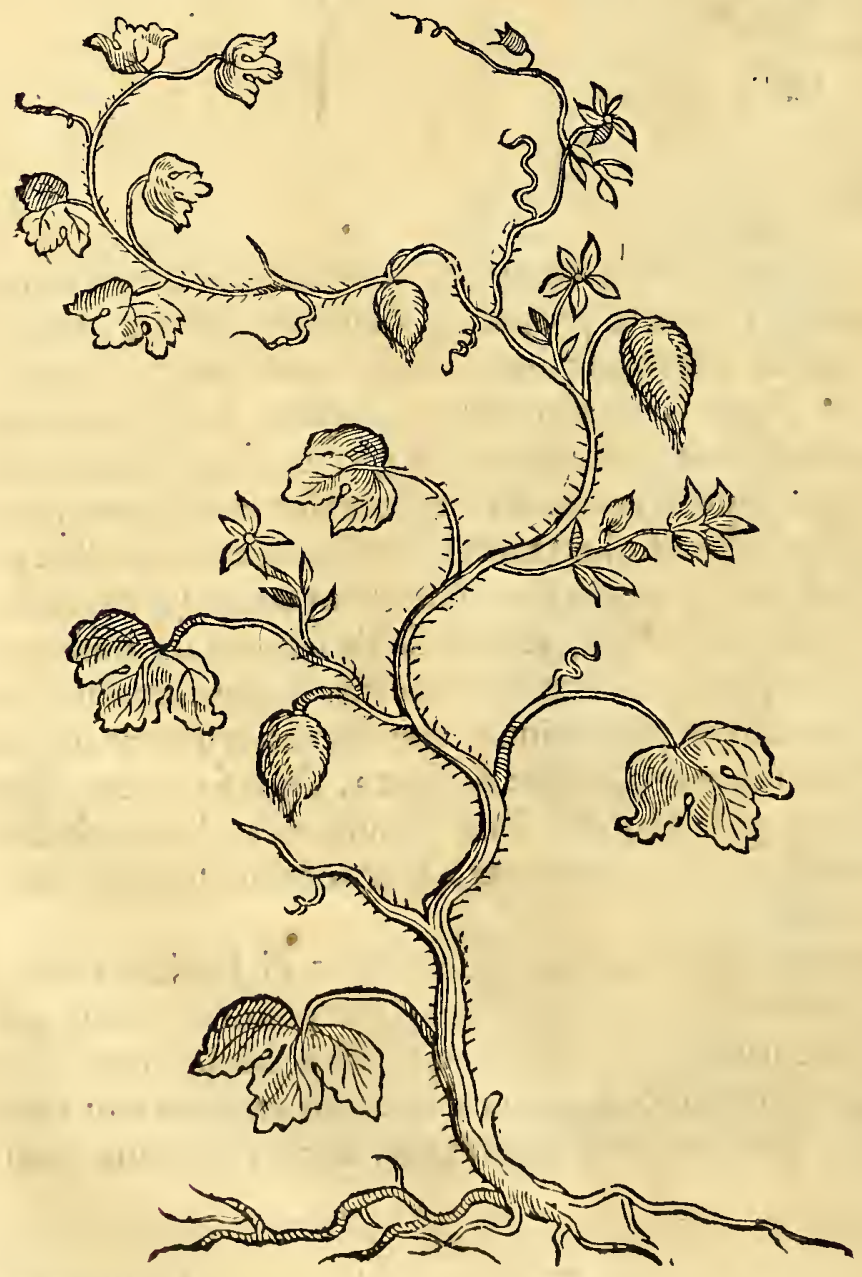

T omni terra arenofa fitienti luxuriat, \& farmentofo caule humi repit Cucumer filveftris. Folia habet in longis pediculis fingulatim pofita, quodlibet in tres lacinias fectum, ac in ambitu dentatum atque hirfutum. Flore, ut folet, flavo, capaci. Fructu magnitudinis ovi gallinacei, elliptic $x$ figur $x$, tuberculis per ambitum acutis, qui ubi maturuerit,pallefcit. Semina tranfverfum multa, in pulpa more Cucumerumfita.

Ita ut, fi quis hujus noftr $x$ Americanæ defcriptionem conferat cum Cucumeris Afinini Europæi , ex parte cum ea convenire, atque ex parte difcrepare, pro vario naturæ lufu comperiet.

Succus autem ejus, quod Elaterii nomen audit, fumme amarus fed ex fecundo calefacientium ordine habetur. Vfus ejus haud frequens apud advenas, multo minus apud indigenas, etiamfi efficacia illius non fit incognita: \& parium credo virium ac illud, de 
HIST. NATVRAI." \& MEDIC. LI B. IV.

quo veteres paffim teftati funt. Ego fane, licet contra hydropem valeat, diffuafor fui iftius medicamenti, idque ob tres potiffimum rationes. Primo, quod perpetua debet effe cautio in Indiis circa ufum medicamentorum tam efficaciter purgancium.

Secundo, quia expertus fum idem quod Mefue de ejus viribus olim teftatum reliquit, fcilicet præter alia quæ adfert nocumenta, vaforum quoque ofcula aperire, tormina excitare, inteftinorumque tunicas abradere, licet correctoriis munitum. Vnde Dyfenteria facile provocatur, quimorbus in Indiis plus quam alibi, medicx artis peritis merito extimefcendus.

Tertio, quia licet ferum fanguinis à remotioribus partibus in articulorum morbis extrahat, tamen minus conducat. Quod Arthritis ut \& Nephritis fere incognitx fint, faltem rarifime hic appareant.

\section{A P $\quad$ V $\quad T \quad$ L X V IIII.}

\section{Tres efrbufcule Marina, Coralloides, Spongiofa, é Baccifera.}

$I^{2}$

$\mathrm{N}$ quibufdam Brafilix locis juxta rupem illam Reçiffo vulgo dicaam, quando maris

receffibus littus minus immerfum eft, infinitæ lapideæ excrefcentiæ, nunc arbufcu- larum, nunc Brafficx Cyprinæe inftar, in ipfo fundo, cælo fereno confpiciuntur. Qux pro diverfitate velalgx, vel fungorum plantarumque maritimarum (quibus cryftalli

ARBVSCVIA CORALIOIDES

SPONGIOSA.
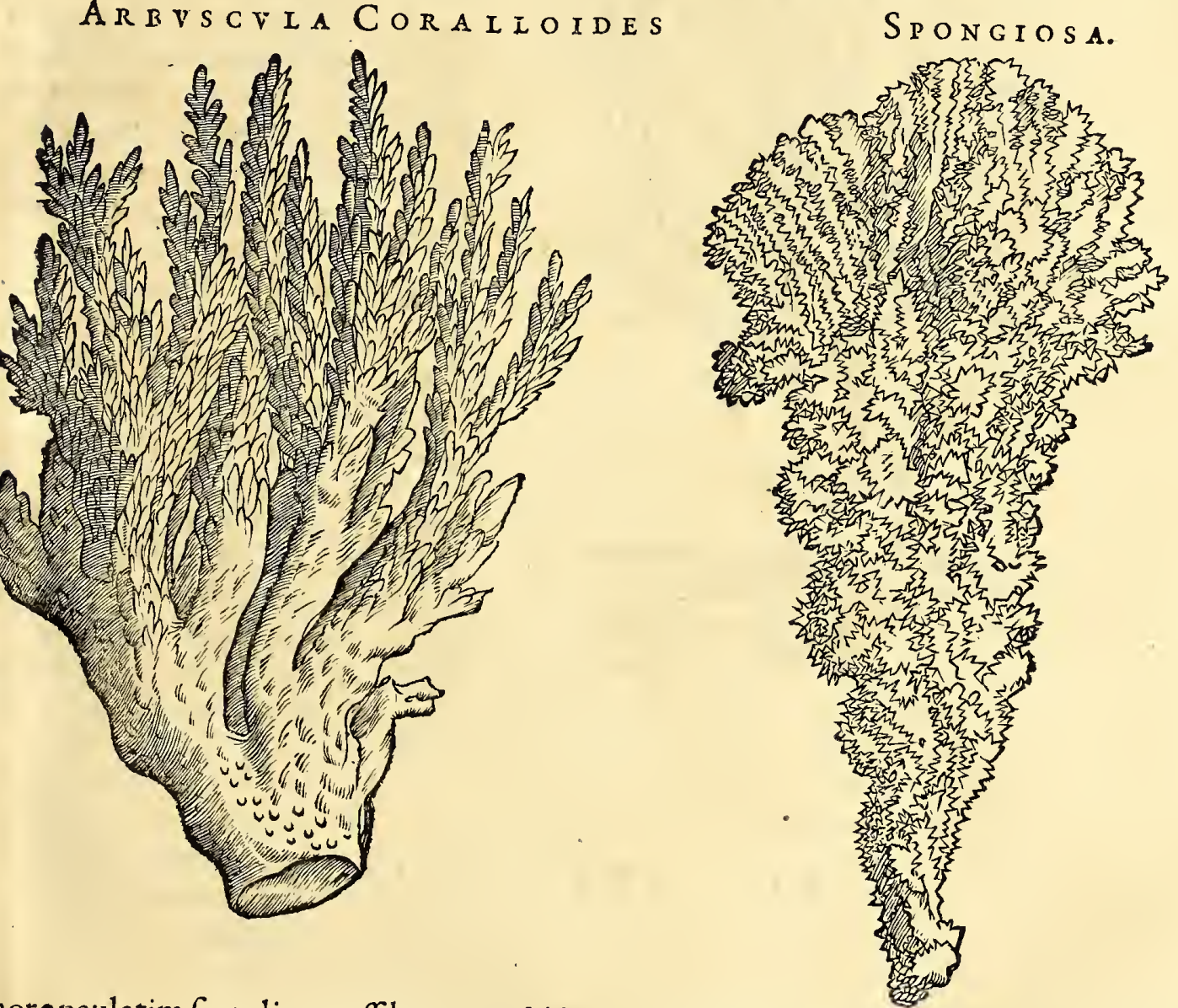

nore paulatim fingulis acceffibus aqua falfa vi Solis agglutinatur) vario $\&$ miro natur ufu crefcunt, atque è fundo erutx, mox duriflime, fi infolentur in littore ficco, nireique coloris fiunt. A magnatibus in Hifpania \& Belgio expetit $x$, ut $x$ des $\&$ fubteraneas cavernas illis exornent. Maris accolæ $\&$ pifcatores in ufum medicum potius $10 \mathrm{c}$ qualecunque coralli genus adhibent, $\&$ rafuram cjus contra fluxus ventris $\&$ ruentoftrates Europæos nondum in ufus applicatpote crudum Barbaris reliqui, atque apud toftrates Europæos nondum in ufus applicavi, nifi arte inftar coralli officinarum pra-
aratum.

Ifdem rupibus \& 2 vadis petrofis fupernafcuntur, quoque fpongiof $x$ arbufculx. Inter illas inufitatæ formæ prodit una cæereris facile elegantior, cujus Iconem hic exhibeo. 
Ad tactum quiden ejufdem cum aliis fpongiis mollitiei \& coloris, fed non tantæ flexibilitatis: erigitur enim inftar petrof $x$ arbufcul $x$ coralloides ad duorum circa pedum longitudinem, \&z duarum palmarum latitudinem, mediocri foliditate prædita,impri-
mis inferius circa plantæ pedicu-

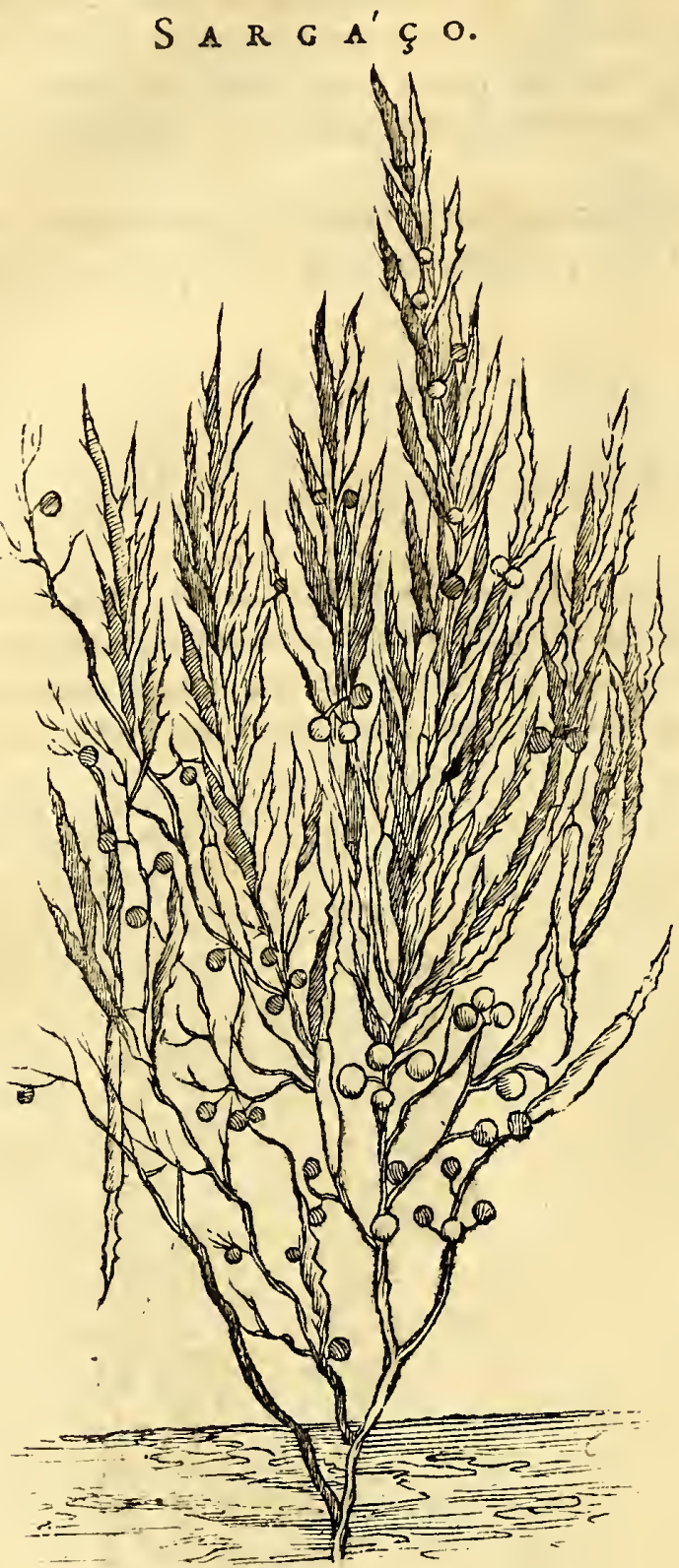
lum. Quia autem nullus ejus præterquam aliarum fpongiarum ufus innotuit, illius defcriptioni fuperfedeo, fed ob elegantiam tantum $\&$ raritatem, mantifix loco, eam lectoribus exhibeo.

T Erbailla Marina quæab Hifpanis Sargáço, à Noltratibus Stem-Krooft nomen accepit, Lenticula marina, licet improprie, nominatur. Eft enim non Alga, fed Arbufcula baccifera, palmum longa, tenuibus caulibus grifeis, \& perpetuis foliolis ferratis fature rubris in glomos convoluta. Qux circa Infulas Flandricas vulgo diatas, incerta quidem origine undiquaque fluitans, adeo magnam maris partem obfidet, ut folum, nonfalum diceres, $\&$ remiffiore vento moram navibus haud parvam faciat. Atque ideo ille tractus Oceani Lenticularis; de Hrooft- Zee à Belgis ex Indiis redeuntibus nomen accepit. Raram hanc plantam pubes nautica Lufitanorum, ut \& Batavo. rum, indifcreta quantitate macerant $\&$ coquunt cum liquore con venienti, eoque non fine felici fucceffu contra difficultates urinandi utuntur. Infipida eft, præter falfuginem ex aqua contractam. Nulla radix confpicitur, fed fola ruptur $x$ veltigia apparent.

FINIS LIBRI $\mathscr{V} A R T I$. 


\section{G VLIELMVS PIS O}

Clariffimo Viro,

\section{IOHANNI ANTONID AE}

\section{VANDER LIN DEN,}

Doct. \& Prof. Medic. Pract. ordin. in Acad. Lugd. Bat.

\section{Amico veteri \& folido.}

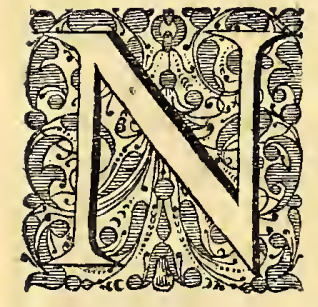

Aturæhæc non tam facra, quam admiranda quæ deinceps animus eft promere, priufquam adeas contemplatum, patere te in ipfolimine paulifper à vetere tuo $\&$ inde à communibus ftudiorum tirociniis conjunctiffimo amico fifti, atque tuo fub nomine paucis me ad lectorem præfari. Quod quidem eo confidentius urgeo, quia, invitis tot eruditis tuis curis facilem te femper atque promtum fuerim expertus, cuique nihil folet evenire gratius, quam veterem amicitiam novis ufque $\&$ ufque fuccendiculis foveri atque perpetuari.

Ita fcilicet fert Natura rerum, Clariffime Vir, ut dum in fpeciofa $\&$ admirabili illa rerum varietate qua Mundus confiftit, alii aliis dediti funt ftudiis $\&$ exercitamentis, certum tamen maneat didum illud, Suum cuique pulchrum. Dum enim tu crebris fcriptis exáfciatis teftaris, facundiam \& eruditionem illum non deferere cui potenter lecta eft res: fic ego mihi congratulor in parergo hoc,jucundiffimi veteris naturæ theatri in Orbe novo obfervata ad incudem denuo redigere. Decennium circiter eft quod exoticas illas lucubrationes meas protruderim potius quam ediderim in lucem, rogatu coactus fere, fi fas dicere, amicorum, \& inter eos Excellentiffimi P. M. viri, Ioannis de Laet, qui fuis fe meritis optimi cujufque memorix atque defiderio intulit velut cælo. Cui viro, cum difficile mihi erat quidquam negare, ad prali curam fe offerenti, non potui non, tum hoc, tum cxtera mea fcripta credere, avocatus ipfe in caftra ad Illuftriffimum Auriacx Principem. Vndefactum, ut omnis mihi adempta fuerit occafio, non dicam addendi qux neceffaria $\&$ generis erant difficilioris, adeoque otium $\&$ meditationem requirebant attentiorem; fed vel relegendi ea qux non nefciebam reftare emendanda in fchediafmatis meis frepe fubito nàtis \& è memoria limandis poliendifque. Pofteaquam ergo flagitare Typographus novam cœpit editionem, prorfus me ad eam curam appuli, \& quidquid fubcidere temporis curfitationibus \& werodofod (qux, ut ipfe olim egregie es expertus in hac urbe, totos requirit dies) potui, id

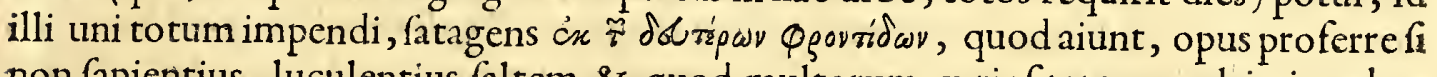
non fapientius, luculentius faltem \& quod multorum curiofitatem multis in rebus oblectaturum confido. Revocare itaque conftitui hoc libro ad examen, primo Venena quæ plantæ partim, partim animantia produnt, una cum eorum antidotis feu ipfis venenorum venenis. Deinde Infectorum aliquot cum naturam tum metamorphofin vere admirandam $\&$ in xternum celebrandx Creatoris potentix atque fapientix locupletiffimum teftem. Etfi vero fatis mihi bene fim confcius, non omne me punctum tuliffe in re tam difficilis quam abftrufx $\&$ vix perfequendx indaginis, ob denfam, qua involvitur, caliginem, \& polydxdalam mæandrorum, quibus indagari debet, varietatem atque perplexitatem: tamen videor fpondere Medicorum filiis poffe, non contemnendum ad fe emolumentum ex horum lectione redundatutum : prefertim fi animum dignabuntur advertere ad ea, qux \& ego præmonenda putavi, \& facile Tu, fi quifquam eruditorum, agnofees. Horum primum eft, ut eorum, "qux enarrabimus præcipua ; quantumvis primo intuitu vel nova vel etiam portentofa videbuntur, non modo ceu antiquiffima, fed $\&$ quam maxime Naturx, imo cjus autoris Dei legibus confentanea contemplentur. Homines quippe novi $\&$ in 
fcrutandis Natur $x$ receffibus parum exercitati, de facili fidem derogant his, qux, quod ante fibi inaudita funt, impoffibilia opinantur. Quod videtur haud aliunde ipfis evenire, quam quod pleraque fingularia Naturæ opera in fenfus quidem, tam infrunitorum quam brutorum magiftros atque duces, incurrant: univerfalis autem vis $\&$ incomparabilis ejus majeftas paucorum fe oculis \& menti ingerat; utpote eorum duntaxat, qui indefeflo labore $\&$ irrequieta meditatione nituntur Naturx librum nocturna verfare manu, verfare diurna. Iftos itaque exhortatos velim, ad melior em horum cognitionem adferre judicium rectum \& circumfpectum, quo fe non folum muniant contra nimium credulas Indorum fuperftitiones, \& plufquam aniles perfuafiones: fed vel imprimis contra propriorum fenfuum incantatrices fallacias. à quibus facile eft decipi eum, qui ex uno vel altero intuitu, guftu, olfactu pervenire fe poffe putat in notitiam corporum fublunarium eorumque facultátum : quafi fcilicet Natura rerum, veluti proftibulum in veftibulo fedeat, fuique copiam faciat quibullibet pretereuntium; non vero intims in receflu atque penetrali fe abfcondat, non fine magno labore, fine cafto amore, fine numinis xterni feu parentis faventia atque permiflu adeundam. Ifta ergo avia viarum quo $\&$ certius tutiufque devitent, monendi funt præter ea $\&$ illud, (quod nefcio qua aut temporum injuria, aut ingeniorum focordia, aut nimia fui fiducia abiit omnino in defuetudinem, nempe ut noftra hæc qualiacunque inventa ad prifcorum \& fidiffimorum, imprimis Hippocratis Naturæ \& Medicinæ fidiflimi interpretis, nulli non $\mathrm{Na}$ turx prudenti vere admiranda placita, conferant diligenter $\&$ trutinent exacte. Certum quippe, illum virúm, \& quotquot ejus veftigiis inhæefere preffius, àd illud veritatis ac utilitatis rerum notitix culmen pervafiffe, quo adire quemquam poffe negant, qui aliam fuerit ingreffus viam. Id certe haud invitus fatebitur, quifquis fe tuum imitatus exemplum, totum dabit in ruminationem eorum, quos ex libris ejus reliquos fecit, non dicam, invidiofa vetuftas, fed humanum in genus mire mifericors clementia divina. Neque propterea tamen eos nos quis putet, qui cenfeamus, ullum hominem, quantus quantus etiam fuerit, infallibilem, ulliufque dogmata pro indubitatæ veritatis norma perfectaque faciendi r egula effe habenda. Vt jam fibi parcere liceat iftis Neotericis paraphyficis, qui ipfum hoc de Medicis dogmaticis ad ravim ufque clamitant totiefque ingeminant, \& nullis non argumentis contendunt, fecum ipfi digladiantes. Qui quales fint ipfi, facile eft difcernere detracta jam obfoleta illa Veritatis \& Caritatis larva, qua fe fcioli ifti \& uni quæftui infervientes abfcondere folent apud imperitam $\&$ falli tam pronam quam promptam plebem. Cujus in omnem opinionem per quamlibet \& quantumvis abfurdam, modo fpeciofam jactantiam, mobili ingenio freti, non raro triumphum canunt ante victoriam. Quidenim, an non quotidie videre eft ingentibus promiffis turgidos illos, five V rofcopos impoftores, five fumum olentes ciniflones, magnis excidere aufis, imo excindere è terra viventium multos corum, quos morbi tædium, vitæ dulcedo, fpei fallacia, \& amicorum fre importuna commendatio pellexit in ipforum cafles? Qui tamen, quamvis manifefti fint famam novitate aucupari, ut animas $\&$ crumenas, præfertim opulentiorum negotientur, fi forte cafu in bonum eventum inciderint, vel jejunum aliquod in Macro vel Microcofmo inventum adepti funt, fe propterea audent invidiæ fubjectum crepare. Quafi vero hoc quod vivimus, fxculum, adeo focundum \& ferax effet magnorum ingeniorum $\&$ invidiam vere merentium: Cum per Deum atque hominum fidem perpetua potius commiferatione digni fint omnes hujus farinæ homunciones, qui in contemnendis quæ non intelligunt, imo ne adeunt quidem, funt fervidiores, quam felices in novitatum fuarum aut certitudine demonftranda aut utilitate edocenda. His, inquam, univerfa erudita antiquitas , imprimis nofter Hippocrates, nomen eft, prætereaque nihil. Quem quia pautcilegunt, pauciores intelligunt, idcirco eft, quod multi ad illum Solem crecutientes, nefcio cujus Syderis vel Lunæ lumen malignum fequi potius; \& quamvis Charybdes fe vitare profefli, in Novaturientium Scyllas ferri cum xgris fuis malınt, neque errores fateri prius, quam ubi in fe experimenta capientes; idem in precipitium fe dederint.

Sed hxc quid attinet apud te, Amicorum optime, aut prolixius narrare, aut queri cnixius? quem novimus, ifta non modo non ignorare, fed ne diffimulare quidem; quin omnibus in id unum animi intentis viribus incumbere, ut tandem aliquando Hippocratc nata, an fata dicam, Medicina \& fuo reddatur nitori \& omnium inferatur amori. Vnde fane Viri in Medica republica graviffimi; ut D. Tulpius, D. Vicquius, D. Wulle- 
nius, atque alii multi in arte exercitatiffimi, tibi pariter ac fibi gratulantur, quod incomparabile illud Afclepiadium lumen, hodienx lippitudini ufque adco moleftum, non cefles objicere toties, eoque non paucos aut parvos detegere errores, \& in certam medendi rationem praire. Ita interim denuo reperta \& fua laude digna attemperare prifeis fatagens, ut fperandim fit, populum deinceps Academicum fuccomagis falucari, erectioreque imbutum fpiritu, fore aliquando obfervantiflimum aurei illius apud Tacitum dicti, tam Medicorum filiis, quam Politicorum apprime neceflarii fitu. Intra deforme obfequium $\&$ abruptam contumaciam pergere, iter periculis $\&$ ambitione vacuum. Cujus fi noftri recte fenfum intelligant videbunt moneri fe non minus illiberale effe ingenuo, alterius fe ad opinionem, quam libidinem componere, \&c gregis inftar hunc illumve Caprumfequi ducem, eo præfertim in fudio, in quo nunquam aut finis eft inveftigandi aut pofteritati adempta facultas aliquid vel inventis addendi vel temere creditis demendi. - Sed \& illưd ifta monet gnome, ne nimio quis fudio declinandi vitia in contraria currat, nimiumque confifus vel fuis vel tot recentiorum titubantibus inventis tuto fe poffe putet infultare prifcx fapientix confultis : quin difat potiurs, depofita lafcivientis ingenioli intemperie, putidaque philautia, \& noftrifeculi \& veteris pariter bonis uti frui, medendique viam periculis quam maxime vacuam amplecti. Quo fane fi $\&$ illi, $\&$ nos cum illis, atque adeo animis viribufque $\&$ ftudiis fociatis afpirabimus, procul dubio cum populi falute (cujus nos præfidem artem profiteri gloriamur) agetur longe melius. Quam fibi mentem qui non opèet, è noftris puto effe neminem.

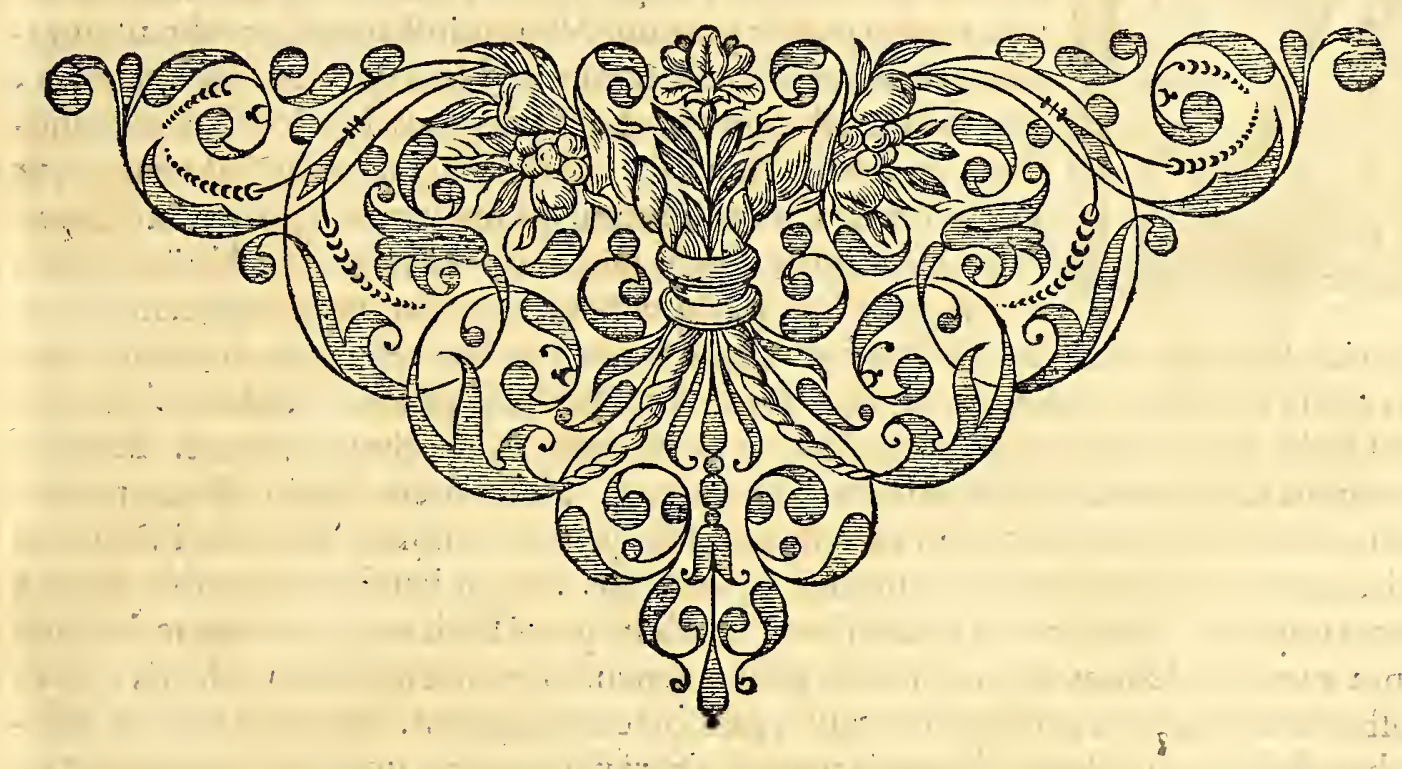




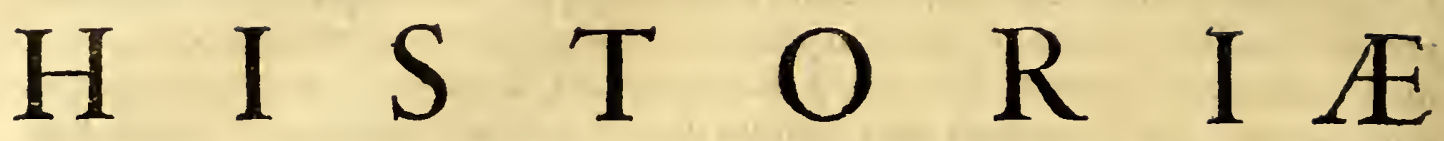 NATVRALIS \& MEDICE}

\section{$L I B E R$ QVINTVS.}

De Noxiis \& Venenofis Vegetabilibus ac. Senfitivis, atque eorum Antidotis. Quibus aliquot Metamorphofes Infectorum, tum \&

Vivx fectiones quorumdam Animalium inferuntur.

$$
\begin{array}{lllllll}
C & \text { A } & \text { P } & \text { V } & \text { T } & \text { I. }
\end{array}
$$

DeVenenis, corumque Antidotis.

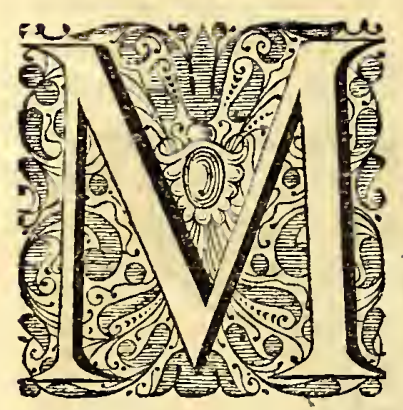

Agno licet Venenorum proventu, quibus paffim Animalia, Plantx, ac Mineralia turgeant, univerfus Orbis terrarum luxuriet: tamen præter primum Naturæinftitutum accidit, ut quiddam alicui fit malum \& noxium. Nam quod multis alimento, quibufdam eft veneno. Lepus marinus Mullo cibus eft innoxius, at lethalis eft nobis: ac viciffim, quoduni eft veneno, ut Elleborus \& Cicuta homini, quibufdam animalibus, ut Capræ Sturno \& Coturnici,eft alimento. Et vice verfa Aloë vulpem, nux vomica Feles, Mures \& aves enecat, nobis medicina eft falutaris. Sic radix altilis Mandiboca à venenato fucco nondum repurgata, homini lethalis, equis \& bobus cæeterifque animantibus nutrimentum præbet. Celebris quoque illa Herba Viva, Iuquirí dicta, Oves \& Capras pinguefacit, interimit homines. Bafilifco venénum eft naturale, \& aliis animantibus minime. Non autem Plinio affentiendum, qui in eum finem à Natura produci teftatur, ut iis pro libitu homo, incurabili vel animi vel corporis morbo detentus, utatur, ac violentis toxico haufto cruciatibus \& vitæ finem imponat. Nifi hoc forte attribuendum huic genti Barbarx, artibufque Magicis fupra modum deditx, \& in omnibus prope venenis dignofcendis mire folerti, quibus hoftes \& focios, lucri aut libidinis caufa, pari forte exftinguunt. Mancipia illa ex Africa huc deducta, ubi horrendi voti compotes freri nequeunt, cum dominorum vitæ infidiantur, durifimæ fervitutis jugi, inedix, acvariarum calamitatum impatientes, ad unicam illam libertatis viam, nemini non perviam, confugiunt. Veneno ubique obvio, fibimet ipfis atroces manus inferunt. Gratulantes fibi Naturx renuntiare, vindictamque, dominis plus jufto feveris, reponere. Sed hac, relicto abufu, fecus interpretanda funt: cum animali non folum rationali fed \& irrationali inftinctus fit datus,per quem creatis omnibus dextre utatur, bona \& vitæ utilia feligat, fugiatque nocitura. Quópectat quoque pulchrum illud patris eloquentix Roman $x$ de finibus. Placet Stoi" cis, quorum ratio mihi probatur, fimul atque natum fit animal, ipfum fibi conciliari \& " commendariad fe confervandum, \& ad fuum ftatum \& ad ea, qux confervantia funt ejus ftatus, diligenda. Ecquid enim, per Deum immortalem, ex quo non aliquam percipiat utilitatem? Ex ipfis Viperis adverfus Viperas conficit antidotum, quo venenis omnibus \& venenatis morbis refiftat. Ex Mandiboca radice, maximo fcatente veneno, optimum alimentum non folum, fed $\&$ antidotum concinnatur. A Scorpio, Scolopendra, Colubro, reliquifque Serpentibus ictus, ab iifdem petit remedium : à folo hepatè pifcis Vruti punctura ejus venenata curatur, cum cxteris remediis refragetur. Nec exiftimandum, benignam Naturam remedium denegafle, ubi morbum invexerit, fed omni veneno alexipharmacum addidiffe atque oppofuiffe. Bafilifci lethifero veneno, Mu- 
HIST. NATVRAL. \& MEDIC. LIB. V.

Atel $x$ virus, falivam hominisjejuni, Serpenti, Viperæ, Scorpio cæterifque venenatis adverfari conftat. Adeo placuit Natura nihil effe fine pari. 'Equidem vix dixeris, venena, an alexiteria plura fint pronata; $\&$ ubi fpecificum incognitum, magnæill $x$ compofitiones ejus vicem fupplent. Folia, flor es \& $z$ fructus herbarum Tangaracá \& Iuquiri, venena Brafilix facile prima, propriam fuam unaquæque radicem oppofitum habet Antidotum. Bufoni Cururí aliifque infectis venenatis, folius Nhambi, decantatæ illius panacex, fuccus fuffufus, vel cinis Tabaci affperfus, præfentem mortem inferunt. Plurima alia hujufmodi hic producuntur, Indigenis Barbaris, quam exercitatiflimis advenis, notiora. Illi enim Serpentum, Viperarum, Bufonum, \& Pifcium venenatorum pinguedinem, capita $\&$ jecinora ictibus venenatis paflim applicant ; imo integra infecta quæe vulnera inflixerunt, propriis vulneribus audacter $\&$ felici cum fucceffu imponunt. Quo quidem experimento comprobant veritatem jam à Galeno 1 s. de fimpl. Cap. de Dracone marino, \& lib. de theriac. c. I r. affertam, aliaque fimilia veterum ac neotericorum obfervationibus frrmatam: ineffe fcilicet multis venenatis propriam antidotum. Poffum ego teftari, aliquas venenatorum puncturas nulli cefliffe remedio, quam hepati ejufdem animalis, \& potiflimum ea parte applicaro, qua veficula fellis eft continuum, teftante id quoque experientiffimo Rondeletio; aliquas autem pro remedio admififfe tantum carnem ejufdem animalis impofitam. De quo exactius in particulari venenatorum enarratione. Hinc manifefte apparet, partes diverfas animalium non tantum diverfo ex primis qualitatibus proveniente temperamento : fed \& peculiari qualitatum occultarum, feu ut aliqui loqui malunt, virtutum fpecificarum harmonia invicem adverfari: \& aliquando noxam à veneno inferendam vel illatam tolli, quia elicitur vel extrahitur proprer fimilitudinem fubftantix, quam pars exterius applicita habet cum veneno impreflo ; aliquando vero, quia extinguitur, \& $\&$, ut ita dicam, mortificatur ptopter contrarietatem \& antipathiam, qux parti impofitx eft cum venenø inflicto.

Hactenus devenenatis ictibus eorumque remediis topicis, quorum fit mentio apud Authores profanos non folum, fed quod facra pagina quoque in Hiftoria Tobix cap. 6. 8. \& i 1. confirmat, ufum fcilicet \& abufum Iecorum \& Fellium antiquifimum fimul \& veriffimum effe. Nunc alius nodus, qui quidem altior is videtur indaginís, diffolvendus reftat, fcilicet de Fellibus \& Iecinoribus quorundam animalium intus affumtis, quod duo illa vicina vifcera, fialterutrum eorum propinetur, maxime contrarios edant effectus. Sicut enim venenatiflimi ferpentis Hæmorr hois ictui Gobii pifcis jecur cum Allio fumtum; Afpidum vulneri, Iecur Apri exhibitum; ipfus denique canis rabidi hepar toftum \& in cibis affumtum; Viperæmorfui, illius caro medeatur, teftante id tota fere erudita antiquitate; Ita Fel Viperinum apud omncs ftatuitur venenum tam præfens, ut vix quifquam ab ejus aflumtione evadat nifi per propriam Viperæ carnem: Fel Leopardi intra fex horas interficiens, nifi per coagulum Hirci filveftris fubveniatur. Fel Leuncæ cito quoque occidens: Fel pifcis Canis, unius grani quantitate deleterium eft. Sic ego, quæ quafi magica vel fuperftitiofa mihi primo intuitu apparebant, cum ftupore vidi exercitatifimos Indos medicaftros, cor umque imitator es, ex propinato unius animalis Felle calamitates \& mortes: ex alterius vero animalis Hepatis exhibitione falurem \& vitam promifffe \& præftitiffe;ficque alterum veneni,alterum Alexipharmacivices fubiiffe. Ratio hujus rei fatis obfcura, quxque me fepe torfit; nec hactenus inveni quod mihi plene fatisfecerit. Lis quidem hæret inter author es, an venena animalium, quorum funt venena, fint nutrimentum, an excrementum. Si primum, haud facile eft dicere cur una pars animalis venenati magis fit venenata quam altera, cum nutrimentum ad omnes partes appellere debeat ; nifi quod in aliis partibus permifceatur aut fanguini aut pituitæ aut ferofis humoribus, quibus vis illius infringitur ; in folliculo vero fellis à bilis acrimonia exacuatur. Si pofterius, facilius poteft dari ratio; quod nimirum venenum illud excrementitium, à maffa fanguinea fegregatum, ad folliculum fellis amandetur. Mentem tamen meam libere aperiam, ut faltem aliis calcar addatur ingenium quoque fuum convocandi. Neque enim facile eft vel fagaciffimo Philofopho tot rerum idiofyncrafias dignofcere, imprimis in novitatibus his à receptr doctrina fundamentis alieniffimis. Cum itaque Fel inter omnia quæ funt in corpore, partium fit maxime acutarum $\&$ tenuium, vimque poffideat folvendi, penetrandi, imo $\&$ erodendi , venenum certe animalis hifce adjutum qualitatibus mul- 
to facilius fefe exferere, \& fanguini reliquifque partibus communicare poteft, quam fi in alia aliqua parte vel humore confifteret hifce qualitatibus deftitutis. Quodvero ratione manifeftarum qualitatum additarum, virtutes rerum fpecificx, vel intendantur vel remittantur, probari poffet multis argumentis. Hepar autem, quandoquidem aliquam habeat cum Felle affinitatem, utpote vifcus Fellis vel generationi vel feparationi dicatum, atque hac ratione aliquo modo fit fimile: diffimile tamen quatenus habet vim fpecificam venenatx Fellis qualitati adverfam: ratione itaque fimilitudinis, venenum petit, cumque eo fe involvit; ratione vero qualitatis fpecificr Felli talis animaiis contrarix, ipfum vel expellit, vel extinguit.

Licet otii mei non fit recentiorum \& veteranorum Anatomicorum componere lites circa officia Hepatum \& Fellium vivorum animalium; enarratx tamen utriufque operationes diver $\mathfrak{x}$, favebunt potius eorum opinioni, quinobiliorem fanguinis portionem à felleo \& fxculento fegregandi officiumjecinori concefferint, quam iis, quibus abfurda Helmontii fententia arridet, ipfum fcilicet Fel balfamum jecoris \& fanguinis clamitantes. Quippe ficut in hepate \& fanguine alexipharmaca videtur latere qualitas ad toxica quxvis fuganda \& obtundenda idonea: Ita è contra Fella quorundam animalium adeo videntur degenerare, ut haud facile quis impune ea affumferit: mitto quod aliquorum venenatorum Fella, qualitate fua deleteria primatum teneant, five incaute, five per dolum ea exhibita fuerint. Etenimut nihil vulgatius apud Plinium aliofque veteres Practicos, quam Tauri, Capri, Vituli, Apri, tum \& quarundam avium \& pifcium Fella vel fola, vel aliis mixta, contra alopecias, oculorum \& aurium affectus, aliaque mala extus applicari, quatenus vi erofiva \& abfterforia admodum funt proficua: Ita quoque inter venena qualiaçunque $a b$ animalibus defumta \&z intus aftumta, nullum præfentius atque efficacius quam ipfum eorum $\mathrm{Fel}$ agnofcunt xque Barbari noftri Americani, ac abftrufioris olim eruditionis Mauritani; Arabes \& Græci. Cujus ufus \& abufus tantum abeftut exoleverit, ut è contra tanquam hibernus flatus extremos Mundi ambitus pervaferit, atque etiam nunc in Indorum animis, proh dolor, vires acquirat eundo.

Quamvis mihi occafione multoties defiderata infinita alia nondum explorare licuerit, ea tamen qux affequi potui, pofteris ulterius indaganda relinquo. Nec enim facile eft veneni fpeciem cito diftinguere; neque etiamfi cognofcatur, protinusillius proprium al exipharmacum fuccurrit. Accedit, quod aliqua reperiantur, quxin Europa venenata, hic vefca, vel faltem minus noxia fint, "\&vice verfa; quippe ran $\&$ pifcí culi hic dantur præter opinionem venenati : E contrario formicæ illæx grandiores, tum carnes aliquot ferpentum, lacertorum, bufonum, vermium \& glirium fylveftrium, primis incolis inter delicias habentur. Idem Plinius de Africa confirmat lib. v I. cap. 29. Celfus lib. v. cap.36. Scaliger Exercit. 18 9. fect. 4. In India atque Æthiopia non folum innoxios ferpentes multos, fed etiam efculentos dari, ita ut Ophiophagi dici poffint. Præcxteris autem in Brafilia, centipedes Carafitú \& Caramouritú virides \& nigri, tofti \& evifcerati; tum imprimis vermes illi Iarumái \& Caramatorí, pingues \& albicantes, inque medullofis filveftrium Palmarum truncis viventes, in pretio illis funt. Plinius lib. xvir. cap. 24. Ælianus lib.xiv. de Animalib. cap. I3. narrant, vermes quoque in ufu multis Indis effe.

Innumera alia portentofa à Tapuyeris fando accepi , qux, quod eorum aliqua fubleft $x$ fidei videbantur, filentio prætereo ; tantifper donec ulteriore inveftigatione atque experimento eorum veritas magis illucefcat. Multa equidem inter hæc notatu digniffima , à paucis tamen, quod fciam, annotata, adeoque neglecta, ut rara veftigia horum ac fimilium natur $x$ mirabilium exftent, undelucubrationes phyficas quis illuftrare poffit. Quamobrem multa partim propria experientia, partim pretio \& precibus à Barbaris extorquere necefle fuit; qui ficut tenebriones funt in porrigendis venenis \& pertinacifimi in revelandis ejufmodi fecretis; ita officiofi in exhibendis antidotis; dictoque citius ubi de natura veneni conftiterit, in filvis efficaciffimas herbas colligunt, quas contufas inftar potionis regris fubminiftrant, animafque pene exftinctas fufcitant:

At vero, his remediorum generibus non contenti miferiac fuperftitiofi mortales, futiliailla acillicita, ut fafcinationes, incantamenta, philtra ac fortilegia amplectuntur. Quod tamen ex parte condonandum huic genti profan $x$, utpote nullis literis vel Dei cultu imbutis, fed Stygiis tantum atque infernalibus auguriis, ulțra quam credi potelt, 
poteft, deditx. Illud mirum, reperiri etiam inter Chriftianos, quos infana hæc \& ridicula credulitas involvat. Pudet profecto, quam indigne homines cxterum corda. tos, mancipiorum \& pecorum fuorum externos \& internos affectus, nefcio quibus præAtigiis à fe curatos gloriari , meamque incredulitatem haud parum accufantes, audiverim. Quum tamen qux primum technis impoftorum, veneficiis ac magicis incantamentis obvelata erant, longo poft tempore ingenii aciem intendentibus, detecta ftolidam opinionem exemerunt. Nemo equidem tam excors, quin fateatur, plurimos preter expectationem Medici, citra artem, abfque manifefta caufa fanitati reftitui vel beneficio naturx folo, accedente imaginationis vi; quin imo vecordia potius effet, omnia manifeftis qualitatibus afcribere \& occultas illas proprietates tollere. Sed hæc nihil ad præftigia aut patrocinium impoftorum refpiciunt. Verba $\&$ characteres funt Medicinæ dæmonum, fyrupi \& apozemata hominum, inquit Paracelfus. Ex Aǵgyrtis $\&$ circumforaneis qui plufculum fapiunt, norunt quo tempore \& quibus morbis fua amuleta inftituant. Si fucceffu res careat, æger incufatur. In minimo enim qui peccat, omnium fit reus. In myfteriis magicis, qui cadit fyllaba, cadit caufa. Plebecula maxime dedita ejufmodi nugis, plus fidei $\&$ fpei iis concipit, gaudens falli fpecie recti. Orationes cum certis cæremoniis dicendas fufcipit, \& jam vix demurmuratis verbis vi fortifimx imaginationis, aliquam convalefcentiam fentire fe clamitat. Quod ipfum queque Galenus his verbis teftatur; plures fanat, cui plures fidunt. Vnde merito credulos Agrippa ad facra magix cæremonialis admittit. Sed longius provectus, dum me tantæ credulitatis piget tædetque:revoco me, $\&$ ad venenatorum enarrationem redeo. Quorum occultr qualitati abditx, quoque medicamentorum proprietate (qux per experientiam fuerit revelaca) ficcurrendum.

Inter venenata Brafilixanimantia, Serpentes primum locum occupant, è quorum numero circirer viginti hactenus innotuerunt, ut funt, Boiguaçú, five Iibóya, Arabó, Boiobi, Boicaiba, Guon, Çacabóia, Boiçininga a, Boitiapó, Boiçupecánga, Boipeéba, Gurucucú, Caninána, çur ucuting a, Guinpiiaguara, Ibyara, Iaşapecóáia, Ibibobócá, Iararáca, MAnima, Tareibóya, ơ Amorepinima, 乌̧ucuriiú, Ibir acoá, quorum pofteriores quatuor funt Angues aquatici. Hos omnes ferpentes generali nomine Boia vel Mboia appellant, quibus ex fuo arbitrio, \& pro Serpentum diverfitate', cognomen \& agnomen imponunt. In quo quum fibi non conftent, fed nimium varient, fit ut adven $x$ que ac ipfi indigen $x$ fluctuent. Proinde benevolus lector facile veniam conceder, fi in his exoticis rite diftinguendis, non omnibus fatisfiat. difficillimum enim eft ex æquo vel affirmare veritatem, vel falfimoniurn refellere, quia perpetuus errorum parens eft vocabuli aut rei alicujus vicinitas $\&$ fimilitudo. Frequentiores, ædes \& filvas perreptantes, in hoc habitato Parnambuci tracu attingo; reliquorum minus cognitorum naturam cogor præterire. Horum Serpentum Americanorum aliqui Europxis minus funt noxii,utcunque tamen majores $\&$ vegetiores iis exiftunt; quafi harum regionum calor externus nativum in hifce frigidis animantibus intendat. Tantumque abeft ut his vel aliis venenatis tarditas poffit attribui à Cardano, ut noverim Angues tantæceleritatis, ut fagittæ fimiles viderentur. Præter Galeni aliorumque teftimonia, multa funt argumenta ab ipfa experientia defumta, qux evincunt, temperiem nactam effe frigidam, omnem Lacertorum \&Serpentum cohortem, contra Avicennæ opinionem: licet quorundam venenum ardorem fummum inferat. Nam non folum contactus ipfe frigidus vel maxima $x$ ftate, hoc arguit, fed eorum plerique ad menfes aliquot vivi abfque cibo refervati,hoc confirmant; cum tamen fi quid efculenti illis præbetur, comederent. Idem teftatur Scaliger commentariis in Hiftoriis Animalium, 1. 1 I. \&c. Cxterum qui plura volet de Serpentibus, confulat Æliani \& imprimis Gefneri Hiftoriam Animalium. In illis enim quidquid Veteres \& Neoterici de eorum natura fcripferunt, congeftum reperiet.

Serpentum venenum in capite potiflimum latere, facile liquet, quod Incolis ophiophagis bene fiat ex efu corum, capite amputato : contrarium vero illis contingere, capitis quorundam vifcerumve minima parte deguftata. Capita enim inter externa remedia adverfis ferpentuim morfus refervarifolent, ut mox demonftrabitur. quafi nullum adeo atrox venenum à Deo creatum, quin liberalem in medicina opem fuppeditet, ipfaçue reptilia majeftatem Creator is humilitate fua perpetuo exaggerent. Porro hoc qualecunque venenum, nunc circa dentes infaliva, nunc in ipfis dentibus latitare, vel exinde patere putem, quod dentes mortuorum ferpentum, hominum \& canum carnes inflamment.

Degunt 
Degunt paffim in cavernis $\&$ arborum truncis, fuftentant fe gliribus, bufonibus, ranis, aviumque ovis. Teftibus carent, eorumqueloco meatus duos habent ficut pifces, qui femine implentur tempore coitus, lacteumque emittunt humorem. Coëunt complexu, adeo fibi circumvoluti, ut unus exiftimari biceps poffit. Ita ut in his aliifque naturalibus functionibus vix quidquam differre ab iis qux Autores in Afia prodiderunt, deprehenderim. Ventriculus laxiori inteftino fimillimus uno ductu ad caudam producitur. Renes \& vreteres quidem apparent, fed non vefica; quafi iis hoc cum avibus aliifque animalibus oviparis pitiflando bibentibus commune effet, lotiumque qualecunque in alvum cum ftercore deponerent. In uteri cornibus infinita pene ovorum funt rudimenta, \& globulorum modo inter fe quafi agglutinata. Ita ut ovipari plerique Serpentes dici poffint, exceptis paucis, præfertim Viperis illis Iararáca diçtis, qux inter vivipara recenfentur. Non tamen ad opinionem quorundam fcriptorum, dicentium, earum partus quafi mor $x$ impatientes, vi erumpere, matremque enecare, quum utriufque fexus Viperæ in vivario pofitæ, more ceterorum animalium pepererint.

An vero bibituræ \& còituræ, venenum deponant, lis hæret inter Autores, \& à me hactenus incompertum fateor. Ab Incolis paffim obfervatur, Angues \& Viperas infito timore à Cancris abhorrere; tum quoque Porcos ab iis læfos, inftinctu naturali fe Cancrorum efu curare.

Hxc de Serpentum, Anguium, Viperarum natura in genere dicta fufficiant, nunc generales quoque cautiones fauciatis præfcribendx. Primo quifque vulneratus ab aqua libi caveat, licet Oppianus \& alii de Cervis Libyæ vulneratis à Serpente, inftinetu Naturæ fluviis fe immergere teftentur, ut curentur. 'Hic autem contrarium datur experiri. Qui diverfitatem venenorum $\&$ antidotorum fupra enarratorum bene confideraverit, caufam facile percipiet, cum diverfi $\&$ inufitati, imo contrarii fubinde curandi modi inde exfurgant.

Secundo fataget quifque, ut vulnus, à perpetuo illo humani generis inimico inflictum, ftatim dilatetur, fi fanguis non abunde profluat. Mox cauteriis tum potentialibus tum actualibus pars læfa muniatur vel exftirpetur.

Tertio decantata illa potio Carimâex Mandiboca facta, largiter potetur. Hxc enim fitim, qux comitari folet, non folum reftinguit, fed peculiari vi antidotali corroborat, fanguinifque ardor em mitigat.

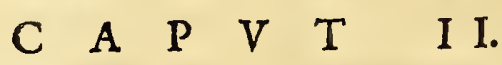 \\ Boiçinininga, đo Boiçuaiba.}

$\mathrm{P}^{\mathrm{n}}$ Rimo,domina illa atrocium Serpentum occurit Boiçinininga, quam Cafcavela \& Tangcdor Hifpani, noftrates Hatel-flang/ Mexicani Hoacoatl, nominant, propterea quod fonitum inftar tintinnabuli cauda edat.In triviisjuxta ac deviis locis cernitur, tam celeriter proreptans ut volare videatur, idque velocius per loca faxofa, quam ter-

\section{BOIद̧IN IN IN GA.}

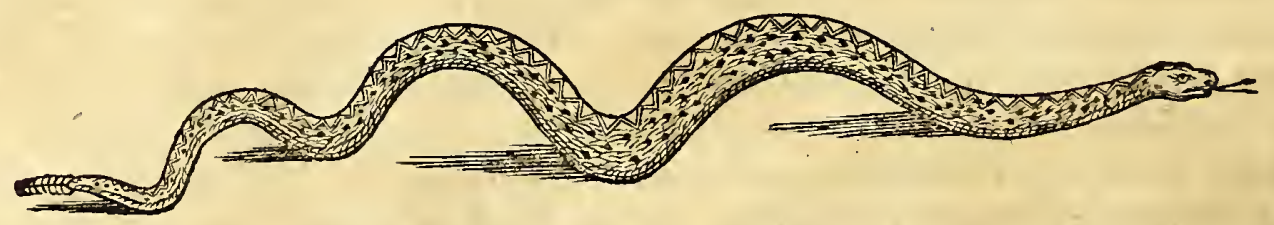

reftria. Huic tam perniciofo Colubro, benigna Natura, cautionis quafi gratia, crepitaculum addidiffe videtur, ut illius fonitu admonitus quilibet, homo non folum, fed \& quale cunque pecus vel jumentum, tem peftive fibi caveat à vicino hofte. Brachii eft craffitic, longitudine interdum quinque pedum, lingua bifulca, dentibus longis $\&$ acutis, colore fuico \&ad flavum vergente. Venter fquammas habet grandiores reliquis, quafi parallclogrammas, pallide Havefcentes. Quotannis articulus, quo infeftare foler, in caucia crefcit, ita ut Serpens decem annorum habeat crepitaculum longum duos digitos, femidigitum latum, fubftantia lavi, glabra, pellucida, ficca. Irritatus in fpiras fe contorquet, itaque fibi cavet undique, ut nulla non partefe vindicet ab illata iniuria.

Caudx 
HIST. NATVRAL. \& MEDIC. IIB. V.

Caudx extremitate in anum hominis immiffa, mortem infert confeftim; venenum autem quod ore vel dentibus infundit, multo lentius vitam tollit. Ex vulnere mox fanies cruenta effluit, caro livet, ulcufque paulatim ferpit. Ad remedia extrahentia, vulnusdilatantia, fcarificationes, cucurbitulas, \& fi pars læfa intercipi poffit, ad vincula feftinandum, idque junco Iaçapé, cui remedio maxime fidunt fuperftitiofi Inco$\mathfrak{l x}$; fin minus, cauterio utendum eft. Interim dum veneni qualitas ad cor penetrat, curandum ut interius præmuniatur Tipioce hauftu \& fucco recenti præftantiffimæ herbx colubrinæ Caatia \& Limonum recentium, fudorefque evocantibus infiftendum. Præfentiffimum præ cæteris remedium, quod Barbaris contra hujus aut qualifunque Serpentis morfus reftat, eft ipfius nocentis caput, quod contundunt, contufum emplaftri forma vulneri calens applicant: vicinifque partibus virentia Tabaci folia imponunt. Præ doloris atrocitate icta humant membra cum felici fucceffu. Cui remedio fimul addunt, in omni fere morfu, falivam hominis jejuni, qua perpetuo partem affectam demulcent, (Plinius lib. v I I. cap. 2. Galenus lib. x. Simplic. Scaliger in Hiftor. Animal. lib. Ir. cap. 18. hancfalivæ vim quoque agnofcunt) adeoque his antidotis nituntur, ut defperent, fi in illis voti compotes non fiant. Ego hæc \& fimilia remedia', quæ longa illis experientia dictavit, jubente neceffitate, lubenter fum imitatus. Non intermittendo tamen ea quæ à veneranda antiquitate $\&$ autoribus nobis funt relicta. Ne nimium temere hifce novitiis, aut pertinacius adhærerem veteribus, quibus negatum fuit Orbem Americanum, ejufque animalium peculiarem genium inquirere.

B $\circ$ I $̧$ G $V$ A I' $I^{\prime}$ A.

B oiçuaiba Serpens craflitie \&longitudine Boiguaçı́ fimilis, fed coloribus difcrepans, quippe hic finemaculis, continuato ductu, anteriori corporis medietate nigricante, pofteriori vero eft flavefcente. Mire quoque eft rabiofus, cum omnibus Serpentibus vel
maxime venenatis perpetuum bellum exercet, eofque infidiofe opprimit, imo venenatiffimum Boiçininínga, fpectantibus viatoribus, aliquando devorat; ipfeque adeo tamen veneni expers deprehenditur, ut incolæ carnem ejus comedere non extimefcant. Ita ut in lioc quoque Serpente occurrat illud quod antea monui, fcilicet in toto rerum ambitu nihil pene effe, quod cuipiam prædæ non fit, \& nihil è contra, quod non alte-
tius damno vivat.

\section{A $\mathrm{A}^{\circ} \mathrm{P} \quad \mathrm{V}$ T III I. \\ Curucúcu, Curvcutinga, Ibiracoà, \&o Boipéba, Hecmorrboum Jpecies venenati/sime.}

Vrucucri eft anguis craflus cineritii coloris, interius flavus, externis maculis nigris diftinctus, $\&$ iifdem ut Cafcavel fquamis veftitus ; novem $\&$ interdum duo decim pedes longus. Capite eft compreffiori quam plerique ferpentes. Maxime eft venenatus \& plurimum metuendus, licet caro ejus preparata ì Barbaris

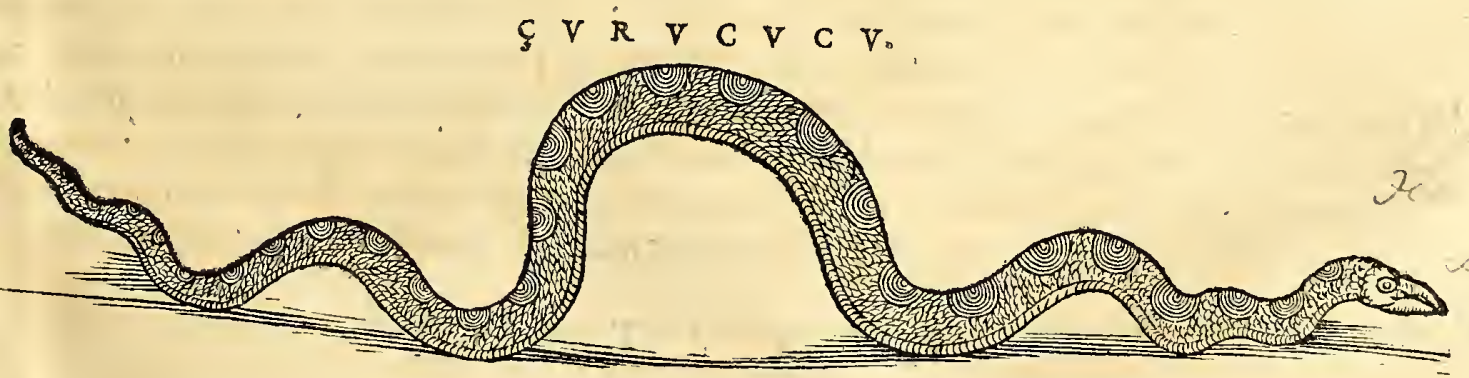

omedatur. Nocere cupiens in gyros fe componit $\&$ infidiofo falturuit in hoftem: Igit homines, nec nocet ullinifi irritatus, tuncque mordet in infinitum tanquam raiofus, grandibus dentibus armatus. Præcipuum illi venenum in capite, ideoque Brafiani intercepto quantocius caput amputant $\&$ cooperiunt humo. Ab illo ictus, corridertigine, tremoribus, torminibus, animi deliquiis, febribus ardentibus, quibus idor frigidus ac ipfa denique mors, intra diem naturalem, aliquando \& celerius, fuc- 
cedir: Prater enarratas qualitates, peculiare eft huic Serpenti diabolico, quod ex morfu ejus virulento, ven 2 crodi videantul, tantamque inflammationem $\&$ ardorem efficiat, ut fanguis bulliens mox è naribus, auribufque, imo manuum \& pedum unguibus promanet. Cujus peftiferx proprictatis caufa ad calcem hujus capitis ventilabitur. Huic malo fi qux Medicina detur, ipfius Serpentis, qui morfumintulit, caput emplaftriforma, vulneri applicatum; tum Allium \& folia Tabaci recentia, leviter tantum ab ignis flamma tacta, mirabiliter profunt, cauterii loco. Idem præftat contra hujus, aliorumque Serpentum morfus radicis Caa-apiá decoctum, ut \& ptifana ex Mandioca , quæ Carimá dicitur; Omnium vero prafentiflimum eft antidotum, fuccus herbæ colubrinæ toties enarratx, Caacica diatx, qui partim haufus', partim vuln eriapplicatus, me aliifque prafentibus, fauciatos reftituerunt. Deinde fuccedunt fudorifera, vel ipfo ftatim initio convenienter exhibita, ut funt radices Iurepébe, Vrucú, Malvijco, laborandí, inter fimplicia fatis fuperque defcripta. Succus Limonum pufillorum recens, refrigerando $\& c$ aftringendo non folum, fed \& fpecifica qualitate modice affumtus mirifice prodeft.

$$
\text { ç V R V C V T I N G A. }
$$

$\mathrm{Q}^{\mathrm{v}}$ Vi ̧̧urucutinge nomen tenet, mole \&longitudine non multum inferior ferpente Boiuaçú; venenata autem qualitate longe fuperior. Duplici ordine dentium acutiffimorum, paulo incurvatorum, in utraque maxilla armatus. Caterum toto corpore eleganter nigro \&albo variegatus \& fquamofus, in caudam inftar fubulæ acutam definens. Deteftabilis hæc bellua omnibus merito formidabilis. Morfus enim ejus difficillim $x$ eft curationis, licet fupra dicta remedia rite adhibeantur.

\section{B I R A C O $A^{\prime} \&$ \& $B$ O I P $E^{\prime} B$}

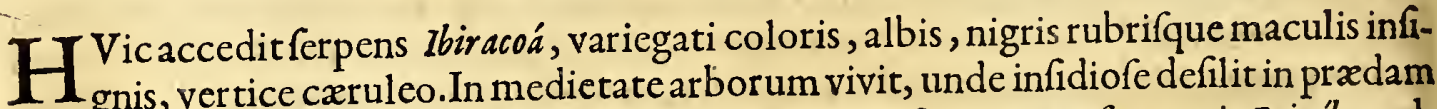
gnis, ver tice cæruleo.In medietate arborum vivit, unde infidiofe defilit in prædam qualemcunque. Vtriufque hujus morfus, ficut $\&$ morfus quoque ferpentis Boipéba, admodum eft venenatus, \& peffima fymptomata infert, haud fecus quam çurucucú, ut à Brafilienfibus exercitatioribus ipfe accepi, quippe fanguis quantocius à morfu, exauribus, naribus, $\&$ oculis profluit, atque, nififtatim fubventum fuerit, moritur vulneratus. fi virus nondum cor infecerit, carne ipfius anguis cocta cum radice Iuripeba, Iaborand, Malva Ifco, Caspéba, Capypuba, additis fummitatibus 2 bambi, ex vino interne exhibitis, $r$ eftituuntur ægri. Stupa arboris Pindaiba vulneri impofita, fanguinem undiquaque profluentem fiftit. Rafura quoque cornu bovis largiter cum frigida, vel ptifana Carimá, pota, equos $\&$ homines curat. Addatur externum remedium, ex capite ipfius fer $æ$ contufo, \& cum Caatiáherba, \& tantillo fucci Limonum aliifque ejufmodi ante enarratis, præparatum.

Cum fupra monuerim, fanguinis fluxum ex morfu horum ferpentum excitari, non tamen exiftimandum, eum, vel per confuetas folummodo vias \& modos, vel ex communi ardore,ac inflammatione;fed ex fpecifica quadam proprietate venenata, quam to. tius fubftantix dixerunt, provenire, qua facta continui profunda folutione, omnes corporis poros orificiaque venarum $\&$ arteriarum difrumpit, unde ex angulis oculorum $\&$ aurium, imo \& ulceribus confolidatis, fanguinem profluere videmus, ficut in peftilentialibus morbis evenire conftat. Tanta enim partis læf $x$ fit combuftio \& denigratio, tanta denique fpirituum vitalium fubita proftratio à permeante fubtiliffimo veneno, ut fpafmi ex inanitione \& ficcitate, tum etiam ex fanguinis aliarumque humiditatum naturalium privatione, vocis $\&$ anhelitus interceptio, $\&$ tandem mors ipfa non raro fubfequatur. Ita ut ex infolito hoc fymptomatum concurfu fatis confirmetur, caufam horum lethalium vulnerum minime ex primis $\&$ fecundis qualitatibus petendam effe.

\section{$\begin{array}{lllllll}C & A & P & V & T & \mathrm{I} & \mathrm{V} \text {. }\end{array}$}

\section{Boiguagu.}

B iguaç, five libóya, Serpentium omnium facile maximus, femur fere homini craflus, Lufitanis Cobra de Veado dictus, quod Dorcades integras devoret, idqu fugendo potius quam mafticando: Ita ut Plinio C. 14.1. 8. fides facile debeatur de ferpentibus qux Cervos hauriant, ac de Bon Serpente qux tempore Claudii infanten deglutie 
$B$ O

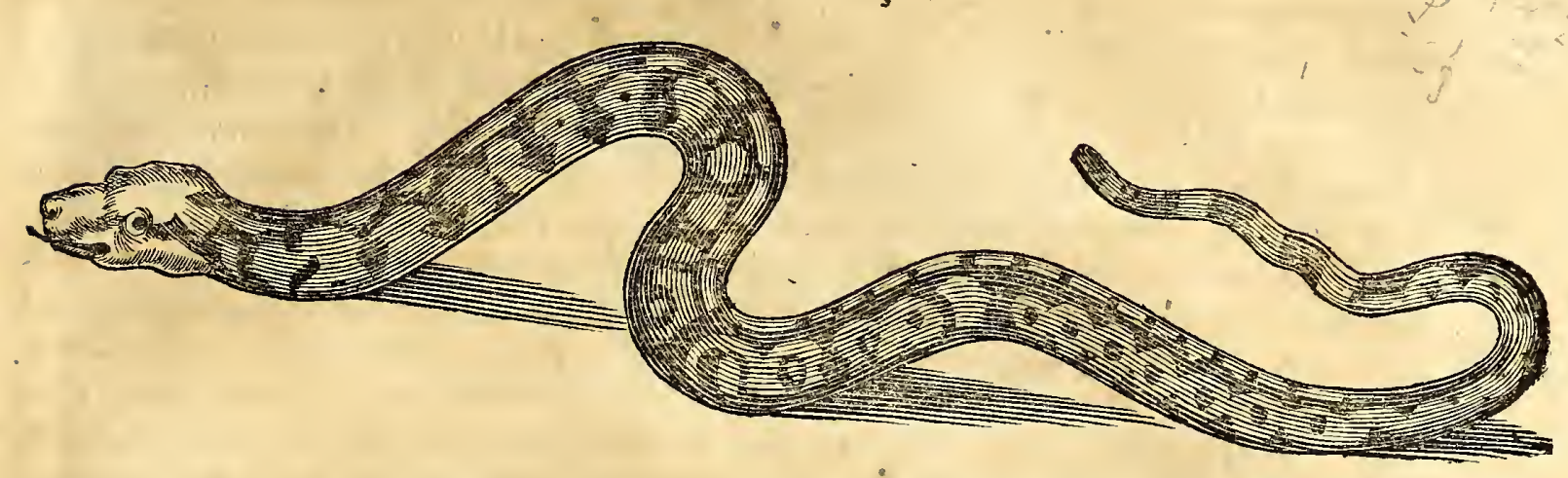

deglutierat. Exhorum generequidam octodecim vel quatuor \& viginti pedes repe: riuntur longi. Cineritio, fpadiceo, elegantiflime variegato funt colore. Tota pellis diverf $x$ magnitudinis nigris maculis quafi incatenatis decoratur, in quarum centro albx confpiciuntur maculx. Non æque veneno, ut multi alii, turgent. Carne eorum alba non folum Indigenx \& Nigritæx, fed \& noftrates vefcuntur. Famelicus hic Anguis vel ex dumetis profilit, caudæque fur duobus unguibus armatænitens, horrende fe erigit \& ftrenue cum feris hominibufque luctatur, \& fibilat irritatus: vel ex arbore infidiofe in viatorem defilit, eumque validiffimis cingit amplexibus, ita ut vel folo complext, tum quoque cauda rigidiffime in podicem immiffa, interimat. Nec minus validiatque feroces exiftunt ingentes illi Arabó, çucurír, feris quoque \& hominibus infidiantes. Omnes Serpentes folidis \& multis vertebris \& coftis præditos ex Anatome animadverti. Anticx \& medix potiffmum corporis partes fpiritu attracto fupra fidem turgent, \& fortioribus coftis munitæ, non folum ad infidiofos faltus, fed ad deglutiendam præxdam longe aptiores efficiunt has belluas repentes: Coftarum enim ope magis profundam $\&$ validam fuctionem exercent, idque in commodum præd $x$ nactx vel nancifcendx. Vertebrarum vero robore fuftentantur \& eriguntur, earumque pluralitate commodius in gyros quofcunque moventur. Sceleton hujus Serpentis, in India Orientali \&z Occidentali familiaris, omniumque Brafilienfium facile principis, Theatro anatomico Amftelodamenfi ex Brafilia à me miffum, fententiam meam confirmat; ficut ex hac appofita icone videre eft.

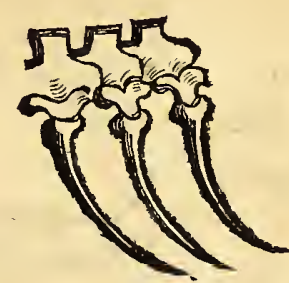

In qua fabrica offea præ cateris notatu digna occurrunt, quod magna pars capitis amplitudinem rictus demonftrat cum acutiffimis $\&$ longis dentibus. Dein vertebræ plus quam feptuaginta concinno \& perpetuo ordine à cervice ad caudx extremitatem compofitx; capitiautem propinquiores majufculx funt, decrefcenteque ordine abeunt ad caudam, quarum circiter viginti pofteriores, conformatione $\&$ figura nonnihil à cæteris difcrepant.

IEtus eorum vix cenfetur venenatus, \& per fe aliquando, vel leviori faltem adhibito remedio,curatur. Ita ut inter rabiofos potius quam venenatos Serpentes haberi debeant: quibus Caninana, Maníma \& Vona annumerare licet. Cxterum hic Boiguaçu adeo rerribilis Cervis \& Capreis, à Formicis tamen necatur, patulum ejus os turmatim ingreflis, quum exdem Formicx à parva vipera Ibiiára in fugam abigantur.Quafi nimirum 
nihil tam potcns fit in rerum natura, (ut in rebus quoque humanis) quod evertinon poffit à multo minori. Ita ut fapientis fit, femper in animo habere vetus illud Diogenia-

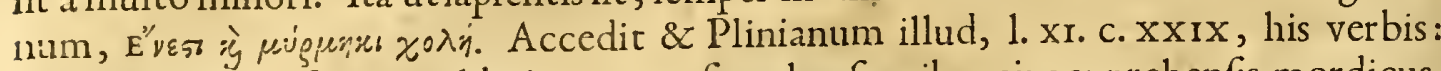
Serpentem (locuftx) cum libuit, necant fingtilx, faucibus ejus apprehenfis mordicus. Talia cum apud Plinium legunt, fidem multi derogant; quia vix credunt, nifi qux vident. Quibus Volfius in lib. de Idololatria Gentilium refpondet, fcilicet quod illi non viderunt, cernere fubinde vulgares animas; quibufcum fi fermonem ferere non gravarcmur, plura fciremus Natur $x$ arcana. Nunc aliis rebus publicis, aut forenfibus, aut umbraticis fudiis occupati, multa non confpicimus, qux illi, quos contemnere folemus, vident \& obfervant.

\section{A $A$ P' \\ Ibibobóca, Boióbi, \& Cacaboía.}

I

Nter infeftiffimos facile Brafilix ferpentes eft pulcher Ibibobóca, Cobra de Coral Lufitanis dictus: duos pedes longus, \& pollicem humanum craflus, verfus polteriorem partem teres $\&$ inftar fubulæacutus. Totus venter eftalbus $\&$ fplendens, dorfum $\&$ latera tincta. Caput craffum, compreflum, oculi foedi, profundi; rictus ingens, dentibus

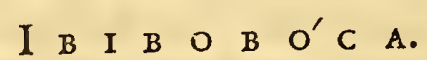

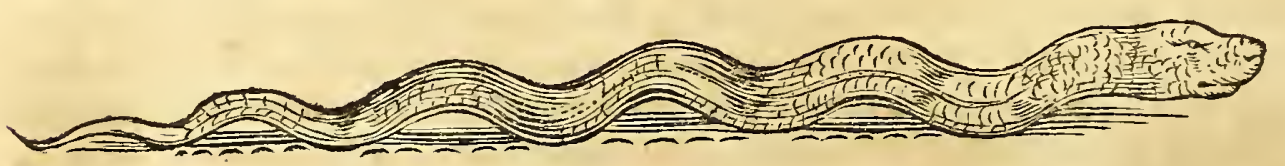

obfitus. toto vertice habet fquamulas albas cubicas, ad oras, nigras, hinc cinnabria fequitur macula, cujus fquamæ per oras nigræ, \& ita femper rubra macula eft, hinc fequitur nigra, hinc alba, iterum nigra, hinc rubra, $\&$ fic deinceps. Rubra macula longa, dux albx, \& tres nigr $x$ fimul fumtx, $x$ quales inter fe: nigr $\mathfrak{x}$ autem macul $x$ totaliter funt nigræ, albarum autem or $x$ nigrx. Circa Formicarum latebras fe occultat, quas paftum ituras perfequitur, \& vaftat. Lente graditur, nec nocet homini nifi irritatus. Sed quantum pulchritudine, tantum quoque virulentia cxteros fuperat. Morfus quippe ejus venenatiffimus, non exremplo vitam depafcitur, fed tarde fe promovet. Sanatur emplaftro è capite ejufdem Serpentis concinnato \& efficaciter appofito. Pulvis plantæ $\Lambda^{\circ} b a m b u$, tum \& fuccus foliorum Caapeba \& Caiatiá, vulneri inftillatus, \& peraliquod tempus exhibitus, expellit virus.

B О I O' B I.

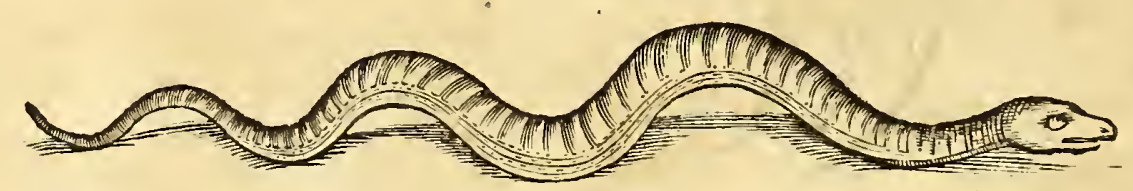

Erpens Boióbi Brafilienfibus, Cobre verde Lufitanis dicitur:ulnx eft longitudine \& pollicis craffitie, coloris porracei \& pulchre micantis. amplo ore, lingua nigricantc. xdificiis gaudet, nec ulli facile nocet nifi irritatus, tuncque erectus cauda nitens, viatoris manus apprehendit. morfus adco habetur venenatus, ut remedio quantumvis preltanti vix cedat. Radix autem illa nodofa herbx Cad-apiá, contufa \& ex aqua pota, iummopere prodeft, caterifque herbis antidotalibus facile palmam prxripit. Miles quidam gregarius, Anguem hunc inter arbufta latitantem, dum pede forte conterit, ab co in femore demorius, paucis poft dicbus, to to corpore tumefacto \& livcfente, deficientibus radicibus Caa-apiá, cxterifque remediis fruftra adhibitis, quam miferrime exfpiravit, prafentibus commilitonibus. 
eft humor crocei coloris, adeo potens, ut viginti horarum fpatio homines de medio tollat. Vtinam vero noxium hoc animal minus prolificum effet, quia duodecimaliquando fimul eniti foetus ab Incolis accepi.

$$
\begin{array}{lllllllllllllllll}
I & A & R & A & R & A-C & O & A & P & I & T & I^{\prime} & \dot{N} & G & A & \text {. }
\end{array}
$$

S Ecunda fpecies dicitur Iarara-coapitínga. teftantibus Lufitanis, ipfa Vipera Hifpa$\checkmark$ lienfi venenofior; extremitas caudx elt alba, unde hoc nomen illi inditum: longitudinis eft quinque vel fex pedum circiter.

$$
\begin{array}{llllllllllll}
I & A & R & A & R & A^{\prime} & C & E-M & I & R & I^{\prime}
\end{array}
$$

TErtia \& minima, cujus longitudo dimidium cubitum vix excedit. Terreo colore, venis quibufdam in capite prominentibus inftar Viperarum, \& haud aliter quam illæ ftrident. Hæ Iararácx-mirí dictæ funt, id eft parvæ. Omnes itaque ha Iararáce mole $\&$ figura corporis potius quam noxia qualitate differunt: inter eas mufcum redolent adeo fortiter, ut dolorem capitis inferant; hoc tamen odore facilius ab hominibus horum gnaris, aut occiduntur, aut evitantur.

I $A \cap A R A E P E^{\prime} B A$.

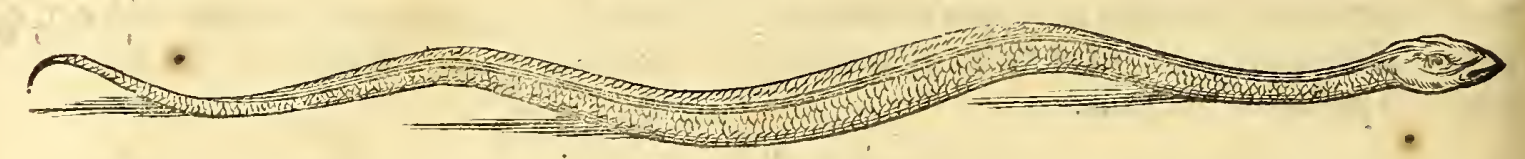

Varta Iararaepeba nomen obtinet. (cujus folius Iconem exhibeo.) Huiclinea rubri coloris, catenulæ inftar, fuper dorfum $\&$ fub ventre difcurrit, cætera fufcus aut cinereus. Ip fa fera poftquam vulnus inflixit, à cute, cauda, capite, \& interaneis repurgata, $8 z$ in aqua radicis Iuripéba, cum fale, oleo, porro, femine Imbira, atque radice 1aborandi cocta, à vulneratis comeditur, magnoque illis folet effe prafidio.

Verum licet caro illarum (ex qua Trochifci illi notiflimi de Vipera parari folent) ufque adeo antidotalis, etiam in hifce regionibus fit habita, tamen hæ bellux longe pluces utique calamitates quam commoda humano generi fuppeditant. Quippe morfu non folum virulento \& fanie fervente lethalia vulnera infligunt ; fed \& Fel earum à Veneficis exemptum \& minima quantitate propinatum, mortem affert, it non quantocius vomitus ex radice Ipecacuanba promoveatur, atque in inftanti fructulum Ananas, Limonum, \& herbæ Cacçica fuccis, reliquix fubtiliffimi veneni, per urinas \& fudores protrudantur, moxque decocto Carimá fpiritus refoluti revocentur \& roborentur. Sed cum requifita hæc vix in tempore fimul concurrant, plurimi fuccumbunt, five $a b$ illato, five $a b$ aflumto verieno. Naturam tahti veneni follicite hic inquirere fupervacaneum puto, quia fymptomata cum fervente fanie \& fanguine, corumque remedia id fatis arguant; medicamina enim pleraque, licet cum manifefta caliditate conjuncta fint tamen proprietate occulta venenum fuperare, ab aliis $\&$ me fuo loco fatis comprobatum effe puto.

\section{I $B$ I I $A^{\prime} R$ A $M$.}

T Iperam quam Brafilienfes nominant Ibiiáram, id eft, Seignor de la ters a, vulgus Lufitanorum Cobre cega, vel Cobre de dos Cabeças vocat, quod duo capita videatur habere. Ipfe Plinius, qui idem de eadem vipera teftatur, aliorum relatu, deceptus fuit. Geminum, inquit, 1.8. c. 23. Amphisbanx caput, tanquam parum effet uno ore fundi venenum. Salit enim in utramque partem retro $\&$ ante, propter coftarum fuarum in utramque partem mobilitatem, informis hec vipera, $\&$ in gyrum quafi compofita ex infidiis opprimitincautos. Adeo difficile eft caudam à capite difcernere: adde quod tam capite quam ore feriat. Non procul ab extremitate caudx anum habet inftar reliquorum ferpentum. Minimi digiti craffitiem xquat, \& longitudine vix fefquipeitem. Color eft albus, fplendens inftar vitri: annulis \& elegantibus lineis notatur, coloris brunni aut aërci : oculos habet minimos \& vix conficuos; harent in cute inftar punctuliacu facti. Sub terra vivit, \& illam fodicndo eruitur. Amat formica- 
I B I I $A^{\prime} R$ A $M_{0}$

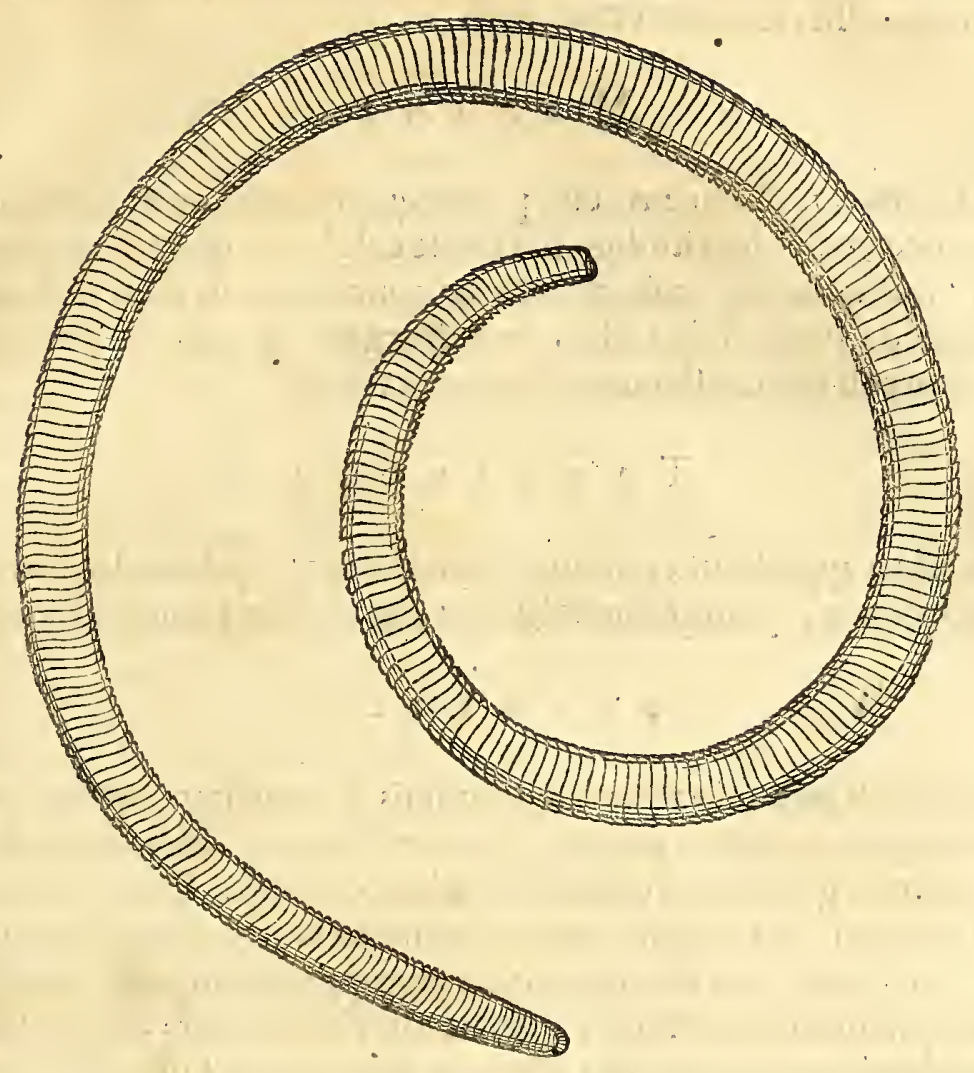

rum latebras, quas adeo perfequitur, ut integras cohortes videas fua domicilia relinm quere, $\&$ avolare quando alatæ factx fuerint. Ejus morfu nihil eft virulentius, qui cum infigni ardore à vulnere ad cor tranfit in momento ; non tamen citra fpem curationis exiftit, fi fupradictis remediis tempeftive interius \& exterius utaris. Qux, quıod nïhil immutandum occurrit, totics repetere fupervacaneum duco.

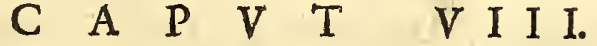 \\ Quatuor Hydri, Amorepinima, Manima, Tareiboia, \& çucuriiú.}

Andem fequuntur Angues, amphibiorum more, modo in ficco, modo in lacubus degentes, ac proinde Hydri vel Natrices merito dicti, minus tamen Europxis perniciofi habentur. Irritati nocent, vulnufque facile curabile infligunt.

$\begin{array}{llllllllllllll}A & M & O & R & E & P & I & N & I^{\prime} & M & A & A\end{array}$

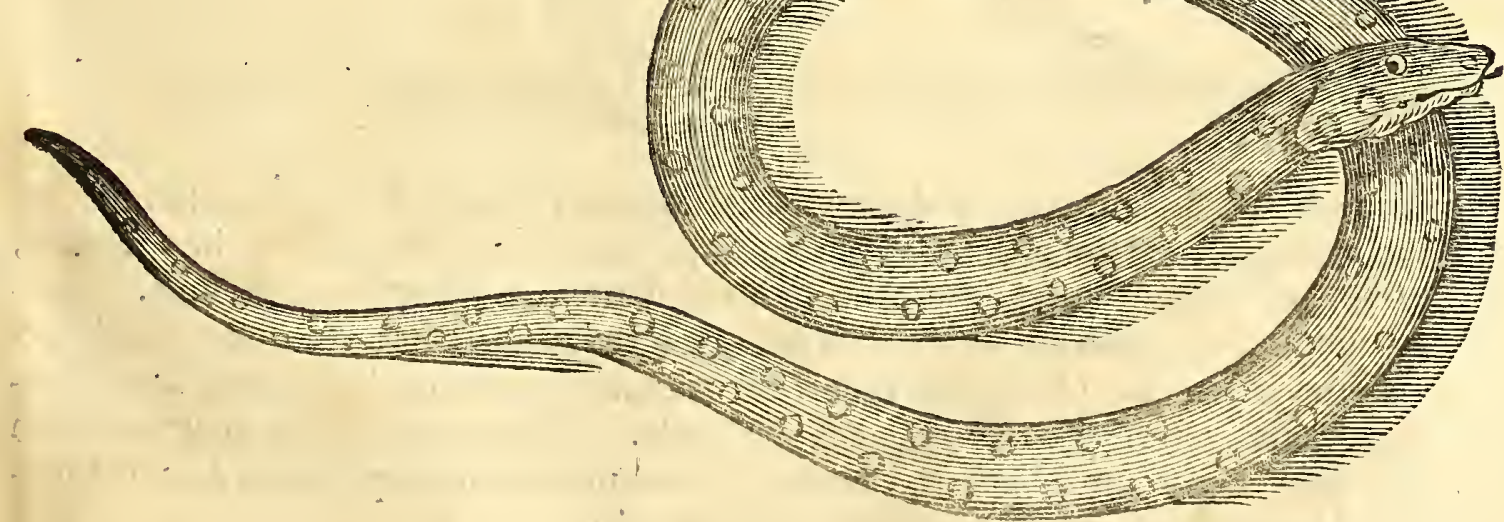

Pimus eft Amorepinima circa fex pedes longus, cute fufca, maculis luteis interius, in 1 ambitu autem brunnis. Etiamfi morfus ejus non ufque adco extimefcatur, incolæ ta- 
men fecuritatis caufa herbas 2 bambi \& Caspiá vulneri imponunt, atque vim veneni, fi quod modo adfit, feliciter retundunt.

$$
M A N \text { Í } M \text { A. }
$$

Ecundus Manima, non nocens, cui, præterquam quod cutis admodum variegatis coloribus micet, ut pulchritudine fua facile celebrem illum \& formofum Nili hydrum fuperet, hoc quoque peculiare videtur conceffum, ut dum in ftagnis a pricatur, tanto cum fulgore adverfo Sole radios de fe fpargat, ut cum admiratione in aftantes homines $\&$ arbores Iridum inftar undati reverberentur.

$$
\text { T A R E I B O I'A. }
$$

Ertius Tareiboía appellatur, quælutei eft coloris, fex palmas longus, ruricolis potius extimefcenda, quod gallinas devoret, quam quod homini venenum inferat.

$$
\text { I } \quad \text { G V C V R I I V'. }
$$

Vartus hydra eft çucuriiu, tantæe magnitudinis \& voracitatis, ut cervos, capreas, imo infantes integros aquatum euntes deglutiat. Sicut in Babia de todos los Sanctos juxta Brafilianum pagum, puerulis ad ripas ludentibus contigit. Cujus portentof $x$ jactur $x$ focii aftantes attoniti, convocant amicos, qui mox cultro armari in aquas fe præcipitant, \& feram onuftam puero fauciant interimuntque, quam aquis emerfam diffecant, illæfumque ferc infantem redimunt, quia ut alias dictum eft, angues non adeo mafticando vel mordendo quam fugendo pradam deglutiunt. Hinc facile eft confirmare, animalia aquatica cum ejufdem fpeciei terreftrium feritate \& magnitudine certare.

\section{A $\quad \mathrm{P} \quad \mathrm{V} \quad \mathrm{T} \quad \mathrm{I} \mathrm{X}$. \\ Iacaréfive Crocodilus vulgo Cayman, \& Teiúfive Lacerti.}

$\mathrm{C}$

Rocodili in fluviorum, ftagnorumque latebris degunt, Africanis \& Afiaticis Crocodilis fimiles, fed utique minores; raro fex vel feptem pedum longitudinem excedunt. Hominibus natantibus infidiantur rictu late diducto, acutiffimifque dentibus ingentia vulnera inferentes. Qux vulgaribus remediis coalefcunt, præfertim

$$
\text { I A } C A R \quad E^{\prime} \text { five } C R \text { O C O } D \text { I I V S. }
$$

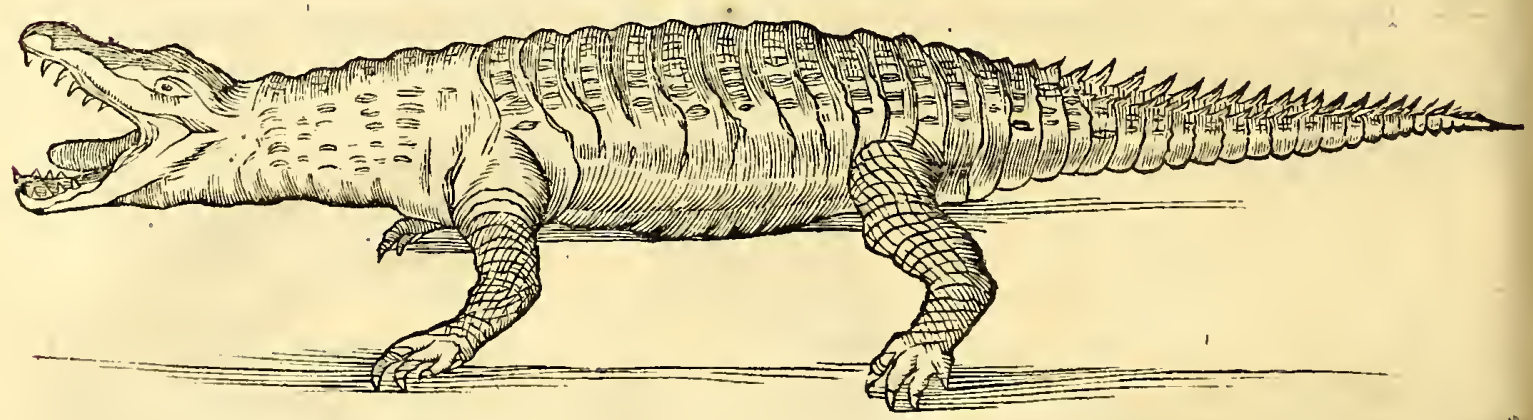

vero adipe ipfus animantis. Vulnerati pariter \& non vulnerati Crocodilos fummo fudio venantur, partim propter virtutem adipis, loco emplaftri vulneri imponend $x$, partimob ipforum teftes, myrothecium redolentes, quos care divendunt. Omafus quoque hujus Iacaréficcatus, \& in pulverem redactus, contra morbos calculi exhibetur. Ova qux plus quam viginti vel triginta fubinde profert, nova Luna contegit arena, veteri vero effodit, edita jam prole. Gallinarum ovorum magnitudinem excedunt, nec folum à barbaris, fed \& militibus noftratibus expetuntur \& comeduntur. Idem de ipfa carne ejus albicante dictumvolo.

Fr. Ximenes obfervat rcmedia qux ex glandulis illius fub gutture pofitis,atque etiam è ventriculo, praparantur. lidem teftatur, animal hoc, cun alio cibo deftituitur, de- 
HIST. NATVRAL. \& MEDIC. LIL: V.

vorare lapillos, cofque fape in ventriculo illius reperiri femi-coctos, quorum pulvis hauftus fingulare remedium fit contra lapides qui in renibus hominum nafcuntur.

Brafilienfis autem Crocodilus $Æ$ thiopibus \& Noftratibus Caymun vocatur. Capité eft compreflo, fuperius firmifima tefta munito. Oris hiatu amplo, qui longe ultra oculos aperiri potelt; mandibulam fuperiorem movet, inferior eft immobilis, (quod nulli animalium, nifi huic conceflum teftatur Ariftot. de Animalibus) utraque autem dentibus acutis, nunc longioribus nunc brevioribus prædita. Linguam habet nullam, fed tantum membranam, qux nandibulæ interiori interjacet, \& lingux figuram refert, quam tamen fuftollerenon poteft. Oculos habet magnos, rotundos, pupilla nigra. Collum fuperius $\&$ dorfum tuberculis majoribus exornatis fquamis veftitur. ultima caud $x$ medietas, firma pinna fuperius erecte ftante, ad finem ufque dotata eft : qua inter natandum, more pifcium fe gubernat.

Elegans hoc amphibium à rapina fatur, exilit è fuvio diebus xftivis, \&ょ ad ripam aperto rictu apricari amat. Quo avicula quxdam advolans fomnolentx ferx dentes à pradz reliquiis expurgat eodem fere modo quo Plinius 1. 8. c. 25. de Nili Africano Crocodilo narrat. Cujus dormiturientis fauces Mus Indicus, Iclineumon dictus, repente intrat ventremque exedit, unde Crocodilus mox tantre defidix pœnas dat crudeli morte. Hi vero Americani Crocodili, etiamfi immunes ab illo Ichneumone, non tamen evadunt barbaros fagaces, qui tunc per infidias opprimunt belluam fatietate enervatam.

'T E I V'.

T $N$ tanta Lacertorum frequentia, filvas $x$ diumque rudera paffim oberrante, unus 1 atque alter tantum quoad hactenus conftat, reperitur venenofus. Omnes nomen Teiú audiunt, \& Philanthropi habentur.

Prima venenata carapopéba tres vel quatuor digitos longa. Figura corporis inftar vulgarium Laçertorum, quatuor eft cruribus \& pedibus : in anterioribus quinque, in pofterioribus quatuor habens digitos. Corpus totum eft hepatici coloris cum albis notulis, in cauda autem albis lineolis, hinc inde etiam aliquid flavi mixtum. Oculos habet fplendentes \& quafi vitreos. Cauda eft cateris latiori \& breviori. Velocifime movetur, pradafque per infidias venatur. Totus veneno turget, unde morfus illius admodum venenofus habetur : qui tamen $a b$ affumptis \& applicatis antidotis infra explicandis reftituuntur.

\section{Ecunda Ameriçíma dicitur : Lacertu-}

$\checkmark$ lus tres digitos longus \& 2 pennam olorinam craflus : crura \& pedes cxterorum Lacertorum fimiles, fed cauda brevior, \& incurvata: ocellos habet nigros, corpus autem fere quadratum videtur.

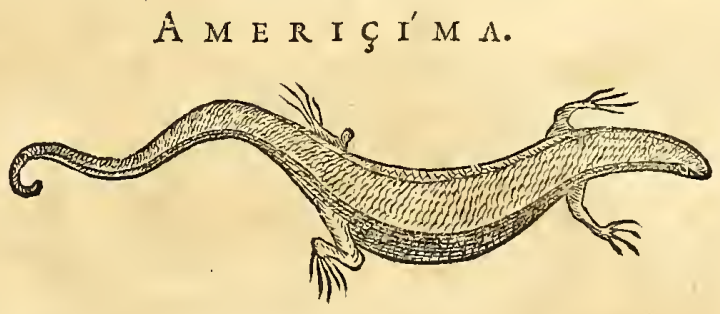
'Totum dorfum fquamul is veftitur leucopœis, latera, caput \& crura fufcis, cauda vero cæruleis: omnes autem fplendent, \& ad tactum apprime funt læves. Digiti in pedibus infar fetarum porcinarum. Admodum venenofum eft animalculum. Si devoretur à Fele, ventrem ejus inflat veneno, hoftemque interimit fuum. Cupidum eft exfugendi fanguinem humanum, proinde in adibus fe abfcondit, lucemque fugir : cum è contra cateri innocui Lacerti perpetui fint apricatores. Referunt, forminam femel tactam ab hoc Lacerto, vel folum indumentum, nunquam poftea concipere, à me autem nondum compertum, quapropter fides fit apudincolas.

Plaga ab hifce noxiis Lacertulis illata, dilutam foctidamque faniem effundit cum tumore livido, cardialgia, torminibus, ac magnis cruciatibus. Peculiare huic malo antidotum nondum eft inventum. Quapropter hæc aliaque communibus al cxipharmacis tam exoticis quam indigenis, exturbanda funt.

Quia nuncfermo incidit de Lacertis, unicum addam de cortum natura in genere, 
quod cum meo Markgravio obfervavi. Veriflimum fcilicet effe quod Plinius I. I I. c. so. teftatum reliquit, caudas Iacertorum ex parte amputatas renafci, fed integreabfciffasnbn renafci, contra Scaligerum. Coire volens mas leni morfu adprehendit fomel$1 x$ cervicem, paulo poft ad latus fe inclinat ; $\&$ fœmina propriam caudam furfum levando admittit marem, qui pedibus complectitur corpus ejus à tergo. Exovis, quæ utcunque pifi funt magnitudinis, fotus fponte excluduntur; iis enim leviter tantum terra tectis non incubat, fed Solis calori ea relinquit.

Illi autem qui Taraguira \& Tejunbana diati \& ubique frequentiflimi, pedalis funt longitudinis, cauda longiflima: velocifime nutantes capite quando aliquid vident, celerrimeque currunt : imprimis tum cum vident hominem dormientem, cui Serpens, aut aliud venenatum animal lædendi caufa appropinquat, illumque expergefaciunt, ne faucietur. Ita ut hi non minus philanthropi, quam prædicti illi mifanthropi nomen mereantur. Præterea tanta fagacitate \& pernicitate mufcas, vermes aliafque prædas venantur, ut nulli animalium fere cedant: abfoluto hoc opere diurno non tamen plane requefcunt, fed integras noctes inter $f e$, continuo ftrepitu vocibufque inconcinnis tranfigunt.

Carterum antequam finiam Lacertorum hiftoriam, non prætereundum puto quod in illorum diffectionibus (grandiorum imprimis, quorum mentio facta in 1. 3. de Alimentofis) comperi;pulmoncs fcilicet admodum capaces $\&$ magnos is conceffos, refpectu fuæ conformationis. Quafi Natura prærogativam voluiffet concedere hifce animalculis ad aliquot menfes aliquando à cibo $\&$ potu fefe abftinentibus, ut rorem $\&$ auram, quibus perpetuo vefci amant, tanto liberius accipere $\&$ acceptam rccondere poffent. Eodem fere modo gulam \& ventriculum jufto majorcs aliis rapacibus animalibus in fuum commodum conceflos vidi fxpiffime.

$$
\begin{aligned}
& \begin{array}{lllllll}
C & A & P & V & T & X
\end{array}
\end{aligned}
$$

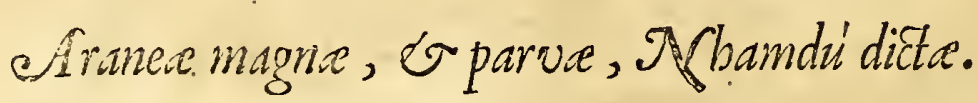

Raneis vulgaribus diverf $\mathfrak{x}$ figuræ, coloris $\&$ magnitudinis telam more noftra: tium facientibus, non deftituta elt Brafilia; qui ab Indigenis communi nomine 2 bamdi appellantur. Horum naximam partem prætereo, illofque tantum exhibeo quibus à natura peculiare quid conceffum eft. Inter eos maxime celebris $\&$

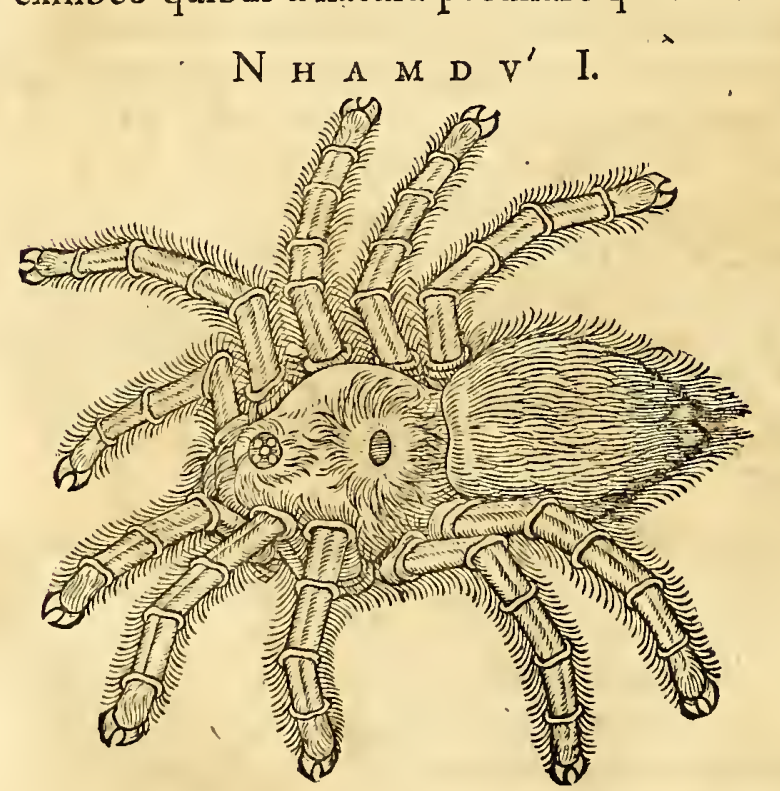
notatu dignus ex Phalangiorum genere qui Thamdu-guaçu, hoc eft, Araneus magnus diatus, quia refpectu cxterorum ftupendx eft molis (forte ejufdem cujus Plinius meminit in Indiis confpici magnitudinis Paflerum) \& more avium in ruderibus $\&$ veterum arborum concavitatibus nidificat. Corpore eft biffecto pilis molliufculis nigris cooperto, quibus nudatur pofterior corporis pars, quando fenefcit, manetque depilis cutis ex albo incarnata, quam integram certis temporibus deponit nova fubtus generata. Capite caret fpeciali, ocellos habet fplendentes, in anteriori corporis parte upia os pofitos, ad cujus latera ex quadam prominentia bini dentes unguiformes femidigirum longi ex nigro fplendentes emergunt, qui auro inclufi pro dentifcalpiis ufurpantui atque in dentium doloribus à multis in pretio habentur. In medio dorfo verfus anteriora foramen habet umbilicale pilis circumdatum, nullius quod fciam ufus. Crura illi funt decem quinque internodiis divifa, in extremitate corniculis nigris curvis biffectis pradita. Infectum eft admodum longevum \& inedix patientiflimum. Mcmini illa ad aliquot menfes capfulis inclufa à mufcis quibus vefci amant abftinuiffe. Procef- 
Proceffus duo juxta fe pofiti prope anum protuberant, quibus nent $\&$ retia capacia conficiunt, licet rarius, eodemque ordine, ut cxter $x$ omnes Aranex, ftamen, tramam, texturam, medium \& cubile defignant ; exindeque omnes illas celebres fapientix \& aftutix actiones folito more exercent, de quibus morales Philofophi tot prodiderunt. Averfis clunibus copulantur \& Venerem abfolvunt. Ova fub ventre portant. Caute funt apprehendendi, ob veneni liquorem, quem primo attactu fpargunt, qui fi oculum feriat, totalem vifus ablationem minatur. Pili quoque venenofi cutem humanam, ficut:Erucx pili folent, vrunt. Irritati venenatum aculeum infigunt, ita tenuem, ut vix confpici poflit. Hinc tumor lividus non fine cruciatu multoque dolore exfurgit. Nonnunquam ratione partis percuff $\&$ fymptomatum fupervenientium malum adeo exafperatur, ut incurabile reddatur, omnibufque remediis applicatis prorfus refragetur. Proinderatio habenda ut vulnus dilatetur, fcarificetur, cauterifetur, fi pars læfa fevera hæc remedia non ferat. Cxteris medelis præferetur Cancer Aratu praparatus eodem modo ficut in Capite de pifce Guamaiacu dixi. Adeo Cancri marini ac fluviatiles peculiares vires antidotales videntur prafe ferre etiam nunc, de quorum utilitate tota erudita olim antiquitas tot prodidit.

A Raneus fecundus, magnitudine noftrates longe fuperat, licet præcedenti multo minor fit. Corpore eft bifecto: parte priori eft pifi ordinarii, pofteriore vero fabx formis $\&$ magnitudine. Corpore toto \& cruribus eft pilofis inftar holoferici fufci detriti, intercurrentibus fuperius maculis nigris. Ab utroque latere quatuor longis tenuibus præditus cruribus tribus internodiis divifis. Anterius duos femilunatos propedes habet exiguos loco promufcidis, quibus apprehendit. His fuccedunt duo denticuli nigri fplendentes acutiffimi, more precedentis magni Aranei. Hi quoque exuvias certo tempore deponunt, dentibus ipfis adharentibus, ita ut cutis exuta Araneum ipfum repræfentet, nam folum inferius finditur, ubi Araneus, nova cuter écuperata, exivit. Cæaterum coëunt, texuntque, \& ova portant, ut major ille, fotus in orbiculari folle fub ventre progenerantes : cum in ædibus frequenter reperiantur, multoque veneno turgeant, fedulo à venenato illo liquore cavendum, 'cum non multo minora fymptomata adferat quam prioris magni. Proinde ad eadem remedia refugiendum eft, qux fupra enarrata funt.

$T^{\text {Ertius Araneus egregii fplendoris eft, cui quafi fa- }}$ 1 cies humana fculpta, \& ex argenteo videtur obducta, ficut exappofita figura liquet, quam pro corollario ob elegantem \& inufitatam formam appofui, quia de peculiari indole, bona vel mala, nihil mihi compertum eft.

$\mathrm{N}$ H $A$ A

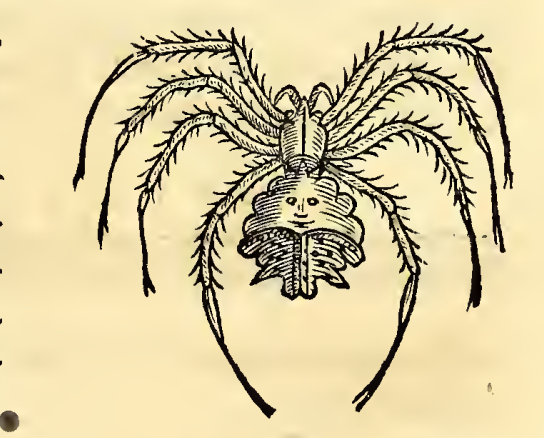

$$
\text { C } A \text { P } \quad V \quad T \quad X I \text {. }
$$

$$
\begin{gathered}
\text { Varia Infectanoxia, Arumatia', Iapuruid, Tataurana, } \\
\text { Ambuá, é Scorpio. }
\end{gathered}
$$

Eftat, ut qux circa cætera noxia Infecta mihi innotuerunt, perftringam. Primo occurrunt varia Arumatiá, quorum majus hoc homini nocere deprehendi. Septem digitos eft longum, \& fere minimum craftum, capite obrotundo, ocellis prominulis, duobus corniculis longis feu pilis. Crura habet fex; corpus internodia duode- 


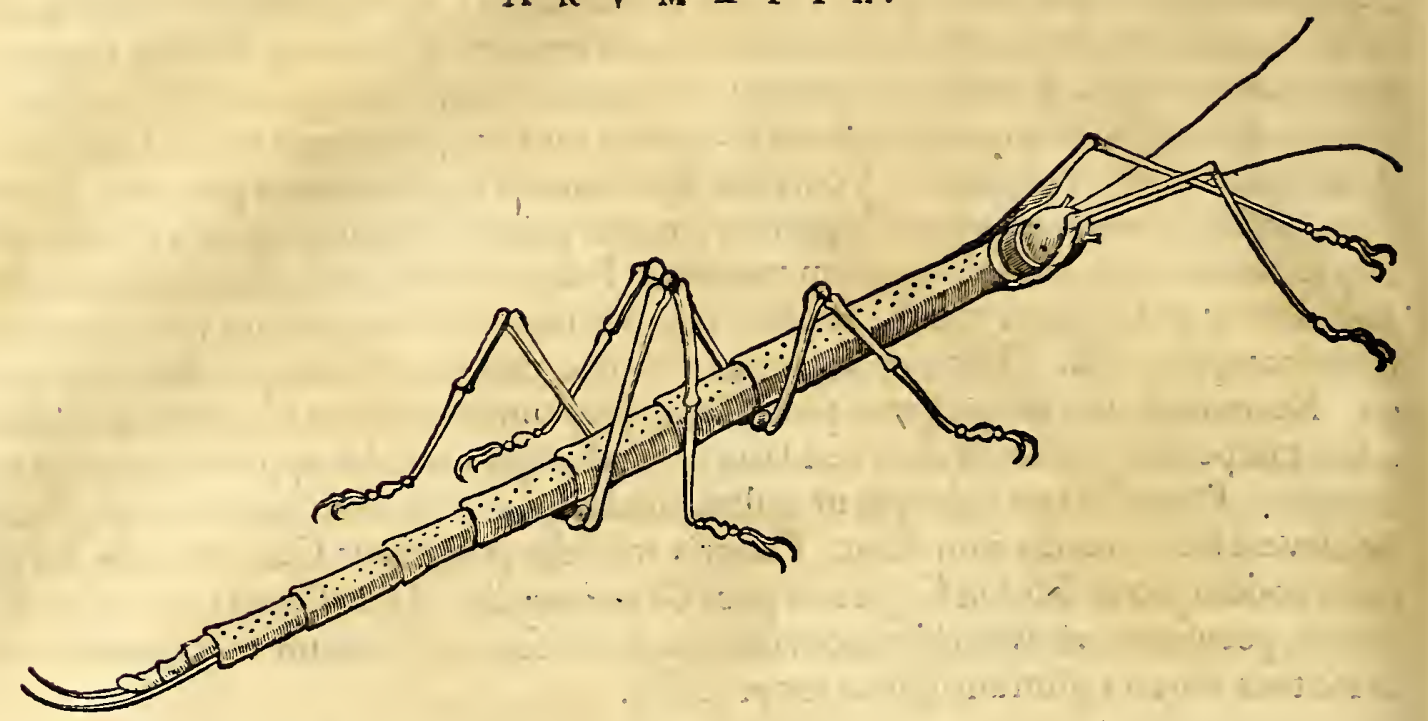

duodecim ; primajunctura eft capitis $\&$ corporis ; mox fequitur alia, in quam \& capitis junctura in duo brachia, quibus $\&$ pedum loco utitur, adnexa funt;tertia junctura longius ab hac diftat, habens $\&$ duo crura ; quarta itidem par crurum tenet: Corpus denique definit in acumen, $\&$ habet aculeum, quem quafi in vaginam recondit. Color ligneus. Tuberculis quoque parvulis corpus fatet, præcipue inter brachia \& fecundum par crurum. Si hominem feriat aliquem, tremorem excitat in toto corpore: non facile autem alicui nocet, nifi quis manibus premat aut pedibus. Dolorofus ille tremor fedatur facile radice Mangle parti affectx applicata, tum quoque inunctione olei fructuum palmx Vrucuri dictæ.

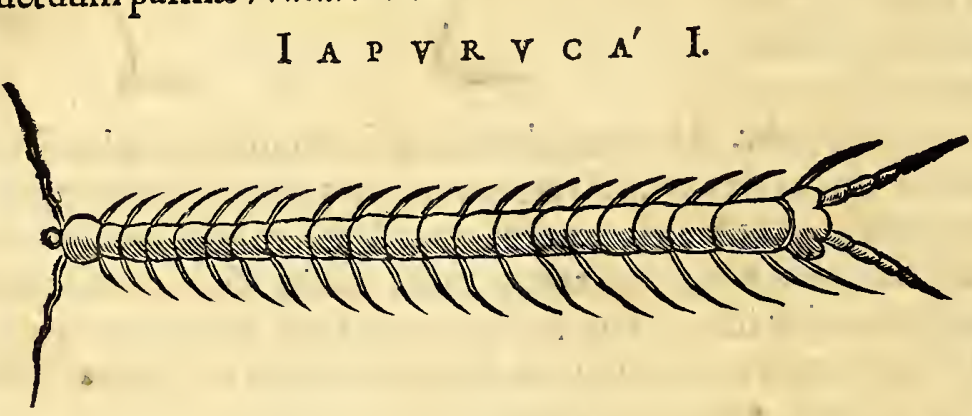

TT Ariæ quoque Sco. lopendræ,Brafilianis Iapurucá, Lufitanis çe. niopta, Belgis Dupfentfuen/ dictx. Infectum hoc quatuor circiter digitos longum, plurimas haberjuncturas, obfcure flavi $\&$ in conjunCtionibus nigricantis coloris : in quolibet latere viginti pedes: caput compreffum, latiufculum, fufcum: cornicula duo: fub ore duos dentes inftar forcipis. Cauda illius eft furcata, \& definit in duo quafi cornua. Admodum frequentes funt in $x$ dibus, $\&$ valde venenof $x$ funt beftiol $x$, fupra enarratis remediis curand $x$.

$$
\begin{array}{llllllllll}
I & A & P & V & R & V & C & A^{\prime} & I I
\end{array}
$$

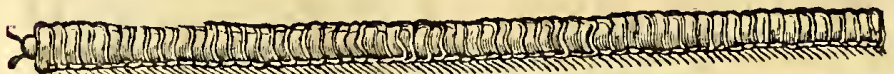
preffis, capitulo parvo cum duobus incurvatis corniculis breviufculis, cruribus exilibus innumeris.

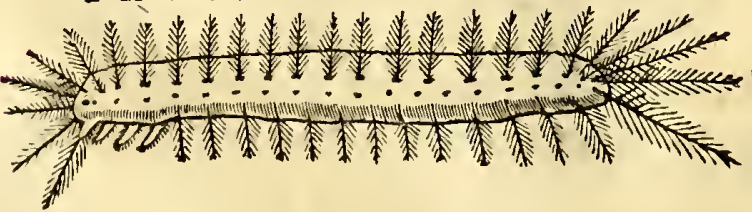

T A T A V R A A \& A M B A.

Entipedes hirfuti duo arcuatim repentes, Tataurána \& Ambua Brafil.centopéa Lufitanis dicti, interque Erucas habiti, ad venenatorum ordinem referuntur. Sicut Scolopendræ ædes; ita hæ filvas perreptant, olerumque hortcnfium frutices non folum, fed \& homines infeftant. Prior duos digitos longus $\&$ majori penna anferina craffior, teres five cylindricus, nigerrimus capitulo fplendente nigro \& maculas majufculas albas habens, in lateribus ordine pofitas : pedes octo, fatis craffos, fed breves nigerrimos. ToPentibus fubftantia inftar tum corpus pilis duriufculis eleganter flavis veftitum ett, contantibus fublantia ilrera, fetarum equinarum. 
H IST. NATVRA L. \& MEDIC. LIB. V. 287

Ltera, ut ex figura apparet, obefiore fed breviore eft corpore, eoque miris juncturis divifo, pilis undiquaque elegantioribus \& majoribus, plumarum more copulatis. Si Vermes hi cutem humanam attingant, urunt inftar ignis. Omnes denique Erucx uridam vim habent, cutique deglubend $x$ \& veficis excitandis aptam.

Scorpiones Europæis externa figura funt fimiles, licet non æque noxii, proinde ictus cortum, curatu minus difficiles. Adeo uthife Scorpionibus idem fere attribui poffit quod Mathiolus de iis qui in Tridentinis regionibus reperiuntur teftatum reliquit, fcilicet illorum puncturas levifimas effe $\&$ non lethales.

Quapropter cum horum infectorum natura, vulnerumque curatio ab Auctoribus paffim ante me traditx fint, nec quicquam ad illuftrationem ulteriorem occurrat, acquiefcam. Quippe folum oleum, quod eorum viventium qualitates abforbuerit, con-tra morfus cum fucceflu applicatur.

\section{$\begin{array}{llllllllll}C & A & P & V & T & X & \text { I I. }\end{array}$}

\section{Copueruçú fine Vespe, Marigúi, Nhatiu', Mberóbi fine Culices,} Tunga fove pedum Vermiculi, \& 'Iatebúcú five Ricini.

\section{I}

Nfeftiflima Vefparum examina in arboribus nidificantia, non armenta folum, fed viatores aufugientes perfequi amant; imo turmis equitum non parcunt irritata. 1 Quibus ob corporis magnitudinem diverfam $\&$ coloris difcrepantiam varia nomina $a b$ Indigenis funt impofita. Omnium maxim $x$ in cavi-tatibus arborum nidificantes Copueruçí, quibus fucceduntVruperána, deinde Aiçáva nigri \& parvi, ut \& Tupeiçava, nigri quoque \& omnium minimi, qui duo pofteriores horrende pungunt præ cxteris. Omnes uno nomine Maripofas vel Maribundas Hifpanis appellati.

Nidus minorum Vefparum (cujus iconem exhibeo) eft plus quam majoris ovi oloris magnitudinis \& form $x$, fed leviffimi ponderis. Exterius obductus villof, tenui \& tenaci materia grifei coloris, qua avulfa apparent tres quatuorve tabul $x$ parietibus diftinctx, exmeris cellulis ro-

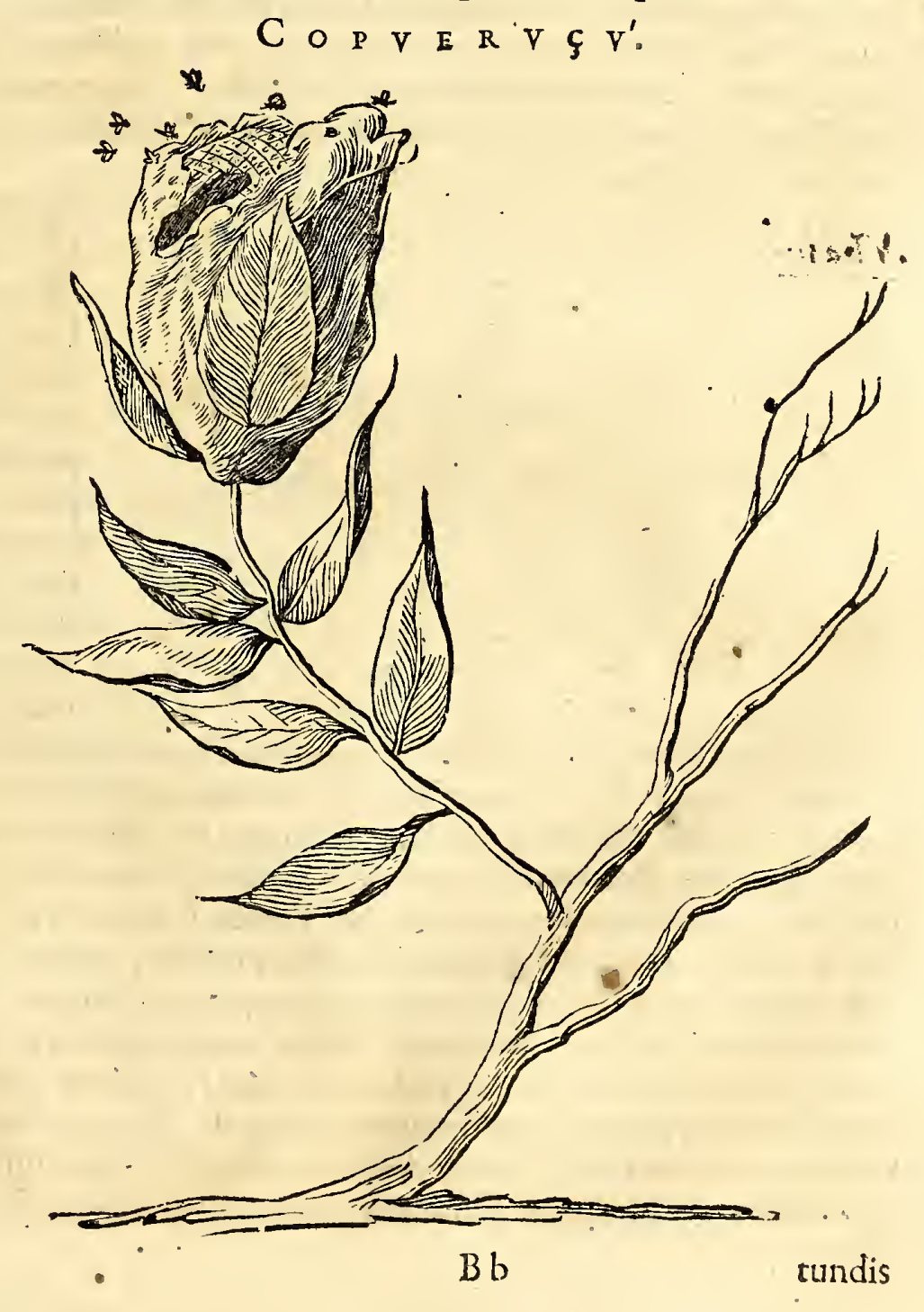


tundis egregie fabricatæ, \& more parviapiarii concinnatæ. Quibus reconditum melligineum humorem haud facile quifquam impune attingit, quia Crabrones vix patiuntur fe irritarier. Vnde quoque fit, ut de harum coitu, deque materia, ex qua generen. tur, nondum fatis perfpectum fit. Idem ille nidus quem in ramorum extremitatibus tabricant, in medicinain receptus eft, atque contra frigidos affectus, interne, fed externe potiffimum adhibetur, ficut nidus Hirundinum. Magnitudine inter fe variant, fed figura Europxis Vefpis haud diffimiles funt, Crabronibus atque Oeftris omnibus infenfiores. Eafque cjufdem putem generis effe, cujus Ariftoteles meminit non in terra fed in arboribus nidificantis. Cum nihil ex floribus hauriant fed animalium carnes tantum petant, facile erit has à $V$ efpis vulgaribus \& A pibus difcernere, quod hx carnem fugiant; ill $x$ fores $\&$ carnem quoque petant. Noxia hæc infecta velociffima, ipfo eodemque momento, quo infultant, aculeo rigidifime faciem petunt, atque mox avolant. Vnde atrocifimus dolor cum ardore fummo exfurgit, duratque ad horas, manente rubore \& elata cute. Vix ullum fatis prafens tam immani cruciatui exiftit remedium conveniens, quod pars eorum balfamis indigenis, atque refrigerante quodam unguento de Imbaiba; pars cauteriis potentialibus, calorem extrahendo præftat.

$$
M \text { A R I G V } I^{\prime} \text {. }
$$

Nter Culices noxios qui maxime familiares, \& ab omnibus pariter incolis ob morfum extimefcuntur, funt Marigui, Nhatiu, \& Mberobi. Horum quidem CMarigui omnium crudeliffime affligunt, fed adeo exigui, ut tactus fenfu potius quam vifus percipiantur. More aliorum Culicum gregatim volitant, atque rarius apparent, nifi fumma exiftente malacia, idque vefpertino tempore potiffimum, circa fluviorum ripas inter paludofas illas arbores Mangues diatas, hærent. Novi- \& pleni-lunio potifimum, raro interlunio vagantur. Merito ab omnibus pariter incolis extimefcuntur hrecinfeata moleftiffima ; quippe adeo exercent \& lancinant agricolas, ut non folum membra eorum nuda, fed \& veftita morfu dolorofo infeftent, acuumque mucrones referant. Scapha fluvium lento gradu afcendentibus mecum Hifpanis, adeo intumuerat, veflcifque acrubore confperfa erat nobis facies, ut à familiariffimis ne quidem dignofceremur amicis. Ethiopes juffu domini fui palo affixos, perque integram noctem (mirum fupplicii genus) relictos, poftridie, ex meris doloribus \& morfuum cruciatibus delirio captos memini.

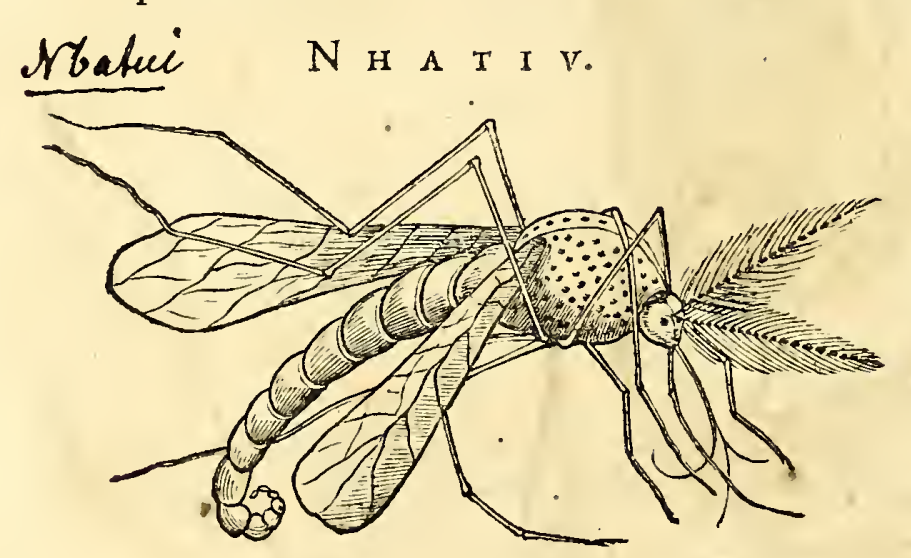

Equitur nunc fecundum $S$ Culicum genus Nhatiun pre cæteris quoque moleftiflimum Lufitanis Mofguito Pefni-longo, noftratibus Tang-bent dictum quod longitudine pedum inprimis pracedentes Culices fuperat. Monitum tamen volo lector em hanc effigiem Nhatiun ficut \& aliorum minimorum infectorum fextuplo effe majorem quam beftiola viva, ac proinde per Megafcopium efle depictam fine cujus ope impoffibile erat fubtiliffimas conformationes $\&$ articulationes noviffe. Capite eft parvo, obrotundo, cui duo cirri ab utroque latere oculorum pilis longis ordine decorati, adftant. Corpore eft elliptico ex flavo \& nigro undato variis fectionibus divifo, in extremitate Scorpionum more incurvato, alis duabus magnis, cruribus fex, tribus internodiis divifis : Totum infectum veftitur pilis fubtilibus brevibus flavefcentibus, variegatum maculis undatis, obfcure flavis. In extremitate roftillo longo tenui fanguinem exfugit, pungitque acerrime, etiam per lineá veftimenta dolor ofum pruritum excitans. Noctu potiffimum in paluftribus $\&$ maritimis locis gregatim vagatur ficut præcedens Marigui; fed ab eo differt, quod hic moleftiam fimul magnam pariat dormiturientibus tinnula fua voce; tum quoque non igne aliave refe abigi pat itur, nifi folummodo fumo accenfi fimi bubuli exficcati.

Tandem tertium genus Culicum reftat defcribendum, quod Mberoli dictum diverfex 
HIST. NATVRAI. \& MEDIC. LIB. V.

eft magnitudinis, adeoque profunde pungens, ut aculeum vulneri infixum relinquat, ifque mox corrupta parte lefa tranfmutetur in infectum huic $M$ berobi fimile, habens fex crura, quorum ultimum par longiffimum. Cornicula duo in capite, alæ quatuor variegatx. Tota mufca viridis eft cum aureo mixti, in fronte fapphirini coloris. Oculi nigri corniculares.

Aliud denique mirum genus vermiculi ex fubfidentia aqux pluvialis nafcitur, quod de fubito depofitis exuviis alatum prodit, longis pedibus \& culicum præcedentium more homines \& pecora infeftat.

Idem faciunt culices çaúa, Taturána, Ietinga, Pinu, Niguas, \& alii, quos enarrare txdiofum foret.

Peregrinantes noctu five per loca littoralia, five per illa nemora quo defatigata aura marina vix pertingit, prelentiorem cautelam non amplectuntur, quam ipfum ignem integrofque rogos: tum quoque Balfamum Copaiba \& Cabureíba, quibus membra nuda inungunt. Ante horam unam atque alteram tumores \& puncturx evanefcere folent, modo non nimia frictione vel frigid $x$ afperfione irritentur partes lafx. Dolores apprime fedantur muccagine Cardu littoralis, tum $\&$ arborum Samouna $\&$ Imbaib ac herbx Paiornirioba, cxterifque ejufdem generis fuccis infpiffatis, qui frigida $\&$ anodyna qualitate pollent.

Brafiliani parvis Cicindelis fplendididiffimis, non folum ad noctis tenebras illuminan. das; fed ad fugandum quoque moleftiflimum hoc genus culicum, utuntur. De quarum indole \& lumine mox ex profeffo dicetur.

$$
T \quad V \quad N \quad G \quad A .
$$

M Inutifimis Infectis qux Lufitan. Bicho, Brafil. Tunga dicuntur , pleræque Regiones Americanæ obnoxiæ funt. Sæpe cum pruritu, raro cum dolore, pedum digitorum extremitatibus innafuntur. Maximopere infeftant præ cxteris eos qui nudis pedibus loca arenofa perambulant; in quibus utpote calidiffimis vivere amant invifibiliter, fugiuntque pavimenta lithoftrata. Initio in cute exteriori aliquandiu latitant. Mox ingenti cum pruritu, præcipue circa plantas pedum, imo \& manuum, cutem fine noxa penetrant, inque ea fe recondunt. Nihil cum Guineenfibus vermiculis commune habent, quilongi, lati \&albicantes, chordarum fpeciem referunt. Hi vero exigui intufque paulo profundius occultati \& veficula orbiculata inclufi, nigricantes apparent, eofque per megafcopium explorare oportet; fecus enim ne à lynceo quidem exacte fatis perf́pici poffunt. Tandem ubi ad juftam magnitudinem, quod eft circa triduum vel quatriduum, excreviffe compertum fuerit, tunc maxime de excifione cogitandum, quod folius aciculæ aut argentex cufpidis beneficio, à Brafiliano aut $\mathbb{A}$ thiope, facillimo negotio fieri confuevit. Ea folum adhibenda cau tio, ut vermis folliculo pellucido \& rotundo inclufus integer eximatur, antequam fobolem progeneret innumeram, qux unguibus icta lendium modo crepitant. Rupto enim fponte folliculo nova parti vitiatæ exfurgunt fymptomata; imo vicinas illafas inficiunt. Et tunc quidem non minus calamitofi, quam illi in Guinea habentur, adeoque gangrænam ipfam intuliffememini, ut pedum digitos amputare non femel neceffe fuerit. Videre mihi contigit in Nofocomio, cutem in calce pedis callofam, fub qua innumeri latitabant vermiculi, militibus penitus fuiffe refectam. Remedium quo pracautionis gratia Lufitani æque ac Brafiliani inungunt plantas $\&$ digitos pedum, eft mordaciffimum ilIud oleum glandium, qui pomis Acaiu adnafcuntur. Quod quidem oleum fit extractum ex immaturis \& crudis glandibus; nam fi maturuerint, qualitate uftiva fere caret, nechuic affectui remedium prabet. Lachryma flavæ arboris Camacari dict a admota cidem malo prodeft. Quod ipfum quoque gentem nauticam pice navali præftare videmus, ut \& pifcium pinguedine, à cujus fotore fugantur vel moriuntur.

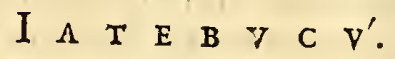

Atebucí Brafil. xpótwv Græecis nuncupatur, beftiola foda ; lentis magnitudine, fubrotunda, plane compreffa, cute punctulata feu tuberculata, cum lurido clypeo triangulari in dorfo. Coloris eft hepatici, octo cruribus pradita, capite prominente qua- 
dratx figur $x$, roftro longo tereti, quo in quacunque parte corporis fugendo fe ingurgitat, ac infignem ibi excitat pruritum dolorofum, ita ut ex cute vi extracta per aliquot dies eo loci fanies profluat \& vix quindecim dierum fpatio vulnus licet exiguum reftituatur. Omnifere anni tempore vigent, \& peregrinantes imprimis fi humi confideant, vehementer exercent. Poftquam autem parti alicui adhærerunt, brevi grandefcunt turgentque, mox à paucis diebus nimiafatietate dehifcunt, ita ut ea Plinius merito inter turpia animalcula appellarit, quorum faginæ finis, mors ipfa eft. Nofter hic Latebucus five Ricinus Americanus, licet ejufdem cum Reduvio generis, ab eo tamen potifimum differt, quod folo fanguine vivi animalis delectetur : à cxteris autem Infectis difcrepat, quod licet fanguine affatim repletus, excrementi tamen exitu deftitutus fit. Idem quoque in Europa ab aliis ante me obfervatum eft. Nec prolem gignere, nec $\mathrm{ab}$ aliis beftiolis gigni animadvertere potui. Sed ex putri quodam humore inter herbarum folia nafci crediderim. Vulnufcula in cute humana ab iis illata, oleis \& fuccis anodynis, atque balfamis nativis fupra enarratis curantur.

\section{A $P$ P $\quad T \quad X I I I$.}

\section{Andira five Vefpertilio, Cupice fuve Formica, \& Memoa fove Cicindela.}

Vnt denique in tota Brafilia, præertim in ruderibus, ut $\&$ in Palmis nuciferis Yefpertiliones majores \& minores, hos appellant Braflii Andira, illos vero Andiraguacu. Majorum corpora columbas æquant Europæas, vocanturque Vefpertiliones cornuti, præpingues, cinerei coloris, mollibus $\&$ longioribus pilis, auribus.latis;

\section{$A$ N D I R A.}

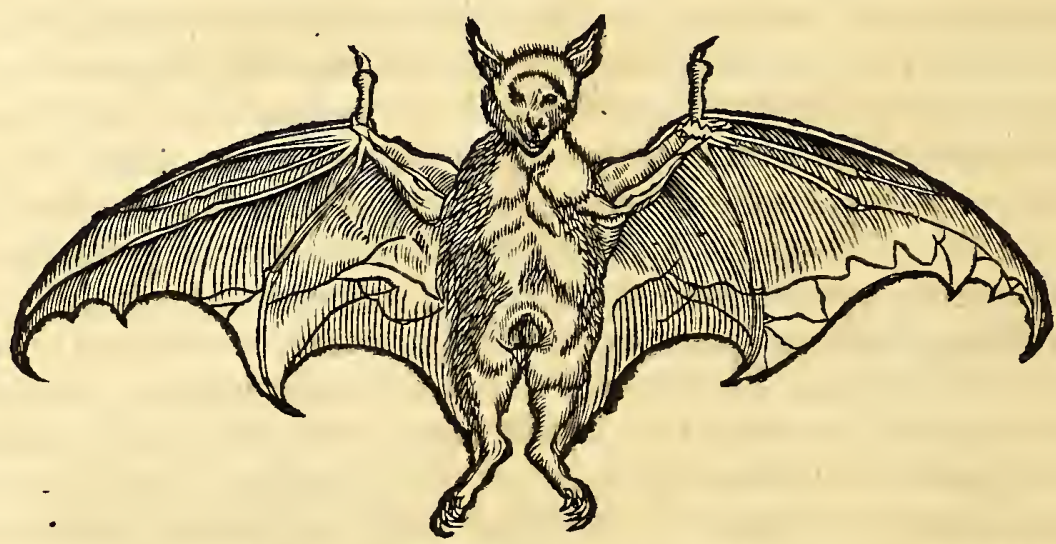

In fingulis pedibus habentes quinque digitos, acutis unguibus armatos. Dentes candidi , \& fupra nafum corpufculum, ejufdem cum auribus longitudinis, fatis grande, ex materia qualis illius rictus, flexile feu mobile. Alarum magnitudo femipedem fuperat. Miræ fane conformationis eft animal (ut verbis Scaligeri utar) bipes, quadrupes, ambulans non pedibus, volans non pennis, videns fine luce, cxcus in luce, extra lucem luce utitur, in luce luce caret, avis cum dentibus, fine roftro, cum mammis, cum la$\mathrm{cte}$, pullos etiam inter volandum gerens. Omne gehus animalium appetunt, eorumque fanguinem exorbent. In prafectura autem Maranhan eft genus quoddam Vefpertilionum, quod de nocte, dormientium hominum pedes veltibus denudatos adoriuntur: $\&$ roftro vulnerant, humani fanguinis exfugendi caufa: morfus tam levis \& fubtilis eft, ut non perfentifcant illum vulnerati, antequam lectus fanguine perfufus, indicium vulneris faciat : tanta copia fanguinis à venenato morfu effluit, ut difficulter fifti poffit; adeoque evidens vitæ periculum dormientibus adfert nifi prædictis internis \& externis remediis opem ferant. Imprimis autem omnes paffim Incolæ vulnera hæc curant lotione aqu $x$ marin $x$ fervid $x$, tum quoque cineribus calentibus, vel tandem uftione, fi fanguis non fiftatur. Vefpertilionum linguam $\&$ cor inter primaria ponunt venena: fed an guftata cjufdem naturx veneni fint, cujus Canis rabidi, hydrophobiam inducentis , ficut gravifimi autores de co teftati funt, à me nondum compertum eft.

Vide Carolum Clufium Exot. 1. v. c. 1. qui ex Oviedo teftatur, ejufdem generis Ve$\therefore$ 
HIST. NATVRAL。 MEDIC IIB. V。

fpertiliones reperiri pingues; quibus aqux ferventi immerfis $\& z$ excoriatis Incolx in Infula D. Ioannis vefcuntur, quia Pafferibus non minus aibi funt, necminus, ut afferunt, bonifapóris.

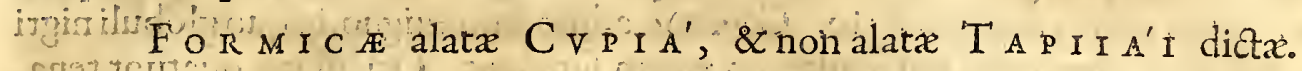

T Mmenfa Formicarum agmina, proh dolor, Brafilia, eaque diverfer fpeciei producit.

1 ut éhim quædam Europæas magnitudine æquant; ita plurimæatriplo iis majores atque amnivorz fint; nam pifces, carnes fruges \& fructus (exceptis acidis à quibus folis abftiment) quin \& venenata Infecta, Scoorpiones, Scolopendras, Glires, \& fimilia impuric de - pafcerémox velociflime vel avolare vel terram Talparum inftar fodere \& fubterraneis non parcere Satis, teftis fum oculatus. Verum ut merito his Infectis fupra narratis \& ipfis quoque agricolis formidabiles; ita $\&$ illæx viciffim fuos extimefcunt hoftes, fcilicet plurimos Serpentes \& imprimis quadrupedia illa Tamendoá quxie iis perpetuo infidiantur, integrafque myriades deglutiunt, ut alio loco probavi. De miranda earum indole \& œconomia, deque condendis femitis \& aggeribus cavernofis, dicere nunc fuperfedeo, quia in traetatu de Aëre, Aquis \& Locis, fatis fuperque de iis egi.

Formicxautem hænon folum magnitudine $\&$ colore, fed fi per megaícopium ri te examinentur conformatione partium quoque inter fe differunt: imo earum aliqux fpecies, certo tempore álas acquirunt eafque poftea rurfus deponunt. Quod à paucis autoribus obfervatum effe reperio, neque ipfe Mouffetus fagaciflimus Infectorum indagator, amplam licet dederit Formicarum defcriptionem, meminiffe videtur Formicarum volantium. Ex earum cadaveribus Vermiculi nafcuntur, qui mox in alatas Formicas prioribus fimiles faceflunt, quafi illud quod ex alterius corruptione generctur, non diverfum, fed fimilem fubinde vultum contraheret. Inter alatas quibuldam. Cupiż nomen à Brafilianis inditum. Mufcis funt æquales, corpere bifecto tenuiffmoque ligamento cop: 1 lato. Alis quatuor tenuibus \& tranfparentibus, quarum pofteriores dur minores anterioribus, aliqux fpadicei, aliqux obfcure flavi funt coloris. Ocellis parvis,nigris, capite fere triangulari, cui duo gracilia cornicula longa impofita, forcipefque duo exerti pro dentibus. In anteriore corporis fectione qux pifi eft figur $x \&$ magnitudinis, fex apparent crura tribus articulationibus conftantia. Pofterior fectio corporis major eft anteriore, quam multi in cibum præparant $\&$ comedunt. Totum Infectum minutulis pilis brunnis cooperitur. Alia præterea datur grandis fpecies Tama-ioura dieta digitiarticulum adæquans. Quarum etiam clunes diffecantur $\&$ friguntur pro bono alimento.

Formicx autem Iapizái alis deftitutx, aliqux pregrandes, corpore tripartito, atro, fplendente. cxtera corporis membra præcedentịum Formicarum fere fimilia, exceptis oculis qui multo majores funt, quippe totum caput nihil aliud apparet, quam duo ocúli magni fibi invicem appofiti.

Atque hæc de grandioribus Formicis tantum brcviter dicta velim, quarum noxias vel proficuas qualitates noviffe conducit. Inter quas illæ qux Taioques dictx peffime mordent.

Morfus earum ruborem, tumorem, pruritum, deinde acrem dolorem $\&$ ardorem inferunt. Qui emplaftro ex ipfis Formicis preparato, partique dolentiapplicato, fanantur, ita ut hæ Formicx more Scorpionum fuis mor fibus pariter medelam cum malo afferant. Sed ne quis opinetur hxc animal cula (infefta licet a deo humano generi) nullis malis internis open ferre. Præterquam enim, quod vefca fint tofta, ut fupra monuis tum quoque $x$ que feliciter uririx difficultatibus fuccurrunt fi affumantur, ac de Afellis feu Milleped is Europais obfervatum eft. Ita ut ex Murmecia, diverfa remedia refultent, quxnon folum ab his barbaris, fed ab erudita antiquitate admodum celebrata funt.

$$
\text { M E M } O A^{\prime} \text {. }
$$

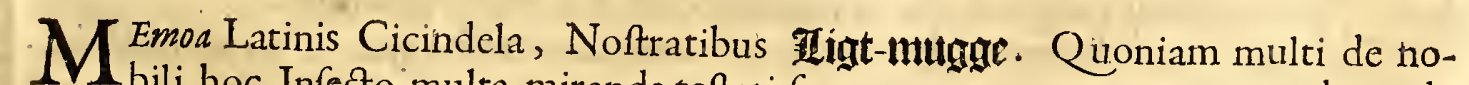
Mili hoc Infecto multa miranda teftati funt, ego pauca tantum notatu digna de
Cicindelà five Noctiluca inferenda putavi. An Veneris faftidium adferant fi affumantur, hic à nemine hactenus compertum eft : ficut Rhafis, Albertus, BenediCus, aliique de fuis Cicindelis teftati funt. Veteres Graciac Latini à noviciis autoribus difcrepant non folum circa eorum nomina, generationem \& conformationem; fed imprimis circa naturam atque fitum tanti luminis. Ego mifis variarum opinio- 


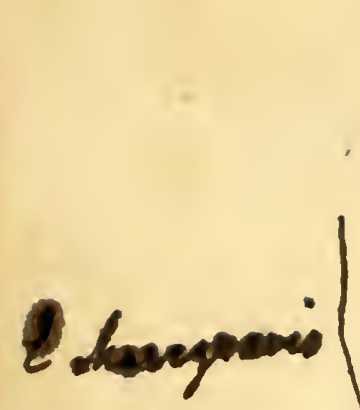

292

GVIIE L M I P I SONIS; I:

num falebris, quibus multa fuperftitiofa videntur intercurrere, aperiam quid mihi de Brafilienfi noftra conftet.

Beftiola hæc exigua, granum cucumeris æquans, nigricantis eft coloris; corpore oblongo in duas partes xquales fecto. Capitulo admodum exiguo, in quo globuli nigri apparent Gagatis fplendore, qui oculor um vicem fupplent. Ori aftant quatuor tenacula, \& duo barbx pili. Crura habet fex pilofa, fingula tribus internodiis diftincta. Alas duas, fub quibus verfus caudam in utroque latere macula apparet magnitudine feminis papaveris, rotunda, alba, (plendens; ex quibus lumen emittit; imprimis noctu, facitque pro lubitu has maculas thalaffini coloris fplendidiffimi. Poft hos ignis focos corniculum eft exiguum flavefcens, vergens verfus pofteriora, quod vix nifi Megafcopii beneficio confpicitur.

Albæ maculæ fupra enarratæ inter volandum tam mirabili fplendore fulgent, ut quafi fcintill $x$ ignex per aër em volitare videantur : ad illud Politiani, Inde opus integrant, donec fub nocte corufcent, Flammiger parve ftellantiluce volucres.

Ita ut mihi non tantum per egrinanti illud lumen, fed $\&$ militibus primo illius infuetis, terrorem injecerit, metu hoftis infidiofi cum ignitis fomitibus poft carecta latitantis: cum tamen idem lumen mox affuefactis folatio fuerit nobis in defertis noctu errantibus, quod lucernarum vicem fuppleverit, adeoque, lun $\&$ ftellarum fplendore jam per imbres \& nubes ablato, harum tamen fulgorem ne Cimmeria quidem caligo diminuerit, imo auxerit. Adde quod multx vivæ fimul collectx legendi copiam præbuerint, ita tamen ut lux illa paulo poft cum f́piritu vitali evanuerit. Quod idem in theatro fuo Infectorum Eruditiffimus Mouffetus aliique non vanx fidei teftati funt. Ita ut non videam quid fibi velint Cardanus, Albertus, Mizaldus de perpetua illa luce quam hic ad ravim ufque contendunt dari. Imo varias compofitiones venditantes, perennem lucem:exinde quafi lunam de colo in varios ufus humanos promittere aufifunt.

An vero medicamenta quoque idonea more Cantharidum ex iis parentur, ut quidam fcripferunt, à me nondum compertum fareor.

Porro cum liqueat naturam non folum fed fitum quoque hujus decantati luminis variare tam in Europxis, quam Ex-curopxis Cicindelis, meo quidem judicio nemo propius accedit ad ea quorum ふ่ยส่тAทs fui in Brafilia quam Plinius, dicens fulgorem igni fimilem alarum compreflu tegi, fccumque lumen habere $\&$ noctem. Quamvis enim, ut fupra monui, à lateribus utrimque juxta clunes fulgor ille exeat inter volandum; illum tamen nifi hiantibus $\&$ elatis alis non rite emicare multoties mecum viderunt multi.

Quantum vero ad generationem hujus Infecti,condonandum mihifi in ea titubem etiam cum doctioribus. Quod haud adeo facile eft difcernere ea qux perpetuo velo metamorphofeos involuta funt. E rore quidem non ipfam vitam, ut quibufdam de $\mathrm{Ci}$ cindelis Europxis placuit, fed vitæ fuftentaculum nancifcuntur. Ego primo admonitus experientia incomparabilis noftri feculi philofophi Scaligeri, eas copulatas volan. tes, \& fedentes, in coitu repperi, diuque in eo hærere comperi, quibus dein folutis, infinita apparuere ova, quix cito vel intra diem vivificata abierunt. quo fpectat illud

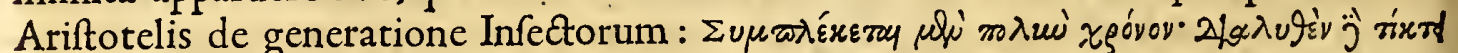
zax́́ss. Mox veftigia fecutus Brueri \& Mouffeti, ea, ut fupra monui, ex ovis exclufa obfervavi. Atque tandem comperi, fecundum confuetum naturæ ordinem animalcula ex iis prodiiffe, Erucas fcilicet minores, nigricantes, pilofas, ex quibus $\mathrm{Ci}$ cindelas primo non volantes, ex iis autem rurfus in Chryfalidem mutatas, volucres ortum duxifle.

Toto anno in hoc Americæ trału, non vero ftatis fementis \&meffis temporibus, ut in Europa, vagantur, atque noctu imprim is efcam exfloribus venantur.

Plura equidem reftarent referenda de hoc animalculo:fed quia id vix unius eft hominis ex profeffo talia tractantis, veniam merebor, fi inftitutum profequar, $2 c$ cætera fedulre pofteritati ulterius indaganda relinquam. 
HIST. NATVRAL. \& MEDIC. LIB. Y.

\section{A P, $\mathrm{V} \quad \mathrm{T} \quad \mathrm{X} I \mathrm{~V}$.}

\section{Nari- Nari, Aieréba, Iabebireté, Niqui, Mouçicu, \& e Amoreatim.}

$\mathrm{P}$

Rxer tot planos Pifces cartilagineos dantur Paftinacx marin $x$, Torpedinum, Raiarum fpecies, læves, cærulex, fine fquamis vel aculeis in toto corpore, præterquam in caudæ principio, ubi duo breves non ferrati, fed ad fagittx figuram formati apparent, ac proinde hi Pifces à noftratibus merito Biflftaet ; à Brafilianis

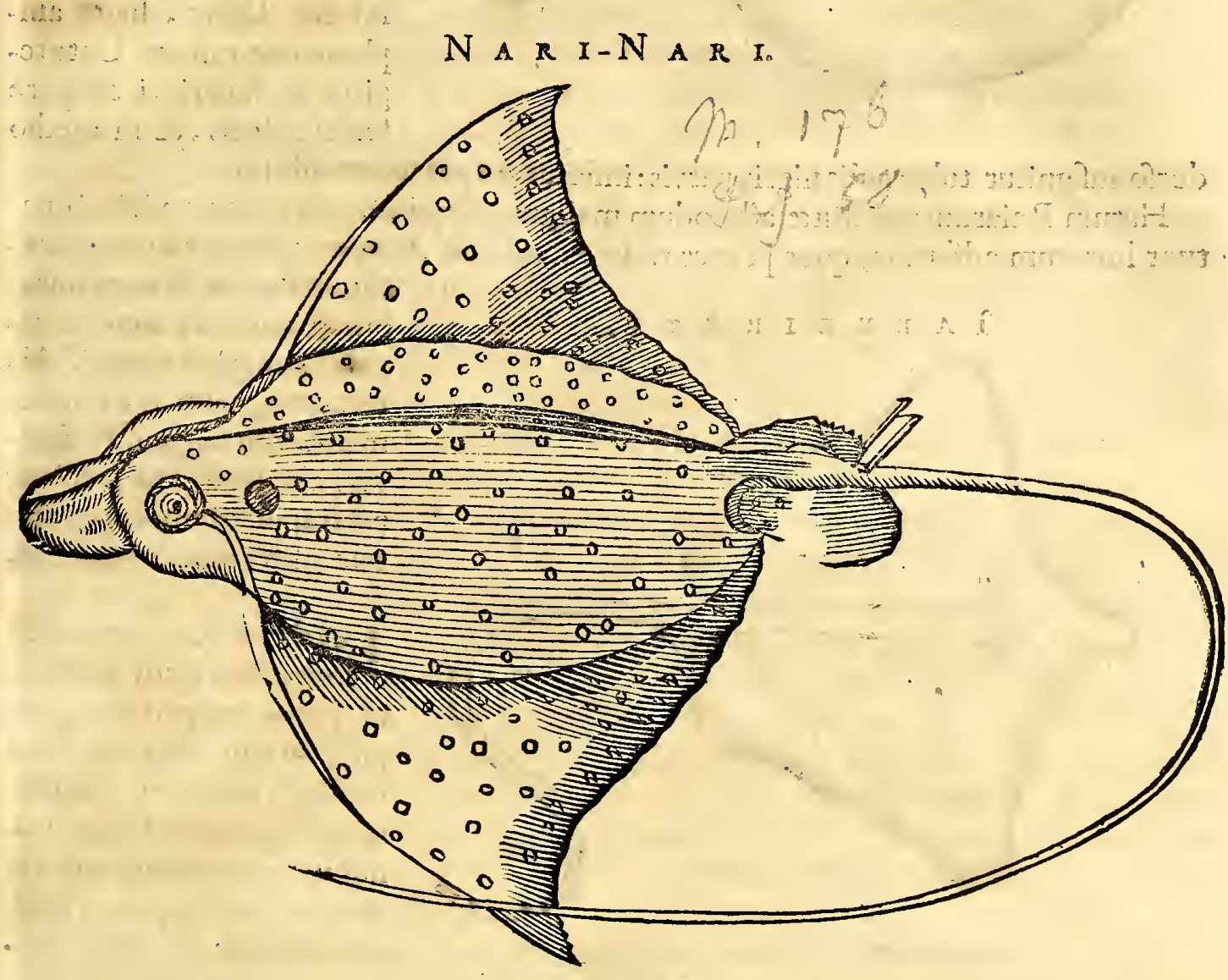

2ari-Nariappellantur. Non procul à littoribus degunt, vefcuntur Pifcibus, quibus ex occulto infidiantur, radiumque iis infigunt, quo ablato edules funt, ficut multis illis terreftribus \& marinis belluis contingit, quæ iatu vel morfu tantum venenum infundunt. Pars vulnerata infeftiffimo dolore, aliquando \& paralyfi mifere afficitur. An aculeus etiam mortua Paftinaca vires fuas fervet, atque non folum in animantes, fed \& $\mathrm{i}$ in faxa $\&$ herbas, exferat eas, ficut Oppianus, 死lianus, \& alii teftantur de Europæa Paftinaca, ego nondum comperi. Dolores fedantur optima illa radice Mangue affata, eodemque modo, ficut in icu Pifcis 2 (iqui dictum eft. Dein dilatato vulneri ejufdem Pifcisjecur, \& teli ipfus cineres cum fucceffu applicantur. Ita ut hic quoque Pifcis veneni fui antipharmacum in fe habere videatur.

De Brafilienfi Torpedine, ejufque malo, vix ad horam unam atque alteram durabili, quia cum Europæa in plerifque convenit, iifdemque remediis $\&$ eodem modo curatur, particulatim nunc agere fupervacuum duco.

F $x$ tanta Raiarum familia, duas tantum adducam ictibus venenatis celebres. CæreErum figura $\&$ alimentofa qualitate differentes, ut in libro de alimentofis pifcibus probavi. Quippe prior hæc Aieréba ex cibis rejicitur. Pofterior Iabebireté probatiffmæeft carnis ; utræque tamen fibi pares malignitate radiorum circa caudam hærentium. Aieréba itaque haud vulgaris quidem eft conformationis, rotundus plane, atque in fuperiorifuperficie punctulis acuminatis variegatur, ibique duo foramina habet fatis 
A I E R E $B$ A.

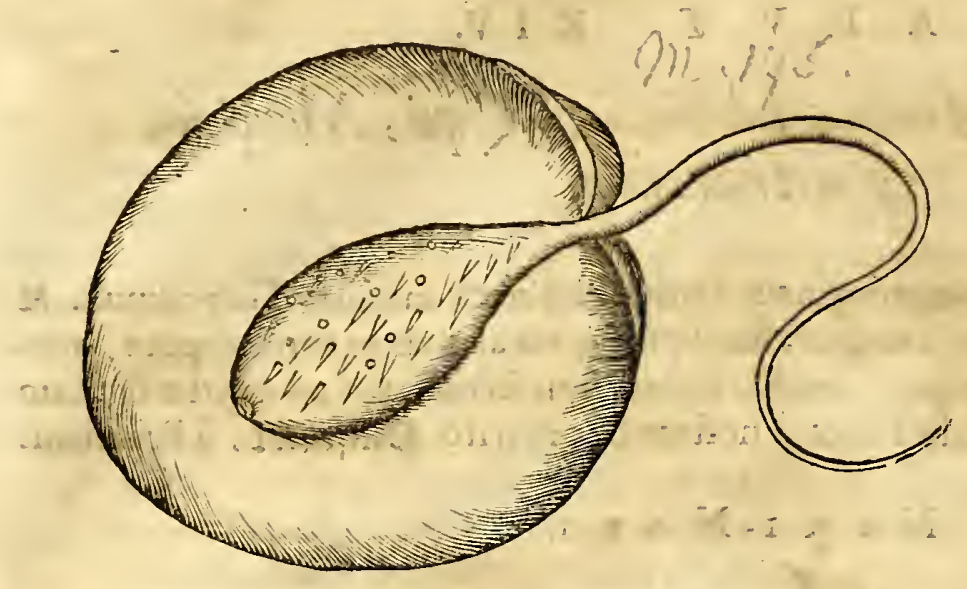

ampla. Prope caudæ exortum orbicularis incifura eft in quolibet latere : cauda teres, longa, \& circiter in medio fui, duas offeas fpinas craffas retro dentatas habet, quibus pungit, quando ad fpiracula apprehenditur, caudam incurvatam fupra corpus levando. Ós inferius habet, haud amplum, edentulum. Cutetegitur in fuperiori corpore ferrei coloris, $\&$ in medio dorfo infignitur tuberculis nigris parvis: inferius corpus totum album.

Harum Raiarum puncturæ admodum malignæ, exquifitofque dolores viginti quatuor horarum adferunt, quos præter radicem arboris Mangue, oleum imprimis fru-

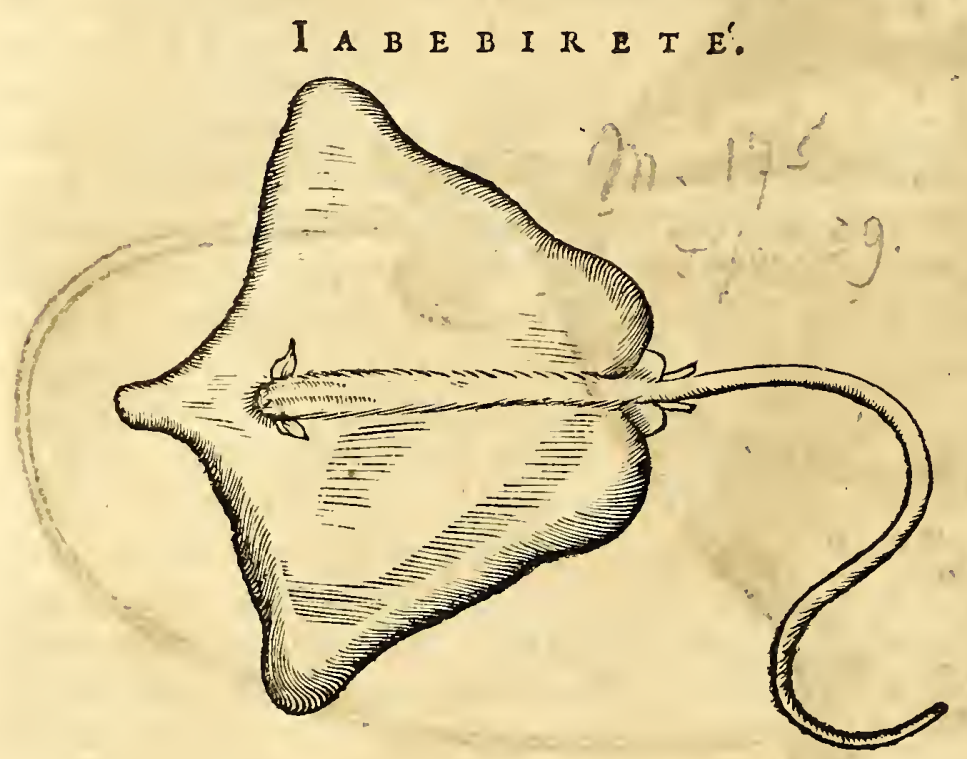
Etuum Palmx Vrucurí mirabiliter mitigat, ficut in capite Palmarum notavi. Alterutrum enim horum remediorum unguenti vel cataplafmatis forma fauciarx parti applicitum, fanat, abfque ullo remedio interno.

TAbebireté vero, cauda eft 1 longiffima quam irritatus in gyros contorquet, ut pifcatorem telis fuis ad caudx exortum prominentibus facilius feriat. Vulnus iifdem remediis curatur ut fupra, addito tamen ipfius pifcis hepate.

$N$ I $Q$ y I.

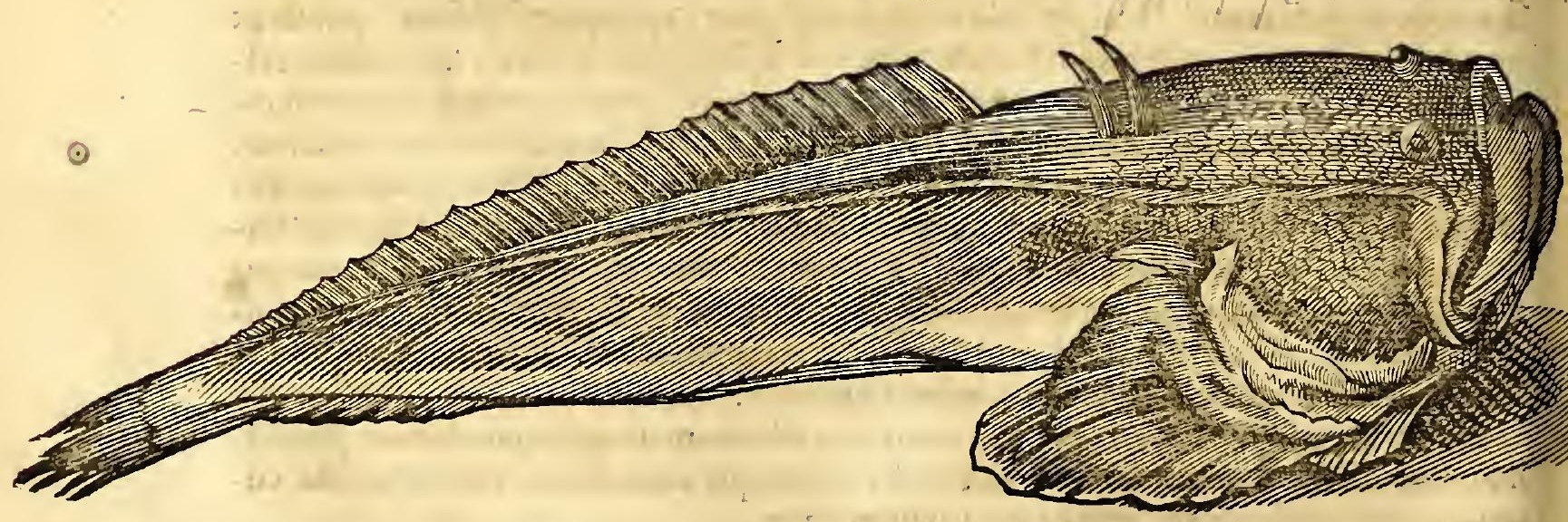

Toxiis pifcibus annum crantur quoque uterque illi, qui 2 iqui dicuntur Brafilienti1 bus. Aculeis in capite \& dorfo præditi funt admodum noxiis, quibus irritati, tanta vehementia pungunt, ut dolor non folum intenfus inde exoriatur, fed membrum paralyticum pro tempore mancat, præfertim fi telum (quod aliquando fit) in parte vulnerata relinquatur. Capite eft craflo fquamofo, ore patulo, edentulo, branchiis am- 
plis. Oculis exertis Cancrorummore, ante exortum pinnæ dorfalis, quæad caudam continuatur, duobus fortibus aculeis armatus. Tegitur cute ex nigro grifea. Cauda tenuis \& parva. Vulneratis præfentiffimo remedio eft, dilatatio vulneris, applicata mox radice Mangue affata \& contufa. Vnde quidem dolores in inftanti exacerbantur, fed mox ceffant.

Atera 2iquí, præcedenti tudinem difimillima, à noftratibus abufive, ob puncturas credo Bieterman appellatur. Capite eft craffo, ore Ranæ amplo, edentulo \& craffa lingua. Anterior corporis medietas eft paulo latior, pofterior angufta \& teres: Ocelli

ipfi parvi cylindracei. Branchias, pinnas $\&$ caudam in ambitu quafi circinatas habet. Ante exortum pinnx dorfalis duos aculeos fortes $\&$ fupra poftbranchialem utramque, unum acutum quibus atrocia vulnera incaute tangenti infert. Per totum dorfum, caput \&latera, punctula nigra, magnitudine feminis papaveris, difperfa. Edulis eft pifcis fi fel bene feparetur, alias lethalis ut Guamaiacu. Notatu dignum quod fella quantum intus affumta, noxia ; ita extus applicata non raro venenatis puncturis medelx exiftunt.

Nter ea animalia qux viva nocent $\&$ mortua profunt, non folum Raix \& Torpedi1 nes exiftunt fed illi imprimis pifciculi qui vulgo Bagres vocantur, de quorum carne alimentofa fuo loco egi. Nunc ex ordine eft de venenatis ejus ictibus quiddam premonere, ut fibi quifque caveat, quia haud facile quis illos impune laceffit: mox etiam edocere conftitui,quomodo fauciatus de promptiffimis fibi provideat remediis;qux quidem varia à variis incolis fuppeditantur, nullum tamen corum tutius eligendum quam ipfius lædentisjecur, quod vulneri applicatum mox immanes dolores fedat.

Miffis cæteris quinque pifcibus Bagres, fextum huc folum adduco Vrutú dictum tanquam primarium hoftem, utpote qui praceteris $B a$. gris horridioribus \& eminentioribus fpinis dupliciter ferratis, eft armatus, quarum altera

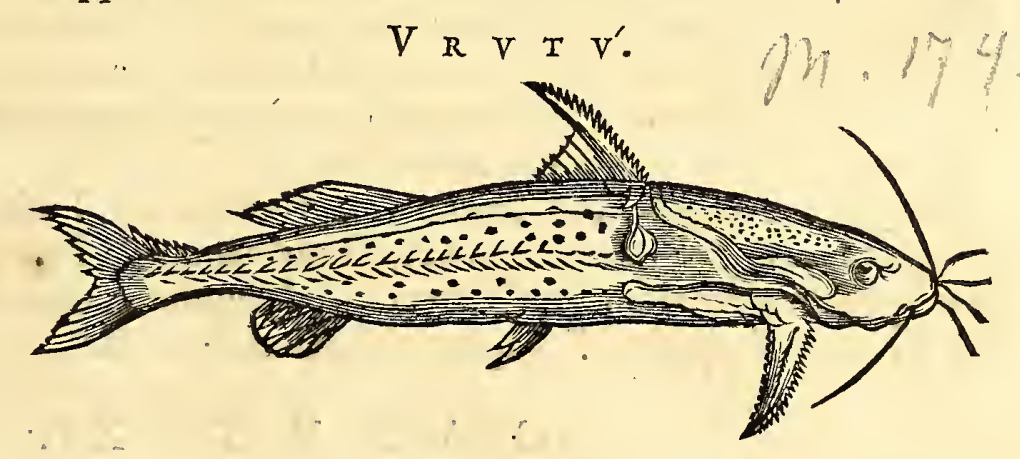
dorfalis, altera fubbran chialis, utraque folida $\& z$ offea, quas pro lubitu erigit, \& in rimarecondit, iifque adeo pungit incaute tangentem, tantumque infert ardorem $\&$ inflammationem, ut vulneratus fubinde animo deficiat. Proinde miffis generalibus illis remediis antidotalibus, ad duo fequentia potiffimum recurrendum eft. Succus recens herbæu ubique obvix Caaçica dictx cum cremore Tipioca intus affumptus ad muniendum cor \& reftaurandos fpiritus accenfos aptiffimus eft: extus jecur vel crudum vel cum oleo paulifper frixum puncturx applicatım, mox quafi per fimilitudinem fubftantix, ut vocant, venenum extrahit. Accedit tertium remedium, quod ligaturis herbæ laçape abfolvitur, membrum fcilicet muniendo, ne altius ferpat malum.

Cm inter marina Zoophyta fponte provenientia,Holothuria,Stcllas \& Pulmones Ariftoceles, Plinius, aliique recentiores repofuerint, ac fruti cis potius quam animalium naturæ participare teftentur; ego, corpus hoc maris pellucidum cMouciciu Bullis marinis afcribercm ; licet externa figura $\&$ internis proprietatibus, $a b$ iis hinc inde difcrepet. Illud enim quod exhibeo (ctiamfi non adeo exacte ejus pictura exprimi potuit) altera extremitatc elevatius, altera depreffius eft. Cxter $x$ omnes par- 


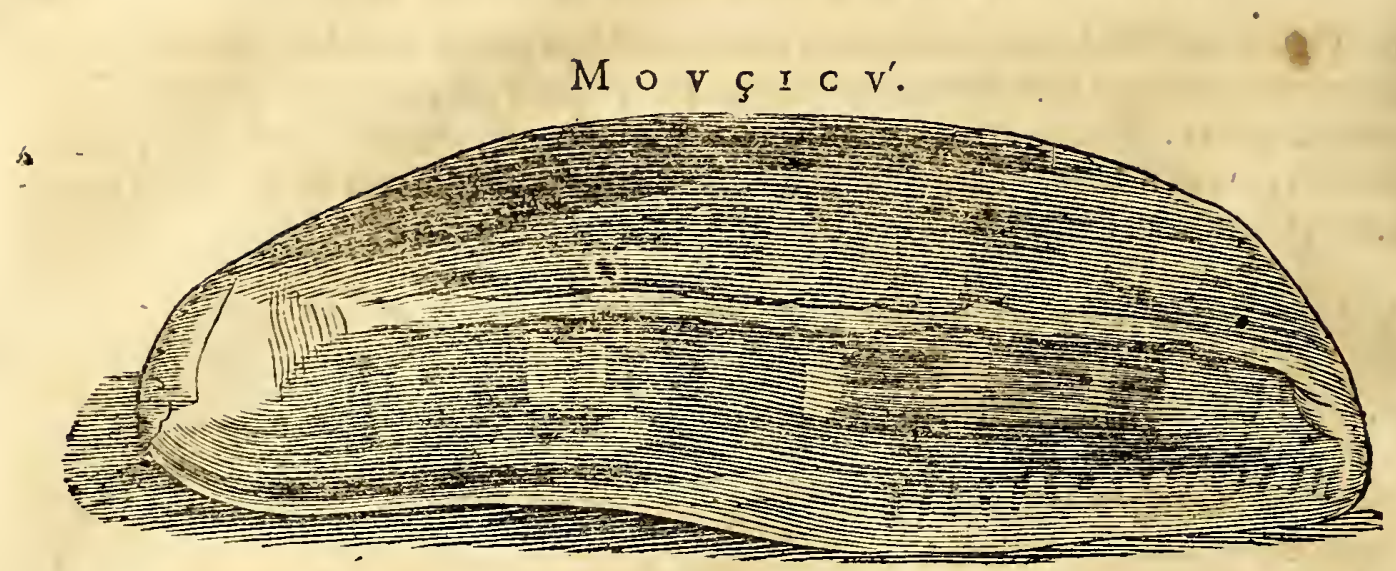

tes externæ \& internæ indifcretx, nec ulla in ambitu apertura. In littore ejectum fponte in fe concidit, ftrepitumque edit fi [vi conteratur. In mari vero inflatum pulchre rubro colore \& purpureis maculis fplendet, aquis fupernatat ac inftar bullx figura variat, multo flatu \& liquore turgens. In faxorum rimis delitefcit aliquando $\&$ inter algas, unde per maris impetus hinc inde fertur. Si multa fimul ad littóra appareant, non minus pro tempeftatis figno habentur, quam Pulmo marinus de quo Plin.1.r8. c. 35. teftatur. Adeo denique Mouçicú urendi qualitates cum Holothuriis \& Stellis communes habet, ut fi qui nudis pedibus littora obambulent, Bullamque hanc venenatan minus provide conculcent, ingenti ardore afficiuntur, qui plantas nonfolum pedum callofas fed \& totius corporis cutem in momento magno cruciatu infeftat. Ad horas aliquot durat malum, invito quovis remedio refrigerante $\&$ anodyno, ad quod confugiunt frepe fruftra. cgo felicius caufticis $\&$ calidis ad extrahendum 2rdorem ufus fum, applicato mordaci illo oleo caftanex de Acain diffoluto in firitu vini, imprimis autem Cancro Aguarauçá dicto, fi recens applicetur.

\section{A M O R E A T I M.}

A Moreatim $\mathrm{Ran} x$ pifcatrici fimilis, multis aculeis afpera, abfcondit fe ad littus fub A arena,pedefque fupergradientium crudeliter vulnerat, \& aliquando cum prefenti vitæ difcrimine nifí cauterio fubveniatur. Idem de Caramurú, Anguibus marinis fimilibus, decem aut duodecim palmos longis, \& pinguibus, dictum volo, quia morfus illorum quoque funt admodum venenati.

His quoque addi debet Solearum minorum fpecies, Lufitanis Peize Sola dicta, non edulis. Qux mira fane efficacia non folum manum vel leviffimo attactu, fed \& pedem licet optime calceati pifcatoris incautc pifciculum conterentis, paralyfi \& ftupore afficit, inftar Torpedinis Europæx, fed minus durabili.

$$
\begin{gathered}
\text { C A P V T XV. } \\
\text { Venena intus a fjumta, Cururú five Bufo, Varice ppecies Pifcis } \\
\text { Guamaiacu, és Piraqué. }
\end{gathered}
$$

$\mathrm{H}$

Actenus de Natura Serpentem eorumque animantium, qux morfu vel ictu virento hom inibus infidiantur \& toxico fuo nocent. Quibus calidas \& humidas hafece regiones abundare haud mirum eft, quod pauca agricolarum induftria excult $x$, nec vi frigoris à venenatis $\&$ noxiis animantibus repurgat $x$, $\mathfrak{e} x$ in immenfum multiplicentur. Proinde haud affentiendum mihi videtur Cardano dicenti, Serpentes non multiplicari ultra metam quandam, quia funt homini peftiferi. Nunc ad illa venena qux intra corpus affumuntur deféndamus. Qux quidem diverforum funt generum, nempe venenata tantum, \& tota fubftantia aliena à natura, ac proinde nilil alimentofi in fe continentia ut quxdam Mineralia, vel quxdam manifefta qualitate nocentia, quadam vero licet occulte vim inferentia aliqua tantum parte id efficientia ut plantx \& animalia. Omnibus his fua remediorum genera, manifeft $x$ vel occultix 
HIST. NATVRAL. \& MEDIC. LIB. V.

- occultx qualitatis oppofita funt, quax licet diverfa,tamen in curandi modo conveniunt. Nam cujufcunque generis venena ore percepta, fi in prima adhuc corporis regione hæreant, per vomitum potifimum \& clyfteres exturbare convenit : fin in co:poris receffus abierint, circumferentiam verfus trahuntur. Proinde fomnus qua poffibile, arcendus quoque. Interim cor adverfus hoftem admiffum muniri debet, etiamfi vera $\&$ infallibilia figna veneni intus affumti non compareant. Non enim xque manifefte hic atque in morfu vel iotu Serpentum morbi caufa fe profert, fed fere laret, quia qui venen a fubminiftrant, variis technis dolum non folum tegunt, fed execrandis artibus novas quotidie mixturas comminifcuntur, fegnia venena exaltando, ficut, proh dolor, apud Veteres quoque in ufu fuiffe legimus, applicando activa paffivis, \& qualitatibus aut addendo, aut demendo, ut longo tempore poft; figna illa \& fymptomata ulla vix feprodant. Nec enim (ut fierifolet iis qui forte improvide fimplex aliquod venenum hauferint) femper animi \& virium defectus, cordis anguftia, vertigo, vomitus, torvus alpectus, aliaque fimilia fubfequuntur, ficut quoque Galénus docet cap. $v$ r. de locis affectis evenire. Quid? quod fubinde vix ulla primis menfibus triftitia aut levifimum xgritudinis indicium in illis notetur. Donec tandem longo temporis intervallo, ungues \& corporis extremalivere incipiant. Aliquando nihil nifi poft mortem exterius apparet prorfus, atque unum vel alterum vifcus corruptum ac tabidum per anatomen fefe offert. Cur, \&z quantum venena lateant, docet Thom. à Vega Com. in loc. Affect. Theophraft. 1. Ix. Imprimis Galen. de fimpl. med. atque alii multi doctiffimi Medicophilolophi. Adeo ut facile conftet ratio, cur hoftis ille infenfus in corpore humano nec vincat nec vincatur, fed delitefcat aliquandiu, donec oportuno tempore \& loco fefe exerat paulatim, ficut feminale principium fpontaneo ortu viventium. Vtinam Barbaro̊rum nequitia numquam excogitaffet tam perniciofos horum venenorum abufus, minorique folertia præparare noviffent, ut ocius vel tardius operar entur! Nam licer ob major em vel minorem fubjectir effiftentiam, ea arte concinnare illa nefciant, ut ftata hora interimant: tàmen ut experientia potilis quam ratione conftat, ignaviorem effe Cicutxac Opii operationem, quam Arfenici aut Sublimati : ita venena illi habent vel fimplicia vel compofita, qux exhibita \& admota, ad menfes aliquot fepulta manebunt, antequam fuas facultates exerant. Vnde liquet, venena haud una eademque ratione operari, neque recta ad cor femper férri, fed eam partem maxime occupare, cum qua occulre inimicitiam exercent: Cum alias, tefte Avicenna oporceret omnia venena effe frigida \& ficca. Nam ficut Solanum \& $\&$ Hyofcyamus ; ita quoque fel pifciculi Guamaiacis cum capite antipathiam habet. Fungi \&z fuccus Manipuera nervosinfeftant, fparmos convulfionefque mortiferas inducunt.

Supplicium quidam Barbari venefici fubituri, mihi obnixe roganti; ut me horum arcanorum, priufquam è vita difcederent, participem facerent, inviti pauciora quxdam revelarunt, faffique funt, impune non folum fe hæc $\&$ fimilia veneficia exercere; fed \& regium effe laudemque mereri inter fuos, ingenii folertia excellere, novafque veneni mifcelas excogitaffe. Illi namque fagittas, veftes, cibos, \& fructus crefcentes, aquam \& integros fluvios inficiunt, ut tardius \& pedetentim, non ftatim homines extinguant. Ita ut rite collatis, animalium brutorum, cum fceleratorum hominum noxis in perniciem humani generis tendentibus, vix me contineam quin cum Plinio doleam ; prapararefe quidem animalia ad nocendum, fed nullum tamen eorum tela.fua excepto homine, venenis tingere? Nos $\&$ fagittas inungimus, \& ferro ipfi nocentius aliquid addimus! Nos $\&$ flumina inficimus, \& rerum nature elementa. Ipfum quoque, quo vivitur, aërem in perniciem vertimus, necab ullo præter hominem, veneno pugnatum alieno. Ita ut merito in hominis inhumanitatem declamandi eflet occafio, quia neque à malis boni tam queunt effe tuti, quan omnes homines ab omnibus ferpentibus, quos in nos irruentes vel declinare vel interficere facilius, quam à venefico impoftore fibi cavere.

Sic fellis Bufonis Cururü, \& Vermiculorum ex venenato fucco Manipuera pronatorum, herbarum deniq̣ue Tamgaracá, Iuquiry', fructuum Ahovai \& Mucuná, aliarumque multarum vires artificiofe $\alpha$ variis modis $2 b$ ill is intenduntur ac retunduntur. Ita ut in his ac fimilibus venenis, ad innatam abditamque eorum vim, occulta quadam mixtura accedat, ac proinde curationis aliquan do fit exfors. Quapropter ipfo Veneno, quo noxa eft illata, incognito, partim ad communia antidota, paffim à Veteribus auto-" 
ribus prodita, partim ad propria illa nativa, ab incolis primis celebrata, confugiendum. Multa fane ad hanc doctrinam facientia defiderantirr, ac fortaffe femper defiderabuntur, invito fedulo ac indefeffo occulta remedia inveftigandi ftudio, adverfus tot abditas \& tam malignas rerum qualitates, calamitofo generi humano infeftas. Si vero contingat, figna venenorum calidor um \& frigidorum, tum $\&$ obftruentium, fuffocantium atque erodentium in $x$ gris apparere, fingulis ftatim qualitatibus fua opponenda effe remedia contraria nemo ignorat. Minus tamen confultum folis illis fidere; quia licet manifeftarum qualitatum fymptomata multa graviora videntur , aliis latentibus, occulta tamen magis exitialia adeoque pluris facienda funt.

$$
C \vee R \quad V \quad V^{\prime} \text {. }
$$

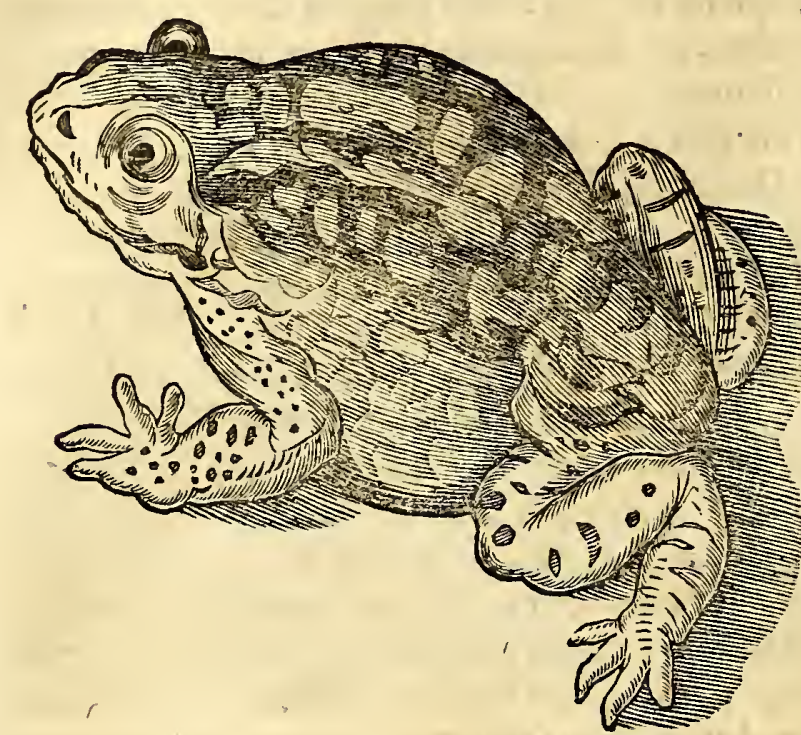

Tter venena qux deleteria potif1 fimum vi pollent eft bufo Cururú, Brafilianis, Lufitanis çápo; ab utraque parte excrefcentias capitis habet, inftar magnarum verrucarum, buccam inferiorem reniffius movet terræimmunditie nutritur, eft infignis \& tumens, duploque Europzo major, cineritii vel fpadicei coloris, nimium notus, ac quovis modo vel mictu \& faliva exterius, vel intus, longe quidem pejus, fanguine, adipe, imprimis felle affumto, inficit. Hos perditiffimi Incolæ aliique eorum $x$ muli torrefactos in pulverem redigunt, \& lethalia inde pocula conficiunt, eaque vel minima quantitate clam propinant. Hinc faucium ftatim \& gutturis inflammationes, ficcitates, anhelitus, fotores, fingultus, vomitus, dyfenterix, animi deliquia, oculorum caligines, convulfiones, deliria, ac pallores. Siremedio locus, corpus ftatim per fuperiora \& inferiora evacuant $\&$ liberant à reliquiis veneni, exercitio, balneo, ægro in furnum calentem vel animal difciffum impofito. Generalia alexipharmaca, compofita, per dies aliquot, juxta \& Tipióca, tum radices nativas antidotales ex vino propinant. Præ cæteris vero herba N bambi, qux prærogativam à benigna natura videtur accepiffe tam magno malo adveriam, exhibenda. Nam etiamfi Bufo hic tam perniciofo turgeat veneno, non tamen ita invincibile eft, ut fuo contrario non cedat. Quippe cineres Tabaci, vel etiam folus fuccus Nhambi expreffus \& capiti vel dorfo Bufonis (prafertim prius in terram fricato) inftillatus, illum dicto citius interimit. Sceleftiffimi inter Barbaros, hujus Bufonis fub Sole fuspenfi bilem \& fpumam colligunt, eamque inter fecretiora venena qux lente occidunt, refervant.

Ranæ quoque dantur varix, terreftres, \& paludof $x$, in arboribus quơque viventes, partim edules, partim, ficut in Europa, non edules. Quod etiam Plinius lib. Xxxir. cap. v. de quibufdam Ranis teftatur. Idem de mira linguxe conformatione obfervavi, cujus Philofophus in Afia meminit ; quod neque ut pifces eam totam cohxrentem, neque ut ferpentes totam folutam habeant.

Illa qux Cotorá à Brafilianis nuncupatur, intus aflumta, veneno eft, quod fupradictis remediis facile expellitur : forinfecus vero applicata \& ex artelinimenti vel emplafri forma prxparata, doloribus articulorum $\&$ membror um ex frigore natis, medetur. Huc fpectat illud Galeni quod 1. de compof. medicamentor. de Rubetis teftatum reliquit. Multi alii dantur Bufones \& Ranx, quibus fuperfedeo,cum nihil in is animadvertere potui, quod adrem noftram faciat, exceptis tamen illis qux Giia Brafilianis di$\mathrm{At}_{x}$, carnof $x$, grandes, dorfo nigricante, ventre albicante, quarum caro albicans bene fapit, imo dixtam $x$ grorum imprimis Tabidorum ingreditur, quod boni fit nutrimenti \& facilis digeftionis.

Minime prater eundum volui, quod de eorum generatione mihi conftat. Contingit cnim fubinde tempore imbrido, comitante fuffocativo tepore $Y$ eris, corruptionem accelerante, 
HIST. NATVRAL. \& MEDIC. LIB. V.

celerante, ex unaquaque gutta aqux craffx, in momento quafi generari Bufones, plus minus avellan $x$ magnitudinis, tot myriades fimul, ut folum univerfum lateat fub iis. Indigenx Cucuruy' appellant. Nec differunt ullo modo à cæteris Ranis vel Bufonibus ex coitu utriufque fexus natis. Plinius $\&$ Ariftoteles aliique circa caufas $\&$ modos generationis variant. Sed cum nunquam hujus fubitæ generationis modum à quoquam fupra tecta ædium vel loca lithoftrota vifum autumem: hic quoque eas non nifi ubi - magna eft copia pulveris terræ glebof $x$ ab imbribus impragnati, generari conftat.

\section{$\begin{array}{lllllllll}\text { C } & A & \text { P } & \text { V } & \text { T } & \text { X V I. }\end{array}$ \\ Varize Jpecies Guamaiacú Denenatre, cum e Antidoto A A atú.}

I

Nter tam immenfas fluviorum \& marium beftias nantes Americanas, quxdam in totum edules, quxdam parte aliqua vel externa, vel interna venenatxhabentur. Quod ut in aliis animantibus, ita in Serpentibus \& quibufdam Pifcibus evenit. Sicut enim Draco marinus in Europa, \& Vrutú in America folis fpinis, Paftinaca folo radio, Iulides folo morfu venenum infundunt, aliis partibus fine pernicie edulibus: ita imprimis in his Pifcibus Guamaiacú vidère eft, qui non minus externa facie, quam interna qualitate funt admirabi-

les. Cæteris autem ejufdem fpeciei praeminet familiariffima Rana pifcatrix, Brafil. Guamaiacu-atínga, Lufitanis Pexe Coelgo, Belgis ÆeteEqel/omnibus merito Suf. flator dicitur, quod mirum in modum $a b$ aquis extraaus ronchum quendam edat $\&$ ad orbis figuram fe inflet, atque in momento intumefcat ac detumefcat. Ego inter Orbes quoque numeraverim licet corpore appareat procero. Rictu eft late diducto, Ranæ fimili, ore edentulo, fed intus loco dentium duritie undiquaque obfito. Oculis itidem maximis rotundis valde protuberantibus, cum circulis flavefcentibus: Branchiis deftituitur, quarum vices ab utroque latere foramen fupplet fatis amplum. Cute eft gryfea ex fufco maculata valde dura prefertim capitis, ubi teftacea cvadir, totque horridis fpinis offeis ex albo flavefcentibus undiquaque fcatet, ut haud facile impune manibus tractetur, excepto infimo ventre, qui fpinis non folum, fed omni duritie deftituitur. Pinne funt parvæe, numero quatuor, duæ poft branchiales, duæ verfus caudam oblongiores. Iuxta primas, macul $x$ infignes rotund $x$, nigerrim $x$, hinc inde diverf $x$ magnitudinis fparf $x$ confpiciuntur.

Hujus Orbis fexum mafculum à fomineo facile eft difcernere, quod ille mole quidem minor, carne probatior, hæc major quidem, fed carne magis flaccida. Ventriculus in mare eft fatis capax, cum multis appendicibus \& vafis gaftricis. Inteftina, ob infuetam hanc pifcis figuram, in gyros compofita more animalium terreftrium; quod rariffime in pifcibus obfervavi. Mefenterii glandulæ lacteo humore refer tx. hepar or dinariæ magnitudinis \& coloris, vefica renibus quafiannexa, juxta mentulam cavitas apparet in lactes definens. Cor juxta mediaftinum \& branchias fitum. Multum expetitur, \& pro epulis, maximo interdum vitæ difcrimine, ab imperita plebe apponitur, fi folliculo fellis non probeliberetur. Intra horx namque fpatium, ejus particula vel ciceris magnitudine affumta, tam horrenda fymptomata infert, ut mox caligent oculi, mens vacillet, lingua tardefcat, membrorum tremor, fudorque frigidus fubfequatur, facultates omnes refolvantur $\&$ fileant, moxque veneno extinguantur. Sed benigna mater natura, prælens ac facile remedium huic calamitati oppofuit. Cum prædicti enim Orbes Guamaiacú juxta fluvior um oftia, ubi paludes \& ftagnantia loca fingulis $x$ ftibus inundantur, fedem figant, iifdem quoque locis plurima Cancrorum genera vivunt \& arbufta habitant paludofa. Quos inter non ita magni reperiuntur, quadratx figu$\mathrm{r} x$, in arborum truncis Jatitantes, ut Oftreis \& Mytilis infidientur. Qui multiplici ac 
300 A $R$ A T $V^{\prime}$.

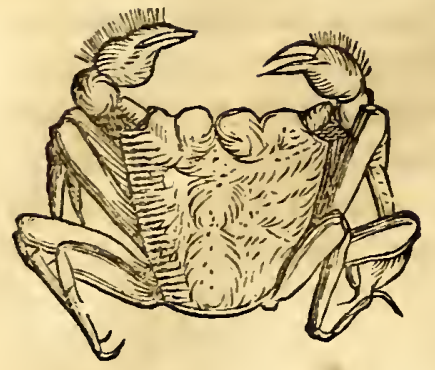

\section{G V L I E L M I P I SON I S}

varicgato colore, albo, rubro, violacco, chelis requalibus armati, crura pilis nigricantibus habent veftita. Hos Aratú appellant Brafiliani. Ex his unus contufus, \& exvino citra moram, aflumto veneno (nam ante horas quinque vel fex lethum (xpe infert) propinatus, per vomitum virus exturbat, qualitateque occulta mảlo validiflimo refiftit. Prxmiffis fpecialibus, communia quoque prefidia fuperius tradita non negligenda, ut funt Tipióca de MMandibóca, radices Iábor andí, Ipepacuánba , Caiapiá ,Vrucú, aliaque fimilia remedia qux neceffitas excogitavit.

Nec forte narura differt hic Cancer Brafilienfis ab. illo, de quo Galenus in libro fimplicium contra Pelopem præceptorem fuum contendit ${ }_{3}$ Cancrum rabiofis conferre, occulta, non maniferta qualitate. Plinius lib. Ix. cap. 3 r. eos Serpentum idtibus mederi dicit. Et imprimis illud lib. v.cap. 32. Cancri fluviatiles triti potique ex aqua recentes, contra omnia venena profunt. Morfis vero à cane rabido, iten Phalangio, Scorpio, aliifque venenatis, prodeffe etiam apud Ariftotelem legere eft lib. IX. cap. v. Diofcoridem lib. I 1. cap. 12. \& Galenum lib. Ix. de fimplicium medicamentorum facultatibus; Aëtium lib. v 1. cap. 2 4. Eginetam lib. v. cap. 3.

$G \quad V A M A I A \quad C \quad V^{\prime}-G \quad V A R A$.

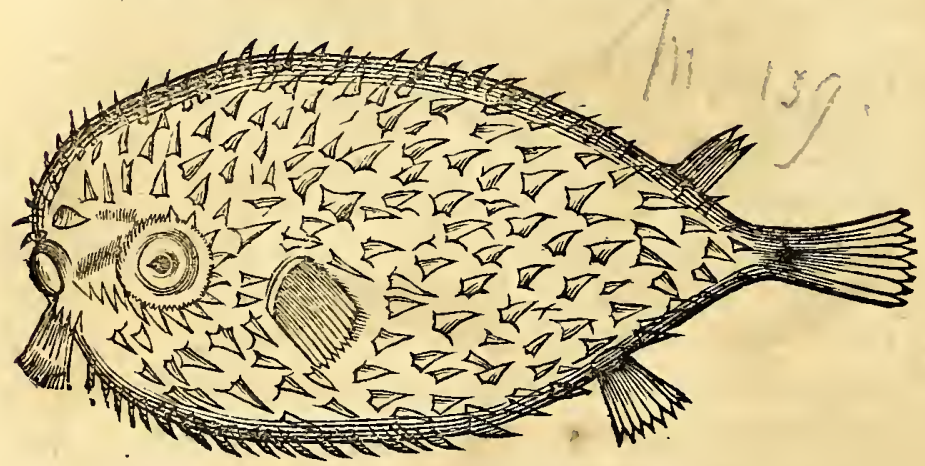

A Lius datur GuamaiacúA guara dictus, priori multum fimilis. Lufitanis Peixe Porco \& Diabe. Orbis eft fpecies, \& muricatus Orbis Gefneri dici poteft, quia aculei ipfius referunt murices. Corpore eft magis rotundo quam præcedens Guamaiacu. Squamarumloco, tegitur cute, ex fufco viridis $\&$ albefcentis colo-

ris, intermixtis maculis nigris. Totum cospus, excepto ventre, adeo aculeis acutis horret indifcretre magnitudinis, ut intractabile fit, finguli tribus infertionibus, quafi triquetris, cuti infixi. Oculis eft magnis admodum, prominentibus, quorum circuli circumdati quoque aculis fatis acutis. Ore exiguo, edentulo, rotundo. More aliorum Orbium fe inflare \& $\&$ in momento confidere facit. Stridorem per os edit inconcinnum. Quatuor habet pinnas. Si quis inflationem defiderat, pinnam dorfalem vellicare oporter. Noxam fere eandem infert fel illius, ut pracedentis, fed multo remiffius; ac proinde facile eifdem remediis ut fupra curatur, Vifcera porro ejufdem natur $\&$ conformationis cum præcedentis inveni ; adeo ut vix inter fe difcrepent.

$$
G \quad V A M A \text { I } A \text { C } \quad V-A \cap E^{\prime} \text {. }
$$

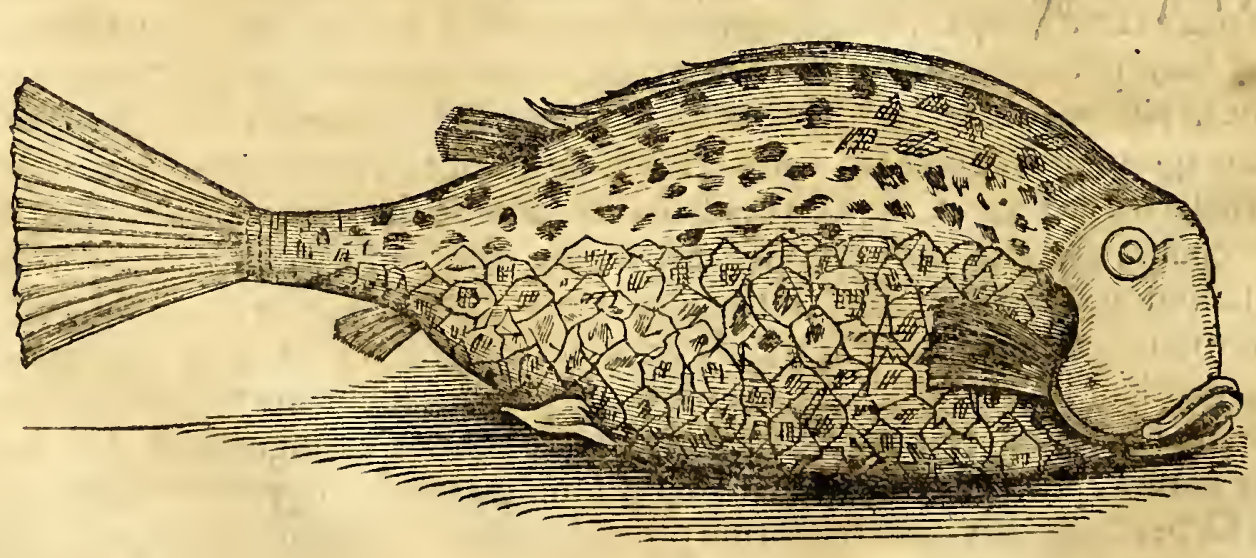

$\mathrm{T}$

Ertius denique, Guamaiacú-apé Brafilienfibus, ejuldem quidem generis, non tamen orbicularis, fed potius triangrularis, à fquamis quoque ut cateri nudus., verum 
quafi fcutifeíus $\&$ loricatus. Duo funt diverfefpecici ejufdem nominis, quortim alter cornutus, hic nofter cornibus deftitutus. Per totum corpus excepto ventre fexangu. laribus figuris infignitus, cum innumeris exiguis tuberculis. Colore eft ex flavo cinereo, in gibbum arcuato.' Ore exiguo in utraque mandibula dentato. Oculis amplis. Pinnas habet quinque haud magnas, præter has fexta eft, quá caudam facic validam, fatis longam \&zlate diductam.

Ab ingentibus pifcibus rapinis aliquando devoratur ; $\&$ integer adhuc ex corum ventriculo eximitur, poftquam hoftes fuos à quibus deglutitus fuerit, fuis aculeis interfecerit.' Tantæ denique eft malignitatis caro, ut fi immediate à cotione comedatur, mentem turbet, ebriifque \& phreneticis fimiles eos efficiat. Quod omnibus fimul illam prandentibus contigific memini, \& vix poft quatriduum fumptis alexipharmacis fupra enarratis convaluerunt. Simile quid obfervavit domefticus meus in pifce Gmamaiacu, qui ab alio pifce antea deglutitus fuerat. Sin vero coctus per integram noctem fervetur, tuto apponitur, fed paucx eft carnis atque intus fere cavus, folam fpinam habens fecundum longitudinem, cui per membranas inteftina adharent.

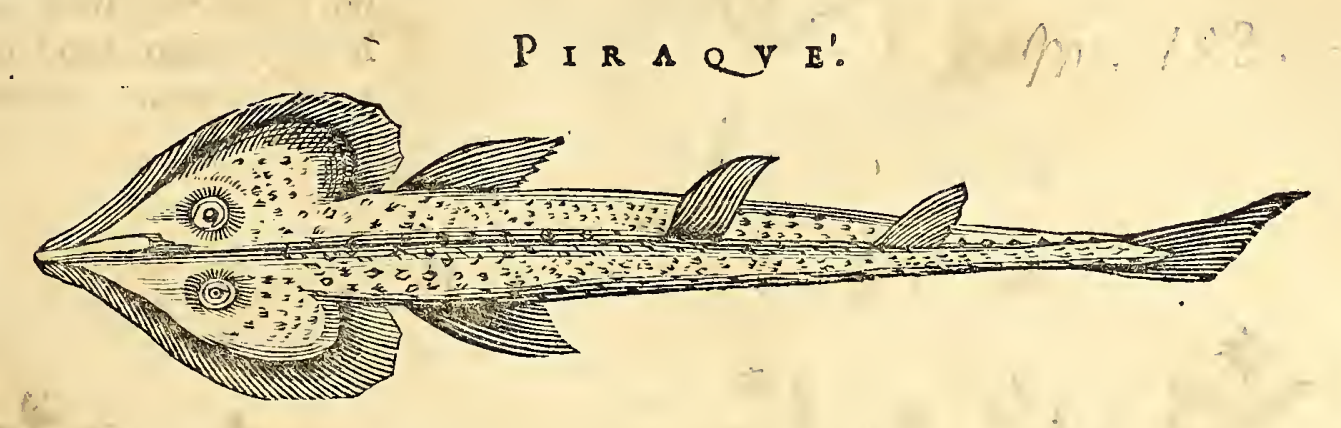

D Iraqué jufdem fere eft efficaciæut Guamaiacú præcedens, Lufitanis improprie Peixeviola dictus. totus pifcis eft cartilagineus, non fquamatus fed mollis, latus non craffus. Caret branchiis. Recens tranfparens fere eft luci obverfus. Caput etiam nodulucet, definens in coni figuram. Vtrique oculo pofterius fiftula appofita eft, per quam aquam evomit. Sub oculis autem in inferiori corporis parte, os habet edentulum cum quinque incifuris utriufque lateris inftar Raiarum \& I iburonum. coloris eft in ventre incarnati cumalbo mixti. in dorfo fufcis maculis, cum punctis ex albo cæetulefcentibus variegatur.

Caro ejus non eft vefca, fed fi per dolum aut infcitiam comedatur, infatuat per aliquot dies. Attactus, mediante licet baculo oblongo, crepitum articulorum caufat, qui tamen brevi ceffat; \& fi in medio tangatur, artuum tremorem efficit. Capitur menfibus pluviis in fluviis in comitatu Raiarum \& Paftinacarum, cum quarum puncturis ex parte convenit, atque eodem modo curatur, ficut videre eft in tractatu de venenatis Raiis.

\section{C $\quad A \quad P \quad V \quad T \quad X V I I$.}

\section{Diverfa fpecies Tangarace venenate, Cadeo fove Herbe cafte dure, \& S.Manipuera fove Succus Mandioce.}

L Vfitani omnes has herbas Tangaracá, ab indigenis æque ac advenis deteftabiles habitas, uno nomine Ervas do Ratto, imerito appellant, quod facultate fingulari deleteria polleant, \& homines rque ac beftias interimant. Tres earum fpecies mihi innotuerunt in triviis nimis obvix: qux licet floribus \& fructibus inter fe differant; ligno tamen, foliis, natali folo, \& qualitate virulenta conveniunt.

Prima, qux omnium maxime noxia, frutex eft ligno lento, cui ramuli fibi oppofiti , atque his denuo duo vel tria femper fibi oppofita adnafcuntur folia oblonga, pritno late, mox dilute viridia, eminentibus nervis \& coftis confpicua. In fummitati- 


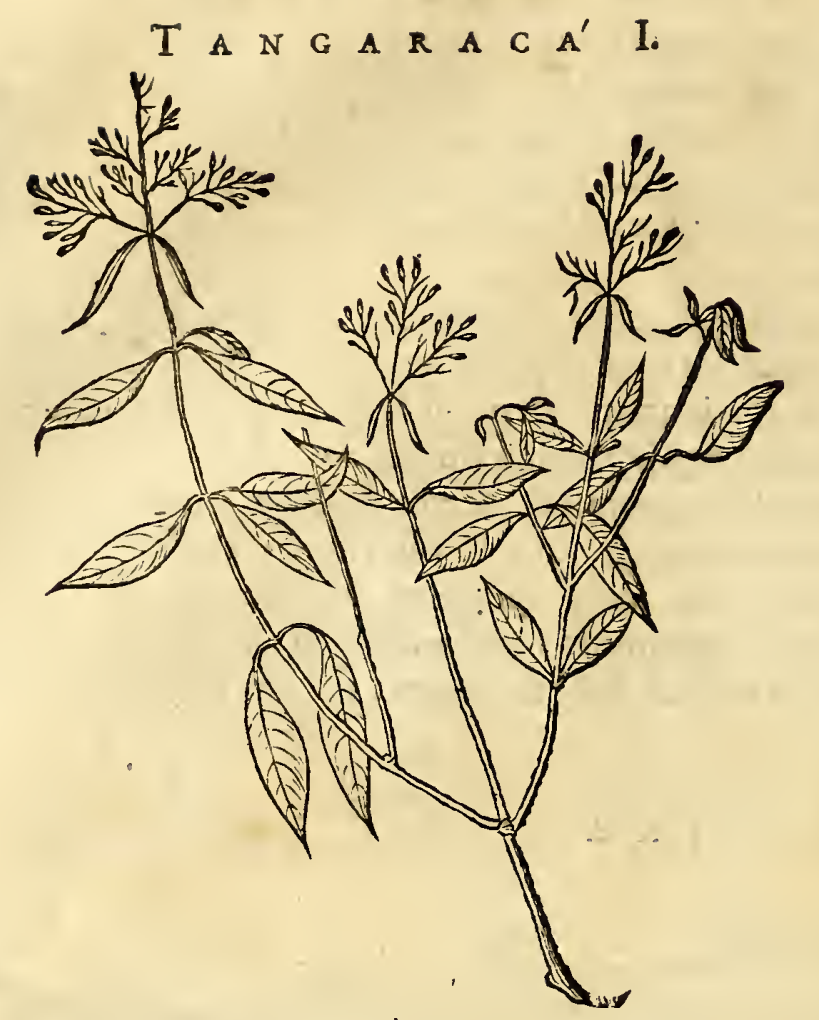

bus ramorum tenues pediculi oblongi,croceico. loris enafcuntur, unde fpicx, ex multis floribus longis umbellatim pofitis conftantes emanant. Quem fructum produ. cat, nondum mihi datum fuit obfervare. Flo. res non folum \& folia, fed oculi imprimis erumpentes, fummo turgent veneno, quirecentes, vel exficcati, per incuriam, vel per dolum guftati, profentiflimo funt veneno. Radix vero mox exhibita, tutum apud Incolas habetur antidotum.

'TANGARACA

II.

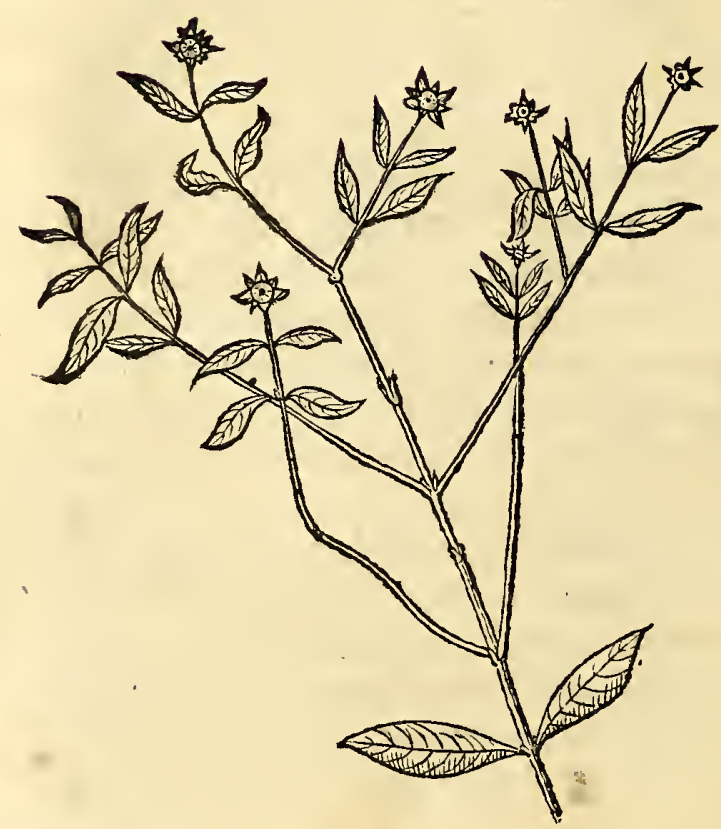

Ecunda paulo excelfior fiutex, ramulis\& foliis bitis fibi directe oppofitis, primx $\mathcal{T}$ angarace non diffimilis quodad figuram, fed cortice magis cinereo, foliis fuperne fature viridibus ubi adoleverint, inferne canefcentibus, quafi leni hirfutie præditis. In ramorum fummitatibus fiores primo aurei coloris ftellares, mox ex brunno purpu-

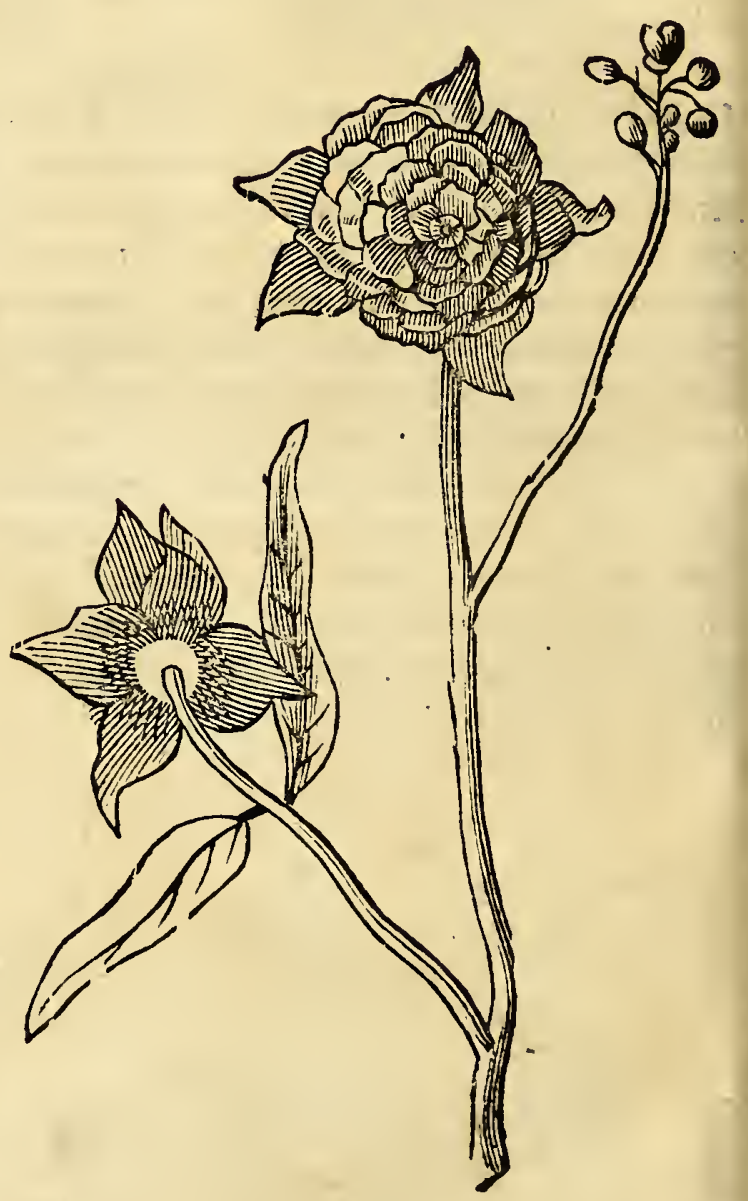
rafcentes. Folia eorum cxteriora, in-

terioribus multo majora \& expanfa. Medium feu totum fpatium florum, more holoferici eft plenum, conftans foliolis parvis, primolæte, mox trifte purpureis, inftar florum Scabiofx peregrinx. Ex horum medio prodit bacca Rubo filveftrihaud difimilis, cærulea, quafigemma Turcois flori effet impofita, qux fumma venenofitate inter omnes Tangaracas primatum facile tenet. Proinde forem qua erat magnitudine, feparatim apponi jufi, ut ex hac icone liquet. 
$T A N G A \mathbb{A} \cap A^{\prime} I X I$.

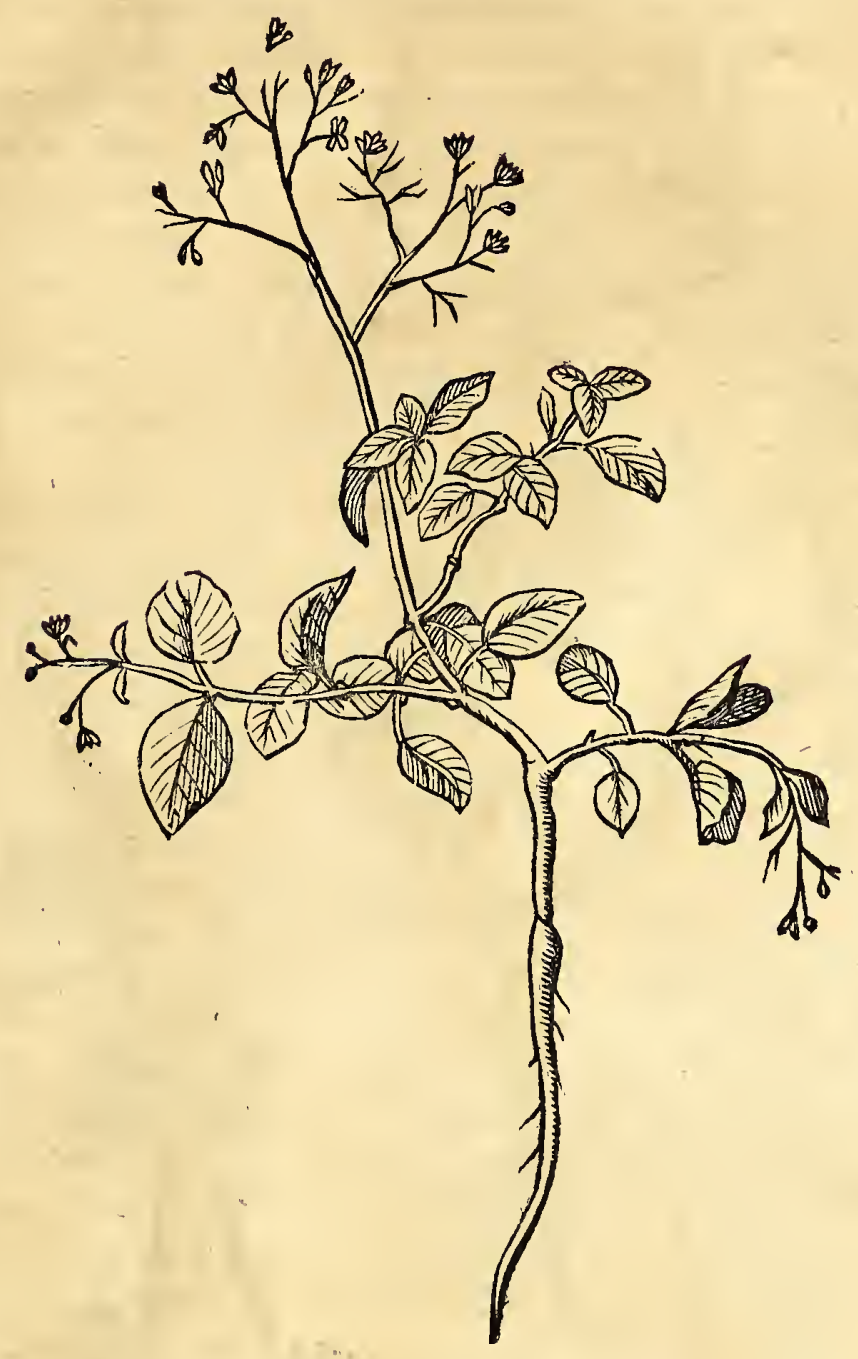

TErtia eft planta fruticefcens, radice craffa, foliis, nunc alternatim, nunc fibi dire-

ate oppofitis, creterum craffioribus \& rotundioribus quam priores Tangaraca. In extremitatibus ramorum pediculi longi, ex quibus flofculi umbellati producuntur: primo albicantes, mox aureo colore nitefentes. Vnde advenx ignari gratoque illecti colore, temeritatis fuæ nimis magnas pœnas aliquando dederunt, modo eos olfecerint $\&$ tractarint.

An plures dentur Tangaracá, mihi nondum conftitit. In harum trium foliis, floribus, \& feminibus, tamalte pofita eft deleteria vis, licet gradu differat, ut vel ex leviffimo corum guftu corpus intumefcat, mens turbetur, oculi incipiant caligare, vertigines, animique deliquia oboriantur, denique mors ipfa fequatur, nifi quantocius prafentiffmo remedio obviam eatur. Reliquis Antidotis merito praferuntur radices illa decantatæ Ipecacuanha \& Caapia, quod cum antidotali efficacia, fimul emetica vi polleant, ut fuo loco probavi; his fuccedunt radices Iaborandi \& Iambw. Aliqui exercitatiores rutiffimum exiftimant, ipfi radici Tangaraca fe fidere, quam miro ac felici cum fucceffu indifcreta quantitate exhibent. Quafi benigna mater natura facultatem non minus falutiferam quam mortiferam eidem plantæ indidiffet. Condonandum facile Barbaris Empiricis, fi non certæ dofi medicamentorum, imprimis vero Alexipharmacorum, nitantur : tutius enim multojudicant, exceflu quam defectu peccare, ne forte antidoti inopia à veneni copia vincatur, ficut al iquando fe obfervaffe mihi teftati funt.

FXimix illæh herb $x$ Caft $x$ fiveMimof $x$ à Clufio, aliifque Exoticorum confultis defcri$E_{\text {ptx, quarum figuram \& faciem quoque ego cum D. Markgravio meo in hiftoria na- }}$ turali prolixe explicavimus, fed à nemine adhuc, quod fciam, earum qualitates bon $x$ vel malre explicatx. 


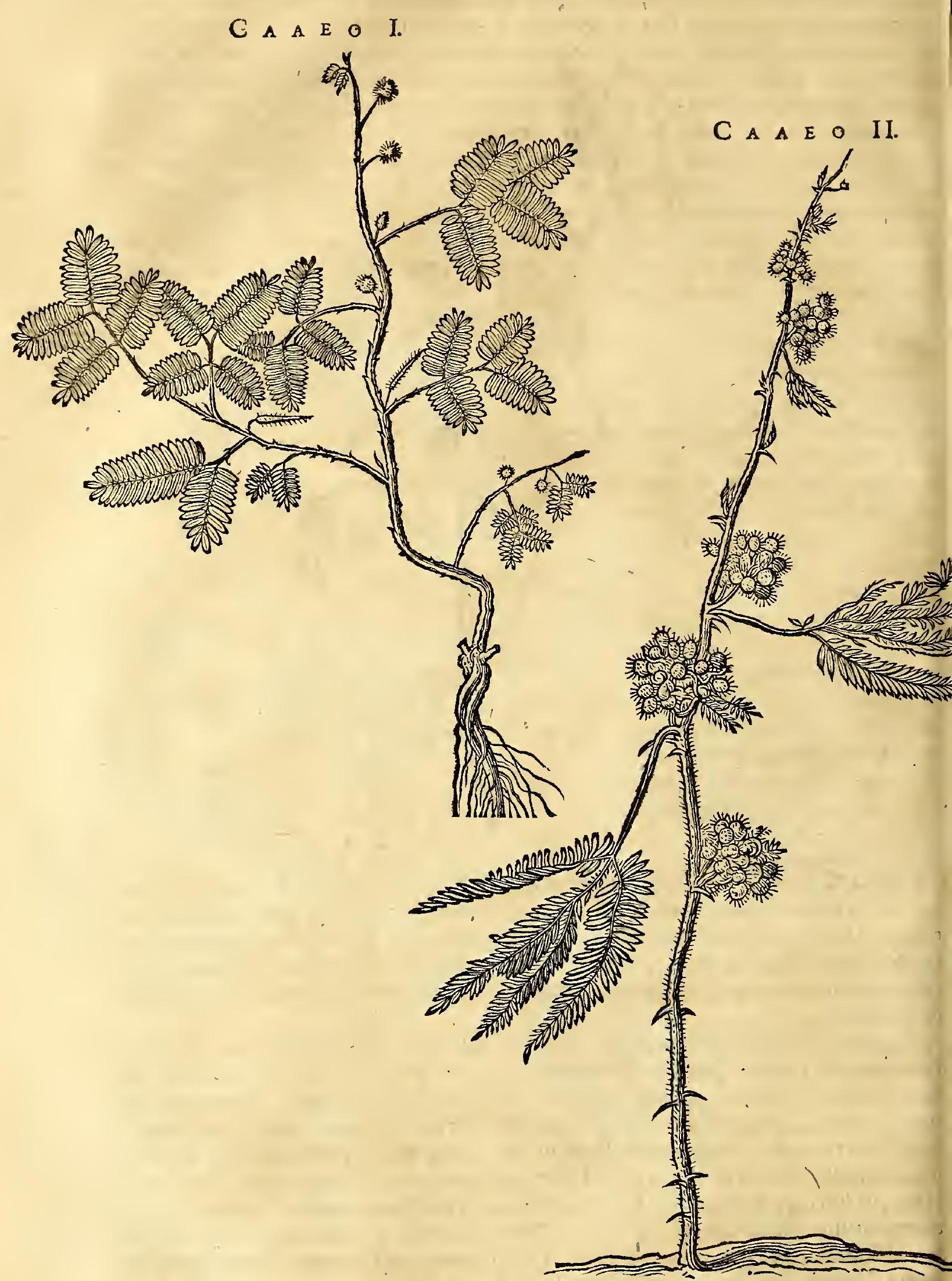

Primo quidem, folia in pulverem redacta, \& exigua quantitate al iquoties exhibita, clam exitium hominibus inferunt, pecoribus alimentalia exiftunt. Idque prefertim de prima fpecie diftum volo.

Secundo, radices earum non minus tutum præftant Antidotum, quam folia perniciofo turgent veneno, fi multum \& fxpe in ufum adhibeantur, ut liceat dicere vulneratis:

Solus Achilleo tollere more potefl. 
HIST. NATVRAL. \& MEDIC. LIB. $V$.

Providi autem eft Medici in hoc $\&$ fimili cafu, preter fpecifica ad generalia quoque confugere alexipharmaca, five exotica, five domeftica. Prxfertim ad omnia illa fupra in eodem capite fub titulo veneni Tangaracá énarrata, \& fub titulo Manipwera mox explicanda. Tum, quod feelerati homines hxc \& fimilia venena, varie componant $\&$ clam cibis immifceant; tum quod fubinde in principio vix quicquam evidenter ac $\mathrm{fi}_{-}$gnis præviis appareat, fed fenfim vitam depopuletur. Quippe non folum pro fubjecti refiftentia, fed veneni quoque mifcela $\&$ quantitate, tardius vel citius vitam depafcitur hæc herba, ut cachectici, anhelofi, triftes incedant, donec tandem vita defungantur. Memini enim feeleratiffimos veneficos, tantillum pulveris foliorum exficcatorum, fiftulx clam Peto inditum fimul fociis propinaffe, nullamque exinde longo temporis fpatio noxam eos perfentiiffe : nihilominus tamen, nullo licet accedente evidenti effectu, tandem emaciatos mortem obiiffe.

C Vm in tractatu de Mandiboce radicis vi alimentofa specifice, atque ex profeffo; de medica vero \& venenofa qualitate egerim tantum tranfitorie $\&$ in genere, ordo nunc poftulat, non intactum reliquiffe venenum tam familiare ne dicam domefticum, Manipueram, id eft, fuccum altilis \& familiariffimæ noftræ radicis Mandiboca, qui potatus vehementer inflat corpus, ventriculum afficit dolore, cum rucu, naufea \& Tenefmo : hinc mox oculi obfufcantur, vertigines, perpetuique dolores capitis accedunt, tandemque extremorum frigus, animi deliquium, \& ipfa mors fuccedit. Quapropter famulis hanc radicem praparantibus, ne à noxiis vaporibus inficiantur, flores 2 Whambi $\&$ radices Vrucú efculentis \& potulentis admifcere neceffe eft, ad muniendum cor, $\&$ ventriculum. Sed diabolici venefici tam præefenti veneno non contenti, ex fucco hoc, ftudio refervato ufque ad totalem ejus putredinem, altiorem corruptionis gradum ex ver. miculis inde pronafcentibus (qui Tapurúipfis dicuntur) quxerunt, iifque in pulverem redactis, hominibus pro libitu infidiantur, ita ut, exigua licet quantitate, vitam certifime \& citiffime adimat, fi fimplex exhibeatur; fi vero compofitum \& viribus imminutis, (quod potiffimum pulvere herbæ Caapéba \& Nbambí fieri folet) longo poft tempore, ne nefanda fcelera in publicum prodeant, mifere interimat. Multa quidem remedia contra hoc malum excogitata, omnium tamen præftantiflima funt, quxipfo ftatim principio morbi, per vomitoria inftituuntur. Horum Ipecacuanba \& Caiapiá facile pracipua funt, quod alexiteria $\&$ vomitiva vi finul: polleant. Clyfteres veneno frigido refiftentes, acflatus tetros difcutientes, mox fuccedant, eofque Tipióca ' $\&$ radix Iaborandé imprimis ingrediatur, quorum antidotalis vis alte pofita eft à Natura. Pofthxc preter Diafcordium \& Theriacam, malum per füdores $\&$ urinas educentia, familiaria præfidia funt, radices de Capiipuba, Aguaxima, Caca-

$$
\text { C c } 4
$$

pomonga, 
pomonga, Nhambi, Iaçapé, Iurupéba, Vrucú, Caapéba. Adhæc radix, \& præertim fuccus fru. atus Ananas, largiter \& crebro hauftus, cum tantillo fucci Limonum recentium. Notatu dignum, quod fuccus Manipuera adeo venenofus eft, ut, fi crudus aflumatur, ftatim enecet; fi vero percoquatur, nutritivus fiat, quum tamen omnium venenorum, tam frigidorum quam calidorum, innata potentia à calore in actum producta, celerius atque validius cor petat. Sed ratio eft, quod ficut ipfa radix Mandiboca diverfis \& contrariis gaudet qualitatibus : ita liquor ejus partibus plurimum inter fe diverfis conftat: quarum prior fubtilis \& vaporofa, atque veneni illius compos, ebullitione exhalat : altera crafla, dulcis \& naturæ noftr $x$ amica remanet.

$$
\begin{gathered}
\text { C A P V T X V I I I. } \\
\text { Araticu-paná, Mucuna-guaçu do miri, Aboay, } \\
\text { do Carapucu five Fungi. }
\end{gathered}
$$

Ctumagerem, fi penficulatim denuo Arboris Araticu-paná partes defcriberem; cum illius figura \& crefcendi modus in tractatu defimplicibus fatis fuperque graphice depiata fit. Quamobrem pauca, eaque veriflima, utpote longo ufu com-

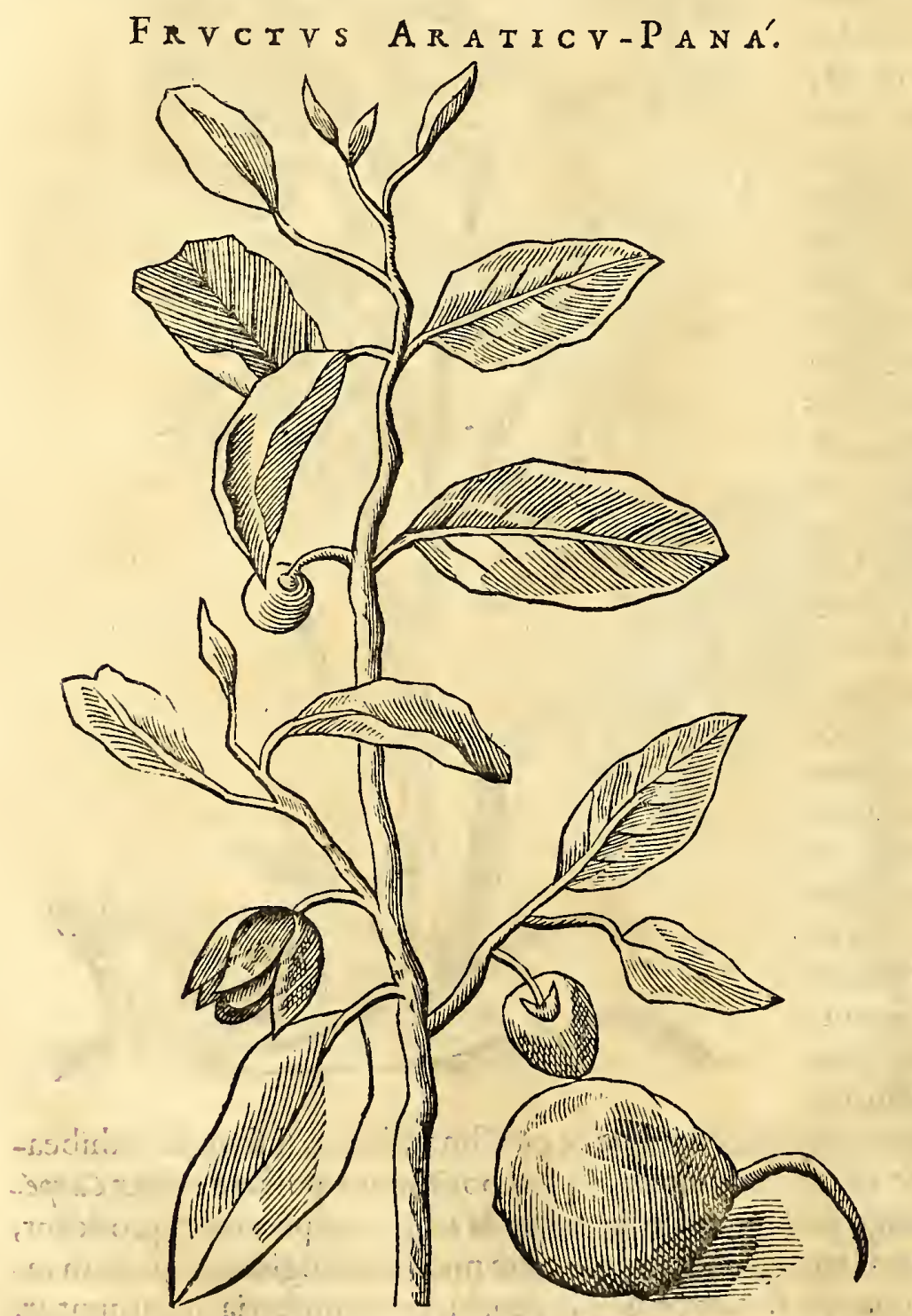
probata, de Fructu folo addenda putavi, ne huic tractatui de venenis quicquam deeffet. Cum enim magna advenarum multitudo, rerum novitateallecta, fructus quoque omnes Araticúlegere amat, cumque iis qui Araticuponbe diEti, his Araticu-paná fine delectu promif́cue vefci cogitent, peflime fanitati confulunt, dum fefe iis ingurgitando, nimio frigore calorem naturalem opprimunt, unde eadem ventris fymptomata excitantur, qua venena, manifefto \& occulto frigore efficacia, movere folent. Quamobrem cum nihil ulterius de hoc fructu dicendum reftat, quod in pracedentibus fit intactum, iifdemque remediis ejus malignitati fuccurratur, quibus Fungorum \& Maripuere inoxx qualitates expugnantur, lectorem co remitto, atque ad alia tranfeo.

Vm ad examen revocarem eximias has $\&$ undiquaque luxuriantes herbas $\&$ arbores fabiferas Mucuná dictas, dubitavi, noxiarumnc eas an proficuarum plantasum catalogo afcriberem, quum illarum lobi utriufque qualitatis participent : attamen $\therefore \therefore$ : 
HIST. NATVRAL. \& MEDIC, LIB. V. cum mihi aliifque rei medicx peritis plus inde mali quam boni hactenus redundarit, Venenatis infereremalui.

$$
M \vee C \vee N \dot{A}^{\prime}-G \vee A \text { ç }
$$

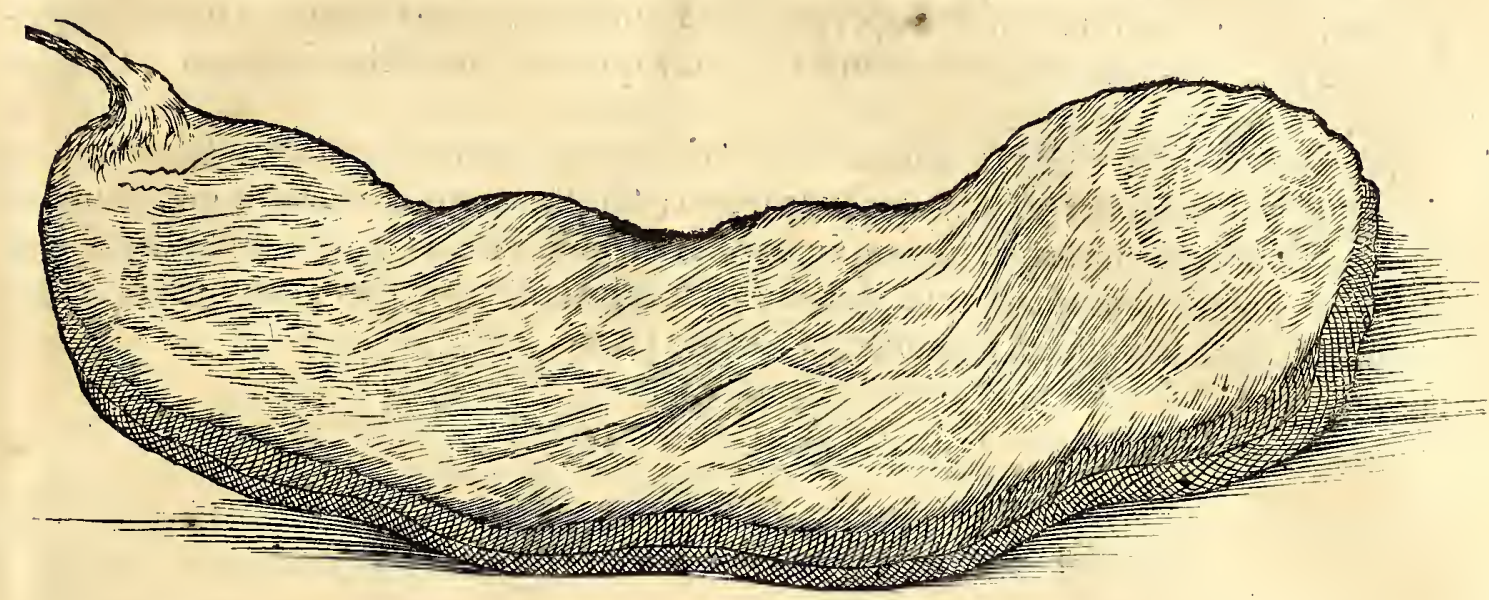

Hæx itaque Mucuná-guaçu in tanta piforum fabarumque filveftrium varietate, cæteris pulchritudine $\& \dot{z}$ magnitudine facile præcellit. Crefcit ex arbore quæ ejufdem eft nominis. Faba autem hæc nigra pelle lapidis fere duritiei, pilis flavis molliter eft vetita, manum longa, \& tres digitos lata. Vi effracta, pulcherrimi globuli, interftitiis divifi, exinde prodeunt, tres quatuorve, punicei \& rubri coloris, rotundi, laves, magno hilo, qui, fi in aqua macerentur, vim noxiam ex parte deponunt, \& cum Tipioca de Mandiboca preparati Barbaris edules fiunt. Ita ut venenata corum qualitas, non ufque adeo alte pofita à natura videatur, quin retundi fe patiatur à correctorio convenienti. Quippe cum interior fabx fubftantia acris fit $\&$ mordicans, vifcera vellicet, $\&$ ufque adeo corpus turbet, ut vomitus violentus $\&$ alvus moveatur; refrigerans $\&$ demulcens alimentum hoc medicamentofum ex Tipioca factum, cæteris Antidotis præferrifolet.

Scunda Mucuná præceden$N_{\text {ti longe inferior, forma }}$ $\&$ figuta imbellis apparet. Interioris fubftantix qualitates cum præcedenti Mucuná convenire perhibent, fed mihi incompertx, non autem exteriores. Quippe nobis per tefqua vi viam facientibus loborum fetx pungentes faciem \& manus ufque adeo inficiebant, ut ardentiflimas puftulas excitarent, qux vel optimis fuccis anodynis \& r refrigerantibus, ultra octiduum adhibitis, vix cedebant. Caule craffo, farmentofo, admodum

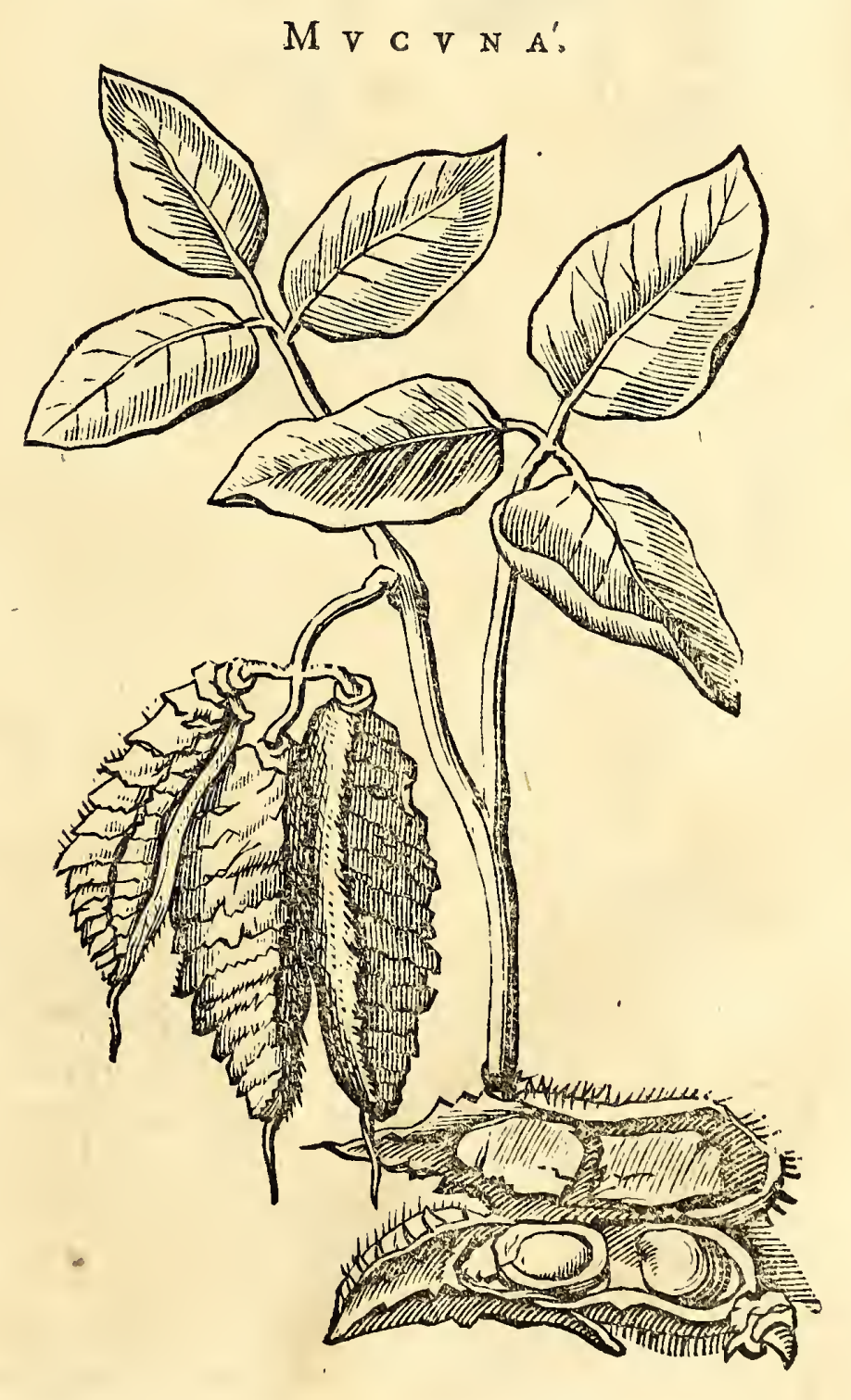


308

G V I I E L M I P I S O NIS

lento $\&$ tenaci, altiflimarum arborum ramis fe implicat. Tria ubique folia in tnoquoque pediculo oppofita habet, qux eminentibus funt nervis, cxterum faturare fuperius virent, inferius albicant, \& fubtiliffima lanugine ad tactum fericum $x$ quant. In pediculis fuperioribus plurimi flavi pentaphylli inodori proveniunt flores juxta fe pofiti, figura filiquarum Pif apertarum. Eminet in medio ftamen fiftulofum pallidum, fuperius multipliciter divifum in fila, quorum quodlibet apicem habet fufcum.

Flores fequuntur filiqux, longx, exterius ex rufo rugof $x$, qux non folum adh $x$ rent, fed \& pungunt, cum dolorofo pruritu; filiquæ matur $x$ exterius nigrefcunt $\&$ fponte diffiliunt : interior earum fuperficies eft inftar matris perlarum, alba, fplendida : in qualibet continentur ut plurimum tres phafeoli orbiculares, compreffi, coloris luridi, cum femilunari macula nigra in uno latere.

$A H O A Y$.
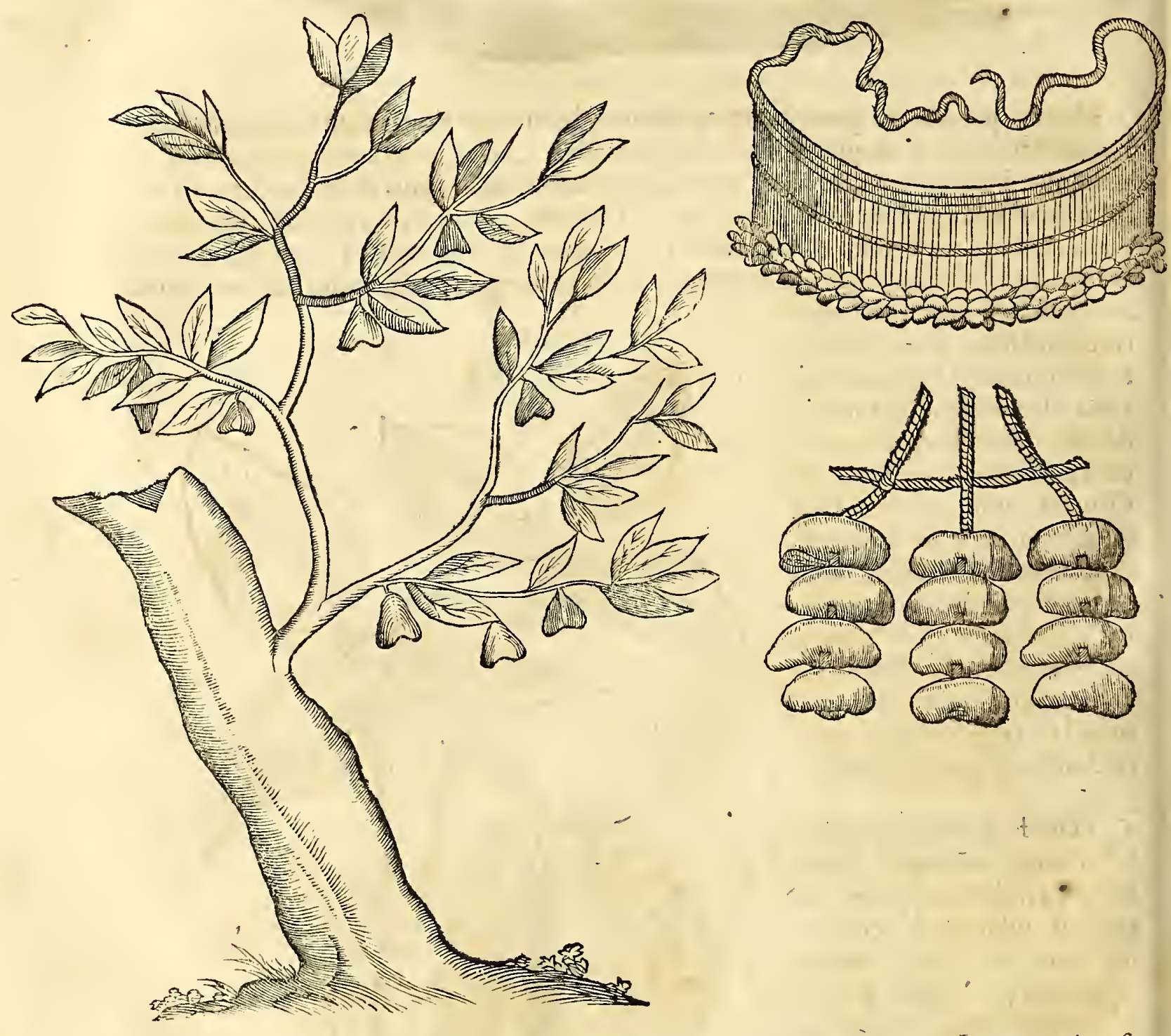

DVplex datur Aboay arbor; altera Aboay-guacu, five major; altera LAboay-mirt, feu minor, dicta. Propter arboris non folum, fed \& fructuum quoque magnitudinem, differunt. Quippe hxc pofterior vix nucem avellanam, cui multum fimilis eft, adxquat: illa plus quam caftanex magnitudre pinis nucesprofert, ut apparet ex triangulari hoc fructu in arboendenti. In diffitis tantum nemoribus utraque hæc reperitur. Folia habet ternos vel quaternos digitos longa, duos lata, Mali noftratis non abfimilia, toto anno virentia. Cortice candicante. Ramus amputatus fuccum emittit album \& quafi lacteum, adcoque teter tunc fpargitur odor ligni, ut ne igni quidem ftruendo idoneum habeatur, ac proinde à Barbaris numquam ad pyras fuas ufurpatum videtur. Vtriufque arboris fructus monftrare, toties negarunt 
HIST. NATVRAL. \& MEDIC. LIB. V.

Barbari, prxmetu ne aliquando in illos hre cuderetur faba. Cum enim præe fentius venenum, quam nucleus prædicti fructus, $a b$ illis nondum fit inventum, id lecretum. fibi fervandum arbitrantur, ut tuto veneficia fua diabolica exerceant. Nucleos enim illi in pulverem redactos, variis dolis \& technis præparant, \& clam ciborum obfoniis vel Nicotian $x$ immifcent, ut ocius vel tardius vires exerceant. Scrupuli enim plus minufve quantitas or e affumta, graviora facile fymptomata, quam ab aliis ullis venenis illata, inducit. Quibus fpecificum antidotum ad hrec ufque tempora nondum eft inventum ; quamobrem mortem quantocius adfert, figeneralia \& communia alexipharmaca nilil profint. Horum fructuum putamina, duriffima funt $\&<$ tinnula, quare ab illis tintinnabulorum vice ufurpantur, \& brachiis pedibufque circa talos in faltationibus potiffimum circumdantur ornatus gratia.

Novem Fungorum fpecies diverCarapvc v' five Frngi. ut alibi traditum eft, quos omnes generali nomine Carspucú nominant. Horum quoque in hoc Americæ tractu, ficut in Europa, alii venenati, qui confracti, varii funt coloris, lividi \& cxfii, ex fterquiliniis lignoque putrido protuberantes; alii edules, ac copia tantum nocere dicuntur. Forte quod in pratis prima xftate nafcantur, ad illud Horatii:

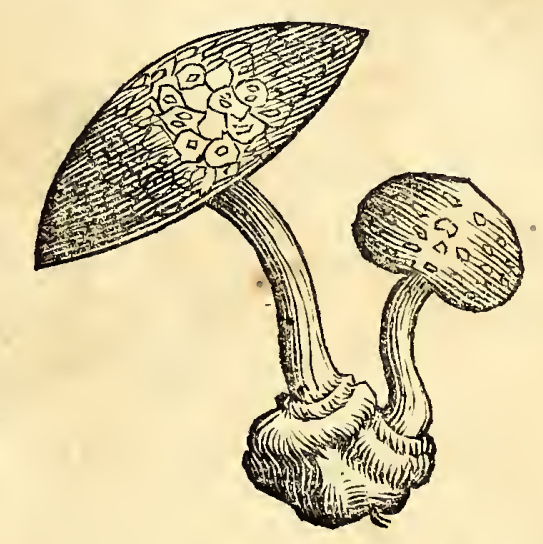

\section{Pratenfibus optima fung is}

Naturaeft, aliis male creditur.

Hinc, puto, ifti fales Iuvenalis \& Martialis, alludentes ad Boletos five Fungos illos qui temere manduntur. Equidem, fi me audias, cavendum fedulo, ab omnibus quovifcunque modo hic natis Fungis. Ob regionis enim temperiem calidam $\&$ humidam, noctium quoque frigus $\&$ vapores venenatos, tot denique venenata $\&$ infidiofa Infecta, minus tuti judicari debent, quam in aliis regionibus, ubi ufque adeo divitum mo. rofo palato arrident, ut eos in mortis difcrimen fxpius adducant. Qux enim voluptas tanta ancipitis cibi ; cum ne merentur quidem inter rufticas dapes recenferi ; Etiamf vel Athenæi, vel ipfius Apitii apparatu exhibeantur? Inter illos, pejores qui funt, fingultum excitant, inteftina exulcerant, corpori ac faciei inducunt pallorem, urinam remorantur, arterias intercipiunt:ad hæc frigus, tremorem, fudorem frigidum, mortem denique afferunt. Præter communia alexipharnaca calidiora, eximium \& præfens Natura produxit Antidotum, nimirum fuccos herbæ 2 bamúí, \& radicum Iaborandi, de quibus fuo loco, qui fudores $\&$ urinas cunctantes provocant, \& calorem nativum fuffocatum à frigido malignoque vapore vindicant : imo defperatos revocant à letho, fiftatim à fumto veneno, fuccus illarum ex haufu vini exhibeatur.

$$
\text { C A P V T } \mathrm{T} \text { X I X. }
$$

\section{$\mathcal{N}$ Cambú, Caabiá, Caaçica five Herba Colubrina, Iiaborandi, \& Caspéba fave Convoluulus Colubrinus.}

$\mathrm{N}$ On actum videbor egiffe, fi Herbas quafdam, antea in 1.4 Simplicium defcriptas, huc denuo adduxero, cum nunc ordo poftulet, proprietates earum fpecificas $\&$ antidotales, non vero primas $\&$ fecundas illas manifeftas qualicates tractare. Has inter nobilis herba Nhambí, primatum facile tenet. Qux quidem fo exferit non folita aliqua fenfuali per vomitum vel fudores vel urinas operatione, fed occulta quadam efficacia; quippe, prxter calidam $\&$ aromaticam vim, quam fatis intenfo gradu continet, venena frigida intus aflumta, \& Araticu-paná, Mucuná, fungos, 


$$
\text { N H }
$$

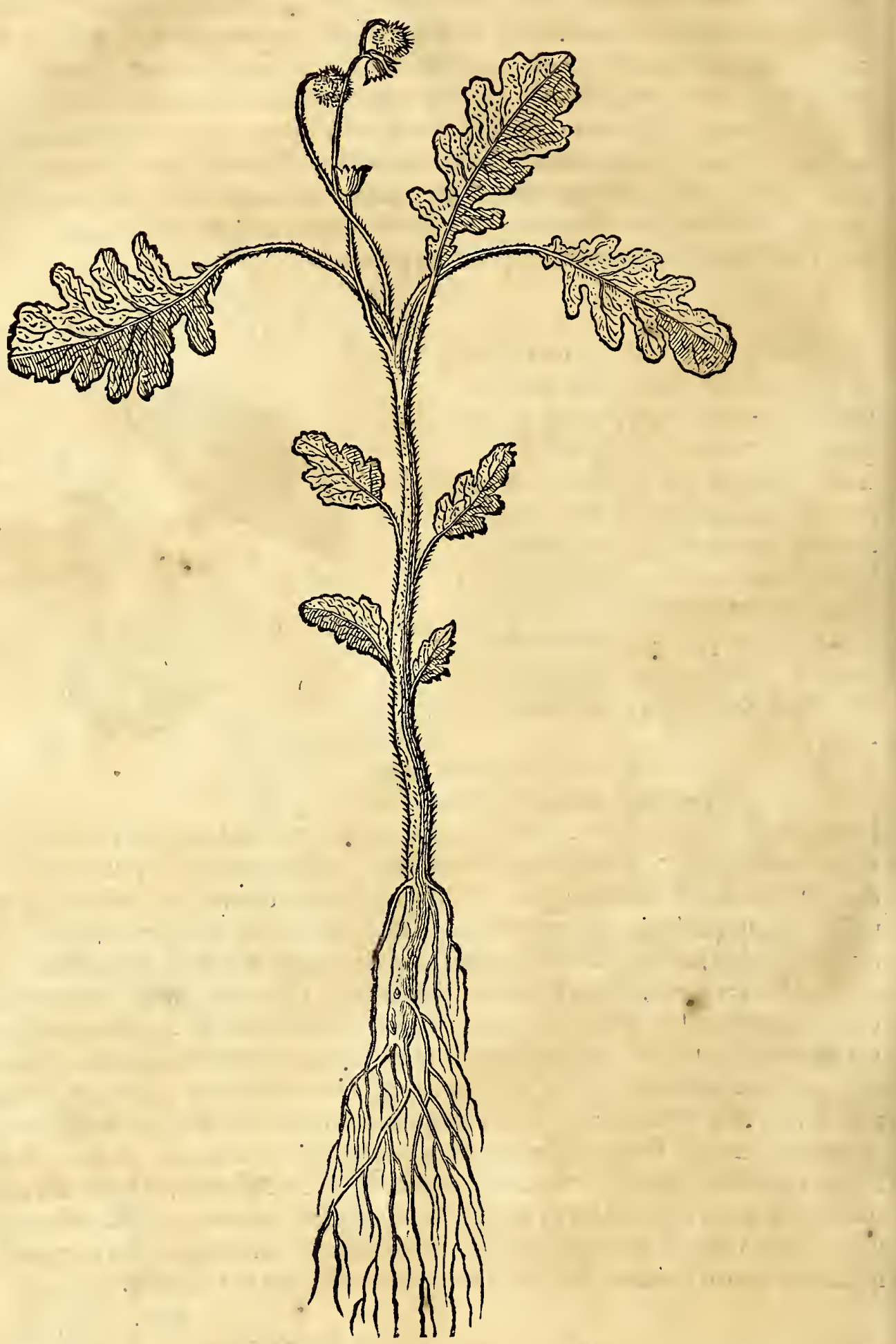

\& fuccos Mandiboce venenatos, \& fimilia retundit ; pra cxeteris autem adeo contrariatur veneno Bufonis, ut non folum fellis affumti vim deleteriam vincat ; fed ipfos Bufones vivos pulvere vel fucco ejus afperfos, enecet in inftanti. Quaproper non tantum ii qui fufpicantur, fe venenum aliquod haufffe, fibi hac Panacez provident, fed ad cam quoque tanquam ad facram anchoram confugiunt illi qui veneficia clandeftina alicujus inimici extimefcunt, caque vel fola in pulte qux Carima dicitur, vel acetariis mixta, fape multumque utuntur. Ita ut, fi quoquam Alexipharmaco fe præfervare \& munirc poffe autument, huic antidoto paffim fe fidant, contra obvia quxvis venena, vel arte per infidias parata.

D V herbæ Antidotales nomen Ipecacuánha fibi vendicant, quarum prior, ob evidentem vim emeticam, ut prxcedenti Libro prolixe docui : pofterior vero hæc quixe
Caapiá 
HIST。NATVRAL。 \& MEDIC. LIB。 Y.

Caapiá vulgo nomen audit, ob alexiterias virtutes magis celebris, proinde quod qualecumque venenum affümtum; antequam ex ventriculo $\&$ primis viis ad penetralia corporis permeaverit, per vomitum benigne ejiciat, fi dux circiter drachmæ ex li-, quore convenienti maceratx propinentur : mox fecundum ejus in fufum, vel folum vel cum radice Iaboraridi mixtum fuperaddituri , non quidem ad. vomitum, fed ad urinas \& fudores concitandos. Ita ut in hac nobiliffima planta diverfa qualitates fe prodant, utræque quidetin veneno exturbando dicatæ, fed ita tamen, ut hx pofteriores altius politex, tum demum fe videantur manifeftare, cum emetica facultates poft primam praparationem \& macerationem evanuerint

TErtia antidotalis plantá, quáx 1 caaçica dicitur, adeo indigenis ac advenis accepta, ut providi peregrinatores fe vix filvis committant, quin infignem hancherbam, vel ejus fuccum exprefium circumferant, non adeo quidem conrra omnis generis venena, quam quidem Serpenttim qualiacunque vulnera inflicta, tum applicandum, tum affumendum. Vnde non immerito Erva de Cobras nómen vulgo audit. Memini, Athiopes ab Ibibobóca Serpente mifere fauciatos, vix quicquam ex alio remedio levaminis fentiiffe, quam ex largiori hauftu propinati liquoris, nullo alio accedente medicamine. Succus ejus eft lactefcens guftuque acris \& ingratus, nulla manifefta operatione veneni victor evadit, fed fpecifica \& occulta vi in inC A A I I A

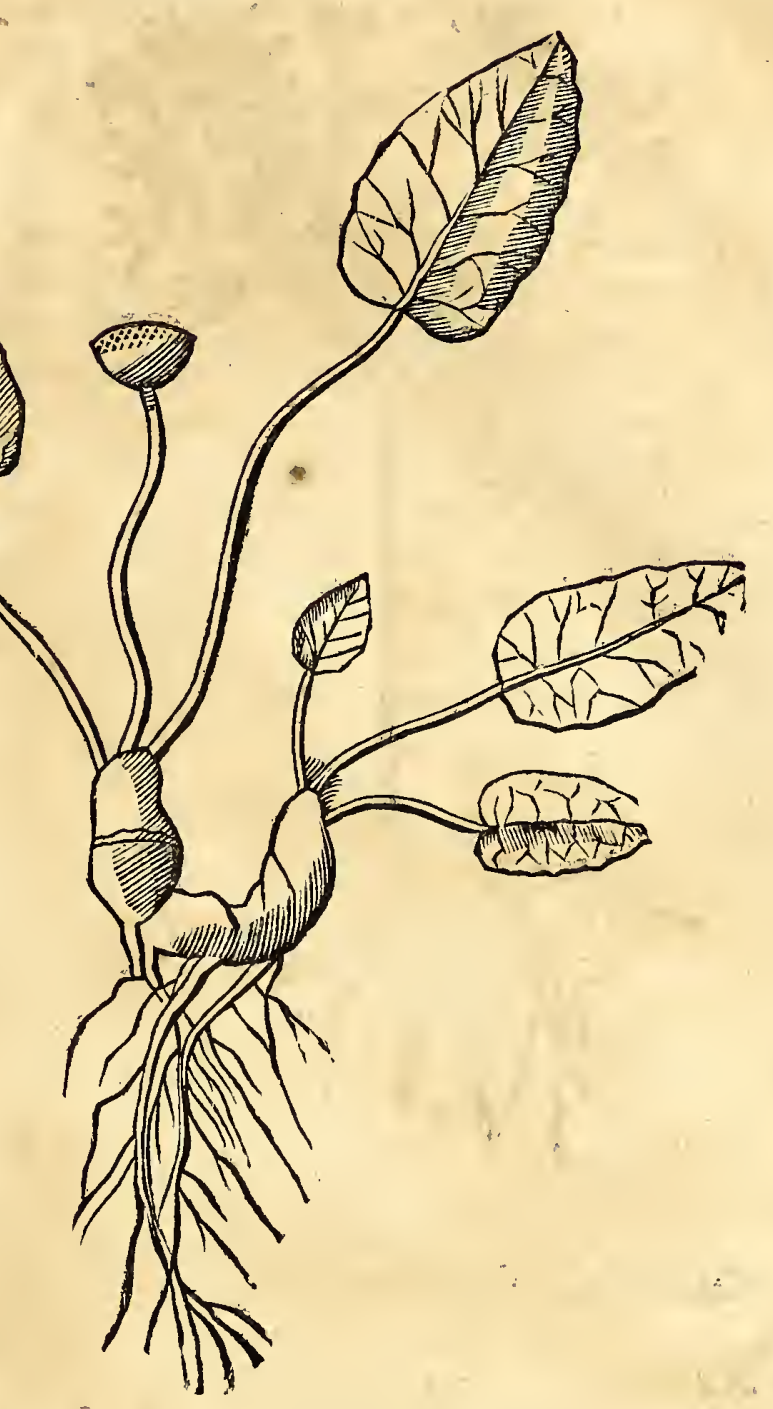

CaAçica five Herbả Colvbrina:

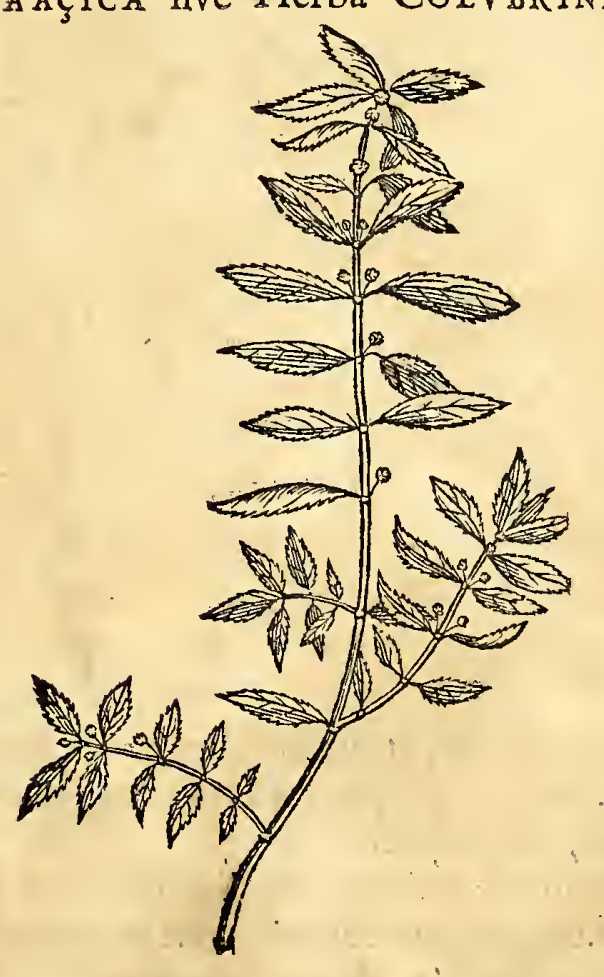

ftanti dolores fedat \& virus obtundit, imprimis fi eadem herba contufa, \& cataplafmatis modo præparata, vulneri fimul applicetur. 


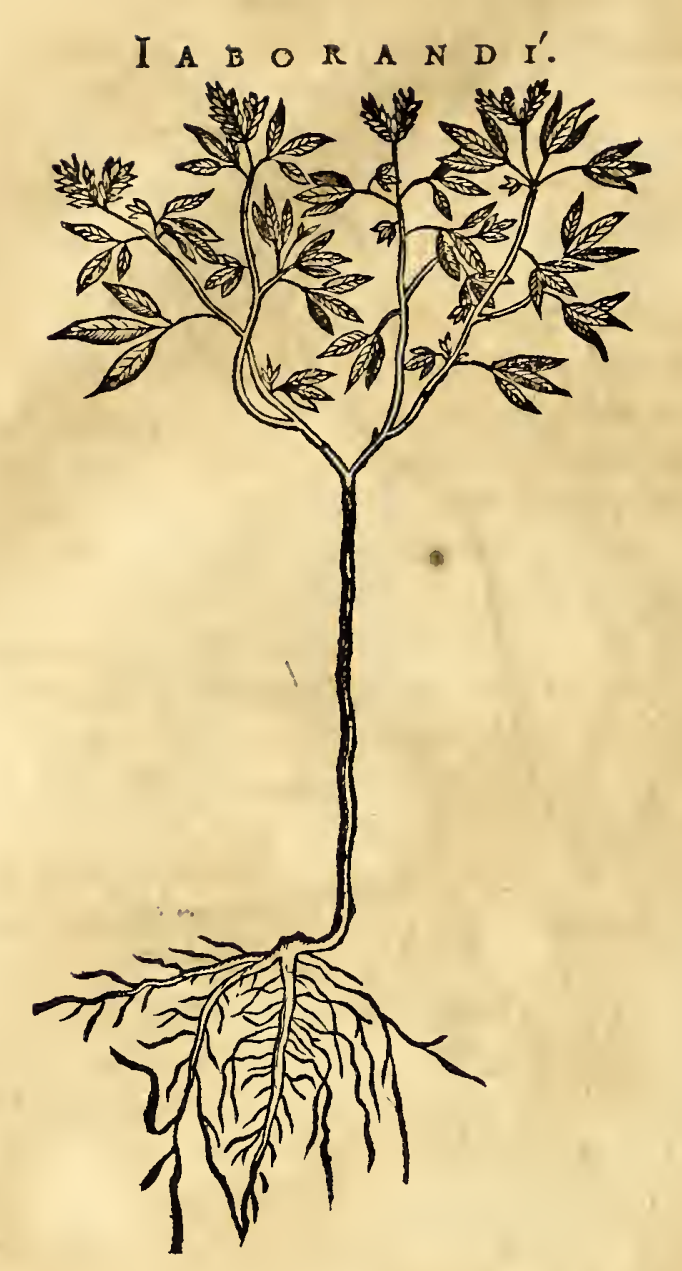

Neractatu Simplicium quatuor 1 fpecies radicum Iaborardí, earum que ufum medicum, quem compertum habeo, expofui ; hoc autem loco primam tantum fpeciem utpote efficaciffimam \& maxime ufualem, atque obviam, traAandam fufcepi, licet crerer quoque dignitatibus alexiteriis non deftitutx fint. Hacitaque, non,ut cæteræ, fruticefcens, ad duarum palmarum altitudinem erigitur; primo guftu aromatica, \& acris pyretri xmula, mox fubtiliffime fauces $\&$ pectus pervadit, adeoque contra malignos humores \& flatus fe exerit, ut venena, licet à multo tempore jam affumta, à corderepellat verfus fuperficiem corporis, ferolofque imprimis humores per fudores \& urinas copiofe ejiciat, unde f́piritus vitales à tetris fuliginibus liberati refocillantur. Atque hæc omnia cum feliciori fucceflu inftituuntur contra venena frigida, ut funt Fungi, \& fuccus ille venenatus radicis Mandiboce, \& fi qux funt alia ejufdem farinx venena fupra enarrata.

CaApe'ba, five Convolvulus Colvbrinvis.

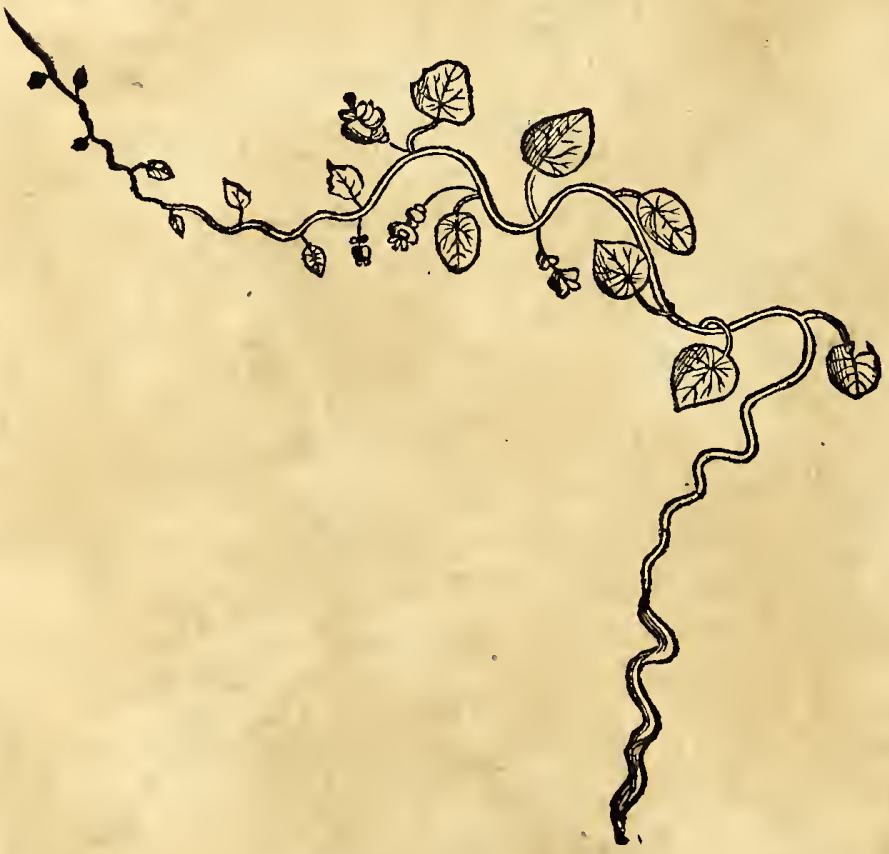

$S_{\text {tum nomen, huic fane }}^{\text {I ulli plantx appropria- }}$ farmentofx Clematiti Lufitani indiderunt, eam çipó de Cobras five Convolvulum colubrinum, ab infigni efficacia antidotali Serpentibus inimica, nominantes. Radix xque ac folia in Medicina celebratiffima; eo tamen difcrimine, ut radices, imprimis illæ qux jam plane adoleverunt, humoribus ferofis movendis, \& calculis frangendis dicatæ; quæ vero primo natæ frondes \& farment2, morfibus Serpentum medeantur, fi femel atque iterum eorum fuccus, recenter expreffusindifcretaquantitate propinetur, atque fimul extus applicetur. Nulla interim fubfequente maniferta evacuatione, neque per vomitum, neque per fu dores, neque per aliam aliquam viam, quantum affequi potui.

Licet autem ab Angtium aliorum que Reptilium \& Infectorum venenatorum ictibus $\&$ morfibus tantum curandis videatur bene au dire hujus Convolvuli fuccus, qui ama ro fapore caloris predominium, quod ad manifeftas qualitates, prxfe fert; venenis tamen fupra enarratis frigidis, quoque contrariari comperi, teftantibus id mecum exer citatiflumis Empiricis.

C. A- 


\section{A $P$ V $T$ T $X$ X. \\ Limonia Malus Americana, Antidotalis.}

A

Ntequam Vegetabilibus Antidotalibus, in hac America partefamiliaribus, fi. nem imponam, ex re fore putavi, Mali Limonix ufus Medicos peculiares, ejufque in Indiis neceffitates edocuiffe. Cum fupra in tractatu de Morbis Ende. miis vulgatiores utilitates Citreorum, Limoniorum, $\&$ Arantiorum (qux communi, nomine, propter vires \& dignitates fibi admodum fimiles, Mala Medicarecte dixerunt autores) in commodum medentium \& delicias ægrotantium perftrinxerim ; nunc occultiores $\&$ minus obvix quoque qualitates, quoufque ab Empiricis Indigenis, atque propria experientia mihi innotuerunt, exponendxreftant. Vt enim rudior antiquitas, fpreta corticum \& feminum amaritudine medullæque acore,frondes, flores, \& fructus, tantummodo ad oculorum \& narium delicias olim affervarunt, mox edoctiores, mediante fedula cultura \& mitiori terræ genio, pro efculentis medicamentofis eos ufurparunt. Tandem benefica Medicarum Malorum vis \& multiplex utilitas paulatim ope eruditæ induftrix compertior, quotidianoque experimento per feculorum gradus proficiente, virtus contra venenum efficax primum in Africa $\& 2$ IEgypto detecta, mox in Europa atque Indiarum quoque Regionibus confirmata fuit, teftantibus id paffim prxter me veteribus ac neotericis exoticorum fruticum fcriptoribus.

Licet vero pleraque ex hoc novo Orbe huc allegata, experientia potius quam auctoritate aliorum niti velim, tamen non pœnitebit, unum atque alterum ex multis allegaf$\mathrm{fe}$ in laudes Limonum. quibus confirmatur, eos ante cibum deguftatos, à putredine ac venenis ipfis præefervare, atque fubinde $a b$ affumto veneno vindicare. Athenæus ætate fua in Agypto eorum vim compertam fic narrat. Sumptum Citreum ante cibum quemlibet, (five is humidus fit, five fiecus) venenis omnibus refiftere ex cive meo didici, cui fuerat Ægypti adminiftratio demandata. Quofdam hic facinorofos homines Alexandrino more ad Serpentum morfus damnaverat. Jllis ad locum ficariorum fupplicio deftinatum procedentibus, muliercula quædam cauponis uxor in ipfá via, quod in manibus forte habebat, admordebatque, Malum Citreum, miferata porrexit. Pomo illi commanducato, ingentibus ac feviflimis Anguibus objecti, citra no$x a m$ venenatos ictus excepere. Attonitus rei novitate judex, $a b c o$, qui cuftodiebat, milite quæfivit, an antidotum aliquod præguftaffent ? à quo certior factus, abfque dolo malo Citreum illis fuiffe datum; juffit, poftridie alteri tantum dari: deinde utrumque Anguibus objici. Ex quo factum eft, ut Citreo paftus, fofpes evaferit; alter illico expirarit. Exinde crebra experimenta fidem fecere certiffimam, venenis Citrea \& Limonia ominibus adverfari. Accedit quod pomi cjufdem fingula membra falubri temperie fic invicem difcrepant, ut varios confanare morbos poffint, \& contra ipfa venena in unam coalefcere Medicinam. Quos ufus Plinius compendiofe \& ingeniofe exprimit, Citrea, contra venena in vino bibuntur, vel ipfa, vel femen. Virgilius quoque, Homerum imitatus, luculentis verfibus per longam periphrafin eorum dotes exprimit:
Media fert triftes fuccos, iardumque Saporem
Felicas Mali, quo non prafentius ullum,
Pocula s iquando Save infecere novercs, Mifcueruntque herbas ơ non innoxia verba;
Auxilium venit, ac membris agit atra venena.
ip fa ingens arbor, faciemque fimillima Lauro,
$E t, f$ non alium late jactaret odorem,
Laurus erat, folia haud ullis labentia ventis.
Flos apprima teraxix , animas of olentia Medi
ora fovent illo, \&j fenibus medicantur anbelis.

Extra inftituti limites effet, me autorum difcrepantibus opinionibus involvere, circa diverfas partium qualitates in hac arbore ejufque fructu contentarum; folia enim, flores, medulla, femen, \& cortex fructuum ac radices in medicinam recept $x$, frequentiffimi ufus exiftunt, atque licet gradu dignitatis, tum \& primis fecundifque qualitatibus in- 
3 i4 G VI I L M I PISONIS

ter fe difcrepent; tamen femen \& medullà inter omnes arboris partes; quod ad qualî. tates fpecificas $\dot{\&}$ alexipharmacas, primatum obtinent. Imo peritiffimi nonnulli Indiarum Orientalium \& Occidentalium medicaftri, prater vulgares.illas toti Orbi celebratiffimas Limonum \& Citreorum vires, quas quoque perpetuo commendabiles habent, plus prefidii in duabus his Limonum partibus ponunt contra malignos morbos \& pertilentes febres, atque ipfa denique venena, quam in Lapide Bezoardico \& faftidiofa Theriacx compofitione. Quafi his arboribus Medicis, non magis patria quam falubritas, Medicæ nomen feciffe videretur. Quæ omnes ut olim in Hifpaniam \& Italiain, fic quoque in Indias Occidentales tranflat $x, \&$, licet illic per infitiones aliaque naturæ adulteria hortenfes, hic vero in America etiam nunc minus excultæ fint, tamen ob cal ores Solis perpetuos \& foli hujus genium, Europæis fativis, fi non præftantiores, faltem pares exiftunt, adeoque fponte in filvis fata ftercoribus avicularum depofita luxuriant, ut ob nimiam ubertatem vilefcant. Quippe toto anno ver, xtas, \& autumnus in is conf́pici datur, quod una eademque arbor, fores fragrantes, fructus virefcentes \& flavefcentes affidua oculorum \& narium ac oris obleatamenta oftentat. Vnde varix compofitiones, Iulapia refrigerantia, Conditura, imo Extracta Chy=

L I M O I A Malus A MER I C A N A, Antidotalis.

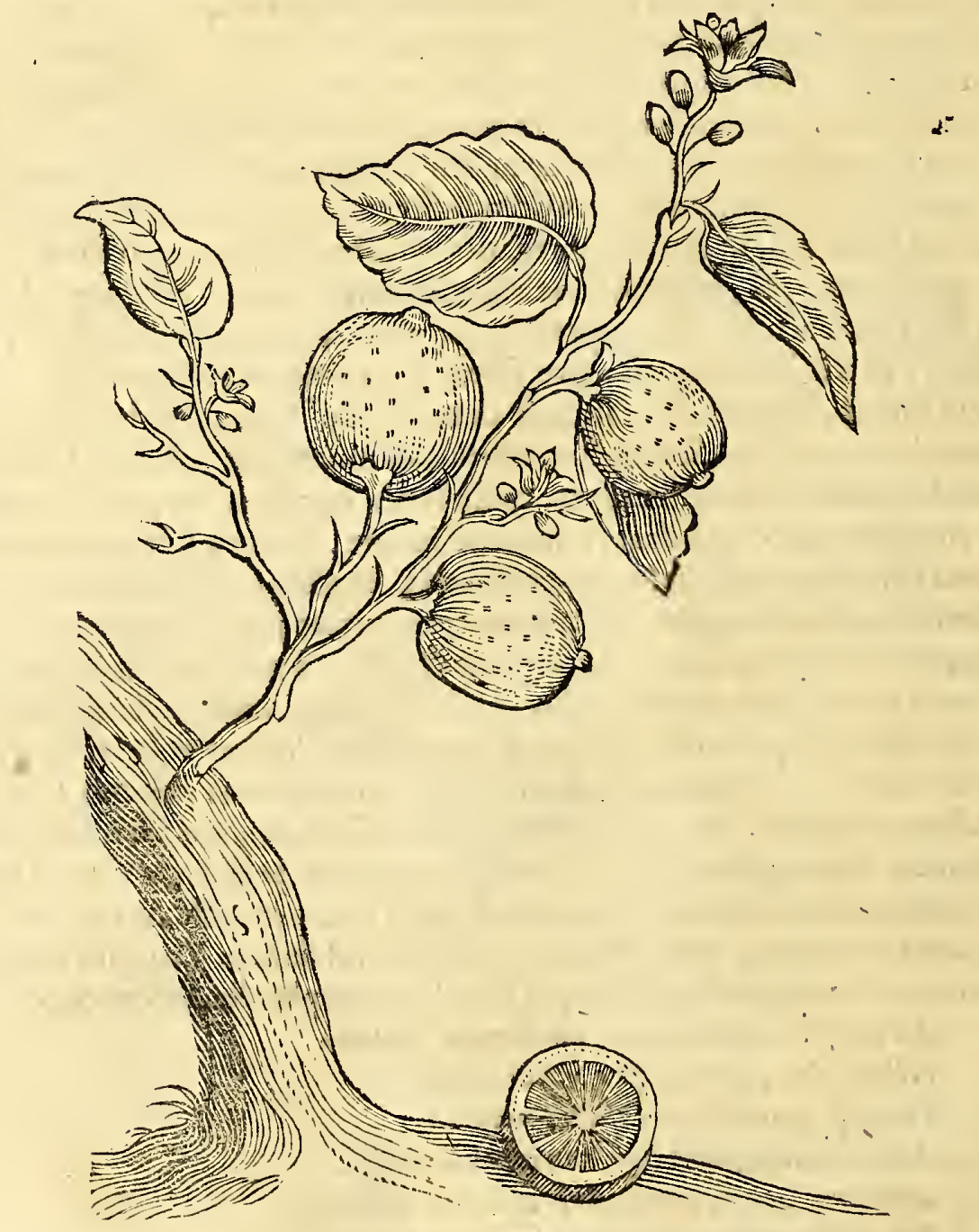

inica, quas quintas effentias vocant, ab induftrioribus incolis nunquam non parantur. Quos ego in hac Indiarum Occidentali parte imitatus, fine jactantia affirmare aufim, me ex nullo alio aliquo remedio fimplici tot felices in tota praxi obfervaffe effectus, quam exfupra enarratis Citrei \&z Limonii arboribus. Cum enim fuccus frigidus \& intenfe acidus, ab advenis \& indigenis aliquando male ufurpatur in fenum vel puerorum frigidis, five pectoris, five nervorum, five inteftinorum, affectibus, runc flores, femina, \& corticesipfus fruetus medelam ifti malo quantocius conciliant; imo, quid fi hac non fufficiant, corum, ut $\&$ primarum frondium, olea deftillata vices fupplent; 
HIST. NATVRAL. \& MEDIC. IIB.

plent, urinas vel fudores egregie protrudentes. Mitto quiod ipfi radicum cortices, ca. lidarum \& tenuium adeo partium àme deprehenfi fint, ut multos vifcerum, à jecoris imprimis \& renum, obftuctionibus vindicaverint. Quod quidem potiffimum de radicibus Mali Limoniæ, cujus iconem folam exhibeo, diaum volo, ejufque defcriptionem nunc fpeciatim aggredior ; cum hactenus in genere malis Medicis earumque virtutibus inhxerim.

Non male equidem foriptores natale folum \& naturam Limonii cum Citreo communem attribuiffe vifi funt mihi, quum circa præciptas earum vires haud multum inter fe difcrepent ; (exceptis dulcibus illis Limoniis minus ufualibus in Medicina) nifi quod pufillus hic Limon agreftis, quantum vifus, odoris \& faporis lenociniis majoribus illis hortenfibus cedat, tantum eos proprietatibus medicis facile fuperet.

Arbor eft Pruni figur $¥$ \& proceritatis, caudice fature cinereo, ramis f́piniferis, foliis laureis fed minutioribus \& dilutioribus, fxparatim hinc inde pofitis, cum appendicibus juxta pediculum, Aurantixmore denfiffima fruticatione luxuriantibus; perpetuis floribus, obfoleto candore albicantibus, \& Lilium convallium nonnihil redolentibus, fœcunditatifque munere affidue nullo non menfe confpicua qui primo nafcitur $\mathrm{Li}$ mon, à fpinis maternis fpineolus, \& ab acutiffimo fapore palatum vellicante, Irritator appetentix merito dicitur. In ipfa enim viriditate præmaturus ac tempeftivus ad obfonia \& medicamina, magnitudinis eft nucis juglandis, fed figura magis fphærica, in pa pillam exiguam definente, tenuiffima, viridi, $\&$ lævi cute obducta, nulla carne, fed fol a medulla, acida, fubviridi, turgida, denis duodenifque intermediis membranulis pari ter difpertita, \& nonnullo fcmine gravida. Radix arboris eft tenuis, ex fufco flavefcens, calida, ficca, amara \& acris tenuiumque partium, ac proinde inter aperientes \& diureticas celebris. Porro Limon hic nofter fapore acerrimo vefcus non eft ut cateri, fed qua palatum fraudat, cum foenore voluptatem fanitati rependit, dum 2 ituantibus $\&$ àbile vomiturientibus parabile condimentum in cibis $\&$ potu promifcue fuppeditat, $\widehat{f}$ tantillo faccharivel jure vis ejus infringatur. Ea tamen adhibita cautela, ut juvenili potiflimum atati \& cholericx tempe ratur $x$ concedatur ; fenibus vero, ut $\&$ pueris pituirofis interdicatur. Hxc eadem fere potio eft in toto Oriente, ac imprimis apud Turcas, admodum expetita, cui vulgarem Sorbetti appellationem Latium forbendi verbum, Scerberti vero nomen vox Arabica, Turcica \& Perfica, impertivit, quam quifque illorum. fuo more ad delicias præparat : hic præcipue fructus nunc in muria nunc in faccharo reconditus, vel etiam ejus liquor folus in doliis refervatus, pubem nauticam in diutinis tra jectionibus ab humorum putredine confervat; imo maritimi non folum Septentriona. les, fed Afix, Africx, \& Americx littorales populi à fcorbutica lue infecti illo reftituun-tur. Eodem hoc fucco, quid mirum, impetigines, vitiligines, aliaque foediora cutis vitia quoque delerifi Chymica arte præparatus valeat ad unioncs $\&$ margaritas in tabem folvendas ? Vidi aliquando Nigritos fceleftos coquendis faccharis dicatos, injuriam dominis clam inferentes, inftillato parum recentis Limonis fucco, vehernentiffima facchari ebullitioni in cacabo capaciffumo reftitife. Ex quo abufu, anfam mihi fuppeditari autumabam, aliquid ad artis noftræ incrementum edifcendi, idque aliquoties tentans, non infeliciter proceffit, in febribus fcilicet intermittentibus, circa initium paroxyfmi, ut Chymiatri fua emetica folent, haufu fcilicet calido fucci prædicti cum facchari \& aque fontanæ tantillo ebulliti, femel atque iterum exhibito, exacerbationes vel in totum ceffaffe, vel faltem indies prxter expectationem fimul cum fiti deferbuiffe, \& intra paucos dies plane filuiffe, deprehendi, fubfequente utique manifefto effectu, urinæ fcilicet $\&$ imprimis fudorum larga promotione. Quafi eximius hic fuccus frigiditate fua fiti fedand $x$, tenuitate fero fanguinis propellendo, acuta aciditate malignitati $x$ ftuantis bilis frenand $x$, adeoque fpiritibus vitalibus concentrandis $\&$ cor roborandis dicatus effet. Pofitis itaque tribus enarratis his manifeftis qualitatibus, rationihaud diffonum videtur, harmoniam fpecificam $\&$ occultam ex earum mixtura poffe refultare, qure ictibus Serpentum \& venenatorum infectorum imprimis omnibus iftis venenis afumtis, igneo \& fubtilifimo piritu venas $\&$ arterias permeantibus, adverfetur.

Atque hactenus de pulpæ fucco ex legibus artis exhibito. Reftant aliæ cjufdem arboris partes, flos, femen, \& cortex, minime prætereund $x$, venenifque potiflinum frigidis, five propinatis five inflictis, obtundendis confecratx. Exfeminibus folis contufis \& decorticatis vel etiam ex corum oleis deftillatis tot ftupendos cffectus videre contigit, 
ut mirari defierim, neotericos æque ac veteres Arabes \& Græcos iis efficaciam vere antidotalem attribuifle, atque non folum contra vermes inteftinorum; morfufque ferpentum, fed \&loco Theriacre, contra peftilentes $\&$ contagiofos morbos feliciffime ufurpaffe. Cum enim femina caliditate, ficcitate, acore $\&$ amaritudine à pulpa differant; folaque fere evidenti aciditate videantur inter fe convenire: Vtraque tamen craffos humores difcutere, incidere, \& attenuare, putredini refiftere conftat; fed femina ob concomitantem manifeftum calorem, frigidis venenis; pulpam vero potiffimum calidis dicatam effe. His fuccedunt extracta quoque florum \& corticum, qux ejufdem naturæ \& efficaciæ habentur, \& maximo diffidio quævis deleteria oppugnant.

Tandem Medicx hujus arboris pars infirmior etiam vim habet falutarem curandi vulnera malcmorata \& à venenatis ictibus relicta, modo fuccus ex prætenuibus foliis \&recentibus germinibus expreflus, vel folus, vel aliis mixtus, applicetur. Quafi perennis viriditas argumentum oleofi \& efficacis fucci, non modo ad ipfarum arborum pabulum; verum etiam ad hominum commoda \& neceflitates exuberans exifteret; quapropter optandum, ut fedula pofteritas ex ejufmodi vivacibus potiffimum firpibus liquores medicatos ulteriori induftria eruere cogitet.

\section{A. P V T $\mathrm{X}$ X I. \\ Locultarum, Papilionum, Erucarum, \& Avicularum Guainumbi transformatio.}

Vprade natura \& cura quorundam Infectorum fuo loco egi, nunc pro mantiffa, de aliquot innoxiorum miranda generatione $\&$ interitu, pofteris ulterius indaganda, pauca addam. Miffis fabulofis vel qux dubix fidei funt, veriffima ac proinde Philofopho non contemnenda fubnectam.

De Bombycibus autem Brafilienfibus nihil ex profeffo dicturus, utpote quorum figura, natura, \& transformatio, ab Europæorum haud differat. Indigenæ eos Içocí, fericum vero Içocúrenimbo vo cant.

Ad Locuftas itaque me accingo. Quarum tria genera tradidit facræ philofophiæ facerdos Mofes, eaque ex Hebræa Lingua in latinum verfa,Locuftam, Aftacum \& Bruchum nominarunt. Græci aliique eruditi recentiores, plures agnoverunt fpecies. In-

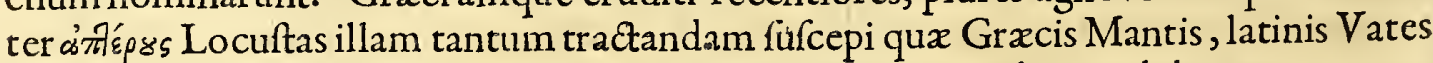
dicta, quod ubicunque apparcat, macra fit \& famem portendere perhibeatur.

Propofiti limites excurrerem, fi vulgarium Locuftarum Americanarum differentes magnitudines, figuras, colores, fonos, volatus $\&$ faltus defcriberem; ortum quoque earum \& interitum, à veteribus ac neotericis fatis fuperque traditum, repetere, fupervacui foret laboris; nam licet generationis \& obitus varii dentur modi, in eo tamen, ni fallor, plerique confentiunt, mares à diutiffimo coitu, fpiritus omnes exigente;fœmellas autem fœur $x$ pluralitate exhauriri, \& brevi poft è vita abfque ulla alia Metamorphofi decedere. Ar vero hæc noftra inufitat $x$ figur $\&$ natur $x$ Locufta, incognito fexus difcrimine, \& nafcendi modo, certo quodam tempore, veris vicem in hac America partefupplente, vitam feifitivam derelinquit, \& in plantam migrans aliquandiu,tandem more cæterorum vegetabilium marcefcis. Dux earum dantur fpecies, ejufdem quidem figurx, fed non ejufidem coloris, quod illa to to corpufculo lurida inftar folii arboris decidui, vulgo feuille morte; hrc vero læte viridis fit coloris. V traque macilenta eft, Caayára, aliis Gaajára, dicta, rore potiffimum victitantes; differentes tamen ab iis, qux à Rondeletio \& Mouffeto in Theatro Infectorum, ad calcem libri, Mantes dicuntur; quod Americanx fint collo longiffimo tenui \& erecto, inftar Cameli. Corpore lxvi,vix digitum longo ab utraque extremitate acuminato, \& dorfi medio, eminenti linea recta per longitudinem, cum obliquis fibris, inftar folii arboris, divifo. Capite funt triangulari, in cujus vertice duo cornicula oblonga, tenuia, ercetaftant. Oculis prominentibus, lenticularibus, fufcis. Crura habent fex, duo in fummo ferc collo, unum digitum longa, tribus internodiis conftantia, \& in extremitatibus denticulata : reliqua duo paria, trifte viridia, liventia, ficut folia ficca. Priores autem pedes quia inftar brachiorum junctos, sz quafi manus ad cælum elevatas, plerumque habeant, Lufitani Lonvadios, Galli Preque Dieu, appellarunt. 
HIS T. NA TVRA L. \& MEDIC. L I E. V.

Vnde Barbari non folum, fed \& Chriftiani imprimis, multa fuperftitiofa fibi imaginantur. Quafi macie perpetua confectx, homines docerent fupplices ad Cxlum palmas tendere. Beftiolæh h in plantam ejufdem fere viriditatis \& tenuitatis, duarum palmarum magnitudinis, transformantur. Pedes primum terræaffiguntur, unde, accedente humiditate requifita, radices exeunt, quæ terræ infiguntur, atque ita paulatim parvo. temporis fpatio totæ convertuntur. Aliquando aùtem inferior tantum cor-

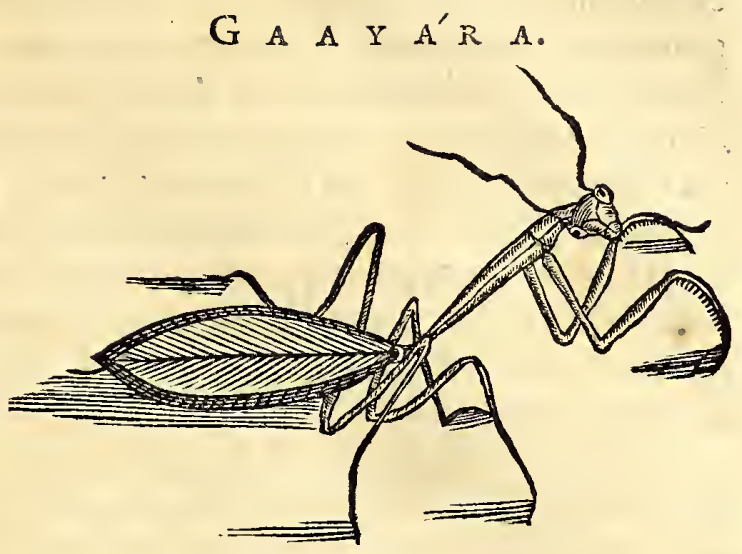
poris pars naturam $\&$ faciem plantæ induit, manente fuperiori parte aliquiandiu mobili, ut ante; donec tandem totum infectum paulatim tranfmutetur, atque fenfitivum quod fuit, vegetativum fiat, natura per circulum quafi, fucceffive agente, motuque perpetuo infe recurrente. Hanc plantam libentiflime curiofo lectori exhibuiffem, fed per varias temporis \& itineris injurias re defiderata potiri non licuit.

Nec eft quod quifquam de veritate dubitet, cum infinitos teftes habeat Brafilia, $\& z$ plures minus hallucinarentur circa ejufmodi mira Naturæ opera, fi animum \& mentem non perfunctoric eo applicarent. Idem contingere in Æ Ægypto præter Plinium', fide digniflimi de fimilibus Locuftis conftanter affirmarunt. A tque annales Iaponize teftantur, cujufdam terreftris animalis transformationem in fquamiferum. Alibi de Agno Tartarico qui in arbuftum degenerat, ab optimis confirmatur. Quorum narrationi nihil tribuo, nec derogo, fed fidem apud Autores relinquo. Iam dudum in. notuit, Concham Anatiferam in Scotia (licet nuper adhuc fubleftx fidei videbatur) ex arbore pronafci.

Quidquid fit, cum appareat, fibulas effe inter germinantia \& fentientia, mutuaque retaliatione animalia germinare, \& plantas fenfu animare, idipfum quoque Ariftotele, Plinio, \& Theophrafto conteftantibus: Quidni tot nova hujus Novi Orbis Zoophyta mereantur, ut vitarum confufionem earumque fodus admiremur ; imprimis fi fenfuum arbitri, non opinioni populari, fabularum artifici, pareamus. Eventu enim naturx prodigiof $x$ autoritatem reftaurante, increduli facile caufa cadunt. Vfque adeo denique omnium corporum fublunarium inter fe commercium patet perpetuum, ut Chymiater magno merito quoque non patiatur hafce metamorphofes metallis denegatum iri polfe.

D Apilionum porro \& Eru1 carum innumerx dantur fpecies, non ab. uno defcribendæ, magnitudine, \& colore difcrepantes. Figuræe aliquot graphice quidem depictx in Clufio \& Hiftoria nofra Brafilia naturali, fed earum metamorphofis neglecta. Omnes, ni fallor, hi Papiliones quatuor funt alis, duobus corniculis, fex cruribus \& f filo convoluto ad os. Alx pulchritudine argentearum macularum \& fimbriarum certant. Horum przedatrices gulx,aliquando in horto IlluAtriffimi Principis Naflaviz

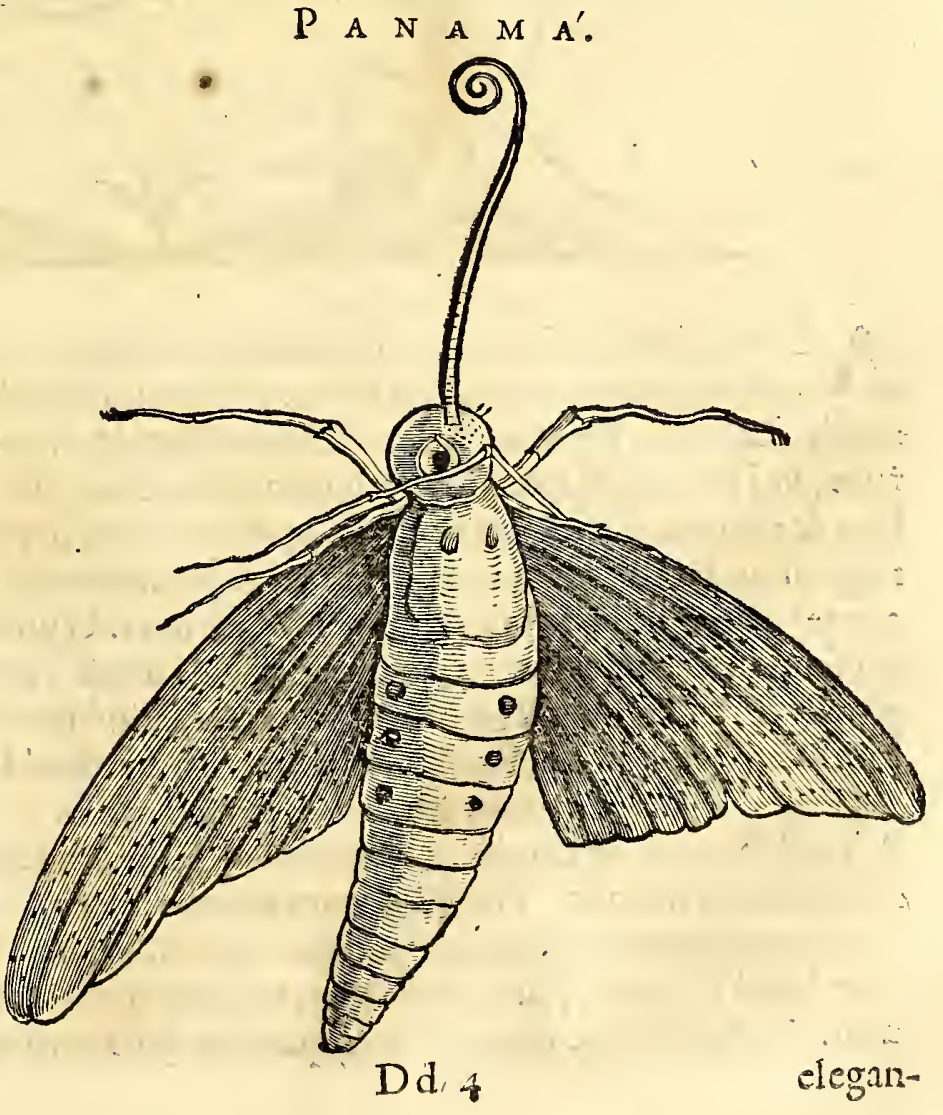


elegantes hederas, Murecuiá dictas depafcebantur, innumerabiliaque ova papaveris magnitudinis ponentes, ex quibus primum parvæ hepatici coloris Erucx, \& ex his fecundo Papiliones nafcebantur.Erucx autem hx in crafitiem pennæx anferin $x$ excrefcunt,nigris aculeis hifpid $x$, capite nigro bicorni, per corpus quafi rufo punctulatæ; morientes grifea obducuntur pelle feu folliculo, qui poft certum tempus fe aperit \& prodeunt denuo Papiliones alati, Brafilianis Panáma, Lufitanis Barboléta dieti. Horum fubinde aliquot myriades fubito apparent, atque fine ulla disjunctione aut interruptione turmatim aëtem inftar denfiffimi imbris replent, idque ductu adeo continuato, ut vix fex horarum fpatio exercitus ille aëreus difpareat, ficut quoque in Europa paffim, ringente agricola, videre contingit. Qui herbarum arborumque helluones, ubi devorandi tempus præxteriit, vaguli huc illuc $\&$ jejuni migrant, fenfim que marcefcentes, locum idoneum quxritant, ubi fefe vel filo appenfi in aureliam membrana tectam, vel in thecam transforment. Nec tamen omnes Papiliones \&Erucx in aurelias convertuntur, fed aliæ contractx, putrefcunt, c̀ quibus nonnunquam ova excidunt, aliorum infectorum matrices. Has Erucarum tranfmutationes Theophraftus reate diftinxit his verbis, 2 Iєe'

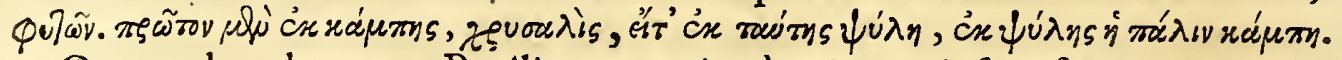

$Q$ uemadmodum vero Papiliones partim à coitı utriufquefexus, partim ex viridibus illis Erucis generari conftat, alis paulatim adnafcentibus: Ita viciflim turmas illas gregariarum Erucarum, non folum roris pluviarumque proles, fed \& Papilionum effe filias; imo maximam Erucarum partem iis debere prolapiam, omnibus experientia confirmatum effe putem.

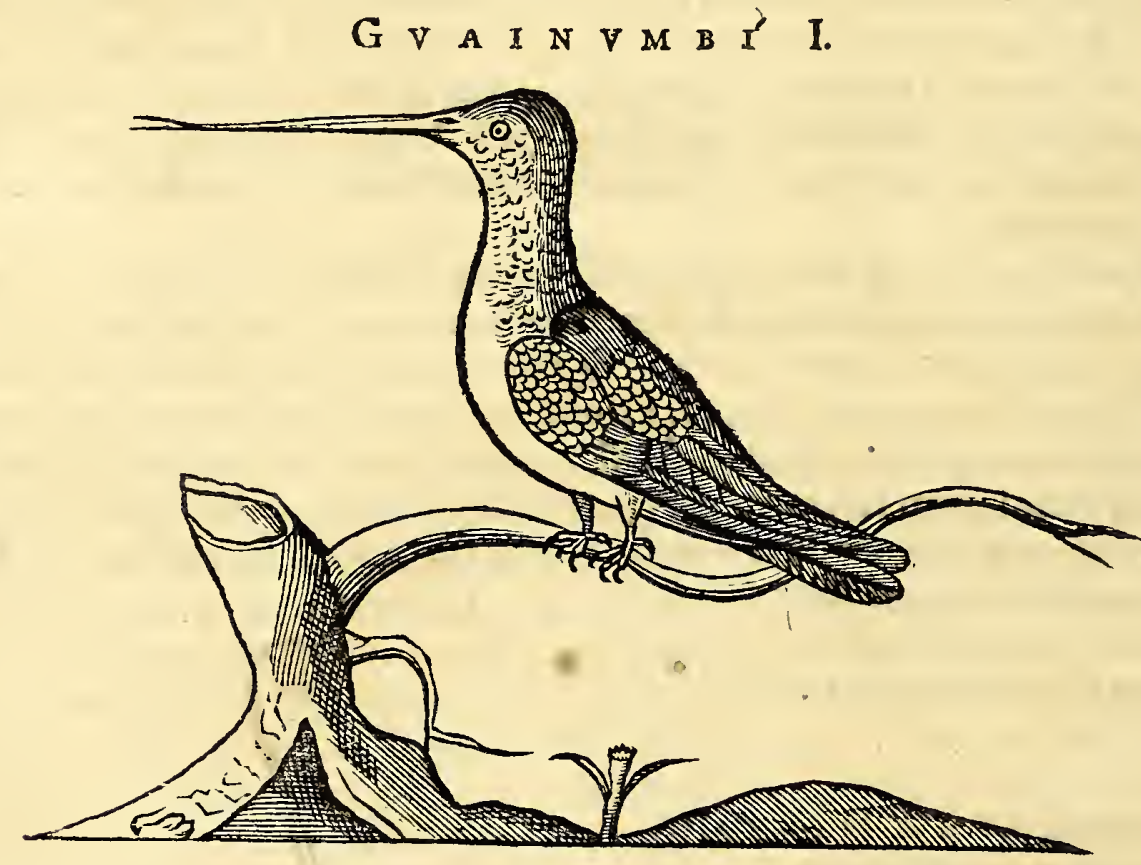

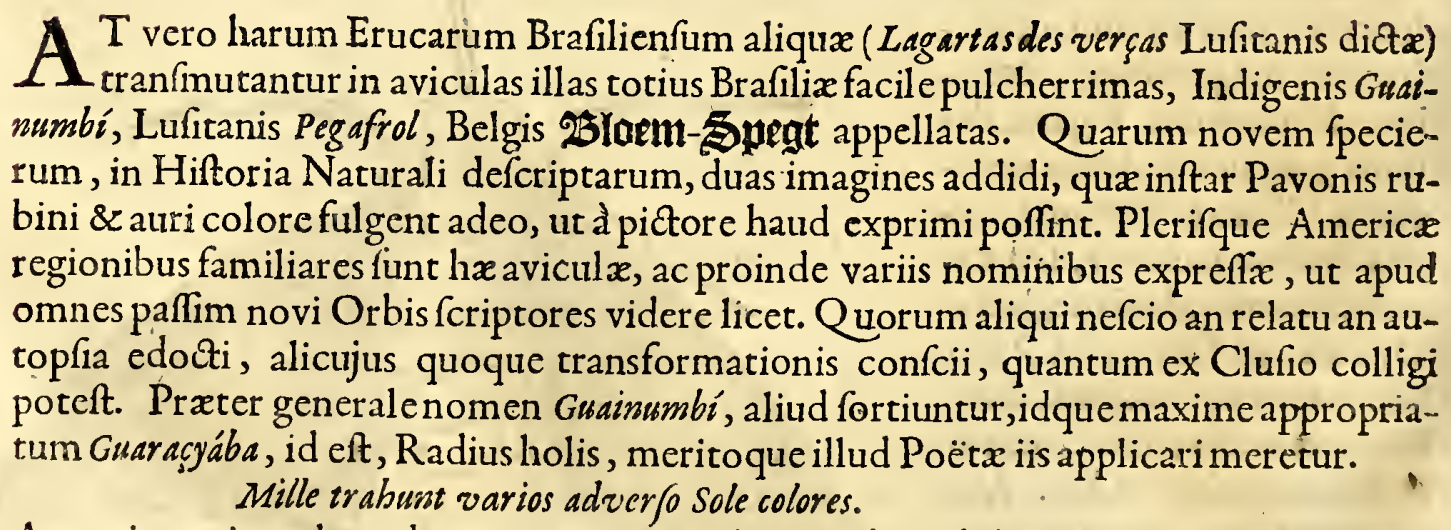
A vertice enim ad caud $x$ extremitatem plum $x$ admirabili colorum varictate inter fc certant \& micant. Volatus earum adeo praceps \& celex eft, ut vifum fere fugiant, alarumque motus non magis confpici queaE, quam Crabronis. Magnitudine Cicadam haud fuperant, adeoque leves, ut intra viginti \& triginta grana unaquxque pen deat. Roftello fimt omnes (non quidem ejufdem longitüdinis, ut ex appolitis Iconibus 
HIST. NATVRAL。 \& MEDIC. IIB。

nibus liquer) tenùi lingua; bifecta, inftar ferici fili tenuiflimi, quam extra roftellum longe exferunt, ut florum rorem lambant. Ocellos habent parvos \& nigricantes. Alarum pennæ fingulari arte à natura funt compofitx. Ab exortu enim alarum duplex ordo pennarum eft, unus longior altero, \& fuperpofitx funt fibi invicem pennx, quafi alx breves fuper longas. His alis expanfis volare diu poflunt,' ac in aëre quafi pendulæx manere. Frequentes funt in filvis, præfertim tempore matutino, dum flores rore turgent, ftrepitumque tunc excitant ingentem, non canendo, ut aliqui fcripferunt, fed fere Pafferum more i bilando Sirep Sorep. Nidulum faciunt in ramis arbo: rum exiguum, ex Xyli floc-

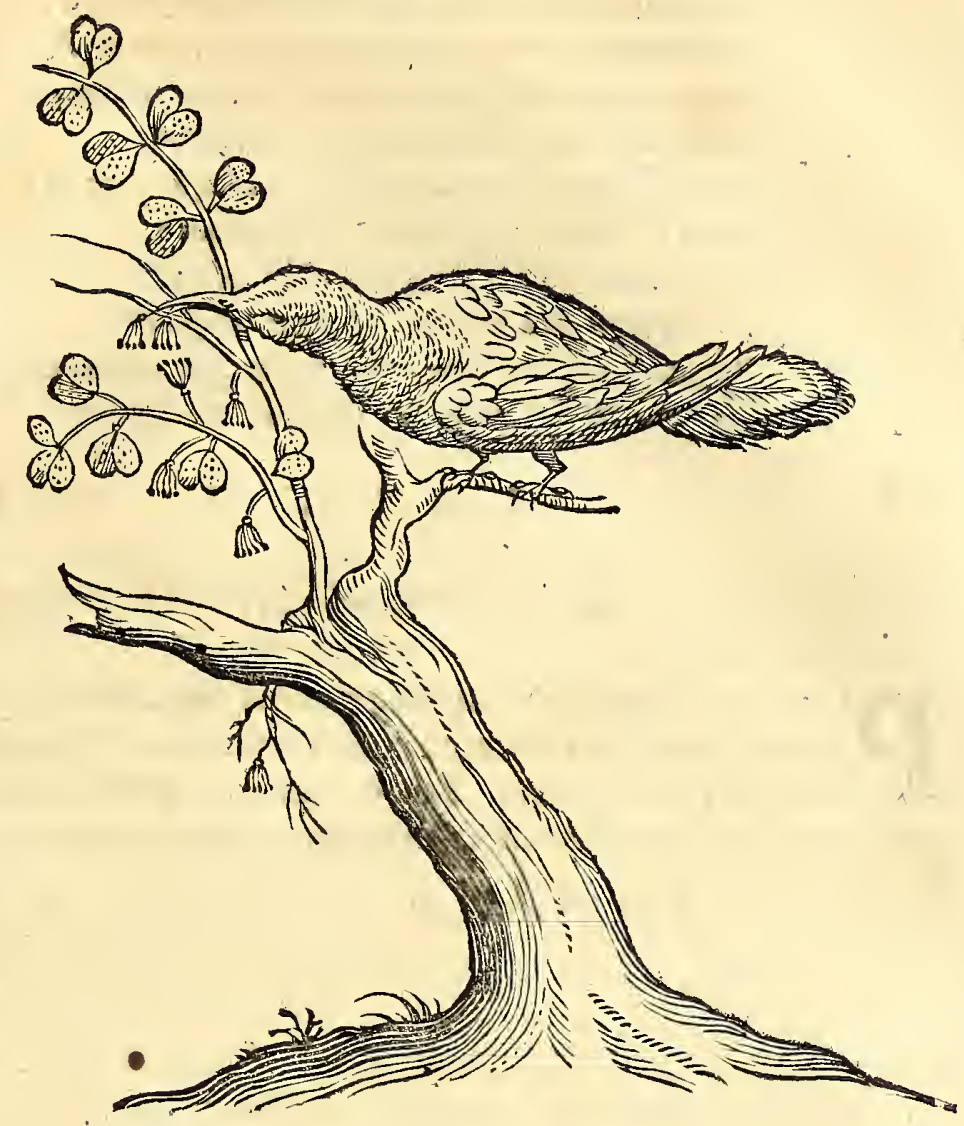
co compofitum, ibique ova ponunt albiffima, duo ut plurimum, ordinarix figurx, pifo haud majora. Pedibus funt valde exilibus, nigris, quatuor digitis, more aliarum avicularum, præditis, definentibus in unguiculos, inftar acus fubtiliffimos. Q uia floribus eorumque rore victitant melligineo, captæe, diu vivæ detineri nequeunt, fed moriuntur, atque bonum de fe fpargunt odorem. Fr. Ximenes fcribit, eafdem à Mexicanis Huitzitzil appellari, teftaturque, eas non diutius vivere, quam durantibus floribus, iifque decidentibus, roftello futo affigi arborum truncis, \& fex menfes ita immotas (five mortuas, fivejejunas) manere, donec pluviis redeuntibus Flora rurfus campos veftiat.Idem confirmat Iohannes Eufebius r.l. Hift. Nat. \& Lopez de Gomara, aliique, Egregii hujus vifci (ex tuberibus aliarum arborum nafcentis) floribus flavis potifimum delectantur quos idcirco hic exprimijuffi.

Quum itaque enarratæ Erucx in a viculas has incipiunt transformari, elegantiffim plumæ cum alis primo apparent, ita ut tunc manifefte confpici detur forma Erucæ, quod ad partem corporis inferiorem, altera fuperiori jam in aviculam tranfmutata. Idem de Papilionibus dictum volo, qui fubinde in eafdem aviculas eodemque modo convertuntur, atque durante illa converfione nafcentis avis \& 2 denafcentis infecti, utriufque medietas eodem temporeliquido appareat. Emanuel de Morais Theologus Lufitanus in Brafilia , multique alii fide digni \& curiofi Monachi, prodigiofa hæc quoque viderunt , \& infecta ipfa tempore h̀etamorphofeos manibus tractarunt.

Scilicet conftat utique Naturæ Autoris potentia in quacunque re minimà, etiamfi novicii ob inf citiam obftupefcant, imo pro lubitu fidem derogent. Apprime Plinius exclamaffe mihi vifu's eft: Qux res eft in hoc univerfo, qux non miraculi inftar multis videtur, quando primo innotefcit! Quid denique à nobis non familiare factum, quod primo intuitu inter impoffibilia judicaveramus! Ita ut hæc, fimiliaque Naturæ admiranda corumque caufas ulterius indagare fatagens, ob incomparabilem cjus majeftatem, \& imperfcrutabilem profunditatem obltupefcens confundar, atque tandem imbecillam obtufam que mentis humanx aciem inculpans, in eafdem cum Fracaftorio querelas erumpam; qua's ingeniofifimis verfibus his expreffit:

$$
\begin{aligned}
& \text { Quid dicam miferum me agere, \& quam ducere vitam; } \\
& \text { Irrequietum animi o quarentem indagine vana } \\
& \text { Daturam femperfugientem, qua fe ubi paulum }
\end{aligned}
$$


oftendit mibi, mox pecies in mille repente

Ceu Proteus converfa, fequentemeludit of angit, Noerenters feniique bor as caffumque laborem? Nuper enim tenues fpecies, fimulacraque rerum, $2 u s$ fuere ex ipfis dicuntur, perque meare Omnia, dum fector, meditans, tacitufque requiro Avis fylvarum, éfecretaflentia folus: Cognovitamers bis Jpectrisilludier ipfis; Vt fenfus feriant noftros femperque laceffant Perque fores, caula (que animi ludantque meentque Ac remeent, ipfumque nec inter fomnis linquant.

\section{$\begin{array}{llllllllll}C & A & P & V & T & X & X & I & I\end{array}$}

\section{Dure Tamandure five Myrmecophagi.}

P Ortentofa afpectu utraque hæc beftia Tamanduá, major \& minor, Formicis potius quam hominibus extimefcenda; attamen ob miros in iis Natur $x$ lufuls $\&$ dotes, minime prætereunda. Feroces quidem irritat $\&$ naribus ftertunt, cruribufque infidentes pofterioribus inftar urfi, unguibus baculum vel telum quodvis fortiffime

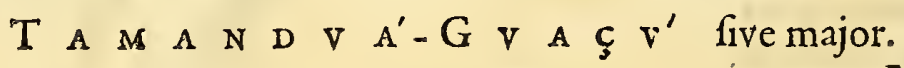

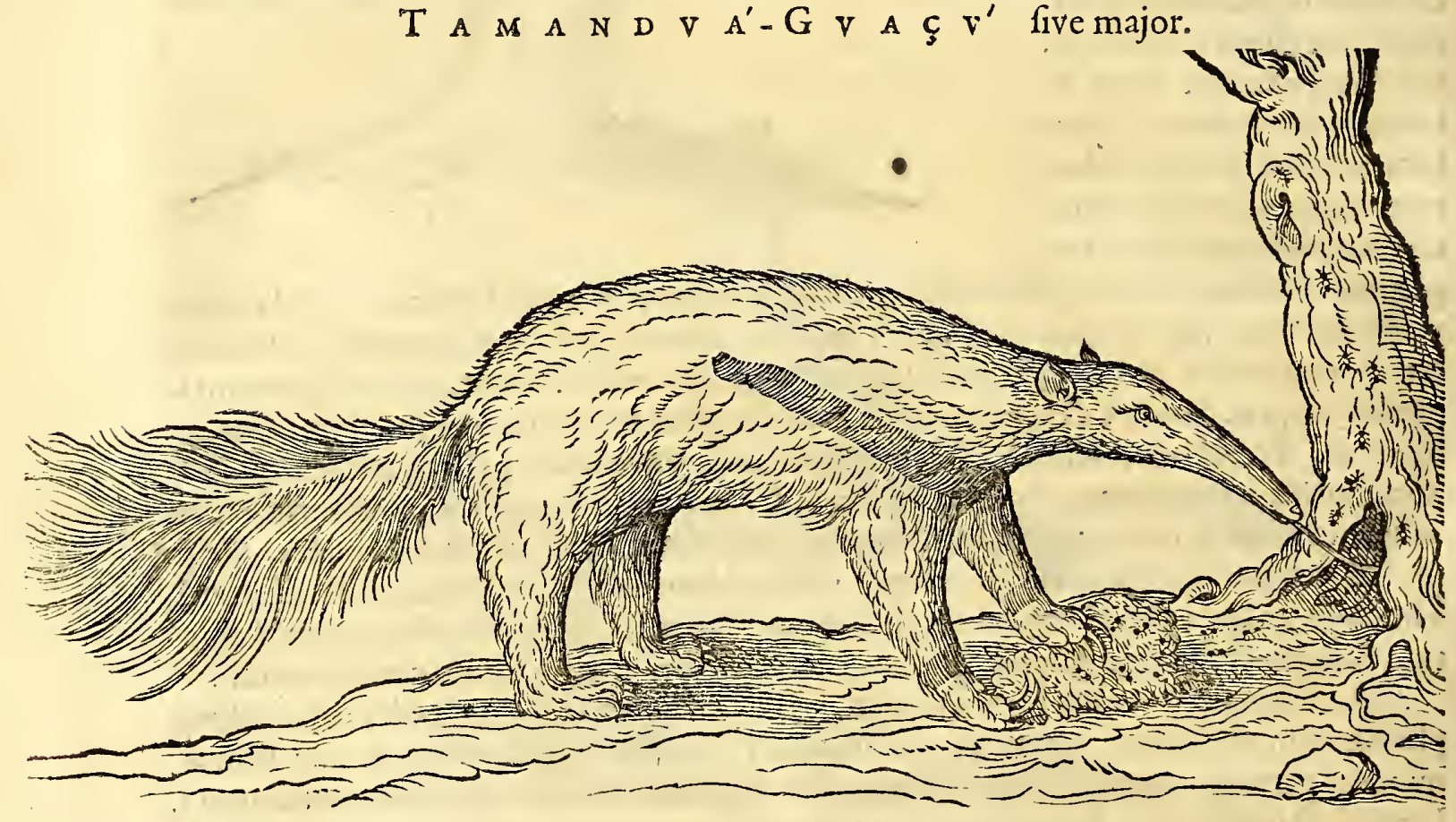

apprehendunt \&z mordent ; fed quia minus agiles, prius manu capiuntur, quam quod præda potiantur : nifi forte eam per infidias opprimant ; tunc enim ipfi Tigres ab iis aliquando interimuntur. Tant $x$ denique funt pervicacix \& ful titix, ut, fi animalia femel apprehenfa emori ipfis fuperftitibus contigerit, non prius fefe explicent, quam cum iis occumbant ac pereant. Mactatæ comeduntur à Barbaris defectu melioris alimenti, quia caro inftar Vulpin $x$, ferinum quid olet. Interiori $\& z$ exteriori conformatione multum inter fe conveniunt; differunt autem mole $\&$ magnitudine, potiffimum vero cauda, quod eam Tamanduá-guaçü habeat latam \& hirtam, fetis canis \& nigris, equinis f1millimam, quam irritata erigit, fomnolenta vero diducit eaque fe tegit.

Tamanduś minor, longa quidem, fed ex parte depili, cauda prædita eft, inftar Simiæ, qua fe arborum ramis fufpendit, ut commodius Formicis infidietur. Ob perpetuam tyrannidem quam in Formicarum myriades exercent, merito à Belgis shicten-cterg appellatæs utræque funt noctambulx pabuli caufa, cicuratx carne quoque vefcuntur, fed minute concifa, quia non folum capite, promufcide, fed $\&$ or e funt angufto, acuminato edentulo que lingua denique inftar craffior is chordx tereti, adeoque longa, prafer tim in Tamanduámajori, ut duorum pédum longitudinem excedat, atque proinde duplicata (quod notatu fane dignum!) quafi canali incumbit inter inferiores genas, quam efuriens madidam 
TA MAN D V A'-MIR I:

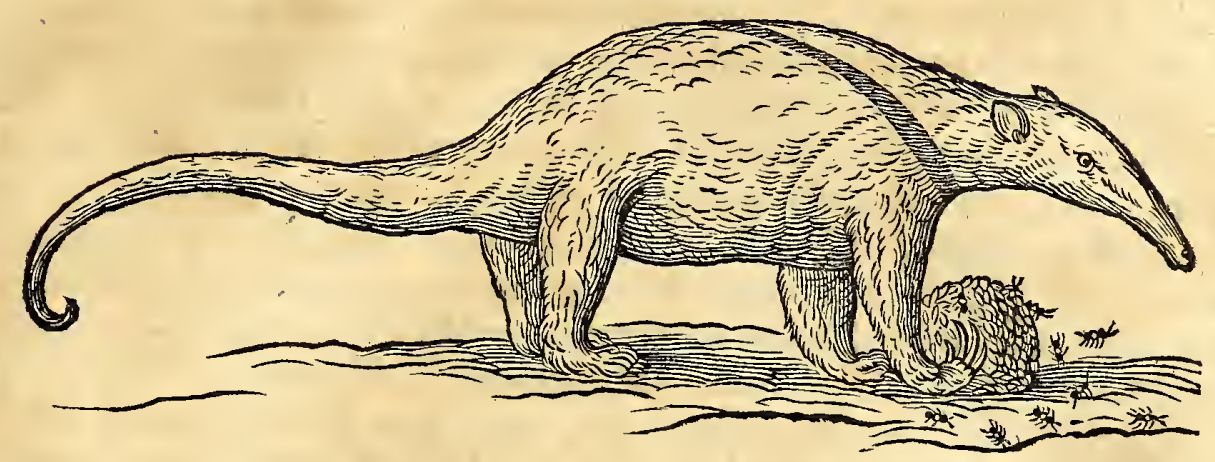

madidam exerit, \& arborum truncis diu imponit, mox Formicis opertam repente re trahit. Si alte fodiendo latebræ earum detegi poftulant, unguibus id preftat com. mode, quibus pedes pofteriores inftructi funt fatis validis \& longis, numero quinque; anteriores, quatuor, iifque recurvis, duobus in medio maximis, vola pedis rotunda, imbelle fatis facta. Tamanduá major undique minori pilofior exiftit. Vtrique per pectus ad latera \& medium longitudinis corporis, ufque grandis macula nigris pilis ex. currit, quam albicans linea defuper attingit continue. Corio funt craffo, carne Vulpina $\&$ vix eduli, tenaciffim $x$ denique vitx, excoriataque adhuc aliquandiu vivunt, etiamfi ultra duodecim dies inediam paffx. In diffectione, renis finiftri fuperius proceffus triangularis inventus, per duplicem tenuem membranam reni annexus : valvu$1 \mathfrak{x}$ autem cordis \& veficula fellis ordinariam excedebant magnitudinem. Cæxter partes internx, ab aliorum animalium vifceribus haud difcrepabant : ventriculo erant unico, inteftinis tenuioribus, qux teretibus lumbricis (ut in multis hic paffim apparet) fcatebant. Nervis \& Tendinibus undique validiffimis \& tenaciffimis prædita。

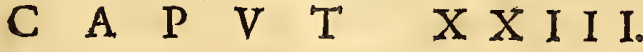 Ai, five Ignabus.}

Q $V$ ia animadverti, autores, Lerium $\&$ Thevetum (quem Gefnerus $\&$ alii poftea fequuti) paffim erraffe in defcriptione, rum \& vera figura hujus animalis, malui pro corollario repentis Iconem ad vivum depictam, tum quoque vivam ejus fectionem addidifle, offiumque compagem delineaffe. De fumma in gradiendo tarditate conveniunt omnes, fed de pedibus erectis, $8 x$ de ventre pendulo, ut hactenus ab illis exhibitæ funt, diffentiunt. Sicut enim inufitata natura eft animal, ita $\&$ effigie, quod à re ipfa Lufitani Prigui$z a$, id eft, Ignavum, five per avti申equv, Agilem, Noftrates Xeun-atrt Brafilienfes $A$, appellant. Quippe tam lentus eft illius greflus \& membrorum motus, ut quindecim ipfis diebus ad lapidis ictum continuo tractu vix prodeat.

AI' REPENS MINOR.

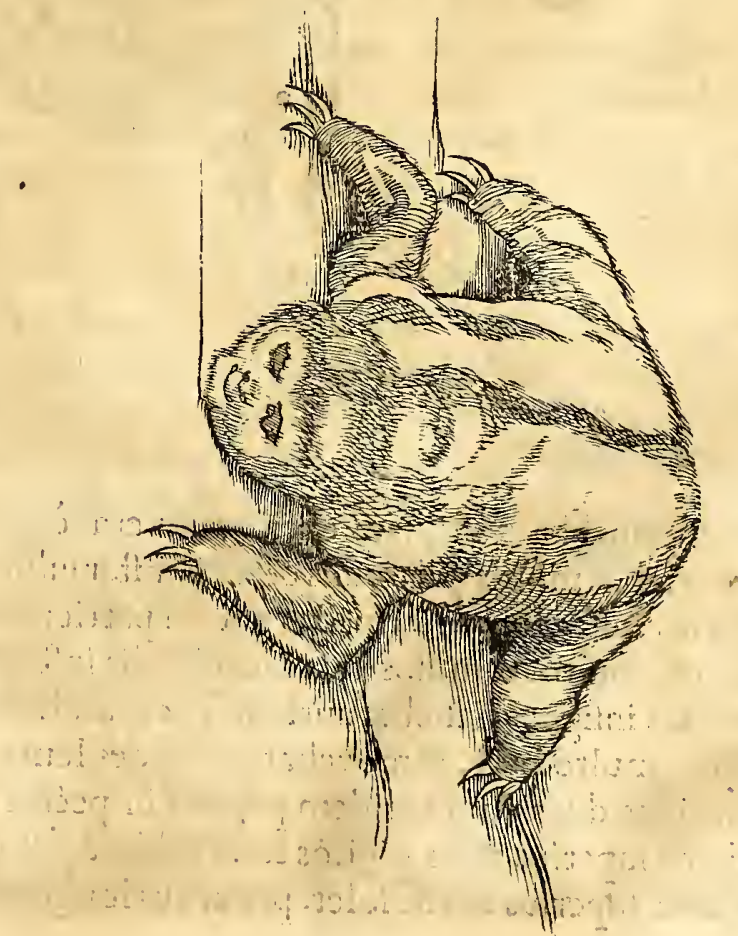

Medio. 
Mediocris Canis eft magnitudine, roftro ad afpectum foedo, \& perpetua faliva madido, cauda admodum brevi, unguibus ad digitorum fimilitudinem prominentibus, tenaciter adeo tenet, quidquid apprehendit, ut pendens dormiat fecure, quia à junctura pedis cum tibia tres nervi folidifimi, ad quemlibet unguem unus intentus tendit, quibus ungues incurvare $\&$ validifime fe fuftentare, poteft. Corio eft folidiffimo $\&$ tenaci. Totum corpus prolixis \& mollibus pilis cinerei coloris eft veftitum, \&z ex occipitio coma cervicem velat jubarum infar, lentoque ipfa ventris adipe verrit humum, nec unquam in pedes exfurgit, etiamfi quædam imagines id videantur exprimere. Non bibit, victitat arborum foliis, $\&$ in earum cacuminibus degit plerumque: quarum in afcenfu biduum circiter, tantumdem in defcenfu ponit. Neque vero adhortationibus tantum aut minis, fed ne plagis quidem, fuftibufve, beftiam vel tantillum de infita ignavia ac tarditate dimoveas. Secui cum domeftico meo fómellam vivam (cujus Sceleton, ex oflibus undiquaque validis compofitum, Theatro Anatomico Leydenfi donavi) habentem in fe fotum omnibus modis perfectum, cum pilis, unguibus $\&$ dentibus, Amnioni, more cxterorum animalium, inclufun. Cor motum fuum

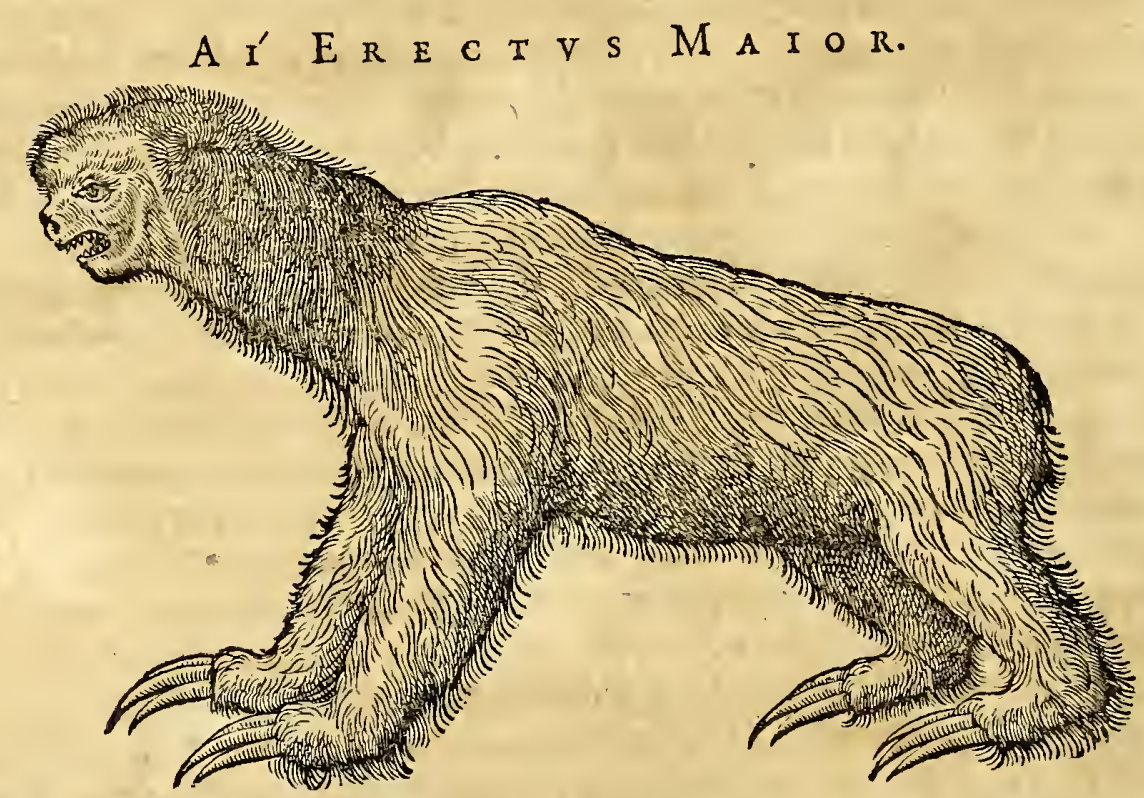

A $I^{\prime} M A I O R I S S C E I E T O S$.

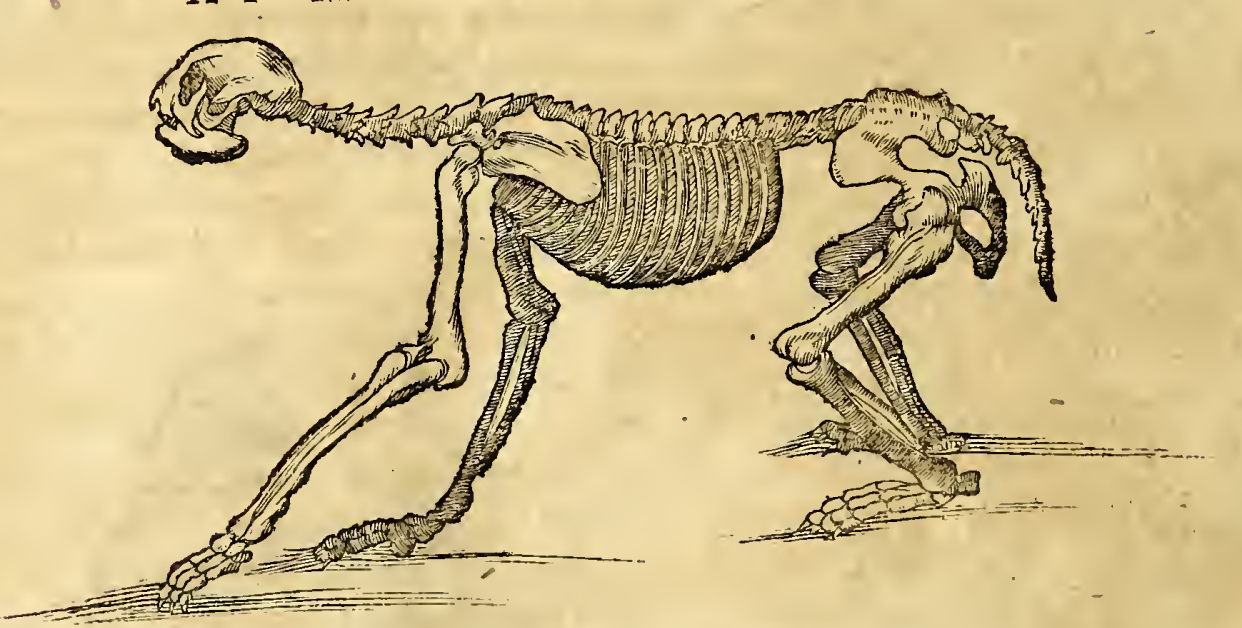

validiflime retinebat, poftquam exemptum erat è corpore per femihorium ; placenta uterina conftabat multis particulis carneis inftar fubftantix renum, rubicundis, magnitudinis varix, inftar fabarum; in illas autem particulas carneas (tenuibus membranulis connexas) per multos ramulos vafa umbilicalia inftar funis contor ta, inferta erant. Co: focmella duas infignes habebat auriculas, cavas. Exempto corde cxterifque vifceribus naturalibus, multo poft, fe movebat, \& pedes lente contrahebar, ficut dormituriens folet. Mamillas duas cum totidem papillis in pectore formella \& foetus gerebant. In ventriculo os fuperius duos digitos tranfverfos à pyloro: eratque in altera parte ventriculi, ubi alias fuperius os effe folet, proceflus longus fine exitu.

C.A. 


\section{$\begin{array}{lllllllll}C & A & P & V & T & X & X & I & \text { V. }\end{array}$}

\section{çarigueyá, \& Maritacáca aliis Biaratacúia.}

Tufitata hæc beftiola majorum Glirium montanorum numero afcribenda, littoralibus çarigueyá, mediterraneis Iupatiima, Lerio çarigoy, Lufitanis Rapaza, dicitur, Vulpeculx eft mağnitudine, capite $\&$ ore vulpino, barba felina, corpore coloris eft nigricantis, fed leucopois pilis admixtis. Cauda ultra pedem longa \& rotunda, in

C A R I \& V E Y A'.

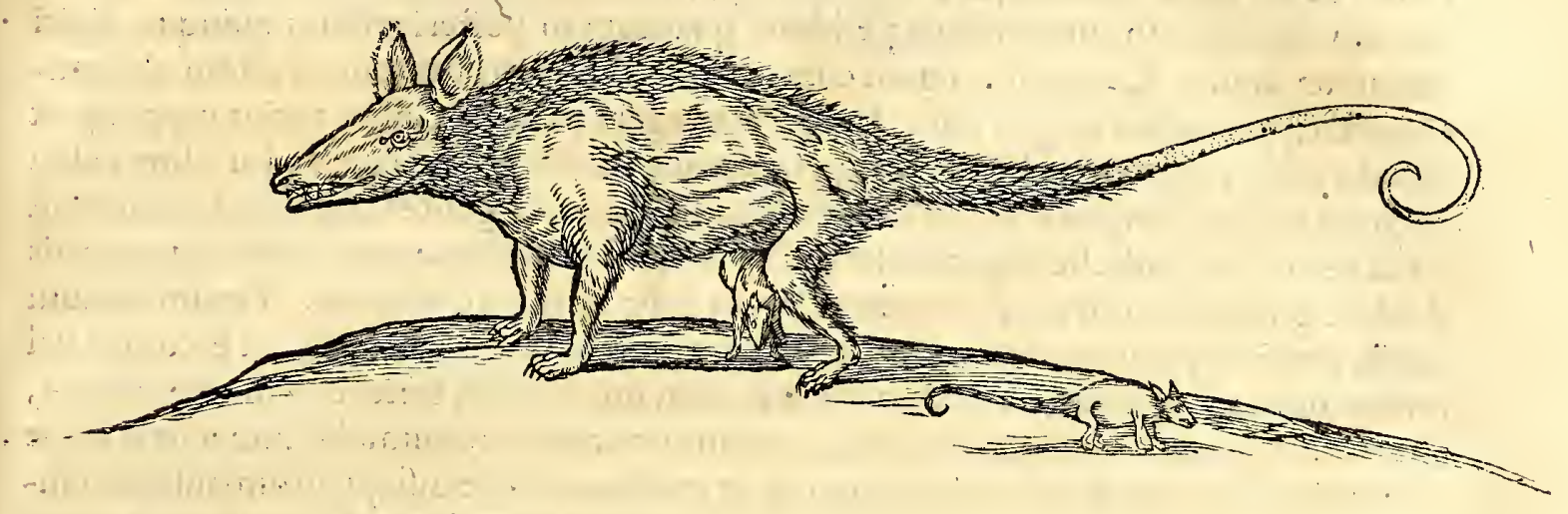

extremitate depili, coloris pardi \& nigri, quam curvatam geftat, eaque fe arborum ramis more Simix adpendet.

Mirum fane animal : nam in infimo ventre circa anum pellis ejus eft dúpla, \& exterior rima fciff, facitque quafi manticam eamque intus pilofam, Tambcio vernaculo idiomate dictam. Cujus os arcte clauditur, ut vix confpiciatur, nifi digitis diftendatur, tumque mamm $x$ in interiore pelle apparent octo papillis.

Ex reiteratis horum animalium fectionibus alium non invenimus uterum præter hanc burfam, in qua femen concipitur \& catuli formantur. Quos deinde quinos vel fenos fimul circumfert, mobiles, perfectos, fed depiles, adeoque pertinaciter uberibus affixos, utà perpetuo fuctu vix avellantur, antequam permittente matre ad paftum ipfi egrediantur ; unde redeuntes denuo, uterum maternum pro lubitu ingrediantur,
Sicut fepe Illuftriff. Princeps Naffavius, aliique multi,non fine admiratione mecum viderunt. Teftes formella fub ano gerit interius abfconditos. Mas formellæ plane fimilis in burfa pendulos more Gati tefticulos fert, \&, quod notatu dignum, manticam (licet à fœmellæ diverfam) habet, qua alternatis vicibus catulos quoque circumfert, ficut avis mas amore pullorum, formellam ab incubatu fubinde liberans. V terque foetent,mordaces funt, ut Vulpes, earumque more Gallinis, \& Columbis non folum, fed avibus in faftigiis arborum infidiantur, quarum defectu Cannis facchareis aliifque optimis vegetabilibus vefcuntur.

Cauda horum animalium ob multos ufus medicos apud incolas in pretio habetur, præcipue autem ad exturbandas vifcofitates \& immundities veficx, renum, \& uteri, fi vel duorum fcrupulorum quantitas reiterata cum convenienti liquore exhibeatur.

Fr. Ximenes idem animal in aliis Americæregionibus reperiri teftatur, quod in nova Hifpania Tlaquatzin nomen accepit. Deque caudx virtutibus mira prædicat, fupra id quod à me dictum eft. Viderint curiofi, an nihil fuperftitiofi intercurrat.

In Indiis Orientalibus, idque folum, quantum hactenus conftat, in Amboina, fimilis beftia frequens ad Felis magnitudincm accedens, mactata ab incolis comeditur, fi rite prepretur, nam alias foetet. Nomen illi Cous Cous inditum.

A Nimalculum eft Felis mole, forma oblonga, Viverram æmulatur : fi referen-

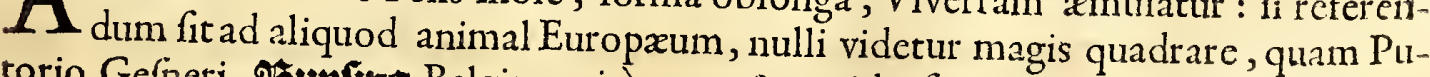
torio Gefneri, 25ımfing Belgis, cui à tetro \& putido fotore, apprime hoc Putorii 


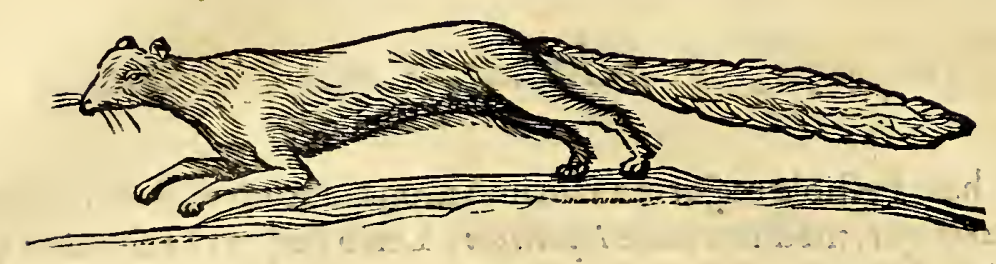

nomen inditum. Quiad Muftelas filveftres retulerit, me judice, non multum aberrabit, etiamfi id doctiflimo Scaligero minus placeat. Os \& dentes habet leporinos, ut $\&$ pilos barbamque, oculorum pupillæ funt cærulefcentes, auticulx breves obrotundx. In anterioribus pedibus, quatuor ; in pofterioribus, quinque digiti unguibus acutis. Caudam longam cum corpore villofam eamque erectam aliquando geftat, qua totum corpus inftar Vulpeculær tegere poteft. Color totius corporis ex pallido Havo cum multo fufco mixtus, leporinus quafi eft. Adlatera dorfi linea alba excurrit quibufdam pro Naturælufu, crucis in modum eleganter diftincta. Manfuetum eft $\&$ velox nec imbelle animalculum. Yolucribus earumque ovis victitat; imprimis Ambræ grife a avidum, cujus appetitu noctu fxpe in littore vayatur. Verum tantum abeft, ut quis opinari poffit ex efu Ambrx gratum fpargere odorem, ut è contra vel leviter modo irritatum, crepitum ventris cum intolerabili fœtore Alliique æmulo, emittat. Quamobrem fupra modum metuitur mirum hoc animalculum à feris æque ac hominibus; non folum quod tetro $\&$ graviflimo odore infequentium infidias eludat, fed quoque plus noxæ iis afferat, quam alixferæ unguibus vel dentibus venenatis armatx. Quippeadeo virulentus eft fotor, ut quibufdam fi non mortem, faltem capitis dolores, vomitus, atque'animi deliquia adducat. Admiratione fane digna proprietas huic beftiolæ conceffa, quod vel folo ani flatu longe lateque aërem non folummodo, fed faxa, militum arma, veftes, capillos inficiat, ut nequidem fortiffimo lixivio $\&$ infolatione viginti dierum fpatio fotorem deponant. Memini, quofdam ad capillitii rafuram, indufii, imo ad $x$ dium totalem abdicationem coactos fuiffe, cum nullum tanto malo hactenus remedium inventum fit. Sagaciores autem barbari, fi quando ejus certiores fiant, nudi vento fecundo eoque forti, eam diuturna venatione fatigant, donec telis fuis venenatis aliquoties fruftra in aërem emiffis, foetoris expers fiat, tandemque illi defiderata potiantur prada, \& cicuratam domi refervent more Scyuri. Vafra hæc Maritacáca nunc decipul is nunc fagittis, occiditur. Technis \& artibus noftrati eft Vulpeculæ fimilis. Cæterum innoxia, eaque ratione folum horridiffma, quod urina, ftercús, \& ventris crepitus fœtidiffima exiftant. Cum tamen tefte I. Eufebio, caroejus in Mexico falubri eventu comedatur. Oleum quoque Vulpinum noftratium more ex inde confici afferit.

$$
\text { C A P V T } \mathrm{X} X \mathrm{X} \text {. }
$$

\section{Cuandú major, Vrubu faetens, \& Tophus Bovinus.}

Q Vamvis utrumque Erinaceum Cuandídictum, inter alimentofos quadrupedes potuiffem recenfuiffe, quod multum inter fe conveniant qua ad figuram, conformationem \& naturam, de quibus egiLibro tertio, quo lectorem remitto;tamen quia minores Cuandú, five ob carnis albedinem \& teneritatem, five ob pellem magis tractabilem minufque fetis rigidam, cclebriores $\&$ familiariores utique exiftant; feparatimnunc de Erinaceo hoc majori, aculeis perpetuis horrido, eorumque noxiis qualitatibus pauca perftringere, operx pretium duxi. Idque non adeo quidem ut lectori mira vel inaudita de illius genio prædicem, quam ut in Indiarum luftratorum \& Natur $æ$ indagatorum commodum, Erinaceorum differentias $\&$ difcrepantes qualitatesfuppeditem.

Omnis quidem Erinacei Americani, ab iis quos Africa, Ethiopia, Tartaria, producere autorcs teftantur, diverfitatem facile dijudicabit, qui piơuras horum animalium 
HIST. NATVRAI. \& MEDIC. LIs. V.

$$
C \quad \begin{array}{llllllll} 
& \mathrm{V} & \mathrm{A} & \mathrm{N} & \mathrm{D} & \mathrm{V}^{\prime} & \text { major. }
\end{array}
$$

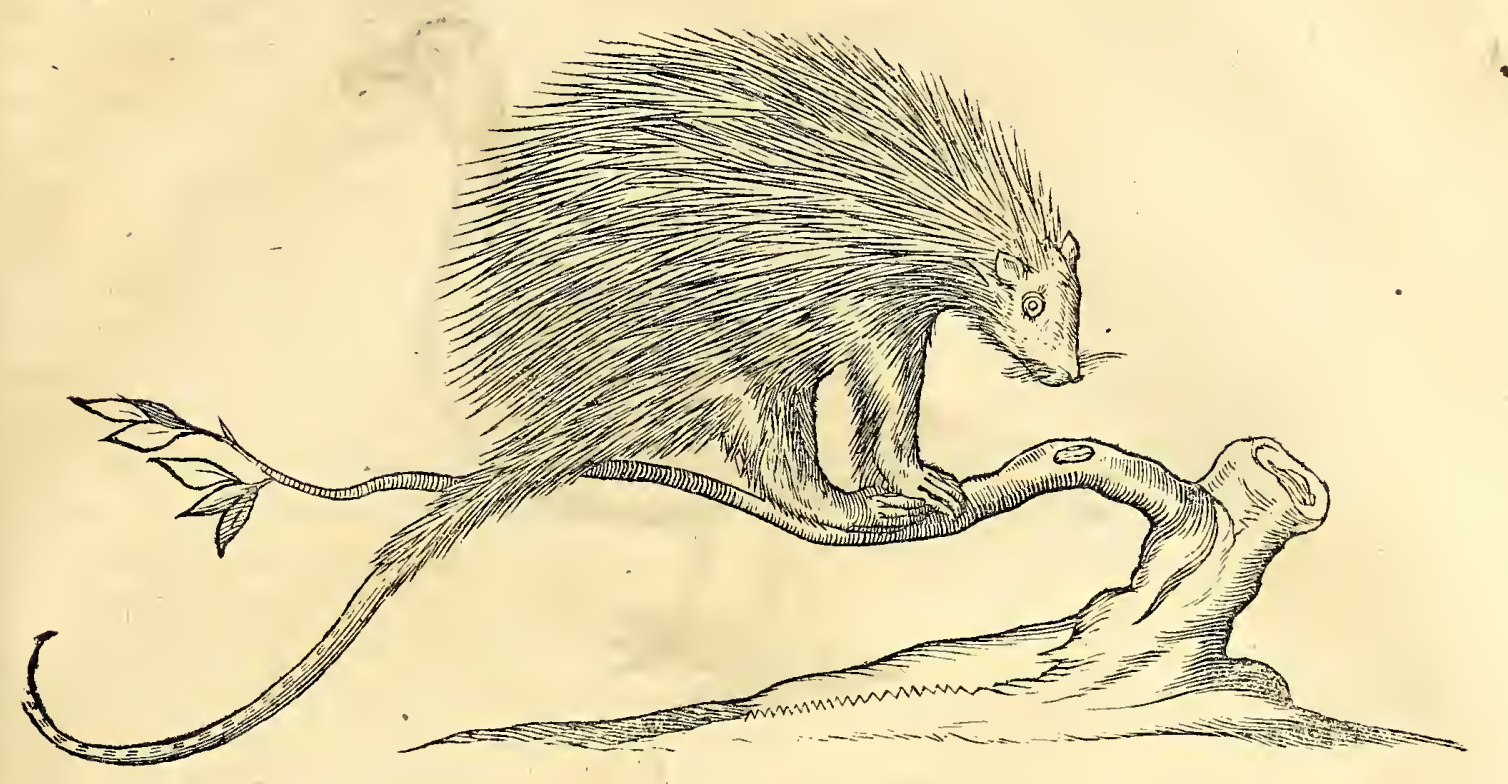

malium internasque qualitates cum illis contulerit: Aliqui enim in novo hoc Orbe (ficut quoque Hieronymus Cardanus de fuis Erinaceis fcriptum reliquit) fpinas emifiarias, aliqui vero immobiles habent: omnes tamen promifcue fetis five aculeis indifcretx magnitudinis multo magis horrent, quam Apri fetis fuis rigere folent. Noftra-

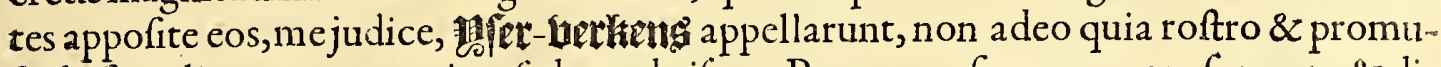
f́ide fint aliquantum porcino, fed quod vifcera Porcorum fere more conformata $\&$ difpofita habeant, ut ex diffectione eorum experiri contigit. Nec Lufitani eos male Orico Cachero nominarunt, quia corpore contracto fefe occultant, ne quid apprehendi poflit præter aculeos: Alterum nomen Lufitanicum E/pinbo, cutis animalis fpiniferum meruit, quod fpinis rigidis, acutis, concavis, diverficoloribus, fpithamam longis, totum corpus, pedes, \& cauda adeo fint armata, ut haud impune manibus tractentur. Has peculiari qualitate venenata infectas irritati in perfecutores fuos ejaculantur tam profunde, ut penetrent fenfim in carnem, \& vifcera inficiant, transfixofque lente interimant. Verum quantum tela hæc viva nocent, tantum emortua profunt, quod pulvis eorum drachmæ plus minus pondere affumcus familiari ifti Indiarum dyfenterico malo medeatur, fi aliquoties reiteretur cum liquore convenienti.

Cum autem major hic Cuandúfrequentior fit, minufque notus indigenis; cumque multa alia de aculeorum ejaculatione, eorumque efficacia, quadrent cum illo Erinaceo Tlaquatzin in Nova Hifpania dicto, non immerito dubitandi anfa mihi fuit data, quod folus Cuandúminor inter Brafilix patrios fit cenfendus: hunc vero majorem ex aliis olim Americx Regionibus huc tranflatum \& tanden tractu temporis indigenam factum putem. Tantæ eft voracitatis $\&$ malitix, ut $æ$ gre feratur aut cicuretur.

Equidem $\{1$ Francif. Ximenem, nec vanæ fidei,nec contemnend $x$ experientia virum, confulamus, cum admiratione legere eft, quam portentofos effectus eorundem aciculorum pulveri afcribat circa curationem lapillorum in renibus \& $\mathrm{Z}$ vefica contentorum, tum quoque ad quemvis capitis dolorem placandum, fi illi applicentur; adeoque tenaciter ahærere cos \& infigi teftatur, ut non ante decidant ad modum fang uifugarum, antequam vafa fanguinis exhauferint. Quxe à me quidem hactenus incomperta fatcor, fed curiol $\mathfrak{x}$ pofteritati ulterius indaganda commendo.

Ntanta Avium Americanarum frequentia pauciffmæe reperiuntur, in quibus vel 1 medicamentofie vel venenof $\mathfrak{x}$ qualitates hactenus detectre, contra quam in $\mathrm{Pi}$ fcibus evenire folet; five quod natura in aquatilibus magis follicita, eas abundantius indidiffe voluerit, five quod Aucupum minor fit induftria quam Pifcatorum in revelandis rerum naturalium viribus. In avibus enim tantum duo mihi experiricontigit ad rem medicam facientia, qux huc afferri merentur: Quorum alterum eft antidotale illud Cornu tenue \& acutum, quod egregia illa avis Anbima diata, in vertice geric, cu. 


$$
\begin{array}{llllllll}
V & R & V_{1} & V^{\prime} & \text { foetens. }
\end{array}
$$

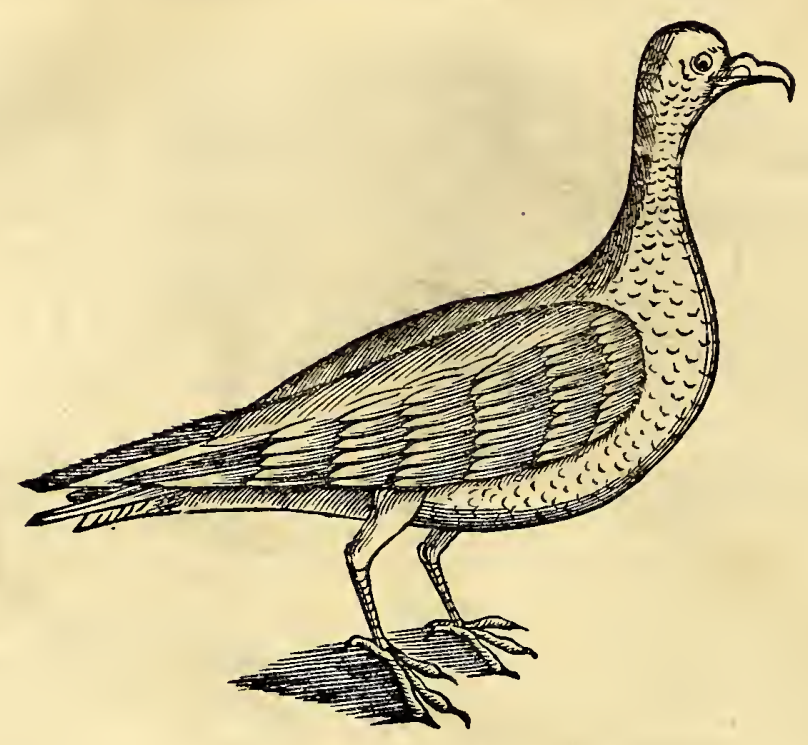

jus mentionem feci 1.3. de Alimentofis: Alterum vero, deterrima \& foetidiflima hæc Vrubí, Mexicanis Aura dicta, qux plerifque Americx regionibus notiflima \& frequens, nomine ac coloribus, non indole tamen nec figura difcrepans. Mediocris Aquilæ vel Vulturis potius eft magnitudinis, cum quibus ratione caud $x$, volatus, \& voracitatis, affinitatem habet; fed quo ad colores, Gallinam Africanam æmulatur; quo denique ad gravem odorem, Corvi fpecies effe videtur, licet vulgaris Corvi foetorem intenfione fuperet, \& proprietate longe differat. Tantum autem abeft, vefcam effe, ut folus odor, five vivæ, five mortux avis, haud impune aliquando feratur, quod fpiritus animales inficiat, quibufdam naufeam quoque $\&$ vomitum promovens. Vnde miror, Fr. Ximenem teftari, Cor ficcatum redolere mufcum; ex efu quoque ipfius carnis, fuadentibus Mexicanis Medicaftris, Hifpanos Lue venerea laborantes, invitis aliis remediis, feliciter reftitutos. Vidi durante obfidione Vrbis Salvatoris, in Sinu omnium Sanctorum, aliifque praliis, ubi ftrages jumentorum \& hominum erat, eas vifcera \& Itercora cum ipfis cadaveribus avidiffime deglutiiffe, quorum defectu Serpentibus, Bufonibus, Lacertis, fimilibufque fordidis beftiis vefcebantur. Memini, etiamfi à caftris noftris diffitiflimas, odorem adeo intolerabilem intuliffe, ut multi exinde male habuerint, \& non fine moleftia reftituerentur. Quamobrem fuafor fui omnibus peregrinantibus, ut earum præfentiam declinarent, cum defublimi æxthere $\&$ incognitis illis mediterraneis defertis catervatim verfus littoralia convolarent ad depafcenda quxcunque cadavera. Egregix ftaturæ aves apparent eminus intuentibus, tetro tamen afpectu, fi cominus examinentur, femper macre, nunquam faturx, etiamfi fe ita ingurgitent, ut ad volandum incptx, fclopetifque impetrabiles fiant. Capite funt rugofo, ex rufo brunni coloris horrido, illudque inftar Gallopavi contrahunt $\&$ diducunt. In vertice dividitur quafi cutis, variegaturque color imprimis verfus later a capitis circa oculos ex croceo \& cæruleo albicante tincta. Ipfi oculi apparent ignei, fatis elegantes, rubini fere coloris, pupilla nigricante, palpebris croceis, roftro craffo, longo, valido, adunco, acuto, \& ad rapinam compofito, atque ultra medietatem ex croceo cærulefcente, narium foraminibus fatis parulis, lingua carinata, in ambitu denticulis acutis circumdata. Nidificatio pullorumque exclufio hactenus incomper ta; tantum abeft eas ex continuo volatu fatigari, ut fupra fidem contra ventum vchementifimum per immenfa fpatia nitantur, feliciufque olfactu è longinquo efcam venentur. Nec credibile eft, Vultures, aliafque cjus generis aves, quas mare tranfvolare, novafque regiones præd $x$ notitia vifitare, Authores olim prodiderunt, ol factus vel volatus fagacitate has americanas fuperaffe.

V Arix magnitudinis Tophi pilofi, fphxrici, in Iumentorum quorumdam, Boumque imprimis ventriculis reperiuntur, quos Laniones ad me deferre folebant. Proinde fitum eorum curiofius inquirere fatagens, pilam fluctuantem in diffecti Bovis 
HIST. NATVRA L. \& MEDIC. LIE. V.

ventriculo inveni, eamque ea, qua erat, figura \& magnitudine depingi juffi, ut ex appofita figura videre licet. Has itaque aliquoties diffecans, ex meris pilis bovinis arctiffme compadis, interius conftare comperi, exterius vero cinerea $\&$ pilofa ; mox, ubiadoleverint, nigra, glabra \& dura pelle tegi. Vnde facile eft dijudicare, Boves fibimet, pruriente cute, dentibus pilos evellere, qui cum ab omafo digeri nequeant, in maffam cogi rotundam, quxe poftea in pilæ majoris magnitudinem excrefcit, unde anhelofi \& quaTOPHVS BOVINVs.

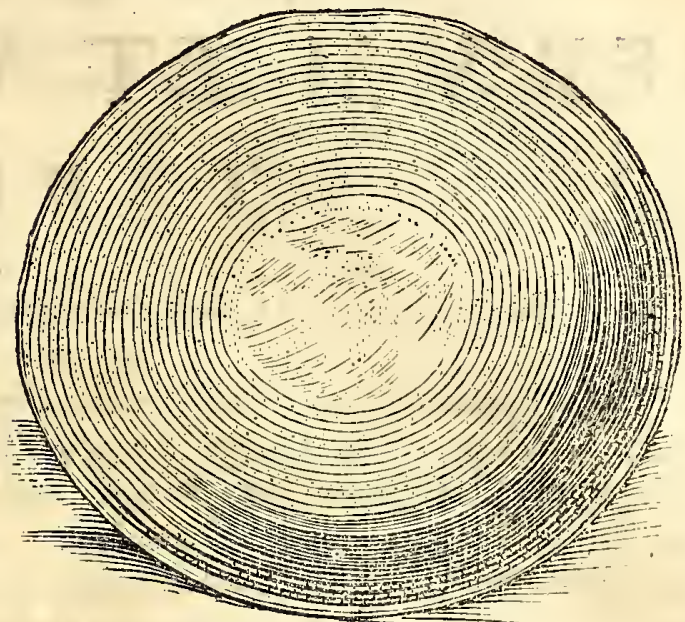
fi afthmatici diu incedunt : (ficut $\mathrm{Ca}$ prex, quibus lapis Bezoar innafcitur) quod animadvertentes ruftici, ne to tius animalis jacturam patiantur, cos mactant. Ita ut hujus pomi conftuctio, fie animalis deftructio.

Barbari rafuram pilofam interne exhibent contra pertinaces alvi fluxus fanguineos. Externe emplaftra, ficut è pilis Leporinis fieri folet, contra hæmorrhagias cum felici fucceflu applicant. Ego hoc externum, quam illud internum remedium imitari malui.

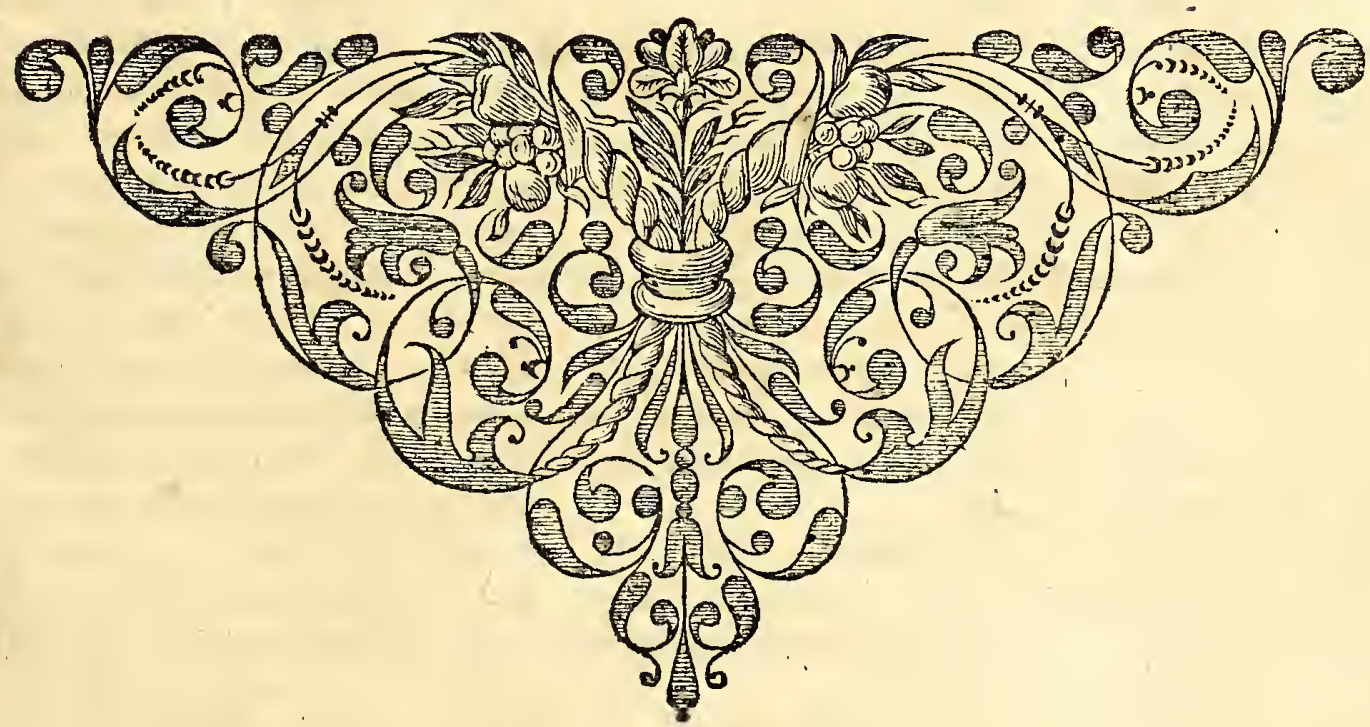

$\mathrm{Ee} ;$

I N.D E X 


\section{RER VM ET VERBORVM}

\section{$N O$ T A B I L I V M.}

A.

A Bacatuárapifois. Acajaiba arbor, \& Acajú fru ctus.

Acariçóba berb.a.

Acarápifcis.

Acara-áya pifis.

Acara-pebapifcis.

Acará-Pinima pifcis.

Acara-pitamba pifcis.

Acaraúnapifcis.

Acetofa berba.

Acori fpecies berba.

Adianti ppecies.

Africe fluctum rara vicifitu-

do.

Aguape Nymphea pecies. 219

Aguara-Quiyáberba. $\quad 224$

Aguaxima frutex. $\quad 197$

Agutiquadrupes. $\quad 102$

Aguti-guepo berba. $\quad 224$

Aboay arbor \& fructus verse-

nati. $\quad 308$

Ai five Ignavus, quadrupes.

Aiereba pifcis.
Airíarbor.

Airíarbor.
Aipimixira pifcis.

Aiurú pfistacus.

Alba Coretta,pifcis.

Albara canna.

Alcea mufcata berba.

Alliárie ires/pecies berba.236

Althae fpecies herba. $\quad 222$

Ambaiba arbor.

321,322

Ambua or Tataurána 286

Ambuya embó berba.

Ameriçina lacertulus. Aminatúfive Goffipium. Amongeába berba. . Amorealimpifcis. Amore-guacú pifcis. Amore-pixumapifis. Amore-pinima Hydrus. Amphilbena vipera. Ananas berba.
294
I 29

53 85

213

210

$\begin{array}{ll}\text { Ands arbor cum fructu. } & 148, \\ \text { Andira vulgo Angelyn. } & 149 \\ \text { Andirá velpertilio. } & 290\end{array} \mid$ Anguria five laeé berba. 263 Anbyma avis.

Anbuiba arbor.

Aninge due frutices

Aninga-periberba

Anime gummi.

Anir, frutex.

Astidotum Iecur Animalium.

4.
Limors pufillus. Tabacum.

Aperća quadrupes.

Apes varia.

Apiaria mariva. Aquarum difcrimen of ufus.

Aracaríavis.

Araça-ibaguaçuarbor. I 52 Araçá-inirifrutex. IS I

Araguágua pifcis.

Ararnacá pifcis.

54

Armadilbo five Tatú, quadrupes.

Aranee varia. $\quad 284,285$ Aratu cancer antidotum. 300 Araticu diver faspecies arbores.

Araticu pana arbor. - arbor \& fructus. $\quad 306$ Arborum insmenfa altitudo.

Arbufcula marine Baccifera. 147 287 260 283 186 239 296 72 ibid. 281 280 195

265,266

Coralloides. $\quad 265$ Spongiofa. $\quad 265$

Ardea aves varia. $\quad 89$

Arocira arbor. $\quad 132$

Arumatia' infectum. $\quad 286$

Arundo facchariferafive $T_{a-}$ comarcé. 108 Avaramo-temo arbor. $\quad$ I 68 Aurantionum ubertas, "las, \& dignitas.

8 8

.

B.

$\mathrm{B}$ Agrepifcesvarii. $\quad 63$ B Bananiera arbor cum fructu Banána. I54 Batataradix. $\quad 254$ Belingela. $\quad 210$ Betijs vel Betre frutex. 196 Biaratacaca quadrupes. $\quad 324$ Blitum berba. $\quad 241$ Boi-guacuferpens. $\quad 277$ Boicinininga ferpens. $\quad 274$ Boiçuaiba ferpens. $\quad 275$ Boiobiferpens. $\quad 278$ Boipeba \& Ibiracoi Jerpens. Boitiapó ferpens. $\quad 276$ Brafilia fitus. 3. ac̈ris temperies. 4 . anni tempeftates. 4. Serenitas. 5.G.equorisfacies \& aftus 6.7. Prefectura.7. furvii. 7. Soli facies 8 . 2Nemora 9. falubritas. I I. I 2. \& feqq.Incolarum longersitas \& fertilitas. I2. Indigenarum diverfitas. I3. Cibus of potus ufitates. 16.17. Animantia. I I. I6.17.mo= dipifcandi. venandi natandi. Religio. I 3. Medicina. 19.morbi Endemii.22.prognoftica.

Braffica fpecies herba. $\quad 236$ Bufo venenatus. 298

C.

\section{.}

.




\section{RERVM E T VERBOR V M}

Caaróba arbor é frutex. 143

II'9

cacaboía Serpens. $\quad 279$

Caiatia'berba.

Camare varia berbe. I76,

177

Camara-iápo berba. 177,218

Camara-unbaherba. 177

Comaripu-guacupifis.

camarú berba.

camaripifcis.

cambuy myrius berba.

Canne Indice varia.

Caminana ferpens.

capibara porcus fuviatilis. 99

Caoopia arbor.

Capeúra pifas.

Capiipubagramen.

Cacaguate, varice frutices. $192,193,194$.

caragneya quadrupes. 323

Carapucúfunges. $\quad 309$

Cara-cará avis.

Cara'radix.

Cararu herba.

82

255

241

Caranaibe varie arbores. 126

Carapópifis.

Carawnapicis.

72

Gargaço berba marine. $\quad 266$

carçaparilla radix, vulgo lua-

pecanga. 255

Cariama' avis.

$8 \mathrm{I}$

Caryopbyllata berba. 209

Caturrbi.

Cavia coba'ya, quadrupes. 102

Cebipira-guajú arbor. $\quad 169$

Ceixupirapifcis.

cereiba arbor.

cicindela infecium.

Ciri-apoá cancer.

cocoí aves variz.

Crocodilus 89,90

Cocos vulgo Iriaingua bor.

Cosambaiá, fove Filix berba.

Conarsbai-miri: berba. 234

convolvulus marinus. $\quad 258$

Coorza pifis.

Copaiba Balfamifera arbor. 18

coperucs infectum.

Coralli jecies.

corororocapifis.

Cotiá quadrupes.

Cotora rana.

Cruftaceipifes. 204

291 76

287

265

59

102

298
Constuberba.

Cuandú major quadrupes. 325

Cuandúquadrupes.

Cukumer a finimus rúa-oba.

sucuriú, bydrus.

sucurucu ferpens.

sucuri pifis.

Cuguacu-peteguadrupes.

Cuipouna arbor.

Cuiete arbor.

Cumandatia herba. 173

Cumanalia berba. 251

Cunarúcancer.

Cunapú-guacu pifcis.

Cupiá formica.

Curemapifis.

Curicáca avis.

Curimatapifcis.

Cururu bufo.

Curuípifis.

Curuata pinimapifis.

Cúrua vel Curuba herba.

cururu-apé berba. 250

(urucutinga ferpens. $\quad 276$

D.

Dieta Medicorum.
Dracunculus berba. 240

Dyfenteria.

\section{E.}

G Irinucu, Eiruba \&े Eixa apes diverfa.

Erria de Santa Maria. 240

Eruca infectum. 3 I 8

T.Eminarum faecunditas. I3 I Febres.

Febrifuga vegetabilia. $\quad 27$ Fellis venenofitatis ratio. 270 Filix berba.

Fluxus ventris.

Formica.

Fungusterra.

74

TAa-yára locufta. $\quad 317$ I Gangila berba. 2 II Garape potus abufus. $\quad$ I 8

Gonorrbaa.

$\begin{array}{lr}\text { Gonorrbaa. } & 44 \\ \text { Granadilla berba. } & 248,249\end{array}$
Graminis variefpecies. 237

Guacaripifis.

Guaia-guacu Cancer. 75

Guaia-apara' Cazcer. 75

Gualeba nrbor. I53

Guaiane-timbóberba. 249

Guaibipocecabiba arbor. 170

Guaibi-Ocára pifcis. $\quad 56$

Guainumbi Avicule varis.

Guamaiacu pifis. 318,319

Guamaiacu-ape pifis. $\quad 300$

- atinga pifcis. 299

- Guarapifis. $\quad 300$

Guandí berba. 252

Guanbumi Cancer. $\quad 77$

Guaperoiba arbor. $\quad 204$

Guaperuapifis. $\quad 57$

Guaracapémapifis. $\quad 48$

Guarapucúpifcis. $\quad 59$

Guara-una avis. 9 I

Guarerúa oba five Cúcumer Afininus. $\quad 264$

Guaraterebá pifcis. $\quad 57$

Guaru-guarúpicis. $\quad 70$

Guatucupapijcis. $\quad 62$

Guatucupa iúbapifcis. $\quad 52$

Guebucupifis. $\quad 56$

Guira-acangatára avis. $\quad 95$

Guira-guacu pifis. $\quad 64$

Guira-giainumbi avis. 93

Guirajenoja avis. $\quad 94$

Guira-peréa avis. $\quad 95$

Guira-querea avis. $\quad 94$

Guirapunza mas of femina, aves.

93

Guirutinga pifcis. $\quad 64$

Guirybacopifcis. 6 I

Guitys varie arbores. 136 ,

Guon ferpens. $\quad 137$

H.

TEpaticus fluxus. $\quad 40$

1 Herba lanuginofa. 230

Herba lanuginofa altera di-

Etamni emula. 24.

Hydrops. 35

Hydri. $\quad 28 \mathrm{I}$

I.
Abebarapicis.

59

abics-guacuarion. $\quad 394$

Ee 4 Ist 


\section{I $\quad \mathrm{N} \quad \mathrm{D} \quad \mathrm{E} \quad \mathrm{X}$}

Iaborandi berbs varie. 2 I5, Inaia-guacaiba vulgo Cocosar216,312 bor. 130

Iaboti teftudo.

Iabotapita arbor.

Iabuticila arbor.

166

$12 \mathrm{I}$

96 inh

Incamaciríavis.

lacaranda arbor varia $\int p e c i e s$.

164,165

Iaçána avis. 90

Iacabucaia arbor fructus.

Inçap: gramens.

135

Iacua acánga berba.

Iacupema avis.

Iacare five Crocodilus.

237

229

81

lacare five Crocodilus. 282

Iace fove Angiraberba. 263

Iaguaqua-guárepifcis.

laguara quadrupes.

Iaguareté quadrupes.

Iaguaracá picis:

Iambia avis.

Inmacart herba varie fpecies. $188,189,190,191$

Ianipápa arbor.

Iaparandiba arbor.

Iapuruca millepes.

Iararace varie vipera.

Iararapeba vipera.

Iaracatiá arbor.

Iaróba berba.

Iatebucu infectum.

Ibabiraba arbor.

Ibibobóca ferpens.

Ibiia'ram ferpens.
Ibira arbor.

Ibiraéém herba.

Ibir arema arbor.

Ibir aba arbor.

Ibiraé arbor.

Ibipitánga arbor. Ibirapitanga five lignum ru-

brum arbor.

Ibiracóa \& Boipéba Jerpens.

$\begin{array}{ll} & 276 \\ \text { Ibiara vipera. } \quad 280\end{array}$

Ibixuma arbor faponaria. 162

Icicariba arbor.

Icocúbombyx.

122

Ietaiba arbor cum fructu. 123

Ietica vulgo Batata herba:

Ietucucu berba.

Iguana lacerta magna.

Iiboin firpens.

Iira mel filveftre.

lito berbu varie pecies 169

Mandihoca flueftris frutex.

Mangara berba.
254

69,

170

dia medicamentorum \&o aromatum ferax.

Inflammatio Ani.

Inhami radix.

Inimboi berba.

Introductio ad animalia aquatilia.

— ad volatilia.

__ ad vegetabilia.

Ipecacuánba radix.

Ipecatiapoa' avis.

Ipeca-guaçı avis.

Itaiaráa pifcis.

Ivabeba frutex.

Ivapecánga vulgo carçaparilla berba.

lundiá pifcis.

Iupicaigramen.

Iupicanga vulgo radix Chir

Inqueri frutex.

Iurepeba dua frutices.

23

4 I

255

47
78

96

107

$23 \mathrm{I}$

83

182

238

cina.

257

201

Iurucua teftudo marina.

Iurumu berba.

Iurara teftudo.

181

105

264

Ios

Iutaifive Tamarindus arbor.

289

150

$27^{8}$

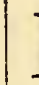

I.

157

L Liquiritiaberba. 245 Mutu-Poranga avis. ibid.

Locufta infectum. $\quad 3$ I 6 Mofquito infectum. $\quad 288$

Lues Indica. 43 Mouçicu excrementum mares.

Lumbriciventris. $\quad 42$

\section{M.}

Acarandiba arbor. 187

W. Macuaguagua avis. 88

Macumba berba. $\quad 208$

Maiggréavis.

Malagueta berba.

Mameluco.

Mamanga frutex.

Manaca frutex.

Mandiibafrutex.

Mandiboca frutex, praparatio,

dignitasnoxa. II 4, 115, 305

Mandobi.

Mangaiba arbor.
82

54

Maturaque picis. $\quad 67$

Mberóbi five Culices. 287 ,

\& feqq.

64

.

218

Mirabilis peruana herba 208

Mutu avis. 80

berba. 227

Aange Arbor. $\quad 204$

Mandioce. $\quad 305$

Maracoana cancer. $\quad 77$

Maribunda infectum. $\quad 287$

arigua infectum. $\quad 288$ quadrupes. $\quad 324$ 25. Medicamentorum compofitiones magna repudiande. ibid.

Melongela berba. $\quad 2$ 10

Mentbagracaberba. 218 Metamorphofes infectorum.

Mouçicu excrementum mares.

Mucuni-guaçu faba magna.

307

Mucuna phafeolus. ibid.

Mulato qui dicantur. $\quad 22$

Mundubi berba of fructus.

Mundui-guacu arbor of fru-

225 thes. 179

Mureci arbor. 171

I 83 Murucuja' berba varie jpecies.

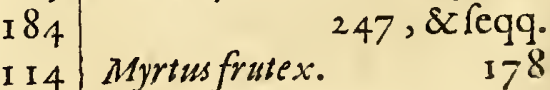

N. •

I i

256 Narcotica.

156 Nari-nsrípifcis. 58,293

136 Nhambiberbn. 228,310

Dham.
Thanipuerá fuccus venenatus 


\section{R E R V M E T V R B O R V M.}

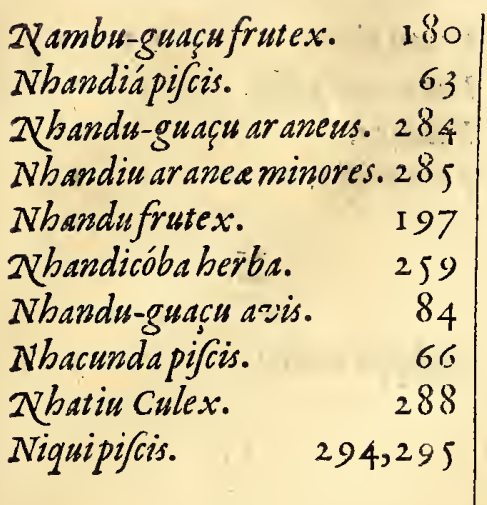

P.

\section{A'ca quadrupes. \\ P Pacamópificis.}

Paco-caatínga Canna.

Paco arbor.

Pacoeira arbor.

Paco çeróca canna.

Paccípicis.

Paiomirióba dua herba.

Panama Infectum.

Papanapifcis.

Papula \& Impetigo.

Pararóberba.

Paratipifis.

Paratura gramen.

Parupific.

Paftinaca Marinapifcis. 297

Pequéa five Pekiá arbor. $14 \mathrm{I}$

Petume berba.

Petumbuábapifis.

Phafeolus.

\begin{tabular}{lr|l} 
Phafeolus. 251 & Sargaço herba marina. & 266 \\
Phlebotomia prerogativa in & Salfa do praya herba. & 258
\end{tabular} Indiis.

piabapifcrs.

Piabucupific.

Picuipinima avis.

Pindaiba arbor.

Pindoba arbor.

101

54

$2 \llbracket 4$

154

2 I 3

53

I 85

317

50

45

255
71

71
238

55

\section{$\mathrm{S}$}

$\begin{array}{|lr|}\text { Portulaca berba. } & 244 \\ \text { Potinsóba planta. } & 22 \mathrm{I} \\ \text { Prolapfus mucronate cartilagb- }\end{array}$

nis. $\quad 36$

Prafatio ad Profefforem Linda-

num. $\quad 267$

Punarúpifcis. $\quad 65,66$

$\therefore Q$

Veraiba arbor. $\quad 165$ Quetele aris. $\quad 92$ Quigombo duc herbe. 2 Io,

$\begin{array}{lr}\text { Quity arbor. } & 162 \\ \text { Quyeéberba. } & 225,226\end{array}$

T, T amarindus froe lutai arbor.

$\begin{array}{lr}\text { Tamatiáavis. } \quad & 157 \\ & 96\end{array}$

Tamoatápifis. $\quad 7 \mathrm{I}$

Tamoatarána berba. $\quad 255$

Tangarace varia herba. $30 \mathrm{I}$.

R.

$\mathrm{R}$ Adix china five Iupi1 cánga. 257

Rane varia. $\quad 298$

Raia varie.

Reciffo Brafilie.

Ricinus Infectum. $\quad 289$

Tapirapecu herba. $\quad \mathrm{I}_{2}$

Tapuyarum loca. I 3. mores. I 4 .

arma. I 4. Crudelitates.

\section{S.}

Accharum ejufque praparatio of ufus. 108,109

66 I I , 8cc.

62 Saamóuna arbor. I75

4 Sajfafras five Aubwiba arbor.

66 I 46

66 Scarificationes. $\quad 26$

86 Sceletosferpentis. $\quad 277$

144 Sceletos Ignavi. 322

125 Serpentaria berba. 240

Pinofive Vrtica herba. 235 Serpentes edules. 273

Pino-guacu arbor, Mas ó foe- Serpentum virus aliqua tantum mina.

Piquitingapifcis.

Pirabebépifcis.

Pira-coába pifcis.

Pira-curoba avis.

Pira-metára pifcis.

Pira-pixangapifcis.

Piraquépifcis.

Pircinbapifis.

Piratiá puápifcis.

Pira-umbipifcis.

Pifces venenati 293,294

Polypodium herba. 233

potigammarus.

Potiquiquíya locufta.
159 parteboret. 273

67 Serpentum frigidites or rapidi-

6 I tas. 273

60 Serpentum Anatomia, Coitus,

86 Generatio, Morfus eorum

60 curatio. 274

52 Solanifpecies herba. 223

30 I Soldanella berba. 243

6) Spafmus.

0,60 Siupor.

- Sudorifera.

Superfitiofe curationes morborum.

78

77
I $4.8 \mathrm{C}$.

Taraguira lacertus. $\quad 284$

Tareiboia bydrus. $\quad 282$

Tarcire variepifcis. $\quad 68$

Tataiba arbor. $\quad \mathrm{I} 63$

Tataurama Eruca. $\quad 286$

Tatufive Armadilbo quadru-

pes. 100

Teju lacertus. $\quad 283$

Teju-guaçu lacertus magnus.

103

Tiiepiránga aris. $\quad 94$

Timbo berba. $\quad 249$

Timucú pifcis. $\quad 62$

Tipifrutex. $\quad 236$

Tipiocafrutex. $\quad$ I 6

Tophus bovinus. $\quad 327$

Transformatio infectorum.

Tranfirationis 316

Tran/pirationis neceffitas. 24

Tremae frutex. $\quad 176$

arbor. $\quad 176$

Trevo. $20 \mathrm{I}$

Tucum arbor. $\quad$ I 28

Tuívaria aves. $\quad 85$

Tune varice arbor. $\quad$ I88

Tunga infectum. $\quad 28 y$

Tupa-
Teti-mixara pifcis. $\quad 38$

Teti poteiba berba. $\quad 250$ 
I N D E X R E R V M E T V E R B O R V M.

Tupa-ipi \& Vrucatu herba. Vepertilio. $\quad \because \quad 290 \mid$ Vrutúpicis. $\quad 65,295$

235 Viba Canna faccbarifera. I09, Vubarána pifcis. 63

Tupei-cava five Scoparia ber- Viperavenenata. …: 279 Vulnera. 44

ba. 246 Vitis arbsfina. $\quad 250$ Vvacrifpa. 242

V. $\quad \begin{array}{ll}\text { Vlcera pedum. } & 44 \\ \text { Vlcus ¿ inflammatio ani. } & 4 \mathrm{I}\end{array}$

Vlcus of inflammatio ani. $4 \mathrm{I} \quad \mathrm{X}$.

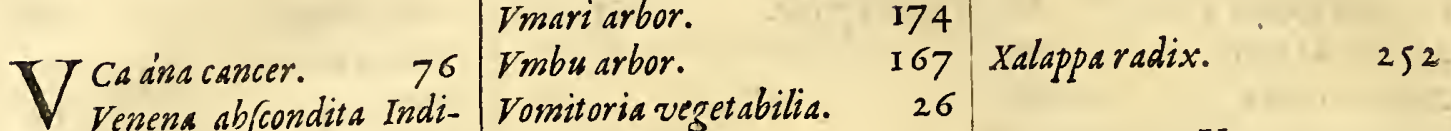

\begin{tabular}{|r|lr|r} 
Venena abjcondita Indi- & Vomitoria vegetabilia. & 26 \\
genarum. & 272 & Vrtica berba. & 235
\end{tabular} - Y.

Snarum compofitiones. 272 Vrubu Avis. $\quad 326$

Venenorum compofitiones. 272

Venenis ineffe fuum antidotum. Vrucatu berba.

235 ruca frutex.

.

Venenum uni, alteri alimen. 133

\begin{tabular}{lr|rr} 
tum. & 270 & Vrucuripalma arbor. & 127
\end{tabular}

Vefpe.

${ }_{2} \delta_{7} \mid$ Vrurumbeba arbor.

19 I Zinziber berba.

Z.

$\begin{array}{lllll}F & I & N & I & S\end{array}$

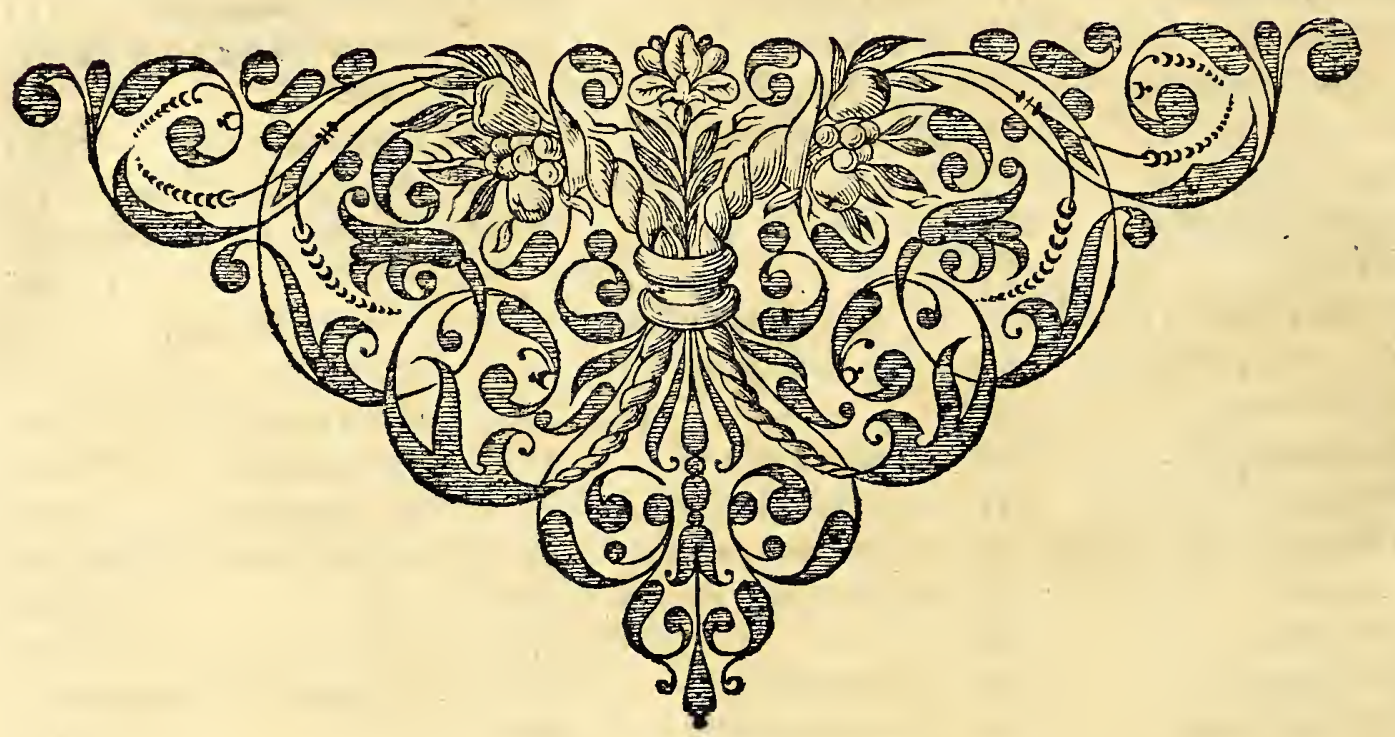


GEORGII MARCGRAVII

D E I I B S T A D,

\section{T R A C T A T V S}

Topographicus \& Meteorologicus

Brafilix, cum Eclipfi Solari;

Quibus additifunt Illius \& Aliorum

C O M M E N T A R I I

De Brafilienfium \& Chilenfium Indole $\&$ Lingua. 


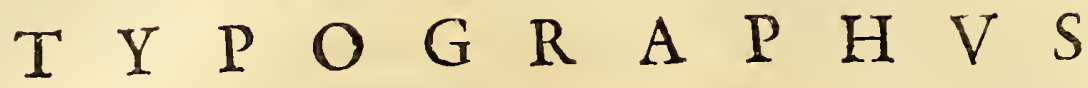 Lectori Salutem.}

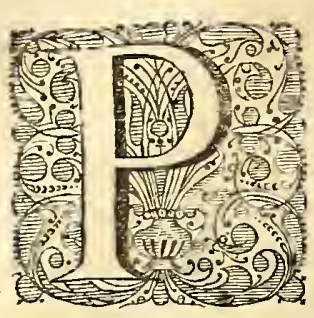

Aucis Lectorem premonendum putavi, quare conflium mutaverim, quod D. Markgravii Progymna fmata illa aftronomica Americana, jam dudum ì 1. de Laet or G. Pifone publice promiffa non fimul ediderim.

Cum enim à multo tempore communi fama mibi innotuiffet, quan inter alia laudate curiofitatis \& induftrie in Illuftriff. Principe I. Mauritio, Terre of Oceani Brafilienfis quondam Prefecti, documenta, non promifcum fuerit, quod per Matbematicos fuos, quos domi militisque fecum habebat exemplo maximorum Imperatorum depingi \& defcribi jufferit phenomena celefi is macbine: Imno naucleris maria confcendentibus in mandatis dederit, ut imprimis Eclipfium moment a omnia vultufaue difformes fuis ingulos locis pofitos attentius obfervarent, of cbartis confignarent. 2Non mibi mirum videri debuit, G. Pifonem ab Illuftriffino fwo Domino, liberalium artium fautore perpetuo, impetrafe, ut ibidem obfervatorium Aftronomicum exftrueretur, atque ita fimul $\&$ fora; $\mathcal{G}^{\circ}$ Markgravii fii, artium Mathematicarum apprime grari vota expleret circa ea, que in ulteriorem Geographice \& Hydrographie ufum à plurimis, rei nautice peritis, admodum defiderari now nefciebat. Verum cum D. Markgravius hac aliaque exercitia laudabili quiders amplexus effet conatu, in annotandis totas aliquando noctes. Mercurii aliorumque Planetarum corufcationibus, becterns à nullo Aftronomorum vifis: tamen ple raque ob immatur am mortem felicius inceperit, quam abfolverit: ego ex multis relictis fchedis pauca tantum, que minus mutila arbitrabar, publice lucis facere conftituerain: Jed bac in re mee diffidens teinuitati, poftquam e a que felectior a arbitrabar, eruditis, \& in aftronomicis verfatiffimis viris fedulo revidenda tradideram, corumque fincerum bac in re judicium poftulaveram; commune fere omnium votum erat, ut manum de tabula tollerem, ne cruda protrudendo defuncti monumenta, cineribus illius injuriam facerem.

Quamvis autem non putem noftrum boc inftitutum-ingenuis Eruditis poffe difplicere: tamen confultum duxi id curfin'indicaffe, ne quis poftbac ingentem Vrania the faurum alicubi latitare, inani expectatione fe fallere pergat. proinde pauc a bac tantum exercitia Topographica of Meteorologica cum Eclipfi folari non conternnenda ; eaque, ut à D. Markgravio folo of feparatim (non vero combinatis cum G. Pifonis laboribus (icut pleraque alia ad Hiftoriam Naturalem pertinentia) obfervata funt, ingenue nunc trado. quibus fimul addidi Compendium de Regionibus Brafilie of Chili, utpote precedentibus foriptis non male quadrans, iifque binc inde inferta videbis, tam nofratium quam Hijpanorum, haud vane fidei, nec foitu indigna ejufdem materia foripta, à Clariffimo Viro P. M. I. de Laet ftudiofe re fervata, ut ad pofteritatem aliquando redundarent.

Hanc interim noftram qualemcumque opellam boni confule, Manibufque Auctoris omnia bona precare: of, $\sqrt{2}$ quid intercurrat vitiofi, id candide reftitue. 
GEORGII MARCGRAVII,

\title{
D E R E G I O N I B V S, \& Indigenis, Brafilix, \& Chili ejufdem Continentis,
}

\author{
$\begin{array}{llllll}L & I & B & E & R \text {. }\end{array}$
}

\author{
C A P V T P R I M M.
}

De Regionis nomine, magnitudine, fitu, ejufque divifione.

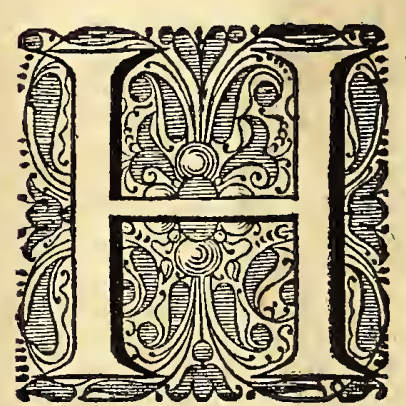

Ecregio primo à Lufitanis appellata fuit $S_{A}$ N T $A C R$ V quod nomen poftea mutarunt in $T E R R A D O B R A S I I$, ob ligni copiam, quod hic cæditur \& in Europam infertur, vulgo notifimum, ita ut hodie communi \& vulgari nomine ab omniburs Europxis BR A S IL I A dicatur.

Sita porro eft Brafilia in zona torrida \& quidem in medietate illius Auftrali, extenditurque ultra Tropicum Capricorni in zonam temperatam meridionalem.

Non autem omnes confentiunt in illius magnitudine feu latitudine definienda inter Septentrionem \& Auftrum. Nos ejus initium ftatuimus à latitudine Septentrionalí unius gradus \& femis, feu à Flumine Para, \& finem ad latitudinem auftralem quatuor $\&$ viginti graduum $\&$ femis, feu ufque ad fluviüm Capiibari, duabus leucis ultra oppidum' S. Vincentii; ita ut magnitudo illius fit inter Boream \& Auftrum trium \& viginti graduum. Inter ortum $\&$ occafum in quantum extendatur, adhuc indefinitum eft, cum pauci adhuc in interiora hujus terrx penetraverint \& quxdam tantum obiter luftraverint.

Quantum judico, adfumendo longitudinem Lime Metropolis Peruvix, quam Hifpani ponunt effe duobus \& octuaginta gradibus Occidentaliorem Toleto (Toletum autem novem-decim gradibus \& quinque fcrupulis Occidentalius eft Vranoburgo) ita ut longitudo Limæ fit ducentorum \& nonaginta quinque graduum $\&$ quadraginta fcrupulorum. Sumendo itidem longitudinem Mauricie civitatis, in Orientalifima fere ora Brafilix, quam ipfe foxpius obfervavi per Eclipfes \& inveni trecentorum \& quadraginta graduum \& fémis refpectu Franoburgi, \& hinc deducendo differentiam quatuor \& quadraginta graduum \& quinquaginta fcrupulorum. Sub parallelo autem 8,40 refpondent ex mea obfervatione uni gradui 28175 decemped $x$ Rhynlandicx, qux per 1500 divif ( tot enim perticx milliarium horarium efficiunt) dabunt horaria feu Hollandica milliaria xv I I I. $\frac{1155}{15500}$ i eft, milliaria octodecim \& tres quadrantes. Differentia ergo 44. 50.dabitur 1263197 decempedarum \& duorum pedum, qux efficiunt milliaria $842, \frac{179}{1500}$, detractis porro centum milliaribus, qux $C u / c o$ Orientalior eft Lima \& in confiniis Peruviæ \& Brafilixfita, magnitudo Brafilix inter ortum \& occafum effet circiter feptingentorum \& quadraginta duorum milliarium ; quod intervallum omnes Tabulx Geographic $x$ circiter centum \& octuaginta octo amplius faciunt. Ponunt enim Brafiliam multo Orientaliorem, quam revera eft, ut ex propriis obfervationibus fapifime comperi.

In gratiam eorum, quibus Phanomena cxleftia, \& immobiles Planctarum vices nofcere ftudium oft, apponam Eclipfis Solaris faciem; pro temporis momentis aliam atquealiam.

Apparere Mauriciam urbem incolentibus coepit ea in finem anni quadragelimi fulpra millefimum \& fexcentefimum, Novembris die decima tertia, hora decima ante. meridiem, \& ad fummum provecta fuit hora undecima, trefque Solis tertias obfcuravit, cum minutis viginti octo; fic ut minus quarta fui parte hî́c mundo luxerit. Verum quadraginta feptem ab hora duodecima minutis, labore fuo tenebrifque evolutus Titan pleno refulfit lumine. 


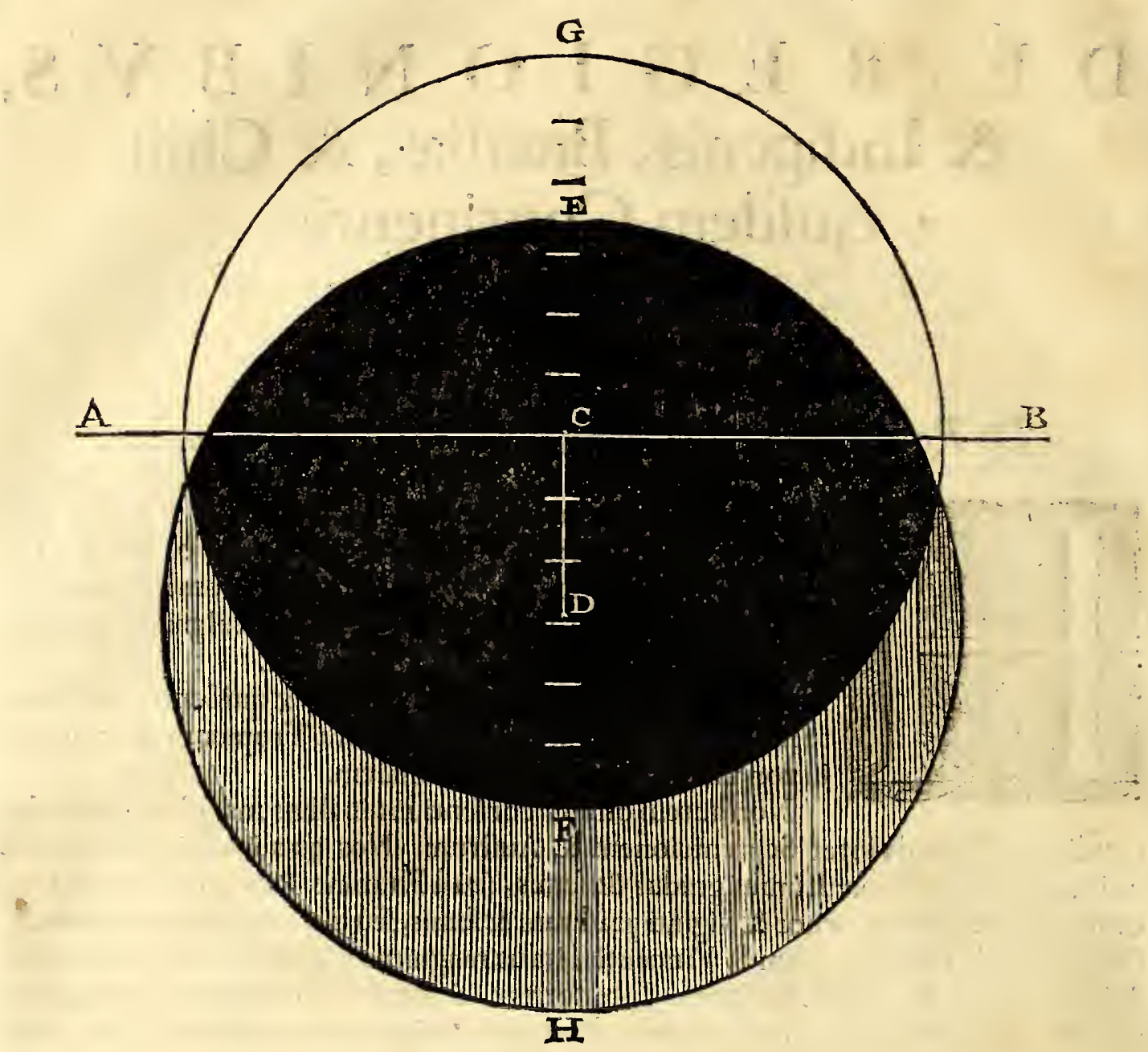

A B. Ecliptica.

C. Centrum Solis.

D. Centrum Lunæ.

C D. Diftantia inter Centrum Sol is \& Lunz.

E F. Magnitudo Eclipfis in digit. \& min.

E G. Reliqua pars Solis lucida.

FCE G. Diameter Solis.

HF D E. Diameter Lunx.

Tempus aquabile Vranoburgi d. $\frac{3}{13}$ Novernb. h. 3.12: $3^{\prime \prime}$.

Locus Terra perpendiculariter Soli fubjectus $3 \mathrm{I}^{\circ} \cdot 4^{\prime} 6.2^{\prime \prime}$. Scorp. Locus $\Omega$

\section{Reductio}

Locus Lune in Orbita Arcus inter centra

$$
\text { Ampliat usphyfice }
$$

21.23 .21 .5 scorp.

6. Subtr.

2 I. $45 \cdot 5$ 6. Scorp.

2. 5. Bor。

2. 7 .

Parallaxis Lune, feu Semidiameter difciterra $63 \cdot 4 \mathrm{I}$. Semidiameter Lune

$$
\text { Solis }
$$

Semifis parallaxis Solis

Semidiameter penumbre

Semidiameter Lunaris Vinbre

Summa Semidiametrorum

Horarius Solis?

$$
\begin{aligned}
& \text { Lune } \\
& \text { Luna à Sole verus }
\end{aligned}
$$

ampliatus phyfice

Erit igitur defedus alicubi centralis ó totalis. Scrupula dimidie durat. ownnimoda Eclipf. Scrup.dimid.more total. umbr. Luna in difco Scrupula dimidia mora penumbre in difco
16.22.

15.27 .

30.

32.19.

55

I. 36.0 .

2.32 .

38.27 .

35.55 .

36.29 .

$1.35 \cdot 59$

I. $3 \cdot 39$. $31.1 S$
Ergo Tesmpus dimidic durationis. more Vmbra

H.

$2.37^{\circ} \cdot 55^{\circ}$

I. $44 \cdot 4$ r. mora penumbra. 0.51 .28$. Tempus adparens media Eclip $\int_{\text {. Mauricic }}$

erit die $\frac{2}{12}$ Novemb. - H. $23 \cdot 47^{\prime} \cdot 48^{\prime \prime}$. Tempus adparens vifa Veneris $b$

maxime Eclipfis Mauricio

in Brafilia, $\frac{2}{32}$ Novemb. $-H .23 .27 .6$. Ad illud tempus daturLatitudoL una vifa $7^{\prime} .25^{\prime \prime}$. Merid, Aggregatum Semidiameter Solis \&o Line 31.49.

Pars deficiens

Et quantitas deliquii Solaris 9. Dig. $20^{\circ} \cdot 32^{\prime \prime}$. Scrupula duratolimidia omimoda $30^{\circ} .56^{\prime \prime}$ yinc H.

Tempus dur ation. dimidic omnimoda $1.13^{\prime} \cdot 59^{\prime \prime}$ Et Initium Eclipfis Maturicis $10.13 \cdot 7 \cdot 2$ Medium

Finis II. $27 \cdot 6.5$ 0. 4 I. 5. polt merd. $\frac{2}{1}-$ Nuressid. 
Ora autem Brafilize à Para ad Maranhon à Coro verfus Vulcurnum extenditur. A Maranhon verfus Şara maximam partem tendit verfus Eurum. A çiara ad Potiyi feu Rio Grande verfus Euroautrum : à Potiyi ad Paraiba verfus Auftum: à Paraiba ad Itamaraca ad eundem modum : ab Itamaraca verfus Promontorium S. Auguftini $\&$ ufque ad Sinum. omnium Sanctorum ora verfus Auftum incurvatur : à Sinu omnium Sanctorum ad al terum flumen Paraiba iterum fere directe Aufrum petit, $\&$ deinceps ufque ad fines fuos verfus Corum extenditur. Sed hæc accuratius è Tabulis hydrographicis cognofei poffunt, ad quas curiofos remittimus.

Dividitur B R A S I L I A, intra hoslimites, in certas Prafecturas (Capitanias appellant vulgo Lufitani) \& quidem vulgo in quatuordecim. Quarum prima verfus Boream eft $P$ ara, fequuntur dehinc ordine Maranhaon, çiara, Potiyi vel Rio Grande, $P a-$ raiba, It amaraca, Pernambaco, Quirimure vel Babia de todos los Santos, cujus metropolis S. Salvador; Nhoecombe vel os Ilbeos; Pacata, vel Porto Seguro; Efpiritu Santo; Nheteroya vel Rio de Ienero, quem Ganabara vulgo vocant Brafilienfes; \& S.Vincente.

Sunt $\&$ hic duo diftrictus (nimirum in Prxfectura Pernambucenfi) quos Lufitani vocant $P$ almairas, à copia illarum arborum ibidem nafcentium, in quos Nigritz fugitivi fe receperunt; eorum unus vocatur minor, alter major. In minori ad fex millia Nigritarum dicuntur habitare, qui jacet viginti milliaria fupra Alagoas, inter filvas, juxta fluvium qui appellatur Cungobubi ( hic illabitur in fuvium Paraibam) fex milliaria à $\mathrm{Pa}$ raiba flu. verfus Arctum, \& quatuor à Mondai fluvio Alagoe Borealis verfus auftrum; ita ut haud admodum longe abfit à coinu terrx quod vulgo Iaragoa appellatur. Pagus illorum conftat è tribus plateis, quarum fingulæ dimidix hor $x$ itinere in longitudinem producuntur. $\mathbb{E}$ des omnes contigux, \& plantaria illorum pone illas. Imitantur quodammodo religionem Lufitanorum, \& habent fuos facerdotes $\&$ judices. Mittunt crebro è fuorum numero ad vicina loca, qui mancipia Lufitanorum abripiant; illa alltem tamdiu ferviunt, donec alia rapuerunt. Mancipia autem qux fponte fe illis aggregant, ftatim eadem qua ipfi libertate fruuntur. Victitant fructibus Palmarum, batatis, phafeolis 3 Farinha Mardioce, milio, \& Sacchari cannis, item gallinis (quarum illis copia eft ,) \& pifcibus quos vicinus amnis fubminiftrat; carnes haud alias habent quam. ferinas. Milium fuum colligunt bis quotannis, \& opere abfoluto per integram feptimanam feftive commeflantur. Antequam fementem faciant, per dies quatuordecim maximos focos accendunt, quibus herbas $\&$ alia adurunt, qui longe videri poffunt. Compendiofifimum ad hunc diftrictum iter effe creditur fecundum fuvium Alagor Borealis, vulgo Alagoa del serte.

Major Palmaria jacet viginti aut triginta milliaria pone S. Amari pagum, juxta Montem qui dicitur Bebe. Creduntur circiter quinque millia effe Nigritarum, qui in vallibus juxta hunc montem degunt, prater alios multos, qui alibi quinquaginta, alibi centum, fparfim habitant. Edes autem horum haud conjunct $x$, ita ut ducenti pene quadrantem milliarii horarii occupent; \& fub filvis metantur, in quibus $\&$ viam cæduam habent ad fugiendum comparatain; nam perpetuo excubitores collocant, qui ipfos moneant de peregrinorum adventu. Siccis itidem menfibus dimittunt fuos ad Ethiopiflas ab incolis fiffurandum. Interdiu parant cibos; \& vefpcra primum nu merant fuos, ut videant an quis defit ; deinde choreis dant operam (tympana pulfantes, qux longe audiri poffunt) ad mediam ufque noctem, dein cubitum difcedunt, \& dormiunt uque ad horam nonam aut decimam antemeridisnam.

Iter ad hos commodiffimum eft ab Alagois per $S$. Amarum, atque inde per campeftria ${ }^{\circ}$ 2 Lbunabu \& Cororipe, donec jugum montis Wairakaco appareat, ubi fluvius Paraiba offenditur, qui defendendus eft, donec prope prædictum montem Behe perveniatur; $\&$ : ibi deflectendum ad convalles.

Antequam autem cxtera adjungam, non inutile erit hic fubjicere quxdam verifi$\mathrm{ma}, \&$ notatu digna de Natura harum Regionum, à rerum naturalium fedulo indagatore obfervata.

Omnes Provincix Brafilix, quas centum milliariorum fpatio, à Rio Grande ad Alagons ufque occupavimus, parum admodum funt cultx. Cultura earum à littore marino verfus mediterranea à Lufitanis ulterius producta non fuit, quam in quibufdam locis, ad tria, quatuor, in quibufdamad quinque, raro ad fex, aut ad fummum feptem ufque milliaria Hollandica : cxtcra funt folitudines ipfifmet incolis plane incognitx : neque 
littoralia hrec loca omnia culta funt, ea tantum coluntur, quibus valles \& nemora interjacent. Quando nomen alicujus diftrictus, quos illi Fregefáas appellant; audis, utpote Poiubam, Camaragibi, Porto Calvo, Serinbaim, \& his fimilia alia, debes fub hac voce intelligere valles integras, campos \& colles his vallibus adjunctos, pagós in illis fitos; rdificia omnia, hinc inde fparfa, \& infuper fluviolos ipfos; qui valles illas irrigant. Ab una Fregefia ad alteram per colles incultos iter eft, interdum trium, interdum quatuor aur plurium etiam nilliariorum Hollandicorum. Exçipiuntur tamen ab hacappellationum regula, domus pifcatorum \& falinæad littus marinum fitaz, quia terram non colunt. Ad hujus culturæx formam importunus $x$ tatis ardor habitatores compulit. Cum enim Regio hæc omnis jaceat fub Zona torrida, coli non poffet fid dies noctibus longiores effent.

Solum omne affurgit in colles mediocres atque amonos: montes infigni aliqua altitudine nulli funt in littoralibus, in folitudinibus tamen hinc inde nonnulli è longinquo confpiciuntur. Inter colles aridos, non ubique tamen, fed ut fupra attigi,aliquot milliarium intervallo, valles interjacent, fingulax exiguis aliquibus fluviolis irrigux, atque ob id non pluviis tantum menfibus, fed \& xftivis ipfis fertiles. Colles ipfis xftivis menfibus ob ardorem Solis funt infrugiferi \& penitus arefcunt, ut non gramen tantum, fed \& arbores interdum emoriantur, \& gramen incenfum aliquando ingenti fatio, vento prafertim urgente, incendium proferat; ita ea qux pluviis menfibus læte virent, xeftivis intereunt in montibus. His incommodis tamen incolx ipfi profpiciunt, aut novum gramen terris inducentes, aut loca illa foecundantes, qux fibi colenda proponunt. Hunctamen ufum colles præftant, præfertim ubi filveftria recens excifa \& combufta funt, quodradix Mandiocalatius in is proveniat, nimirum in declivis illorum, quam alibi. Adhæc ufus collium, vallibus vicinorum, hic eft, quod ædificia incolarum in illis ut plurimum collocantur, \& circa hæc ædificia arbores, quæ cocos ferunt, plantantur, quæ quamlibet terram \& fitum lubenter admittunt. Plantantur etiam aliquando juxta domos Auraicarum \&Limonum arbores, quamvis lætius in locis depreffis proveniant. Reliquarum omnium plantarum cultura ad valles $\&$ loca depreffa rejicitur. Cxeterum bonitas gleb $x$, ut $\&$ terræ univerf $\mathfrak{x}$, ita $\alpha$ omnium fere collium eft infignis, \& in ipfis montanis locis qux hactenus non coluntur, optimæ ubique vites pro. venirent, fi à formicis defendi poffent. Morbos $\&$ mortes fomniant incolæ; fin vallibus habitent, propterea colles fequendo, molefta \& longinqua aquatione plerumque utuntur. Noftro hoc, quod præteriit,fexennio nos plana interdum, etiam paluftria lo$\mathrm{ca}$, fortificationum caufa fecuti, vix aliqua tabe tamen ea propter afflicti fuimus. In Afogados quidem Fortalitio prafidiarii aliquando, fed fatis benigne tamen \& breviter, morbis corripiebantur; verum animadverfum fuit, id propterea accidiffe, quod plerique defides humi cubarant, quod ubi iis interdictum \& lectorum ufus introductus eft, malum hoc illico ceffavit. Hæc de collibus notavi. Quod valles attinet, hx Cannarum facchariferarum cultu, (quoniam ob duritiem formicæiis nocere non poffunt) \& $\mathrm{pa}-$ f́cuis occupantur. Cærterum feracifima effent omnis generis frumentorum ètiam noftratium, puta tritici, filiginis, hordei, aven $x$, piforum, qux fingulis annis binam méffem darent; fi contra formicas remedium inveniri poffet. Quicquid qualiumcunque fructum extraordinaria aliqua cura, in loco aliquo angufto, contra formicas defenditur, miraculofa ubertate provenit: Brafilia verum horreum foret Europx totius, fi peftis hæc auferri poffet. Rumoror hic ad nos perlatus fuit, Lufitanum quendam AmfteIodami Confeffui x I x remedium obtuliffe contra formicas; equidem non credo remedium univerfale contra has inveniri poffe, quia animadverto, non à Soli vitio, fed à Solis vi id procedere.

Quod fluvios attinet vel potius fiuviolo's per valles prxdictas decurrentes : hi paucis exceptis longitudinem trium, aut quatuor milliariorum vix cenetiuntur à fontibus fuis, $\& z$ nihilominus in oftiis fuis magnorum fluminum lpeciem pr $x$ fe ferunt; quod fit ob acceffus az receflus maris, fauces ipforum cluentes; exemplo fit Rio Formo/o, item Rio Grande, $\dot{\mathcal{X}}$ alii omnes, capaces in oftiis magnarum fatis navium, qui tamen verfus mediterranca, vix duarum leucarumitinere à littore abfoluto genu tenus pedibus tranf. cuntur.

Fluvii, ferc nulli funt apti ad minimarum etiam navium onera è mediterraneis deferenda: Monguape tantun fumcn fex milliarium longitudine navigavi, \& multum 
DE BRASILIE REGIONE ET INDIGENIS

thtra navigari pofe,ex profunditate illius \& aliquorum relatu comperi, reliquanon item. Horum tamen exiguorum fluviorum aliqui, alveos fuos, fed ficcos ærtate $\&$ fine aqua, longiffime in folitudines profertint; quale eft fumen Capivaribi, quod prætereundo Mattam do Brafil, Mafyapi, S. Laurenzo, Real, prope Afogades cum alio fluviolo fe conjungit, \& juxta Reciffum influit in mare; item Rio Grande; per quorum fluviorum alveos ficcos, Tapuya fex feptimanarum iter frepius fe feciffe profeffi funt; pluviis tamen menfibus, alvei ipforum aqua replentur, fed ob catarnctas faxorum frequentiffimas etiam parvas naviculas non ferunt.

Flumen unicum nobile eft in hifce regionibus, vulgo Rio S. Francifo, quod limitem claudit inter Prafecturam Pernambucenfem \& Sinum omnium Sanctorum', imprimis illuftre eft; creditur enim ex intima parte hujus Continentis defcendere, \& quidem è Lacu illo multorum fermonibus celebrato, qui amnes omnes atque torrentes, ab altiffinis Peruvix montibus verfus ortum dimifos, recipit, \& per maximos fluvios in oceanum emittit, imprimis Riodela Plata, de quo jam non dubitatur; Marahaon, \& hunc noftrum. Nam licet hujus fluminis fons aut origo nondum à quoquam fuerit luftatata, tamen evidens ratio id neceffario videtur evincere, nan contra quam cxteri fluvii, qui ad hanc Brafilix oram in oceanum effluunt, xftivis menfibus quibus pluviæ hic raræadmodum $\&$ parcæ , tantam undarum copiam cvolvit, ut ejus $\mathrm{l}_{2}$ tices ad aliquot milliaria in mari adhuc dulces hauriantur. Noftrates proxime fuperioribus annis hoc flumen celoce afcenderunt ad quadraginta pene milliaria, ubi adhuc fatis latum \& profundum erat. Cæetera Indigenarum \& Lufitanorum fide ita fe habere dicuntur, circiter quinquaginta milliaribus à mari , ipfum de altiffimis rupibus feu cataractis, Cácoeras vocant, preceps ruere, itaque altius ab is, qui è mari veniunt, afcendi non poffe. Supra cataractas fluminis alveum porro pergere verfus Corum ad aliquot milliaria, dein ingentem lacum fequi, in quo multe infulx amoenifimx fint fparfae, quæà Barbaris habitantur, uti \&zora univerfi Lacus. In ipfo autem lacu auriferas arenas colligi, \&taccolas auro abundare quidem, fed vilipendere. Id autem à rupibus auriferis qux verfus Peruviam jaceant, detritum ab infinitis torrentibusin lacum deduci. Præeterea hic reperiri maximam optimi nitri copiam; quod à Præfecto Bahix aliquando petitum narrabat Sacerdos quidam Lufitanus minime vanus nec indoctus : qui fe nitrum illud vidiffe noftris affirmavit.- Haud dubium eft, noftros operam aliquando daturos, ut hæc certa indagine profequantur.

Pifcatio littoris, fuit antehac ditiffima, \& Lufitanis, dum res ipforum effent in integro, quæftuofa; nunc penitus abjectajacet. Sed hæc poftea repetita magno noftratibus ufui exiftit. Feras multas, etiam formarum inufitatarum, cafu oblatas viḍi $\& z$ comedi, quamvis venationibus \& talium rerum indagini nondum vacare hic liceat. Rem pecuariam inveni initio adventus noftri florentem, nunc hæc non noftri tantum, fed etiam hoftilis exercitus ufu vehementer eft attrita. Hecille.

Operx pretium autem putavi hic inferere Itinerarium quod à Wilhelmo Glimmerio noftrate accepi. Is narrat, eo tempore, quo ipfe in Prxfectura S. Vincentii degeret, veniffe ad illas partes è Præfectura Bahiæ Francifcum de Soufa; acceperat enim à quo. dam Brafiliano metallum quoddam, è montibus Sabaroafon, ut ferebat, erutum, coloris cyanei five caleftis, arenulis quibufdam aurei coloris interftinctum, quod cum à minerariis effet probatum, in quintali triginta marcas puri argenti continere deprehenfum fuit. Hac illecebra provocatus Gubernator, montes hofce \& metalla diligentius inveftiganda putans, feptuaginta aut octuaginta qua Lufitanos, qua Brafilienfes, eo mittere in animum induxit. Cum his Glimmerius nofter profectus, itineris rationem ita defcribit.

Ab oppido S. Pauli, in prefectura S. Vincentii, profecti, primum ad municipium S. Micha ëlis pervenimus, (quod diftat à fuperiori verfus ortum quinque aut fex leucas) \& ad ripam fluvii Anhembi, atçue ibidem commeatus paratos invenimus, quos Barbari humeris érant portaturi. Deinque fluvium illud trajecimus, \& quatuor aut quinque dierum pedeftri itinere per denfas Silvas promovimus verfus Arctum, ad fluviolum qui oritur è montibus Guarimumis aut Marumiminis, ubi auri funt metalla. Hic Canois aliquot è corticibus arborum conjunctis, fecundo hoc amniculo defcendimus quinque aut fex diebus, incidimufque in majorem fluvium ab Occidentali plaga defcendentem. Prior ille fluviolus labitur per humiles \&irriguos campos \&amonitate 
fpectabiles. Secundum hunc majorem cum biduo defcendiffemus, incidinus in fluvium adhuclonge majorem, qui c̀ montis Paranapiacaba Arctoo latere oritur (ficuti Anbembi ex Auftrali ejufdem latere) \& primum fecundum montium ductum verfus occafum di12 bens, dein cubito flexus, aliquandiu fertur verfus Aroum, \& tandem, ut vilgo creditur, illabitur in Oceanum inter Promontorium Frio \& Præfecturam Spiritus Sandi, pifcibus tam majoribus quam minoribus egregie fcatens : vocant fluvium de Sorobis. Hurrc quoque quindecim aut fedecim diebus defcendentes pervenimus ad Cataracten, ubi fluvius ab editis montibus conftrictus, præceps ruit verfus ortum: quapropter hic Cancas noftras depreffimus, \& rurfus pedeftre iter aggrefii, juxta \& per alium amnem, qui ab occafíadvenit, \& navigiorum non eft patiens, quinque aut fex diebus pervenimus ad altiffimum montem; quo fuperato dércendimus in patentiffimos campos, lucis quoque hac illac opacos, in quibus pulcherrim $x$ Pini vifuntur, qux fructus ferunt mole capiris humani, cujus nuces medium digitum craffx, cortice teguntur inftar caftanex, \& optimi funt faporis \& nutrimenti: (vix dubito, illum loqui de Zabucaio arbore) ejufmodi arbores per multa milliaria in mediterraneis reperiuntur. Deinceps triduo pervenimusad fuvium qui ab ortu defcendit, quem tranfeuntes, quatuordecim diebus promovimus verfus Corum, per patentes campós \& colles arboribus nudos, adalium fluvium navigiorum patientem, \& venientem ab Aquilone; huncratibus, quas Inngadas vocant, trajecimus; \& quatuor aut quinque leucarum intervallo alium fluvium offendimus, pene ab Arcto allabentem, \& navigiorum patientem. . Credo autem, tres hofce fluvios tandem in unum alveum confluere, \& ferri in Paragayum, co argumento, quod verfus Africum aut occafum fe proripiant. Porro toto illo itinere quod hactenus defcripfimus, nihil culti vidimus, nullos mortales, hic illic tantum ruinas pagorum: nihil vicui opportunum prater gramen $\&$ aliquot fructus filveftres: obfervavimus tamen nonnumquam fumum afcendentem, vagantur enim per has folitudines barbari quidam cum conjugibus \& liberis , incertis fedibus, qui obviis utuntur, nulla fementis cura. Ad poftremum hunc fluvium demum pagum indigenarum invenimus; \&annon $x$ copiam, tempeftive admodum, fiquidem omnis, quam nobifcum tuleramus, jam erat confumta \& jam aliquandiu filveftribus fructibus aut herbis campeftribus famem expleveramus.

Menfem pene integrum hic morati, \& annona parata, denuo iter promovimus verfus Corum, \& menfe uno abfoluto, nullis fluviis obviis, peryenimus ad viam latam \& tritam, \& duos amnes diverf $x$ molis, qui ab Africo allabentes inter montana Sabaroafis eluctantur verius Boream; atque hos effe fontes feu capita fluvii S. Francifci opinor. A pago fupra dicto adhos amnes nullos mortales vidinus, fed accepimus, ultra montes nationeḿ barbaram admodum populofam agere ; qui de Europarorum horum adventu ( nefcio quo pacto) certiores facti, unum fuorum dimiferunt, ut nos fpecularetur. Hic cum in noftros incidiffet; metu horum barbarorum atque annonx inopia, nondum explorato metallo, cujus caufa miffi eramus, repedare maturavimus, \& $\mathrm{pe-}$ ne fame enecti rediimus ad pagum illum barbarorum. Vbi viribus recuperatis $\&$ annona parata, eodem itinere quo veneramus, ad fluvium illum, ubi Canoas deprefferamus, fumus reverfi; atque his refectis flumini nos commifimus, eoque adverfo proreptavimus ufque ad illius fontes; atque ita novem menfibus in hanc expeditionem impenfis, primo Mogomimin, dein ad oppidum S. Pauli rediimus. Sed jam redeamus ad inftitutum, ubi hoc obfervaverimus, non plane verifimile videri, hos fontes effe fluvii $S$. Francifci, nam fi rationes itineris accurate fubducas, non videntur eoufque ad Arctum promoviffe, ut ad illius altitudinem pervenerint; \& opinor longiffime in Continentem penctraffe.

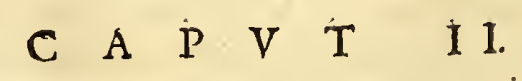

\section{De e feris temperic atque Anni tempeftatibus.}

A Vtor hic nofter quandiu in Brafilia vixit, nimirum annis fere fex, fingulis diebus, imo \& diei partibus, obfervaverat $\&$ annotaverat, qux effet aëris conftitutio, quxaura, atque etiam cxtcra quxad meteorologiam pertinent, ut ex illis hoc caput conftitueret; glod tamen morte preventus perficere non potuit; ut antem 
DE BRASILI REGIONE ET INDIGENIS. autem guftum aliquem percipiant harum rerum curiofi, typos trium annorum dabo, è quibus colligi poterit, quot \& $\approx$ quibus diebus pluerit, \& qui venti fingulis tempeftatibus, perflaverint: cæteri enim anni fere ad fimilem fe habent modum, neque multum variant. Raro porro per totum diem \& noctem pluit, rarifime per aliquot dies continuos fine intermiffione. In Typis autem his litera $P$. notavimus omnes dies, quibus vel levifima \& brevifima pluvia cecidit, ne quis exiftimet, illis diebus continuo pluife: Ventos autem litteris notavimus, S. O defignat Eurum, N. O Boream five Aquilonem ; nam duo hi venti, viciffitudine quadam ad univerfam hanc oram dominantur, $\&$ differentiam inter navigandi regulam conftituunt.

TY PVS A N N I cIo Io c X L.

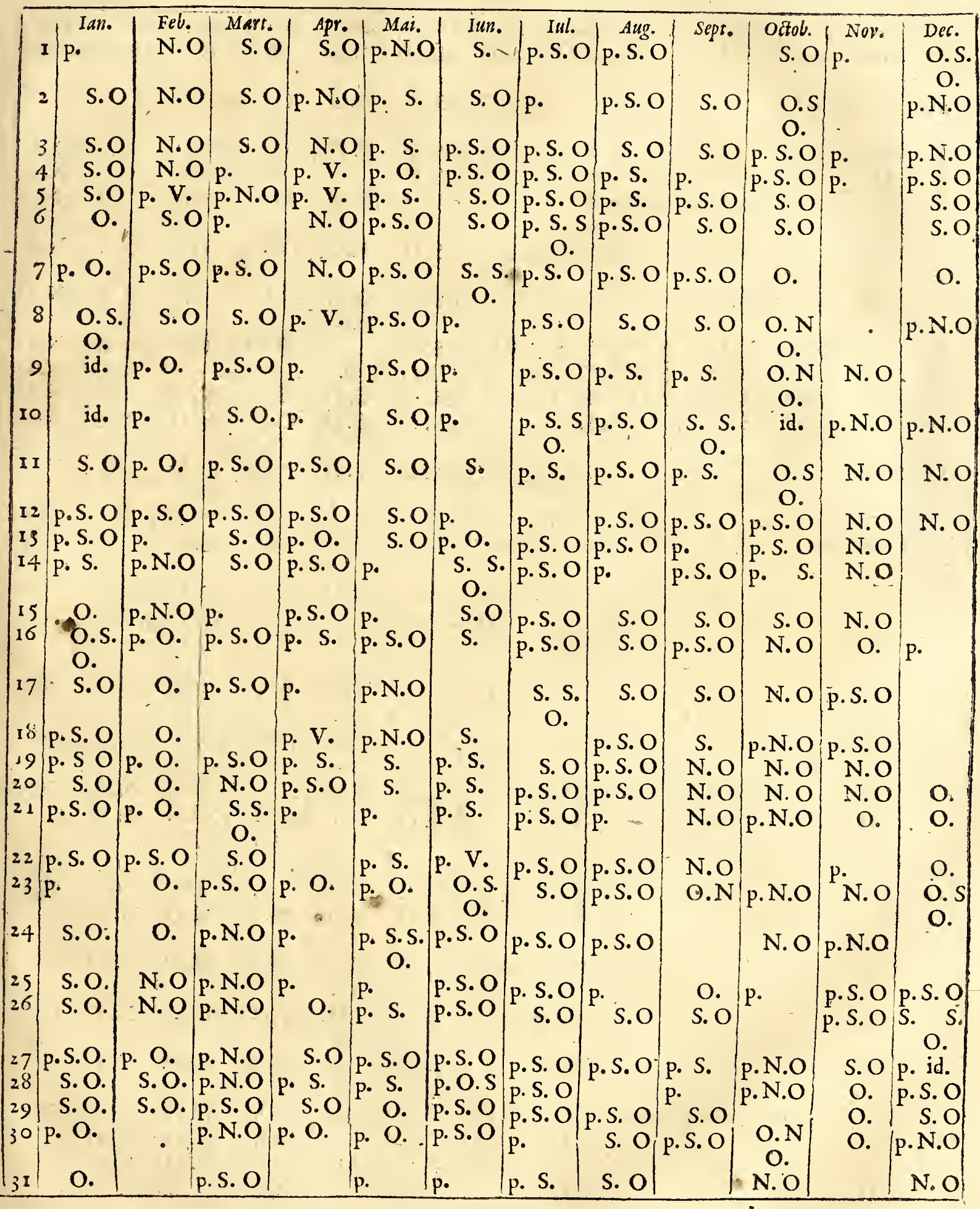

Ex quo obferva primo, hoc anno ducentis $\&$ duobus diebus aut parum, aut multum pluiffe, reliquis minime. Deinde menfes pluvios fuiffe illo anno,Februarium, Martium, Aprilem, Maium, Iunium, Iulium, Auguftum : maxime autem \& pene continuo Maium \& Iulium. Tertio ventum Aquilonarem demum xIx Septembris 
fpirare cocpifle, neque co minus ab initio Ianuarii \& etiam ante auram afpirafle ab E l- $_{\text {- }}$ ro : atque etiam ventos illos binos Eurum \& Aquilonem involafle in fines aliorum, \& Eurum hoc anno palmam tuliffe. Obfervavi quoque tantum tonuiffe Ian. 19 Martii 4, 6, 15, 20. April.9, 10. Maii 14. Et utcunque pluerit interdiu, longe maximam partem noctes claras \& ferenas fuife, quafdam etiam frigidas. Denique nebulas hic efle admodum raras. Fulgura quoque crebra tantum hoc anno annotat Ianuarii decimo octavo : Februarii decimo fexto, \& Martii quarto. Nebulas denique annotat tantum utimo Octobris; \& primo, fccundo, quinto, fexto, feptimo, octavo Novembris: ita ut hoc anno rarx fuerint.

\section{T Y P S A N I cIoİoc XI.}

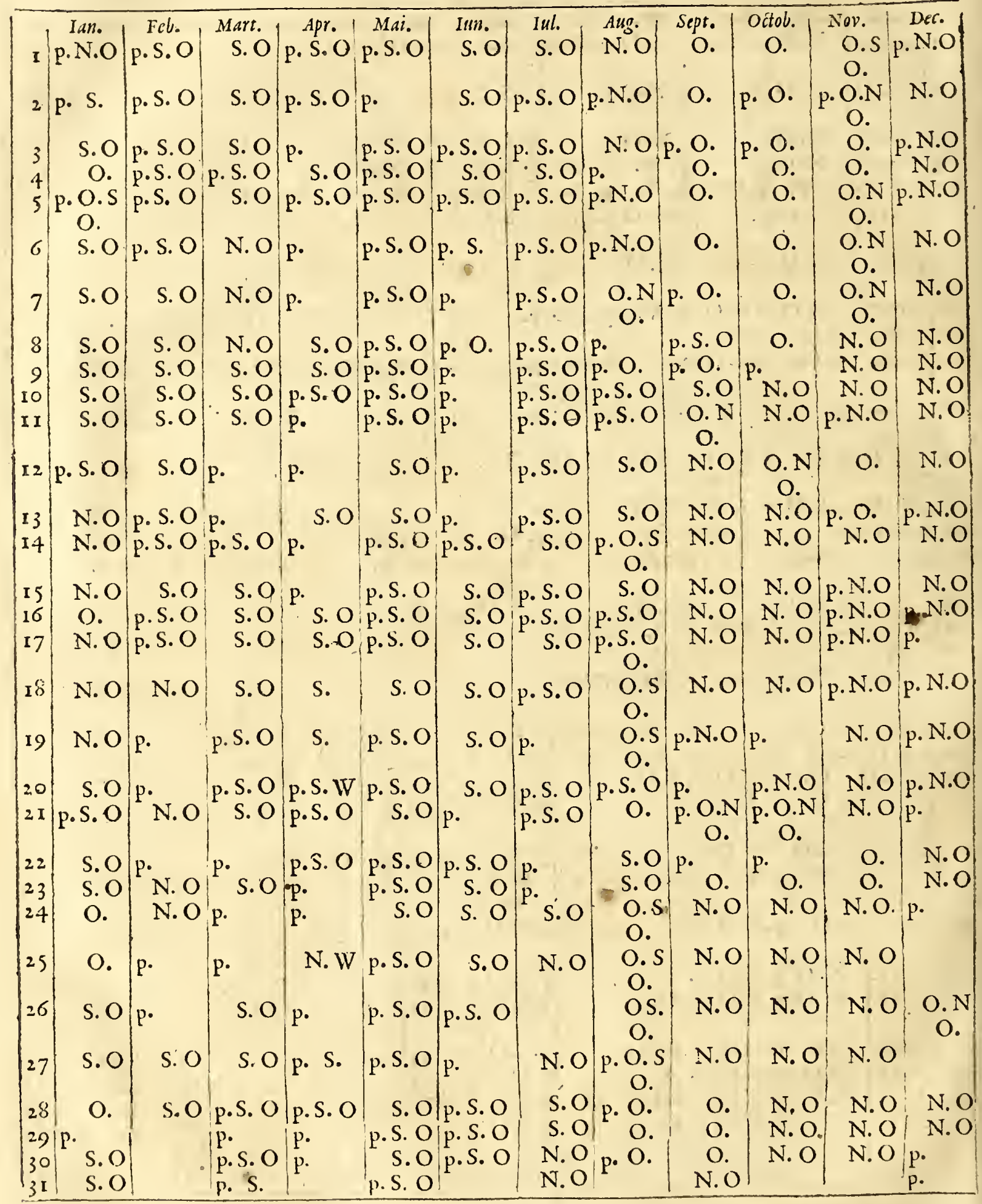

E quo obferva primo, hoc Anno centum \& feptem fupra fexaginta dicbus, aut parum, aut multum pluife, reliquis minime. Deinde illo Anno menfes maxime pluvios fuife Februatium, Martium, Aprilem, Maium, Iunium, Iulium, Auguftum; maxime autem \& penc continuo April cm, Maium, \& Iulium. Tertio ventum Aquilonarem 
DE BRASILIA REGIONE ETINDIGENIS。 It. demum $x_{1}$ Septembris perfiare cœpifie, \& Eurum maxime hoc anno dominatum; licet hi duo venti non raro in alienos fines irruperint. Obfervandum quoque hoc anno rarius tonuiffe \& tantum Februarii fexto \& vigefimo fecundo: Martii vigefimo tertio, vigefimo quinto, \& vigefimo nono: A prilis fecundo, vigefimo tertio \& quinto; Decembris trigefimo. Fulguravit tantun Martii vigefimo tertio, \& Decembris trigefimo. Nebulx, \& quidem craffe, hoc anno frequentiffima fuerunt ; nimirum Martii tertio : Aprilis I 5, 17, 1 8, Maii 3, 7, 9, 24, 25. Iul. 2, 17, 19, 27, 28, 29, 30, 3 1. Augulti 1, 2, 3, 4, 18, 20, 22, 23, 24, 25, 29, 30. Septemb. I. Octob. 3, 4, 5. Nov. 4, 5, 2I, 22 , 23. Decemb. I 9, 20, 2 I , 24. Annotat autem ad fecundum Iulii : mane nebula craffa, ante meridiem nubilum, montes fumantes, Sol rarus, Eurus fortis, frigidus, interpluit crebro, poft meridiem itidem, nox nubila, interpluit crebro. Frigidifimum erat etiam ipfa meridie in monte altifimo Itapuamuru, ita ut barba \& capilli alpergine obducti nobis effent \& manus rigerent pra gelu. Ita \& fape notat noctes frigidas.

T Y P V S A N I cIo Io C X LII.

\begin{tabular}{|c|c|c|c|c|c|c|c|c|c|c|c|c|}
\hline I & p. & $\begin{array}{l}\text { Feb. } \\
\text { S.O }\end{array}$ & $\begin{array}{l}\text { Mart. } \\
\text { N. O }\end{array}$ & P. S.O & $\begin{array}{c}\text { Mar. } \\
\text { S. O }\end{array}$ & $\begin{array}{l}\text { Iun. } \\
\text { S. O }\end{array}$ & $\begin{array}{l}\text { Iul. } \\
\text { p. S. }\end{array}$ & $\begin{array}{l}\text { Aug. } \\
\text { S. O }\end{array}$ & $\begin{array}{l}\text { Sept. } \\
\text { p.S.O }\end{array}$ & $\begin{array}{l}\text { octob. } \\
\text { p. O. }\end{array}$ & $\begin{array}{l}\text { Nov. } \\
\text { N. O }\end{array}$ & $\begin{array}{c}\text { Dec. } \\
\text { O. N } \\
\text { O. }\end{array}$ \\
\hline 2 & p. & S.O & N.O & p.S.O & p.S.O & S. O & p. S. & S.O & S.O & N.O & N.O & N. O \\
\hline 3 & p. & p.S.O & N.O & p.S & p. S.O & p.s.o & p.S. O & p.S. O & S. O & O. & N.O & O. \\
\hline 4 & p.N.O & S.O & N.O & P. S.O & p.S.O & S.O & P. S.O & S.O & P.S.O & O. & P.S.O & O. \\
\hline 5 & p. & S.O & N.O & P.S.O & p.S.O & S.O & S.O & S.O & p. S.O & O. & S.O & O. \\
\hline 6 & & S.O & O. & p. O. & S. O & S.O & S.O & S.O & p. S.O & N.O & O. & O. \\
\hline 7 & N.O & S. O & $\begin{array}{c}\text { O. } \\
\text { N. O }\end{array}$ & p.S.O & $S . O$ & p. S. O & p. S. O & S. & P.S. S & N.O & N.O & $\begin{array}{l}\text { O.S } \\
\text { O. }\end{array}$ \\
\hline 8 & P.N.O & p.S.O & p. O. & p.S.O & p. & p.s.o & S.O & p. & S.O & N.O & N. O & S.O \\
\hline 9 & p.N.O & S.O & p. & S.O & P.S.O. & p.s.o & S.O & p. S. & S.O & N.O & O. & S. O \\
\hline 10 & P. & S.O & p. & S.O & P.S.O & P.S.O & p:S.O & P.S.O & N.O & N.O & O. & S.O \\
\hline I I & S. 0 & P.S. O & P. O. & P.S.O & p.S. O & p.S.O & p.S.O & S. O & P.N.O & V. & N.O & O. \\
\hline I 2 & & p.s. & p. O. & p.S.O & p. S.O & S.O & P.S.O & $\begin{array}{ll}\mathrm{S} . \mathrm{O} \\
\mathrm{S} & \mathrm{O}\end{array}$ & N.O & P.S.O & $p \cdot V$. & O. \\
\hline 13 & O. & 5.0 & p.S.O & P.S.O & p. & p. & p.S.O & S.O & N.O & p.S.O & p.S.O & P.S.O \\
\hline I4 & p.N.O & p. & p.S. O & p.S.O & p. S.O & p.S. O & S.O & $\begin{array}{c}\text { S. S. } \\
\text { O. }\end{array}$ & N.O & p. N.O & p. O. & S. O \\
\hline 15 & p. N.O & & p.S.O & S.O & S.O & S. O & p.S. O & S. O & N.O & N.O & p. O. & S. O \\
\hline 16 & p. & p.S. O & p.S.Q & S. O & P.S. O & S.O & S. O & S.O & N.O & N.O & O. & \\
\hline 17 & & P. $\mathrm{s}$ & p.S.O & S.O & p.S.O & P.S.O & S.O & S.O & N.O & N.O & O. & S. O \\
\hline 18 & & 3.0 & p. & $\mid \begin{array}{c}\text { p. } \\
\text { o. }\end{array}$ & p.s. & p. & S. O & P.S. O & p.s. 0 & N.O & p. O. & S. O \\
\hline 19 & & P. S.O & N.O & S. O & p.S.O & $\begin{array}{l}\text { p. S. } \\
\text { S. o }\end{array}$ & S.O & p. & p. S. & N.O & N. O & $\mathrm{S} . \mathrm{O}$ \\
\hline 20 & $\begin{array}{l}\mathrm{O} . \\
\mathrm{N} . \mathrm{O}\end{array}$ & S. O & O. & p.S. O & p.S.O & $\begin{array}{l}\text { P. S. } \\
\text { S.O }\end{array}$ & p.S.O & p. & p. S. & N. O & N. O & S. O \\
\hline $2 I$ & N.O & & p. O. & p.S.O & S. O & p. S. & P.S.O & P.S.O & p.N.O & N. O & N. O & N. O \\
\hline 22 & S.O & S.O & O. & p. S.O & S.O & P. S. & S.O & p.S.O & p. O.N & p. N.O & N.O & P.N.O \\
\hline 23 & p. & $\begin{array}{l}\text { O. } \\
\text { S.O }\end{array}$ & $\mathrm{S} . \mathrm{O}$ & p. & S.O & P. S. & S.O & p. & $\begin{array}{l}\text { S. S. } \\
\text { O. }\end{array}$ & O. & N.O & $\begin{array}{l}\text { O.S } \\
0 .\end{array}$ \\
\hline 24 & & O. & O. & S. O & p. S. Q & p.S. O & S. O & p.S.O & $\begin{array}{c}\text { S. S. } \\
\text { O. }\end{array}$ & $\begin{array}{l}\text { O.S } \\
0 .\end{array}$ & p. N.O & S. O \\
\hline 25 & & & p. $O$. & S. O & S.O & p.S & S.O & S.O & $\begin{array}{l}\text { S. S. } \\
\text { O. }\end{array}$ & $\begin{array}{c}\mathrm{p} \cdot \mathrm{O} . \mathrm{S} \\
\mathrm{O}\end{array}$ & N.O & S. O \\
\hline 26 & N.O & & p. O. & {$\left[\begin{array}{c}\text { p. } \\
\text { O.s. }\end{array}\right]$} & $\mathrm{S} . \mathrm{O}$ & O & S.O & P. & $\begin{array}{c}\text { S. S. } \\
\text { O. }\end{array}$ & p: & O. & .0 \\
\hline 27 & p. & N.O & p.N.O & S.O & p. S. O & $\begin{array}{l}\text { P. S. } \\
\text { S.O }\end{array}$ & P.S.O & p. & $\cdot V_{0}$ & $\begin{array}{l}\text { O.S } \\
\text { O. }\end{array}$ & $\begin{array}{l}\text { O.S } \\
\text { O. }\end{array}$ & $5 . \mathrm{O}$ \\
\hline 28 & p. O. & N. $\mathrm{O}$ & O. & S. O & S. O & p. S. & $\mathrm{S} . \mathrm{O}$ & $\mathrm{p}$. & & N.O & N.O & S.O \\
\hline 29 & S. O & & O. & |p.S.O & S. OI & p. & S.O & $\mathrm{p}$ & & O. & N. O & $\mathrm{P} . \mathrm{O}$. \\
\hline $\begin{array}{l}30 \\
31\end{array}$ & p.N.O & & $\begin{array}{l}0 . \\
0 .\end{array}$ & -S. O & $\left|\begin{array}{r}\text { p.S. O } \\
\text { S. O }\end{array}\right|$ & p. & $\begin{array}{r}\text { p.S.O } \\
\text { S.O }\end{array}$ & $\left|\begin{array}{c}\text { p. } \\
\text { s. s. } \\
\text { o. }\end{array}\right|$ & $\begin{array}{l}\text { O. } \\
\text { N. }\end{array}$ & $\begin{array}{c}\mathrm{O} . \\
\mathrm{O} . \mathrm{N} \\
\mathrm{O} .\end{array}$ & N.O & $\begin{array}{l}\text { S. } \\
\text { S. O }\end{array}$ \\
\hline
\end{tabular}


E quo obferva primo, hoc anno centum \& fexaginta tribus diebus aut parumaut multum pluifle, ac dıcentis $\&$ duabus diebus non pluife. Deinde menfes Martium; Aprilem, Maium, Iunium, Iulium, \& Auguftum, maxime pluvios fuiffe. Tertio ab initio Februarii ventum à plaga S. O. cœpifle flare; atque ita pertendiffe ad decimum Septembris. Obferva quoque tantum tonuiffe Ianuarii primo, quarto, de. cimo; Martii decimo; Aprilis vigefimo fecundo \& tertio; Maii octavo, nono, \& vigefimo.

Fulgura autem tantum obfervat Aprílis vigefimo primo \& fecundo : nebulas Martii decimo octavo.

Reliquorum annorum fere eadem aut non multum diffimilis eft ratio ; è quibus prudens Lector facile intelliget, qux fint communes in hifce regionibus tempeftates, nimirum quatenus intra Tropicum jacent, nam in iis regionibus quæ magis ad Antarcticum tendunt, paulo alia eft ratio.

\section{A $\quad P \quad V \quad T \quad I I I$.}

\section{De Incolis Braflice.}

$\mathrm{I}$ Ncolarum naturalium hujus terræ funt quatuor nationes, fuis nominibus diftinctæ: nimirum Tupinambu, Tobajara, Petiguara, \&Tapuiga. Et poftrema hæc natio iterum in alias multas nominibus diftinctas, $\&$ idiomate differ entes, divifa eft. Tres reliquæ una utuntur lingua, dialecto tantum ex parte differente, ut capite de Brafilianorum lingua obiter à nobis explicabitur.

Tapuiyarum nationes qux habitant ad flumen $S^{\text {eti }}$ Francifci,funt Arodera, Cajau, Maquaru, \& Poyme.

Lufitani hic plurimi habitant, uti \& Belgx; iifque permixti Germani, Galli, Angli, \&c. Brafiliani vocant Belgas, Germanos, Gallos, Anglos, Ajuru-juba, ideo, quia pler umque ruffas feu flavas habent barbas $\&$ capillos. In genere autem vocant omnes Europxos \& advenas Caraiba, itemque Pero.

Denique ob mifturam variarum nationum, alix quinque diftinctx hominum fpecies reperiuntur : nimirum qui ab Europxis par entibus, patre atque matre, hicnatus eft, appellatur Mozombo.

Qui natus eft ex patre Europæo \& matre Brafiliana, nominatur Mameluco.

Natus ex patre Europæo \& matre Æthiopiffa, dicitur Mulato.

Natus ex patre Brafilienfi \& matre Æthiopiffa, vocatur Curiboca, \& Cabocles.

Natus hic ex utrifque parentibus Nigritis, appellatur Criolo.

$\checkmark$ idi hic Africanam feminam, non nigram, fed ruffa plane cute \& pilis ac capillis ruffis. Ex qua regione effet, non potui refcifcere, nam linguam ejus non intelligebant reliqui Nigritæ.

Multos hic vidi $\mathbb{E}$ thiopes fenes barba magna $\&$ totaliter cana, ut \& capillis capitis canis. Lepidum fpectaculum ! atra barba qux incanuit, in nigra cute, videtur quafi farina effet afperfa.

Vidi hic etiam plane albiffimum juvenem octodecim annorum, pilis crifpis albiffimis \& fuperciliis albis, cute albiffima, nafo plane more Ethiopum, qui natus hic è patre \& matre Nigritis.

Annotatio. Tapuiyarum fines \& fedes à lacobo Rabbi, qui plures annos inter illos vixit, ita defcriptas accepimus. Rio Grande, ad cujus oftium jacet arx Colonia dicta, ad fex horarum iter penetrat in Continentem verfus occafum: uti \& $\&$ fluvius Mupeo novem horarum itinere à Rio Grandi verfus meridiem. Syrag minor trium horarum itinerè̀ $R$. Grandi verfus Arctum, ferme quinquaginta horarum itinere defcendit è Continente.

A Rio Grandi porro verfus Arctum exit in mare infignis fluvius Mapreucauch, longe è Continente defendens, \& Por corum aquaticorum ferax; ad ripas illius multævagan tur Caprex \& Struthiones. Tertius fuvius duodecim mill. à Rio Grandi, vocatur Ypotinge. Quartus autem Vguafu dictus, feptemdecim horarum itinere diftat à Rio Grandi. Deinceps dici itinere ab Vguafu occurrit Yponi, ubi Salinæ funt:à quibus ad alias Salinas milliaria numerantur quindecim: atque ab his ad Aritavva novem:ad maximas Salinas, \&: per excellentiam ita noftris dictas, tria: ad Vnabatubam totidem : ad Marytupa duo: ad tTarerugh 
DE BRASILIE REGIONEET INDIGENIS. Warerugh unum. Hic fluvius alio nomine appellatur ofcthunogh, qui fupra centum milliaria penetrat in continentem verfus Auftrum. Q uinque autem \& viginti mill. à littore maris, jacet grandis lacus Bajatagh, pifcium foecundus: \& ad finiftram ab hocverfus ortum alter, qui Igtug appellatur ab Indigenis, quem tamen nemo ingredi audet, ob copiam mordacium pifcium, $\&$ hominibus admodum infeftorum. Adjacet huic vallis Kuniangeya, viginti milliaria in longitudineth patens, in latitudinem tantum duo: quam permeat fluvius otf chunogh, pifcibus abundans, ficut ipfa vall is maxima copia ferarum, \& variis fructibus : quarum præcipui funt, Kuraura Barbaris, magnitudine pomi noftratis, qui ubi fponte deciderunt, tum demum edules funt : dein Dier sda, magnitudine globuli fclopetarii, plane nigricantes antequam defluant. Atque hifce fructibus Barbari quotannis trimeftre fpatium victitant : quibus accedit $K a k a r a$, fructus inftar juglandis, qui coquendus eft,antequam comedatur: crudus enim amaricat inftar glandis. Magna quoque copia nafcuntur hic Ficus filveftres, pugni magnitudine: quarum quædam intus rubræx, externe virides : aliæe extus rubr $\mathfrak{x}, \&$ interius alb $x, \&$ plen $\mathfrak{x}$ granulis albis, qux, ubi præ maturitate dehifcunt, admodum dulces funt inftar Sacchari; harum plantarum folia inftar fubulx acuta $\&$ digitum humanum longa. Prxterea funt radices è quibus Indigénæ panem faciunt, ipfis Atug, Harag, Hobig, Engepug, qux crudx comedi poffunt: Eniapugh, qux torrend $x$ funt: Packoda, qux crud $x$; \& Hompugh, quas potiffimum ad fitim exftinguendam ufurpant. Ita ut hic terrarum tractus longe amoeniffimus fit \&victum hominibus fufficiat.

Porro ab otfchunogh ad opponne milliaria numerantur decem, qui fuvius ab Auftro pene centum milliarium fpatio defcendit: $a b$ hoc âd tauarug iter eft bidui : ad Bëryvere unius milliaris; ad Vatepug duorum, atque ita porro per Wieferro \&\& Bacvvatigg ad çiaram grandem iter eft duorum dierum.

Inter hos fines, qui fatis amplum terrarum fpatium occupant, incolunt varii Tàpuiyz etiam idiomate diverfi, \& fub diverfis Regulis: quorum primus landuy late tendit in 0t fchunogh, ot fchuayayuch, \& Drerinagh: huic proximus Pritiyaba cum priori pacem \&amicitiam colens: mox Arigpoygh; Wanafervafug, Tfhering, \& Dremmemge; quibus male cum precedentibus convenit, ita ut frepe hoftiliter alii in aliorum fines incurrant. Iarday autem jam fupra centefimum $x$ tatis annum agens, eft Regulus ille qui pacem cum noftris colit, \& ex foedere aliquoties aut ipfe noltris fubfidio venit, aut filium atque affinem cun copiis mifit contra Lufitanos, quibus infenfifimus eft: fed non eft hifce Barbaris, nifi in fumma neceffitate utendum, nam tam immanes funt, ut tam animalia quart homines neci tradant, \& magnam vaftitatem inducant, neque noftri facile ejufmodi furiis ufi fuiffent, nifi fimiles Lufitani in noftros immififfent.

\section{$\begin{array}{lllllllll}C & A & P & V & T & \text { I V. }\end{array}$ \\ De Statura habitu corporis Braflienfum, és de corum ctate do moribus.}

$I^{2}$ Ndigenx qui inter nos degunt, ftatura funt mediocri, róbutit, largis humeris; bene compofiti : hec facile eft inter illos invenire, diftortum vel lufcum aut clautdum. Quod mirum videri potel?; quum infantes recens natos nunquam fafciis involvant aut ligent, ne caufam morborum illis prabeant. Ligant tantum fuis in infantia crura certis fafciis, quas vocant Tapa cura, ea de caufa ut robuftiora fiant. Oculos habent nigros, nafum compreffum, os amplum, capillos nigros, rectos. Barbam raram aut nullam. Multi tamen dantur qui barbas habent nigras. Mulieres quoque mediocris funt ftatur $x$, bene difpofit,$\&$ form $æ$ haud inelegantis, nigris comis, $\sqrt{2}$ tis robuft $x$, \& qux facillime pariunt.

Annos fuos numerant ab exortu Heliaco Pleiadum, quos Ceixu vocant, atque ideo amnum eodem nomine denotant: accidit autein is ortus menfe noftro Maio.

Numerum annorum xtatis fux ut retinere poffint, fingulis annis reponunt unam caftaneam de Acajü, quam ipfi Acajü acaya appellant, itemque Acaiuti \& itcmboera. Fruftus enim illius arboris fingulis annis femel maturatur, nimirum menfibus Decembri \& Ianuario, ufque in Martium durans. Plura de hac arbore dicta in lib. I I I. de Arboribus. 
Diu plerumque vivunt, \& videre inter illos licet multos fenes, centum, atque etiant viginti fupra centum annorum, neque facile canefcunt, nifi in decrepita ætate.

Pueri illorum ingcnio funt fatis docili : verum quando adolefcentiam ingrediuntur; funt hebetiores, ita ut paucos videreliccat literis inftuctos, aut qui artem fcribendi norint; aut alias artes Europxas, à quibus quodammodo abhorrent, laborum impatientiores.

Tranquille fatis agunt inter fefe: nifi quando poculis indulgent, tunc dies noctefque faltando \& cantillando tranfigunt. Sunt cnim ebrietati admodum addicti, tam mulieres quam viri : neque facile ab hoc vitio deterreri poffunt, quod longe maximum illis eft, è quo \& rixæ atque aliæ pravæ confuetudines nafcuntur.

Pigritix quoque valde obnoxii funt : præfertim Tapuiye, qui laborum vel maxime intolerantes funt; nam cum paucis fint contenti, \& terra abunde ipfis victum fuppeditet, \& divitias non appetant aut norint, ad labores fubeundos non excitantur.

Quomodo hofpites advenientes lacrymando excipiant feminæ illorum, \& quibus fermonibusillos alloquantur; atque quo pacto mortuos fuos deplorent, jam ab aliis dictum cft, præfertim à Ioanne Lerio, qui inter Tupinambos egit, à quorum moribus cetcri non diffident; quare hic nihil repetendum duximus.

\section{$\begin{array}{lllllll}C & \mathrm{~A} & \mathrm{P} & \mathrm{V} & \mathrm{T} & \mathrm{V}\end{array}$}

\section{De Vefitu \& ornatu Virorum, \& Mulierum Brafilienfum.}

V

Iri fubligaria jam ex linteamine plerumque induunt, quidam quoque indufia habent, \& pileis utuntur , fed maximam partem nudo incedunt capite, \& capillis more Lufitanorum tonfis. Nudis incedunt pedibus, nullis calceis induti. Quidam etiam folummo do fubcinctorio panno lumbos tegunt, catcra fune veftitu. Mulieres vero jam longis indufiis veftiuntur, factis ex linteo vel goffypino panno, neque quicquam præterea veftimentorum habentes. Comas autem capitis vel dependere finunt, vel more feminarum noftratium treniolis involvunt.

Tam viri quam feminæ $\&$ infantes variis coloribus cutem tingunt, nigro, rubro; flavo, ad quem ufum ufurpant fuccum è fructu Ianipaba immaturo, qui nigro; Iracous qui rubro tingit, \& ita in cæeteris aut fructu aliquo aut ligno utuntur.

Tapuiyx, tam mulieres quam viri, fere nudi incedunt, \& pilos circa pudenda evellunt. Virimembri fui genitalis fiftulam in fe contrahunt \& involvunt, ligantes taniola quadam, vocantque id, quo ligant membrum, Tacoaynbaa. Religant autem, quando opus eft ut meiant. Majore autem pudore afficiuntur monftrando virgam cxplicatan quam nos. Eodem modo \& alii quidam Brafilienfes membra fua genitalia ligant.

Capillos capitis ad humeros ufque dependentes alunt, \& inferius æqualiter præcidunt more rufticorum Sueviæ. In fronte quoque $x$ qualiter detonfum gerunt; fed pr: cifione æqualiter facta ufque ad aurium regionem fuperius, \& angulis ita factis in itroque latere ad tempora. Eodem plane modo etiam feminæ cum comis fuis agunt , \& virorum more geftant.

Viri corollas factas ex pennis Guara vel Caninde, capiti circumligant : dépendent à pofterioie parte corollæaliquot longiores pennzè cauda Araravel Caninde. Angulos itaque factos cum capillis adprime firmant, ne corolla circumligatæ fefe ipfas deligent. Quidam etiam folum funiculum è goffypio capiti circumligant, è quo poftica parte aliquot perinx longæ, rubræ vel cxrulex propendent, vocant Acanbuaçaba.

Pallia quoque conficiunt è filis craffis góflypinis inftar retis nexis, \& cuilibet nodo innexa eft penna, ita ut pallium totum pennatum fit, \& , eodem pene modo $\&$ concinno ordine pennx fibi invicen incumbunt, uti fquamæ pifcium. Pallium autem poffuperius cucullum habet, ita ut totum caput, humeros, $\$ 2$ coxas ad anum ufque hoc fit tegere. Hoc pallio utuntur ornatus \& neceffitatis caufa: ornatus quidem, quia clegantiflimis pernnis rubris avis Guara contextum elt, vel eriam admixtis pennis nigris, viridibus, flavis, variis , avium LAracucaru, Carinde, Arara, \&c. Necenitatis autem, quia pluvia non pertranfit illud pallium, fed aqua cum his defluit. Appellant hac pallia Guara abucu. Solent quoque cum cera feu melle filveftri, cer- 
DE BRASILIA REGIONE・ET INDIGENIS. IS tas ex avium elegan tium pennis criftas capiti agglutinare, quas criftas ipfinominant Aguana.

Auriculas perforant in tantum, ut digitum immittere poffis foramini. Huic immittunt vel os aliquod Cercopithecorum, \& vocant Nambipaya; vel lignum aliquod digiti humani longitudine filis goffypinis circumvolutum.

Viri labium inferius perforatum habent, \& foramini immittunt lapidem aliquem feti cryftallum feu fmaragdum vel jafpidem, magnitudine nucis avellanæ, vocant talem lapidem Metara, \& fi viridis vel cxruleus fuerit Metarobi nominant. Viridem attem imprimis amant $\&$ ut plurimum geftant.

Ad utrumque etiam oris angulum buccæ perforatæ funt conjugatis folum viris, \& cuilibet foramini indunt lignum, figura \& magnitudine pennæx anferinæ, quod inftar clavi infixi prominet, vel etiam immittunt lapidem aliquem, quem vocant Tembe cosrete

Nares non raro perforant atque indunt ejufmodi ligna, Apiyati appellantes.

Corpus autem varie pingunt: atque infuper toti corpori agglutinare folent plumas variarum avium fubtiliores cum maftiche, melle filveftri vel Mingaupomonga. Vocant hunc actum Acamongui. Atque ita apparent quafi toti hirfuti effent.

Brachia quoque ornant certis corollis factis è plumis avium rubris \& flavis, vocantque Aguamiranga. Item aptant corallia varia, quæ à noftratibus acceperunt, atque hunc ornatum appellant Papixoara.

Pennas denique Struthionum multas, vel pennas è cauda Arara, in orbem quafi colligunt $\&$ connectunt filo craffiori, atque adligant lumbis, ita ut anum tegant $\&$ fere ad genua propendeant, \& appellant hunc ornatum Aracoaya.

Ex fructus Aguay, qui triangularis eft, corticibus, quos filo annectunt, etiam monilia faciunt, qua cruribus infra furas circumligant, qui cortices inter faltandum fonum quendam edunt.

Loco calceorum noftratium, è certo cortice Curaģua ipfis vocato, factis utuntur, atque illos vocant Miapapacaba, Lufitani autem Alpargatas.

Mulieres pudenda fua folummodo tegunt fafciculo herbarum aut foliorum alicujus arboris, qux fubinferunt chord $x$, qua cinguli loco fe circumligant. Similem fafciculum etiam ufurpant pro tegmine ani. Haud multum tamen utraque hxc janua ad rem facit, nam facile \& anterior \& pofterior porta apparet.

Mulieres quoque ad virorum modum, corpus fum variis coloribus pingunt.

Atque hæc inter gentiles adhuc obtinent, nam qui Chriftani facti funt, ad Euro= pxorum amictum \& ornatum fe componere confuefunt.

$$
\text { C A } \quad \mathrm{P} \quad \mathrm{V}, \mathrm{T} \quad \mathrm{V} \mathrm{I}_{\mathrm{o}}
$$

\section{De Supellectile Brafilienfurm.}

VpellexBrafilienfum admodum pauca eft, ita ut cum loca mutant, aut peregre 1 ) proficifcuntur, mulier omnem fecum portet, onerata inftar muli, maritum femper fequens.

Primaria fupellex eft rete, quod ipfi vocant Ini, Lufitani Rede, Belgx vulgo Hamacca : in hoc dormiunt, alligata utraque extremitate ad $x$ dium fuarum trabes. Sunt autem hxc retia ex filis goffypinis contexta, fex aut feptem pedes longa, quatuor ampla.

Lufitanæ quoque feminæ elegantia conficiunt, ampla \& variis figuris intertexta.

Tapuiye Cariri duodecim vel quatuordecim pedes longa faciunt, fex vel feptem ampla, ita ut quatuor homines fimul in co cubare poffint.

Habent unam atque alteram ollam ex argilla factam, qua utuhtur ad cóquendum.

Adhre mortarium ligneum cum piftillo ligneo, quod vocant Angua \& Vmbua vel Inqua: Cultros à noftratibus redemtos, nominant Itaquice : vulgo alias è petra faciunt, etiam vocant Itaque : item ex Arundine, quos dicunt Taquonquice.

Specula ex Europa allata, quibus fupra modim delectantur, vocant Guarugua \& Artga. Loco patinarum utuntur cucurbitis, quarum mult \& $\&$ variæ hic reperiuntur fpecies; has per medium fecundum longitudinem fecant \& rubro Vrucu colore exterius tingunt, interius antem obducunt nigredine: Vocant fic Cuyaba : qux eft medietas gran- 
dis \& ampla cucurbit $x$, qua integra triginta aut triginta quinque cantharos vini po. teft capere.Medietatem tamen cucurbita longx nominant Cuipeba: denique quamcunque medietatem Cuya: Caruaba autem omne in quo \& fuper quo cibum fumunt.

Cochlearum loco inferviunt ipfis digiti manus, vel mytulli, aut aliæ conchx.

Menfa ipforum eft vel terra ipfa, vel fcamnum quoddam, quod Patagui vocant, faCtum ex arundine vel virgis ligneis, more noftratum fcamnorum.

Caniftra faciunt ex foliis Palm $x, \&$ appellant Patigua : in his recondunt quicquid habent. Alios quoque prxterea habent corbes ex arundinibus concinnatos. Hanc fupellectilem generali nomine vocant Caramemoa.

Ex virgultis quoque conficiunt corbes oblongos, fatis amplos, quos capite portant impletos, vocant Panacu. Inferviunt ipfis prxcipue ad tranffortandum radices Mandioca, quando farinam faciunt: nam iter facientes utuntur aliis illis, quos vocant $P$ atigua. Ethiopes autem hic Panaca utuntur ad res quaflibet portandas.

Lagenæ, canthari, cyathi illorum, funt cucurbitæ varix, ut Cuieté, Karoba, Cuibuca.

Quando peregre proficifcitur maritus, mulier femper illum lequitur quocunque abeat, five in expeditionem militarem, five alio, five procul, five prope: Ille nihil prater arma fua portat: mulier vero inftar muli onerata eft, præterquam enim quod à capite in tergum dependet corbis, quem Patigua vocant, quam chord $x$ annectit, (chordan autem non collo, fed fronti circumponit geftando illam) etiam capiti fuperius imponit alium corbem cum mobilibus fuis, vel ingentem cucurbitam farina refertam: lateribus præterea adhærent cucurbitæ minores, quibus aquam hauriunt ad bibendum. Nec tamen adhuc fatis onerata eft mulier, infantem etiam geftare debet, infidentem linteamini, quod ab humero dextro dependet. Infidet autem infans cruribus divaricatis, uno ad ventrem, altero ad tergum matris verfo, ventrem vero fuum lateri matris dextro applicat. Præterea una adhuc manu vel Pfittacum geftat, vel Cagui, altera autem manu canem funiculo alligatum ducit. Ita abeunt fine curis, non inftuctiloculis argento repletis, fed cucurbita pauca folum farina, referta, non folliciti de hofpitio nec hofpite fido vel infido, fufficiunt enim filvæ \& campi, qui gratis præbent cibum, potum vero fluvii, lacus, vel fontes, vel planta qux vocatur Caraguata, qux inter folia femper aquam pluvialem continet : fummum remedium in locis aridis \& fterilibus, ubi fxpius nec fluvius, nec rivus, nec lacus fpatio ofto, novem, duodecim milliarium reperitur. Adventante vefpera, ubi pernoctare animus, ibi retia fua feu lectos penfiles alligant arboribus, vel palis terræ infixis, ignem prope ftruunt, præparant fuum cibum, hauriunt potum, comedunt, bibunt. Si autem metus fit à pluvia, hic funt Palmæ arbores, præciduntur rami, baculi duo terræ infiguntur, alii oblique inftar tignorum alligantur opera viminis, complicantur folia palmæ cynaris, fit tectum, atque ita domus confecta eft \& fimul pitta ; viriditate enim fplendent naturali folia, qui color gratiffimus eft oculis, nec parietes calce incruftati albedine fua hebetant vifun. Hxc domus \& pluviam arcet $\&$ homines à vento nozturno defendit, quod regioni venti opponatur.

Cum domi exiftentes, viri mane cum arcubus $\&$ fagittis fuis in filvas abeunt vel campos, ad figendum aliquam feram vel avem : vel abeunt ad mare pifcandi caufa, vel pifcantur in fuviis vicinis: mulieres plantaria adeunt, \& labores fibi impofitos fubeunt. Quædam \& maritos comitantur, ut prædam domum reportent.

Feras capiunt variis modis, vel enim figunt fagittis, vel foveas faciunt profundas in terra, \& defuper cooperiunt ramulis arborum certo loco, in quas incidunt inopinato fer $x$, vocant Petacu : vel etiam è ligno certas decipulas faciunt. Alius modus feras grandiores capiendi vocatur Mande aratacá, quo in capreis capiendis utuntur. Alius item infidiarum Poé: tertius pro eifdem capreis Munde guaçu; pro Tatú \& Agutí, \& fimilibus animalibus, adhuc alium habent, quem dicunt Mundeguaya.

Ad volucres autem capiendas, utuntur certis inftrumentis, qux vocant Iucana : qux illis funt trium generum : ninirum Iucanabipiara, quod aves pedibus capit: Incarajuripiara, quod eas cervice apprehendit: Iucanapitereba, quod inedio corpore.

In fluviis Pifces vel fagittis figunt, vel hamulis capiunt, quibus applicant vel lumbricos teretes, qui ab ipfis vocantur Cardaguaç, vel gammaros, cancellos, pifciculos. Vel inebriant illos, ut quafi mortui fuperfluitent, cum foliis Iapicai, vel cum Timbopotiana, vel cum Tinguii, vel cun Tinguiri, vel cum fructu Cururu ape; aut radicibus $M a$ guí, 
gaì, corticibus arboris Anda, \& fimilibus. Pifcantur quoque certis cribris, Vrupema vocatis, qux faciunt ex arundine Iruguibondipia appellata.

In mari pifcantur hamulo efca inftructo \& filo alligato, infidentes tribus lignis fibi invicem annexis, vocant Igapeba, \& Lufitani Iangada. Fiunt autem è ligno arboris Apeiba, ut jam fupra diximus. Fila autem fua pifcatoria faciunt è filis Tacu, vel etiam Icipoicica, vocantque Pinaçama : hamulos denique faciunt è ferro, \& appellant $P$ inda.

\section{C $\begin{array}{llllllllll} & \text { P } & V & T & \text { V I I. }\end{array}$ \\ De Cibo es Potu Braflienfum.}

$\mathrm{V}$

Niverfale Brafilienfium alimentum eft $V_{\hat{t}}$, Lufitanis Farinba de Mandioca dicta: cujus varias fpecies prxparant, uti in defcriptione Mandiiba dixi, ubi $\&$ varios illam praparandi modos prolixe explicavi.

Carnem variam ufurpant animalium filveftrium, aviumque, uti \& pifcium variorum, etiam teftaceorum \& cruftaceorum; fructus itidem arboreos, terreftrefque, varia legumina; de quibus omnibus fpecialiter dixi fuis locis. Imo $\&$ infecta quædam
comedunt, nimirum ea de quibus dixi in lib. de Infectis.

Carnem autem comedunt vel coctam, vel affatam, vel toftam. Coquunt in ollis terreis, quas Camu vocant, rotundis ( quas è proba argilla ipfi norunt facerc) affundendo aquam, atquc ita coctam comedunt cum Inquitaya, jufculo Caarimaciu, admifcentes Mingain, viel immittendo Viata, ut fit Minipiro; comedentes illud cum carne loco panis.

Ignem eliciunt ope duorum lignorum, uno molli, altero duro, durum acuunt , \& applicant molli, circumagendo inftar terebri \& admovendo goffypium, vel arida folia arborum, atque ita flammam eliciunt. Ligna mollia quibus utuntur, aut fumunt à
Tataiba, aut Ambaiba, aut Caraguataguaçu, aut fimilibus.

Affatam carnem fic perficiunt, \& eft ea faporis excellentiffimi, atque adco excellit omnem aliam carnem quoquo modo affatam. Vocant Biaribi. Faciunt fovean in terra , \& hujus fundo primo imponunt folia grandia alicujus arboris, illifque impontunt carnem affandam, quam itidem foliis tegunt, terraque obruunt. Super terra illa focum ftruunt luculentum, eumque continuant, donec caro fit probe affata.

Tortam carnen in prefentes \& futuros ufus, faciunt hoc modo. Infixis quatuor furcis ligneis, è baculis cratem defuper efformant, quem Mocae vocant, huic carnem in frufta oblonga, haud craffa, concifam, \& fale afperfam, (vel illius defectu Pipere Brafiliano) imponunt, prunas fubjiciunt, atque ita torrent ufque ad fufficientiam. Hxc caro ita tofta, ad decem vel quatuordecim $\gtrsim$ plures dies durare poteft. Hic enim faliri ita caro non poteft, ut in Europa. Numquam affant carnem veru affixam, uti nos folemus. Lufitani carnes ad eum modum toftas appellant Poftas.

Pifces affatos vel ebullitos comedunt cum Iuquitaya. Cancros vel gammaros quando coquunt, numquam adjiciunt falem inter coquendum, uti noftrates folent facere, fed coctos comedunt vel cum fimplici fale, vel Iuquitaya, Lufitinis Sal-pimenta; \&
ficgratioris deprehenduntur faporis.

Minutiores Pifces, ut Piaba , Piquitinga, \&zc. Foliis herbáceis aut arboreis involvunt \& operiunt cineribus calidis, ita brevi tempore ad cibum parati funt, licet neque co-
cti neque affi dici poffint.

Farinam duobus vel tribus pofterioribus digitis dextræ manus prehenfam inter edendum ori injiciunt, nullo cochleari utentes. Eodemque modo legumina cocta non immittunt ori, fed injiciunt ; ita dextre, ut vix aliquid pretercat.

Edunt fepius interdiu, imo \& noctu, neque ftata edendi tempora obfervant. Capiunt autem cibun cum fummo filentio: raroque inter edendum bibunt, fed demum
poft paftum adjiciunt potum.

Dormiunt in retibus fuis: funt admodum pigri, \& non raro totum diem ftertendo perdunt, \& $x$ grefe levant, fi victus abundet, $\&$ neceffitas illos foras non propellat.
Prope rétia fua penfilia ftruunt focum tam noctu quam interdiu; ut interdiu ferviat coquendo cibo, noctu autem aërem arceat frigidum, qui in hifce regionibus noctu fri- 
gidior eft , \& interdum frigidiffimus, ob noctium $\&$ dierum perpetuo pene æquabilem longitudinem.

Potus ordinarius Brafilienfuum eft aqua frigida, fontan? vel fluviatilis, qux hic \& valde bona \& clara reperitur, ita ut non facile quis noxam ab hauftu ejus patiatur, quantumvis largius bibcrit: quod de fontaina imprimis intelligendum eft.

Vites autem licet hic ter atque ctiam quater uno anno fructus ferant, quia tamen earum nón eft tanta copia ut vinum premiaut opportunum aut operæ pretium fit, earum loco plures modos commenti funt Brafilienfes, quibus è variis fructibus atque etiam radicibus potus concinnent, qui vini locum expleant. Et quidem primo vocant Caoi, quem nimirum faciunt ex Acaiibe arboris fructu maturo, quem contundunt in mortario ligneo, vel etiam tantum manibus exprimunt ; fuccum paulum fubfidere $f_{1}-$ nunt, \& tum percolant. Hoc vinum, fi ita licet vocare, recens : albicat inftar lactis, poft aliquot autem dies fit pallidius. Saporis eft adfringentis; forte, ita ut quoque inebrict paulo largius hauftum. Poteft aliquandiuadfervari, fed denique degenerat in acetum optimum \& boni faporis, ita ut ab ignaris pro aceto vini fumi poffet.

Alterum vinum vocant _Aipiz, quod praparant duobus modis, vel mafticando vel contundendo radicem; utrovis tamen modo per ebullitionem. Priori modo radices de Aipimacaxera concifas vetulæ dentibus mafticant, ollæque infpuunt, vocantque hanc veluti pultem Caraçu : dein aquam fuperfundunt, coquunt lento igne, continuo agitando, per expreffionem deinceps feparant liquorem, quem vocant Cavicar acu: hic potus bibitur tepefactus. Pofteriori modo eadem radix recens bene purgata confcinditur , contunditur ; \& ebullitur in potum candicantem inftar lactis ebutyrati, qui \& tepefactus bibitur. Saporis eft grati, fubacidiufculi, \& vocatur Cacimacaxera. Vtrumque tamen potum communi nomine appellant Aipii.

Tertii generis appellant Pacobi, quem conficiunt è fructibus arboris Pacobete \& Pacobucu : de quibus in arborum defcriptione à nobis dietum eft.

Quarti generis nominant $A b_{a t i i}$, Lufitani autem Vinho de Milho, quia fit è milio illo grandi, quod vulgo Turcicum vocamus, \& Maizium.

Quinti generis dicitur ipfis Namai, quia fit è præftantifimo illo fructu Nana, de quo plura in illius defcriptione diximus. Obfervandum autem, hoc effe fortius reliquis omnibus $\&$ facillime inebriare.

Sexti generis ipfis vocatur Ietici, Lufitanis autem Vinho de Batatas; fiquidem fit è notiffimis illis radicibus, \& quidem varic mixtis.

Septimum locum obtinet potus qui conficitur è fructu Ianipaba maturo.

Octavum autem, quem Brafilienfes vulgo vocant Beeutingui.

Nonum, quem vocant Tipiaci, qui utrique potus itidem fiunt è farina Mandiocx, nimirum è Beiu \& Tepioia, de quibus alibi dictum.

Cxterum hi Barbari fupra modum amant aduftum noftras, vocant Cacitata, \& enormiter , cum datur, fe illo inebriant. Potu itidem quem Nigritæ hic faciunt \& vocant Garapa ( fit autem eo modo quem in Cannarum facchari defcriptione dixi) magna copia fe ingurgitant, ita ut integros dies noctefque canendo $\&$ faltando traducant, potui continuo indulgentes tam femin $x$ quam viri. Mirum tamen quod rarius inter pocula rixentur, nifi forte Zelotypia caufa.

Tapuiye quando hunc potum preparant, five Acavi, five Aiipii (ii fcilicet qui pagos incolunt, \& è Tapriyarum genere Cariri dicuntur) faciunt id omnes fimul. Dies dein conftituitur $\&$ indicatur fingulis. Conveniunt omnes mane, incipiendo que ab uno pagi angulo, evacuant ordine omne vinum per omnia domicilia, donec nihil fuperfit.Poruific indulgendo cantillant, faltant rara intermiffione. Quando eorum aliquis fenimio potu diftentum fentit, vomitum fibi excitat, \& denuo haurit ; ita ut qui plus vomere poteft \& denuo bibere, pro optimo $\&$ ftrenuiffimo habeatur inter reliquos potatores.

Tabaco quoque frequentifime utuntur omnes Brafilix incolx : vocant hanc herbam Petima, \& folia illius Petimaoba. Hanc in aëre ficcatam ponunt ad ignem, ut manu conteri in minutas particulas poflit : hinc indunt inftrumentis fuis è cortice fructus Pindoba, vcl Vracturuiba, vel loçara, aut Aque, \&cc. confectis; precidunt quippe una extrcmitate, nucleum eximunt ac corticem poliunt; hinc foramine in latere facto applicant tubulum è ligno factum. Hoc inftrumentum vocant letimbusbs, Lufitani autem corrth. 
DE BRASILI A REGIONE ET INDIGENIS.

corrupte Catimbaba, Belga adhuc corruptius latgenbow. Vtuntur quoque tubulis ex argilla à fe factis \& excoctis, ficuti \& illis qui ex Europa ad eos afferuntur, quos nominant Amrupetimbuaba.

Tapirye autem utuntur tubis rectis, amplis, ligneis vel etiam argillaceis, ita amplis, ut integrum pugnum Tabaci capiant, quibus repletis $\&$ accenfis fugendo fumum hauriunt.

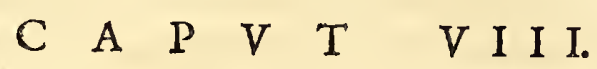

De éfrmis Braflienfum, of exercitios illorum.

A Rcus habent è duro ligno factos, quos vocant Guirapara \& Vrapara: Lignum autem unde funt Guirapariba \& Vrapariba, Lúfitanis Pao d'Arco. Chordas arcuum è goffypio contorquent; vocant Guirapacuma. Sagittas ex arundine filveftri faciunt, \& vocant utramque rem uno nomine Vuba. Extremitates fagittarum, quas anha vocant, funt ex ligno alperatx, vario modo; quædam enim multa acumina Vutapoaeta, quxdam unicum acumen habent, quxdam dentata, quxdam ferrata: quibufdan etiam dentes pifcium qui lperu vocantur, aptant.

Iurupara appellant fagittam, qux acumen habet ex arundine $\tau_{a c o a r}$ vocata.

Tapuiyarum nationes quxdam nullis arcubus utuntur, fed fagittas fuas emittune manus jactura folummodo, imponendo ligno cuidam excavato inftar tubi, per medium fecundum longitudinem diffecti. Caririantem arcubus utuntur.

Tapuiye clavas habent ex folido ligno nigro confectas, vocant lapema, longas \& latas anterius, \& officulis interdum afperatas. Manubrio autem circumvolvunt teniolas è goflypio, vel aliud quid: vocatur Iatirana quicquid ita circumligatur. In extremitate clava poftica dependet fafcicul us pennarum è cauda Arara, uti \& in medio parvus fafciculus adligatus eft. Vocatur id, quod fic à clava dependet, Atirabebe \& $1 a-$ tirabebe.

Tubas faciunt ex offibus humanis, quas nominant Canguenca.

Habent alias tubas, quas vocant Muremure.

Alias itidem tubas grandes factas ex conchis, quas Guata pi gragçu nominant, \& ipfas tubas N Numbu goaçu. Item alias quas dicunt Vruca.

Tubaitem alia, qux ex canna eft facta, ipfis dicitur Membiapara. Tubas autemnofttates vocant Itamembi: quia è metallo factre funt.

Saltationibus fupra modum funt addicti, quas generali nomine vocant Gualu.

Habent autem varios faltandi modos: quiorum unus vocatur Vrucapi. Habent \& inter faltandum varios cantandi modos.

Pueri quoque certos exercent lufus ; quorum unus vocatur Curupirara: alter Guaibipaie : tertius Guaibiguaibiabucu. Atque hre tantum obiter ab Auctore defignata inveni, uberius explicaturum fuiffe liquet, fi fipervixiffet; fed apud Ioannem Lerium hxe pluribus explicata inveniuntur.

\section{A P V T IX. \\ De Braflienfum religione.}

$\mathrm{C}$ Redunt ex antiquorum traditione immortalitatem animarum, \& feminas $\&$ fortes viros, qui multos inimicorum trucidarunt $\&$ comederunt, poft mortem ad campos Elyfeos, quos pene montes quofdam effe autumant, abire, ibique tripudiare. Ceteros ignavos \& focordes qui nihil in vita digni gefferunt, credunt à Diabolo ftatim poft mortem cruciari. Vocant autem Diabolum Anhanga, Inrupari, Curupari, Taguaiba, Temoti, Taubimama.

Habent fiuos fortil egos five facrificulos, quos $P$ aye \& $P$ ay vocant, hos de futuris confulunt, quando ad bellicam expeditionem proficifcuntur, ipfifque predicunt quicquid accidere debeat.

Multi inftruoti funt in Religione Chriftiana, non tamen feduli funt in doctrina de Deo; nec magno ardore afficiuntur. Deum vocant Tupa $\&$ Tupana. Magnos licct pro- 
greflus nonnulli eorum fuerint, circa inftituta divinitatis, tamen in moribus corrigendis maxima eft difficultas, ob magna quxdam vitia, qux ægerrime domantur.

Hxc omnia fufius profequitur I. de Laet, hoc modo.

Brafilienfes Barbari nullum pene habent religionis fenfum, nec de origine, \& creatione hujus univerfi quicquam norunt, de diluvio univerfali obfcurc \& fabulofum quiddam recordantur: nimirum mortalibus aqua hauftis, fuperfuiffe unum aliquem cum germana fua , jam uterum ferente, atque ab iis rurfus genus fuum originem \& incrementum accepiffe. Neque Deum aliquem noverúnt, neque proprie adorant quicquam, unde nec illud nomen in ipforum idiomate reperire eft, quod Deum exprimat: nifi forte Tupa, quo excellentiam aliquam fupremam denotant; unde Tonitru vocant Tupacunung $a$, id eft, ftrepitum factum à fuprema excellentia, à verbo Acunving ftrepere: Fulgur autem Tupaberaba, id eft, fplendorem excellentix, à verbo Aberab refplendere. Illi fe ligones $\&$ agricultur $x$ fcientiam debere profitentur, atque ideo pro numine aliquo agnofcunt. Cxlum aut inferos poft hanc vitam pariter ignorant, licet animas poft feparationem à corpore fupereffe credant, atque nonnumquam in dxmones converti , \& ad campos irriguos, variifque arboribus amone confitos, traductas, ibidem jugiter choreas ducere. Spiritus malignos impenfe metuunt, quos Curipira, Taguai, Macachera, lurupari, Marangigoana vocant: fed diverfis fignificationibus, nam Curipira fignificat numen mentium: Macachera numen viarum, viatores præcedens. Petigares fingunt boni nuntii paranymphum: contra Tupiguauos \& Caryos medicum humanx falutis hoftem. Iuripari \& Anhanga fignificant fimplicitcr Diabolum. UMarangigoana non fignificat numen, fed animam à corpore feparatam vel aliud quid, inftantem mortem prenuntians, ipfis Brafilianis non fatis notum, \&.tamen illud vel maxime timent: ita ut interdum imaginario \& vano illorum terrore fubito exanimentur. Nec tamen ullis ceremoniis aut idólis venerantur : quidam tamen nonnumquam ftipitibus folo defixis, \& munufculis juxta pofitis illos fpiritus placare nituntur: rarius autem hi fpiritus vifibiliter inter illos comparent, licet multi aliter prodiderint.

Habent \& fagas, quibus vix aliter quam Medicis utuntur, iifque valetudinis recuperand $x$ defiderio valde funt obnoxii : interdum " $\&$ inter ipfos reperiuntur homines nequam, qui magicarum quidem artium rudes, fedludendi $\&$ ductandi miferorum animos gnari , infolitis quibufdam corporis jactationibus $\&$ gefticulationibus fui admirationem excitant, \& falfis quibufdam miraculis fibi fidem conciliant : illi popularibus fuis \& interdum integris provinciis perfuadent culturam agrorum penitus omittere, veniffe enim tempus, quo tellus omnia fponte fua ipfis fit productura, atque ipfa feræ illis uitro pabulum allatur $:$ : His aut fimilibus næniis miferos hofce, natura fua plerumque defides, ita infatuant, ut neglecto terræ cultu, fenfim commeatu deftituantur, præque inedia deficiant, donec impoftor ille folus fuperfit, nifi ante à fuis dolum perfentientibus trucidetur. Ceterum magos vocant Page : at "Caraiba eft illis poteftas miracula perpetrandi: quare Lufitanos, quia multa faciebant qux ipforum captum fuperabant, Caraibas appellabant, atque ita etiam hodie vocant \& Europxos omnes.

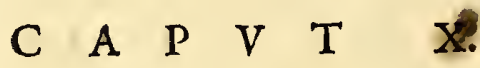

\section{De Lingua Braflienfoum, è Grammatica P. Iofephi de Anchieta, S. I.} Oc caput ab Autore noftro plane affectum tantum fuit derelictum : fed pervenit ad manus meas Grammatica lingux maxime ufitatx in Brafilia, compofita \& digefta à P. Iofepho de Anchieta, S. I. edita Conimbricx, Anno c Io Io x c v. è qua pauca delibabimus,ut guftum aliquem lingux demus.

I. De Litcris: Hæc lingua non habet $f, l, f$, 2, rr duplex, neque mutam cum liquida, ut, cra, pra, \&c. pro $\int$ autem in principio aut medio diçionis fervit $c$ cum zeura.

Non conjungitur confonans cum altera confonante in eadem dictione, excepto $m b, n d, n g$, ut, Acmomber, Aimondo, Aimeeng. Petiguares, qui juxta Paraibam incolunt, \& reliqui 
reliqui indigen $x$ ufque ad Tamoyes qui Rio de Ienero accolunt, verba, qux definunt in confonantem, pronuntiant integra: Tupis autem $\mathrm{S}$. Vincentii numquam pronuntiant ultimam confonantem in verbo affirmativo; ut, pro apab, dicunt $A p \hat{a} ; \&<$ ita in ceteris. In verbis item compofitis ut plurimum abjiciunt confonantem ultimam prioris verbi.

II. De Orthographia: P. m. mb. Fepe ufurpantur una pro altera, hoc modo : dictiones abfolute fumtæ pronuntiantur cum $m$ aut $m b$; ut, $M o$, vel $m b o$ manus : præcedente autem adjectivo mutatur in $p$, ut, Xepo, manus mea : excipe Mbae quænumquam mutat, ut, Xembae, mea res. $B$ autem in principio dictionis numquam pronuntiatur fine $m$, licet per incuriam interdum non frribatur. In medio quoque dictionis communiter ponitur $b$ poft $n: \&$ ufitatifima pronuntiatio, $b \& p$ in medio $\&$ fine diationis fere femper mutantur in $m$, aut $m b$, \& $c$.

III. De Accentu: Omnes dittiones qux definunt in quatuor ultimas vocales, habent accentum in ultima, \& notantur circumflexo. Quxdam autem qux definunt in $e$, videntur habere accentum in penultima, quod fit, quia funt compofitx. Qux definunt in a, partim habent in ultima, \& notantur eodem accentu, partim in penultima, \& notantur acuto: Monofyllaba autem accentu gravi. Verba denique maximam partem accentum habent in ultima fyllaba, in qualemcunque demum confonantem aut vocalem definant.

IV. De Nominibus: Nomina non habent cafus aut numeros diftinctos, præter Vocativum cafum, cum hac differentia; nimirum, quod ea quæ habent accentum in ultima, nihil mutantur in omnibus omnino cafibus.

V. Decompofitione Rominum: Nomina fubftantiva componuntur cum adjectivis, ita ut fubftantiva femper præcedant, \& fi habeant accentum in ultima, manent integra : fin in penultima $\& \mathrm{Z}$ vocales concurrant,perdunt ultimam vocalem, ut, Tuba ete, Tubete, pater verus. Si concurrant cum confonante, perdunt totam ultimam fyllabam. Denique fubftantiva cum fubftantivis junguntur ad eumdern modum.

V I. De Pronominibus: Pronomina habent aliquot cafus: ut Ego, Nominativ. $y x \hat{e}, x e^{\prime}$ Dativ. yxebe, yxebo, xebe, xebo, mihi : Nominativ. Pluralis, orê, yandê, nos: Dativ. orebe, orebo, yandebe, yandebo, nobis. Tu, Nominativ. cnde, nde, ne. Dativ. endebé, cradebo, $n d e b e, n d e b n$, tibi. Nominativ. Plural. peê, vel pe, vos: Dativ. Peême, vel Peémo, vos: Accufativ. opho, vel pé. Vocativ. pế, vel pe. Orêe, yandế, funt etiam Adjectiva, nofter, no-

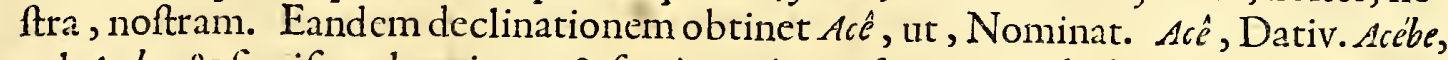
vel $A c e b o, \&$ fignificat hominem, \& fervit tertiæ perfonx, in ambobus numeris \& utro; que fexu; $c$, cum zeura, \& $i$ funt pronomina relativa in omnibus cafibus, \& numeris, $\&$ fignificant, is, $e a, i d$. Reciprocumo, id eft, fe, fuus, fua, fuum, ufurpatur fimpliciter, quando fermo refertur ad perfonam agentem, ut in lingua Latina, exempli caufa, Petrusoiucâoguba, Petrus occiditfuum patrem.

V II. De Verbis: quamvis omnia verba habeant unum modum Conjugationis, licet tamen dicere habere duos, quia Negativus adjicit aliquas particulas : exempli caufa; Aincû, ego occido; Nasncaî , non occido. Similiter autem fe habent Indicativi modi, Prafens, Imperfectum, Perfectum, \& Plufquamperfectum, in Futuro, Aiucine, occidam; Naamcaixorene, non occidam. Plurima autem obfervanda funt in Conjugationibus, qux brevitatis caufa omitto.

V III. De Prapofitionibus: qux tamen ipfis potius funt poftpofitiones, quales $M \hat{o}$ in, $P e ́$ in, ad, pro, cum Dativo. Bê in, per. 'Q2upé pro, cum Dativo. Cui de, ex, præter. Coce fupra, fuper. Tobaque, çobaque, coram. Tenonde ante, de tempore. Cupí per, de loco. Cotî verfus. Cecếvi, cum, propter, pro, in, à. lorupî longe: Pocê cum, inftumentale, in, intra. Pabê cum, focietatis. 2 ái i idem. In fingulis autem multa obfervanda, quorum pauca tantum hic fubjungam. Pe fi jungatur cum nominibus qux definunt in $b a$, cum accentu in penultima, facit perdere ultimam fyllabam, ut Taba aldea, Tape in aldea. Bo femper eft plurale. Coce fignificat locum \& exceffum, atqueita fervit pro comparativo, ut, Itâcocếfuper lapidem, vel plus quam lapis.

Porro ut guftum demus aliquem hujus lingux, Dictionariolum adjungo, quale ab Emanuele de Moraes, linguxillius peritiffmo, accepi, \& quidem primo Nominum. 


\section{$\begin{array}{llllllllll}C & \text { A } & \text { P } & \text { V } & \text { T } & \text { X I. }\end{array}$}

\section{Dictionariolum nominum \& verborum lingue Brafilienfibus maxime communis.}

$1 \begin{aligned} & B \hat{a}, \text { homo. } \\ & A b a, \text { vir. } \\ & A b a, \text { crines. }\end{aligned}$ $A b a i b a$, fponfus futurus. Acangapé, cranium. Acaya, matrix. Acayûroig, Annus. Aceoca, jugulum. Acu, finiftra manus. Acuabeimbae, fatuus. Amaberaba, fulmen. Amacûnunga, tonitru. Amandiba, grando. Arîma, cognatus. Anga, anima. Angaibara, macer. Angaipaba, pravus, antutus. Angaturama, gratus. Apara, curvus. Apecum, lingua. Apicaba, fedes. Ara, aër. Ara, dies. Ara ibicoquime, meridies. Ara, tempus. Araya, avia. Atepuana, levis. Atapuâtia, velox. Atucupe, dorfum. Atyba, humerus. $A y$, Cig, mater. Ayûra, collum.

Boya, fervus.

Cama, mainma.

Canga, os oflis.

Caraibcbề, Apiabebê, Angelus. Caruca, vefipera.

Capiî, gramen.

Capiigoacu, Atramen.

Catû, delicatus.

Cay, fimia.

Ceba, folium,

Cebira, nates.

Cemiraco aôbae, viduus.

Ceo, animal.

Cetecímibaê, Spiritus.

Cig, Cygra, amita ; eifdem nominibus fignificant \& avunculum \& materteram.

Coaracî, Sol.

Cobra, anguis.

Coernitanga, aurora.

Coribae, letus.

Coya, gemini.

Cunba, femina.

Cunbaiba, fponfa futura.

Cunumigoacu, adolefcens.

Cunumi, puer.

Ecatuaba, dextra manus. Eyruba, apes.

Gibâ, brachium.

Guaibino, vetula.

Guirarupia, ovum.

Iaci, Luna.

Iaci, menfis.

Iacitatá, Stella.

$I b a$, arbor.

Ibâia, Cxlum.

Ibatinga, Ibitinga, nubes.

1 lbatebae, altus.

$I b i$, terra.

Ibitira, mons.

Ibut $\hat{u}$, ventus.

Icapî, ros.

Ig, aqua.

Iguaba, calix.

Ipeca, anfer.

Ique, latus.

It a, ferrum.

It $\hat{a}$, lapis.

Itacira, ligo.

Itapigua, clavus.

Imba, flavus.

Mâupiâra, bilis.

Mbaê apapuara, fáfis.

Mbaean̂bora, xgrotus.

Mbiñ , cibus.

Mbô, manus.

Membeca, mollis.

Mendara, matrimonium.

Mitu, digitus pedis.

Mitâ, cal canẹus.

Mocu, anguilla.
Mormotara, iracundia. Mua pendaba, articulus.

Nhia, cor.

opacatumbae, mundus.

Pocembuera; membrum.

Potia, pectus.

Poranga, pulcher.

Porerobiara, fielelitas.

Porucuicôbora, pauper.

Potiví, anas.

Poxî, deformis.

$P \hat{i}$, pes.

$P i \hat{a}$, jecur.

Pirâ, pifcis.

Pirâ, cutis.

Piquîra, minor natu. His nominibus utuntur feminæ inter fe.

Pitanga, infans.

$P u a ́$, digitus.

Puâ guaçu, pollex.

Purva, umbilicus.

Pucu, longus.

Putuna, nox.

Roig, frigus.

Tagica, vena.

Taguî, fanguis.

Tagira, filia. His duobus nominibus pater tantum utitur, mater dicit Menbira.

Tair , liberi, \& filius.

Tamûa, avus.

Tata, ignis.

Tecoacû, felicitas.

Tecoateima, avaritia.

Temireco, maritus \& uxor.

Terdiba, mentum:

Tendì, fputum.

Tendipia, genu.

Tecobecatu, fanus.

Temâ, tibia.

Tetê, corpus.

Tiaya, fudor.

Tibira, minor natu. His nominibus 
minibus utuntur fratres tantum inter fe : ficuti Tiquers, foror major natu. Quibira, frater, forores tantum erga fratres, \& Teindira foror, fratres tantum erga forores.

Tigne, venter.

Tigueperg, inteftinum. Tinga, albus.

\author{
Tyurì, vefica. \\ $V b a$, coxa. \\ Vnhr puapem, unguis. \\ $r \hat{a}$, fons. \\ $\Upsilon$ Imeneóbac, vidua. \\ ryabeimmbae, nudus.
}

\section{Dictiondriolum verborum maxime communium.}

\section{A} $B \hat{i}$, errare. Abiqui, pectere. Acanbern, morior. Acoy, operire. Aề : crrare. Ami, premere. Amotareima, odifle. Ana'uba, fentire. Angaipaba, delinquere: Aóba mondêba, induere. Apina, radere. Apition, ligare. Aroca, minuere. Ayaima, fternutare.

Berâba, fplendere.

Caanga, metiri. Caanga, guftare.

Caanga, dicere. Cacábs, tranire: Caé, fanarc.

Capira; purgare. Capucaya, clamare: Capucầya, ringi. Carom, fperare. Caruca, mingere. Cauccuba, diligere. Cecarâya, oblivifci.

cema, exire.

Cenduba, audire.

Cenoya, appellare.

Cenoya, vocare.

Cepiaca, videre.

Cepiaca, reprehendere.

Cerûra, portare.

Cetîna, odorare.

Ceyara, deferere.

Cica, arare.

Cipîja, rigare.

Ciquige, timere.

Cồ, ire.

cobaitim, occurrere.

Coguendaboya, aperire
Cuâba, cognofcere.

Cupira, levare.

Cuu, defendere.

Ecatth, poffe.

Genonbeca, precari.

Goameenga, mordere.

Guapua, federei.

Guata, ambulare.

Gueena, vomere.

Iabâba, effugere.

Iecoacuba, abftinere.

Lenumuina, fpuere.

Ierure, pofcere.

Igtaba, natare.

Ig $\hat{u}$, bibere.

Macnduara, recordari.

Mano, mori.

Maramonbanga, belligerare.

Mayaoca, dividere.

Mbaeraca , emere.

Mbaeû, edere.

Meenga, tradere.

Menbirara, parere.

Moabaîba, incántare.

Moabaîba, impedire.

Mosguêba, reftinguere.

Moanga, cogitare.

Moaquima, madefacerc.

Mobibua, fuere.

Moete, laudare.

Moetê, adorare, honorare.

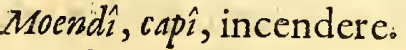

Mogiba , coquere.

Mogycô, polire.

Momiya, movere.

Momiya, movere. Potara, cupere.

Monberaba, vulnerare.

Monbeu, nuntiare.

Monbuca, perforare.

Monbuja, terebrare.
Mondoca, incidere.

Mondoca, fcindere, aufer-

re.

Mondôca, findere.

Mondoroca, frangere.

Monguy, molere.

Monguya, folvere.

Monhanga, facere.

Moperu $\hat{a}$, frigerc.

Mopotaya, ncctere.

Moriba, confentire.

Moropiaña, commutare.

Moyarî, jocari.

Moyeceâra, mifcere.

Nheangeru, fufpirare.

Nheenga, loqu.

Nhemboe, difcere.

Nengara, cantare.

Paepina, refpondere.

Paraboca, eligere.

$P$ aronduba, inquircre.

$P e \hat{a}$, vitare.

$P e \hat{a}$, deponere.

Pita, manere.

Pitanga rempî, concipere.

Pitêra, of culari.

Pitêra, forbere.

Pitilô, juvare.

Pituba, ungere.

Poacêma, gemere.

Pobâna, nere.

Pocuâba, confuefcere

Pocaucuba, fomniare.

Porabiqui, operari.

Porâra, mentiri.

Potareima, recufare.

Priaya, jubere.

Puca, ridere.

Pura, uti. 
2uera, dormire.

शereraro, vigilare.

\begin{tabular}{|l|l|} 
Tara, capere. & Tima, fepelire. \\
Tecobe, vivere. & \\
Tiguioca, fanguinem redde- & Yacế, plorare. \\
re. & Yeaôboca, exuere. \\
Tiî̀, pudere. & Yeupîra, afcendere. \\
Tíma, plantare, terere. & Yucî, occidere.
\end{tabular}

Raba, folvere.

Rerecî, haberc.

Rura, venire.

Notandum autem, illos multa habere vocabula, tam nomina quam verba, qux plura \& diverfa fignificent : exempli caufa: $A$, fignificat fructum : item dilectum commilitonem, ut cum dicunt, Mamô cuipe ereym Xe $a$ : unde venis, dilecte commilito? Item $A$, membri virilis caput: ex modo autem \& tempore loquendi intelligitur de quo loquantur.

Accang jaculor, lego, metior, pondero, delibo. Aâr cado, ut Aâr quecể lbípe, heri cecidi in terram. Item $A \hat{a} r$, intelligo, ut aár coite aipô recế, nunc hoc intelligo. Sed de his fatis.

\section{A P V T X I I.}

\section{De Tapuiyarum moribus, \& confuetudinibus, è Relatione Iacobi Rabbi, qui aliquot annos inter illos nixerat.}

I

Ncertis picrumque fedibus vagantur inftar Nomadum, inter certos tamen limites, inter quos caftra mutant fecundum Anni tempeftatum mutationem; itaque Regulus eorum, qui otshisayayne dicitur, à maximo flumine, quod fines corum permeat, ut fupra diximus, cujus gentile nomen eft landui, vefperi \& mane per caftra proclamari curat pro arbitrio fuo , \& confultis ante divinatoribus fuis \& hariolis, quo proximo mane promaturi fint, $8 c^{\prime}$ ubi confefluri, atque quid interdiu a ouri. Mane antequam iter aggrediantur, fluvium ingrediuntur, \& fe abluunt, \& nitidiffima arena corpora fua fricant, \& rurfus abluunt: atque inde egreffi artus fuos ita extendunt $\&$ contorquent, ut articuli ipfis crepitent; Hinc ad focum accedunt, \& calefacti, denticulis quorumdam pifcium ita fe fcabunt, ut fanguinem multis locis eliciant, quod ad lafftudinem in itinerando demendam plurimum putant prodeffe. Scribit Rabbifefe id fxpe effe expertum utile effe.

Ad lapidis jactum à Reguli tabernaculo, duo trunci arborum humi jacent unius paffus intervallo à fe invicem diffiti, populus autem univerfus in duas turmas divifus ex adverfo confiftit ; hinc unaquxque turma eligit unum è robuftifimis, qui truncos illos fuccollant \& quam poffunt celerrime portant, fuccedunt dein alii aliis ex eadem turma; qui autem primi ad locum caltris deftinatum pervencrint, tardioribus infultant, atque illos exfibilant. Operiuntur hic juniores qui arma illortim $\&$ fecures af ferunt, hinc arbores certatim cædunt $\&$ pergulas conftuunt, fub quibus æatum folis vitare poflint; inter ipfos rivulos. Inter ea adveniunt $\&$ femin $x$ cum reliquis impedimentis : \& viri egrediuntur, pro locorum conditione aut ad pifces, aut ad feras capiendum ; atque itidem mel filveftre colligendum: vetulæ vero ad radices eruendas, è quibus farina confici polfit, \& panes coqui : domi autem alix aliis auxiliantur \& parant manibus cibum $\&$ potum : qui deinceps tempus terunt haftilibus certando, luctando, currendo; quibus certaminibus dux femin $x$ ad id felect $x$ præfident, \& judicant de fingulorum virtute $\&$ viatoribus.

Vbi vefpera advenit, coëunt adolefcentes in varias cohortes, \& caftra perambulanres cantillant ante tuguria, adolefcentulæ autem quæ juvenibus delectantur, prodeunt, \& cantillantes arque tripudiantes fequuntur adolefcentes, \& $\mathbf{a}$ tergo confiftunt eorum, quos amant, id enim ipfis amoris teftimonium eft. Cum porro juvenes jam ad nuprias afpirant, venantur feras, $\&<$ colligunt mel filveftre, aliaque, atque ad Patres dilectarum conferunt: qui fi plures filias nubiles habeant, advocant prophetas \& fortilcgos fitos, medicolque; illi autem adcunt Regulum ad deliberandum. Regu- 
DE BRASILIE REGIONE ET INDIGENIS. 25 lus porro convocat per præconem Adolefcentes procos in proximum extra caftra, ubi plurimi, tam adolefcentes quam puella, conveniunt, \& conjunctim per fylvas vagantur, donec ad locum vcnationi deftinatum pervenerint; atque hic confilio capto paucillorum progrediuntur, ut ferarum latibula indagent, qui, ubi illa offenderint, ocyfime ad reliquos regrediuntur, $\&$ indicant quo loco ferarum fit copia : deinceps omnes cum armis \& canibus feras indagine cingunt, atque ita propere in illas rutun, ut nonnumquam ducentas feras fimul capiant, \& mactent, atque poftquam latcribus apertis inteftina canibus objecerint, illas inferunt caftris. Accurrunt dein teminx, $\&$ foco facto, vifcera primum torrent viris in cibum: dein pilis ablatis, ferarum corpora concidunt in plures partes: poftilla fovea intra terram facta, prunas illis indunt, atque eifdem carnes ita concifas fuperimponunt, aggeftaque arena, rurfus focum fuperftruunt, ita ut carnes percoquantur, haud fecus quam in furno. Quidam \& mella colligunt \& potum conficiunt; atque ita comeflando diem exigunt. Dein iterum accedunt ad Reguli tabernaculum ad deliberandum ubi proximo die venatio fit inftituenda; quo conftituto, difcédunt in cohortes ad cantillandum, è cantionum enim modo augurantur an venatio bene proceffura fit necne. Venatione abfoluta, rurfus comeflantur ad eumdem modum, \&\& ii qui domi manferunt, conferunt farinam è radicibus factám.

Diximusjam ante, Barbaros hofce labia, auriculas \& genas perforare: hic actus ab ipfis inftituitur ad hunc modum. Adolefcentes ad hoc parati educuntur ad locum in quem populus convenit ad cantillandum \& faltandum. Sortilegi autem cortin atque dxmonum incantatores duplici ordine ex adverfo confifunt, atque eorum unus arripit puerum aliquem, \& manus illius atque pedes arde conftringit, \& $\&$ ita tenet, ut fe movere non poffit, accurrit alter qui puero inferius labium acuto ligno perforat, uti \& auriculas, matre pueri interea ejulante. Adolefcentibus porro foramina terebrant in genis, atque hre funt veluti fponfalia; neque enim ante adolefcentes hæc fubeunt, quam ad nuptias afpirent : dein per triduum aut quatriduum comeffantur : in ifto autem nu ptiali convivio Regulus ipfe fuas cuique partes diftribuit, de cibis qui parati fuerunt.

Matres imprimis hoc curant, ne filix ipfarum ante ad conjuges accedant, quam menfes earum fluxerint, quod fortilegis fuis \& medicis indicant, atque illi Regulo, \& ita demum fponfa ad fponfi fui cubiculum adducitur : celebratur porro cantilenis mater, quod filia pudicitiam tam bene cufodiverit.

Quod fi matris fit filia aliqua matura viro, quæ tamen non petatur;tunc mater eam fub oculis rubro colore pingit; ubi menfes fuos femel paffa fuerit, $\&$ adducit illam ad Regulum , \& exponit quid defideret, tum Regulus, juvenculam ad fevocat, $\&$ in ftorea juxta fe confidere mandat, \& fingens fe medici partibus fungi, manus ad focum calefacit atque iis fe demulcet; dein \& $\&$ e, \&juvenculam Tabaci fumo affat; denique pene juvenculie pudenda ferit , fi autem fanguinem eliciat, hunc delingit, atque hoc imprimis honorificum putant.

Feminx prxgnantes factæ deinceps à virorum confortio abftinent. Vbi autem pepercrunt, fecedunt in filvam, \& infanti umbilicum concha prxcidunt, \& una cum fecundinis coctum devorant : puerpera autem atque infans mane $\&$ vefperi frigida abluitur : neque, femina quamdiu infantem furm lactat, cum viro fuo confuefcit, nifi for te ille unicam tantum conjugem habeat.

Si femina cum alterq confuefcat, $\&$ viro id innotuerit, abigit illam à fe : fin autem in ipfo actu forte deprehenderit, utrumque occidere licet, fi poffit. Narrat Rabbi Regulum Ianday aliquot fuarum conjugum ita trucidaffe, mœchis dilapfis.

Regulus Ianduy habet in medio tabernaculi fui ingentem cucurbitam, fuper ftoream ita difpofitam, ut ab altera ftorex parte cooperiatur, ad quam fine mandato Reguli nemini accedere fas eft,aut cucurbitam incrofpicere, fed cum Tabacum fumunt, licet fumum in illam exfpirare : feras autem $\&$ mella quæ inferuntur, juxta illam deponunt, donec Regulus imperet illa auferre: fingulari autem fuperftitione $\&$. timore percellit fuos hac cucurbita. In illa funt lapides quidam, quos illi appellant Kebnturah, \& fructus quidam, ipfis Tiizsheynos, ques majoris faciunt quam aurum.

Non poffum praterire quin hic addam, quibus præftigiis illi qui medicinam inter illos profitentur, hominibus ægris illudant. Narrat Lacobus Rabbi, cum Regulus 
Drarugh xgrotaret magnumque dolorem pateretur in latetibus \& cruribus; neque à fuis medicis quicquam folatii acciperet, ad vicinum Regulum profeetum, ut ipfius medicis uteretur ( adhibiti tres, quortm primus, Tabaco fumto totum Regis corpus eo perroravit, dein, arreptis illius genibus, illa ita fuxit quafi devoraturus effer, \& boatu quodam inftar tauri edito, primum plurimum fputi è gutture in manum effudit, atque una femivivum animal inftar parve anguillx, quod Regulum ita dolore cruciaffe afferebat. Alter medicus poftquam ventrem Reguli eodem modo fuxiffet, \& inftar fer $x$ rugiiffet, album lapidem è gutture evomuit, figura pene rofx. Et repetita fuctione in lateribus, evomuit aliquid fimile radici. Ad eundem modum perpetuo agunt \& à credulo vulgo creduntur magni effe medici.

Martio \& Aprili menfibus maxima aquarum vis de montibus defcendit, ita ut $\mathrm{flu}$ vius otfchunogh fe inflet \& ripas fuas egrediatur atque in vicinum lacum Bayatag exun$\mathrm{det}$, quo tempore tantam pifcium multitudinem capiunt, quantam feminæ in caftra vix referre poffunt: eodem \& præcipui illorum fructus maturantur. Vbiautem Allvius intra alveum fuum coërcetur, ad confuetas fedes redeunt, \& fementi dant operam: ferunt autem imprimis grandius Milium feu Maizium, Phafeolos varios \& Cucurbitas lagenxformes, aliafque.

Antequam femina terræ committant, folum à fortilegis \& prophetis illorum ab ortu ad occafum luftratur, \& femina vaporantur fumo Tabaci, hoc ad foecunditatem proficere autumant. Nec minus anxie \& fuperftitiofe divinatores fuos confulunt de anni fertilitate, qui vario plumarum ornatu atque aliis monilibus infignes credulum vulgus miris praftigiis effatuant : quod interea cantillando tempus terit.

Ubi fenentis eorum ad maturitatem pervenerit, \& fruges collectr fuerint, tanzum feponunt, quantum ad proximam fementem fufficere putant, reliquum abliguriunt.

Imprimis venerantur Pleiadum exortum, \& ftellas illas numinis loco colunt, canendo \& choreas ducendo ; prefertim in loco ad id deftinato, quinque fupra quadraginta horarum itinere $\mathrm{ab}$ ot fichunogh , quo tendunt, cum fructus filvarum \& camporum maximam partem jam maturi funt. Hic autem Adolefcentes omnes qui haftis lufuri funt, poft triduum cantando $\&$ faltando exactum, fe parant ad certamen; \& quidem primo furas vinciunt lento quodam vimine, è quo $\&$ calceos confectos induunt : deinde melle capita inungunt, \& capillos poftica parte fubligant, \& longiori avis penna erecta infigniunt: mox rubro pulvere capillitium ad occiput afpergunt, fronti autem albas applicant plumas; denique faciem variis pingunt coloribus, uti $\&$ reliquum corpus; dorfo autem alligant fafciam è frondibus confectam inftar caudx, brachiifque alas volucris, quam vocant $K o f e t u g$, \& cerviciitidem circumdant pennas rubras. Ita ornari certant per triduure, \& vidtores ovantes faltant. 


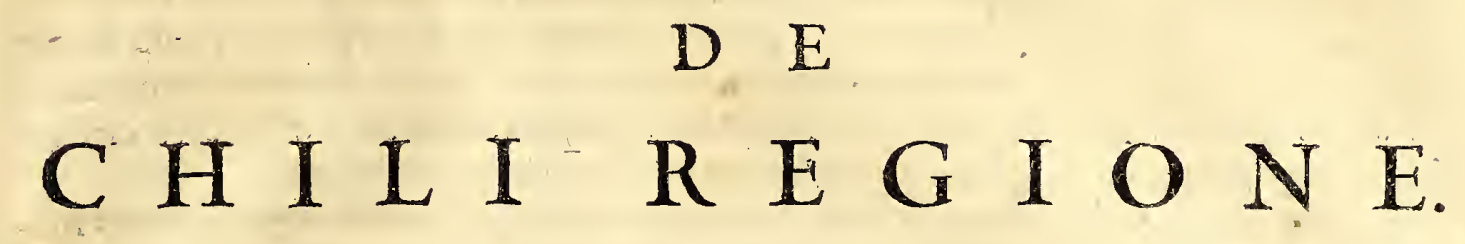

$\begin{array}{lllllllllllllllllllllll}C & A & P & V & T & P & R & I & M & V & M\end{array}$

De Cbilenfium fatura, o babitu corporis, atque veflitu.

Icet Chilenfes longe diffiti fint à Brafilienfibus, quia tamen ì eodem Continenti fere à tergo habitent, atque à noftris nuper fuerunt luftrati, non prorfus alienum putavi quædam de illis hîc fubjungere, è variis Commentariis noftrorum, quos Illuftr. Princeps Ioan. Mauritius fubminiftravit.

Indigenz Chilenfes in communi, fatis robufto \& compacto funt corpore : coloris inter album \& fufcum: nigris \& craflis capillis : qui autem illorim $\mathrm{H}$ fpanis ferviunt, geftant illos prolixos $\&$ intonfos, verum quiadhuc fui funt juris $\&$ cum Hifpánis belligerant, vulgo Vcais appellati, attondunt illos, ne, ut ferunt, $\mathrm{ab}$ hoftibus fuis, iis apprehendantur, ita ut hoc figno à fubjectis Chilenfibus dignofcantur:

Capite ut plurimum funt grandiufculo \& facie lata, imberbes, quia illàin evellunt duabus mytulorum conchis, arete connexis, \& una parte firmiter ligatis, quas fecum \& quidem ad collum appenfas geftant: etenim non tantum è merito \& genis; fed 80 pudendis partibus omnes pilos evellunt, tam mares quam feminx, \& primum cineribus calidis illos fricant, ut ita facilius radicitus evellant.

Nudo incedunt capite, $\&$ folummodo redimiculo capillos capitis fubligant, quod vinculum fuo idiomate vocant Tariwelonco: primorefque illud paulo operofius $\&$ pretiofius geftant, utpote lamellis quibufdam argenteis \& Turcoidis gemmæ fragmentis, \&aliis quibufdam quifquiliis, quas illi tamen magnifaciunt, intertextum. Quidam etiam ornamenti loco geftant exuvias volucrum \& pelliculas muftelarum $\&$ fimilium, animalium, divifas, ita ut caput frontem, cauda cervicem, tegat: at que nominant Maniewelonco; pauciflimi denique pileos geftant, quos ipfi faciunt groffo modo.

Femin $x$ itidem capite nudo \& comis folutis incedunt : certis tantum teinporibus fubligant, videlicet quando menfibus laborant, atque hoc indicium facic. Feminz tamen Chilenfes, quæ prope Caftro degunt, comas colligant \& cincinnos geftant pene ad noftrarum hodiernum modum : In Coquivabo denique \& Loquimbo Peruanarumi mulierum cultum imitantur, utpote iis viciniores ; aliis provinciis Chili hoc infolitum.

Amiciunt fe panno, quem texunt ipfè è lana fuarum ovium: paucx cnim reperiuntur feminæ qux texere nefciant, atque adeo machinas ipfas diponere; maximi autem eorum quos texunt pannos, vix fuperant quatuor aut quinque ulnas noltrates: Mares autem fumunt hujufce panni quadratam portionem, circiter duas \& femis (paulo plus aut minus) ulnas longan, \& circiter ulnam aut fefquiulnam latam; in cujus medio rimam faciunt, oblongam, qua caput exferunt : fub hac vefte veluti tunica, pro frigoris modo, bis terve revoluta, nudum corpus tegunt, fine thorace aut indu\{io, bracca ab umbilico ad genua ufque propendente contenti, more pene Europæo. Pannus hic ut plurimum diverforum eft colorum, albi, rubri, cærulei, \& lutei , \& ad oras ftriati, inftar lodicis Hifpanicx. Ceterum nudipedes incedunt, praterquam quod quidam feftivis diebus caligas induant fatis affabre factas, \& quadratis albis nigrifque teffulatas : calceorum autem ufum penitus ignorant.

Feminæ, quoque quæ circa Chiluen degunt \& fere Peruanarum mor es æmulantur; fimilem pene amictum ferunt, à poftica parte ad talos demifium, in lateiribus confutum, ad pectus apertum, fuper humeros magnis aciculis, qux capitella habent lata, ambitu fere dupli fuferi, utramque fimbriam connectunt : funt aut aciculx ifte five fibulæ ex ære aut ftanno pro illarum opulentia. Hanc togam redimiculo fubligant; ceterum $\&$ ipf $x$ nudis pedibus ambulant. Cetera Chilenfes femina amictum hand 
ita compofitum ferunt, folummodo geftant quadratum pannum fub uberibus circumjeetum $\&$ dependentem ad furas ufque. Superior veftis eft alius pannus paulo laxior fub humeris, fuper eofdem angulis fuis in nodos coactus : hic earum communis amictus, fin vero maritis fuis placeant, \& paulo exquifitius ornentur, orbiculos circum collum geftant vitreos, \& æxeos annulos in auriculis, neque aliud quid.

Ommes autem Chilenfes munditiarum amantiffimi funt ; quare ingulis diebus manefefe abluunt, etiam gelu fæviente, tam mares quam feminæ.

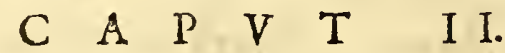

\section{De Cbilenfoum actibus, fupellectile, agricultura, victu, es connubiis.}

$\mathrm{I}$ Pforum domicilia funt tuguria feu cafre humiles; quarum tam larcra five parietes, quam tecta, è ftramine, juncis aut arundinibus funt contexta : atque hæ hîc illic funt difperf $x$, neque enim aut oppida aut pagos inhabitant, fed per vicinitates, atque adeo familias $\&$ confanguinitates in unum locum aggregantur: \& Hifpanico nomine appellantur $P$ artialidados, quatenus ad unum primorem, feu, ut ipfi vocant, $C a-$ racam, referuntur, à quo \& ifta communitas regitur.

Supellex quoque illorum tenuis \& pauca : nimirum dux aut tres amphoræ, quibus potum fuum indunt, quem vocant Chicam : item cyathus corneus quo illum hauriunt: duo aut tres lignei lintres: Lapis fiper quem far fuum frangunt; mum atque alterum ligneum fedile. Opulentiores tamen habent vellera aliquot ovium, qux humi fpargant, quando à potentioribus invifuntur.

Vivunt fine ulla folicitudine, neque ferunt neque plantant, quam quantum in annum proximum opus habent: fiquidem opes illorum confiftunt in pecudibus: quarum ta:men haud magnam habent copiam.

Sementem faciunt hoc modo: OAobri ingrediente, familix unius vicinitatis, decem, viginti aut plures pauciorefque conveniunt, \& conjunctis laboribus, mares uno atque altero die fodiunt terram, aut etiam arant, feminaquc injiciunt : atque hac opera defuncti, feminis relinquunt reliquam culturam, neque ipf amplius manus admovent. Communiter à mane ad vefperan comedunt $\&$ potant, cum funt domi ; fi vero foras proficifcantur, nimirum ad conventum aliquem aut expeditionem bellicam, bis tantum fingulis diebus cibum capiunt, quod \&à paucis qui frugaliores funt,etiam domi fervatur. Raro aquam folam bibunt, fed mifcent illam communiter cum farina hordeacea, tritici, aut certæ fpeciei farris, quan vocant Tecam (defcriptam à I. de Laet lib. XI I. Defcr. Ind. Occident. cap. 2.) atque ita fimul forbent: vcrum fefivis diebus, \&zvoluptatis caufa, bibunt certum potum quem nominant Chicam, qui colorem \& faporem habet lactis acidiufculi : fit autem è maizio molito \& in mafam coaCto inftar panis; hæc maffa à vetulis mafticatur (uti apud Brafilienfes) ita ut mollis $\&$ diluta evadat inftar pultis aut feri lactis, admifcent deinde aliquantum aqua \& fermentari finunt, donec perfe confidat : hoc potu inebriant fefe: faciunt quoque ficeram è variis pomis, cui tantum aquæ admifcent, ut fere tenuem cerevifiam referat. Vcrum optimum porum conficiunt è certo fructu, quem Hifpani appellant Frutillo; credo effe fructum arboris Molle, aut Myrtillam, quam vocant Vnni (vide lib. fupra citatum:) qui inftar vini eft rubicundus $\&$ fortis, accedens nonnihil ad vinum Infula: Mader : è quo $\&$ optimum fit acetum.

Tot uxores accipiunt, quot poffunt alere; opulentiores enim plures habent : fiquidem illas emunt à parentibus, unde proverbio inter illos fertur, cos ditiores evadere qui plurimas habent filias : in uxoribus autem eligen dis non tam rationem habent formæ aut generis, quam roboris $\&$ induftrix in familia alenda : licet neque formam aur nobilitatem puellarum afpernantur.

Ducturus autem uxorem, puellam haudalloquitur, fed tantum fuos confarguineos, opem illorum implorans; nam filiusfamilias non habet proprias opes, quibus illan redimat, fed ab amicis adjuvatur, quorum aliusovem, alius porcum, cercius vaccam, $\&$ ita porro largiuntur: ubi jam parata habet, qux fufficere autumat, adit patrem puellx \& ape- 
\& aperit fuum defiderium: fi autem fit \#lmen aut alicujus dignitatis, neceffe etiam eft ut paratum habeat monile aliquod è Turcoidibus aut argenteis lamellis (majoris enim faciunt argentum quam aurum) quod patris puellæ capiti aut collo circumdet, \& tum de reliquo pretio conveniat; quod pro diverfa contrahentium conditione variar, \& interdum decem, interdum viginti , vigintiquinque, quinquaginta, imo \& centum penfionibus aftimatur, penfiones autem fingulx funt ovis aut equus aut vacca aut porcus, aut etiam quatuor amphor $x$ Ciche, toga denique $\&$ gallina, atque ita porro. Vbi ita de pretio inter patrem puell $x \&$ procum convenit, emtor preftat pretium $\&$ pater venditam puellam adducit domum fponfi: fympofium nuptiale inftruitur, quoad cibum à fponfo, quoad potum à focero, qui pretii dimidiam partem inter fuos confanguineos diftribuit, ut illi fuccurrant in Chica conquirenda. Aliquot diebus poft hanc conjunctionem confanguinei venundatam invifunt, \& convivio excipiuntur à marito, \& canunt in honorem Maruapeante : prafertim fi animadvertant illam à conjuge diligi.

Fit $\&$ interdum, ut, fi animadvertant, illam durius haberi quam par eft, conjugen per vim à marito abducunt, nilla pretii foluti compenfatione facta, atque alteri elocent. Licet mariti more ipfis communi jus vitæ $\&$ necis in uxores ufurpent, uti in mancipia , è quo facile animadvertere, quam firma fint vincula conjugii è parte mariti, néque enim ipfi illam dimittere licet, quandiu ipfi vivit ; non alteri vendere; tantum ejicere, fi perperam fegerat: quanquam nonnumquam fiat, ut fine jufta caufa egerat, fed. tunc ipfi metuenda eft confinguineorum fimultas $\&$ vindicta, fi conjux paulo potentiores habeat. Nihilo fecius hic nultz conjuges per vim à maritis fuis abducuntur, $\&$ quidem impune.

Viri paulo opulentiores fingulis uxoribus conftruune cafam peculiarem : ubi autem cum aliqua illarum confuefcere eft animus, mittit ad illam, ut ipfum expectet: quod $\&$ interdum clanculum fit, ob cæterarum invidiam : nihilominus utitur jure fuo , \& cum dilectifina convenit, cærereas pene mancipiorum loco habet, quæ \& metere \& cætera domeftica munia obire coguntur, fiquidem mares, ut ante dictum, folummodo fementem faciant.

Vbi autem conjugum aliqua peperit, feftum agitur, \& ovis illius terr $x$, qux Chiluvaque ipfis dicitur, mactatur, \& puerper $x$ datur comedenda caro; ut robur denuo acquirat ; licet feminx hic ftatim poft partum aqua frigida fe abluant, \& redeant ad domeftica munia. Quinimo affirmant Hifpani, fuas quoque conjuges ab aëre ad eundem modum indurari, \& robuftiores fieri ad facillime enitendum.

Chilenfes omnes funt valde Zelotypi, itaque fi quis peregrinus ipfos invifat, \& feminaillos modo intueatur, vapulandum ipfi eft: fin autem deprehendant, illas cum aliis moechari, fine ullo judicio publico trucidant : neque tamen propterea caftius vivunt, \&non raro viri multa coguntur diffimulare.

Viduis áutem feminis fecundo matrimonio fe tradere haud quidem illicitum eft, honeftius tamen exiftimatur, fil liberos habentes; innuptæ maneant, \& aut ad parentes aut confanguineos fios redeant. Sin autem nullos habeant liberos, veluti in peculio mariti cenfentur, \& cum cæteris bonis ad hæredes tranfeunt.

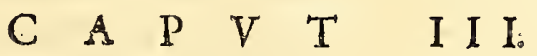

\section{De Cbilen fum Jenfu de Religione, \& cultu numinis:}

$\mathrm{C}$ Hilenfes neque Deum norunt, neque illius cultum, nullum obfervant dierum. difcrimen, ne mortuorum quidem refurrectionem credunt, fed poft obitum nihil hominis putant fupereffe $:$ nihilominus noverunt Diabolum, \& quidem ut adverfarium boni ; \& quemadmodum vitam hanc fummum bonum judicant eorum omnium quibus fruuntur, ita vulgo aiunt, ubi quis inter eos defunctus fuerit, illumà Diabolo abreptum effe : quod ipfi fuo idiomate dicunt slverey.

Cærterum aliquo defuncto, is plangitur à confanguineis \& amicis; fervant autem cadavera dudum infepulta, interdum duos, tres, aut plures menfes, reponunt ea fuper herbas bene olentes, atque iifdem cooperiunt, ne foetor offendat; ubiautem fepulturx tradere volunt, triduo ante amicos convocant, \& convivantur, ove illius 
terra mactata, cujus \& partem aliquam cum amphora Chicx capiti illius apponunt; atque ita tandem cadaver intra terram deponunt prope cafam illius quam inhabi: tavit.

Veruntamen his non obftantibus videntur aliquantulam habere notitiam fupremæ eflentiæ $\&$ alicujus divinitatis, à qua omnia terrena $\&$ human $æ$ quoque actiones gubernentur $\&$ dirigantur, cujus tamen effentiam non intelligunt: quidam enim illorum credunt aërium fpiritum, quem appellant Pillan, \& in fympoliis fuis potifimum venerantul \& celebrant, cuique cantiones attribuunt, peregrino geftu \& cjulatibus: maxime autem illum colunt cum tonat, fumuntque fagittam aut etiam fecurim lapideam inftar cunei, \& infigunt terr $\mathscr{x}, \&$ circumftantes vociferantur \& canunt, petentes, ut Pillan hoftes iplorum perdat: nam dictio Pillan etiam tonitru iplis fignificat , \& tonitru pronumine agnofcunt: nam cum hilariores funt $\&$ comeflantur, $\&$ tonitru interea accidat, omnia omittunt, \& concurrunt ad arma, credunt enim tonitru monere ipfos, hoftes fuos Hifpanos adeffe, \& affirmant fe idiplum perpetuo effe expertos.

Porro omnes fortes \& preftantes viros, itemque primores, confilio \& manu prom: tos, infigniunt nomine pillan, ipfis divinas virtutes attribuentes.

Cum Tabaci fumum hauriunt, quod $\&$ ipfis familiare, miris quibufdam cæremoniis illum in aërem exhalant, dicentes, accipe hæc Pillan, cum aliis quibufdam fermonibus, quos neutiquam noftri intelligere potuerunt, fed videntur hoc pacto numini litare.

Quando aliquam victoriam ab hoftibus reportarunt, tunc feftum celcbrant, non fine compotationibus, \& (quemadmodum jam diximus de tonitru) fecurim illam lapideam infigunt terr $\mathfrak{x}, \&$ circumftant cum armis fuis, \& cantillant epinicia , qux nominant Pavvary, in honorem Pillan. Eodem modo agunt cum aliquem exhoftibus captum, occidere deftinarunt; feriunt autem illum inter fympofia (nam \& illum convivari \& canere permittunt) fecuri aut clava in capite, ita ut concidat, \& cor eximunt è pectore, $\&$ dentes cruento infigunt, cum cantu $\&$ vociferatione ad Pillar, ut ante.

Puniunt quoque homicidas $\&$ famofos latrones atque fures, proditores, \& fimiles, morte ; eifdem cæremoniis, quibus hoftes captivos. Verum hæc fiunt inter ipfos cum acceptione perfonarum, nam qui potentes habent amicos, aut plurimum Chica largiri poffunt, facile hafice ponas evadunt: præterquam fi quis veneficii autincantationis reus fir convictus; tales enim fine ulla venia aut diffimulatione vivos comburunt, $\&$ in ciner es redigtnt, fimul cum omnibus qux poffident, neque enim cuiquan fas quicquam illius retinere, metuunt enim ne quid fafcini in illis lateat.

Nullos habent facrificulos aut alios miniftros qui Pillan facrificent : neque fortilegos : tantummodo eos qui comœdiam cum Pillan probe norunt agere, \& cæremoniis illis defungi, \& Pavvary bene pracinere, maximi faciunt.

Colunt præterea alium fpiritum feu falfum numen, quod appellant Marmapoante, quod ipfis indicat, quando potiffimum uxor ducenda fit, aut cognofcenda : credunt enim, illas certo imprægnari, cum Maruapoante ipfis præceperit cum ipfis confuefcere: fi autem illos interroges, quomodo cum hoc dxmone colloquantur, aut quo pacto ab illo moneantur , refpondent, id fieri per infpirationem aut in fomniis, ubi ante ipfi cecinerunt $\&$ genio indulferunt. Atque in hifce duobus nominibus tota ipforum fupertitio confiftit.$$
\text { C A P V } \quad \mathrm{T} / \mathrm{I} \text { V. }
$$$$
\text { De Chilenfun regimine Politico, eo armis. }
$$

$\mathrm{R}$ Egimen illorum eft penes optimates, quos vocant Vlmen, aut quando tantum unus eft Pulmen. Et qui alibi vulgo Cafiqui audiunt, ab ipfis indigitantur $C$ wrace; nam Cafique nomen ab Hifpanis ex Infulis Americx tranflatum.

Ejufmodi Vlmeni, five Curace, funt inter illos plurimi, qui viginti quinque, interdum quinquaginta, imo \& centum aut plurimis familiis prxfunt : quorum tamen regimen pracipue confiftit in bello adminiftando, aut in generalibus Conventibus, cum de re- 
bus magni momenti deliberandum eft, ipfi enim conviocant ejufmodi Conventus: nor poffunt autem $a b$ illis tributum aliquod exigere, aut alia onera imponere, prxterquam cum fumma neceffitas exigit, fed tantum imperare ut adverfus hoftes egrediantur : quo cafu ipfi præire coguntur, reliqui autem fé adjungere generali, quem vocant Apocuraca, aut gubcrnatori illius communitatis, quem dicunt Nentoque, illique in
omnibus obedire.

His autem generalibus feu rectoribus non licet de rebus publicis privatim cum quoquarn deliberare, fed neceffe eft, ut confiliuni habcatur palam $\&$ fub dio, omni populo prafente, ut omnem fufpicionem amoveant.

Hxc dignitas Curaca, aut munus inferioris rectoris, fuccedit à parentibus ad liberos: fin autem defungentes nullos relinquant, ad proximos confanguineos aut affines.

Nifi forte hæredes parum idonei fint, tunc enim dignitas illa aut munus interdum arripitur ab aftutioribus. Reliqui eminentiores perfonæ eliguntur à Curacis aut Pulmenis; nimirum generales aut gubernatores: nunc autem nullum habent generalem, fed fingularum communitatum rectores pro talibus fe gerunt.

Electio autem zentoque, feu rectoris alicujus communitatis, fit ad hunc nodum : Loco vacante, is qui illam dignitatem ambire faragit, primo examinat facultates feu opes fuas: neceffe enim eft primores demereri \& folenni fympofio excipere: rebus aultem rite paratis, convocat Curacas omnes \& Pulmenos communitatis ad locum publi-. cum illi actui deftinatum, qui ubi frequentes cum armis fuis convenerint, orationem adillos habet, pradicans $\&$ genus fuum, opes, amicos, atque fortia facinora, aliaque, qux ad rem judicat facere, \& petit, fé in defuncti locum furrogari : dein unus aliquis Curacarum, aut Pulmenorum, orditur orationem, (candidatus autem ftatim illius collo circumdat collare compofitum è Turcoidibus, aut certis conchis albis politis, quasinftar auri æeftimant) \& commendat candidatum, atque permovet reliquos ad jplum eligendum, \& fine ulla conditione aut ftipulatione pravia obediendum: EleCtus autem vicifim promittit, fe omnia fideliter pro communi falute acturum, \& $\mathrm{mu}$ nus fuum diligenter obiturum. Dehinc orator ille collare, à candidato acceptum, inter reliquos difpartit primores; denique totus hic actus abfolvitur prolixa $\&$ f flendida comeflatione.

Eodem quoque modo eligunt Apo Curacam, id eft, fupremum Rectorem : quem ta. men Vcaes jam à longo tempore non habuerunt.

Arma iplis funt haftx fivelancex, fragmento veteris cujufdam gladii ad fpithamx longitudinem afpératx , plus minufve: hx autem haftz ut plurimum longitudinem habent duarum noftratium communium. Vtuntur \& Clavis, ferro afperatis : vifuntur quoque inter eos frequentes gladii Hifpanici,quos nudos geftant, quia vaginx jam olim putruerunt. More tamen $\& z$ confuetudine majorum fuorum ufurpant quoque arcus $\& z$ fagittas, Japillis quibufdam afperatas, \& veneno imbutas admodum lethali : verum hoc non eft commune omnibus, fed is potiffimum qui Pulches appellantur, qui origine Chilenfes creduntur, licet ad Orientem habitent trans altiffimorum illorum mon-tium juga, qux ab Hifpanis la Cordilbra appellantur; de quibus in Defcriptione Indix Occidentalis, in tractatu Peruvix, I. de Laet egit.

Fabricant \& galeas \& thoraces è crudis tergoribus vaccarum, valde craffos $\&$ robuftos, ita ut gladiis penetrari neutiquam poffint.

Equites funt optimi; \& illis haftis fatis dextre etiam in equis uti poflunt : non ita boni funt pedites, fiquidem fere ufum mufquettorum ignorant, \& illa valde metuunt. In bello plerumque ex infidiis graflantur: in quibus adnodum funt induftrii. Crudeliffimi funt in victos, omnefque trucidant, \& corda eximunt, \& palpitantia adhuc dentibus laniant, ut ante diximus de captivis quos mactant,

Fodeta ineunt \&z ftabiliunt in hunc modum: qui aliun prinatem aut rectoren communitatis ad foedus $\& z$ armorum focietatem invitat, mitrit per aliquem fuorum (aut etiam porcatiple) fagittam, quam invitatus, fi confentiat, manu dextra tangens vicejurisjurandife obligat; atque hoc pracipuum inter ipfos eft fidei vinculum.

Ad cundem modum, cum nequie legere neque fcribere fciant, fiquid alteri nuntiare velint, quod bellum, aut aliud Reipublicả negotium tangat,per fidum aliquem fuum miniftrum, mittunt fagittam, cui fafcia alligata eft, focietatis armorum index: quam ille, ad qucm mittitur, dextra manu accipit ; \&x, fi viciffim aliquid nuntiare velit, ad- 
32

\section{GE ORG I I M A R G R V I I}

dit $\&$ alteram fáciam, atque ita fagittam candem remittit. Si autem opus fitaliós quoque moneri, retinet prior fagittám cum fafcia, \& ad alios confoederatos per fuos circumferri curat ad eundem modum.

C A P V T V.

\section{De Cbilenfunm Lingua, \& Vocabularium dictionum Cbilenfrum.}

A Dem, fudor. Aero, pectus. Ahquem, arbor. Alchabawal, Gallinaceus. Alchawal, Gallina. Alel, flamma. Alengei, nimium. Alvee, Diabolus. Anca, lumbi. Angen, facies. Anguen, ficcus. Ante, Sol. Apo curaca, Princeps. Apô, Generalis. Aullyn, Apis. Aulonconey, fapiens. Auri, dorfum. Avass, ebullita,

Bachiante, hodie. Berse, Mus. Bidabida, palatum. Biliante, femper. Boru, dentes. Botum, filius. Bulmerre, guttur. Buri, retro. Buta changel, pollex. Buta, magnus. Buytha, fenex. Bylcum, Lacertus.

Cachu, herba.

Cadi, colt $x$.

Cairon, fonum.

Calbu, cæruleus.

Calch, corpus.!

Cancan, alla.

Carel, viridis.

Caulla, Noverca.

Cervinam, Cervus.

chadi, fal.

Challo acaman, Pifcator.

Challua, Pifcis.

Chagelcue, digiti.

Changel namon, digiti pedum.
Chan, femora:

Chaquana, fcala.

Cheche, Avus.

Chiqueles, furfures.

Choroi, Pfittacus.

Choot, luteus.

Chou, Pater.

Chouno, piger.

Chuquibot, fur.

Collu, teftes.

Compay, intus.

Cona, Miles.

Coun, ipurum.

Cuchi ilon, porcina:

Cuchy, Sus.

Cude, anus.

Cue, manus.

Cujun, carbo.

Culenei, dives.

Cuneira, orphanus.

Cunswal, inops.

Cura, lapis.

Curaca, Dynafta.

Curam, ovum.

Curi, niger.

Curique, hepar.

Dani inem, nidus.

Depen, fupercilia.

Domo, Femina.

Domo cheche, Avia.

Domo penien, puella.

Eimi, tu.

Emmo, ita.

Eppeum, mane.

Eppoê, perendie.

Gualio, Fulmen.

Hemum, furx.

Hueno, Calum.

Ilga, molaris.

Illuiboe, mendicus.

Ilon, caro.

Ilungei, veftitus.
In, nafus.

Inches, nos.

Innersgen, ante.

Inoyn, butyrum.

Lamoen, foror:

Langyancheboe, homicida.

Leve, fluvius.

Lien, argentum.

Lipan, humerus:

Lolo, cerebrum.

Lonco, caput.

Lonques, mare.

Lucu, genua.

Lulcura, penuarium.

Lye, albus.

Lyppe, penna.

Machi, Medicus.

Manco, Aquila.

Marache, dextre.

Maoni, Pluvia.

Mappo, Regio.

Maviel, lignum.

CNee, ftercus.

Mellbue, labia.

Mepoi, inem, ala.

Methen, farina.

Metu, pudendum muliebre.

Michon, Felis.

Millia, aurum.

Mintay, nunc.

Mois, mamma.

Molgei, nudus.

Mollbuen, Molvin, fanguis.

Montimey, pinguis.

Muh, non.

Munala, parum.

Nagueh, Tigris.

2Nama, Matertera.

Namon, pes.

2e, oculi.

Nesque.

Nebo, nuces.

Nenque, Mater.

Nentogue, Gubernator.

2Newonei, 
DE CHILI REGIONE ETINDIGENIS。

Newonei, fortis.

Pylken, Anas.

Towonghen, caput.

Toy, crura.

2ue, ventriculus.

Quelebe, inteftina.

Queli, ruber color.

Tubei, ille.

Tubquen, cineres.

Tue, Terra.

Quempo, affinis. ...... Tuco, Vlula.

Quennei, arrogans.

Tuivedewe, Talpa

शuereb, Aër \& Ventus.

Quetal, Ignis.

Queten, humidus.

Quette, mentum.

Quewen, lingua.

Quicbiquichio, Accipiter.

Quicdmiger, adolefcens.

Quichio, nates.

2uiltui, nucleus.

Quin pilon, Oftrea.

Quital cura, filex, pyrites.

Quito, woe, Textor.

Retare.camen, Faber ferra-

Vecaque, lien.

Ven, caro, nervus.

Ven molvin, vena.

Vercum, pulmo.

Verqumao, Ros.

Villin, vefica.

Vilo, Serpens.

Vilochalua, Anguilla.

Vllin, janua.

Vlmen, Primates.

Voerquin, nuntius.

Vile, cras.

rius.

Ró, Aqua:

Iabiuya, vefpera.

Tacume, palpebra.

Tapel, folium.

Tapton, fero.

Taun, genx.

Tau, Tou, macer.

Teinengou ennen, vos.

Tewa, Canis.

Tien, Menfis, \& Luna.

Tien, Luna.

Tipanto, annus.

Titi, plumbum.

Tol, frons.

Tolqui, cutis, membrana.

Tomo, Nubes.

Tominco, feptimana.

Topil, claudus.

Topilgers, lufus.

Toucou, fatuus.

Touma, cæcus.

Vyà, heri.

Wamapenco, cognatus,

Wana ruca, tectum.

Wangelen, Stellæ.

Wantarules, maturè.

Warailon, vaccina.

Wafen, Glis.

Weddo, umbilicus,

Weitwa, tunc.

Wellcue, finiftra.

Wenco, Patruus,

Wento, Vir.

Wietum, fumus,

Wili, ungues.

Woecon, foras.

Wono, fupra.

Woranei, deformis.

Wul, radix.

recha, juvencula.

rly, lac.

Zcnem, avis,

\section{VERBA ALI QVOT.}

\section{A Mon, ire. Aninge, federe.}

Bemeine, reficere. Butum, bibere.

Chuquin, furari. Cucbulein, jacere. Cudepain, ludere.
Dungnne, loqui.

Guallulveno, reftituere.

Ien, edere.

Illuwyr, dare.

Langawyn, occidere.

Lay, mori.
Mecowyn, ferre.

Mepai, cacare.

2eceul, currere.

Nilla cayu, permutare,

Nilla wyn, emere.

20illa Tewoyn, vendere.

Padenatum, cadere. 
Playn, reperire.

Puronge, canere.

Pylconge, clamare.

Quedaucapay, laborare. Queguatum, pugnare. Quipay, venire.

\begin{tabular}{|l} 
Rengalgey, fepelire. \\
Tangnone, frangere. \\
Tecanen, faltare. \\
Temelenge, tacere \\
Tuegnei, læari.
\end{tabular}

\author{
Vanguenbyn, perdere. \\ Vmatum, dormire. \\ Vtalenge, Itare. \\ $V$ talewen, furgere. \\ Wi, Wyn, effe. \\ Willan, mingere.
}

\title{
N V M E R OR V M NOM I N A.
}

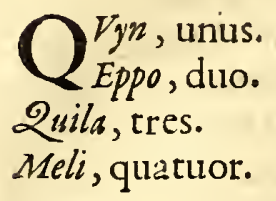

$$
\mid \begin{aligned}
& \text { Quechu, quinque. } \\
& \text { Cayn, fex. } \\
& \text { Relgi, feptem. } \\
& \text { Pura, octo. }
\end{aligned}
$$

Ut autem fpecimen aliquod habeant Lectores hujus lingux, fubjungendum puta= vi colloquium familiare, quod à noftratibus accepi.

Iuei pingeimi? quomodo vocaris? Iuanpingen? Ioannes vocor. Cheo ruaimi ? quo vadis? Moppo murran, in regionem. Cheo tui mi? unde venis? Nirocomotoun, ex redibus meis.

Chumel quipa tuai mi ? quando venies? Chumelputuai mi? quando ibis? Ale pungei tamruca? eft ne domus tua procul hinc? Pichirungei; prope eft. Ale pungei, procul abeft:

Inchi quiparui mi camappumu: volo proficifci in aliam regionem.

Chemnibla quiparuimi camappumci? quare vis proficifi in aliam regionem ? Merelaya tiva mappumu, inedia ciborum eft in hac terra. Aleibelaj twachi tipanto benibla ale genepayn: Annus hic fuit fterilis, propterea inediam patimur. Cheo mappungen tamichou? in qua terra eft tuus pater ? Alueiei, diabolus illum abfulit.

Aieimi ruani in chio? vis mecum ire? Ailan, nolo; Aien; volo. Chuben quecken neieimi tamia? habes ne aliquid quod comedamus? cancan achawalneen, habeo aflas gallinas: mu wy? quot? munal eienchin tavia ; qux nobis fufficiant. Chuben put uayn? quid bibemus? Aile mangunmeimi, ago tibi gratias. Chuben domotrwa? qux eft ifta femina ?"insbitam crri, eft mea uxor: ninave, mea filia: ni domo, mea concubina. Ale temiragei vei domo, eft pulcra femina. Quipangnei, veni huc? amotunge, difcede. Vmatuann? ibimus cubitum? ut aiuca, furgamus. Wira cuchaj Compaytam mapumu, Hifpani irruptionem fecerunt in hanc terram. Quipa waich laimi? vis ne una purgnare? Waiquinagelan, non habeo arma : Inaenpea in warqui, fequere me, invenicmus arma : aliteun inchi, confentio.

\section{$\begin{array}{lllllll}C & A & P & V & T & V & \text { I. }\end{array}$}

\section{Obfervationes ex Hiftorica Relatione P. Alonfo d'Ouaglie, S.I. de anni tempeftatibus.}

Q Vatuor anni tempeftates huic Regno accidunt, quemadmodum Europx, vcrum diverfo tempore : Ver enim exordium fumit à menfe Augufto, \& definit in medium Novembrem; \& à medietate Novembris Æfftas incipit ufque ad medium Februarii ; à quo Autumnus ducitur ufque ad medium Maium, quem excipit Hyems, qux admodum nimbofa eft, \& fpoliat arbores foliis, \& cum vehementi gelu fpargit altam nivem, tamen à Sole diffolvitur; nifr, quod raro Sole non comparente, ad aliquot dies durant. Raro autem nives accidunt vallibus, nam licet.copiofiffim $x$ fint, \& in tantum aggerentur, ut ad cacumina montium afcendant $\&$ cum iis exæquentur, \& in aperturis montium veluti in puteis coacerventur, \& pene toto anno durent, ibidem diffolutx inflant fluvios $\&$ torrentes, qui per valles cum magno impetu decurrunt ufque ad mare, \& terras mirum in modum focundant. Verum licet hic non ningat, nifr raro in planicie, frigus facit tam exceffivum, ut in multis partibus Europx vix tantum fentiatur, quod accidit partim ab altitudine Poli, fub quo hrec regio fita eft, partim à vicinitate montium, è quibus defcendunt venti fubtiles \& penetrantes, 
trantes, qui nonnumquam funt infupportabiles. Vnde fit ut loca maritima fint magis temperata. Nihilominus in his venti magis funt molefti, quam in planicie, utpote remifiores ibidem, neque tam rigide ferientes. Contra hoc frigus creavit Deus latiffimos \& fififfifimos montes, plenos Quercubus, qux eft communiffima materies diftrictus S. Iacobi \& aliarum vallium, è qua \& carbones fiunt ad fornaces $\&$ alias officinas: in aliis partibus ferviunt eidem ufui Robora, uti in diftrictu Conceptionis, ubi tam innumera funt $\&$ ita vafta, ut licet jam tam multis annis cefa fuerint, filvæ \& \& faltus hodieque ita abundent illis, ut vix penetrari poffint, neque aditum dent nifi ad duo milliaria $\mathrm{ab}$ oppido, ulterius autem fint inacceffi, licet hæc regio plufquam centum millia hominum fuftentaverit, ut fcribunt Autores. Ifta autem uti $\&$ arbores fruatiferx hyeme amittunt folia; fed filveftres arbores maximam partem illa confervant, quia funt crafliora, \& licet gelu cooperiantur, non onerantur ut aliarum arborum, fed liquefacto gelu à radiis Solis, magis læte virefcunt. Vere enim ingrediente medio Augufto, tanta copia florum nafcitur, \& numeravi aliquando duas fupra quadraginta diverfas illorum fpecies brevi tempore, \& quidem omnes campeftres, \& maximam partem odoriferos, è quibus conficiunt aquam, quam vocant Angelorum, ob fingularem ejus fragrantiam. Herbæ quoque campeltres tam feliciter germinant, tantumque fumunt incrementum, ut vixà̀ Satis diftingui poffint, \& menfe Novembri \& Decembri ita adoleverunt, ut equis vix penetrari poflint.

Sinapi, Fœniculum, Trifolium, Rapus, \& Mentha, qux plantæ in Europa feruntur $\&$ coluntur, hîc abundantifime fponte proveniunt, \& quidem tanta copia, ut campos ad multa milliaria occupent, \& pecudes $\&$ capr $x$ illis pafcantur. Sinapi autem in tantam molem excrefcit, ut caules viderim craflitie brachii humani, \& tam proceros, ut arbores $x$ mularentur, \& fuperarent altitudinem equitis.

Plurim $x$ hic nafcuntur herb $x$ Medicinales, \& magn $x$ virtutis, Chilenfibus folum notæ \& illorum Medicis, quos vocant Maci, qui facultates illarum aut celant aut parce admodum docent Hifpanos; magni hi funt non tantum ab Indigenis, fed $\& a b$ Hifpanis cum gravi aliquo morbo affliguntur; \& imprimis ubi aliqua fufpicio eft haufti veneni. Neque viri tantum, fed \& feminæ quædam hanc artem profitentur, in eaque excellunt.

Lib. I. cap. 2. Enumerat tres herbas qux fingularem ufum habent in medicina.

Prima, inquit, eft famofa illa herba quam vocant 2 2uincia mali, qux non affurgit ab humo fupra dimidium palmum: cujus ramuli fe dilatant ad modum fafciculi florum, $\&$ definunt finguli in unicum florem, figure $\&$ coloris Croci in Indiis diati Romi. Hæc herba evellitur cum radice, \& ebullitur tota in aqua, qux calida æegris exhibetur; \& inter alia illius effecta, unum eft, educere è corpore quemcunque fanguinem extra vafa conftitutum $\&$ corruptum, cum maxima efficacia; quapropter Indi vulnerati quantocius fumunt hanc herbam, fiquidem fanguinem qui per vulnus effluere non poteft, educit antequam corrumpatur.

Altera eft, quam Hifpani vocant Albaçiga ( $\&$ Indiani Culerz) quia habet folia fimilia Ocymo five Bafilico, verum in tantam altitudinem affurgit, uז arbor videatur, \& folia funt fragrantiffima; Hxc contufa applicatur vulneribus extrinfecus, \& guttæx aliquot fucci eifdem inftillantur, $\&$ mirabiles edunt effectus.

Tertia eft inftar graminis, admodum fubtilis $\&$ delicata, neque reperitur in omnibus partibus hujus regionis: ufus illius eft admodum mirabilis contra febres malignas \& dolores laterum: coquitur tantum in aqua, \& ita haufta infigniter mundificat fanguinem, introrfumque educit, ita ut xgri brevi tempore perfanentur, uti fxpiffime vidi.

Multx præterea funt herbæ valde efficaces adverfus dolores nephriticos, quxque calculim in vefica rumpunt, \& ruptum expellunt. Quemadmodum $\&$ aliæ adverfus dolores Sciáticos, aliafque ejufcemodi infirmitates quamplurimas.

Siquidem jam de herbis cœepimus, addimus ea qux alibi de illis tradit hic Anctor. Lib. s. cap. X I I I. In valle Lampa, qux diftat ab oppido S. Iacobi milliaria quinde$\mathrm{cim}$, nafcitur quadam herba, ad modum Ocymi, licet ejus folia potius fint cinerefcentis coloris neque tam læte vireant, \& planta haud fupra palmi altitudinem à folo affurgat: Hxc granulis quibufdam falis aftivis menfibus cooperitur, inftar minutarum perlarum, qua fuper folia illius coagulantur, aut è rore qui noctu incidit, aut aliquo humore aut vapore, quem Sol in illa regione fullevat cum afcendit, aut quod herba ipfa 
fit ejus naturæx, ut exfudet aut protrudat hunc humorem, qui à Sole ficcatus convertatur in granula falis: five autem ab hac, five ab illa caufa, aut etiam alia hoc procedat, hi effectus folum obfervantur in hac valle, \& fupra hanc herbam, quam Indigenæmaximi faciunt, quiafal ifte eft boni faporis 8 delicatus. Nefcio an ad hoc alludat Ioannes de Laet indeferiptione Novi Orbis; in qua agens de Regno Chili 3 infignibus illius qualitatibus, poftquam illud cxteris Americx regionibus praxuliffet, adjungit, in aliquibus vallibus hujus Regni certis anni tempeftatibus cadere rorem ita fpifum, ut congelatus ad modum faechari, \&r fervatus, pene eumdem ufum preltet quem Manna. Idem refert Antonius de Herrera Chronographus, \&c. Et fane hæc illius fide retuli in defcriptione mea ; fed quod hic ab Autore affertur, plane aliud eft.

Eodem lib. cap. xv I. In tota ora maritima hujus regni crefcit quædam herba inftar Cichorii, quam appellant Luce, quæ nafcitur è rupibus, uti a lix plantæè terra, \& verno tempore colligitur,cum maxime adolevit, \& cum Soli fuerit expofita ut ficcetur, funt ex illa panes grandes qui pro deliciis habentur in illis regionibus, $\& x$ præcipue in $\mathrm{Pe}$ ruvia, Cuio \& Tucumana, quia fervit ad condimenta ciborum. Nafcitur hæc herba in fummitare rupium, qux aliquando extant è mari, aliquando fuctibus operiuntur, quibus radices innituntur , è quibus profilit caulis, brachii humani craffitudine, quem vocant Vltea ; hic præciditur \& paulifper igni admotus decorticatur inftar thyrfi lactucxaut cinaræ, licet habeat longe alium faporem. Ex hoc trunco nafcuntur aliquot herb $x$ aut folliculi, plufquam tres pedes longi, aut quatuor, fex etiam aut octo digitos, appellant Cochayngo, \& funt duarum fpecierum, \& licet fint ejufdem figuræ \& coloris, tamen Indigenæ magnam agnofcunt inter illas differentiam, nam bonas colligunt in ufum Quadragefimæ : \& inutiles relinquunt in mari, quod illas abfolvit à rupibus, \& expellit in littus.

Eodem libro cap. xx I r. Faciunt \& potum è fructu, quem Indigen $x$ vocant Huigane \& Hifpani Molle, qui habet figuram \& colorem Piperis ; \& arbor quæ illos fert, eft fatis grandis, fed magis onufta frondibus, \& potusille valde eft gratus: Reperiuntur hîc quoque (Herrera decad. Ix. lib. 9.) fructus arboris filveftris, quæ nafcitur à gradu trigefimo feptimo \& deinceps, quos. Indigenx vocant $V n g h i$, \& Caftellani Myrtil$l_{a}$, qui fructus funt rubri \& inftar exiguæ uvæ, faporis admodum grati, \& grana illius funt inftar Ficus, nec fentiuntur inter manducandum: qualitate funt cálida \& ficca: ex his fit vinum longe optimum, clarum, fubtile, calidum, \& palato gratum, ventriculo amicum, quodque vapores capitis abfumit, \& roborat ventriculum, promovetque appetitum : denique tantum aqux tolerat, quantum vinum : coloris eft aurei, \& durare poteft octo menfibus, forte \& pluribus: Acetum illius fuperat acetum vini noftratis , fapore \& colore.

In toto diftrictu hujus regionis non reperiuntur Vipera, Serpentes aut alia animantia venenofa, ita ut cuivis liceatrecumbere fub aíboribus, \& inter herbas fe volutare, fine ullo difcrimine aut metu. Haud magis hic inveniuntur Cimices, quinimo, fi forte c̀ regionibus tranfmontanis, ubi frequentes funt, adducantur, ftatim emoriuntur, ubi fenferint aërem hunc Chilenfem.

Eodem lib. cap. xx r. Inter quadrupedes animantes, domeftici \& quafi proprii funt hujus regionis, certi Cuniculi, quos ipfi vocant Regus, \& mentis pro' delitiis inferunt. Venantur illos infundendo aquam in ipforum cavernas, qua cogunt illos progredi, ita. ut à canibus capiantur.

Reperitur $\tilde{\alpha}$ alia fpecies Cuniculorum, qui familiares funt, \& variorum colorum, valdeque communes: fecus quam illi, quos vocant Arde, dubito enim an alibi reperiantur quam in Guafoo, vallium Chilenfium prima: hi funt cinerei coloris, \& pclles illorum maximi faciunt Indigen $x$, ob fubtilitatem \& lavorem pilorum ad tactum, \& poftquam egiffet de Ovibus illis, ut vulgo vocant, Peruvianis, fibdit;funt illis fatis fimiles Caprex, tam figura corporis quam velocitate, verum differunt colore, qui in his eft roffus inftar Rubini; \& numquam cicurantur. Non eft equuss ita velox qui adultos affequi poffit: juniorum caro admodum eft delicata, \& mánducatur recens; adultiorum autem falita \& ficcata, facile reliquias fuperat carnes. Hæc animalia generant lapides Bezoares in finu quodam ventriculi, qui maximi aftimantur.contra venena \& febres malignas, ad roborandum \& refocillandum cor, aliofque effectus: materia è qua generantur, funt herbi infignis virtutis, quibus vefcuntur natur $x$ inftinctu ad fanitatem tuendam, aut morbos 
DE CHILI REGIONE ET INDIGENIS.

morbos \& venena fuperandum. Hi.lapides inveniuntur in adultioribus hifce animalibus, atqueinterdum tam grandes, ut unum in Italiam attulerim; qui pendet uncias duas fupra triginta. Experientia autem docet, in regionibus in quibus funt plures Viperæe, aliique Serpentes, \& animalia venenofa, plures generari lapides ; \& caufa eft manifefta, nam cum hæ Caprex fint tam veloces, $\&$ difcurrant in varias partes, venenatis illis animalibus magis funt expofitx; \& ab illis læl $\mathfrak{x}$, feftinant naturaliter ad herbas medicinales. Vnde in Provinciis Cujo majores ejufmodi lapides reperiuntur', quam in Chile, quia ibidem offenduntur multæ Viperæ \& alia animalia venenofa, à quibus libera eft chile, ut diximus; ad hæc cum chile magis fit habitata, non funt Caprex ibidem tam frequentes, quam in Cujo. In qua Provincia \& multi reperiuntur Lepores, quorum quidam, qui appellantur 2uïriquincios, carnem habent, qualem Poícelli lactentes.

Quum autem Regio hæc, cum Peruvia fibi contermina, id præfertim commune habeat, quod fimile Pecus lanigerum nutriat, licet pro Cæli \&\& foli ratione nonnihil variet, ut tamen eorum convenientia $\&$ difcrepantia melius elucefcat, unam atque al-

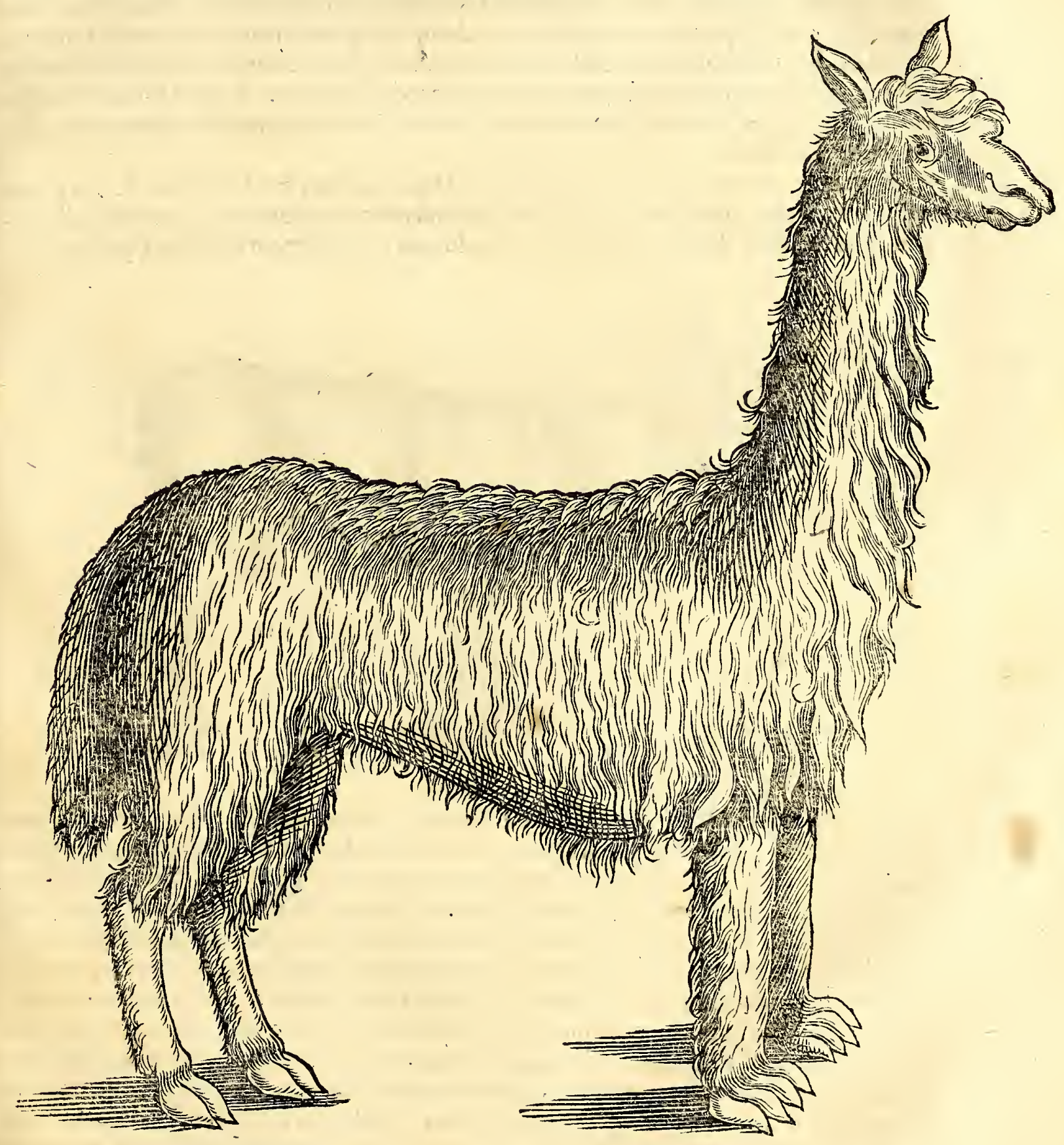

teram iconem, ad vivum expreflam, fubdere confultum fuit : imprimis cum multi ufus in is terris exiftant Ovi-Cameli : nam licet rarius mactentur ad comedendam carnem : tamen bajulando, $\&$ imprimis lana fua preftantiffima ( qua ut colore, tenui. tate \& imprimis longitudine; ita \& dignitate inter (e difcrepat), majorem facile uti- 
litatem Incolis prettant. Hxc autem major Ovi-Camcli fpecies Paco illis dicta, quam primo depietam damus, à cateris differt potiflimum, quod poiticos tantum pedes in ungulas bifulcas, priores autem in quatuor divifos ungues habeat, \& quod prolixis àdnodum villis lanæx veftiatur, quam imprimis commendant. Cæterum natura bene convenit cum fequentibus, ita ut haud dubium fit unius generis animal effe, nifi forte inter utrumque fit diftinctio illa, quam obfervavit I. de Laet in tractatu Ind. Occidental. ut omnino exiftimo. Sputum ejaculatur in vexantes; \& fcribit P. Alonfo d'Ovaglie in Hiftorica Relatione Regni Chile;' vulgo credi in parte corporis humani quam fputum illud contigerit, fcabiem generari. Forma ad Camelos accedunt hæ Oves, nifi quod gibbo careant, cxterum longe majorés quam Europæx \& plerumque ulinam Hifpanicam procerær, collo oblongo \& tereti, rictu fiffo,; per quem fpumạm, quum irafcuntur, ejaculantur in illos, à quibus fe lædi opinantur; caro illarum paulo ficcior quam Europæearum ; cicures colore utplurimum funt candido aut nigro, interdum \& cinericio ; filveftres vero \& montenfes colore funt igneo aut fulvo; longa, levi atque adeo nitenti lana veftiuntur, qux pretio Hifpanienfem longe fuperat: nam quum vellus ovillum in Hifpaniis uno regali venundetur (Hifpani autoris fune verba) harum fingula vellera aureo æxtimantur. Ex hac lana cer ti panni texuntur, quorum fplendor ad Camelottorum nitorem quamproxime accedere dicitur. Porro Ovibus hifce aures perforant, \& foraminibus innectunt funes, quorum attractu eafdem regunt $\&$ educunt quo libet.

Altera \{pecies qux pene villis nuda eft, atque tantum modo levibus $\&$ curtis tegitur, ex India quondam Occidentali in Bataviam tranflata fuit; cujus ego defcriptionem ex Epift. Andr. Machioli huc traducan, ut differentia facilius pareat.

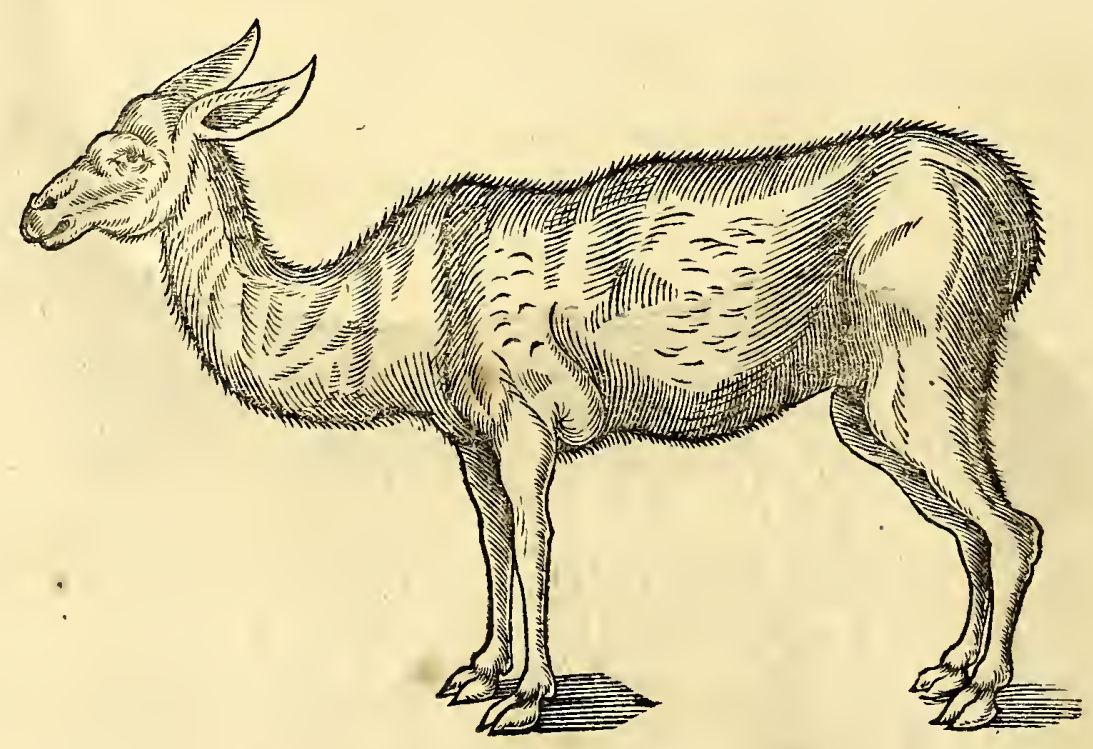

Refert hoc animal partin Camelum,partim Cervum, adeo ut recte quidem Græco

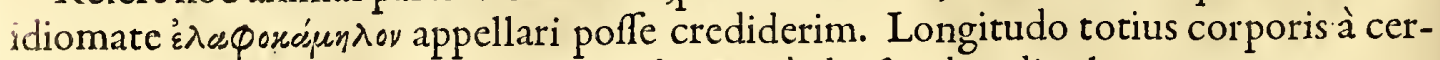
vice ad caudam fex pedum eft : altitudo vero à dorfo ad pedis plantam quatuor tantum, \&z colli longitudo à fcapulis ad cervicem, duûm. Capite, collo, ore, fuperioris prefertim labii fciffura ac genitali Camelum fere refert. At caput oblongius eft: aures habce cervinas, oculos bubulos. Anterioribus dentibus in fuperiori mandibula caret, fed molares utrimque habet, ut bifulca fere omnia, \& ut illa etiam.ruminat. Dorfo eft fenfim prominente, quod per incuriam à pictore neglectum eft. Scapulis prope collum depreffis, lateribus tumidis, ventre lato, clunibus altioribus, \& cauda brevi , fithame fere longitudine: quibus omnibus Cervum fere refert, quemadmodum etiam cruribus, prefertim pofterioribus, pedes illi bifulci funt, diducta anteriori parte divifura. Vngues habet acuminatos, qui circa pedis ambitum in cutem craflam abeunt. Nam pedis planta non ungue fed cute, ut in multifidis, $8 \mathrm{in}$ ipfo Camelo, contegitur. Retromingit hoc animal, ut Camelus, \& teftes fubftrictos habet. Pectore eft amplo, fub quo, ubi thorax ventri connectitur, extuberat globus, ut in Camelo, vomicx fimilis, è quo nefcio quid excrementi fenfim manare videtur. Color 
colli, cervicis, peetoris $\&$ anteriorum crurum, eft illi albus, reliqui vero corporis fubruber, vel ex nigro rufefcens. Roftro tamen eft nigro \& anterioribus cruribus à genu albicantibus. Cicur ac manfuetum eft animal, fed frigoris impatiens, ut alia quæ ad nos è calidis regionibus afferuntur. Neminem offendit: fed miro admodum ingenio ab illata fe vindicat injuria. Nam ubi aliquis illud vexet, vel circa clunes opprimat, non calcibus aut morfibus fe defendit, fed vomitu vel cibi vel humoris in vexantem retrorfun cum impetu ejaculato, ob protenfam colli longitudinem. Salaciffimum hoc effe animal, id mihi conjecturam facit, quod, cum fui generis femellis fit deftitutum, magna cum prurigine Capris fe commifceat, non tamen erectis, ut alias Capra Hirco afcendente folent, fed humi ventre accubantibus, ita cogente animali anterioribus cruribus. Itaque fuperafcendens coit, non autem, ut falfo de retromingentibus animalibus affirmat Ariftoteles, averfis clunibus. Adeo Venere vernali autumnalique tempore ftimulatur hoc animal, ut illud viderim humile quoddam præíepium avena refertum confendiffe, genitaleque illi magno cum murmure tamdiu confri caffe, quoufque femen redderet, plurimis una hord replicatis vicibus. Non tamen concepere Capræ hujufce animalis femine refertx, quod, ut puto, vi coactx illi proftiterint continuo balantes, tum quod cum hoc animali earum non conveniat fpecies. Indicam Ovem appellabat hoc animal, qui illud ad nos advexit, atqui à noftris Ovibus quantum diftet, tu ipfe judicare poteris.

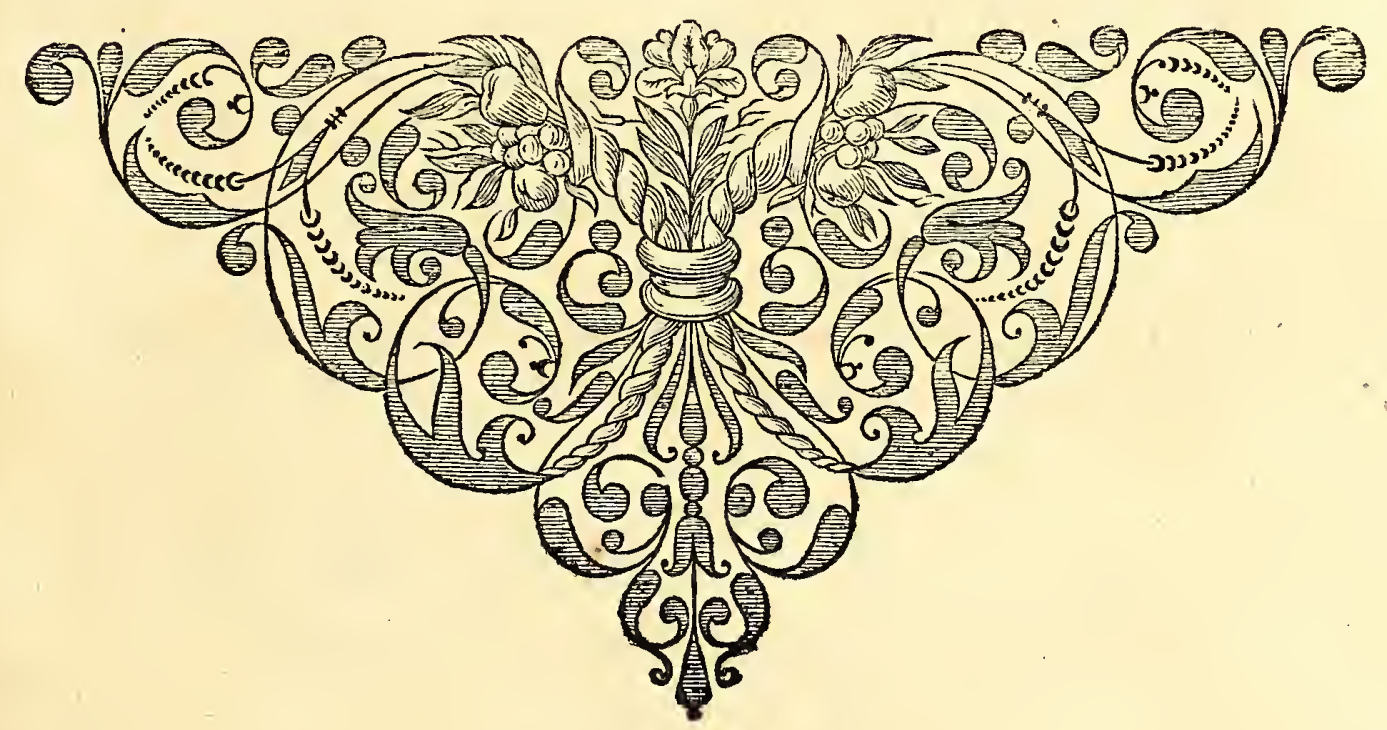




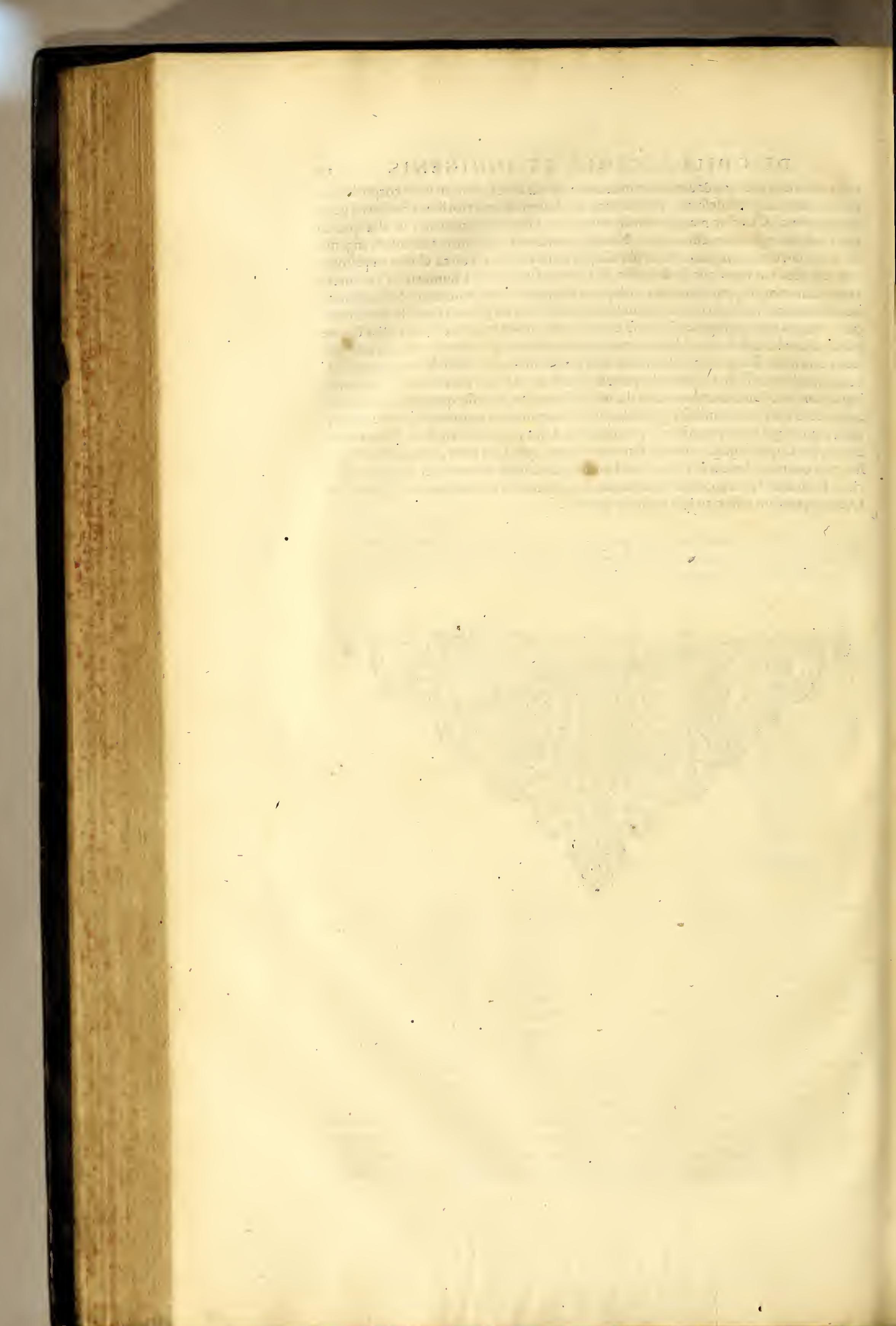




\title{
I A C O B I B O N T I I,
}

Medici Civitatis Batavie Nove in Iava Ordinarii,

\section{H I S T O R I $\nRightarrow$} Naturalis \& Medicx

INDIÆ ORIENTALIS

\author{
$L I B R I S E X$.
}

I. DECONSER A N D A A L E T V D I N E.

II. METHODVS MEDEN D I.

111. OBSERVATIONES E CADAVERIBVS.

IV. NOTA IN GARCIAM AB ORTA.

V. HISTORIA A NIMALIVM.

VI. H IS TOR I A PLANTARVM.

In quorum Librorum penultimo, Nature Animalium, Avium, or Pifcium: In ultimo autem, Arborum er Plantarum Species mire, Europeis incognite, ac adViDum delineate, explicantur.

C O M M E N T A R I I,

Quos Auctor, morte in IN D I s preventus, indigeftos reliquit,

$A$

G V L I E L M O P I S O N E, In. Ordinem redacti \& illufrati, atque Annotationibus of Additionibus Rerum \& Lconum necefJariis adaucti. 


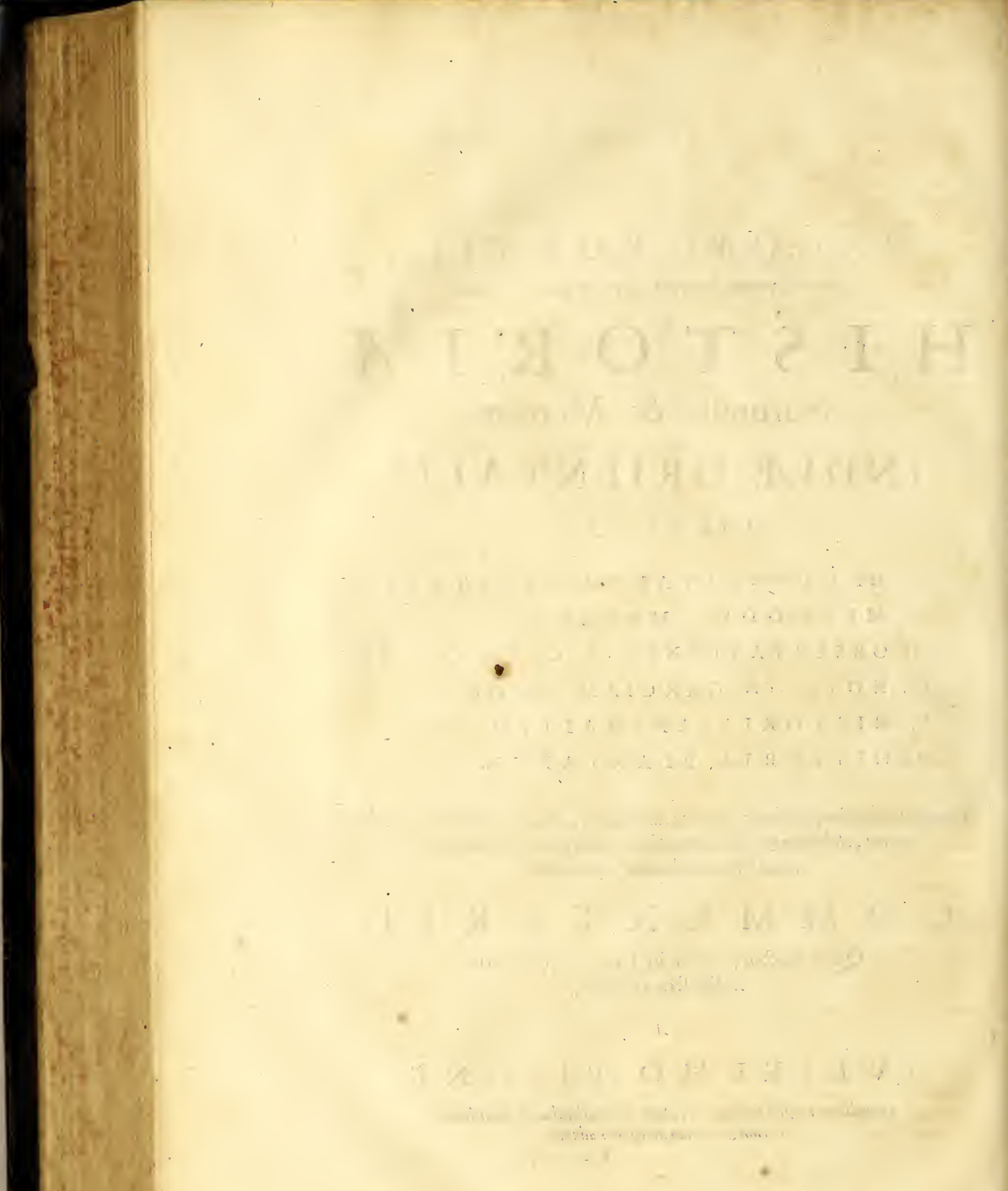


I A C OB I B O N T I I

D $E$

\title{
CONSER VANDA VALETVDINE, \\ A C
}

\author{
Dixta, Sanis, in I N D I s obfervanda.
}

\section{DIALOGVS PRIMVS。}

De Aeris qualitatibus, anni temporibus, diernum intervallis, ac
ventis in Indiis bifce familiariter. pirantibus.

I A COBUS BONTIUS.

ANDREAs DuR a ús.

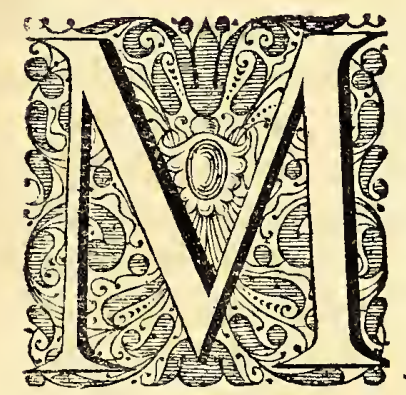

I Bonti, quoniam matutinis ægrorum vifitationibus jam ten-peftive admodum defuncti fumus, fi libet, eamus extra pomoria civitatis aliquanto longius deambulatum, ut dum nondum Sol calore fuo aërem prorfus excalfecerit, inter nos conferamus, quali Dixta in hifce locis præcipue fit utendum. B o N T. Bene mones, mi Duræe, præfertim cum quotidie videamus, in Nofocomio noftro hoc Batavico, non folum plerofque ægros, jam à morbis convalefcentes, recidivas pati, propter malam dixtam ac inopportunam, fe ipfos in mortem certifimam precipitare : verum etiam bene fanos, ob eandem caufam periculofos morbos incurrere; Hinc enim obftructiones frequentes vifcerum, Hydrops, ac denique Marafmi infanabiles; fed cum Dixta confiftat apud Veteres in fex rebus non naturalibus dictis, corum veftigiis nos quoque infiftentes, ne hæretici in Medicina videamur, Colloquiurn noftrum finiemus. D u R E us. Quas tu vocas res non naturales? Bon t I u s. Quxe corporis humani fabricam non conftituunt, neque intus in nobis funt : fed qux externe accerfenda funt, ut ufui humano inferviant. Tales funt aër, cibus $\&$ potus, fomnus $\&$ vigilix, motus \& quies, excernenda \& retinenda, Affectus denique animi. Deiis igitur fingulatim nobis hic agendum eft. Ac primum, ut ordine cuncta percurranus, de aëris conftitutione dicendum, quum eo vel invitis mortalibus fit utendum, dum refpiratione $\&$ infenfili tranfpiratione, carere non poflimus. Du \& « us. Optime, fed quoniam aëris calor vehemens toto anni tractu, clima hoc quoque ficcum valde exiftimarim. Bo N т rus. Minime vero, immo aër ac in circumjacentibus infulis, \& in Continentis regionibus, humidus valde eft. Cujus rei, quum plurima Argumenta poffum adferre fatis valida, vulgaribus omiffis, hoc unum dicam, quod vel ficciffima in his locis anni tempeftate, ferrum, chalybs, æx, argentum denique, citius rubiginem $\&$ xuginem contrahunt, quam in Europa pluviofo, ac Autumnali anni tempore. Du R \& u s. Verum dicis, cum \& veftimenta, arcis bene inclufa, fitum breviffimo momento contrahant, \& nifi ventis interdiu fpirantibus ac Soli exponantur, facilline putredine corripiuntur. Sed, fi placet, explica, qualem circa Bataviam experiamur. Bon Trus. Aër in circumvicina regione non admodum falubris exiftit, tum quod calor $\&$ humiditas putredinis effectrices ac genitrices, Phyficis dicantur, tum propter ftagna \& loca paludofa hic frequentia, dum cnim venti è montibus fpirant, foetidos \& craffos, ne dicam, propter multitudinem infectorum, venenatos, vapores fupra urbem noftram adigunt, ac ita aërem inficiunt. Itaque ventus è Continenti oriundus, ferło nobis cavendus eft, atque is præcipue, qui poft gallicinium è montibus fpirat, ob primarum vigiliarum tepidum calorem, ac aperta inde in homine fudaria, feu corporis poros, vehementius, propter fubtilem \& penetrantem 
qualitatem corpus afficiunt, quam vel frigidifimus Boreas media hyeme in patria: Hine gravedines longiores, ac Catarrhi difficiliores oriuntur, quam in patria. Penetrabilis præterea hujus aëris natura, miferabilem illam paralyfeos fpeciem producit, qux Beriberii in method. mea Med. Indica nominatur, quo lectorem remitto. D u R. Montanorum quidem ventorum nobis naturam explicafti, velim, ut fententiam feras, de auris è mari f pirantibus. B o N T. Eas ego autumo longe falubriores terreftribus efle: Caufa in promptu eft, quod illæ foridos illos ac paludofos vapores longe à nobis rejiciant aëremque verrunt \& expurgant; inde fpiritus alacriores, ac vegetiores ad functiones peragendas reddunt, humor efque qui in nobis funt, à putredine confervant. DuR. Hxc qux dicis, in memoriam mihi revocant, qux de ventis in Gallia Narbonenfi, ac vicinis Hifpanix locis, ac in Italia in Rom $x$ ac Neapolis territorio, è montibus, fpirantibus, incolis Serene vocantur, qui blandiente frigorchomines incautos, advenas prxfertim, pervadunt potius, quam invadunt, inde crebr $x$ in is locis Hxmoptyfes, Phthifes, ac Afthmata, cxteraque Pulmonum vitia, fxpe incurabilia. B o N T. Ita eft, ut dicis, hinc non inconcinne Horatium ceciniffe memini.

Matutinaparum cautos jam frigor a mordent. D u R. Quum porro in omnibus terrelocis, quotannis infignes in aëre mutationes in Elementorum primis qualitatibus fentiantur, ac pro iis anni tempora Phyficis diftinguantur, velim ut mihi etiam viciffitudines illas tempeftatum in Iava noftra demonftres. B o N T. Lubens fecero, itaque cum per rotum anni decurfum, in fola ficcitate, ac humiditate, mutationes infigniores oriantur in hifce locis, tantum duo anni Tempora novimus. Nam quoad mutationem caloris ac frigoris; calor plerumque femper eft æqualis, cum Sol hic à linea Æquinoctiali non longe recedar: itaque anni tempora, in ficcum, ac pluviofum dividemus, qux nobis Fftatis, ac Hyemis vicem fupplent. $D$ u $R$ \& u s. Quando igitur Eltatem incipere exiftimas? B o N T. ubi perpetux pluvix cadere incipiunt : nam tum Sol propior Æquatori è directo nos feriens, ac è mari, paludibus, \& fagnis nubes in altum cogit, incipitque hæc tempeltas, à Novembr. initio, ac ufque initium Maii excurrit, cœlo tum temporis tam irriguo, ac tam pluviofo, tum cadentibus tam continuis pluviis, ut infolitis merito fecundum Deucalionis diluvium metuatur. E contra à Maii initio, ufque ad Oatobris exitum, ficcus plane \& ferenus êt aër, vix pluvia toto fex menfum intervallo decidente, contrario plane modo, quam in Patria noftra, ubi recedente Sole plüviofus fit ä̈r , appropinquante vero Sole ficcior evadit. Sed terra tamen his non obfantibus longe feraciffima elt, tum ob roris noctu cadentis copiam, tum propter temperatam matutini ac vefpertini temporis naturam, qux Veris qualitates amulatur: fed de co infra. Du $\mathrm{R}$. utrum tempus anni exiftimas falubrius efle? B o N T. ex dictis prudenti conftare deber. Tempus pluviofum feu xftivum maxime infalubre cenferi, quod nimirum aëris calor \& humiditas naturalibus Philofophis putredinis effectrices merito putantur effe; Nam nifi tum temporis venti fucceffivi matutini, ac vefpertini, tum aëris craffities ac nebulofa conftitutio xfum arcerent, terra propter calorem non ferendum inhabitabilis effet : fed de his docte ac ampliter philofophatur Iofephus à Coft a ex propofito Lib. Naturalis Indiarum Hiftor. quem lector curiofus adeat. Tempeftate porro anni ficca \& fereno aëre, ut convenit, corpora funt bene fana, ac tum venti etiam aliquanto frigidius fpirantes aërem melius ventilant \& expurgant. Dur. Vt ex dictis intelligo, dum xftatem \& hyemem vicinitate, ac abfentia Solis metiris, in Indiarum hoc tractu patimur hyemem, cum in Hollandia ver ac æetas florent, \& è contra hic \& $\mathbb{E}$ ftas eft, cum in patria hyems ac Boreas feviunt. B o N T I v s. Ita fanc eft. Du R. fed quid de dierim intervallis, ac eorum temperamentis fentis? B O N T. Diei tempora hic commode diviferim in Matutinum, Antemeridianum, Poftmeridianum, ac Vefpertinum, fub quo quoque noctem comprehendemus. Quoad qualitates fingulorum; Matutinum ac Vefpertinum diei tempus falubriús reliquis, negotiis ac actionibus accommodatius peragendis eft. Quod tum temporis, venti, è mari \& montibus fpirantes, aërem ventilant acrefrigerant: Vt autem à matutino tempore incipiamus; Ego illud definio, quod ab hora quinta ufque ad nonam fe extendit, tum auræ molles blande aërem temperant, acfí in Hollandia Maiales ventos fentires. Antemeridianum à nona porro ad duodecimam fe extendit, quo tempore, Sole altum fcandente, maximus $x$ fus $f x$ vit, qui temperari paulatim poft duodecimam ufque ad quartam pomeridianam inci- 
pit ob auras èmarifurgentes. Vefperam autem terminabimus à quarta pomeridiana ad fextam, aut paulo ultra vefpertinam, qua Sol fe condit.Itaque, fiquid negotii gerendum fit interdiu, id fiat vefperi ac mane; : antemeridianis jam commemoratis horis progreffus in publicum plane vitandus; ob fervoris violentiam, quod tam manifefte quifque fentiat, fe tum temporis magis quadrantis hor $x$ fatio defatigari, quam fpatio diarum horarum alio tempore. A duodecima porro ad quartam pomeridianam, etiam fuadeam à negotiis publicis abftineri, fed tamen hx hor $x$ tam infalubres non funt', quam antemeridianx nominatx.

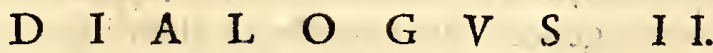

\section{De cibo acpotu: ubi de Carnibus, Pifcibus, Fructibus, Herbis, Oleribus, Potu, Pane, ac Oryzequalitatibus.}

$\mathrm{E}$ Xpofitis aëris Indici in his oris qualitatibus, tum anni temporibus, horis dieiac ventorum temperamentis, vellem ut mihi tuam fententiam diceres de cibum fumendi tempore.

BON T I S. Lubens faxo, itaque hoc in genere accipe; jentandum hiclargiter, prandendum mediocriter, cœnandum parum. non quod mex opinioni alios ita ftriate alligare velim, fed ego mei judicii rationem reddere conabor. Du R x us. Rationem itaque velim mihi dari. B o N T. Ea in promptu eft, quod tempore matutino, ob poft nocturnum frigus, ventriculi melius ad digeftionem funt difpofiti. Prandendum porro mediacriter fuadeo, ne dum meridiamur, plerumque ob fummum calorem aliquantulum ftomachus à nimietate cibi gravatus, cruditates, ac inde morbos, hicfolitos oriri, gignat: nam plurimi morbi in Indiis à frigida caufa gignuntur. Du R. Hoc adeo durum mihi videtur, in calidis regionibus frigidos morbos predominari. BON T. Aft ubi caufam infpexeris, fortaffis minus mirabere, quod nempe propter affiduas firituum per fudores ac cutis fpiracula evaporationes, membra naturalia, concocioni ciborum infervientia, calore deftituantur ; inde frigidiores ventriculiac inteftina, ob concodtricis facultatis labefactationem, cibos omnino mutare non valentes, crudos ac incoctos humores, ad mefenterium, dein ad Hepar, tandem per venas ac arterias in univerfum corporis habitum tranfimittunt. Hinc quoque non mirum eft, populos ad feptentrionem fites, vivaciores longe effe hifce meridianis gentibus, nam ambiens frigus, per antiperiftafin calorem ad interna cogit, hinc elt quod Hippocrates etiam dicat, ventres hyeme effecalidiores, ac alibi propterea hyeme largius effecibardum affirmat. Du R. Satisfecifti huic fcrupulo, veniamus, fi placet, ad genera ciborum hic utilia vel refpuenda. B ON T. Age uthoc fiat, imaginarium tibiapponam prandium, quia nemo, quod fciam, nos hodie vocavit. Du R. Dummodo ne Chamæleontes è nobis facias, qui vento vivere dicuntur, fed falfo. Bo N T. Bona verba, quxfo, aft ejus loco aures tuas lepidis fermonibus opplebo. Itaque cibos primum per claffes diftribuamus; ac primo loco Carnes in confiderationem veniant; earum itaque faluberrimx funt gallinarum, quibus hæc Infula abundat. Aves montan $x$ ac fylveftres, quales funt turtures, columbx, coturnices, \& minutiores, ut funt pafferes, fringuillæx, tum ficedulx feu fclopaces, turdi, quæ omnes volatilium fpecies nobis abunde campi ac fylvæ fuppeditant. Dein anates $\&$ anferes, \& cxteræ aves aquatiles hic carnium bonitate preftant. Du R. Miror, te hæc aquatilia inter falubres reponere cibos, cum in Patria inter infalubria alimenta numerentur, quod nimirum

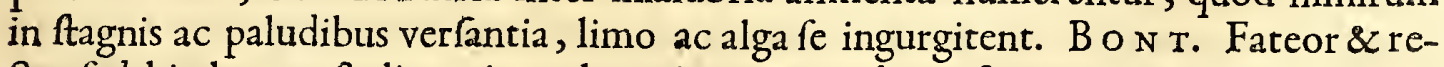
ate: fed hic longe eft alia ratio, tales enimaves non hic in ftagnis, nec paludibus verfantur; fed in profluentibus fluviis, unde carnes ipfis longe meliores, præterealicet domi ipfasalere Oryza ac panis fruftulis, ac tum carnis tam delicatæ evadunt, ut cum gallinarum ac caponum carnibus contendere poffint. Sunt prxterea hic grues, ac ardex, quas quoque contemnere non licet. $\mathrm{D} \mathrm{u} \mathrm{k}$. quas carnes porro in fecundo bonitatis gradu locas? B o N . Caprillas: nam ab ovibus, propter penuriam hic abftinendum eft. Dein vitulinas ac bovinas, \& illas quidem præftantiores habemus hic feras, ac fylveftres. Bubalinx carnes non funt omnino contemnendx: fed has juven-

$$
\text { A3 culas }
$$


culas intellige; nam vetuft propter infignem nervofitatem fortiffimi animalis vix fertratos Plautini parafiti dentes admitterent:- D u R. Sed quid de ferinis carnibus fentis? B o N T I U s. Haud male mones, inter has itaque praftantiffimas effe puto aprinas, cum $\&$ porci domeftici hic optimi fune, acfacilis concoctionis, fecus quam in patria: nam \& ægris hic fuilla caro bene præfcribitur: Cervos denique (ut fcis) hic quam plurimos habemus, $\&$ has omnes ferinas carnes milites $\&$ cives fclopetis à fe occifas huc in urbem quotidievenales adferunt. D u R. Ita eft: fed omiffis carnibus tranfeamus ad pifces. B O N T. ut hoc commodius fiat, diftribuemus pifces, in marinos; ac fluviatiles. Inter marinos (meo quidem judicio præftat ifte pifcis, quem Incolæ Cacap vocant, qui è cyprinorum laxatilium eft genere (quem nófri Hollandi Stent-braeffems vocant) quique tam grandis aliquando capitur, ut \& Afellum callarium æquet. D u R. Habemuíne hic Afellos majores iftos, quos Caberjau Belgæ indigetant? Bo N T. Capitur hic quidem fpecies aliqua eorum, quam nautici focii noftri Facob etertien vocant, ob nigros in Hava cute fparfos nævos ac maculas, quales habuifle quendam ejus nominis nautam dicunt. Eft præterea hic magna quantitas petroforum cyprinorum, figura varia, lata, rotunda, oblonga; inter quos excellunt ii, qui rubrifunt coloris. Scaros quoque delicatifimos habemus, quos Belonius in obfervationibus fuis 1. 2. deferibit, qui nobis hic percarum loco funt. Capitur præterea Salmonis quoddam genus, Ican-Banda Malaii vocant, quod Bandenfem pifcem frgnificat, quia in litoribus ejus infulæ frequentius capiatur. Certe præter colorem à Salmone non differt, qui in hoc pifce albus eft, in Salmone caro rubra eft: fed noftri ficcioris funt carnis, ac proinde falubrio.res, fi Plinio credamus, qui omnem pifcium pinguedinem profitetur malam effe, præter Anguillarum, quxfit peffima. Du R. Quid de Auratis, Corcovadis, Bonitis, \& id genus pifcibus fentis? Bon T. Oinnes hos efle è thynnorum ac delphinorum fpecie, tum propter natationis fummam veloçitatem, qua expanfis velis navigantem navem. tranatant, ac etiam è mari exiliunt ad tres quatuorve cubitos in altum, ut venentur hirudines aqua ticos, feu pifces volaticos dictos, qui etiam funt boni faporis, ac demtis alis Alecem non male referunt nec forma, necfapore. Cxterum inter delphinos iftos palmam fert Aurata, ab aureo colore Dorado Lufitanis dicta, cxteri funt carnis durioris ac proin concoctu difficilioris. Sanis tamen ventriculis bene conveniunt, quum fanis; ut inquit Latinus Hippocrates Cornelitus Cel/us, non opus fit exquifita dixta. D u R. quid de planis pifcibus marinis? an illos omnino oblivioni trademus. Bo N T. immo vero ego in hoc eram, ut ipfos hoc ultimo loco refervarem: nam extra controverfiam è faluberrimorum pifcium funt genere. Tales inter præcipuos funt, Rhomboides, Lingulacæ, ac Rhombi, quorum Rhomboides optimi inter pifces funt nutrimenti ; dein Lingulaca, ac ultimo Rhombi, qui adeo confuevere in deliciis apud Romanos efle, ut inde mate. riam ceperit ingeniofus Iuvenalis Satyr. falfifimam in crudelia \& nugacia Domitiani tempora ejaculandi. Raias habemus præterea clavatas ac læves, qua quo juniores, eo meliores concoctu ; à vetuftioribus enim jubeo abftinendum, ut de Lamiis, ac laris pifcibus anen / quí acutiflimis fuis dentibus roftratim ftipatis tam multis fociis navalibus temere natantibus exitium intulere. Paftinaca marina, ipfis Chinenfibus pifcatori. bus confitentibus, venenofum è tranfverfa cauda enafcens telum gerit, quo abfciffo edulis eft, fed carnis infalubris, ac faftidiof $x$, idco ego Chinenfibus ac Mauris, qui iis avide vefcuntur, fuas deliciąs reliquerim, contentus fupra commemoratis Neptuni peavide vercuntur, fuas deliciąs D R R E u S. Marinis pifcibus videor jam affatim fatiacus, velim mihi fluviatiles etiam apponas. B O N T. In me non eft mora. Igitur primo loco mihi occurrit Carpio, feu Cyprinus rotundus, quem ego carne, ac guftu meliorem effejudico patriis, ut pote qui hic in fluviis, non in Itagnis ac paludibus, ut apud nos plerumque capitur, \&, ut, quod diximus, Anates hic præftantiores funt, fic \& hi pifces ob prædictam caufam laudabilior es hic capiuntur, nec enim tam limofim fapiunt. Tam infigni porro mole aliquando capiuntur, cute candida, ac carne delicata, ut is nil ulterius addi poffe confidam. Sunt prater hos lupi pifces in alveis fluviorum, quos propterea num inter marinos, aut fluviatiles numerare debeam, dubius harco : fed certe magis in mari capiuntur magna mole, pelle alba, guftu five affi five clixi fuavifimo. Mugiles five aroetg / ac ea pifcium fpecies, quam ob eminentiam nafinafutos appellant accol $x$ Mof $x$ in Hollandia, ac vernaculo vocabulo outinef indigitant, hic affatim capiuntur, ita ut pauperioribus etiam in cibum cedant. $\mathrm{H} x$ 
dux pifcium fpecies ftatutis temporibus, ab Octobie nimirum menfe ad Aprilent ufque, propter pluvias qux falfam aquam edulcorant (nam hi pifces etiam in alveis fluminum capiuntur), pingues ac fuaviffimi funt. Sicciori vero tempertate carne funt durioris acfinofin. Alburni Booznen preterea noftratibus fimiles hic in fluviis cam piuntur, boni fane faporis, acnutrimenti. Congri Conger ael quoque infignes aliquando in fluviorum ore, fepius in mari videntur, unde eos potius inter pifces marinos locaverim. Infalubriores jam porro pifces enumerare libet, quales funt Anguill $x$, qua cute funt fuperne nigerrima, fubtus foede flava, tum etiam cum hydris coire certiffmum eft, \& quamvis plurimi eis fuaviter utantur, ego tamen ob prædictas caufas ac propter naufeabundam illarum pinguedinem facile eas contempferim. Eft præterca pifcis quidam duriffimis fquamis obfitus, quem Ican Cabo/ch Malaii vocant, ego à figura, \& capitis , ac reliqui corporis, Mugilem fluviatilem dixerim, qui in limofo hxret fundo, ac originem fuam non obfcure fapit: $\mathrm{Habemus}$ hic porro Tencarum $\mathbf{3}$ telt quoddam genus fine fquamis, pelle lævi, teretes, cum duabus pinnis, ut Anguillæx, ac capiuntur hic in magna copia ifti pifces (quos noftrates à capite bufonis \#)unt-atl vocant) fed ego, ut Murxnas fluviatiles omne id genus cupientibus non invideam. Poffem jam alias pifcium fpecies enumerare qux plurimx reftant, fed quia non hiftoriam: fed tractatum de dixta indica fcriber egeftio: ideo his contentus, cancros tantum ac aftacos, oftrea quoque, fquillas ingentes tibijam apponam, qux omnia præter reliqua oftracoderma, hic delicatiffima funt. Tum teftudines amphibias addo, cum ovis fuis, ac carne fuaviffima, ut aitunt ii qui de iis millies fe guftaffe gloriantur: fed credo, ipfos famem fecum, optimum condimentum, attuliffe, ego teftudinum carnes in-. ter medicamenta ifta collocaverim, feu mavisalimenta medicamentofa, qux Phthificis, Empyematicifque conveniunt ; quia glutinof $x$ cum fint, pulmonibus confolidandis conveniunt.

\section{I A L G V S III.}

\section{De Oryza, ac Pane in Indiis. Depotu, Vino, Arac. Depotuex aqua, Saccharo, Tamarindis concinnato. De naturalibus liquoribus potulentis ex arboribus depromtis.}

\section{$\mathrm{D}$}

$V_{R}$ A u s. Quoniam in his locis Oryza cocta plerumque pro pane utimur, ve lim ut mihi narres, quid de hoc nutrimento fentias, prafertim cum cibus fit folidior, \& qux tanquam bafis fuftinere debet reliqua alimenta, ne in fundo ventriculi fluctuent. B o N T I us. Certe fi id, quod res eft, fatear. Si tritici (ut folet) copia nobis è Iaponia \& Zuratte advehatur, Oryza libenter carere velim, cum è farina tritici panes hic confecti patriis bonitate non cedant, \& melioris (meo quidem judicio) quam, Oryza fint nutrimenti : fed fi tritici adfit inopia, tum ifta eligenda eft, qux colore fit candidiffima, \& qux manu contenta bene ponderet, \& colore quafi perfipicua cernatur : fed cum excocta eft, antequam ea utare, expectes oportet, donec refrixerit : nam experientia conftat, calidam Oryzam non folum noxiam effe ventricus lo, verum cerebro, ac univerfo nervorum generi: hínc quoque fit à vaporibus craflis \& ficcis ex hoc cibo in cerebrum elevatis, nervos opticos fxpe in tantum obftrui, ut crcitas inde oriatur: de qua, \& de cjus cura latius in Methodo mea medendi Indica ex profeflo agam : hinc etiam non facile videas Iavanos, ac Malaios edere calidam Ory zam, quia Indi (fi qux gens alia) fanitatis confervand $x$ fux funt apprime curiofi, inde fobrii exiftentes, fumme exactam dirtam obfervant. DuR $\&$ us, fed heus tu ! nobis nimium ficcum in pictura convivium apponis, \& interea, Nos miferi aremus; nec quod potemus, babernus. Velim potum nobis prabeas. B ONT. Haud male mones, nam \& mihi loquendo fauces folito ficciores funt, verum defluente licet nobis accipere, quoniam al terius liquoris hic nobis non eft copia ac primum de aqua puriffima, ac fimpliciflima fecundum elementum fuum nativum agamus, namque hæc potio etiam nobis cum reliquis animalibus eft communis. DuR $₫$ us. Quid igitur de fluvio hoc Bataviam noftram interfluente cenfes? B o N T. Aquam eam qualitate quidem non ef fe malam, fi altius è flumine petatur : nam in ore fluvii propter affluxum maris, falfedine 
imbuitur: \& hæc eft illa caufa, quod cum anno $16_{2} 8$, à lavanis Matarannenfibus arcte obfeffi effemus, \& propterea ex fluvio altius aquam petere non auderemus, multic potu falfo in dyfenteriam inciderent, addito etiam infuper hoc, quod cadavera Iavanorum, à nobis quotidic excurfionibus occiforum, in fummo tiatarent, ac aquam non folum tabo defcendente flumine: fed $\&$ aërem, putrido halitu inficerent. D u R. Sed licet nobis hic potum factitium bibere, quid tu de eo fentis ? Bo N T. Quoniam Cerevifia nobis deeft, non quod coqui hic non poffit: fed quod propter calorem aëris, citiflime acefceret, alioqui non minus bona, quam in patria parari poffet: nam (ut dixi) triticum, è Siratte nobis abunde fubvehitur, tum quoque ex Ory'za, non decorticata iftud frumentigenus commode confici poteft, quod flitout in patria vocamus. $\mathrm{Cu}$ jus rei exemplum vidimus apud Marefchallum, mercatorem bene cognitum, qui in hac urbe ex predicta materia cerevifiam coquebat, nulla ratione Hollandicæe cedentem, qux non fecus ac patria quoque cerebrum tentabat, ac gultunon deterior erat:fed durabilis non crat propter fummum in his locis calorem, ac cito acefcebat: verum falubris ifte eft potus, qui modo fequenti paratur. Sume vafculum ferreis vinculis bene cinctum, triginta, aut amplius (pro familix magnitudine, amphorarum, quod imple aqua fluviatili pura, cui facchari Iavanici nigri infunde to $\mathrm{i}$. Thamarindorum unc. $1 \mathrm{v}$. Citreorum malorum diffectorum $\mathrm{N}^{\circ}$. iij. bene obturata hæc reponantur loco frigidiore, à Solis radiis libero, fermententur fimul per 24 horas, \& 2 , quod mirandum, fine fubjecto igne ebulliunt, ut eminus aftantibus exaudiri poffit fonus, non fecus quam valido igne coquitur cerevifia noftra patria, tum fæces in altum' ejicit, quas aperto operculo abjicimus. Hic potus nofter eft quotidianus, guftu jucundiffimus, ac vifceribus minime, ut pracedens, gravis. Et certe illi qui noviter huc è patria pervenere, à me ridendi gratia decepti difceflere, putantes, me is Anglicam vel Martiam cerevifiam propinaffe, cujus faporem magis amulabitur, fi manipulum Caryophyllorum in vas conjicias. Du R. Sed quid de potu ifto exiftimas, qui hic ex aquæ partibus fex, \& vini duabus eodem modo fermentando in cantaris Hollandicis lapideis angultioribus conficitur? B o N T. Limpidus, fateor, ac frigidus eft potus : ideoque etiam tempore cibi fumendi utiliorem effe puto : fed altero urendum cenferem interdiu, quod pectori paulo fit infeftior, nefcio quid acidi penetrantis fapiens. DuR. fed utrum vinum falubrius effe exiftimas, Gallicumne, an Hifpanicum? Bo N T. funt qui Gallicum praftare putent : fed meo quidem judicio hallucinantur, Fanius enim credo in his locis vinum Hifpanicum effe vel Creticum. Du R. attamen hoc rationi plane contrarium videtur, quod fub climate calidiffimo, calida vina, ac oligophora exhiberi velis. BoN T. ubi rationem audieris, mirari defines : nam cum calor hic interdiu, præfertimà decina matutina ufque ad pomeridianam tertiam horam, admodum fit vehemens, necefle eft, homines multo fudore diffluere, unde quoque calor nobis ingenitus debilitatur, proin partes naturales coctioni ciborum infervientes, ac chyli, debito frigidiores remanent, fecus quam in partibus feptentrionalibus accidit, ubi ex Hippocrat. decreto ventres hyeme funt calidiores, ratio eft quod per antiperiftafin externus aër internum calorem. augeat. huic quoque argumento fidem addit experientia mercatorum, per deferta Arabix in Perfiam, aut Turciam iter facientium, qui in fummis caloribus fitim optimefedant hauftu fpiritus vini, vel fortiffimi vini Perfici, vel Hifpanici: nam, fi ob inexplebilem fitim affiduo aquam ingererent, in cachexiam proculdubio, ac in ventris infignem tumorem, acipfum denique hydropem, inciderent. Adde quod vinum Gallicum, quod huc è patria adfertur, œnopolæ apud Hollandos liberalius ifto fuffumigio imbuunt, quod Iutft vocant, quod cum arfenico, fulphure, \& colophonia conftet, vino perniciofam accaufticam qualitatem inurit, quamvis efficiat, ut fapor diutius illi incorruptus confervetur. Vnde ego aliquos vidi ex folo Gallici vini potu largiore in lechalem dyfenteriam incidiffe. D u R. Ex præediatis apparet te etiam à vino adufto, nec Arac Chinenfe, abhorrere. Bo N T. ufum commendo, abufum abominor. Si quis igitur mane, aut vefperi, ventriculi roborandi gratia, unc. ij. aut unc. ijj. iftius liquor is fumat, haud male, mejudice, fecerit. Sed,fi id vinum diftillatum haberi poteft, quod . è Gallia venit, non eft quod Arac confectum defideremus : fed fi ejus copia non detur, quod conficitur è liquore nuce Indica contento, ac ex ipfa arbore diftillato cum Oryza, cligendum eft. at cane pejus $\&$ angue vitandum eft, quod Chineafes avariflimi 
HIST. NATVRAL。\&MEDIC. LIB。

riffimi fimul, ac aftutiffimi bipedum mixtis Holothuriis in mari fluctuantibus parant; qux excrementa maris Belgx (Auallen vocant, eaque tam exurentis funt caloris, ut folo attactu veficas in cute excitent, atque hinc exulcerationes pulmonum, fanguinis fputa, tabes, ac mors ipfa adveniant, atque hoc eft, ut Plautus ait, quod homines hic tam brevem vitam colunt, cum, inftar ftrigilum, inteftina abradant, ac cxedant.

\section{I A L O G V S IV.}

\section{De Totionibus naturalibus ex arboribus depromptis in India Tovnat, ac Saguër dictis, tum de liquore nuce Indica contento.}

D $V R$. In omnibus his mihi abunde fatisfecifti, jam fententiam tuam explices ve lim de liquoribus iftis potulentis, qui vel ex fructibus arborum, vel ex ipfis ar boribus depromuntur. B o N T. Sciendum itaque eft, tres hujus potus effe fpecies; primam, qux continetur in Nucis Indicx cavitate; fecundam, quxe è floribus ejufdem arboris elicitur; tertia frequens eft in Banda acreliquis infulis Moluccis, qux dettillat ex arbore non abfimili Palmæ Indicx, ifque potus indigenis Saguër vocatur, hx tres potus naturalis fpecies per totam Indiam admodum familiares funt. Achoc in genere de iis dictum fit, ipfos frigida qualitate excellere, ac proinde nervis effe infe. Atos, fi quis nimia quantitate iis abutatur, prefertim corpore per exercitium aut Solis ardorem excalefacto: non fecus ac vidimus frepe in patria noftra, fi quis xftate, vel oriente Canicula, curfu defatigatus, \& fudore perfluens, intempeftive nimis avide frigidum, vel lactis preffivum hauriat, ipfum in momentaneam mortem incidiffe, vel fummum vitæ periculum. Itaque potu exhis arboribus parcius eft utendum : nam conftat, frequenti illorum ufu, prafertim liquoris Saguër dicti, non folum diarrhoas ditturnas ortas : fed \& paralyfin, Beriberii diatam, hinc natam effe. Hinc eft, quod in Ban-da, cæeterifque Moluccis infulis, prafertim quæ noftro fub funt imperio, plerique homines cachectici fint, ac foedo colore ad luteum vergente, $\&$ vix unus, aut alter è noItris Batavis paralyfin prædictam effugit, quod $\&$ norunt Lufitani, qui non folum in hoc potu : fed in reliqua omni dixta temperatiores funt, quam noftrates.

\section{$\begin{array}{llllllllll}D & I & A & L & O & G & V & S & V\end{array}$}

\section{De Aromatis, ac de ufu illorum. Vbi quedam a' Garcia ab Orta, ac ceteris aromatariis friptoribus non fatis liquido tractata explicantur.}

D $V_{R}$ A $v s$. Cibum jam ac potum tiobis affatim in pictura appofuifti: fed fimplicem, ac nullis condimentis imbutum, cum tamen nullibi copiofius aromata proveniant quam in Iava. B o N T I us. Quam tu delicatus es! an nefcis naturam fimplici victu effe contentam? veruntamen, ne videamur earum rerum per negligentiam curam non gerere, in hoc te non deferam. Ac de Aromatis dicam, non quod auditu percepi, fed quod fenfu proprio ac vifu verum effe didici. Piper primum attingamus, cujus qualitates cum per totum orbem notiflim $x$ fint, non eft quod pluribus de eo hic agamus. Certe Convolvuli eft fpecies, fi modum crefcendi refpiciamus, nam arbores ac bacillos eodem modo, quo Convolvulus, fcandit. Condiuntur hujus viridis racemi, (nam ut uvæ Corinthiacæ crefcit) muria $\&$ aceto ad orexin excitandam, ac cum carnibus affis aut elixis apponuntur, eodem modo inco12 condiunt radices recentes $Z$ inziberis, Galangx, cum fructibus cManga, Caram. bola, Billingbing, Curcuma, tum Cucumeribus primum adolefcentibus, Melonibus infuper, ac Peponibus, quxnobis Capparum vicem fupplent ac Olearum, quanquam \& hx delicize non deficiant, cum quotannis eas defiderantibus fatis copiofe huc è Perfia,\& Sirrate advehantur; ridiculum porro eft quod Garcias ab orta peculiari cap. refert, de opinione Iavanorum ac Indorum de Piperis qualitate, ipfum nimirum effe frigidum. Credo ea ratione, qua quidam fophiftx olimignem frigidum, ac glaciem, 
\& nivem calidam effe affirmare aufi funt: quibus ego cum Ạriftotele refponfun velim, fola experientia contra hos ineptos affertores effe difputandum: nifi forte velint calorem nativum, nimio cjus ufu foras pelli, \& intus debilitari; ac hoc modo corporis temperiem verfus frigidam mutari. Sed Indi, credo, tam alte non Philofophantur. Idem quoque inde de Caryophyllis, eodem modo conditis, fentiunt. Du R Æ us. Quid de Maci \& Nuce Myriftica condita fentis? B o N r u us. Iis, ego dico,parcius in his regionibus effe utendum: nam ventriculum fua oleofitate ac pinguedine gravant, tum vaporibus ad cerebrum elatis fomnolentiam \& ftupiditatem inducunt, immo vidi ex nucis Myrifticx nimio ufu, aliquot non parum periclitatos effe, qui per diem unum atque alterum, non fecus ac caro correpti,immobiles, \& muti jacuere, certifimo indicio, cerebrum \& nervos non parum male affectos effe. Porro è corticibus viridibus Nucis Myrilticx in Banda infula co quunt pultem, faccharo condiunt, ac tum faporem referunt acidorum pomorum fic coctorum in patria. Sed $\&$ nos in Iava ex corticibus falitis ejufdem Nucis, primum aqua maceratis, non infuaviter fimile condimentum conficimus: experientia quoque conftat, fomnum accerfere, ideoque cautius eo utendum cenfeo. D u R \& u s. Itáque, ut audio,nimium in cibis Aromatum ufum nonlaudas? B o N T. Ita eft. Cardamomo excepto, quod blando fuo calore, \& natur $x$ noftr $x$ familiari, mafticatum, nullum empyreuma vifceribus inurit. Crefcit copiofe hæc planta in Iava; \& mulieribus Malaicis frequenti in ufu eft, condiendis pircibus, ac carnibus elixis. Du $Æ$ us. Calamum Aromaticum, qui tam familiariter crefcit, nonne in ufu in culina effe autumas? Bo N r ru s. \& quidem commodiffime, quamvis Garcias ab orta illius, ut \& Iunci odorati, nullum in India ufum agnofcit, quam fubfternendis equorum cubilibus; verum, $f$ tam diligens fuiffet in rimandis Aromatum qualitatibus, quam perfpicax in legendis Medicis Arabicis, non debuiffet commoditates earum plantarum ignoraffe, nam per totam Indiam vix pifces coquuntur, aut carnes, quin fafciculus calami Aromatici, aut Iunci odorati, is injiciatur, ad gratum faporem, ac ventriculi non levern corroborationem. Idem de Nardo, quxin montibus crefcit, efto judicium. Hxc quoque aceto infufa per aliquot dies, ut flores Calendulæ exficcatæ apud nos, putredini \& corruptioni humorum egregie refiftit. Ego viridem Nardum hadenus non vidi, quia montes hic inacceffi nobis funt propter Tigridum inibi frequentiam \& prædones Iavanos. Du R \& u s. Dixeras: antea , etiam Curcumæ radicem incoqui cibis. Bo N T I us. Recte quidem $\&$ hane radicem Garcias ab orta vocat Crocum Indicum, non quod Croci Britannici filamentis fimilis fit: fed quod flavo colore tingat. Eafdem radices quoque crefcentes, quia Garcias non vidit, putare fe ait fine noxa intra corpus fumi poffe, ejus rei audacter fponforem me do, nam qui plantam millies vidi, \& alibi largius defcripfi, non folum cibis utiliter incoqui affirmo, fed egregios etiam ejus ufus in medicina alio volumine oftendi, arque hæc de Aromatis diata hic fufficiant. D u R \& u s. Perfæpe miratus fum Malaios, ac lavanos, tum Chinenfes quoque, Mandragoræ iftius fructu, quam Lufitani pomo d'oro vocant, tam avide vefci, cum in fummo gradu funt frigida. B o N T. Bona verba, quafo, an nefcis, cos addere fructum Ricini Americani, quod lada Chili Malaii vocant, quafi dicas, Piper è Chile, Brafilix conterminæregione, ita alterius fummam frigiditatem, alterius exceffivo calore temperant, aceto, acoleo fuperinfufo, non male cum carnibus, aut pifcibus affis comedunt. Sunt qui mafticationi iftius Ricini ita affueverunt, non fecus \& 8 fumigatores ifti Nicotianx. Q uantum ad me, eo tamen libenter caream, nam dum animi gratia idem tentare aggreflus effem, totum mihi palatum ac linguam excoriavi, à cauftica iftius $R$ icini vi, hinc videre eft, quantum faciat confuetudo.

\section{$\begin{array}{lllllllllllllllllll}D & I & A & I & O & G & V & S & V & \text { I. }\end{array}$}

\section{De Fructibus, omnigenis Oleribus, ac Acetariis berbis in Iava.}

R fus. Quoniam convivium noftrum jam ad finem tendere videtur; fine bellariis credo hoc non dimittes. B o N r. Nullo modo, itaque à fructibus incipiamus, quorum non parvus eft habendus delectus, optimi enin inter eos funt, qui guftu funt aftringenti, pejores, quifaporem dulcedine fallunt : fed, ut de fin- 
HIST. NATVRA L. \& MEDIC. LIB. I.

gulis aliquem fermonem gufternus. Primi nobis occurrunt Manga dicti fructus, qui in altiflimis ac expanfis arboribus cref'cunt, forma Quercum noftratem non male, æmulantibus; qui, dum immaturi, acidiffimi funt faporis, unde nobis demtis corticibus \& nucleis in medio, puls coquitur fapore acido, poma acida, \& uvas crifpas coctas referens, ut quis vel exquifitiffini guftus, faporis differentiam vix agnofcere fe fateretur: atqui fructus Manga, hoc modo præparati, ventriculo \& inteftinis corroborandis conveniunt, maturi minus funt falubres, fed tamen fi quis iis parcius utatur, nullam noxam inferent. Dur. DeDurionibus, Iaacis, ac cæeteris echinatis fructibus, quid fentis ? B o N T I us. Duriones ob fœtorem Allium referentes, primum guftantibus, fateor, faftidiof funt \& naufeabundi, tamen inter fructus faluberrimos Indicos eos merito repono: nam diuretici funt, \& fudores eliciunt, tum flatus difcutiunt, tamen fi nimia quantitate eos quis fumferit propter calidam $\&$ ficcam, qua præditi funt, qualitatem, inflammant fanguinem \& hepar, puftulafque in facie excitant : itaque eos reponamus inter medicamenta alimentofa, de quibus in Meth. Indica mea Medendi. DuR. haud difficulter mihi perfuades: fed quo gradu locas Ananas fructus fapidiffimos ac odoratiffimos? B o N T. Si qualitates cxteræ fupradictis à te refponderent, nobiliorem fructum in toto orbe terrarum non nafci contenderem : fed tam erodentis porro funt qualitatis, ut fuccus eorum, chalybem, \& ferrum erodat, unde nifi vino, aut aqua per aliquot tempus macerentur, palatum, \&linguam excoriant, ac horribilem Choleram, lethalemque fepe Dyfenteriám creant. Du $\mathbb{R}$ \& s. Iacas, pus to, fapor dulcis commendabit! B O.N T. Immo ego illas maxime infalubres effe puto, cum carnis fint tenacis ac duræ $\& 2$ qux incoctx $\&$ crudx, ut ore aflumuntur, fere per alvum dejiciantur. unde etiam cruditates in ventriculo, \& inteftinis gignunt, quæ moleftas, diuturnafque Diarrhoas creant, dein Tenefmum, cuifepe fuccedit mortifera Dyfenteria. D u R. Qui fructus funt ergo, quos mox ob aftrictiorem faporem com. mendabas? B o N T. Ii funt primum Iambos fructus vocati, pulcherrimo exalbo ad purpureum vergentes colore. fapore ferme, ut Caprex vitis, ut bene monet Chrifloph. à Cofta, aftringunt vehementer, ac proinde. Dyfenteriis \& Choleris accommodatum eft remedium, de quo alias. Adfertur ad nos præterea fructus quidam, Lances vocatus, qui racematim ut, uvx, crefcit, rotunda plane figura, magnitudine Pruni, intus nucleum habet, qui veftitur carne alba, \& faporis vinofi, qualis fere eft in uvis urfinis in patria. Huic confimilis guftu eft fructus, Iavanis Bor Rampout vocatus, quod crinem fignificat, quod cortex externe fructum ambiens multis capillamentis fit præditus, nucleus plane fimilis eft prædicto Lancium, ac qualitate frigida conveniunt; cortex Lancium tamen fuccum lacteum emittit, qui amarus valde $\&$ corrofivus eft. datur præterea fructus Billinbing indigenis diatus, forma adolefcentis primum parvi Cucumeris, adeo acido fapore, ut acorem ipfum dicas, in quo illud miri obfervatur, quod fi ab aliis acidis fructibus cuipiam obftupefcant dentes, iftius fructu comefus ftatim acor abfefferit, credo ea ratione, qua in affectibus præter naturam major dolor minorem. obfcurat. Dur. Quid tibi deFicubus noftris Indicis videcur? B o N T r u s. Hos fructus Pr. Alpinus Mufam vocavit, Malaii Banana indigitant, Iavani Py/ang. fapore quidem grato funt \& pyro noftro 2 mulantes, qux ob dulcorem Batavi Supefier peeren vocant : hi fructus: fi crudi comedantur, flatuofi admodum funt, \& naufeabundi, unde infolitis ftomachum fubvertunt: fed melius comeduntur cum pane $\&$ Oryza cocta, juncto cafeo, alias quis facile in Dyfenteriam, \& ipfi congenerem Choleram,inciderit. Non fecus ac $f_{1}$ in Gallia, aut Hifpania quis, qui recens iftuc advenerit, uvis fine pane fe affatim ingurgitet, nxille certo certius in fluxum Dyfentericum incider.' Hi fruaus cum ovis fricti in fartagine multo falubriores funt, \& tum Phthificis, Afthmaticis; $\&$ cateris malis pectoris admodum utiles funt, tum extus impofita inflammatorios tumores quofcunque ad maturitatem perducunt. Du R. Alt ubi relinquis Mangoftan, Iambo, \& Cydonia Bengalenfia? B o N T I u s. Ego ea probellariis refervabam, tit fimul cum Chinenfium potu The vocato, \& T cbia laponibus dicta convivium finiremus, $\&$, quod hic moris eft, ut Syrii pynang vobis apponeremus. Iambo igitur primum arbor eft magnitudine Pruni, \& nifi quod paulo acutioribus fit foliis, ipfi plane refponderet, flore rubro, fructu pulcherrimo, ex candido purpurafcentis coloris : guftu funt aftringenti, \& fapore ferme Vitium capreolas referunt, fapore itaque minus praftant, quam colore promittunt : frigidx funt nature, ideo xttuantibus utiles five ab exercitio, five 
à calore febrili, Cydonia Bengalenfia defcribit Garc. ab Orta, 1. I1. cap. XIv. Itaque de iis hoc tantum addemus, quod his Pyris feu Malis Cotoneis eximant nucleos, ac totos Saccharo, vel muria, \& aceto condiant, qux ad nos ex interceptis Lufitanorum navibus qua Malaccam verfus navigant, à Sirate, \& ora Chormandel. Nam nulla gens in mundo ita afluevit conditur is ejufmodi, quam Lufitani, ita ut per totam Indiam in proverbio fit ; Indos odoribus, Lufitanos condituris, rem difperdere. Sapore æmulantur Pyra ifta, Autumnalia grandia noftratia, qux vulgus Minter-peeren vocat. Frußtus porro Margoftan dicti, tam excellentis funt faporis; ut mea quidem fententia omnes cæteros in his regionibus fructus anteeat, cortex plane Mali Granati cortici fimilis eft, nifi quod in fuperiori parte coronam habeat ut papaver, cujus quot funt radii, tot nucleos intus habebis, veftitos carne nive candidiori, fapore ex dulci vinofo, fuperante fraga, ac Ananas in India. Dur. Memineras de Chinenfrum Thee vocato Potu, quid tu de eo fentis? B o N r. Herbula unde hoc The conficitur,Bellidis feu Confolid $x$ minoris folia refert, cum parvis in ambitu incifuris. hujus foliorum exficcatorum manipulum in ferventem lebetem ad hoc paratum conjiciunt, $\&$ ad fufficiens tem pus ebullire finunt, huncliquorem qui faporefubamarus eft, calidum forbent. Hunc porro potum tanquam facrum China obfervant, \& hoc venientes, hoc abeuntes, hofpites excipiunt, \& non creduntur jus hofpitalitatis impleviffe, nifitibi eum propinaverint, non fecus ac Mahometani fuum Caveab æeftimant. Exficcantis eft qualitatis, ac fomnum prohibet, dum vapores è ventriculo in cerebrum afcendentes abfumit, præterea Afthmaticis, ac Sufpiriofis prodeft. Quid jam poftremo tibi memorem Mala Aurea, Citrea, Granata, \& cxteros fimiles fructus, quorum fumma eft copia, cum ifta in noftra Europa notiflima funt, \& nos hinc Syrupos conficimus, quique fitientibus aqua mixti, Iulapii locum in fanis, ac xgris, obtinent? Vites taceo, qux, fi diligentem putatorem, \& cultorem nancifcantur, quater in anno maturos fuos fructus proferunt. itaque fi diurnus calor non adfit, propter perpetuum virorem femper hic Ver, ac veri Hefperidum Horti.

\section{$\begin{array}{llllllllll}D & I & A & L & O & G & V & S & \text { V I I. }\end{array}$}

\section{De Oleribus, of Leguminibus in Indiis, of Radicibus quibufdam edulibus.}

$\mathrm{D}$ $V_{R}$ \& u s. Finito jam imaginario tuo convivio, domum remeantes, faltem aliquid olerum in vefpertinam cœnam colligamus. Bo s T. Dic modo quid primum expediri velis? DuR. Radices eas narres mihi, quas Batatas vocamus. Bon т. Pleni quidem eas nutrimenti effe, attamen fuccum melancholicum producere, non fecus ac caftanex in Europa, quarum faporem hæradices, fub cineribus tofte, vel etiam elixa cum carnibus, plane referunt, nifi quod fint humidiores, 8 molliores paululum: fed fi fale, oleo, pipere, $\&$ aceto perfundantur, betæ rubrx coct $x$ nobis loco funt in acetariis. DuR. De Raphanis fativis hic luxuriantibus quid tu fentis? B o N T. Horum, ut fcis, habemus duo genera, primum breve, \& rotundum, vel cylindri faltem formam referens: hi cocti loco raparum nobis in familiari funt cibo ; fecundum eft oblongum; \& teres, ut Hollandicus raphanus, quod cum pane, butyro, \& fale, crudum more patrio comeditur. Cxterum longe præftant Raphani patriis, quod non fint tam lignof, nec à teredine ita perforentur, fed efculentiores, \& fapidiores funt. Du R. Quid Indi de oleribus fentiunt? B o N T. Illi ifta, \& omnes herbas edules in magno pretio habent: nam qui à Sirate, \& oris Chormandel hucadveniunt, plerique ferme folis vegetativis vefcuntur, fequuti Pythsgoram,

Cunctis animalibus abftinuit qui,

Tanquari homini, ac ventri indulfit son omne legumen.

[Iuvenalis Satyr. 16.]

Ita hi homines etiamnum abftinent Fabis rubris, \& quicquid inter herbas rubrum colorem obtinet. Hinc etiam fit, quod homines, in cxteris rebus idiotx, tam exactam herbarum, \& firpium nancifcantur fcientiam, ut fivel doctiflimus $P$ avvius, noftri rvi botanicorum princeps, è mortuis refurgens huc veniret, miraretur, fe ab his hominibus barbaris doceri pofle. Cxterum olera omnia, \& manfiles herbas, Malaii generali vocabulo 
cabulo Seir vocant, ut contra, herbas medicamentofas, \& venena quoque oubat indigitant. Vt rem in pauca contraham, \&; ne tractatus modum excedam, enumerabo reliqua olera in nutrimentum hominum nafcentia, utramque Betam rubram $\&$ albam. Petrofelinum quoque luxuriat. Lactucarum omnes fpecies. Anethum, \& Fœniculum, Afparagos etiam non infeliciter ferere incepimus. Tum fructus terreAtres quoque proveniunt, ut funt Melones aquatici, Pepones, Cucumeres, Citrulli ; fed cum hec omnia in patria abundent, de is ad faftidium nolo dicere. Semina horum fructuum eundem ufum in medicina proftant, quem apud Batavos antiquos. Legumina, non folum in farmentis, fed in præaltis arboribus, ut alibi diximus, nafcuntur; fapore bono \& nutrimenti ejufdem, ut apud nos, flatulenti , \&c. Habemus præterea fructum quendam, quem Focqui Focqui Malaii indigitant, cubitali fæpe magnitudine, brachium humanum craffitie aquans, $\&$ teres, eodem modo quo Cynara coctus cum vino \& pipere \& butyro, ei fapore non cedit. Figuram in Exoticis meis Indicis videre eft $\&$ defcriptionem, qux proximo anno faxo habeatis. Sed hre de Oleribus fufficiant, tranfeamus ad Exercitia, \& animi pathemata, ut tandem opta. tum portum attingamus.

\section{I A O G V S VIII.}

\section{De Exercitiis, fomino, of vigilia, fanguinismiffone, purgatione, \& de animi affectibus.}

D VR xus. Quid de reliqua diatæ parte cenfes, qux in exercitiis feu motu \& quiete confiftit? Bon T. Vt hæc obiter percurramus, Exercitia, procul dubio moderata effe debent: nam propter humidam $\&$ calidam aëris temperiem corpora hic fluxa effe, extra controverfiam eft. Et hec quidem matutino vel vefpertino tempore inftitui debent, cum Sol non ita fervidus eft, itaque commoda deambulatio, iis temporibus fanitati conducit, tum equitatio modefta, ut ditioribus mos eft, \& veatatio per fluvium cum navicula, ut amœniffimas fylvás, \& fluminum oras tranfvehamur, qux floribus \& herbis confitx perpetuo virent. $D$ u R. Quid de fomno, ac eum capiendi tempore, autumas? B $\mathrm{N}$ T. De fomno nil habeo, quod addam, nifi iftud antiquum, ut moderatus fit. Sed vereor, ne hic Apocryphus fim, fi fomnum meridianum fanitati conducere dicam : fed ut res cafura eft, ego ab ifta opinione non,recedam, nifi melius edoctus. Fit certe, fi in memoriam revocare velis, qua ante dicta funt, quod mane propter poftnocturnum frigus concoctioni ventriculi magis apti fint, qua propter etiam largiusjentandum præcepi. Meridianus fomnus hic non folum utilis, fed 8 neceffarius ferme, cenfebitur. Præfertim cum hoc tempore tantus calor aérem occupet, ut vel levifimus motus te defatiget, \& fudore diffluere faciat, quid obftat, quominus lectione jucunda, feu levi fomno, curas diluas ? Nam \& illi qui Hifpanias, Italiam, ac Gallias, frequentavere, hoc in iis locis folitum effe affirmabunt, cum tamen nullo modo calor ibi tantus fit, ut in his locis. Secus habet in locis Septentrionem verfus fitis, ubi femper largius prandemus, $\&$ digeftioni ciborum motus levior vel deambulatio conducat, fed hic parce prandendum cum fit, fomnus concoctioni ciborum nullo modo officit : fed eam magis promovet. Dur. Quid cenfes de retentione ac vacuatione humorum? B o N T. Non eft, quod hoc à me expectes, purgationem, aut venxfectionem eam, qux in morbis adhiberi folet: fed eam, quæ fervandæ valetudinis gratia contra affectus non naturales inftituitur. Ergo fi alvus folito aftrictior fuerit, eam commode folvemus praftantifimis nafcentibus laxativis, Thamarindis nimirum, \& medulla Caffix fiftula. Vel fi paulo validius medicamentum defideres, addatur his Rhabarbari Extractum vel Syrupus ejus. Si porro fanguis mittendus, ratio etiam talis eft habenda, qualis in patria, plenitudinis nimirum vocatæ ad vafa, ac ad vires : prior fi adfit plethora, fecundum Hippocratem, 1. I. aphor. 3. large aliquando fanguis mittendus; altera ad vires, fi adfit, ventilandis vifceribus, præfertim hepati \& cordi, fecundum judicium fanguis mittendus vel femel, vel iterato. Si porro alvus fit folutior, \& inde Dyfenteria, \& Diarrhœa metuatur; fyrupus fumatur è fucco granatorum, vel decoct. è cor- 
14 IACOBI BONTII HIST. NATVR \& MEDIC. Lir. I.

ticibus eorum. Sed quia hxc magis ad morborum curam attinent, illa in aliud commodius tempus rejiciamus. D $\mathrm{k}$ k. Reftat parvus fcrupulus de animi affectibus \& perturbationibus intempeftivis. Bo NT. De is Medici multa \& varia feripfere, quomodo domari vel temperari debeant. Verum cum motus animi vix fint in poteftate noftra : Ego illis illud Hor atii objicio : quod animus,

\section{- qui nifiservit,}

Imperat, bunc frenis, bunctu compefce cateris.

Quod uni facile, alteri difficile, factu effe pro diverfo temperamento, quis non fatebitur ? ideoque de affectibus \& pathematis animi certam reguläm velle ferre; nugatoris magis puto effe, quam Philofophi naturalis: Tum etiam hoc cogitandum; ut jejunium noftrum folvamus, ne nobis Plautinum iftud eveniat, dum de frenandis animi paffionibus difputamus, fames \& mora bilem in nafum conciat; itaque fuadeam, dum Sol nondum radios in verticem noftrum dimittat, jentatum eamus. D u R ef us. Oppor-, tune mones, nam \& gula me monet, ventrem famelicum carcre auribus. Ergo, fiplacet, in urbem nos recipiamus. B O N I I s. Me lubente fiet.

Dedit Deus his quoque frnem, 1631 , Ianuarii 18 , Batav. Iacatr.

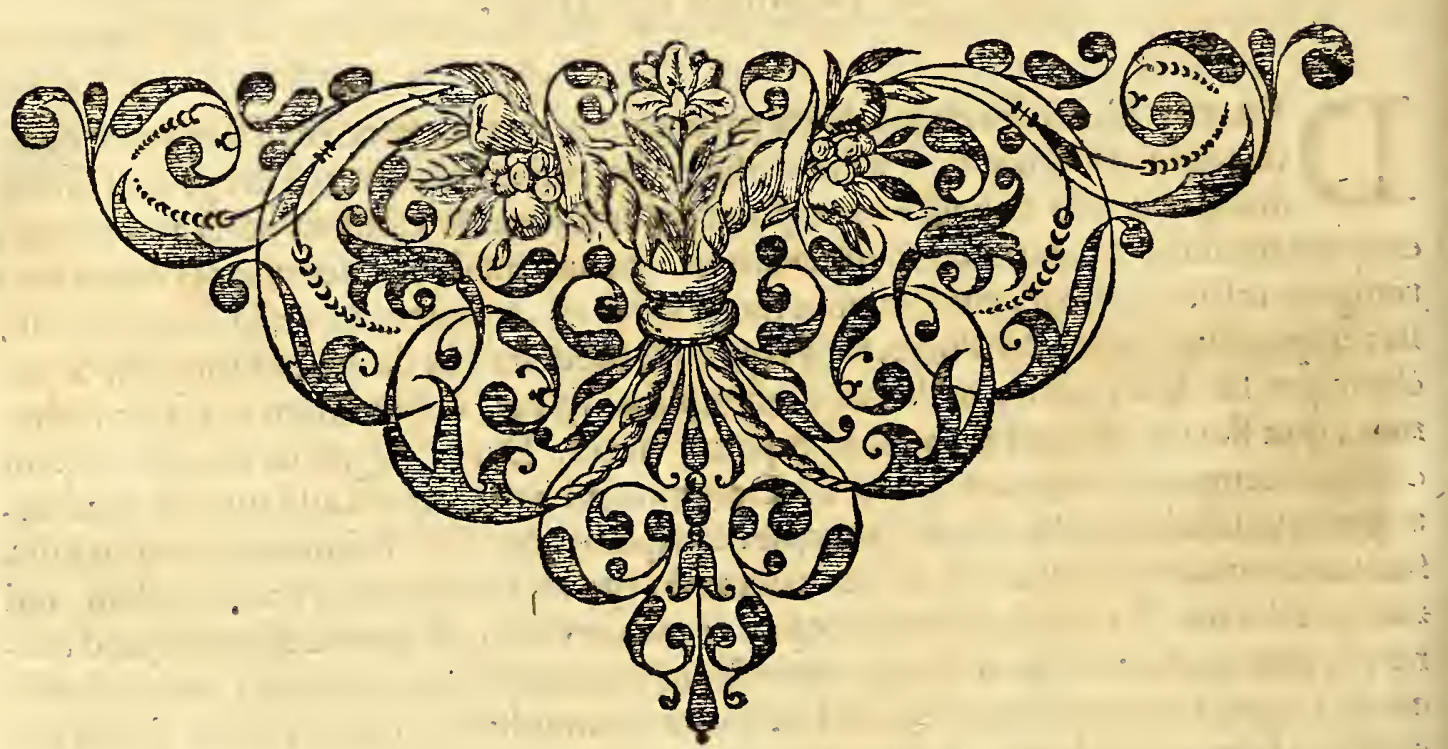

I A C O- 
I A COB I B O N T I I

MED I C I

\title{
METHODVS MEDENDI
}

\author{
$2 V \cdot 1$
}

I IN DIIS ORIENTALIBVS

oportet uti, in cura morborum illic vulgo $\&$ popularitergraffantium.

$\begin{array}{lllllllllllll}L & I & B & E & R & S & E & C & V & N & D & V & S .\end{array}$

\section{Amplißimis, Magnificis, ac Prudentißimis Viris, \\ PR坐FECTIS MAIORIBVS Negotiorum in INDlis ORIENTALIBVs;}

Dominis meis, mihi fumma obfervantia colendis.

\section{S. P. D.}

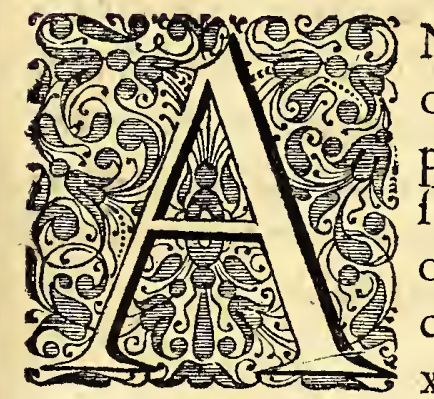

Nni jam fere tres elapfi funt (Viri Ampliffimi) quod operam in re medica meam, V.A. addixi : quam, cum primum in Indias veftras veni, non fterilem jacere paffus fum: fed ftrenue in actum traducere cœpi. Vt eo oftenderem, me non velle, ut fumptus à vobis in me collati, fruftranei effent: Itaque, quod interdiu in pracuris aliquantum vacuus, re libet. Vt faltem ex parte debitx mex rem: nam in folidum folvendo impare præcipue obfervari debere putavi Eofque morbos defcripfi, quos Endemios effe, animadverti. Neque in cura quicquam addidi, quod non folida prius experientia comprobatum effe vobis affirmare aufim. Scribant alii, quibus ifta mens eft, miracula ex auditu: Ego, quod hifce oculis, \& qualicunque meo judicio percepi, vobis fpectandum propono. Quod cum nemo ex noAtris Batavis, (ut credo,) affequutus fit: immo, ne tentaverit quidem ante me; ideoque cum ego, qui primus in hanc arenam defcendo, non fine caufa, malevolorum tela metuam, patrocinium mihi V. A. quxrendum erat, quo adverfus eorum ictus, velut clypeo, hre contegerentur. Quos autem xquiores patronos me invenire poffe confiderem, quam vos (Viri Ampliffimi) qui me hactenus favore veftro profequuti eftis, quem fi fenfero erga me continuari, animum mihi, ac vigorem addetis, hifce majora, \& auri-

$$
B 2
$$




\section{A C OB I B O N T I I}

bus veftris digniora tentandi. Et, fi vitæx fpatium mihi fuperfit, oftendam, me non indignum, cui hxc facra Medica concredita fint. Interea (Viri Amplifimi) chartaceum hoc munufculum, quo folus valeo, eo animo accipere dignemini, quo ego V.A. infcripfi, \& quo adhuc me ipfum; \& quicquid in me eft, fincere vobis offero. Quod A. V'. notius reddam, ubi qux de firpibus, arboribus, ac herbis, in Iava crefcentibus, commentari copi, abfolvero; \& demonftravero, alios, quorum nomen tamen celebre inter doctos eft, hoc negotium nimis levi pede tranfcurriffe. Valete, Viri Ampliffimi, ego interim D. O. M. fupplex veneror, ut, ad crefcentis veftræ Batavix, \& rerum porro Indicarum augmentum, vos nobis diu incolumes conferver. Datum Colonix Batavix Novx, in Regno Iacatrenf, Anno 1629 , Novembris 19 .

\section{$V$. A. addictiffimus Cliens}

I A C O B V B B NTIVS M. D.

\section{AVRELIVS CORNELIVS CELSVS}

De Re medica: 1. 5. Cap: 26. Confilium Practicum

hoc nobile Medicis reliquit.

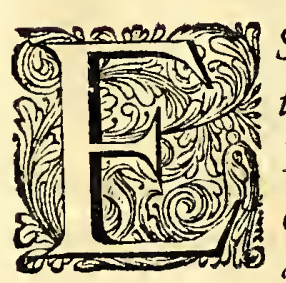

St prudentis hominis; Primum, eum, qui ferparinon poteft, non attingere; nec fubire fuppicionem ejus, ut occifl, quem fors fua peremit. Dein ubigravis metus, fine certa tamen deperatione, indicare neceffariis periclitantis, in difficli rem effe, ne, $\sqrt{2}$ victa ars malo fuerit, vel ignoraffe, vel fefelliffervideatur: Sed, ut hac prudentiviro conveniunt, fic rurfus bifrionis eft parpam rem attollere, quo plus praftitiffe videatur; obligarique aquius eft, confe ffione prompte rei, quo curio fins etian circumpiciat, ne, quodper $\int e$ exigumm est, malum majus curantis negligentia fiat.

Invide, quid tentas abrodere mordicus ungues?

Vel mea ne carpas fcripta, vel ede Tua.

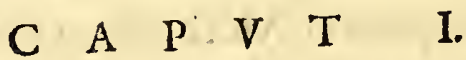

De Paraly Jeos quadam pecie, quam Indigene Beriberii vocant.

A

Ffectus quidam admodum moleftus, homines infeftat, qui ab incolis $\mathrm{Bc}$ riberii (quod Ovem fonat) vocatur. Credo, quia,quos malum iftud invafit, nictando genibus, \& elevando crura, tanquam oves ingrediantur. Eftque fpecies Paralyfeos, feur potius Tremoris : Nam motum, fenfumque manuum, ac pedum, immo vero aliquando totius corporis, depravat, $\&$ tremere facit. Caufa hujus morbi præcipua eft, craflus, \& lentus humor pituicofus, qui nocturnis temporibus, præefertim pluvio colo, (pluvix autem affidux cadunt ab initio Novemb. ufque ad Maii initium,) nervos corripit, dum nimirum homines diurnis caloribus defatigati, noctu omnc tegmen \& lodices à fe rejiciunt; unde facillime, jam in cerebro præcipue genitus, nervos ifte humor phlegmaticus invadit. Nam noctes, in his locis, comparatione caloris diurni, frigid $x$ appellari pofiunt. In hoc cafu artus prolongantur, non contrahuntur, 
huntur, infinuante fe inter juncturas phlegmate, ita ut nervi \& ligamenta inde laxentur. Quamvis autem hoc malum plerumque per gradus, \& pedetentim homines invadat, tamen aliquando valde fubitum eft, dum nimirum homines æftu defatigati, potum ex Palma Indica copiofe \& confeftim ingerunt; non fecus ac in patria, dicbus Canicularibus aliquando vidimus fieri, cum quis curfu, aut aliquo alio vehementi motu, calefactus, potum cerevifix, aut lactis preffi, nimis avide haurit, ita ut inde fæpe fummum vitæ difcrimen, immo ipfam mortem incurrat. Porro figna hujus mali afpectu obvia funt. Adeft enim fpontanea univerfi corporis laffitudo; motus \& fenfus; pracipue manuum \& pedum, depravatur, hebefcitque; atque in iis fentitur plerumque titillatio talis quxdam, qualis in patria frigida, \& hyemali tempeftate, manuun, ac pedum, digitos corripit, nifi, quod hic tantus dolor non adfit. Tum etiam vox aliquando ita impeditur, ut xger vix articulate loqui poffit : quod mihi ipfi accidit, dum ho'c morbo laboranti vocis fonus, per integrum menfem tam exilis effet, ut me vel proxime afidentes vix intelligerent. Adfunt, præter hæc, aliquando multo plura figna, \& Sympromata, quæ tamen omnia tenacem, \& frigidum, humorem fapiunt: fed præcipua enarrafle fufficiat. Accingamus ad curationem itaque, qux plerumque in longum trahitur; dum nempe humor. ifte lentus, \& frigidus, ægre difcutitur: per fe tamen (ut plurimum, ) lethalis non eft : nifi mufculos pectoris, \& thoracis invaferit, $\&$, hoc modo, ípiritus, ac vocis, viam intercludat. Verum hoc imprimis curandum eft, ne (fi ullo modo fieri poffit) telecto affigas decumbendo: Sed vel ambulando, vel equitando, vel fimili aliquo motu validiore, omni conatu te exerceas : currere quidem impoffibile eft. Frictiones quoque fortes, $\&$ dolorifica, fumme neceffarix funt, quas commode hic fervi Bęngalenfes, ac mulieres Malaycx adhibent. Nam noftra gens tali exercitio non afiuevit, ut nec balneis, qux hic frequentia funt. Fomenta, ac Infeffiones conficiunt ex herba nobili Lagondi dicta, qux folio quidem Perficariam refert, cftque odoris fuavis, \&aromatici. Certe nobis non tantum ufum Chamomeli, \& Meliloti, præbet, fed difcutiendi \& refolvendi viribus, iis, meo quidem judicio, præftat ; Pedes \& manus prater ea inungendi funt oleis Caryophyllorum, \& Macis : fed mixtis ol. rofaceo : nam fola adhibita, nimis cauftica funt, \& cutem facillime eroderent. Habemus præter hæc nobilem Naphthæ fpeciem, allatam ex Sumatra, Iavæ regno, è regione in confpectu fita. Quam Minjac Tannnab Indi vocant, ol eum terræ fignificans, quod, non fecus, ac nobis cognita Naphtha, quod oleum petr $x$ vocamus, è terra erumpat; vel ex rupibus, in fubjecta flumina præcipitetur. Hoc oleum à Barbaris in tanto pretio habetur, ut rex Achinenfis, qui potentiflimus iftius infulx eft Tyrannus, fub capitali pæna iftud evehi inde prohibeat: ita ut incolæ, nocte intempefta, fi qux noftra, aut Anglorum navis, eorum littoribus adpellat, ad nos iftud furtim deferant. Hoc oleum, partibus affectis illitum, miraculi inftar egros confolatur. Odore ef por. ro gravi : tamen non faftidiofo.

Sed cum hic morbus fit chronicus, \& longi temporis, nihil xque prodeft, quam decocta ex radicibus Chinæ, Sarçæparillæx, ac Ligno Guajaco; qux blando, \& amico noftro corpori, calore, frigidos iftos, \& craflos humores, per fudores, \& urinas, egrcgie difcutiunt, \& evacuant. Interpofitis tamen fubinde commodis per alvum evacuationibus, inter quas principem locum obtinet Extractum, quod hic conficimus. Exaloë, \& Gutta Cambodja dicta vulgo (corrupte apud nos gutta gamba:) cujus defcriptionem inferius videbitis.

Sanguinem mittere nefas : non enim plethora, fed cacochymia, in vitio eft: \& quis fanguinem fontem caloris, \& thefaurum vitæ, non efle intelligit.

Hujus affectus reliquix porro commode difcutiuntur Theriaca, Mithridatio, \&c. fudorem, \& urinam moventibus, ac nervos roborantibus medicamentis. Reliquas hujus mali moleftias opportuna excrcitatio, \& valida Naturæe vis fanabunt. 


$$
\begin{aligned}
& \text { C A P V T } \\
& \text { De Spafmo. }
\end{aligned}
$$

I I.

Vi apud nos in Hollandia rarus eft Spafmus, in Indiis tam familiaris eft affectus, ut merito inter Endemios, ac populares morbos, numeretur.

Tam repentinus, \& fubitus eft aliquando ejus impetus, ut, dicto citius, honines; rigidi non fecus ac ftatux, permaneant; dum vel in anteriorem, vel pofteriorem corporis partem, mufculi, involuntario motu, verfus principium fuum trahuntur: Crudele (me Hercules) malum! quod fanis partibus vitalibus, \& naturalibus, cum funmo cruciatı miferos mortales, intra breviffimum temporis fpatium, è vivis ad mortem rapir : dum nihil, hec efculenti, necpocul enti per œfophagum in ventriculum deducerequeunt. Sunt \& alii particulares, crurum, ac furarum fpafmi: Sed de his, quia leviores funt ; $8<$ per fe tranfeunt, hinc non agimus.

Póro hoc malo affecti, truculentc admodum aftantes intuentur, prxfertim, (quod fape fri ') interveniente Spafmo Cynico, feu Convulfione canina, cum utravis maxilla aures verfus trahitur. Ruber $\&$ viridis color ex oculis, \& facie, oritur; dentibus ftrident, \& murmur inconditum; vice vocis human $x$, edunt, tanquam ii, qui è cella fubtertanea loquintur? ita ut imperitis vere dxmoniaci appareant.

Cura in hocaffectu à copióf fanguinis miffione inchoanda eft. Tum frictiones, \& ligatur $x$ validx adhibendx. Inunationes quoque fiant oleis Macis, Caryophyllorum, permixtis oleo Anethi, aut Rofarim. Tum ol. Therebinthin $x$, ac Spicx Indicx, quam Iava copiofe fert. Cucurbitx quoque vitrex, \& amplx, cum multa flamma, fine fcarificatione affigend $x$ cervici, lumbis, humeris, ac mammillis, ita enim, ferofus ifte, \& biliofus humor, commode à nervis, \& mufculis revelletur.

Si remediis iftis paroxyfmus paulo mitior evaferit, \& xger aliquo modo jam deglutire incipiat, Antidota adverfus hanc peftem, in forma liquida, exhibenda funt, quxvenenofam hanc, ut plurimum, materiam, impugnando, per fudores, \& urinas celeriter ejiciant. Taliafunt Eapis Bezoar, rafura cornu Rhinocerotis, cum Theriaca, \& Mithridat." mixta, \&c. gux in prógreffu videbitis. Tum vomitoria ex Infufinne guttæ Cambodja, \& Hepate Antimoniif feu Croco Metallorum, deglutienda funt: In hoc porro affectu nil procraftinandum; cum fit morbus acuriffimus, qui, fi quis alius,veporro affectunter, cito, \& cum periculo, movetur. Si autem malum invaluerit : \& ager deglutire non valeat, per acerrimos clyfteres alvus eluenda eft. Quorum hoc fit exemplar.

Bx. Hèrbx Lagondi dictx, Abutali Avicennx, Bifmalvx, qux omnia hic

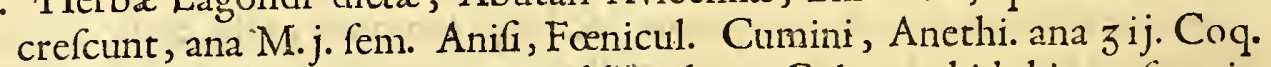
in f.q. aq. Fluvii. Colatur, tt. j. add. pulver. Colocynthid. hic crefcentis,

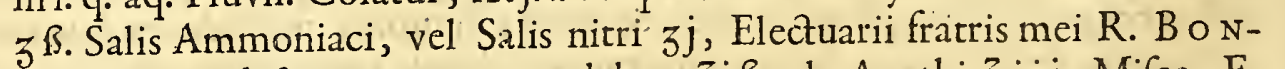
T I I, cujus defcriptionem mox dabo, žjß. ol. Anethi $z^{2} i \mathrm{ij}$. Mifce, F. Énema.

Dein æocr à capite ad calcem inungatur oleis fupradictis, \& Naphta Sumatrenfifeu . Miniac Tannah. Balnea quoque ac fotus fiant ex Herba Lagondi, \& foliis fruticis cujufdam Dawllontas incolis dicti, qui frutex in humanam altitudinem affurgit, folio ad marginem diffecto Balfaminx, cujus ódorem etiam proxime refert. Specifica quadam vi hæc folia crudelifimum hoc malum impugnant, \& funt anodyna, doloremque fedant, qui in hoc malo, ex contractione nervorum, violentifimus eft: Lapis, \& fal prunellæx per os funptum, peculiare eft remedium, ac materiam biliofam per urinas copiofe excernit , \&, fi febris adfit, cor \&arterias refrigerat benigne. Imprimis vero habenda eft ratio, freviffimi fymptomatis doloris nimirum, cui omiffa tantifper caufa principali, fape cogimur occurrerc. Quod commode fiet Laudano Quercetani,Philonio fine Euphorbio, fed præxipuc extracto Croci, quod infra defcribemus. Fortaffis fciolus quifpiam, ncgabit his remediis, propter vim ftupefactivam, \& narcoticam, nervifque inimicam, efle utendum. Speciofa hxe quidem prima fronte videntur; fed tamen vana funt: nam praterquam, quod calidifima hujus climatis tempcries hoc requi- 
HIST. NATYRAI. \& MEDIC. IIB. II.

requirat, certifimum eft, in'tali neceffitate, fine his ægrum evadere non poffe. Adde quod nos tam rite Opium hic praparamus, ut vel infanti innoxie detur ; \& fane (ut verbo abfolvam) fiopiata nobis deeflent, in morbis calidis, hic graflantibus, fruftra remedia adhiberemus, quod, etfi imperitis durum, ex progerflu tamen, menihil temere dixifie patebit. Circa victus rationem non admodum curiofi fumus; quia vehementia, celcritafque, mali, ac atrocitas, nobis longiorem deliberationem eripiunt; inclinante tamen morbo, gallinis, \& hoedina, \& vitulina, carne, utendum, cujus jufculis incoctum fit Cardamomum, \& Thamarindi, qux duo fimplicia lava copiofe fert , ut medicamenti fimul ac alimenti vicem fuppleant.

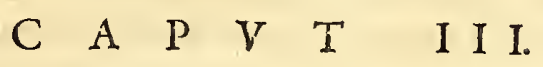

\section{De Alvi Proftuviis, ¿s primum, de Dy enteria vera.}

Q Voniam Profluviorum Alvi, hic (ut \& apud nos) varix funt fpecies, de fingulis agemus, partefque affectas demonftrabimus, tum caufas inveftigabimus, \& fymptomata denique obfervando, curam his annectemus. Et prinum de Dyfenteria vera loquemur, horribili ifto, \& confuetiffimo his regionibus malo, quod plures homines necat, quam affectus quifpiam alius prater naturam. Dyfenteria igitur vera, eft Exulceratio Inteftinorum cum affidua dejectione, mucofa primum, cruenta dein, \& ultimo purulenta, cum ramentis, ac ipforum inteftinorum fubftantia, cum dolore intolerabili, torminibufque ventris; Hoc vitium partim contrahitur ex aëre calido, \& humido; Falluntur enim, (uthoc obiter quoque dicam) qui, propeer Linex Æquinoctialis proximitatem, aëris temperiem, ficcam, \& calidam, effe putant. Cujus rei inviatifimum, inter alia, argumentum eft, quod chalybs, ferrum, xs quoque, ac ex his confecta inftrumenta, rubiginem citius, \& æruginem, contrahant, etiam ficcifima anni tempeftate, cum nullæ pluvix cadunt, quam in patria, Autumnali tempore pluviofiffimo.Præterea fructus maximum huic malo fomentum præbent, quibus fi quis cum fumma cautione non vefcatur, \& cum Oryza, vel pane \& pauco falis, vix unquam hoc malum effugiet, non fecus quam in Gallia, \& Hifpania, qui uvas avidius fine pane vorant, ftatim Diarrhœam, vel Dyfenteriam incurrunt. Tales funt fructus: Ficus nempe Indicx, quas Bananas, \& Pifang incolic vocant; Garcias ab Orta, \& Profper Alpinus, Mufam appellant. Duriones deinde, Iacas, Ananas; Adde his Cucumeres \& Melones aquaricos, \& c. Quorum defcriptionem apud eundem Garciam, \& Ioannem ì Linfchoten, videte. Hifructus, preterquam quodhorarii fint, etiam humiditate fua, \& calore, temperamento noftro infeftifunt, Melones, \& Cucumeres, excipio, qui prxter frigus, de humiditate non parum participant. Præcipua vero hujus mali caufa eft, potus vini aduft, quod Arac vocatur, \& quod Chinenfes ex Oryza, admixtis Holothuriis, in mari fuctuantibus, conficiunt, quxnos Belgice Ruabben \& Qualyen folemus vocare. Hæc Holothuria tam acris funt caloris, ut attactu cutem exulcerent, \& veficas inducant. Vtinam noftri navales focii hoc potus genus non tam avide, biberent! non tot funeribus extuberaret hic humus: Quantum ad curam, commune remedium eft infulio Rhabarbari in decocto Thamarindorum, ad minuendum (ut aiunt) \& temperandum, acrem hunc fuccum: notandum eft, hoc remedium fape non prodefle: fed aliquando xgros in certam perniciem conjicere: dum nimirum bilis acerrima turget, \& orgafmo fertur; ac metus eft, ne ex levifimo laxativo, irritetur, \& majore cum impetu, ad partem affectam feratur, cum incredibili agri cruciatu, \& certa fape pernicie. Adde fummam plerumque, in hoc cafu, virium imbecillitatem, qua reftaurativi potius aliquid, quam purgativi requirit. Ita que caute Medico circumfpiciendum eft, quid agat. Ego, quod experientia longa verum effe didici, ad xgrorum falutem libere in medium profero. Potus quotidianus itaquefit decoctum Oryzx, quod Caudgie Indi vocant; cum Endivia, \& Cichoreo, quod, ex femine allato ex patria, in hortis luxuriat. His addatur Lingua Cervina, feu Phyllitis, qux circa fluenta copiofe crefcit, \& aftrictoria fua vi, Hepar, \& Inteftina, roborat, tum acrimoniam iftius furentis humoris infringit.

Si vero propter favitiam fymptomatum, doloris prafertim acerbiffimi, temporis anguftia, tam longam in cura moram non patiatur, ftatim ad Extractum Croci deveniendum 
niendum eft, quo remedio (aufim dicere) nullum humana cura exquifitius excogitare potuit : putoque veriflimum hujus morbi, fape etiam venenati, Antidoton effe. Speciatim porro omnia remedia ad hunc affectum referre mei inftituti non eft. Et ego tantum ea requiro, qux non primis modo qualitatibus, fed proprietate etiam fubftantix, huic morbo feviflimo adverfentur, $\&$, in hoc folo, maxime nafcuntur. Fructus etiam illi, quos Mangas vocamus, qui conditi, proper aftringentiam, \& aciditatem, fumme utiles funt. Inmaturi quoque coquintur cum ovis, ut apud nos uvæ crifpx; neque facile quis, etiamfi exquifitiflimi guftus, faporis differentiam cognofcit. Conficitur etiam ex iifdem fructibus conditum feu miva, non fecus ac caro cotoniata in patria ex Cydoniis malis, cujus vicem fupplet; nefcio an \& fuperet. Ad ulterior em porro vifcerum corroborationem egregie confert Syrupus è Granatorum fucco, recens ex arbore decerptorum; tum flores ipforum conditi, excellenti in hoc malo remedio funt.

\section{A P V T IV.}

\section{De Fluxu Aloi Hepatico.}

$\mathrm{F}$ Luxus Alvi Hepaticus, etiamfi non minus, quam Dyfenteria, periculofus, non tamen tam frevis fymptomatis concomitatus eft. Adeft enim multo minor, acfepe nulla inteftinorum excoriatio: nam in hoc cafu plerumque purus fanguis dejicitur, vel propter debilitatam jecoris vim retentricem, vel propter acrimoniam fanguinis, of cula venarum referantis per anaftomofin, vel denique cruor propter copiam regurgitat in venas mefaraïcas, $\&$ inde in inteftina, \& fic per alvum rejicitur, $\&$ hic quidem omnium fluxuum Hepaticorum ninus pericul ofus eft, \& fape plus terroris, quam damni, infert. Si itaque acrimonia fanguinis in caufa eft, frigidioribus decoetis utendum eft, è feminibus Cucumerum, Cucurbitarum, Citrulli, Peponum, ac Melonum aquaticorum, quorum omnium fumma eft quantitas. Ex iifdem conficiuntur quoque Emulfiones, Eclegmata, \& Pulveres, ad idem malum perutiles. Tum ad peccantis humoris revulfionem, cucurbitæ cum fcarificatione lumbis, \& natibus, admovendx, tum diureticis fipra nominatis cum faceharo cibi condiendi.Sin autem quantitate nimia fanguis luxuriet, fine mora vena media pertundenda eft, habita femper recta ratione virium, quia in his regionibus propter aêris ambientis calorem, \& evaporationem fpirituum affiduam, homines, præfertim ægri, fiunt debiliffimi. Hinc (ut obiter hoc dicam) non facile, nifi in fumma neceflitate, ad ven $x$ fectionem defcendo, quod cor pora noftsa mollia, \& à calore fupradicto effominata, iftam evacuationem non facile tolerant : Secus eft in compactis corporibus Iavanorum ac Lufitanorum, qux calori aftueta, venæ fectionem largam admittunt. Expertus, credite, loquor. Sed femper , in anguftiis, ceu ad facram anchoram, confugiendum ad nobile iftud Extractum Croci, jam aliquoties commemoratum. Cujus defcriptionem hic fubjicio.

R.. Opii electiffimi ( quod $M i f$ ri vocant, \& antiquorum eft Thebaicum, nam Mifri eft Egyptus,) Sanguinis draconis, gummi Benjuini, Croci Orientalis, ex Perfia, ana partes $x$ quas, Ambr Iaponicx, feu nigr $x$, partem tertiam;conjice in vas vitreum oblongi, \& angufti, colli; adde aceti fortiflimi ex vino, ut materiam feu maffam in fundo fuperemineat, tres, aut quatuor, digitos. Vitrum bene claufum exponatur radiis Solaribus; qui nobis propter fervorem, funt inftar ignis chymici; colata hxc omnia \& expreffa fortiter, eodem Sole infpiffentur in confiftentiam Extracti.

Hujus dofis eft à granis fex, ad novem ; in formam catapotii coactum; vel, in cochleari, vino, vel convenienti aliquo alio liquore diffolutum, detur prxcipuo circa noctem, quo tempore obfervavi, o mnia inteftinorum mala exafperari.

De Lienteria, feu lævitate inteftinorum, quæ plerumque Dyfenteriam diuturniorem fequitur, \& etiam de Diarrhøea, volens taceo, quia notifima hrec funt in patria, \& quorum cura fxpe fuperioribus annexa eft, \& tantum fxpe, in corroboratione ventriculi, \& inteftinorum, confiftit. Sed de reliquis Alvi Fluoribus dicamus. 


\section{A P V T V. De Tenefmo.}

$\mathbf{T}$ Enefmus, propter fummam moleftiam, quamfecum conjunctam habet, magis metuitur, quam Dyfenteria ipfa ; \& certe, fi eam pracedit, ut plurimum lethalis effe folet, quia omnes morbi, qui fucceffrone augefcunt, primogeniiis funt magis calamitofi: Sin autem Dyfenteriam fequatur, facilior ejus eft curatio, quia tantum reliquixipfius funt, $a b$ acri humore partem affectam exulcerante. Eft autem Tenefmus exulceratio inteftini recti, cum crudeli $\&$ affiduo dejiciendi conatu, ubi pauca, \& mucofa, permixta fanguinis aliquot guttis, extremum pus excernitur : unde noftrates perappofito vocabulo hunc affectum Den Timgh-loop vocant, quod fillatim, \& guttatim humor peccans dejiciatur; Mulieres gravidx hoc affectu correptx, (ut ferefemper) abortiunt, vel ante tempus foetum excludunt. Vterus enin inter anum, \& veficam, fitus, ex affiduo, \& forti ifto conatu, embryonem ante tempus ejicere cogitur. Ex eademi etiam caufa, procidentiam ani infert, ac Hæmorrhoidas, \&, fi diutius perfeveret, (quod fxpe vidi) Hydropem; \& hinc Extabefcentiam, \& poft fava tormenta Mortem. Quoniam autem hicaffectus tantum occupat inteftinum rectum, $\&$ anum, cura ejus præcipue confiftit in clyfteribus, fomentis, \& infeffionibus, qux pa. rantur ex herbis partim emollientibus, partim detergentibus. Talia funt fol. fuprad. Dansl Lontas ac Lagondi, Bifmalva', \& Abutali. Add. fem. Cumini, Anifi, Foniculi, \&zc.

Cum his, \& fimilibus ulcus jam ex parte mundatum fuerit, \& dolor fedatior, aftringentibus decoctis pro fotu utemur, \& hoc eo magis, fi ani procidentia fimul adfit. Ejufmodi funt, Lingua Cervina, feu Phyllitis, folia Thamarindorum, tum fructus quoque, \& folia Billinbing fuprad. Qui magnitudinem $\&$ formam referunt primo adolefcentium Cucumerum, quos Agureas Lufitani, ac Itali vocant, quibus fructibus puto Naturam nihil acidius è terra produxiffe: $\mathrm{Nam}$, fi cui dentes aliis cibis acefcunt, his comefis omnis aciditas evanefcit. Ferme ea ratione, qua major dolor minorem obfcurat. Has herbas præcipue in fcenam produxi, ut fciant curiofi Medicinx indagatores, ubi fupra commemorati morbi , \& mala ita frequentiafint, ibi D. O.M. per Naturam contraria his remedia larga manu, ex terra, produxiffe. Caxterum remedia, in patria cognita, leviufcule volens tranfeo, quia potiffimum iis Medicinx amatoribus prodeffe ftudeo, qui mecum, aut poft me in longinquis hifce regionibus praxin medicam exercituri funt. Et utinam hactenus per morbum, quo circiter quatuor menfes decubui, tum per undique nos cingentes lavanos, nobis, ut in principio mei in has terras adventus, licuiffet in amøeniffimas Iav $\mathfrak{x}$ fylvas exfpatiari: $\&$ herbas, nobiliffimas, \& plurimas, exactius noffe: Dabo tamen alio volumine, nomina multa, arborum, fruticum, \& herbarum, hic paffim nafcentium. Tum avium, \& pifcium, quornm femper curiofus fui, quique in his regionibus capiuntur, naturam, $\&$ indolem vobis explicabo, \& quid exotici, \& alieni in iis, \& in quibus cum noftratibus conveniant, docebo. Interim hoc Caput finiendum eft aurea C. Celfi fententia, qux talis eft 1. Iv. c. XVI. Cum in omni fluore ventris, tum in hoc pracipue. (de Tenefmo loquitur) neceffarium eft, non quoties libet, defidere, fed quoties neceffe eft, ut hac ipfa mor a in confuetudinem ferendi oneris inteftina deducat.

\section{$\begin{array}{lllllll}C & A & P & V & T & \text { V I. }\end{array}$ \\ De Cholera.}

$P$

Rater jam dicta Alvi Profluvia, etiam Cholera familiariter ægros infertat; cujus caufam, figna, \& fymptomata, curam denique, hoc capite abfolvere eft animus. Fit itaque Cholera, cum materia biliofa, \& retorrida ventriculum, \& inteftina, infertans, per gulam fimul, \& per anum, continuo ferme, cumque magna copia, rejicitur: Morbus eft acutiffimus, ideoquc præfenti eget remedio. Caufa præcipua hujus mali, prater aëris calidam ac humidam temperaturam, eft nimia fructus edendi li-

centia; 
eentia; qui quod plerumque fint horarii \& putredini obnoxii, tum humiditate fua fuperflua ventriculo infeft $\&$ infieti etiam, bilem æruginofam hanc gignunt. Hæc excretio, \&non fine caufa, alicui videretur falubris, quod talia purgentur, qualia oportet: tamen quia cum tanta quantitate fimul effunduntur fpiritus vitales, \& naturales, debilitato quoque per foedos halitus corde, calor is omnis , ac vit $x$ fonte, ut plurimum commoriuntur $x g r i$,idque celerrime, utpote qui intra viginti quatuor horas, vel etiam pauciores, expirent, ut accidit inter plurimos Corneliovan Royen, xgrorum in Nofocomio Oeconomo, qui, hora fexta vefpertina, adhuc valens, fubito Cholera corripitur, \& ante duodecimam noctis horam vomendo fimul, per alvum dejiciendo, cum diris cruciatibus, convulfionibus, miferiime expiravit; vincente morbi violentia, ac celeritate omne remediorum genus: Si tamen, ultra prædictum fpatium, pernicies ifta protrahatur, magna de cura fpes eft, pulfus admodum debilis eft, refpiratio molefta, membra externe frigent. Calor vehemens, ¿x fitis, interne urgent; vigilix adfunt perpetux. Iactario corporis inquietiflima, qux fi comitetur frigidus $\&$ foetidus fudor, mortem in propinquo efle, certifimum eft. Danda in hoc affectu primum opera, ut acerrimus ifte humor, qui tanto furore, ac orgafmo, fertur, nitigetur. Quod fieri poterit maxime per aftringentia medicamenta, ventriculum, \& inteftina , corroborantia, \& fimul modico frigore furorem materix morbific $x$ refrenantia. In his præftantiflimus eft Syrupus ex Billinbing, fuprad. Tum fructus ejus faccharo conditi, adjecto croco. Syrupus præterea è fucco Limonum recentium. In lava nafcitur infuper ad hunc affectum Ṕeudomyrobalanus, qui forma Bellericos refert, magnaque copia à Nigris in urbem venalis adfertur, \& fola aftriatoria vi præftat, cum cæteræ Myrobalanorum fpecies etiam laxativi aliquid habeant; hinc conditus hic fructus, utiliffimus, ad Choleram non folum, fed ad cæeteros omnes alvi fluores nimios. Cum cornu cervi ufto, lapide Bezoar, rafura cornu Rhinocerotis, vel Margaritis prxparatis.

Sed his non adferentibus juvamen, confeftim ad Extractum Croci deveniendum eft; tum, ut vigiliz arceantur, $\&$ fomnus concilietur, qui propter fummam virium dejeCtionem neceffarius eft, tum ut, tantifper mitigato atroci ifto humore, Natura fortior denuo ad vincendum hoftem infurgat: Cholerici (ut fere femper) convulfi moriuntur.

\section{A P V T T VII. \\ De Affectibus Hepatis Vifceris nobilis : E primum de ejus Obftructione, é Inflummatione.}

$\mathrm{N}$

Vllum vifcus, præter inteftina, frequentius in his regionibus infeftatur, quam jecur; quod, prætermifla, jam toties dicta, vißus ratione mala, à potu iftins maledicti $A r a c$, non tantum in temperamento immutatur, fed etiam in fubftantia fua corrumpitur : Dum enim ejus haufu ebriofi ifti excalefacti, ingentem aqux copiam in ventriculum ingerunt, ut conceptum æftum reftinguant, dein humi, tanquam pecudes, procumbunt, $\&$ in navibus, fe rori, qui poft fecundam aut tertiam noctis horam, copiofe cadit, exponunt : inde venenatos vapores è terra erumpentes, intra corpus recipiunt, \& fic obftructionem hepatis facillime incurrunt, cui adeft tenfiva, in hypochondrio dextro, gravitas, dolor que obtufus, \& quafi pondere premens. Difficilis quoque adeft fpiratic, propter gravitatem vifceris, diaphragma deorfum trahentis, cui, mediante ligamento fufpenforio, anneatur : \& hrc infarctio fi perfeveret, humor, hepar obfruens, dum non ventilatur facillime, putrefcit. Vnde febris etiam oritur, \& ipfius hepatis intiammatio, cum dolore acuto, \& pungente, febrifque augefcens, in ardentem tranfit, cum fiti intolerabili, faciei rubedine, \& difficili,ob prædictas in obftructione causfas, refpiratione: Hi duo affectus cum, quafi invicem, concatenati fint, \& unus ex altero ferme nalcatur, curam amborum hoc capite conjungam, incipiendo, (ut par eft) ab obftructione. Itaque in hac primum obfervandum eft, ne nimium calidis medicamentis in principio utamur, ne minutx ifta hepatis ven $x, \&$ capillares, ab exficcante calore magis obftruanrur, \& ne hoc modo, (quod in proverbio eft;) olcum camino addamus. Ergo tempcrate calidis, \& per confequens leniter deobftuentibus, \& rateriam peccanters 
cantem incidentibus opus eft, qua familiaritatem quandam cum noftra natura habeant. Talia funt, qux à practicis Anodyna vocantur. Nimirum femina Anifi, Foniiculi, Cumini, quæ nobis hic fuppetunt. Tum radices graminis cujufdam aromatici, \& Caryophyllatze odorem $x$ nulantis: Adde his, (quodin principio dici oportuit, ) $\mathrm{Ca}$ lamum aromaticum verum, quem Paftum Camelorum vocat ab Orta, abunde hic crefcentem, quo etiam incolx cibos; pirefertim pifces, non infuaviter condiunt. $\mathrm{C} x$ terum reliqua addantur, qua blando calore diuretica funt, ut vifcus hoc nobile ab in farctu liberent. Præparata jam morbi materia, eam medicamento, non femel nec fimul, fed iterato, ftudebimus educere: Ejufmodi funt , Thamaindi, Caflix fintul $x$ pulpa, adjecto pulvere Therebintinz coct: fec. artem; mirum enim quam blande hxc fimul per alvum, \& veficam morbificum fuccum ejiciant : fi paulo fortius defideres, adde $z \mathrm{j}$ Rhabarbari, mifceatur cum fupradictis in formam boli. Inflammationem porro in procinctireffe cum compereris, ex febris augmento, \& dolore vehementiori , \& magis pungente, ftatim venam recato copiofe, pro viribus agri. Cibis, Syrupis, \& Con fervis refrigerantibus, jam aliquoties commemoratis utere, qux, ne actum videar agere, egolubens omitro. Conficitur conditum ex fructibus, quos poma Amoris vocamus; Italis Bella Dona, \& Lufitanis Poma d'oro, appellantur. Certe fpecies Mandragorx eft. Chinenfes inter acetaria in hortis colunt, $\&$ toftam fub cineribus cum aceto \& pipere edunt. Hæc Planta, etiamfi frigida eft tertio gradu, tamen, in climate hoc calido, \& bile acerrima dominante, maximum Hepati, \& reliquis vifceribus vicinis, per confenfum laborantibus, præftat refrigerium. Condiuntur quoque muria, \& aceto, addito pipere, \& aromatibus. Quod genus conditur 2 communi nomine Achar Indi vocant. Denique Hypochondria ; prafertim dextrum inungendum eft, unguento nobili, quod Ind $x$ mulier es conficiunt, cujus ingredientia præcipua funt, Radix Curcumx, (quam Borborii incol $x$ vocant, ) \& unde univer fa compofitio hrec etian nomen fortita eft. Santali omnibus fpecicbus, addita Caphura: \& olen recenti ex Cocco expreff. vel fi mavis, rofaceo; quod nobis ex Perfia fuppetit : Hæc omnia in marmore fubiguntur in unguenti confintentiam. Hoc oleo, forminx fimul, \& viri, totum corpus inungunt adverfus xefus: Et quia colore propter Curcumam eft flavo, homines quafi croco tincti fpectantur, odore tamen eft admodum grato, \& cerebro utili: (Curcumæ meminit ab orta, 1. 2. cap. 39. Et quamvis eam ibi defcribat: tamen fatetur, id fe ex auditu facere, ego millies vidi, \&à terra evulfi. Defcripfit autem fub nomine croci Indici 3. Folio eft Pfeudoridos, feu Gladioli.) Prxterea, ad idem, Oleum conficimus, ex floribus cujufdam arboris, non nimis alta, ferentis folia, Perficx arboris fimilia. Flores funt viroris dilutioris, quem Belgx \&ethorm vocant, \& primo intuitu, potius fafciculum foliorum putes effe: fed pediculi intus in calice, quales in rofis funt, flores effe arguunt. Arboris fimul, \& florum nomen Sampaga incolis eft, \& apud eos in fummo funt honore: Nam Indi, fi qux gens alia inter Mahumeranos, odoris grati funt avidifimi, hinc nullas ferme in plateis mulieres confpicias, qux non capillos intertextos habeant, his \& fimilibus floribus, ut gratiores fe maritis, aut amantibus fuis, fe reddant: (ed in viam redeamus. Si (quod fxpe fieri folet) dolor in Hepate, \& ligamentis fit intolerabilis, caufa tantifper omiffa, huic fymptomati occurremus. Quod fiet per Extractum Aureum Croci, quo vel folo (aufim affirmare) xgros plurimos curavi, natura, per quietem, ad fe redeunte, \& virus per alvum, urinas, $\&$ fudores, ejiciente.

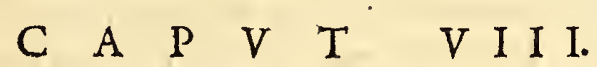 \\ De Apoftemate Hepatis, é ejus cura unica.}

Q

Vod fi hepatis inflammatio non bene fanetur, vel pertinacius cura refiftat, confequitur admodum miferabilis affectus, Hepatis nim A poftema; quo, fi parenchyma, feufubftantia ipfa jecoris occupetur, jam incurabile eft malum; Ideoque de eo fuperfedeo dicere. Sed fi pus hæreat, inter membranam cingentem hoc vifcus, \& ipfius carnem, (quod perfape fit,) unica falutis fpes eft in Apoftematis apertione; qux hoc modo fieri debet. Primum, in regione hepatis applicetur cauterium potentiale, ita, ut efchara tantum penetret abdominis mufculos, nec inficiatur 
peritonæum ; Deinde, parvo foramine per fcalpellum in ipfo fecto, per id immittatur inftrumentum argenteum concavum, quali utuntur in fectionibus calculi lithotomi; dein fatis late vulnus dilatandum : Et tum ftatim in confpectum fe dabit membrana Iecur ambiens, vehementer tumefcens ab amurca intus latente. Ea pertufa, faniofus humor, carnium loturx fimilis, effluet, qui quo minus fotet, eo major de cura fpes eft. Poft hxc vulnus detergendum, modice ficcantibus $\&$ mundantibus. Fol. n. -rofarum. Cortic. granatorum, add. mell. rofac. \&c. Dein farcoticis; $\$$ epuloticis, à perito Chirurgo vulnus ad cicatricem perducendum. Interea ægro omnino à pharmacis $\&$ ca tharticis abftinendum, \& tantum roborantibus utendum; ut Conferva-rofar. cum Pulvere Santali rubri. cui mifceatur cornu cervi ufti rafura, cornu Rhinocerotis; quihic plurinus in fylvis eft, Margaritx , \& corallum rubrum præparatum. Adh $x c$ Syrup. condita , \& mivæè Billinbing, Mangas, Granatis, è fucco Limonum, quæ omnia refrigerantia fimul $\&$ hepar roborantia, xgro folamen adferunt. Porro debili (utfe: re femper) exiftente xgro, lapidi Bezoar non eft parcendum.

\section{A $\quad P \quad V \quad T \quad I X$.}

\section{De Hydrope, familiariffimo in Indiis Morbo.}

$\mathrm{H}$

F.c pauciffima de Hepatis apoftemate: quia cura non verbis, fed ágili Chirurgi experti manu, \& prudentis Medici ingenio peragenda eft. Iam ad Hydropem, frequentiffimum in his loci's malum, deveniendum eft.

Hydrops, ut omnes docti confentiunt, oritur ex frigida hepatis intemperie, qux frepe à diuturna obftructione originem ducit. $\mathrm{H} x \mathrm{c}$ vero obftructio nafeitur $\mathrm{ex}$ cibis mali fucci \& fruetibus fupra defcriptis: hinc fit, ut fanguificatio vitietur.Iecur enim, dum chylum, ex venis mefaraicis attractum, in fanguinem convertere nequit, ejus loco ferofum illum \& aquofum humorem gignit; intumefcitque (ut \& in Patria) vel univerfum corpns, vel abdomen, idque vel à flatibus vel humore ferofo. Unde illæ tres tantopere decantatæ Hydropis fpecies, Anafarca, Afcites, \& Tympanites, (proh dolor) nimis frequentes funt in Indiis. Pars tamen principaliter affecta, eft nobile vifcus hepar. Tuffis propterea ficca comitatur $\&$ refpirandi difficultas, quia jecur infita fua , \&jam per mọrbumadaucta gravitate, deorfum feptum tranfverfum trahens, thoraci \& pulmonibus hanc moleftiam infert. Adeft febris plerumque lenta, urinæ ob cruditatem, $\&$ functionum naturalium debilitatem, tenues \& albr. Sitis propter ferofi humoris falfedinem adeft indefeffa. Præterea univerfi corporis fpontanea laffitudo. $\mathrm{H} x c$ funt aqux intercutis præcipua figna, fi qux fint leviora, ea prudens prætereo, quia milhi non eft animus formare Medicum : fed jam formatum docere, quid hic in praxi opus fit. Antequam hujus morbi curam aggrediamur, fciendum eft in genere, $\mathrm{Hy}$ dropem in his locis facilius fanari, quam fub noftro climate. Itaque cautus medicus non temere judicium fuum præcipitet, nec primo afpectu lethale dicat, quod paulo poft cum ingenti fua irrifione, à mulierculis, vel potius ipfa natura, obfervata tantummodo convenienti vietus ratione, fanatur. Prrcipua vero cura confiftit in prxparatione primum, dein eductione humoris peccantis; tum reliquiarum difcuffione, denique in correctione intemperiei in hepate conceptx. Dixta quoque fit boni fucci, ut funt Gallinx (quod avium genus hic frequentiflimum) exque fint elixx potius, quam affex: fed inter c:ereras iftud genus eligendum eft, quod carne fit nigra; nam has habere vim medicamenti diuretici longo ufi ab incolis compertum eft; Harum jufculis incoquantur femen Anethi, Foeniculi, radices Cichorei, Majorana, Bafilicum, quibus omnibus abundamus. Eodem modo præparatx etiam carnes caprin $x$ medicamenrifimul ac alimenti vim præftabunt; fed nihil æque confert, quam quotidianus ufus decoct. radicum Chin $x$, Sarçxparill $x$; adjectis Curcumæ radicibus, Succifa \& Scabiofa, quarum herbarum vires mulieres Malaicx obftetrices, ufque ad irrifionem extollunt. Sic quoque prodeft decoct. Guaiac. cum corticibus ejus.

Humorem hoc modo preparatım educere per alvum ftudebimus vehementioribus catharticis, ne fímbecillibus utamur, fuccum peccantem moveamus potius, quam promoveamus. Inter qua preftat Extract. gutt. Cambodja, quod paratur hoc nodo à me.

35. Aloěs 
3. Aloës Socoterinx,

Guttx Cambodja,

Gummi ammoniaci, ana partes $x$ quales.

Aceto vini acerrimo diffolvantur; pone in vafe vitreo ad Solem, fortiterque colatum exponatur rurfus, donec contraxerit confiftentiam, maffe pilularum.

Dofis ejus à $z^{\text {ß. ad }} z$ j.

Cref́cit quoque in fumma copia, Cucumer afininus, unde Elaterii fuccum non femel confecimus, cujus $\exists \mathrm{j}$. ad 3 ß cum magno fucceflu ægris fxpe exhibuimus. Dantur enim commode Extract. Elulx, grana $\mathrm{x}$. vel xv. in convenienti aliquo liquore. Et quia fato pius incidimus in mentionem Guttæ Cambodja, \& Efulx. iftius Iavanx, utriufque defcriptionem à me accipite. Nafcitur in fylvis Tithymali quxdam fpecies, in tantam altitudinem, ut acumina magnarum arborum, quas inftar hederæ amplectitur, xquet, imo fuperet: craffities ejus eft brachii facile humani. Hujus cattle villnerato, lacteus humor effluit ubertim, qui collectus, \& in extracti confiftentiam redactus, ad ufum fervatur. Planta ifta, qux Guttam Cambodja fert, feu lacrymam iftam flavam, quam in patria habetis, fupradictxadfimilis eft: nif quod non tam alte excrefcat: ita ut ferme folo colore fuccihi inter fe differant. Crefcit hæc planta, ut \& Aloë, in maxima copia in Cambodja regione Chinx vicina, unde etiam nomen fortita eft. De Paracentefi, aut de umbilici perforatione, nihil addo, non quod non frequenter exerceatur, fed quod hac Chirurgo \& Medico experto cognita effe debet. Adde quod mihi propofitum eft, tantum de ea cura agere, qux his regionibus maxime familiaris; magis enim mihi curx eft bonum practicum agere, quam in fcholis de omnibus morbis, eorumque curis otiofe difputantem, $\&$ medicum in charta fuperb $x$ agentem. Hoc aufim affirmare, (abfit verbo invidia,) fi hanc methodum Medici \& Chirurgi fequantur, non longe à fcopo aberrabunt. Evacuato maxima ex parte hoc ferofo humore, ne recidivam pariantur xgri (quod alias fxpe fit, \& à recidivis in Indiis ferme ad fanitatem nunquam eft reditus, ) reliquix hujus mali difcutiend $x$ funt, $\&$ hepar, quantum fieri poteft, ad priftinam temperiem reducendum eft. Ad quod, prater folita antidota fudorifica Theriacam, Mithridat. \&cc.) Decoctum levius Sarf́x, radicis China : \& Guajaci per aliquot dies continuandum eft, quod tum in hoc, tum in aliis chronicis morbis longe praftantiffimum, indubitatum eft remedium.

\section{$\begin{array}{lllllll}C & A & P & V & T & X\end{array}$ \\ De Iclero in Indiis.}

M Orbus regits, feu ICterus, inter quotidianos in India morbos merito numeratur. Hic quoque vel morbos alios comitatur, vel eofdem fequitur. Exempligratia Inflammationem, Scirrhum, A poftema denique hepatis, \& quia tum, ut plurimum fymptomaticus, \& ex violentia morbi ortus eft, ut fere quoque femper lethalis eft. Prxterea, quia cjus cura cum primariis affectibus conjuncta eft, de eo fuperfedebim: dicere; veruml, eft $\&$ altera Icteri fpecies, ubi folliculus fellis obftructus, excrementum fuum ad alvum non tranfimittit, unde etiam in ftercore color albus apparet, urina vero croceo plane colore, lintea tingit; Nam bilis, verfus jecur regurgitans, cum fanguine dein per venas, \& arterias in univerfum corpus diftribuitur, cutemque tingit colore luteo, ut $\&$ in oculis manifefto appareat. De hoc affectu nobis eft fermo. Sxpe ita momentaneus eft, ut intra pauciffimos dies oriatur, $\&$ occidat, quod cis paucos menfes accidit doctiflimis, \& reverendis viris $D$ : Iuffo Heurmio, ac $D$. Abrahamo de Roy, quibus amiciffime fimul \& familiariter utor, qui aliquoties exhibito pharmaco fudatorio, \& cordialibus, intra breve temporis fpatium curati funt. Qui autem diuturnior eft leterus, majorem in cura diligentiam requirit, quod in eo longe validior fit obftructio: adde quod fepe delirium, \& phrenitidem infert , bile flava per metaftafim ad mentis arcem elevata. Hic neglectus certifímun hydropen infert. In eo igitur iifdem medicamentis utendum, qux fuperius in obftructione Iecoris adduximus, Aviculz quoque Chlorides dictx, propria \&occulta qualitate adverfus hoc fymptoma valere incolx produnt. Excellit decoctum Chinx \& Salfx, quo 
copiofe fudores eliciuntur. Tum porro ad evacuationem eundum. $2 \%$. Folior. Sen $x$ $\xi \mathrm{j}$. infuf. in decoat. Thamarindorum cum Rhabarbar. $3 \mathrm{j}$ ß. Sed fi propter fortem ubftruationem paulo valentiori pharmaco fit opus, Electuario fubfequenti utatur æager, quod è fratre meo P. M. Reynero Bontio, dum viveret, Principis Auraici Mauritii Archiatro, or Medicine Profeffore in Academia Leydenfi, accepi.

7. Ligni Guajacini to ij.

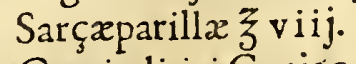

Cortic.ligni Guajac. 3 i ij. poft macerationem inf. q.aq. fluvii per 24 horas, coquant. q. f. Hujus colaturæ ferventifimæadde,

. Folior. Senx mundator. tb.j.

Polypodii to $B$.

Sem. Anifi. Fœniculi, ana $z i 1 j$.

Hellebori nigri $\zeta \mathrm{v} \mathrm{j}$.

Myrobalanorum omnium,

Thamarindorum, ana tb $\mathrm{j}$.

Bulliant q. f. in fupradicto decocto. Colaturæ rurfus adde,

Pulpx Caifrix Fifulx $\bar{z}$ xij.

Pulveris Senx,

Pulveris Rhabarbari, ana $\bar{\zeta}$.

Pulveris Cortic. ligni Guajacini 3 rv.

Scammonea elect. pro quaque el ectuarii tb $\mathrm{j}$. ad $\xi j$.

Sacchari albifimi, q.f.

F. Electuarium molle. Cujus dofis eft à 3 i iij, ad 3 j.

Pleraque ingredientia hoc Electuarium hic inveniri fcitote: Nam Polypodium, craffius longe, \& fucculentius, in Mangiferis arboribus, non fecus ac in Quercubus in patria, crefcit. Si porro Helleborus niger defit, ejus loco utimur Hellebori albifpecie', quam Pot fock Chínenfes, \& lavani vocant, eftque in fummo pretio. Thamarin-: di quoque \& Caffia hic in fylvis paffim crefcunt. Loco Scammonex, qux tamen, ut $\&$. reliqua Convolvulorum fpecies, hic abunde nafcitur, uti commode poffumus Gutta Cambodja, prius per aliquot dies in aceto macerata, vel fpiritu vini. Nam hoc modo. vomitoriam, \& infeftam fuam ventriculo qualitatem, plane deponit, \& blandius, quam, Scammonea, alvum ducit. Pro potu utatur æger fecundo Decocto Chinæ, cum radicibus Curcumæx, quas Lufitani Saffräm de tierra nominant, ac fi Crocum fubterrefrem dicas. Pulvis ejus mell e exceptus"; \& in Electuarii formam redactus à $3^{\beta}$. ad 3 j. tanquäm fpecificum huic morbo remedium exhibetur, \& tum per fudores, tum per urinas, egregie humorem, qui in vitio eft, educit. Flatus, qui in hoc morbo affidui funt, feminibus Carminativis, \& ol. Anifi, difcutiuntur. Crefcunt enim omnia hæe, \& à lavanis, \& Chinenfibus, in fimiles ufus refervantur.

$$
\text { C A P V T XI. }
$$

\section{De Atropbia, feu Extabefcentic quadam, Indicis regionibus familiari, ob obftructione iiffcrum, prafertion Mefenterii, orta.}

C Epe fine manifeftá caura zgri extabefcunt, ac emaciantur, febri nulla vel falS tem lentifima fe huic malo jungente, fine magno fenfu doloris; gravitas tantum quadam fentitur circa umbilicum, \& Hypochondria. Hoc malum, prater obfructioném vifcerum, fxpe caufam latentem habet in venis mefaraicis, vel in iṕa Mefenteriifubftantia, qux fxpc infignem abfeffum patitur : quod in diffectis cadaveribus non femel obfervavi; Immo repperi aliquando totum Mefcnteriam abfumptum; \& tamen inteftina cohærebant, ac potius inter fe confundebantur nullo ordine, tenuibus pelliculis, feu membranulis adnatis. Ita miferi mortales ad extremam maciem perducti, ut jam magis Sceleta ; quam corpora carne veftita, dici polint, abfumpto calore nativo, vita excedunt. Notabilc in hoc malo eft, plerumque adeffe $B \dot{x} \lambda, \mu \nu v, \&$ appetenciam caninam : cuife Lienteria, feu lævitas inteftinorum conjungit; unde cibi nihil, 
aut parum immutati, $\&$ incocti, per alvum cjiciuntur. Taliter affecti, quamvis plerumque commoriantur, tamen, ne omnino defperare videamur, aliquid tentandum. eft potius, quam nihil. Si forte natura benignior, adjuta autem blandis medicamentis exterius, vires refumens, ex defperato lanabile faciat malum; temperate itaque calidis , \& anodynis, moderateque, citra infignem calorem, deobftruentibus, utemur. Talia funt decoct. \& condita, ex feminibus Anifi, Fœniculi, Carui, \& reliquis carminativis fupra relatis. Praterea crefcit quoddam gramen, cujus nomen, \& defcriptionem videre eft apud Profperum Alpinum, libro de plantis IEgypti, capite $\mathrm{xL}$. quod merito gramen Crucis vocatır, quia quatuor fpicas è fummitate caulis cmittit, quæ perfecte Crucem formant. Radix hujus graminis, qux tantum in uiu eft, odorem habet aromaticum, \& proxime ad Caryophyllatx radicis accedentem, guftu quoque eft

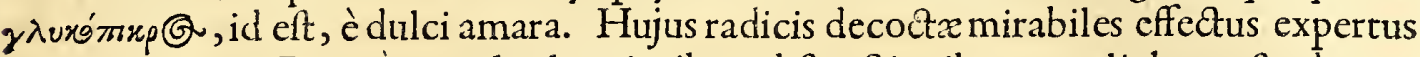
fum, in calculo Renum, \& aliis longioribus obftructionibus, qualis hæc eft, de qua loquimur. Confert quoque Anagallis aquatica, feu Becabunga, quæ cum elegantiffimis fofculis fuis albis in ripis fluviorum crefcit. Vefcatur ager carnibus Turturum, \& Fringuillarum, quas milites \& Mauri, fclopetis occifas, quotidie venales in civitatem ferunt. Lac quoque caprillum mirifice prodeft, dum nitrofitate fua, qux fero ineft, venas mefaraicas detergit, \& obftructione liberat. Abftinendum denique à purgantibus medicamentis,ne, dum humorem violenter conamur revellere, obftructiones per acrem calorem, qui folet pharmaca ifta comitari, adaugeamus. Adde quod in hoc cafu, propter alimonix defectum, vires femper fumme imbecilles funt.

\section{A P $\quad \mathrm{V}$ T $\mathrm{T}$ X I.}

\section{De quibufdam Pulmonum vitiis, que bic graffantur, es primum, de Homoptyfi, Jeu Janguinis Sputo, \& P Pbtbifi, Jeu Vlcere Pulmonum.}

D

Ebuiffem quidem hos Thoracis affectus præmifife fecundum ordinem, qui in Scholis obfervatur ; tamen ego, qui non umbras rerum, fed res ipfas, tanquam practicus, fector, nihil ad curam referre arbitratus fum, utrum id prius, an poAterius, agam.

Quoniam itaque, ut \& $x$ fupra retuli, aëris conftitutio eft calida \& humida, frepe fit, ut acribus catarrhis caput oneretur; unde etiam gravedines tam frequentes, \& fape diuturniores quam in patria, oriuntur. Tum milites $\&$ focii navales, bene poti, luumi fine ftragulis dormiturientes, vaporibus è terra afcendentibus, \& rore è cœlo cadente, obruuntur : unde hoc notandum eft obiter, habitationes in fuperiori xdium parte longe effe falubriores, quam in inferiori, qux propter humiditatem foli Formicis, Scorpionibus, \& Scarabxis, (quos Caccarlaccas vocant,) fcatent : fed hæc parergice ; ad rem veniamus. Hi cátarrhi fape ad fubjectos pulmones è cerebro præcipitantur, ipfofque falfedine, \& acrimonia fua erodunt , unde Hæmoptyfis, hinc Tabes , \& dein Empyema, feu fuppuratio. Affiduam tuffim, difficilem anhelitum, febrem tandem hecticam, hic lubens pretereo, tanquam nota practicis, \& jam ad curam me accingo. Et quia, in his regionibus, affectus hi à catarrhis, \& deftillationibus, ut plurimum oriuntur, ifti per commodas purgationes divertendi funt. Ejus ergo fiat Catapotiorum maffahoc modo.

24. Aloës Socoterinx,

Guttæ Cambodja,

Colocynthidos pulverifatx,

Scammonex eleet. ana partes xquales : infunde in aceto, vel fpiritu vini, modo jam frepius dicto, \& fole evaporentur in maffam pilularum. Dofis eft à $\exists$ j. $\operatorname{ad}_{z}$ ß. vel, in valentioribus, ad $z$ j.

Namhoc in genere fciendum eft, quod ut Huores alvi, (ut Celfus vocat) hic funt violentiores, ita quoque è contra obftuctiones, validx, \& pertinaces funt: quæ non nifi valentioribus catharticis cedunt. Electuarium fupra dictum Fratris mei, hic etiam $C_{2} 2$ maxi- 
maximum emolumentum adfert. Averfa jam per alvum materia, reliquix particularibus remediis tollendx. Caput-purgiis nimirum, Errhinis, \& Mafticatoriis', è Pyrethro, Staphide agria, femine Raphani, Nafurtii, Pipere, \& cæeteris notis. Præter hoc peculiare habemus nobile medicamentum, quod conficitur ex Arecca \& Berele, \& calce viva ex oftreorum conchyliis ufta, quod mafticando pituitam è capite elicit, camque, qux in ventriculo eft, confumit, $\&$ prohibet, ne vaporibus caput impleat, unde hi catarrhi nafcuntur. Medicamentum hoc, Malaice vocatur Sirii $P_{i-}$ nang. Ejus defcriptionem, \& reliquas infigneś virtutes, quibus fine dubio præditum eft, vide apud Garciam, hiftoria Aromatum capite de Betele, ac Arecca. Eft quoddam genus iftius Pinano quod Mabock Indi vocant, tanquam cbrium dicas, qui pauco tempore, Cerebrum eo modo, quo potio vini nimia, afficit. Sed manfo paulo falis, ftatim vertigo ifta evanefcit : Cum jam ifti catarrhi, aut neglecti, aut non bene averfi, per falfuginem fuam, qua præditi funt, aut pulmonum venas eroferint, aut acrimonia fua per anaftomwfin orava fculorum referaverint, \& æger in hænoptyfin: feu copiofam fanguinis excreationem inciderit, cum tuffi valida præfertim, ftatim fanguis ad revulfionem copiofe detrahendus eft. Poft pectoralibus incraffantibus, \& fanguinem fiftentibus, utendum, quorum defcriptionem inferius dabimus, ne neceffe fit ifta repetere. Si patientes contingat evadere tantifper fanguinis fputum, neque tamen tuffis minuatur, \& per eam pus exfpuatur, fignum eft, affectum hunc jam in tabem, feu ulcus Pulmonum tranfifle, cui, fi fupervenit febris hectica, fequitur Marafmus, quem dein comitatur certiflima mors. In his duobus morbis, quia agnati funt, $\&$ alter ex altero fepifime oritur, eandem, vel perquam fimilem medendi rationem fequimur. Vtendum eft igitur in principio Diatragacantho frigido, cui optime conficiendo hic nafcuntur femina $\mathrm{Cu}$ cumerum, Cucurbitarum, Melonum, \&c cætera : tum è Suratte Amygdala fuppetunt, \& Papaveris femen : cum aliis fpeciebus, quas abunde habemús, in formam liquidam Electuarii, aut etiam in tabulas concinnata ad ufum fervantur. Sed nihil xque prodeft, quam toties commemoratum Extractum Croci, quod non tantum fanguinis fpiritum fiftit, fed \& Tufim fedat, pus incraffando habilius ad expectorationem reddit, quin etiam pulmones, jam exulceratos, confolidat, ad cicatricem perducit. Eoque folo remedio plurimosjam defperatos fanavi. Sumant præterea ægri, ad minimum ter quo: tidie, hauftum decocti jan defcribendi,

25. Scabiof. Morfus diaboli,

Lingua Cervinæx , ana M.j.

Capitum papaver. demptis fummitatibus, numero I $\%$.

Glycyrrhilix raf. 3 j. coq. in f. q. aq. comm. Colatur. tb. ij. ß. adde ol. Sulphur. q. f. ad gratum acorem.

M.F. Apozema.

Si in Tabe, feu Phthifi, pulmones paulo magis mundare velis, add.huic decoet. $z^{\mathrm{ij} .}$ mellis rofacei, tum ad eundem effectum, \& faciliorem expectorationem hac Conferva utamur.

26. Conferværofarum è Perfia antiqux $z$ i j.

Sem. papaver. albi contufi $\zeta \beta$.

Flor. Sulphur. $z \mathrm{j}$ ß.

Pulver. Solidaginis Saracenic $x$; \& pulveris Scabiof $x$, ana $z \mathrm{j}$.

Ol. Sulphur. q. 1. ad gratum acorem.

M. F. Conditum.

Pro potu communi uratur decocto fecundo Chinx, aut Sarfx, fuperius relato.

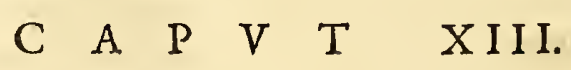

\section{De Empyemate, so fuctuatione puris fuper Septum tranfverfum.}

$\mathrm{E}$ Mpyematis quidem per eadem jam dicta medicamenta: fed longe tamen difficilior eft curatio ; quod pus, \& fanies libere, ab alterutro, vel etiam utroque, latere, fuper diaphragma fluctuct \& pulmones; \& quamvis ejus portionem frepe aliquam, tamen totam exfugere non valeat. Tamen per alteram viam, quam per 
HIS T. NATVRAL. \& MEDIC. L I B. II.

Trachæam arteriam, purulentx ifti materix non eft exitus, quicquid illi dicant, qui ejici aliquando affirmant hoc pus, per finiftrum Cordis ventriculum, ad major es venas inde deferri! \& unde hinc ad lecur, \& venas Mefaraicas, per alvum exonerari, vel ad Renes deferri quoque, $\&$ critice per urinas evacuari. Eorum quidem fidem, qui hrec fcripferunt, ego non elevo: fed nunquam tam fortunatus fui, quamvis in frequentifiima praxi, ut talem excretionem mihi videre contigerit. Hoc quod jam præponam, etiamfi anceps $\&$ dubium fit remedium, tamen fine dubio nugacibus verbis, \& loquacitate tam fominarum futilium, quam virorum, relicta, longe preftantifimum eft: fupra diaphragma, inter quartam \& quintam coftam, mufculi thoracis intercoftales, cauterio admoto potentiali adurendifunt, donec fatis lata efchara oriatur; quod circiter fpatio trium horarum plerumque fiet, dein iftud fatis lato vulnere pertundendum eft, \& (uthoc obiter dicam) eo opus eft, ne fi fine tali cauterio, incifio fiat, vulnus nimis cito coalefcat $\&$ citius, quam neceffe eft ; fed oportet ut labiis longiflime à fe invicem diftantibus, (quod in rotundo vulnere fieri certiflimum eft, ) facilior exitus puri, \& amurcx ifti, fiat : ante omnia, curandum eft, ne confertim pus, \& fanies, fed repetitis vicibus, emittatur, pro ægri viribus; quarum in regionibus maxima habenda eft ratio. Hoc remedio miraculi inftar aliquot curatos vidi: \& inter plurimos vietor quidam, \& miles, hicin arce Batavica funt, qui cum me vident, non officiofe tantum falutant, fed pene importune adorant; Verum de his in obfervationibus particularibus acturus fum. Si hæc vobis placuiffe intellexero, efficiam, ut non otiofe tempus in Indiis me exegiffe boni fciant. Nam de malevolis mihi nulla eft cura, quoniam ego me fupra eorum invidiam effe arbitror; \& abunde mihi fufficit, fi Eruditis \& Ingenuis, non dippliceam.

\section{$\begin{array}{llllllll}\text { C } & \text { A } & \text { P } & \text { V } & \text { T } & \text { XIV. }\end{array}$}

\section{De Febribus in Indiis.}

$\mathbf{F}$ Ebres, qux in Indiis nafcuntur, pleræque aut funt fymptomaticx, aut continux per fe, \& (ut fere femper) Synochi putridx. Qux vero certam periodon ferva-

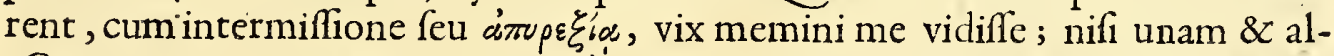
teram Quartanam, eamque cum xgro è patria delatam, quæ miferrime in hydropem, \& inde in certiffimam mortem defiere. Itaque erratica plenumque febres fine certo ordine, quibus fingulis, fi nomina dare velis, Oedipo conjectore tibi opus erit. Non tamen Tertianas intermittentes, aliquando oriri negaverim : fed hxtam rar $x$ funt, ut liceat dicere, quod in proverbio eft, hirundinem unicam non efficere ver. Præterea propofitum mihi eft fribere, de is affectibus, qui ut plurimum, \& quotidie, hic eveniunt. Hoc faltem in genere verum eft, morbos quibus febris fupervenit, magis periculofos effe, quam quos à principio comitatur febris. De cura igitur febrium, $\&$ fymptomatibus earum, quia cum affectus primarii fanatione conjuncta eft, fuperfedebimus actum agere. De continuis ergo aliquid agendum, qux plerumque cum tanto furore invadunt, ut tanquam attonitos de ratione mentis Ratim dejiciant, \& fxpe intra paucifimos dies, imo, aliquando horas, cum phrenitide, \& continuo delirio, xgros è vita rapiant. Adfunt perpetuæ vigilix, vomitus varii coloris, pracipue viridis, \& xruginof $x$, bilis. Externa rigent. Calor interne cum ingentifiti vitales \& naturales facultates depafcitur. Cum febris hac itaque fit Synochi putridx fpecies, úbi fanguis tam qualitate, quam quantitate, peccat, duo magna antiquitus decantata remedia neceffaria effe quis dubitet? Sed utrum illorum pramitti debcat, in quxftionem poffet venire. Nos, fubtilibus fcholafticorum difputationibus, \& altercationibus, omiffis, purgationem debere pracedere autumamus; ne in venis major perturbatio fiat, quam emolumentum ex pramiffa phlebotomia fperari poteft. Et no humores ifti mixti aliquam ex principibus partibus, per motum, occupent, \& terribiliffima fymptomata excitent. Itaque in principio leniter, ut Thamarindorum, \& Caffix pulpa, agri purgandi funt. Injecto quoque Clyftere communi, \& adjecta Electuarii : fupra defcripti 3 . His peractis, jam tuto vena copiofe fecabitur, vel etiam iteratis vicibus, qúod judicio medici relinquimus, tum unguento Borborii univerfum corpus 
inungendum. Quod fi vigilix, \& Phrenitis infeftat, vena frontis recte fecabitur; tum fomnus omnimodo conciliandus. Philon. fine Euphorbio, Requie Nicolai ; Mithridatio confecto recenti, \&c: : Sed in periculis, tanquam ad facram anchoram, ad Laudanum noftrum ex croco confugiendum eft, quod in his regionibus, nunquam fatis laudabitur. Creterx, quas dixi, erraticx Febres curandx funt eo modo quo illx, qux certos paroxyfmos habent, $\&$ ad quorum naturam videbuntur proxime accedere. Qux quoniam notiflima funt ex aliorum fcriptis, Enchiridii hujus ratio non patitur me longius de iis agere.

$$
\begin{gathered}
\text { C A P V T } \quad \text { X V. } \\
\text { De Febribus quibufdam, quas Incole vocant Tymoren Jes, in } \\
\text { Indiis, peculiaribus. }
\end{gathered}
$$

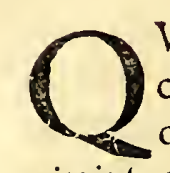

Vinavigant in Infulas Solor, \&'Tymor, cædendarum Santali arborum gratia, corripiuntur febri quadam putrida, quæ fi continua fit, delirium $\&$ Phrenitidem fecum comitem etiam habet, fi vero per intervalla exafperetur, (nam remittic (e aliquando hæc Febris: fed intermittitur nunquam) ea cxacerbatio plerumque ef circiter quatuorh orarum, qua durante ridiculas admodum actiones æxri edunt;imitantes ea opificia, quæ fani exercuerunt, \& omnia effutientes temere, qux in vita, tacen:da loquendaque, peregerunt, cum maximo aftantium rifu. Adeft praterea B४' $\lambda$ us feu Appetentia canina, ita ut, dum in delirio funt, omnia etiam foediffima devorent, quæ ipfis præbcntur. Oritur hæc Febris ex diverfis caufis, quarum præcipuæ hæ funt: Odor recenter cæfarum arborum Santali; quæ (fatentibus ipfis incolis) nefcio quid virofum, \& cordi maxime, \& cerebro, inimicum exfpirant. Santali Hiftor. vid. apud Garc. ab Orta, 1. 1. cap. 17. Adhxc aëris conftitutio nebulofa, \& admodum gravis; nam habitacula Incolarum funt in fummis montibus; ubi, propter aëris mediam regionem, nebulx \& pluviofi vapores funt; tum frigus aliquando tam violentum, quam in Hollandia folet effe, qux omnia non nifi craffos humores, \& turbidos fpiritus gignunt. Addita fructus nafcentes edendilibertate, qui , cum plerique funt horarii , \& propter humiditatem putredini maxime obnoxii, in corporibus jam ante faftidio maris, laboribus, \& craffis cibis, tum aëris intemperie immutatis, peffimos fuccos gignunt. Adde (quod pene omiferam) mutationem fubitam aëris, quam fubeunt noftri; dum defcendunt ex montibus frigidis ad littus, \& naves, ubi calor fummus corpora urit : Nam infula hac fita eft verfus meridiem, circiter decem gradus, à linea Æquinoctiali. Et (ut Ovidius ait)

\section{Cum modo frigoribus, calido modoftringimur aftu, \\ Tempore non certo corpora languor habet:}

Præcipuc quoque cavendi funt venti ex montibus, poft medium noctis, fpirantes, ut \& in Iava, \& cæteris circumjacentibus infulis ; non fecus, \& $\approx$ in quibufdam Galliæ Narbonenfis locis, \& Italiæ, præcipue in regno Neapolitano, ac Romæ territorio, ventus frigidus è montibus fpirans, (quem Serenas vocant,) Pleuritidem, Peripneumoniarn, $\&$ reliquos acutos morbos, infert. unde Horatius; Matutina parum cautos jam frigora mordent.

Cura confiftit in purgatione leni, \& clyftere præmiffo, in celeri fanguinis miffione, eaque in plethoricis, $\&$ conftantibus viribus, ufque ad animi defectum. Cucurbitæ quoque affigantur cervici, fcapillis, \& , vertice rafo, capiti; incolæarterias crotaph feu Temporales, lamina candenti, vel fune fclopetario accenfo, urunt, cum ftupendo fructu, quod etiam faciunt in omnibus capitis longis doloribus. Purgatur quoque commode humor vitiofus Elect. Fratris mei fupra relato. Tum vomitoria è Croco inctallorum, \& fale vitrioli pracipitato, utiliffima in hoc cafu effe experientia didici. $Y$ igilix (qux funt fomentum phrenitidos) fi perpetux adfint, utimur, præter cxtera narcotica , Extracto noftro Croci in pilulam formato, vel vino diffoluto. His omni-

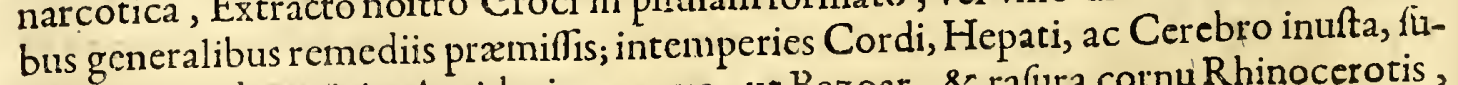
doriticis, \& diureticis; Antidotis quoque, ut Bezoar, \& rafura cornuRhinocerotis, com- 
HIST. NATVRAL: \& MEDIC. LIB. II.

commode difcutitur. Et Confervis refrigerantibus, \& Syrupis, fupra fatis ad faftidium nominatis, emendatur.

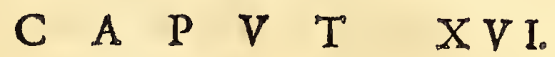

\section{De Cacitate, \& debilitate vifus, que navigantibus Amboynam, \& Mo- luccas verfus, Es in circumjacentibus Fretis, accidit.}

Q

Vi Amboynam, Bandam, \& Moluccas verfus navigant, infeftantur fape debilitate vifus, immo totali cæcitate, è craffis lentifque vaporibus, caput, \& cerebrum, opplentibus, nervofque opticos obftruentibus: qux tamen cæcitas non femper permanet; fed alterius aëris mutatione, vel melioris Diætx, free recedit. Incolx harum infularum originem trahere dicunt, (quod \& experientia, cui contradici vix poteft, comprobatum eft) ex efu Oryzx calidx. Hinc Iavani, \& Malaii Oryzam, jam primum coctam, femper prius frigidiori aëri exponent, vel vanno calorem eventilabunt. Tum nautæ noftri fociis fuis navalibus imperant, fub poena aliqua, ne Oryzam calefactam comedant. Quod fi caufam altius inquirere velimus, ratione eam prædicta niti inveniemus: nan Oryza hac femper plantatur in locis uvidis , \& paludofis, undenefcio quid freculenti, ac uliginofi, contrahit: quod calidum altius penetrat, quam frigidum : nam etiam ficcx Oryzx, crudxque, odor caput gravat, \& fomnolentiam quandam introducit. Communis in hoc affectu cura, (qua \& ego utor, \& plures ad priftinam fanitatem reduxi, ) hrec eft; Primum purgandum caput, \& ventriculus, à craffis humoribus, qui hos vapores ad cerebrum mittunt: Quod optime fiet per Pilulas panchymagogas Reineri Bontii fupra defcriptas. Dein fternutatoriis è pulvere Tabaci, \&cc. Tum Errhinis, \& Mafticatoriis utendum eft. Vena fecta quoque prodeft. Sed in hoc malo (quod poftremo loco refervavi) fpecificum, \& crebro ufu comprobatum medicamentum eft, Iecur Lamix pifcis, crudun cum fale comeftum, quem pifcem ten ane Belgice vocamus, quin \& oleofitas, ex eo in Sole inde deftillans, Craen Belgice, \& oculis inuncta, pro prefentaneo eft remedio; quod procul dubio proprietate fubftantix fit : Nam tantum abeft, ut aliorum pifcium jecinora hoc præftent, ut potius præfentem noxam inferant. Notandum poftremo eft, quod, quamvis hæc cæcitas frepe tranfitoria fit, tamenneglecta, \& incommoda dixta, maxime importuno ufu Aracci, frepe in veram vifus orbitatem degenerat; quorum exempla paffim obvia funt. 


\title{
De Externis quibufdam Corporis Affectibus, in IN D I IS.
}

\author{
C A P $\quad$ V $\quad$ T $\quad$ XVII. \\ De Herpetis, Jeu Impetiginis Indica Jpecie, quam Incole \\ Courap indigitant.
}

$\mathrm{E}$ Xpofitis morbis Internis præcipuis, qui in hifce remotiffimis à noftro cœelo locis graffantur, omiffis etiam levioribus affectibus, qui (ut in patria quoque) quotidiani funt, ad Externa quxdam corporis vitia, nimis familiaria, devenire conftitui.

Inter hæc principem locum obtinet Herpes, feu Impetigo quædam moleftifima, ut plurimum alás, pectus, inguina, faciem, immo aliquando totum corpus, occupans, cum pruritu intolerabili, adeo ut ægri à fcalpendo, dies, \& noctes, manus abftinere nequeant : Sed ftatim iftam voluptatem, quam ex unguium attritu homines fentiunt, acerba poenitentia fequitur : ingens nempe dolor, in crudis, \& cuticula nudatis, partibus, quas ungues aperuerunt, dum mordicans, \& nitrofus ifte humor peccans, partes affectas vellicat, $\&$ inde interul $x, \&$ indufia , fine cruftarumlaceratione, avelli nequeunt: Indigenæhunc affectum Courap, $x a r^{\prime} \dot{\xi} \xi \xi_{0} \chi_{\eta}^{\prime} \nu$ appellant, quod alias omnem Scabiem fignificat: Caufa hujus affectus cutanei eft falfa \& nitrofa pituita, mixta bili, $\&$ melancholix : eftque affectus contagiofus, quia attactu facillime in aliud fubjectum tranfit : ita ut pauci hanc moleftiam effugiant. Quamvis autem fcabram, $\&$ deformem cutem reddat, cum furfuribus : tamen hoc commodum fecum fert, quod quamdiu quis taliter affectus eft, vix alio graviori morbo corripiatur; tum Cour ap fubito evanefcens, majoris morbi fuperventuri indicium folet effe; humore nimirum peccante, per metaftafin', ad partem nobiliorem aliquam delato. Ideo funt qui per aliquot annos hoc malo affecti, non adeo folliciti funt de ejus cura. Sed nos qui novimus, fublata caufa, etiam tolli effectum, quod vulgus fanum per fe putat, per accidens fcimus evenire; quod nempe fit effectus bonus à mala caufa. Non fecus, ac in Gonorrhøa virulenta, \& vencrea, contingit, Hepate $\mathrm{fc}$. expellente à fe iftud virus ad glandes paraftatas, \&inde ad penem, quo miferi fe confolantur: cum in confeffo fit aliquo modo in re medica expertis, fi ifti malo convenientibus remediis non occurratur, ipfum morbum venereum inde oriri. Sichoc malum neglectum, præfertim in fubjectis melancholicis, \& atrabiliariis, in Lepram Arabum, vel (quod multo pejus eft) in ipfiffimam Elephantiafin,tranfit. Cura hujus mali in principio prxcipue conftat in ablatione caul$f_{x}$ morbificx, quod per totiesjam diatas purgationes optime fiet: fruftra enim, neglectis generalibus, ad particularia, \& topica medicamenta devenitur. Pulvis quoque præeltantifimus ad hunc affectum, ut $\&$ ad reliquos melancholicos, à me conficitur hoc modo ;

24. Folior. Sen $x$ mundatorum $\zeta$ X I v.

Rhabarbar. optimi,

Turbith albi, ana $\breve{\jmath} v i j$.

Tartar. albi,

Scammonez elect. ana 3 I v.

M. F. Pulvis fubtiliffimus.

Dofis eft in convenienti liquore $\mathbf{z} j$.

Iam ad Topica deveniamus, inter qu $x$ excellens eft, quod mihi reverendus ac doctiflimus vir Dominus Iuffus Heurnisus communicavit, vir in omni Scientiarum genere exercitatiflimus.

25. Ferruginis $3 j$.

Sulphur. $z^{\beta}$.

Subciliter in marmore fricentur, adde fucci è foliis Bafilici crefcentis, \& hinc fiant paftilli, qui accto diffoluti \& vefperi Courapo illiti, mane ob deformitarem ablui poflunt. 
HIST. NATVRAL. \& MEDIC. II S. II.

Hoc fi minus efficax fit,

24. Opii $\exists \mathrm{j} ß$.

Calcis vivæ ex conchyliis uft $\ni \mathrm{ij}$.

Fricentur in marmore, cum fucco Pomorum Amoris, ufurus abradat cru-

ftam Herpetis, dein abfterfo ichore, illinat.

Ad eadem confert Oleum è gummi Benjuin adjecto nitro,vel fale Prunell $x$, vel momento Mercurii fublimati. Commode his quoque mifcetur ficcus Limonum. Cum Tutia preparata, aut Ceruffa, quo folo remedio topico, præmifla unica purgatione, me ipfum curavi, cum fub alis ac in pectore hac colluvie infeftarer. Diæta, ut in omnibus cacochymicis affectibus moderata, \& boni fucci effe deber. Quod curanțis prudentix relinquo, ne fruftra actum agam.

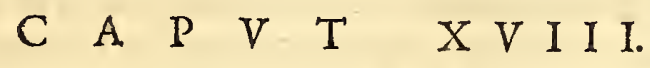

\section{De Papulis rubentibus, feu fudaminibus, que vulgo nofrates bet Liootuont Docant, \& obiter de molefijfjemis Culicum morficus.}

Q Vas Latinus Hippocrates Cornelius Celfus papulas, Plinius fudamina vocat, (noftrates Belga foutuont) ita crebra funt, ut ego adhuchifce in locis neminem. noverim, qui moleftias has effugerit, non magis, quam morfus culicum, quos Lufitani Mofquitas vocant. Sunt autem hre papulx rubentes, \& afper $x$ aliquantum, per fudorem in cutem ejectx; plerumque à capite ad calcem ufque, cum fummo pruritu, \& affiduo fcalpendi defiderio erumpentes. Hæc exanthemata magis afficiunt recens advenientes, ut \& Mofquitarum punctur $x$, quam eos, qui aliquamdiu morati funt : ita ut , deridiculi ergo, hicinter noftrates dicterium enatum fit, Eum qui hoc modo affectus fit, effe Orang Barou; quod novitium hominem fignificat, \& propterea culices, $\&$ papulas, fibi tributum, è lacte, \& butyro, quod eum devoraverint, petere : nam qui hic diutius hæferunt, fe orang Lamme, id eft veteranos, gloriofe nominant. Hæc porro moleftia, cum à natura expellente fiat, inter affectus cutaneos tantum recenfenda venit : fed tamen temere habita, ut \& morfus culicum, unguibus fcilicet cute aperta, ulcera, fape cacoëthea, \& maligna, oriuntur, difficilia fane fanatu.

sicneglectajolent incendia fumere vires.

Vt itaque pruritui ifti moleftifimo occurramus, acettim cum aqua mifceri jubeo, addito Nitro, feu fale Prunella, eoque corpus linteolo immerfo tingi : vel, fi acrius defideres, addendus Limonum fuccus recenter expreflus. Qux quamvis primo acrem dolorem inferant, tamen is cito evanefcit, \& multo magis tolerabilis eft, quam pruritus ifte infignis. Hoc denique medicos, \& chirurgos obiter monitos volo, ne in his papulis purgationes, quantumvis leves', inftituant; ne materia acris, \& biliofa, ad intetina delata Dyfenteriam creet : fed vel potius naturæ hæc fananda relinquant : vel fudorificis excretionem hanc adjuvent: Nam ego, per incuriam, \& imprudentiam quorundam, hac infortunia evenire non femel vidi.

\section{A P V T X I X.}

\section{De Topbis gummatis, és ulcerationibus Endemis in infula Amboyna, \&o Moluccisprecipue; quas no frates, D'Ximbounte Borken bocant.}

Ndemius, feu popularis quidam morbus in Amboyna, ' \& Moluccis infulis pracipue, oritur, qui fymptomatis fuis admodum fimilis eft morbo venereo. Sed in his inter fe differunt, quod fine congrefli venereo quoque nafci folet. Erumpunt in facie, brachiis, \& $\&$ cruribus Tophi, feu Tumores, duri primum, \& fcirrhofi, \& tam crebri per univerfum corpus, quam clavi, \& verrucx oriuntur in manibus, \& pedibus in patria; fi vero cos ulcerari contingat, materiam lentam, \& gummofam à fe red-

dunt, 


\section{IACOBI BONTII HIST. NATVR. \& MEDIC. LiB. II.}

dunt, attamen tam acrem, $\&$ mordacem, ut profunda, $\&$ cava ulcera inde oriantur, cum labiis callofis, $\&$ inverfis ; foedum, $\&$ deforme malum, $\&$ cum lue venerea conveniens, nifi quod tanti dolores non adfint, neccaries in offibus tam facile oriatur, nifi per curantis incuriam. Hic affectus originem trahit, primum ex peculiari cueli \& foli iftius genio; tum ex aëre, vaporibus fallís, è mari undique afcendentibus infecto; cibis prxterea craffis, \& melancholicis \& pituitofis, ut funt pifces marini, quorum, magna captura eft : quibus incol $x$ affiduo vefcuntur, quod reliqux annon $x$ fit fatis indiga regio. Magntim etiam momentum huic malo adfert ufus placentarum, quas vice panis, per totum iftum tractlim edunt ; $8 \mathrm{z}$ ab incolis Sago vocatur, \& eft è corticibus arborum excufia farina. Adhrec confert potus importunus liquoris cujufdam $\mathrm{Sa}_{-}$ guer vocati, qui ferme eodem modo ex arbore elicitur, quo è palma Indica feu $\mathrm{Co}-$ guos arboreliquor ifte, quem incolx Tovac; Lufitani Vinbo de Palma vocant. Immo derate fumptus non fecus, ac vinum, \& cervifia , in ebriat; caput, \& nervos, infeftat, hinc etiam in his infulis crebrior eft ifta Paralyfeos fpecies, quam Beriberii, fupra diximus,appellari. Quantum ad curam attinet, ea,firecens fit hoc malum, non admodum difficilis eft. Sin inveteratum jam, moleftior eft curatio. Porro iifdem ferme remediis cedit, quibus lues venerea, obftuctiones lienis, Leucophlegmatia, \& ipfe Hydrops, \& cxeteri chronici \& rebelles morbi. Decocta itaque parentur è Chinxradice, Sarçaparilla, Guajaco \& corticibus ejufdem; quibus incoquantur Anagallides aquatic $x$, feu Becabung $x, M$. ij. Poft peccans materia vehementioribus catharticis educenda eft: nam levia non profunt. Talia funt Extract. guttæ Cambodja, Elaterium, \&, fi his non cedit, ad chymica, \& mineralia, deveniendum eft: ut funt Mercurius vit $x$, feu Butyrum Antimonii, Turbith minerale; tum Mercurius præcipitatus albus. Vnguenta quoque Mercurialia, fecundum artem parata, externe adhibenda funt. Qux omnia è Crollio, \& aliis doctioribus, \& verfatioribus Chymicis, petite.

\section{FIXIS LIB RI SECVNDI。}

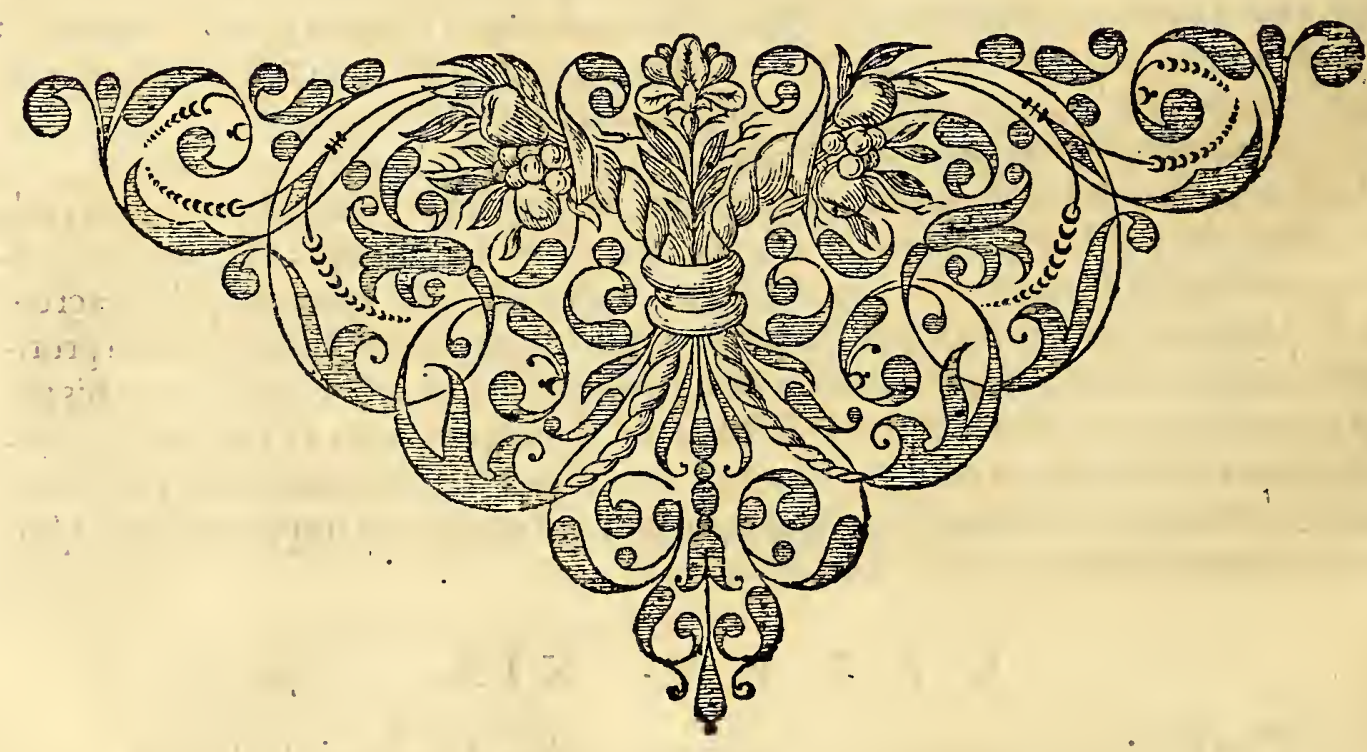

$I \mathrm{ACO}$. 


\section{A C O B I B O N T I I}

\section{OBSERVATIONES}

Aliquot felecte, ex

\section{DISSECTIONE CADAVERVM}

- AC A 'TO I A DESVMPTÁ:

Qux præcedentibus jam dictis non parum lucis adferunt.

O B S E R V A T I O $\cdots$.

De quodam, è Spafmo, mortuo.

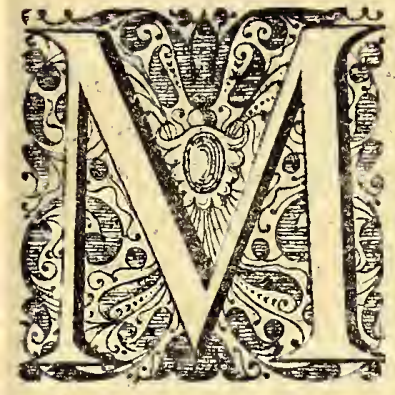

Iles quidam, cum per integram noctem, ebrius in folo decubuiffet, evigilans tam repente Spafno correptus eft, flexo in pofteriorem partem corpore, ut omnino rigidus, \& incurvus per. maneret. Ipfe in Nofocomium delatus noftrx curx mandatus eft. Nihil deglutire poterat, \& turbide loquebatur, tanquam ex loco fubterraneo vocem emittens, truculenter nos intuebatur ; cui cum omnia fruftra adhibuifetmus remedia , (qux fupra in Methodo Medendi videre eft, ) ille poft fevifimos cruciatus, intra quatuor dies interiit. Libuit mihi caufam tam atrocis mali indagare, itaque adhibito Magiftro Andrea Durao, Nofocomii Batavici chirurgo expertiffimo, cadaver aperuimus: Vitalia, ut cor, \& pulmones, $\&$ Naturalia membra , ut hepar, ventriculum, \& lienem, omnia integra invenimus. Itaque (quodres erat) fufpicati, malum altius hrere, Cerebrum ad ventriculos ufque diffecuimus, quos repletos invenimus materia quadam vifcida, \& glutinofa, colore luteo, vitello ovorum perquam fimili:fed foetida admodum : hae incumbens principio nervorum, tam feva fymptomata in fubjeatis partibus excitarat. Venxintercurrentes utramq̨ue cerebri meningem, admodum turgid $x$ erant biliofo fanguine: Öbiit anno 1629 , menfe Februario. Eodem modo, pauco poft tempore, affectus fuit fignifer, qui in arce, valli Rubini dieta, prefidium agebat; fed hic prater prædicta fymptomata, fpafmo Cynico in dextra maxilla, torquebatur, ita ut loqui plane durante ifto paroxyfmo non poffet ; \& intra 24 horas ex vivis exceffit; juvenis, fi quis alius, fortis, \& robuftus.

\section{O B S E R V A T I O II.}

\section{De Pbtbifico quodam, ér Empyematico.}

Enricus N N. mercator Danus, decumbens in ædibus Ambrofii vander Keer, hujus urbis Scabini, poft mortem, à Magiftro Andrea diffectus fuit : tuterque lobus pulmonum, non tantum arcte coftis adnatus erat, fed etiam inferius diaphragmati, ut fine laceratione, inde avelli non poffet.In dextro latere; fenferat, inventa funt fragmenta bronchiorum, \& fubftantix pulmonum avulf $\mathfrak{x}$; cum fanie copiofa ; qualia, dum viveret, in magna quantitate excreare confueverat; vox illi erat clangofa, qualis gallorum Africanorum, aut Calecutienfium. Laboraverat longo tempore antea fputo fanguinis; unde hujus miferandi mali principium; q quo etiam, extreme extenuatus, objit 1629, die Augufti 19: 


\section{O B S E R V A T I O III. \\ De $\mathcal{D} y$ fenterico.}

$\mathrm{E}$ X mandato Domini Gencralis, ego, \& Magiffer Adamus, Arcis Batavice Chirurgus, aperuimus aliquot cadavera ex Dyfenteria mortuorum: inter qux corpus militis cujufdam, è diuturna Dyfenteria vita functi, qux tum temporis, cum obfeffi effemus à lavanis, tanquam morbus epidemicus graffabatur. Et invenimus inteftina vehementer inflata, \& eorum interior em tunicam plane abrafam; Tum folliculus fellis, quod maxime in eo mirum erat, repletus, \& diftentus erat, humorelento \& $\&$ vifcido, alboque inftar pultis ex Amylo, quam noftræ mulierculæ $\mathbf{S}$ tuffel vocant: Bilis autem ne quidem veftigium reliaum erat, 1629. Nov. 14.

\section{O B S E R A TIO IV.}

\section{De quodam Pulmones plenos Pure babente.}

A Nno I629, menfe Maio, aperuimus cadaver nautici focii, ex Phthifr mortui, cujus pulmones fubftantia \& colore externe fani apparebant, quibustamen diffectis, exiit pus copiofum, viride, \& foctidiffimum: dexter autem pulmonum lobus coftis adnatus erat. Quod obiter notandum in plurimis, quos aperuimus, nunquam finiftrum lobum folum adnatum vidinus ; fed vel utrumque, vel dextrum tantum. Ratio (ut ingenue fatear) me latet, nifi forte, quia in dextro latere tantum vena azygos fine pari eft, qux in Pleuritide, tuffi valida rupta, hanc amurcam à fer ejicit; unde etiam in dextro latere Plcuritides exquifitx magis oriuntur.

\section{O B S E R V A T I O V.}

\section{De Empyematico Janato.}

M Iles quidam, cum potu Arac apprime fe ingurgitaffet, \& ferme fine fenfu, \& motu in arcem ferretur, credebamus ipfum ifta nocte fupervivere non poffe: ille tamen, partim evomita, partim edormita crapula, poftridie in dextro latere Pleuritide exquifita correptus eft; cui, licet poft fanguinis miffionem, dolor aliquantum fedatus effer: tamen inflammatio in ulcus, \& inde, eo rupto, in Empyema defiit, materia, in dextro latere, fuper diaphragma effufa. Erat adhuc viribus fatis conftantibus, neque febris jam tam vehemens vigebat. Itaque inter quartam, \& quintam coftam cauterium potentiale, quod vocant, applicavimus, dein fcalpello efcaram porro aperuimus. Indeque effluxit fanies copiofa, cum ramentis, \& particulis aliquot membran $x$ fuccingentis coftas, jam putrefactx. Et ille, adhibitis opportunis Syringationibus, convaluit præter fpem, \&, cum hæc fcribimus, Malaccam verfus na. vigavit.

\section{O B S E R V A T I VI. \\ De infgni Cranii fractura.}

$\mathrm{N}$ Auticus quidam focius, dum navem, in ftationehic ftantem, à fordibus, quas in mari contraxerat, cum cxteris purgaret, \& conto fcapham prohiberet, ne temere navi allideretur, dum fe inclinat, ut funem, qui fcaph inferius impactus impedimento erat, auferret, trifti fato, fcapha navi undarum pulfin impegit, \& caput ipfius, quodintra fcapham \& navem mcdium crat, ita collifum eft, ut totum cranium comminutum crederctur;ipfe mutus repente, \& fanguinem, per os, aures, \& nares rejicicns, inde delatus eft in Nofocomium. Huic jam, ut putabamus, defperato, cum Mag. Andreas, \& ego feriam manum praftaremus; Primo a polteriore capitis parte contufionem 
sufionem ingentem invenimus; quam; poftquam aperuimus, plurimum concreti fanguinis inde extraximus. Poltero die, cum jam mundatiora effent omnia, cranium in multa fragmenta comminutum apparuit: hinc cum aliquot particulas exemiffemus, reliquam curam (ut in tali cafu decet,) aggreffi fumus. Ille porro hæfit inrer noftras manus circiter fex menfes, quo tempore totum illud os, quod circumfcribitur Sutura Lambdoide, per fragmenta exemptum eft, paulo fupra illud foramen, cui inferitur prima cervicis vertebra, dentiformis dicta. Ille quidem, optime fanus, Novemb. menfe patriam repetiit, appofita pofteriori capitis parti femigalea argentea, ei, in eum finem, donata à Domino Generalicoen, ut cerebrum ab ictibus excernis tueretur.

O B S E R V A T I O VII.

\section{De Cbronicis, \& implicitis morbis in uno Jubjecto.}

A Nno 1629, Septembr. 5, diffecuimus cadaver militis cujufdam Germani, qui ferme per integrum annum languerat, fluxu ventris æruginofo, tuffi ficca, $\&$ infigni refpirandi difficultate, \&c. Mortuo eo, Omentum, \& Mefenterium repertum fuit ferme abfumptum ; ita ut inteftina fibi invicem adnata, vel potius nullo ordine inter fe confufa effent, parvulis villis hine inde enatis. Lien erat contractus in minimam pil $x$ magnitudinem, \& rotunditatem, ita ut Renes fubjectilonge major es effent. Iecur tam varii erat coloris, luridi, pallidi, flavi, \& viridis, ut miraculo fpectantibus nobis effet. Cyftis fellis longe major folito, repleta $\&$ diftenta erat bile æruginofa: Ventriculus, \& Inteftina erofa, infignem quoque hujus humoris copiam retinuerant. Præterea è vitalibus dexter lobus Pulmonis coftis $\&$ Diaphragmati erat adnatus, ut invicem continui viderentur. Videant benevoli lectores, num mirum fit, difficiles effe curationes, cum tot fimul mala concurrant, quod non in hoc uno, fed plurimis fubjectis, reperi. Et hoc nobis præftat nimius potus maledicti Arac, ex Oryza \& Holothuriis confecti. Et quoniam dicunt fcriptores Phyfici, Leporem marinum, (qui,ut $\&$ Sepix, de Holothuriorum funt genere) venenofa \& peculiari qualitate, Pulmonem erodere, lubens in eam fententiam defcendo, omnes iftas immundities eandem tabificam vim habere, \&c.

\section{O B S E R V A I O VIII. \\ De quodam, cuivena cava, loco fanguinis, repleta crat adipo fa es medullofa fubftantia quadam.}

$S$ Eptembris 7, Anni i 629, me præfente, apertum fuit corpus cujufdam civis Batavienfis, qui per tres annos languerat miro \& incognito affectu : Nam fifuper umbilicum, aut circiter, quis manum inpofuiffet, pulfus, qualis cordis, \& arteriarum, tam vehemens fentiebatur, inftar falientis infantis in matris utero, quxjam partui vicina eft, ut manum elevando repelleret. Æqualem fuifle hunc pulfun cum arteriarum \& cordis, hoc modo deprehendi; Siniftram umbilico xgri impofui, dextra arteriam, circa carpum, tetigi; invenique in fyftoles, \& diaftoles intervallo plane convenire. Vnde ego ftatim conjeci,arteriam magnam laborare; quod \& poft mortem invenimus. Nam vena cava repleta erat, loco fanguinis, adipofa fubftantia, $\&$ medull $x$ fpinali admodum fimili, qux, ponderefuo, arterix vicinæ incumbens, dumilla è contra iftud onus à fe rejicere conar etur, hunc pulfum excitabat. Arteria magna duplo folito laxior erat, \& repleta fanguine nigro, \& ferofo. Cor etiam Magifter Andreas diffecuit; quod, folito majus, \& flaccidius inventum eft, \& fpongiarum modo comprimebatur; tum uterque cjus ventriculus amplior, \& etiam fanguine ifto nigro repletus. Quis,rogo,mortalium non obftupefcat, taliter affectum, tam diu vitam protrahere potuiffe ! Iecur erat vividi coloris, \& confiftentix, nifi quod communem menfuram ferme duplo excederet. $\mathrm{Cy}$ tis, qua bilis continetur, etiam bovinam magnitudine xquabat, eratque intus referta 
cholera ex nigra viridi, lenta, \& tenaci, craflitudine fyrupi fpiffioris, aut potius extracti: Objit 7 Sept. 1629:
Ii
O B
B S E R V A T I O I
De Apoftemate Hepatis.

IX.

$\mathbf{M}$

Iles Anglius, cum inflammationem primum Hèpatis paflus effet, \& fruftra tentaffemus ea, quibus opus erat, dolor fe remifit quidem : fed defit malum in fluxum Hepaticum ; tumore, qui ante erat in hypochondrio, plane evanefcentc. Cum hoc modo per fex ferme menfes languiffet, tandem ad extremam maciem ita perductus eft, ut ipfifinam, qualis pingitur, mortem dixiffes, \& fic miferrimain vitam cum morte permutavit. Aperto corpore invenimus loco Hepatis, folam membranam ipfum veftientem, fatis craffam, inftar facci, cui adhuc portio faniei, lotur'x carnitum finilis, inerat, quialem tam longo tempore excreverat. Objit, 1629, April. menf.

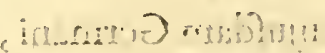 \\ O B S E R V A T I O X. \\ De Vulnere capiits, ubi perperam fiffum Cranium credebatur.}

$\mathrm{M}$

Enfe Maio, 1629, vocatis fui à Chirurgo quodam, ut vifer em militem in fuprema frontis parte vulneratum; vulnufque, ferme ante tres feptimanas, laxius inciderat, ferramento fuo credens, quod Provettam vocamus, dum afperitatem in cranio, \& offe frontis, fentiret, fiffuram fubeffe judicavit, \& etiamnum erat in ea opinione; Sed, dum ego oculos propius admovi, inveni, quam ille fifluram putabat, efle excurrentiam futurx fagitralis (ut in iis folet natura ludere) ufque ad nares. Itaque corrripiens Chirurgum, oftendi ei errorem fuum. Interea $a b$ aëre os jam alteratum erat; itaque curavi ægrum in Nofocomium deferri ad Magifrum Andraam, \& jam fextus menfis eft, quo fub cura noftrá egit. Exemimus ipfi à futura coronali partem ofis ufque ad os temporale, feu petrofum, \& ab altera parte non contemnendum fragmentum; tum offis frontis duas partes, qux futura excurrente diftinitx. Apud Magiftrum And. Dur aum etiamnum refervantur: \& jam, dum hæc feribo, die 10 Novemb. I62y, totum vulnus confolidatum, \& cicatrifatum eft, \& ille, hac vefpera, iturus ad navem bene fanus; \& in Patrian, intra tres, aut quatuor dies, remeaturus eft.

\section{O B S E R A T I O XI.}

\section{Cataribofuffocanti in Nobiliflmo D. Ioanne Petri Coen, Generali in Indiis Prafecto.}

U Vm generofus Dominus nofter Ioannes Petri Coen, aliquandiu Diarrhœa laboraffet, \& tamen, ut illi erat fummus animi vigor, nilhil de folita diligentia remitteret, dum opera, \& munitiones bellicas ipfé coram inficicere vult, \& tamen à me aliquoties monitus, ut paulum quieti fe daret, \& valetudini fux confuleret, negavit, fibi tantum otii effe, ut decumberet, quafi diceret prafagiens, Imperatorem ftantem mori oportere. Tandem, decimo nono Septembris, 1629 , circa octavam vefpertinam repente in arcem ad Dominum fum vocatus, quem inveni xgre firantem, cum tuffi ficca ; externe membra frigebant, fudor aderat frigidus, \& glutinofus. Dejectio per inferiora erat admodum multa, flatulenta, aquofa, \& bullis plena; vomitus præcefferat biliofus. Pulfus arterix tam languidus erat, ut vix fentiretur, \& jlle quidem vermiculans. His ego omnibus confideratis, adftantibus Ampliffimis Dominis meis Confiliariis Indix, D. Antonio van Dyemen, \& D. 2uirino à Raemburch, ftatim pronuntiavi, D. Generalem fupremis appropinquare :ipfis re fubita attonitis, \& $\&$ tantum deliquium animi, ex vomitu, dicentibus, dum paulatim vires, \& f firitus redituros putarent, cum pauco ante tempore cum ipfis difcumbens familiariter confabulatus effer: Ideoque dicebant, 
fe mirari, quod tam audacter de tanto viro pronunciarem: Refpondi modefte, mihi in more non effe pofitum, artem meam ludibrio exponere, dum autignoraffe, aut fefelliffe viderer, fi fententiam meam non explicuiffem: $m e$ tamen in eo optare, uti vaticinium meum fallat. Interea Dominus Generalis inter duodecimam, \& primam noctis horam, fuperveniente fafino, quem momento temporis ante prædixeran, animam Creatori fuo reddidit. Qui Ampliffimi hujus Viri ftaturan \& formam contemplati funt, nihil miri accidiffe fciant. Erat enin longa \& erecta cervice, alis feu fcapulis prominentibus. Complexione exmelancholica, pituitofa, opportunifima ad phthifin $\&$ catarrhum fuffocantem, quo etiam mortuus eft. Obiit anno Domini noftri, 1629, Septemb. 19.

\section{O B S E V A T I O XII.}

\section{De quodam ex bulnere in pectore mortuo.}

$\mathrm{C}$

Ivis Batavus,Ioannes Dragon nomine, I6 Septembr. 1629, in pectore punctim vulneratus eft, ictu tranfeunte os fterni, feu feutiforme, per pulmones in Oefophagum: fuperveniente febre, \& fingultu, octiduo poft vulnusillatum, mortuus eft. Aperuimus prefente magiftratu cadaver, invenimus fecundum conjecturam noftram partes antedictas lafas. Thorax plenus erat fanguine ferofo, cum potu, quiex gula effluxerat, mixto.

\section{Obfervationes aliquot ex plurimis felectx; de Epide- miis, \& Contagiofis, in I D I I $s$, Morbis.}

\section{O B S E R V A T I O I \\ $D_{c}$ Dy fenteria Epidemica.}

$\mathrm{D}$ Vmanno 1628, à Iavanis Mataranenfibus obfidione cingeremur, Amoliffimus Vir Ierensias de Meefter, Senatus Indici Confiliarius, primum in febrem continuam incidit, dein in Dyfenteriam, qux tum populariter graffabatur; exonerans per alvum cum facibus fanguinem nigerrimum, fummo cruciatu, \& foetore: tandem, cum omnia remedia, qux excogitari ad hujus mali levamen poruiffent, adhibuiffemus, ex vivis exceffit; fupervenientibus, paulo ante mortem, exan-

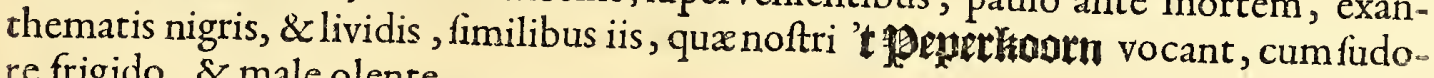
re frigido, \& male olente.

Similiter, Iacobus à Doorefiaar, Secretarius prædicti Dornini Generalis, de Meefter, paucis diebus poft, Dyfenteria viridi, \& genere venenofa, mortuus eft, apparentibus co= piofis maculis lividis, in pedibus, \& brachiis, ante dictis refpondentibus.

\section{O B S E R A T I O II.}

\section{De eadem Dy fenteria Epidemica.}

E Odem tempore Gulielmus Wyntgis, fifci advocatus, mihi fraterna amicitia devinCtus, incidit in Dyfenteriam veram cun fummis torminibus, qux perdurans cum febre ardentiflima per quinque aut fex dies, adhibitis omnibus, qux morbi violentia, \& neceffitas fubita requirebant, cum fummo meo, \& bonorum omnium morore, juvenis optimus mortuus eft, apparentibus, tam crebris \& denfis per univerfum corpus maculis lividis, ut (quod in proverbio eft) locus non effet, cui caput
aciculix imponeres. 


\section{De Febre ardenti, Dy Jenteria, Vlceribus malignis, ¿ $\sigma c$.}

$\mathbf{R}$ Evercndus, \& Doctifimus vir, Ioannes Cavallerius, verbi divini præco, circa idem tempus correptus eft Febre ardenti, fuperveniente Dyfenteria atrabiliaria ; qux cum per aliquot dies continuaffet, eruperunt fub axillis, in tergo circa lumbos, \& in inguinibus, etiam in collo, puftulx ac veficx quædam, plen $x, \&$ diftentæx, pure viridi, \& fubjectam cutem ad carnem ufque erodente, qux nobis, prima facie, ipem crifeos faciebant: fed Dyfenteria non ceffante, \& Febre, cum Phrenitide, ingravefcente, probifimus fimul ac doctiffimus juvenis, ex hac vita ad coelos raptus eft. Eodem tempore, liberi pulcherrimi $D$. Adriani Blocq, eadem Dyfenteria maligna obierunt.

\section{Differtatinncula, utrum Morbi Epidemici, \& Teftilentiales, etiam bic in Indiis Orientalibus graffentur?}

$\mathrm{H}$

Ac paucula , exfexcentis aliis, exempla eo in medium produxi, ut probarem, fruftra eos dixiffe, qui, Peftilentiales, \& Epidemicos, morbos in his locis grafo fari negaverunt: Quo nomine, alii eos appellent, mea nihil intereft. Certe mihi conftat, contagiofum hunc, de quo loquor, fuiffe, \& qui plurimos fimul,ac celeriter occuparet. Caufas, quæfo, audite, deinrccte judicate. Obfeffi arcte eramus, à triginta quatuor millibus Iavanorum Mataranenfium, Duce Tommagom Bauraxa, expertiffimo, inter ipfos, \& audacifimo milite. Quotidieà noftris excurfiones $\&$ velitationes fiebant, frepe plurimis ex hofte, tum hic, tum in oppugnationibus, qux ferme fingulis noctibus fiebant, defideratis: quorum cadavera in flumen precipitabantur, \& fummum fotorem, \& corruptionem, aqux conciliabant. Tum corpora hominum, \& jumentorum, ex fame, \& vulneribus, mortuorum, paflim in campis, \& filvis, infepulta jacebant, guænon levem contagionem aëri addiderunt. Prærerea flumen inficiebatur radice Serpentari $\boldsymbol{\infty}$, quam Indi, in profluente, aliquot mille corbibus impofitam, macerabant, ut veneriofam qualitatem, \& glutinofam fuam fubftantiam, exueret, quam vidimus, fi virtum aqua plenum reponeremus, per aliquot horas, in fundo, tanquam albumen ovi, defidere; $Q$ ua dein tofta, vice Oryzz $x$, cujus in caftris fumma penuria erat, uterentur; dum unico infultu nos poffe capi fperaffent, \& hinc minus fibi providiffent. $\mathrm{H} x \mathrm{c}$ non tam mira videbuntur iis, qui fciunt in Indiis Oecidentalibus radicem Cafavi, loco panis effe, cujus tamen fuccus expreffus prefentaneum eft venenum. Ad rem venio: Adde his potum aqux fubfalfx: Nam, dum ventis è mari fpirantibus, ftato tempore aqua marina in fluvium impellitur, ejus alveum falfedine inficiebat: $\&$ nos propter obfidentes hoftes, altius ex flumine petere aquam non audebamus;Ad hxc,cadaveribus infectum flumen, vermibus fcatebat, omnibus iftis adde tempus anni, quod tum calidiffimum fimul $\&$ humidiffimum erat, propter affiduas pluvias tum temporis, utpote à Septembri ufque ad Februarii initium, tum Solefupra verticem noftrum exiftente in linea Equinoctiali : Qux omnia me quoque, per quatuor continuo menfes lecto affixerunt, cum fummo vitæ mex difcrimine. Primo invadente me Febre ardenti ; fubfequente dein Dyfenteria, $\not z$ augefcente, qua jam ante menfem affigi cœepcram, Paralyfeos ifta fpecie, quam Beriberii vocari diximus. Quxomnia Deo proa pitio fuperavi, uxore interea, \& utroque filio meo,iifdem moleftiis, vexatis, \& decumbentibus. 


\title{
A N I MA D VER S I ONES $I 2 T$
}

\author{
G A R C I A M A B O R T A.
}

$L I B E R \quad \mathcal{V} A R T V S$.

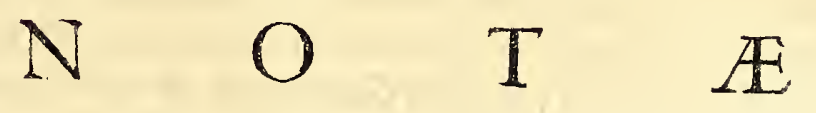

I N C A P V T III,

Quod infcribitur, De Altiht, Jen Affa foetida, Iavanis,
of Malairs, Hin'dicta.

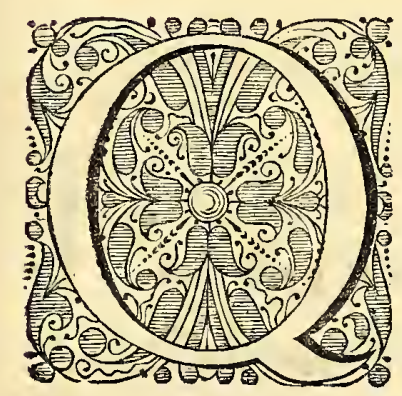

Voniam pracedentia duo Capita abunde \& fufficienter de Ambaro. \& Aloé egerunt, ego, quod in ea commentarer, non habui : fed quia Auctor hoc cap. negat, non folum fe vidifle hanc herbam, fed nil certi de ejus forma adfert; ego qux de Affa fatida planius comperta habeo, hic vobis fuppedito.

Iraque planta è cujus radice Affa exprimitur, magna quantitate crefcit in imperio Perfico, inter Laram, \& Gamaron civitates, quarum prima non longe diftat à mari, \& noftris mercatoribus, \& Anglis etiam, frequentatur. Eftque hæc planta duorum generum. Prima, farmentofa, ferme ut $S a l i x$ aquatica, ex cujus foliis, \& ftolonibus incifis Affa foetida per torcular exprimitur, qux, ut reliqui fucci, Sole indurata in con- fiftentiam evadit, qualis ef Aloés.

Secunda porro Affx fpecies longe fœcundior exiftit, eftque fuccus expreffus ex radicibus hujus plantx, qux craffiflimos raphanos, folia autem Tithymali folia refe runt. Hujus generis aliquot radices domi habui, à mercatore Armeno mihi amico donatas, qui illas huc è Perfia detulerat, \& etiamfi jam effent exfuccæ, tamen tam fortis erant odoris, ut totas ædes fotore replerent; qui infuetis vix tolerandus effet. Quod Iavani, \& Malaii, \& cateri Indiarum incolre negabunt, fe quicquam odoratius naribus unquam percepifle. Apud hos Hin', hic fuccus nominatur, eftque in tam frequenti ufu in cibis condiendis, quam autor hoc cap. refert, ut propter hanc caufam una fit cum Opio ex precipuis mercibus qux per Indiam diftrahuntur : $\&$ femper Societas Indica magnam quantitatem hujus fucci in armariis habet, quam incolis Iavæ; permutatione aliarun mercium aut pecunia impertiantur.

\section{$1 \mathrm{~N} C \mathrm{C} P \mathrm{P} T \mathrm{TV}$ \\ De Opio. Fol. 21}

Ecundoparagrapho hujus Capitis auctor mentionem facit Opii Meferidicti, quod putat Opium Thebaicum fuifle : nam in I Igypto Thebx iftx Centiportx extite. re: \& Meferi, \& contracte $M i f r i$, Agyptus hifce incolis, \& reliquis Indis, eft. Paragrapho 3 inquit, eos, qui Opio utuntur, dormitabundos videri: tamen nil minus quam fulta funt hx nationes in mercaturis excrcendis; armis, \& arte belli, ab Europæis forte fuperantur. Certe laudes hujus fucci è Papaverc expreffi, fi referrem, viderer Chymicis velle fuum honorem prxripere. Hoc faltem dico, fi nobis de Opio,

$$
\text { D } 3 \text { \&Opia- }
$$




\section{A C O B I B O N T I I}

\& Opiatis non effer profpectum, fruftra in calidifimis his regionibus medicinam faceremus, Dyfenterix, Cholerx, febribus ardentibus, \& reliquis biliofis affectibus or galino turgentibus : \& ne vobis fucum videar obtrudere, quid in noftris regionibus confectiones ex Opio tantopere celebratx, Theriacam, dico, \& Mithridatium; quid denique Philonium ? qux nifi Opio tanquam bafi fuffultx effent, fruftra ab iis effectus tam manifefte juvantes quis expectet. Et profecto infignis eft ofcitantia ifta, qux in abufum medicamenti, \& minus bene prxparati, dicuntur, in ufum nobilifimi inter omnia pharmacivellereferre, fine fundamento fxpe, acin Scholis fine Experientia.

Pauperes porro Indi, ex foliis, \& ftolonibus Papaveris, Opii fpeciem vilior em excoquunt, quam Soli porro indurandam exponunt: hoc medicamentum Pouft vocant, quique co utuntur, contumelix ergo,Poufti à ditioribus vocantur, tamquam fummonianos, \& proletarios dicas. Pauperiores porro in divites convitium regerunt; eos Affionii vocantes, tanquam fi luxuriam, \& delicias vellent exprobrare. Affon enim, ac quiburdam Ampbion, Arabibus, \& Indis, Opium Græcorum eft: indeque magis adducor, ut credam, Graculos, à vetuftiffimo populo vocabulum Opii derivaffe, cum ab omni memoria illi co ufi fint. Græci vero tantum noxas hujus medicamenti videntur noviffe, ufum verum, \& virtutes ejus plane divinas, non fatis exploratas habuiffe. Paro ego Exrractum utiliffimum ex Opio, \& Croco Indico,id eft, Curcuma; ad quod in extremis tanquam ad facram anchoram confugere foleo: in jam ferme defperatis Cholera, Dyfenteria, Phrenitide, \& Spafmo, admodum frequentibus : fed hoc melius è Method. med. Indica noftra videbitur.

\section{N C A P V T V.}

\section{De Gummi Benjoin. Fol. 26.}

$\mathrm{P}$

Aragrapho 18 , autor ait, Benjoiferam arborem valde effe proceram, \& v2ftam, \&c.

Ego vero Benjoiferam arborem in Iava, ubi optimum Benjoin colligitur, longe alia facie vidi, quam qua defcribitur, immo vero videtur planta, (feu fiarborem appellare malis, ) ex pluribus farmentis coalita, qualis eft Smilax afpera, feu Salçaparilla, nifi quod farmenta brachii craffitudinem $x$ quent, vel etiam fuperent, ita ut hæc in medio fape truncus arboris continuus, fatis craffus, appareat. Subtus vero, \& fupra Coelum per farmenta à fé invicem diffita liceat contemplari: Sxpe quoque alia virgulta, à Benjoifera arborefpecie plane diverfa, hac coalitione includuntur,itaque fi quis ignarus diveriitatem foliorum in hujus arboris farragine videat, miretur fane: fed hoc etiam fieri in trunco Aloës feu Calambac, poftea dòcebimus. Et porro ex hujus feu ftirpis, feu arboris, cortice incifo, fepifime odoratifimi Benjoini gummi frufta aliquoties collegi.

\section{IN CAP P T VIII.}

\section{De Lacca. "Fol. 29.}

A Vtor hic Formicarum iftarum, qux Laccam elaborant, mentionem facit, unicum hoc addo, quod Formicx ift alat $x$ funt; $\&$ coloris punicei, \& fuper flores, frutices, arbores, \& herbas, circumvolitant, ex quibus, non fecus ac apes, Lacc $x$ conficiend $x$ materiam colligunt, $\&$ in communes operas conferunt; non alat $x$ autem Formicx eam non claborant. 


\section{I $N$ C A P V T XIII.}

\section{De Tutia. Fol. 48 .}

F Allitur vehementer nofter Garcias ab Orta, quod Tutiam è cineribus cujufdam arboris uri dicat: fed confitetur, hoc fe auditu percepiffe, itaque deceptus
fallit alios.

Nam fit ex terra quadam, Argill $x$ inftar glutinofa, quam colligentes Indi,ollis in eam rem ex argilla, longe fortiori, quam in noltra patria, confectisindunt, \& aquam addentes, eam curiofe baculis circumagitant, dein fornacibus in hunc ufum effictis im. ponunt, \& per ignem exficcata omni aqua, dein terra hac calcinata lateribus predictarum ollarum,demptis fordibus qux in fundo hærent, Tutiam lateribus affixam abradunt, quam arcis inclufam venalem ferunt per totam Indiam, ejus enim ufus eft in de. pilatoriis apud hafce gentes, præfertim forminis, dum fe in balneis, vel fuviis lavant.

In Perfix autem Provincia, Kirmon dicta, hujus terræ a rgillacex, ex qua Tutia coquitur,à Perfis,\& Armeniis mercatoribus, qui negotiandi caufa huc advehuntur, magnam copiam reperiri non femel audivi, qui etiam ut lucrum ex Tutia, quam Perfica lingua Tutyab vocant, uberius faciant, eam diftribuunt in lapidem $T$ utyah, \& in pulverem ejus magis vilem, quam feorfim volentibus tum divendunt.

\section{I $N \quad C \quad A \quad P V T$ T XVI.}

\section{De Agallocho Jeu ligno Aloës, Calumbac Indis dicto. Fol. 64.}

$\mathrm{L}$

Ignum Aloës preterquam quod in Infula Sumatra, directo in confpcetu Iave fita, nafcatur: etiam frequens oritur, \& optimum in Champac, vicina Chinz regione, \& in Chochincbina. Ac quod cortice nudatum hinc in patriam feratur, non ideo evenit, quod fine cortice crefcat : fed quod fxpe quafi uno trunco etiam diverfafpecies virgultorum, \& ftirpium,temporis diuturnitate coalefcant, haud fecus quam in Benjuifera arbore fieri diximus: nam hoc mirum nobis videri non debet, cum fciamus,per artificium ctiam diverf $\mathfrak{x}$ fpecieiarbores alienx fpeciei inferi. Cáterum hoc modo Incolx lignum Aloës, ab aliis virgultis \& ligno feparant. Truncos Aloës cxfos deponunt in ripis fluviorum in cœno \& luto, ut diverfi generis lignum carie confumptum fe à ligno Calambac, feu Aloes feparet, unde cortice Calambac confumpto, qui tam oleofus non eft, quam ipfum lignum, quod præterea minus teredinibus ac putredini obnoxiuna eft, tale, quale in officinis in patria, ad nos quoque defertur. Lignum hoc porro Aloes guftu plane aromaticum eft \& fubamarum, unde forfan Aloes nomen mutuatum eft. Pulvis ejus ad fcrup. unius pondus fumptus Choleræ prodeft, quam Mordexi incolx vocant, \& omnibus inteftinorum affectibus frigidis, \& ventriculi medetur egregie. Tum tineas, \& afcarides puerorum efficaciter necar. Chinenfibus porro \& omnibus Mauris ethnicis in facrificiis pro fuffumigio elt.

\section{N C A P V T XVII.}

\section{De Santalo. Fol. 68 .}

$P$ Aragrapho tertio auctor nofter refert, pallidum \& flavum Santalum, plurimum in Tymor infula nafci, de quo hoc porro memorabile certo accepi, è mercatoribus noftris, advehendi Santalini ligni gratia, eo commeantibus, In hac infula nafci febris continux $\&$ ardentis quandam fpeciem, qux fit è Synochi putrid $x$ genere, cum delirio \& mentis alienatione mira; durante namque exacerbatione, qux plerumque quatuor eft horarum (nam hoc obiter fciendum eft, quamvis ad apurexiam hee febris non perveniat : tamen exafperationes fuas habere, non feccus ac tertianas continuas), ridiculas admodum actiones rgri edunt, id opificii, vel muneris imitantes, quo fani functi funt ('ut latius in Met bod. medendi mea Indica) \& aftantibus rifum excutiunt. Tenentur quoque bulymo, \& fame canina infatiabili, ut quicquid iis obtuleris, etiam 
foedum, (ut mos eft nauticis noftris fociis co genere fourrilitatis delectari) avidiffime devorent : extra exafperationem cam, cretera fani, \& mentis integrx. Hunc porro affectum ortum fuum trahere ex recens cæfarum arborum Santali, cortice viridi, incolæ certo certius affirmant : nam cortex tum virofi nefcio quid expirat, \& cerebro inimici, tum cito in corporibus cacochymis, \& pejoris diætæ, ut funt nauticorum noftrorum, tales effectus edit. Sed latius in præd. mea Meth.

Antequam cedantur arbores Santali,cortice incifo exploratur ab expertis odor,num maturx fint \& tempeftivx ad fecandum. Auctor porro, Santalini fructus ait effe Cerafi magnitudine, baccas lauri non male referunt, nam exficcatas habui, \& mafticati purpurco \& morino colore inficiunt. Fructus hi avide comeduntur à Turdorum quadam fpecie, ut baccx Orni in patria, quos denuo per alvum excernentes, arva \& montes novis arboribus conferunt, ita ut quamvis tanto tempore tot millia arborum cxe fint $a$ Lufitanis \& noftris, tamen Sylvæ nunquam deficiant.

Porro cum Auctor mentionem hic faciat unguenti ex Santali pulvere; Ego hujus compofitionis ulum, in gratiam tironum Medicinæ fubjiciam, \& primum hoc.modo paratur. 2E. Santal. tenuiff moliti,fiórum Champoc, florum Mogori, ana m. I. his parum contul. adde rad. Curcum. unc.ij. camphor. q.f. ad gratum odorem: hre omnia in plano marmoreo lapide piftillo fubigunt, addendo fub finem olci nucis Indicx recentis, q. 1. Vng. formant in pultis confift. Hocinungunt tam viri, quam mulieres Malaicx torum corpus, \& quamvis propter flavum colorem, quem c̀ Curcuma contraxit, primo afpectu foedum fit ; tamen fuaviffimo \& faluberrimo odore nares ferit. Prodeft vexatis à Solis, vel etiam à febrili æftu, rigotem quoque in febribus tollit, \& nimias vigilias arcet, impofitum quoçue regioni ventriculi choleram fiftit, cor roborat. Qux latius in prad. Meth.

\section{N C A P V T XX. \\ De Maci. Fol 79.}

$\mathrm{F}$ Eruntur c̀ Banda, Moluccarum infula, grandia vafa fictilia huc, perque reliquos aliquando (cum permiffione Superiorum) infularum circumjacentium tractus; plena Nucibus myrifticis, aceto ac muria condita : nam fine permifiu nullo modo efferre licet, quod infulx Bandenfes noftris armis fubacta provincia Batavorum fact fint. Nuces has maceratas per diem unum, aut alterum, dein leviter excoctas, faccharo condimus.

Caterum de Cortice nucis hujus condito hoc dictum fir, ac de nuce quoque ipfa, iis parcius in his locis effe utendum, quoniam olcofi, \& 2 pingues vapores ex efu ejus in cerebrim elati, obftructionem ventriculis cerebri afferunt, ac inde fomnolentiam, immo ftuporem quendam univerfis fubjectis membris inferunt. Et quod majus eft, ex nimio hujus Nucis ufu aliquot periclitari vidi, qui amplius quam per diem naturalem fine fenfu, \& motu jacuere, tanquam Caro correpti, certiffimo indicio cerebrum, \& univerfum nervorum genus non leviter correptum fuiffe. Praterea incolx in Banda, \&jam etiam noftrates, ex viridi cortice Nucis Myriftica pultem excoquunt non infuavem, qux ferme fapore refert ifud ferculum, quod in patria conficitur ex pomis acidis coctis : fed qui ea pulte ufi funt, ex fide mihi retulere, fluporis $\&$ fomnificos jam dictos effectus edere.

\section{I $N$ C A P V T $\mathrm{T}$ XXII.}

\section{De Pipere. Fol. 86.}

T. On tantum Piper provenit in Malabar, ut Auctor, ro paragrapho, ait: fed maxi-<smiles>[AlH2]</smilesma etiam quantitate nafcitur in Rćgno lava, prafertim in Bantamenfi provin cia: Prxterea crefcit abunde in Iambienfi Sumatræe tractu, qui peculiarem Regem obtinet non fubjectum imperio Regis Achinenfis, qui potentiflimus hujus infulx Tyrannus. Ex hac provincia ab amico Rege, noftra naves quorannis bis terve petunt.

Quod porro Autor,paragrap. I I. fol.89, inquit, aceto \& muria condiri piperis racemos virides, verum eft. Ac quia aliquotics repetendum erit, id condirurx gentus Indi ge - 
H.IS T. NATVRAL. \& MEDIC. L I в. IV.

nerali vocabulo $A c h a r$ vocant. Ac tali modo condiuntur etiam $Z$ inziber viride, ra. dices Galangx, Caryophyllorum racemi. Hoc modo etiam faliunt Cucumeres juvenculos, quos Agurcas Lufitani vocant; preterea Mangas, addito Capc, Allio, \& Porro. Et certe in his locis, ad or exin excitandam, \& ciborum concoctionem, nihil fanius reperiri poteft. Cum propter aëris in hoc climate calorem fimul ac humiditatem, fubject $x$ Capiti partes, ut funt Pulmones præcipue, \& Ventriculus, affiduis Catarrhis infeftentur: ad hunc ufum Genifta quoque hic crefcens \& Cappares è Perfia, \& Surate, adferuntur huc:

Autor porro, hujus Capitis parag. I 2, refert ridiculam Indorum de Piperis qualitate opinionem, quam etiam lavani confirmant, nimirum quod frigidum fit Piper, credo, forte ea ratione, qua quondam quidam perverfi Sophifx argumentabantur, ignem frigidum, \& nivem feu glaciem, calidam effe, vel ut Hyperbolice Poëta ait, $P e$ netrabile frigus adurit: Contra quos tamen, bene monet Ariftoteles, non effe difputandum, nifi fola experientia; nifi for te vellent, nimio ejus ufu, calor em nativum diffipari, \& debilem inde reddi : aft illi (credo) tam alte non philofophantur.

\section{I $N \quad C A P V T$ XXVI.}

\section{De $\mathcal{N}$ uce Indica, Coquo Luftanis dicla. Fol. 120.}

$\mathrm{C}$ Arolus Clufius in annotationibus ad hoc Cap. fol. I I9, refert, Solerc Indos follis hujus palmæ infcribere literas fuas; immo, quod vero propius, literas hifce foliis oblongis infculpunt ftylo ferreo, atque id adeo artificiofe faciunt, ut vel clegantiffimum fcriptorem è noftris longo intervallo poft fe relinquant, \& tam emendate characteres fuos Indi (Arabicis autem utuntur) hifce foliis imprimunt, ut fubirafci mihi aliquoties contingat noftris Europæis, \& præfertim noftræ Nationi; quæ ferme nil niff fua admirantur, \& has Nationes, Barbaras vocitant, cum multo fignificantius paucis characteribus, more Laconun, animi fui fenfum exprimere queant, quam noAtri longis periodis, \& verborum farragine inutili. Præterea quamvis Regum in Iava videatur Tyrannicum imperium: tamen id ita pro conditione gentis fux politice gerunt, ut aliquis, cui non cornea fibra eft, neque de genere eft Arcadici pecoris, hic fatis cito addifcere queat, compendiofam politices viam effe, Regibus, bene imperare; \& fubditis, melius obedire.

\section{N C A P V T XXXII. \\ De Calamo Aromatico. Fol. 125.}

$P$ Ræter ufus excellentes, quos preftat in Medicina Calamus aromaticus, hoc Cap. defcriptus, etiam Malaicis mulieribus in culina infervit, in condiendis pifci bus, \& carnibus elixis, cum radicibus Zinziberis recentis, radice Curcumæ, \& Galangx, \& reliquis Aromatis; \& fic cibis odorem, \& faporem fuavem conciliat, \& concoctioni ventriculum, \& inteftna apta efficit. Cærerum, ut hoc parerges dicam, hæn nationes, quantumvis noftris Barbaræ vocatæ, Polonos, \& Germanos in condiendis piícibus fuperant, qui tamen hic palmam fibi vendicare non erubefcunt.

Cæterum Auctor ait, Calamum aromaticum, nec Galangam, nec Acorum effe;bene quidem cum Acorus, \& Galanga, quantum ad folia,potius ad Gladioli fpecies debeant referri , \& Calamus aromaticus fit Gladiolifpecies.

\section{N C A P V T XXXIII.}

\section{De $\mathcal{N}$ ardo. Fol. 128.}

Ardus Indica in Iava, magna quantittae, crefcit, ejufdem in culina apud lavanos ufus eft, qui Calami aromatici, \& Iunci odorati : nimirum in condiendis jufcul is pifcium, \& carnium elixarum. Plantam Nardi viridem hactenus non 
vidi, quod in montibus circiter I 4 Leucas ab urbe Batavia crefcat, \& eo propter pradones lavanos, \& Tigrides, excurrere non audemus. nos, non fecus ac Calendulæ flores exficcatos in patria, Nardum infundimus in aceto, \& dein Syrupum quoque inde conficimus adverfus frigidos vifcerum affectus, Heparis nimirum, Lienis, \& Mefenterii obftructiones, qux poftremæa deo frequentes funt, ut hine mifere multi extabefcant \& marafmo moriantur, fine dolore tamen, \& pauco fenfu, de quo latius in Method. Med. mea. Acetum porro, \& Syrupum hunc Nardinum, (certo milhi conftar) ad morfus venenatorum, ut Serpentium, Scolopendrarum, Scorpionum, \& fimilium, valere impofita, vel intus fumpta: quod experimenco comperi, pracipue in uno, qui morfus erat à ferpente quodam, quem Lufitani Cobra de Capello vocant, atque hujus morfus adeo venenarus, ut certe Lufitani hunc Regulum feu Bafilifcum effe putent, fed de co aliquid inferius dicemus.

Sequenti cap. de Iunco odorato nihil addo, quam quod Autor fallatur, qui dicat, Iunci odorati nullum alium effe ufum apud Indos, quam fubfernendis equorum cubilibus, cum etiam eo in culina ad condiendos cibos, ut Calamo aromatico, Indi utantur, quapropter etiam, quamvis in fylvis copiofe crefcat, fudiofe à mulieribus Malaicis in hortis colitur, tum quoque ad lavacra, fomenta, infeffiones, utiliffimus eft; ut \& ad omnes muliebres affectus. \& cum fit graminis fpecies, fimplicifque, \& vulgaris Graminis ufus, in multis tantopere commendetur, quis neget, Gramen hoc plane aromaticum vires longe excellentiores poffidere.

\section{N C A P V T XXXV. \\ De Cofto. Fol. 137 .}

Vtor hoc Capite tantum unicum genus Cofti effe afferit, quod \& ego affirmo: nam vetuftiores Medici, fua tria Cofti genera diftinxere magis à carie, \& vetuftate corrupta, quam à Cofto. Colti porro radices huc è Cambodja plenis faccis adferuntur, cum plurimus ejus ufus fit in medicamentis apud omnes Indos, \& Chinenfes pracipue. Caterum Coftus vulgato vocabulo inter mercatores Indos Pucho, Chinenfibus Potfrock, vocatur. Notas omnes hxc Coftus habet, cum ea, qux hoc Cap. defcribitur. Cum ego primum radicem Cofti viderem, putavi effe Hellebori albi radicem, \& nifi me odor monuiflet, in ed opinione adhuc hxiffem, quia Cofti radice per medium fecta, tot initia fibrarum, quot in Hellebori radice, reperies : Adulterari porro radicem hanc, ut Autor ait, non credo:nam vidi ego integrum Picol, quod pondus centum, \& viginti tb, in auctione decem realibus diftribui.

Autor fequenti cap. XxviI , de Radice Chinæ, multas \& veras laudes refert. Quibus ego hoc tantum addo: quod hæc radix non tantum ad affectus Venereos urilis fit : led \&zad omnes Chronicos morbos, qui hic communiter graffantur, ut funt $\mathrm{Ca}$ chexia, Lcucophlegmatia, Hydrops, denique Paralyfeos ea fpecies, quam Beriberii in Meth. mea Indica Medendi vocari dixi, ad quam curiofum remitto, quod in meipfo, dum moleftifimo hoc malo per quatuor menfes decumberem, expertus fum, cum ante ejus ufum neque pedes, neque brachia,commode movere poflem, quod \& in plurimis aliis experientia didici.

\section{I $\mathrm{N}$ C A P V T XLIV.}

\section{De Ligno Colibrino. Fol. 145 .}

A It hoc Capite Autor, Lignum Colubrinum valere adverfus circuitus febrium intermittentium; hoc verum effe non femel expcrientia didici, prxcipue in Tymorenfibus febribus cum delirio, \& fxpe phrenitide, conjunctis, de quibus, \& de carum cura, alibi. Lignum Colubrinum hoc vehementer denfum eft, \&, fi quando Indi velint eo uti, fricant fortiter cum aqua in marmoreo lapide, \& friabile cum fit, teritur facile, ac fic cum aqua aut alio liquore xgro exhibent, guftu eft longe amariore, quam lignum Aloës; valet quoque ad tineas, lumbricos, ¿afcarides, \& potenter ictibus venenatorum animalium refiftit.

Para- 
HIST. NATVRAL. \& MEDIC. LIB. IV.

Paragrapho porro tertio, mentio fit Serpentis cujufdam, quem Lufitani Cobra de capello vocant; hi Serpentes; cum irritati funt, duas bullas in cervice erigunt flavo colore, quales Ranx iftx paluftres coaxantes, in temporibus attollunt, \& h h bull $x$ forfan coronæ fpeciem Autòri fecere. Cxterum ferpens non multo craflior eft digito minimo auriculari humano, in tergo colore éft nigro in ventre fode flavo.

Quod feq.paragr. dicitur de pugna Viverræ cum hoc Serpente, non adeo difonun eft, cum ego frepius à Felibus occifos viderim, fed nunquam de carnibus corum guftant, cum rèliquos Serpentes, præfertim aquaticos, avide devorent. Sigtno inter ca. tera evidenti, quam virofum fit hoc infectum. Vidi enim Maurum quoddam Arundineti genus cæedentem, quod Rottang Indi vocant, \& eo omnia ligant, ut apud nos hoc funibus fit, quorum vicem fupplet, \& dum imprudens unum ex Serpentibus his lædir, ab eó morfu in mufculo pollicis eft petitus, veftigio vix exftante, \& cum, ne venenum altius ferperet, brachium ipfi arctiflime ligaretur, \& ille præ dolore vinculum laxari obnixe oraret, hoc facto fatim mifer expiravit, corpore foedum in modum intumefcente, tanta erat vis veneni ad cor momento penetrantis.

\section{N C A P V T XLV.}

\section{De Lapide Bezahar; Per/es, Pa-zahar. Fol. 165.}

$P$

Aragr. Secundohujus Cap. Autor ait, Lapides Bezahar paleam,vel quid tale, incus habere, quod nunquam fallit, nifi in adulterinis, $\&$, fi fuperficiali tunica abrafa, non fuccedat alter orbis, cxparum modo, donec ad paleam iftam deventum fit, fictitius eft lapis procul dubio : fed fequenti modo ejus adulterium melius percipitur. Si lapidem frices pauca calce, $\&$, fi in loco fricato puniceus color appareat, conftat verum effe, \&genuinum : fecundo, fi ponderatum accurate lapiden conjicias in pelvim aqua repletam, \& poft duas aut tres horas eundem eximas $\&$ rurfus ponderes, ac nihil de priori pondere aut perdiderit, aut eo gravior factus fuerit, verus eft lapis Bezahar : verum ficalce fricatus rimam ducat, aut fi aqux exemptus, de pondere amiferit, vel eo auctus fuerit, falfum $\&$ adulterinum effe, audacter dicito.

Paragr. 6. Garcias inquit, lapidem hunc non folum generari in Perfia, fed etiam in aliis commemoratis locis : fed quoniam nullus, quod fiam, ante me verum etymon hujus lapidis edidit, nec quomodo, aut ex quo, generetur; paucis aufcultate rem. Perfx igitur hunc lapidem vocant $P a$-zabar, compofito vocabulo ex $P a \& Z$ abar, quorum prius fignificat contra, \& fecundum venenum nominatur, ac fi Graco vocabulo antidoton dixeris; perfpicitur quam fallax fit ifta Etymologia, quia Pazar, vel Bazar, lapidem hunc dictum volunt, cum nullus unquam eum venalem in foro viderit. $\mathrm{Na-}$ fcitur hoc porro modo lapis Bazar in Perfia, ut ab Armenis, \& Perfis mercatoribus fide dignis certo accepi. Eft locus in Perfia Stabanon dictus, trium dierum itinere fupra Laram civitatem celebre in Perfia Emporium, in cujus campis nafcitur herba quxdam Croco, \& Hermodactylis admodum fimilis, ubi caprarum copia pafcitur, in quarum ventriculis ex efu hujus herbulæ hi lapides concrefcunt, qui apud Reges Perfix in tanto pretio funt fupra reliquos, qui in aliis locis gignuntur, ut magnus Xaabes, Imperatorum Perfarum ultimus, mortuus anno 1628 , inibi vigiles locaverit, ut omnes iftos lapides Bazahar qui certum pondus excederent, fibi vendicarent: Iraque, quod caufa materialis hujus lapidis, fit caufa fupra dicta, non folnm Armeni, \& Perfe mercatores mihi retulere : fed idem ferme affirmat $P$. Texeira, Lufitanus, in tractatu fuo eleganti, quem Hifpanica lingua confcripfit, de rebus geftis Regum Perfix, qui inquit, Infulan quandam effe inter Ceylon infulam, \& terram continentem Chormandel, qux à Lufitanis Ifla de Vacas vocata (quod infulam, vaccarum fonat) noftris naucleris etiam optime nota, in qua etiam nafcitur copia predictorum lapidum, quam ob caufam etiam ibi mult $x$ capr $x$ paficuntur. Atque idem autor ait, quod anno i 85 , hanc infulam maxima $\&$ horribilis inundatio invafiffet, \& etiam totam continentem terram chormandel, ita ut hæc infula tota fubmerfa fuerit, quxque fervari inde capræ poterant, alio tranflatæ, deficrunt gignere iftos lapides, quod prædicta herba ibi non crefceret : fed elaplis paucis annis, cum infula falfugine maris liberata, rurfus hanc herbam produceret, capræ ejufmodi, iterum co tranflatx, lapides hos, ut ante, produxerc. Hxc mihi vobis

commu- 
communicare vifum eft, quoniam \& mercatores noftri, \& Angli, idem certo confirmant. Cxterum quantum ad hyperbolicas hujus lapidis virtutes, \& facultates portentołas, non tantas in eo mille experientiis edoctus inveni, alioqui etiam natura non pronus fiperftitiofas medicamentorum facultates facile admittere, nifi experientia id verum invenerim. Quoque id magis credatis, lapides hi miferis Hircis, \& Capris, tam molefti funt, quam hominibus lapides veliç; \& renum. Capræ ift $x$ non abfimiles valde funt Capris Europxis, nifi quod habeant erecta , \& longiora çornua, \& quædam ex iis verficolore funt pelle, ut Tigrides pulchro afpectu,quales duas in arce Batavia noftra quotidie videmus; itaque hæ Capre prout magnum lapidem, aut parvum gerunt, unumque, aut plures, co moleftius, vel citius incedunt, quod aftutiffimis Armenis, $\&$ Perfis perbene notum eft. Porro vidi \& lapides Pazahar natos in ventriculis Simiorum, qui teretes funt, \& longitudinem digiti aliquando excedunt, qui præftantiffmi omnium cenfentur.

\section{I $N \quad C A P V T$ XLVI.}

\section{De Lapide Porino. Fol. 168.}

$\mathrm{L}$

Apis ifte Malacenfis, cujus autor hic tranfitorie meminit,in memoriam mihirevocat alterum lapidem quendam genitum in Felle Porcorum,aut etiam Ventriculis Hyftricum, oblongis pinnis preditorum, quem Lufitani propterea Piedra, de Puerco vocant, mollis, \& pinguis eft attactu, ac fi raponem Hifpanicum tractes. ego duos domi habeo, unum parvulum ex Hyftrice, alterum ex Apro, excifum. Infunditur hic lapis in vino adverfus choleram, quam Mordexi Infulani vocant, \& hictantopere timetur, quam peftis in Hollandia, utpote qux hominem aliquando foleat occidere paucifimis horis: Prægnantibus tamen hic lapis non bene datur: nam abortum provocare adeo certum eft, ut foeminx Malaicx mihi retulerint, ut fi quando menftrua corum purgario non bene procedat, fi faltem hunc lapidern manu geftent juvamentum fe inde fentire. Sed profecto mihi confideranti judicium humanum de omnibus hifce concretis lapidibus in ventribns, \& cavitatibus animalium rationis expertium, ridiculum mihi videtur, lapidem concretum in vefica humana, \& fape è renibus elapfum, \& per penem redditum, in nullo pretio haberi, cum homo non tantum fit animal longe nobilifimum, \& quidelicatiffimis cibis vefcatur, \& certe quod di$\mathrm{xi}$, de circulis iftis inftar cxparum in lapide Pazahar repertis, fimiles circuitus \& orbes in lapide humano videre eft. Frt ut propius ad externam fuperficiem pervenias, ut lapides Eazabar, friabilior, \& mollior eft, donecad parvum nucleum circulis his inclufum pervenias, qui rubro fuo colore non obfcure lapidis originem è renibus effe oftendit. Nil porro de his lapidibus addo, ne videar eos elevare, \& lithotomos monere, ut vel cum periculo plures mortales fecent. Hoc certe compertum habeo, lapidem in vefica hominis repertum, urinam \& fudores probe ciere, quod tempore ingentis illius peftis, qux anno $1624, \& 25$, Leydam partiam meam, \& reliquas Hollandix civitates, miferandum in modum vaftabat, in penuria lapidis $\mathrm{Ba}$ Gartici nos exhibuiffe memini, \& fudorificum (aufim dicere) melius, \& excellentius inveniffe, cum admixta Theriaca, aut Mithridatio, cum olei Succini, aut Iuniperiguttis aliquot. 


\title{
In Lib. II, Garcix ab Orta, De Planta quadam I N I CA, I A C. в O N. Animadverfio.
}

\author{
I N C A P V.T I.
}

\section{De Arbore trifti dicta Pariz.}

 Vod hæc arbufcula noctu flores expandat, inde eam Lufitani Arvore da 2Notte vocant, copiofe in Iava flofculos fuos albos profert, quos fervi venales in urbem ferunt, faciendis corollis, \& intertexendis capillis mulierum Malai-

carum.

Par. 6, Auctor mentionem facit florum Fula Mogori dictorum : hi flores in arbuftis crefcunt non ineptis texendis fepibus, humanam altitudinem vix hoc arbufum excedit, flores quoque albos fert odore gratiffimo, \& afpectu longe pulcherrimo. Stillaticius porro liquor ex floribus arboris triftis, \&c hac arbufcula, igne elicitur, qui cordialis admodum eft, quocirca ad Lipothymias, qux in febribus continuis, Cholera, $\&$ Dyfenteria , crebro accidere folent, fummum adjumentum præftant.

Paragr. 7, Autor mentionem facit florum fibi Champe dictorum, Iavani autem cum arbore eos Champacca vocant. Arbor eft mali Perfici folio, fed crafliori paulo. Flores porro colore inter fefe variant: nam alii funt è colore viridi dilutioris, ut potius primo afpectu ab arbore avulfi, fafciculum foliorum mentiantur : fed pediculi intus in calyce, quales ferme in rofis, flores effe declarant. Sune $\&$ hujus arboris flores, alii colore aureo fubflavo (quem colorem noftri Oragne vocant) uterque flos aque eft odoratus admodum, verum caput gravat, non fecus ac Camphor $x$ odor infuetis gravis eft. Indos quoque autor ait bonis odoribus effe deditos. "Vt \& reliqui, qui Mahumetis fectam fequuntur omnes, ita ut nunquam ferme mulierem Indicam in publicum prodire videas, quam cum hifce floribus, capiti vel capillo (ut dixi) impofitis, ut gra tiores maritis, vel fape, amatoribus, fuis occurrant.

\section{F12LIS LIBRI QVARTI.}

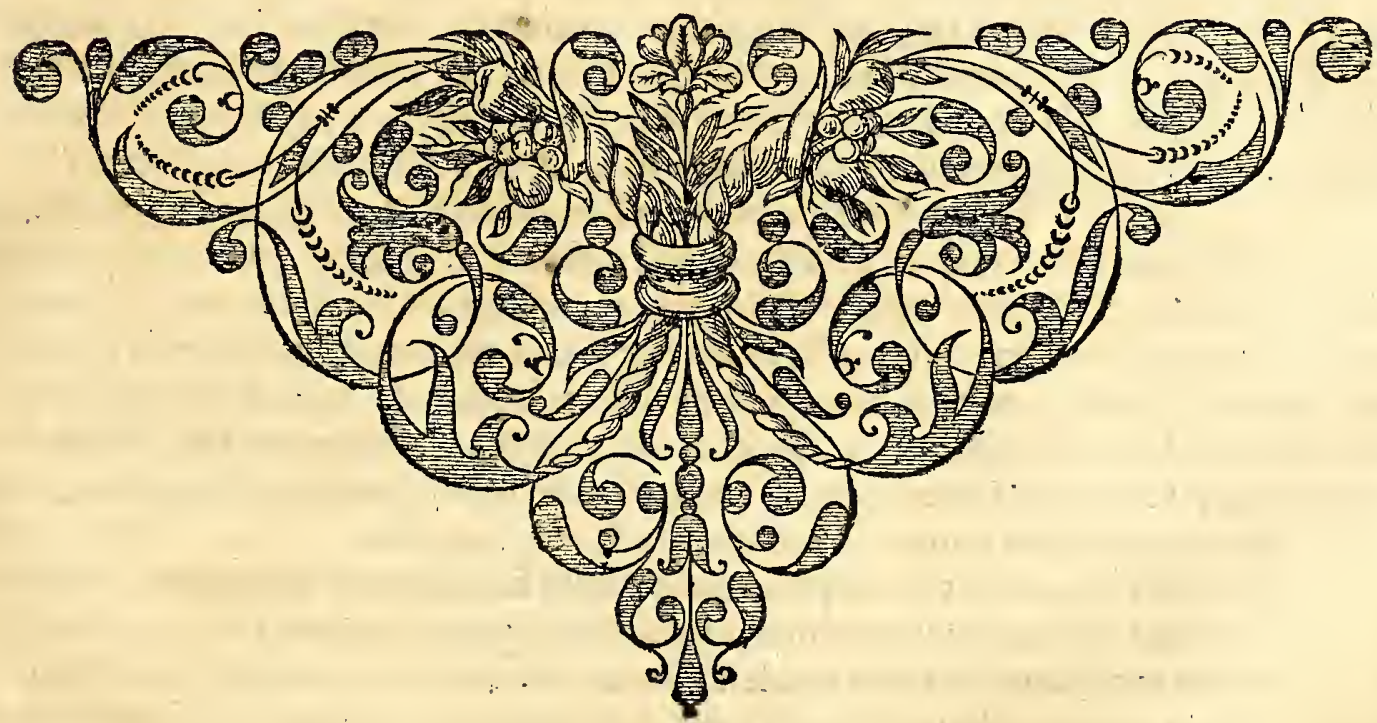




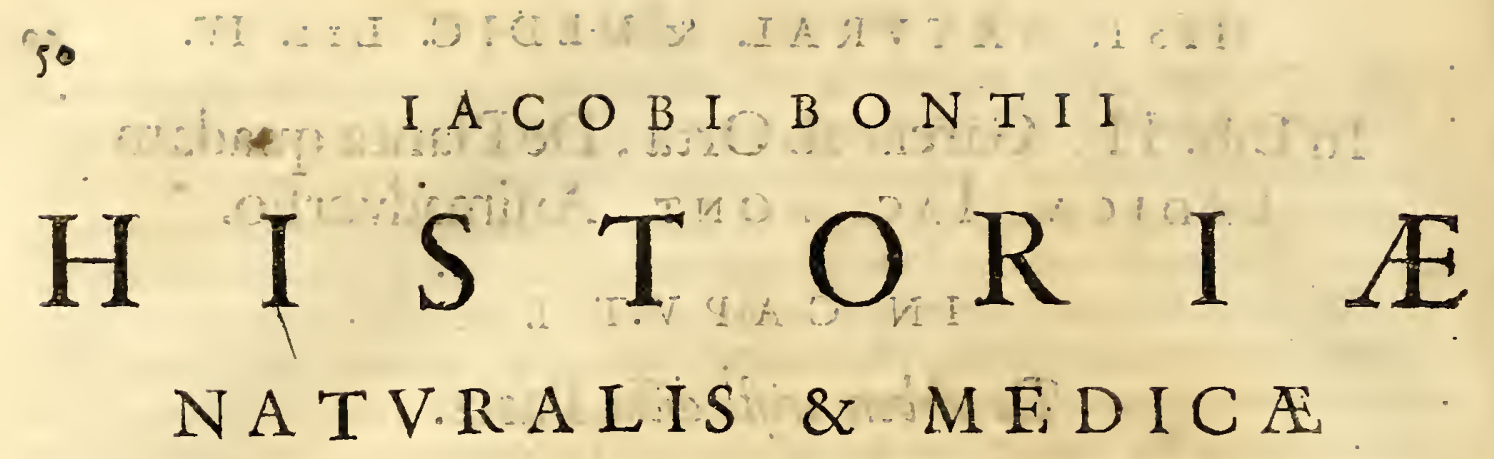

LIBE R $Q V I N T V S$, De Quadrupedibus, Avibus, \& Pifcibus.

Que nova fertilibus progignat Semina Terris, Et quidquid pandat divite Iava finu:

Et queis vicinum natitetir Pifcibus Equor:

2 ue vacuum pennis Aëra pulfet Avis:

Et quis Squamiferis proserpat in orbibus Anguis:

Denfa Feras umbra quas quoque Silva tegat.

Hesperidum os pulcros rois contemplarier Hortos?

Me lege, eve electo Codice doctus abi:

$$
\text { C A.P Y T I. }
$$

\section{De Abada, fibe Rbinocerote.}

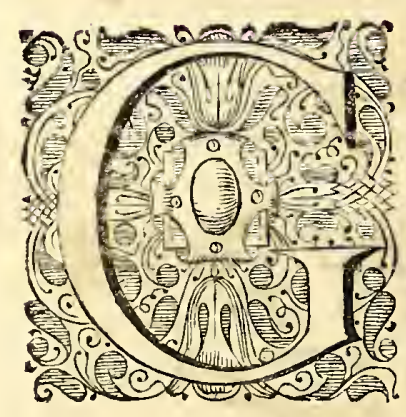

Arcias ab Orta, Medicus Proregis Goënfis, Lib. I. Aromatum, cap. 68 , confitetur, fe nunquam confpexiffe Rhinocerotem. Ego eum vel millies vidi, tam cavea inclufum, quam aliquando in filvis ad pafturam euntem: Quantum igitur in me eft, hoc animal ad vivum hip defcribam, ut piotorum error eluceat, qui illud fcutatum, \& fquamis obfitum, ob oculos ponunt. Cute eft è nigro cinericea, qualis "color etiam conf́picitur in Elephantis, \& Bubalis Indicis : glabro eft corpore, vel pauciffimis pilis obfito : cutis porro rugofa plane eft, \& plicis fuperinducta, qux fcuta $\&$ clypeos iftos mentiuntur, quos ipfi pictores affingunt, fed revera pellis eorum, ut aliorum animalium, non eft difcreta, fed continua ; Corium autem tam craffum eft, ut machæra Iaponica illud vix diffecare quis valeat. Roftro eft Stuillo, non tamen tam obtufo, fed acutiore, \& fuper foraminibus narium, id tam famofum Cornu confpicitur, unde lingua Græca etiam hæc Bellua nomen fortitur. Colore id Cornu plerumque eft nigro; fxpe cinericeo, aliquando, licet rarius, albo, quod etiam multo caritus, quam reliqua, venditur.

Magnitudine Rhinoceros \& corporis mole facile Elephantem zquat, fed pedibus brevioribus non tam confpicuum animal oftendunt. Quoad naturam $R$ hinocerotis, innoxium eft,nifi laceffitum; fed tum crudeliffimum eft, non folum in ipfos qui eum offendunt, fed in quxque obvia, arbores totás profternendo cum ingenti fragore: quod fcite Martialis expreflit lib. I. Epigramm. 22, hifce verfibus:

Sollicitant pavidi dum Rbinocerota magiftri, Seque diu magne colligit ira fere,

Defperabantur promiffi pralia Martis, Sed tamen is rediit cognitus ante furor; Namque gravem gemino Cornu fic extulit Vrfarm, Iactat ut impofitas Taurus in aftra pilas. 
HIST. NATVRAL. \& MEDIC. LIB. V.

$R$ H I N O C E R O S.

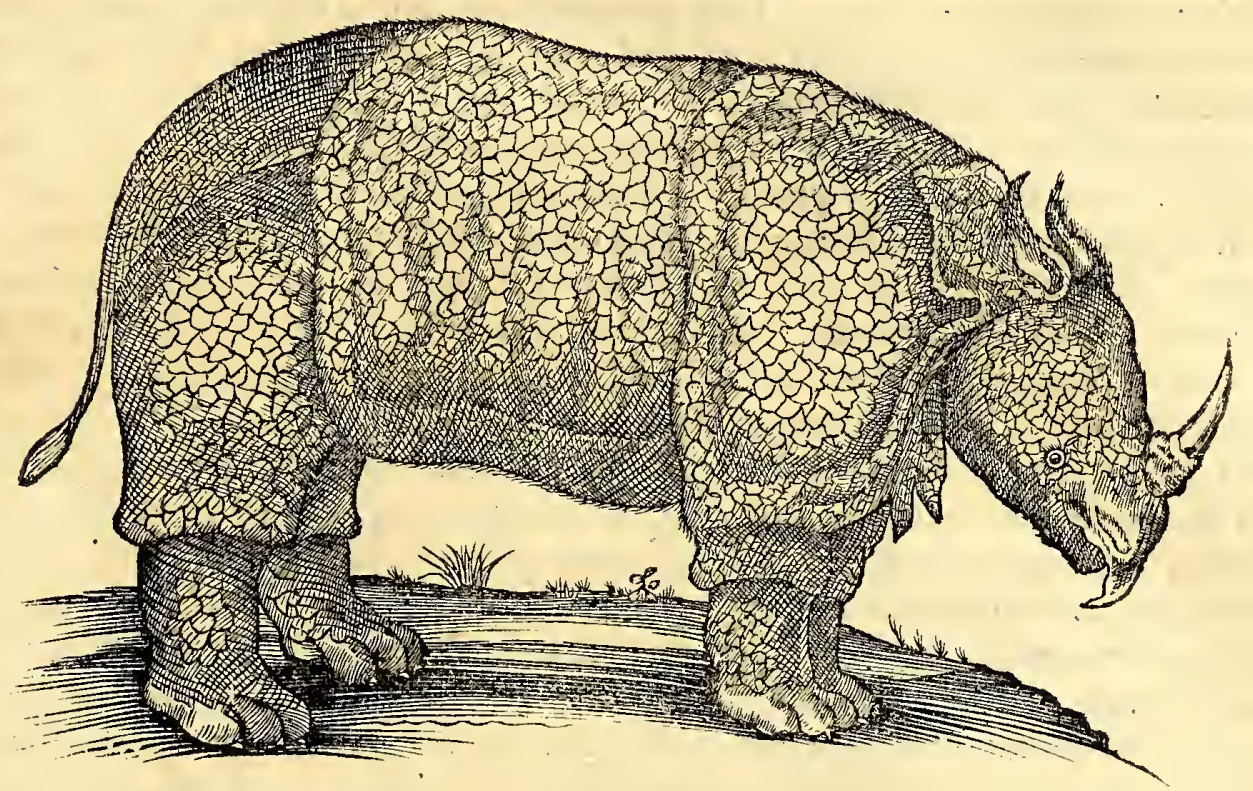

$\begin{array}{lllllllllllllllllll}C & R & A & N & I & V & M & R & H & I & N & O & C & E & R & O & T & I & \end{array}$

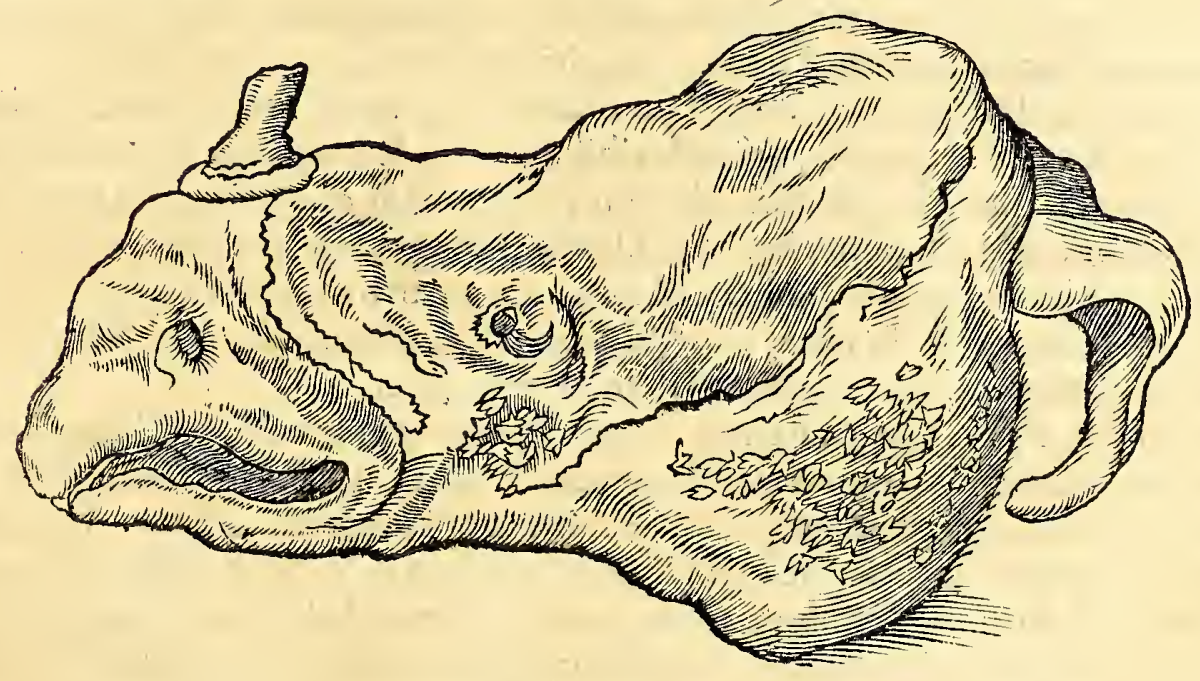

Idem Martialis id cod. lib. Epigr. 9, adhuc clarius enarrat, hifce verfibus, quibus ( prout tum crudelia tempora erant) Domitiano adulatur:

Prafitit exbibitus tota tibi, Cafar, arena,

Quenon promilft pralia Ribinoceros,

o! quam terribilesexarjit pronus in iras!

Quantus erat cornts, cui pila taurus erat!

Vbi porro hominem proftravit, afperrima fua lingua illum lingendo enecat, tum cutem \& fubjectam carnem abradit ufque ad offa; hinc etiam fpinis ac vepribus libentiffime vefcitur;

Lingua vivum occidit lambendo Rbinoccrotis, Aulicafalfidici fic quoque lingua recat.

Animal hoc, crudivorum non eft, ut Tigris, de cujus anicitia cum Rhinocerote proxime agemus: Cxterum de irritatx beftix furore aliquid addam, quod nuperrime accidit Secretario noftrx Civitatis Theodoro Iemmingio, qui cum nuper duobus aliis comitatus eques in filvam exiiffet exfpatiatum, in paludofo loco in Rhinocerotem cum catulo fuo incidit (nam hoc animal non fecus cœno, quam Porci \& Apri, libenter volutatur) qui illis vifis furr exit, ac tarde recedens pr $x$ fe agebat catulum. fuum filvam verfus, qui cum lafciviens aliquando reftaret, mater ipfum roftro protrudebat. Interea quidam ex eorum confortio pratemeritate, equo infidens, belluam in- 
fequitur, \& exerta nachæra, quam gerebat, Iaponica, pofterior es partes Rhinocerot is ferit, (ed ictibus non penetrantibus, propter cutis craffiticm, aliquot ftrix alb $x$ in tergo \&natibus beftiæ apparebant. Quod parientiffime Bellua ferebat, quoufque Catulum fuum inter vepres $\&$ falicta, occuluiflet, tum enim repente converfa in equitem noftrum , cumimmani grunnitu, \& ftridore, ejus caligis mordicus apprehenfis, eas mordicus difccrplit, materia levi, utpote Bombycina, fequenti, alioqui plane actum de eo fuiffer: fed equus forte prudentior aliquanto fuo rectore, retro faliit, $\&$ in fugam convertitur, inf́equente ipfos omni vi Rhinocerote, profternendo cum horribili fragore arbores, \& quicquid obvium ipfi impedimento eflet. Dum nofter eques devenit in eum locum, ubi focios reliquerat, quibus vifis, Rhinoceros, eo derelicto, alios impetit, qui furorem bellux declinantes, poft duas ingentes arbores fe abfcondiderant, vix duos pedes intermedia rima à fe invicem diftantes, \& five hoc felici eorum fato, feu fupore huic animali ingenito, evenerit, beftia folummodo per iftam rimam fummo conatu fibi viam quærebat, \& arbores, non fecus ac arundines, tremere facicbat; fed tamen craffities earum, frontis ipfius impetum infringebat. Interim dabatur eis locus Sclopeta fua explodendi (qux propter latrones Iavanos, ibi tum temporis vagantes, unicuique gerere mos erat) \& belluam adactis aliquot ictibus per cerebrum feriendi, \& fic beftiam immanem proftravere, fuppetias ferentibus Mauris fervis, qui iftuc à dominis fuis lignatum miffi erant, qui animal hoc porro dolonibus, \& fecuribus contrucidavere : Sed hoc crat vere excitare Crabrones. Porro, ut cum Plinio finiam, is refert lib. natural. hiftor. 8, cap. 20, hæc verba: Pompeius primum Rhinocerotem Rom in fpectaculis fuis \&ludis exhibuit, dicitque porro longitudine fere Elephanto effe parem: Sed crura ipfilonge effe breviora, inde quoque non tam confpicuum eft animal, quam Elephas, qui altis pedibus, \& cruribus infiftit.

Quidquid de Elephantum docilitate dicitur, verum eft : $2 \mathrm{C}$ defino, fi prius Plinii \& \& Eliani errores detexero, qui inflexibiles pedes, \& crura fine flexuris Elephantes habere fcribunt, quod adeo falfum eft: nam præterquam quod homines tantum circa crura ac femora, articulationes habeant,Elephantibus præterea flexuræ in medio tibiarum funt. Probofcide porro ( ut bene Plautus) tanquam manu utuntur in cibo capiendo, \& ea in os ingerunt. In Iava, quod fciam, non producuntur, fed quidem multi \& magni in Sumatra, quæ nobis è regione in confpectu jacet.

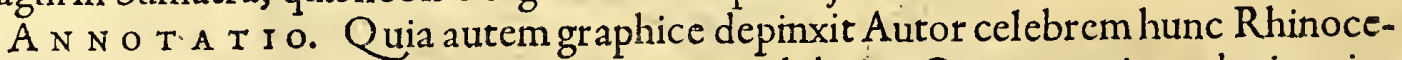
tem, \& non nifi cranii à trunco avulfi iconem exhibuit. Operæ pretium duxi totius animalis picturam acquirere, ut pofthac fimul errandi occafio auferatur. Quapropter elegantem \& genuinam hanc bellux effigiem ad vivum in Indiis depitam favore pr $x$ fantiflimi Viri, Ioannis Wtenbogaert, in Amftelodamo Hollandix Quxftoris, hic offero. Caterum non indignum quoque notatu, quod in diffectione capitis in cerebro repertus fit lapis, ann 1630 , huc ex Iava allatus: Vifu non imbellis, tactu admodum glaber, durus, ponderofus, uncias circa duas pendens;pollicem fere longus, gibbofus, renifque Porcelli figur $x$ rmulus, utraque extremitate obtufus, exterius coloris coracini, interius ex fpadiceo undulatus: de cujus ufu altum mihi filentium, donec qualitates penitius per experientiam revelata fuerint.

\section{A $\quad \mathrm{A} \cdot \mathrm{V} \quad \mathrm{T} \quad \mathrm{I}$ \\ De Tigride.}

Q Voniam Tigris in patria noftra, magis fama, ac fcriptis veterum innotuit, quam vifu, \& quia multa de hac ferociflima Beftia, veritatiminus confona feruntur, ego propter viciniam, quæ nobis, quamvis invitis, cum hac fera intercedit, cam paulo exactius defcribam. Primum itaque quod Plinius difertis verbis ait lib. 8. Natur. Hiftor. cap. I 8 , quod Tigris fit animal tremendæ velocitatis, manifeftus in co eft error : nam è contra beftia tardigrada eft, \& propter cam caufam magis homines appetit, quam carnem Bubalorum, Cervorum, \& Aprorum, \& reliquorum animalium, qux hic paffim in Sylvis, ut feræ, vagantur. Tum 'Tauros, \& Vitulos feros reticco, quorum in Infula Iava ingens eft copia; nam hæc animalia, nifi ex infidiis impetantur, facilc ferociam hujus ferx effugiunt pernicitate fua, quapropter quicquid horum 
TIG I I.

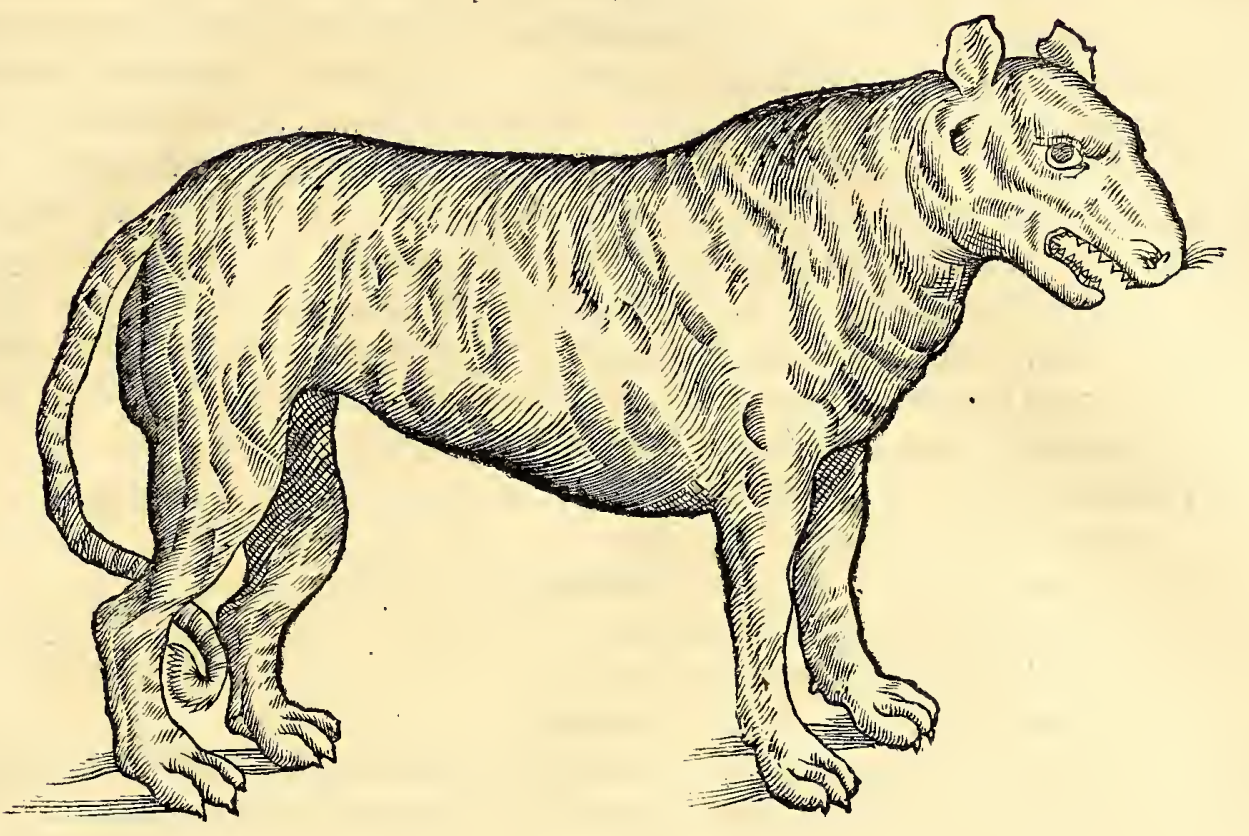

horum venatur Tigris, ex infidiis hoc facit, dum latens inter vepreta, \& falicta, in prætereuntes beftias faltu tranfverfo irruit. Q uod fi aberraverit, femel rugiens recedit, \& circumit Sylvæ aliquot fpatium, ubi rurfus eas beftias preterituras obfervat: Vnguibus præterea prædam femper ferme in cervice ferit, ac unico ictu, quodvis valentiflimum, $\&$ robuftiflimum animal, humi profternit, \& exfucto cruore, cujus appetentiffima eft, cadaver reliquum in Sylvas trahit, ut carne fe exfatiet. Itaque Tigris libenter dogit, ubi hominesfcit verfari, qui odore non funt tam acri, quam pradictalia, anima tum quod homines pernicitate pedum ipfüm effugere non valeant. Ego Tigridem è Felium genere effe dixerim : nam præterquam quod capite, \& reliquis membris, $\mathrm{Ti}_{-}$ gridem egregie referant, etiam moribus cum ipfa plane conveniunt : nam Felis quoque (ut notum eft) unico faltu Mures \& Glires impetit, ac unguibus prius ipfos necat, quam devoret. Hoc clarius patet in Felibus magnis verficoloribus iftis, qux è Perfia, \& infula Cypros adferuntur, quæ hiatu, \& rictu, plane Tigridem referunt. Cærerum frequens eft in fylvis conterminis fluminibus preterlabentibus, ut dum aquatum reliquæ feræ co adveniunt, ipfa ex occulto è fylvis, ac latebris fuis exiliens, aliquam earum dilaceret. Tum quoque reliquis animantibus ingens terror Tigridis ingenitus eft propter ingentem ejus ferociam; unde quoque non male Iavani eam Radja othtang vocant, quod Regem Sylvæ fignificat. Denique robur hujus feræ incredibile eft: nam occifum à fe Bubalum, quamvis tribus partibus ipfa majorem, non fecus ac feftucam in Sylvas trahit. Ac ut id magis credas, Nobil. D. Generalis Petrus Carpenterius, circa Sylvas infidias, \& decipulas Tigribus capiendis, ex folidis trabibus compactas, locari curaverat, quibus intus alligatus Caper,balatu fuo Tigridem eo pelliceret: ac forte evenit, ut valvis reclufis, ingens Tigris capta effet, qux trabes, quamvis ferreis clavis ligagatas, unguibus, quibus plurimum valet, à fe invicem divulfit , acita evafit, incolumi, \& intacto, Capro. Iam mirum quiddani de Tigridos, \& Rhinocerotis amicitia vobis referam, \& deinde definam. Vbicumque forte Rhinoceros habitat, etiam Tigris iftic plerumque ftationem habet, \& ut plurimum una incedentes videas: fed ego curiofius id inquirens à Iavanis, ab ipfis probabilem hujus rei caufam elicui, quod nempe Tigris; utpote carnivora, propter ingluviem pleraque deglutiat, unde cruditates ipfi in Ventriculo oriri neceffe eft. Rhinoceros autem tantum herbis vefcitur; ideoque Tigris eum fectatur, ut ftercore ejus pro pharmaco utatur, non fecus ac Nepeta feu Mentha Felibus, Canibus Gramen, Cervis Dictamnus, pro remedio eft. Nam fimulatam inter ipfos effe amicitiam inde collegi, quod R hinoceros femella, Catulum alens, non patietur Tigridem penes fe incedere: Er ego cum forte extra Vrbem circa fluminis ripas exfpatiatum iviffem, ut amnenifimas plantas, circa fluenta hic crefcentes, contem- 
st

\section{A C OB I B O N T I I}

plarer furmmo mane, repperi Iuvenculum Rhinocerotem in fuminis ripa jacentem, cui mordicus cluncs ablati erant, \& unguibus avulfi, ipfo adhuc firante, \& mifere barriente, quod fervi mei Mauri, quos duos adduxeram, procul dubio, à Tigride factum effe dicebant : praterea hæ fer $x$ una incedentes, femper fe tranfverfis oculis intuentur, $\&$ inter le grunniunt, \& ringunt, quod certe amicitix fignum effe non arbitror. Et fane non male, tanquam Emblematc, hæc animalia exprimunt, amicitixillius typum quiam Incolæ Iavani inter fe colunt, qui tanta fufpicione inter fe laborant, ut propriis filiis, nedum agnatis, \& confanguineis diffidant. Vnicum hoc de Tigride addo, quod dubius fim, utrum Leo huic animali robore praftet: Saltem quos ego Leones in Africa, ad Promontorium Bonæ Spei vidi, magnitudine, his Tigribus longe erant inferiores. Hoc quoque mihi jam in mentem revocat, quod aliquando apud Valerium Martialem, ingeniofum Poëtam, legi, lib. I. Epigram. I 8.

Lambere fecuri dextram confueta magiftri, Tigris, ab Hyrcano gloriarara jugo:

Sevia ferum rapido laceravit dente Leonem, Res nova non ullis cognitatemporibus:

Aufa eft tale mibil Sylvis dum vixit in altis; Poftquam inter Nos eft, plus feritatis habet.

Anno quoque 1628 , Tigris hic Cavex inclufa evafit, \& quamvis à Catulo iftic educata erat, \& hominibus quotidie aflueverat, ftatim in area exteriore arcis Bataviæ invafit equum ibi pafcentem, \& trucidavit, ita ut Cives Batavi, \& milites, coactifuerint feriffimum hoc animal fclopetis occidere, ne plus damni daret; quodiple coram vidi, \& nuper etiam cuin jam fecundo noftram urbem Iavani der elinquere coacti erant, 'Ti-' gris ingens capta, \& occifa fuit circa monia Vrbis noftre prafente generofo Domino noftro Generali, Iacobo Spex : ac nuper hic perfuga fufpenfus eft, qui ante aliquot annos hiantem Tigridem finiftra invafit, \& linguam ejus arripiens, cultrolato quem penes fe habebat, ventrem ei aperuit, \& trucidavit; fed hoc temeritatis magis (cui aliquando Fortuna favet) effe arbitror, quam fortitudinis, exemplum. Atque hac de Tigride.

\section{$\begin{array}{llllllllllllll}H & Y & S & T & R & I & X\end{array}$}

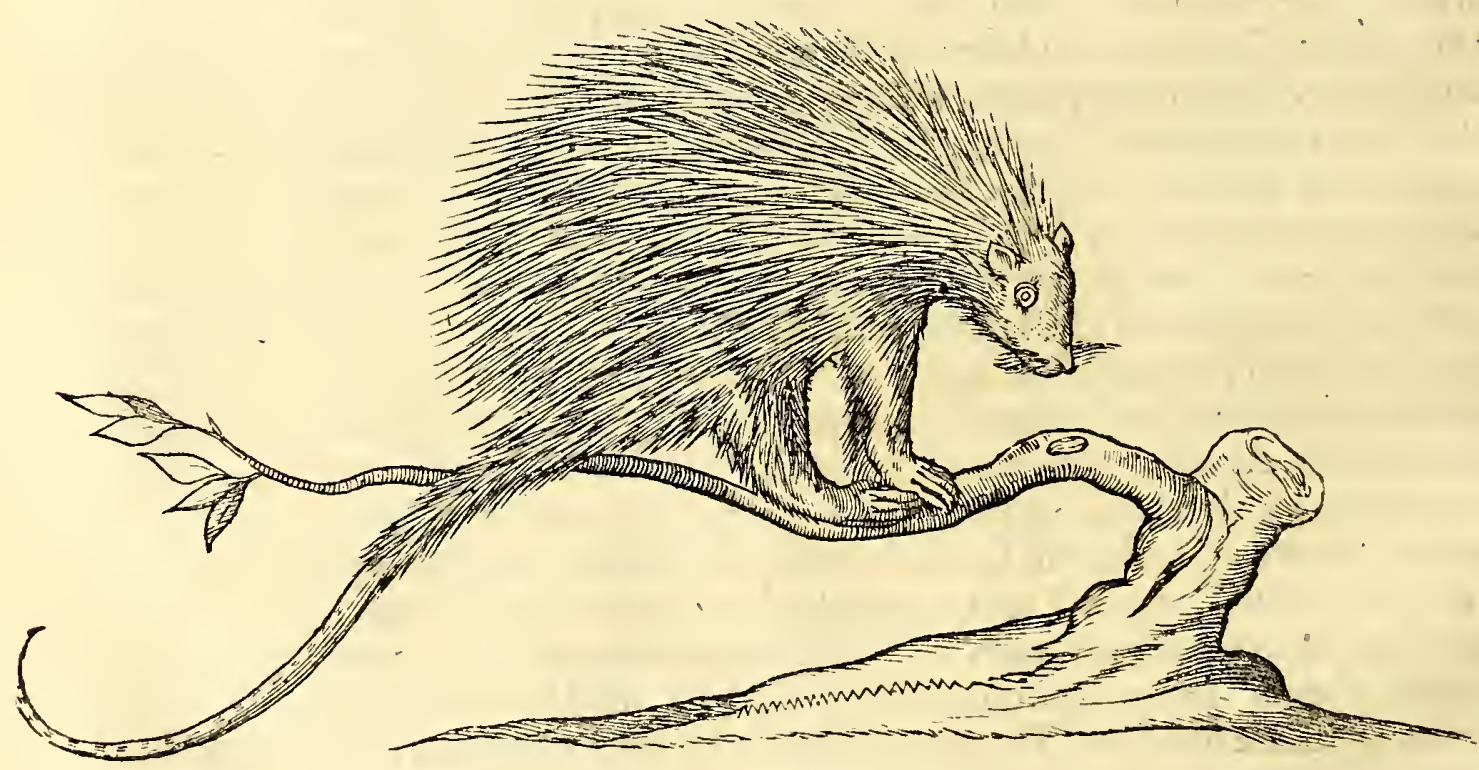

TY Ytrices vero familiares funt undiquaque in filvis, non raro poft Carecta latitan-

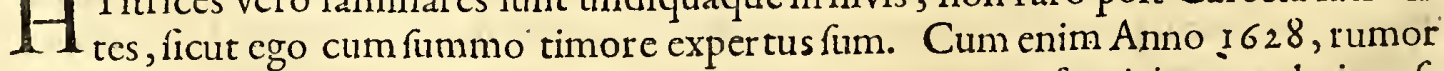
effet Enatacanum nos obfidere velle, filvam circa civitatem, cxfum ivimus, ut latior effet ex urbe in fubjectos campos profpectus. Chinenfes itaque hortatus, ut eam demolirentui:, motum aliquem cum ftridore percepimus, rati Tigridem effe. Illi alta voce Hari-mou, quod Tigridem denotat, inclamant, ut quifque fibi à fera caveat. Ego perterritus, cum, quo fugerem, anxius hærercm, Hyftrix intra pedes meos dilabitur, ac ego ferc pra metu exanimis concido, refpiciens, num, vel crus, vel brachium fecum ra-

peret. 
peret. Interea Chinenfes Hyftricem affequuti occidunt, mihique offerunt, ita fummus metus in maximum rifum folutus eft. Catcra qux de ejus indole \& figura externa referuntur, cum hac Hyftrice non male conveniunt.

Leopardifeu Pantheræminus hic frequentes funt, quam Tigrides. Nuper unum ex iis, infidentem Apro recenter à felacerato, fclopeto oceidit miles, duplicique fretus præda, utramque belluam in arcem nobis obtulit.

Leones quoque, quantum conftat, in Iava non gignuntur, fed copiofiffime in Africa ad Caput Bonæ Spei, ubi cos catervatim incedere vidi, quorum rugitus poftea è filvis $\&$ montibus non parvum nobis timorem incutiebat, imprimis cum noctu circa tentoria noftra obambulare audebant, \& recens fepultos è terra erutos devorabant, nobis parcentes ob ingentes rogos, quos focii perpetua nocte alebant.

Equos parvos alit Iava fed omnes craffa \& denfa Cervice, ficut Nortvegia, quos Belga Spertityalfen vocant. Generofiores autem è Suratte \& Perfia huc adferuntur.

\section{$\begin{array}{llllllll}C & \text { A } & P & V & T & \text { I I I. }\end{array}$}

\section{De Crocodilo, qui per totam Indiam Cayman audit.}

$P$ Linius lib. 8 , cap. 2 , hæc de Crocodilo vere ait: Crocodilum habet Nilus quam drupes malum, ac terra pariter, \& flumine, infeftum. Vnum hoc animal terreftre lingux ufu caret, unum fuperiori mobili maxilla imprimit morfum, alias terribile pectinatim fe ftipante dentium ferie, magnitudine aliquanto excedic duode-

C $\mathbb{R}$ O

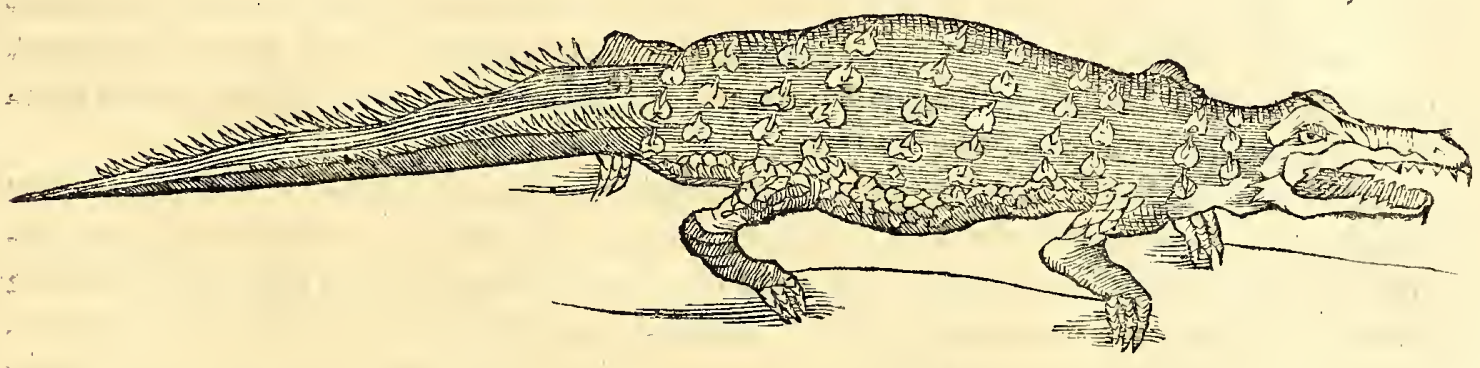

viginti cubitos, parit ova quanta Anferes. Sed quod poft ait, ipfum efle invicta cuteadverfus omnes ictus, non ita eft: nam contrarium ipfe oculatus teftis dicere poffum. Cum in præfentia generofi $D$. Iami Coenen, magnus in palude circamonia civitatis $\mathrm{Ba}$ tavix caperetur, longus autem erat pedes viginti, craffus quatuor: fed certe ftipatores Nobiliff. D. bipennibus ipfum in tergo, ac alibi, fexpius tranfverberarunt. Carne funt Crocodili candidiffima, ego de ea comedi ; fed agrefte mihi \& paludofum fapiebat : \& forfan non male faperet pifcatoribus noftris Ranarum, qui aliquanto largius de hoc animalicœnarent, quam de extremis Ranarum pedibus. Ve porro aliquid dicam de exceffivis viribus hujus terribilis beftiæ, Hiftoriam narrabo; quæaccidit tempore Gubernatoris Nobiliff. D. Petri Carpenterii: Vni itaque de ftipatorum ejus numero, dum equum ad potum ducit, Crocodilus in ripa latens fluminis, equum infdenti fubripuit, qui nififaltu fe falvaffet, una cum equo, ad fluvii fundum pertractus foret, ut ipfe, cum Plauto in Moftellaria vere, potuiflet dicere, vivum me rapiunt ad Acherontem mortui.

Serpentes porro hæc Iava in fylvis alit, tanta alvi capacitate, ut integros apros hauriant; $\&$ in Ternata accidit capi aliquem qui ultra 40 pedes longus, Aprum in ventre gereret, quem excifum coxerunt, \& de co Generalis D. Petrus, cum aliis qui adhuc in vivis funt, comederunt. Ego pellem unius feu exuvias domi mex habco, longam pede 36 , quem ipfe in fylvis, (dumillas cæderemus, ut hoftem eo melius confpicere poffemus, qui tum in procinctu erat) cum fociis navalibus contrucidavi. Itaque eft ut Plinio facile fidem adhibeam in illis, Qux de maximis Serpentibus, qux Cervos totos hauriant, '\& de Boa Serpente, quæ tempore Claudii infantem deglutierat, dixit: cap. I4, lib. 8. Chinenfes, \& Mauri eorum carnibus avide vefcuntur, fed ego iis facile ftras delicias reliquerim.

$$
E 4 \quad C A-
$$




\section{$\begin{array}{llllllll}C & A & P & V & T & I & V\end{array}$}

\section{De Lacerte quadam /pecie, Incolis Leguan, ac Infectis variis.}

N Sylvis Iavx, in paludibus, \& cono, tum etiam in cavernis, \& antris, reperitur Lacertx quoddam genus, aut, ut aptius dicam, Crocodili terreftris fpecies, quia magis in terris, quam in aquis degit : nam quod forma ei refpondeat, figura hic appolita fatis indicat, magnitudine tamen longe infra Crocodilum eft : nam ex pluri-

L A C E R T A, vulgo Leguan dicta.

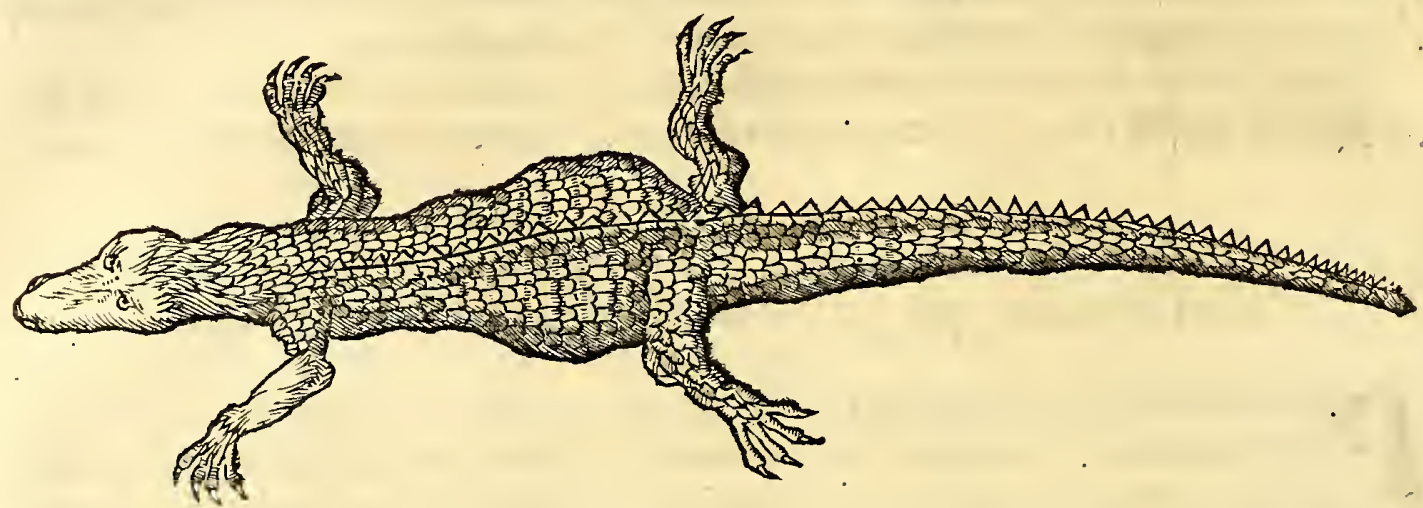

mis, quos vidi, nullus ultra quinque pedes excreverat : ferunt tamen Iavani, $\mathfrak{x} x$ vos, \& majores in montibus verfari. Animal, per totum vertebrarum dorfi proceffum, ferratum ef, cute rugofa $\&$ fquamofa fode viridi, \& maculofa; ita ut folo afpectu fuo infuetis horrorem incutiat; Hoc tamen tam deforme animal dempta cute, carnis eft albiffmi Cuniculi inftar, \& ut aiunt, qui de ea guftaverunt, faporis delicati.Rictu eft magno, capite oblongo. Cauda totius corporis longitudinem æquat. Vnicuique pedum quatuor digiti cum unguibus funt conceffi.

Porro,ut de Infectis reliquis in India hic aliquid dicamus, locus hic videtur poftulate: itaque tanta minutiorum Lacertarum campeftrium eft copia, pedem non ultra longiorum, ut vix veftigium quis in gramine ponat, quin timidiffimum hoc animalculum alicunde exiliat: Eft præter ea adhuc alia domefticarum Lacertarum fpecies, longe minorum prædictis, quæ colore viridi è pallido eft, ac in laquearibus $\&$ $x$ dium parietibus degentes Mufcas, Formicafque venatur; atque licet cum magna voluptare, infignem velocitatem earum confpicere in venandis hifce Infectis, \& quam fe contineant immotæ, acfi parietibus appictx effent, donec predam certam videntes, eam invadant. Verum quoque eft, quod Plinius ait lib. 9 Natural. Hiftorix, Lacertis caudas renafci, nam hocin domefticis meis non femel animadverti, dum filioli mei lufitabundi, bacillo caudas iis decutiebant, quas tamen poft diem unum, aut alterum, adfolitum pabulum revertentes vidi, caudafque iis paulatim reaccrefcere.

Scorpiones quoque copiofos, \& grandes fert hæc India, vidi enim qui partem quartam ulnæimplerent, coloris è nigro cyanei, \& fplendefcente : minufculi quoque hic plurimi funt, ita vix lapidem loco moveas, quin fub ea aliquot Scorpiones lateant: morfus tamen, aut punctura eorum, tam venenofus non eft, quam in Italia, vel Hifpania.

Scarabxi ita frequentes funt, ut nil ab is intactum \& illæfum remaneat, prxfertim, fi quis in inferiore parte $æ$ dium habitare cogitur. Fitque hoc propter foli humiditarem, 8 calorem, qux duo genitrix funt putredinis, idcirco habitacula in fuperiore xdium parte funt longe falubriora, quoniam ficciora, utpote qux his beftiis, \& Formicarum myriadibus non ita infeftentur. Scarabæos autem hos Lufitani Caca-laccas vocant, quod ova qux excludunt, colorem, \& lævorem, Lacc $x$ factitix referant, ac, fi ea chart $x$, vel linteo, vel panno denique, affigantur, totum illud fpatium, quod occupant, Blattarum inftar, excdunt.

Eft preterea Formicarum quxdam fpecies, qux totas arcas lintcaminibus repletas, $\&$ cribro cicbrius perforant, cum ingenti frepe mercatorum damno; nam linteorum è cotonea contextorum, ingens per totam Indiam fit diftractio.

Scolopendra etiam hic paffim reperitur, cujus punctura tam acerbum dolorem infert, ut hominem ferme ad infaniam adigat : non fecus ac in patria Draco Marinus, quem 
HIST. NATVR. \& MEDIC. LIB. V.

quem Belgx Bieterman vocant : fed ictus hujus Infecti, ut $\&$ Scorpionis, oleo ex ipfis compofito fedatur, \& fanatur.

\title{
$\begin{array}{lllllll}C & A & P & V & T & V\end{array}$
}

\section{Lacertec cujufdam, admodum veneno $\int e$, pecies, que merito Salamandra Indica dici queat, quacque à $\mathcal{N}$ oftratibus à fono quemedit, Gecco vocatur.}

\begin{abstract}
Serva Lacerta rubris fellata in tergore guttis, Contactirque nocens, viridi vomit ore venenum Mortiferum, fuperans que dant Aconita noverce. Hoc tabo inficiunt, metuendi cuspide Iave, Tela fua, \& certam que dant baftlia mortem. Huic cedat Lybica dirus Bafilifcus arena: Cum tantum viridi lateat $\int u b$ felle venenum.
\end{abstract}

$\mathrm{E}$ St Lacerræ quoddam genus venenofiflimum, cujus figuram, ad vivum expreffam, vobis exhibemus : ejus morlus tam eft virofus, ut, nifi pars affecta ftatim, aut precidatur, aut cauterio a duratur, intra paucifimarum horarum f $\mathrm{pa}$ tium, procul dubio actum fit de vita hominis. Hoc de folo hujus Infecti attactu experientia didici, in decumbente quodam focio navali, in Nofocomio noftro Batavi-

$\begin{array}{llllllllllllllll}S & A & L & A & M & A & N & D & R & A & I & N & D & I & C & A\end{array}$

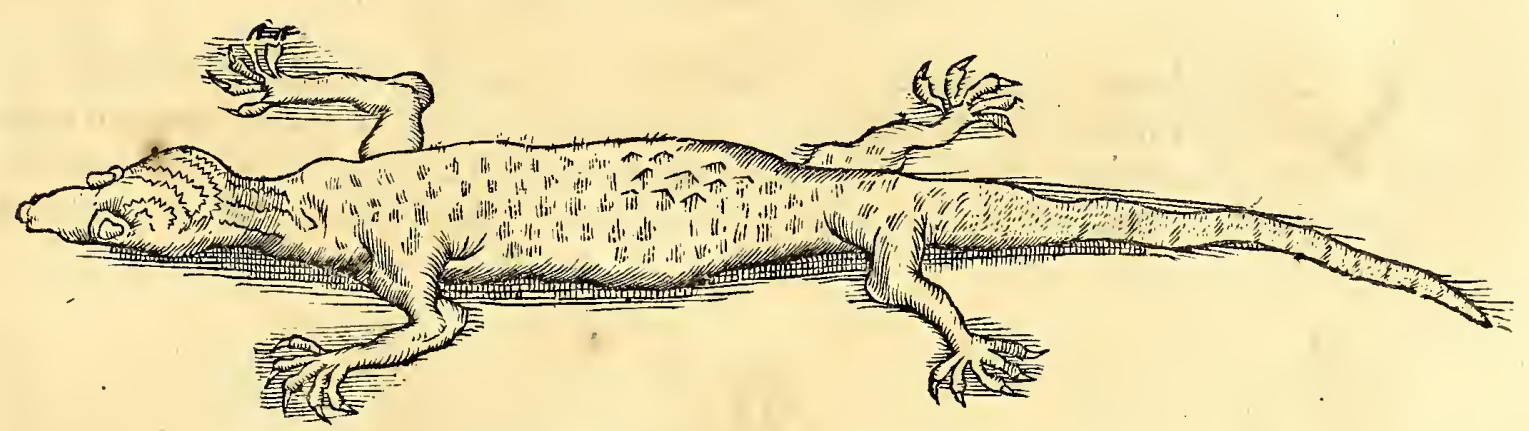

co, cujus pectori, dum denudatus dormiret, fupercurrerat Lacerta hæc, \&, folo contactu, veficam per tranfverfum in mufculis thoracis excitaverat, qualem in cute oriri videmus, à ferventi aqua, qux pertufa à Mag. Andrea Duræo, Chirurgo hujus Nofocomii expertiffimo, emifit ichorem flavum, \& fœetidum: fubtus vero caro, jam livida erat, \& ad Gangrenam tendens, qux etiam per duos latos digitos, impofitis topicis neceffariis, \& munito corde medicamentis Befoarticis, non fecus ac in Gangræna, decidir, non fine fumma admiratione $\&$ horrore noftro : Magnitudine paulum vincit hoc Infectum, communem Lacertam campeftren; ita ut pedem circiter in longitudinem excurrat. Cutis eft coloris è viridi dilutioris, quem Belgice $\mathbb{Z}_{\mathfrak{e} e-\mathfrak{g t a e n}}$ vocamus, interftincta maculis rubris, acfir Minio tincta effet: Capite eft Bufonis, oculis magnis, foede protuberantibus; Dentes habet tam acutos, ut eos etiam chalybi imprimat, quod vidi in hac Lacerta, his venenofum \& lethale infert vulnus, nifi pars affecta, aut ferro exuratur, aut novacula amputetur, dum Prretoris urbani fervus eum gladio transfigeret, aperto ore palatum rubrum, inftar fornacis, apparet. Tardigrada eft, \& ubi pedes fixerit, vix inde vi ipfamavelles, non fecus acfiglutino cohæreret, quod etiam in hac deprehendi, dum chartæ impofitam depingi curarem, quamvis mortuam, pedes non nifi cum chartx laceratione inde avelli poterant; quinque enim digitis pedum, acutis \& curvis unguiculis, armatis, prædita eft. Noftrates ipfum animal appofito vocabulo Gecco vocant; $Q$ uippenon fecus, ac Coccyx apud nos, fuum cantum iterat, etiam Gecco affiduo fonat, prius edito ftridore, qualem Picus emittit. Degit porro in arboribus vetuftis cariofis, locifque humidis, frpe \& , cum fummo, tam Noftratium, quam Incolarum, metu, circa cubilia verfatur, adeo ut Mauri cafas fuas integras demoliantur, 
ut hoc animalculum migrare faciant. Hinc optime convenit huic Infecto, quod de Salamandra Plin. lib. 29, cap. 4, his verbis refert : Inter omnia vcnenata Salamandræ fcelus maximum eft; cxtera enim fingulos feriunt, nec plures pariter interimunt, ut omittam, quod reliqua perire confcientia dicantur homine percuffo, neque amplius admitti ad terras; Salamandra pariter necare populos improvidos poreft : nam ii arbori irrepfit, omnia poma inficit veneno, \& eos qui comederant, frigida vi, nil Aconito diftans, quinimmo fi contacto ab ea ligno panis crufta incoquatur, idem veneficium eft, vel fii in puteum cadat, \&c. Sanguis ejus è rubro colore ad pallidum vergit, $\&$, ut verbo abfolvam, ipfifimum venenum dicas effe. Iavani fanguine, \& fanie hujus Lacertx, tela fua tingunt. Tum fcelefti ifti veneni propinatores, qui hic utriufque fexus plurimifunt, hoc animalculum c̀ laquearibus fune cauda alligato fufpendunt, quod rum prx ira glutinofum \& flavum liquorem affiduo è gutture deftillat, quem exceptum fictili fubrus appofito colligunt, \& Soli expofitum, in maffam cogunt, tali modo in vivis hoc Infectum alendo quotidie fervant ad aliquot menfes. Hoc veneno nullum magis prefentaneum reperiri certum eft, ac puto de eo genere effe, quod Imperator Nero Britannico per Locuftam famofam Veneficam exhibuit, quod tam præcipitem mortem adferebat ( ut inquit Tacitus) ac fi ferro urgeretur. Vrina porro ejus tam acris eft, ut non folum veficas excitet in quamcunque corporis partem inciderit, fed nificonfeftim fuccurratur, carnem fubtus nigram \& gangrænofam reddit. Hujus morfui mederi teftantur Indi Crocum fubterraneum Lufitanis dictum, quod planta fit, qux radicem habear flavam croceo colore tingentem. Hre eft radix Curcumæ officinis noftris vocata , quæ quantas vires habeat, fuo loco probavimus.

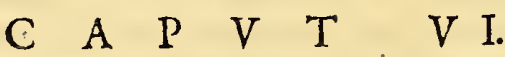

\section{De Chamcleonte in Infula Iava.}

Cio ego longe alia facie ab aliis Chamxleontem pingi: fed certe eos iftud genus S imalculi, vel non vidiffe fufpicor, vel hic alius ab illorum Chamæleonte:ut quicquid fit, ego hunc ex fide defcribam, qui onnibus Lufitanis, \& Malaiis Cambilon corrupta voce nominatur: Eftque frequentiffimum in his locis animal, feu Lacertæ

$$
\text { C H } \perp \text { M E L E O N. }
$$

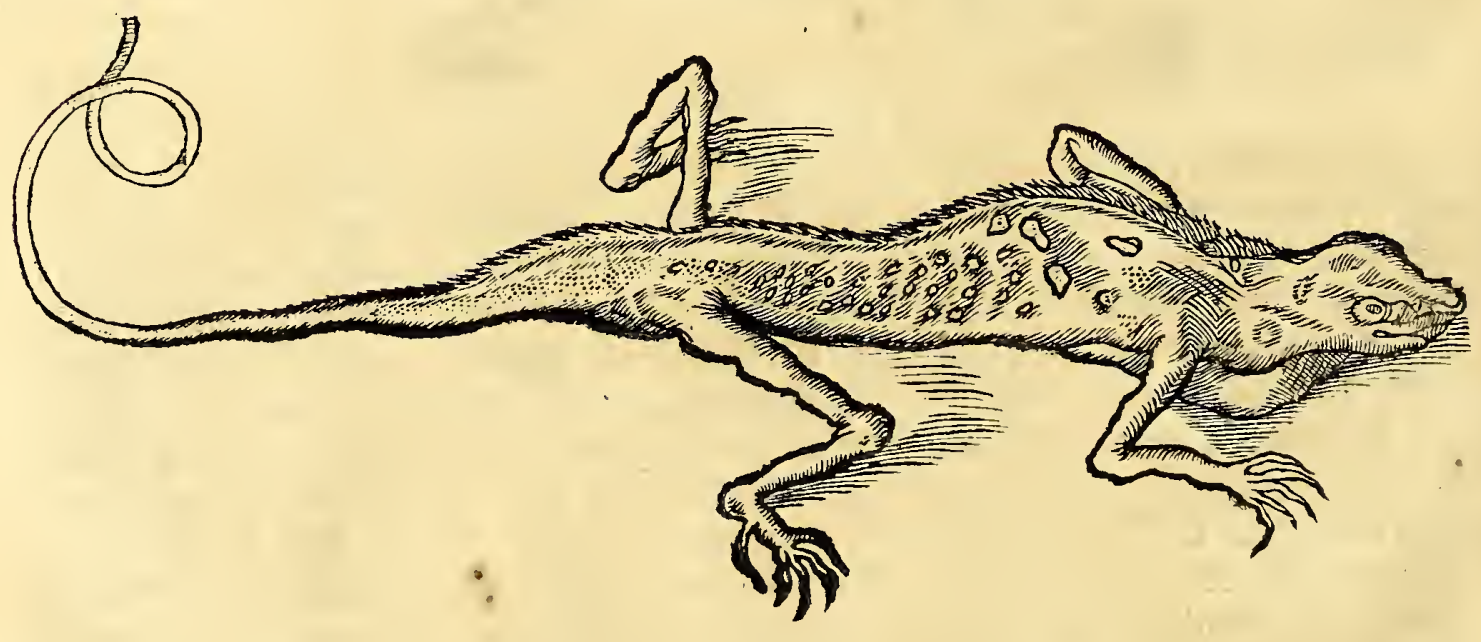

fpecies, naturali colore eft viride, rubris hinc inde in tergo, maculis diftinctum. Criftam in tergo habet, quam quietum demittit, irritatum erigit, ac tum etiamfub gutture bulla enafcitur, quod ubi videris, eft quod tibi ab eo caveas:nam acerrimos dentes habet, $\&$ Incol $x$ morfum ejus venenatum effe affirmant. Pedes anteriores flexuram habent unicam inftar brachiorum cubiti:pofteriores vero pedes funt multo longior es cum duabus flexuris: omnes tamen quinque digitis $\&$ longis unguiculis armati. Cauda longifl$\mathrm{ma}, \&$ verfus extremitatem tenuiflima quam in gyros contortam geftat. De eo ego idem credo, quod doat. Belonius ait 1.2. obfervat.c. 25 , in hæc verba: Chamæleon fe mutat in varios colores, communiter viridis eft, tendens verfus flavum, \& aliquando cæruleum colorem. Quod eft veriffimum, nam hos duos colores, prxira, vel metu ipfum induere vidi,ut qui domi in cavca alucrim hanc Lacertam aliquotics: mutare autem colorem in 
HIST. INATVRAL. \& MEDIC. LIB, V.

ejus corporis fpeciem, cui infidet, nugacifimum eft, ut $\&$ illud, vento victitare : nam ut idem Belonius paulo pof ait, Mufcis, Formicis, immo Locufis, alitur, tum Scarabrorum ea fpecie, quas Caccalaccas Noftrates \& Lufitani appellant, quos in ventriculo plus quam dimidia parte confumptos inveni. Quod vero longo tempore fne victu poffit darare, hoc commune cum reliquis Infectis habet, ut Serpentibus, quos Circulatores circumforanei aliquot menfes pyxidibus inclufos fine ullo cibo circumferunt. Idem de Ranis dicendum, qux integra hyeme in fundo Paludum latitantes immobilos fub ulva latitant; itaque vere dicit poëta, quod minuat præfentia famam. Atque hæc funt qua de Chamelaonte certo comperi. Quo fpectat illud Alciati Emblema in adulatores. Semper biat, femper tenuens, qua vefcitur, auram, Reciprocat Chamaleon;

Et mutat faciem, varios fumitque colores

Práter Rubrum vel candidum:

Sic \& Adulator populari vefcitur aura,

Hianfque cuncte devorat:

Ac folum mores imitatur Prinsipis atros, Albi, \& pudoris nefcius.

\section{A P V T VII}

Lacertus Dolans, feu Dracunculus alatus.

Lëra pervolitans junxiffe Medea Dracones

Dicitur: è Iava num tulit has volucres?

Epingi hic curavi Lacerti quoddam genus volaticum, quod Belonius obfervationum fuarum Orientalium lib. 2. cap.70, defcribit fub nomine Draconis volantis : fed ita curfim hoc attingit, ut coactus fuerim beftiolam hanc paulo exa-

L A C E $\quad$ R $T$ T V S V V O I A
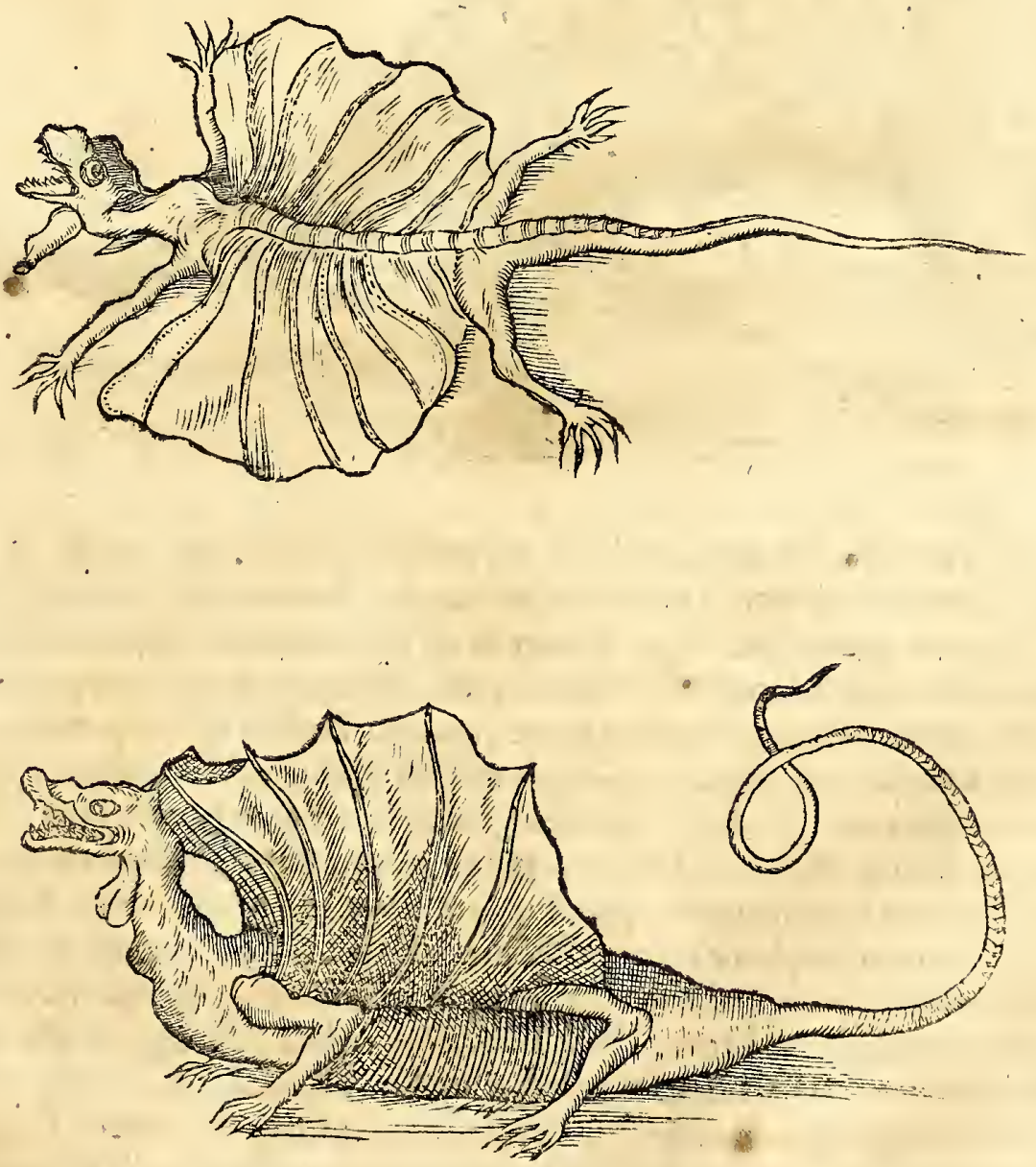

atus defribere, utpore qui eam, non mortuam tantum, icd fapius vivam, hic in lava 
viderim. Belonius effigiem hujus Infecti adfert bipedem, quum quadrupes fie, praterea duas bullas flavi coloris circa guttur externe gerit, quas inter volandum inflat, $\&$ veli loco utitur. Cauda, pro proportione corporis, longa eft, verficoloribus pulcherrime maculis cutis diftincta. Tum al $x$, alis $V$ efpertilionum admodum fimiles funt, $\& x$ membranacex, quas attollunt, hoc modo quo hic depictum vides, alias ubi eas demifere ad latus, vix apparent. Magnirudine funt duarum unciarum, grandiufculam domi habui, qux tres partes uln $x$ impleret. Volant quidem, fed non diu perfeverant in volando, $a b$ una nempe arbore cum ftridore, in aliam tranfiliunt, qux paffus viginti, aut triginta à fe invicem diftant, non fecus, $2 \epsilon$ pifces volatici, qui Hirundines aquatic $x$ Gefnero dicuntur,pauco temporc fe ex aqua attollunt. Num venenatæ fint hæL Lacertæx, compertum non habeo, Iavani faltem negant, \& eas, ut \& alias Laccrtas, impune manibus tractant. Cxterum, Mufcis, Formicis, \& aliis parvulis Infectis, victitant, in Silvis Iavæ frequentes funt, \& fxpe grandioribus Serpentibus efca deveniunt, quod \& inter homines familiare effe, Plautus bene dixit hoc modo, Homo homini Lupus, potentiores innuens, minores deprimere folere.

\section{A P V T V III.}

\section{Appendix. De Lacerto Indico, fquamofo.}

A Dmirabilis hujus exentcrati Lacerti iconem, quam exhibeo, ejufdem fpeciei,fed non ejufdem magnitudinis, eft, cujus Carol. Clufius exuvium in exoticis dedit. In Infulx Tajoán filvis frequens eft. Nomen ejus vernaculum hąenus nobis incognitum; verum ne quid pubi nauticx noftrx innominatum effer, placuit quibufdam

L A C E I T T S S Q T A M O S V S.

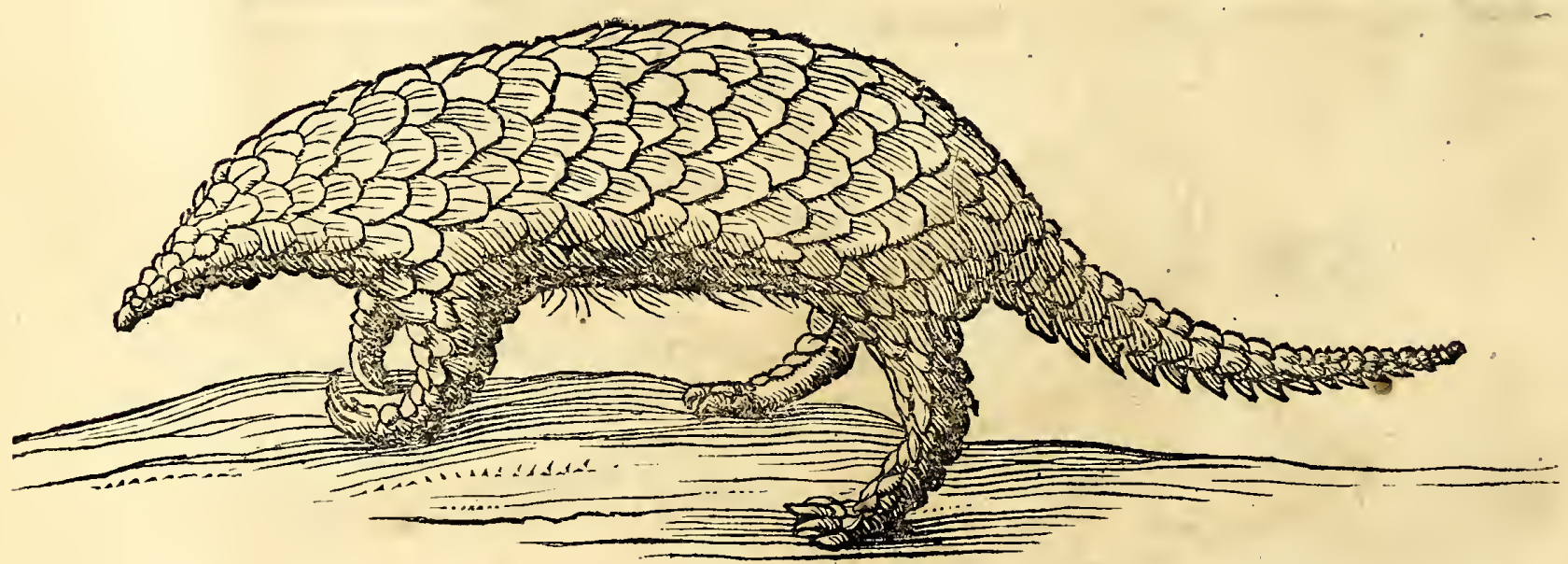

Porcum, aliis vero Diabolum de. Tajoán, appcllare, fortaffis ob miram \& horridam fquamarum conformationem, quas irritata erigit. Animal eft duorum pedum longitudine, Vulpis magnitudine. Totum corpus ab oris ad cauda $\&$ pedum ufque extremitates, perpetuis fquamis nigricantibus, rigidis , \& mucronatis, coopertus, excepto gutture, ventrifque, \& crurum infima parte, qux durioribus pilis leporinis veftiuntur. iidemque pili hincinde erumpunt in dorfo ex ipfis fquamis. Magnitudo fquamarum pro diverfitate partium corporis difcrepat; omnes ad exortum ftriatx, \& adfinem quafi lævigatæ. Cauda eft valida, fere pedem longa, præ cæteris membris mira fquamarum textura ornatur : earum enim, qux ejus latera utrimque claudunt, forma prorfus à reliquis difimiles, nam planæ non funt, aliarum inftar, fed cavæ quafi incurvatæ, quia pronam \& fupinam laterum partem tegunt. pedes breviufculi palmam circiter longi, pofteriores quinque unguibus brevioribus, anteriores tribus oblongis, craffis, fed imbelle curvis, armantur, ficut in Brafilienfi Tamandoá, quibus, æque acilla, Formicarum \& Vermium latebras detegit, predamque qualemcımque mordicus tenet. Capite $\&$ pro mufcide non eft porcino, ut Armadilho,fed tenuiori \& acutiori, more Talparum, quo terram commodius cvertat. paftum iturus, Lacertis, aliifque Infcetis, infidiatur, quibus pin- 
HIST. NATVRAL. \& MEDIC. LIB. V.

guefcit. Vnde caro ejus vefca non folum, fed ficut magnæ illæ Lacertæ Brafilienfes Leguáne \& Iatu, inter epulas ab omnibus paffim incolis expetita.

$$
\text { C. A. P V T I X. }
$$

\section{Appendix. De Baby-Rouffa.}

Q

Via Author nofter I. Bontius, fedulus alias Naturalium in Indiis indagator, hujus animalis, non meminerit, ego ejus genuinam figuram $8 z$ defcriptionem ab Indiarum noftratibus confiliaris, fide dignis,fuppeditatam, operx pretium duxi addidiffe. Quadrupes hoe inufitatæ figuræ, monftrofis beftiis afcribunt Indi, quod
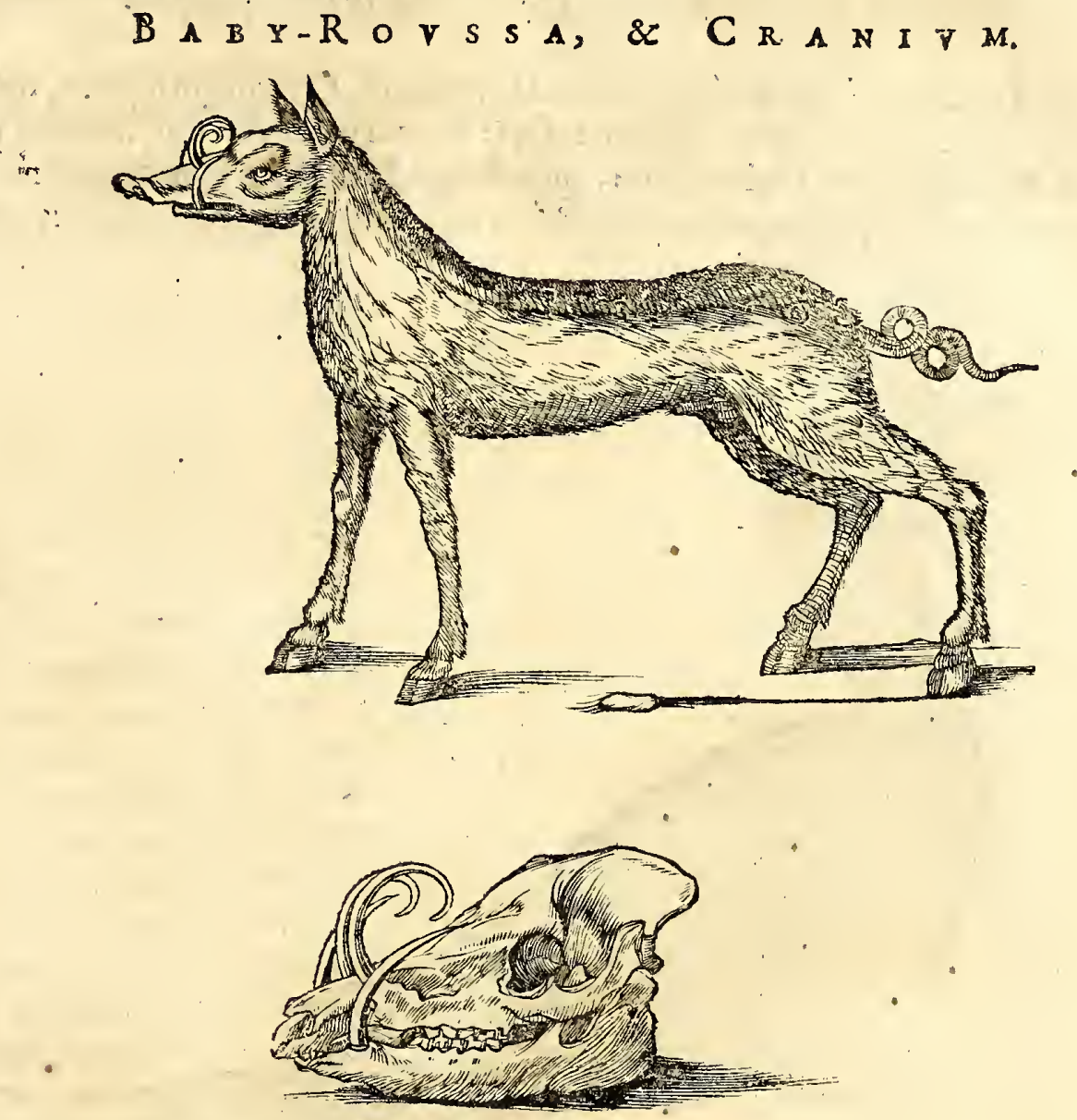

à diverfæx fpeciei animalibus, Porco fcilicet, \& Cervo,pronatum putent. Reperitur tantum in infula Bouro, triginta milliaria diftante ab Amboina. Nec alibi terrarum ab aliquo vifum fuiffe omnes teftantur. Eft majoris Canis vel Cervi magnitudine. Pilos habet more Canis venatici, fufci \& grifei coloris,inftar Gliris. Capite \& roftro eft Porcino, oculis $\&$ auribus parvis. Cauda tortuofa, Porci rmula,pedibus $\&$ ungulis Cervinis. Velox \& ferox habetur animal, \&longxvum quoque, fi Ariftoteli fides, dicenti, quibus plures funt dentes, eorum vita, magna ex parte, longior.

Sceletos capitis (cujus accuratam iconem hic exhibeo, favore optimi viri D. Swa. merdami pharmacopoei Amftelodamenfis, \& rerum exoticarum inftructiffimi), Vitulini eft magnitudine, ex validiflimis offibus, imprimis utriufque maxillæ , confirmatus. $Q$ uibus ab utroque latere pofterius verfus fauces, duodecim circa dentes, molares dieti;anterius autem initio roftri fex incifores inferiori maxillre, duo grandiufculi fitperiori parte inferti fint, \& more aliorum brutorum rapacium, bucca vel roftro teguntur. At vcro loco caninorum dentium ex intermedia maxilla inferioris parte duo validi infignes erecti dentes erumpunt roftrumque perforant. Semipedis funt longitudine, pollicis crafitic, paululum incurvati, inftar dentium Apri, quibus hoftes fios invadunt. In fuperiori denique maxilla parte ab utroque latere proceffus oflei concavi apparent, ex quibus promanant cornua, digitum craffa, duas palmas longa, glabra, \& dentium inftar lavigata, fed unci inftar incurvata, ita ut primo intuitu quatuor corni- 
bus juxta fe pofitis videatur armatum hoc animal Baby-Rouffa; ac proinde ob duplicem rationem inter monftrofa habitum, primo, quod contra Ariftotelem, cornigera animalia in altera maxilla tantum dentes habere, \& primoribus maxilla fuperioris . carere, teftetur. Secundo, quod idem Ariftoteles, nullam dicat inveniri animantem, qux cornua \& exertos fimul gerat dentes.

Cxtera qux circa indolem hujus animalis defiderantur, quia fluxæ fidei mihi videbantur, difuli proferre, donec veritas magis elucefcat ; $\mathrm{Ab}$ advenis æque ac Indigenis caro ejus inter delicias expetita, atque loco Cervin $x$ apponitur:

$$
\text { C A P, V T X. The }
$$

\section{De Corvorum, Columbarum, \& P Pttacorum, quadain Jpecie.}

$\mathbf{M}$ Ira eft quxdam in Moluccis, \& Banda præcipue, Corvorum fpecies, quæ no. ftratem Corvum roftro quidem refert: Verum in temporibus fimiliter pictus eft , ut Indicx ift $x$ Meleagrides, quas Belgx (ltalcouffe-1)antn vocant. -Roftro eft magno, craffo, parum acuminato, $\&$ ad rapinam compofito, natibus patulis;

$$
C \circ R \text { V us IN D I C. V s. }
$$

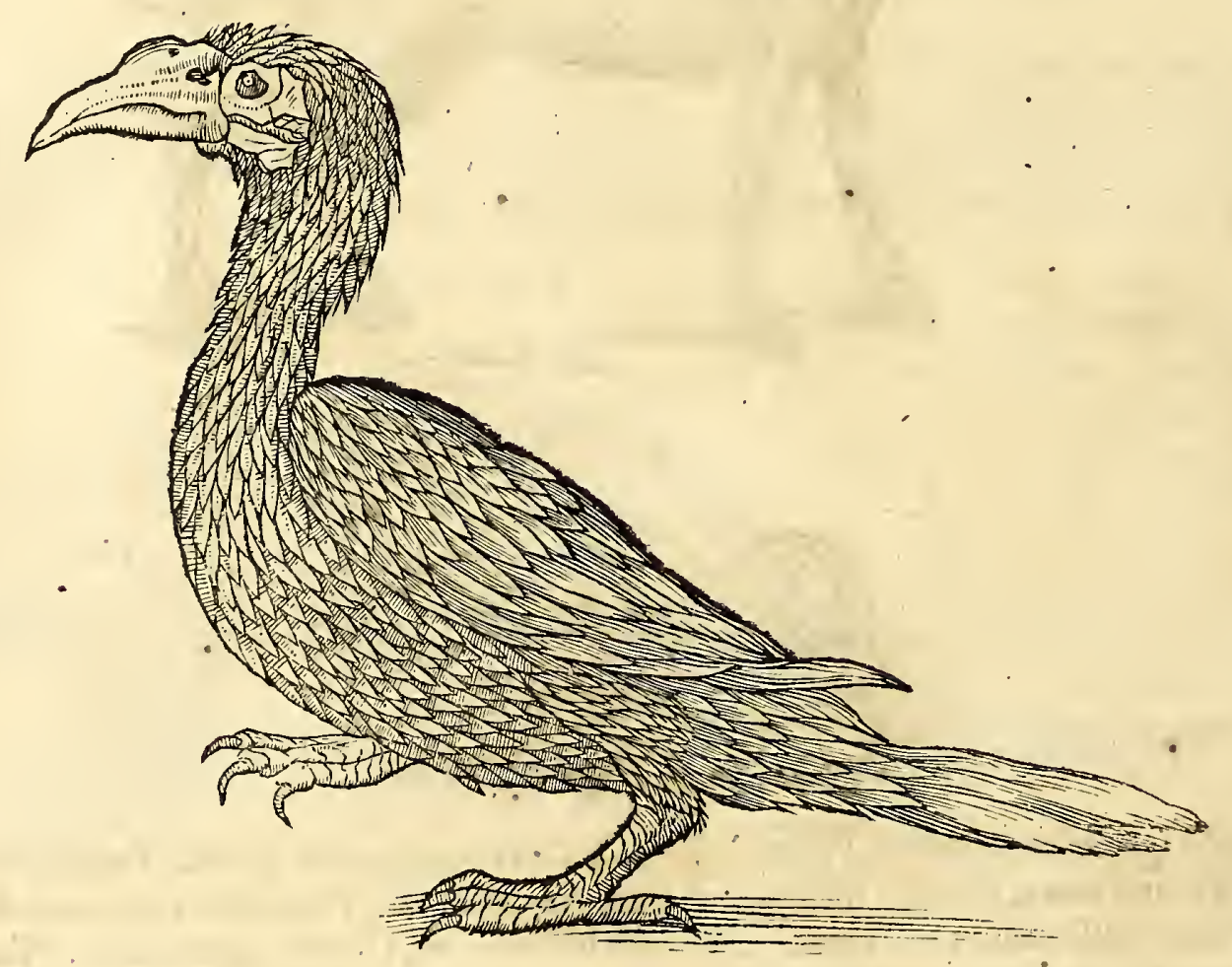

oculis magnis, nigricantibus, afpectu fæedis. Capite $\&$ collo oblongis, nigricantibus plumis, ornate vettitis. Pedibus, eorumque digitis, fatis validis unguibus, oblongis, curvis, folidiffimis, præditus. More Corvi noftratium graditur, Indole à noftris Corvis differt, quod non cadavere, fed potiffimum Nucibus Myrifticis avide vefcatur; iifque infigne damnum infert. Caro eorum quoque delicata eft, $\&$ affa faporem à paftu plane aromaticum habet.

Preter vulgares Columbarum, \& Turturum, fpecies, reperiuntur in Iava Columbx viridiffimi coloris, inftar Pfittacorum. Eft præterea in Banda aliifque locis, .Columbarum quarundam albarum fpecies, qua fimiliter Nuces Myrifticas immaturas deccrpit, \& depafcitur, guftu quoque inde jucundo, ventriculo, ac inteftinis falubri.

Pfittaci etiam ibidem albi funt, vel potius Corvos albos eos nominem,non tantum $\mathrm{ab}$ adunco roftro, fed à rapacitate quoque : nam nodos à veltibus avellunt, chartas, $\& 6$ libros decerpunt, 
HIS T. NATYRAL. \& MEDIC. LI B. V.

me has aves cum Simiis, \& Pfittacis, qux quamvis ad delectationem hominis in ata videantur : tamen operam eorum non nifi dannofam reperimus effe.

\section{Appendix. De Psitt a co parro.}

$E_{\text {genere,cui vulgo nomen } P \text { - }}^{X}$ roket inditum, hrec pulcherrima avis exiftic. Alaudx eft magnitidine, roftro adunco \& grifeo, ut \& gutture, oculis nigris, quos circulus argenteus ambit. Linguam habet fere ut Pfittacus cum folidis ligamentis, verticis plumas egregias criftx more erigit. Crura \& pedes cinerei coloris, caudam longifnmam, decem circier digitos prominentem, ultra finem alarum. Quemadmodum ventre inferius, ita capite, collo, \& cauda, fuperius eft pulchre rubicantibus. Peetus vero, \& inferiores caudx pennx, dilute rofacei fint coloris, quæ elegantiffime in cxruleum ex albedine $\&$ viridi mixtum, definunt. Alx potifimum virides, rubicundis pennis intertextis, quarum medietas, luteo $\&$ rofaceo colore hinc inde adeo variegatur, ut adverfo Sole mille aureos colores fecum trahat, atque à pictorehaud facile exprimi poffir, dignus fane, ut à Magnatibus in pretio habeatur.

Reperiuntur hraves in mediterraneis potifimum, confi-

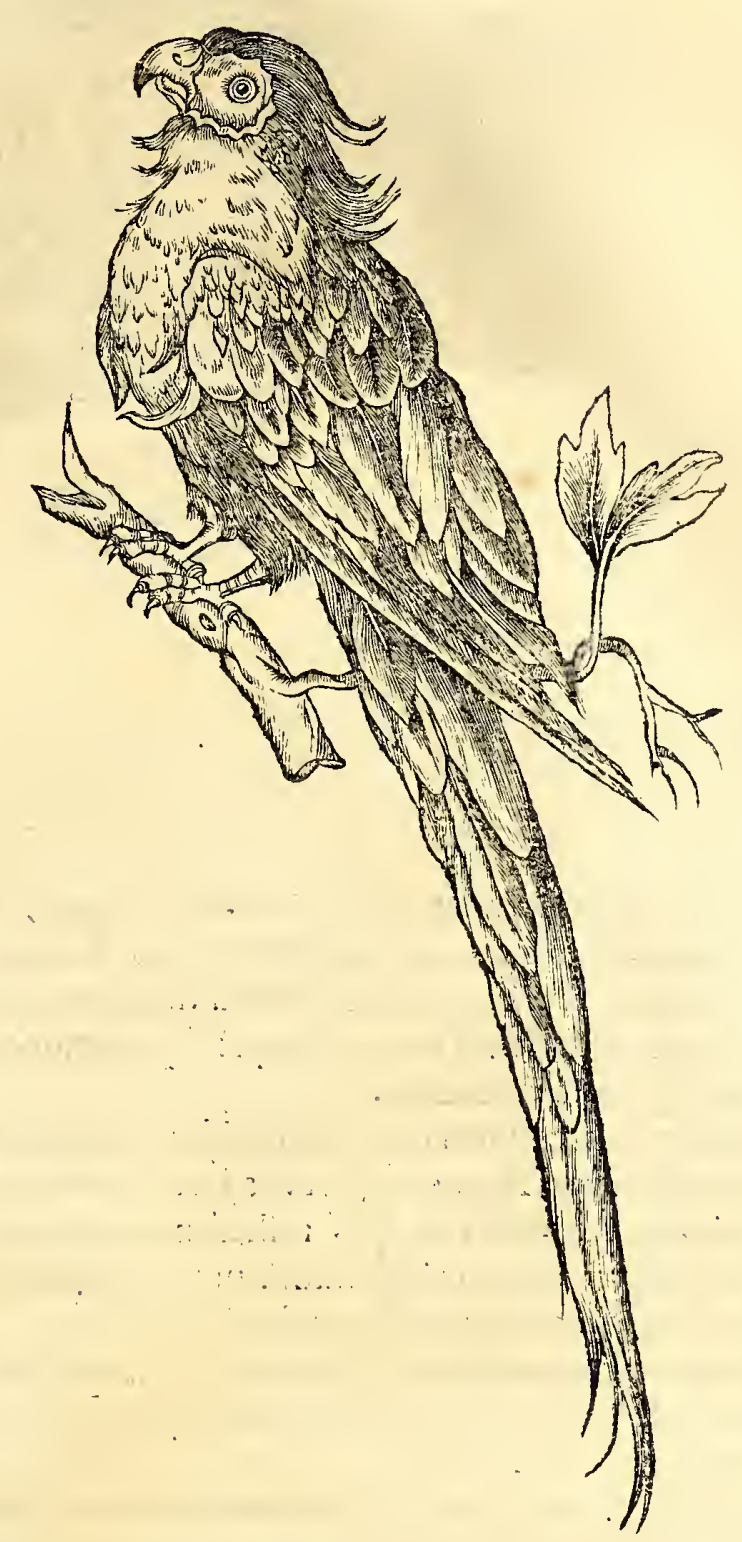

dent $\&$ nidificant in altifimis arboribus. Catervatim $\&$ multo cum ftrepitu, ficue tota Pfittacorum familia, volant, garrulæ quoque funt, vocefque quafdam fonare difcunt,ficicurentur.

\section{$\begin{array}{lllllllllll}\text { C } & \mathrm{A} & \mathrm{P} & \mathrm{V} & \mathrm{T} & \mathrm{X} & \mathrm{I}\end{array}$}

\section{Cornus Indicus Cornutus fou Rbinoceris avis.}

Et mare cornigerum eft, er cornibus aëra pulfat

Hec Avis in Iava: Cornua terra gerit, Afpice in aëreis volitantem Rbinocerotem Confpicuum cornu, quam bene fronte gerat.

$\mathrm{V}$

T odore gravis, ita \& afpectu foeda, eft rara hæc avis cornuta, longe fuperans magnitudinem Corvi Europæi. Collo \& capite eft craflo, oculis magnis, roftro, refpectu corporis, mediocri, in hac imagine expreffo, \& à capite avulfo. Productior \& acuminatior pars, inferne curvata, roftrum ad rapinam compolitum expri- 


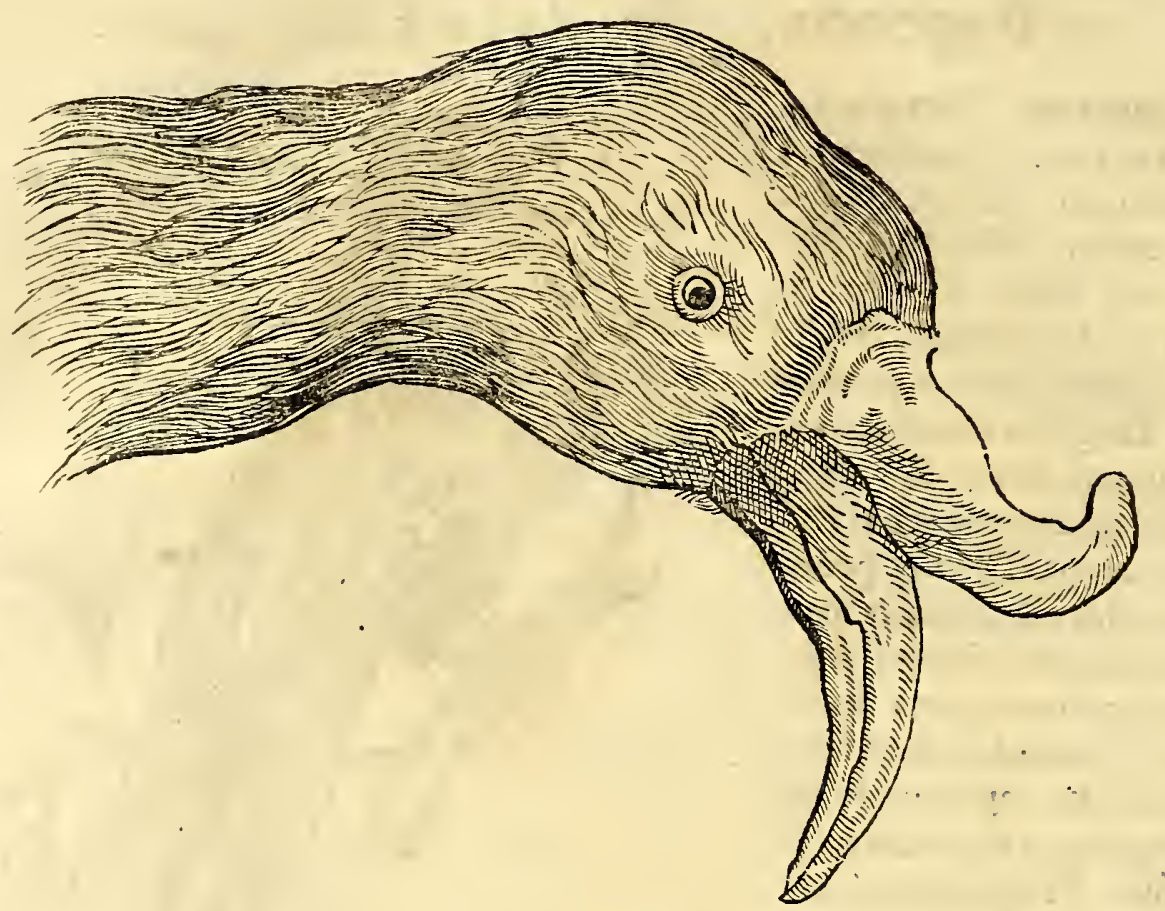

mit; fupcrior vero pars brevior, craffior, \& fuperne incurvata, verum cornu ad vifum $\&$ ad tactum repræfentat, quod, ficut altera medietate verfus caput quafi roftro contiguum, atque utrumque fimul eodem modo capitis extremitati annatum; ita, \& altera medictate à fe dehifcunt, adeoque feparantur contraria incurvatura, ut inftar pifcis caudx bifurcatæ videantur.

Victitat avis cadaveribus inteftinifque animalium, unde venatores qui fclopetis Vaccas fylveftres, A pros, \& Cervos jaculantur, comitari folent, ut fe eorum vifceribus ingurgitent. Animalia ab ipfis militibus exenterari folent, ac fape, in partes diffecta propter gravitatem, ad ripas fluminum in cymbas ab illis deferuntur, finolint,ur dictarum avium rapacitati proftituta fint.

Incolæ teftantur, Iavam ingentes alere Aquilas: fed ego non nifi Aquilas marinas vidi, quæ terreftribus longe minores $\&$ imbecilliores funt , \& non nifi pifcibus in littore vivunt.

Lapides Aëtitas, in nido Aquilarum repertos, duos habeo, in quorum meditullio nucleum, fimoveatur, audire licet.

\section{C $\quad A \cdot P \quad V \quad T \quad X I I$.}

De Coturnice Indica, cui adduntur queddam in tranfitu, de Gallis, of Gallinis, Pabonibus, \& Avibus Paradif, Indicis.

Sic querula Sum vocis ego Jpectanda Coturnix, Sacra ego fum Ṕbabo: nam cumfe condidit Indo Oceano, parvis condor fou mortua plumis:

Poftera lux oritur, tum me cantare viator Audiet, or raucos crocitantem murmure bombos.

A

Vis hxc in filvis Iavx gregatim, ut Perdix, pafcitur, \& quamvis etian cicuretur, \& cum pullis fuis comitata femella, non fecus, ac Gallinx, in areis xdium circumit, mares quoque non fecus, ac Galli, pugnaciffimi ufque ad mortem inter fe fint, 


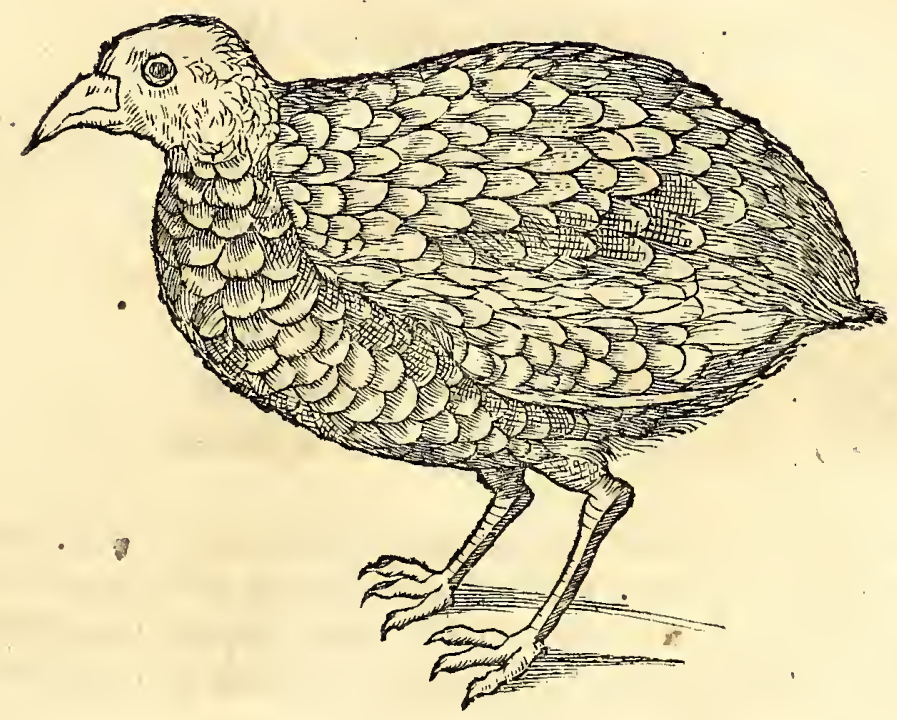

funt, colore plumarum vero Coturnici admodum refpondent : verum roftro paulo longiore, fonum quoque per intervalla edunt, ut Coturnices etiam folent : verum. is longe diverfus eft à Coturnicum voce, $\&$ magis refert fonum illum horribilem, quem Ardex ftellares inter arundineta in paludibus edunt, quem Belgice pittoor vocamus: \& quo longius continuant vocem, eo generofiores etiam putantur aves hæ. Cxterum hæaves adeo frigid $x$ funt natur $x$, ut, fi cavex inclufas non exponas folaribus radiis, \& arenam ipfis fubfternas, fratim languefcant, periculumque vitæ incurrant, ideoque noctu, \& occidente Sole, non fecus in fe convolvuntur, quam Coccyx hyeme in cavis arboribus apud Nos, \& in truncis arborum, plumis fuis fe obtegunt. Oriente vero Sole, ftatim cantant, ifque fonus ad aliquot paflus exaudiri poteft, ut mireris tantillas aves, nam Columbum, aut Turturem, magnitudine non excedunt, tam gravem vocem poffe edere. Alui ego aliquoties in caveis tales, quæ me advenientis aurorx admonerent, fi quid ferio agendum effet; nam, fi quid negotii gerendum fit, id vel mane vel vefpertino tempore, commodiffime fiet, cum inutiles fere reddantur actiones interdiu, dum Sol fummo fuo calore omnia adurat, tum etiam fanitati hoc tempus diurnum maxime officit: fed de eo latius alibi.

Gallis \& Gallinis hæc Regio abundat, inter quos aliqui carne funt nigra, optimi faporis, \& pro egris tanquam faniffimi commendantur.

Parvuli Galli è Ziam adferuntur $\&$ hic aluntur, qui tant $x$ funt pugnacitatis, ut quantumvis alium Gallum maximum aggrediantur.

Pavones filveftres $\&$ domeftici, ut $\&$ aves Paradifi (quos apodes olim arbitrati funt multi) in magna copia apparent; tam horum, quam illorum, caudis fe Indigenæe exornant, iifdem in galeis pro criftis utuntur. Tantum vero abeft, has Paradifi aves vel pedibus carere, vel aëre nutriri, ut unguibus incurvis \& peracutis parvas aviculas, Chlorides, Fringillas, \& fimiles, venentur, eafque mox, ficut reliqux rapaces aves, devorent; ut nec illud verum fit, eas non nifi mortuas inveniri, cum $\&$ arboribus infideant $\&$ fágittis à Tarnacenfibus figantur. Vnde etiam à celeri \& reciproco volatu Hirundineo Hirundines Tarnacenfes ab Indis vocentur.

Quanta porro frequentia fit omnis generis avium edulium in Iava, in primo libro de Confervanda valctudine actum eft, ut funt imprimis, Rufticulx, Ardex, Grues, Anates, Anferes, 'Turdi, Pici, Paferes, Fringillx, \& alix infinitx.

$$
F_{3} \mathrm{CA} \text { - }
$$




\section{A P V T X I II.}

De $\mathcal{X}$ idis Etirundinum edulibus.

\section{Quid fcopulos Progne, quid inhospita littora nidis}

Optas, per medias bos Gula quaret aquas?

En Pbilomela tuum laceravit ut EnfibusIphyn,

China cafas veftras dentibus \& lacerat.

Quid gemis infelix! alienis parcere pullis

Qui cupis? aft propriis parcere defideras.

$\mathrm{I}$

N tractu maritimo or $x$ Chinenfis, avicul $x$ parvæx difcolorcs Hirundinum fpecie, certo anni tempore, ubi æftus prolificandi eas invafit, è locis mediterraneis ad ma. re in fcopulos meant, \& ex fpuma maris bafin fcopulorum alluentis, tenacem quandam materiam colligunt, five ea Baiznarum, feu aliorum pifcium fit, femen, ex

$\begin{array}{lllllllllllllll}N & I & D & \text { I } & H & \text { I } & R & V & N & D & I & N & V & M\end{array}$

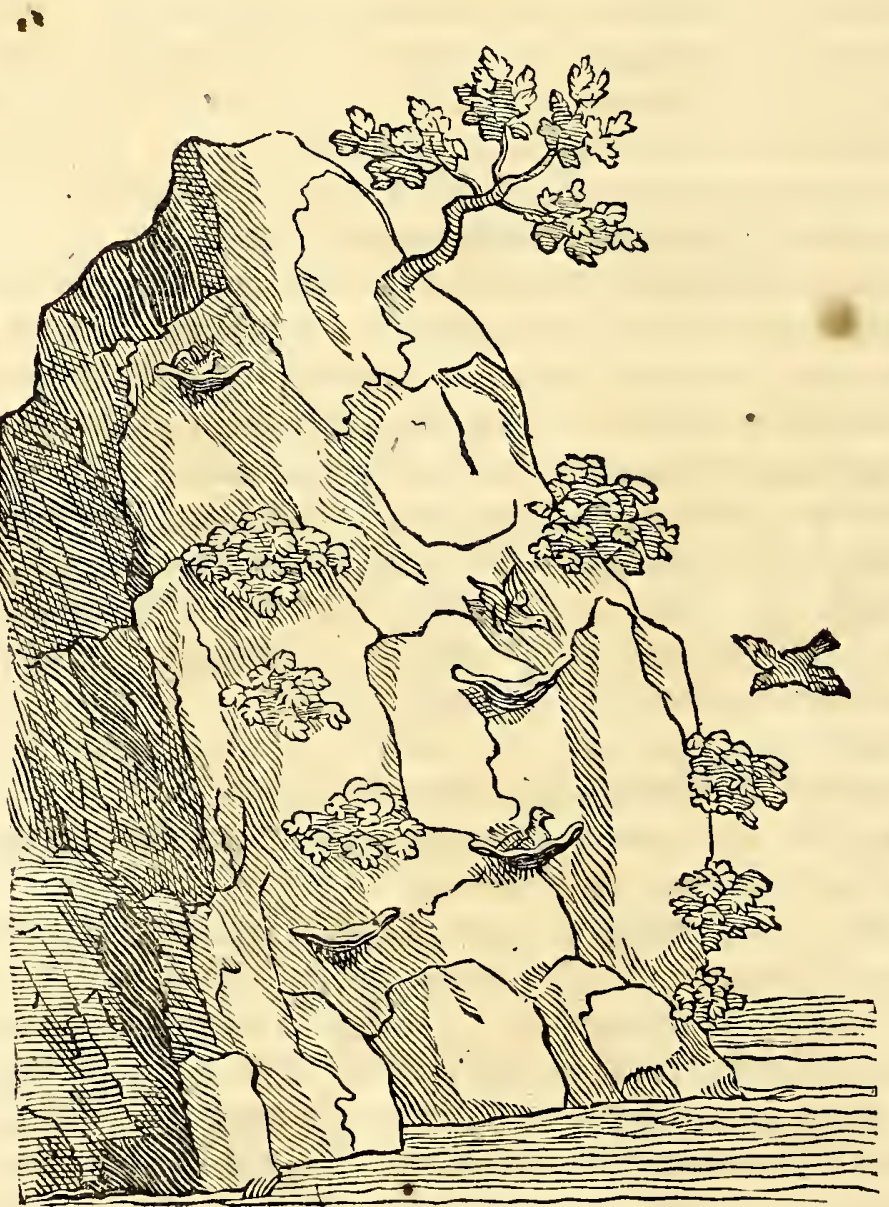

qua nidos fuos ædificant, in iifque ovi ponunt, \& pullos excludunt. Cærerum Chi.* nenfes hos nidos è Scopulis avulfos, ingenti quantitate per Indiam venales ferunt, gulofis in fummas delicias, qui eos Gallinx, feu Vervecis, decocto diffolutos, 2vide devorant , \& Oftreis, Fungis , \& cæteris gulæ irritamentis, longe anteponunt. 


\section{A P V T $\quad \mathrm{X} I \mathrm{~V}$ 。}

\section{Pica, feu potius Stuirnus Indicus.}

\section{Pfittacus Eois quamvis tibi miffus ab oris} Iufa loquar: vincit me Sturnus garrulus Indus.

$\mathrm{E}$

Regione ædium mearum in Batavia habitabat anus Iavana, ferva Chinenfis hortulani, qux Picam feu Sturnum Indicum alebat, valde loquacem, quem cum ego depingi optarem, fapius rogavi, ut eam mihi venderer; fed cum impetrare iftud non poffem, petii ut faltem tantifper mihi concederet, dum pictura exprimere. tur,quod tandem anus ægre annuit: fed ego caufam deinde intellexi ; nam, cum obnixe mulierMahumetanaftipularetur, ne avi fibi cariflimx Porcinam comedendam offerrem, atque ego id promififfem, avis perfima fubinde hoc mihi \& pictori occinebat, Orang NafaraniCatjor Macan Babi; quod vult, Chriftiane canis, comeftor Porci; timebat enim aftutifi-

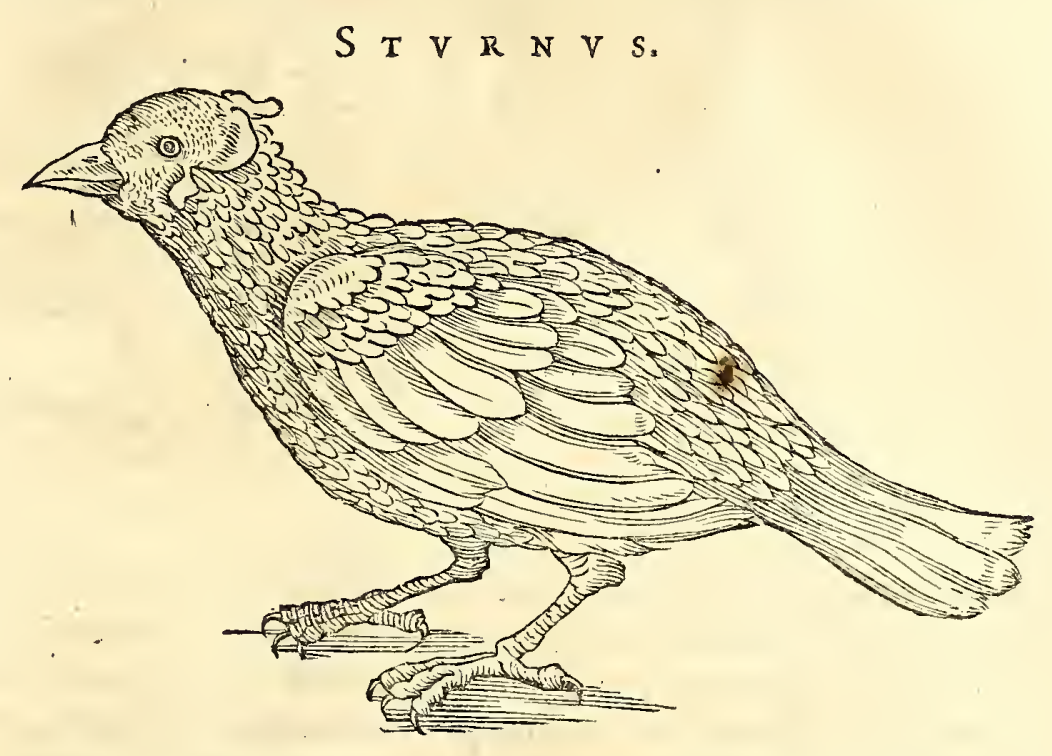
ma Anus, ne ego, vel domeftici mei, offenf, avi huic Laridum guftandum daremus,aut occideremus hac contumelia irritati.

Plumis cyaneis, \& fubobfcure cæruleis ac cinereis guttis interftinatis Sturnum no'fratem refert, verum criftam flavam in cervice gerit, \& caput nigris mollibufque plu. mis obfitum eft , ut contactu te holofericum tractare putes. Multo accuratius humanas voces imitans, quam Plittacus, fed cum importuna frepe garrulitate.

\section{$\begin{array}{lllllllll}\text { C } & A & P & \text { V } & \text { T } & X & \text { V. }\end{array}$}

\section{De Onocrotalo ave.}

Famofum ingluvie contempla do gutture pando, Et qui cuncta voret, confpice Onocrotalum.

Preditus eft duplici (Jicfripfit Plinius) alvo, Candidus af plumis effe videtur Olor.

Audiat bunc quifquam crocitantem voce molefra, Arcadicum dubitet rudere (credo) pecus.

Externus mulios vefitus, formaque, laudat:

Commendat tacitos linguaque muta viros.

Impleti Baccho rocem fi forte refolvunt, Nil, nifi Brunones, Potitiofque, fonant.

$P$ Linius fagaciflimus natura indagator Lib.X. Natural.Hiftorix, C.Xu v I I. Avem quandam defcribit his verbis, Olorum fimilitudinem Onocrotali habent, nec diftare exiftimarentur omnino, nifi faucibus ipfius ineffet alterius uteri genus. Hucomnia inexplebile animal congerit, mira ut fit capacitas. Mox perfecta rapina, 


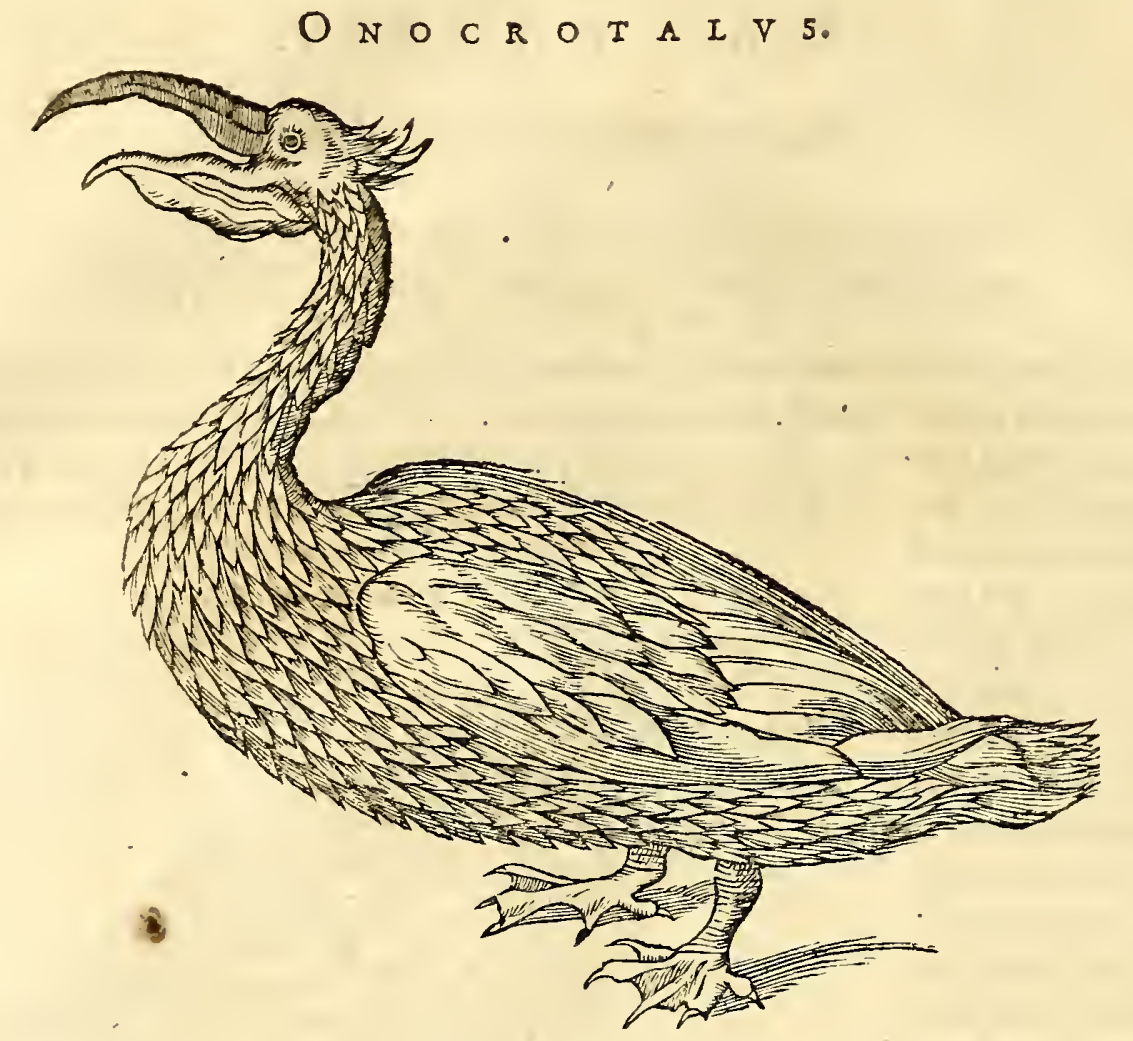

fenfim inde in os reddita in veram alvum, ruminantis modo, refert: Hactenus Plinius, qui tam exacte hanc avem mihi defcripliffe, $\&$ delineaffe fuis coloribus videtur, ut nil addi huic defcriptioni poffit. Nam colore eft albo in plumis, pedes Anferinos, vel Olorinos habet, rubros illos plerumque, voracitatis tantx eft, ut etiam grandes pifces deglutiat. Vidi unam ejus generis avem, quæ vivum Felis catulum deglutiit, \& cum in forum pifcarium veniret, Chinenfes pifcatores illi guttur colligabant, alioquin aftutiffima, \& audax avis, momento temporis, cum fummo rifu aliorum, aliquot pifces furtim à tergo veniens deglutiebar. In litoribus Iavx $x<$ circumjacentium infularum, pifcatura pifcium vivit, voce eft rauca, \& foeda, unde ei ctiam nomen Onocrotali inditum eft, quod Tympanum Afini fignificat, \& certe fi talis cantus fit Oloris morientis, quem tamen nullụm auidiiffe puto, infuavis fane eft, nec tam gratus, quam Poëtx ipfi affingunt. Sed

2uidlibet audendi femper fuit aquapoteftas.

\section{$\begin{array}{llllllll}C & \mathrm{~A} & \mathrm{P} & \mathrm{V} & \mathrm{T} & \mathrm{X} & \mathrm{V} & \mathrm{I} \text {. }\end{array}$}

\section{Appendix. DeVespertilione admirabili.}

Q

Vam Africa non foluni,fed \& Afia atque America, monftrorum fit ferax, ut ex mult is fupra narratis; tum quoque ex hifce Velpertilionibus imprimis liquet.Illi enim in Gufaratta fub Imperio Magni Mogolis gregatim Anferum filveftrium inftar, volitant, \& circa vefperam in aëre vel arboribus penduli confipiciuntur, omnefque advenas ob inufitatam magnitudinem, molem, \& miram conformationem, attonitos tencnt. Ac proinde Belgx, novitate rci hrefitantes, an volatilium generi afcriberent, $\mathrm{Si}$ mias alatas nominarunt fatis incongrue. Quod membranaceis pinnis alarum loco utantur, quod itidem auriti fint, unguibus quoque, \& quatuor pedibus præxditi, pullofque, non ova, pariant \& lactent, cxterorum Vépertilionum fanilix afçribendi funt:Verum quod Felis fint magnitudine, ventre \& pectorc craffo $\&$ carnofo; item quod à cervice capitis ad unguium ufque extrenitaten membrana continuata inftar veli expanfi, pone cooperiantur, à cxteris quibufcunque Verfpertilionibus difcrepare videntur. Adde, quod velum hocfubtus quidem membranaccum, ut in aliis, lanugine, venulis, \& fibris obdu 
$V E S$ P E R T T I L I O

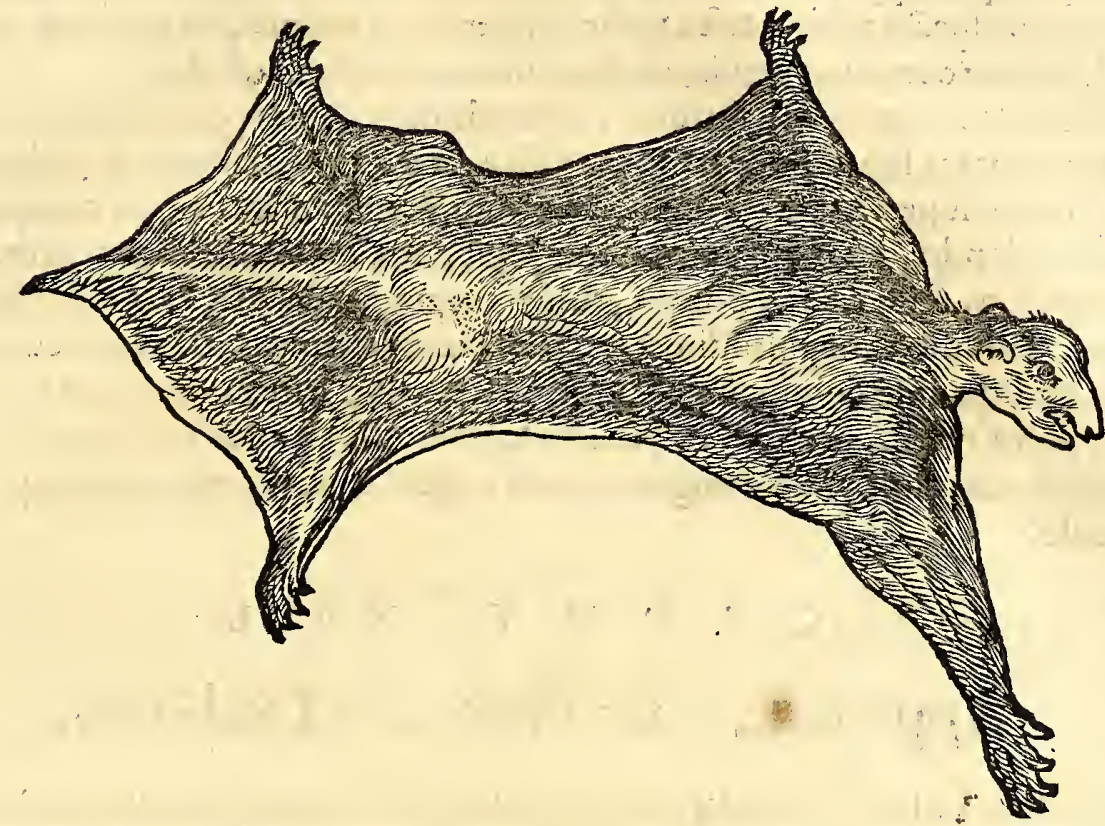

$V$ E S P E R T I L I O arte $E X$ T E N S V S.

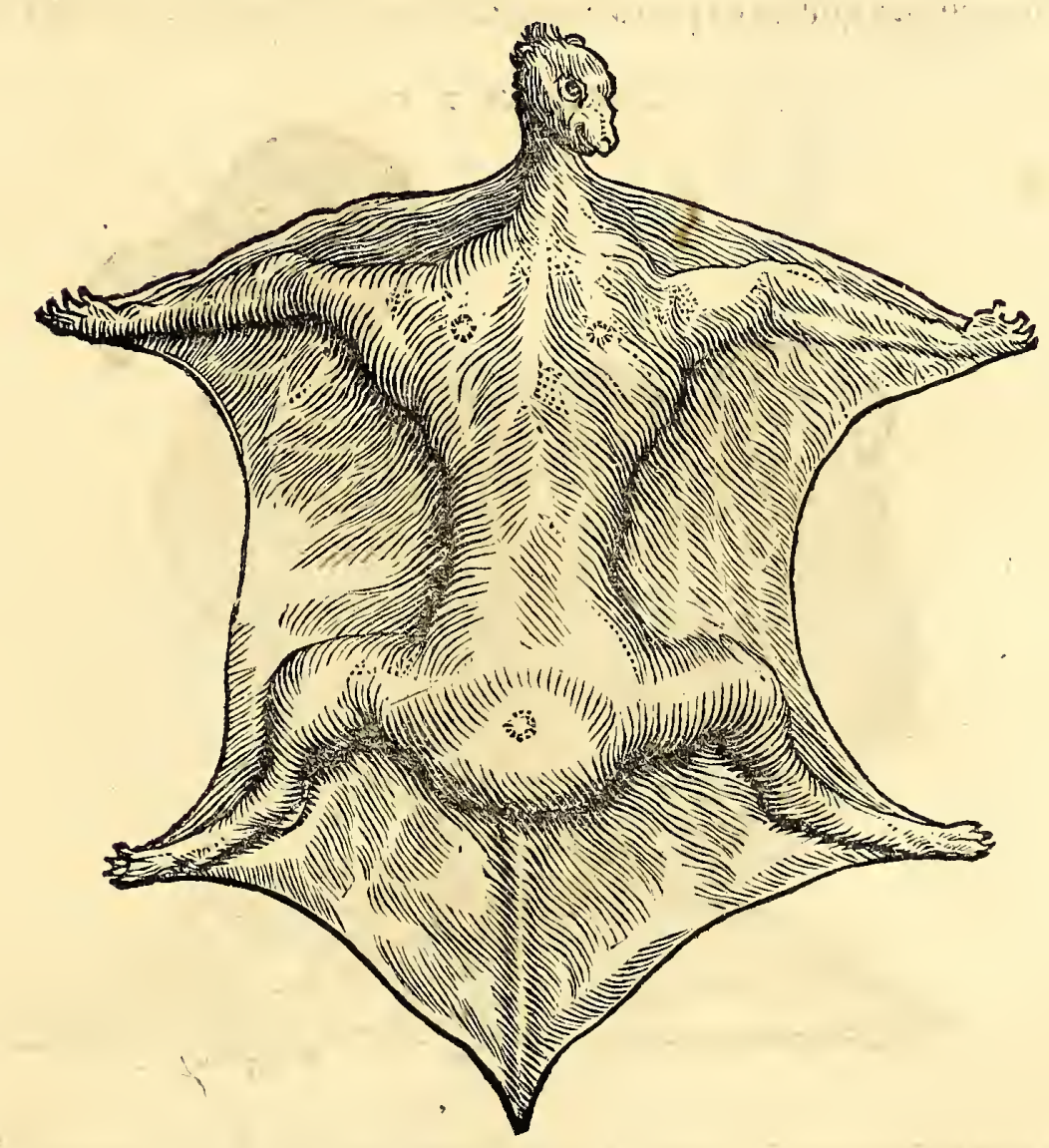

obductum appareat, fed extus perpetuis molliffimis pilis, Cuniculorum more, canis \& ex nigro cinereis, mirum in modum veftiatur. Tum quoque plicis illis, quibus al $x$, morealiorum, contrahuntur \& relaxantur, deftitutum fit. Ita ur, fi conferatur icon cum Brafilienfis, vel cujufcunque Indicj, Vefpertilionis figura, hanc ab illis admodum diverfam reperies. Ne autem curiofus Lector quid defideret, duas exhibui figuras, al teram volantis, alteram tergo incumbentis \& expanfi.

Tota beftia eft longitudinis trium ferepedum, ejufdemquc latitudinis. Cauda tenuis, fpithamam longa, eaque quafi immerfa hxret eidem membranx, qua totum cor- 
pus tegitur. Crura molliori qioquelanugine flavefcente obfidentur. Ex ulcimis pedum articulis quinque ungues tenues, valde acuti $\&$ curvi, erumpunt, quibus mordicus tenet, quidquid apprehendit, imprimis arborum fructus, quos depopulatur. Capite eft oblongo, afpectu fodo, rictu imbelli, dentibus exiguis, ad rapinam compofitis, auribus denique rotundis, parvis, ex tenuiffima membrana factis.

De Indole \& generatione horum Vefpertilionum plura poffem addere, qux mihi quidem fuppeditata funt à pubenantica noftra; fed quia variabant, $\&$ dubix fam $x$ videbantur, malui fiperfedere eorum deferiptioni,donec veritas magis comperta fuerit, ne paginas replendo, errores (ut repe contingit circa exotica) propagentur.

Dantur porro, tefte noftro Bontio, vulgares quoque in lava Vespertiliones, in lucis habitantes, Columbre magnitudinis, quibus Iavani vefcuntur, affirmantes fapidifimos effe. Noetu aliquando cubilia ingrediuntur, fi propter xftum diurnum, fpecularia vel feneftr $x$ apertx relict $x$ fuerint, \& pedes dormientium nudos mordentes, quantitatem magnam fanguinis inde exfugunt, cum majori timore, quam ejus, qui hæc patitur, periculo.

$$
\text { C A P V T X V } 1 \text { I. }
$$

\section{Appendix. De Dronte, aliis Dod-aers.}

Nier Infulas Indix Orientalis, cenfetur illa quxab aliis Cerne dicitur, à noftratibus Mauritii nomen audit, ob Ebenum nigrum potifimum celebris. In hac infula frequens eft mirx conformationis avis Dronte dicta. Magnitudinis intra Struthionem \& Gallum Indicum,à quibus ex parte figura difcrepat, \& ex parte cum iis convenit, im-

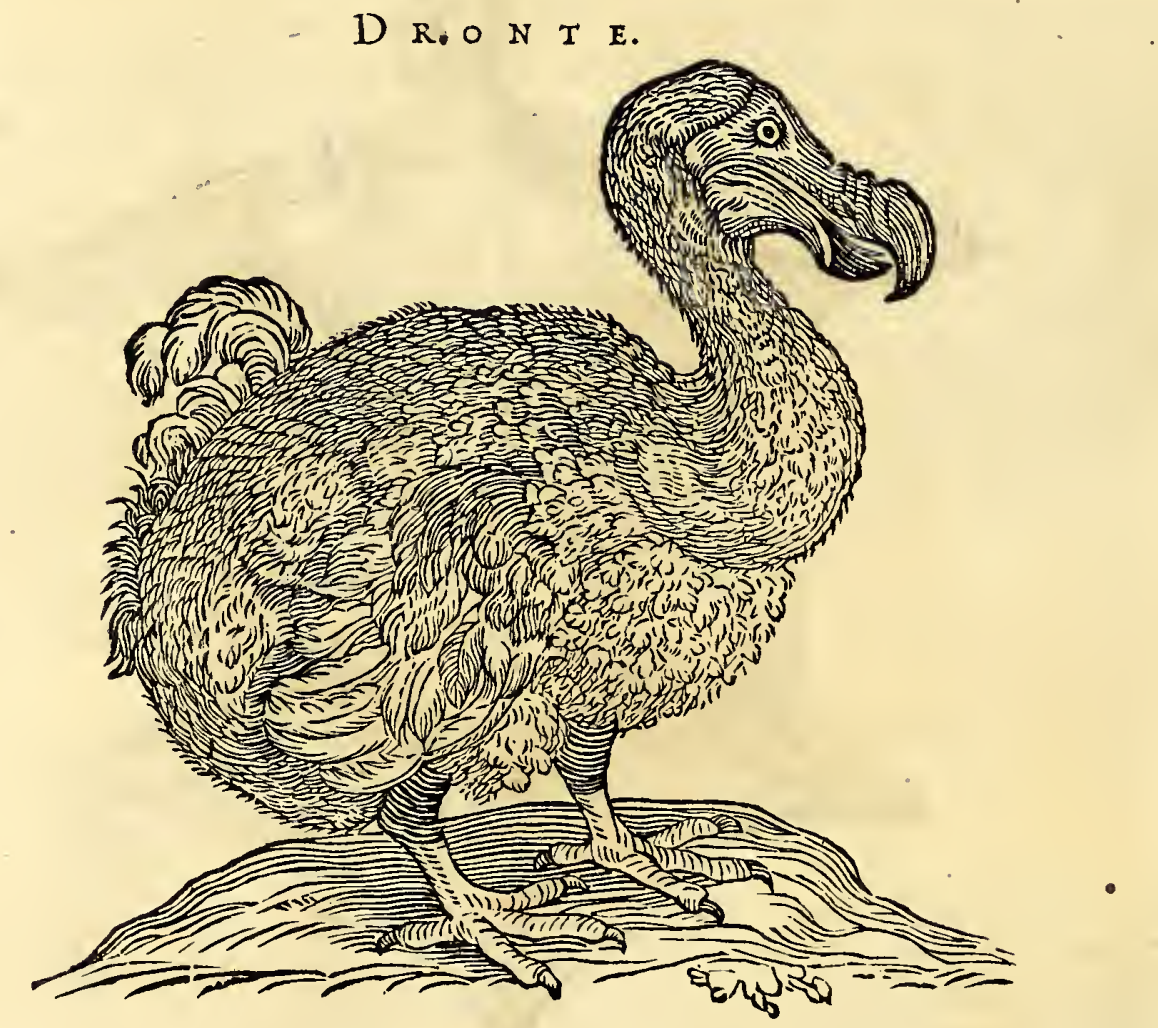

primis cum Struthionibus Africanis, fi uropygium, pennas, \& plumas confrieres; adeo ut Pygmaus quafi inter eos apparcat, fi crurum brevitatem refpicias. Carterum capite eft magno, deformi, tecto quadam membrana,cucullum referente. Oculis magnis, nigris; collo curvo, prominente, pingui; roftro fupra modum longo, valido, ex cxruleo albicante, exceptis extremitatibus, quarum inferior nigricat, fiiperior flavefcit, utraque acuminata \& adunca. Rictu focdo, admodum patulo, quafi ad ingluviem nato. Corpore obefo, rotundo, quod mollibus plumis, grifeis, more Struthionum veftitur: ab utroque latere, loco remigum, exiguis alis plumatis, ex flavo cinereis, \& pone uropygium, loco caudx, quinis pennulis crifpis, cjufdem coloris, decoratur. Cruribus eft flave- 
HIST. NATVRA\&. \& MEDIC. IIB. V.

flavefcentibus, craffis, fed admodum curtis, quatuor digitis pedis folidis, longis, quafí fquamofis, totidem unguibus validis nigris incedit. Cæterum tardigrada eft avis $\&$ Itupida, quæque facile præda fir venatoribus. Caro carum, imprimis pectoris, eft pinguis, vefca, adeoque multa, ut tres quatuorve Drontes centenis fociis faturandis aliquando fuffecerint. Si non probe elixentur, vel veteres fint, difficilioris funt concoctionis, \& falitæin penu reconduntur.

Lapilli diver $\mathfrak{x}$ form $x$ magnitudinis, cinerei coloris, in ventriculo harum avium reperiuntur; non tamen ibi nati, ut vulgus \& pubes nautica arbitratur, fed in littore devorati ; quafi \& hoc quoque figno cum Struthionis natura aves has participare conftaret, quod duriffima quxque deglutiant, nec tamen digerant.

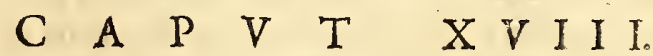

\section{Appendix. De Emeu, bulgo Cajarris.}

N Infula Ģeram, aliifque cholucenfibus vicinis infulis, celebris hæc avis reperitur. Surrecto capite \& collo decenter incedit, tuncque fere quinque pedum altitudinem xquat ; Corporis autem longitudo, à pectore ad uropygium, trium eft pedum. Capite, pro magnitudine corporis, fatis exiguo, glabro, coloris ex nigro carulei. Oculi

$$
\text { EM E v vulgo C A S O A } R \text { I S. }
$$

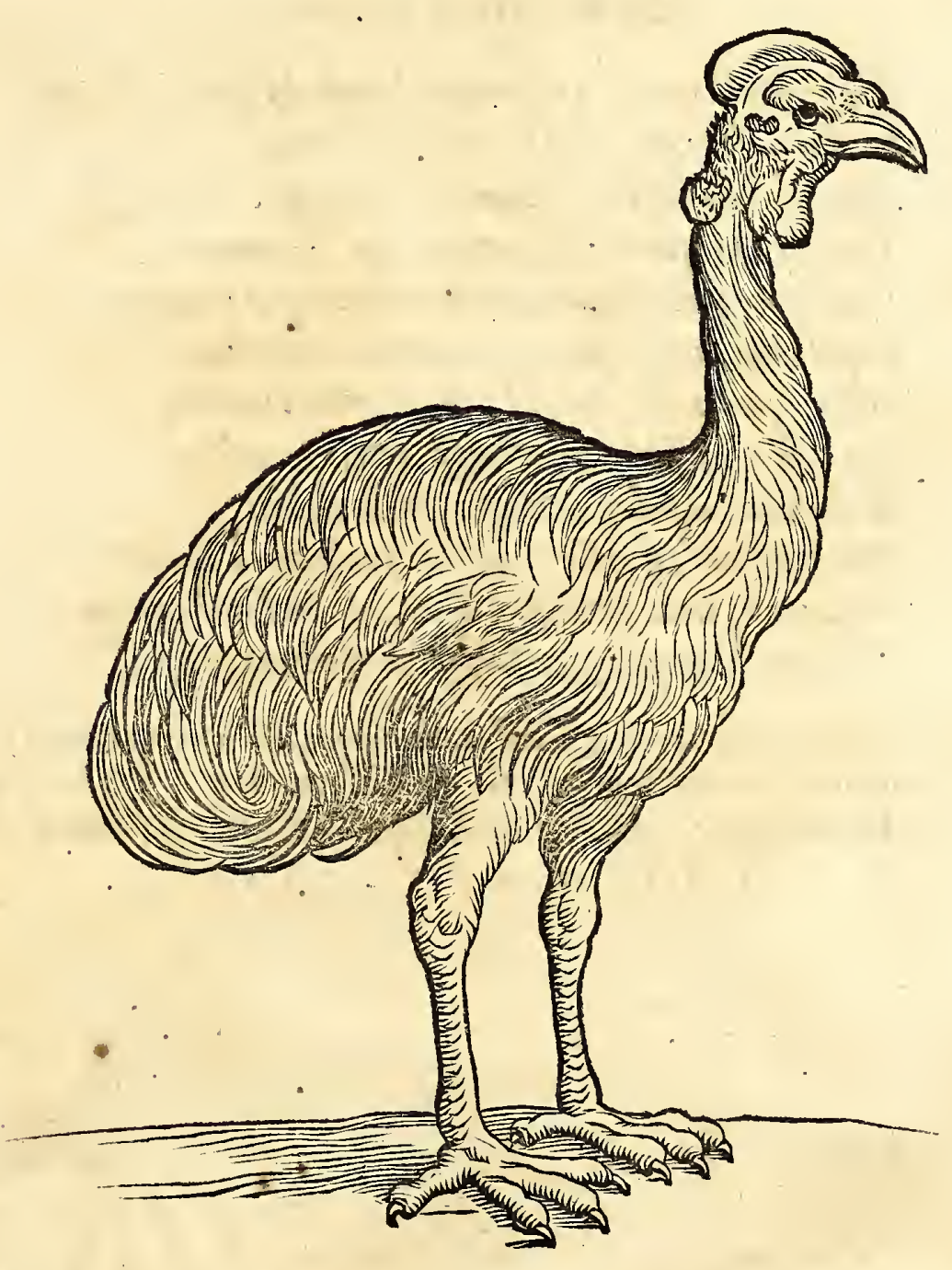

magni, ardentes, \& truces, poft quos, aurium meatus parvi, nudi. paulo fupra mucro. nem roftri, bina foramina, narium ufum fupplent, à cujus medio ad capitis ufque verticem, cornex fubftantix, coloris ex flavo fuffi,porrectum diadema, quod cum plumarum defluvio cadit, iifque renafcentibus renafcitur: anteriori colli parti bina veluti membranacea palearia, five barbulæx,more quodammodo Galli Indici, coloris miniati, propendent. Cruribus ẹt al tis, craffis, qquafi corticiburs callofis, teetis, pedibus eorum- . 


\section{A C Q B I B O N T I I}

que digitis quogue craflis, duris, fquamofis, fine calcaribus. Vnguibus itidem longis, corneis, in quo hxe avis à Struthiocamelo differt, quod pedes, ut ille, bifulcos non habeat; licet notxaliqux communes cum illo fint, Ccilieet caput parvum, erectaftatura, alæque ad volandum ineptx, quodque fine delectu, quidquid objicitur, voret, idque, fi durius, per annum indigeftum rejiciat. Pennis, five verius plumis, tota fere veftitur, miniaris \& nigris, qux pectori \& femori proxim $x$, femper gemin $x$ ex eodem parvo tulbulo prodeunt. $111 \mathfrak{x}$ autem qux uropygium conftituunt, cxteris longiores $\&$ duriores funt, adeo miræ naturx lufu conformatx plumx, ut à procul afpicientibus, non plumis, fed villis dumtaxat, tectum ejus corium appareat; eoque magis, quod alx cxigux fub plumis latera tegentibus abfcondantur. Alæ enim ad curr endum pro velo, non ad volandum inferviunt, quamobrem cum vix à terra fe tollere valeat, non inter volucres ponendam putem; robur quo fe contra hoftem tuetur, non in roftro, fed in pedibus, confiftit; itritatus enim, non antrorfum, fed oblique fe convertit, averfis retrorfum pedibus eum impetens. Ovipara eft, fed ova à Struthionis longe diverfa, ratione tenuitatis \& coloris; hujus enim tefta eft virefcens, perpetuis tuberculis, fature viridibus ornata. Vitellum comedunt incolx.

\section{A P V T. XIX.}

\section{De Ṫbymis, é Delpíninis, quos Corcovados, Dorados, \& Bonitas vocant.}

Hic videas celeres Delphinas femper in Indis Ludere lafcivas, do ducere rite Choreas, 2uos tamen infames Lamia; Larique cruenti, Tardigrado quamvis, natatu Sape fequnntur, Dum gyros celerefque meant remeantque proterve, Improvido mor fu Jub triftia tartara mittunt. Difcite, mortales, quod fit fua Tigris in undis, Que folet in filvis tranfverfo in currere faltu Incautum, infidiis reftigia tarda dolofis. Compenfans. Homines fic tetra calumnia femper obfervat, tum quidquid agas, nil undique tutum $V i x$ quis quam effugiat falfisfima verbera linguse.

Q

Voniam pifces Bonita vocati Lufitanis, huc quotidie ad mercatum feruntur, ego potiffimuminter eos depingi curavi, qui è Thynnorum, feu Delphinum, fun genere. Incolx Iavx hunc Ican Bouda appellant, quod perinde eft, ac fi pi-

T H Y N N I S P E C I E S.

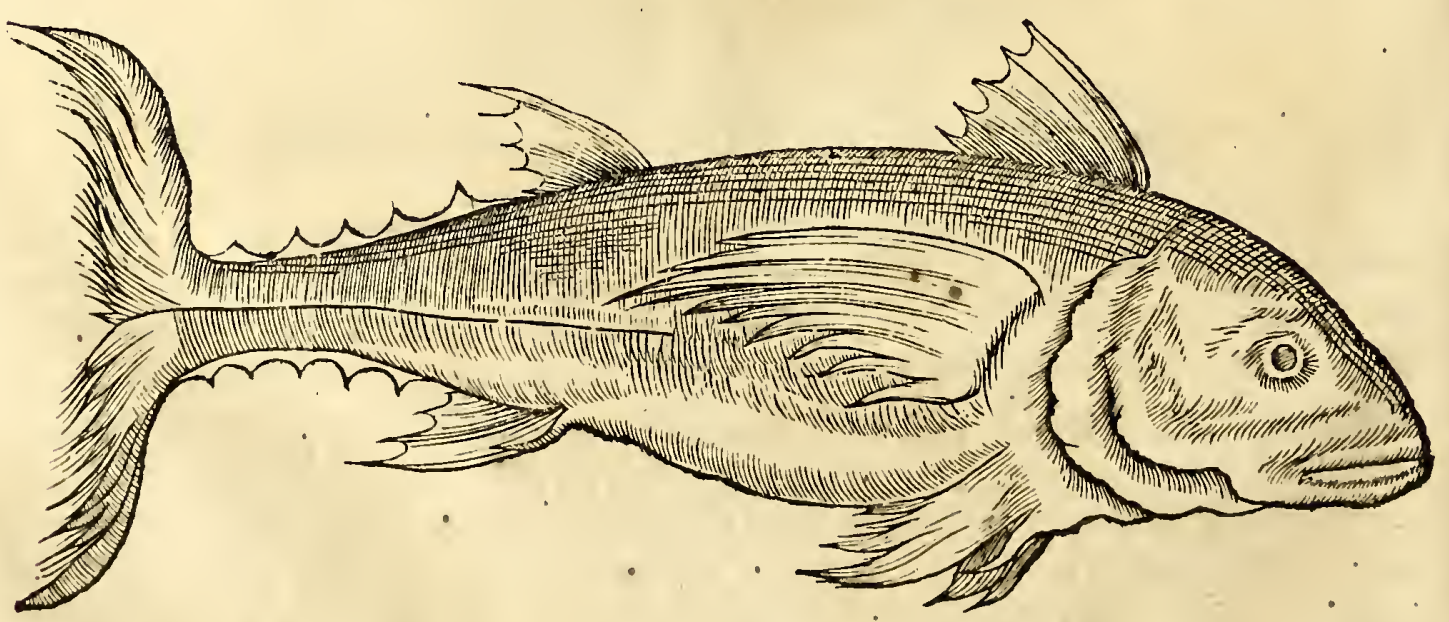

- fcem equum dicás : procul dubio ideo, quod faltando fe extra filctus marinos ultra huma- 
HIST. NATVRAI. \& MEDIC. IIB. V.

humanam facile alcitudinem efferat, aut propter fummam velocitatem, qua navem profpero vento, expanfis velis, tam facile praternatat. Capiuntur praterca pifces Dorados dicti Portugalenfibus, ab aureo, quem ferunt in cure, colore, ubi recens captus fuerit, nam mortuis per horæ fpatium is color decedit : hic pifcis eft longe optimi faporis Bonitas bonitate excellens : Omnes è Delphinum funt genere, lati, \& longi, inter cos quoque numeratur pifcis, qui iifdem Lufitanis Cortovados vocatur, quod gibbofum fonat, quia gibbum in tergo gerit. Igne elixi dimidia ex parte condiuntur porro, olco, \& aceto, admixto pipcre, allio, \& fale, vel etiam aliis aromatis: $\&$ ita confervantur longo tempore, ut utiles fint iis, qui hinc Ternatam verfus, \& Moluccas navigant, ubiannonæ parcior copia, quam in reliquis noftræ Indiæ eft partibus. Tali modo conditi egregie fapiunt, tum corum muria pro condimento eft, \&orexin, \& appetitum ventriculo addit : fed oportet, ut Oryzx coctx bonam pro ratione menfuram fimul comedas, atque ita nullum empyreuma, feu aduftionem, inteftinis adducent. Hoc adhuc addo, nos habere preftantes hic pifces: Verum tamen, ut fatear, Afello majori ac minori caremus, qui fi adefíet, nos, Patriæ de praftantia pifcium non cederemus. De Delphinum porro velocitate, hæc Plinius, Lib.9, natural. Hiftor. Cap. \&, Velociflimum omnium animalium non folum marinorum eft Delphinus, ocyor volucre, ocyor telo, ac, nifi multum infra roftrum osilli foret medio pene in ventre, nullus pifcium. celeritatem ejus evaderet. Qux fequuntur, vera pleraque funt : fed hoc mihi dubium eft, quod paulo poft dicat, tanta eos vi exilire, ut plerumque vela navium transvolent, nifi forte vela Horiarum, feu navicularum pifcatoriarum, intelligat :

orphens in Sylvis, inter Delphimas Arion.

Lamix porro, Galex, Lari, nimis hic multi funt, quorum ingluviem miferi noftrinavales focii fepius experiuntur, dum incautius natando fe exercent. Hi pifces tarde natant, \& nifi in tergum fe volventes prædam appetunt, quafi ita natura fevifimi pifcis hujus ferocix, moram injecerit, ut miferi mortales ipfos prævifos facilius evitare queant.

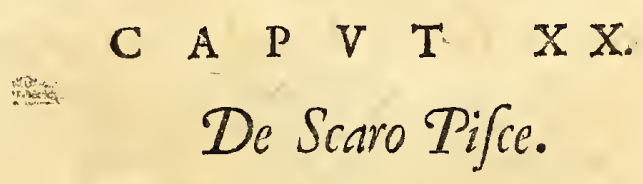

P Etrus Belonius in Obfervationibus fuis doctifimis, Lib.2, Cap. 3, meminit Scarì pifcis, qui frequens in litoribus, olim Cretx, nunc Candix, Infulx capitur: ille vero huc quotidie in forum pifcarium venalis adfertur. Ego ipfum de genere Percarum effe autumem: nam five colorem fpectes, qui in hoc pifce è rubro egregie

$S \subset A R \vee S$.

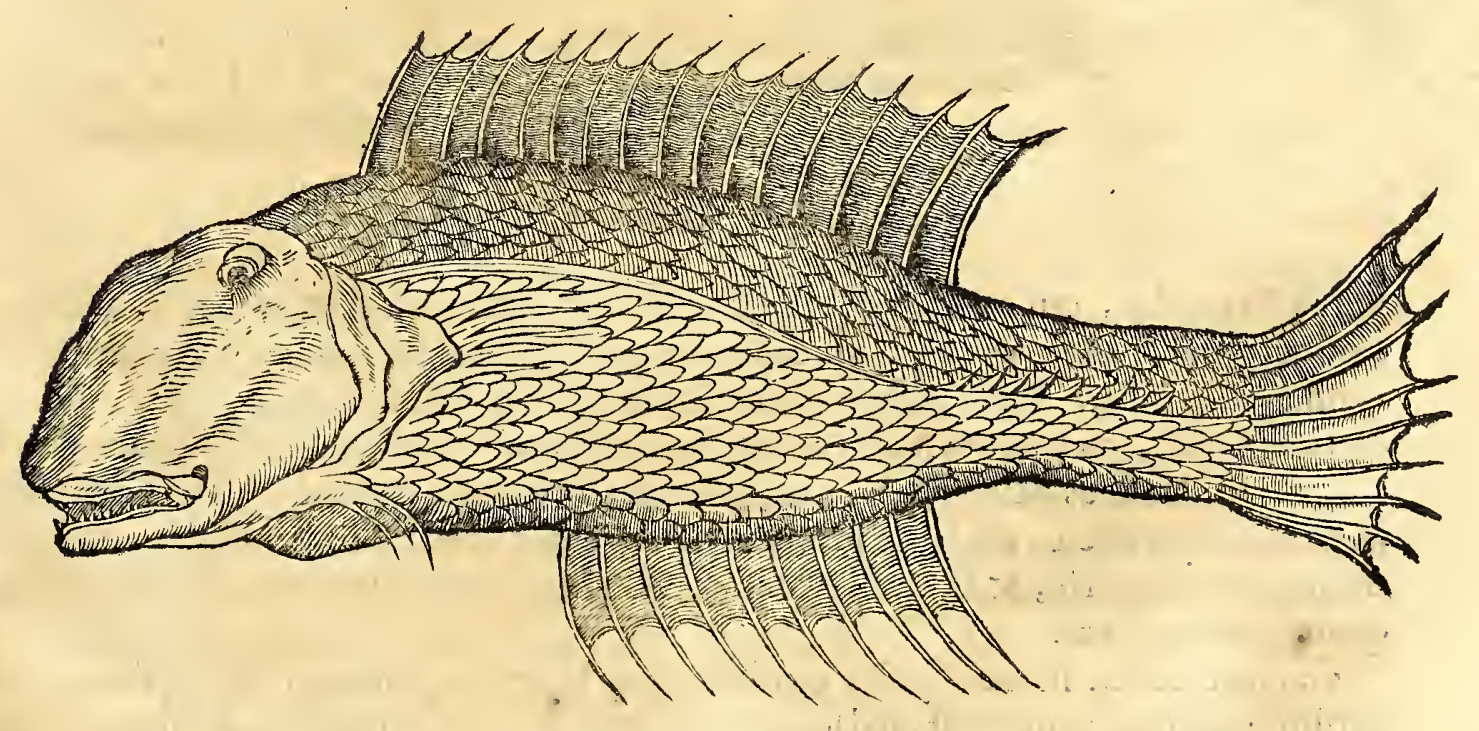

viridis eft, acutos aculeos in pinn̈is, denique fquammas ejus afperas, quxque cum moleftia abradi folent, cumdem ferme pifeem cum Perca noftrate effe dicas. Caterum delicati adeo eft faporis, quam quifpiam pifcis alius in his oris : concotionis quoque eft 
facilis ; $\&$ inter faxatiles Indiarum pifces principem locum obtinet, Dentes fert, non, ut alii pifces, acute definentes, fed obtufos plane, ut humanos dentes effe dicas, quibus etiam ftridet, ut homines iratos $\&$ infanos facere videmus. Vere quoque dicit ibid. Belonius, hunc pifcem labris aduftis, \& toftum ridentis hominis faciem mentiri. Capiuncur etiam inter rupes, \& faxofa vada pifes quidam coloris plane viridis, qui à figura, fquammis, \& rubris oculis, Alburni vocantur, Belgxnoftri Sternboorntu vocant, optimi quoque funt faporis. Hos \& reliquos pifces Malaii noftri tam f́cite condire, \& prxparare fiunt, ut in eo Germanos ac Polonos fuperent, qui tamen palmam in coquendis pifcibus in Europa ferunt, addita radice Curcumx, ad faporcm \& colorem luteum conciliandum. Eodem modo ctiam prxterea condiunt Lupum marinum, qui à fluviatili colore tantum differt: Nam albus planeeft, \& frepe tam magnus in mari \& alveis fluviorum capitur, ut Afellum noftratem majorem mole fuperet. Scarus inter pifces folus ruminat, \& herbis vefcitur, teft. Plin. 1.4 . c.

\section{A P V T $\quad$ X X I.}

\section{De Cyprinis Saxatilibus marinis, de Carpionibus é conum in India magnitudine. Item depifce Cacap indigenis dicto.}

Yprini lati faxatiles in magna copia capiuntur, genus pifcium, me judice, inter præftantiflima eft numerandum, hujus plures funt form $x$, rotundos enim habes quales ferme Rhombi, oblongiores quoque, quales hic depinguntur, omnes tamen lati, ac duris fquamis obfiti, atque hi tantum in mari capiuntur. Cyprini

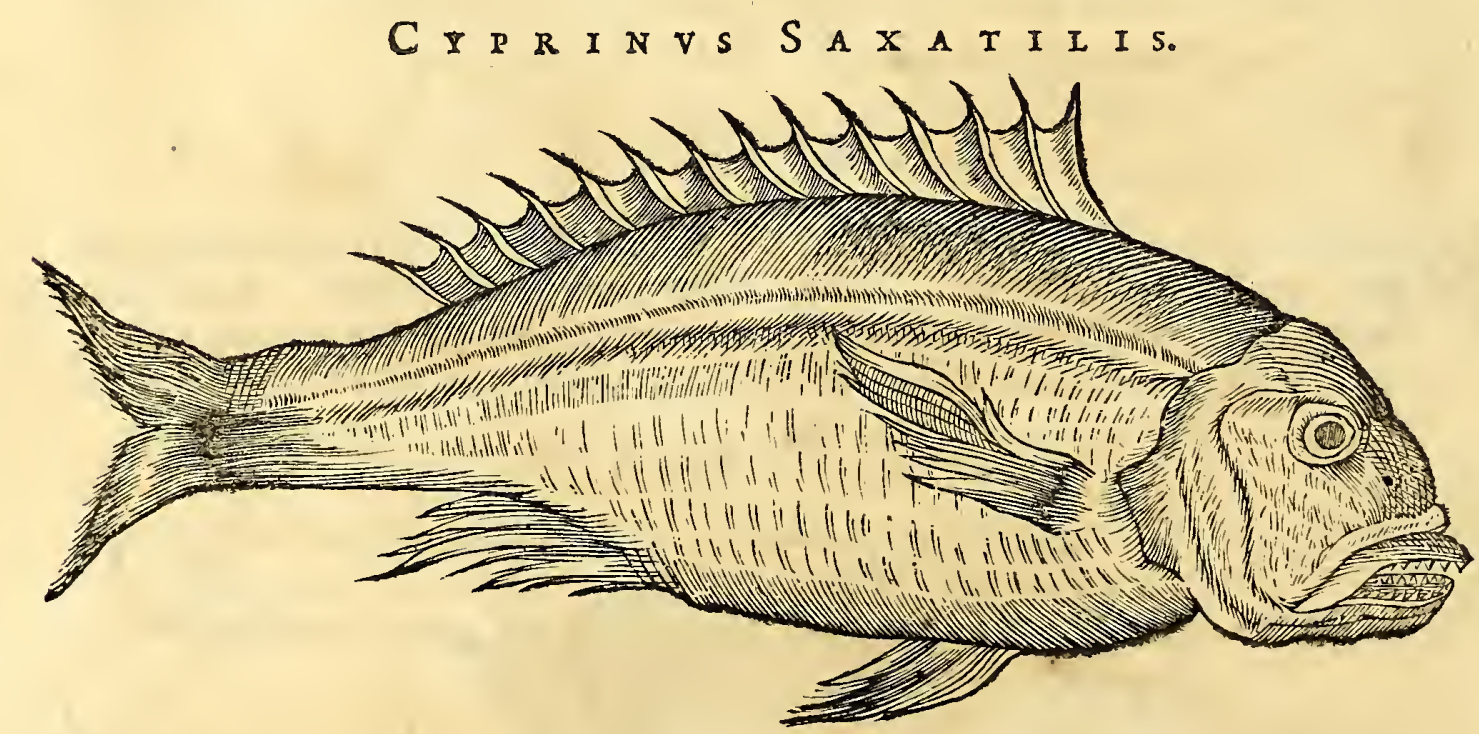

porro fluviatiles, qui magna copia in fuviis capiuntur, \& Catper noftatibus vocantur, patrios bonitate carnis vincunt, utpote qui non in ftagnis, \& paludibus, fed in profluenti alantur. Vnde etiam colore funt albo; \& tantæ aliquando funt molis, ut ego habuerim, qui triginta libras penderent. Lingux eorum apud Chinenfes non fecus, ac apud noftros delicatiores in deliciis haberi confuevere, \& ubi pifcem ichthyopolæ vendiderint alicui, nifi bene profpexerit fibi, aftutifimi Chinz linguam illi eruent momento temporis, \& fibi refervabunt, vel aliis feorfim vendent, forte tam caro quam ipfum pifcem.

Capitur etiam in mari pifcis quidam Cacap Indigenis vocatus. E Cyprinorum faxatilium quoque genere eft, fed longe majores funt : nam aliquando Afellum noftum Callaricum feu majorem (noftris Eabeljau dictun) excedunt. Guftus præ omnibus aliis marinis pifcibus in Iava fapidiflimi, \& proxime Afellum jam pradiatum referentis, \& in muria per noctem macerata pars quadam, atque cum Raphanis, aut Batatis radicibus, cocta, addito Sinapi pro condimento, fapiunt plane, ut Afcllus falitus apud 
HIST. NATVRAL. \& MEDIC. LIB. V.

nos, quem wetridaen vocare folemus. Et cum paftinacis flavis, ant rapis eodem mo. do coquuntur, $8 z$ comeduntur in patria , fed nos iis carentes Raphanis, brevioribus $\&$ craffioribus contenti vivimus, quamvis \& Paftinaca alba, \& flava, hic fata,bene proveniunt, tamen lignofa funt, \& nullo modo tam boni faporis, quam in patria ; quod non agro, qui fertilior hic eft patrio; fed foligenio, imputandum eft :

Hic Jegetes, illic crefcunt felicius Vve. Virgil.

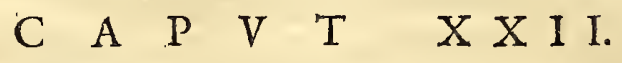

\section{De Congris, Murenis, of Anguillis, in fuminibus, do mari Iavano.}

$P$ Linius, Cap.xx. Lib. Ix. ubi pifces in figuras corporis digerit, hæe ait ; Pinnarum quoque funt difcrimina, qua pedum vice funt datx pifcibus. Et paulo poft; Bina omnino (de primis intellige) data funt longis \& lubricis, ut Anguillis, \& Congris. Hec omnia flexuofo corporum impulfu ita mari utuntur, ut Serpentes terra. Hactenus

$$
\text { C O N G R I. }
$$
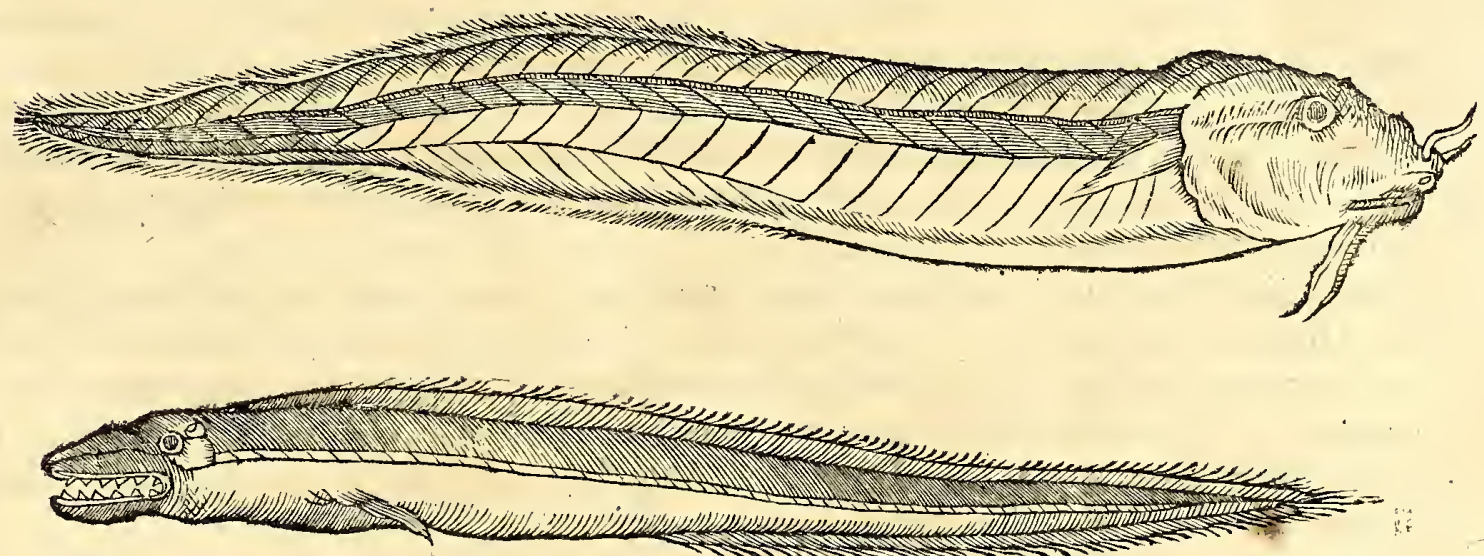

ille. Cxterum ifte Conger \&Muræna, quæe tanto in pretio apud Romanos habebantnr, hic viliffimi funt.

Anguillx, etiam frequentes, fluminibus \& ftagnis capiuntur: fed earum ufu cgo facile caream, cun certiffimum mihi fit, eas cum Hydris coire, tum colore fuperne nigrofunt, \& fubtus fœede flavo, maculis luridis diftincto, ut afpicientibus faltem horrorem incutiant.

Conger porro ftipatus eft ferrata dentiumferie, quibus, fi imprudens Pifcator eum tractet, acerrimos morfus imprimit, \& difficilia inde curatu vulnera, non fecus, acfi à Serpente quis demorfus effet. Caterum capitur quoque in mari, \& alveis fluminum: fed marinum pratulerim, utpote qui frequentet vada faxofa, \& arenofa, neque limuni fapiat, ut fluviatilis. Carterum Congrum huncfi coquant, etiam exoffare folent Incolæ, more Romanorum, ut eft apud Terentium in Adelphis :

Congrum iffum finito tanti/per in equaludere, dum exoffetur.

Quod 8z Murxnis folere antiquitus fieri, Plautus in Amphitruone teftatur, dum Sofia fervus Mercurium minantem aufcultat, mirum ni is bomo me, tanquam Murenam, exoffare cogitat. Sed li verum fatear, puto, hoc fic intelligendum, quod voluerit ipfum exoffem reddere, qualis Muræna eft, qux loco fpinx, cartilaginem teretem, \& viridem, in dorfo gerit , \&, ut Plinius ait, pinnis caret. 


\section{Appendix. De Congro monfrofo.}

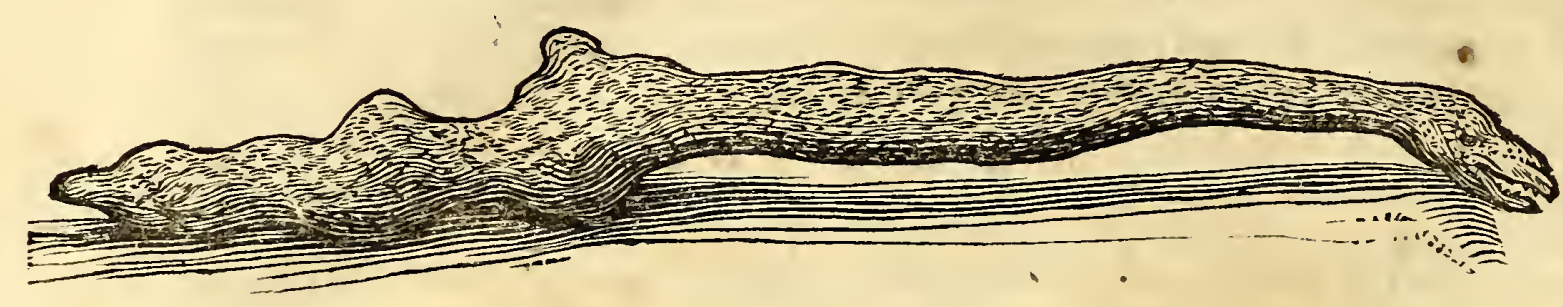

On mirum, fi admodum differat forma \& figura Congrus hic Indicus, ab his quos autor nofter exhibuit; cum ille Inful $x$ potiffimum Iavx , ubi vixit, animalia traAtaverit ; rarus autem hic pifcis, aliaque à me huic operi addita, ex diffitis Indiarum partibus prodeant. praterquam quod merito dubitari poffet, inter Congrofne, an Hydras, recenferi mereatur, licet pubes nautica ex Indiis redux inter Congros haberi teftetur : Sed cum meum non fit, eam litem componere, faltem inter monftrofos Congros repofuerim.

Quem hic exhibeo, trium fere pedum eft longitudine, coloris fpadicei,fed nigris maculis cancellatis, more Serpentum, diftinctus. anterior dimidia pars corporis tenuis, pofterior duplo pene craffior, \& inftar clavi nodofi, imbellis fatis apparet. Capite \& ore eft oblongo, rictu, $\&$ dentibus acutiflimis, ad rapinam factis, adeo tamen exiguis, ut vifum fere fugiant. In petrofis fundi cavernis victitat, pabuligratia, ibique pinguefactus, grato Incolarun alimento exiftit.

Peculiare autem quid obfervatur in his Congris, quod quicunque illos mactant, quafi horrore, \& tremore, imo fubinde animi defectu, eoque non durabili, fed mox ceffante, corripiuntur. Quod quidem venenofitatem in aliqua parte latentem, videtur arguere, qux deficiente beftiæ vita, in aërem fe difpergit: unde non immerito quis furpicabitur, hos quoque Congros, ficut $\&$ Anguillas qualdam,cum Hydris coire, quoniam idem de Hydris quibufdam teftantur Barbari.

\section{A P V}

\section{De Serpentibus in genere, of de Ampbisbiena in $\int p e c i e$.}

\section{Non Satis eft uno diffundier ore venenum?}

Amphisbena tamen gemino boc exfibilat ore:

Has, dubitem, furias intexere crinibus bydras,

Atque bominum ad rabiem trifteis invertere menteis; Obtrectatorum duplici fic lingua reneno, Intumet in faciem, or mittunt poft terga fcelefti.

Erpentes undique adeo multi funt, ut prius mihi charta defecerit, quam omnes enumerem:tamen de ingentibus aliquid dicturus, qui aliquando triginta fex pedum longitudinem excedunt, tantæque gulæ \& alvi capacitate, ut integros hauriant Apros. Ventrem enim habenttriplo majorem, quam collum, \& pars ea, quxin caudam definit. Atque, ur hoc mirabile eft in Crocodilo, quod ei fuperior tantum maxilla moveatur, fic in hoc Serpente utraque movetur, quo grandem hiatum oftendit. Vt hoc confirmem, funt adhuc in vivis, qui cum D. Generali Petro Both, de Porco excifo è ventre fimilis Serpentis comederunt, quem recens deglutierat. Venenati non funt, fed plicatura circa corpus hominis vel alterius animalis locatura, id viftrangulant. Sequitur nunc

A M P I IS SE N A:

Hxc eft illa Plinii lib. 8, cap. 23 , Amphisbænx, ait, geminum eft caput, hoc eft, ad caput, \& ad caudam, tanquam parum effet uno ore fundi venenum. Hanc ego oc- 


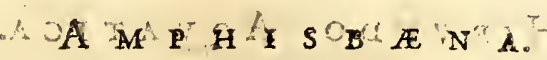

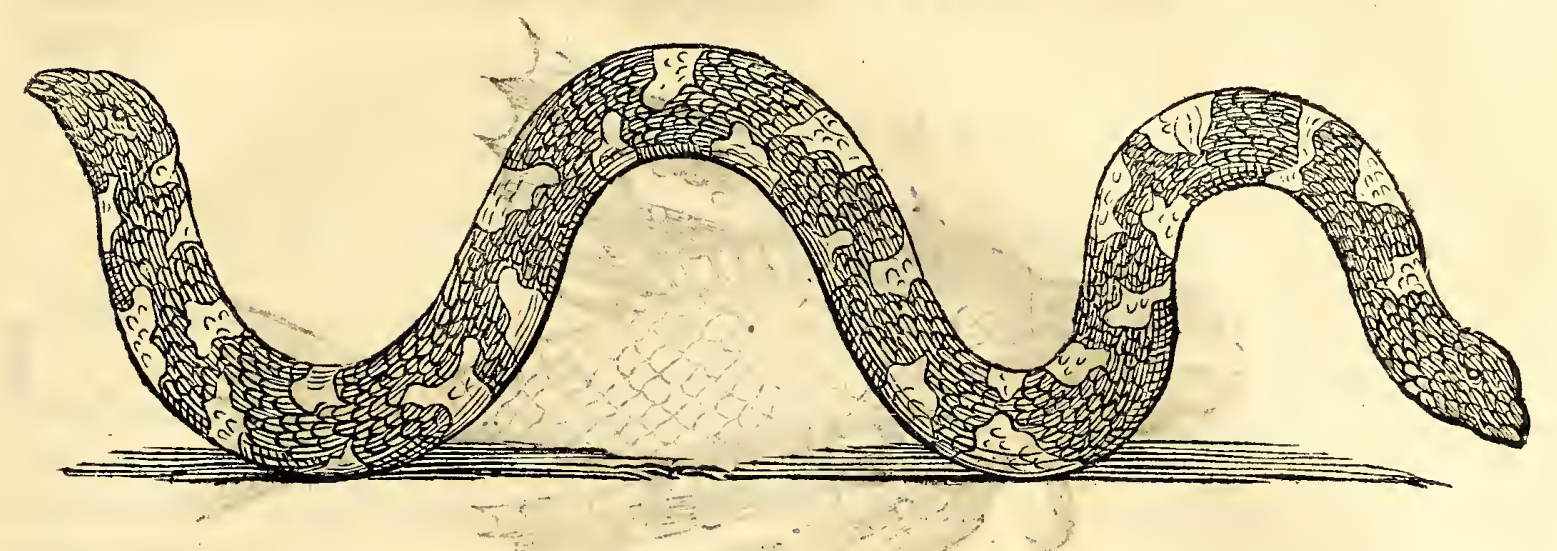

cifam in domo mea, ad vivum hic delineatam exhibeo. Alebam enim Gallum prægrandem, pugnacem valde, ipfumque, fummo mane cum furrexiffem, luctantem confpexi, ut mihi videbatur cum duobus Anguibus, quia duo capita animadvertebam, medium quippe corporis curvatum in latebris adhuc herebat. Iuffi fervo Mauro, ut Serpentem occideret, quem ille protractum, oftendit Amphisbænam effe. Plinius alibi dixit, fi mulier mortuam Amphisbanam tranfcenderit, eiftatim menfes moveri : \& lib. 20, c. 20 , Silveftris Lentis decoaum (quam $\phi$ aròv Grxci vocant) ejus idtibus mederi. Iavani, ut ejus lethalem vim exprimant, eam oular Matti, hoc eft, vermem mortis, vocant; namque hxe gens, ut fimulandi eft artificiofiffima, fic paucis vocabulis in fua lingua contenta, fciens taciturnitatem meditationi alicujus facinoris convenire: Namque vocabulum oular Serpentem, quidem, fed proprie Vermem, denotat: comprehendens etiam quidquid Infectortm tereti corpore fine pedibus humirepit. Tum in fluviis ac mari Anguillas, Murænas, \& Congros, hoc nomine indigitant, addito vocábulo oular-ican, quod poftremum, pifcem dẹfignat.

\section{A.P V T X X I V.}

\section{De Afelli Indici pecie, item de pifcibus Alatis.}

Apitur pifcis, quoad formam, \& molem, Afello Callarix, feu majori, non $a b-$ fimilis, fapore optimo, fed tamen carne ficciori , quam nofter Afellus, qui meo quidem judicio, inter omnes totius orbis pifces elt fapidiffimus. Pif́cis porro hic cure eft flava, nigrioribus maculis per totum corpus diftincta, unde noftri nava-

A S E I I I S P E C I E 3.

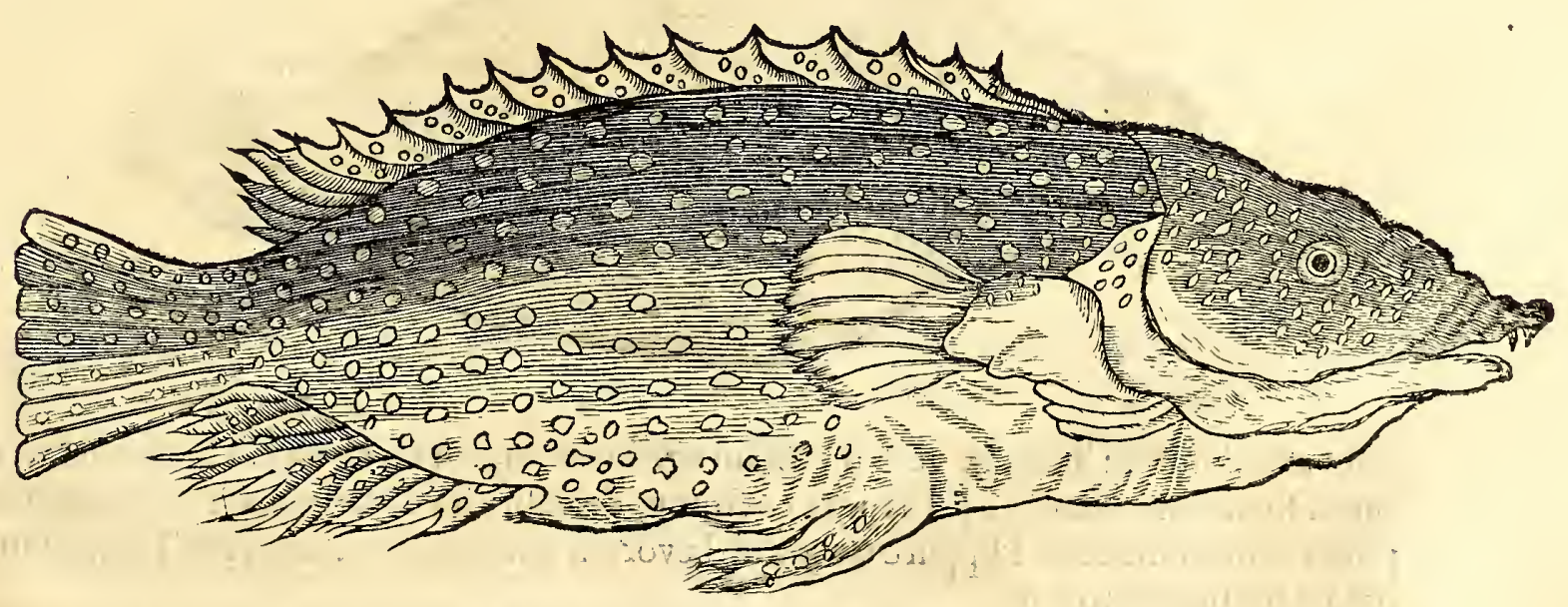

les focii, cum primum in Indiam navigantes, circa Infulam Mauritii, cum cepiftene, Gacab \&bertfen vocabant, qui iplorum Navarchus, \& homo parva, \& comprefla ftatura, flava cute; plurimas fimiles maculas in facie gerebat, unde $\&$ per totam Indiam adhucidem nomentetinet.

$$
\text { ?oj }
$$




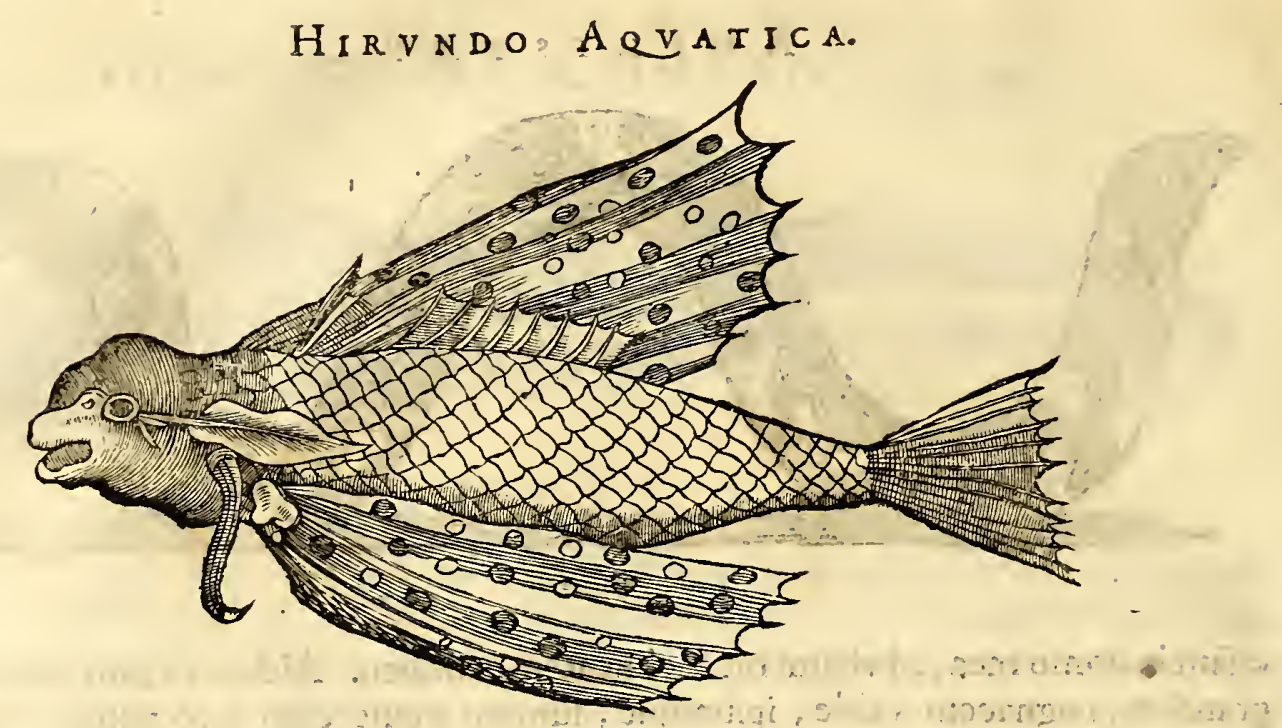

$\mathrm{V}$

Olatici porro pifces, (Hirundines aquaticas Gefnerus vocat), ex Halecum mihi videntur effe genere, cum corpore, fquamis, \& fapore eum plane referant: Nam plurimos in itinere noftro cepimus, quibus toftis, \& elixis, jucunde vefcebamur, cum falfamentorum nos jam pridem fatietas cepiffet. Hos pifciculos ad paftum perfequuntur Thynni, \& Delphines, qui Dorados, Corcovados, Bonitas, Lufitanis dicuntur. De quibus alias fufius difputavimus. Alax ipforum alis Vefpertilionurn affimulantur, nifi quod in ambitu acutis aculeis muniantur; Cærterum, tantum ad aliquos paffus volant, \&, exficcatis alis, rurfus in mare decidunt. Mira funt hæc, pifces volare:fed multo mirabilius, quod Plautus ait in Milite gloriofo, homines fuiffe volaticos, quos ifte miles miro, illic dicto, modo occiderit uno die.

\section{C $A \cdot \mathrm{P}$ V T $\mathrm{XX}$.}

\section{Tince marine, fove Hippuri, mira quedam Jpecies.}

Vid. Nam gaudent pelago, quales Scombrique Bovefque

Hippuri celeres, \& nigro tergore Milvi.

Tinca marina, feu Hippurus, quod pinnam equinam habeat ; caudam equi:

$$
\text { TIN C. A MA I NA }
$$

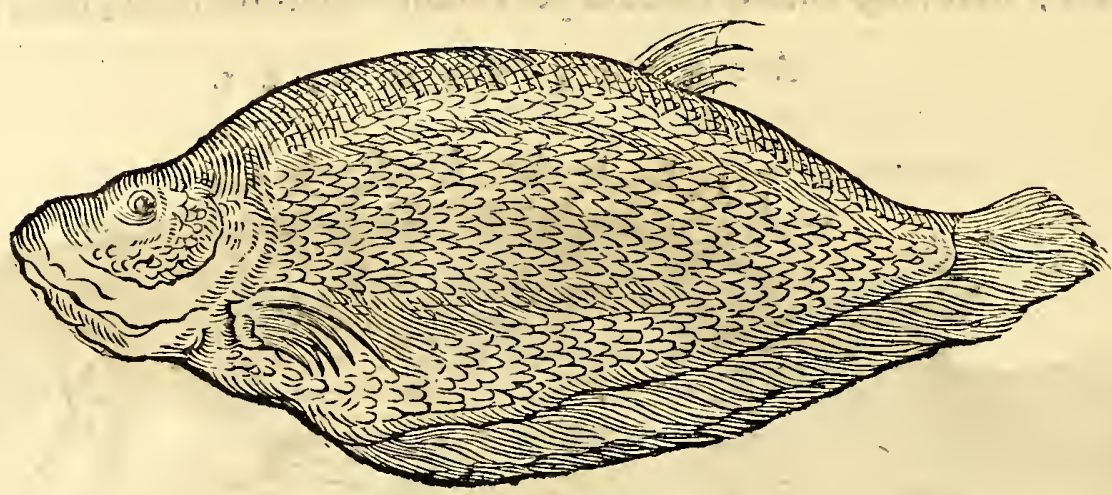

nam $x$ mulantem: Tincam vero marinam ego hunc pifcem ob læxvorem cutis vocàvi, \& quod foleat hic etiam ei pellis ante cocturam detrahi ; ita ut rarus pifcis, ob infuetam pinne continuitatem, Hippuro ;atque ob lævorem cutis $\&$ carnis faporem Tincæ, comparari optime potuerit.

Prxter enarratos pifces, infiniti adhuc edules quotidic è mari \& fluviis ad nos deferuntur, \& venum in pifcario exponuntur, ut funt imprimis, Alburni, Muftelx, Muranx, Gobii, Polypi, Lupi, Anguillx, Apux, Pectinum quoque, Solearum, Lingulacarum, Rhomborum, cxterorumque planorum pifcium genera, plura, quam in Patria. Paftinac $x$ denique, \& Rai $x$, marin $x$, abfcifo, quod à laterc \& cauda eminet 
HIST. NATVRAL. \& MEDIC. LIB. V.

telo venenariflimo, comeduntur, ut reliqux Raiarum fpecies. Vidi inter eas, qux duos oculos in capite, \&alteros duos in tergo gererent; capiuntur \& pluribus luminibus, preditx.

\section{C $A \quad P \quad V \quad T$ X X X V I.}

\section{De pifciculo Cornuto, feu Ican Setáng.}

$\mathrm{C}$ Apitur hic Pifciculus inter rupes plerumque littoribus Iavæ vicinas, non majoris magnitudinis, quam qua ad vivum depictus eft: armatur duobus pre.. acutis, \& duris, cornibus, in parte anteriore frontis; gerit praterea duo cornua circa podicem, quibus feabinjuria majorum pifcium egregie defendit : namalacer valde eft, \& mobilis inftar Porcelli pifcis. Lupo marino, \& huic pifçculo (ut à pifcatoribus Chinenfibus accepi) fummæ inter fe ininicitix funt. Nam, ut omnia devorare cupit Lupus marinus, fi prehenderit hunc pifciculum, ille fuis cornibus tantum moleftix exhibet in ventre, ut,nifi prompte ipfum evomat, certiffimam mortem incurrat, quamvis \& inimicus ejus quoque fuffocatur, tamen non inultus moritur. Pifcatores Indi-vocabulo Arabico ipfum Ican Setaing vocant,id eft,pifcem diabolum, vel quod. cornua gerat, feu, quod ictus ejus a dmodum virulentus fit, ut frepe diximus de Dracone marino, feu gleieterman Belgis. Caput valde fimile eft bubalino capiti, cum pregran. dibus oculis, fquamis undique tam duris obfitus eft, ut avelli fine cute non poffine, :

$$
\text { PIS I I VIVSCOR N T V S. }
$$

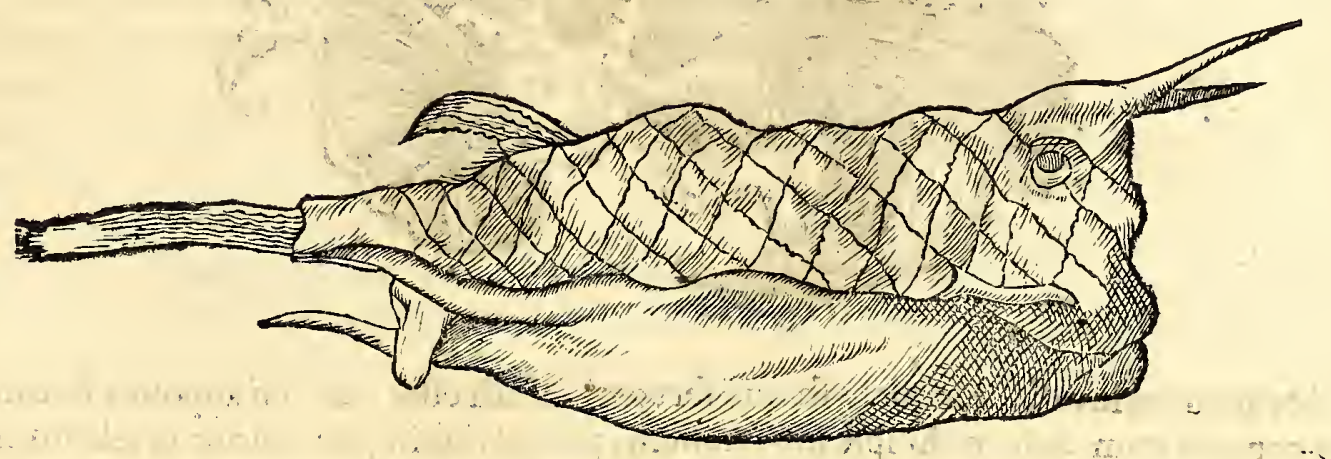

propterea Chinenfes, \& Matri, qui eo vefcuntur, non fecus ac Ranas, excoriant : fed certe carnis eft duriffim $x, \&$ minus falubris, ideo delicatioribus ventriculis vitandus, non fecus, ac Orbis pifcis, Sepix, Loligines, \& Polypi, quibus abundamus, \& quorum omnium mirx fpecies quotidic in forum venales feruntur. Imo ego Polypos tam grandes vidi, qui, fi hominem prehenderint, non facile eum amittant a fe. Credo de corum genere effe, de quo Plautus feftive ait;

Novi ego iffos Polypos, qui fibi, quicquid tetigerint, terient.

$$
\text { C A P V T X X V I I. }
$$

\section{De $\mathcal{N}$ autilo pijce, Sepiis, \& Holotburiis.}

$\mathrm{P}$ Linius, antiquiffinus Nature indagator, \& rimator, Nautilos pifces inter Polypos ponit, \& vere lib. 9 , cap. 29 , his verbis. Inter præcipua vero miracula eft, qui vocatur Nautilos, ab aliis Pompilos, fupinus in fumma xquorum pervenit, ita fe paulatim fubrigens, ut emiffa omni per fiftulam aqua,velut exoneratus fentina, facile naviget, poftea prima duo brachia reflectens, membranam inter illa miræ tenuitatis extendit, qua velificante in aura, cxteris fubremigans brachiis, media cauda, ut gubernaculo, fe regit. Hactenus Plinius; qua verba tam naturaliter hujus Nautili formam exprimunt, quam $f_{1}$ ipfe in eo habitaffet. Ac paulo poft. Ita vadit alto, liburnicarum ludens imagine, \& fi quid pavoris interveniat, haufta fe mergens aqua. Hxc quia ipfe frepius vidi, \& cum damno meo expertus fum, veriffima effe novi : nam dum talem pifciculum in mari captum imprudentius manibus meis contrectaffem, tantus 


\section{$N$ A Y I L Y S, \& SE I A}

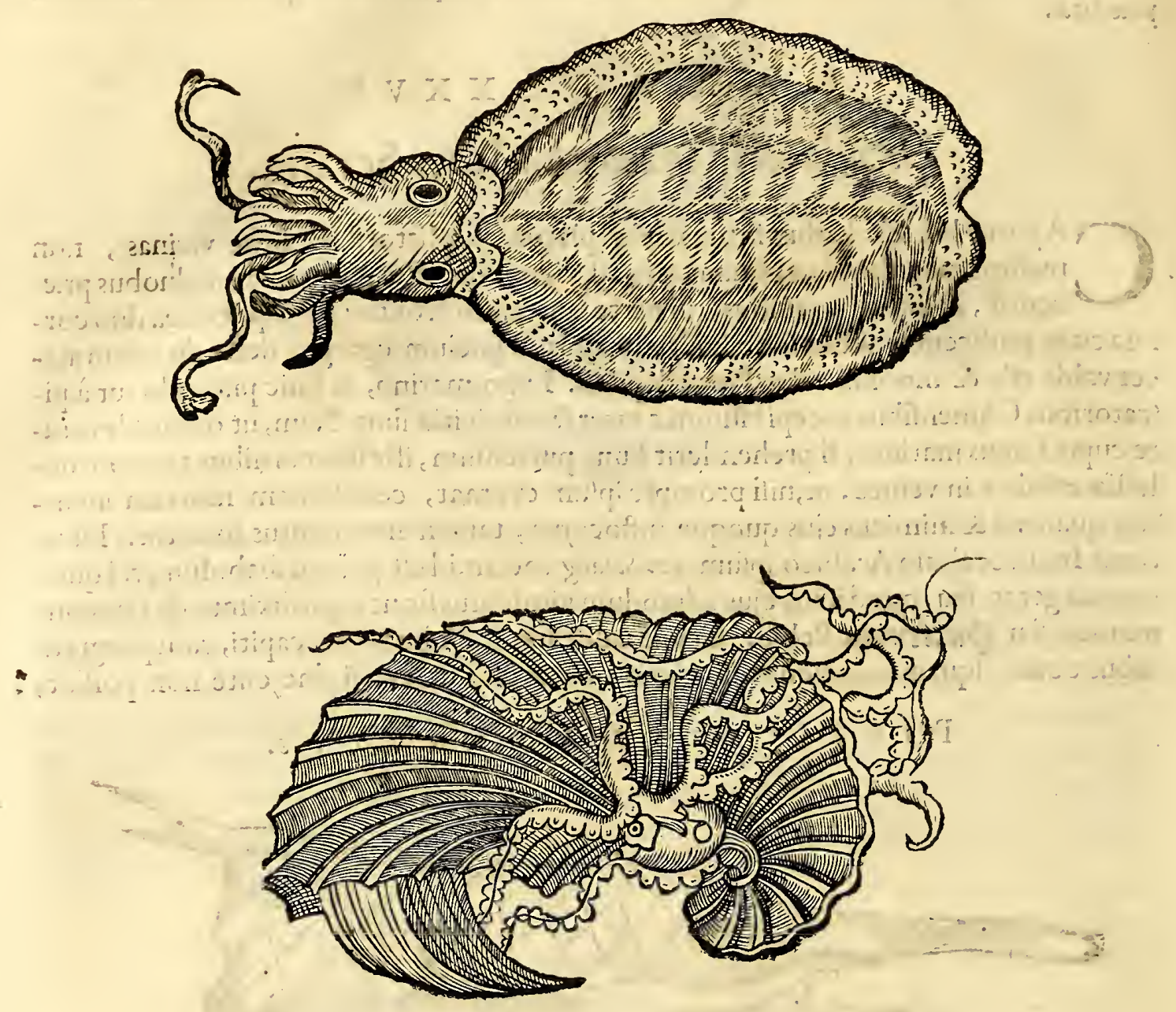

ardor manum invafie, tanquam fiaqua ferventi fuffufa effet, $\&$, nifi appofito ftatim als lio contufo cum aqua mihi ipfe fubveniffem, procul dubio præe dolore in febrim incidiffem: unde ego ipfim pifcem de Holothuriorum effe genere contenderim, ut qure omnia in mari fluctuantia; tam acrem calorem attrectantibus inurunt, quod \& fallacifimi omnium morralium Chinenfes noverunt, qui illa Oryzæmifcent, ut liquorem fuum deftillatitiun (quem. Arac nos hic vocamus) tanto calidius reddant, perniciofo invento, quod hinc miferi noftri focii navales, fanguinis Sputum, Phthifin, Marafmum denique, \& ipfam tandem mortem incurrant.

Sepiam hic appingi etiam curavi, ut videatis, quid de eo nofter Plinius dicar lib. fupra citato, \& cap. eodem, de Loligine, \& Sepia loquens. Ambo autem, ubi fenfere fe apprehendi, effufo atramento, quod pro fanguine his eft, infufcata aqua abfconduntur. Quod adeo in me ipfo expertus fum; Dum enim Sepiam curiofius contemplarer, effufo illo Pliniano atramento fuo totam faciem mihi infufcavit, non fine rifu aftantium.

\section{A P V T X X VIII.}

De Muftela, of aliis quibufdam pifcibus lacufribus, fone fquamis.

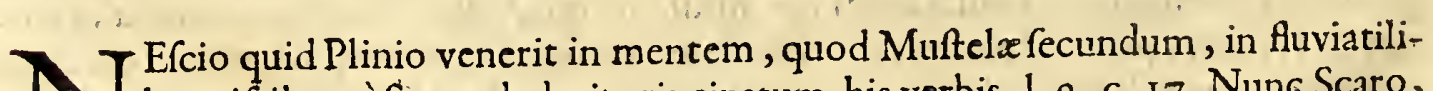
$\mathrm{N}$ bus pircibus, à Scaro dederit principatum, his verbis, 1. 9, c. 17, Nunc Scaro, datur principatus, qui folus pifcium dicitur ruminare, herbifque vefci, non aliis pifcibus. Ec paulo poft. Proxima eft his menfa, generi duntaxat Muftelarum. Er quxe lequtintur, dum ipfas diftinguit in fluviatiles, \& marinas. Certe tanta copia hic Muftel $x$ capiuntur, ut fit è vilifimis cibis, \& ab Incolis. Sembilang nominatur. Fateor equiden, Muftelam faporc excellere inter pifes, qui in fluviis degentes, fquamis carent, 
M V S T E I A.

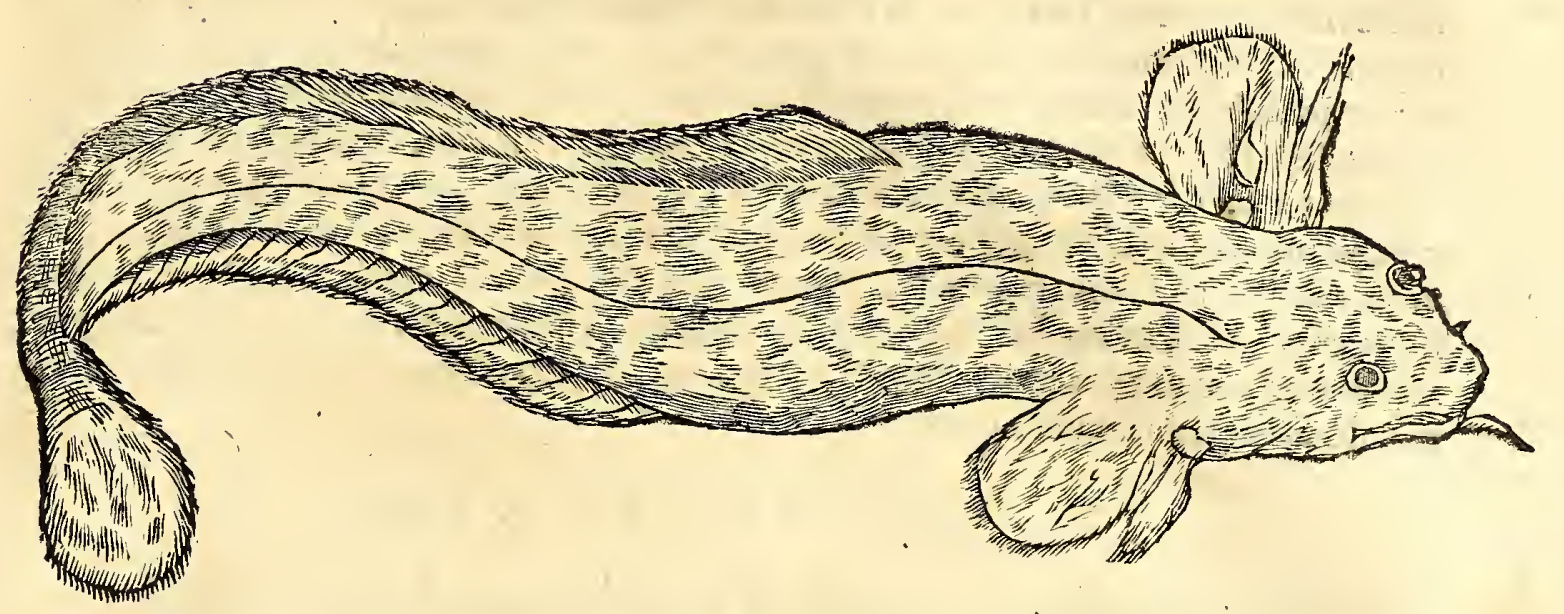

ut funt Anguillarum genera, Tincx, \& fimilis fpeciei. Cxterum maneat Plinio fua autoritas, ego certe longe praftantiores pifces me hic comediffe autumo, aut guftus me fallit. Anguillas porro, \& Muranas habemus, fluviatiles, \& marinas, qux pofteriores mihi bonitate reliquas vincere videntur; ego faltem lacuftres cum. Hydris, $\& x$ Serpentibus coire non femel vidi, quod fufficit mihi, ut abfterrcar ab iis, aliifque tales delicias relinquam.

Capitur preterea in lacubus \& ftagnis, Mugilum quædam fpecies, fquamis duriffimis, \& dentibus tam acutis, ut natantes pullos Anatum devoret, \& laceret, ac Anferibus frepe pedes mordicus demetat, vocaturque Incolis Ican Cabofch: hic tamen etiam limum fuum fapit. Mugiles denique marini (quos Belgx, fartort vocamus) hic in fumma quantitate capiuntur, \& venales in forum feruntur, quiftatis temporibus fapidiffimi funt: fed aliquando ipfos morbus invadit, ut vermes intra carnes eorum genesentur, non fecus ac Apuis in patria accidere vidi, \& tum offibus $\&$ fpinis abundant (quod noftri arigh twefen vocant), infuaves quoque funt, minufque falubres; $M u^{\prime}$ ftelx porro funt foedo afpectu, \& caput ferme Bufonis oftendunt, aft oculis grandiori. bus, corpus quoque multis luridis, \& lividis maculis interftinctum gerunt.

\section{$\begin{array}{llllllllll}C & \text { A } & \text { P } & \text { V } & \text { T } & X & X & \text { I X. }\end{array}$ \\ De Squillis Indicis.}

Quillarum hic omnis generis capiuntur, inter easillx etiam, in magna quantitate, qux in dorfo ferratx funt, quas Belgx. 5 teur-fituluheng vocant: Quam porro Squillam depictam damus, tant $\mathscr{X}$ inufitat $x$ eft magnitudinis, ut habuerim, qux fex numero, libram fexdecim unciarum penderent.. Saporis funt delicatif:

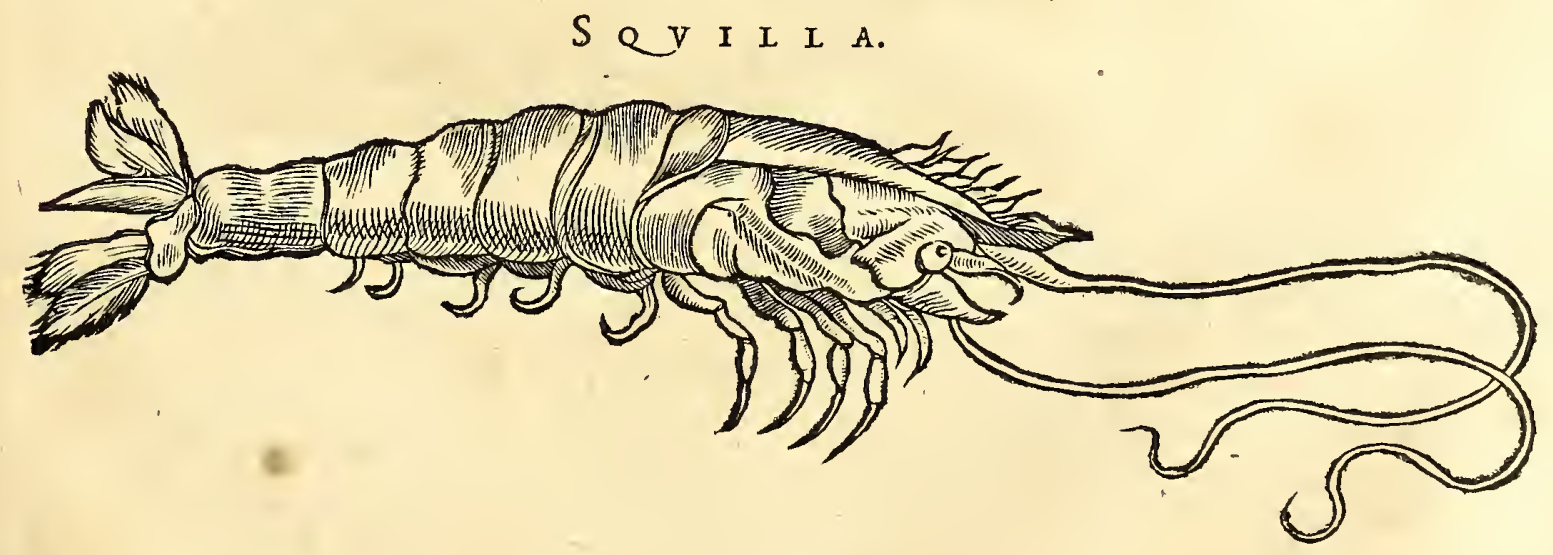

fimi , \& inter omnia Oftracoderma, faluberrimi, unde, \& phthificis, \& qui fanguinem c̀ pulmonibus fundunt, medicamenti funt loco: at tum cum pauco fale coqui debent : nam fal omne erofivum eft, \& proinde pulmonibus inimicum.

Cancri qquoque in aq̣ua dulci fluminum capiuntur,pedali magnitudine, in cavernulis 
circa ripas fluminis ab ipfis excavaris. Sapore funt praftantiores, quam marini, qui ficcior is funt carnis, Loeuftas eas Plautus in Menechmo vocavit, dum medicus interrogans Menechmum hoc modo, folentne tibi unquam oculi duri fieri? ille feftiviffme refpondet. Quid tu me Locuftam effe cenfes, homo ignaviffime? nam Cancrorum oculos lapideos clle, notius eft, quam ut ego hoc prædicem, \& quantam utilitatem adferant affectibus Renum, \& Vefic $x$, tum Gonorrhœx, è concubitu Vener eo ortæ, fi mifceatur pulveri Therebinchina Venetx, coctx, melius apud Practicos dicetur. Vnde vero illud proverbium natum fit, Squillas à fepulcro vellas, ego certeignoro, nifijam invenerim, dum in hac Infula circa mare fuctuans Cadaver Iavani occifi contcmplor, id plenifimum magnis hujufcemodi Squillis inveni : fed taceo, ne delicatioribus ven-triculis facile naufeam concitem.

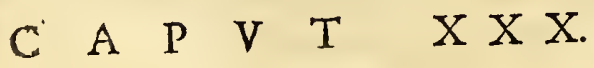

De Teftudine Squamata, Tamach, aliis Larii, dicta.

Quid monfri boc? Pifcis vel num fera terrea dicar, Amphibium. terris, quod aquis os pafcar in udis, Quum Squamas gero, tum duras in tergore fetas, Inque excavatis prope ripas dormio cunis? Sic ev adulator tumida dum vivit in aula, In cunctas facies vertit $\int e$ : Principis ora Et vultum fequitur, jurans in verba, neganfque, Rurfus ea, ut Spectat mutari à Rege colorem.

Nter varias, \& miras, tam terreftrium, quam aquatilium, Teftudinum formas; nullam ego huic affimilem, neque depictam, neque vivam vidi, preter duas, quarum una mihi dono data, aliquamdiu in aqua vixit. Capite eft exiguo Serpentis inftar, oculis parvis, \& in omnem partem mobilibus, dentibus acutiffimis,

TES T V D O S Q Y A is A T A, Tamach D I C T A.

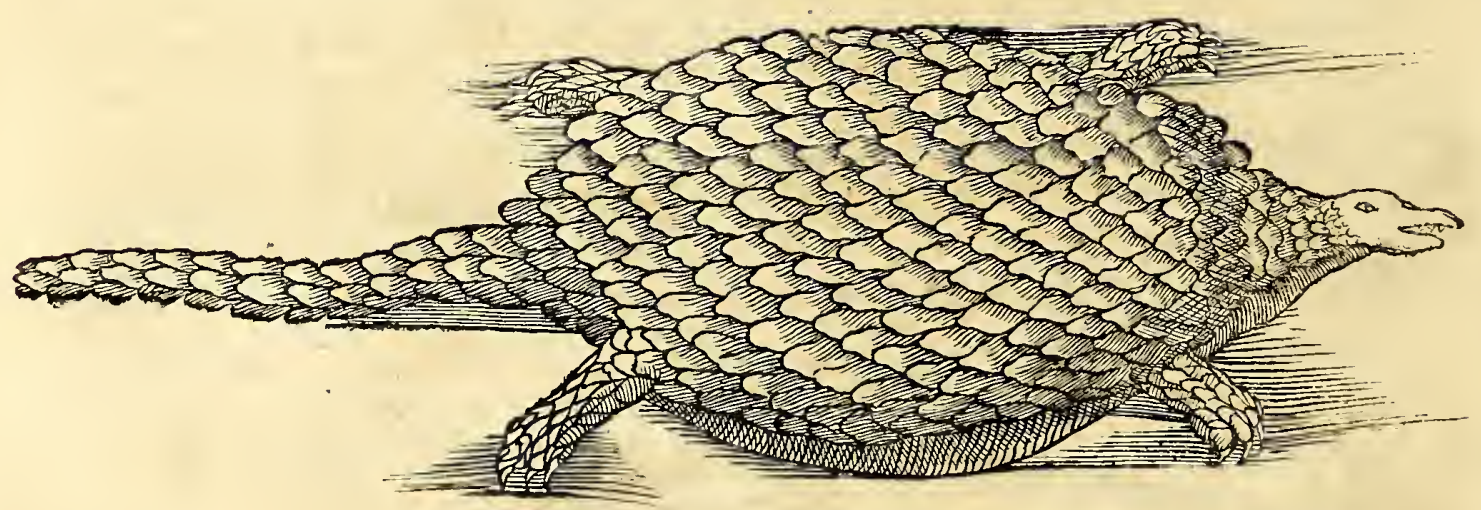

quibus pifciculos venatur, \& lacerat. Squamis fuperne per univerfum corporis proceflus textus eft, quamvis Carpionis, jeu Cyprini fimilibus, nifi quod cratliores fint. Cauda eft longa', item fquamis obfita, ventre levi , \& mollict, \& ictibus per. Hujus fquamas Chinenfes medici in fumma tenent exiftimatione in Cholericis affcetibus, Dyfenteria, \& Cholera ; Exficcatis cnim fquamis, \& tritis in pulverem, uruntur, $\mathrm{B}$ pondus, in vino fuo adufto, vel aqua Oryz $x$, quam Candgic vocari alibi for Colicos, atque alios extremos dolores, vim narcoticam obtinere, diximus. Adverfus Colicos, atque alios extres do fua frigidum, fomno lentum, \& cxperimento comperi ; \& non mirum, anmal natura fla frgeptimi faporis, ut mihi retardigradum, tales effectus à fe edere. Edulis ch acar, naturali inclinatione abhorreo tulerunt, qui de ca comederunt. Ego, ut ver for à cibisiftis, quxà Teftudinibus, Scrpentibus, Lacertis Le tuntur, indemalo iis carere, quam imaginatione in Naufeam, \& Choleram incidere, 
HIST. NATVRAL. \& MEDIC. LIB. V.

quod mihi contigit, dum, in menfa Dn. Generalis I.P. Coenen de, Crocodilo comediffem, cujus faporem cum reliqui laudarent, ego ex illius guftu tanto horrore correptus fum, \& domum reverfus in tam atrocem (perimaginationem) Choleram incidi, ut vitæ periculum incurrerim, cum tamen primis labris tantum guftaflem. Iavani hoc Monftum merito Taunab vocant, quod idem eft, ac fi dicasfoflorem terr $x$, quia circa fluminum ripas cavernas in terra excavat, ubilateat: efque Animal amphibium. Chinenfes Lary appellant, quod curforem fignificat, per antiphralin proculdubio, cum ne Teftudo quidem tardius incedat, quam hoc animal.

Cxterum, ut hoc obiter addam, Teftudines fluviatiles alit Iava, longe marinis minores, pifcinarum depaftrices, adeo roftrata oris capfide fine dentibus, ut facillime alicui incauto digitum amputent.

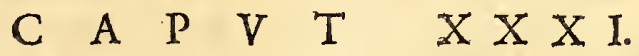

DeCancris, Afacis, Oftreis, \& Oftracodermis reliquis, in India.

\author{
2uifquis caudati fenfffti tela Paguri, \\ Difce meo exemplo morfus vitare dolofos: \\ Dente leonino, quos aula volubilis infert \\ A tergo, or pejus retinet fors cauda venenum.
}

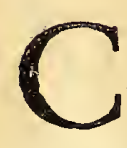

Ancrum, quem tibi depictum hic damus, coloris eft viridis dilutioris, fcuto levi fupra dorfum \& orbiculari, caudam prælongam fert, atque in fine,fpiculi inftar, acutam, qua fi quem imprudentem pifcátorem laferit, ei non minorem, quañ Scorpius dolorem infert. Caro ejusnon tam delicata eft, quam reliquorum Cancrorum, qui varii, \& in magno funt numero.

Aftacos quoque fluviatiles fimul, \& marinos habemus, faporis optimi: fed quod mirere, plenilunio hic omnia Oftracoderma funt inania, decrefcente vero $\mathrm{Lu}$ na, implentur contratio modo, quans quo in Patria.

Oftrea quoque familiaria duorum generum; alterum quod in rupibus affigitur, quod \& delicatius eft; aliud vero, quod in virgultis pendens capitur, refluente nimirum mari , fylvas, \& fruticeta nuda relinquente. Sed hrc $C A N C R$ I.

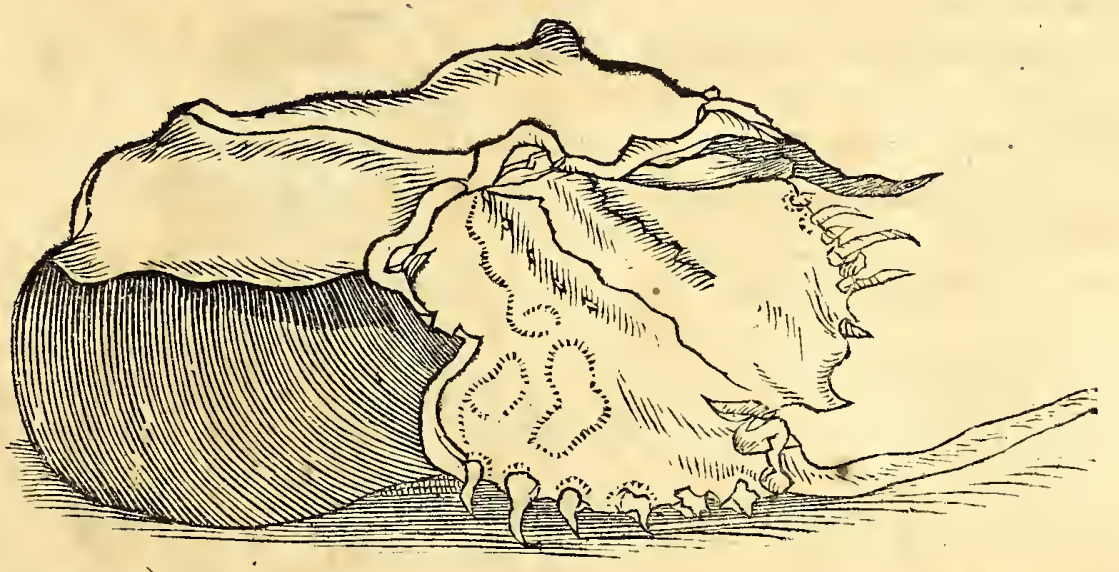

Oftrea ego non probem, quod littora \& fundus fint limofa. Prxterea foedi funt faporis? 
84

I A C O B I B O N T I I

faporis, limum, $\&$ fundum, referunt, quo etiam velcuntur : Sed quamvis figura, hæc Oftrea inter fe non differant, tamen ego guftu facillime differentiam diftinxerim, ita ut de nobis hinc non infulfe aliquis dicar, quod Iuvenalis, Satyricorum Princeps, Satyra quarta ait de Montano. Qui

Lucrinum ad/axum, Rutupinove edita fundo, oftrea callebat primo deprendere morfu: Etfemel appecti littus dicebat Echini.

De Conchis, Turbinibus, \& cxteris Oftracodermis aliquid libens dixerim, nifi ill $x$ per myriades, apud curiofos phanaticos in patria confpicerentur.

\section{$\begin{array}{llllllllllll}C & A & P & V & T & X & X & X & I & \text { I: }\end{array}$}

\section{Ourang Outang five Homo filveftris.}

Hircipedes Satyros, Sphingas, Faunofque petulcos, Nec pueri credunt: tamen boc mirabile Monfrum Humana jpecta facie, tum moribus illi Afjimile in gemitu, tum fletibus ora rigando.

$\mathrm{P}$ Linius, ille Naturæ Genius, lib.7, cap.2, de Satyris dixit: Sunt \& Satyri, fubfolanis in Indiis locis \& montibus perniciflimum animal; tum quadrupedes, tum $\&$ recte currentes humana fpecie \& effigie, propter velocitatem nonnifi fenes aut æagri capiuntur.
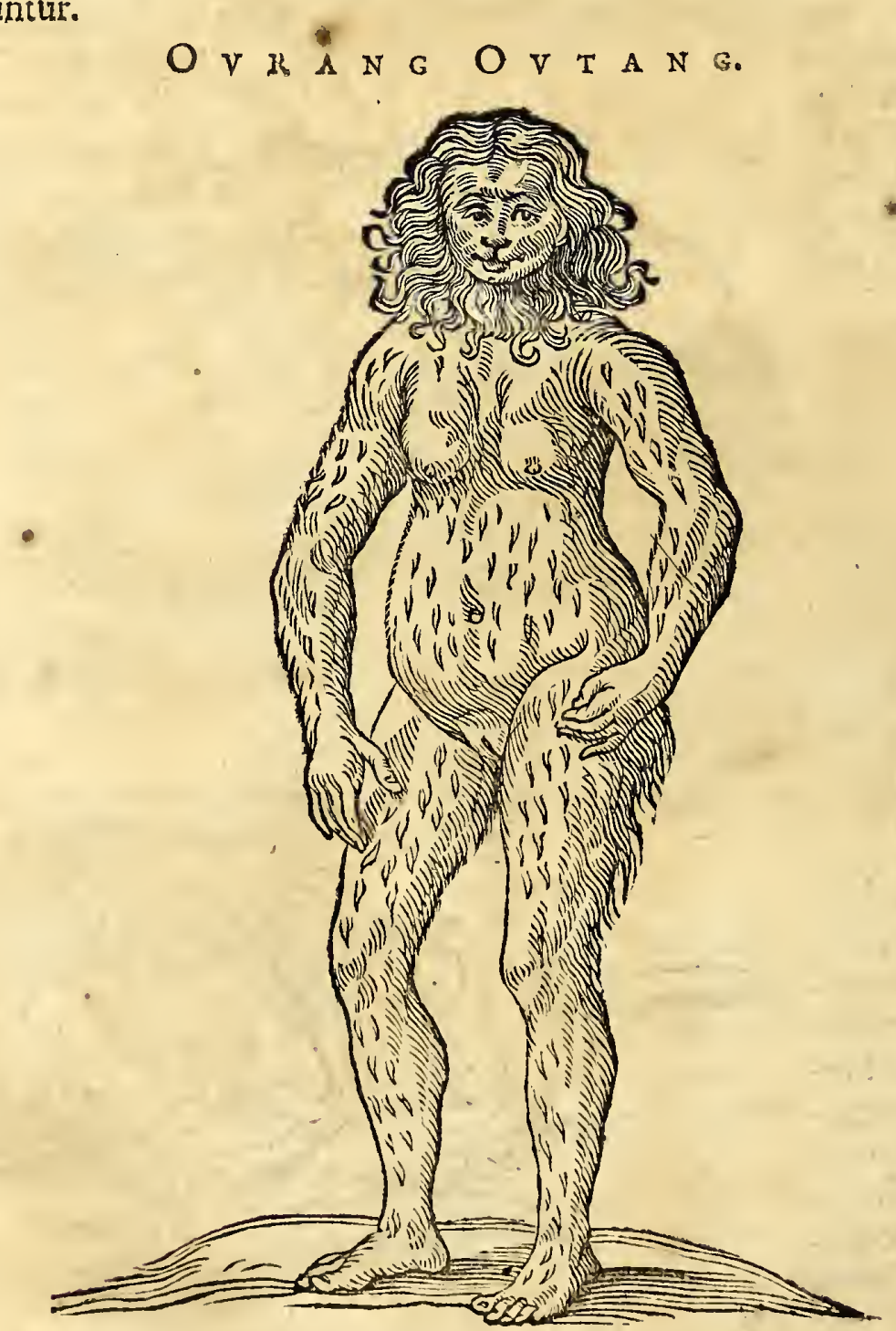

Aft quod majorcin meretur admilationem, vidi ego aliquot utriufque fexus efecte 
HIST. NATVRAL. \& MEDIC. L I B. V. 8 incedentes,imprimis eam (cujus effigiem hic exhibeo) Satyram fomellam tanta, verecundia $\mathrm{ab}$ ignotis fibi hominibus occulentem, tum quoque faciem manibus (liceat ita dicere) tegentem, ubertimque lacrymantem, gemitus cientem, \& cxteros humanos actus exprimentem, ut nihil ei humani deeffe diceres preter loquelam. Loqui ve ro eos eafque poffe, Iavani aiunt, fed non velle, ne ad labores cogerentur : ridicule me hercules. Nomen ei indunt Ourang outang, quod hominem filv $x$ fignificat, eofque nafci affirmant è libidine mulierum Indarum, qux fe Simiis \& Cercopithecis deteftanda libidine mifcent.

Nec pueri creduni, wifi gai nondum are lavantur.

Porro in Infula Borneo, in Regno Succodana dicto, à noftris Mercatoribus proprer Oryzam \& Adamantes frequentato, homines montani caudati in interioribus $R$ egni inveniuntur, quos multi è noftris in aula Regis Succodanæ viderunt. Cauda autem illis eft prominentia quxdam oflis Coccygos, ad quatuor, aut paulo amplius, digitos ex-m crefcens, codem modo, quo truncata cauda Canum, (quos nos Spligiones vocamus) fed depilis.

Simias denique, Cercopithecos , Bavianos plurimos Sylvæ lavanorum alunt.

$$
\text { C A P V T X X X I I I \& Vltimum. }
$$

\section{In quo Nature quadam opera miraculofa pofteris Iatrofopbis ulterius indaganda proponuntur.}

$\mathrm{O}$

Stracoderma, ut Oftea, Purpura, Turbines, \& qux funt fragilioris teftr, Cancri, Paguri, Aftaci, Locuftx, Squillæ denique, hic Novilunio plena funt fucco; codem, Plenilunio, deftituuntur.

Quidnam dicemus de Etneis cavernis \& montibus ignivomis in Iava \& Banda, quæ ingentes lapides, quos ne viginti quidem homines loco movere poffent, aliquando ex imis faucibus eructantes, non fecus ac tela, extra confpectum in aëra mittunt? Cujus noftri hic plures oculati teftes exftant.

Sileat Bitumen \& Afphaltum fuum Lacus Palæftinus; cum \& Sumatra Naphtham ferat, qux in mediis fluctibus flammam alat, quod cum maximo fuo damno, noftris infpectantibus, Lufitani cum duabus navibus, Galeonibus diatis, combufti fenfere, cum prolpero vento $\& x$ ftu eam in mare effundentes accenfam in hoftium naves conarentur avertere.

In Iaponia arbor Palm xigura crefcit, qux fi à pluviis permaduerit, tanquam pefte correpta ftatim exarefcit, quam mox curn radicibus avulfam in locum apricum ficcandam exponunt indigen $x, \&$ tum in eandem frobem injecta prius arena fervida, aur fcoria ferri, replantant, $\&$ fi qui rami exficcati, vel avulfi fint vel decidẹre, eos clavis ferreis trunco affigunt, \& fic priftino virori reftitu itur.

Potulenti liquores ex arboribus ejufque fructibus depromuntur, non fecus ac vinum, inebriantes. Hi potus ex diverfis arboribus eliciti Zagueer \& Towac vocantur.

Quod autem in Iaponia narrabo fieri, miracula ipfa fuperat. In doloribus capitis antiquis, in obftructionibus Hepatis, \& Lienis, in Pleuritide quoque, perterebrant ftylo argenteo, aut è chalybe confecto, non multo craffiori, quam cythararum chordx efre folent, tranfadigendo paulatim \& lente prxdicta vifccra, ut altera parte ftylus exeat, quod $\&$ in Iava fieri vidi.

Sed jam tacebo ; fi de Regis Macaflarenfis in Infula Celebes veneno, quo jacula fua parva per tubulos miffilia inficit, dixero, quod tantæ pernicitatis eft, ut celerius mortem inferat, quam fi ferro urgeretur : nam aliquis vel leviter lafus ad fimplicem fanguinis miffionem vel in extrema calce, ftatim nutabundus, tanquam ebrius, mortuus in terram concidit : fed $\&$ carnes intra dimidix hor $x$ fpatium à feptico hoc veneno, ita computrefcent, ut tanquam mücus à fubjectis offibus manibus avelli queant: Et quod mirere magis, fit, ex. grat. aliquis in femore vel altius lafus fuperficialiter à telo alio veneno non intincto, \& fanguis etiamnum calidus in fubjectos pedes defluens tangatur fimpliciter hife venenatis fagittulis, ocyor Euro aura peftilens vulnus: yerfus afcendet, eademque celeritate \& modo hominem è vivis rapiet: Hxc non funt 
86 IACOBI BONTII HIST. NATVR. \& MEDIC. LIB. V. nugx; fed oculata experientia, non folum à Noftris, fed \&Danis, \& Anglis, ufurpara.

Sacerdotes Bandanes inediam facile, ex fimplicivoto, viginti $\&$ amplius dierum ferunt.

In Malacca, \& Continentis quibufdam Indixlocis, crefcit herbula, qux femen fert inftar Hordei; fed nigrius \& hirfutius; cujus fucco fi folummodo dentes imbuantur, filicem in pollinem redigere valent.

Semen quoque aliud parvum inibi nafcitur, adeo effieax promovendo partui , ut, fi diutius quam par eft, ore contineatur, ipfum uterum præcipitet.

Nux Myriftica, \& Macis, in Infulis Bandx tantum proveniunt, cæteris terris negata.

Lapis Pa-fahar, vulgo Bezoar, concrefcit in Perfia exfolo efu herbx, Colchici, vel Crocifloremgerentis.

Quid Laccam elaborantes Formicas loquar, quarum operas fi noviffet Plinius, non tantus in folis Apibus laudandis fuifet ?

Adde, Mofcum hic $" 2 x$ in China fieri ex putrefactis carnibus beftiarum, Muris Pontici forma, \& odoratifimum Zibethumè vomica penes nates Vulpis Indicx erui.

\section{FI $\mathcal{X} I S \quad L I B R I$ QVINTI.}

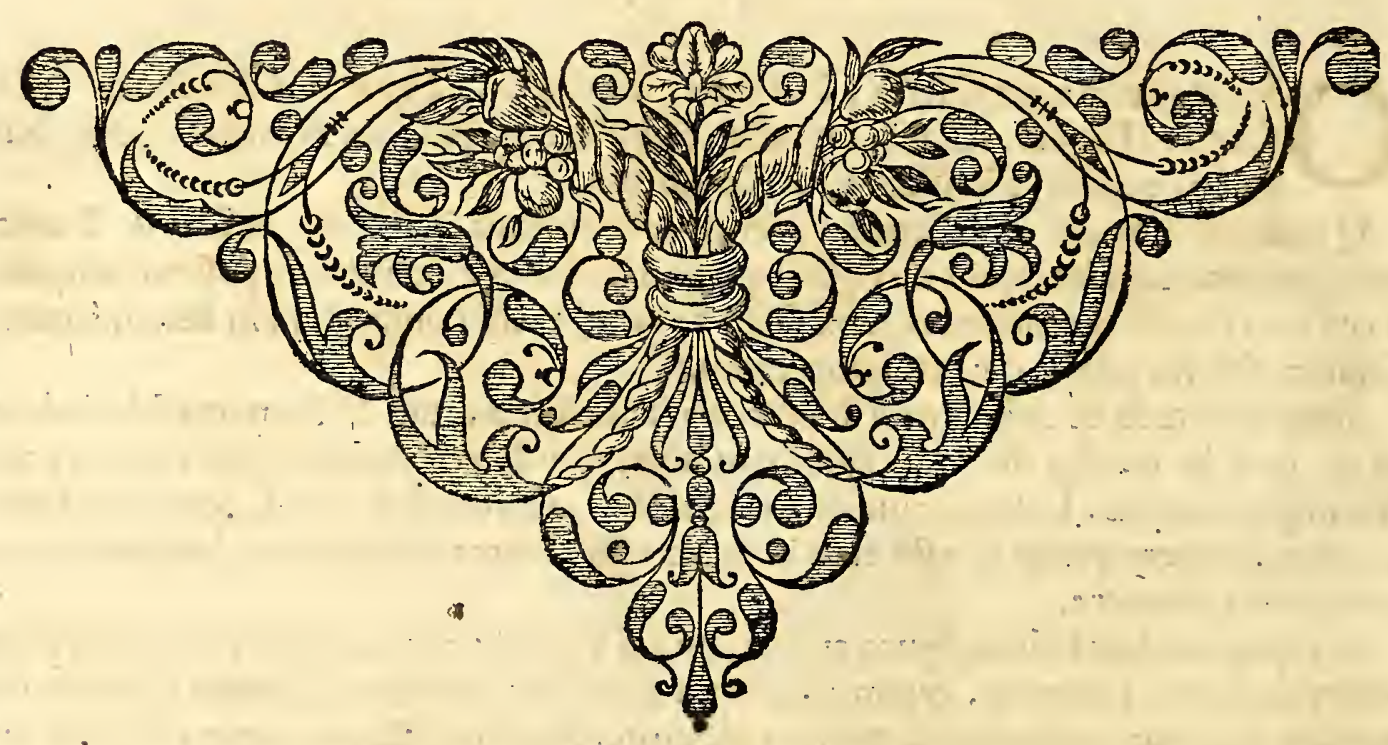

I A C O. 


\title{
I A COBI BONTII
}

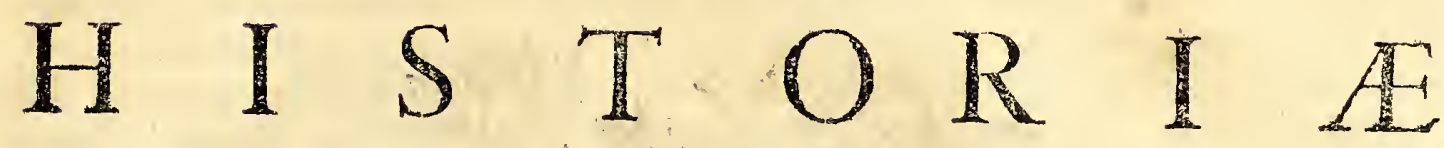

\section{NATVRALIS \& MEDICE.}

\author{
$L I B E R \quad S E X T V S$.
}

De Plantis, \& Aromatibus.

$$
\begin{array}{lllllll}
C & A & P & V & T & 1
\end{array}
$$

\section{De Herba, feu Frutice, quem Cbinenles The dicunt, unde potum funm ejufdem nominis conficiunt.}

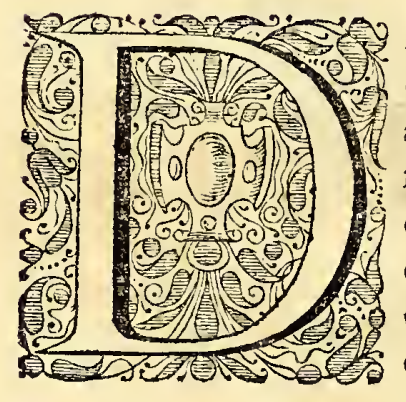

E hoc frutice hactenus eloqui erubui, cum Chinenfes id tan. quam arcanum fibi refervent, $\& r$ li quis cos interroget, unde adferatur, \& ubi nafcatur, variant omnino, neque quicquam ftabile adferent, nam modo dicent, herbam effe, modo fruticem; ita ut nil firmum inde concludere hactenus valuerim, cum tandem generofus nofter D. Generalis Iacobus Spex, eam difputarionem, \& fcrupulum mihi partim ademit. Qui haud dubie fruticem effe pronunciavir, nam nobiliffimus Dominus dum ante aliquot annos in Iaponia Legatus, \& Gubernator effet ibi, frepiffime crefcentem conficatus eft. Viridia folia mihi nunquam hic videre contigit. Sed dum arefacta in aqua tepida difolverem, inveni ea omnino fimilia effe foliis Confolid $x$, fed incifa funt in circumferentia, $\&$ dentata. Porro hanc herbulam cum aqua Chinæ decoquunt, \& calidum decoctum dein forbent, fanitatis confervandx gratia, quod decoctum fapore eft verfus amarum vergenti, unde $\&$ faccharum ditiores indunt. Porro de hoc potu tantas laudes celebrant Chinx, tanquam ifta The facra effer herba, \& omnibus languoribus, morbifque accommodatum folatium. Et certe, ut verum, fatear, fanitati procul dubio conducere dicendum eft, \& piruitæcraflæè pectore avellendæx non infima eft medicina; ficcitate namque praftar, \& calore, quod amaritudo cjus fatis indicat, Phthificis, quoque hic potus prodeft, \& Orthopnoicis, tum vefica, \& calculo renum accommodatum effe remedium extra controverfiam eft, cum fit fumme diureticum. Creterum non minoribus à Chinis laudibus effertur hic potus, quam Mahometanorum Cave, quod potus genus etiam apud ipfos fervidum forbetur in eofdem, quos diximus ufus. Hactenus Bontius.

A N N O T A T I O. Non abfonmm exiftimavi, fi circa figuram differentias \& qualitates nobilis hujus Afiaticx plantæa, huc quædam notatu digna adduxero, ex relatu eorum qui per integros campos in China \& laponia cam ftudiøfe coluerunt. Quo, cum hatld multi penetrarmnt Europæi, ut neque nofter Bontius, \& proinde viventis plantx ejufque Iconis fe compotes fieri nequiffe conquefti fint, ego tandem defectum illum. favore D. Caron, olim in Iaponia Præfecti meritiflimi, fupplevi; ipfo nobis inufitatam. foliorum difcrepantiam fuppeditante, piatori quo ad magnitudinem \& figuram, mihi quo ad vires \& pretium. Qux plcraque cum hactenus neglecta, non mirum eft, multos etiam nunc in illo errore verfari, quafi diverfa fpeciei plantæe effent The \& Ifia: cum è contra eadem fit, cujus decoctum Chinenfibus The, Iaponenfibus Tfia nomen audiat ; licet horum Tfia ob majorem foliorm contritionem \& coctionem, nigrum The appelletur. Vnde fit, ut Iaponenfium $\mathcal{T}$ fia gratioris utique fit faporis, majorifque efficacix, ac altioris quoque pretii.

Omnis itaque $T$ he, five $T$ fla, nullibi terrarum, quantum quidem conftat, nif in Ia-

$$
\mathrm{H}_{2} \text { ponix, }
$$


F R V T E X T H E.

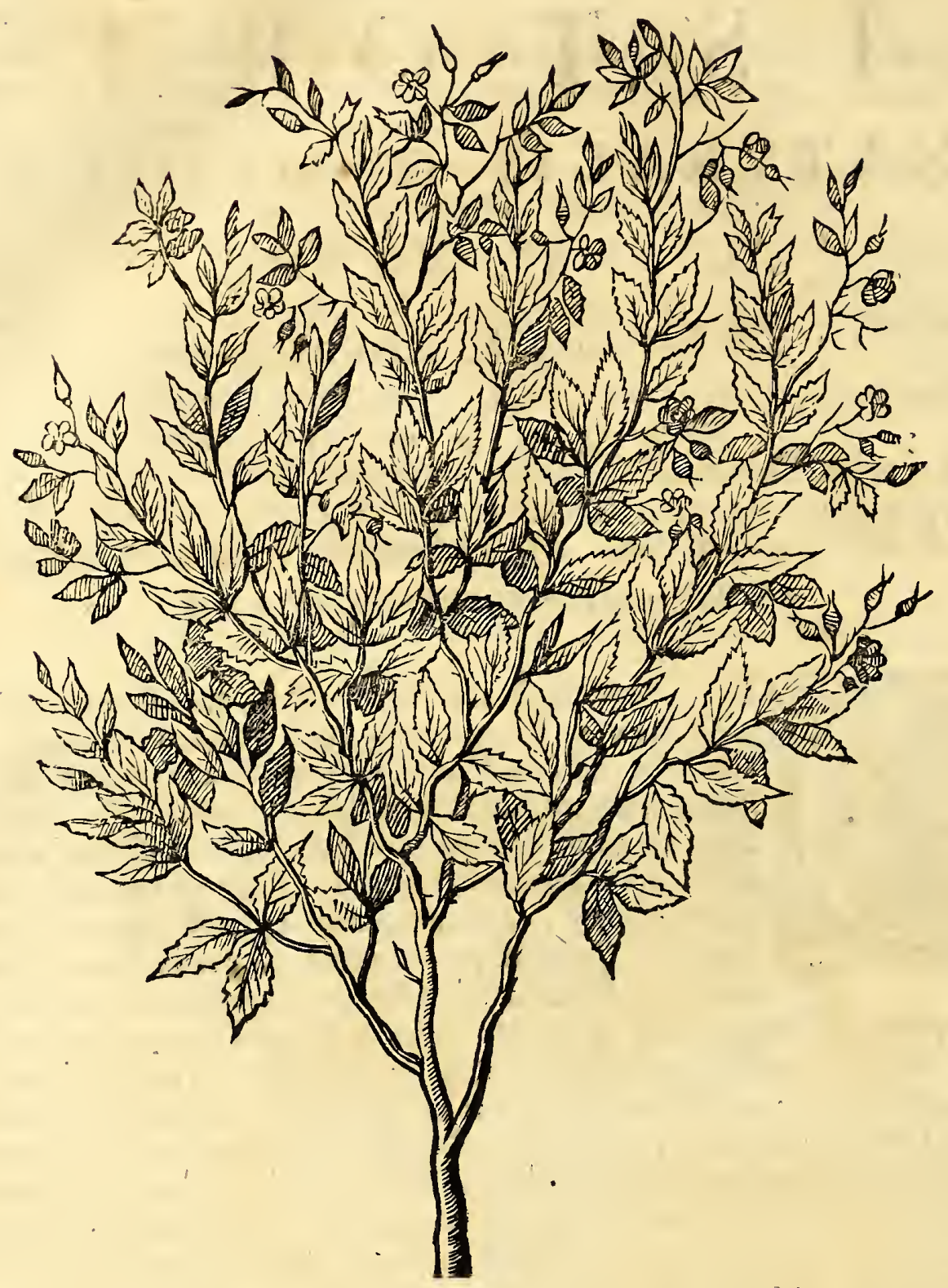

ponix, Chinæ, \& Chiam, campis colitur, exfurgitque ad Ribefiorum vel Rofre Europæa molem $\&$ altitudinem. Caules $\&$ ramunculi totius fruticis à pede ufque ad verticem, perpetuis $\&$ infinitis floribus $\&$ foliis tenuibus, acuminatis, in ambitu crenatis, ornace veftiuntur. Qux ejufdem licet form $x$, diverf $x$ adeo funt magnitudinis, ut quinque differ entix foliorum uni eidemque frutici adnatæ appareant. Prima $\&$ maxima in inferioribus ranufculis, Balfami hortenfis foliis fimillima exifunt. His fuccedunt ea,qux fecund $x$ magnitudinis \& prioribus multo minora funt, ut fic gradatim afcendentia quinquies manifefte differant. Verum quantum hxc folia furfum magnitudine decr efcunt, tantum pretio accrefcunt : quippe primæ magnitudinis exficcatarum $\&$ pr $x-$ paratarum libra valet quinque affes; fecund $x$, quinquaginta; tertix vero, quinque florenos; quart $x$, quindecim : quint $\&$ ultim $x$ magnitudinis, quinquaginta, imo fubinde centum $\&$ quinquaginta florenos valet, fi rite prxparata fuerit. Iaponenfes folia hixc in pulverem ( quo viridiorem co prxftantiorem) redacta, ferventis aqux cyatho immifcent, quantum duobus cochlearibus continetur, eamque potionem ita permixtam potant. Sinæ vero in aqua ferventis vafculum aliquot ejufmodi folia injiciunt, inde calida, pofteaquam corum vim imbibit, epotatur, ipfa vero folia relinquuntur.

Flores porro fert $T$ he albicantes, magnitudine, figura, colorc, Rofx filveftri Europxx, qux Eglanticr vocatur, excepto odore, fimillimos. Quorum foliolis decidentibus, umbilicus manet, ubi femen horum fruticum rotundum \& nigrum continetur Rofarum inftar, quod terrx commiflum novas producit plantas triennii fatio, ex quo- 
rum foliis meffis luculenta illis annuatim redit, etiam is Iaponix locis, tibi gelu \& nir: vigent æque ac in Hollandia. Ita ut fperandum fir, fi femen capfulis inclufum, \& contra, aëris injurias munitum, huc deferatur, ibidemque umbrofis $\&$ fertifioribus terræ locis commendetur, feliciter quoque educatum iri poffe. Radices funt fibrof $x, \&$ in minimas particulas difperfa circa terræ fuperficiem, nullius hactenus ufus habitæ. Ita ut fola hujus decantat $x$ fruticis praftantia in frondibus exiftat, qux Vere Iaponenfi lect $x$, $\&$ in umbra exficcatæ, ad quotidianas decoctiones refervantur. Quas quidem potiones pretiofiflimis culinaribus inftrumentis ab ipfis Magnatibus, diverfis modis religiofe preparatas, intimis tantum amicis, veluti exquifitum quid noctes atque dies propinant: Eafque non frigidas, fed calidas tantum, prodefle, ratum habent, more veterum, qui frigidam calidx poftponebant. Si vero quibufdam ob amaritudinem infuavior videacur, tantillum facchari addunt, eamque fumma cum voluptate \& levamine for bent fani ad arcendum fomnum; $\&$ imprimis $x$ gri, quibus poft largiora convivia caput $\&$ ventriculus oppletus fuit.

Sed, ne in alieno opere prolixior fram, onittam ea, qux de ufu $\&$ deliciis hujus celeberrimæ potionis Autores probatæ fidei fcripferunt, ut funt Petrus Maffæus lib. vi , Ejuld. lib. x 11, Ludovicus Almeida in codem opere 1. 4 , fel. epift. Petrus Farricius'foc. Ief. Tom. 11, Rer. Ind. Matthæus Ricius, de Expeditione Chriftiana apud Sinas. Aloifus Frois, in relatione Iaponica, \& alii. Quorum omnium Compendium D. Tulpius noftr $x$ Reipublicx Medicx Coryphæus, in calce obfervationum fuarum fuccincte tradidit. Cum enim hic pōtus indies celebrior fiat, etiam apud Europx Magnates, omnes fatentur uno ore ipfis bene effe ex ejus ufu, unde fit ut magna copia \& magno pretio ipfa folia exficcata $\&$ in capfulis piumbeis recondita, undiquaque nunc diffrahantur : Verum fi earum potiones forte non $x$ que feliciter in Europæis Regionibus evincant fomnolentias confuetas; nec renum calculos, \& catarthos, aliaque fanitatis incommoda æque efficaciter arceant, ficut illi in natali folo expertum habeant; tamenille defectus non adeo ipfi herbæ; vel Afiaticorum fuperRtitioni, quam noftro præparandi \& utendi modo, ut \& corporum noftrorum difpofitioni, aliifque impedimentis, imputari poffe, facile eft dijudicare. Collatis itaque allegatorum autorum fcriptis, \& noviciorum quorundam vivo relatu, omnes inter fe convenire videntur potius circa ufum, dignitatem, \& effectus hujus potionis, quam circa vires \& qualitates. Nam quantum ad faporem foliorum The, præter amaritudi. nem, \& calorem, aromaticum quid, \& tenuitatem partium potius prædominantem, quam aftrictionem, videntur arguere. Accedit, quod infiniti mecum experti fint, ex reiterata hac potione ferum fanguinis levefque fudores moveri, urinalque fimul copiofe protrudi. Vnde ego crediderim, illud quod affert impedimentum vaporibus, fomnum ordinarium inducentibus, non adeo aftringendo fto machum, quam difcutien do flatus, attenuando fpiritus, exficcando $\&$ corroborando cerebrum, præftare; imo dolores univerfales mitigare, ut inter anodyna primatum obtinere poffit. Accedit quod omnes evidentes operationes, quas in humano corpore exerit, mex opinioni faveant, cum non folum tefte noftro Bontio, fed $\&$ omni Sinenfium, Iaponemfiumque experientia , fumme diuretica, $\&$ ficcans craffæque pituit $x$ abftergend $x$ dicata habeatur. Imo quidni præter has enarratas manifeftas qualitates, etiam antinarcotica five antiopiales (fi ita loqui liceat) proprietates illiattribui poffent; fcilicet ut The difcum tiendo, \&zfeparando vapores, atque exacuando fpiritus, ferenitatem quandam menti $\&$ corpori conciliet, blande vigilias inducat, vinculumque illud vaporum familiare paulatim diffolvat æque commode, quam Opium coagulando, obtundendo, figendo, fomnum inducere creditur.

Porro lis hæret inter Autores, an planta tam nobilis ejufque ufus fuerit antiquifimus, quia in vetuftis Sinarum voluminibus nullus ad eam fignificandam hieroglyphicus character (quales funt illorum litter $x$ ) reperitur. Noftratium aliqui Præfecti in Indiis probabilitatem indigenatus territorii Chinenfis $\&$ à multis $x$ vis agr eftem $\&$ incultam fuiffe mihi teftati funt: Sed ejus culturam, vires eximias, praparandi modos, dignitates; qux quotidie adhuc incrementum fumunt, apud illos minus obfoletas effe.

Quod fi ita fit, non male quadrat cum iis, qux de Tabaco \& Canna faccharifera perhibentur : quarum illa olim in natali folo Indix Occidentalis folummodo herba vulneraria fuit habita; Hæc vero inftar Iridis circa ripas vaga fuit \& contemta, antequam $\therefore$ is $\mathrm{H}_{3}$ dulcedo 
dulcedo ejus à Barbaris detecta, tandemque per manus tradita, atque cum labore exculta, toti Orbi ceperit effe oblectamento.

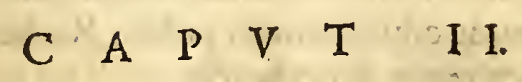

De Nuce Faufel Jen Pynang Malaiis dicto, de Sirii,

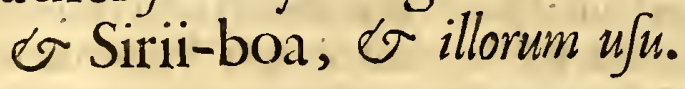

Quis foliis credat commixta calce tenellis, Cum fructu boc Indos veeci, unde ore cruento, Purpureum ejiciunt fuccum, tum dentibus atris Horrendum arringunt, of dentibus ore minantur?

$\mathrm{R}$

Es iftz; de quibus jam acturifumus, adeo familiari funt in ufu apud omnes Indix populos, ut videamur operam velle perdere, fi latius de iis agamus, tum quia Ianus Linfcotanus expertiffimus rerum Indicarum fcriptor, de iis fatis copiofe egit, quem Autorem (ut hoc obiter dicam) immerito multi fluxx fidei incufant,

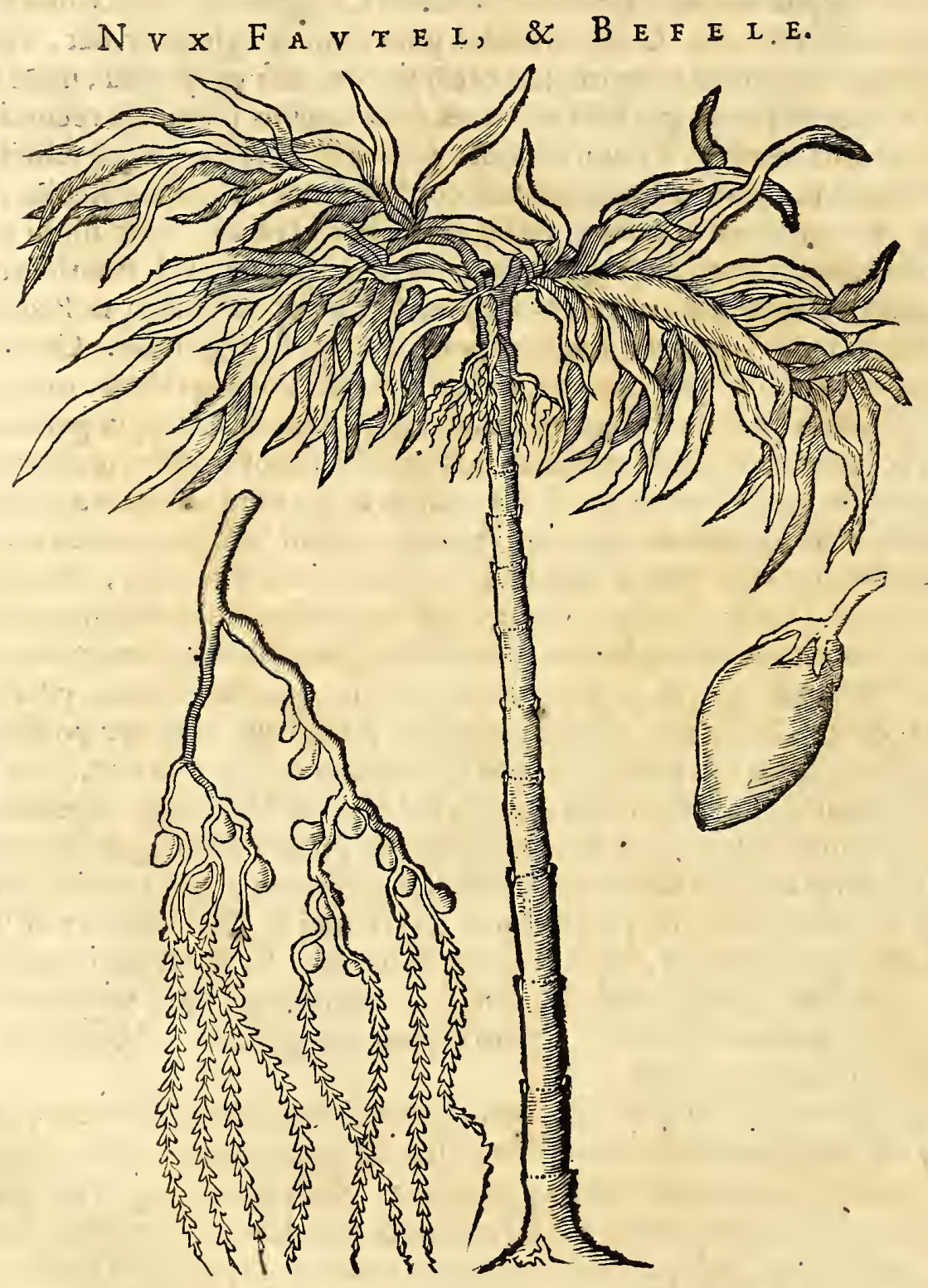

cum certe in iis, qux ipfe vifu percepit, optima fide egerit. Cxterum de meo hic illud addam, quod vel reliqui fcriptores omifere, vel non fatis luculente defcripfere: Folia, igitur ifta, quæ Malaii Sirii vocant, Iavani Betele, ubi mafticantur finè admixta calce, amara funt, \& linguam pungentia, inde addito fructu hoc Pynang dicto Iavanis, Arabi- 
HIST. NATVRAL. \& MEDIC. LIB. VI.

bus, Fanfel, cum calce è teftis oftreorum ufta mafticant Incolx. Hoc Sirii Pynang formam refert glandis quercin $x$, quamvis quadruplo fit major , antequam ad medullam, qux in medio eft, venias, veftitur multis filamentis, iifque tam lentis ut admafticando confringere poffis. Hanc nucem quadripartiuntur incolæx, fi grandiufcuIa fit, fin minus, difpartiuntur, \& fingulas partes, fingulis foliis involvunt Betele, vel sirii dictis. Folia autem hæc è Convolvulorum funt genere, nifi quod craffiora fint paulo, tum ifta folia pauca calce, ut fupra dixi, admixta, orc terunt , \& priorem quidem fuccum exfpunt, ne"calx fua acrimonia, gingivaș, palatum, \& guttur lædat, reliquum fuccum deglutiunt, qui fanguinis $\&$ minii inftar rubicundus fit ab admixta calce, nam fine ea viridis eft fuccus, unde etiam co colore dentes inficit, \& nimium fumptus atro colore imbuit, quo Indi adeo gloriantur, quam noftrates puella den. tium candore.

$\mathrm{B}_{\text {ris modo appofitos bacillos fcandit; }}^{\text {Etele }}$ Et fructum fert Piperialbo, \& oblongo fimilem, feu mavis, caudam Gliris referentem, quem Incolx Sirii-boa vocant, eftque propter raritatem in longe majori exiftimatione, quam ipfum folium Betele. Nunc fi quis fententiam me de harum rerum ufu roget, dicam libere quod fentio, id eft, me mafticationem hanclonge praferrefumigio Nicotianx, feu Tabaci; attamen fi quis fine modo (quod fape fit) his utatur, corrodunt dentes, inmo eos excidere faciunt; novi ego, hic Iuvenes, qui vigefimum quintum annum riondum exceffere, tamen plane edentulierant, ab ufu hu. jus folii frequentiori. Ideo quoque videre eft plerofque Iavanos, ut Malaios, rariores habere dentium ordines, in quorum vacuos loculos, ditiores, aureos rurfus includunt, quibus etiam non modice fuperbiunt. Praterea, fi Nux Pynang non fatis - maturuerit, tum mafticata vertiginem cerebro fubitam inducit, non fecus ac fi fumpto vino quis ebrietatem contraxerit, qux alteratio quamvis fumpto pauco fale, $\&$ hauftu aqux gelid $\dot{x}$ cvanefcat, tamen non omnino phyficarum rerum ignaris fufpecta merito effe debet, quid id fit, quod in nobiliffinam corporis partem, qualis eft cerebrum, \& mentem hominis ipfam, tam fubitam mutationem inducat. Norumque fiet indaganti caufas rerum, mafticationem hanc univerfo nervofo generi BE TEE I E.

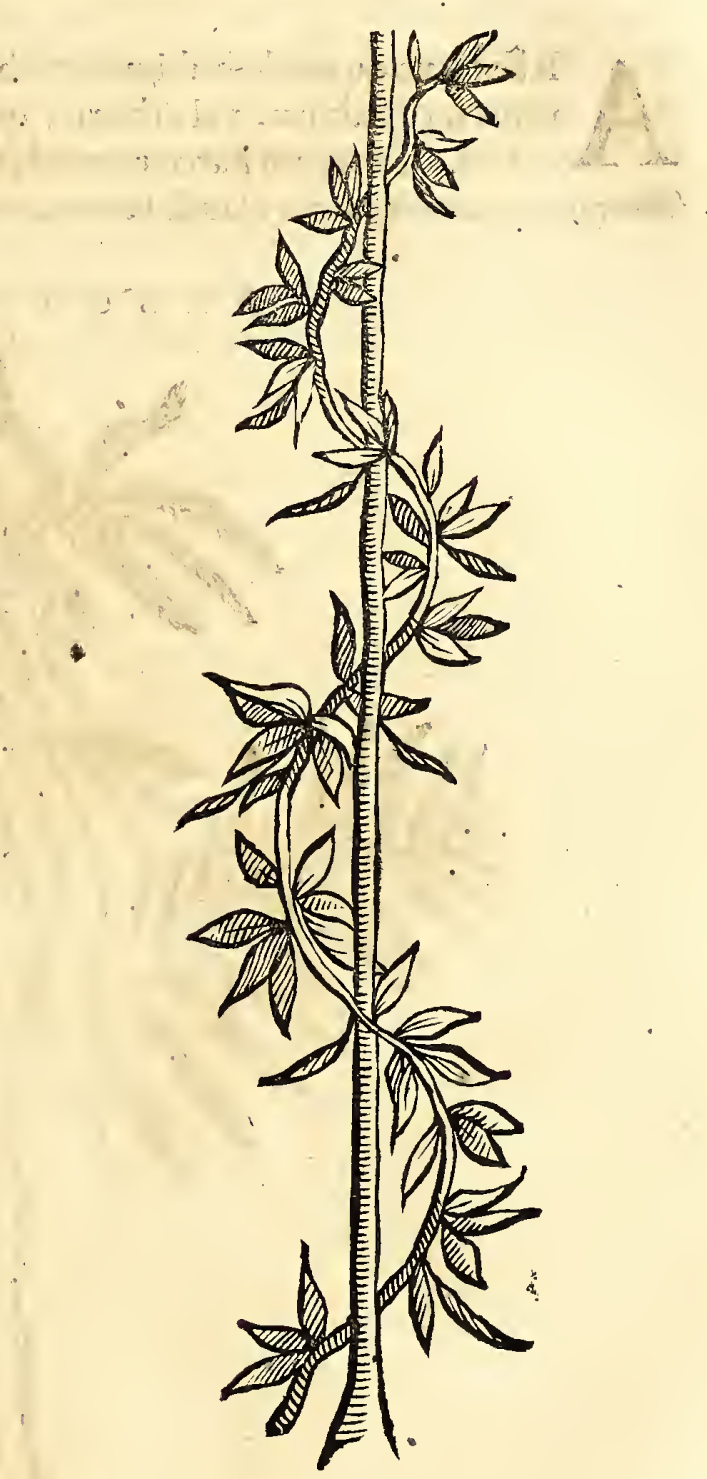
non admodum effe amicam, \& falubrem. Itaque ego pronuncio; fi quis hoc medica. mentum ad commendationem halitus oris, \& dentifricium moderate fumere velit, ine lubente, nec male fecerit. Atque hic cuin Horatio concludo, quod,

Sit modus in rebus, fint certi denique. fines, 2uos ultra, citraque nequit confiftere rectum. 


\title{
C A P V
}

Arbor Spinofa, unde Cate Jen Lycium exprimitur.

\author{
En Lycii firpem, cujus jam Plinius olim \\ Tam bene laudavit fuccum, fed notior ille eft. \\ Hifce locis bodie, lacrymaque Papaveris ipfum \\ Equiparant Indi, biliofaque tormina ventris \\ Tollit, or aúfero confringit robore dentes, \\ 2 nos nimis erofit creberrimus ufus Arecce, \\ Quam Calci mixtam Iava conterit ore cruento.
}

A

Rbor hæc quam defcribimus, creberrimis, in trunco, \& ramis, fpinis eft obfitus, foliis fere Sabinx, vel arboris, quam vocant Vitx; fed non tam pinguibus, \& craffis. Caterum Fabas rotundas fert punicei coloris, in quibus tres, aut ad 'summum quatuor, nuces claufx latent, tanta duritie, ut dentibus frangi nequeant, hifce

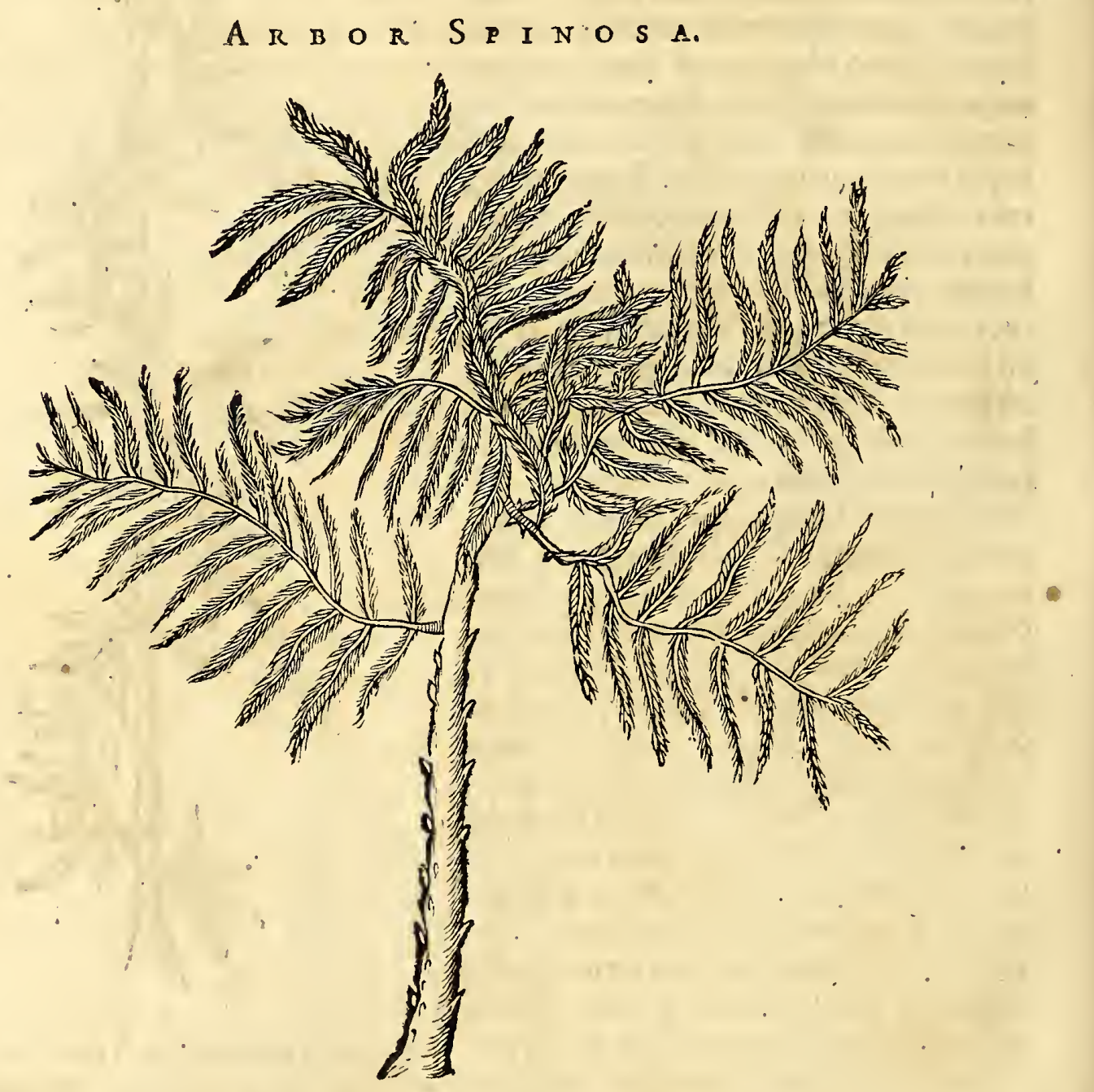

pueri apud nos loco (phæricarum lateritiarum in lufú fuo utuntur. Vfum porro ejus in medicina duplicem vobis monftrabo ; primo, ex fapore foliorum aftringente, \& \& tiptico, ficcum effe contendo, ideoque ejus fucco è foliis expreffo, ubi alia medicamenta defint, in ulceribus audacter utinon dubitavi : fed in tanta reliquarum plantarum copia, viliffima feu potius notiffima contemnuntur, ut alibi de Graminis hic nafcentis fpeciebus diximus. Secundo, longe nobilior $\&$ antiquior radicum, corticum $\&$ foliorum ufus, quem mox docebo.

Ve hoc quoque obiter dicam, plurimos etiam preter hanc habemus fpinofos frutices 
frutices non tantum: fed ingentes, \& valtas arbores, qux fpinas in ramis \& trunco ferunt dodrantales, inter quas arbor ea eft, qux Fabas rubras fert edules, Turdis jucundum pabulum, ur alibi videbimus. Tum hic Carduus \& fpinis furgit Paliurus acutis, \& fi quis in fylvis à via aberraverit, quod fxpe iis accidit, qui cum fclopetis eo occidendorum Cervorum, Aprorum, \& Vaccarum fylveftrium, gratia abeunt, illi fine laceris veftimentis in viam non redibunt, $\&$, quod pejus eft, ferociflima fape Tigris inter hæc fenticeta cum multorum exitio latet.

Sed, miffa digreffione, revertamur ad arborem, quam vobis ob oculos pono, è cujus radice non folum; fed ex cortice, \& foliis, multoties præftantiffimum excoxi Lycium. Cujus vires in Medicina fi enumerare velim, prius me dies deficiat. Hoc unicum addo, Malaios, \& præcipue Chinenfes, fi quando Areccam \& Betele mafticant, parum Lycii ipfi Cate dikti admifcentes ad præfervationem non folum; fed \& corroborationem dentium \& gingivarum, qux alias ab admixta calce infirmiores redduntur, $\&$ tempor is tractu dentes exefi ante tempus fenii decidunt.

Garcias ab Orta l. primo. cap. decimo. Cate feu Lycii fecit mentionem : verum in ejus defcriptione parcus eft. Arbor unde fuccus Lycii exprimitur, Rhamni fpecies, folia Erucx fert aut Sabinx potius. Quod \& Plinius confirmat 1. 24. c. I 4: Alterum genus (defecunda Rhamni fpecie loquitur) nigrius eft, \& quadantenus rubens, eft $\&$ filveftre. Fert veluti folliculos (femen, credo, intelligit). Hujus radice in aqua decoeta, fit Lycium vocatum medicamentum. Semen fecundas trahit : Alter ille candidior aftringit magis, collectionibus \& vulneribus accommodatior, \&c. Et paulo poft. Lycium præftantiffimum è Spina fieri tradunt, qualis in Indicis arboribus, quonım longe optimum eft Indicum.

\section{$\begin{array}{llllllllll}C & A & P & V & T & \text { I V. }\end{array}$ \\ De Tamarindis, er Carandis.}

$\mathrm{T}$ Amarindorum arbor denfo eft fatis ligno, \& in altitudinem Cerafi plerumque affurgit ; folia fert minuta inftar Ciceris Arietini, egregie viridia, ita ut jucundum profpectum intuentibus præbeant; Cxterum Ciceris, \& Viciarum foliis in Zeelandia, quibus tam avide armenta vefcuntur, perquam funt fimilia, guftu Oxalidis acido, unde incolis, \& propter aftringentem qualitatem, in Cholera \& Dyfenteria funt familiaria. Fructus Fabarum fpecies funt, paulum incurve nafcentes, pulpa intus contenta, phœniceo eft colore, nam quod atra apud nos vifitur, longo temporis tractu contraxit. Hic color iu Caltaneis perf́picuus eft ; tum Pifa ipfius faxea fere funt duritie, ac Pifa Lupinorum referunt; fed colore funt atro. De minorativis corum viribus, quia toti Orbi innotuit, hic volens taceo: Hoc tantum filentio non pratereundum cenfeo, ut nos potum noftrum quotidianum cum Saccharo \& Tamarindis conficiamus ho c modo: Vafculum bene vinculis ferreis vinctum, circiter triginta amphoris aqua fluviatili repletur, quibus induntur Sacchari nigri Iavanii to $\mathrm{ij}$. Tamarindorum $亏_{3} \mathrm{ij}$, Limonum recentium inciforum, $\mathrm{N}^{\circ}$. ij. Hxc bene obturata ponantur in loco umbrofo per viginti \& quatuor horas. Mirandum eft, ut hæc invicem fermententur, \& fine igne cum ftrepitu ebulliant, non fecus ac leberes cerevifiarii ifti in Patria,fuppofito copiofo igne, effervefcunt ; ad fuperiorem vafculi partem fordes \& fæces fuas amandans: Et hæc lavanis, \& noftratibus ccrevifix loco eft : fapore delicato, necullo modo cedente Hollandicx cerevifix, tum falubrior longe in his calidiffimis locis potantibus eft. Et certe fi mihi utriufque optio detur, ego me hoc Iulapio contentum effe profiterer; nam experientia didici, cum naves è Patria Martiam Cerevifiam longe optimam huc advehunt, tum Angli quoque defecatum fuum potum Cerealem, delicatioribus ventriculis minus effe commodum, \& fiepe nifi quis fibi temperet, infignes cruditates in vifceribus progignere. De cæteris potulentis rebus abunde egimus in Direta Indica noftra, ad quam curiofum remittimus.

Prater hanc Tamarindorum jam defcriptam fpeciem, crefcit $\&$ alia fructu longeà præcedente diverfo, quam Garcias ab Orta cap. 6. lib. I I, fub nomine Carandas defcribit. Carandje autem Malaiis vocatur, folia quidem hujus arboris cum Ta. marindi arboris foliis plane conveniunt, ficut ex ramufculo hoc appicto juxta ar- 


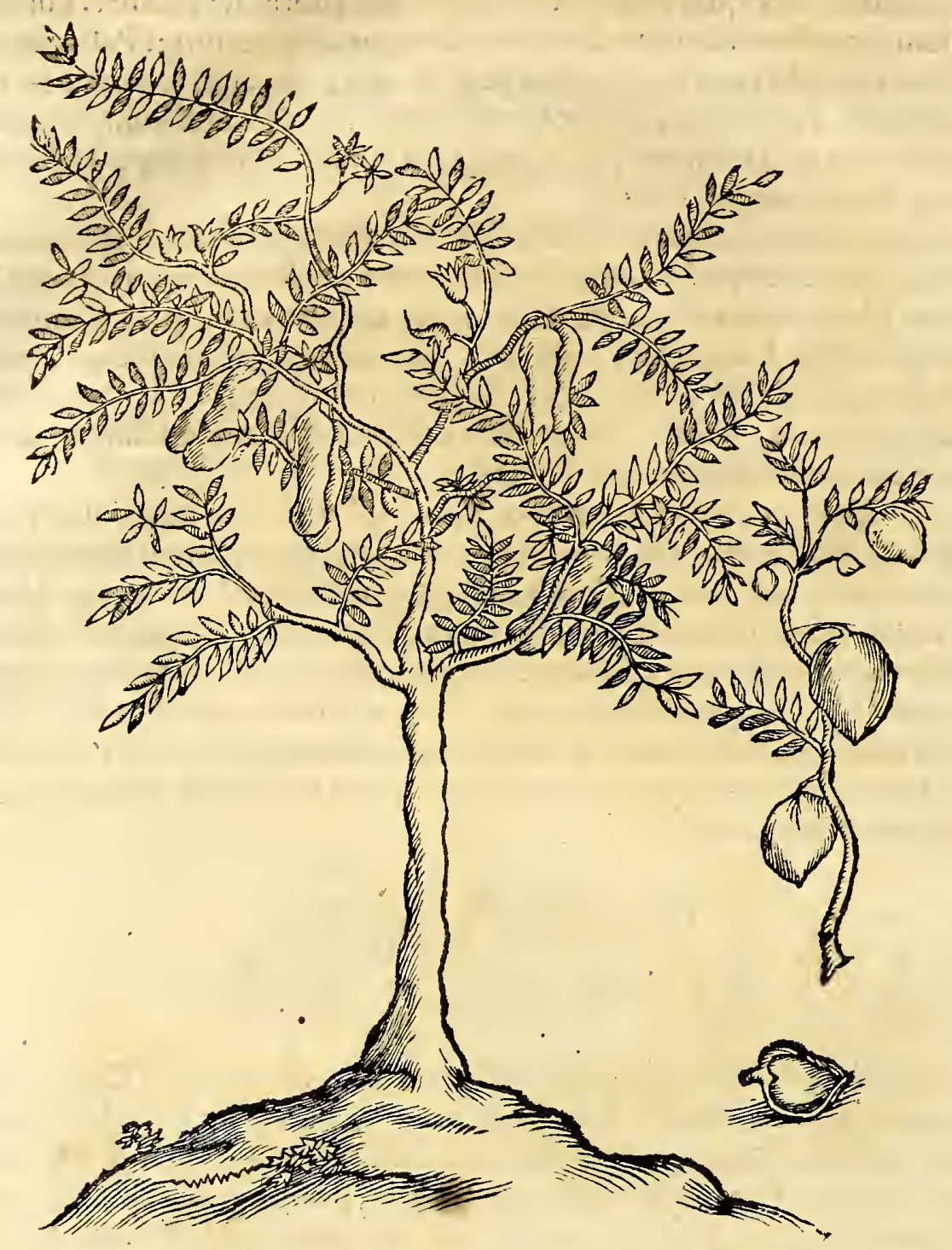

borem vulgarium Tamarindorum videre licet. Fructus maturi nucleis tanquam nu= ces inclufi, finguli fingulis, fecus ac Tamarindis, qux ut Fabæ, plura Semina, \& Pifa profert. Colore hic fructus eft aperto, nucleo aureo, quem orange noftrates vocant, $\&$ caro ejus exterior gratifimi eft faporis, neque dentes tam acidos reddit, quam Tamarindorum pulpa: fed de dulci fapore participat. Certe utramque hanc defcriptam Tamarindorum fpeciem Iavani offem Iava vocant, quafi acorem Iavæe dicas. Et fimilibus quoque facultatibus præeditæ funt, nifi quod Carandas non participent de poreftate laxativa.

\section{A P V T V.}

\section{De Arbore Mangifera.}

Manga Salutiferis fic crefcit predita fuccis, Atque intus flavas oftendit limpida carnes Caftaneasque Nuces referunt tofta igne Saporem, Que fructus media fixe conduntur in alvo.

Hriftophorus à Cofta hanc Arborem, pag. 293, bene defcribit, ad quem nos lectorem remittentes, hoc tantum, quod cxteri omifere, dicemus. Crefeit non fecus, ac Quercus in noftra Patria, hinc inde incurvis, \& ingentibus ramis $\{e$ extendentibus, flos Havus eft, $\&$ in fafciculos congeftus, qualis ferme eft Liguttri, 
$A R$ B O $R$ MA N G I F E R A.

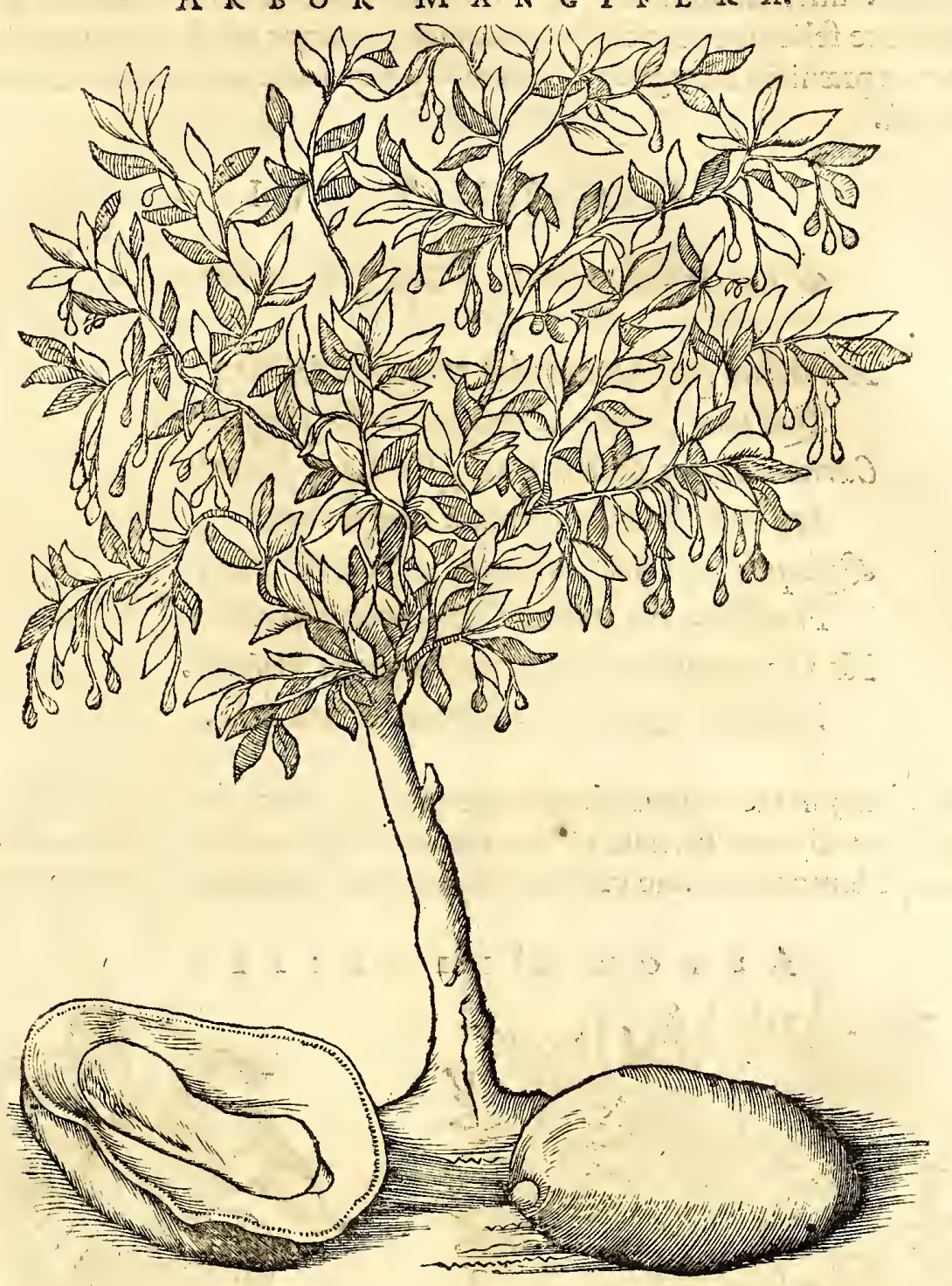

guftri, fed in multo'longius fpatium fe extendit. Fructus immaturi acidi plane funt, ut nifi cocti dentibus non fint ferendi, quapropter nucleum excidentes, quem pramagnum in meditullio gerunt, ex ea pultem coquimus, quæ, Saccharo afperfa, omnino faporem refert iftius condimenti, quod apud nos coquitur, ex uvis crifpis acerbis immaturifque, fi ova ei mifceantur; \& certe guftus acrioris effe deberet, fi quis differentiam faporis cognofcere vellet, hoc modo prapara ti ventriçulo roborando efficaces funt , \& refrigerando fanguinis in Iecore, venis, \& arteriis, inferviunt: maturi vero ubi devenerint, non folum viridem fuum colorem, in flavum mutant: verum, \& qualitatem fuam frigidarn amittunt: tum \& faporem aftringentem in dulciorem commutant, \& calidi humidique deveniunt, bili gignendx accommodati, ut eodem fol. apud Chriftoph. à Cofta, paragr. s. dicitur.

Itaque, fi maturis Mangis, fe aliquis fine modo ingurgitet, facile in Dyfenteriam, \& Choleram incidit, qui duo affectus non fecus, ac dira peftis in Europa, homines hic jugulat. Sed quoniam de his affectibus, \& cura eorum abunde in Method. mea medendi Indica egi, de iis fuperfedeo dicere.

A N N O T A T I O. Videntur diverf $x$ fpecies Mangarum apud Autorem noftrum fuiffe cognitas, figura non folum, fed imprimis guftu \& dignitate, inter fe difcrepantes. Nam alibi mentionem facit deterioris cujufdam Manga, qux fapore refert Paftinacam illam fativam, quam noftrates Gerle-peen vocant.

Alibi vero commemorat Manga fpeciem fortis admodum odoris, Terebinthinam fcilicet, \& Picex arboris lacrymam, redolentes ; quas propterea noftri Stintltet appellant. Sapore, fateor, non funt tam grato quam pracedentes Mangre; verum fudorifica \& diuretica funt admodun qualitate; ideoque eos merito inter alimentofa medisamenta recenfeam. Quin \& gummi ipfe, fructus, \& arbor, Laricis inftar, ex fe deftil- 
lat, quod glutinofum non minus eft, \& odoratum æque quam Terebinthina prædicta. In nulla arbore felicius excrefcir Polypodium, quodque preftantius habeatur in medicina, quam in predicta Mangifera, dein in Quercu Indica Kiati diça, de qua ex pron fello diEtum eft.

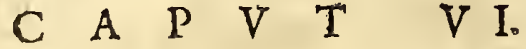

Arbor Melonifora, Papayo mulgo dicta.

Arboribus quifnam credat creviffe Melones, Qui non Hejperias viderit bafce plagas?

Carne quidem fimiles intus, fimilique fapore:

Sed calor in nigro femine nempe latet.

2uisquis at è patriis Indas adveneris ores,

Fruttibus his nimium vefcier ufque cave:

Ne te pracipitent ad certam tormina mortem.

Ventris, $c r$ ex alvo fanguinolenta bilis.

A

Rboris in juftam magnitudinem excrefcit five hre planta, five frutex, five denique arbor dicenda fit: nam trủnco tam molli eft, ut unico ictu machær $x$, quamvis fxpe femori humano craffitie refpondeat, tranfverfim diffecare quis poffit.

$A$ R B O R M E I O N I F E R A.
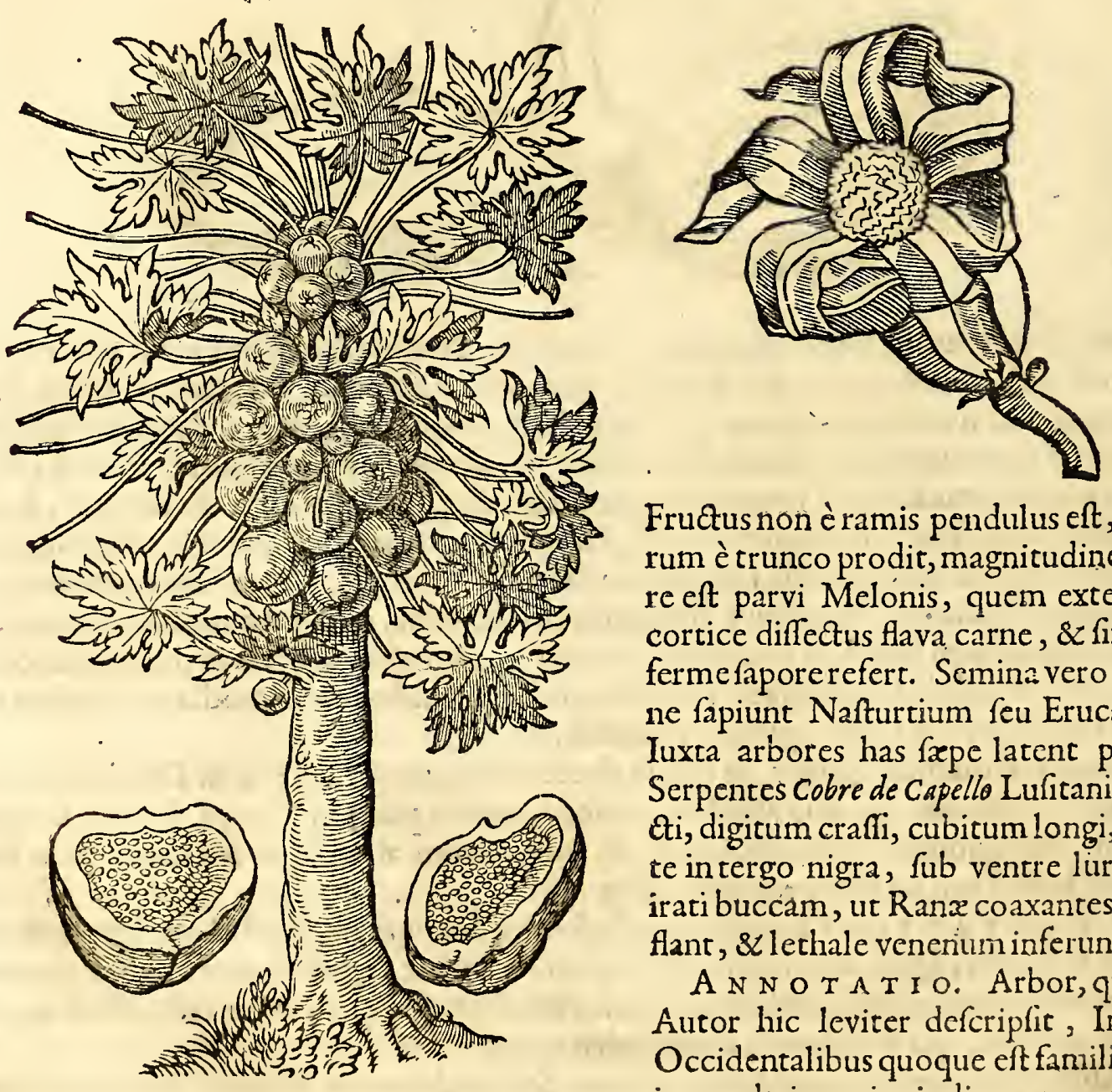

Fructus non è ramis pendulus eft, verum è trunco prodit, magnitudine fere eft parvi Melonis, quem externo cortice diffectus flava carne, \& fimili ferme fapore refert. Semina vero plane fapiunt Nafturtium feu Erucam. Iuxta arbores has frepe latent parvi Serpentes Cobre de Capello Lufitanis diEti, digitum craffi, cubitum longi, cute in tergo nigra, fub ventre lirida; irati buccam, ut Ranæ coaxantes, inflant, \& lethale venenum inferunt.

A n n o T T I O. Arbor, quam Autor hic leviter defcriplit, Indiis Occidentalibus quoque eft familiaris; ita ut de jure ejus indigenatus adhuc lis hæreat, quia quantum ex autoribus colligo, plantatur, non fponte provenit. Miroi: Bontium cum Clufii, \& Dodonei Papayonon contuliffe. Ego hujus arboris maris \& foeminx Icones exhibui \& defcriptioncs in opere meo paulo fufius, quaria autor hic nofter, profequutus fum F. I $5 \%$. lib. 4. fub nomine Pino-guach.

C. A: 
HIST. NATVRAL. \& MEDIC. LIB. VI. 97

$$
\text { C A P V T } \quad \text { V I I. }
$$

\section{De Arbore Conifera Macandou.}

A

Rbor hxe profert folia admodum lata, craffa, colore pulchre viridi, qux non abfimilia funt floribus Ari, quem Pedem Vituli botanici vocant : fores fert albos, oblongos, inftar Periclymeni, queis decidentibus ordinatim fuccedit fruCtus Macandou Iavanis dictus, hic depictus, nucem Pineam plane referens, nifi, quod

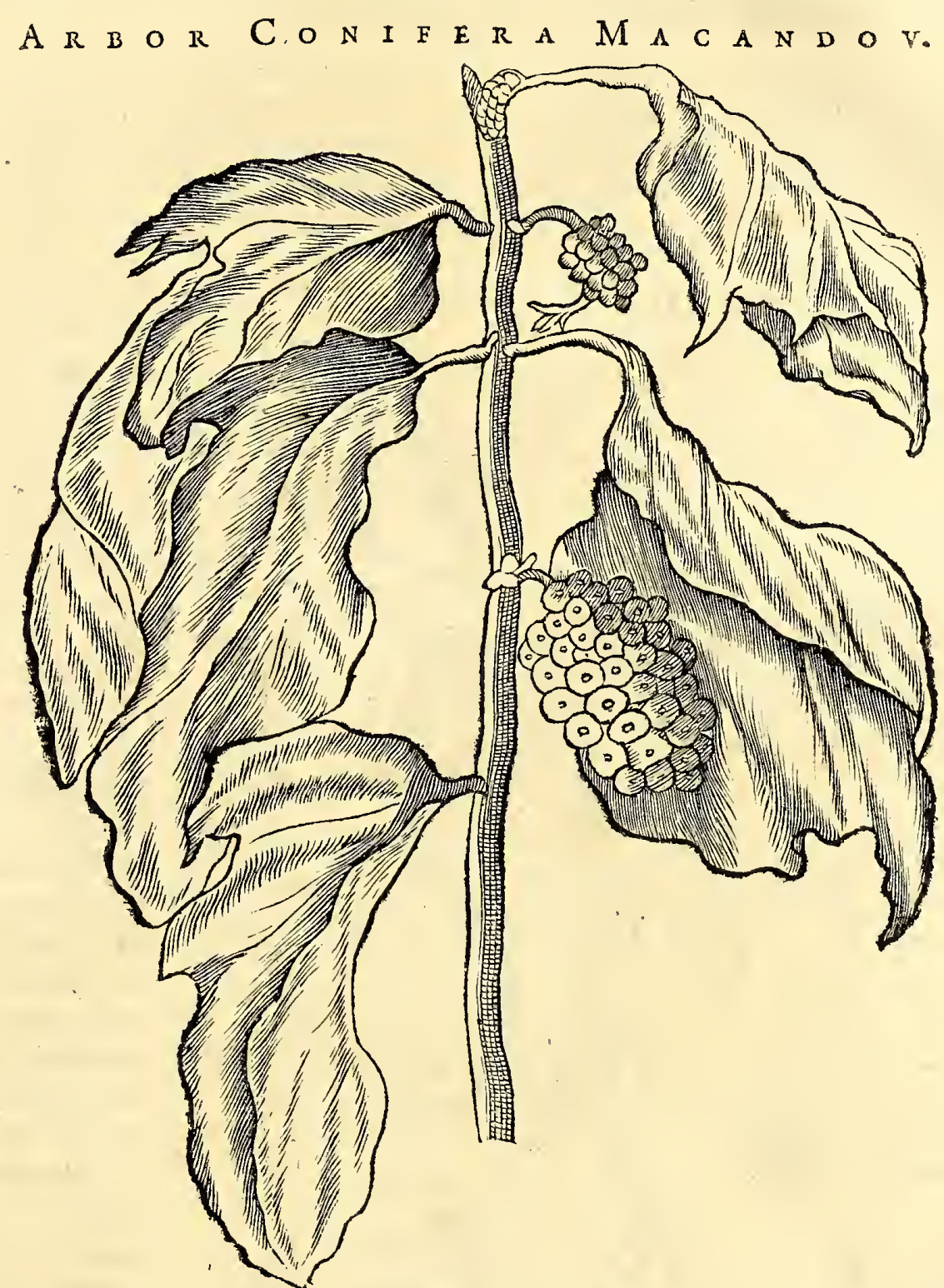

t.m acute in conum non definat, neque tam lapidea eft duritie; fed mollis plane, immaturus viret, maturus flavo eft colore: porro muccilaginofus eft fructus, fapore fatuo, aut infipido potius. Malaii fub cineribus affatum comedunt, ad Dyfenterias, \& Cholerx orgafmum fiftendum, tum pectoris vitiis, Afthmati, Phthifi, Pleuritidi conducere aiunt, propter vim emplafticam, qux in ipfius muccagine eft: Ego certe co nomine arborem hanc Confolidam Indicam arboream nominare non dubitem, utpote qui primus eam defcripferim: \& quare mihi non idem jus fit, quod veteribus, qui vegetativa, ab effectu, fapore, colore, \& primis qualitatibus fxpe nomen indidere? Prefertim cum in Nofocomio vim hujus fructus confolidantem, in Hæmoptyfi, feu fputo fanguinis, non femel cum fucceffu expertus fim. Folia quoque farcotica funt , \& in vulneribus, \& ulceribus, carnem egregie generant, \& cutem cicatrice obducunt. In quam rem fal ex foliis quoque arte Chymica elicere liccret, quod præter confolidativam qualitatem, etiam, quamvis inveterata, \& caçöthia ulcera, munda reddit. 


\section{A P V T V I I I}

\section{De Malis Cydoniis in India.}

Credo aliquem è Creta vexiffe Cydonia Sylois Mala hac, Hefperios do confeviffe per agros; Carne flava, \& multo circumlita femina mucco oftendunt, duro fed predita cortice cernor.

A

Rbor, qux depictum hic fructum fert, alta eft, \& patulis ramis, foliis arboris $\mathrm{Li}$ monifer $x$, fed gracilioribus, \& friabilibus admodum. Fructus Citreis Malis non funt abfimiles;ubi nondum maturuerint, viridem; maturi corticem flavum oftendunt. Durus eft cortex, itaque cum frangere, cultro vero diffecare non licet; carne

$M$ A I V $M$

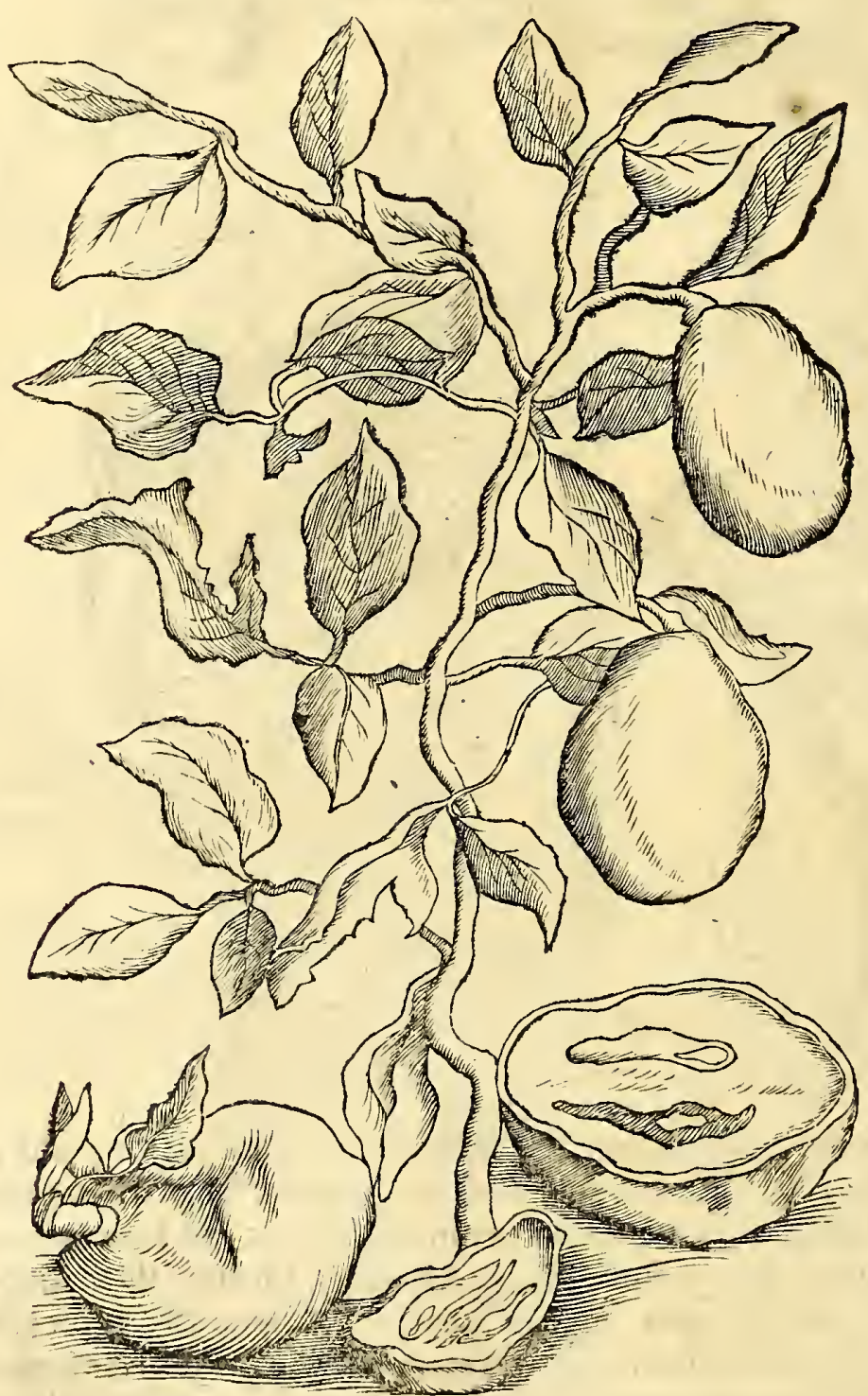

intus funt flava, $\&$,

Cydoniorum inftar, denfa, in medio femina continentur; non fecus ac in Cydoniis, glutinofa materia, fed copiofiore circumlita, unde $\&$ Cydoniorum nomen is indidi. Porro hac muccilago etiam omnibus oris effervefcentiis \& gutturis infervit, tum Aphthis medetur : cum aurem hxc Mala adhuc viridia funt, nefcio quid virofi, \& ingrati naribus odoris, expirant ; verum matura, Violas iftas murales odore referunt, quas Keiri Arabes vocant. Subftantia feu caro ejus, affata, indubitatum eft remedium adverfus Dyfenterias, tum Choleræ immanem orgafmum. In Syl-

vis paffim hxc Arbor crefcit. Vnde Mauri fructus hos cum fumma cura auferunt, $\&$ venales in civitatem ferunt, aut fibi ad præedicta mala refervant: Nam, virides fruetus durabiles funt a dmodum. Creterum à muccilagine, quam intus gerunt, Noftrates ea appofite Sigm-appelen vocavere. 
HIST. NATVRAL. \& MEDIC. II в. VI.

C A P V T I X.

De Vtraque Nimbo Jeu Lauro Indica.

Nimbo wocor Iavis, fum nobilis Indica Laurus,

Que morbos uteri pellere rite folet:

Indice me fi prima datur fua palma Liguftro,

Tunc cro ab bac facile feptra fecunda fero.

Onfat mihi ferme, Garciam ab Orta hanc arborem, feu potius fruticem, oculis non ufurpaffe, tum quod tribus verbis de ea fcripferit, cum non debuiffer no-

bilifima hxc folia ignorafle, quibus nil magis apud Indos in ufu eft medico: nam, prxterquam quod in lotionibus, fomentis, infeffionibus, Indx mulieres, ad morbos gy -

$N$ I $M$ B

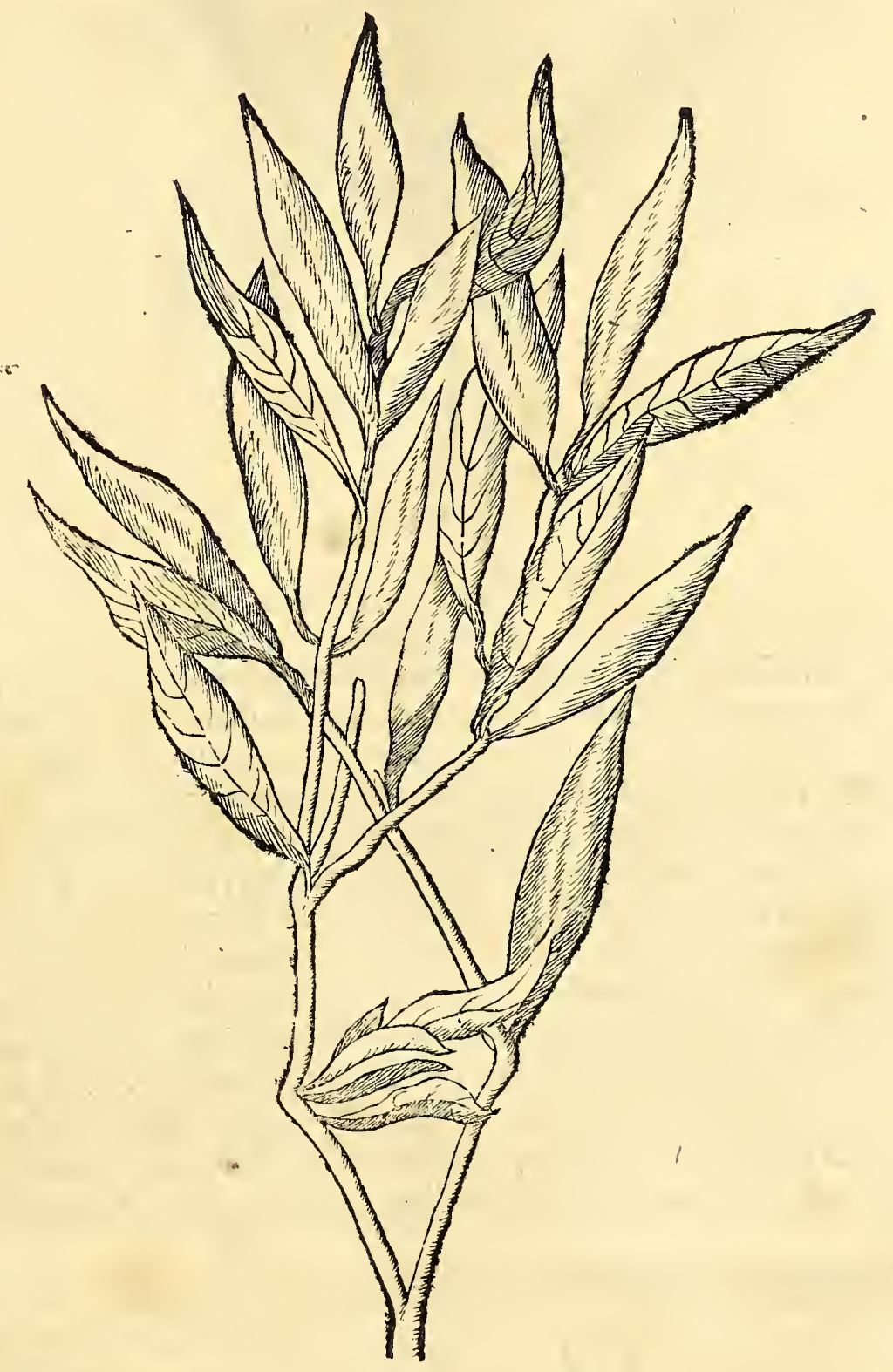

naceos his foliis utantur, nil tam juvare dicunt adverfus Colicos dolores, longas Diarrhoeas, Hydropen, \& ad perniciofflimam vifcerum, prefertim mefentcrii, obftructionem. Foliis quoque non eft in ambitu ferratis, cxterum foliis Lauri non abfimilibus : fed craffioribus longe, ut potius ea Rhododendri foliis affimilem. Nervos folia habent inftar Plantaginis ferme, fed non tam crebros, colore è nigro purpurafcente; totus frutex obicure viridis cft. 


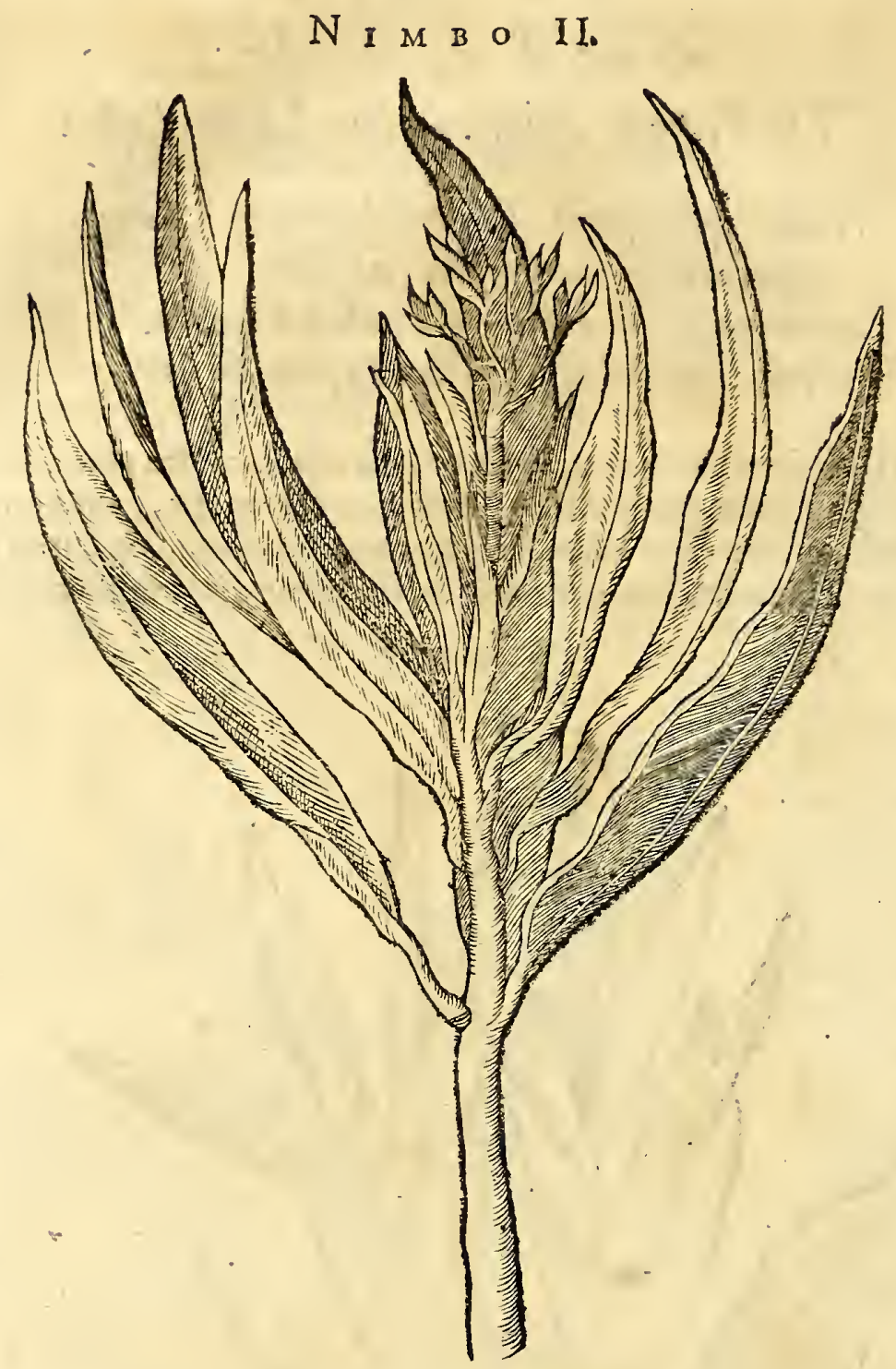

Refcit $S$ altera Nimbo fpecies, quam averfa pagina cum flore hic appofui, primam florere non vidi, cum tamen in hor to meo eam curiofe alam. Flos fubpallidus eft, non plane albus, ut Garcias affirmat. Vulneraria quoque ei ineft vis, \& fuccus è viridibus foliis expreffus, utiliffimus eft ulceribus antiquis mundificandis.

Qualitate ex amarofubaftringente calidam, fed magis ficcantem effe verifimile eft: porro Indi veneno, vel intus fumpto, vel telis inflicto, mederiteftantur, \& apud illos in frequenti eft ufu, fi in bellis vel haftis, vel Criffis (id eft Sicarum genus) vulnerati fint : nam Iavani vel fuccis ex herbis venenofis, vel fanguine Salamandre Indicx, quam alibi fub nomine Gecco defcripfimus, tela fua tingunt, ideoque ea femper atris maculis infecta confpiciuntur:nam hæ nationes adverfus hoftes fuos adeo crudeles funt, ut vel cum vitæ periculo vindictam acerrimain exerceant, quod ipfe coram vidi, dum in bello in eruptione aliqua noftrorum miles quidan Iavanum tranfixiflet gladio, ipfe contra nitens arrepto capulo enfis, fica fua hominem trucidavit, \& ipfe mille vulneribus à reliquis militibuṣ confoflus, ftridens dentibus, cecidic, vitæ non vindictæ exfaturatus.

Vitaque cum gemitu fugit indignat a fub umbras.

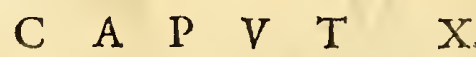

$$
\begin{aligned}
& \text { Arbor Caffiam ferens. }
\end{aligned}
$$

Rbor qux Cafiam folutivam fert, feu mavis fabaceam, magnitudinem xquat Pruni, foliifque eft Mali Perficx foliis, fed tenuioribus paulo, flores, Genifte. floribus adfimilantur, iifque decidentibus fuccedunt filiqux, primum viridis 
ARBOR CASSIAM SOLYTIVAM FERENS。

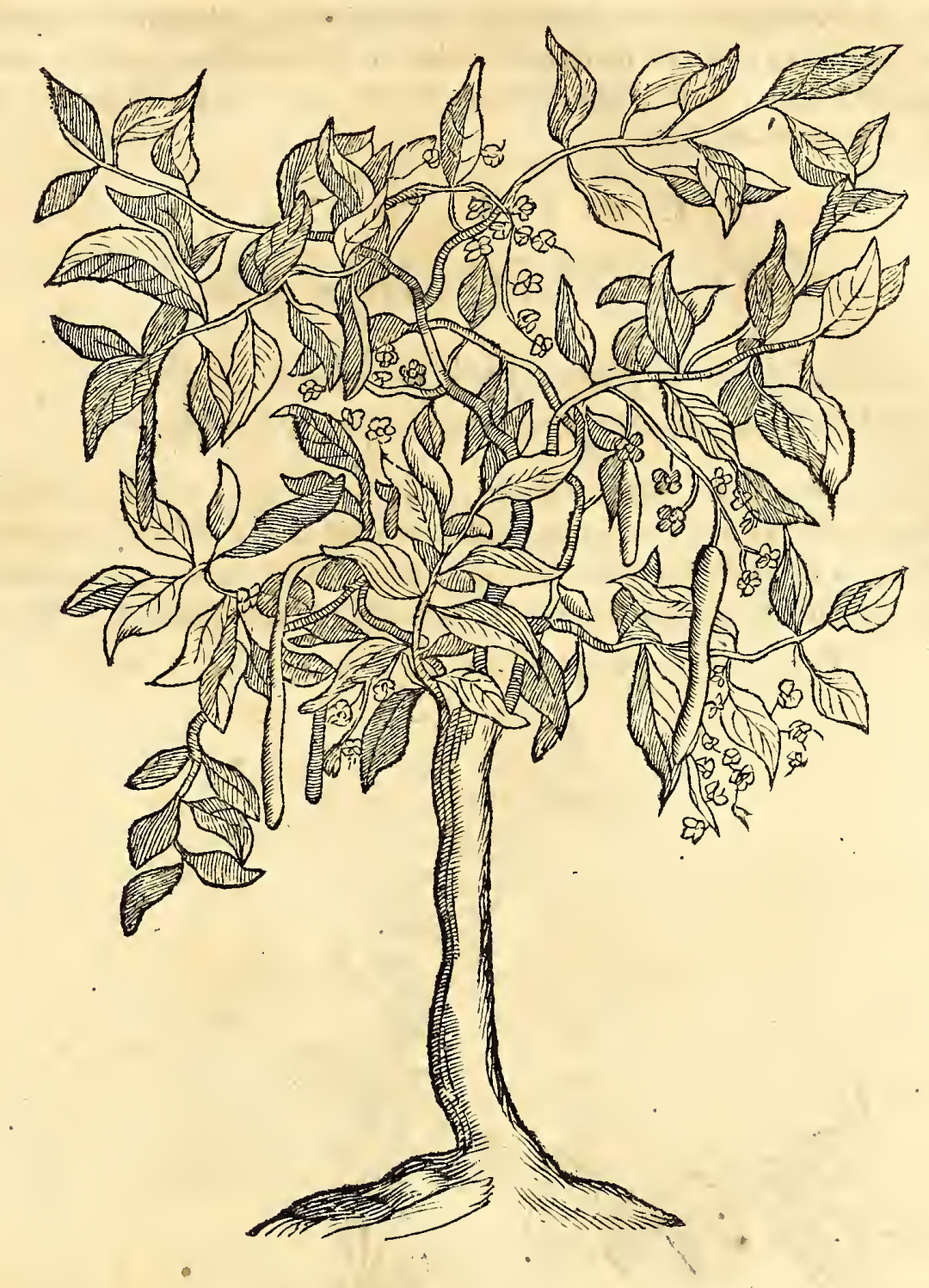

coloris, dein in magnitudine accrefcentes, ad maturitatem pervenientes, nigrun colorem, \& majorem duritiem induunt, quales in Europxis pharmacopoliis vifuntur. In filvis Iavæ crefcit copiofe, quas inde Chinenfes Incolæ, Malaii, \& Gufaratæ afferunt, fed propter nuperrima duo bella cum Iavanis Matara nenfibus longo temporis tractu huc in urbem venalis non allata eft Caflia: fed jam refpirantibus nobis à bellis, \& metu Tavanis incuffo, rurfus in fatis magna quantitate adfertur. Flores (quod pene omiferam) aromatici funt odoris, proxime Caryophyllorum flores referentes. Vtnotas qualitates hujus Fabx pradicem, non eft mei inftituti; utpote qui aliquid infoliti, \& patriis auribus inauditi, latius explicare defiderem : fed ne videar nobilifimam arborem, quam fape vifu ufurpavi, preteriiffe, hac pauca de ea commentatus fum.

Neque hoc filentio praterire poffum, ad vitia Renum, \& Veficx, ad Gonorrharas denique Venereas, nullum efficacius in his locis remedium inveniri, quam pulpam ex Fabahac extractam, $\mathbb{\&}$ cum Therebinthina Veneta mixtam ad 3 . ij $\mathfrak{B}$ pondus, vel ejus defectu, Gummi.Benjouin, quod nefcio an Pláutus Refinam ÆEgyptiam vocaverit, dum conquerenti fervo, fe heri caufa rupiffe currendo ramices, ipfe herus re fpondet, Refinam Egyptiam ex melle vorato, \& falvum feceris. Hoc faltem fcio, GummiBenjouin in Ceromatis utiliflime mifceri ad omnis generis Hernias. Vt definam, merito hæc Caffia inter laxativa principem locum habet in morbis, quifebre carent' nam eam in Dyfenteriis, Cholcris, caterifque affectibus, qui ut fere femper Febrem fymptomaticam continuam fecum ferunt, non facilel aufim exhibere, cum periculum fit ne in bilcm convertatur; \& fic caufam horum affectuun adaugeat.

13 Porto 
Porro paragr. 9, f. I I9, Garcix ab Orta ridicula refertur quorundam opinio, nempe boves hic afliduo alvi fluxu laborare ex paftu foliorum arboris Caffix, \&cc.

Caufa autem vera hujus fluoris, mea quidem opinione, eft, quod regiones fub vel circa $Æ$ quatorem fitæ, aërem fortiantur calidum \& humidum, ut alias latius explicavimus, qui vifceribus, ventriculo, lieni $\&$ inteftinis putredinem inurit, Aluxufque inteftinorum $\&$ hepatis inducit.

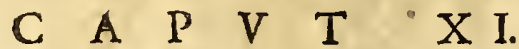

\section{De Fructibus Carambolas dictis.}

\section{Oxalidos guftu gratum prabemus acorem}

Fructibus, atque iifdem ventris profludia fifto.

Arcias ab Orta hunc fructum defcripfit libro 2, cap. I 5 , fed, me Iudice, valde perfunctorie, cum tamen inter faluberrimos Indix fructus merito numerari dcbeant. Folia Pruni foliis adfimilantur, qux ut folia in Populo fubtus albefcunt, flores fert ut flores Geniftx: fed colore è pallido funt puniceo. Quibus fucce-

F R V C T V S CARAMBOIAS.

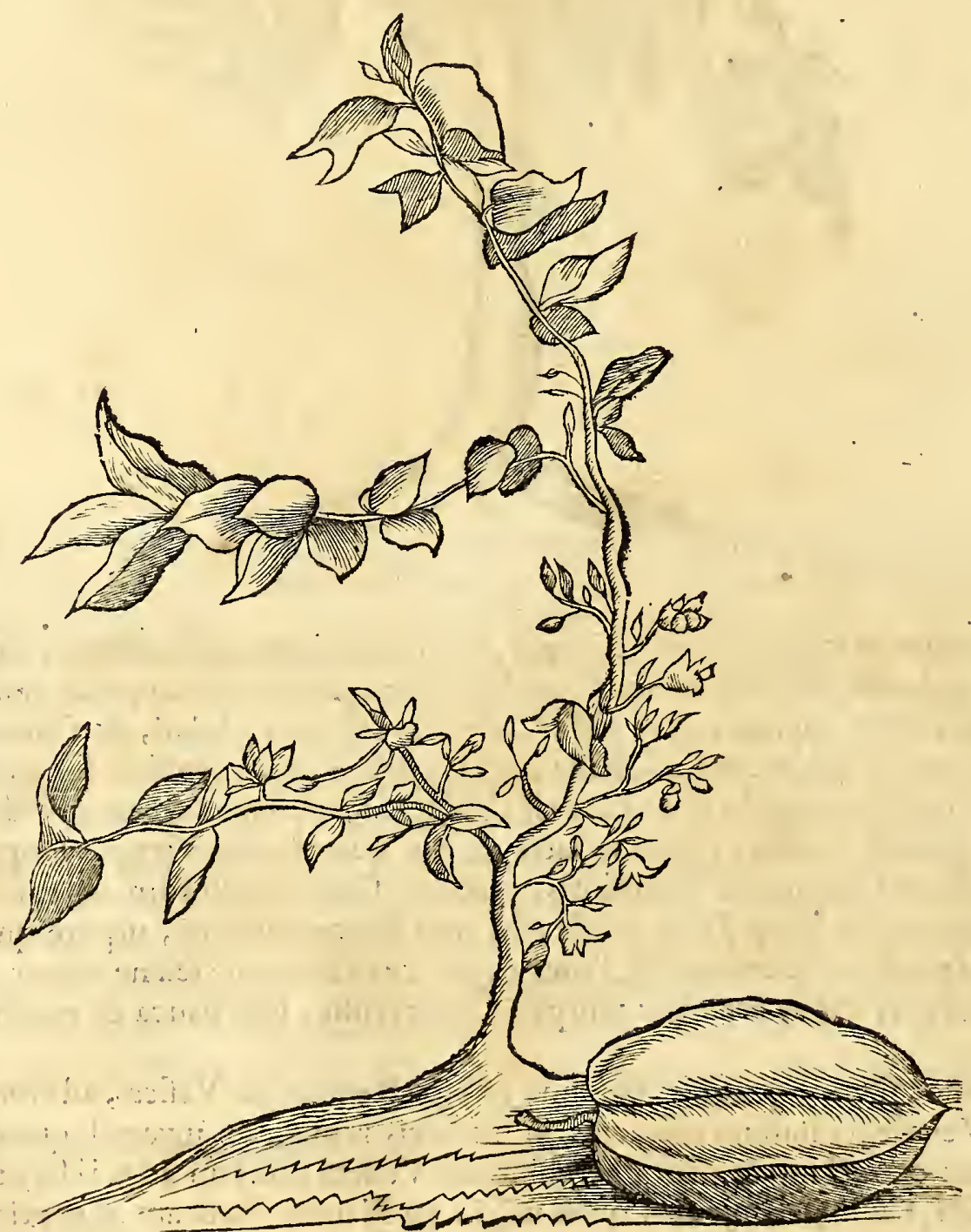

dunt filiqux oblong $x$, in quatuor partes interftitis diftinct $x$, qualia interftitia videre eft in Corona imperiali Clufii, qua femen ejus continent ; immaturus hic fructus fubacidus eft, \& aftringens; maturus vinofus eft. Murria quoque conditur \& aceto, ut plurimi alii fructus Indici cun Allio, Porro, Cæpis, Zinzibere viridi, \& racemis Piperis, \& tum ponuntur inter ea fercula, qua bellariis orexin excitant. Praterea Syrupus c̀ viridi ejus fucco confectus, Dyfenterix, Cholerx, Spafmo, Febribus ardentibus, \& reliquis norbis biliofis, utiliffimus eft, Saccharo quoque in eundem finemà 
HIST. NATVRAL. \& MEDIC. LI的 VI。

Chinenfibus conditur.Ad oris Aphthas præterea mixtus hic Syrupus in collutionibus, cum pauco mellis rofacei adhibetur, tum in gargarifinatis adverfus incipientem Anginam. Facile propter vim repercuffivam fummum locum obtinet.

$$
\begin{array}{llllllll}
C & A & P & V & T & X & \text { I I }
\end{array}
$$

\section{De Corni cujufdam feu Sorbifpecie.}

Seva Dy/enterie que torquent tormina ventrem, Queis tot letbeas anime ductontur ad umbras.

His fimul or Cbolere bene fubvenit Indica Cornus:

At multos agros è faucibus eripit Orci.

Refcit hic in Iava ampla \& vafta quxdam arbor, in altitudinem Batavica $Q$ uer * cus facile affurgens, foliis oblongis, craflis, $\&$ egregie virentibus, fapore aci do (ut Oxalidis eft) \& aftringenti : flores funt parvi, fafciculatim crefcentes, ferme ut flores Sambucini, quibus fructus fuccedunt rotundi, \& etiam ut uv $x$ inter fe

- Sor b i S p e c i e s.

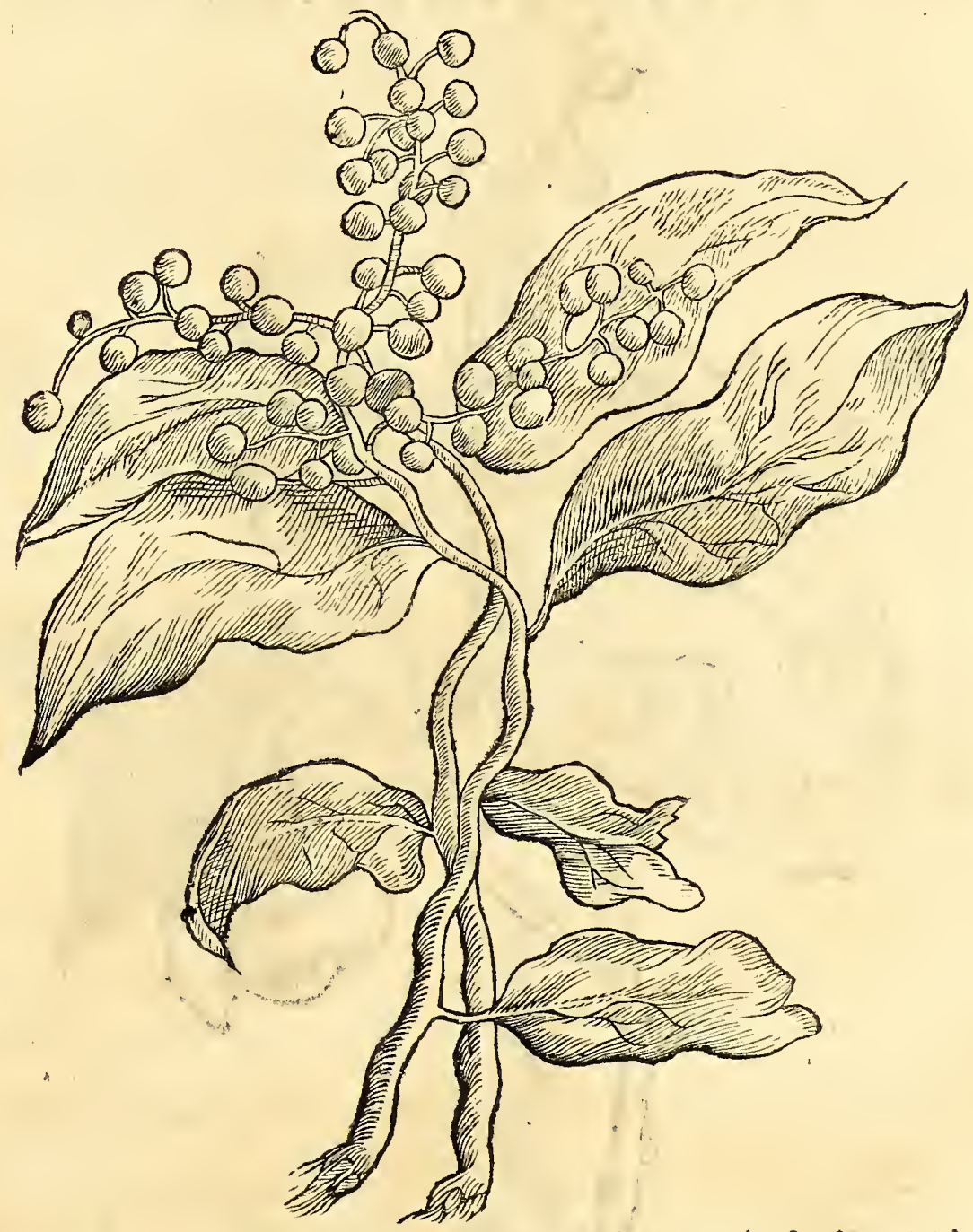

cohærentes, fed rariore intervallo à fe diftantes. Primum hi fructus virides apparent: mox maturefcentes paululum flavi deveniunt, plane maturi ex nigro purpurei funt, $f_{\text {a }}$ * pore aftringenti, quod indubitatum fignum eft, effe frigidioris natura, \&Z qualitatis : la pillos intus habens, quales reperiuntur in Sorbis, \& Corni arboris fructibus, $\&$ in earum genere arborem hanc pono, qux prater dictum in fructibus faporem, etiam truncum nodofum oftendit. Succus ex floribùs expreffus, colore plane refert Mori fuccum, ac certe eodem modo tingit purpureo colore: Ex hoc fucco nos hinc conficimus fyrupum faluberrimum ad Dyfenterias \& Choleras refranandas: Qux dux morbo- 
morborum fpecics prefertim pofterior, xque metuuntur, quam Peftis in Europa: \& in hife locis (proh dolor!) nimis familiares funt. Præterea conducit Syrupus in ardentibus $\mathcal{X}$ continuis febribus: has atque alias non minus utiles operationes nos quotidiana experientia in Nofocomio Batavico, ubi vixunquam tales affectus defunt, veras effe deprehendimus. In hepatis porro calidioribus affectibus praftantius remedium reperiri non puto: nam phlogofin, \& fanguinis effervefcentiam, egregie temperat. Habemus præterea Sorbos \& Cornos, noltris omnino fimiles: fed qua fructus noftratibus majores fert, \& colore purpureo plane. Condiri hi fructus folent aceto, \& muria, atque in bellariis nobis olearum vicem implent : Saccharo quo. que macerati ad fupradictos jam morbos idem juvamenti adferunt.

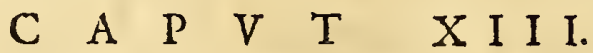

\section{De Fraxino Indica, ejufque fructu.}

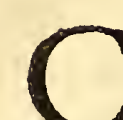

Refcit hic arbor fatis patula, \& Fraxini fimilibus foliis, trunço quoque nodofo: fructus fert, quales ferme funt Nuces Avellanx, corticibus ablatis, edules fane, \& non mali faporis, fed paulum aftringentis, unde frigid $x$, \& ficc $x$ natur $x$ effe conftat; ut $\&$ folia, qux impofita vulneribus, $\&$ ulceribus, ea mundant fa-

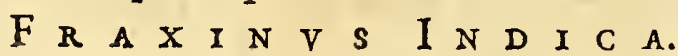

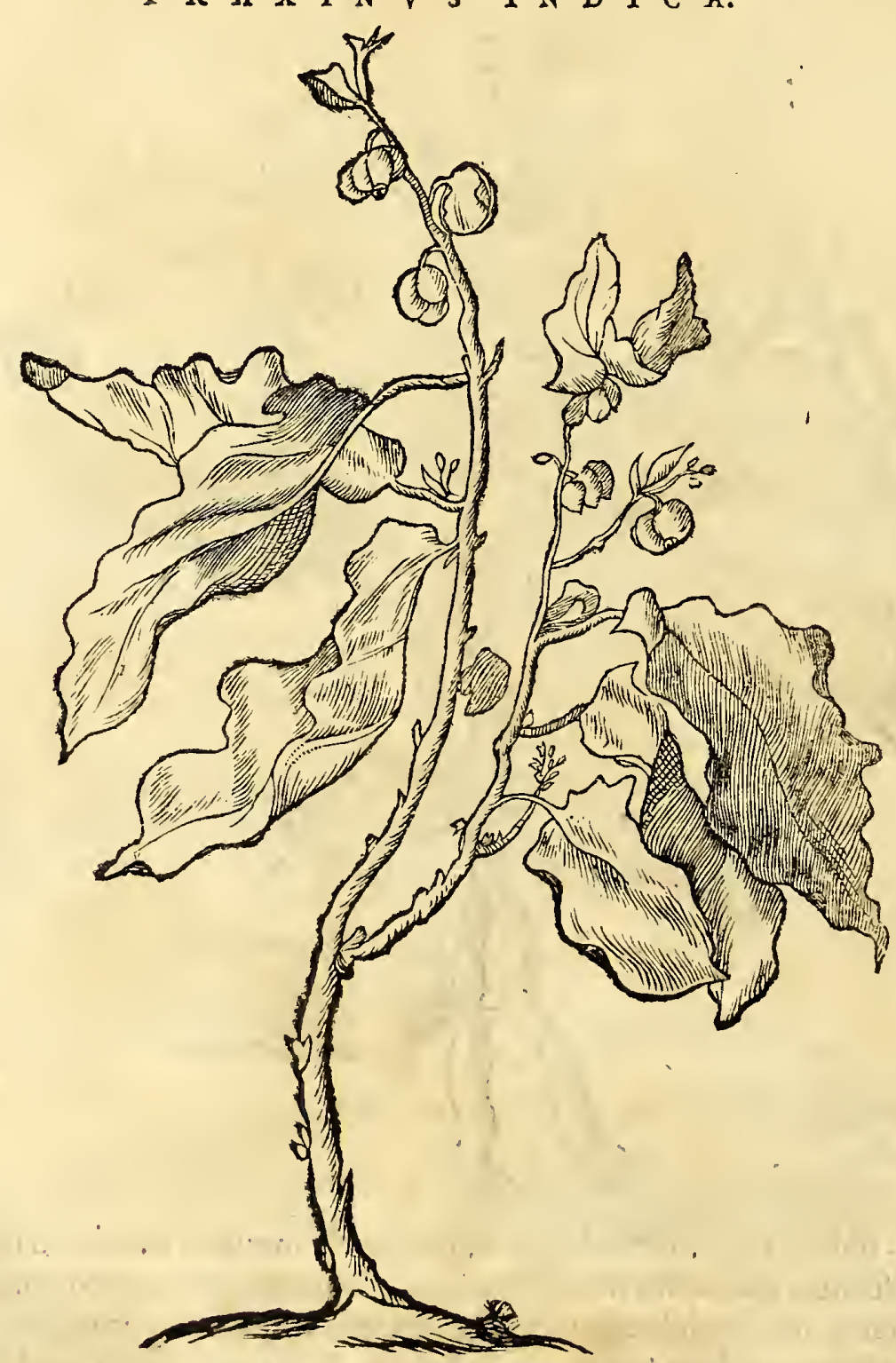

nan tque, tum cicatricem iis brevifimo temporis fpatio fuperinducunt. Succus ejus Cochlearis menfura exhibitus, Lumbricos, Afcaridas, \& Tineas necat, quibus propter Solis, \& aëris humidam \& calidam intemperiem, putredinis effectricem, homineș;, pixfertim pucri, affiduo aftliguntur. 
HIST. NATVRAL. \& MEDIC. LIE. VI.

Nec eft quod miretur quis, Indos à compofitis medicamentis abhorrere, cum adeo feliciter fimplicibus herbis, affectibus contra naturam mederi contingat; ; ta ut merito imaginer milhi veterem medicinam frimilem fuiffe, \& compofitiones iftas medicamentorum à recentioribus Arabibus inventas effe: quo commodo ego dicere non aufim, ne hrreticus apud modernos audiam. Saltem hocfcio, veterem \&antiquam effe regulam, Fruftra fieri per plura, quod poteft fieri per pauciora.

$$
\begin{array}{lllllllll}
C & A & P & V & T & X & I \\
\hline
\end{array}
$$

\section{Arbor Lanigera froe Goffampinus Plinii.}

$\mathrm{D}$ E Lanigeris feu Golfampinis Plinio dictis, lib. I 2 , cap. I i , \& lib. I 2, cap. io, quoniam plures ante me fcripferunt, ego tantum arboris ejus generis figuram vobis ob oculos pono, qux nulli, quod fciam, hactenus defcripta fit. Arbor hexc pulcro foliorum virore non folum oculos oblectat: fed \& caule viridi; \& in celfi.

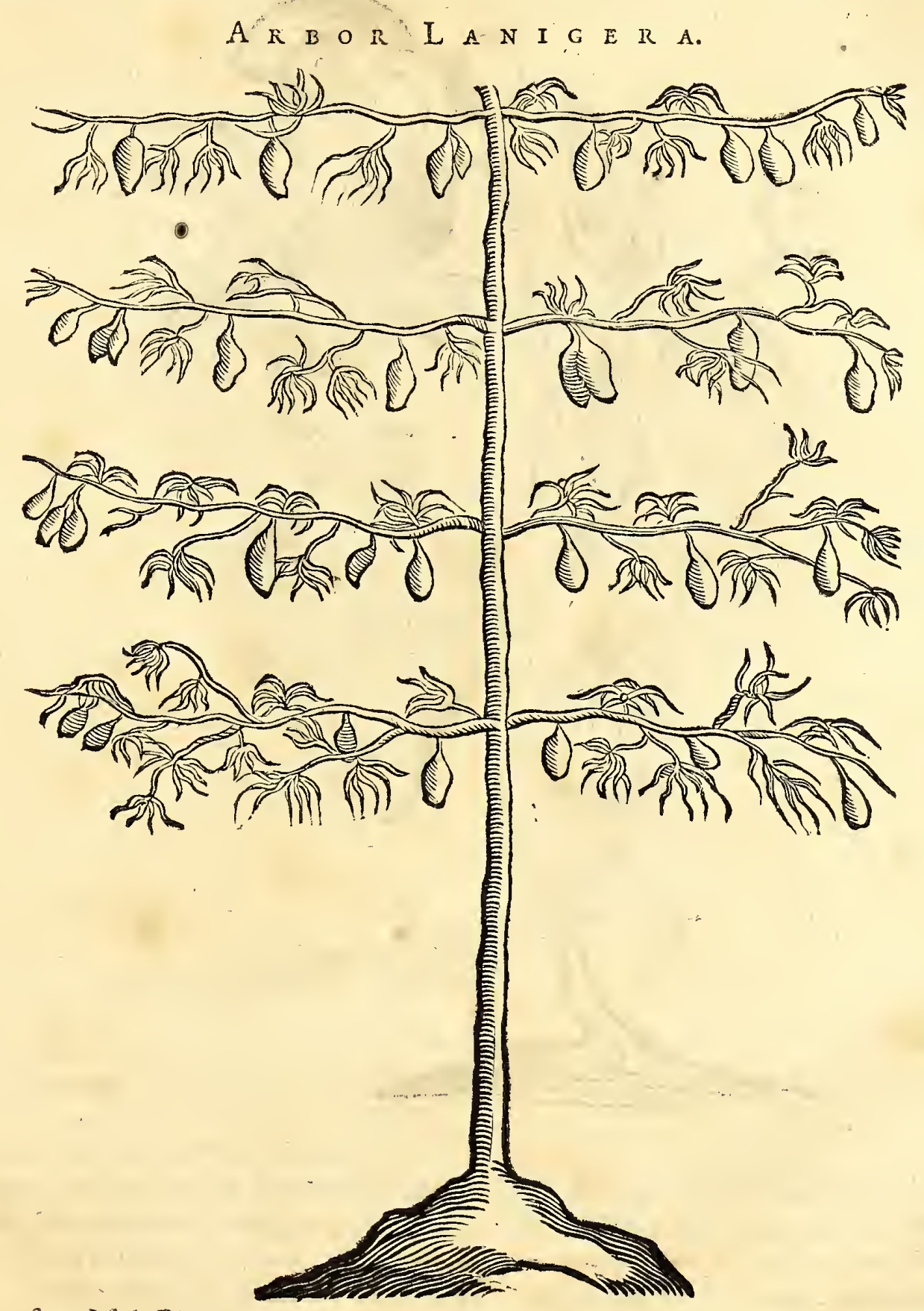

tudinem fxpe Mali Picex, rectis fius ramis cxpanfis, tranfverfim $x$ quali ordine, \& lon gitudine c̀ trunco furgentibus erigitur. In quibus polt flores rubros, oblongos tubulos fert, qui maturi Lanam, \& femen nigrum Piperis inftar producunt. Lana hxc propter brevitatem carminari non poteft; neque inde lintea texuntur; fed per totam Indiam ex- 


\section{A C O B I B O N T I I}

peritur, quod fulciendis culcitris \& pulvinaribus fit aptiffima. Cavendum unice eft, ne hæc Lanugo flammæ vel miniman fcintillam excipiat: nam ignis huic materix tam tenaciter harendo ferpit, ut vix aqua reftingui valeat.

$$
\text { C A P V T XV. }
$$

\section{Planta Spinofa incognita.}

Refcit hic quidam frutex non admodum alte à terra exfurgens, qui primum flores flavos fert inftar Solani : quibus fructus fuccedunt copulati, qui immaturi virides funt, maturi vero pulcre rubri, forma rotunda, fricati manibus adeo foetidum odorem à fe emittunt, ut Affan foctidam', Sagapænum, \& Caftoreum longo in-

P I A N T A S P I N O S A.

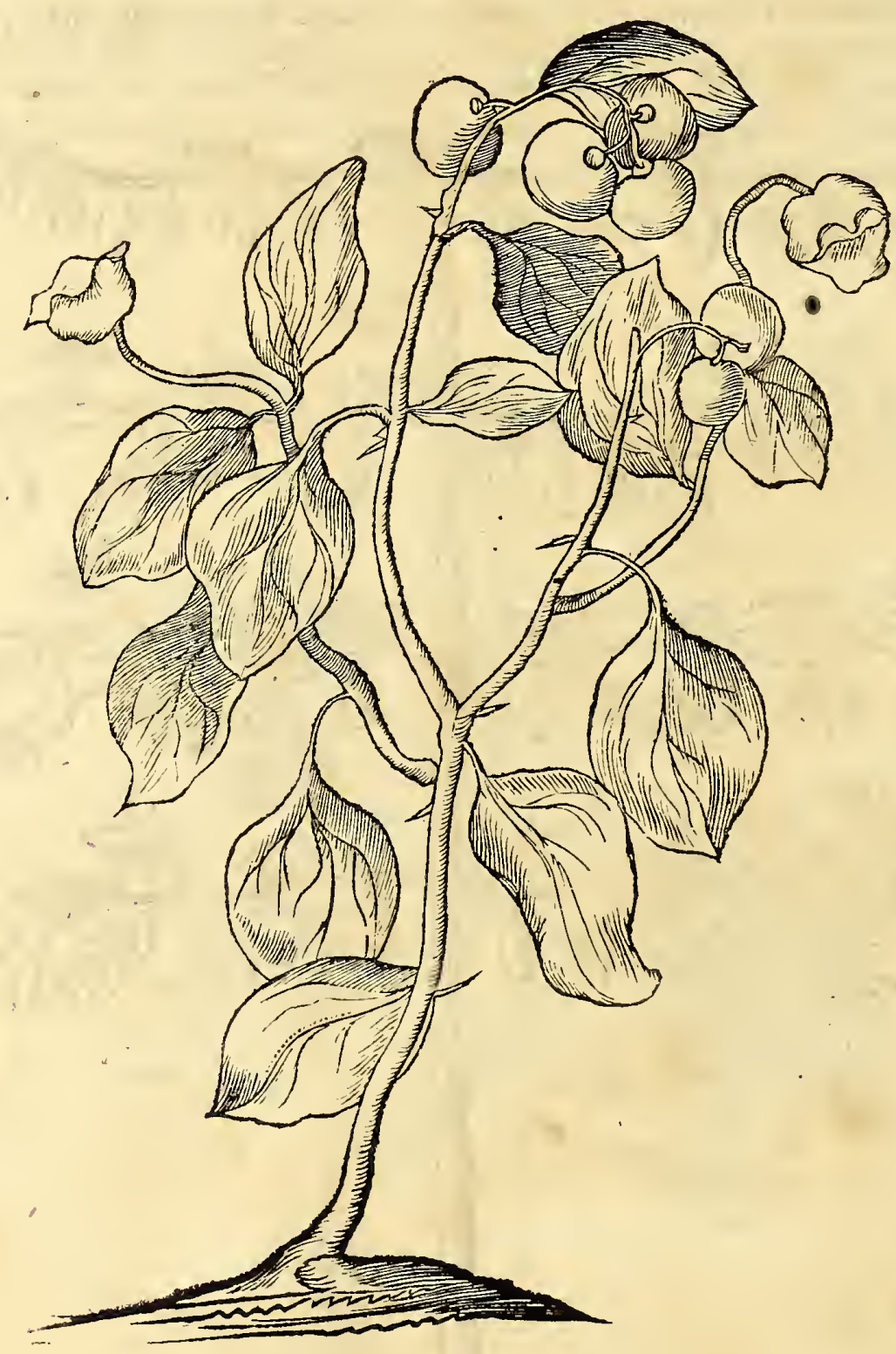

tervallo fuperent. Quapropter cos quoque Indx mulieres hyftericarum naribus admovent. Edules porro efle negant, neque, quod fciam, ad alios ufus adhibentur; itaque non fuaferim, ut propter pulcrum colorem, is aliquis temere vefcatur; nam forte in perniciem fefe daret. Cim hic fecundum Homerum crefcant Pharmaca multa bona, multa mixta, plurima vero vencnofa, $\&$ deleteriam vim obtinentia.

C A. 
HIST. NATVRAL. \& MEDIC. LIE. VI.

\section{A P $\quad \mathrm{V}-\mathrm{T} . \quad \mathrm{X} \quad \mathrm{VI}$.}

\section{Quercus. Indica Kiati Malaiis dicta.}

Indica fum Quercus, foliis ego crefco ficulnis, Duritie infigni patrium fed Robur adequo;

$\checkmark$ ndula quin etiam me permeat undique curba.

Anc arborem merito Quercum Indicam vocavi propter vaftitudinem lateque patulos ramos non folum: fed \& propter infignem ejus ligni duritiem \& undulatam ejus afferum picturam, qux duo in Quercu noftrati etiam reperiuntur, tum in rdificando maxime hoc lignum probatur, quod durabile fit, nec facileà tere-

Q V E

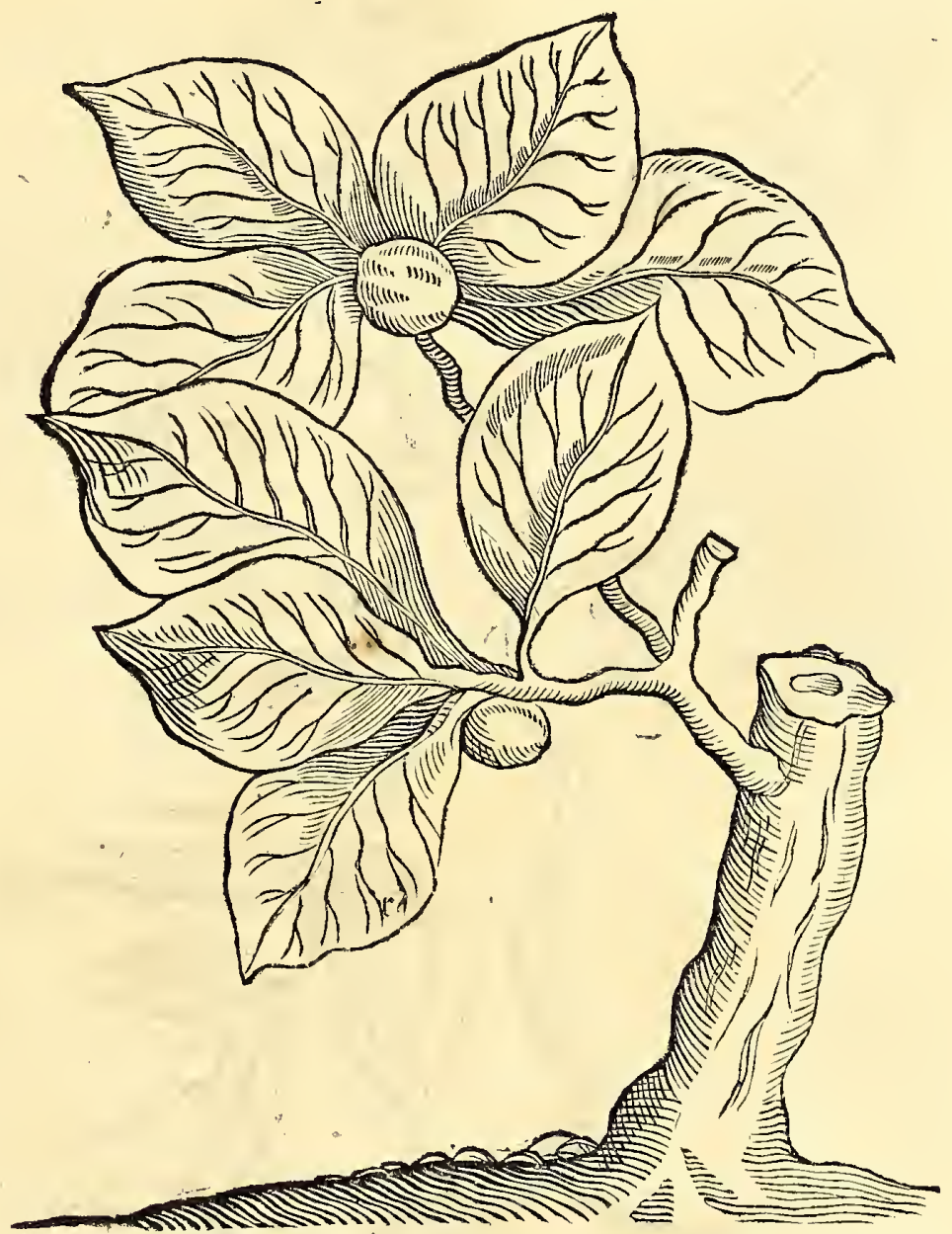

dine fecetur, neque tam opportunum Formicis quibufdam albis, qua ligna exedunt pauciflimo temporis fpatio, ita ut ingentes trabes, quamvis externa facie integræ videantur, fxpe intus ab his infectis exefx fint, non fine metu etiam magnarum adium. Folia pacula funt \& attactu afpera, ut nifi fine incifuris in ambitu effent, quis ficulnea folia effe putarer : florem fert flavum inftar Peponum floris, quibus fuccedit fructus, Nucem gallam fapore, magnitudine, 2 forma referens. 


\section{C $\quad A \quad P \quad V \quad T \quad X \quad$ V I I.}

\section{De Sambuco Indica, de Ebuli peciebus, \&o deVinea Thaminæ Plinii , de Bryonia, aliifque berbis purgantibus.}

Ambucus hic quidem cref́cit, fed non ea fpecie, \& forma, qua in Patria, foliis enim non eft in ambitum dentatis: fed xqualibus, floribus quidem non admodum differt, neque baccis: fed bacc $x$ grandiores funt, $\&$ rariores : odore porro, \& effectibus Sambucus eft, tum ramis, pulpam albam continentibus, ei plane refpondet.

$S$ A M B V C V S.

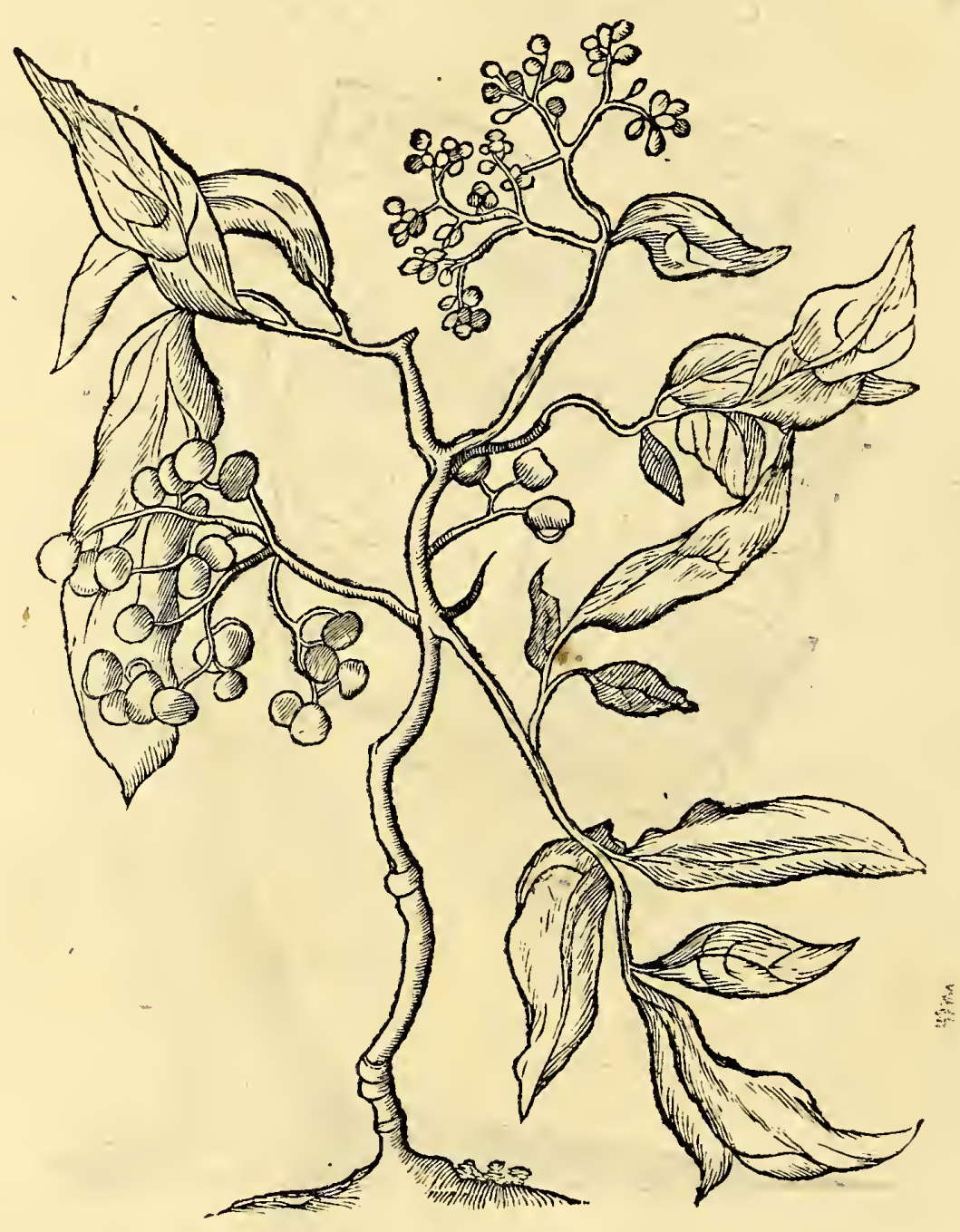

Ebuli quoque fpeciem reperire eft, tum Bryoniam, \& Uvam Thaminam, qux tria cum viribus inter fe ferme conveniant, ego ea de induftria conjunxi. Valent fiquidem, in morbis longis, \& chronicis, quales funt Cachexix, Hydrops, obftructiones lienis, mefenterii, qux quidem medicamentis mediocribus, fi non cedant, malo nodo malus eft quarendus cuneus, \& fxpe in tali cafu praftat tentare anceps remedium, quam nullum : fed id non tentandum, nifi ubi videris imbecillioribus rem nullo modo peragi polfe, \& viribus etiamnum integris, neque adeo collapfis, ut remediis validioribus refiftere non valeant, quod judicio prudentis Medici relinquendum eft. Ego hoc fincere affirmo, me extracto ex hifce plantis, \& fruticibus, defperatos curaffe. Quidni ? cum \& Efulx extracto omnibus his longe valentiori, quotidie utamur cumfucceflu, ut alibi dictum eft. 
HIST. NATVRAI. \& MEDIC. LIB. VI.

Immenfas praterea Convolvulorum fpecies paffim in filvis crefcere vidi, inter quas Scammonea, \& Efula, frequentiores. In montibus autem luxuriabat Colocynthis, \& Cucumer Afrninus, ex quo Elaterium optimum conficitur.

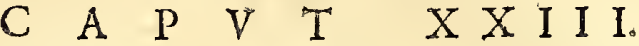

\section{De Fructibus Lance, \& Rampoftun.}

$\mathrm{H}$

I duo fructus externa tantum facie \& nominibus inter fe difcrepant. Nuclei albi intus conditi cum carne fua eundem faporem acidum \& vinofum obtinent. Alter Rampoftan vocatur, quod fructum crinitum denotat, quia filamentis quafi capillis, externe fit munitus : Alter fructus, Lauce dictus, laxvis eft \& corti-

L A N C E, \& RAMPOS TAN.
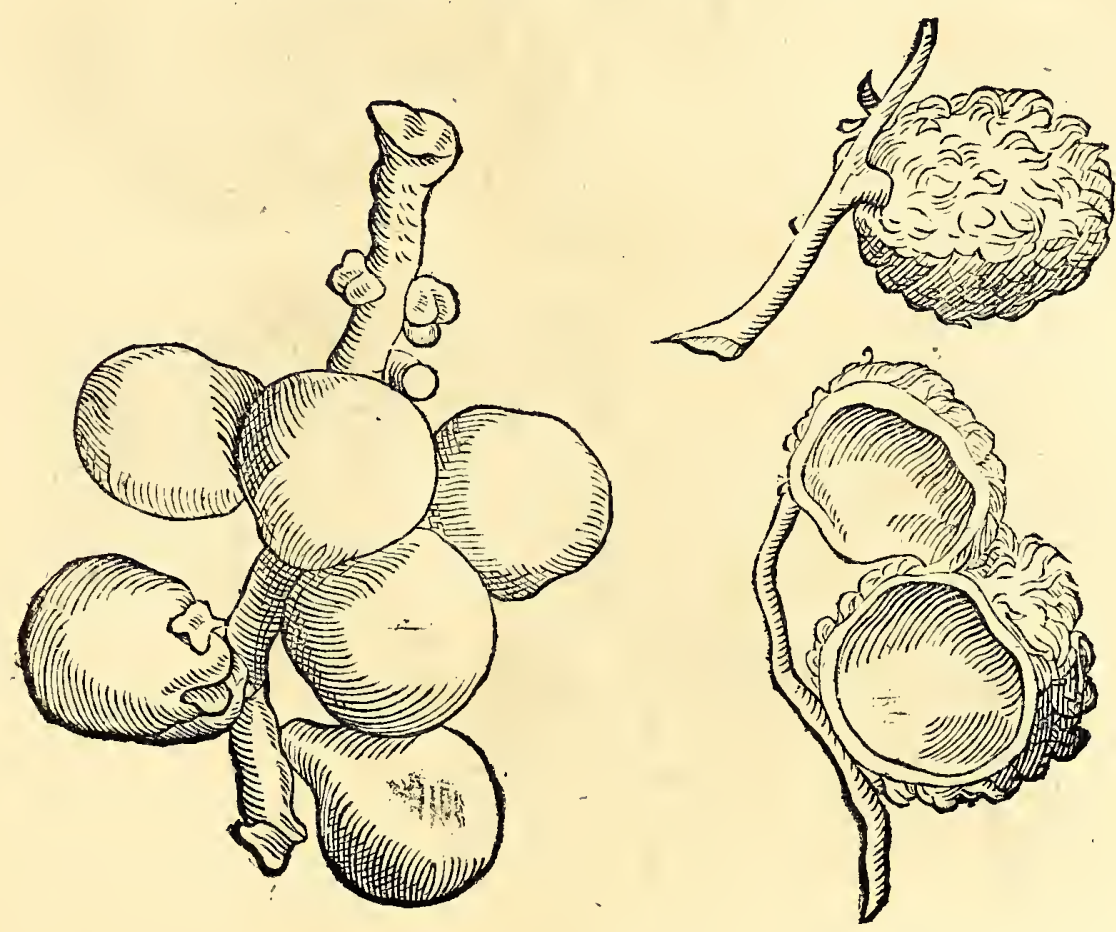

ce flavo, qui læefus lacteum humorem emittit $\&$ acrem; qualem $\&$ in Tithymalis reperire eft.

Creterum arbores magnæ \& vaftx funt, foliis Laurinis, è quibus hi fructus racematim magna quantitate pendent, \& pulcherrimo afpectu:facultates utriufque fructus inter fe conveniunt, \& apud omnes paffim incolas celebratx, quod ardoribus febrilibus reftinguendis eximie conducant.

\section{$\begin{array}{lllllllllllllll}C & A & P & V & T & X & X & I & V\end{array}$}

\section{De Myrobalanis in Iava.}

Nefcio cur Medici vocitent me Myrobalanum, Cw:n non fim Plinii Myrobalanius ego;

Nec mibi tam grato fructus laudatur odore, 2 uam jecori vis ineft fyptica grata mibi.

Amum, quem vobis ob oculos pono, ipfe in fylvis ex arbore difcidi. Hi funt Myrobalani Emblici officinis diêt. 'Arbor, que hos fert, magnitudine elt ferme Cerafi, pulchre virentibus foliis, qux faporem Oxalidis, feu Acetof $x$, habent. Fructus primum viridis eft, dein maturus flavefcit, fapore acido, \& fumme eft aftrin- 
$M$ Y R O B A I A A N $\mathrm{V}$ S.

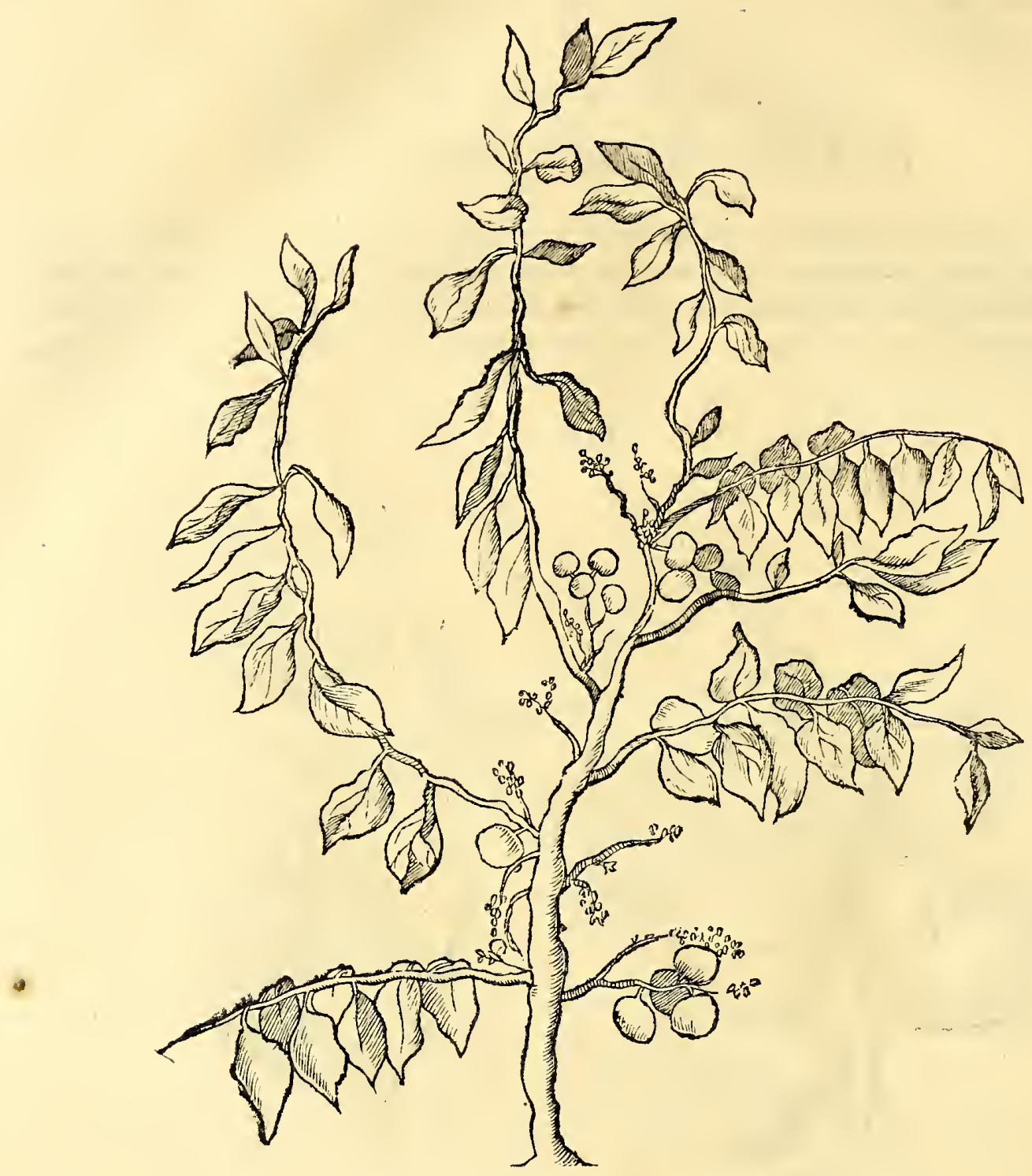

genti, qui \& exficcatis adhuc apparet : rugas quas in patria ipfos habere videmus, in arbore pendentes non habent, fed læves funt, interftitis tamen apparentibus, tanquam fibris : Non dubito, quin omnes Myrobalanorum fpecies in Iava crefcant, quas Garcias ab Orta defcripfit : fed dum ob metum latronum Bantamenfum, \& Tigridis ferociam, altius fylvas petere non audemus, vel montes afcendere (libenter enim in locis ficcioribus crefcunt) mihi eas virides videre hactenus non contigit, fed præter ibi defcriptas fpecies, hic aliam crefcere vidi, quæ Nucis Iuglandis facile eft magnitudine; rotundus, \& plane fphæricus eft fructus ejus, lavis adeo, ut tanquam fpeculum, imaginem hominis reddat. Hos Myrobalanos Mauri fapenaviculis plenis ad mercatum deferunt \& $\&$ vili vendunt, ita ut paucis affibus tantum emere poffis, quantum ad condituram tibi toto anno fufficiat. Conditi autem valent adverfus Dyfenterias, Choleras, \& cateros è bile natos affectus. Condiuntür quoque muria, \& aceto, cum Cucumeribus, Mangis, Pipere, Allio, \& Zinziberis radicibus viridibus, ad orexin excitandam, Capparum, \& Olearum vice; hoc conditurx genus Achár vocari antea diximus. 
HIST. NATVRAL. \& MEDIC. LIE. VI. IIL

$$
\text { C A } P \quad \dot{V} \cdot T \quad X X V \text {. }
$$

\section{De Iangomas Jeu Paliuro Aegyptio $\mathcal{P}$ r. Alpini.}

Arcias ab Orta lib. 2, hiftor. Plantarum Indicar. cap. 5 , hos fruatus Imngomas vocari ait, ut \& apud Malaios hic etiannum vocantur. Quantum autem ad arbo$\mathrm{rem}$, qux eos fert, ea Prunis fylveftribus in Hollandia \& foliis perquam fimilis

I A N G O M A S .

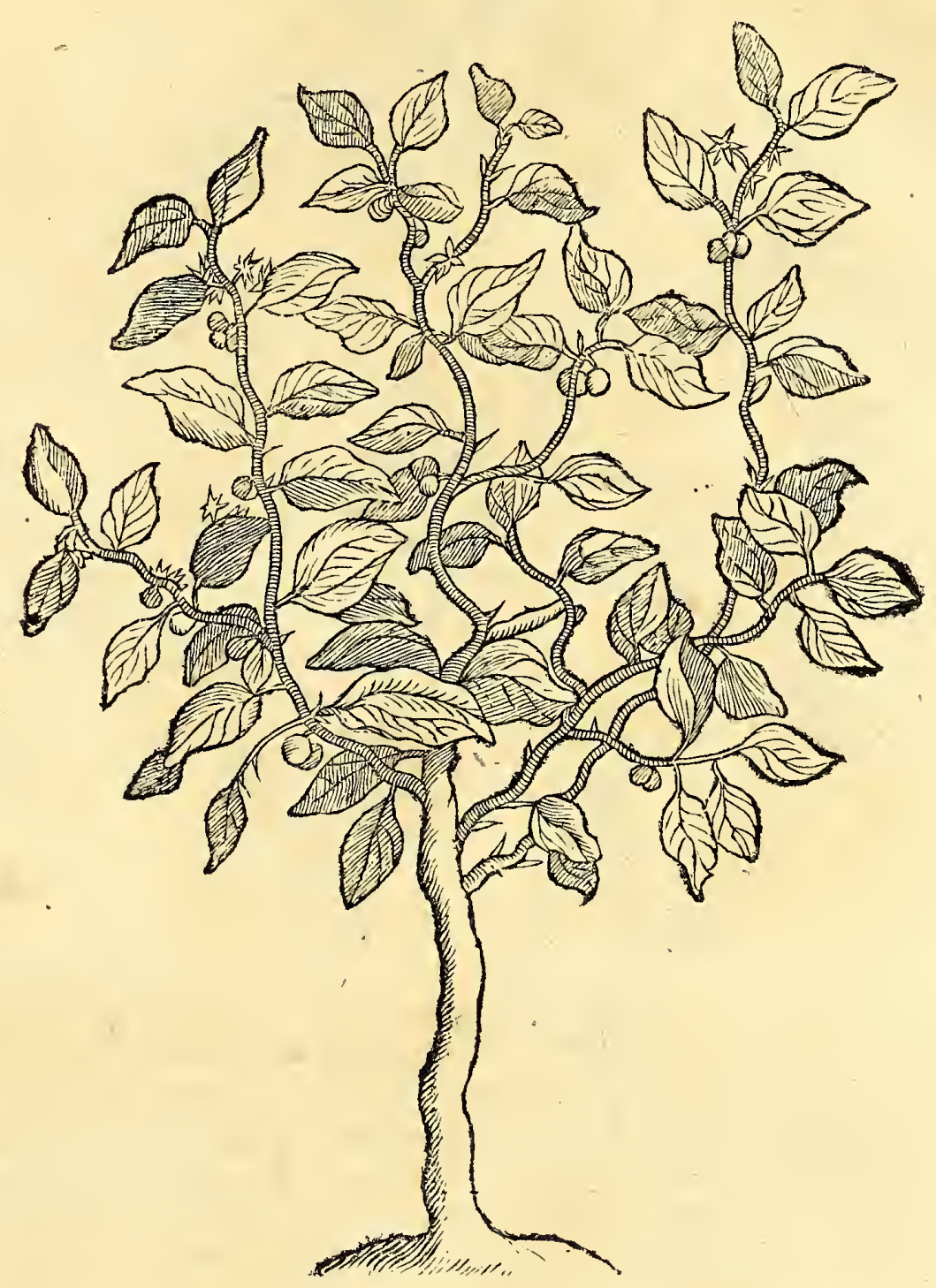

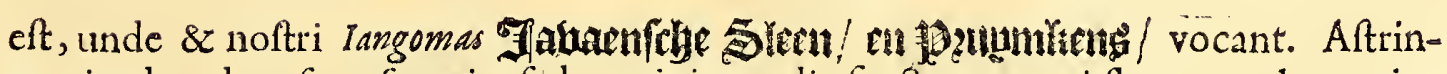
gentis admodum funt faporis: fed non injucundi: fructus maturi flavum colorem induunt: fecus quam in patria, ubi Pruna fylveftria matura, è purpureo nigro funt colore. Viribus inter fe conveniunt:nam eodem modo, quo apud nos, fuccus horum mixtus cum aq. Champacce, \& Rofarum, ardoribus gutturis, tonfillarum, \& aphtharum denique, medetur. AdDyfenterias, Choleras, \& fluxus hepaticos, expertum, intro fumptus eftremedium. Summa, Acacia fuccus nobis ufum per omnia prabet.

Profper Alpinus has langomas in fua de plantis ÆEgyptiis hiltor. Paliurum vocavit, credo, quia rami Spinis fint obfiti.

Si quis porro Acacix arborem videre velit, adeat Pr. Alpinum, lib. cod. cap. $4, \&$ fic nos compilandi aliena, opere levabit. Nam certum eft mihi non fcribere, nifi cujus ipfe notitiam è vifu, \& experimentum ex ufu, percepi. Porro arbores hx paflim \& indifcriminatim per campos hinc inde vifuntur; quod mihi fidem facit ejus, quod de hac fcribit Garcias ab Orta, lib. Ir, cap. $v$, aves quafdam hunc fruetum comeden- 
tes, excrementa fimul alvi, \& nucleos cjus omnibus locis dejicere, qui nuclei in fervido avium ventriculo macerati, eo facilius emergunt. Vnde Virgil. in Eclogis ait,

Carduns, \& Spinis furgit Paliurus acutis.

$$
\text { I A N G O MAS AITERA. }
$$

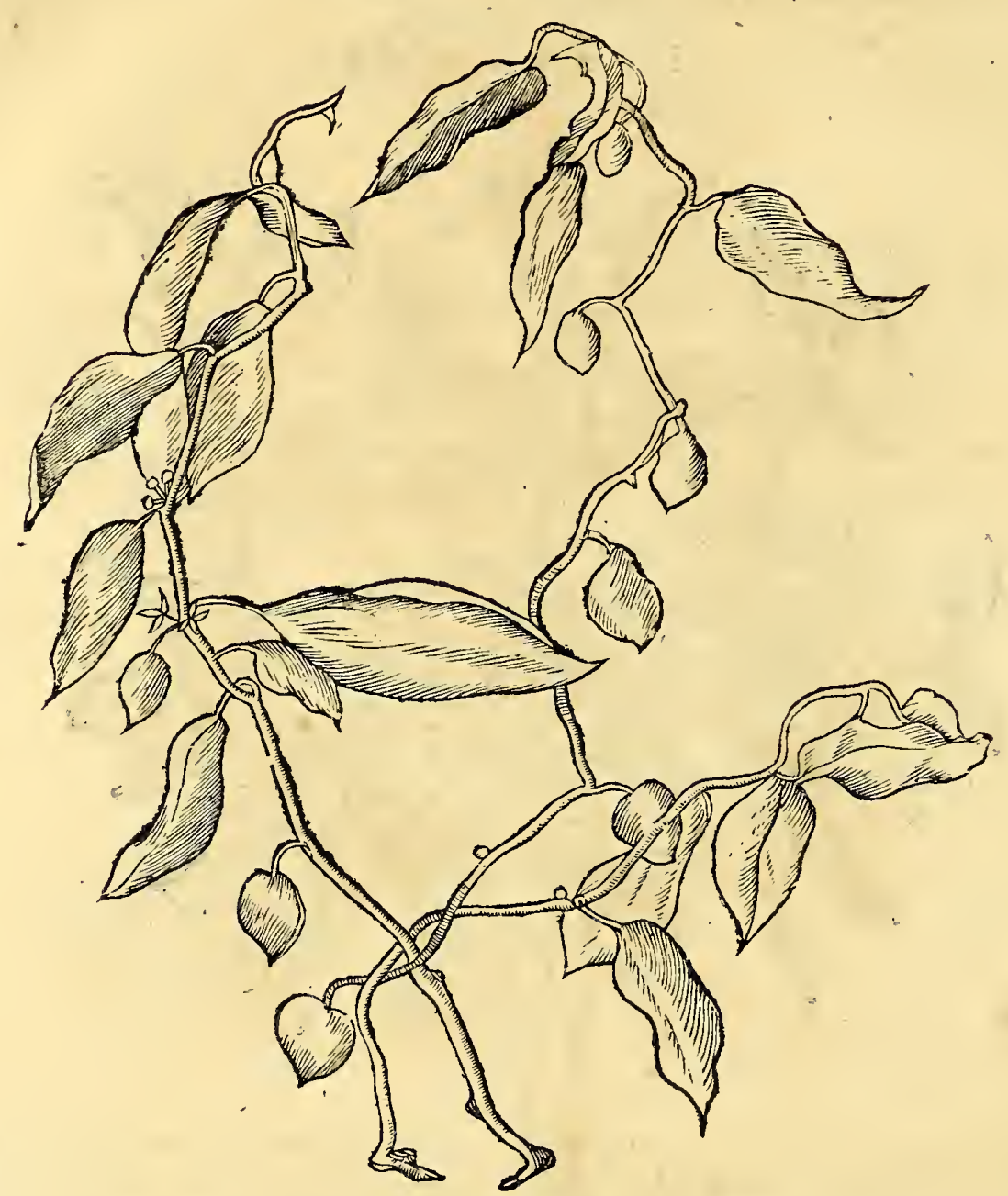

A N N O T A T I O. Alterius Iangomas fpeciei autor promittit defcriptionem, fed nihil de ea inveni, nifi folam hanc iconem, quam idcirco pofteris ulterius indagandam, hic apponi malui, quam ut tota negligeretur. Mul tum fane, qua ad externam figuram, hi duo ramufculi, primx langomas, paucis exceptis, fimillimi funt, niff forte pictor nimia licentia , in magnitudine exprimenda, ufus fuerit.

\section{$\begin{array}{llllllllll}C & \text { A } & P & \text { V } & \text { T } & \text { X X V I. }\end{array}$}

De Frutice odorifero quodam, Incolis Daullontas dicto.

- Cede Melilotus, Chamamelon cedito nobis Viribus exupero ros, quamvis Barbara planta.

Rutex hicin fylvis fupra altitudinem humanam affurgit, \& ramos fuos late à fe -1 expandit, ut Salix aquatica, qua corbes in Patria contexunt, hicquc frutex tam crefcendo luxuriat, ut Hortulani Chinenfes illum flamma \& ferro excidere cogantur, folia fert Balfaminx foliis non abfimilia, \& fimiliter in ambitu incifa, florum fafciculos gerit, ut Sambucus, quibus etiam amarx fuccedunt bacca: quod vero odore plane referat Chamæmelum noftrum, \& quod cofdcm nobis hic ufus in foti- 
HIST. NATVRAL. \& MEDIC. LIR. VI. II

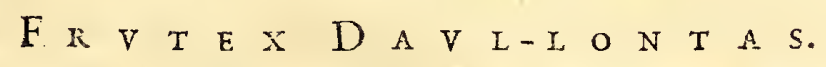

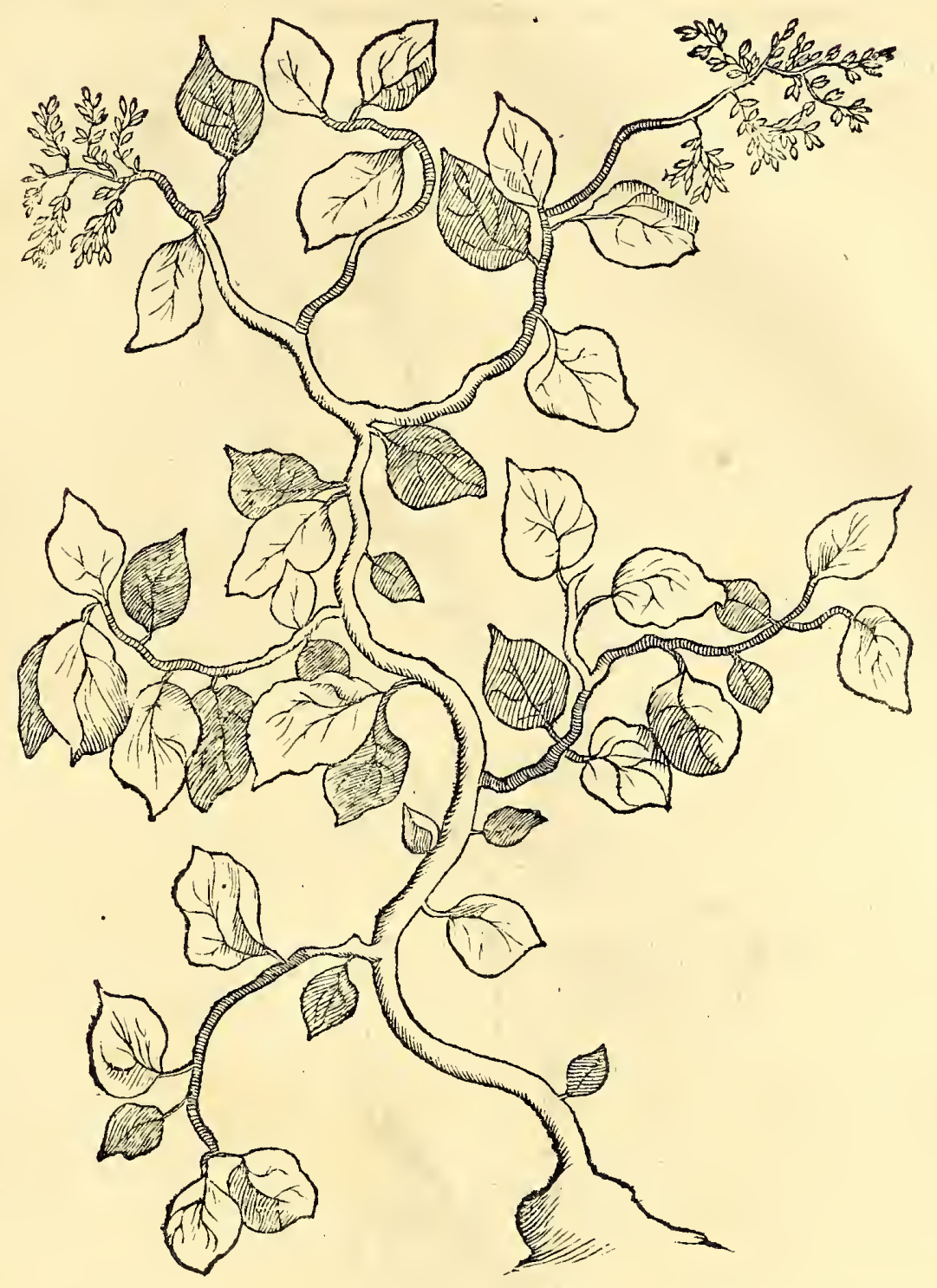

bus, \& balneis præbeat, quem Chamamelon, \& Mclilotus; Ideo nomen ipfindidi Chamæmeli arborei. In Cataplafinatis porro, \& Ceromatis pro tumoribus refolvendis, foliorum pulvis perutilis eft, atque apud has gentes fecundum locum, à Liguftro Indico, feu Lagordi, obtinet. Florum quoque $\&$ baccarum decoctum afthmaticis, $\&$ diuturnis pulmo num affectibus, mulierum quoque menftruis movendis, nihil utilius fumi poteft: Prædictum porro Lagondifeu Liguftrum Indicum, vehementer prodeft, injarn toties diata paralyfeos Indicx fpecie, qux Beriberii dicitur. Porro hunc fruticem habentes facile ufu Chamameli, Meliloti, Anethi, \& Faniculi, carcmus.

\section{A P V T $T$ T X X V I I.}

De Acetoja Indica, ailifque Acetariis, \& Olcribus.

Oxalis ex acido fec appellata fapore,

Purpureo flavum forem circumdatalimbum.

NIava, \& circumjacentibus Infulis, crefcit quxdam Acctof $x$ fpecies mirabilis, nihil quoad formam cum Europæa Oxalide, aut Acetofa, commune gerens. Affurgit porro in altitudinem facile humanam, caule firma, \& in modum Cannabis angulata, folia Agrimonia, feu Eupatorii foliis, quam funt fimilia, cum acutis \{pinulis, hinc inde extuberantibus : Florem fert inftar Malvæ arborefcentis, folio fimplici, ejufdem quoque magnitudinis, qui in circumferentia quidem colore ex albo luteus eft, in $K_{3}$ calice 


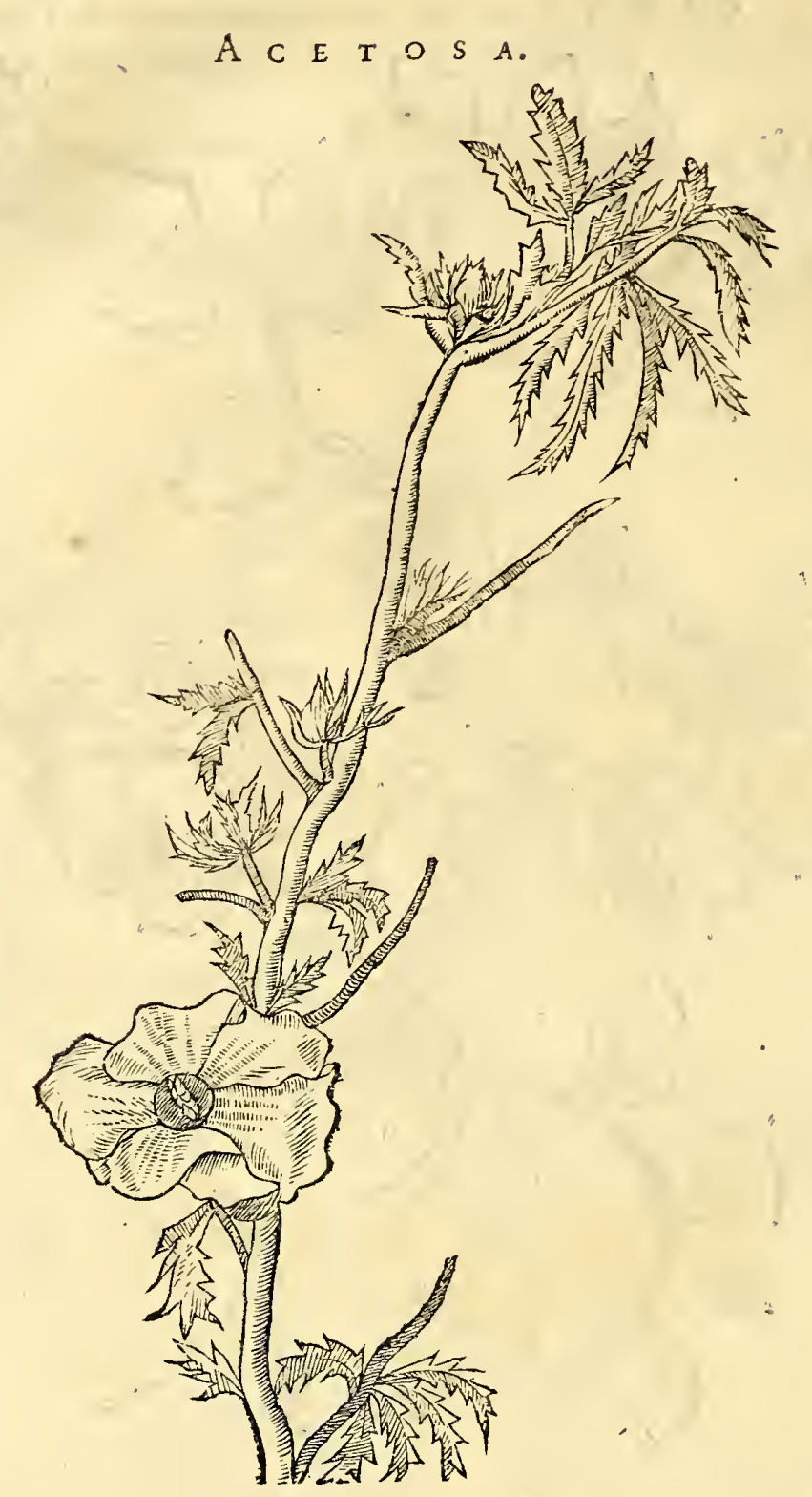

calice vero intus pulcherrime purpuratus. Folia fi nuafticentur, Acetofam plane fapiunt, nifi quod guftui pinguius quiddam, \& glutinofius repræfentent: Semen ejus plant eft inftar feminis Cardui benedicti fpinofum.

Qualitate eft è frigida vergente ad ficcam: Malaii quoque Bengalenfes \& cxteri Maur1 eam in edulibus pro olere reponunt: Olus autem, vel quicquid herbarum pro alimentis in ufu eft, hx Nationes communi vocabulo, Saiir, vocant; contra quicquid è terra nafcens medicam, vel adeo venenofam qualitatem obtinet, oubat indigitant. Herba hæc quoque in frequenti ufu eft pro topico medicamento; conterunt quippe folia fuper lapidem marmor eum fcrobe ligni Santalini, \& intinctos pannos capiti imponunt, mixto oleo Nucis Indicx, \& aceto, in doloribus capitis biliofis, qui plerumque meninges cerebri infeftare folent. In febribus ardentibus eriam \& phrenitide admodum frequenti in ufu eft. Certe hæc gens, magis addieta eft medicamentis localibus, quam intro fumendis: atque adeo pharmacis, prafertin validioribus, non, nifi in fumma necefitate, utuntur: \& profecto, meo quidem judicio, hoc faciunt minus àbfurdo propofito, quam qui inter nos in patria vel levicile affecti, ftatim catapotia, \& plarmaca liquida deglutiunt, fine difcrimine; tum extemplo lafcivix magis, quam neceffitatis ergo, venam fibi pertundi curant: aft hx gentes fola inedia, \& accommodata victus ratione, non tantum corpus neutrum : fed $\mathbb{E}$ infigniter preter Naturam affectum,curant, non ignari, medicamentis pro cupediis \& deliciis non efle utendum. Vt autem hoc obitcr addam, videtur Natura voluife ex profeffo multas acidas, \& conltringentes herbas (ut in progreflu videbitur) è terra producere, contra violentos \& Endemios morbos, Dyfenteriam nempe, Choleram, \& Spa- 
HIST. NATVRAL. \& MEDIC. LIB. VI. IIS fmum, plerumque à bile ortos. Vt quafi digito monftraret, ubi hæc vel fimilia mala nafcuntur, ibilocorum remediorum manifefta $\&$ etiam occul ta qualitate pugnantium penuriam non fore ; haud iccus quam in Septentrionalibus regionibus, ad Scorbutum Endemium vel iftis locis familiarem morbum, herba Britannica, feu Cochlearia abunde fuperque è terra nafcitur, ut in Indiis quoque Occidentalibus Lignum Guajacium ad morbum Venereum, inde oriundum, terra liberaliter profert.

Trifolii variafpecies, imprimis Acetofum, tam in filvis circa fucnta, quam hortis luxuriant. Idem de Portulaca, Cichoreo, Malva, Althæa, Endivia, Lactuca,Soncho, Plantagine, Becabunga, Nafurtio aquatico, Perrofelino, Raphano hortenfi, utraque Beta, aliifque ímilibus, partim exfemine à patria allato, partim fponte nafcentibus, diatum volo, quarum aliquæ noftratium inferiores, aliquæ dignitate fuperiores exiftunt.

Caucio porro adhibenda, quod Flammulæ quædam fpecies in aquis circa prædicta acetaria crefcat, Lactuca perquam fimilis, ejufque elegantem virorem $x$ mulans, qua ego deceptus, frigidam herbam ratus, eam guftavi, unde tanta acrimonia $\&$ fervor lin. guam invafit, ut erumpentibus per totum os veficis, plus quam per tres horas ardoris ifticis fenfus in ore remanferit.

Mandragor fpecies illa Italis Belladona vocata, apud Indos in frequenti eft ufu conrra febres continuas $\&$ ardentes. Aceto vel muria conditam, fructus quoque fub cineribus toftos, pro acetariis fani \& agri apponunt.

\section{A P V T X X VIII.}

\section{De Fructu Mangoftan.}

Cedant Hesperii longe binc, Mala aurea, fructus; Ambrofia pafcit Mangoftam, or Nectare, divos.

$\mathrm{H}$ Ic fructus à Garcia ab Orta lib. 2 , cap. I 2 , nimis leviter defcriptus eft, cum fit inter omnes Indix fructus longe fapidiffimus. Cortice refert plane Malum Granatum feu Medicum ; eodemque modo aftringit, cum paulo majore amarore. In bafi feu inferiore parte veftitur circa caudam tribus vel quatuor quafi

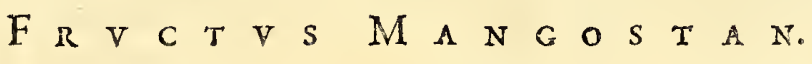

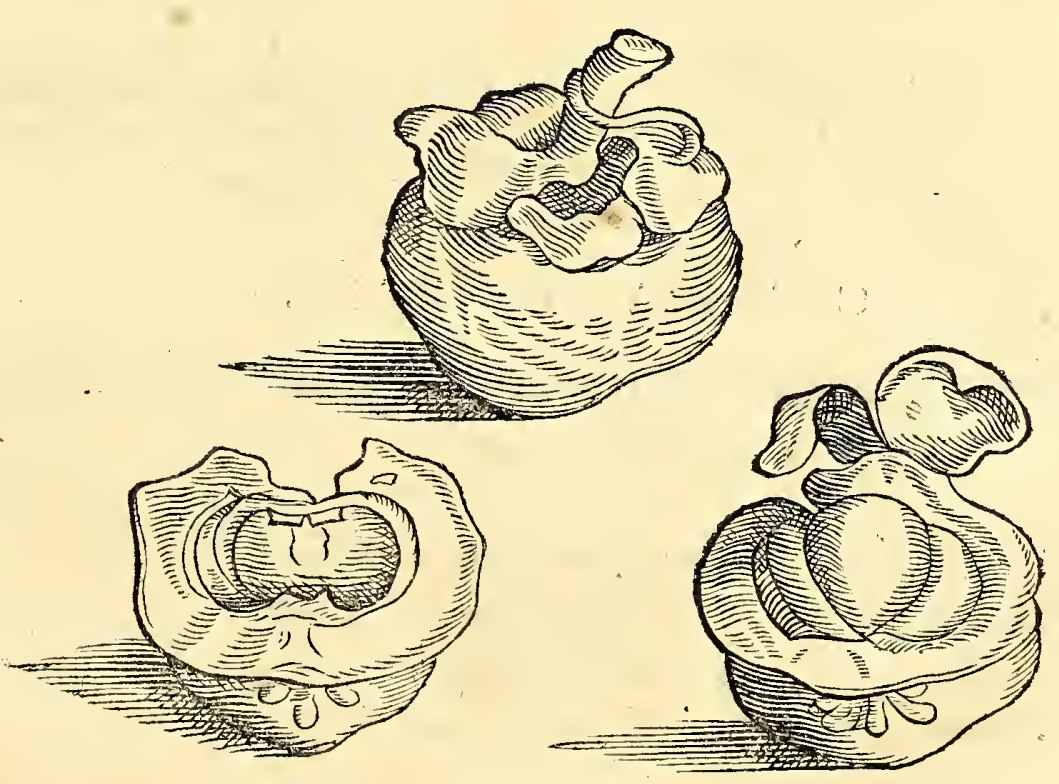

feparatis corticibus, minutioribus, ut in Rofa videre eft. In vertice vero coronam geric, qua quot radios habet, tot nucleos in aperto Mangoftano, candidiffima carne nivis inftar veftitos reperies, ita aliquando fex, aliquando octo, pro radiorum multitudine. indubitato intus occluduntur. Folia porro hujus arboris, ut \& truncus \& rami, nifi $K 4 \quad$ gुuod 
quod fipinofi non fint, Mali Citrei arborem xmulantur, \& nifi odore diftinguerentur, qui hujus Mangoftan foliis nullus eft, procul dubio afpectum fallerent.

$$
\begin{gathered}
\text { C A P V T } \text { X X I X. } \\
\text { Mangam fruclus apud Iavanos facer. }
\end{gathered}
$$

Antidoton adverfus Iavanum dira venena Mangam quintuplici fic jpector segmine fructius.

$\mathrm{F}$ Abulas lectori narraturus, an veri quippiam ignoro, vos judicate: Iavani hunc fructum majoris xftimant, quam quicquid antidoti fit in mundo, five id Lapis Bezar fit, feu aliud quippiam, ur Nux de Malediva; plantaturque tantum in regum fepulcris. Magnitudine eft Nucis, quam Palma Indica fert, Coguo vocant

FKVCTVS SACER MANGA M.

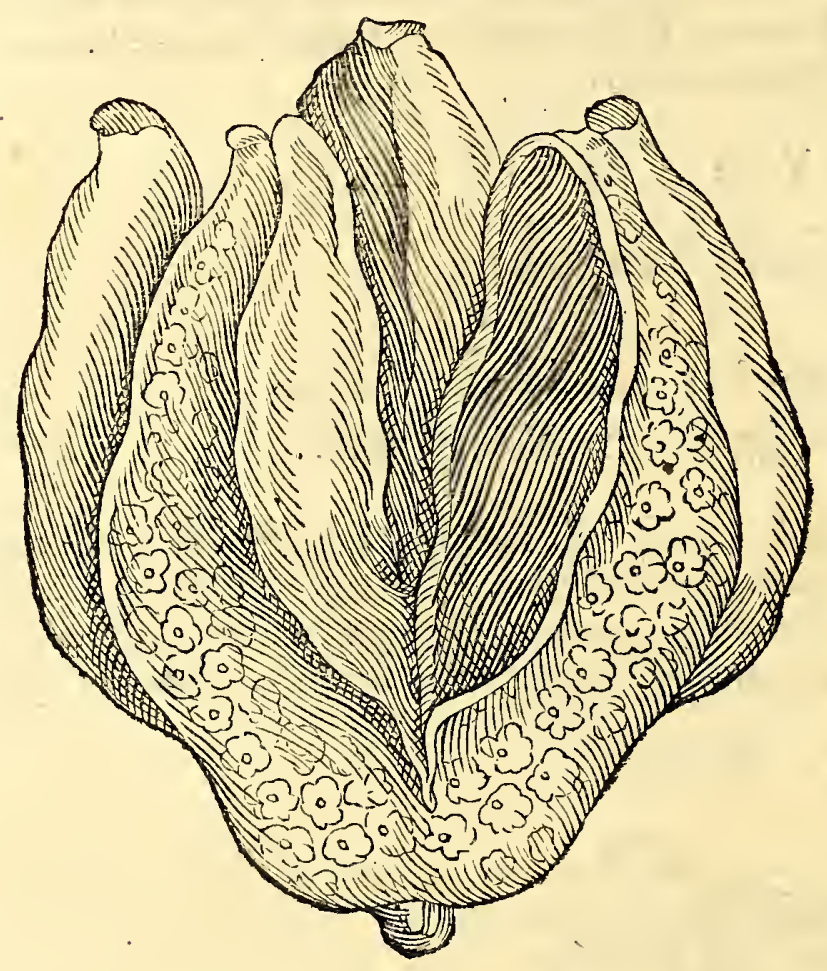

Lufitani, Malaii Calappa. Vbi nondum maturuit, continuus videtur, maturus autem à feinvicem diffilit \& difrumpitur, femen intus oftendens lanugine cinctum, feu femen Goflampini arboris Plinio dictx, quod nifi tempeftive colligatur, facile à vento difipatur. Summitatibus hujus fructus Rex Bantamenfis aureum poculum torcularibus infert, atque hoc fummi favoris loco Magnatibus vel Iegatis peregrinis propinat. Dono porro mihi hre Nux data eft à Chirurgo hujus civitatis, qui ipfum cum non contemnenda argenti copia acceperat, à Regis Bantamenfis filio majore, in præmium reftitutx à fe valetudinis. Cxterum partesà fe invicem fupra difruptx, tam arcte bafi fuxinhærent, ut ne fortiflimus quidem eas dia vellere queat.

\section{A.P $\mathrm{V}$ T $\mathrm{X} X \mathrm{X}$.}

\section{Crocus Indicus, Arabibus Curcum, Officinis nofris Radix Curcumx dicts.}

\section{Magnis fum foliis, tum flavo Curcuma fucco}

Nobilis bic Nymphis frutexque Salutifer Indis.

Cortice rugofo, fed edulia Pifa recondo,

Quam multis plantis fimul bac natura neganit.

$\mathrm{H}$

Æc eft nobilis illa Curcuma, de qua Garcias ab Orta mentionem facit Aromatum lib. 1. cap. 39 ; fed cum exigua cjus notitia. fub finem prædicticap. ait, putare fe, hanc radicem fine noxa edi pofle : audacter, quamvis illud non meo pcriculo dicat: Nam non folum ea Malaii in medicamentis utuntur : fed etiam fimul cum pifcibus \& carnibus coquunt, condimenti \& fanitatis gratia. Caterum excelleritifimum eft remedium in obftructionibus vifcerum, Pulmonis nimirum, lecoris, 80 
C V R $\quad$ C $\quad$ V $M$ M.

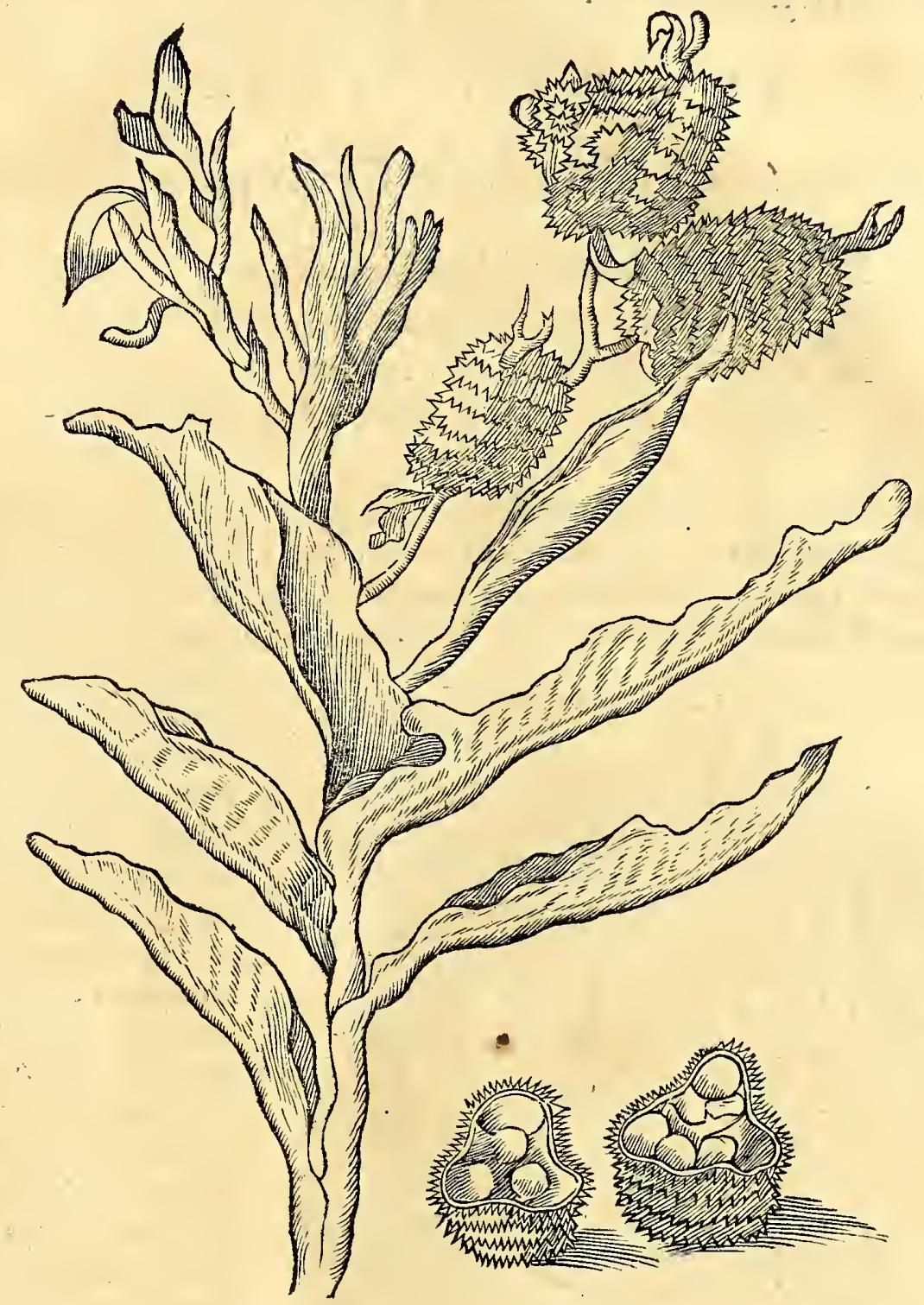

Lienis, tum in oppilationevenularum mefaraïcarum, tum Nephriticis doloribus Calculo Renum \& Veficx efficaciter opitulatur, tum fœminis menftrua promovet, difficultatem pariendi aufert. Et quod in ea caput rei eft, peculiare $\&$ fpecificum remedium eft in Ictero, quod multoties feliciter expertus fum. Chinenfes quoque eam propter hunc ufum præcipue Saccharo condiunt. Folia lata habet hæc planta, non abfimilia foliis Hellebori albi, nifi quod non tam ftriata : fed lævia fint. Radicem habet qualem ferme Gentiana. Flore eft pulcherrime purpureo. Radix porro coloreflavo tingit, non fecus, ac Crocus, unde etiam Garcias ei nomen indidit Croci Indici : Lufitanice vocatur quoque Saffran da Tierra, quafi Crocum Subterreftrem dicas : Iavani radicem hanc Borborii vocant, unde etiam ejufdem nominis nobile unguentum conficiunt. Hanc cum pulvere Santali \&ialiis floribus odoratis poft dicendis, in marmore fubigune in unguenti confiftentiam, quo univerfum corpus, tam viri quam formina inungunt: Quod quamvis infolitis afpectu foedum propter flavum colorem fit, tamen adverfus calores febriles \& $\&$ Solis ardores, tum moleftiffimos quoque Culicum morfus, fummum cft juvamen. Fructus hujus Curcumr, qui foribus fuccedunt, Echinatifunt, ut in hac figura videre eft, inftar Caftancarum in Europa. Aperti femen fuum oftendunt, Piforum forma rotundum, quod ctiam coctum in jufculo gallinarum vel carnium hocdinarum, alimenti fimul, \& medicamenti præftantilimi, adverfus fupra commemoratos morbos, vicem obtinet. Catcrum, ut finiam, radix bxc merito ob fummas \& praftantiflimas qualitates, inter Medicamenta deobftruentia mihi principem locum obtincre. videtur. Nuperrime obfervavi, Chinenfes etiam infternutatoriis hac radice uti, inftar, radicis Hcllcbori albi : \& certe fapor ejus aliquantum linguam vellicat: unde non mi- 
rum eft, proceflus mammillares in naribus exafperare, \& ita Cerebrum concurere, \& Rternutamentum è Cerebro elicere.

\title{
C A P V T $\quad X \times X I$.
}

De Durionibis, Iaaca, es Champidaca diftis.

\author{
Diffectis foliis, latam prabentibus umbram, \\ Pradita fum, viridi quaque colore nitent. \\ His à Laurinis folius ego difto Iaaca; \\ Nam Sapor, $\mathcal{O}$ fimilis fructus, adefe folent.
}

$\mathrm{D}$

Vriones fructus dictià corticis duritie, feu fpinis, quamvis primum guftantibus faftidiofi funt faporis, \& odoris Allium putridum referentis, tamen merito inter faluberrimos Indix fructus numerari debent, ficut ex fequentibus patebit: Si quis iis affueverit, eum non tam cito fatietas hujus fructus capiet, quam alio-

Fr V CTVS DVRIONIS Majoris IA A A.

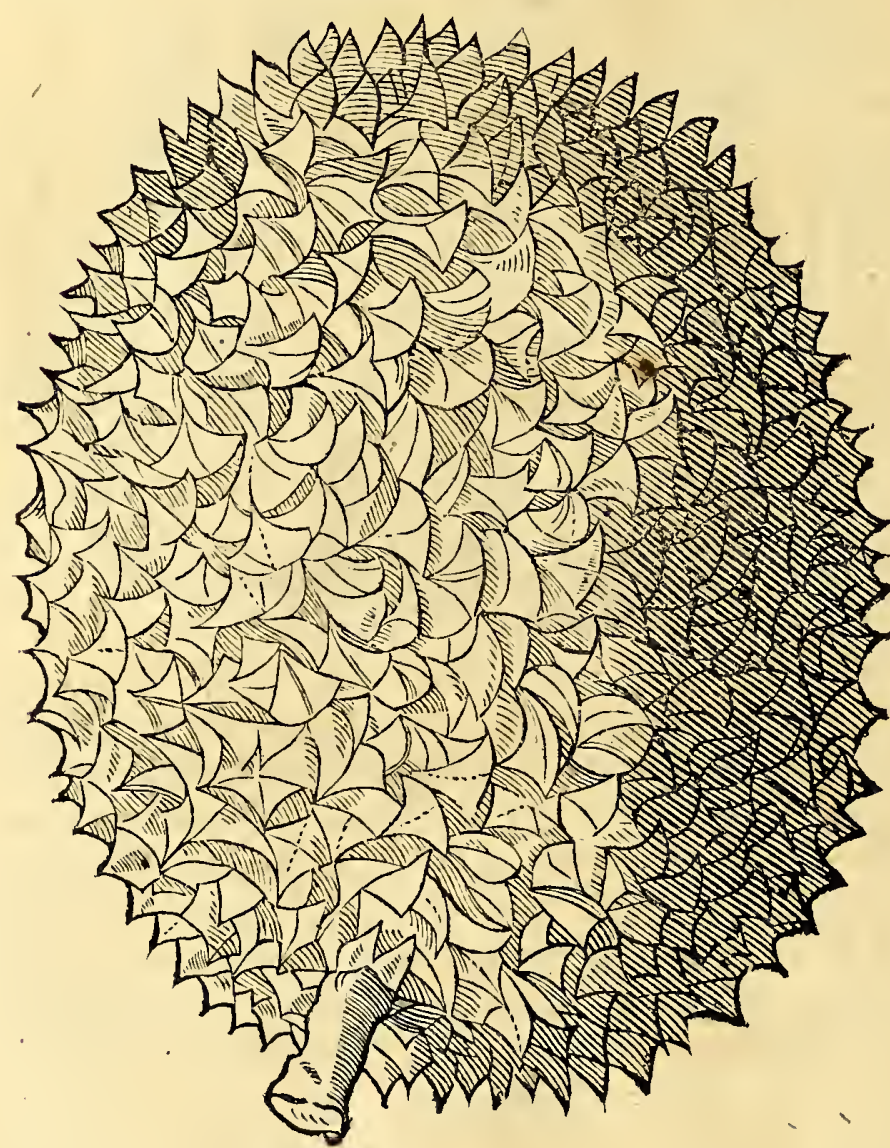
rum. Qualitatis funt cali$\mathrm{d} x, \&$ ficc $x$, quod ex effeats facile conjicere liceat; nam non folum copiofe urinas cient, fed \& flatus difcutiunt, tum fudores egregie eliciunt: nihilominu's ego inter fructus eos numerem, qui inedicamentofi, \& alimentoli $f$ mul dici merentur, ideoque parcius iis quoque urendum effe autumo. Nam immodice fumpti inflam mationem hepati, \& fanguini inducunt, $\&$ exanthemata in facie copiofa excitant. Et, fi quis Indica Scabie, feu Prurigine. ifta, quam Courap Iavani vocant, laboret, is, hoc fruEu comefo,ftatim tam ingentem in cute pruritum fentit, ut à fcalpendo fibi temperare nullo modo queat. InterEchinatos porro, \& Spinofos quoque referuntur hi fructus Incolis Iaaca, \& Champidaca vocati : qui ejufdem funt generis, \& uterque obfitus protuberantiis fpinofis;fed, ut laaca fructus tota mole \& magnitudine fupcrat Champidaca, ita \& pungentioribus fpinis; de quo Garcias ab Orta lib. 2, cap. I I, fed melius multo Chriftophorus à Cofta egit, f. 289 .

\section{Afpera me veftit cutis, binc ego dicar Echinus \\ Non male, me nimium vefcier ufque cave; \\ 2i faciem cupias diro rubore notari,}

Quem, fi me comedas, puftula fava facit.

Iaca infalubris plane eft, \&difficillimx concoctionis, $\&$ fere incoctus per alvum rejicitur, ut ore affumptus eft : nam caro ejus circa nucleos fixa, tam lenta eft, ut vix dentibus lacerari valcat, flavi coloris eft, fed ipfi nuclei, à fe fubftantiam albam reddunt, inftar cremoris lactis, fed lentam, \& vifcidam, digitifque adhxrentem. Hxc autem 
HIST. NATVRAI. \& MEDIC. LIB. VI.

autem laaca non è ramis dependet, fed miro modo è trunco Arboris prodit. Ingentes nuclei intra fpinarum concamerationes contenti carne alba veftiuntur.

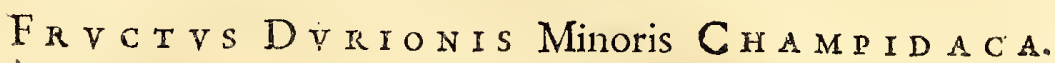

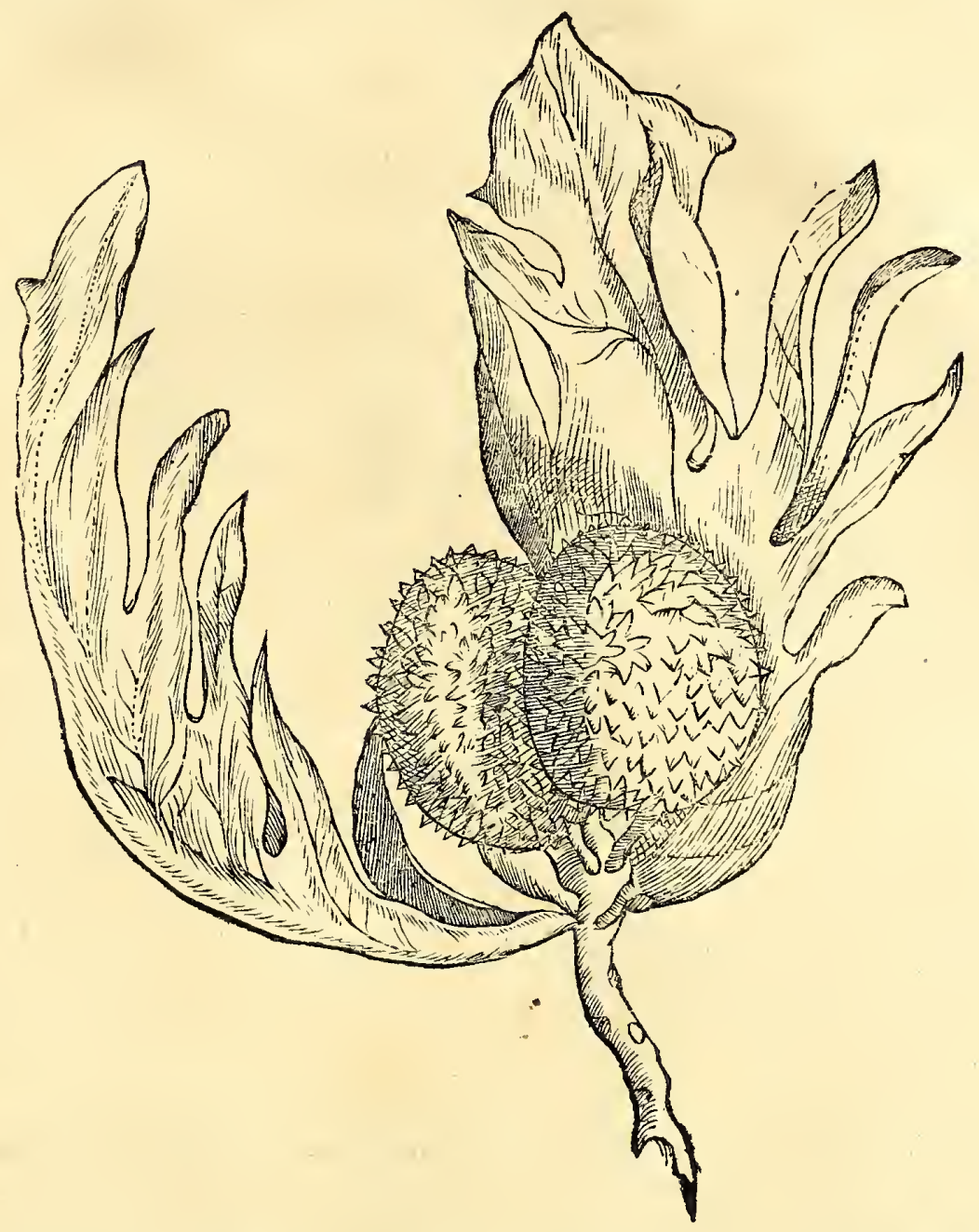

W St tamen illius aliqua fpecies, quam hic depictam damus, qux è ramis depender. Ac Arbor illa in qua crefcit, vafta eft \& praalta, foliis Platani latis, aut Quercinis, fed profundelaciniatis: Fructus autem peculiari voce Champidaca vocatur, \& melioris eft faporis, falubriorifque fucci quam Iaaca. Ex corticibus horum Echinatorum fructuum Indi cineribus combuftis Lixivii loco in lavandis linteis, \& veftibus, utuntur, $\& 2$ nos iis in Cauteriis potentialibus non femel ufi fumus.

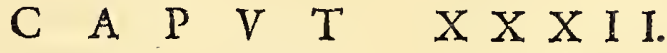

\section{De Herba Sentiente, \& pudica, quam Luftuni Yerva Sentida $y$ Vergonhada appellant.}

Cur tactum refugis, cur nervos contrabis? anne Hic Daphne latitas, que Lauro forte relicta Pbceboos radios fugias vetere qque calores?

Pone metusm, nullos Phobi verearis amores, Arita pudicitie fatis bic cuftodia pofta eft:

cyntbius bic vacua nec folus regnat in aula.

Arcias ab Orta Medicus quondam Proregis Goënfis hanc herbam defcripfit lib. 2. Aromatum \& Stirpium Indicarum, cap. 27. Sed quod dicat foliis Polypodii crefcere, non ita eft ; nam foliola habet longe minutiora: Yerum acce- 


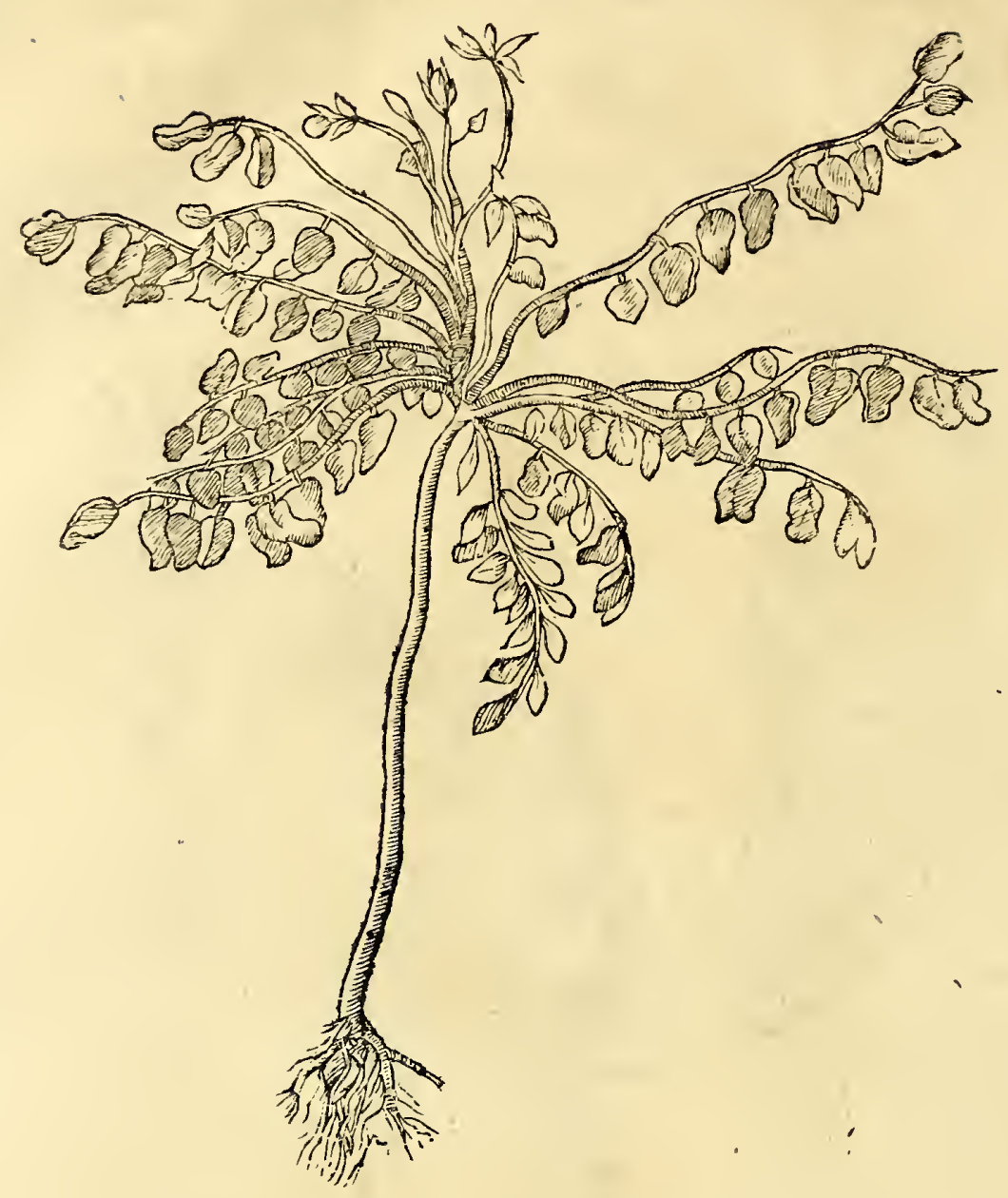

dunt proxime ad Viciarum \& Ciceris Arietini formam: Cxterum planta hæc no. men fortita eft, quod contacta, in fe contraharur, tanquam fi pudore afficeretur: flofculum profert eleganter flavum, fimilem flofculis Anagallidos ; non ultra palmx altitudinem affurgit. Quoad qualitates ejus manifeftas, eas ex guftu parum amaro, \&aftringente, ficcas \& calidas effe conftat, proximeque Viciarum naturam redolent, è quarumgenere eam effe affirmare aufim : nam floribus parvulæ filiqux fuccedunt, nifi quod teretes \& oblongiores funt, quam Cicerum liliqux. Prima facie $\&$ fuperficialiter naturam hujus plantul $x$ contemplanti, mirum videtur herbam refilire à contactu hominis; fed cum videam idem etiam in aliis multis plantis evenire, miraridefino : Naminter cxteras videre eft femen Trifolii acetofi, fi contrectetui , exfilire \& manum hominis fugere. Hoc Trifolium cum fumma quantitate crefcir ad Promontorium bonæ Spei, eaque fola herba ferme xgri à Sceleryrbe reficiuntur; Cum nefcio quam ob caufam, aut à noftris, hominibus hujus regionis illatam injuriam, non amplius defcendant ad littus, cum vaccis, bobus, \& ovibus venalibus. Prxterea Cucumer Afininus, unde Elaterium confici folet, ubi maturuit, linteo excipi debet, ut decerpatur, alioquin cum frepitu difilit à fe invicem, \& mar num carpentis eludit. Notum quoque de herbæiftius filiquis, quam Noli me tangere, in Patria vocant, quàm etiam tactum, ubi maturuere, effugiant. Itaque non eft, quod putemus miraculum hoc peculiare huic planta effe; ne dum in hac re nimis altum philofophemur, idem nobis accidat, quod Chriftophorus à Cofta refert eveniffe Philofopho Malabarenfi, qui præ nimis accurata hujus herbæ contemplatione amens redditus fit. Prxterea Iavani illud pro philrro habeant: Ego natura non propenfus ad credendum fupernaturales, \& fuperftitiofas medicamentorum vires, cum Horatio concludo Epift. ad Numicium :

Nil admirari, prope res of una, Numici,

solaque, qua pofjit facere of jervare beatum. 
HIST. NATVRAL. \& MEDIC. LIB. VI.

\section{A P. V T XXXIII。}

\section{De Planta Tavanis Simbor Mangianam; Malaiis vero Tando \\ Roufa. Quod utrumque nomen Cormu Alcis dे fimilitudine exprimit.}

Et mare cornigerum eft, \& cornibus ä̈ra pulfat,

Multa avis in Tava, Cornua terra gerit:

Afpicis hanc plantam, fimilis quam Cornibus Alcis;

Affixam fcopulis, terra nec ulla tegit:

Atque è fungofa mitto radice fibellas

Queis quicquid tango, fic retinere fcio.

$\mathrm{N}$

Atura genitrix \& rerum 'confervatrix, non folum videtur contenta fuife, in effingendis cornutis animalibus, in terra, \& etiam in mari, ut poft oftendemus; verum hoc videtur etiam rmulari voluiffe in vegetativis, feu plantis, ut in Cicerum, \&aliquibus Piforum fpeciebus:Sed prxcipue in hac planta, qux circa fluen-

$C \circ \mathbb{R}$ Y A I C I S S I M B O $R$ D D I C $T$ A.

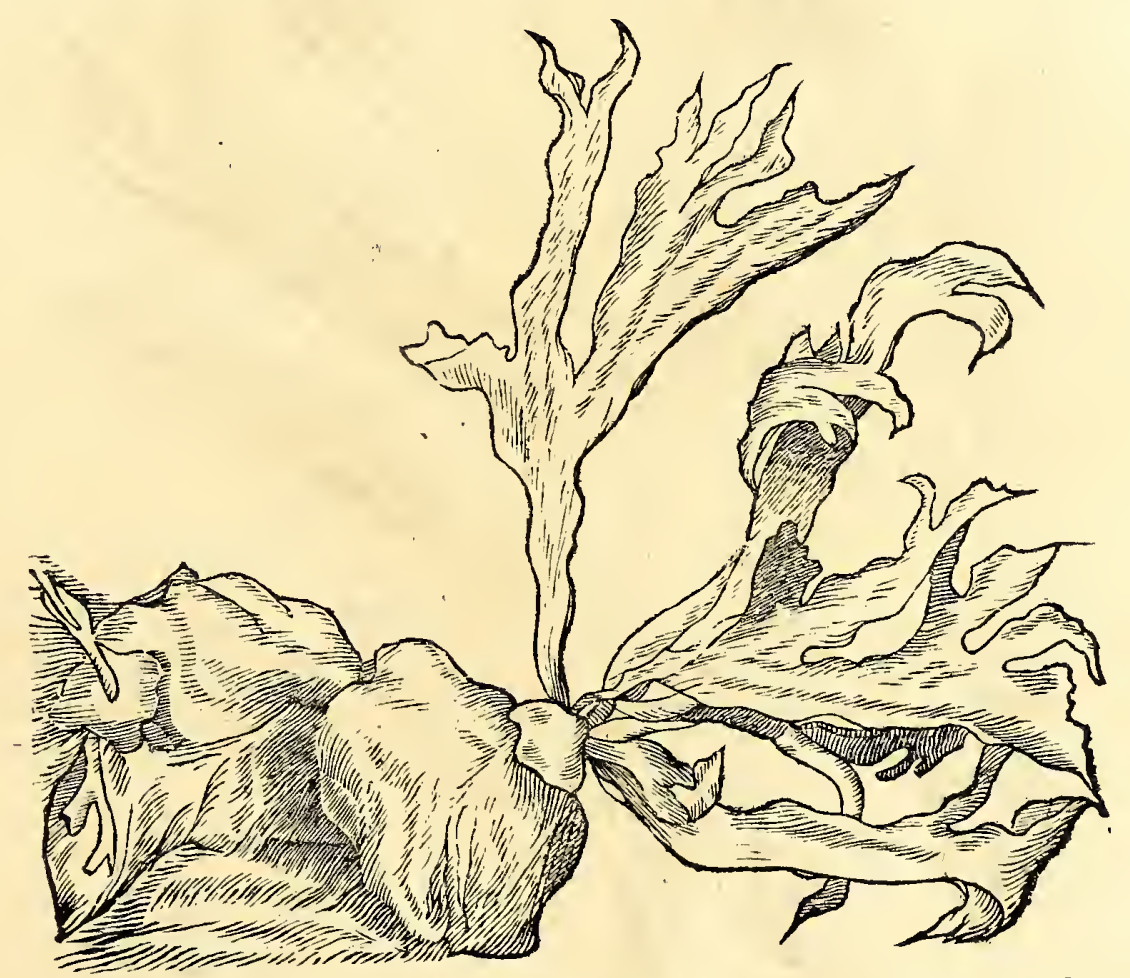

ta in lava, prefertim regno Bantamenfi, crefcit, adeoque ad vivum foliis fuis Cornu Alcis refert, ficut in hac figura videre eft, ut ne quidem Pictor vel Plaftes illud melius arte efficere poffet : Radice enim caret; in cujus vicem fuccedit maffa quxdam è materia fungofa, qualis apud Hollandos in paludibus (quas $\mathbb{B}$ Eeenenvernacule vocanus) è fundo aquarum retibus extrahitur, unde ifti céfpites flammatiles conficiuntur, quos Citumen indigitant Batavi noftri. Crefcit illa praterea, terra non contecta : fed vel fimpliciter lapidi impofita, vel arboris cavo trunco, demittens hinc inde fua folia.

Supra hæc, defcripta herba merito propter fucculentiam fuam, \& quod perpetuo vireat, inter Seda feu Semperviva, numeranda venit : nam nunquam arefcit; fed per pluvias aliquando putrefcentibus foliis, ftatim primo Sole nova fuccedunt. Quantum ad foliorum fubftantiam, \& formam attinet, ea eft plane talis, qualis in Liliis apud nos albis: Horem ferre credo, fed eum non vidi, neque adeo fcifcitandi occafio data fuit, 
propter lavanos Bantamenfes, fi non inimicos, faltem fimulate amicos nobis, in quorum territorio hxc planta pracipue crefcit.

Vfus foliorum apud Iavanos idem eft, qui apud nos foliorum Lilii albi, in Cataplafnatis ad Oedemata ac ad Tophos à frigida caufa ortos; At in Eryfipelate Malaii minus convenire aiunt, unde calidior hujus herbæ Natura facile colligitur: Quod \& fapor ejus amarus $\&$ faftidiofus indicat, intus fumpta, alvum fatis vehementer movet, necat quoque Lumbricos \& Tineas puerorum, umbilicis contrita, \& impofita.

\section{A $\begin{array}{lllllllll} & \text { P } & \text { V } & T & X & X & \text { I } & \end{array}$}

\section{De Pbyllitide Jeu lingua Cervina, ubi de Polypodio, ef reliquis} Filicum Speciebus in India crefcentibus. Irca fluenta in Iava Phyllitis feu Lingua Cervina crefcit magna copia, frepe
in humanam altitudinem exfurgens, colore pulcre viridi: forma ejus in $\mathrm{Pa}$ Ad Dyfenterias itaque fiftendas \& orgafmum in Cholera refrenandum, ejus deco

P H

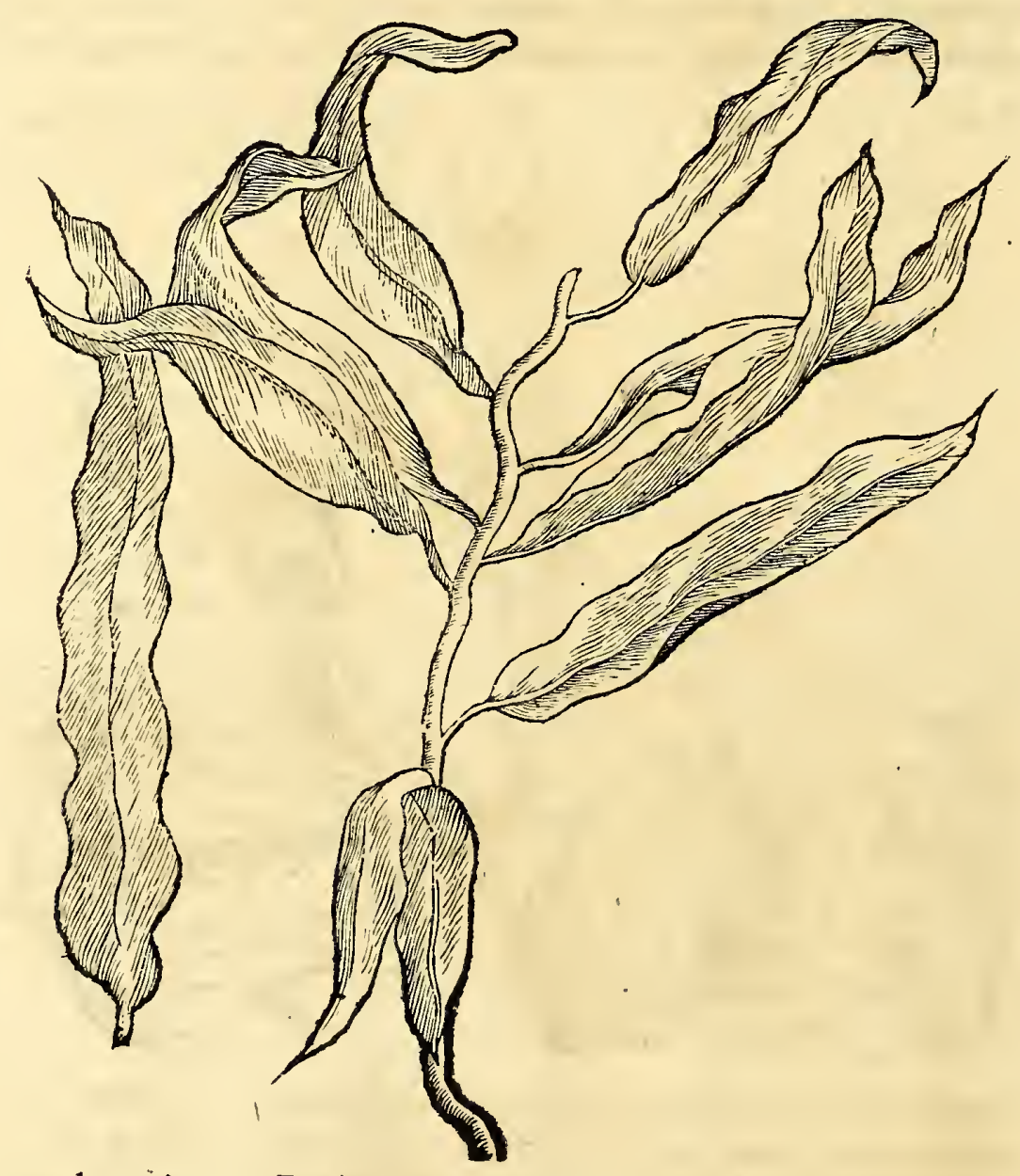

feliciter quotidie utimur. Radices ejus faporem dulcem, qualis etiam in Polypodii radicibus eft, præ fe ferunt ; harum decoctum excellens eft remedium in obftruAionibus Lienis, Quartanis, Scorbuto, \& fimilibus è melancholico fucco ortis affeCtibus : efficacius hæc omnia præftabunt, fiaddas Sarfamparillam \& radicem Chinx. Præterea hoc nobis cxperimento compertum eft, folia hujus Plantæarte Chymica in fal redacta, medicamentum topicum effe praftantiflimum in ulceribus inveteratis, prxcipue pedum, \& tibiarum exficcandis. Tum in carie offum, qux hæc ulcera frequenter comitatur, tollenda, efficax eft remedium : nam propter aëris humiditatcm, ulcera tibiarum difficulter fanantur, tum propter negligentiam $\& \mathrm{z}$ malam victus rationem, in nauticis Sociis præfertim, fxpe in infanabile malum convertuntur: fed de hoc alibi fufus diximus. Iavani, \& Malaii ipfam quoque herbam in Morfibus venena- 
HIST. NATVRAI. \& MEDIC. LIB.VT. i23 tarum beftiarum conducere aiunt. Cæterum ex fupradictis effectibus fatis conftat herbam hane effe temperatam, præfertim radice, qua deobftruens eft, præcipue in obfructionibus predictis lienis, cujus affectibus peculiari, \& formali, qualitate medetur.

\section{A P V T. $\mathrm{X} X \mathrm{X}$ V.}

\section{Solani Indici Fructus' Edulis, quem Indi Fockii Fockii vocant. Et Hyojcyamus Indica.}

Fructibus in Patria Solani Narcotica vis ef, India at è contra Solanum producit edule; Defituunt Medicum fic Medica Mala faporem Naturamque novam Europe in finibus illa. o quoque fit wtinam, vebimur quum per mare ad Indos, Longum iter! Infames liceat deponere mores.

Vantum ex foliis, floribus, fructuque denique hujus Plantx conjicere licet, certo certius eft, hancfpeciem Solani effe, nifi quod fructus longe grandiores fint, quam Solani noftri, utpote qui cubiti longitudinem aliquando excedant, corticeque tam lavi, ut fpeculi modo, humanam effigiem remittere pofiit. Foliis

$S$ - I A N I Species F O C K I I F O C $\mathbf{K}$ I I dicta.

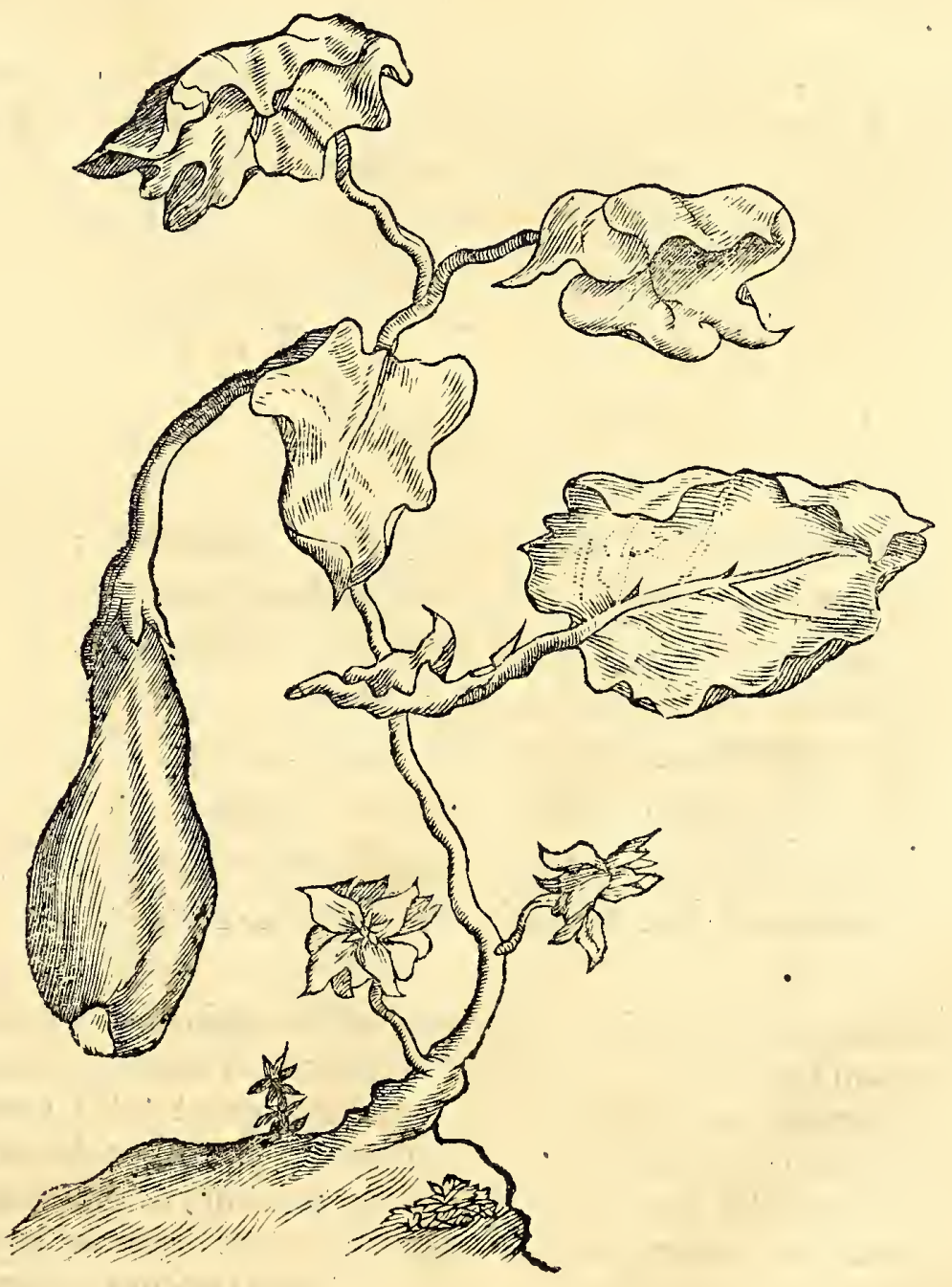

quoque hirfutioribus \& quafi lanam fuperinductam gerentibus. Craflitudine brachium humanum facile æquent. Pleni intus funt feminibus minutis, qualia etiam in fruL 2

ctibus 
atibus feu baccis noftri Solani inveniuntur. Fructus porro in his regionibus, non folum funt edules; verum etiam delicatifinni Laporis, fi coquantur cum Vino, \& Pipere. Eun-: demque guftum obtinent quem Cinaræ bafis, feu Carduus altilis in Patria. Commune cft edulium apud Indos \& etiam noftrates, qualiter funt Rapx in noftra Patria. Boni porro funt nutrimenti, tum diureticam vim obtinent, eoque calculo vefica, \& renum affectibus admodum utiles: Malaii, \& Iavx incolæ fructum hunc vocant Focqui Focqui iterato vocabulo, quod etiam in aliis rebus faciunt, quas excellerefciunt; atque in eo conveniunt cum cæteris Orientalibus linguis, præfertim Arabica \& Hebræa ut ex. gr. Si propheta rei alicujus excellentiam cum emphafi exprimere volunt, non folum diationes; fed integras fententias ingeminant, ut mos in Bibliis loquendi frequens eft. Ita loquitur Domirus, Dominus Zebaoth \&c. Hoc eo Parergice addidi, quod lingua Malaica, quamvis, ut pleræque Orientales linguæ, vocabulorum indigens, tamen fignificativa fit valde, $\&$ amona, meo quidem judicio, quænon folum per totam Indiam familiaris: fed \& in Surate, Chormandel \& cateris Afra oris, in mul to eft ufu.

Vt ad rem redeamus, unde digreffi fumus, hujus Fosqui fpecies eft \& alia fylveftris; fed hujus fructus, non, uit jam dicti, oblongus eft \& teres; fed fphæricus plane, \& ubi maturuit, colore flavo, cum domefticus, fit colore vel purpureo, vel grandinis inftar albo. Caterum fylveftris hic fructus amarus eft, ideoque non nifi ab Apris \& Rhinocerotibus devoratur. Porro hujus plantæ caulis (quod fere omiferam) plabe fpinofa eft, unde imprudenter, non fecus, ac Rubus, attingi non deber. Rhinocerotis porro lingua, \& palatum tamafpera funt, ut vepres, \& fpinas cubitales de. voret, ac quo quid pungentius eft, eo libentius ifto alimento utitur, fin hominem irritata hæc beftia feviat, folo lingux attactu carnem, \& cutem, ufque ad offa ei delingit, ut alibi in animadverfionibus Garc. ab Orta, ad v i I Caput de Ebore, latius diximus.

Quam plantam Indi Daturam, ego Hyofcyamum Indicam appellavi, non folum quod narcotica \& fupefaciens vi ei fimilis fit: Sed quod odore foliorum \& forma floris maximerefpondeat. Semen in echinato cortice conclufum gerit, qui maturo femine diffilit cun ftrepitu, fi vel leviffime tangatur, fabafque cinereas, nigris gurtis diftinctas, intus oftendens.

\section{A P V T $\quad \mathrm{X} \times \mathrm{XVl}$. \\ De Sedo arborefcente.}

Rofa vale, \& Viole, quas Arcticus orbis adorat;
Nam melius multo complentur odoribus aure
Flore boc Sedifero, quem dives Iava virentem
Oftendit, diris pellit contagia morbis,
Ac guftu Oxalidos gratum diffundit acorem,
Et femper toto viridis jpectatur in anno;
Scorpius banc plantam nec tanget Araneus uniquam,
Antidotum binc Medicis adverfus dira venena.

$\mathrm{F}$ Rutcx hic non in folo crefcit, fed arboribus Mangiferis aut Quercus cujufdam fpeciei, quam Indi Kiati vocant, affixa non fecus, ac vifcus apud nos, qui tamen in dictis arboribus non deeft. Planta feu frutex hic eft foliis Oxalidis faporis, oblongis, qualia funt Perficarix; fed craffioribus longe, \& fucculentioribus, qualia funt Sempervivi iftus folia, quod in tectis apud nos nafcitur, \& Wuugh-lonck vocatur. Radices edit mirabiles, teretes, ex quibus fibras demittit, quæ vel lapidem, vel arborem apprehendunt, \& fine limo, vel terra, fic affixa crefcunt, magnitudine glandium, forma \& figura tali, quali eft manubrium haft $x$ feu lancex, quibus Perfæx, \& Turcx equites ctiamnum utuntur (nam ufus illarum apud plerafque Europ $x \mathrm{Na}$ tiones exolevit) : forem profert parvulum, Anagallidis flori firnilem, fedalbum, \&z 
HIST. NATVRAL. \& MEDIC. LIB, VI. I25 $S E D V M A R$ B ORE S C E N S

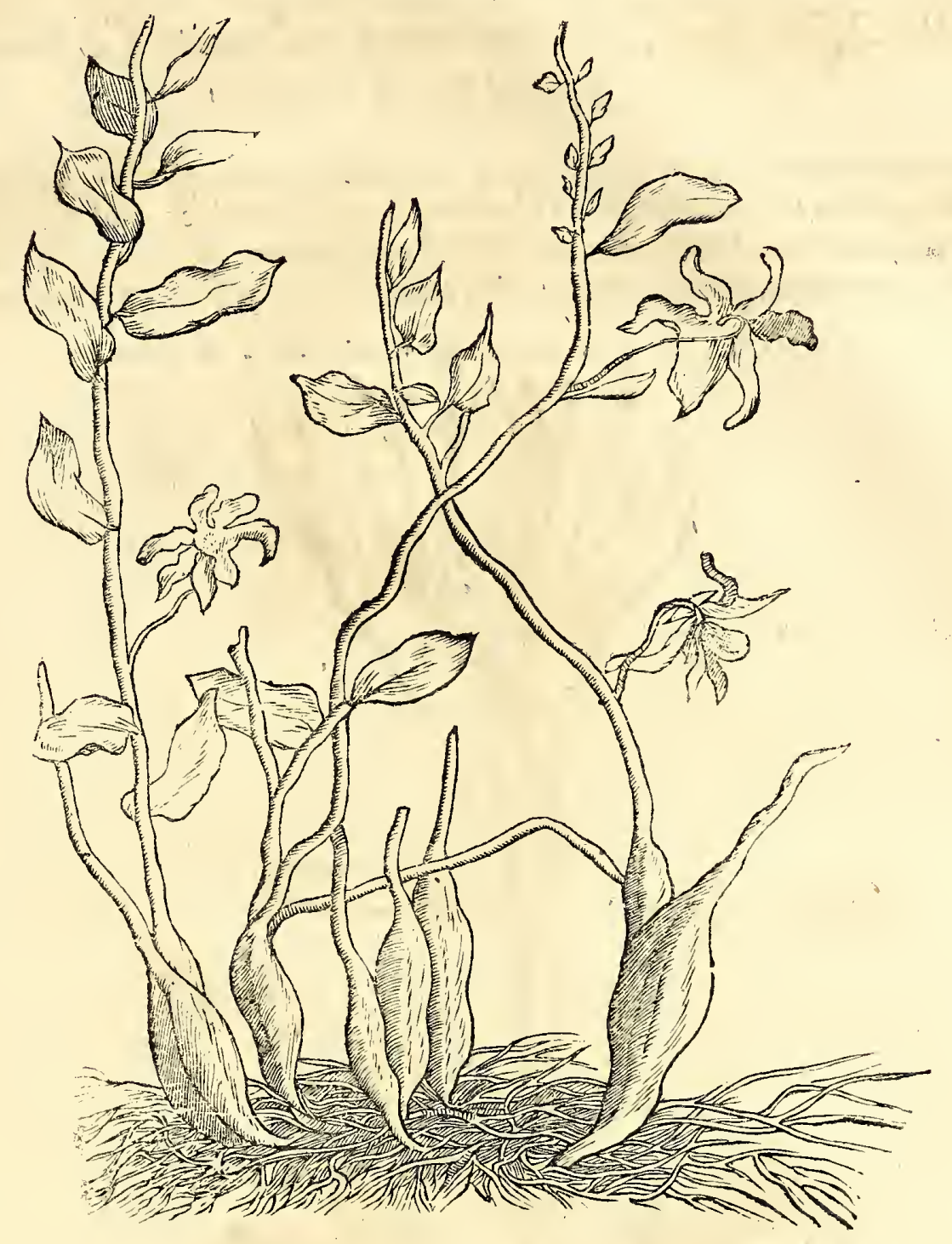

tam aromatici odoris, Citri amuli, ut me in vita nil quicquam odoratius naribus percepiffe fciam. Vnde etiam apud Malaios nil ad Cerebri \& INervorum prxternaturales affectus æque conducere fertur: Hinc quoque in Spafmo \& Cholera, Conferva ex floribus, \& foliis hujus Planta, fingulare eft remedium. Comperi quoque egregios ejus effectus in Dyfenteriis; habent enim folia qualitatem aftringentem, \& faporem plane talem, qualis eft in Acetofa patria, fed palato longe gratiorem : flores quoque conditi non minus cordiales funt, quam Bugloffx aut Borraginis. Fructus medium digitum non dunt paulo majus quam Milii, itidem muccilaginofum, quod decufiatim fitum eft, ut ferme arcem reprefenter, quatuor fuis vallis \& propugnaculis exornatam. Qualitate quantum manifelte ex fapore elicere poffumus, hac Planta frigida eft \&z ficca: Virtute vero occulta, putredini, \& omni corruptioni refiftit, unde merito inter violentos jam diatos morbos, pro Alexipharmaco apud incolas in ufu eft. Dum hxe fcri * bo, retulit mihi fenex quidam Malaius, qui medicinam inter fuos exercebat non infeliciter, nihil aque conducere ad venenata vulnera à pugionibus, \& lanceis Iavanis alicui inflicta. Solent etenim Iavani, mortalium longe crudeliffimi, tela fua tingere cruor cujufdam Lacertx venenofifimx', quam à fono, quem edit, Gecco vocamus, ut alibi dicemus. Hinc conjicere licet, candem herbam etiam ad ictus venenatorum animalium utilem effe.

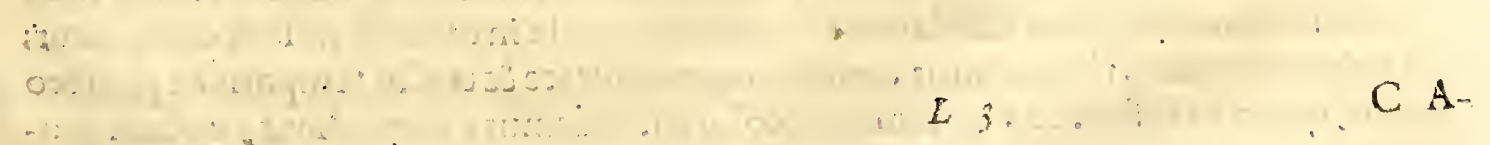




\section{A P V T X X X V I I.}

\section{De Nobiliffemo, \& Saluberrimo A Aromate Cardamomo, Majori \& Minori.}

Ner alias herbas, \& Aromata, qux fertilis Infula Iava profert, merito inter excellentifima Cardamomum eft numerandum : Planta hæc caulem habet Arundinis modo internodiis à fe invicem diftinctam, \& certe folia non abfimilia Arundinis foliis, \& eodem quoque modo catervatim crefcit, primumque intuenti, vix dif-

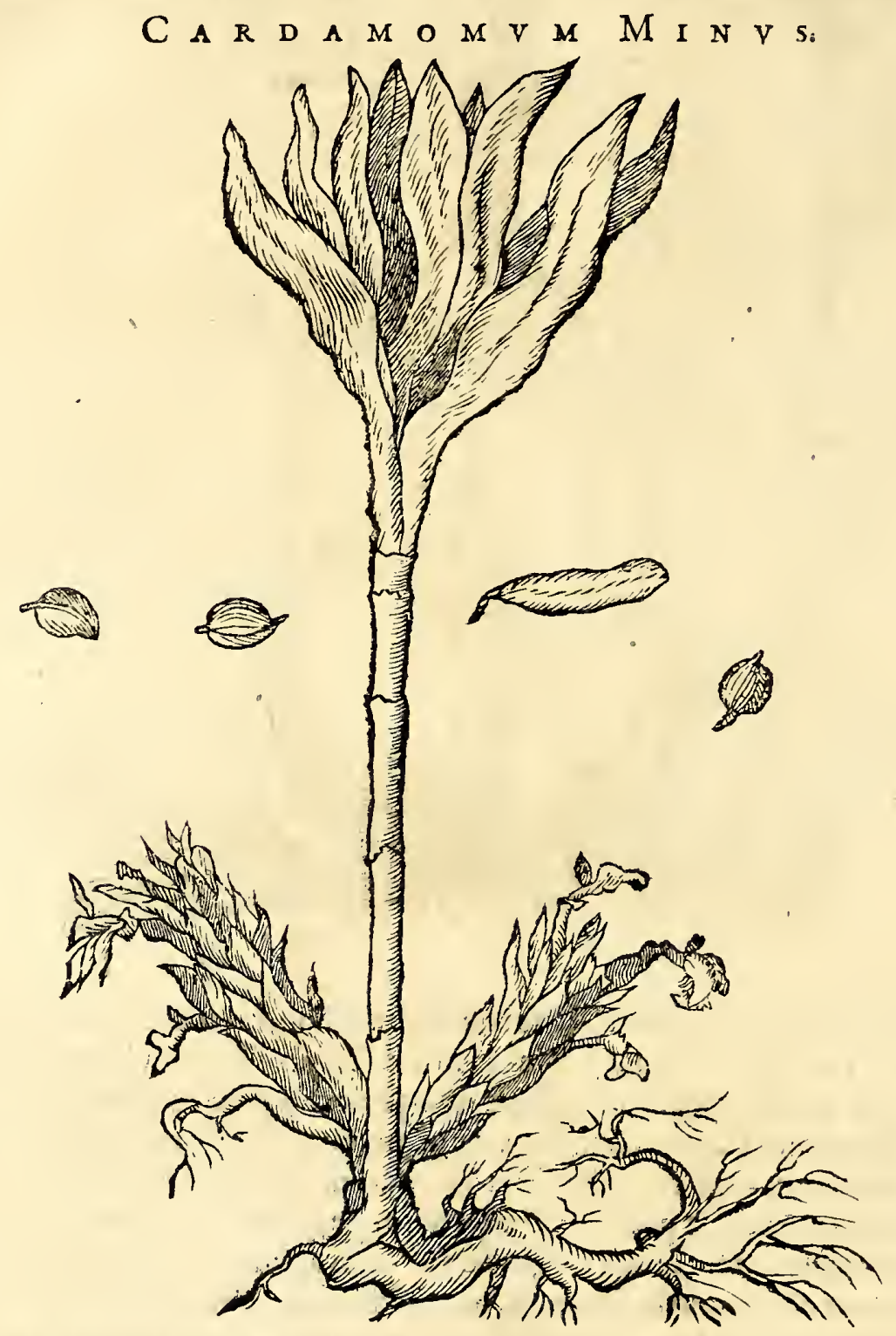

ferentia inter duas has ftirpes videbitur, nifi quod Cardamomum vix ultra duos aut ad fummum tres pedes in altitudinem affurgit; folia quoque contrita fuavifimum odorem à fe reddunt. Dum florentem eam primum confpexi, animadverti infignem Garcix ab Orta in defcriptione errorem, lib. I, cap. 24, qui ait, Cardamomum, non fecus, acFabas, \& Vicias, feri, \& eodem modo crefcere, pendentibus filiquis, Piforum inftar, in fummitatibus Plantx; quod longe fecus fe habet.

Ideoque ego, qui plantam hanc millies contemplatus fum, primus eam ad vivum delineatam exhibeo. Circa radices igitur primum emittit fpicam, qualis in Spica Nardi confpicitur, verum longe craffiorem, cujus calycibus fupernafcuntur flores, pallidi potius in peripheria, quam albi; in calyce vero flavum colorem oftendunt, funtque admodum fimiles floribus Mali aurei. Flofculis his decidentibus filiqux corum loco fuccedunt; femen fragrans Cardamomi continent, quale in officinis noftris confpicitur; fed colore funt flavo femina intus conclufa, qux ariditate \& tractu temporis ex puniceo atrum, quem in exficcato Cardamomo colorem videmus, contrahunt, eodem mo- 
HIST. NATVRAL. \& MEDIC. I I B. VI. I\&? do, quo lector effigiem, ob oculos fibi ponere poteft ; Certe fi egregias hujus praftantiffimi Aromatis qualitates enumerare quis velit, vix horx fpatio iftas eloqui poterit: Nam calorem habet blandum, \& Natur $x$ nofræx amiciffimum, nullum empyreuma in vifceribus noltris relinquens; ideoque etiam folum abfque alio cibo mafticari, \& comedi potef, fecus, ac Piper, Zinziber, Caryophylli, \& reliqua calidiora Aroma ta, qua fummo fuo calore, vix nifi admixtis aliis eduliis deglutiri poffunt, \& nimis lar. ge ufurpata phlogofin in fanguine, \& febres frepe continuas excitant; Vrinas porro commode ciet, menftua fœminarum blande movet, anhelitum commendat, tum obntruAionibus Hepatis, Lienis, \& prefertim Mefenterii, ad miraculum ufque, conducic, etiam in jufculis gallinarum, carnis hcedinæ, \& vitulorum.

Ex hac Cardamomi defcriptione facile deprehenditur Plinii error, qui 1. I 2, Natur. Hift. cap. I 3 , Cardamomum ait nomine \& frutice fimilem efle Amomidi, quod falfiffmum eft, cum Amomis, ut poft docebimus, ferulacea fit herba, \& radice refert radicem Spicx Indicx, pro qua imperitis ctiam obtrudi poffet. A tque hoc loco eft, quod glorier, me primum effe, qui nobiliffimam Cardamomi Plantam exacte defcripfi: Cum etiam Garcias cap. \& lib. fuprad. fe tantum auribus famam Cardamomi percepiffe affirmet. I. 3 cibis porro condiendis, præfertim carnibus, $\&$ pifcibus elixis, apud Malaios in fummo ufu eft, \& certe fragrantem guftum iis addit, concoctionique adjuvand $x$ fum. me conducit.
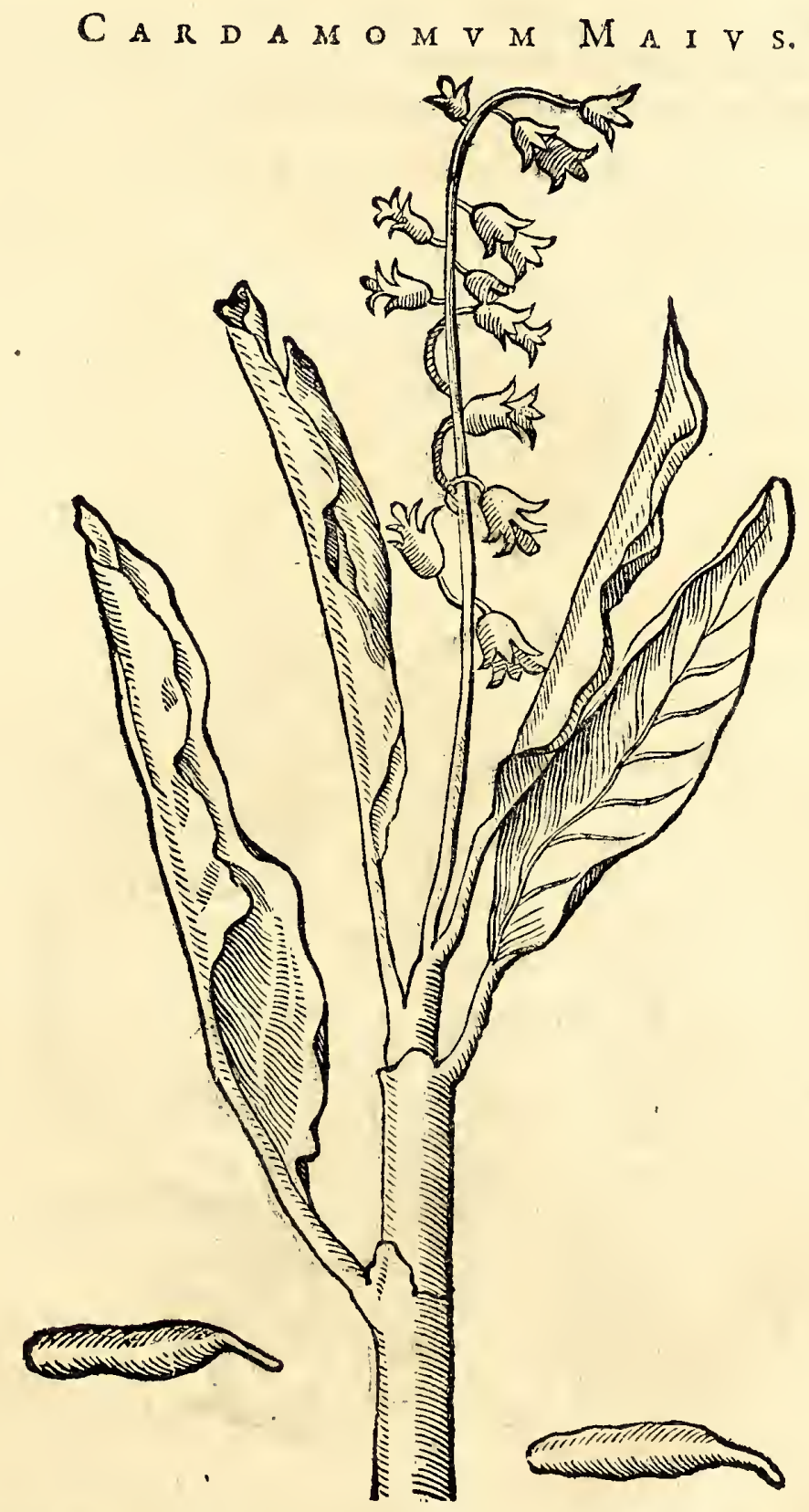

Ardamomum majus copiofe crefcit in filvis Iavanis, flore, Hyacinthimodo, fafciculato. Differt à minori Cardamomi fpecie, fupra defcripta, plurimis modis;primo, 
quod ultra humanam altitudinem affurgat; quod folia quoque longe ampliora habeat, quod caule non fit geniculato, aut Arundinis inftar nodofo, fed qui Cxparum more foliatim à fe invicem feparetur. Prxterea, ut diximus, Cardamomum minus fpicas fuas circa radices cum floribus emittit; è contra majus, Hyacinthi modo in faftigio gerit. Semen denique cjus vel filiqux oblongiores funt, digitali aliquando longitudine: folia tamen odore convenitunt, ut $\&$ flores. Nifi quod folia majoris Cardamomi, praterquam quod fint majora citra comparationem, etiam averfa parte, inftar Verbafci fint mollia. Tota Planta pulcherrimo eft afpectu, grato virore floribufque albis cum purpureo limbo nitet. Vires ejus plane conveniunt cum Cardamomo minori.

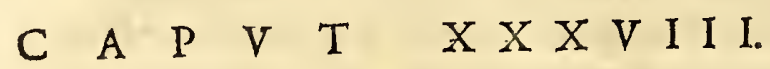

\section{$\mathcal{N}$ ympbea Indica flore purpureo, cujus Calyx feu Fructus quafo} per nebu! am à Clufio defcribitur.

\section{Indica purpureum prefert Nymphea colorem, Atque Nuces gignit maturo calyce eduleis.}

$\mathrm{P}$ Lanta fubfequens certe digniffima eft, qux defcribatur, tum ob qualitates excellentes, tum propter pulcherrimum ejus florem; denique propter admirandum, qui Horibus fuccedit, fructum; cujus mentionem facit Car. Clufius, Exo-

$$
\text { N Y M P H EA E P E C I E S. }
$$

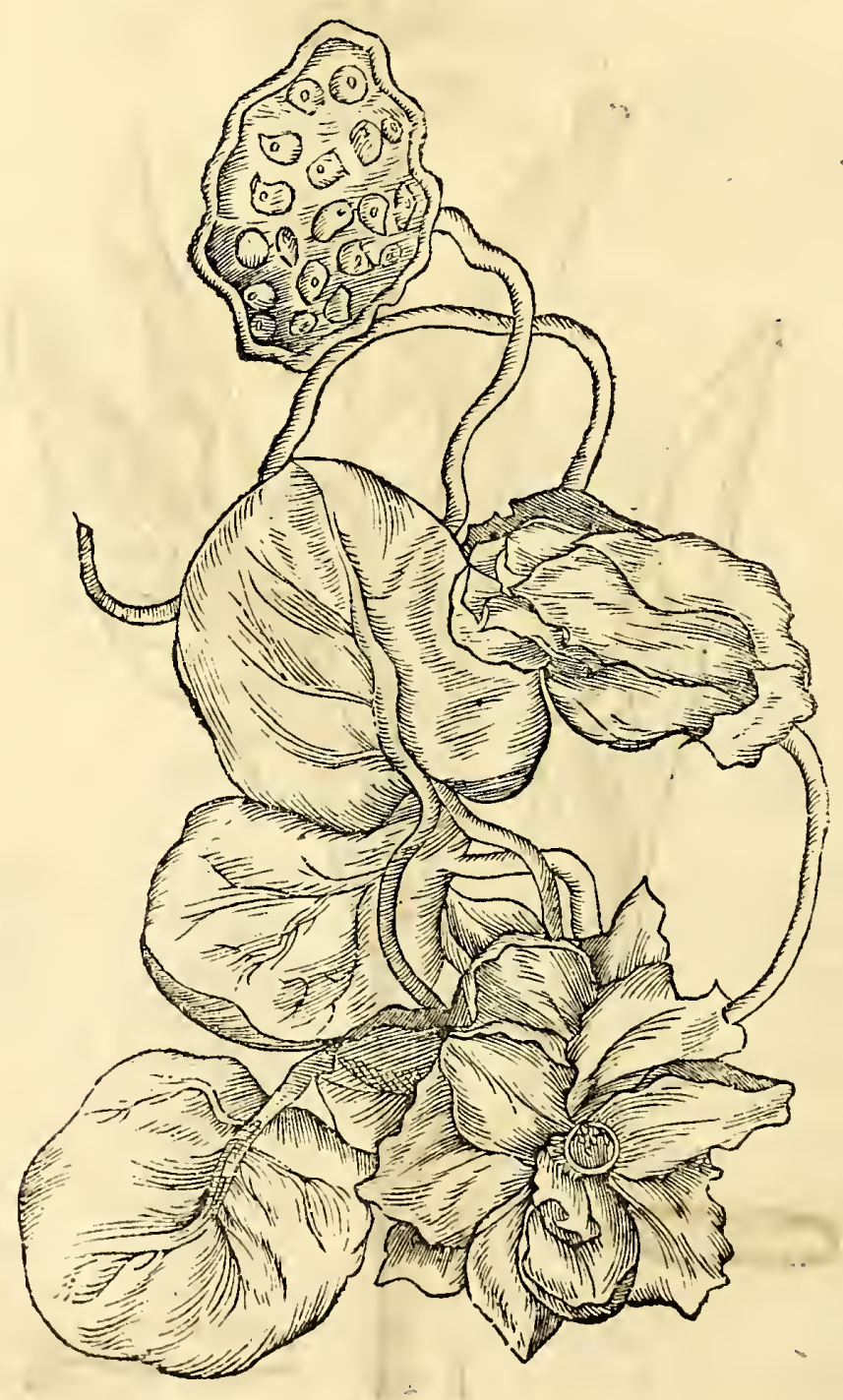

ticorum lib. 4 : fed tantum per tranfennam, utpote qui deferiptionem non inftituit ex vifu; fed exrelatione navalis cujufdam focii à quo fructum hunc coëmptum elle ait : 
Ego, qui plantam millies vidi, eam paulo luculentius vobis ob oculos ponam, ut conatus viri diligentiffimi fimul, \& doetinimi in re herbaria adjuvem : Itaque verum eft, quod ominetur plantam aquaticam effe;nam Nymphxa eft, in omnibus noftrati, tam in latis quam rotundis foliis, caule, \& radice plane conveniens: Flore vero à patria Nymphxa differt, qui in Hollandia vel albus, vel flavus eft, hic autem pulchre purpureus, odore gratiffimo nullo modo noftrati cedens. Fructu quoque, \& calyce longo à patria Nymphxa diftar, qui in fuperficiehic planus confpicitur, tanquam fi per medium cultro diffectus effer; verrucas parvas in orbem diftinctas fuper oftendens circiter triginca $\mathrm{N}^{\circ}$, qux paulatim grandefcentes, calycem fibi unaquaque effingit, donec maturefcens Nucem Avellanam dempto putamine, tum forma, tum nucleo valde referunt; faporem quoque ejus non male amulatur, qui tamen fatuus aliquo modo, \&aqueus eft, naturam redolens elementi, in quo crefcit.

Quantum ad vires attinet, in tertio gradu frigidas, de iis hic conticeo, cum in his patrix Nymphax fimilis fit, ideoque decocto hujus plantæ, à Malaiis edocti, utimur in calidis morbis, febribus ardentibus, Phrenitide, Cholera, \& in mortifera Dylenteria.

Nymphæa porro alix fpecies hic etiam circa ripas fluminum, \& 2 in ftagnis crefcunt abunde, ufque ad Lentem aquaticum, gratum Anatibus (quos Chinenfes in copia alunt) pabulum.

Potamogeiton quoque feliciter provenit, tum Plantago aquatica, quam frigidam effe nullus mortalium mihi facile perfuaferit: nam dum experiendi gratin (ur Botanicis mos eft) hujus plant $x$ folia paulam mafticarem, tantam acrimoniam in ore fenfi, quantam. ne quidem Ranunculi aquatici ea fpecies dare poteft, quam Flammulam apud nos, rei herbarix periti ab ardore vocant. Ita ut meminerim nos, non fruftra aliquando in Patria de ejus qualitatibus difputaffe : nam \& folia hujus Plantaginis etiam apud nos mafticata aliquam acrimoniam in ore relinquunt, verum tranfitoriam tantum, \& momento durantem; hæc vero Indica palatum \& guttur excoriat. Quodfi adhuc incredulus quis rei Botanica fudiofus, de hoc dubius hreret, huc veniat velim, eibona fide promitto, hac planta deguftata omnem fcrupulum ex animorejiciet.

\section{A P V T $\quad$ X X X I X.}

\section{DeVeronica Iavana, ubi \& quadam parergice tractantur de familiari potu Aracco.}

\footnotetext{
$\mathrm{C}$
}

Refcit hæc herba copiofe in pratis, \& fylvis Iavanenfibus, flore albo, Malaii, \& Iavæ Incolæ eam Oubat Matta, vocant, quodmedicamentum pro oculis denotat, quia illi fuccum expreffum ad lippitudinem, \& Ophthalmiam oculorum adhibent, non fecus ac noftri fucco vel aqua deftillata Veronicx ad affectus oculorum utuntur. Porro hic fuccus, \& totius herbx decoctum in affectibus thoracis commendatur, ut funt Athma, Phthifis, \& reliqui morbi Pulmonum, qui cum tuffi homines moleftant. Tum propter vim diureticam Incolx ea utuntur in affectibus renum \& veficx; tum in Gonorrhois è concubitu Venereo conceptis. Itaque ut fape mirer of fitantiam noftræ gentis, qux hos populos Barbaros appellare non veretur; cum non folum in herbis cognofcendis, fed in omni oconomica adminiftratione noftros longo intervallo poft ie relinquant. V tuntur porro Incola foliis hujus contritis ad ulcera pedum \& tibiarum; nam qualitatis eft egregie exficcantis, atque ulcera, ut fupra dixi, propter climatis humidam conftitutionem, admodum difficilia funt curatu. Imo propter intemperantiam militum, \& nauticorum fociorum in potando Aracco feu vino adufto Indico, hac ulcera cacoëthia, \& mali moris, \& fxpe infanabilia efficiuntur.

$V_{t}$ tranfitorie aliquid de Aracco, feu vino adufo Indico, dicamus; fciendum eft Chinenfes, gentem totius Orbis avarifimam, \& fubtilifimam, hoc potus genus; ut Oryza parcant, adulterare Holothuriis, in mari fluctuantibus, admixtis, ut fic ei perniciofum Pulmonibus ardorem concilient ; \& hinc fit , ut miferi nautici \& milites in Phthifes, Marafmos, fanguinis fputum incidant, \&, poft diuturnam emaciationem, miferrime 


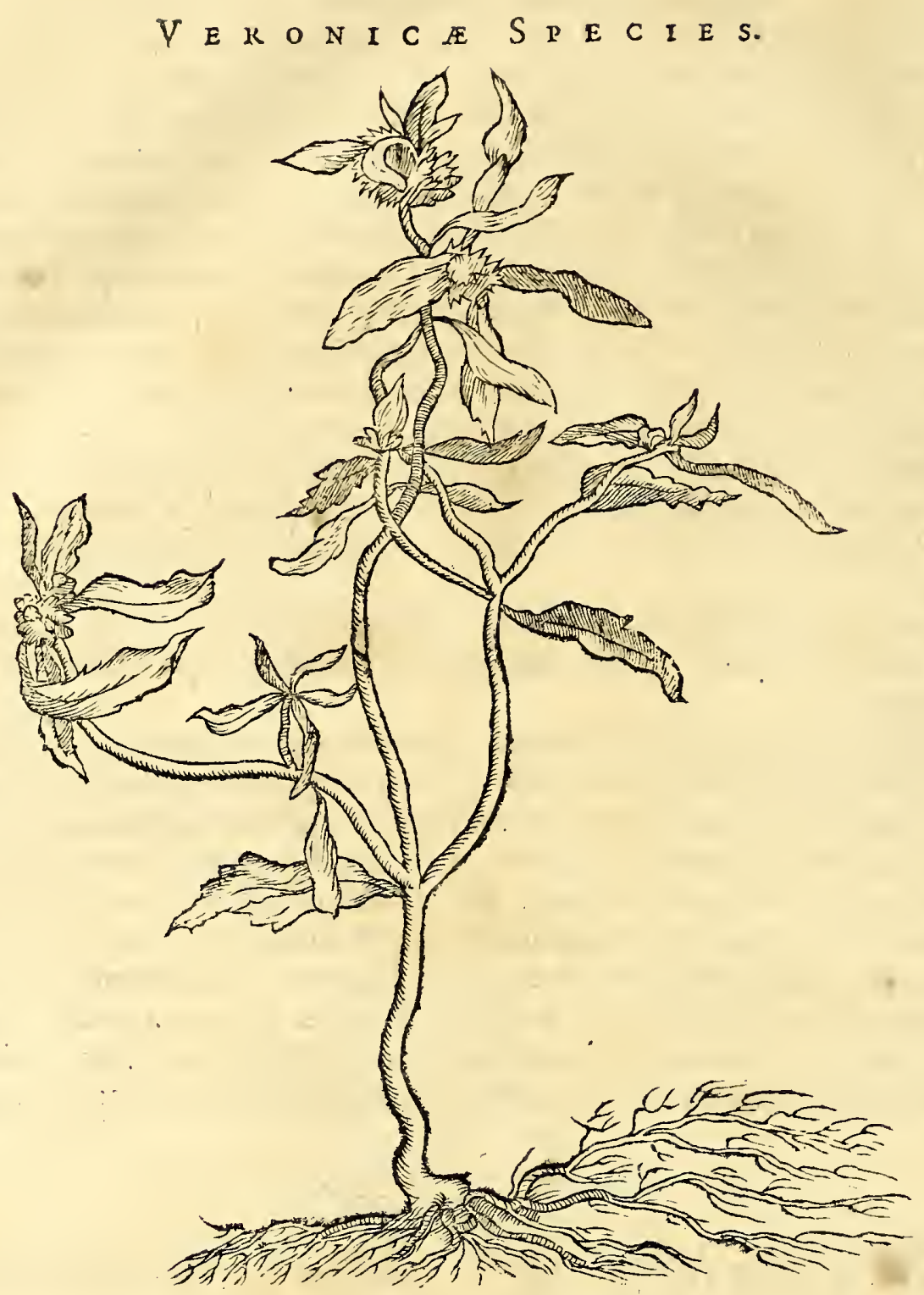

moriantur : Nam hæc Holothuria, ut \& cxtera recrementa maris, inter qux eft Nautilus pifcis, Stellæ marinæ \& \& alia, tam exurentis funt caloris, ut folo attactu in cute veficas excitent, non fine fummo dolore. Hujus generis funt non tantum Lepus marinus, fed Stellæmarinæ, \& Afterites, tum Nautilus pifcis, cujus defcriptionem poft dabimus, qui tam ardentis eft caloris, ut dum è Patria in Indiam navigarem circa infulas Canarias, marivehementer tranquillo, in fcapham cum aliis defcenderem, pifcandi gratia, \&, extracto reti, cum inclufus effet unus ex hifce Nautilis, quem dum imprudens \& infcius contracto, tam vehemens calor manum meam invafit, ut is fieri folet, qui à Dracone pifce, quem 10ieterman noftrates vocant, puncti funt, \& nifi admoto Allio in aqua marina macerato, mihi fubveniffem, certe propter dolorem febrem incurriffem.

$$
\text { C A P V T X L. }
$$

De Ricino Braflienfr, Lada Chili rocato, quod fonat Piper Cbilenfe es de ejus ufu bactenus nobis incognito.

Vamvis planta hxe fub nomine Ricini Americani, jam etiam apud Batavos in hortis feri, \& coli inceperit : tamen quia ejus ufus non nifi quam inter cauftica medicamenta cognitus eft, ego non potui, quin oftenderem familiare Lufiennis, \& Indis condimentum, \& edulium effe ad cibos aftos, vel elixos, hoc modo; 
HIST. NATVRAL. \& MEDIC. LIB. VI. I3!

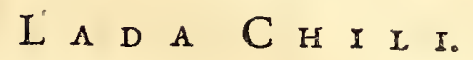

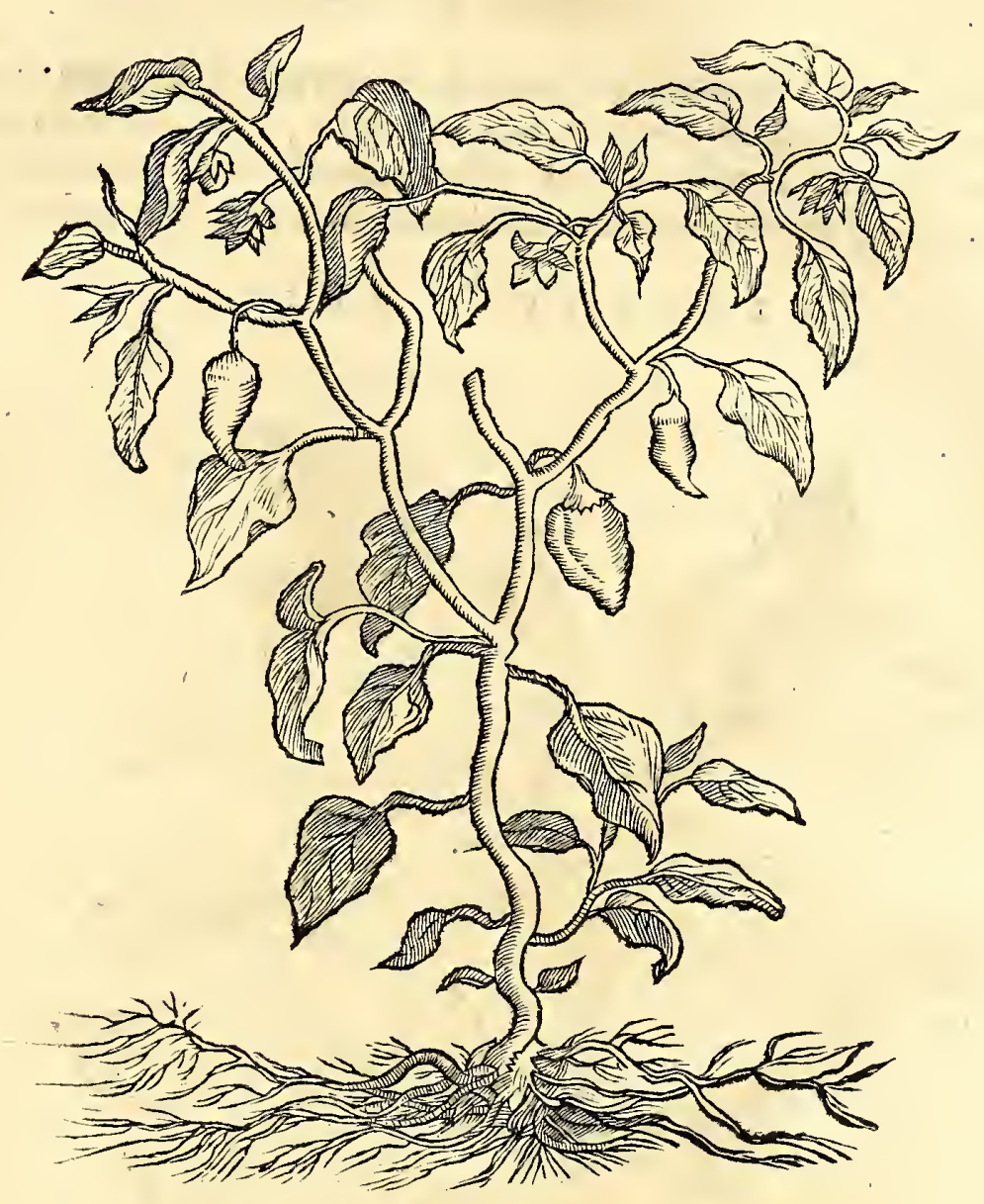

Sumunt poma feu fructus illius Mandragorx, quam Itali Melanfana vocant, Neoterici Poma Amoris, Lufitani Tamatas, \& Poma doro, à pulcherrimo, \& lucido in maturis rueafque crudas, oleo $\&$ aceto perfundunt cup Pipere Chilenfi in minutiffimas particulas, Hoc modo fricidificto perfundunt cum pauco fale, eque pro cupediis utuntur. Hoc modo frigidiffimam, \& narcoticam Mandragor $x$ qualitatem calidiffimo alio fructu temperantes, ne frigus prioris folum comefi naturalem calorem fuffocet, \& extinguat. Conftat autem Piper iftud Chilenfe, Capfici fpeciem effe, ut bene notat doctiffimus Clufius in annotationibus fupra Nic. Monarden Medicum Sivilienfem,
fol. 386 .

Incolæ praterea (quod \& à quibufdam noftratibus fir) iftud Chili quoque affiduo ore ferunt mafticando: aft ego id conans animi gratia imitari, tam exurens hoc inveni, ut mihi non videretur operx pretium affuefcere ei mori, qui, præterquam quod jam dicto modo præpar fit, etiam nihil emolumentiadferat; tamen afferunt Lufitani jam dicto modo præparatum, utile effe adverfus pituitam, \& cruditatem ftomachi; qux Porro defcripta Ricini fpoufas huic regioni admodum familiaris eft.

Porro defcripta Ricini fpecies eft è minutioribus: nam funt etiam majores, qux
ollicis craffitudinem exxquent, ejufdem tamen ufus, ox factis, pollicis craffitudinem exxquent, ejufdem tamen ufus, \& facultatis, quam fuperiores,

A N N O T A T I O. Improprie admodum nomen Ricinihuic plantx inditum effe mihi videtur; cum neque forma, neque figura externa, ullifve qualitatibus internis cum Ricinis Americanis conveniat; fed vera Piperis five Capfici Brafilienfis fpecies appareat. Nifi forte, (ut fxpe contingit, circa exotica imprimis, ) varia nomina nunc huic,
nunc illi plantæa approprientur. 


\section{A P V T X L I.}

\section{De Telepbio Indico.}<smiles>[BH3-]</smiles>
Elephii feu Sempervivi ea fpecies, quam Belgx emel Seltelen vocant, hicin hortis crefcit caule paulo elatiore, quam patrium, foliis etiam aliquantum in figura variantibus. Incolæ Malaii id à forma Moulit Bebec vocant, quod Anatis softrum fignificat: nam inverfum Anatis roftrum admodum bene refert, prefertim

$$
\text { T E I E P H I I S P E C I E S. }
$$

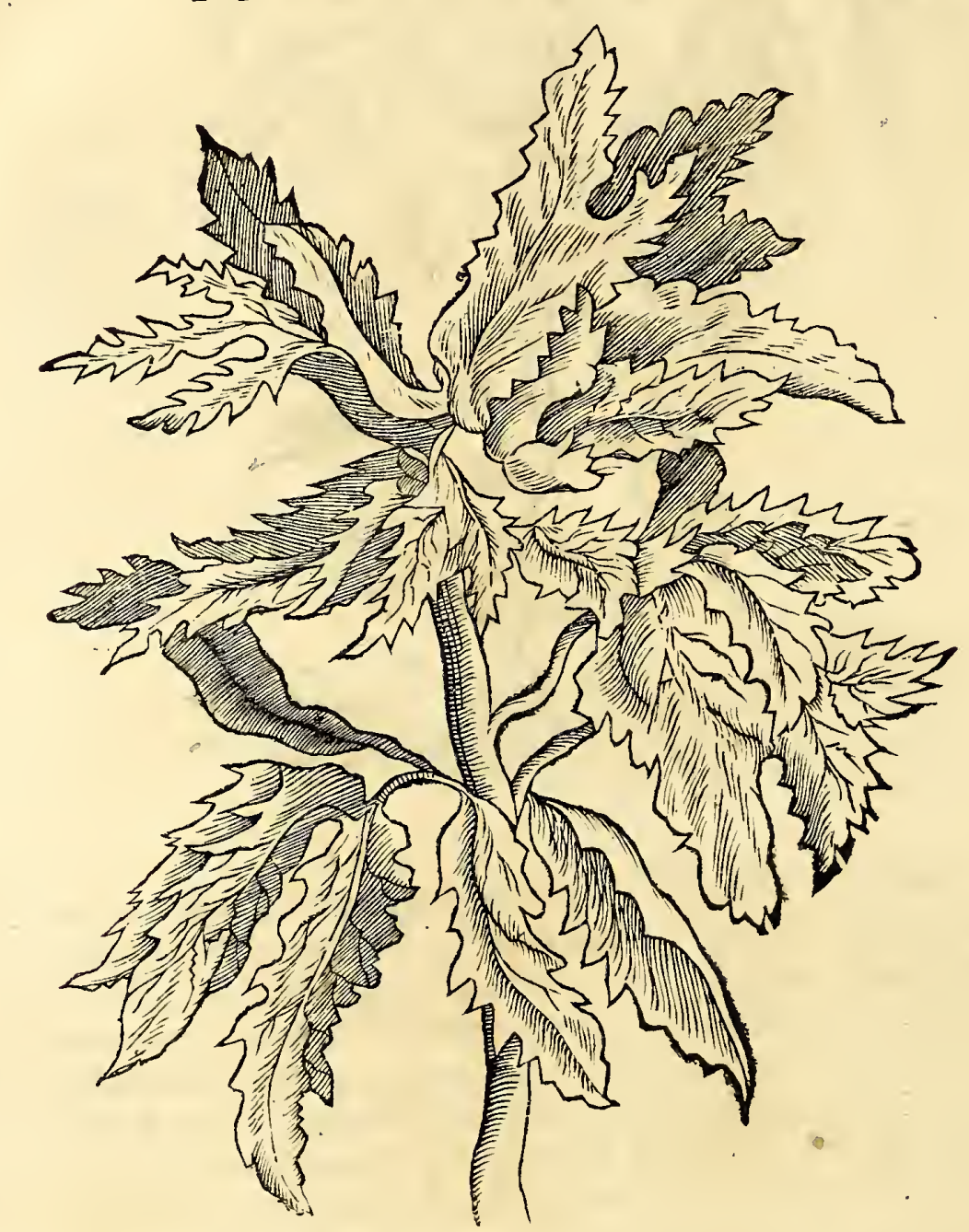

iftorum, qui incifuras ad latus roftri habent, ut in hac figura videre eft. Sempervirethæc planta, quæ ad cæteras qualitates frigida \& ficca eft, ideo Incolx utuntur ea contrita ad ipforum fcabiem \& cxtera biliofa ulcufcula in cute, qux hic nunquam defunt. Tum ad Eryfipelata utilis quoque eft cum aceto contufa. Malaicx mulieres ea quoque utuntur pro topico fuper bregma puerorum, ubi futuræ nondum coaluerint, referentes, id ad robur cerebri facere, \& 2 ut id topicum melitus applicent, novacula capillos infantium abradunt. Cxterum mirari fubit Incolarum horum induftriam, qui veterum Arabum, A vicenn $x \&$ r eliquorum inftar, à forma herbis nomina indunt externa : tum in herbis dignofcendis, \& noxiis ab innoxiis feparandis, Gufaratti \& qui ab ora Chormandel huc veniunt, adeo excellunt, ut ne quidem optimo Botanico cedant. Ratio eft, quod hx gentes fectam Pythagor $x$ fequuntur ut plurimum, qui nihil, quod anima fentiente praditum fuit,ullo modo comedent; fed vegetativis ftirpibus $\&$ herbis tantummodo vefcuntur; quare etiam à crebra experientia edocti ad unguem herbas edules ab herbis medicinalibus, vel etiam venenofis, diftinguent, imo hoc norunt pueri feptennes $\&$ infra. 
HIST. NATVRAL. \& MEDIC. IIR, VI.

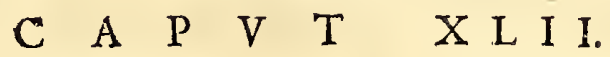

De fructu Billing-bing indigenis vocato.

\section{Stypiticus è Citreis acor etfi dentibus hafit \\ Billing-bing guftum bunc fructus abire facit. \\ Non fecus, ac magnus dolor arcet Sepe minorem, \\ Hic acor his acidis fructibus eruitur.}

Refcit arbor quædam foliis Ciceris arietini quoad figuram : fed grandioribus, acido fapore præditis. Fructus porro tam pendentes ex ramis, quam ex trunco ipfo arboris prodeuntes, magnitudine funt \& forma Cucumerum, primum adolefcentum, quos Agurcas Lufitani vocant; qui certe propter extremam fuam acidi-

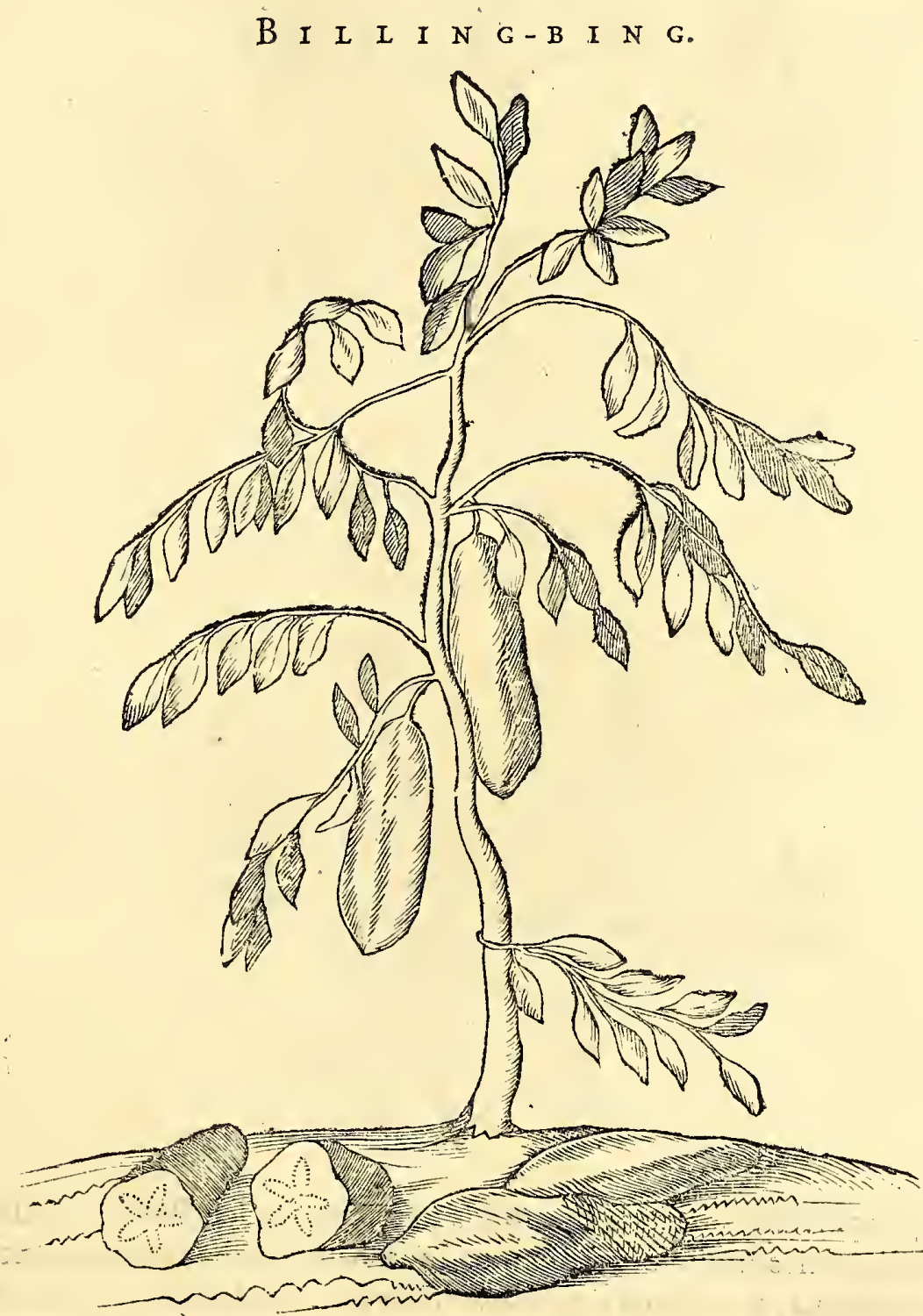

tatem, ipfe acor vocari merentur, \& quod magis in is miror, fi cuidentes, abacido aliquo fructu guftato obftupefcant, his fructibus tantum deguftatis, ftatimacor ifte evanefcet, credo, eadem ratione, qua in quibufdam affectibus mixtis præter naturam major dolor minorem obfcuriorem reddit. Billing-bing hic fruatus Malaiis dicitur, \& nos ex ejus fucco expreflo (nam fucculentus admodum eft) Syrupum conficimus, adverfus hepatis intemperiem calidam, \& Phlogofin in fanguine venis $\mathbb{E}$ arteriis centento;tum eo utimur etiam cum Oryzx non decorticat $x$ decocto, quod Padii yocamus, egregio juvamento in febribus ardentibus, $\&$ continuis, tum fiti fedand $x$ 
optime confert. Cholerx quoque impetum fiftit. Hinc facile quis colligat, qualitate effe è frigida verfus ficcam, quod aftringens ejus guftus etiam indicat.

$$
\begin{aligned}
& \begin{array}{lllllll}
C & A & P & V & T & X & L
\end{array} \\
& \text { De Cypero Indico. }
\end{aligned}
$$

$\mathrm{H}$

Erba hæc in fumma quantitate circa fiuenta Iavæ crefcit, radices cjus bulbof $x$ funt, non fecus, ac Chamæbalanus, feu glans terreftris, qui in Zeelandia in agris foditur è terra: Odoris funt plane aromatici, \& Caryophyllos referentis. Vnde earum decocta per aliquot dies fumpta, nervorum frigidis affectibus fumme condu-

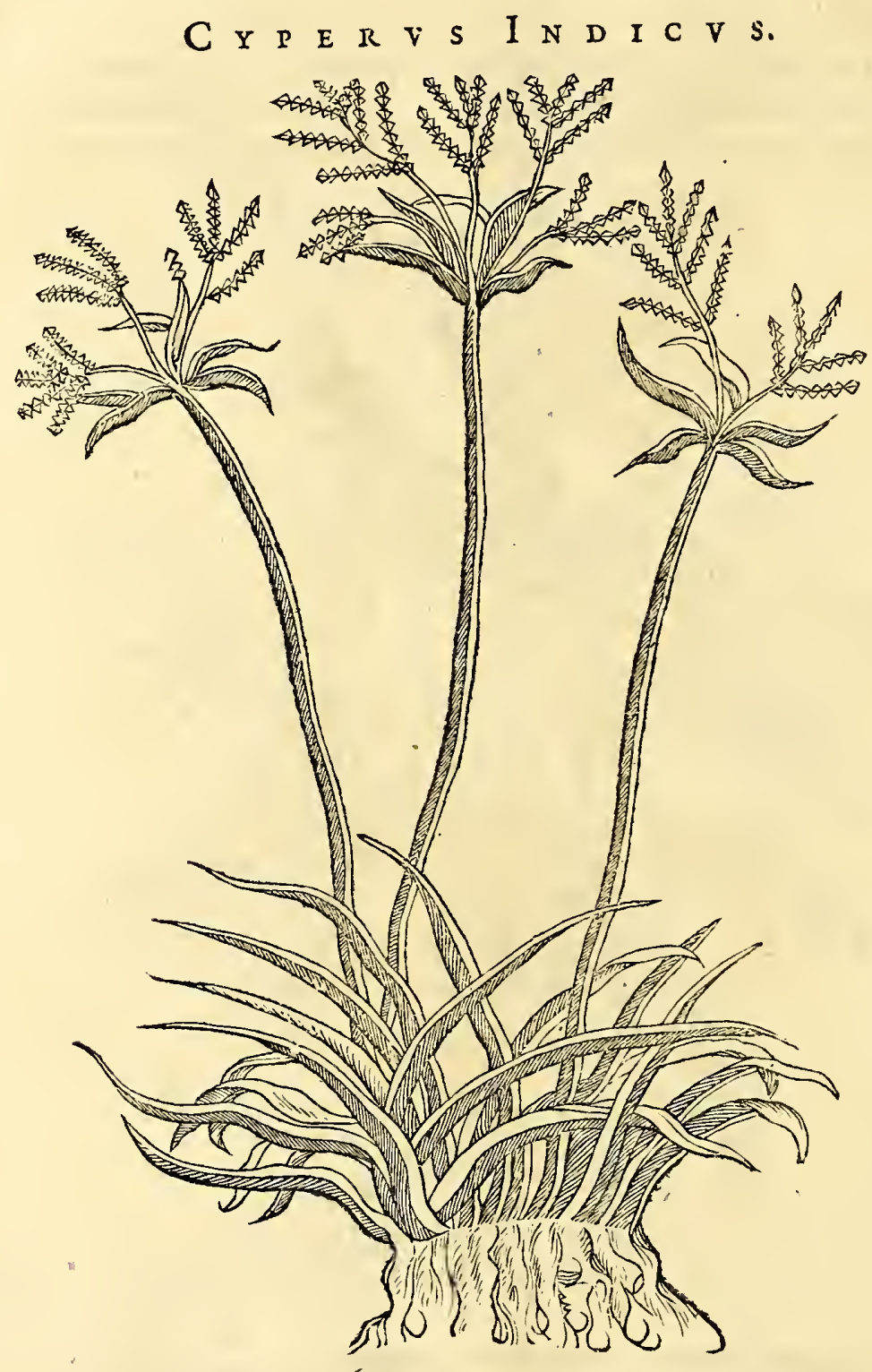

cunt, imprimis multum adferunt levaminis in tremoris, feu Paralyfeos ifto genere, quod Beriberii aliquoties Indis vocari diximus. Ind $x$ Mulier es hanc plantam ctiam ciendis menftruis adhibent, nam diuretica admodum eft. Ideo hydropicis quoque convenit, \& propterea habemus in Nofocomio femper radices Cyperi exficcatas ad manum, cum ille frequentiffimus fit, \& decocto Chinæ, atque hoc Cypero feliciter curatur. Ex hac radice porro conficimus arte Chymicafal, apprime utile confumendis excrefcentiis in ulceribus, prefertim pedum, \& tibiarum : nam præterquam quod eas ábfumat, etiam os à carie defendit, \& loca inania carne replet, eique cicatricem fuperinducit. Idem \& Cyperus in Patria præftat, in cinerem redactus, \& infperfus ulceribus iftis calcium, qux Perniones vocitari folent, quxque hyeme prefertim mortales infeftant. Cyperus porro inter Graminis fpecies reponi debet: ideoque, quiade iis alibi latius diximus, hic fupervacuo labore fuperfedebimus. 
HIST. NATVRAL. \& MEDIC. LIß. VI.

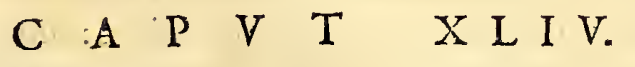

De Fabis, \& Leguminibus in arboribus nafcentibus, \& primum de arboris fabifere flore, qui Boa Tfinkring dictus Lavianis.

$\mathrm{F}$

Los, quem depiatum videtis, in præalta arbore crefcit, cujus truncus mul-1 tis, \& acutis pinis obfitus eft, folio plane, quali Tilia in noftra Patria. Apertus tam egregie ruber cft, ut è longinquo nihil gratius oculis objici pofle putem, cui magna copia filiqux fuccedunt, in quibus rubrx Fabx itidem naicuntur, quibus

ARBOK FA IEERAI, BOA-TSIN KRING diata.

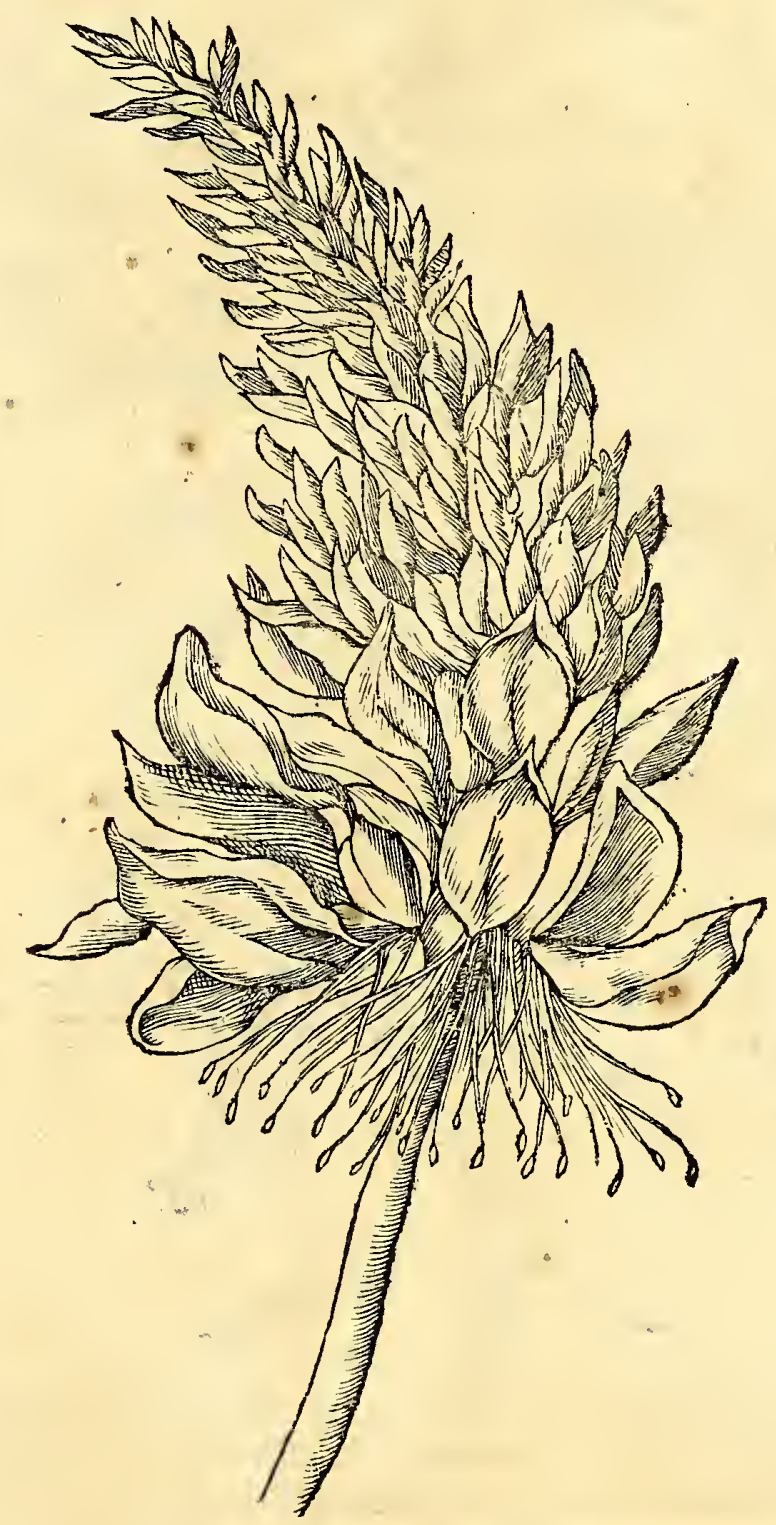

Turdi avide vefcuntur, non fecus, ac in Patria noftra baccis Orni rubris, laqueo inditis capiuntur.

Plurimæ funt arbores, qux varia Piforum genera, \& Legumina ferunt, more plane noftris incognito, ubi miraculum effet, Fabas è ligno nafci. Saporis tam boni funt ut notra Legumina, quxdam, melioris: attamen funt Pifa, Jegumina, \& Lupini, quæ non fecus, ac noftratia in farmentis nafcuntur, $\&$ bacillos appofitos fcandunt. Fabæ, quas Turficas nos vocamus, plures fpecies hicnafcuntur, qui fapore nullomodo aliis cedunt. 
Cærterum quoad vires Leguminum, ea conftat verfus ficcum pleraque vergere; ac flatulenta effe, torminaque in ventre \& inteftinis ciere: diuretica tamen funt omnia, $\&$ hydrotica; unde ea inter medicamenta alimentofa reponamus, \& non nifi aliquoties iis vefcamur.

Inter eos quoque familiares funt, Phafeolifeu Fabx purgantes, Piforum noftrorum forma, fed folio. Trifolii, vel Meliloti, verum craffiori. Harum Fabarum jus hydropicorum aquas potenter per fuperiora $\&$ inferiora educit.

PHASEOLVS II IN D I C V S R V B E R, qui $A$ E $R S$ Profp. Alpino dicitur.

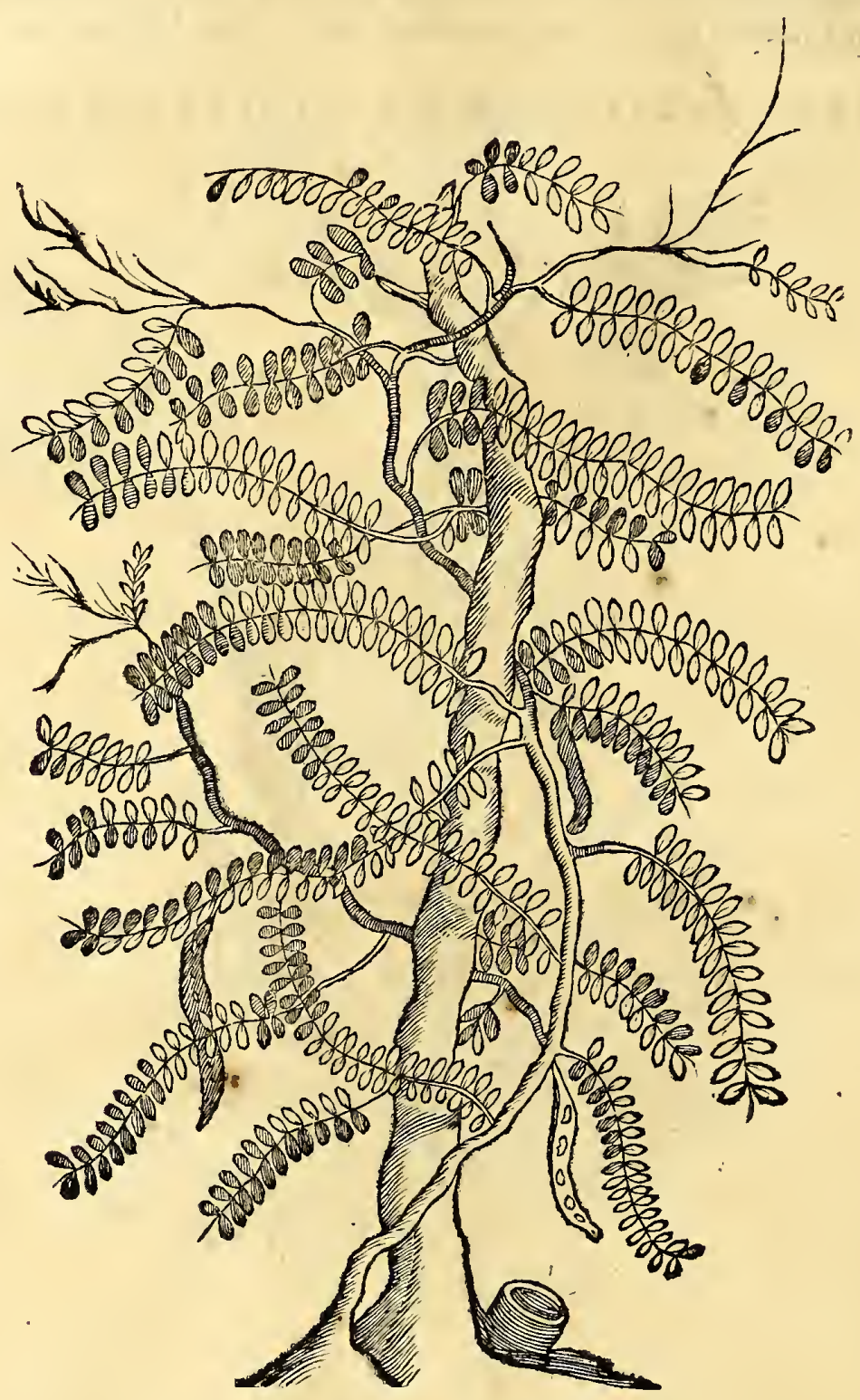

A N N O T A T I O. Cum Autor nofter folam iconem hujus plantæ fine aliqua defcriptione exhibuerit; Cumque eadem $x$ que in Brafilia luxuriet ac in India Orientali, vel Ægypto; paucis defectum hunc fupplebo, eaque traditurus qux mihi innotuerunt. Quod vero ejus figuram \& defcriptionem in opere meo neglexerim, non eft quod quifquam miretur; quoniam ea tàntum attigi, qux majoris funt efficacix in Medicina; hoc vero, rectius in puellarum cultum, quam corporis alimentum vel medicamentum cedat; Corallorum enim uniones, quas collo geftare folent, ex rubris Pilis conficiuntur; nec memini unquam in Brafilia hac ficut cætera Legumina advenis vel indigenis, etiamfi probe elixa, accepta fuiffe, quod ea pravi nutrimenti, \& difficillima concoctionis deprehenderint. Idem quoque de iis teftatum reliquit Profper Alpinus, etiamfi fateatur ab Agyptiis parari \& pro cibis apponi.

Silveftris \& volubilis hæe planta femper virens arboribusfe involvit, cafque enititur 
HIST. NATVRAI. \& MEDIC. IIB. VI.

teaci farmento. Cui, ramialternatim oppofiti, uti \& folia ad eundem modum xqualia, paria in quolibetramulo, circiter digitum longa, figura Buxi, vel Sesban Alpini potius foliis fimilia, fplendentia, fine petiolis, ramulis ornate innitentia confpiciuntur : moventurque ut nonnullix alix herbx ad Solem, fefe claudentes ac aperientes ad ejus ortum vel occafum; quafi eo converter entur, quo humor radiante Sole provocatur. Ex parvis floribus filiqux proveniunt omni anni tempore, qux mature factx. dehifcunt, unde fex, feptem, vel octo femina apparent Pifi fere magnitudinis, fed paulo ovalis figuræ, dura, fplendentia, læto coccineo colore decora, excepta ca parte, qua folliculo annectuntur, ubi macula nigra loco hili egregie fplendet.

P H A S E O I V S III $Q$ Y A D $R$ A $A$ N G V I V S.

En Pbacos, or docti quadrata Legumina Plini.

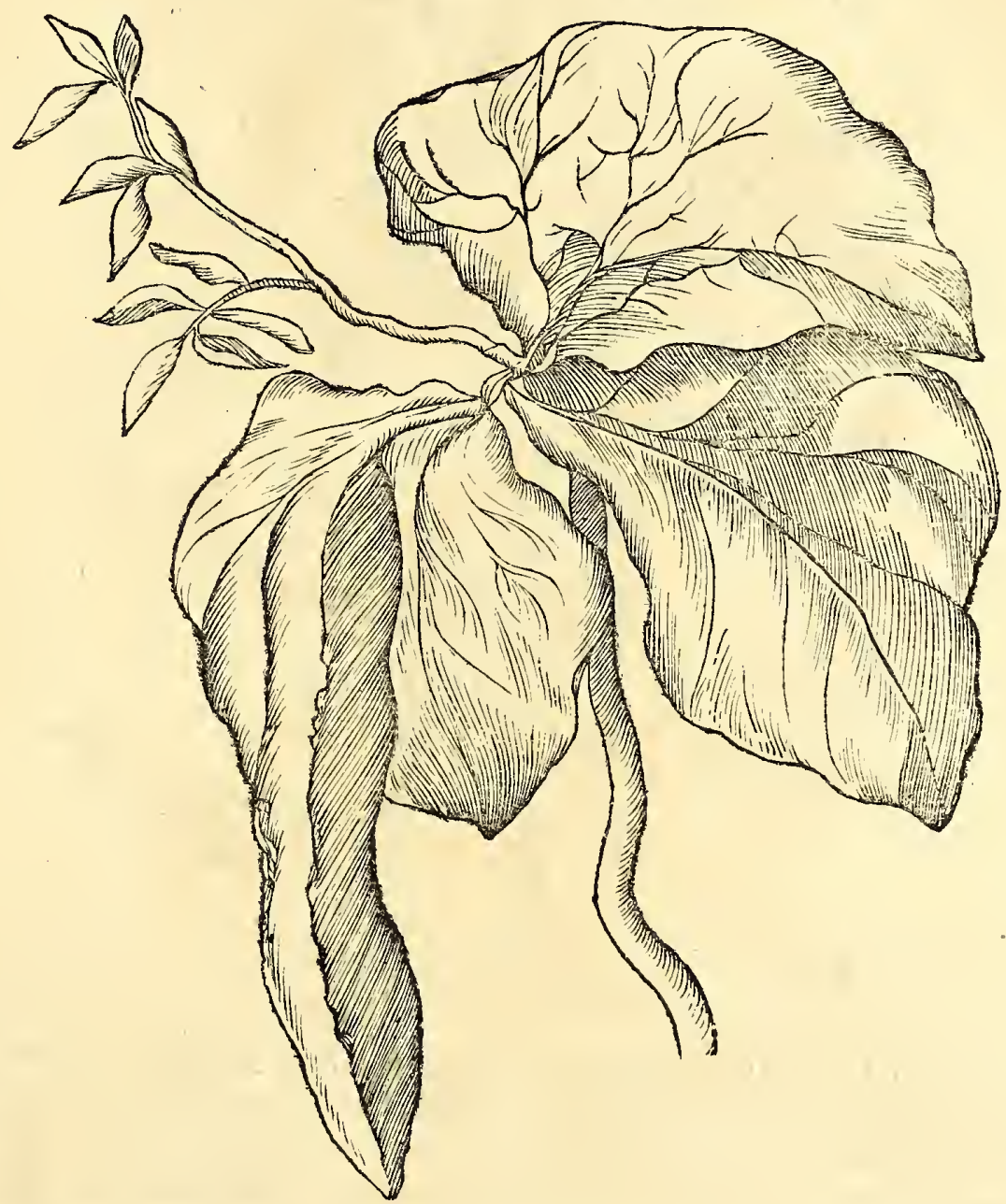

Irum hoc Leguminis genus foliorum magnitudine, \& fructuum infueta figura,

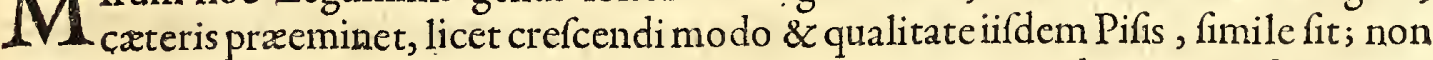
enim ingratioris faporis funt fructus, quam Pifa illa in Patria apud nos, qux finemembranaceo illo cortice (noftrates gulen fonver Schillen vocant) appofitos bacillos farmentofis fuis ramis, fcandunt. Ex uno eodemque caule tria folia fibi conjuncta emergunt, atque ex eodem quafi centro pediculus provenit; ex quo Phafeolus quadrangularis dependet, Pifis rotundis repletus, qui ubi maturuerit, dehifcit, \& fit edulis.

De eorum natura \& gufu nihil ulterius addam utpote quæ reliqua id genus Iegumina amulantur, ut fupra monui. 


$$
\begin{aligned}
& \text { P H A SE O L V S I N D I C V S, I V qui } \\
& \text { SEE C A M O O }
\end{aligned}
$$

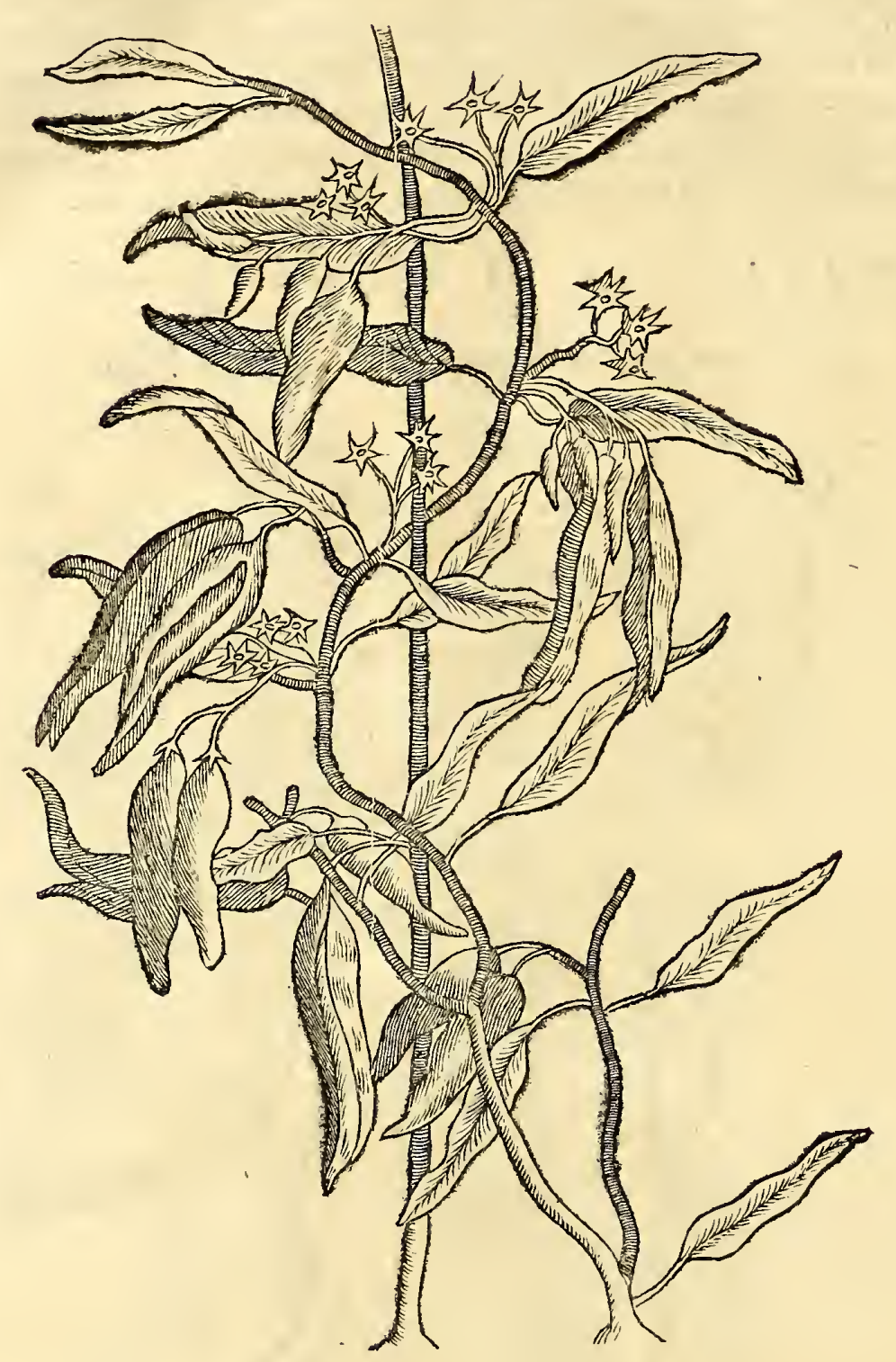

A N 0 T a t i o. Quam fexpe inter fe conveniant, Agypti \& Iavx Plantx; ex hoc quoque Phafeolo liquet, qui nihil plane differt, ab eo quem P. Alpinus in Plantis $A$ Eyptiacis tradidit; quamvis ille, ut \& Autor nofter, nihil fere de ejus qualitatibus fpecifice egerint; ille enim tanquam novam $\&$ adhuc minus ufitatam, eam exhibet, \& difputat, ad quam fpeciem redigenda fit, \& Apocyno Clufii , angufti folio non male comparat. Nofter vero autor qualitate hujus Phafeoli, communes cum cæteris Leguminibus \& plantis fabiferis, fub hoc capite comprehenfis, ftatuit: quamobrem eo lectorem remittit.

Planta hre exotica fponte in filvis nafcitur, alteque faliens, arbores vel bacillos fcandit, foliis longis, duris, acuminatis. Flores fert albicantes ftellares, tres quatuorve fimul copulatos, ex quibus nafcuntur filiqux longx, lanuginofx, craffx Rhododendri filiquis fimiles, fed longiores, feminibus parvis refertx.

Teftatur Pr. Alpinus, ex hac planta manare fuccum flavum, urentem, quem ficcetum Ægyptii valenter tenues humores purgare aiunt. Vnde nonnulli Scammonei fpecicm cfe affirmant, quam Secamoné appellant; cujus tamen nullum in medicina ufum fe novifle dicit. 
HIST. NATVRAI. \& MEDIC. LIB. VI.

L Y P I N

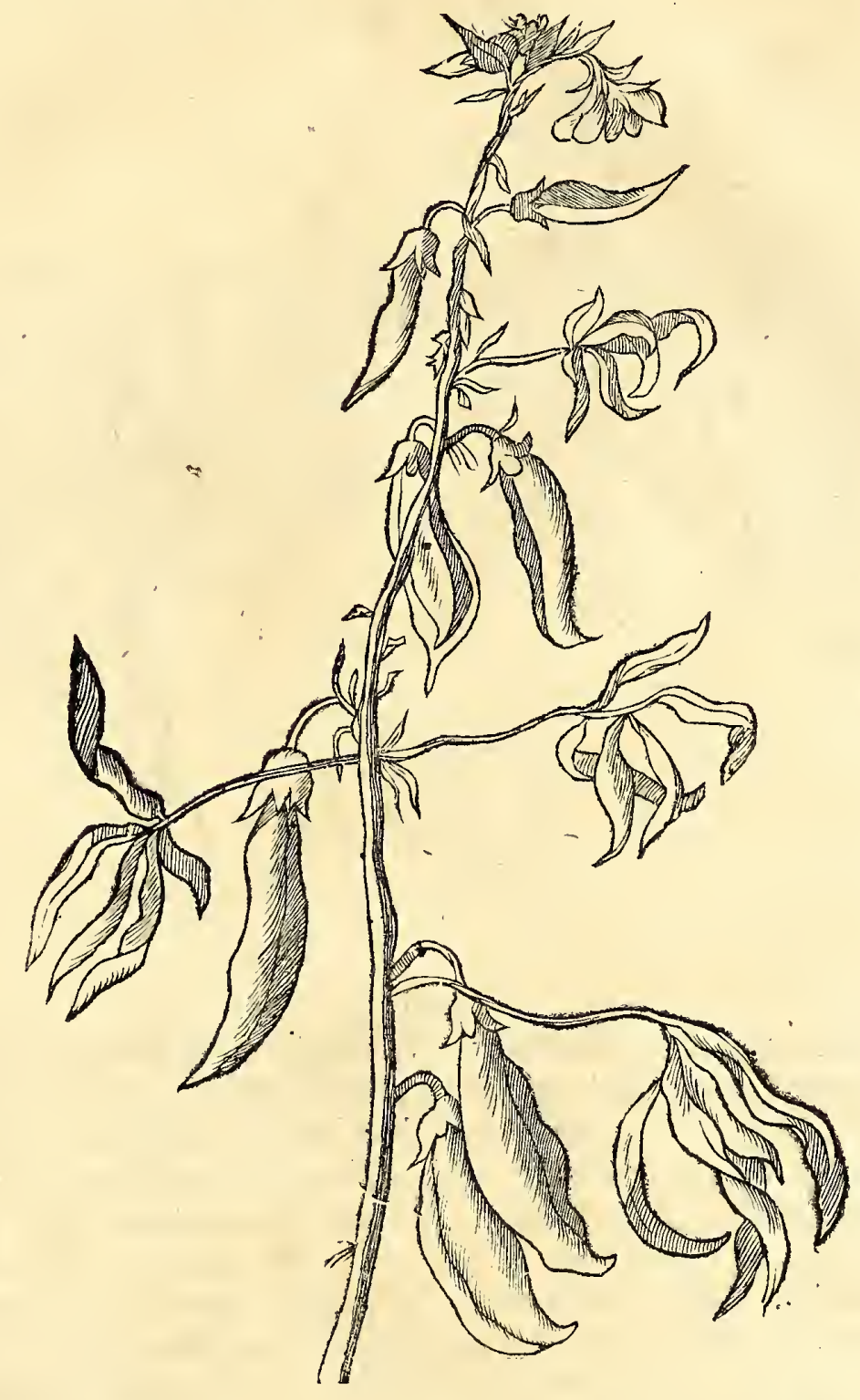

DIforum hoc genus, fivel ex fapore faftidiofo, \& amaro, judicare velis, è Lupino. rum eft fpecie. Flores fert flavos, quibus filiqux fuccedunt, Piforum noftrorum filiquis fimiles. Decoctum eorum alvum movet, $\&$ urinas, ideoque magis inter medicamenta, quam alimenta locanda veniunt; agreftes funt, \& in hor tis, quod fciam, non coluntur. Ramunculi exipfo caule fatis longi $\&$ recta extenfi emergunt, qui definunt in quinque vel fex folia oblonga tenuia. Flores autem $\&$ filiqux etiam caule cum tenui pediculo adnafcuntur.

$$
\begin{array}{llllllll}
C^{\prime} & A & P & V & T & X & \text { L } & \text { V. }
\end{array}
$$

\section{De quibusdam Indicis floribus, corumque grato odore és ufu apud Incolas.}

Trani, imo omnes Indi, qui Mahumetisfectam fequuntur, florum bonorum odorum funt amantiffimi, ut hinc proverbium enatum fit, Iudæos rem difpendere in facrificiis, Chriftianos in epulis, Mahumetanos in odoribus. Itaque fuaferim Hollandis noftris, qui tanti faciunt florum varios colores, \& odores; ut fape integra patrimonia in eos abfumant, huc veniant, fi emolumentum è floribus fuis defiderent, nam ingens in Iava eft bene odoratorum, \& coloratorum florum copia, ita ut fi particulatim de fingulis agere velim, charta \& atramentum mihi prius deficiant, quam $\mathrm{Na}$ - 
FI O S I N D I C $\mathrm{Y} S \mathrm{~S}$ C H A M P A C C A diatus,
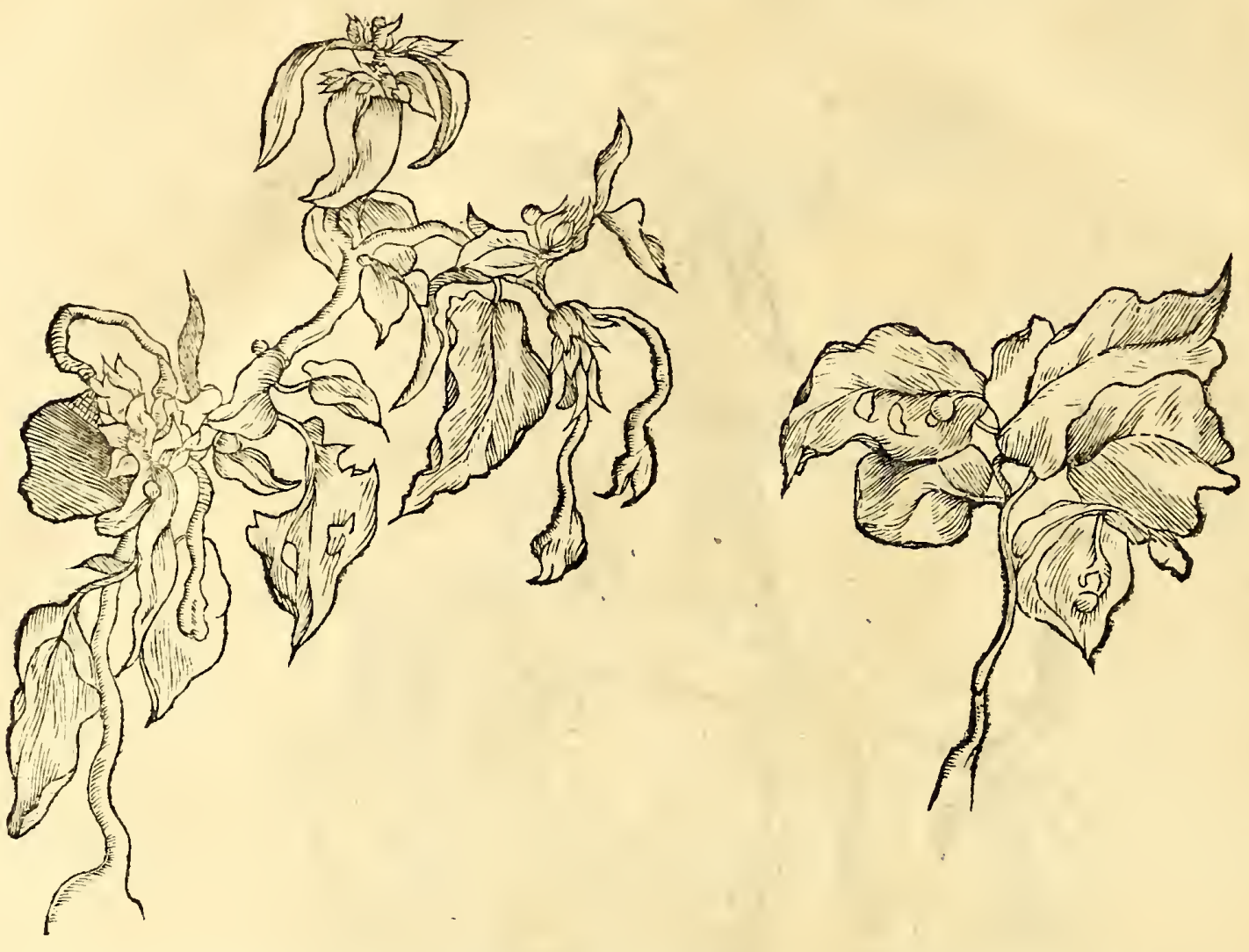

turas eorum explicem. Itaque felectiores, \& magis odore praftantes enumerabo. Inter odoratos igitur, facile principem locum obtinet Flos ille, quem Champacca indigitant, qui cref́cit in arboribus non abfimilibus Perficx Mali, foliis eodem modo oblongis , \& in cufpidem pyramidaliter definentibus. Colore flores funt duplici, viridiori \& aurco, qualis eft in Malis Aureis Hifpanicis. Forma funt, quali apud nos flores Colchici, vel etiam Croci Anglici. Porro odoris jucundi, \& Rofam mixtam cum Viola æmulantis. Vnde etiam fæminæ Indicæ is in nobili fuo unguento Borborit fupradicto utuntur, ut corpus à capite ad calcem eo inungant. Capillos quoque ferme femper intertextos habent hifce $\&$ aliis bene olentibus floribus, ut maritis fuis, vel potius amantibus, gratiores occurrant.

Nafcuntur præterca in arbufculis, nivis inftar albentes flofculi, qui Fula Mogori à Garcia ab Orta vocantur, tam grati odoris, ut Violæ ipfis cedant longo intervallo. Exhis aqux deftillaticix cordiales conficiuntur pro Lipothymiis, (qux fréquentes, $\&$ periculof hic in Choleris eveniunt, ) præftantiores certe, quam aqua Rofarum vel Bugloflix poflint effe. Ad Epithemata porro in continuis febribus, \& doloribus Capitis biliofis accommodatiffimæ funt hæa qux; unde natura horum florum, è tem. perato verfus frigus vergens facile conjicitur.

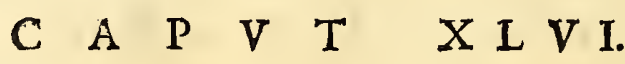

\section{De Rofa Batabico - Indica inodora feu Malva frutefcente.}

$\mathrm{F}$ Rutex quidam hortorum fepibus contexendis plantatur, cum farmentofis, \& oblongis ramis, è quibus corbes conficiuntur. Folia habet pyramidalia, in circumferentia dentata , florem fert rubicundum plane, qualis eft Rof fimplici folio apud nos. Sunt \& frutices cjufdem Ppeciei, qui carnei coloris flores gerunt, quem Belgx ILijfuetwigh nominant; totus porro frutex inodorus eft, \& fuo virore folum, \& pulchre florum rubro colore, afpectum delectat amœeniffimum. Mafticatus Flos nigrum fuccum àfe emittit, quapropter nobis aliquando denigrandis calceis infervit. Ex 
HIST. NATVRAL. \& MEDIC. LIB. VI. I4I

ROSA INODORARVBRAL I ROSAINODORA PALLIDAII.

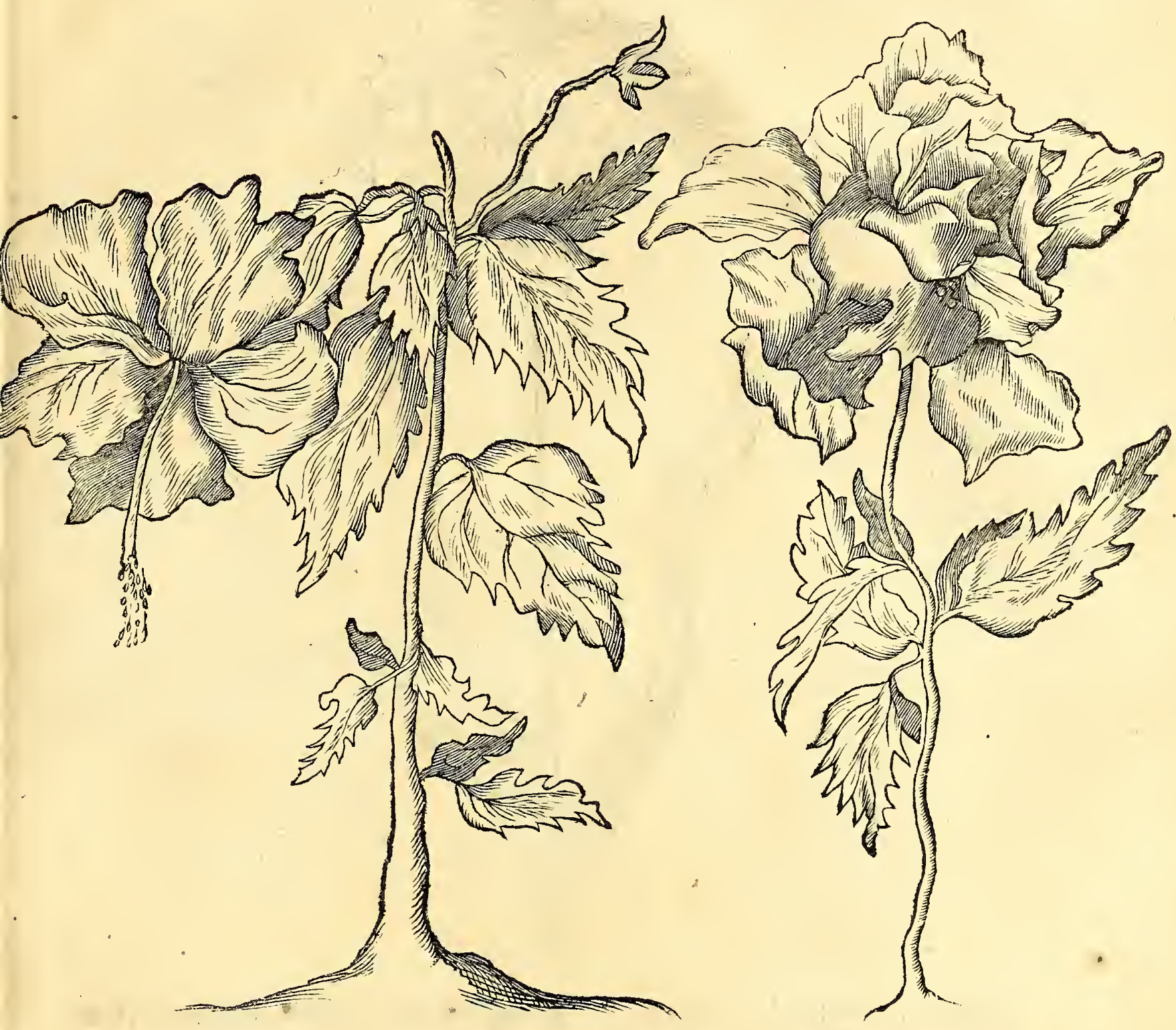

fapore tamen aftringenti, conftat frigidioris effe naturx, \& in Febribus continuis aqua deftillata ex his floribus ad conciliandum fomnum ufus fum pro frontali: Non incommode etiam poffe fumi in Dyfenteria propter aftringentem vim contenderim, fed cum notiora, \& meliora ad hunc affectum medicamenta nobis fuppetant, non eft quod ad minus ufualia curramus. Ego huic frutici lubens Malvæ frutefcentis nomen indiderim. Cum Flos ipfi Malvæa arborex flori non fit ablimilis, prafertim quantum ad pediculum prominentem è Floris calyce, ut hic depictum videre eft.

Ecunda Rofa Batavico-Indica inodora hic appofita eft, qux quoniam colore tantum differt à priore, quod illa rubro, hxe vero carneo fit colore, peculiariter quod de ipfa amplius fcribamus, non habemus.

$$
\text { C A P } \quad \text { V } \quad T \quad X \quad \text { L V I I. }
$$

\section{Appendix. Moly, vulgo Lilium Indicum.}

$\mathrm{P}$

Ro miro \& vario naturx lufu flores Afiatici Europæos æmulantur. Belgx in Indiis pulcherrimum hunc Liliis rubris noftris annumerant, quibus fane figur $x$ coloris elegantia haud cedit, \& proinde apud indigenas, perpetuos florum \& odorum admiratores, in pretio habitus. Si ulli florum Indicorum comparandus, certe 


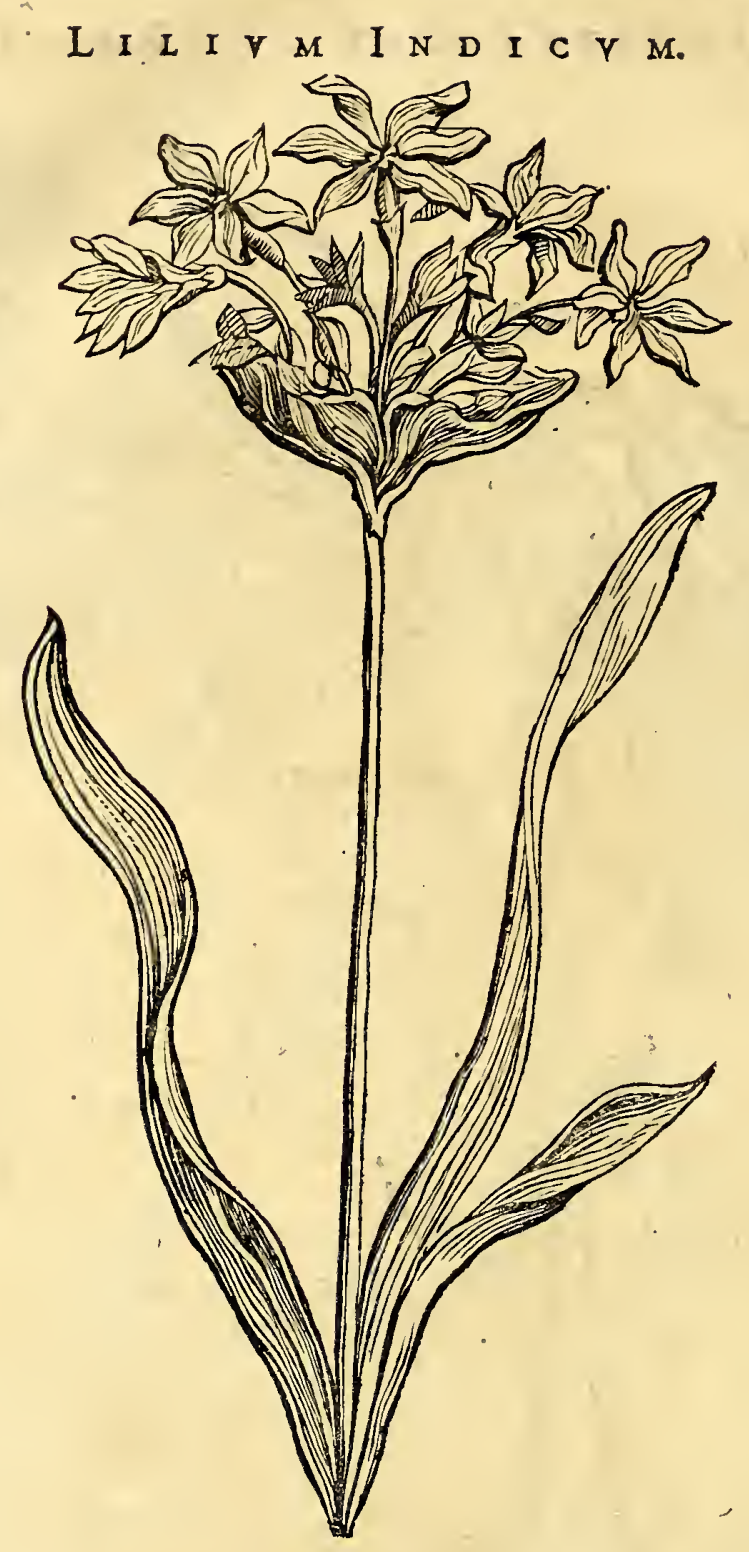

Moly montano latifolio, flore flavo, Clufii fimilis exiltit. Caule unico, enodi, firmo, fed tenui, ad altitudinem noftratis Lilii exfurgit. Cui infra tria quatuorve folia oblonga, furrecta, fupina parte carinata \& contorta adnafcuntur. Summo autem faftigio, ex membranaceo folliculo, bifariam divifo, quindecim aut plures flores uncialibus vel longioribus pediculis, fenis foliis, ftell $x$ in modum expanfis, emergunt, qui fimul eleganter juncti coronam imperialem reprafentant. Ideoque non indignam putavi plantam hanc ad vivum in Indiis depictam pro corollario annectere, licet ulterior ejus ufus \& dignitas à nobis adhuc defideretur.

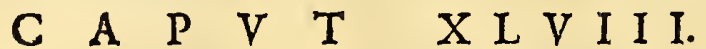

\section{De Liguftro Indico, \& Alcanne frutice.}

Hriftophorus à Colta, hiftoriarum libro, de aromatis, \& plantis Indicis, f. 285 , vehementer laudat hanc plantam: Quod adeo verum eft, ut nihil praftantius

inveniri in terra poffet, fovendis membris corum, qui à moleftiffima paralyfeos fpecie, Beriberii dicta, affecti funt; de qua cum latius in Method. medendi egerim, non eft quod hic repetam. Planta eadem eft, quam Profper Alpinus fua, de Plantis Egyptiis, hiftoria Liguftum Indicum nominat: \& certe flos, folia, \& farmenta omnino Liguftum referunt; odoratius tamen fpirant folia quiddam, quam noftrum Ligufrum: Hos quoque, quamvis forma conveniat, colore variat; nam in Liguftro Indico fubcyaneus eft, cum in Liguftro patrio, nive fit candidior; Vaccinia tamen utriufque 
LIGVSTRI SPECIES I.

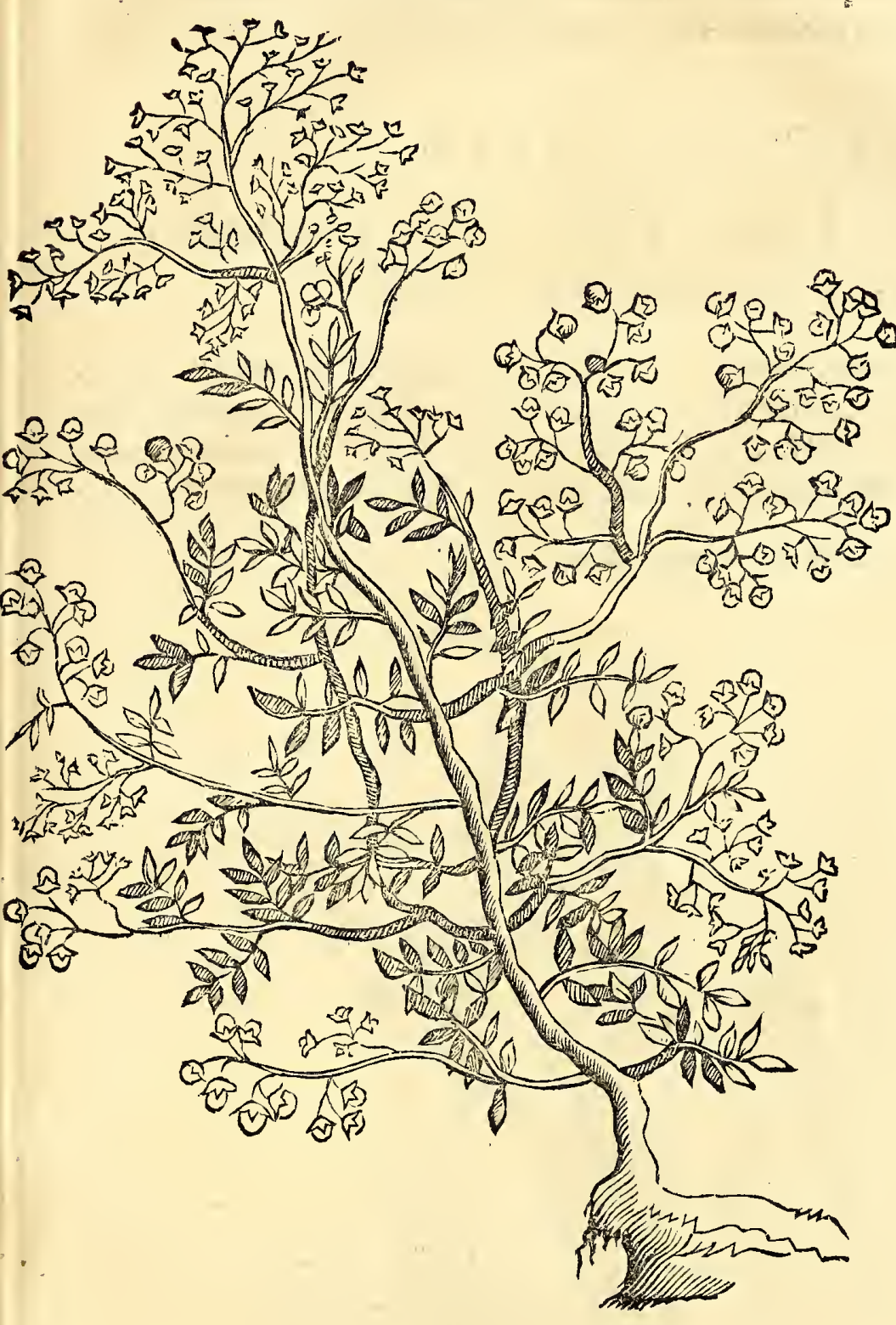

LIG V'STRI SPECI'ESII.

A I C A N A dicta.

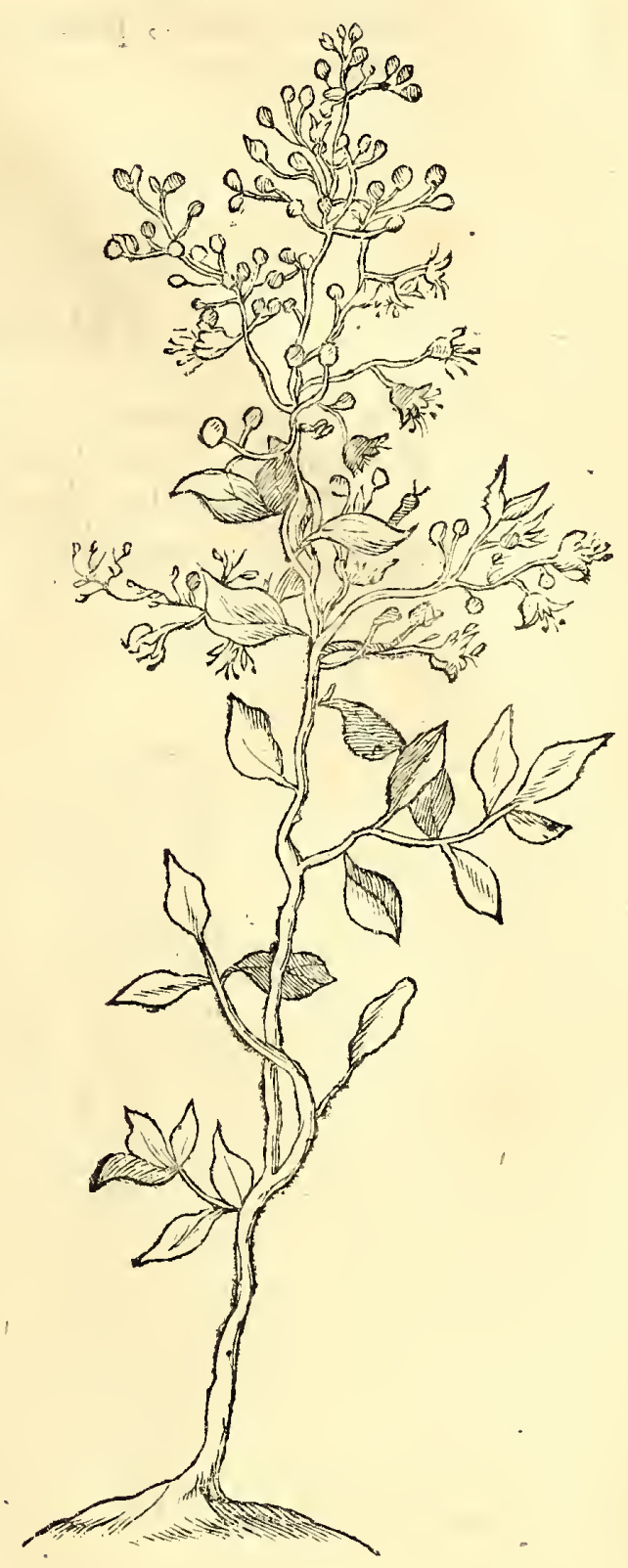

nigro funt colore. Nobilifimus eft frutex per omnem Indiam, longe virtutibus excedens Chamæmelum, \& Melilotum, quum in fomentis difcufforia fua vi paralyfin fanet, folia mafticata aliquantum linguam vellicant, fine tamen infigniacrimonia.

Alcannx frutex, quem fimul hic appingi curavi, huic congener eft, nifi quod fit foliolis minutioribus, quam Liguftrum Indicum, quod Malaii Lagondi vocant, Garcias ab Orta 2eergundo, \& Negundo appellat.

Alcanna porro folia per totam Indiam in ufu funt tingendis dentibus, labris, \& $\mathrm{xin}-$ guibus prefertim, rubro colore. pulcrum inter Mauros exiftimatur, quod hoc modo faciunt; folia in lapide marmoreo piftillo confracta macerant in aqua pura, cum pauca calce, \& fic rubrum nafcitur hoc pigmentum, quo \& caudas equorum fuorum Turcx, \& Perfa, eleganter tingunt, non fecus, ac fi videas equos iftos in Zelandix partibus, ubi Rubia tinctorum nafcitur, qui quia Molas illas circumactiles trahunt; quibus radices dictx Rubix, in fornacibus exficcatx, teruntur in pulverem, tori rubro colore picti confpiciuntur.

Denique ut concludam, hi duo frutices in tanto funt honore apud mulieres Malaicas, ut facrilegus habeatur, qui malum de iis protulerit verbum, \& femper in lotionibus, quibus utuntur in puerperiis, omnibus denique vulvæ morbis, ditiores, hæ plantxa adeffe debent. Quin \& fenectutern arcere dicunt, \& (fi auderent) mortem ipfam. Certe virtutes ejus egregias ego nunquam fatis laudare definam, cum foliis hujus nobi- 
lifimi fruticis, fecundum Deum, fanitatem meam reftitutam debeam à moleftiffimaifta paralyfeos fupra dicta fpecie, qua ego per integros quatuor menfes, cum prima vice, à Iavanis Mataranenfibus obfeffi eflemus, vexatus fum, fotu, \& decocto intus fumptohujus Lagondi, plane ab ea liberatus fum, $\&$ in Nofocomio eodem modo plures alios percuravi.

\section{A P $\quad$ V}

\section{De Colocaßia feu Culcas Troperi e Alpini, quam Ari effe Jpeciem proxima defcriptio oftendet.}

$\mathrm{P}$

Rofper Alpinus libro fuo, quemedidit de plantis ÆEgypti, hanc Culcas ab incolis vocari ait, ipfe Colocafliam vertit, qua ratione ego equidem ignoro , cum Colocaffia longe quid aliud fit, prxterea edulem effe ait, quod quidem verum eft, fed cum cautione eft intelligendim, ne ignarus quidam vite periculum incur-

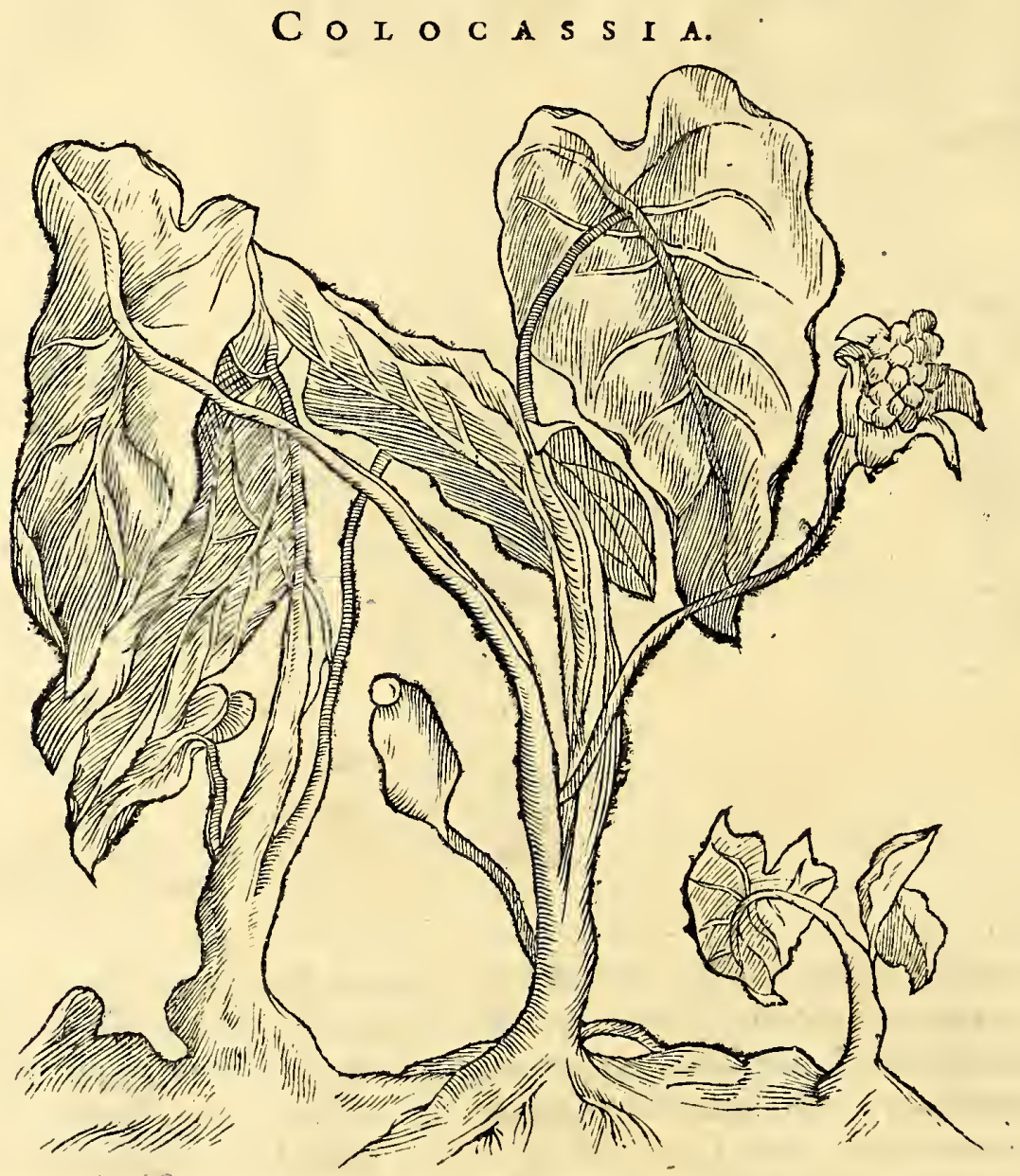

rat, cum planta hæc na tura fua venenata fit. Itaque radices ejus craffas, \& in taleolos difciffas, Iavani per triduum aut quatriduum in profluenti macerant, ut muccilaginofa, qux in iis eft fubftantia, ablua tur, nam in hac muccagine deleteria ejus vis confiftit, tunc expreffas torculari eafdem radices Soli ficcandas exponunt, \&z dein eas in pollinem terentes, placentas ex iis loco panis \&. oryzx conficiunt. Et hæc eft radixea, clade Iavanorum Mataranenfium nos obfidentium tam nobilis, quxinter eos perniciofam in caftris Dyfenteriam excitavit, dum miferi fame oppreffi, quod à noftris oryza omnis intercepta, \& incenfa effet, qux à Tengal civitate in caftra advehi deberet.Itaque hac fola fere radice fe per aliquot feptimanas fuftentare in fumma fame coacti funt. Chinenfes, \& Malaii codem modo praparatis ejus radicibus utuntur. Quantum me fpectat, ego non libenter fruar deliciis tam caro confantibus. Prxterea (quod pene ómiferam) dum hanc radicem coquunt, prius decoctum abjiciunt, \& addita aqua recentirecoquunt, \& tum is quoque vefcuntur, cum aceto, \& oleo Nucis Indicx, \& 
HIST. NATVRAL. \& MEDIC. LIB. VI. 145 Pipere, ut nos radicibus Betærubrx. Cærerum quod Pr. Alp. loco citato dicat, plantam hanc florem non ferre, falfum eft , immo ego ejus florem, \& fructum, millies vidi, \& ex iis conjeci, 'Ari effe fpeciem, ut in hac figura videre eft : adde quod fructus maturus omnino ruber fit.

$$
\text { C. A } \quad \mathrm{P} \quad \mathrm{V} \quad \mathrm{T} \quad \mathrm{L} \text {. }
$$

\title{
Cynara Indica feu Ananas Indis dicta.
}

\author{
2ui legitis Cynaras, atque Indica dulcia Fraga, \\ Ne nimis bac comedas, fugito hinc, latet Anguis in berba, \\ Ne tibi lethifero Sapor impleat ilia Jucco.
}

Vm Chriftophorus à Cofta hunc fructum egregie defcribat, nolo ego honorem fuum illi invidere, fed lectorem eo remitto : hoc tantum addito, guftu adeo delicato effe, quam Fraga in Patria, vino, \& faccharo macerata. Externam cutem hujus fructus aufert, qui co uti volet, \& reliquum difcindit in taleolas, quas aqua,

$A N A N A S F R$ V C T V S

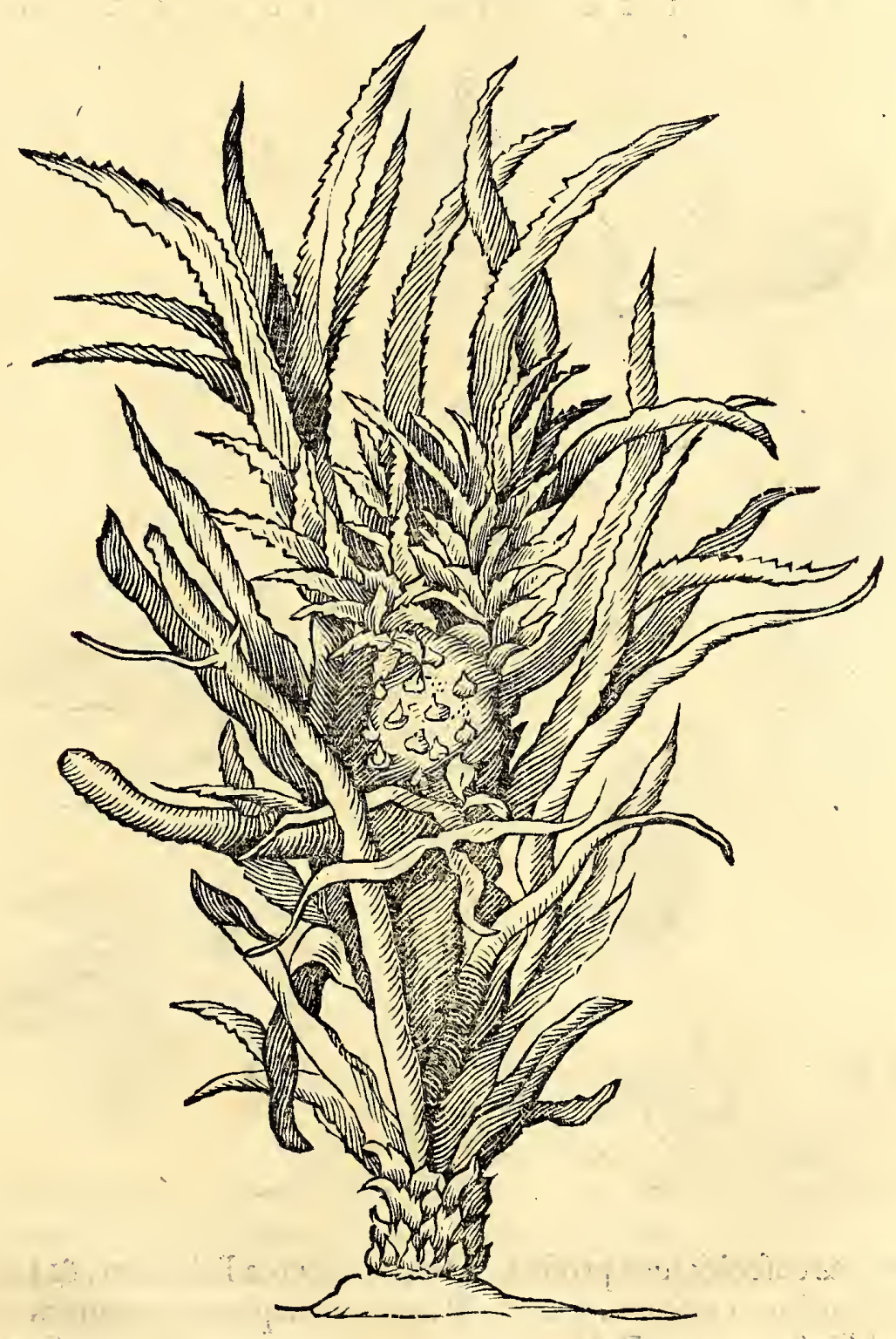

aut vino, paulum macerare neceffe eft, ut erodens vis ipfi infita extrahatur, alias calore fuo palatum, \& linguam exulcerant, bullafque in is excitant. Quapropter omnibus \& fingulis fuaferim, ut his fructibus moderate utantur, ne decepti à gratiflimo fapore incurabilem Dyfenteriam incurrant. Quamvis fructus hic ex effectu fuo procul dubio ca+ 
lidus judicari debet, tamen folia frigida funt, quod acidus ejus, \& adfrringens fapor, fatis indicat, qui guftus non nifi in frigidioribus plantis reperitur. Neque hoc alicui videri mirum debet, plantam, aut fructum, una parte calidum, altera fre frigidum efe, cum exempla in promptu fint; fed unicum hoc tantum adferam huc de Malis Citreis, Limonibus, \& Aureis, quorum pulpa egregie refrigerat, exterior vero cortex calidus eft, quod fapor ejus amarus facile indicat, præterquam quód mulieres Indx, nullum efficacius medicamentum ad obftructiones menftruorum effe quotidiana experientia teftantur, \& nos corticibus horum fructuum conditis, ad frigidos Ventriculi, \& Inteftinorum affectus commode utamur.

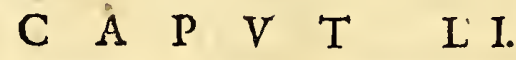

\section{De Betonica fruticefcente.}

A Ntequam plantam hancfruticofam defcribam, illudlectorem admonitum vo. lo, me inter Naturæ miracula, qux in hac Infula vifuntur, referre, quod herbæx \& plantæ , alibiànatura molles, hic caule lignefcente multæ confípiciantur, ut inter cxteras videre eft Malvam vulgarem, quæ pumilis ftolonibus ligneis

$$
\text { B E T O N I C A F R V T I C E S C E N S. }
$$

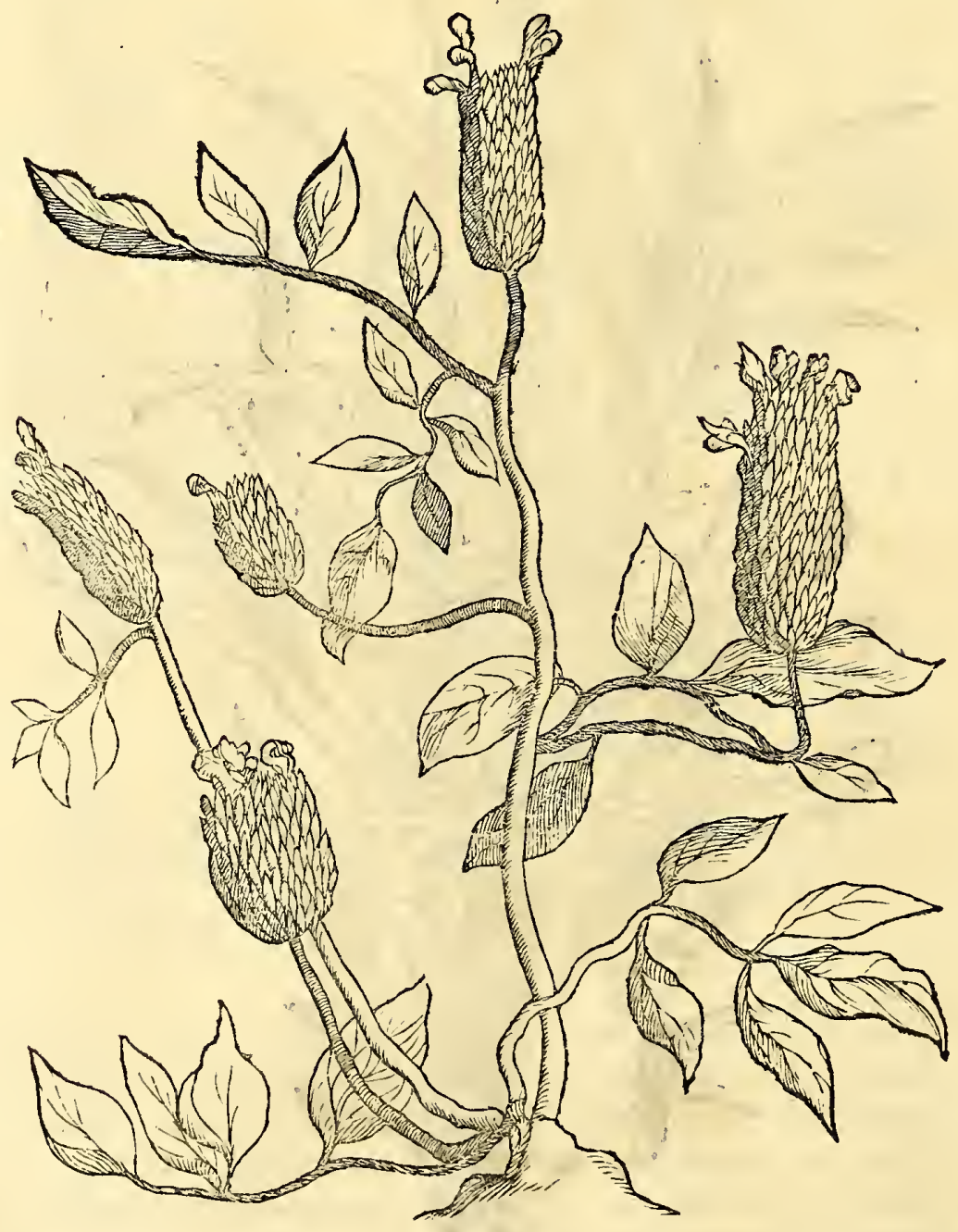

egregic floret, \& cafeolos fuos profert. Multæ præterea Fabarum, \& L Lupinorum fpecies hic in arboribus crefcunt, quod in Patria noftra plane inauditum eft, fed de is fuo loco. Ad Noftram hanc Pulmonariam jam deveniamus, quam fic nomino, quia maculas fert in foliis fuis; quales in Pulmonaria noftra videmus, qux ibi inter olera refertur, fed revera flores; feu fpicæ ejus, eam de Betonicx genere effe arguunt: tamen hic pulmonibus ejus decoctum utile fertur, Sputo fanguinis; Phthif, Afthmati denique conducit, quod Sakit hatii Malaii vocant, feu morbos Cordis, cum Cor, Hepar, 
HIST. NATVR AL: \& MEDIC. LI B. VI.

Pulmones, Lienem denique ipfi nomine Cordis infigniant, ac, uno ex fupradictisinfrumentis laborante, Sakit bat ï, id eft, fe dolere è Corde conquerentur; \& dum locum affectum manu demonftrant, facile Médicus verfatus errorem intelliget, alias ludibrio fe exponi Tiromedicus putaret. Spica hujus planta frutefcentis, ut dixi, Be-tonicx flori refpondet: colore funt flofculi, qui mille fere, una fpica exiftunt, ex pallido cyanei, quales funt flores Roris-marini in Patria. Indre porro mulieres fuccum hujus plantze expreffum, ac viridem, excellens antidotum dicunt effe adverfus morfus Serpentum, Scorpiorum, Scolopendrarum, \& cateros venenatos ictus. In quo ego illis facile fidem adhibeo, cum fciam, ipfas perfectifimas magiftras, \& repertrices venenorum effe, quibus illos, quibus male voluit, ad Orcum demittunt, \& in hoc genere fraudis nullo modo Italis cedunt, cuin terra hæc, ut optimarum, \& $\mathrm{c}$ pr $x$ ftantifimarum herbarum eft ferax, fic venenorum, \& medicamentorum delcteriorum copiam gerat.

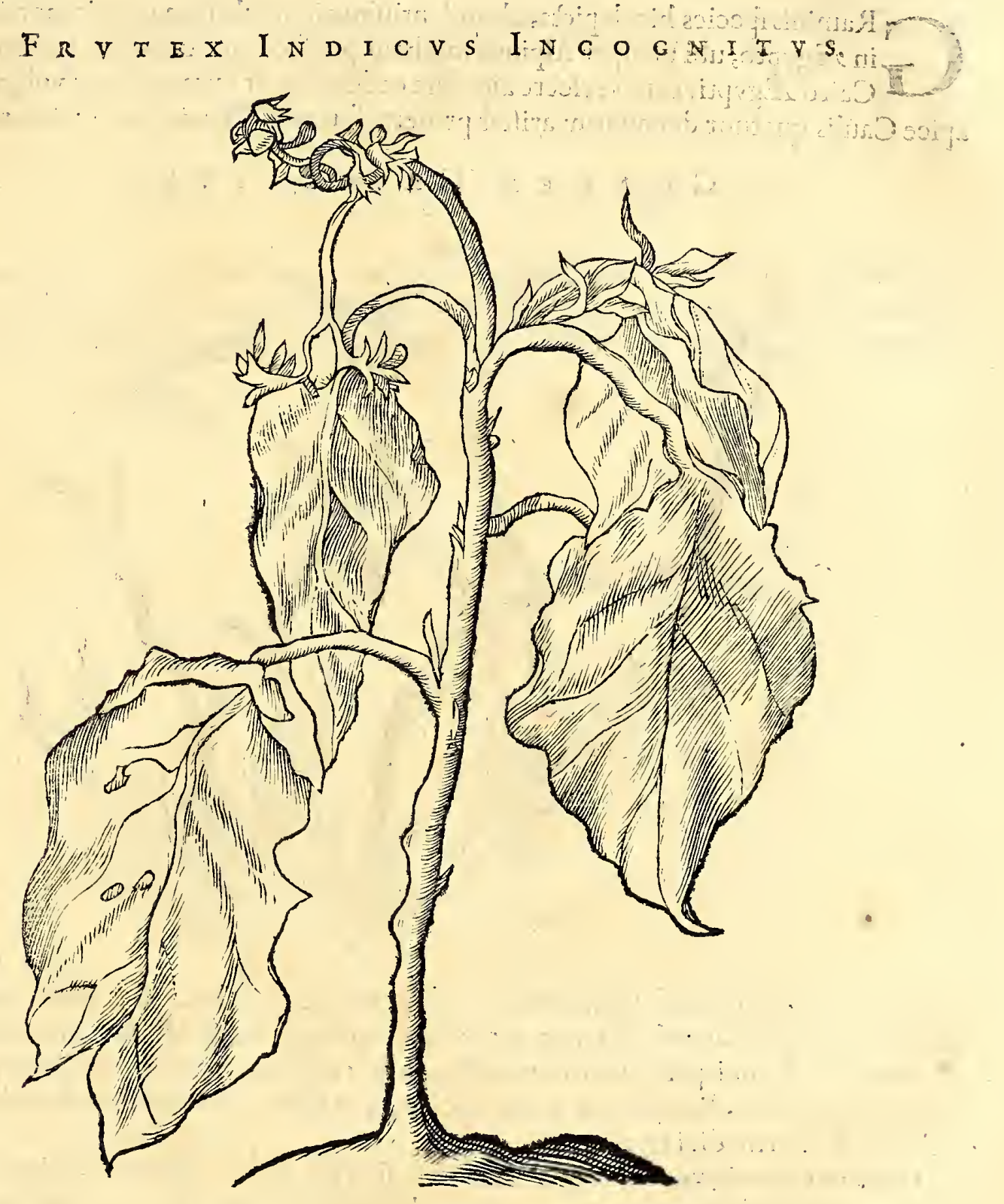

FRutex hic exoticus, anonymus eft, cum floribus exiguis copulatis, foliis autern magnis, deorfum pendentibus, ex pediculis folidis, ligneis. Eorum fuccus ulceribus malemoratis exficcandis dicatus eft. Catera, quæ de hujus plantx viribus dicenda forent, quia mihi incomperta; polteris indaganda relinquo. 


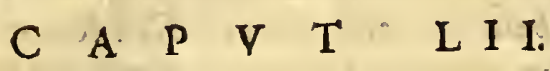

De Gramine Cruciato Tropperi Alpini, lib. 1. de Plantis Aegypti, cap. 40. E de cateris Graminibus medicinalibus, \& radicibus corum in fava.

\section{Gramen ego quamnis vociter viliffima Planta, Sed tamen in morbis notus me pretulit ufus, Qui Renes diro vexantque dolore veficam.}

$\mathrm{G}^{\prime}$

Raminis fpecies hic depiota, abundantiflime in Infula Iava crefcit, non fecus, ac in $\mathbb{E}$ gypto, ubi Profper Alpinus medicus præfecti mercatorum Venetorum in Cairo Ægypti, eam crefcere ait, folia eadem habet cum gramine vulgari: fed in apice Caulis quatuor decuffatim ariftas profert, formam Crucis plane referentes. Eft

$$
G \text { R A M E N } C \text { R V C I A } T \text { V } M \text {. }
$$

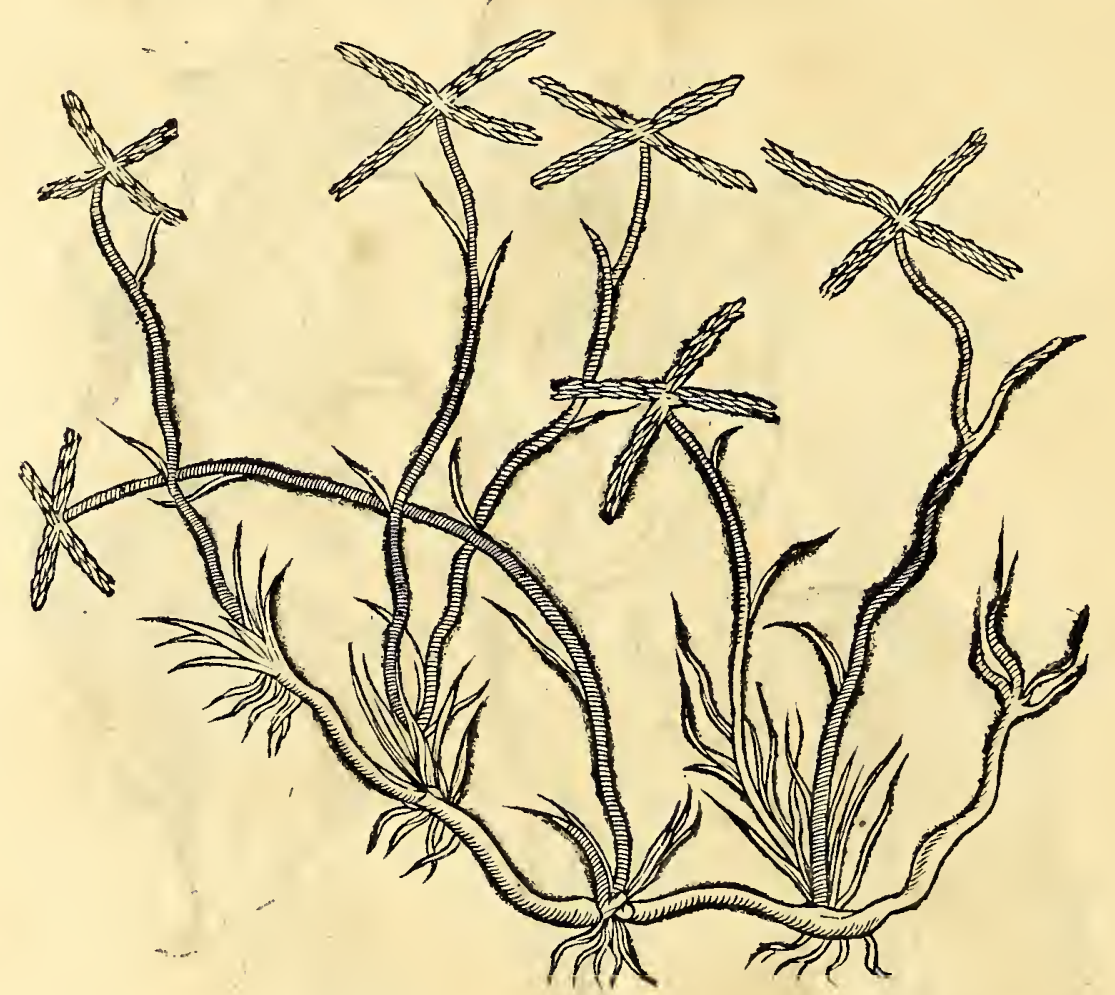

præterea Gramen ejufdem generis, quod fex vel octo, tales ariftas ferat, quales hic pinguntur, \& ftellas cxleftes non male tum referunt; in his ariftis femen continetur parvum, \& femini per quam fimile. Radices cum tota planta coquuntur, ad Dyfurias, Strangurias, Renum, \& Veficx dolores, \& ulcera ; excitandos dein fluxus muliebres, Malaii medici iis utuntur.

Graminis omnigeni adhuc plurimæ funt fpecies, figura diverfa, Dodonæus quindecim, vel fexdecim diverfas ponit, Lobellus aliquanto plures : fed huc veniant velim, vel centum iis oftendero. In hoc genere etiam (omiffis vulgaribus) Iuncum odoratum repono, quem quamvis Garcias ab Orta nullitus ferme ufus effe dicat, quam equorum fubfternendis cubilibus, tamen in Iava vix unquam carnes, vel pifces elixantur, quin fafciculus hujus vere aromatici Graminis addatur, cum ad faporem conciliandum, tum ad naturalium membrorum concoctionem adjuvandam. Tacco vim ejus deobftruentem, in Iecoris, Lienis, Mefenterii denique, \& Pancreatis infarctionibus, qux dux pofteriores obftructionum fpecies, hic perquam familiares funt, \& miferos mortales fine ullo fere fenfu doloris in marafinum \& extremam extabefcentiam conjiciunt, ita it verius Sceleti, ac umbra hominum, quam homines 
HIST. NATVRAL. \& MEDIC. LIE. VI.

appareant: fed de his in privatis.meis Obfervationibus, \& Methodo medendi Indica.

Crefcit \& aliud Graminis genus, fola radice à vulgari differens, qux tres, quatuorve tubercula profert, Ciceris, aut Pifi magnitudine, qux mafticata plane faporem Caryophyllorum reddunt, nifi quod fint moderatiori \& $\Sigma$ blandiori calore. Denique quamvis Gramen vulgatiflima fit herba, \& propterea ab omnibus exiftimetur viliffma, \& abjectiffima: tamen inter faluberrima eft è terra nafcentia medicamenta.

Quapropter, quia multi nihil nifi pretiofa prodeffe putent, monitum volo qualem cunque novicium huc adventantem, nil quod vulgo contemptiffimum videtur, temere abjiciat; cum vel exercitatiflima ingenia in eo fxpe reperiant, quod omnes univerfi Orbis thefauros fuperet, fanitatem dico, fine qua multi hic ardeliones fruftra delicias exopibus quaritant.

Corona quidem nulla graminea nobilior in majeftate populi terrarum Principis, præmiifque gloriæ Gemmatæ, \& Aurex , Vallarefque, Roftratæ, Civica, Triumphales \&zc. Plin. lib.2 2. tum quoque lib. 4. cap. 55. Graminea (corona) non nifi in defperatione fuprema contigit nulli, nifi ab exercitu univerfo, fervata $\&$ decreta. Cateras Imperatores dedere, hanc folum miles Imperatori.

$$
\begin{array}{llllllllll}
C & A & P & V & T & \text { L I I I } & \text {. }
\end{array}
$$

\section{De Halicabo feu Alke-kingi Arabibus dicto.}

$\mathbf{P}$

Lanta hæc nobilis circa fluminum ripas copiofe nafcitur, cum floribus fuis pulcre flavis, quibús minores paulo patriis veficulx fuccedunt, quibus femen contia netur: Indi, \& Chinenfes hanc plantam cum Mandragorx pomis, qux Poma d'ore

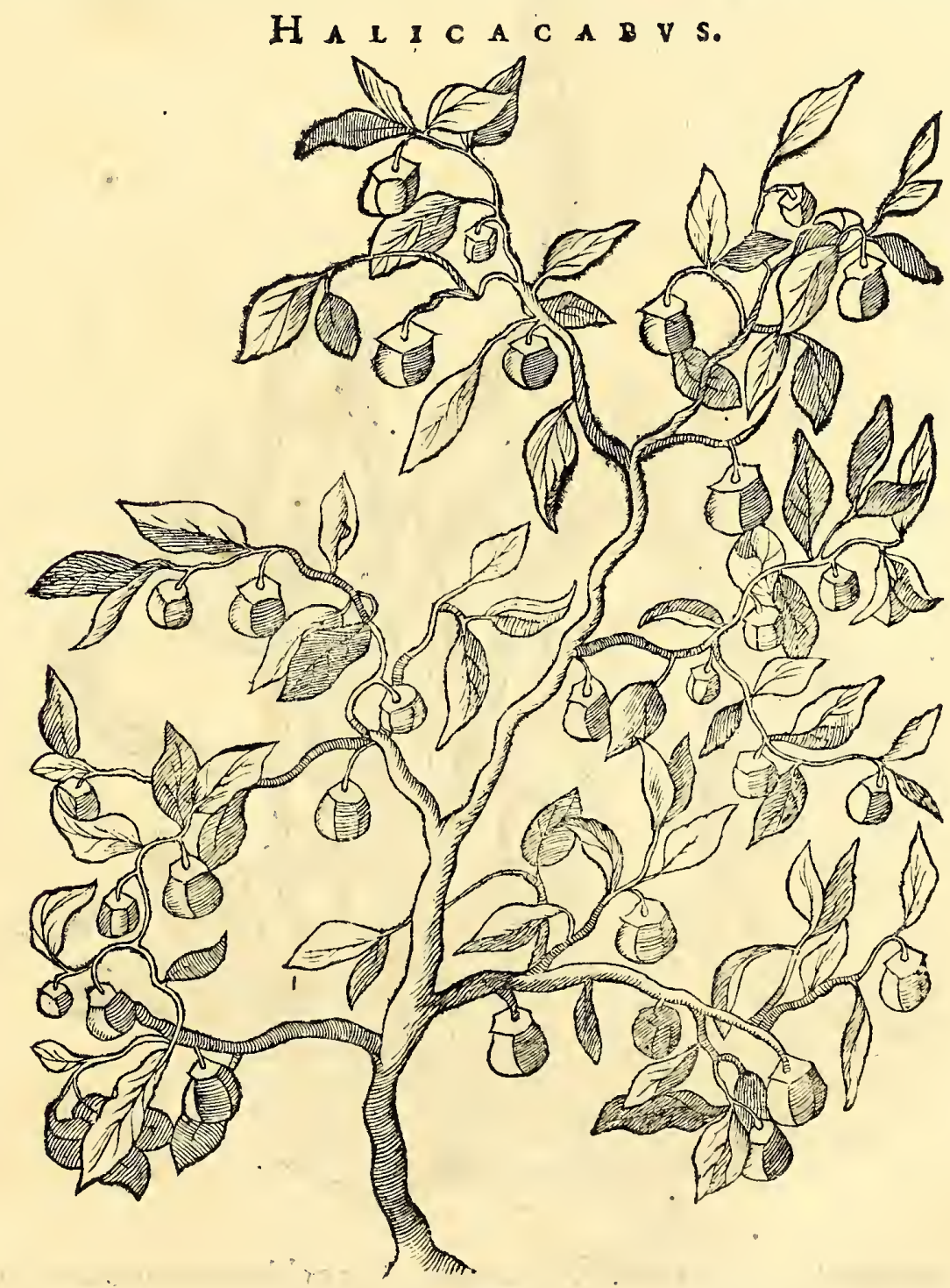

Lufitani vocant, \& Chili feu Ricino Americano comedunt, de quo cum in deferiptio. 
ne Ricini commemoravimus, non eft, quod actum, hic agamus. Succus viridis expreflus in ufu eft ad calidos Renum, \& Veficx affectus: Tum in Gonorrhœis Venereis, quæ hic eveniunt acerbifimæ, remedium eft anodynum fumme ; \& certe hinc videre licet, quam confone, hægentes, quamvis Idiotæ, cum nobis medicinam exerceant, ut mihi non dubium fit, Græcos potius hanc artem à vetuftiflimis $Æ$ gyptiis, \& Arabibus hanfiffe, quam ipfis tradidiffe ; nam quis, quxfo, Grxcorum huc unquam devenit? præterea Malaica unaquæque mulier medicx fimul \& obftetricis munere $f_{a-}$ cile fungatur, ac (ut fatear, quod res eft) ego meillarum manibus libentius commiferim, quam fciolo alicui Medico, vel Chirurgo arroganti, è fcholis ftudia in umbra eduçata, \& inflatam præfumptionem, pr $x$ fe ferenti, \& fine ulla experientia, medici folummodo in charta, tamen ( $f$ Dis placet) rationales dici volunt.

$$
\text { C A P V T L I V. }
$$

\section{De Verbena Indica, \& nugacibus de ea anicularumopinionibus.}

$\mathrm{V}$

Erbena hæc fimilis eft Verbenæ noftræ mari, fpicæ tamen hic duriores, \& longiores funt ; foliis hujus Plantæ contufis utuntur Incol $x, \&$ nos quo que, ab is edocti, ad ulcera tibiarum : nam egregie exficcant, quod requiritur in omnibus ulceribus, quæ hic propter aëris calidam \& humidam conftitutionem, difficulter

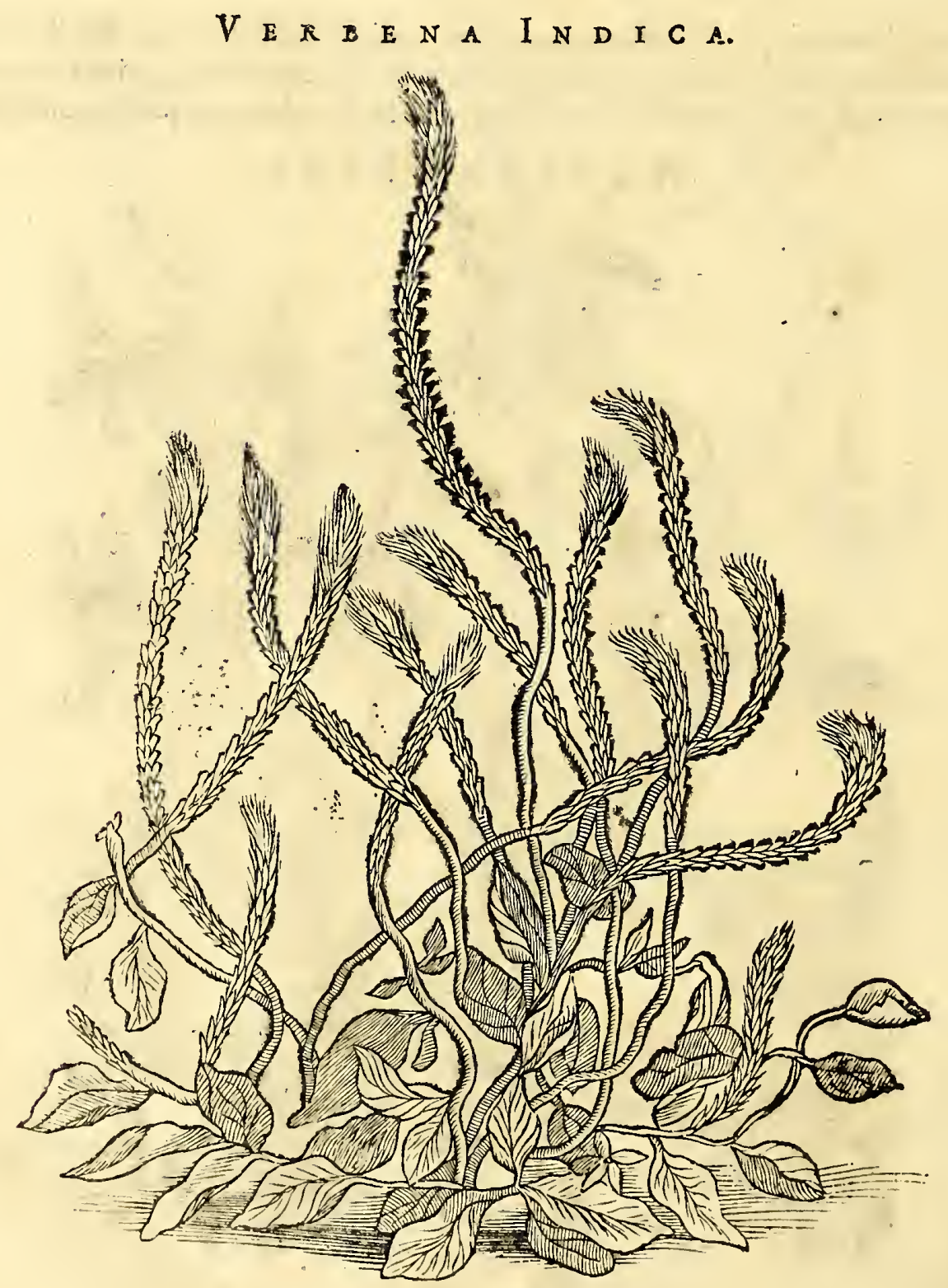

admodum curantur. Succo expreffo recenter, \& cochlearis unius menfuram ægri ad Cholicos dolores, Dyfenteriam, Choleram, \& reliquos indifcriminatim Inte- 
HIST. NATVRAL, \& MEDIC. LIE, VI.

ftinorum affectus, cum fummo fuccefli hauriunt. In Syncope quoque, \& animi deliquiis cum aceto contufam pectori applicant.

Cxterum herbam hanc facram effe dicunt anus Indicx (quod cum noftris aniculis commune habent) omniaque inçantamenta arcere aiunt, \& maleficia : fed credat Iudæus Apella , non ego; qui, ut natura non propenfus fum credendis fuperfitiofis medicamentorum viribus, hoc faltem ridendi caufa huc adduxi, ut oftenderem, infanam, \& futilia credendi Cacoëthiam, \& malum morem inter totius Orbis deliras aniculas verfari.

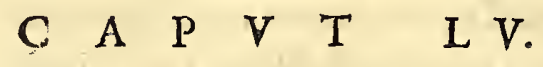

\section{De Myracantho Jeu Eryngio Indico.}

Affectos renes or tormina dira vefica, Cortice qua fcabro producit calculus, atque Mille minas mortis Sanat Myracanthon odora Radice, or rauco ducit de pectore pblegma.

Vantum ad folia Eryngium hoc Patrio fimile eft, quod in collibus arenofis circa mare in Hollandia, \& in Zeelandia circa aggeres, copiofe crefcit. Flore tamen omnino differt, qui fpicatim prodit, non fecus, ac flos Lavendu.

ER I N N G I I I I N D I C I S P E C I E S.

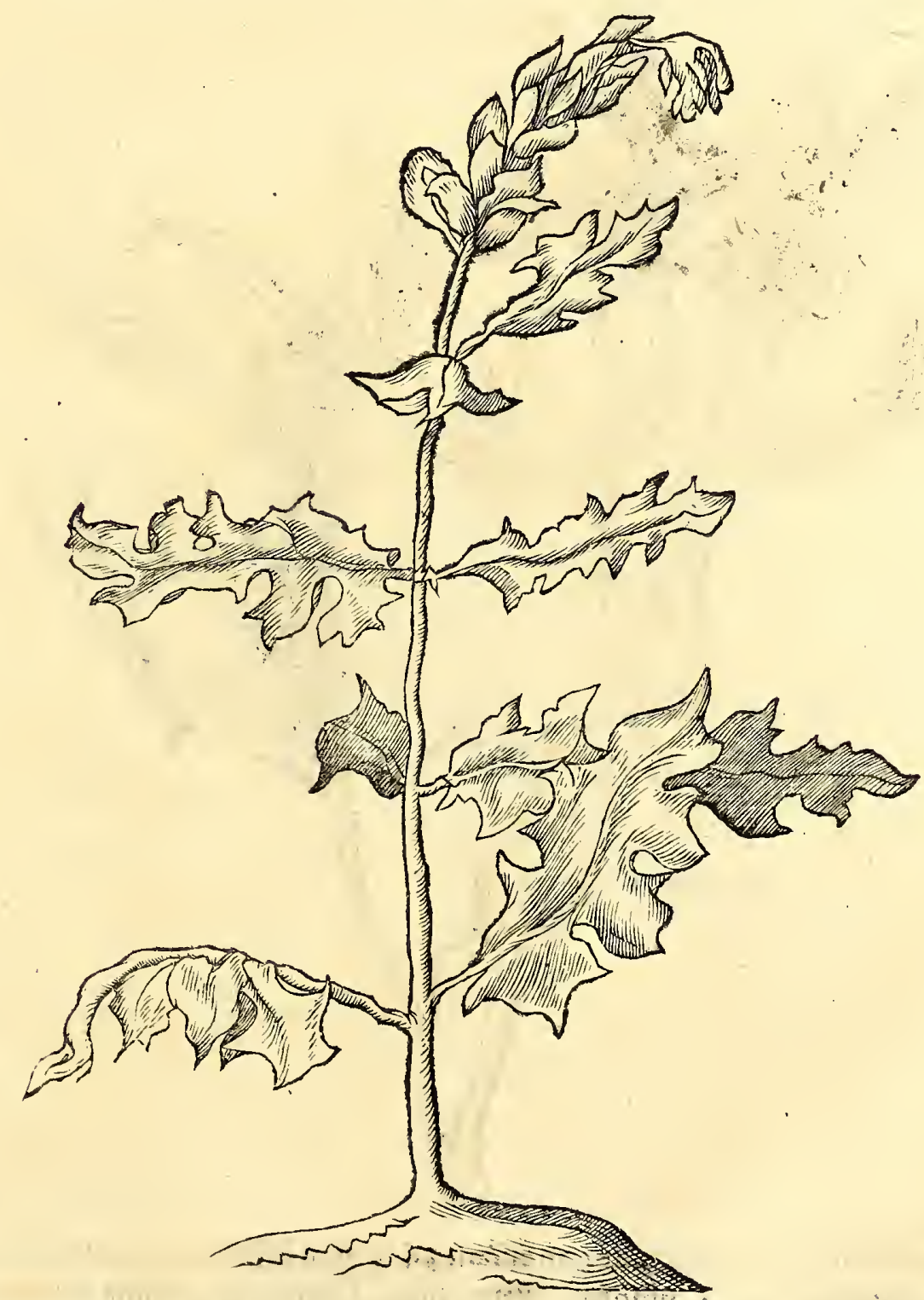

$\lfloor x$, feu Spica Nardi, nifi quod longe major fit hujus Eryngii flos, coloris eft ex cartuleo pallidi, florens per totum annum confpicitur, \&, fecus quam in Parria, liben- 
ter circa paludes crefcit: \& longa f́atia occupat, lato fane ob pulcherrimos flores afpectu. Radicem habet Aromaticam, \& blande calidi faporis: Vnde non fruftra Myracanthi nomen apud Grxcos meruit. Ego radices hic faccharo condirijubeo, \& illis cum fummo fucceffu exhibeo, qui paralyfi Indica, Beriberii Incolis dicta, laborant, quod in me ipfo expertus fum, dum moleftiffimo, \& pigro hoc malo, per quatuor continuos menfes miferrime decumberem. Copiofas quippe urinas hæe radix elicit, \& fudare facit; tum Afthmati, quod plerumque hoc malum comitatur, utiliffima eft, neque ego inter vegetativa medicamenta ullum prextantius reperiri poffe confido, ad expectorationem Pituita falf $x$, \& craff $x$, ut taceam notifimas ejus vires adverfus Calculum, $\&$ Renis affectus. Colicum quoque dolorem temperato fuo, \& blando calore, confeftim fedat, \& flatus inteftinorum difcutit.

$$
\begin{array}{llllllll} 
& \text { A } & \text { P } & \text { V } & \text { T } & \text { L V I. }
\end{array}
$$

\section{Milium Solis feu Lithoppermon Indicum.}

Oc Milium Solis, quia à Patrio floribus, caule, \& foliis,non longe differt,peculiarem de eo defcriptionem hic non adjunximus, id folum dico, fructum longe majorem, ac lapidis inftar durum, ferre, qux farinam edulem intus con. cineat : Portugallice vocatur berba da Rofarios, quod Malaica mulieres pauperiores,

MIII $\checkmark$ S SOIIS.

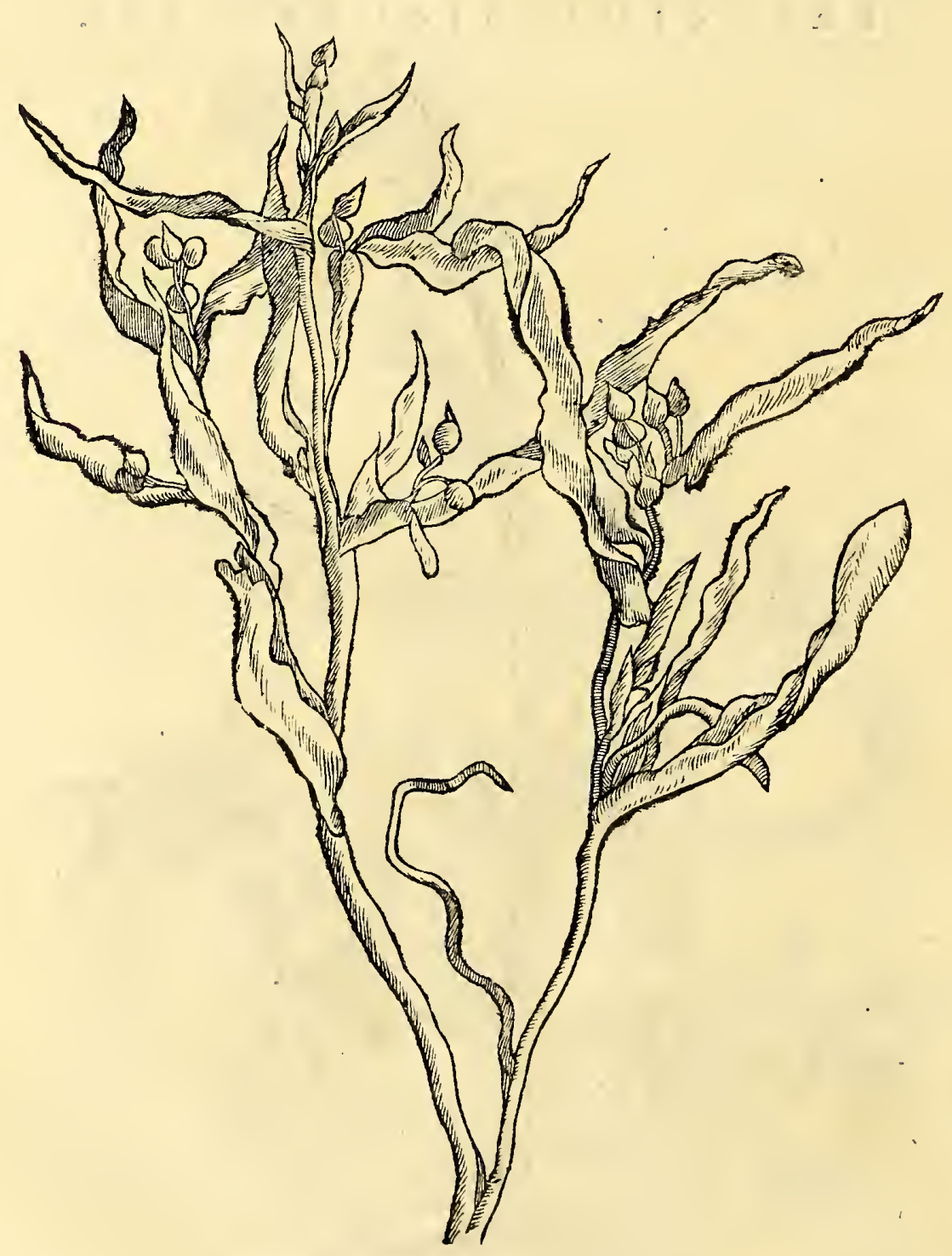

ferv $x$, horulas fuas precarias inde conficiant, \& etiam iifdem catenarum feu torquium loco, ut ditiores ex auro, utantur. Vires hujus feminis notx funt adverfus Renum, \&Veficx affectus, \&cc. 
HIST. NATVRAL: \& MEDIC. IIB. VI.

$$
\text { C A P V }
$$

De Efula Indica, \& de Plantailla, qua lacrymam illam emittit, Gutta Gemou vocata.

Scammonii fuccum quid laudas Gracia mendax? Indica nam Latbyris liquorem fert meliorem; Aureus eft illi color, ov virtutibus aurum Exfuperat, quod dirus Hydrops teftabitur, atque Indica Paraly/is Beriberii nomine dicta.

$P$ Affim hic in filvis crefcit mirabilis, Efulx, feu mavis, Lathyridos,fpecies, qux in tantam altitudinem aflurgit, ut ingentes arbores fcandat, craffitudine frpe brachiali, \& amplius, plena eft fpinofis extuberantiis, qux tamen, utpote molles, puncturas non inferunt : foliolis hinc inde excrefcentibus, qux admodum fimilia funt

E S V I A I N D I C A.

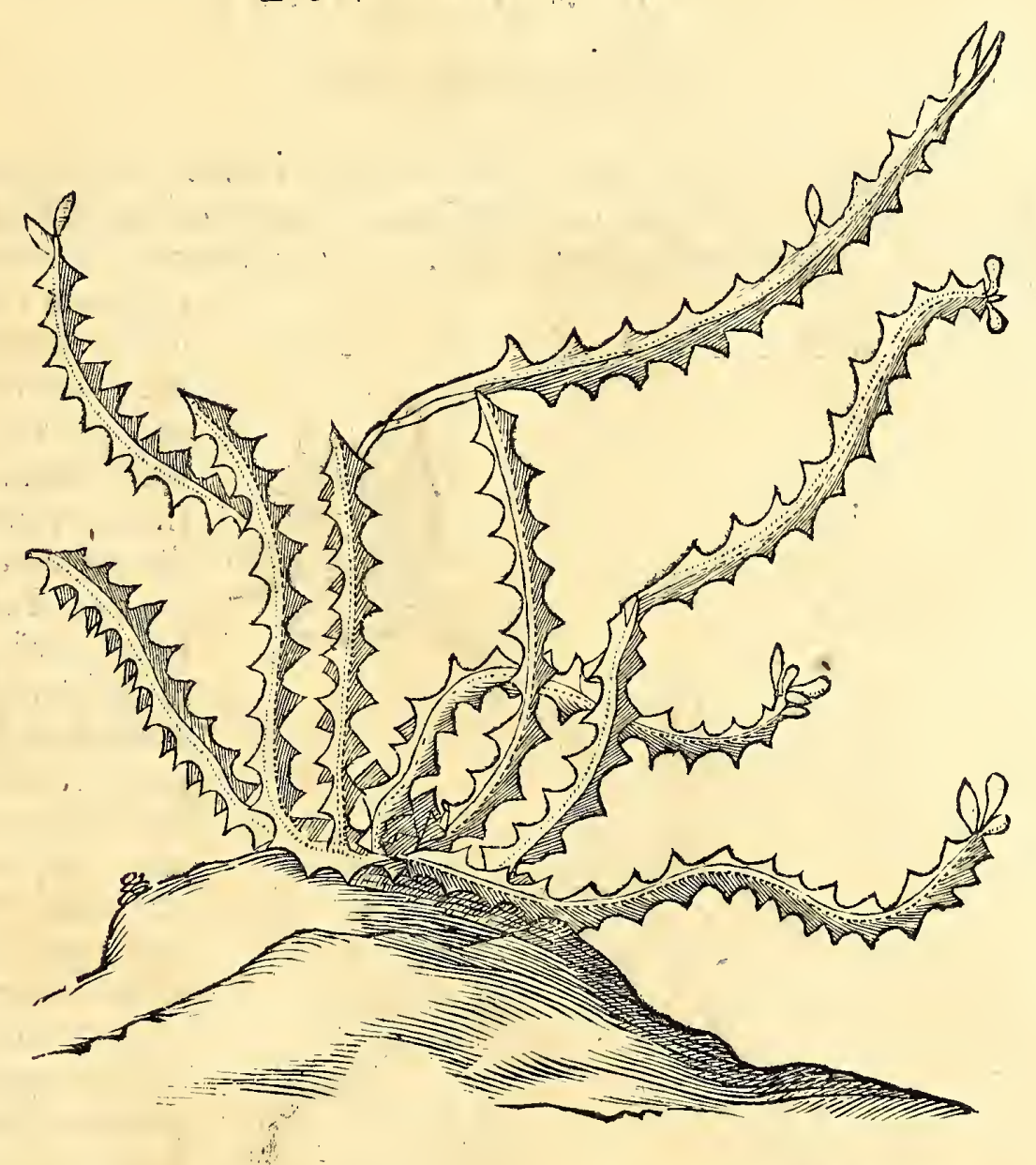

foliis cjus Sedi, feu Sempervivi, quod nos vernacula lingua Caule eft trigono, quo vulnerato fuccus lacteus, qualis ex Efula, defultim exit, ut, nifi tibi caveas, facile veftem, \&, quod pejus eft, faciem, \& oculos commaculet, quibus propter vim caufticam admodum inimicus eft. Ex hoc fucco conficimus extractum utile ad Cachexiam, Hydropem, Paralyfin, \& reliquos ftupidos, \& frigidos affectus, qui levi pharmaco non moventur: dofis ejus eft à gr. $\mathrm{x}$. ad $\mathrm{x}$ x.

Ab hac Planta, nequc forma, neque figura, neque crefcendi modo differt ea, qux lachrymam iftam flavam à fe emittit, quæ officinis noftris Gutta Gemou corrupte dicitur, Indis Lonan Cambodja vocatur, quod in Cambodja, vicina Chine regno Provincia, proveniat, ubi ctiam copia Aloës hepaticx exprimitur.

Hujus 
Hujus porro flavi fucci fi virtutes enumercm, deficiat me prius dies, quam loque. 1a, praparatus autem longe tutits, quam crudus fumitur, nam eo modo vomitivam fuam, \& infeftam ventriculo facultatem maxima ex parte deponit. Modus autem prapatandi talis eft. Re. Gutt. Cambodja to j. contundat. groffo modo, contufa inf. in vitrea phiala capaci in aceto fortiffimo diftillato, ut materiam fuperet tres digitos circiter, expone dein folatibus radiis, qui propter.fervorem, nobis in multis ignis Chymici ufum præftant, poft octo, aut decem dies rurfus arctiffime coletur, \& rurfus f.a. infpiffectur in extracti debitam confiftentiam: hujus extracti gr. xIr, ad viginti exhibentur in forma catapotiorum folida, vel vino diluta, $\&$ fic materiam peccantem per alvum folum modo educimus copiofe, \& fine mioleftia. Ego certe hoc Gummi, eo, quo dixi,modo preparatum;longe prætulerim Scammonio in his calidis, \& humidis regio. nibus, quam ob caufam jarn dicum Scammonium, aëris injuriis non valens refiftere, ftatim corrumpitur, \& vires fuas amittit, fecus quam hicfuccus, qui denfus, \& compactus facile aërem ambientem contemnit ; Et hæc de nobili illo flavo fucco dicta fufficiant, de quo, quod fciam, nullus ante me quid exacti edidit.

Sed quia in mentionem Scammonii incidimus, illud hic etiam per quam copiofe crefcit, ut \& innumerabiles Convolvulorum fpecies, inter quas ponimus etiam Piper, ac tantopere decantatum folium, Syripynang dictum, de quo alibi egimus.

\section{A \\ De Gentianella Indica.}

Q Voniam herba hæc, tam forma, quam floribus cyaneis, Gentianellx patrix apprime refpondet, merito mihi illi Gentianellæ nomen indidiffe videor ; guftu tamen non amaricat, namque Gufaratis , \& Indis inter olera ac Seir fuum,

G E $\quad$ N $T$ I I A N E I I A S P E C I E S.

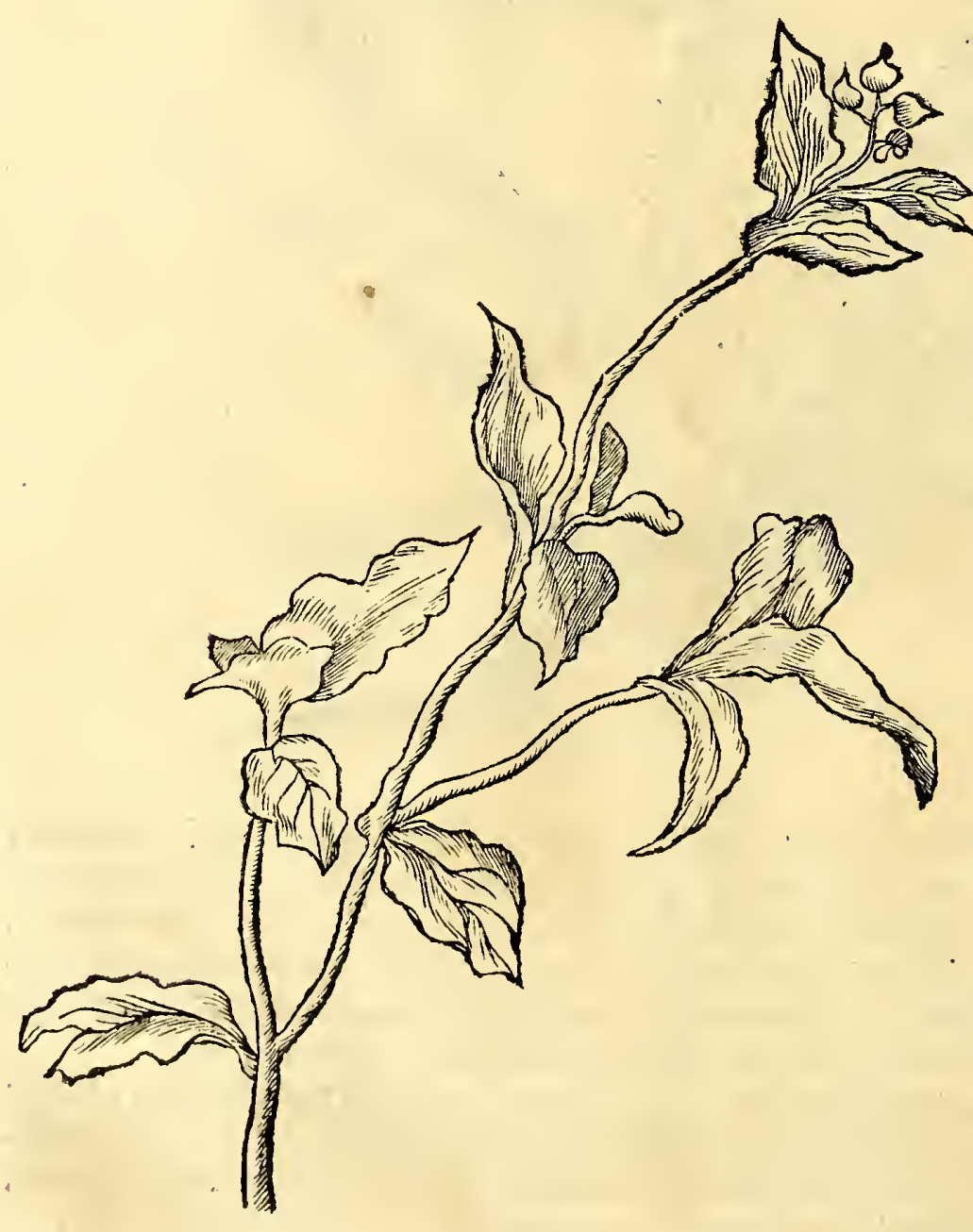

reponitur; tum alvum modice cit; urinas movet; obftructionibus denique vifcerum tollendis infervit, ut merito interalimenta medicamentofa reponenda fic. Folia in ufu funt adverfus tibiarum, \& pedum ulcera, hic admodum familiaria, propter exficcantem, $\&$ abftergentem cjus vim. Aquam quoque ex illius foliis elicimus, qua conducit Colicis doloribus, diuturnis Diarrhœis, cxcerifque ventriculi, \& inteftini affectibus à frigore ortis. Foliahujus plantx; quia nervofa funt, Plantaginem in mentem mihi revocarunt, quam tamen in locis filveftribus hic crefcentem nunquam me vidifle fcio : fed in hortis inter lactucarias herbas aliquando eam fpecien furgere confpexi, 
HIST. NATVRAL. \& MEDIC. LIB. VI. fpexi, qux anguftifolia vocatur (vulgo Coftam caninam appellant) quam tamen inter femina Lactucx è patria allata, \& minus bene purgata, latitafle crediderim. Et certe hæc terra tam fertilis eft, ut noftra femina, \& quæè Perfia , \& Zirate, huc adferuntur, cum foenore reddat. Iam nuper enim Afparagos, primum fatos, luxuriofe crefcere vidi, tum Braflicas noftrates, fi opportine terra ipfis aggeratur, hic quoque in fe contractas optime provenire certum eft : Sed fi quis negligentius eas tractet, in folia diffunduntur fruticofa, \& lignofa.

Raphanus fativus porro longe melius, \& fapidior crefcit, quam in patria, è quibus craflior, \& brevior quxdam fpecies nobis cocta pro Rapis refpondet. Chinenfes quoque Raphanos \& folia aceto \& muria, ad orexin excitandam, condiunt.

\section{A P V T L I X. \\ Guanambonus.}

$\mathrm{R}$

Ei Botanicx fagaciffimus indagator Carolus Clufius, in animadverfionibus fuis ad Garciam ab Orta, de plantis Indicis, lib.2. cap. I o, citat Iulium Scaligerum, hunc fructum utcunque defcribentem, ex auditu, credo ; fed intermixtis non parvis erroribus: nam quod dicat fructum, Guanamban nafci in al tis arboribus, plane er-

$G \vee A$ N A $M$ B $A$ N $\mathrm{V}$ s.

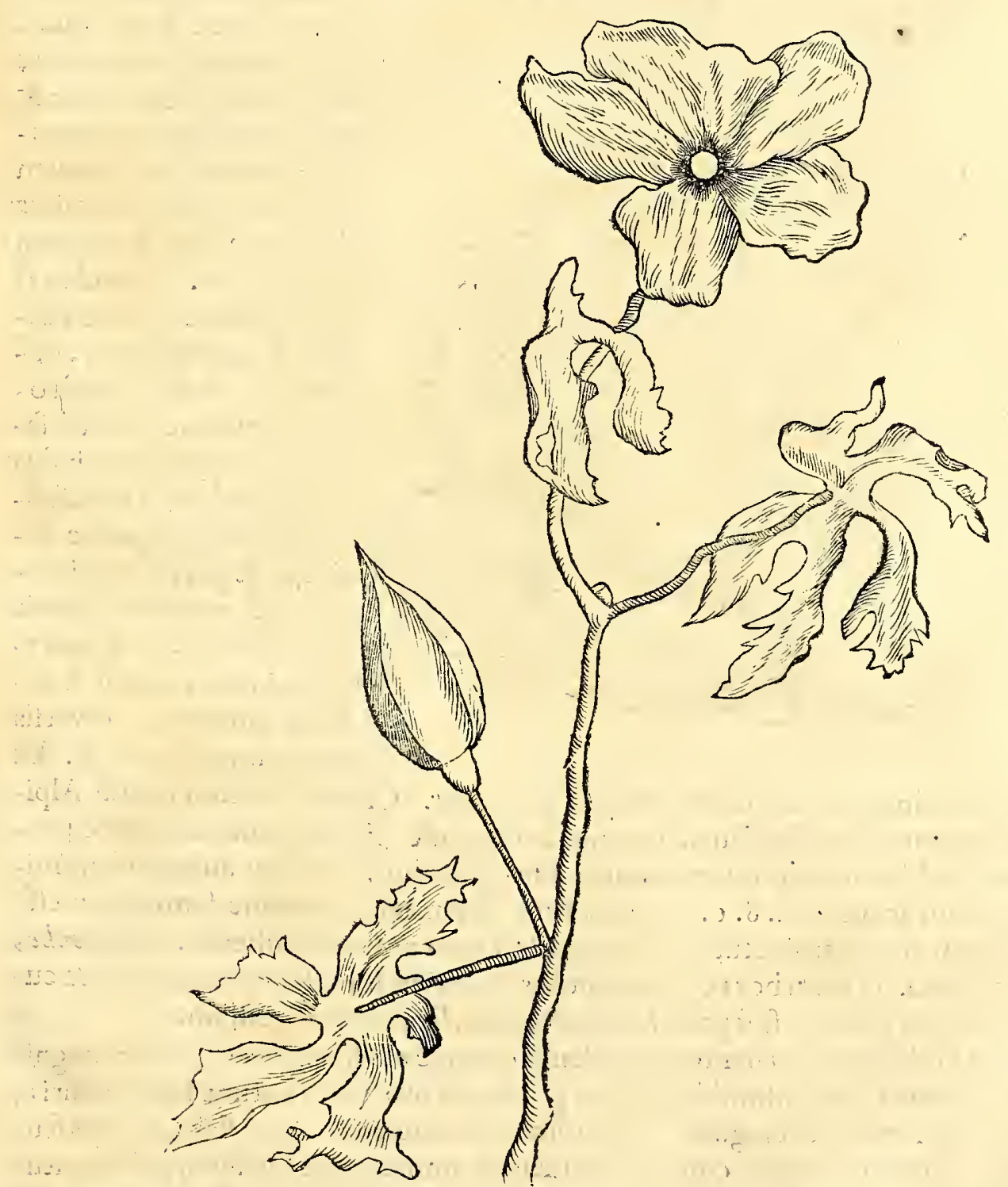

roneum eft: nam vix frutex dici poteft, qui fructum hunc profert, \& vix ultra medium humanx ftaturx affurgit, Sarmenta potius emittens, quam ramos, qux egregie flavos flores ferunt, quibus Guanambain fructus fuccedit hac figura, qui quinquangulus eft $\&$ totidem commiffuras habet, prominentiores paulum, quæ apertæ femen oftendunt, 
inftar Ciceris, quod viride primum, mox maturefcens, ex cyaneo atrum 2 fplendentem color em contrahit, qualem videre eft in Corallo nigro expolito. Fructus hic in fuperficie lanofus eft, \& pungens, ut in foliis Cardui Benedicti etiam fit. Folia referunt planc Pentaphyllum noftrum. Apud Malaios eorum alius ufus non eft, quam quod inter cætera legumina $a b$ iis coquantur, cum jure gallinarum, aut aliarum carnium, \& etiam flatus excitant, ut cxtcra Piforum \& Cicerum genera; atque nefcio quid faftidiofi fapiunt, unde etiam infuetis alvum movent.

Hæc ex vifu vera eft Guarambani defcriptio; \& nemo mihi,fcio, hoc vitio vertet, quod credam, oculatum unum teftem' plus fidei mereri, quam auritos decem.

$G \quad V A N A M A \cap N \vee S$ Africanus.

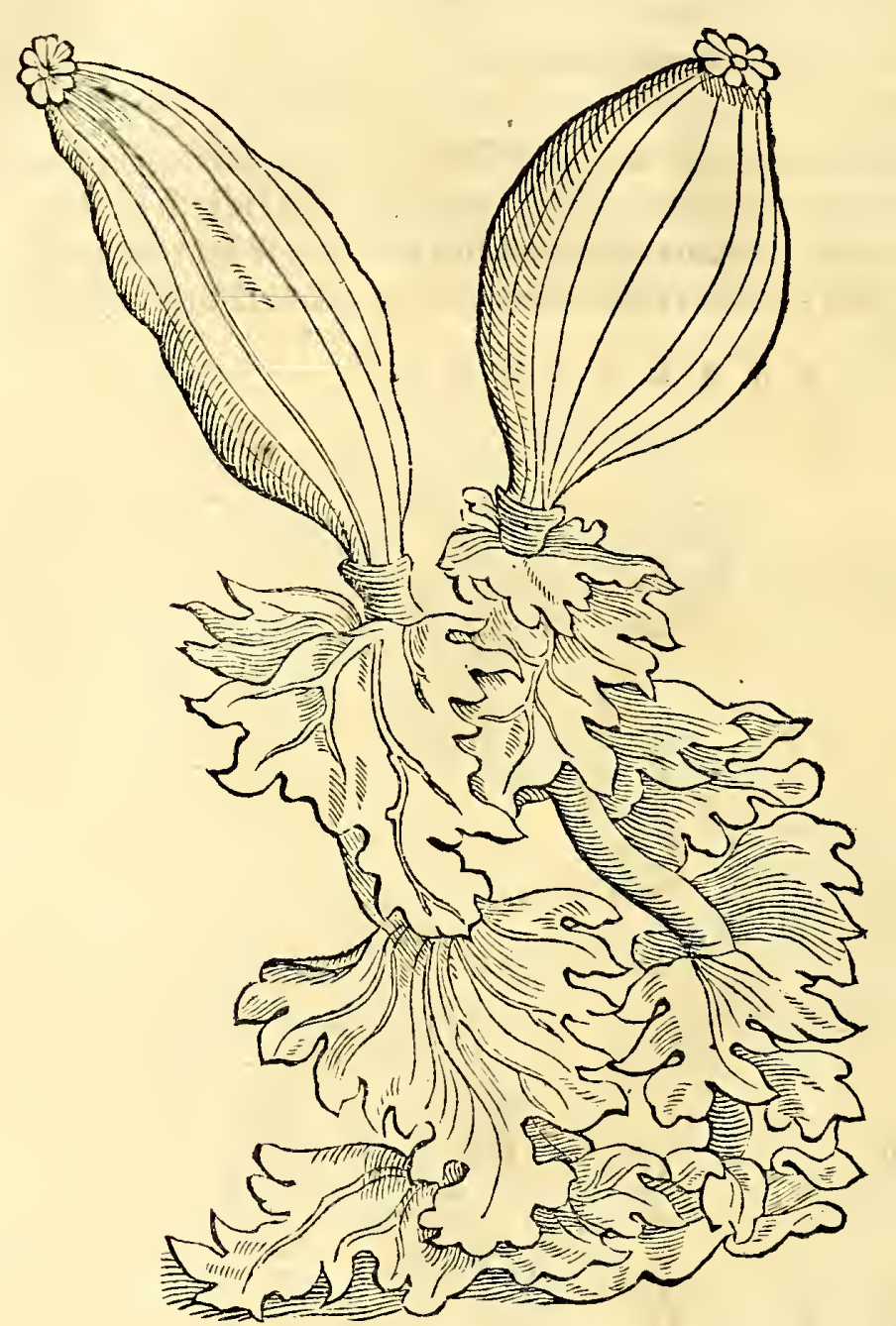

An NOTATIO. Ego cum noftro Bontio, O. viedum, Clufium, Scaligerum aliofque erroris quoque infimulare poffem; quod in defcriptione hujus plantre admodum difcrepent ab Afratico \& Africano Guanambano; fed ob multas rationes videntur hi excufari poffe : prxterquam enim quod inter fe haud conveniant de arboris magnitudine $\&$ figura; nullus quoque eorum plantam vel fruticem ficut nos, fed unanimiter Arborem fatis proceram effe afferunt. Proindevel diverfa plane fpecies illo. rum Guanambanus, difcrepans ab hoc noftro, etiam ratione diverfi $f_{2}$. poris, \& qualitatis ipfius fructus;vel error ille afcribendus eft perpetur varietati \& perplexitati nominum exoticis plantis impofitoruni. nam interdum idem nomen à diverfis autoribus, diverfis rebus impofitum eft. Ex rufius fructum Boabab Alpideret, \& non foliis effet admodum à noftro difcrepantibus. Oviedus autem fub nomine Guanambani, accurate. 1. 8. c. 17 , arborem in America undique familiarem effe teftatur. Qux fi rite examinetur, exacte quadrat cum noftro Brafilienfi Araticuponbe, fol. 142, defcripta. Qua arbor revera in multis Americx locis fponte luxuriat, \& cujus fructus pulpa , ejufdem eft faporis \& confiftentix, ficut defcripfit illam.

Hic autem Guineenfis Guanambanus planta quoque eft fruticefcens, foliis magnis Cardui vel Acanthi non diffimilibus, cum profundis pro vario naturx lufu incifuris, eaque caules farmentofos cingunt. Ex his fuperius emergunt flores flavi, quibus fructus oblongi, craffi, fuccedunt, cum multis ftriis, \& eminentibus incifuris, per longitudincm excurrentibus, definuntque in coronam, ex octo foliolis tenuibus conftantem, qux corona his Guineenfibus fructibus peculiaris effe videtur. Num qualitatibus \& ufi cum Bontii lavenfi conveniat, vel difcreper, nihil mihi hactenus certi compertum eft proinde ulteriori defcriptioni fuperfedeo. 


\section{A P V T I X.}

\section{De Salvia Indica arborécente.}

Alviam pumilam, humi ferpentem, in India nondum mihi videre contigit, Anthos feu Roris-marini plantulam unam atque alteram aliquando confpexi, eaque tanta cura à Solis injuriis confervari debet, quam apud nos à fevientis hyemis frigore, \& nivibus. Salvia autem, quam tibi depictam damus, frutex eft

$S A I \nabla I A$ A $R$ B O R E S C E N S.

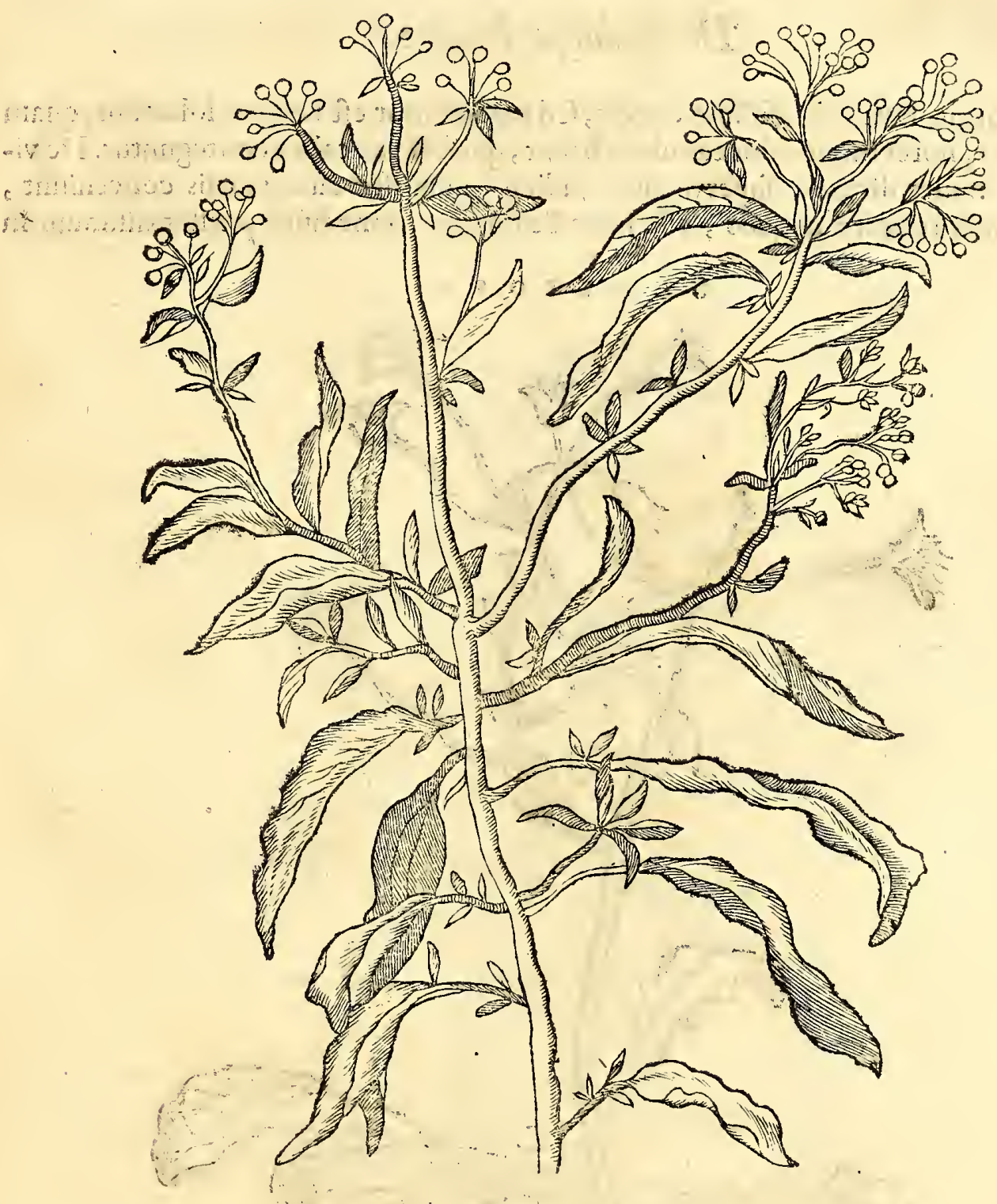

furgens ultra duorum hominum altitudinem ; \& tanta copia crefcit, ut fylveta integra conficiat: nam longe lateque luxurians radices agit non fecus ac Glycyrrhiza in Europa, ita ut qui eam in hortis plantant, poft aliquod tempus cum fumma moleftia radicitus effodiant, cum fubinde repullulafcat. Ad Promontorium quoque Bonæ Spei crefcentem in magna copia hanc Salviam vidi, cæerum flores fert ex al. bo cyaneos, ut reliqua Salvia, foliis admodum longis eft, qux præter gratum odorem, etiam umbram commodam præftant. Si autem bene colatur in hortis, plurimum de feritate fua remittit, quod fiet, fi radices, \& luxuriantes ftolones ftatis temporibus commode refecentur; $\& x$ tum non minus utilis eft in cibis, quam manfieta pumila apud nos, tum vino macerata , $\&$, ex ea quotidie fi fumas aliquot liquoris uncias, nullum praftantius medicamentum invenias in familiari hic tremoris feu paralyfis fpecie, 
I58

\section{A C O B I.BO N T I I}

qux Beriberii Incolis dicitur, quod ut in pluribus aliis, fic in me ipfo cum fumma utilitate expertus fum.

Malaicx quoque Mulieres ad̀ eumdem ufum ea Salvia utuntur, tum ad omnes uteri \& nervorum affectus in fomentis fuis, \& lavacris familiaribus, cum Liguftro Indico feu Lagondi, \& frutice alibi Daullontas dicto. Flores quoque, à nobis condiuntur, \& ad omnes frigidos inteftinorum \& cerebri affectus fumme conducunt, tum hydrotici funt, \& urinas bene movent : fed de hoc melius in Methodo mea mederidi Indica dicetur; Quia hic tantum nudam Plantarum Hiftoriam proponere eft animus. Finio itaque cum fcholæ Salernitanæ verfibus Leoninis. cur moriturus bomo, cui Salvia crefcit in borto?

$$
\begin{aligned}
& \text { C A P V T L X I. } \\
& \text { De Scabiofa Iavana. }
\end{aligned}
$$

Cabiofa in Iava copiofiflime crefcit, fed macilentior eft ratione foliorum, quam noftras, flores minufculos caruleos habet, qui foliis ut calice conteguntur. De viribus multa dicere, fupervacuum judico, quia ift $x$ cum patriis conveniunt, unum tamen reticere nequeo, effe hanc Scabiofam remedium praftantifimum in

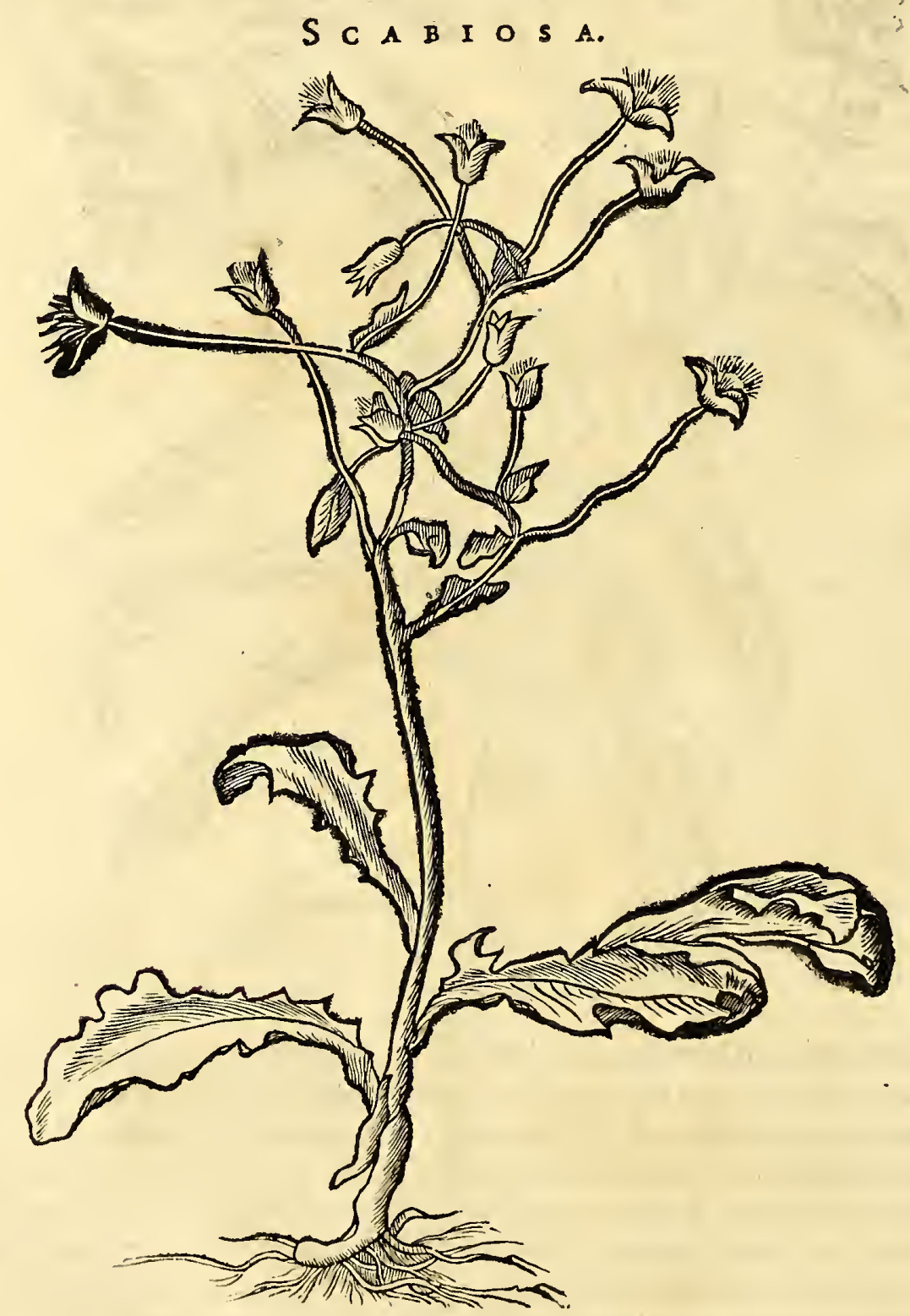

extabefcentia feu Marafmi quadam fpecie, in his locis admodum familiari, quo affecti xgri ad extremam maciem perducti, tandem tenuem animam exhalant, ita ue pellis, \& ofla deveniant, \& Sceleti potius videantur, quam homines. Quod morbi genus 
HIST. NATVRAL. \& MDIC. LIB. VI. ex obftructionibus hepatis, ac lienis ortum trahit : fed fepius ex obftuctione mefente. rii,ac ejus Scirrho, \& A poltemate. In hoc affectu dico,Scabiofa hæc cum Gramine cruciato $P$. Alpini, alibi à me defcripto, \& cum radicibus Chinz fimul coeta, excellens eft medicamentum. Ac polliceri id certe audeam, quod fi mefenterium non adeo corruptum fit; ut ad priftinam temperiem reduci nequeat, certiflimam adferre falutem. Malaii porro hac Scabiofa inter olera fua utuntur, \& , ut nos, pectorale effe medicamentum autumant, vitiifque pulmonum egregie mederi.

Crefcit porro etiam Succifa feu Morfus Diaboli vocatus, tum Morfus Ranæ quoque, in foflis, \& paludibus : fed quoniam vires cum patriis conveniunt, non eft, quod eas denuo referamus.

$$
\text { C A P } \quad \text { V } \quad T \quad \text { L X I I. }
$$

De Ly/amachio Indico, or obiter quadam de Indis Pythagoricis.

Refcit hæc Lyfimachii fpecies in Iava circa fluminum ripas, colore florum à patrio varians, qui ibi purpurei plerumque funt, hic vero albi confpiciuntur, $\&$ flores referunt non male Periclimeni flores, quos vulgo Lilia fylveftria appel lant. Vt florum color, ita $\&$ totius plantx facies à vulgaribus Lyfimachiis multun

$$
\text { LXSIMACHIIS DECIES. }
$$

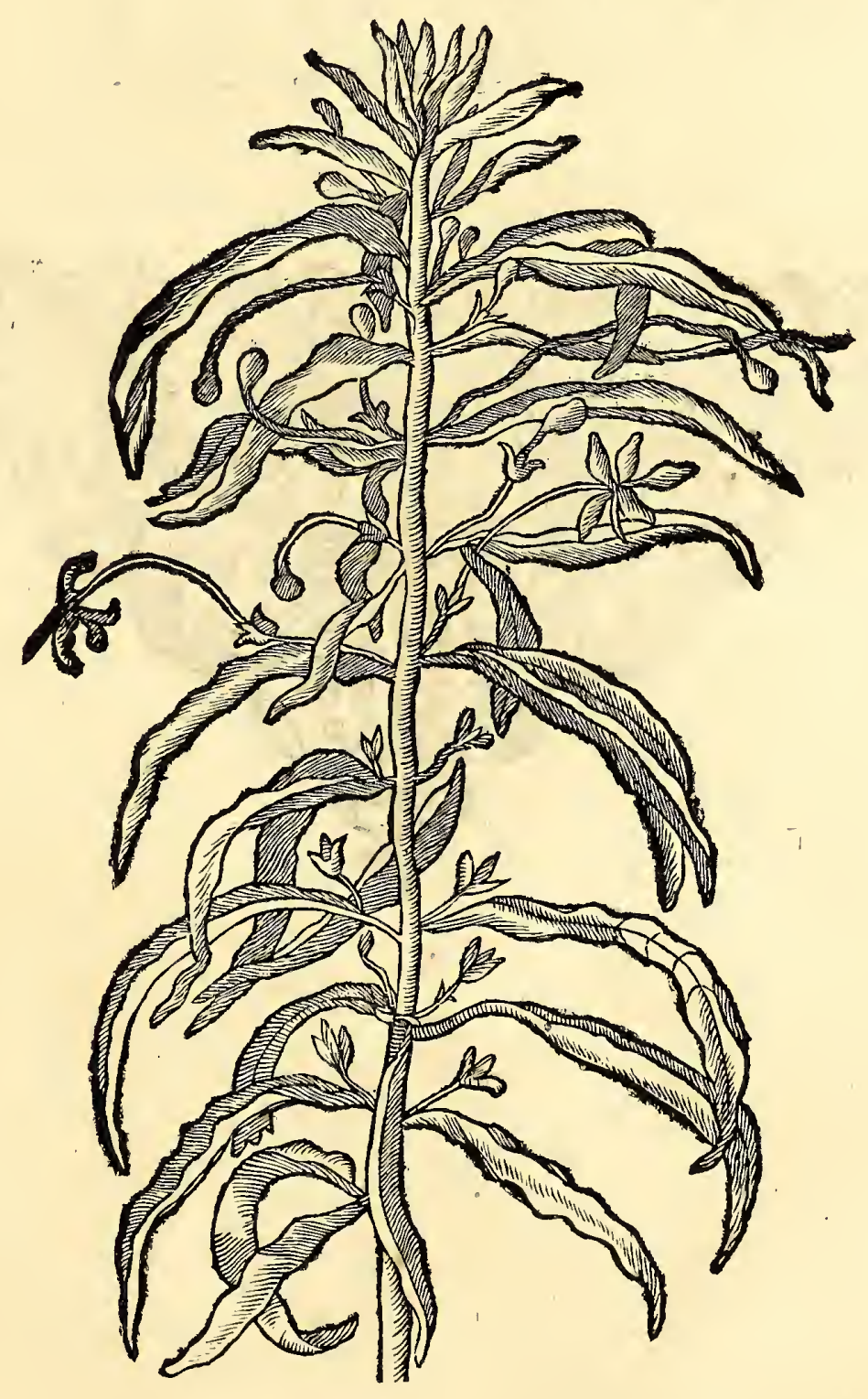

abludit, ficut non raro in Indiis contingit, prxterquam quod alia Lyfimachia inter fe maxime difcrepent, ficut præfertim in Clufii rarioribus plantis apparet. Planta hæc eft

$$
{ }_{2} \quad \text { Europxo }
$$


Europxo Lyfimachio procerior, caule unico, duro, firmo, in coronam aliquot foliorum noviciorum definente, quem ambiunt ordinata quadam ferie ab imo ad fummum folia bina, ex adverfo pofita, longiora \& folito anguftiora, unico nervo recto, multis venulis obliquis divifa. Circa horum pediculos ad caulem alii cauliculi emergunt longiufculi, in quorum extremitatibus flores nalcuntur. Inter Olera à Mauris recipitur, \& non fecus, quam apud nos Beta, in Spinachiis coquitur. Qualitates ejus ex guftu pingui, \& paulum aftringenti ad temperatas referre aufim, $\&$ ad Malvx naturam quam proxime accedere: nam $\&$ in clyfmatis, ad ventrem, \& inteftina eluenda, in frequenti eft ufu; hoc \& experientia à Malaiis edoctus, verum effe compéri non femel in Nofocomio noftro Batavico, neque ego id mihi pudori duco, à barbaris, ac idiotis doceri, nam revera hægentes, piæelertim Gufaratæ, \& qui ex ora Continentis Chormandel huc veniunt, fagacius diftinguunt inter herbas Medicinales, edules, ac venenatas, quam expertus quifpiam Botanicus in Patria : ratio hxc eft, quod plęrique folis herbis victitent; five id à Pythagora habuerint, five (quod credibilius eft) id per manus à frugalibus majoribus traditum refervent; quidam namque in eo tam funt pertinaces, ut quamvis fe fcirent per tormenta ad mortem effe adigendos, nunquam tamen eo vefcentur, quod vitam fenfitivam acceperit : Immo fi vel Chriftianum, vel Maurum alterius feeta, videant aviculas, vel fimile quid vivum habere, ab iis eas pretio rediment, \&libertati reftituentes avolare finent; Hinc mirum ergo non eft, cum vegetativis tantum fuftinentur, eos præ reliquis mortalibus, guftu, \& odoris fenfu, in dignof cendis herbis præetare.

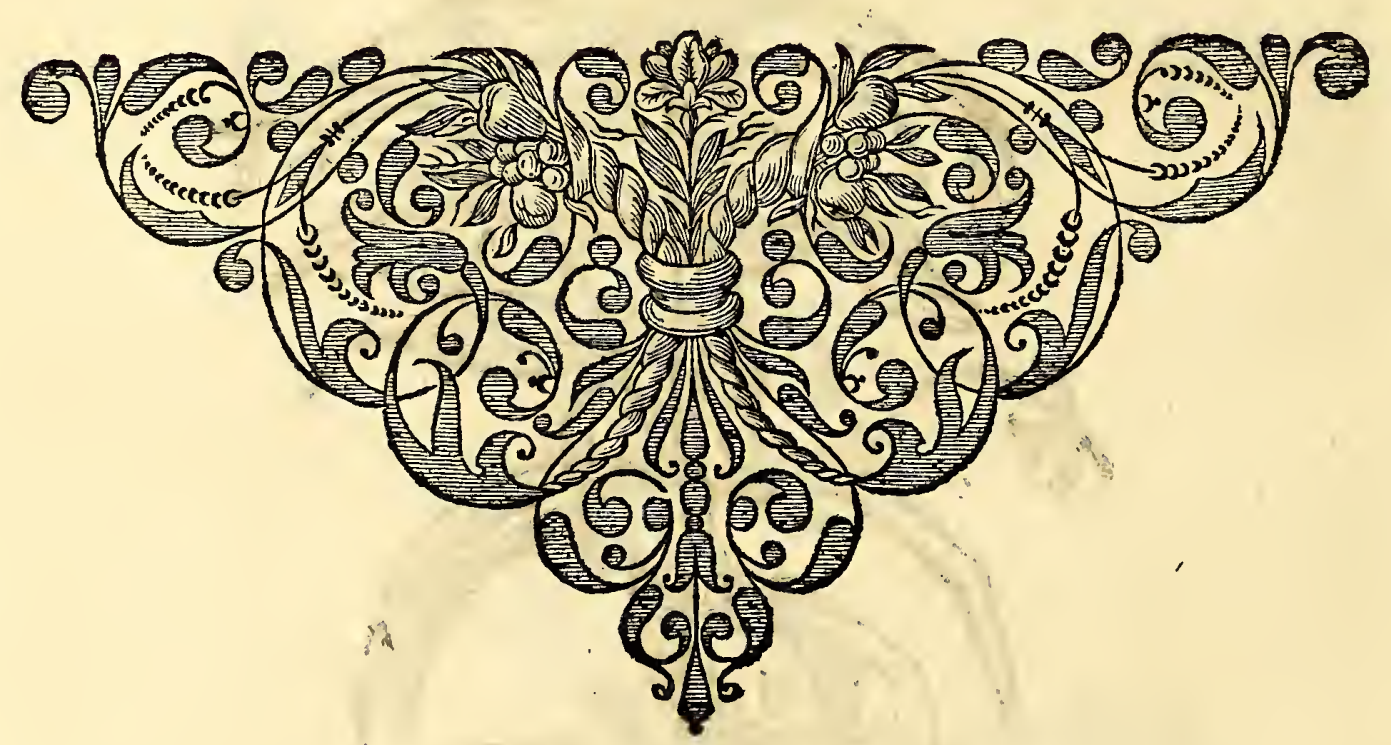


GVLIELMI PISONIS

MANTISSA AROMATICA;

$S I V E$

DE AROMA TVM

Cardinalibus Quatuor,

$\begin{array}{lllllllll}\text { E } & \mathrm{T} & \mathrm{P} & \mathrm{L} & \mathrm{A} & \mathrm{N} & \mathrm{T} & \mathrm{I} & \mathrm{S}\end{array}$

Aliquot Indicis in Medicinam receptis,

R E L A T IO N O V A. 


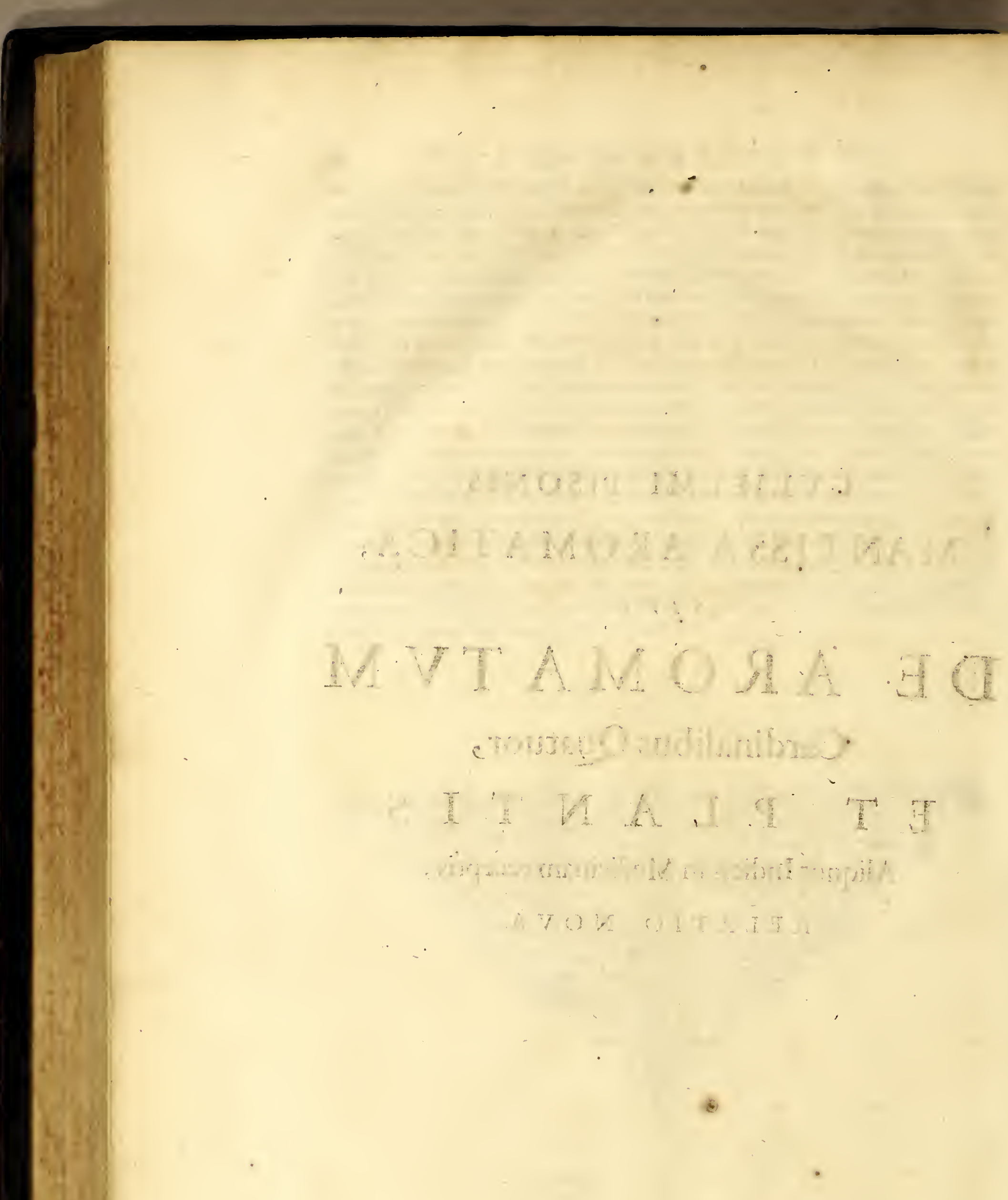


GVLIELMI PISONIS

\title{
MANTISSA AROMATICA;
}

$S I \vee E$

\section{E A R O A T V M Cardinalibus Quatuor,}

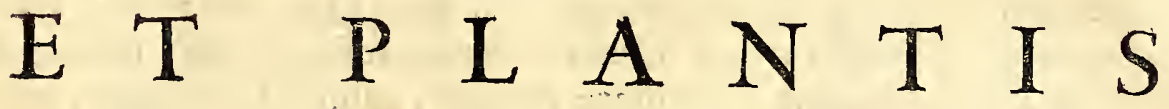 \\ Aliquot Indicis in Medicinam receptis, \\ - RElatio nova.
}

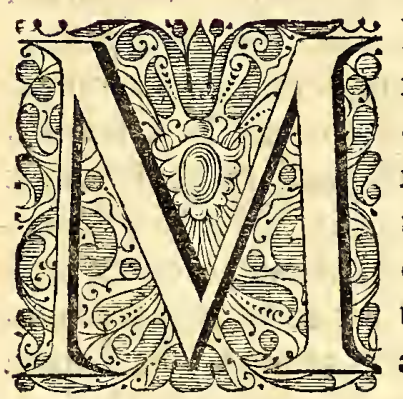

Editari forfan Iliada poft Homerum videbor his, quorum in animofedet illud longo ufu trítiffimum: Nihil dici, quod non fit dictum prius. Quid enim toto Orbenotius iftis, de quibus promitto, Aromatis? Quorum naturalis Hiftoria utcumque putetur ex pleno tradita, neque quid ad ulteriorem notitiam defiderare; fpero tamen tales me mei facti redditurum rationes, ut conftare liquido queat, nihil hic fine caufa effe tentatum, $\$$ aliquid dictum, quod ignorarunt hactenus, quotquot eamdem materiam confcribere funt aggreffi. Quo ipfo videri debèo, nihil equidem detraxiffe de laude tot Clariffmorum Virorum, qui egregiam fanein iftis operam pofuerunt; quin addidiffe potius ad cujufque merita, \& perfeciffe qux varias ipfi ob caulas relinquere imperfecta debuerunt. Hæc enim, ut olim, ita \& nunc agimus, ut, quænefcivere majores, proferamus in apricum; qux fciverc quidem, fed incerto, certa faciamus ; quxque pofteritati tradidere, fed fide dubia, indubia reddamus. Quoddum facio, quia fieri non poteft, ut non detegam errores quos errarunt anteceffores noftri ; invidia litem nemo mihi movere tenter, priufquam paucis perlectis pagellis cognoverit, fatin' inveniat juftam actionem in his, quæ \& publici à me boni caula funt fufcepta, \& teftimoniis afferta fidelibus. Occafionem quippe non unam nactus de Aromatis iftis principalioribus, maximique per univerfam Europam ufus, fimul \& de aliis quibufdam in Medicinam receptis Plantis, conferendi cum exercitatiffimis \& integrx fidei Medicinæ peritis, aliifque Indicarum rerum fcrutatoribus fagaciffimis, deprehendebam, in non paucis, non magis Ætra Lupinis differre, quam eorum relationes \& annotationes æatatum fuperiorum. Quod idcirco monendum volui, ne quis arbitretur, me in rebus Naturalibus minus obviis temere aftipulari iis, qui vulgari funt peritia, nec judicio adeo acri, ut probatiffimorum Virorum fcriptis, maxime controverfis, refragari mereantur. Veritatis itaque amor ftimulum addidit promovendi rem Medicam, fimul $\&$ detegendi fontem errorum, tam circa externam eorum faciem, quam natale folum \& cultum, atque caufas adulterationum. Veteres cnim, quod mare ipfis effet ömsega átzpov, \& adiri Solis ul tra terminos pofitx regiones nifi per longas ambages \& mille pericula non poffent, non videntur fua aliter quam per varias accepiffe traditiones. Quam etiam ob caufam factum eft, quod unam eamdemque tem $\&$ diverfis fubinde nominibus appellarent, \&r tractationibus exhiberent: accepta videlicet errandi occafione à mercatoribus, \& locis fixpe, per qux deveherentur. Etenim mercatorum avarioribus, nemo non novit id effe jn more pofitum, ut commendandis mercibus, quantumvis unius generis, femper novum affingant nomen, cum à cxli folique bonitate, tum à varietate odoris, faporis, coloris, corporis, aliorumque id 
genus. Quodut optimis quibufque Aromatis, ita vel imprimis omnium nobilifimx Cannellx ( quam nomen Caffix ferunt olim audiviffe) contigit. Hæc enim vel quod trunco fuit arboris vicinior aut remotior; vel intempeftive cæe a ; itemque rite aut non bene prxparata, vel inter tranfvehendum affervata; vel denique integra aut deterior um mixtura corrupta, nomine, facic externa, efficacia interna, variare folet. Vnde profectum, quod non folum contenderint inter fe. Autores vel diverfi vel ejufdem generis efle Cimamonum \& Cannellam \& Caffiam; fed \& pro vera Cannella quidam habuerunt corticem quemdam fuppofititium, spev fe non fatis cognitum; ducti in eam videlicet opinionem fola quadan odoris faporifve fimilitudine. Quæ caufa eft, quod plurimi cum Medici tum Pharmacopoi, partim mercatorum technis decepti, partim autoritate Diofcoridis, Galeni, Plinii, aliorum ejus \& infequentium fecuJorum nitentes, \& ipfi impofuerunt per imprudentiam fuis difcipulis, quibus notas, ad delectum hujus alteriufve Aromatis cognitu neceffarias, traderent: præfertim illi, qui haud fatis circumfpecte crediderunt Arabibus; Quorum multi, quod neque rerum ipfarum neceffariam, neque Græci fermonis fufficientem, haberent cognitionem, fatali quadam gentis credulitate perfuafi, nihil à Diofcoride, aut Galeno (unde fere omnia fua compilarunt) effe prxtermiffum in defcribendis Simplicium cum notis tum facultatibus, ne dubitarunt quidem affeverare hoc illud, etiamfi folo dumtaxat auditu haberent cognitum, medicamentum effe id ipfum, cujus laudati modo Autores meminerint, quoties putar ent illis quadrare notas $\&$ facultates aflignatas. Qux fi quis confideret, definet haut dubie mirari, quare pleraque Exoticorum fint tot difputationibus \& controverfiis obnoxia. Neque enim aliter hæc facra potuerint conftare, quandoquidem nobis tradita fint à Græecis primum, deinde ab Arabibus. Non poffum hic non dolere, periiffe nobis qua ea de re parata habuit D. Claudius Salmafius, feculi Phœnix, qui rei medicamentariæ hiftoriam præftare conftituerat certiorem \& ab erroribus repurgatam. Quo in labore olim Garcias ab Horto, Proregis Gox celeberrimus Medicus, certe laudem meruit, detegendo aliquos errores, probandoque multorum Aromatum nomina effe ab Arabibus pariter ac Græcis depravata prorfus ac corrupta. In iis tamen quæ de Cinamomi, Cannellæ, atque Caffix natura prodidit, quod unum idemque effent, non poflum ipfi confentire; utpote qui Gox vixerit, loco ab Infulis Aromata ifta ferentibus remotiffimo, ubi facile potuit falli Vir optimus à Lufitanis imperitioribus, qui non veritatis eruend $x$, fed negotiandi \& acquirendi gratiain ea loca incidertunt. Quippe, etiamfi concedi facile poteft, Cannellam noftram vulgarem apud veteres Caffian fuiffe appellatam, quod ex ejufdem generis ejufdemque form $x$ arboribus, fponte in filvis nafcentibus, proveniant, eodemque modo præparentur; tamen fatis fuperque confat, ea, quæ nunc Caffix nomen audit, licet ejufdem cum Cannella fit faporis Aromatici, multis tamen partibus ab illa abludere; primo, quod vifcofa fua humiditate in ore præluceat, colore quoque intus fit nigricantior, dein quod Caflix dos primaria in meditullio cortticis fpongiofo confiftat; (fuperficie ejus, ut ex rafura patet, fere infipida exiftente) cum in Cannella noftra fecus appareat, qux tota perfufa eft vi illa Aromatica, licet ob' minorem materix fux vifcofitatem, minoris durationis fit, quam Caffia hodierna. His accedit, quod çeylon null am ferat enarratam Caffiam, fed ea nafcatur omnis in parva \& ignobili Infula Floris, qux Infulis Solor \& Timor viciniflima \& tantum non contigua eft, longeque à çeylon Cannellifera remota, quem admodum cognofcerc eft è Tabulis hydrographicis. Imo fupra has enarratas differentias, adde, quod mafticata, majorem, quam vifciditate promittit, humiditatem in diftillando non praftet, fed oleum, quod exftillat, Cannellæoleo, fi non qualitate, faltem quantitate cedat. Ex quibus omnibus colligi facile poteft, Cannellam à Caffia non folum nomine, fed \& re differre; imo etiam ex alle. gatis labefactata putem illorum adverfariorum argumenta, qui ex folla languiditate vel vivacitate faporis, differentiam inter Caffiam \& Cannellam metiri pofle pratendant, finc fupra cnarratis conditionibus. Nec eft etiam quod objiciant, Cafliam hodiernam . idco infrequentiorem efle, quod vilioris notx Aroma exiftat, led quod Cannella Ceylonnica, tam ob majoren ufum, imprimis in re cibaria (in qua Caftia longe poftponenda into inutilis cenfenda, ob myccofam, \& vifcidam humiditatem ) quam ob uberiorem proventum, natalifque fui foli commoditatem, à mercatoribus per Europam ipfafque Indias diftrahi confuetudo obtinuerit.

C. A- 


\section{$\begin{array}{lllllll}C & A & P & V & T & I\end{array}$}

\section{De Cannella qux Cuurdo; \& Caffia vulgari, çalibacha dicta.}

A

Romatum ergo, qux Catdinalia vocavi, quod $\&$ copia $\&$ dignitate cæeteris antecellant, primo fe nobis loco defcribendum offert Cannella appellata ab alis quot retro feculis. Nam \& recentioribus Gracis, Nicolao Myrepfo aliifque Kevésłla dicta ex Latino eft. Quod vocabulum diminutum ex Canna videtur, à quo "Ifi-

C A N NELLA.

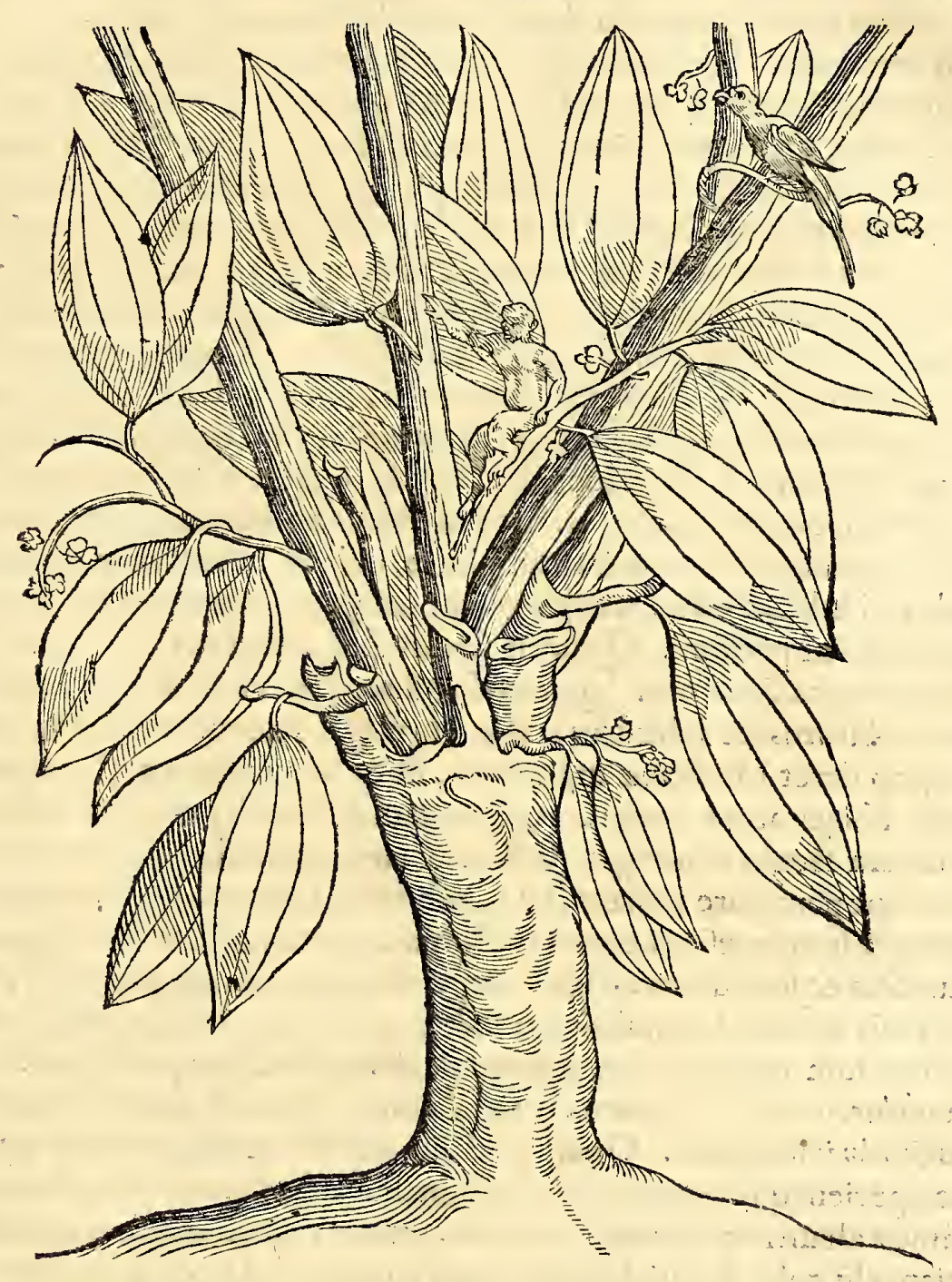

dorus $1 . x$ Ix. Orig. cap. v i I , Cinamomum dictum fcribit:quod cortex cjus in modum Can. sze fit rotundus \& gracilis. Vetus appellatio fuit Cinamomum, \&e Cinamum. Plinius in X I I. cap. X IX. diferte: Cinamomim, idemque \& Cinamum, ir at thiopia Troglodytis conssubio permixta. Dalechampius, ut mendacium hoc fatis pellucidum obcrufter, Ghinenfes ab Autore Athiopas vocatosfcribit. Sed antequain propius rem defcribam, audiamus Scaligerum quoque Exercit. CXI Iv. In şeylon nafcitur Cinamomum, ce \& $\approx$ in Mutir una ex Molucis. Nullum fert fructum. IEAtu cortex finditur, atque " abfiftit. Quod \& Commaro accidit. Bis in anno deglubitur. Dulcis primum : men- " fe poitea perficitur. Iccirco ibi Caunama vocatur. Cals namque lignum fignificat: na- "s ma dulce. Tam propinquus etiam nunc vocis fonus' eft vocabulo noftro, \& Syri vo- " ce affini, Chamam dicunt, ut queri jam definant noftri feculi Medici, Cinamo- " mum nobis incognitum: cum fit hoc aliud, quam quod defcribitur à Galeno." Pro- "“ fecto quale prodit ille, nufquam comparet. Mirum fane. Sed mirüm magis: in to+ " to terrarum ambitu atque complexu, qui nunc univerfus notior, quam illi domus "“ Sua fuerit:apud tot Reges ¿Ethiopiarum, Arabiarum, Perfiarum, Indiarum omnium, "“ 
i, nulla in Infula, nullo in Continentis angulo, latere, meditullio reperiri. Nam Otho„, mannus ipfe, cui lac affluit gallinaceum, fuam Theriacam vero Cinamomo perfici ", curavit. Diofcorides optimo nigrum ftatuit colorem, vinofum, fubcineritium, Mof„, filitix Caffix fimillimum. Acutum vult, mordacem, levi fuperficie, non fine aliqua „, falfedine, lenta fragilitate, non fine pulvere. Quxomnia nifi in iftis fiftulaceis corti", cibus invenias, non invenias in mari falem. Cum igitur à locis, in duas fpecies Can,, nellam partiantur, Ceylanitam \& Mutircam:priorem puto effe Caffiam; craffior enim ", eft: hoc quod è virgultis eximitur exilioribus Cinamomum. Quæ omnia ad incudem cenfurx noftrx revocare non putamus effe noftrum. Terrent enim me veftigia tot eru? ditorüm neotericorum, qui monumenta veterum triverunt circa Cinamoni inveftigationem \& interpretationem, ctiam nunçatis fluctuntem. Si tamen calculum meun addere liceat, non video quomodo décantatus ille furculus Cinamomi nomine infignitus (five is, cum, vel fine cortice, olim fuerit cognitus) ratione odoris fui caryophyllati idem cenferi poffit cum Caffia vel Cannella noftra. Imo operam ludere videntur Viri alias fummi, Cardanus, Scaliger, Garcias, \& alii, fi confultis naribus \& lingua de pertinacia fua nihil remiferint. Quamobrem ego declinans mæandros, ea tantum profequuturus furn, qux de natura Caflix \& Cannell $x$ hodiern $x$ milhi conftant, eaque pofteritati trado, ut lector deinde fuo utatur judicio circa ea, qux alibi legit. Andreas Mathiolus varias hac de re Autorum opiniones recenfens, omnibus in utramque partem ventilatis, tandem \& ipfis \& fibi ipfe diffidens, de Caffia \& Cinamomo erumpit in hæc verba, candoris certe plena: Hac autem dicere volui, non quod hac in re certi aliquid exploratique babeam, cum tantum conjecturis agam; fed ut aliis ulterius explorandi latius pateat iter. $\mathrm{Q}$ ux dubitatio quoniam de plerifque etiam hodie eft eorum, qux ex Indiis ad nos devehunt ur, certe optandum effet, uti in tot millibus Batavorum, Anglorum, Lufitanorum, qui fe eo conferunt, invenirentur plures, qui privatis lucri (cui nunc uni, velut vultures, cadaveri inhiant) ftudiis adjungerent publicum commodum ; \& cum amore fui, amorem fociarent proximi. Quod fi fieret, fpes effet, brevi nos ex tot titubantibus Plinii aliorumque Autorum (quibus familiare fuit vocum æquivocatione falli) relationibus eluctaturos, \& habituros certiorem plenioremque notitiam remediorum. Quod uti magno fieret Medicin $x$ augmento, fic \& reipublicx emolumento : unde \& ipfi immortale fibi pararent nomen. At quoniam ejufmodi raro vota audiuntur, ime ne integro quidem feculo contingat, doctum \& fagacem herbarum \& animalium fcrutatorem utramque peragrare Indiam, vifus fum recte facturus, fi ipfe manum admoverem ftiv $x$, aliifque irem præfenti conatu inftimulatum ad perficiendum opus, quod inchoo fubnixus fide $\&$ fubfidio erectioris animi aliquot $\&$ viridis ingenii Virorum, qui præfecturam in iis Indix Orientalis regionibus gefferunt, ubi, qux de hoc cæeterifque Aromatibus fum dicturus, cognofcere oculis auribufque potuerunt.

Cannella igitur, ut $\&$ Caflia, funt cortices ejufdem faciei $\&$ generis arboris incultx; Infulis çeylon \& Floris indigenz. Quamvis enim Malabar \& alix fortaffis utriufque Indix Regiones fpeciem quamdam corticis Cannellx affimilem, \& ignobiliorem proferant; vera tamen aliam non agnofcit patriam, præter; quam dixi, utramque Infulam: quidquid etiam alii nobis perfuadere conentur, inducti ad hoc faporis quadam affinitate cum Cannella genuina. Memini in ea Americx parte, ubi partem xtatis contrivi, nonnullos ibi cenfuiffe \& obtrufiffe unum atque alterum genus corticis, qui guftatu olfactuque xmulari quidem videretur Cannellam: fed diligentius examinatus arque vel igne vel contufione exploratus quamplurimum ver $x$ cederet bonitate $\&$ dignitate. Fateri interim me, quod res eft, oportet: Peruana illa, de qua Francilc. Gomara, Auguftus Carate, Perrus çicca, Nic. Monardus aliique Peruani fcriptores referunt, admodun \& quam proxime accedit ad Ceylonnicx virtutes;nifi quod primaria illi dos in fructu folo, non in vero arboris cortice confiftat; Sicut ex fequenti eorum relatu pa. tet. Provincix enim de los 2uixos proxima regio eft ad Peruvix Orientem, quam $\mathrm{Ca}$ nclam Hifpani vocant ab arborum copia, (atque adeo integris illarum filvis, qux in multarum leucarum (patia patefcunt) quas ob finilitudinem quandam cum notifimo Aromace vocant Canelas. Sed quamvis multx hujus generis filveftres exiftant, diligenter tamen \& magna cura eas in fuis prædiis colunt, ut evadant meliores; quas poftea in vicinas regioncs deferunt, al ias merces, ad vitam humanam neceflarias, hoc Aromate redemturi. . Omnes perpetua coma funt præditx, foliis Laurinis, fruetu racematim 
cohærente, fed qui calyce fuberino, duplo tamen ampliore $\&$ magis cavo; contineatur; intus levi, extus afpero, utrimque ex purpura nigricante. Harum arborum fructui, foliis, cortici \& radici (licet Cannell $x$ faporem \& odorem referentibus゙) longe calyces præferuntur, quorum dumtaxat pulvis in ufu eft. Si Cannellæ modo cum cibis decoquatur, tantum abeft,ut fuavitatem eduliis conciliet, quin potius ejus facultas, \& $\mathrm{f}$ poris gratia decodione evanefcit : horum pulvere in multis morbis utuntur ; fed pr $x$ fertim adverfus coli, inteftinorum \& $\&$ fomachi dolores in potionibus propinant.

ceylon, quam ufualis noftr $x$ Cannell $x$ genitricem $\&$ altricem dixi, Infula eft ; quam Tapobranam I. Barrius multis argumentis probat: utut hoc neget Scaliger vir fummus; Exerc. CXL I I. 5.Non defunt, inquit, qui obturbent: ac Ceylon Tapobranam, non $\mathrm{Su}$ matram, putent. Polum hæc Infula fupra fe habet elevatum à fexto ad nonum gradum: Figura pene ovali eft, leucis in circuitu plufquam ducentis. Ambiuntque ejus mediam vaftamque planitiem, jucundo admodum fpectaculo, montes filvofi, \& theatralem in modum circumducti. Fluminibus aliifque perennium aquarum laudatiflimis, quibus plurimis omnino locis irrigua, magnam fux fertilitatis partem debere certum eft. Regio non folum populofa, fed \& quadrupedum aviumque genus omne feraciffima. Pra ftat $\&$ cornu copiæ fructuum delicatiffimorum $\&$ fola foli benignitate nafcentium. Aromata fert plurima, neque ulli aliorum locorum fecunda. Primatum tamen obtinent ibi Cannelliferx arbores, tam denfx, ut integras nec unas conftituant filvas, adeoque luxuriantes, ut, nifi flammis èam incolæ luxuriem coërcerent, univerfus terrarum orbis corticibus non fufficeret confumendis. Quam veroluxuriofe fert Cannellam, tam operofe Caryophylla aut Nuces Aromaticas. Quemadmodum neque Cannelliferæa alienum in folum amant transferri. fuere enim, qui horum pericula fecerunt, tranflatis quibufdam ex dictis arboribus ad regiones cum vicinas tum diffitas, æque fe:lices, iifdemque $\&$ ventis $\&$ à Sole caloribus expofitas : inibique fummo fudio cultis. Verum compererunt fe operam, quod aiunt, \&oleum perdidiffe. Quamvis enim tralatitii frutices excrefcerent in juftas arbores, exque fuos fructus in tempore darent: attamen, ubi ad examen ventum fuit, deprehenderunt eorum \& longe minorem in virtutibus efficaciam, \& hanc ipfam promt $x$ corruptioni obnoxiam: Contra quam hortus lanis fape evenit tranfplantantibus filveftres plantas in pinguiore ac læatiore folo, atque ifta eas ratione reddentibus longe meliores efficaciorefque. Ex quo liquere poteft varius ille \& admirabilis rerum omnium parentis Natura lufus, quo tam facilem aliis transformationem, quam felicem tranfmigrationem concedit; aliis contra utramlibet adeo difficilem, frepe impoffibilem; ut citius è pumice oleum exprinas, quam in tranflatis invenias vires eas, quas dare Solum natale folet. Mirum, videre id in plantis : fed magis mirum, videre id in hominibus ; ficuti nos vidimus, qui palatiorum maje1tates urbium illecebras afpernati,nullis potuere vel blanditiis vel culturæ humanioris officiis retineri, quo minus ex clementiffima fervitute fe reciperent in folitudines $\&$ deferta unde erant oriundi, præferentes in mapaliis fuis, interque agreftes $\&$ omnis humanitatis exortes vivere homines (fi modo frc merentur appellari) quam inter di vina præditos ratione, eofque moribus infuper \& virtutum omni genere excultos. Quos natalis foli \& libertatis, imo viliffim $x$ fervitutis, dulcedo retrahat in patriam, an indoles incul ta culturæque inepta, non facile dixeris, nifi ejufcemodi humana fpecie mortales à feris \& plantis filveftribus pene concedas non differre, nifi corporis conftitutione. Quemadmodum vero, quod retuli, verum eft de arboribus aromaticis iftis; ita: \& idipfum non femel cum magno meo tædio fui expertus in plurimis plantis Americanis, quas transferendas curabam è nemoribus, aliifve locis, in hortos, quos eo in Brafilix tractu, animi caufa, colebam.

Cannellæ arbor; quemadmodum \& Caflix, ad magnitudinem affurgit Mali medi: cx : eftque ramis multis, longis, craffis, enodibus, nulpiam curvis, fed ubique rectis; \& mirabili inter fe ordine difpofitis : quemadmodum appofita in figura utcumque videre eft : Ex iftis deinde ramis ramulos exigit alios foliofos : folia magna fatis, nec admodum diffimilia funt foliis Lauro-Cerafi, figuram fifpectes. Eorum fingula tum alternatim excunt tenuibus brevibufque pediculis ex furculis fuis, tum è latior e bafi definune. in acumen, tribus quatuorve interim ftipata nervis per longitudinem, ficut in plantagrine, excurrentibus. Ex eifdem ramulis etiam Flofuli quidam efflorefcunt hinc inde parvi, aivei, odori. His fuccedunt fructus parvi, Oliva tnagnitudine \& figura; quique 
primum vireant, \& maturefcentes præ nigredine fplendeant. Hos Simii decerpunt; rapiuntque aves, priufquam cadere prorfus maturis accidat. Ex his feu Solis vi feuigne exftillat liquor viridis, acris, amarus, oleaginofus; quique, perinde ut qui è floribus arte elicitur, Cannellam quidem odore faporeque referat, fed plurimum virture cedat: unde $\&$ ufus haud multi eft. Ligni materia faporis $\&$ odoris expers exiftit. Adeo ur omnis hujus arboris vis cæteris quidem omnibus partibus dencgata videatur, $\&$ unum in corticem collata, quo plus ex eo fonoris natura reportaret. Duplicem, ur plerifque arboribus, illi tribuerunt Corticem autores veteres $\&$ novitii. Superiorem Garcias craffum effe, eumque tanquam inutilem rejici, nefcio quo fundamento, pronuntiavit;cum tamen ramorum partes Ceylannicx Cannellæ ad nos delatæ arguant,primum illum corticem, effe pelliculam faporofam, adeoque tenuem, ut non nifi viridis tolli poffit: nam poftea ficcefcens interiori cortici quafi contiguus fit, ut nec vifu nec guftu dignofci, nec manu feparari poffit: Si aliter eveniat, Cannella vel corrupta, vel Pfeudocaffia erit cenfenda. Neque tamen mirum debet videri, odoris illam fuavitatem, qua viridis Cortex fere deftituitur, poft tres menfes à delibratione acquirere; quia multa funt viridia, qux parum vel nihil olent; ficcata odorem fpirent optimum: ut ante bis mille annos obfervavit Theophraftus, quod nimio abundent humore, cum odor in medietate, non in extremo, tefte Philofopho, confiftat; ac proinde Aroma recte definiatur, vegetabile, quod odore $\&$ guftu fuave eft. Recens.itaque Cortex à pellicula illa cineritia inæquali libratus, lubricus eft, imo is qui Caffiæ venit nomine, fi mafticetur, glutinofus deprehenditur: delibratus purgatufque $\&$ in laminas diffectus exponitur ad Solem : quo illas ficcante, in cannas fponte'convolvitur, excinereo in rufum colorem mutans, abfumta videlicet, ardore tandem Solis, omni, quam habebat, nativa humiditate. Cortice ablato per biennium (non ternis quibufque men. fibus, ut voluit Fr. Hernandez in opere fuo de Aromatibus, ) arbor frepe triennium perfiftit nuda ; fed tum denuo induitur Cortice novo $\&$ delibraturæ rurfus apro. Ra. dicem incolæ ferunt exfudare fuccum Camphor $x$ non abfimilem.

Cannellægenerationem perfecutus, addam de qualitatibus aliquid ut \& facultatibus. Qualitates $f i$ frutere, deprehendis infigni gradu calefacientem $\&$ ficcantem. Acrimoniam habet, qualem in nullo reperias Aromate aque guftu jucundam. Odor admirabilis, præfertim ejus, quæ de novis furculis fuit ademta. Quæ \& tenuium magis partium eft, \& incidendo aptior, minufque ficcans aut aftringens. Sapor ei aromaticus \& egregie. Sapor ifte, ut omnino debet haberi diverfus $\&$ alius ab amaro, dulci, falfo, unctuofo; ita proprius cenferi rebus odorem fpirantibus gratum, quæque fu. bito noftrum fpiritum reficiant atque confortent : Sunt interim aromatici faporis diverfafpecies. Eft enim Caryophyllo acutior \& pinguior, Piperi ardentior, Cannclla aftringentior, ut \& Nuci Aromaticæ. Quemadmodum vero Cannellæ major eft, qua odorem, qua faporem, fuavitas præ his Aromatis, de quibus fum poltea dicturus : ita \& utrumque amittit citius, quam aliud ullum. Habet enim utramque prærogativam in fubftantia prætcnui \& exhalabiliore; unde nec ætatem fert, præxertim aëri expofita fquaiido. Communis ei cum aliis Aromatum facultas eft vegctandi fpiritum, Naturæ omni in actione miniftum. Aft uti Caryophyllum cerebro magis, Nux Aromatica \& Piper ventriculo potius, convenire deprehenditur : ita Cannella cordi, vitæ fonti. Vnde nobis in animum linquentibus, aliifque nobiliffimi vifcerum afféctibus, efle ufui confuevit: Indi præterea pro antidoto habent, \& $x$ venenis offerunt expellendis. Su-

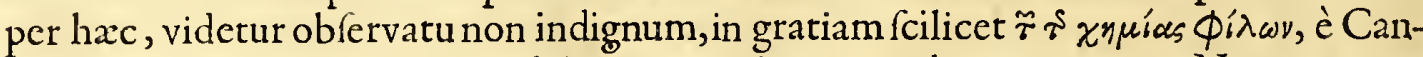
nella \& Caryophyllis elicitum diftillatione oleum,quod vocant, non ut Nucum caterorumque Aromatum, fupernatare fuo phlegmati aut fpiritui, fed balfami inftar petere fundum. Porro quantum Cannella vel per fe exhibita, vel in compofitionem recepta, feu cruda, feu arte Chymica præparata, calefaciendo, attenuando, digerendo, excitando, vegetandoque vitalem f́piritum, præftet,cum ægris auxilium, tum fanis oble ctamentum, fi velim cnarrare, longum crit, \& modum excedet inftituti. Indi criam ex viridi cortice $\&$ floribus recentibus extrahere ad varios ufus folent liquores, non aliter acrioftratcs aquas egregic odoratas eliciunt ficcata è Cannella. Quin \& è fructu oleum cxprimitur (teftantibus, juxta cum Garcia ab Horto, etiam noftratium non paucis, qui viderunt) quod fponte fua duratum plebs cogunt in panes, $\&$ adhibent ad affectus cum externos tum internos. Eft autem ut pretii vilioris, ita $\&$ virium imbecilliorum. 


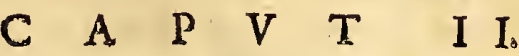 \\ De Caßia Caryophyllata.}

$\mathrm{P}$

Ofteaquam, qux de Cannella \& Caflia vulgàri milii dicenda putabam, diluside $\&$ fufe fatis fum perfecutus, vifum fuit tertiam quafi fpeciem prioribus adjungere, propter novitatem fimul \& virtutem eximiam. Quemadmodum' enim novitas ipfa invitat, ita $\&$ rei dignitas prorfus me incitat ad patefaciendùm poiteritati , quod hactenus fuit ignoratum. Præfertim cum hoc Aroma, non, ut cæetera, ferat aut dives Afia, aut felix Arabia, fed prifcis incognitus orbis vaftaque Americæ deferta \& folitudines filvof $:$ unde \& Americanam vocamus. Caffia autem ifta Americaina adeo veræ Afiaticx qua faciems externam fimulis eft, ut ovo non magis ovum. Quod fi guftum deinde adhibeas jud s $_{\mathrm{i}} \mathrm{em}$, fatebitur $\&$ ipfe Caffiam aliquam languidam effe, quamdiu primoribus dumtaxat labris explorat: at mox ubi mafticata fuerit $\&$ contrita dentibus, non jam Caffiam fed Caryophyllum dicet, cujus vices explet advenis Lufitanis pariter atque Indigenis. Quorum commendatione factum, quod coe. perit Cafia ifta \& in ipfam Lufitaniam \& ad Amftelodamenfes quofdam Iudxos migrare. Nec dubium eft, quin fe magis magifque commendaturus fit apud pofteros Aromatis tam nobilis ufus. Si fiat, non poterunt poithac gloriari çeylonitæa \& Moluccenies fibi folis id effe de cælo muneris conceflum, ut illi quidem Cannelliferas, alteri vero Caryophylliferas poffideant arbores, fuique muneris effe quod univerfus orbis utrarumque fructu gaudeat. Fietque eorum gloria hoc ipfo minor, quod Cannel$1 x$, inquam, facies \& Caryophyllorum vis Medicinalis in uno exhibeatur cortice,adeoque excellens, ut Orientalibus non cogatur cedere. Neque vero eft quod quis fufpicetur, Aroma hoc, aliudve fimile, effe ex veteri orbe in novum tranflatum; Cum minime id ftudium teneat homines ab omni pene etiam ingeniorum cultura alienos, $\&$ domi natis propriifque divitiis contentos; Imprimis cum conftet quamplurima Americx effe familiaria,al ibi in totum ignota. Quod enim Seneca Natural. quxft. lib.v 1 I. cap. Xxv. ait, id hodieque verum non una in re experimur. Veniet tempus, inquit, in qus ifta, qua nanc lasent, in lacem dies extrabet \& longioris avi diligentia. Verun à digreffu זegrediamur ad novi hujus Aromatis ulteriorem expofitionem.

Arbor, qux iftam fert Caffiam Caryophyllatam, crefcit in diftrictu Guaianx \& Maranban in eadem Brafilix continenti. Q uxe regiones fitx funt inter primum quintumque gradum ab 2 quatore verfus Septentrionem. Vbi quemadmodum filveltris, ita \&neglecta, neque ulli afferta domino, fed promifcui ufus, communifque juris.

Arbor cujus Icon ob itineris injurias periit, eft mediocriter procera, ramofaque. Flores parvi ut Violæ, cæruleo colore, fed umbilicum albicante, \& croceis aureilque lineis variegati. Cortex tenuis, quique $\&$ ipfe decorticatus à trunco pariter ac ramis, atque velut in corrigias confciffus ficcatufque, Orientalis Cannellæ in modum convolvitur, qui mox primis labiis guftatus faporem videtur reddere immixtum Cannellx, fed cum Caryophylli prædominio, qui etiam ( pereunte primo, utpote languido) vires acquirit cum tempore, tantaque vivacitate, fragrantia \& acrimonia fe exerit, ut lingua quafi levioris cauftici fentiat effectum, imprimis qui ex furculis tenuioribus \& vegetioribus provenerit.Vnde eft, quod levi maceratione aqux fontan $x$, colorem rubicundum, \& odorem caryophyllatum fupeditet, ad medicinam, \& cofmetica utilem; vina quo que medicata inftar hypocratici gratiffima exinde parantur. Aromatis hujus tam nobilis mediocrem penes fe quantitatem habet David Naf $i$ doctiff. \& humaniflimus Iudxus Amftelodamenfis. Vt vero de fuco fufpectum Aroma vindicaret natur $x \&$ potentix $\& x$ benignitati, periculum ejus fecit Carolus Chivry, affeffor Collegii apud nos Medici, Pharmacopoeus, \& rei tam Botanicax eximius cultor quam Chymicx ferutator diligens. Qui ex eo oleum præftantifimum more Chymico,ficut ex ipfis Caryophyllis fieri for let, paravit; tum quoque cum fpiritu vini extractum reperit prorfus igneum, nec ingratum tamen, fed merum refipiens redolenfque Caryophyllum, \& f piritibus impræzgnatum ufque adeo fubtilibus, ut in vitro etiam diligenter obturato fefe non fiverint retineri, quemadmodum \& ipfe nuper. fum expertus. Vt dubitandum non fit, fpeciem effenonfolum egregie Aromaticam, fed \& infignium facultatum. Quarum ufus fuic- 
cedaneus Caryophylli cœpir effe, \& forte jam dudum fuiffet, li non regio diplomate cohibitus fuiffet in Moluccenfium favorem. Medicina etiam docuit pulverem ejus craffiufculum (nam fubtilius odit pulverari ob firitum, quem habere dixi admodum volatilem) drachmæ pondere affumptum ex conveniente liquore (piritum efficaciter revocare labantem, \& parturientibus partum accelerare tam tuto quam felicitčr. Hoc paucum eft, quod de ufu ejus atque virtute poflum in prafens communicare. Non dubito tamen, quin fe brevibus fit inferturum in hominum experientiam \& cognitionem uberiorem.

Cæterum iis è locis Americæ, quæ propofui, reduces, narrant reperiri ibi integras filvas arbutorum, quorum cortex, etfi tenuicr fit, eadem tamen omnia, qua naturam \& odorem faporemque, præ fe ferat ; imo qui eum, quem defcripfimus, corticem fa- $^{-}$ poris a crimonia magis ignea antecedat.

Quæa aliaque infinita natur $æ$ beneficia, dies \$x hominum fagacia brevi proferent in publicam notitiam. Quo non parva fane afful vi:Philiatris fpes, cumjam novæ expeditiones $\&$ Colonix in procinctu fint, quas nottri moliuntur verfus eandem (cujus vicinæ terr $x$ in Maranhan nuper poffeffores fuere Batavi) Brafilix continentem, quxre: cepro nomine Guaiana, vel, ut nautæmalunt, Ora barbara dicitur. Eaque fane Regio divifa quidem eft à Brafilia per Bullam Pontificis Romani ; \& illa qux poftea inter Re. ges Caftellæ \& Portugallix convenerant. Cæxterum illi contermina, eademque cæli clementia, hec minus felici foligenio gaudens, ficut continens mediterranea edocuit, poftquarn noviflime confirmari cœpit id, quod antehac I. de Laet, aliique, quos ille fecutus, circa fertilitatem medicaminum \& frugum in fcriptis fuis adumbrarunt; ut ex fequenti digreffione facile patebit.

Tempeftates anni in hoc climate plurimum variant;nam in orientali Glaiainx parte, qux vergit verfus Flumen Amazonum, xftas inchoatur à menfe Augufto, hyems à Februario : in occidentali autem parte \& verfus orenoquen fumit æeftas exordium $a b$ O\&tobri, hyems ab Aprili: Quxe tempeftates, quod \& alibi monuimus, tantum pluviis ( unde barbari pluvias \& hyemem uno nomine denotant) \& ficcitatibus, iremque graviffimis ventorum flatibus $\&$ malaciis diftinguuntur: nam quum hæx regiones tam exiguo intervallo abfint $\mathrm{ab}$ Æquatore, exiguam admodum caloris $\&$ frigoris patiuntur viciffitudinem. Neque tarren omnibus annis, æxualiter aut æque diu pluit; fed difcrepant interdum uno atque altero menfe, \& pluviarum copia aut mediocritate.

Solum quoque plurimum differt: nam pritho ad oram maris fere cft humile, \& nifi aur $x$ pene perpetim interdiu $a b$ oriente valide perflantes, $x f$ tum egregie temperarent, à mortalibus habitari nestiquam pofent, nunc vero vel maxime à barbaris habitatur, ob fluminum, qux paffim hic effuunt, opportunitatem, \& telluris focunditatem, atque adeo cxli (paucis quibufdam locis exceptis qux incolarum valetudine male audiunt) bonitatem atgue falubritatcm. Intra continentem plurimi vifuntur montes, quorum quidam fœcundo folo culturam facilo admittunt; alii penitus funt afperi, fed variis metallorum venis fcatere creduntur: in hifce montibus nonnihil algetur, nihilo tamen fecius aër faluberrimus judicatúr, quo fit, ut plures barbari ibidem habitent. Inter hxc extrema, veluti medium eff, folum modice editum, prxcedentibus longe feracius, atque amœnius, nemoribus atque lucis, campis atque pratis grata varietate diftinctum, adhæc pluribus amnibus \& torrentibus riguum; cæloque imprimis falubri. Carterum duas peftes hic patiuntur indigen ; culices, ipfis $M a-$ piery, \& Niguas, ipfis Sico: adverfus priores tamen in prompta remedium eft, noctu luculentum focum in adibus alere.

Abundat hæc Regio æque ac Brafilia , radice Mandioca Mayzio Melle filveftri, ac ligno illo rubro tincturis dicato. Sed preter illa, certis radicibus oblongis, Rapis Similibus vefciamant, quas 2Napi vocant. Dein arboribus frugiferis, Pinis, Platanis, Mefpylis, quarum fructus noftrates fuperant: Prunis etiam diverforum generum, fed fructus minus commendantur, quia crebrius comefti lienteriam in illis regionibus periculofiffimam provocant. Nucibus quoque variorum gencrum, \& inufitatæ form $x_{2}$ non deftituitur. Mult $x$ infuper plant $x$, refin $x, \&$ ligna, tam mercaturæ quam Medicinx dicata, luxuriant, quorum precipua enumerafle fufficiet.

Inter preftantifimas plantas, qux fponte hic nafcuntur, merito primum locum fibi flagitant Caunz Sacchari, è quarum cul tura ingens quxitus poffet fieri, fi hic machinæ 
$2 d^{3}$ cannas molendas comparatæe excitarentur, quemadmodum à Portugallis in Brafilia videmus factum, ad quas quidem initio magnis expenfis opus eft, qux deinceps maximo quxitu refunduntur.

Proximum locum merentur arbufculæ qua goffypium ferunt, qua \& frequentiffmæ funt , $\&$ facile admodum coluntur $\&$ propagantur, $\&$ intra annum ex quo fat $x$ funt, uberes fructus reddunt. Barbari autem noverunt illud in fila ducere \& ex illis leatulos fuos penfiles contexere, magni in hifce partibus ufus.

Nafcitur hic quoque infinita pene copia cannabis five lini quxdam f́pecies, admodum elegans \& tenuis, ita ut byffum æmuletur; è cujus filis varii panni texi poffunt, uti experientia eft comprobatum.

Præterea varii nafcuntur fructus, qui tincturas edunt fupra modum elegantes, quarum ufum $\&$ barbari noverunt; qualis eft Annoto, quam alii vocant Orellanam, $\mathrm{Brafi}$ liani Vrucu, ut fuo loco probavi, qua lanæ \& præfertim byflus, colore inficiuntur aurantio. Habent \& alium acinum, qui cyaneum colorem edit. Necnon gummi quoddam, quod à certa arbore funditur, quod pannos eleganti \& pertinaci colore flavo tingit. Atque frondes cujufdam arboris, quæ bene præparatæ, colorem obfcure rubentem fundunt. Neque etiam defideratur lignum quod elegantem colorem purpureum edit ; ut \& alterum quod croceum : tertium denique cujùs liquor excoctus, fervens quidem purpureo tingit colore, frigidus autem coccineo. Nec dubium eft diligenti inquifitione \& alia ejufcemodiligna hic poffe reperiri, quæ magno uftui fint futura.

Gummi $\&$ refinæ bene olentes $\&$ magni in medicina ufus reperiuntur plures, inter quas celebrantur ab Harcourtio, Colliman five Carriman, \& Baratia.

Colliman, ut inquit ille, refina eft nigricans $\&$ refplendens, inftar picis duræ, quæ prunis impofita gratiffimum fundit odorem; Waltherus Caryus Buckingamius, vir exacti defimplicibus quæ in medicina ufurpantur judicii, teftatur fumum hujus ter quaterve quotidie naribus haufum egregie mederi gravedini capitis, \& cerebro humido frigidoque plurimum prodeffe, \& $\&$ rheumata fiftere : adhæc efficaciffinum effe remedium adverfus paralyfin, cujus capitis gravedo $\&$ fomnolentia prognofticon folet judicari. Medetur quoque doloribus, quos fœminæ quæ crebro pepererunt, patiuntur juxtalumbos, $\&$ in inferiore dorfi parte, fi liquefactum illinatur pellicul $x$, \& calidum applicetur parti affectx, inftar cerati. Creditur \& nervos corroborare; \& levamen adferre illis qui arthritidis doloribus forquentur ; denique $\&$ recentia vulnera egregie confolidare.

Baratta itidem prunis impofita egregium fundit odorem; eftque balfamum præitantiffimum, $\&$ adverfus recentia vulnera imprimis efficax, uti experientia à multis eft comprobatum. Reperiuntur $\&$ plures hic refinæ, quæ gratum odorem fundunt; $\&$. præfertim una qux odorem fpargit inftar Major ane nobilis.

Nafcitur paffim præfertim juxta littora, arbufcula five frutex, cujus jam ante aliquoties meminimus, ferens fructum (ut inquic Harcourtius) inftar viridis pomi, \& quidem minuti, pollens fomnifera qualitate, ita vehementi, ut vel particula quævis exigua imprudenter ufurpata lethalem fomnum inducat ; \& vel una gutta illius liquoris haufta tam valide dejiciat alvum, ut obfervatum fir fexaginta fedes non fine extremo difcrimine operatam : Putatur tamen, fi maligna illius qualitas à medicis corrigatur, caute in medicina poffe ufurpari.

Acinus qui barbaris dicitur Kellete utiliter adhibetur contra dyfenteriam. Succus autem herbæ quam vocant $Y p p e e$, adverfus vulnera à venenatis fagittis inflicta. Denique fuccus foliorum quæ Icarinominantur, a dverfus dolorcs capitis. Pluraque fimplicia, quæ peropportune ad Mèdicinæ \& Chirurgiæ ufum poffent traduci.

Nafcitur preterea hic arbor, quam barbari maximi faciunt, \& plerumque juxta domicilia fua colunt, ob infignem in pifcatione ufum : folent enim in receffibus $\&$ elicibus, poftquam reftus maris implevit, \& copiam pifcium adduxit, è cymbis fuis, ramulos hujus arboris, prius nonnihil fractos, manibus terere inter undas, ita ut fuccus corticis fe diffundat; pifces autem illo fucco ita foporantur, ut ftatim fuperna tent, \& manibus capiantur.

Huic accedit arbor quæ materiem fert quantivis pretii, barbari vocant Pira Timine$r e$, holtrates vulgo Xletter-lyout ; eft enim valde folidum, durum \& grave, colore roffo elegantibus notis fubnigris grata varietate diftinctum, \&z infignis ad fabrilia opera

$P 2$ ufus: 
ufus: Arbor eft procera \& recta, glabro cortice, frondes tantummodo ferens in faftigio trunci, quæ ad pyri folia quam proxime accedunt.

Gemmarum quoque copiam plurimis locis reperiri volunt, ut Iafpidis, Porphyrii, \& illius quam fummopere commendant adverfus Nephritidem. Nec metallorum etiam præetantiorum effœta creditur tellus, licet hactenus nullæ auri aut argenti venæ hic apertæ fuerint; quamvis fudiofe à multis quæfitæ.

Plurima reperiuntur ferx, venationi peropportunæ: nimirum Cervi; Apri duorum generum, qui tamen fere mole diftinguuntur; majores vocant $P$ ingo vel Panigo, Europæis haud quaquam inferiores : minores pockiero, qui umbilicum in dorfo obtinent. Infinitus numerus Leporum \& Cuniculorum, qui à noftratibus diverfi efle dicuntur. Et Vaccx filveftres quas vocant Maypouri vel Maipuries, carne inftar bovillæ, $\&$ qux ad eundem modum muria condiri fe patitur. Aliud animal quod vocant $\mathrm{Ba}$ remo, carne inftar ovillx: varix Damarum fpecies $\&$ ab Europxis nonnihil diverf $x$; etiam Aprorum quædam fpecies, quæ lardo caret, \& ipfis dicitur Abibera : \& animantia illa qux à pigritia nomen meruerunt, quia tardiffime progrediuntur aut ad faftigia arborum fubrepunt, ipfis Waricarii : infiniti Simii \& Cercopitheci : \& plures majorum atque minorum quadrupedum fpecies, qux paffim in hac America Meridionali reperiuntur ; etiam feroces $\&$ hominibus infeftæ animantes, Tigres, Leones, Pardi , Lynces.

Avium quoque magna copia atque varietas, nam præter Anferes atque Anates quas hi barbari vocant Raponne; Ardeafque quas vocant Ovakare; Grues, Ciconias, Phafianas aves, Perdices, Columbas, Merulas, Ficedulas five Scolopaces, Pfittacos variorum generum \& Cornices elegantibus plumis; aliafque. reperiuntur hic quoque fere omnes illæ volucres, quas in Brafilia utraque defcripfimus: aviculam autem illam monftrofo \& grandi roftro vocant Covakan: Pfittacos Courga. Nec defunt plures aves quæ raptu vivunt, præfertim Falcones variorum generum.

Pifcium quoque maxima cft varietas, tam marinorum quam fluviatilium ; \& quidem prater eos qui noftro quoque mari familiares funt; pifcem habent Salmoni noftrati non abfimilem, præterquam quod carnes illius funt crocei coloris, uti noftratium rubri. Itemque quem fuperiori libro defçripfimus fub nomine Arsovaova, quem hi barbari vocant Chipari. Adhæc fpeciem Raia five Paftinacæe, cujus cauda offe femipedem longo armata eft, acutis denticulis utrimque afpera, quorum punctura imprimis noxia eft; barbari hi vocant Pakamen; alibi fub nomine Yaveboajre. Quibus noftrates addunt Cavimo pifcem Afello majori mole pene parem, fine fquamis, verum armatum fex acutiffimis fpinis, , valde venenatis; in cer ebro illius lapidem reperiri tradunt, admirabile remedium contra arenas $\&$ lapillos renum. Et Accaren Crocodilis haud abfimilem, - fed magis gracilem, longioremque $\&$ roftro breviori atque obtufiore, victitat pifcibus, egreditur tamen nonnunquam in terram : cibis idoneus, fed captu perdifficilis, licet grato odore, quem fundit, fe prodat: minor ejufdem fpecies appellatur à barbaris owanna. Aymaren item inftar grandis alof $x$, qui in fuviis tantum capitur. Quos autem alibi vocant Manatos, hi barbari vocant Cojumero.

Harcourtius addit hifce Caffoorwan rarum pifciculum, paulo majorem Apua, Cobite, vel Spiringo, fed multo meliorem : hic in fingulis oculis duas habet acies, ita ut inter natandum alteram infra aquam, alteram fupra teneat : dorfum habet planum cum fpina; $\&$ coftis rotundis, pene ad humanum modum. Denique fluviatiles pifces tam multi, $\& z$ tam præftantes apparent (licet à noftratibus multum diverfi) ut vixulla regio in terris magis illis abundare poffit. Teftaceorum pifcium quoque infinitus eft numerus; maxime Oftreorum, \& Cancrorum \& Aftacorum.

Sedlongius provectus in Occidentem quam conftitueram, nunc vela contraho, \& me denuo ad Orientalis Indix infulas aromatiferas recipio. 


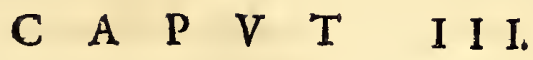

\section{De Pala, \& Bongo. Tala, hoc eft, Nuce Aromatica cum Maci fuo.}

$\mathrm{M}$ Oluccenfes Infulx, ut multx funt, atque fub Æquatore aut juxta fitæ; ita \& ab amonitate locorum omnes, omnes à fertilitate prxfertim Aromatum, atquè̀ porttum ftationeque navium opportunitate, mercibufque evehendis $\&$ advehendis mira commoditate magnis celebrantur laudibus ab his, qui funt experti qux dixi omnia. Quibus è cælo donis etfi inter fe certare videantur, principem tamen locum inter ipfas obtinet, quæ Banda vocatur. Hac fefe à Septentrione ad Auftrum incurvans, equinam velutfoleam conftituere videtur : longa tres leucas, unam lata: Hujus in finu emporium eft nobile, \& frequens mercantibus. Incolarum viri quidem

$B \circ N \in O-P$ A L A.

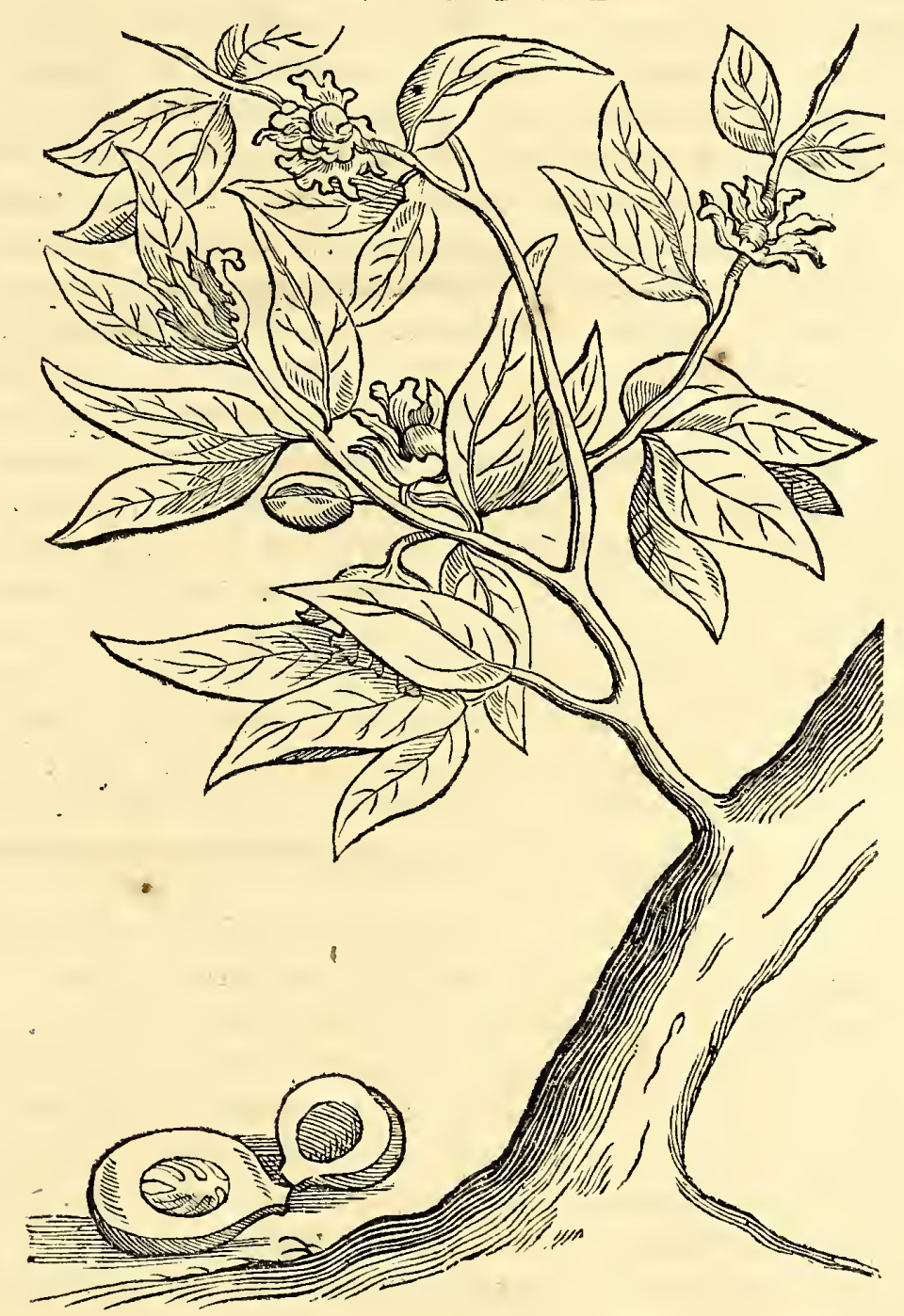

diftrahendis mercibus indigenis, fomin $x$ colendis $\&$ cogendis, operam navant. Fo minx, inquam, agriculturam: viri mercaturani exercent.' Q uemadmodum autem fupra notabamus, uni Infulx Ceylon conceffum effe fponte Cannellam ferre: ita uni Bandx (quantum hactenus conftat) Pala \& Bongo-Pala qux dicuntur fuis. Pala eft quam doctiores Nucem Myrifticam, ego Aromaticam malui appellare: natura fua, non ficur illi, ab ufu. Neque enim, ut Balanus Myrepfica, adhiberi concinnandis unguentis \& unctoribus infervire folet. Interim, ut Nux Mofchata vocetur cum vulgo, non refrae gor. Bongo-Pala eft, quam vocant Arabes Macin. Cum quo confundi non debere Macer aut Machir, probat Scaliger Exercit. cxiv. quenn vide.

$$
P_{3} \text {, Quis- }
$$


Quisquis autem, quæ Nuces iftas profert, arboris iconem, quam apponimus delineatam ad ipfus Naturæ exemplar, confiderat, haut diffimilem dicet aut Perficis Malis aut Pyris. Perfico folio effe, recte Cardanum fcripfiffe laudat, quem modo laudabam, vir doctiflimus. 'Nafcitur arbor fponte $\&$ frequens admodum $\&$ fine cultura. Eft $\&$ annofa \& perpetuo virens \& florens, perpetuoque Nuces gerens, alias aliis maturiores. Cortice cinereo eft, ligno medullofo, medulla ex fufco rufefcente. Folia parvis pediculis è ramis', quibus arbor luxuriat alternatim $\&$ fere catervatim, raro fingula dependent, lxte viridia $\&$ tenuia, glabra, $\&$ nervo unico reato cum plufculis venulis obliquis pradita. Ea non recentia tantum contrita manu fragrant, fed $\&$ cum exaruerint, acrimoniam fervant, \& vim Aromaticam infignem, ut effe etiam ufui Indigenis queat. Flores floribus Pyri Cerafive funt, $\&$ magnitudine pares, $\&$ colore fimiles, quique facile cadant, \& parum fragrent. Fructus fuccedens, circa pediculum nonnihil turbinatus, cxtera orbiculatior, non ipfis' ramorum faftigiis naf́citur, ut Nuces Iuglandes, neque in foliorum alis, quemadmodum Mathiolus depingit; fed in ipfis hine inde ramulorum articulis. Qua defloruit, fummum Nucis operimentum virens \& rugofun villofumque primo fatifque denfum eft:deinde maturefcens interftinguitur multis luteis, purpureis, aureifque maculis, ficut apud nos Bericocca, five Armenica Perficave Mala. Primum nucamentum, inquit Scaliger, carnea pulpa, craffa: fed veluti birfutum per initia. Sub eo non ftatim tefta, qua nucleus continctur, fed cutiscoriacea, quam vocant Arabes Macin. Villus ifte mox fiffus $\&$ hians Nucem oftentat fuo Maci, quafi reticulo, amictan. Deinde amplius $\&$ ex to to finditur, maturo fru $\& u$, haut fecus ac Iuglandium apud nos nucamentum, nuce matura. Quo facto reticularis ifta tunica five Macis pulchre, initio rubens, mox aureo colore apparet, intra includens putamen, quo nucleum contineat; velut oftendit Icon Nucis per medium divif $x$, appofitæque ad arboris pedem. Itaque nucleus ifte, qui Mofchatæ Nucis appellatione paffim \& Synecdochice venit, tribus eft amictus velamentis : extimo viridi denfoque : medio tenuiori quidem, fed aureo \& 2 pretiofo ; intimo teftaceo denique. Quandoque contingit autem fine $\mathrm{Ma}$ ci reperiri Nucem. Id fit fi quando præpropere tumefcente nuce reticula difrumpitur \& perit, antequam firmari jufta craffitie ac pinguitudine potuit. Hunc fructum varix quidem aves depafcuntur, fed maxime Columbre genus album \& parvum. Qux dehifcente nucamento, illeetx fuavitate Macis, hunc cum nuce eripiunt $\&$ devorant, nec nifi repleta ingluvie capaciflima faginam deferunt. Noftrates ibi mercantes ob id Columbis iftis Peut-etertive Nucivoris nomen dederunt. Quas autem vorarunt nuces poftea, integras per alvum reddunt. Redditx citius deinde germinant, utpote præmaceratæ fervore ventriculi. Arbores exinde natæ, ceu præcociores, facili funt corruptioni obnoxix, fructumque ferunt cxteris multo vilior em, \& hac caufa negleatum Incolis contemtumque, præter Macin, quem ad adulterandum meliorem adhibent, decerpunt.

Porro femper quidem bis, fubinde ter fructum fuum ferunt arboresiftx uno in anno. Vindemia prima fit Augufto \& Septembri, altera Martio circiter. Tertia alio atque alio menfe, prout faverit tempeftas cæli.Legi vero Nuces nifi bene maturæ non de: bent. Fallit interim non raro vindemiatrices color, rofeo colore, feu qualis eft Malis Perficis, maturitatem juftam referens tam exacte, ut fatis alias ad carpendum peritas, intempeftive invitet. Decerptæ enim minus funt durabiles ob fucci paucitatem $\&$ cruditatem, qux \& teredini obnoxias reddit. Hoc genus Rumpi vocantur. Quæ autem mature leguntur, exemtax nucamentis fuis ficcantur primum ad Solem. Siccatis adimitur Macis fuus. Poftea nuclei, quas Nuces vocamus, lavantur calce.Hac enim fola contra corruptionem, \& omnem etiam externam injuriam, tutæ præftantur, \& aptæ per univerfum terrarum orbem longis navigationibus transferri. Optimæ funt, quibus color eft ex rufo cinereus, fed interpolatus ftriis quibufdam albidioribus. Probari folent ponderofiores \& bene compactx , oleofx, \& quibus punctura aciculx confeftimè vulnufculo emanet liquor. Cxterum evenit quandoque, ut in magna illa Nucum uber tate per Naturæ lufum quxdam magnitudine figuraque \& colore difcrepent à carteris', quemadmodum haut infrequenter idem eft videre in Iuglandibus atque Avellanis, quas tunc Pala-lava appellant, quod Iavani eas, non in condimentum, fed folam Medicinam requirant.

Priufquam vero qualitates, quibufque gaudent, facultates iftarum Nucum perfequar, 
quar, fpectemus primum qua fit natura Macis, five fecundi Nucum involucri, ubi ante omnia neceffe Indorum Macin decernere à Græcorum Macere, quæ ut confunderent recentiores, nullam habebant rationem. Nam fi color ipfos, qui pene idem eft utrique, Maci \& Maceri, aut vicinitas ifta appellationis, adduxerit in eam opinionem, effe rem unam; nimis certe leves fecuti funt conjecturas. Hunc errorem Cardanus quoque admifit, \& notat eum Scaliger, fed argumentis refellit momenti minor is. Vocant Arabes, inquit, Macin. Non enim Macer aut CNachir eft, ut foribis tu. Cui etiam vel fruflra, vel temere, ut Galeno atque Diofcoride biftoriam tuam conciliares, adfrictionem attribuifti, maltam calefactionem quafi ceffsm fubtraxifti. Hoc enim de Machire uterque corum fcribit. Cum tamen ynacis adeo calefaciat, ut ei pauca ex odoratioribus aquiparentur. Que fuit caula, ut de Maci feparato Capite Jcriberet Aboali, de Talefafar alibi ea omnia, qua de Macere Diofcorides. Quibus ut aliquid addamus,ipfa res exigit. Et Macis igitur \&Macer frequens eft apud Indos, \& frequentis ufus, fed in Medicina tantum. Macer autem cortex eft radicis arboris in Malabri nafcentis. Is fubftantize eft frigidioris \& terreftrioris, \& ob id fiftendis alvi fluxibus deftinatus. Macis contra tegumentum Nucis \& quidem egrcgie Aromaticum eft, multoque $\&$ fpirituofo calore plenum; unde $\&$ adverfus frigidos affectus, itemque venenatos, folet ufurpari. Quin Avicenna \& Serapion \& Arabum alii fatis prodidere fuis fcriptis, bonam fe \& Macis \& Maceris habuiffe notitiam. De Græcis non idem conftat. Quin videntur illifolius Maceris habuiffe cognitionem: uti nunc nos, quid fit Macer, ignoramus. E quibus liquere poteft, non folum effe mul ta hodie nota nobis, quæ veteribus erant ignota; fed \& multa nos ignorare, quæ veteres habebant in notifimis. Sic omnia tempus habent; $\&$ accidit, quod verbis, etian rebus, ut, qux fuere in pretio, cadant, $\&$ in lucem neglecta protrahantur.

Macis autem ille, quem reticulæ inftar amicire primitus Nucem aromaticam dicebamus, priufquam ex pleno maturuit, $\&$ adhuc colore eft elegantiffime coccineo, condiri apud fuos fale $\&$ aceto folet, $\&$ inferri prim $x$ menf $x$ ad excitationem appetitus. Pofteaquam vero maturuit Macis, adimitur Nuci, \& exficcatus ad Solem collectufque cum cura reponitur fervaturque. Odore femper quidem grato eft, fed recens mire jucundo. Sapore aromatico \& fuaviter amaro, \& qui quamdam à fe ficcitatem ori relinquat. Si quid aftringentis habet, id in Maci non æque ac Nuce poteft guftu deprehendi. Brachmanes aliique Indorum Medicaftri nervis refrigeratis opitulari credunt, \& ad hoc tam Macin, quam Nucem, exhibere folent, eorumque fpiritus atque extracta adhibere foris. Quin habet vulgus in eumdem ufum femper paratum oleum, è fructu recenti expreffum, ceu præfens \& familiare remedium affectibus frigidis. Exprimunt autem \& è Maci \& è Nuce. Macis oleum vero ut oleo Nucis quantitate cedit, fic qualitate antecedit. Habentque IncolæMacin tanto Nuce præftantiorem, ut etiam fextuplo pluris aftiment $\&$ vendant fere.

Nuces virides $\&$ immaturiores condiri ab Indorum magnatibus folent, aliæ aceto, alix faccharo, \& probellariis effe in menfa. Ex ab aliquot retro annis etiam ad nos deferri cœperunt, \& non in medicinam folum venire, fed $\&$ in menfas epulafque lautiores. Neque vero per Europam tantum diftrahuntur, etiam Afiaticis notæ funt $\&$ expetitx. Delicatior es etiam nucamento, feu exteriore corticeviridi, delectantur folo, eumque ipfi Nuci praferunt, dum plane eft immaturus, tam propter odoris fuavitatem, quam faporis fubaftringentis, $\& \mathrm{ob}$ id ftomacho amici; jucunditatem. Docuit interea ufus, non omnino innoxias effe iftas delicias, neque tantum quando fine, fed $\&$ quando una cum fuis Nucibus fumuntur. Pollent enim, eaque infigni, facultate narcotica, qua frequentiore aut largiore ufu foporofos invehunt affectus. Idem de pulte quadam, quam ex iftis nucamentis, eo, quo nos ex Pomis acidis, modo coctam, familiarius ufurpant, Iac. Bontius alicubi teftatur.

Quantum vero attinet ad Nucum maturarum $\&$ ficcatarum qualitates manifeftas, vix operæ videtur pretium eas hic recenfere, cum fatis fint omnibus ex ufu quotidiano not $\&$ perfpectx. Vnde in Scholis Medicorum habentur fecundum inter $\&$ tertium gradum calidæ \& ficcæ, \& fubltantix craffioris, fed permixtis partibus igneis atque aëreis. Habent facultatem cum urinas ciendi, tum alvum fiftendi. 


$$
\text { C A P V T } \quad I \text { V. }
$$

\section{De Palo-Metfiri five Nuce mare dicta.}

$\mathrm{H}$ Actenus de Nuce Aromatica vulgari , \& nóbili. Nunc \& communio natura $\&$ opinio hominum me vocat, ut aliquid quoque dicam ad fatisfaciendum curiofitati lectoris, haut dubie id expectantis, de Nucum Mofchatarum oblongioribus; quas Incolx Pala-Met firi, Clufius \& cum eo alii Nuces mares appellant, \& tantum non præferunt prioribus; nefcio qua de caufa. Neque enim quia mares dicuntur, idcirco dignitate \& facultate antecellunt, quafi fi natura majoritatem $\&$ longitudinem feciflet notam precellentix. Quippe fecus fe res habet. Nam quantum mole creteras fuperant, tantum ab his fuperantur virtute aromatica, omnibufque doti-

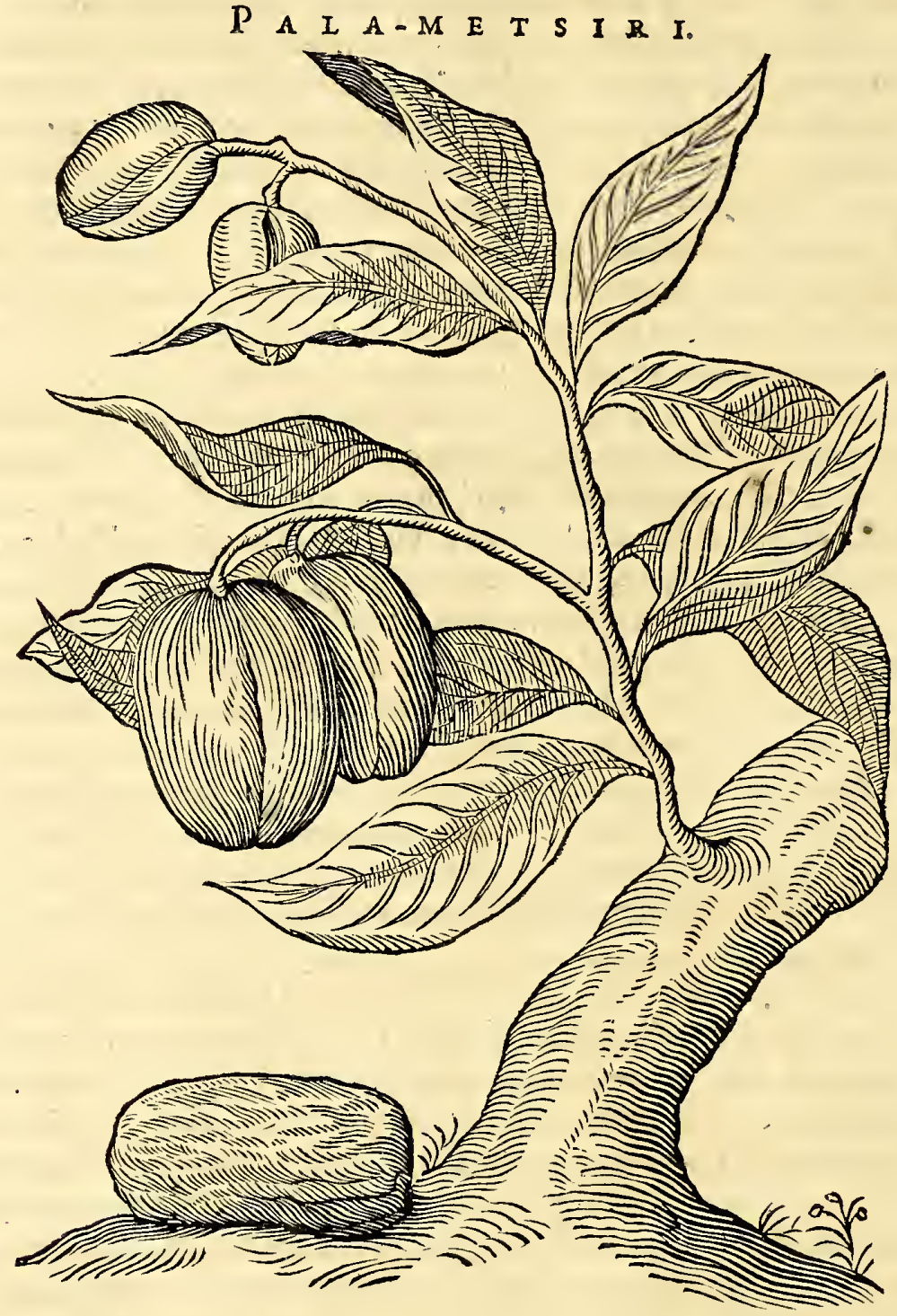

bus Mofchatæ Nuci genuinæ \& nobiliori conceffis. Nomen vero à plebe habet, qux fibi perfuadet non ratione aliqua, fed fuperftitione mera, oblongam Nucem, in cibo viris datam, potenter eos ciere in Venerem, \& facere folito ftrenuiores. Macis tamen ejus, quamvis elegantiffimi quoque coloris fit, adeo eft infirmis viribus, ut etiam nullo apud fuos, nedun apud naturx peritos, fit in pretio. Vnde eft, quod arbor, ex qua nafcitur, inter degeneres \& filveftres habeatur negligaturque. Ea enim nulla quoque cultura humnna crefcit in ejufdem Band $x$ confiniis, non tam fpecic \& facie diverfa ab altcra illa, qua indole \& virtutc. Q uam quia Incolæ inefficacem deprehendunt, idcirco \& fructum, ceu viliorem, non dignantur vindemiare. Quin Bandenfibus fatis jufta negligendi caufa videtur, quod Macin ejus deprehendunt virium infirmiorum. Arbor ipfa foliis eft longioribus, craffioribus, nervofioribus. Nuces non folum oblongre lunt, fed \& quadratx fere. Ex non è ramorum interftitiis, ut priores, excrefcunt; fed 
fummis, \&, luglandium inftar, fimul ternæ quaternæve; quemadmodum videre eft ex eoicone, quem exhibeo cum \& fine naturalibus operimentis.

$$
\text { C A. P } \quad \text { V } \quad \text { T } \quad \text { V. }
$$

\section{De Tsbinka five Caryophyllo.}

Oluccx vocate Infula; ut $\&$ ante monui, juxta $\mathbb{E q u a t o r e m}$ ita funt fitx, ut fe à Borea in Auftum exporrigant, à fe invicem non amplius vicenis leucis diffitx. Earum maxima ultra fenas leucas in ambitu non habet. Omnibus folum eft adeo aridum \& fiticulofum, ut non folummodo calo lapfos imbres momento

T \& H I N K A.

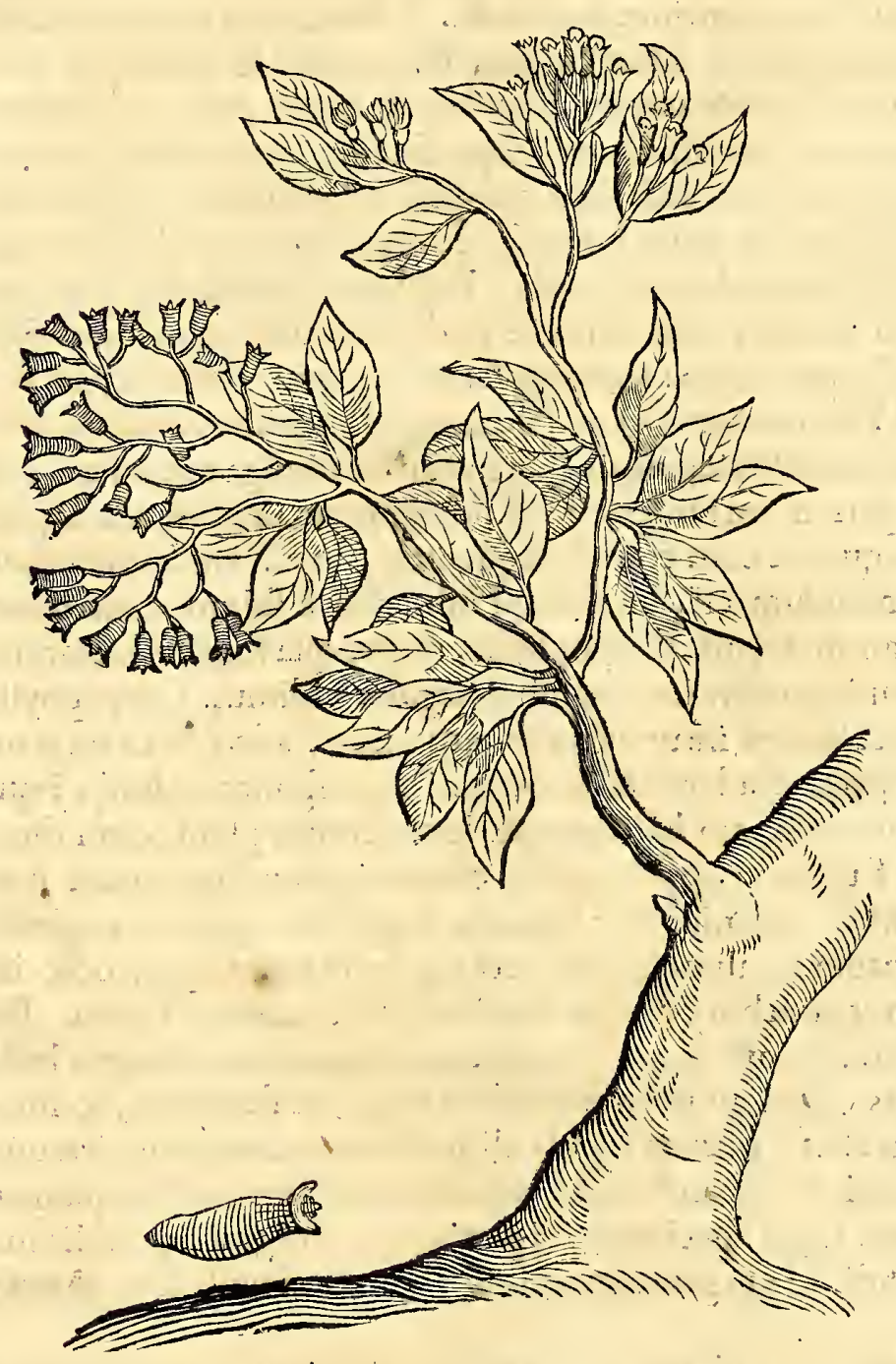
imbibat, verum etiam è montibus defcendentes aquas abforbeat, antequam colligere $\mathrm{fe}$ in flumen aliquod atque ita in mare delabi queant. Quin aliquot locis è terra fponteignes $\&$ magno ftrepitu eructantur. $\checkmark$ nde carera quidem fteriles, folis fuperbire Caryophyllis geftiunt. Certc qux ad victum funt neceffaria, ea Incolx coguntur omnia petere à vicinis Infulis. Qux etfi Caryophyllis deftituantur, Moluccenfibus tamen funt fertilio res corum, qua cedere homini in alimentum debent. In quo videre eft nobile Divit x providentix fpecimen; qux ita fua munera terris, ut hominibus diftribuit, quo, dum alias aliarum rerum egenas voluit,omnes in mutuam collegit focictatem. Porro ex Infulis, quæ Moluccæx dicuntur, fub unius Reguli impetio funt Ternate; Makian, \& Mutier. Quarta,quæ Baciam, alium fibi Regulum habet. Hx quatuor olim abundare Caryophyllis folebant, nunc penitus iis deftitutx, culpa non novercantis Natur $x$, fed largiffimæ $\&$ benigniffim $x$ matri invidentis fortunx. Reguli enim à Batavis noftris aliquot millenis imperialibus excxcáti, ex pacto omnes ibi Caryophylliferas arbores eradicarunt. Noftri vero ut uni lucro fatis ftudent, fua intereffe putant, ne tam nobile Aroma vilefcat copia \& fertilitate divina. Ita avaritia lege, modo, ratione carens audet ipfi Naturæ anctori, omnifque boni largitori , tantum non fuam exprobrare benignitatem \& liberalitatem. Moluccenfium interea cater $x$, Tidor \& Marigeron, quas fui juris Hifpanus fecit fuo more, Caryophylla fatis abundanter ferunt. Quemadmodum \& Amboina, quæ noftratium commerciis patet, eorundem arboribus $\&$ arte confira eft, \& natur $x$ beneficio frequentibus locis dotata.

Aroma ipfum quod attinet, id Incolæ fua lingua vocant Tsbinka, Grxcis recentioribus, \& ad quos rerum Indicarum aliqua pervenit notitia, rapui $\varphi$ usxor dicitur. Hoc fibi nomen in Latino fervat. Arabibus \& Perfis \& Turcis, ut \& Indis quibufdam, Calafior vocatur. Belgxà figura nomen impofuerunt, Hugt-nagel/ quafi dicas clavum Aroma- 
Aromaticum : fane appofite adeo, ut nifi apud Botanicos invaluiffet confuetudo ap.: pcllandi voce Græca, rectius hoc novo veniret nomine. Græca enim, unde unde fit (nihil attinet inquirere) inepta eft, neque ullatenus rei conveniens. Belgica vero appellatio, \& ad ejus imitationem facta Latina, quadrat quam optime. Scaliger exercit. CXL v I. fcribit tribus vocari nominibus Gomode, Chiáncha, Bugalavam, proculdubio alio ab aliis Infulanis. Anthophylla vocant Apothecx.

Arbori magnitudo noftratis Cerafi. Caudici craffitudo quanta pene humano corpori. Cortex olex. Folium Pyri noftratis, quandoque fingulum, fed fxpius vno èloco numerofum. Folio petiolus eft longiufculus, in medio nervus, \& ex eo plures $\mathrm{f}$ bræ in utramque partem. Rami plures \& multum fruticantes;quorum plurimi definunt in tenues valde furculos. E quibus fummis prodeunt tenues petioli, \& ex his alabaftri $\&$ in his flores conferti, deni $\&$ viceni, oblongi, lato capite, criftato, atque ftell $\boldsymbol{x}$ in modum coronato radiatove. Alabaftri ipfa funt Caryophylla. Flos intra alabaftrum, fuum claufus multa ipfa \& complicata continet ftaminula. Efflorefcens initio albicat; poftea virefcit; tum rufefcit \& indurefcit. Flori infignis fragrantia, \& qualis ipfi fructui. Hæc ipfa major fudo cælo, pluviofo minor ; à quibus \& major minorve ubertas pendet. Tempeftate ficca enim, admirabili luxurie frepe fructus, quam folia, numerofiores. Neque tamen etiam per annos conftante tempeftate omnibus par ubertas : Nam altero tertiove aliquando feptimo anno minor hæc, quafi vires recolligente arbore, per nimis liberalem fructificationem exhaufta. Poftremo alabaftri in fructum excrefcunt fatis lentum, dum crefcit; cum adoleverit, duriffimum: rubicundo primum colore; poftea, ut mox dicam, nigro: leguntur femel in anno (non bis, ut voluit Scaliger, ) ab Octobri ad Februarium. Quod ibi tempus maxime \& xftivum \& tempeftivum legendis eft. Pars manibus leguntur : pars arundine longa aut è funiculis flagello difcutiuntur. Ab his periculum tamen eft, ne non fatis aut provida aut experta manus furculorum extrema quaffet cun certa in fequentem annum vindemiæ etiám fperatxjactura. Cum vindemiandum eft, univerfum fub arbore folum exherbatur purgaturque; quo facilius legantur decuffa Caryophylla, neque qua fugiant lectorem. Idem in Brafilia fieri ab hortulanis prudentioribus fub Mangabas vidimus. Caryophylla five clavi Aromatici in arbore reftantes intumefcunt maturando, adeo ut cæeteris ingenti mole $\&$ magnitudine difpares evadant, $\&$ infequenti anno ponte cadunt, iique languefcente licetvi Aromatica in pretio habentur $\&$ loco feminis plantationi dicati funt, ideoque cos Matrem fructuum appellarunt, convenientius fane quam Avi. cenna 1. I I.c. 3 I . qui illos Mares nominavit. Horum aliqui ab agricolis neglecti, fponteque nacti gremium \& fotum $\&$ alimentum è terra germinant, atque, odto intra vel novem annos juft interea arbores factx, fructum juxta cateras ferunt. Felicius tamen, quotquot altero tertiove anno frutices tranfplantantur. Recens lecti, ruf funt, \& leviter nigricantes. Qui, ut prorfus evadant nigri, \& ficcantur, \& infumantur, atque, ne teredo invadat, marina tepida aliquantum macerantur iterumque ficcantur. Ita, \& praparati ad durandum $\&$ collecti in acervos poftea quaquaverfum per orbem diftrahuntur. Quo appellunt, ibi plerumque purgari à petiolis fuis confuerunt, $\&$ hi feorfim vendi. Id purgamentum Lufitani Bafton, noftrates 12 agelarups/folent appellare.

Quamvis autem Caryophylliferæa arbores propter folum fructum fuum colantur, $\&$ xftimentur, eft tamen, $\&$ in foliis, $\&$ in floribus ramulifque, quin $\&$ in gummi quod fundunt, egregia vis Aromatica, $\&$ ad medicinam apta. Fructus potenter admodum calefacit $\&$ ficcat. Sapor fubamarus, $\&$ acris, viridi pariter ac maturo, fed imprimis ficcato. Quas autem facultates habeat, quibus ufibus in culina, in medicina, ferviat; fatis fuperque, \& proditum eft ab autoribus, \& notum mulierculis: Nolo itaque tuo abuti, Lector, otio. Vnum addam, licet probatione ulteriori haut indigeat, quantopere fpirituofis, $\mathbb{X}$ igneis fcateat partibus. Indi vendituri, aut vendita tradituri, biduo ante folent in horreis five Caryophyllorum conditoriis apponere magnum \& fatis capax vas, atque hoc replere aqua. Qux omnis brevi exhalans fubit in Caryophylla, \& ponderofiora reddit certo lucro; Quín invenitur fere Caryophyllon in tantum pondus auctum, quantum fuerat aqux appofitæ. Cujus experimenti noftratium aliqui hautignari, adulterium hoc facile \& lucrofum non femel imitati funt.

E floribus \& Caryophyllis adhuc viridibus Ind $x$ pariter ac Lufitan $x$ fomin $x$ deftil- 
lando elicitint aquam, vel fpiritum, mira odoris fuavitate fragrantem, \& cerebriaffecti. bus finguläri poteftate convenientem. Imprimis autem paralyféos ifti fpeciei Beriberizi dict $x, \dot{a}$ Bontio noftro accurate defcriptx. Quibus medendis ex iifdem etiam condita parant prxeftantiffima. Magnates infuper acetum ex infufione Caryophyllorum viridium parant, durabile valde, $\&$ cibis condiendis ac ventriculo roborando atque concoctioni promovendx aptiffimum. Achar id appellant. Plura quifquis defiderat ex arboris hujus indole, de fructuum ufu atque abufu, adeat Garciam ab Horto, \& Ludovicum Romanum, \& Maximilianum Tranfilvanum, potius, quam Arabes, \& Grxcos. Tanti enim nion funt qux Serapion autoritate Galeni de iis tradidit, quantumvis affeveranter ea, qux ignoravit, tanquam fifciviffet vel ipfe vel Galenus bene, prodiderit.

\section{A P V V T V I.}

\section{De Tsbinka-Popouá five Caryophyllo Spicato.}

C Aryophylli genus hoc alterum eft, vulgo inufitatum, quia, \& rarum, \& carum walde. Vocatur apud fuos Tshinka-Popoua', quafi dicas Caryophyllum dentarüm aut crifpatum. Ego fpiculatum vocavi, à fimilitudine, quam habet cum (pica, \& quia fpicx inftar è fummis ramorum furculis enafcitur. Noftrates appellant Caryo-

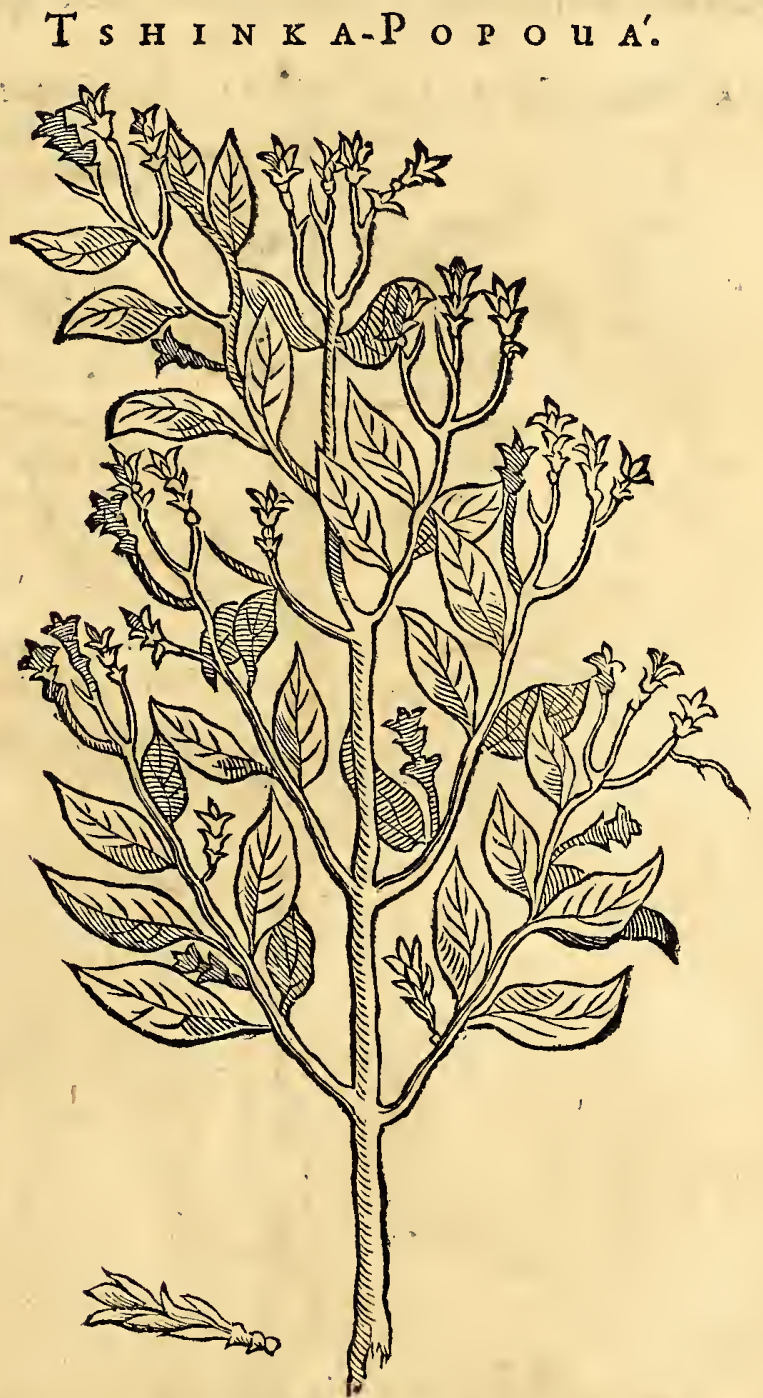

phyllum regium: quia Moluccenfibus Regulis, \& Magnatibus, ad fuperftitionem ufque in pretio eft, non tam ob guftum, \& fragrantiam, etfi eam præ cxteris habet excellentiorem, quam ob fingularem formam, imo raritatem fummam. Hactenus enim, prater unam \& alteram arborem, negant repertam ; \& quidem in fola Infula Makian, idque ante ullam violentam fuppre enarratam Caryophylliferarum arborum extirpationem 
180 $\therefore$ GVIIEIII PISONIS

obfervatum eft à plurimis prefecturam ibidem loci tenentibus, nec perfunctorie eas indagantibus. Quxitam egregii fructus raritas, \& arborum infrequentia, merito poffet dubitari, an ex inftituto Naturæ, an vero ex negligentia eorum qui ibidem loci vixerunt, judicari debeat; coque magis, cum fructus eorum five Caryophylla decidua in terram, fponte ibidem germinant. Arborum harum altera altera eft major, utraque tamen cæteris fupra defcriptis fimilis, excepta proceritate. Quantum vero Caryophylla hæc magnitudine difcrepent inter $f e$, ex appofitis utriufque fpeciei fructibus liquere poteft, quortum externa facies, ut'ex toto diverfa à præcedentibus, ita qualitatibus, \& $\mathrm{fa}$ cultatibus pollere iifdem, quibus priora, \& odor, \& fapor, perfuadent. Nihil ultra certi defunire eft, quia vocari in experimentum quotidianum nequeunt ob paucitatem.

\section{A P V T V I I.}

\section{De Lada, aliis Molanga, five Pipere Aromatico, Mare \& Fomina.}

$\mathrm{Q}$ Vam hactenus ignotum Caryophyllum fpicatum, vel Cannella Caryophyllata tam femper \& ubique gentium notum, \& familiari in ufu Piper fuit. Hoc non uno aliquo in loco, ceu de Cannella, deque Nuce Mofchata, atqueCaryophyllis jam notavimus, nec fua crefcit f́ponte, fed feritur omne, præter quoddam agrefte genus,

L A D a aliis $M \circ I A N$ G A five Piper $M A s$.

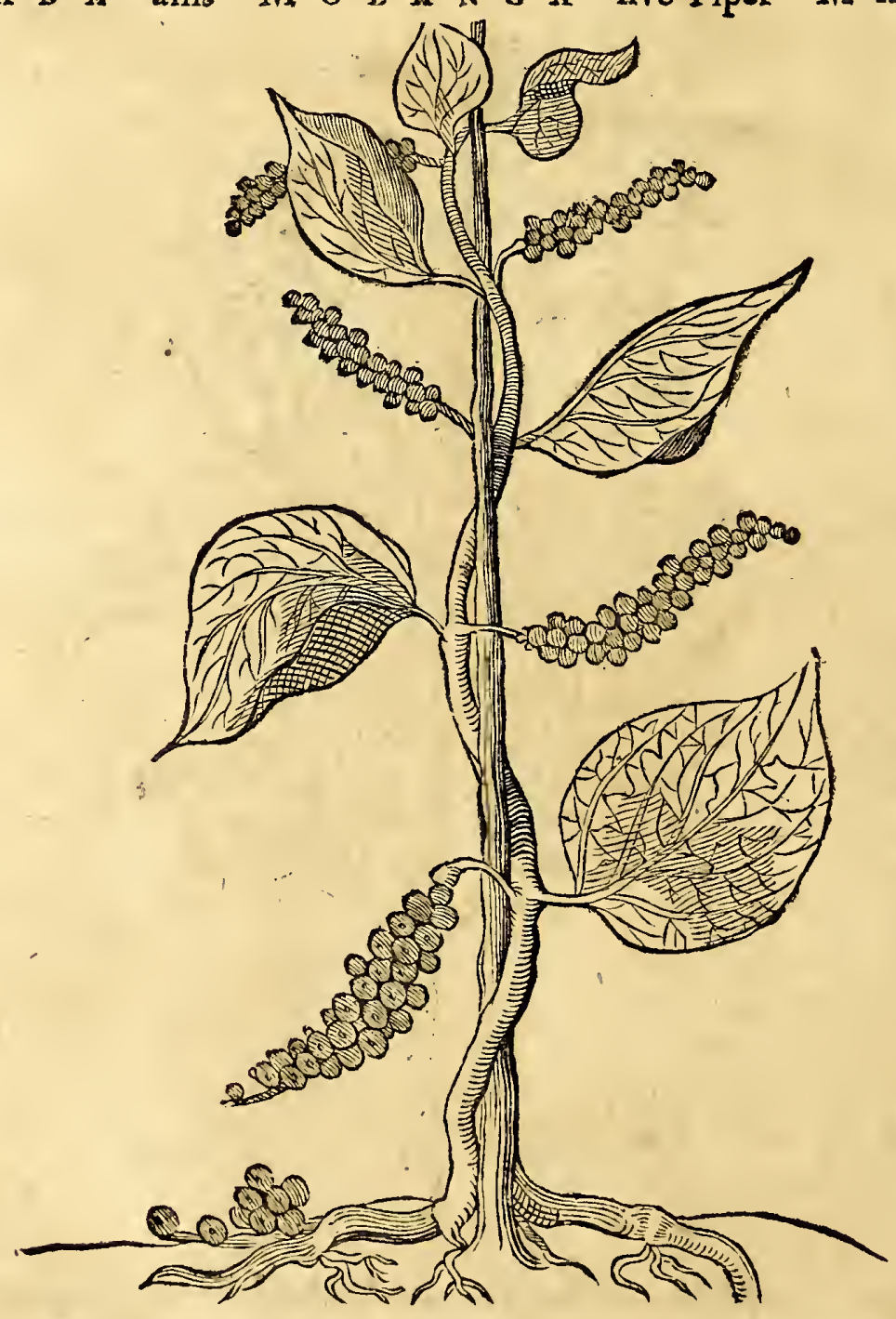

ignobile \& amarum. Quibufdam autem regionibus vix tantum redundat ex cultura," quantum ipfis Incolis fufficit : aliis vero locis, præcipue in Malaca, Iava \& Sumatra adeo luxuriar Piper hoc Aromaticum, ut inde per totum orbem diftrahatur. Licet au- 
L $\triangle D$ aliis $M O I A N G$ five Piper $F O E M I N A$

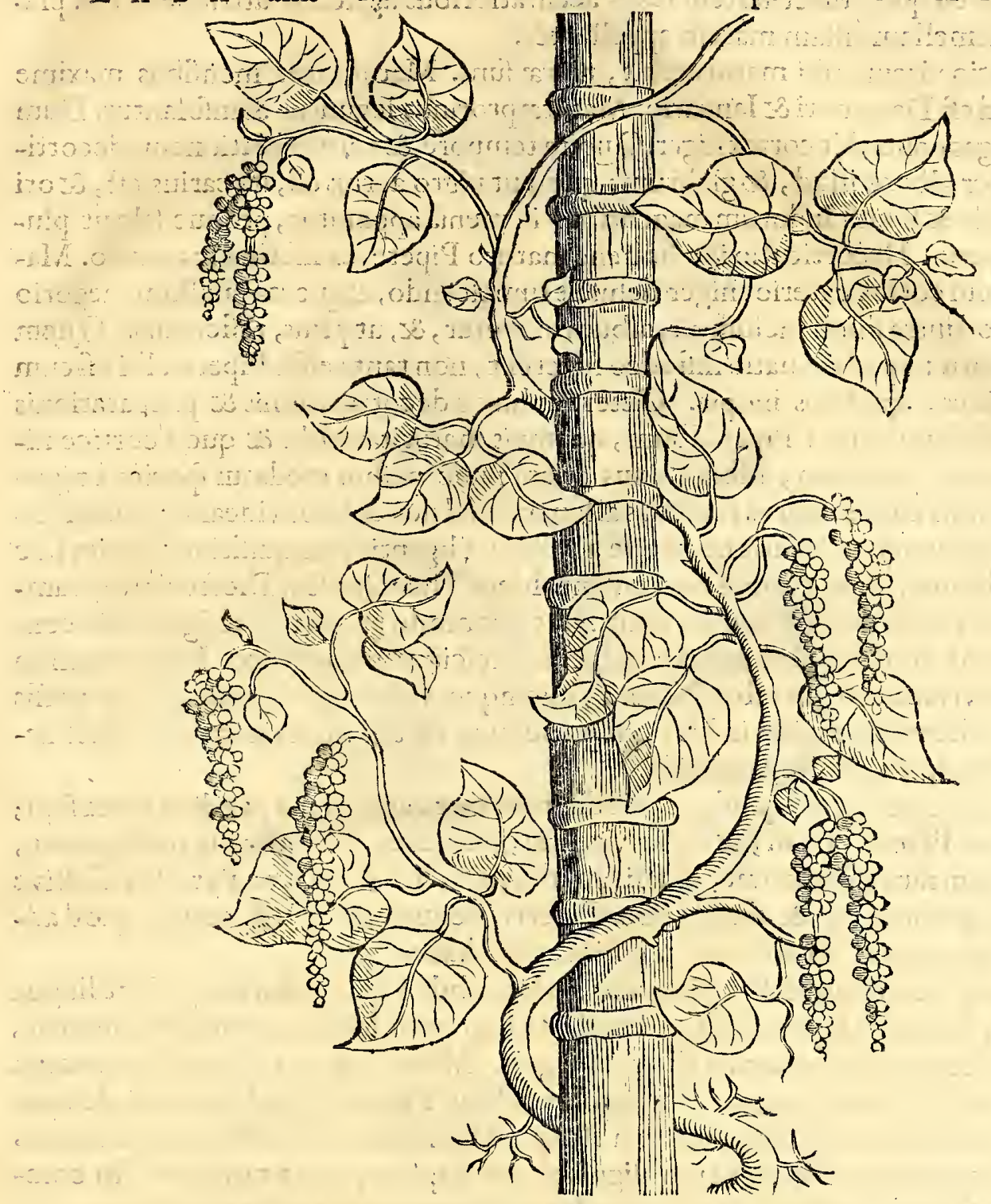

tem civilioris notx Indigenis rarior folet effe ufus Aromatum; nullum tamen inter omnia aque expetitum, nec condimentum illis videtur vel fanum vel gratum, nifi recipiat certam Piperis quantitatem. Adeo ut omnes qui eas terras piperiferas frequentarunt, facile plus in Indiis, quam in Europa confumi teftentur. Miflis itaque cæter is Piperis generibus qux India Occidental is profert (utpote de quibus ex profeflo egi in mea Hiftoria Naturali), communis potiffimum Piperis aromatici marem \& fominam exhibeo hoc capite. Seritur autem in Indiis non procul à mari, $\&$ ad radices arborum, pr $\mathfrak{x}$ fertim quas Faufel appellant, vel appofit is perticis, quibus adnititur more Vitis.Magnitudo ei par cum ea arbore, aut pédamento, cui advolvitur. Sxpe cum veterafcit, \& cineribus fumoque ftercoratur, excedit altitudinem fulcrorum fuorum, ur Lupuli inftar fe, cum fcandere altitis non poteft, demittat. Planta ipfa eft farmentofa, nodofa, lenta, $\&$ flexilis adeo, ut nifi inveniat, cui adnitatur, vel arborem vel aliud pedamentum, humi repat prorfus ut Lupulus falictarius, aut Phafeolus turcicus nobis dictus. Si fertili folo fata eft, intra annum dat fructum, eumque uberem. Si minus bona terra eft, ferius cum adolefcit tum fructificat. Fit $\& 2$ de anno in annum fertilior, minus, magis, pro foli genio. Terræfe infigit radice fibrofa, fibrifque parvis \& lentis, nec adeo Coft fimilibus, ut Diofcorides notat. Qua nodi funt, folia prodeunt multipliciordine ac $\mathrm{Na}$ turæ lufu: hærent autem petiolis longiufculis è ramis farmentofis quoque. Figura his, qualis hederaceis : alii Cordi malunt comparare; medio nervum habent, qui plures fibras apicem verfus exporrigat bififlas. Color exterius viridior ; interius dilutior eft. Fructus racemofus eft prorfus üt Ribes : fed racemo longiore, \& frequentio re, baccis, quaque ipfi fcapo fine aliquo petiolo adhæreant. Racemi ifti modo ex 
mediis farmentis, modo ex fummis dependent, ut ex hifce appofitis iconibus conffici datur. Vnde eft quod diverfitatem fexus accuratioribus agricolis attribuere illis placuit, hanc foemellam, illam marem appellantes.

Baccx initio virent; ubi maturuerint, nigrx funt. Maturantur menfibus maxime xftivis, quod eft Decembri \& Ianuario. Maturæ protinuis leguntur \& infolantur. Dum ficcantur, rugas contrahit cortex niger. Quo, in temporè, \& ante infolátionem, decorticato, fit Piper album illud, \& glabrum: quod ut nigro acrius eft, ita carius eft, \& ori gratius. Vnde \& folum Indorum magnatibus in menfa apponitur, proque fale ut plurimum ufurpatur. Decorticatio illa fit bene maturo Pipere, ex marina macerato. Maceratione enim cortex exterior niger dehifcit tumefcendo, atque ita facillimo negotio granum, quod intra illum includitur, album eximitur, \&, ut prius, reficcatur. Quem laborem laboris impatiens natio nifiadeo fugerent, non tanta effet Piperis albi, fi cum nigro compares, apud nos inopia. Cxterum hujus décorticationis $\&$ præparationis ignoratione factum, quod Piper album, quamvis maturitate folla \& quod cortice nigro rugofoque fit privatum, nihilominus etiam nunc paffim credatur fpecies à nigro diverfa, imprimis cum integros racemos aliquando ad nos delatos videant, perfuafi ficilicet hujus illiufve jejuna rclatione, neque adhibira diligentiore inquifitione, ftatim hoc literis tradiderunt, quod auribus accepiffent. Idem Theóphrafto, Diofcoridi, eorumque imitatori Plinio latuife non miramur. At quomodo etiam major ignoratio condonari poffit Arabibus, quiid \& bene potuerunt refcifcere, non video. Inhærere enim errori, quamvis vetufto, in rebus Nacuræ, quemque vel mediocri inquifitione poffis detegere, ca demum fupinitas in his, qui præfumunt de tali materia fcribere, \& fe fæpe jactant Cornicum oculos confixiffe.

Porro non baccæ folum, quod proprie dicitur Piper, acrimonia præditæ ignea funt; fed tota etiam Planta. Nam, \& folia virentia, farmenta, \& radix, fi mafticantur, prorfus linguam faucefque urunt, \& falivam movent, haud fecus ac Pyrethri Coftive radices. De qualitatibus $\&$ facultatibus. Piperis, deque ejus ufu $\&{ }^{\prime}$ abufu, quodaddam ad ea, quxe toties ab aliis funt repetita, nihil habeo.

Præter ante diata aliud eft Piperis genus, fed ignobile Piper, Canari appellant lingua Malabarica, à Canara loco natali. Id noftrati Fagopyro fimile, coloris eft cineritii, intus cavum, \& repletum granulis aliquót exiguis. Manducatum pari pene acrimonia cum prioribus, fed minus aromaticum deprehenditur. Ejus, nifi apud infimam plebem, nullus eft in Indiis ufus. Ea vilitas in caufa eft, quod non folum non deferatur ad exteras gentes; verum etiam noftrum nemo dignatus fuerit ipflus plantæ notitiam fibi comparare. Qux caufa, quod \& nos cogamur hic expectationem Lectoris deftituere.

Carolus Clufus, vir doctiffimus in Exoticis, meminit alicujus Piperis caudati, $\mathrm{Cu}-$ beb $x$ fimilis quidem, fed minus ufitati, quodque aliorum quandoque defectum fupplere apud fuos foleat. At enimvero, cum neque ille quid plenioris notitix habuerit, nec alii ex Indiis reduces quicquam de eo mihi communicaverint hactenus, cæetera pofteritati ulterius indaganda relinquo.

\section{$\begin{array}{llllllllll}C & A & P & V & T & \text { V I I I. }\end{array}$}

\section{De Timpilim five Pipere longo.}

$\mathrm{B}$ Engalcnfes Pimpilims nuncupant, quod nos, auctoritate Græcorum, Piper longum. Hujus in culina quidem nullus eft ufus: Frequens in medicamentis, præfertim theriacis aliifque confectionibus antidotis; \& merito ; virtutes enim non contemnendas obtinet. Vnde fortc \& pretium ei majus. Nobis hoc potiffimum dicendum, cujufccmodi plantæ fructus fit. Nam hoc à quoquam nefcimus dictum. Bengalenfium in terris frequens admodum eft, indeque ad Europam defertur, quod ibidem, \& latius crefcat, \& copiofius fructificet. Qua faciem tota, fi fructum excipis, fimillima eft Pipcri rotundo, nifi quod aut humi repat, aut perticis contenta fit non altis adniti. Quo magis mirari fubit, quid Garcix ab Horto fuerit in mente, fatis alias fedulo Naturx fcrutatori , cum fcriberet, longi Piperis plantam cum planta rotunpi haut plus habcre fimilitudinis, quam faba cum ovo. Sed ita eft, ex auditu habet, non autopfia. Crediditreferenti, \& deceptus eft. Interea hujus plantx folia funt utcunque 


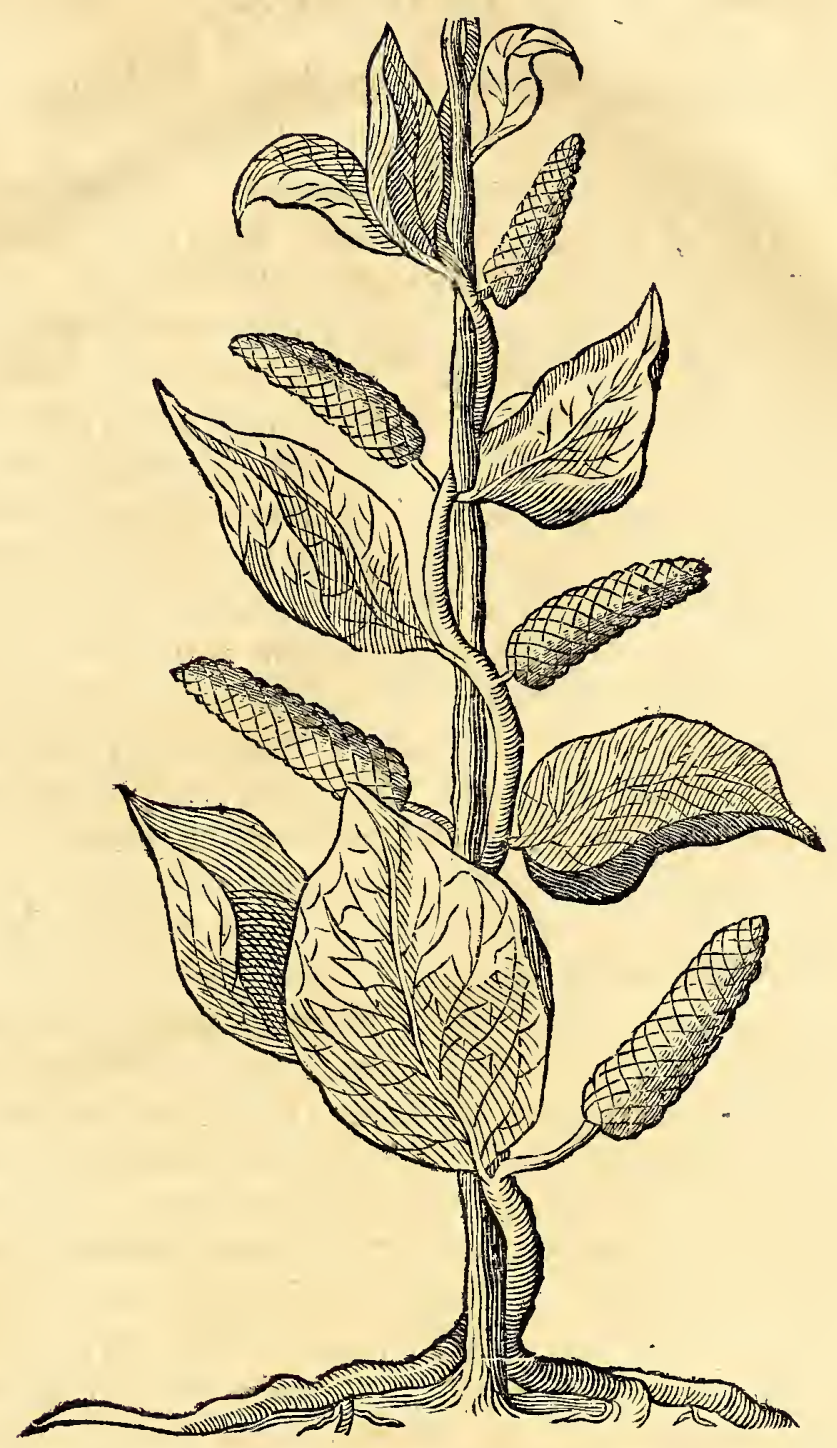

teneriora, \& virore faturato magis, ac breviore petiolo har entia. Cxtera eadem. Fructus, nucamentis aut iulis oblongis fimiles, ad fingulos articulos hinc inde ex adverfo foliorum enafcuntur, pendentque à mediocri petiolo. Sunt initio virides; poftea cum ficcantur, cinereum acquirunt colorem. Longitudo non omnibus una : etfi figura eadem , \& fimilis toto ductu difpofitio granulorum. Intra fcapum, cui granula jam diata inferuntur, aliquando plus humidi eft. Quo evanido caric exeduntur. Decerpuntur autem, $\&$ in ufum ficcantur, antequam maturefcant. Siccatum, etfi initio minus, poftea támen non minus rotundo urit palatum, fi vel leviter deguites. Optimx conditionis habetur id quod ponderofius, folidius, intus granis plenius, ac, fi in aqua decoctum aut plurimis diebus maceratum, minime diffluat.

Indi linimentis addunt; quibus adverfum dolores artuum à frigore utuntur ; $\&$ ita , ut bafis hoc Piper fit, corpufque addat Santalum rubrum. Vtuntur \& contra venena, vertigines, catarrhos, oculorumque nebulas, \& cum fucceffu. Quod \& Diofcorides teftatur, fic fatis alias infelix ipfius plantæ defcriptor. Verum de planta ex aliena fide haut dubie; de viribus ex multorum obfervatione teltatus eft. Indorum plebs adverfus diuturnam ftomachi languiditatem bibit aquam, cui infufa eft fatis bona Piperis copia. In eundem ufum quoque eliciunt è Pipere r ecenti f piritum mire igneum. V trumque,cum adhuc viret, Piper, longum æque ac rotundum, condiri muria aut aceto fol et, $\& z$ condi in penum ad ufum familiarem menfeque delicias. Quo loco vel imprimis habetur, cui quædam alia fimul adduntur Aromata, Achar nuncupant. Ejus ufus frequentior menfibus pluviofis, \& in phlegmatica corporis conftitutione. Sunt, qui maiunt virentibus integris racemis or e recepris ( ut nos ribefiis) baccas eo retinere, avulfo petiolo, \& parum mandere, \& folum glutire fuccum, utpote gratum guftu, \& fuavem, oblevem acrimoniam acerbitate quadam mixtam.

$$
\text { 22 } \quad \text { C A }
$$




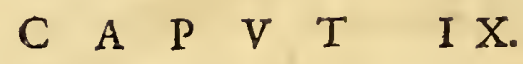 \\ De Aromatum enarratorum abufu Epilogus.}

$\mathrm{H}$

Actenus exfequutus fum, quæ ad hiftoriam pertinent quatuor Aromatum, cum in medicina, tum in culina, maxime ufualium. Sunt enim, præter ifta, multo plura, quibus vis, eaque non contemnenda, ineft Aromatica, nullum tamen, cui fit tam acris, aut nobilis, aut durabilis. Quid Pipere acrius? quid Cannella nobilius ? quid Caryophyllo, aut Nuce Mufcata, ejufve præfertim Maci, durabilius? Non repetam fingulorum dotes, utpote decantatiflimas, libris omnibus, \& commendatas laudibus, quas, non ratio dictaffe, fed admiratio videtur effudiffe potius: proinde unum atque alterum reftat, de quo tacendum non duxi, nec ita tamen loquendum, ut hoc me agere aliter quam in tranfitu voluiffe oftendam. Nam fi ex profeffo de abufu Aromatum velim differere, fateor me dicendi carceres videre, non metam.

Principio effe in confeffo arbitror, \& audias frepe eam apud nos querelam, majores noftros, \& firmiore ufos fanitate, \& vitam vixiffe longiorem. Nempe ita revera eft: Exas parentum debilior avis, tulit nos infirmiores, mox datura progeniem morbofiorem. Cujus effe caufas in rebus quærendas, quas Medici non-naturales vocant, uti dubium effe non poteft : ita inter eas vel præcipua eft victus mutata ratio. Qux, ur intelleximus, \& partim ipfi vidimus, majoribus erat parca, fimplex, dura; nobis vero, prodiga, dubia, mollis. Imo Apiciorum cœnas olim magis fuiffe molles quam fint hodierna, multis de caufis dubitari poffet. In cibis ipfis quam fulta, \& ad effominandum etiam optime natorum corpora potens! Quid non indies machinantur cupedinarii adverfus mortalium falutem, infatuando eorum palatum? quid non irritamentorum, ut fatuam rurfus linguam fapere cogant? fed inter vitæ illecebras hodiernas Aromata quoque in patrias menfas invecta funt. In dia nobis cum coepit fuas merces da$\mathrm{re}$, ut omnia divitiis implevit,fic multorum fanitatem corrupit. Quod ne gratis dixiffe videar, confideremus, utrum Aromata adeo humanæ naturæ conducant? quæ accipiuntur fcilicet, non è medicina ad neceffitatem, fed è culina ad prodigalitatem. Ita loquor : quia nullus dubito, quin æque nos atque majores noftri carere rebus iftis externis queamus : præfertim cum fatis condimentorum dederit natura noftri vicinique foli, qua licet non admodum numerofa, abunde tamen fufficere poffunt. Res dicit, quod Galenus, omne Aroma calidum effe, I I. de fac. Alim. xv: \& fubtilium partium, vir. de impl. fac. III. At qux ejufcemodi funt, facile fubeunt in corpus, fpiritumque incendunt, \& confumunt. Vnde eft, quod Galenus, \& bono quidem confilio, vir. de comp. fec. loc. 11. Arteriacis dictis confectionibus jubeat addi Aromata craffa ac integris partibus. nempene, quibus illæ compefcendis componuntur, concitandis fluxionibus evadant aptiores. Hippocrates maximus Medicorum nufpiam in cibum legituradmififfe Aromata. Vfus eft nunc hoc nunc illo cum in aliis quibufdam morbis, tum maxime in mulicbribus ; \& plerumque in fuffitibus, in fomentis, in externis; in potionibus vero, $\& 2$ raro admodum, \& parce. Sed $\&$ in iftis quam circumfpecte. Aph. v. 28. cum ad mulicbria educenda valere dixiffet fuffitum Aromatum: protinus addit, Sapius vero; $\&$ ad alia utilis effet, nif capitis gravedines induceret. Addit Galenus: 2uod omnia fere Aromata natura apta funt facere capitis dolorem, \& experientia oftendit \& ratio docet. Sed Hippocratem iter um audiamus, hxc nobis mala Aphor. v. 16. recenfentem. Calidum hac dat nocumensa iis, qui lape utuntur ; carnium effeminationem, nervorum impotentiam, mentis torporem, fanguinisfluxiones, animi defectiones : hac quibus mors. Tota autem talis concatenata fymptomatum fequela fe debet firituum languori, concoctionum cruditati, pituitæ, \&\& feri indics increfcentium multitudini, vifcerum atonix,$\&$ corruptelæ: una vero omnium caufa cft calidi calefactio, \& attenuatio nimia , \& nimis crebra. Exemplorum ad fidem Aphorifmi abunde poteft adferri, attende modo ad eos, qui fe negant vivere poffe, nedum preeffe rebus fitis, nifi aut venas mane medicato impleverint vino, aut ejus igne ( quem (piritum vocant) multis fxpe Aromatis ignito,fuum ignem, hefternæ cœ$n x$ cruditatibus obrutum, velut è cineribus excitaverint, quafi nocere multum nequeat, cujus parum, prodeffe, femel fibi paffi fint perfuaderi. Cum itaque jam intelleximus ex Galcno, \& res fit apud onanes confeffa, Aromata; \& calida efle, \& fubtilium

partium: 
partium; Neceffe igitur, ut $\&$ facile fumta incalefcant \& pervadant in fanguinem, eumque incendant, $\&$ urant non tantum, fed $\&$ f́piritum ejus jufto plus calefaciant $\&$ calefaciendo agitent, agitando attenuent, attenuando diflipent. Habet enim \& fpiritus fuum modum fubftantix. Intra quem nifi contineatur, fieri non poteft quin excedat, evadat, erumpat, pereat, \& poft fe corpus tam viribus enerve, quam cruditatibus graverelinquat. Atque ita quidem facere Aromata, ne dubitare quidem nos finit leucophlegmatia, virgineus pallor, \& febris alba dicta Medicis : Namque hos affectus fape aliofque foporofos, cum fenfus $\& 2$ motus depravatione, judicio devigefcente, \& memoria obliviofa, multis accidere ex Nucis Mufcatze frequentiore ufu, \& ipfi vidimus non femel, $\&$ alios vidiffe, probe fcimus. Quamobrem, cum eæ fint Aromatum facultates, \& calefaciant potenter, atque ita \& f piritum inflamment ac digerant, \& fanguinis nutritium fuccum ficcent, quis non merito fibi metuat ab eorum largiori ufu? Imo, quis neget recta à nobis ratione referri inter ea, qux nos noftris majoribus reddunt magis morbofos? Quafi Aromaticitas illa, quænon nifi intra Tropicos à Sole potentiffimo ex folida \& fitienti terra proveniens, nobis advenis, toto fere cælo inde remotis, quadraret potius, quam iis apud quos nafcuntur Aromata. Nam aut omnino illis non utuntur in cibo, aut crudis, $\&$ ob nimiam humiditatis aquofe copiam impotentioribus, aut parce admodum, $\&$ valetudinis duntaxat caufa. Neque enim negandum cenfeo, illius gratia quandoque recte fumi, five incidendo, \& attenuando phlegmati, five refiftendo putredini, five nutriendis fpiritibus deficientibus, id fiat, ficut in præcedentibus capitibus uniufcujufque Aromatis docuimus. Verum ut recte fumas definire non coquus debet, fed Medicus, feu verus humanæ falutis cuftos ; alias enim tutius foret ea in fubfidium vocare, qux eadem aut vicina fert tellus, quæ non dicam tulit nos, fed nutrit tam benigne, tam liberaliter. Europæi equidem quantum cxteris mundi populis excultiores habentur, fi tantum quoque iis temperatiores, \& 2 abftinentiores eflent, non plus inhiar ent longe petitis dapibus Indorum, quam illi noftratium. Quin non pauci Indiæ Orientalis \& Occidentalis Indigenæ haud fune ratione Europæor um iftuc adventantium intemperantiam deridentes, $\&$ incontinentiam culpantes, fibi congratulantur, quod fuis contenti bonis, tam fanitatis quam deliciarum ergo, fe fuftentent. Si enim opus eft calidis, quibus in corporibus frigidioribus cibi coquantur, quorfum temere ab Indis petimus, cum tot remedia fuccedanea, aromatica vi prædita, nobis dederit natura, quæ fingula fufficiunt? Sicut Campanella inter Italos , Beverovicius inter Batavos , in multcrum falutem fieri pofle probarunt. Imo predicta Aromata,ipfis licet medicamentis purgantibus indita, five palati \& ftomachioblectamento, five alterius qualifcunque neceffitatis caufa, fi tamen non exacta proportione refpondeant, parvaque indantur quantitate, folventium minuunt facultatem ; atque non minus fubftantia fua terreftria \&zftyptica occludunt denfantque, quam tenui $\&$ aërea aperiunt. Plura equidem huc poflent afferri argumenta, à quotidiana experientia defumta, quibus fuperiedeo. Qua enim hactenus dixi,non eo fine dicta funt, ut Aromatibus quicquam derogem, hoc enim. effet Naturam criminari , \& fimul fupra enarratis contradicere : fed ut nimis promifcuum abufum eradicem ex animis non guloforum, fed fux fatagentium fanitatis.

$$
\begin{array}{llllllll}
C & A & P & V & T & X
\end{array}
$$

\section{Arundines Mambu cum fuo Sacarfive Tabaxir.}

I Nter tot varix figuræ,$\&$ magnitudinis Arundines in incultis Indiarum regionibus luxuriantes, dux dantur fpecies Mambu, Lufitanis corrupte Bambu. Quarum altera minor intus magis farcta, altera multo major, \& minus repleta, ligni proceritate \& foliditate cæteras omnes antecellit ufque adeo, ut non mircr quofdam veteres $\&$ neotericos propter infignem illarum altitudinem hæfitantes, nunc arbores, nunc cannas appellaffe ; ficut $\&$ ipfe Garcias ab Horto eas Populo allimilavit. Fi rboref́centes itaque Arundines Mambu udofis locis fponte fia recta exfurgunt. Arte fubinde torquenturinter crefcendum, ut incurvatæ lecticis portatilibus aptiores fiant; pro bacillis quoque ad fulcienda Piperis farmenta in quotidiano funt ufu. Inferius femoris humani plus minus ftunt craffitiei (cujus ni fallor fragmentum exftat in porticu horti Academici Lugd. Batavorum) tantæque inter illas reperiuntur amplitudinis \& folidi23 זatis, 


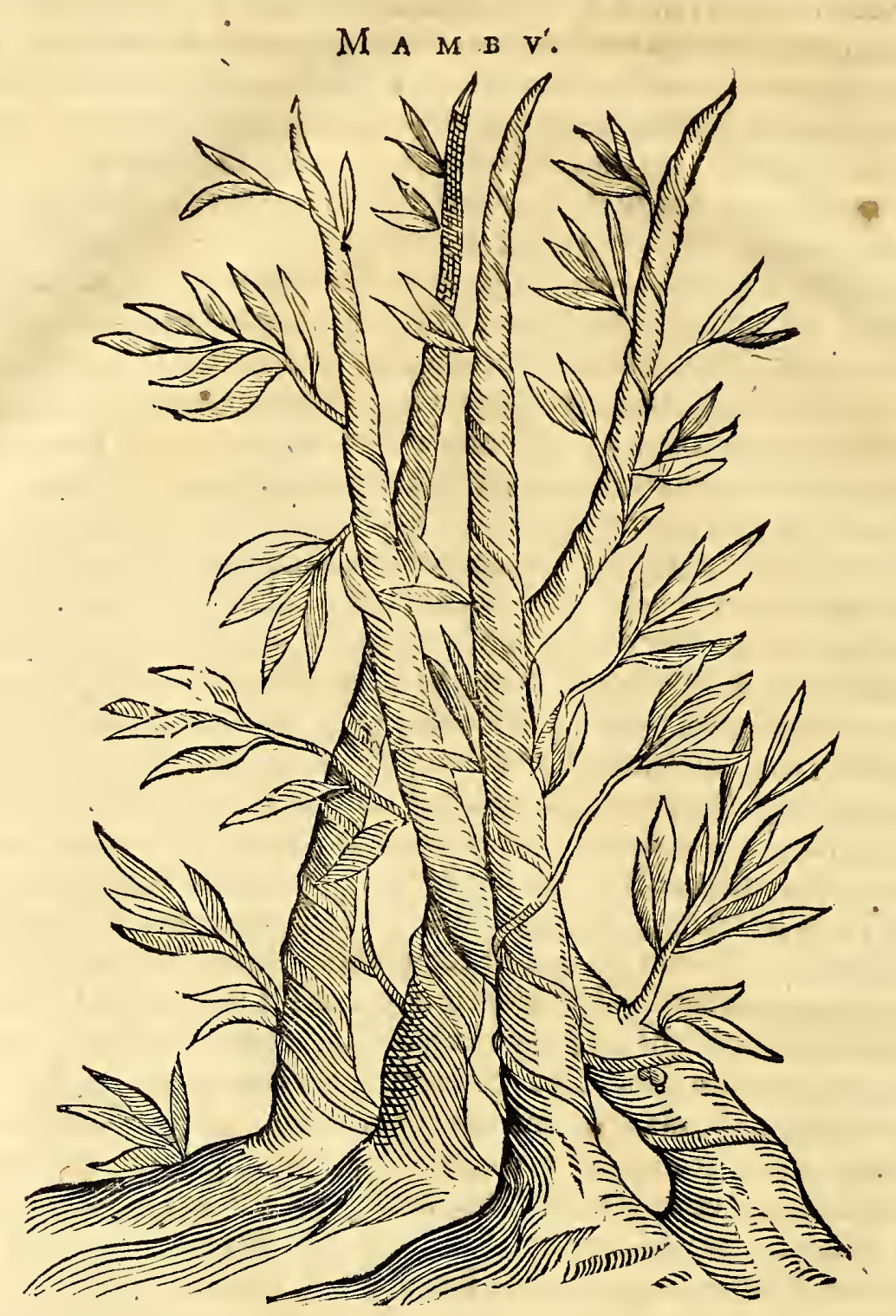

tatis, ut cymbx exinde parentur, exque non quidem excavatx, fed relictis folum duobus utrimque internodiis inferioribus per medium fectis. In harum extremitatibus bini Indi confidentes eas tanta dexteritate remis impellunt, ut rapiditatem fluminis facile fuperent. Ejufdem natura arundines Solinus videtur noviffe, quas his verbis expreffit: In Indie paluffribus arundo crafa progignitur, ut fffis internodisslembi vice vectitet navigantes. I pfius vero ligni five materix craffities trientem uncix fxpe fuperat, circumferentia . fexdecim, diameter aliquando quinque eft unciarum, unde ampla ejus capacitas facile poteft dijudicari, ideoque fubinde cannarum craffiores partes, vaforum loco mercibus vel aquis in longo itinere replent. Nodis perpetuis conftant (qui in adolefcentibus cannis hic depictis minus conf(picui funt) finguli ultra palmi longitudinem ab invicem diffiti, ex quibus rami emergunt utcunque erecti, fed arte aliquando incurvati, ut topiarii operis defectum fuppleant, ad evitandos diurnos xftus. Folia funt Olex figura, fed multo longiora, aliquando folitarie pofita, aliquando fibi oppofita. Ipfex autem Arundines Mambu adolefcentes medulla levi, fpongiofa, \& liquida (non adeo farcta ut vulgares cann $x$ faccharifer $x$ ) refert $x$ funt, quam vulgus grati faporis gratia avide exfugit. Novifimi autem ftolones qui maxime fucculenti funt, \& faporofi, magni fiunt in Indiis apud advenas æeque ac Indigenas, quod bafes fint celebris iftius compofitionis Achar diexx, qux in Europam invecta inter delicias habetur palatum doctis, $\&$ à me quoque non femel cum voluptate guftata. At vero, ubi arundines hx proce$\mathbf{r} x, \&$ annol $x$ factx fuerint, liquoris contenti fubftantia , color, fapor \& efficacia mutatur. (ficut in Nuce Coco adulta etiam fieri videmus) atque paulatim protruditur foras, \& juxta internodia vi Solis coagulatur, ac inftar pumicis albi indurefcit; mox nativæ fizavitatis expers facta, peculiarem faporem cum parva aftriatione, eboris ufti æmu- 
lum, acquirit, vocaturque apud Indigenas Sacar-Mambu. Qui quo levior, albicantior \& glabrior, eo praftantior; quo magis inæqualis atque cinerei coloris evadit, eo vilior habetur.

Rarior quidem ufus exiftit tam boni medicamenti in Indiarum maritimis habitatis, ubi Arundines hx luxuriant, idque duplicem ob caufam: primo, quod licet omnes liquore fuavi in principio fcateant ; fuccus tamen ille lapidelcens ad internodia, nec in omni arundine, nec in omni terra apparet, fed pro folis vi \&\&foli genio felicius vel infelicius producitur, ficut in oris Malabar \& Cormandel fieri conftat. Secundo, quia Arabes Medici \& Brachmanes vehementer appetant hoc medicaminis genus, \& care emant à Regulis fub quorum ditione crefcunt arundines hæx facarferæ. Prater Garciam ab Horto, $\measuredangle$ Hugonem Linfchotanum plurimi optimates nuper inde reduces, inregræque fidei viri,teftati funt, quod, licet pretium ejus ex anni fertilitate variet; tamen utcunque in Arabia pari argenti pondere divendi, idque potiffimum quia Medicorum tum Indorum, tum Arabum, Maurorum, Perfarum, Turcarum unanimi teftimonio $\&$ experientia conftat, externis $\&$ internis convenire ardoribus \& inflammationibus ut $\&$ dyfenteriis biliofis, fi trochifcorum vel potus forma exhibeantur. Indi ipfi contra Strangurias, Gonorrhœas \& Hæmorrhagias utuntur, magnumque putant caritatis officium noftratibus præetare, $f \mathrm{i}$ in fimili renum \& genitalium incendiis hoc Sacar-Mambu five Tabaxir, aqua diffolutum, largiter fuppeditent. Plura Arabes \& Perfa huic Tabaxir attribuerunt, quibus fuperfedeo, ne videar iis inhærere qua longe petita, \& nobis incerta funt: adeoque fimul huic capiti finem imponerem : fed cum de nomine, \& natura veterum acrecentiorum Sacar \& Tabaxir, non folum fub medicorum filiis, fed $\&$ fub præftantiffimis totius Europæeruditis lis una atque altera hæreat, non abfonum fore putavi, fi rationibus, \& probatæ fidei virorum experientia, difcrepantes opiniones, qua poffibile conciliavero. Tabaxir itaque, è lingua Perfica defumtum, nihil aliud denotat, quam laclapidefcens : cum tamen placuit \& quibufdam fuperftitiofis Arabibus $\&$ Turcis, nihil aliud effe quam cinerem exuftum çannarum, vi venti inter fe confricatarum, \&z ignem exinde concipientium: adde, quod teftimoniis plurium, qui rem ex vero defcribunt, conftet trochifcos ex cineribus ejufntodi confectos, pro fuppofititio Tabaxir agnofci. Hunc interim errorem propagarunt Arabum interpretes Latini, $\mathcal{T}_{a-}$ baxir Spodium vertentes, utpote aliquam in eo qua ad guftum $\&$ vifum fimilitudinem cum ebore, cornu cervi ufto, animadvertentes: qui quam craffe impegerint, dilucide fane à Garcia, \& Clufio aliifque probatum eft. Proinde ut nos tales preternavigemus fcopulos, \& certum quid ftatuamus, confultins erit cum erudito Garcia in polterum Spodio five Tutia uti in medicamentis externis à Græcis defcriptis: noftrum autem hoc Sacar-Mambu five Tabaxir, in Arabum compofitionibus intus plerumque affumere.

Alter reftat diffolvendus nodus circa nomen, qualitatem \& ufum hujus concreti fucci, quod ipfi Indi Sacar lingua vernacula indigitant, idque non refpectu alicujus dulcedinis, fed quod à multis feculis apud Indigenas humor hic in nodis antiquarum cannarum concretus nomen Sacar obtinuir: poftea autem cum liquor vel mel cannx Saccharifer $x$ hodiern $x$ vi expreffus, \& igne coctus, in fubftantiam duram, fiecam, \& albam migraverit, videtur ad imitationem extern $x$ figur $x, \&$ nominis Sacar, nunc nomen Sacchari impofitum effe. Nam apud veteres Græecos, \& Romanos autores,apparet, nomine Sacchari nihil aliud eos voluiffe exprimere, quam id quod ex Plinii verbis 1. XI r. c. virr. colligere eft, Saccharum \& Arabia fert, fed landatius India. Eft autem mel in Arundinibus collectum, gummis modo candidum, \& fragile, ampliffima 2uucis Avellane magnitudine, ad Medicina tantum ufum. Quo etiam Galeni verba fpectare videntur, 1. 7 . fimpl. Medic. de Saccharo. Sacchar quod ex India atque felici Arabiaconvebitur, incalamis, ut aiunt, concrefcit \& ip ipum melliseft fpecies, minus certe noffrati dulce, fed affimiles ei vires obtinens, quod ad abfergendum, deficcandum, \&detergendum attinet. Ita ut ex hacmea enarratione, $\&$ interpretatione labefactata putem argumenta fummi noftri feculi viri $\mathrm{Cl}$. Salmafii, dicentis Sacar five Tabaxir ob defectum mellex dulcedinis non poffe fumi pro Saccharo antiquorum: nam præterquam quod Plinius mellis in arundinibus collecti, late fumpti,mentionem fecerit, ficit de lactis, \& aqux fontanæ dulcedine com. muniter loquimur; accedit, quod Arundinum harum Mambu primogenitus fuccus, ut dictum fupra, fuavis deprehendatur, licet poftea evanefcat. Multa veterum $\&$ neotericorum fuper hacre monumenta Mathiolus in Comm. Diofcorid. docte ponderavit \& 
dilucidavit, qux mex opinioni favent, folum in eo à doctifl. viro diffentiens, quod putarit, ex iifdem Arundinibus Saccharum emanaffe, è quibus vulgare noftrum exprimitur, eamque folum effe inter fe differ entiam, quod à Natura factum, fit noftrate fàctitio longe tenuius.$$
\text { C A P } \quad \text { V } \quad \text { T } \quad X \text { I. }
$$$$
\text { Arundo Rotang dicta. }
$$

A

D Arundines præftantiores, humanis quoque ufibus infervientes referenda eft $\& \mathrm{~h} x \mathrm{c}$, lingua vernacula Indorum Rotang diata, qux licet huc ex Indiis venalis afferatur, ut pro baculo vel fcipione inferviat, \& corrupte à Noftratibus Rotting appelletur, tamen in natali loco ftolones earum, grato quoque, ut Mambu, fucco tur-

$A R$ V N D O R O T A N G.

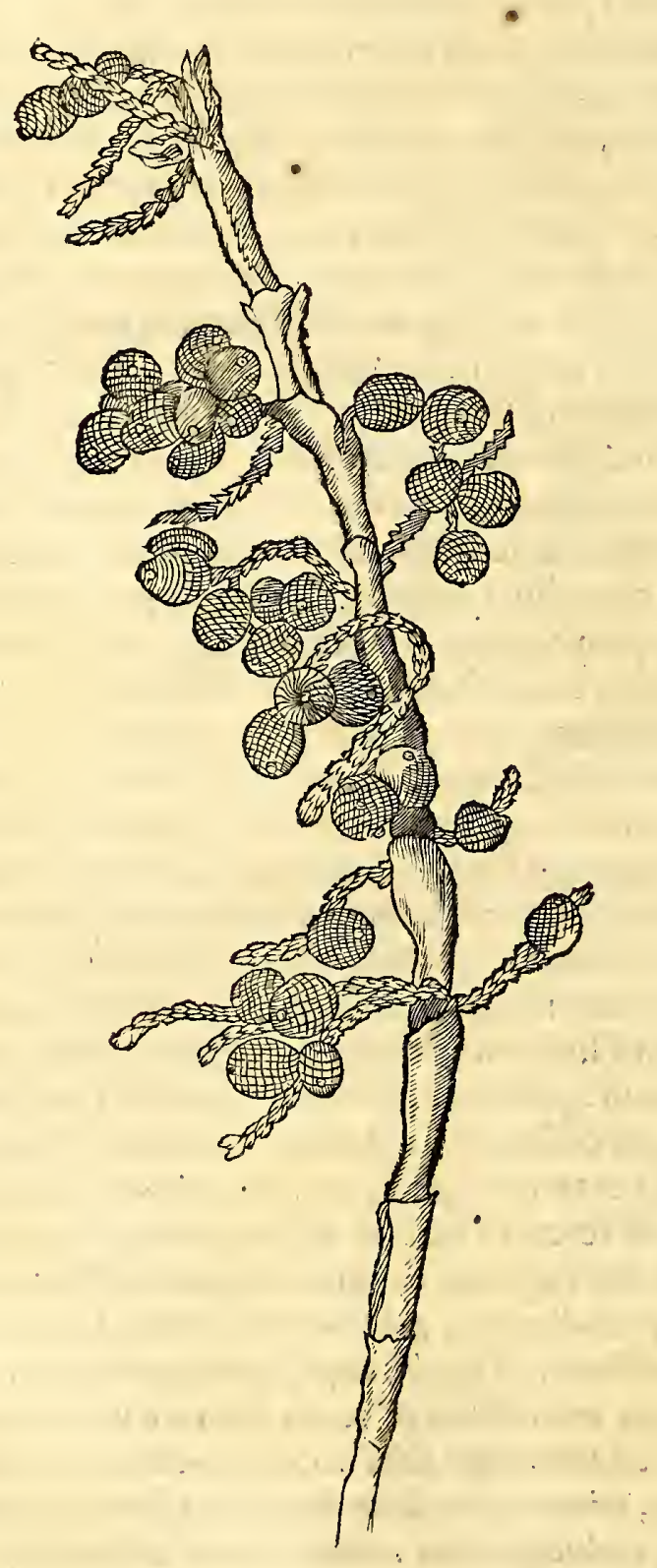
gidi, vel crudi manducantur vel condimento Achar toties enarrato induntur. $\mathrm{H} x$ minus concavæe funt quam CMambu, fed fubftantia fpongiofa, inftar herbæ ferulacex farcta. Baculi five furculi, fi poftea exficcati impetuofa manu collidantur, multas igneas fundunt fcintillas, inftar concuffi filicis, cujus defectum fupplere folent quibufdam Indis.

Crefcit paffim in filvis circa fluenta Arundinis hæc fpecies mirabilis, in omnem partem flexilis, eoque ad omnia liganda utilis: nam Incolæh hac Arundine funium loco utuntur, \& ædes fuas ex magnis Arundinibus conftructas, quas Bambous Lufitani vocant, iis loco clavorum ferreorum ligant, \& mireris tenacitatem hujus Arundinis, quxe crafftie digiti humani ferme cum fit, tamen in quatuor partes diffecatur, non fecus ac Salix aquatica apud nos, unde corbes \& cunæInfantium confarciuntur: in quem ufum ctiam hæ Arundines affumuntur: hinc $\&$ anchorarum funes à Iavanis in navibus conficiuntur, $\&$ fane longius durant in aqua falfa, quam funes, immo deficientibus funibus, nos is anchoras quantumlibet graves

ligamus. Atque ut verbo abfolvam, duo habet India ad vitam \& commoda hominum admodum neceffaria, nimirum, hanc plantam, \& Nucem, feu Palmam Indicam, Coquo Lufitanis dictam : fed hæc cum decantata fint ab aliis, ego fruftra opcram infumferim. Cærerum hoc Rotang, fructum talem fert, qualem depiEtum cernere eft, cumque edulem, \& faporificum, cum aciditate quadam grata, rotundum, parvæ pilx magnitudinis, tectum fpadicei coloris, putamine duriufculo, fragili, ftriis perpetuis cancellatis ornatum, ficut fere videre eft in calyce glan- 
dis quercinx. Ex fingulis arundinis nodis ad fummitatem ufque farmenta, funium modo contorta, \& tenacia, foliorum quafi loco emergunt, hifque fructus globulares, raro folitarie, frepe copulatim adnafcuntur. 'Nucleum porro intus ferunt durum, ex quo contufo extrahitur, \& exprimitur oleum, non edule folum, fed in medicamentis topicis, præfertim in ungendis nervis, fumme utile. Itaque, fi quid læfionis accefferit fervis, ex farmentis hujus arundinis, quibus flagellari folent, ejufdem fructus oleo. poffint fanari. Vt liceat iis dicere:

\section{- 2ui mibi vulnera fecit:}

Solus Acbilleo tollere more poteft.

$$
\text { C A P V T } \quad \text { T } X I I \text {. }
$$

\section{Zinziber, Indigenis Gingibil. Mas \& Fomina. atque Ga- langa, Lanquas dicta.}

Vm Bontius nofter Zinziberis, \& Galangx defcriptionem,ob inopinatam mortem, vix initiatam, \& plane mutilam reliquerit, adeoque pauca tantum de earum inter fe fimilitudine externa, \& interna, cum fola Zinziberis Icone inter adverfaria ejus repererim; ego partis mex effe putavi utrumque fudiofo Lectori exhibere

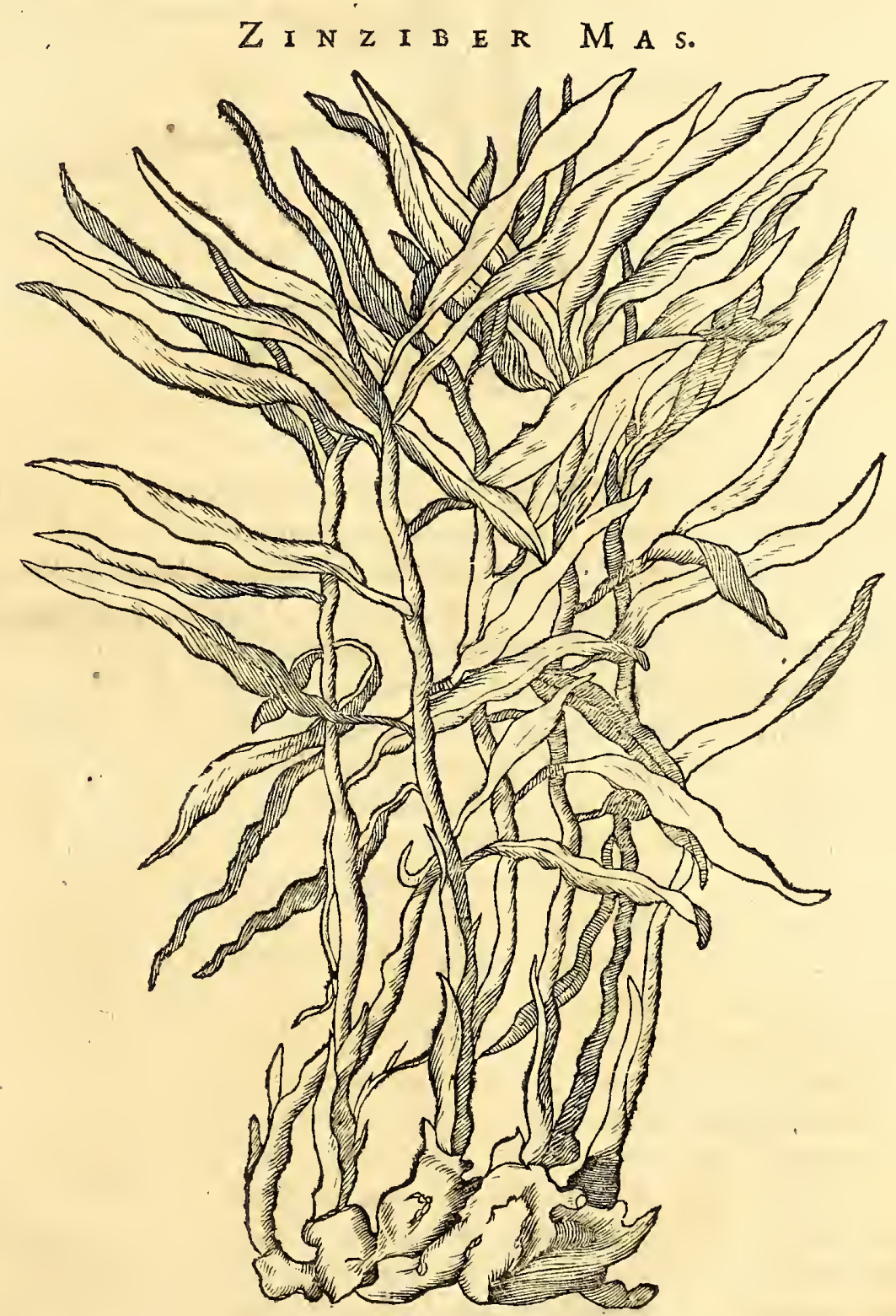

eaque finul addere qux ab exercitatiflimis viris, \& Chirurgis, ex Indiis redecincibus accepi; fimulque differentiam inter Orientale \& Occidentale Zinzibcr ob oculos po. nere: ut inde clarius elucefcat, quod Zinziber, licec inter ea numerandum fit Aromata, 


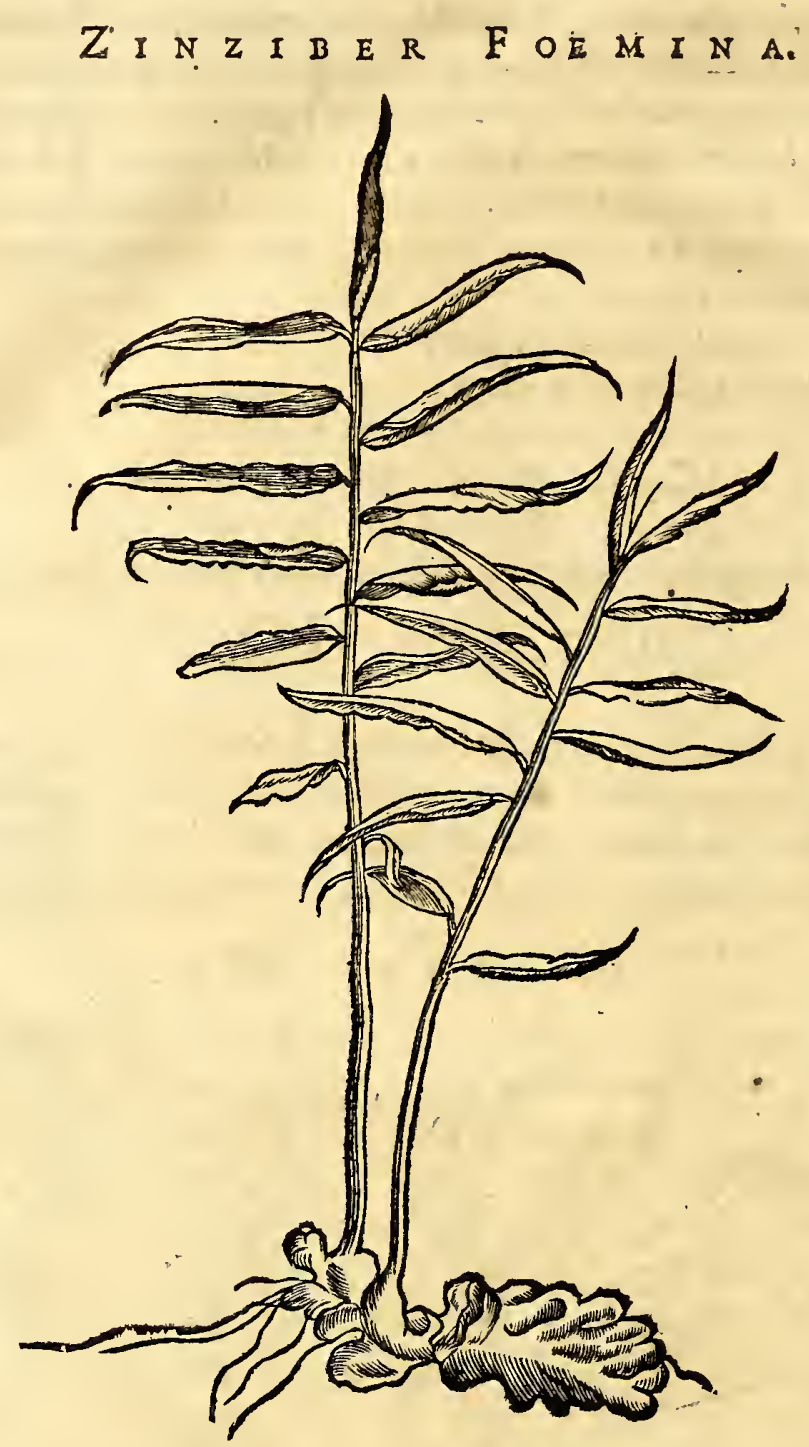

qux utriufque Indix folum $\&$ folem haud difficile admittat ; tamen, qua ad externam faciem, \& internam virtutem, aliqualem difcrcpantiam pro perpetuo Naturx lufu præ fe ferat. Optimæ notæ, \& maxime ufualis, eft Malavaricum, $\&$ Bengalenfe, cui Molucenfe fuccedit. Loca maritima, ut fere omnia Aromata, non mediterranea amat. Licet autem Chinenfes, aliique Indi Orientales, inter olera Zinziber plantare confuerint, tamen filveftribus quoque locis f ponte, vilioris licet notæ, crefcit. Quod vix memini in Indiis Occidentalibus obfervatum effe; unde hanc plantam hifce potius Indiis nativam crediderim. Duo genera effe perhibent Incolæ; maris filicet, \& fœminæ: quarum hæc foliis $\&$ radicibus eft minoribus, illa vero majoribus confpicitur. Folia admodum fimilia funt foliis Arundinum, ut qui nunquam viderit crefcentem hanc plantam, Arundinetum vere dixerit, quod primum è terra furgit : in qua comparatione Bontius à Garcia difcrepat, qui Iridis non Arundinis fimilia effe ftatuit. Sed variant Auctores, etiam ii, qui ex Indiis reduces funt, circa foliorum figu$\mathrm{ram}$, five ob territorii diverfitatem, five, quod alii marem, alii fominam Zinziber viderint. Nam maris hujus folia non ultra tres pedes excrefcunt in altitudinem. Afpera funt, unico nervo recto, in longitudinem excurrente, confpicua; caulibus hinc inde fine pediculo, inferius folitarie, fuperius frequentiori coma adnata. Radices diverfi funt ponderis, \& amplitudinis; omnes tamen imbelles, \& tuberof $x$, atque in fuperficie terr $x$ ficut Arundineta, expanfx. Quarum unum atque alterum internodium in fcrobe reliAtum, terraque aggeftum, loco feminis ftercoratur, \& ftatim à fatu aqua dulci plus minus pro terræ ficcitate rigatum, proximo anno à fatione fructus eruitur, qui eft regerminata radix, ipfum f́ilicet $Z$ inziber. Vindemia illius fit arefcentibus foliis, quod eft media xftate, fcilicet Decembri, \& Ianuario. Radices recentes minus fervent, ob prædominium humiditatis; paulo ficcat $x$, limo obducuntur, ne, evanefcente nativa humiditate, teredine, cui alias maxime obnoxire funt, afficiantur. Vt condiantur, prius de- 
corticantur, moxque in muria vel aceto conjiciuntur $\&$ macerantur per horam unam atque alteram, dein xquali fere temporis momento fub dio probe infolantur, ac denuo ftragulis fub tecto cooperiuntur, donec omnis humiditas exhalaverit. Si aliunde transferend $x$ fint radices, tunc, thecis inclufx, \& aqua irrigat $x$, noctu terra operiuntur, interdiu cxlo patent. His omnibus rite inftitutis ab exercitato agricola, poftea faccharo non folum, fed muria vel aceto condiuntur, nulloque tunc infigni calore palatum afficiunt, nec filamenta ulla ingrata in or e relinquunt. Si nimio tamen mangonio nimiifvelotionibus fatigentur, pars quoqủe aromaticæ ejus acrimoniæ evanefcit. Quo ad qualitates; Piperi refpondet, fed craffioris eft fubftantix, ut docte ex Galeni monumentis, \& propria experientia probavit Mathiolus in Diofcoridem, quo Lectorem remitto.

Præterquam quod recens Zinziber fativum Indigenis inter olera ufurpatur, remedio illis eft quoque præftantifimo ad Colicos dolores, Cœliacam ac Lienteriacam paffiones; Diarrhœas diurturnas ex frigore natas, flatus, ventrifque tormina, \& gravia his fi. milia accidentia, ut multoties in Indiis fe feliciter comprobaffe teftatur ipfe Bontius, aliique Medici exercitati. Ea tamen perpetua adhibita cautela, ut qui fanguine funt fervidiore five fani five agri parciffime eo utantur, quia Zinziber fere omne, fanguinem accendit, \&orificia venarum aperit.

\section{E $\quad G \quad A \quad L \quad A \quad N \quad G$ A.}

$\mathrm{Q}$ Vantum attinet ad Galangam,eam hic fubjungere conducit, quia foliorum facie, \& radicis qualitate, multum fibi fimiles funt, licet Zinziberis radix albefcat, Galanga autem fubrufa fit, tum internodiis pluribus inter fe diftinguatur. Duo ejus genera, majus, \& minus, ab autoribus defcribuntur, nos tamen radicem majorem folam exhibemus, utpote Zinziberi foliorum figura, \& qualitate radicis, magis vicinam; licet Neoterici de vera Galanga inter fe haud conveniant, partim quod Græcis incognita, \& Arabibus minus perfpecta fuerit, partim quod Batavi \& Lufitani reduces ex lava (ubi plurimum luxuriat Galanga) nimis negligenter eam obfervarint. Seritur radice fua ut Zinziber, eodemque fere modo excolitur, \& fummoperefe propagat. Caules arundinacei ad Zinziberis fere altitudinem exurgunt. Folia, longa, mucronata, fuperius fature, inferius dilute viridia. Flores albiçantes inodori, femen fatuum. Radix craffa, tuberofa, rufefcens, Zinziberis radice major. Illa porro ad omnia utilis, ad qux Zinzi. ber, atque eodem modo quoque condiri folet; quod genus condituræ Achar vocari aliquoties diximus, ac magnus ejus ufus eft in bellariis ad orexin excitandam, non fecus, ac cappares, \& olex fructus apud Europæos. Recens vero utriufque dictorum Aromatum radix, in taleolas diffecta, cum carnibus pifcibufque coquitur in eundem nem. Sic quoque cruda, fale $\&$ aceto $\&$ oleo infperfa, cum pifcibus, $\&$ carnibus affis commode editur ad juvandam concoctionem. Malabarenfes $\&$ lavani eam, non folum contra hominum, fed \& jumentorum mala frigida, magni faciunt, quoquo modo præparatam. Polentas, ex farina radicis confectas, in frequenti ufu habent, quas cum fucco Nucum Cocos praparant, atque, teftibus Bontio, \& A cofta, contra uteri \& veficæ mala exhibent. Sed quid diutius hæream in elogiis harum præftantiffimarum radicum, quarum ufus jam pridem toti mundo innotuit ? Cum hujus inftituti potius fit, aliquod exoticum, minus hactenus cognitum, in fcenam producere.

\section{A P V \\ Iambos.}

$I^{N}$ Nter nobiles, \& familiares arbores fructiferas, à Bontio noftro neglectas, eft illa cui Indigenæà fructu fuo nomen lambos indiderunt. Vnde Lufitani corrupte Iambeiro, Arabes acPerfx Tuphat, Turcæ Alma nominarunt. Ejus indoles à Garcia ab Horto aliifque recentioribus eum fequentibus tradita eft; ac proinde, cum pleraque illa qux mihi à rerum Indicarum peritis fippeditata funt, ex parte conveniant cum prædictis autoribus, hæc leviori penicillo attingenda, \& pauca tantum cum genuina ejus icone ad vivum expreffa addenda putavi. Arborum harum dux reperiuntur pecies fibi fimillimæ , fructibus nonnihil difcrepantes, utraque ut forma \& figura, ita 8 magniiudine Malum Europæam æmulatur, nec culturam, nec peculiarem terræ genium 


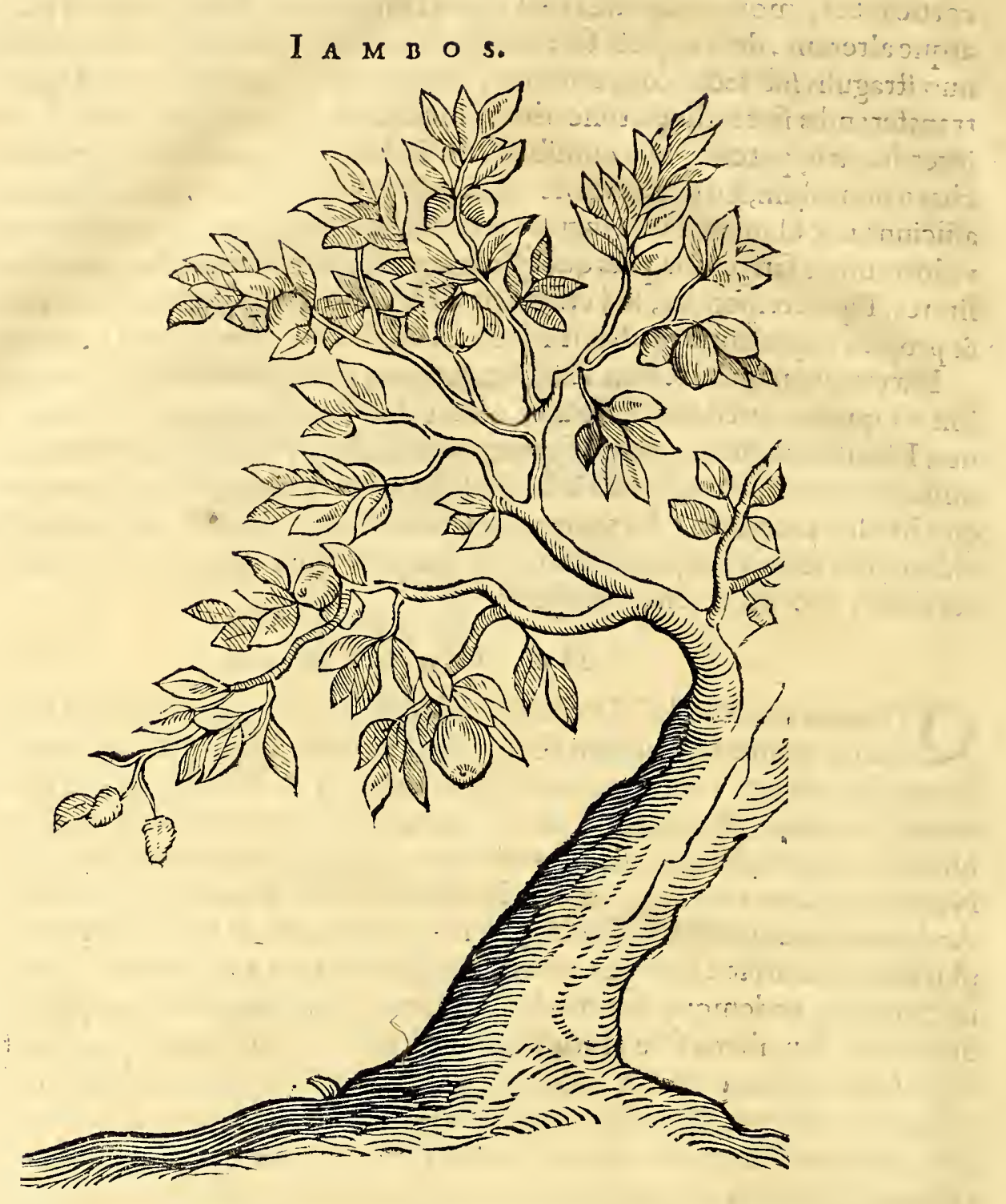

poftulat, fedmultis Indiarum locis adeo feliciter arte vel fponte provenit, ut fape ante quintum annum fructificet, \&, quod raro videtur in Indiis, profunde radices in terram exerat. Ex Malaca Piperifera in diffitas quafque regiones ob florum fragrantiam, \& fructus fravitatem, tranflatam ferunt. Arbor eft patula, ramofa $\&$ frondofa. cortice cinereo, glabro, ligno fragili. Folia Pruni magnitudinis ; in extremitate magis acuminata, exterius fature, interne dilute viridia apparent, nervo unico craffo recto, venulis obliquis in medio prædita. Flores rofacei odoris \& coloris, fed magis variegati cum multis ftaminulis in umbilico pulchre nitentibus, qui vinofo fapore quafi ipfius fructus præludium exhibent. Quippe pulpa illi eft fucculenta, mollis, optimi odoris, \& faporis. Horum fructuum Garcias diverfas effe fpecies putavit, alii majores fature rubri , minoris mali Cydonii figurx \& magnitudinis exiftunt, tenuiffima pellicula fplendente veftiti, atque vix quicquam lapidei infe continentes: alii minores ex pallido purpurafcentes lapidem tenent compreflum, oblongum, albicantem.

$H x$ arbores funt ex numero earum, qux pulcherrima florum, \& fructuum varietate advenas in admirationem rapere folent, non ob gratum folum afpectum, fed imprimis ob perpetuam florum, \& fructuum vicifitudinem, quod in altera arboris medietate frondibus \& floribus orba, altera pars fructibus maturis, \& immaturis tam diu oneretur, \& ornetur, donec frondes recuperaverit; ita ut in iis, perpetuo tempore vernali atque fimul autumnali frui conceffum fit; quod $N$ atur $x$ beneficium ipfe quoque in plurimis Americx arborum fructibus fxpe in folatium xgrotantium expertus fum.

Flores \& fructus Iambos frigid $\&$ humid $x$ funt qualitatis, infigniter fragrantes, ac proinde inter primas delicias omnibus pariter incolis habiti : plurimi quoque ufus paffin in Medicina exiftunt. Fructus enim crudi \& flores faccharo conditi, ab xftuan- 
MANTISSA AROMATICA. tibus æegris cum fucceffu ufurpantur, quod fuccofa frigiditate fitim in febribus exftinguant, ipiritufque vitales confortent.

\section{A P Y T XIV.}

\section{Arbor Acajú, vulgo Cajú.}

$S$

Vpra monui, quxedam vegetabilia, \& fenfitiva, alicui tantum Indiarum Regioni propria ; aliqua vero utrifque Indiis, inter Tropicos fitis, communia effe. Qux particulatim recenfere, nimis operofum foret. Inter ea qux pofterioris ordinis funt, non infimum locum tenet umbrofa \& patula arbor Acajü; à veteribus omni-

A C A I $v^{\prime}$.

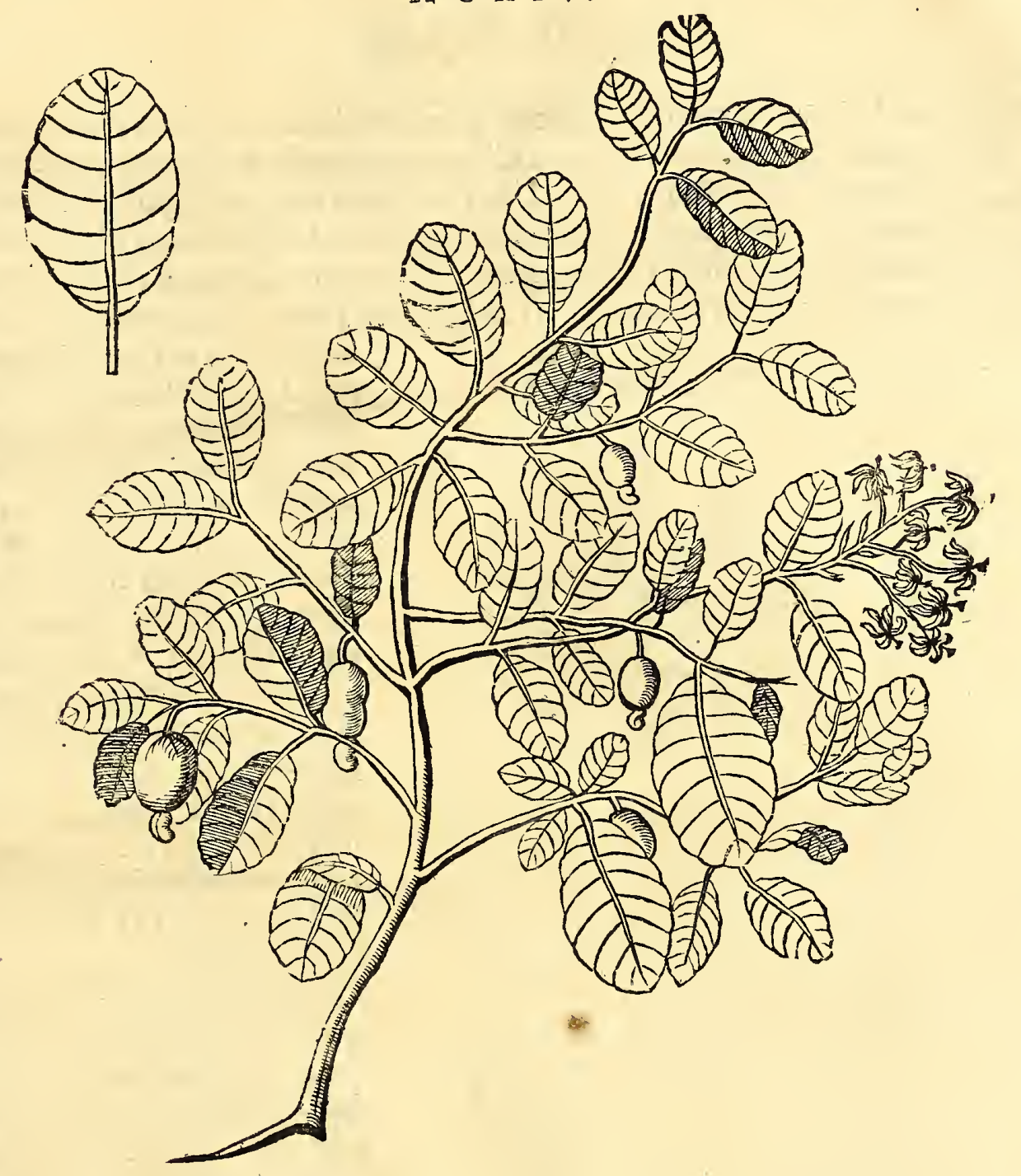

bus, ni fallor, neglecta vel incognita. Malus hrec femel tantum in anno, fed per multos menfes, eofque maxime xftivos, fructificat, quxque pro vicinitate, vel remotione ab $\mathbb{E}$.. quatore, tardius vel citius deficit.Non autem, ut alix plurim $x$, bifera aut trifera unquam inventa fuit, ficut in hiftoria mea Americx Naturali probavi, ubi naturam, ufum, \& noxam graphice fatis me depinxiffe puto ; ideoque iftuc Lectorem remitto, cum arborem hanc Acaju Orientalem, ab Occidentali vix quicquam difcrepare animadverti;ea enim cum facilis fit migrationis, atque ex fola glande fructus (utpote femine deftituti) terræ licet fitienti immiffa germinet; \& cum nomen quoque vernaculum Acajú retineat in Indiis Orientalibus, vix dubium eft, quin ex Brafilia iftuc tranflata fit; accedit, guod in natalifua terra, \& non alibi, filvas integras circa habitata litoralia conficiat, frondibufque fuis gratiffimam umbram; fructibus vero glandiferis perpetuum penu Indigenis fuppeditet. Quantum ad fructus eorumque glandes, hx toft $x$, illi crudi,non in minori pretio Afiaticis quam Americanis habentur. In folo apparatu, quautum refci- 
feere potui, inter fe difcrepant. Scilicet gens liæc magis cicurata fructuum horum annatam aftrictionem cum aufteritate conjunctam, gulæque minus abblandientem, licet ventriculo proficuam, vino \& fale obtundere fol ent, adeoque, in illo condimento aliquandiu maceratos, cum voluptate comedunt $x$ ftuantes, quod fitim egregie reftinguant, naufeam tollant, $\&$ dejectum appetitum ventriculo reftituant. At vero annatæ glandes (à quibus ipf fructus incrementum fumunt fubftantiamque hauriunt, convertendo illud oleum non fecus, ac Anacardii oleum urens, in fuccum edulem, ) toft \& decorticatæ, pro bellariis ufurpantur : tum quoque ad Venerem excitandam Piftaciorum loco, quibus nec guftu nec dignitate cedunt, Magnatibus in frequenti ufu exiftunt.

\section{A P V T X V. Radix $\mathcal{X}$ inzin.}

$\mathrm{Q}$ Vemadmodum vixullibi terrarum, quantum quidem conftac, Nuces Aromaticæ, quam in Infula Banda; neque Caryophylli, nifi in Infulis Molucenfibss, fponte nafcuntur : Ita nullus in orbe locus hactenus innotuit, qui celebrem illam radicem Ninzin producit, quam Corea Regnum, fitum ad latitudinem Borealem circa quadraginta tres gradus. Nullus Belgarum eam crefcentem vidit, quia in mediterraneis tantum, ultraque ducentas leucas à mari diffitis locis proveniat; unde fit, ut varient

$R A D I X N I N Z I N$.

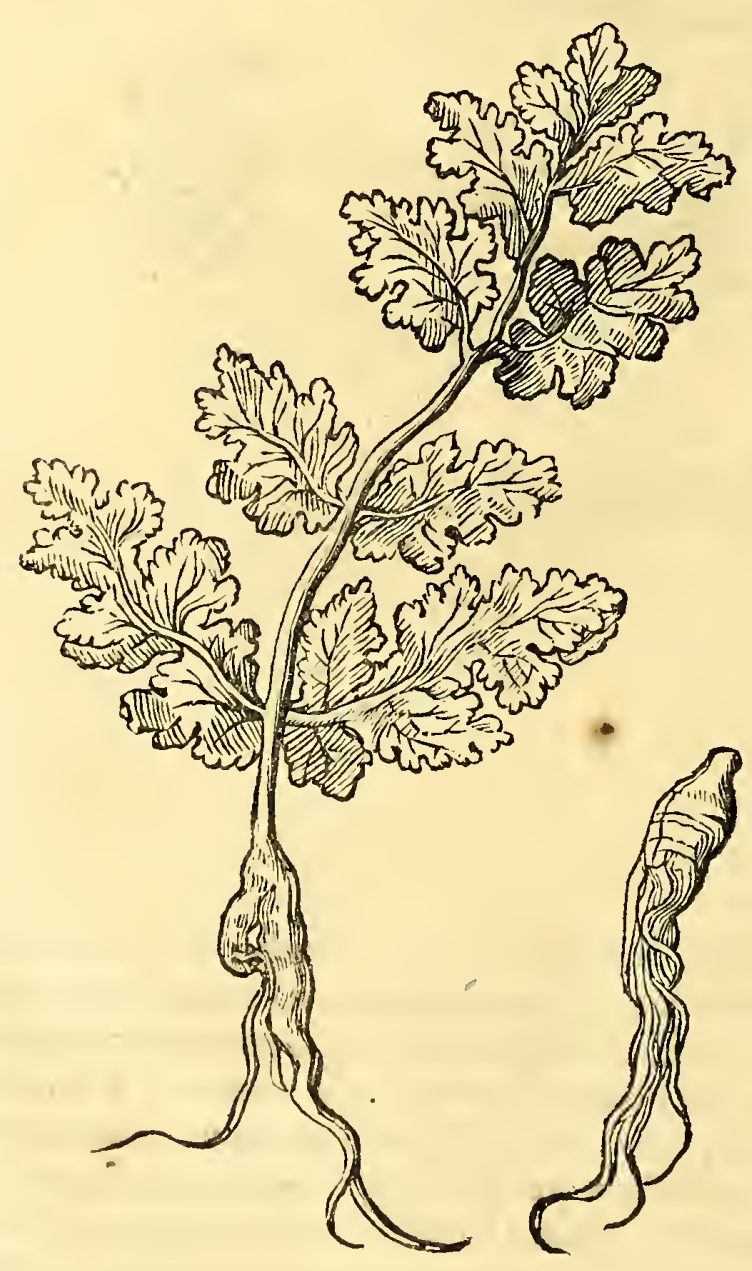

circa effigiem frondium, qua tamen foliis Paftinacarum fativarum noftratibus Geele-peen / fimiles funt : moles autem \& magnitudo ipfius radicis, Paftinacis multum cedit; ita ut in Iaponenfi terra ipfa Paftinaca; magnæ filveftris Ninzin nomen vulgo obtineat. Radix plant $x$, de qua nobis agendum, digiti eft longitudinis \& craffitiei, in fine filamentofa. Colore ex flavo albefcente, fapore fubdulci, non ingrato, pingui : cujus genuinam effigiem ope $\&$ favore Clariffimi 82 Amiciffimi viri Fr. de Vicq Lectori offero.

Hujus decantat $x$ Panacex ufus quotidianus eft, non folum apud incolas Regni Coree, fed \& Tarskinde, Chine, \& Iaponie, adeoque ad illam tanquam ad facram anchoram confugiunt. Qua tamen non femper fola \& fimplici utuntur, fed utcunque aliis remediis nativis mixta, manente Nizzin, compofitionis bafi. Illa autem medicamenta qux adduntur, $\mathrm{CO}_{-}$ ree incola celant \& tanquam ar canum fibi refervant. Quando autem animus eft oppugnaremagnos aliquos Naturx hoftes, ut motus Epilepticos, Vertigines, Spafmos, Hydropes, Lipothymias, Choleras, \& qua ejus farinæ porro exiftunt, tunc Medici robur addunt huic radici ex valido aliquo additamento pro vehiculo. At vero nullialteri mixta, omnibus languidioribus \& cachecticis non folum in ufu eft, fed eam, tanquam prafervans contra malignos \& venenatos affectus, domi forifque perpetuo ad manus habent; atque bis ter- 
ve de die exiguam particulam recentis radicis mafticant. Vnde mirifice virium reftaurationem, cordis refectionem omnes fe experiri teftantur.

Prolixior effe poffem in enarrandis dotibus hujus Ninzin, fi verbotenus fchedas medicinales ex lingua Iaponica à Præftantiflimo viro D. Caron, ibidem Prafecturam tenente, in vernaculam tranflatas, hic exhiberem. Sed malui contrahere ftylum, partim ne verborum ambagibus vel tautologiis Lectorem detinerem; partim, quod verear (ut fubinde animadverti fuperftitiofos Indos) nimium huic medicamento, tanquam labafcentis Natur $x$ foli reftauratori, tribui;ficut Chymicis fxpe \& Circulatoribus mulris ufu venire folet; qui qualecumque fere novum remedium, dum tanquam Panaceam. Natura, \& arcanum mundi venditanr, fibi xque ac profano vulgo imponere confueverunt ufque adeo, ut, fe fallere $\&$ falli, vix fentiant.

\section{A P V T X X I.}

\section{Polypodium Indicum.}

$\mathrm{V}$ Ir literacus, \& rei Medicxe addįus ex Indiis Orientalibus nuper redux, raram hanc \& eleganti afpectu plantam apportavit, cujus neque nomen, neque vires noverat: ideoque ego eam penficulatius tactu, vifu, \& guftu examinans, \& dein conferens cum Medicinx peritioribus, vix quicquam ab egregio illo \& raro Clufii Polypodio exotico difcre. parede prehendi. Quam cum ibidem paflim in filvisluxuriare, $\&$ ab advenis æque ac Indigenis magni fieri intelliger em, operæ pretium me facturum putavi, fi pofteritati ulterius indagandam offerrem. Bontius nofter, Polypodii Indici quoque mentionem fecir in catalogo herbarumfponteibidem nafcentium; verum morte præventus, defcriptionem atque ufum pollicitus eft, fed non prxftitit. Noftrum hơc Polypodium radice eft nigricante, obliqua, longa , craffa, hirta, ad modum Europxi Polypodii fumma tellure repente. Huic bina folia, aliquando plura, folida, firma filpernafcuntur, breviffimo pediculo à radice emergentia, etians aliquando eam tegentia, atque ftatim $a b$ exortu in latera fatis ornate fe fpargentia. Folia quercinis foliis amplioribus in novellis prafertim furculis natis, \& modice laciniatis, magnitudine \& forma fimillima funt: P $O$ O I I Y

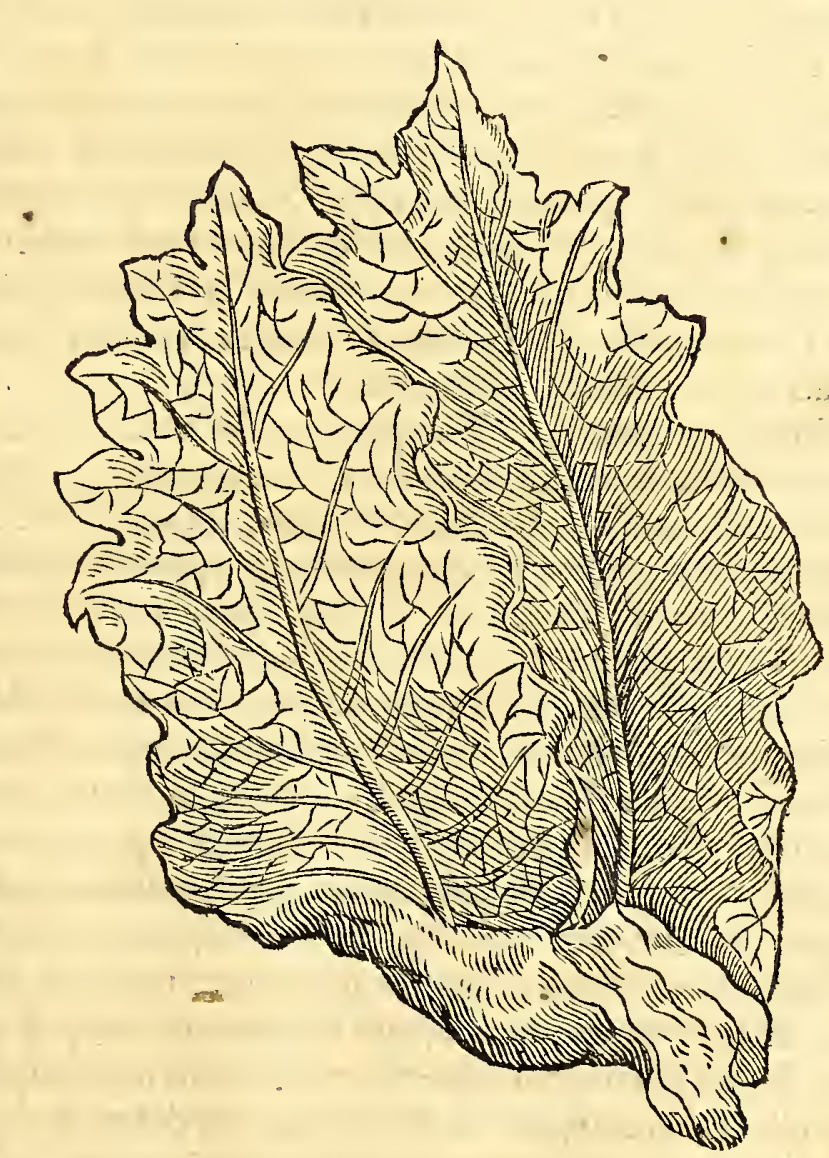
E medio nervo, prater morem craffo \& valido, foliorum longitudinem fecante, ficut coftx è fpina dorf, inordinate pofitx, furfum in latitudinem ufque ad extrema laciniarum extenfix, apparent. Inter quas multiplices venulæ, reticuli inftar contextæ, \& fefe invicem fecantes, excurrunt. Radix (in qua fola vis medicinalis hactenus deprehenfa fuit) recens evulfa fubdulcem vulgaris Polypodii faporem præ fe fert, cui admixta eft acrimonia quædam levis, quam vel ex regionis calidioris intemperie, vel ex veruftate forte contraxifle autumandum eft. Tifdem hoc ufibus, quibus noftratium dicatum eft Polypodium: quamobrem illius defcriptioni non inhxrebo. 


\section{A P P V T T X V II. De Chocolata Inda. .}

$\mathrm{C}$ $V m$ totus in eo effem, ut Mantiffx mex Aromaticx finem inpiponerem, conveniunt ecce cum Typographo nefcio quot Philiatri, fummopereque urgent, ut ne, priufquam de tabula manum, gravarer Operi adjungere egregios tractatus duos : nempe unum de Nuce Maldivix, ejufque infigni antidoto; alterum de Americana arbore Cacavifera, \& celebratiffimo ejus potu chocolata. Quod quidem eo difficilius à me impetrari fum paftus, quia non ignorabam exftare jam doctorum virorum de utraque illa materia monumenta, non perfunctorie tradita. Adeo ut jufta de caufa omnis mihi ablata videretur anfa gratificandi Artis noftr $x$ Symmyftis : eoque magis, quod haud multum in duobus his exocicis à me aliifque potuerit obfervari, quod non Cl. D. Augerius Clutius, urbis hujus, dum viveret, Practicus, opera $\&$ fama celebris circa Nucem Maldivienfem, \& Hifpani Medici circa potionem Chocolatam, jam ante attigerint.Itaque Clutii quidem trąctatum propter exemplarium diu defectum defideratum, denuo exhibeo; Hifpanorum vero aliquot, ut Antonii Herreræ, Iofephi d'Acofta, Francifc. Hernandez, Antonii de Ledefme, Antonii de Leon, Ioannis Carden $x$, Ioannis Barrii , aliorumque graviffimorum doctorum fparfas, \& plerafque in nova Hifpania confcriptas, animadverfiones, in ordinem atque in compendium Latino fermone coactas hic promo : eorumque Authorum, quorum laboribus adjutum me fuiffe lubens agnofco, idcirco nomina fubjicio, ut fidem meam liberem, \& gratum me praftem iis, à quibus ea, quxhicfequuntur, accepi. Qua noviffima mea opella, fi non reipublicx literariæ, faltem meis amicis, \& mihimet ipfi hoc fun gratificatus, quod, qux de effectibus utriufque hujus medicaminis enarro, eorum aliqua ipfe pericula fecerim, \& porro facienda atque indaganda nunc aliis proponam, \& $\&$ eum in finem, ut quifque per caufás perque fedulas ire prius experientias difcat, $\&$ vera à falfis difcernere, antequam judicium ferat de rebus hactenus minus fibi perfpectis. Licet aurem ftudiofe caverim, ne in eundem lapidem impingerem, tamen vereor, ne alicubi fimile quid acciderit; quare eandem veniam, quam aliis libenter concedo, viciffim ab xquis Lectoribus flagito.

Cuivis, vel mediocriter in gentium hiftoriis verfato, conftare fatis fuperque credo, quam nulla non earum, five culta, five inculta, qux vinum ignorant, præter potum fimplicem à Natura conceffum, etiam alium excogitaverit, non modo ad delicias, fed $\& x$ contra fitim. Americ $x$ certe pars maxima potiones fibi \& plures adinvenit, $\&$ familiares fecit, ex radicum fructuumve fuccis expreffis \& aqua diluris. Præ cæeteris autem tractus ejus Septentrionalis in potum fibi illum pracipue afcivit, qui in Hifpania nova, $\&$ Mexicana vicinifque terris, fermone quidem vernaculo Chocolatl, externo autem Chocolata, folet appellari, \& haberi in fummis deliciis: adeo ut Incol $x \&$ ipfi illum depereant ufque ad corruptionem fui, \& hofpitibus in teftimonium grati acceffus atque lingularis amicitix offerant: prorfus ut de Chinenfium, \& Iaponenfium Thé, five Chiá, fupra fum teftatus. Qui quidem in eo potiffimum ab aliarum nationum potu factitio difcrepat, quod nec uno modo, nec ex eifdem rebus componatur: fed modo ex his : modo ex illis feu floribus, feu feminibus aliifque plantarum partibus in farinam redactis. Chocoláta hac acieo Hifpani magifque Hifpanæ inefcantur, ut, poftquam, præfertim calid $x$, affueverint, fe fine illa negent poffe vivere, etiamfi initio afpernati fuerint. Vnde inirandum non eft, fi male coeperit audire potus tam deliciofus, prefertim à quo, qui ab indigenis olim minus compofitus ex folis humectantibus, \& nutrientibus, cum paucis quibufdam correctoriis parabatur, crefcente Hifpanorum aliorumque Europxorum luxu, \& ipfe copit excrefcere, \& ingredientibus Aromaticis ufque adco luxuriare, ut lafcivix potius fovendx fit, quam reftinguendx fiti. Quam ob caufam, \&, ut mili videtur, non prxter rationem exorta eft inter cordatiores Hifpanos controverfia non jejuna, An falvo Monachi jejunio concedi poffic potus ex pafta tam alimentaria , \& faporata atque aromatica confectus ? Quam litem componere non eft orii mei, neu falcem mittere in meffem Ecclefiafticam. Itaque eam D. Antonio de Lcon, qui prolixe utriufque partis argumenta ventilavit in libro quodam fuo Hifpanice confcripto, cui 
titulus eft, Queftion moral fi el Chocolate quebrarata el ayuno Ecclefaflico, decidendam relinquere malo, quam male ob periergiam audire. Interea, fi libere mihi, \& cum pacejejunantium, dicere fententiam licet, diçam hanc: videri omnes, qui ex Chocolata, quocunque fub pratextu bibunt, non abftinentix operam, fed ejus famx potius dare, $\&$ in jejunio delicias quærere, atque in numero haberi poffe eorum, quos Próper Aquitanicus lib. I I. cap. 23. de vita contemplativa defignat. Quotquot, inquit, parciores viderivolunt, \& gloriam fibivelut de abftinentia diftrictiore conquirunt, fic ab omnibus animalilibus judicant temperandum, ut peregrinis pomis ac forbitiunculis delicatis, caterijque aliis cibis, immanem fui corporis impleant appetitum.

Sed miffa digreffione, ad inftitutum redeo: bafin primo totius Chocolate, mox catera ingredientia examinaturus; quo Compofitionis univerfe fimul temperies atque facultates cum falubres, tum noxix, elucefcant. Quas omnino expedit fciviffe,propterea, quod non folum in Occidentalibus Indiis, quibus firos debet natales; fed \& per totam Italiam, \& Hifpaniam, \& utramque Germaniam, \& facta fit, \& frat indies magis ac magis familiaris, quin abire jam in varios abufus cœperit, variafque noxas dare, eoque nomine non paucos abftinere ab ufu etiam legitimo \& commendabili. Idcirco difpiciendum imprimis, ob eorum qux mifcentur diverfitatem, quid ad compofitionem requiratur ; quibus deinde conveniat; $\&$ quantum denique cuique fit ex ea pro natura viribus bibendum; adhoc, ut tam fanitati, quam gulæ fatisfiat. Qux ut clarius $\&$ explicari $\&$ intelligi queant, age, primo vires ingredientium videamus.

\section{$\begin{array}{lllllllllll}C & A & P & V & T & X & V & I & I & I\end{array}$ \\ De Arbore Cacavifera.}

$\mathrm{C}$ Acaviferas quas appellant arbores, in Hifpaniæ Novæ locis irriguis, \& præcipue in Guatimalx ac Nicaragux diftrictu uliginofo fponte luxuriant. Earum Mexicani Medici, alii quatuor, alii quinque conftituunt fpecies. Omnium interim fructus (quos vel imprimis convenit noviffe) ejufdem fere effe facultatis, ejufdemque ufus uno omnes ore Autores fatentur, non obftante, quod in ipfarum arborum, qua figuram, qua magnitudinem, defcriptione non admodum inter fe conveniant. Omnes naturx fint adeo delicat $x$, ut non modo alium foli genium afpernentur, fed in patrio ipfo ferendo non fint, aut frigus nocturnum, aut tempeftates ventorum, aut Solis etiam ardores. Vnde eft, quod ex, qux ex deciduis fructibus fponte germinant, nifi in vallibus umbrofis non appareant. Hinc illis ars, Naturx imitatrix, in feliciorem proventum docuit incolas, patulam \& umbrofam quandam arborem, quam idcirco Cacaoquanantbli, five matrem Cacavifer $x$ appellant, apponere; ut à creli injuriis ejus velut fub umbone tutiorfit ipfa Cacavifera. Facile fe cicurari patitur. Hifpani certe integra ex ipfis arboreta, \& plantant $\&$ colunt, non fecus ac in Europa vineta atque oliveta. A fecundo xtatis anno fructificat, \& quolibet anno bis. Vindemiatur enim primum, \& uberiore fructu, circa Iunium; iterum circa Ianuarium. Ab anno vigefimo devigefcit, \& fterilefcit. Hxc communia. Quod ad fpecies, Prima \& omnium maxima eft Cacava 2 iatbuitl dicta, quam mox dabimus. Huic proxima Mecacauntl, proceritate $\&$ foliorum ac fructuuim magnitudine. Tertia, Xocbicacauatl vocata, minor eft, minoremque profert ftuctum, \& femen foris rubefcens; intus vero cxterorum colore. Quarta omnium minima, \& ideo Tlalcacabuatl feu humilis dicta, fructum fert minimum, ejufdem cum prioribus coloris. Omnium fructus eifdem præditi funt $\mathrm{fa}$. cultatibus: poftremarum tamen,potionibus magis inferviunt. Cæterarum vero,nummis atque commerciis.

Prima autem, \& facile omnium princeps (cujus iconem hic, qua ramos, \& fructus atque nucleos, exhibemus) mediocri eft altitudine $\&$ egregie frondofa, foliis acuminatis, anguftioribus \& Aurantix longioribus (Antonius Herrera Caftancx foliis comparat) nullo fere pediculo cauli adnatis, nervoque unico \& recto præditis, \& ex quo multæx obliqux venulæ furfum emergunt. Flos ei magnus; \& colore ex flavo albefceris inftar croci. Q uo deciduo remanent tenuia, viridia, oblonga, lanuginofa filamenta. Ex his deinde fructus proveniunt turbinati, quos Cacavacenalli vocant. $\mathrm{Hi}$, cum maturuere, Melonibus magnitudine, craffitie, pondere non cedunt : coloreque funt croceo 


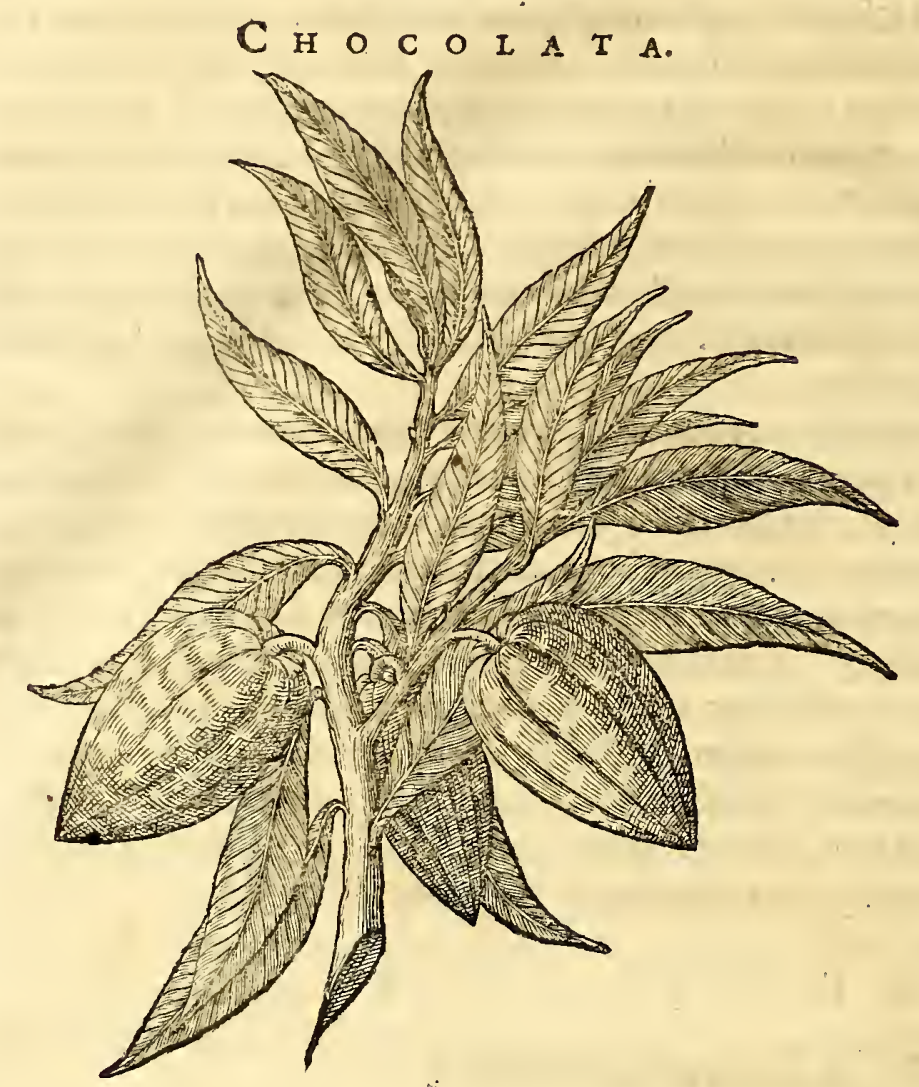

ex luteo albidi. Pediculius cuique modicus : incifuræ per longum varix : nuclei viceni, frepe triceni; qui 3 racemi inftar, medio ftipiti adhærent, Piftaciis aut Ricini majoris femini fimiles, paulo tamen grandiores $\&$ pellicula fulva veftiti; qua fublata, videntur non abfimiles reni vaccino, fecundum incifuras, quibus erant divifi. Subftantia eorum intus eft tenuis, \& fpadicei ferecoloris, in difpares divifa particulas, fed quæ arcte inter fe hareant; adeoque fir pinguis, ut fponte humor; quantumvis lentus, aliquando exftillet: imo oleum ex ea abundantius, quam ex Anjygdalis exprimi poffit. Pulpa hæc fubamari, non ingrati tamen, faporis, multi nutrimenti, temperamenti fubfrigidi atque humidi,

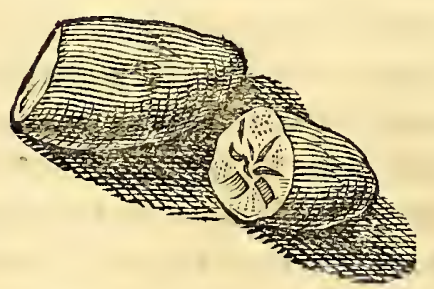
eft. Hi funt decantati illi ab Indigenis Cacabuatl, $a b$ Hifpanis corrupte Cacaó nuncupati, quorum caufa arbor tantopere expetita eft; utpote Chocolate potionis caput. Merx ditifima, \& obid Hifpanis æque ac Barbaris $x$ timata \& amata. Qua, mirum, quantopere quondam emporia ferbuerint. Ad Solem enim exficcati fructus ifti artatem ferunt, nec facile corrumpuntur, etiamfi navibus reconditi, ufque in Europam deferantur. Ante Hifpanorum in ea loca adventum, fpreto vinum conficiendi modo, (licet nonnulla vitium filveftrium aclabrufcarum genera apud illos fuapte natura copiofas \& variorum colorum uvas ferant paffim) potionem fimplicem ex folis fere Cacaciis, \& fine tot rcrum mixtura, quibus nunc fuperbit celebris Confectio, ad fitim duntaxat fedandam hepatifque fervores temperandos, Ptifanx loco folebant parare. Adde quod iideri Cacacii in tanto apud fuos habeantur pretio, ut non potus tantum delicati, \& alimentarii, verum etian nunımorum, nulli adul terio obnoxiorum vices praftent egregie, ob durabilem, lentam tenaccmque fubftantiam, atque is præcipua vitæ prxmia, cum opus erant, comparaban-

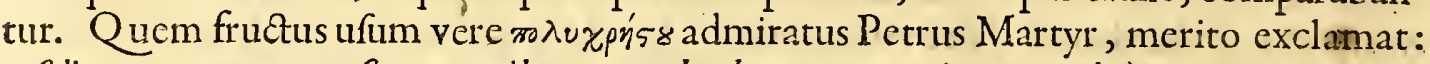
o felicem monet am! qua fuavem utilemquc prabet bumano generi potum, ¿d à tartarea pefte avaritie fuos immunes fervat poffeffores, quod Juffodi aut diu fervarinequeant. Huc quoque illud Francifci Hernandez, alludentis ad hoc, quod per arborem hanc Cacaviferam detegan, tur magna humanx fortis volumina. In veteri fiquidem orbe, perque prifa illa tempo, , ra , qua vita hominum erant neceffaria, atque adeo apud alios, cum deeffent, quaren„, da, non rependebantur ære. Nondum aureus argenteufve nummus circumferebatur, ,, aut pecudum, Regumve aut Principum fimulacra metallis cernebantur infculpta. Re,, rum vivebatur permutatione, ut olim factum cecinit Homerus, \& fructuum, quos re,, condebant, facta aliis copia, mutuum ferebatur auxilium. Tandem ara percufia at2, que fignata funt, \& mille rerum effigies n!mifmatis impreffa confpiciebantur. At in , , rovum hunc Mundum nunquam avaritix figna penetraverant, aut caput exeruerat am", bitio, donec noftri velis ventove devecti, impetum fecere, \&c.

Sed revertamur in viam, \& veniamus ad Cacacii qualitates intrinfecas. Has equidem cx effectibus cxterifque indiciis conftat efle temperatas. Subftantia ci cx craflioribus fumul \& tenuioribus partibus compofita eft prorfus, ut in infinitis aliis vegetabilibus obler. 
obfervatum eft, diverfas omnino fub eadém forma fubftantias contineri. Nofter autem Cacacius in pulverem redigiturprimum, \& fola mox,etfi frequenti, tufione pinfitur, \& in maffam cogitur. Quod cum fiat fine ullius rei admiftione, ratio arguit aliquid effe in eo tenacis \& bituminofi inftar humoris, aëris elemento refpondens. Multa infuper eidem quibufcum fuapte natura immifcetur, infunt ignea, qua neceffario incidere atquereferare debent corporis meatus, non vero præcludere, ut quidam voluerunt; nifi hoc in telligant de crudo; vel tofto, vel Saccharo condito, quo mulieres in Indiis nimium vefciamant, unde uteri,alvi \& hypochondriorum obftructiones incurrunt difficil limas. Verum totum hoc oritur, quod interior ejus fubftantia dentium incifione non exacte comminuiturnec perfecte commifcetur; requiritur enim artificiofa molæ verfatilis contritio. atque tunc demum, fi quid noxiæ fuperfit frigiditatis, aliorum calidorum commiftione tempèratur, communicata fingulis partibus hac intima ejus fubftantix qualitate: ca tamen adhibita proportione, ut fimul omnia Aromata five Indica fivenoftratia aromatica, mox recenfenda, vix mediam partem, cum fructibus Cacaciis in confectione Chocolata obtineant : adeo, ut ex actione illa \& reactione partium (quod quoque in contrariis medicamentorum qualitatibus, ad certam quandam temperatamque 2ysiGeov redactis, apparet) Cacacii frigidorum \& calidorum ingredientium Crocolata ipfa emergat temperatx facultatis. Hinc etfi Cacacius quantitate cxtera exccdat ingredientia, illius tamen partes frigidiores calidioribus coadunatæ retunduntur, atque vim fuam priftinam, remiflam licet, videntur retinere.' Atque hæc de arbore, ejufque nobiliffimo fructu, chocolate bafi, dikta fufficiant. Reltat, ut breviter percurramus fubordinata ingredientia alimentaria atque aromatica, non folum huic confectioni conterranea, fed etiam eorum fuccedanea exotica.

Primo occurrit Maizium, Mexicanis Tlaolli, vulgo frumentum Turcicum, vel potius Indicum, omnibus mundi partibus, fi non familiare, faltem notifimum:cujus iconem, \& culturæ defcriptionem, utpote nemini, credo, incognitam, prætermitto. Hocautem huic imprimis potioni magnum quid fuppeditat, unde $\&$ laudes ejus adeo paffim extollunt graviffimi, qui in In diis vixerunt; Medici, ut non patiantur Ptifanam, ex cremore ejus confectam, Hippocratis P tifanæ quicquam concedere: præfertim quia Maizium in Indiis negant fubftantize effe adeo terreftris difficiliorifque concoctionis, ut vulgo audit in Europa : tum quod exillo, aqua dumtaxat fubacto, inque ea ad modum pulticulæ diffoluto (Atoli vocant) potionem cum vel fine Cacáo conficiunt, quam mille experimentis compertum habent, infigne folatium aftuantibus, \& febricitantibus, imprimis autem nephriticis doloribus, \& urinæ retentionibus; adferre. Sed in conficiendo hoc Atoli ea eft diverfitas, qüod alii duas eumque Xoco-atole, id eft, acidum, vocant, idque cxteris facile præferunt : alii Maizium crudum, \& tantummodo molitum : alii prius coctum cum calce fumunt, atque in varios ufus applicant, tum fimplex, tum noftræ Chocolate mixtum. Qux omnia accurate \& prolixe defcripfit Francifc. Hernandez in Hiftoriæ Medicæ Mexicanz lib.7. c. 40. ubi plurima de iftius frumentacei generis natura, mixtura \& ufu quotidiano interpretatus eft: quxe etiamfi lectu digniffima, quia brevitati ftudeo, ex profeffo hic denuo repeterefupervacaneum putavi.

Ordine \& dignitate fuccedit Acbiote arbor, ab Oviedo \& Clufio Bixa ; à Braflianis Vrucú dicta. Cujus planta in mea Hiftoria Naturali, fol. i $32 . \&$ in Fr. Hermandez lib. 3 . c. 4 1. utraque ejufdem faciei; exhibita eft, Ea per omnes fere Americx regiones fponte luxurians, à barbaris æque ac Europæis, tam propter ufus medicos, quam tincturam rubram expetitur \& circa illorum prædia cicuratur: materies ejus, fi lignum ligno frice.tur, utilis eft igni veluti è filice excitando ; cortex vero funibus texendis, qui funt cannabinis firmiores. Fructuum grana rubra, de quibus potifimum agendum, frigida funt $\& \&$ ficca,cum modica aftrictione ; ex quibus placentulas efformant, projicientes grana jam matura in aquam calentem, agitantefque continenter, donec totus pene color a qua adhre eat : hi paftilli nonfolum medicamentis contra quofvis fluxus fanguinis inordinatos,fed.\& cibariis immifcentur, gratumque fimul faporem \& colorem iis fuppeditant; imprimis autem, omnia hæc beneficia praftant confectioni noftræ Chocolate, fi ea certa quantitate, ut infra docebitur, addantur; tutius enim tunc bibitur, \& citra fatictatis \& naufex incommodum, adde quod fanguinem magis purificet, \& vifcera corroboret.

Hactenus tria Chocolate ingredientia temperatiora, \& ad frigidum inclinantia recen-

$$
\text { R } 4
$$


fui. Quartum, quod chilli, five Piper Americanum, vulgo Brafilianum, dicitur, qualitate multum difcrepat à præcedentibus, \& primum locum videtur obtinere inter correctoriz aromatica calidiora ; proinde caute Chocolate folet indi ad orexin tantum excitandam, non vero tanta quantitate, ut fanguis inde poffit inflammari, ficit iis contigit, qui ejus ufui modum imponere nefciverunt.

Sequitur nova \& peculiaris Piperis Species, qux Mecaxochitl dicitur Mexicanis, quibus folis, quantum conftat, natales fuos debet. Volubilis eft herba, tefte Francifco Hernandez, (qui in Hiftoria fua plantarum Iconem ejus dedit fol. 1 44.) binos dodrantes longa , per terram repens, foliis magnis, oblongis, pinguibus, fragrantibus, \& acris faporis : caulibus teretibus, contortis; radicibus fibratis, \& filamentofis. Fructus funt teretes, longi, longo Piperi fimiles, bini vel terni junctim, ex unico caule furfum nati: qui quarto gradu calidi, \& tertio ficci habentur. Induntur Chocolate, non folum quod gratum illi concilient faporem; fed quod obftructa referare, frigora, $\&$ ex iis ortos dolores, mitigare, lentos humores attenuare, ventriculum roborare, oris halitum commendare, atque venenis adverfari, credantur.

Tertia inter calidas vocatur Xochinacatlis, feu fos auriculx. Arbor eft longis.\&anguftis foliis, virore exaturato tinctis, \& è pediculo veluti marcido, flores grandiufculi ex longo pediculo incurvato deorfum tendunt, eorum foliola interna parte fünt purpurafcentia, externa herbacea, auricularum pene forma, odore jucundo. Fructus funt filiqux, fex unciarum longitudine, digiti craffitie. Semina intus multa, \& ex mutua compreffione angulofa, funtque coloris fanguinei. Nullæx hujus arboris partes Chocolatam ingrediuntur, exceptis floribus, qui in magno apud Incolas habentur pretio; nec quicquam frequentius eft invenire in Indorum emporiis, quod celeberrimæ potioni gratiffimum faporem $\&$ odorem, \& falubrem prorfus efficaciam concilient. Quia autem ejufdem gradus temperiei cum præcedenti habeatur herba, ejufdem quoque cenfetur operationis. Icon exftat in opere Fr. Hernandez fol. 30.

Quarta inter calidas eft herba Mexicanis Tlilxochitl dicta, quam Francifc. Hernandez Araco Aromatico comparat. Volubilis herba Hederx more arbores confcendens. Foliis eft unciis undecim longis, fex latis, figura Plantaginis, fed pinguioribus, faturate viridibus, fingulis ex utraque parte caulis alternatim exorientibus, foribus nigricantibus. Siliquis fex uncias longis, anguftis, \& penc teretibus, nigris, olentibus Mufcum aut Balfamum indigenam, quas vulgus Hifpanorum à vaginarum fimilitudine Vaynillas appellat. $H x$ ad tertium ordinem habentur calid $x$, addique fọlitze potioni Chocolata, ob filavem non folum odorem, $z$ faporem; fed quod urinas \& menftrua moveant, cerebrum confortent, flatus difcutiant, humorefque crudos concoquant, $\&$ attenuent. Icon exftat in opere Fr. Hernandez fol. 38.

Inter Chocolate ingredientia, licet remiffiori gradu calida, celebratur polychreftus ille liquor refinofus, quem Indi Holli, Hifpani Vlli nominarunt: deftillat ex arbore Holquabuytl dicta, feu arbore Chilli, qux ftipite eft levi, fulvo,medulla lenta referto; flores habet candicantes, late expanfos, cum orbiculis ftellatis, ex pallido rubefcentes, hi ipfis ramis \& trunco fine pediculo adnati funt, dein fphærulx emergunt pleni fructibus candidis avellanarum inftar, qui cooperiuntur tela fufca, fapore amaro, ficut $\&$ cortex arboris, ex quo emanat fuccus, primo lacteus, mox luteus, ac tandem niger evadens, quem in pilas rotundas cogunt, eafque non folum in varios medicos ufus, fed etiam ad petauriftarum ludos refervant: de quibus videre potes Fr. Hernandez, lib. 3. fol. 50 .qui laudes ejus profequitur. Ego paucis attingam quomodo, \& qua quantitate Chocolate inferviat; nam hoc gummi minus familiare eft ingrediens refpectu cxterorum enarratorum, fed tunc potiffimum quando Diarrhois \& Dyfenteriis mederi volunt, nucleifque quatuor Cacacii, uncia unica hujus refinæ Holli mifcetur : verum Cacacii nuclei ob pinguedinem, \& gummi Holli ob tenaciffimum gluten, primum debent torreri, ne vifcera obftruant, \& cachexias producant. Iconem arboris dedit Fr. Hernandez, lib. 3. cap. $1 \odot$.

$\mathrm{H} x$ c aliaque vegetabilia, Novx Hifpanix patria,non idcirco putavi recenfenda, quod omnis porio Chocolata fimul ea recipere debeat; fed ut ex iis quifque fibi maxime conveniens eligat. Imo vero, quia maxima ingredientium pars, excepto Cacacio, in $\mathrm{Eu}-$ ropam non deferuntur, fubititui poffunt \& folent, vel vulgaria illa Indix Orientalis Aromata, vel alia aliqua femina aut flores cuique regioni \& individuo convenientia. 
Quod \& fieri fape in Belgio vidi, \& ipfe cum voluptate viriumque reftautatione hic confectam guftavi. Porro non memini, aliquem noftratium (modo non ferverent illi hypochondria) ex quotidiano ufu hujus potus male habuiffe. Multis contra morbofis medelam potius attuliffe fcio, præfertim hecticis, catarrhofis, afthmaticis, quibufque precordia languerent.

Quia autem placuit excellentiflimo Medico Romano Paulo Zacchix, in tractatu fuo de malo hypochondriaco, Italice confcripto, Chocolate quoque compofitionem $\&$ facultates notare, ibique fuccedaneorum etiam meminiffe, non abs re fore putavi, tanti Viri Iudicium hic annectere.

Mentionem, inquit, nunc faciam medicamenti cujufdam, paucis abhinc annis è Portugallia, quod Indis acceptum refert, ad nos Cbocolate nomine adferri coepti. Hoc ingredientium indicio, non obfante eo, quod temperatam ejus naturam plerique afferant, calidum magis eft, pratendentibus iis licet Cacuo frigiditatem, qux calidorum admiftione obtufa, moderatam confectionis efficiat qualitatem. Ego contrarium fentio, femenqué ipfum nullatenus frigid $x$, fed temperatæ potius conftitutionis judico, judicandumque cuivis id guftanti \& examinanti relinquo. Quoniam vero hoc novum aliquod eft atque peregrinum medicamenti genus, cjus componendi modum non abs re fore duxi tradendum. Recipiunt Cacao (fructus eft, aut, fi mavis, femen grandiufculum, Piftaciam magnitudine referens, cortice tenui, fapore Amygdalæ fimiIi) excorticati, bene mundati, feduloque triti, I 2. lib. Cinamomi fubt. pulv. lib. I. Anifi felecti \& fudiofe pulv. lib. femis, Vanillas (funt baculi longi, angulti, fubtiles, coloris fulvi, odoris balfamici, faporis fubacris) comminutorum, \& per fubcerniculum transactorum $n^{\circ} .6$, CHecacuce (femen Avellanam nucem repræfentans) manipulos $4 \cdot$ (aut, fi libeat, in locum Vanillas $\&$ Mecacuce, Mofchat a Nux, \& Caryophylli aromatici I 2. affumi. poffunt) Maiz (Indicum frumentum eft) contufi, cretique per fetaceum, floris feparati lib. 3. Ajonzoli confracti beneque triti lib. I. (aut vice Ajonzoli Amygdalarum Ambrofin. piftarum lib. femis) Acbiotes (grana fanguinei coloris inftar Santali rubri) unciam femis. Sacchari, pro libitu, ad lib. 4. Subigunt Saccharo Achiotes, omniaque adinvicem bene mifcent; ex maffa tabulas conformant foliis Mali aurei impofitas. Qui proinde hac uti gaudent confectione, ejus unciam dimidiam cum quinque Sacchari drachmis, bullientis aqux fex unciis injiciunt, beneque contemperant, \& , quam poffunt calide, bibunt. Id quoque obfervare folent, ut fi parum Sacchari Chocolate admiftum fuerit, dofm ejus, dum potant, adaugeant. Matutino bibunt tempore, quatuor dein horis aut pluribus à cibo abftinentes. Plurimi magnopere ejus in confortando ftomacho, \& adjuvanda ciborum digeftione virtutem depradicant, quod eximie nutriat ob feminum \& frumenti, Maiz præcipue, quæ infigni fatis quantitate compolitionem ingrediuntur, facultatem atque fubftantiam : non tamen, ne promedicamento multum calido habeam, adduci patiar ; hinc ejus ufum apud illos, quibus hypochondria calent, prudenter nec abfque judicio admittendum cenfeo.

Sequitur \& alia Chocolate defcriptio ex Ant. de Ledefma, in India \& Hifpania maxime familiaris. Centenis, inquit, quibufque Cacacii Chiles duo mifcentur, quos majoreseffe diximus, Chilpatlaqua vocatos, vel pre his Indiarum Chilis accipipoteft Hifpanorum Piper, omnibus majus atque calidius. Recipe dein tantum Anifi, quantum manu capere potes, Orichelas, que Dinataldides nuscupantur, atque duo Mecafuchil. Et nifialvi angufia premat, Alexandrinas rofas in pulverem redactas, item Vanillam unam, Cinamomi uncias duas, Amygdalas duodecim, 10tidemque Nuces Avellanas, mediam Saccharilibram: Achiotes vero, quantum fatis eft, ad hat omnia conglacianda.

\section{Methodus conficiendi.}

Cacacius cateraque ad mixturam hanc pertinentia pinfuntur lapide quodam Metstis nomine dicto, ad hujufmodi ufum excavato ; animadvertendum autem eft primo, ut omnia, quo melius frangi poflint, ante coquantur ingredientia, præter $A$ feotem. Secundo, ut diligentia adhibeatur, ne adurantur, nigrumque contrahant colorem; aut nimio admota calori infitam fuam exhalent virtutem, amarumque acquirant faporem. Pracedunt in comminutione Cinamomum \& Chile, quæ f1mul cum Anifo moluntur; poftremo autem loco Cacacius ipfe, qui paulatim confringendus reftat; fingulis quippe vicibus, quoties quid de eo molæ fibjicitur, circumagatur lapis, ut facilius diffiliat, meliufque conteratur: deinde in ahenum polt $\mathrm{Ca}$ - 
eacii comminuti ingredientium pulveres injiciuntur, qui lignea quadam fpathula eidem permifcentur. Coacta in unum mafla lapidi rurfus fubdita, cui fubjectæ candentes fuerint prunx, perquam optime diluitur. Cavendum tamen eft, ne vehementior fupponatur ignis, ut butyrofus nimio calore effervefcens humor effundarur. Achiotem velim Cacacio admifceas, ut cum eo molatur, coloremque melius acquirat: cæteri pulveres cribro, antequam confundantur, fecerni debent. ficut \& Cacacii cortices removeri longe melius eft. Quod fi fufficiens facta fuerit contritio (quiod videbitur, cum nulla amplius putamina apparuerint) (pathula maffx pars eximitur, qux ftatim fundetur in orbem, atque in arculas tunc reponitur: cumque congelafcit, dura confiftit. Notandum autem hic, Cacaciimaflam Papyro, feu latis arborum frondibus, quales funt Platani, fuperimponendam effe, in quibus gens Inda dictos efformat orbiculos; vel faltem, ut dixi, papyrus accipitur, fi extenditur mafla, duplicata, pofitaque fub umbra obdurefcir : Duplicata deinde papyro iterum exficeatur : papyrus etenim, quam habet pinguedinem, attrahit. Si vero tabulx infundatur, integra colligi atque reponi non poterit.

Duplici modo ab Indis affumitur, alio eoque frequentiore, quo igniadmota bibitur, Acolle immixta. Atque hæc olim potio in ufu fuiffe traditur. Acolle vocant Indi maflam ex Maiz farina colleetam, quam deinde Chocolate immifcent. Vt.vero falubrior fit potantibus, exterior corticis pars, qux flatus excitat, bilemque commovet, removetur, eaque faltem, quæmelior fanitatique conducibilior, remaret. Sed revertamur ex iis diverticulis ad ea, quae hactenus à nobis aliis occupatis intermiffa fuere. Referam novam, poftquam apud Hifpanos inclaruit, potionis methodum, qua dupliciab ipfis fieri ratione confuevit. Primo quidem modo diluitur Chocolata cum aqua frigida, fpumeufque ejus humor cuidam infunditur pollubro, id vero, quod remanet, igni admovetur una cum Saccharo; Hoc poftquan incaluit, cum fpumea illa, à qua fejuncta fuit, iterum confunditur parte, atque ita ebibitur. Alter autem modus vult calefieri aquam, $\&$ in vafe repofitam Chocolatam, quantum fatis eft, haberi, fuperque illam parum aqux fundi, ac verfatili difpergi mola; tunc ftatim, atque bene diluta eft, reliquum calidx cum faccharo in eadem Chocolata diffundi $\&$ hauriri. Si placuerit frigidam potare Choco latam, quam à præcipuo ingrediente Cacacium appellant, quo ad xeftum hepatis attemperandum utuntur, dilues chocolatam in aqua, molxque verfatilis fubfidio fpumam elicies, quæ magis augebitur, quo diutius cacacius ipfe comminuitur : effufam in aquali fpumam paulum fepones; id, quod remanfit, mifcebis cum Saccharo fupraque fpumam immittes, frigidamque potabis. Verum hoc potionis genus ob nimiam, qua pradita, frigiditatem omnibus conducere nequit. experientia fi quidem conftat, ftomachi dolor em eodem cieri. Qux detrimenta mulieribus pariat, afferrem lubens, nifi brevitatis rationem habens longiorem detrectarem relationem. Similem fere frigidam potandi Chocolatam habebis modum, qui talis. Addatur Chocolate dilutæ Maiz toft $x$ in pulveres redaćx refpondens quantitas, qux adinvicem bene permifta $\mathrm{Su}$ meum dabunt liquorem, qui perinde fupradictum, frigidus hauritur.

Reftat nuncut pauca de quantitate Chocolate affumenda, item de modo, tempore utendi, à quibus ufurpari queat, difquirere. Neitaque immoderatus Chocolate porus ob pinguiores, quibus pollet, partes, venas mefaraïcas oppilet, quinque vel fex uncix mane tutiffime forbentur omni fere anni tempore. Ea tamen perpetua cautela, ut quifque eviter terreftrem illam $\&$ craffam Cacacii portionem, quæ fundum vafis petit; pr 2 terquam enim quod vehementer obftruat, vim quoque ciendi bilem infignem habet, \& naufeam excitat: Idem cogita, fi quis incaute potionem Chocolatam recenter factam potaverit: cum è contra, ut ægris æque ac fanis profit, ad menfem vel ultra requiefcat oportet, ut contrarix ingredientium qualitates infringantur. Atque tunc omnibus exinde bene fit, \& corpora acquirunt lacertofa, \& vegeta. Idem quoque probata fidei \& experientix vir Ant. de Ledefma de fe ipfo teftatur; Motus enim iis, inquit, qua in Indiis fieri folent, cum illuc perveniflem, ægrotantiumque domus ä̈ris calore ferventes percurrerem, aliquando haufum aquie petere folitus, vitales reftinguendi faees gratia, Indorum fuafu Chocolatam fiti compefcenda convenientiorem bibi; fapiufque id factum, Icnicbatur exinde ardens bibendi defiderium; etiamfi jejunus affumfiffem, ftomachi tamèn vires refectas fentiebam. Ex cujus potionis continuato ufualii mecum impinguefakt funt: cum tamen pleraque ingredientia excepto $C_{a-}$ eacio \& Maizio, quod calida \& ficca fint ordinc tertio, ad extenuationem corporis 
facere videantur, fed conftat ratio, butyrof enim Cacatii partes pingue reddunt corpus : calidx vero, quæ confectionem ingrediuntur, pro vehiculo inferviunt, quo pinguis ifta fubftantia ad jecur deferatur, \& inde in ceteras dimanet partes, tandemque ad carmeas demum derivetur.

\section{A P V T $\quad \mathrm{X} I \mathrm{X}$.}

\section{De Trvarcaréfeu Nuce Medica Maldivenfium.}

$\mathrm{C}$ Lutius nofter, \{pectata fidei Vir, multa fine dubio Nuci Maldivenfi tribuit, qux hactenus, ut mihi perfuadeo, plurimis funt inexperta: fed multa, quæ noftrum non pauci jam fumus experti. Quod enim attinet ad fpecificam facultatem promovendi partum difficilem, ac refiftendi infultibus epilepticis, ejus non unam experientiam habent fpectatifimi aliquot apud nos Medicinæ Coryphæi, \& teftari de felicifimis fucceffibus queunt.

Preter vero Nucis iconem, quod nihil à Clutio, nihil etiam à nobis exhibeatur corum, qux ad cxterorum arboris notitiam pertinent, hæc caufa eft, quod Infulx iffx, in quibus olim folis crefcebant, à mari abforptæ fubfederint altitudine minimum fedecim orgyarum. Vnde eft quod non nifi fingulari fortuna à fupernavigantibus \& linum demittentibus Nux capiatur. Exorditur fupra nominatus Autor, hunc in modum.

Nter immenfa beneficia quibus humano generi poftremis hifce feculis divinum 1 Na MEN affulfit, non poftremas obtiner tot Pharmacorum ad tuendam hominum valetudinem inventio, cum poft animæ falutem humani corporis fanitas primum locum fibi vendicet. Quod enim ad machinarum ænearum inventum attinet, quibus fupra antiquitatem noftra xtas gloriatur, eas potius ad hominum perniciem quam ad bonum publicum comparatas dixerim. Typographia vero, quanquam confervandis literarum monumentis imprimis idonea, nihiloninus fcribentium Kakozeliam $\&$ \% teratorum ineptias plérumque fovet, nec eft etiam quod Erythræi maris fpolia; aut exhauftre Atlantidis pallida vifcera tantopere jactemus', cum ex mente cordatiffimi Poëtæ fulvum metallum fit chalybe nocentius. Nafo Metamorphofios primo:

\section{Iamque nocens ferrum, ferroque nocestius aurum \\ Prodierat; prodit bellum, quod pugrat utrogue.}

Verum enimvero Argonautarum Europxorum gloria nunquam fatis extolli poteft, quorum folertia patefactus novius orbis tot feculis latitans, aperta maris clauftra, \& cot infularum chiliades in Indico pelago fparfe.

Horum enim opera effectum eft, ut propemodum

Omnis ferat omnia tellus.

Et pharmaca exotica eximii \& rarifimi ufus, noftro Orbiillata fint. Inter qua, five raritatem fpectemus, five pretium $\&$ xeftimationem, five ufum nunquam illaudatum, five incertitudinem originis, $N$ X X ME D I C A M A L D I V E N S I jure fummoprimatum obtinet. De qua acturus, operx pretium me facturum exiftimo, fi de Infulis apud quas reperitur, earum fitu, latitudine $\&$ opibus, pauca pr $x$ fatus fuero.

Nfulx, de quibus fermo eft, inter Infulam Madegafcarfeu Sandi Laurentii \& Pro1 montoritum Indix Commori vulgo dictum, fit $x$ fint, à Continente centum \& quinquaginta leucis diftantes. Latitudo fe extendit ab ocavo gradu cis Æqquatorem ad quartum trans eundem; quod maris fpatium complectitur ducentas circiter leucas $\mathbf{z}$ Borealioribus nempe ad Auftraliores: \& poteft ejus Regni longitudo dici, petita à Septentrione ad Auftum. Earumdem vero latitudo,fi maris fuperficiem fpectemus, ultra triginta aut triginta quinque leucas non extenditur. Cenfentur numero ab Indigenis duodecies mille, (fides appellat autorem) divife in Provincias tredecim, brevibus vadis feu anguftis fretis vel Euripis diftinctas. Harum fingulx, abruptis fcopulis, tanquam naturali muro cinguntur, \& in complures alias iterum fubdividuntur: quafdam cultas \&c luxuriantes Naturæ bonis, citra hominum laborem divites, alias culturæ expertes, \& folis 
\& folis volucium cubilibus relictas. Qux magis accedunt ad Septentrionem, foccundiores funt; qux ad Auftum vergunt, fteriliores, \& noxiorum feu damnatorum exilio plerumque deftinat $x$. Tanta eft cxli \& foli bonitas, ut omnium rerum copia, non folum ad ufum humani generis, verum etiam ad luxum \& delicias exuberent; quamquam fruges \& animalia Europæ noltrx illic rara aut nulla. Verum benigna mater Terra vel Natura bona noftra compenfans Indigenis \& Advenis affatim fuppeditar. In harum Infularum littoribus Nux hac, de qua agimus, folummodo reperitur, non alibi terrarum confpicua, allabénte enim maris xftu non fecus ac Ambarum fufcum (Ambra grifea Medicorum filiis dicta) in littus ejicitur, nec cuiquam tollere fas eft, nifi ftatim delaturo ad Regem, vel miniftros Regios, cum,

Quicquid confpicuumpulchrumque ex equore toto eft, Res Fifci eft, ubicunque natat. Iuvenalis Sat. 4 .

Quodeftargumentum xeftimationis admirand $x$ Nucis, cum conferatur Ambaro, imo praponatur; adeo ur fi quis exiftat repente dives, vulgo exiftimetur Tavarcaré inveniffe (id huic Nuci in iis Infulis nomen). Nihil inter Gazam Regiam aliud majore cura confervatur, fiquidem in cohoneftandis amicis Regibus, Satrapis, vel Thalaffiarchis ornandis, non alio pretiofiore dono utitur harum Infularum $R$ ex.

Quemadmodum locus inventionis certus; ita origo anceps \& incerta. Vulgus Indigenarum ex arboribus in mari latentibus, vel olim inundatione demerfis, vel intra aquas in avito folo radices agentibus, fructum hunc provenireautumant, non fecus ac Ambra videtur effe ramus arboris vel ftipitis in bitumen induratus. Religiofiores fecus exiftimant; in Infula fiquidem Palloys diça, quarentibus abditâ, ignaris obviâ, Nucem hanc gigni arbitrantur, inde caducum fructum poft maturitatem pelagi $x$ ftu $\& c$ reciprocatione huc illuc jactatum, in oras Maldivenfum Infularum tandem ejici, huic Palloy proximius utpote adjacentium. Infula hæc creditur Maldivenfibus effe omnium terrarum beariffima, quam Ḱakodæmonis vel mali Genii invidia \& artibus humano afpectui fubtrahi perfualum habent, quanquam nonnunquam ignaris fefe offerat videndam.

Fidem facit,quod fepius tentata Regis Maldivenfis aufpiciis, illibata permanferit, \& rariffime, imo nunquam, Regiis miniftris nauticis, tefte Francifco Pyrard de Laval, comparuerit. In appulfu quippe gravibus procellis $\&$ tempeftatibus conflictantur, \& quotquot illuc appuliffe contigit, à fpectris $\&$ Kakodæmonibus fpecie vifibili torquentur $\& 2$ cruciantur,ut ut eft, ubicunque terrarum hæc Nux nafcatur, hocloci folum reperitur, reliquis orbis partibus ignota, nifi hinc deferatur.

Nufquam confpicitur nifi gemina, cujus utraque pars ovalem $\& z$ oblongam figus ram exhibet. Quae etfi unico obtutu præfe feerat gemellos duos Melones lateraliter cohxrentes, nihilominus naturali vinculo ufque adeo funt colligatx, ut nullo paato divelli poffint. Nucleus feu medulla excrefcens in altum tegit interiora utriufque putaminis, affurgens ad figuram rotundam feu fabaceam aut renalem, ex una nucum inalteram permeans, ita ut non injuria tota hac nux gemina affimilari poffic duabus fcaphis, vel fcaphæ duplici, communi onere gravatæ. Ad nuclei tutelam naturale \& ingenitum munimentum Natura largita eft tunicas quafdam, fpecie licet inter fe diffimiles, non tamen à tunicis, iifque velamentis difcrepantes, quibus Iuglandes ante maturitatem extrinfecus tectas cernimus, aut ad majorem convenientiam tunicx illi fimiles, qua Caftaneam marinam opertam aliquoties vidimus. Cyathus vero expolitus binis alveolis geminam quafi formam exprimens proxime accedit ad Cymbia duo (quorum in facris olim ufus) lateraliter cohærentia, vel ad Sambucas ( $\mathrm{f}$ fcalas exceperis) queis in expugnatione Syracufarum Marcellum olin ufum legimus. Ad fcyphi autem hujufcemodi pretium \& $x$ fimationem augendam totus nucleus feu medulla non excernitur, verum exigua pars relinquitur accreta \& adglutinata bafi ipfus Nucis, in duritiem xtate, non abfimilem ipfi Cocco, verfa,interyeniente tenui quadam cortice, feu integumento, haut impare medianx Ilicis, Qucreus, aut Fagi exaridx. Confervatur autem in ufum medicum internum, velut è catenula aurea per artem appenditur, ut liquori immergatur,in eam præcipue gratiam, uti ctiam fuas in ufu virtutes coacervet accumuletque. Quod fi negetur \& calu medulla à bali abfecflerit, arte, uti infra diccmus, fuppletur.

Dividitur autem hac ratione nux gemina, fi per intervallum illud, quo lateialiter altera 
altera alteri cohæret, $\&$ iterum harum quxlibet diffecetur ferra fecundum priorem aperturam, ex utraque figillatim fieri poffint duo pocula. Quod fi utraque fimul \& femel bifariam dividatur, per latus alterutrius externum principio fectionis fumto, habeantur pocula gemina bina. Cujus poculi gemmi, nifi extrema Cymbiorum auro aut alio metallo conjungerentur, exigutus aut nullus in bibendo effet ufus ob periculum effufionis: verum pyxidis vices fuppler e poteft. Hoc autem genus fcyphorum virtutes \& remedia contra morbos habet plurima, qux fuis fingula locis docebinus.

Expolitæ autem Nucis putamen naturali quadam cælatura, quam ars æegre adfequatur, fculpta \& elaborata cernitur colore nigro, faturato. Magnitudo huc adlatarum Nucum, ut \& figura, non à majorum Melonum pecie $\&$ magnitudine recedit.Perpoliri poterunt pulvere lapidis Tripelæ dicti : teritur, Tripela fubtilifime in mortario xereo, piftilloque ferreo, affufa frigida; Et ne altetationem fubeat Cocci putamen, laneo panno, fxpiufcule liquori huic intincto, ipfi teftx afficatur : non autem oleo, quod inferret noxam \& graveolentiam.

D. R u D O I P u S II. Roman. Imperator \&c. qui dignitate, majeftate, inge nio, variaque rerum omnium cognitione cxteros omnes Principes antecellebat, percepta Nucis præftantia, eam quatuor millibus florenorum in pofleffionem fuam redigere conatus eft. Sed quia Familix Wolferdianæe traduces alio tranferri negarent, in loculamentis folitis ftationem fervavit. Quo autem modo Nucis copia Wolferdo facta fit, tribus peragam verbis Hiftoriam. Kalendis ipfis Ianuariis anno millefimo fexcentefimo fecundo, D. W C L F E R D S HAR A N I D E S Archithalaffus, vifis fortuito navigiis Lufitanorum, civitatem Bantam obfidione cingentibus, inter jpfum velificationis tenorem prius anchora naves infrænavit fuas, dein laxato velis finu ad curfum eas preparavit, prora in Lufitanorum claffem verfa ; quos licet numerus frequens animaret, pauculis tamen manipulis Batavorum, quinque nimirum navibus, in fugam egit, everfa ad non exigumm numerum fubfidiariarum clafle : Ita Civitati \& Regno Bantam libertate rcftituta, magnifice à Rege exceptus eft; qui præter laudes fufe dictas decoravit eum fructu, cujus imago in appendicem venit. Doloreautem non parvo perculfus erat, quod obannifterilitatem Piperis proventu victoriam jam partam huic Wolferdo plene compenfare non poffet. Decrevit interim ut acceflu libero Batavis quxvis coëmendi ac collectandi copia foret; quod experientia deinceps fida teftatum reddidit.

Verum ut obfervatu dignum, ita filentio non prætereundum eft, à Rege fummain faciem fructus, lineamentorum ductu impudice lafcivientis, ferra ablatam effe;ne, Clariff. Wolferdo offerenda, honefti viri oculis offenfam præberet. Refert enim rugarum am. bitu mulicbre pudendum cum podice $\&$ interfeminio, à quibus verfus gibbam partem cxlaturx inftar fubalternant acclivè $\&$ declivè in laxitatem fenfim accrefcentem, uti unda undam trudit, inon fine gratia oculis acceptifima, quæ ipfa iterum terminatur in aperturam germini fuperne annato dicatam, non abfimiliter concomitatam duobus fpiraculis feu foraminibus, uti in Indica Nuce five vulgari Cocco tam majore quam minore, pluribufque ejufdem familix \& congeneribus, videre eft. Spiracula porro illa in margine aperturæ pofita ufum atque emolumentum fuum nacta funt. $\mathrm{Ob}$ ducuntur enim introrfum tenellis medullx portiunculis ut fpiritibus in germinatione tranfitus detur, ficut Natura in fottu elaborando, (quum fint Iovis omnia plena) polypragmos \& follicita eft.

Rogatus a me Clariflimus D. R E $\wedge$ I I u s, ut fuam fententiam fuper dubiis quibufdam meis communem facere dignaretur, non invita Minerva (mira'enim Viri tractabilitas) præftare aggreffus eft, in Aphorifmos \& Theoremata concifa ex tempore eam digerens, qux ex ordine à me in contextu depromuntur, in Latium tranflata.

Aphorifm. I. Nux Indica vulgaris tantæ utilitatis, tamque fructuof eft, ut omnia qux jus vitx confervant, velut efcam , potum, condimenta, cultum, amictum, $x$ dificia, \& naves, proferat. Nux vero Maldivenfis Medica omnia adverf 2 valetudinis amuleta in fe continet.

Scholion. Palma coccigcra vulgaris omni, tempore fert nuces, viretque toto anno, fructibus femper aliis fubnafcentibus, dum alii maturefcunt: \& quod Pontamus alibi in Hefperidum hortis, de Malis Citriis tefta tur, de hac Palma dici poteft, Flore novo femper, femper quoque fotibus aubla. 
Necinjurie pronuntiare licebit, nihil aliud Coccum Medicum effe, quam Coquum Panacex, vel Orphea miri ab interitu receffus artificem, Fatifque imperare folituin, cum multi, ad vitæe defperationem ducti, eo mirifiee convalefcant.

Quxautem commoda è vulgari Nuce proficifcuntur, ea habentur apud Cardanum, Scaligerum, H. Linfchotanum, Francifc. Pyrard de Laval, M. Ignatium. Videantur obfervationes eorum, cum non fit hujus loci plura recenfere.

Aphorifm. II. Tenelli Cocci Indici vulgaris compago per fruckus adolefcentiam cultri acie facile divaricatur, \& è vulnerc humor clariffimus \& potui aptiffimus eliquatur, qui tractu temporis in vegeto ac illxfo fructu, poft concoetionem, digeftionem, \& fegregationem è craffioribus ac terrenis partibus internos parietes inveftit. Serum vero omne in centro locatur, \& quafi cafeatione facta medium locum occupat, ficur rufticum artificium in lacte vaccino demonftrare folet: Pari ratione conjectari fas eft , humorem Nucis Medicx coagulando in folidiorem maffam redigi, quod tamen nullus autopfia aut oculis fuis dimenfus eft, quoniam in maris profundo acceflum humanum non tolerat.

Scholion. Quxftio à quibufdam infcita movetur, habeatne Coccus Maldivenfis ortum homonymum, ut quxdam animalia ex limo fine fpermate? gemma feu germen negat, quod nucis involucro claufum Palm $x$ arboris partu originem funit, $\& \mathrm{c}$ ex principiis arbori infitis velut animalia exfanguine, femine $\&$ calore innato, augmentum capit, \& adolefcit in eum form $x$ ftatum qui naturæ decreto illi præfixus eft. De arboris vero ipfius generatione tutius cavillari licet, an ex limo prodeat, poftquam in maris profundo radicata eft, in quo germinis acceffus recipi nequit, mari perpetuum motum explicante, neque natatilis rei in imo fui permanentiam ferente. Hinc Cocci ipfi,ad maturitatem perlati in aqux fuperficiem velut eructantur. Neque verifimile eft, ubi fublunari aëre inaruerunt, ponderis gravitatem, ut fubmergi poffint, induere. Ex terra ergo, velut plantx (ut infra dicimus) \& marini frutices, generantur; aut potius ex terra in limum maris uligine diluta. Qui limus velut feminis effentiam nactus, arborem fuigeneris educit. Speciei autem perpetuatio fit, nunquam ceflante in profundo maris opifice Natura.

In plantis unius animævegetantis tria officia funt; generant, nutriuntur, $8 x$ crefcunt.' Non tamen omnia una Naturæx lege progenerantur, quandoquidem è terra, fucco, fitu $\&$ fole variantibus, diverfimode pullulant. Marini frutices duabus folum vitæ functionibus pollent; nutriuntur, \& crefcunt; fimile fui non gignunt. De vita $\&$ nutricatu plantarum fentiendum quod de animalium alimonia, trahunt fuccum fibi familia rem, retinent, concoquunt, fegregant, \& recrementa expellunt, beneficio caloris \& firituum, quibus perfunduntur. Quod doctiffimis Aphorifmis Cl. Petrus Lauremsbergius Ph. \& Med. D. \& Profeffor in Gym. Hamb. declarat. Cl. Realizes cafeationis exemplum, quod manuum opera praftatur, aptiffime applicuit.

Aphorif. III. Cocci vulgaris cortex induratus, ferr $x$ aut mallei vi ad apertionem opus habet. Ferro autem tranfciflus ac difruptus omnia velut in profcenium educit, folidior em nempe medullam, intermedium corticem, 8 humorem limpiditate abblandientem paulo ante, jam vero potui ineptiorem $\&$ olei ferme facie indenfatum. Medulla vero, nucleo Avellanæ noftratis duritie graphice affimulatur; quare limæ contumacix ex facili cedens ad lac \& emulfiones temperatur, è quibus omnia coquinæ neceffaria', velut oleum, vinum, acetum, mellifque \& facchari xmula colligifolent. Idem de Maldivenfi fentire, non effet piaculum; verum quum ea non nifi indurata \& in littus, poft longam moram, ejecta reperitur, humanx mentis caligine conjecturx tantum locus remanet; quod definite in apricum exiret, fi fublucata arbore fructum manu carpere liceret.

Scholion. Cocco vulgari, Areccx \& confimilibus fructibus involucra multa circumpofita funt; haut fecus ac feetui membran $x$ ad tutelam. Vulgaris Cocci nucleus variis ufibus aptus, fed medico ufui inconcinnus; uti Garçias, Sepulvedam Autorem $\&$ ipfos Indos increpans, Paralyticos, è vafculis vulgaris Cocci bibentes, nunquam juvari ait. Variam Cocci indolem hucufque enarratam vides, fed non hifce tantum differentiis conftringendam, poft quam alia quoque Coccorum propago in aliis territoriis invenitur, prout Natura Polydxdala unicuique Regioni peculiare fuum eft clargita.

sphorifm. 
Aphorifm. IV. Ufus medullx vulgaris Nucis eft multifarius : verum Maldivenfis Medic $x$ apud Indigenas, Reges, Magnates Indos non unus, fed infinitus ferme, \& fuperftitione non vacuus; cum hic fanitati confervand $x$, ille vit $x$ fuftinend $x$, privilegio Natutæ , confecratus feratur.

- Scholion. Medulla utriufque Nucis eft potior pars. Vulgaris, culinarix ; Maldivenfis autem, medicamentarix rei, quod infra docebimus, peculiariter deftinata, quare de vulgaris medulla plura dicere fuperfedeo, cum citra meum fit infticutum.

Aphorifm. V. A nemine, quod quidem fcire licuit, fcripto hactenus teftatum eft, germen feu gemmam promi, qux Piif formam reprefentat, fubinde Fabx effigiem exprimit, è rotundo longiufcula, aliquantum acuminata, è mediis liquoribus nata, pr $x$ dulci fapore linguam afficiens. Hoc germen in fpeciei confervationem adolefcit; \& $\mathrm{i}$ fide alienum non eft,aliorum quoque fructuum nucleis à natura id datum effe. Ut jure à Plinio majori Trogus taxetur his verbis : Nam folia Palmarum apud Babylonios feri, atque ita arborem provenire Trogum credidiffe demiror. Unno tamen infigni noftrum prævalet, quod in gemmam lapillis aut margaritis nitore fuo \& lævore æmulam fubinde transfiguratur. Sed Naturæ feu decreto feu invidix tribuendım eft, è decem millibus fructuun vix unum tam faufti puerperii \& foecunditatis participem effe. Eadem vero in Maldivenfi Medica ufu venire poffe, judicio non aberrante dicere licet. neque à ratione abfonum eft, quum in fructu Pinang, Arecca, Palma-Pino \& confimilibus experientia magiftra veritatem adepti fumus.

Scholion. Lapillus hic vel gemma ipfiffimum \& purum putum germen eft,quod partibus internis (aperturæ nimirum) quamdiu adhæret, fpiritibus atque alimento communi fruitur; donec ad juftam magnitudinem perlatum, naturx decreto , non cafu aliquo, aut aperturæ vitio, extra folitum locum fubinde movetur. In cavitatem vero Nucis receptum germen fuis fe igniculis futentat, quos Natura formatrix ad fomentum illi indidit, velut foetus humanus exacto noni menfis Spatio ad lucis ufuram extra uteri receptaculum amandatur; fcilicet adminicula vitæ, ut adolefcat, ad plenum nactus. Qux hic prolixius recenfere alieni muneris fore judico. In duritiam vero nativam non frigoris ambitu concrefcit, \& (quis enim in latebris nuclei occultus effe queat??) fed feminio interno, quod illià matris velut utero remanfit, ut vi efformatrice in fpeciem fuam, qux oculis obvia eft, \& virtutes illi debitas, qux occultæx funt, effigietur. Quod rationi confentire, fanguinis extra venas effufio evincit; qui ex quo affimilationem aut (ut Medici aiunt) appofitionem effugit, deftitutus fomentis folitis coagulatur, vel in putredinem degenerat. Noftrum vero germen architectonem internum fecum ferens, magis magifque ad perfectionem adolefcit; velut foctus nuper editus ad ftatus fui complementum perducitur. Quocirca neque germinationi ineptun effe, etiam in aliquo duritiei rigore una hac ratione deduci poteft. Neque eft ut ab hac fententia recedamus ob duritiz aliqualem habitum, poftquam occultis natur $x$ fpiraculis; quicquid humanis fenfibus abditum aut impoffibile videtur, in actum experientiis fuis comitandum deduci folet, non fine miraculo \& judicii humani ftupore. An vero arboris primitivæ, unde ortum eft, fpeciem edere queat, multæ dubitandi rationes affirmare vetant; quas hîcfuperfluorum ferie comprehenfas praterire libet, etfi in Scholio ad Aphorifmum fecundum bona earum portio inveniatur.

Ad lapillos noftros feu ingemmatas gemmas revertamur, quarum numerum aliquem habeo in loculamentis meis, eas dico pre laxitate aperturx (quod aliquando fieri confuevit in exficcatis \& neglectis, aut è natali loco tranflatis Coccis) intro redaatas \& coactas, atque ita,cum non fit magna germinis diuturnitas, effe in lapillos converfás; quod auctoritate clarorum virorum varie docebó \& non abfimilibus exemplis. Lapillum habeo fingularem, articuli majoris digiti magnitudine \& forma, pondere dragmarum trium (cum vulgarium Coccorum, dragmæ dimidix pondns non fuperent) lævore \& nitore fplendentem, $\&$ in fumma parte acuminatiore, tranfparentia unionis dotatum, mirum in modum oculos oblectantem. Hic fua quadam gratia foliclorum primitivorum idæam quandam oblique contortorum (ficuti in gemmis pluribus grandium plantarum videre $\mathrm{eft}$ ) promittit; quare mihi \& delicatioris fenfus viris acceptior eft. Illud interim non prætereundum hanc foliolorum divifionem acta radice \{pargi, \& lateraliter afparagis aut turionibus adlıxrefcere, \& è terra exfurgere aliquamdiu, tandemque, ut inutilia, decidere alimento deftituta. Omne fabaceum $\&$ Pha- 
feolorum genus, nec non Indicarum ftirpium aut arborum grandiores fructus meo hortulo commifi, vivum exemplum afferunt. Faba ex Wingandacow, Cola alba, rubraque, \& ejus generis plura; quarum Thefaurus nofter utriufque Indix plantarum aliquando fidem faciet.

Aphorifm. V l. Verum in quibufdam Coccis, coagulatum, quod à cafeatione remanfit, maffulam dixeris, ceu pomulum exiguum leve \& fpongiofum, \& mafcula Palmx proprium effe dicitur, dulcedine excellens, nivemque albedine adæquans, in mediis liquoribus fluctuans. Vulgo etiam germinis nomine infignitur, efui perquam aptum. Cujus in Maldivenfi forte fimilitudinem nunquam videris.

Scholion. Fr. Pyrard arbitratur liquorem tantummodo in germen abire \& verti , medullamque germinationi in folum fomitem adaptatam effe, quod ex plantationis modo videtur probare : verum rationem fuam infirmam facie, cum paulo infra in tractatu peculiari de commodis Nucis Indic $x$ vulgaris, maturam \& ficcam Nucem terr $\mathfrak{x}$ mandandam dicit ; \& è maffula quadam interna ex fucculentia aut liquore concreta nempe figura pomuli, extrorfum fublutea, introrfum candida, tenella atque ore detenta folubili, veram Coccorum propaginem feu gemmam ipfam effe affirmat, cum ipfiffimam ignoret: quod autopfia propria \& ex relatu clarorum virorum Generalium habui, qui ad plantationem Nucum decem mille in acervos cumularunt, è quibus trium hebdomadarum circiter fpatio elapfo feligere eas jubebant, qux germen jam ante numeris fuis abfolutum, \& nunc in promptu ut exeratur \& exertum gererent, terræ gremio committerent, \& reliquas huic fini ineptas ad alios ufus relegarent. Quo verborum fenfu facile germinis aperturæ infidentis prafentiam non fruftra à Natura fabricatam, docet Caftanea marina \& noftra ipfamet domeftica. Omnis gemma folitaria fi in terram deprimatur, radicum fibras tantum non materias creat. Egregie Doctiff. Thobias Roelfius in Epiftola ad Clufium his verbis germinis naturam explicat.

Habui hujus PalmæNuces aliquot integras (intelligit vulgaris) cum fuis villofis corticibus, qux in itinere vafi inclufe, germinare cœperunt. Harum tibi binas mitto. Alterius Nucis corticem fuftuli, ut germinis exortum \& ejufdem radicationem poffem videre commodius : tertiam cum germine Nucem penes me fervaveram, cujus prædurum $\&$ ligneum putamen internum aperiens ex hujus medulla germen traxiffe initium obfervavi. Nucleus five Medulla conclufam in fenon habebat aquam (quxnucibus Indicis recentibus \& non germinantibus ineft femper); fed aqueum illud in materiam fungofam excreverat, dum forte in germinis alimentum converti cœpit. Germen exit è Nucum harum foramine tertio, \& mox extra foramen fatim ab exortu per corticem exteriorem craflum ac villofum quinas fenafve radicum fibras dimittit in terram, per quas alimentum fux natur $x$ conveniens attrahat. Germen quod per foramen emergit unicum, fimiliter perforat villofum corticem, atque in unius Nucis folone veftigia foliorum arundineorum confpiciuntur, qux bifida vel bina funt, \& vix aliquam videntur habere latitudinem, quod quinque vel fex plicis commiffa fint: folia primum in vagina latuiffe videntur, è qua prodierunt necdum expanfa, fed plicis commiffa, utimet ipfe hæc omnia in altera hac, quam mitto, Nuce contemplari potes, cujus germen in longum exceffiffe videbis trium palmarum menfuram. In hoc argumento prolixior fum prxter morem; quod autem fpectatad fexum Palmarum, CI. REALI Us affcribit maribus germinationem effe propriam. Palmx perdite fefeamant, quod \& rufticis ipfis notum eft; \& conftat, rebus furdis \& fenfu carentibus odia $\&$ amicitias ineffe, ficuti etiam errores in animalibus \& plantis infunt.

Aphorifm. V I I. Spiracula autem illa duo in vulgari Nuce, infervientia forte exhalationi recrementorum, fede paulo inferiöre locata aperturæ germinis aftant. Ea habent in Medica Nuce etiam locum; non infiniliter cjus germen, quod vere in gemmam feu pretiofiffimum lapillum verti poteft, cum diutius ab alvo natali magna matris femota, \& cæalo foleque patre fruftrata in lucem fertur.

Scholion. Apparet ex facili in quem ufum illa foramina Nuci indita fint, fcilicet ut alimentum fuum $\&$ fpiritum Opificis Naturæ vehiculum ex nuclei ubere \& fubftantia in fe reciperet. Vbi autem faftigium incrementi fui nacta gemma aut germen à nucleo aliquomodo defertum, veltigia tantum foraminum qux fenfim obturata funt, pratcndit; non jam alieno nutricatu opus habens, fed intra fe claudens quo in pro- 
prix fubftantix fpecimen $\&$ formam mutari poteft. Quod aliorum quoque fructıum exemplis ftabilire facile eft, qui nucleis inter fe claufis, pragnantes funt, ut hoc velut parente arboris congeneris fpecies aliquando nafcatur. Erfi non omnes fructus nuclei neceffitate ad propagandum opus habent;quod in Scaligeri Exercitationibus fufe probatum invenitur.

Aphor. V III. Coronidis loco addam, Lapillos, præcipue hos è germinibus utriufque Nucis ortum ducentes, uti \& è Pinang \&zc. fructu, Panacæam, fententia Indorum, in fe habere ; quocirca præter internum ufum, Indi eos annulis etiam aureis $\&$ argenteis includunt, foramine relicto, per quod Lapillus carnem humanam contingat, quod pro amuleto adverfus incantamenta non abfque fuperftitione feu humanæ mentis ludibrio affervant. Pronum enim natura ad vanitatem genus Barbaricum.

Scholion. Opinio, cum in Idiotas cadit, indelebilis eft dicente CL. V. C. Bartholino, horum autem gratia non explodenda funt, qua à prifcis aut neotericis accepta, feu de occultis Naturæ viribus five inauditis, licet fidem fuperare videantur, à me in medium afferuntur : ficuti \& fententiis adverfariorum occurrere, probabilitatemque fulcire, levidenfis operis erit. Redeo ad gemmarum quarumlibet $\&$ plantarum, imo feminum, præcipue exoticorum, hiftoriam. Senna Alexandrina, Lithofpermon, Lacryma Jobi fata, vertuntur in lapillos dentibus examinandos, amicis propofita pluries in horto meo, licet pars horum excreverit. Certe mira in vifceribus terræe efformantur, quorum caufa ignoratur, tefte eodem Bartholino, in opufculo de unicornu ejufque affinibus \& fuccedaneis, qui diferte omnia enarrat huc fpectantia. Quare in folidiflim $x$ compaginis gemmam Cocci Maldivenfis, ut $\&$ vulgarium, germen verti pofle, Naturæ privilegiis ad eam formam concipiendam dotatum, affirmo. Atque hæc de utriufque Nucis germinibus in lapillos verfis diata funto.

Alterum non vulgare eftimationis exemplum reddetur, quo Clariflimus Speccrus inftitutum noftrum decorare dignatus eft: Epiftola enim, propria manu exarata,in publicum profert non infignia tantum, fed \& utilitates rariffimæ Nucis, quæ ægritudines humanum corpus affligere folitas, velut Averruncus, depellere confueverunt. Ita de Medicinæ hac parte optimus \& excellens Vir bene mereri voluit; Quadringentis infuper ad fplendorem Facultatis attinentibus Thefauris orbem ditaturus, qui nondum ufu comperti, aut ab aliis neglecti \& male defcripti hactenus infufcantur. Quos petitioni illius obfecundans in ordinem digerere aggrediar ubi otium animi mei gaudio allubefcere volet. Epiftolæ vero tenor em non de verbo ad verbum, fed quantum Latinitas permittit, fenfuillafo explanare levitas laboris eft, fed ea cura, necubi fides interpretis vacillet, vellegentium fudio turbæ fiant. Apographum vero infequentium ferie proferre non piget.

Cl. V.D. C I u T I. Inftinctum tuum boni \& magni zeli expertus fum, poft nuperum ex India reditum iteratis tecum colloquiis, non tantum humanæ falutis curiofis, fed etiam de honore patrix folicitis. Quocirca velut aculeo me propulfafti, ut memorix mex arculas eventilareth, indagaturus quantum in is fuper effet, quo Cocci de Maldiva, atque aliarum minoris pretii Nucum, genus elticidari poffet. Quod etfi ejús monetze aut valoris non reperio, ut appetitui tuo acriter flagranti fatisfieri queat, ne quid tamen officio meo deeflem, fermonis breviario quicquid memorix mex velut pofthumum remanfit; tibi confecrare aggreffus fum, in quo te promumcondum effe jubeo, eorum quæ materiæ tuæ $\&$ propoliti terminos ampliare queant. 'Et in prima quidem ferie, Antefignani partes occupat, legitimum de Maldiva Coccum, qui in aulis Indorum Principum; atque inter Nobilioris gradus viros, ob rara infignia \& Medicinæefficaciam, tanto honoris pretio attolli folet, peculiaris arboris fobolem $\&$ fructum effe, longo diffipio à vulgarium Coccorum atque nuciferarum arborum indole remötum. Quemadmodum experientia duce, anno millefimo fupra fexcentefimum \& octavum, in litore \& maritimis Indix locis addidici, occafione navigii ex Infulis Maldivenfibus adventantis, ut vèterum Coccorum proventu ferax Calecuticam terram aut

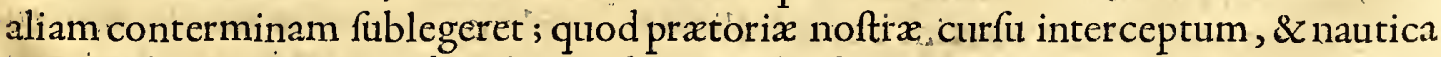
gens explorata intelligendi anfam præbuerunt fapham eam cum omniarmamentorum genere penes mercimoniorum congeriem, atque ipfum cibi \& potus penu, totam ex ligno; foliis, cortice, fructibus Cocci arboris conftare, pauculo tantum oryza adjuncto. Popellus vero hic affirmandoratefcere jubebat, negotiationem fuam hoc fructu circum-

$$
s_{3} \text { feribi, }
$$


fcribi, atque ejus vecturam certis anni temporibus in Continentem fe facere, veftium atque aliorum neceffariorum verfura eam commutantes, quorum penuria Infulanos fuos torquet. Quo occafionis ductu ad ftudium tam appretiati Cocci de Maldiva excitatus fum, quem plebecula illa in paucis Infulis $\&$ numero contracto reperiri, \& diligenti cuftodia à territorii proceribus ad poffeffionem fuam rapi afferebat ; ut raro, \& non nifi, aut titulo munnificentixad Malabarenfes, aliofque Principes, aut furti aftutia in peregrinas regiones, transferatur. Adeo ut mirarife dicerent, noftros tam foleninem Cocci Maldivenfis proventum in pauperculo rerum fuarum ftatu inter proletarios \& rureftres Coccos indagare, aut antithefin aliquam comparandi inftituere velle. Horum omnium perfuafu, penes ea qux experimentis propriis in prænominato \& genuino Cocco adhaufi, adducor ut credam $\&$ fententia à me feratur, fui generis arborem \& fructum effe, longe à femitariis Coccis recedentem; eo magis, quod nunquam nifi inter Summates magna pretii aftimatione affervari intellexerim, in quorum fidem memoria mihi fuggerit, me anno millefimo fexcentefimo decimo quarto menfe Maio à Moluccis ad Bantamenfes reverfum, juffu Archithalaffi Botbii iP. M. cum jam defunEto Coenio, eo tempore Prefidis munus adepto, auctoratum effe, ut, quxdam Societatis negotia ibidem procurantes fenem Pangoranum Arifam Mangaca, jam tum Regis fceptro Bantamenfibus imperantem, conveniremus. Eum vero in Regix feceffu, inftrumentis ad tornum paratis, \& adminiftrorum frequentia , circa magnæ molis Coccum Maldivenfem adeo defudantem offendimus, ut longo temporis difpendio curas noftras fufpendere coacti fimus, atque in vicem de predicto Cocco colloquii textum ordiri; quem manibus Pangorani verfatum, memoria aftipulante, magnitudinis rar $x$, \& magis in longitudinem extenfx, quam rotunditatem convolutæ, effe pronuncio; fed fubtilis fubftantix teftam incifura aut fragmentis atram, cæterum vulgaris Cocci tam externe quam interne, non abfimilem colore. Is in frufta varia difperfus erat, ut fciendi apud nos difficultas remanferit, cafu inaugurato, an ftudio humano, in eam formam redactus effet. Ea tamen Principis adminiftratio fuit, ut non minori cura minutas particulas, quam magnas cuftodiret, poftquam eas fpeciatim ad ufum fuum proprio digeftu difpenfaret, ne quid à particulis, imo ipfo ramento \& bracteolis à torno relictis, deperiret. Animadvertendo delineabam, minora fragmenta ab eo appropriari caliculis, fcyphulis \& cochlearium atque ejus generis aliis formis, quibus ficcus, humidus, \& fuccofus cibatus depromi poffet, maximam ejus portionem, qux Nucis pene dimidium accomplebat, intactam finente. Qux omnia, in arbitrio oculorum \& confpectu noftro facta, facile evincunt, neque Principem operis fui circa Coccum Maldivenfem puduiffe, neque nos veritatem obtorto collo trahere. Ea, tam curiofe inftituta, adminiftratio; Præfidis Coenii linguam diffibulabat, ut Principis mentem modo variegato pertentaret, cujus fcilicet energix nux ea for et, in qua tantæ fublimitatis Pangoranus \& Princeps fe diftrictum tenebat, omnia proprix cuftodix tradens. Ad qux refponfum dedit, eam Nucem legitini \& pretiofiffimi Cocci de Maldiva progeniem effe, quam Codiacti aliquot Mercatores, nempe Mauritani, ante longum temporis fpatium parenti fuo magni muneris inftar advexerant, eamque inter lavanenfes, Malayenfes, Malabares, nec non alios Indici natalis poptlos prafentiffima Medicinx laude cenferi, ad omnem toxici hauftum, \& morbos divinos, febrefque magni difcriminis. : Ita prefidi Coenio miram videri non debere (poftquam fanitati nullus Thefaurus pravaler) fi ipfe manu propria verfaret, $\&$ pervigili cura omniailli infervientia cuftodiret. Intra huncrefponfi tenorem, tornando fe occupabat, tam ftudiofe omnia defignans, ut Legationis noftrx propofitum exequi nulla ratione liceret. Qux caufa Prxefidem Coenium inftigabat, ut, dum ille fermonis filo infifteret, frufta quxdam Nucis oculari infpectione ufurparet, \& manibusfuis infereret, velut mihi quoque fpectaculi commoditas non deerat. Atque in hoc fermonis curriculo Coenius petere inftitit, num fruftulenta quedam, in ufum Generalis Botbii, corradere illi liceret, quod aulico ritu accomplete praftabat; quo audito in habitum ridiculi furoris verfus Pangoranus fragmina ea ex manibus coenii eruebat, refponfum interim bucca follicante fupplens, fipercilio nubilo \& in rugas caperata fronte, felicitatis \& $\&$ favoris affatim effe, tantam majeftatem Cocci, oculis peragrari poffe ; abfonum infuper videri, mendicando inde aliquid extorquere velle. Ad qux Cl. Coenius verbis bene digeftis reponebat, non proprii commodife Oratorem efle, fed petitionis fure cardinem in eo verfari, ut Generali Boshio doni gratiam fa- 
MANTISSA AROMATICA.

ceret, qui, Vir pracellentia celebris, \&, velutipre Princeps fama accepit, jam in procinctu eft, ut in patriam revertatur; \& proinde doni iltus magnum meritum illi fore. Qux omnia Pangoranum adeonon ad liberaliorem habitum perducebant, ut refponfi vicem praberet, in procaciam verbis adaptatis, Coccum Maldivenfem ejus pretii, apud Reges \& Principes, non minorum gentium Generales, diverti debere. Quo refponfo mirifice genio fuo litabat, poftquam, intra Belgarum \& Anglorum apud Bantamenfes moram, oraculi inftar fanciverat, ne quis Generales aut alterius ordinis Rectores, utriufque Nationis, inter Principes \& Aulicos adminiftros numeraret; quod Mercurio vota facerent \& lucri cupiditate turgerent, eofque viliori refpectu \& fpretu majori femper dignatus eft, quam territorii fui Dynaftas $\&$ Inquilinos, quorum curæ circa Principum \& Regni negotia limitarentur. Quibus ita decurfis Pangoranus ritus fuos in aliam faciem mutare occepit, Cocci Mald. frufta feponens, nofque ad auditorium. furum expeditionis ergo admittens, nulla ratione fe induci paffus, ut tantillum Cocci Mald. Generali Botisio admetiretur. Qux omnia domum reduci Coenio, recenfendi occafionem præetabant, ut de dignitate Cocci Maldivenfis \& aviditate Pangorani colloquium texens in cachinnos genas laxaret. Tam raram Cocci Mald. dignationem ex Pangorano ubi percepiffem, atque oculari infpectione affecutus effem, qua folicitudine eum tantus Princeps verfaret $\&$ cuftodix fux traderet, cupiditatem in me \& curam ingeneravit Coccos ejus not $x$ aut faltem talcolas aliquot acquirendi, velut deinceps poft bonam temporis menfuram minutula Nux Maldivenfis ad dominium meum tranflata eft, in totum differentia à jam dicta aberrans; poftquam ea anferino ovo major non effet, compagine teftx craffior \& fcabrofior, nec non ratione proportionis magis extenfa in longitudinem, quam in præcedentibus enarrata. Multoties lima aliquid abraf, \& fubinde in gelidam,fubinde in calidam, demerfi,explorandi induftria, qux varietas coloris, odoris aut faporis contra ordinarii Cocci indolem fe propalaret; atque experimento comperi, eam fimili quantitate, \& dofi liquoris, in xquilibrio foliti Cocci, faturatiorem Cocci colorem, fragrantius ferientem odorem, \&zacutioris fenfus faporem manifentare: quod cum me interni farctus aut medul$1 \mathfrak{l}$ defiderofum efficeret, Nucem meam ad digiti latitudinem in fuperficie ferra detruncavi, quod ipfum non nif fubtiliacie \& poft multos labores effectum dare potui, poftquam fecundum jam dicta, tefta craffa admodum $\&$ immenfa duritiei contumacia refifteret. In aperta, contra genium \& naturam vulgarium Coccorum, medullam albam deprehendi, qux, communi velut lege, teft $x$ coaluit, non diffolvendo pene nexu, qua à calyce feparata, offendi, folidam velut medull $x$ maffam, ad pal ex latitudinem à̀ circuitu teftx diffitam, fui quafi jurıs, ad ıcf e effigiem conclufam, \& excitato motu ftepere folitam, tanta ariditate refragantem, ut cultro aut novacula exiguum modo ramentum feparare liceret, quod ipfum duritie cum offe certabat; nihiloninus aliquales aftringentis amaroris vires promebat.

Atquehæc præcipua funt, quæ tibi V. Cl. de Cocco Maldivenfi communicanda novi, hac quidem temporis occafione. Cxterum non mihi deeft ampliora, de communi Coccorum atque aliarum Palmarum genere, participandi, poftquam experientia, proprio fatu parta, talem eorum cognitionem mihi largita eft, qualis fpecierum defcribendarum modulis neceffaria eft. Quoniam vero præfens operis tui tractatus de folo Cocco Maldivenfilapidem verfat, quicquid reliquum eft, in futuram commoditatem differemus. Tuum interim exit ea cordis propenfione jam communicata amplecti qua tibi oblata funt. Tuus animo totus I. SP.E C X.

Scholion. [Tornando fe occupabat] Mira naturx fedulitas in ferinx propemodum nationis Principe, fed quam cultioris feculi exemplis probabilem reddere licet. Quippe Imperator quoque Rudolphus II, noftra atate Toreutices avidifimus fuiffe dicitur, manus fuas fabrili opere occupare folitus. Ne tamen in mundi fenecta eum morem invaluiffe quis arguat, poftquam Iulium quoque Cafarem in ipfo Orbis pene natali ftudium fuum tornando detinuiffe conftat, vel Suetonio tefte, qui in ejus vita afferit Cxfarem gemmas, toreumata, figna, tabulas operis antiqui femper animofifime comparaffe. Vtinam pejus collocatx oper $x$ nemo rationes reddere cogatur! Quippe otio intervallum largiente pluirimi voluptati \& Fefcenninæ licentiz fe dedicare folent, Alea \& Fritillo potiorem atatis partem oblimantes; unde tandem res domefticx franguntur, fanitas labefactatur, honos profcinditur, dum iftis

$$
S 4 \text { frugiferz: }
$$


2 I 2

frugifer $x$ manus gloriæ immortalitatem, familix \& falutis, imo \& $x$ feculi temperiem parare folent.

V Vem in tenebris quærere, neque unius, neque plurium fimul eft negotium, qui quidem vel oculorum caligine laborant, vel mentis acie hebefcunt. Quod in Botanices campo exertis indiciis documentum præbet, quilicet fertilitate hilari, \& extricabili copia abundet, humani tamen ftuporis vitio atque intellectus impervio tranfitu diu neglectus jacuit, imo pedibus varie difperfus eft. Antiquorum autem induftria coli coptum Seplafiarii, atque his pejores Monachi, velut irreptione facta, radicitus everterunt. Quippe tenebrarum alumni, atque inf citix propagines, divinorum arcanorum incuriam ad Medicinæ lanienam tranftulerunt, fcilicet in delegato fibi munere inertes, in afcititio atque alieno ingenio $f_{1}, f_{1}$ dîs placet. Tanta vero male rem gerentium efficacia fuit, ut Europæ, imprimis Italiæ, non folum literatos, verum $\&$ Afre, Arabix, atque Africæ incolas traductionibus iniquis non fine flagitio confundentes, ad quifquilias fuas $\&$ gerras pertraxerint. Quam fundi Medici calamitatem nitori folito reddere $æ$ quanimi \& folido judicio præditi hominis res eft, quique varia per orbem jactatione, linguarum adminicula, quibus Botanica fuftentatur, $\&$ herbationum, rerumque naturalium arcana penetravit. Ego autem licet eruditione \& ingenio gregalis, pro viribus tamen effectum dabo, ut aliquam perniciei fur maculam tam falutaris f́cientia deponat. De Coccis vero $\&$ Palmarum generibus fudium - meum brevi intendere voveo, poftquam ad illuftrandum à probis viris faces mihi prætenfas non diffiteor. Quippe $\&$ noftri feculi in communicando liberalitas \& fuperioris non averfanda diligentia, rei Botanica locupletiorem me effe volunt. Quos omnes ad inquirendi ftudium preffo veftigio fequi me fateor, ut fi non æqualis aliquando, faltem parvo intervalli fpatio ab iis avellar. Quod effutitione in audaciam laxata à me dictum qui putabit, candoris noftri patrocinio adductus, boni interpretis habitu excipere debet. Neque enim eruditioni mex, qux tenellas dotes habet, palpum facio, fed diligentix merita apud ftrenuos quofcunque ad abbacum vocare non erubefco. Hac fola ordinem aliquem tuerime invenient, qui Herbariæ quoque rei notitiam, jam longa temporis ferie partam, apud me vigere non ignorant. Neque plura in acceffum aut augmentum cotivafare libet, ne operi noftro brevitas confecrata, verborum abundantia in Pandectas aut longitudinem immenfam evagetur. Rem vero negotii \& difficultatis plenam propenfa animi alacritate decurrere fatui, qux una multorum laborum exantlatrix effe foler. Si tamen propriis ingenii viribus fuccumban, ad eruditorum virorum fcripta confugiens pedamentum mihi præbebo. His quoque alibi defectum fuum quiritantibus, ad Exoticorum thefaurum à me receptus fiet, quem proprio Marte ex fcriptis \& quandoque colluvie (ut ita dicam) Auctorum corrado, ut mihi \& polthumis fubfidii loco fervire poffit. Quippe ex umbris domefticis in claram cxli lucem aliquando exaufpicabit, modo pari vitæ \& fanitatis beneficio frui nobis dabitur. Quod D. O. M. largiri nobis dignetur, ut quæ verbis hactenus fucata apparent, in veram operis effigiem perduci poflint.

Quemadmodum nihil efficacius aut probabilius docet, quam Icones lad res propofitas adhibitæ, ita omnino neceffarium duxi noftræ huic Medicæ Nuci tabellis fidem \& auctoritatem afferre, quod verbis non fatis convenienter fieri potuit. Ex libris enim folis neminem aut Anatomicum aut Botanicum infignem deveniffe conftat. Quia autem oculi minifterium quod ingenii acumine $\&$ præcellentia dirigitur, pictorem fubinde facit; nunquam rcjiciendi videntur, qui in utroque officium præftiterunt, fcilicet rem verbis dilucidatam figuris exprimentes; poftquam, velut mutuum muli fcabunt, ita oculus exterior internam mentis aciem illuftrare folet. Quippe Scalizero patre Auctore, Exerc.7 5 . Sect. 2. Imago rerum nibil agit prater impreffionem in fenfus vel exteriores vel interiores, ad cognitionem. Quæ impreffio nifi facta eft, otiofam figuræ oftentationem diccre licet. Ait enim paulo ante, Quippe imagines, Species, reprafentationes, amota fpecic omnes abeunt: nifi que in fenfibus recipiuntur. Sunt enim borum pictura ille.

Vandoquidem Nucis Medicx divifionem in partes, quibus facies diverf $x$ figurantur, prafatus fui, non inconcinnum judicavi, poftquam ad vivum delinearas tabellis offerre licuit, paucula notatu neceffaria depromere, quo plus lucis afferatur. 
TAVARCARE' five NUX MAIDIVENSIVM。

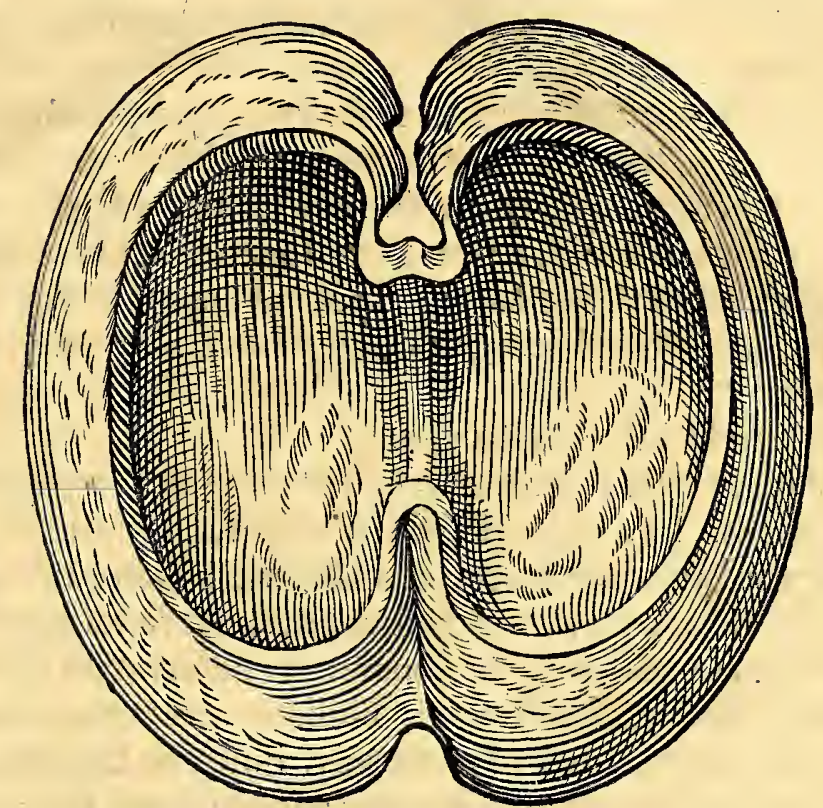

A.

A litera denotat geminam Nucem. Hæc figura Nucis Maldivenfis, non oblique intuenti , fed è directo introfpicienti , \& $z$ manibus contentæ vifuique oppofitx, duplicatæ pyxidi comparanda venit.

TAVARCARE' five NUX MAIDIVENSIVM.

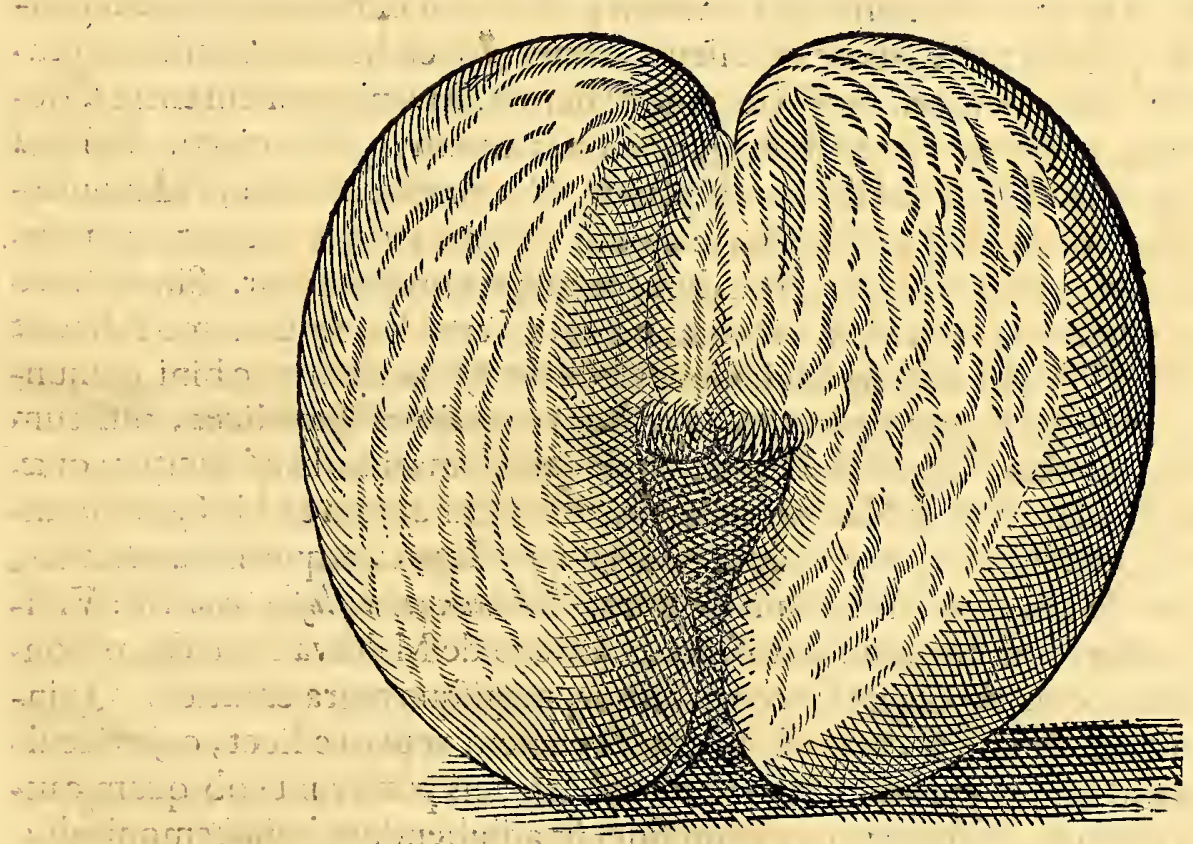

B.

B. Seffilem \& fummam partem exhiber, qux fenfim declinat in modum interfemi。 nei, facie oculis pudicis afpicienti horrida \&c. Hanc etfi xqualiter per latus alterutrius divifam exhibeo, nihilominus, ne Lectoris animo dubium aliquod offeratur, monendus eft, beneficio fectionis, quả ferra facta eft in præcedente A, extrema orificia conjungi B. \& partibus refectis extimis, nos integram Nucem oblaturos. Confideratis tantum tribus; nempe partis fumm $x$ acuminatioris pr $x$ fertim habendam efle rationem, in cujus bafi apertura eft, pauló ante à me dicta, qux fedes eft germinis feu genimx, qüam podici non inique accomparavi. Dein Spiracula duo confideranda effe lateraliter in parte hac fuprema regione locata, qux cæteris paribus magnitudine etiam non fuperant vulgarium Coccorum fpiracula. Ea ad fcyphum confolidandum obturantur., quod videre eft in minore Cymbio Maldivenfi honeftifimi Mercatoris 
$2 I$ i

G VIIE L M I. PISONIS

Samuelis de Bendana, qui duo poffidet, $\mathrm{ab}$ artifice quondam Antwerpienfi, argento affabre inveftita. Tertium yero non eft prætereundum, in integra Maldivenfi Nuce, colliculum quafi Veneris, fæminex pubis faciem dextre æmulari, qux ferræ molimine tranfadacta deperditur.

His ita in praliminarioperis difpofitis, auctoritates quoque alienas velut in depo. fitum addere non vanum judico. Garcix prafertim ab Horto \& aliorum Medicorum fententix non preterlegendx, qux ejus roboris Clariffimo Clufio vife funt, ut eas in Latium ex Lufitana lingua transferre non fubterfugerit. Quas ipfiffimis C I u S I I verbis reprafentare operx $x$ pretium eft, ne interpolando aut mutando,alien $x$ diligentix fraus fiat, aut publico ufui aliquid derogetur, dum verborum, ut ita dicam, foliis attenta mens infenefcit.

Garcias apud Clufum pagina 190.

" Laudatur hic Coccus aut Nux (fed præfertim ejus medulla) adverfus venena ab ipfis " earum Infularum Incolis. Et à viris fide dignis accepi, ad Coli dolores, Paralyfim, " Epileptiam aliofque nervorum affectus fe utilem fenfiffe: à Coli quidem doloribus,quod " vomitum cxcitaret, $a b$ aliis vero $x$ gritudinibus immunes reddi ægros, $f(f$ aquam in iis " Nucibus (adjecto medulli momento) aliquamdiu confervatam ebiberent. Sed cum " "non fim id expertus, minus fidei his tribuo. Nullam autem periculum faciendi, oc"cafionem habui, quod uti malim medicamentis, quorum facultates jam mihi per" "pectx, \& multa experientia comprobatx funt : qualia Lapis Bezar, Theriaca, Sma"s ragdi, Terra figillata, \& alia pleraque medicamenta (de quibus fuo loco), quam re" centibus, minufque certis. Nam quod nonnulli dicant, fe hujus ufu commodum fen" fiffe, an id perfuafione $\&$ imaginatione factum fit, ignoro: hinc fit, ut nihil affirmare " poffim. Sed fi quid certius cum tempore exquifivero, fententiam revocare non pude" "bir. Niger eft autem hujus Cocci cortex, \& nitidior vulgari Cocco, figura ovali ma" gna ex parte, necita rotunda ut vulgaris. Medulla five pulpa interior, qux ficcata " dura eft admodum \& candida, non nihil tamen ad pallorem inclinans, in fuperficie ri" mofa cft $\&$ valdè porofa, nullo fapore excellens. Dofis vero eft hujus medulla ad gra" na decem cum vino aut aqua, pro morbi ratione $\&$ natura. Inveniuntur autem hi Coc" ci grandes admodum, interdum etiam exigui, omnes autem in litus ejecti. Vulgari " porro fama accepimus, Infulas Maldivas aliquando Continentem fuiffe, fed inunda" tione maris fubmerlas has Infulas effeciffe, in quibus obrutæ Palmæ fuerint, quæhos

" Coccos protuliffent, qui terra indurati, in hunc modum conficiciuntur. Sintne vero " ejuldem generis cum noftris, facile judicari non poteft, cum hactenus nemo folia aut

* arboris truncum videre potuerit; fed foli Cocci in litus ejiciantur,nunc bini conjun-

- "ctim, nonnunquam vero finguli feparatim. Sed hos nemini colligere licet, nifi cum

" capitis periculo ; quoniam Regis effe afferunt quidquid è mari in litus ejicitur; qux,

" " res majorem auctoritatem huic Nuci conciliavit. Eximitur autem ex his Coccis pul-

" " pa five medulla, deinde exficcatur eadem ratione qua Copra, atque indurefcit eo, " "quo venditur, modo: diceres effe cafeum ovillum. Ad hec verba Clufius adnectit: Vidi" "mus tum Uliffiponæ, tum aliis in locis vafcula ex Cocco de Maldiva confecta, oblon" giora plerumque iis; qux ex vulgari Cocco parantur, magifque nigra \& nitida. Quin" imo ipfam medullam Nucis ficcatam Uliffiponæ venalem reperire licet, cujus facul" " tates mirifice extollunt, atque omnibus fere alexipharmacis preferunt; ob quam cau" fam ingens cjus pretium. Quam vero parum fidei fit adhibendum hujufcemodi fabu"lofis \& commentitiis facultatibus, ex noftro Autore fatis liquet.

Refert porro Clufius bifforiam vafisex Cocco Maldivenficonfecti o argento incluafi, quod 1a" cobo Gareto acceptum ferebat. Magnitudine (inquit) illud fuperabat reliqua vafcula ex fi“ mili Cocco coifecta; repertum erat in prxtoria illa navi, M. D. X CII. ab Anglis oc" cupata: longum erat uncias quatuor \& decem, latum feptem, ovalis inferna parte fi" gurz, fuperna paulo planioris, later edextro magis rotundum \& $\alpha$ tumens, externa par: « te calcei pedi inducti pene initar. Color qualis in Cocco vulgari levigato \& expolito. Chriftophorus à Cofta apud eundem Clufium, Fol.270.

«Coccus de Nalcdiva (ita quibufdam dicere placsit) cognominatus, adeo commenda. “ " tus ab ipfis Incolis \& à Malabarcnfibus, non nodo à plebe, fed à Regibus \& Principibus " viris, ut in omni fere morborum genere ad eam confugiant, tanquam adfacram an. "choram. Fiunt in cam gratiam exillo pocula qux auro vel argento excipiuntur; \& 
in navium triremiumque figuram efformantur, ad aquam bibendam, in qua ex cate- i 6 nula, medullæ ipfius Cocci fragmentum pendere finunt: fibique certo perfuadent, il- c lis qui aquam ex fimilibus poculis hauriunt, nullum venenum nocere poffe, futurof- is que immunes à multis morbis; in quos fane memini multos incidere qui ex iis pocu- c lis bibere foliti erant. Et licet omnem diligentiam adhibuerim, nunquam tamen ob- $c c$ fervare potui, fimilia pocula aliquem ex morbis curare, ad quos utilia effe creduntur : c 6 potius igitur arbitror tantam laudem obtinuiffe à vulgi opinione.

Nonnulli, ex hujufmodi vafculis bibere foliti, mihi affirmarunt fefe experientia didi- c ciffe, jecur incendi, renes noxam contrahere, \& calculum generari : nihilominus ta- c men magnum eft eorum pretium, longeque pluris aftimantur.iis locis ubi inveniuntur, " c quam aliis procul inde diffitis : nam interdum ejufmodi Nuces nudæ, neque auro aut 6 argento exornatx, quinquaginta aut amplius nummis aureis xftimantur. Nigrior au- c tem, nitidior, longior, majorque eft hic Coccus, quam alix Nuces Cocci com- cs munis.

Hactenus Chriftophorus à Cofta, qui potiorem commenti fui partem ex Garcizaromataria hiftoria deprompfit ; quod facili oculorum tranfenna animadvertendum, qui Palmx Indice defcriptiones ab utroque editas conferre dignabuntur. fed neque heterogenea fcripferunt, quotquot calami opera in hac arbore defudarunt; in quorum choro $\mathcal{M}$ Hartinus Ignatius, ordine Francifcanus, non poftremas occupat, qui in tertia hiftorix Sinenfium feu Itinerarii Novi Orbis parte, capite octavo, hæc non perfunctorie tradit.Ioannes autem Hugo Linfchotanus, folio exemplaris noftri I 7. I 8.cap. I 3. eodem mutui privilegio hæc ad fe derivavit ; ibidem promittens. Nucis Medicæe arborem integra hiftoria enarrare, in quo tamen velut corvos hiantes nos eludit; vulgarem vero pertractate decurrit, fubfidiis in hanc mentem non excuffus. Sed neque à more meo alienum eft fcriptis mutuatis opellam meam ditare, cum ne ipfe quidem Iulius Cafar gregarios militesad rei certitudinem vocare non erubuit, fruftra Afinio Pollione Imperatoris $\mathrm{ftu}$ dium criminante. Rivulis enim ex Francifco Pyrard de Laval ad me ductis omnia ea digeffi, qux capitis fecundi \& tertii confiniis detinentur, fed idiomatis Gallici vefte in Latini fermonis habitum mutata : velut neque of citando praterlabi paffus fum, quibus Infularum fpatiis, quove limite, ea Nucis colligendæ meflis fieri foleat, non dimifa cæli temperie \& foli dotibus, magnam in genio defcribendo laudem fibi arrogare folitis; ubi de earundem Infularum latitudine (qux poli elevationem adxquat) fermo: cinamur, eodemque filo difpofitionis efficaciam ad plantas, fructus, flores promanantem, detexere libuit. Nucum vero legendarum artificia, aut pifcandi modum,neglectum jacere permifi, in qua ferie, anni quoque rempeftas ordinem fuum non invenit, velut extimæ quoque faciei delineatio penicillo noftro caret, fi qua integatur, ut vulgaris. Inquifitione vero fua dignatus fum, an Medica Nucis gemini femper alvei à crefura circumacta, ut in Bafilica feu Iuglande. De reliquis in fidei tutelam muflitabundus federe malui, quam otiofa proferre, qux ipfis forte indigenis non obvia, aut inveftigationislabori tam in aviis fita terra, difficultatem afflare folent. Hoc mihi liquido conftare fateor, Nucis Maldivenfis exemplo adductus, aliam aliarum effe forman, quippe noftra (cujus in prafatione ad Lectorem memini) fummis labiis argento recipiendo fedem prabuit, in circumactum crufta ducta, pro vafis figura: Wolferdiana autem ferræ fpatium cum injuria fuiffet paffa; quare duplicatæ tantum capfulæ pronam habilitatem aptavit, quarum cuftodia Betel, Calx offium, Siri, Pinang, Arecca \&c. quorum apud Indos ufus Mafticatorii vicem præbet, ab aëris injuria vindicantur; velut his clauftris Ambra Grifea àfordibus libera affervatur.Quanta vero Nucum capedo fit, ex Linfchotanifedulitate cognofcere licet, qui ad Regem Hifpaniarum deferendas, duarum circiter amphorarum capaces fuiffe ait, fed in dimidiatis tantum eam menfuræ rationem prøbabilem videri, poftquam integrarum circuitu duplam liquoris condi poffe affeverat, fimili dimenfo, imo largius excurrente, noftra cel ebratur. Eam vero Gemmis (qux ad ufus diverfos falutiferæ vocari folent) adornatam volui; quarum pars mobili aptitudine neceffitati urgenti infervire valet, utpote Nephritico \& Caineolo lapidibus, pars in cera radicem agens, aut firmiter inferta argento, tranflatitia fieri pernegat. Vt autem varietatis illicio indulgerem, vicenis fpeciebus, imo pluribus, copiam eam diftinxi, in quibus fplendoris gratia non vulgaris \& fuas delicias oculi curiofi invenire gaudent. Cymbium vero ea forma edolatum eft, ab Artifice ingeniofiffimo 
niơfifimo Hermanno Martens, argentifabro \& cive Amftelædamenfi, ut inter avem \& pifcem medium animal referat. Gloffopetra etiam linguam exertam animalis mentiens, obfirmat epiftomium, quod in effundendo liquore intro recepto aperitur. Rhinocerotis autem affabre elaboratum cornu, operimenti claudentis vafis aut Cymbii infuper $\&$ vitri excipuli effundendum $\&$ ebibendum liquorem locum dat : Ita Philotefias \& Iatrices poculum habes. Hactenus Nucem noftram Medicam enucleavimus, ea in fronte operis congerentes, quie neceffitas \& filum rei exigere videbantur, nunc in pofticam reliqua trahere libet, fine quibus tractatum mutilari contingeret; quare filendo non decoquentuir.

Putaminis rafura \& pulvifculus concinnatus nulla faporis idea infignitur, dum lingux vehiculum, deglutienti tranfitum præbet, neque odoris ullam fpeciem nafo ad. motus imprimit, fed neque ventriculo exceptus naufex occafionem ulla qualitatis repugnantia irritat, nullo vomitus incitabulo infeftus, neque al vum aftringendo fiftens. Qux omnia non tantum fide $a b$ aliis mutuata affirmantur, fed domeftico etiam in me exemplo auctoritatem invenerunt. Quod cum venix prefatione $\mathrm{Ch}$. ̀̀ Cofta $\& \mathrm{Cl}$. Cluffo dictum volo; qui rem male perpendentes jufto rationis xquilibrio non inferviunt. Veritas enim hoc folo, velut dictatore, enucleatiflima prodit, dum experimentorum indago menti tenebras involvit. Nux vero noftra incertx fidei teftimonium prabet, quod promptuariis alienis rariflimo ufu inferatur, apud paucos duntaxat in orbe Europzo reperiri affueta, ut infrequens effecti exploratio fit, \& fi maxime ad ufum manus tranfeat, mentis humanx caligine difficilis ad veritatem acceffus detur.

Color autem putaminis Maldivenfis natura fua ater eft, \& non abfimilis Ebeno. Vulgaris autem tinctura \& 2 tate ater redditur \& pulligine tantum levi afpicientium oculos detinet.

\section{Tabella bec Medullam, atque inte- gumentum, feu corticem inter- medium exbibet.}

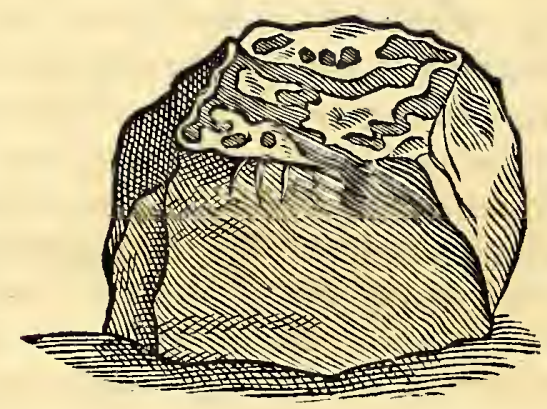

Liquorem vero putamini committere alieni arbitrii rem facio; velut neque lioc pramanfo opus habet, quo temporis intervallo fcyphum obturare deceat, quove loci, calore an frigore confervandus veniat, poftquaim liberam unicuique ex re natajudicii affertionem facio. Neque enim periculofa indago eft, poftquam præter unam ficcitatis notam, nilil fenfui objicit, quod faporis ingraticudine Naturam aut guftum offendar, frigiditatis enim temperamento ab exceffu immoderato avellitur; etfi fux quoque caloris particulæ adhæreant, ita Elementis inter fe commiftis, ut fida fubftantix permanentia reddatur. Quod exemplo vafculorum $\&$ doliolorum quotundam, \& medicamentofis cornibus levi opera probare licet. Ex Thamarifci prefertim ligno $\&$ corticibus fabricata fidem indubitatam faciunt,à multis ufque feculis veritati nihil detractum effe. Quippe ne in continuo quidem ufu doliola ea nativam virtutem exuunt, operi fuo jugiter ftudiofa natura. Quod Medicinam factitanti experientix adminiculum prabere poteft, poftquam fcyphulus, ex Antimonio arte Chymica factus, neutiquam fux energix dotes deponat, ut ut frequens ejus adminiftratio fit. In Nuce autem noftra clarum documentum erit, qux non minorem leptomerix guftufve gratiam habet, quam Thamarifcus, qui roborando, atque referando, aliifque modis ftrenuus effe folet. In toto autem Naturx opere multa fenfibus obvia, rationi occulta funt, qux deindc ufu adhibito velut fplendefecre confueverunt. Quare Medici rationalis munus eft, abditas qualitates non rejicere, quas. confervand $x$ vitx \& pellendis morbis utibiles effe multorum falus declarat.

Supereft Medullx quoque effecta \& virtutes incomparabiles enarrentur. Quippe nỏn folitaria tantum, fed aliis etiam fimplicibus admifta, valenter fe exerit. Hxc cornea duritie limam refpuit, fed cultro intern $x$ parti adacta $\&$ malli percuflu fiffa, mor-

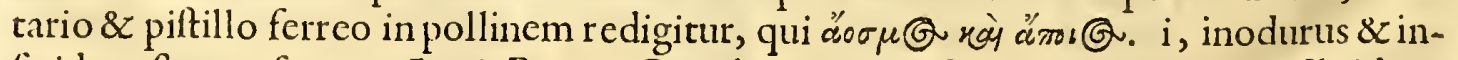
fipidus eft, non fecus ac Lapis Bezoar Occidental is, cui ftriis, minus tamen vifibilibus, \& colorc affinis eft. Ovilli autem cafei crufta veteri affinulanda videtur, cujus pars interna 
interna rimofa vifitur, externa qua parietibus Cocci interius adhæfit, foliditatis fir$\mathrm{m} x$, interventu corticis intermediiftabilita, à quo fpano aut noctuino afficitur colore extrinfece; materia albida cum dentium humanorum duritie certans. Pulvis nullum moleftix comitatum habet, cum affumitur. In actum vero à calore $\&$ fuccis ventriculi velut fermentando diffoluta fubftantia perducitur, atque éa operis efficacia eft, ut fidem requirenti fufficere queat.

Hinc ad integumentum internum, feu corticem intermedium tranfitus fiat; Qui oculorum arbitrio in capfis meis tenellum fe declarat ; coloris ferruginei aut fpani, inftar corii hircini in calceorum ufu craffus, fibris quibufdam à centro aut umbilico ad convexa fuperficiei exteriora variegatim diftinctis præditus, velut à Iocinore venæ \& à Corde arterix ad omnia humani corporis membra derivantur. Hic autem è craffioribus partibus contextus videtur, fapore (quem Græci črovov s yoúows vocant) ignave fubaltringens. Intra mandendum non fe colligit $\&$ conglobatur, fed per univerfam lingux capacitatem fe fpargit. Quorım omnium confenfu $\&$ fuffragiis facilis deductio eft, qua temperie vigoretur, \& quam indolis habilitatem fortitus fit.

Gemmæ porro feu germinis Hiftoriam in Aphorifmis Cl. Realii \& Scholiis noftris digeftam reperies; qux eo manus libramento à me confcripta fateor, ut publico ufui prodeffem, non inani verborum oftentatione turgerem, modum fervans, ut potius infra rem quam fupra, aftrictius quam effufus dicere videar. Quid enim me moveret corticofun aut villofum integumentum, uti Nucis vulgaris eft, in Maldivenfi noftra fingere, cum forte ea deftituta reperiatur? ita non exceffiffe, fed potius non impleffe materiam dici malui, nec aliis fcribendi poft me anfam præripere; imo fententiam meliora edoctús revocare non pigebit. Hæc quantum per medioctitatem noftram licuit , Rei Medicæ \& Naturæ ftudiofis ftrictim delibaffe fufficiat.

\section{Hec autem Tabella Germen, aut Gemmam in lapillum Gernmee nitoris verfam, icone vivi delineat, quibus Cocci Medicipartibus lapillum è Cocco vulgari Indico adjicere non peenituit; ut fides of veritas intra tutelam fuam exempli allegatione confifterent.}

Quandoquidem opufculum hioc abfque Hiftoriis non legendum eft, obfervatio= nes $\&$ experientias noftras ad firmandum inftitutum adfcribo; à Collegis enim meis fubinde rogor, ut præter ea, quæ à Garcia recitantur, generatim, alia experimenta

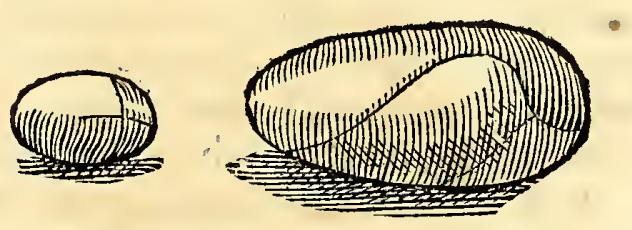
peculiaria aliquot, in quibus æuritudinis $\&$ curationis feries fingulatim confiftit, explicarem; quo non modo quanta in hujufmodi præfidio vis \& poteftas infit, ipfis innorefcat, verum etiam utendi modus, tempus $\&$ alia id genus. Horum igitur rogatu, auctoritate \& confilio paucos ægritudinum cafus fubjungere haud gravabor. Qui vero infrafcriptas perpeffi funt affectiones, eorum pars adhuc fuperfunt $\&$ fidei indubitatum teltimonium dabunt. Interim ne præter ordinem videar agere, ad xestúes refpicio, ut rite judicem; qux funt Experientia, qua Epicurus; atque Empirici eam folam fequentes, nitebantur: præterea Ratio, cui Academicorum princeps Ariftoteles tanktum tribuebat, ut nunquam ab ea fecedere vifus fit, fed cum Galeno ut rationem non defpiciendam, fic neque experientiam dimittendam dixerit. Quare (ut ad penfum redeam ) exemplis aliquot proferam eas xgrorum Hiftorias, apud quos ntlla humorum preparatio, evacuatio, aut ven $x$ fectio \&c. locum habere potuit ; utpote veneno manifefto affectis, ferius Medicina paratur : nec non ægrorum quorumdam, quibus \& venx fectionem adminiftrare, aut lenientis, aut folventis ufu, humorales dictas agri- tudines blande per alvum educendo lenire \& folvere conatus femper fum; inducias nactus. Neque enim unquam vomitus, à veneni pravitate, aut morbi divini excitus ferocia, impediendus venit, quo Naturæ beneficio forte medicamentum, tamquenobile Alexiterium impar refiftendo \& corrigendo poffet effe. Tepidam vero, oleum amygdalinum, lac, vinum, prabium aut dofim Cocci noftri antecedentia, concedo; \& licet femel exhibitum non fungatur fuo munere, bona mente ut conftantifimo patrono munitus, repeto eadem, fubinde paulo mutata; neque fexus, atatis aut 
virium multam rationem habeo, cum in dofi non peccetur, qux, exempli gratia, fit a dimidia dragma ad integram, aut fcrupulos quatuor in appropriato liquore.

I. Lucas à Salingen efu jocinoris pifcis Afelli, quod inter devorandum foetore quodam fauces illius oblederat, in dubium venit, num patella qua uxor fuiflet ufa in excoquendo eo, nova effet. Paulo enim ante pulticulam, muribus interficiendis adparari jufferat. Is folo pectore (quod mirum $\&$ nunquam milhi ante confpectum) extemplo adeo intumuerat, ut crepaturæ vel difplofionis periculum videretur præfens, $\&$ intoxicatus præ difficultate refpirationís fubinde animo pene deficeret, pulfu varie agitato, fic uti thorax folus fyftoles $\&$ diaftoles motibus cum livore faciei $\&$ totius pectoris, mortem violentam minaretur. Ab hoc vocatus, etfi invifendi munus non abfolveram, rei tamen certitudinem ex relatu filii cum haberem, confugiad rafuram quam ex interna parte noftre Nucis inter poliendum ufibus medicis refervaram. Eique $z^{\text {B }}$ pondus, ad oculi (quod vocant) dimenfionem cum Hifpanici vini haufulo, pr $x$ feftinatione exhibui : moxque domum me contuli, cum viderem xgrum citra naufeam ventriculi aut vomitum paulatim ad fe redire. Præefripfi enema commune malacticum cum acumine falis gemmæ, ftatim injiciendum; quod cum recufaret, fe fluidam habere alvum dicens, exhiberi juffi haufulum ex majore dofi corticis feu Cocci $\&$ ipfius etiam medullæ momento. Exempligratia.

26 Rafur $æ$ Cocci $\ni \mathrm{ij}$. Medullæ ejufdem $\ni \mathrm{j}$ : quibus in pollinem fubtilifimum redactis, adde fyrupi ex multiplici Infufione florum Caryophyllæorum feu Tunicx hortenfis (quem tunc forte fortuna præ manibus habebamus) $\xi$ j. aq. Meliffx $\xi$ j. B. Cinnamomax $z$ iij. F. Hauftulus. Eo affumpto convalefcere ccepit, ftatim poft bihorii fpatium , quo præfatigatione $\&$ corporis agitatione incredibili, quiete \& fomno fupervenientibus, integre reftitueretur.

II. Non vereor alta voce, \& explanata oratione prædicare hiftoriam fecundam, in filia Tibicinis \& Mufci mugiftratus Amfteledamenfis, Magiftri Cornelii, oblatam.

Hæc Arfenici intoxicatione varie fejactans, fymptomatibus huic veneno confuetis affici cœpit. Mater ad me cucurrit querula quod citra notitiam filiz Arfenici aliquantillum gliribus interficiendis alicuifarinæ portioni commiftum, filiæ ad manus veniffet; qux, pro more virginum, pica,fymptomate depravatæ ac vitiof apperentiæ,laborantium lambendo avida lingua tertiam quafi partem abfor pferat:Ilico ad olei amygdalini recenter expreffi uncix unius dofim confluxi,cum fyrupi violati fefquiuncia \& duabus aquæ Mcliffæ ftillatitiæ: Quam potionem ubi vomitu rejeciffet poft horam affumptionis, \& ftatim alvo turbata laboraret, ilico fub manu confilium capiens propinavi.

₹ Rafuræ nuclei, \& medullæ ejufdem Cocci Maldivenfis, an. 3 B. Syr. ex infufione multiplici Violarum, $\bar{\jmath}$. aqux Bugloff $x$, q. f. F. Potiuncula. Huic poft horam fubfequentem denuo exhibui.

2f Medull $x$ Nucis noftrx Medicx, 3 ß. Syrupi de Mentha $ろ$ j. olei Amygdalarum rec. expreffi $\xi$ ß. aquæ Cinnamomi $z$ iij. aq. Rofarum $\xi$ B.F. brevis Potiuncula. Qua cordi, ventriculo, inteftinis \& fimul alvo fatisfactum judicavi, cum nullum grave fymptoma fequere tur, fuitque reftituta citra fodam macularum eruptionem, juvante I. O. M.

Exempla autem corum in quibus eft $\left.\dot{\jmath}^{\prime} \delta^{\prime} x\right\lrcorner \mu(G)$ voũs. i. mens perverfa, qux non regitur luce \& affectu temperato, ceu Satanæ mancipia præterire malui, quod triftis ut plurimum eventus eos fequatur, licet quibufdam ex confternatione animi \& culpæerga Deum immortalem vera recognitione profper extiterit; quia cum fudium internecandi fefe adfuit, nominum corundem innominatx plebis nullam mentionem facere propofui; licet major pars fanitatem recuperarit, non fine macularum foedarum impreffione \& reliquiis, quod ab auripigmento. i. Arfenico luteo affumpto ad fex menfium ferme fpatium miferos occupavit.

II I. Cuftojour Eques Lemovix, Regis Galliarum \& Reginx Matris nomine in Belgio Legatus anno 1625 . ob Colicam paffionem à bile graviffimis fymptomatibus conflictatus, frigidam pr fiti fermc inextinguibili ingurgitare avcbat; quod cum recufaremus, fefe hydropotam natur $x$ fympathia \& ufus frequentia declaravit. Præmiffo itaque enemate, \& qux ejus generis morbus requirebat; aquam putcalem (cum fontana deficeret, cui potus generi à tenera $x$ tate affictus fuerat) voluit fibi porrigi : Nobis vero, Experientiflumo nimirum Medico D. Iofepho Buoeno Lufitanx nationis, \& milhi in men- 
tem venit, Egrum jugiter vifitantibus, potabilem aquam coctam frigidamque è $\mathrm{Nu}$ ce noftra Maldivenfi propinare, dantes confuetudini \& xtati, fecundum dogma Hippocraticum; quantum per artem licet:Quo facto fanitatem adeptus eft, dolor ibus atro * ciffimis fugatis, \& à Mordexi, i. e. torminum morfibus, liber factus.

IV. Idem Eques capitis pertinacifimo dolore infeltatus anno $162 \%$ poft provifio. nem ab indicatione factam, clyftere $\& x$ fanguinis detractione, ufus noftro confilio, ex Medica Nuce manum quafi Dei Pxoniam prxftolatus eft. Cui infuper fyrupum è cochleari deglutiendum præefcripfimus :

₹ Syrupi de fucco Betonicæ $弓$ iiij. pulv. Medullæ \& Nuclei Maldivenf. ana $z$ j ß.F. Mixtio pro fex dofibus biduo abforbendis. Cephalæa in exilium ablegata, \& Ophthalmia , qux, ut gravilimum fymptoma, lucem diei aut candela ferre eum non permittebat, præ gaudio, faltu \& cantu, Gallorum juvenum more, animi alacritatem recuperata lanitate manifeftavit.

V. Denique anno I 628 . veris initio, idem Iuvenis ex multi-jugo \& infatiabili efu fragorum, frigida afperforum cum facchari pulvere, nihil vini in temperamentum admifcens, ventriculi tonum ad atoniam omhimodam deduxit, \& monitis noftris haud obfecundanti, toto habitu mutato cachexia pituitofa fubfequuta eft, atque ita, temperamento qui fuerat ranguineo preditus, in hydropem mediante cachexia, curabilem quidem, incidit. Tandem ad factam anchoram feu fcyphum noftrum confugere, ut liberaliter potare pollet, voluit ; quod veriti, ne bibendo fibi officeret, recufavimus. Agger interim impatiens, nobis vale dicto, xftatem morbi fui curatricem fore exiftimavit. Interea vini ufum $\&$ potum dubia adhuc $\&$ crepera valetudine fupra omnem modum aggreffus eft, \& tremoribus convulfivis, Paralyfeofque prodromis imprimis Hemiplegia, affectus eft; tandem Epilepticis infultibus, ferme quovis momento percuffus in terram profternebatur. Convocatus denuo, defperatis licet rebus, deveni ad Ellebor:fraum, ex Ellebori nigri veri tota planta chynice apparatum, confenciente ornatiffimo Doctiflimoque D. Theodoro Schuttio, Amesfortii Medico Practico; nec non Magiftra':a ex Maldivenfi noftra Nuce propinavi; qux ante Epilogum, hiftoriis recitatis aliguot, fubjungo. His prattitis omnibus, prorfus in integrum reftitutus fuit.

V I. Eger quondam meus Tongerloo P. M. civis Amftelædamenfis, dum decumberet \& febre laboraret acuta, obtulit mihi intermedii corticis feu integumenti inter ni cruftacea aliquot fruftula, voluitque eorum dragmx pondus apud Pharmacopœum potionifudorific: Theriacali à me præfcribend $\mathrm{x}$ immifceri. Id quod ego iniquius ferens, cum mihi ignotam prorfus rem obtruderet, medicamentum pro rei exigentia exhibenti, refpondi, tmo non induci poffe ut admittám hunc medianum \& intermedium corticem, quin alicujus in Medica facultate præftantis Practici anctoritatem afferret: retulit, falutarem femper inventum fuiffe in febribus acutifimis, quibus laborarat, cum in India Orientali degeret , \& imprimis in difficultate partus effe Indis fœminis probatiffimum. Interim impulfus feriis monitis curavi quod poftulavit, \& feliciter, miti paroxyfmo, febris terminavit, \& me majore parte corticis fuperfite donavit ; qua mifellis parturientibus (fenis ad minus) opem fubinde tuli, cum Creatoris fummi laudibus. Huc fpectant exempla duo ornatiflimi ac doctiflimi Ionnnis à Grol, M. D. \& Collegæ noftri, quæreticere non volui s $\&$ ita fe habent.

VII. Bernbardi à Lummickbuyfen aurifabri honeftiflima uxor in platea vitulina, cum triduo parturiendi doloribus cruciaretur, \& ferme totam viciniam clamoribus im. pleret, exhibitis exhibendis, nihilque proficientibus, ab affumpta Cocci Maldivenfis Medull $x$ femidragma, ex fyrupo \& aqua Artemifix exhibita, feliciflime peperit.

VIII. Ejufdem Nucis rafura eodem modo propinata mirum in modum acceleravit Anne Gxlielmi filix, Ioannis Calcearii uxori exclufionem demortui fotus : huic ab obAtetrice imprimis, dein à nobis poft, exhibita varia $\&$ admota incaflum, perfeverantibus graviffmis fymptomatibus à febre ortis, tandem ad falutarem hanc Panacxam Maldivenfem confugimus. Et brcvifimo intervallo fotum in utero materno extinctum Natura exclufit, quem magno cum gaudio excepit obftetrix.

IX. In eadem vicinia uxor Georgii Nawwingii acupictoris, viri humanifimi \& perquam indufrii, ipfis Maii Kalendis me vocari juflit, voluitque fibi è Cocco Maldivenfi Medicinamapparari, mota felicibus fucceflibus xgre parturientinm vicinarum, qui- 
bus affuerat, cum Collega meus medicinam Maldivicam aduniniftraret. Verum tridui fpatio elapfo ruptis membranis ichorofus fuccus excuffus erat, atque fominei fotus rexprever foras exceptum ad necrofim perductum, non fine maximis anguftiis, annofiorem puerperam ad mortis limen vocarat papaverculo jugiter ferme muliebria foảante. Ego rogavi obftetricem, num aliquid ab illa praftitum aut exhibitum effet: qux, animo ferme deficiens, aiebar fefe fpem in anchora falutari Maldivenfilocaffe, neque aliud apud illam fuper efle parturitionis votum, cum triduo foctus certo certius extinAus \& prater naturam fitus videretur. Venimus ad hauftulum hunc.

26 Putaminis \& Medulla Mald. utriufque $3^{\beta}$. Diafcordii Fracaftorii $5 \mathrm{ij}$. aq. Cinnamomi 3 i ij. Boracis \& Trochifcorum de Myrrha ana $\exists$ j. . cum aq. foniculi. Potionem hanc ad duas dofes præfcriptam ægra moræ faftidio impatiens facta, una dofi aflumfit, \& forti animo preter expectatum enixa eft, demortuum infantem, grandem decem ad minus librarum pondere, una cum puerperalibus : \& gavifa maximopere cum laudibus Magni Parentis, qui tantarum virium advenam Maldivicum donaffet.

X. Illultriflimus Princeps de Guimené, Ducis de Monbafon filius, Amftelædami anno 1625 : xftate media incidit in Dyfenteriam, qua miferrime excruciabatur. Ego primus vocatus præltiti quæars \& res poftulabant; quatuor deinde convocati Medici funt, quibus $\mathrm{ab}$ amicis in tanto morbi furore perfona illuftris, pro juftiflimis meritis commendata erat; quod etiam illuftris Mauritii Principis cura effectum, cui confanguinitate junEtus erat. Ita ut non defuerimus ægro Principi, omnis gencris præfidia \& auxiliares manus afferendo, \&, juvante Medicorum fummo Medico, reftituendo fanitatem. Hic $\mathbb{A}$ ger fummopere exhilaratus, cum viduffer noftrum monile Maldivicum tam fpeciofum, jam paulatim convalefcens, voluit fuam hordeaceam, qua vinum rubellum dilueret, eo contineri \& fibilexinde bibendam dari; quod recufare nulla ratione potuimus, poftquam novitate rei pellectus $\&$ fpe reconvalefcendi accenfus nobis videretur. Itaque cum reliquiis morbi, ventriculum \& inteftina roborando, adeo ftrenue pugnatum eft, ut brevi fanitatem priftinam recuperarit.

XI. Generofus Dominus des Gouttes Eques or dinis Melitenfis, in Cardialgia anno 1627. pluries excellentiam pulveris intermedii corticis $\&$ rafuræ nuclei eft expertus, ex confervis Rofarum rubrarum, aut florum Tunicæ hortenfis, Lavendulæ, Pæoniæ, \& Meliff $x$; prout res \& occafio requirerent.

X I I. Nuperrime viri Dordraceni, annorum viginti-feptem, intricati morbi negotium, nobis anfam præbuit ad meduliam Mald. Cocci confugiendi, cum omnia viderentur fruftra applicata \& exhibita. Vocatus ego \& Cl. D. Tulpius Collega nofter, repperimus in xtatis flore \& poft laudatifimam remperiem ægrum, qui primis binis diebus Spafmo compofito, feu tremoribus convulfivis, truculenter afficiebatur; ac dein fingulis ferme horis poft prælúdia, modo in articulo pollicis pedis finifri, modo pollicis dextræ manus prodroma, conftante perpetuo mente, membra omnia conquaffari ille fenfit, \& nos vidimus toto fere biduo. Sed quicquid à nobis tentaretur, pro ratione temporis fucceflive, id omne à morbi \& fymptomatis ferocia fuperabatur. Tandem cum non effet derelinquendus, ad fpecifica occulr $x$ proprietaris devenimus, dantes ex fimplice cerevifia dragmam unam medull $x$ fuprafcript $x$ in pollinem redact $x$; haufulo vixdum ebibito, continuit fefe perquam quiete, \& fomno fuperveniente fudoribus copiofis toto corpore maduit; neque, uti ante, morbi tam gravis fymptomate oppreflus eft, verum leviculis, ubi expergifceretur, premonitionibus incitatus ab articulis in manu \& pede altero ; quo interim tempore quietem fibi ipfe imperare poterat, \&z refiftere fimul huic venienti malo. Quare quater iteravimus haufulum, \& ufualibus ac pecificis pulverem medullæ immifcuimus, $\&$ adeptus eft fanitatem. D. O.M. fit gloria.

Magiftralia, Compofitiones noftris Officinis vocantur, qux ex diverfis fimplicibus paulo accuratius conftruuntur; ut plurimum cæ, quæ Antidotariis publicis recepta non funt, neque bafim ullam exprefTe agnofcunt, \& ex fpecificis concinnantur pro arbitrio uniufcujufque Medici. Hoc autem loco eas tantum Compofitiones proponemus, qux ex Maldivenfi Nuce concinnantur, folo pulvere medullx, nuclei, aut intermedii corticis interveniente. Res vero fupervacua effet, fi horum pulverum alicui, aur ounnibus fimul, menftuum aliquod Chymicum, quod refolvat, affundatur, ut inde 
Magifterium formetur, veluti in Margaritarum, Coralliorum \&c. prxparationibus confuetum eft fieri.

- Magifterium enim eft (dicente Theoph. Paracelfo) quod ex rebus extractum eft, fine feparatione \& præparatione elementali, quod fit additione aliarum rerum. Vide Archidoxa de Magifteriis. Quandoquidem horum pulverum indubitatum ex tota fub. ftantia commodum expectatur. Non autem opus eft, ut hifce immoremur, exemplo Bezoartici lapidis edocti, qui ventriculum ingreffus, à fuccis acidulis ibidem contentis, \& calore nativo, folvitur, ut quam primum operationem fuam profequatur. Nofter enim pulvifculus eandem quoque fubit alterationem citra magnum moræ difpendium, $\&$ ab iifdem fuccis $\&$ calore fermentatus in actum ducitur.

Hac autem ferie pro r ei exigentia Medicus præfens induftrie difponat, habita ratione precepti noftri, fupra à me memorati.

(I. Syr. de Betonica, Violaceus, Capill. Veneris, infur. Fl.

Cocci Maldivenfis Me- Tunicx, Iulepus rofatus, Syr. Limonum, de Alth. Ferdullæ pulveri, ut \& puta- nelii,Borraginis, è fucco Citri, è fucco Card. Scabiołæ minis, nec non corticis intermedii, Granatorum, Myrtin. de Mentha \&c. $३$ j. f. pondus.

Dragmx unius pondus \{I I. Aqua Cardui-bened. Menthx. Meliffx, Portulacx, admifceri poterit. Acetof $x$, Artemifix, Borraginis, Bugloff $x$, Ruth $x$, flor. Tiliæ, Roris Solis, Rofarum, Agrimonix, florum Liliorum convallium, Primulx veris. Vel decoctum ex hifce, $\zeta$ ij. aut circiter.

Atque ex hifce fimpliciflimam medicamenti è Cocco compofitionem colligere eft.

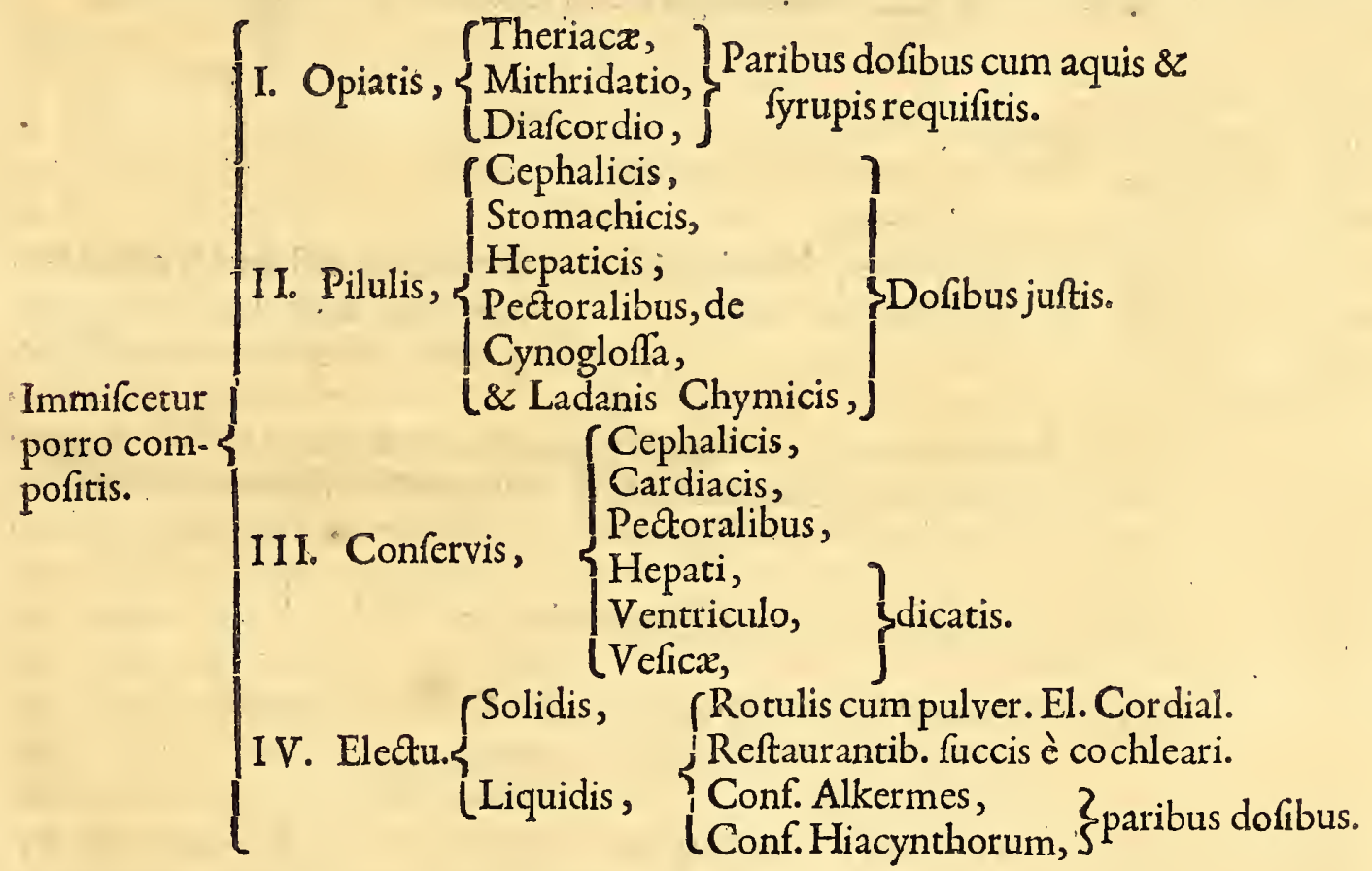

Ex fimplicibus præterea fpecificis \& Alexipharmacis feligere licebit ca, qux prudenci Medico ad confructionem Bolorum, Electuariorum, Rotularum feu Tabellarum facere videbuntur: quibus Medullæ Cocci Medici, Corticis intermedii,\& ipfus Putaminis pulvifculus adjungi poffit. Veluti funt :

Acetofe femen deglubatum, quod piftillo ligneo in marmoreo mortario præftatur à religiofioribus Pharmacopcis,

Ambræ grifex grana tria quatuorve,

Antithor radicis pulvifcul. $\ni$ j. Vide Ant. Guainer. de pefte.

Bolus Armenus verus,

Bezoarticus Lapis utriufque Indix ,

Biftortxradix,

Cornu cervi, praparatum ut infra docetur. 
Cornu Afini Indici, cujus præconia C. Barthol. profert.

Cinnamomum electum.

Caryophyllon Plinii. Quod fi veteruin dixerim effe Amömum, non multum aberrarem: alibi,

Caflia liginea.

Croci $\ni_{\mathrm{j} \text {. non ultra. }}$

Ceraforum dulcium nuclei.

Drakenæ radicis pulveris $\Theta$ j. vocatur Contrayerva.

Ebur nativum \& foffile. videatur C. Bartholin.

Hiacynthus gemma. pondere $\ni ß$ praparatus.

Ligni aloës $\exists j$.

Lapilli pretiofi ferme omnes, preparati, pondere $\ni$ B. quales funt, Topafius, Rubinus, Granatus, Sapphyrus, \&c.

Mofci Orientalis grana ij. aut ijj. fit dofis.

Monocerotis cornu, preparatum ut infra dicetur.

- Margaritæ prxparatæ vulgari modo.

Marga felecta feu Bezoar minerale. Vide Bauhin.

Proniz maris radix, ejufque femen mundatum, 3 B pond.

Petafitidis radicis pulvifculi $\exists j$.

Perfici nuclei.

Smaragdus ad $\exists j$.

Santalum citrinum.

Scorzoneræ radix.

Scordium.

Rhinocerotis cornu. Vide Ant. Schnebergerum in Cat. Med.

Terra Lemnia.

Tormentillæ radix.

Tilix florum pulvifculus.

Vifcus quercinus.

Vngula Alcis cxhibita \& adplicata.

Adverbia porro tria Cito, Tuto, Iacunde, plus opis \& auxilii præftabunt, quam tres inftructifim $x$ officinæ. Ego ingrata omnia illubens immifceo alexipharmacis, cum

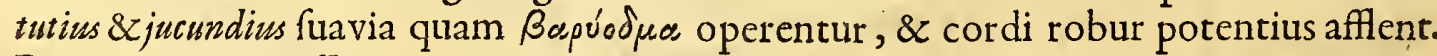
Porro venenum affumptum, aut ejus faltem fufpicio, dilationem, minus quam venter famelicus, imo nullam, patitur. Quare quod præe manibus eft quam citiffime in ufum vocandum. Simplicium autem memoratorum, q'ibus ponderis fignum additum eft, habenda ratio, cum dofim unam tantum hoc nomine intellexerim. Cærterorum vero in dofinon peccatur.

Formularum por ro magiftralium diverfitatem adnecto.

In Capitis vitiis gravioribus, uti ér nerporum, Epilepfia, Paraly/f, Convulsonibus, Tremoribus crudelibus ovc.

2f Pulveris Medullæ Cocci Medicæ (utpote potioris partis) 3 j. Confectionis Alkermes \& Hiacynthorum ana $3^{\beta}$. Vifci querni \& ungul $x$ alcis ana $\ni$ j. cum Syr. de Stocchade, Betonica, aut julepo rofato. F. Bolus una vice affumendus, \& repetendus ubi vifum fuerit.

Aut F. Potiuncula cum aq. meliffex, \& Syr. limon. \&zc. feu Conditum Magiftrale cum fyrupis \& confervis cephalicis \& pulveribus.

\section{In Dyfenteria cruenta, $\sigma$ Torminibus: facta ante preparatione debita per Rheum or Clyfteres.}

24 Corticis intermedii Nucis Medicx $3 \mathrm{j}$. ( $f \mathrm{i}$ defit, Medulla aut Putamen vicem fuppleat) Terr $x$ Lemnix, Lapidis Bezoartici Orientalis \& Biftort $x$ radicis ana $\ni$ j. Syr. de fucco Portulacx parum, ad confiftentiam. Bol. F. \& infuper adjectis requifitis, Conditum, Potio, \& frmilia. 


\section{In difficili Partu.}

26 Pulveris Medull $x$ aut Corticis intermedii, aut Putaminis $z$ j. Borracis 3 ß. Caffix lignex aut Cinnamomi felecti $\ni$ j. Croci Orientalis, \& Ambr $x$ grifex, ana grana ₹. Syrupi de Artemifia 3 j. Decocti radicum Tormentillx, aut Caryophyllon Plinii, q. f. F. Potio.

\section{In Pefte \& Febribus malignis Contagiofis.}

2 Cocci Maldivenfis 3 j. Seminis Acetof $x$ mundati $\ni j$. Syrupi è fucco Granato. rum acidorum, aut Scabiofx, aut florum Tunicx $Z_{j}$. Diafcordii Fracaftorii 3 j. DecoCti radicum Petafitidis, Scordii \& Scorzoneræ, aut aquarum Borraginis, Buglofl 2 , q. f. F. Potio.

\section{In Coli doloribus or aliis Intefinorum vitiis.}

26 Medicx Nucis noftrx quantum in precedentibus dictum eft ( ea enim dofis eft concinna) Mithridatii Damocratis $z j$ R. Pulver. Draken $x$ radicis $\&$ nucleorum Perfici Mali aut Ceraforum ana $\Xi$ j. Syr. de Mentha majori 3 j. Decocti aut Aquix Meliffre, Ruth $x$, aut fimilis, "q. f. F. Potio.

\section{In Veneni affumptione varia formula pro natura veneni.}

1 B* Ol. Amygdalarum dulcium rec. expreffi $z_{\text {j. aut }}$ jj. B. Lactis Ovilli aut Vaccini aut Caprilli $\xi$ v. pulveris Eboris nativi, aut foffilis, aut præparati per vaporem Cordialium $3^{\text {B. F. Potio cum }} z^{j}$. Cocci.

2 R\& Theriac\& \& Cocci Maldivici ana 3 j. PulveBezoartici Occidentalis, aut mineralis, feu margx felectx 3 B. aqux aut decocti Cardui benedicti q. fufficit. F. Potio.

3 Rx Pulveris noftri Cocci cujuf-tandem-cunque partis $z j$. pulv, Smaragdorum aut è pretiofis quinque $\exists \mathrm{j}$. Emulfionis ex frigidis Seminibus, Amygdalis amaris, f. a. aq. florum Tilix factx $弓$ v. F. Potio cum Syrupi violati $\xi$ j. B. ad faporis gratiam \& mitigationem.

Hactenus.

$$
\text { Hiacynthorum Confectio nofra, buc fpectans. }
$$

Vere cardiaca, cumprimis utilis : cujus dragma una commifceri poteft pulveri noftro, Cocci Putaminis, Medulla, aut Corticis intermedii.

Hujus autem accuratam excerpfi ex Mercati, Venetorum \& Montifpelienfum Antidotariis defcriptionem, noftrx patrix aptatam \& à D. D. Collegis meis.omnibus approbatam \& Antidotario fpecialinoftro aliquando inferendam; cujus fpecimen DoCtifl. 2N. Fontanus Collega nofter anno præcedente exhibuit.

Re Hiacynthorum prxparatorum.

z vijo:

Boli veri Armeni, Coralliorum rubrorum præparatorum. Terræ Lemniæ. Bezoartici lapidis Orientalis. Smaragdorum. Rubinorum. Granatorum. Sapphyrorum. \& Topafii, preparatorum. ana $z^{\mathrm{ij}}$.

Coriandri praparati aceto. Cortic. rad. Pentaphylli. Tormentilla. Coralliorum alborum præparatorum. Ligni aloës præftantis. Granorum Kermes. Spodii præparati. Rad. Diptami. Sem. citri mundati. Rofarum rubrarum ab unguibus purgatarum. Rad. Caryophyllatæodoratæ. Summitatum Scordii. Caryophyllorum. Seminis Acetof $x$ mundatx. Portulacx. Florum Bugloffx. Violarum. Rafur $x$ Eboris. Sem. Endivix. Margaritarum preparatarum. Cornu cervi citra uftionem preparati. Santali Rub. Albi. Citrini. Radicum Scorżoneræ. Carlinx. Offis de corde cervi, \& Vincetoxici. ana $z$ j.

Caphurx. Ambræxrifc $x$, \& Mofci Orientalis ana $\exists$ ß. Bractearum auri. num. xxx. Syrupi de fucco Citriorum aut Limoniorum, q. fi. aut 3 xxiv. F. Confectio.

Hæc tempore aftatis à fermentatione, qux menfis fpatio peragitur, fyrupi prafcripti

$$
\tau_{4} \text { Vncia- }
$$




\section{4 \\ GVI I E L M I PIS:O N I S}

Vnciarum trium aut circiter augmentum requirit, \& vitreo vafe adfervatur, citra fitum aut ullam cotruptelam.

Atque hæc Officinæarcificiis ad habilitatem idoneam transferuntur; qux fequuntur, naturx ipfius induftria commoditatem fere acquirunt. Obfervatu enim non indignum, quod à Rufcix Imperatore quodam, ante annos forte centum, dens Elephanti multis Alcis coriis circumvolutus, \& confutus, terræ gremio commiflus eft; c cujus tandem copia ( cafu ita ferente) huic Imperatori facta dicitur; qui fundamina ædium in Regie fua jaciens Thefauro fe beari credebat, cum erueretur: multijugis autem coriis hic folutus Thefaurus, dentem aperuit librarum forte quadraginta; cujus offca prius \& quafi lapidea (qualis dentium eft) fubftantia, tota ferme converfa erat in medullx compagem faxorum margrenon abfinilem, dentibus friabilem, atque manu folubilén; denique in Bezoartici lapidis fubftantiam Medicinx aptam. Quibus gavifus Imperator, \& pofteritati eodem munere profpectum volens, novum ejufdem rei expérimentum conditorio facto fumere ftaruit. Accedit $8 \mathrm{choc}$, quod in Boruffia in fummis cerevifiarii ædibus cornu cervinum fuit repertum, cujus, ob continuum quinquaginta circiter annis vapidi halitus afflatum, cornea durities in mollem $\&$ pulpofam verfa erat. Ita experiundi \& Medicinx dotes inveftigandi anfam cafus präbuit; etfi non femper lubrica fors fe interponit, poftquam Naturze potentia limitibus nullis circumfcripta, in perficiundis miraculis nunquam ignavefcit. Sed hxc Natur $x$ effecta, multo ad maturandum tempore opus habentia, artis adminiculo velut præcocia reddi queunt, fi legitima adminiftratione opus inftituatur. Quod fequenti exemplo documentum invenit, quo offa, cornua, dentes, trium feptimanarum fpatio in aliam fubftantiam verti poffe declaratur. Modus autem àccelernndx prxparationis, fequentium digeftu ap. paret. Offa enim, Cornua, Dentes, Cranium, fcilicet Humanum, Lapides è pifcis Phocx aut Manati capitibus, \& Balen $x$ inftrumentum auditus, lapidex prorfus duritiei , quod à forma Anatomicis Concha apte dicitur; ea , inquam, caput Alembici filis æneis conftringere debent, ut firmiter inhæreant. In Veficam vero fubjectam induntur Cardiaca, velut Meliffa, Mentha, quxlibet denique herbx, \& flores aut ligna odorata; qux juftam aquæ multitudinem nacta eâ cautione locari debent, ne Alembici interiorem partem ebulliendo contingant. Ignis vero continuo alimento fovendus eft, ut in opere hoc nullo mor $x$ interpofitu perpetuari poffit. Ita totum tranlationis in aliam fubftantiam negotium trium hebdomadarum fpatio abfolvitur; $\&$ qux ob duritiem contumacia reddebantur, in teneram compagem tranfvecta cernuntur. $\mathrm{Cu}$ , jus fecreti tanta hadtenus majeftas fuit, ut participes futuri juramentofe obftringere coacti fint, nunquamillorum opera myfterii arcana in lucem ventura.

Lector cm diutius detinere non fert animus, cum quxcumque curiofo naturalium rerum indagatori non minus ac Medico Theorico \& Practico fufficere valent, pro viribus meis obtulerim ; \& profpere femper quaflibet Cocci Maldiv. in morbis exhibitiones aut præbia (ut cum Fefto loquar) evenire animadverterim, dotes illius non folum efficaces admodum, fed ctiam tutx, admirabiles incredibilefque celebrantur. Quare vera cum gloria prædicare non dubito, Antiftitem Alexipharmacorum Coccum noftrum effe, experimentis indubitatis non fallacem. Qux ftentorea voce ex veritatis fuggeftu deprompta à me cum dicantur, nemo confternato animo effe debet, velut pueri vocum terticulamenta exhorrefcere folent, poftquam facilis ad fidem acceffus in rem eunti patefcit. Iure autem merito, dixerim Cocci,noftri maris accol $\&$ velut novi coloni, acceffu, rei medicamentarix pomœria immenfum dilatata ornatius fplendere. Quod ipfum fi de Ephemero Infecto affirmem, nulla veritati laniena inferetur : Etfi ob veneni pervicaciam minus tuta illius adminiftratio eft, in morbis præfertim $\&$ tædiis vifcerum internis, in quibus fumma cautela, magis ut deferatur, quam ut applicetur, opus habet. Nam in externis ad explorationem non adeo intuta experimenta offeruntur.Sed Ephemerus nofter in aliud diarium transferri debet, poftquam præfens laboris noftri peculium eft, Cocco nominalia fua \& luftricum diem ftatuere. Quod ferotino quidem ftu io aggredi contendo, fed non contemnenda ratione impulfus. Quippe levicula nominis explicatione oper is frontifpicium obfidere non volui, dum majoris momenti res fe calamo noftro ingererent, in quibus Medicus \& Naturæindagator folers, non grammaticus, aut locutuleius ofcitabundus, armos fuos experiri poffet. Palma Coccifera Indica, non fuit Veteribus nota. Videatur Clariflimus Salmafius qui rationes affert, Pag. 132 r. exercitatio- 
citationum Plinianarum. Indi Nucem Indicam vulgarem Caré \& fubinde Cocoibne \& $\mathrm{Cot}$ vocant; quod nomen Lufitani fyllabæ augmento bearunt: Hifpanico enim flexu Cocco eam indigitant. Sed neque rationis expers appellatio eft; quippe ideo huic fructui nomen hoc dederunt, quod tria foraminum veftigia in fummitate perpetuo monumento confervat, quibus Cercopitheci aut fimilis animalis faciem reprafentat, qux oculorum cavis atque oris rotunditate diftingui folet. Quod ipfum Garcia adftruente roboratur, qui hac Etymologiz ratione commentum fuum defendit. Minus firmum vero eft ideo Nuci vulgari, Cocco, nomen datum effe, quod Simia talis foni vocem gutturis applicatione, præcipue irritata, promere folet. Si enim ne ipfa quidem Simia ob hanc vocis articulationem Coccus nuncupatur, iniquius in fructum, qui foraminum modo veftigiis Simix affimilatur, onomatopœia hæc transferetur:fed quid diutius quam par eft, circa hanc levitatem diftringimur? poftquam ex Græcorum armario vera nominis ratio derivari poteft. Kóxx(G) enim illis non omne granum, fed rotundum aut ovi forma effigiatum denotare lolet. Etfi : Ant. Nebricenfis in Dictionario fto Latino-Hifpanico affirmat, generali fignificatu granum ita defcribi. Qui vir Græcarum literarum cum Latii fecretis experientiflimus fuit, unico in fidem vocando Ituvenale, cujus Satyras commentariis fuis olim illuftriores reddidit. Quo verborum complexu definiri poteft, Cocci nomen ex Grxcorum abundantia ad Latinorum penuriam derivatum effe. Aquitani Cocco del you,ous efcrovello, ovi putamen aut corticem, \&

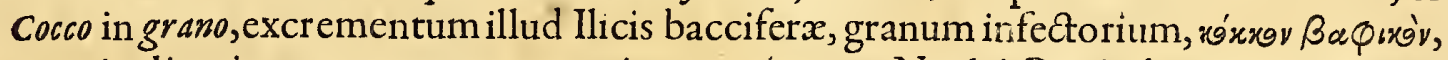
vermiculis etiamnum prægnans, vocitant. Kóx«a $\lambda_{0}$ Nuclei Pini indigitantur. Ricini

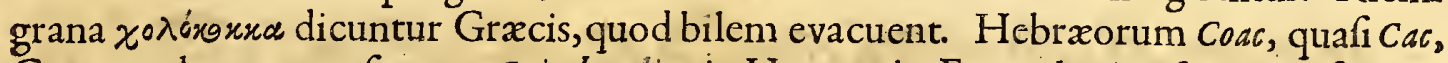
Coccum denotat, referente Guicchardino in Harmonia Etymologica fua. Care fructus feu Coccos infularibus Mald. eft nuncupatus ; quid Tavar fignificet, ignoratur : Si noAtra Nux Medica Tavarcaré in Tamarcaré mutari poffet, Coccorum palmam denotaret per excellentiam, unius liter $x$ mutatione. Coccorum arbor, ut \& Dactylorum, Palmæ denominationem habent, ut Principes inter congeneres: Palma autem quafi Parilema à pariendo nuncupatur, Varrone tefte, \& Carolo Stephano, in Vineto fuo, pag. 5. Gemma $: \oint \theta a \lambda \mu \dot{s}$ Botanicis autoribus oculum \& germen fignificat, tranllatione à Lapillis pretiofis. Germen interim dupliciter accipitur; primo ut Gemma quæfolubilis è carne Nucis eximi poteft, quam Pyrard Gallice l'amande, totam nempe medullam, vocitat; fecundo ut apex Palmæ vulgaris. Garcias Indos dicit Palmarum germinibus vefci, quorum collectio præcipue fit, cum cæduntur arbores ad $æ$ dificia fabricanda, ut efui fint. Expetuntur \& Dactyliferarum à Formicis, tefte Plinio, cum jactura arboris, quia non ferunt decacuminationem: gratiora longe funt palato, quam aut Caftanere molles, aut humiles Palmæ, quas vulgo Palmites, Itali Cefaglioni vocant. Quo etian vetuftior eft Palma, co tenerius \& delicatius germen producit; at eo fublato perit $\mathrm{Pal}$ ma. Hinc fit, ut qui hujufmodi germen edit, non immerito Palmam vorare dicatur. Datur, tefte $P$ yrardo, fpecies quædam Palm $x$ feu Nucis Indic $x$ pr $x$ ter vulgarem; cujus primitivus fru\&tus, ad inftar Pomi noftratis, tota fubftantia edulis, teneritate \& fuavitate acceptiffimus; verum inventu rarior \& quanto antecellit vulyarem primis incrementi menfibus, tanto, ubi maturitatem confequitur, deterior \& ineptior ufibus. Mollufca, exfententia Ruellii, molliore ac teneriore carne fructus dicitur, aut Malum cum primum fugax, quale Perficum eft. Gefwerus Nucem Mollufcam inter Iuglandes ponit qux molliore eft putamine; quod Amygdalis quibufdam etiam familiare, cum ex leniflima digitorum compreffione frangantur. Et quandoquidem hæc fola Pyrardi inter Indicas Nuces putamen ipfum molle \& vefcum habet, mihi in Lexico Botanico meo bilingui necdum evulgato Mollufca cognominatur : è contra Moracia, Moracilla, vulgaris Indica Nux, propter durum putamen, à frangendi mora. Palmarum quotquot funt fpecies, exhilarantur flore; fecus ac triftes arbores, qux fine eodem annorum gaudia non fentiunt. Flos vulgaris luteo fulget colore, magnitudine fructui $x$ qualis. Quid autem de Maldivenfis Medica flore dicendum fit, adhuc fub Iudice lis eft, poftquam nulli plantam \& florem vidiffe contigit. Impellor fubinde ab amicis, ut Mald.minorum fpecies aliquor proferam ; quia fama percrebuit, a pud plurimos Noftrates, qui in Indix diverfis locis vixerunt, dari varietatem aliquam Coccorum, eofque Maldiveníium titulo, forte ob effecta aut faciem, beari volunt. Ego, ut verum fatcar, non agnovi, neque in mufao meo coacervavi fructus Palmarum aut Coccorum congeneres, praterquam quinos 


\section{GVLIELMI PISONIS MANTISSA AROMATICA.}

aut fenos; quos tamen minus Maldivenfi conferre, quam Murem Elephanto compa. rare licet: quorum defcriptiones præfentis laboris non effe volui. Exempli gratia, Famigeratiflimi Matbioli Cuciophora, nec non alterius Palın fructus, vere baccifer $x$, huc advocandi non funt;quorum amborum \& plurium praconia cum iconibus mecum (ut fpero) non moritura funt. Neque incon cinne ad Palmarum claffem referendus fructus, quem tabella exprimit Clarifimus I. de Laet, duriffimo \& lignofo putamine, quo duze Nuces continentur, mole pugni unius; nec non alter, Totocke dictus, cujus idem accuratifimam defcriptionem profert: Hujus autem fructus integri vicenis nucibus prægnantis iconem fum exhibiturus, fi Deus vitam protrahat. Theophrafti vero, Plinii, Abinzenna, Serapionis, tam Medicorum, quam Hiftoriographorum, atque etiam Neotericorum fententiis ad amuffim perpenfis, \& ipfiffima rerum indagine fervata, penfum meum cum bono Deo abfolvere conor. Interim Pxonio Medicamento noftro Maldivico, maximopere utilifimo, fuaviffimo, imo manui quafi Dei operantis tutò , citò, jucundè, fatisfactum pro viribus opinor.

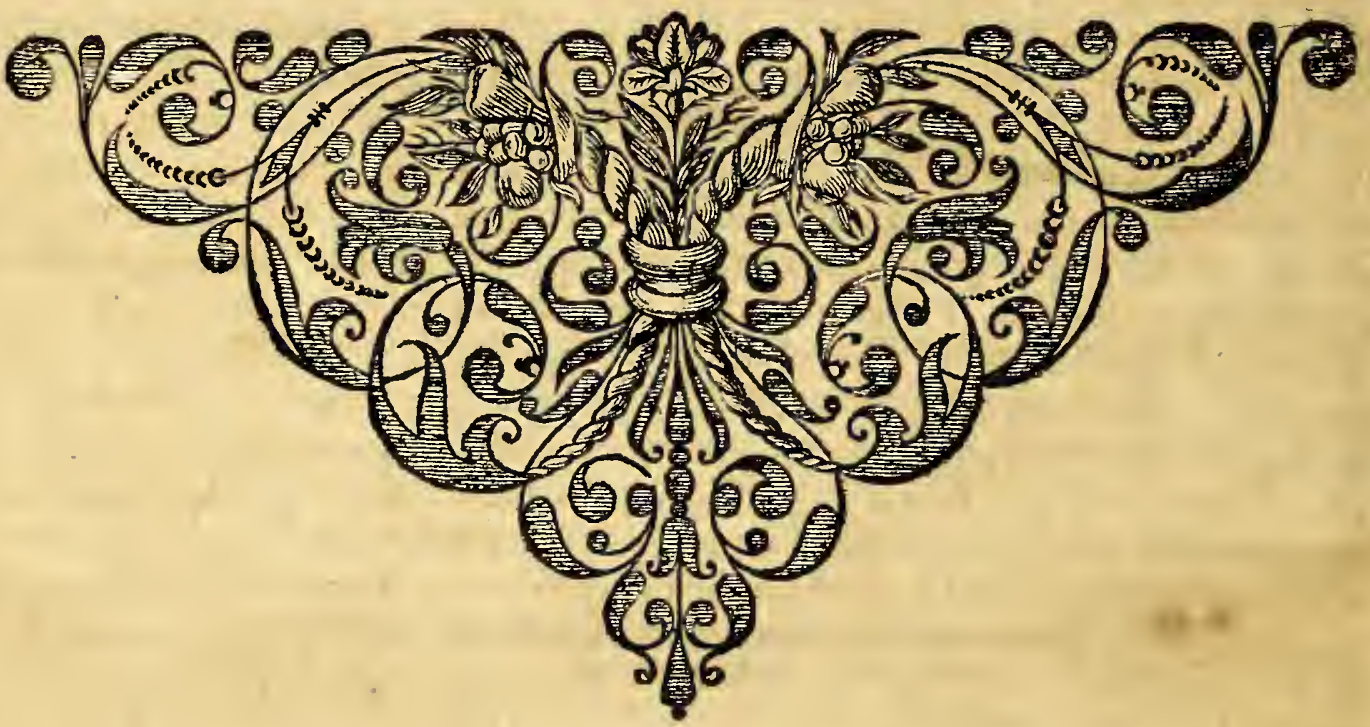




\section{RERVM ET VERBORVM}

\section{In Hiftoria Nat. Ind. Orientalis Notabilium.}

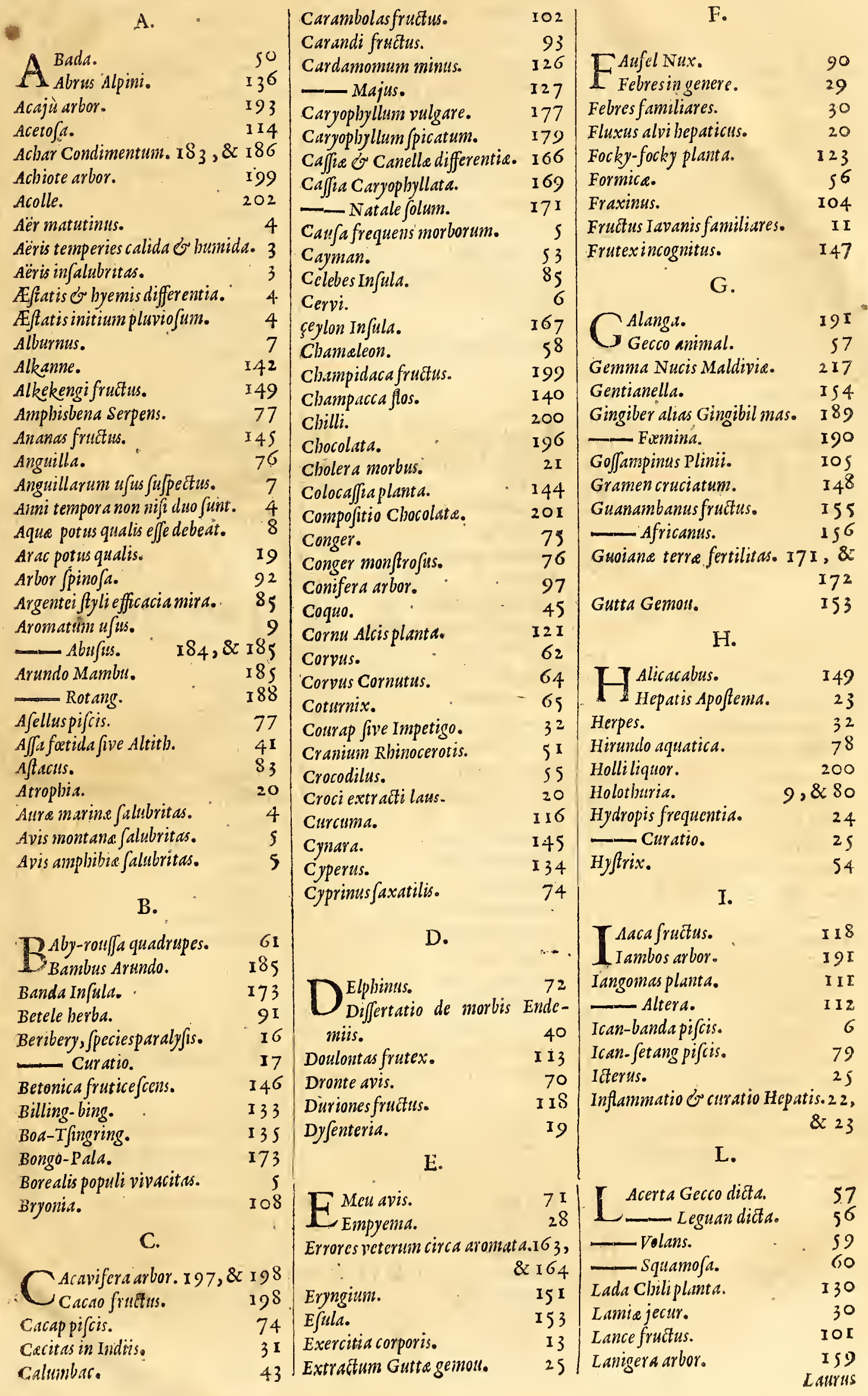


INDEX RERVM ET VERBORVM.

Laurus.
Legumina.
Liguftrumi.
Lupinus.
Lyfimachiijpecies.
Lycium feu Cate.

\section{M.}

$1{ }_{\text {Macer Veterum. }}^{\text {Acandon. }}$

\section{Riacis.}

Maizium.

Mala Aurea, Citrea, esc.

Mala Cydonia.

Maldivie Nux.

$\begin{array}{lr}\text { Maldivie Nux. } & 203 \\ & \text { ejus visantidotalis.211,\&214 }\end{array}$

Mandragora.

Mangain fructus.

- Mangifera arbor.

Mangoftan fructus.

Mecaxocbitl.

Melonifera arbor.

Milium Solis.

Molanga five Piper.

Moluccen fes Infule.

Molyflos.

Montes ignivomi.

Mugil.

Murana.

Myrobalanus.

\section{N.}

Maphtha.

1 Naturamiraculi.

Nautilus pifcis.

Nidi birundinum.

Nimbo.

- Altera.

Ninzin Radix.

Note in Garciam ab Orto de Affa fot ida.

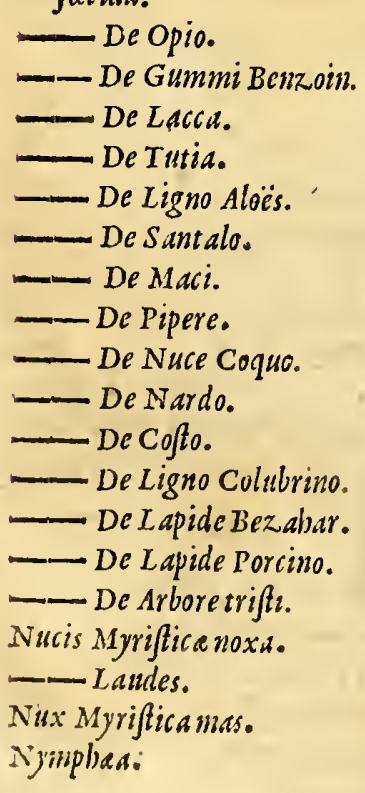$$
\begin{array}{r}
9 \\
135 \\
142 \\
143 \\
139 \\
159 \\
92
\end{array}
$$

159
92

175

I75

199

I 2

98

10

94,895

\& 95

IIS

96

I 52

180

177

I 42

. 85

7

$x 10$

.

94

Aff $a$
$4 \mathrm{I}$

$4 I$

42

42

43

43

43

44

44

45

45

46
46

47

48

49

IO

173

I 76
135

142
143

143
I 39

2

BServatio De Spafmo.
De Phtbifico. De Dyenteria.

- De Empyematico.

De Craniifratura.

- De Chronicis morbis.

- De Vena Cava adipe repleta

7

P

18 R
- De Apoftemate Hepatis. 37

- De Vulnere Capitis. $\quad 38$

-De Catarrbo Suffoc ante. 38

- De Vulnere Pectoris. 39

- De Dy Jenteria Epidentica. 39

- De Febre ardent.

Olftructio Hepatis.

s lavana.

Onocrotalus.

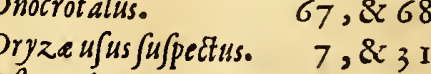

tracoderma.

Oftrea.

Ourang Outang, homo filveftris. 84

DAla.

1 Pala Metfiri.

Paliurus Aegyptius.

Papaio.

Papula rubentes.

Paris arbor.

Paftinaca marina.

Pavones.

Phajeolus quadratus.

Pimpilin five Piper longum.

byllitidis $\int p e c i e s$.

Piper Aromaticum mas.

- Fomina.

- Album.

- Canara.

Tefacei.

Pifciculus cornutus.

Plantago Aquatica.

Polypodium.

Potus compofitus.

Potus fimplex ex arboris fucco.

Profluvium alvi:

Pfittacus parvus.

Pulmonis vitia.

Curatio.

Purgatio bumorum.

Pynang nux.

$Q_{\text {Vercus. }}$

Q.

R Aire.

K Rampoftan fructus.

R.

Raphanus.

Rhomboidespifcis.
Ricinus
Rofa.

Roga

S.

Scar. I $85,2 \times$ I $86, \&$ r 87 $\checkmark$ sago placenta.

Saguer potus.

Salvia arborefcens.

Sambucus. $\quad 108$

Sanguinis miffiogualis. I Scabiofa.

Scarabei.

Scaruspifis. $\quad 56$

Scolopendra. 73

scorpio. $\quad 56$

Secamone Alpini. $\quad 138$

Sedum arborefcens. I 24,8 I 25

Sentiensherba. II9, \& I 20

Sepia.

Serpentes ingenere. $\quad-\quad 76$

simber planta. "I2I

Sirii pinang. $\quad 90$

Solanifpecies. $\quad 123$

Somnusmeridianus. . 13

Sorbifpecies.

Spafmuspopularis. $\quad 18$

Spinofaplanta. IOG

Squilla: $\quad 3$ I

Sturmus. 67

$T:$

TAbaxir. I 8, $5, \& 186, \& 187$

1 Tamarindi. 93

Tavarcare. $\quad 203$

Telephium. $\quad 132$

Tenefmus. $\quad 2 \mathrm{~T}$

Teftudo fquamata. $\quad 82$

The five Tchid. $87, \& 88, \& 289$

Thjinka. $\quad 177$

Thynnus. $\quad 72$

Tigris. $\quad 92, \& 53$

Tinca marine. $\quad 78$

Tlaolli. 199

95 Tlilxocbitl. . 200

Tophi Endemii. $\quad 33$

Tovat potus.

9

V.

$V^{\text {Aynillas. }}$

200 Veneni mira efficacia. $\quad 85$

Verbena.

Veronic a. $\quad 129$

Vefpertilio monftrofus. 60

Vinea Taminea Plinii. - 108

Vine arum in I v vabertas. $\quad 12$

6 Vini Hifpaniciprerogativa. 8

T $\quad X$.

$F I N I S$.

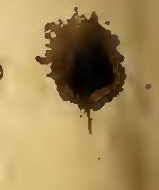

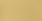

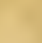





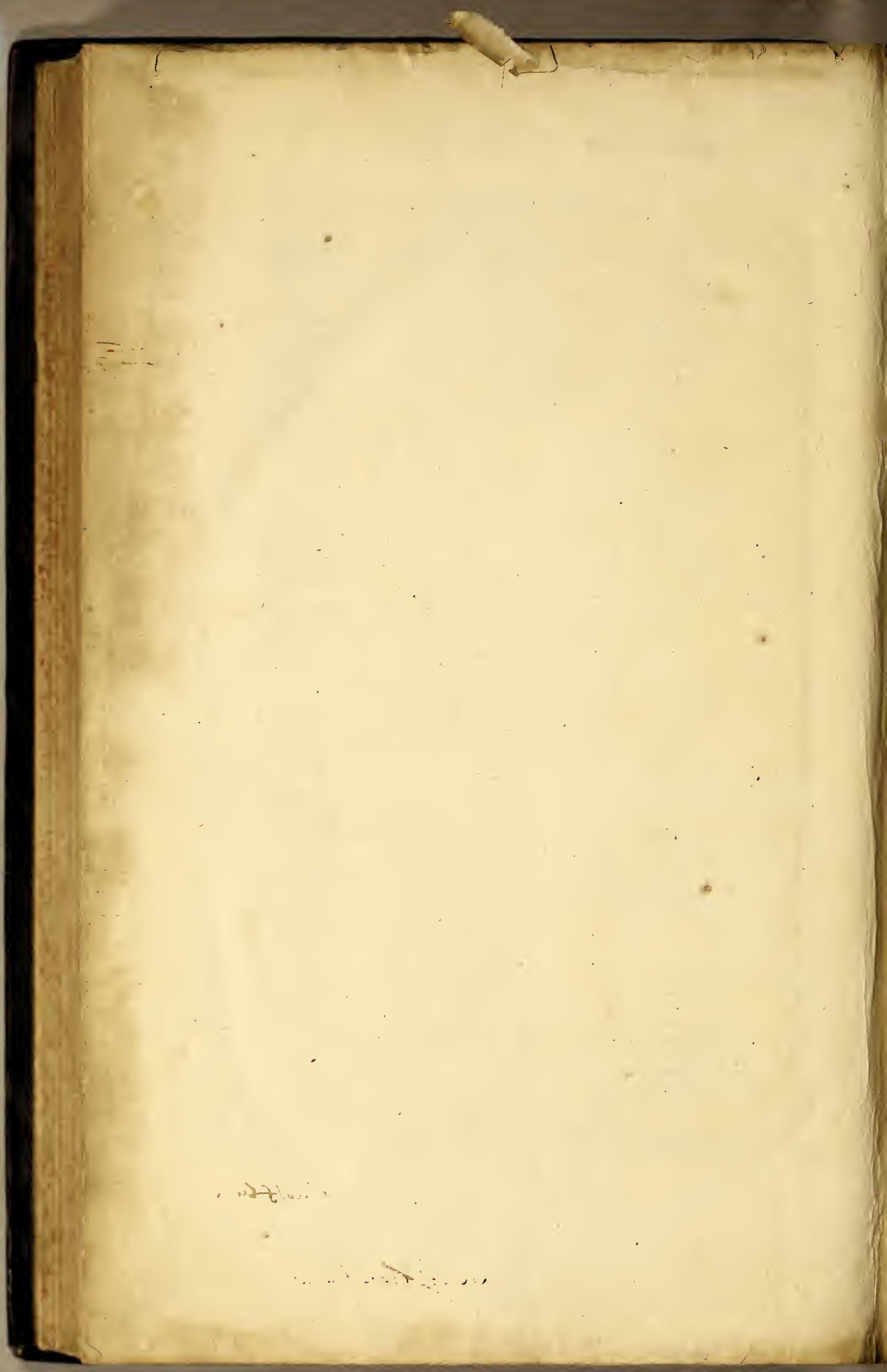


$t^{20}$

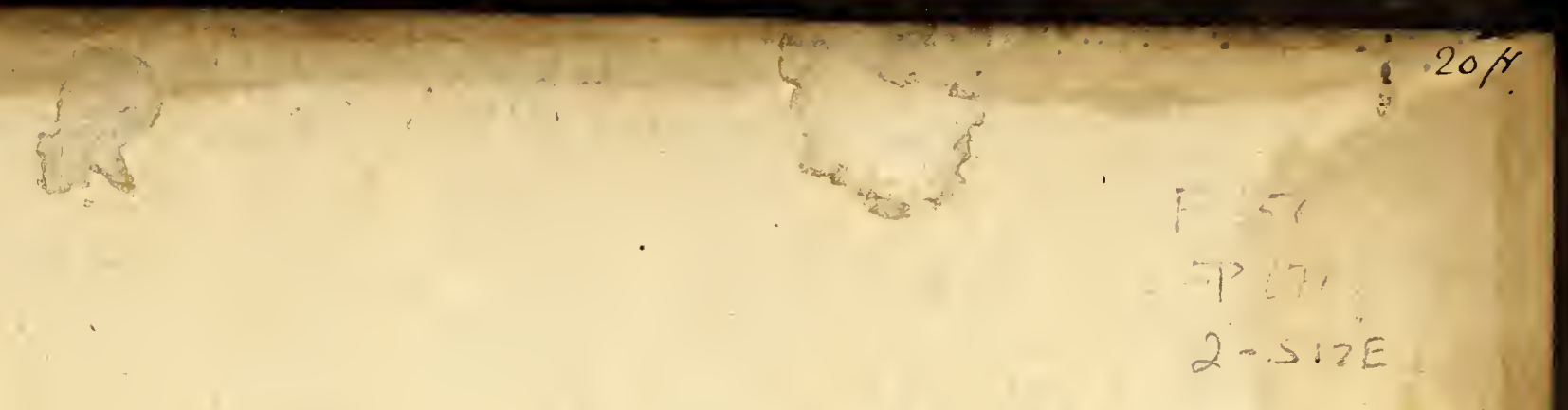

t'ualfsuld:

Sext'kier buld: 
